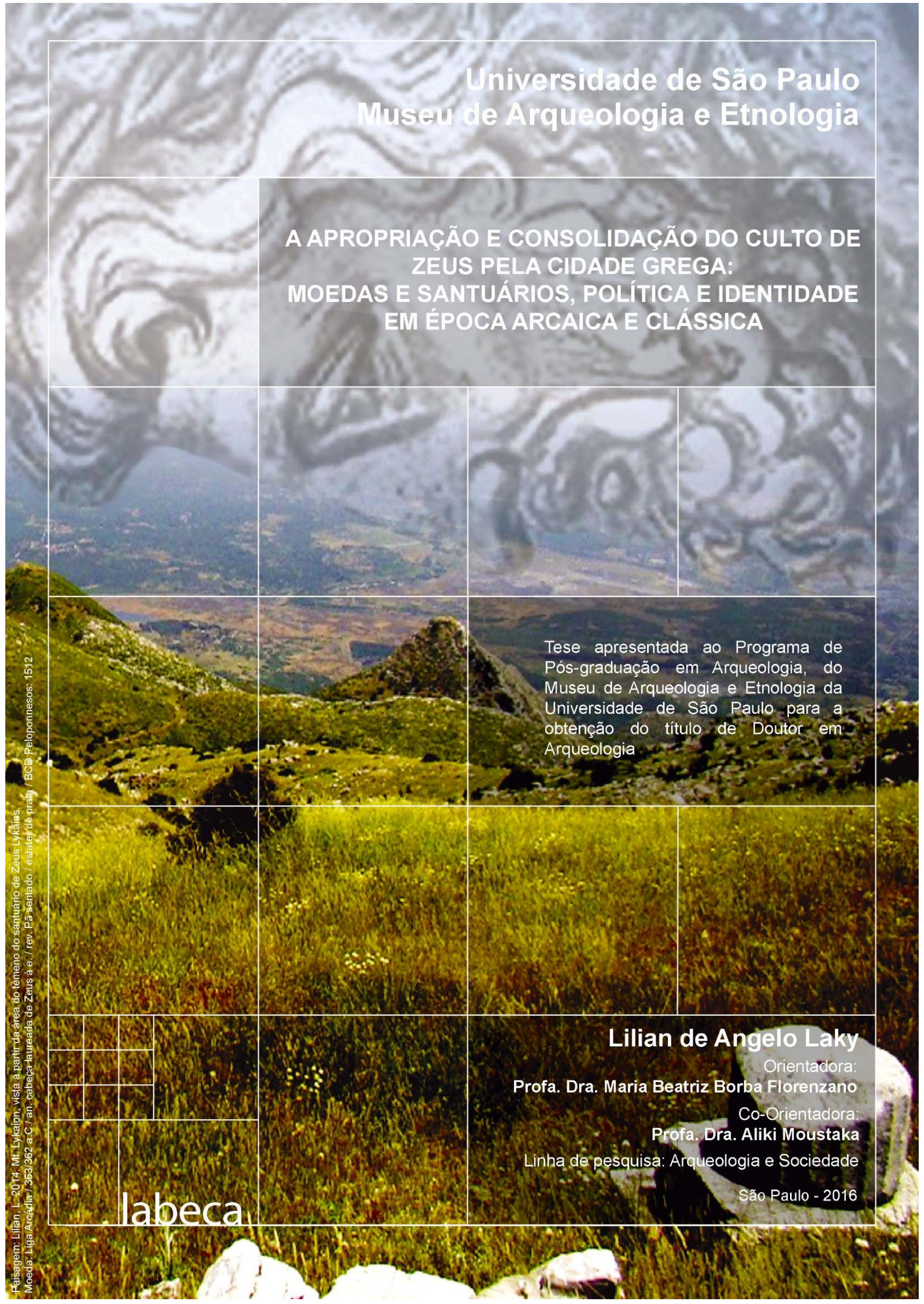





\author{
UNIVERSIDADE DE SÃO PAULO \\ MUSEU DE ARQUEOLOGIA E ETNOLOGIA \\ PROGRAMA DE PÓS-GRADUAÇÃO EM ARQUEOLOGIA
}

\title{
A APROPRIAÇÃO E CONSOLIDAÇÃO DO CULTO DE ZEUS PELA CIDADE GREGA: MOEDAS E SANTUÁRIOS, POLÍTICA E IDENTIDADE EM ÉPOCA ARCAICA E CLÁSSICA
}

\section{Lilian de Angelo Laky}

Tese apresentada ao Programa de PósGraduação em Arqueologia, do Museu de Arqueologia e Etnologia da Universidade de São Paulo.

Orientadora: Profa. Dra. Maria Beatriz Borba Florenzano

Co-orientadora: Aliki Moustaka

Linha de Pesquisa: Arqueologia e Sociedade

São Paulo 



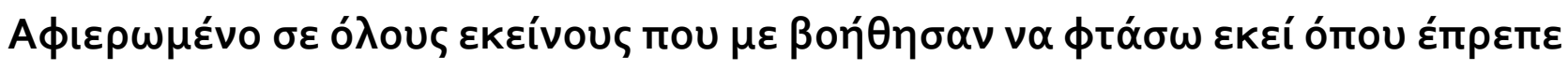

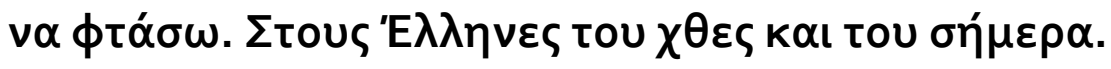





\section{AGRADECIMENTOS}

À Fundação de Amparo à Pesquisa do Estado de São Paulo (FAPESP) pelos quatro anos de bolsa de doutorado que tornou possível a realização desta pesquisa e as viagens de campo à Grécia em todos esses anos e, principalmente, pelo estágio de pesquisa de quatro meses, com a bolsa BEPE, sediado na Universidade de Thessaloniki.

Ao Laboratório de Estudos sobre a Cidade Antiga (LABECA/MAE-USP) por ter sido e ainda ser a base e a possibilidade de pesquisa em Arqueologia do Mediterrâneo e viabilizar as minhas pesquisas e a de muitos estudantes nessa área provenientes do Brasil e do exterior.

À minha orientadora Profa. Dra. Maria Beatriz Borba Florenzano, a quem devo toda a minha formação em Arqueologia Clássica, pelos 14 anos de convivência, amizade e muito aprendizado, que me possibilitou chegar até a esta pesquisa de doutorado.

À minha co-orientadora Profa. Dra. Aliki Moustaka (Universidade de Thessaloniki), pela generosidade, intercâmbio de ideias, mesmo à distância, todo o apoio e novas e fundamentais experiências vividas na Grécia, como a escavação em Olímpia, que marcaram para sempre a minha vida pessoal e profissional.

À Profa. Dra. Elaine F. V. Hirata pelo apoio sempre inconteste, no âmbito profissional e pessoal, durante mais de uma década de convivência no MAE-USP.

À Profa. Dra. Maria Cristina N. Kormikiari Passos por todo o suporte pessoal e profissional para a realização desta tese de doutorado.

À ambas professoras agradeço as observações na banca de exame de qualificação que foram fundamentais para o direcionamento da escrita da tese.

Aos Profs. Drs. Maria Isabel D. Fleming e Vágner C. Porto pelo apoio fundamental durante todos esses anos de vida acadêmica na USP.

Ao Dr. Reinhard Senff (Diretor das escavações em Olímpia, Instituto Arqueológico Alemão de Atenas) pela oportunidade ímpar e generosidade em participar das pesquisas arqueológicas em Olímpia durante os anos de 2012, 2013 e 2014, e sobretudo pela possibilidade de estudar os achados monetários das escavações do setor sudoeste do antigo estádio na reserva técnica do Museu de Olímpia.

Ao Prof. Dr. David Gilman Romano (Diretor das escavações no Mt. Lykaion, Universidade do Arizona) pela visita de campo ao santuário de Zeus Lykaios na Arcádia, pelas explicações in loco, e pelas entrevistas e bibliografia cedidas por e-mail.

Ao Prof. Dr. N. Keith Rutter pelo aceite no curso de pós-graduação em Numismática Grega na Escola Britânica de Atenas durante o período de estágio de pesquisa com a bolsa BEPE-FAPESP. Sou muito grata pelo intercâmbio de ideias, bibliografia e às visitas a tantas coleções numismáticas na capital grega que enriqueceram a minha compreensão sobre o tema.

Ao Prof. Dr. Emanuele Greco (Diretor da Escola Arqueológica Italiana de Atenas) pelo apoio fundamental e generosidade para a realização da pesquisa bibliográfica nas dependências da biblioteca da Escola.

À Escola Britânica de Atenas por todo o suporte e afiliação concedida durante os quatro meses de estágio de pesquisa na Grécia em 2014, fundamentais à realização da pesquisa bibliográfica e escrita desta tese. Agradeço sobretudo à equipe da biblioteca.

À toda equipe da biblioteca do MAE-USP por todo o suporte inigualável e amizade durante mais de uma década de pesquisas na universidade. 
Ao Prof. Dr. Giovanni Gorini (Universidade de Pádua) pela entrevista por e-mail e comentários acerca das novas cronologias sobre as moedas de Cirene na Líbia. Agradeço também por encaminhar-me à sua aluna Lucrezia Rizzo, que me cedeu seu estudo, não publicado, sobre as moedas de Abakainon na Sicília.

Ao Prof. Dr. Joseph MacGillivray (Diretor das escavações em Palaikastro, Escola Britânica de Atenas) pelas indicações para a visitação do sítio cretense e do santuário de Zeus Dicteu.

À Irmina Doneux Santos pela amizade e apoio incondicional sobretudo na finalização desta tese.

Ao Rodrigo Lima pela amizade, apoio e criação da capa desta tese de doutorado.

Ao Paolo Daniele Scirpo pela tradução de textos em grego e ajuda bibliográfica.

Aos Profs. Drs. Evi Markou, Manolis Stefanakis, Georgia Gargano, Christina Williamson, Olga Zolotnikova e Teododoro Renó Assunção pelo compartilhamento de bibliografia.

Às colegas e amigas Viviana Lo Monaco, Camila Souza e Juliana Figueira da Hora e Sandra Zipprich pelo envio de bibliografia da Grécia nos momentos finais dessa pesquisa. E também à Carolina Kesser.

Ao apoio incondicional, nesta caminhada da tese, dos amigos e colegas Daniela La Chioma Silvestre Villalva, Claudio Duarte, Estevam Lima de Almeida, Felipe Leonardo, Chistiane Teodoro e Danilo Tabone (in memoriam).

Ao suporte e amizade de Neila Papidis, que foram fundamentais durante minhas permanências na Grécia. E à Sylvia Dermanaki, minha professora de grego, por todo suporte durante estes anos de doutorado.

À Magda e toda a família Godoy, Demi, Daniela e Gabriela Martins, Tatiane Pavan e Mário Bonfim por todo o suporte, sobretudo nestes últimos meses da conclusão dessa pesquisa.

E, enfim, à minha família: meus pais Sandra de Angelo Laky e Carlos Laky Filho, meu irmão Antonio Carlos Laky, minha cunhada Thaís e minha sobrinha Beatriz. À Genoaria Nanni e a Miguel Nanni pelo seu amor e paciência incondicionais nesta grande jornada. A todos vocês dedico esta tese. 
SUMÁRIO

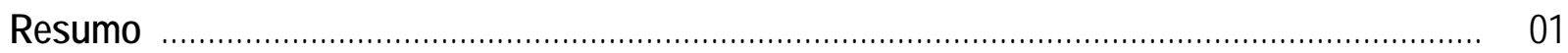

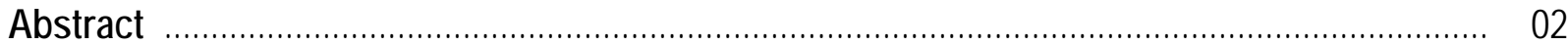

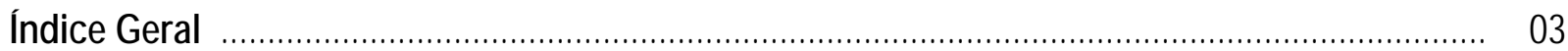

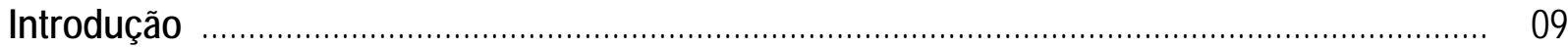

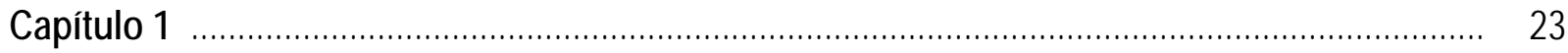

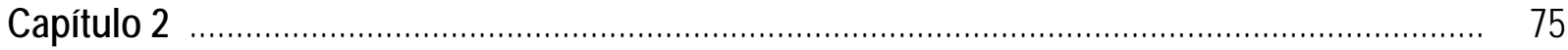

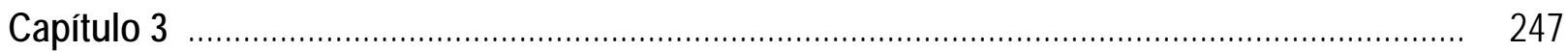

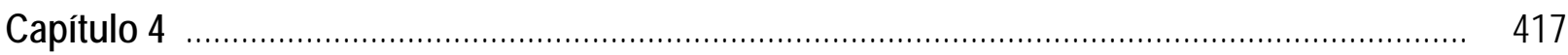

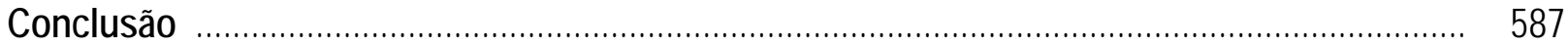

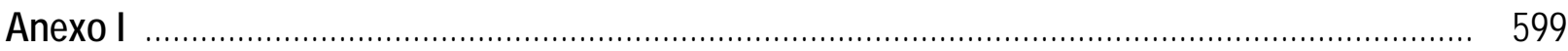

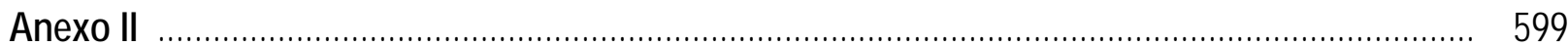

Referências bibliográficas ........................................................................................... 601 



\section{RESUMO}

O presente estudo pretende examinar o papel desempenhado pelo culto de Zeus na legitimação de grupos e regimes políticos nas póleis gregas, bem como na construção de redes de identidade grega em contexto políade. Queremos oferecer explicações válidas sobre quais fatores políticos e sociais levaram à emergência do culto de Zeus na pólis grega no final do século VII a.C., à apropriação de seu culto a partir do século VI a.C. - o período no qual a pólis alcançou o seu primeiro ápice de urbanização e no qual ocorreu o primeiro aumento de santuários cívicos do deus (no território e na área urbana) e do uso da imagem da águia em moedas gregas -, assim como ao fenômeno de proliferação dos santuários e de imagens monetárias de Zeus e do raio nos séculos V e IV a.C., quando o culto se consolidou na cidade grega. A nossa documentação básica será: 1) todos os componentes de todos os santuários gregos dedicados a Zeus, conhecidos arqueologicamente, entre a Idade do Bronze e a época clássica (até 345/44 a.C.); e 2) todas as moedas conhecidas com imagens de Zeus e de seus atributos, o raio e a águia, cunhadas a partir do período arcaico e até 345/44 a.C. Moedas e santuários compõem a documentação, pois têm em comum o caráter de oficialidade e de identidade da cidade grega: os dois tipos de documento partem de uma mesma entidade política, a pólis. Essa pesquisa oferecerá um panorama geral do culto de Zeus na pólis na longa duração, além de uma abordagem regional que sublinhará os casos mais significativos a respeito de ambos os tipos de documentação referentes à divindade no Peloponeso, em Creta, na Sicília e na Itália do Sul.

PALAVRAS-CHAVE: Zeus; pólis; santuários; tipos monetários; identidade grega 


\begin{abstract}
The present study is designed to examine the role played by the cult of Zeus in the legitimization of political groups and regimes in Greek poleis, as well as in the construction of networks of Greek identity in a polis context. This investigation aims to offer valid explanations to the following subjects: a) the political and social factors that caused the emergence of cult of Zeus in the Greek polis in the end of the $7^{\text {th }}$ century BC; $b$ ) the appropriation of his cult in the poleis from the $6^{\text {th }}$ century BC (the period in which the polis achieved the first apex of urbanization, when occurred the first increase of civic sanctuaries of the deity and the use of eagles types on Greek coins); c) the phenomenon of proliferation of sanctuaries and coin types of Zeus and thunderbolts during the $5^{\text {th }}$ and $4^{\text {th }}$ centuries $\mathrm{BC}$, when the cult was consolidated in the Greek cities. The basic sources of this research are: 1) all components of all known Greek sanctuaries dedicated to Zeus between the Bronze Age and the Classical period until 345/44 BC).; and, 2) all known coins with images of Zeus or his attributes, in this case the thunderbolt and eagle minted between the Archaic period and 345/44 BC. The choice of coins and sanctuaries as the main sources was due to the fact that both share characteristics of identity and officiality of the Greek city, both types of data originate from the same political entity, the polis. This research will provide an overview of the cult of Zeus in poleis in a long-term perspective, as well as a regional approach which will focus on both types of data (sanctuaries and coin types) regarding the deity in four areas of the Greek world Peloponnese, Crete, Sicily and Southern Italy.
\end{abstract}

KEY WORDS: Zeus; polis; sanctuaries; coin types; Greek identity 


\section{ÍNDICE GERAL}

INTRODUÇÃO

CAPÍTULO I - OS SANTUÁRIOS DE ZEUS NO MUNDO GREGO DA IDADE DO BRONZE À ÉPOCA CLÁSSICA:

APRESENTAÇÃO E DISCUSSÃO DA DOCUMENTAÇÃO

I. QUANTIFICAÇÃO GERAL DOS SANTUÁRIOS DE ZEUS POR PERÍODO, REGIÃO, CATEGORIA E

ESTRUTURA DE CULTO

I.1 POR PERÍODO

I.2 POR PERIODOS/REGIÕES

I.3 POR TIPOS DE LOCALIZAÇÕES GEOGRÁFICAS

I.4 POR TIPOS DE CATEGORIAS DE SANTUÁRIOS

I.5 POR TIPOS DE ARQUITETURA OU ESTRUTURAS DO CULTO

II. ANÁLISE E INTERPRETAÇÃO GERAIS DOS SANTUÁRIOS DE ZEUS POR PERÍODO (DA IDADE DO BRONZE À ÉPOCA CLÁSSICA (ATÉ 345/44 a.C.)

II.1 A IDADE DO BRONZE $\left(3^{\circ}-2^{\circ}\right.$ milênios a.C. $)$

II.2 A IDADE DO FERRO (XII-VIII a.C.)

II.3 A ÉPOCA ARCAICA (VII-VI a.C.)

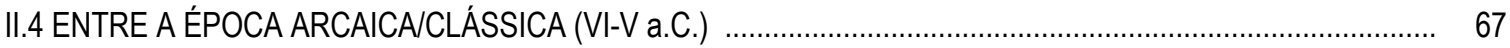

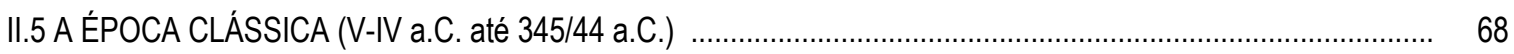

CAPÍTULO II - ANÁLISE REGIONAL INTERPRETATIVA DOS SANTUÁRIOS DE ZEUS ......................................... 75

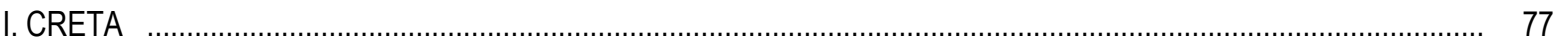

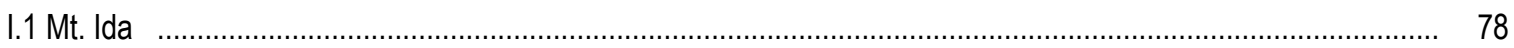

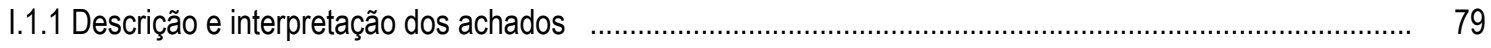

I.1.2 A natureza do culto e a função do santuário ………….................................................................. 81

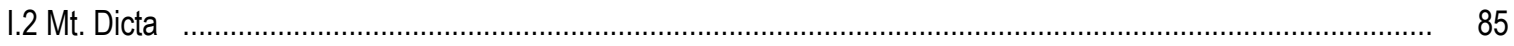

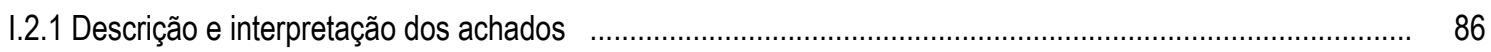

I.2.2 A natureza do culto e a função do santuário .................................................................................... 88

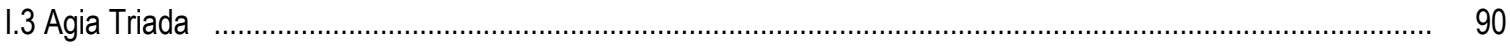

I.3.1 Descrição e interpretação dos achados .................................................................................. 90

I.3.2 A natureza do culto e a função do santuário ………………........................................................... 92

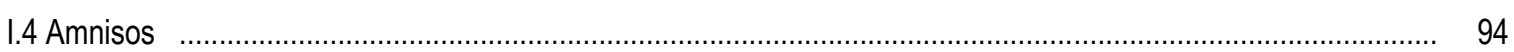

I.4.1 Descrição e interpretação dos achados ......................................................................................... 96

I.4.2 A natureza do culto e a função do santuário ..................................................................................... 100

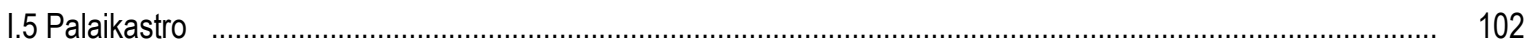

I.5.1 Descrição e interpretação dos achados ...................................................................................... 102

I.5.2 A natureza do culto e a função do santuário .............................................................................. 106

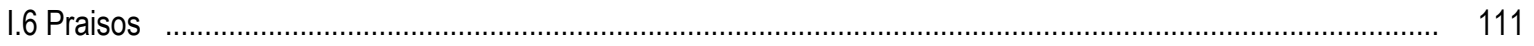

I.6.1 Descrição e interpretação dos achados ........................................................................................... 111

I.6.2 A natureza do culto e a função do santuário ....................................................................... 112

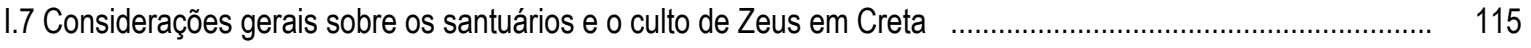

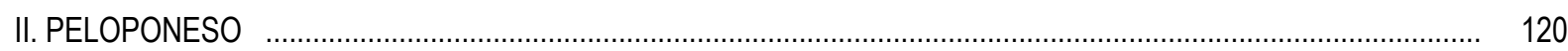

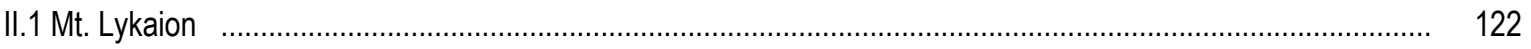

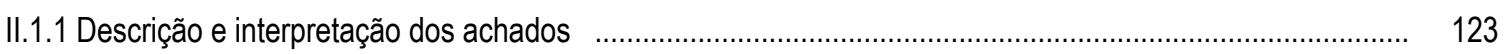

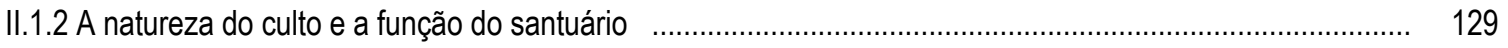




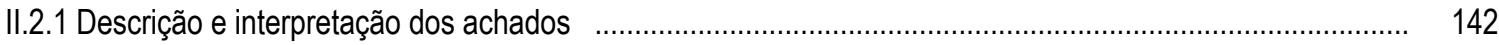

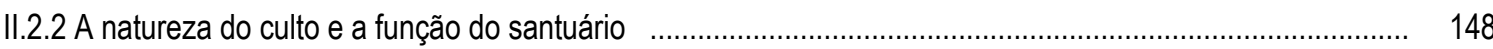

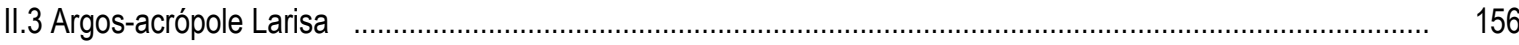

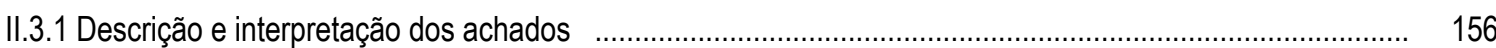

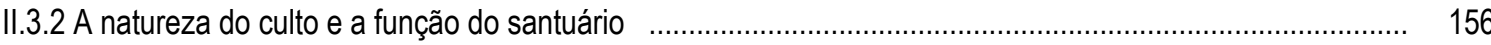

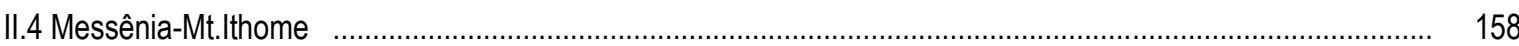

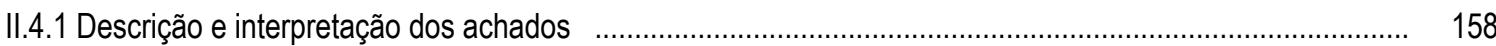

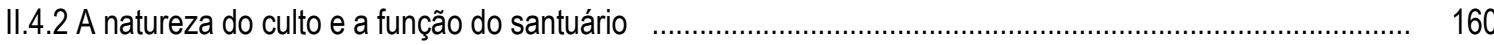

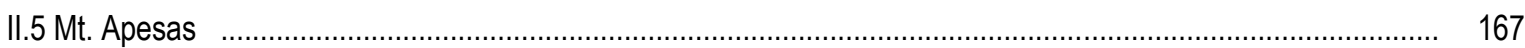

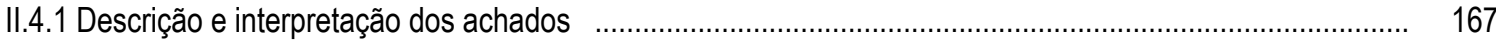

II.4.2 A natureza do culto e a função do santuário $\quad$.................................................................................... 168

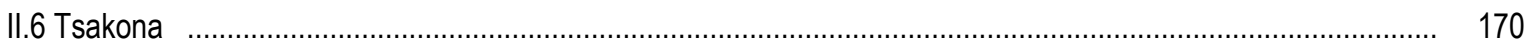

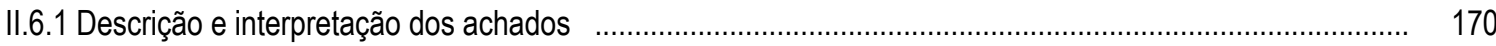

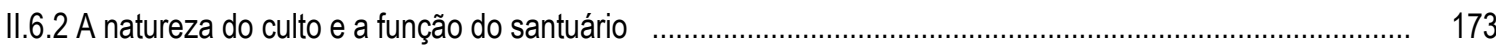

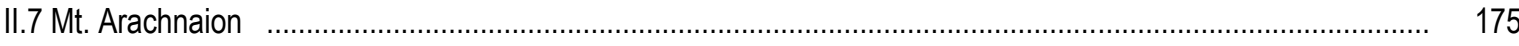

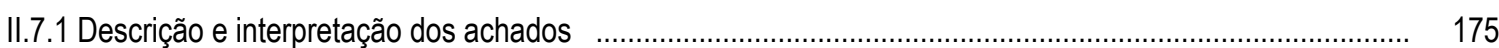

II.7.2 A natureza do culto e a função do santuário ......................................................................................... 176

II.8 Neméia

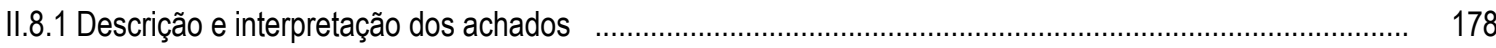

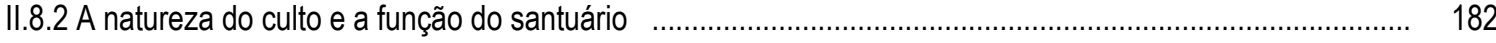

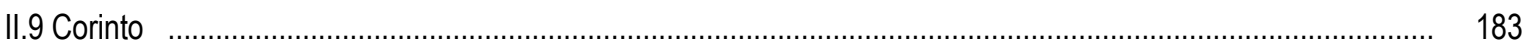

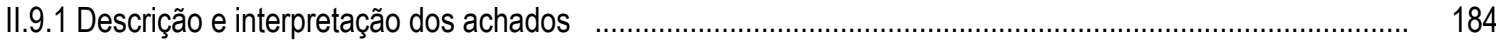

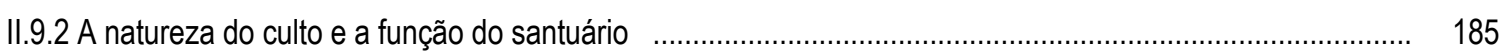

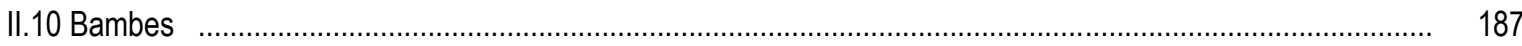

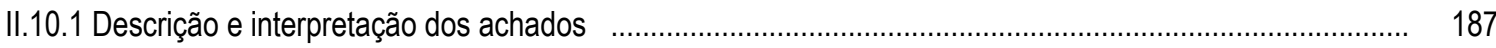

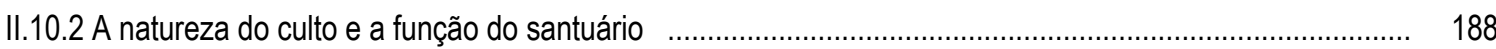

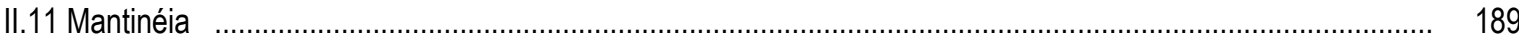

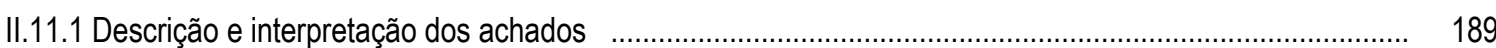

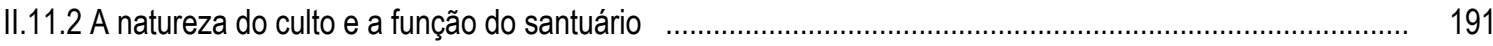

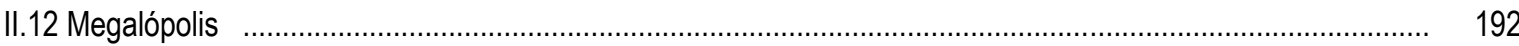

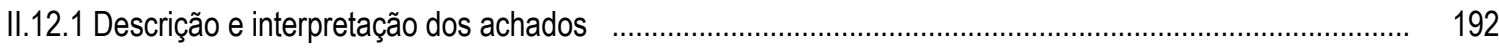

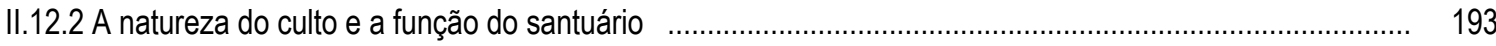

II.13 Considerações gerais sobre os santuários e o culto de Zeus no Peloponeso ................................................. 195

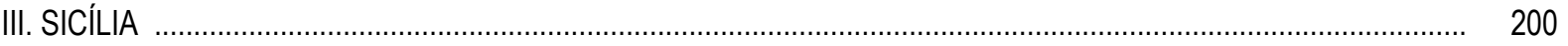

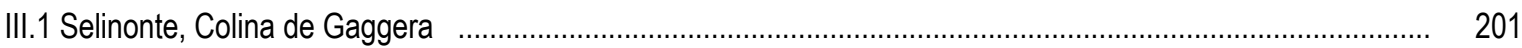

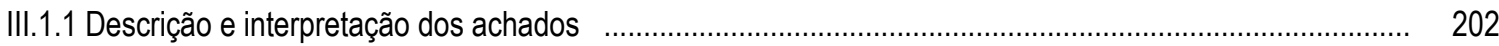

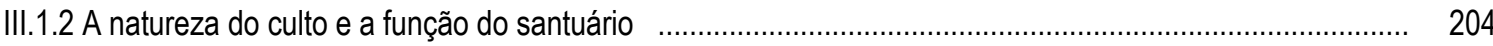

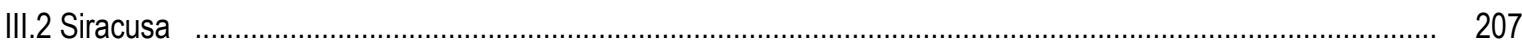

III.2.1 Descrição e interpretação dos achados ..................................................................................... 207

III.2.2 A natureza do culto e a função do santuário ............................................................................. 210

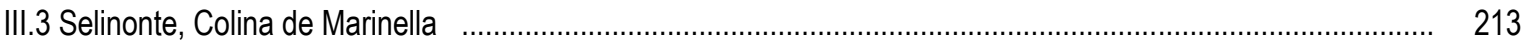


III.3.1 Descrição e interpretação dos achados

III.3.2 A natureza do culto e a função do santuário .............................................................................. 217

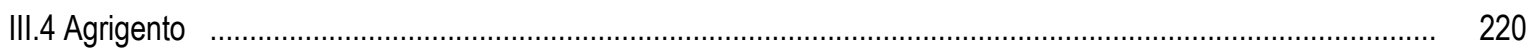

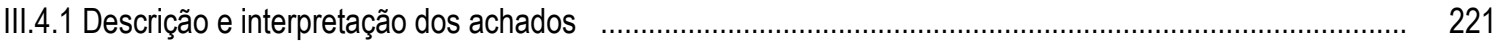

III.4.2 A natureza do culto e a função do santuário .................................................................................. 223

III.5 Considerações gerais sobre os santuários e o culto de Zeus na Sicília ...................................................... 225

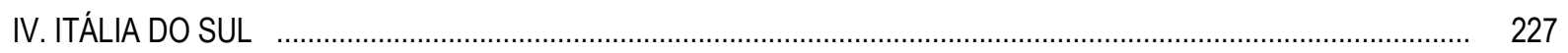

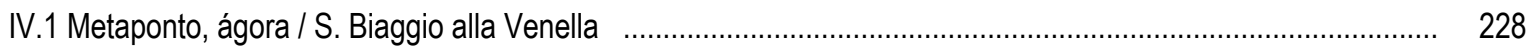

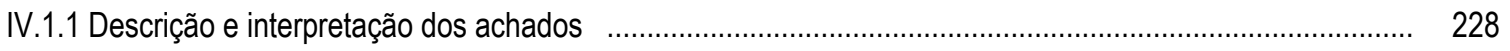

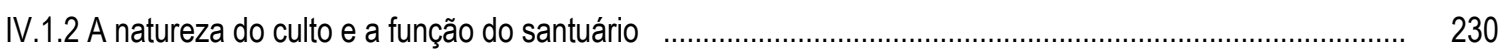

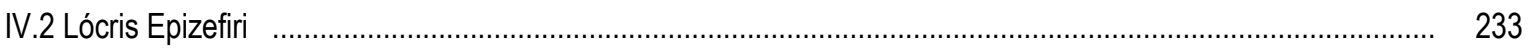

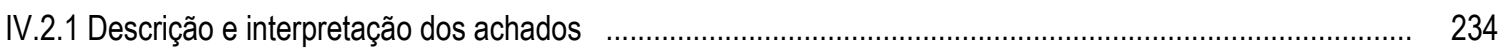

IV.2.2 A natureza do culto e a função do santuário ............................................................................... 237

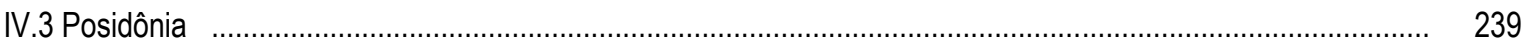

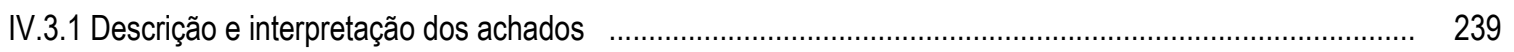

IV.3.2 A natureza do culto e a função do santuário .............................................................................. 240

IV.4 Considerações gerais sobre os santuários e o culto de Zeus na ltália do Sul ............................................ 241

V. CONSIDERAÇÕES FINAIS: CORRELAÇÕES DOS SANTUÁRIOS E DO CULTO DE ZEUS ENTRE CRETA,

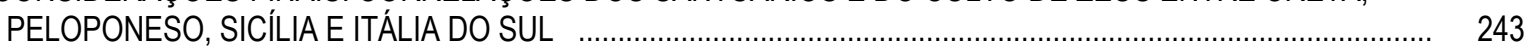

CAPÍTULO III - AS IMAGENS DE ZEUS, ÁGUIAS E RAIOS EM MOEDAS GREGAS DO PERÍODO ARCAICO AO

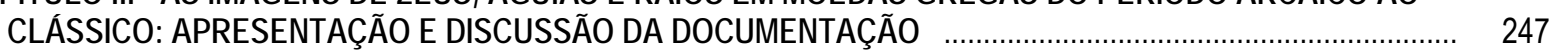

I. QUANTIFICAÇÃO DOS TIPOS MONETÁRIOS POR PERÍODO, REGIÃO E AUTORIDADES EMISSORAS ........... 249

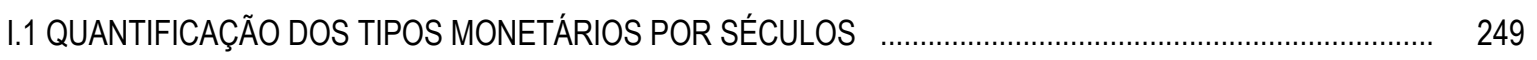

I.2 QUANTIFICAÇÃO DE AUTORIDADES EMISSORAS POR REGIÕES .................................................... 251

I.3 QUANTIFICAÇÃO DE TIPOS MONETÁRIOS POR AUTORIDADES EMISSORAS, REGIÕES E SÉCULOS ... 254

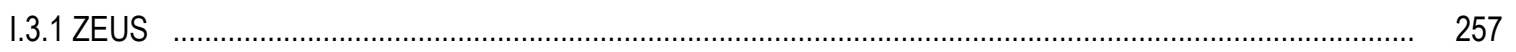

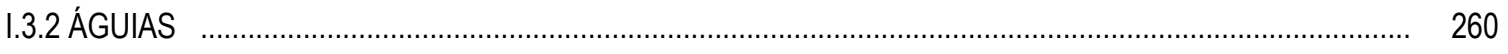

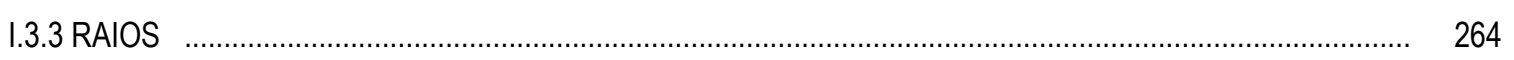

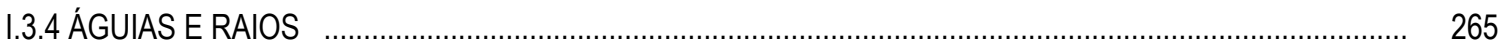

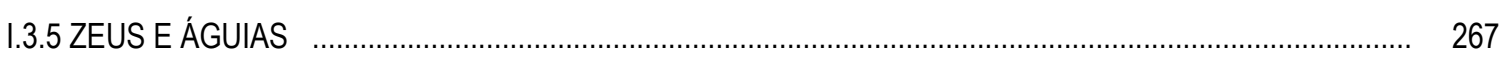

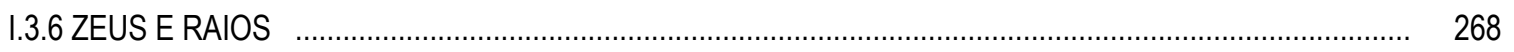

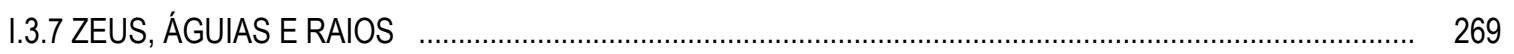

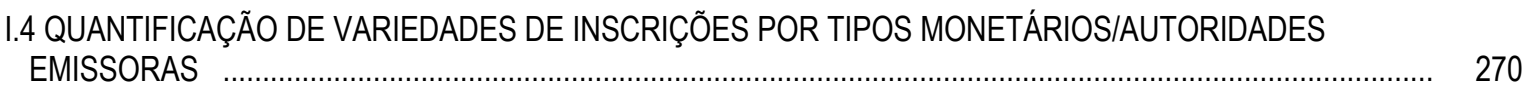

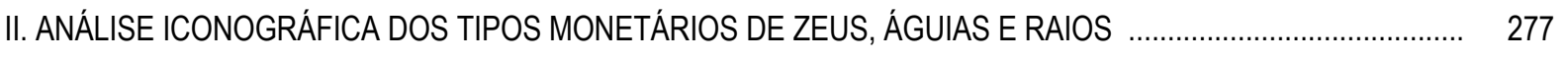

II.1 A REPRESENTAÇÃO DE ZEUS NA ARTE GREGA ATÉ A ÉPOCA CLÁSSICA ......................................... 277

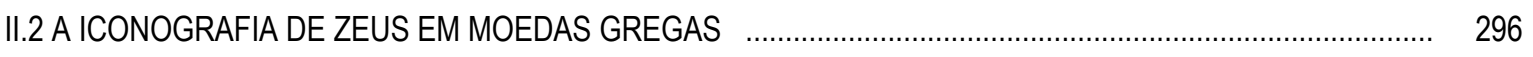

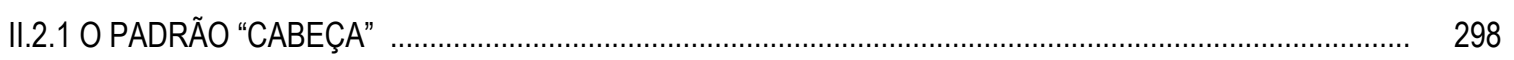

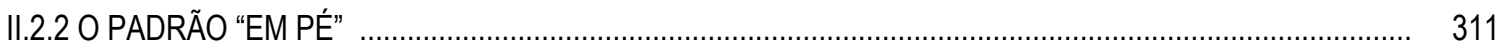

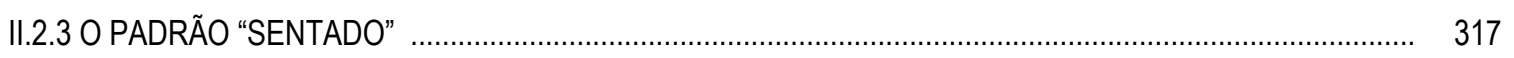

II.3 A REPRESENTAÇÃO DO RAIO NA ARTE GREGA ATÉ A ÉPOCA CLÁSSICA .......................................... 326

II.4 A ICONOGRAFIA DOS RAIOS EM MOEDAS GREGAS ....................................................................... 333

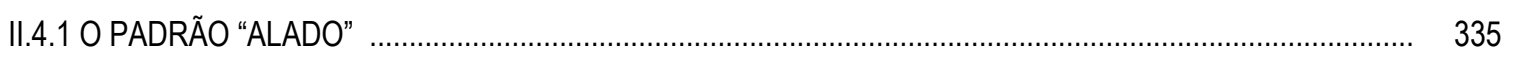

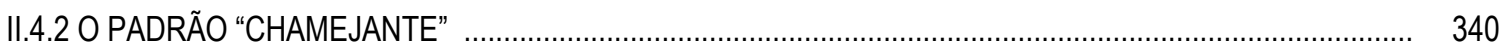


II.4.3 O PADRÃO "FLOR DE LÓTUS"

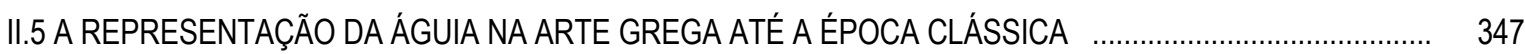

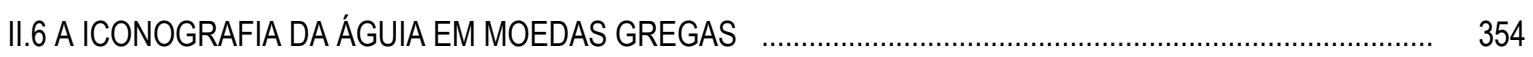

II.6.1 O PADRÃO "CABEÇA" ................................................................................................ 356

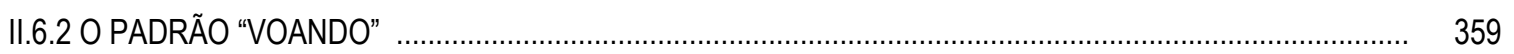

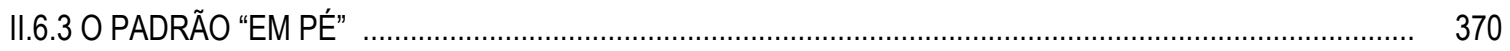

III. ANÁLISE CONTEXTUAL DO SIGNIFICADO SIMBÓLICO DAS IMAGENS DE ZEUS, ÁGUIAS E RAIOS ............. 388

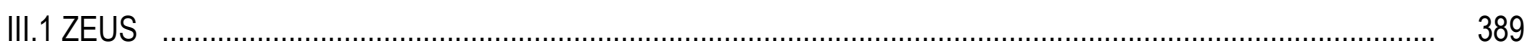

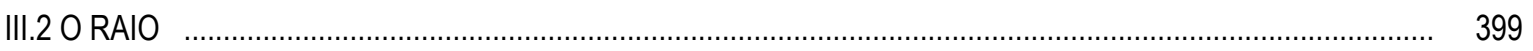

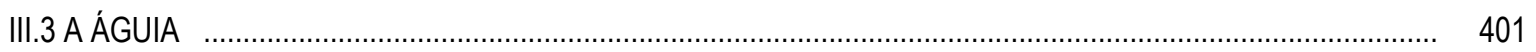

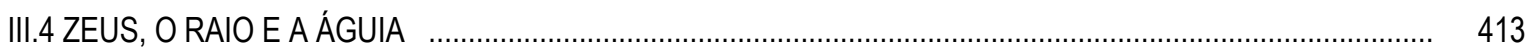

CAPÍTULO IV - ANÁLISE REGIONAL INTERPRETATIVA DAS IMAGENS MONETÁRIAS DE ZEUS, ÁGUIAS E

RAIOS

I. TENDÊNCIAS REGIONAIS NA REPRESENTAÇÃO DE ZEUS, ÁGUIAS E RAIOS EM MOEDAS GREGAS EM ÉPOCA ARCAICA E CLÁSSICA

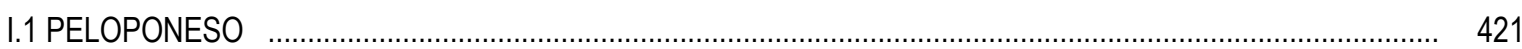

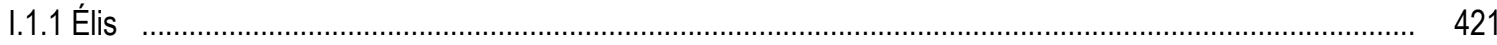

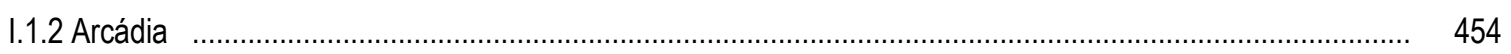

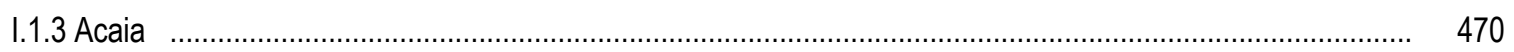

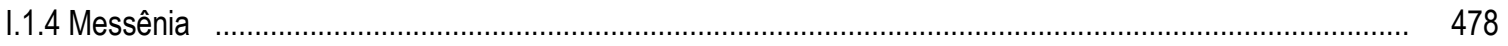

I.1.5 Considerações gerais sobre as imagens monetárias de Zeus e de seus atributos no Peloponeso .............. 484

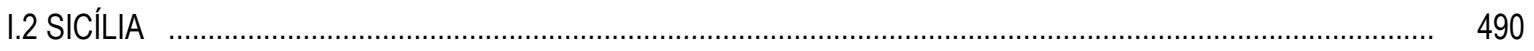

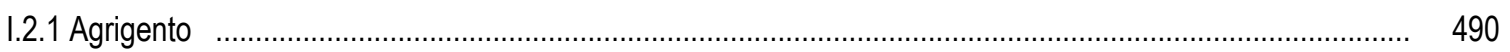

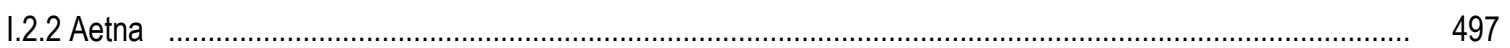

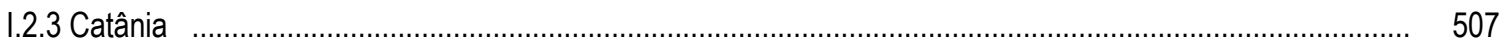

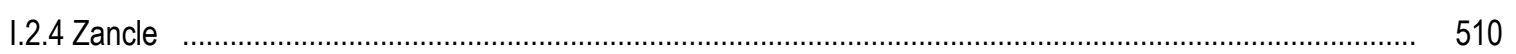

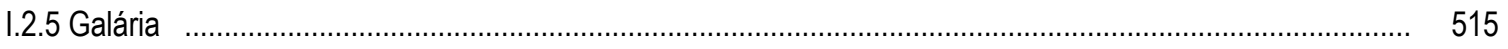

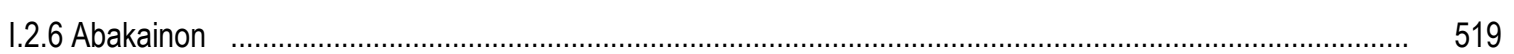

I.2.7 Motya, Eryx, Hipana, Nakona, Agyrion .................................................................................. 523

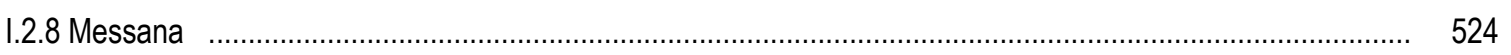

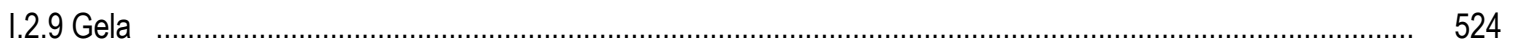

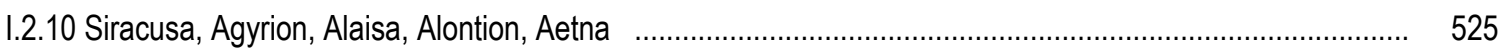

I.2.11 Considerações gerais sobre as imagens monetárias de Zeus e de seus atributos na Sicília ..................... 531

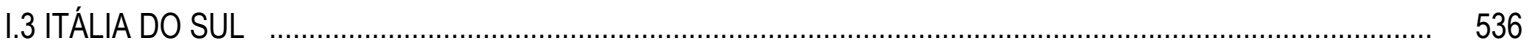

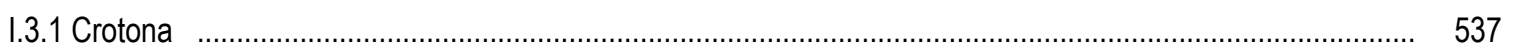

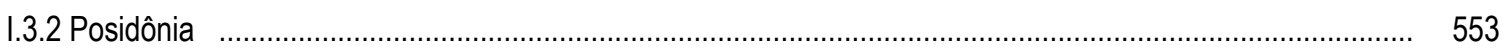

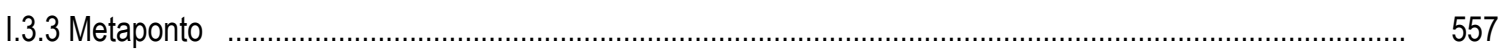

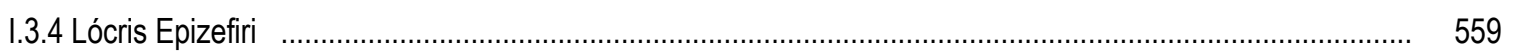

I.3.5 Considerações gerais sobre as imagens monetárias de Zeus e de seus atributos na Itália do Sul .............. 561

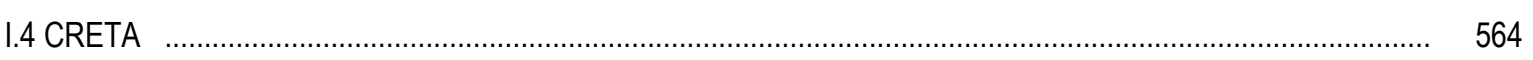

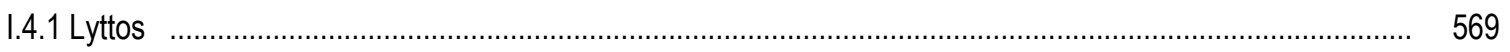

1.4.2 Considerações gerais sobre as imagens monetárias de Zeus e de seus atributos em Creta ...................... 572 
II. CONSIDERAÇÕES FINAIS: CORRELAÇÕES DO CONTEXTO DE USO E DO SIGNIFICADO SIMBÓLICO DAS IMAGENS MONETÁRIAS DE ZEUS, ÁGUIAS E RAIOS ENTRE PELOPONESO, SICÍLIA, ITÁLIA DO SUL E

CRETA

II.1 AFIRMAÇÃO DE SOBERANIA E DE IDENTIDADE DAS COMUNIDADES POLITICAS

CONCLUSÃO - A APROPRIAÇÃO E CONSOLIDAÇÃO DO CULTO DE ZEUS PELA CIDADE GREGA EM ÉPOCA ARCAICA E CLÁSSICA

I. O CULTO DE ZEUS NO DESENVOLVIMENTO DA CIDADE GREGA: POLÍTICA E IDENTIDADE 587

II. CENTROS REGIONAIS DE INOVAÇÃO DO CULTO DE ZEUS 587

ANEXO I - CATÁLOGO - SANTUÁRIOS DE ZEUS 596

ANEXO II - CATÁLOGO - IMAGENS MONETÁRIAS DE ZEUS, ÁGUIAS E RAIOS 599

REFERÊNCIAS BIBLIOGRÁFICAS 599 601 


\section{INTRODUÇÃO}

omente muito recentemente os estudiosos, sobre o culto e a religião grega, se dedicaram a investigar os vários papéis de Zeus no funcionamento da cidade grega. Nesse tema, alguns autores se debruçaram sobre aspectos pontuais do culto de Zeus, ou seja, sobre a esfera de atuação de determinado culto, tal como fizeram S. G. Cole no artigo Civic Cult and Civic Identity (1995), um dos dois únicos artigos publicados pelo CPC (Copenhagen Polis Centre) que de alguma forma aborda o culto de Zeus Polieus, e K. Raaflaub em Zeus Eleutherios, Dionysos the Liberator, and the Athenian Tyrannicides - Anachronistic Uses of Fifth-Century Political Concepts (2000). Estudos a respeito do papel político de Zeus na cidade, e não relacionados a Zeus Polieus, têm sido uma tendência nos últimos anos. Além de K. Raaflaub, M. Valdés-Guía em Hectémoros, Campesinos y Culto a Zeus en Atenas Arcaica (2003-2005) examina, entre outras coisas, a relação do culto de Zeus no Himeto com o campesinato de Atenas no século VII a.C., e C. E. Greco, em Agora e Zeus Agoraios (2006), examina as evidências arqueológicas disponíveis sobre Zeus Agoraios em época arcaica e o desenvolvimento da ágora como espaço político nesse período, concluindo o papel da divindade nas transformações das póleis oligárquicas. Antonetti em Riflessioni su Zeus Agoraios a Selinunte (2009) proporciona uma análise sobre a função da divindade no âmbito da isonomia que protegia a pólis do perigo da tirania e da stasis. Dentre todas essas contribuições, ressalta-se a de B. Linke, Zeus als Gott der Ordnung (2006), que procura explicar as razões pelas quais Zeus, o mais poderoso dos deuses, não desempenhou 0 papel de divindade principal da cidade. Destacamos também, nessa perspectiva da função política de Zeus, a nossa dissertação de mestrado Olímpia e os Olimpiéia: a origem e difusão do culto de Zeus Olímpio na Grécia

dos séculos VI e V a.C. (2011) que objetivou compreender o processo pelo qual o culto de Zeus Olímpio, a partir do santuário interestadual pan-helênico de Olímpia, no Peloponeso, se difundiu ao redor do mundo grego e se instalou nas póleis nos séculos VI-V a.C.

Estudos que abordassem toda a gama de evidências arqueológicas e textuais na busca da compreensão do culto de Zeus, na longa duração, surgiram na primeira década do ano 2000 em ambiente acadêmico alemão. Trata-se de estudos que se ocuparam da análise não apenas de templos e santuários de póleis específicas, mas das variedades e padrões do culto do deus no mundo grego. Nessa perspectiva, M. Vonderstein em Der Zeuskult bei den Westgriechen (2006) recolhe e discute, de forma inédita, toda a sorte de evidências arqueológicas sobre a divindade na Sicília e na Magna Grécia. E N. Kreutz em Zeus und die griechischen Poleis: topographische und religionsgeschichtliche Untersuchungen von archaischer bis in hellenistische Zeit (2007) oferece, pela primeira vez, uma contribuição geral sobre os santuários de Zeus nas póleis gregas, com ênfase na descrição sistemática dos edifícios de culto nas áreas sagradas, proporcionando conclusões sobre a relação do culto de Zeus com a cidade grega desde a época arcaica até a helenística. 
No campo da numismática, o uso da iconografia de Zeus e de seus dois atributos, a águia e o raio, em moedas gregas até hoje não havia sido estudado sistematicamente em relação à cidade grega. Nessa área, Zeus foi estudado prevalentemente no campo da arte strictu sensu, portanto, na análise comparativa de suas representações em moedas em relação às esculturas mais famosas da divindade que se conservaram ou não da antiguidade. Dentre esses estudos, destacam-se o de L. Lacroix em Les Reproductions de Statues sur les Monnaies Grecques (1949), que analisa as representações de estátuas de culto arcaicas e clássicas de Zeus em moedas gregas, de S. Garrafo, o qual elaborou uma pesquisa sobre as séries monetárias de Zeus Eleuthérios em Siracusa em Zeus Eleutherios-Zeus Olimpio, Note di Numismatica Siracusana (1979), e de G. Manganaro, Ancora sui Culti della Sicilia Greca: Zeus Soter e il Fiume Sichas (2003), no qual examina um tipo monetário de Zeus Sóter de Galária em associação a outros suportes imagéticos. Apesar do estudo de Garrafo tratar da representação de Zeus Eleutherios e em certo momento associá-lo às moedas de Élis-Olímpia, o único estudo exclusivamente dedicado à imagética de Zeus em moedas gregas foi realizado por nós e intitula-se As Moedas de Olímpia e a consolidação da imagética de Zeus na Grécia Clássica (2008). Somente muito recentemente, também, os aspectos simbólicos das imagens de Zeus e de seus atributos passaram a ser alvo de investigações no campo numismático, por influência da abordagem metodológica da Escola de Messina. Destacam-se, nesse âmbito, os artigos de B. Carroccio, I bronzi Zeus Hellanios/Aquila e l'organizzazione dell'attività monetaria siracusana tra officine parallele e concentrazioni cronologiche (2005), Tra iconografia e storia: aquile epirote o aquile tolemaiche nelle monetazioni magnogreche? (2007) e Come Zeus: aquila, fulmine e cornucopia segni dei poteri nelle monete ellenistiche (2007). M. Caccamo Caltabiano também ofereceu contribuições acerca do significado simbólico da imagem de Zeus em moedas ao tratar dos tipos monetários de Aetna em seu artigo Why is there the head of a Silenus on the Aitna tetradrachm? (2009).

Assim como um estudo completo sobre as representações monetárias de Zeus, águias e raios no mundo grego em relação à cidade já era há tempos necessária, uma investigação sobre o desenvolvimento do culto de Zeus na pólis grega, que colocasse imagens monetárias e santuários em associação, estava ainda por se fazer. Nessa perspectiva, essa tese de doutorado objetiva oferecer uma contribuição original sobre 0 desenvolvimento do culto de Zeus na pólis grega, em época arcaica e clássica, com base na associação entre evidências numismáticas e dos santuários relativos a Zeus. A correlação do histórico do uso das imagens monetárias de Zeus e de seus atributos pelas cidades gregas com aquele dos santuários da divindade, nesses dois períodos, amplia nossa compreensão a respeito dos períodos de mudança do culto do deus, de apropriação e consolidação de sua função na pólis, não perceptíveis apenas da documentação dos santuários. Trata-se de uma abordagem factível, pois esta considera moedas e santuários como produções formais da pólis. Partimos do princípio que toda essa documentação provém de um único contexto histórico: santuários e moedas são produções formais da pólis e mesmo tendo públicos e razões diferentes, se articulam a um mesmo contexto histórico, obedecendo, assim, a tradições culturais únicas, a contextos de produção únicos (Andrén, 1998: 153 e ss.). Não se trata, portanto, de usar a documentação numismática como evidência complementar 
àquela dos santuários, na busca de corroborar o culto de divindades em determinada localidade, conforme alguns estudiosos têm feito até muito recentemente.

Nossa intenção, é avaliar e concluir em que medida Zeus pode ser de fato considerado uma divindade urbana ou da cidade em detrimento do que até hoje postula a bibliografia a respeito do assunto. Há uma tendência geral entre os especialistas em considerar Zeus um deus dos santuários inter-regionais, conforme indica sua proeminência como divindade principal em Olímpia, Neméia e Dodona (De Polignac, 1995: 25, Kreutz, 2007: 265 e 268; Larson, 2007: 15; Morgan, 1994: 26-28; Zolotnikova, 2011: 239). O deus não esteve entre as divindades relacionadas à formação da pólis grega, como ocorreu no caso de Apolo, Atena e Ártemis, por exemplo, tal como demonstrou F. De Polignac em seu estudo de 1995 (Laky, 2013: 321). Em sua tese sobre os santuários de Zeus na pólis, N. Kreutz chega a concluir que Zeus não foi uma divindade tipicamente urbana, pois este nunca ocupou uma posição proeminente como divindade principal de uma cidade, não possuiu santuários, enquanto tal, nas acrópoles, consideradas por essa autora como o espaço que qualifica a atuação da divindade mais importante de uma comunidade. Já B. Linke oferece uma perspectiva totalmente diferente com relação a essa ausência de Zeus como divindade patrona da pólis. Baseando-se na interação entre crença e ordem social, os gregos reconheceram Zeus como o principal guardião da lei divina e da ordem, embora seu culto tenha sido de importância relativamente marginal às póleis. Segundo esse estudioso, a onipotência de Zeus o impediu de se tornar a principal divindade da cidade devido à sua inquestionável autoridade, em relação às demais divindades do panteão - o poder, a vitória e a ordem de Zeus teriam sido, ao mesmo tempo, base e ameaça para a ação dos outros deuses no panteão, a razão, portanto, de sua dita ausência como divindade patrona ou da pouca incidência de seus santuários nas cidades em relação à outras divindades (Linke, 2006: 103-104).

Isto posto, estas interpretações mereciam um estudo que analisasse as várias expressões do culto de Zeus tanto em esfera regional e cívica a partir da documentação numismática e dos santuários de modo a revelar as várias atuações de Zeus não somente dentro do funcionamento das cidades, mas seu papel em articular identidades em vários níveis, inclusive as regionais. Nossa intenção última, nessa tese, é compreender o papel desempenhado pelo culto de Zeus na legitimação de determinados grupos no poder e regimes políticos nas póleis gregas e na formação e articulação de redes de identidade grega (em seus vários níveis) em contexto cívico ou políade.

Para tal propósito, realizamos dois levantamentos sistemáticos, um acerca da documentação dos santuários e o outro sobre a documentação disponível sobre tipos monetários de Zeus e de seus atributos. No levantamento sobre os santuários de Zeus, consideramos todas as áreas sagradas datadas entre a Idade do Bronze e o final da época clássica (345/44 a.C.), conhecidas arqueologicamente. Trata-se dos santuários da divindade que apresentam algum tipo de evidência material (remanescentes arquitetônicos da área sagrada, objetos votivos, inscrições epigráficas) e que possuem ou não informações literárias. A existência de evidências materiais, portanto, foi o principal critério para a seleção das áreas sagradas de Zeus para esta pesquisa. Esse 
levantamento, que encontrou 60 santuários da divindade datados nos períodos referidos, levou a criação de um catálogo, anexo à tese em formato multimídia, organizado a partir da cronologia, pois buscamos compreender as mudanças do culto de Zeus, ou seja, como o culto se organizou e foi se caracterizando ao longo do período estudado. Foram considerados os detalhes da localização, do tipo de santuário (de pico, colinar ou de planície/vale, extra-urbano, suburbano e urbano) junto às suas respectivas funções específicas (inter-regional, sub-regional, oracular, agonístico, cívico), referências textuais, inscrições, histórico dos achados (breve relato da descoberta dos principais remanescentes), documentação arqueológica (partes arquitetônicas, objetos votivos, suportes de inscrições epigráficas), tipo de culto (comentário da bibliografia sobre a característica do culto praticado no santuário).

Com relação ao levantamento numismático, também anexo à tese em formato multimídia, foram reunidos todos os tipos monetários, disponíveis, de Zeus, águias e raios cunhados entre a época arcaica e clássica. 0 primeiro critério adotado para a organização da documentação monetária foi o cronológico, pois buscamos compreender as razões político-sociais que motivaram a adoção das imagens de Zeus e de seus atributos, o raio e a águia, pela cidade grega desde o início de seu uso como representação em moedas gregas no período arcaico (no século VII a.C.) até o final da época clássica propriamente entendida (345/44 a.C.). A tipologia das imagens foi o segundo critério adotado na estruturação do catálogo: (1) imagens de Zeus (no anverso ou reverso representadas com outras imagens não relacionadas ao culto do deus); (2) do raio (no anverso ou reverso associadas a imagens não relacionadas ao deus); (3) de águias (no anverso ou reverso representadas com outras imagens não relacionadas ao culto do deus); (4) de águias e raios (os dois tipos representados no anverso ou reverso de uma mesma moeda); (5) de Zeus e raios (o deus representado no anverso ou reverso acompanhado pelo raio no anverso ou reverso); (6) de Zeus e águias (o deus representado no anverso ou reverso acompanhado pela águia no anverso ou reverso); e (7) de Zeus, raios e águias (representados conjuntamente no anverso ou no reverso de uma mesma moeda). Escolhemos organizar os tipos monetários desse modo em primeiro lugar por uma razão prática: a documentação revelou haver exemplares de tipos de Zeus, de raios e águias representados apenas em um dos lados do documento monetário, associados às imagens alheias ao seu culto. E em outros em que Zeus e seus atributos figuram juntos nas moedas (no anverso e/ou reverso). Separá-los dessa maneira nos permite visualizar as cidades/regiões que escolheram assim representá-los.

A reunião da documentação numismática e dos santuários, sistematizada a partir de uma ordenação cronológica, possibilitou o conhecimento do culto de Zeus, em primeiro lugar, na longa duração e, em segundo lugar, a partir de uma perspectiva regional. Dentro da variabilidade do mundo grego em regiões, sub-regiões e cidades, expressa no uso das imagens monetárias e da fundação das áreas sagradas, foi possível estabelecer tendências do culto de Zeus em relação aos seus santuários em cidades e regiões do mundo grego, em determinados períodos, assim como também da utilização da representação de sua imagem e de seus atributos ao longo do tempo por autoridades emissoras e sua dispersão em determinadas regiões. Nessa pesquisa, 
então, além de realizarmos uma análise minuciosa do desenvolvimento do culto de Zeus na longa duração, optamos por um enfoque regional, portanto uma análise interpretativa do desenvolvimento do culto do deus, em ambas as documentações, em quatro regiões do mundo grego - o Peloponeso, Creta, Sicília e Itália do Sul. O enfoque regional revela a característica que o culto assumiu dentro de regiões e como algumas delas se relacionaram difundindo idéias, traços do culto, etc., e ainda como este se expressou regionalmente em uma perspectiva diacrônica. Nessa perspectiva, o Peloponeso e Creta foram selecionadas porque foram áreas do mundo grego onde o culto de Zeus ganhou primeiro expressão, principalmente, em santuários inter-regionais, ao passo que a Sicília e a Itália do Sul se caracterizam como áreas onde o culto do deus ganhou expressão diretamente no contexto da pólis grega. As quatro áreas também oferecem exemplos de como traços do culto, se no contexto dos santuários ou das imagens monetárias, circularam entre essas áreas através de uma rede específica, proporcionada, entre outros fatores, no contexto da mobilidade no Mediterrâneo antigo entre a época arcaica e clássica.

Nessa pesquisa consideramos redes como "processos que conectam povos e lugares com o fim de transportar mercadorias, pessoas, idéias / tecnologias, podendo ser discutidos simplesmente como conexões entre nós, ou como a união de pontos em um mapa" (Malkin; Constantakopoulou; Panagopoulou, 2009: 2; Vlassopoulos, 2009: 13). A teoria de redes se baseia "na existência de relações, ou seja, no estabelecimento de links entre unidades que interagem, em outras palavras, a interação social em menor escala é vista como a chave para a criação e desenvolvimento de networks, o padrão de duração das relações entre atores sociais, indivíduos e estruturas de formas" (Malkin; Constantakopoulou; Panagopoulou, 2009: 4). É, portanto, dentro desse "ambiente estrutural, através dos caminhos criados pelos membros de grupos, que informação e ideias, recursos e serviços podem ser transmitidos" (Malkin; Constantakopoulou; Panagopoulou, 2009: 4). Uma vez que "algumas dessas estruturas são formadas por tipos de instituições políticas, obrigações de parentesco, amizade e relações de trabalho sobre as quais temos alguma evidência, permite-se aos historiadores investigar como relações sociais interligaram-se na antiguidade, de que maneira interações latentes em uma relação afetaram aquelas que ocorriam em outras" (Malkin; Constantakopoulou; Panagopoulou, 2009: 5). Sobre a definição de mobilidade (migrações, encontros coloniais, comércio/troca), nessa investigação, consideramos a perspectiva de P. Van Dommelen e A.B. Knapp. Por mobilidade estes autores "consideram a conectividade, insularidade, viagens e transportes como mecanismos que serviram para estabelecer, motivar e modificar identidades "diaspóricas", trans-regionais e locais" (Van Dommelen; Knapp, 2010: 8). Também consideramos, em nossa análise e interpretação de santuários e imagens monetárias, a definição de materialidade desses dois estudiosos - "as dimensões materiais de encontros culturais e contextos sociais com o foco na função da cultura material na formação de identidades e na transmissão cultural na longa duração" (Van Dommelen; Knapp, 2010: 8).

Nesse enfoque regional, portanto, consideraremos as dinâmicas internas, próprias de cada região, e a interação entre elas - a "variabilidade religiosa entre cada uma das regiões", ou seja, "as dinâmicas internas 
que lhes eram próprias", e a premissa de que "regiões não foram entidades fechadas em si mesmas - as várias comunidades, medianas ou pequenas ou ainda poderes hegemônicos, mantiveram interesses e envolvimento em áreas e atividades fora de sua região política, cultural e econômica" (Mili, 2015: 3; Vlassopoulos, 2011: 14 e 24). Como bem colocou K. Vlassopoulos, em seu estudo sobre perspectivas regionais no estudo da história grega, "a formação de regiões políticas, culturais e econômicas nunca foi um processo estritamente interno: envolveu frequentemente comunidades externas à região, a formação de redes para além de uma região em particular" (Vlassopoulos, 2011: 27). A análise interpretativa das quatro regiões escolhidas oferecerá parâmetros de estudo para as demais regiões do mundo grego onde o culto de Zeus ganhou expressão em santuários e imagens monetárias em época arcaica e clássica.

Com relação ao recorte e critério cronológico dessa tese, entre a época arcaica e clássica, é importante lembrar que a nossa análise da documentação considerará as transformações ocorridas no mundo grego durante o período do recorte temporal escolhido (VII a.C. - 345/44 a.C.) as quais tiveram implicações no universo da pólis. O século VI a.C., por exemplo, foi a época de processos importantes para configuração da cidade grega clássica. Foi nesta época que os gregos se tornaram os primeiros a adotar a moeda (invenção dos lídios no século VII a.C.) e a utilizá-la em larga escala, quando do Oriente ao Ocidente grego a cunhagem havia se tornado uma instituição da pólis. Nesta época também, a pólis grega monumentalizou-se com a construção de edifícios públicos e principalmente dos primeiros templos perípteros em pedra os quais atingiram 0 ideal de monumentalidade e proporção, tornando-se emblemas de prestígio e poder das póleis (Laky, 2004: 37; Osborne, 1996: 262). Na transição do século VI a.C. para o século V a.C. recordar-se-á a reordenação política, militar e cultural das póleis gregas promovidas pelo efeito das guerras contra os persas na Grécia Balcânica e contra os cartagineses no Ocidente grego (Osborne, 1996: 292 e 325). Na transição do século V para o século IV a.C. consideraremos a configuração do mundo grego após a Guerra do Peloponeso a qual acarretou mudanças nas instâncias políticas da pólis grega e nos critérios de identidade grega. No século IV a.C. a nossa data limite será aproximadamente 345/44 a.C., porque após esse ano o mundo grego e as cidades gregas já sofriam as conseqüências do domínio macedônio: trata-se, portanto, do momento em que o espaço físico e as instituições da pólis assumiam os contornos da época helenística (Amouretti; Ruzé, 1990: 287).

É preciso destacar que para a época arcaica consideramos a definição de J. Bintliff, que abarca os séculos VII-VI a.C. (Bintliff, 2012: 234-235). Para a época clássica (V-IV a.C.), consideramos o início do período que também segue esse autor (c.500 a.C.) (Bintliff, 2012: 265). Apesar dos períodos arcaico e clássico serem o recorte cronológico principal dessa investigação, a Idade do Bronze e a Idade do Ferro são períodos que também foram considerados na análise dos santuários de Zeus e do desenvolvimento de seu culto para a compreensão de seus períodos mais antigos, bem como da continuidade cultual dessas áreas em época arcaica e clássica. Assim, no levantamento das áreas sagradas, e de sua respectiva análise, foi seguida a definição da Idade do Bronze, na Grécia Balcânica e em Creta, e de suas várias fases, do manual de M. Bettalli, A.L. D’Agata e A. Magnetto, e da Idade do Ferro, a cronologia de J. Bintliff (Bettalli et alii, 2013: 35; Bintliff, 2012 : 
209). Abaixo, seguem no quadro as várias fases de cada período seguidas na organização e discussão da documentação dos santuários:

Tabela 1- Cronologia da Idade do Bronze e da Idade do Ferro na Grécia Balcânica e em Creta

\begin{tabular}{|c|c|c|c|c|}
\hline Heládico antigo I & 3100-2650 a.C. & Minoico antigo I & 3100-2700 a.C. & Fase pré-palacial \\
\hline Heládico antigo II & 2650-2150 a.C. & Minoico antigo II & 2700-2200 a.C. & Fase pré-palacial \\
\hline Heládico antigo III & 2150-2000 a.C. & Minóico antigo III & 2200-2000 a.C. & Fase pré-palacial \\
\hline- & - & Minóico médio IA & 2000-1900 a.C. & Fase pré-palacial \\
\hline Heládico médio I & 2000-1900 a.C. & - & - & - \\
\hline Heládico médio II & 1900-1720 a.C. & Minoico médio IB & 1900-1800 a.C. & Fase proto-palacial \\
\hline Heládico médio III & 1720-1680 a.C. & Minóico médio II & 1800-1700 A.C. & Fase proto-palacial \\
\hline Heládico tardio I & 1600-1510 a.C. & - & - & - \\
\hline Heládico tardio II & 1510-1390 a.C. & Minoico tardio IA-B & 1600-1425 a.C. & Fase neo-palacial \\
\hline Heládico tardio IIIA & 1390-1360 a.C. & - & - & - \\
\hline Heládico tardio IIIB & 1360-1200 a.C. & Minóico tardio II & 1425-1390 a.C. & - \\
\hline- & - & Minóico tardio IIIA1 & 1390-1360 a.C. & - \\
\hline- & - & Minoico tardio IIIA2 & 1360-1320 a.C. & - \\
\hline- & - & Minoico tardio IIIB & 1320-1200 a.C. & - \\
\hline Heládico tardio IIIC & 1200-1070 a.C. & - & - & - \\
\hline Sub-micênico & 1070-1000 a.C. & Sub-minoico & 1100-1000/975 a.C. & - \\
\hline Proto-geométrico & c. $1050-900$ a.C. & & & \\
\hline $\begin{array}{l}\text { Geométrico inicial - } \\
\text { médio }\end{array}$ & IX a.C. & & & \\
\hline Geométrico tardio & VIII a.C. & & & \\
\hline
\end{tabular}

Além do critério cronológico, é preciso dizer sobre outros critérios adotados na análise e interpretação da documentação numismática e dos santuários de Zeus, como as definições de pólis, de moeda e tipo monetário, de santuário e culto. Com relação à pólis grega, o culto de Zeus nas cidades foi contextualizado de acordo com o período do desenvolvimento da cidade em época arcaica e clássica. Nessa pesquisa definimos a pólis a partir de cada período de sua formação e urbanização. Assim, na Idade do Ferro, as evidências arqueológicas provenientes de vários assentamentos indicam que "somente no decorrer do século VIII a.C. a pólis emergiu a partir da organização de grupos populacionais em torno de objetivos comuns" (Florenzano, 2010: 41). Os sinais desse processo são indicados pelo "surgimento do templo, o aumento das oferendas votivas nesses templos e, em contrapartida a diminuição das oferendas em sepulturas, o posicionamento do 
templo em relação ao assentamento e a instalação dos herôa nesses assentamentos" são as principais evidências desse processo (Florenzano, 2010: 41). A formação da pólis foi um processo gradual e não homogêneo para todos os assentamentos/comunidades da Idade do Ferro. Na época arcaica, é consenso que o século VI a.C. representou o primeiro ápice de urbanização da pólis ou foi o momento quando "o modelo de cidade grega foi elaborado" (De Polignac, 2005: 46; Hansen, 2006: 99). A cidade grega adquiriu os formatos físicos e políticos que lhe caracterizaram em época clássica - um centro urbano e um território com autonomia política e governado por um sistema aristocrático formado por cidadãos organizados em tribos e pequenos grupos de parentesco (Murray, 2012: 1170). Embora tenha havido muitas variações no funcionamento das instâncias políticas entre as cidades gregas, foi entre os séculos VII-VI a.C. que se "estabeleceu um código de leis escrito, ou consuetudinário, o qual limitou os poderes arbitrários aristocráticos e regulou o conflito social (eunomia). E por fim, foi no final do século VI a.C. que "a evolução do conceito de cidadania levou ao estabelecimento da igualdade nos direitos políticos entre os membros desse grupo (isonomia)" (Murray, 2012: 1170). A pólis em época arcaica e clássica pode ser caracterizada, portanto, como "uma comunidade política (uma politike koinonia), o que chamamos de "governo" ou "Estado", às vezes identificado com seu território (consistindo em uma pólis com sua khóra), com sua população (especialmente seu corpo de politai), com suas instituições políticas (especialmente sua ekklesia), e às vezes concebida como um poder público abstrato acima de cidadãos e instituições políticas" (Hansen e Nielsen, 2004: 43). Além disso, "quando usada como um termo genérico denotando um número de comunidades políticas nomeadas, pólis compreendeu não apenas o sentido da palavra descrita acima (uma pólis com sua khóra organizada como uma koinonia politon politeias), mas todos os tipos de comunidade que em outros contextos foram geralmente classificadas como éthne" (Hansen e Nielsen, 2004: 43).

Nessa tese sobre a pólis também foi considerada a definição de éthnos, "um grupo étnico associado com e vivendo em uma região específica assim também denominada". Exceto as ilhas do mar Egeu, 0 continente grego era subdividido em regiões que eram etnicamente mais bem definidas, como a Beócia, a Arcádia, a Acaia, a Tessália e a Acarnânia, que, por exemplo, era um éthnos habitado pelos acarnânios (Hansen e Nielsen, 2004: 4). Mas, como a investigação do Copenhagen Polis Center (CPC) mostrou, "as póleis podiam existir dentro do território dos éthne e seus habitantes podiam ter, assim, uma afiliação mais ampla dentro de um éthnos" (Morgan, 2003: 8; Hall, 2007: 88-89). Uma nova abordagem que prefere ver os éthne como produtos da etnicidade, renovando, dessa maneira, o entendimento da natureza real dessas regiões frequentemente deixadas de lado por serem consideradas atrasadas (Morgan, 2003: 14-15). Longe de serem formas de Estado distintas e alternativas, "pólis e éthne foram níveis de identidade com os quais comunidades podiam se identificar conforme o momento" (Morgan, 2003: 1). Etnicidade, nesta perspectiva, é uma "questão de escolha contínua, manipulação ou politização que ressalta as características de acordo com sua importância ativa na estruturação e expressão de relações sociopolíticas entre a comunidade e na relação com os de fora" (Morgan, 2003: 15). É um processo de "escolha por meio do qual um nível de identidade é construído ou priorizado em 
função da vantagem oferecida para o grupo: os éthne são entidades enraizadas no tempo e no espaço, as consequências visíveis de tal processo" (Morgan, 2003: 16). Nesta perspectiva de etnicidade, "a influência dos éthne na construção de identidades regionais entre pólis explica-se bem pelos vários laços de identidade, os quais operaram dentro de áreas geográficas específicas, que adquiriram proeminência política em determinada época" (Morgan, 2003: 13). Esta chamada "politização de etnias regionais origina-se do fato de que os gregos antigos, principalmente em época arcaica, pensavam em termos de identidade étnica quando consideravam sua própria organização política" (Morgan, 2003: 14).

$\mathrm{Na}$ definição de culto consideramos aquela de C. Renfrew sendo este "um sistema de crenças que encontra expressão na ação - um sistema de ações padronizadas em resposta às crenças religiosas" (apud Christensen, 2009: 19). Também entendemos culto como "um complexo de atividades religiosas concentradas em uma ou mais divindades ou heróis, incluindo rezas, rituais, sacrifícios e dedicações" (Christensen, 2009: 21). Na definição de santuários, seguimos aquela de $C$. Williamson - como espaços organizados onde uma ou mais comunidades poderiam, simultaneamente, definir-se e celebrar a si mesma sob a sanção de uma divindade (Williamson, 2013: 1). Como espaços públicos, os santuários revelam a maneira com a qual a "pólis percebeu-se espacialmente e como os usou para expressar identidade" (Williamson, 2013: 2). No caso dos santuários cívicos de Zeus (nos casos que se aplicam, como ocorre principalmente na Sicília), seguiremos a perspectiva de De Polignac que considera o papel dos santuários na definição do próprio espaço da cidade e sua importância na estruturação religiosa e política do território (apud Thromas, 2009: 64). Situados em espaços intencionalmente escolhidos no espaço urbano (a ásty) ou no território da cidade (a khóra), os santuários gregos, por sua vez, também foram meios de expressão de poder e de identidade da pólis em sua paisagem (Laky, 2011: 390-399). Construídos, projetados e idealizados pela pólis, os templos no período arcaico e clássico eram em primeiro lugar emblemas da identidade políade, de riqueza, poder e superioridade das comunidades que os erigiam (Burkert, 1995: 205; Marconi, 2007: 30-31). E segundo os estudiosos, a interrelação entre a pólis e a construção de templos é muito mais antiga, remonta, pois, à evolução da própria pólis (Burkert, 1995: 207). A edificação e monumentalização desses edifícios no século VIII a.C., em época tão recuada, nos mostram que a religião e o culto estatal comum estiveram no centro da criação institucional da pólis grega (Florenzano, 2010: 43).

Com relação à parte numismática da pesquisa, a moeda grega representa 0 grau de organização e autonomia política da pólis. Foi um meio de afirmar sua existência e seu direito à soberania. Mas quais são os valores políticos da cunhagem de uma pólis grega? De acordo com T. R. Martin, "o significado político da cunhagem, para uma pólis que emitiu suas próprias moedas, começava com o simples fato de que a cunhagem é resultado de uma decisão feita pelo demos (ou por qualquer corpo chamado para tomar decisões em uma pólis em particular)" (Martin, 1995: 267). Nesse sentido, "as moedas eram produtos tangíveis de um acordo sobre 0 aspecto prático do nomos da pólis, assim como foram pesos e medidas também enredados no complexo de decisões e acordos que juntos formaram o corpus das leis definidoras e reguladoras da vida na 
pólis" (Martin, 1995: 267). Como produtos originários no nomos, "as moedas naturalmente carregam os sinais de sua origem. Seus tipos e legendas transmitem mensagens sobre a pólis na qual a decisão tinha sido tomada para emiti-las, se por referência às suas divindades ou cultos, ou por alguma narrativa de seu passado, ou ainda por emblemas ou por carimbos públicos da cidade" (Martin, 1995: 267). Ao retratar a imagem de um deus, as moedas expressavam, em certo sentido abstrato, um aspecto da identidade de uma pólis que não poderia existir separada da divindade com a qual estava intimamente ligada (Martin, 1995: 281). Este tipo de expressão de identidade era inevitável em qualquer situação que a levava a emitir moedas independentemente dos tipos escolhidos, pois as moedas da pólis eram resultado de uma decisão implementada no nomos (Martin, 1995: 281). As moedas diferiam de outras manifestações do nomos por serem tangíveis e carregarem legendas e tipos determinados pela cidade. Por essa razão, elas dificilmente poderiam escapar da necessidade de expressão da identidade da pólis (Martin, 1995: 281).

No trato os dois tipos de documentação, santuários e imagens monetárias relacionadas a uma divindade grega, consideramos mais adequada a abordagem de C. Sourvinou-Inwood acerca da religião da pólis, apesar de seu modelo ter sido criticado recentemente por alguns autores, por não dar conta de outros aspectos da religião grega que não perpassam a pólis (Eidinow, 2011; Kindt, 2009, 2012) C. Sourvinou-Inwood, a responsável por cunhar o termo, descreve 0 "caráter imbricado da religião grega na pólis como a unidade básica da vida política e social" (Sourvinou-Inwood, 2000: 22). Conforme a estudiosa, a pólis grega articulou a religião e ao mesmo tempo foi articulada por ela; a religião tornou-se a ideologia central da cidade, pois estruturou e deu sentido a todos os elementos que formavam a identidade da pólis, seu passado, sua paisagem física, a relação entre suas partes constituintes (Kindt, 2009: 9-10; Sourvinou-Inwood, 2000: 22). Nessa perspectiva, consideramos também a definição de agência na análise e interpretação de ambas as documentações. De acordo com Hodder, "os objetos têm agência não porque simbolizam simplesmente, mas porque incorporam uma força que trazem à mente associações significativas para a pessoa ou para o grupo afetado pelo objeto. Assim, nós damos poderes aos objetos de tal modo que eles podem agir em nós" (Hodder, 2003: 101-102).

Na abordagem metodológica da documentação dos santuários realizar-se-á uma descrição detalhada destes espaços sagrados associando-os a outros elementos da organização e do uso do espaço entre os gregos, portanto, o posicionamento desses espaços em relação ao assentamento (santuários na ásty ou na khóra), a associação às demais áreas sagradas da localidade e às áreas cívicas, que são de suma importância para a compreensão da instalação / recepção do culto de Zeus em uma cidade. A articulação do santuário com espaços especializados da cidade (ágora, acrópole, etc.) mostra a relação do culto de Zeus com as instâncias políticas e de identidade da pólis. Na interpretação das áreas sagradas nos apoiaremos, inicialmente, no diálogo estabelecido entre F. de Polignac (1994; 1995; 1999 e 2006), F. Veronese (2006) e I. Polinskaya (2006). Apesar de o estudo de De Polignac (1995) ter sido criticado, sobretudo, pela generalização dos papéis dos santuários de fronteiras e por ter desconsiderado o papel político diversificado dos santuários no contexto das 
comunidades políticas específicas, permanece, nos estudos sobre a temática, a premissa estabelecida por ele de que no mundo grego o santuário representa um símbolo de posse territorial e que sua distribuição no território havia sido reflexo de uma escolha política (de Polignac, 1995: 98; Veronese, 2006: 36-37). Essa dimensão política dos santuários gregos proposta por de Polignac foi recentemente seguida e readequada por Veronese em seu estudo sistemático sobre as áreas sagradas arcaicas da Sicília. Ao dar um grande passo adiante ao considerar a variabilidade dos santuários gregos e adotar os princípios metodológicos da arqueologia do espaço e da paisagem na sua interpretação, a arqueóloga italiana é influenciada pelo estudo de de Polignac ao aplicálo no seu conceito de concepção do sagrado, como vimos anteriormente (vide p.15) (Veronese, 2006: 34-35; 37). Já a contribuição de Polinskaya, por sua vez, está em questionar as idéias de urbano / não-urbano presentes na interpretação dos santuários gregos que vêm sendo permanentemente seguidas pelas pesquisas influenciadas por de Polignac. A autora defende que as distinções entre posições urbanas suburbanas e espaço rural têm de ser ajustadas, modificadas e verificadas, separadamente, para cada unidade sócio-territorial no mundo grego e, por isso, para ela é contra produtivo estabelecer ligações universais entre divindades particulares e conotações urbano-rurais (Polinskaya, 2006: 89). A contribuição de I. Polinskaya está em mostrar como essa distinção entre santuários urbanos e não-urbanos não é tão fixa como alguns estudos procuraram mostrar, visto que a definição de cidade e campo e de fronteiras e oposições entre estas categorias eram relativas e muitas vezes se apresentavam misturadas na documentação primária. Todas estas são posições que teremos que levar em conta ao lidar com o nosso documento.

No trato com a documentação numismática, consideraremos o caráter multifacetado da moeda grega, a sua especificidade. Considerar-se-á que a moeda foi concebida como uma instituição social oficial, emitida por um poder político. 0 peso, o metal, o formato, as denominações e a iconografia, possuem funções e significados próprios, os quais assumiram características distintas conforme o tempo (Florenzano, 1992: 15). No caso das moedas gregas se pode afirmar que os tipos gravados são emblemas cívicos, representam a comunidade na sua totalidade, sendo, então, importantes guardiões de intenções e significados. Apesar das abordagens variadas sobre as moedas, privilegiaremos a iconografia monetária e seguiremos a metodologia de análise multidisciplinar e interdisciplinar do Lexicon Iconographicum Numismaticae (LIN), um projeto nascido na Itália por iniciativa das cátedras de Numismática das Universidades de Messina, Bolonha, Gênova e Milão. De acordo com o LIN cada imagem monetária é dotada de um significado específico que torna possível a comunicação entre o emissor da moeda e o seu destinatário. Os significados dos tipos monetários devem ser pesquisados pelo estudioso como método análogo àquele que se aplica aos estudos das linguagens faladas. Deve-se, assim, reconstruir cada imagem monetária no espaço e no tempo (análise diacrônica e diatópica), onde se definem as origens, a evolução, a permanência, as mudanças e o enriquecimento de significado (Caccamo Caltabiano, 2005b: 535). Dentro dessa perspectiva de análise, para a nossa pesquisa, é interessante o conceito de sistema semântico hierarquizado, desenvolvido por M. Caccamo Caltabiano, em que através de imagens adotadas em todo sistema monetário, o emissor da moeda (a pólis se em período de governo tirânico, 
oligárquico, democrático ou monárquico) desenvolve um programa icônico internamente coerente em que procura representar a estrutura de seu poder político e a comunicar os pressupostos ideológicos sobre os quais se fundamenta (Caccamo Caltabiano, 2005b: 535). Na análise simbólica dos tipos monetários do deus e de seus atributos, consideramos a abordagem de J. Bayet sobre as energias divinas contidas nas representações de divindades em moedas gregas. Para a compreensão do contexto do uso dessas imagens em moedas, será necessário introduzir o estudo das imagens monetárias com um histórico da representação de Zeus e seus atributos na arte grega em associação àqueles de outros suportes imagéticos (cerâmica pintada, esculturas, relevos), que permite perceber em que medida as imagens que aparecem nas moedas foram criadas especificamente para elas ou não. Através dos tipos de narrativas nas fontes literárias, nas cerâmicas pintadas, e da proveniência dos achados, é possível estabelecer um contexto simbólico para os tipos de representações do deus e de seus atributos usados nas moedas gregas entre os séculos VII-IV/III a.C.

Isto posto, a tese divide-se em quatro capítulos, além da introdução, da conclusão e dos dois catálogos anexos que contém toda a documentação disponível acerca de santuários e tipos monetários de Zeus e águias no mundo grego.

No primeiro capítulo, intitulado Os santuários de Zeus no mundo grego da Idade do Bronze à época clássica: apresentação e discussão da documentação, a partir da sistematização dos dados de todas essas áreas sagradas selecionadas, realizamos uma análise geral do desenvolvimento dos santuários do deus, por período na longa duração e em várias regiões, para compreender as características principais e as diferentes fases do culto de Zeus, e sobretudo o momento quando foi apropriado e se consolidou na pólis grega.

No segundo capítulo, Análise regional interpretativa dos santuários de Zeus, analisamos os santuários do deus a partir de uma perspectiva regional. Nossa intenção é compreender em que medida, por meio de seus vários tipos de santuários, o culto de Zeus articulou identidades políticas e regionais no Peloponeso e Creta, na Sicília e na Itália do Sul, em quatro das dezesseis áreas do mundo grego onde foi estabelecido. Escolhemos essas quatro regiões, como unidades de análise, porque se trata daquelas onde 0 culto alcançou sua mais antiga e maior expressão (Peloponeso e Creta) e foi primeiro, em grande parte, apropriado pela pólis grega (Sicília e Itália do Sul). Nesse sentido, trataremos, em nossa análise e interpretação, do culto de Zeus em relação ao desenvolvimento da pólis e dos diferentes níveis de identidade nessas áreas (político, étnico e regional), portanto, as várias interações dessas comunidades políticas com os santuários da divindade.

No terceiro capítulo, As imagens de Zeus, águias e raios em moedas gregas do período arcaico ao clássico: apresentação e discussão da documentação, apresentamos a documentação integral sobre tipos monetários de Zeus e seus atributos. Como se verá, consideramos na descrição dos dados todas as imagens monetárias emitidas no período descrito. Esse capítulo foi dividido em três partes. Na primeira, apresentamos a quantificação dos tipos monetários por períodos, regiões e autoridades emissoras para visualizarmos quais dos três tipos monetários (Zeus, águias e raios) foram mais e menos recorrentes ao longo dos séculos VII-IV/III a.C. Também os momentos em que as imagens monetárias foram e deixaram de ser requisitadas, em quais 
áreas do mundo grego predominaram ou não e quais autoridades emissoras se destacaram na escolha dos tipos monetários. A segunda parte é dedicada ao estudo iconográfico de Zeus, águias e raios em moedas gregas. Se na primeira parte oferecemos a descrição dos dados gerais da documentação numismática, na segunda, apresentamos a descrição dos tipos monetários ordenados de acordo com uma classificação tipológica, reveladora de padrões de representação do deus e de seus atributos em moedas gregas. Essa ordenação também propicia um contexto histórico acerca da criação e do uso dos padrões de representação entre as autoridades emissoras e regiões. Para a compreensão do contexto do uso dessas imagens em moedas, introduzimos o estudo das imagens monetárias com um histórico da representação de Zeus e seus atributos na arte grega. A análise dos padrões de representação dos tipos monetários em associação àqueles de outros suportes imagéticos (cerâmica pintada, esculturas, relevos) permite perceber em que medida as imagens que aparecem nas moedas foram criadas especificamente para elas ou não. Na terceira parte, discutiremos os significados simbólicos por trás das imagens de Zeus, águias e raios, adquiridos ao longo do período estudado, por meio das descrições nas fontes literárias e das representações tal como aparecem na arte grega, principalmente em vasos. Através dos tipos de narrativas nas fontes literárias, nas cerâmicas pintadas, e da proveniência dos achados, é nossa intenção, estabelecer um contexto simbólico para os tipos de representações do deus e de seus atributos usados nas moedas gregas entre os séculos VII-IV/III a.C.

No quarto capítulo, Análise regional interpretativa das imagens monetárias de Zeus, águias e raios, realizaremos, nesse capítulo, uma análise interpretativa das imagens monetárias no contexto de emissão das autoridades emissoras a partir de uma perspectiva regional. Examinaremos cada situação histórica relacionada ao uso das representações de Zeus e de seus atributos em moedas gregas - as motivações político-sociais vigentes relacionadas à cada emissão em época arcaica e clássica - para compreender os significados simbólicos assumidos por essas imagens quando apropriadas pela cidade grega. Para tanto, partiremos dos significados simbólicos primários de cada representação, revelados na análise contextual das artes visuais e literária, para ver em que medida esses se somaram a novos significados que podem ter emergido por influência ou não, por exemplo, de uma história regional única em relação ao culto de Zeus. Em última análise, objetivamos compreender em que medida esses novos significados estiveram relacionados à política e à identidade da pólis. Nesse caso, analisaremos as emissões monetárias do Peloponeso, da Sicília, da Itália do Sul e de Creta - as regiões do mundo grego onde os tipos monetários do deus e de seus atributos mais se propagaram entre as autoridades emissoras (com exceção de Creta), que, por sua vez, foram responsáveis pela criação de certos padrões iconográficos e trocaram, entre elas, variedades de representações nas moedas.

A conclusão, intitulada A apropriação e consolidação do culto de Zeus pela cidade grega em época arcaica e clássica, foi dividida em duas partes dedicadas à associação da documentação numismática e dos santuários na perspectiva do contexto único. A primeira parte foi dedicada à análise e interpretação da documentação numismática e dos santuários de Zeus - foi possível identificar, entre os quatro séculos da época arcaica e clássica, momentos de transformação do culto do deus em relação à pólis grega, que correspondem 
às várias fases do desenvolvimento das cidades nesses dois períodos da história grega antiga. A segunda parte apresenta os resultados acerca da importância de certas regiões e santuários de Zeus no mundo grego que tiveram um papel importante na criação e difusão de traços do culto a outras áreas, sobretudo com relação à iconografia do culto, como foram Olímpia e o Mt.Lykaion e suas relações com Creta, a Sicília e Itália do Sul. 


\section{CAPÍTULO I - OS SANTUÁRIOS DE ZEUS NO MUNDO GREGO DA IDADE DO BRONZE À ÉPOCA CLÁSSICA: APRESENTAÇÃO E DISCUSSÃO DA DOCUMENTAÇÃO}

\section{INTRODUÇÃO}

Esta pesquisa de doutorado apresenta a documentação referente a 60 santuários dedicados a Zeus no mundo grego, entre a Idade do Bronze e o final da época clássica (345/44 a.C.), conhecidos arqueologicamente. Trata-se dos santuários da divindade que apresentam algum tipo de evidência material (remanescentes arquitetônicos da área sagrada, objetos votivos, inscrições epigráficas) e que possuem ou não informações literárias. A existência de evidências materiais, portanto, foi o principal critério para a seleção das áreas sagradas de Zeus para esta pesquisa. A partir da sistematização dos dados de todas essas áreas sagradas selecionadas, intencionamos, nesse capítulo, realizar uma análise geral do desenvolvimento dos santuários do deus, por período na longa duração e em várias regiões, para compreender as características principais e as diferentes fases do culto de Zeus, e sobretudo o momento quando foi apropriado e se consolidou na pólis grega. Abaixo, segue a lista das 60 localidades dos santuários de Zeus de acordo com a numeração do catálogo, que obedece uma ordem cronológica decrescente:

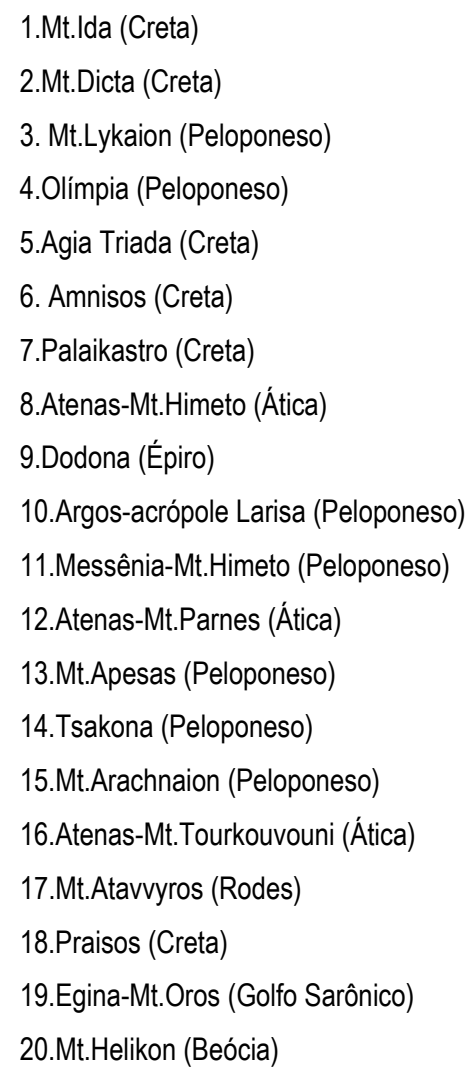

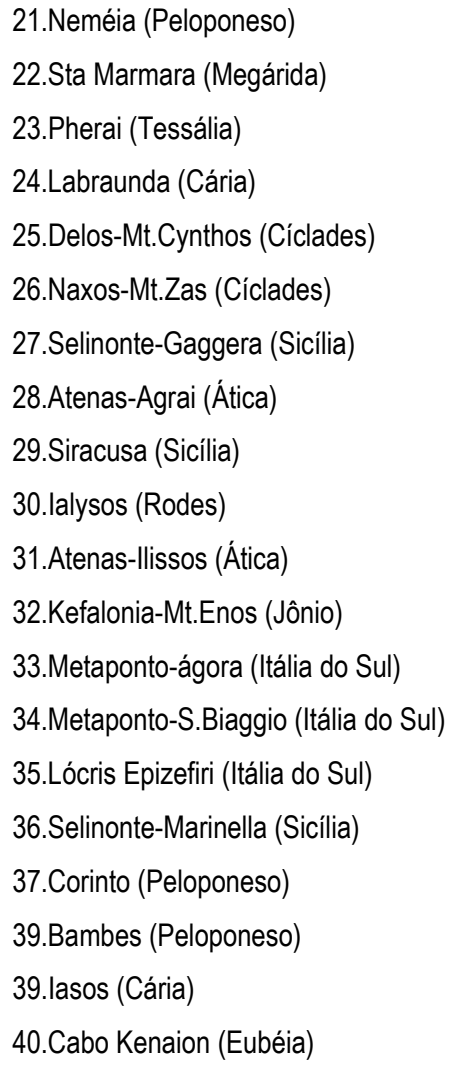

\author{
41.Figaléia (Peloponeso) \\ 42.Kamiros (Rodes) \\ 43.Mégara (Megárida) \\ 44.Atenas-colina das Ninfas (Ática) \\ 45.Cirene-setentrional-oriental (Líbia) \\ 46.Atenas-acrópole (Ática) \\ 47.Agrigento (Sicília) \\ 48.Cálcis (Eubéia) \\ 49.Cirene-Ain Hofra (Líbia) \\ 50.Paros-Mt.Kounados (Cíclades) \\ 51.Mylasa (Cária) \\ 52.Mantinéia (Peloponeso) \\ 53.Posidônia (Itália do Sul) \\ 54.Díon (Macedônia) \\ 55.Thasos (Trácia) \\ 56. Lindos (Rodes) \\ 57.Megalópolis (Peloponeso) \\ 58.Aphytis (Macedônia) \\ 59.Aegiae (Macedônia) \\ 60.Argos-ágora (Peloponeso)
}


Como se vê no catálogo dos santuários (anexo à tese), a documentação foi organizada a partir da cronologia, pois buscamos compreender as mudanças do culto de Zeus, ou seja, como o culto se organizou e foi se caracterizando ao longo do período estudado. Sobre a datação dos santuários é preciso dizer que, em alguns casos, a primeira data se refere ao início da atividade cultual constatada com base nas evidências de culto mais antigas (presença de objetos votivos na maior parte dos casos) e, em outros, ela se refere somente à data mais antiga do edifício de culto já que, muitas vezes, não dispomos dos achados de oferendas, mas apenas dos restos arquitetônicos. Neste último caso, assim, é preciso considerar que o santuário pode ser mais antigo que o próprio templo. Foram considerados os detalhes da localização, do tipo de santuário (de pico, colinar ou de planície/vale, extra-urbano, suburbano e urbano) junto às suas respectivas funções específicas (inter-regional, sub-regional, oracular, agonístico, cívico), referências textuais, inscrições, histórico dos achados (breve relato da descoberta dos principais remanescentes), documentação arqueológica (partes arquitetônicas, objetos votivos, suportes de inscrições epigráficas), tipo de culto (comentário da bibliografia sobre a característica do culto praticado no santuário). Além da datação que procura abarcar o início e o fim da atividade cultual no santuário, acrescentamos, na organização dos dados nesse capítulo, as datas do ápice e do declínio do santuário (muitas vezes diferentes daquelas do início e do término), pois indicam o período do auge e consolidação do culto uma em dada localidade.

Com relação à cronologia das áreas sagradas, é preciso dizer ainda que para ao menos 10 delas a bibliografia fornece alguma informação sobre a possibilidade de que o culto seja mais antigo do que a data proposta para o início da atividade cultual. Este é o caso dos santuários de Neméia, Sta Marmara, Delos, Atenas-llissos, Cabo Kenaion, Bambes, Atenas-acrópole, Agrigento, Dion e Megalópolis.

Dos 60 santuários de Zeus selecionados (todos com evidências materiais), a atribuição à divindade foi atestada com base epigráfica em 23 áreas sagradas (Agia Triada, Atenas-Himeto, Tsakona, Mt.Helikon, Pherai, Naxos, Selinonte-Gaggera, Metaponto-ágora, Metaponto-S. Biaggio, Lócris, Selinonte-Marinella, lasos, Figaléia, Kamiros, Atenas-Ninfas, Bambes, Cirene-Ain Hofra, Paros, Posidônia, Thasos, Lindos, Messênia e lalysos); com base textual e epigráfica em 22 delas (Mt.Ida, Mt.Lykaion, Olímpia, Dodona, Ithome, Egina, Neméia, Labraunda, Delos, Atenas-Agrai, Atenas-llissos, Cabo Kenaion, Mégara, Cirene-colina setentrionaloriental, Agrigento, Cálcis, Mylasa, Díon, Mantinéia, Megalópolis, Aphytis, Amnisos, Palaikastro); em 14 somente com base textual (Mt.Dicta, Atenas-Parnes, Mt.Apesas, Mt.Arachnaion, Atenas-Tourkouvouni, Mt.Attavyros, Praisos, Argos-Larissa, Argos-ágora, Sta Marmara, Siracusa, Kefalonia, Corinto, Atenasacrópole); e 1 com base iconográfica (Aegiae), neste caso, a atribuição do santuário a Zeus foi atestada a partir de um relevo encontrado na área sagrada. Além desses 60 santuários, não foram incluídos nessa pesquisa 11 áreas sagradas citadas pela bibliografia como pertencentes, provavelmente, ao deus em razão da ausência de evidências textuais, epigráficas e iconográficas associadas aos remanescentes arqueológicos (Halos, Tessália; Mt.Laphystion, Beócia; Mt.Gargaron, Trôade; Mt.Mesavouno, Thera; Mts.Pani, Merenda, Keratovouni, Profitis 
Elias, Aguiliki, todos na Ática; Tretos e Evangelistria, na região de Neméia). Trata-se de santuários com objetos votivos e localização que supostamente podem indicar uma relação com o culto de Zeus.

Dessa quantidade total de áreas sagradas de Zeus, incluídas na tese, é preciso destacar que em 15 delas é possível que o culto do deus tenha sido praticado, a partir de um período específico, ao lado de outras divindades, predominantemente femininas como Atena (em Argos-Larissa, Delos, lalysos, Figaléia, Kamiros, Atenas-acrópole e Lindos), Hera (Mt.Arachnaion e lasos), Ártemis (Pherai e Metaponto-S.Biaggio), Deméter (Selinonte-Gaggera), Eukleias (Aegiae); e algumas masculinas, com heróis não especificados (Atenas-colina das Ninfas e Cirene-Ain Hofra). No caso das divindades femininas, em geral, o culto de Zeus parece ter sido introduzido posteriormente nos santuários já a elas pertencentes, como é o caso, por exemplo, de lalysos, Kamiros, Lindos, Atenas-acrópole e Figaléia.

\section{QUANTIFICAÇÃO GERAL DOS SANTUÁRIOS DE ZEUS POR PERÍODO, REGIÃO, CATEGORIA E ESTRUTURA DE CULTO}

\section{I.1 POR PERÍODO}

Os 60 santuários de Zeus selecionados foram distribuídos em 5 períodos, a saber, a ldade do Bronze $\left(3^{\circ}\right.$ e $2^{\circ}$ milênios a.C.), a Idade do Ferro (XII-VIII a.C.), a época arcaica (VII-VI a.C.), entre a época arcaica e clássica (VI-V a.C.) e a época clássica (V-IV a.C. até 345/44 a.C.). Como se vê a partir do gráfico 1 , a ldade do Ferro e 0 arcaico são os períodos nos quais a maior parte dos santuários de Zeus

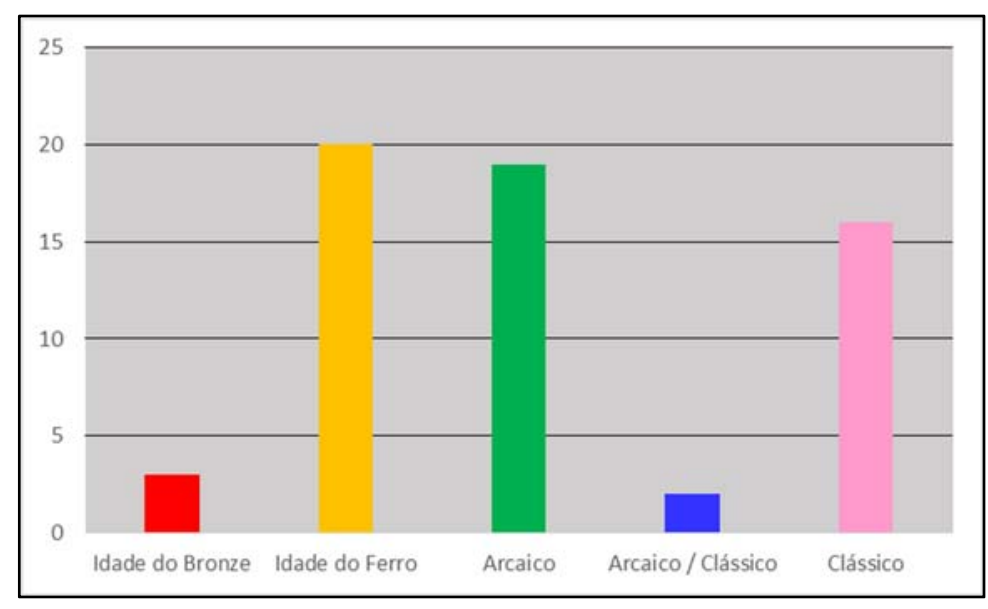

Gráfico 1- Quantidade total de santuários de Zeus por período (Idade do Bronze à época clássica (até 345/44 a.C.) iniciaram suas atividades cultuais (total de 20 e 19, respectivamente), seguidos pelos santuários que remontam ao período clássico (total de 16 áreas sagradas). Em relação a esses números, poucas áreas sagradas de Zeus iniciaram a atividade cultual na Idade do Bronze e no período entre o arcaico e o clássico (total de 3 e 2, respectivamente). Contudo, se somarmos a quantidade total de santuários que datam entre os períodos arcaico/clássico (VI-V a.C.) (2 áreas sagradas) ao número total daqueles do período arcaico (19) e do período clássico (16), o arcaico passa a ser a fase com maior concentração de áreas sagradas (21) e o período clássico quase se iguala à época arcaica (ambos com 18 no total).

Com relação ao ápice da atividade cultual, no gráfico 2 estão os dados dos santuários sobre os quais dispomos de tal informação. Acerca dos santuários que remontam à Idade do Bronze, o auge do culto na área 


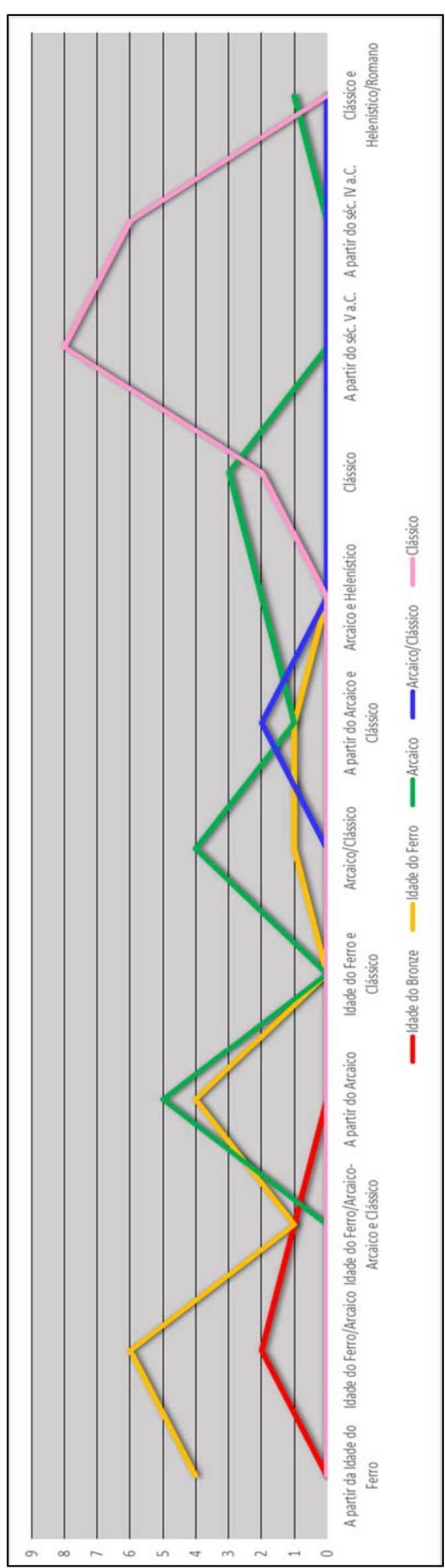

Gráfico 2-Quantidade de santuários por períodos de ápices da atividade cultual dos santuários de Zeus (Idade do Bronze à época clássica) sagrada ocorreu, posteriormente, ao início da atividade cultual, entre a Idade do Ferro e o período arcaico (2 santuários no total de 3 áreas sagradas). Apenas 1 santuário de Zeus, que remonta ao período teve duas fases de ápice cultual, ocorrido entre a ldade do Ferro e o período arcaico e entre 0 arcaico e o clássico. $\mathrm{Na}$ Idade do Ferro, o ápice cultual dos santuários de Zeus desse período ocorreu, na maior parte dos casos, a partir da própria Idade do Ferro e a partir da época arcaica (6 áreas sagradas, respectivamente) e, e em menor grau, entre o período arcaico/clássico (VI-V a.C.) (1 santuários no total) e a partir do arcaico e clássico (VI-IV a.C.) (1 santuário no total). Dentre aqueles santuários que remontam à época arcaica, o auge de uso da área sagrada parece ter ocorrido a partir da própria época arcaica, seguido pelo período durante 0 arcaico e clássico e a época clássica (total de 5, 4 e 3 santuários, respectivamente). Ainda com respeito aos santuários datados a partir da época arcaica, um menor número teve o ápice da atividade de culto entre o período arcaico e o helenístico (2 áreas sagradas no total). Já em época clássica, o auge de culto dos santuários parece ter ocorrido principalmente no século $V$ a.C. e em menor grau no século IV a.C. (8 e 6 áreas sagradas, respectivamente). No gráfico, "clássico" se refere àquelas áreas sagradas, cujos ápices situam-se em algum momento desse período, nos séculos V-IV a.C. ou em algum desses dois séculos. Assim, uma visão geral dos picos de ápice da atividade cultual, dos santuários de Zeus entre a Idade do Bronze e a época arcaica, mostra o século $V$ a.C. como o principal período de ápices cultuais, seguido pelo da ldade do Ferro / Arcaico e daquele a partir da época arcaica. Os períodos helenístico e romano são inexpressivos no gráfico, pois representam fases de declínio do culto. Tal análise será retomada mais adiante, na segunda parte do capítulo quando trataremos do desenvolvimento dos santuários de Zeus, em mais detalhe, durante os cinco períodos estudados. 
No que diz respeito ao declínio da atividade cultual das áreas sagradas, observa-se no gráfico 3 que para aquelas datadas a partir da Idade do Bronze as fases de declínio se concentram no período clássico e helenístico / romano, no helenístico, no período romano em geral (sem data específica) e no romano tardio. Dentre aqueles santuários que remontam à Idade do Ferro, houve duas fases principais para quando o culto cessou, a época arcaica e o período romano também em geral. Um pico de declínio também ocorreu, embora em menor grau, em período clássico e romano. Sobre os santuários iniciados em época arcaica, os dois picos de declínio ocorreram em época clássica e helenística e, em menor grau, em período romano. As áreas sagradas datadas entre os períodos arcaico/clássico (VI-V a.C.) tiveram seu declínio em época clássica. Sobre aqueles que remontam à época clássica, o pico de declínio das áreas sagradas ocorreu predominantemente no período romano e em bem menor grau na própria época clássica (na grande parte dos casos no século IV a.C.). De uma maneira geral, se vê no gráfico que o período clássico, helenístico e principalmente o romano como as fases principais de declínio dos santuários de Zeus datados desde à Idade do Ferro à época clássica.

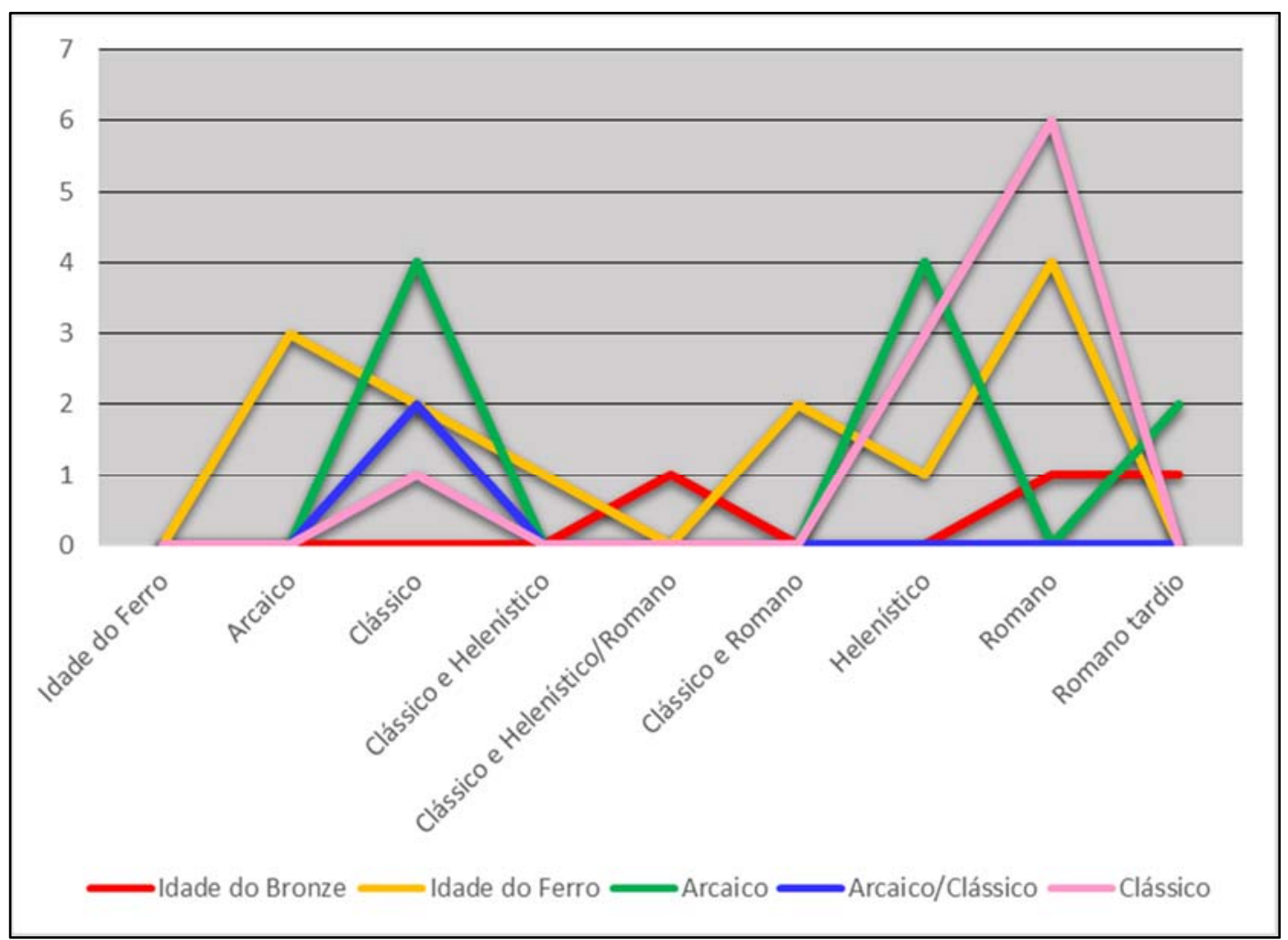

Gráfico 3 - Quantidade de santuários por períodos de declínio da atividade cultual dos santuários de Zeus (Idade do Bronze à época clássica) 


\section{I.2 POR PERÍODOS/REGIÕES}

Os 60 santuários de Zeus, atestados arqueologicamente, encontram-se distribuídos em 16 grandes regiões do mundo grego, a saber: Creta, Peloponeso, Épiro, Ática, Egeu, Beócia, Megárida, Tessália, Cária, Sicília, Itália do Sul, Jônio, Eubéia, Líbia, Macedônia e Trácia (Figs.1, 2, 3 e 4). Esse número de regiões é bem maior, se considerarmos as sub-regiões do Peloponeso (Élis, Arcádia, Messênia, Lacônia, Coríntia e Argólida) e do mar Egeu (Cíclades, Rodes e Golfo Sarônico, sem falar de Creta considerada aqui como uma grande região). Portanto, se trata de áreas sagradas localizadas desde à Ocidente à Oriente e de norte a sul do mundo grego.

Conforme se vê no gráfico 4,0 Peloponeso é a região do mundo grego com a maior concentração de santuários de Zeus (14 no total), seguido pela área do mar Egeu ${ }^{1}$ (8 áreas sagradas no total), a Ática (com 7 no total) e a ilha de Creta (com 6 no total). A Sicília e a Itália do Sul são as quintas regiões com a maior quantidade de santuários (cada qual 4 áreas sagradas), seguidas pela Cária e a

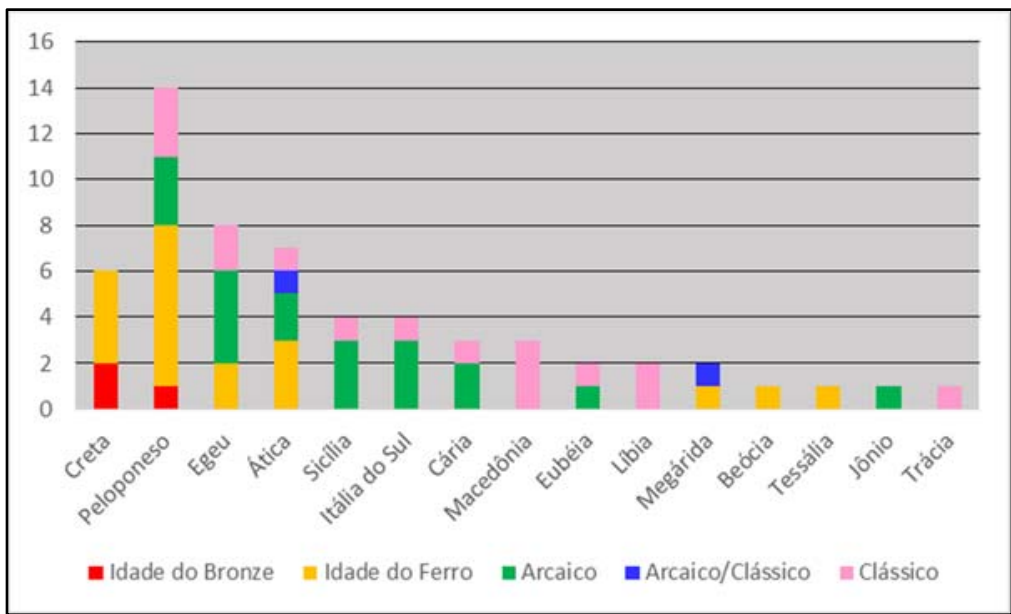

Gráfico 4- Quantidade total de santuários de Zeus por regiões e períodos (Idade do Bronze à época clássica) Macedônia (cada qual 3 no total). A Eubéia, a Líbia e a Megárida (cada qual 2 no total), e a Beócia, Tessália, Jônio e a Trácia (cada qual 1 santuário) são aquelas com menor concentração de santuários da divindade. É preciso lembrar que esses números se referem aos santuários sobre os quais dispomos de evidências materiais - se considerássemos aqueles dos quais apenas dispomos de evidências textuais, esse número poderia mudar, como é o caso da Beócia para a qual existe informação literária a respeito de outros santuários de Zeus na região.

O gráfico 4 também nos mostra a antiguidade das áreas sagradas em cada região. Observa-se que Creta e o Peloponeso são as regiões que concentram os santuários mais antigos de Zeus, cuja data inicial da atividade de culto data da Idade do Bronze (2 santuários no total: Ida, Dicta) e da Idade do Ferro (4 no total: Amnisos, Palaikastro, Praisos, Agia Triada), esses no caso de Creta, e de todos os períodos no caso do Peloponeso: da Idade do Bronze (1 no total: Lykaion), da Idade do Ferro (7 no total: Messênia, Mt.Apesas, Tsakona, Mt.Arachnaion, Neméia, Argos-acrópole Larisa, Olímpia), da época arcaica (3 no total: Corinto, Bambes, Figaléia) e da época clássica (3 no total: Mantinéia, Megalópolis, Argos-ágora). Repara-se que em Creta os santuários de Zeus remontam em maior número à Idade do Ferro e em menor número à Idade do

\footnotetext{
1 Embora tenhamos localizado Thasos na Trácia, a ilha também pode ser acrescentada à quantidade de santuários na área do mar Egeu.
} 
Bronze e que no Peloponeso o grande período de início da atividade cultual dos santuários da região é a Idade do Ferro. Na Ática e no Egeu as áreas sagradas mais antigas também remontam à Idade do Ferro (3 santuários na Ática: Mts. Himeto, Parnes, Tourkouvouni e 2 no Egeu: Mt. Attavyros, Egina). Em ambas as áreas há santuários datados a partir do período arcaico (2 áreas sagradas da Ática: Agrai, llissos e 4 do Egeu: Delos, Naxos, lalysos, Kamiros) e da época clássica (1 santuário da Ática: acrópole e 2 no Egeu: Paros, Lindos). Apenas na Ática há a ocorrência de uma área sagrada entre a época arcaica/clássica (Atenas-colina das Ninfas). Ressalta-se aqui que todos os santuários da Ática estão localizados em Atenas. Na Sicília e na Itália do Sul predominam, em igual número, santuários datados a partir da época arcaica, o período com maior número (3 áreas sagradas da Sicília: Selinonte-Gaggera, Selinonte-Marinella, Siracusa e 3 da Itália do Sul: Metaponto-ágora, Metaponto-San Biaggio, Lócris), e da clássica (1 da Sicília: Agrigento e 1 da Itália do Sul: Posidônia). Devido às razões históricas locais, de as fundações gregas nas duas áreas remontarem, na maior parte, ao início da época arcaica, não há nessas regiões santuários de Zeus datados a partir da Idade do Ferro, como se vê na Grécia balcânica ou nas ilhas do Egeu. Na Cária não há também santuários anteriores à época arcaica, lá predominando áreas sagradas datadas a partir do arcaico (2 no total: Labraunda, lasos) e do clássico (1 no total: Mylasa). Na Macedônia todas as áreas sagradas remontam ao período clássico (3 no total: Díon, Aphytis, Aegiae), assim como na Líbia (2 no total: Cirene-setentrional/oriental, Cirene-Ain-Hofra) e na Trácia (1 no total: Thasos). Na Megárida (Sta Marmara), na Beócia (Mt.Helikon) e na Tessália (Pherai), os santuários remontam à Idade do Ferro (cada qual com 1 no total). Na Megárida, ainda, há uma área sagrada datada a partir do período entre o arcaico/clássico (Mégara). E finalmente, no mar Jônio, o único santuário remonta à época arcaica (Kefalonia). Abaixo, na sequência, seguem os mapas das regiões do mundo grego com as respectivas localizações dos santuários de Zeus distinguíveis por período. 


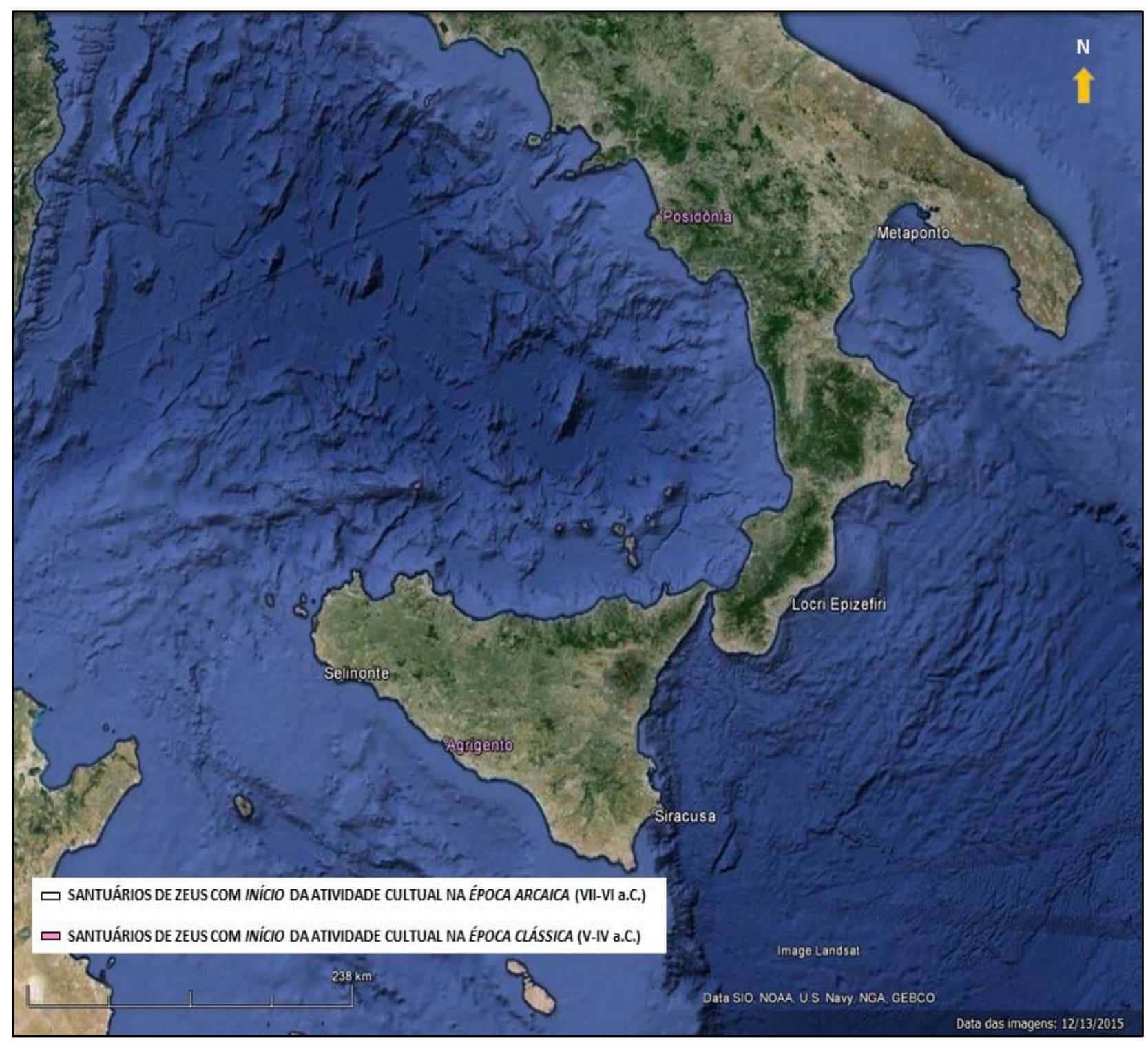

Fig.1- Mapa: Sicília e Itália do Sul: os santuários de Zeus por períodos e regiões (Época arcaica e clássica) 


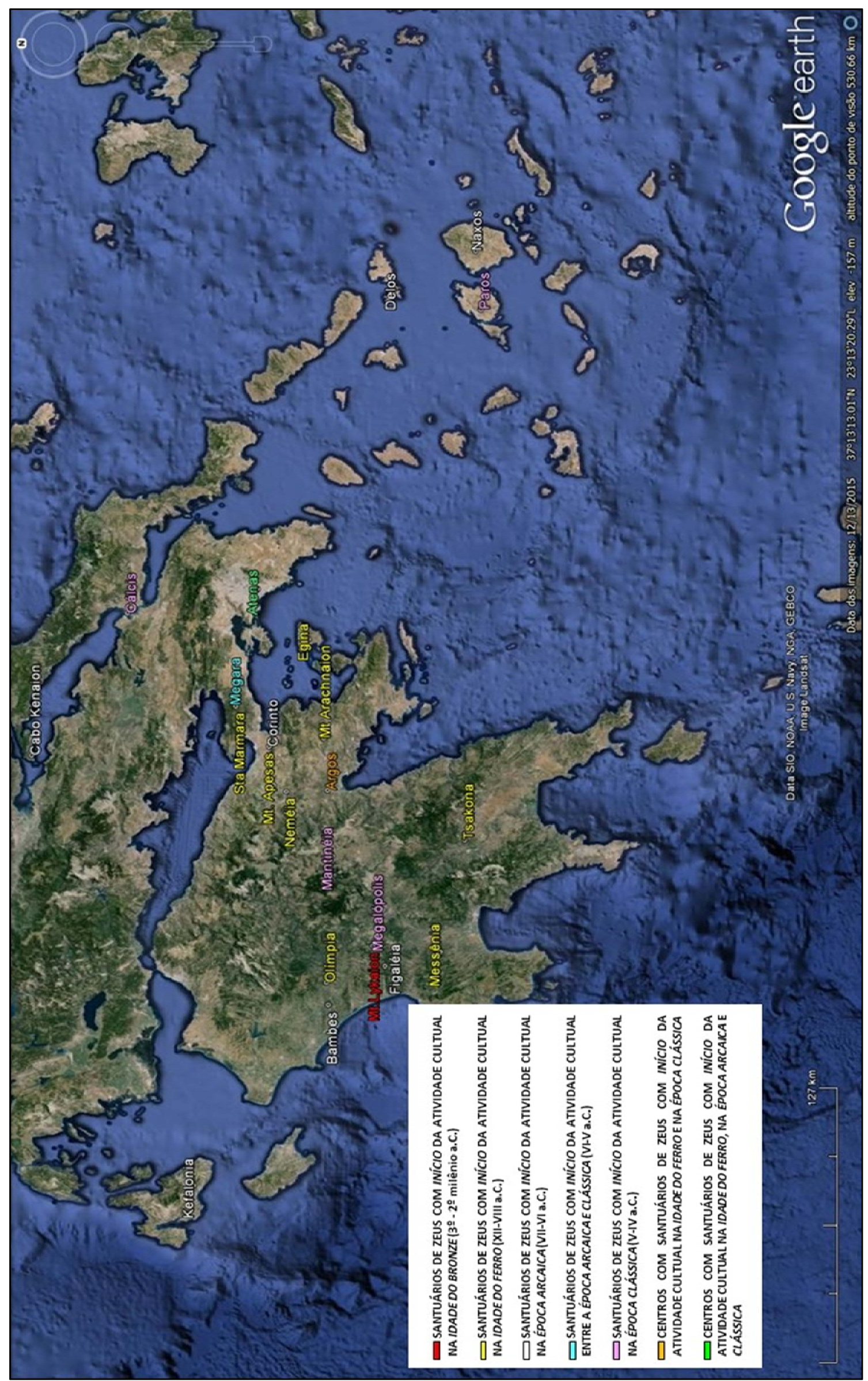

Fig.2- Mapa: Mar Jônio, Peloponeso, Megárida, Ática, mar Egeu e Cária: os santuários de Zeus por períodos e regiões (Idade do Bronze à época clássica) 


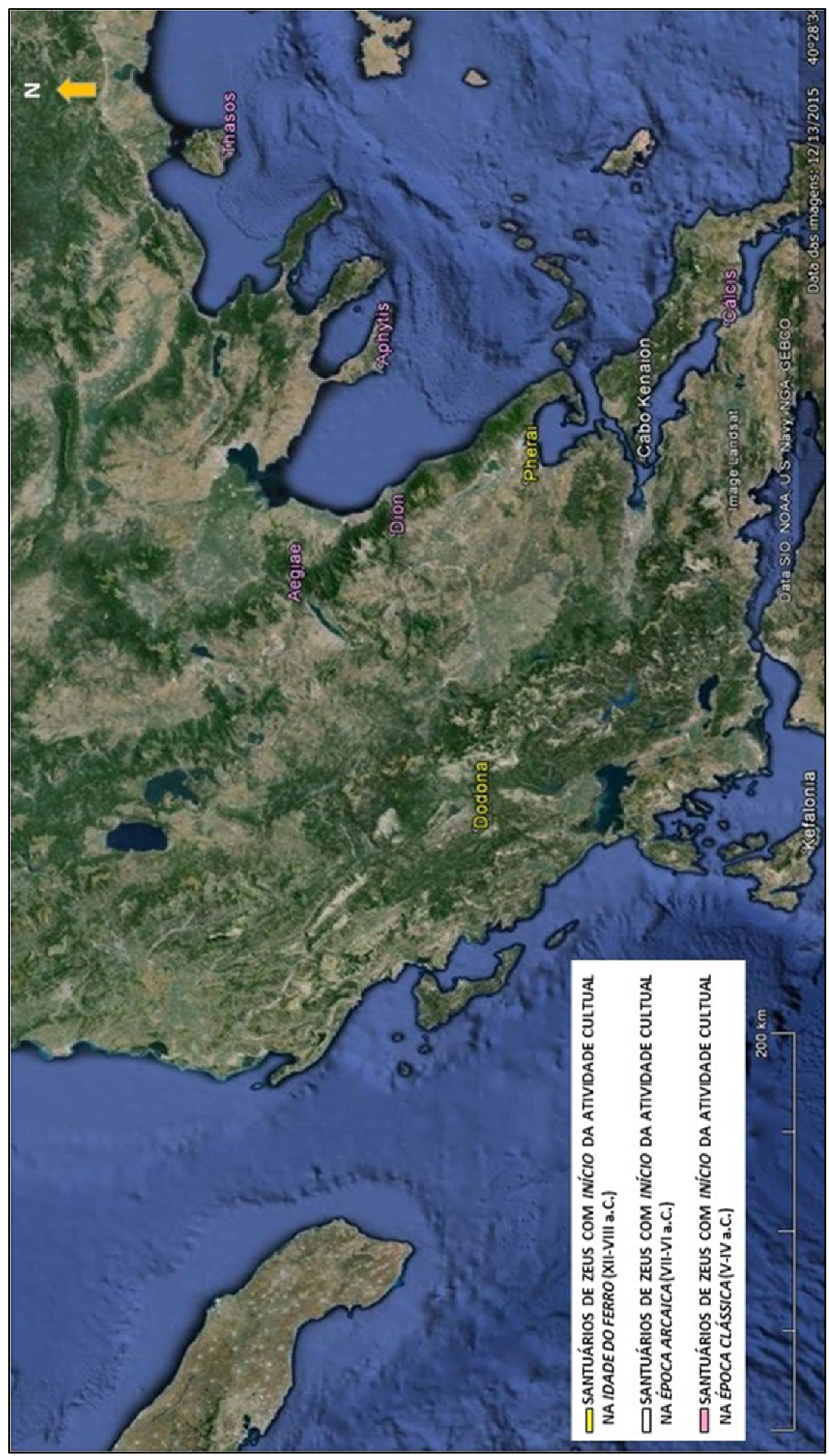

Fig.3- Mapa: Norte da Grécia Balcânica (Macedônia, Trácia e Tessália) e Grécia central (Beócia e Eubéia): os santuários de Zeus por períodos e regiões (Idade do Ferro à época clássica) 


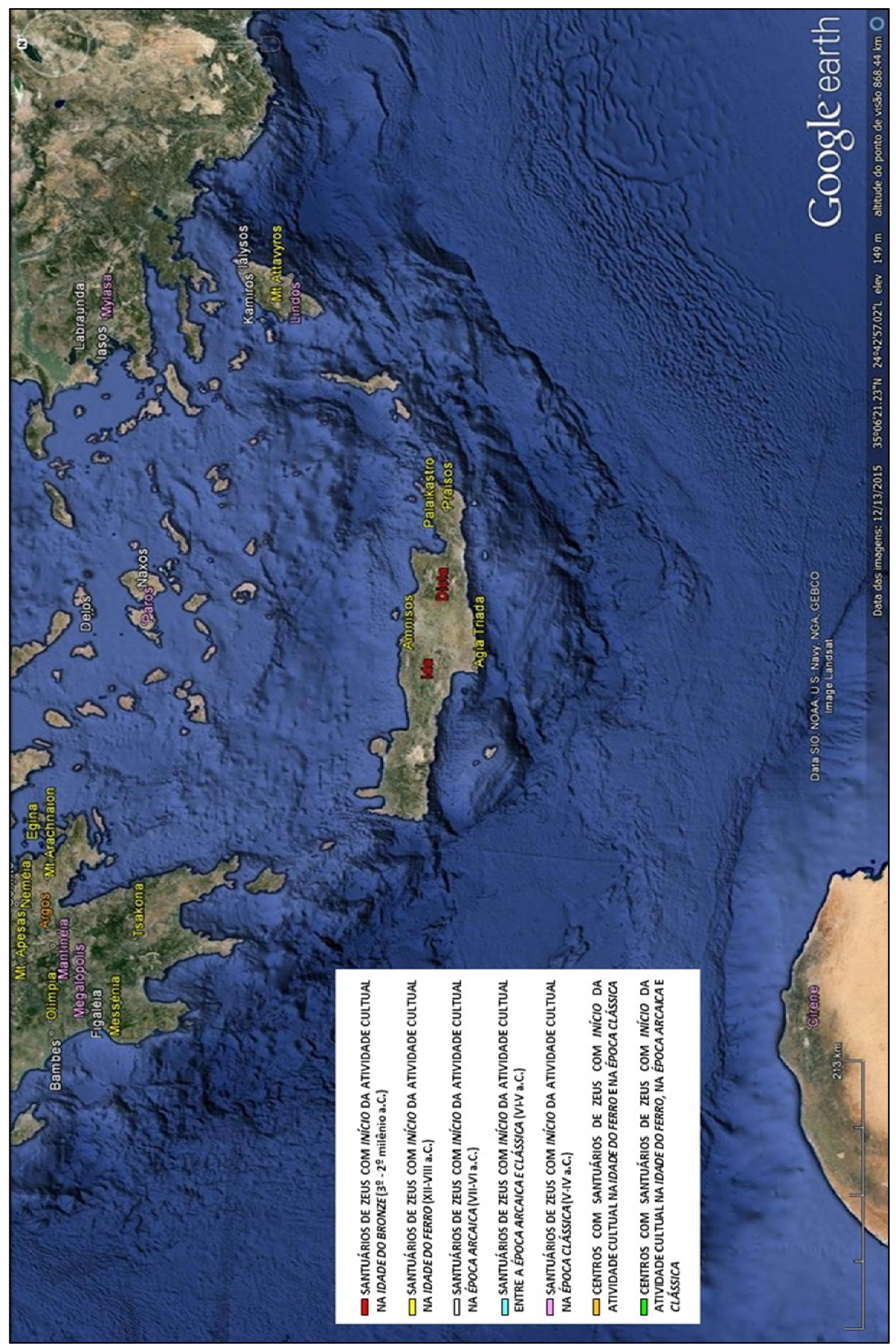

Fig.4- Mapa: Líbia, sul do Peloponeso, Cíclades, mar Egeu e Cária: os santuários de Zeus por períodos e regiões (Idade do Bronze à época clássica) 


\section{I.3 POR TIPOS DE LOCALIZAÇõES GEOGRÁFICAS}

Com relação aos tipos de localizações geográficas dos santuários de Zeus, a sistematização dos dados referentes às áreas sagradas levou-nos a estabelecer 3 tipos ou padrões gerais de localizações para a instalação de santuários de Zeus no mundo grego entre a Idade do Bronze e a época clássica: 1-) em montes (grutas e cumes), 2-) em colinas (sopés, encostas, cumes), e em 3-) planícies/vales (próximos à costa e a rios). Na sequência, segue a lista dos tipos de localizações e os respectivos santuários por período:

- Planícies/vales: Dodona, Neméia (Idade do Ferro); Metaponto-ágora, Metaponto-S. Biaggio (época arcaica); Agrigento, Cálcis, Mylasa, Posidônia, Díon, Mantinéia, Aegiae, Argos-ágora (época clássica).

- Planícies/vales (próx. à costa e rios): Siracusa (época arcaica).

- Planícies/vales (próx.à costa): Palaikastro (Idade do Ferro); lasos, Cabo Kenaion (época arcaica); Thasos (época clássica).

- Planícies/vales (prox. a rios): Olímpia (Idade do Ferro); Atenas-Agrai, Atenas-llissos, Corinto (época arcaica); Megalópolis (época clássica).

- Colina (cume): Tsakona, Argos-Larisa, Atenas-Tourkouvouni, Praesos (Idade do Ferro); Delos, Selinonte-Gaggera, Selinonte-Marinella, Ialysos, Figaléia, Kamiros (época arcaica); Bambes (entre arcaico/clássico); Cirene-setentrional/oriental, Atenas-acrópole, Paros, Lindos (época clássica.

- Colina (encosta): Agia Triada, Pherai (Idade do Ferro); Labraunda, Lócris (época arcaica); Atenascolina das Ninfas, Mégara (entre arcaico/clássico); Cirene-Ain-Hofra, Aphytis (época clássica).

- Colina (sopé): Amnisos (Idade do Ferro).

- Monte (cume): Mt.Lykaion (Idade do Bronze); Atenas-Himeto, Atenas-Parnes, Messênia, Mt.Apesas, Mt.Helikon, Mt.Arachnaion, Mt.Attavyros, Egina, Sta Marmara (Idade do Ferro); Naxos, Kefalonia (época arcaica).

- Monte (gruta): Mt.Ida; Mt.Dicta (Idade do Bronze).

Conforme se observa no gráfico 5, os montes ou picos foram os primeiros tipos de localizações escolhidas para a instalação de santuários de Zeus, remontando à Idade do Bronze e se tornando o padrão principal de áreas sagradas da Idade do Ferro. Apesar de não existir uma diferenciação clara entre monte e colina, adotamos, como critérios, a altura de até $350 \mathrm{~m}$ acima do nível do mar para definir uma colina e de a partir de $400 \mathrm{~m}$ acima do nível do mar para definir um monte. Assim, vê-se que instalar santuários de Zeus em montes foi, embora em menor grau, uma prática vigente na época arcaica, caindo totalmente em desuso em época clássica. Em montes, os santuários de Zeus foram instalados em grutas (fenômeno típico de Creta na Idade do Bronze) ou nos cumes, geralmente nos picos mais altos dos montes, que foi a área preferida para a instalação de áreas sagradas do deus na Idade do Ferro (principalmente), e na Idade do Bronze e na época arcaica 
(ambas em menor grau). Já a partir da Idade do Ferro, zonas colinares passaram a ser áreas escolhidas para a instalação de santuários de Zeus, tornando-se uma tendência a partir da época arcaica até a clássica. Em colinas, as áreas sagradas foram instaladas em três tipos de áreas - no cume, na encosta e no sopé. Assim como no caso dos montes, os cumes foram as áreas mais requisitadas para

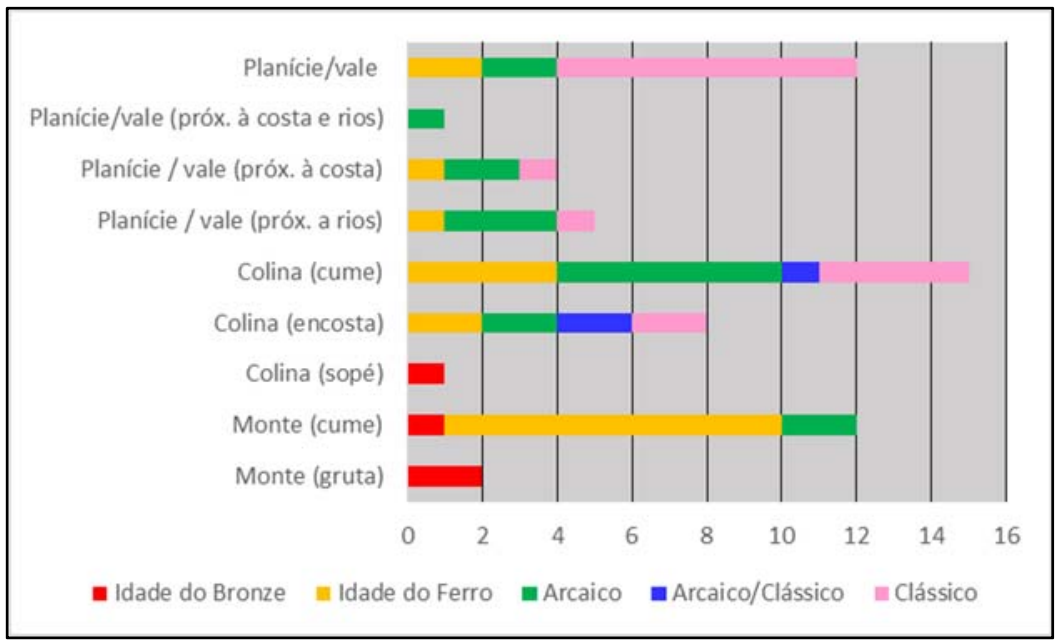

Gráfico 5- Quantidade de santuários por tipos de localizações de santuários de Zeus (montes, colinas e planícies) (Idade do Bronze à época clássica) santuários da divindade na Idade do Ferro e na época clássica, mas principalmente na época arcaica. As encostas foram o segundo tipo de área colinar mais escolhido pelos gregos para os santuários de Zeus a partir da Idade do Ferro, predominando em mesma proporção na Idade do Ferro, na época arcaica, entre a arcaica/clássica e na clássica. Sopés de colinas foi uma localização pouco requisitada e restrita à Idade do Bronze em Creta. Planícies, em vales ou não, foi um padrão de localização de áreas sagradas de Zeus que também remonta à Idade do Ferro e que foi uma característica predominante de santuários do deus em época arcaica e principalmente em época clássica. Em planícies, as áreas sagradas de Zeus foram fundadas em proximidade a rios ou à costa do mar durante a Idade do Ferro, época arcaica e clássica, e a rios próximos à costa em época arcaica.

Em linhas gerais, embora os três tipos de localizações tenham sido requisitados para os santuários de Zeus durante os cinco períodos, pode-se dizer que a instalação de áreas sagradas em montes foi uma tendência da Idade do Bronze e da Idade do Ferro, em colinas foi uma tendência da época arcaica e em planícies/vales uma tendência de época clássica. Essa mudança da preferência das grandes alturas dos montes e colinas, nos períodos mais antigos do culto de Zeus, na Idade do Bronze e na Idade do Ferro, pelo terreno das planícies/vales no período mais recente da nossa pesquisa, a época clássica, expressa transformações no culto de Zeus observadas na longa duração, relacionadas de certa maneira, como veremos mais adiante, com mudanças no tipo, prática e função do culto a Zeus praticado no mundo grego em suas fases mais antigas quando, a partir da época arcaica, adquiriu funções cívicas e é inserido no espaço urbano e território da cidade grega.

Acerca dos santuários de Zeus em altitudes, portanto, em montes ou colinas, é interessante ver a variação das alturas escolhidas para a fundação de áreas sagradas à divindade, considerando-se as diferentes áreas do mundo grego, de cujos santuários dispomos das alturas corretas de sua localização. 0 gráfico 6 mostra que a localização dos santuários variou entre c. $110 \mathrm{~m}$ da colina do Monte Cynthos em Delos aos 1748 m do Mt. Helikon na Beócia. Nesse sentido, os santuários em zonas colinares mais baixas estão em Delos, 
lalysos, Argos, Praisos e Atenas-Tourkouvouni e os santuários mais altos, em montes, localizam-se no Mt. Lykaion, no Mt. Parnes em Atenas, Mt. Ida, Mt. Enos em Kefalonia e no Mt. Helikon na Beócia.

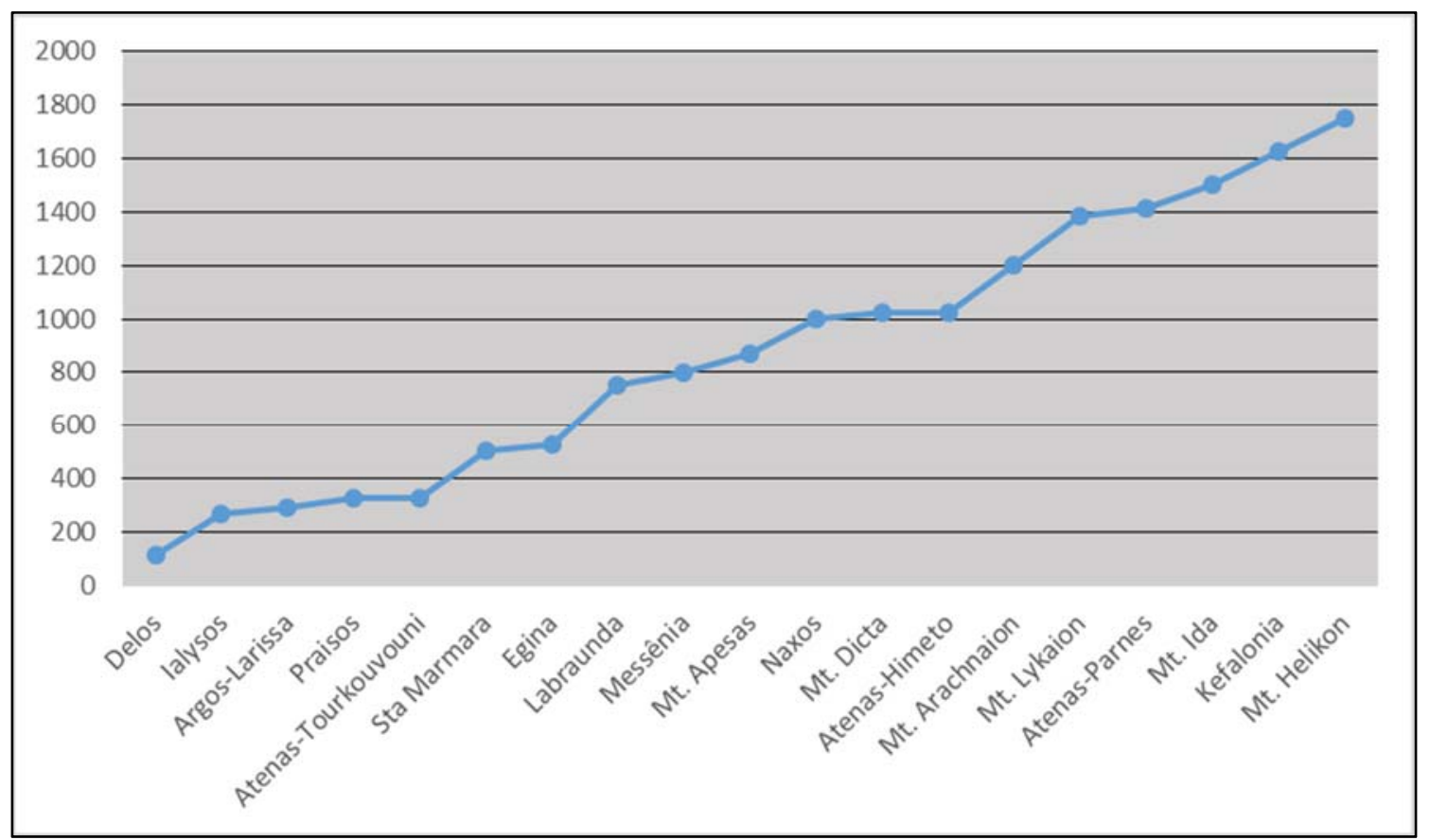

Gráfico 6- Variações das altitudes dos santuários colinares e de pico de Zeus no mundo grego (Idade do Bronze à época clássica)

\section{I.4 POR TIPOS DE CATEGORIAS DE SANTUÁRIOS}

A sistematização dos dados referentes à documentação dos 60 santuários de Zeus propiciou ainda um panorama geral sobre as categorias ou tipos de áreas sagradas e as funções específicas que assumiram entre a Idade do Bronze e a época clássica (até 345/44 a.C.). Foi possível definir 3 categorias gerais de santuários (urbano, suburbano, extra-urbano) divididas, por sua vez, em 3 diferentes funções (inter-regional, sub-regional e cívica). As funções inter-regional e sub-regional são específicas dos santuários extra-urbanos e suburbanos de Zeus, enquanto que a cívica não é restrita a alguma categoria de área sagrada, podendo ser vista tanto naqueles urbanos como também nos extra-urbanos e suburbanos do deus estabelecidos, principalmente a partir da época arcaica, no centro urbano e no território da cidade grega.

Até hoje os especialistas em santuários gregos tem debatido a validade em conceituar as áreas sagradas entre o que se define por urbano e não-urbano. Desde G. Vallet na década de 1960 até F. de Polignac na década de 1990, tentou-se classificar os santuários gregos dentro de categorias para então compreender a sua função em relação à pólis grega². Os estudiosos, atualmente, têm cada vez mais concluído que essas classificações não podem ser tão fixas assim - são as realidades de cada santuário, representadas pelo contexto do assentamento em relação à dada região e as evidências arqueológicas de cada área sagrada

2 Sobre o estado da arte dessa discussão, vide Laky, 2013, pp.278-283. 
(remanescentes arquitetônicos e objetos votivos), que devem nortear determinada definição. Além disso, como bem coloca M. Prent, para os santuários cretenses da Idade do Ferro, em muitos casos o critério de distância a um determinado assentamento "é uma consideração relativa, podendo, nesse sentido, ser vaga a diferenciação entre suburbano e extra-urbano, por exemplo" (Prent, 2005: 128). É relativo também, como chama a atenção esse mesmo autor, "nomear de urbano qualquer santuário dentro de uma área construída de um assentamento, pois o termo urbano pode implicar um grau avançado de urbanização" (Prent, 2005: 128). Mesmo diante dessa crítica, os especialistas ainda preferem usar as definições básicas de urbano, suburbano, extra-urbano, contudo, passando a levar em consideração toda a problemática envolvida na conceituação dos santuários gregos.

Foi sob essa mesma perspectiva que procuramos definir em categorias os 60 santuários de Zeus, optando por seguir tais definições básicas, assim como as das respectivas funções, a saber, inter-regionais, sub-regionais e cívicas - e considerando, nas classificações, muito além do posicionamento da área sagrada em dado assentamento, o tipo de culto, os objetos votivos e a relação com uma ou mais comunidades. Assim, seguindo a conceituação de M. Prent, consideramos santuário urbano e suburbano "aqueles situados dentro ou em proximidade a um assentamento, respectivamente", e extra-urbano "aquele localizado fora de um assentamento" (Prent, 2005: 128 e 154). Com relação às funções específicas, definimos santuários interregionais como aqueles uma vez localizados em uma área marginal, ou extra-urbana, que funcionou como local neutro de encontro para comunidades/assentamentos/Estados de várias regiões para além daquela onde se localiza a área sagrada. Santuários sub-regionais estiveram localizados também em uma área marginal, extraurbana na maior parte dos casos, foram usados também como locais neutros de encontro para comunidades/assentamentos/Estados, mas da mesma região da área sagrada. E por fim, santuários cívicos são aqueles estabelecidos por determinada comunidade e estiveram sempre sob sua única esfera de influência, sendo geridos por ela, desempenhando um papel cívico sempre a nível de culto local. J.-P. Vernant foi que definiu muito bem o termo cívico em relação às divindades e à religião grega em geral. É a sua definição que seguimos para conceituar um santuário de Zeus como cívico. Segundo o estudioso, religião cívica é aquela que "consagra uma ordem coletiva e que integra nesta, no lugar que convém, suas diferentes componentes, deixando fora de seu campo as preocupações relativas a cada indivíduo" (Vernant, 2006: 8). Todas as cidades gregas "tinham suas divindades políades, cuja função era a de cimentar o corpo de cidadãos para fazer dele uma comunidade autêntica, unir num todo único o conjunto do espaço cívico, com seu centro urbano e sua khóra, velar, enfim, pela integridade e o funcionamento do Estado - homens e território - diante das outras cidades" (Vernant, 2006: 41-42).

O gráfico 7 mostra a quantidade total de categorias e funções dos 60 santuários de Zeus distribuídos nos cinco períodos estudados. Com relação à quantidade do número de santuários em cada período, é preciso dizer que foi necessário repetir determinada área sagrada em períodos diferentes, devido às funções 
específicas assumidas em épocas diversas (Mt.Lykaion, Argos-Larisa, Dodona) ou à possibilidade de terem pertencido a categorias diferentes em um mesmo período (Messênia-lthome, Bambes).

Os santuários extra-urbanos de Zeus foram os mais numerosos (36 áreas sagradas no total), seguidos pelos urbanos (22 no total) e suburbanos (5 no total). Pode-se afirmar, portanto, que apesar do maior número de áreas sagradas extra-urbanas indicar uma preferência por estas no estabelecimento do culto de Zeus em uma dada área, o número elevado de santuários urbanos, em contraste, também indica a área urbana como uma localização típica para a áreas sagradas da divindade. Essa constatação leva-nos a rever o que alguns especialistas têm reiteradamente afirmado sobre os santuários de Zeus e a pólis. A predominância do culto de Zeus em áreas marginais à cidade grega, ou fora da ásty, tem direcionado os estudiosos a ressaltar apenas 0 seu caráter extra-urbano ou o seu papel menor / inexistente como principal divindade da cidade 3 .

Santuários extra-urbanos são uma característica muito antiga no culto a Zeus, remetem, pois, à Idade do Bronze em Creta e no Peloponeso. Uma primeira vista do gráfico, também mostra que santuários extraurbanos foram uma tendência do culto de Zeus nos períodos mais antigos - na Idade do Bronze foi a única categoria existente de santuários do deus, tornando-se o principal padrão na Idade do Ferro. Apesar de muitas vezes ter sido difícil diferenciar uma área sagrada extra-urbana de uma suburbana, por falta de mais dados sobre o assentamento, foi possível precisar o uso de área suburbanas para a instalação de santuários do deus a partir da Idade do Ferro e depois somente em época clássica, quando foi escolhida em menor grau. Embora santuários extra-urbanos de Zeus tenham persistido, sido comuns em época arcaica, a área urbana passou a ser a mais procurada para a instalação das áreas sagradas principalmente a partir dessa época. Uma vista geral dos dados no gráfico também indica que a área urbana das cidades foi a preferida para a instalação de santuários à divindade durante a época clássica. Essa mudança de preferência para a instalação de santuários de Zeus - do extra-urbano na Idade do Bronze e do Ferro ao urbano em época clássica - também indica certa transformação no culto de Zeus observável somente na longa duração a partir da amostragem de uma grande quantidade de áreas sagradas datadas de cinco períodos da história grega antiga. As razões que levaram a essa inversão de categorias de santuários da divindade, do período mais antigo ao mais recente estudados nessa pesquisa, serão melhor investigadas na segunda parte desse capítulo, quando analisaremos os dados dos santuários no contexto de cada período.

Com relação às funções específicas, santuários extra-urbanos de Zeus datados da Idade do Bronze assumiram função inter-regional e sub-regional já nesse período, como ocorreu com a área sagrada do Mt.Ida, em Creta, ou apenas sub-regional, no caso do Mt. Dicta, em Creta, e do Mt. Lykaion, no Peloponeso, que conservou tal função até o final da atividade cultual do santuário em época helenística, mesmo quando durante o século V a.C. adquiriu também função inter-regional. Santuários extra-urbanos de Zeus, que remontam à Idade do Ferro, adquiriram, nessa época, funções inter-regional e sub-regional (Olímpia), apenas inter-regional

${ }^{3}$ A esse respeito ver, Kreutz, 2007, pp. 265-268. 
(Mt.Apesas, Neméia) e sub-regional (Amnisos, A.Triada, Palaikastro, Atenas-Himeto, Dodona, MessêniaIthome, Parnes, Tsakona, Atenas-Tourkouvouni, Mt.Attavyros, Egina-Mt.Oros, Mt.Helikon, Sta Marmara). Conforme se vê no gráfico, santuários extra-urbanos com função sub-regional formam o maior número dessa categoria dedicados à divindade e remontam na maior parte à Idade do Ferro quando iniciaram também esse tipo de função. Alguns santuários extra-urbanos, datados a partir da Idade do Ferro, passaram a ter uma nova e diferente função em períodos posteriores. Em época arcaica, os santuários extra-urbanos de Dodona e EginaMt.Oros e do Mt.Lykaion passaram a ser, também, áreas sagradas inter-regionais. Nesse período, a maior parte de santuários extra-urbanos fundados são sub-regionais (Naxos, Kefalonia, Cabo Kenaion) inter-regionais, datadas a partir de época arcaica (Delos), e em menor número, os inter-regionais (Delos) e aqueles com as duas funções (Labraunda). Em época clássica, os santuários datados de períodos anteriores mantiveram suas funções, datando dessa época poucos santuários extra-urbanos com algum tipo de função regional, como Paros (sub-regional) e Dion (inter-regional e sub-regional). Funções oraculares e agonísticas dos santuários de Zeus, não incluídas no gráfico, remontam a períodos bem específicos e foram características de áreas sagradas de frequentação em nível tanto sub-regional quanto inter-regional. Da Idade do Ferro data a função oracular em Dodona e Olímpia, da época arcaica data a função agonística de Olímpia e Neméia.

Sobre as categorias extra-urbana, suburbana e urbana que aparecem no gráfico, sem as ditas funções específicas, se trata de santuários com funções cívicas. No caso desse tipo de santuário extra-urbano, a maior quantidade se refere à época arcaica (Selinonte-Gaggera, Selinonte-Marinella, Atenas-Agrai, Siracusa, Corinto, Metaponto-S.Biaggio, Bambes) e a menor à época clássica (Cálcis, Aphytis, Cirene-Ain Hofra). No caso dos suburbanos, a Idade do Ferro é o período sobre o qual remontam o maior número de santuários (MessêniaIthome, Praisos, Pherai, Argos-Larisa) e o período clássico o menor (Cirene-colina setentrional/oriental). E por fim, sobre as áreas sagradas urbanas, as épocas arcaica e clássica possuem quase a mesma quantidade de santuários - trata-se de 9 áreas sagradas arcaicas (lalysos, Atenas-llissos, Metaponto-ágora, Lócris, lasos, Figaléia, Kamiros, Argos-Larisa, Bambes) e 11 clássicas (Atenas-acrópole, Agrigento, Mylasa, Posidônia, Thasos, Lindos, Mantinéia, Megalópolis, Aegiae, Argos-ágora, Messênia-Ithome) - como dissemos, os dados mostram a época clássica como o principal período da fundação de santuários urbanos de Zeus. 


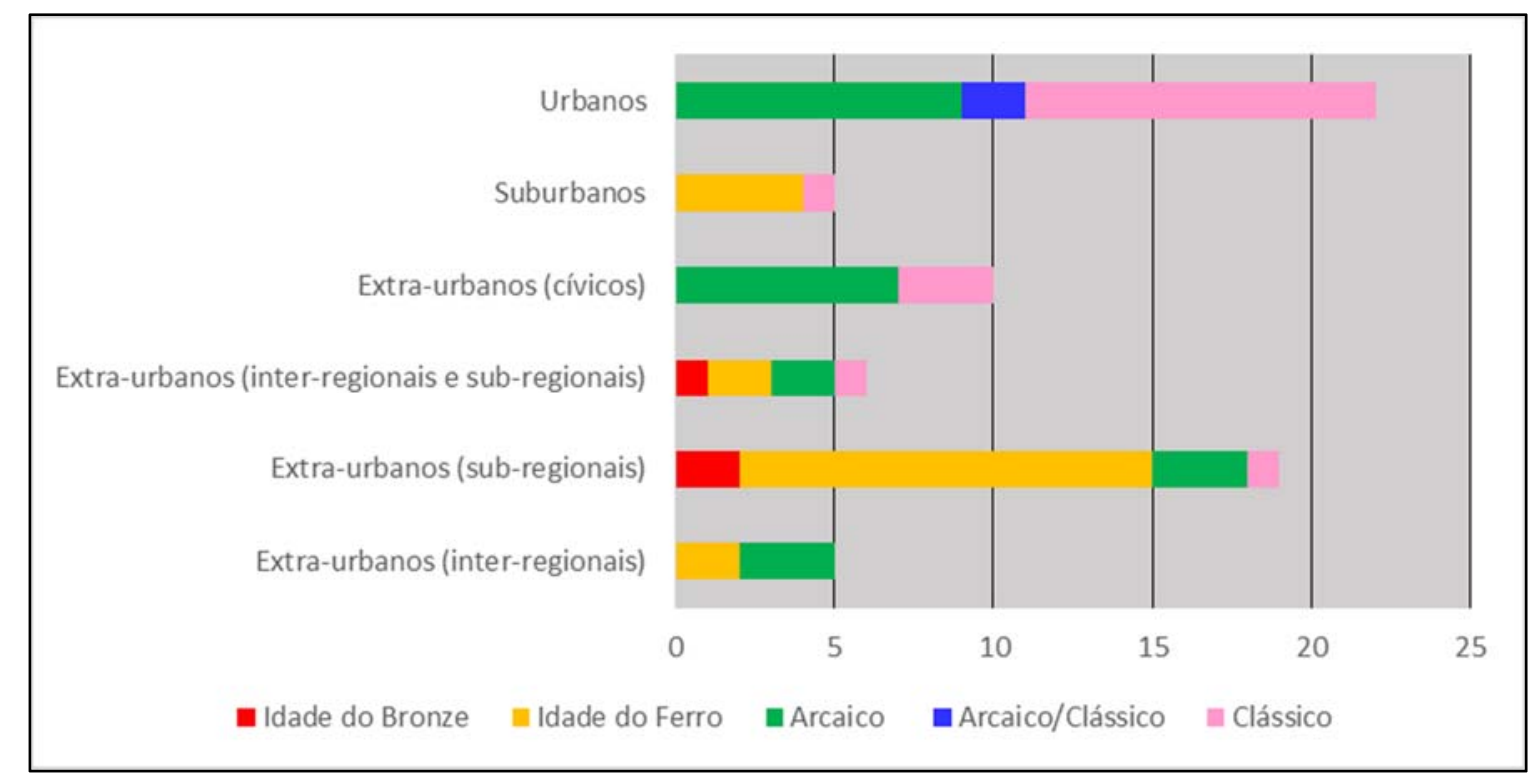

Gráfico 7- Quantidade de santuários de Zeus por categorias de santuários (Idade do Bronze à época clássica)

\section{I.5 POR TIPOS DE ARQUITETURA OU ESTRUTURAS DO CULTO}

Além dos tipos de localizações geográficas e categorias de santuários, foi possível estabelecer os padrões de arquitetura ou estruturas de culto, os tipos de construções, associadas aos santuários de Zeus desde à Idade do Bronze à época clássica. Ver a prevalência de determinado tipo de construção, em relação a um período específico, ajuda a compor o quadro histórico do desenvolvimento dos santuários de Zeus, e, por conseguinte, do culto na longa duração. A sistematização dos dados dos 60 santuários revelou 8 tipos principais de estruturas de culto em santuários da divindade, são elas: 1-) altar (de cinzas, de pedras, de alvenaria associados ou não a um témeno ou a um edifício pequeno); 2-) témeno (quando somente há a área sagrada demarcada por um muro de pedras); 3-) edifício oval; 4-) pequeno edifício (oîkos, naískos); 5-) edifício de culto (não especificado) e outros anexos (aparatos cultuais); 6-) templo prostilo com ou sem altar (prostilo in antis e prostilo distilo in antis); 7-) períptero; 8-) ou tipo não especificado pela bibliografia; e 9-) ninfeu escavado na rocha. A bibliografia também informa sobre áreas de culto a céu aberto e construções sobre as quais não foi possível identificar a tipologia.

O gráfico 8 reúne os dados relacionados a todas essas estruturas de culto. Conforme o gráfico, é possível ver, de antemão, que altares (como principais estruturas, normalmente não associados a um edifício de culto) e templos (não pequenos edifícios) são os tipos de estruturas de culto mais recorrentes em santuários de Zeus. Entre os dois tipos, são os templos as construções mais numerosas, com destaque para aqueles perípteros (rodeados por uma ou mais fileiras de colunas). Dentre os vários tipos de altares, 0 altar de cinzas ${ }^{4}$ é o mais numeroso e por isso o mais comum em santuários de Zeus e fez parte das áreas sagradas mais

\footnotetext{
4 Trata-se de "grandes montes de cinzas misturados com terra e sangue dos animais sacrificados, que foram intencionalmente acumulados, durante longos períodos de tempo de sacrifícios em lugares sagrados, para formar um altar" (Yavis, 1949: 208).
} 
antigas da divindade. Apesar de altares de cinza terem sido já parte do culto em santuários que remontam à Idade do Bronze (Mt.Ida, Lykaion), foi na Idade do Ferro que se tornaram a estrutura de culto mais comum em santuários de Zeus (Amnisos, Palaikastro, Atenas-Parnes, Mt.Apesas, Mt.Arachnaion, Praisos, Neméia, Olímpia). O segundo tipo de altar recorrente também na Idade do Bronze é aquele feito de pedras simples, diferente daquele de alvenaria, feito de blocos de pedra. O único altar de pedras datado da Idade do Bronze é associado a um témeno de pedra (Mt.Dicta), como parece ter sido o caso do único santuário da época arcaica (Cabo Kenaion). Já os altares de pedras de santuários datados a partir da Idade do Ferro são os mais numerosos e não estão associados a outro tipo de construção (Atenas-Himeto, Atenas-Tourkouvouni). Durante a Idade do Ferro, altares de alvenaria também foram utilizados como única estrutura de culto em santuários de Zeus (Mt.Helikon), embora em menor grau. Sem uma característica definida pela bibliografia, outros altares, como estrutura de culto principal e única na área sagrada, são datados da Idade do Ferro (Mt.Attavyros, Egina) e da época arcaica (Naxos). Um altar associado ainda a um edifício foi integrado em um santuário datado a partir da Idade do Ferro, mas ambas as estruturas são posteriores, datam de época helenística (Agia Triada).

Além dos templos perípteros e prostilos, a bibliografia informa sobre outros tipos de edifícios de culto, menos recorrentes nos santuários, como o edifício de planta oval típico da Idade do Ferro (Olímpia, Dodona) e o pequeno edifício sem característica específica conhecida (Tsakona) datados da Idade do Ferro, do mesmo período no qual os santuários iniciaram a atividade de culto. Já o pequeno edifício de tipo oîkos ${ }^{5}$ pertence a um santuário que remonta a Idade do Ferro (Dodona), mas a estrutura foi incorporada ao culto somente no século IV a.C. Durante a Idade do Ferro o culto em Dodona ocorria, até certo momento, a céu aberto (se trata da única área sagrada a qual o gráfico se refere). 0 pequeno edifício de tipo naískos 6 é comum a partir da época arcaica em santuários de Zeus (Selinonte-Gaggera, Figaléia). Embora tenho sido parte de santuários que remontam à época arcaica, os naískoi de lasos e Figaléia ( $2^{\circ}$. edifício) foram construídos apenas na época clássica e clássica/helenística, respectivamente.

Com relação aos templos, os tipos de construções mais comuns em santuários de Zeus, estes apareceram a partir do período arcaico nas áreas sagradas do deus, embora o gráfico indique a presença deles na Idade do Ferro. Nesses dois períodos os altares (como construções únicas) foram as estruturas típicas dos santuários da divindade. Neste caso, incluímos o santuário no gráfico a partir da data de início da atividade cultual, embora a estrutura de culto seja posterior. Assim, acerca dos templos com ou sem altar (sem características especificadas pela bibliografia e tipo mais numeroso depois dos perípteros), os santuários datados da Idade do Ferro (Amnisos, Palaikastro) tiveram seu primeiro templo datado de época arcaica e clássica, respectivamente, da época helenística (Egina) e em um período desconhecido (Sta Marmara). Os santuários datados a partir da época arcaica receberam seus primeiros templos no próprio período arcaico

\footnotetext{
5 Trata-se de um edifício ou cômodo retangular, com apenas uma cela e uma porta, sem o pronaos, opistódomo e perístasis (Hellmann, 2002: 349).

6 Trata-se de um pequeno templo, de tipo edícula ou capela, sem perístasis (colunata) (Laky, 2013: 86, nota 20).
} 
(lalysos) e entre o arcaico/clássico (Kamiros, Neméia). As áreas sagradas que remontam entre os períodos arcaico/clássico tiveram seus primeiros edifícios nessa mesma época (Mégara, Atenas-colina das Ninfas) e aquelas datadas a partir da época clássica (Paros, Mylasa, Posidônia, Díon, Mantinéia) receberam os templos também no próprio período. Sobre os templos perípteros, com ou sem altar encontrados, estes apareceram posteriormente em santuários que remontam à Idade do Ferro, mas em períodos posteriores, como no arcaico (Olímpia, Pherai) e no clássico (Olímpia, Pherai na $2^{a}$.fase de construção, Neméia). Em santuários datados a partir da época arcaica, alguns dos templos perípteros apareceram pela primeira vez nesse mesmo período (Siracusa, Atenas-llissos, Lócris, Selinonte-Marinella, Corinto) e no clássico (Labraunda). Naquelas áreas sagradas que datam a partir da época clássica, esses tipos de edifícios parecem remontar ao mesmo período da instalação do santuário (Cirene-colina setentrional/oriental, Agrigento, Cálcis, Thasos, Megalópolis e Aphytis, cujo edifício teve uma $2^{\mathrm{a}}$. fase de construção em época helenística).

Com relação às tipologias de templos prostilos ${ }^{7}$, sobre os distilos in antis ${ }^{8}$ com ou sem altar, há um datado da época arcaica que pertenceu a um santuário da Idade do Ferro (Neméia) e outro de época arcaica, cujo santuário remonta a esse mesmo período (Labraunda). Outros datam de época clássica e pertencem a santuários que remontam ao período (Atenas-acrópole, Posidônia, Lindos). Já o tipo de templo prostilo in antis (talvez caracterizados apenas por antas ${ }^{9}$ laterais na fachada) data da época arcaica (Bambes), e também da época clássica, embora um dos santuários remonte à época arcaica (lalysos), e o outro ao próprio período (Aegiae).

O ninfeu escavado na rocha data de época clássica e se refere a um santuário datado do mesmo período (Cirene-Ain Hofra). O edifício de culto, e outros anexos, é datado da transição do arcaico/clássico e pertence a um santuário desse mesmo período (Atenas-colina das Ninfas). Construções não-identificadas se refere a um santuário de época arcaica, cujos remanescentes da estrutura são posteriores, de época helenística e romana (Delos).

\footnotetext{
7 Trata-se de templos somente com um pórtico frontal e fechado na parte dianteira (Duarte, 2010: 37, nota 76).

8 "É um edifício formado por duas colunas entre antas somente no pórtico da fachada frontal, sendo uma das formas mais simples e comuns de templo" (Duarte, 2010: 37).

9 Tipo de pilastra.
} 


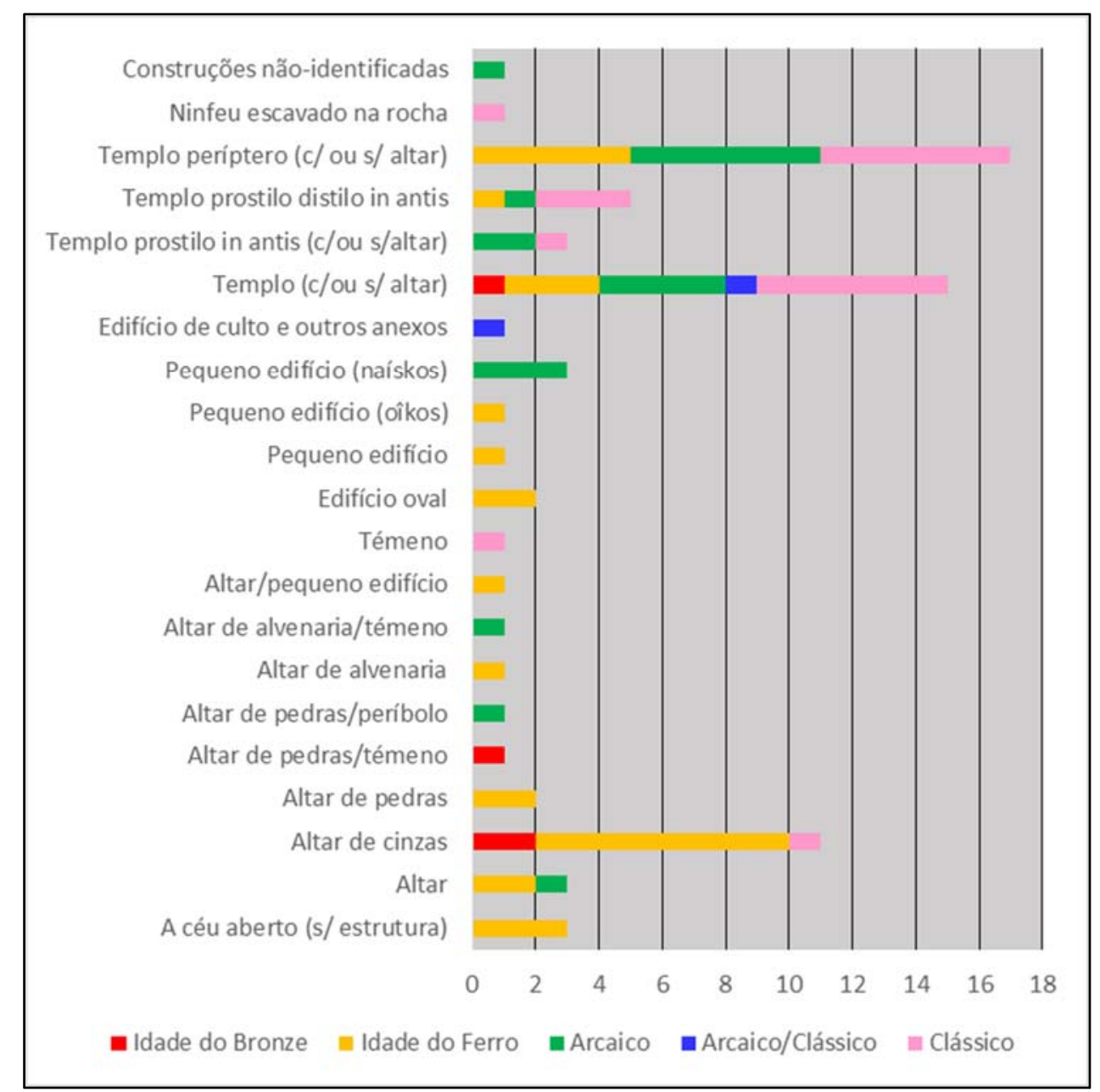

Gráfico 8- Quantidade de santuários e estruturas de culto (Idade do Bronze à época clássica) 


\section{ANÁLISE E INTERPRETAÇÃO GERAIS DOS SANTUÁRIOS DE ZEUS POR PERÍODO (DA IDADE DO BRONZE À ÉPOCA CLÁSSICA (ATÉ 345/44 a.C.)}

\section{II.1 A IDADE DO BRONZE (3 - 2o milênios a.C.)}

Conforme mencionamos anteriormente, os 4 santuários de Zeus da Idade do Bronze foram um fenômeno circunscrito à ilha de Creta e ao Peloponeso no período (tabela 2). Em Creta se concentram as 2 primeiras áreas sagradas da divindade, dentre as quais a mais antiga do deus no mundo grego localiza-se no Mt.Ida com início da atividade cultual no período minoico médio IA ou fase pré-palacial (2100/2000-1900 a.C.). O segundo santuário mais antigo de Zeus situa-se no Mt.Dicta e remonta ao período minoico médio IA ou IB (1900-1800 a.C.), de acordo com a datação de Watrous, ou ao minoico médio I e II (1800-1700 a.C.), segundo M. Prent. Observa-se, assim, que os santuários cretenses de Zeus datados a partir da Idade do Bronze remontam, em geral, ao período minoico médio. Em contrapartida, o terceiro santuário mais antigo de Zeus situa-se no Mt.Lykaion na Arcádia, no Peloponeso, remontando à atividade cultual no local entre os períodos heládico tardio II B (1510-1390 a.C.) e IIIC (1200-1070 a.C.). Dentre esses 4 santuários mais antigos de Zeus foram encontradas evidências de ocupação humana no local já a partir do período neolítico nas áreas sagradas do Mt.Ida, do Mt.Dicta e do Mt.Lykaion. Nos Mts.Ida e Dicta as evidências do neolítico atestam somente a presença de habitação no local e não de atividade cultual, diferente do que ocorre no Mt.Lykaion. Neste santuário peloponésio, as escavações americanas encontraram cerâmicas do neolítico misturadas àquelas do período heládico nos níveis mais inferiores do altar, situado no cume do monte, atestando, assim, a atividade religiosa no local já em época tão recuada. É por essa razão que os pesquisadores americanos, responsáveis pelas escavações no Mt.Lykaion, têm defendido que este se trata do santuário mais antigo de Zeus no mundo grego, ultrapassando a antiguidade, tradicionalmente reconhecida, daqueles cretenses. Embora haja essa possibilidade, consideraremos, em nossa pesquisa, a data indicada pelos próprios pesquisadores americanos (indicada acima) para o início da atividade cultual no Mt.Lykaion, que o coloca, ainda, em quarto lugar em antiguidade entre as demais áreas sagradas.

Como também vimos na análise geral dos santuários, todos os santuários de Zeus da Idade do Bronze eram extra-urbanos. No período, estes se caracterizaram pela instalação do culto em montes, tanto em Creta, quanto no Peloponeso, mas apenas os santuários cretenses de Zeus foram instalados em grutas, situadas a caminho do cume, e não no pico mais alto, como é o caso do santuário peloponésio do Mt.Lykaion. Santuários "nas alturas foram típicos da fase proto-palacial", incluindo-se aí tanto aqueles situados no cume dos montes como aqueles em grutas, que existiram em certo número em Creta (Bettalli et alii, 2013: 39). Santuários de grutas, portanto, não foram restritos ao culto de Zeus na região e no período. De acordo com $B$. Rutkowski, em Creta, os minoicos viram as grutas como "locais de culto devido a aparência misteriosa de seu interior, desde as formas estranhas de estalagmites e estalactites e as propriedades miraculosas da água pura coletada nas 
concavidades da caverna" (Rutkowski, 1972: 121). Para esse autor, "o efeito criado na mente das pessoas, pela atmosfera sugestiva do ambiente, tornava-se mais forte ainda pela quase completa escuridão que prevalecia em certas grutas, como é o caso da gruta de Dicta" (Rutkowski, 1972: 121). Alguns santuários de gruta cretenses estiveram situados em "pontos altos das montanhas, não acessíveis em todos os meses do ano", como é o caso dos santuários dos Mts.Ida e Dicta, "já outros localizavam-se em áreas mais baixas, podendo ser visitados, facilmente, ao longo de todo o ano" (Rutkowski, 1972: 143). Como bem chama a atenção M. Prent, apesar dos contrastes morfológicos evidentes entre grutas e cume de montes, em termos de culto e função não há diferenças entre áreas sagradas situadas em ambas os tipos de localizações, como indicam os estudos comparativos acerca do equipamento de culto e os objetos votivos nelas recuperados (Prent, 2005: 554-555). Grutas e cumes, ambos em montes, podem ser caracterizadas "pela zona selvagem do campo, geralmente imprópria para o cultivo agrícola em larga-escala" (Prent, 2005: 556). Em linhas gerais, na Idade do Bronze, ambos os tipos de santuários serviram a propósitos agrários e pastoris, como indicam boa parte dos tipos de evidências encontradas (miniaturas de rodas, figurinhas de animais, etc.) ${ }^{10}$.

Assim, apesar de ter sido em Creta que as áreas sagradas do deus foram estabelecidas em montes, foi na Grécia balcânica, a princípio no Peloponeso, que o culto foi pela primeira vez realizado totalmente ${ }^{11}$ a céu aberto em um altar no pico mais alto de uma montanha, tendência seguida, majoritariamente, no próprio Peloponeso e na Ática a partir da Idade do Ferro que, como veremos em detalhe mais adiante, tem relação com o tipo de culto praticado. Sobre a arquitetura do culto, é um traço característico dos santuários de Zeus do período o uso de altares de cinzas, sendo a única exceção o altar e o témeno de pedras do santuário do Mt.Dicta, provavelmente a única área sagrada com outro tipo de construção além do altar.

Outra característica desses 3 santuários da Idade do Bronze é o tipo de função regional adquirida na frequentação das comunidades locais ou mais distantes. Os autores têm aceitado que todos esses santuários assumiram certa especialização de funções somente a partir da Idade do Ferro. O santuário do Mt.Ida se tornou um centro de culto sub-regional e inter-regional a partir da Idade do Ferro. $\mathrm{O}$ santuário do Mt.Dicta parece ter adquirido função sub-regional entre a Idade do Ferro/arcaico (teoria de Prent) ou inter-regional no final da Idade do Ferro (no século VIII a.C.) (teoria de Watrous). Na análise interpretativa sobre esse santuário no capítulo 2 , concluímos que o Mt.Dicta se tratou de uma área sagrada extra-urbana sub-regional. Já o santuário do Mt.Lykaion parece ter tido um papel sub-regional a partir da Idade do Ferro, função que manteve a nível regional até o fim de suas atividades, e inter-regional, com segurança, a partir do século $V$ a.C. No entanto, é possível assumir tais funções já na Idade do Bronze, como mostraremos no estudo de caso de cada santuário no capítulo 2.

\footnotetext{
10 Segundo a tese de Rutkowski, santuários em montes ou picos "teriam emergido no período minoico médio como reflexo das necessidades econômicas dos habitantes de Creta, especialmente os criadores de ovelha e gado e os agricultores" (Rutkowski, 1972: 185). "Com o rápido crescimento da criação de animais e da agricultura, devia ter sido uma preocupação a segurança e a prosperidade" (Rutkowski, 1972: 185).

11 Há indícios de que o culto nas grutas de Ida e Dicta eram realizados na entrada, no lado externo das cavernas.
} 
Todos os 3 santuários de Zeus da Idade do Bronze continuaram sendo centros importantes de culto nos períodos subsequentes, quando aumentaram ainda a sua popularidade. No entanto, a continuidade cultual, da Idade do Bronze à Idade do Ferro não é atestada arqueologicamente para todos esses santuários. No santuário do Mt.Ida, "achados sem estratigrafia, atribuíveis aos períodos subminóico e proto-geométrico, indicam que o culto continuou sem interrupção do minóico tardio III ao período geométrico" (Watrous, 1996: 58). No santuário do Mt.Dicta, oferendas continuaram sem diminuição entre o minoico tardio IIIB e o período proto-geométrico (Watrous, 1996: 53). Além disso, certos padrões próprios de objetos votivos da Idade do Bronze são encontrados naqueles da Idade do Ferro e da época arcaica, tais "como símbolos e características arquitetônicas, indicando atividade ritual similar entre os dois períodos na gruta de Dicta" (Watrous, 1996: 106107). No santuário do Mt.Lykaion, os achados na área do altar indicam que o culto não foi interrompido entre a Idade do Bronze e a Idade do Ferro.

A continuidade cultual da Idade do Bronze à Idade do Ferro coloca a principal questão sobre os santuários de Zeus na Idade do Bronze: a identificação da divindade cultuada, nessas áreas sagradas durante o período, com Zeus. Em Creta, a atribuição dos santuários a Zeus (tanto aqueles que remontam à Idade do Bronze quanto aqueles que remontam à Idade do Ferro) leva ao debate da identificação de uma divindade local masculina e jovem, relacionada à vegetação (definida pelos estudiosos como Zeus Kretagenes ou Dicteu), com o dito deus celeste, o Zeus heládico ou grego. A maior parte dos estudiosos tem considerado, o minoico tardio III, o período no qual a antiga divindade minoica da vegetação, que anualmente nasce e renasce, sincretizouse com o Zeus héladico, o pai celeste (Prent, 2005: 597; Sakellarakis, 1988a: 212). De acordo com Prent, "0 nome indo-europeu "Zeus" provavelmente se vinculou à divindade cretense da vegetação e da natureza na Idade do Bronze tardio, durante o período de sincretismo com a religião micênica" (Prent, 2005: 592). Segundo O. Zolotnikova, "o nome de Zeus é seguramente identificado nos tabletes micênicos, dentre os quais os de Pylos e Chaniá, na forma de Diweus = $\Delta I F \varepsilon u ́ \varsigma$ = ZEús, embora a função exata do deus na religião micênica (se principal ou não divindade do panteão) não seja totalmente conhecida" (Zolotnikova, 2011: 234). O que se sabe é que em época micênica Zeus possuía seus próprios santuários e um mês derivado de seu nome (Duev, 2008: 223). Muitas teorias foram propostas para a origem do sincretismo entre a divindade minoica e a micênica. Talvez a mais recente seja aquela de MacGillivray (atual diretor das escavações em Palaikastro), o qual propôs uma "identificação da constelação de Orion com a divindade masculina minoica, a qual marcava o advento anual do início da colheita durante o período de Hesíodo" (apud Prent, 2005: 592). Como coloca Prent, "se a teoria de MacGillivray estiver correta, a assimilação da divindade cretense com o deus celeste do continente pode ter sido baseada em qualidades celestes compartilhadas" (Prent, 2005: 593).

Esse deus jovem minoico, associado ao reflorescimento da vegetação, é descrito principalmente em textos tardios, como no hino de Palaikastro, sobre o qual trataremos no próximo capítulo. Na documentação de período minoico, "a iconografia o mostra como um jovem, sempre nu, vestindo um cinto com uma adaga ou faca" (Prent, 2005: 592). Esse sincretismo levou a formação de um culto específico a Zeus na ilha de Creta, do 
dito Zeus cretense ou Kretagenes, praticado em santuários durante os vários momentos da época grega. Essas características iniciais do Zeus cretense se mantiveram em períodos posteriores em cultos locais a Zeus, como os de Zeus Idaios (Mt.Ida), Thenatas (Amnisos), Dicteu (Mt.Dicta, Palaikastro e Praesos) e Velchanos (Agia Triada) - "a ênfase na sua juventude, as histórias de seu nascimento, seu casamento com uma deusa e a sua morte, e a relação com ciclos da vegetação" -, conforme descreve a literatura antiga, principalmente aquela de época helenística (Watrous, 1996: 106).

É com base nessa explicação que os estudiosos têm aceito a continuidade do culto nos santuários de Zeus da Idade do Bronze à Idade do Ferro, mesmo quando não há evidências arqueológicas que sustentem tal continuidade, como é o caso de Amnisos, como veremos no item seguinte. Sobre o santuário do Mt.Ida, "evidências desse processo são "os objetos votivos do início da Idade do Ferro, encontrados na gruta, que retratam uma mistura de elementos das tradições minoicas e micênicas, tal como um dos escudos que contém, com muita probabilidade, a imagem de um raio, talvez uma referência às qualidades de Zeus como pai celeste" (Prent, 2005: 603). No caso do Mt.Lykaion, situado fora da ilha de Creta, na Grécia balcânica, os especialistas têm aceito que o Zeus heládico celeste, muito provavelmente, já era a divindade cultuada no santuário durante a Idade do Bronze, pois esta se relaciona a aspectos celestes e atmosféricos, que estão na origem micênica de Zeus (Zolotnikova, 2011: 233).

E assim, essas são as principais questões com relação às características dos santuários e do culto de Zeus na Idade do Bronze, as quais de certa forma continuaram no período posterior, levando à conformação dos santuários e do culto da divindade na Idade do Ferro. 
Tabela 2- Santuários de Zeus da Idade do Bronze

\begin{tabular}{|c|c|c|c|c|c|c|c|c|c|}
\hline $\begin{array}{c}\text { Santuário } \\
\text { (no. cat.I } \\
\text { região) }\end{array}$ & Localização & $\begin{array}{c}\text { Início } \\
\text { atividade } \\
\text { cultual }\end{array}$ & $\begin{array}{l}\text { Término } \\
\text { atividade } \\
\text { cultual }\end{array}$ & $\begin{array}{c}\text { Ápice } \\
\text { atividade } \\
\text { cultual }\end{array}$ & $\begin{array}{l}\text { Declínio } \\
\text { atividade } \\
\text { cultual }\end{array}$ & Tipo santuário & Tipo culto & $\begin{array}{l}\text { Tipo } \\
\text { epíteto }\end{array}$ & $\begin{array}{l}\text { Estrutura de } \\
\text { culto }\end{array}$ \\
\hline 1. Ida (Creta) & $\begin{array}{l}\text { Gruta I } \\
\text { Monte Ida } \\
(1500 \mathrm{~m})\end{array}$ & $\begin{array}{l}\text { Minóico médio } \\
\text { IA (2100-1900 } \\
\text { a.C.) }\end{array}$ & $\begin{array}{l}\text { Romano } \\
\text { tardio (V } \\
\text { d.C.) }\end{array}$ & $\begin{array}{l}\text { Minóico I } \\
\text { VIII-VI a.C. }\end{array}$ & $\begin{array}{l}\text { Romano } \\
\text { tardio }\end{array}$ & $\begin{array}{l}\text { Gruta em pico / } \\
\text { extra-urbano, } \\
\text { inter-regional e } \\
\text { sub-regional (a } \\
\text { partir da Idade do } \\
\text { Ferro) }\end{array}$ & $\begin{array}{l}\text { Ritos de } \\
\text { iniciação } \\
\text { aristocráticos } \\
\text { (Idade do } \\
\text { Ferro) / ritos } \\
\text { de mistério } \\
\text { (época } \\
\text { clássica) }\end{array}$ & $\begin{array}{l}\text { Idaios / } \\
\text { toponí- } \\
\text { mico }\end{array}$ & $\begin{array}{l}\text { Altar de } \\
\text { cinzas / altar } \\
\text { em rocha } \\
\text { externo à } \\
\text { gruta } \\
\text { (romano?) }\end{array}$ \\
\hline $\begin{array}{l}\text { 2. Dicta } \\
\text { (Creta) }\end{array}$ & $\begin{array}{l}\text { Gruta I } \\
\text { Monte } \\
\text { Dicta (1025 } \\
\text { m) }\end{array}$ & $\begin{array}{l}\text { Minoico médio } \\
\text { IA ou IB (1900- } \\
1800 \text { a.C.) } \\
\text { (Watrous), ou } \\
\text { minoico médio I } \\
\text { e II (1800-1700 } \\
\text { a.C.) (Prent) }\end{array}$ & $\begin{array}{l}\text { Romano } \\
\text { tardio }\end{array}$ & $\begin{array}{l}\text { Ferro } e \\
\text { arcaico? }\end{array}$ & $\begin{array}{l}\text { Clássico - } \\
\text { helenístico } \\
\text { / romano }\end{array}$ & $\begin{array}{l}\text { Extra-urbano sub- } \\
\text { regional (a partir } \\
\text { da Idade do Ferro) }\end{array}$ & $\begin{array}{l}\text { Ritos de } \\
\text { iniciação? }\end{array}$ & $\begin{array}{l}\text { Dicteu / } \\
\text { toponí- } \\
\text { mico }\end{array}$ & $\begin{array}{c}\text { Altar de } \\
\text { pedras / } \\
\text { témeno de } \\
\text { pedra }\end{array}$ \\
\hline $\begin{array}{l}\text { 3. Lykaion } \\
\text { (Arcádia, } \\
\text { Peloponeso) }\end{array}$ & $\begin{array}{l}\text { Cume I } \\
\text { Monte } \\
\text { Lykaion } \\
(1382 \mathrm{~m})\end{array}$ & $\begin{array}{l}\text { Heládico tardio } \\
\text { II B (1510-1390 } \\
\text { a.C.) / IIIC } \\
\text { (1200-1070 } \\
\text { a.C.) }\end{array}$ & $\begin{array}{l}\text { Helenístico } \\
\text { tardio } \\
\text { romano }\end{array}$ & $\begin{array}{l}\text { VIII-VII a.C. } \\
\text { / VI-V a.C. }\end{array}$ & I a.C.? & $\begin{array}{l}\text { Pico I extra- } \\
\text { urbano, sub- } \\
\text { regional (a partir } \\
\text { da Idade do Ferro } \\
\text { I sub-regional e } \\
\text { inter-regional com } \\
\text { função agonística } \\
\text { (a partir da época } \\
\text { arcaica) }\end{array}$ & $\begin{array}{l}\text { Atmosférico e } \\
\text { celeste } \\
\text { (origem do } \\
\text { culto) } \\
\text { agonístico / } \\
\text { pan-arcádio } \\
\text { (a partir do } \\
\text { séc. V a.C. ou } \\
\text { antes) / pan- } \\
\text { helênico (a } \\
\text { partir dos } \\
\text { sécs. V-IV } \\
\text { a.C.) }\end{array}$ & $\begin{array}{l}\text { Lykaios } \\
\text { / } \\
\text { toponí- } \\
\text { mico }\end{array}$ & $\begin{array}{c}\text { Altar de } \\
\text { cinzas (a } \\
\text { partir da } \\
\text { Idade do } \\
\text { Bronze) }\end{array}$ \\
\hline
\end{tabular}


Os 19 santuários de Zeus (tabela 3), datados a partir da Idade do Ferro, se dividem em 9 subperíodos, conforme se vê no gráfico 9. Os mais antigos datam a partir do período heládico tardio IIIC (12001070 a.C.) / sub-micênico (10701000 a.C.), como é o caso de Olímpia, no Peloponeso, e do minoico tardio IIIC (1200-1100) / subminoico (1100-1000/975 a.C.), como

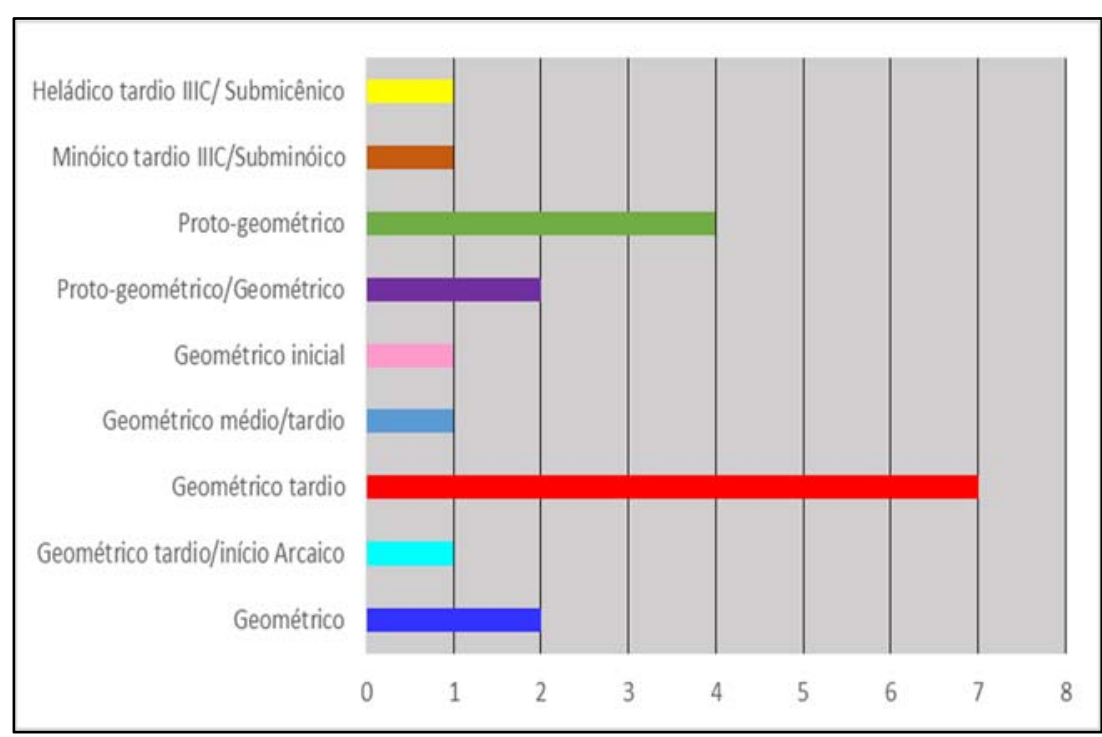

Gráfico 9- Quantidade de santuários de Zeus por períodos da Idade do Ferro é o caso do santuário de Agia Triada, em Creta. O período proto-geométrico (1000-900 a.C.) pode ser considerado a primeira grande fase do início da atividade cultual, de dedicações de santuários à divindade na Idade do Ferro, datando desse período 4 áreas sagradas, as de Amnisos e de Palaikastro, em Creta, de AtenasMt.Himeto, na Ática, e de Dodona, no Épiro. Entre o período proto-geométrico/ geométrico inicial data 0 santuário de Argos-Larisa, do proto-geométrico/geométrico tardio (nesse caso, na $1^{\text {a }}$.metade do séc. VIII a.C.) data o santuário de Zeus em Messênia, no Mt.Ithome. Do período geométrico inicial (século IX a.C.) remonta 0 santuário de Atenas-Mt.Parnes, na Ática. Entre o geométrico médio (século IX a.C.) / geométrico tardio (século VIII a.C.) data o início da atividade cultual no santuário do deus no Mt.Apesas, no Peloponeso. Como se vê no gráfico, o período geométrico tardio é a principal fase do início da atividade cultual de santuários de Zeus durante a Idade do Ferro, dado o maior número de áreas sagradas da divindade datadas a partir desse período (7 no total). Trata-se dos santuários de Zeus em Tsakona, no Mt.Arachnaion, ambos no Peloponeso, em Atenas-Mt.Tourkouvouni, na Ática, no Mt.Attavyros, em Egina, ambos no Egeu, em Praisos, em Creta, e no Mt.Helikon, na Beócia. Entre o geométrico tardio / e o início do período arcaico data o início da atividade cultual em Neméia, no Peloponeso. E por fim, 2 outros santuários são datados genericamente em época geométrica (900-700 a.C.): Sta Marmara, na Megárida, e Pherai, na Tessália.

Dentre as 8 regiões com santuários na Idade do Ferro, no Peloponeso, onde se concentra a maior quantidade de santuários de Zeus (7 no total), está uma das duas áreas sagradas mais antigas do período, Olímpia. Em Creta e na Ática, as segundas regiões em maior número no período (cada qual 3 no total), também estão outros santuários dentre os mais antigos, o de Agia Triada e de Atenas-Mt.Himeto.

Os santuários de Zeus da Idade do Ferro são extra-urbanos, na maior parte dos casos, como ocorre na Idade do Bronze. Apesar de a maior parte ainda das áreas sagradas serem caracterizadas por estarem em cumes de montes ou picos (Atenas-Himeto, Messênia-lthome, Atenas-Parnes, Mt.Apesas, Mt.Arachnaion, 
Mt.Attavyros, Mt.Helikon, Sta Marmara), há mais santuários em planícies/vales, como ocorre com quatro santuários dentre os mais antigos do período - o de Olímpia, Amnisos, Agia Triada, Palaikastro e Dodona, sendo o primeiro deles localizado entre dois rios, o segundo, próximo à costa e o terceiro muito próximo à costa (não à praia, como o de Amnisos). É a partir da Idade do Ferro que apareceram os primeiros santuários de Zeus em zonas colinares, ou seja, ainda que os montes tenham sido procurados para o estabelecimento do culto a Zeus, altitudes baixas e médias passaram a receber áreas sagradas da divindade. Zonas colinares também são as áreas onde foram estabelecidos os únicos santuários suburbanos (Argos-Larisa, Praisos, Pherai) da divindade no período. Apesar de planícies/vales passarem a ser zonas do culto de Zeus, as alturas, na Idade do Ferro, ainda são uma característica típica dos santuários do deus conservada do período anterior, a Idade do Bronze. É preciso dizer que a escolha por esses tipos de localizações, para o estabelecimento das áreas sagradas de Zeus, não teve, necessariamente, a ver somente com o tipo de culto do deus praticado no local. Embora não haja dúvidas de que o tipo de culto influiu, de alguma forma, na escolha por essas localizações, fatores locais também determinaram a fundação dos santuários em certas localizações, como foi o caso de Olímpia, por exemplo. A localização do santuário de Olímpia, em uma grande área plana e aberta entre as sub-regiões da Trifília, Arcádia e Messênia, explica-se, entre outros fatores, pela área ter sido a principal rota dos antigos habitantes das vilas das montanhas da região ao mar Jônico, por meio dos rios Alfeu e Cladeus, que passam pelo santuário (Valavanis, 2004: 21). Sobre os santuários localizados nos cumes dos montes, como bem coloca 0 . Zolotnikova, estes "nem sempre devem ser relacionados à função de Zeus como o deus da chuva", como muitas vezes encontramos na bibliografia a respeito12 (Zolotnikova, 2013b: 122). Veremos mais adiante, que alguns santuários de cume de montes, datados da Idade do Ferro, estiveram relacionados, além das funções atmosféricas, àquelas purificatórias e também pastoris.

Vimos anteriormente, que os santuários extra-urbanos de Zeus, datados a partir da Idade do Ferro, assim como aqueles da Idade do Bronze, tiveram uma longa continuidade cultual, alcançando o declínio em dois períodos principais, em época arcaica e em época romana. Todas as áreas sagradas extra-urbanas exerceram funções regionais específicas (inter-regionais e sub-regionais, esta última na maior parte dos casos) a partir da própria Idade do Ferro. Também é preciso lembrar aqui que foi a partir da Idade do Ferro que os santuários do Mt.Ida, do Mt.Dicta e do Mt.Lykaion, todos datados da Idade do Bronze ${ }^{13}$, tiveram seu primeiro ápice cultual e passaram a adquirir funções inter-regionais, portanto, atraindo comunidades provenientes de regiões para além de sua localização. Neste caso, é possível afirmar que as áreas sagradas de Zeus, que remontam à Idade do Bronze, além de terem conservado suas funções extra-urbanas regionais, também podem tê-las ampliado em período posterior, na Idade do Ferro.

\footnotetext{
12 Vide, a esse respeito, por exemplo, Kreutz, 2007, p. 265.

${ }^{13}$ Aqui não citamos o santuário de Amnisos, pois não encontramos informações sobre a função da área sagrada extra-urbana em termos regionais.
} 
Como nos chama a atenção O. Zolotnikova, muitos santuários de Zeus, que remontam à Idade do Ferro, foram instalados em áreas próximas ou em assentamentos datados do final da Idade do Bronze, podendo, dessa forma, terem sido resultados de algum tipo de prática de culto local pré-existente ao deus ou não (Zolotnikova, 2011: 235). Em Creta, essa prática de estabelecer santuários em assentamentos minoicos abandonados foi muito comum não apenas no estabelecimento de áreas sagradas de Zeus, como foi o caso de Amnisos, Agia Triada, Palaikastro e Praisos. No Peloponeso, tal fenômeno ocorreu em Olímpia e possivelmente em Neméia, onde os santuários foram assentados sobre ruínas de ocupação micênica. Nesses seis casos, a continuidade cultual com a Idade do Bronze não foi atestada arqueologicamente, mas o culto em alguns desses locais (Amnisos, Agia Triada, Palaikastro, Praisos) pode ser associado, em algum grau, a uma tradição religiosa preexistente em outros a ligação, de qualquer tipo, com o período anterior permanece especulação (como em Olímpia e Neméia). Além da permanência religiosa da Idade do Bronze associada à essas áreas de culto da Idade do Ferro, os pesquisadores têm propiciado várias explicações para o que se pode chamar de "re-uso ritual para o culto de Zeus" nesses locais (Zolotnikova, 2011: 235). Ao tratar do caso de Palaikastro, M. Prent traz conclusões interessantes sobre a apropriação de determinados espaços dentro de sítios minoicos para a instalação de um culto. Segundo esse autor, "parte da razão da localização do santuário de Zeus Dicteu, nas ruínas da cidade minoica, se deve à natureza remota da área no período" e "em seu aspecto significativo, na memória respeitável da grandeza de outrora da cidade entre as comunidades locais" (Prent, 2005: 539-540). Esses santuários cretenses de Zeus, instalados em sítios minoicos, também têm levado os especialistas a pensar na continuidade cultual ou não dessas áreas sagradas da Idade do Ferro com a Idade do Bronze. O santuário de Palaikastro, como veremos em detalhe no próximo capítulo, oferece o maior debate nesse tema. Embora não haja provas diretas da continuidade do culto de Zeus no santuário em Palaikastro - "há um intervalo de 300 anos entre o abandono final do edifício, onde se localiza o santuário de Zeus nesse sítio, e a dedicação do primeiro trípode de bronze no período proto-geométrico" - há uma série de evidências que sugerem "a preservação de uma associação (geral) da área de Palaikastro com o culto do deus de Dicta (Zeus Dicteu)" (Prent, 2005: 544).

Além desses tipos de continuidades observáveis nos santuários e no culto de Zeus entre a Idade do Bronze e a do Ferro, nesse período, pode-se dizer que a arquitetura ou estrutura do culto, na maior parte dos casos, ainda era caracterizada pelo altar, principalmente o de cinzas, instalado a céu aberto, como também concluiu O. Zolotnikova (Zolotnikova, 2011: 236). Edifícios de culto são muito raros em santuários de Zeus datados a partir da Idade do Ferro, mas não inexistentes. Zolotnikova chama a atenção para as denominadas "casas ovais", edifício típico da Idade do Ferro, que foram identificadas em Olímpia, Dodona e em AtenasMt.Tourkouvouni, "cuja função não foi ainda precisamente estabelecida" (Zolotnikova, 2011: 236). No caso de Olímpia, desde muito recentemente, os especialistas desse sítio têm interpretado a estrutura como o primeiro templo de Zeus no Altis (Duplouy, 2012: 109). No santuário de Zeus em Tsakona, na Lacônia no Peloponeso, as escavações identificaram os remanescentes de dois pequenos edifícios, sendo um deles datado do século 
VIII a.C. (Catling, 1990: 34-35). Os demais edifícios existentes em santuários de Zeus da Idade do Ferro foram todos introduzidos em períodos posteriores, a partir da época arcaica.

Com relação aos objetos votivos encontrados nos santuários de Zeus da Idade do Ferro, de uma maneira geral, estes se dividem em três grupos: 1-) tipos de recipientes cerâmicos; 2-) figurinhas humanas e animais, ambas de terracota ou bronze; 3-) trípodes e caldeirões de bronze, jóias e armamentos (miniaturas ou não de partes de armaduras ou armas). Os recipientes cerâmicos, como cântaros e taças, indicam o ritual de libações e de bebidas em honra a Zeus, já a presença de outros formatos de vasos são evidência também de refeições rituais (Zolotnikova, 2011: 237). Esses tipos de oferendas são predominantes em Olímpia, em AtenasMt.Himeto, Atenas-Mt.Tourkouvouni, Mt.Apesas, Palaikastro, Amnisos, Argos-Larisa e Neméia, indicando a presença desses rituais nesses santuários de Zeus (Zolotnikova, 2011: 237). Figurinhas de animais e tipos específicos de figurinhas humanas (cocheiros, por exemplo) são tidas como indicativos do culto pastoril e agrário de certos santuários de Zeus onde foram encontradas, como Mt.lda, Mt.Dicta, Amnisos, Olímpia, Palaikastro, Mt.Attavyros. Dentre essas figurinhas de terracota humanas, destacamos os tipos encontrados em Tsakona, que sugerem um culto relacionado à fertilidade e reprodução. Oferendas votivas importantes em metal, como trípodes e caldeirões de bronze, armamentos e jóias ${ }^{14}$ são evidência de um culto de conotação aristocrática-militar a Zeus. Trípodes e caldeirões de bronze são objetos votivos típicos da Idade do Ferro (IXVIII a.C.), que se tornaram "menos significativos em época arcaica e clássica quando uma sociedade mais democrática emergiu" (Bintliff, 2012: 230). Trata-se de objetos com função doméstica para refeições comunais que, devido ao valor intrínseco do metal, o alto custo na confecção, etc., transformaram-se em símbolos de status, autoridade e prestígio social das elites das várias comunidades, que frequentavam santuários de Zeus durante o período (Bintliff, 2012: 230; Taita, 2007: 101). Todas essas categorias de oferendas são típicas dos santuários de Amnisos, Palaikastro, Messênia-Mt.Ithome, Mt.Helikon, Tsakona, Praisos, com destaque para aqueles inter-regionais de Olímpia, Mt.Ida, Dicta e Dodona, onde esses objetos se destacam e se diferem pela quantidade, qualidade artística e dimensões.

A arquitetura do culto e os tipos de objetos votivos, descritos até o momento, ajudam a delinear o culto de Zeus ao longo dos vários subperíodos da Idade do Ferro. Assim, as evidências oriundas dos santuários indicam que o culto de Zeus no período era predominantemente relacionado à esfera agrária e pastoril, requisitado pelas populações das comunidades da Idade do Ferro para "garantir a fertilidade da terra e a fecundidade dos rebanhos" (Taita, 2007: 95). Ao mesmo tempo que o culto de Zeus era requisitado entre as populações agrícolas e pastoris, também exercia influência entre as elites das comunidades da Idade do Ferro, principalmente na esfera militar, um traço do culto que se conservou em determinadas áreas sagradas da divindade em época arcaica e clássica.

\footnotetext{
${ }^{14}$ As jóias são tidas como evidência da presença feminina no culto desses santuários de Zeus.
} 
De acordo com O. Zolotnikova, durante a Idade do Ferro, Zeus provavelmente foi concebido como um "deus do céu claro e progenitor", "da natureza, da fertilidade da terra, das colheitas e dos animais domesticados" (Zolotnikova, 2011: 239 e 242). A seu ver, o deus nessa época, não tinha sido ainda "associado a conceitos de autoridade e poder monárquico, como obteve em períodos posteriores quando o seu culto foi introduzido nas cidades" (Zolotnikova, 2011: 239). Todas as evidências disponíveis sobre os santuários de Zeus na Idade do Ferro, sobretudo a sua característica extra-urbana e influência regional, levaram a essa autora corretamente a concluir que nesse período, a divindade "não era relacionada ainda ao Estado e a vida urbana (a pólis) em geral" (Zolotnikova, 2011: 239).

De fato, todas as evidências disponíveis sobre os santuários de Zeus na Idade do Ferro levam a tal conclusão. Mas, será que aqueles poucos santuários suburbanos e urbanos de Zeus não podem nos fornecer alguma indicação sobre quando o culto de Zeus passou a ser domínio de algum tipo de comunidade política emergente, de estar situado dentro de um assentamento urbano?

Os santuários de Zeus em Messênia-Mt.Ithome, em Pherai e em Argos-Larisa são os únicos que podem indicar tal relação no período. Como bem coloca J. Bintliff, "no período geométrico a maioria da população vivia em uma rede de pequenas e grandes comunidades nucleadas, dispersas regularmente na paisagem, frequentemente em sítios que se transformaram em pequenas e grandes cidades em época arcaica e clássica" (Bintliff, 2012: 215). As evidências arqueológicas provenientes de vários assentamentos indicam que "somente no decorrer do século VIII a.C. a pólis emergiu a partir da organização de grupos populacionais em torno de objetivos comuns" (Florenzano, 2010: 41). Os sinais desse processo são indicados pelo "surgimento do templo, 0 aumento das oferendas votivas nesses templos e, em contrapartida a diminuição das oferendas em sepulturas, o posicionamento do templo em relação ao assentamento e a instalação dos herôa nesses assentamentos" são as principais evidências desse processo (Florenzano, 2010: 41).

A formação da pólis foi um processo gradual e não homogêneo para todos os assentamentos/comunidades da Idade do Ferro. Dentre os quatro santuários de Zeus citados apenas Argos e talvez Pherai e Praisos (situados em assentamentos com graus diferentes de urbanização na Idade do Ferro) alcançaram o desenvolvimento de uma pólis inicial nessa época. Sobre Messênia-Mt.lthome, há evidências sobre a existência de um antigo assentamento, na área de Mavromati, datado entre o século IX-VIII a.C., que precedeu a fundação da pólis de Messênia no período clássico (Luraghi, 2008: 112). Esse assentamento, que segundo a bibliografia, teria sido denominado de Ithome, teria exercido algum tipo de domínio em relação ao santuário de Zeus no Mt.lthome, no sopé do qual estava situado. Trata-se do único assentamento messênio em proximidade ao monte que poderia ter exercido certa influência na organização da área sagrada e do festival, que, como veremos no próximo capítulo, remonta ao século VIII a.C. Na tese de M. Prent, sobre o santuário no Mt.Dicta, este teria sido a área sagrada de Papoura, o principal assentamento no platô do Lassithi. O tamanho do assentamento de Papoura, a sua posição estratégica nas principais rotas de acesso e sua proximidade à gruta de Dicta, indicariam, segundo esse autor, que a organização do culto em Dicta pertenceu 
aos habitantes desse assentamento já na Idade do Ferro (Prent, 2005: 609). Contudo, em nossa interpretação desse santuário cretense de Zeus não seguiremos essa proposição de Prent sobre a caracterização suburbana da área sagrada no Mt. Dicta.

É fato que as comunidades emergentes, que frequentaram os santuários extra-urbanos inter-regionais e sub-regionais de Zeus, também indicam a relação de assentamentos urbanos com áreas sagradas da divindade, embora de uma maneira diferente, talvez sem a preponderância de um assentamento sobre o outro pelo domínio desses santuários extra-urbanos, como ser vê a partir da época arcaica. Em contraste, os quatro casos de santuários suburbanos e urbanos de Zeus descritos podem ser os exemplos mais antigos de interferência direta da pólis emergente ou de pré-polis (no caso de Ithome e Papoura) na organização/controle de santuários de Zeus. É certo o papel de Argos em relação ao santuário situado na acrópole Larisa, assim como de Pherai em relação ao santuário de Zeus Thaulios, situado na encosta de sua acrópole, e o de Zeus Dicteu na terceira acrópole de Praisos. A relação do assentamento de Ithome, com o santuário de Zeus Ithomates, no cume do Monte Ithome, talvez seja o caso mais significativo ou mais conhecido a respeito desse fenômeno. 


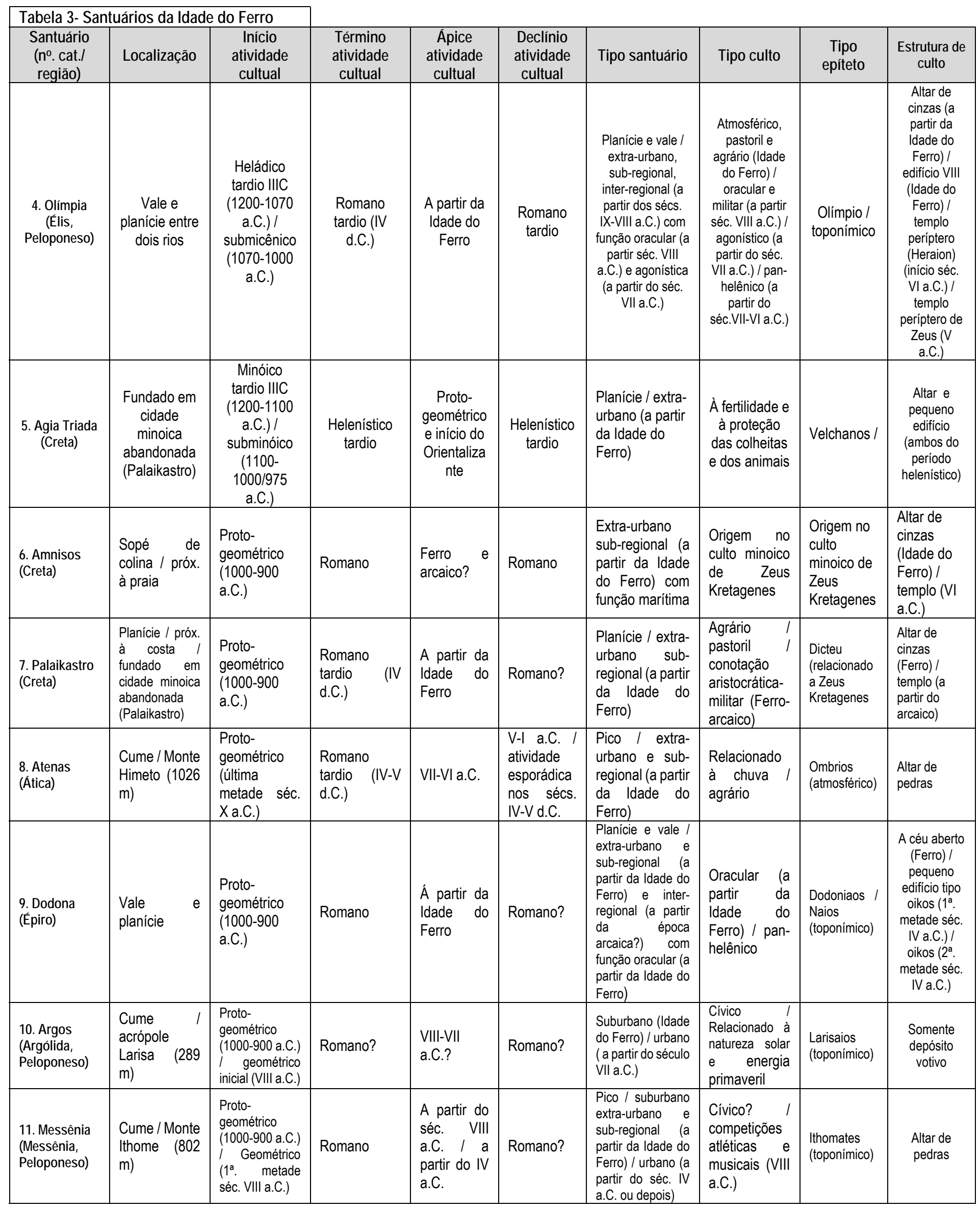




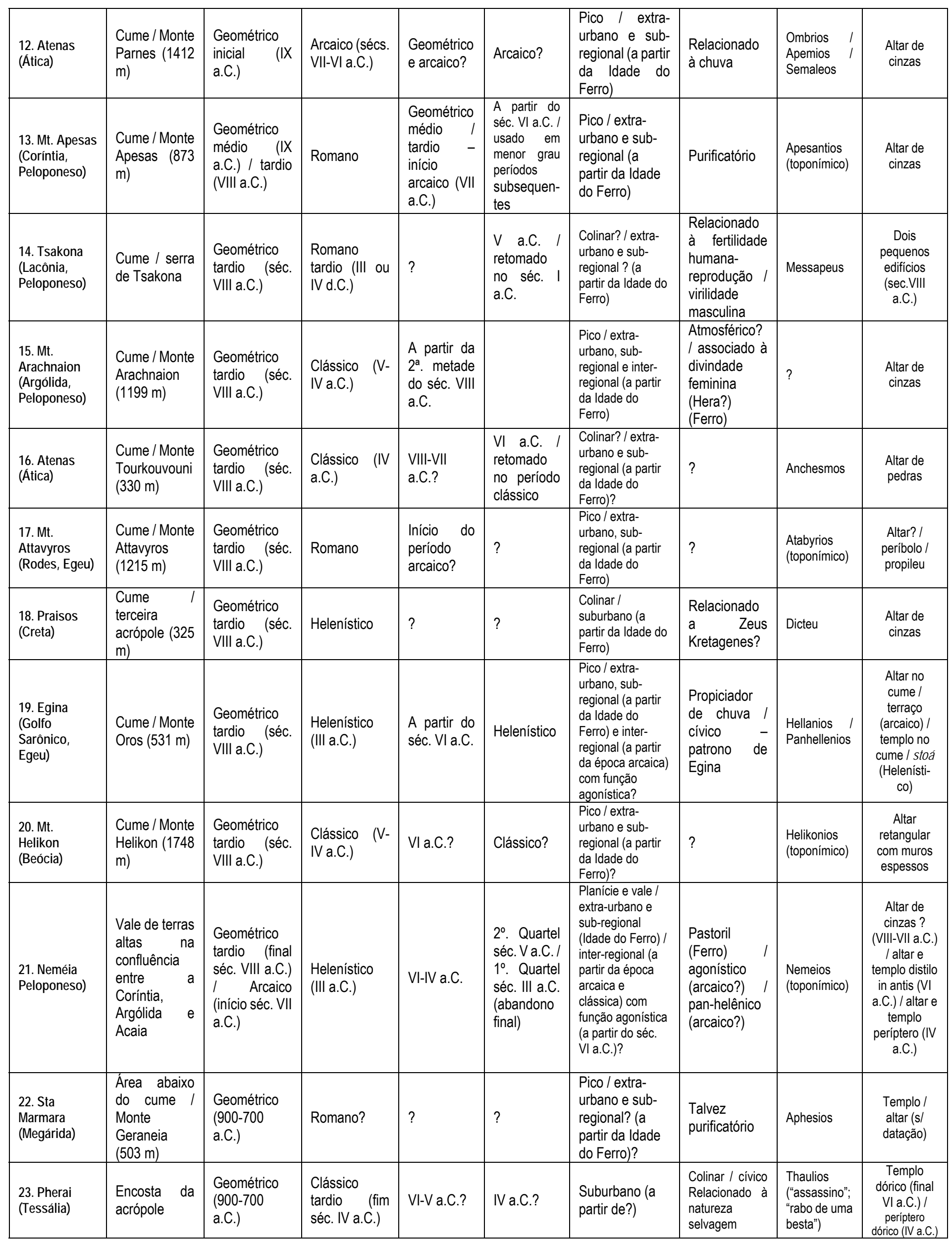




\section{II.3 A ÉPOCA ARCAICA (VII-VI a.C.)}

Como vimos anteriormente, a época arcaica representou o segundo grande período de dedicação de santuários de Zeus, ao lado da Idade do Ferro (tabela 4). Conforme se vê no gráfico 10, ainda que as 19 áreas sagradas da divindade, datadas a partir da época arcaica, tenham sido em grande parte estabelecidas no século VII a.C. (6 no total: Labraunda, Delos, Naxos,

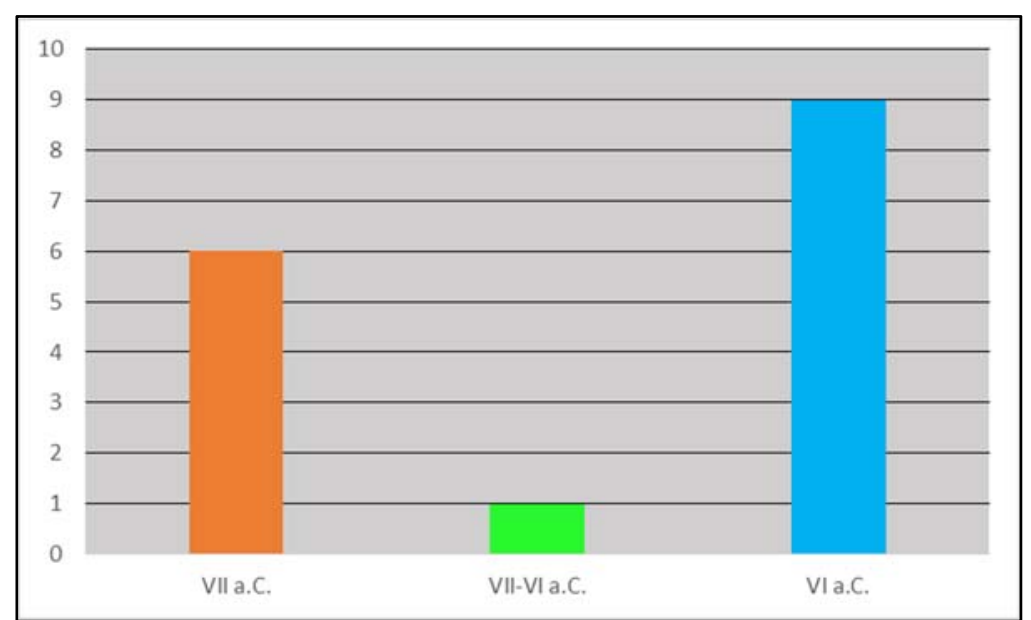

Gráfico 10- Quantidade de santuários de Zeus por séculos na época arcaica

Selinonte-Gaggera, Atenas-Agrai, Siracusa), foi durante o século VI a.C. que a maioria dos santuários de Zeus foram dedicados no período (9 no total: Atenas-llissos, Kefalonia, Metaponto-ágora, Metaponto-S.Biaggio, Lócris, Selinonte-Marinella, Corinto, lasos, Bambes). Da transição do século VII-VI a.C. é datado o início cultual de apenas 1 santuário (lalysos).

Em época arcaica, as regiões onde se concentraram os santuários de Zeus, datados a partir desse período, ao mesmo tempo que se mantiveram, como é o caso do Peloponeso, da Ática e do Egeu, também se diversificaram. A partir da época arcaica, novas regiões do mundo grego passaram a abrigar áreas sagradas da divindade, sendo o caso da Cária, da Eubéia, do mar Jônio, da Sicília e da Itália do Sul. As regiões com maior número de santuários de Zeus estabelecidos a partir de época arcaica (cada qual com 3 áreas sagradas no total), são a Sicília (Siracusa, Selinonte-Gaggera, Selinonte-Marinella) e a Itália do Sul (Metaponto-ágora, Metaponto-S.Biaggio, Lócris). Embora tenha sido contabilizado 4 áreas sagradas de Zeus no mar Egeu em época arcaica (Delos, Naxos, lalysos, Kamiros), é preciso dizer que em lalysos e Kamiros, ambas na ilha de Rodes, os santuários datados de época arcaica referem-se ao culto de Atena e não ao de Zeus, que foi introduzido junto ao da deusa somente em período posterior, em época clássica e helenística. Assim, para o Egeu, pode-se considerar apenas dois santuários de Zeus datados a partir da época arcaica (Delos, Naxos). As áreas sagradas mais antigas do deus, no período (do século VII a.C.), se concentram na Cária (Labraunda), no Egeu (Delos, Naxos), na Ática (Atenas-Agrai e talvez em Atenas-llissos) e na Sicília (Siracusa, SelinonteGaggera)

Com relação às categorias de santuários, apesar de em época arcaica ainda predominarem santuários extra-urbanos de Zeus (Labraunda, Delos, Naxos, Selinonte-Gaggera, Selinonte-Marinella, Atenas-Agrai, Siracusa, Kefalonia, Metaponto-S.Biaggio, Lócris, Corinto, Cabo Kenaion, talvez Bambes), áreas sagradas urbanas passaram a ser estabelecidas no período em grande número (Atenas-llissos, Metaponto-ágora, Lócris, lasos, Figaléia, Kamiros, lalysos, talvez Bambes), em contraste à Idade do Ferro. Em Figaléia (Peloponeso), 
Kamiros e lalysos (Rodes) o culto a Zeus, muito provavelmente, foi introduzido a partir do século IV a.C. em santuários arcaicos de Atena. Aqui cabe dizer que foi muito recorrente o compartilhamento de áreas sagradas arcaicas, de divindades femininas, com Zeus em períodos posteriores (Figaléia, Kamiros, lalysos) ou a partir da própria época arcaica (Delos, Selinonte-Gaggera, Metaponto-S.Biaggio).

Sobre os tipos de localizações dos santuários de Zeus em época arcaica, vimos que cumes de colinas permaneceram como uma tendência no período, uma característica do culto da Idade do Ferro que se conservou em época arcaica (nas áreas sagradas de Delos, Selinonte-Gaggera, Selinonte-Marinella, lalysos, Figaléia, Kamiros, Bambes). Planícies/vales, também uma tendência iniciada na Idade do Ferro, tornou-se, em época arcaica, a principal localização dos santuários de Zeus, em proximidades a rios (Atenas-Agrai, AtenasIlissos, Corinto), em proximidade à costa e a rios (Siracusa), à costa (lasos, Cabo Kenaion) ou não (Metapontoágora, Metaponto-S.Biaggio). Repara-se que tanto colinas como planícies não estiveram relacionadas estritamente com determinada categoria de santuário (extra-urbano e urbano) em época arcaica: há santuários extra-urbanos em colinas como em planícies, assim como há santuários urbanos em ambos os tipos de localizações.

Funções regionais também foram um traço de santuários extra-urbanos de Zeus datados a partir de época arcaica, embora em menor grau, como é o caso de Cabo Kenaion, Naxos e Kefalonia, cujos santuários adquiriram funções sub-regionais no período e inter-regionais e sub-regionais (Labraunda). Já no caso dos santuários que remontam à Idade do Bronze e à Idade do Ferro, alguns deles adquiriram novas funções somente em época arcaica. Dodona e o Mt.Lykaion tornaram-se um santuário inter-regional, muito provavelmente, a partir da época arcaica, o santuário em Egina, no Monte Oros, e Neméia também devem ter se tornado centros de culto inter-regionais nessa época. Olímpia, ainda, adquiriu função agonística a partir do século VII a.C. e Neméia, provavelmente, no século VI a.C. Alguns santuários da Idade do Bronze e da Idade do Ferro tiveram, também, seu ápice cultual em determinado período do arcaico. 0 santuário de AtenasMt.Himeto teve o ápice de atividade cultual entre os séculos VII-VI a.C., o do Mt.Attavyros, no início do período arcaico, o de Egina-Mt.Oros e talvez do Mt.Helikon tiveram o auge do culto a partir do século VI a.C. Já outras áreas sagradas alcançaram o ápice do culto entre a Idade do Ferro e a época arcaica (Mt.Ida, Mt.Dicta, Amnisos, Mt.Lykaion, Atenas-Mt.Parnes, Atenas-Mt.Tourkouvouni, Mt.Apesas). Com relação das áreas sagradas datadas a partir da época arcaica, algumas delas alcançaram o auge do culto no próprio período (Delos, lalysos, Atenas-llissos, Lócris, Cabo Kenaion, Kamiros) e outras apenas entre a época arcaica/clássica (Siracusa, Metaponto-ágora, Selinonte-Marinella, Corinto, Bambes) e em época clássica e em diante (SelinonteGaggera, Atenas-llissos, Figaléia).

Apesar de altares ainda serem o único tipo de estrutura do culto em alguns santuários arcaicos de Zeus, com predominância para altares de pedra e alvenaria associados em certos casos a um muro de períbolo (Metaponto-ágora, Cabo Kenaion), edifícios de culto de várias formas (naískos, templos prostilos e perípteros) passaram a ser a estrutura mais importante nas áreas sagradas da divindade, que remontam à época arcaica. 
Trata-se este de um fenômeno específico do período arcaico, quando, como bem coloca J. Bintliff, a "criação de um complexo de templos pertencente a uma comunidade simbolizou a reorientação da sociedade para longe da residência da elite (aqui se refere às denominadas "casas dos chefes") e em direção à residência simbólica da divindade patrona da cidade (Bintliff, 2012: 229). Atualmente é unanimemente aceito entre os especialistas que os templos gregos, cuja forma final foi alcançada já a partir do século VII a.C., derivaram sua planta das casas dos chefes de época geométrica (Bintliff, 2012: 229). A planta dessas estruturas era retangular e alongada, com divisões internas, fechada na parte dianteira por um muro semi-circular, sendo de Lefkandi 0 exemplo mais conhecido (Bintliff, 2012: 229). De acordo com Bintliff, a divisão interna desses edifícios, e suas funções, estão na origem do templo arcaico e clássico - "um pórtico de entrada, uma sala principal com um foco (originalmente uma lareira, mais tarde a estátua de culto) e frequentemente uma sala mais ao fundo, que servia como uma área "privada-tesouro" (mais tarde o tesouro do templo)" (Bintliff, 2012: 229). 0 desenvolvimento do templo em uma "residência da divindade" protetora da comunidade política, entre os séculos VIII-VII a.C., foi parte de um fenômeno histórico e social muito maior, o da formação da pólis grega nesse período. Assim, o templo grego alcançou a sua forma final (tal como ficou conhecido em época clássica) ao longo da época arcaica, justamente no período no qual a cidade grega adquiriu os formatos físicos e políticos que the caracterizaram em época clássica - um centro urbano e um território com autonomia política ${ }^{15} \mathrm{e}$ governado por um sistema aristocrático formado por cidadãos organizados em tribos e pequenos grupos de parentesco (Murray, 2012: 1170). Embora tenha havido muitas variações no funcionamento das instâncias políticas entre as cidades gregas, foi entre os séculos VII-VI a.C. que se "estabeleceu um código de leis escrito, ou consuetudinário, o qual limitou os poderes arbitrários aristocráticos e regulou o conflito social (eunomia)". E por fim, foi no final do século VI a.C. que "a evolução do conceito de cidadania levou ao estabelecimento da igualdade nos direitos políticos entre os membros desse grupo (isonomia)" (Murray, 2012: 1170).

Com respeito ao desenvolvimento urbano da pólis, ainda hoje não há muito consenso entre os especialistas sobre o tema (Hansen, 2006: 98-99). O que é comumente aceito é o fato de que a pólis não foi um fenômeno homogêneo ou único. A pólis alcançou diferentes graus de urbanização em diferentes períodos e regiões do mundo grego, sendo por essa razão que os especialistas têm procurado interpretá-la sob níveis distintos e modos de urbanização (Vink, 1997: 111). A esse respeito, De Polignac alerta para o problema de se eleger certas categorias para definir o grau de urbanização de uma cidade grega - densidade, tamanho, monumentalização, diversificação social e econômica, arquitetura pública, etc. (De Polignac, 2005: 46). De todo modo, sobre a época arcaica, é consenso que o século VI a.C. representou o primeiro ápice de urbanização da pólis ou foi o momento quando "o modelo de cidade grega foi elaborado" (De Polignac, 2005: 46; Hansen, 2006 : 99).

\footnotetext{
${ }^{15}$ A pesquisa do Copenhagen Polis Center, para a elaboração do inventário das póleis, mostrou que o critério de autonomia política é relativo na definição da cidade grega - nos períodos arcaico e clássico centenas de comunidades não eram autônomas, mas podiam ser definidas como póleis (Vlassopoulos, 2011: 10).
} 
É nesse contexto, portanto, do desenvolvimento da pólis em época arcaica que vemos a construção de templos em santuários arcaicos de Zeus e uma primeira fase edilícia de monumentalização em santuários mais antigos da divindade, datados da Idade do Bronze e da Idade do Ferro. A esse respeito, no santuário da Idade do Bronze de Amnisos restos arquitetônicos e escultóricos de um templo atestam uma importante atividade edilícia na metade do século VI a.C. O mesmo ocorre nos santuários da Idade do Ferro de Palaikastro, com a construção de um templo datado entres os séculos VII-VI a.C.; de Olímpia com a dedicação do Heraion em c.600 a.C., considerado por alguns autores o primeiro templo períptero de Zeus no local; de Neméia com a edificação do templo prostilo distilo in antis do século VI a.C.; e Bambes (templo dórico prostilo), datado do final do século VI a.C. e de Pherai, um templo dórico (não se sabe se períptero ou prostilo) datado também desse mesma época. No caso do santuário inter-regional de Neméia, e mais destacadamente no de Olímpia, de acordo com J. Hall, esse primeiro grande desenvolvimento arquitetônico, nesses tipos de santuários, corresponde a dois momentos, não considerados acidentais por esse autor: 0 uso do termo helenos e a formalização dos festivais pan-helênicos realizados nesses espaços durante o século VI a.C. (Hall, 2007a: 271). Trata-se do período que ocorreu um alargamento da participação de grupos de gregos nos jogos olímpicos. Tal assunto será melhor tratado no próximo capítulo.

Nos santuários datados a partir de época arcaica, o estabelecimento da área sagrada parece ocorrer em concomitância ou não à instalação de um edifício de culto. Em Labraunda, o templo prostilo distilo in antis foi construído no final do século VI a.C., portanto, um século depois da data do início da atividade cultual, como parece ser o caso também do santuário de Selinonte-Gaggera, cujo naískos remonta ao primeiro quartel do século VI a.C. e o santuário ao século VII a.C., e daquele de Atenas-llissos (de Zeus Olímpio), com possibilidade de remontar à época geométrica e que recebeu o primeiro edifício de culto no início do século VI a.C. e o segundo templo (períptero) no final desse período. Em Bambes, o santuário de Zeus pode remontar ao século VII a.C., cerca de um século antes da data do templo. Já os santuários de Zeus de Siracusa, Lócris, SelinonteMarinella, Corinto e Cabo Kenaion podem ter recebido os edifícios de culto após um espaço de tempo menor que um século desde a data de início da atividade cultual. É importante destacar que foi durante o século VI a.C. que os santuários de Zeus receberam templos perípteros (na maior parte dóricos), sendo os mais antigos o edifício de Siracusa (c.580 a.C.) e talvez o Heraion de Olímpia (c.600 a.C.). Apesar de remontarem ao século VIII a.C., como indica os remanescentes do Heraion de Samos, datados dessa época, a forma e a aparência essencial dos templos perípteros gregos foram obra do século VII a.C., sendo na primeira parte do século VI a.C. que esses tipos de edifícios (principalmente os da ordem dórica) estavam essencialmente formados, sofrendo apenas modificações e refinamentos nos períodos posteriores (Lawrence, 1995: 67). Templos perípteros, "o tipo de edifício de culto grego de mais prestígio"16 devido ao seu desenho arquitetônico e à sua monumentalidade, foram predominantes em 5 dos 16 santuários de Zeus datados a partir da época arcaica,

\footnotetext{
16 Tomlison, 2012, p.1438.
} 
em contraste aos templos de tipo prostilo, encontrados em 4 santuários. Os templos perípteros são todos relacionados aos santuários de Zeus Olímpio, tornando-se mais comuns em áreas sagradas da divindade em época clássica.

Abundantes nas áreas sagradas datadas a partir da Idade do Bronze e do Ferro, objetos votivos não são encontrados em todos os santuários de Zeus de época arcaica. Em alguns dos santuários, os depósitos votivos devem ter sido removidos durante algum momento de sua história, não tendo sido por isso localizados pelas pesquisas arqueológicas, como ocorre naqueles de Siracusa, Atenas-llissos, Metaponto-ágora, Lócris, Selinonte-Marinella, Corinto, Bambes e Cabo Kenaion. De um modo geral, as oferendas cerâmicas encontradas nos santuários de Delos e Naxos, ambos de área egéia, datados do século VII a.C. e associados a um único altar, sugerem rituais de libação e bebida, e talvez refeições comunais, no culto de Zeus nessas áreas durante o primeiro século da época arcaica. Assim, trata-se de uma característica comum às áreas sagradas da Idade do Ferro, atestando, dessa forma, continuidade com prática de culto a Zeus realizada no período anterior. Nos santuários extra-urbanos inter-regionais de Mt.Ida, Dicta e Olímpia se vê, em época arcaica, uma continuidade na dedicação de partes de armaduras, indicando o aspecto guerreiro da divindade e relação com uma aristocracia militar também em época arcaica.

Outros tipos de oferendas nos levam a casos específicos em relação a caracterização do culto de Zeus em época arcaica. É o caso do santuário de Zeus em lasos, onde prevalecem oferendas de terracota de figurinhas femininas em época arcaica e começaram a ocorrer pequenas estatuetas votivas de um casal divino. Esses objetos votivos são tidos como evidência do culto de uma divindade feminina ao lado de Zeus, considerada Hera. São também testemunhos do compartilhamento de santuários de Zeus com divindades femininas, prática que se iniciou, ao que parece, em época arcaica. A esse respeito, lembramos que não consideramos as oferendas encontradas nos santuários de lalysos, Kamiros e Figaléia, pois estas, em época arcaica, se referem a objetos dedicados não a Zeus, mas às divindades femininas cultuadas nessas áreas.

Os objetos votivos encontrados no santuário de Selinonte-Gaggera referem-se à características novas no culto de Zeus dentre aquelas que remontam à Idade do Bronze e à Idade do Ferro. Trata-se de um santuário, cuja configuração espacial é única em relação a Zeus em termos de mundo grego em época arcaica e períodos posteriores. Os objetos votivos encontrados no santuário de Zeus em Selinonte-Gaggera indicam o culto de Zeus Meilichios, que remonta à época arcaica e foi muito difundido no mundo grego em períodos posteriores. Nesse santuário foi encontrado um grande número de estelas votivas (datadas a partir do início do século VI a.C.) que ficavam expostas em uma área aberta anexa ao santuário do deus. Trata-se de estelas sem ou com imagens e inscrições - dentre aquelas inscritas algumas fazem menção ao epíteto Meilichios e à pessoa ou ao grupo de fiéis (Grotta, 2010: 47). De acordo com C. Grotta, especialista nesse santuário, as estelas atestam uma forte relação com 0 ambiente familiar e nobiliário, predominando a característica privada da experiência religiosa e não a pública (Grotta, 2010: 226). Além de representar um culto ctônio de Zeus, não observado na documentação sobre os santuários do deus dos períodos anteriores, parece se tratar do primeiro santuário da 
divindade a exercer uma função específica na esfera do privado dentro do contexto da cidade grega em época arcaica. Infelizmente, não dispomos em plena época arcaica de mais evidências sobre o culto de Zeus Meilichios que pudessem ser correlacionadas a estas do santuário de Selinonte-Gaggera. O santuário de Zeus Meilichios em Atenas-Agrai, atribuído às fontes literárias ao século VII a.C. não dispõe de oferendas datadas de época arcaica. Os relevos votivos atribuídos a esse santuário são datados dos séculos IV-III a.C. Na área sagrada de Atenas-collina das ninfas, datada entre os séculos VI-V a.C. também não foram encontrados objetos votivos.

Como se vê, as conclusões advindas dos objetos votivos nos levam a perceber que em época arcaica houve certa continuidade das características do culto de Zeus da Idade do Ferro, principalmente no século VII a.C. em santuários extra-urbanos sub-regionais na área egéia. É possível que nessas áreas os santuários tenham exercido ainda algum tipo de papel relacionado à esfera agrária ou pastoril entre as populações locais. Este pode ser ao menos o caso da área sagrada da ilha de Naxos, que era dedicada a Zeus com o título Melósios ("pele de carneiro"), que indica função pastoril. Já no caso dos santuários extra-urbanos interregionais, que remontam a Idade do Bronze e do Ferro, o culto aristocrático-militar continuou a predominar, de certa forma, sobre aquele sub-regional (agrário e pastoril) da Idade do Bronze. Em Olímpia, por exemplo, desde o final da Idade do Ferro o culto de Zeus Olímpio no local foi marcado pelo papel da divindade entre uma elite aristocrática guerreira, que consultava o oráculo para fins bélicos e dedicava despojos de guerra na área do estádio a partir da época arcaica. É preciso ressaltar que a partir dessa mesma época, as elites que frequentavam esses santuários, naquele momento, oriundas das cidades gregas, eram atraídas a centros de culto inter-regionais para a competir nos jogos, instituídos entres os séculos VII-VI a.C. em Olímpia e Neméia. É desse período que datam as primeiras oferendas votivas de Olímpia com o nome do ofertante e de sua cidade de origem. Outros tipos de oferendas, provenientes de santuários da Cária e da Sicília - áreas novas em relação as antigas regiões predominantes nos períodos anteriores - indicam características inovadoras no culto de Zeus dentre aquelas observadas em períodos mais antigos, como o compartilhamento do culto com divindades femininas e o culto privado no contexto da cidade grega.

Com relação às regiões da Sicilia e da Itália do Sul, nessas áreas, os santuários de Zeus foram estabelecidos em época arcaica sem nenhuma das características observadas no culto na Grécia Balcânica e na área egéia (incluindo-se aí Creta), que remontam à Idade do Ferro e o início do período arcaico. Não há nessas duas regiões, santuários de Zeus localizados em cumes de montes ou relacionados aos aspectos agrários e pastoris. Em época arcaica, no Ocidente grego, o culto de Zeus se desenvolveu diretamente em relação à pólis - seus santuários, no período, ainda que na maioria extra-urbanos, foram instalados nos territórios das cidades gregas e estavam sob o seu controle. Assim, em época arcaica, na Sicília e na Itália do Sul, ao menos a partir do final do século VII a.C. (de quando data o início do culto do deus nessas áreas), Zeus já era considerado uma divindade cívica. Acreditamos que esse fenômeno típico do Ocidente se deva, de algum 
modo, ao grau de desenvolvimento urbano alcançado pelas apoikiai já desde a fase mais antiga desses assentamentos, que ocorreu de forma diferente daquela observada, por exemplo, na Grécia Balcânica.

Os epítetos de Zeus dos santuários de época arcaica nos encaminham à mesma conclusão sobre continuidades, com relação a períodos anteriores, e inovações em época arcaica. De um modo geral, se trata de epítetos de toponímios, que parecem derivar do nome da localidade do santuário, como na maior parte dos casos também ocorre na Idade do Bronze e na Idade do Ferro. Já com relação às inovações no culto de Zeus em época arcaica, sobre as quais os tipos de epítetos e os santuários nos fornecem novas evidências, destacamos o culto de Zeus Olímpio (santuários em Atenas-llissos, Lócris, Siracusa, Selinonte-Marinella) e de Zeus Agoraios (Metaponto-ágora). O epíteto Olímpio, difundido em algumas cidades a partir do século VI a.C. não se refere apenas a um toponímio relacionado ao santuário que difundiu o seu culto à póleis (Olímpia) ${ }^{17}$, mas a um aspecto do poder de Zeus. Trata-se de um culto que se destaca dos demais, pois foi estabelecido nas cidades gregas, a partir de época arcaica, por uma aristocracia e mais destacadamente pelos tiranos (Laky, 2013: 293 sq). Com início em época arcaica, "a tirania parece ter sido um fenômeno que nasceu do desenvolvimento das cidades - 0 tirano era um membro marginal da aristocracia governante que tomava 0 poder com o suporte de membros descontentes da comunidade" (Ehremberg; Rhodes, 2012: 1523). Os santuários dedicados a Zeus Olímpio possuem os maiores templos em dimensão já dedicados à divindade templos perípteros cujas dimensões estiveram entre 20 x 60 m até 55 x 110 m (Laky, 2013: 17). Trata-se das maiores dimensões para os edifícios de culto à divindade se observarmos àquelas dos templos prostilos dedicados à divindade em outros santuários (aproximadamente $2 \times 5,50$ e 4 × 8 m). Podemos afirmar, assim, que 0 culto de Zeus Olímpio, ao ser difundido de Olímpia, expressou na cidade grega arcaica o poder de um importante grupo político. Sobre o epíteto Agoraios, o santuário de Metaponto, datado da primeira metade do século VI a.C., é, com muita probabilidade, a área sagrada mais antiga de Zeus Agoraios na cidade grega, como também observou C. Antonetti (Antonetti, 2009: 36). 0 epíteto também é toponímico e se refere à localização do santuário na ágora e à função de Zeus na esfera pública e política da cidade grega arcaica. Segundo C. Antonetti, que se baseia em R. Martin, "a noção de ágora se desenvolveu nessa época, manifestando todos os progressos políticos e morais da pólis e concentrando em si os órgãos jurídicos, os tribunais que asseguraram a ordem e a paz às cidades, principalmente em momentos de stasis (apud Antonetti, 2009: 29-30). Nesse contexto, segundo essa autora, "Zeus Agoraios atuou na esfera judiciária, na das instituições, das magistraturas públicas e dos juramentos oficiais" (Antonetti, 2009: 30).

Nota-se que, tanto no caso de Zeus Olímpio como no de Zeus Agoraios, os santuários mais antigos foram estabelecidos primeiro nas apoikiai no Ocidente grego, onde, como vimos, o culto de Zeus emergiu diretamente no contexto da cidade grega. Nesse sentido, o culto de Zeus Olímpio e o de Zeus Agoraios podem

17 O fenômeno de difusão do culto de Zeus Olímpio do santuário de Olímpia à póleis gregas entre os séculos VI-V a.C. foi anteriormente estudado por nós, vide Laky, 2013. 
ser considerados os primeiros cultos cívicos do deus, aqueles que efetivamente foram criados e apropriados pela cidade grega a partir de época arcaica - estabelecidos dentro de seu centro urbano e/ou território.

Isto posto, é possível concordar com O. Zolotnikova em relação ao culto de Zeus até o século VII a.C., período no qual conservou as características das Idades do Bronze e do Ferro: um deus progenitor, ligado à natureza, a aspectos celestes e atmosféricos, desligado do urbano, do estado, e que não lembram o poderoso deus dos poemas homéricos. No entanto, discordamos dessa estudiosa quando ela afirma que "somente no final do período arcaico prevaleceu a característica de Zeus como o rei glorioso", poderoso, onipotente, "filho de Cronos e Rhea" (Zolotnikova, 2011: 242). A nosso ver, as evidências dos santuários de época arcaica, referentes à cidade grega, principalmente com relação a Zeus Olímpio, já caracterizam o deus homérico, que exerce o poder de decisão sobre os deuses e os homens, e por decorrência sobre a cidade grega, muito diferente daquele da esfera agrária e pastoril dos períodos mais antigos. 


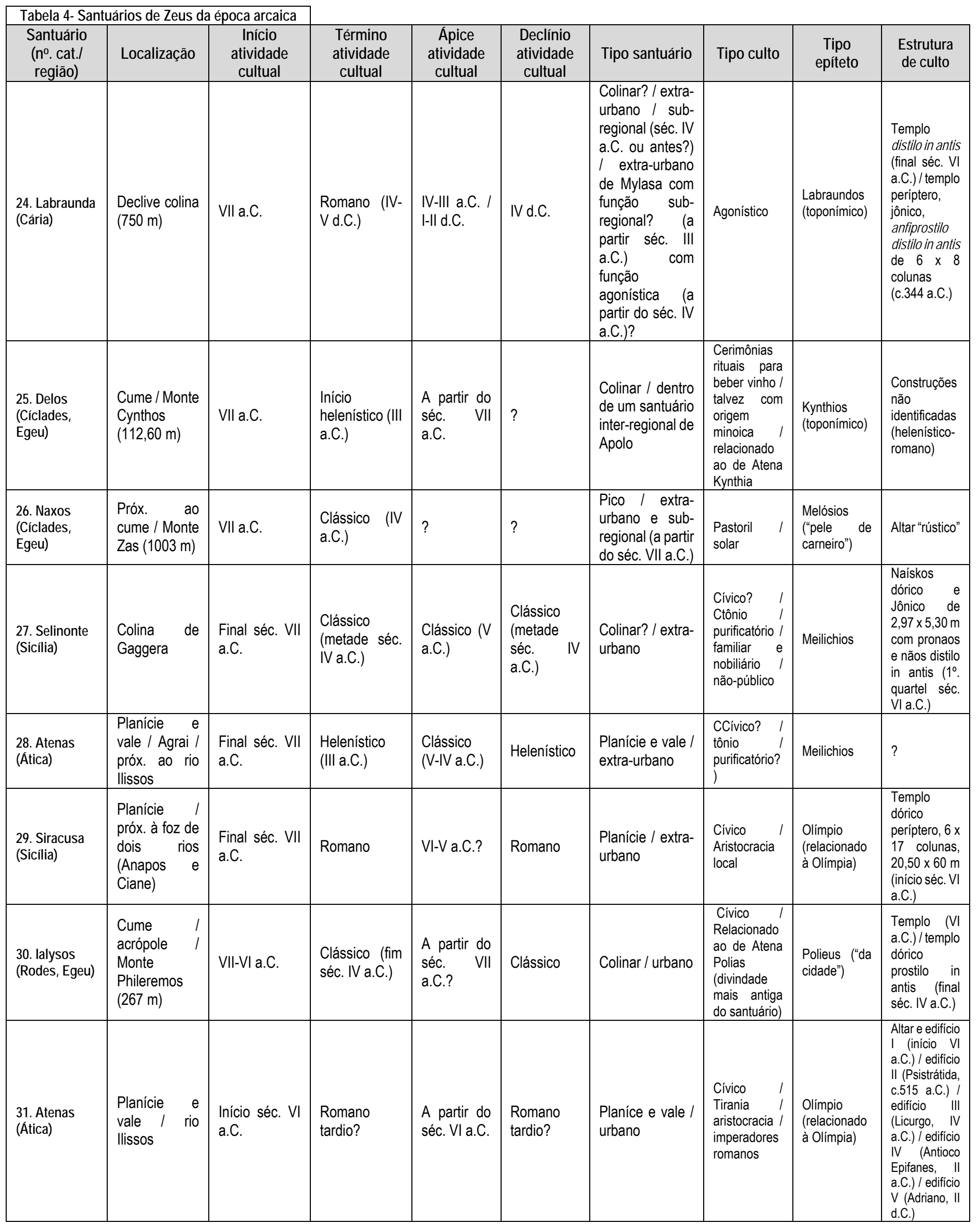




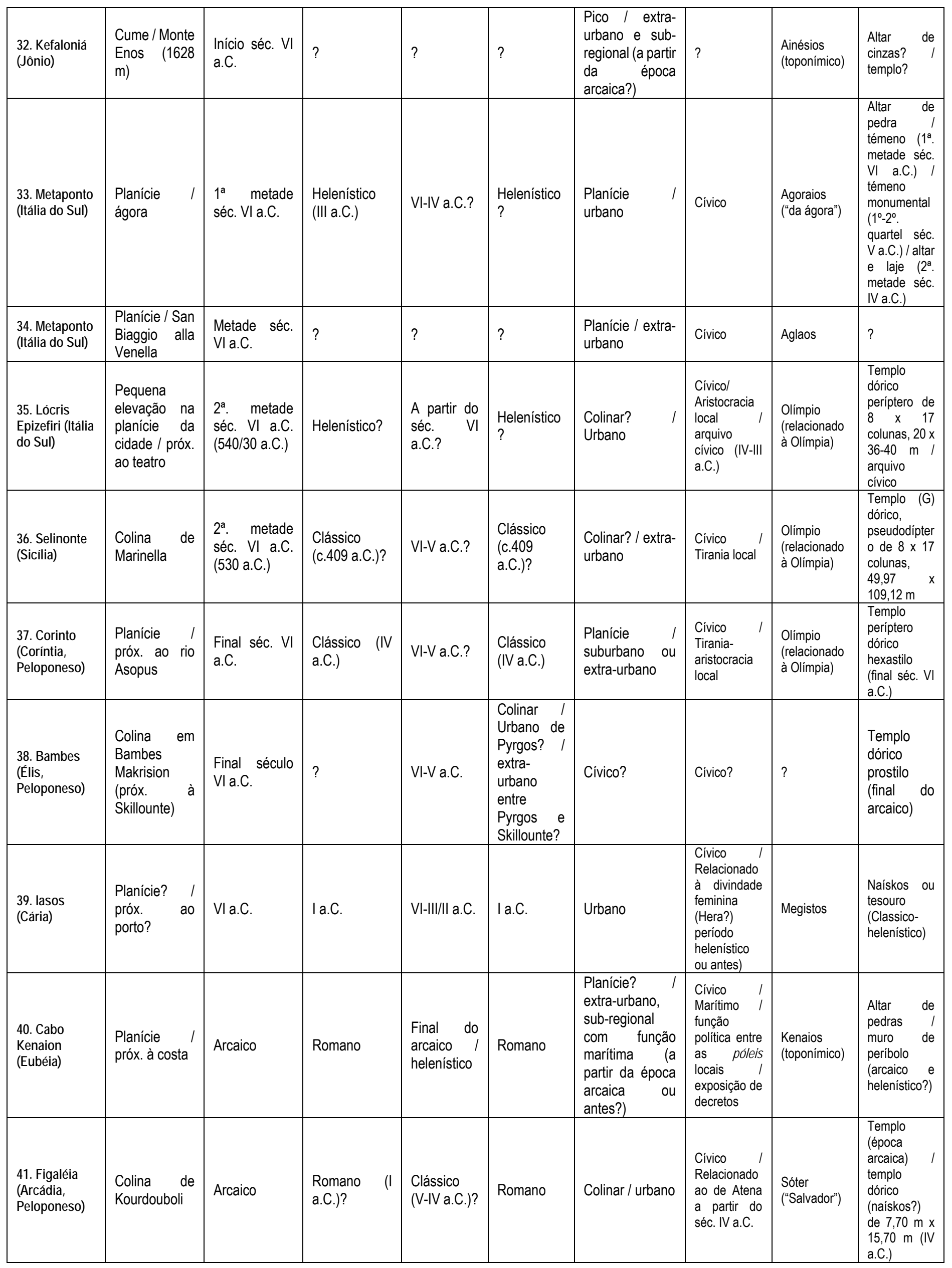




\begin{tabular}{|l|l|l|l|l|l|l|l|l|}
\hline $\begin{array}{l}\text { 42. Kamiros } \\
\text { (Rodes, Egeu) }\end{array}$ & $\begin{array}{l}\text { Cume } \\
\text { acrópole }\end{array}$ & Arcaico & Helenístico & $\begin{array}{l}\text { A partir do } \\
\text { arcaico? }\end{array}$ & Helenístico & Colinar/Urbano & $\begin{array}{l}\text { Cívico } \\
\text { (arcaico- } \\
\text { clássico) / } \\
\text { templo } \\
\text { (helenístico) }\end{array}$ \\
\hline
\end{tabular}

\section{II.4 ENTRE A ÉPOCA ARCAICA/CLÁSSICA (VI-V a.C.)}

Há poucos santuários datados entre os séculos VI-V a.C., portanto entre o último século da época arcaica e o primeiro da época clássica (tabela 5). Trata-se de somente 2 santuários localizados na Megárida (Mégara) e na Ática (Atenas-colina das Ninfas), regiões antigas de culto a Zeus. Esses santuários correlacionam-se pela localização em zonas colinares e por serem urbanos. Sobre a arquitetura ou estrutura do culto desses santuários, das 2 áreas sagradas é certo a existência de um templo (períptero ou prostilo) para o santuário em Mégara. No caso de Atenas-colina das Ninfas não se sabe exatamente se se tratava de um edifício de culto ou de um abrigo para os fiéis.

Os tipos de epítetos para os cultos de Zeus praticados nos santuários em Mégara e em Atenas-colina das Ninfas indicam nessas localizações a continuidade de uma tendência iniciada em época arcaica em relação à divindade e a cidade grega. Em Mégara, o santuário se refere a Zeus Olímpio, que, como vimos em um estudo nosso anterior, tinha relação com certos grupos políticos da cidade (aristocracia em período oligárquico e tirânico e até o governo de reis em cidades). É importante dizer que durante o século IV a.C., esse santuário funcionou como local de exposição de decretos públicos e arquivo da cidade. Em Atenas-colina das Ninfas, 0 santuário foi dedicado a Zeus Meilichios, em associação talvez a heróis locais, se tratando de um culto provavelmente de tipo purificatório com função na esfera privada, assim como em Selinonte-Gaggera.

\begin{tabular}{|c|c|c|c|c|c|c|c|c|c|}
\hline $\begin{array}{l}\text { Santuário } \\
\text { (no. cat.I } \\
\text { região) }\end{array}$ & Localização & $\begin{array}{l}\text { Início } \\
\text { atividade } \\
\text { cultual }\end{array}$ & $\begin{array}{l}\text { Término } \\
\text { atividade } \\
\text { cultual }\end{array}$ & $\begin{array}{c}\text { Ápice } \\
\text { atividade } \\
\text { cultual }\end{array}$ & $\begin{array}{l}\text { Declínio } \\
\text { atividade } \\
\text { cultual }\end{array}$ & $\begin{array}{c}\text { Tipo } \\
\text { santuário }\end{array}$ & Tipo culto & Tipo epíteto & $\begin{array}{l}\text { Estrutura de } \\
\text { culto }\end{array}$ \\
\hline $\begin{array}{l}\text { 43. Mégara } \\
\text { (Megárida, } \\
\text { Peloponeso) }\end{array}$ & $\begin{array}{l}\text { Fora das } \\
\text { duas } \\
\text { acrópoles } \\
\text { da cidade }\end{array}$ & $\begin{array}{l}\text { Após met. } \\
\text { ou final séc. } \\
\text { VI a.C. I } \\
\text { início séc. V } \\
\text { a.C. }\end{array}$ & $\begin{array}{l}\text { Clássico } \\
\text { (IV a.C.) }\end{array}$ & VI-V a.C.? & $\begin{array}{l}\text { Clássico } \\
\text { (IV a.C.) }\end{array}$ & $\begin{array}{l}\text { Colinar? } \\
\text { Urbano }\end{array}$ & $\begin{array}{l}\text { Cívico I } \\
\text { Relacionado } \\
\text { à tirania ou } \\
\text { aristocracia } \\
\text { local / arquivo } \\
\text { cívico }\end{array}$ & $\begin{array}{l}\text { Olímpio } \\
\text { (relacionado } \\
\text { à Olímpia) }\end{array}$ & $\begin{array}{l}\text { Templo (VI-V } \\
\text { a.C.) }\end{array}$ \\
\hline $\begin{array}{l}\text { 44. Atenas } \\
\text { (Ática) }\end{array}$ & $\begin{array}{l}\text { Colina das } \\
\text { Ninfas }\end{array}$ & $\begin{array}{l}\text { Antes final } \\
\text { séc. VI a.C. } \\
\text { / início séc. } \\
\text { V a.C. }\end{array}$ & $\begin{array}{l}\text { Clássico } \\
\text { (IV a.C.) }\end{array}$ & VI-V a.C.? & $\begin{array}{l}\text { Clássico } \\
\text { (IV a.C.) }\end{array}$ & $\begin{array}{l}\text { Colinar } \\
\text { Urbano }\end{array}$ & $\begin{array}{l}\text { Cívico? I } \\
\text { Purificatório }\end{array}$ & Meilichios & $\begin{array}{c}\text { Altar / bacia } \\
\text { lustra / edifício } \\
\text { de culto ou } \\
\text { abrigo }\end{array}$ \\
\hline
\end{tabular}


Como vimos na primeira parte desse capítulo, apesar de haver uma diferença no número de santuários datados da Idade do Ferro e da época arcaica, pode-se dizer que houve um número aproximado de santuários entre esses dois períodos e a época clássica (tabela 6). Como se observa no gráfico 11, nesta época, foram estabelecidas 16 áreas sagradas de Zeus quase em

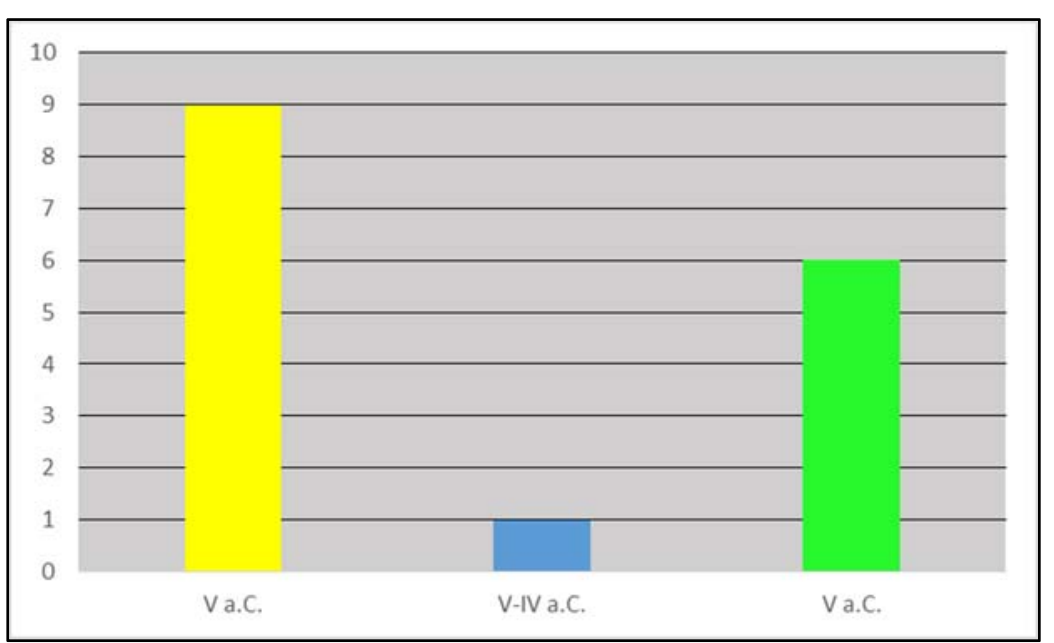

Gráfico 11- Quantidade de santuários de Zeus por séculos na época clássica igual número no século V a.C. (9 no total: Cirene-colina setentrional/oriental, Cirene-Ain Hofra, Atenas-acrópole, Agrigento, Cálcis, Paros, Mylasa, Dion, Mantinéia) e no século IV a.C. (6 no total: Thasos, Lindos, Megalópolis, Aphytis, Aegiae, Argos), predominando o maior número no século V a.C. Entre os séculos V-IV a.C. data apenas 1 santuário da divindade (Posidônia).

Em época clássica, ocorreu o estabelecimento de novos santuários de Zeus no Peloponeso, na Ática e no Egeu, antigas áreas do mundo grego com concentração de culto ao deus. Dentre essas regiões mais antigas do culto de Zeus, a ilha de Creta é a única, cuja fundação de novos santuários da divindade não ocorreu após a idade do Ferro, portanto, em época arcaica e clássica. Novos santuários de Zeus voltaram a ser estabelecidos em Creta predominantemente a partir da época helenística. Regiões antigas, então, permaneceram como centros de culto ao deus em época clássica, assim como novos santuários continuaram a ser fundados em regiões, cujo culto começou apenas em época arcaica, como a Sicília, a Itália do Sul, a Eubéia e a Cária. Em novas áreas no norte da Grécia Balcânica - a Macedônia e a Trácia - e no norte da África - a Líbia - santuários de Zeus foram estabelecidos somente a partir de época clássica. No período, 0 Peloponeso (Mantinéia, Megalópolis, Argos-ágora) e a Macedônia (Díon, Aphytis, Aegiae) são as áreas onde mais se concentraram novos santuários de Zeus (cada qual 3 no total), seguidas pela Líbia (Cirene-colina setentrional/oriental, Cirene-Ain Hofra) e pelo Egeu (Paros, Lindos) (cada qual 2 áreas sagradas no total). Nas demais regiões, na Cária (Mylasa), na Sicília (Agrigento), na Itália do Sul (Posidônia), na Eubéia (Cálcis) e na Trácia (Thasos), são datados apenas 1 santuário que remontam à época clássica.

A época clássica foi o grande período de monumentalização dos santuários de Zeus, sejam aqueles datados a partir do período, como aqueles mais antigos, situados majoritariamente em áreas marginais à cidade grega. Com relação a estes últimos, datados a partir da Idade do Ferro, em Olímpia, aceita-se tradicionalmente que a divindade recebeu seu primeiro templo dórico períptero no século $V$ a.C.; em Dodona, os primeiros dois edifícios de culto (de tipo oîkos) datam da primeira e da segunda metade do século IV a.C.; em Neméia, o 
segundo edifício de culto, o altar e o templo também períptero e dórico datam do século IV a.C.; em Pherai (uma pólis e não um santuário inter-regional como os demais citados), o santuário recebeu seu segundo templo, um períptero dórico, no século IV a.C.; e durante a época arcaica, o segundo templo de Zeus em Labraunda, um templo jônico prostilo e distilo in antis, que data da segunda metade do século IV a.C. Com relação aos santuários cívicos, não regionais, de época arcaica, lalysos recebeu seu primeiro edifício de culto, um templo dórico prostilo no final do século IV a.C.; o de Atenas-llissos, o templo períptero dórico de Zeus Olímpio recebeu uma nova estruturação no tempo de Licurgo no século IV a.C.; em Metaponto, o santuário de Zeus recebeu um témeno monumental no século $V$ a.C.; e em lasos, o santuário recebeu um naískos que data a partir do período clássico. Já acerca dos santuários que remontam à época clássica, é possível dizer que a maior parte deles possuiu algum tipo de edifício de culto: um templo dórico períptero (Cirene-colina setentrional/oriental, Agrigento, Cálcis, Thasos, Aphytis, Megalópolis), um templo prostilo (Atenas-acrópole, talvez Posidônia, Lindos, Aegiae), um témeno (Argos-ágora), um altar e um templo de tipo não-determinado (Dion), e apenas um templo não-determinado (Mantinéia e talvez Paros).

Como já mencionado, em época clássica predominaram os santuários urbanos de Zeus (Atenasacrópole, Agrigento, Mylasa, Posidônia, Thasos, Lindos, Mantinéia, Megalópolis, Aegieae, Argos-ágora), apesar de áreas sagradas extra-urbanas (Cálcis, Cirene-Ain Hofra, Paros, Dion, Aphytis) e suburbanas (Cirenecolina setentrional/oriental) também terem sido dedicadas no período. Mas essa predominância de santuários urbanos em época clássica é um fenômeno típico do período, que se iniciou em época arcaica, principalmente no século VI a.C. Tanto é assim que o santuário extra-urbano de Zeus em Messênia-Mt.lthome, datado da Idade do Ferro, foi transformado em uma área sagrada urbana a partir do século IV a.C. na época da fundação da pólis de Messênia. Dentre esses santuários de Zeus alguns deles foram instalados em áreas de culto predominantemente de divindades femininas (Atenas-acrópole, Aegiae), onde o santuário foi quase um anexo dos santuários de Atena e Eukleias, ou o santuário de uma divindade feminina passou também a abrigar o culto de Zeus no final da época clássica (Lindos) ou ainda, Zeus foi cultuado em seu santuário ao lado de outras divindades (Cirene-Ain-Hofra).

Ainda que colinas tenham permanecido como tipos de localizações de santuários de Zeus (cumes: Paros, Lindos, Atenas-acrópole, Cirene-colina-setentrional oriental / encostas: Cirene-Ain Hofra, Aphytis) - uma permanência da Idade do Ferro e da época arcaica -, são as planícies/vales as áreas predominantes dos santuários clássicos do deus (Agrigento, Cálcis, Mylasa, Posidônia, Dion, Thasos, Mantinéia, Megalópolis, Aegiae, Argos-ágora). Também no caso da época clássica, tanto colinas quanto planícies/vales não foram áreas exclusivas à determinada categoria de santuário de Zeus (extra-urbano, suburbano, urbano).

Com relação às funções específicas das áreas sagradas de Zeus, datadas a partir de época clássica, estas adquiriram papéis variados dentro das comunidades nas quais foram estabelecidas. Durante o século $\mathrm{V}$ a.C., observa-se, na esfera cívica, a função desses santuários em relação a grupos específicos no poder nas cidades gregas, como é o caso daqueles dedicados a Zeus Olímpio (Cirene-colina-setentriona/oriental, 
Agrigento, Cálcis) e a Zeus Osogollis (Mylasa), principal santuário cívico de sua cidade, onde o culto era relacionado à phyle dos Otorkondeis (Williamson, 2012: 97). Nesse período, também, além do culto cívico de Zeus Polieus, na acrópole de Atenas - relacionado à "proteção física" e vinculado a uma "função política" na cidade - observa-se também um culto na esfera privada, ainda que no contexto da cidade, como é o caso do santuário extra-urbano de Zeus Meilichios em Ain Hofra em Cirene que com muito probabilidade também exerceu certo papel entre o grupo aristocrático da cidade (Cole, 1995: 304; Fabbricotti, 2000: 182). Foi durante o século $V$ a.C. que certos santuários extra-urbanos de Zeus adquiriram ou ampliaram funções regionais. Este é o caso do santuário do deus no Mt.Lykaion, datado a partir da Idade do Bronze, que consolidou sua função inter-regional nesse período, e de outros dois santuários que adquiriram funções sub-regional (Paros) e interregional e sub-regional (Dion) nessa época. Já com relação aos santuários datados entre os séculos V-IV a.C. e principalmente no século IV a.C., observa-se um aumento de áreas sagradas urbanas (instaladas dentro de pontos cívicos importantes na cidade) e da relação do culto com aspectos políticos da cidade grega. Em Posidônia, Thasos, Mantinéia, Megalópolis, Argos, e talvez Aegiae, os santuários urbanos de Zeus foram instalados dentro da ágora dessas cidades, e em Lindos na acrópole. Nas ágoras, Zeus foi cultuado, na maior parte dos casos, com os epítetos de Agoraios (Thasos) e de Sóter (Mantinéia, Megalópolis) e, na acrópole de Lindos, com o epíteto Polieus, ao lado de Atena Polias. De acordo com S.G. Cole, em sua função de Agoraios, Zeus "protegia as instituições que tornavam possível a vida política na cidade" (Cole, 1995: 304). Com o título Sóter18 ("Salvador"), Zeus foi evocado, em contexto público, na libertação de um inimigo externo à cidade ou em momentos de sinecismo, como foi o caso de Megalópolis (Cole, 1995: 304). Esse também parece ter sido o caso do título Polieus de Zeus, relacionado além do papel de protetor da cidade ao lado de Atena, também ao sinecismo de Kós no século IV a.C. (Cole, 1995: 305). Interessante notar, como determinados cultos de Zeus, sem tais epítetos, puderam ser inseridos em espaços cívicos e políticos da cidade. Esse é o caso de Argos, onde o santuário de Zeus Nemeios foi estabelecido na ágora, na época quando o culto de Neméia no século IV a.C. foi transferido para essa cidade. Em Aegiae, é também provável que o santuário de Zeus Meilichios esteja na área da ágora da cidade. Como se vê, a partir da época clássica, os epítetos de Zeus já não são mais toponímicos como ocorreu para os períodos mais antigos do culto do deus. Em época clássica, de uma forma geral, os epítetos expressaram as funções políticas de Zeus, em vários níveis, em relação à pólis, tendência que se iniciou em época arcaica (século VI a.C.).

Assim, com base nas evidências referentes à monumentalização dos santuários de Zeus e ao aumento significativo de áreas sagradas urbanas, associado também à predominância de epítetos do deus relacionados à esfera política da cidade grega, é possível afirmar que a época clássica foi o grande período de vinculação do culto de Zeus à pólis grega. Consideramos o século $\mathrm{VI}$ a.C. como o período no qual a cidade grega se apropriou do culto de Zeus, como demonstram um número significativo de áreas sagradas que passaram a ser

\footnotetext{
18 O título também aparece em Figaléia no século IV a.C., quando o culto parece ter sido introduzido no santuário de Atena. Mas o contexto da introdução do culto de Zeus Sóter em relação à essa pólis, permanece desconhecido.
} 
estabelecidas no centro urbano e no território da cidade, além também dos epítetos Olímpio e Agoraios de Zeus, que apareceram e se difundiram nesse período ${ }^{19}$. Essa tendência, iniciada no século VI a.C., se intensificou no século V a.C., atingindo o ápice no século IV a.C. Nesse sentido, consideramos o século IV a.C. como o período de consolidação do culto de Zeus na cidade grega, como indicam o número significativo de santuários do deus instalados principalmente na ágora, e em menor grau na acrópole, e os epítetos Agoraios, Sóter e Polieus pela primeira vez muito recorrentes. Evidência de tal processo, no século IV a.C., é o uso recorrente dos santuários de Zeus como arquivos cívicos das cidades exatamente nesse período, quando foram também usados para a exposição de decretos públicos (Mégara, Mylasa, Dion, Lócris, Mantinéia, Megalópolis, Cabo Kenaion). Os principais períodos dos ápices das atividades cultuais dos santuários de Zeus, datados da Idade do Bronze até a época clássica, comprovam tal constatação - a época arcaica e a época clássica representam também os períodos de auge do culto de Zeus tanto em seus santuários regionais quanto naqueles cívicos.

As razões que promoveram a inserção do culto de Zeus na cidade grega em época arcaica e clássica serão aprofundadas no capítulo 2 da tese, quando analisaremos o seu desenvolvimento em quatro regiões do mundo grego, o Peloponeso, a Sicília, a Itália do Sul e Creta. Essa análise dos santuários em termos regionais, mostrará como o culto esteve relacionado, diacronicamente, com os vários níveis de identidade grega. As conclusões obtidas a partir dos capítulos 1 e 2, a respeito dos santuários de Zeus, serão correlacionadas, na conclusão, àquelas sobre o uso ou apropriação das imagens de Zeus e de seus atributos em moedas pela cidade grega ao longo das épocas arcaica e clássica.

\footnotetext{
${ }^{19}$ A documentação arqueológica e literária indica que o culto de Zeus Olímpio emergiu no início do século VI a.C., ao passo, que o de Zeus Agoraios parece ter surgido no final do século VII a.C., em Creta, e se difundido durante o século VI a.C.
} 
Tabela 6- Santuários de Zeus da época clássica

\begin{tabular}{|c|c|c|c|c|c|c|c|c|c|}
\hline $\begin{array}{l}\text { Santuário } \\
\text { (no. cat.I } \\
\text { região) }\end{array}$ & Localização & $\begin{array}{c}\text { Início } \\
\text { atividade } \\
\text { cultual }\end{array}$ & $\begin{array}{l}\text { Término } \\
\text { atividade } \\
\text { cultual }\end{array}$ & $\begin{array}{c}\text { Ápice } \\
\text { atividade } \\
\text { cultual }\end{array}$ & $\begin{array}{l}\text { Declínio } \\
\text { atividade } \\
\text { cultual }\end{array}$ & $\begin{array}{c}\text { Tipo } \\
\text { santuário }\end{array}$ & Tipo culto & Tipo epíteto & $\begin{array}{l}\text { Estrutura de } \\
\text { culto }\end{array}$ \\
\hline $\begin{array}{l}\text { 45. Cirene } \\
\text { (Líbia) }\end{array}$ & $\begin{array}{l}\text { Colina } \\
\text { setentrional- } \\
\text { oriental }\end{array}$ & $\begin{array}{l}\text { Início séc. } \\
\text { V a.C. } \\
(500 / 480 \\
\text { a.C. })\end{array}$ & $\begin{array}{l}\text { Romano (II } \\
\text { d.C.) }\end{array}$ & $\begin{array}{l}\text { A partir do } \\
\text { séc. V a.C. }\end{array}$ & $\begin{array}{l}\text { Romano (II } \\
\text { d.C.) }\end{array}$ & $\begin{array}{l}\text { Colinar / } \\
\text { suburbano } \\
\text { até o séc. III } \\
\text { a.C. }\end{array}$ & $\begin{array}{c}\text { Cívico / } \\
\text { Relacionado } \\
\text { à monarquia } \\
\text { local }\end{array}$ & $\begin{array}{c}\text { Olímpio } \\
\text { (relacionado } \\
\text { à Olímpia) }\end{array}$ & $\begin{array}{c}\text { Altar de cinzas? } \\
\text { / Templo dórico } \\
\text { períptero de } 8 \text { x } \\
17 \text { colunas, } 32 \\
\text { x } 70 \mathrm{~m} \\
\text { (500/480 a.C.) }\end{array}$ \\
\hline $\begin{array}{l}\text { 46. Atenas } \\
\text { (Ática) }\end{array}$ & $\begin{array}{l}\text { Cume / } \\
\text { acrópole }\end{array}$ & $\begin{array}{l}\text { Início séc. } \\
\text { V a.C. (500 } \\
\text { a.C.) }\end{array}$ & $\begin{array}{l}2^{\text {a }} \text {. met. } \\
\text { séc. V } \\
\text { a.C.? }\end{array}$ & $\begin{array}{l}\text { A partir do } \\
\text { séc. V a.C. }\end{array}$ & $\begin{array}{l}2^{\text {a }} \text {. met. } \\
\text { séc. V } \\
\text { a.C.? }\end{array}$ & $\begin{array}{l}\text { Colinar / } \\
\text { Urbano }\end{array}$ & $\begin{array}{c}\text { Cívico / } \\
\text { Relacionado } \\
\text { à festa } \\
\text { Diipolia }\end{array}$ & $\begin{array}{l}\text { Polieus ("da } \\
\text { cidade") }\end{array}$ & $\begin{array}{c}\text { Pequeno } \\
\text { edifício distilo } \\
\text { ou prostilo in } \\
\text { antis, } 4,62 \times 6,6 \\
\mathrm{~m} / \text { altar }\end{array}$ \\
\hline $\begin{array}{l}\text { 47. (Agrigento } \\
\text { (Sicília) }\end{array}$ & $\begin{array}{l}\text { A oeste da } \\
\text { Porta V }\end{array}$ & $\begin{array}{l}\text { Início séc. } \\
\text { V a.C. (480 } \\
\text { a.C.) }\end{array}$ & Romano & $\begin{array}{l}\text { A partir do } \\
\text { séc. V a.C. }\end{array}$ & Romano & $\begin{array}{l}\text { Planície? / } \\
\text { urbano }\end{array}$ & $\begin{array}{c}\text { Cívico / } \\
\text { Relacionado } \\
\text { à tirania/ } \\
\text { aristocracia } \\
\text { local }\end{array}$ & $\begin{array}{c}\text { Olímpio } \\
\text { (relacionado } \\
\text { à Olímpia) }\end{array}$ & $\begin{array}{c}\text { Templo dórico } \\
\text { pseudodíptero } \\
\text { de } 7 \times 14 \\
\text { colunas, } 56,30 \\
\text { x } 112,60-70 \mathrm{~m} / \\
\text { altar de } 54,50 \mathrm{x} \\
17,50 \mathrm{~m}(480 \\
\text { a.C.) }\end{array}$ \\
\hline $\begin{array}{l}\text { 48. Cálcis } \\
\text { (Eubéia) }\end{array}$ & $\begin{array}{l}\text { Canal de } \\
\text { Euripos / } \\
\text { prox. à } \\
\text { costa? }\end{array}$ & $\begin{array}{l}\text { Início séc. } \\
\text { V a.C. ( } 480 \\
\text { a.C.) }\end{array}$ & $\begin{array}{l}\text { Helenístico } \\
\text { (II a.C.?) }\end{array}$ & $\begin{array}{l}\text { A partir do } \\
\text { séc. } V \text { a.C. }\end{array}$ & $\begin{array}{l}\text { Helenístico } \\
\text { (II a.C.?) }\end{array}$ & $\begin{array}{c}\text { Planície? I } \\
\text { extra- } \\
\text { urbano? }\end{array}$ & Cívico & $\begin{array}{c}\text { Olímpio } \\
\text { (relacionado } \\
\text { à Olímpia) }\end{array}$ & $\begin{array}{c}\text { Templo dórico } \\
\text { períptero (480 } \\
\text { a.C.) }\end{array}$ \\
\hline $\begin{array}{l}\text { 49. Cirene } \\
\text { (Líbia) }\end{array}$ & $\begin{array}{l}\text { Na entrada } \\
\text { do uadi de } \\
\text { Ain Hofra }\end{array}$ & V a.C. & $?$ & $\begin{array}{l}\text { A partir do } \\
\text { séc. V } \\
\text { a.C.? }\end{array}$ & $?$ & $\begin{array}{c}\text { Colinar? / } \\
\text { suburbano? } \\
\text { extra- } \\
\text { urbano? }\end{array}$ & $\begin{array}{c}\text { Cívico? / } \\
\text { Relacionado } \\
\text { às águas / } \\
\text { culto } \\
\text { associado } \\
\text { aos } \\
\text { Eumênidas e } \\
\text { aos heróis } \\
\end{array}$ & Meilichios & $\begin{array}{l}\text { Ninfeu } \\
\text { escavado na } \\
\text { rocha / } \\
\text { aquedutos / } \\
\text { associado à } \\
\text { necrópoles }\end{array}$ \\
\hline $\begin{array}{l}\text { 50. Paros } \\
\text { (Cíclades, } \\
\text { Egeu) }\end{array}$ & $\begin{array}{c}\text { Cume / } \\
\text { Monte } \\
\text { Kounados }\end{array}$ & V a.C. & $?$ & $\begin{array}{l}\text { A partir do } \\
\text { séc. V } \\
\text { a.C.? }\end{array}$ & $?$ & $\begin{array}{l}\text { Pico? / extra- } \\
\text { urbano e } \\
\text { sub- } \\
\text { regional? }\end{array}$ & Pastoril? & Hypatos & Templo? \\
\hline $\begin{array}{l}\text { 51. Mylasa } \\
\text { (Cária) }\end{array}$ & $\begin{array}{l}\text { Setor sul da } \\
\text { cidade }\end{array}$ & Va.C.? & $\begin{array}{l}\text { Helenístico } \\
\text { (I a.C.)? }\end{array}$ & $\begin{array}{l}\text { A partir do } \\
\text { séc. V } \\
\text { a.C.? }\end{array}$ & $\begin{array}{l}\text { Helenístico } \\
\text { (I a.C.)? }\end{array}$ & $\begin{array}{l}\text { Planície? / } \\
\text { Urbano }\end{array}$ & $\begin{array}{c}\text { Cívico / } \\
\text { Relacionado } \\
\text { à phyle dos } \\
\text { Otorkondeis / } \\
\text { exposição de } \\
\text { decretos } \\
\end{array}$ & Osogollis & $\begin{array}{l}\text { Muro de } \\
\text { períbolo / } \\
\text { templo }\end{array}$ \\
\hline $\begin{array}{l}\text { 52. Mantinéia } \\
\text { (Arcádia, } \\
\text { Peloponeso) }\end{array}$ & $\begin{array}{l}\text { Margem da } \\
\text { ágora }\end{array}$ & V a.C. & $?$ & V a.C. & $?$ & $\begin{array}{l}\text { Planície / } \\
\text { urbano }\end{array}$ & $\begin{array}{c}\text { Cívico } \\
\text { (exposição } \\
\text { de tratados) }\end{array}$ & $\begin{array}{c}\text { Sóter } \\
\text { ("Salvador") } \\
\text { (a partir do } \\
\text { séc. IV a.C.) }\end{array}$ & $\begin{array}{c}\text { Templo de 4,75 } \\
\text { x } 12,10 \mathrm{~m}\end{array}$ \\
\hline $\begin{array}{l}\text { 53. Posidônia } \\
\text { (Itália do Sul) }\end{array}$ & Na ágora & $\begin{array}{l}\text { Final séc. V } \\
\text { a.C. - } \\
\text { início séc. } \\
\text { IV a.C. } \\
\end{array}$ & $\begin{array}{l}\text { Helenístico } \\
\text { (III a.C.) }\end{array}$ & V-IV a.C. & $\begin{array}{l}\text { Helenístico } \\
\text { (III a.C.) }\end{array}$ & $\begin{array}{l}\text { Planície / } \\
\text { Urbano }\end{array}$ & Cívico & $?$ & $\begin{array}{c}\text { Templo de 3,60 } \\
\text { x 4,75 m (V-IV } \\
\text { a.C.) }\end{array}$ \\
\hline $\begin{array}{l}\text { 54. Díon } \\
\text { (Macedônia) }\end{array}$ & $\begin{array}{l}\text { Setor sul / } \\
\text { região dos } \\
\text { teatros } \\
\text { romano e } \\
\text { helenístico }\end{array}$ & $\begin{array}{c}\text { Final séc. V } \\
\text { a.C. }\end{array}$ & Romano & $\begin{array}{l}\text { A partir do } \\
\text { final do } \\
\text { séc. V a.C. }\end{array}$ & Romano & $\begin{array}{l}\text { Planície / } \\
\text { extra- } \\
\text { urbano, sub- } \\
\text { regional. }\end{array}$ & $\begin{array}{c}\text { Cívico / } \\
\text { Relacionado } \\
\text { à monarquia } \\
\text { local / } \\
\text { exposição de } \\
\text { decretos } \\
\end{array}$ & $\begin{array}{c}\text { Olímpio } \\
\text { (relacionado } \\
\text { à Olímpia) }\end{array}$ & Templo / altar \\
\hline $\begin{array}{l}\text { 55. Thasos } \\
\text { (Trácia) }\end{array}$ & Na ágora & $\begin{array}{l}\text { Início séc. } \\
\text { IV a.C. }\end{array}$ & ? & $\begin{array}{l}\text { A partir do } \\
\text { séc. IV a.C. }\end{array}$ & $?$ & $\begin{array}{l}\text { Planície / } \\
\text { Urbano }\end{array}$ & Cívico & $\begin{array}{l}\text { Agoraios ("da } \\
\text { ágora") }\end{array}$ & $\begin{array}{c}\text { Templo dórico } \\
\text { períptero de } 6 \text {, } \\
10 \times 11,64 \mathrm{~m} \\
\text { (IV a.C.) }\end{array}$ \\
\hline $\begin{array}{c}\text { 56. Lindos } \\
\text { (Rodes, Egeu) }\end{array}$ & $\begin{array}{l}\text { Cume / } \\
\text { acrópole }\end{array}$ & IV a.C. & $?$ & $\begin{array}{l}\text { A partir do } \\
\text { séc. IV } \\
\text { a.C.? }\end{array}$ & $?$ & $\begin{array}{l}\text { Colinar / } \\
\text { urbano }\end{array}$ & $\begin{array}{c}\text { Cívico / } \\
\text { compartilha- } \\
\text { do com Atena }\end{array}$ & $\begin{array}{l}\text { Polieus ("da } \\
\text { cidade") }\end{array}$ & Templo in antis \\
\hline
\end{tabular}




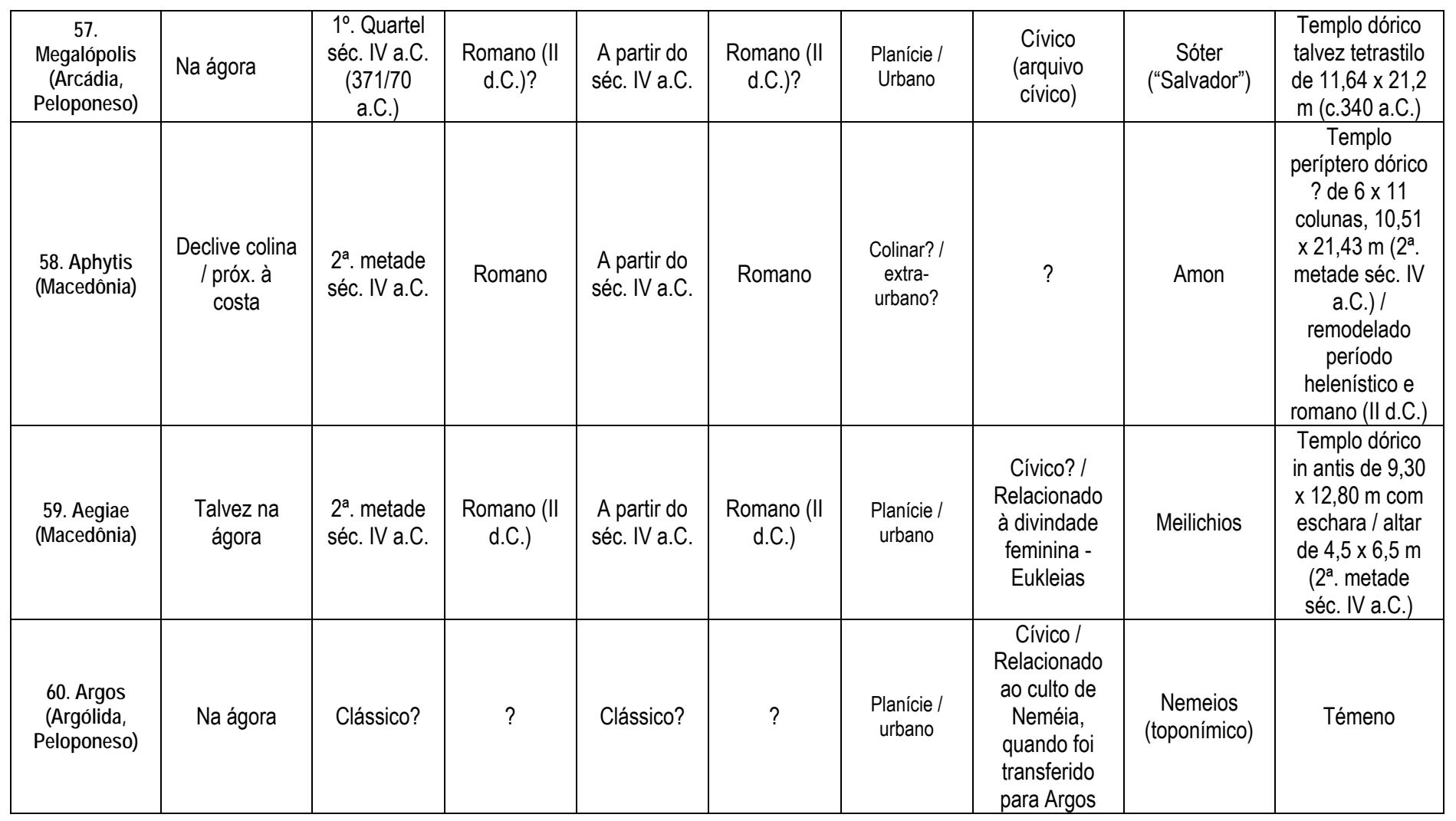




\section{CAPÍTULO II-ANÁLISE REGIONAL INTERPRETATIVA DOS SANTUÁRIOS DE ZEUS}

\section{INTRODUÇÃO}

Após a apresentação e discussão gerais acerca do desenvolvimento dos santuários de Zeus no mundo grego na longa duração, e com base nas conclusões acerca do culto dessa divindade em suas várias expressões - de divindade predominantemente pastoril e agrária desde a Idade do Bronze até o início do período arcaico até divindade cívica em época arcaica e clássica -, nesse capítulo, objetivamos analisar os santuários do deus a partir de uma perspectiva regional. Nossa intenção é compreender em que medida, por meio de seus vários tipos de santuários, o culto de Zeus articulou identidades políticas e regionais no Peloponeso e Creta, na Sicília e na Itália do Sul, em quatro das dezesseis áreas do mundo grego onde foi estabelecido. Escolhemos essas quatro regiões, como unidades de análise, porque se trata daquelas onde 0 culto alcançou sua mais antiga e maior expressão (Peloponeso e Creta) e foi primeiro, em grande parte, apropriado pela pólis grega (Sicília e Itália do Sul). Nesse sentido, trataremos, em nossa análise e interpretação, do culto de Zeus em relação ao desenvolvimento da pólis e dos diferentes níveis de identidade nessas áreas (político, étnico e regional), portanto, as várias interações dessas comunidades políticas com os santuários da divindade. Nessa análise, consideraremos a "variabilidade religiosa entre cada uma das regiões", ou seja, "as dinâmicas internas que lhes eram próprias", e a premissa de que "regiões não foram entidades fechadas em si mesmas - as várias comunidades, medianas ou pequenas ou ainda poderes hegemônicos, mantiveram interesses e envolvimento em áreas e atividades fora de sua região política, cultural e econômica" (Mili, 2015: 3; Vlassopoulos, 2011: 14 e 24). Como bem colocou K. Vlassopoulos, em seu estudo sobre perspectivas regionais no estudo da história grega, "a formação de regiões políticas, culturais e econômicas nunca foi um processo estritamente interno: envolveu frequentemente comunidades externas à região, a formação de redes para além de uma região em particular" (Vlassopoulos, 2011: 27). Nessa perspectiva, ao final, correlacionaremos as características do culto de Zeus e de seus santuários entre as regiões, em busca de diferenças e similaridades no tocante aos papéis regionais do culto em relação às póleis locais e às identidades locais ou não (em alguns casos pan-helênicas) e ao compartilhamento de traços culturais do culto e das áreas sagradas observáveis entre as quatro regiões em determinado período.

Assim, o presente capítulo organiza-se a partir da descrição dos santuários de Zeus dentro de suas respectivas regiões, cuja sequencia foi estabelecida a partir da antiguidade do culto nessas áreas, começando por Creta e depois pelo Peloponeso e finalizando com a Sicília e a Itália do Sul. Cada região terá uma pequena introdução que propiciará um panorama geral das características dos santuários e do culto nessas áreas, e situará as questões mais importantes em relação à região, seguida, então, pela discussão de cada santuário, dentro de um tópico próprio, cuja sequência também obedece uma ordenação cronológica (das áreas sagradas mais antigas às mais recentes de suas regiões). Ao final, dedicaremos um item às conclusões acerca do culto 
em cada área com relação às questões principais da tese. Os santuários serão descritos e discutidos a partir de sua respectiva área geográfica ou sub-região, em relação ao início da atividade cultual, à categoria de santuário, à documentação arqueológica, textual e/ou epigráfica disponíveis e, em última análise, em relação às diferentes fases dos santuários e do culto (como a pólis e os tipos de identidade foram articulados pelo culto ao longo do tempo). Como bem sintetizou L. Thromas com relação à Atena, que nos inspira em nossa análise sobre Zeus: devemos mostrar quais foram "as competências e atribuições da divindade no espaço" e "como se ligaram a ela a estrutura política e social das cidades onde houve o culto" e, especialmente no caso de Zeus, considerar também àquelas cidades que frequentaram seus santuários regionais (Thromas, 2009: 63-64).

Em nossa análise interpretativa sobre os santuários de Zeus em Creta, no Peloponeso, na Sicília e na Itália do Sul consideraremos os santuários (tanto os cívicos como os regionais) como "marcadores sociais que proporcionaram a definição e construção da identidade dos membros de uma dada comunidade" (Thromas, 2009: 66). Nessa perspectiva, seguiremos C. Williamson, que define os santuários como espaços organizados onde uma ou mais comunidades poderiam, simultaneamente, definir-se e celebrar a si mesma sob a sanção de uma divindade (Williamson, 2013: 1). Como espaços públicos, os santuários revelam a maneira com a qual a "pólis percebeu-se espacialmente e como os usou para expressar identidade" (Williamson, 2013: 2). No caso dos santuários cívicos de Zeus (nos casos que se aplicam, como ocorre principalmente na Sicília), seguiremos a perspectiva de De Polignac que considera o papel dos santuários na definição do próprio espaço da cidade e sua importância na estruturação religiosa e política do território (apud Thromas, 2009: 64). Nesse sentido, trata-se também da percepção das áreas sagradas (sobretudo as cívicas extra-urbanas) como símbolos de independência territorial, poder e soberania de uma determinada comunidade (apud Prent, 2005: 500). Na interpretação dos santuários extra-urbanos com funções regionais, seguiremos a abordagem de $A$. Chaniotis, que vê esses tipos de áreas sagradas como locais onde uma identidade regional foi formada pelo encontro e interação com o outro (diferentes comunidades de igual ou diferente origem étnica) por meio da competição, do conflito e da diferenciação (Chaniotis, 2009: 61). Na definição do ritual relacionado ao culto de determinada área sagrada do deus, consideramos também a definição de Chaniotis na qual rituais determinam, expressam relações hierárquicas, refletem tensões ou criam solidariedade e unidade na organização interna de uma comunidade e/ou com outras comunidades participantes também no santuário (Chaniotis, 2009: 65). Assim, a partir da premissa de que uma parte substancial dos rituais serviram para forjar a necessária coesão social entre os diferentes membros de uma comunidade, tentar-se-á compreender em que medida os santuários de Zeus foram restritos a determinados grupos políticos ou serviram à comunidade política como um todo. 


\section{CRETA}

Como vimos no primeiro capítulo, na ilha de Creta, entre a Idade do Bronze e a época clássica, Zeus possuiu 6 santuários, sendo 2 datados a partir da Idade do Bronze (Mt.Ida, Mt.Dicta) e 4 datados a partir da Idade do Ferro (Agia Triada, Amnisos, Palaikastro, Praisos). Trata-se da região, ao lado do Peloponeso, onde se concentra a maior parte das áreas sagradas mais antigas da divindade, sendo a única onde está a maior quantidade daquelas que remontam à Idade do Bronze. Os santuários de Zeus encontram-se estabelecidos, predominantemente, no lado central e extremo oriental de Creta, não havendo áreas sagradas na porção extremo ocidental da ilha (vide mapa p.33). Interessante notar que não há santuários da divindade em Creta, cujo início da atividade cultual date da época arcaica e da época clássica. Nesse sentido, se por um lado não foram fundados novos santuários de Zeus, nessas duas épocas, por outro, foram as antigas áreas sagradas que serviram como os centros de culto ao deus em Creta em época arcaica e clássica.

$\mathrm{Na}$ análise interpretativa sobre os santuários cretenses de Zeus, nos interessa, especificamente, como o culto da divindade, a partir da Idade do Ferro, esteve em algum grau relacionando ou não às comunidades políticas emergentes e a seus grupos políticos. Interessa-nos, também, compreender a que propósitos, esses mesmos santuários, na maior parte extra-urbanos, serviram às cidades gregas cretenses durante as épocas arcaica e clássica. Além disso, verificar-se-á se os santuários cretenses de Zeus, sobretudo aqueles interregionais, mobilizaram identidades regionais em um nível além do cívico e do político, ou seja, em nível étnico e pan-helênico, assim como ocorreu em alguns casos no Peloponeso, como em Olímpia, Mt. Lykaion e Neméia. Em última análise, procuraremos compreender em que medida o culto cretense de Zeus alinha-se àquele balcânico, do deus homérico guerreiro e celeste. De acordo com J. Whitley, "ainda que o Zeus cretense tenha tido o nome da divindade cultuada em Olímpia, ele compartilhou poucos de seus atributos" (Whitley, 2009: 277). A seu ver, não é uma mera questão de nome e epítetos - o Zeus cretense parece ter sido mais um deus jovem da fertilidade, "o maior kouros", nascido em uma caverna e assistido por outros jovens (os Kouretes), do que um deus pai celeste de Homero" (Whitley, 2009: 277). Para o estudioso, "os atributos iconográficos e cultuais de Zeus em Creta são diferentes" daquele oriundo da Grécia Balcânica (Whitley, 2009: 278). Como bem coloca, nos estudos das divindades gregas em Creta "deve-se considerar que não se está lidando com uma variação regional padrão do panteão olímpico, mas com um panteão cretense distinto que foi sendo gradualmente assimilado ao olímpico" (Whitley, 2009: 278).

Questões já sinalizadas no capítulo anterior, como a continuidade cultual ou não dos santuários entre a Idade do Bronze e a do Ferro, a fundação de áreas sagradas da divindade em assentamentos minoicos abandonados e o culto cretense a Zeus (como as versões literárias a respeito de seu nascimento na ilha), serão abordadas ao longo de nossa análise. 
O santuário de Zeus no Mt. Ida (cat.no.1) localiza-se no lado centro-oeste de Creta, mais precisamente em uma gruta situada no Mt. Psiloritis (como se denomina atualmente também o lda), o mais alto da ilha (2456 m) (Fig.5). A gruta posiciona-se a uma altitude de 1500 m na montanha e está a $100 \mathrm{~m}$ acima da planície alta ou platô de

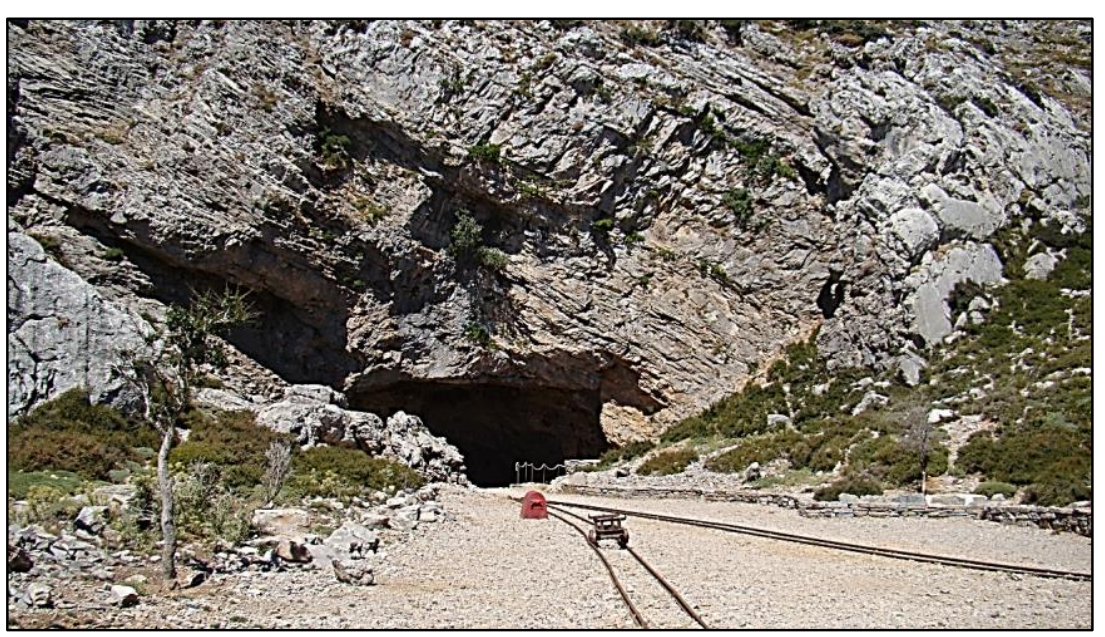

Fig.5- Entrada da gruta de Ida a partir de norte (Foto: arquivo pessoal/2014)

Nida (Figs.6 e 7) (Prent, 2005: 158; Watrous, 1996: 58). Localmente conhecida como a gruta de Voskopoulos, esta foi identificada pela primeira vez em 1591 pelo botânico italiano Casabona como a famosa caverna na qual teria nascido Zeus, segundo as fontes literárias, nomeadamente Diodoro. As primeiras investigações arqueológicas foram empreendidas em 1885 por Halbherr e Aerakis após antiguidades terem sido mostradas a eles por alguns pastores. A descoberta de inscrições votivas romanas confirmou que, ao menos nesse período, a caverna foi dedicada a Zeus Idaios. Mais escavações foram realizadas por Faure em 1955 e por Marinatos em 1956, as quais propiciaram informação sobre o período mais antigo, o minoico. Escavações sistemáticas em larga escala foram iniciadas em 1982 por Sakellarakis (Prent, 2005: 158).

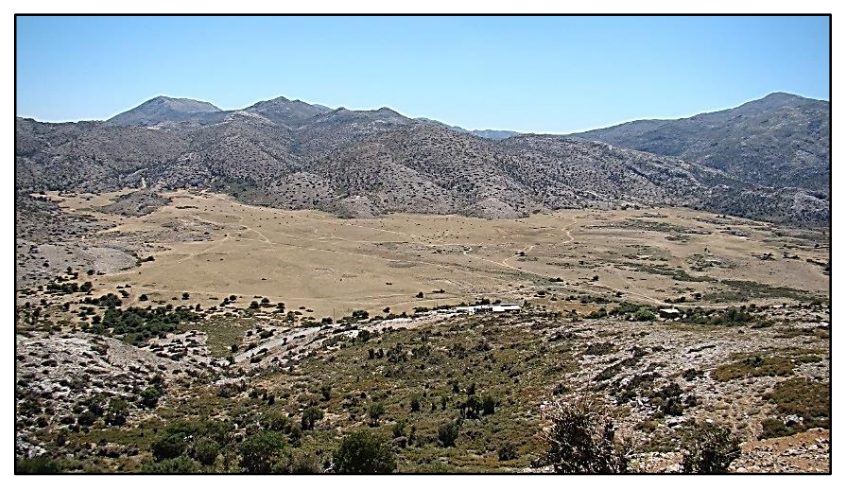

Fig.6- Platô de Nida vista da área da entrada da gruta de Ida (Foto: arquivo pessoal/2014)

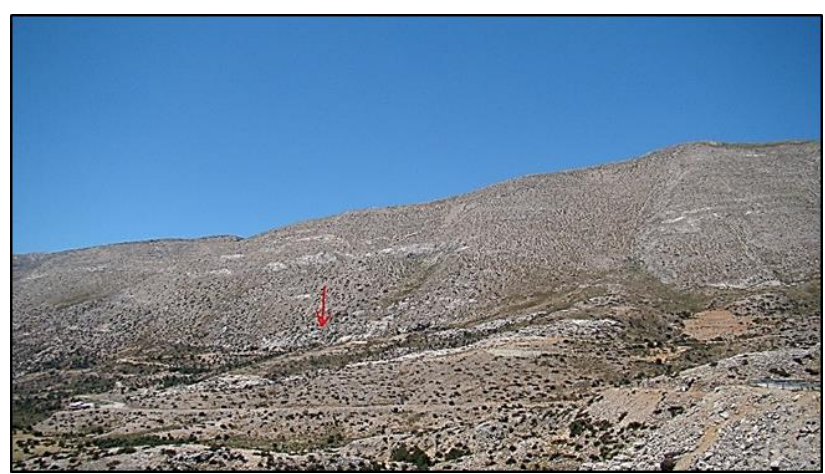

Fig.7- Monte Psiloritis ou Ida, a flecha vermelha indica a localização do santuário da gruta de Ida (Foto: arquivo pessoal/2014) 


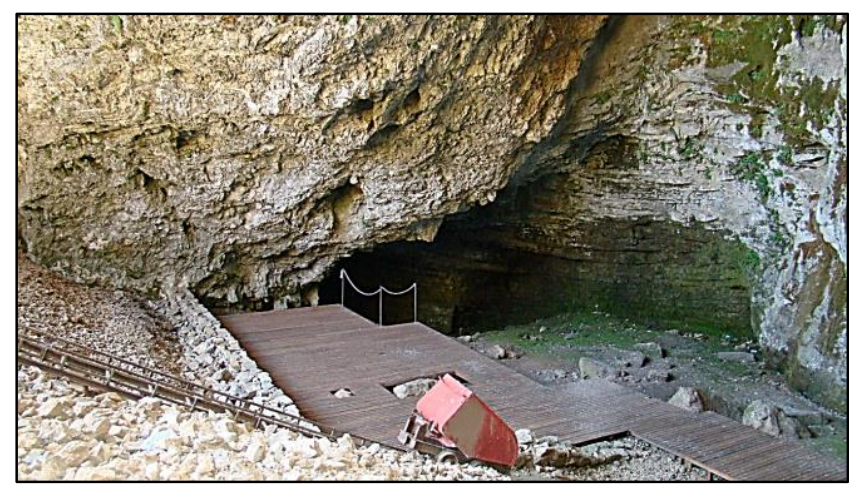

Fig.8- Vista interna parcial da gruta de Ida (Foto: arquivo pessoal/2014)

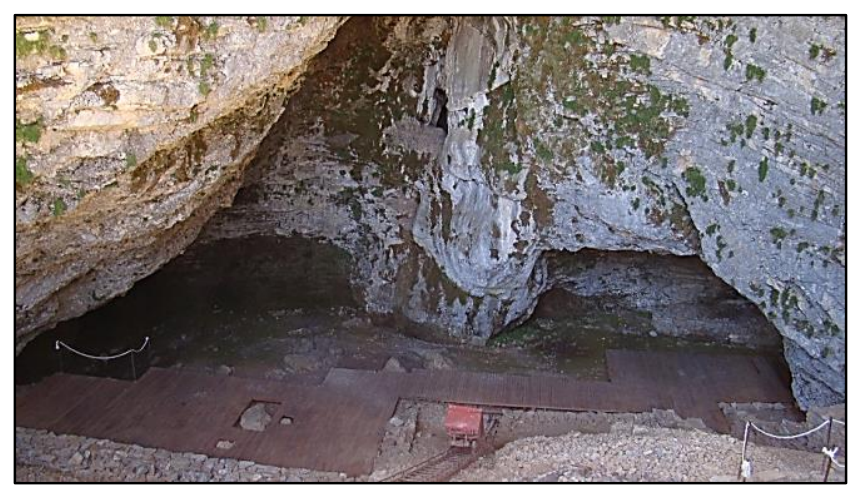

Fig.9- Vista interna total da gruta de Ida (Foto: arquivo pessoal/2014)

\section{I.1.1 Descrição e interpretação dos achados}

As escavações arqueológicas de Sakellarakis permitiram precisar a duração do culto, no santuário de Zeus no Mt.Ida, entre o período minóico médio IA (2000-1900 a.C.) e o período romano (séc. V d.C.). As pesquisas também determinaram a ocupação da gruta entre o final do período neolítico e o minóico antigo I (3100-2700 a.C.). Mas o início da atividade cultual, ocorrido no minoico médio IA, é indicado pela grande quantidade de cerâmica - taças e jarros com decoração barbotina, sendo algumas delas provenientes da planície de Mesara -, pela argamassa nas pedras do chão da gruta e lâminas de obsidiana encontradas na parte traseira da caverna (Watrous, 1996: 58). Já o término da atividade cultual em época romana, é atestado por numerosas oferendas que datam até o século V d.C.: vasos (na maior parte são do tipo terra sigillata), placas (com representação de bucrânios, de folhas de cântaros, de Pluto e Cérbero), milhares de lamparinas, anéis (de homens e mulheres) e outros objetos de joalheria (Watrous, 1996: 59). São datados dessa época, também, uma placa de argila com inscrição que nomeia Zeus Idaios, e talvez um grande altar feito de rocha no terraço natural, fora da entrada da caverna (Watrous, 1996: 59).

É preciso destacar que não foi encontrado nenhum tipo de estrutura arquitetônica nem no interior e nem fora da caverna, exceto um suposto muro de témeno dentro da gruta, atribuído ao período neo-palacial (1700-1425 a.C.), e um grande altar feito na rocha (c.4,9 x 2,1 x 0,90 m), situado na área aberta em frente à entrada da gruta (Prent, 2005: 159). Esse altar, atribuído à época romana ou a um período indeterminado, tem sido considerado evidência de que o culto transcorria, em certos momentos, também fora da caverna (Prent, 2005: 159; Watrous, 1996: 59). Dentro da gruta, uma camada de terra, queimada e oleosa, contendo carvão e ossos (alguns deles queimados) é descrita como o antigo altar de cinzas (Prent, 2005: 160). Segundo Watrous, uma estrutura grande datada do minoico tardio IA (1600-1425 a.C.), situada entre a caverna e o vilarejo de Anogeia (na localidade de Zominthos) pode ter sido relacionada ao culto na gruta de Ida (Watrous, 1996: 58). Diante do caráter lacunoso dessas estruturas, as oferendas votivas encontradas no interior da gruta, permanecem sendo as principais evidências materiais para a reconstituição do santuário e do culto local de Zeus em todos os períodos. 
Com relação ao período minoico, como vimos, são numerosos os objetos votivos do minoico médio IA, mas são relativamente poucos aqueles da fase subsequente, o período proto-palacial (1900-1700 a.C.) - os relatórios mencionam um número de louças de Kamares e um selo de cristal de rocha (Watrous, 1996: 58). Os objetos votivos aumentaram no período neo-palacial. Trata-se, na maior parte, de cerâmicas (vasos decorados com relevo, do tipo rhyton e pithoi com decoração incisa), figurinhas humanas e animais de bronze, jóias (colar de contas de cristal), selos, machado duplo em bronze, mesas de pedra para libação e kernoi (Watrous, 1996 : 58). Uma miniatura de espada, ou adaga, é seguramente datada do período neo-palacial (Watrous, 1996: 58). Do minoico tardio (1600-1100 a.C.), foram recuperados, além de jóias, figurinhas humanas e animais, rodas, vasos de difentes tipos (dentre eles várias taças finas), grelha em terracota, selos, espada feita em cristal, etc. (Watrous, 1996: 58).

A continuidade cultual entre a Idade do Bronze e a Idade do Ferro é atestada, segundo Sakellarakis, a partir de achados sem estratigrafia, atribuíveis aos períodos subminóico (1100-1000/975 a.C.) e proto-geométrico (1000-900 a.C.). Estes indicam, com muita probabilidade, que o culto no santuário de Zeus no Mt.Ida continuou sem interrupção entre o minoico tardio III (1390-1100 a.C.) e o período geométrio (900-700 a.C.) (Watrous, 1996: 58).

Com relação aos achados de época grega, um período prolífico de dedicações ocorreu entre o geométrico tardio e 0 arcaico (VIII-VI a.C.). Entre os objetos votivos desse período estão aqueles que são produções locais e uma grande parte proveniente do Oriente próximo. Trata-se,

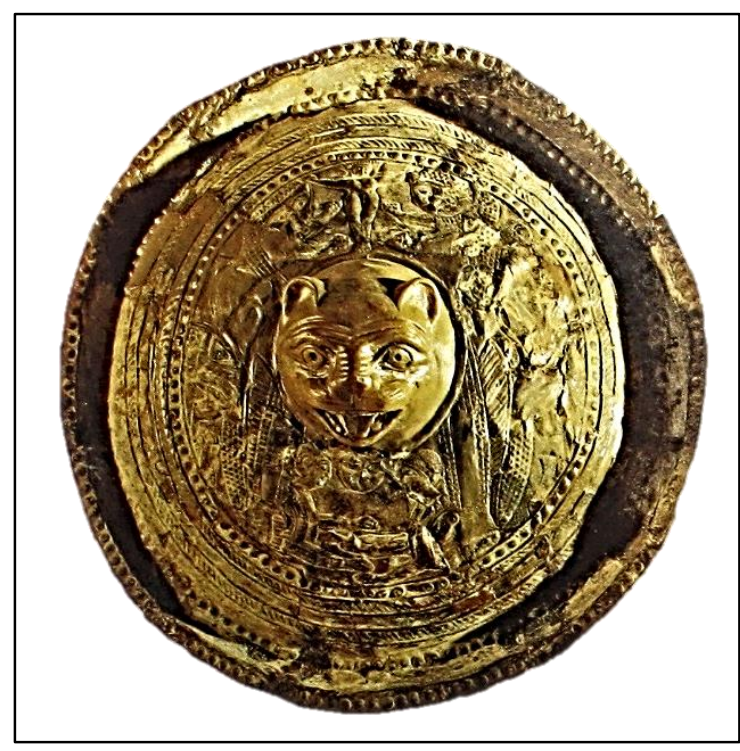

Fig.10- Escudo em bronze com prótomo de leão, período geométrico (Sakellarakis; Sapouna-Sakellaraki, 2013: vol.Г, pr.28) então, de figurinhas de argila de humanos e animais (muitos bovinos), rodas votivas de terracota, trípodes de

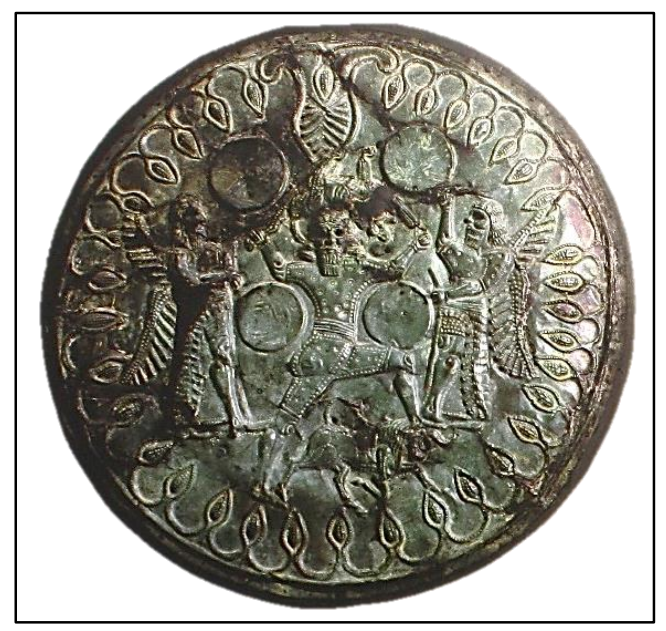

Fig.11- Tympanon de bronze, período geométrico (Sakellarakis; Sapouna-Sakellaraki, 2013: vol.H, 166) bronze e as famosas séries de escudos de bronze (Figs.10 e 11), muitas lanças inteiras e pontas de lança em ferro, fíbulas e ornamentos (broches de ouro, colares, botões, contas), um aplique de ouro de dois guerreiros, tigelas fenícias de bronze, uma fiala de bronze, fragmentos de pyxides de marfim, selos de marfim e lampararinas (Watrous, 1996: 59). Muito material do período clássico é relatado, tal como dois vasos encontrados com cinzas e ossos de animais. Dedicações helenísticas incluíram anéis, vasos de terra sigilata, placas, figurinhas, lamparinas e moedas (provenientes de Itanos, Quersoneso, Cnossos, Gortina, Tylissos, Eleutherna e Polyrhenion) (Watrous, 1996: 59). 


\section{I.1.2 A natureza do culto e a função do santuário}

É consenso entre os especialistas que a gruta localizada no Mt. Psiloritis foi o famoso santuário dedicado a Zeus Idaios. Conforme mencionamos no início, a identificação de seu culto em Ida é confirmada por uma inscrição romana (I.Cret. I, XII.I) (Prent, 2005: 591). Enquanto P. Themelis acredita que o culto de Zeus na gruta de Ida teria se iniciado somente no período geométrico tardio (século VIII a.C.), Sakellarakis defende a continuidade do culto no local entre a Idade do Bronze e a Idade do Ferro, postulando uma mudança decisiva no culto da divindade durante o período minoico tardio III (1390-1100 a.C.), quando a antiga divindade minoica da vegetação, que anualmente nasce e renasce, teria se sincretizado com o Zeus héladico, o pai celeste (Prent, 2005: 597; Sakellarakis, 1988a: 212; Themelis, 2004: 144). De acordo com Prent, que concorda com a posição de Sakellarakis, "a fusão de um deus indígena e o Zeus heládico teve lugar vários séculos antes da dedicação do tympanon e de escudos no final do século IX a.C., provavelmente, portanto, no final da Idade do Bronze" (Prent, 2005: 603). Evidências desse processo "são os objetos votivos do início da Idade do Ferro, encontrados na gruta, que retratam uma mistura de elementos das tradições minoicas e micênicas, tal como um dos escudos que contém, com muita probabilidade, a imagem de um raio, talvez uma referência às qualidades de Zeus como pai celeste" (Prent, 2005: 603).

Na gruta de Ida, em época grega, o foco do culto foi o Zeus nascido em Creta, uma divindade com uma formação histórica longa, com início no período minoico, conforme se aceita atualmente (Prent, 2005: 591). São fontes literárias e epigráficas de época helenística que melhor caracterizam o Zeus cretense, cujo culto assumiu os mesmos contornos nos santuários do Mt.Ida, Mt.Dicta, Amnisos, Palaikastro, Praisos e Agia Triada. Conforme uma inscrição epigráfica de Lisos do século III a.C., durante o período helenístico foi usado pela primeira vez o epíteto Kretagenes de Zeus, que remete ao culto da divindade nascida em Creta (Willets, 1962: 200).

O mito do nascimento de Zeus em grutas, localizadas em montanhas em Creta, circulava na ilha, e no mundo grego, ao menos desde a época arcaica, como indica uma menção de Hesíodo na Teogonia (453-506) a respeito do nascimento da divindade em Aigaion, uma montanha localizada na área da pólis cretense de Lyttos. Foi no texto do poeta tebano que se conservou a matriz do mito - Rhea teria dado à luz escondida em uma caverna para proteger Zeus de seu pai Cronos, que pretendia devorá-lo (Prent, 2005: 591-592). De acordo com Prent, muitas versões posteriores diferentes foram preservadas e novos detalhes foram acrescentados, principalmente com relação aos seres mitológicos que teriam protegido o deus - abelhas, uma cabra, uma porca, ninfas e os Kouretes -, mas os elementos principais da estória foram preservados (Prent, 2005: 592). Além de Creta, outras tradições localizam o nascimento de Zeus "em áreas remotas da Arcádia, Acaia e Messênia" (Prent, 2005: 602). Thorne, contudo, oferece uma explicação coerente sobre a variedade de versões desse mito e sua origem em períodos mais antigos - "o fato de que diferentes tradições localizem o local de nascimento de Zeus no Ida, no Dicta e no Aigaion, assim como em vários lugares na Arcádia, pode indicar a 
difusão de um mito relacionado na Idade do Bronze e uma subsequente fragmentação em variantes locais e regionais durante a Idade do Ferro" (Prent, 2005: 602; Thorne, 2000: 141, 153-154). Assim, a tradição conservada em Hesíodo, do nascimento de Zeus em uma montanha em Creta, tem raízes muito mais antigas, que remontam ao menos desde a Idade do Ferro.

Com relação às tradições literárias, que relacionam o Mt.Ida como o local de nascimento de Zeus, a única referência, e também a mais antiga, do mito no local remonta ao período helenístico tardio ou ao início do romano - trata-se de um grande trecho conservado na obra de Diodoro (V.70.1-2/2-6). De acordo com sua versão, após Rhea dar à luz a Zeus no Mt.Ida, confiou o deus aos Kouretes que viviam na vizinhança da montanha. Estes, por sua vez, levaram-no a uma caverna, onde Zeus foi cuidado pelas ninfas que 0 amamentaram com uma mistura de leite e mel, ficando, depois, sob os cuidados de Amaltheia, a cabra que teria amamentado o deus. Além de fornecer a versão do mito, Diodoro refere-se ao Mt.Ida, à gruta e aos prados sobre as cristas da montanha como locais sagrados à divindade. Já sobre informações literárias que fornecem alguma indicação sobre o culto e o rito no santuário, antes de Diodoro, Eurípides no século $V$ a.C., em um fragmento de Cretenses (fragm.472), propicia um testemunho sobre o culto de Zeus no Mt.Ida, que não trata do nascimento do deus no local, mas fornece alguns detalhes sobre o caráter místico e iniciatório do culto na gruta de Ida à época desse autor ateniense (Willets, 1962: 239-240). A esse respeito, também, há uma tradição que registra a visita do filósofo Pitágoras ao santuário e descreve os ritos iniciatórios nos quais teria participado (Willets, 1962: 242).

Com relação à função, vimos no capítulo anterior, que o santuário de Zeus no Mt.lda teve, ao mesmo tempo, um papel sub-regional e inter-regional, atestado com segurança, a partir da Idade do Ferro. A sua função chave foi a de propiciar um local de encontro neutro para indivíduos de diferentes comunidades a partir desse período (Prent, 2005: 566). Significativo a esse respeito é o posicionamento da gruta de Ida em uma área marginal que formou a transição entre as regiões noroeste e sudeste de Creta (Prent, 2005: 566). Assim como o santuário de Syme, a gruta de Ida não se localizava em proximidade às principais rotas antigas - a jornada a esses santuários foi, portanto, uma verdadeira peregrinação, que passava pelo 'campo selvagem' normalmente não percorrido (Prent, 2005: 567). Essa configuração do santuário da gruta de Ida durante o início da Idade do Ferro, a certa distância de um grande número de assentamentos da ilha nesse período, destacou o seu potencial de neutralidade (Prent, 2005: 568). Watrous acrescenta, com base na informação de Diodoro sobre a campina sagrada, que muito provavelmente, "o platô de Nida, entre os períodos geométricos e arcaico, era consagrado a Zeus, implicando que não pertencia a nenhuma comunidade específica" (Watrous, 1996: 103). Pelo seu posicionamento na paisagem, e a dedicação em grande escala de objetos votivos, "o santuário da gruta de Ida revela fortes paralelos com aqueles santuários inter-regionais do início da Idade do Ferro em outras áreas do mundo grego, como Olímpia e Delfos", por exemplo (Prent, 2005: 565-566; Watrous, 1996: 103-104).

A quantidade numerosa de bronzes e orientalia evidencia, no santuário de Zeus no Mt.Ida, a presença dominante de peregrinos da aristocracia a partir do século IX a.C. (Prent, 2005: 569). Apesar de serem escassas 
evidências diretas sobre a participação ou organização do culto por comunidades locais, o estudo das oficinas dos escudos de bronze, por exemplo, revelou a presença de indivíduos de assentamentos do setor central e centro-oeste de Creta nessa época (Prent, 2005: 569-570). Tais assentamentos, segundo Watrous, teriam sido Axos, Eleutherna, Cnossos, Tylissos, Festos e Gortina (Watrous, 1996: 103-104). Os autores têm aceito que, muito provavelmente, ritos de iniciação aristocráticos ocorreram no santuário já na Idade do Ferro (Prent, 2005: 598). Segundo Prent, esses ritos devem ter sido praticados por homens adultos, guerreiros já estabelecidos, conforme indicam os tipos de dedicações (Prent, 2005: 598). Já segundo Chaniotis, tratava-se de ritos efébicos entre indivíduos provenientes da aristocracia de diversas comunidades (Chaniotis, 2009: 65). Também deve ser lembrado que o culto no local também teve um componente feminino importante a partir dessa época, como indicam a grande quantidade de jóias em ouro, o tipo de objeto votivo feminino mais precioso, não visto em outros santuários cretenses do período, como Psychro, por exemplo (Prent, 2005: 570-571). Chaniotis resume o culto no santuário do Mt.Ida na Idade do Ferro do seguinte modo: "as oferendas de alimentos no período minoico foram substituídas por sacrifícios cruentos, a dedicação de armas - possivelmente em conexão com ritos militares de passagem - e a celebração de um culto de morte e renascimento" (Chaniotis, 2009: 65).

Se por um lado o santuário de Zeus no Mt.Ida exerceu um papel inter-regional, atingindo a aristocracia de várias comunidades cretenses, fora da área de sua localização, durante a Idade do Ferro, por outro, manteve uma função sub-regional entre a população local. A princípio, a raridade de objetos de terracota indica uma participação limitada de membros, não pertencentes à elite, das comunidades da região, tais como pastores locais (Prent, 2005: 571). No entanto, figurinhas de animais em bronze foram encontradas em certa quantidade, podendo representar uma continuidade funcional com a grande quantidade de oferendas de animais em argila e "chifres de consagração" no período minoico tardio IIIC-sub-minoico (Prent, 2005: 571). A preocupação expressa por figurinhas de animais tem uma base agrícola e pastoril, diferindo das conotações mais militaresaristocráticas relacionadas aos escudos e armamentos de bronze (Prent, 2005: 571). Usando um dado etnográfico moderno, Chaniotis lembra que durante o século XIX o platô de Nida era uma área de pastoreio disputada entre os pastores dos vilarejos de Anogeia e Vorizia, sendo ainda hoje uma zona dedicada à essa prática (Chaniotis, 2009: 64). Nesse sentido, concordamos com Prent, o qual conclui que a gruta de Ida manteve suas mais antigas funções em nível sub-regional - funções locais para pastores que frequentavam as montanhas ao redor e, talvez, em menor escala para grupos, não pertencentes à elite, de comunidades vizinhas (Prent, 2005: 571).

Durante a época arcaica, os tipos de objetos votivos sugerem a continuidade do papel do culto em atrair membros da aristocracia de comunidades cretenses que frequentavam 0 santuário. De acordo com $A$. Chaniotis, certas evidências do século VIII a.C., como os selos de marfim com a representação de um homem usando um elmo, acompanhado por um cavalo, cão ou pássaro, e de astrágalos, sugerem, respectivamente, rituais aristocráticos militares e também ritos de passagem, nesse caso, de efebia (Chaniotis, 2009: 63). No entanto, conforme esse mesmo estudioso, tal conclusão não pode ser assumida para a época arcaica 
(Chaniotis, 2009: 63). A nosso ver, contudo, é muito provável que em época arcaica o santuário de Zeus no Mt.Ida tenha assumido tais papéis, já que em época clássica, como vimos, testemunhos literários indicam a presença de ritos iniciatórios provavelmente relacionados às aristocracias locais cretenses ou de fora da ilha de Creta. A partir da época clássica, e muito provavelmente da época arcaica (como indica a suposta participação de Pitágoras no santuário), é possível atestar o caráter místico do culto em lda, o de ritos de mistérios, tal como descreve o fragmento de uma peça de Eurípides (Prent, 2005: 599 e 604). No referido fragmento, Eurípides descreve o rito noturno à luz de tochas, a proibição da carne, o uso de roupas brancas a todos os iniciados de Zeus Idaios (Willets, 1962: 240).

No que diz respeito às póleis que frequentaram o santuário em época clássica, é provável que Gortina tenha controlado (ou administrado), durante certo período, a área sagrada, como indica uma inscrição de c.500 a.C. ${ }^{1}$ (Chaniotis, 2009: 62). Trata-se de "um tratado entre Gortina e sua pólis dependente, Rhizenia, o qual estipula que esta última poderia manter suas leis e seus tribunais sob a condição de a cada dois anos fornecer animais de sacrifício, com o valor de 350 estateres, para o sacrifício de Zeus no Ida" (Chaniotis, 2009: 62; Prent, 2005: 568). Outra cidade na vizinhança, Axos, também deve ter sido associada ao culto, pois esta pagou multas a Zeus Idatas por certos crimes (Chaniotis, 2009: 62). 0 que é certo, em relação ao santuário nos períodos clássico e helenístico tardios é a função que adquiriu em termos pan-cretenses e pan-helênicos (Prent, 2005: 568 e 593). Há várias inscrições e referências literárias que comprovam a função ampliada do santuário nesses períodos. No período clássico, a notoriedade do culto de Zeus Idaios já havia ganho os textos do teatro ateniense. Tratados entre as cidades, como foi o caso de Apolonia (centro-norte) e Kydonia (oeste), essa última localizada no oeste de Creta, eram expostos na gruta, e juramentos/acordos entre as cidades eram evocados no nome de Zeus Idaios - como foi o caso de Arkades, Sybrita e Eleutherna (centro-oeste), Cnossos (centronorte), Gortina e Priansos (centro-sul), Lyttos (centro-leste), Olonte e Hieraptyna (leste) (Prent, 2005: 568).

\footnotetext{
1 Em um estudo anterior, Chaniotis (1998) chegou a supor que a organização do culto, no final do período helenístico, estivesse nas mãos de uma anfictionia, na qual Gortina teria sido um membro importante (apud Prent, 2005: 569; Watrous, 1996: 103-104).
} 


\section{I.2 Mt. Dicta}

0 santuário de Zeus no Mt.Dicta (2148 m) (cat.no.2) localizase no lado centro-leste de Creta, na região do platô do Lassithi (Fig.12). Assim como no caso do santuário da divindade no Mt.Ida, o culto no Mt.Dicta também foi estabelecido em uma gruta na montanha, atualmente denominada de Psychro, em uma altitude de 1025 $\mathrm{m}$ em relação ao nível do mar e a uma

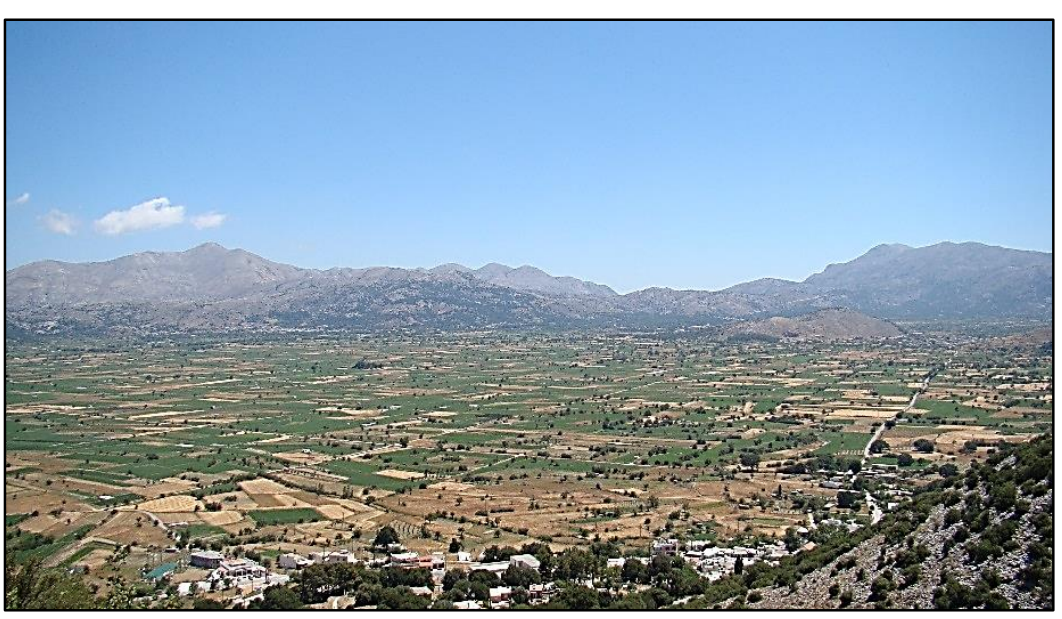

Fig.12- Platô do Lassithi visto a partir da área da entrada da gruta de Dicta (Foto: arquivo pessoal/2014)

altura de 130 m acima do nível do platô (Prent, 2005: 167). A entrada da caverna, voltada para norte no Lassithi, dá para o antigo assentamento de Karphi e, o lado oeste, para a pólis de Lyttos (Watrous, 1996: 17).

Após as descobertas de antiguidades por habitantes locais em 1883, as primeiras escavações foram empreendidas por Chatzidakis e Halbherr, que trabalharam na entrada da caverna em 1886 (Prent, 2005: 167). Arthur Evans escavou a parte posterior da câmara superior em 1896, seguido por P. Demargne em 1897. David Hogarth foi o primeiro a explorar sistematicamente a caverna (Prent, 2005: 167). Hogarth e Evans foram os primeiros a identificar Psychro com a caverna de Dicta, famosa na antiguidade como um dos locais de nascimento de Zeus (Prent, 2005: 167; Watrous, 1996: 17-18). J. Boardman na década de 1960 realizou uma síntese da história da gruta, baseando-se nas evidências estratigráficas dos relatórios mais antigos das escavações e na análise estilística dos artefatos (Prent, 2005: 167-168). 


\subsubsection{Descrição e interpretação dos achados}

Assim como no caso do santuário de Zeus na gruta do Mt.Ida, o da gruta de Dicta, ou Psychro, foi usado como local de habitação durante o final do período neolítico (Watrous, 1996: 48). Não há evidências de qualquer visitação humana após o neolítico tardio até o minóico médio I (2000-1800 a.C.). Há duas proposições para o início da atividade cultual no santuário de Zeus no Mt.Dicta. Watrous propõe o início do culto no minóico médio IA (2000-1900 a.C.) ou no início do minoico médio IB (1900-1800 a.C.) (Watrous, 1996: 47). Mais recentemente, Prent propôs o início da atividade cultual em uma data um pouco mais baixa, "entre o minoico médio | e || (1800-1700 a.C.), com um ápice entre o minoico médio III (1700-1600 a.C.) e 0 minoico tardio I (1600-1425 a.C.), caracterizado pela dedicação de numerosos objetos votivos de bronze, incluindo figurinhas humanas e animais (como touros),

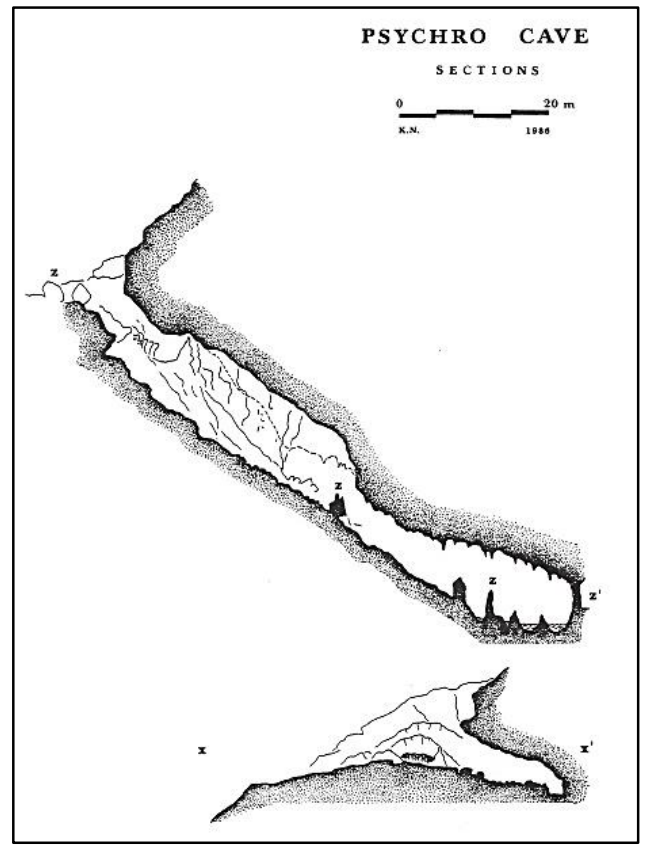

Fig.13- Perfil da parte interna da caverna de Psychro ou Dicta (Watrous, 1996: pr.III) armas, ferramentas e ornamentos pessoais" (Prent, 2005: 168). O término da atividade cultual na gruta de Dicta ou Psychro data do período romano tardio, quando o culto já ocorria de uma maneira muito reduzida, como indicam a quantidade de objetos votivos (jarras, três lamparinas, fíbulas, cinco contas de vidro) datados do período (Watrous, 1996: 55).

O culto na gruta de Dicta ocorreu em três áreas de seu espaço interno e externo: no terraço amplo fora da entrada da caverna, na câmara superior (a denominada Upper Grot de Hogarth) e na câmara inferior (Fig.13) (Lower Grot) (Watrous, 1996: 17). O terraço exterior estende-se norte-sul por um comprimento de mais de 40 $\mathrm{m}$ e tem $4 \times 5 \mathrm{~m}$ de largura. Nessa área foram encontrados alguns achados, mas não restos arquitetônicos (Prent, 2005: 168). Na câmara superior, cuja sala principal tem cerca de $25 \mathrm{~m}$ de largura e $20 \mathrm{~m}$ de profundidade, 0 amontoado de rochas visto atualmente (ocasionada pelas escavações de Hogarth) cobre 0 chão original (Watrous, 1996: 17). O primeiro nicho nessa área da gruta possui uma estrutura retangular pequena, interpretada como um altar, feito de pedras esquadrinhadas e provavelmente coberto, na época minoica, por um estuque colorido (Watrous, 1996: 48). Este altar era cercado por quatro estratos de terra com objetos votivos que permitiram data-lo nos períodos minoico médio, minoico tardio, geométrico e em diante (Prent, 2005: 168; Watrous, 1996: 17). A entrada da câmara inferior está localizada na extremidade sul da câmara superior e leva para baixo, a 35 m nas profundidades da gruta (Watrous, 1996: 17). No fundo da caverna localiza-se uma piscina profunda de água e uma matriz de estalagmites e estalactites, nas fendas das quais Hogarth encontrou centenas de facas de bronze, adagas, pontas de lança, navalhas, pinças e machados duplos (Watrous, 1996: 17). Essas características da gruta, na câmara inferior, tiveram um importante papel no culto 
durante a Idade do Bronze até quando um desmoronamento tornou impossível o acesso à área entre o minoico tardio III e o período geométrico (Prent, 2005: 168). Conforme a descrição de Hogarth da estratigrafia do témeno, a área da câmara superior cessou sua função após o minóico tardio I (Watrous, 1996: 52-53). Já a câmara inferior continuou em uso no período geométrico e arcaico e o terraço foi usado para refeições cultuais e dedicações (Watrous, 1996: 54).

Como se vê, em contraste ao santuário do Mt.Ida, na gruta de Dicta foram encontradas, além das oferendas, alguns tipos de construções associadas ao culto. Com relação aos objetos votivos, aqueles mais antigos (do minoico médio IB-II) foram encontrados na câmara superior, nos níveis mais baixos do estrato de terra preta em meio a ossos de animais foram recuperados potes de tipo kamares, mesas de pedra para libação, fragmentos cerâmicos pintados, taças decoradas, tigelas, jarros, vasos em miniatura, figurinhas humanas femininas e masculinas (Watrous, 1996: 49-50). Do minoico médio III e minoico tardio I, datam mesas votivas para libação, taças cônicas, armas, ornamentos pessoais, ferramentas e outros objetos (Watrous, 1996: 48). Do minoico tardio II-IIIB1, datam oferendas em argila e bronze (armas, figurinhas) e objetos de

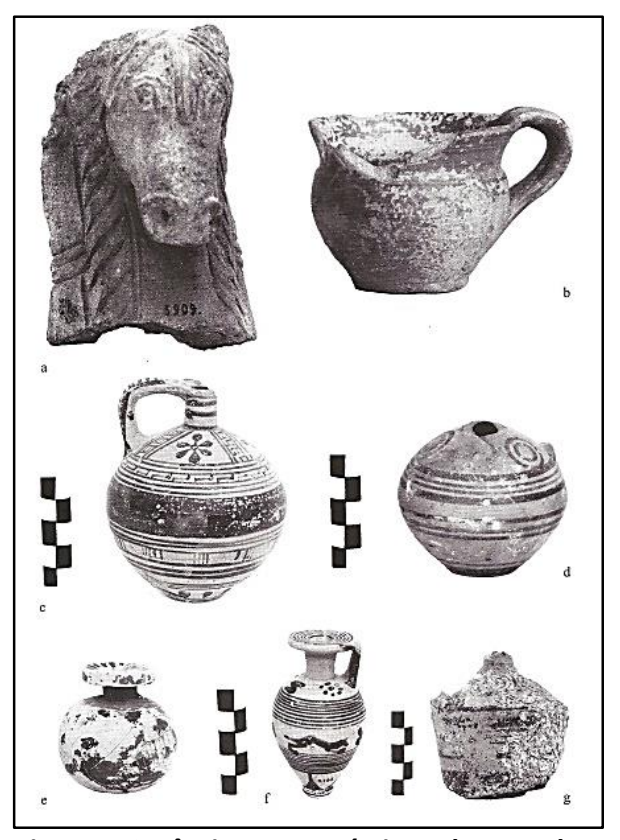

Fig.14- Cerâmica geométrica de Psychro (Watrous, 1996: pr.XXVIII) joalheria (Watrous, 1996: 52-53). Entre o minóico tardio IIIB2 e o período proto-geométrico, as oferendas continuaram a diminuir em ambas as câmaras. Sobre as oferendas do minoico tardio IIIB2, trata-se do mesmo padrão do período anterior e do período proto-geométrico foram recuperadas várias contas de argila (Watrous, 1996: 53).

No que diz respeito aos achados votivos dos períodos geométrico e arcaico, a maior parte deles provém de uma camada uniforme de terra preta misturada com pedras e um pouco de cerâmicas, de figurinhas em argila, objetos em bronze e ferro (Fig.14) (Watrous, 1996: 55). Armas continuaram a ser ofertadas em ambos os períodos, assim como cerâmica e figurinhas de animais e humanos em bronze (Watrous, 1996: 55). Placas, encontradas no terraço, indicam que foram penduradas em árvores na entrada da caverna, tal como a que retrata o peregrino trazendo uma cabra selvagem para o sacrifício no santuário (Watrous, 1996: 55). Novos objetos em bronze foram ofertados nos períodos, tais como a figurinha de um coche, a de carroças puxadas por um boi ou cabra, miniaturas de fiala, figurinhas femininas e masculinas (Watrous, 1996: 55). As figurinhas masculinas são mostradas nuas ou com elmo ou são representadas como guerreiros armados (Watrous, 1996: 55). Uma figurinha feminina retrata a pose de Vênus pudica (Watrous, 1996: 55). Foram encontrados também entre os votivos, objetos provenientes do Egito, como a estatueta de Amon-Ra (Watrous, 1996: 55). Entre os períodos clássico e helenístico, pouquíssimos achados foram encontrados, mesmo as duas moedas 
helenísticas podem ter sido trazidas à caverna em um período posterior (Watrous, 1996: 55). É preciso dizer que a maior parte dos achados votivos se concentram na câmara superior da gruta de Dicta.

\subsubsection{A natureza do culto e a função do santuário}

Diferente da gruta de Ida, para a qual não há controvérsias sobre a atribuição do santuário a Zeus, sobre a gruta de Psychro, em razão da ausência de evidências epigráficas no local, até hoje permanecem dúvidas se de fato ali funcionou o santuário da divindade relacionado à versão do mito, conservado em Apolodoro (1.1.6), que localiza o nascimento de Zeus na gruta de Dicta². Watrous é quem possui uma posição a favor sobre essa associação. Segundo essa estudiosa, estudos de tabletes de Cnossos podem indicar que a gruta de Dicta não se situava no extremo leste da ilha, como alguns estudiosos têm reiteradamente afirmado com base em testemunhos literários helenísticos. Segundo a estudiosa, a exploração de 120 cavernas por Faure, no leste de Creta, indicou que estas não foram usadas na região como santuários na Idade do Bronze e na Idade do Ferro (Watrous, 1996: 19). A presença de vasos de Cnossos ofertados na gruta de Psychro e a referência a uma oferenda de óleo a Zeus Dicteu, registrado no tablete em Linear B (Fp1) de Cnossos, levaram Watrous a propor a localização da caverna em uma área na porção central de Creta (Watrous, 1996: 18-19). Além disso, Psychro foi o maior santuário de gruta conhecido no lado centro-leste da ilha durante a Idade do Ferro, suficientemente importante para atrair peregrinos de dentro e de fora de Creta nessa época, sugerindo, assim, que o santuário tenha sido amplamente conhecido como o local do nascimento de Zeus entre os séculos VIII-VII a.C. (Watrous, 1996: 19).

Diante da fragilidade das evidências, e não descartando a sua proposição a favor da identificação de Psychro com Dicta, a estudiosa considera ser mais provável que "durante o período minoico e o início da Idade do Ferro, o nascimento e juventude de Zeus foram celebrados em vários tipos de santuários por toda Creta (como também no período clássico e períodos posteriores)" (Watrous, 1996: 19). O santuário de Psychro foi, portanto, provavelmente um dos vários santuários dedicados ao jovem Zeus cretense na ilha (Watrous, 1996: 19). Vimos no capítulo anterior, como Zeus na ilha de Creta - caracterizado pelo sincretismo da divindade jovem minoica ligada ao reflorescimento da vegetação com o deus celeste micênico - ao longo de sua formação histórica foi cultuado em santuários com diversos epítetos, dentre eles Dicteu (Watrous, 1996: 19). Os diferentes epítetos refletem diferentes tradições sobre versões do mito de Zeus em Creta, e Dicteu parece ser o mais antigo dentre eles, como indica a referência no tablete de Cnossos. Infelizmente, essa evidência epigráfica da Idade do Bronze não nos informa se o santuário de Zeus Dicteu se localizava em uma caverna ou no cume de uma montanha ou em um único lugar em Creta (Watrous, 1996: 19). De acordo com O. Zolotnikova, o culto de

\footnotetext{
2 De acordo com o tradutor da obra de Apolodoro, J.G. Fraser, os autores antigos não estiveram de acordo se Zeus teria nascido em Ida ou Dicta. Apolodoro afirma ter sido em Dicta com base em Virgílio (Geórgicas, 4.153) e nos mitógrafos vaticanos (Scriptores rerum mythicarum Latini, ed. Bode, i. pp. 34, 79, Primeiro mitógrafo vaticano, 104; Segundo mitógrafo vaticano, 16). Por outro lado, o Mt.Ida aparece também em Calímaco (Hino i,51) e em Ovídio (Fasti, 4.207) (Fraser, 1921: nota 1).
} 
Zeus Dicteu, localizado inicialmente no lado central de Creta, tal como defende Watrous, teria se difundido ao leste da ilha na Idade do Ferro, explicando a introdução de seu culto em Palaikastro e Praisos nessa época, durante o movimento da população minoica-micênica à essa área, ocorrido no final da Idade do Bronze sob pressão das recém-chegadas tribos gregas (Zolotnikova, 2013a: 115). Essa é também a opinião de M. Prent (Prent, 2005: 594).

Quase uma década depois, M. Prent oferece uma posição totalmente contrária àquela de Watrous sobre a identificação de Psychro com a gruta de Dicta. A seu ver, os escritores antigos, bem posteriores a Hesíodo, teriam confundido Dicta (localizada mais a leste de Creta) com Aigaion, a montanha descrita pelo poeta tebano como o local de nascimento de Zeus. A proximidade de Aigaion, nas vizinhanças de Lyttos, com Psychro, no platô do Lassithi, teria levado a tal confusão (Prent, 2005: 169).

Com relação à função do santuário, Watrous e M. Prent também mantiveram posições contrárias a esse respeito. Watrous defende que a gruta de Dicta foi um santuário extra-urbano com função inter-regional a partir da Idade do Ferro, tal como a gruta de Ida e Syme, como indicam a proveniência dos objetos votivos de Creta e de outras partes do mundo grego encontrados lá. Nesse sentido, Watrous compara o santuário da gruta de Dicta com Olímpia e Bassai no Peloponeso (Watrous, 1996: 104). A estudiosa considera que o culto na gruta de Dicta esteve sob influência da pólis de Lyttos em razão do poder adquirido pela cidade entre a Idade do Ferro e a época arcaica, não chegando a afirmar se o santuário esteve sob o controle dessa cidade. Apenas considera ser muito provável que o platô do Lassithi tenha sido parte do território de Lyttos. A seu ver, a partir da Idade do Ferro, a gruta de Dicta atraiu peregrinos da parte central e leste de Creta, provavelmente incluindo a área entre Lyttos e Lato (Watrous, 1996: 102-103).

M. Prent, em contraste, defende que Psychro foi um lugar de culto extra-urbano durante a Idade do Bronze, transformando-se em suburbano no início da Idade do Ferro por interferência do desenvolvimento da pólis de Papoura, o maior assentamento da região do Lassithi nesse período (Prent, 2005: 609). Com base no tamanho do assentamento de Papoura, sua posição estratégica nas principais rotas de acesso e sua proximidade à gruta de Psychro, é muito provável, segundo Prent, que a organização do culto em Psychro no início da Idade do Ferro pertenceu aos habitantes desse assentamento (Prent, 2005: 609). A relação entre Psychro e Papoura seria, talvez, o paralelo mais próximo, em Creta, do modelo bipolar de De Polignac (Prent, 2005: 609). Uma mudança no tipo de objetos votivos - de figurinhas de bronze para figurinhas e objetos de terracota - durante o século VII a.C. pode indicar que foi justamente nessa época que Psychro se tornou 0 santuário suburbano de Papoura (Prent, 2005: 610). Ao mesmo tempo, o santuário da gruta de Psychro teria funcionado como um centro de culto sub-regional, portanto, para os diferentes assentamentos presentes naquela época no platô do Lassithi, o que teria inibido o desenvolvimento de Psychro em um grande santuário inter-regional (Prent, 2005: 610).

Esse é o estado atual das pesquisas acerca do santuário da gruta de Psychro ou Dicta. Acreditamos ser possível considerar Psychro como um dos vários locais de culto a Zeus em Creta e, nesse caso, de Zeus 
Dicteu, cujo culto pode ter sido perfeitamente associado a uma gruta, tal como descreve o mito conservado em textos posteriores. Os tipos de votivos, tal como observa Watrous, são similares àqueles encontrados na gruta de Ida, embora não se encontre em Dicta, por exemplo, oferendas de trípodes ou dos grandes escudos de bronze de época geométrica (Watrous, 1996: 59). Mas as oferendas de armas em bronze, jóias, figurinhas humanas e animais em bronze levam a atribuir, ao santuário de Dicta, um papel semelhante àquele de Ida. Mas a falta de evidências sobre a origem das comunidades que frequentaram o santuário desde ao menos a Idade do Ferro nos impede de propor uma função inter-regional para a gruta de Dicta, tal como pode-se comprovar para a gruta de Ida. A nosso ver, é razoável afirmar que o santuário de Zeus na gruta de Dicta foi extra-urbano e desempenhou um papel sub-regional no lado centro-leste e leste de Creta, servindo a tipos de ritos agrários e pastoris e talvez iniciatórios a uma aristocracia, como lda a partir da Idade do Ferro.

\subsection{Agia Triada}

O santuário de Zeus Velchanos localiza-se em Agia Triada (cat. no.5), no lado centro sul de Creta, na planície fértil de Mesara (Prent, 2005: 162). Agia Triada foi uma das cidades minoicas mais antigas ${ }^{3}$ de Creta, abandonada no minoico tardio IIIB (1320-1200 a.C.) após uma destruição (Prent, 2005: 162). A área sagrada foi estabelecida sobre as ruínas da cidade minoica, na denominada Piazza dei Sacelli, o pátio pavimentado a sul da stoá da Idade do Bronze (Fig.15) (Prent, 2005: 162-163).

O santuário foi identificado nas primeiras escavações, realizadas por Halbherr e Paribeni entre 19021914, quando o depósito votivo foi encontrado no local. Estudos dos objetos votivos, recuperados no grande depósito, foram realizados por membros da Escola Arqueológica Italiana de Atenas que iniciaram os trabalhos no sítio a partir dos anos 1970 (Prent, 2005: 162).

\section{I.3.1 Descrição e interpretação dos achados}

Os objetos votivos são os principais testemunhos sobre a existência de um santuário a Zeus, possivelmente com o epíteto de Velchanos, dedicado em Agia Triada. Como veremos adiante, foram encontrados alguns remanescentes de estruturas arquitetônicas sem função definida, ao menos para a Idade do Ferro. Antes de descrevê-los, é preciso dizer que o santuário em Agia Triada, em razão do início da atividade cultual datar entre o minoico tardio IIIC e o sub-minoico, é situado, por alguns autores como Prent e Zolotnikova, dentro da Idade do Bronze. Queremos dizer que em nossa análise e interpretação consideramos essa área

\footnotetext{
${ }^{3}$ De acordo com Prent, a ocupação da área do assentamento de Agia Triada data do período neolítico e dos primeiros períodos do minoico antigo (Prent, 2005: 162).
} 
sagrada pertencente à Idade do Ferro com base em S. Wallace, em seu estudo sobre Creta, que define a data entorno a 1200 a.C. como o início desse período (Wallace, 2010: 22).

Isto posto, o grande depósito votivo, que assinalou a identificação de um santuário na área, "é composto por objetos datados entre o minoico tardio III e o período helenístico" (Prent, 2005: 163). Todo o material referente aos objetos votivos foi estudado pela arqueóloga italiana A.L. D'Agata, que a partir de sua sistematização distinguiu três fases de uso interrupto do santuário: 1-) do minoico tardio IIIC (1200-1100 a.C.)

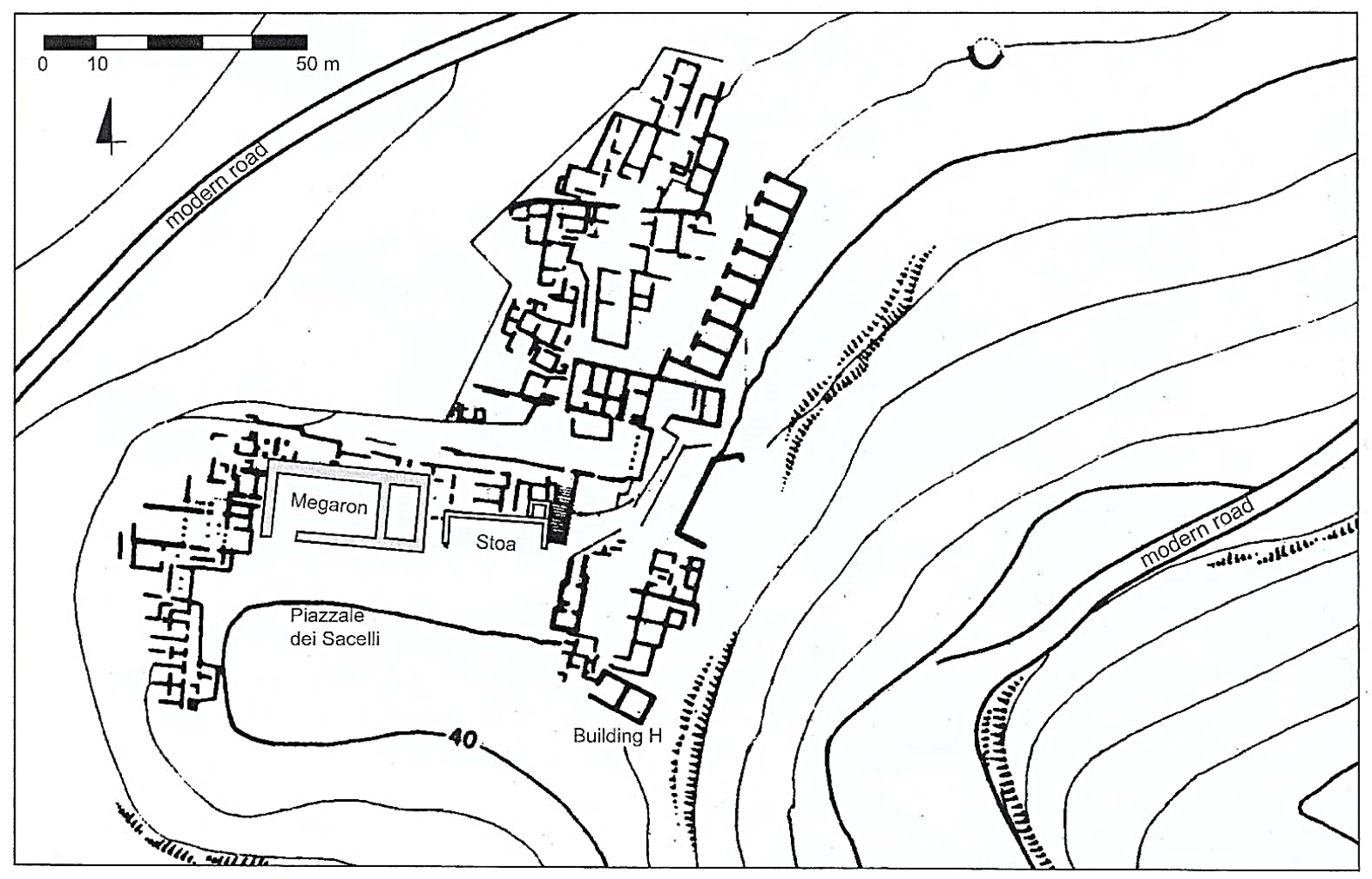

Fig.15- Planimetria de Agia Triada (Prent, 2005: fig.15)

ao sub-minóico (1100-1000/975 a.C.); 2-) do proto-geométrico B (c.840-810 a.C.) ao início do Orientalizante (c.700-?); e 3-) o helenístico (Prent, 2005: 163). Segundo seu estudo, houve uma interrupção nas atividades de culto após o minoico tardio IIIC e o sub-minoico, com uma retomada no período proto-geométrico $\mathrm{B}$. A fase mais importante da vida do santuário ocorreu entre o proto-geométrico B e o início do Orientalizante (Prent, 2005: 321). Assim, os achados mais antigos formam um grupo homogêneo que data entre o minoico tardio IIIC e o sub-minoico até à época após o abandono do assentamento no minoico tardio IIIB (Prent, 2005: 163). Devido a uma erosão no solo, os votivos foram encontrados espalhados por uma grande área cobrindo a Piazzale e parte da encosta mais baixa a norte. A área a sul do Piazzale não forneceu restos nem do minoico médio e nem do minoico tardio, sugerindo que talvez tenha sido o local de um bosque sagrado (Prent, 2005: 163). Da fase mais antiga do culto, entre o minoico tardio IIIC e o sub-minoico, foram recuperados poucos objetos de bronze (apenas 3 figurinhas de bovinos) em comparação ao total de 141 objetos de terracota (figurinhas de touro e cavalos, de animais fantásticos metade touro e metade homem, figurinhas humanas vestindo túnicas, sandálias e caneleiras, chifres de consagração, machados duplos e rhyta) (Prent, 2005: 163- 
164). A leste da stoá foi encontrada uma fossa com ossos de animais e fragmentos de kernoi assinalados aos períodos proto-geométrico B e ao início do Orientalizante (Prent, 2005: 321). Entre as dedicações desse período predominaram figurinhas de animais em bronze de animais e humanas em terracota (Zolotnikova, 2013a: 113).

Com relação a possíveis construções na área do santuário, é provável que uma "construção fragmentária a sul, possivelmente do minoico tardio IIIC, deve ter servido para demarcar o pátio ou servido como uma área com degraus para os celebrantes sentarem" (Prent, 2005: 163). Alguns restos arquitetônicos do período geométrico foram descobertos a norte do Piazzale, a leste da stoá e podem indicar certas atividades de construção no espaço do santuário nessa época (Zolotnikova, 2013a: 114).

De acordo com o estudo de D’Agata não foram encontrados objetos votivos de época clássica, talvez indicando uma interrupção no culto entre o final do período arcaico e todo o período clássico. As evidências helenísticas sugerem uma retomada do culto nesse período.

\subsubsection{A natureza do culto e a função do santuário}

Como no caso do Mt.Ida e de outros santuários cretenses de Zeus, como veremos na sequência, o culto na área sagrada de Agia Triada também foi atribuído ao deus a partir de evidências muito posteriores ao início da atividade cultual na área. São somente evidências epigráficas do período helenístico tardio, que testemunham o culto a Zeus Velchanos associado a um antigo altar no Piazzale e a um pequeno edifício a nordeste do local ${ }^{4}$ (Prent, 2005: 164, 323). Como coloca Zolotnikova, há algumas dúvidas sobre se Zeus foi a divindade masculina cultuada em Agia Triada (Zolotnikova, 2013a: 114). Mas, a seu ver, é possível associar o deus Velchanos a Zeus em Agia Triada já no período histórico mais antigo, considerando-se os santuários atestados a Zeus em fase posterior em outros centros de culto cretenses dedicados a ele na Idade do Ferro, sempre relacionados ao aspecto de um deus jovem (Zolotnikova, 2013a: 114). De acordo com R.F. Willets e M. Prent, o epíteto Velchanos (ou Welchanos) significa "deus do salgueiro" e refere-se a um tipo de árvore ou vegetação em geral (Prent, 2005: 164, 323; Willets, 1962: 250). A divindade representou um outro culto sobrevivente do deus minoico jovem relacionado à fertilidade e ao ciclo da vegetação, que entre a Idade do Bronze e a do Ferro se sincretizou com o Zeus micênico (Willets, 1962: 251).

A ausência de estruturas de culto, tal como um templo, levou os pesquisadores a definirem o santuário de Zeus em Agia Triada como uma área sagrada a céu aberto, cuja atividade pode ter mudado em caráter e local (Prent, 2005: 321). Diferente do caso de Palaikastro e Amnisos, como se verá mais adiante, "não é possível estabelecer uma relação do culto com as ruínas dos edifícios abandonados da cidade minoica - nenhum deles parece ter sido reutilizado ou incorporado às atividades cultuais" (Prent, 2005: 520).

\footnotetext{
${ }^{4}$ Referências literárias são inexistentes acerca do santuário e do culto de Zeus em Agia Triada.
} 
Com relação à sua função, "há pouquíssimas evidências para a reconstrução do ritual - os relatórios mais antigos afirmam explicitamente que nenhum dos votivos mostravam traços de queima e não há indicações de um altar de cinzas" (Prent, 2005: 164). Contudo, com base no material votivo disponível, "é possível afirmar que o culto em Piazzale, muito provavelmente, foi relacionado à fertilidade e à proteção das colheitas e dos animais" (Prent, 2005; 164). Segundo Prent, "a similaridade entre o objeto votivo de uma figurinha humana, tocando flauta, encontrado em Syme e em Agia Triada pode ser evidência de que ritos iniciatórios podem ter ocorrido no santuário de Zeus Velchanos" (Prent, 2005: 323). Talvez um consumo coletivo de comida, preparada deliberadamente fora da área sagrada, fez parte das atividades religiosas no início da Idade do Ferro (Zolotnikova, 2013a: 113-114). O sacrifício animal com queima parece ter sido excluído do ritual, como indicam os ossos de animais encontrados sem traços de combustão (Zolotnikova, 2013a: 114). Nessa perspectiva do culto ligado à fertilidade da terra e à criação de animais, M. Prent postula que "parte da escolha do sítio de Agia Triada para o estabelecimento do santuário, após o abandono do assentamento minoico, se deveu à proximidade a seu vale fértil a norte" (Prent, 2005: 520). Essa pode ter sido a principal razão para a fundação do santuário em uma área extra-urbana, diferente, portanto, de Palaikastro, onde o antigo culto local a Zeus Dicteu e a memória da cidade minoica foram fatores importantes para o estabelecimento da área sagrada no local. Além da relação com a fertilidade da terra e a criação de animais, o santuário de Zeus Velchanos pode ter sido local de culto "para jovens ou homens aspirantes à aristocracia", como indicam alguns dos tipos de objetos votivos (imitação de escudos, carros), alguns deles em bronze, indicando certo investimento de riqueza e conotação aristocrática militar (Prent, 2005: 523). No entanto, esse tipo de oferenda não é suficiente para se afirmar que o santuário extra-urbano em Agia Triada funcionou como um local de encontro neutro para aristocracia das comunidades locais, em razão da ausência marcante de grandes objetos de bronzes, como se vê nos santuários do Mt.Ida e do Mt.Dicta, por exemplo (Prent, 2005: 522).

Em termos regionais, o santuário em Agia Triada esteve relacionado, desde a Idade do Bronze, com mais dois assentamentos importantes localizados na planície de Mesara: Kommos e Festos. Importante cidade portuária durante a Idade do Bronze, Kommos tornou-se local de outro importante santuário extra-urbano, na região, durante a Idade do Ferro e parece ter ganho certa supremacia sobre o de Zeus em Agia Triada a partir do período proto-geométrico (Prent, 2005: 520-521). A importância assumida por Kommos é explicada pela "necessidade do estabelecimento de uma presença na área, abandonada desde o final da Idade do Bronze, e retomada devido ao aumento das comunicações além-mar no período proto-geométrico" (Prent, 2005: 526). Segundo M. Prent, "a localização costeira de Kommos marcou, claramente, uma fronteira física e simbólica do território que provavelmente pertenceu a Festos" (Prent, 2005: 526). Tal rearranjo territorial no período protogeométrico deve ter ocorrido por influência de Festos na região (Prent, 2005: 521).

Se por um lado os autores relacionam o santuário de Kommos a Festos, por outro, o santuário de Agia Triada, na bibliografia, não é relacionado ao território ou à interferência dessa ou de outras comunidades. $\mathrm{A}$ nosso ver, contudo, é muito provável que a população de Festos tenha tido uma participação significativa no 
culto de Zeus Velchanos mesmo durante a Idade do Ferro, a época arcaica e a helenística. A relação de um assentamento com o outro parece remontar ao final da Idade do Bronze, quando, muito provavelmente, a população da cidade minoica de Agia Triada transferiu-se para Festos (Prent, 2005: 162 e 521). Algumas inscrições dão alguma indicação sobre o interesse de determinadas comunidades de Creta no culto de Zeus Velchanos e talvez no santuário em Agia Triada. No Pythion de Gortina, importante cidade na planície de Mesara, há uma menção a um festival primaveril ao deus em época arcaica, que com alguma probabilidade era relacionado ao santuário em Agia Triada, o principal local de culto ao deus na região 5 (Willets, 1962: 250, nota 147). Outras inscrições de época helenística (século II a.C.) de Gortina ${ }^{6}$ e de Cnossos $^{7}$ referem-se a um mês, cujo nome deriva do epíteto Velchanos (Willets, 1962: 250, nota 147 e 149). Uma inscrição de Lyktos ${ }^{8}$ de época romana (II-III d.C.) menciona também um festival (Willets, 1962: 250, nota 148). Essas inscrições não informam sobre a participação direta dessas cidades no santuário em Agia Triada, mas são evidências da importância do culto da divindade em época arcaica e helenística, que se encontrava disseminado em algumas áreas da ilha, principalmente em seu lado central (norte e sul) a ponto de um mês ter sido dedicado à divindade no calendário de Gortina e Cnossos. Dentre as três cidades, as quais pertenciam as inscrições, por ter pertencido a mesma região, é provável que a população de Gortina tenha, em algum grau, participado do culto a Zeus Velchanos em Agia Triada a ponto, talvez, de ter incorporado uma festividade na primavera ao seu calendário. Assim, é possível ao menos estabelecer uma função sub-regional para o santuário de Zeus Velchanos na planície da Mesara, adquirida a partir do início da Idade do Ferro, sendo difícil de estabelecer se comunidades de outras regiões da ilha frequentaram a área sagrada em períodos posteriores.

\section{I.4 Amnisos}

O santuário de Zeus Thenatas (cat.no.6) foi estabelecido no assentamento minoico de Amnisos, localizado na planície costeira de Karteros no centro-norte da ilha de Creta, a c.6 km a nordeste de Cnossos. De acordo com M. Prent, "antes da descoberta do assentamento, Amnisos era conhecida da Odisséia e de fontes literárias helenísticas, as quais falam de sua função portuária, de sua associação a um rio ou de seu contexto mitológico" (Prent, 2005: 332-333). Tabletes em Linear B de Cnossos dão indicações que Amnisos "serviu como o principal porto dessa cidade durante a Idade do Bronze" (Prent, 2005: 333). 0 assentamento da Idade do Bronze, que data a partir do minoico médio, parece ter sido abandonado no início do período minoico tardio IIIC (1200-1100 a.C.), como indicam os achados cerâmicos quase escassos datados dessa época e a ausência de material do período subsequente, o sub-minóico (1100-1000/975 a.C.) (Prent, 2005: 333, nota

\footnotetext{
5 I.Cret. 4.3 .1 (a-c).

6 Idem 184.3.

7 Ibidem 1.XVI.3.2.

8 Ibidem 1.XVIII.11.2.
} 
655). A vila minoica de Amnisos foi estabelecida ao redor e sobre a pequena colina de Palaiochora, em cuja base ocidental se situa a área sagrada de Zeus (Fig.16) (Prent, 2005: 332).

A localização de Amnisos na planície de Karteros tem sido aceita até hoje desde a sua identificação pelo viajante Spratt durante o século XIX (Prent, 2005: 333). As primeiras escavações, na vila minoica e no santuário de Zeus, foram realizadas por Sp. Marinatos entre 1932-1938 (Prent, 2005: 333; Schäfer, 1991: 348). Entre 1963-1967, as escavações de salvamento de Alexiou revelaram mais restos da Idade do Bronze em

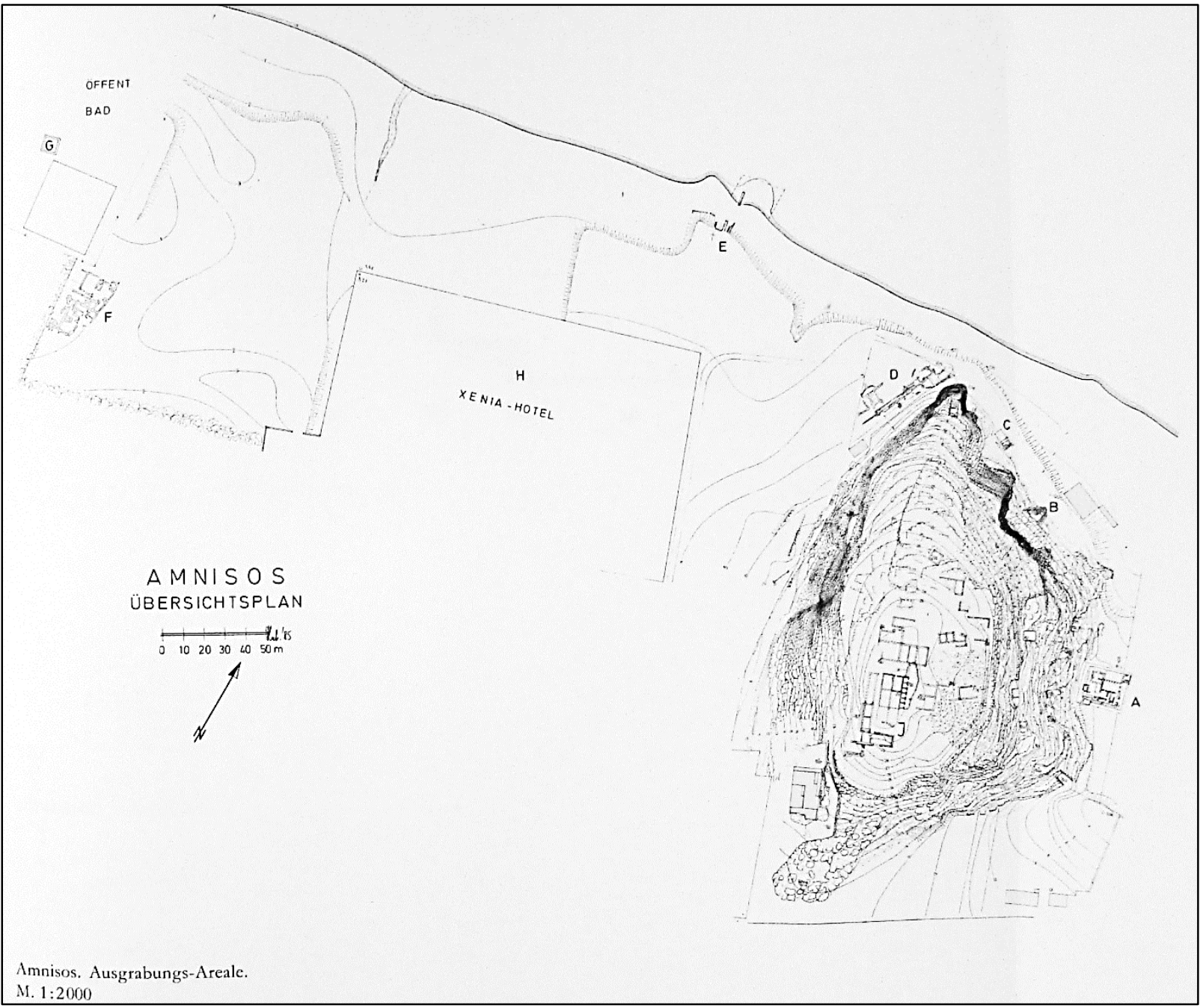

Fig.16- Planimetria geral de Amnisos (Schäfer, 1992)

diferentes pontos ao redor e sobre a colina Palaiochora (Prent, 2005: 333; Schäfer, 1991: 348-349). Achados do período minoico tardio, recuperados das escavações de Marinatos, foram reexaminados por Kanta em 1980, enquanto o trabalho topográfico e um estudo completo das antigas escavações foram retomados pelo Instituto Arqueológico Alemão de Atenas sob a direção de Schäfer entre 1983-1985 (Prent, 2005: 333). 


\subsubsection{Descrição e interpretação dos achados}

As escavações no santuário de Zeus Thenatas identificaram diferentes tipos de construções de períodos variados - estruturas minoicas, reparadas em época helenística, outras de época arcaica -, assim também como uma série de objetos votivos datados desde a Idade do Bronze até a época helenística. Como veremos em detalhe na sequência, apesar da presença de estruturas e oferendas minoicas na área do santuário, as evidências mais antigas de atividade de culto remontam ao período proto-geométrico (1000-900 a.C.) (Prent, 2005: 333).

As estruturas minoicas, sobre as quais nos referimos acima, são o muro e seus anexos (escadas e pódios) encontrados por Marinatos na denominada área $D$ (Figs.17 e 18). Trata-se de um muro de contenção (A-F), em alvenaria, de mais de $44 \mathrm{~m}$ de comprimento, datado do minoico médio IIIB, de duas escadas na porção leste do muro (D-E) e dois pequenos pódios norte e sul (ambos do período neo-palacial) (Prent, 2005: 333; Schäfer, 1991: 351). A continuação do muro, e de outros remanescentes, estão, provavelmente, ainda enterrados de baixo da área (Prent, 2005: 33-34; Schäfer, 1991: 351). Marinatos sugeriu que os muros foram preservados de tal maneira que podem ter sido reutilizados em períodos posteriores à Idade do Bronze, como indica também as duas escadas de época helenística, anexadas na parte central e sul dessa construção e as pedras de calcário acrescentadas nesse período facilmente distinguíveis daquelas de época minoica, feitas de outro material (Prent, 2005: 333-334, Schäfer, 1991: 349 e 351). De acordo com M. Prent, por ter sido parcialmente escavado, a função original do muro da Idade do Bronze não pôde ser estabelecida (Prent, 2005: 334). Devido à proximidade à escarpa oeste da colina, foi sugerido que a estrutura, e os dois pódios menores de frente a ela, foi parte de uma plataforma ao invés de um complexo de edifício (Prent, 2005: 528). A presença de uma fossa ou depósito votivo pode indicar que o muro serviu para propósitos cultuais na Idade do Bronze e foi relembrado como tal, ou representa a descoberta da fase do início da Idade do Ferro, dando origem a suposição de que se trataria do edifício mais antigo do santuário (Prent, 2005: 528). O depósito votivo, que continha cerâmica do minoico médio (figurinhas de touro e parte de um kernos de terracota), foi assinalado por Marinatos a um ritual de purificação, de limpeza do santuário, realizada pelos fundadores do culto posterior (Prent, 2005: 528). 


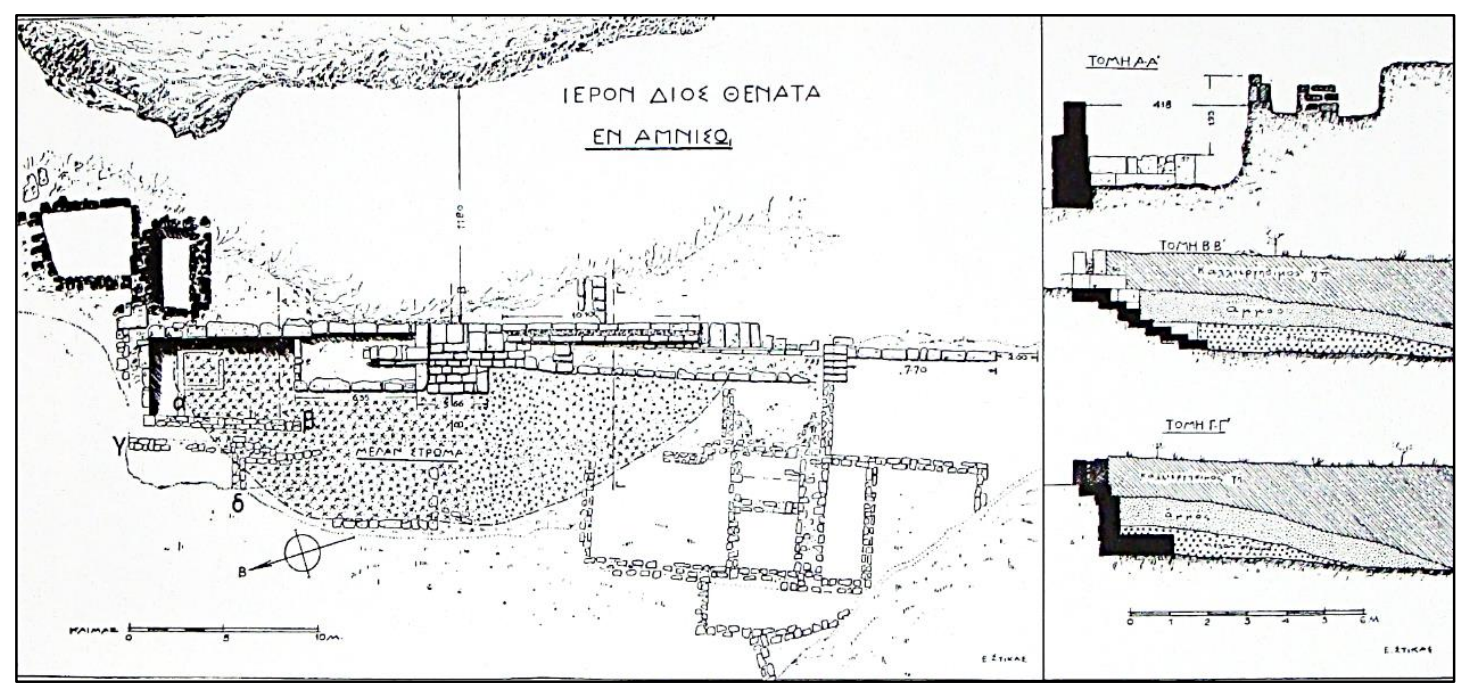

Fig.17- Planimetria do santuário de Zeus Thenatas (área D) $\alpha-\delta$ (por E. Stikas, 1938) (Schäfer, 1992)

Assim, o muro não fornece qualquer evidência de uso ritual durante a Idade do Bronze e novas escavações serão necessárias para esclarecer a função dessa estrutura, que estava longe da linha da praia no momento de sua criação (Schäfer, 1991: 355). Em nossa visita ao sítio em julho de 2014, vimos partes dos remanescentes de uma estrutura (blocos de pedra muito semelhantes aos do muro minoico), para além da cerca do sítio, que terminava próxima à beira da praia. A estrutura, que estava em péssimas condições de conservação, seguia a mesma direção norte-sul do muro minoico (Fig.19).

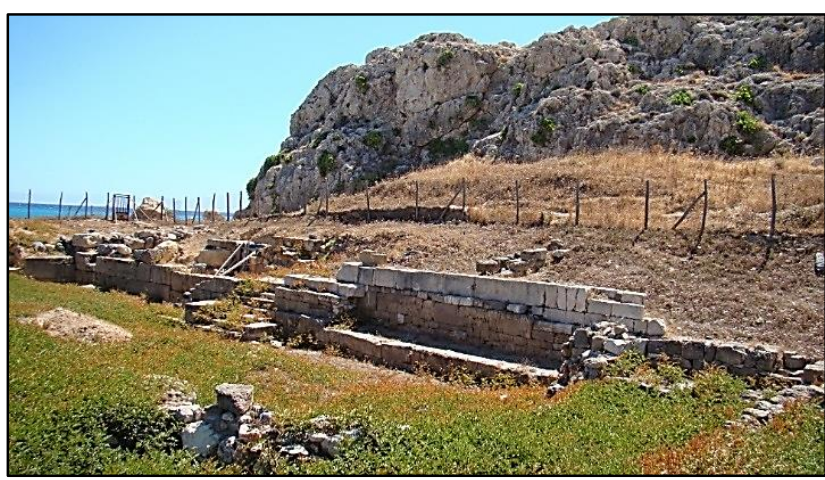

Fig.18- Área D, muro minoico visto de oeste (Foto: arquivo pessoal/2014)

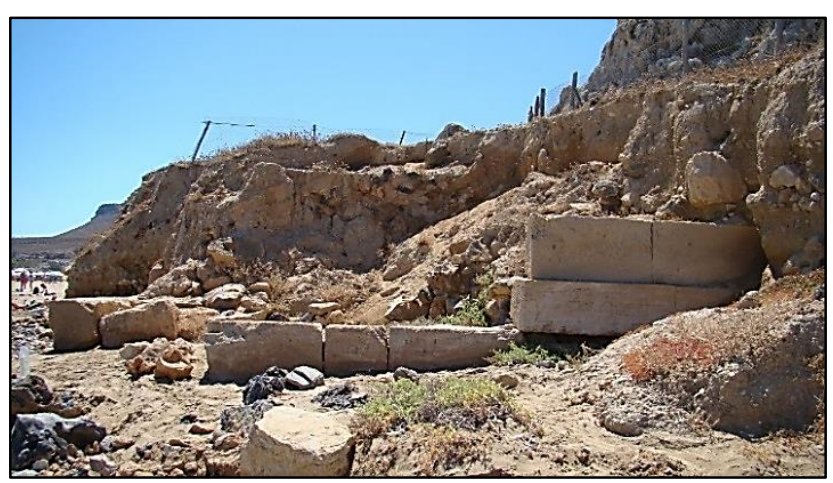

Fig.19- Vista de oeste da Área D a norte, restos da continuação do muro minoico? (Foto: arquivo pessoal/2014)

Com relação à Idade do Ferro, "talvez devido ao caráter incompleto da escavação, não há construções atribuídas ao período"9, mas apenas objetos votivos (Prent, 2005: 333-334). Na área de frente ao muro, em um grande espaço aberto, uma camada de solo preto e oleoso, de c.0,70 m de espessura, contendo ossos de animais e objetos queimados pelo fogo, foi encontrada por cima dos dois pódios até a base do muro (Prent, 2005: 334; Schäfer, 1991: 349). Nenhuma estratigrafia pôde ser determinada dentro da camada de cinza,

\footnotetext{
${ }^{9}$ Além das evidências da Idade do Ferro provenientes do santuário de Zeus Thenatas, não há, nas cercanias de Amnisos, nenhuma evidência de ocupação datada desse período (Prent, 2005: 333).
} 
perturbada durante a antiguidade, permanecendo problemática a sua datação (Prent, 2005: 334; Schäfer, 1991: 349). Todos os objetos votivos da Idade do Ferro provêm dessa camada, definida como um altar, formado por cinzas e ossos que se acumulou ao longo dos mais de $44 \mathrm{~m}$ do muro de contenção no sopé da colina. Os achados desses objetos indicam uma fase importante para as atividades cultuais no santuário de Zeus Thenatas durante a Idade do Ferro, não menos monumental do que se observa nos casos de Cnossos, Festos e Kommos (Prent, 2005: 528).

A maior parte dos objetos votivos foi recuperada no altar de cinzas. Oferendas do período minoico médio Ill e minoico tardio, tais como duas miniaturas de lâminas de machado duplo, adaga com rebites dourados, também foram encontradas em meio às camadas de cinza e ossos, mas a grande concentração de material data da Idade do Ferro e do início da época arcaica (período Orientalizante - c.700-630 a.C.). De época proto-geométrica (as evidências mais antigas da atividade cultual no local), são duas figurinhas humanas de bronze, sendo uma masculina de joelhos dobrados (Fig.20), e dois fragmentos de trípodes de bronze.

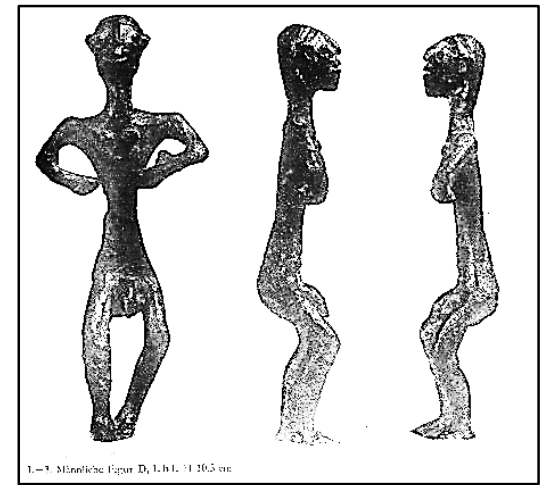

Fig.20- Figurinha em bronze masculina, proto-geométrico-início geométrico (Schäfer, 1992: D,1.b1, pr.73) Um aro de bronze foi datado entre o início do período geométrico e o início do Orientalizante (Prent, 2005: 334). Figurinhas de touro e de cavalo e pequena roda de um modelo de coche, todas em terracota, e escudo votivo com figura de prótomo de leão são oferendas datadas entre o geométrico médio e o Orientalizante. Datadas entre o geométrico tardio e também o Orientalizante, são a figurinha de touro, a alça de uma vasilha, uma pequena roda votiva, um pequeno disco, fragmento de trípode e chapa de um pingente, ambos em bronze, e a escultura de uma cabeça humana, em calcário, com pólos e olhos com incrustação em ossos, provém uma oficina de origem norte síria10 (Fig.21) (Prent, 2005: 335). Do início da época arcaica, do período Orientalizante, data um número de objetos de faiança datados da segunda metade do século VII a.C., tais como vasilhas e figurinhas (Bes e uma de Astarte) várias das quais podem ser de produção egípcia e outras levantinas ou do leste do mundo grego (Prent, 2005: 335). Do início do século VI a.C. foi encontrada uma figurinha feminina parcialmente preservada sentada sobre um bovino ou equídeo (Prent, 2005: 335). Figurinhas de touro em bronze datam entre os períodos arcaico e clássico (Prent, 2005: 335). Nenhum vaso completo foi recuperado no altar de cinzas, mas apenas fragmentos (de skyphoi, ânforas e crateras) datados de todos os períodos mais antigos até o início do Orientalizante. As cerâmicas de outros pontos do santuário possuem o mesmo alcance de formas e têm sido assinaladas ao geométrico e períodos posteriores (Prent, 2005: 335). As inscrições helenísticas dedicatórias (c.110-69 a.C.), e posteriores, que se referem a Zeus Thenatas (THNI OENATAI) (Fig.22), não foram encontradas no altar (Schäfer, 1991: 353).

\footnotetext{
10 De acordo com J. Whitley, citando uma tese de J. Boardman, trata-se de objetos não confeccionados no Oriente Próximo, mas por imigrantes norte-sírios estabelecidos em Creta (Whitley, 2009: 284).
} 


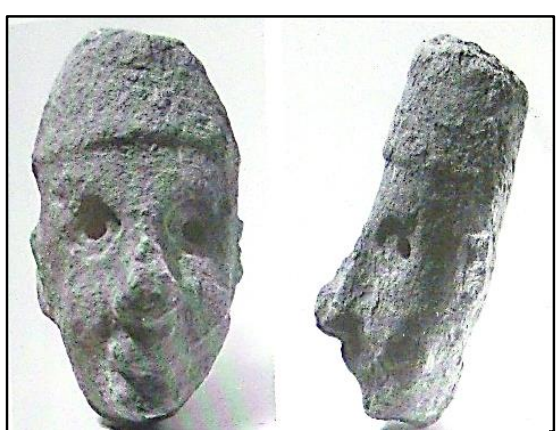

Fig.21- Cabeça em calcário com pólos, geométrico tardio ou Orientalizante (Schäfer, 1992: D,1.b1, pr.81)

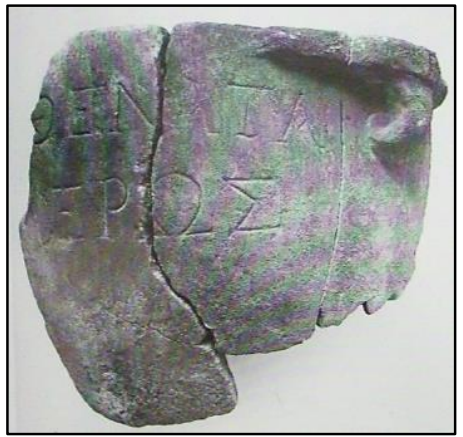

Fig.22- Fragmento de cratera em mármore com inscrição [---]

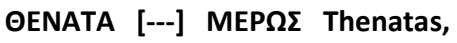
sécs. II-I a.C. (Schäfer, 1992: D,1.d5, pr.109)

Além dos remanescentes das construções minoicas e helenísticas tardias, também deve ter existido uma construção do período arcaico tardio, pois uma grande parte dos blocos de calcário, distinguíveis pelo formato irregular, pode ter pertencido à parte de um estilóbato dessa época. Apenas novas escavações poderão mostrar a localização original desse edifício (Schäfer, 1991: 353).

Mas o mais notório acerca do santuário de Zeus Thenatas, para nossa investigação, é o achado de duas esculturas monumentais de aves (em pé e de asas fechadas), feitas em calcário, que datam da mesma época do suposto edifício arcaico (Figs.23 a 26). De acordo com Marinatos, trata-se de duas águias, muito maiores do que o tamanho natural (c.1m de altura), que, muito provavelmente, ficavam expostas sobre dois pilares na área sagrada (Schäfer, 1991: 353). Na exibição das duas esculturas, no Museu Arqueológico Nacional de Heráclion, a placa informativa diz que se trata de uma águia e de um falcão, o símbolo de Zeus e de Hera, respectivamente, datados da metade do século VI a.C., que guarneciam a área do santuário para serem visíveis a partir de certa distância. De acordo com Ph. Brize, trata-se das únicas esculturas monumentais de pássaros, de época arcaica, que se conservaram em Creta (Brize, 1992: 255). A forma específica de suas bases e as formas jônicas, sobre as quais as esculturas se apoiam, permanecem também sem paralelo na escultura arcaica cretense (Brize, 1992: 255). O mais importante para o nosso estudo, a respeito dessas duas esculturas, é a interpretação de Marinatos que as relaciona às águias, descritas por Pausânias, na entrada do témeno de Zeus no santuário do Monte Lykaion na Arcádia. Segundo Brize, ao interpretá-las como águias de Zeus e postular a relação entre os santuários de Amnisos e o do Mt.Lykaion, Marinatos mostrou que as esculturas do santuário cretense podem ser evidências de um elo importante entre os cultos mais antigos a Zeus em Creta e no Peloponeso (Brize, 1992: 255). Tal possível elo será discutido mais adiante, quando analisaremos o Peloponeso e o santuário de Zeus Lykaios. 


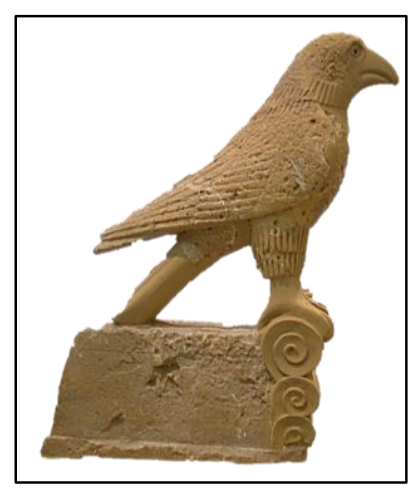

Fig.23- Escultura de águia de calcário, 0,99 $\mathrm{m}$, metade do séc.VI a.C., Museu Arqueológico Nacional de Heráclion (Foto: arquivo pessoal/2014)

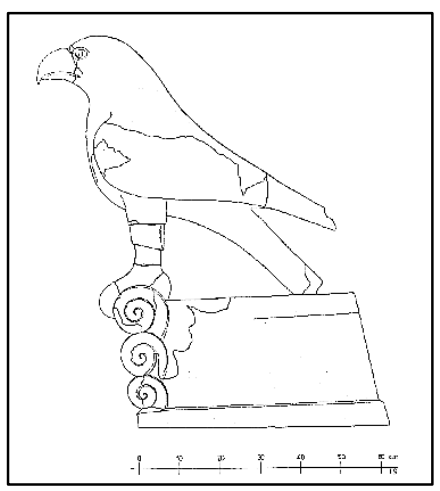

Fig.24- Desenho da escultura da águia (Schäfer, 1992: D,1.d2, pr.107)

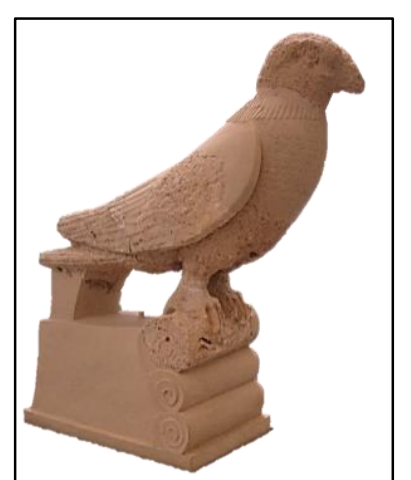

Fig.25- Escultura de falcão de Fig.26- Desenho da escultura de calcário, $1 \mathrm{~m}$, metade do séc. falcão (Schäfer, 1992: D,1.d3, VI a.C., Museu Arqueológico pr.108)

Nacional de Heráclion (Foto: arquivo pessoal/2014)

\subsubsection{A natureza do culto e a função do santuário}

O santuário tem sido atribuído ao culto de Zeus Thenatas com base no achado de várias inscrições do final do período helenístico (Schäfer, 1991: 351). Nesse caso, o culto ao deus é atestado a partir de evidências muito posteriores ao início da atividade cultual, tal como ocorre para o santuário do Mt.lda, cuja atribuição da área sagrada a Zeus foi baseada em uma inscrição romana, e de Agia Triada, atribuído a Zeus a partir de inscrições do período helenístico. Os pesquisadores alemães defendem a atribuição do culto a Zeus desde a fundação do santuário. Tendo em vista o uso contínuo do altar, é muito provável que Zeus, atestado apenas no período helenístico a partir das inscrições, tenha sido cultuado ali desde o período geométrico (Schäfer, 1991: 355). Nessa perspectiva, mas considerando uma continuidade religiosa do culto com o período minoico, $A$. Chaniotis argumenta a favor de uma origem aqueia do final da Idade do Bronze do culto de Zeus Thenatas, considerando ser muito provável que o culto em Amnisos tenha sido dedicado à divindade desde 0 início da Idade do Ferro e em diante (apud Prent, 2005: 335-336). Esse autor defende que Thenai, palavra da qual deriva o epíteto Thenatas, pode ter sido um toponímio em Creta vinculado a Zeus no período de sincretismo minoicomicênico (Prent, 2005: 529). Somente a tradição literária posterior, de época helenística, explica a relação de Thenai com Zeus: teria sido lá, segundo Diodoro ${ }^{11}$ e Calímaco ${ }^{12}$, que o cordão umbilical de Zeus teria caído quando as ninfas o levaram de Dicta para Ida. Nessa época, a planície ao redor de Thenai era chamada de Omphalion Pedon (Schäfer, 1991: 355).

Assim, embora não haja evidências materiais para a continuidade de culto da Idade do Bronze (nem no minoico tardio IIIC nem no subminóico) ao início da Idade do Ferro, o tipo do culto praticado em Amnisos mostra claras ligações com o final da Idade do Bronze tardia (Prent, 2005: 529). A continuidade cultual é

\footnotetext{
11 Diodoro 5.70.4.

12 Calímaco, Jov. 42-45. Também Stephanos de Bizâncio, s.v. Oعvaí.
} 
atestada apenas entre a Idade do Ferro e a época helenística (Schäfer, 1991: 355). Nessa perspectiva também, Schäfer, embora coloque em dúvida a continuidade cultual com a Idade do Bronze, não descarta a ligação histórico-religiosa com o período minoico - de Zeus com um deus que nasce e morre, ligado ao ritmo das estações do ano, descrito no hino de Palaikastro (Schäfer, 1991: 355 e 357). Para Schäfer, as ruínas minoicas podem ter atraído comunidades para o estabelecimento de um altar de cinzas a Zeus durante os anos de 1000 700 a.C. (Schäfer, 1991: 357).

Com relação à função extra-urbana e marítima do santuário, é M. Prent que oferece a única explicação, entre os autores, a esse respeito. Considerando o uso tradicional de Amnisos como porto desde a Idade do Bronze, esse autor defende que o início do culto na Idade do Ferro aconteceu por razões similares que em Kommos - restabelecer uma presença em uma área de limite, que adquiriu nova importância com o aumento das comunicações além-mar a partir do período proto-geométrico em diante (Prent, 2005: 527). Essas comunicações além-mar são evidenciadas pela ocorrência repetida de objetos importados, como vasos e figurinhas de faiança, os quais indicam contato com o leste grego, o Egito e o Oriente Próximo durante a segunda metade do século VII a.C. (Prent, 2005: 528). Alguns tipos de oferendas, em especial, tal como trípodes e figurinhas de bronze, vasos e outros tipos de materiais também em bronze, sugerem, segundo Prent, um status social diferenciado dos fiéis (Prent, 2005: 528). O santuário de Zeus Thenatas é a área sagrada mais antiga da divindade localizada imediatamente a costa e em proximidade a um rio, característica de santuários mais posteriores, datados de época arcaica.

A relação do santuário de Amnisos com comunidades políticas emergentes na Idade do Ferro, ou com póleis em época arcaica e em diante, não é explorada em profundidade por Prent, com ocorre em relação aos outros santuários, provavelmente pela ausência de evidências epigráficas e literárias ou de um estudo comparativo sobre as oficinas responsáveis pela confecção dos objetos votivos em bronze, por exemplo, encontrados no local. No entanto, esse autor defende que a área sagrada de Zeus em Amnisos funcionou como "um local de encontro para a competição ritualizada entre homens aristocratas de apenas poucas comunidades cretenses e provavelmente a mercadores não cretenses e outros visitantes", como sugerem os votivos (Prent, 2005: 502 e 560). Embora assuma o papel do santuário entre diferentes comunidades, sem citar quais, esse autor ressalta que, no caso de Amnisos, a área sagrada reteve antigos laços com um assentamento específico, no caso, Cnossos (Prent, 2005: 527 e 560). De acordo com J. Whitley, o santuário de Zeus Thenatas em Amnisos deve ter pertencido ao território da pólis de Cnossos (Whitley, 2009: 280). Como santuário extraurbano de Cnossos, a área sagrada deve ter conservado o papel portuário antigo da área, e servido a algum tipo de função marítima, à essa pólis, da forma como coloca Prent. $O$ autor não chega a afirmar, claramente, que tipo de função regional (sub ou inter-regional) teria exercido o santuário de Zeus Thenatas. De sua interpretação sobre a relação com Cnossos, e a semelhança, nesse aspecto, com o caso de Agia Triada, podemos inferir que se tratava de um santuário extra-urbano sub-regional, a partir da Idade do Ferro, considerando as poucas comunidades que deveriam tomar parte do culto, como mencionou Prent, com uma 
função marítima aberta também a visitantes não cretenses (gregos ou não). Mas essa característica não 0 definiu com um centro de culto inter-regional em Creta.

\section{I.5 Palaikastro}

Assim como no caso do santuário de Zeus Thenatas em Amnisos, a área sagrada de Zeus em Palaikastro (cat. no.7) foi estabelecida sobre as ruínas de um assentamento da Idade do Bronze, que data a partir do minoico antigo, abandonado também no final do período minoico tardio IIIC (Fig.27) (Prent, 2005: 532). Situado no extremo leste de Creta, no vale fértil costeiro de Roussolakkos, Palaikastro foi o maior assentamento da Idade do Bronze nessa região da ilha até o final do período minoico tardio IIIB, embora nunca tenha se desenvolvido em um centro palacial, como indicam as evidências até o momento (Prent, 2005: 533). 0 santuário de Zeus Dicteu foi localizado na área das quadras Chi e Pi, situadas na parte leste da cidade minoica (Fig.28) (Prent, 2005: 350).

A área sagrada foi escavada, pela primeira vez, na campanha realizada, em Palaikastro entre $1902 \mathrm{e}$ 1906, pela Escola Britânica de Atenas com direção de Robert Carr Bosanquet e Richard MacGillivray Dawkins (MacGillivray; Sackett, 2010: 572). Na campanha de 1904 foram encontrados os fragmentos do hino a Zeus Dicteu em fossos próximos ao bloco Chi (Crowther; MacGillivray, 2002: s/p). Em 1905, foram recuperadas partes das simae do templo arcaico. Outras partes ainda foram adquiridas pelo antigo Museu de Heráclion na década de 1880, após terem sido vistas em um estábulo na área de Palaikastro (Driessen-Gaignerot, 2011: 425-426). Durante as campanhas de 1987, 1988 e 1990 foram recuperados no edifício 5 os cem fragmentos da estatueta de marfim, argila e ouro denominada de Kouros de Palaikastro, atribuído ao culto de Zeus Dicteu no local (Sackett, 2002: s/p).

\section{I.5.1 Descrição e interpretação dos achados}

De acordo com M. Prent, a atividade cultual na área dos blocos Chi e Pi pode ser atestada a partir do período proto-geométrico, embora as evidências sejam mais contundentes em relação aos períodos geométrico e Orientalizante (Prent, 2005: 350). Nenhuma estrutura de culto, datada da Idade do Ferro, foi encontrada, levando-se a se considerar que o culto foi realizado a céu aberto desde quando foi estabelecido em meio às ruínas da cidade minoica em Roussolakkos até a construção do templo em época arcaica (Thorne; Prent, 2002: $\mathrm{s} / \mathrm{p})$. Até a época arcaica, o altar de cinzas deve ter sido a parte central do culto, como indica uma concentração desse material, de 0,25 m de espessura e $3 \mathrm{~m}$ de comprimento, encontrada ao longo das quadras Chi 25-26 e Pi 38-40 dentro da área do témeno arcaico (Prent, 2005: 351). Ali foram recuperados vários objetos (vasilhas de bronze, selos e esculturas miniaturísticas) (Prent, 2005: 351 e 538; Watrous, 1996: 104). 


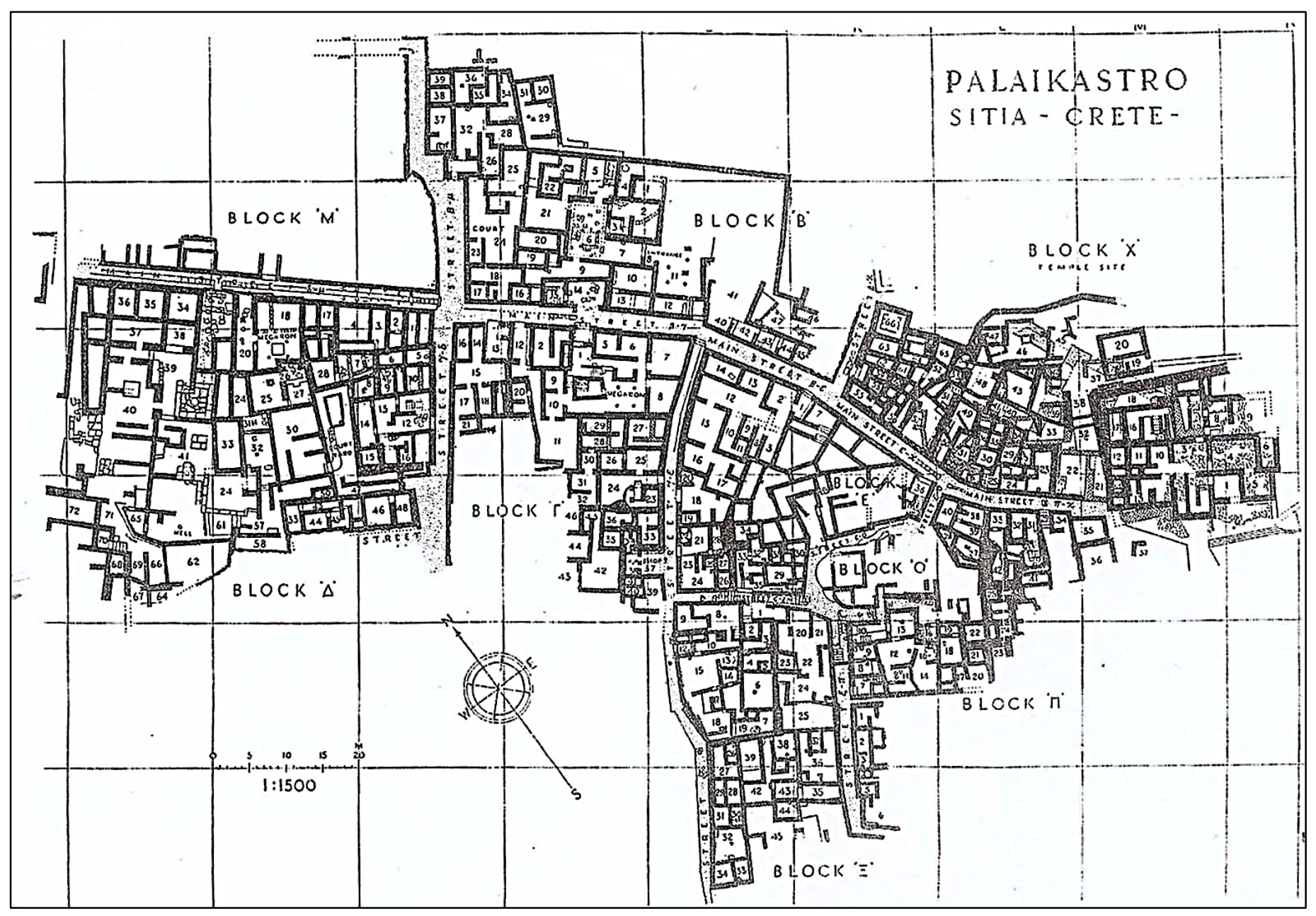

Fig.27- Planimetria geral de Palaikastro (Thorne; Prent, 2000: fig.1)

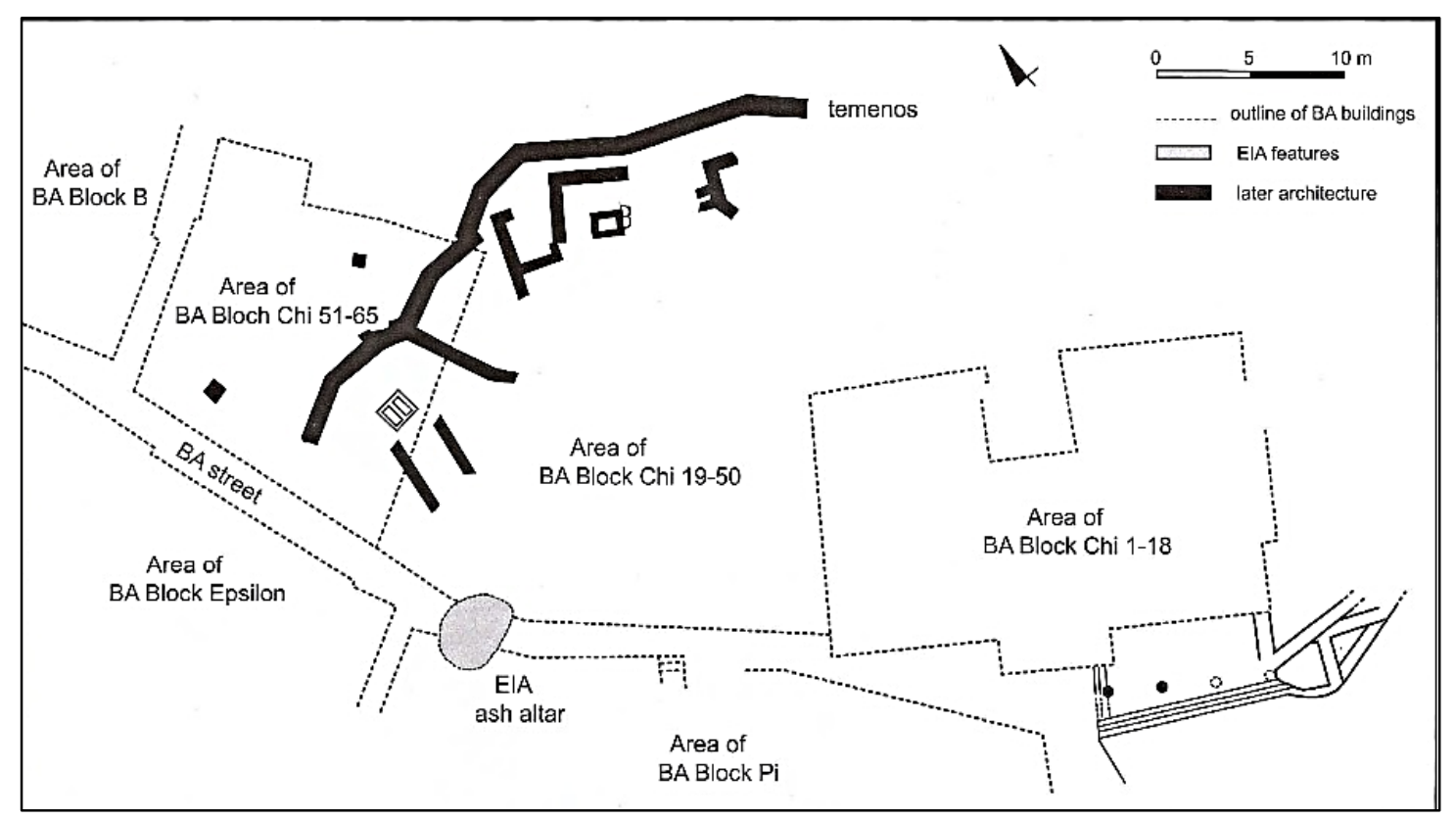

Fig.28- Planimetria do santuário de Zeus Dicteu em Palaikastro (Prent, 2005: fig.73) 
A maior parte dos objetos votivos da Idade do Ferro foi encontrada dentro do muro de témeno, mas não foi restrito apenas à essa área (Prent, 2005: 350). Alguns objetos foram recuperados no pátio do bloco Beta e no bloco Delta (Prent, 2005: 350-351). Durante o período mais antigo de culto em Roussolakkos, Zeus Dicteu recebeu oferendas votivas de bronze - trípodes, figurinhas de touro, escudos elaboradamente decorados (Fig.29), tipos de armadura (couraças, elmos, miniatura de escudos) - e de argila - taças e tigelas, lamparinas e suportes de tochas (MacGillivray; Sackett, 2010: 575). O achado mais antigo do santuário é a haste de um trípode de bronze, datado, possivelmente, do período proto-geométrico. Dentre os inúmeros

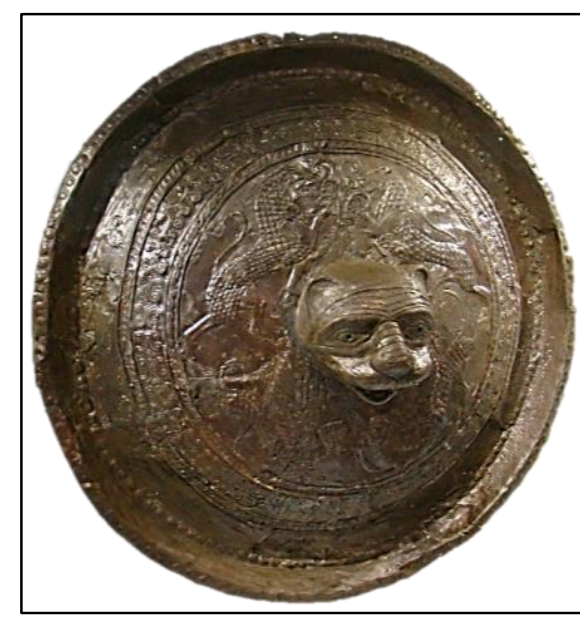

Fig.29- Escudo de bronze com prótomo de leão, período geométrico, Museu Arqueológico Nacional de Heráclion (Foto: arquivo pessoal/2014) objetos votivos encontrados, pode-se citar do século VIII a.C., fragmentos de uma perna e a alça de trípodes de bronze, escudos de bronze decorados com figuras de animais (um deles com uma figura feminina e prótomos de leões), do início da época arcaica (século VII a.C.), um elmo em tamanho natural e um em miniatura, uma figurinha de leão em metal e figurinhas de touro (Prent, 2005: 351-352). É importante ressaltar que nenhum objeto votivo de terracota (como figurinhas ou placas) foi encontrado no santuário, mas apenas vasos cerâmicos (na maior parte taças, pyxides e pithoi) (Prent, 2005: 352).

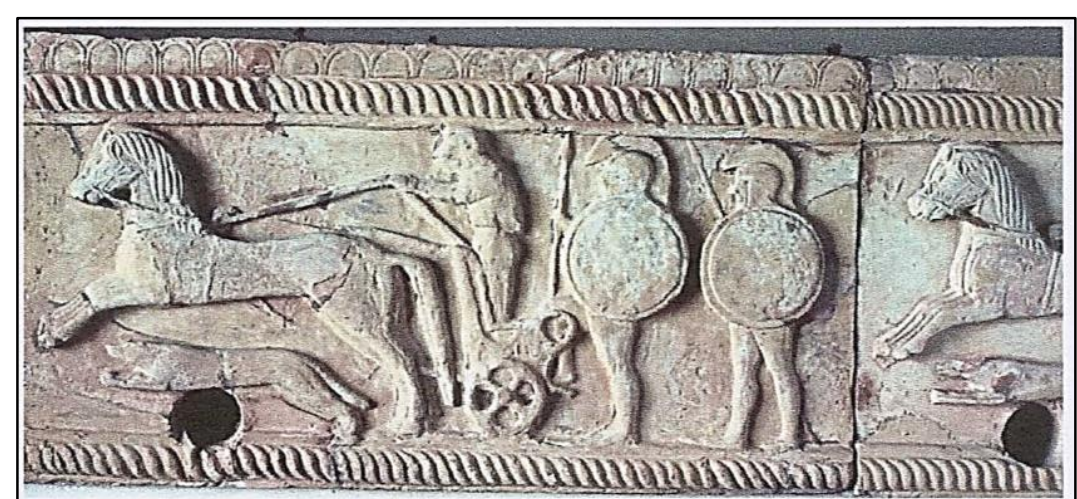

Fig.30- Friso (sima) do templo de Zeus Dicteu em Palaikastro (Driessen-Gaignerot, 2011: 431, fig.4)
De acordo com os especialistas desse sítio, o santuário foi monumentalizado, pela primeira vez, durante a época arcaica. Uma data no século VI a.C. para a primeira fase da construção de um templo, e para o muro do témeno (de $36 \mathrm{~m}$ de comprimento), foi proposta por $\mathrm{M}$. Prent, com base em sua datação dos relevos das simae de terracota (550-480 a.C.), as únicas evidências da existência de tal edifício (DriessenGaignerot, 2011: 428; Prent, 2005: 350-351). Trata-se de seis blocos de terracota, cada qual mede 0,35 x 0,65 $\mathrm{m}$, que formam um único friso de 3,90 $\mathrm{m}$ de comprimento, e retratam, cenas de procissão de caçadores, conforme a interpretação mais recente (Driessen-Gaignerot, 2011: 430). A cena retrata um carro de corrida, puxado por dois cavalos, dirigida por um auriga, sendo seguidos por dois guerreiros armados com escudos, lanças e elmos - a caça é interpretada a partir do desenho do cão embaixo dos cavalos do carro (Fig.30) (Driessen-Gaignerot, 2011: 430-431). Segundo o estudo iconográfico e estilístico comparativo de F. DriessenGaignerot, as simae devem ser datadas no final do século VII a.C., em concordância ao que havia afirmado Bosanquet anteriormente (Driessen-Gaignerot, 2011: 430). Para tal proposição, a estudiosa se baseia nas 
evidências arquitetônicas dos templos cretenses datados dessa época, caracterizados pelo tipo de decoração do friso, tal como no caso do templo $\mathrm{A}$ de Prinias, e em exemplos de vasos, decorados em relevo, e de relevos de frisos, provenientes da área do Egeu (Driessen-Gaignerot, 2011: 428, 433). 0 fragmento de um friso em terracota, proveniente de Melos, datado do século VII a.C., retrata uma figura idêntica de um guerreiro visto nas simae de Palaikastro (Driessen-Gaignerot, 2011: 432). A ânfora cicládica decorada em relevo, do final do primeiro quartel do século VII a.C., proveniente de Tenos, registra cenas de batalhas entre homens e animais, uma corrida de carros ou uma procissão e uma série de hoplitas muito semelhantes àqueles do relevo de Palaikastro

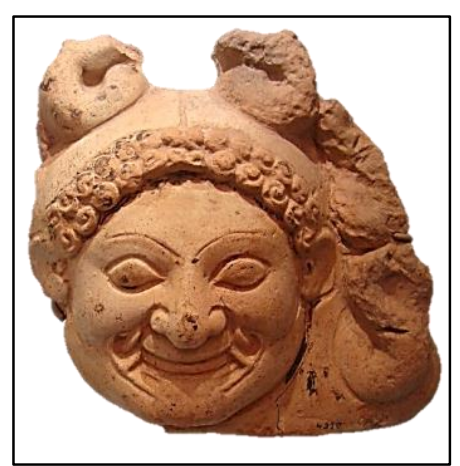

Fig.31- Sima de terracota de Górgona, segundo templo de Zeus Dicteu, Palaikastro, VI-V a.C., Museu Arqueológico Nacional de Heráclion (Foto: arquivo pessoal/2014) (Driessen-Gaignerot, 2011: 433). Além disso, essa mesma ânfora, retrata a cena de uma divindade nascendo a partir de uma figura feminina (Métis ou Rhea), interpretada como sendo Zeus (Driessen-Gaignerot, 2011: 434). O paralelo iconográfico entre a cena nas simae e na ânfora de Tenos, levou Driessen-Gaignerot a propor que o tema do nascimento também adornou o friso do templo arcaico de Palaikastro - em vista do hino encontrado, que evoca o renascimento perpétuo de um jovem deus, o tema nascimento de Zeus não estaria fora de contexto (Driessen-Gaignerot, 2011: 434).

O templo de Zeus Dicteu foi reconstruído várias vezes, em períodos posteriores, como testemunham uma sequência de telhas e elementos escultóricos - uma série de antefixas de cabeças de Górgonas, datadas entre os séculos VI-V a.C. (Fig.31), e um friso de flores de lótus e palmetas encontrados no local (Prent, 2005: 538; Thorne e Prent, 2000 apud MacGillivray; Sackett, 2010: 575).

O famoso hino atribuído a Zeus Dicteu, mencionado na interpretação final de F. DriessenGaignerot sobre as simae do templo, foi encontrado em inúmeros fragmentos em uma fossa próxima à quadra Chi (MacGillivray; Sackett, 2010: 574). Tratase de uma inscrição datada do século III d.C., cujo texto, segundo a opinião mais aceita atualmente, teria sido composto entre os séculos VI-III a.C. (Fig.32) (MacGillivray; Sackett, 2010: 574; Prent, 2005: 352). 0 hino faz referência ao "jovem kouros", interpretado com

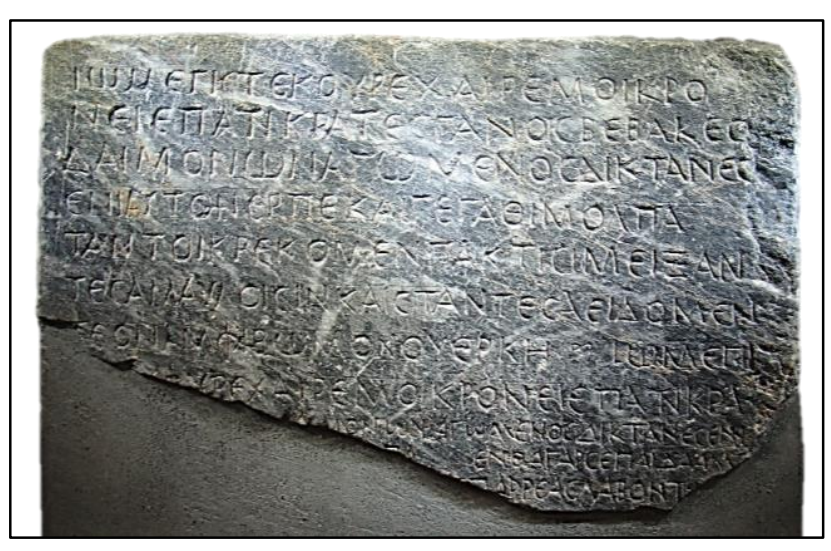

Fig.32- Primeira parte da inscrição do hino a Zeus, séc. III d.C., Museu Arqueológico Nacional de Heráclion (Foto: arquivo pessoal/2014)

Zeus Dicteu, convocado a retornar à Dikte, onde estava seu altar sagrado (MacGillivray; Sackett, 2010: 574). Na sequência analisaremos a relação desse hino com o culto e a função do santuário.

O uso do santuário no período helenístico e romano é atestado pelos remanescentes arquitetônicos do templo de Zeus Dicteu, reconstruído também no século II a.C., e pela inscrição do hino, datado do século III d.C. 


\subsubsection{A natureza do culto e a função do santuário}

Tal como no caso dos santuários de Ida e Amnisos, a atribuição do culto no santuário de Palaikastro a Zeus com o epíteto Dicteu tem sido aceita, pelos especialistas, com base em documentação epigráfica e literária muito posterior ao início da atividade cultual no local. No caso de Palaikastro, os especialistas têm associado a descrição da divindade, no texto do hino, às informações literárias de Diodoro e Estrabão.

Os escavadores de Palaikastro partem, em primeiro lugar, do fato de que o hino faz referência à característica do Zeus cretense, cujo culto tem raízes na jovem divindade masculina minoica, que renasce anualmente, cultuado no leste de Creta com o epíteto Dicteu ${ }^{13}$. Em segundo lugar, a alusão a Zeus é evidenciada no hino pela referência ao deus como filho de Cronos e pelo seu chamado a retornar à Dicta. Essa seria a primeira grande prova de que o santuário de Zeus e toda a área da antiga cidade minoica de Palaikastro foi considerada como Dicta na antiguidade. Nesse sentido, o trecho de Diodoro (5.70.6) que menciona o retorno de Zeus ao local de seu nascimento para fundar a cidade de Dicta, é tomado como mais uma evidência a esse respeito (MacGillivray; Sackett, 2010: 574). Já o trecho de Estrabão também é considerado como evidência da existência do culto de Zeus no santuário de Palaikastro, pois menciona a existência de um santuário da divindade em associação à pólis de Praisos que, como veremos mais adiante, provavelmente controlou 0 santuário em época helenística (Prent, 2005: 534-535).

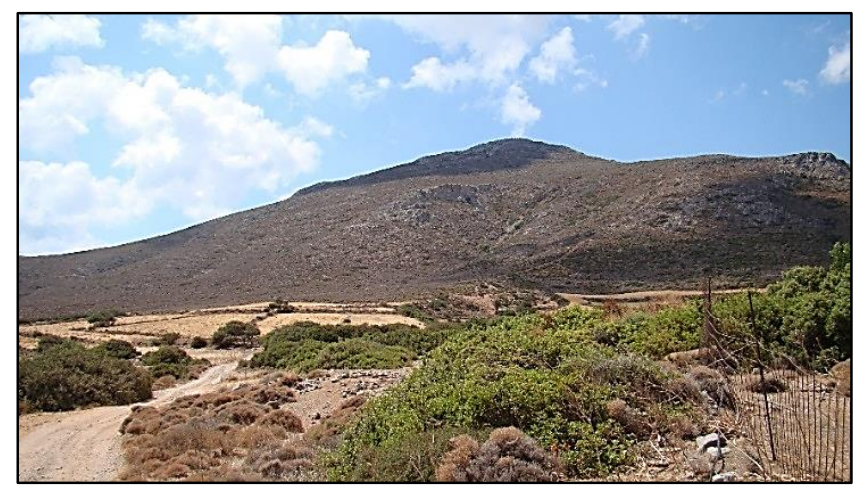

Fig.33- Mt. Petsofas visto de oeste, da área arqueológica da cidade minoica de Palaikastro (Foto: arquivo pessoal/2014)

Além das evidências literárias e epigráficas, datadas a partir de época helenística, que permitem associar a área de Palaikastro ao culto de Zeus Dicteu, dois achados específicos da Idade do Bronze, associados ao sítio ou à sua área, também têm sido considerados provas de uma antiga associação de Palaikastro com o culto de Zeus de Dicta. O primeiro achado se refere à inscrição JA-DI-KI-TE-TE em linear A, inscrita em mesas de libação, encontradas no santuário da Idade do Bronze localizado no topo do Mt. Petsofas (215 m), ao sul do santuário de Zeus Dicteu e do assentamento minoico de Palaikastro (Fig.33) (apud Prent, 2005: 353). Essa inscrição, em associação à informação de Diodoro, levou Crowther, um dos especialistas do sítio, a identificar Dicta com esse monte e o santuário lá localizado (apud Prent, 2005: 353). Já o segundo achado se refere à famosa estatueta de ouro, marfim e argila denominada de Kouros de Palaikastro encontrada em centenas de fragmentos espalhados pelo edifício 5 , situado a certa distância da área do santuário. Os especialistas têm interpretado o objeto não como um votivo, mas como uma estatueta de culto ${ }^{14}$

\footnotetext{
13 Segundo Willets, esse Zeus "nascido em Creta" foi especialmente associado à Dicta e ao epíteto Dicteu no lado leste de Creta (Willets, 1962: 207).

14 Sobre essa discussão ver, MacGillivray e Sackett, 2000, p.166 e sq.
} 
(MacGillivray; Sackett,2000: 166). Os dois tipos de evidência, em associação à referência ao "grande kouros" no hino de Palaikastro, têm levado os pesquisadores a relacionar o culto existente na Idade do Bronze na área àquele celebrado no santuário na Idade do Ferro" (Prent, 2005: 544). Nesse sentido, "enquanto não há provas diretas da continuidade do culto em Palaikastro - há um intervalo de 300 anos entre 0 abandono final do edifício 5 e a dedicação do primeiro trípode de bronze no período proto-geométrico - os achados descritos sugerem uma preservação de uma associação (geral) da área de Palaikastro com o culto do deus de Dicta" (Prent, 2005: 544).

Com relação à função do santuário, é comumente aceito entre os especialistas do sítio, que o santuário de Zeus Dicteu em Palaikastro, entre a Idade do Ferro e a época arcaica, funcionou como um local de culto extra-urbano sub-regional - um local neutro de encontro aos membros das elites de diferentes comunidades do extremo leste de Creta (Prent, 2005: 537 e 550). Os objetos votivos - a preponderância de trípodes, miniaturas ou não de escudos e outros tipos de armas e a ausência de oferendas em terracota - sugerem que o santuário foi o espaço para o desenvolvimento "de rituais relacionados às elites militares de comunidades vizinhas" (Chaniotis, 2009: 64). A grande presença de armas, sobretudo os escudos, é tomada, por Chaniotis, como evidência de um tipo de "ritual de efebos de várias comunidades aliadas" - "representantes de uma classe mais velha" (Chaniotis, 2009: 64). Conforme explica esse autor, "o encontro de cidadãos jovens, os futuros guerreiros, de mais de uma cidade em um lugar sagrado, permitiu-lhes experimentar mais intensamente sua própria identidade, sentir mais fortemente a hostilidade e a competição com outras comunidades, e, às vezes, estabelecer alianças regionais, supra-locais" (Chaniotis, 2009: 65). Nessa perspectiva, o hino aos Kouretes também é tomado como evidência, para os períodos mais antigos, da realização desse ritual. De acordo com Chaniotis, é possível que "o hino tenha sido cantado pelos homens jovens durante um festival" em época arcaica ou ainda em um período anterior (Chaniotis, 2009: 64). Para N. Kreutz, os votivos de armas, em associação ao texto do hino dos Kouretes, permitem supor que eram realizadas, pelos efebos, danças rituais com os escudos de bronze, imitando o papel dos Kouretes na dança de guerra por meio da qual haviam protegido o pequeno Zeus (Kreutz, 2007: 133-134).

Sobre o estabelecimento do santuário de Zeus Dicteu, sobre as ruínas da cidade minoica de Palaikastro, há algumas divergências entre os especialistas. P. Pearlman prefere relacionar a fundação do santuário ao processo de formação da pólis, apesar do desconhecimento sobre qual comunidade teria controlado a área sagrada desde a sua fundação (Pearlman, 1995: 164). A seu ver, "definição e proteção territoriais podem ter contribuído para a decisão de estabelecer o santuário em Palaikastro, embora também não seja possível determinar a que fronteiras a área sagrada ajudou a definir e a proteger" (Pearlman, 1995: 165). Com base nas similaridades entre os votivos encontrados em Palaikastro e no santuário da acrópole de Praisos (atribuído ao culto de Zeus Dicteu), situada a alguns poucos quilômetros a sudoeste, e no testemunho de Estrabão, Perlman defende que Praisos, desde o início, pode ter sido a cidade que controlou o santuário de Zeus Dicteu em Palaikastro (Pearlman, 1995: 165). Essa tese é seguida também por Watrous, a qual afirma 
que Praesos fundou o santuário em Palaikastro, na costa, para servir como o limite oriental de seu território (em face de Itanos a norte) (Watrous, 1996: 104-105). Posições contrárias a essa tese foram propostas por Prent e Chaniotis. De acordo com Prent, é difícil afirmar se Praisos teria tido parte na fundação do santuário na Idade do Ferro, "diante das evidências de similaridades entre o santuário de Palaikastro e aquele do "Altar Hill" em Praisos, tal como defendeu Bosanquet" (Prent, 2005: 537). A seu ver, "a participação de Praesos no controle do santuário pode ser atestada para períodos mais posteriores, como indica a similaridade entre as antefixas de górgona, datados entre os séculos VI-V a.C., encontrados em Palaikastro e muito semelhantes aos do santuário em Praesos" (Prent, 2005: 538). Prent, como Chaniotis, não relacionam a fundação do santuário de Zeus a nenhuma comunidade emergente da região. Segundo Chaniotis, é provável que desde a Idade do Ferro o santuário de Zeus Dicteu não pertencesse a nenhuma comunidade em particular - a área sagrada estava em sua própria terra sagrada, era um santuário "extra-territorial" (Chaniotis, 2009: 64). Tal proposição, como veremos, se baseia em um testemunho muito posterior, na interpretação da inscrição de Toplou, datada do século II a.C.

A tese de Chaniotis sobre o catáter extra-territorial do santuário de Palaikastro é complementar àquela de Prent que, a nosso ver, parece ser a mais acertada sobre a fundação do santuário, já que se baseia somente nas evidências arqueológicas da Idade do Ferro e não apenas em testemunhos literários e arqueológicos posteriores. Segundo a tese de Prent, "razões territoriais e outras considerações práticas, como o acesso a um bom porto, parecem ter sido menos relevantes, do que em Amnisos, na escolha do local para o estabelecimento da área sagrada, já que não há importados entre o conjunto de objetos votivos do santuário de Palaikastro, que indicariam contatos além-mar" (Prent, 2005: 538). Também não encontra justificativa na documentação, "atribuir ao santuário a função de marcar fronteiras agrícolas de uma das comunidades do leste de Creta, pois há escassez de pequenos assentamentos de agricultores no período nas áreas costeiras" (Prent, 2005: 538-539). Para Prent, "parte da razão da localização do santuário nas ruínas da cidade minoica se deve, em primeiro lugar, à natureza remota da área no período - no aspecto significativo da área, na memória respeitável da grandeza de outrora da antiga cidade - e à associação da área de Palaikastro com o culto de um importante deus local" (Prent, 2005: 539-540). Em segundo lugar, foi a localização em uma área dedicada originalmente ao pastoreio ${ }^{15}$ que estabeleceu a função do santuário como um local neutro de encontro (Prent, 2005: 539).

Esse mesmo autor é também o único que sugere um papel do santuário de Zeus Dicteu na formação de uma identidade local, típica do leste de Creta. Conforme Prent, "mais do que atrair visitantes de além-mar, e servir na manutenção de contatos entre indivíduos de outras regiões, como a gruta de lda, por exemplo, o santuário de Palaikastro ajudou a criar e a reforçar, por meio de uma antiga divindade regional, uma identidade típica comum no lado leste de Creta" (Prent, 2005: 545). Esse autor assume que "essa identidade regional tomou a forma de uma consciência autóctone ou eteo-cretense a partir da Idade do Ferro e em diante" (Prent,

15 Para Chaniotis, essa é uma função comprovada apenas nos santuários extra-urbanos do Mt.Ida e de Syme (Chaniotis, 2009: 64). 
2005: 545). Esse papel, segundo Prent, teria sido motivado pela localização de Palaikastro em uma região de Creta amplamente desabitada e isolada, diferente, por exemplo, do caso da gruta de Ida, situada na confluência de três diferentes regiões no lado central da ilha, fator que teria levado esse santuário a atrair comunidades de várias regiões cretenses (Prent, 2005: 545).

O padrão do culto de Zeus Dicteu, descrito até o momento, em época arcaica manteve-se quase inalterado, conforme indicam a continuidade dos tipos de objetos votivos, e a narrativa presente no relevo das simae do templo arcaico, de acordo com a interpretação de Driessen-Gaignerot. Certa transformação deve ter ocorrido em época arcaica, quando o culto foi abrigado, pela primeira vez, em um templo. Já em época clássica, os autores supõem o declínio de sua característica original aristocrática e militar, conforme indica o fim da dedicação de escudos e o predomínio de cerâmicas e lamparinas (Kreutz, 2007: 134; Prent, 2005: 550). Segundo Kreutz, "em época clássica houve uma perda de importância do santuário, retomada somente durante o período helenístico, quando Palaikastro certamente se converteu em um lugar de ritos noturnos, como indicam os inúmeros fragmentos de lamparinas" (Kreutz, 2007: 134). A seu ver, "embora não tenham sido consagrados mais escudos após o período arcaico, o hino a Zeus Dicteu mostra que a memória da dança dos Kouretes sobreviveu" em época helenística e posteriormente (Kreutz, 2007: 134). E Chaniotis defende o rito dos efebos no santuário de Palaikastro, em época helenística, com base, sobretudo no hino dos Kouretes, cuja texto é atribuído também ao período entre os séculos VI-III a.C. (Chaniotis, 2009: 64-65).

A partir da época helenística, datam as primeiras informações sobre a participação das comunidades locais e seu interesse pelo santuário em Palaikastro. A esse respeito, a inscrição de Toplou (I.Cret. III.iv, 9ab), do século II a.C., descreve uma longa disputa territorial entre várias cidades do leste de Creta em relação ao santuário de Zeus Dicteu no período (Prent, 2005: 534). Há duas interpretações diferentes sobre o texto da inscrição. Para a maioria dos estudiosos, o texto se refere a uma disputa entre Hierapytna e Itanos pelo controle do santuário em Palaikastro. Nessa perspectiva, Hierapytna, no texto, clama pela possessão do santuário após destruir Praisos que, segundo o texto de Estrabão, era a cidade que controlava a área sagrada até antes de ser destruída (Pearlman, 1995: 165; Prent, 534-535). Itanos, por sua vez, reivindicava o santuário, afirmando que este estava dentro de suas terras a sul, herdadas de seus ancestrais (Perlman, 1995: 165). De acordo com a interpretação mais recente, proposta por A. Chaniotis e baseada na contextualização dos termos gregos, 0 objeto de disputa, na realidade, não era o controle do santuário ou de sua área, mas a terra vizinha - Itanos afirmava que a terra era deles, já Hierapytna que esta era sagrada a Zeus, pertencia à divindade (Chaniotis, 2009: 63). Para esse estudioso, a terra era sagrada a Zeus e não poderia pertencer ao território cívico nem de Itanos e nem de Hierapytna (Chaniotis, 2009: 63). É por essa razão que Chaniotis conclui que o santuário de Zeus Dicteu em Palaikastro era extra-territorial - não pertencia ao território de nenhuma cidade em particular (Chaniotis, 2009: 64). Outro testemunho do envolvimento de comunidades políticas no santuário em Palaikastro, também nesse período, é uma inscrição referente a um tratado entre Hierapytna e Cnossos, encontrado no santuário (I.Cret. Iviii, 13) (Chaniotis, 2009: 64). Uma das cláusulas do tratado impunha a 
colocação de uma estela, de ambas as partes, no santuário de Zeus Dicteu (Chaniotis, 2009: 64). Essa inscrição é considerada uma evidência de que em época helenística, o santuário de Zeus Dicteu, em Palaikastro, atraiu comunidades para além de sua localização no lado extremo leste, como indica a participação de Cnossos, localizada no lado centro-norte de Creta (Kreutz, 2007: 135).

Embora inscrições indiquem que o santuário continuou a funcionar como um importante lugar de culto para os habitantes das cidades a leste de Creta nos períodos helenístico e romano ${ }^{16}$, de acordo com Chaniotis, "os rituais efébicos no santuário em Palaikastro foram interrompidos com a chegada dos romanos e, a interrupção desses rituais, significou o fim da função da área sagrada como um local de culto supra-local" (Chaniotis, 2009: 65).

Esse é o estado atual das pesquisas a respeito do santuário de Zeus Dicteu em Palaikastro. Sobre a origem do culto e a fundação do santuário, concordamos com M. Prent e A.Chaniotis. A associação antiga da área a Zeus Dicteu, a qual remonta à época minoica, muito provavelmente levou a fundação do santuário ao deus em meio às ruínas da antiga cidade durante a Idade do Ferro. A nosso ver, o santuário, que já não pertencia ao território de nenhuma comunidade emergente, pode ter sido fundado pela população de várias comunidades da área, como pela população de um assentamento específico que, pelo caráter antigo e regional da divindade não limitou o culto à sua própria comunidade. Nessa perspectiva, o santuário em Palaikastro, de fato, nunca teria sido ou se transformado em um centro de culto cívico. Por outro lado, se o local de culto não pertenceu a nenhuma comunidade específica do lado leste de Creta, por outro, acreditamos ter sido provável a participação de Praisos, em algum nível, no santuário desde os períodos mais antigos. Ora, dentre as três póleis que se relacionaram à área sagrada em época helenística (Praisos, Hierapytna e Itanos), Praisos era a mais antiga, a única, no extremo leste de Creta, que alcançou desenvolvimento urbano já na Idade do Ferro a ocupação do assentamento data do minoico tardio IIIC até o século II a.C. (Pearlman, 2004: 1184). De acordo com P. Pearlman, Hierapytna foi fundada somente no final do século V a.C., enquanto que Itanos já devia existir como pólis em época arcaica, conforme indicam principalmente inscrições desse período (Pearlman, 2004: 1166-1167). Durante a Idade do Ferro, Praisos era a comunidade mais organizada na área e, por isso, pode ter tido certa primazia na participação do culto, talvez como administradora do santuário tal como é possível ver na comparação entre os remanescentes dos santuários de Zeus Dicteu em Praisos e em Palaikastro nesse período. Essa primazia deve ter continuado em época arcaica e clássica, como indicou M. Prent com relação às antefixas encontradas. Assim, mesmo diante da falta de testemunhos sobre quais comunidades frequentaram o santuário na Idade do Ferro ou em época arcaica e clássica, é possível considerar que a partir do período arcaico Itanos se envolveu no culto enquanto comunidade política estabelecida, assim como Hierapytna a partir do século V a.C. Mas, se é difícil estabelecer a participação das póleis do leste de Creta no

\footnotetext{
${ }^{16}$ MacGillivray e Sackett, 2010: p.575.
} 
culto, é impossivel saber, no estado atual das pesquisas, se centros cretenses de outras áreas da ilha também procuraram o santuário em ambos os períodos.

\section{I.6 Praisos}

Localizada a sudoeste de Palaikastro, também no extremo leste de Creta, em Praisos, o santuário atribuído a Zeus Dicteu foi estabelecido no topo da terceira acrópole, na denominada "colina do altar" (325 m), que se situa na rota de acesso sul à cidade e a sudoeste das demais colinas do assentamento (cat.no.18) (Fig.34) (Prent, 2005: 304). Os remanescentes do santuário foram descobertos por Halbherr, cujas escavações em 1894 "revelaram um provável altar no meio do topo da colina" (Prent, 2005: 304). Restos sacrificiais foram estudados por Bosanquet em 1901 (Prent, 2005: 304).

\subsubsection{Descrição e interpretação dos achados}

Os objetos votivos, os restos sacrificiais e partes da estrutura do altar são os únicos remanescentes disponíveis para a reconstituição da história do santuário. Do altar, a escavação de Halbherr encontrou "dois muros baixos de 4,95 e 5,95 m de comprimento, feitos de em uma única fileira de pedras e construídos defronte ao afloramento de calcário, cercando uma área na qual o escavador encontrou traços de queima, ossos de bois e carneiros queimados e votivos de terracota e bronze" (Prent, 2005: 304). Em seu estudo dos achados, "Bosanquet concluiu que atividades posteriores de construção misturaram 0 nivelamento e distribuição do estrato datado entre a época geométrica e Orientalizante" - informações sobre a estratigrafia e a posição dos objetos é

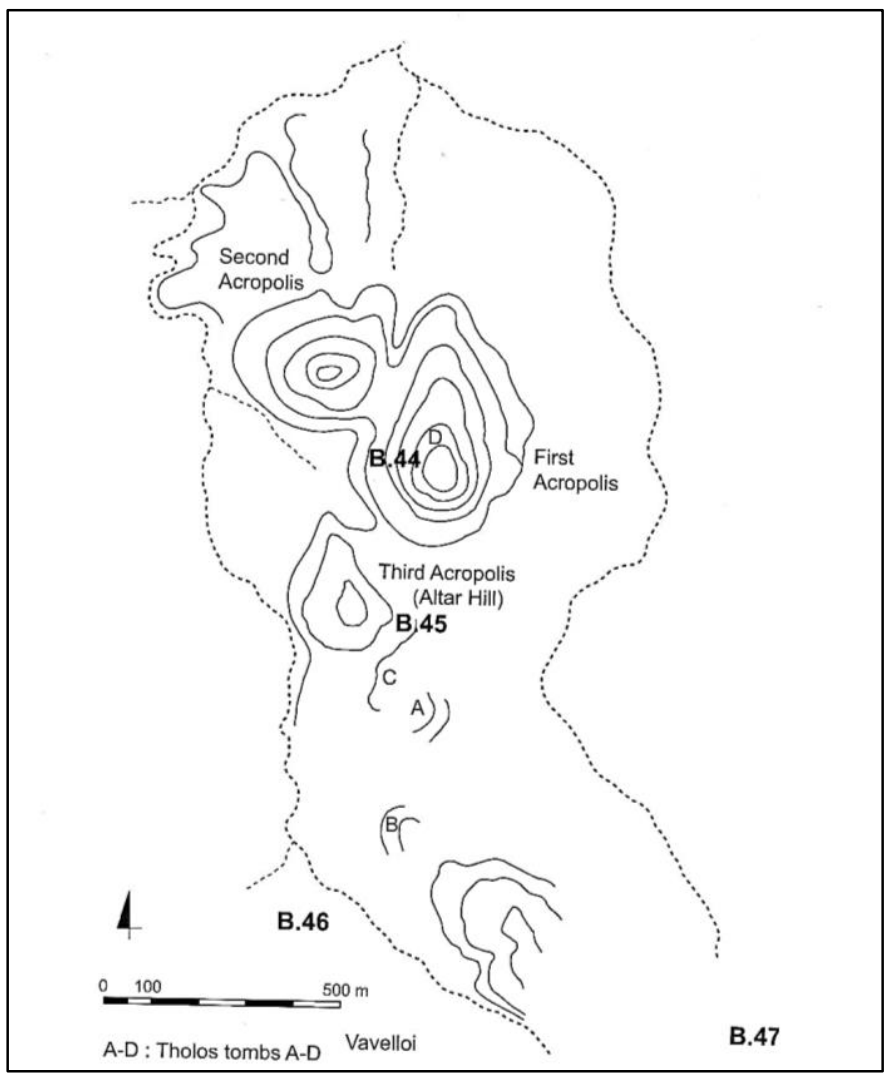

Fig.34- Planimetria de Praisos, B.45 identifica a área do santuário de Zeus Dicteu (Prent, 2005: fig.52) ausente nos relatórios de escavação mais antigos (Prent, 2005: 304).

Sobre os objetos votivos, estes foram encontrados misturados à fragmentos de ossos de animais e são datados entre os séculos VIII e V a.C. - o geométrico tardio é considerado, portanto o período de início da atividade cultual na área sagrada (Prent, 2005: 304). As dedicações em bronze incluem trípodes ou caldeirões, 


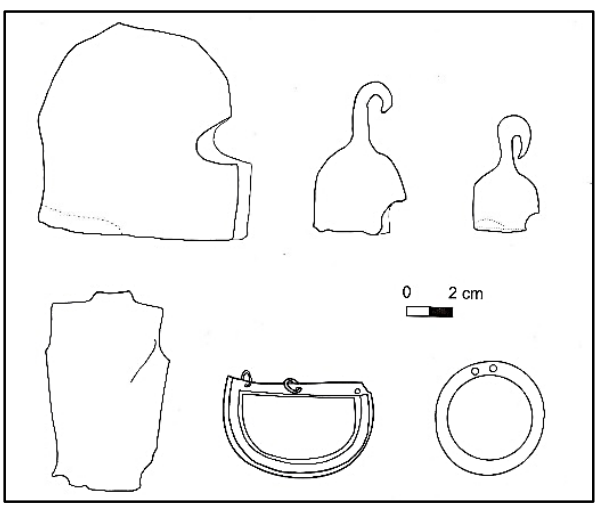

Fig.35- Objetos votivos de bronze relativos às armaduras (Prent, 2005: fig.53)

pequenos discos, seis miniaturas de elmos e um elmo coríntio grande (Fig.35), uma lança, pontas de lança, uma fíbula, fragmentos de corpetes, caneleiras, uma cabeça de machado, fragmentos de ao menos duas estátuas menores do que o Kouros de Dreros, feitas na técnica sphyrelaton, e apenas a figurinha de um carneiro foi registrada (Prent, 2005: 304-305; Zolotnikova, 2013a: 114). Já imitações de escudos, da Idade do Ferro, figurinhas, a maior parte datada do século VI a.C., figuras cilíndricas femininas e figurinhas de touro, ambos os tipos datados da Idade do Ferro, compõem o conjunto de dedicações em terracota encontradas na área sagrada (Prent, 2005: 305). Segundo Prent, "embora nos relatórios é dito que foi encontrado um número significativo de cerâmicas, apenas dois pequenos kalathoi, fragmentos de um jarro do geométrico tardio, duas ânforas, e fragmentos de pithos aparecem descritos ou ilustrados" (Prent, 2005: 305).

Embora a bibliografia não informe sobre achados de época clássica e helenística, assume-se que o santuário funcionou até a destruição da cidade em época helenística, com base no testemunho de Estrabão a respeito do templo.

\section{I.6.2 A natureza do culto e a função do santuário}

O santuário sobre a terceira acrópole de Praisos tem sido identificado como um lugar de culto a Zeus com o epíteto Dicteu a partir de uma referência literária em Estrabão e nos tipos de objetos votivos, principalmente nas semelhanças entre estes encontrados na área sagrada na denominada "colina do altar" e aqueles recuperados em Palaikastro. Estrabão (10.4.6) propicia um testemunho que indica a existência de um templo dedicado a Zeus Dicteu, mas sem fornecer qualquer informação adicional sobre sua localização, por exemplo. Já que os achados da área sagrada sobre a colina do altar indicam terem pertencido ao santuário "mais importante de Praisos"17, os especialistas têm considerado se tratar do santuário do templo noticiado pelo geógrafo grego, apesar de nenhum remanescente do edifício ter sido encontrado na área. Uma referência no mapa de Bonsaquet de uma "estrutura helênica", na encosta norte da terceira acrópole, é a única estrutura que poderia ser relacionada ao templo, mas infelizmente não há uma descrição e discussão do estudioso sobre tal construção (Prent, 2005: 306). Foi Bosanquet que "primeiro atribuiu o santuário na colina do altar a Zeus Dicteu baseando-se nos votivos de armas e em particular nos discos pequenos de bronze, interpretados como címbalos usados no ritual de êxtase na dança dos Kouretes, já as terracotas de leão (de uma data tardia), a seu ver, talvez indiquem que Rhea foi cultuada ao lado do filho" (Prent, 2005: 306). Além disso, o estudioso

\footnotetext{
17 Prent, 2005, p.305.
} 
percebeu similaridades na prática de culto e nos tipos de votivos entre os santuários de Palaikastro e o de Praisos - em ambos os locais o culto ocorria a céu aberto e era centrado em um altar de cinzas e as oferendas predominantes eram grandes quantidades de trípodes e miniaturas de armas em bronze (Prent, 2005: 535). Como vimos, na opinião de M.Prent, as similaridades entre a prática de culto e os objetos votivos, da Idade do Ferro, de ambos os santuários são consideráveis, mas não provas suficientes para atestar a relação entre ambos, tal como postula Bosanquet (Prent, 2005: 537). Não descartando a interferência de Praisos sobre Palaikastro ao longo do tempo, segundo esse autor, os séculos VI-V a.C. é o único período que de fato essa pólis pode ter interferido no santuário em Palaikastro e sido responsável por um programa de construção, como indicam o templo arcaico e a similaridade entre as antefixas encontradas nos dois sítios, mencionadas anteriormente.

Assim, também no caso de Praisos, o santuário, que remonta à Idade do Ferro, foi atribuído ao culto de Zeus com base em fontes literárias tardias, não havendo sequer qualquer analogia com um culto minoico local tal como há para os santuários de Zeus no Mt.Ida, no Mt.Dicta, em Agia Triada, Amnisos e Palaikastro. Como bem coloca Zolotnikova, "a identidade real da divindade cultuada na área, durante o início do período histórico, não é documentada e sua identificação atual com Zeus não pode ser atestada com certeza" (Zolotnikova, 2013a: 114). A identificação do culto a Zeus Dicteu no santuário em Praisos pode ser considerada mais vaga em relação àquela das áreas sagradas do Mt.Ida, de Agia Triada, Amnisos e Palaikastro, onde 0 culto foi atribuído ao deus a partir de evidências epigráficas encontradas no local do assentamento ou no próprio santuário. 0 caso de Praisos é diferente dos demais santuários cretenses de Zeus, pois se trata apenas de uma menção literária ${ }^{18}$ a um templo, sem referenciais no tempo e no espaço em relação à cidade. Mas mesmo assim, acreditamos ser possível relacionar o santuário no topo da colina do altar a Zeus Dicteu a partir da tradição local, do extremo leste de Creta, com o culto da divindade, já bem estabelecida na Idade do Ferro, e também das semelhanças do aparato cultual e votivos com a área sagrada da divindade em Palaikastro, mesmo que a relação entre os dois sítios possa ser atestada apenas em época arcaica e clássica.

Com relação à função da área sagrada, "Bosanquet sugeriu que esta serviu como um santuário para a comunidade de pastores que viviam em vilarejos espalhados nas montanhas ao redor" (Prent, 2005: 306). Mas tal proposição não encontra relação com os tipos de objetos votivos dedicados na colina do altar - não foram encontradas figurinhas de terracota de animais ou mesmo em bronze que indiquem um culto pastoril ou agrário no local. Como bem definiu Prent, o culto no santuário em Praisos é caracterizado, predominantemente, "pela dedicação de grandes objetos em bronze e sacrifício de animais, que revela o papel dominante e estabelecido de homens de uma aristocracia" (Prent, 2005: 497).

De todas os santuários cretenses de Zeus analisados, a área sagrada de Zeus Dicteu em Praisos é a única estabelecida dentro de um assentamento que se desenvolveu em uma pólis a partir da Idade do Ferro.

\footnotetext{
18 Não há evidências epigráficas a respeito do santuário e do culto de Zeus Dicteu em Praisos.
} 
Trata-se, com muita probabilidade, do único santuário suburbano da divindade na ilha de Creta em um grande arco temporal, entre a Idade do Bronze e a época clássica (até meados do século IV a.C.). Há evidências de ocupação contínua em Praisos entre o período minoico tardio IIIC e o século II a.C., quando foi destruída (Pearlman, 2004: 1184). O assentamento começou sobre a primeira e a segunda acrópoles, como indicam os achados do período mais antigo da cidade (Pearlman, 2004: 1184). A maior parte dos achados da ldade do Ferro provém dos santuários relacionados à terceira acrópole, localizados fora da cidade (de Zeus Dicteu e Vavelloi) e à necrópole, situada na encosta sudeste dessa mesma colina (Pearlman, 2004: 1184). Não há informações sobre um circuito de muros de qualquer época nessa cidade.

Nessa perspectiva, o santuário de Zeus Dicteu em Praisos é o único também que pode ser relacionado, em algum grau, a outro local de culto dentro do mesmo assentamento, já que todos os outros santuários da divindade eram extra-urbanos e sem relação com algum centro. Nesse caso, trata-se do santuário, também suburbano, de Vavelloi, localizado na encosta de uma colina a c.900 m do assentamento, na rota sul de acesso a Praisos, como o santuário de Zeus (Prent, 2005: 497). Diferente do santuário localizado na colina do altar, 0 de Vavelloi é caracterizado por uma profusão de figurinhas em terracota (femininas e masculinas), datadas a partir do século VII a.C., e também plaquetas com imagens de jovens homens vestindo um longo quíton (Prent, 2005: 496). Esses tipos de oferendas levaram os pesquisadores a concluir que se tratava de um santuário relacionado a rituais de transição à fase adulta e ao casamento (Prent, 2005: 496). Não foram encontradas, nesse santuário, terracotas mostrando guerreiros e nem votivos com fortes conotações militares, como ocorre no santuário de Zeus Dicteu (Prent, 2005: 497). Conforme explica Prent, o santuário de Vavelloi pertence a um tipo de santuário suburbano que promovia a coesão entre diferentes grupos sociais de uma mesma comunidade, em contraste ao tipo da área sagrada suburbana na colina do altar, onde o culto era restrito a um único grupo social da comunidade - uma elite de homens (Prent, 2005: 502). Esse autor, parece sugerir que um festival complementar, ao culto em Vavelloi, pode ter ocorrido naquele de Zeus Dicteu, espaço de iniciação de jovens homens aristocratas (Prent, 2005: 497). Essa seria a única relação que se poderia estabelecer entre esses dois santuários de Praisos, com funções distintas e ao mesmo tempo complementares dentro da comunidade.

Uma última peculiaridade do santuário de Zeus Dicteu, em Praisos, é este estar situado dentro de um assentamento, cuja população se identificava como descendente dos eteo-cretenses ${ }^{19}$ (Pearlman, 2004; 1183; Prent, 2005: 546-547). São fontes literárias do período clássico e helenístico, como Heródoto ${ }^{20}$ e Estrabão21, que descrevem "os eteo-cretenses como uma população autóctone, etnicamente distinta, que vivia no leste de Creta, sendo especialmente relacionada, por esses autores, à Praisos (Prent, 2005: 535 e 546). Inscrições em eteo-cretense, descobertas na terceira acrópole ou colina do altar, datadas a partir de época arcaica, são provas

\footnotetext{
190 grupo é mencionado pela primeira vez em Homero (Prent, 2005: 548).

20 Heródoto 7.167-172.

21 Estrabão 10.4.6,12.
} 
de que esta era uma língua viva no período (Prent, 2005: 548). Segundo Prent, "não há provas de que o uso da língua no período arcaico, serviu como um "marcador étnico", naquela época, para distinguir a população autóctone do leste de Creta da população falante grega nas outras partes da ilha" (Prent, 2005: 548). É provável que a língua tenha derivado, em algum grau do minoico, sendo, portanto, ao lado de tradições religiosas um dos elementos que teriam sido preservados da Idade do Bronze (Prent, 2005: 548-549). Conforme o estudioso, "tais tradições eram revividas ou retomadas de tempo em tempo, podendo servir como âncoras para a elaboração de uma noção de identidade eteo-cretense" (Prent, 2005). Nessa perspectiva, na Idade do Ferro, "conotações eteo-cretenses podem ter servido a grupos da elite em se auto distinguir por meio de uma associação com o passado baseado na Idade do Bronze" (Prent, 2005: 550). Na época clássica e helenística, como deixam claro os testemunhos literários, essa identidade deve ter novamente emergido, sobretudo em época helenística "nos conflitos políticos e militares no leste da ilha" (Prent, 2005: 549).

Em síntese, é nesse contexto que devemos compreender o culto de Zeus Dicteu em seu santuário em Praisos - "uma comunidade que se imaginava diferente de outras cretenses"22 - e mais amplamente, no lado leste de Creta, como em Palaikastro (Prent, 2005: 547). Se no caso de Praisos não é possível determinar o papel do culto em termos regionais, mas apenas locais (com relação a uma mesma comunidade) deve-se ao menos se considerar que o culto da divindade foi realizado por um grupo específico dentro da ilha de Creta. As inscrições em eteo-cretense, de época arcaica, são contemporâneas a uma fase importante do culto de Zeus Dicteu na terceira acrópole, indicando que na época do funcionamento da área sagrada, a população se caracterizava como tal.

\section{I.7 Considerações gerais sobre os santuários e o culto de Zeus em Creta}

Em Creta, os santuários de Zeus, que datam entre a Idade do Bronze e a época clássica, são na maioria extra-urbanos, na minoria suburbanos e os urbanos são inexistentes. Diferente de Apolo e Atena ${ }^{23}$, santuários de Zeus não emergiram nos mais antigos e principais centros urbanos da ilha ao menos até a época helenística, quando as cidades cretenses adotaram o culto cívico da divindade, como por exemplo em Axos, Hierapytna, Olonte, Cnossos e Gortina24. Não há santuários urbanos de Zeus em Creta a partir da época arcaica, como se vê no Ocidente grego e na Grécia Balcânica já no século VII a.C.

No que diz respeito a relação do culto de Zeus com as comunidades políticas e seus grupos, a análise minuciosa de cada tipo de remanescente material, dos santuários cretenses do deus, leva-nos a concluir que todas as seis áreas sagradas exerceram papel destacado entre uma aristocracia militar presente em comunidades da ilha desde a Idade do Ferro até a época helenística. Os santuários no Mt.Ida, no Mt.Dicta, em

\footnotetext{
22 Prent, 2005, p.547.

23 Sporn, 2002, p.318.

24 Idem, p.319-320.
} 
Agia Triada, Amnisos, Palaikastro e Praisos, cada qual em diferentes níveis, foram espaços neutros de encontro para a "competição ritualizada de uma elite masculina"25. Ritos de natureza militar, entre homens adultos, devem ter existido, especificamente, na gruta de Ida. Mas a todos os santuários de Zeus são atribuídos, pelos autores, os ritos iniciatórios de efebia, de jovens homens de uma aristocracia. Prova dessa participação, "é a dedicação de preciosos objetos de bronze no contexto de uma emulação acumulativa ou competição ritualizada característica de membros aristocráticos de uma sociedade" (Prent, 2005: 626-627). Conforme explica Chaniotis, "o encontro de jovens cidadãos, os futuros guerreiros, de mais de uma cidade em um espaço sagrado, permitiu-lhes experimentar mais intensamente sua própria identidade, sentir mais fortemente o inimigo e a competição com outras comunidades, mas também, às vezes, estabelecer alianças supra-locais, regionais" (Chaniotis, 2009: 65). Nesse aspecto, Éforo26 registra, no século IV a.C., um testemunho que mostra como o rito da efebia em Creta era relacionado a Zeus - "o rapto simulado de um adolescente por um homem mais velho, seu instrutor e amante" (Prent, 2005: 646). Junto a um grupo, "o jovem se retirava ao campo por vários meses, onde passava o tempo caçando e banqueteando para, ao final do período, retornar à cidade como um novo cidadão-guerreiro, ser apresentado ao andreion portando uma taça, apetrechos militares e um boi, que deveria ser sacrificado a Zeus" (Prent, 2005: 646). Além desse testemunho, segundo K. Sporn, o texto do hino dos Kouretes, encontrado em Palaikastro, também pode ser considerado uma referência ao rito efébico, onde Zeus Dicteu, descrito como o maior dos Kouros, "estava predestinado a proteger os efebos cretenses" (Sporn, 2002: 319).

Assim, conclui-se que os santuários de Zeus em Creta (tanto o suburbano quanto os extra-urbanos) não serviram para "forjar coesão social entre diferentes grupos sociais"27, mas ao contrário, serviram, unilateralmente, à integração social de um grupo específico, a elite das comunidades cretenses desde a Idade do Ferro. Nesse sentido, os santuários cretenses de Zeus se opõem a outros tipos de áreas sagradas encontradas na ilha, entre a Idade do Ferro e a época helenística, onde prevaleceram oferendas de terracota de figurinhas femininas e masculinas, tidas como indicativos de participação de grupos não pertencentes à elite, evidências de ritos relacionados à fertilidade, ao casamento, que interessavam a toda a comunidade (Prent, 2005: 502). Essa aristocracia, que teve uma afinidade específica com o culto de Zeus, desde a Idade do Ferro, caracterizou especialmente a pólis em Creta, diferenciando o seu funcionamento em relação ao que se observa nas cidades gregas na Grécia Balcânica. De acordo com S. Wallace, "as póleis em Creta tinham suas próprias características - uma economia baseada em um sistema de servidão, um pesado poder de um clã, um importante papel da refeição pública, como uma instituição social, e a ausência total de política democrática" (Wallace, 2010: 354). O papel da lei28 emergiu nas póleis cretenses no início do período arcaico, mas a

\footnotetext{
25 Prent, 2005, p.502

26 Éforo, FGrH $70 \mathrm{~F} 149$.

27 Prent, 2005, p.502.

${ }^{28}$ De acordo com Whitley, "mesmo as leis expressam preocupações com regras de sucessão dentro de um grupo de parentela, e então em assegurar a continuidade de famílias e a propriedade familiar de uma geração a outra” (Whitley, 2009: 291).
} 
democracia nunca se desenvolveu (Whitley, 2009: 291). Na época clássica, nas cidades cretenses membros de um conselho, os kosmoi, eram eleitos entre poucos e poderosos clãs, em contraste à escolha entre todos os cidadãos aplicado ao conselho ateniense já no século VI a.C. (Wallace, 2010: 358). S. Wallace explica que "desde muito cedo as sociedades cretenses tiveram o poder concentrado em clãs, tendo sido difícil para um único grupo ou um indivíduo adquirir uma posição proeminente" (Wallace, 2010: 358). Esse sistema "teve origem na riqueza e no poder baseados na posse da terra e no trabalho servil a ela relacionado, diferente do trabalho escravo que financiou a exportação de mercadorias nos principais centros gregos" (Wallace, 2010: 358). Outra diferença importante entre a aristocracia das póleis cretenses e àquela em centros gregos fora de Creta, foi o poder baseado no nascimento e na riqueza e não na performance e na exibição (Whitley, 2009: 291). De acordo com Whitley, a performance e a exibição têm origem na emergência do indivíduo aristocrático em época arcaica, que ocorreu em concomitância ao surgimento da pólis ${ }^{29}$ (Whitley, 2009: 290). A partir dessa época, "a performance poderia ser relativamente íntima, como em um simpósio, ou mais pública e internacional, como nos jogos e nas dedicações nos santuários pan-helênicos de Olímpia e Delfos" (Whitley, 2009: 291). Conforme explica esse autor, "o contraste entre a pólis comunal e o ideal aristocrático, típico da época arcaica, não se aplica para Creta, onde a comunidade prevaleceu sobre o indivíduo - em c.500 a.C., quando as póleis cretenses tomaram sua forma final, a proeminência do indivíduo não emergiu, como ocorreu em outras áreas do mundo grego (Whitley, 2009: 291). A nosso ver, isso pode explicar, por exemplo, porque não vemos em santuários inter-regionais cretenses a dedicação de objetos votivos no nome de indivíduos e suas respectivas comunidades, como ocorre em Olímpia e em outros santuários desse tipo na Grécia Balcânica. Mesmo no santuário de Zeus no Mt.Ida, o único que alcançou o prestígio comparável a Olímpia e Delfos, armamentos e outros objetos de valor não portam inscrições referentes ao ofertante, nem em Palaikastro, se vê elmos e escudos com tais inscrições. Houve de fato ostentação da parte da aristocracia cretense, mas a prática de inscrever o nome do ofertante revela tal fenômeno apontado por Whitley, a ausência do indivíduo aristocrático. Essa seria outra característica específica dos santuários cretenses de Zeus.

Isto posto, é possível associar o culto de Zeus em Creta a dois aspectos principais: de forma mais restrita ao pastoril e agrário, aspectos típicos das fases mais antigas do culto à divindade não somente na ilha mas no mundo grego (vistos apenas nos santuários das grutas de Ida e de Dicta), e de forma mais ampla ao poder político - à afirmação de um grupo específico da cidade grega, onde o culto do deus foi vinculado aos ritos que renovam e perpetuam a permanência e o poder do grupo em sua comunidade. Essa relação de Zeus com a afirmação de um grupo específico das cidades cretenses é, portanto, diferente do papel de Zeus como regulador das instâncias políticas da cidade que vemos em outros contextos regionais. Entre os seis santuários cretenses do deus, é possível relacionar três deles a comunidades políticas locais - o santuário extra-urbano de Amnisos e Cnossos, o santuário extra-urbano de Palaikastro e Praisos, e o santuário suburbano de Praisos.

\footnotetext{
${ }^{29}$ Esse processo teria sido concomitante, pois a pólis, um estado de homens cidadãos, colocou grande valor no dever de cada um de seus membros em participar, decidir e defende-la (Whitley, 2009: 290).
} 
Mas nos três casos não é possível identificar um papel cívico do culto de Zeus em relação à essas póleis entre a Idade do Ferro e a época clássica. Todos eles desempenharam tipos de funções regionais, relacionados predominantemente à aristocracia, como até mesmo a única área sagrada suburbana de Praisos, que serviu a esse grupo político específico da cidade ou quiçá ao mesmo grupo de outra comunidade da área.

Para Creta, é possível assegurar a função de Zeus, na esfera cívica, já a partir do final do século VII a.C., de quando data uma menção a Zeus Agoraios em uma inscrição de Dreros, considerada a referência mais antiga conhecida sobre o deus com esse título (Greco, 2006: 329). Além da inscrição arcaica no Pythion de Gortina sobre um festival primaveril a Zeus Velchanos, é possível que entre os séculos VI-V a.C. tenha havido nessa cidade e em Axos um festival (Hekatomboia), no qual uma hecatombe era dedicada a Zeus (Willets, 1962: 239). Mas se trata apenas de uma especulação baseada em uma inscrição incompleta de Gortina, sobre uma lei relatando sacrifícios a determinadas divindades, e em uma menção à uma grande hecatombe em Axos (Willets, 1962: 239). Como bem coloca K. Sporn, "infelizmente, a maioria das referências sobre o culto a Zeus, nas cidades cretenses, só pode ser atestada numismaticamente ou epigraficamente" para períodos mais tardios (Sporn, 2002: 319). Devemos considerar que a ausência de evidências sobre áreas sagradas cívicas da divindade em época arcaica e clássica pode tanto indicar que de fato, em Creta, o culto a Zeus ocorreu, nesses dois períodos, somente na esfera regional, como falsamente levar à conclusão que o culto do deus não se desenvolveu no meio cívico antes da época helenística.

Há um problema semelhante com relação à documentação dos seis santuários de Zeus em época clássica. Os tipos e a quantidade de objetos votivos dos seis santuários indicam que a Idade do Ferro e a época arcaica foram os principais momentos de culto à divindade, sendo a época helenística, também, uma fase profícua do culto nessas áreas. A época clássica, contudo, nesses santuários parece não ter sido um período importante ou sido um período de declínio. De fato, poucos achados do período clássico são relatados nos santuários do Mt.Dicta e Amnisos, nenhum achado é mencionado em Agia Triada e em Praisos, e um declínio do culto é descrito em Palaikastro. Apenas no Mt.Ida, o culto parece ter vivido uma fase importante e de transformação em época clássica. É provável que se trate realmente de um padrão de desenvolvimento do culto nesses santuários nessa época ou se trate de algum tipo de determinismo da bibliografia ${ }^{30}$, que se propõe ao estudo dos santuários cretenses em suas fases mais antigas (Idade do Bronze, do Ferro e arcaico).

Mesmo diante desse problema sobre a época clássica, tanto com relação às áreas sagradas de Zeus no contexto cívico como no regional, há algumas poucas informações epigráficas que permitem inferir o papel dos santuários extra-urbanos e suburbanos do deus, entre as comunidades cretenses em época clássica e helenística. Testemunhos epigráficos informam sobre o uso do santuário de Zeus no Mt.Ida, entre os períodos

\footnotetext{
30 Embora o escopo de seu livro seja os santuários cretenses na Idade do Ferro e na época arcaica, M. Prent considera as evidências de culto de época helenística. Já A. Chaniotis, em seu estudo sobre os santuários extra-urbanos em Creta, em época clássica e helenística, oferece conclusões sobre as áreas sagradas em época helenística, há poucos comentários sobre os santuários no período clássico. O estudioso, apesar de propor uma investigação para o período clássico, foi influenciado pela documentação disponível, majoritariamente de época helenística.
} 
clássico e helenístico, para a exposição de tratados e o nome da divindade (Zeus Idaios) era evocado em juramentos e acordos entre as cidades. $\mathrm{O}$ santuário de Palaikastro também foi usado para a exposição de um tratado entre duas cidades em época helenística. Assim, é possível afirmar que o culto de Zeus desempenhou um papel regulador, político, entre as cidades cretenses em contextos regionais (em áreas neutras) a partir da época clássica.

Assim como é possível definir o papel dos santuários e do culto de Zeus em relação às comunidades políticas cretenses e a um grupo específico no poder, também se verifica certa função das áreas sagradas de Zeus na articulação de identidades. Os santuários cretenses de Zeus não só articularam a identidade de um grupo, a aristocracia, mas tiveram um papel em articular identidades locais em uma ilha "marcada pela diversidade entre as regiões" 31 . Esse foi o caso do culto de Zeus Dicteu no leste de Creta em seus dois santuários, principalmente em Palaikastro - lá ajudou a criar e a reforçar, por meio de uma antiga divindade regional, uma identidade típica comum no lado leste de Creta" (Prent, 2005: 545). Em outro nível, o santuário do Mt.Ida, a partir da Idade do Ferro, pode ter desempenhado um papel importante na reunião e na interação entre as comunidades das várias partes da região central de Creta, ajudando na manutenção de uma identidade local que deveria ali existir já que "em termos materiais, segundo Whitley, não houve diferenças significativas entre as áreas centro-norte e centro-sul de Creta"32. Pode-se afirmar que o santuário do Mt.Ida, o mais antigo da divindade na ilha e no mundo grego, ao menos a partir da época clássica, foi o único a desempenhar uma função pan-cretense, já que atraiu comunidades de norte a sul, leste e oeste da ilha de Creta. Esses são os três casos (Palaikastro, Praisos e Ida) nos quais é possível determinar certo papel regional no culto de Zeus. Mas os santuários da divindade não se restringiram apenas à uma audiência local ou cretense, desempenharam funções inter-regionais para além da ilha de Creta, como foi o caso da gruta de Ida, cuja fama, no século V a.C. já se estendia ao teatro ateniense, e o santuário de Amnisos, cuja função marítima atraiu peregrinos de alémmar, de fora de Creta, gregos de outras origens e gente não-grega, do Oriente. O santuário do Mt.Ida é o único dentre os seis que deve ter adquirido uma função pan-helênica, para além das comunidades cretenses, já durante o século $\mathrm{V}$ a.C.

Assim, diante de todas essas características observadas nos santuários e no culto de Zeus em Creta, em relação às comunidades políticas e identidades regionais ou não, será que a afirmação inicial de J. Whitley se sustenta, quando diz que o Zeus cretense compartilhou poucas características com o Zeus da Grécia Balcânica?

Acreditamos que apesar de o culto cretense de Zeus ter se originado de uma divindade local minoica, ligada ao reflorescimento da vegetação, à morte e ao renascimento, e ter conservado tal característica no culto posterior, a audiência aristocrática de seus santuários demonstra, a partir da Idade do Ferro, um culto a uma divindade guerreira, um traço importante de Zeus na Grécia Balcânica, o qual se vê também em suas áreas

\footnotetext{
31 Whitley, 2009, p.276.

32 Idem, p.275-276.
} 
sagradas lá localizadas, principalmente, naquelas inter-regionais a partir do mesmo período. Se esse foi 0 aspecto com que a aristocracia das comunidades cretenses mais se identificou, então não é de se negligenciar essa característica homérica de Zeus em Creta. Embora o desenvolvimento de seus santuários cretenses tenha alcançado em Creta uma configuração muito diferente da observada nos santuários regionais na Grécia Balcânica, inclusive é notório não haver entre os votivos estatuetas ou figurinhas representando a divindade, como se vê na Grécia Balcânica ${ }^{33}$, a audiência aristocrática (militar) é semelhante, ainda que não tenha tido a mesma expressão na dedicação de votivos com o nome dos ofertantes, seguido pelo nome da comunidade, e ritos efébicos não tenham sido praticados em Olímpia, Mt.Lykaion, Neméia, centros da prática agonística.

Se por um lado em Creta predominaram as características locais de Zeus em seus santuários extraurbanos regionais, não cívicos, por outro, há evidências, ainda que poucas, de que o aspecto celeste do culto balcânico e homérico da divindade foi um elemento integrante também em algumas áreas sagradas do deus na ilha. M. Prent lembra de um escudo em bronze, dedicado no Mt. Ida durante a Idade do Ferro, que muito provavelmente contém a imagem de um raio. Já a escultura da águia em calcário, que deveria ornar o santuário em Amnisos, é a maior prova de que ao menos a partir da época arcaica, em Creta, o Zeus celeste já havia se firmado no culto cretense. Tais conclusões serão melhor contrastadas a partir da análise dos santuários de Zeus no Peloponeso, que realizaremos na sequência.

\section{PELOPONESO}

A antiguidade e a maior concentração de santuários de Zeus tornaram o Peloponeso a principal região do mundo grego de culto à divindade desde a Idade do Bronze até a época clássica e depois. Se em Creta se localiza o maior número de santuários de Zeus datados da Idade do Bronze, o Peloponeso se caracteriza pela maior quantidade de áreas sagradas do deus datadas a partir da Idade do Ferro. Na região se encontram os mais importantes santuários inter-regionais e algumas das áreas sagradas cívicas mais antigas (MessêniaMt.Ithome, Argos-Larissa). Os 14 santuários atestados arqueologicamente distribuem-se ao longo de todas as sub-regiões do Peloponeso: na Argólida (Argos, Mt.Arachnaion), Coríntia (Mt.Apesas, Corinto) e na confluência entre essas duas áreas (Neméia); na Lacônia (Tsakona), na Messênia (Mt.lthome), na Arcádia (Mt.Lykaion, Megalópolis, Mantinéia, Figaléia); e em Élis (Olímpia, Bambes) (vide mapa p.31). É preciso dizer que Figaléia não será abordada em um tópico específico porque toda a descrição do santuário se refere ao culto de Atena, apenas nas considerações finais da região mencionaremos do culto de Zeus nessa cidade, instituído na área sagrada da deusa somente no século IV a.C. Sobre o santuário na ágora de Argos, tratemos de seu caso no tópico sobre Neméia. Na análise final da região, consideraremos, excepcionalmente, o santuário de Zeus Homarios em Aigion, localizado na Acaia, atestado apenas a partir de informações literárias. Trata-se de uma

\footnotetext{
33 Burkert também chegou à mesma conclusão a respeito da ausência de imagens de culto de Zeus nos santuários cretenses da divindade (apud Prent, 2005: 19).
} 
área sagrada que propicia um debate importante acerca da relação do culto com a pólis e a identidade em época clássica e encontra também correspondência nas evidências numismáticas. Ao se olhar o mapa, percebe-se uma predominância de áreas sagradas no nordeste (Argólida e Coríntia) e no oeste do Peloponeso (Élis, Arcádia, Messênia).

Diferente de Creta, o Peloponeso foi o centro por excelência do culto do Zeus heládico e homérico definido como o deus celeste e pai. Em nossa análise, mostraremos como a divindade se desenvolveu como tal, em seus santuários mais antigos, sobretudo no Mt.Lykaion, até a passar a ser a divindade cívica, onde as evidências mais antigas desse processo estão nas áreas sagradas de Argos-Larissa e principalmente em Messênia-Mt.Ithome e sua consolidação como divindade da cidade em Megalópolis e Mantinéia. O santuário em Megalópolis, especialmente, nos mostra como o culto de Zeus pode ter ajudado a criar redes de identidade em contexto políade durante o século IV a.C.

Diferente também da maior ilha do mar Egeu, o Peloponeso se caracteriza por regionalismos baseados em critérios étnicos bem definidos. Conforme T.H. Nielsen e J. Roy, o Peloponeso é "tradicionalmente visto como formado por um número de regiões - Acaia, Sikyon, Coríntia, Argólida, Lacônia, Messênia, Élis e Arcádia -, onde as várias comunidades adotaram uma identidade associada à sua respectiva região" (Nielsen; Roy, 2009: 256). As origens de tal regionalismo eram, sem dúvidas, muito antigas, mas ainda na época arcaica essas sub-regiões não estavam nitidamente definidas - foi apenas em época clássica que ocorreu uma transição em direção a uma rede mais estável de identidades locais (Nielsen; Roy, 2009: 256). Esses dois autores explicam ainda que "em várias partes do Peloponeso, particularmente em áreas de fronteira, comunidades puderam escolher a sua afiliação a determinada identidade ou grupo étnico, afetadas pela influência das comunidades mais poderosas" (Nielsen; Roy, 2009: 256). Nesse contexto, em época arcaica e clássica "solidariedades regionais, em termos peloponésios, emergiram apenas quando as comunidades locais se viram sob a hegemonia de Esparta" (Nielsen; Roy, 2009: 255). Durante a época arcaica "não existiu uma união política ou ideológica peloponésia" (Nielsen; Roy, 2009: 255). Como bem sintetiza K. Vlassopoulos, "o Peloponeso não foi simplesmente uma entidade geográfica - foi uma região vista como uma entidade com interesses, características, divisões e lideranças próprias" (Vlassopoulos, 2011: 15). Em seu estudo sobre a percepção grega de uma identidade peloponésia, o estudioso conclui que, "embora a região não tenha abrangido um único estado ou tenha sido uma unidade cultural ou étnica, esta foi percebida como um país com suas próprias características" (Vlassopoulos, 2011: 15). Vlassopoulos defende a emergência de uma identidade peloponésia em época arcaica e clássica motivada por experiências fora da região de indivíduos de várias comunidades do Peloponeso, como a colonização e o serviço mercenário (Vlassopoulos, 2011: 29). Será a partir desses contextos, das realidades sub-regionais e daquela regional, que procuraremos compreender como o culto de Zeus, por meio de seus santuários, articulou e foi articulado por identidades regionais peloponésias.

Da relação do culto com as comunidades políticas, as póleis, procuraremos compreender em que medida, no Peloponeso como todo e em suas sub-regiões, o culto esteve relacionado à esfera cívica das 
cidades, sendo instalado no centro urbano ou no território, servindo ao funcionamento da comunidade, em algum nível, e apropriado por algum grupo político específico, como vimos no caso de Creta. Nesse sentido, consideraremos o desenvolvimento político e urbano da região, sobretudo a partir da época arcaica, quando remontam as primeiras áreas sagradas cívicas consolidadas de Zeus. Já nessa época no Peloponeso, segundo Nielsen e Roy, a pólis havia se tornado a forma básica de organização política das comunidades locais, todas com um território bem definido, mas diferentes padrões de urbanização (Nielsen; Roy, 2009: 262-263).

\section{II.1 Mt.Lykaion}

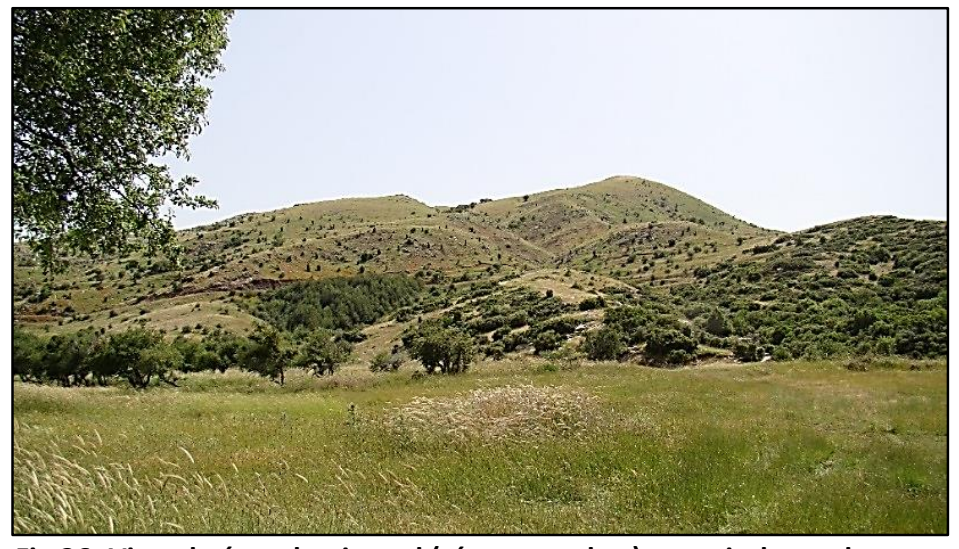

Fig.36- Vista da área do pico sul (témeno e altar) a partir de nordeste do hipódromo (Foto: arquivo pessoal / 2014)

O santuário de Zeus no Mt.Lykaion (1382 m), atual Monte Ágios Elias, localiza-se no sudoeste da Arcádia, a oeste de Megalópolis, nas proximidades do vilarejo moderno de Ano Karyés (Fig.36) (cat. no.3). 0 santuário foi escavado pela primeira vez por Kontopoulos em 1897 e mais tarde por Kourouniotis em 1902, ambos da Sociedade Arqueológica de Atenas. Estas investigações iniciais identificaram e descobriram várias características do santuário, incluindo o altar no pico sul da montanha, e o témeno situado a $24 \mathrm{~m}$ abaixo do altar. Na parte inferior do santuário, Kourouniotis também encontrou o hipódromo, o estádio, a casa de banhos, duas fontes, uma stoá, os assentos (de frente em uma área aberta), e um edifício que ele denominou como o xenon, ou hospedaria, identificado atualmente como um prédio administrativo. No final dos anos de 1990, Spyropoulos, então superintendente das regiões da Lacônia e Arcádia, escavou trincheiras no altar, no témeno e no santuário de baixo (Romano; Voyatzis, 2014: 575). Todo o complexo do santuário permaneceu quase 100 anos sem ser escavado até 1996, quando a Universidade da Pennsylvania, sob a direção de D. G. Romano e M. Voyatzis, conduziu um importante survey na topografia e arquitetura do santuário no Mt. Lykaion. A primeira escavação americana (Univ. Pennsylvania e Arizona) se iniciou em 2004 e durou até 2010. A partir de 2011 até o momento atual, o time iniciou os trabalhos de análise da documentação em um local em Trípolis, que funciona como o depósito e laboratório para o estudo dos achados. Novas escavações e outras pesquisas estão previstas para os próximos anos. Os achados da escavação de Kourouniotis encontram-se no Museu Arqueológico de Atenas e os achados das escavações americanas estão em Lykossoura e no depósito de Trípolis. Os resultados das escavações americanas foram publicados em dois relatórios somente muito recentemente, nos anos de 2014 e 2015. 


\section{II.1.1 Descrição e interpretação dos achados}

Antes de iniciarmos a descrição e a interpretação dos achados acerca do santuário de Zeus no Mt. Lykaion, devemos destacar que Pausânias, principalmente no livro oitavo sobre a Arcádia, é o único autor antigo que propicia informações sobre a topografia, o culto e sobre algumas construções da área sagrada, como o témeno ${ }^{34}$, o altar ${ }^{35}$, a fonte $\mathrm{Hagno}^{36}$, o hipódromo e o estádio ${ }^{37}$, e rituais, como aquele que teria envolvido a proibição a humanos de entrar no témeno, a licantropia (transformação de Lycaon em lobo após sacrificar uma criança no altar), o ritual do sacerdote na fonte Hagno para fazer chover, etc.

Isto posto, a área arqueológica do santuário de Zeus no Mt.Lykaion divide-se em duas zonas: o denominado santuário de cima ou superior e o de baixo ou inferior

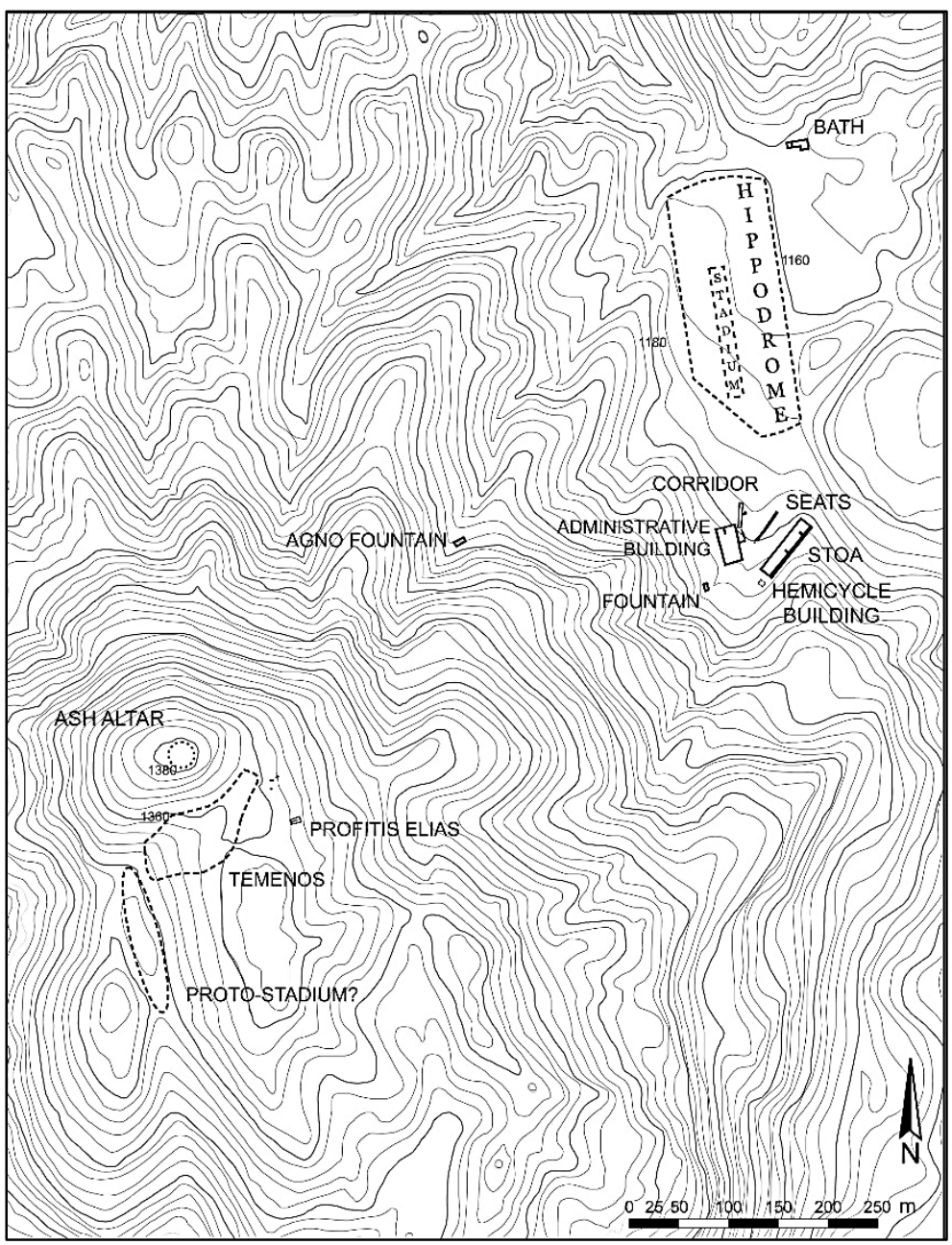

Fig.37- Planimetria santuário do Monte Lykaion (de cima e de baixo) (Romano; Voyatzis, 2014: fig.2)

(Fig.37). O santuário de cima ou superior corresponde desde o pico mais alto da montanha, onde esteve o altar de Zeus Lykaios e foram encontradas as evidências mais antigas do culto, até a área do témeno, a aproximadamente $20 \mathrm{~m}$ abaixo do cume. Entre a área do altar e do témeno, os americanos parecem ter encontrado um antigo estádio. Trata-se, portanto, da área sagrada propriamente dita, onde se concentraram as atividades de culto a Zeus Lykaios. Já o santuário de baixo estende-se a c.200 m abaixo do témeno, em uma área plana nas encostas da montanha na qual foram construídos vários tipos de estruturas, a maior parte relacionada à prática agonística, que ocorria no santuário, e às funções administrativas. Somente muito recentemente as pesquisas americanas determinaram 0 início da atividade cultual no Mt.Lykaion entre 0 heládico tardio IIB (1510-1390 a.C.) e o heládico tardio IIIC (1200-1070 a.C.) a partir do achado de material cerâmico, datado entre esses períodos, encontrado no nível mais baixo da trincheira $Z$ aberta na área do altar,

\footnotetext{
34 Pausânias VIII, 38.6.

35 Idem, VIII, 38.7

36 Ibidem, VIII, 38.4.

37 Ibidem, VIII, 38.5.
} 


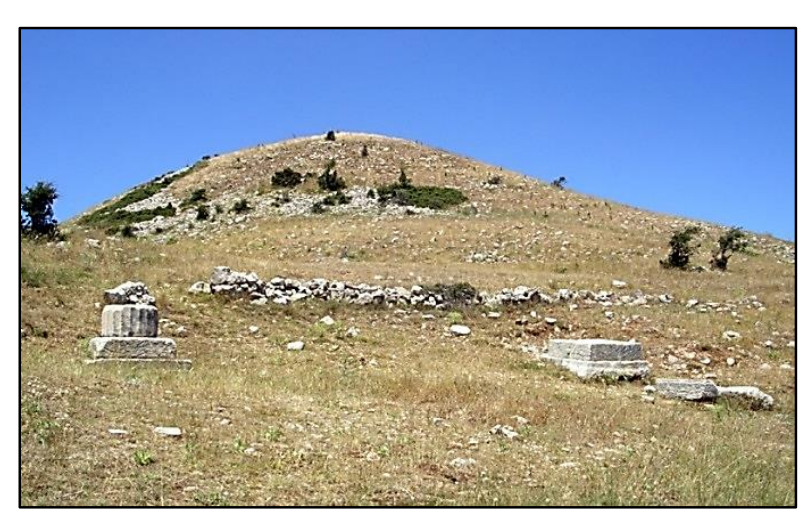

Fig.38- Vista a partir do leste do témeno, bases de colunas e altar no pico sul (Romano; Voyatzis, 2014: fig.4) no topo do pico mais alto. Esse é o período, assinalado pelos pesquisadores americanos, do início do culto, apesar de achados do mesmo tipo terem sido recuperados também no mesmo nível inferior da trincheira, os quais datam dos períodos neolítico, heládico antigo e médio. Essa datação colocou 0 santuário do Mt.Lykaion entre aqueles mais antigos da divindade no mundo grego, os quais remontam à Idade do Bronze. Como dissemos no capítulo anterior, acerca dos santuários de Zeus durante esse período, o santuário de Zeus Lykaios pode se revelar, futuramente, como a área sagrada mais antiga da divindade, ultrapassando em antiguidade aquele da gruta de Ida em Creta, mas isso dependerá de novos estudos sobre os achados cerâmicos do neolítico e do heládico antigo encontrados na área do altar. O período final do uso do altar remonta ao século III a.C., em época helenística. Já o uso da área do santuário de baixo ocorreu entre o início da época arcaica e o final da época helenística.

Assim, com relação as partes que compõem 0 santuário de cima (témeno, altar, antigo estádio), 0 témeno, que se situa a $24 \mathrm{~m}$ abaixo do cume da montanha, ocupou uma área de $55 \times 120$ m no pequeno platô denominado Taverna, onde hoje está a capela de Ágios Elias (Fig.38 e 39). Na época das escavações de Kourouniotis, no início do século XX, apenas uns alinhamentos de pedra marcavam os limites do témeno, dentro do qual 0 arqueólogo

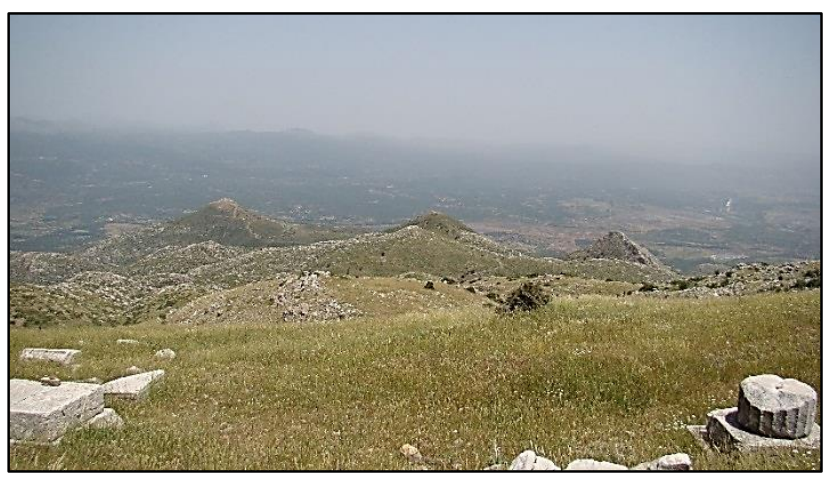

Fig.39- Vista a partir de oeste das bases das colunas no santuário de cima; embaixo no vale, Megalópolis (Foto: arquivo pessoal/2014) escavou várias trincheiras sem encontrar algum traço de construção. A leste do témeno, onde a camada de terra foi mais espessa e preta, Kourouniotis concluiu que se tratava do local de um tipo de prothysis, onde as vítimas eram abatidas antes de serem queimadas no cume da montanha. $O$ arqueólogo grego abriu trincheiras dentro da área do témeno, mas nada foi encontrado, exceto alguns objetos de ferro na área sul. Essa ausência de achados associa-se à descrição de Pausânias (VIII, 38.6) do témeno como um ábaton, onde nenhum homem poderia caminhar por medo da morte que poderia Ihe ocorrer dentro de um ano (Romano; Voyatzis, 2014: 577).

A maior concentração de achados foi ao redor da área das duas bases de colunas - trata-se de duas bases quadradas de pedra, distantes $7 \mathrm{~m}$ uma da outra, próximas das quais foram encontradas outras bases de pedras (Jost, 1985: 181). Kourouniotis sugeriu que estas bases teriam originalmente suportado duas colunas com duas águias sobre elas, as quais teriam marcado a entrada leste do témeno, conforme a descrição de Pausânias (VIII, 38.7). Mais recentemente, os pesquisadores americanos têm sugerido que esse caminho teria ligado o lado norte ao lado leste do pico sul da montanha, passando pela fonte Hagno, localizada no caminho 


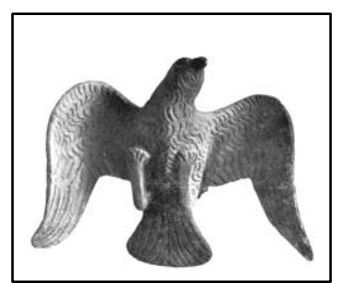

Fig.40- Águia de bronze, século $v$ a.C. (Korouniotis, 1904: figs.18 e 19)

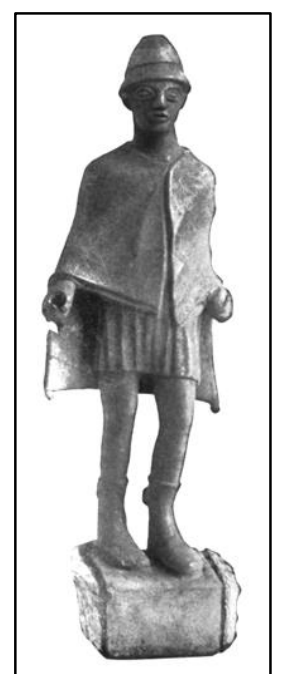

Fig.41- Estatueta em bronze de Hermes, século $V$ a.C. (Kourouniotis, 1904: fig.9)

para o santuário de baixo, que será descrito mais adiante (Romano; Voyatzis, 2014: 626). Essas bases, segundo D.G. Romano, são provavelmente datadas entre os séculos V-IV a.C. ${ }^{38} \mathrm{Com}$ relação aos objetos votivos encontrados próximos da base a norte, de frente ao témeno, Kourouniotis encontrou estatuetas e, perto da base a sul, duas moedas do século $V$ a.C. (uma da Liga Arcádia e a outra de Argos). Dentre as estatuetas encontradas, várias representações de Zeus e de uma da águia: uma figura em bronze de Zeus nu segurando o raio com sua mão direita e uma águia pousada sobre a esquerda - o objeto mais antigo encontrado que data do final do século VII a.C. deve ter sido parte de um trípode. Outras estatuetas de Zeus, todas de bronze, incluem uma imagem de Zeus Ithomatas do início do século VI a.C., um Zeus sentado arcaico (540530 a.C.), uma estatueta de Zeus com um himátion, uma mão de Zeus segurando uma forma de raio (haste) do século $V$ a.C.; um pé, provavelmente de Zeus, do século V a.C., e uma miniatura de águia do século V a.C. (Romano; Voyatzis, 2014: 577-578). De frente ao témeno, a $10 \mathrm{~m}$ a oeste das bases das colunas, Kourouniotis recuperou 9 estatuetas de bronze completas e parte de uma décima (dentre as quais duas são representações de Hermes), assim também como as bases de outras estatuetas similares, e uma águia de bronze, que datou do início do século V a.C. (Fig.40). Além das estatuetas foram recuperadas na área uma variedade de objetos votivos em bronze - jóias (10 anéis gravados, sendo apenas 1 em ferro), uma placa, a representação de uma cobra com duas cabeças, um askos, uma perneira do século V a.C. com uma inscrição votiva dedicada a Zeus Lykaios e Atena (IG V, 2, linha 551) (Fig.42) -, em prata (duas moedas) e nenhum material cerâmico, exceto várias telhas. Ao contrário de Kourouniotis, que recuperou estatuetas de Zeus e Hermes fora do témeno (Fig.41), as escavações americanas não encontraram sequer um objeto no témeno e nem área ao redor. Acredita-se que isso se deva ao uso moderno da área, principalmente aquele relacionado às festividades anuais do Profeta Elias, cuja capela foi construída na área, o que deve ter provocado 0

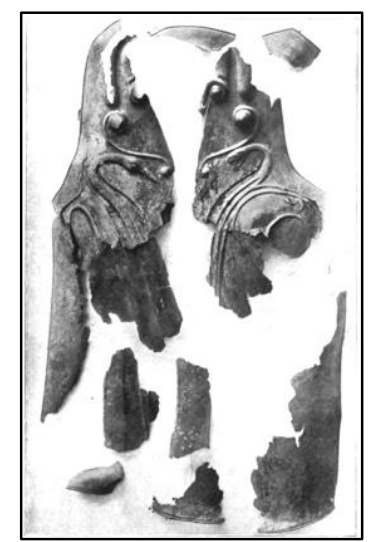

Fig.42- caneleira de bronze de armadura com detalhe de inscrição a Atena e Zeus Lykaios, séc. $\checkmark$ a.C. (Kourouniotis, 1904: figs.25 e 26) desaparecimento dos achados (Romano; Voyatzis, 2014: 626 e 628).

Embora Kourouniotis tenha, com convicção, identificado a localização e determinado a dimensão $\left(6438 m^{2}\right)$ e o perímetro do témeno (363 m), sua extensão e seus limites precisos permanecem incertos. De acordo com Romano e Voyatzis, é provável que a região ao redor das duas bases de colunas, como também aquela imediatamente a oeste, identificada por Kourouniotis como pré-sacrificial, não foram parte do témeno, mas a área fora dele (Romano; Voyatzis, 2014: 629). A maior parte da área considerada anteriormente como 0

38 Trata-se de uma informação propiciada pelo diretor das escavações em uma entrevista concedida por e-mail no dia 23 de dezembro de 2015. Segundo o professor, a datação das bases será confirmada em breve. 
témeno é plana e segue até a base do pico sul da montanha. Uma linha parcial de pedras baixas, encontrada por Kourouniotis na base do pico sul, podem ter sido os restos do muro de témeno (Romano; Voyatzis, 2014: $629)$.

Situado no pico sul, o altar de Zeus Lykaios estava no ponto mais elevado do Mt.Lykaion (Fig.34). De acordo com Romano e Voyatzis, a área inteira do pico sul da montanha (de aproximadamente $700 \mathrm{~m}^{2}$ ) foi coberta por cinzas e ossos queimados de animais dos sacrifícios (Romano; Voyatzis, 2014: 579). A menção literária mais antiga sobre o altar de Zeus Lykaios aparece em Píndaro (OI.13, 105-110) (Zolotnikova, 2005: 106). Na descrição de Kourouniotis, o altar não era uma construção de pedras e nem um amontoado de cinzas, mas um monte artificial de $30 \mathrm{~m}$ de diâmetro e 1,5 m de altura, feito de terra enegrecida pelo fogo das cinzas e dos ossos de animais queimados, e pontilhado por grandes pedras, que na época o arqueólogo grego acreditou se tratar de um túmulo na montanha (Jost, 1985: 180). Em sua escavação do altar, Kourouniotis recuperou uma grande variedade de objetos votivos datados da época arcaica e clássica: duas miniaturas de trípodes de bronze do século VII a.C., uma faca de ferro de época arcaica, uma moeda arcaica de Egina, pequenas fialas e skyphoi, com verniz sólido preto, típicas dos séculos V e IV a.C., fragmentos de lamparinas de terracota e muitas telhas, algumas com inscrições estampadas datadas, provavelmente, do século IV a.C., uma figurinha de pássaro de terracota do século IV a.C. e uma moeda da Liga Arcádia (Romano; Voyatzis, 2014: 575-576). Também foram recuperados alguns objetos sem datação indicada, como alguns anéis de bronze e uma chave de ferro (Romano; Voyatzis, 2014: 576).

Durante os anos de escavações americanas (2007-2010) foi possível estabelecer as fases de uso do altar. A grande concentração de material dos períodos mais antigos do altar foi encontrada na base de pedra, que corresponde ao nível mais baixo da trincheira Z, datado entre o heládico tardio IIB e IIIC até a Idade do Ferro. Embora a maior parte do material seja micênico, foram também recuperados material cerâmico do final de neolítico, do heládico antigo e médio (Romano; Voyatzis, 2014: 581). Figurinhas do héladico tardio de animais e de humanos foram também recuperadas na área (Romano; Voyatzis, 2014: 582). Da análise do material cerâmico recuperado na trincheira $Z$, concluiu-se que este foi usado entre o final do neolítico e o período clássico tardio (Romano; Voyatzis, 2014: 584). Essa descoberta amplia a cronologia do altar, datada por Kourouniotis a partir da época arcaica (Romano; Voyatzis, 2014: 584). Já a área que corresponde a parte de intensa queima (Z3) foi datada entre o século X a.C. e os períodos arcaico e clássico a partir dos achados encontrados - fragmentos cerâmicos do período héladico, geométrico e arcaico e uma miniatura completa de um trípode de bronze) (Romano; Voyatzis, 2014: 581). Assim, a descoberta significativa de uma grande quantidade de cerâmica micênica no altar de cinzas pode ajudar não só a identificar um culto micênico no local, mas a demonstrar a continuidade de culto desde o final da Idade do Bronze até a Idade do Ferro (Romano; Voyatzis, 2014: 591).

Sobre os demais tipos de achados votivos na área do altar, recuperados pelas escavações americanas, da Idade do Bronze tardia, figurinhas de terracota e um selo de cristal, da Idade do Ferro, 40 miniaturas de 
trípodes de bronze, talvez machados duplos, e fragmentos de trípodes, da época arcaica, coroas de chumbo são provavelmente do século VII a.C. e uma miniatura de kouros, dois espetos de ferro, uma faca, entre a época arcaica e clássica, uma pequena mão de uma estatueta de bronze segurando um raio em prata (semelhante a uma encontrada por Kourouniotis), e da época clássica, lamparinas, fragmentos de vasos de vidro, ferramentas de pedra e 33 moedas $^{39}$ (Romano; Voyatzis, 2014: 615).

Dos achados das miniaturas de trípodes de bronze, concluiu-se que a prática de dedicar tal objeto no altar começou no início do século X a.C. e durou até o século VII a.C. Miniaturas de trípodes de bronze foram encontradas em poucos santuários, como em Olímpia, onde também foram encontrados trípodes de tamanho grande na camada de terra preta entre o setor sul do Heraion e o Pelopion (Romano; Voyatzis, 2014: 618).

Outra importante descoberta feita pelas pesquisas americanas refere-se, provavelmente, a um edifício antigo. Restos de telhas, de tipos coríntio e lacônio, encontrados no altar e no témeno sugerem que estas teriam pertencido ao telhado de um ou mais antigos edifícios no pico sul, provavelmente um naískos (Romano; Voyatzis, 2014: 624). Outra novidade proporcionada pelas pesquisas americanas no santuário de cima referese à existência de um antigo estádio, que teria sido usado para as os jogos lykaios, anteriormente às construções do santuário de baixo, e como um caminho de procissão ao pico sul durante a antiguidade. Tratase de uma área a sul do altar e do témeno, a aproximadamente $130 \mathrm{~m}$ a sudoeste do pico sul do altar (a $48 \mathrm{~m}$ abaixo deste), em um terraço plano e limitado a leste e oeste pelas encostas da montanha. A área tem c.150 x 12 m (Romano; Voyatzis, 2014: 629). $O$ achado de uma estatueta de bronze de um corredor, por Kourouniotis, na área do témeno ajuda a reforçar tal tese (Romano; Voyatzis, 2014: 626 e 628).

A aproximadamente meio caminho entre o santuário de cima e 0 de baixo, localiza-se os remanescentes da fonte Hagno, a 145 m abaixo do altar de Zeus Lykaios no pico sul (Romano; Voyatzis, 2014: 630). Kourouniotis a identificou, anteriormente, com a fonte Korités, situada a dez minutos a norte do altar (no lugar chamado de Anémorrachi ou Phatoureïko), entre o setor de baixo e o de cima (Jost, 1985: 181-182). A localização indica que a fonte deve ter sido um ponto de parada importante na antiga rota entre os dois setores (Romano; Voyatzis, 2014: 630).

Já com relação ao santuário de baixo, uma série de novas estruturas foram descobertas durante os anos das escavações americanas: 1-) a casa da fonte; 2-) assentos ou degraus, terraços e área de monumentos; 3-) edifício semi-circular; 4-) stoá; 5-) corredor; 6-) edifício administrativo; 7-) hipódromo; 8-) estádio; 9-) banhos.

A casa da fonte foi mantida por uma fonte natural na encosta da montanha, serviu como a principal fonte de água no santuário de baixo, sobretudo para as estruturas a sul do hipódromo e do estádio, como 0 prédio administrativo, a stoá e os assentos (Romano; Voyatzis, 2015: 230). 0 edifício localiza-se a c.20 m a sudoeste do prédio administrativo, mede c.6,97 x 3,83 m e possui várias fases de construção, sendo a mais

\footnotetext{
${ }^{39}$ A descrição dessas moedas e o significado de seu uso como objeto votivo no santuário de cima do Mt.Lykaion são discutidos, em detalhe, na parte sobre a Arcádia no cap.4.
} 
antiga datada do século IV a.C. (Romano; Voyatzis, 2015: 229). A aproximadamente $21 \mathrm{~m}$ a norte da stoá, localizam-se os assentos ou degraus, os terraços e a área dos monumentos, construções relacionadas aos eventos agonísticos (Romano; Voyatzis, 2015: 241). Os degraus ou assentos medem 39,09 m de comprimento, são datados do século IV a.C. e, possivelmente, foram usados para se assistir as procissões ou para a avaliação de cavalos ou atletas (Romano; Voyatzis, 2015: 238 e 241). Outra estrutura na área é o edifício circular, de função desconhecida, que mede 6,8 × 5,8 m e possuía cinco colunas jônicas prostilas (Romano; Voyatzis, 2015 : 237-238). Localizada logo a leste dos assentos ou degraus, a stoá mede 67,08 x 13,70 m e data do período clássico tardio, embora seja provável uma fase mais antiga, como indica as fundações mais baixas da construção (Romano; Voyatzis, 2015: 231). A oeste da stoá, situa-se o corredor, feito de paredes de pedras poligonais e dimensões de 2,60 x 2,38 m, em suas extremidades, e $25 \mathrm{~m}$ de comprimento total (Romano; Voyatzis, 2015: 217). $O$ uso do corredor mudou drasticamente durante a história do santuário - foi aparentemente convertido em área de descarte em algum momento no século III a.C. Os pesquisadores americanos sugerem que o material descartado provavelmente veio do edifício administrativo e talvez da stoá nas proximidades (Romano; Voyatzis, 2015: 228). Originalmente serviu como corredor que trazia os atletas da área do edifício administrativo à área atlética a norte, assim como pode the ser atribuída uma função religiosa/cerimonial (Romano; Voyatzis, 2015: 228).

A oeste de todas essas construções descritas, e a sul do hipódromo e do estádio, localiza-se o denominado edifício administrativo, identificado anteriormente por Kourouniotis como o xenon ou hospedaria. Os pesquisadores americanos concluíram que o edifício foi usado para determinadas funções durante o festival religioso, o que incluía a organização das competições atléticas em honra a Zeus Lykaios. Sabe-se que a construção era dividida internamente em várias salas e pátios, características comuns dos pritaneia, por exemplo (Romano; Voyatzis, 2015: 216). 0 achado de uma grande quantidade de cerâmica assinalou uma função de refeição a esse edifício ou a uma área próxima (Romano; Voyatzis, 2015: 216). Encontradas em uma das salas do lado oeste do edifício, duas estelas contêm uma inscrição (IG V ii 449-550) que menciona os damiourgoi, um grupo aparentemente relacionado à organização do festival dos jogos lykaios (Romano; Voyatzis, 2015: 216). A inscrição fornece, além disso, informações importantes relacionadas ao festival religioso, como o nome dos sacerdotes dos deuses e informações sobre os atletas (os eventos nos quais foram vitoriosos e suas origens). É possível que tenha existido uma ligação entre o lado leste do edifício administrativo, o corredor adjacente e o local das competições, como o hipódromo e o estádio a norte (Romano; Voyatzis, 2015: 216).

O hipódromo40 e o estádio (c.102 x 260 m) (fig.43) situam-se mais a norte na área do santuário de baixo, a c.217 m abaixo da elevação do altar de cinzas (Romano; Voyatzis, 2015: 245). Com base nas investigações de Kourouniotis e no trabalho arqueológico mais recente no local, parece que o hipódromo e 0

40 O hipódromo do santuário de Zeus no Mt.Lykaion é o único exemplo, no mundo grego, que pode ser visto e medido (Romano; Voyatzis, 2015: 245). 
estádio foram construídos como duas partes de um todo, com os dromos do estádio sendo encontrado dentro dos limites do hipódromo (Romano; Voyatzis, 2015: 246). Trata-se de um projeto arquitetônico único, não só na Grécia continental, mas também em todo 0 mundo grego (Romano; Voyatzis, 2015: 246). No que diz respeito aos elementos arquitetônicos do hipódromo, Kourouniotis encontrou evidências para dois marcos

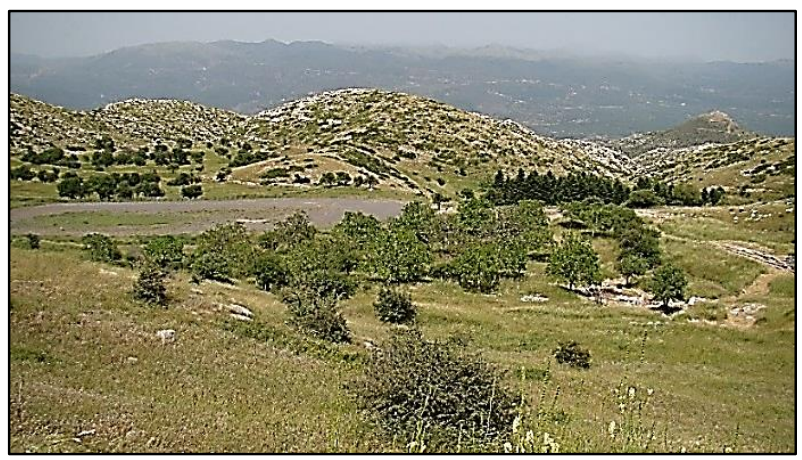

Fig.43- Hipódromo e santuário de baixo visto a partir de seu lado oeste (Foto: arquivo pessoal / 2014) (colunas de pedra) na superfície do campo do hipódromo, bem como duas bases circulares de pedra em seus prováveis lugares originais (Romano; Voyatzis, 2015: 246). As escavações mais recentes redescobriram os componentes de ambos os postes e foi possível, assim, reconstruir como os marcos pareciam (Romano; Voyatzis, 2015: 248). Os resultados das escavações americanas revelaram uma pequena porção do nível do pavimento do hipódromo que data entre os séculos III-II a.C., como indicou uma taça helenística encontrada no estrato (Romano; Voyatzis, 2015: 248). Concluiu-se que a extremidade sul do hipódromo era ao menos $80 \mathrm{~m}$ a norte do ângulo nordeste da stoá (Romano; Voyatzis, 2015: 248). Fragmentos de cerâmicas de figuras negras indicaram atividades próximas ao hipódromo durante os séculos V e IV a.C. (Romano; Voyatzis, 2015: 248). Também foram encontradas na área evidências do pavimento do dromos do estádio (Romano; Voyatzis, 2015: 248). Embora não se conheça ainda a data mais antiga para o uso do estádio e do hipódromo, os americanos tendem a sugerir que a atividade atlética mais antiga no santuário pode ter ocorrido no chamado antigo estádio, adjacente ao pico sul da montanha, próximo ao local do altar de Zeus Lykaios (Romano; Voyatzis, 2015: 258).

As estruturas mais setentrionais do santuário de baixo são os banhos, localizados a nordeste do hipódromo e do estádio. Deles, é possível ver um reservatório grande e retangular no lado final do que teria sido o edifício de 49 m de comprimento (Romano; Voyatzis, 2015: 259).

As escavações americanas não encontraram qualquer evidência do santuário de Pã, descrito por Pausânias (VIII, 38.5) nessa área do santuário, o que levou a pensar que teria se tratado de um culto modesto sem templo (Romano; Voyatzis, 2015: 245).

\section{II.1.2 A natureza do culto e a função do santuário}

O Mt. Lykaion é amplamente atestado como local do santuário de Zeus Lykaios a partir de evidências literárias e epigráficas datadas a partir de época clássica. As pesquisas arqueológicas mais recentes no local esclareceram as fases mais antigas do culto da divindade na montanha, revelando o seu início já na Idade do Bronze, diferente do que se pensava até a primeira década do século XXI, quando a bibliografia ${ }^{41}$ ainda se

\footnotetext{
41 Por exemplo, Langdon, 1976; Jost, 1982; Zolotnikova, 2005, 2011 e 2013a; Kreutz, 2007; Lo Monaco, 2009.
} 
pautava nas descobertas de Kourouniotis. Assim, com base nos resultados obtidos durante as campanhas americanas entre 2006 e 2010, concluiu-se que o pico sul do Monte Lykaion foi claramente um lugar importante de culto no período micênico (entre o heládico tardio IIB e o IIIC), confirmando a tese de G. Mylonas sobre 0 altar do monte em períodos pré-históricos (Mylonas, 1946: 206; Romano; Voyatzis, 2014: 628). Sem ter tido conhecimento dos achados micênicos, somente revelados muitas décadas depois pelas escavações americanas, a seu ver, o altar de cinzas e as colunas embaixo, representaram um culto primitivo e pré-micênico que sobreviveu até o período histórico (apud Romano; Voyatzis, 2014: 628). Em uma publicação parcial dos resultados, publicada em 2010, os pesquisadores americanos já assumem que a atividade cultual no Mt. Lykaion, durante a Idade do Bronze, já havia sido dedicada a Zeus, com base nas evidências epigráficas que atestam a existência do culto da divindade nessa época (Romano; Voyatzis, 2010: 13). Nos períodos mais antigos, o culto teria sido realizado em conexão a fenômenos atmosféricos ou a terremotos, associados à divindade (Romano; Voyatzis, 2010: 13).

A continuidade do culto de Zeus Lykaios no Mt.Lykaion, da Idade do Ferro à época arcaica e a períodos posteriores, é indicada pela cerâmica do período proto-geométrico e pela dedicação de miniaturas de trípodes de bronze e outros objetos votivos no altar (Romano; Voyatzis, 2014: 628). Há uma atividade contínua no altar durante os períodos proto-geométrico e geométrico, mas foi durante o século VII a.C. que parece ter ocorrido uma expansão significativa no sítio tanto no santuário de cima quanto no de baixo (Romano; Voyatzis, 2014: 632). No altar de cinzas pode ter ocorrido uma organização maior no século VII a.C., como evidenciam a construção de um sistema de contenção e o aumento de atividades em ternos de oferendas e dedicações queimadas. Essa atividade no santuário de cima continua forte até o período clássico tardio - as dedicações do século V ao IV a.C. são consideráveis, mas durante o século III a.C., já no início do período helenístico, há poucas evidências de atividade no altar (Romano; Voyatzis, 2014: 628 e 632).

Como chamam a atenção, Romano e Voyatzis, "a continuidade do culto da época micênica à Idade do Ferro e deste período ao século IV a.C., tão bem atestadas pelas evidências materiais, é um fenômeno comprovado apenas em poucos sítios no mundo grego" (Romano; Voyatzis, 2014: 629). Os estudiosos também dão destaque ao fato de que a atividade ritual ocorreu no altar do Monte Lykaion séculos antes do início daquela atestada em Olímpia, santuário distante c.35 km a noroeste da montanha (Romano; Voyatzis, 2014: 631).

A atividade de uso do santuário de baixo não é tão antiga como a atestada para o altar de Zeus Lykaios. As evidências mais antigas encontradas naquela área são datadas do século VII a.C., enquanto as mais recentes remontam ao século I a.C. (Romano; Voyatzis, 2015: 258 e 263). Todos os tipos de achados na área indicam que o santuário de baixo foi o local dos festivais atléticos em honra a Zeus Lykaios durante os períodos arcaico, clássico e helenístico (Romano; Voyatzis, 2015: 262). Dentre esses períodos, o século IV a.C. é considerado a única e maior fase de construção nessa área do santuário, como indicam a datação da maior parte das construções e das cerâmicas e moedas encontradas nos assentos e no corredor e a da cerâmica recuperada no terraço a oeste do hipódromo (Romano; Voyatzis, 2015: 262- 263). Segundo a tese de Romano 
e Voyatzis, essa fase de revitalização e reorganização do santuário pode estar associada à fundação da pólis de Megalópolis em 369 a.C., a qual teria adquirido o santuário de Zeus Lykaios como parte de seu sinecismo (Romano; Voyatzis, 2015: 262- 263). O período entre 368-362 a.C., é considerado pelos dois autores, como 0 mais provável para a maior fase de monumentalização do santuário de Zeus Lykaios (Romano; Voyatzis, 2015: 263). É provável, assim, que Megalópolis tenha controlado os jogos lykaios no santuário na montanha desde a época da fundação da cidade até ao menos o final do século IV a.C. quando ainda eram realizados no local, como atesta a inscrição encontrada no edifício administrativo sobre uma lista de atletas vencedores. A partir do século III a.C., contudo, os jogos lykaios, assim como o próprio culto de Zeus, podem ter sido deslocados para Megalópolis, como indica uma inscrição (IG II2 993) datada dessa época (Romano; Voyatzis, 2015: 263). De fato, Pausânias (VIII, 30.2) menciona um santuário de Zeus Lykaios na ágora de Megalópolis, mas a data da área sagrada permanece incerta (Romano; Voyatzis, 2015: 258, nota 96). A data dessa inscrição (215 a.C.) pode refletir o início do festival renovado ocorrido na cidade. Mesmo que os jogos e o culto tenham passado a ocorrer na cidade, houve uma continuidade do uso do santuário na montanha para a atividade de refeições rituais ao menos no santuário de baixo, como evidencia a abundância de cerâmica datadas entre os séculos III-I a.C. encontradas na área (Romano; Voyatzis, 2015: 263).

Este é o resumo do estado atual das pesquisas sobre a arqueologia do santuário a partir dos novos dados obtidos nas últimas escavações na área. Assim, é possível tecer algumas considerações com relação à esfera de atuação de Zeus Lykaios e o tipo de culto à divindade realizado na área sagrada na montanha arcádia com base em informações históricas, na configuração espacial do santuário e nos tipos de objetos votivos dedicados.

De acordo com a bibliografia a respeito de Zeus Lykaios e de seu santuário, a divindade teve uma "esfera de atuação muito variada e ampla", funções que foi adquirindo ao longo do desenvolvimento de seu culto (Langdon, 1976: 82). Além dos resultados mostrados nas pesquisas arqueológicas mais recentes, a antiguidade do culto de Zeus no Mt. Lykaion também foi demonstrada, por G. Mylonas e O. Zolotnikova, a partir de elementos da topografia, arquitetura e iconografia do culto e pelos significados etimológicos do epíteto da divindade em associação à certas características do culto descritas pelas fontes literárias. A etimologia do

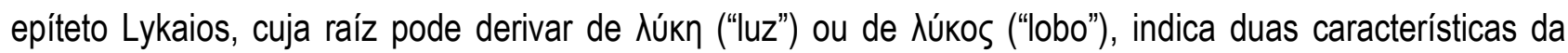
divindade - as celestes e atmosféricas que se contrapõem a do deus lobo (Jost, 1985: 268; Lo Monaco, 2009 : 413). Os aspectos celestes e atmosféricos de Zeus Lykaios são evidenciados pelos objetos votivos e pela configuração espacial de seu culto no santuário de cima no Mt. Lykaion - pela escolha topográfica do pico mais alto para o estabelecimento de seu altar, cujo culto, muito provavelmente ocorria a céu aberto, mesmo que tenha havido um pequeno edifício na área. Ainda que não seja uma regra42, a localização dos santuários de Zeus em cumes de montanhas relaciona-se a tais aspectos (Jost, 1985: 254). Algumas categorias de objetos

\footnotetext{
42 Zolotnikova, 2013b, p.122.
} 
votivos também demonstram a característica de Zeus Lykaios como um deus propiciador de chuva, como indicam as inúmeras estatuetas em bronze de Zeus em pé segurando o raio, datadas a partir do século VII a.C. - consideradas como "testemunhos materiais do culto de Zeus como um deus da tempestade na religião grega" (Zolotnikova, 2005: 112). Dentre os votivos, a maior evidência dessa relação de Zeus Lykaios com fenômenos atmosféricos, particularmente da tempestade e de propiciador de chuva, é a fulgurita encontrada no altar de Zeus - "um mineral formado somente quando um raio atinge um solo arenoso"43. Já que o "altar de cinzas de Zeus Lykaios não contém areia, concluiu-se que a fulgurita ${ }^{44}$ foi levada até o local como uma dedicação à divindade" (Romano; Voyatzis, 2010: 15). Pausânias (VIII, 38.4) também fornece uma notícia a respeito dessa característica do culto de Zeus no Mt.Lykaion conservada, provavelmente ainda em seu tempo - durante a época de seca na região, o sacerdote de Zeus Lykaios, após a realização de sacrifícios, emergia um ramo de carvalho na fonte Hagno para propiciar a vinda de chuva à Arcádia.

Com relação ainda ao aspecto celeste, a partir de paralelos com a religião indo-européia, O. Zolotnikova defende que Zeus Lykaios foi "basicamente uma divindade do céu claro e do sol" (Zolotnikova, 2005: 112). A evidência mais importante sobre essa característica, apontada pela estudiosa, é o epíteto Lykaios, relacionado à "raíz l(e)ukh- que significa brilhar, o brilhar branco", e certos motivos solares que podem ser reconhecidos no culto descritos principalmente nas fontes textuais, sobretudo nos famosos trechos de Pausânias, que relatam a proibição de se entrar no témeno de Zeus Lykaios e a licantropia (Zolotnikova, 2005: 110). Conforme 0 periegeta (Pausânias VIII, 38.6), era proibido aos seres humanos entrar no témeno, podendo ocorrer a morte dentro de um ano a quem desrespeitasse a regra. De acordo com a explicação de Zolotnikova, a pessoa que entrava no témeno era dedicada à divindade com a designação de élafos ("veado"), que na religião indoeuropéia se relaciona à águia e aspectos solares (Zolotnikova, 2005: 110). O outro trecho, que suscitou muitos debates entre os historiadores da religião grega, se refere ao sacrifício humano a Zeus Lykaios e a transformação em um lobo daquele que realizava o sacrifício (Pausânias VIII, 2.3). Como não há evidências materiais sobre o sacrifício humano no Mt. Lykaion, e tampouco sobre a associação do culto ao lobo, como a princípio indica o epíteto, Zolotnikova propõe que "a licantropia foi um aspecto dos sacerdotes da divindade no santuário, comum à uma categoria primitiva de sacerdotes-mágicos indo-europeus que agiam como lobisomens no culto de uma divindade solar" (Zolotnikova, 2005: 114). A seu ver, "as formas do sacerdócio de Zeus Lykaios remontam às tradições religiosas gregas mais antigas ou pré-gregas no território da Arcádia (Zolotnikova, 2005: 114-115). Ao explicar a licantropia e a interdição do témeno em relação aos aspectos solares do culto na montanha arcádia, Zolotnikova resolve a controvérsia sobre o elemento "lobo" no culto de Zeus Lykaios, não atestado materialmente, em nenhum aspecto no culto local.

\footnotetext{
43 Romano; Voyatzis, 2010, p.15.

44 Trata-se de uma oferenda não relatada em outros santuários de Zeus no mundo grego, podendo, assim, ser específica do culto no Mt.Lykaion.
} 
Ainda sobre o debate acerca do aspecto solar e da antiguidade do culto de Zeus Lykaios, outro ponto importante em nossa investigação, refere-se à águia, especialmente associada ao deus no Mt.Lykaion. Em seu estudo sobre 0 altar de Zeus Lykaios, G. Mylonas defende que a águia, como epifania do deus, remontou à época pré-histórica do culto no monte, tendo sido essa uma associação que, em termos cultuais em relação a Zeus, teria ocorrido primeiro no local (apud Jost, 1985: 254). O estudioso tem como base dois tipos de evidências: o testemunho de Pausânias (VIII, 38.7) acerca de duas colunas, cada qual com duas águias douradas no topo, que flanqueavam o altar de Zeus Lykaios na direção leste, e a estatueta de Zeus Keraunios, segurando o raio com a mão direita e uma águia com a esquerda, datada do século VII a.C. ${ }^{45}$ por Kourouniotis (a estatueta votiva em bronze de Zeus mais antiga do santuário e provavelmente do mundo grego). Baseandose na informação de Pausânias, sobre a descrição do altar e das colunas, e em paralelos minoicos-micênicos, Mylonas postula que durante o período pré-histórico, duas águias já teriam sido exibidas no altar - as aves e os outros elementos do altar teriam sido mantidos pelos novos grupos que se estabeleceram na região, pelos arianos que cultuavam Zeus. Nesse sentido, para o estudioso, o altar teria sido um lugar de culto pré-histórico, que foi retomado para o culto de Zeus quando as tribos gregas do período histórico completaram sua posse da terra. Em tempos pré-históricos, as aves indicavam a epifania da divindade. Provavelmente, no início dos tempos históricos, as aves continuaram a indicar a epifania de Zeus, mas, gradualmente, foram concebidas como companheiras e atributos da divindade (Mylonas, 1946: 206). Para Mylonas, a prova contundente desse processo, concluído em períodos históricos, é a estatueta votiva de Zeus Keraunios encontrada no Mt.Lykaion, cuja datação no século VII a.C. indica ser esta a mais antiga representação da divindade portando a águia. Em resumo, o estudioso defende que a associação da águia a Zeus, até então descrita de várias maneiras nos textos homéricos, ganhou expressão material no culto de Zeus no santuário do Mt. Lykaion na Arcádia e de lá teria se difundido, no século $V$ a.C., ao santuário mais próximo, o de Olímpia, e depois ao restante do mundo grego (Mylonas, 1946: 206).

A nosso ver, é difícil afirmar se já havia águias ornando o altar em tempos pré-históricos, já que evidências da associação da águia a Zeus são certas apenas em representações datadas a partir do início da época arcaica, a única escultura de águia encontrada no santuário se refere ao século $V$ a.C., não havendo, portanto, evidências sobre a associação da águia no culto de Zeus já na Idade do Bronze, nem na epigrafia, nem nas artes visuais. 0 que é provável, a nosso ver, é uma especial associação local, do pico sul do Mt. Lykaion, às águias, conforme uma experiência de observação que tivemos durante nossa visita à área arqueológica do Mt. Lykaion em 25 de junho de 2014, na companhia do diretor das escavações americanas, D.G. Romano. Quando havíamos descido do ponto mais alto, onde se situa o altar, e estávamos a oeste no témeno, avistamos duas águias voando, pairadas no ar, exatamente sobre 0 pico onde está 0 altar,

\footnotetext{
${ }^{45}$ A maioria dos especialistas considera a datação dessa estatueta no século VII a.C. No entanto, no LIMC, esta é datada da primeira metade do século VI a.C. O Prof. D. G. Romano em uma entrevista concedida por e-mail, já citada aqui, prefere situar a datação da estatueta no final do século VII a.C. Para maiores detalhes sobre essa discussão, vide cap.3.
} 
aproveitando, provavelmente, uma corrente de ar que por ali passava. Acreditamos que, muito provavelmente, esse mesmo fenômeno já ocorria em tempos muito antigos, sobre o pico mais alto do Mt.Lykaion, e foi observado pelos homens antigos / a população local em tempos pré-históricos. Estas, baseadas na observação da natureza, de um sinal divino da presença de uma divindade celeste já relacionada à águia, estabeleceram ali, a ela, um altar que, ao longo do tempo, passou a pertencer a Zeus, o pai celeste, dos fenômenos atmosféricos e da luz solar, à medida que seus contornos, como tal, se consolidavam entre a Idade do Bronze e a Idade do Ferro. Nesse aspecto, Mylonas, que quase intuitivamente acertou sobre a antiguidade do culto de Zeus na montanha arcádia, intuitivamente também parece ter acertado a respeito da antiga associação local da águia a Zeus e de como, em tempos pré-históricos, a ave podia ser considerada uma epifania da divindade ao menos nessa área do Peloponeso. As origens e a consolidação da associação da águia como uma epifania, um atributo de Zeus na religião grega serão discutidas em profundidade no próximo capítulo. Também a presença da águia na arquitetura do culto no Mt. Lykaion e em Amnisos, em Creta, na época arcaica, e a provável relação entre as duas regiões serão analisadas mais adiante, na parte final desse capítulo, quando correlacionaremos as conclusões a respeito das áreas sagradas e o culto de Zeus entre as quatro regiões.

Esses são considerados, tradicionalmente, os principais aspectos do culto arcádio de Zeus Lykaios. Na análise e interpretação, que iremos empreender na sequência, sobre as funções assumidas pelo santuário nos cinco períodos de sua existência, se verá outras características importantes da divindade com respeito à guerra, aos jogos e à identidade regional. Assim, durante o período mais antigo do culto, a ldade do Bronze, os restos dos vasos cerâmicos (taças e potes para cozinhar do heládico médio e tipos de jarros, outras taças, askoi do héladico tardio) - associados a ossos queimados de animais (principalmente cabras e ovelhas), sugerem a prática de refeições rituais na área do altar, envolvendo sacrifícios de animais (com queima). Segundo Romano e Voyatzis, "restos de ossos de animais e uma variedade de vasos para beber foram encontrados em todos os níveis da escavação do altar, o que sugere a continuidade da prática durante os séculos" (Romano; Voyatzis, 2014: 615). A única exceção, conforme os autores, parece ser indicada por uma parte do estrato micênico com cerâmica não perturbada, onde há pouca incidência de queima e uma variação de ossos de animais (de porcos) em comparação aos demais níveis mais baixos da trincheira do altar (Romano; Voyatzis, 2014: 615). Neste caso, tal característica pode indicar "certa heterogeneidade no ritual no altar durante a época micênica" (Romano; Voyatzis, 2014: 615). Já a dedicação de figurinhas em terracota (humanas e animais), datadas do heládico tardio - a categoria de oferenda mais comum e típica da Idade do Bronze no altar de Zeus Lykaios indica, a nosso ver, que o santuário serviu ao culto pastoril e agrário às populações locais, evidenciando uma função sub-regional ${ }^{46}$ do santuário no Mt.Lykaion nessa época. Trata-se de um caso muito semelhante ao que ocorreu em Olímpia durante a Idade do Ferro, segundo a interpretação de J. Taita a respeito dos mesmos tipos

\footnotetext{
460 estudo dos fragmentos cerâmicos da Idade do Bronze mostrou a predominância de material local e a existência de cerâmica proveniente da Argólida (Romano; Voyatzis, 2014: 615). Acreditamos que a proveniência de material de outra região do Peloponeso não seja informação suficiente para atestar uma função inter-regional do santuário já nessa época. A presença de cerâmica da Argólida pode indicar algum tipo de rede entre as regiões na circulação desse material na região da Arcádia.
} 
de votivos: "a divindade venerada teve uma conotação eminentemente atmosférica e foi procurada para garantir a fertilidade da terra e a fecundidade dos rebanhos" (Taita, 2007: 95). Como vimos no caso dos santuários cretenses dos Mts.Ida e Dicta, esses tipos de figurinhas em terracota (principalmente as de animais) são consideradas evidências desse tipo de culto, ligado à população silvo-pastoril. A nosso ver, portanto, a interpretação de Taita para Olímpia, na Idade do Ferro, explica perfeitamente o culto no Mt.Lykaion na Idade do Bronze, onde o aspecto atmosférico era o principal, o mais antigo de Zeus no local.

Apesar dessa vinculação mais destacada para o culto pastoril e agrário, não se pode desprezar a dedicação de determinados objetos de valor no altar, como o selo de cristal com o desenho gravado de um touro, datado de heládico tardio, e as prováveis primeiras dedicações em metal, os machados duplos de ferro, associados também ao heládico tardio. Esses tipos de objetos podem indicar o início da participação de uma elite local no santuário, que se tornou mais evidente no período seguinte. Além disso, embora seja bem atestado o culto a Zeus no local, é importante explicar que touros e machados duplos, entre objetos votivos, são típicos do culto de divindades masculinas em santuários datados entre a Idade do Bronze e a Idade do Ferro em contexto cretense (Prent, 2005: 208).

$\mathrm{Na}$ Idade do Ferro, apesar da continuidade no ritual de refeições no altar (envolvendo a bebida de vinho e sacrifícios de animais com queima), houve uma mudança significativa na prática da dedicação de votivos. Figurinhas em terracota foram substituídas pelos trípodes em bronze (todos miniaturas), que passaram a ser os principais objetos votivos dedicados no altar (ofertados entre os séculos X e VII a.C.), ao lado, embora em menor grau, de outros objetos em metal (ferro), como talvez machados duplos datados a princípio do século $X$ a.C. ${ }^{47}$ Os trípodes são tipos de dedicações que também testemunham rituais comuns de comensalidade "perpetuavam, como oferta, a recordação do banquete sacrificial" (Prent, 2005: 382; Taita, 2007: 85). Nos poemas homéricos, trípodes e caldeirões, em bronze, "figuram como objetos de alto valor e prestígio, são mencionados como presentes caros e como prêmios nos jogos, como no funeral de Pátroclo" (Prent, 2005: 381). Durante os períodos geométrico e o início do arcaico, trípodes em tamanho grande, objetos de considerável valor material, serviram como objetos votivos de prestígio em santuários, onde são associados a uma aristocracia masculina (Pilz, 2011: 21). A questão, é que em algumas áreas sagradas, se observa a dedicação de trípodes em miniatura, como no caso do Mt.Lykaion, onde foram encontrados 33 trípodes nessa escala menor. Nesse santuário também foram dedicados vasos votivos em miniaturas. A nosso ver, a intenção em miniaturizar, nesse caso, é o ato de destituir o objeto de seu uso funcional, mas ao mesmo tempo de conservar o seu significado original com determinada intenção. Segundo O. Pilz, "como símbolos icônicos de suas contrapartes em tamanho grande, os trípodes em miniatura assumiram um importante papel como instrumentos de comunicação: não podendo ser usados como potes para cozinhar e nem como prêmios em competições, estes expressaram e acentuaram o significado conotativo dos trípodes em maior escala" (Pilz,

\footnotetext{
47 Os fragmentos de machados duplos, embora datados do século X a.C., estão mais associados ao material do heládico tardio (Romano; Voyatzis, 2014: 620).
} 
2011: 22). Assim, para esse autor, "em um nível mais abstrato da comunicação social, a dedicação de um trípode em miniatura funcionou para promover e reforçar um modelo de uma função social de um membro masculino da aristocracia" (Pilz, 2011: 22). Apesar de assinalar esse tipo de objeto em miniatura a homens da aristocracia, Pilz considera que o ofertante não precisava ser necessariamente um homem aristocrata, mas também acha precipitado associá-los a uma camada social mais inferior, somente porque eram versões menores (Pilz, 2011: 22).

Nesse sentido, é possível considerar, a partir da Idade do Ferro, a participação das elites das comunidades arcádias emergentes, no culto a Zeus Lykaios, de uma forma mais consistente do que a observada no período anterior. É possível inferir também, uma função sub-regional do santuário de Zeus no Mt.Lykaion ainda nessa época, como base na dedicação dos trípodes em bronze, os votivos em metal entre os mais importantes em santuários dessa natureza, no período, por exemplo, na ilha de Creta, ou mesmo em Olímpia, que, como veremos, conservou função sub-regional durante a Idade do Ferro.

Durante a época arcaica, assume-se, como já mencionado, uma reorganização do santuário, tanto na área superior como na inferior, a partir do século VII a.C., o que indica, segundo Romano, "algum aumento do sentido de comunidade"48. 0 ritual, durante a época arcaica, parece ter sido o mesmo no altar, envolvendo refeições rituais, mas a presença de outros tipos de objetos votivos indica uma nova mudança na prática de dedicação, especialmente no século VI a.C. No século VII a.C., miniaturas de trípodes em bronze ainda eram ofertadas no altar, mas ao lado de outros objetos, datados dessa época, como aqueles feitos em chumbo (coroas e um kouros) e uma flauta feita em osso. Esses últimos objetos, em particular, podem sinalizar algum tipo de ritual de iniciação ligado à fertilidade ${ }^{49}$. Também foram recuperados no altar, dois espetos de ferro (de data indeterminada) e uma faca, também de ferro, datada genericamente na época arcaica. Apesar de não ter sido possível data-los, é provável que os dois espetos de ferro pertençam ao século VII a.C., quando esse tipo de objeto (um espeto para assar carnes) passou a ser usado como um meio de troca e ser dedicado em santuários, como ocorreu no Heraion de Argos nesse período (Evgenidou et alii, 2007: 13).

A ausência de objetos votivos de períodos anteriores à época arcaica, no témeno e no santuário de baixo, pode indicar que durante a Idade do Bronze e a Idade do Ferro, o altar foi a única área de culto do santuário de Zeus no Mt. Lykaion nessas duas épocas. O objeto votivo mais antigo encontrado até o momento no témeno, a estatueta de Zeus Keraunios, datada entre os séculos VII-VI a.C., indica o início da prática de dedicar votivos nessa época na área, mais precisamente na parte de fora da área sagrada, como os demais objetos dos períodos posteriores.

Durante o século VI a.C. ocorreu uma nova mudança na prática da dedicação de objetos votivos, provavelmente iniciada ainda em algum momento no século VII a.C. Estatuetas em bronze de Zeus (em pé ou

\footnotetext{
48 Entrevista concedida por e-mail em dezembro de 2015, já mencionada anteriormente. Esse "aumento do sentido de comunidade", também se observa, em certo grau, na Idade do Bronze e na Idade do Ferro, segundo o Prof. Romano.

${ }^{49}$ Coroas de chumbo, por exemplo, foram encontradas em centenas no santuário de Ártemis Orthia em Esparta e estão relacionadas a um culto ligado à fertilidade (Romano; Voyatzis, 2014: 620; Waugh, 2009: 162).
} 
sentado no trono, portando o raio e às vezes a águia) passaram ser um tipo de oferenda recorrente no santuário de Zeus Lykaios até o século $V$ a.C. Trata-se de um tipo de dedicação mais recorrente na área do témeno, embora partes de estatuetas tenham sido encontradas no altar. Moedas também parecem ter sido usadas como oferendas no témeno a partir do século VI a.C., como indica o achado de um exemplar de Egina datado dessa época, caso o objeto não ter sido ofertada posteriormente em outro período. Como veremos, moedas foram usadas como votivos predominantemente na época clássica. Se a moeda de Egina foi dedicada em época arcaica, assim como os dois espetos de bronze encontrados no altar, pode ter se tratado de uma tendência, iniciada no período, na dedicação de objetos de troca no santuário de Zeus Lykaios, que se se afirmou no século V a.C.

A reorganização do santuário a partir do século VII a.C. pode ter levado à instituição de jogos em honra a Zeus Lykaios, ainda que não se tenha uma data para o início da prática no Mt.Lykaion. Como em Olímpia, "os jogos podem ter sido introduzidos como parte do cerimonial em honra a Zeus"50 - a reorganização do culto em época arcaica pode ter pedido a celebração de um ritual que incluísse competições atléticas em algum nível, como indicaria o antigo estádio e as evidências mais antigas no santuário de baixo, que indicariam uma expansão da área sagrada talvez para abrigar algum tipo de festividade a esse respeito já em época arcaica. É preciso lembrar que a introdução de competições atléticas em santuários de Zeus no Peloponeso remonta à época arcaica, sendo por isso muito provável que os jogos lykaios tenham se iniciado nesse período. Nesse sentido, é provável que o culto de Zeus Lykaios tenha assumido um novo papel em época arcaica, portanto, na esfera agonística.

Assim, para a época arcaica, assume-se, também, uma função sub-regional para o santuário de Zeus no Mt.Lykaion entre as comunidades arcádias. De acordo C. Morgan, um sentido de identidade arcádia já existia no final do século VI a.C. e nesse aspecto acreditamos que o culto de Zeus Lykaios, já na época, teve um papel importante na articulação da identidade local regional. Políbio (4.33.2-9) e Pausânias (IV, 22.7) narram um evento ocorrido no início da época arcaica que pode ser um testemunho importante a respeito da influência da divindade sobre os arcádios. $O$ trecho, em ambos os escritores antigos, se refere a um pilar de pedra, com uma inscrição, erigido na área sagrada de Zeus Lykaios pelos arcádios (segundo Pausânias) ou pelos messênios (conforme Políbio) após a morte do rei arcádio Aristocrates devido à sua traição ao rei messênio Aristomenes, no assalto secreto, arcádio e messênio, a Esparta. No pilar, segundo Políbio, descrevia-se o ato da morte ao rei arcádio por traição, talvez como um ato de purificação, e pedia-se a proteção de Zeus sobre toda a Arcádia. Nesse sentido, o testemunho mostra a função de Zeus Lykaios em estabelecer a ordem entre os arcádios em um momento de instabilidade entre eles (pela traição e morte de seu rei), justamente quando encontravam-se unidos contra os espartanos. Veremos como Esparta teve um papel importante na definição étnica e política entre os arcádios. Já se o testemunho de Políbio representar a versão correta, em relação ao estabelecimento

50 Taita, 2007, p.106. 
da estela pelos messênios, então é possível afirmar uma função inter-regional no Peloponeso para o santuário no Mt. Lykaion já em época arcaica. Acreditamos, assim, que o Mt. Lykaion, em época arcaica, teria exercido uma função mais abrangente em termos regionais, muito maior do que aquela apontada por $\mathrm{M}$. Jost, circunscrita apenas à Parrhasia51, sub-região arcádia onde se situa a montanha.

Em época clássica se consolida uma série de mudanças iniciadas no santuário em época arcaica, ao mesmo tempo em que novas mudanças passaram a ocorrer no culto e na configuração do santuário a partir do período. O mesmo tipo de ritual (envolvendo consumo de bebida e sacrifícios de animais) é atestado durante a época clássica no altar, mas algum tipo de ritual noturno deve ter sido acrescentado ao culto na área no período, conforme indica o número de fragmentos de lamparinas encontrados, associados ainda a fragmentos de objetos em vidro (pela primeira vez dedicados no altar), como contas e vasos. O que chama a atenção entre os objetos votivos encontrados no altar, datados da época clássica, é a grande quantidade de moedas (maior parte em prata) dedicadas no local a Zeus Lykaios, sendo a maior parte pertencente à Liga Arcádia. Como veremos em detalhe no próximo capítulo, trata-se, na maior parte, de moedas do século $\mathrm{V}$ a.C. com a imagem de Zeus Lykaios sentado no trono, no anverso, e com a representação da cabeça da ninfa Calisto, no reverso, acompanhada pela inscrição "dos arcádios". A análise interpretativa sobre a dedicação das moedas no altar desse santuário será melhor abordada no capítulo 4, no entanto, podemos adiantar que as moedas em prata foram os objetos em metal valiosos ${ }^{52}$ que substituíram, em época clássica, aqueles que vinham sendo dedicados no altar, cuja prática caiu em desuso, como, por exemplo, as miniaturas de trípodes de bronze.

$\mathrm{Na}$ área do témeno, percebe-se certa continuidade no tipo de dedicações de estatuetas de Zeus Keraunios em bronze e a prática de dedicar moedas, mas novos tipos passaram a ser usados como oferendas no século V a.C., como uma miniatura de águia e outra de bronze, duas estatuetas do deus Hermes, em bronze, e uma perneira, também em bronze, com uma inscrição votiva. Dentre esses objetos a dedicação de águias, como representação principal, pela primeira vez, indicam a consolidação da ave na iconografia do culto de Zeus no Mt. Lykaion, sendo ser possível, por isso, datar dessa época as duas águias douradas, da descrição de Pausânias, que ornavam duas colunas a leste do altar. As estatuetas de Hermes, a nosso ver, podem indicar que ainda em época clássica, o santuário conservou sua função pastoril, "pois esse deus era considerado, entre os arcádios, a divindade dos pastores"53. Já a perneira é a primeira e única dedicação de um despojo de guerra e o primeiro e único objeto votivo com inscrição dedicatória encontrada no santuário de Zeus Lykaios ${ }^{54}$. Sua dedicação pode ser considerada reminiscência, em certo grau, de um antigo costume nesse aspecto, como a

\footnotetext{
51 Jost, 1985, p.183.

52 É preciso destacar que muitos objetos de joalheria (principalmente anéis de bronze e ferro, alguns gravados outros não) foram encontrados principalmente no altar de Zeus Lykaios. Estes não foram considerados na interpretação do culto por período, pois os relatórios de escavação não informam suas datações. De todo modo, anéis em ferro se enquadram na categoria de jóias, e não na categoria de objetos de troca como os espetos ou moedas, então, provavelmente "serviram para marcar algum tipo de evento pessoal ao serem dedicados à divindade em seu altar" (Prent, 2005: 399).

53 Jost, 1985, p.440 e 447; segundo Romano e Voyatzis, a dedicação de estatuetas de Hermes entre a área de fora e a de dentro do témeno também pode indicar a função de Hermes em guardar as fronteiras (Romano; Voyatzis, 2014: 626).

${ }^{54}$ Romano não descarta achados de outros objetos desse tipo, no santuário, em futuras pesquisas na área.
} 
dedicação de facas ${ }^{55}$ ao deus em época arcaica. A nosso ver, a dedicação da perneira indica 0 aspecto guerreiro de Zeus Lykaios, não mencionado dentre as esferas de atuação, tradicionalmente atribuídas à divindade, como a atmosférica e celeste, por exemplo. Acreditamos que a partir da época arcaica tal característica do deus no culto do Mt. Lykaion se sobressaiu, como indicam as estatuetas de Zeus Keraunios, um tipo de votivo que costuma ser atribuído ao aspecto atmosférico do culto do deus na montanha arcádia. No capítulo seguinte, a partir de uma análise contextual desse tipo de representação, baseada nas fontes literárias e iconográficas (esculturas, cenas em vasos), mostraremos como o tipo de Zeus em pé, segurando o raio, é especialmente relacionado nos textos, à luta e à guerra. $\mathrm{O}$ trecho de Políbio e Pausânias, já mencionado, também mostram como, no contexto, da guerra contra os espartanos, os arcádios ou messênios buscaram a interferência de Zeus Lykaios. 0 aspecto agonístico de Zeus Lykaios, que remonta ao culto provavelmente a partir da época arcaica, também se relaciona ao aspecto guerreiro de Zeus ${ }^{56}$. Muito provavelmente, a emergência desses dois aspectos no culto de Zeus Lykaios, em época arcaica e clássica, foi um fenômeno inter-relacionado. Embora tenha se consolidado como uma característica de Zeus Lykaios, sua esfera de atuação em regular os fenômenos atmosféricos não terminou nos períodos anteriores, como indica 0 testemunho de Pausânias sobre o ritual do sacerdote do deus na fonte Hagno em relação à chuva.

Com relação à função do culto em termos regionais em época clássica, é possível afirmar que a partir do século $V$ a.C. o santuário de Zeus no Mt. Lykaion conservou sua função sub-regional, em relação às comunidades arcádias, mas adquiriu um papel inter-regional. Tal função costuma ser atribuída, na bibliografia, apenas ao século IV a.C. com base na lista dos vencedores nos lykaia, encontrada no edifício administrativo. No entanto, um testemunho de Tucídides (5.16.3) informa que, durante o final da guerra do Peloponeso, Plistoânax, o filho do rei espartano, se exilou em uma casa que ficava metade fora e metade dentro do santuário de Zeus no Mt. Lykaion. $O$ asilo do espartano indica que o santuário, já nessa época, era frequentado por indivíduos oriundos de outras áreas do Peloponeso. Em detrimento da localização do Mt.Lykaion próximo às fronteiras da Arcádia com a Messênia e Élis, e a situação especial da área sagrada, instalada sobre o cume da mais alta montanha arcádia, de onde se avista tais regiões a partir de uma visão em 360 graus ${ }^{57}$, acreditamos que o santuário, ao menos desde a época arcaica, havia sido frequentado por indivíduos dessas regiões e também da Lacônia, que procuravam, continuamente, estender seu domínio sobre a Arcádia e mantê-lo sobre a Messênia. Entretanto, provas materiais e literárias datam somente a partir da época clássica.

$\mathrm{O}$ que se pode afirmar para o século $\mathrm{V}$ a.C. é o papel do culto de Zeus Lykaios na articulação da identidade étnica arcádia, que nesse período teve "real saliência política" 58 , como indicam, principalmente, as

\footnotetext{
55 Facas representam a categoria de armas que, segundo M. Prent, "eram dedicadas como troféus, em comemoração a importantes feitos de membros de uma elite e seus ancestrais" (Prent, 2005: 386).

56 Sobre essa relação vide cap. 3 e 4.

57 Tal amplo panorama, visto a partir do altar de Zeus Lykaios, foi notado também por Pausânias (VIII, 38.7).

58 Morgan, 2003, p.39. Uma visão mais conservadora é fornecida por Nielsen (1999: 56-57). Para esse estudioso, "uma organização política arcádia verdadeira", unindo todos os arcádios, só é atestada no século IV a.C. A seu ver, as evidências numismáticas, que analisaremos no capítulo 3 e 4, não são suficientes para afirmar a existência de uma liga no século V a.C.
} 
moedas com as imagens de Zeus, cunhadas com a legenda no nome dos arcádios. Píndaro (Ol.13.105-110), nessa época, refere-se ao domínio de Zeus Lykaios sobre os arcádios. Tal papel na articulação da identidade regional arcádia, que se consolidou no século V a.C., teve origem na época arcaica.

Com relação ao século IV a.C., vimos como uma grande fase de monumentalização no santuário (provavelmente a primeira) ocorreu nessa época, principalmente no santuário de baixo. Vimos como essa nova configuração do santuário esteve relacionada com o sinecismo de Megalópolis ${ }^{59}$ e sua provável administração da área sagrada até o culto ser transferido para essa cidade. Como bem coloca N. Kreutz, "no século IV a.C. a divindade e os jogos lykaios adquiriram fortes conotações políticas na época da confederação arcádia - primeira organização política que uniu todos os arcádios ${ }^{60}$-, tanto é assim que sua importância diminuiu com o colapso da liga posteriormente" (Kreutz, 2007: 266).

\section{II.2 Olímpia}

O santuário de Zeus em Olímpia (cat.no.4) localiza-se na sub-região de Élis, no noroeste do Peloponeso, no vale dos rios Alfeu e Cladeus, na antiga área denominada Pisatis - cercada pela Trifilia e Messênia a sul, pela Acaia a norte e pela Arcádia a oeste (Fig.44). As primeiras escavações arqueológicas na área foram conduzidas em 1829 pela Expédition Scientifique de Morée, considerada a pioneira da exploração moderna de Olímpia e cujo trabalho se concentrou principalmente sobre as ruínas do templo de Zeus (Kyrieleis, 2001: 47-48; 2007: 102-103). O primeiro e decisivo período de escavações em Olímpia ocorreu entre os anos de 1875 e 1881. No decurso de seis temporadas de escavações empreendidas graças ao trabalho de Gustav Hirschfeld, Adolf Bötticher, Georg Treu, Wilhelm Dörpfeld e Adolf Furtwängler sob a direção geral de Ernst Curtius e Friedrich Adler, a maior parte das ruínas de Olímpia vieram à luz junto a uma imensa coleção de inscrições, esculturas e dedicações de todos os tipos. Nos primeiros dois anos (1875-1877) foram removidas as camadas de sedimentos sobre o templo de Zeus. Durante essas explorações sistemáticas ao redor do edifício revelaram-se as esculturas dos pedimentos e as métopas, as quais foram consideradas a descoberta mais importante das escavações de Olímpia (Kyrieleis, 2001: 50). Entre 1954 e 1958 a Oficina de Fídias foi descoberta sob a igreja bizantina a oeste do templo de Zeus (Kyrieleis, 2001: 53-54; 57; 2007: 106; 110). As campanhas entre 1937-1967 recuperaram inúmeros achados de objetos de bronze durante as escavações do estádio, na maior parte, despojos de guerra (escudos, elmos e perneiras). Nessa última década, além das escavações no setor sudeste do estádio, os projetos em Olímpia têm se ocupado da conservação dos monumentos e da sua reconstituição visual, através da restauração de sua arquitetura original, na paisagem do santuário (Kyrieleis, 2007: 116). Também resultados das antigas escavações têm sido revisados, assim

\footnotetext{
${ }^{59}$ Megalópolis é a única comunidade política arcádia sobre a qual sabemos ter tido um papel relacionado ao culto de Zeus Lykaios no santuário na montanha. Não há evidências literárias ou epigráficas que identifiquem outras comunidades arcádias participantes no culto.

${ }^{60}$ Nielsen, 1999, p.57.
} 
como aqueles das escavações dos anos de 1980 e 1990 têm sido publicados, como é o caso daquelas chefiadas por $\mathrm{H}$. Kyrieleis nessa época, que têm trazido novas perspectivas sobre o início do culto de Zeus no santuário.

O santuário de Olímpia, e o culto de Zeus Olímpio, foram extensivamente estudados em nossa dissertação de mestrado (Laky, 2013). Por essa razão, apresentaremos, aqui, um resumo sobre as principais questões acerca desse santuário, relevantes aos objetivos da presente investigação. Assim, descreveremos na sequência apenas os achados votivos e as construções mais diretamente relacionados ao culto da divindade ${ }^{61}$.

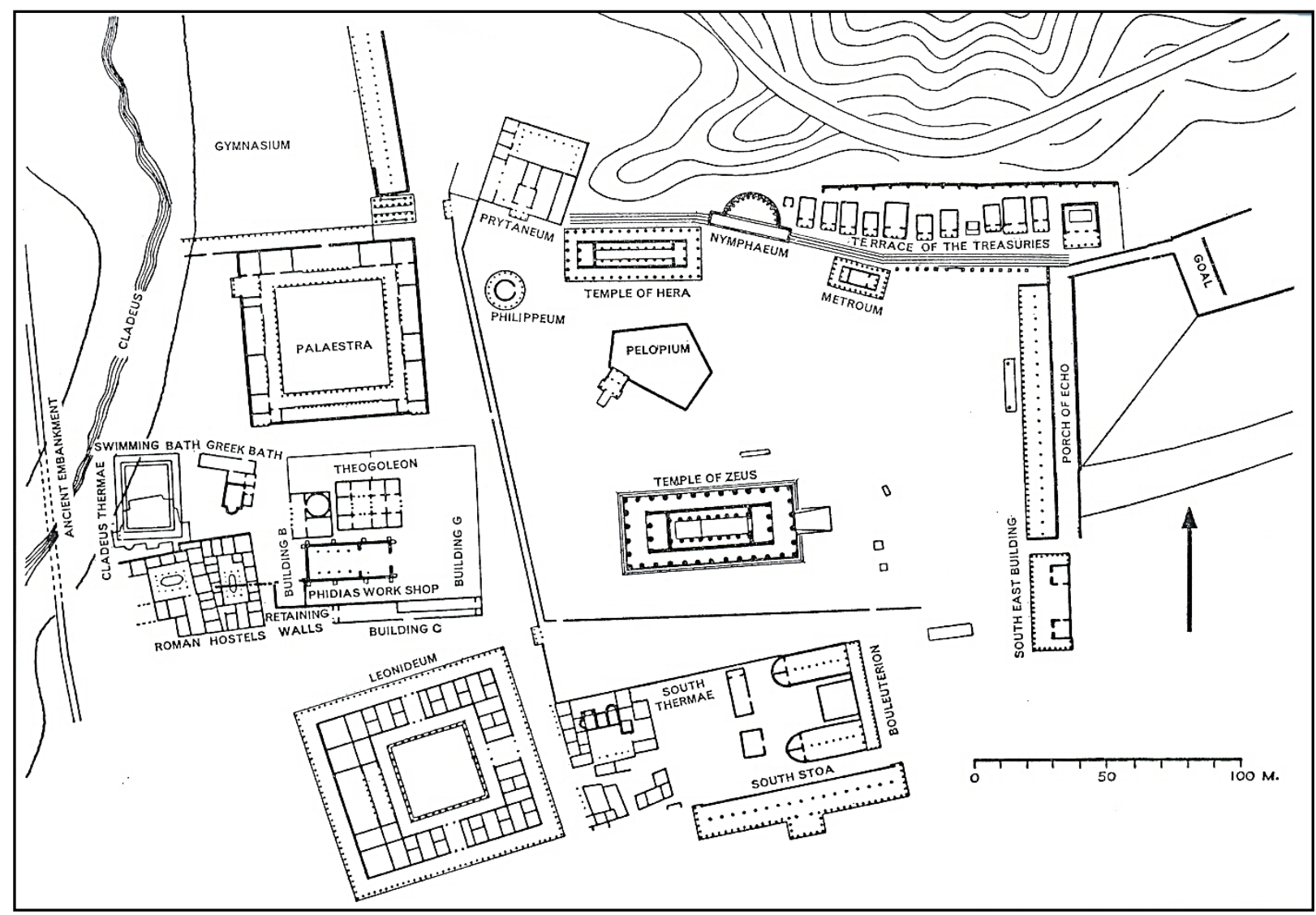

Fig. 44- Planimetria do santuário de Olímpia (Berve; Gruben, 1963: s/pág.)

61 Para uma descrição completa do sítio de Olímpia, vide Laky, 2013, pp.37-54, 191-220. 


\section{II.2.1 Descrição e interpretação dos achados}

O início da atividade cultual em Olímpia data a partir do início da Idade do Ferro, entre o heládico tardio IIIC (1200-1070 a.C.) e o sub-micênico (10701000 a.C.). $O$ término de suas funções ocorreu no período romano tardio (IV d.C.) com o Edito de Teodósio. As evidências sobre o período mais antigo do estabelecimento de Olímpia, como um santuário, foram encontradas em meio à grande camada de terra preta (formada por restos sacrificiais) que se estende entre o Heraion, o Pelópion e o Metroon

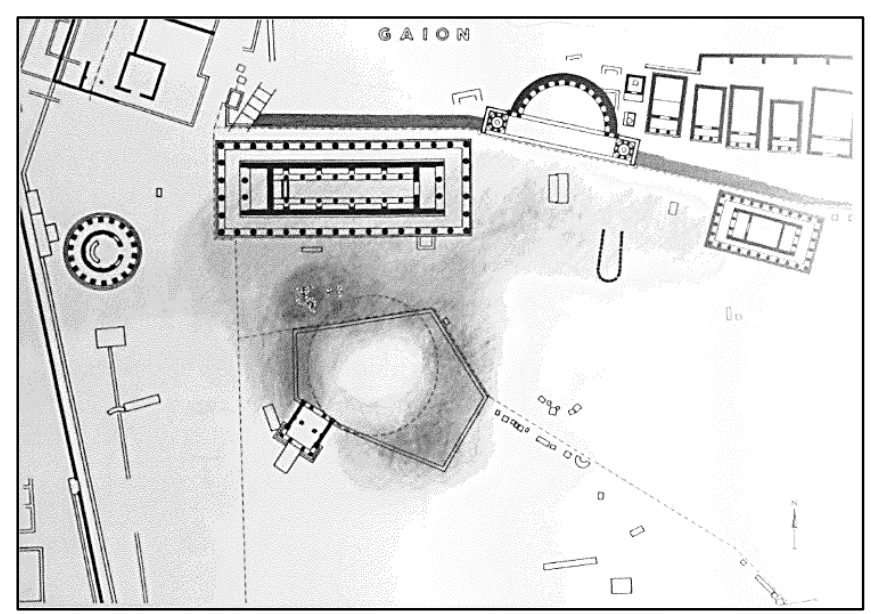

Fig.45- Planimetria da área da chamada "camada preta" no santuário de Zeus em Olímpia (Kyrieleis, 2006: Pr. 12)

(Fig.45). Nela foram encontradas taças do período sub-micênico, uma grande quantidade de vasos para 0 consumo de bebida, datados da metade do século XI a.C, um pequeno número de fíbulas do heládico tardio, alfinetes de época sub-micênica e figurinhas humanas e animais em bronze e terracota, sendo as mais antigas em terracota aquelas datadas entre os séculos X-IX a.C., e os objetos mais recentes, encontrados na camada, datados do século VII a.C. (Zolotnikova, 2013a: 90 e 93). Segundo a opinião dominante, trata-se de um aterramento dos resíduos de atos rituais realizados durante os trabalhos de desenvolvimento e aplainamento da área do Altis no período geométrico (900-750 a.C.) (Kyrieleis, 2001: 60). Alguns autores atribuem às cinzas, e os materiais encontrados na terra preta, ao grande altar de Zeus (Himmelmann, 2001: 155; Morgan, 1994: 33-34). Conforme Zolotnikova, tratar-se-ia, na realidade, dos traços do antigo altar de Zeus, que teria sido usado até c.600 a.C., quando foi substituído pelo grande altar, descrito por Pausânias (Zolotnikova, 2013a: 92). A área da grande camada preta é considerada, atualmente, a área original das atividades de culto em Olímpia (Zolotnikova, 2013a: 92).

Uma nova posição, contudo, a respeito da camada de terra preta, passou a vinculá-la a uma antiga construção (Duplouy, 2012: 106). De acordo com novas pesquisas na área, a terra preta pode estar relacionada, na realidade, a uma estrutura em pedra da Idade do Bronze (Edifício I) situada a noroeste do Pelópion - ao redor do qual foi encontrada a maior concentração de oferendas votivas de época geométrica (Duplouy, 2012 : 106-107). É provável que o Edifício I, uma estrutura absidal datada do heládico antigo III transformada em um edifício retangular no final da Idade do Bronze, possa ter sido utilizado como o altar mais antigo do santuário62 (Duplouy, 2012: 107). Essa é a posição mais recente acerca do primeiro altar de cinzas em Olímpia. A tese

\footnotetext{
62 Ao longo dos séculos, o Edifício I sofreu uma série de outras transformações, como o seu uso como área de enterramento no heládico médio I e, cerca de um milênio depois, quando a sepultura deve ter aflorado do solo, começaram ali a ocorrer sacrifícios e, por consequência, a acumular restos de oferendas e banquetes (Duplouy, 2012: 107).
} 
sobre a substituição desse antigo altar em c.600 a.C., por aquele visto por Pausânias, ainda é aceita, mesmo diante dessa nova hipótese.

Entre os objetos votivos mais numerosos encontrados no santuário, e datados da Idade do Ferro, estão as figurinhas de animais (touros, bois, cavalos, carneiros e cães) de terracota e bronze - a maior parte recuperada na camada de terra preta. Estas foram dedicadas em Olímpia entre o período proto-geométrico, o sub-geométrico e 0 início do período arcaico (Zolotnikova, 2013a: 96). Boa parte dessas figurinhas em bronze adornavam a parte superior dos trípodes e caldeirões. Estes tipos de objetos também correspondem a uma grande quantidade de votivos recuperadas no santuário, tendo sido dedicados desde o início ao final do período geométrico (Zolotnikova, 2013a: 94). Trípodes e cadeirões de bronze "foram encontrados, na maior parte, no setor leste do santuário, entre o estádio e o oktogon romano, para onde provavelmente foram removidos durante as contínuas mudanças arquitetônicas no Altis", como era chamado

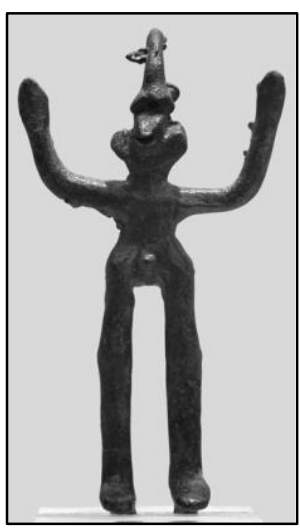

Fig.46- $\quad$ Figurinha masculina de bronze, geométrico tardio, Novo Museu de Olímpia (Barringer, 2010: fig.8.4b) o bosque de Olímpia na antiguidade (Zolotnikova, 2013a: 94-95). Além daquelas de animais, alguns tipos de

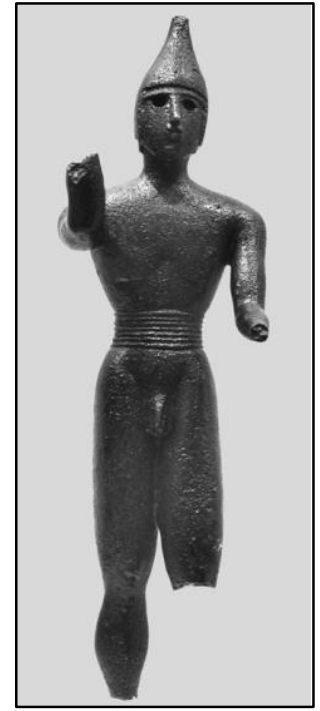

Fig.47- $\quad$ Figurinha masculina de bronze, c.680 a.C., Novo Museu de Olímpia (Barringer, 2010: 8.50) figurinhas humanas masculinas ornavam os trípodes e caldeirões. As mais antigas delas, do início do geométrico tardio, provenientes dos trípodes mais antigos, representam um homem nu, grosseiramente retratado, com os braços levantados, usando, o que parece ser, um elmo na cabeça. Estas figurinhas masculinas chegaram a ser identificadas como uma representação de Zeus "epifânico" (Fig.46) (Zolotnikova, 2013a: 95). Já as figurinhas mais recentes, datadas a partir do final do geométrico tardio, elaboradas com um maior rigor estilístico, retratam claramente um homem, também, nu, vestindo um elmo e um cinto e segurando, supostamente, uma lança ou espada (Fig.47) (Zolotnikova, 2013a: 94). Apesar de terem sido identificadas como representações de Zeus, aceita-se, atualmente, que se tratam de figurinhas de guerreiros. Nesse mesmo aspecto também se enquadram as figurinhas de cocheiros e seus carros, também adornos de trípodes, que de alguma forma "podem ser uma referência aos jogos mais antigos" (Zolotnikova, 2013a: 94).

Figurinhas de terracota feminina, datadas somente entre o geométrico e o sub-geométrico, foram encontradas em bem menor número no santuário, em relação aos tipos masculinos, o que implicou, como veremos, na supremacia de uma divindade masculina sobre um antigo culto de divindades femininas no local (Zolotnikova, 2013a: 94). Pequenos objetos em bronze (alfinetes, anéis, braceletes, miniaturas de machados duplos) datados entre o proto-geométrico e o geométrico foram recuperados em vários pontos do santuário (Zolotnikova, 2013a: 96). 
Uma das grandes questões sobre Olímpia e o culto de Zeus, durante a Idade do Ferro, está na identificação de algumas das figurinhas humanas (masculinas) de terracota, aquelas mais antigas encontradas na camada de terra preta. Embora haja poucos elementos que possibilitem uma classificação precisa, alguns especialistas as têm considerado como as imagens mais antigas de Zeus encontradas em Olímpia e as únicas evidências que asseguram a identificação de seu culto no santuário a partir

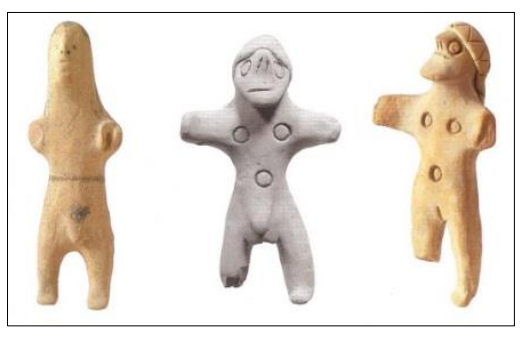

Fig.48- Terracotas de figurinhas protogeométricas masculinas (Heilmeyer et alii, 2012: p.115, fig.3) do século X a.C. (Fig.48) (Morgan, 1994: 26; Valavanis, 2004: 35). Já outros estudiosos, atualmente, preferem interpretá-las como imagens dos próprios ofertantes usando partes de armadura (Taita, 2007: 95, nota 42). De todo modo, essas figurinhas são associadas exclusivamente a Olímpia, pois tipos similares não foram encontrados em nenhuma outra parte da Grécia63.

Outra nova teoria referente à Olímpia durante a Idade do Ferro refere-se a uma construção que tem sido considerada o primeiro edifício de culto de Zeus no santuário. Até muito recentemente, assumia-se que durante esse período não existia nenhum tipo de construção relacionada ao culto do deus no Altis. Trata-se do denominado Edifício VII, situado entre o templo de Zeus e o Metroon (Duplouy, 2012: 108; Zolotnikova, 2013a: 92). À época de sua descoberta em 1880, o edifício foi considerado por Dorpfeld como uma construção préhistórica em $U$ (da metade do $2^{\circ}$. milênio a.C.), mas, mais recentemente, a pesquisa de J. Rambach reexaminou a estrutura absidal e mostrou que esta havia sido construída sobre uma mais antiga da Idade do Bronze e deve ser datada, na realidade, da Idade do Ferro (Duplouy, 2012: 108). Além disso, o Edifício VII é muito maior do que o proposto no século XIX - mede entre 7,5 e 8 m e pode ser considerada a maior construção do santuário naquele período (Duplouy, 2012: 108-109). A relação da construção com a concentração de oferendas da Idade do Ferro na área, e as suas grandes dimensões, levaram o estudioso alemão a propor que se tratou do primeiro templo de Zeus em Olímpia (Duplouy, 2012: 109). Propõem-se, assim, que se trataria, desde o início, de um culto a Zeus e não a um herói mítico local como Pélope (Duplouy, 2012: 107). Como bem coloca Zolotnikova, essa conclusão a respeito do Edifício VII "representa uma reviravolta sobre todas as teorias anteriores a respeito do início do culto em Olímpia e ainda não tem sido amplamente seguida e discutida por outros especialistas, por isso, deve ser ainda considerada como uma probabilidade (Zolotnikova, 2013a: 93).

Entre o final do século VIII e o início do século VII a.C., houve um forte declínio na dedicação de figurinhas em terracota e bronze, como indica o menor número encontrado desse tipo de objeto votivo, ao passo que trípodes e caldeirões em bronze com prótomos de leões e grifos, de proveniência oriental, se mantiveram como oferendas principais durante o século VII a.C. (Moustaka, 2002a: 201; Taita, 2007: 97 e 106-107). A partir do início do século VII a.C., ocorreu, também, um rearranjo arquitetônico e espacial no santuário: o recinto de Pélope foi erigido sobre as ruínas do assentamento da Idade do Bronze, um espaço especial para o estádio foi

\footnotetext{
63 Informação obtida no painel Figurines of Zeus Warrior type da sala 2 do Novo Museu de Olímpia. Sobre a discussão completa a respeito dessas figurinhas de terracota, vide Zolotnikova, 2013a, pp. 93-94.
} 
organizado a leste dessa estrutura e, no início do século VI a.C., ao redor de 600 a.C., o primeiro templo dórico períptero (tradicionalmente atribuído à Hera) foi construído em Olímpia (Zolotnikova, 2013a: 92). Foi nessa época, no início do século $\mathrm{VI}$ a.C., após a reestruturação completa do santuário, que o altar de Zeus foi deslocado a leste, provavelmente para o lugar no qual viu Pausânias (Duplouy, 2012: 107). Essa operação de mudança foi realizada contemporaneamente ao nivelamento do terreno e à dispersão dos restos de culto do estrato de terra preta (Duplouy, 2012: 107). De acordo com J. Taita, "a instalação da pista de corrida, no primeiro quartel do século VII a.C., que atesta o início dos jogos nessa época, e o deslocamento do altar, ao redor de 600 a.C., foram mudanças significativas realizadas para ampliar o espaço para a realização de sacrifícios no setor leste do santuário" (Taita, 2007: 107). Conforme a autora, "tratou-se de várias medidas que refletiram a exigência em reorganizar o espaço do santuário, demarcando os setores sagrados daquele agonístico e profano" (Taita, 2007: 107). Uma outra opinião, contudo, interpreta o estabelecimento do primeiro estádio dentro da área sagrada, em proximidade ao altar de Zeus, pois os jogos eram parte integrante das celebrações religiosas (Koutsoumba, 2004: 99). Repara-se, assim, que essa nova configuração do santuário em época arcaica concentrou-se, justamente, no setor onde o culto em Olímpia se iniciou na Idade do Ferro.

Foi a partir dessa época, entre os séculos VII-VI a.C. que o santuário atingiu uma complexidade maior em termos espaciais, em razão do aumento do número de lugares de culto, de dedicações e eventos atléticos frequentados pelo número crescente de visitantes provenientes, cada vez mais, de várias áreas do mundo grego (Scott, 2010: 147). Data-se de fins do século VII a.C. o início da atividade do Estado em Olímpia, como indica a construção do primeiro templo períptero, dos primeiros tesouros a partir do século $\mathrm{VI}$ a.C. - edifícios dedicados pelas cidades gregas para salvaguardar as oferendas mais preciosas dedicadas a Zeus -, localizados no sopé da colina de Cronos, e do buleutério (entre 550-500 a.C.), no setor sul do santuário (Morgan, 1994: 223). A atividade do Estado, refere-se tanto à formalização da participação das cidades em Olímpia, quanto pressupõe a existência de uma autoridade na organização e administração do santuário, como foi 0 caso de Élis. A participação exclusiva de Élis, no desenvolvimento das funções cultuais, sem algum tipo de envolvimento de outras comunidades da área do Alfeu e do distrito de Pisa, é confirmada por evidências arqueológicas ao redor de 570 a.C. (Taita, 2007: 141). A documentação disponível não permite precisar se se tratou de "um fato completamente novo com respeito aos períodos anteriores - se durante os séculos VIII e VII a.C., os eleios já estivessem de algum modo envolvidos no controle político do santuário de Olímpia" (Taita, 2007: 141). De todo modo, a época assinalada para o início da administração de Élis, corresponde às mudanças espaciais significativas no santuário.

Durante essa época, também, a dedicação e exposição de tropaia (despojos de guerra) parecem ter sido uma prática entre os espectadores e participantes dos jogos. Milhares e diferentes tipos de armamentos defensivos datados entre o início do século VII e o final do século V a.C. com inscrição dedicatória a Zeus 
Olímpio - escudos, elmos, perneiras, pontas de lanças, braçadeiras, espadas, adagas e couraças em fragmentos ou em objetos inteiros - foram e ainda são encontrados em Olímpia, principalmente no setor leste do santuário, na área do estádio (Fig.49) (Barringer, 2010: 167). De acordo com J. Barringer, "traços de buracos nos blocos do muro sul do estádio I sugerem que os tropaia eram ali expostos pendurados, em estacas de madeira - justamente no local da corrida de cavalos de maior audiência" (Barringer, 2010: 167). A prática "continuou a existir no estádio II e há evidências de que os despojos eram expostos em outras áreas do Altis" (Barringer, 2010: 167). De acordo com M. Scott, "a memorialização de conflitos militares através da dedicação de

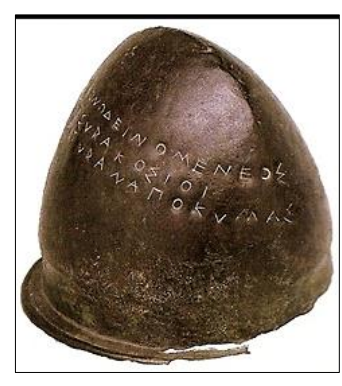

Fig.49- Elmo etrusco dedicado por Hieron em Olímpia. c.474 a.C., Novo Museu de Olímpia (Bruno, 2005: 15) despojos de guerra era uma característica regular do santuário desde ao menos o século VIII a.C." (Scott, 2010: 169).

Ao mesmo tempo em que a dedicação de tropaia havia se tornado uma prática mais popular em Olímpia, estátuas votivas de Zeus, em bronze, também aumentaram em popularidade. Dedicadas desde ao menos a época do tirano coríntio Cípselo, as estátuas do deus tinham uma durabilidade muito maior no tempo de exposição e ainda no início do século $V$ a.C. eram usadas especialmente para representar vitórias militares (Scott, 2010: 172). No final do século VI a.C., estatuetas de Zeus, em bronze, na posição em pé e lançando o raio, e às vezes segurando uma águia, também apareceram no final do século VI a.C. e tornaram-se um padrão de dedicação até meados do século V a.C. (Himmelmann, 2001: 158).

Como bem coloca J. Barringer, "entre o fim das guerras pérsicas e o início da construção do templo de Zeus em c.470 a.C., a topografia do Altis manteve-se a mesma de antes da guerra: os tesouros do século VI a.C., no terraço norte, aos pés da colina de Cronos, o altar de cinzas de Zeus, e o Heraion, até então, o único edifício monumental construído no santuário" (Barringer, 2009: 223). Em meados do século V a.C. o templo de Zeus, tradicionalmente considerado o primeiro edifício de culto à divindade, foi construído no setor central do santuário, "redefinindo toda a configuração espacial estabelecida desde a época arcaica" (Laky, 2013: 220). Datado de c.470-456 a.C., orientado leste-oeste, o templo de Zeus Olímpio era dórico, períptero e hexastilo regular com 6x13 colunas e suas dimensões, de 27,68 x 64,12 metros no estilóbato, fizeram dele um dos maiores templos dóricos construídos na Grécia balcânica (Berve; Gruben, 1963: 319; Grupico, 2008: 208; Hellmann, 1998: 113; Hirmer, 2001: 56; Tomlison, 1995: 34; Valavanis, 2004: 72; Veroia, 2009: 9; Younger; Rehak, 2009: 53). Os achados escultóricos mais importantes do edifício foram as métopas com a representação dos Doze Trabalhos de Héracles as quais ornavam os frisos do pronaos e do opistódomo, as esculturas do pedimento leste, que retratam um dos mitos associados ao santuário, a corrida de carros entre Pélope e Enomau e as do pedimento oeste, caracterizadas pela batalha entre Lápitas e Centauros (Dinsmoor, 1950: 152; Berve; Gruben, 1963: 323). O templo de Zeus foi minuciosamente descrito por Pausânias (V, I. X, 1-9; V, I.XXIV, 1-4) e Estrabão (8.3.30). 
Relacionada ao templo, a famosa estátua de ouro e marfim de Zeus Olímpio, obra de Fídias, foi instalada no edifício provavelmente menos de duas décadas depois do término do templo, ao redor de 430 a.C. (Berve; Gruben, 1963: 322; Dinsmoor, 1950: 153; Richter, 1966: 167; Valavanis, 2004: 94). Assim como 0 templo, a estátua foi descrita somente por Estrabão (8.3.30) e por Pausânias (V, I.X-1-4; I. XI. 2-5). Além dos remanescentes da oficina de Fídias, instalada a oeste do templo de Zeus para a confecção da estátua, os achados de moldes de terracota encontrados na oficina - usados para fazer os componentes ornamentais da roupa da estátua - são as únicas evidências materiais provenientes da própria estátua (Berve; Gruben, 1963: 323). A importância da estátua de Zeus Olímpio, acerca da iconografia da divindade em época clássica, será discutida, em mais detalhes, no próximo capítulo.

A construção do templo de Zeus significou a mais importante mudança na configuração do espaço do santuário desde o final do século VII a.C. Em nossa pesquisa de mestrado, quando contextualizamos espacialmente o edifício em relação às demais construções e oferendas em Olímpia, concluímos, "a partir do estudo de simetria de C.A. Doxiadis, que o edifício foi incorporado à paisagem natural local (à simetria da colina de Cronos) e à paisagem mais antiga arcaica (o Heraion, o Pelópion, etc.)" (Laky, 2013: 220). Além disso, "mais tarde, foram os novos edifícios que se arranjaram de acordo com a sua posição: o plano helenístico obedecera à conformação clássica da paisagem criada a partir do templo" (Laky, 2013: 220). Concluímos, também, que "0 edifício norteou a articulação da exposição de diversas oferendas" (Laky, 2013: 220). Nesse sentido, "todas estas referências simbólicas na paisagem do santuário confluíam para o grande templo, criando e reforçando, por assim dizer, um cenário único no qual Zeus Olímpio se impunha - em meio à diversidade de cultos - como o deus de Olímpia" (Laky, 2013: 220).

Outra importante mudança também de impacto em Olímpia, nessa época, foi a consolidação de uma cunhagem de moedas, batidas no nome da comunidade de Élis e usadas para circular no santuário. As denominadas moedas de Olímpia começaram a circular no local no século $V$ a.C. e portavam as imagens de Zeus e de seus atributos (a águia e o raio), de Nike e de Hera. Como veremos na análise interpretativa do capítulo 4, estas moedas, de uma certa forma, refletiram a iconografia do culto de Zeus consolidada em Olímpia em época clássica e a relação política e de identidade de Élis com o santuário.

A última mudança ocorrida durante o século V a.C. refere-se à dedicação de despojos de guerra. Após a metade do século $V$ a.C., houve o fim da dedicação de despojos de guerra (tropaia) na área do estádio prática ativa no local principalmente entre 500-450 a.C. (Scott, 2010: 191). A interrupção da dedicação de tropaia ocorreu repentinamente e os estudiosos têm buscado explicá-la pelo argumento de que o santuário de Olímpia teria imposto um conjunto novo de regras sobre dedicações no período. Nessa perspectiva, tropaia não teriam simplesmente acabado, mas teriam sido banidos. A razão para o banimento da prática tem sido creditada a uma mudança realizada para tornar o santuário mais pan-helênico através da ocultação de sinais da inimizade entre as póleis muito visíveis nas inscrições sobre os escudos, elmos, pontas de lanças expostas no estádio ou ao redor do santuário (Scott, 2010: 193). Tal mudança ocorreu na época em que antecede a Guerra do 
Peloponeso, quando as póleis gregas passaram novamente a se atacar após o período em que celebravam conjuntamente o fim da ameaça persa. Assim, é possível que o santuário tenha procurado mascarar o conflito interno nascente entre os gregos (Scott, 2010: 193). Enquanto a dedicação de tropaia passou pelo seu florescimento final e declínio na primeira metade do século $V$ a.C., contraditoriamente, houve o aumento da prática de dedicação de grupos de estátuas para comemorar também vitórias militares e conquistas políticas. A partir dessa época, a dedicação de estátuas de atletas continuou a aumentar se tornando uma prática comum até ao menos o fim da época grega (Scott, 2010: 193; 196-197). Tal prática foi reflexo de uma mudança nos ideais agonísticos, ocasionada pelo início do atletismo profissional, que predominou durante o século IV a.C. (Yalouris, 2004: 306).

\section{II.2.2 A natureza do culto e a função do santuário}

O culto a Zeus em Olímpia foi estabelecido sobre ruínas micênicas ${ }^{64}$ de forma semelhante como ocorreu em alguns santuários cretenses da divindade, instalados sobre antigos assentamentos minoicos abandonados. Por essa razão, alguns estudiosos chegaram a propor que o culto de Zeus teria se iniciado em época micênica ${ }^{65}$, mas se trata apenas de especulação ${ }^{66}$ - não existem evidências sobre atividade cultual em Olímpia em época micênica, tal como existem para o culto no altar no Mt. Lykaion, por exemplo.

O culto de Zeus em Olímpia é atestado pelas evidências materiais apenas a partir do século VI a.C., de quando datam as primeiras inscrições epigráficas que fazem referência à divindade como a principal do santuário (Zolotnikova, 2013a: 97). Como vimos, as figurinhas masculinas de terracota e de bronze, datadas da Idade do Ferro, não se caracterizam como representações do deus. Nesse sentido, assume-se, então, que, na fase mais antiga do santuário, houve a primazia de um culto dedicado à uma divindade masculina em um ambiente onde se cultuavam também divindades femininas, como indicam o baixo número de terracotas de figurinhas femininas datadas igualmente dos períodos proto-geométrico e geométrico (Zolotnikova, 2013a: 97). Como coloca A. Moustaka, essas estatuetas femininas são consideradas evidências de que que durante os tempos mais antigos de Olímpia havia o culto, no sopé da colina de Cronos, dedicado a Gê, Rhea e Eileithyia, deusas da fertilidade (Moustaka, 2002a: 204; 2002b: 302). Desde a época sub-micênica, aos séculos X-VIII a.C. e o início do período arcaico, a esse deus eram realizados sacrifícios de animais com queima, no altar de cinzas, rituais de refeições comuns, como indicam os trípodes e caldeirões, e de libações de vinho e consumo

\footnotetext{
64 "Achados micênicos identificados sobre e ao redor da colina de Cronos testemunham a existência de um assentamento da Idade do Bronze tardia na própria colina e no Altis" (Zolotnikova, 2011: 235). Para uma discussão completa a esse respeito, ver Zolotnikova, 2013a, pp.87-92.

65 Kyrieleis não exclui, totalmente, a possibilidade de que um culto micênico (modesto) de Zeus tenha existido no topo da colina de Cronos em Olímpia (apud De Polignac, 1995: 29).

66 Zolotnikova, 2013a, p.89-90.
} 
ritual de bebida, como evidenciam a maior parte dos achados cerâmicos datados desse período (taças, cântaros e crateras) (Zolotnikova, 2013a: 96 e 98). Aceita-se que tal divindade masculina cultuada durante a Idade do Ferro teria sido, desde o início, Zeus, como indicam as características militares, já presentes no culto nessa época, as quais se mantiveram como aquelas principais da divindade em Olímpia em época arcaica e em diante - ao menos desde a época geométrica, a predominância do culto de Zeus em Olímpia teria sido completa, se sobreposto, portanto, àquele das divindades femininas anteriormente cultuadas no local (Koutsoumba, 2004: 18; Moustaka, 2002a: 204).

Antes de introduzirmos a questão sobre o aspecto militar do culto de Zeus, é preciso dizer que o tema sobre o antigo culto de divindades femininas, ao lado da antiga divindade masculina, em Olímpia, permanece, ainda, sem solução. Zolotnikova, por exemplo, assume o culto às divindades femininas e o culto de Hera em Olímpia a partir de determinados achados. Um objeto específico, um grupo de bronze, representando uma figura masculina e outra feminina, pertencente a um objeto maior do século VIII a.C., tem sido interpretado pela estudiosa (em associação às figurinhas femininas de terracota) como evidência do elemento de hieros gamos (de Zeus e Hera) no culto no santuário nessa época (Zolotnikova, 2013a: 96). Outra evidência, a esse respeito, datada entre o geométrico e o arcaico, é um tipo de figurinha de bronze de uma cavaleira, ou seja, uma figura feminina sobre um cavalo, encontrada em Olímpia e também em santuários de divindades femininas nessa época (em Tegea, Lousoi e Perachora) (Zolotnikova, 2013a: 96). Já A. Moustaka oferece uma posição totalmente contrária, principalmente sobre o culto de Hera, na sua opinião, inexistente em Olímpia até o século V a.C. Segundo a estudiosa, não foi descoberta em Olímpia qualquer tipo de oferenda que seja semelhante àquelas encontradas em outros santuários de Hera: miniaturas de modelo de casas - um denominador comum aos principais santuários da deusa como em Argos, Perachora e Samos - não foram encontradas no Altis (Moustaka, 2002a: 200; 2002b: 302). Em todos os três santuários de Hera são registrados diferentes tipos de dedicações com inscrições referentes à deusa, "ao contrário de Olímpia onde não há evidências na epigrafia até a época clássica (os primeiros tipos monetários com a representação da deusa que portam seu nome como inscrição)" (Moustaka, 2002a: 200; 2002b: 302). Além disso, "a pletora de armas e elementos de panóplias de todo o tipo, que forma grande parte dos achados de Olímpia, é praticamente inexistente em santuários da deusa" (Moustaka, 2002a: 200). Moustaka está entre os pesquisadores que defendem a atribuição a Zeus do primeiro templo monumental do santuário, o Heraion67 (Moustaka, 2002a: 204).

Ainda que tenha existido um elemento feminino no culto mais antigo em Olímpia, que é admitido pelos pesquisadores, concordamos com a proposição de A. Moustaka. As evidências citadas por Zolotnikova, a nosso ver, parecem representar casos isolados e por isso não comprovam, ainda, o culto de Hera entre os períodos geométrico e arcaico.

\footnotetext{
67 Para mais detalhes a respeito dessa proposição sobre o Heraion como o mais antigo templo de Zeus em Olímpia, vide capítulo 4.
} 
É comumente aceito entre os pesquisadores o forte aspecto militar do culto de Zeus em Olímpia, desde a Idade do Ferro, evidenciado a partir do tipo de objetos votivos a ele dedicados no período. As figurinhas de terracota e de bronze, aparecem, predominantemente, armadas ou usando algum tipo de equipamento defensivo, e os trípodes, adornados com figurinhas de guerreiros, evidenciam também a associação do deus às funções militares (Barringer, 2010: 160; Zolotnikova, 2013a: 95). Embora haja evidências apenas a partir do século V a.C. para sua existência, assume-se que já desde o século VIII a.C. o oráculo68 de Zeus em Olímpia tenha atuado em questões relativas a conflitos militares de forma parecida como nas épocas arcaica e clássica (Barringer, 2015: 24).

Outra perspectiva, contudo, prefere relacionar o culto de Zeus em Olímpia, durante a sua fase mais antiga, aos aspectos agrários e pastoris. De acordo com J. Taita, "a tipologia das oferendas recuperadas em Olímpia (principalmente as de figurinhas de animais), pertencentes aos séculos X e IX a.C., demonstram o caráter eminente pastoril do culto no local nesse período"69 (Taita, 2007: 89). A seu ver, "o quadro histórico, social e econômico do culto em Olímpia induz a admitir que a divindade venerada desde a segunda metade do século IX a.C. teve uma conotação eminentemente atmosférica e foi procurada para garantir a fertilidade da terra e a fecundidade dos rebanhos" (Taita, 2007: 95). Em sua perspectiva, o oráculo de Zeus, nessa época, teria servido, na realidade, "às consultas relativas aos interesses das populações para as quais a criação de animais representava a principal fonte econômica e de prestígio social" (Taita, 2007: 91 e 95).

Uma terceira interpretação, sobre a fase mais antiga do culto de Zeus em Olímpia, foi recentemente proposta por 0 . Zolotnikova, que, ao nosso ver, é quem caracteriza de forma mais completa a divindade no santuário nessa época. Em linhas gerais, segundo essa estudiosa, todas essas características apontadas (militar, agrária e pastoril) relacionam-se, no fundo, ao culto, em Olímpia, de uma divindade indo-europeia relacionada ao céu claro (Zolotnikova, 2013a: 97). Na ausência de evidências arquitetônicas seguras, é muito provável que o culto a Zeus no santuário, por muito tempo, ocorreu a céu aberto, uma característica que corresponde ao conceito de Zeus como o deus celeste, do céu claro (Zolotnikova, 2013a: 97). Os tipos das figurinhas masculinas de terracota têm fortes conotações ligadas à sexualidade masculina, ao poder masculino relacionado à fertilidade, o que indica, para essa autora, o culto de um Zeus maduro, de uma figura paterna, outro elemento do culto indo-europeu de uma divindade relacionada ao céu claro (Zolotnikova, 2013a: 97). E por último, a característica guerreira do culto de Zeus Olímpio também esteve presente entre divindades indoeuropeias com aspecto celeste (Zolotnikova, 2013a: 97). Essa interpretação da pesquisadora russa, propõe uma explicação mais ampla para essas características e funções de Zeus em Olímpia, mais de acordo com o contexto regional (peloponésio) do culto de Zeus entre a Idade do Bronze e a Idade do Ferro, como é especialmente o caso do santuário do deus no Mt.Lykaion.

\footnotetext{
68 Sobre a discussão completa da função do oráculo de Zeus Olímpio em época clássica, vide Laky, 2013, pp.43-44.

${ }^{69} \mathrm{Na}$ perspectiva de Taita, o caráter fragmentário de tais objetos votivos não oferece elementos precisos para atribui-los à tipologia de um Zeus guerreiro, mas apenas como imagens dos próprios devotos em vestes armadas (Taita, 2007: 95, nota 42).
} 
A partir do início da época arcaica, o aspecto militar de Zeus se sobrepôs, para sempre, às demais características antigas do culto ao deus em Olímpia (o agrário e o pastoril) (Taita, 2007: 97). Como bem explica Taita, a comensalidade sagrada e a oferta de miniaturas (figurinhas humanas e animais) entraram em declínio entre o fim do século VIII a.C. e início do século VII a.C. devido a um tipo de devoção nova em Olímpia: 0 prestígio do oráculo de Zeus pediu a celebração de um ritual mais solene com a realização de uma grande festa que previa competições esportivas (Taita, 2007: 106). Trata-se do período, como vimos, da instalação do primeiro estádio. As competições atléticas foram parte do processo que levou à consolidação de Zeus Olímpio como uma divindade militar em época arcaica, como demonstra a inter-relação entre atletismo e guerra na cultura grega antiga ${ }^{70}$. O estabelecimento dos jogos nessa época atesta, então, a crescente tendência do aspecto militar de Zeus no culto em Olímpia, desde a Idade do Ferro, que se afirmou como característica principal do culto local da divindade até o término das atividades religiosas no santuário. Como vimos no item anterior, a prática de dedicar despojos de guerra a Zeus Olímpio a partir do século VII a.C., e sua exposição na área do estádio, foi parte desse fenômeno, assim também como dedicações de estátuas de Zeus para comemorar vitórias militares, sem falar ainda nas pequenas estatuetas de bronze de Zeus Keraunios, tipos de representações do deus com importante significado militar, como mostraremos em detalhes na análise contextual de seu significado simbólico no próximo capítulo. Essa função militar do culto de Zeus em Olímpia, culminou, durante o século $\mathrm{V}$ a.C. no papel do deus em mediar conflitos entre as comunidades políticas em nível local e inter-regional, como veremos na análise na sequência.

Já desde a Idade do Ferro, Olímpia desempenhou a função de um santuário sub-regional e interregional. A partir da segunda metade do século XI a.C. "o culto praticado no local funcionou como fator vinculante à unidade dos diversos grupos que gravitavam na bacia do rio Alfeu" (Taita, 2007: 86). Entre os séculos IX-VIII a.C., "os objetos votivos evidenciam que a festa a Zeus Olímpio havia alcançado notoriedade além desse rio", como indicam a dedicação de trípodes monumentais por visitantes da Messênia e da Arcádia, e a presença, no santuário, de artesãos provenientes da Arcádia, Messênia, e de Argos, conforme indica 0 estudo de tipologia e de proveniência dos objetos votivos dedicados no local nessa época (Morgan, 1994: 89 90; Taita, 2007: 102). Assim, é possível afirmar que a função inter-regional do santuário de Olímpia se consolidou entre os séculos IX-VIII a.C., quando o local passou a ser frequentado não apenas pelas populações do noroeste do Peloponeso, região a qual pertenceu, mas por aquelas provenientes do sul e nordeste dessa grande área ${ }^{71}$. Embora a função sub-regional tenha se mantido nos períodos posteriores, a tendência interregional do santuário de Olímpia passou a se ampliar cada vez mais a partir do século VII a.C. com a instituição e expansão das competições atléticas, da prática de despojos de guerra a Zeus Olímpio, e com a participação de membros de comunidades políticas do Ocidente grego e de outras áreas da Grécia Balcânica (Laky, 2013:

\footnotetext{
70 Tal relação em Olímpia foi brilhantemente discutida por J. Barringer (2005). Um resumo sobre a tese dessa autora pode ser visto em Laky, 2013, pp.301-302, e nessa tese, nos capítulos 3 e 4.

71 É provável ainda que a função inter-regional de Olímpia tenha se iniciado no início da Idade do Ferro, quando se originou a relação do santuário com Argos, pólis localizada no lado nordeste do Peloponeso (Morgan, 1994: 89).
} 
46). É interessante destacar, sobre os despojos de guerra, que "nenhum destes foram dedicados por Élis ou por comunidades da área do Alfeu"72 - tratou-se, portanto, de um tipo de oferenda tipicamente inter-regional e pan-helênica, dedicado por indivíduos de comunidades de várias partes do mundo grego.

Um traço característico de santuários extra-urbanos, como Olímpia, foi a participação das elites aristocráticas das comunidades políticas emergentes, ainda durante a Idade do Ferro, e das cidades gregas, a partir da época arcaica. A localização extra-urbana do santuário, a certa distância das maiores comunidades participantes, já na fase inicial do culto, foi um reflexo da função política e social de Olímpia como um lugar de encontro neutro às aristocracias locais das comunidades emergentes (Morgan, 1993: 26; 1994: 191). Tais santuários nasceram essencialmente por duas razões: "forneceram espaços para o consumo conspícuo dos aristocratas, via atletismo e oferendas votivas, e ajudaram a resolver conflitos internos em Estados emergentes" (Neer, 2007: 226). De fato, a dedicação de trípodes monumentais de bronze, que aparece pela primeira vez no século IX a.C. em Olímpia, "atesta a participação de membros de aristocracias locais os quais fizeram parte de um circuito de ostentação de riqueza (e possivelmente também de proeza atlética) e pela qual os aristocratas podem ter mantido seu status pessoal dentro de suas comunidades individuais" (Morgan, 1993: 26; 1994: 191). R. Neer explica que o investimento em ostentação e em comportamento de auto engrandecimento, em um culto inter-regional, poderia ser uma maneira de solidarizar-se com membros da aristocracia de outras póleis ao mesmo tempo em que estes santuários foram espaços para disputas políticas e para competições entre aristocracias locais (Neer, 2007: 228).

Durante o século $\mathrm{VI}$ a.C., quando Olímpia atingiu seu primeiro grande ápice como santuário interregional, mudanças importantes ocorreram em relação à participação das elites aristocráticas, e à afiliação às suas cidades de origem, como também à atividade do Estado no culto e o papel do santuário na formação da identidade grega no período - todos fenômenos interligados, em certo nível. Em primeiro lugar, tratou-se do período do "protagonismo da individualidade aristocrática no campo das relações entre as póleis e das atividades externas destas em escala regional e pan-helênica" - "o ágon pan-helênico, experiência privilegiada do estilo de vida aristocrático, havia se consolidado, nessa época, como um dos modos preferidos de afirmação do status social das elites diante de sua própria cidade e diante do mundo grego" (Giangiulio, 1993: 115). Em segundo lugar, "entre o final do século VII e o decurso do século VI a.C. ocorreu a terceira fase de desenvolvimento de Olímpia, comum também a outros santuários inter-regionais da Grecia Balcânica: pela primeira vez o investimento em arquitetura monumental se tornou aparente", como mostra a construção do dito Heraion e dos primeiros tesouros ${ }^{73}$ (Hall, 2007a: 271). Esse fenômeno teve a ver com "o aumento do interesse do Estado em Olímpia (a formalização de sua participação) e com a institucionalização do festival olímpico e

\footnotetext{
72 Taita, 2007, pp.113. Trata-se de um dado muito interessante e que merece um aprofundamento em uma pesquisa futura sobre as diferenças entre os tipos de votivos inter-regionais e aqueles sub-regionais.

73 Trata-se dos tesouros de Síbaris, Metaponto, Gela, Sicione, Epidamnos, Selinonte, Cirene e Mégara - todos são obras do século VI a.C. (Hall, 2007a: 271).
} 
de sua incorporação dentro do círculo pan-helênico nesse período74" (Morgan, 1993: 26). Essa presença do Estado no santuário também tem relação com uma mudança na participação das elites aristocráticas em Olímpia, quando, durante o século VI a.C., estas passaram a competir nos jogos como representantes de suas póleis (Hall, 2007a: 272-273). Uma evidência importante desse fenômeno foi a dedicação de edifícios, como os tesouros, ou outros tipos de monumentos, no nome das comunidades, ainda que estes tivessem sido financiados pelos mais ricos - enquanto que no século VII a.C. tal prática era realizada para os membros das elites obterem renome e glória individuais nos santuários inter-regionais (Hall, 2007a: 272-273). Tratou-se, nesse caso, de uma mudança observada também em outros santuários além de Olímpia.

Corresponde a esse contexto, a terceira e última transformação nessa época, que refere ao papel de Olímpia como espaço da elaboração da identidade grega em época arcaica. Segundo J. Hall, a partir do século VI a.C., "apenas em Olímpia as competições eram restritas àqueles que podiam provar descendência helênica" (Hall, 2002: 154). Conforme esse autor defende, a formação da identidade grega teria alcançado um estágio importante em Olímpia, quando no século VI a.C., membros da elite de comunidades da Tessália foram permitidos a participar nos jogos olímpios, um ambiente predominantemente dório desde suas origens. Assim, uma identidade mais abrangente, teria surgido "na medida em que as elites de comunidades dórias, jônias e aqueias (cujas participações são atestadas desde o século VIII a.C.) começaram a forjar relações de parentesco fictícias com os eólios da Tessália no século VI a.C." para assim justificar a participação de membros dessa região no santuário (Hall, 2001: 219; 2007a: 274). Trata-se do alargamento de uma relação, em nível étnico, que nunca havia sido antes estabelecida em outros contextos no mundo grego.

Todo esse contexto descrito permitiu, a partir do início do século VI a.C., a ocorrência de um outro fenômeno muito importante, relacionado ao culto de Zeus em Olímpia, à participação das elites das póleis e à formação da identidade grega. Trata-se do processo de difusão do culto de Zeus Olímpio, desse santuário, às póleis de determinadas regiões do mundo grego - um fenômeno vigente até o século $V$ a.C. - objeto de um estudo nosso anterior (Laky, 2013). Nesse estudo, concluímos que "Olímpia, como propagadora de uma rede específica do culto de Zeus Olímpio, teve um papel único, diferenciado e destacado nesse processo de difusão, cujo motor ou agentes catalisadores, foi a participação das elites gregas em Olímpia e o papel do santuário na construção da helenidade no século VI e V a.C.: o culto do deus, a nosso ver, emergiu nas cidades gregas impulsionado pelo envolvimento de uma elite e pela afirmação da identidade grega no período" (Laky, 2013: 317). O culto foi instituído em sete regiões do mundo grego (Sicília, Itália do Sul, Peloponeso, Ática, Eubéia, norte da África e Macedônia) e em doze póleis (Lócris, Selinonte, Agrigento, Siracusa, Cirene, Esparta, Corinto, Mégara, Atenas, Cálcis, Díon e Patras) (Laky, 2013: 25 e 28). Com relação à identidade grega, e seus vários níveis, concluiu-se que foi "uma rede de cidades dórias a responsável pela maior parcela de apropriações do culto da divindade nas áreas coloniais e balcânica do mundo grego, explicando a característica dórica assumida

\footnotetext{
74 Já a partir do século VI a.C. "Olímpia fazia parte de um circuito de jogos stefaníticos estabelecidos nos principais santuários interregionais além de Olímpia, como de Apolo em Delfos, de Poseidon em Ístmia e de Zeus em Neméia” (Hall, 2002: 154).
} 
arquitetonicamente pelos Olimpiéia e a predominância dórica e ocidental em Olímpia" (Laky, 2013: 318). Chegamos à conclusão do papel das elites no processo de difusão e de instituição do culto nas cidades gregas, com base no envolvimento desse grupo no estabelecimento dos santuários políades da divindade e em sua relação destacada com o santuário inter-regional: "a busca, permanente, em reforçar laços e valores culturais (sobretudo aqueles manifestos na relação guerra-atletismo) em Olímpia" (Laky, 2013: 303). Tratou-se, portanto, "da identificação dos valores políticos desse grupo político das cidades gregas com as características (a personalidade) de Zeus Olímpio, um deus guerreiro que expressou autoridade sobre os deuses e os homens de uma maneira permanentemente almejada pela aristocracia na sociedade grega" (Laky, 2013: 303). Nesse processo de difusão, foi também constatado que o aspecto militar de Zeus Olímpio, tão presente no santuário inter-regional, desde suas origens, manteve-se nos cultos políades da divindade (Laky, 2013: 318). Na análise interpretativa sobre a Sicília e a Itália do Sul, nesse capítulo, será possível mostrar, a partir de estudos de caso, como o culto de Zeus Olímpio ganhou especial expressão nessas duas áreas do mundo grego.

Após essa longa explicação da função de Olímpia entre a aristocracia, desde o início da atividade cultual no local, resta mencionar o papel mais importante desempenhado pelo santuário em relação às comunidades políticas a partir do século $\mathrm{V}$ a.C.: a mediação e arbitragem de conflitos locais e inter-regionais. Como bem coloca Taita, "a autoridade de Zeus Olímpio representou a garantia suprema que sancionava a instauração de relações pacíficas intercomunitárias e regulava eventuais controvérsias a nível local" (Taita, 2007: 141-142). Em nível sub-regional, evidências epigráficas testemunham acordos entre comunidades da área do Alfeu durante o século V a.C., como o tratado de piNía entre os Anaítoi e os Metápioi75 (Taita, 2007: 45-46). De acordo com Barringer, no início do século V a.C., "a implementação da arbitragem em Olímpia foi uma consequência direta das guerras pérsicas: a vitória alcançada em Platea por meio da unidade dos gregos inspirou a implementação de uma arbitragem para evitar conflitos entre os gregos" (Barringer, 2015: 30). A partir dessa época, "tratados internacionais passaram a cada vez mais a serem publicados em Olímpia para obter a sanção religiosa, no caso de Zeus Olímpio, e para assim garantir uma grande audiência e direitos contra violações dos termos" (Nielsen, 2007: 79-81). Conforme Nielsen e Roy, "ao publicarem tais tratados, as comunidades também ostentavam sua 'estatura' e afirmavam seu lugar no mundo grego" (Nielsen; Hansen, 2009: 266). A função de asylia de Olímpia tornou o santuário um lugar igualmente propício para a realização de acordos entre as cidades. Missões diplomáticas colocavam-se sob a proteção do santuário a fim de tornar difícil aos negociantes do outro lado rejeitar seus pedidos. Tucídides (III. XIV. 1-2 - XV) nos fornece o principal testemunho a esse respeito ao narrar o discurso dos mitilênios em Olímpia em 428 a.C. no contexto da guerra do Peloponeso. Após terem deixado a liga ateniense, os mitilênios requereram a adesão à liga peloponésia em uma reunião no santuário: "em vista do fato de que estavam reunidos em Olímpia, tornavam-se

\footnotetext{
75 Essas inscrições, encontradas em Olímpia, sobre acordos, atos públicos, ao lado de outros tipos em oferendas, todas datadas do século V a.C., são testemunhos também da existência de várias comunidades independentes à Élis na área da bacia do Alfeu nesse período. A esse respeito, ver Taita, 2007, pp.41-48.
} 
automaticamente suplicantes de Zeus o que impedia a rejeição de seu pedido de adesão" (Sinn, 2000: 157; 158; nota 8).

De acordo com interpretações mais recentes, esse papel de Olímpia e de Zeus Olímpio, na mediação e arbitragem de conflitos, alcançou um momento importante após a metade do século $V$ a.C., no contexto da guerra do Peloponeso. 0 declínio da dedicação de despojos de guerra, nessa época, teria sido um reflexo de uma proibição para evitar ofensas entre as cidades participantes nos jogos e no culto. No entanto, outros tipos de dedicações, relativas à certas comemorações militares, continuaram a ocorrer em Olímpia. Tal fato é explicado por J. Roy, em um recente artigo, como negociações entre a comunidade ofertante e Élis ou às pressões que, às vezes, a pólis administradora do santuário precisava ceder ao aceitar tal tipo de dedicação (Roy, 2013: 116).

O papel do santuário na exposição de decretos, leis, tratados, referentes às regras do santuário, envolvendo ou não outras comunidades, continuou como uma prática no local até o período romano (Barringer, 2015: 30).

Em síntese, Olímpia foi o "centro mais importante de interação e exibição para as póleis desde a época arcaica" (Nielsen; Roy, 2009: 266). De acordo com Nielsen, Olímpia foi uma instituição de importância crucial na cultura da cidade grega, "pois ajudou a criar e a manter um grau de similaridade na enorme diversidade produzida pela existência de mais de mil póleis altamente individualizadas e radicalmente auto diferenciadas" (Nielsen, 2007: 99). Foi também "uma instituição que contribuiu para a formação e manutenção da diversidade dentro da similaridade que ela própria promoveu" (Nielsen, 2007: 99). Em outras palavras, "através do processo de interação, em Olímpia foi confirmada e continuamente reconfirmada a identidade helênica global, a qual todas as póleis gregas compartilharam, e as identidades locais das póleis individuais pelas quais foram demarcadas como únicas, cada uma em sua própria maneira" (Nielsen, 2007: 99).

Nenhum santuário de Zeus alcançou papel comparável àquele exercido pelo deus em Olímpia em relação às comunidades políticas, e aos seus grupos políticos (a aristocracia), e a articulação de vários grupos étnicos gregos, a ponto de influenciar a formação de uma identidade maior, grega. Também Olímpia é o santuário de Zeus onde mais se conservou e mais oferece informação sobre o envolvimento da pólis em um culto da divindade, tanto no nível político como no da identidade. Dentre os santuários extra-urbanos, é também aquele sobre o qual mais sabemos do papel da cidade administradora / organizadora da área sagrada, no caso Élis. O papel político dessa cidade, em época arcaica e clássica, em relação à Olímpia e à sua região, será exposto no capítulo 4, quando analisaremos o caráter político das emissões monetárias de Olímpia. 


\section{II.3 Argos-acrópole Larisa}

Localizado no nordeste do Peloponeso, o santuário de Zeus Larisaios (cat. no.10) foi estabelecido na área nordeste do topo da colina de Larisa (289 m), a acrópole da pólis de Argos (Fig.50) (Zolotnikova, 2013a: 86).

\section{II.3.1 Descrição e interpretação dos achados}

O início da atividade cultual no santuário de Zeus na acrópole Larisa é atestado entre o protogeométrico (900-700 a.C.) e o início do geométrico (IX a.C.), com base em um pequeno número de fragmentos cerâmicos datados desses períodos (Zolotnikova, 2013a: 86). A principal evidência arqueológica sobre o santuário é o importante depósito votivo descoberto na área do santuário

contendo uma grande quantidade de material

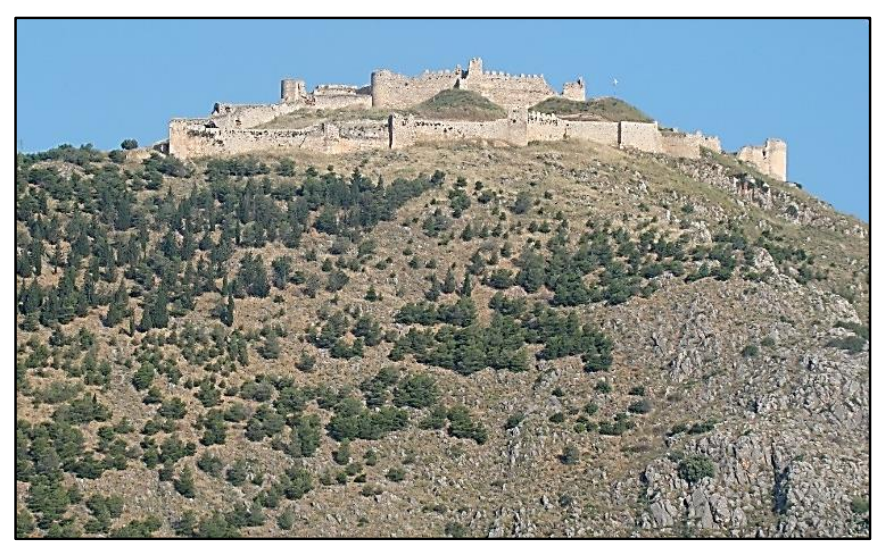

Fig.50- Acrópole Larisa e fortificação de época veneziana vista a partir da cidade moderna de Argos (Foto: arquivo pessoal/2011) cerâmico (Zolotnikova, 2013a: 87). O volume do depósito, "constituído por mais de 300 pequenos vasos cerâmicos, foi datado pelos escavadores entre a metade do século VIII a.C. e a metade do século VII a.C. estes possuem motivos e cenas específicas de carros, cavalos, grupos de dança de mulheres com homens, sendo especialmente abundantes os símbolos solares" (Zolotnikova, 2013a: 87). No mesmo depósito, também, foram encontradas miniaturas de machados duplos (um de osso e o outro de bronze), romãs de terracota, centenas de anéis, armas de ferro e alguns outros objetos (Zolotnikova, 2013a: 87). Não foram relatados qualquer traço de um altar (Zolotnikova, 2013a: 87).

\section{II.3.2 A natureza do culto e a função do santuário}

O culto de Zeus Larisaios, na acrópole argiva de Larisa, foi atribuído com base em uma notícia de Pausânias (II, 24.3), que descreve um templo e uma estátua da divindade no local ao lado de um culto de Atena. O santuário, portanto, é identificado como um lugar de culto a Zeus a partir da associação de uma informação literária com o depósito votivo encontrado no topo da colina.

De acordo com a opinião dominante, o santuário na Larisa foi inicialmente somente dedicado a Atena (Zolotnikova, 2013a: 87). Contudo, há elementos na narrativa de Pausânias, e na história mítica de Argos, que relacionam o seu culto a períodos bem antigos da cidade. Nessa perspectiva, Zolotnikova defende que Zeus "pode ter sido cultuado em Argos desde o final da Idade do Bronze, como sugere a associação do santuário na 
acrópole Larisa com Zeus na época da guerra de Tróia, conforme a narrativa de Pausânias, e como demonstra a etimologia do nome do rei mítico argivo Diomedes (llíada 2.559-568), derivado do genitivo Diós, que implica certa ligação direta da família governante local micênica com o deus" (Zolotnikova, 2013a: 87). Outra evidência da antiguidade do culto de Zeus no local, na Idade do Ferro, "seria a aparência primitiva da estátua de madeira do deus, com três olhos, descrita por Pausânias, que pode indicar, na realidade uma antiga estátua de tipo xoána, característica de cultos bem antigos" (Zolotnikova, 2013a: 87). Assim, também é provável que o culto de Zeus tenha sido "associado ao de Atena, durante a fase mais antiga, embora se desconheça de que forma" (Zolotnikova, 2011: 241).

Diante da ausência de restos de um antigo altar, é possível afirmar que o culto a Zeus Larisaios ocorreu a céu aberto em sua fase mais antiga. Em determinado, período, o qual não podemos precisar, o culto recebeu um templo (sem teto, segundo Pausânias) e uma estátua de culto. Essa característica do templo sem o teto pode indicar algum tipo de característica antiga celeste do culto a Zeus, conservada em um período posterior. Na interpretação de Zolotnikova, as representações contidas no material cerâmico indicam que "o culto, durante a Idade do Ferro, parece ter sido especialmente relacionado à natureza solar, à energia primaveril (como as representações de danças com ramos pode indicar) e a fertilidade em geral, assim como às habilidades militares" (Zolotnikova, 2013a: 87). Os tipos de recipientes cerâmicos indicam que o culto a Zeus na colina de Larisa compreendeu "cerimônias coletivas e individuais, envolvendo o consumo de bebida, refeições rituais e danças" (Zolotnikova, 2013a: 87).

Com relação à função do santuário, é provável que se tratou de um santuário suburbano a partir da Idade do Ferro, que atendou à população da comunidade de Argos a partir dessa época. Com a incorporação das colinas de Larisa e Aspis à fortificação da cidade no início do século VII a.C. ${ }^{76}$, o santuário de Zeus Larisaios passou a se tornar um santuário urbano da cidade. Mesmo com essa nova configuração urbana, que tornou definitivamente a colina em uma acrópole, a área sagrada deve ter conservado a sua função mais antiga, como indica a grande concentração de achados cerâmicos datados até a metade do século VII a.C. no depósito na acrópole, os quais também indicam um ápice cultual nessa mesma época de mudança urbana.

${ }^{76}$ Nielsen; Roy, 2009, p.259. 


\section{II.4 Messênia-Mt.Ithome}

O santuário de Zeus Ithomatas (cat. no.11) localiza-se no topo do Mt.lthome (802 m), na sub-região da Messênia no sudoeste do Peloponeso - a leste da pólis de Messênia, estabelecida na grande planície aos sopés da montanha no século IV a.C. (Fig.51). Durante a época bizantina, sobre as ruínas do santuário, foi construído o mosteiro de Voulkano (a oeste no topo da montanha), que

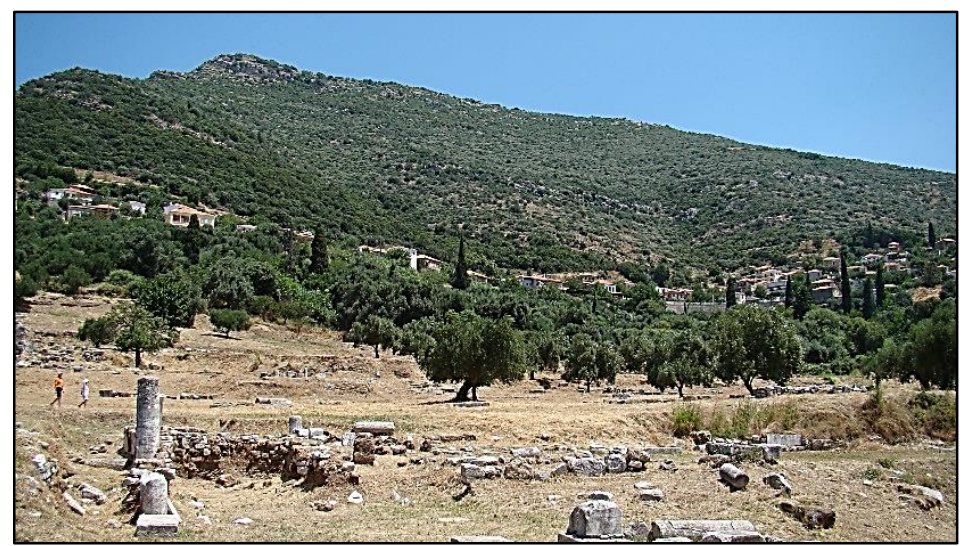

Fig.51- Mt.Ithome visto a partir da pólis de Messênia (área do teatro) (Foto: arquivo pessoal/2009) impossibilitou qualquer tipo de pesquisa arqueológica na antiga área sagrada do deus (Fig.52 e 53) (Luraghi, 2008: 133; Themelis, 2004: 117-118; Zolotnikova, 2013a: 106). Se por um lado a construção do mosteiro limitou as pesquisas no local e implicou em graves danos aos remanescentes arqueológicos do santuário, por outro, ajudou a preservar um dos achados materiais da área sagrada - o grande bloco quadrado de pedra calcária, que servia como base para trípodes. Na construção do mosteiro percebe-se o reuso de blocos de pedra muito antigos, provavelmente pertencentes ao santuário de Zeus, contudo, o único que pode seguramente ter pertencido à área sagrada é aquele que possui incisões para a colocação do trípode de bronze (Fig.54) (Zolotnikova, 2013a: 106). Ao lado dessa base de pedra, fragmentos de um trípode de bronze (partes das pernas), "encontrados fortuitamente na superfície do solo", perto do mosteiro, são os únicos remanescentes materiais disponíveis para o estudo do santuário de Zeus Ithomatas (Zolotnikova, 2013a: 106).

\section{II.4.1 Descrição e interpretação dos achados}

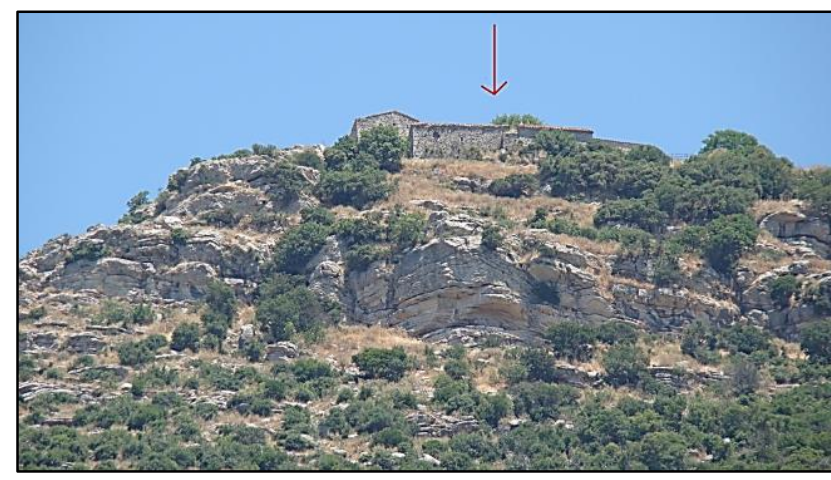

Fig.52- Mosteiro de Voulkano no Mt.Ithome visto a partir da pólis de Messênia (Foto: arquivo pessoal/2009)

Mesmo diante dos poucos achados arqueológicos foi possível datar o início da atividade cultual no santuário de Zeus Ithomatas entre os períodos proto-geométrico (1000-900 a.C.) e geométrico tardio (especificamente na primeira metade do século VIII a.C.). O trípode de bronze é o único elemento material que permite datar o funcionamento do santuário, com segurança, ao século VIII a.C. (Themelis, 2004: 117-118; Luraghi, 2008: 115; Zolotnikova, 2013a: 106). Uma datação um pouco mais antiga, para o trípode, entre os séculos IXVIII a.C. também tem sido aceita (Kreutz, 2007: 18). Sobre uma fase mais antiga ainda do culto, consideramos a proposição de Zolotnikova, que antecipa a datação da área sagrada ao período proto-geométrico. Essa 
pesquisadora se baseia em dados arqueológicos sobre ocupação micênica e da Idade do Ferro, nas imediações do santuário, e em antigos relatos conservados nas fontes literárias a respeito da antiguidade do culto - como um de Pausânias (IV, 3.9) sobre uma obrigatoriedade, imposta pelo rei messênio Glaukos (IX-VIII a.C.), aos dórios de venerarem Zeus Ithomatas, após o estabelecimento desse grupo na região (Zolotnikova, 2013a: 105).

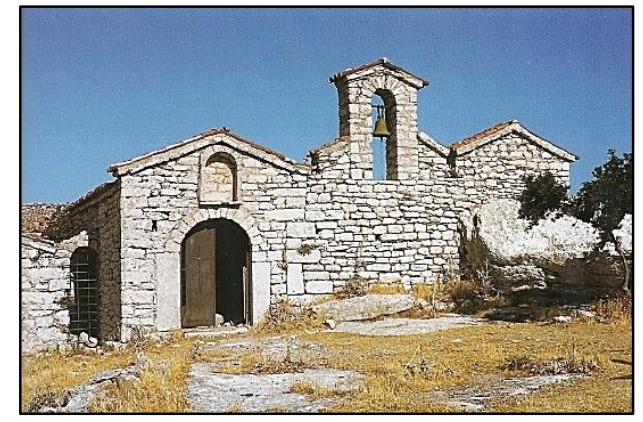

Fig.53- Monastério de Voulkano no cume do Monte Ithome (Themelis. 2004: fig.120)

Pouco há para se dizer sobre o trípode de bronze, a não ser que este possuía um tipo de relevo na parte que se conservou (Kreutz, 2007: 18). Já a base quadrada de pedra, que ainda se encontra afixada no ângulo sudeste da face de um dos muros do mosteiro de Voulkano, foi estudada minuciosamente por P. Amandry. Segundo sua descrição, o bloco da base, cortado de uma pedra de calcário muito rachada, tem um formato quadrado de 1,25 m em média de lado, uma altura que varia, de um lado a outro, de c. 0,42 a 0,50m.

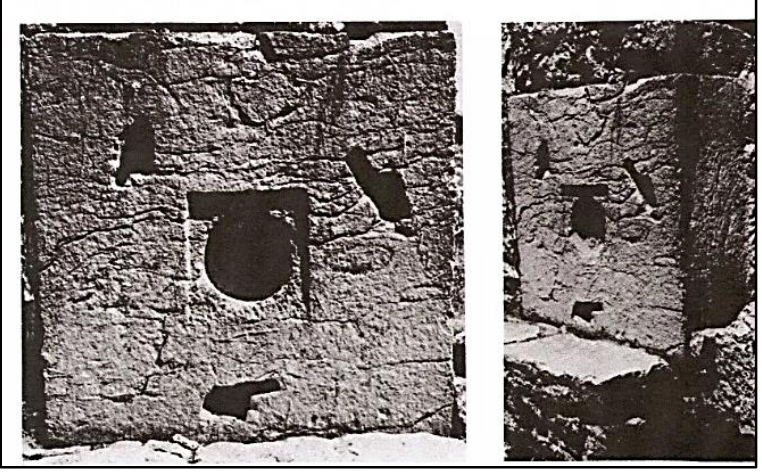

Fig.54- Base de tripé encaixada na parede do monastério de Voulkano (Amandry, 1987: 129, fig.30)
A parte inferior da base permaneceu em estado bruto, mas na face superior há uma cavidade circular talhada no centro, que está, por sua vez, dentro de um quadrado de profundidade rebaixada, rodeado por três cavidades dispostas em triângulo, dentro dos quais eram firmados os pés do trípode (Amandry, 1987: 127). O estudioso notou a ausência de inscrição dedicatória nas partes visíveis da base e não oferece nenhuma datação para o achado, sendo possível deduzir, de seu estudo, que este pode remontar desde a fase mais antiga do santuário até à época clássica e helenística, quando trípodes ainda eram os votivos dedicados no santuário de Zeus Ithomatas.

A maior parte da bibliografia disponível sobre o santuário de Zeus Ithomatas não faz referência alguma às ruínas de um templo da divindade na área. N. Kreutz chega a afirmar que nenhum templo foi construído ao deus, mesmo depois da fundação de Messênia no século IV a.C. (após a derrota da hegemonia espartana em Leuctra), quando o culto teria sido renovado (Kreutz, 2007: 19). Contudo, Zolotnikova menciona a existência das fundações do templo de Zeus (provavelmente do final do século IV a.C.), que podem ser vistas dentro de algumas partes do mosteiro, como na área do pátio (Zolotnikova, 2013a: 106).

Outra indicação adicional da pesquisadora russa, sobre os remanescentes do santuário e do culto, refere-se a uma imensa rocha natural, localizada no ângulo nordeste do mosteiro, que possui buracos, feitos para a colocação de estátuas (Zolotnikova, 2013a: 106). Assume-se que nas fases de época clássica tardia e helenística do culto, a rocha serviu como o altar de Zeus Ithomatas (Zolotnikova, 2013a: 106). Zolotnikova propõe ainda que a rocha pode ter tido a mesma função durante a Idade do Ferro, partindo de uma associação com o altar externo, talhado na rocha, localizado na entrada da gruta do santuário do Mt.Ida em Creta (Zolotnikova, 2013a: 106). 
Assim, esses são os únicos remanescentes físicos que podem ser atribuídos à área sagrada de Zeus Ithomates. Se por um lado há escassez de documentação arqueológica para a interpretação do culto, por outro, há uma variedade de referências literárias sobre 0 deus e o santuário que auxiliam na reconstrução do culto e da área sagrada.

\section{II.4.2 A natureza do culto e a função do santuário}

O culto a Zeus Ithomates no topo do Mt.lthome é amplamente atestado por fontes literárias e epigráficas, embora bem posteriores ao início da atividade cultual no santuário. A maior parte dos testemunhos estão conservados na obra de Pausânias, que se refere, na maior parte dos trechos, ao culto praticado no período clássico tardio e helenístico. Entretanto, em certas referências, o periegeta oferece informações sobre a terceira guerra messênica (510-490 a.C.) e sobre o culto no século VIII a.C. e no século V a.C., que nos permitem reconstituir aspectos da história da área sagrada nessas épocas. Ainda, dezenas de inscrições de época romana (século I d.C.) se referem a sacerdotes de Zeus Ithomatas ${ }^{77}$. De acordo com M. Zunino, o epíteto da divindade deriva do nome do Mt.lthome que, por sua vez, tem origem no nome da ninfa Ithome - na versão do mito messênio do nascimento de Zeus na montanha, ao lado de Neda, Ithome teria sido responsável por amamentar Zeus (Zunino, 1997: 101).

É preciso destacar, que a análise e interpretação do santuário e do culto de Zeus Ithomatas pressupõem dois momentos principais: a fase mais antiga do culto, quando o santuário no Mt.lthome esteve relacionado ao assentamento de mesmo nome, da Idade do Ferro, localizado no sopé do monte; e a época da fundação da pólis de Messênia em 370/69 a.C., a partir de quando o culto foi reorganizado e passou a pertencer ao território dessa cidade. Assim, antes de analisarmos o santuário nessas duas fases, apresentaremos as características do culto de Zeus Ithomatas, ao longo do tempo, com base na associação entre os testemunhos literários e as evidências arqueológicas, quando possível.

Relatos sobre a instituição do culto e do mito do nascimento de Zeus no local, conservados em testemunhos de Pausânias, indicam a percepção da antiguidade do culto de Zeus Ithomatas e a criação de narrativas sobre suas origens em um passado mítico para justifica-la. De acordo com Pausânias (IV, 1-2; 3-9), 0 culto de Zeus Ithomates teria sido estabelecido, no Mt.lthome, por Polykaon, primeiro rei mítico messênio e por sua esposa Messene, figura mítica epônima da região e da pólis de Messênia (Zolotnikova, 2013a: 106). Outro mito, que também indica a antiguidade do culto e estabelece a ligação do monte com Zeus, descreve 0 nascimento e a criação do deus no local: "segundo a tradição messênia, após Zeus ter sido levado pelos Kouretes, teria sido banhado na fonte Klepsidra, no sopé do Mt.lthome, pelas ninfas Ithome e Neda, que também o amamentaram na montanha" (Pausânias IV, 33.1) (Zolotnikova, 2013a: 105).

\footnotetext{
77 SEG XLI 334-339 e 374 B-D; IG V 1,1468-1469; BCH (94), 1970, p.984. Sobre a transcrição e tradução dessas inscrições, ver Zunino, 1997, pp.90-93.
} 
Afora esses trechos sobre mitos relativos à origem do culto no topo da montanha, outras referências literárias oferecem informações sobre as práticas de culto no santuário de Zeus Ithomatas em sua fase mais antiga. Fragmentos da poesia de Eumelos de Corinto (relacionados à batalha entre os messênios e Esparta em c.725 a.C.), citados por Pausânias (IV, 33.1-2), indicam a existência de um tipo de concurso musical relacionado ao santuário no século VIII a.C. (Zolotnikova, 2013a: 106). Outra notícia de Pausânias (IV, 12, 7-10), que se refere à época da primeira guerra messênica contra os espartanos (c.743-724 a.C.), informa sobre uma consulta dos messênios no oráculo de Delfos, que previu a vitória a quem primeiro (messênios ou espartanos) oferecesse a Zeus Ithomatas, em seu santuário, uma centena de trípodes (Grandjean, 2003: 62). Os espartanos teriam conseguido dedicar primeiro os trípodes, porque os confeccionaram em argila, enquanto os messênios os fabricavam em madeira, um material mais trabalhoso (Zunino, 1997: 106). A associação dessas referências literárias ao achado do fragmento do trípode de bronze na área do santuário, indica que durante a ldade do Ferro a dedicação de trípodes, e a realização de competições, ao menos musicais, foram importantes componentes do culto de Zeus Ithomatas no topo da montanha.

Entre o período geométrico e a época arcaica (principalmente sobre o século VII a.C.), não dispomos de nenhum tipo de evidência sobre o culto e o santuário de Zeus Ithomatas. Pausânias (IV, 19.3) recorda apenas de um episódio de um sacrifício oferecido por Aristomenes à época da terceira guerra messênica (entre o final do século VI e o início do século V a.C.). Trata-se do denominado hekatomphonia, que teria dedicado, segundo o relato, cem inimigos espartanos ao deus (Zunino, 1997: 107). Sabemos que durante o século V a.C., o culto de Zeus Ithomatas ganhou um componente novo - a escultura da divindade feita pelo escultor Ageladas de Argos, à ocasião do exílio dos messênios em Naupactos (Zunino, 1997: 102). Após o final do exílio dos messênios, estes trouxeram a estátua, que, segundo um relato também do periegeta, passou a ser abrigada na residência do sacerdote da divindade, eleito anualmente (Pausânias IV, 33. 1-2) (Kreutz, 2007: 19; Zunino, 1997: 102). Esta notícia tem sido considerada como uma indicação da inexistência de um templo no santuário da divindade no Mt. Ithome, embora algumas ruínas dentro do mosteiro de Voulkano sugira um antigo edifício de culto na área (Kreutz, 2007: 19; Zunino, 1997: 102). Nos tempos de Pausânias era realizada uma festa anual relacionada ao santuário de Zeus Ithomates, denominada de Ithomaia (mencionada pelo periegeta). De acordo com Zolotnikova, as Ithomaia devem ter sido uma reminiscência da antiga versão dos concursos musicais realizada durante a Idade do Ferro, que naquela época, muito provavelmente, envolviam a realização de sacrifícios e a prática de simpósios (Zolotnikova, 2013a: 106). A seu ver, "os concursos musicais devem ter sido interrompidos por um longo período de tempo até a a libertação da Messênia na primeira metade do século IV a.C., quando devem ter sido retomados com algumas características novas" (Zolotnikova, 2013a: 106). As Ithomaia, segundo Zunino, "compreendiam, seguramente, o transporte de água da fonte Klepsidra (situada no caminho para o Mt.Ithome) pelos chaleidophoroi, competições atléticas e sacrifícios provavelmente concelebrados pelos agonoteta e pelos hierothytai (um colégio de magistrados da pólis de Messênia)" (Zunino, 1997: 103-104). Após a renovação do culto no século IV a.C., Zeus Ithomates assume uma função na esfera 
agonística, como se vê, embora em diferentes graus, em outros santuários peloponésios (Mt.Lykaion e Olímpia). É preciso destacar que essa função agonística do culto messênio de Zeus ocorre na esfera cívica, diferente do caso dos dois santuários extra-urbanos inter-regionais citados.

Essas são as informações literárias e arqueológicas, disponíveis, que permitem reconstituir parte das práticas de culto a Zeus Ithomates em seu santuário no Mt. Ithome entre a Idade do Ferro e a época clássica mas também na época de Pausânias, já que algumas dessas práticas cultuais (as Ithomaia, por exemplo) ainda eram ativas em seu tempo.

O estabelecimento do santuário de Zeus Ithomatas no topo do Mt.Ithome, em associação a alguns dos aspectos descritos das práticas cultuais, levaram os especialistas a proporem a esfera de atuação da divindade ou a natureza de seu culto. Baseada no posicionamento da área sagrada no topo da montanha mais alta da região, e ao culto, que a seu ver foi sempre realizado a céu aberto sem a presença de um templo, N. Kreutz define Zeus Ithomates como um "deus dos fenômenos atmosféricos" (Kreutz, 2007: 18-19). Já O. Zolotnikova defende que o conceito inicial do culto deve ter sido, em certo grau, relacionado àquele de Zeus Lykaios, essencialmente um deus do brilho solar, da luz do sol (Zolotnikova, 2013a: 107). A estudiosa traça a relação entre os dois santuários peloponésios com base em aspectos semelhantes no mito de origem do culto, no ritual e no tipo de localização: em ambos mitos sobre o nascimento de Zeus no Mt.Lykaion e no Mt.lthome, a ninfa Neda (epônima do rio que corta a Arcádia e a Messênia) é quem teria amamentado Zeus, em ambos os santuários parte do ritual envolvia fontes de água, e ambas as áreas sagradas foram estabelecidas sobre os cumes dos montes mais altos de suas regiões, possíveis de se avistar por contato visual (do Mt.Lykaion se avista o Mt.Ithome e vice-versa) (Zolotnikova, 2013a: 106-107). Conclui que essa correspondência entre os traços dos dois cultos de Zeus, indica uma tradição religiosa comum no sudoeste do Peloponeso, de onde teriam sido derivados (Zolotnikova, 2013a: 107). Conclui também que no período clássico tardio, Zeus Ithomates teria assumido a característica de um deus da tempestade, com base na representação de Zeus Keraunios nas moedas cunhadas pela pólis de Messênia ${ }^{78}$, cuja descrição e interpretação encontram-se nos capítulos 3 e 4 . A Messênia é uma das regiões analisadas onde o culto de Zeus ganhou também expressão na representação do deus em moedas.

A nosso ver, é provável que certa característica celeste tenha prevalecido no culto de Zeus Ithomatas até a época romana. 0 costume de levar água da fonte Klepsidra pode indicar o ritual ao deus pelo pedido de chuva, tal como ocorria na fonte Hagno, no Mt.Lykaion, ainda no tempo de Pausânias. Contudo, nesse caso trata-se apenas de uma conjectura, já que a descrição de Pausânias, a esse respeito, não é detalhada, como ocorre no trecho sobre o santuário arcádio.

Embora 0 aspecto celeste tenha representado um importamente e antigo elemento no culto de Zeus Ithomatas, ao longo de um processo histórico muito gradual, com início em época arcaica, a divindade adquiriu

78 Zolotnikova, 2013a, p.107. 
uma função de destaque na esfera identitária dos messênios quando estes estiveram sob e fora da dominação espartana (c.700-370/69 a.C.). O domínio de Esparta sobre as populações da região da Messênia (comunidades de perioikoi), a oeste do Mt.Taygetos, forneceu a base econômica espartana a partir da conquista do vasto território fértil messênio (Bettali et alii, 2013: 116; Kraay, 1976: 102). A conquista espartana foi gradual, tendo sido somente em c.600 a.C. que a dominação sobre a região da Messênia foi completa (Shipley, 2004: 550). Ao longo do domínio espartano, parte da população messênia emigrou e aquela que permaneceu tentou se libertar em três guerras, sobre as quais sabemos a partir de Pausânias. A primeira delas ocorreu no final do século VIII a.C., a segunda na metade do século VII a.C. e a terceira revolta na primeira metade do século V a.C., após um forte terremoto que devastou as duas áreas, a leste e a oeste do Mt.Taygetos (Shipley, 2004: 549-550). Nesse momento, os messênios tinham ocupado e fortificado o Mt. Ithome, cujo local, a partir daí, se tornou o centro da resistência aos espartanos (Dumbabin; Hooper; Spawforth, 2012: 752). Ao fim da guerra, os messênios foram rendidos pelos espartanos após um longo cerco e os sobreviventes foram assentados pelos atenienses em Naupactos (Woodward; Hooper; Spawforth, 2012: 938). Conforme N. Luraghi, "Naupactos permaneceu como um reduto messênio por mais da metade de um século até após o final da guerra do Peloponeso" (Luraghi, 2008: 188). Durante essa guerra, as comunidades de perioikoi realizaram uma série de revoltas esporádicas incitadas por uma guarnição ateniense estabelecida em Pylos após a vitória na batalha de Sphacteria (c.425 a.C.) (Woodward; Hooper; Spawforth, 2012: 938).

Somente no século IV a.C., em c.370/69 a.C., no contexto da primeira invasão beócia à Lacônia, por Epaminondas e seus aliados, que parte da região da Messênia foi libertada do domínio espartano. De acordo com N. Luraghi, "o nascimento da Messênia livre de Esparta foi possível graças a uma convergência de extraordinárias condições favoráveis - não poderia ter ocorrido sem a vitória tebana sobre Esparta em Leuctra em 371 a.C., onde o envolvimento arcádio e argivo foram claramente importantes" (Luraghi, 2008: 248). A pólis de Messênia foi fundada nessa época, na planície a oeste e logo abaixo do Mt. Ithome, em reação à preponderância de Esparta no Peloponeso. É preciso destacar, como bem coloca G. Shipley, que "entre o final do século VIII e o início do século IV a.C. não haviam comunidades cívicas autônomas na Messênia, estas eram comunidades periecas ou dependentes de Esparta - as póleis somente foram existir na região após a libertação parcial da dominação em 370/69 a.C. com a fundação da cidade de Messênia" (Shipley, 2004: 547).

Foi nesse contexto, aqui brevemente apresentado, que o culto de Zeus Ithomatas se tornou, gradualmente, um elemento importante da identidade messênia. Segundo a interpretação mais recente de Luraghi, a identidade messênia foi formada durante dois momentos importantes nos séculos V e IV a.C.: à ocasião da revolta contra os espartanos no Mt.lthome e da fundação do Estado messênio em 370/69 a.C., criado no contexto de redefinição de fronteiras étnicas e novas entidades étnicas nas primeiras décadas do século IV a.C. no Peloponeso (Luraghi, 2008: 212). Se por um lado, a etnogênese dos messênios surgiu em confronto à Esparta, por outro, foi um fenômeno flexível o suficiente para acomodar o padrão cultural 
essencialmente lacônio ${ }^{79}$, encontrado na área da Messênia no final do período arcaico e início do clássico (Luraghi, 2008: 246 e 248). Paradoxalmente, portanto, traços espartanos fizeram parte da identidade messênia desde a sua mais antiga manifestação, ultrapassando, inclusive, o momento da criação e consolidação de uma entidade política na região, a pólis de Messênia.

Os estudiosos costumam listar alguns fatores que teriam determinado a ligação da divindade à identidade messênia. Em primeiro lugar, o santuário de Zeus Ithomatas foi parte do grupo de antigas áreas sagradas estritamente messênias, à parte da grande variedade de santuários de traços lacônios distribuídos por toda a região da Messênia (Luraghi, 2008: 134, 206, 235 e 247). Em segundo lugar, o Mt. Ithome e 0 santuário de Zeus são reputados por terem tido uma função importante nas guerras messênicas: ficaram conhecidos, na chamada pseudo-história local, como o centro de resistência aos espartanos - a montanha foi o local onde os messênios se mantiveram por vários anos contra os espartanos durante a revolta do século $\mathrm{V}$ a.C. (Grandjean, 2003: 62; Luraghi, 2008: 209-210; Zunino, 1997: 101). Referências adicionais em Pausânias demonstram o papel simbólico do Ithome e do santuário de Zeus Ithomatas na elaboração da identidade messênia. De acordo com C. Grandjean, uma famosa notícia propiciada pelo periegeta mostra como Zeus Ithomatas era considerado a divindade tutelar dos messênios na época da terceira guerra messênica. Segundo Pausânias (IV, 20,4), os messênios possuíam um talismã que, se fosse perdido, a Messênia estaria para sempre submersa pela água, mas se fosse conservado, com o tempo os messênios recuperariam a sua terra. Na sequência da narrativa, Aristomenes teria guardado esse talismã no Mt.Ithome, pedindo a Zeus para guardar o objeto e não ceder aos espartanos a única esperança de retorno dos messênios. Na leitura de Grandjean e de Zunino, a narrativa expressa um significado político e religioso relacionado a Zeus Ithomatas, representado, assim, como o símbolo da promessa de renascimento e independência do Estado messênio (Grandjean, 2003: 52; Zunino, 1997: 101). Ainda sobre esse papel político de Zeus Ithomatas, Zunino, se baseando em outra indicação de Pausânias (IV, 27, 6), recorda que foi dedicado ao deus o primeiro sacrifício pan-messênio no ato da fundação da nova capital livre, Messênia (Zunino, 1997: 105). Assim, pode-se afirmar, por essas e outras informações, que Zeus Ithomatas foi evocado, desde o início da fundação da cidade no século IV a.C., como um ponto chave da identidade dos novos messênios que pode ter tido origem em períodos mais antigos (Luraghi, 2008: 209).

Nessa perspectiva, percebe-se que o culto de Zeus lthomatas, ao menos desde a época arcaica, foi ligado exclusivamente ao elemento messênio e a partir do início da época clássica se tornou um culto fortemente relacionado à oposição à Esparta, como indicam as informações literárias. Considerando a especificidade da etnicidade messênia, que abarcava, em certo nível, o elemento lacônio, é possível ver

\footnotetext{
${ }^{79}$ De acordo com N. Luraghi, "as evidências arqueológicas mostram que a Messênia arcaica foi uma extensão significativa da Lacônia, habitada por um povo que aparentemente falava a mesma língua dos lacedemônios, a leste do Mt. Taygetos - estes empregaram 0 mesmo alfabeto e produziram o mesmo tipo de cerâmica e de bronze" (Luraghi, 2008: 142-143). A formação da identidade messênia foi parte de um "processo gradual no qual as populações messênias de perioikoi e hilotas teriam de tempos em tempos se engajado em um comportamento cultual diferente daquele da população da Lacônia - tradições locais, portanto, não estiveram completamente ausentes no período arcaico na região" (Luraghi, 2008: 145).
} 
também, ainda que de forma menos marcada, essa característica da identidade local no culto de Zeus no Mt.Ithome. Apesar de as narrativas de Pausânias representarem uma pseudo-história, como definiu Luraghi, dois trechos mostram como essa etnicidade fluida pode ser vista na presença espartana no culto do deus. 0 primeiro trecho, já referido aqui, é aquele da dedicação de trípodes de argila pelos espartanos após a consulta do oráculo de Delfos, quando um destes se escondeu entre os messênios e conseguiu realizar primeiro a dedicação no santuário de Zeus no Mt.Ithome. O segundo trecho é o mais significativo a esse respeito: de acordo com Pausânias (III, 26.6), um incêndio na pólis lacônia de Leuctra teria destruído um bosque e revelado a presença de uma estátua de Zeus Ithomatas. Esse acontecimento é tomado pelos messênios como prova de que Leuctra teria pertencido à Messênia. No entanto, o próprio periegeta conclui que a estátua seria uma prova de que a divindade teria sido cultuada entre os lacônios também. Na opinião de Zunino, essa conclusão de Pausânias encontra comprovação em várias evidências de uma koiné religiosa entre as populações das duas regiões (Zunino, 1997: 109).

Isto posto, é possível tecer algumas considerações sobre a função do santuário de Zeus Ithomatas em dois períodos diferentes: antes e depois da fundação de Messênia.

Durante sua fase mais antiga, a partir da Idade do Ferro, o santuário de Zeus Ithomatas, muito provavelmente, esteve relacionado a um antigo assentamento localizado no sopé do Mt.lthome, na área da cidade clássica de Messênia. De acordo com Zolotnikova, esse assentamento foi datado, com base em achados cerâmicos sem informação estratigráfica, entre os períodos proto-geométrico e o geométrico, sendo contemporâneo, portanto, ao início da atividade cultual na área sagrada no Mt.Ithome. A ocupação na área parece ter tido uma longa duração, até a fundação de Messênia. Até então, segundo Luraghi, teria se tratado, possivelmente, de uma comunidade periokoica (Luraghi, 2008: 140-141). Os pesquisadores consideram a possibilidade de 0 assentamento ter se chamado Ithome, assim como também foi chamada a pólis de Messênia em seus anos iniciais, talvez sinalizando a antiga comunidade ali outrora localizada (Luraghi, 2008: 140-141).

A nosso ver, portanto, o santuário de Zeus Ithomatas, entre a Idade do Ferro e e a fundação e organização de Messênia no século IV a.C., teria funcionado como uma área sagrada suburbana frequentada por membros da comunidade de Ithome. Consideramos suburbana em razão da distância entre assentamento e santuário, e da possível interferência de sua população no local de culto, embora não se conheça o grau de urbanização atingido por essa comunidade. No entanto, não se pode excluir uma função sub-regional ao culto de Zeus Ithomatas, dado o forte elemento messênio contido no culto. Nesse sentido, para membros de comunidades messênias periecas mais distantes, a área sagrada no alto do Mt.Ithome teria sido, então, extraurbana. As evidências disponíveis, para a fase que pré-data a pólis de Messênia, apenas permite oferecer tais conclusões.

Com a fundação de Messênia no século IV a.C., e o fortalecimento do significado étnico messênio em relação a Zeus Ithomatas, na implementação e configuração urbana da cidade, o santuário de Zeus Ithomatas 
no alto do Mt.lthome, foi incorporado à área urbana pelo circuito de muros nesse período ${ }^{80}$ (Fig.55). Assim, 0 Mt.Ithome assumiu a função de acrópole da pólis de Messênia (Kreutz, 2007: 19; Luraghi, 2008: 209).

A respeito dessa fase urbana do culto de Zeus Ithomatas, N. Kreutz coloca uma questão que, no fundo, perpassa a percepção dos gregos sobre Zeus e a pólis. Como coloca a estudiosa, mesmo após a reorganização do culto, o santuário de Zeus continuou sem templo e a ser cultuado a céu aberto, embora tenha se estabelecido, no século IV a.C., na acrópole como a principal divindade de Messênia (Kreutz, 2007: 19). A seu ver, isso mostra que "o culto a Zeus sempre permaneceu marginalizado até mesmo quando havia se tornado a divindade oficial da pólis" (Kreutz, 2007: 19). Como vimos no final do capítulo anterior, Kreutz coloca muita ênfase na acrópole como o espaço reservado à divindade patrona da pólis, sendo esse um critério baseado principalmente no modelo de Atenas, onde o culto mais importante foi sediado nessa área da cidade. Acreditamos que o santuário de Zeus Ithomatas representa bem a variabilidade do culto e dos santuários no mundo grego e deve ser interpretado fora do padrão atenocêntrico. A nosso ver, se o culto de Zeus Ithomatas de fato não recebeu um templo e permaneceu cultuado a céu aberto, mesmo tendo sido a divindade principal da cidade, isso teve a ver com o aspecto conservador de seu culto mantido, intencionalmente, durante o século IV a.C.: ainda nessa época, a divindade era associada a trípodes (um votivo típico da Idade do Ferro, associado às narrativas heroicas) e possivelmente, a representação de sua estátua, feita por Ageladas, ao lado dos próprios trípodes, foi escolhida como a imagem para a recém criada cunhagem da cidade. Assim, a manutenção de certos elementos no culto demonstra o interesse dos antigos messênios, por meio de Zeus Ithomatas, em se ligar ao seu passado heroico.

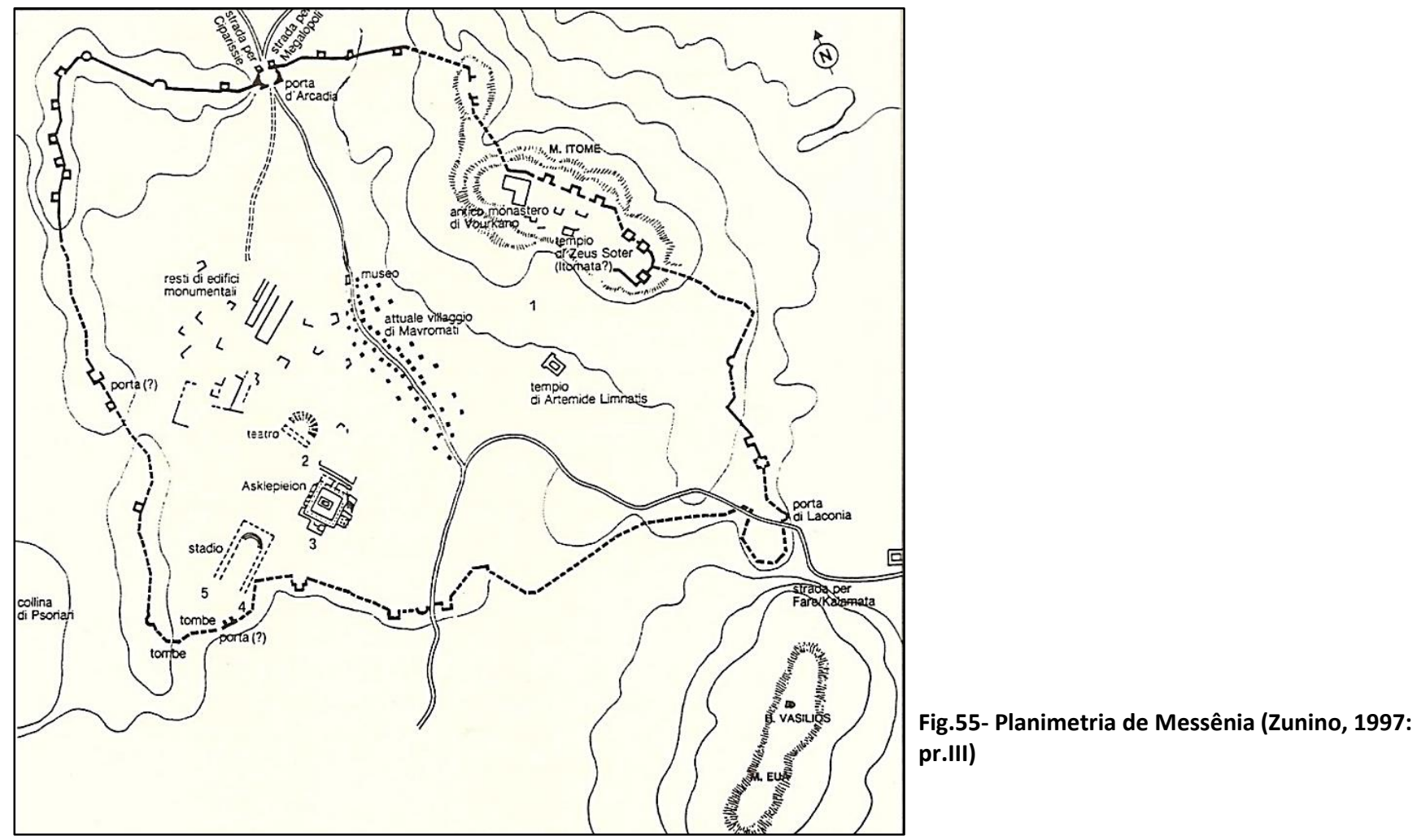

80 No Mt.Ithome foram encontrados restos de fortificações poligonais que datam da revolta em c.460 a.C. (Shipley, 2004: 564). Entretanto, estes indicam que apenas a montanha foi fortificada nessa época. 
Situado no nordeste do Peloponeso, o santuário de Zeus Apesantios encontra-se no topo do Mt. Apesas (873 m) (cat.no.13), atual Monte Fokás - no sudoeste da região de Corinto e a c.6 km a norte de Neméia (Fig.56) (Langdon, 1976: 107; Zolotnikova, 2005: 111). Ernst Meyer foi quem primeiro descreveu o sítio em uma publicação de 1939, seguido por M.K. Langdon na década de 1970, que

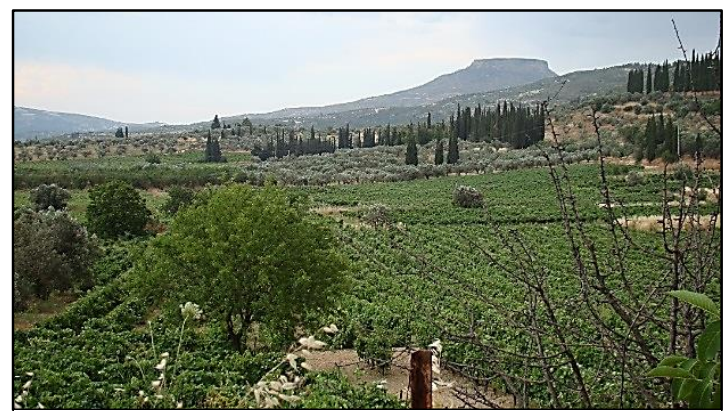
Fig.56- Monte Apesas ao fundo visto a partir de Neméia (Foto: arquivo pessoal/2009) desenvolveu a hipótese dos achados na área pertencerem aos restos do altar de Zeus Apesantios mencionado nas fontes textuais. A instalação de marcos topográficos, para uma pesquisa do exército grego no ano de 1953, levou a dispersão dos achados arqueológicos (cerâmica e das cinzas do altar) do santuário (Zolotnikova, 2013: 113). A maior pesquisa no topo do Monte Apesas ou Fokás foi empreendida pelo Nemea Valley Archaeological Project dirigido por J.C. Wright entre 1984-1989, que recolheu e datou a maior parte das cerâmicas (Zolotnikova, 2013: 113). Uma nova e mais completa interpretação sobre o santuário foi recentemente proposta por 0. Zolotnikova (2013b).

\section{II.5.1 Descrição e interpretação dos achados}

O início da atividade cultual no santuário de Zeus Apesantios é datado entre o geométrico médio (IX a.C.) e o geométrico tardio (século VIII a.C.) a partir do material cerâmico mais antigo encontrado (Zolotnikova, 2013b: 113). A continuidade cultual com os períodos seguintes (ainda que de diferentes formas e intensidade) também é atestada a partir de fragmentos cerâmicos datados de época arcaica, clássica, helenística e romana (Zolotnikova, 2013b: 113). A quantidade de cerâmica de cada período evidencia que o período entre os séculos VIII e VII a.C. representa o ápice da atividade cultual, enquanto que a partir do século VI a.C. houve um importante período de declínio no santuário, que se acentuou, progressivamente, durante os períodos clássico, helenístico e romano (Zolotnikova, 2013b: 115). Apesar desses resultados, obtidos através do material cerâmico, a cronologia da área sagrada não é ainda clara sem uma escavação sistemática, não realizada até o momento, e o estabelecimento de uma estratigrafia (Zolotnikova, 2013b: 113).

Os únicos achados do santuário são fragmentos de material cerâmico e ossos queimados dos sacrifícios de animais no altar - nenhum objeto votivo de terracota e bronze foi encontrado no topo do monte (Zolotnikova, 2013b: 114). O Nemea Valley Archaeological Project datou a maior parte da cerâmica coletada do final do geométrico tardio ao século VII a.C., sendo ao menos uma parte de uma jarra pertencente ao geométrico médio (Zolotnikova, 2013b: 113). Aríbalos proto-coríntios de tipo globular representam a maior parte 
do tipo de vasos usados no ritual no altar de Zeus, seguidos pelos tipos de oinochoai do geométrico tardio e kotyle (Zolotnikova, 2013b: 113).

A área sagrada foi instalada no cume em formato de mesa, uma área espaçosa inclinada de leste a oeste (Langdon, 1976: 107; Zolotnikova, 2013b: 111). Zolotnikova define a área ritual do santuário no Mt.Apesantios não apenas restrita ao cume da montanha, mas distribuída ao longo dos três platôs que formam a montanha, que teriam tido, cada qual, um papel no culto. Assim, "a área plana do cume do monte mede mais do que 400 m de leste-oeste e c.200 m de norte-sul" (Zolotnikova, 2013b: 112-113). "O platô de cima mede c.100 m noroeste-sudeste e 70 m nordeste-sudoeste; o platô do meio, localizado c. 10 m abaixo, mede c.90100 m nordeste-sudoeste e 60-70 m noroeste-sudeste; e o terceiro e mais baixo platô, a leste do platô do meio, cai levemente a sudeste" (Zolotnikova, 2013b: 112-113).

Com relação à tipologia (localização, tamanho, e achados arqueológicos), o altar do santuário no Mt. Apesas é comparável aos altares de cinza de Zeus da Idade do Ferro em topos de montanha, como do Mt.Himeto e Mt.Parnes, na Ática, Mt.Oros, em Egina, e Mt.Arachnaion, na Argólida (Zolotnikova, 2013b: 115).

\section{II.5.2 A natureza do culto e a função do santuário}

A atribuição do santuário no Mt.Apesas a Zeus Apesantios tem como base fontes textuais que localizam um altar do deus no cume dessa montanha. Não há, além disso, qualquer outro tipo de evidência arqueológica, como por exemplo inscrições, que possam também identificar o culto a Zeus no local. Nas fontes literárias, 0 santuário é mencionado em duas narrativas míticas importantes: o assassinato da Górgona-Medusa, pela princesa argiva Danaia, que teria sacrificado a Zeus no Mt.Apesas antes de partir para sua missão (Pausânias II, 15.3); o mito do Leão de Neméia, no qual Héracles teria também realizado um sacrifício a Zeus Apesantios antes de partir para a batalha com o leão (Hesíodo, Teogonia 327-331); e o mito de Deukalion, que teria estabelecido um altar à divindade no topo da montanha (Píndaro, Ol. 9, 43-45) (Zolotnikova, 2013b: 111-112).

O santuário no topo do Monte Apesas parece ter sido um lugar de culto destacado entre o geométrico médio/tardio e o início do arcaico, que, apesar de seu difícil acesso, teria sido propício às cerimônias envolvendo grandes grupos de pessoas. $O$ foco do culto, muito provavelmente, foi o altar de cinzas, de grande tamanho, a julgar pela grande área plana no topo da montanha e a quantidade de cinzas e material cerâmico acumulado em sua superfície (Zolotnikova, 2013b: 114).

A partir dos tipos de achados cerâmicos, e descrições de antigos rituais nos textos homéricos ${ }^{81}$, Zolotnikova oferece, pela primeira vez, uma reconstituição do ritual no santuário do Mt.Apesas. De acordo com sua interpretação, "o fogo, no altar, deve ter sido o elemento principal, assim como a destruição de vasos diretamente nas chamas, dentre outros atos, envolvendo a participação de famílias" (Zolotnikova, 2013b: 114).

\footnotetext{
${ }^{81}$ A estudiosa cita os seguintes trechos da llíada: 23, 219-220; 237-238; 250-251 (Zolotnikova, 2013b: 114).
} 
Provavelmente, "os fiéis cercavam o fogo e realizavam certos atos com óleo (talvez libação ou unção) trazidos em aríbalos, como também usavam as enócoas para libações e taças para beber vinho" (Zolotnikova, 2013b: 114). O vinho poderia também "ser aspergido no fogo ou nas cinzas após o fogo ter se extinguido" (Zolotnikova, 2013b: 114). Ainda, "todos os vasos, envolvidos no ritual, devem ter sido destruídos diretamente no fogo, enquanto a cerimônia ocorria e outros atirados nas cinzas, quando o fogo já havia se apagado" (Zolotnikova, 2013b: 114). Os restos dos vasos teriam, então, "sido quebrados e usados, deliberadamente como material para o altar de cinzas" (Zolotnikova, 2013b: 114). Sacrifícios de animais teriam sido realizados em "um momento específico do ritual, seguido por uma refeição comunal, como indica o achado de uma categoria de vaso usado para tal fim" (Zolotnikova, 2013b: 114).

Nessa perspectiva, esse tipo de ritual relaciona-se ao tipo de culto a Zeus Apesantios. O epíteto "Apesantios" ("que manda embora", "que afasta") tem conotação apotropaica e indica o caráter purificatório do culto, que encontra comprovação nos vestígios do ritual encontrados na superíficie do topo da montanha (Zolotnikova, 2013b: 115). De acordo com a tese de Zolotnikova, "é possível que o grande fogo, periodicamente aceso no topo da montanha, teve como finalidade intimidar ou repelir os espíritos das terras nos arredores" (Zolotnikova, 2013b: 115). A seu ver, portanto, "a chama do altar de Zeus pode ter sido vista como um poder purificador, no qual os participantes no ritual se consideravam limpos de um miasma - as cerimônias teriam sido um tipo de purificação comunal (KáӨapoıৎ) na qual o deus teria sido procurado para levar embora as impurezas e absolver todos os atos contaminados" (Zolotnikova, 2013b: 115).

Com relação à função do santuário, de acordo com a tese da pesquisadora russa, se tratou de uma área sagrada extra-urbana e inter-regional. Assim, "a julgar pelo tamanho do altar, e pela proximidade da montanha a importantes centros urbanos do início da Idade do Ferro como Corinto, Kleonai e Phlious, é possível que o santuário no Mt.Apesas tenha tido uma função regional, tendo sido, portanto, muito mais do que um santuário rural para habitantes locais" (Zolotnikova, 2013b: 114-115). A partir do final do século VIII a.C. e por todo o século VII a.C., o santuário pode ter sido a principal área sagrada de Zeus na região da Coríntia e no norte da Argólida (Zolotnikova, 2013b: 115). No nordeste do Peloponeso, além dos santuários do Mt.Apesas, Neméia e Mt.Arachnaion, Zolotnikova lista mais duas localidades que acredita terem sido locais de culto a Zeus: a colina de Evaggelistria e o desfiladeiro de Tretos (Dervenakia) (Zolotnikova, 2013b: 111). No entanto, esses dois santuários não foram considerados em nossa investigação pela ausência de evidências materiais e textuais que possam assegurar a atribuição do culto a Zeus. 0 declínio abrupto nas atividades do santuário no século VI a.C., é explicado por Zolotnikova como causa do prestígio do santuário de Zeus em Neméia alcançado a partir dessa época (Zolotnikova, 2013b: 115). O santuário de Zeus em Neméia teria propiciado, a partir do século VI a.C., "condições mais favoráveis para o culto de Zeus no nordeste do Peloponeso para cada vez numerosos grupos de fiéis - tornando-se mais apropriado para as competições atléticas inter-regionais, cada vez mais populares a partir de época arcaica" (Zolotnikova, 2013b: 122). 


\section{II.6 Tsakona}

Localizado na Lacônia, no sudeste do Peloponeso, o santuário de Zeus Messapeus (cat. no.14) foi estabelecido na colina mais alta da serra de Tsakona - situada na área do vilarejo de Aphyssou, a 2,25 km a leste-sudeste de Esparta (Fig.57) (Catling, 1990: 15 e 18). A área sagrada em Tsakona foi identificada em 1984 durante o survey na Lacônia realizado pela Escola Britânica de Atenas, mas a escavação propriamente dita ocorreu em duas campanhas entre maio e agosto de 1989 (Catling, 1990: 16). O sítio sofreu muita destruição pela erosão, cultivo da terra e incêndios. Também até 1988 a área era usada como depósito de entulho doméstico pelas autoridades municipais de Esparta (Catling, 1990: 16 e 18).

\section{II.6.1 Descrição e interpretação dos achados}

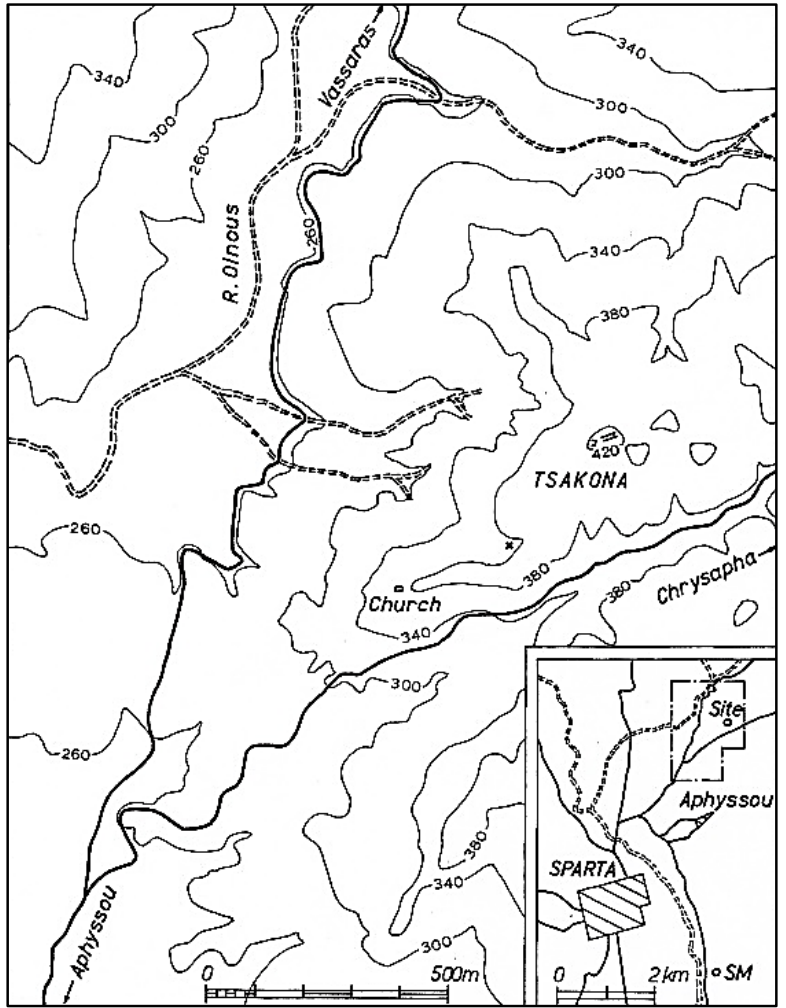

Fig.57- Planimetria da área de Tsakona, Lacônia (Catling, 1990: fig.1)

A atividade cultual do santuário de Zeus Messapeus tem sido situada a partir do período geométrico tardio (século VIII a.C.) com base em fragmentos cerâmicos recuperados na encosta norte da colina e em um alfinete de bronze fragmentário proveniente do edifício I (Catling, 1990: 34-35). O término do culto ocorreu, provavelmente, em época romana (séculos IV e $V$ d.C.), como indicam os achados de lamparinas e de alguns tipos de estatuetas (Catling, 1990: 34-35).

O survey realizado pelos arqueólogos ingleses, determinou a extensão do santuário, a partir da dispersão dos achados na área, em um espaço de $45 \mathrm{~m}$ leste-oeste e 10 m norte-sul (Catling, 1990: 18). Já a dispensão dos objetos votivos abaixo das encostas norte e sul levou a 1990: 18). As pesquisas também identificaram os remanescentes de dois edifícios (Fig.58), ligados ao culto, mas nenhum traço do muro de témeno foi encontrado (Catling, 1990: 21).

De acordo com os relatórios de escavação, os remanescentes do santuário impõem problemas com relação à cronologia e continuidade do uso da área sagrada. Em primeiro lugar há longos estágios dentro do período de 1000 anos sobre os quais não se recuperou nenhuma evidência (Catling, 1990: 33). Em segundo lugar, os objetos votivos representam períodos diferentes de uso do santuário, mas não podem ser associados aos contextos arquitetônicos e estratigráficos, pois foram encontrados dispersos pela área (Catling, 1990: 33). Como dissemos, achados cerâmicos, provenientes da encosta norte da colina, e um alfinete de bronze, 
encontrado próximo ao edifício I, são as únicas evidências que podem assinalar o início do culto no século VIII a.C. (Catling, 1990: 33). Já o material cerâmico proveniente dos dois edifícios sugere o seu abandono simultâneo no final do século V a.C. (Catling, 1990: 33). Para Catling, talvez tal abandono esteja relacionado aos severos terremotos ocorridos em Esparta noticiados por Tucídides (Catling, 1990: 33). As telhas, por sua vez, indicam que o edifício I sofreu uma reconstrução no séc. I a.C. Uma grande lacuna, então, existe entre os séculos I a.C. e os séculos IV e V d.C. de quando datam as lamparinas e as estatuetas (Catling, 1990: 33). É provável, segundo os estudiosos que o culto não tenha sido atrativo em época romana, como também ocorre no caso do Menelaion em Esparta (Catling, 1990: 33). Já as evidências mais recentes do santuário (as lamparinas e as estatuetas) podem indicar um reavivamento antiquário do culto de Zeus Messapeus no período romano tardio (Catling, 1990: 34-35).

Assim, com relação ao edifício I, provavelmente 0 principal do santuário, este localiza-se sobre o topo da colina, seu longo eixo orientava-se na direção nordestesudoeste (Catling, 1990: 21). Trata-se de uma estrutura retangular de pedra construída no centro da colina, que tinha uma dimensão total de $5 \times 22 \mathrm{~m}$ - nas partes mais preservadas e os muros devem ter medido 0,60 m de largura (Catling, 1990: 21 e 23). Com relação a estrutura arquitetônica, o edifício teve uma entrada a leste de aproximadamente $1,50 \mathrm{~m}$ de lagura e é provável que os muros norte e sul tinham antas, embora não tenha sido encontrada nenhuma base de coluna, para o fuste, necessária para suportar o lintel de um pórtico com antas (Catling, 1990: 21 e 23). Os blocos encontrados no local indicam que o edifício foi construído em calcário local e xisto azulado da região, mas não se sabe, ao certo, se era

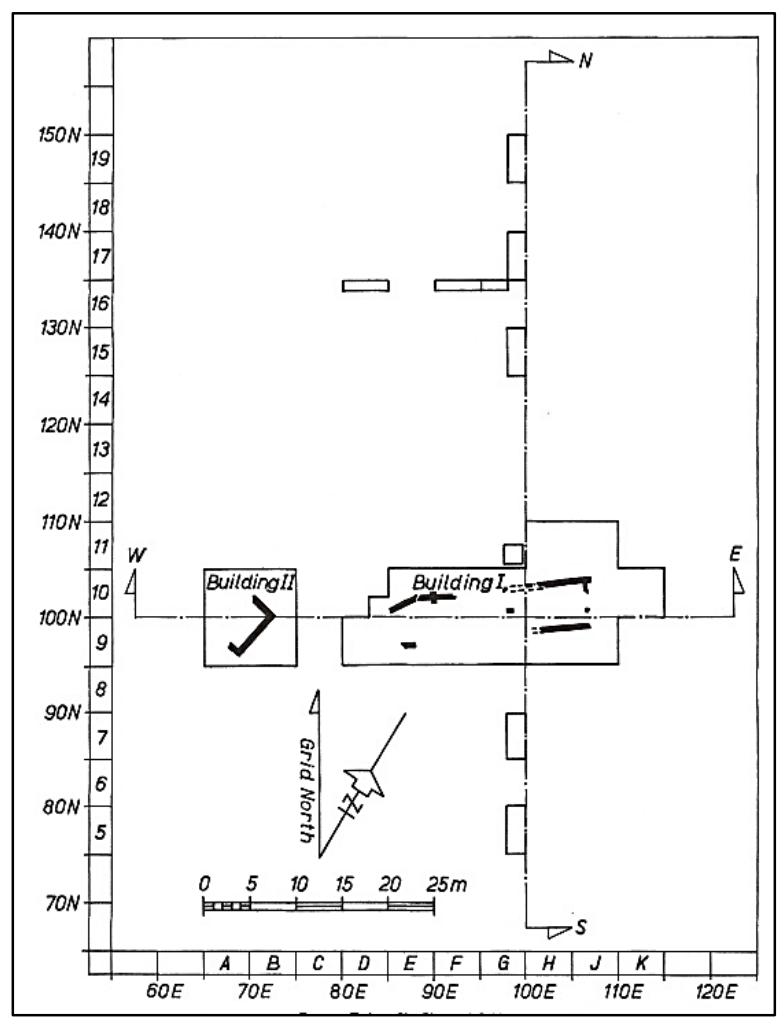

Fig.58- Planimetria do santuário de Zeus Messapeus em Tsakona (Catling, 1990: fig.2) todo feito neste material ou se a parte superior dos muros era feita de tijolos de barro (Catling, 1990: 24-25). Nenhum tipo de pavimento foi encontrado. O edifício I foi certamente coberto com telhas lacônias, esmaltadas, com antefixas e acrotério em disco, como indicam os achados no local (Catling, 1990: 25). Dentro da área da construção, foram encontradas seis fossas votivas, dentro das quais foram recuperadas uma ponta de lança de bronze, um material bastante escuro de cinzas contendo lamparinas de terracota, pequenos fragmentos de vidro, estatuetas de terracota, miniaturas de aríbalos e os fragmentos de lamparinas romanas feitas em moldes (Catling, 1990: 26). Fora do edifício, outra fossa foi encontrada, contendo lajes de calcário cuidadosamente ali depositadas - estudos revelaram se tratar de estelas não decoradas que possivelmente foram usadas, danificadas (propositalmente) e enterradas dentro do témeno (Catling, 1990: 26). Uma sepultura de época 
romana tardia, datada entre os séculos III e IV d.C. foi encontrada atravessada no canto sul do edifício (Catling, 1990: 26).

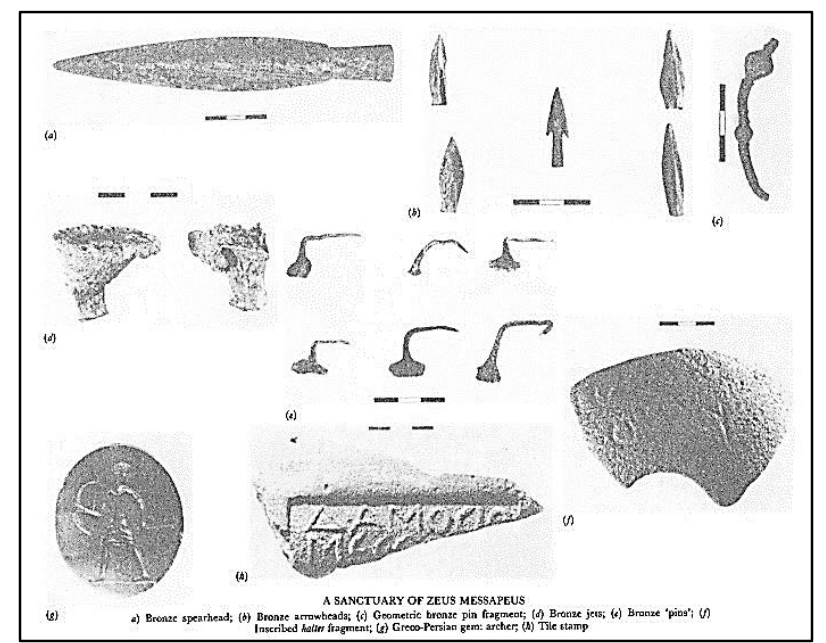

Fig.59- Pontas de lança de bronze, selo greco-persa e telha com estampa inscrita $\triangle \mathrm{AMOCIO} / \mathrm{MECC}$ (Catling, 1990: prancha 5)
Sobre o edifício 2, este foi definido, pelas pesquisas arqueológicas, como um tipo de edifício auxiliar de função desconhecida, eregido sobre uma erosão natural na borda oeste da colina - uma característica natural do terreno aproveitada para a realização de sua construção. Os remanescentes indicam que se situava a $14 \mathrm{~m}$ a sudoeste da extremidade oeste do edifício I e era orientado norte-leste e sul-oeste (Catling, 1990: 21). A construção media $3 \times 5 \mathrm{~m}$ e apenas a parte sul do edifício restou. Com relação à sua arquitetura, os muros mediam de 0,45 de espessura e 0,75 m de altura (Catling, 1990:

27). O edifício II é aparentemente posterior ao edifício I, como indica um amontoado de lajes e blocos de xisto sobre um nível de solo escuro contendo duas estatuetas de terracota (Catling, 1990: 27). Uma confirmação adicional da sequência relativa da construção foi propiciada por fragmentos de aríbalos de verniz preto e por duas ou três estatuetas de terracotas encontradas na composição dos muros do edifício (Catling, 1990: 27).

Com relação aos tipos de objetos votivos (Figs.59 e 60), poucos objetos de bronze e acima de 100 objetos de ferro foram registrados (soquetes-encaixes de pontas de lanças, pregos ou ganchos), desses, apenas seis peças foram recuperadas no edifício II (Catling, 1990: 30). Normalmente encontrados aos milhares nos santuários da Lacônia, apenas 20 figurinhas votivas de chumbo foram encontradas em Tsakona (16 coroas, 2 fragmentos de guerreiros, uma coroa grande, um possível diadema) (Catling, 1990: 30). Mais de 2600 estatuetas de terracota feitas à mão (não em moldes) foram recuperadas, sendo a maior parte um tipo de figura masculina agachada, sentada ou ajoelhada com um grande falo, já figurinhas itifálicas em pé são raras (Catling, 1990: 30). Foram encontradas também figurinhas

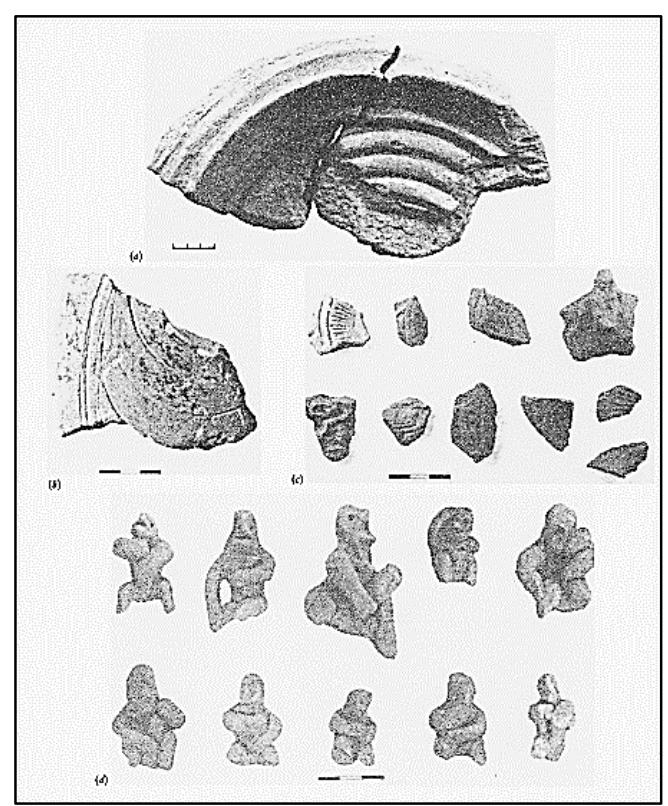

Fig.60- Acrotérion, antefixa e figurinhas de terracota masculinas (Catling, 1990: prancha 6) humanas de sexo indeterminado (com veste aparentemente drapeada), figurinhas femininas nuas na posição de pé, grávidas, mulheres de cócoras, com as pernas abertas (talvez em posição de parto), uma figurinha de um quadrúpide carregando cestos (equino, presumivelmente) e outra de um quadrúpide indeterminado (Catling, 1990: 30). Fragmentos de terracotas, feitas em moldes, incluem algumas figurinhas raras, no contexto do santuário, como de uma mulher de tipo dedálico (provavelmente um apêndice de vaso), uma cabeça de um 
kouros e outra de um homem com barba, ambas do período arcaico tardio (Catling, 1990: 30). Pouco material cerâmico de vasos foi encontrado: de 450 potes, 347 são miniaturas, sendo 46 aríbalos de tamanho normal, 6 taças sem alças e dois oinochoi (Catling, 1990: 30). No edifício II foram encontrados 18 aríbalos de tamanho normal e apenas 11 miniaturas, enquanto que ao redor do edifício I foram encontradas 302 miniaturas de aríbalos, 32 aríbalos de tamanho normal, taças sem alças e também oinochoi (Catling, 1990: 30). Nenhuma cerâmica decorada ou contendo figuras (a maioria possui apenas um verniz preto) (Catling, 1990: 30). Da fase romana pertencem 388 lamparinas de moldes, encontradas na metade do edifício I, e fragmentos de vasos de vidro (Catling, 1990: 31). Um selo de tipo grego-persa possivelmente datado do século IV a.C. e armas, armaduras e equipamentos de atletas também compõem o repertório de objetos votivos (Catling, 1990: 32 e 34).

\section{II.6.2 A natureza do culto e a função do santuário}

A atribuição do santuário em Tsakona ao culto de Zeus Messapeus foi feita com base na associação entre evidências epigráficas, provenientes da própria zona do santuário e das proximidades, e testemunhos nas fontes literárias. Uma inscrição incompleta (---] EME $\Sigma A \sqcap E Y)$, em um fragmento de uma taça lacônia do século VI a.C., descoberto na superfície do solo a 250-300 m do santuário, foi identificada como uma dedicação a Zeus Messapeus, cujo epíteto é atestado apenas em Pausânias e Teopompo82 (Catling, 1990: 32). Uma estampa impressa em uma telha, encontrada nas escavações em Anthochori (a $2 \mathrm{~km}$ de Xerokambos), contém

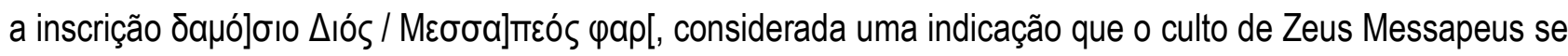
localizava no assentamento de Anthochori (Catling, 1990: 32). No edifício I, quatro ou cinco estampas fragmentárias de telhas recuperadas parecem confirmar o culto, como a mais preservada, que contém a inscrição $\triangle \mathrm{AMOCIO} \mathrm{/} \mathrm{MECC[-} \mathrm{(Catling,} \mathrm{1990:} \mathrm{32).} \mathrm{Segundo} \mathrm{o} \mathrm{testemunho} \mathrm{de} \mathrm{Pausânias} \mathrm{(III,} \mathrm{XX.2-5),} \mathrm{um}$ témeno de Zeus Messapeus teria se localizado, aparentemente, no lado oeste da planície espartana, em algum lugar a norte do moderno vilarejo de Xerokambos (Catling, 1990: 32). O testemunho de Pausânias e o achado de inscrições em áreas diferentes, levou os pesquisadores a pensarem na existência de dois santuários da divindade no vale de Esparta ou no possível extravio da telha com a inscrição de Tsakona à Anthochori (Catling, 1990: 32). De todo modo, a identificação do culto a Zeus Messapeus em Tsakona é considerada certa pelos seus escavadores (Catling, 1990: 22).

O. Zolotnikova explica que a origem do epíteto Messapeus de Zeus não é muito clara (Zolotnikova, 2013a: 107). A partir da etimologia do nome, a pesquisadora russa conjectura que Messapeus é relacionado a uma divindade peloponésia pré-grega, associada a alguma localidade no meio da península ou a uma divindade originalmente cultuada entre tribos no noroeste da Grécia Balcânica - relacionada aos ilírios, entre os quais há

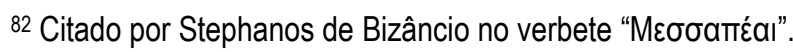


a ocorrência do prefixo que compõe o epíteto - trazida posteriormente à Lacônia pelos dórios (Zolotnikova, 2013a: 107).

Com relação ao culto realizado a Zeus no santuário, Zolotnikova sugere que este pode ter sido realizado "a céu aberto durante a fase mais antiga, sendo, posteriormente, entre o século VII a.C. e a época romana abrigado nos dois ou em um dos edifícios" (Zolotnikova, 2013a: 107). Já os objetos votivos propiciam muitas indicações sobre a natureza do culto, sinalizando a presença de divindade masculina como a principal (Catling, 1990: 21). As estatuetas votivas de homens itifálicos (a maioria) e mulheres grávidas (a minoria), por exemplo, "são interpretadas como uma clara referência a um culto relacionado à reprodução". Catling supõe que um culto "relacionado à fertilidade/virilidade masculina, na área sagrada, pode ser um indicativo do problema da oligantropia em Esparta" (Catling, 1990: 34).

De fato, os votivos feitos em chumbo (a maioria coroas e diademas) são considerados evidências típicas de ritos iniciatórios, ligados à fertilidade, em santuários lacônios, conforme já mencionamos na análise do santuário no Mt.Lykaion, e confirmam, portanto, a presença de tal característica no culto de Zeus Messapeus. Já as armas e armaduras, podem indicar ritos iniciatórios relacionados a uma aristocracia militar masculina ou talvez a jovens da aristocracia, de uma maneira semelhante como ocorre no caso dos santuários cretenses extra-urbanos de Zeus. Contudo, a presença de outros tipos de objetos votivos dedicados, como as estatuetas masculinas e femininas indicam um culto que propiciou a coesão social entre grupos de uma ou mais comunidades, não tendo sido restrito, aparentemente, a um grupo específico, como foi o caso dos santuários cretenses de Palaikastro e Praisos, por exemplo. Também se deve considerar que armas, armaduras e equipamento de atletas podem ter sido oferendas, deixadas ao deus no santuário, em agradecimento às questões relacionadas à fertilidade ou à reprodução masculina. De todo modo, o elemento militar esteve, em algum grau, presente no culto, praticado com rituais envolvendo o consumo comum de vinho, como indicam as taças e as enócoas. Sacrifícios de animais também devem ter sido realizados, embora não tenha sido relatado a presença de ossos de animais, mas apenas de cinzas em uma fossa - o único indicativo de um altar.

É difícil classificar a que categoria de santuário pertenceu o culto de Zeus Messapeus em Tsakona. A nosso ver, apesar da pouca distância de Esparta, se tratou de uma área sagrada extra-urbana sub-regional, frequentada não só por Esparta (talvez com a preponderância dessa cidade), mas pela população de comunidades vizinhas, pertencentes à outras áreas da Lacônia talvez não muito distantes do santuário. 0 santuário de Zeus Messapeus deve ser analisado no contexto das demais áreas sagradas (as funções do culto, os tipos de votivos) espalhadas na área de Esparta, datadas entre a Idade do Ferro e época clássica. Essa é a interpretação que propomos a esse santuário de Zeus. 


\section{II.7 Mt. Arachnaion}

Localizado na fronteira entre a Coríntia e a Argólida, no nordeste do Peloponeso, a leste de Micenas, o denominado santuário de Zeus e Hera (cat. no.15) foi estabelecido sobre o pico de Ágios Elias (1199 m), o mais alto do Mt. Arachnaion (Langdon, 1976: 108). De acordo com M.K. Langdon, a exploração do santuário no local foi iniciada por Boblaye, que primeiro forneceu uma descrição dos remanescentes (Langdon, 1976: 107, nota 24). Desde sua época outros viajantes também estiveram na área (Langdon,

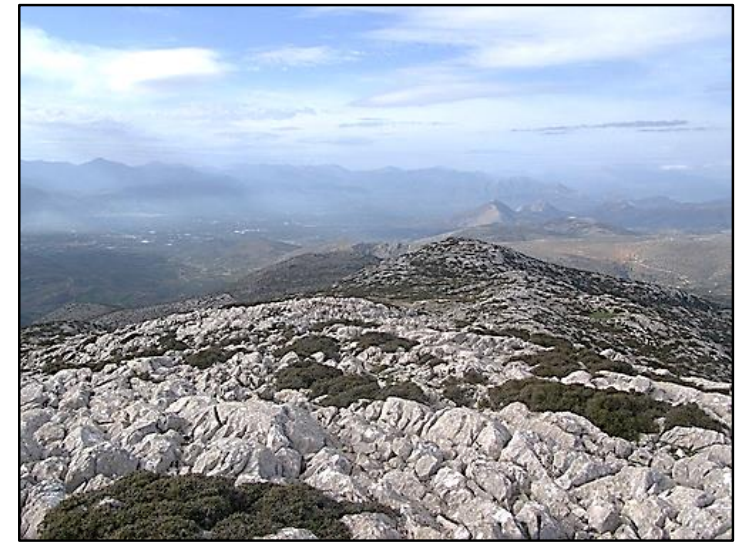

Fig.61- Vista a partir do Mt.Arachnaion (Foto: Mellotron/Peakery.com) 1976: 107, nota 24). Recentemente, escavações arqueológicas do Serviço Arqueológico Grego propiciaram a descoberta de achados micênicos na parte leste do platô do pico de Ágios Elias (Zolotnikova, 2013a: 86).

\section{II.7.1 Descrição e interpretação dos achados}

A atividade cultual no santuário de Zeus e Hera no Mt.Arachnaion inicou-se no período geométrico tardio (século VIII a.C.), conforme indica a concentração de fragmentos cerâmicos argivos e proto-coríntios datados a partir dessa época (Zolotnikova, 2013b: 120). A baixa concentração de evidências arqueológicas de época clássica indica o término do culto nesse período, embora tenha havido um esporádico reuso durante 0 período romano (Zolotnikova, 2013b: 121).

Achados arqueológicos da Idade do Bronze foram encontrados na área dos picos do Mt.Arachnaion. Entre os dois picos da montanha (o Ágios Elias e o Mavrovouni) é atestado um assentamento dessa época, ao passo que na área do santuário de Zeus e Hera, no pico de Ágios Elias, foram recuperados, fora de contexto estratificado, restos micênicos - "figurinhas de argila femininas e de animais e fragmentos cerâmicos do heládico tardio III (taças e potes para cozimento)"(Zolotnikova, 2013: 86). Apesar desses achados indicarem uma prática cultual na área já nessa época, estes "não são relacionados ao culto de Zeus e Hera e, portanto, não indicam a continuidade cultual do santuário entre a Idade do Bronze e a Idade do Ferro" (Zolotnikova, 2013a: 86).

Estruturas arquitetônicas foram encontradas no platô do pico, "mas sua datação não pôde ser estabelecida" (Zolotnikova, 2013a: 86). Descritas por Langdon na década de 1970, as fundações de duas estruturas antigas situam-se no cume e estão completamente enterradas na terra enegrecida que cobre o topo (Langdon, 1976: 108). Contudo, o suficiente está visível para a determinação de seu tamanho e formato (Langdon, 1976: 108). Ambas são construções retangulares bastante grandes, uma com 6x13 m e a outra com 5x2 m (Langdon, 1976: 108). O interior de ambas foi cavado e estão preenchidos com quantidades de cascalho 
(Langdon, 1976: 108). Os muros têm a espessura de 0,50 e 0,75 m e são construídos com blocos de calcário de tamanho médio com as faces exteriores grosseiramente regulares (Langdon, 1976: 108).

Com relação aos achados cerâmicos, o principal tipo de material pertencente ao santuário, estes foram encontrados em três concentrações na área, alguns deles contendo ossos de animais queimados (Zolotnikova, 2013b: 120). A primeira concentração, situada próximo ao ponto mais alto do pico de Ágios Elias, "era cercada por um muro baixo de c. 5×10,50 m e continha cerâmica datada entre 700-480 a.C." (Zolotnikova, 2013b: 120). Na segunda concentração, "localizada na encosta leste da montanha, recuperou-se os fragmentos cerâmicos argivos e proto-geométricos, já mencionados, o material mais antigo encontrado" (Zolotnikova, 2013b: 120). E na terceira concentração, "foram encontrados fragmentos cerâmicos de época arcaica e clássica" (Zolotnikova, 2013b: 120). Essas três concentrações de objetos votivos podem ser as "candidatas ao altar de cinzas do santuário" (Zolotnikova, 2013a: 86).

Isto posto, "a fase mais ativa do santuário no Mt.Arachnaion parece ter sido o período entre a segunda metade do século VIII a.C. até o final do século VII a.C." (Zolotnikova, 2013b: 120-121). Os achados cerâmicos "evidenciam o uso contínuo do santuário de Zeus e Hera entre a segunda metade do século VIII a.C. até o século V a.C." (Zolotnikova, 2013b: 121).

\section{II.7.2 A natureza do culto e a função do santuário}

A atribuição do santuário no Mt.Arachnaion ao culto de Zeus e Hera foi baseada no único testemunho de Pausânias (II, XXV.10) que indica a presença de um altar das duas divindades na área. Os remanescentes de um antigo altar de cinzas no local, em associação à notícia do viajante grego, foram suficientes para Langdon atribuir o culto destas divindades no local (Langdon, 1976: 108).

Conforme Zolotnikova, a associação de Zeus, com o cume do monte, pode ser datada ao período histórico, já a natureza de seu culto, tal como foi praticada na Idade do Ferro não é indicada pelos achados recuperados na área (Zolotnikova, 2013a: 86). De acordo com a notícia de Pausânias sobre o altar no monte, o culto era relacionado à chuva, "mas tal função atmosférica do culto não é muito clara nos tipos dos achados encontrados" (Zolotnikova, 2013b: 121). Com relação a Hera, o tipo de culto praticado no pico, durante a Idade do Bronze, indicado pelos achados na área, "parece ter sido relacionado, ao menos parcialmente, a uma divindade feminina, mas até o momento não é possível ter um quadro mais claro de seu caráter e funções diante do estado das evidências, nem pode ser confirmado que se tratou do culto de Hera nessa época" (Zolotnikova, 2013a: 86). Além disso, "nenhuma tradição literária a respeito do mito de fundação do santuário foi preservada" (Zolotnikova, 2013b: 121).

Os tipos de cerâmicas encontradas no santuário indicam que o culto praticando no Mt.Arachnaion envolveu cerimônias para beber vinho e libações, "semelhantes ao padrão de ritual encontrado no Mt.Apesas, embora sem o envolvimento do mesmo contingente de indivíduos" (Zolotnikova, 2013b: 121). 
Com relação à função do santuário, o tipo de culto e sua localização o identificam como uma área sagrada extra-urbana sub-regional, datada a partir da Idade do Ferro, que serviu, principalmente, à população da Argólida, como indica a sua "clara origem norte argiva" e também sua posição em

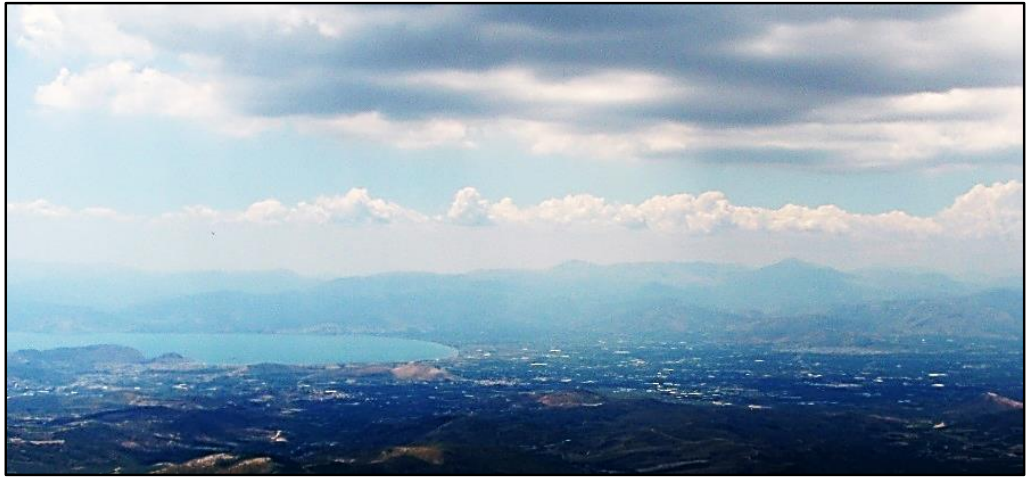

Fig.62- Vista da Argólida a partir do Mt.Arachnaion (Foto: Dan Diffendale/Flickr.com) uma área do cume que oferece uma visão de toda a Argólida83 (Zolotnikova, 2013b: 121). Contudo, a sua posição entre duas sub-regiões indica um papel inter-regional, em algum nível, servindo também às comunidades da Coríntia ${ }^{84}$, como indica também a proveniência de alguns dos fragmentos cerâmicos da região encontrados no santuário.

\section{II.8 Neméia}

Situado também em uma área de confluência entre sub-regiões no nordeste do Peloponeso (entre a Coríntia, a nordeste, a Argólida, a sul, e a Arcádia, a leste), 0 santuário de Zeus Nemeios foi estabelecido em Neméia (cat. no.21) - em um vale de terras altas, nos sopés orientais das montanhas arcádias, cercado a sudeste pela colina de Evanggelistria, a sudoeste

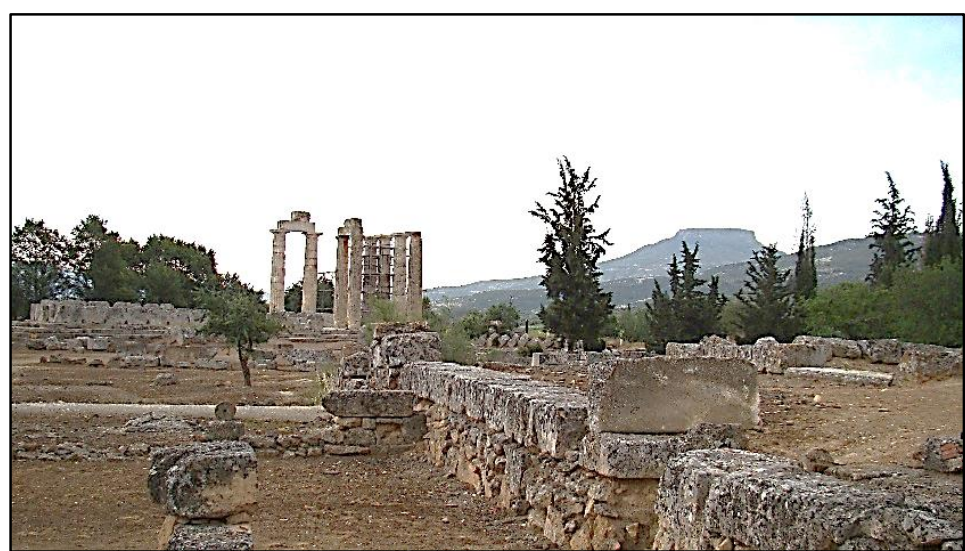

Fig.63- Vista do templo clássico de Zeus em Neméia; ao fundo Mt.Apesas (Foto: arquivo pessoal/2009)

pelo Mt. Daouli, a oeste pelo Mt. Trikaranon e a leste pelo Mt. Apesas (Figs.63 e 64) (Miller, 2004: 19-20). A pesquisa arqueológica no santuário em Neméia ocorreu, pela primeira vez, em 1766 promovida pela Sociedade dos Dilentates de Londres, que abriu uma trincheira no templo de Zeus (Miller, 2004: 23-25). Em 1884, arqueólogos franceses escavaram o templo, retornando em 1912 (Miller, 2004: 23-25). Em 1924, a Escola Francesa de Atenas cedeu os direitos de escavação em Neméia à Escola Americana, que iniciou os trabalhos na área sob os auspícios da Universidade de Cincinnati e a direção de B.H. Hill e C.W. Blegen (Miller, 2004: 23-25). As escavações americanas no santuário foram contínuas entre 1926 e 1964 com um intervalo de uma década até 1973, quando foram retomadas pela Universidade da Califórnia sob a direção de S.G. Miller (Miller,

\footnotetext{
83 Zolotnikova também atribui um papel do santuário à população de Micenas (Zolotnikova, 2013b: 121).

${ }^{84} \mathrm{~A}$ relação com a região de Corinto, desde tempos antigos, é sugerida por Zolotnikova (Zolotnikova, 2013b: 121).
} 
2004: 23-25). A pesquisa arqueológica em Neméia, mais recente, ocorreu entre os anos de de 2009 e 2012 sob a direção de Kim Shelton.

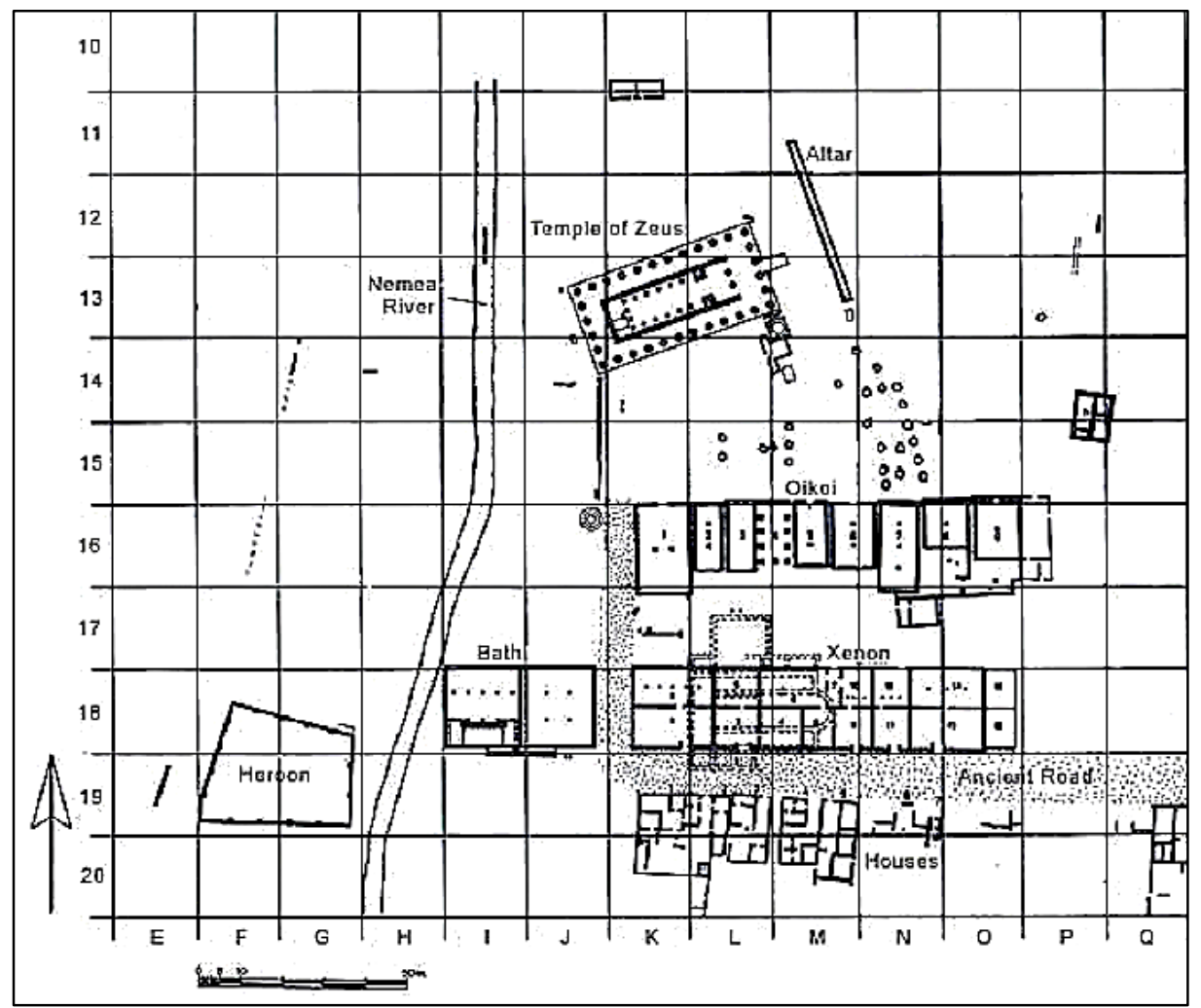

Fig.64- Planimetria do santuário de Neméia após 340/30 a.C. (Miller, 2004)

\section{II.8.1 Descrição e interpretação dos achados}

A atividade cultual mais antiga em Neméia é atestada entre os períodos geométrico tardio (século VIII a.C.) e o início do arcaico (século VII a.C.), a partir do achado de fragmentos cerâmicos, sem referências estratigráficas, do geométrico tardio recuperados no lado norte e no ângulo sudoeste do templo clássico de Zeus e na parte norte do altar de mármore (Zolotnikova, 2013b: 116). Nessas mesmas áreas foram encontrados fragmentos de cerâmica micênica, consideradas evidência de algum tipo de atividade no santuário durante a Idade do Bronze (Zolotnikova, 2013b: 116). Apesar da existência desses achados da Idade do Bronze na área do santuário (tomado por alguns estudiosos como evidência de culto no local em época micênica), assume-se que estes não são suficientes para atestar uma continuidade cultual em Neméia entre a Idade do Bronze e a Idade do Ferro (Zolotnikova, 2013b: 116). Por outro lado, como supõe Zolotnikova, é possível que a partir da Idade do Ferro tenha ocorrido o "reuso ritual da área", que encontra correspondência em outros sítios datados da Idade do Bronze - "este seria um dos fatores que teriam contribuído para a emergência do santuário em Neméia" (Zolotnikova, 2013b: 116). O término das atividades cultuais no santuário ocorreu em época helenística, quando, em c.271 a.C., o santuário entrou em declínio, como se explicará mais adiante (Miller, 2004: 215). 
Sobre a fase mais antiga do culto em Neméia, o período geométrico tardio, traços de queima no solo e no material cerâmico misturados a ossos queimados na área escavada, na parte norte do altar de mármore (onde também foram encontrados os mais antigos restos cerâmicos), "indicam a presença de um antigo altar de cinzas na área" (Zolotnikova, 2013b: 117). Um muro sólido de blocos de calcário (0,55 m de largura), identificado próximo ao ângulo sudoeste do templo de Zeus, tem sido interpretado como parte do muro de períbolo do início do período arcaico - "um indício de que o antigo culto em Neméia adquiriu o status de um recinto no início do século VII a.C." (Zolotnikova, 2013b: 118). Nesse sentido, em sua fase inicial (entre os séculos VIII-VII a.C.), "o culto de Zeus em Neméia deve ter sido muito simples, não muito elaborado" (Zolotnikova, 2013b: 118). Somente a partir do primeiro quartel do século VI a.C., o santuário recebeu a construção de seu primeiro templo e altar, fato que coincide com a instituição dos jogos nemeanos em honra a Zeus em c.573 a.C., organizados pela pólis de Kleonai, situada a leste no vale de Neméia (Miller, 2004: 30; Zolotnikova, 2013b: 118).

O templo arcaico de Zeus foi encontrado sob as fundações do edifício de culto do final da época clássica, situado no setor norte do santuário (Fig.65). Embora a planta seja de difícil reconstrução, sondagens efetuadas dentro das extremidades leste e oeste, das fundações do templo do séc. IV a.C., indicaram que o primeiro templo tinha a mesma orientação, leste-oeste, mas um eixo longo c.0,60 $\mathrm{m}$ a sul de seu sucessor (Miller, 2004: 155-

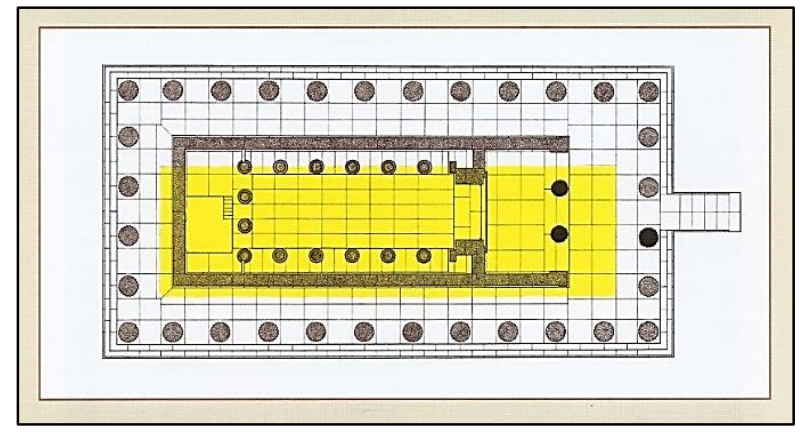

Fig.65- Planimetria do templo clássico de Zeus; em amarelo, área do templo arcaico (em Hill 1966, no.116, pr.IV) (apud Miller, 2004: fig.110) 156). O templo arcaico também era menor, embora mais longo em proporção e largura: as suas dimensões totais foram medidas em c. 10,10 x 36,30 m (Miller, 2004: 155-156). Este tamanho e a ausência de evidências, com relação às colunas, sugerem que 0 antigo edifício não tinha perístasis, sendo provavelmente um prostilo

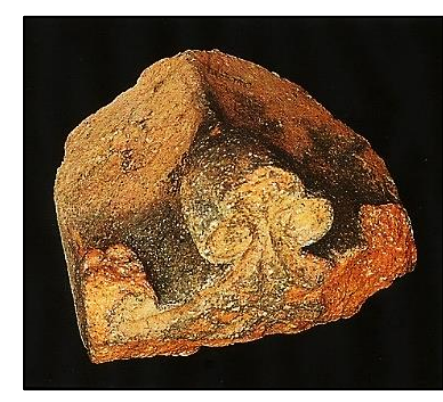

Fig.66- Antefixo de terracota do templo arcaico de Zeus (Miller, simples com uma fachado distila in antis, um telhado inclinado na sua fachada oeste e um pedimento pintado na fachada leste (Miller, 2004: 155-156). O templo arcaico de Zeus Nemeios, como alguns do mesmo período de Ístmia e Corinto, não tinha frontões ou pedimentos nas duas fachadas, sendo o lado oeste fechado por um telhado caído (Miller, 2004: 50). Vários fragmentos de telhas de terracota (contendo estampas de oficinas) foram encontrados, o que permitiu a reconstrução do tipo de telhado, assim como antefixas que permitiram reconstituilo na fachada oeste (Fig.66) (Miller, 2004: 51). O estilo de um acrotério recuperado, datado em c.500 a.C., indica uma fase de reparação ou renovação do antigo templo nessa época (Miller, 2004: 51-52).

Dúzias de blocos de calcário, provenientes da parte de cima do muro, preservam buracos, usados para o seu içamento durante a construção do templo, e traços de incêndio (Miller, 2004: 52). Esse é o caso também de duas telhas retorcidas e vitrificadas pela ação do fogo (Miller, 2004: 52). As camadas com os restos do 
templo arcaico de Zeus, contendo um depósito de cinzas, carvão e detritos queimados, também renderam várias pontas de lanças de bronze, lanças inteiras e cabos de ferro (Miller, 2004: 52 e nota 48). Esses traços de queima na construção e o achado dessas armas, em associação ao templo, têm sido interpretados como evidências de uma batalha campal ocorrida no santuário no final do século V a.C. (Miller, 2004: 50 e 153-154). Se tratou, muito provavelmente, de uma manobra militar em Neméia entre 419/18 a.C. sobre a qual sabemos a partir de uma notícia de Tucídides (V, 58-60; VI, 95) (Miller, 2004: 52 e nota 48). Nessa perspectiva, possivelmente, foi essa batalha que ocasionou a transferência dos jogos nemeanos à Argos, onde passaram a ser realizados entre o final do século V a.C. até antes de 340 a.C., quando voltaram a ser realizados em Neméia (Miller, 2004: 52 e nota 48; Valavanis, 2004: 317). Essa suspensão dos jogos e da atividade de culto em Neméia encontra correspondência no achado de dois poços, preenchidos com entulho de uma destruição ocorrida ao redor do final do século V a.C. (Miller, 2004: 49). Além disso, entre esse período, até as três décadas finais do século IV a.C., nenhum poço mostra evidência de atividade na área, nem moedas e cerâmicas foram encontradas datadas desse período (Miller, 2004: 5).

Além do templo arcaico, as fundações do altar, também datado do século VI a.C., foram encontradas a leste do edifício (Lippolis, 2007: 647). Assim, durante o século VI a.C., o culto de Zeus ganhou um novo formato com o templo e o altar. Dessa época datam também o herôon de Ofeltes, no setor sudoeste do santuário, e o primeiro estádio, talvez localizado a sudoeste do templo arcaico / clássico de Zeus (Zolotnikova, 2013b:118). Durante o século V a.C., antes da destruição ocorrida no final desse século, o santuário manteve essa configuração, tendo recebido somente a construção de nove edifícios de tipo oîkos, a sul do templo de Zeus, definidos como um tipo de tesouro, armazéns e lugar de encontro entre fiéis e competidores das comunidades que os construíram (Valavanis, 2004: 315).

0 interesse de Argos nos jogos nemeanos tem origem em época arcaica, em uma política de hegemonia que previu interferências em importantes centros agonísticos, como Olímpia, onde essa pólis tentou tomar a organização dos jogos olímpicos na época do tirano argivo Fídon no século VII a.C. (Valavanis, 2004: 308). Os mitos sobre a fundação dos jogos de Neméia, que contêm várias referências argivas nas narrativas, expressam a "tentativa em disseminar uma tradição mítica apropriada para confirmar ou justificar uma antiga relação de Argos com Neméia" (Valavanis, 2004: 308). A princípio, a pólis de Kleonai exerceu o controle do santuário e do festival, ao menos formalmente, até perde-lo para Argos no final do século $V$ a.C., no confronto bélico ocorrido no santuário (Valavanis, 2004: 308). Atualmente considera-se que Kleonai administrou os jogos nemeanos sob a interferência de Argos, sendo possível assim que o controle argivo do santuário tenha começado muito mais cedo (Miller, 2004: 31, nota 26). Interessante notar que, ao menos entre o final do século V e o século IV a.C., a intenção dos argivos era realizar as competições em sua própria cidade e não no santuário, uma área extra-urbana, neutra, distante $23 \mathrm{~km}$ de seu território. Por algum motivo, que pode ser explicado na disputa de forças entre as comunidades políticas da Coríntia e da Argólida, ou de além, os argivos escolheram abrigar as competições dentro de sua cidade, onde poderiam controla-la sem a interferência de 
nenhum outro Estado. Uma evidência da consolidação dos jogos nemeanos como uma instituição argiva, foi a apropriação e incorporação do culto extra-urbano e inter-regional de Neméia à esfera cívica local - 0 estabelecimento de um santuário de Zeus Nemeios (cat. no. 60) no centro político da pólis de Argos, a ágora, tal como relata Pausânias (II, 20.1-7). Remanescentes desse santuário, localizado no noroeste da ágora, foram encontrados entre a sala hipostila e a estrutura semi-circular ao abrigo do terraço de Apolo85 (Lippolis, 2007: 633).

Os jogos nemeanos e o culto a Zeus Nemeios retornaram ao santuário em Neméia entre 340-330 a.C., no contexto da política pan-helênica de Felipe II e Alexandre, o Grande, entre as cidades gregas (Valavanis, 2004: 308). A partir dessa época, seguiu-se um período de florescimento do culto e dos jogos com um grande programa de renovação do santuário em Neméia, envolvendo a construção de novos edifícios, como as casas, os banhos, o herôon de Ofeltes e o templo de Zeus (Fig.59) (Miller, 2004: 126; Valavanis, 2004: 317). Este foi construído sobre o anterior arcaico - os construtores do templo do século IV a.C. desmantelaram e reutilizaram os blocos do antigo templo quando montaram as fundações do edifício posterior (Miller, 2004: 50 e 153-154). O novo templo era maior, media $22 \times 45$ m, um dórico e períptero com 6x12 colunas (Valavanis, 2004: 318).

Os jogos nemeanos permaneceram em Neméia por 70 a 80 anos até serem, pela segunda vez, transferidos a Argos ao redor de 270/60 a.C., onde continuaram a ser realizados até a época romana (Valavanis, 2004: 334). Outras tentativas ocorreram a favor de retornar os jogos e o culto de Zeus a Neméia, como a de Aratos de Sikyon, líder da Liga Acaia, ao redor de 235 a.C. (Valanis, 2004: 308). Em época romana, jogos foram realizados em Neméia a partir de 146 a.C., mas foram transferidos a Argos dentro de poucos anos (Valavanis, 2004: 308). Fato é que desde 270/60 a.C. nenhum novo grande programa de construções ocorreu no santuário de Neméia, apenas pequenas intervenções durante os pequenos períodos nos quais os jogos retornaram esse foi, portanto, o período de completo declínio do santuário (Valavanis, 2004: 334).

Antes de empreendermos a discussão sobre o tipo de culto e de santuário em Neméia, é preciso dizer que as oferendas votivas, deixadas em época arcaica e clássica no santuário, pertencem a grupos muito heterogêneos - não há um padrão de dedicação bem preciso para cada período do culto, como há no caso de Olímpia, por exemplo. Em Neméia, as oferendas foram recuperadas, na maior parte, em poços ou

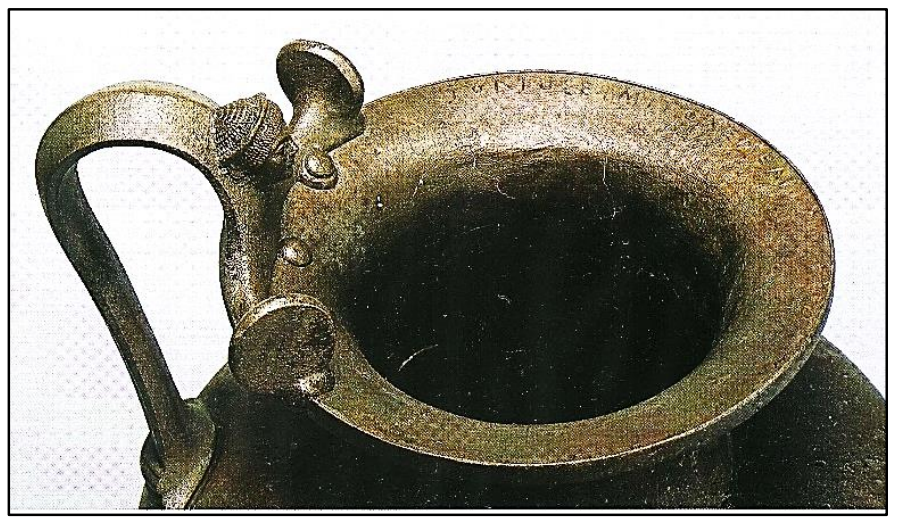

Fig.67- Hydria de bronze com inscrição dedicatória a Zeus, final do século VI a.C., Museu Arqueológico de Neméia (Valavanis, 2004: fig.455) depósitos votivos datados entre os séculos VI e V a.C., pré-datam, portanto, a destruição do santuário e a primeira transferência dos jogos para Argos no final do século $V$ a.C. Nesses poços, de uma maneira geral,

\footnotetext{
85 De opinião diversa é P. Marchetti, que sugere a localização do témeno de Zeus Nemeios imediatamente a sul da área dedicada ao culto de Apolo Lykeios (Marchetti, 1994) (apud Lippolis, 2007: 633).
} 
foram encontrados restos sacrificiais (cinzas e ossos de animais) misturados a certos objetos, como moedas, vários tipos de vasos de cerâmica e bronze (Fig.67), lamparinas, figurinhas de terracota de animais (cavalos), figurinhas humanas (de cavaleiros), etc. (Miller, 2004: 39-40). Em meio aos restos do templo arcaico de Zeus, também foram recuperados um número de objetos votivos, "que testemunham a riqueza de Neméia na época", tais como uma miniatura de machado duplo, restos de esculturas, apliques de vasos e mobília em bronze, e uma figurinha de um kouros feita em chumbo (Miller, 2004: 41). Poucas estátuas dos atletas vitoriosos foram encontradas, mas apenas pequenas partes delas, testemunhando, portanto, a destruição e saque que Neméia sofreu (Miller, 2004: 41). Interessante notar a quase ausência de estátuas ou estatuetas de Zeus, comumente encontrada em outros santuários inter-regionais de Zeus, como Olímpia, Mt.Lykaion e Dodona - se por um lado há várias referências a Zeus nas inscrições dedicatórios nos votivos, por outro, pouco se vê do deus na iconografia do culto de seu santuário. Miller cita apenas uma figurinha de terracota de Zeus ${ }^{86}$ na exposição do Museu Arqueológico de Neméia, cabendo aí uma pesquisa aprofundada a esse respeito.

\section{II.8.2 A natureza do culto e a função do santuário}

O culto de Zeus no santuário em Neméia é amplamente atestado pelas fontes literárias e arqueológicas (principalmente inscrições sobre objetos votivos locais). Apesar dos achados cerâmicos atestarem o início do culto entre o geométrico tardio e o início do arcaico, há evidências (epigráficas) sobre o início do culto de Zeus em Neméia somente a partir do século VI a.C. De todo modo, tende-se a aceitar que já na fase mais antiga, 0 culto no local era realizado ao deus (Zolotnikova, 2013b: 118).

De acordo com Zolotnikova, "a localização do santuário no campo pode ser tomada como um indicativo do conceito inicial de Zeus Nemeios como o de um deus rústico, responsável pelas colheitas, rebanhos e da prosperidade em geral da comunidade agrícola que confiava nele", como indica o epíteto Nemeios - derivado

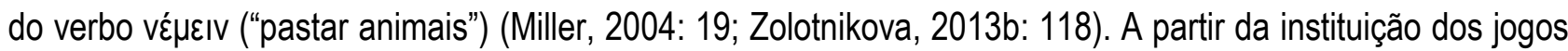
no início do século VI a.C., o aspecto agonístico é incorporado ao culto de Zeus Nemeios, essa antiga divindade relacionada à esfera agrária e pastoril. Não é possível associar, com segurança, outros aspectos a Zeus em Neméia, como, por exemplo, o militar (comprovado a partir da dedicação de despojos de guerra) já que está prática parece não ter sido recorrente no santuário ao menos até o século $\mathrm{V}$ a.C.

Como vimos na análise e interpretação do santuário de Zeus no Mt.Apesas, a pesquisadora russa defende a tese de que o santuário em Neméia teria emergido como o principal centro de culto à divindade no nordeste do Peloponeso a partir do século VI a.C., assumindo o papel da área sagrada de Zeus Apesantios entre os períodos geométrico e o início do arcaico (Zolotnikova, 2013b: 117). Entre os séculos VIII e VII a.C. 0 ritual nas duas áreas sagradas era muito semelhante (envolvia 0 ato de libação e de beber vinho), embora 0

\footnotetext{
${ }^{86}$ Miller, 2004, p.41.
} 
santuário de Zeus Apesantios tenha sido muito mais procurado que Neméia nessa época, como indica a quantidade de material, ligado ao culto, encontrado nas duas áreas. Assim, tal mudança, no século VI a.C., teria sido ocasionada, principalmente, à demanda pela prática do atletismo, que já havia se consolidado em santuários inter-regionais agonísticos, como Neméia, em época arcaica (Zolotnikova, 2013b: 122).

Com relação à sua função extra-urbana, o santuário de Zeus em Neméia deve ter assumido um papel inter-regional no nordeste do Peloponeso entre o final do geométrico e o início do arcaico, já que também esteve situado em uma região de confluência, sobretudo entre a Argólida e a Coríntia. É provável que tal função tenha se ampliado, a outras sub-áreas do nordeste peloponésio, durante o século VI a.C., conforme indica uma inscrição referente a um vencedor de Sicione nos jogos nemeanos nessa época. Considerada a evidência mais antiga referente a vitória de um atleta nos jogos nemeanos, a inscrição, datada de c.550 a.C. atesta a vitória de um atleta de Kleonai e indica como ainda nessa época o santuário podia estar restrito à uma função interregional, ainda que mais voltada à Argólida (Miller, 2004: 44; Valavanis, 2004: 312). A função de Neméia como um santuário inter-regional, que atraía comunidades além do nordeste do Peloponeso se consolidou de fato durante o século $V$ a.C., como atestam, também, a construção dos edifícios de tipo oîkos nessa época - é provável que um desses edifícios tenha sido dedicado pelos ródios ${ }^{87}$.

\section{II.9 Corinto}

Localizado no nordeste do Peloponeso, o santuário de Zeus Olímpio (cat. no.37) foi estabelecido no território da pólis de Corinto, a noroeste da cidade, na estrada para Sicione, nas cercanias do rio Asopus (Fig.68) (Laky, 2013: 232). Pesquisas arqueológicas ${ }^{88}$ em Corinto identificaram os remanescentes de um importante templo dórico, atribuído por alguns autores a Zeus Olímpio, cujo santuário sabemos a partir de Pausânias. Os remanescentes desse edifício foram reutilizados em construções posteriores da cidade, em uma área diferente daquela onde teria se situado a área sagrada, tal como indicam os relatos do periegeta. Muitas dúvidas existiam entre os pesquisadores, se este se tratava do Olimpieion visto por Pausânias. A partir de correlações arquitetônicas, realizadas por nós em uma pesquisa anterior, entre o templo de Corinto e outros edifícios dóricos contemporâneos, foi possível concluir que suas proporções correspondiam àquelas dos templos de Zeus Olímpio de Olímpia e de Siracusa. Foi possível concluir também, que suas dimensões se

\footnotetext{
87 Valavanis, 2004, p.315.

88 Em 1806 o viajante inglês Leake observou que na estrutura do denominado "muro epsitilo" havia também vários fragmentos arquitetônicos de um templo grego e foi o primeiro a descrevê-los e a medí-los. A primeira escavação sistemática na estrutura foi realizada por Richardson em 1896, quando abriu uma trincheira encontrando vários tambores de colunas (Dinsmoor, 1949: 104-105). O material foi estudado por Dinsmoor o qual propôs em 1949 que os achados pertenciam ao maior templo do Peloponeso (Dinsmoor, 1949: 104; Pfaff, 2003: 116; Wiseman, 1978: 84). Escavações na área do ginásio empreendidas por Wiseman em 1966 revelaram outros achados que proporcionaram novas interpretações, sendo a mais recente a de Pfaff de 2003 (Wiseman, 1967b: 412-413; Pfaff, 2003: 116-118).
} 
alinhavam àquelas dos templos dóricos da apoikia de Corinto, Siracusa, onde o culto da divindade foi também estabelecido. Nessa perspectiva foi possível assumir, com mais segurança, que tal templo dórico teria sido de fato o edifício mencionado pelo viajante grego no santuário de Zeus Olímpio. Assim, os remanescentes arquitetônicos desse templo são as únicas evidências materiais do culto do deus em Corinto ainda no século VI a.C., em época arcaica.

\section{II.9.1 Descrição e interpretação dos achados}

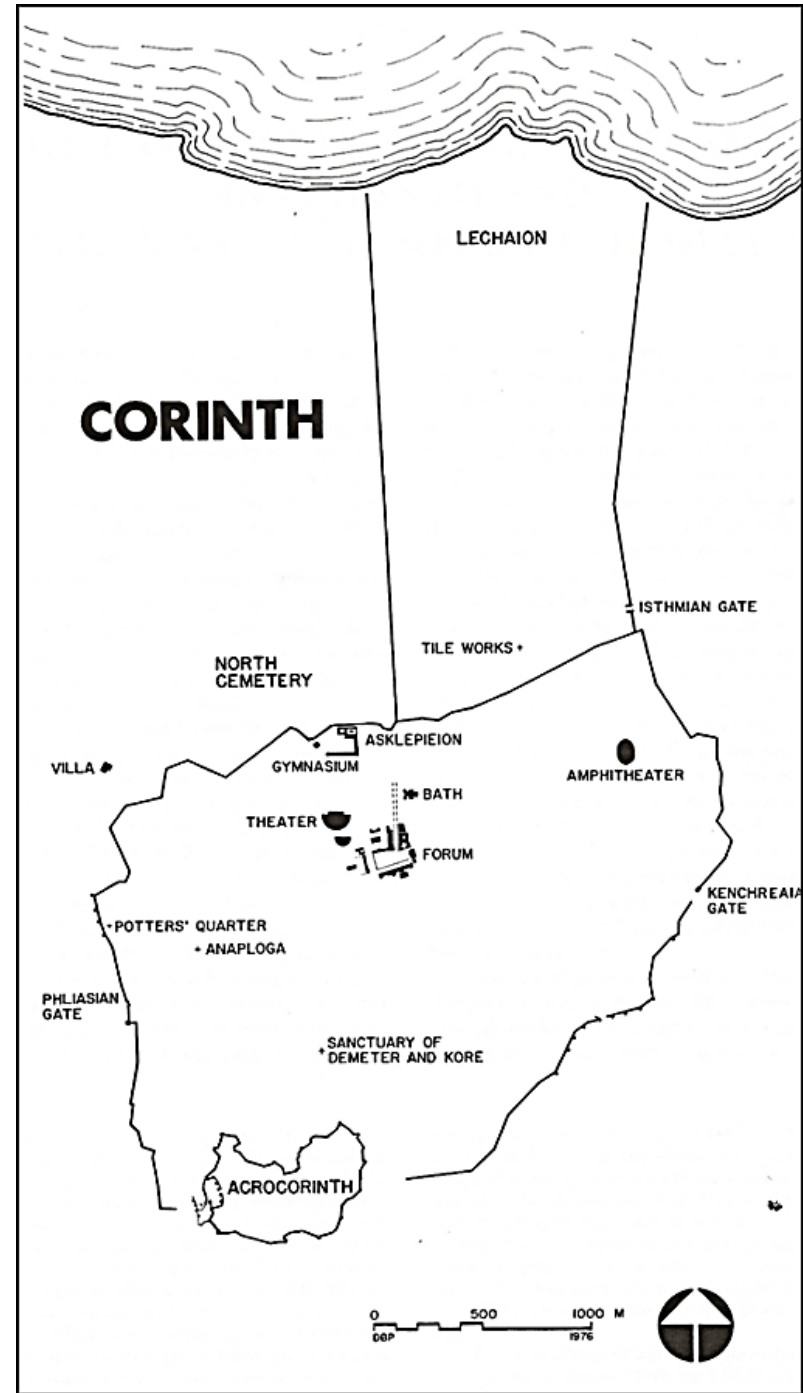

Fig.68 - Planimetria geral de Corinto (Williams II; Bookidis, 2003: XXVIII)
A partir de certos elementos arquitetônicos do templo de Zeus Olímpio foi possível estabelecer uma datação, aproximada, de seu santuário no século VI a.C. De acordo com as interpretações sobre sua arquitetura, 0 edifício não pode ser datado antes do final do século VI a.C. devido a detalhes da cornija - especificamente 0 perfil curvo, para o gotejamento, e aos mútulos largos com três fileiras de seis gotas, que se tornou um padrão para as cornijas dóricas do último quartel do século $\mathrm{VI}$ a.C. (Pfaff, 2003: 118-119; Wiseman, 1978: 84). A data do final do século VI a.C. é também indicada pelo aspecto da arquitrave, que não é atestada antes de c.540-530 a.C. (Pfaff, 2003: 118-119; Wiseman, 1978: 84).

O templo de Zeus Olímpio era um períptero dórico e hexastilo (Laky, 2013: 259). Infelizmente, os remanescentes arquitetônicos disponíveis, e 0 desconhecimento da localização de suas fundações, não permitiram o estabelecimento de suas dimensões totais, mas as medidas de algumas de suas estruturas permitiram inferir o grau de monumentalidade da construção. $O$ diâmetro de base das colunas $(1,893 \mathrm{~m})$, o diâmetro superior das colunas (1,558/1,615 m), a largura do ábaco (2,89-2,93 m), a altura da arquitrave (1,731 m), a largura do tríglifo $(1,175 \mathrm{~m})$ e o intercolúnio $(4,958 / 5,293 \mathrm{~m})$ indicam, suficientemente, que se tratou de um dos maiores templos dóricos do Peloponeso e também de sua época, tal como indica a comparação dessas 
medidas com o templo de Zeus em Olímpia - somente um pouco menores do que aquelas daquele que é considerado o maior templo dórico em sua região e em seu período de construção89 (Laky, 2013: 259).

Como mencionamos, "escavações no setor norte da antiga Corinto não revelaram traços do templo, possivelmente porque não foram realizadas mais a oeste, ao longo da estrada para Sikyon após os muros, onde Pausânias viu as ruínas do edifício" (Laky, 2013: 233). Não há ainda evidências materiais disponíveis acerca da localização do templo, que permanece um mistério (Wiseman, 1978: 84). Todavia, há a possibilidade de que algumas partes do Olimpiéion tenham sido descobertas no denominado Muro Epistilo (Fig.69) formado por materiais reutilizados - situado próximo ao

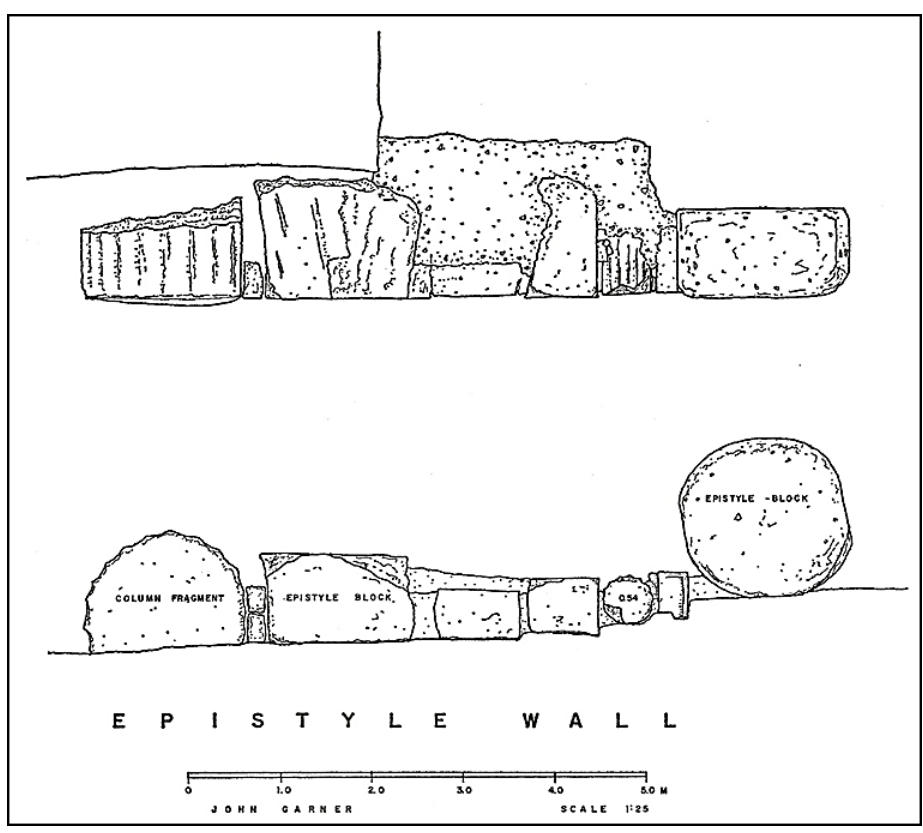

Fig.69- Desenho do Muro Epistilo (Wiseman, 1967b: 411, fig.3) ginásio no setor norte da cidade antiga e construído no século IV d.C. para conter as invasões dos Godos de 395 d.C. (Bookidis, 2003: 253; Pfaff, 2003: 115; Wiseman, 1967b: 411-412; 1972: 7; 1978: 84). Os remanescentes referentes ao templo de Zeus Olímpio, recuperados, nesse contexto, referem-se às partes de um grande tambor de coluna e de um bloco da arquitrave. Mais partes do templo foram encontradas em escavações na década de 1960 na área do ginásio, como um bloco de cornija, partes de colunas dóricas e 0 ábaco de um dos capitéis, todos atribuídos pelos pesquisadores ao edifício (Laky, 2013: 235-236). Todos esses remanescentes arquitetônicos foram minuciosamente estudados por importantes pesquisadores da área de arquitetura grega - um resumo detalhado dessa pesquisa pode ser visto em nossa investigação anterior, quando realizamos um estudo comparativo arquitetônico entre os Olimpieia ou templos de Zeus Olímpio (Laky, 2013: 232-237).

\section{II.9.2 A natureza do culto e a função do santuário}

O santuário e o culto de Zeus Olímpio são atestados em Corinto a partir de três relatos de Pausânias e dos resultados da análise comparativa do templo dórico atribuível à divindade. Se por um lado o templo dórico data a existência do santuário já no século $\mathrm{VI}$ a.C., por outro, é provável que o culto remonte a um período anterior, mas, infelizmente, não há dados que confirmem a anterioridade do culto e da área sagrada. Embora não dispomos de dados sobre uma suposta fase mais antiga do santuário da divindade, um dos trechos em

89 Para maiores detalhes sobre tais correlações, vide Laky, 2013, pp.258-260. 
Pausânias (III, VIII.9-IX.2) fornece um terminus ante quem para a destruição do templo de Zeus Olímpio e provavelmente, por consequência, de se seu santuário (Laky, 2013: 232). Segundo o trecho, o edifício teria sido queimado no ano de 396 a.C., quando o general Agesilaos foi enviado à Asia: (...) os coríntios foram mais ávidos para tomar parte na expedição à Ásia, mas considerando um mau presságio que seu templo de Zeus chamado Olímpio tinha sido repentinamente queimado, eles relutantemente permaneceram atrás (Laky, 2013: 232). Assim, é provável que já no início do século IV a.C. as atividades cultuais no santuário de Zeus Olímpio tenham acabado em virtude da destruição do templo pelo incêndio e talvez nunca mais retomadas, conforme indica outro trecho no qual Pausânias descreve a localização do santuário e seu templo queimado.

Uma característica dos cultos políades ou cívicos de Zeus Olímpio, datados entre os séculos VI e V a.C., é a ausência de oferendas votivas ou de qualquer tipo de objeto arqueológico (vasos cerâmicos, por exemplo), associado aos remanescentes do santuário, que possam indicar a característica do ritual e do culto à divindade. Os únicos testemunhos materiais para o estudo do culto são os remanescentes arquitetônicos dos templos de Zeus Olímpio - a hiper dimensionalidade dos edifícios corresponde aos grupos políticos envolvidos na instituição de seu culto e de sua construção nas cidades gregas (tiranos, reis e aristocratas, estes, sobretudo em tempo de governo oligárquico). Vimos na descrição do santuário de Olímpia como a ideologia destes grupos se alinha às características da divindade. E referências literárias também têm ajudado a estabelecer a característica do culto cívico de Zeus Olímpio e a função de seus santuários, como locais de asilo político, de arquivo cívico e de exposição de tratados e decretos (Laky, 2013: 275 e 288). Com o padrão bem estabelecido / conhecido sobre o culto de Zeus Olímpio no mundo grego, entre a época arcaica e clássica, é possível inferir que em Corinto o culto tenha sido associado à tirania Cipsélida, caso o santuário tenha sido fundado entre a metade do século VII e o início do século VI a.C., período de duração desse grupo no poder em Corinto (Laky, 2013: 237). A participação de Cípselos no culto e nos jogos em Olímpia é uma evidência da relação do culto com esse grupo (Laky, 2013: 236). Contudo, caso o santuário tenha sido fundado após o início do século VI a.C., então, o culto estaria associado ao longo período oligárquico que durou em Corinto até o século IV a.C. (Laky, 2013: 237).

Com relação à função cívica do santuário à comunidade política de Corinto, sua localização extraurbana, fornecida em detalhes por Pausânias (II, V.2-5; VII.2-4), permite atribuir um papel semelhante àquele santuário da divindade existente em Siracusa, sua apoikia. 0 santuário siracusano também é extra-urbano, situa-se em proximidade a um rio e é datado também do século VI a.C. Como veremos em detalhes na análise interpretativa sobre a Sicília, a área sagrada de Siracusa funcionou como arquivo cívico, desempenhou um papel militar em vários momentos de assalto externo à cidade e possuía uma magistratura dedicada exclusivamente à divindade. É provável que o santuário coríntio de Zeus Olímpio tenha, em algum grau, desempenhado o mesmo tipo de atribuições na vida cívica da cidade (Laky, 2013: 233). Infelizmente, diante do estado das evidências arqueológicas e textuais disponíveis é impossível propor algo além sobre a função dessa 
área sagrada, a não ser estas baseadas em comparações com os demais santuários de Zeus Olímpio no mundo grego, ou a partir de um caso específico e mais próximo ao de Corinto, como foi aquele de Siracusa.

\section{II.10 Bambes}

Situado no noroeste do Peloponeso, o santuário de Zeus (cat. no.39) foi estabelecido na área rural do atual vilarejo de Bambes (ou Bábes-Makrisíon), distante entre 3 a 4 km de Olímpia (Fig.70) (Lippolis, 2007: 650; Taita, 2007: 43). O templo foi localizado e escavado, pela primeira vez, no ano de 1953 por N. Yalouris e os resultados da pesquisa foram publicados em 1954. Os achados cerâmicos foram estudados por A. Moustaka (1991) e F. Lang (1992).

\section{II.10.1 Descrição e interpretação dos achados}

0 início da atividade cultual no santuário de Zeus em Bambes é atestada, com segurança, no final da época arcaica (século VI a.C.) com base nos achados dos remanescentes arquitetônicos do templo da divindade datados dessa época (Taita, 2007: 43, nota 10). O período final da atividade cultual do santuário é desconhecido. J. Taita menciona 0 achado de duas perirrhanteria (uma do último quartel do séc. VII a.C., e a

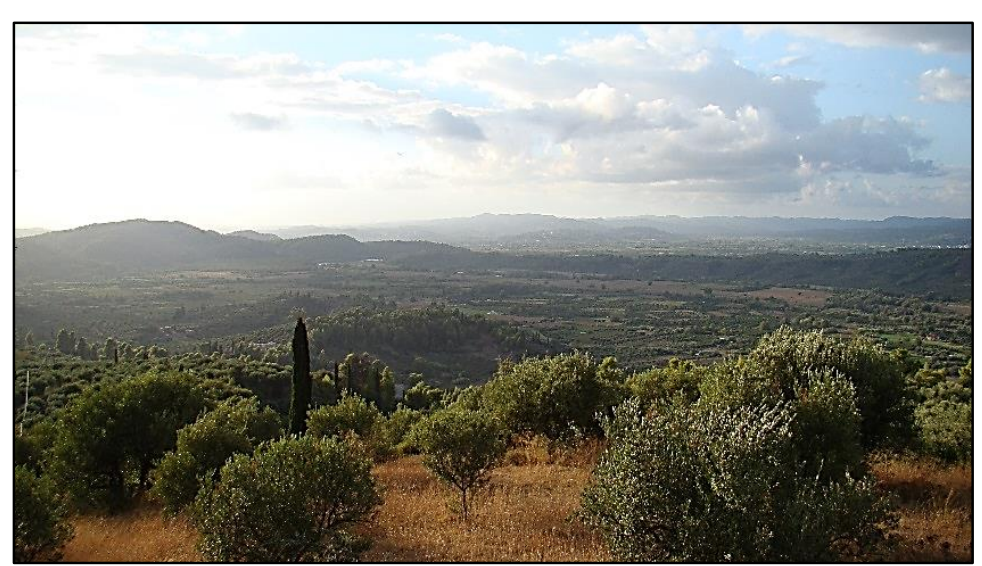

Fig.70- Vista do vale do rio Alfeu a partir de Bambes (Foto: arquivo pessoal/2013)

outra da primeira metade do séc. VI a.C.) que toma como evidência de que a comunidade, do assentamento também descoberto na área, praticava atividades sagradas há mais tempo do que a data proposta para 0 edifício de culto (Taita, 2007: 43). Não consideramos a datação mais antiga desses objetos na proposição do início do culto de Zeus no local, pois não é certo se estes realmente estiveram relacionados às atividades do santuário. Além dos perirrhanteria, a bibliografia menciona o achado de objetos votivos do período geométrico tardio, mas não precisa a localização de seu achado (Taita, 2007: 44). Não é possível saber o período do término da atividade cultual, contudo, as telhas de cobertura do templo, datadas de época clássica, indicam o funcionamento do santuário ainda nessa época. 


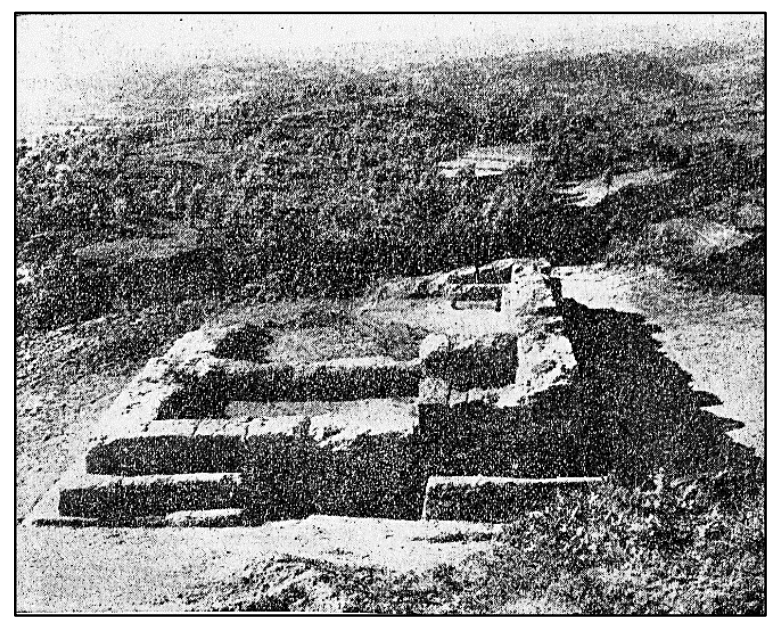

Fig.71- Ruínas do templo de Zeus em Bambes; foto da escavação de Yalouris em 1953 (Yalouris, 1954: fig.1)
De acordo com os resultados das escavações, 0 templo de Zeus era um edifício dórico prostilo, com a dimensão total de 4,55 x 8,40 m, articulado em pronaos e cela (Lippolis, 2007: 650). Este tinha um crepidoma de 2 degraus, sua altura conservada atinge $0,90 \mathrm{~m}$ e era todo construído em calcário conchífero. Dos remanescentes escultóricos foram encontrados fragmentos de tríglifos e, da cobertura, telhas de tipo coríntio e lacônio de época clássica - o frontão não hospedava algum grupo escultórico (Lippolis, 2007: 650). A datação das telhas

indica uma renovação do templo em algum momento do período clássico.

\section{II.10.2 A natureza do culto e a função do santuário}

A atribuição do santuário em Bambes a Zeus tem como base apenas inscrições encontradas no local, não há informações literárias a respeito da área sagrada. Trata-se da epígrafe TO $\Delta \mid O \Sigma$, encontrada inscrita sobre um bloco fragmentário, encontrado na cela do templo, no nível do solo, e de um peso de bronze (a bibliografia não menciona o local exato do achado) com a inscrição $\Delta$ ıo ka入 (Lippolis, 2007: 650; Taita, 2007: 43, nota 9).

Nenhum achado votivo foi encontrado diretamente associado ao templo, o que impede a reconstituição do tipo de culto e ritual. No entanto, relacionados ao templo, são as ruínas de um complexo de quatro habitações, localizado ao longo do declive da colina mais alta na parte nordeste da área. A construção mais antiga é datada do final do século VII a.C. Vasilhames, encontrados nesses edifícios, situam a data dessas construções entre o final do século VII e o início do século VI a.C. (Taita, 2007: 43). Assim, a documentação arqueológica situa a fase mais antiga desse assentamento no final o século VII a.C. (Taita, 2007: 43). Já a cronologia do material cerâmico indica o ápice do sítio entre os séculos VI e V a.C.

De acordo com J. Taita, é possível que tais habitações tenham estado relacionadas às atividades religiosas do santuário de Zeus - estas são interpretadas, por essa estudiosa, como prováveis estruturas para os funcionários da área sagrada (Taita, 2007: 43). Assim também, "não foi definitivamente resolvida a função destes vasilhames: podem ter se tratado tanto de recipientes para o uso cotidiano como instrumentos de uso ritual" (Taita, 2007: 43). Já segundo T.H. Nielsen, é provável que o assentamento em Bambes tenha sido a pólis de Pyrgos, ainda não localizada definitivamente (Nielsen, 2004: 545). Esse autor se baseia nas impressões de Yalouris, que definiu o sítio como uma importante cidade com uma área considerável (Nielsen, 2004: 545).

Pesquisas futuras acerca dos achados do santuário, e do assentamento em Bambes, devem precisar a função da área sagrada em relação às ditas habitações e às comunidades da região. J. Taita sugere que 0 
"cume da colina de Bambes, que domina o vale do Alfeu, deve ter sido reservado ao desenvolvimento de cerimônias" (Taita, 2007: 43). Essa estudiosa sugere também a relação do santuário em Bambes, em algum grau, com o culto em Olímpia. A seu ver, "a singularidade de tal santuário faz pensar as razões que levaram a dedicar um templo a Zeus não apenas algumas décadas antes da construção do templo de Zeus em Olímpia, mas também a brevíssima distância do grande santuário" (Taita, 2007: 16). O estabelecimento de um santuário a Zeus naquela localização, pode ter significado "a valorização com o culto central (em Olímpia) em termos de eventual filiação ou até mesmo concorrência" (Taita, 2007: 16). A nosso ver, tal relação com Olímpia é assegurada, de alguma maneira, pelo achado no local do peso de bronze com a inscrição (também própria do santuário inter-regional) referente a Zeus, um objeto típico do santuário de Olímpia.

Isto posto, é possível assumir, dado o estado atual das pesquisas, que o santuário de Zeus em Bambes pode ter sido um culto cívico urbano, relacionado à comunidade de Pyrgos, ou ter sido uma área sagrada extraurbana sub-regional. Somente será possível definir a função da área sagrada e do culto de Zeus quando forem melhor definidas a localização e as fronteiras entre as póleis de Pyrgos e Skillounte, identificada em Makrísia, que vilarejo relacionado à Bambes (Nielsen, 2004: 546).

\section{II.11 Mantinéia}

Localizado na Arcádia, no centro leste do Peloponeso, o santuário de Zeus Sóter (cat. no.52) foi estabelecido na pólis de Mantinéia, na margem ocidental da ágora - de frente ao analemma sudeste do teatro (Fig.72 e 73) (Lo Monaco, 2009: 356). Os remanescentes do santuário foram escavados por Fougères no final do século XIX, que também atribuiu a área sagrada ao culto da divindade (Lo Monaco, 2009: 356). Atualmente, o sítio arqueológico de Mantinéia tem sido permanentemente escavado pela Eforia (Superintendência) da região da Arcádia.

\section{II.11.1 Descrição e interpretação dos achados}

A datação do santuário de Zeus Sóter no século IV a.C. (em 371/70 a.C.) é problemática: tem como base uma proposição de Fougères que associa uma referência de Tucídides do século $\mathrm{V}$ a.C. (sobre a existência de um santuário de Zeus na ágora), para existência de um templo da divindade em Mantinéia, com uma menção de Pausânias sobre um santuário de Zeus Sóter e ao contexto de instituição do culto do deus na Arcádia após a derrota espartana em Leuctra em 371/70 a.C. 
Fougères identificou o templo de Zeus com o edifício retangular $(6,75 \times 12,10 \mathrm{~m})$, orientado norte-sul, aparentemente sem colunata - uma fundação de lajes de calcário, sobre a qual há um muro feito em grossos blocos nesse mesmo material (Lo Monaco, 2009: 356-357). Provavelmente, a parte superior do muro foi construída com material mais leve, talvez com tijolos de barro cru ou de pedra (Lo Monaco, 2009: 356-357). Buracos de uma soleira encontrados sobre a fileira superior do lado norte parecem pertencer a um remanejamento sucessivo, a respeito do qual não foi fornecido nenhum dado complementar (Lo Monaco, 2009: 357). A entrada principal do templo devia se localizar no lado meridional, como indica a ausência de espaço no lado setentrional entre este edifício e o templo sucessivo (Lo Monaco, 2009: 356-357). É preciso dizer que a identificação do edifício com o culto de Zeus na ágora ainda aguarda confirmação. É preciso dizer também que não há outras evidências arqueológicas disponíveis sobre o santuário além das ruínas desse templo na parte oeste da ágora.

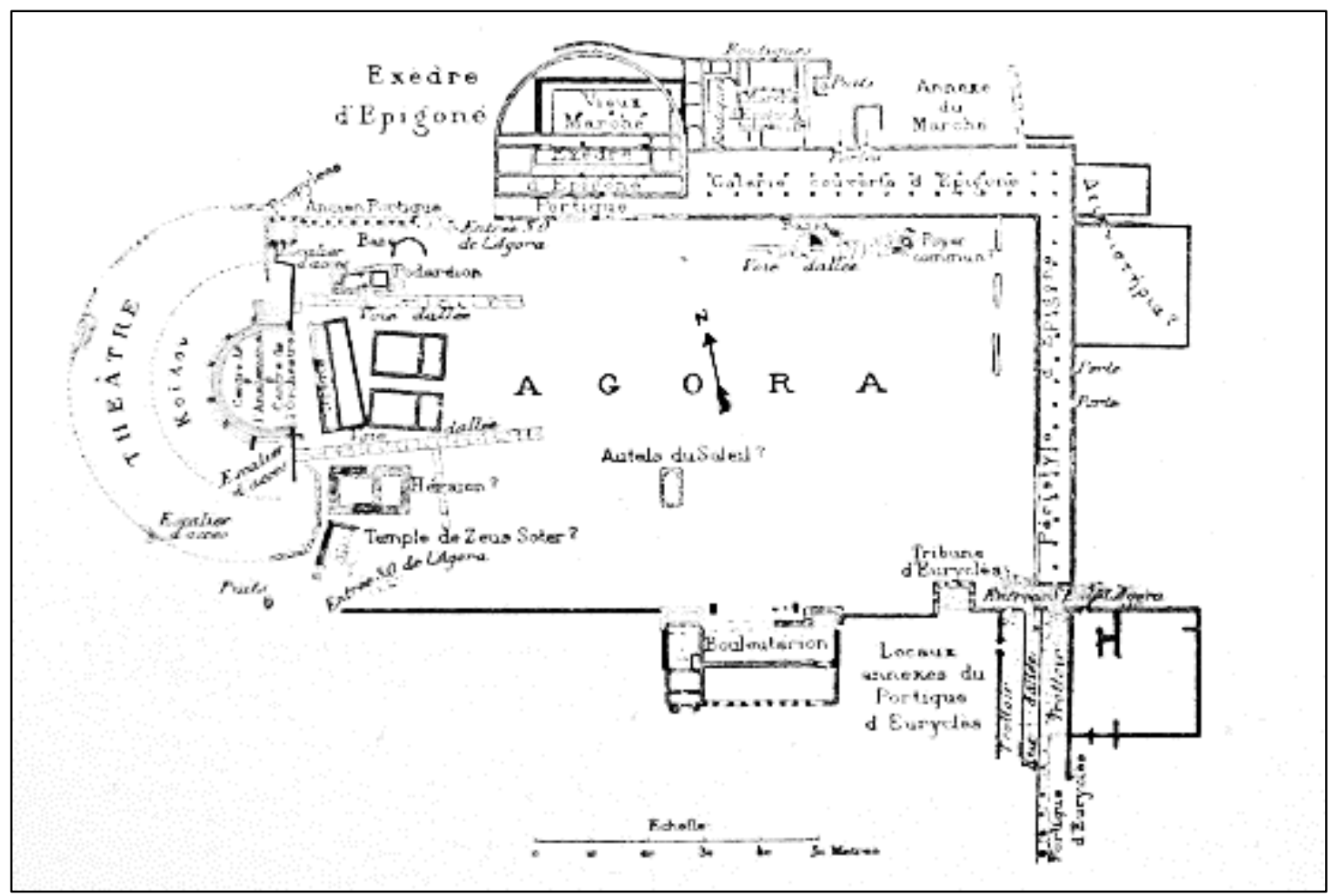

Fig.72- Planimetria da ágora de Mantinéia (Fougères, 1898: fig.44) 


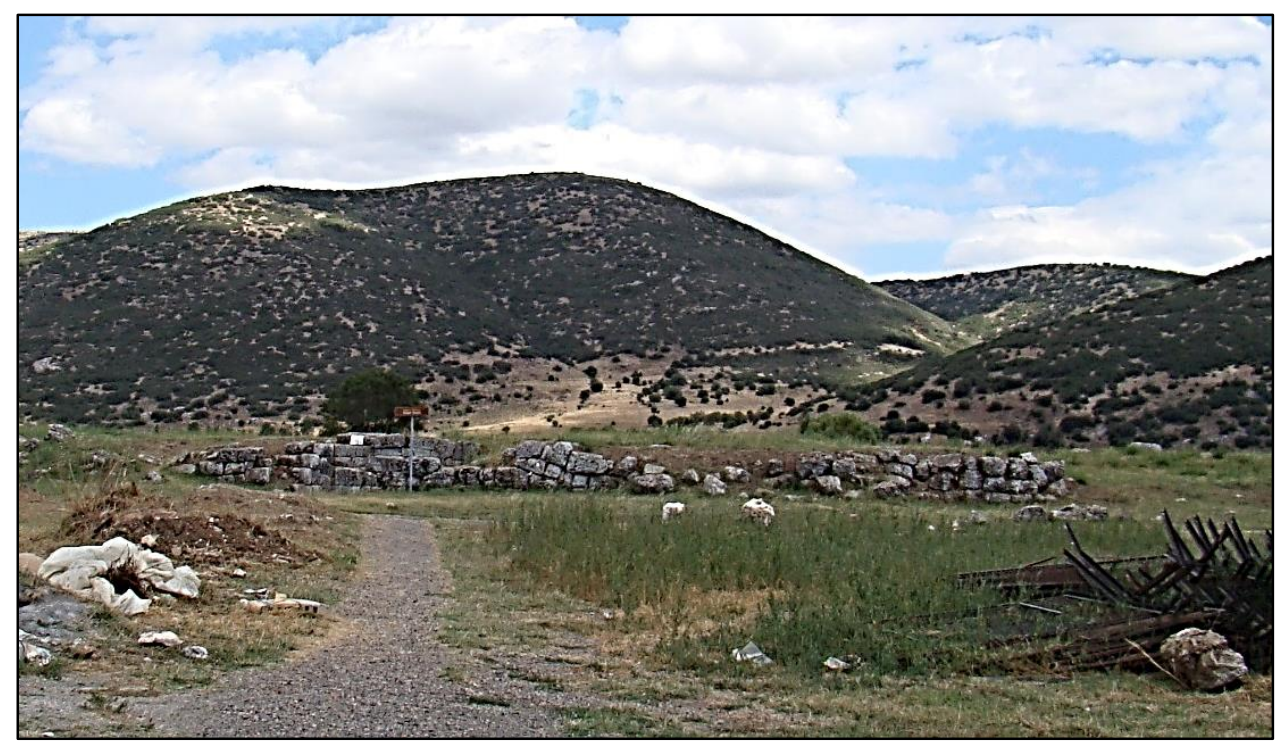

Fig.73- Analemma do teatro de Mantinéia visto a partir de leste (Foto: arquivo pessoal/2014)

\section{II.11.2 A natureza do culto e a função do santuário}

Como mecionado, a atribuição do santuário a Zeus tem como base principal o testemunho de Tucídides (V, 47.11), o qual menciona que no templo de Zeus (sem mencionar o epíteto do deus), na ágora de Mantinéia, deveria ser exposto o tratado de aliança de c.421 a.C. entre mantineus, atenienses e argivos. Um hóros do século V a.C. parece confirmar a existência do santuário como arquivo cívico (Lo Monaco, 2009: 357). Pausânias (VIII, 9.2) apenas menciona a existência de um santuário de Zeus Sóter sem localizá-lo na cidade. A nosso ver, é possível que Pausânias se refira a um santuário diferente da divindade, fundado posteriormente àquele da ágora, ou se trata da mesma área sagrada - nesse caso, o título Sóter teria sido acrescentado depois ao antigo culto de Zeus já existente, durante a segunda fase do desenvolvimento urbano da cidade após 370 a.C., motivado, portanto, por razões históricas, como a vitória em Leuctra (Nielsen, 2004: 520). De acordo com A. Lo Monaco, foi nesse contexto que Zeus Sóter adquiriu o caráter de divindade propiciadora do renascimento citadino no século IV a.C. - no âmbito da renovação (Mantinéia) ou fundação novos núcleos urbanos (Messênia, Megalópolis) no Peloponeso (Lo Monaco, 2009: 357).

Assim, com as poucas evidências de que dispomos, é possível afirmar que o santuário urbano de Zeus, no século V a.C., ou de Zeus Sóter, no século IV a.C., desempenhou um papel político importante à comunidade de Mantinéia no contexto da guerra do Peloponeso, ao expor e arquivar o tratado de 421 a.C. e no contexto da derrota da hegemonia espartana a partir de 370 a.C. 


\section{II.12 Megalópolis}

Localizado também na Arcádia, no centro oeste do Peloponeso, o santuário de Zeus Sóter (cat. no.57) foi estabelecido na pólis de Megalópolis, no setor sudeste da ágora (Fig.74) (Lo Monaco, 2009: 385). Segundo A. Lo Monaco, "o santuário foi explorado apenas parcialmente devido a uma inundação do rio Helisson que encombriu o lado sul da área sagrada" (Lo Monaco, 2009: 385). As pesquisas arqueológicas no santuário foram realizadas, pela primeira vez, pela Escola Britânica de Atenas sob a direção de E. Gardner e W. Loring em 1890 e 1891, tendo sido apenas retomadas nos anos 1940 por Knoblauch (Gans; Kreilinger, 2002: 187; Lo Monaco, 2009: 385). Somente a partir de 1991 novas escavações foram realizadas pelos Instituto Arqueológico Alemão de Atenas, por H. Lauter, em colaboração com a V Ephoria, dirigida por

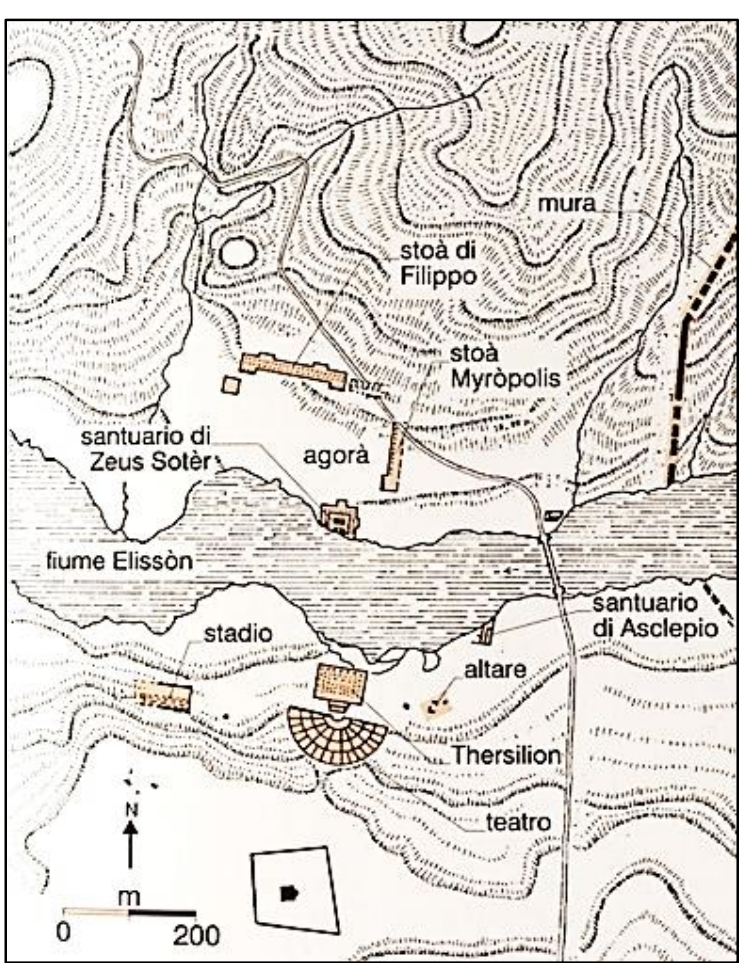

Fig.74- Planimetria de Megalópolis (Torelli; Mavrojannis, 2002: 205)

Spyropoulos (Gans; Kreilinger, 2002: 187; Lo Monaco, 2009: 385). Uma nova proposição da datação do santuário e templo de Zeus Sóter foi publicada por U.W. Gans e U. Kreilinger em 2002.

\section{II.12.1 Descrição e interpretação dos achados}

Há ainda muita controvérsia com relação à fundação do santuário de Zeus Sóter em Megalópolis. A ausência de material cerâmico, embaixo das fundações na área sagrada, fez os especialistas pensarem que 0 santuário tivesse sido estabelecido logo depois da fundação da cidade em c.370/69 a.C. (Lo Monaco, 2009: 388). No entanto, a análise arquitetônica, associada a um material cerâmico, indicou definitivamente uma datação mais baixa em c.340 a.C., com base principalmente na semelhança entre os elementos arquitetônicos da stoá de Felipe e o templo de Zeus Sóter (Gans; Kreilinger, 2002: 187). Aqui consideramos que 0 estabelecimento do culto e do altar à divindade remonta à fundação da cidade, ainda que a monumentalização do santuário tenha ocorrido em c.340 a.C. (Corso, 2005: 225). Evidências epigráficas situam a existência do santuário em época romana. Assim, é preciso destacar que toda a documentação arqueológica descrita na sequência, sobre o templo e o santuário, é datada a partir de c.340 a.C. em diante.

Apesar da inundação do rio Helisson ter comprometido a pesquisa sobre o setor sul do santuário, sabese, que esse lado da área sagrada sofreu uma obra de contenção, ao passo que no setor norte as fundações 
foram realizadas diretamente no terreno natural (Lo Monaco, 2009: 3860). É preciso destacar que todas as estruturas do santuário foram conservadas apenas no nível da fundação (Lo Monaco, 2009: 386).

As pesquisas na área puderam definir o témeno do santuário como uma área quadrada (47 x $54 \mathrm{~m})$, articulada ao redor de um pátio com pórticos em três dos quatro lados, tal como informa Pausânias (VIII, 30.10) (Lo Monaco, 2009: 386). O viajante grego é a única fonte literária que menciona a existência do santuário e de uma estátua de culto90. As escavações revelaram um propileu $(5,85 \mathrm{x}$

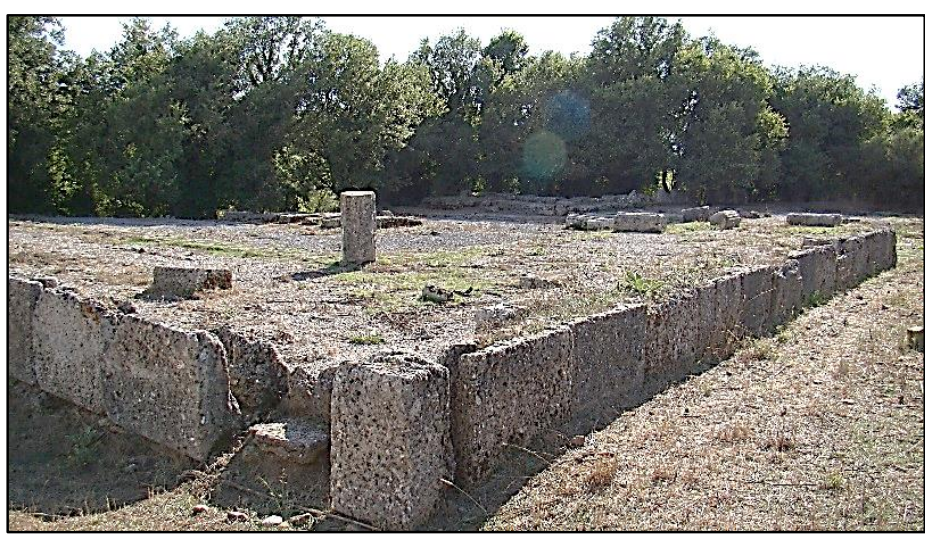

Fig.75- Fundações do templo de Zeus Sóter em Megalópolis visto a partir de sul (Foto: arquivo pessoal/2014) 10,05 m), do qual apenas as fundações do lado oriental estão conservadas (Lo Monaco, 2009: 386). Também revelaram a existência de uma stoá, em colunata dupla de ordem jônica e dórica, como indicam os achados de uma base de coluna jônica e um capitel dórico (Lo Monaco, 2009: 386). Foi sugerido por Gans e Krelinger que o edifício, na verdade, se tratava de um hestiatório (apud Lo Monaco, 2009: 386). Com relação ao templo, este localizava-se de frente ao propileu, no lado oeste do santuário, tinha uma dimensão de 11,64 x 21,2 m, um pronaos muito estreito (3,71 x 11,64 m) talvez tetrastilo com cela ampla (Fig.75) (Lo Monaco, 2009: 387). Na parte central do santuário foram encontradas as fundações de um grande altar longo (5,39 x 11,36 m), alinhado ao templo, que foi pensado se tratar de uma estrutura funcional para suportar talvez um grupo escultórico (Lo Monaco, 2009: 387). Os últimos remanescentes da área sagrada que podem ser citados são os monumentos honorários - três bases para a sustentação de estátuas a norte e de frente à fachada do pórtico do templo (Lo Monaco, 2009: 387).

\section{II.12.2 A natureza do culto e a função do santuário}

A atribuição do santuário de Zeus Sóter em Megalópolis foi possível graças à notícia de Pausânias, que o situa na ágora, e às evidências epigráficas que atestam a existência do santuário - estas registram uma festa (as Soterias) celebrada em honra à divindade, a dedicação de estelas por cidadãos no témeno e o uso do santuário em época romana (Lo Monaco, 2009: 386).

Apesar do templo ser datado em c.340 a.C., portanto, fora do recorte cronológico dessa investigação, consideramos o santuário, na análise e interpretação, em razão da importância do culto de Zeus Sóter no Peloponeso a partir do primeiro quartel do século IV a.C. no contexto do fim da hegemonia espartana, resultante

\footnotetext{
90 Trata-se de uma estátua de Zeus sentado no trono, tendo ao lado direito Megalópolis e uma imagem de Ártemis Soteira à esquerda, obra dos importantes escultores atenienses Cephisodotos e Xenofonte (Gans; Kreilinger, 2002: 190). Sobre o significado da associação de Zeus à essas imagens, ver Gans; Kreilinger, 2002, p.190 e Corso, 2005.
} 
da batalha de Leuctra. $O$ caso de Megalópolis se relaciona certamente ao de Mantinéia. Em outros casos, se trata apenas de uma suposição, como em Figaléia (cat. no.41) - cidade membro da confederação arcádia, onde 0 culto foi introduzido no século IV a.C. no santuário arcaico de Atena conforme uma inscrição datada dessa época - e em Messênia, onde Pausânias menciona um santuário de Zeus Sóter relacionado por alguns autores à essa época e, por outros, à época helenística, de quando datam os remanescentes do santuário (Jost, 1985: 938; Nielsen, 2004: 528).

Megalópolis foi fundada em c.370/69 a.C. pela confederação arcádia - um movimento democrático antiespartano liderado por Mantinéia e Tegea (Nielsen, 1999: 36-37; Roy, 2012: 135). Cinco póleis arcádias, dentre elas Mantinéia e Tegea, registram fundadores, mas uma forte influência é creditada, nas fontes literárias, ao tebano Epaminondas (Roy, 2012: 924). Megalópolis é definida pelos estudiosos como um Estado federal estabelecido na base de uma coerência étnica arcádia (Nielsen, 1999: 36-37; Roy, 2012: 135). O propósito da nova cidade teria sido proteger a Arcádia contra uma possível expansão espartana (Gans; Kreilinger, 2002: 187). A hegemonia espartana no Peloponeso havia se consolidado após a derrota do movimento arcádio no século V a.C., e a vitória de Esparta na guerra do Peloponeso (Nielsen, 1999: 58-59). Esparta se manteve em posição hegemônica e militar dominantes até ser derrotada definitivamente pela confederação beócia e pela confederação arcádia na batalha de Leuctra em c.370 a.C. (Nielsen, 1999: 58-59).

É preciso explicar que a confederação arcádia do século IV a.C. foi uma unidade política não atestada na união dos arcádios ocorrida no século V a.C. - construída apenas sob critérios de etnicidade, sendo um dos quais a oposição à Esparta (Nielsen, 1999: 29, 56-57). Essa organização política e étnica arcádia foi parte de um fenômeno maior ocorrido no Peloponeso nas primeiras décadas do século IV a.C. - um número de mudanças, que não apenas afetaram o equilíbrio de poder e o mapa político da região, mas incluiu também a redefinição de fronteiras étnicas e a emergência de novas entidades étnicas, como a sub-região peloponésia da Trifília, as póleis de Pisa e de Messênia (Luraghi, 2008: 212-213). De acordo com N. Luraghi, "a unificação política da Arcádia, imediatamente após a batalha de Leuctra, foi o ponto culminante na saliência da etnicidade arcádia (Luraghi, 2008: 212).

De acordo com Gans e Kreilinger, o santuário de Zeus Sóter provavelmente funcionou como um culto federal (Gans; Kreilinger, 2002: 190). Tal interpretação se baseia no fato de a cidade de Megalópolis ter sido fundada pela confederação arcádia. Se tal função existiu, deve ter prevalecido no santuário de Zeus Sóter ao menos até c.363 a.C., quando a confederação começou a perder sua união política até se dissolver totalmente ao redor de c.324/23 a.C. (Nielsen, 1999: 29 e 56-57). Para M. Jost, "a importância do culto de Zeus Sóter em Megalópolis é atestada pelo caráter monumental da arquitetura de seu santuário urbano e pela exposição de documentos importantes"91 (Jost, 1996: 104). Como explica essa autora, "a introdução do culto do deus, na cidade federal arcádia, relacionou-se à sua função cívica e ordenadora (Jost, 1996: 104). A epíclese Sóter 
“implicou em idéias de salvação e moral - Zeus Sóter foi considerado o deus que 'preservava do perigo', 'que conservava a integridade', tivessem sido eles a dominação exterior ou mudanças na constituição" (Jost, 1996: 104-105). Nesse contexto do século IV a.C. no Peloponeso, portanto, Zeus Sóter assumiu o papel de "árbitro dos destinos políticos e tornou-se símbolo da reconstrução de entidades políticas regionais" (Jost, 1985: 272; 1996: 105). Em síntese, tal papel político do culto de Zeus Sóter, à comunidade de Megalópolis, e em algum grau à confederação arcádia, explica a instalação do santuário do deus no centro cívico e político por excelência da pólis, a ágora.

Muito provavelmente, no século IV a.C., o culto de Zeus Sóter em Megalópolis exerceu tais funções ao lado do culto de Zeus Lykaios, que pode ter sido instituído nessa época na cidade, como veremos adiante. Assim, na Arcádia, é possível dizer que dois cultos de Zeus assumiram importância regionais em época clássica: Zeus Lykaios e Zeus Sóter cada qual em diferentes níveis e funções. Trata-se de diferenças que serão importantes na análise interpretativa da imagem monetária de Zeus, batida pela confederação arcádia no contexto da fundação de Megalópolis, que realizaremos no capítulo 4.

\section{II.13 Considerações gerais sobre os santuários e o culto de Zeus no Peloponeso}

Um traço característico do culto de Zeus no Peloponeso, entre a Idade do Bronze e a época clássica, é a função extra-urbana de seus santuários. A maioria das áreas sagradas extra-urbanas desenvolveram funções inter-regionais e sub-regionais - alguns centros de culto desde a fase mais antiga exerceram, ao mesmo tempo, papéis inter-regionais e sub-regionais, outros começaram como santuários sub-regionais e ampliaram suas funções regionais em períodos posteriores e outros ainda se mantiveram sub-regionais até 0 fim de suas atividades cultuais. Áreas sagradas extra-urbanas de Zeus, localizadas em centros cívicos, são a minoria no Peloponeso, há apenas um caso (Corinto). Embora tenham sido uma minoria em relação aos extraurbanos, santuários suburbanos de Zeus emergiram, naqueles que se tornaram posteriormente importantes centros urbanos na região, durante a Idade do Ferro, alcançando um desenvolvimento maior entre o final do geométrico tardio e o início da época arcaica (VIII-VII a.C.), como foi o caso da acrópole Larisa em Argos e do Mt.Ithome na Messênia. Os santuários urbanos de Zeus, que representam o menor grupo na região, emergiram no início do século VII a.C. e ao longo da época clássica - ou eram originalmente áreas sagradas suburbanas incorporadas à área urbana durante o desenvolvimento da cidade (acrópole Larisa em Argos no século VII a.C. e Mt.Ithome na Messênia no século IV a.C.) ou foram fundadas e estabelecidas diretamente no centro urbano (o caso de Mantinéia no século V a.C., Megalópolis no século IV a.C. na ágora e talvez de Bambes no século VI a.C.). Se o século VI a.C. representa o período em que o culto de Zeus passou a existir na esfera cívica no Peloponeso, a época clássica, como veremos, sobretudo o século IV a.C. representa o período em que o culto do deus se consolida como culto cívico na região. 
Nos santuários extra-urbanos sub-regionais e inter-regionais, a função pastoril e agrária prevaleceu como elemento principal do culto de Zeus durante as fases mais antigas, durando entre a Idade do Bronze e 0 geométrico tardio e entre o geométrico tardio e o início do arcaico. Na maior parte dos casos, o papel do culto entre as populações silvo-pastoris das comunidades emergentes foi relacionado ao aspecto atmosférico/celeste de Zeus, próprio do culto da divindade nesses tipos de santuários nesses períodos específicos (Mt.Lykaion, Olímpia, Mt.Arachnaion, Neméia). Essa função deve ter continuado após o geométrico tardio ou o início do arcaico nos santuários no Mt.Arachnaion e no Mt.Lykaion, onde é provável que tenha coexistido ao lado de outras funções assumidas pelo culto de Zeus Lykaios em época arcaica e clássica. É importante destacar que em Olímpia, em Neméia e no Mt.Lykaion o declínio dessa antiga função de Zeus corresponde ao período de introdução da prática agonística nesses santuários. Outras antigas funções do culto também são observadas, embora em menor grau, como a oracular ${ }^{22}$ em Olímpia, a purificatória no Mt.Apesas e a relacionada à fertilidade e à reprodução em Tsakona.

Com relação à função do culto às comunidades políticas e a seus grupos políticos, no Peloponeso, os santuários extra-urbanos de Zeus na maior parte, principalmente aqueles com papéis regionais, serviram, em difentes níveis, a membros da aristocracia. Observa-se tal papel a partir da Idade do Ferro em Olímpia, no Mt.Lykaion, e possivelmente em Tsakona e no Mt.lthome (suburbano ou talvez extra-urbano sub-regional). Nesses quatro santuários, a dedicação de trípodes de bronze e despojos de guerra ou miniaturas de armas e armaduras (neste caso, a exceção é o Mt.Ithome), entre a Idade do Ferro e a época arcaica, indicou o consumo conspícuo da aristocracia e rituais envolvendo membros de uma elite masculina nos santuários. Vimos como 0 aspecto militar de Zeus foi um importante elemento no culto que atraiu a participação desse grupo, sendo Olímpia o caso de maior relevo a esse respeito. No contexto cívico, Corinto representa o caso mais emblemático, em área peloponésia, do envolvimento do culto (a sua instituição) com grupos políticos específicos da cidade, como a tirania ou a oligarquia, grupos pertencentes à aristocracia. Assim, é possível afirmar que Zeus teve uma função importante na articulação da identidade de um grupo específico da cidade grega, desde a época da formação da pólis na Idade do Ferro até a época clássica (como se observa principalmente em Olímpia). Tal função não foi uma regra a todos os santuários extra-urbanos regionais da divindade no Peloponeso, como foi no caso de Creta, onde todos os santuários da divindade desse tipo serviram para forjar coesão social somente entre membros de uma aristocracia masculina.

Além dessa função, relacionada especificamente a um grupo político, observa-se, no Peloponeso, o papel regulador, do culto e dos santuários de Zeus, nas instâncias políticas da cidade principalmente a partir de época clássica, como demonstram os casos de Mantinéia e de Megalópolis, cujas áreas sagradas funcionaram como locais de exposição de tratados e decretos e arquivos cívicos da comunidade. Nesse aspecto, o culto de Zeus Sóter no século IV a.C. exerceu um papel importante exclusivamente na esfera política

\footnotetext{
92 Além da função oracular bem conhecida no santuário de Olímpia, Zolotnikova defende o mesmo tipo de papel nos santuários de Zeus no Mt.Lykaion e em Neméia (Zolotnikova, 2011: 238; 2013b: 119).
} 
na Arcádia. Na Acaia, o santuário de Zeus Homarios em Aigion, sobre o qual conhecemos apenas das fontes literárias, foi espaço de assembleia políticas dos aqueus, podendo ser considerado o único de tipo federal dessa divindade no Peloponeso (Nielsen, 2013: 241; Rizakis, 2013: 14). O papel político de Zeus também é observado no contexto inter-regional nessa época: vimos como Olímpia, a partir do século V a.C., se tornou local de arbitragem de conflitos em nível sub-regional e inter-regional. A resolução de conflitos e a publicação de tratados internacionais entre comunidades políticas, dentro do santuário, tinham como objetivo último "regular as controvérsias entre as comunidades, a instauração de relações pacíficas entre as comunidades sob a sanção de Zeus Olímpio" (Taita, 2007: 141-142). Vimos como tal papel de Olímpia não foi alcançado, no mesmo grau, por nenhuma outra área sagrada da divindade no mundo grego. O santuário do Mt.Lykaion pode ter desempenhado um papel semelhante entre arcádios e os messênios, embora em um grau muito menor, ainda em época arcaica, como indica a estela posta por um desses grupos na área sagrada (noticiada por Políbio e Pausânias) com relação ao resultado do conflito com os espartanos e a morte do rei arcádio.

Além do papel visto na articulação da identidade de grupos políticos da cidade grega, o culto e os santuários de Zeus exerceram um importante papel na auto-percepção, afirmação e articulação de identidades regionais. No Mt.Lykaion, o culto de Zeus Lykaios, se consolidou como divindade pan-arcádia, por excelência, no século V a.C. no primeiro momento de afirmação da identidade étnica arcádia, como indicam, principalmente, as moedas cunhadas com a imagem do deus no nome dos arcádios. No século IV a.C., como vimos, à época da confederação arcádia, tal associação do culto se tornou ainda mais evidente no contexto da participação das comunidades arcádias confederadas no culto e nos jogos lykaios, como atestam a monumentalização do santuário de baixo e a lista dos vencedores dos jogos lykaios, cujos participantes das comunidades arcádias foram identificados como arcádios em contraste aos participantes de outras regiões, associados aos nomes de suas cidades de origem (Nielsen, 1999: 28). Na Messênia, o culto de Zeus Ithomatas também foi um elemento importante na elaboração da identidade étnica messênia desde a época arcaica até a época clássica, quando no século V e IV a.C. se consolidou como um símbolo da resistência contra os espartanos. Como veremos em detalhe no capítulo 4, na Acaia, onde a imagem de Zeus foi usada em moedas da liga aquéia no século IV a.C., Zeus Homarios foi considerado o deus de todos os aqueus já no século V a.C. e seu santuário em Aigion, 0 principal local de reuniões religiosas e políticas da região nessa época (Rizakis, 2013: 14). Conforme A. Rizakis, "Zeus teria se tornado depositário da identidade aqueia e de um lugar de culto comum - na qualidade de um deus que protege, que reúne, Zeus Homarios teria reunido o genos pela primeira vez na região - após um longo processo de oposições de identidade na região (entre Aigialeus e jônios, aqueus e eólios)" (Rizakis, 2013: 22). Principal santuário pan-helênico do Peloponeso, Olímpia teve um papel na articulação de vários níveis de identidade grega. Em primeiro lugar, a participação de diversos grupos étnicos gregos (dórios, jônios, eólios, aqueus) levou à elaboração da identidade grega a partir do século VI a.C. Em segundo lugar, ao mesmo tempo que a interação entre esses grupos culminou na formação de uma identidade mais ampla, o santuário de Olímpia foi também espaço de afirmação étnica de cada grupo grego que participava no culto e nos jogos. 
Dentre esses grupos, o grande número de comunidades de origem dória definiu Olímpia como um centro dório, assim como o grande contigente de póleis da Sicília e da Itália do Sul levaram alguns especialistas a definir 0 santuário como um centro ocidental em época arcaica e clássica93.

Todos esses casos descritos demonstram, em última análise, a vinculação do culto e dos santuários de Zeus na afirmação de identidades étnicas e regionais, de várias maneiras, no nível político. Na Messênia, 0 antigo culto de Zeus Ithomatas, com forte significado étnico para os messênios, foi incorporado ao culto cívico da pólis de Messênia como principal divindade da cidade - a associação do culto ao passado heroico messênio foi um fator importante nesse processo. Na Acaia, a incorporação do culto aqueu de Zeus Homarios à esfera política parece ter sido simultânea à formação da identidade aqueia no século V a.C., conforme Rizakis (Rizakis, 2013: 37). O funcionamento de um santuário como espaço de reuniões e deliberações comuns para todas as comunidades aqueias demonstra, claramente, o papel político regional de Zeus Homarios na Acaia. Nesse processo, "a ameaça de Sicione, contra as cidades aqueias orientais, e de Esparta, na metade do século VI a.C. favoreceram a união política regional, que alcançou expressão política no século $V$ a.C. com a constituição da liga aqueia" (Rizakis, 2013: 22-23). No Mt.Lykaion, o culto de Zeus Lykaios foi importante na coalização das comunidades políticas arcádias tanto no século $V$ a.C., quando bateram conjuntamente moedas com a imagem do deus, e no século IV a.C., conforme vimos anteriormente. Em Olímpia, todas essas participações de grupos étnicos gregos se deram no nível político: participantes dórios, jônios, eólios e aqueus eram representados no santuário por meio de suas comunidades políticas de origem.

Em contraste, é interessante notar como Zeus Sóter foi um culto com função política, sempre presente em contextos cívicos, que adquiriu significado, no Peloponeso, no momento de afirmação de identidades regionais no âmbito político, como foram as fundações da cidade de Megalópolis ou a renovação de Mantinéia nessa época.

Alguns casos, contudo, demonstram ainda um outro tipo de importância étnica / regional do culto de Zeus na esfera política: quando o culto regional foi apropriado pela pólis e lá instituído como um santuário cívico. Tal fenômeno ocorreu na Arcádia muito provavelmente durante o século IV a.C. em relação a Zeus Lykaios, quando seu culto parece ter sido instituído na ágora de Megalópolis, conforme uma referência de Pausânias (VIII, 30.2). Ainda que o viajante grego não ofereça referenciais para a datação do santuário, e este não tenha sido localizado, muito provavelmente o santuário de Zeus Lykaios em Megalópolis foi fundado no século IV a.C. no momento em que o deus assumiu um papel político na confederação arcádia, que também corresponde a participação dessa cidade na organização da área sagrada no Mt.Lykaion. E em períodos posteriores, em época helenística o culto entrou em declínio, devido, entre outros fatores ao fim da confederação ${ }^{94}$, o que justificaria a não introdução do culto após o período clássico. A nosso ver, no Peloponeso, Megalópolis oferece o único

\footnotetext{
${ }^{93}$ Laky, 2013, pp.47, 312-313. C. Antonaccio defende que Olímpia foi o local em que as apoikiai do Ocidente grego afirmaram seu status e identidade. A autora argumenta a favor de Olímpia como um centro de culto siceliota (Antonaccio, 2001: 134).

94 Kreutz, 2007, p.266.
} 
caso sobre o qual se pode afirmar que o culto de Zeus teve importância na formação de redes de identidade grega (no caso étnica e regional) em contexto cívico ou políade.

Um último exemplo, mostra como, de outra maneira, o culto de Zeus podia se tornar parte da identidade política de uma cidade em determinado momento. Acreditamos que esse foi o caso de Argos em relação ao santuário de Neméia: a apropriação dos jogos nemeanos e do culto de Zeus Nemeios e a instituição destes na cidade no século IV a.C. indicam que de alguma forma e por algum motivo, que remonta possivelmente à época arcaica, estes passaram a fazer parte da identidade política argiva, conforme evidencia a localização do santuário de Nemeios na ágora da cidade. Este caso, portanto, é diferente dos demais vistos até o momento: o santuário em Neméia, de acordo com as pesquisas atuais, não teria exercido um papel regional na Argólida tal como se observa em relação ao Mt.Lykaion e a Arcádia, por exemplo. Tratou-se de uma relação direta entre santuário e pólis, sem a influência ou interferência de identidades étnica e regional, vinculadas ao culto de Zeus, nesse processo.

A respeito ainda do culto e dos santuários de Zeus no Peloponeso, é preciso também destacar as relações estabelecidas entre áreas sagradas da divindade na região. Compartilhamento de traços culturais ocorreu entre Olímpia e o Mt.Lykaion acerca da iconografia do culto de Zeus - vimos como o santuário arcádio pode ter difundido, no início do século $V$ a.C., a representação de Zeus Keraunios com a águia (das estatuetas de bronze) ao santuário de Olímpia que passou a adotar o tipo com a ave em estatuetas desse tipo. 0 desenvolvimento das práticas agonísticas no Mt.Lykaion pode, de alguma maneira, ter sido influenciado pela instituição dos jogos no culto de Zeus em Olímpia no início da época clássica. Narrativas mitológicas sobre o nascimento de Zeus, presentes no culto no Mt.Lykaion e no Mt.lthome são considerados indícios de uma tradição religiosa comum no sudoeste do Peloponeso. Os tipos de trípodes dedicados no Mt.Lykaion e no Mt.lthome, na Idade do Ferro, também são considerados semelhantes a alguns dos tipos de Olímpia95, indicando, também, a relação, em algum nível, entre os três santuários. Essa relação pode ter estado na origem dos artesãos responsáveis pela confecção desses objetos e nos frequentadores comuns a esses três santuários de Zeus durante a Idade do Ferro e no início da época arcaico. Essas similaridades indicam um tipo de rede existente entre os principais cultos da divindade no oeste do Peloponeso entre a Idade do Ferro e a época clássica. Já a localização e a datação do ápice da atividade cultual nos santuários no Mt.Apesas, Neméia e Mt.Arachnaion, indicam, segundo O. Zolotnikova, "uma rede de lugares de culto a Zeus no nordeste do Peloponeso entre a Idade do Ferro e a época arcaica" (Zolotnikova, 2013b: 122). De acordo com sua tese, "a mesma localização geográfica e a relativa curta distância entre um santuário e o outro, evidenciam um tipo de rede e cooperação entre as áreas sagradas" (Zolotnikova, 2013b: 122).

Em síntese, é possível estabelecer alguns elementos observados somente no culto peloponésio de Zeus entre a época arcaica e clássica: a prática agonística como elemento integrante do culto, a relação do

95 Zolotnikova, 2013a, p.106 (sobre a semelhança com o fragmento do trípode encontrado no Mt.lthome), Romano; Voyatzis, 2014, p.618 (sobre similaridades com os trípodes encontrados no Mt.Lykaion). 
culto com identidades regionais e étnicas, santuários federais como centros de deliberação de comunidades políticas em termos regionais, e, por último, a influência da ameaça espartana como fator catalisador do aumento de importância do culto de Zeus entre messênios, arcádios e aqueus. Vimos como na Messênia, na Arcádia e na Acaia, a hegemonia e expansão de Esparta, no Peloponeso, desde a época arcaica, foi um fator de importância na elaboração da identidade étnica/regional nessas três sub-áreas.

\section{SICÍLIA}

Se a ilha de Creta e o Peloponeso se caracterizam pela antiguidade de culto de Zeus e por terem sido centros inter-regionais de santuários da divindade, a Sicília se destaca por ter sido uma das duas áreas do mundo grego onde o culto de Zeus adquiriu somente características cívicas - ganhou significado ou materializou-se entre determinadas cidades gregas na região já a partir do século VII a.C. A concentração de áreas sagradas datadas de época arcaica nessa região, em relação às demais áreas do mundo grego, onde 0 culto ganhou expressão nesse período, mostra que se tratou de um fenômeno exclusivo siceliota e que somente alcançou expressão, da mesma forma, em outras partes do mundo grego, a partir de época clássica.

$\mathrm{Na}$ Sicília, o culto de Zeus ganhou expressão de vários modos em muitas comunidades políticas da ilha, onde foi instituído a partir de uma variedade de epítetos em vários períodos. A maior parte dessas expressões do culto é conhecida apenas das fontes literárias: estas registram uma quantidade significativa de informações a respeito de áreas sagradas, altares e outros tipos de formas de culto a Zeus em cidades siceliotas, desde dedicação pública de estátuas até magistraturas e festas em sua honra. Dentre todos os casos conhecidos, foi possível selecionar, para essa pesquisa, apenas os santuários de Zeus em Siracusa, Selinonte e Agrigento, pois são as únicas áreas sagradas conhecidas arqueologicamente, o critério adotado por nós para a seleção dos santuários de Zeus (vide mapa p.30).

Apesar de o culto de Zeus, de uma maneira geral e de vários modos, ter sido difundido em várias áreas da ilha, percebe-se um padrão da localização de santuários no lado leste e sudoeste da Sicília, principalmente com relação às áreas sagradas de Zeus Olímpio. Como veremos na análise e interpretação na sequência, tratou-se de um culto do deus que ganhou especial expressão na Sicília, seja nas proporções de seus templos como na instituição de seu culto pelos tiranos siceliotas e na forma como os santuários foram usados como símbolos de poder e soberania das comunidades políticas siceliotas. Em contraste ao culto de Zeus Olímpio, que alcançou importante significado na esfera cívica e política, o santuário de Zeus Meilichios em Selinonte mostra como o culto do deus também poderia ter se desenvolvido em relação à esfera privada, ou seja, não pública da cidade. Contudo, se verá, na análise final, que se tratou de uma exceção em contexto siceliota.

Como aprofundaremos na conclusão sobre a Sicília, muito provavelmente tal difusão e expressão política e cívica do culto de Zeus entre as póleis siceliotas no início da época arcaica, muito provavelmente, teve a ver com o grau de desenvolvimento urbano e político alcançado pelas cidades gregas já nessa época. 
Como colocam alguns autores, entre eles I. Morris, "vários desenvolvimentos, entre eles o urbano e o político, alcançaram um grau maior primeiro entre as fundações gregas - um fenômeno que promoveu a urbanização e integração das comunidades metropolitanas" (apud Antonaccio, 2009: 314-315). Como explica E. Greco, "no mundo grego das apoikiai da Sicília e Itália do Sul o planejamento urbano atingiu formas originais e tais experimentações influenciaram, em certo grau, o desenvolvimento urbano em outras áreas do mundo grego" (Greco, 1990: 10).

\section{III.1 Selinonte, Colina de Gaggera}

Localizado no sudoeste da Sicília, o santuário de Zeus Meilichios (cat. no.27) foi estabelecido em Selinonte, no setor oeste da pólis, na área central da colina de Gaggera, a noroeste do santuário de Deméter Malophoros (Fig.76) (Veronese, 2006: 527). As pesquisas arqueológicas na área da colina de Gaggera se iniciaram em 1874 sob a direção de Cavallari após a expropriação do terreno pelo Estado (Grotta, 2010: 2). Entre 1888 e 1889, G. Patricolo retomou os trabalhos na área, descobrindo 0 témeno de Deméter Malophoros, mas a escavação foi interrompida até uma nova expropriação da terra naquela

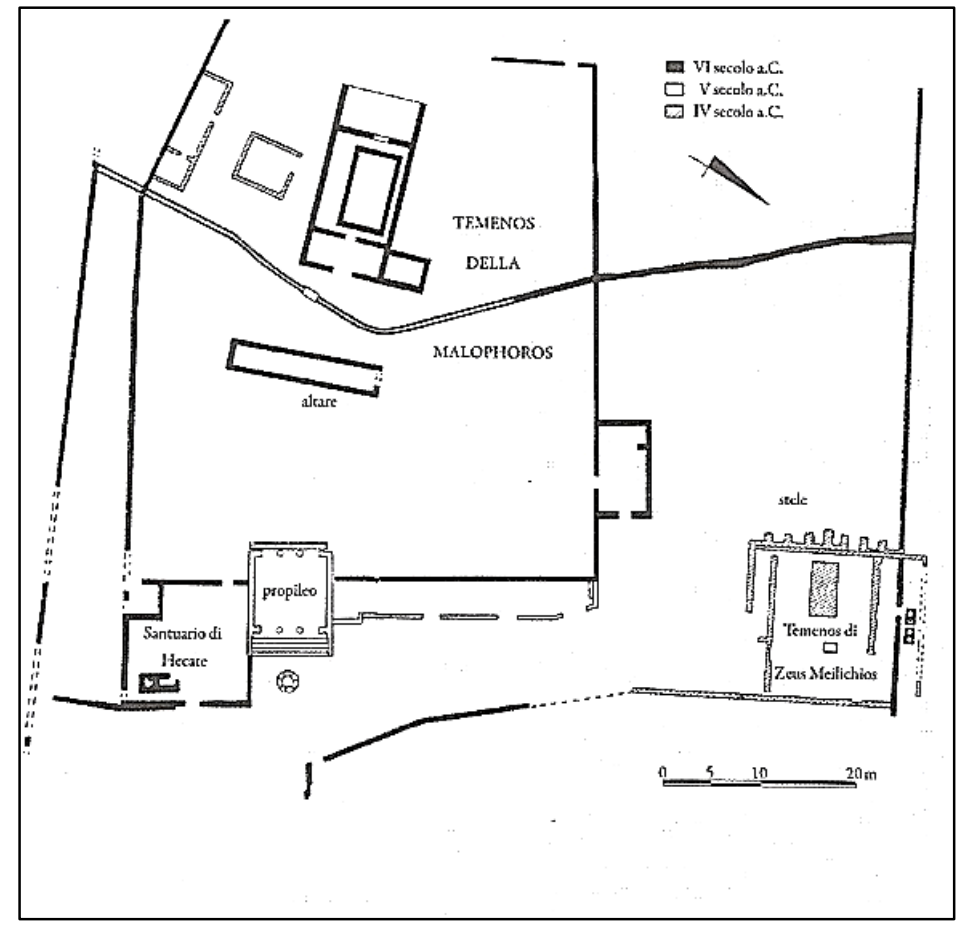

Fig.76-Planimetria santuário de Deméter Malophoros e Zeus Meilichios (por Hellmann, 2006) (apud Lippolis, 2007: 837, fig.34.9.4b) área (Grotta, 2010: 2). 0 témeno de Zeus Meilichios, assim como o pequeno templo e algumas estruturas, foram descobertas durantes as escavações sob a direção de A. Salinas nos anos de 1902, 1903 e 1905 (Grotta, 2010: 2-3). Infelizmente, os resultados das pesquisas arqueológicas referente a esses anos não foram publicados, embora tenham sido, posteriormente, registrados por J. Hulot e G. Fougères (Grotta, 2010: 3). 0 estudo, a interpretação e a publicação sistemática do santuário de Zeus Meilichios e do complexo dos santuários da colina de Gaggera foram realizados por E. Gabrici, que efetuou sete campanhas de escavação na área entre 1915 e 1926, completando o trabalho iniciado pelos arqueólogos anteriores (Grotta, 2010: 3). Após a pesquisa de Gabrici não ocorreram mais escavações sistemáticas na Gaggera, apenas trabalhos de manutenção das ruínas e alguma pesquisa arqueológica mais pontual no local (Grotta, 2010: 4-5). 


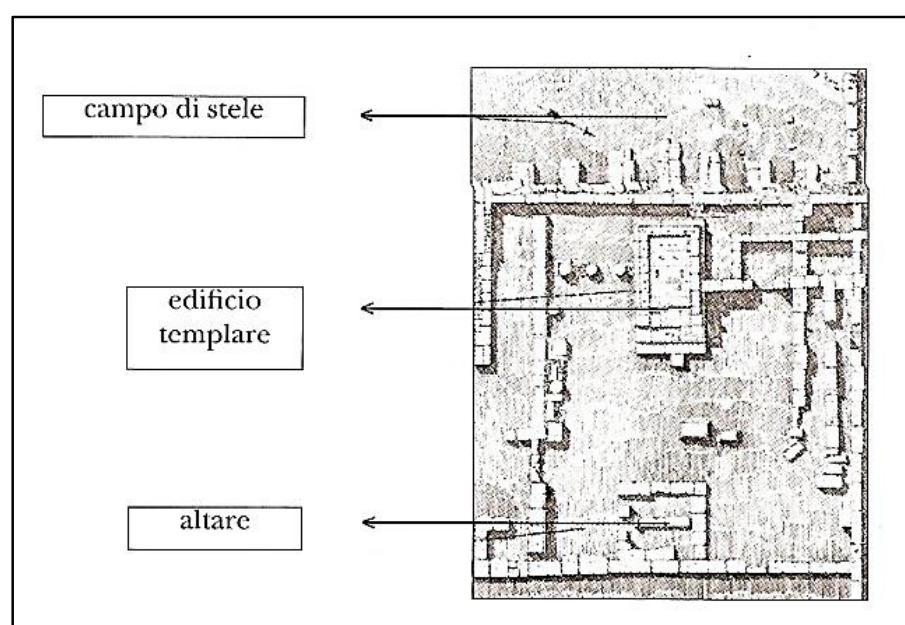

Fig.77- Planimetria do santuário de Zeus Meilichios (Veronese, 2007: fig.11.17)

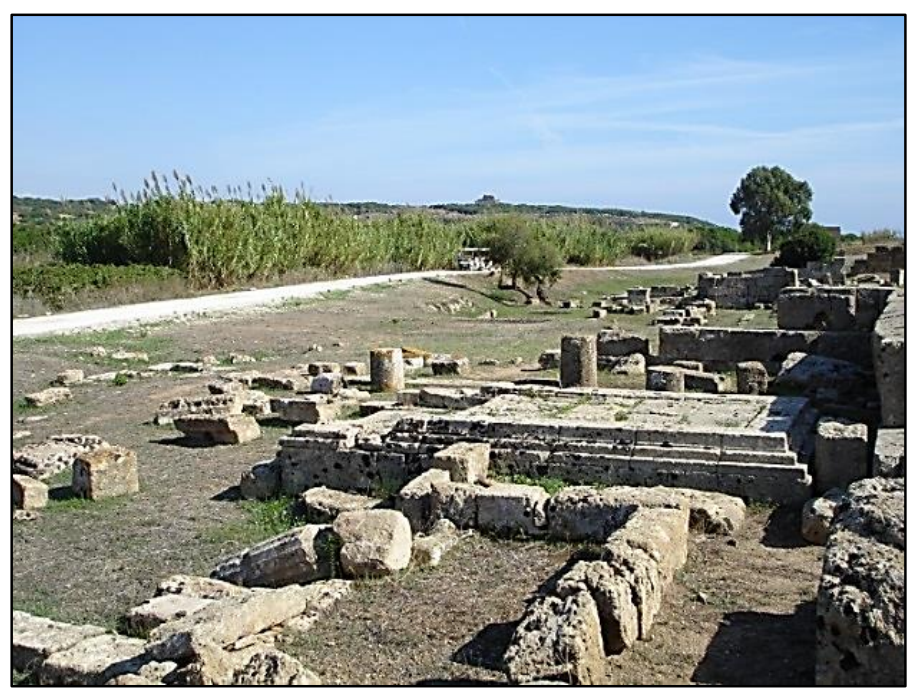

Fig.78- Vista do santuário de Zeus Meilichios (acervo Labeca/2005)

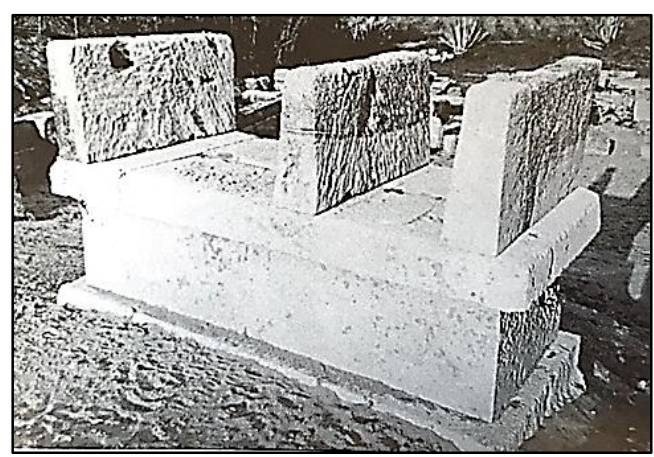

Fig.79- Altar com três "betili" da área do campo de estelas, a partir de oeste (Grotta, 2010: tab.X, fig.a)

O início da atividade cultual no santuário de Zeus Meilichios em Selinonte remonta ao final do século VII a.C., como indica a datação do altar, no campo de estela, e de alguns objetos votivos encontrados (Veronese, 2006: 527). A área sagrada funcionou ininterruptamente durante os séculos VI e V a.C. Durante o século V a.C. houve uma intensa monumentalização da área sagrada. A destruição de todo o complexo dos santuários na colina de Gaggera ocorreu ao redor da metade do século IV a.C. (Veronese, 2006: 527).

Conforme F. Veronese, para a época arcaica, "os dados referentes ao santuário são muito lacunosos e a datação das estruturas é controversa, sobretudo a do edifício de culto, de acordo com os últimos estudos" (Veronese, 2006: 527-528). As estruturas principais do santuário são o altar, o muro do témeno, 0 pequeno templo e o campo de estelas (Fig.77). 0 témeno, de forma quase quadrada de $17 \mathrm{~m}^{2}$, abriga o altar e o naískos (Lippolis, 2007: 838; Veronese, 2006: 527-528). O naískos ou pequeno templo, datado do primeiro quartel do século VI a.C., mede 2,97 x 5,30 m, era articulado em pronaos e naós distilo in antis, tinha um crepidoma similar, do ponto de vista planimétrico, ao do mégaron do santuário de Deméter Malophoros (Fig.78) (Veronese, 2006: 527). As colunas monolíticas eram dóricas e o entablamento possui elementos da ordem jônica (Veronese, 2006: 527). O acesso ao naíkos provavelmente se dava na parte leste (Veronese, 2006: 527). Conservaram-se do edifício os blocos de fundação e do crepidoma, alguns deles inseridos nos ângulos do edifício segundo a técnica de "armação horizontal", provavelmente de finalidade anti-sísmica (Veronese, 2006: 527). A elevação do edifício era constituída por muros com espessura de 0,37m, que se estreitavam na parte superior (Veronese, 2006: 527). É provável que 
o naíkos tenha sido coberto por um telhado de madeira (Veronese, 2006: 527). O edifício era precedido, a leste, por um altar, segundo F. Veronese, ou por dois altares, segundo C. Grotta (Grotta, 2010: 30; Veronese, 2006 : 527-528). De acordo com Grotta, "trata-se de dois altares de dimensões diferentes - um mais alto destruído na parte superior $(0,90 \times 1,30 \mathrm{~m})$ e o outro mais baixo e menor $(0,60 \times 0,85 \mathrm{~m})$, não visível atualmente" (Grotta, 2010: 30). Segundo esse estudioso, "altares dessa tipologia eram usados para rituais de libação e de purificação, como indica a presença de alguns pequenos poços próximos utilizados para recolher a água da chuva" (Grotta, 2010: 30).

Com relação ao campo de estelas, localizado a oeste do témeno de Zeus Meilichios, trata-se de uma área de 25 x 40 m de extensão, com deposições votivas (sendo as mais importantes as estelas), caracterizada pela presença de um altar de tipo oriental com três "betili" sobre uma base alta $(1,05 \mathrm{~m})$ situado no centro do campo (Fig.79) (Grotta, 2010: 41, 47, 49, 53 e 57; Lippolis, 2007: 838; Veronese, 2006: 527528). A datação do altar permanece ainda controversa: alguns autores preferem data-lo entre o final do século VII a.C. e o século V a.C., já outros entre o século VIIV a.C. (Grotta, 2010: 41 e 44). A dificuldade no estabelecimento de uma cronologia para estrutura reside na indefinição de sua função e na sua tipologia, de provável origem não grega (egípcia ou fenício-púnica) (Grotta, 2010: 42-44). De acordo com Grotta, "a inexistência de uma documentação fotográfica adequada do campo de estelas, à época de sua escavação, impede a compreensão completa das características e definição da área" (Grotta, 2010: 45). Nessa área foram encontradas "centenas de estelas votivas, quase todas anepígrafas e anicônicas" (Grotta, 2010: 45).|As estelas, que possuem inscrições, "foram datadas entre o início do século $\mathrm{VI}$ a.C. e a metade do século $\mathrm{V}$ a.C. e são caracterizadas por um texto

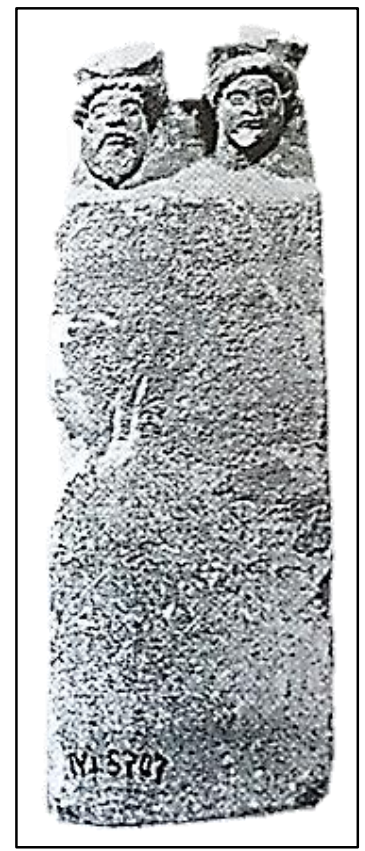

Fig.80- Estela de tipo gêmeo do santuário de Zeus Meilichios, Museu Arqueológico Regional A. Salinas, Palermo (Grotta, 2010: tab.XIII) muito simples" (Grotta, 2010: 47). O nome Meilichios "aparece inscrito de três formas (Meilichios, Melíchios ou Milíchios) em setes inscrições, acompanhando o nome de um indivíduo ou de um grupo de indivíduos sempre no genitivo, e em apenas uma estela o epíteto é precedido pelo nome de Zeus" (Grotta, 2010: 47). Três exemplares de estelas apresentam traços de combustão devido, provavelmente, à uma prática relacionada ao culto de Zeus Meilichios - "durante as escavações na área, Gabrici notou a presença de pequenos vasos queimados junto a restos de ossos de animais colocados aos pés das estelas" (Grotta, 2010: 48). Também foram recuperadas estelas portando algum tipo de representação - alguns poucos exemplares são datados do final do século V a.C., a maioria pertence ao século IV a.C. (Fig. 80) (Grotta, 2010: 49). Dentre essas, destacamse aquelas com a representação de uma figura masculina barbada, interpretada como Zeus Meilichios (Grotta, 2010: 50).

Com relação a outros objetos votivos, encontrados durante as escavações de Gabrici nos anos 1920, como o material cerâmico associado a fragmentos de estatuetas femininas e masculinas, encontradas 
abundamentemente, infelizmente a bibliografia disponível se concentra apenas na descrição e interpretação das estelas. Mesmo o estudo de Grotta não oferece uma explicação sobre a relação das estatuetas com o culto de Zeus Meilichios. Apesar de não se referir diretamente a esse tipo de votivo, Veronese parece concluir que 0 elemento feminino, associado ao masculino, foi importante no culto selinontino do deus (Veronese, 2006: 527). É provável, a seu ver, que o deus tenha sido cultuado ao lado de uma divindade feminina (Veronese, 2006: 527). Contudo, tal associação ainda aguarda comprovação.

\section{III.1.2 A natureza do culto e a função do santuário}

A atribuição do santuário em Selinonte ao culto de Zeus Meilichios é atestada, como vimos, a partir de evidências epigráficas. Não há testemunhos literários a respeito do santuário. Conforme Grotta, "a documentação epigráfica, datada entre os séculos VI a.C. e a metade do V a.C., constitui a única indicação de que a área sagrada, nesse período, era consagrada à divindade" (Grotta, 2006: 222). Sem a associação às inscrições, as representações do deus, em algumas das estelas, não seriam suficientes para identificar o culto, pois não possuem elementos iconográficos próprios da iconografia de Zeus Meilichios no mundo grego, como a serpente, por exemplo, seu atributo (Larson, 2007: 22).

Em linhas gerais, em vários contextos no mundo grego, o culto de Zeus Meilichios ("o benigno") teve uma característica ínfera importante, por isso, de uma maneira geral, foi relacionado ao mundo dos mortos (Larson, 2007: 21-22; Veronese, 2006: 527). Ao mesmo tempo, a divindade foi evocada na necessidade de purificação ou na expiação de um delito cometido ${ }^{96}$ (Grotta, 2010: 144). Nessa perspectiva, o culto de Zeus Meilichios foi muito requisitado na esfera familiar e individual (Larson, 2007: 22). No caso de Selinonte, muitas interpretações foram propostas para a função do santuário da divindade à comunidade entre a época arcaica e clássica - principalmente sobre a relação da área sagrada com o campo de estelas. Baseado na característica ctônia do culto de Zeus Meilichios, Gabrici propôs que essas estelas foram "dedicadas por parentes ou pessoas relacionadas a um indivíduo já morto, que realizaram um sacrifício propiciatório no santuário, invocando a clemência do deus a favor do defunto" (apud Grotta, 2010: 50-51). Segundo Grotta, autor do estudo mais recente sobre a divindade em Selinonte, "tratou-se de um culto que exprimiu uma forte relação com o ambiente familiar e nobiliário, predominando a característica privada da experiência religiosa, como indicam as estelas votivas" (Grotta, 2010: 226). A representação do indivíduo e o seu nome, associado ao epíteto da divindade, nas estelas, "'indicam as características de um culto familiar, que não demonstra nenhum aspecto público" (Grotta, 2010: 223 e 226). Grotta também não exclui a possibilidade de que uma estela, outrora dedicada pelo grupo, tivesse se tornado, ao longo do tempo, o local de culto, de uma inteira família, a Zeus Meilichios (Grotta, 2010: 223). Nesse sentido, a seu ver, as estelas de Zeus Meilichios "parecem ter se configurado como

96 Um exame completo do culto de Zeus Meilichios no mundo grego foi realizado por Grotta, 2010, pp.137-175. 
verdadeiros semata destinados a assegurar, aos descendentes de um indivíduo ou aos membros de um grupo, a continuidade ritual" (Grotta, 2010: 223-224). Com relação ao caráter não público do culto, Grotta conclui que a área sagrada de Zeus Meilichios em Selinonte "não representou um Meilichieion, no sentido de um santuário oficial (cívico ou comunitário) da divindade, mas um local no qual cada grupo oficiava o próprio culto a Zeus Meilichios" (Grotta, 2010: 225).

O estudioso italiano também defende a independência do santuário de Zeus Meilichios em relação àquele de Deméter Malophoros, situado logo a leste e sudeste. Por muito tempo, foi defendido, a partir de Gabrici, a dependência da área sagrada de Zeus, mais modesta, como menos objetos votivos, em relação à de Deméter, maior, mais monumental e rica em objetos votivos de vários tipos (Grotta, 2010: 224). A seu ver, se tratou de duas áreas sagradas muito distintas, que devem ser analisadas de forma independente, em seus próprios termos (Grotta, 2010: 224).

Outra discussão com relação ao santuário de Zeus Meilichios refere-se à presença de elementos não gregos no santuário da divindade. De acordo com Veronese, "algumas particularidades, que caracterizam 0 santuário, denotam, do ponto de vista cultual e arquitetônico, a constante interação entre o mundo grego, 0 fenício-púnico e o elímio" (Veronese, 2006: 527-528). A. Di Vita, baseando-se nas estelas com representações de tipo gêmeo (com dois prótomos humanos na parte superior), muito difundidas no mundo fenício púnico e siceliota entre os séculos V-IV a.C, parece ter sido o primeiro a propor uma influência não grega no culto (apud Grotta, 2010: 53). A seu ver, esses tipos de estelas não teriam sido produzidos em âmbito siceliota, mas em cidades púnicas do norte da África (apud Grotta, 2010: 53). A proposição de Di Vita, sobre o elemento feníciopúnico no culto de Zeus Meilichios é a mais seguida atualmente (Grotta, 2010: 54). Dentre as interpretações atuais, acerca do elemento não grego, acreditamos que aquela de Jameson, Jordan e Kotansky é a ideal para a compreensão do sincretismo no culto da divindade em Selinonte. Segundo esses estudiosos, "a presença fenício-púnica na área da colina de Gaggera é atestada somente a partir do século IV a.C., como evidencia um altar em miniatura de pedra, com a inscrição em alfabeto fenício, datado dessa época e considerado o achado mais antigo sobre a presença desse povo na área da colina" (Grotta, 2010: 59). Nesse sentido, os três autores defendem a presença fenício púnica no culto do santuário de Zeus Meilichios somente após a destruição da cidade em c.409 a.C. Nessa perspectiva, mesmo durante a ocupação púnica da cidade durante o século IV a.C. o culto a Zeus Meilichios não teria sido substituído pelo de uma divindade estrangeira - além disso, a população grega, embora menor, deve ter continuado a frequentar a área e a participar do culto ao deus (apud Grotta, 2010: 59).

Assim, essas são as principais interpretações sobre a função do culto e do santuário de Zeus Meilichios em Selinonte. Para terminar, cabem algumas considerações sobre o posicionamento extra-urbano do santuário na cidade e uma correlação com a colina de Marinella, onde se encontra o culto de Zeus Olímpio, localizada 
no lado oposto do assentamento ${ }^{97}$, o qual ainda analisaremos nesse tópico sobre os santuários siceliotas de Zeus.

A colina de Gaggera, situa-se a c.1 km a oeste do rio Modione ou antigo Sélinos, e foi local do mais importante dos dois portos fluviais da pólis (Coarelli; Torelli, 1984: 97). A colina, caracterizada como uma duna arenosa, "tinha uma projeção topográfica diferenciada em direção à zona de expansão púnica, favorecendo a criação de um complexo de santuários "internacionais", não estranhos aos fenício-púnicos do extremo Ocidente da ilha" (Veronese, 2006: 506). Sabe-se também que a área já era freqüentada pelos elímios na fase anterior à chegada dos gregos (Veronese, 2006: 506). As evidências arqueológicas disponíveis permitiram identificar ao menos cinco témenos na área (entre eles o de Deméter Malophoros e de Zeus Meilichios), autônomos e separados, dispostos em sucessão desde a parte sul, próximo à altura da foz do rio, até a parte norte, na altura da área de Manuzza, onde se situa a acrópole da cidade (Veronese, 2006: 506). Aceita-se que na área predominaram os santuários de cultos ctônios em contraposição aos santuários localizados na colina oriental de Marinella. Conforme Veronese, "a área sagrada extra-urbana, da colina ocidental, apresenta cultos e arquitetura que escapam de uma identificação exclusivamente grega e se aproxima ao mundo não grego, ao passo que os três santuários extra-urbanos da colina oriental (dentre eles o de Zeus Olímpio, que analisaremos mais adiante) é caracterizado por templos monumentais de tipo grego e cultos seguramente gregos" (Veronese, 2006: 507). Costuma-se assumir, também, que "os santuários da colina de Gaggera, a oeste, e da colina de Marinella, a leste, e aqueles situados na acrópole, formavam um cordão sagrado ao redor da cidade" (Greco; Torelli, 1983: 191-192; Jannelli, 2004: 261).

Assim, na pólis de Selinonte, o culto de Zeus ganhou expressões bem diferentes em áreas extraurbanas. De um lado da cidade assumiu características híbridas, em um período posterior, foi relacionado à esfera ctônia e privada, provavelmente à uma aristocracia como postula Grotta, e de outro, foi um culto cívico, voltado à esfera pública, e se tornou expressão do poder de um grupo político (tiranos) e da comunidade política como um todo, como indicou a monumentalidade nunca vista, até então, na arquitetura dórica e nos templos de Zeus Olímpio. O culto de Zeus Meilichios foi desprovido de uma função política ou cívica, no sentido de que não serviu ao funcionamento da comunidade política em nenhum nível.

\footnotetext{
97 Sobre uma análise completa da configuração urbana de Selinonte, ver Laky, 2013, pp. 117-124.
} 


\section{III.2 Siracusa}

Localizado na costa leste da Sicília, o santuário de Zeus Olímpio (cat. no.29) foi estabelecido em Siracusa, no sudoeste da cidade, no subúrbio de Polichne, logo a sul da foz dos rios Anapos e Ciane e a oeste da estrada Helorina (Fig.81) (Laky, 2013: 80). As primeiras notícias de época moderna sobre o santuário, e as pesquisas arqueológicas posteriores na área, são todas referentes às ruínas do templo de Zeus Olímpio do qual partes arquitetônicas ainda permanecem bem visíveis no

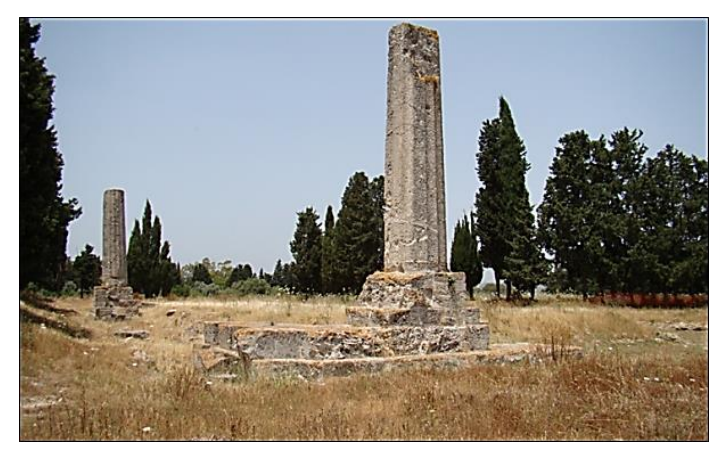

Fig.81- Templo de Zeus Olímpio em Siracusa visto a partir de leste (Foto: arquivo pessoal/2009) local, como duas colunas e os estilóbatos. É preciso dizer, de antemão, que além da rica documentação literária disponível sobre o santuário, o edifício é a única evidência material que dispomos acerca dessa área sagrada. Assim, data do século XVI a primeira notícia moderna sobre o templo de Zeus Olímpio, e por consequência, de seu santuário, que nos é dada4 por Fazello. A partir dele, outros nos séculos seguintes se ocuparam de descrever os remanescentes do edifício (Laky, 2013: 73). As primeiras escavações somente foram ocorrer ao longo do século XIX - em 1839 pelo engenheiro Cavallari e em 1893 sob supervisão de Paolo Orsi (promovida pelo Serviço Arqueológico do Reino), responsável pela primeira pesquisa sistemática no templo e no santuário (Laky, 2013: 73). Durante a nova campanha de Orsi em 1902, foram descobertas partes importantes da estrutura inferior do Olimpieion, como parte dos estilóbatos oriental e sudeste que sustenta uma das colunas sobreviventes, e partes do estereóbato meridional, setentrional e sudoeste os quais permitiram o conhecimento do comprimento do edifício (Lissi, 1958: 197-198). As próximas escavações somente foram realizadas quase meio século depois, em 1953, sob a direção de E. Lissi - estas foram marcadas pelo achado de partes arquitetônicas e escultóricas importantes do templo, como fragmentos de colunas, de um capitel, de terracota arquitetônicas, do friso decorativo da sima e partes de um gorgoneion (Laky, 2013: 74). Novas pesquisas na área ao redor do santuário foram realizadas pela Superintendência em 2009.

\section{III.2.1 Descrição e interpretação dos achados}

A datação mais antiga do santuário de Zeus Olímpio em Siracusa, no final do século VII a.C., foi proposta por Orsi a partir da associação entre certas referências literárias e dados arqueológicos de suas escavações. Assim, "a evidência de ocupação sícula na área do santuário98 e principalmente a informação de Diodoro (X, 28.1-2) sobre a estátua de Zeus Olímpio foram consideradas pelo arqueólogo italiano indicações

\footnotetext{
98 Orsi encontrou vasilhas sículas, na fundação e ao redor da colunata sul do Olimpieion, datadas do primeiro período de ocupação dos sículos na cidade. Isso levou o arqueólogo italiano a propor a existência de uma construção templária em madeira no século VII a.C., onde poucos séculos antes havia uma cabana sícula (Osi, 1903: 371 e 390).
} 


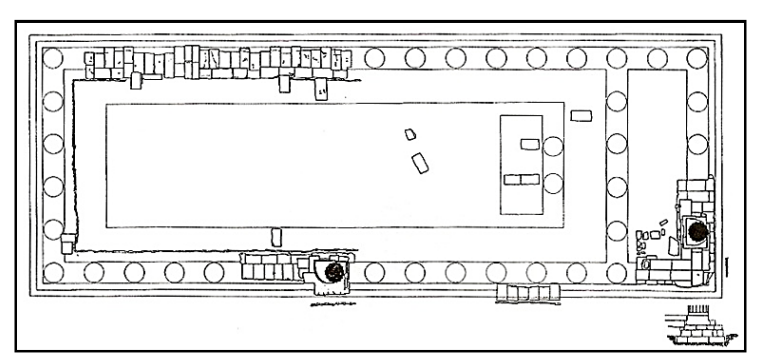

Fig.82- Planta do Olimpiéion (por Orsi 1903 e Lissi 1958) (apud Mertens, 2006: 111, fig.173)

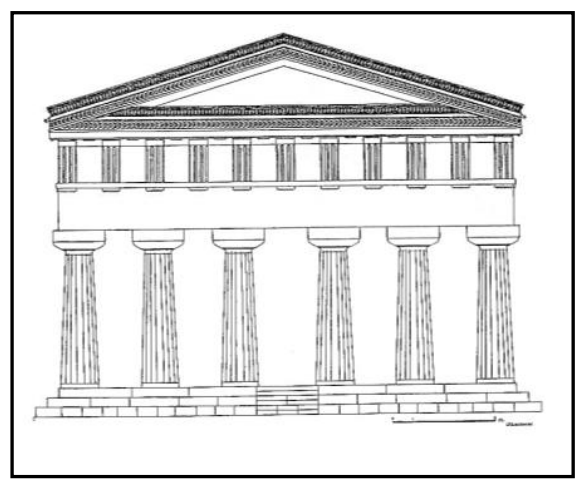

Fig.83- Fachada oriental do Olimpiéion (por são as fontes literárias que propiciam indicações sofre as fases nos Lazzarini) (apud Lissi, 1958: 208, fig.14)

da existência de um templo em madeira contendo um xóanon do deus já no final do primeiro século da época arcaica" (Laky, 2013: 74). Nessa perspectiva, "a construção templária em madeira, então, teria sido substituída pela de pedra no início do século VI a.C., permanecendo da época anterior a antiga imagem de madeira do deus mencionada pelo historiador sículo" (Laky, 2013: 74). Já para o templo de Zeus Olímpio, estudiosos de arquitetura grega propuseram datações entre 0 final do século VII a.C. até meados do século VI a.C. (Laky, 2013: 75). Em nossa pesquisa de mestrado sobre os Olimpieia, seguimos a datação proposta por Marconi entre 580-570 a.C. que, a nosso ver, está mais de acordo com as características dos elementos arquitetônicos do edifício (Laky, 2013: 75). Com relação à duração do culto e do santuário, períodos clássico, helenístico até seu declínio em época romana. Um testemunho de Tito Lívio (XXIV,33) noticia que o Olimpieion foi ocupado em 214 a.C. pelos romanos, já a última notícia sobre o edifício, proveniente de época antiga, menciona a remoção da imagem de Zeus do interior do templo (Cícero, Verr. IV.57.128). Se a informação for verdadeira, é provável que o templo na época de Cícero (século I a.C.), e por consequência o santuário, estivessem abandonados ou em decadência (Laky, 2013: 82).

Assim, sobre os elementos do santuário em Siracusa sabemos apenas do templo e de sua estátua de culto. Não foi encontrado nenhum depósito votivo dentro do templo ou na área do témeno, portanto não há evidências sobre os tipos de oferendas, que poderiam auxiliar na reconstituição do tipo de culto e ritual na área sagrada de Zeus Olímpio na cidade. Somente menções nas fontes literárias, como veremos na sequencia, informam sobre a riqueza das oferendas. No que diz respeito ao templo, os remanescentes arquitetônicos do Olimpieion permitiram reconstituir a sua tipologia e situá-lo na arquitetura dórico arcaica siceliota. 0 edifício, orientado leste-oeste, era dórico e hexastilo com uma segunda fileira de colunas no lado oriental (Figs.82 e 83) (Laky, 2013: 75). A característica alongada e estreita da planta foi definida pelas $6 \times 17$ colunas e pelas dimensões de 20,50 x 60 metros (Laky, 2013: 75). Devido ao estado de conservação da área do edifício no nível do estilóbato, não é clara a articulação dos espaços internos (Laky, 2013: 75). Contudo, a hipótese é de que o templo tinha uma cela alongada com pronaos distilo in antis e um ádito sem opistódomo (Coarelli; Torelli, 1984: 281; Gullini, 1989: 471; Lissi, 1958: 199, nota 2; Marconi, 2007: 50; Mertens, 2006: 111; Veronese, 2006 : 326). Com relação às partes inferiores do templo, foram encontrados cinco trechos de diferentes dimensões do estilóbato, que permitiram estabelecer as medidas da planta do edifício, e é provável que tenha possuído um crepidoma de 3 degraus (Laky, 2013: 76; Marconi, 2007: 50). As duas colunas que se conservaram são monolíticas e feitas de calcário, medem $6,50 \mathrm{~m}$ de altura, mas podem ter alcançado 8 metros como ocorreu no 
templo de Apolo, um pouco mais antigo e localizado em Ortígia, no centro urbano de Siracusa (Laky, 2013: 77). A coluna do lado leste tem 1,87 m de diâmetro na parte inferior e 1,42 m de diâmetro na parte superior. Já a coluna do lado meridional mede 1,85 m de diâmetro na parte inferior (Coarelli; Torelli, 1984: 281; Lissi, 1958: 199, nota 2; Orsi, 1903: 376-377). O único fragmento de capitel do templo foi encontrado durante as escavações de 1953, mas o estado do material impossibilitou a reconstituição de seu aspecto (Laky, 2013: 77). De todo modo, o capitel devia apresentar uma aparência semelhante àquela dos capitéis do Apolonion, do antigo Athenaion de Siracusa e de Gela (Laky, 2013: 77).

Com relação à parte superior do templo, nenhum elemento arquitetônico escultórico do entablamento (friso e arquitrave) foi encontrado (Laky, 2013: 77). Entretanto, essa lacuna é parcialmente preenchida pelo bom estado de preservação de várias terracotas arquitetônicas do revestimento (sima, cornija e telha) encontradas na escavação de 1953 (Fig.84) (Marconi, 2007: 50). Três fragmentos com forma de voluta (com traços de branco e preto) e dois fragmentos diversos (com cor vermelha bem preservada), pertencentes à cabeleira de uma Górgona, e outros três fragmentos encontrados, pertencentes à pelaria e a crina de um cavalo, sugerem que a parte

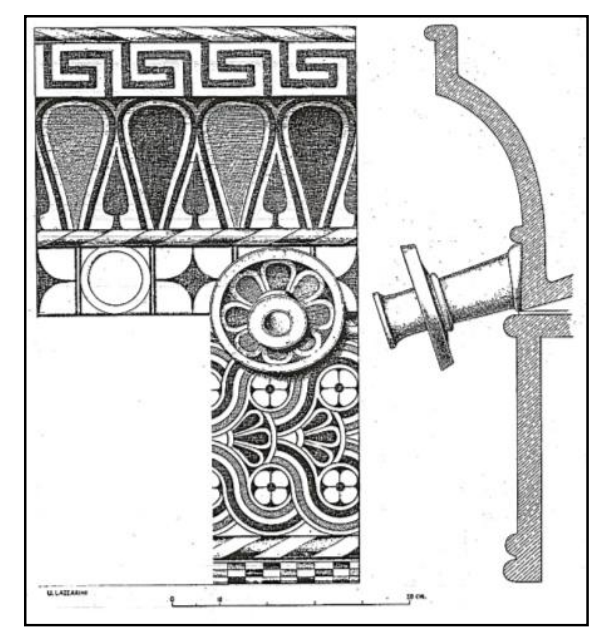

Fig.84- Sima encontrada nas fossas A e B (Lissi, 1958: fig.10) frontal era decorada por uma gorgoneion (uma cabeça de Górgona) e um cavalo (Lissi, 1953: 212).

As três escavações empreendidas no Olimpieion não localizaram indícios do altar e nem de outro tipo de edifício relacionado ao santuário (Laky, 2013: 78). Além dos achados do templo, as únicas intervenções antigas, encontradas relacionadas ao santuário, foram dois cortes irregulares nas fossas $A$ e $B$, nas escavações de 1953, relacionados a alguma obra de defesa (Lissi, 1958: 219-220). 0 achado de cerâmica negra de tipo italiota, no estrato, relacionou os dois cortes ao episódio do assédio a Siracusa pelo general cartaginês Himilcon, que estabeleceu um acampamento próximo ao templo em 396/5 a.C. (Lissi, 1958: 219-220).

Da estátua de culto de Zeus sabemos por meio dos relatos de Diodoro e de Cícero (Verr. III.34), que informam sobre o manto que ornou a imagem em diversas épocas. Infelizmente nenhum deles descreveu a estátua (Laky, 2013: 78). Os trechos se referem à época de Hipócates de Gela (491 a.C.), quando o sacerdote do templo e siracusanos tentaram roubar as dedicações do santuário e o manto de ouro que estava sendo elaborado para a estátua do deus (Laky, 2013: 78). Cícero nos informa que Gélon, tirano de Gela, após a vitória na batalha de Himera (480 a.C.), mandou fazer um manto de ouro para a estátua, retirado mais tarde pelo tirano siracusano Dionísio I (405-368 a.C.), que o teria substituído por um outro manto de algodão (Laky, 2013: 78).

Tal trecho sobre a estátua também fornece indicações sobre o tipo de dedicações do santuário, como o manto de ouro dedicado por Gélon e as oferendas que teriam sido alvo dos saques naquele evento. Um relato de Plutarco (Nícias, XVI, 6) também se refere às oferendas de ouro e prata no santuário de Zeus Olímpio e, por consequência, sobre o tesouro do deus. Trata-se de um episódio à época da invasão ateniense à Siracusa em 
que Nícias permitiu a entrada dos soldados siracusanos no templo de Zeus, temendo que os atenienses, após terem tomado a área, cometessem sacrilégio se saqueassem o tesouro (Laky, 2013: 78-79).

\section{III.2.2 A natureza do culto e a função do santuário}

A atribuição do santuário em Siracusa ao culto de Zeus Olímpio é amplamente confirmada por testemunhos literários de várias épocas, não havendo, é preciso lembrar, testemunhos epigráficos a respeito do culto e nem do santuário. Os relatos mais antigos sobre a área sagrada datam do século $V$ a.C., são propiciados por Tucídides e relatam um evento contemporâneo ao autor, a invasão ateniense à Siracusa. Relatos de Diodoro, Pausânias, Plutarco, Cícero e Tito Lívio se referem ao evento da invasão siracusana ou registram episódios anteriores ao testemunho de Tucídides, como aquele sobre a dedicação do manto de ouro por Gélon I ocorrido no início do século V a.C. Assim, apenas a documentação arqueológica pode nos fornecer informação sobre o santuário em Siracusa antes da época clássica. É possível inferir, da datação do Olimpieion em 580-570 a.C., que uma fase de restruturação e reorganização da área sagrada deve ter ocorrido no primeiro quartel do século VI a.C., como indica a construção do primeiro edifício de culto em pedra nessa época. Sobre o tipo de culto e ritual praticados no local, é impossível saber, dada a ausência completa de objetos votivos de qualquer tipo e de material cerâmico associado diretamente ao ritual religioso. Entretanto, foi possível estabelecer tanto a característica da divindade cultuada quanto as funções políticas e cívicas do santuário a partir das fontes literárias, que propiciam a história da área sagrada.

Em nosso estudo sobre o santuário siracusano de Zeus Olímpio, chegamos a uma série de conclusões sobre a função política desempenhada pela área sagrada. A primeira conclusão a esse respeito se refere ao posicionamento extra-urbano do santuário - "a posição do Olimpieion a sul do rio Anapos e do Ciane pode ter assinalado o limite do território urbano na direção sul desde os primórdios da cidade"99 (Fig.85 e 86) (Laky, 2013: 81). A fundação do santuário extra-urbano de Zeus Olímpio significou, portanto, "a afirmação da soberania grega na área" (De Polignac, 1995: 123). Até a primeira metade do século VI a.C. "a paisagem religiosa urbana de Siracusa era definida, por terra ou mar, pelos templos de Apolo e Zeus: um demarcava a área urbana e o outro a hegemonia na área extra-urbana da pólis" (Laky, 2013: 87). Nessa perspectiva, concluímos que "a construção do segundo templo períptero mais antigo, numa área pantanosa e insalubre, pode ter tido a finalidade de proteção e afirmação da presença grega na entrada do Porto Grande e na direção sul à khóra siracusana" (Laky, 2013: 81). Essa posição estratégica do templo tornou o santuário de Zeus Olímpio o ponto importante de acampamento, ataque e fuga à Siracusa nas várias tentativas de conquista à pólis ao longo dos séculos V, IV e III a.C. ${ }^{100}$ (Laky, 2013: 81). A primeira delas foi durante a batalha no rio Heloro, em c.

\footnotetext{
99 Ver também, Orsi, 1903, p.390; Vallet, 1968, p.93; Parise Presicce, 1984, pp.66-67.

100 A escolha da zona do santuário de Zeus Olímpio para acampamento de tropas inimigas de Siracusa se deve à defesa natural e à conformação da zona (Veronese, 2006: 327). Do Olimpiéion era possível uma visão da movimentação da baía do Porto Grande e também do lado oeste de Ortígia (Laky, 2013: 82-83). Além disso, ali era o local ideal para o ancoradouro das embarcações e para 0
} 
491 a.C. - o tirano Hipócrates de Gela estabeleceu 0 acampamento no Olimpiéion, fez refém o sacerdote e repreendeu alguns siracusanos que tentavam remover dedicações valiosas e o manto da estátua de Zeus $^{101}$. Na segunda tentativa de conquista de Siracusa, à época da invasão ateniense, entre 415 e 413 a.C., estes desembarcaram e acamparam em frente ao Olimpieion ${ }^{102}$, e os siracusanos, em determinado momento, usaram a área como base para a cavalaria e os lanceiros $^{103}$. Na terceira tentativa, em 396 a.C., na primeira guerra de

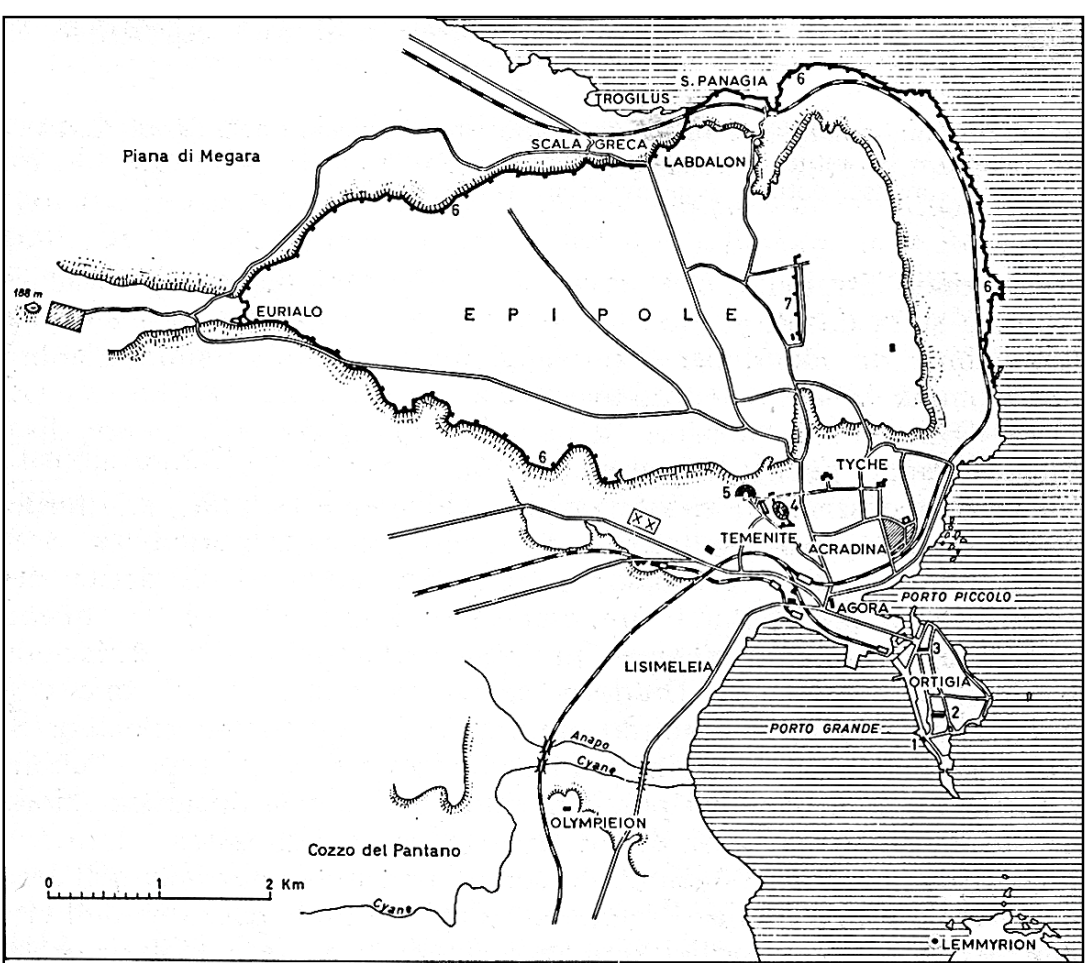

Fig.85 - Planimetria de Siracusa - 1. Fonte Aretusa; 2. Templo de Atena; 3. Templo de Apolo; 4. Anfiteatro romano; 5. Teatro; 6. Muros de Dionísio; 7. Muros de Gélon (Coarelli; Torelli, 1984: 221)

Siracusa contra Cartago, o general cartaginês Himilcon bloqueou com as galés o porto grande de Siracusa e estabeleceu seu quartel no templo de Zeus ${ }^{104}$. Na quarta tentativa, no tempo de Dionísio II (367-344 a.C.), Hícetas, um siracusano que havia se tornado tirano de Leontino e de Corinto, aliou-se a Cartago, planejandose fazer senhor de Siracusa. Para isso, tomou o campo contra Dionísio, construindo um acampamento no templo de Zeus Olímpio, abandonando-o posteriormente devido ao esgotamento das provisões ${ }^{105}$. Na quinta tentativa, Amílcar, enviado por Agrigento, cercou Siracusa entre 311 e 309 a.C., destruindo as colheitas e capturando a região entorno do Olimpiéion ${ }^{106}$. E na sexta e última tentativa de conquista de Siracusa, o templo foi ocupado novamente em 214 a.C. pelos romanos ${ }^{107}$. Foi nesse contexto de uso da área sagrada siracusana de Zeus Olímpio que esta adquiriu função de asilo. Conforme U. Sinn, "o espaço de um santuário grego era dividido em duas zonas: a primeira era a mais estreita, onde está o tradicional témeno, situada ao redor do altar e do templo, a segunda zona foi a mais ampla, mas também sagrada (apud Marinatos, 1993: 232). 0 autor a chama de "campina-sagrada"; nesta área ocorreram os banquetes, mas os refugiados puderam aí se abrigar

desembarque, acesso e ponto de espera de ataque das tropas ao território siracusano. Portanto, ao longo da história o Olimpiéion foi área de entrada e fuga daqueles que queriam conquistar a pólis (Laky, 2013: 82-83).

101 Diodoro, X.28.1-2.

102 Tucídides, VI.LXIV.1-5 - VI.LXV.3.

103 Idem, VII.XXXVII.3; VII.XLII.6.

104 Diodoro, XIV.62.3-4. Dionsio I, tirano de Siracusa armou um acampamento próximo ao templo de Zeus para enfrentar os cartagineses (Diodoro, XIV.76.2).

105 Diodoro, XVI.68.1-2.

106 Idem, XX.29.2-3.

107 Tito Lívio, XXIV,33. 
(apud Marinatos, 1993: 232). Assim, santuários com uma ampla "campina-sagrada", e uma localização geográfica proeminente, tornam-se asylia ideais (apud Marinatos, 1993: 232). É possível atribuir tal função ao santuário siracusano de Zeus Olímpio à época da invasão ateniense a partir de um trecho específico em Tucídides (VI, LXIV.3): os atenienses estabeleceram o acampanhamento em um terreno onde não seriam hostilizados (Laky, 2013: 291).

Parte dessa função política do santuário siracusano de Zeus Olímpio (na qual o aspecto militar lhe foi associado ao longo do tempo) também foi marítima. O templo de Zeus Olímpio, destinado aos olhares dos navegantes do Porto Grande, juntamente ao templo de Apolo, situado entre os dois portos de Ortígia, carregaram um significado simbólico próprio da geração de edifícios do início do século VI a.C.: eram endereçados principalmente às pessoas vindas do mar. Estes templos foram feitos "para impressionar os visitantes gregos do mundo colonial e da Grécia continental" (Marconi, 2007: 51). Por estar em proeminência na visão ocidental de Ortígia, há a hipótese de que o templo foi concebido para produzir em cada navegante a impressão de que Siracusa era uma cidade consideravelmente maior e que englobava todo o golfo (Marconi, 2007: 51). Tratou-se, portanto, de mais uma forma de expressão política da cidade.

A segunda conclusão com relação à função política do santuário à pólis de Siracusa, refere-se ao seu papel de arquivo da cidade, que também expressa a sua função cívica. O Olimpiéion deve ter sido central para a vida política e social da apoikia porque ao menos até a expedição ateniense lá eram guardadas as listas com o censo dos cidadãos (Brelich, 1964-1965: 53; Marconi, 2007: 50; Orsi, 1903: 371; Vallet, 1968: 93). Sabemos através da passagem em Plutarco (Nícias,

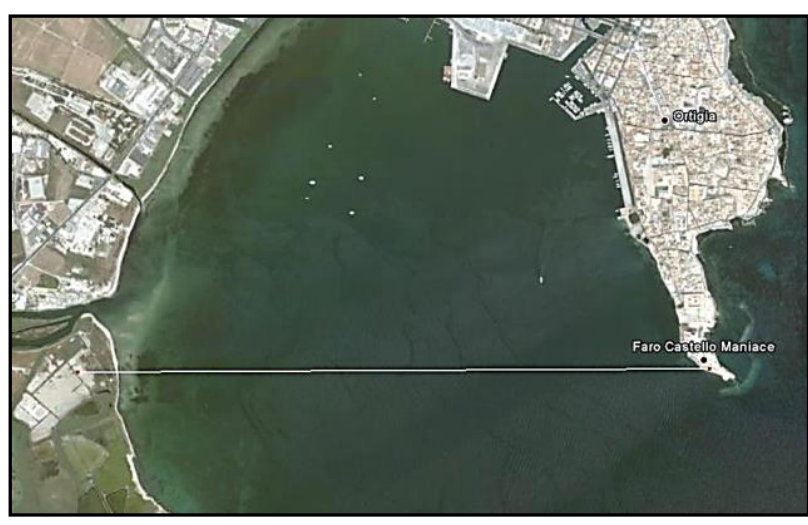

Fig.86 - Vista de satélite da posição correspondente entre o Olimpiéion e a ponta de Ortígia (GoogleEarth/2008) XIV), que os atenienses capturaram um navio siracusano que levava as listas com os registros dos cidadãos por tribos e onde seriam inscritos os nomes daqueles que tinham atingido a idade militar. Na seqüência da passagem, Plutarco nos informa que elas eram depositadas no santuário de Zeus Olímpio. Sobre o papel político do culto de Zeus Olímpio em Siracusa, além do trecho em Plutarco, dispomos apenas de mais uma notícia de Diodoro (XVI.83.2), o qual nos informa que o general coríntio Timoleonte ${ }^{108}$ criou, em c.345 a.C., a anfipolia de Zeus Olímpio a qual determinava a magistratura de sacerdotes de Zeus nessa época.

Essas são as únicas funções políticas e cívicas que podem ser atribuídas ao santuário de Zeus Olímpio em Siracusa, de acordo com as fontes literárias disponíveis a seu respeito. Além da função cívica, desempenhada pela área sagrada e pelo culto à comunidade política siracusana, é preciso dizer que o culto, ao menos em sua fase inicial, esteve relacionado a um grupo aristocrático local. Em nosso mestrado,

\footnotetext{
108 Sobre o papel político de Timoleonte em Siracusa, ver capítulo 4.
} 
concluímos que "o culto de Zeus Olímpio foi instituído no período de governo oligárquico, no caso, dos Gamoroi (os proprietários de terra), aristocratas oligarcas que estiveram no poder da cidade entre 600-500 a.C." (Laky, 2013: 71). Assim, "embora tenha sido vinculado a um grupo político específico da pólis, o culto ao deus de Olímpia esteve ativo na cidade tanto em fase oligárquica, como na tirânica e também democrática, como evidencia a criação da anfipolia de Zeus Olímpio por Timoleonte, demonstrando a importância do santuário como centro político e a tradição do culto na cidade" (Laky, 2013: 71). Diante das evidências que dispomos é difícil saber em que medida, mesmo nesses períodos, o culto teria sido mais restrito a determinado grupo no poder na cidade. De todo modo, em todos esses três tipos de governo, a aristocracia sempre foi um componente integrante e por isso o culto pode ter se mantido vinculado a esse grupo em época clássica e em diante.

Vimos na análise interpretativa do santuário de Olímpia como o culto de Zeus Olímpio esteve vinculado à aristocracia e foi difundido desse santuário inter-regional a outras póleis do mundo grego entre os séculos VI e V a.C. Siracusa foi uma das comunidades políticas onde o culto da divindade foi instituído pela aristocracia no poder em época arcaica. Uma prova de que o culto é originário de Olímpia é a presença de indivíduos eleios entre os coríntios que fundaram a cidade. Estrabão diz que Árquias fundou Siracusa juntamente a outros dórios, provavelmente entre eles estiveram eleios e arcádios. Píndaro (OI.VI, 45-95) confirma tal associação: ao enaltecer a figura de Hagésias de Siracusa diz este ter sido um descendente de lamos o fundador dos lamides, a família de sacerdotes responsáveis pelo antigo oráculo de Zeus Olímpio em Olímpia (Ciaceri, 1894: 5; Philipp, 1991: 40; Veronese, 2006: 281; Yalouris, 1980: 11). É possível, também, que o culto a Zeus Olímpio possa ter sido trazido da metrópole Corinto, pois lá havia um templo consagrado à divindade, venerada desde tempos antigos devido as relações entre os coríntios com Élis (Ciaceri, 1894: 5). Se é difícil reconstituir a característica de Zeus Olímpio no culto siracusano, dada a ausência de objetos votivos, é possível assumir que o seu aspecto militar foi um componente importante, como indica o tipo de documento arquivado no santuário (sobre indivíduos que tinham atingido idade militar) e o uso extensivo da área sagrada nas campanhas militares, não restrito, assim apenas à localização estratégica do santuário (Laky, 2013: 289). Trata-se, como vimos, de uma característica de Zeus Olímpio que permaneceu no culto da divindade durante seu processo de difusão às cidades gregas (Laky, 2013: 318).

\section{III.3 Selinonte, Colina de Marinella}

Localizado no sudoeste da Sicília, o santuário de Zeus Olímpio (cat. no.36) foi estabelecido em Selinonte, no setor leste da pólis, na colina de Marinella, a oeste do rio Cottone (hoje seco) e a norte dos templos F e E, respectivamente (Fig.87) (Laky, 2013: 118). Assim como no caso dos santuários de Zeus Olímpio em Corinto, no Peloponeso, e em Siracusa, o templo é o único remanescente material da área sagrada da divindade. Não há objetos votivos ou material cerâmico pertencente ao santuário. A única evidência material disponível, além dos restos do edifício, é a denominada tábua de Selinonte, encontrada na área do ádito do 


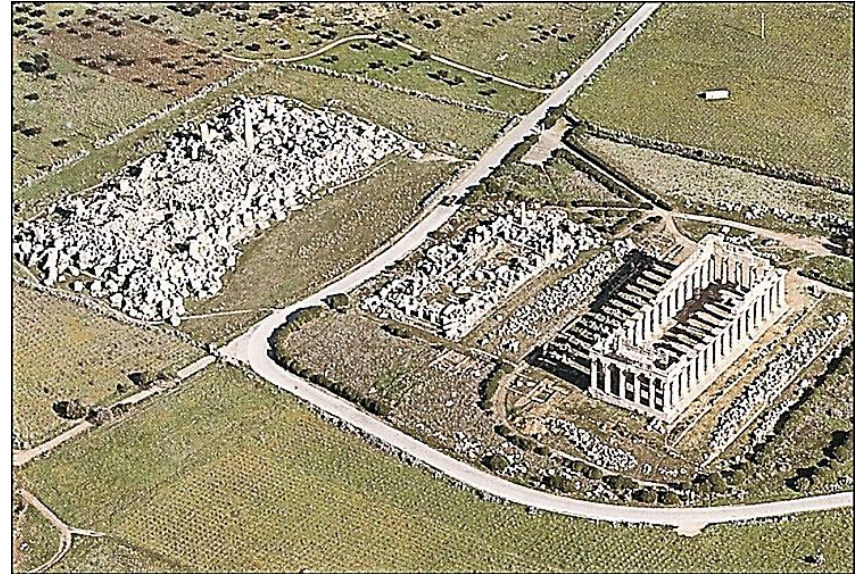

Fig.87 - Vista a partir do lado oeste dos templos G, F, E na colina oriental (Di Giovanni, 1991: 17) templo - esta contém uma inscrição que permitiu identificar o culto no local a Zeus (Fig.88). Com relação ao templo, até a década de 1970 não havia certeza, entre os estudiosos, sobre a divindade cultuada no templo, por isso o edifício e os dois outros na colina de Marinella foram denominados, respectivamente, G, F e E. Assim, a primeira escavação no Olimpiéion ou templo G ocorreu em 1831 e 1832, cujos trabalhos foram dirigidos pelos comissários Domenico Lo Faso Pietrasanta Duca di

Serradifalco e Valerio Villareale com supervisão arquitetônica de Cavallari (Laky, 2013: 112). A escavação da Comissione di Antichità e Belle Arti della Sicilia foi a primeira tentativa de investigação das ruínas dos templos da colina oriental (Marconi, 1994: 23-24 e 27). Na temporada de 1832 as operações estenderam-se ao templo F e G (Marconi, 1994: 30). Foi durante os trabalhos de 1832 que Valerio Villareale restaurou a coluna do lado sudeste do templo, a denominada pelos camponeses de "fuso da velha" (Laky, 2013:112). Em 1871 Domenico Cavallari descobriu a tábua de Selinonte na anta direita da entrada do ádito do edifício (Bianco; Sammartano, 2004: 94; Di Giovanni, 1991: 56). A atribuição do templo a Zeus foi estabelecida, com segurança, por Bejor em seu artigo de 1977.

\section{III.3.1 Descrição e interpretação dos achados}

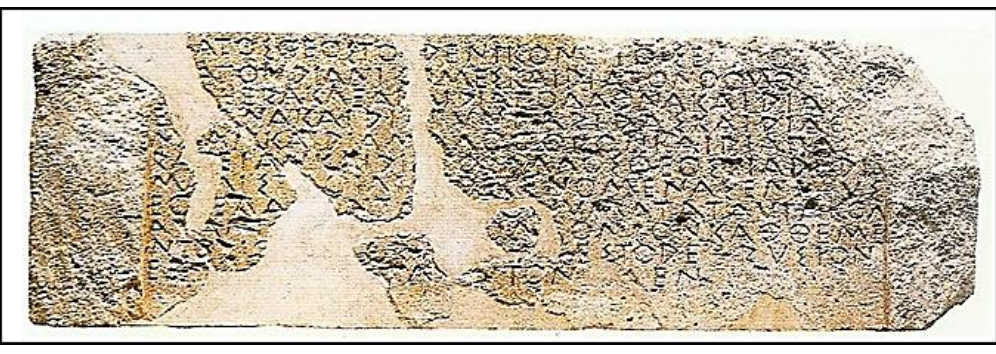

Fig.88 - A Tábua de Selinonte (metade séc. V a.C.). Museu Arqueológico Regional A. Salinas - Palermo (Di Giovanni, 1991: 54)
A datação do santuário de Zeus Olímpio foi proposta com base na cronologia dos remanescentes arquitetônicos do templo, que remontam a partir da segunda metade do século VIa.C. (c.530 a.C.). As escavações na área do templo parecem não ter encontrado outros tipos de evidência, como no caso de Siracusa, que pudessem indicar uma data mais antiga para o santuário, tampouco há testemunhos literários que pudessem propiciar algum tipo de informação a esse respeito, como ocorreu no caso do santuário siracusano da divindade. Mesmo diante de evidências mais antigas, deve-se considerar que o santuário era mais antigo do que sugere a datação do edifício de culto. A datação da tábua de Selinonte, da metade do século $V$ a.C., sugere o funcionamento do santuário nessa época. O fim das atividades da área sagrada corresponde à destruição de Selinonte pelos cartagineses em 409 a.C. (Laky, 2013: 112). 


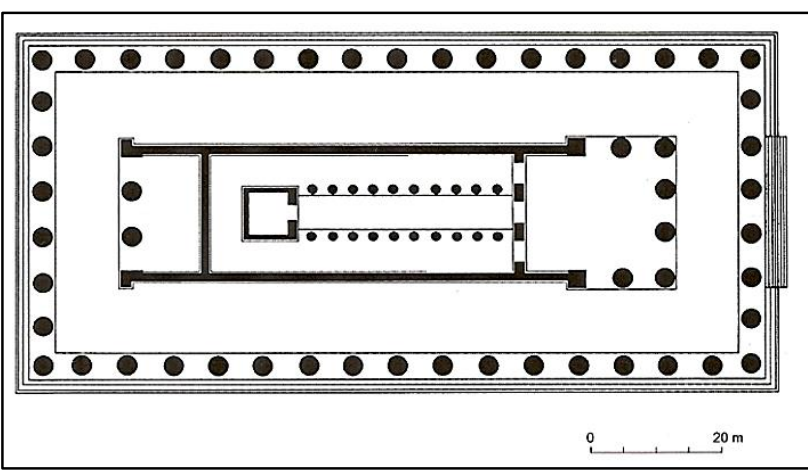

Fig.89 - Planta do templo G (Mertens, 2006: 232)

Assim, apesar do deplorável estado das ruínas, o Olimpieion ou templo $\mathrm{G}$ tem uma planta suficientemente conhecida. Orientado leste-oeste, era pseudodíptero109, tinha uma planta retangular alongada, $8 \times 17$ colunas $\mathrm{e}$ media, no estilóbato, entre 49,97 x 109,12 $\mathrm{m}^{110}$ e 54,05 x 113,34 $\mathrm{m}^{111}$ (Fig. 89) (Laky, 2013: 114). Com relação às suas divisões internas, a cela possuía um pronaos profundo prostilo e tetrastilo, portanto, com $4 \times 2$ colunas e tinha a dimensão de c. 17 × 20 metros de largura interna. Já o naós era dividido em três naves de duas fileiras de 10 colunas que terminavam em um naískos interno - o ádito - destinado à conservação da estátua de culto e considerado um elemento típico da arquitetura sagrada da Sicília e de Selinonte em particular (Fig.90) (Laky, 2013: 114). O tamanho das colunas, pequenas para sustentar um teto, e 0 achado de um canal para escoamento de água, acuradamente trabalhado no pavimento da cela, induziram a reconstrução do naós na forma de sêkós (não coberto pelo teto) ${ }^{112}$ (Laky, 2013: 114). 0 opistódomo, distilo in antis, não se comunicava com a cela e provavelmente funcionava para a conservação do tesouro do templo (Laky, 2013: 115). Sobre as fundações, o crepidoma e o estilóbato nenhuma informação está disponível na bibliografia consultada (Laky, 2013: 115). Com relação às colunas, estas constituem a maior parte dos achados arquitetônicos do templo. Como todos os elementos arquitetônicos escultóricos encontrados, as colunas eram feitas de calcário. Aquelas da perístasis atingiram 16,27 metros de altura, tinham uma circunferência de 10,70 metros. $O$ diâmetro na base do fuste mede 3,41 metros, na parte mais alta media 1,41 metros e o capitel possui um ábaco de $16 \mathrm{~m}^{2}$ (Bianco;

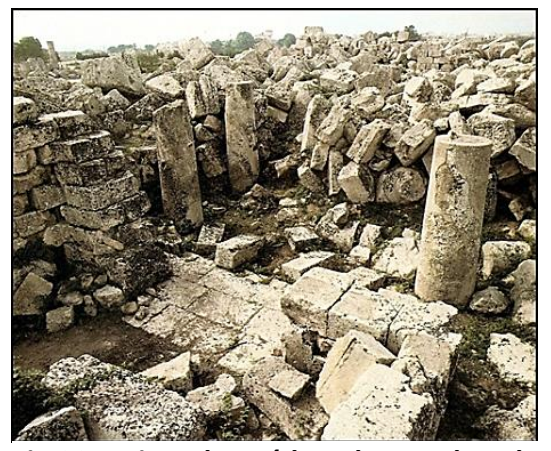
Fig.90 - Vista do naískos dentro da cela com o início de duas fileiras de colunas que dividiam a cela em três naves (Gullini, 1989: fig.510) Sammartano, 2004: 89; Coarelli; Torelli, 1984: 85; Di Giovanni, 1991: 56; Veronese, 2006: 514). Dos membros arquitetônicos da parte superior do templo, conhecemos somente um elemento do entablamento: a arquitrave. Realizados também em calcário, os blocos da arquitrave medem 6,50 x 2,30 m (Veronese, 2006: 514). 0 entablamento media quase 14 metros de altura e a associação das dimensões das colunas com as dimensões

\footnotetext{
109 Trata-se de um templo cuja perístasis "é separada da cela pela largura não apenas de um intercolúnio, como é norma para os templos perípteros, mas por dois para simular a presença de uma dupla perístasis como nos templos jônicos dípteros em voga na Grécia de leste, em Éfeso, Dídima e em Samos a partir da metade do século VI a.C." (Coarelli; Torelli, 1984: 86). Mertens acrescenta que "a prova de que se trata de um pseudodíptero é a ausência das fundações indispensáveis para sustentar o segundo anel de colunas internas da perístasis" (Mertens, 2006: 232).

110 Mertens, 2006, p.232; Veronese, 2006, p.514.

111 Coarelli; Torelli, 1984, p. 85.

112 Esta é uma das características principais do templo de Apolo Didimeus em Dídima, concebido em forma de sêkós e com um naískos semelhante ao templo G, o qual novamente "encontra paralelos de relevo nos grandes templos dípteros do Oriente" (Coarelli; Torelli, 1984: 86; Mertens, 2006: 233-234; Veronese, 2006: 514).
} 


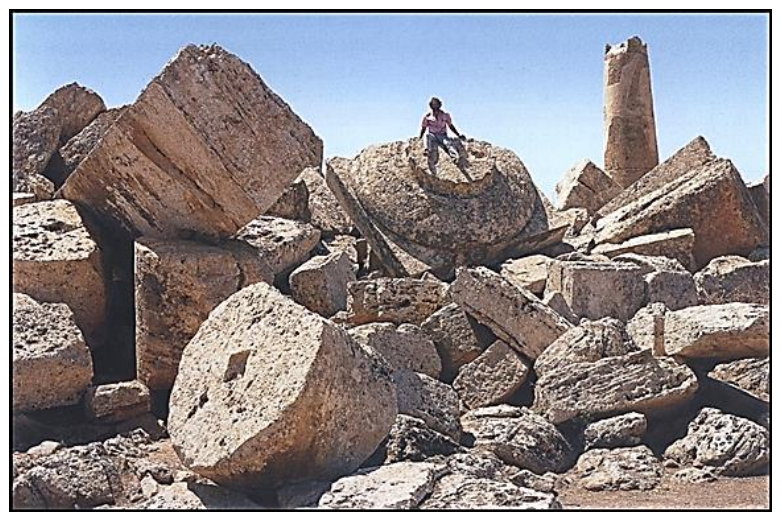

Fig.91- Vista de capitel com ábaco, tambores, colunas e blocos de arquitrave do lado leste (Mertens, 2006: 231, fig. 399) da arquitrave indica que o templo teria alcançado 30 metros de altura (Coarelli; Torelli, 1984: 85; De Angelis, 2003: 138; Veronese, 2006: 514).

São as colunas, principalmente, que propiciaram os elementos de datação do edifício (Fig.91). O longo período de construção do templo refletiu-se, sobretudo, na diferença estilística. A transformação da forma e nas proporções dos membros arquitetônicos, e de um modo mais claro nas colunas e nos capitéis, demonstram fases distintas da construção do edifício (Mertens, 2006: 233). Sabemos, assim, que a frente oriental, o lado setentrional e o meridional se caracterizaram por colunas do último quartel do século VI a.C., são, portanto, os lados mais antigos, onde predominaram colunas relativamente mais finas com ábacos bem expandidos (Laky, 2013: 116). Já na frente ocidental, as colunas, de proporções mais robustas com equino mais proporcional e sem a cavidade entre este e o fuste, indicam que este lado foi realizado no século V a.C. no estilo severo (Laky, 2013: 116). A ausência de caneluras em várias colunas e os restos de estuques em outras indicam que o templo não foi finalizado (Coarelli; Torelli, 1984: 85 e 87; Mertens, 2006: 232 e 233; Veronese, 2006: 514). Ainda acerca dos elementos de datação, algumas considerações advêm da planta do templo. As modificações transcorridas durante as fases de construção mostram que o opistódomo foi realizado na fase de estilo severo e o pronaos e naós, a julgar pela forma dos membros, foram concebidos na época tardo-arcaica (Laky, 2013: 116). A decoração do capitel de anta do pronaos é posterior a 520 a.C. (Mertens, 2006: 233).

Como se percebe das medidas monumentais dos elementos arquitetônicos e da planta, o Olimpieion ou templo $\mathrm{G}$ foi o maior templo dórico do mundo grego até a construção do Olimpieion de Agrigento no princípio do século V a.C., em 480 a.C., como veremos mais adiante (Laky, 2013: 112). $O$ único edifício contemporâneo de dimensões grandiosas na ordem dórica foi o Olimpéion Pisistrátida de Atenas de 515 a.C. (Mertens, 2006: 232). O templo $\mathrm{G}$ foi o primeiro da ordem dórica, cuja largura e comprimento se aproximaram e ultrapassaram os templos da ordem jônia da Grécia de Oriente (Apolonion de Dídima, Artemísion de Éfeso e Heraion de Samos) (Laky, 2013:248). Acreditamos que os diversos elementos jônicos presentes na planta e no projeto do templo $\mathrm{G}$ se deva ao fato de que os edifícios da Jônia eram os únicos paradigmas conhecidos naquele momento (meados do século VI a.C.) para a elaboração de um projeto de templo de dimensões colossais (Laky, 2013: 248). Em Selinonte, então, alguns dos elementos jônicos foram incorporados, mas assumiram o contexto ocidental: a ordem dórica (Laky, 2013: 248). Mais à frente retomaremos essa questão acerca da atribuição do templo G a Zeus Olímpio.

Nenhum traço do altar foi encontrado no santuário selinontino de Zeus Olímpio e pouco sabemos da cobertura e do aparato decorativo do edifício (Coarelli; Torelli, 1984: 86; Veronese, 2006: 514). O único achado escultórico na área interna do edifício foi um torso de gigante de época tardo-arcaica, recuperado na área do 
ádito (Coarelli; Torelli, 1984: 86). No ádito do templo também foi recuperada a tábua de Selinonte, cujo comentário segue abaixo no próximo item de discussão (Coarelli; Torelli, 1984: 86).

\section{III.3.2 A natureza do culto e a função do santuário}

A atribuição final do santuário a Zeus Olímpio, na área da colina de Marinella, tem como base a informação da tábua de Selinonte, encontrada no interior do edifício, como os estudiosos do sítio têm defendido, e o padrão de dimensões dos Olimpieia erigidos entre os séculos VI e V a.C. nas póleis, principalmente o templo posterior dedicado à divindade na pólis vizinha de Agrigento (Laky, 2013: 250).

Única fonte de informação direta para a elucidação do culto, a tábua de Selinonte foi escrita em dialeto megarensecoríntio e é datada, conforme já mencionado, da metade do século $\mathrm{V}$ a.C.

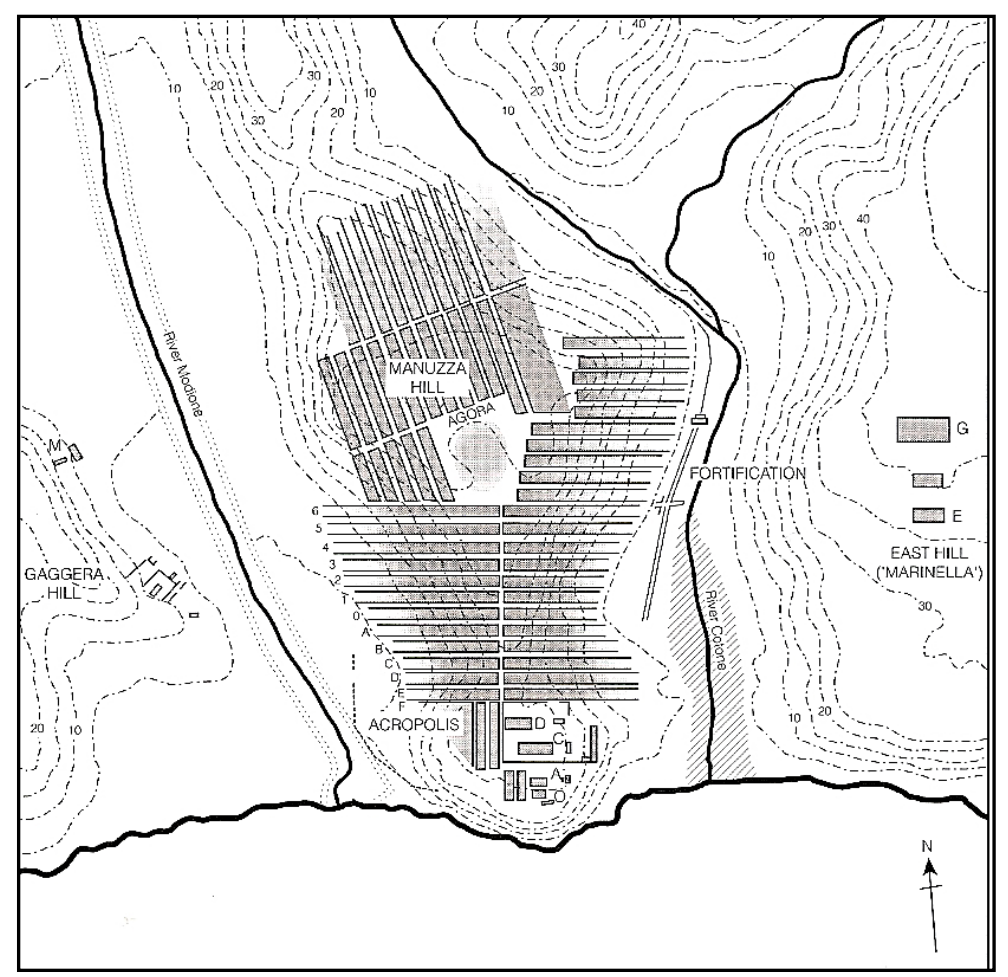

Fig.92- Planimetria de Selinonte (De Angelis, 2003: 129) (Bianco; Sammartano, 2004: 91 e 94; Bejor, 1977: 440). A tradução ${ }^{113}$ da inscrição (IG XVI, 268) é a seguinte: os selinontinos são vitoriosos graças aos deuses Zeus, Phobos, Héracles, Apolo, Poseidon, os Tindarides, Atena, (Deméter) Malofóros, Pasicrateia e a outros deuses, mas sobretudo graças a Zeus; depois da restauração da paz, foi decretado que uma obra realizada em ouro com a inscrição dos nomes das divindades fosse depositada no templo de Apolo, sendo para isso disponíveis sessenta talentos de ouro (Veronese, 2006: 515 , nota 61$)$.

Por causa da menção ao Apolonion e a Zeus, que ocorre duas vezes, a divindade, à qual era dedicada o templo G, foi identificada ao longo do tempo com Apolo ou Zeus (Bejor, 1977: 441). Nas teses da atribuição a Apolo, é levada em consideração a semelhança do templo G com o grande templo do deus em Dídima, na Jônia. No entanto, em nosso estudo anterior, concluímos que o templo de Apolo Didimaios alcançou a mesma dimensão do templo G somente em época helenística (Laky, 2013: 248). O templo IV de Apolo data de 225 a.C. e media 51,13 x 109,34 metros, enquanto que o Didimeion, contemporâneo ao templo de Selinonte, media apenas 38,39 x 85,15 metros (Laky, 2013: 248). A bibliografia, portanto, "não é precisa ao comparar a planta

113 Tradução de Coarelli; Torelli, 2000, p.83 (apud Veronese, 2006: 515, nota 61). 
de um templo arcaico (G) com a de um helenístico (Didimeion)"(Laky, 2013: 248). Atualmente, contudo, os estudiosos já aceitam Zeus Olímpio como divindade titular baseados em algumas constatações (Antonetti, 2009: 42; Bejor, 1977: 441; Coarelli; Torelli, 1984: 87; Tusa, 1967: 187 e 191; Veronese, 2006: 514). A primeira ressalta as duas menções a Zeus, sendo a segunda mais enfática, porque é acompanhada pelo advérbio

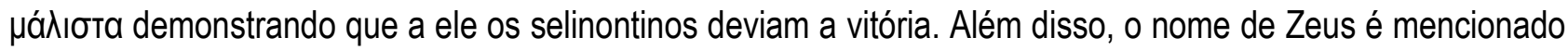

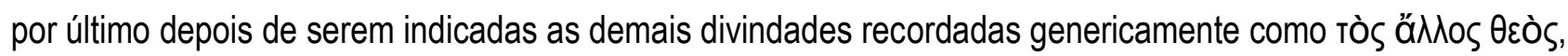
ressaltando de maneira particular o deus que se desejava venerar majoritariamente (Tusa, 1967: 191). A segunda constatação diz que não haveria sentido se o templo $G$ fosse o templo de Apolo, o local do depósito da obra em ouro. A inscrição é clara em dizer que uma obra em ouro teria de ser guardada no Apolonion. A informação seguinte, acerca dos sessenta talentos de ouro disponíveis para a realização da obra é um registro das finanças da cidade muito semelhante àquelas inscrições nas tábuas de bronze da teca do arquivo de Zeus Olímpio em Lócris, cujo caso será apresentado na análise regional e interpretativa no próximo tópico sobre a Itália do Sul. Por isso, os pesquisadores defendem a idéia de que o templo $G$ funcionava como um arquivo público, como ocorreu em Lócris no século IV a.C., em Siracusa, onde o Olimpiéion guardava o arquivo citadino com as listas dos membros da comunidade, e como em Mégara (cat. no.43) (a metrópole de Mégara Hibléia que por sua vez fundou Selinonte) onde o arquivo público no século IV a.C. era colocado no Olimpieion, conforme indicam diversas inscrições ${ }^{114}$ (Bejor, 1977: 442; Coarelli; Torelli, 1984: 87).

É notável, ainda, que nenhum dos autores justifique a origem do epíteto Olímpio em suas discussões. A inscrição menciona Zeus, mas não o epíteto que qualificaria o templo como um Olimpiéion (Laky, 2013: 114). Ora, os estudiosos esqueceram-se de salientar que a atribuição do templo a Zeus dito Olímpio não tem base direta em informações arqueológicas ou textuais (Laky, 2013: 114). Ressaltamos, portanto, que a atribuição do templo $\mathrm{G}$ a Zeus Olímpio é apoiada na sua dimensão colossal, medida do posterior Olimpiéion de Agrigento, e na recorrência do uso dos Olimpieia como arquivos públicos da pólis (Laky, 2013: 114).

Com relação à sua função para a comunidade política de Selinonte, apenas o estudo da área sagrada, em relação à configuração urbana e o histórico das demais construções da cidade, permitiu o estabelecimento, em certa medida, do papel do santuário de Zeus Olímpio entre os séculos VI e V a.C. com relação à função política da área sagrada extra-urbana. Na sequência, apresentaremos apenas as conclusões principais a esse respeito ${ }^{115}$.

O santuário selinontino de Zeus é considerado extra-urbano, porque está fora do trecho leste do muro da cinta murária (Fig.92). A colina de Marinella, em seu sentido oeste-leste, é separada da cidade por duas barreiras: uma primeira artificial (a muralha) e a segunda natural (o rio Cottone) (Laky, 2013: 118). A ausência de construções para uso político e civil e a presença dos três templos $(E, F, G)$ demonstram que área foi destinada somente às atividades religiosas (Laky, 2013: 118). Pesquisas arqueológicas na colina oriental

\footnotetext{
114 SGDI 3003-3005; 3007-3011; 3024; IG VII, 1-14; 31.

115 A análise completa do santuário em relação ao desenvolvimento urbano de Selinonte pode ser visto em Laky, 2013, pp.117-124.
} 
revelaram que o templo $E$ teve um edifício antecessor (E1) do início do século VII a.C. (De Angelis, 2003: 130; Parise Presicce, 1984: 25). Esse dado, associado à informação da existência de edifícios religiosos do século VII a.C. na acrópole (templo C) e na colina de Gaggera (santuário de Deméter Malophoros), é considerado a evidência de que a partir do último quartel do século VII a.C., os gregos já tinham se apoderado de toda a área compreendida entre o topo das colinas oriental e ocidental e entre o mar a sul e a ponta mais setentrional da planície da acrópole da cidade, Manuzza, como demonstram as residências datadas dessa época (Parise Presicce, 1984: 26). A posse da área da colina oriental, e o seu uso como local sagrado, é tão antiga quanto às demais áreas sagradas da cidade. Portanto, vemos também no caso de Selinonte a função dos santuários extra-urbanos em sancionar a captura do território pelos colonos - a distribuição das áreas sagradas periféricas delimitava o território apropriado pelos gregos, separando o espaço urbano daquele externo da cidade (Parise Presicce, 1984: 59).

Assim, essa foi uma das funções políticas da área extra-urbana de Zeus Olímpio, comum às demais localizadas na colina oriental. A outra função relaciona-se ao controle dos canais de comunicação da cidade (rio e mar) e ao caminho ao interior. A colina oriental foi uma área extra-muros em relação direta com a função empórica - motivada pelo rio e pelo porto localizado na sua foz - e os seus santuários são interpretados em estreita ligação com o caráter da zona (Coarelli; Torelli, 1984: 81). Sabemos que os santuários extra-urbanos se posicionavam ao lado de rios, onde exerciam o controle sobre os canais de comunicação com a cidade, se por estrada, rio e/ou mar (Pedley, 2005: 47). Definiam frequentemente os confins do território de influência de cada cidade e funcionavam como via de ligação natural e facilmente percorrível em direção ao interior (Parise Presicce, 1984: 43). No caso de Selinonte, o rio Cottone, além de abrigar o porto leste, era um dos caminhos de quem ia ou vinha do norte da khóra, portanto, era a comunicação do interior com a área dos santuários e a área portuária. Neste contexto, o Olimpiéion ou templo G encontra paralelo no Olimpieion de Siracusa, parte também de um santuário extra-urbano, posicionava-se após os rios Anapos e Ciane. Nesta perspectiva, 0 templo, o edifício religioso mais setentrional do setor e também da pólis, era a primeira construção monumental avistada de quem vinha do interior (norte-sul) descendo o rio para o porto e o mar, ou por terra a partir da direção nordeste. O Olimpiéion era o último templo a norte da cidade e o que mais se aproximava do interior e do traçado norte, das habitações, que segue da acrópole. Nesse sentido, é possível considerar que a construção do maior edifício da pólis nessa posição teve intenções de simbolizar soberania e poder da comunidade política de Selinonte a partir da época arcaica, sobretudo na direção norte da cidade.

É possível afirmar que os selinontinos, por alguma razão precisa, escolheram justamente o santuário de Zeus Olímpio, com a construção mais monumental da cidade, para marcar a saída norte da cidade. Essa é a única função política, no caso simbólica e relacionada à característica extra-urbana, que se pode atribuir ao santuário da divindade na cidade. No caso de Selinonte é difícil precisar as funções política e cívica do culto a partir das evidências que dispomos sobre o santuário. Não foram encontrados objetos votivos e não há testemunhos literários sobre o culto e o santuário selinontino de Zeus. 0 achado da tábua de Selinonte no 
Olimpiéion indica, como vimos, que o santuário funcionou como um arquivo cívico da cidade, como em outros santuários de Zeus e de Zeus dito Olímpio. Essa é, portanto, a única função cívica conhecida sobre o santuário de Zeus Olímpio entre os selinontinos: guardar e/ou expor decretos da cidade.

Com relação ao envolvimento do culto com determinado grupo político da cidade, é provável que o santuário tenha sido fundado ou ao menos planejado por tiranos ativos na época da construção do templo. Vimos em nosso estudo anterior, que os três edifícios perípteros ${ }^{116}$ da colina de Marinella foram concebidos, provavelmente, como um único projeto de edificações monumentais entre 550-500 a.C., que corresponde, justamente, ao período dos tiranos Pitágoras e Eurileonte ou de Téron, considerados os responsáveis pela realização do Olimpieion ou templo $\mathrm{G}$, pela segunda fase do templo $\mathrm{E}$ e pela da construção do tesouro de Selinonte em Olímpia (c.530 a.C.) (Coarelli; Torelli, 1984: 76). O tesouro tem sido considerado a principal evidência da relação entre o santuário inter-regional e a pólis ${ }^{117}$. Para F. Coarelli e M. Torelli (1984: 87), a construção do tesouro de Selinonte em Olímpia - e a dedicação de um sélinon de ouro no santuário interregional, o símbolo da pólis - no mesmo momento da edificação do templo $G$ é o maior argumento para identificarmos no maior templo da cidade o culto de Zeus Olímpio (Coarelli; Torelli, 1984: 87). No caso de Selinonte, também é possível afirmar que a característica militar do culto inter-regional de Zeus Olímpio permaneceu naquele selinontino, quando este foi instituído na cidade, conforme indica a inscrição da tábua de Selinonte: esta se refere a um agradecimento por uma vitória militar (Laky, 2013: 289).

\section{III.4 Agrigento}

Localizado no lado sudoeste da Sicília, o santuário de Zeus Olímpio (cat. no.47) foi estabelecido em Agrigento, no setor sudoeste da cidade, a oeste da porta IV, do templo de Héracles e da ágora inferior, e a leste do complexo de construções que abarca o santuário das Divindades Ctônias, o Novo Santuário Arcaico, a Colimbetra e o templo de Hefesto (Laky, 2013: 184). Assim como nos casos de Siracusa e Selinonte, o Olimpieion é o único remanescente material disponível sobre o santuário do deus, não tendo sido encontrados

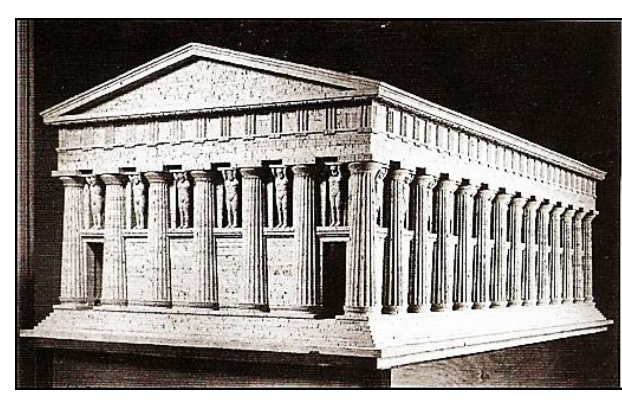

Fig.93 - Reconstituição plástica do Olimpiéion (por Prado 1954), Museu Arqueológico Regional de Agrigento (Marconi, 1997: 8, fig. 7; Mertens, 2006: 262, fig.468) objetos votivos e outros tipos de vestígios rituais, como material cerâmico associado à área sagrada (Fig.93). As fontes literárias, que mencionam o templo, apenas oferecem uma descrição do edifício e algum dado histórico que permite situar a destruição do templo e por consequência do santuário. Assim, as primeiras

\footnotetext{
116 Todas as construções que envolvem a colina oriental (o trecho da muralha e os templos) são datadas a partir da metade do século VI a.C. Dos três templos edificados no setor, o templo F - localizado entre o templo G e o E - é o mais antigo, data de 550/40 a.C. Na cronologia é seguido pelo templo G iniciado em 530 a.C. e pelo templo $E$ iniciado em 520/10 a.C. (Laky, 2013: 119).

117 Pausânias (VI, II, XIX7-11) relatou que os selinontinos dedicaram um tesouro a Zeus em Olímpia antes de a cidade ser destruída pelos cartagineses (Laky, 2013: 111).
} 
escavações no Olimpieion foram realizadas entre 1802 e 1804 sob a supervisão de G. Lo Presti, superintendente de antiguidades de Agrigento, e foram patrocinadas pelos reis Carlos de Nápoles e Carlos III de Espanha (Laky, 2013: 174). As escavações de Bourbon, como ficaram conhecidas, embora tenham revelado partes da planta do templo, pouco documentaram os achados (Laky, 2013: 174). As escavações de Bourbon pela primeira vez tornaram possível o estudo da planta do templo como um todo, permitindo aos escavadores estabelecer os aspectos básicos da planta e finalmente abriram o caminho para os estudos sistemáticos das ruínas (Broucke, 1996: 85-87). Novas pesquisas foram realizadas na área das ruínas da colunata sul entre 1925 e 1927 por Pirro Marconi e supervisão de P. Orsi. Em 1940 G. Ricci, superintendente de antiguidades, conduziu escavações na parte nordeste da cela, descobrindo os muros do pronaos e duas plataformas que contém cisternas. As pesquisas continuaram sob a direção de P. Griffo, que assumiu a Superintendência (Laky, 2013: 174). E. De Miro, novo superintendente, realizou novas escavações em 1969, descobrindo os blocos do entablamento. $O$ altar foi noticiado pela primeira vez pelo pintor francês de topografias Jean Pierre Laurent Hoüel (1735-1813) e Koldewey e Puchstein (1890) foram os primeiros pesquisadores a publicarem uma discussão e descrição sobre a construção (Laky, 2013: 174). O último estudo arquitetônico completo do Olimpieion foi realizado por Brouke em 1996.

\section{III.4.1 Descrição e interpretação dos achados}

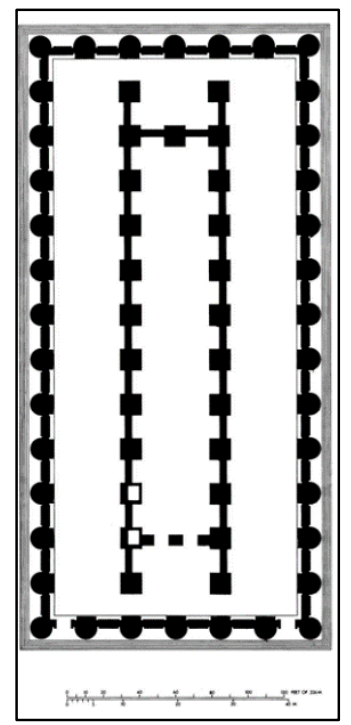

Fig.94- Planta do Olimpiéion (Bell, 1980: 360; Coarelli; Torelli, 1984: 142; Dinsmoor, 1950: 102; Mertens, 2006: 262)
A datação do santuário agrigentino de Zeus Olímpio no início do século $V$ a.C. tem como base os remanescentes arquitetônicos do Olimpiéion, cuja construção foi datada em c.480 a.C. Outras evidências arqueológicas foram usadas por alguns especialistas para anteriorizar o culto de Zeus Olímpio na cidade, mas não foi possível provar a sua relação com o culto. Um naískos dentro da área do santuário de Zeus Olímpio, datado de 580-550 a.C., a sudeste do grande templo, foi interpretado por alguns pesquisadores como o primeiro edifício dedicado ao deus na cidade (Brouke, 1996: 325-327). No entanto, o achado de estatuetas votivas femininas indicou um outro uso para o edifício (Brouke, 1996: 325-327). Uma inscrição de c. 550-500 a.C. (['Aya]oías $\Delta\left[\right.$ [ì] / [то।] Naíoı) ${ }^{118}$ parece fazer refência a Zeus, mas seu caráter lacunoso impede de se tirar mais conclusões a respeito (Laky, 2013: 171). Como nos outros casos sobre os santuários de Zeus Olímpio, é muito provável que o culto e a área sagrada sejam anteriores à datação inicial do templo. Nessa perspectiva, pode-se considerar que a evidência mais antiga e segura para estudo do culto do deus na cidade 
é o templo de Zeus Olímpio, cuja atribuição e descrição é-nos fornecida por Políbio (IX.27.6) e por Diodoro (XIII, $82,1-5 ; X X I I I, 18,2)$.

Tradicionalmente, o Olimpieion é associado à Batalha de Himera, em c.480 a.C., quando a construção do templo teria sido iniciada como um monumento à vitória dos gregos sobre os cartagineses (Laky, 2013: 175). A essa hipótese é somada a idéia de que com o influxo de dinheiro e de mão de obra servil, provenientes da vitória na batalha, teriam possibilitado ao tirano Téron (488-472 a.C.), e depois à

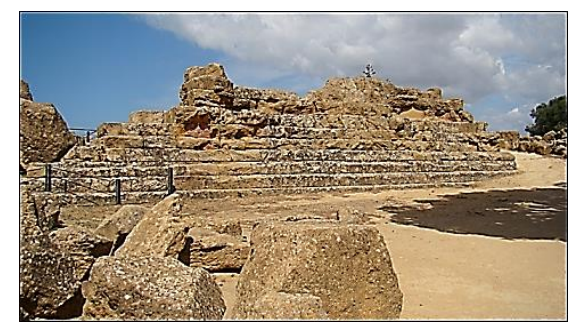

Fig.95 - Crepidoma do lado leste (Foto: arquivo pessoal/2009) democracia, um poderoso programa de obras públicas (Berve; Gruben, 1963: 439; Coarelli; Torelli, 1984: 132). E ainda, se supõem que para a construção do Olimpiéion teriam sido utilizados milhares de cartagineses escravizados (Berve; Gruben, 1963: 439; Coarelli; Torelli, 1984: 132). São os testemunhos de Políbio e Diodoro que permitiram também saber que o templo permaneceu inacabado e sem telhado devido à invasão cartaginesa em 406 a.C. (Laky, 2013: 175). Em época romana, o edifício, e consequentemente o santuário estavam em uso, como indicam eventuais reparos romanos, presentes nos achados arquitetônicos do templo, e informações literárias (Laky, 2013: 175).

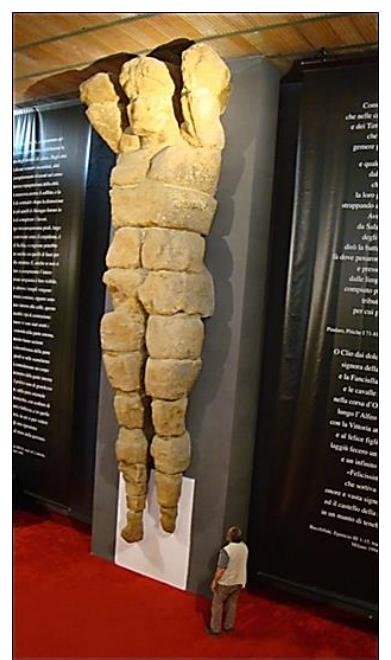

Fig.96- Atlante original exposto no Museu Arqueológico Regional de Agrigento (Foto: arquivo pessoal/2009)

Orientado leste-oeste, o templo de Zeus Olímpio era dórico e pseudodíptero, tinha a dimensão total de $56,30 \times 112,60-70$ m, no estilóbato, e uma pseudoperístasis $^{119}$ de 7 x 14 semi-colunas dóricas (Fig.94) (Mertens, 2006: 261). Com relação à planta e à divisão interna, o templo se dividia em pronaos, naós e opistódomo - o pronaos e o opistódomo eram abertos e a parte interna da cela, 0 naós, foi concebida em forma de sêkós, como no caso do Olimpieion de Selinonte (Coarelli; Torelli, 1984: 143; Griffo, 2005: 117; Mertens, 2006: 265). As escavações nos anos 1920 e na época da Segunda Guerra revelaram partes importantes das fundações, que chegaram a medir entre 6 e $7 \mathrm{~m}$ de profundidade a partir do nível do solo (Broucke, 1996: 222; Mertens, 2006: 261). Com relação à parte inferior do edifício, o crepidoma, não preservado em todos os lados do edifício, é composto por cinco degraus, sendo que o superior possui o dobro de altura dos inferiores, formando assim o conjunto uma espécie de pódio que separava notadamente a elevação do templo do ambiente ao redor (Fig.95) (Broucke, 1996: 233; Mertens, 2006: 261). Já com relação às colunas, foram propostas as medidas entre 19,20 e 21,57 m de altura e entre as antas das pilastras, de forma dórica, teriam ainda c.1,90 m a mais de altura (Mertens, 2006: 262). O diâmetro das colunas mede 4,05 metros na base e é considerado o maior já realizado (Broucke, 1996: 250-254; Dinsmoor, 1950: 101; Griffo, 2005: 116). Da parte superior do Olimpieion

${ }^{119}$ A colunata, portanto, não era aberta, e entre as colunas foram construídos muros com pilastras quadradas (Mertens, 2006: 261). 
foram recuperados 2 das famosas esculturas dos Atlantes $(7,65 \mathrm{~m})$, que foram criados e usados, entre outras razões, para sustentar o peso da arquitrave do templo (Fig.96) (Laky, 2013: 18).

Ao contrário dos demais Olimpieia, o altar do templo em Agrigento foi localizado pelas escavações (Fig.97). Este está a 50 $m$ de distância da fachada leste do templo, em posição paralela, mede $54,50 \times 17,50 \mathrm{~m}$. Dele restaram uma série de pilastras sobre as quais se apoiava uma laje da plataforma para os sacrifícios e os blocos da escada de acesso (Mertens, 2006; 265). Segundo Mertens, este foi o maior altar do Ocidente grego até a construção

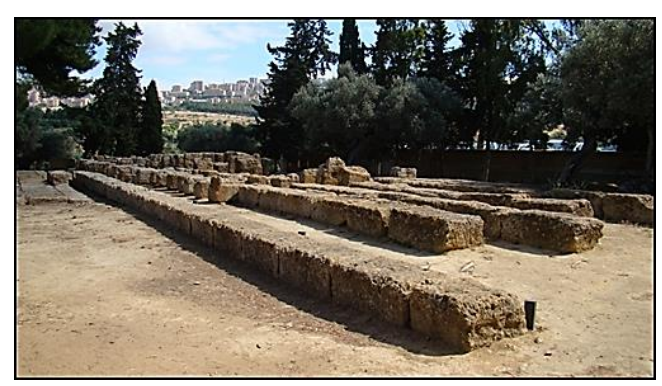

Fig.97 - Ângulo sudeste do altar (Foto: arquivo pessoal/2009) do altar de Hieron II em Siracusa no período helenístico (Mertens, 2006; 265).

Essas medidas colossais dos remanescentes arquitetônicos do Olimpieion, fizeram dele o maior templo dórico já construído pelos gregos antigos. Seguramente maior que o templo G de Selinonte $(49,97 \times 109,12 \mathrm{~m})$, o templo de Zeus Olímpio em Agrigento (56,30 x 112,60 m) não foi suplantado em tamanho pelos colossais templos jônicos de Ártemis em Éfeso (560 a.C.: 55,10 x 109,20 m) e pelo de Hera em Samos (570/60 a.C.: 52,5 x 105 m / 538/22 a.C.: 55,16 x 108,33 m) (Brouke, 1996: 3; Berve; Gruben, 1963: 437). Além disso, se destacou da norma em todos os pontos essenciais: disposição planimétrica, implantação dos blocos do muro e forma singular (Mertens, 2006: 261).

\section{III.4.2 A natureza do culto e a função do santuário}

A atribuição do culto e do santuário em Agrigento a Zeus Olímpio tem como base apenas as fontes literárias - os trechos de Diodoro e Políbio. Políbio é a mais antiga, que dispomos, sobre a atribuição do templo a Zeus Olímpio se pensarmos na anterioridade deste autor (viveu entre c.203-120 a.C.) em relação a Diodoro (viveu no século I a.C.) (Laky, 2013: 176).

No caso do santuário agrigentino de Zeus Olímpio foi difícil estabelecer a função cívica e política da área sagrada urbana, pois as fontes literárias se ativeram apenas à monumentalidade do maior templo da cidade e do mundo grego. Dentre os três trechos disponíveis (um de Políbio e dois de Diodoro), é possível apenas inferir que a área sagrada serviu como asilo aos habitantes da cidade após o cerco cartaginês à cidade em 245 a.C. ${ }^{120}$

Isto posto, se não há dados disponíveis sobre as funções práticas e específicas desenvolvidas pelo santuário em relação ao funcionamento da comunidade de Agrigento, a monumentalidade do templo de Zeus Olímpio, associada a alguns dados sobre sua localização na cidade, permite inferir o tipo de função simbólica exercida pelo templo e santuário à pólis. Da contextualização do Olimpieion no espaço da cidade, realizada em

\footnotetext{
120 Diodoro, XXIII, 18.2.
} 
nossa pesquisa de mestrado ${ }^{121}$, concluímos que "todas as medidas e projetos dos demais oito templos perípteros construídos em Agrigento (contemporâneos ou posteriores) tornaram o Olimpieion incomparável em planta e em dimensão: a permanência do uso de medidas inferiores, nos templos que se seguiram, serviu para hiper-dimensionar, em relação às demais construções, o templo de Zeus Olímpio na paisagem urbana da cidade" (Laky, 2013: 191). Ao longo da muralha no lado sul, onde foram estabelecidos todos os templos perípteros, entre eles o Olimpieion, a monumentalidade do edifício ganhou mais significado no papel simbólico desempenhado por tais edifícios religiosos nesse tipo de localização: estabelecidos ao redor da área urbana, em proximidade aos muros, tiveram a função de proteção da linha da muralha (Longo, 2004: 252; Parise Presicce, 1984: 91). Muito provavelmente, as proporções maiores do Olimpieion, na sequência de templos ao longo da muralha, exerceram grande impacto, aos membros da comunidade e àqueles não pertencentes à pólis agrigentina, devido ao contraste de sua monumentalidade em relação aos demais edifícios, considerados impactantes aos indivíduos daquele tempo. O Olimpiéion foi construído no setor sudoeste - área onde se concentra a maior parte das edificações da cidade. Imediatamente a leste do templo, localiza-se, nesta seqüência, a porta IV e uma parte da muralha, o templo de Héracles e a ágora inferior. Já a oeste, estão partes da grade urbana (estenopes e quarteirões), o santuário das Divindades Ctônias, o Novo Santuário Arcaico, a Colimbetra e o templo de Hefesto - todas construções situadas dentro dos muros da pólis. Assim, o templo de Zeus Olímpio foi construído em proximidade à ágora e às duas vias principais de entrada e saída do setor sudoeste da cidade, as portas IV e V, que permitiam o acesso da ágora ao porto e vice-versa (Laky, 2013: 186). Também nessa posição, o templo do deus também marcava, como nenhuma outra estrutura, a passagem daqueles que seguiam às áreas mais importantes da cidade, a ágora e o porto.

Assim como no caso de Selinonte, é possível afirmar que a comunidade política de Agrigento procurou expressar, em vários níveis, o seu poder político por meio da monumentalidade do templo de Zeus Olímpio, embora de uma maneira diferente, trazendo o templo para dentro da cidade. A nosso ver, o templo do santuário agrigentino de Zeus Olímpio deve ter sido um importante símbolo da realização política da comunidade de Agrigento no início da época clássica, seja ele o triunfo da cidade após a batalha de Himera e a sua posição soberana no lado sudoeste da Sicilia, no contexto de soberania territorial alcançada pela cidade durante a época arcaica após a conquista de Heraclea Minoa e o controle da costa setentrional, incluindo Himera (La Torre, 2011: 84). Esse valor simbólico político e de poder do Olimpieion, nesse contexto do início do século V a.C., será correlacionado ao do uso da águia nas moedas da cidade, cuja emissão é quase contemporânea à construção do templo de Zeus Olímpio. Templo e moedas são atribuídos ao período de tirania de Téron na cidade. Vimos nos casos de Siracusa e de Selinonte, como o culto de Zeus Olímpio foi instituído nas póleis gregas por esse grupo no poder e esse também foi o caso de Agrigento. No caso de Agrigento, além dessa associação da tirania ao poder de Zeus Olímpio, acreditamos que também houve uma intenção em associar à

121 Sobre a análise completa do Olimpiéion na configuração urbana de Agrigento, ver Laky, pp. 184-191. 
cidade à soberania e à onipotência da divindade, como mostra o uso do atributo do deus como emblema da cidade no mesmo período da concepção do templo. Tal constatação será aprofundada no capítulos 4 dessa tese.

É certo que essa possível associação intencional da cidade ao poder de Zeus Olímpio, que se materializou durante o período tirânico, tem origem na relação de Agrigento com o santuário de Olímpia: foi à época da maior proeminência de Agrigento nos jogos olímpicos - na transição entre os séculos VI e V a.C e ao longo deste século - que a pólis erigiu o Olimpieion e passou a emitir os tipos monetários de águias, justamente no período da vitória de Téron em Olímpia (Laky, 2013: 172). Olímpia fez parte da identidade política de Agrigento, podendo, portanto, explicar a apropriação do culto inter-regional por essa comunidade política.

\section{III.5 Considerações gerais sobre os santuários e o culto de Zeus na Sicília}

Diferente dos casos vistos em Creta e no Peloponeso, o caso da Sicília mostra como o culto de Zeus se desenvolveu em contexto colonial. Como dissemos inicialmente, na Sicília, o culto de Zeus emergiu quando as póleis já estavam bem estabelecidas. Em Siracusa, o santuário de Zeus foi estabelecido no final do século VII a.C., mais de um século após a fundação da cidade na metade do século VIII a.C. Em Selinonte, o culto de Zeus Meilichios parece ter se iniciado no final do século VII a.C., enquanto que a pólis foi fundada na segunda metade desse mesmo século, e o santuário de Zeus Olímpio foi estabelecido no segundo quartel do século $\mathrm{VI}$ a.C., mais de um século após a fundação da cidade. E em Agrigento, o santuário também de Zeus Olímpio parece remontar ao início do século V a.C., exatamente um século após sua fundação em c.582 a.C. Ainda que estes santuários sejam mais antigos do que a datação dos remanescentes materiais encontrados, foi durante esses períodos que essas áreas sagradas foram monumentalizadas. Acreditamos, assim, que na região o culto emergiu no momento do amadurecimento das instâncias políticas das cidades siceliotas e da urbanização dessas áreas. De acordo com G. F. La Torre, "o período que abarca o final do século VII a.C. até 480 a.C., representa a fase de maior desenvolvimento das póleis gregas de Ocidente, de um ponto de vista econômico, político e cultural" (La Torre, 2011: 67). Em contraste ao Peloponeso e Creta, onde o culto ganhou expressão principalmente em áreas sagradas inter-regionais, e a outras regiões do mundo grego, como mostra o nosso levantamento dos santuários vistos no capítulo 1, na Sicília, como também na Itália do Sul, como veremos mais adiante, houve uma difusão significativa do culto da divindade em contexto cívico a partir da época arcaica. Talvez, nesse caso, a única exceção esteja na Ática, em Atenas, pólis onde se encontra mais santuários da divindade, depois da Sicília e da Itália do Sul, em contextos cívicos na época arcaica. Trata-se justamente da pólis onde as instâncias políticas da cidade e a urbanização alcançaram um amadurecimento no início da época arcaica.

Com relação à articulação do culto pelas comunidades políticas siceliotas, foi possível caracterizar apenas algumas funções cívicas específicas dos santuários de Zeus. Apesar da quase ausência de informações 
literárias a respeito, foi possível determinar, que na Sicília, os santuários de Zeus Olímpio em Siracusa e Selinonte foram usados como arquivos cívicos da cidade. Já em Agrigento, as informações disponíveis não informam sobre a existência do uso do santuário de Zeus Olímpio como arquivo cívico da cidade. A segunda função encontrada sobre esses santuários refere-se ao uso de algumas dessas áreas sagradas como asilo, como foi o caso de Siracusa, durante a invasão ateniense no século V a.C., e de Agrigento, no século III a.C., no cerco cartaginês.

Se não foi possível precisar, de forma completa, o papel do culto em relação ao funcionamento das comunidades políticas siceliotas, a expressão simbólica dos santuários de Zeus Olímpio, no espaço e paisagem das cidades, nos informa sobre a função política dessas áreas sagradas às suas comunidades. Em Siracusa, o santuário de Zeus Olímpio desempenhou, no posicionamento extra-urbano da área sagrada, a afirmação de soberania na demarcação da entrada do porto grande e do caminho na direção sul da khóra siracusana. Também desempenhou uma função marítima, expressando o poder da cidade a quem a avistava a partir do mar. Nesses aspectos, a arquitetura do templo de Zeus Olímpio exerceu a função importante de marco na paisagem através da monumentalidade da sua edificação, que não alcançou a monumentalização dos Olimpieia de Selinonte e Agrigento, mas, no contexto de Siracusa, esteve entre os maiores templos perípteros (na comparação com o Apolonion siracusano). Em Selinonte, a função simbólica política caracterizou-se no posicionamento extra-urbano do santuário de Zeus Olímpio na saída norte da cidade à khóra. Nesse caso, o Olimpieion selinontino, o maior templo dórico do mundo grego até o final do século VI a.C., foi considerado a expressão máxima de poder da pólis naquela época. Em Agrigento, a pólis expressou seu poder político (naquele contexto, de soberania territorial na Sicília) por meio do alto grau de monumentalização do Olimpieion, estabelecendo o santuário dentro da cidade, em um ponto de passagem importante e em proximidade aos muros. Acreditamos que nesses três casos houve uma associação intencional da comunidade ao poder de soberania e onipotência exercido por Zeus Olímpio, tendo sido em Agrigento que tal associação alcançou sua maior realização na construção do Olimpieion e na cunhagem, concomitante, de moedas com a imagem da águia. A respeito do santuário de Zeus Meilichios, como dissemos, não são atribuídas à área sagrada selinontina nenhum aspecto político, mas apenas o privado. Apesar desse santuário não oferecer um exemplo sobre o qual buscamos, o papel político das áreas sagradas de Zeus, trata-se de um exemplo importante sobre a partir de quando o culto de Zeus Meilichios emergiu no mundo grego e passou a atuar no âmbito privado, familiar, nas cidades gregas.

Além de terem sido símbolos da realização política das comunidades (sobretudo no caso de Agrigento), vimos como o culto de Zeus Olímpio nas três póleis foram instituídos por grupos políticos específicos, no caso os tiranos, em Selinonte e Agrigento, e oligarcas, no caso de Siracusa. Mesmo tendo sido instituídos por esses grupos no poder nas cidades, e seus templos poderem ser considerados expressões de poder, o culto nos santuários de Zeus Olímpio foram parte do calendário religioso cívico e desempenharam papéis no funcionamento das comunidades nos períodos pós-tirania, como em fase democrática. Queremos dizer que 
apesar de o culto ter sido vinculado inicialmente à tirania e à oligarquia, não serviram apenas à determinado grupo da cidade grega, como a aristocracia, tal como vemos nos casos dos santuários extra-urbanos interregionais em Creta e em alguns casos no Peloponeso - os santuários de Zeus Olímpio tiveram, provavelmente, uma função mais ampla na sociedade.

Com relação à identidade, é possível afirmar que o culto de Zeus Olímpio articulou a identidade de certos grupos políticos das cidades gregas siceliotas, como tiranos e aristocratas durante período oligárquico, um traço do culto da divindade comum à outras áreas do mundo grego, onde o culto também foi instituído. Já no que diz respeito à identidade étnica, no caso da Sicilia, não é possível afirmar o papel do culto na afirmação de identidades regionais. É possível, no entanto, vincular o culto de Zeus Olímpio, na Sicília, às cidades de origem dória, como foram Siracusa, Selinonte e Agrigento, tal como também concluiu M. Vonderstein (Vonderstein, 2006: 229). A nosso ver, o culto de Zeus Olímpio fez parte do que era ser dório na Sicília em época arcaica e clássica, portanto, da identidade política das comunidades siceliotas dórias. Muito provavelmente foi uma das formas de afirmação da doricidade de determinados centros gregos da ilha, em época arcaica e clássica, nos quais o culto de Zeus ganhou expressão em santuários relacionado ao seu aspecto Olímpio por várias razões dentre as quais o vínculo cultural com Olímpia foi a mais importante. É preciso destacar que se trata de um contexto, o século VI a.C. e o início do século V a.C., quando as afiliações étnicas entre as cidades gregas da Sicília ainda eram fortes - o principal critério de identidade até a emergência da identidade siceliota no último quartel do século V a.C. (Donnellan, 2012: 180-181; Hall, 2004: 49).

\section{ITÁLIA DO SUL}

Na Itália do Sul, o estabelecimento de santuários de Zeus ocorreu, na esfera cívica, na primeira metade do século VI a.C., apenas um pouco depois do que vimos com relação à Sicília. O desenvolvimento do culto à divindade alcançou o mesmo grau de expressão visto em contexto siceliota: além dos quatro santuários atestatos arqueologicamente em Metaponto, Lócris Epizefiri e Poseidônia, os quais serão aqui analisados como estudos de caso, o culto a Zeus foi muito difundido entre certas cidades da região, como indicam referências literárias e epigráficas ${ }^{122}$. A nosso ver, o amplo desenvolvimento do culto de Zeus em contexto cívico, na ltália do Sul, também esteve relacionado ao grau de organização política e também urbana alcançado pelas póleis da região já no final do século VII a.C.

Já a partir da primeira metade do século VI a.C., foi instituído, ao que parece, o santuário mais antigo conhecido de Zeus Agoraios, no centro urbano da pólis de Metaponto. Na segunda metade do século VI a.C., o culto de Zeus Olímpio foi estabelecido em um santuário urbano em Lócris, assim como um culto local do deus em Metaponto, de Zeus Aglaos, parece ter sido instituído em uma área sagrada extra-urbana. Em Posidônia,

\footnotetext{
122 Sobre um exame completo do culto de Zeus na Itália do Sul até a época romana, vide Vonderstein, 2006. Uma listagem completa das referências literárias e testemunhos epigráficos sobre Zeus na região, vide Laky, 2011, pp.447-482.
} 
um santuário de Zeus, talvez Agoraios, parece ter funcionado, no centro urbano, durante o período de ocupação lucana na cidade (entre os séculos V-IV a.C.) (vide mapa p.30). É importante dizer que nesses três centros gregos, o culto de Zeus ganhou expressão não apenas nestes santuários, mas de outras formas entre a época arcaica e clássica. Em Lócris, fossas votivas encontradas na área de Parapezza revelaram pequenas estatuetas votivas do dito Zeus Saettante, que atira o raio (Laky, 2013: 92). Em Posidônia, ainda que não haja muita comprovação, Zeus pode ter sido cultuado ao lado de Hera no santuário na foz do rio Sele e uma famosa estátua do deus sentado no trono, feita em terracota, indica, para alguns estudiosos, o culto da divindade no templo dedicado a Poseidon (Vonderstein, 2006: 63-68). Em Metaponto, Vonderstein também menciona um culto de Hera ao lado do de Zeus a partir de pínakes de terracota com a representação de um casal divino (Vonderstein, 2006: 51-52).

Como veremos na conclusão, ainda que tenha havido certa correspondência temporal e na quantidade do culto de Zeus difundido entre centros cívicos durante a época arcaica, semelhante ao caso da Sicília, na Itália do Sul, o culto de Zeus foi apropriado, predominantemente, de uma forma diferente pelas comunidades políticas com relação ao monumentalização do santuário e seu uso como expressões de poder das cidades. Também a Itália do Sul oferece um caso, somente documentado pelas fontes literárias, sobre como o culto de Zeus teria articulado identidades locais em um nível político. Trata-se do culto de Zeus Homarios, que apresentaremos na discussão final acerca dessa região.

\section{IV.1 Metaponto, ágora / S. Biaggio alla Venella}

Localizado no golfo de Tarento no mar Jônio, o santuário de Zeus Agoraios (cat. no.33) foi estabelecido em Metaponto, na ágora da cidade, exatamente no ângulo noroeste do eclesiatério (Figs.98 e 100). A área sagrada foi descoberta durante as escavações de D. Adamesteanu na área do eclesiastério nos anos 1970, quando foi encontrado o hóros com a inscrição relativa a Zeus Agoraios. 0 hóros com a inscrição sobre Zeus Aglaos foi encontrada durantes escavações em 1989 (De Juliis, 2001: 169). Já o santuário de Zeus Aglaos (cat. no.34) situou-se na khóra de Metaponto, no distrito moderno de San Biaggio alla Venella, próximo ao santuário de Ártemis.

\section{IV.1.1 Descrição e interpretação dos achados}

A datação mais antiga sobre o santuário de Zeus Agoraios em Metaponto, na primeira metade do século VI a.C., tem como base a inscrição $\triangle \mathrm{IO \Sigma}$ / AГOPA ("ágora de Zeus") gravada em uma laje de pedra, datada dessa época. Sabe-se que o santuário ainda esteve em atividade durante a época helenística, ao menos no século III a.C., quando data uma das fases de organização da área sagrada em relação ao eclesiatério. 
Assim, sabemos da existência desse santuário do deus a partir do achado de duas lajes de pedra ou hóroi, contendo inscrições, um altar e um muro de períbolo. Da primeira fase do santuário metapontino de Zeus Agoraios, pertence a inscrição acima mencionada, escrita em aqueu arcaico, gravada sobre uma laje de rocha vulcânica, medindo $1,11 \times 0,35 \times 0,60$ m, com superfície irregular: esta foi datada na primeira metade do século VI a.C. a partir de dados estratigráficos e epigráficos (Greco, 2008: 236-237). Dois muros paralelos, que circundam essa laje, constituíram o témeno do deus nessa época (Greco, 2008: 236237). O santuário de Zeus Agoraios,

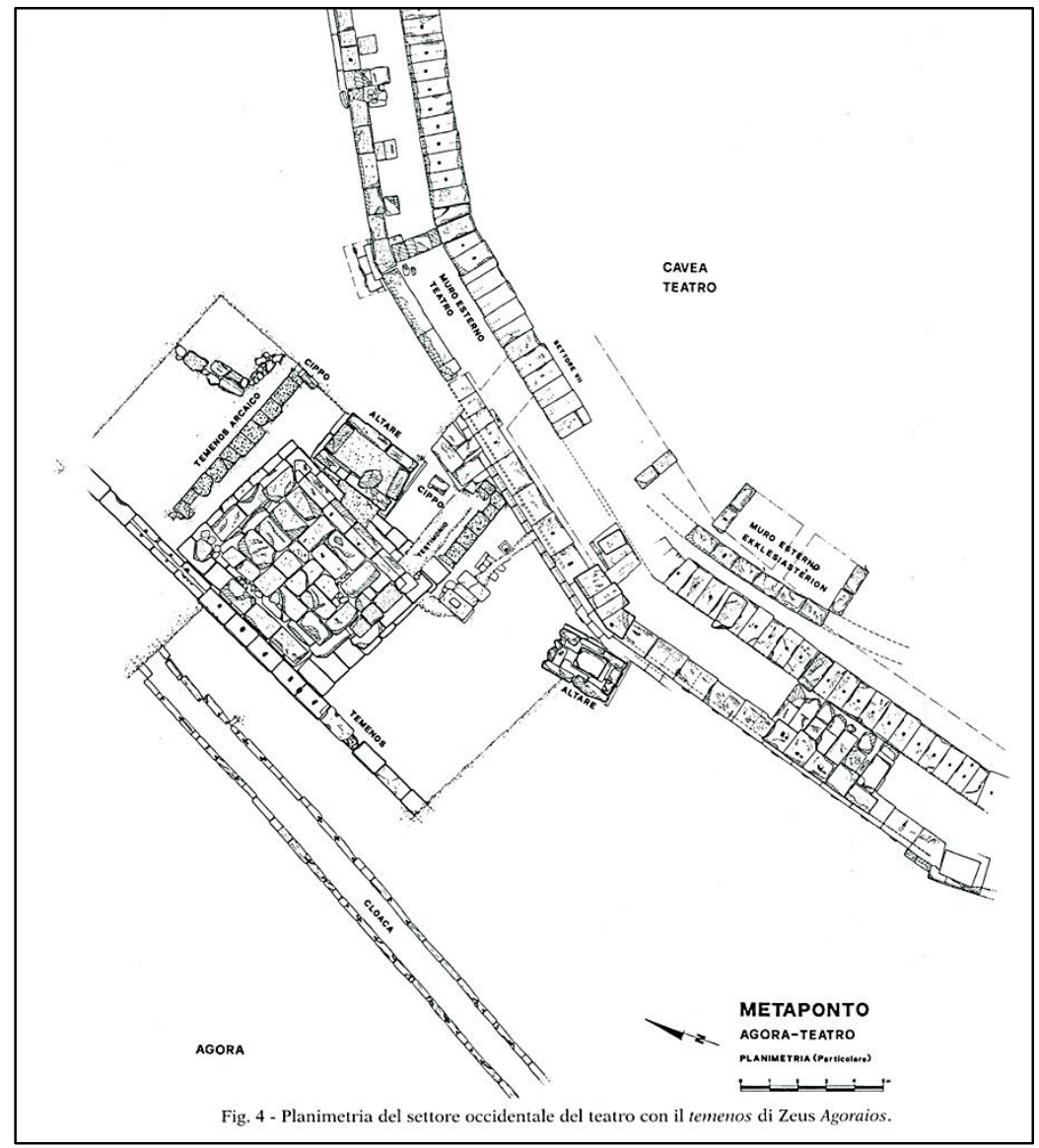

Fig.98- Planimetria do setor ocidental do teatro com o témeno de Zeus Agoraios (estrutura à esquerda) (De Siena, 1998: 150, fig.4) assim, pode ter existido à época do edifício circular de madeira (com fundações de pedra), datado do final do século VII a.C., que foi anterior ao eclesiastério (Cerchiai. 2004: 132; Greco, 2006: 329). Ao redor da metade do século VI a.C., com a construção do eclesiastério (I) nessa época, o local de culto dedicado a Zeus recebeu uma sistematização e monumentalização - um altar em pedra ladeado pela laje contendo a inscrição a Zeus Agoraios (Greco, 2008: 236-237). Com relação à inscrição na laje, Adamesteanu, descobridor e autor da publicação do achado, foi quem primeiro traduziu o texto como "ágora de Zeus", dando-lhe um valor topográfico (apud De Juliis, 2001: 167). Já Lo Porto, interpretou a inscrição, abreviada na parte final, lendo-a $\Delta$ ıo ayopa(ío) - teria se tratado, a seu ver, de uma referência aos debates na ágora, portanto no eclesiastério. A

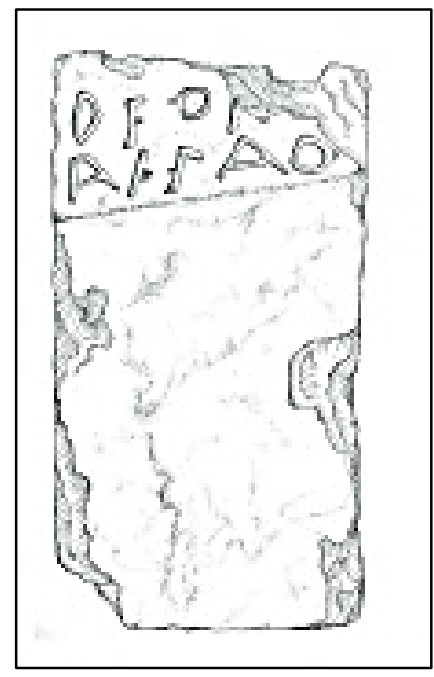

Fig.99- Hóros com inscrição a Zeus Aglaos (De Siena, 1998: 152. fig.6) segunda fase do santuário ocorreu entre o primeiro e o segundo quartel do século $\mathrm{V}$ a.C., conforme indicam a transformação monumental do eclesiastério (II) e a colocação da segunda laje de pedra com inscrição em cima do velho muro do témeno arcaico, demolido na parte superior, em correspondência com o altar, provavelmente também refeito nesta ocasião (De Juliis, 2001: 168-169). Sobre a segunda laje de pedra encontrada, trata-se da inscrição $\triangle \mathrm{IO \Sigma}$ / AГАAO ("esplêndido", "luminoso"), em alfabeto aqueu (Fig.99) (De Juliis, 2001: 169). Atribuise a essa segunda fase, também, a construção de um amplo recinto com blocos regulares, o qual abarca 0 


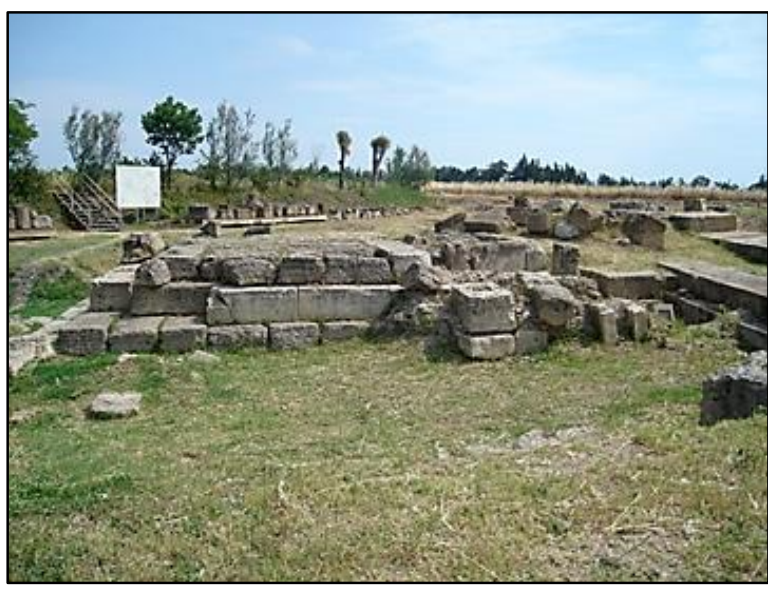

Fig.100- Santuário de Zeus Agoraios visto a partir de sul (Foto: arquivo pessoal / 2007)

témeno de Zeus e outros monumentos sagrados da área, que devia ser limitado, a oeste, por uma barreira de madeira (De Juliis, 2001:169).

A terceira e última intervenção edilícia, na área, ocorreu na segunda metade do século IV a.C. com a transformação do eclesiastério em um grande teatro, cujo perímetro externo se aproximou do témeno de Zeus (De Juliis, 2001: 170). Devido à instabilidade do terreno, construiu-se um reforço no analemma do eclesiastério, em correspondência à laje com inscrição a respeito de Zeus Agoraios, que apesar da extrema proximidade foi respeitada nas transformações da área (De Juliis, 2001: 170). De acordo com De Juliis, isso indica que o altar e as duas lajes com inscrição eram ainda visíveis e 0 recinto sagrado era utilizado no período (De Juliis, 2001: 170).

Somente na metade do século III a.C. foi reforçado, com um terraplenagem, o ponto do analemma do eclesiastério, que recobriu todas as estruturas presentes entre o muro do teatro e a parede ocidental do témeno de Zeus Agoraios (De Juliis, 2001: 170). Entre o fim do século IV a.C. e a metade do III a.C., se situa a construção de uma grande base de blocos reutilizados, que parece ter encoberto o altar e as duas lajes de pedra, nessa época já soterradas (De Juliis, 2001: 170). A imponência dessa base (construída com uma grande quantidade de material em pedra da área metapontina), induziu os estudiosos a atribuí-la a uma base para uma estátua de grandes dimensões de bronze ou de pedra, dedicada, provavelmente, a Zeus nessa época (De Juliis, 2001: 170).

Com relação a objetos votivos, possivelmente associados ao santuário, numerosos fragmentos de pínakes da segunda metade do século IV a.C., contendo a representação Zeus segurando o raio e a águia sobre seu cetro ou uma coluna, foram recuperados dentro do témeno e em outros pontos próximos ao local (De Siena, 1978; Lo Porto, 1988; Moreno, 1995 apud De Juliis, 2001: 170).

\section{IV.1.2 A natureza do culto e a função do santuário}

A atribuição do culto a Zeus Agoraios no santuário de Metaponto no século VI a.C. é atestada, como vimos, a partir de evidências epigráficas: o hóros contendo o nome e o epíteto do deus. Ainda que a inscrição e a localização assinalem a área sagrada ao culto de Zeus Agoraios, é possível afirmar o culto de Zeus Aglaos no mesmo local durante o século V a.C., como indica o outro hóros, de datação posterior. De acordo com C. Antonetti, o santuário metapontino de Zeus Agoraios, muito provavelmente, "é o mais antigo conhecido sobre a divindade" (Antonetti, 2009: 35-36). No entanto, o testemunho epigráfico mais antigo referente a Zeus 
Agoraios ainda é a inscrição encontrada na pólis de Dreros, em Creta, datada do final do século VII a.C. (Greco, 2006: 329).

Como vimos no capítulo 1 e ao longo desse capítulo, Zeus Agoraios foi uma divindade relacionada à "esfera judiciária, às instituições e magistraturas públicas e aos juramentos oficiais" (Antonetti, 2009: 31). Segundo E. Greco, "o ato de se reunir em assembleia não foi apenas uma prerrogativa dos homens, mas também dos deuses, por isso, o espaço de deliberação, a ágora, foi também espaço religioso, onde se encontra 0 culto às divindades" (Greco, 2006: 328). Conforme explica Greco, "aos poucos e a certo ponto, Zeus com o epíteto Agoraios assumiu o papel de regulador absoluto do funcionamento da vida civil e organizada no coração da própria pólis" (Greco, 2006: 328). Esse estudioso lembra que apesar de Zeus ter sido o thèos agoraios por excelência, outras divindades atuaram ao lado de Zeus na ágora, como é o caso de Hermes, muito recorrente nesse tipo de espaço cívico (Greco, 2006: 328-329).

Com relação às funções política e cívica evidentes do santuário urbano de Zeus Agoraios, é também E. Greco que oferece as conclusões mais interessantes a esse respeito. Segundo Greco, o caso do santuário de Zeus Agoraios em Metaponto, em associação ao eclesiastério, "oferece um caso único no mundo grego, em época arcaica, em que o termo ágora não se referiu à praça, mas ao edifício circular onde ocorria a assembleia - situado em um grande espaço vazio que, ao longo do tempo, foi ocupado e definido por outros edifícios, recebendo o nome de ágora" (Greco, 2006: 330). Contextualizando o santuário em época arcaica, Greco assume que "Zeus Agoraios adquiriu significado na esfera cívica no período da pólis oligárquica", recusando, dessa maneira, as interpretações que aceitam a existência da pólis democrática já nessa época (Greco, 2006: 333). Assim, o culto de Zeus Agoraios em Metaponto ganhou expressão, em época oligárquica, no momento de definição do uso do espaço da cidade e do primeiro período de monumentalização da área urbana, ocorrido a partir da primeira metade do século VII a.C. Já em época arcaica, portanto, Zeus Agoraios foi expressão do desenvolvimento político e cívico da comunidade política de Metaponto. Tal função política do culto se consolidou na cidade nos períodos subsequentes, como mostra a permanência do culto na área e a monumentalização do santuário, que acompanhou sempre àquela do eclesiastério, o edifício público mais importante da pólis.

Durante o século V a.C. ocorreu o que se pode chamar da introdução do culto extra-urbano de Zeus Aglaos, ao lado daquele urbano de Zeus Agoraios, a partir do segundo quartel do século V a.C. (De Siena, 1998: 166). O posicionamento de um hóros com a inscrição referente a Zeus Aglaos, na área do eclesiastério, é tido pelos estudiosos como evidência do culto do deus no local. Atualmente é consenso entre os estudiosos da cidade, que Zeus Aglaos foi venerado em um santuário na área da khóra, atual San Biaggio alla Venella, distrito também de uma importante área sagrada de Ártemis. Os achados de outro hóros mais antigo, datado da metade do século VI a.C., com a inscrição $\Delta I O \Sigma$ / AГ A AIO, numa laje de calcarenito $(0,60 \times 0,50 \times 0,30 \mathrm{~m})$, e de uma estatueta masculina de terracota, ambos na área do santuário da deusa, têm sido consideradas evidências da existência de tal santuário do deus no local (Figs.101 e 102). 
Muitas interpretações foram propostas sobre a localização ou não do santuário na área. A maior parte dos estudiosos considera o hóros como pertencente às ruínas de um santuário do deus, reconhecendo a presença do culto de Zeus ao lado daquele principal de Ártemis (De Juliis, 2001: 100-101). Sobre uma posição contrária a esta tese, coloca-se Lo Porto (1988) o qual suspeita que o hóros tenha sido recolhido em época imperial entre as ruínas da área sagrada urbana de Metaponto e transportado para o local juntamente a outros materiais recuperados e assim reutilizado como cobertura de uma tumba romana, tal como foi encontrado (De Juliis, 2001: 100-101). Nessa perspectiva, não teria havido um santuário extra-urbano de Zeus Aglaos, mas apenas aquele na área urbana, como testemunha o hóros no témeno de Zeus Agoraios. Em contraste, De Siena (1998) defende a impossibilidade de se transportar o hóros de Metaponto para San Biaggio e defende a transferência do culto de Zeus Aglaos do santuário extraurbano para a ágora durante 0 século V a.C. (De Juliis, 2001: 100-101). Esse autor é o único a oferecer uma explicação a esse respeito. A seu ver, teria se tratado de uma duplicação do culto após a gradual dissolução do poder econômico e político dos ghene (De Juliis, 2001: 100-101; De Siena, 1998: 169). De acordo com sua interpretação, os santuários de Metaponto, localizados na khóra, durante a época arcaica, desenvolveram a função de distritos territoriais administrativos e foram locais

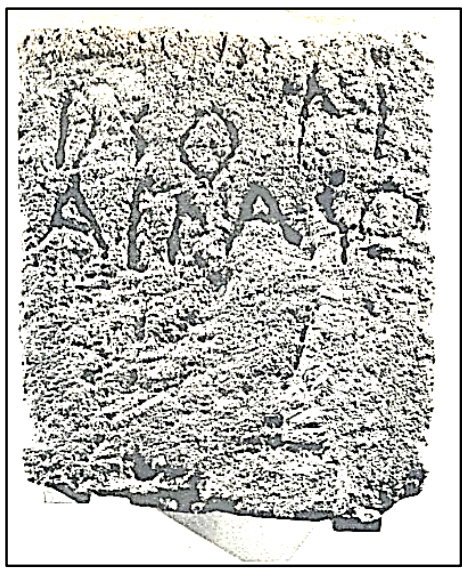

Fig.101- Cippo com inscrição a Zeus Aglaios (Adamesteanu, s/ano: 87, fig.48)

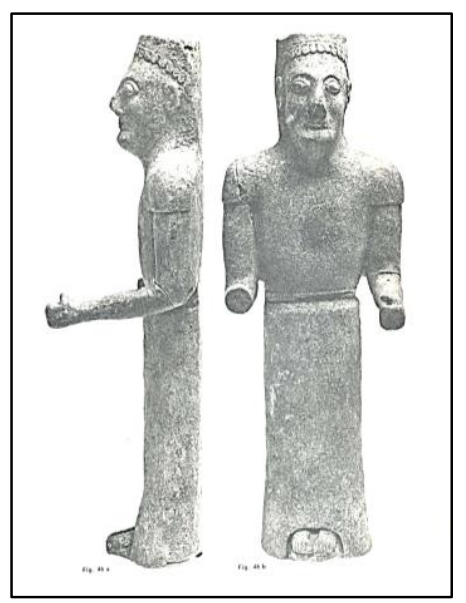

Fig.102-Estatuetas de terracota de Zeus Aglaos (Adamesteanu, s/ano: figs.46a e 46b) privilegiados de agregação dos grupos aristocráticos da cidade (De Siena, 1998: 169). Em sua perspectiva, uma mudança pode ter ocorrido nessa época, nesses santuários, quando "a pólis produziu os maiores esforços no sentido de dar unidade, homogeneidade e coesão à inteira comunidade de cidadãos - se tratou de uma nova organização político administrativa, que anulou os poderosos grupos, reduzindo as propriedade fundiárias, controlando seus pontos de referência no território (os santuários), tornado-os cultos comuns da pólis e não mais privados das famílias aristocráticas (De Siena, 1998: 170). Nesse sentido, a transferência do culto de Zeus Aglaos ao centro urbano pode ser explicada por uma "interferência política com o propósito de integração social e religiosa, para evitar e sanar conflitos e criar um novo sistema institucional, superando a divisão da comunidade política arcaica, baseada no poder de grupos aristocráticos e em seus cultos familiares" (De Siena, 1998: 170).

A nosso ver, trata-se da explicação mais viável para a introdução do culto de Zeus Aglaos no centro cívico da cidade. Assim, em Metaponto, entre os séculos VI e V a.C., o culto de Zeus Agoraios expressou 0 grau e a maneira como os metapontinos se organizaram politicamente a partir da época arcaica, e o de Zeus Aglaos, por sua vez, pode ter sido, inicialmente, um tipo de culto privado muito semelhante àquele de Zeus 
Meilichios, de aspecto ctônio ${ }^{123}$ e voltado às famílias aristocráticas de Selinonte. No entanto, no caso de Zeus Aglaos, por razões políticas específicas de Metaponto em época clássica, foi introduzido no coração do centro urbano, tornando-se também um tipo de culto cívico não mais específico a determinado grupo político da cidade.

\section{IV.2 Lócris Epizefiri}

Localizado na costa do mar Jônio, entre Régio e Caulônia, o santuário de Zeus Olímpio (cat. no.35) foi estabelecido em Lócris Epizefiri, no setor leste da cidade, em proximidade aos muros na área de Contrada Cusemi - a 100 metros a noroeste do teatro e a cerca de 90 metros ao norte da teca de seu arquivo cívico (Fig.104) (Laky, 2013: 95). De todos os santuários de Zeus Olímpio, no mundo grego, o de Lócris é o único onde foi encontrado os remanescentes do arquivo cívico da área sagrada. Assim, nesse caso, dispõem-se das evidências materiais sobre o templo, como nos outros casos já vistos sobre Zeus Olímpio, mas também sobre a teca (as tábuas de bronze com inscrições e a caixa de pedra que as armazenava) e 0 muro de contenção da área sagrada. Assim, sobre o histórico dos achados, "Jean Claude Richard De Saint

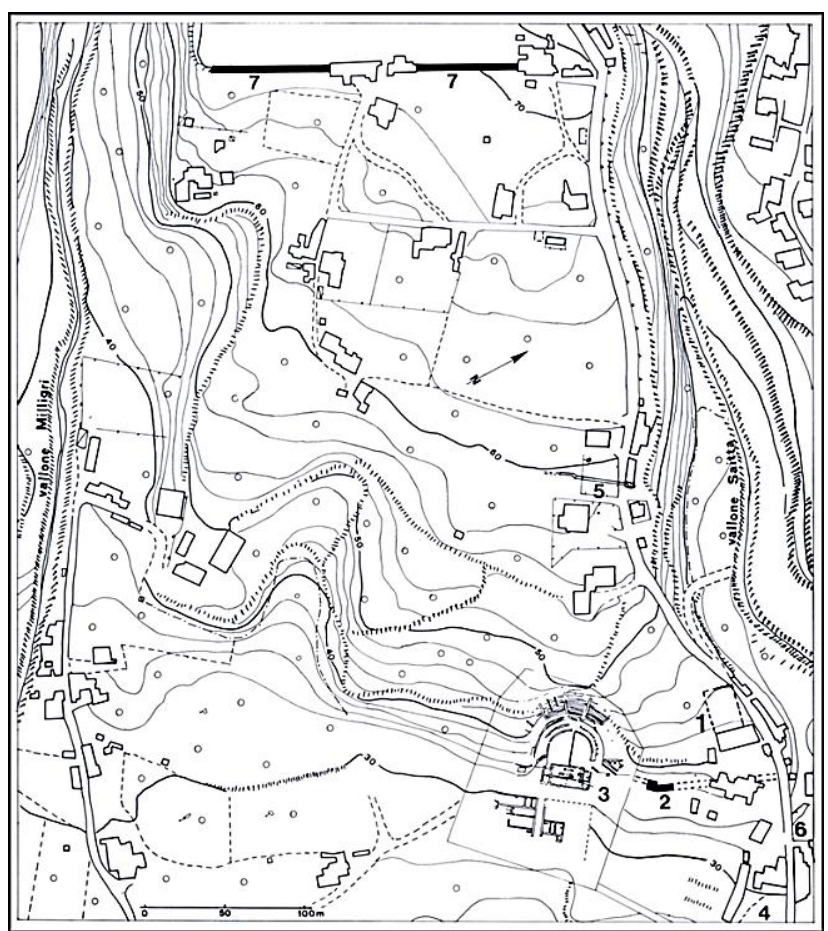

Fig.103 - Planimetria do setor leste de Lócris- 1. Sítio do santuário de Zeus Olímpio de Casa Marafioti; 2. Muro de Contrada Pirettina; 3. Teatro e casas helenísticas; 4. Teca do arquivo de Zeus Olímpio; 5. Ninfeu helenístico; 6. Muro de Contrada Callipari; 7. Muro de Contrada Cusemi (Costabile, Nôn e François Bielinski, respectivamente, em suas obras Voyage Pittoresque ou Description des Royaumes de Naples et de Sicile (1783) e Troisième Centaine que commence avec l'année 1791 (1791) descreveram a área do templo de Zeus Olímpio e, principalmente, registraram que ainda naquela época (décadas finais do século XVIII) duas colunas do templo ainda estavam em pé" (Laky, 2013: 96-97). O primeiro a escavar o santuário e o templo foi o Duc de Luynes em 1830 o qual relatou que a última, das duas colunas restantes, tinha sido demolida dois anos antes por um viticultor para servir como cerca ao seu jardim (Costabile, 1992: 5455). Mas o santuário de Zeus Olímpio, sob a Casa Marafioti, foi "escavado sistematicamente pela primeira vez por P. Orsi em uma campanha em 1910, quando foram identificados os restos do templo e o muro de contenção entre a teca e o santuário" (Laky, 2013: 97). Em 1959 foi descoberta, "a 90 m a sul do santuário, a teca do arquivo de Zeus Olímpio, um fosso de pedra contendo 37 tábuas de bronze com inscrições sobre registros financeiros da cidade" (Laky, 2013: 95). Duas outras tábuas foram encontradas dias depois por Ugo Serafino

123 Não se conhece ao certo a característica de Zeus Aglaos, cujo culto parece ter existido somente em Metaponto. Giacometti somente menciona 0 aspecto ctônio da divindade (Giacometti, 2005: 123). 
escondidas em um estábulo (Costamagna; Sabbione, 1990: 261). Novas escavações foram realizadas na área da teca ou do arquivo de Zeus Olímpio no início dos anos 1990 e revelaram novos achados arquitetônicos em terracota do templo de Zeus Olímpio e objetos votivos, encontrados pela primeira vez.

\section{IV.2.1 Descrição e interpretação dos achados}

A datação do santuário de Zeus Olímpio, em Lócris, na segunda metade do século VI a.C. (c.540/30 a.C.) foi baseada nos elementos arquitetônicos e escultóricos do Olimpieion, situados ao redor dessa época. É provável, no entanto, que a área sagrada tenha sido mais antiga do que os remanescentes arquitetônicos do edifício, mas é impossível provar tal inferência diante da quase ausência de achados arqueológicos anteriores ao templo, como objetos votivos, por exemplo. Já é possível dizer que o santuário esteve ativo durante a época helenística, como indicam as tábuas de bronze do arquivo da área sagrada, datadas entre os séculos IV-III a.C.

O templo de Zeus Olímpio, em Lócris, era dórico e períptero (de $8 \times 17$ colunas), com uma fileira interna de colunas em cada fachada, e dimensão de 20 x 36-40 m (Fig.105) (Laky, 2013: 99). As escavações na extremidade sudeste do edifício localizaram uma fileira de seis rochas de $45 \mathrm{~cm}$ de altura e 1,50 metros de comprimento, que pertenceu ao estilóbato (Laky, 2013: 98). Nesta extremidade, também, foi encontrada a maior parte dos elementos arquitetônicos escultóricos importantes, tais como o fragmento de métopa, o pentaglifo angular, o fragmento calcário de cornija com influência jônica, uma parte da sima (calha) decorada com palmeta, flor de lótus e a extremidade com prótomos leoninos (apud Costabile, 1992: 57 59). Os capitéis de colunas mais preservados provêm desta parte - ambos arcaicos e de calcário, um sem ábaco e anéis e

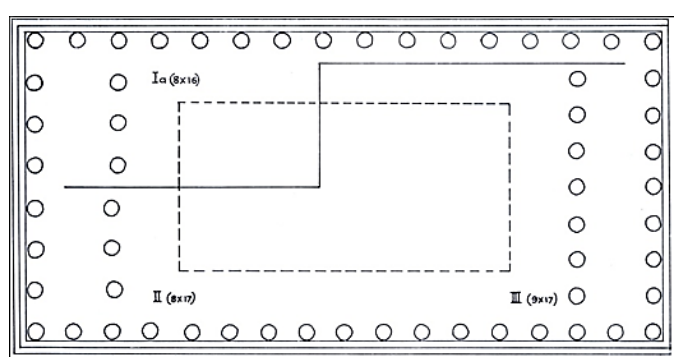

Fig.105 - Planta do Olimpiéion de Casa Marafioti (por Østby 1978) (apud Costabile, 1992: 41)

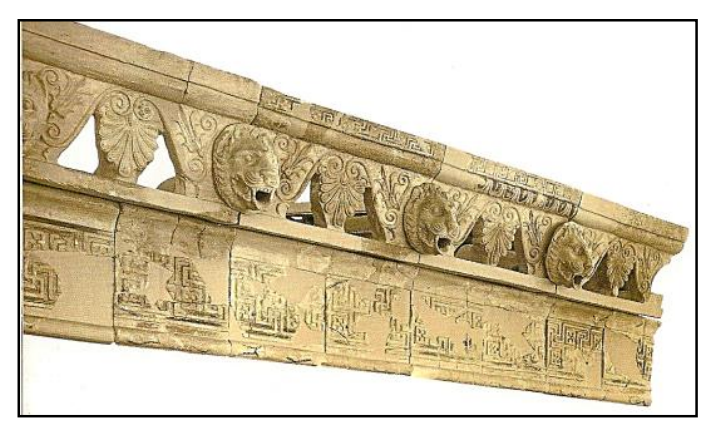

Fig.106 - Sima lateral com prótomos leoninos encontrada no lado setentrional (Cerchiai, 2004: 96) o outro liso -, um fragmento de tambor de coluna de calcário com vinte caneluras e fragmentos da arquitrave (apud Costabile, 1992: 59-61). No lado oeste do templo, foram recuperados abundantes elementos de terracota, provavelmente provenientes da decoração do frontão ocidental do templo (Laky, 2013: 98). Destes achados, destacam-se uma sima frontal decorada com relevo de palmeta e flores de lótus; e uma placa decorada com meandro com uma parte da cornija (Laky, 2013: 98). Mas o achado em terracota mais importante nesta porção do templo foi um grupo, pertencente ao acrotério, de um cavaleiro e seu cavalo sobre uma esfinge com influência jônica, que está assentada sobre uma telha larga (apud Costabile, 1992: 66-70). No lado norte foram localizados seis fragmentos (comprimento 3 metros) das rochas que compunham o estilóbato central e uma parte mínima pertencente ao muro interno do opistódomo ou da cela (Laky, 2013: 99). Dos elementos 
arquitetônicos escultóricos, todos de calcário, os mais importantes são a anatirose arcaica, partes da cornija em calcário e dois fragmentos de colunas (fustes e restos do equino) (Laky, 2013: 99). De terracota, foi encontrada uma sima lateral, com prótomos leoninos, composta por uma telha grande vertical com cornija em cima e embaixo (Fig.106) (Laky, 2013: 99). Foram encontrados também onze exemplares de prótomos leoninos que deviam decorar a cornija (apud Costabile, 1992: 74-79).

Com relação à cronologia do edifício, P. Orsi datou-o do final do século VI a.C. com base no tipo de planta e nas poucas informações obtidas da análise dos capitéis. As terracotas - recuperadas em maior número e correlacionadas aos tipos de Metaponto - pertencem ao estilo da metade do século V a.C., indicando, nesse caso, que a estrutura da parte superior do templo deve ter sido refeita nesta época (apud Costabile, 1992: 8081). Orsi também destacou, em sua descrição da escavação, os elementos jônicos presentes no fragmento de cornija e no grupo escultórico de terracota do acrotério. Lembrou que entre os séculos VI e $\mathrm{V}$ a.C. Lócris importou muitos objetos de arte produzidos pelos artistas jônicos ocasionando uma influência jônica ao dórico da região (apud Costabile, 1992: 82). Já Østby propõe uma nova datação para o edifício - mais anterior - a partir dos elementos da elevação. As colunas com vinte caneluras sugerem uma data na segunda metade do século VI a.C., ao passo que as colunas monolíticas e as proporções do capitel sugerem a primeira metade do século VI a.C. A partir da correlação arquitetônica com o templo de Atena em Posidônia e com o de Hera em Metaponto (Tavole Palatine) - os paralelos mais próximos ao Olimpiéion lócrio - Østby conclui que o edifício pertence à segunda metade do século VI a.C., após 540/30 a.C. (Østby, 1978: 34). A datação de Østby é a atualmente seguida pelos estudiosos, como C. Parise Presicce e F. Martorano (Martorano, 1992: 42; Parise Presicce, 1984: 76). Nesse sentido, em nossa pesquisa seguiremos a cronologia proposta por Østby acerca da construção do templo após 540/30 a.C. e a de Orsi sobre a restruturação da parte superior do edifício na segunda metade do século $\mathrm{V}$ a.C.

Com relação à monumentalidade do Olimpieion lócrio, a correlação com os demais Olimpieia realizada em nossa pesquisa anterior, mostrou se tratar do "menor templo de Zeus Olímpio já construído" (Laky, 2013: 250).

As escavações de Orsi não localizaram o altar e nem depósitos votivos por causa das alterações e dos desníveis do terreno (apud Costabile, 1992: 72). Além do templo, a única estrutura descoberta na época das escavações de Orsi foi o denominado muro de contenção (Fig.107). Construído no declive da colina, o muro de Contrada Pirettina era feito de blocos isodômicos de arenito de 2,5 metros de largura, orientado leste-oeste e se ligava a leste provavelmente ao vale Saitta. É possível que esta estrutura murária

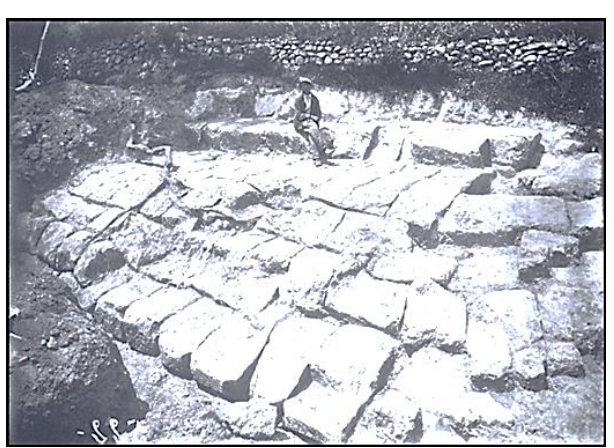

Fig.107 - Muro de Contrada Pirettina, foto tirada no momento da escavação de 1911 (Costabile, 1992: 88) fosse o períbolo (muro do témeno) do santuário de Casa Marafioti, ou o analemma de sustentação da colina, 
ou ainda, como pensou P. Orsi, tenha tido a função militar além da de sustentação (Costamagna; Sabbione, 1990: 63-64; Costabile, 1992: 37 e 39).

Com relação ao arquivo do santuário de Zeus Olímpio, trata-se de uma única caixa de pedra (denominada de teca pelos italianos), feita em um único bloco de calcário, internamente oco e de forma cilíndrica, que mede 1,57 metros de diâmetro, 1,26 metros de altura e as paredes $31 \mathrm{~cm}$ de largura são fechadas por uma sólida tampa (Fig.108) (Laky, 2013: 96). Na parte externa da tampa há quatro anéis grossos de bronze maciço diferentes entre eles pela dimensão e sistema de fixação, quando eram usados para deslocar lateralmente a tampa (Laky, 2013: 96). Dentro

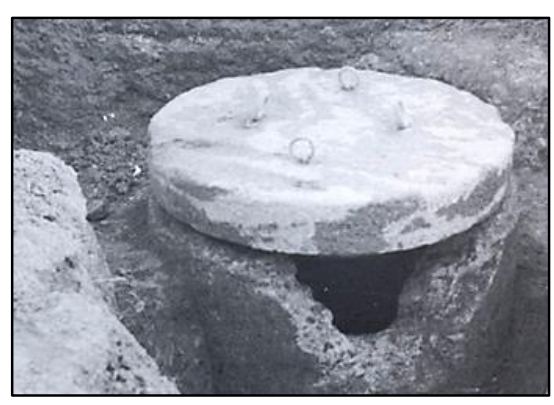

Fig.108- Teca lítica do arquivo de Zeus Olímpio no momento da escavação em 1959 (Costamagna; Sabbione, 1990: 164) da teca, foram encontradas 39 tábuas de bronze datadas do período democrático de Lócris, portanto ao redor da segunda metade do século IV a.C. e da primeira metade do século III a.C. (Laky, 2013: 96). Os textos, estudados pelo arqueólogo italiano Alfonso De Franciscis, estão escritos em dialeto dórico local que tem influência ateniense (Laky, 2013: 96). As tábuas constituem uma documentação única em todo o mundo grego e representam uma excepcional fonte de informação sobre a vida e a organização política da cidade no período, como veremos mais adiante (Laky, 2013: 96).

Durante escavações entre os anos de 1993 e 1994 na área da teca ou arquivo de Zeus Olímpio foram descobertos quatro pithoi depositados dentro de quatro fossos (Cardosa; Barello, 1996: 69). Nos pithoi, preenchidos com uma quantidade grande de terra compactada, foram encontrados fragmentos de material cerâmico em miniatura e ossos de animas (Cardosa; Barello, 1996: 69). Os vasos e o material depositado foram considerados evidência do caráter sagrado do local (Cardosa; Barello, 1996: 69). Um acrotério em formato de palmeta, fragmentos de telha e cerâmicas de verniz preto, do século IV a.C., foram os materiais encontrados associados no estrato da área, datados, na maior parte, do final da época arcaica (Cardosa; Barello, 1996: 69). A leste dos fossos, foram encontrados os restos da fundação de um muro preenchidos com os restos de cinzas e carvão e uma grande quantidade de material votivo (cerâmica em miniatura, um fragmento de terracota arquitetônica, uma cabeça de uma estatueta feminina com polos e uma estatueta de esfinge, datados do final do período arcaico). Em uma escavação no ano de 1995, na área da rua que passa ao lado do vale Saitta, um estrato de terra com estratigrafia arcaica não perturbada pertencente ao témeno de Zeus Olímpio, revelou fragmentos de terracota arquitetônica, muito similares àquelas encontradas por Orsi, e materiais votivos (cerâmica votiva em miniatura, uma fiala de bronze) (Cardosa; Barello, 1996: 70). Assim, foram essas últimas escavações na área sagrada de Zeus Olímpio que revelaram algum tipo de material votivo pertencente ao santuário. 


\section{IV.2.2 A natureza do culto e a função do santuário}

A atribuição do santuário em Lócris, ao culto de Zeus Olímpio, é atestada apenas a partir de evidências epigráficas relativas às inscrições nas tábuas de bronze recuperadas do arquivo cívico - não há referências literárias a respeito do santuário e do culto da divindade na cidade. Nesse sentido, a identificação da área sagrada é baseada em evidências posteriores ao templo (datam entre a época clássica e helenística) - não há evidências, que atestem o culto no local, contemporâneas ao edifício (Laky, 2013: 104). Além dessa questão, há ainda, na bibliografia a respeito do santuário, uma dúvida se se tratou de uma área sagrada dedicada à divindade. Trata-se de um problema com relação à indefinição da função do muro de Contrada Pirettina, que ainda existe entre os estudiosos - se se tratava de um simples muro de sustentação do terraço do templo ou se era o próprio muro de témeno, o que nesse caso, impediria o pertencimento do arquivo de Zeus Olímpio ao santuário (Laky, 2013: 96 e 250). Em nossa pesquisa anterior, concordamos com Orsi de que o muro teve a função de conter o terraço do templo. Também concluímos que o templo de Casa Marafioti foi de fato um Olimpieion, embora suas dimensões não correspondam ao padrão de monumentalidade dos templos de Zeus Olímpio, datados do período, no mundo grego. A nosso ver, "se as dimensões do templo Marafioti são muito inferiores em comparação a dos Olimpiéia, se deve ao fato de que em Lócris não houve uma tradição na construção de grandes edifícios monumentais ${ }^{124 " ~(L a k y, ~ 2013: ~ 257) . ~ N e s t a ~ p e r s p e c t i v a, ~ o ~ O l i m p i e ́ i o n ~ l o ́ c r i o ~}$ "representa uma exceção nos padrões de dimensão destes tipos de edifício" (Laky, 2013: 257). Assim, afora esses problemas, uma proposição diferente localiza o santuário de Zeus Olímpio não em meio aos principais edifícios de Lócris, mas nos confins da pólis, próximo à fronteira com Régio ${ }^{125}$ (Cordiano, 1998). No entanto, tal tese ainda aguarda comprovação. De toda maneira, é fato que existiu um santuário de Zeus Olímpio em Lócris Epizefiri, como evidencia o arquivo cívico da divindade, localizado, como o santuário, dentro da área urbana da cidade.

Com relação à função do santuário, é possível somente atestar um papel político e cívico, à comunidade de Lócris, entre a época clássica e helenística devido à presença do arquivo e do conteúdo das inscrições, que remontam a essa época. Contudo, isso não impede de se supor que o santuário e o templo já em época arcaica tenham sido usados para tal fim também. De todo modo, entre os séculos IV-III a.C., as inscrições nas 39 tábuas, de um modo geral, registram informações sobre "a articulação dos cargos públicos, a subdivisão da população, e a função econômica do santuário, que concedeu à pólis contribuições em dinheiro, muitos destinados à restauração e ao reforço da cinta murária" (Costamagna; Sabbione, 1990: 164 e 261). Sobre 0 papel simbólico do posicionamento do santuário de Zeus Olímpio, não foi possível estabelecer uma função política como foi possível para as áreas sagradas siceliotas da divindade. A função marítima é a única que se

\footnotetext{
124 A dimensão dos templos perípteros, em Lócris, considerando-se o templo de Casa Marafioti, não atingiu grandes proporções. 0 templo II de Afrodite em Marasà (550-500 a.C.) foi medido em 17,05 x 35,30 metros e o templo III (480 a.C.) alcançou 19 × 45 metros de dimensão, sendo maior, portanto que o templo Marafioti de 20 × 36/40 metros (Laky, 2013: 257).

125 Sobre essa discussão, ver Laky, 2013, pp. 102-104.
} 
pode atribuir ao santuário, conforme P. Orsi. Em seu relato de escavação, o arqueólogo italiano comparou a visão do templo e da área sagrada do deus em Lócris àquela de Siracusa - "úteis sinais aos navegantes" embora ambos os santuários estivessem posicionados em localidades diferentes (em Lócris numa colina e em Siracusa numa planície próxima ao mar) (apud Costabile, 1992: 84). Não se pode descartar a hipótese de que o posicionamento do santuário lócrio de Zeus Olímpio significou algum tipo de função simbólica política, no aspecto marítimo, como observado no caso de Siracusa.

No caso de Lócris, a instituição do culto de Zeus Olímpio é atestada, também, por influência do santuário de Olímpia. Em nossa investigação anterior, concluímos que o culto a Zeus Olímpio, e a construção de seu templo em Lócris Epizefiri, podem ter sido motivados pela vitória na batalha de Sagra (metade do século VI a.C.), como pode indicar o agradecimento ao deus de Olímpia (Laky, 2013: 93-94). A partir da metade do século VI a.C., Lócris se envolveu, ao lado de Régio, na batalha contra Caulônia e Crotona por motivos de disputas territoriais. Justamente deste evento provêm a última evidência da relação da pólis com Olímpia: os lócrios, medmeios e hipponiatas após a batalha dedicaram um escudo a Zeus Olímpio em que se lê Os hipponiatas dedicaram (pela vitória) sobre os crotoniatas; e os medmeios e os lócrios (SEG 11:1211) (Costamagna; Sabbione, 1990: 37-37). Trata-se de uma hipótese, dada a ligação entre esse evento, a dedicação da comunidade em Olímpia e o aspecto militar do culto de Zeus Olímpio em Olímpia, que também se observa no culto lócrio da divindade, como indica a construção do templo no contexto da batalha, no século VI a.C., e os registros das tábuas do arquivo cívico que se referem a empréstimos do santuário para reparos na muralha defensiva da cidade (Laky, 2013: 29). O momento da batalha de Sagra, ou seus resultados à pólis, podem ter promovido a apropriação do culto pela comunidade política de Lócris que, por algum motivo, procurou trazer para seu centro cívico o culto da divindade.

E síntese, ainda que não haja muitos dados sobre o governo vigente em Lócris durante o século VI a.C., é possível assumir que o santuário e o templo do deus "devem ter sido empreendimentos da aristocracia (em governo oligárquico?), já que não dispomos de registros que atestem a tirania na cidade e nem tampouco uma monarquia" (Laky, 2013: 293). 


\section{IV.3 Posidônia}

Localizado na costa do mar Tirreno, o santuário de Zeus (Agoraios) (cat. no.53) foi estabelecido em Posidônia, na ágora da cidade, a algumas centenas de metros a oeste do eclesiastério (Fig.109) (Greco, 2008: 40).

\section{IV.3.1 Descrição e interpretação dos achados}

O santuário de Zeus em Posidônia é atribuído ao período de ocupação dos lucanos na cidade (final do século $V$ a.C. e século IV a.C.) a partir dos remanescentes de um pequeno templo datado dessa época estabelecido na área do eclesiastério. Uma estela com inscrição, datada do século III a.C., assegura o funcionamento da área sagrada ainda nessa

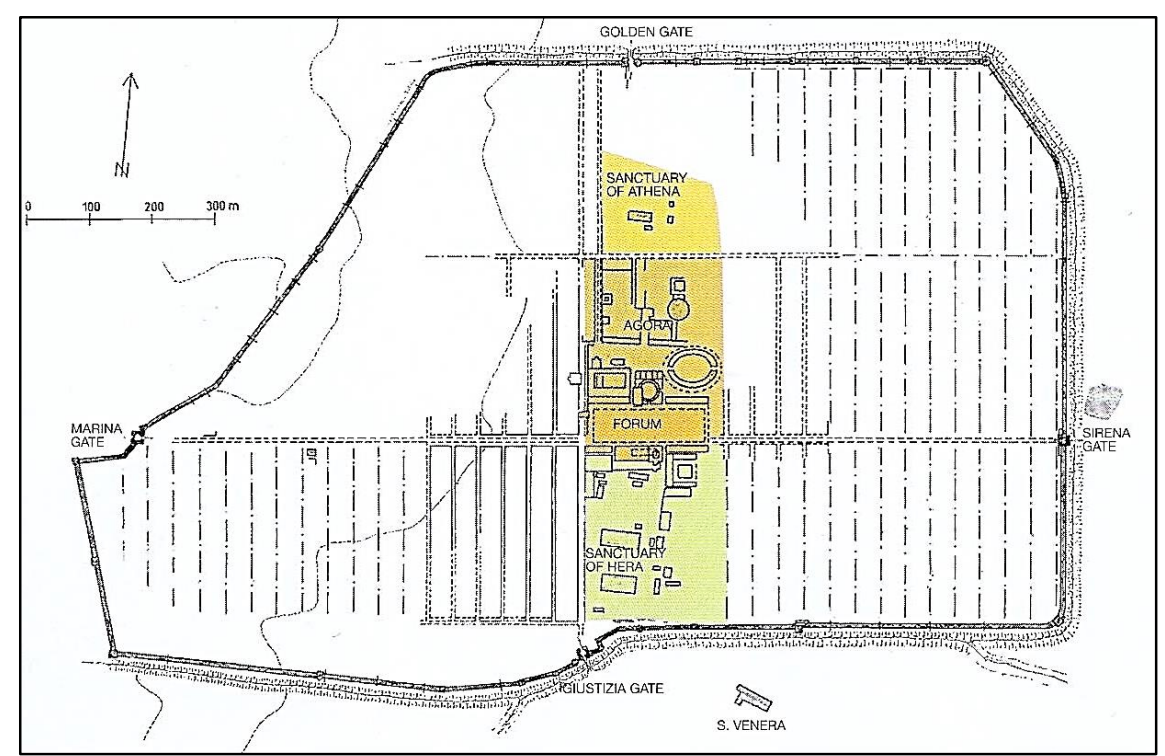

Fig.109- Planimetria de Posidônia (no centro, a ágora) (Cerchiai, 2004: 62) época.

O denominado templinho (T) foi construído com blocos reutilizados de um edifício de época arcaica (Fig.110) (Greco, 2008: 40). Da pequena estrutura, que mede $3,60 \times 4,75 \mathrm{~m}$, resta somente parte da cela que possui um pavimento feito com lajes de pedras retiradas de uma tumba de época medieval (Greco, 2008: 40). 0 edifício foi reestruturado em época lucana e funcionou após este período também (Greco, 2008: 40). Com a

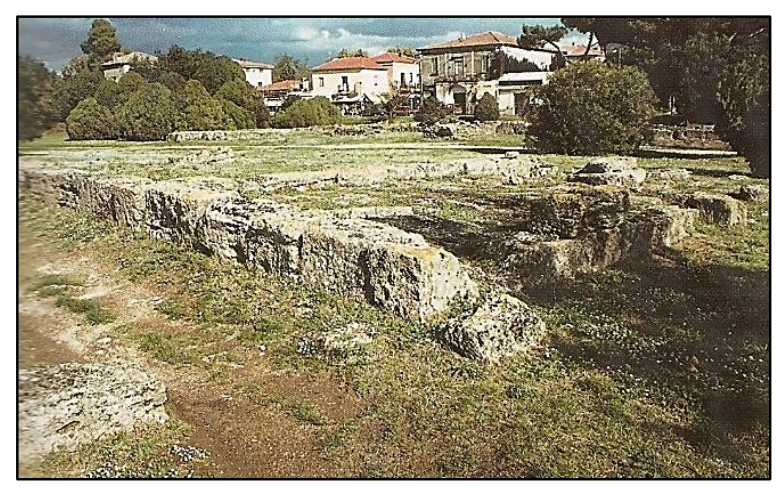

Fig.110- Vista a partir de sudoeste do templinho de Zeus Agoraios (Greco; D’Ambrosio; Theodorescu, 1995: 43) chegada dos romanos na cidade em c.273 a.C., o edifício foi desmontado e preenchido com pedras, terra e ossos de boi (restos sacrificiais). Acima do preenchimento foi edificado um santuário a que pertencem os blocos escuros mais altos (Greco, 2008: 40).

O outro achado, referente à essa área sagrada, é a estela votiva, datada do final do século IV a.C., com uma inscrição em alfabeto grego e língua osca, cujo texto é uma dedicação a Zeus feita por um magistrado lucano de nome Stazio (Greco, 2008: 39). 


\section{IV.3.2 A natureza do culto e a função do santuário}

A atribuição do pequeno templo e da área sagrada ao culto de Zeus foi baseada no achado da inscrição referente a Zeus. Os estudiosos do sítio identificaram o santuário à divindade, pois a o edifício se encontra perfeitamente em eixo com um pequeno altar e a estela votiva, que foi recuperada dentro do eclesiastério (Greco; Longo, s/ano: 34; Greco, 2008: 40). Já a atribuição ao culto Agoraios de Zeus foi baseada na analogia com o témeno da divindade em Metaponto (Greco; Longo, s/ano: 34; Greco, 2008: 40). Contudo, não há nenhuma evidência arqueológica, epigráfica ou textual que confirme o culto do deus na área do eclesiastério tenha sido aquele de Zeus Agoraios.

Ainda não está claro se o culto a Zeus na área do eclesiastério pré-data a época lucana, se remonta ao período grego (Vonderstein, 2006: 68). De todo modo, o uso ou instituição do santuário ao deus no período de ocupação lucana coloca a questão sobre a continuidade do culto grego entre esse povo itálico após a conquista de Posidônia. Graças às descobertas arqueológicas, sabemos que Posidônia foi ocupada pelos lucanos ao redor de 420 a.C. As mesmas descobertas arqueológicas - na cidade, na área do Heraion na foz do Sele e nas necrópoles - nos autorizam a precisar que, já ao menos três decênios antes, havia começado na cidade o processo de infiltração de grupos itálicos, facilmente reconhecível, principalmente, pelos seus costumes funerários (Cerchai, 2004: 62; Cipriani et alii, 1996: 5; Kraay, 1976: 186). Isso permite situar a "lucanização" da cidade em um contexto precedido pelo assentamento na khóra de grupos militarizados, provavelmente utilizados como mercenários (em um confronto com Vélia) (La Torre, 2011: 119). Segundo La Torre, isso explicaria o motivo pelo qual o processo de "lucanização" não alterou minimamente a planta urbana nem o sistema dos cultos da fase grega até o primeiro quartel do século IV a.C. (La Torre, 2011: 119). Os monumentos e os espaços públicos e religiosos e as instituições políticas estabelecidas pelos gregos continuaram como antes durante o tempo dos lucanos (Cerchiai, 2004: 65).

Nessa perspectiva, duas interpretações são possíveis: que o culto de Zeus na ágora de Posidônia já tenha existido, de alguma forma, em época grega, permanecendo no culto em época lucana, ou que tenha sido instituído pelos lucanos, os quais conheciam e reconheciam a atuação de Zeus na esfera política das cidades. De qualquer forma, o deus desempenhou um papel na esfera política e cívica entre a comunidade política posidoniata, ainda que ocupada pelos lucanos, a partir da época clássica. $O$ único objeto votivo encontrado, a estela, indica que foi dedicada por um "indivíduo portador de um cargo oficial" (Vonderstein, 2006: 68). Vonderstein sugere que o agradecimento a Zeus se relaciona ao seu cargo como um magistrado da cidade (Vonderstein, 2006: 68). Como veremos no capítulo 4, em época lucana, o culto de Zeus ganhou visibilidade na esfera política em Posidônia, como demonstra o uso da imagem da divindade, pela primeira vez em moedas da cidade. 


\section{IV.4 Considerações gerais sobre os santuários e o culto de Zeus na Itália do Sul}

Como já mencionamos, na Itália do Sul, o surgimento do culto de Zeus na esfera cívica corresponde também ao desenvolvimento político e urbano das cidades na região - conforme a cidade amadureceu politicamente, apropriou-se do culto da divindade. $O$ culto de Zeus Agoraios em Metaponto é o caso mais notório a esse respeito.

Com relação às funções cívicas e políticas dos santuários de Zeus, como Agoraios em Metaponto, foi o regulador da reunião política da comunidade em fase pré-democrática e democrática, como indica a continuidade do culto após época arcaica. Como Aglaos foi um culto voltado a um grupo político da cidade, às famílias aristocráticas, de uma forma semelhante ao caso do santuário de Zeus Meilichios em Selinonte. A partir do século $\mathrm{V}$ a.C. Zeus Aglaos se tornou um culto público no sentido de ter passado a servir à comunidade inteira ao ser estabelecido ao lado de Zeus Agoraios na área pública por excelência, a ágora. 0 santuário de Zeus Olímpio, ao menos entre os séculos IV-III a.C., hospedou um arquivo cívico e seu tesouro serviu a empréstimos em dinheiro às necessidades organizacionais da comunidade nessa época. Como Zeus talvez Agoraios em Posidônia, entre os séculos V-IV a.C., desempenhou um papel político e cívico entre a comunidade, ainda que a inscrição ateste o culto somente no século III a.C.

Com relação às características dos santuários, e suas funções no espaço das cidades onde foram instalados, na Itália do Sul, as áreas sagradas do deus não foram usadas, na maior parte dos casos, como expressões do poder político de suas comunidades, tal como se observa na Sicília com relação a Zeus Olímpio. Na Itália do Sul, onde esse culto do deus não recebeu tantos santuários como na Sicília, seu santuário e templo em Lócris não atingiu o mesmo grau de monumentalização. Lócris também oferece o único caso no qual uma função marítima, e por decorrência de algum tipo de sinal de poder na paisagem da cidade, pode ser atribuída a um santuário do deus.

Com relação à articulação de identidades, além do provável papel do culto de Zeus Aglaos entre a aristocracia em Metaponto, e de Zeus Agoraios como parte da identidade política da comunidade em Metaponto, na Itália do Sul, em época clássica, o deus teve um papel em articular, em um nível político, os aqueus e depois os italiotas. Trata-se do culto de Zeus Homarios do qual sabemos somente das fontes literárias.

Como resultado da crise na região, ocorrida durante o século $V$ a.C., principalmente relacionada às póleis aqueias na costa jônica, organizou-se, pela primeira vez uma liga entre algumas dessas cidades. Políbio é a principal fonte de informação a respeito da primeira fase da liga, denominada, em seu segundo momento no século IV a.C., de liga italiota. De acordo com Políbio $(2,39,1 ; 2,39,7)$, após o incêndio dos sinédrios pitagóricos em Crotona, que se alastrou a outros centros aqueus na região, com a consequente desordem interna, fez-se necessária uma mediação vinda de fora - foi com os aqueus da metrópole, no Peloponeso, que as cidades aqueias da Itália do Sul solicitaram intervenção (De Sensi Sestito, 1994: 198; Fronda, 2013: 124). Essa que pode ser considerada a primeira intervenção não-militar da metrópole nos acontecimentos do 
Ocidente colonial, foi chamada, em primeiro lugar naquele momento, a recompor as divisões internas em Crotona, as turbulências que acometiam também toda a área aquéia, e em segundo lugar, à defesa contra os povos nativos do interior, nesse caso os lucanos (Braccesi; Raviola, 2008: 142). Os aqueus da Itália do Sul não apenas aceitaram a orientação dos aqueus da metrópole como também, após algum tempo, tornaram-se imitadores de sua constituição, organizando uma liga ao redor de 430 a.C. com a liderança de Crotona e a participação de Caulônia e de Síbaris (a quinta cidade fundada no rio Traente). À mesma maneira dos aqueus do Peloponeso, crotoniatas, sibaritas e cauloniatas escolheram o templo de Zeus Homarios como lugar de reunião comum e conselho (Braccesi; Raviola, 2008: 142; De Sensi Sestito, 1994: 199). A adoção da politeia dos aqueus da metrópole teve uma finalidade política bem determinada - a busca por um governo moderado $\mathrm{e}$ estável em Crotona e nas fundações aqueias (que incluiu também Metaponto) (Braccesi; Raviola, 2008: 142; De Sensi Sestito, 1994: 204). Segundo G. De Sensi Sestito, trata-se da primeira experiência de federalismo em âmbito colonial (De Sensi Sestito, 1994: 201-202). No século IV a.C. a liga abandonou o modelo aqueu de estado federal e configurou-se de outra maneira - diante de novos perigos (Dionísio l e os lucanos) a federação teve necessidade de abrir-se a uma forma de agregação de tipo militar e defensivo maior, acolhendo cidades com outras origens e organizações políticas (De Sensi Sestito, 1994: 204). É Diodoro (XIV, 91, 1) que nos fornece as informações sobre essa segunda fase da liga, situando a sua nova conformação após a paz de Dionísio I com Cartago em 392 a.C., quando o tirano pôde reforçar a sua presença na Itália do Sul (Braccesi; Raviola, 2008: 152). Enquanto a forma mais antiga da liga reuniu-se no santuário de Zeus Homarios, refletindo e promovendo a identidade aquéia dos membros originários, quando a liga se tornou mais inclusiva, e panitaliota, o local para reunião, provavelmente, fora o santuário de Hera Lacínia em Crotona, que naquele tempo já havia se tornado, ao menos desde o final do século $V$ a.C., em um local frequentado pelas cidades gregas da Itália do Sul (Fronda, 2013: 133 e 136).

Repara-se, assim, o papel do culto de Zeus Homarios entre os aqueus durante o século $V$ a.C., em um nível federativo semelhante ao dos aqueus na Acaia, conforme vimos na análise interpretativa sobre 0 Peloponeso. Trata-se de um caso no qual o culto teve uma importância em reunir um grupo étnico que, em nível político, em época arcaica se encontrava dividido, como veremos no capítulo 4 acerca das cidades aqueias dentre elas, Síbaris e Crotona. Foram as ameaças externas que levaram a coalização das cidades, sendo Zeus Homarios o regulador das diversidades no nível político e da igualdade em nível étnico e regional ao menos durante a fase da liga no século $V$ a.C. 


\section{CONSIDERAÇÕES FINAIS: CORRELAÇÕES DOS SANTUÁRIOS E DO CULTO DE ZEUS ENTRE CRETA, PELOPONESO, SICÍLIA E ITÁLIA DO SUL}

A análise interpretativa regional dessas quatro regiões do mundo grego mostra as várias formas pelas quais o culto de Zeus interferiu no nível político e identitário das cidades gregas em época arcaica e clássica, como se desenvolveu em âmbito regional e cívico na longa duração: de divindade predominantemente regional até a Idade do Ferro, sobretudo em Creta e no Peloponeso, à divindade cívica a partir do final do século VII a.C. nas quatro regiões. $\mathrm{O}$ estudo de caso referente à essas regiões fornecem subsídios comparativos às demais áreas do mundo grego onde o culto da divindade também floresceu.

Isto posto, cabe aqui sumarizar as conclusões mais importantes a respeito do papel dos santuários e do culto de Zeus em Creta, no Peloponeso e no Ocidente grego (nesse caso, a Sicília e a Itália do Sul) com relação aos objetivos de nossa investigação, ou seja, as várias maneiras em que a divindade foi apropriada pela cidade grega: 1-) como expressão de determinados grupos políticos no poder nas cidades gregas; 2-) como expressão de poder e soberania das comunidades; 3-) como regulador do funcionamento das instâncias políticas da cidade; 4-) e como formador e articulador de redes de identidade grega (em seus vários níveis) em contexto políade.

Assim, com relação ao primeiro aspecto, é possível confirmar que Zeus teve um papel destacado na integração social das elites das cidades gregas desde suas origens. Os santuários extra-urbanos inter-regionais da divindade em Creta e no Peloponeso mostram como foram espaços neutros de afirmação e competição entre as aristocracias das comunidades políticas. Santuários cívicos nas quatros regiões, datados entre a Idade do Ferro e a época clássica, também evidenciam, de uma forma geral e marcante, a participação e a instituição do culto por membros da aristocracia, tanto no culto público (a maioria dos casos), como no privado (a minoria dos santuários analisados). Áreas sagradas do Peloponeso e do Ocidente grego já oferecem exemplos de como o culto foi apropriado e instituído por tiranos e membros da aristocracia, por expressão de poder do grupo político no controle das cidades. $O$ aspecto militar de Zeus foi um elemento comum ao culto de Zeus em Creta, no Peloponeso, na Sicília e na Itália do Sul, tanto em áreas sagradas com função regional quanto naquelas cívicas.

Com relação ao segundo aspecto, tal papel do culto não foi observado na ilha de Creta, tendo sido uma característica própria do Ocidente grego (principalmente a Sicília) que também se vê, em certo grau, no Peloponeso. Através do uso do espaço e da monumentalizaçao da área sagrada, principalmente do templo, determinadas comunidades políticas gregas apropriaram-se do culto e o usaram como expressões de poder e soberania em seu território e também na área urbana. Na Sicília e no Peloponeso tal característica do culto relaciona-se também ao período de governo tirânico, responsável pela iniciativa da instituição e apropriação do culto dessa maneira pela cidade. No Ocidente grego, principalmente na Sicília, com relação aos santuários, 
floresceu uma associação intencional da comunidade ao poder de soberania e onipotência exercido por Zeus Olímpio.

No que diz respeito ao terceiro aspecto, tanto em áreas sagradas inter-regionais como naquelas cívicas se observou o papel do culto da divindade na organização política das comunidades em época arcaica e clássica, tanto no seu funcionamento interno como, na mediação política com outra comunidade, conforme mostrou o conteúdo de determinados arquivos cívicos, o culto de Zeus Agoraios e o culto em Olímpia.

Com relação ao quarto e último aspecto, a análise interpretativa regional revelou um papel destacado da divindade em articular e formar identidades regionais e até mesmo em um nível maior, pan-helênico, como vimos no caso de Olímpia. Embora tal papel da divindade se observe nas quatro regiões, no Peloponeso vemos melhor o papel do culto na elaboração/articulação de identidades regionais no nível político, como vimos nos casos da Arcádia, da Messênia e da Acaia sobretudo em época clássica. Na Itália do Sul, Zeus Homarios articulou a identidade aqueia, na reunião política das cidades com essa origem, a partir do último quartel do século V a.C. É importante destacar que nos casos do Peloponeso e da Itália do Sul, a divindade assumiu tal papel, em agregar as cidades de mesma origem étnica, no contexto da ameaça da perda de soberania das comunidades políticas perante os espartanos (Peloponeso) e as ameaças dos povos itálicos e de Dioniso I (Itália do Sul). Na Sicília, o culto de Zeus Olímpio tornou-se parte da identidade política de cidades dórias, por meio de uma relação politica e social construída com o santuário de Olímpia. Um caso diferente é o de Argos, onde o culto de Zeus Nemeios e os jogos foram apropriados pela cidade não por uma questão étnica, como nas demais regiões, mas por algum motivo, que deve estar na esfera do poder das cidades, quando a prática agonística nos santuários pan-helênicos havia alcançado grande prestígio entre as comunidades políticas. Isso pode explicar, em parte, a apropriação dos jogos e do culto em Neméia pela comunidade argiva, tornando-se parte da identidade política argiva já a partir da época arcaica. Em Creta, o papel do culto na articulação de identidades é observado de forma marcada no caso do santuário em Palaikastro, onde o culto ajudou a criar e a reforçar uma identidade regional típica do lado leste de Creta, aquela dita eteo-cretense desde a Idade do Ferro. Já o santuário no Mt.Ida oferece um exemplo da articulação do culto, muito provavelmente, na identidade regional das comunidades políticas (não étnica como se vê nos casos peloponésios) da porção central de Creta, com segurança, a partir da época clássica.

No que diz respeito à formação de redes entre as quatro regiões, nas quais circularam o culto e traços culturais a respeito dos santuários e do próprio culto de Zeus, foi possível distinguir redes entre o Peloponeso e Creta e entre o Peloponeso e as áreas analisadas do Ocidente grego. Nesse último caso, observa-se uma rede principalmente entre as cidades dórias e o santuário de Olímpia que levou a instituição do culto de Zeus Olímpio entre comunidades com essa origem na Sicília. Observa-se, também, uma rede entre as cidades aqueias da Itália do Sul e da Acaia, que levou às apoikiai aqueias a instituir o culto de Zeus Homarios. Com relação ao Peloponeso e Creta, muito provavelmente houve uma rede entre o culto arcádio de Zeus Lykaios e o Zeus cretense em época arcaica, que levou a introdução de aspectos próprios do culto heládico de Zeus, 
como pai celeste, conforme se vê no santuário em Amnisos. Ora, como vimos na discussão sobre Creta, 0 único paralelo no mundo grego para as duas colunas com as duas águias douradas no topo, descritas por Pausânias no altar de Zeus Lykaios, são as esculturas de calcário de duas aves (uma águia e um falcão, segundo o museu de Heráclion, e duas águias, segundo Marinatos) que ornavam o santuário de Zeus Thenatas em Amnisos. Ambas datam da metade do século VI a.C., portanto, da época em que a águia já fazia parte da iconografia do culto de Zeus no Mt. Lykaion, a mesma época, como veremos no capítulo 3, que a ave passou a ser associada, pela primeira vez, na cerâmica lacônia à imagem de Zeus - outro fenômeno regional (peloponésio) importante sobre a consolidação da águia como um atributo de Zeus em época arcaica. Nesse sentido, se a associação da águia como um atributo de Zeus (em santuários e nas artes visuais), foi um fenômeno peloponésio - primeiramente arcádio a partir ao menos do século VII a.C. e lacônio a partir do século VI a.C. -, então, o uso da águia na arquitetura do santuário cretense em Amnisos justamente a partir do século VI a.C. deve ter ocorrido por alguma influência peloponésia mais direta, motivada por um rede específica entre Creta e o Peloponeso em relação ao culto de Zeus no final da época arcaica, ou indireta, motivada, também, por uma tendência peloponésia vigente no culto de Zeus em termos de mundo grego no período. Evidências de toponímios e nomes lendários comuns na Arcádia e em Creta são fortes evidências de algum tipo de rede estabelecida entre ambas as regiões, conforme mostra M. Jost e A. Snodgrass sobre a presença cretense nessa sub-região peloponésia (Jost, 1985: 248; Snodgrass, 1974: 196-201). A águia não é encontrada relacionada a Zeus em nenhum de seus santuários em Creta e em nenhum período, com exceção de Amnisos e com exceção das moedas de Lyttos a partir do século V a.C. 


\section{CAPÍTULO III - AS IMAGENS DE ZEUS, ÁGUIAS E RAIOS EM MOEDAS GREGAS DO PERÍODO ARCAICO AO CLÁSSICO: APRESENTAÇÃO E DISCUSSÃO DA DOCUMENTAÇÃO}

\section{INTRODUÇÃO}

Esta pesquisa apresenta 375 tipos monetários de Zeus, raios e águias emitidos a partir do século VII e durante os séculos VI, V e IV a.C. (até 344 a.C.) em 21 grandes regiões do mundo grego e em suas respectivas sub-regiões - no Ocidente grego, a Sicília e Itália do Sul; no sul da Grécia Balcânica, o Peloponeso e suas subregiões (Élis, Arcádia, Messênia, Acaia, Coríntia e Argólida); no norte da Grécia balcânica, a Macedônia, Tessália, Trácia, Épiro e llíria; na Grécia central, a Eubéia e a Beócia; em Creta e em outras ilhas do mar Egeu, em Sifnos, Lesbos e Rodes; na Ásia Menor, a Trôade, a Jônia, Mysia, Cária, Lycia, e Aeolis; no Mar Negro; no norte da África, a Líbia; e em Chipre. Os tipos monetários foram emitidos por 93 autoridades emissoras cada qual com razões bem diversas, que evidenciam a heterogeneidade e complexidade da documentação. As legendas das moedas indicam que estas imagens foram escolhidas e cunhadas pela pólis emissora para seu próprio uso (tendo seu étnico gravado no anverso ou reverso), por póleis para ligas ou federações de uma dada região (neste caso a moeda da pólis emissora tem o nome do éthnos gravado), no nome de uma tribo grega ou éthnos, no nome da pólis para o uso nas necessidades administrativas de um santuário interestadual, e ainda por póleis cujas oficinas emitiram no nome de governantes (reis, sátrapas, magistrados).

O primeiro critério adotado para a organização da documentação monetária foi o cronológico, pois buscamos compreender as razões político-sociais que motivaram a adoção das imagens de Zeus e de seus atributos, o raio e a águia, pela cidade grega desde o início de seu uso como representação em moedas gregas no período arcaico (no século VII a.C.) até o final da época clássica propriamente entendida (344 a.C.). A tipologia das imagens foi o segundo critério adotado na estruturação do catálogo: (1) imagens de Zeus (no anverso ou reverso representadas com outras imagens não relacionadas ao culto do deus); (2) do raio (no anverso ou reverso associadas a imagens não relacionadas ao deus); (3) de águias (no anverso ou reverso representadas com outras imagens não relacionadas ao culto do deus); (4) de águias e raios (os dois tipos representados no anverso ou reverso de uma mesma moeda); (5) de Zeus e raios (o deus representado no anverso ou reverso acompanhado pelo raio no anverso ou reverso); (6) de Zeus e águias (o deus representado no anverso ou reverso acompanhado pela águia no anverso ou reverso); e (7) de Zeus, raios e águias (representados conjuntamente no anverso ou no reverso de uma mesma moeda). Escolhemos organizar os tipos monetários desse modo em primeiro lugar por uma razão prática: a documentação revelou haver exemplares de tipos de Zeus, de raios e águias representados apenas em um dos lados do documento 
monetário, associados às imagens alheias ao seu culto. E em outros em que Zeus e seus atributos figuram juntos nas moedas (no anverso e/ou reverso). Separá-los dessa maneira nos permite visualizar as cidades/regiões que escolheram assim representá-los. E em segundo lugar porque há razões e significados bem distintos entre querer representar somente a águia ou o raio ou o próprio Zeus com outros elementos alheios ao culto da divindade, mas pertinentes à autoridade emissora, e querer representar na moeda os atributos reunidos ou o deus com um ou os dois de seus atributos. A princípio, neste último caso, é possível afirmar uma intenção deliberada, em algum grau, em reforçar um significado específico relacionado à energia da divindade para aquela comunidade que assim escolheu fazer representar os elementos completos do culto.

Nesse capítulo, assim, apresentamos a documentação integral sobre tipos monetários de Zeus e seus atributos. Como se verá, consideramos na descrição dos dados todas as imagens monetárias emitidas no período descrito e, como dissemos, até mesmo aquelas, cujas legendas indicam terem sido emitidas no nome de governantes (como reis e/ou sátrapas). Por não terem sido batidas no nome da pólis, é preciso dizer que essas moedas não serão consideradas no quarto capítulo interpretativo sobre essa documentação. Apesar de constarem nas quantificações, também não serão consideradas, na discussão da interpretação, as imagens de Zeus, águias e raios que aparecem no campo da moeda como tipos secundários - aquelas representações menores que acompanham outra imagem principal não relacionada ao deus e aos seus atributos, já que se trata de marcas de controle de emissões de moedas, não relacionáveis ao significado de identidade e política da pólis dos tipos principais, como é o caso dos tipos monetários de Corinto e da Ambrácia.

Isto posto, esse capítulo foi dividido em três partes. Na primeira, apresentamos a quantificação dos tipos monetários por períodos, regiões e autoridades emissoras para visualizarmos quais dos três tipos monetários (Zeus, águias e raios) foram mais e menos recorrentes ao longo dos séculos VII-IV/III a.C. Também os momentos em que as imagens monetárias foram e deixaram de ser requisitadas, em quais áreas do mundo grego predominaram ou não e quais autoridades emissoras se destacaram na escolha dos tipos monetários. A segunda parte é dedicada ao estudo iconográfico de Zeus, águias e raios em moedas gregas. Se na primeira parte oferecemos a descrição dos dados gerais da documentação numismática, na segunda, apresentamos a descrição dos tipos monetários ordenados de acordo com uma classificação tipológica, reveladora de padrões de representação do deus e de seus atributos em moedas gregas. Essa ordenação também propicia um contexto histórico acerca da criação e do uso dos padrões de representação entre as autoridades emissoras e regiões. Para a compreensão do contexto do uso dessas imagens em moedas, introduzimos o estudo das imagens monetárias com um histórico da representação de Zeus e seus atributos na arte grega. A análise dos padrões de representação dos tipos monetários em associação àqueles de outros suportes imagéticos (cerâmica pintada, esculturas, relevos) permite perceber em que medida as imagens que aparecem nas moedas foram criadas especificamente para elas ou não. Na terceira parte, discutiremos os significados simbólicos por trás das imagens de Zeus, águias e raios, adquiridos ao longo do período estudado, por meio das descrições nas fontes literárias e das representações tal como aparecem na arte grega, principalmente em 
vasos. Através dos tipos de narrativas nas fontes literárias, nas cerâmicas pintadas, e da proveniência dos achados, é nossa intenção, estabelecer um contexto simbólico para os tipos de representações do deus e de seus atributos usados nas moedas gregas entre os séculos VII-IV/III a.C. Os resultados dessa análise serão fundamentais na interpretação do uso dos tipos de Zeus e seus atributos pelas cidades gregas no próximo capítulo.

\section{QUANTIFICAÇÃO DOS TIPOS MONETÁRIOS POR PERÍODO, REGIÃO E AUTORIDADES EMISSORAS}

\section{I.1 QUANTIFICAÇÃO DOS TIPOS MONETÁRIOS POR SÉCULOS}

O levantamento das 375 moedas revelou que, das três representações aqui estudadas, não foi a de Zeus que mais figurou como imagem monetária no período. Foi a águia, um de seus atributos, que superou o uso da imagem da divindade. Conforme demonstra o gráfico 12 abaixo, enquanto o tipo de Zeus considerando-se toda a gama de sua representação (Zeus + Zeus e águias + Zeus e raios + Zeus, águias e raios) - somou 136

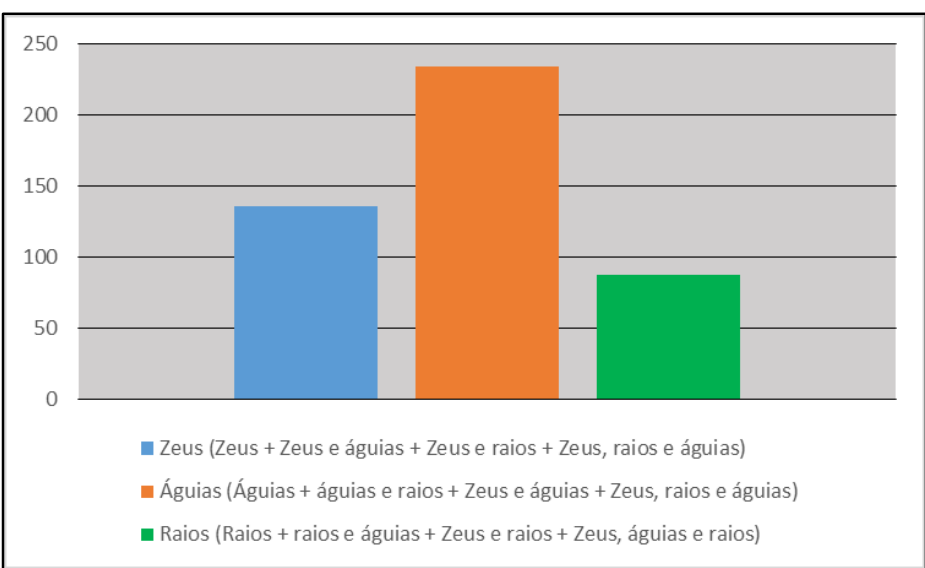

Gráfico 12- Quantidade total de tipos monetários de Zeus, raios e águias

exemplares, os tipos de águias (águias + águias e raios + Zeus e águias + Zeus, águias e raios) alcançaram o total de 234 imagens monetárias. 0 tipo monetário do raio (raios + raios e águias + Zeus e raios + Zeus, raios e águias) foi o menos usado pelas autoridades emissoras, apenas 87 moedas com essa representação foram encontradas.

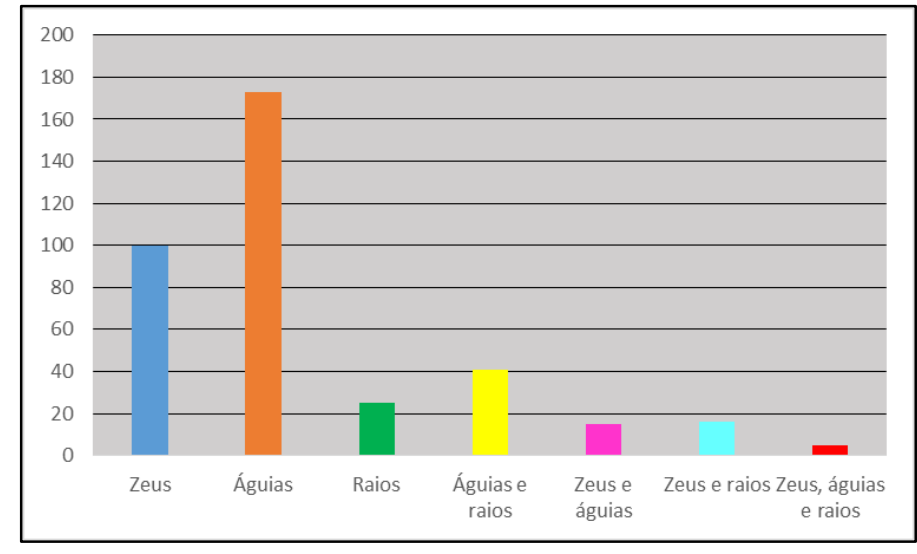

Gráfico 13-Quantidade total de cada variedade de tipos monetários de Zeus, raios e águias (sécs. VII-IV/III a.C.)
Os dados no gráfico 13 mostram que, de cada variedade de imagens monetárias dentro da representação de Zeus e seus atributos, o uso da águia (sozinha e não associada ao deus e/ou ao raio) foi o mais recorrente (173 tipos), seguido pelo uso da imagem de Zeus sem nenhuma representação associada (100 tipos). A composição águias e raios foi a terceira representação mais utilizada como imagem monetária (41 tipos), ao passo que o raio foi a quarta imagem mais usada (25 tipos). Percebe-se uma escolha maior pela representação dos dois atributos associados do que pela do raio propriamente dito. A composição 
Zeus e águias e Zeus e raios foram usadas como imagens monetárias quase na mesma proporção (15 e 16 tipos respectivamente). E finalmente a composição com as três imagens, Zeus, águias e raios formaram a representação menos adotada em moedas em relação às demais (5 tipos).

Conforme revela o gráfico 14, dentre as imagens monetárias de Zeus e seus atributos, a águia foi 0 primeiro tipo a figurar em moedas gregas. A representação aparece pela primeira vez em exemplares datados entre os séculos VII-VI a.C. (2 tipos), tendo ocorrido um aumento significativo em seu uso no século VI a.C. (7 tipos). A imagem de Zeus em moedas gregas surge entre o século VI-V a.C. (1 tipo) e a representação da águia permanece sendo a mais usada nesse período (2 tipos). No século $V$ a.C. surgem pela primeira vez o uso da imagem do raio em moedas ${ }^{1}$, assim como composições dos atributos com ou sem a divindade. São datados desse período 10 tipos monetários de raios, 5 tipos de Zeus e águias e apenas 1 tipo de Zeus e raios. Águias e raios formam a composição mais usada (25 tipos). As águias permanecem sendo os tipos mais escolhidos para figurar em moedas (76 tipos), ao passo que a imagem de Zeus sofre um aumento importante no século $\mathrm{V}$ a.C. (34 tipos monetários foram encontrados no levantamento). Com datações entre o século V-IV a.C., são 27 tipos monetários de águias e 13 tipos de Zeus, sendo a composição águias e raios a única utilizada no período (2 tipos).

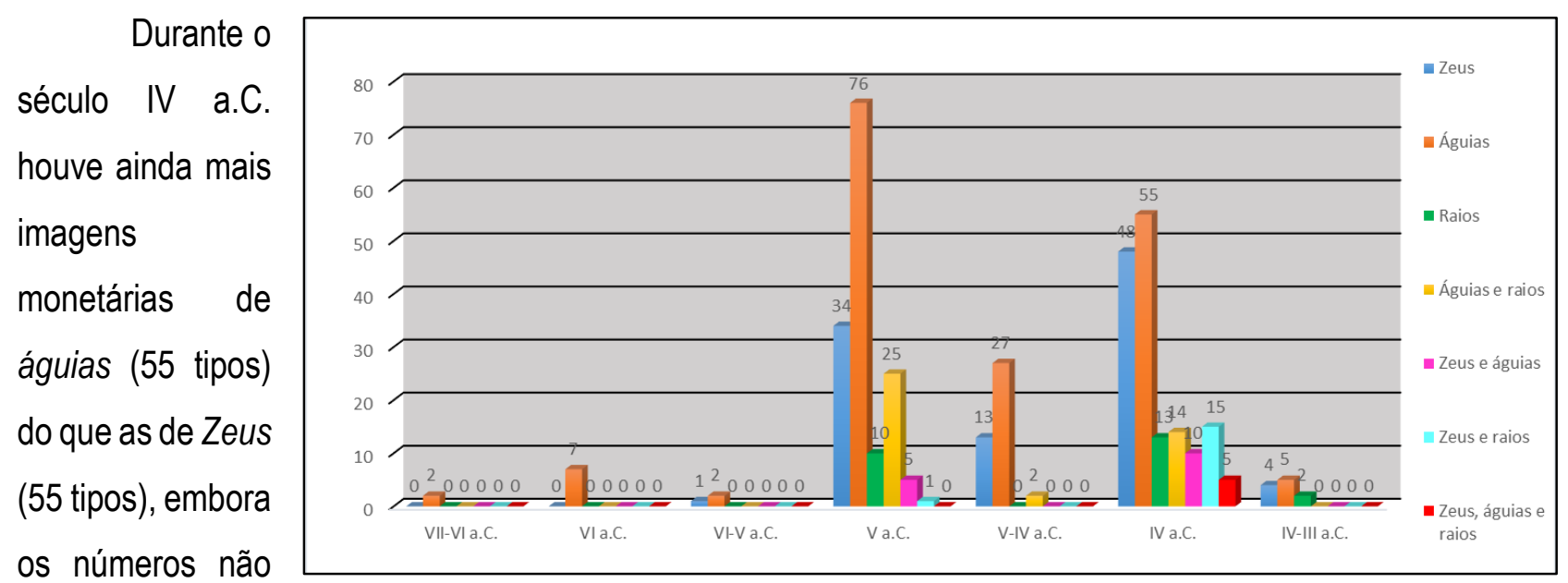

sejam tão

Gráfico 14 - Quantidade de cada variedade de tipos monetários de Zeus, raios e águias por período distantes assim. 0 mesmo ocorre com a representação do raio (13 tipos) e das composições de Zeus e águias (10 tipos), de Zeus e raios (15 tipos) e de águias e raios (14 tipos), que foram bem mais usadas nesse período. Apesar da ligeira diferença de número entre as representações, as composições de Zeus e raios e de águias e raios foram as preferidas pelas autoridades emissoras no século IV a.C. No século IV a.C. foi associada, pela primeira vez, a representação Zeus e de seus dois atributos em moedas (5 tipos). Os séculos IV-III a.C. referemse às moedas cuja datação começa no século IV a.C. (até 344) e termina no século III a.C. Percebe-se nesse período que as imagens da águia e de Zeus permanecem ainda as preferidas (5 e 4 tipos respectivamente), seguida pelas do raio (2 tipos). O levantamento não encontrou a composição Zeus, águias e raios em moedas

\footnotetext{
${ }^{1}$ Como se verá no capítulo seguinte, é possível que a imagem do raio tenha sido usada em moedas pela primeira vez no século VI a.C., conforme um debate acerca das primeiras séries monetárias de Élis-Olímpia.
} 
entre os séculos IV-III a.C., mas isso se deve ao recorte cronológico dessa pesquisa até 345/44 a.C. Após esse período tem se registrado o uso disseminado dessa associação, principalmente em autoridades emissoras do Ocidente grego. Percebe-se, assim, que, inicialmente, nos períodos mais antigos (do século VII-VI, VI ao VI-V a.C.) as imagens de Zeus e águias foram utilizadas sem serem associadas. Foi somente a partir do século $\mathrm{V}$ a.C., quando o raio passou a ser representado em moedas gregas (sem considerar a hipótese da datação dos primeiros tipos monetários de Élis no século VI a.C.), que os atributos de Zeus foram usados associados, indicando uma tendência nova também em associar a imagem de Zeus aos seus dois atributos ou a um deles.

\section{I.2 QUANTIFICAÇÃO DE AUTORIDADES EMISSORAS POR REGIÕES}

\section{O gráfico 15 reúne os} dados referentes a quantidade de autoridades emissoras por regiões do mundo grego a emitirem tipos monetários de Zeus, raios e águias entre os séculos VII e IV/III a.C. Assim, nota-se que a Sicília é a região com a maior quantidade de autoridades emissoras responsáveis por usar tais representações em moedas gregas

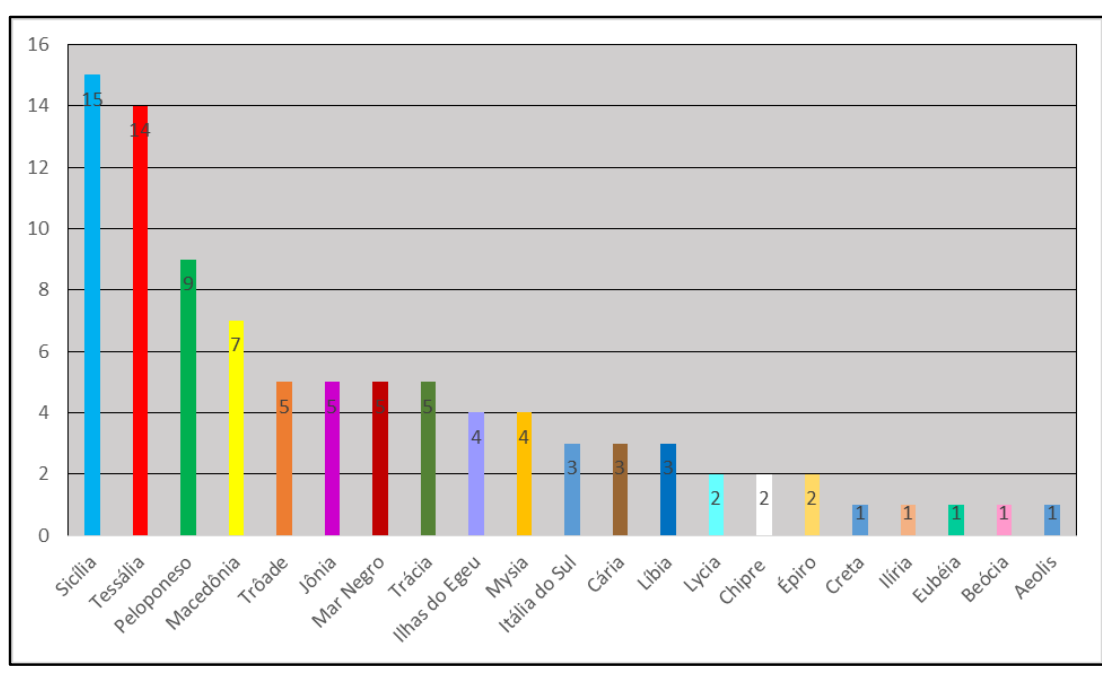

Gráfico 15 - Quantidade de autoridades emissoras por regiões a emitir tipos monetários de Zeus, águias e raios (sécs.VII-IV/III a.C.) no período (Galária, Zancle, Aetna, Eryx, Siracusa, Gela, Agrigento, Motya, Messana, Hypana, Agyrion, Catânia, Alaisa, Abakainon e Alontion), seguida pela Tessália com 14 (Larissa, Gomphi, Kierion, Ekkara, Aenianes, Gonnus, Phalanna, Gyrton, Krannon, Melitaia, Halus, Dia, Liga Tessália, Hypata) e pelo Peloponeso com 9 (Élis, Corinto, Parrhasia, Messênia, Liga Acaia, Liga Arcádia, Argos, Megalópolis, Pisa). A Macedônia é a quarta região com a maior quantidade de autoridades emissoras, tendo 7 (Alexandre I, Arquelaos, Perdicas, Amyntas III, Pydna, Pella, emissão incerta). Com 5 autoridades emissoras estão as regiões da Trôade (Cebren, Thymbra, Abydus, Gargara, Dardanus), da Jônia (Leuce, Mileto, Éfeso, Magnésia, emissões incertas), do Mar Negro (Sinope, Sesamus, Cromna, Ólbia, Istros) e a Trácia (Anfípolis, Abdera, Olinto, Sparadocus, Philippi). As imagens foram usadas por 4 autoridades emissoras em ilhas do Egeu (Sifnos, Mytilene, lalyssos e Rodes) e a Mysia (Iolla, Lampsacos, Pitane, Cyzicus). Cada qual com três autoridades emissoras estão a Itália do Sul (Crotona, Metaponto, Posidônia), a Cária (Mylasa, Halikarnassos, Nisyros) e a Líbia (Cirene, Euesperides, Barce), já com 2 diferentes estão a Lycia (Kherei, Kheriga), Chipre (Paphos, Amanthus) e o Épiro (Molossi, Ambrácia). As regiões com menor quantidade de autoridades emissoras a usar imagens monetárias no período 
(cada qual com 1) são a ilha de Creta (Lyttos), a llíria (Pharos), a Eubéia (Cálcis), a Beócia (Mycalessos) e Aeolis (Cyme).

No gráfico 16 reunimos a quantidade total de tipos monetários de Zeus, raios e águias emitidos por cada uma das 93 autoridades emissoras no mundo grego entre os séculos VII e IV/III a.C. Percebe-se, assim, que a pólis de Élis foi a que mais realizou emissões de tais tipos monetários no período (57 tipos). Agrigento foi a segunda cidade com a maior quantidade de tipos emitidos (17 tipos) e Cirene e a Liga Arcádia as terceiras autoridades emissoras (16 tipos monetários diferentes). Lyttos emitiu a quarta maior quantidade de imagens monetárias (13 tipos). Cálcis e Abydus também emitiram um grande número (11 e 10 tipos respectivamente), assim como Kierion e Ólbia (9 e 8 respectivamente). Paphos e Sinope emitiram na mesma proporção (7 tipos cada), também Melitaia, Cyzicus e Cyme (6 tipos cada). Somente Aetna e Mytilene emitiram 5 tipos monetários no período, já Halikarnassos, Barce e Catânia emitiram 4 imagens monetárias cada uma. Abaixo dessa quantidade de tipos monetários, ocorre um aumento de autoridades emissoras, portanto, que emitiram poucas moedas com imagens de Zeus, raios e águias. 12 autoridades emissoras diferentes cunharam apenas 3 tipos monetários (Siracusa, Corinto, Aenianes, Gomphi, Mylasa, Olinto, Molossi, Sparadocus, Pharos, Éfeso, Sifnos, emissões incertas) e outras 12 emitiram apenas 2 tipos monetários (Metaponto, Megalópolis, lalyssos, Motya, Agyrion, Eryx, Pella, Parrhasia, Pitane, Magnésia, Amyntas III, Lampsacos). Mas foi a maior parte das 93 autoridades emissoras que emitiu a menor quantidade de tipos monetários: 45 delas foi responsável por emitir somente 1 imagem monetária (Larissa, Galária, Zancle, Euesperides, Phalanna, Krannon, Messênia, Liga Acaia, Liga Tessália, Philippi, Iolla, Ekkara, Nisyros, Gonnus, Gyrton, Mileto, Hypana, Messana, Kherei, Kheriga, Arquelaos I, Gela, Rodes, Istros, Pydna, Perdicas, Amanthus, Mycalessos, Alaisa, Argos, Halus, Dia, Anfípolis, Alexandre I, Pisa, Hypata, Ambrácia, Thymbra, Leuce, Sesamus, Cromna, Cebren, Abdera, Gargara, Dardanus, emissão incerta Macedônia).

É interessante observar que a Eubéia, uma das regiões com as menores quantidades de autoridades emissoras, teve Cálcis que foi uma das cidades que mais emitiu tipos monetários de Zeus e seus atributos no período. Da mesma forma a Líbia, onde a cidade de Cirene foi responsável por uma das maiores quantidades de imagens monetárias. Em Creta, com poucas autoridades emissoras, Lyttos cunhou uma das maiores variedades de tipos, igualmente a Itália do Sul com a cidade de Crotona, locais de duas importantes e numerosas emissões. Na Trôade, Abydus se destaca por uma das maiores quantidades de imagens monetárias, assim como Ólbia e Sinope no Mar Negro e Paphos em Chipre. Já a Tessália, a região com a maior parcela de autoridades emissoras, teve apenas Kierion a emitir mais tipos no período, seguida por Melitaia, o que ocorre também na Sicília com Agrigento. O Peloponeso, terceira região com a quantidade mais numerosa de autoridades emissoras, possui a pólis (Élis) que mais usou a representação de Zeus, raios e águias em moedas gregas no período. 


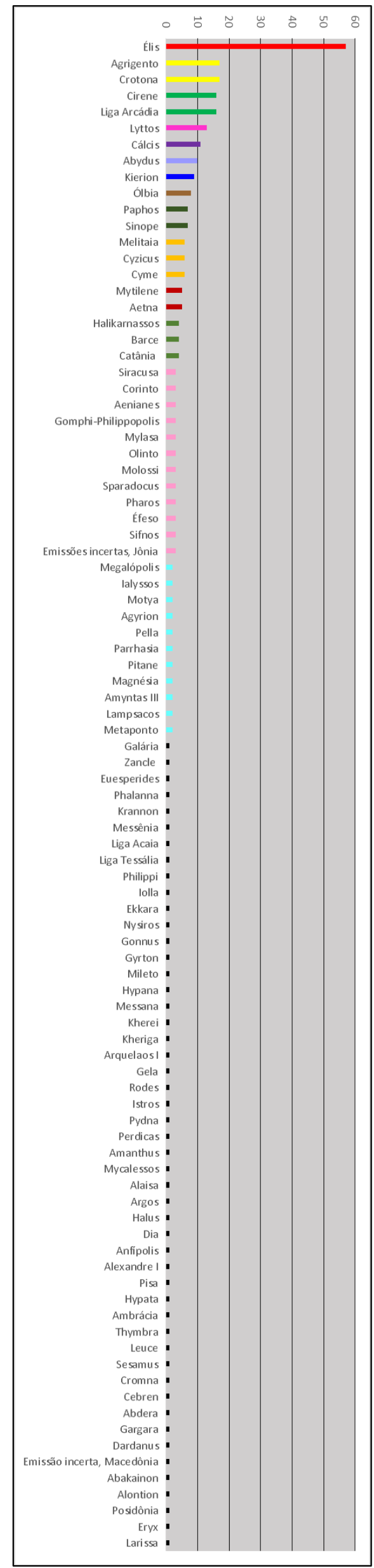

Gráfico 17 - Quantidade total de tipos monetários de Zeus, raios e águias por autoridade emissora (sécs. VII-IV/III a.C.) 


\section{I.3 QUANTIFICAÇÃO DE TIPOS MONETÁRIOS POR AUTORIDADES EMISSORAS, REGIÕES E SÉCULOS}

No gráfico 18, podemos visualizar a quantidade por séculos de tipos monetários de Zeus, raios e águias cunhados pelas autoridades emissoras no período estudado. Observa-se que Élis emitiu uma menor quantidade de imagens monetárias no século V a.C. (23 tipos) e uma maior no século IV a.C. (34 tipos). Agrigento iniciou sua emissão no século VI a.C. (com 1 tipo), cunhou a maior parte de suas imagens monetárias no século V a.C. (15 tipos) e uma pequena parcela no século IV a.C. (apenas 1 tipo). Cirene bateu pela primeira vez tais imagens entre o século $\mathrm{VI}$ e $\mathrm{V}$ a.C. (1 tipo) e a maior parcela também no século $\mathrm{V}$ a.C. (8 tipos), continuando a emitir em menor escala entre os séculos V-IV a.C. (3 tipos) e IV a.C. (4 tipos). A Liga Arcádia bateu no século $V$ a.C. o maior número de imagens monetárias (16 tipos), podendo-se dizer que cunhou também no século IV a.C. (2 tipos monetários em seu nome, mas emitidos pela oficina monetária de Megalópolis). Crotona começou a emitir moedas com os tipos entre o século VI-V a.C. (1 tipo), mantendo sua emissão no século V a.C. (com 3 tipos), aumentando-a consideravelmente entre o século V-IV a.C. (8 tipos) e diminuindo-a no século IV a.C. (5 tipos). A maior parte dos tipos monetários de Lyttos foi emitida entre o século V-IV a.C. (12 tipos) e uma mínima parcela no século IV a.C. (1 tipo). Cálcis bateu tipos monetários pela primeira vez no século VI a.C. (3 tipos), diminuindo o número no século $V$ a.C. (2 tipos) e aumentando-o no século IV a.C. (6 tipos). Abydus, por sua vez, iniciou a emissão de tipos entre os séculos VI-IV a.C. (1 tipo), cunhando a maior parte dos exemplares encontrados no século V a.C. (5 tipos), diminuindo o uso das imagens nos séculos seguintes, no V-IV a.C. (2 tipos) e no IV a.C. (3 tipos). Kierion emitiu todos os tipos monetários no século IV a.C. (9 tipos). Ólbia bateu os tipos pela primeira vez no século V a.C. (1 tipo), mantendo sua emissão entre 0 século V-IV a.C. (1 tipo) e aumentando o uso das imagens em suas moedas no século IV a.C. (6 tipos). Paphos emitiu os tipos monetários somente no século V a.C. (7 tipos) e Sinope iniciou suas cunhagens no século VI a.C. (1 tipo), aumentando sua produção no século V a.C. (3 tipos) e mantendo-a no século IV a.C. (3 tipos). Melitaia bateu as imagens monetárias apenas no século IV a.C. (6 tipos). Cyzicus é uma das únicas cidades a usar os tipos já no século VII-VI a.C. (1 tipo), depois emitindo-os somente a partir do século V a.C. (2 tipos) e em diante, entre os séculos V-IV a.C. (2 tipos) e século IV a.C. (1 tipo). Cyme iniciou suas emissões no século V a.C. (3 tipos), diminuindo-a nos períodos seguintes, no século IV a.C. (1 tipo) e no século IV-III a.C. (2 tipos). Mytilene começou a bater a maior quantidade dos tipos no século IV a.C. (3 tipos), diminuindo-os no período seguinte, entre o século IV-III a.C. (2 tipos). Aetna emitiu majoritariamente no século V a.C. (4 tipos) e em menor escala no século IV a.C. (1tipo). Halikarnassos, por sua vez, emitiu as imagens monetárias somente no século IV a.C. (4 tipos). Barce passou a emiti-las a partir do século $V$ a.C. (2 tipos), continuando-a nos séculos seguintes, no V-IV a.C. e no IV a.C. (1 tipo em cada período). Siracusa cunhou suas imagens monetárias no século IV a.C. (3 tipos). Catânia bateu moedas com as imagens somente no século V a.C. Já Corinto iniciou o uso dessas representações em suas moedas entre o século V-IV a.C. (2 tipos), diminuindo-o no século IV a.C. (1 tipo). Os Aenianes começaram a emitir os tipos no século IV a.C. (2 tipos), diminuindo-o entre os séculos IV- 
III a.C. (1 tipo). Gomphi-Philippopolis e Mylasa usaram as imagens em moedas apenas em emissões do século IV a.C. (cada qual 3 tipos). Olinto cunhou moedas com as representações no século V a.C., assim como Sparadocus (cada qual com 3 tipos). Os Molossi e Pharos emitiram os tipos monetários somente no século IV a.C. (cada qual 3 tipos). Já Éfeso bateu os primeiros tipos monetários entre os séculos VI-V a.C. (1 tipo), mantendo esse número no século $V$ e entre os séculos V-IV a.C. No século VI a.C., Sifnos iniciou as emissões monetárias com os tipos (1 tipo), mantendo-a no século V e no século IV a.C. (1 tipo em cada período). Na Jônia, há emissões incertas de tipos monetários a partir do século VII-VI a.C. (1 tipo), que se mantiveram nos séculos VI e no século V a.C. (1 tipo em cada período). Megalópolis, Pella, Amyntas III e Lampsacos usaram as representações em moedas somente no século IV a.C. (cada qual 2 tipos). Já a Parrhasia usou as imagens em moedas tão somente entre os séculos V-IV a.C. (2 tipos). lalyssos e a Magnésia apenas no século V a.C. (cada qual 2 tipos). Motya usou na mesma quantidade os tipos a partir do século $V$ a.C. e posteriormente no século IV a.C. (1 tipo em cada período). Agyrion iniciou as emissões com as imagens entre o século V-IV a.C. (1 tipo), mantendo o uso no século IV a.C. (1 tipo). Pitane cunhou moedas com as representações a partir do século IV e entre o século IV-III a.C. (1 tipo em cada período). E Metaponto emitiu seus tipos monetários em igual número entre os séculos VI-IV a.C. (1 tipo) e entre os séculos IV-III a.C. (1 tipo).

Das autoridades emissoras responsáveis por apenas cunhar um tipo monetário entre os séculos VIIIV/III a.C., elas o fizeram a partir do século V a.C., tendo sido 11 autoridades emissoras no período (Galária, Zancle, Euesperides, Mileto, Hypana, Messana, Kherei, Kheriga, Gela, Alexandre I, emissão incerta na Macedônia). Entre o século V-IV a.C. apenas 3 autoridades emissoras fizeram uso das imagens em moedas (Arquelaos I, Ambrácia e Eryx). No século IV a.C. esse número mais que dobrou em relação ao século V a.C., alcançando 29 autoridades emissoras (Larissa, Phalanna, Krannon, Messênia, Liga Acaia, Liga Tessália, Philippi, Iolla, Nisyros, Gonnus, Gyrton, Rodes, Istros, Pydna, Perdicas, Amanthus, Mycalessos, Alaisa, Argos, Halus, Dia, Anfípolis, Pisa, Hypata, Thymbra, Sesamus, Cromna, Cebren, Abdera, Dardanus). E finalmente, entre o século IV-III a.C. esse número caiu para 4 autoridades emissoras (Ekkara, Leuce, Gargara). 


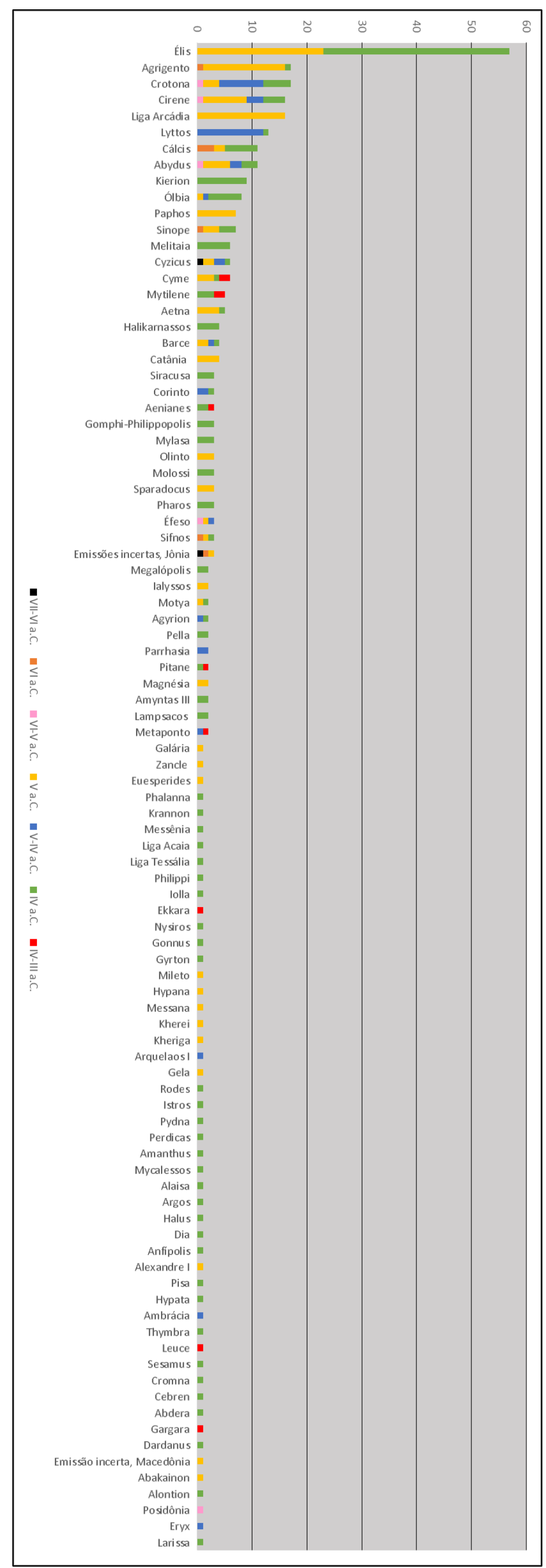

Gráfico 18 - Quantidade por séculos de tipos monetários de Zeus, raios e águias por autoridade emissora (sécs. VII-IV/III a.C.) 


\section{I.3.1 ZEUS}

O gráfico 19 evidencia a quantidade de autoridades emissoras por região a emitir tipos monetários de Zeus entre os séculos VII-IV/III a.C. Em primeiro lugar, percebe-se que autoridades emissoras de 20 regiões do mundo grego escolheram usar a imagem de Zeus em moedas gregas no período, a saber: Líbia, Tessália, Arcádia, Sicilia, Élis, Coríntia, Creta, Cária, Messênia, Acaia, Mysia,

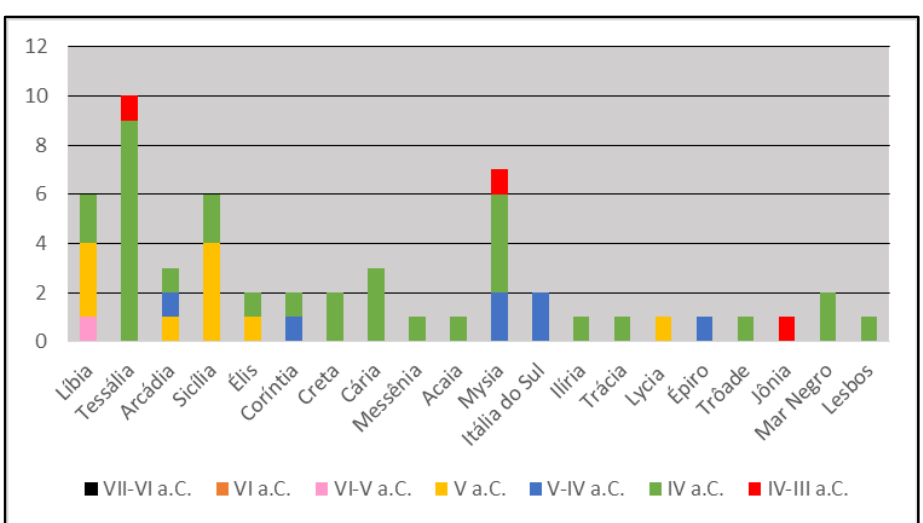

Gráfico 19 - Zeus - Quantidade de autoridades emissoras por regiões a emitir tipos monetários (sécs. VII-IV/III a.C.) Itália do Sul, llíria, Trácia, Lycia, Épiro, Trôade, Jônia, Mar Negro e Lesbos. É preciso dizer que nessa monta não foi considerada a região do Peloponeso, mas as suas sub-regiões (Arcádia, Élis, Coríntia, Messênia, Acaia). Percebe-se também que em nenhuma região autoridades emissoras usaram tipos monetários da divindade nos séculos VII-VI a.C. e nem somente no século VI a.C. O uso da imagem de Zeus em moedas gregas ocorreu pela primeira vez na Líbia entre o século VI-V a.C. Repara-se que autoridades emissoras de 4 regiões iniciaram suas cunhagens com tipos de Zeus no século V a.C., continuando a usá-los em períodos posteriores (com exceção da Líbia, que iniciou entre os séculos VI-V a.C.): a Tessália, a Arcádia, a Sicília e Élis. E apenas em uma região, a Lycia, houve o uso da imagem da divindade somente no século V a.C. Entre os séculos V-IV a.C. autoridades emissoras de 2 regiões (Coríntia e Mysia) iniciaram suas emissões no período, dando continuidade nos séculos seguintes, e a Arcádia a única região que vinha já utilizando os tipos de Zeus em moedas desde 0 século V a.C. O Épiro é a única região onde o uso da imagem de Zeus em moedas iniciou-se entre os séculos V-IV a.C. O período de maior uso de imagens monetárias de Zeus ocorreu no século IV a.C. Autoridades emissoras de 8 regiões bateram pela primeira vez tipos monetários da divindade no século IV a.C., continuando a usá-lo em períodos posteriores (Líbia, Tessália, Arcádia, Sicília, Élis, Coríntia, Mysia e Itália do Sul). Creta, Cária, Messênia, Acaia, Ilíria, Trácia, Trôade, Mar Negro e Lesbos foram as 9 regiões onde autoridades emissoras usaram a representação da divindade em moedas somente no século IV a.C. Autoridades emissoras de 3 regiões (Tessália, Mysia e Itália do Sul) continuaram a emitir tipos monetários de Zeus nos séculos IV-III a.C., ao passo que somente na Jônia uma autoridade emissora usou pela primeira vez a imagem da divindade em moedas no período.

O gráfico também mostra que a Tessália é a região com a maior quantidade de autoridades emissoras responsáveis por usar a imagem de Zeus em moedas gregas sobretudo no século IV a.C. (9 autoridades emissoras no século IV a.C. e 1 entre os séculos IV-III a.C.). O mesmo ocorreu no século IV a.C. com a Mysia, a segunda região com a maior quantidade de autoridades emissoras que usaram o tipo monetário da divindade (2 autoridades emissoras entre os séculos V-IV a.C., 4 no século IV a.C. e 1 entre os séculos IV-III a.C.). A 
Líbia e a Sicília são as terceiras áreas do mundo grego em autoridades emissoras a usarem o tipo de Zeus principalmente no século $V$ a.C. A Líbia teve 1 autoridade emissora entre os séculos VI-V a.C., 3 no século $V$ a.C. e 2 no século IV a.C. e a Sicília 4 autoridades emissoras no século V a.C. e 2 outras no século IV a.C. A Autoridades emissoras da Arcádia usaram imagens de Zeus em suas moedas a partir do século V a.C. (apenas 1, a Liga Arcádia, já que não se conhece o nome da cidade responsável pelas emissões) e continuaram a usar o tipo de Zeus em moedas entre o século V-IV a.C. e subsequentemente no século IV a.C. (1 no século V-IV a.C. e 1 no século IV a.C.). A Cária é a quinta região em quantidade de autoridades emissoras responsáveis por cunhar imagens monetárias de Zeus (somente 3 no século IV a.C.). Élis possui 1 autoridade emissora no século V a.C. (Élis) e 1 no século IV a.C. (Élis). A região da Coríntia teve 1 autoridade emissora a usar o tipo de Zeus entre os séculos V-IV a.C. e 1 no século IV a.C. e na Itália do Sul as imagens monetárias de Zeus foram usadas entre os séculos V-IV a.C. (2 autoridades emissoras). O Mar Negro teve 2 autoridades emissoras que usaram o tipo de Zeus somente no século IV a.C. A Lycia teve apenas 1 autoridade emissora no século V a.C. a usar o tipo de Zeus, ao passo que a Messênia, a Acaia, a llíria, a Trácia, a Trôade e Lesbos tiveram cada qual 1 autoridade emissora que usou as imagens monetárias somente no século IV a.C. E finalmente, o Épiro com 1 autoridade entre os séculos V-IV a.C. e a Jônia com 1 entre os séculos IV-III a.C.

O gráfico 20 traz os dados referentes a quantidade de tipos monetários de Zeus por autoridade emissora no período. Foram 42 autoridades emissoras que cunharam moedas com imagens de Zeus. Observase que a Liga Arcádia foi a autoridade emissora que mais emitiu tipos monetários de Zeus (16 tipos no século V a.C. e 2 tipos no século IV a.C., sem considerar nessa soma as 2 emissões de Megalópolis do século IV a.C.). Cirene foi a segunda autoridade emissora que mais emitiu tipos monetários de Zeus (não associados a nenhum outro atributo da divindade) entre os séculos VI-IV a.C. (total de 15 tipos). A pólis na Líbia iniciou emissões de moedas com imagens do deus entre os séculos VI-V a.C. (1 tipo monetário), aumentando-as no século V a.C., o período com maior número de tipos (7 no total). Entre os séculos VI-V a.C., Cirene diminui 0 uso da imagem de Zeus em suas moedas (3 tipos), ao passo que no século IV a.C. o número de imagens monetárias ligeiramente aumentou (4 tipos). Depois de Cirene, Kierion, na Tessália, foi a terceira a mais cunhar tipos monetários de Zeus e somente no século IV a.C. (6 tipos monetários). Atrás de Kierion, a pólis de Barce, na Líbia, emitiu mais tipos no século V a.C. (2 tipos), 1 tipo entre os séculos V-IV a.C. e mais 1 outro no século IV a.C. Aetna, na Sicília, cunhou seus 3 tipos monetários de Zeus (sem estar associado a alguns de seus atributos) somente nos séculos V a.C. Os Aenianes, Melitaia e Gomphi, na Tessália, Pharos, na líria, e Mylasa, na Cária, emitiram tipos monetários de Zeus somente no século IV a.C. (cada qual cunhou 3 tipos). Élis, Corinto, Parrhasia e Megalópolis, na Arcádia, Halikarnassos, na Cária, Pitane, Cyzicus e Lampsacos, na Mysia, emitiram cada qual apenas 2 tipos monetários de Zeus. Desse grupo, as póleis de Corinto e Cyzicus e o éthnos da Parrhasia foram as únicas a usar a imagem de Zeus em moedas entre os séculos V-IV a.C. Élis, Megalópolis, Halikarnassos e Lampsacos emitiram os tipos monetários somente no século IV a.C. Pitane emitiu 1 tipo 
monetário no século IV a.C. e outro entre o século IV-III a.C. Metaponto e Posidônia emitiram, cada qual, 1 tipo monetário do deus entre os séculos V-IV a.C.

Phalanna, Krannon, Liga Tessália, Gonnus, Gyrton e Ekkara, na Tessália, Euesperides, na Líbia, Galária, Zancle e Abakainon, na Sicília, Mytilene, em Lesbos, Messênia e Liga Acaia, em suas regiões homônimas, Nisyros, na Cária, Philippi, na Trácia, lolla, na Mysia, Kheriga, na Lycia, Ambrácia, no Épiro, Thymbra, na Trôade, Leuce, na Jônia, e Sesamus e Cromna, no Mar Negro, e Metaponto e Posidônia, na Itália do Sul, são as 24 autoridades emissoras que menos emitiram tipos monetários de Zeus no período (cada uma bateu 1 imagem monetária da divindade). Euesperides, Galária, Zancle, Abakainon e Kheriga foram as únicas autoridades emissoras a cunhar tipos de Zeus no século $V$ a.C. A maior parte, contudo, emitiu tipos no século posterior - Phalanna, Krannon, Mytilene, Messênia, Liga Acaia, Liga Tessália, Philippi, lolla, Nisyros, Gonnus, Gyrton, Thymbra, Sesamus e Cromna são as 14 autoridades emissoras que emitiram 1 tipo monetário de Zeus somente no século IV a.C. A Ambrácia, Metaponto e Posidônia realizaram suas emissões com o tipo de Zeus entre o século V-IV a.C. e Ekkara e Leuce bateram seus tipos somente entre o século IV-III a.C.

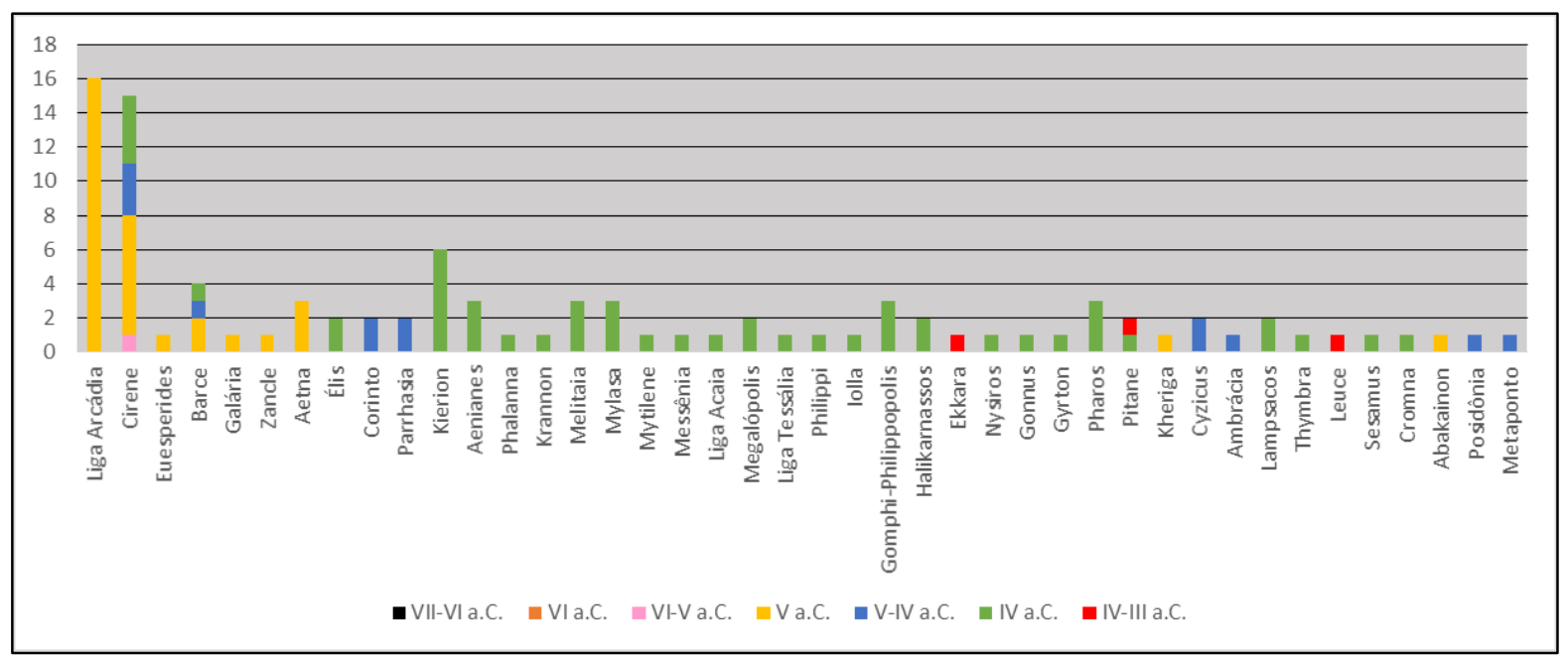

Gráfico 20 - Zeus - Quantidade de tipos monetários por autoridade emissora (séculos VII-IV/III a.C.) 


\section{I.3.2 ÁGUIAS}

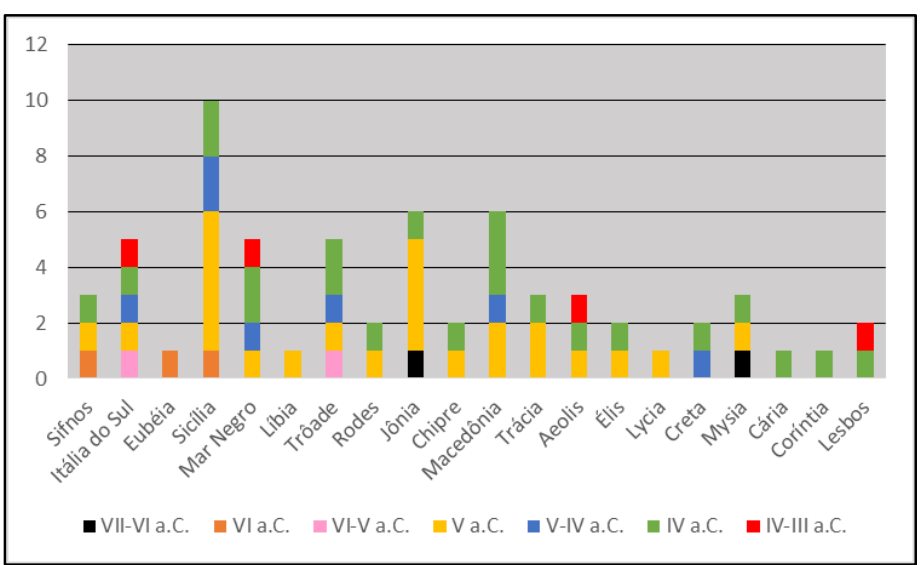

Gráfico 21- Águias - Quantidade de autoridades emissoras por regiões a emitir tipos monetários (sécs. VII-IV/III a.C.)

O gráfico 21 traz os dados a respeito da quantidade de autoridades emissoras por regiões a emitir tipos monetários de águias entre os séculos VII-IV/III a.C. Também no caso das imagens monetárias de águias (a representação sem a de Zeus ou a do raio) autoridades emissoras de 20 regiões usaram a imagem da ave em moedas gregas do período. Foi a partir do século VII-VI a.C. na Jônia e na Mysia (ambas regiões na Ásia Menor) que as imagens de águias foram usadas em moedas gregas pela primeira vez. Autoridades emissoras de 3 regiões (Sifnos, Eubéia e Sicília) iniciaram emissões de tipos com águias no século VI a.C., continuando-as em períodos posteriores, com exceção da Eubéia. A Itália do Sul e a Trôade são as duas regiões que iniciaram cunhagens com os tipos entre os séculos VI-V a.C. e continuaram posteriormente. No século V a.C., 7 regiões do mundo grego (Mar Negro, Rodes, Chipre, Trácia, Aeolis, Élis e Creta) começaram a emitir tipos com as águias e deram continuidade ao uso da imagem da ave em moedas nos séculos seguintes. Outras 2 regiões (Líbia e Lycia) bateram seus primeiros tipos somente no século V a.C. Autoridades emissoras de nenhuma região iniciaram suas emissões com imagens monetárias de águias entre os séculos V-IV a.C. No século IV a.C., autoridades emissoras de 3 regiões iniciaram suas emissões (Cária, Coríntia e Lesbos), mas destas apenas Lesbos deu continuidade a emissão de tipos monetários no período seguinte. Autoridades emissoras de nenhuma região iniciaram emissões monetárias com tipos com a águia entre os séculos IV-III a.C.

Do gráfico também é possível observar que o tipo monetário de águias foi mais utilizado no lado ocidental do mundo. A Sicília é a região com o maior número de autoridades emissoras responsáveis pelo uso do tipo com as águias em moedas (10 autoridades emissoras). Percebe-se que, na região, 1 autoridade emissora iniciou emissões com o tipo no século VI a.C. e que o século $V$ a.C. foi o período de maior uso da imagem de águias na região (5 autoridades emissoras). Nos períodos seguintes, entre os séculos V-IV a.C. e IV a.C., o uso da imagem de ave em moedas diminuiu (2 autoridades emissoras para cada século). As segundas regiões com maior número de autoridades emissoras a usar a representação das águias em moedas estão mais ao leste, ao norte da Grécia Balcânica e na Ásia Menor. Na Macedônia, foram 2 autoridades emissoras que iniciaram o uso da imagem de águias em emissões monetárias no século V a.C., diminuindo esse número para 1 autoridade emissora entre os séculos V-IV a.C. Em contraste, o maior número de autoridades emissoras a usar o tipo de águias em moedas concentrou-se no século IV a.C. (3 autoridades emissoras). A Jônia, por outro lado, cuja 1 única autoridade emissora lançou o uso da imagem de águias em moedas na região já entre 
os séculos VII-VI a.C., teve a maior parte de autoridades emissoras a usar imagens da ave em moedas no século V a.C. (4 autoridades). No século IV a.C. esse número caiu para apenas 1 autoridade emissora. A Itália do Sul, a Trôade e o Mar Negro, correspondem às quartas áreas em número de autoridades emissoras em imagens monetárias de águias (cada qual com 5 autoridades emissoras). A Itália do Sul teve 1 autoridade emissora que cunhou tipos para cada período (séculos VI-V, V, V-IV, IV e IV-III a.C.). A Trôade teve 1 autoridade emissora que usou pela primeira vez imagens monetárias de águias na região entre os séculos VI-V a.C. Esse número continuou nos séculos V a.C. e entre o V-IV a.C. Foi no século IV a.C. que o número de autoridades emissoras dobrou em relação aos períodos anteriores (2 autoridades emissoras). Já no Mar Negro, teve 1 autoridade emissora que iniciou o uso de imagens de águias em moedas somente no século $V$ a.C. e esse mesmo número permaneceu entre os séculos V-IV a.C. Durante o século IV a.C. o número de autoridades emissoras dobrou (2 autoridades emissoras) em relação aos períodos anteriores, tendo diminuído no período seguinte (1 autoridade emissora entre os séculos IV-III a.C.).

Sifnos, Trácia, Aeolis e Mysia são as regiões com o sexto número maior de autoridades emissoras no período. Sifnos teve 1 autoridade emissora em cada um dos três períodos (séculos VI, V e IV a.C.). Aeolis também teve 1 autoridade emissora responsável por usar tipos de águia em três períodos (V, IV e IV-III a.C.). O mesmo caso ocorreu com a Mysia, embora em períodos diferentes. Nessa região houve 1 autoridade emissora que usou os tipos pela primeira vez já entre os séculos VII-VI a.C. e depois o mesmo número para os séculos V e IV a.C. Já na Trácia, 2 autoridades emissoras iniciaram o uso do tipo com águias na região durante o século V a.C., tendo o número caído para 1 autoridade emissora no século IV a.C. Rodes, Chipre, Élis e Lesbos são as regiões com o sétimo maior número de autoridades emissoras a ter feito uso dos tipos de águias em moedas gregas no período. Rodes, Chipre e Élis tiveram, cada qual, 1 autoridade emissora no século $\mathrm{V}$ a.C. e 1 autoridade emissora no século IV a.C. Lesbos, contudo, teve uma autoridade emissora a partir do século IV a.C. e a outra entre os séculos IV-III a.C.

As regiões com menor quantidade de autoridades emissoras a cunhar moedas com imagens de águias foram Creta, a Eubéia, a Líbia, a Lycia, a Cária e a Coríntia. A Eubéia foi a única a ter tido 1 autoridade emissora no século VI a.C. E a Líbia e a Lycia as únicas regiões a terem tido, cada qual, 1 única autoridade emissora no século V a.C., assim como a Cária e a Coríntia no século IV a.C. E Creta, é a única região que possui 1 autoridade emissora responsável por cunhagens entre os séculos V-IV a.C. e IV a.C.

Já o gráfico 22 traz a quantidade de tipos monetários de águias emitidos pelas autoridades emissoras no período. Das 42 autoridades emissoras, a pólis de Élis foi a que mais emitiu tipos monetários de águias (28 tipos), quase na mesma proporção nos dois períodos de emissão. Élis começou a bater moedas com imagens de águia no século V a.C. (13 tipos), tendo aumentado o uso da imagem da ave no século IV a.C. (15 tipos). Já Agrigento, na Sicilia, é a segunda pólis a emitir mais tipos monetários de águias (18 tipos). Suas emissões com os tipos de águias iniciaram-se no século VI a.C. (1 tipo) e aumentaram substancialmente no século V a.C. (15 tipos), o período mais prolífico no uso de imagens monetárias da ave pela pólis. É preciso dizer que Agrigento 
foi a cidade que mais usou a imagem monetária da ave durante o século V a.C., seguida somente por Élis. No século IV a.C. esse número caiu drasticamente (1 tipo monetário). Crotona, na Itália do Sul, foi a terceira pólis que mais cunhou moedas com a imagem de águias (cada qual 15 tipos). Lyttos foi a quarta (13 tipos), batendo moedas com a imagem de águias a partir do período entre os séculos V-IV a.C. e em maior profusão (12 tipos). Apenas 1 tipo monetário dessa pólis é datado apenas do século IV a.C. Já Crotona emitiu 1 tipo monetário a partir do período entre os séculos VI-V a.C. e 2 tipos monetários no século V a.C. Foi entre os séculos V-IV a.C. que Crotona aumentou consideravelmente a variedade de imagens monetárias de águias (8 tipos), em contraste ao período seguinte, o século IV a.C. (4 tipos). Abydus, na Trôade, é a quarta autoridade emissora a mais bater tipos monetários de águias (11 tipos). A pólis bateu um tipo entre os séculos VI-V a.C., aumentando a variedade de imagens monetárias no século V a.C., o período com maior quantidade de tipos monetários (5 tipos). Esse número diminuiu entre os séculos V-IV a.C. (para 2 tipos monetários) e aumentou no século IV a.C. (3 tipos monetários). Cálcis, na Eubéia, foi a quinta região que mais usou imagens monetárias de águias (10 tipos). Das autoridades emissoras que emitiram tipos de águias no século VI a.C. (Sifnos, Cálcis, Agrigento e Sinope), a pólis foi a que mais bateu os tipos monetários no período (3 tipos). No século $\mathrm{V}$ a.C. esse número caiu para 2 tipos monetários, aumentando no século IV a.C., o período de maior uso de imagens monetárias de águias pela pólis (5 tipos). A sexta autoridade emissora a mais emitir tipos monetários de águias foi Ólbia, no Mar Negro (8 tipos). A pólis iniciou suas emissões com 1 tipo monetário de águia no século $V$ a.C. e depois com 1 outro entre os séculos V-IV a.C. A maior parte de emissões com imagens monetárias de águias ocorreu no século IV a.C. (6 tipos). Também na região do Mar Negro, Sinope foi a sétima autoridade emissora que mais usou imagens de águias em moedas. Suas emissões monetárias com a representação iniciaram-se no século VI a.C. com 1 tipo monetário, aumentando no século V a.C. (3 tipos) e mantendo essa quantidade no século IV a.C.

Cyme, na Mysia, e Paphos, em Chipre, emitiram cada qual o total de 6 tipos monetários. Cyme bateu a maior parte dos seus tipos no século V a.C., diminuindo esse número no século IV a.C. (1 tipo) e aumentandoo ligeiramente entre os séculos IV-III a.C. (2 tipos). Paphos, contudo, emitiu os 6 tipos monetários somente no século V a.C. Cyzicus, na Mysia, e Éfeso, na Jônia, emitiram cada qual 4 tipos monetários de águias. Cyzicus foi uma das duas autoridades que emitiu as imagens mais antigas de águias em moedas gregas entre os séculos VII-VI a.C. (1 tipo). A pólis aumentou o uso da imagem monetária da ave somente no século V a.C. (2 tipos), diminuindo-o no século IV a.C. (1 tipo). Éfeso, no entanto, cunhou a maior parte de seus tipos monetários de águias no século V a.C. (3 tipos) e apenas 1 tipo entre os séculos V-IV a.C. Sifnos, Olinto, Sparadocus foram as autoridades emissoras que emitiram 3 tipos monetários. Sifnos, no Egeu, bateu cada um dos três tipos em cada período: 1 tipo no século VI a.C., 1 tipo entre os séculos VI-V a.C. e o outro somente no século IV a.C. Já Olinto, pólis na Trácia, e Sparadocus, rei trácio, emitiram cada qual os 3 tipos somente no século $\mathrm{V}$ a.C. Emissões de tipos monetários de águias com autoridades emissoras incertas na Jônia também somaram 3 tipos monetários: 1 tipo cunhado entre os séculos VII e VI a.C. (um dos mais antigos juntamente com aquele de Cyzicus), 1 tipo no século VI a.C. e outro no século V a.C. lalysos, em Rodes, Motya, na Sicília, Magnésia, 
na Jônia, Halikarnassos, na Cária, e Amyntas III, na Macedônia bateram cada qual apenas 2 tipos monetários de águias. As póleis de lalysos e Magnésia bateram as imagens monetárias somente no século V a.C. A pólis de Halikarnassos e o rei macedônio Amyntas III emitiram cada qual somente nos séculos IV a.C. Já Motya nos séculos V e IV a.C. (1 tipo em cada período).

As autoridades emissoras que menos emitiram tipos monetários de águia (apenas 1 tipo) foram as seguintes: Cirene, na Líbia, Mileto, na Jônia, Eryx, Hipana, Messana, Agyrion e Gela, na Sicília, Kherei, na Lycia, Arquelaos I, Perdicas, Alexandre I e Pydna, na Macedônia, Rodes em sua região homônima, Istros, no Mar Negro, Amanthus, em Chipre, Metaponto, na Itália do Sul, Corinto em sua região homônima, Cebren, na Trôade, Abdera, na Trácia, e uma emissão incerta na Macedônia. Datados do século V a.C. são os únicos tipos de Cirene, Mileto, Hipana, Messana, Kherei, Gela, Alexandre I e a emissão incerta na Macedônia. De entre os séculos V-IV a.C. são os tipos de Agyrion e Arquelaos I. Do século IV a.C. são aquelas únicas imagens monetárias de águias emitidas por Rodes, Istros, Pydna, Perdicas, Amanthus, Corinto, Cebren e Abdera. E finalmente, de Metaponto data o tipo monetário emitido entre os séculos IV-III a.C.

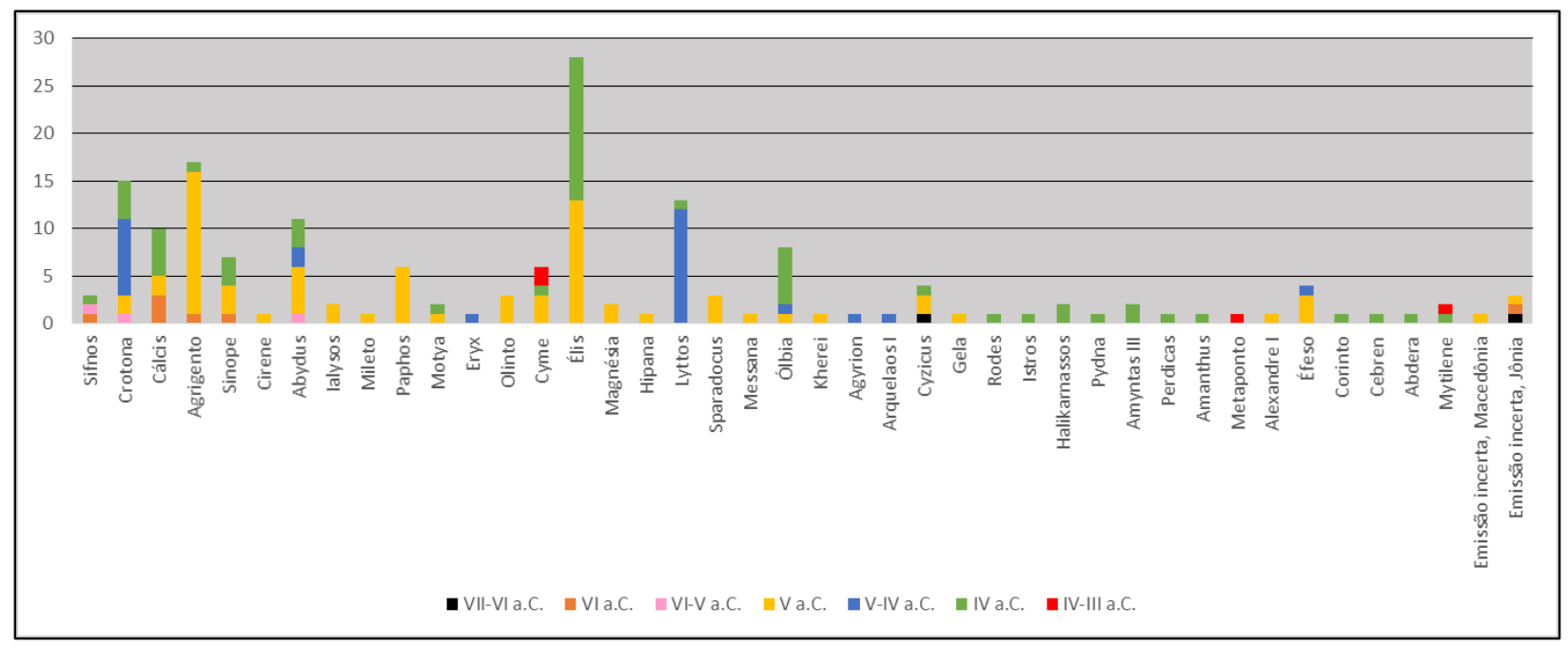

Gráfico 22- Águias - Quantidade de tipos monetários por autoridade emissora (sécs. VII-IV/III a.C.) 


\subsubsection{RAIOS}

O gráfico 23 mostra os dados acerca da quantidade de autoridades emissoras por regiões a emitir tipos monetários de raios (não associado aos tipos de Zeus e das águias) entre os séculos VII-IV/III a.C. Em contraste aos tipos monetários de Zeus e os das águias, autoridades emissoras de apenas 10 regiões do mundo grego usaram a imagem do raio em moedas gregas no período (Sicília, Élis, Beócia,

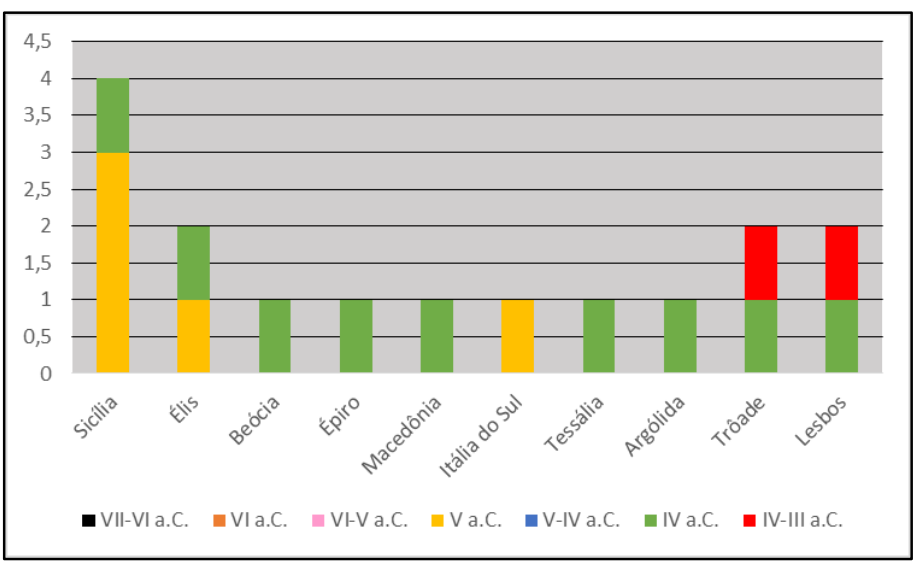

Gráfico 23 - Raios - Quantidade de autoridades emissoras por regiões a emitir tipos monetários (sécs. VII-IV/III a.C.) Épiro, Macedônia, Itália do Sul, Tessália, Argólida, Trôade e Lesbos). O interesse na representação do raio em moedas gregas ocorreu somente a partir do século $V$ a.C., não havendo tipos monetários do atributo anteriores a esse período, portanto, entre os séculos VII-VI a.C., VI a.C. e VI-V a.C. como existem para as imagens monetárias de águias e de Zeus, isto se não considerarmos que os tipos monetários das séries mais antigas de Élis tenham sido emitidos já no século VI a.C. Apenas autoridades emissoras da Sicília, Itália do Sul e de Élis emitiram tipos monetários de raios a partir de e somente no século $V$ a.C. E não há regiões com autoridades emissoras de tipos monetários do atributo entre os séculos V-IV a.C. A maior parte das autoridades emissoras em suas respectivas regiões ( 9 no total) escolheu emitir imagens monetárias do raio no século IV a.C. Dessas 9 regiões, 5 delas cunharam tipos somente no século IV a.C. (Beócia, Épiro, Macedônia, Tessália e Argólida). Autoridades emissoras das outras 2 regiões (Trôade e Lesbos) continuaram a emiti-los entre os séculos IV-III a.C.

A partir do gráfico é possível também perceber que, assim como ocorre com os tipos monetários de águias, a Sicília é a região do mundo grego com o maior número de autoridades emissoras que usaram o tipo do raio em moedas (4 no total). A maior parte das autoridades emissoras siceliotas usaram os tipos de raios no século V a.C. (3 no total), diminuindo esse número no século IV a.C. (1 autoridade emissora). São 3 as regiões com a segunda maior quantidade de autoridades emissoras: Élis, Trôade e Lesbos. Élis, no entanto, foi a única das três regiões, cuja autoridade emissora usou imagens monetárias de raios no século $V$ a.C. A região teve a mesma quantidade de autoridades emissoras no século V a.C. e no IV a.C. (1 autoridade emissora em cada período). 0 mesmo ocorre com a Trôade e Lesbos, embora ambas as regiões tiveram autoridades emissoras que emitiram tipos monetários de raios no século IV e entre os séculos IV-III a.C. Autoridades emissoras das regiões da Beócia, do Épiro, Macedônia, Itália do Sul, Tessália e Argólida foram as que menos usaram o tipo do raio em moedas (1 autoridade emissora para cada região). Dessas, apenas a Itália do Sul possui 1 autoridade emissora que usou o tipo do raio em moedas no século V a.C. Percebe-se, assim, que no caso das imagens monetárias de raios há poucas autoridades emissoras em relação aos tipos de Zeus e aos das águias. 


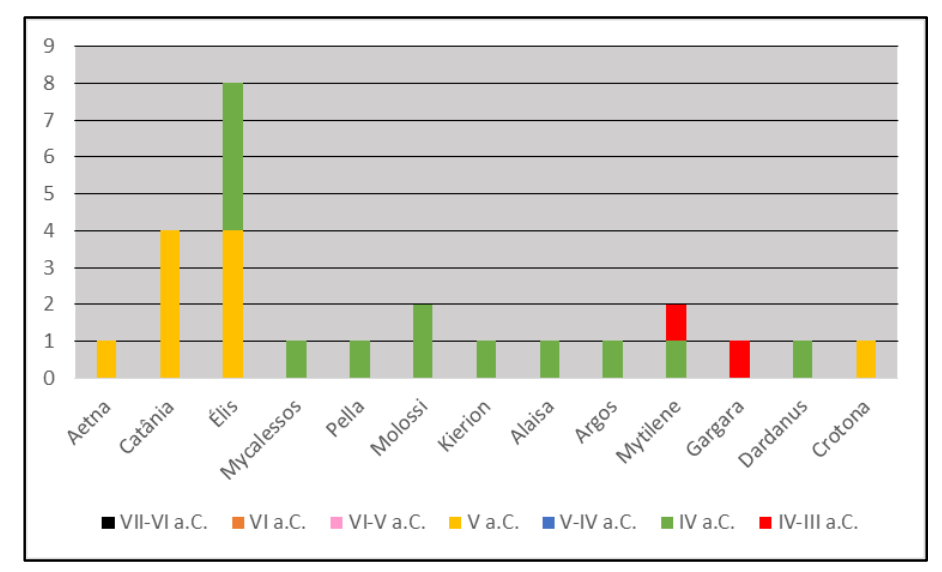

Gráfico 24 - Raios - Quantidade de tipos monetários por autoridades emissoras (sécs. VII-IV/III a.C.)

0 gráfico 24, por outro lado, mostra os dados referentes a quantidade de tipos monetários de raios por autoridades emissoras no período. Das 13 autoridades emissoras - um número também muito menor em comparação aos tipos de Zeus e aos de águias -, Élis, no Peloponeso, foi a pólis que mais emitiu tipos monetários de raios entre os séculos V e IV a.C. (8 tipos), sendo na mesma quantidade em ambos os períodos (4 tipos no século V a.C. e 4 tipos no século IV a.C.). Catânia, na Sicilia, foi a segunda autoridade emissora que mais emitiu moedas com imagens de raios: a pólis emitiu seus tipos monetários somente no século $V$ a.C. (4 tipos no total). Como no caso dos tipos monetários de águias, Élis e a área Ocidental do mundo grego (sobretudo a Sicilia) são as que mais emitiram tipos de raios. Mytilene, na ilha de Lesbos, e o éthnos dos Molossi, no Épiro, foram as terceiras autoridades emissoras em quantidade de tipos monetários emitidos. Mytilene usou imagens monetárias de raios nos séculos IV e entre o IV-III a.C. (1 tipo em cada período), ao passo que os Molossi emitiram seus tipos somente no século IV a.C.

Aetna e Alaisa, na Sicília, Crotona, na Itália do Sul, Mycalessos, na Beócia, Pella, na Macedônia, Kierion, na Tessália, Argos, na Argólida, Gargara e Dardanus na Trôade, foram as 9 autoridades emissoras que menos utilizaram a representação de raios em moedas gregas no período estudado (cada qual 1 tipo monetário). Desse grupo, Aetna e Crotona são as únicas autoridades emissoras a emitir no século V a.C., em contraste a Mycalessos, Pella, Kierion, Alaisa, Argos e Dardanus, que os emitiram apenas no século IV a.C. Cnossos e Gargara são as únicas póleis que cunharam os tipos entre os séculos IV-III a.C.

\section{I.3.4 ÁGUIAS E RAIOS}

0 gráfico 25 traz as informações sobre a quantidade de autoridades emissoras por regiões a emitir tipos monetários de águias e raios. Observa-se que autoridades emissoras de apenas 5 regiões do mundo grego - Élis, Itália do Sul, Épiro, Eubéia e Tessália - usaram a imagem dos dois atributos de Zeus associados no anverso e/ou no reverso de suas moedas. 0 número bem menor de autoridades

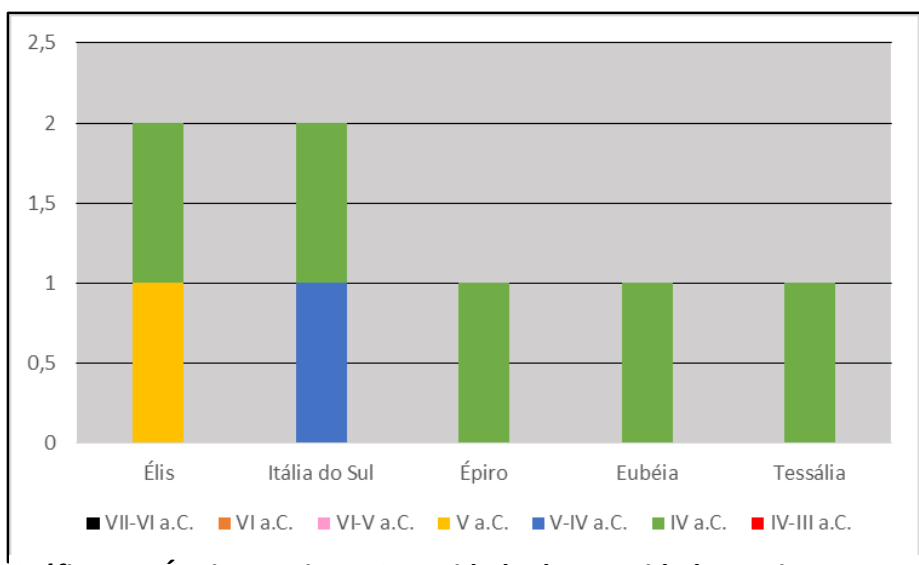

Gráfico 25- Águias e raios - Quantidade de autoridades emissoras por regiões a emitir tipos monetários (sécs. VII-IV/III a.C.) 
emissoras/regiões (no máximo 2 para cada região) em relação aos tipos de Zeus e aos das águias e ainda menor em relação aos tipos dos raios, demonstra que o uso dos dois atributos associados, águias e raios, foi bem específico regionalmente e restrito aos séculos V e IV a.C. Águias e raios não foram representados em moedas gregas em períodos anteriores, portanto nos séculos VII e VI a.C. e nem entre os séculos IV-III a.C. Élis e autoridades emissoras da Itália do Sul foram as que mais usaram as imagens de águias e raios associadas em moedas (cada qual 2 autoridades emissoras), indicando que a associação entre os dois atributos foi também uma tendência que circulou entre Élis e o Ocidente grego, no caso a Itália do Sul. Élis foi a única autoridade emissora a emitir tipos de águias e raios já no século $V$ a.C. (1 tipo), continuando a emiti-los no século IV a.C. (1 tipo). Uma autoridade emissora na Itália do Sul iniciou as emissões das imagens monetárias entre os séculos V-IV a.C. (1 autoridade emissora), mantendo o mesmo número no século IV a.C. Épiro, Tessália e Eubéia tiveram, cada qual, 1 autoridade emissora que usou as imagens de raios e águias somente no século IV a.C.

No gráfico 26, por sua vez, observa-se a quantidade de tipos monetários de águias e raios por autoridades emissoras. Das 5 autoridades emissoras que usaram os atributos associados em moedas gregas, Élis foi a que mais emitiu o tipo monetário (34 no total). No século $V$ a.C., Élis inventou o uso associado de águias e raios em moedas, emitindo principalmente nesse período (25 tipos) e em menor quantidade no século IV a.C.

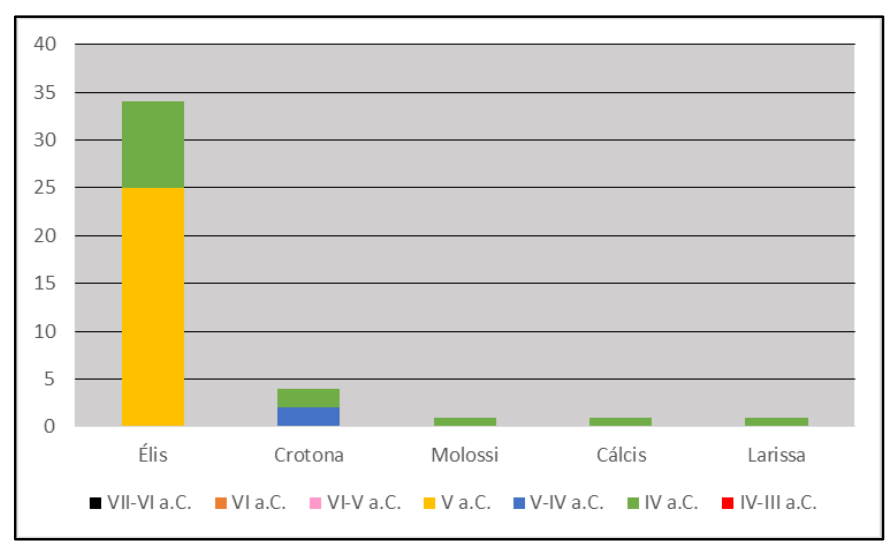

Gráfico 26 - Águias e raios - Quantidade de tipos monetários por autoridade emissora (sécs. VII-IV/III a.C.) (somente 9 tipos). Crotona, na Itália do Sul, foi a terceira autoridade emissora que mais usou os dois atributos de Zeus associados. Seguindo a invenção de Élis, foi a única pólis a usar o tipo monetário entre os séculos VIV a.C. (2 tipos) e depois no século IV a.C. (2 tipos). Os Molossi, no Épiro, Cálcis, na Eubéia, e Larissa, na Tessália, foram as três autoridades emissoras que menos utilizaram as imagens monetárias, apenas emitiram 1 tipo monetário no século IV a.C. 


\section{I.3.5 ZEUS E ÁGUIAS}

O Gráfico 27 traz os dados acerca da quantidade de autoridades emissoras por regiões a emitir tipos monetários de Zeus e águias entre os séculos VII-IV/III a.C. Trata-se de apenas 4 regiões (Élis, Sicília, Itália do Sul e Chipre), cujas autoridades emissoras escolheram usar em suas moedas as imagens de Zeus e de seu atributo, a águia, associados. Vê-se que a quantidade de regiões é ainda menor em relação aos tipos de águias e raios e que

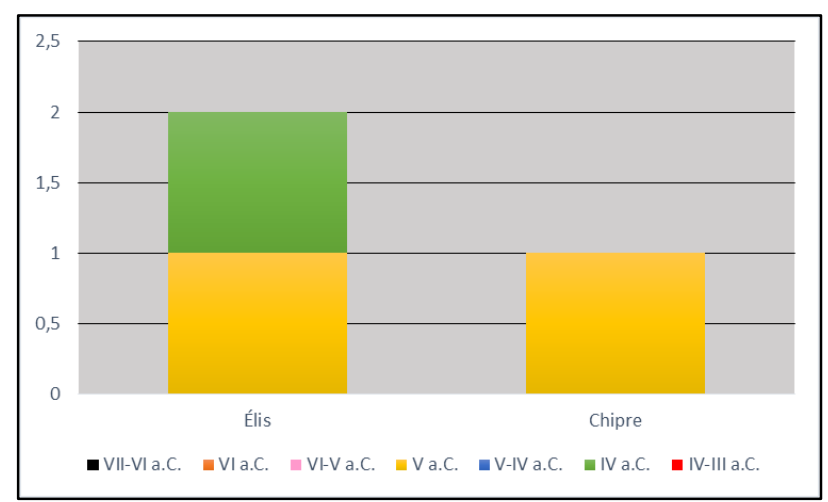

Gráfico 27 - Zeus e águias - Quantidade de autoridades emissoras por regiões a emitir tipos monetários (sécs. VII-IV/III a.C.) também não houve tipos monetários no período anterior ao século $V$ a.C. Élis, no lado ocidental da Grécia Balcânica, e 1 autoridade emissora de Chipre, no extremo leste do mundo grego, são as únicas que usaram as imagens monetárias de Zeus e águias a partir do século V a.C. Em Chipre não houve autoridades emissoras que nos períodos posteriores fizesse uso do tipo monetário, já Élis continuou a utilizar as imagens monetárias de Zeus e águias no século IV a.C. É preciso lembrar que os dados apresentados nesse gráfico se referem ao período clássico, mas até c.345/44 a.C. De logo após essa data, Lócris e Hipônio, na Itália do Sul, e outras cidades da Sicilia, como Agrigento, emitiram várias séries monetárias as quais possuem os dois tipos associados, mostrando uma predominância do uso da imagem de Zeus e águias no Ocidente grego, ao lado de Élis, a partir do período após esse ano e principalmente durante o século III a.C.

O gráfico 28 mostra os dados sobre a quantidade de tipos monetários de Zeus e águias por autoridades emissoras. Nota-se que apenas 2 autoridades emissoras (Élis e Paphos) emitiram tipos monetários de Zeus e águias, sendo, portanto, os menos utilizados por autoridades emissoras entre todo o repertório de imagens monetárias de Zeus, raios e águias. Élis é a autoridade emissora que mais bateu os tipos monetários (14 no total),

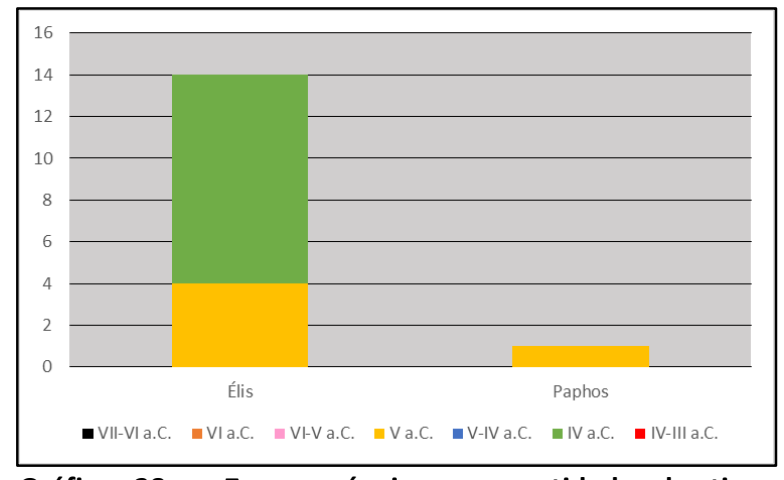

Gráfico 28 - Zeus e águias - quantidade de tipos monetários por autoridade emissora (sécs. VII-IV/III a.C.) tendo iniciado com 4 imagens monetárias no século $\mathrm{V}$ a.C. e aumentado o número consideravelmente no século IV a.C. (10 tipos). Paphos emitiu somente 1 tipo monetário no século V a.C. 


\section{I.3.6 ZEUS E RAIOS}

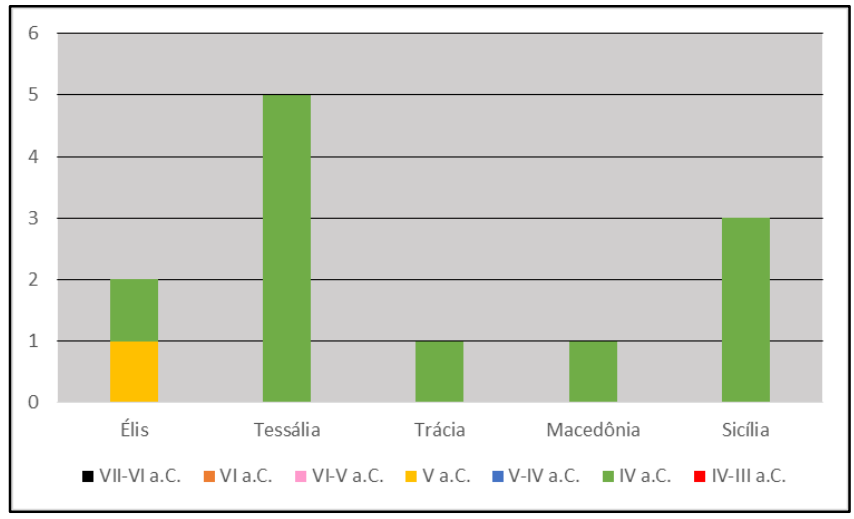

Gráfico 29 - Zeus e raios - Quantidade de autoridades emissoras por região a emitir tipos monetários (sécs. VII-IV/III a.C.)
O gráfico 29 traz as informações a respeito da quantidade de autoridades emissoras por regiões a emitir tipos monetários de Zeus e raios. Trata-se de autoridades emissoras de 5 regiões do mundo grego (Élis, Tessália, Trácia, Macedônia e Sicília) - a mesma quantidade dos tipos monetários de águias e raios. Observa-se que Élis é a única região, cuja autoridade emissora usou no século $V$ a.C. a combinação Zeus e raios em suas moedas, tendo sido

lá que, muito provavelmente, tenha surgido a ideia em juntar a imagem de Zeus e do raio e usá-las em moedas. No século IV a.C. em Élis, a ideia foi seguida por Pisa. A Tessália foi a região com a maior quantidade de autoridades emissoras a usar os tipos monetários de Zeus e raios (5 no total) no século IV a.C. A Sicilia é a terceira região com a maior quantidade de autoridades emissoras (3 no total). Apenas 1 autoridade emissora na Trácia e na Macedônia emitiram moedas com os tipos no século IV a.C. Percebe-se, assim, que a associação entre os tipos de Zeus e de raios em moedas foi uma preferência de regiões mais ao norte na Grécia Balcânica (Tessália, Macedônia e Trácia), ao mesmo tempo em que foram, como os demais tipos associados, uma tendência que circulou entre Élis e o Ocidente grego, no caso, a Sicília.

0 gráfico 30 reúne os dados referentes a quantidade de tipos monetários de Zeus e raios por autoridades emissoras. Foram 12 autoridades emissoras que usaram a associação entre a representação da divindade e um de seus atributos, o raio, portanto, mais que o dobro de autoridades emissoras que emitiram tipos de Zeus e águias. Como se vê, Élis emitiu

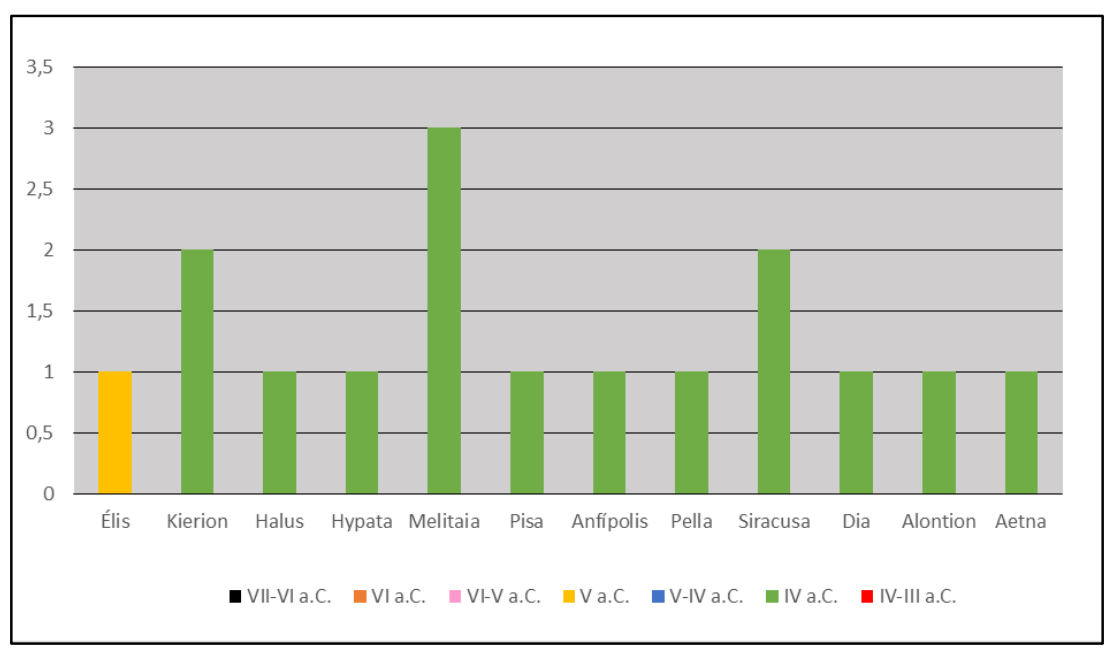

Gráfico 30 - Zeus e raios - Quantidade de tipos monetários por autoridades emissoras (sécs. VII-IV/III a.C.)

apenas 1 tipo monetário no século $V$ a.C., não usando a associação de imagens em períodos posteriores. Observa-se que uso do tipo de Zeus e raios em moedas foi uma tendência tessália do século IV a.C. Melitaia, na Tessália, foi a autoridade emissora que mais utilizou a imagem em suas moedas no período (3 tipos), seguida por Kierion, também na Tessália, e Siracusa, na Sicilia, que emitiram cada qual 2 tipos monetários). 0 mesmo pode ser dito da Sicília com relação às emissões de Siracusa, Alontion e Aetna. Alontion e Aetna, na Sicília, 
Halus, Hypata e Dia, na Tessália, Pella, na Macedônia, Anfípolis, na Trácia, e Pisa, em Élis, foram as que menos emitiram tipos monetários (cada qual 1 tipo).

\section{I.3.7 ZEUS, ÁGUIAS E RAIOS}

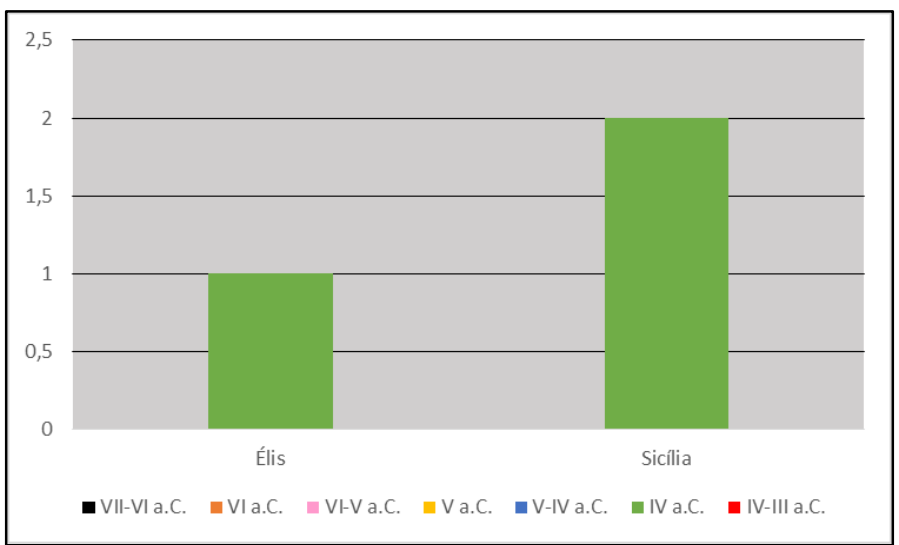

Gráfico 31 - Zeus, raios e águias - Quantidade de autoridades emissoras por regiões a emitir tipos monetários (sécs. VII-IV/III a.C.)
O gráfico 31 traz, por sua vez, as informações relativas a quantidade de autoridades emissoras por regiões a emitir tipos monetários das três representações associadas estudadas por esta pesquisa: Zeus, águias e raios. Ao lado dos tipos de Zeus e águias, tratase do tipo monetário menos comum no mundo grego, ou seja, que esteve presente em menos regiões - Élis e Sicília. Observa-se que este foi, dentre todos os analisados, o tipo monetário exclusivo de Élis e do Ocidente grego, criado e utilizado em um único espaço cronológico, o século IV a.C. A Sićlia foi a região que mais utilizou a combinação (2 autoridades emissoras) e apenas Élis, em sua região homônima, fez uso do tipo monetário.

Já o gráfico 32 mostra os dados sobre a quantidade de tipos monetários de Zeus, águias e raios por autoridades emissoras. Trata-se de 3 autoridades emissoras que fizeram uso do tipo monetário nos séculos IV a.C. Élis foi a autoridade emissora que mais utilizou o tipo monetário (3 tipos) e Agyrion e Siracusa, na Sicilia, foram as póleis que menos utilizaram a combinação de representações em moedas (cada qual 1 tipo).

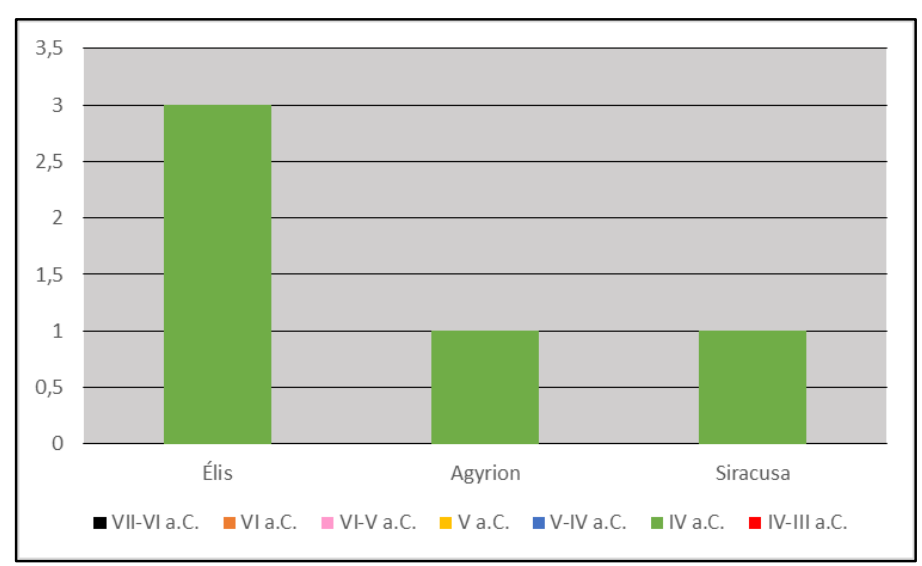

Gráfico 32 - Zeus, águias e raios - Quantidade de tipos monetários por autoridade emissora (sécs. VII-IV/III a.C.)

É preciso dizer que essa associação dos tipos de Zeus com seus dois atributos foi muito difundida entre póleis da Itália do Sul e da Sicília após os anos de 345/44 a.C. Os dados aqui expressam apenas o início dessa tendência em utilizar essa combinação em moedas gregas. 


\section{I.4 QUANTIFICAÇÃO DE VARIEDADES DE INSCRIÇÕES POR TIPOS MONETÁRIOS/AUTORIDADES EMISSORAS}

Nessa pesquisa, caracterizar as inscrições auxilia, com precisão, na definição dos tipos de autoridades que estiveram por trás da emissão de imagens monetárias de Zeus e de seus atributos. E, através da quantificação dos tipos de inscrições, saber que tipos de autoridades emissoras tiveram mais ou menos afinidade com essas imagens. De acordo com o The Inventory of Archaic and Classical Poleis, o levantamento sobre as comunidades que tiveram emissões de moedas em época arcaica e clássica estabeleceu a seguinte lista de autoridades: (1) póleis; (2) éthne, sub-éthne e ilhas com várias póleis; (3) federações; (4) anfictionias; (5) alianças; (6) governantes; (7) generais e líderes mercenários; e (8) santuários (Hansen; Nielsen, 2004: 145). As legendas podem aparecer inteiramente no campo das moedas ou de forma abreviada, comuns em períodos mais antigos, como no século VI a.C. (Hansen; Nielsen, 2004: 144; Kraay: 1976: 5). Assim, as inscrições ou legendas em moedas gregas do período arcaico e clássico formam os seguintes grupos: (1) étnicos de cidades (abreviados; no nominativo ou genitivo singular indicando um toponímio ou nome de divindade epônima da cidade; e no genitivo plural, indicando a população que habita uma pólis com seu centro urbano e sua hinterlândia); (2) étnicos regionais (abreviados; singular; plural, indicando o povo que habita uma região inteira ou um éthnos); (3) étnicos ktetikós (adjetivos possessivos no neutro singular, testemunham nomes de ligas e federações e podem estar relacionados a um éthnos ou a um santuário); (4) sub-étnicos (denotam no singular um membro de uma subdivisão cívica como uma phyle ou fratria, patra, kóme e demo e, no plural, os seus membros); (5) nome de governantes (no nominativo singular, indicando o nome de reis, sátrapas e magistrados, os oficiais responsáveis pelas emissões); (6) nome de um deus ou herói (no nominativo singular frequentemente junto à representação da divindade em questão); (7) no nome de santuários (podem estar no neutro singular); e (8) no nome de alianças (indicado pela palavra symmachia); (9) símbolos indicando data e denominação; (10) outros termos que transmitem uma mensagem ao usuário da moeda (Hansen; Nielsen, 2004: 144 e 146). Há também um grande número de moedas que são anepígrafas, portanto, desprovidas de inscrições. As moedas gregas mais antigas eram anepígrafas e muitas delas permaneceram assim até o fim de suas emissões em períodos posteriores. Muitas moedas sem inscrições pertencem ao período arcaico e início do clássico e podem ser inseridas nas comunidades que, no período clássico tardio, continuam a bater moedas com os mesmos tipos, porém usando legendas (Hansen; Nielsen, 2004: 147).

O gráfico 33 traz informações sobre a quantidade e variedade de inscrições que figuram no campo das moedas junto às imagens de Zeus, águias e raios emitidos pelas autoridades emissoras entre os séculos VIIIV/III a.C. Trata-se de uma variedade de 14 tipos de inscrições que aparecem juntos aos tipos monetários de Zeus, águias e raios nesse período. Percebe-se que a maior parte das inscrições é formada por vários tipos de étnicos de cidades, se somarmos todas as suas variedades (abreviado; toponímio-nominativo-singular; genitivo-singular; e genitivo plural). A variedade mais numerosa é o étnico de cidade abreviado (34 autoridades emissoras usaram esse tipo de inscrição), seguido pelo étnico de cidades no genitivo plural (28 autoridades 
emissoras). A terceira maior quantidade de étnicos de cidade refere-se aos de toponímio e nominativo singular (10 autoridades emissoras), seguido pelo étnico de cidade no genitivo singular, o menos usado nessa categoria de legendas (1 autoridade emissora). Abaixo, segue a lista das autoridades emissoras, que utilizaram étnicos de cidade, e suas respectivas inscrições:

1. Étnico de cidade (abreviados): Cirene (KYPA); Euespérides (ELYE); Kierion (KIE); Phalanna ( Krannon (KPA); Melitaia (ME^I); Argos (A); Galária (CA^A) ; Crotona (koppaPOTO); Metaponto (ME); Nisyros

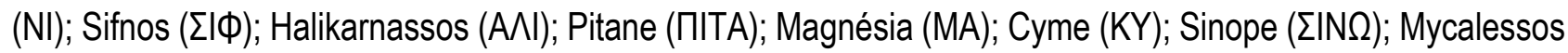

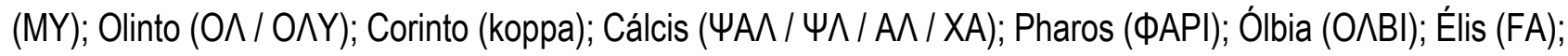

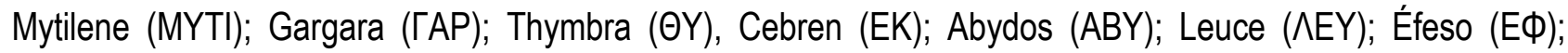

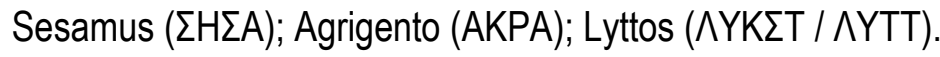

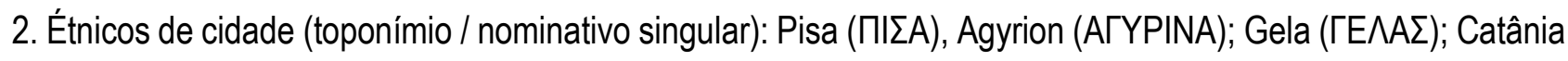

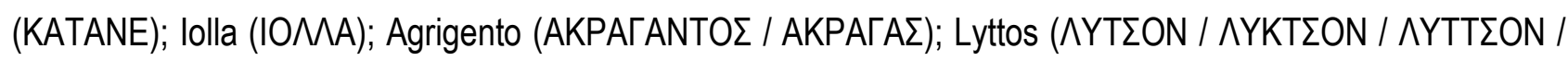

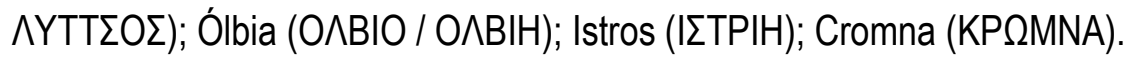

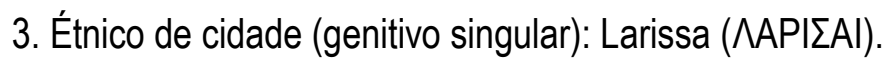

4. Étnico de cidade (genitivo plural): Barce (BAPKAION); Gomphi (ФI/IחПОПOЛITSN); Kierion (KIEPIEISN);

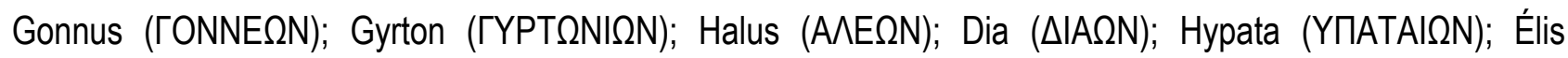

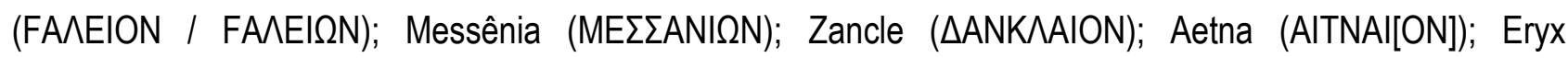

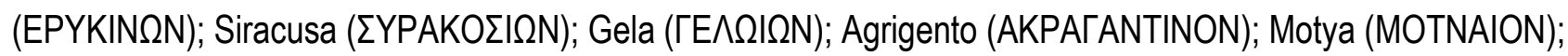

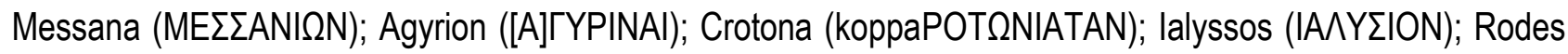

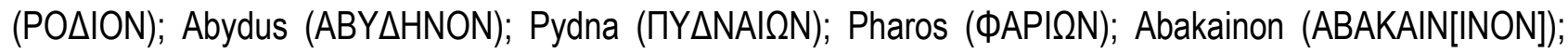

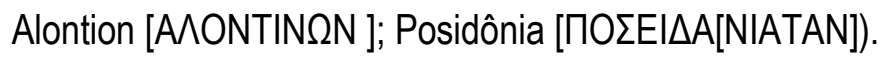

Outro tipo de étnicos são os regionais, os quais formam uma categoria menos numerosa de inscrições associadas aos tipos de Zeus e seus atributos. Dos étnicos regionais, o mais numeroso é aquele no genitivo plural (foi usado por 4 autoridades emissoras), seguido pelos étnicos regionais abreviados (usado por 1 autoridades emissoras). Já 0 étnico regional no singular é o que menos aparece nos tipos monetários (1 autoridade emissora). E por fim, os étnicos ktetikós que também aparecem em poucos tipos (2 autoridades emissoras). Segue abaixo a lista:

1. Étnico regional (abreviado): Parrhasia (ПA / RAГГ). 
2. Étnico regional (nominativo ou genitivo singular): Aenianes (AINIAN).

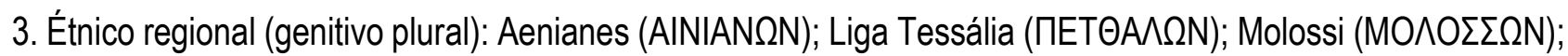
Liga Acaia (AXAISN).

4. Étnico ktetikós (neutro singular): Liga Arcádia (APKALIKO); Élis (O^YNПIKON).

5. Étnico ktetikós (neutro singular abreviado): Liga Arcádia (AP); Megalópolis (Liga Arcádia) (AR).

A segunda categoria mais numerosa de legendas são aquelas inscrições nos nomes de governantes (19 autoridades emissoras usaram esse tipo de inscrição). Sobre essas legendas, dividimos a categoria em dois tipos: nome de governantes com autoridades emissoras conhecidas (quando se conhece a cidade da oficina responsável pela emissão) e nomes de governantes sem autoridade emissora conhecida (quando não se conhece a cidade responsável pela emissão). A mais numerosa se refere ao nome de governantes com autoridades emissoras conhecidas (12 no total) e a menos numerosa é em relação ao nome de governantes sem autoridade emissora conhecida (7 no total). Abaixo, então, está a lista das inscrições de nomes de governantes e suas respectivas autoridades emissoras quando conhecidas:

1. Nome de governantes com autoridades emissoras conhecidas: Cirene (magistrado $\mathrm{KY} \Delta \mid \mathrm{O} \Omega \Theta$ ); Mylasa (reis/sátrapas EKATOMNO MA); Halikarnassos (reis/sátrapas MAY $\Sigma \mathrm{O} \wedge \mathrm{O} \Sigma \mathrm{I} \triangle \mathrm{PHY} \Sigma$ ); Pitane (magistrado

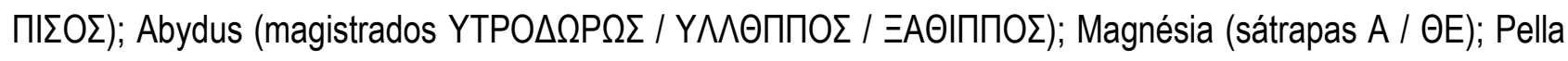

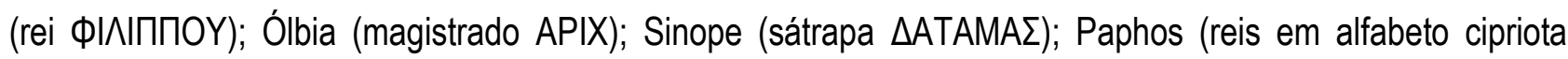
Pa.s.sa.ta.sa / Mo.a.ke.ta / Pu.pa I / Pu.pa II / Aristo); Anfípolis (rei ФІЛІППОY); Philippi (rei ФІ/ІППОY).

2. Nome de governantes sem autoridade emissora conhecida: Kherei (rei inscrição em lício); Kheriga (rei inscrição em lício); Alexandre I (rei A^E三AN $\triangle P O)$ ); Arquelaos I (rei APXE^A); Perdicas (rei ПEPAIKA); Amyntas III (rei AMYNTA); Sparadocus (rei $\Sigma П A P A \triangle O K O)$.

No gráfico chama a atenção a grande quantidade de moedas anepígrafas. Foram 11 autoridades emissoras que escolheram não usar legendas junto aos tipos monetários. São elas: Mytilene, Cyzicus, Mileto, emissão incerta na Macedônia, Ambrácia, Lampsacos, Dardanus, emissões incertas na Jônia (3 tipos monetários) e Sinope.

Legendas incompreensíveis representam um número relativamente baixo em relação à quantidade que pôde ser categorizada. Trata-se de 5 autoridades emissoras (Aetna, Hipana, Alaisa, Lampsacos, Amanthus), cujas letras das inscrições não formam uma palavra compreensível ou o as informações de catálogos 
numismáticos (foto e descrição) não são suficientes para entender a inscrição. Atrás em quantidade, está a categoria de inscrições relativas aos epítetos de Zeus e às divindades e heróis míticos que aparecem junto às imagens de Zeus, águias e raios em moedas ( 3 autoridades emissoras usaram esse tipo de legenda). Foram

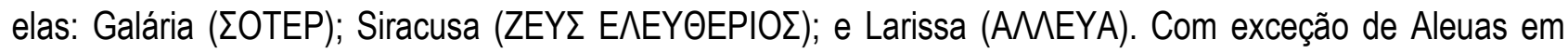
Larissa (herói mítico), todas as demais inscrições que acompanham a imagem de Zeus fazem referência ao seu nome e a dois de seus epítetos (Sóter e Eleutérios). Como se vê, todas póleis do Ocidente grego, exceto Larissa na Tessália, abarcam o período entre o século V e IV/III a.C. E por fim, a inscrição referente a alianças é a que menos aparece nos tipos monetários estudados (1 autoridade emissora): somente em Alaisa (IYMMAX).

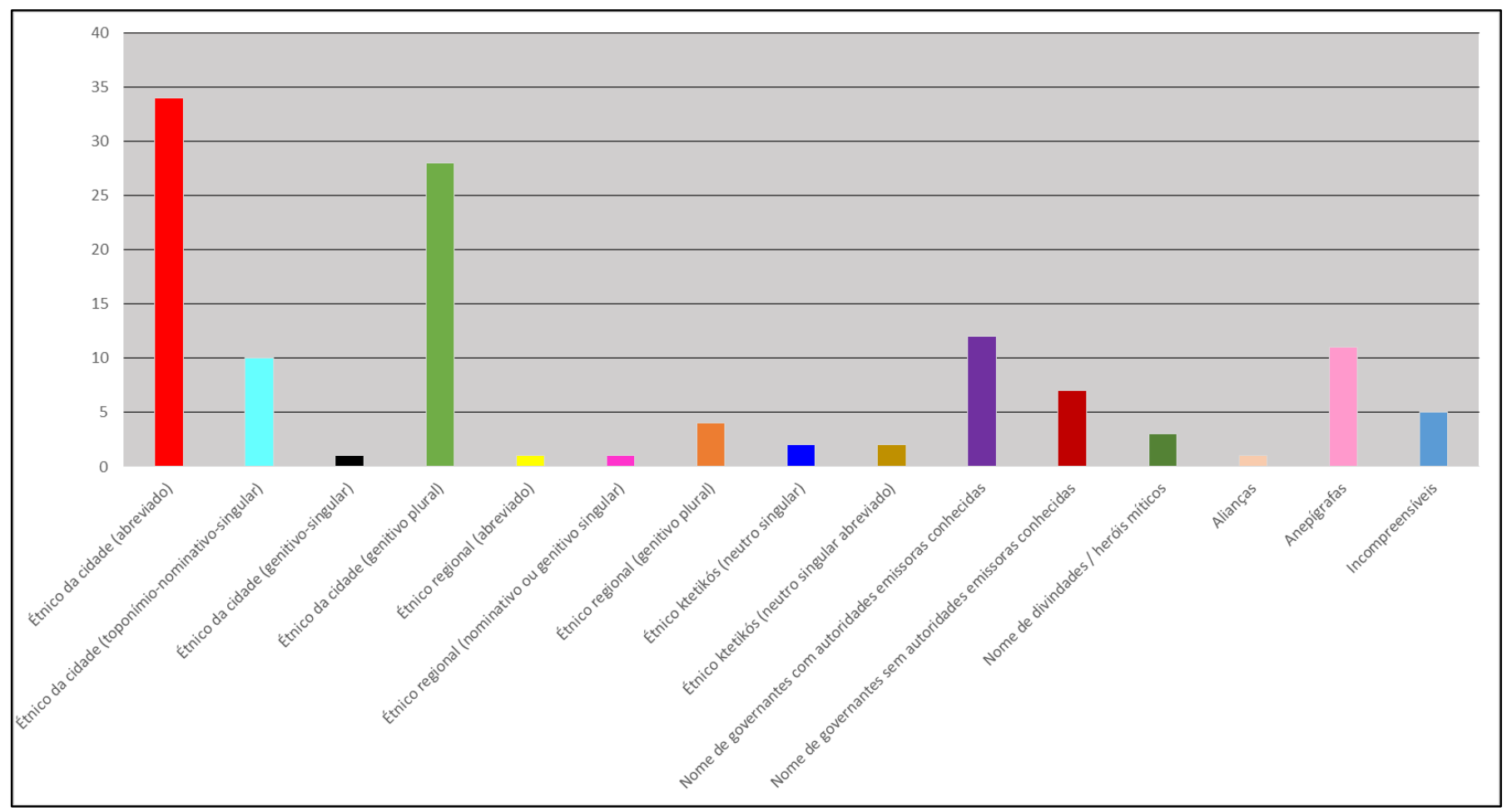

Gráfico 33 - Quantidade e variedade de inscrições por autoridades emissoras de tipos monetários de Zeus, águias e raios (sécs. VII-IV/III a.C.

O próximo gráfico foi elaborado a partir das informações referentes aos tipos de legendas encontrados nas moedas estudadas. Assim, o gráfico 34 apresenta os dados referentes a quantidade de tipos de autoridades emissoras que emitiram imagens monetárias de Zeus, águias e raios entre os séculos VII-IV/III a.C. Observa-se que as póleis foram os tipos de autoridades emissoras que mais usaram as imagens monetárias (66 no total). A quantidade maior é acerca das póleis que bateram moedas em seu nome (59 no total). São elas: Cirene, Euespérides, Kierion, Phalanna, Krannon, Melitaia, Argos, Galária, Crotona, Metaponto, Nisyros, Sifnos, Halikarnassos, Pitane, Magnésia, Cyme, Mycalessos, Olinto, Corinto, Cálcis, Pharos, Ólbia, Larissa, Pisa, Agyrion, Catânia, lolla, Agrigento, Lyttos, Istros, Barce, Gomphi, Gonus, Gyrton, Halus, Dia, Hypata, Élis, Messênia, Zancle, Aetna, Eryx, Siracusa, Gela, Motya, Messana, lalyssos, Rodes, Abydus, Pydna, Cebren, Thymbra, Gargara, Éfeso, Sesamus, Cromna, Abakainon, Alontion e Posidônia. Outras 2 delas bateram 
moedas com inscrições em seu nome e também anepígrafas (Sinope, Lampsacos) e 5 apenas anepígrafas (Mytilene, Cyzicus, Mileto, Ambrácia, Dardanus).

Depois das póleis, os reis são o segundo tipo de autoridade emissora que mais usou as imagens monetárias (17 no total): Ekatomno, Mausolos, Idreus, na Cária; Kherei e Kheriga, na Lycia; Alexandre I, Felipe II, Arquelaos I, Perdicas, Amyntas III, na Macedônia; Stasandro, Moageta, Pnytos I, Pnytos II, Aristo, em Chipre, e Sparadocus, na Trácia. Somou-se aqui também o tipo monetário de Amanthus em Chipre, cuja inscrição ilegível, faz referência ao rei cipriota dessa pólis. Os magistrados também são autoridades emissoras comuns e aparecem na quantidade de 7 no total: Kydiosth[...] em Cirene, Pisos em Pitane, Hytrodoros, Hyllippos e Xathippos em Abydus, Arix em Ólbia, e Peithesileos em Abdera. Foram 6 os sátrapas responsáveis pelas emissões dos tipos: Datamas em Sinope, no Mar Negro; Archepolis e Temístocles em Magnésia, na Jônia; e Ekatomno, Mausolos, Idreus, na Cária, que além de reis eram considerados também sátrapas da região. Na mesma quantidade estão os éthne que bateram tipos monetários: os molossi, no Épiro; os Aenianes, na Tessália; os parhásios, sub-éthnos arcádio; e os acaios, da Acaia e os arcádios, da Arcádia, ambos bateram os tipos dentro da Liga Acaia e Liga Arcádia (federações). Apenas 3 federações emitiram os tipos monetários em seu nome: a Liga Arcádia (tipos emitidos por autoridades emissoras desconhecidas no século $V$ a.C. e por Megalópolis no século IV a.C.); a Liga Tessália e Liga Acaia (cujas oficinas responsáveis pelas emissões são desconhecidas). E finalmente, 4 são as autoridades emissoras desconhecidas. Trata-se dos tipos monetários que não possuem inscrições e cuja atribuição é, ainda hoje, desconhecida.

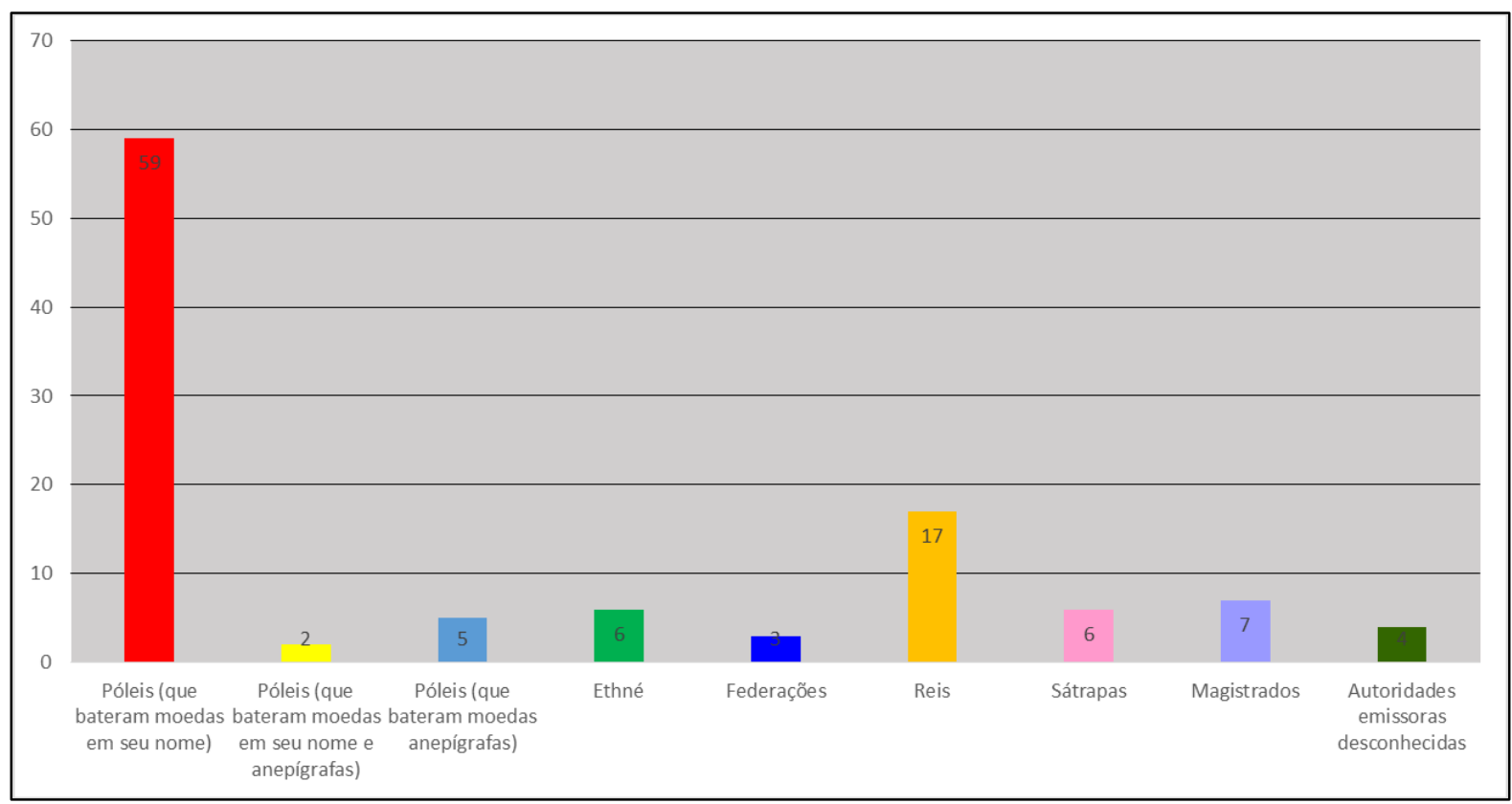

Gráfico 34 - Quantidade de tipos de autoridades emissoras que emitiram imagens monetárias de Zeus, águias e raios (sécs. VII-IV/III a.C.) 
Já 0 gráfico 35 resume as informações dos dois últimos gráficos. Ele traz os dados sobre a quantidade de cada variedade de imagem monetária por tipo de autoridade emissora (póleis, éthne, federações, reis, sátrapas e magistrados). Como observou-se no gráfico 22, as póleis são o tipo de autoridade emissora que mais usou os tipos monetários de Zeus e seus atributos. Nesse novo gráfico, observa-

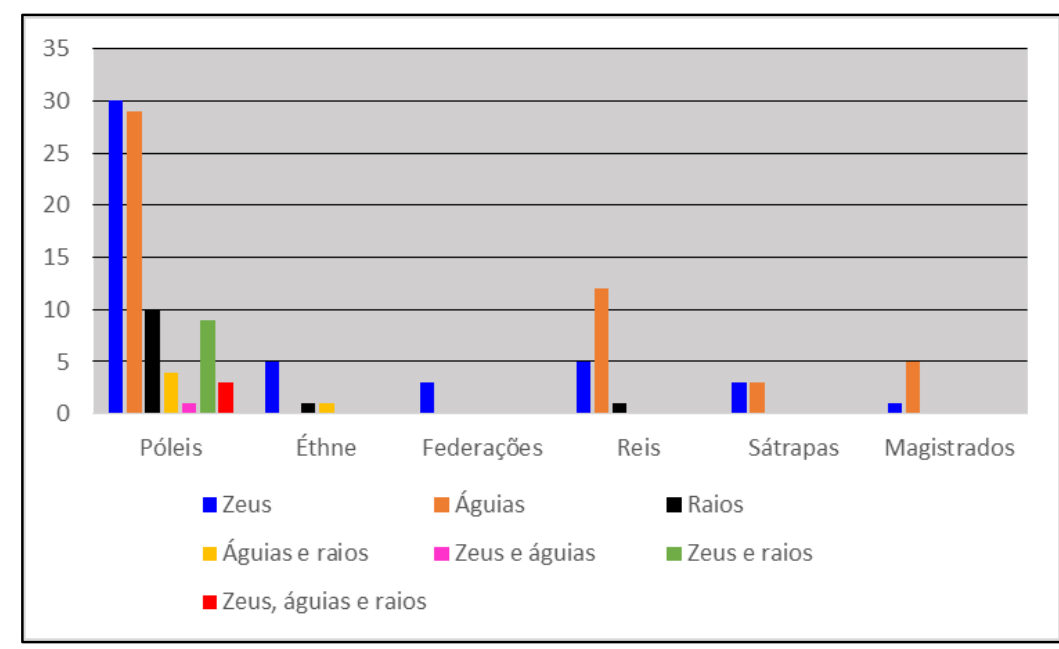

Gráfico 35 - Quantidade de cada variedade de tipos monetários de Zeus, águias e raios por tipo de autoridade emissora (sécs. VII-IV/III a.C.) se que os tipos monetários de Zeus foram, ainda que por uma diferença tênue, os mais usados pelas póleis (30 no total), seguido pelos tipos monetários de águias (29 póleis no total). As imagens de Zeus e das águias, então, foram as mais usadas pelas póleis gregas em contraste aos demais tipos. As imagens monetárias dos raios, por exemplo, são usadas consideravelmente em menor número (apenas 10 póleis as usaram). Esse número cai ainda mais em relação às imagens monetárias com as representações associadas (águias e raios, Zeus e águias, Zeus e raios e Zeus, águias e raios). Os tipos monetários de Zeus e raios são os mais usados pelas póleis dentre aqueles de imagens associadas (9 póleis os usaram), seguidos pelos tipos monetários de Zeus, águias e raios (4 póleis) e de águias e raios (3 póleis). E as imagens de Zeus e águias foram as que menos figuraram nas moedas das póleis (apenas 1 pólis no total).

Os reis foram o segundo tipo de autoridade emissora que mais usou as imagens monetárias estudadas. Os tipos monetários de águias foram os preferidos pelos reis (12 no total usaram os tipos da ave), sendo as imagens de Zeus as segundas mais utilizadas por eles (5 no total). Os tipos de raios foram utilizados em um número inexpressivo (1 rei no total). Não há tipos monetários de Zeus e/ou com seus atributos associados para esse tipo de autoridade emissora. Os éthne foram o terceiro tipo de autoridades emissoras que mais usaram algum dos tipos monetários. A imagem de Zeus foi a mais utilizada pelos éthne (5 no total), em contraste aos de raios e de águias e raios (cada qual 1 éthnos). Póleis que bateram no nome de sátrapas e magistrados usaram imagens monetárias na mesma quantidade (cada qual 6 tipos no total) e apenas imagens de Zeus e de águias aparecem associadas a eles. Há tipos monetários de Zeus e de águias na mesma proporção em relação aos sátrapas (cada qual 3 no total). $E$ nomes de magistrados aparecem associados em moedas mais às imagens monetárias de águias ( 5 no total) do que com as de Zeus (1 no total). E, por último, apenas imagens de Zeus foram utilizadas por federações (3 delas no total).

Percebe-se, assim, que os tipos monetários de Zeus, águias e raios, não associados entre eles, foram os mais utilizados por todas as variedades de autoridades emissoras, principalmente entre as póleis, ao passo que os tipos associados foram usados quase que exclusivamente pelas póleis, fazendo exceção apenas aos 
tipos associados de águias e raios, que são os únicos que aparecem fora da esfera das cidades gregas, tendo sido usados por um éthnos. Nesse caso, também não deixa de ser uma exceção o uso que o santuário de Olímpia fez de todos os tipos associados emitidos por Élis.

Assim, essa análise das inscrições mostra que foram as póleis gregas que mais utilizaram as imagens de Zeus e seus atributos em moedas gregas da época arcaica até a clássica. Apesar de serem o segundo tipo de autoridade emissora que mais usou tais imagens, como dissemos no início desse capítulo, reis e/ou sátrapas que cunharam os tipos monetários em seu nome não entrarão na análise e interpretação no próximo capítulo, pois nessa investigação buscamos compreender os processos que levaram a apropriação do culto de Zeus pela cidade grega. 


\section{ANÁLISE ICONOGRÁFICA DOS TIPOS MONETÁRIOS DE ZEUS, ÁGUIAS E RAIOS}

Nessa segunda parte do capítulo, apresentaremos um estudo sistemático acerca dos padrões de representação de Zeus, águias e raios em moedas gregas, datadas do século VII ao IV/III a.C. A partir de uma ordenação cronológica, tipológica, obter-se-á um histórico dessas imagens monetárias no mundo grego. Na análise iconográfica das moedas, associaremos cada padrão de representação encontrado àqueles que aparecem na arte grega em geral, portanto, nas representações do deus e de seus atributos em esculturas, relevos e, principalmente, na cerâmica pintada. Nossa intenção, é construir um repertório de unidades mínimas, definidas como os elementos constitutivos da imagem (como por exemplo, posição sentada ou em pé, atributos associados, adorno de cabeça, etc), de sorte a analisar a remontagem desses elementos em outros suportes, nesse caso, em moedas (Bérard; Durand, 1984: 19). Para tanto, a cada estudo iconográfico realizaremos, primeiramente, uma contextualização histórica de cada tipo de representação na arte grega, buscando compreender até que ponto os padrões de representação nas moedas têm origem naqueles das chamadas artes maiores, em que medida esses padrões são repetidos nas moedas ou se existe uma autonomia ${ }^{2}$ em relação às imagens criadas para as moedas - que são próprias do documento monetário e não figuram em outro tipo de suporte imagético. Por meio desse tipo de análise será possível obter um mapa das autoridades emissoras e regiões responsáveis por certas inovações e, assim, da distribuição de certos padrões iconográficos em determinadas regiões.

\section{II.1 A REPRESENTAÇÃO DE ZEUS NA ARTE GREGA ATÉ A ÉPOCA CLÁSSICA}

Até hoje, não foram publicadas muitas obras de referência que se ocupem do estudo sistemático da representação de Zeus na arte grega. A primeira delas é a obra magistral de A.B. Cook, Zeus: a study in ancient religion publicada em três volumes, cada qual com uma segunda parte, totalizando seis livros (1914-1925) Devotado ao estudo do culto de Zeus, a riqueza do material arqueológico e literário a respeito do deus, comentado e descrito pelo autor, desde as origens em período pré-helênico até o final da antiguidade, torna esse estudo uma obra monumental e rica fonte de informação e documentação acerca de Zeus na arte grega em geral. Entre o período de tempo da publicação do estudo de Cook e os dias atuais, foram publicados estudos

\footnotetext{
2 Isso coloca a questão acerca da dependência das chamadas artes menores (moedas, gemas e anéis) em relação às artes maiores (esculturas, relevos). Para alguns autores os artistas responsáveis pelos desenhos das moedas eram influenciados pelo padrão de representação de esculturas e relevos do momento, assim como outros estudiosos acreditam na dependência da arte em relação aos textos. Mas atualmente muitos pesquisadores questionam essa dependência, levantando a hipótese de que a correspondência existente entre certos padrões artísticos em moedas e esculturas pode indicar uma ideia coletiva presente em uma determinada época a qual foi apropriada simultaneamente tanto pelos artistas das artes menores e das artes maiores, quanto pelos artistas visuais (pintores de vasos, escultores, gravadores de cunhos monetários) e literários (Laky, 2007: 130).
} 
mais compactos, curtos e específicos sobre algum aspecto da representação de Zeus em algum tipo de suporte imagético em particular. O próximo livro estritamente dedicado à imagética de Zeus foi escrito por K. Arafat, Classical Zeus: a study in art and literature (1990), o qual apresenta um estudo acerca da representação de Zeus na cerâmica ática do período clássico. Talvez a última pesquisa mais completa acerca da divindade, desde a obra de Cook, seja o verbete a respeito de Zeus no Lexicon Iconographicum Mythologiae Classicae (LIMC), que traz o exame geral mais recente sobre a divindade na arte grega numa longa duração. No Volume VIII de 1997, M. Tiverios e I. Leventi examinam a iconografia de Zeus desde o início de sua representação na Idade do Bronze até a época clássica, privilegiando o estudo da estatuária, dos vasos e relevos como suportes imagéticos da divindade. Uma seção é dedicada às ditas artes menores, como gemas e moedas. Sobre as moedas, S. Kremydi-Sicilianou discute brevemente a época clássica e prioriza a representação de Zeus em moedas dos períodos helenístico e romano. Embora muito completo, o verbete do LIMC não oferece a reunião exaustiva de toda a documentação iconográfica sobre Zeus no mundo grego. Por essa razão, deve ser considerado apenas o ponto de partida para qualquer pesquisa a respeito da iconografia da divindade, seja ela sobre algum aspecto iconográfico que se busque ser aprofundado. A última obra publicada, que comenta a representação de Zeus nas artes visuais, é o livro de M. Vonderstein, Der Zeuskult bei den Westgriechen (2006), o qual se ocupa do culto de Zeus na Sicília e Itália do Sul. Vonderstein reúne toda a documentação do culto da divindade nas duas áreas, inclusive comenta a parte numismática, mas o seu objetivo é discutir o culto em termos regionais e não especificamente a imagem da divindade na arte figurativa em geral.

\section{Na Idade do Bronze}

As representações mais antigas de Zeus foram reconhecidas pelos pesquisadores em monumentos cretomicênicos. A presença do deus na Grécia durante o $2^{\circ}$ milênio a.C. foi reconhecida após a leitura de seu nome nos tabletes de Linear B encontrados em Chaniá, Pylos e Cnossos. É preciso dizer, contudo, que essas identificações são meramente especulativas (Tiverios, 1997: 315). Dentre essas representações a mais antiga parece estar em um sarcófago de pedra de Agia Triada em Creta, datado de c. 1400 a.C. A cena retrata, na parte direita, uma procissão de três sacerdotes segurando oferendas e indo em direção a um deus jovem, provavelmente da vegetação, em frente do qual há uma árvore

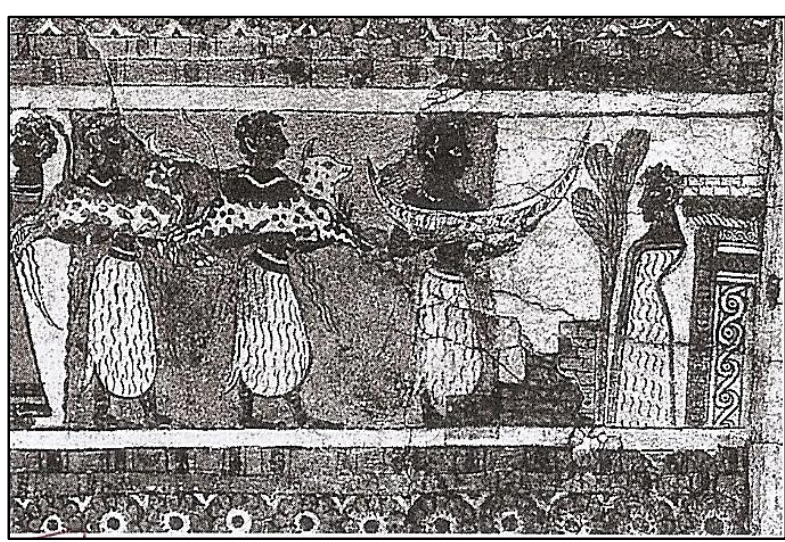

Fig.111- Sarcófago de pedra de Agia Triada, Museu Nacional de Heráklion, c.1400 a.C. (LIMC, VIII: fig.1) e um altar. Alguns estudiosos identificaram a divindade como Zeus Velchanos (Fig.111). Outra representação que pode ser citada provém de Micenas. Datada do século XIII a.C., se trata de uma figurinha de argila de uma divindade masculina apotropaica segurando um martelo-machado ou cetro (Tiverios, 1997: 315). 


\section{Nos períodos geométrico e arcaico}

Para a maioria dos pesquisadores, as representações mais antigas de Zeus já confirmadas parecem datar de c.700 a.C. e das décadas mais antigas do século VII a.C. Representações de Zeus antes de 700 a.C. não podem ser confirmadas como tais em razão da ausência de elementos que distinguem a divindade (Tiverios, 1997: 318). Incerta, por exemplo, é a interpretação de uma série de figurinhas masculinas de terracota e bronze com os braços levantados e pernas abertas, que foram encontradas em Olímpia. Datadas dos séculos IX-VIII a.C., algumas vestem na cabeça um tipo de touca, petasos ou elmo e são interpretadas como Zeus "em epifania" (Tiverios, 1997: 316). Assim, com base nas mais antigas representações de Zeus na arte grega que sobreviveram, pode ser afirmado que,

primeiramente, nenhum tipo iconográfico amplamente aceito do deus havia sido

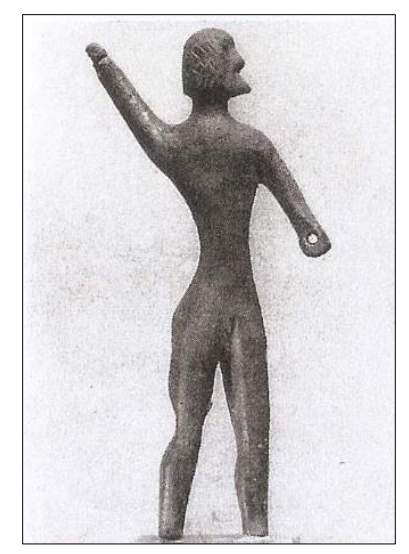

Fig.112- Figurinha de bronze, Dodona, 1a metade do século VII a.C., Museu Arqueológico Nacional, Atenas (LIMC, VIII: fig.9) estabelecido. Diferentes tipos desenvolveram-se em diferentes regiões, evidentemente relacionados a natureza do culto da divindade nesses lugares. Então, em Olímpia e em Dodona (Fig.112), o tipo de Zeus guerreiro

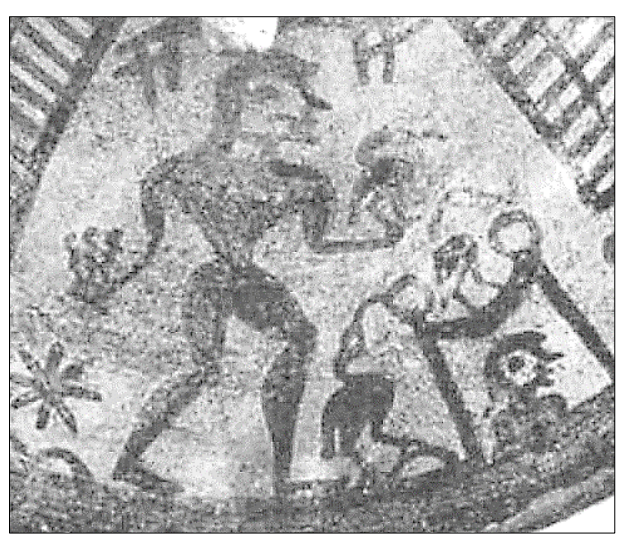

Fig.113- Figura masculina nua e imberbe, segurando uma ave com a mão esquerda e um raio com a direita, à sua frente um trípode e embaixo, Gê. Pithos, Cnossos (cemitério de Fortetsa), c.700 a.C., Museu de Heráklion (LIMC, VIII: fig.12). apareceu. Estatuetas de figurinhas masculinas de bronze de ambos os santuários aparecem segurando uma lança com um braço e escudo com o outro. Enquanto em Creta e nas ilhas - áreas com influências orientais pronunciadas - a representação de um Zeus oriental emergiu, o qual não se assemelha apenas com os deuses anatólios do clima, mas também com o antigo deus da vegetação e da fertilidade. Contudo, a partir do século VII a.C. os principais traços iconográficos de Zeus, que prevaleceram por toda a antiguidade greco-romana, começaram a tomar forma. São eles: Zeus em pé ou sentado no trono, barbado ou imberbe, nu ou vestido com um traje leve e curto ou talvez com um quíton e himátion,

segurando um raio com uma mão (ou dois raios um com cada mão), um cetro ou uma águia (Figs. 113 e 114) (Tiverios, 1997: 319). Na Fig. 113, é aceito que se trata da figura de Zeus com o raio, mas não é possível afirmar com certeza se se trata da águia em razão do pescoço, bico e pés alongados daquela ave (que está na mão do deus e também aparece no chão e sobre o trípode) não

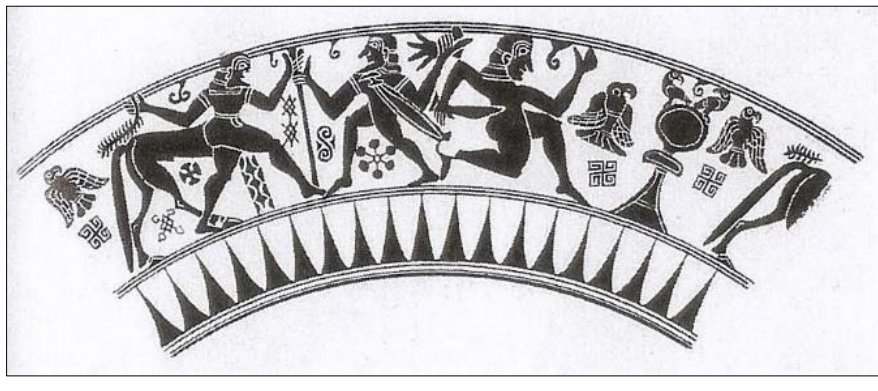

Fig.114- Zeus usando um quíton curto, uma espada grande, segurando um cetro com a mão direita e o raio com a esquerda em batalha com um centauro. Aríbalo proto-coríntio, c.680 a.C., Boston, Museum of Fine Arts (LIMC, VIII: fig.16) possuírem traços anatômicos compatíveis ao de uma águia. 
A partir do século VI a.C. a variedade considerável na iconografia de Zeus, característica do período mais antigo, diminuiu significantemente. Tipos iconográficos específicos do deus começaram a emergir, vários dos quais tiveram uma grande duração: como o de Zeus sentado e o de Zeus em pé, que se consolidou nesse período. Os objetos ou atributos que ele carrega, virtualmente todos familiares do século VIII ao VII a.C., são consistentemente reproduzidos. Assim, do século VI a.C. em diante, Zeus é identificado muito mais facilmente do que nos períodos geométricos ou no início do período arcaico. Em vasos e estatuetas, de um modo geral, o deus é basicamente representado com cabelos longos ou curtos $e$

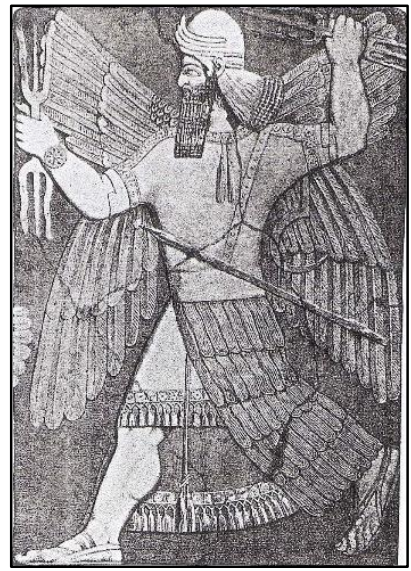

Fig.115- Relevo em alabastro, deus da tempestade (Marduk?), segurando dois forks, 884-860 a.C., palácio de Ashur-nasir-pal III, Museu Britânico (Cook, 1925: vol.II, fig.728)

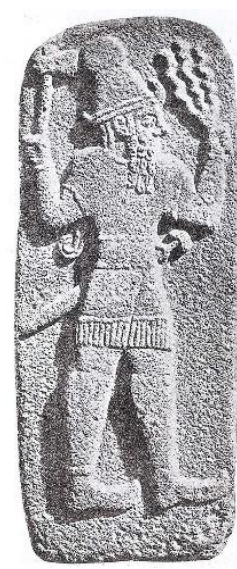

Fig.116- Estela hitita, Tesub em pé com o machado $\mathrm{e}$ fork-raio, século $X$ a.C., Babilônia (Cook, 1925: vol.II, fig.724) barba longa ou curta ou imberbe, nu ou quase nu usando apenas um himátion na cintura ou uma clâmide sobre os ombros ou ainda um himátion e quíton longos, quando está sentado (Tiverios, 1997: 322). 0 tipo de representação mais disseminado no período foi o de Zeus Keraunios ("em pé atirando o raio"), que é originário do Oriente. A. B. Cook mostra uma série de representações em relevo de divindades assírias relacionadas à tempestade, carregando o "garfo" ou "garfo-raio" em pé com uma das mãos ou dois raios cada um em uma mão, ou ainda sentadas segurando um raio (Cook, 1925: Vol.Il, 764-769). Veremos mais adiante como a representação do "garfo" junto às divindades assírias deu origem a representação do raio na arte grega (Figs. 115 e 116). P. Themelis lembra também da similaridade entre esse tipo de representação de Zeus Keraunios e as estatuetas do deus sírio-palestino Reshef, que foram encontradas em vários santuários gregos (Themelis, 2004: 149).

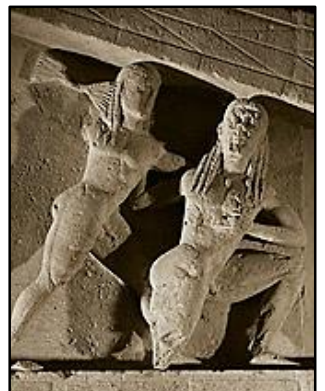

Fig.117- Relevo do pedimento oeste do templo de Ártemis em Corfu, c.580 a.C., Museu Arqueológico de Corfu.

Em relevos e em vasos do período, o tipo de Zeus Keraunios ocorre em cenas da Titanomaquia, como no relevo do pedimento do templo de Ártemis em Corfu (Fig.117), e da luta contra Tifeu, como aparece retratado na hídria calcídica (Fig.118) e nos relevos em bronze de braçadeiras de escudos, provenientes de Olímpia e de fabricação coríntia (Figs.119, 120,121), e de prata proveniente da Itália do Sul (Fig.122). Já na estatuária, Zeus é representado com cabelos longos ou curtos, barba curta, segurando o raio com a mão direita e braço esquerdo estendido, cuja mão pode ou não carregar uma águia (Tiverios, 1997: 323). Este é o caso da estatueta de bronze de Zeus encontrada em Ugento, na Itália do Sul, que é de produção tarentina, datada de 510-500 a.C

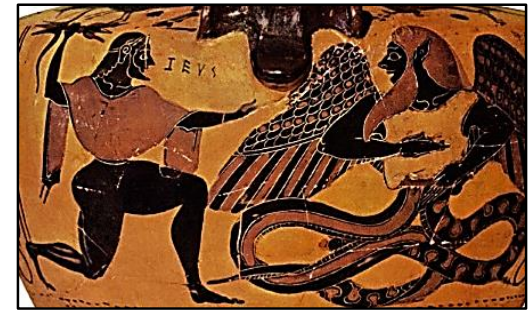

Fig.118- Hídria calcídica de figuras negras, Zeus lutando contra Tifeu, c.540 a.C., Antikensammlungen,

(Fig.123) (Tiverios, 1997: 319). Nessa estatueta, Zeus usa uma fita com rosetas e uma coroa de folhas na cabeça. A representação de Zeus Keraunios segurando a águia parece ser a mais antiga desse tipo ao menos 
na estatuária. Citando Elderkin, G. Mylonas afirma que esse tipo de representação de Zeus com o raio na mão direita e a águia na mão esquerda "parece ter aparecido primeiro no Peloponeso a partir do século VII a.C.", como sugere a estatueta mais antiga do tipo encontrada no Monte Lykaion por Kourouniotes ${ }^{3}$ (Fig.124) (Mylonas, 1944: 152). Como veremos, esse tipo de representação na estatuária foi comum no início do século V a.C. quando Zeus Keraunios foi representado também sem a águia.

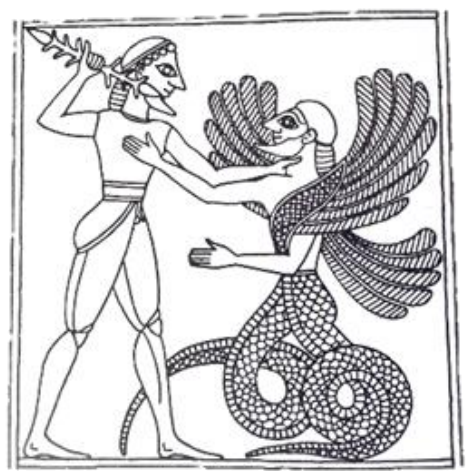

Fig.119-Relevo em bronze de braçadeira de escudo, Zeus lutando contra Tifeu, c.550 a.C., Olímpia (Schefold, 1992: 54, fig.58)

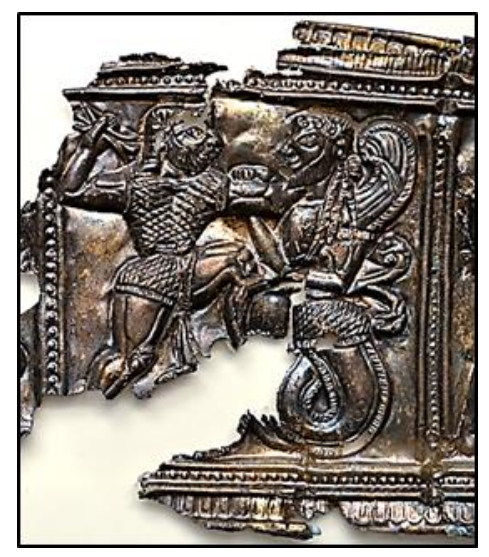

Fig.122- Placa de relevo em prata, Zeus lutando contra Tifeu, c.540530 a.C., Itália do Sul, Paul Getty Museum.

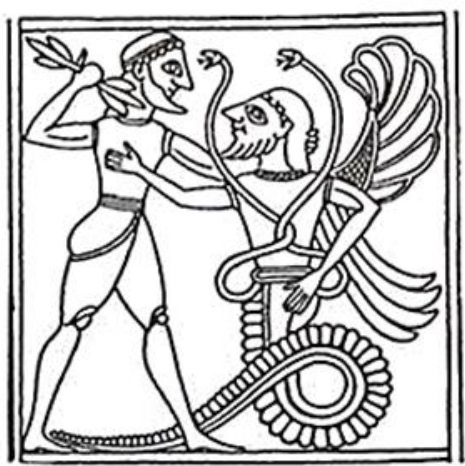

Fig.120- Relevo em bronze de braçadeira de escudo, Zeus lutando contra Tifeu, c.550 a.C., Olímpia (LIMC, VIII: fig.17)

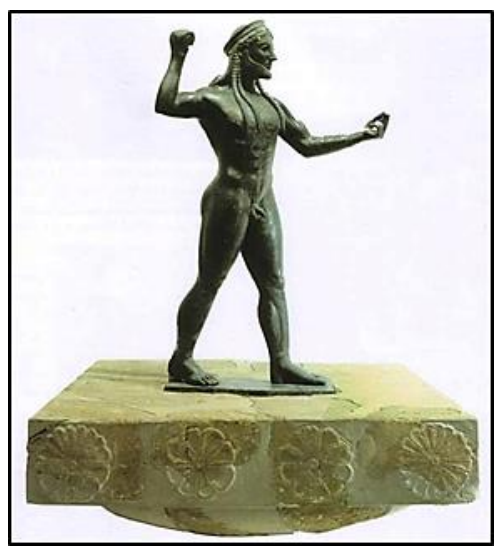

Fig.123- Estatueta de bronze, c.510500 a.C., de Ugento, Museu Arqueológico Nacional de Taranto.

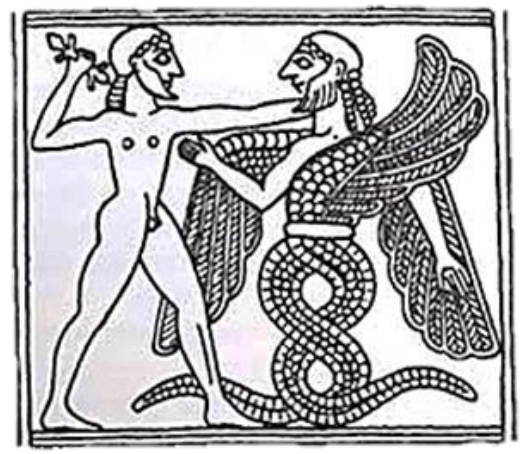

Figura 121- Relevo em bronze de braçadeira de escudo, Zeus lutando contra Tifeu, c.550 a.C., Olímpia (LIMC, VIII: fig.18)

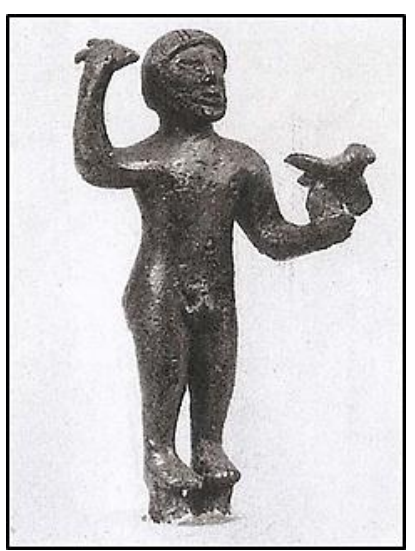

Fig.124- Estatueta de bronze de Zeus Keraunios com águia, VII a.C., santuário do Mt. Lykaion, Museu Arqueológico Nacional de Atenas (LIMC, VIII: fig.27)

O padrão de Zeus sentado foi o segundo tipo de representação usado no século VI a.C., principalmente em vasos. Durante o período, Zeus sentado no trono aparece frequentemente em cenas mitológicas específicas nos vasos áticos datados entre 570-540 a.C., tais como o "Nascimento de Atena", a "Apresentação de Héracles ao Olimpo" e a "Reunião dos deuses" (Tiverios, 1997: 323). Nesses temas, Zeus aparece representado segurando o raio com a mão esquerda e o cetro com a direita (Fig.125), segurando apenas o raio com a mão esquerda ou direita (Figs.126, 127 e 128) ou apenas o cetro (Fig.129). Os seus cabelos aparecem

\footnotetext{
${ }^{3}$ Kourouniotis foi quem primeiro sugeriu a data no século VII a.C., ao passo que no LIMC a estatueta é datada da primeira metade do século VI a.C. Aqui seguiremos a proposição de Kourouniotis, seguida por D. G. Romano e M. Voyatzis mais recentemente (2014).
} 
representados longos com a barba geralmente curta. A representação de Zeus usando a coroa de folhas na cabeça é rara, exceto talvez como mostra a Fig. 126, embora seja difícil de caracterizar se se trata de uma fita ou de uma coroa de folhas. Na cerâmica lacônia, datada entre 560-550 e 530-525 a.C., Zeus aparece sentado no trono associado à águia, o que não ocorre na cerâmica ática desse período. Na famosa taça de 560-550 a.C., Zeus aparece representado com cabelos e barba longos, com os braços por dentro do longo himátion. 0 deus está sentado sobre um assento em degraus e uma grande águia voa diante dele (Fig.130). Na segunda taça, de 530-525 a.C., encontrada no aterro do norte do estádio de Olímpia, Zeus é retratado também com cabelos e barba compridos, vestindo um himátion longo, sentado em um trono com apoio para os pés, ao lado, ao que parece de Hera, conforme a descrição da imagem. A águia aparece em pé, de asas fechadas, atrás do trono do deus (Fig.131).

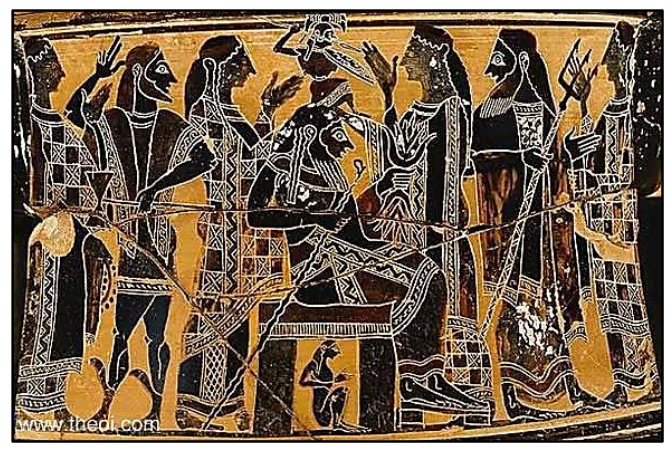

Fig.125- Trípode kothon ático de figuras negras, Nascimento de Atena, c.570-565 a.C., Paris, Museu do Louvre.

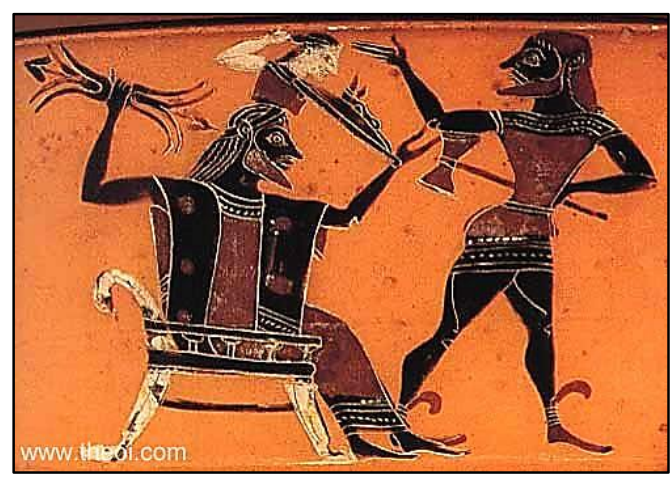

Fig.127- Kylix ático de figuras negras, Nascimento de Atena, c.560 a.C., Londres, Museu Britânico.

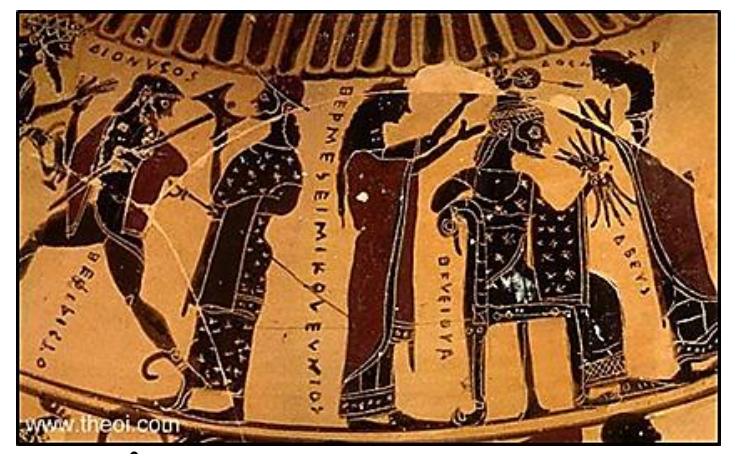

Fig.126- Ânfora ática de figuras negras, Nascimento de Atena, c.570-560 a.C., Berlim, Antikenmuseen.

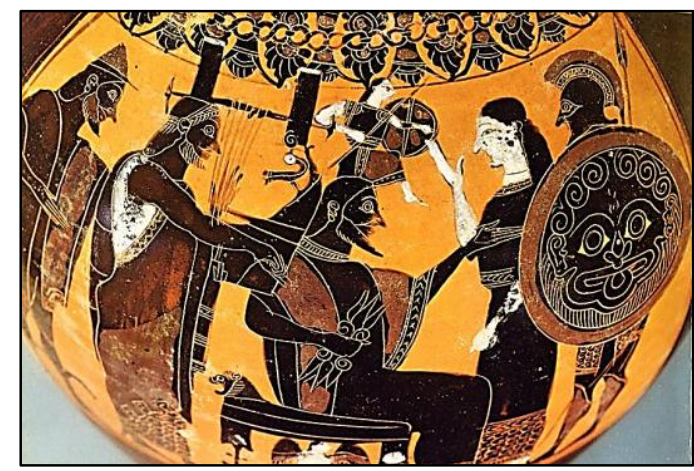

Fig.128- Ânfora ática de figuras negras, Nascimento de Atena, c.540 a.C., Boston, Museum of Fine Arts.

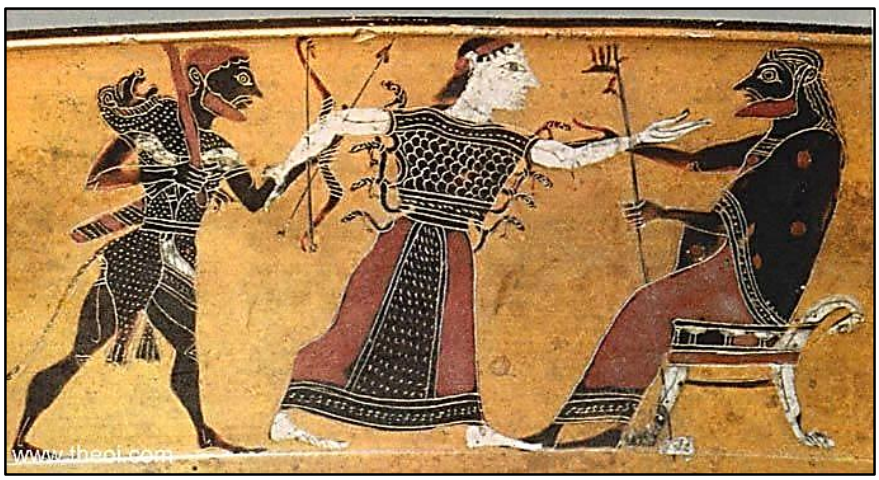

Fig.129- Kylix ático de figuras negras, Apresentação de Héracles ao Olimpo, c.560 a.C., Londres, Museu Britânico. 


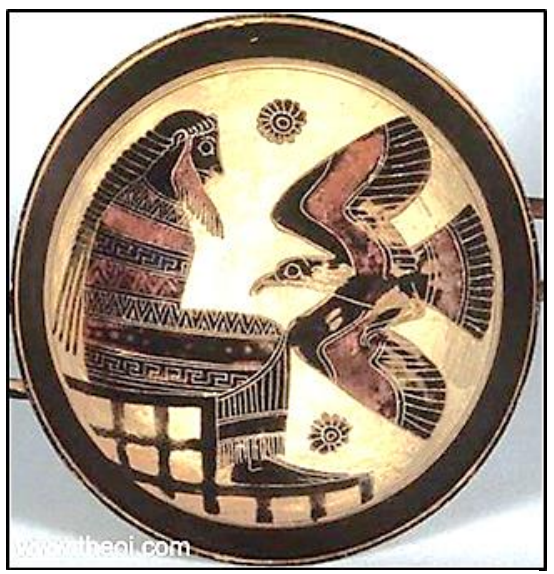

Fig.130- Taça lacônia de figuras negras, Zeus sentado diante da águia, c.560-550 a.C., Paris, Museu do Louvre (LIMC, VIII: fig.45)

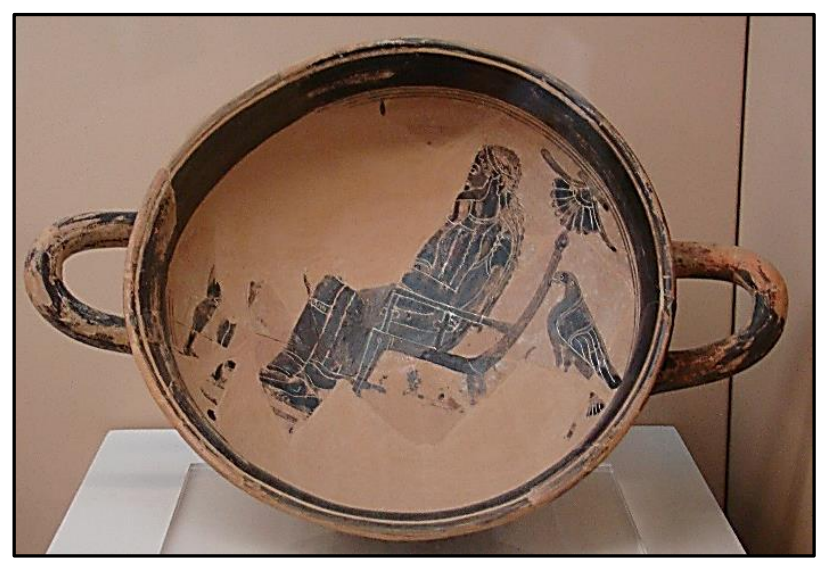

Fig.131- Taça lacônia de figuras negras, Zeus e Hera, c.530-525 a.C., Antigo Museu de Olímpia (Foto: arquivo pessoal/2014)

Embora não tenha sido tão comum no período, na estatuária Zeus sentado ocorre em estatuetas de bronze em que segura dois raios (Fig.132) ou em que atira um raio com a mão direita, nesse caso, um tipo raro de Zeus Keraunios sentado (Fig.133) (Tiverios, 1997: 323). Na base dos dados existentes, concluiu-se que as representações de Zeus em pé precederam as de Zeus sentado (Tiverios, 1997: 324).

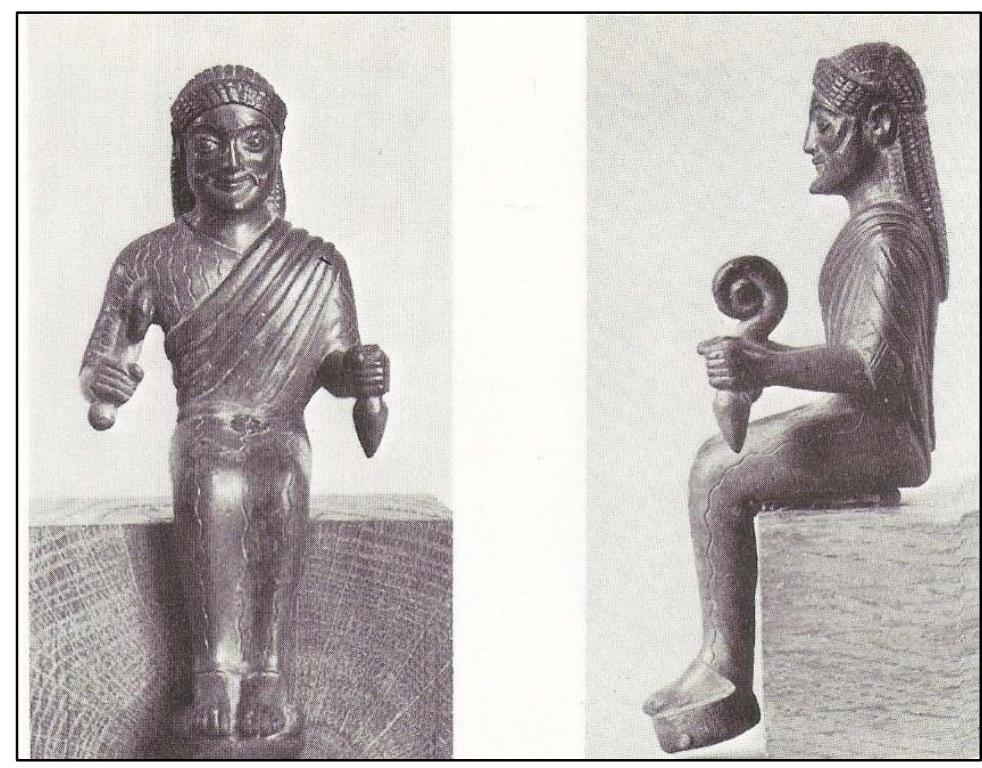

Fig.132- Estatueta de bronze, 530-520 a.C., Santuário do Mt. Lykaion, Museu Arqueológico Nacional, Atenas (LIMC, VIII: fig.37)

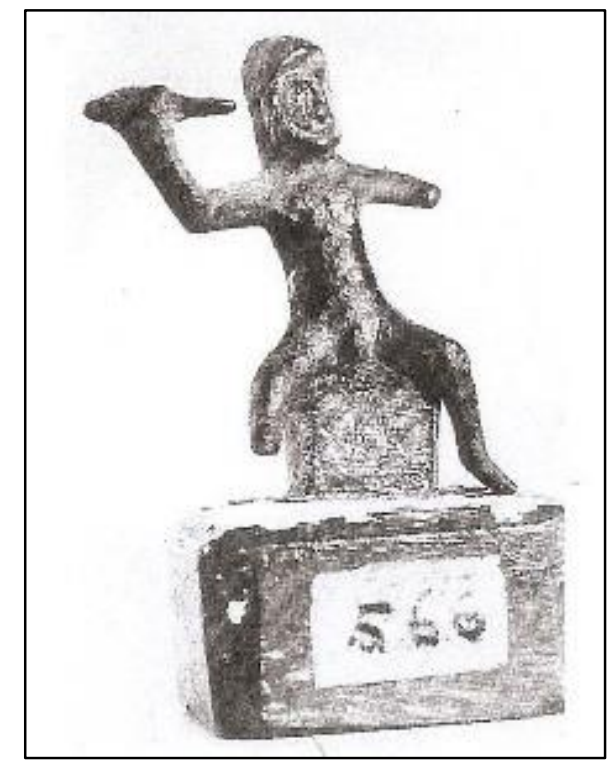

Fig.133- Estatueta de bronze, VI a.C., procedência desconhecida, Museu Arqueológico Nacional, Atenas (LIMC (VIII:fig.34).

\section{No período clássico}

A partir de 500-480 a.C., o tipo predominante de representação do deus na estatuária foi o de Zeus Keraunios, sendo encontrado em esculturas, relevos e vasos (Tiverios, 1997: 332). Esse padrão recebeu 0 nome Keraunios nos tempos modernos com base na llíada (V, 280; VII, 244; XVII, 516; XX, 438; XXII, 273) e na Ode Olímpica de Píndaro $(13,77)$ (Laky, 2008: 225). Há várias representações na estatuária, 
frequentemente de pequenas dimensões e de bronze, tendo sido a maior parte delas oferendas votivas provenientes dos santuários de Zeus no Monte Lykaion, em Dodona e em Olímpia (Tiverios, 1997: 332). Algumas dessas estatuetas de Zeus Keraunios do período possuem a águia sobre a mão esquerda do deus, enquanto outras não, provavelmente porque as águias se perderam ou porque a estatueta foi confeccionada sem a ave. Com base na procedência e datação das estatuetas com ou sem a águia, G. Mylonas sustenta que Zeus Keraunios sem a águia é um tipo de representação do norte (Dodona) (Figs.134, 135, 136, 137, 138), enquanto que aquela com a águia é um tipo oriundo do sul da Grécia Balcânica ou do Peloponeso (Mt. Lykaion e Olímpia). A estatueta encontrada em Ambrácia foi confeccionada em Corinto (Fig.139) (Mylonas, 1946: 205). Segundo Mylonas, todas as evidências parecem apontar o sul do Peloponeso como o local onde se originou 0 tipo de Zeus Keraunios com a águia (Mylonas, 1946: 205). Nesse sentido, o local responsável pela criação dessa representação do deus teria sido, então, o santuário de Zeus Lykaios na Arcádia, onde o deus e a águia foram usados pela primeira vez na estatuária no século VII a.C. ${ }^{4}$ (Fig.124) e de onde o tipo teria se difundido a outras áreas do mundo grego (Mylonas, 1946: 205-206). Do Lykaion (Fig. 140), provavelmente, o uso da águia nas estatuetas de Zeus Keraunios se difundiu para Olímpia no início do século V a.C. (Fig. 141 e 142). De acordo com Mylonas, oficinas peloponésias teriam contribuído para a difusão desse padrão de representação para fora do Peloponeso no século V a.C., principalmente ao Ocidente grego, como indica a estátua ofertada pelos metapontinos em Olímpia, descrita por Pausânias (V, I.XXII.4-7) (Mylonas, 1944: 152). E ainda é possível ver o padrão de representação no estrigilo datado de 430 a.C. encontrado no mar entre Siracusa e Leontino, na Sicília, que possui a figura de Zeus Keraunios com a águia junto a inscrição 乏OTEP (epíteto de Zeus "Salvador") (Fig.143) (Manganaro, 2003; Laky, 2008: 226-227). Do Peloponeso também - descrita nas fontes textuais (Pausânias IV, XXXIII, 1-2) -, provém outra estatueta conhecida de Zeus Keraunios com a águia. Tratase da famosa representação de Zeus do Monte Ithome, uma escultura de Ageladas criada após 455 a.C., 0 ano em que os messênios procuraram refúgio em Naupaktos após sua derrota pelos espartanos. Tratava-se de uma estátua pequena e não pesada que poderia ser transferida de Naupaktos à Messênia (Tiverios, 1997: 332333).

As considerações de Mylonas procedem até certo ponto sobre o santuário de Olímpia e o Monte Lykaion. É importante dizer que o estudioso não cita, por exemplo, o pithos de Cnossos com a representação de Zeus que segura um raio com a mão direita e uma ave com a esquerda (Fig.113), datado de 700 a.C., que poderia ser a imagem de uma à águia. Quando Mylonas diz das águias que ficavam no témeno de Zeus no santuário do Monte Lykaion, considerada por ele mais uma evidência de que o santuário foi o pioneiro na associação entre a ave e Zeus, também não menciona a escultura monumental (da metade do século VI a.C.) de uma águia de arenito que, sobre um pilar, ficava na área do santuário de Zeus Thenatas em Amnissos, Creta

\footnotetext{
${ }^{4}$ De acordo com O. Zolotnikova, essa estatueta (em que aparece segurando o raio) "é a evidência material mais antiga sobre Zeus como o deus da tempestade na religião grega"(Zolotnikova, 2005: 112). Mas, a nosso ver, trata-se de uma das evidências mais antigas, considerando-se as datas do início do século VII a.C., das cenas nas cerâmicas pintadas das fig.113 e 114.
} 
(Fig.227). Como se vê, não parece ter sido apenas o Peloponeso a região pioneira na construção de um padrão de representação de Zeus em relação à águia e/ou ao culto do deus e sua associação com a ave, o que sugere uma relação entre o Peloponeso e Creta nessa questão, discutida mais à frente na iconografia da águia.

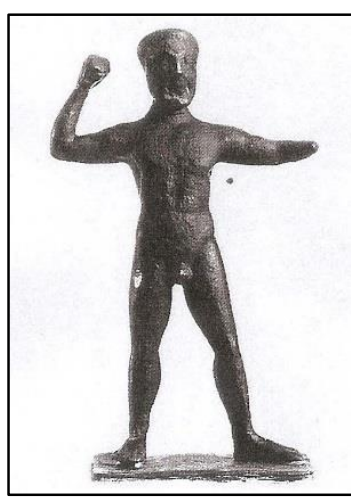

Fig.134- Estatueta de Zeus Keraunios sem águia, c.490 a.C., Dodona, Museu Arqueológico Nacional de Atenas (LIMC, VIII: fig.29c)

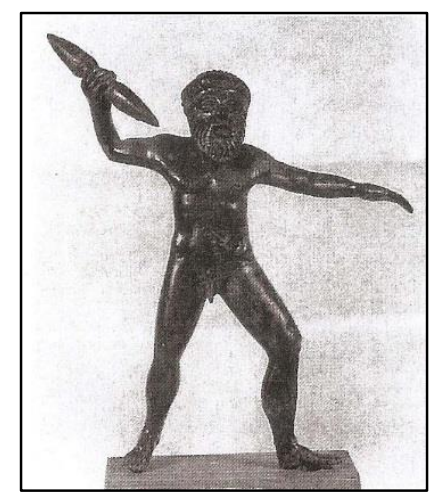

Fig.135- Estatueta de bronze de Zeus Keraunios sem águia, c.480-470 a.C., Dodona, Museu Arqueológico Nacional de Atenas (LIMC, VIII: fig.62d)

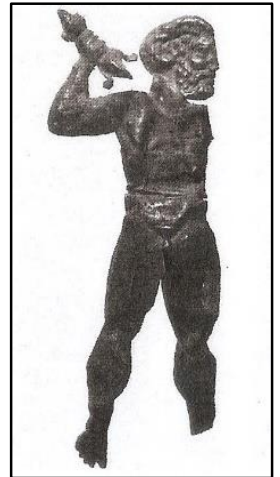

Fig.138- Lâmina de prata de Zeus Keraunios sem águia, c.450 a.C., Dodona, Museu Arqueológico de loánnina (LIMC, VIII: fig.66)

Fig.142- Estatueta de bronze de Zeus Keraunios sem águia e vestindo uma clâmide, início do séc. $\mathrm{V}$ a.C. Olímpia, Museu Arqueológico Nacional de Atenas (LIMC, VIII: fig.31)

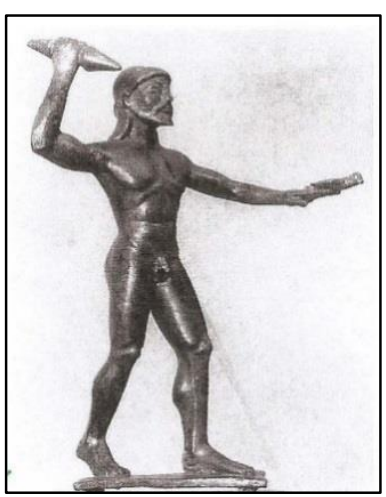

Fig.139- Estátueta de bronze de Zeus Keraunios com a águia, c.490-480 a.C., Ambrácia, Museu Arqueológico Nacional de Atenas (LIMC, VIII: fig.29a)

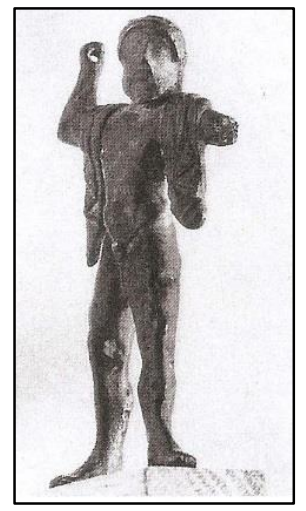

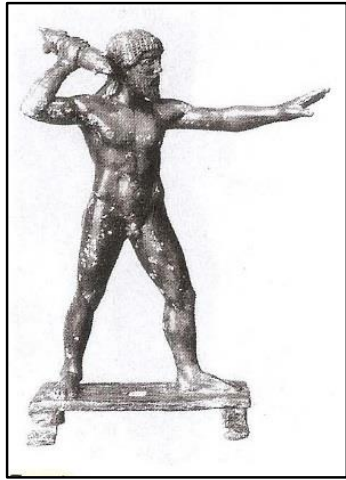

Fig.136- Estatueta de bronze de Zeus Keraunios sem águia, c.470-460 a.C., Dodona, Museu

Arqueológico Nacional de Atenas (LIMC, VIII: fig.62c)

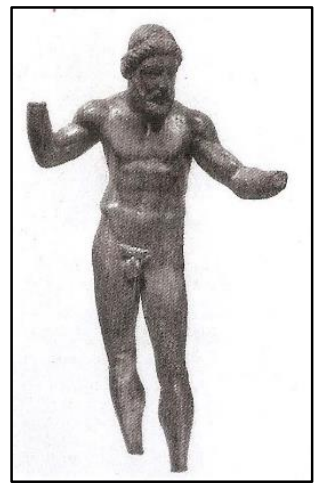

Fig.137- Estatueta de bronze de Zeus Keraunios sem águia, c.450-440 a.C. Dodona, Paris, Museu do Louvre (LIMC, VIII: fig.62j)

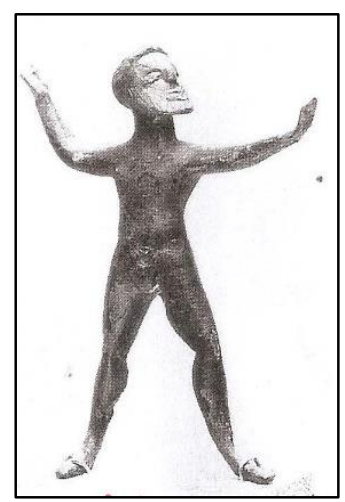

Fig.140- Estatueta de bronze de Zeus Keraunios, sem águia, 1a met. V a.C., Mt. Lykaion, Museu Arqueológico Nacional de Atenas (LIMC, VIII: fig.62a)

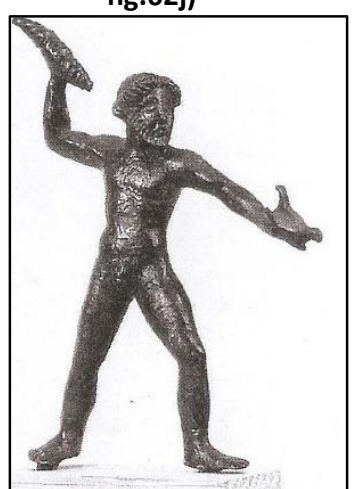

Fig.141- Estatueta de bronze de Zeus Keraunios com a águia, c.480 a.C., Olímpia, Museu Arqueológico Nacional de Atenas (LIMC, VIII: fig.29e)
Fig.143- Estrigilo, Zeus Keraunios com a águia, inscrição ¿OTEP, 430 a.C., Sicília (Manganaro, 2003). 
Ao contrário das pequenas representações de Zeus Keraunios descritas até o momento, a famosa estátua de bronze encontrada no Cabo Artemísio ${ }^{5}$, na Eubéia, (datada de 460 a.C.) é considerada por muitos estudiosos como sendo a representação de Zeus Keraunios em tamanho grande, talvez uma estátua votiva (Fig.144) (Mylonas, 1944: 155; Themelis, 2004: 151).

Saindo da Grécia Balcânica em direção ao Ocidente grego, da Itália do Sul, de Lócris Epizefiri, provém uma estatueta de terracota com a representação de Zeus nu, em pé, atirando o raio com o braço direito erguido, a qual é datada do século V a.C. Localmente, o tipo de representação foi denominado Saettante, em referência à posição de Zeus que parece saltar para atirar o raio. Trata-se de um achado que definiu a localização de um suposto santuário de Zeus em Centocamere, no sudeste da área urbana (Fig.145).

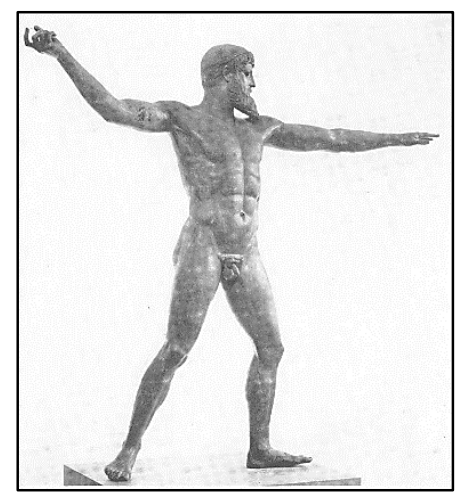

Fig.144- Estátua de bronze do Cabo Artemísio, c.460 a.C., Eubéia, Museu Arqueológico Nacional de Atenas.

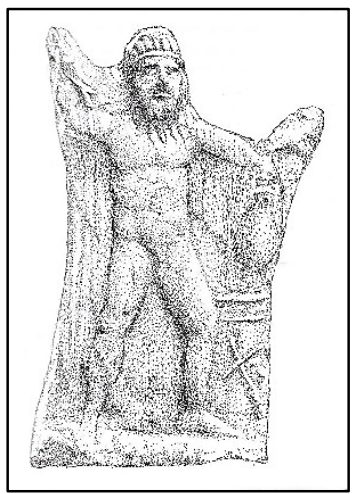

Fig.145- Estatueta de terracota, Zeus Saettante, séc. V a.C., Lócris, Museu Arqueológico (Vonderstein, 2006: 96 fig.25)

Em busca dos padrões de representação de Zeus em pé e sentado no período clássico (quando o deus passou a ser dessa maneira retratado nas moedas), assim como das unidades mínimas junto a ele representadas (presença ou não da águia, do raio ou do cetro, tipo de vestimenta, comprimento de cabelo e barba), realizamos um levantamento da imagem do deus em vasos gregos do período, porque este é o tipo de suporte que oferece as informações mais ricas e completas acerca da representação da divindade na época. O nosso levantamento encontrou 40 tipos de vasos, predominantemente áticos, com representações de Zeus datados do início do século VI até meados do século IV a.C. Ainda que não seja exaustivo, o levantamento proporcionou uma amostragem acerca das mudanças da iconografia de Zeus ao longo de três séculos - do último século da época arcaica até quase o final do período clássico. Assim, acerca da temática onde Zeus foi

\footnotetext{
${ }^{5} \mathrm{~A}$ ausência de atributos, que possam identificá-la a alguma divindade, e a posição dos braços tornou a estátua alvo de debates que a classificam como uma representação de Zeus ou Poseidon ou até mesmo a representação de um atleta. Georges Mylonas, que em um artigo levanta fortes evidências de que Zeus é a divindade representada na estátua. Mas acerca dessa escultura existe um debate sobre se era uma estátua de culto ou um ex-voto (Mylonas, 1944: 155). Themelis diz que o bronze não era o material utilizado para as estátuas de culto, mas o mármore ou marfim (2004: 151). A estátua de Artemísio é incompatível com o padrão de estátuas de culto do século $V$ a.C., que nesta época eram representadas de modo frontal para estabelecer uma relação direta com o fiel. Por isso, o autor considera que esta estátua é de natureza votiva.
} 
retratado, foi possível estabelecer que, nos vasos gregos áticos, o tema do "Nascimento de Atena" (nascendo da cabeça do deus ou em pé sobre o colo da divindade) predominou da primeira metade até a segunda metade do século VI a.C. (570-540 a.C.). É provável que essa temática seja a mais antiga sobre Zeus em vasos áticos, já que não há imagens de Zeus confirmadas na cerâmica ática antes de 580 a.C. (Tiverios, 1997: 319). Paralelamente, e em menor grau, o tema de Zeus lutando contra Tifeu também foi usado em cerâmicas calcídicas nesse período. Até a primeira metade do século $\mathrm{V}$ a.C. foi predominante o tema de "Zeus com Ganimedes": a partir do final do século VI a.C. até o início do século V a.C. (520-480 a.C.), Zeus sentado é retratado com Ganimedes lhe servindo vinho, ao passo que na metade do século V a.C. (460-450 a.C.) predomina a cena de Zeus em pé correndo atrás de Ganimedes ou o cortejando. Paralelamente, nesses dois períodos, o tema de Zeus em pé correndo e capturando a ninfa Egina foi muito usado na cerâmica ática de 480/70 até 450/40 a.C. e o tema "Reunião dos deuses" o menos usado (ao redor de 500 a.C.). $O$ terceiro tema relacionado a Zeus, que circulou em vasos áticos no período, refere-se à representação de Zeus com Dioniso. Na primeira metade do século V a.C. (470-460 a.C.) o tema do "Nascimento de Dioniso" é muito recorrente: da perna de Zeus sentado aparece a cabeça de Dioniso em nascimento ou o deus é representado em pé sobre as pernas de Zeus sentado. $O$ tema voltou a ser usado entre os séculos V-IV a.C. (405-385 a.C.) na cerâmica ápula. Nesse período (410-400 a.C.), aparece o tema de Zeus em pé, lutando com o gigante Porphyrion. Durante todo o século IV a.C. os temas relacionados a Zeus se tornaram variados, assim como também se ampliou a área geográfica desses temas com o deus em direção à Itália do Sul (cerâmicas pestana, ápula e lucana).

Acerca das unidades mínimas - importantes para definirmos uma cronologia de seu uso em vasos e contrastarmos com a sua cronologia de uso em moedas -, foi possível estabelecer que a representação de Zeus com cabelos longos e barba longa ou curta predominaram nos vasos do início do século VI a.C. e eventualmente aparecem em vasos do século IV a.C. A partir de 500/480 a.C., Zeus começou a ser representado com cabelos longos e presos, embora ainda com a barba longa. Foi a partir de 460 a.C. que foi retratado com cabelos curtos. A imagem de Zeus com cabelos e barba curtos começaram a ser usados em representações em vasos no final do século $\mathrm{V}$ a.C. Ao que parece, Zeus voltou a ser representado também com barba longa, embora a curta predominasse, em meados do século IV a.C. A coroa de folhas de oliveira passou a ser usada na cabeça do deus entre 500-450 a.C., permanecendo a ser utilizada até o final do século IV a.C. Anteriormente, nada se usava na cabeça de Zeus ou apenas uma fita. Com relação às vestes, nas imagens mais antigas do século VI a.C. até a primeira metade do século V a.C., Zeus usa um himátion longo e a partir de 460 a.C. aparece sendo representado usando um himátion curto. A clâmide, o pequeno manto que cobre os ombros ou apenas um braço de Zeus, geralmente é usado quando o deus é representado em pé, aparece sendo usada de frente em 540 a.C., sobre um ombro só entre 470/460 a.C. e dessa forma e acompanhada por um himátion curto entre 430-400 a.C. 
A águia começou a ser representada em associação à imagem de Zeus, ao que parece, na cerâmica lacônia a partir da metade do século $V$ a.C., onde é retratada voando ou em pé no campo do vaso. Somente na cerâmica ática do início e até a metade do século $V$ a.C. que vemos a ave em contato direto com a imagem da divindade, sendo retratada em pé de asas fechadas ou abertas sobre o cetro (500/490-480 a.C.) (com Zeus sentado) (Figs.158 e 159) e com asas abertas na mão esquerda de Zeus (480-470 a.C.) (com Zeus em pé) (Fig.153).

A representação de Zeus em pé é própria do século V a.C., ainda que existam alguns casos nos séculos VI e IV a.C. Assim, em 540 a.C. Zeus aparece nu (apenas com uma clâmide sobre os ombros) atirando o raio, ajoelhado sobre uma das pernas (cerâmica calcídica) (Fig.118). Na cerâmica ática, entre 500-450 a.C. aparece retratado em pé com himátion longo e segurando cetro (Fig.146), ao passo que em 480 a.C. é representado da mesma forma, mas segurando o raio além do cetro (Fig.147). Entre 480/470-450 a.C., Zeus aparece em pé nu com cetro e clâmide (Fig.148), ao passo que entre 470-450 a.C. ele é retratado nu, atirando o raio, segurando cetro e usando uma clâmide sobre um ombro (Fig.149 e $150 \mathrm{com}$ coroa de folhas de oliveira). Esse tipo é comum também entre 410-390 a.C. (Fig.151 e 152). Entre 480-470 a.C. Zeus aparece representado usando um himátion longo, uma clâmide sobre os ombros, atirando o raio e segurando a águia (Fig.153). Entre 460450 a.C., Zeus é retratado usando himátion curto e clâmide sobre braço esquerdo estendido, atirando o raio (alado) (Fig.154). E entre 460-440 a.C. Zeus aparece em pé com himátion longo e quíton, segurando apenas o cetro (Fig.155). Também é importante dizer que ao redor de 470 a.C., Zeus foi representado em pé com 0 raio na mão esquerda e com o tridente, atributo de Poseidon, na mão direita. Nesse caso, "Zeus é representado não só como senhor do céu e da terra, mas também do mar" (Fig.156) (Tiverios, 1997: 333).

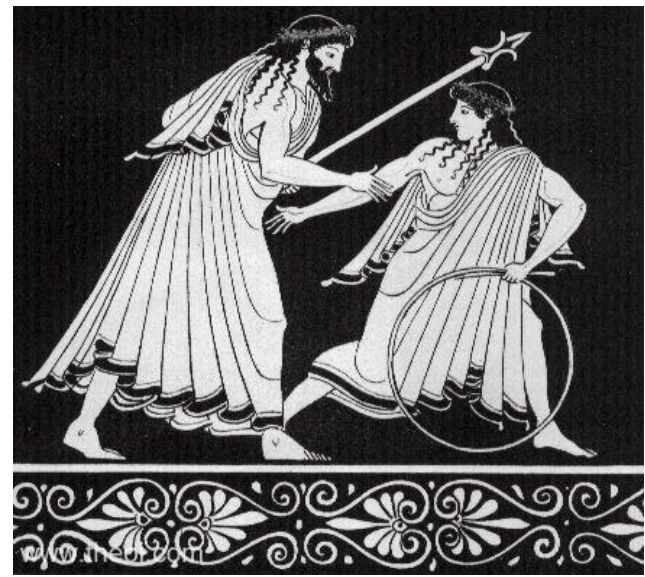

Fig.146- Zeus correndo atrás de Ganimedes, ânfora nolana ática de figuras vermelhas, c.500450 a.C., Boston, Museum of Fine Arts.

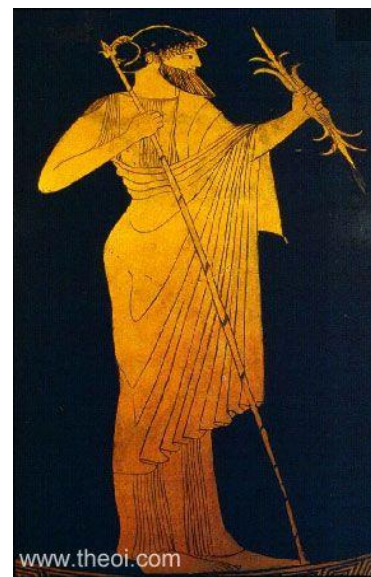

Fig.147- Zeus, ânfora panatenaica ática de figuras vermelhas, c.480 a.C., Munique,

Antikensammlungen.

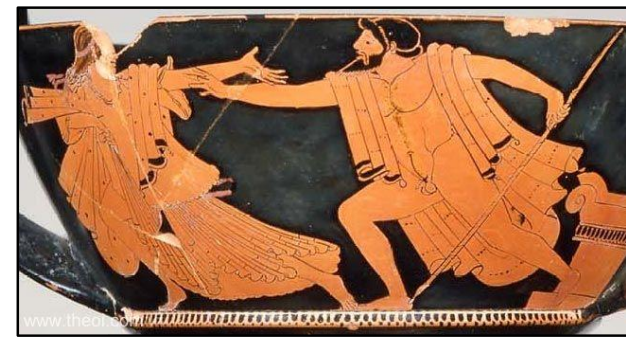

Fig.148- Zeus correndo atrás de Ganimedes cântaro ático de figuras vermelhas, c.480-470 a.C., Boston, Museum of Fine Arts. 


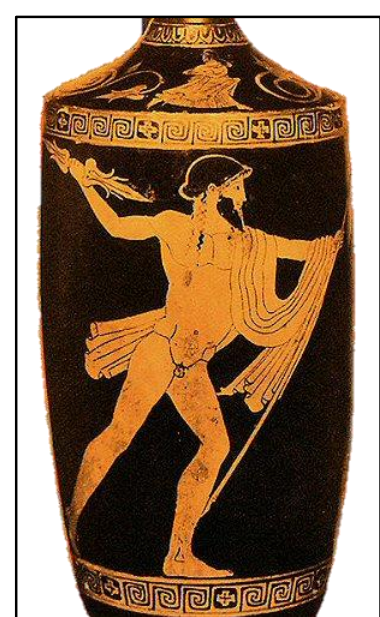

Fig.149-Zeus, ânfora nolana ática de figuras vermelhas, c.470-460 a.C., (LIMC, VIII: fig.70)

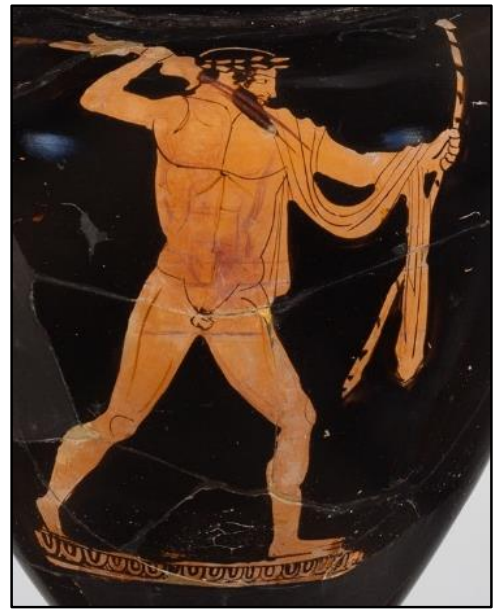

Fig.150- Zeus, ânfora nolana ática de figuras vermelhas, c.460 a.C., $\mathrm{N}$. York, Metropolitan Museum.

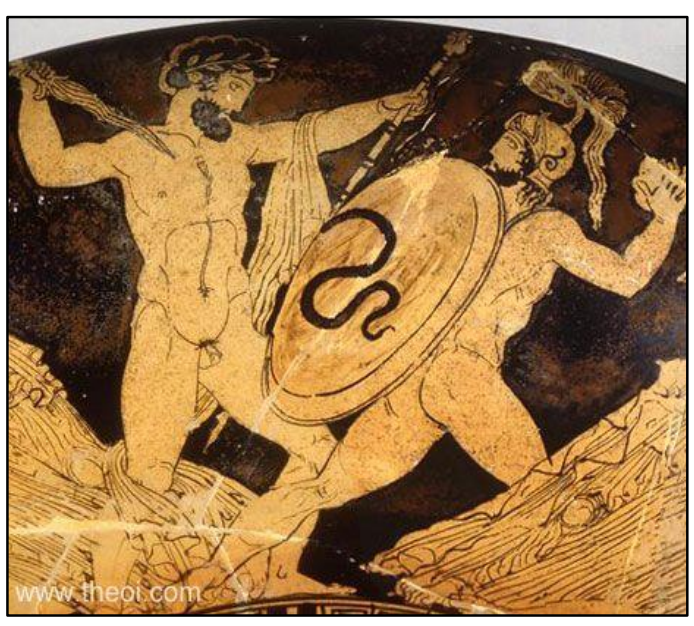

Fig.151- Zeus lutando contra o gigante Porphyrion, Kylix ático de figuras vermelhas, c.410-400 a.C., Berlim, Antikenmuseen.

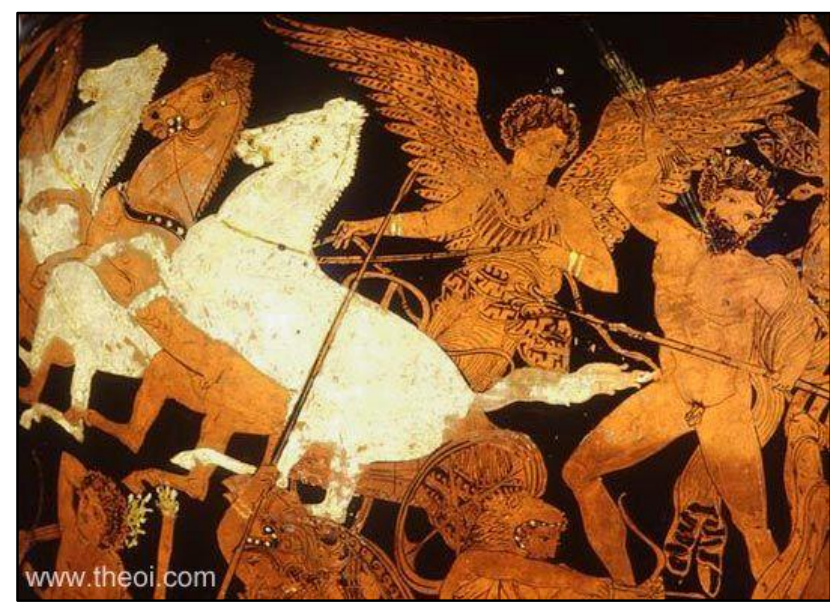

Fig.152- Nike cocheira de Zeus, ânfora ática de figuras vermelhas, c.400-390 a.C., Paris, Museu do Louvre.

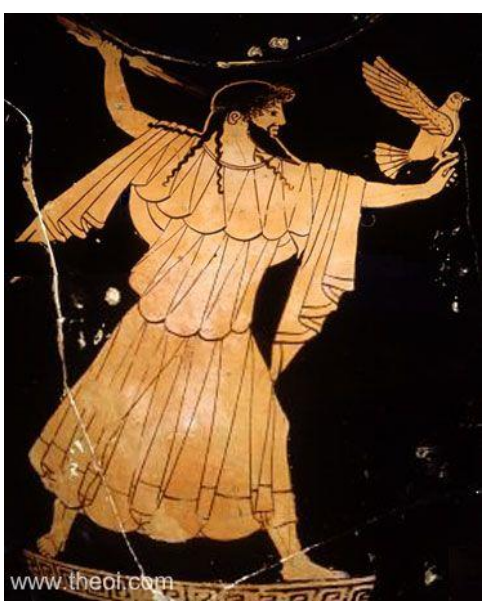

Fig.153- Zeus, ânfora ática de figuras vermelhas, c.480-470 a.C., Paris, Museu do Louvre (LIMC, VIII: fig.68)

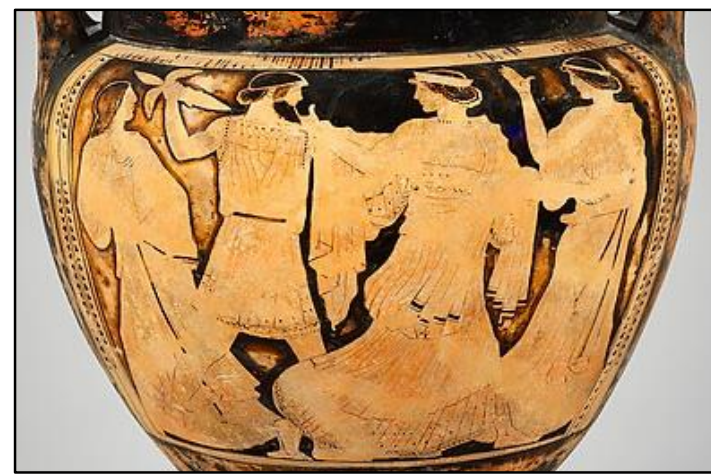

Fig.154- Zeus capturando Egina, cratera ática de figuras vermelhas, c.460 a.C., N. York, Metropolitan Museum.

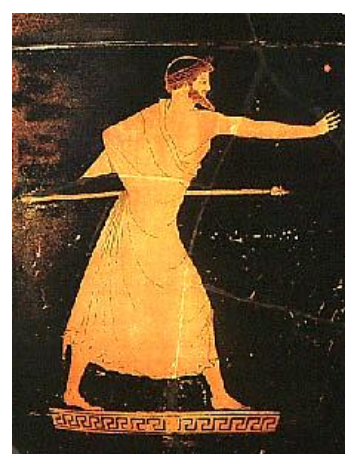

Fig.155- Zeus, ânfora nolana ática de figuras vermelhas, c.460 a.C., Paris, Cabinet Médailes (LIMC, VIII: fig.109).

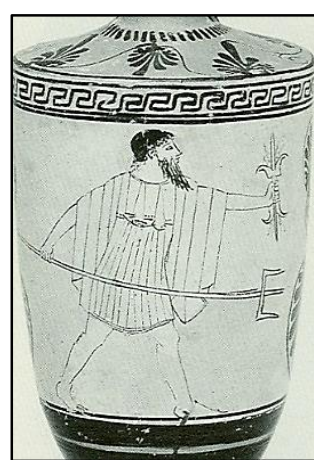

Fig.156- Zeus Enalios, lécito ático de fundo branco, c.470 a.C. (LIMC, VIII: fig.75). 
Já o padrão de representação de Zeus sentado (no trono ou banco) é o mais antigo na cerâmica ática. Em 570 a.C. Zeus aparece sentado no trono, segurando o cetro com a mão direita e raio com a esquerda (Fig.122) e entre 570-540 a.C. segurando apenas com o raio (Figs.125, 126 e 127). Em 560 a.C., o deus é retratado sentado segurando somente o cetro (Fig.129) e somente sentado no trono, sem nenhum atributo em mãos em 550-540 a.C. Em 520 a.C. a divindade aparece segurando o raio e a taça (para ser servido por Ganimedes) (Fig.157), ao passo que em 500 a.C., já no início do século V a.C., ele aparece sentado segurando raio e cetro com águia (Fig.158). Entre 490-480 a.C., Zeus é retratado sentado, segurando cetro com águia e taça (Fig.159), ao passo que em 480 a.C. é representado segurando cetro sem águia e taça (Fig.160). Entre o século V-IV e no século IV a.C. o tipo de Zeus sentado sofreu algumas alterações em sua representação. Entre 405-385 e 450-400 a.C., Zeus aparece reclinado (ápula) (Fig.161) ou sentado usando himátion na cintura e segurando o cetro (ática) (Fig. 162 e 163). Entre 400-380 a.C., na cerâmica ápula, Zeus é retratado sentado com himátion na cintura e segurando o cetro com Nike em cima, na posição ocupada pela águia no século $\mathrm{V}$ a.C. (Fig.164). Também na cerâmica ápula, entre 350-340 a.C. Zeus aparece representado sentado com himátion na cintura, usando uma clâmide sobre os ombros e segurando o cetro sem Nike (Fig.165). Assim, nos parágrafos, descrevemos os padrões iconográficos de Zeus nos vasos gregos. O próximo passo será contrastálos à imagética de Zeus e de seus atributos (águias e raios) nas moedas.

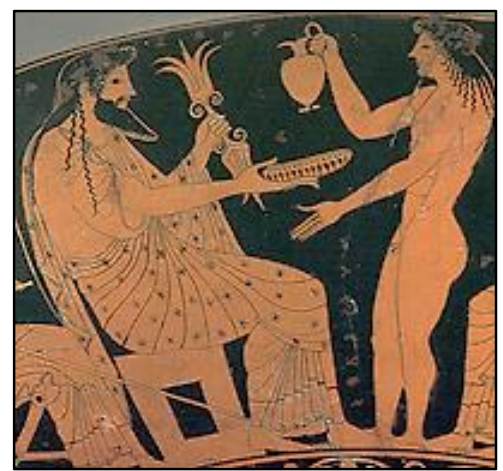

Fig.157- Ganimedes servido vinho a Zeus, kylix ático de figuras vermelhas, c.520 a.C.

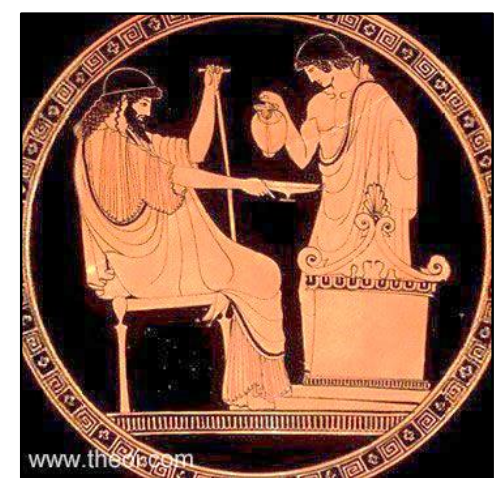

Fig.160- Ganimedes servindo vinho a Zeus, kylix ático de figuras vermelhas, c.480 a.C., Los Angeles, Paul Getty Museum.

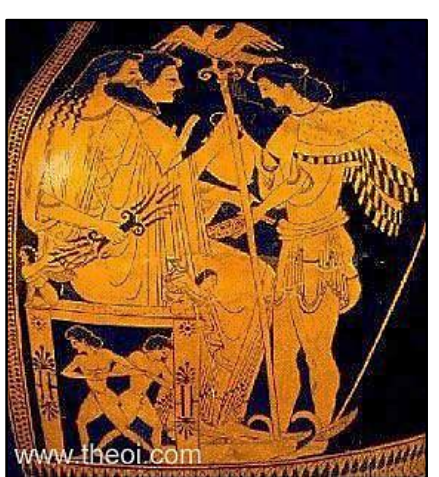

Fig.158- Reunião dos deuses no Olimpo, ânfora ática de figuras vermelhas, c.500 a.C., Munique, Antikensammlungen.

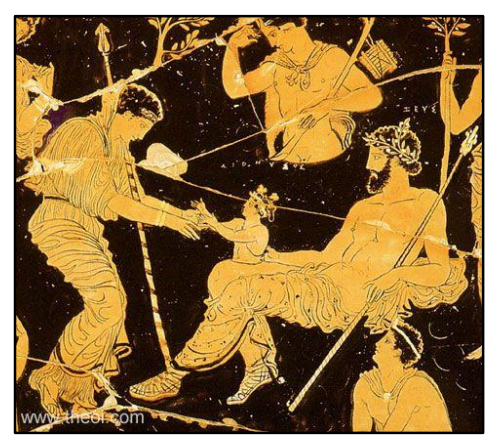

Fig.161- O nascimento de Dioniso, cratera ápula de figuras vermelhas, c.405-385 a.C., Museu Nacional de Tarento.

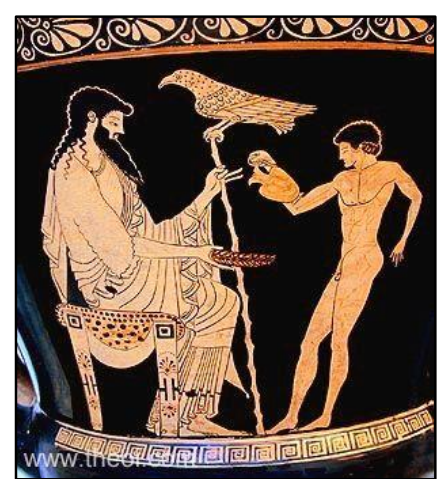

Fig.159- Ganimedes servindo vinho a Zeus, cratera ática de figuras vermelhas, c.490-480 a.C., N. York, Metropolitan Museum.

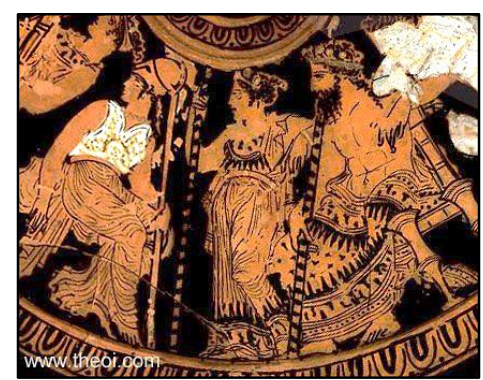

Fig.162- Zeus e Hera, Pyxis ático de figuras vermelhas, c.450-400 a.C., Museu da Univ. Pennsylvania. 


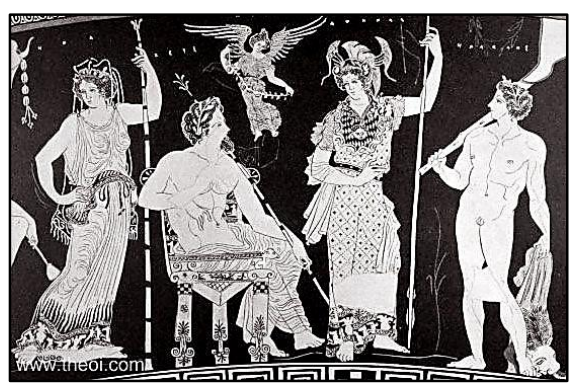

Fig.163- Zeus, Hera e Atena, cratera ática de figuras vermelhas, c.400 a.C., Roma, Museu Nacional de Villa Giulia.

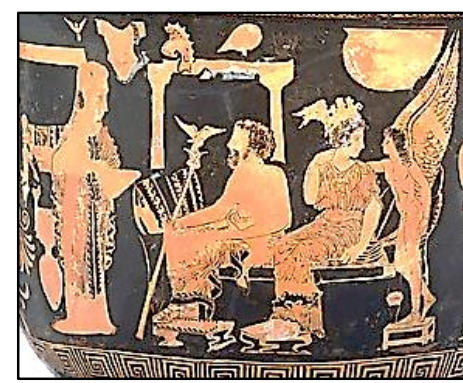

Fig.164- Europa suplicando pela vida de Sarpedon, cratera ápula de figuras vermelhas, c.400-380 a.C., N. York, Metropolitan Museum.

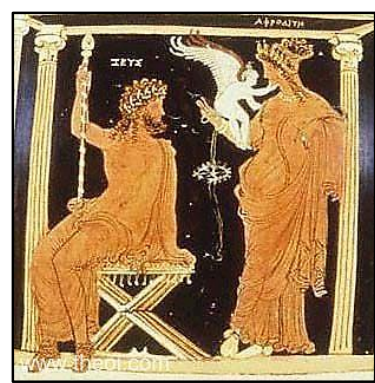

Fig.165- Zeus e Afrodite, loutrophoros ápulo de figuras vermelhas, c.350340 a.C., Los Angeles, Paul Getty Museum.

Diante de todas essas informações sobre os padrões de representação de Zeus na arte grega, que vimos até agora, é preciso dizer que no século $V$ a.C. houve um divisor de águas na forma como a divindade vinha sendo retratada. A estátua de culto criselefantina de Zeus Olímpio, obra de Fídias para o templo de Zeus em Olímpia, inevitavelmente influenciou os artistas da época e subsequentemente todas os tipos de representações de Zeus na arte, da escultura à pintura nos vasos (Tiverios, 1997: 334). Segundo descreveu Pausânias (X, 9-11), o deus estava sentado no trono e era feito em ouro e marfim. Na sua cabeça existia uma coroa de brotos de oliveira e na sua mão esquerda a estátua segurava a deusa da vitória, Nike, igualmente feita em ouro e em marfim. Zeus Olímpico segurava em sua mão esquerda um cetro com uma águia sentada no topo. Assim, diante das evidências arqueológicas e textuais podemos supor que "a gigantesca estátua (12,37m de altura) tenha sido em parte responsável por consolidar o culto de Zeus no santuário" (Laky, 2008: 227-228).

Aos poucos, o deus dos passos largos foi suplantado pelo deus em pé e pelo deus sentado (Cook, II: 745). Ao longo do período clássico, Zeus tornou-se cada vez menos o impetuoso trovejante, e cada vez mais o soberano respeitável (Cook, II: 731). No século IV a.C., houve uma divisão na iconografia de Zeus entre seus tipos heróicos em pé da estatuária, representando o maior deus grego como um defensor, e seus tipos sentados de majestade com o seu aspecto paternal, que o caracteriza como o soberano divino por excelência (Leventi, 1997: 346). No primeiro caso, a estátua colossal de bronze feita por Lisipo para a ágora de Tarento, na Itália do Sul, que conhecemos somente a partir das fontes textuais, é o principal exemplo. Datada do final do século IV a.C, ela combinava a tradição iconográfica de imagens de Zeus do final do período arcaico e do início do clássico, em sua nudez heróica segurando e atirando o raio, com a imagem do pai dos deuses e dos homens, "em pé em sua majestade real segurando seu cetro e vestindo um himátion" (Leventi, 1997: 344). O estilo de Zeus em pé foi utilizado no período por Lisipo em estátuas de Zeus na ágora de Argos e na de Sicione, influenciando outros artistas da época (Leventi, 1997: 344-345).

A maior parte das estátuas de Zeus é descrita apenas pelas fontes textuais ou chegou até nós como cópias de época romana. Por essa razão, escolhemos mostrar essas novas características na imagem de Zeus no período, usando relevos escultóricos, nesse caso, relacionados ao culto ctônio de Zeus Meilichios (sugeridos pela presença da fiala para libação na mão do deus), encontrados no Pireu (Figs.166, 167 e 168). Repara-se 
0 aspecto paternal, propiciados pelos cabelos e barba longas, e de majestade proporcionados pela postura no trono e na kliné. Observa-se esse tipo de representação de Zeus com cabelos longos e cheios e barba cheia na cabeça de Zeus encontrada em Tarento datada do final do século IV a.C. Em um estudo anterior sobre a imagética de Zeus e as moedas de Olímpia, concluímos que "esse tipo de representação de Zeus foi próprio de esculturas a partir da segunda metade do século IV a.C. e permaneceu sendo usado para a divindade até a época romana" (Laky, 2008: 230).

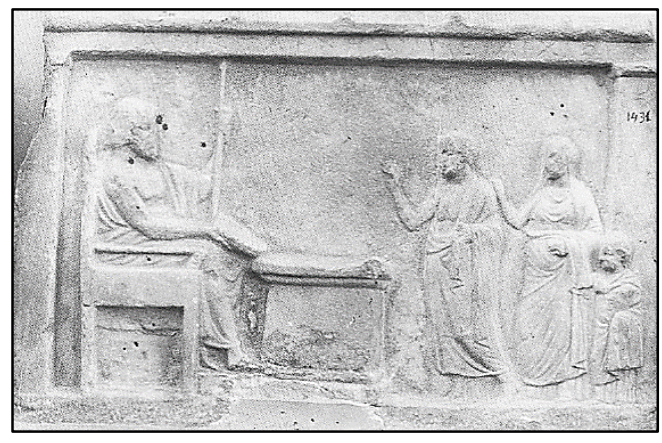

Fig.166- Zeus Meilichios sentado no trono, segurando uma fiala com a mão direita e o cetro com a esquerda, $2^{\text {a }}$ metade do século IV a.C., Pireu (LIMC, VIII: 200).

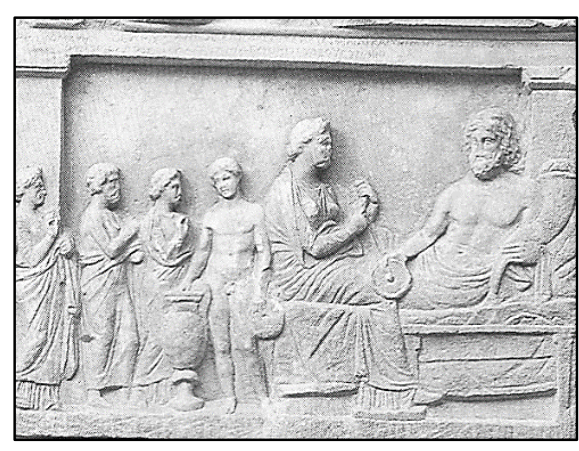

Fig.167- Zeus Meilichios sentado em kliné, segurando uma fiala com a mão esquerda e cornucópia com a esquerda, 2 ametade do século IV a.C., Pireu (LIMC, VIII: 210).

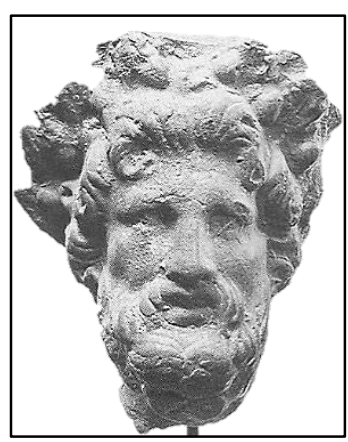

Fig.168- Cabeça de Zeus, final do século IV a.C., Tarento (LIMC, VIII: fig.218).

Também concluímos que o século IV a.C. significou o período de consolidação da imagem de Zeus transformada no século anterior. Diante de uma visão geral da representação de Zeus no período clássico vimos que até a primeira metade do século $V$ a.C. predominou a imagem de Zeus em pé e atirando o raio nos vasos e nas esculturas. Esse tipo de representação indica o aspecto guerreiro de Zeus que remonta ao período arcaico. À medida que se chega à segunda metade do século $V$ a.C. esse tipo de imagem é trocado pela imagem de Zeus sentado. Essa posição de Zeus sentado e no trono é um indicativo de majestade e de poder consolidado. Nesse sentido, essa forma de representação associada aos cabelos compridos e barba comprida, que passou a acompanhar a imagem do deus, indica a consolidação de Zeus como o grande deus dos gregos. Lembremos que a arte tanto pode querer transmitir uma ideia em vias de se consolidar ou já consolidada (Laky, 2008: 233).

\section{A representação de Zeus Amon na arte grega}

A representação de Zeus Amon merece uma consideração à parte, deve ser estudada separadamente e ao mesmo tempo em paralelo ao desenvolvimento da iconografia de Zeus na arte grega em razão de, na associação ao deus egípcio Amon, ter assumido uma característica iconográfica nova e particular: portanto, os chifres de carneiro na cabeça de Zeus. 
Amon foi um deus egípcio proveniente de Tebas cultuado como deus solar e da fertilidade. Como um deus-carneiro, na arte egípcia, Amon foi representado com o corpo de um homem e com a cabeça do animal (Parke, 1967: 194). No início do segundo milênio a.C., na vigésima dinastia, por um processo familiar na religião egípcia, Amon, a divindade local de Tebas, alcançou uma posição dominante acima das demais divindades. Tebas tornou-se a capital do Egito, e então o deus local foi igualado a Ra, o deus solar já reconhecido como supremo. Como foi longa a permanência de Tebas como capital, Amon-Ra manteve seu domínio, mesmo ao longo do período do monoteísmo de Akhenaton. Na décima oitava dinastia o culto de Amon assumiu função oracular, prática que se consolidou no período Ramessida, quando importantes questões foram decididas através das respostas dadas pelos sacerdotes do deus (Parke, 1967: 194-195). A data da instalação do culto de Amon em seu famoso oráculo em Siwa permanece desconhecida. Parece que o culto de Amon-Ra foi identificado com um deus-carneiro líbio venerado em Siwa na época que um grupo de sacerdotes egípcios instalou-se por lá, no momento em que os residentes e o seu chefe eram líbios (Heródoto, II.32;33). Mesmo incerta, a data para o estabelecimento dos sacerdotes é sugerida na vigésima quinta dinastia (716-664 a.C.) ou ainda mais tarde (Malkin, 1994: 159; Parke, 1967: 196).

O conhecimento grego e os contatos pessoais com o oráculo de Amon parecem ter se iniciado no século VII a.C. com a chegada de mercenários, mercadores e colonos gregos no Egito, que se assentaram em Naucrátis em 630 a.C. Outras comunidades gregas também se assentaram na cadeia de oásis iniciada em Kargeh, o provável local de um povoado estabelecido por Samos ao redor de 525 a.C. (Malkin, 1994: 159-160). Siwa nunca foi considerado um oráculo grego, mas, mesmo assim, os gregos identificaram Amon com Zeus porque ambos eram clamados como divindades supremas (Malkin, 1994: 160; Parke, 1967: 203). O relato mais antigo, sobre o conhecimento do oásis de Amon no mundo grego, é a famosa passagem em Heródoto (l.46) que descreve a consulta do rei lídio Creso ao oráculo. Não há referências a Zeus Amon em Homero e nem em Hesíodo, cujos textos guardam os registros mais antigos sobre as divindades gregas (Parke, 1967: 200-201).

O culto de Zeus Amon foi adotado por Cirene, responsável pela fundação de cidades gregas na costa da Líbia, tendo sido através dessa pólis que o culto se difundiu às demais fundações gregas da região. Já na primeira metade do século $V$ a.C. as fontes literárias mencionam o deus considerando-o como uma hypostase de Zeus. É preciso dizer que Zeus Amon foi tido realmente como um deus grego, como demonstra um certo número de cidades gregas que lhe renderam um culto público, e não como uma divindade exótica relegada às áreas dos portos reservadas aos estrangeiros (Leclant; Clerc, 1997: 666). No século VI a.C., o culto de Zeus Amon parece ter penetrado no Peloponeso. Nesse período, o deus havia ganho um templo em Gythion (Pausânias III, XXI, 8) e em Esparta (Pausânias III, XVIII, 3). Fora do Peloponeso, em Tebas, na Beócia, havia um templo dedicado à divindade no século $V$ a.C. do qual sabemos por meio de Píndaro, que consagrou ali uma estátua do deus, obra de Calamis. 0 oráculo de Siwa e seu deus eram muito populares entre os atenienses, que o consultavam frequentemente antes de tomar as decisões mais importantes. Eles Ihe renderam um culto oficial no século IV a.C.: um templo no Pireu (Leclant; Clerc, 1997: 666). Durante o século 
IV a.C. houve um declínio no culto à divindade dos gregos de fora da Líbia em relação à divindade de Siwa. Parece que o seu segundo oráculo na ilha de Pallene passou a ser mais procurado pelos macedônios. Nesse período, na Calcídia, os macedônios Ihe dedicaram um santuário e um templo em Aphytis, que se tornou popular entre os dinastas macedônios (Leclant; Clerc, 1997: 667).

A adoção de Amon pelos cireneus foi provavelmente facilitada pela antiga veneração de Apolo Carneios pelos dórios espartanos de Thera, cujo culto também era o de um deus carneiro. Ao ser apropriado por Cirene, Zeus com o aspecto de Amon passou a ser representado com os chifres de carneiro (Bonacasa, 2007: 243; Chamoux, 1963: 335; Malkin, 1994: 160). Esta pólis parece ter sido a responsável pela criação da imagem do deus na arte grega ao cunhar moedas com o perfil de Zeus com os chifres do carneiro (Bonacasa, 2000: 46; Malkin, 1994: 160; Parke, 1967: 203). De fato, a representação mais antiga de Zeus Amon que temos na arte grega é a imagem da cabeça do deus em moedas de Cirene datadas de 525-480 a.C. A primeira obra em escultura conhecida da divindade é a estátua dedicada por Píndaro em Tebas, na Beócia, ao redor de 460 a.C. (Leclant; Clerc, 1997: 684). Outra estátua do deus, da qual sabemos apenas das fontes textuais, é aquela do deus sobre um carro dedicada por Cirene no santuário de Apolo em Delfos entre o século V-IV a.C. (Leclant; Clerc, 1997: 670). De acordo com o verbete Amon no LIMC, poucas estátuas do deus chegaram aos dias atuais (Leclant; Clerc, 1997: 684). Nessa mesma obra, são escassos os objetos não-monetários (cenas de vasos, estátuas, relevos, etc) datados do século $\mathrm{V}$ e IV a.C. A maior parte da documentação é datada das épocas helenísticas e romana. Do século $V$ a.C., encontramos apenas uma máscara de bronze, de estilo severo, encontrada em Dodona, no Épiro, onde o deus é representado com barba longa e bigode (Fig.169). Os autores do verbete chegam a citar um conjunto de estatuetas do tipo de Zeus Amon sentado provenientes de Chipre. A única delas, com datação, é atribuída ao período arcaico já que o santuário a que pertencem são desse período, embora, infelizmente, o catálogo não forneça a foto da peça. No entanto, podemos ter uma ideia da representação a partir de um dos exemplares não-datados disponíveis na publicação (Fig.170). Trata-se de uma estatueta em que Zeus Amon é retratado sentado no trono ladeado por dois carneiros. $O$ deus veste um himátion longo e segura uma cornucópia com a mão esquerda e sua mão direita está apoiada sobre a cabeça de um dos carneiros. A parte superior da estatueta não se preservou e assim não podemos ter alguma informação sobre os detalhes iconográficos utilizados nessa parte. Por se tratar da ilha de Chipre, os autores do verbete informam que essas estatuetas podem, na verdade, ser atribuídas à divindade fenícia BaalHammon, cultuada em Chipre, cuja representação é semelhante a de Zeus Amon (Leclant; Clerc, 1997: 684).

Acerca das cenas em vasos gregos, no verbete sobre Amon no LIMC, há apenas dois exemplares. Um deles, traz uma cena caricaturesca de Zeus Amon em um vaso ápulo de figuras vermelhas datado entre os séculos IV-III a.C., o qual não pode ser considerado numa análise iconográfica da divindade. No vaso, Zeus Amon aparece sobre uma plataforma suportada por duas colunas jônicas, aguardando um dos fiéis em seu oráculo (Fig.171). O segundo vaso datado da metade do século IV a.C., também ápulo, traz a representação 
de uma figura jovem com os chifres do carneiro (Fig.172). No entanto, trata-se, a nosso ver, da figura de Apolo Carneios que foi representado em moedas dessa maneira (jovem e imberbe).

Assim, cabe-nos dizer que, se tratando da representação de Zeus em seu aspecto Amon, a nossa grande fonte de informação para o período arcaico e clássico são as moedas batidas por Cirene, Barce e Euesperides.

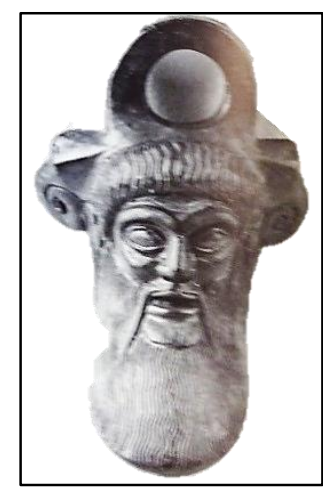

Fig.169- Aplique de bronze, séc. V a.C., Dodona, Museu do Louvre, Paris (LIMC, I: fig.88).

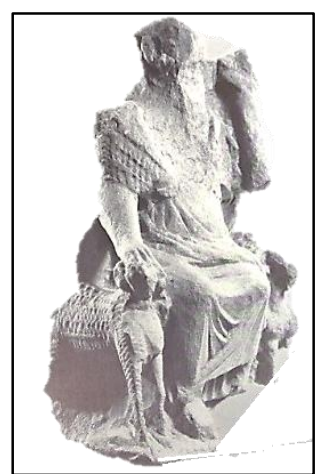

Fig.170- Estatueta de calcário, Nicosia, Museu de Chipre (LIMC, I: fig.12).

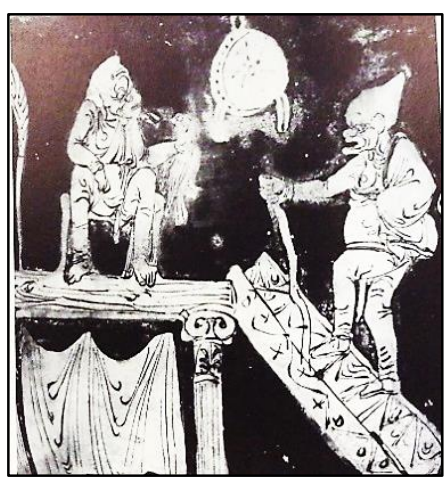

Fig.171- Cratera ápula de figuras vermelhas, IV-III a.C, Museu Arqueológico de Bari (LIMC, I: fig.13)

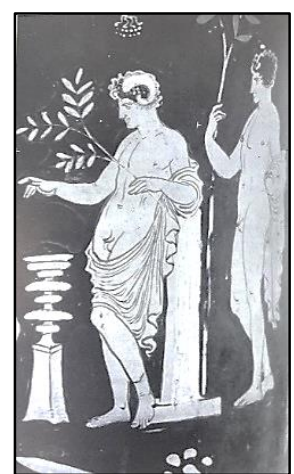

Fig.172- Cratera ápula de figuras vermelhas, metade do séc. IV a.C., Museu Ermitage (LIMC, I: fig.170) 


\section{II.2 A ICONOGRAFIA DE ZEUS EM MOEDAS GREGAS}

Como vimos, há três padrões de representação de Zeus em moedas gregas: 1-) cabeça; 2-) em pé; e 3-) sentado, usados entre os séculos VI-IV/III a.C. De acordo com o gráfico 36, o padrão de representação do deus mais numeroso é o tipo cabeça (101/136 tipos monetários), havendo uma diferença significativa no uso entre os dois outros padrões. 0 padrão sentado é o segundo mais recorrente (25/136

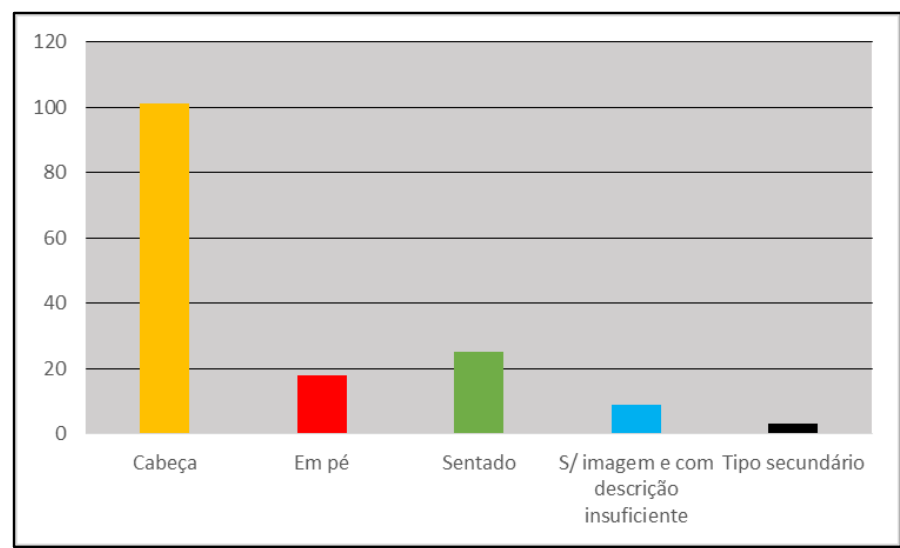

Gráfico 36- Zeus-Quantidade total de tipos monetários para cada padrão de representação (sécs.VI-IV/III a.C.) tipos), ao passo que o "em pé" foi um pouco menos usado (18/136 tipos) em moedas gregas até o século IV/III a.C. Conforme o gráfico 37, o padrão "cabeça" de Zeus começou a ser utilizado em moedas gregas entre os séculos VI-V a.C. (1 tipo monetário no total), em contraste ao século $V$ a.C., quando a representação passou a ser adotada em maior quantidade (16 tipos no total). Esse número caiu entre os séculos V-IV a.C. (8 tipos no total). Foi durante o século IV a.C., contudo, que a imagem foi adotada em larga-escala (70 tipos monetários no total). Esse número diminui significantemente entre os séculos IV-III a.C. (5 tipos monetários). 0 padrão de representação de Zeus "em pé" foi utilizado pela primeira vez em moedas gregas no século V a.C. (4 tipos monetários). Entre os séculos V-IV a.C. houve uma continuidade nesse número (para 4 tipos monetários no total). Como no caso das imagens monetárias de "cabeças" de Zeus, os tipos monetários de Zeus "em pé"

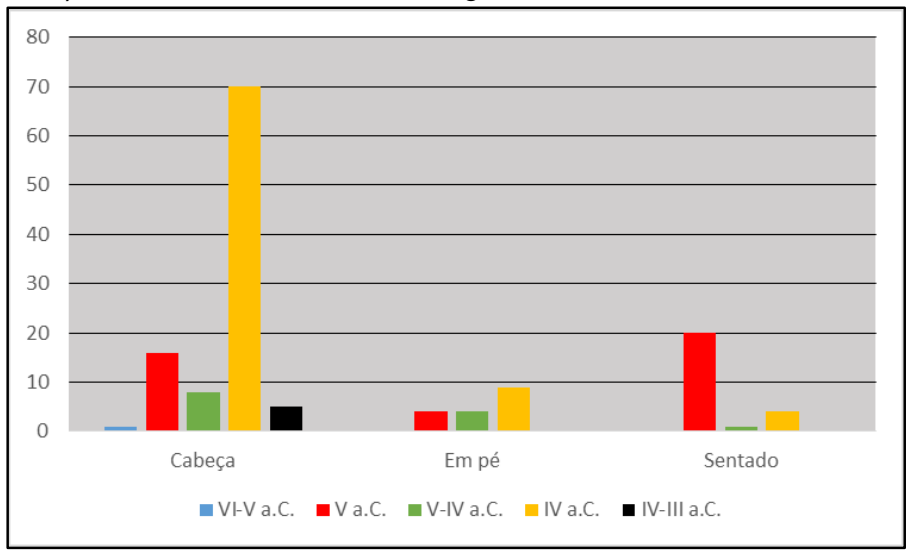

Gráfico 37- Zeus- Quantidade por séculos de tipos monetários de "cabeça", "em pé" e "sentado" (séculos VI-IV/III a.C.). foram mais adotados como representação no século IV a.C. (9 tipos no total), em comparação aos períodos anteriores. Com relação ao padrão de Zeus "sentado" a situação é inversa: a imagem foi mais usada em moedas no século $\mathrm{V}$ a.C. (20 tipos no total), quando começou a ser adotada na representação de Zeus em moedas gregas. Essa quantidade diminui consideravelmente entre os séculos V-IV a.C. (1 tipo monetário no total), aumentando ligeiramente no século IV a.C. (4 tipos no total). Não foram encontrados pelo levantamento imagens monetárias de Zeus "sentado" entre os séculos IV-III a.C.

O gráfico 36 também mostra que, dos 136 tipos monetários de Zeus encontrados pelo levantamento, somente 9 deles não puderam ser incluídos em nenhuma classificação, pela ausência de fotografias no catálogo numismático e/ou pela descrição insuficiente do tipo. Desse total de tipos monetários, somente 3 deles foram utilizados como tipos secundários, portanto, não figuram como a imagem principal no campo das moedas, mas 
como tipos secundários (menores junto aos tipos principais) usados como símbolos para diferenciar uma emissão de outra, por exemplo. Os gráficos 38 e 39 mostram que, desses 3 tipos monetários encontrados, 0 padrão "em pé" foi o único a ser usado como tipo secundário. Foi entre os séculos V-IV a.C. que somente Corinto e Ambrácia, sua fundação, escolheram usar imagens de Zeus dessa maneira em suas moedas. No único tipo monetário de Ambrácia, datado de c.432-342 a.C. (n.396), Zeus aparece no reverso em pé atirando o raio com a mão direita e, nos dois tipos monetários de Corinto, de c.430-330 a.C. (n.41/42), Zeus é representado também no reverso em pé, parado, segurando raio e cetro. Na sequência, segue o estudo quantitativo e de iconografia de cada padrão de representação de Zeus em moedas gregas.

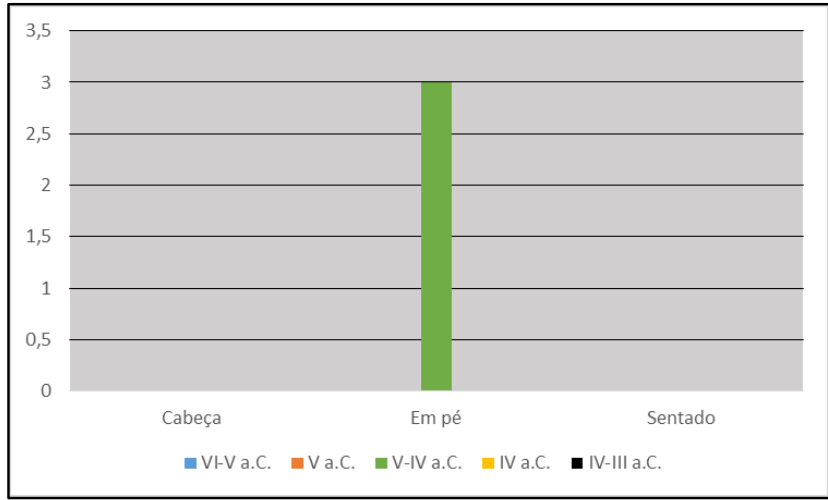

Gráfico 38- Zeus- Quantidade por séculos de tipos monetários usados como tipos secundários (sécs.VI-IV/III a.C.).

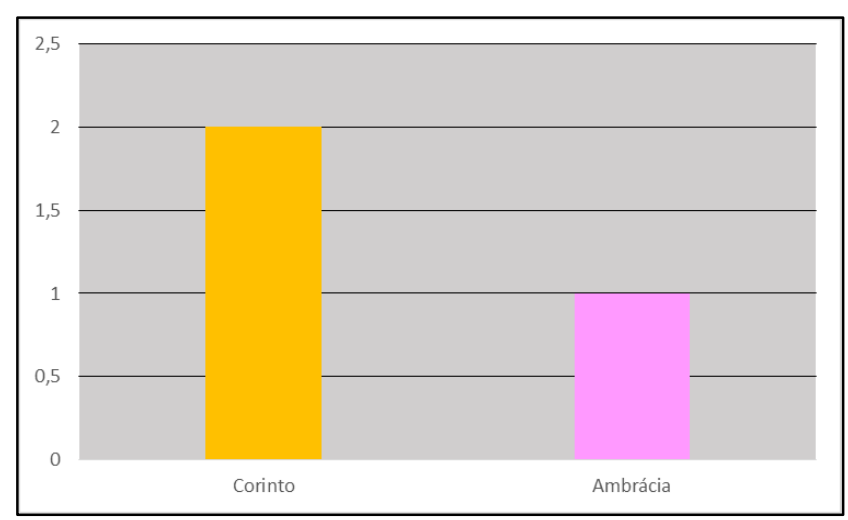

Gráfico 39- Zeus- Quantidade por regiões de tipos monetários de Zeus usados como tipo secundário (sécs. VI-IV/III a.C.).

Antes de iniciarmos a descrição e análise iconográfica dos tipos monetários, devemos dizer que organizamos as imagens monetárias de Zeus, águias e raios dentro de padrões, sub-padrões e variedades de representações. Os padrões se referem às representações principais (como cabeça, em pé e sentado, para Zeus; cabeça, voando e em pé, para as águias; e alado, chamejante e lótus, para os raios). Já os sub-padrões, são as representações encontradas dentro de cada padrão (por exemplo, no padrão de cabeças de Zeus há os sub-padrões de cabeça de Zeus Amon, de não-Amon e sem coroa e de não-Amon com coroa). Chamamos de variedades aqueles tipos de representações que estão dentro dos sub-padrões, os quais se referem a elementos que compõem as imagens, as unidades mínimas mencionadas anteriormente (por exemplo, dentro do sub-padrão de representação da cabeça de Zeus não-Amon e sem coroa, há a variedade de imagens monetárias com cabelos curtos com fita e barba curta). Essa forma de classificação nos auxilia na visualização de como se distribuem, cronologicamente, regionalmente e por autoridades emissoras, todas as imagens monetárias.

\footnotetext{
6 Trata-se do número do tipo monetário no nosso catálogo numismático e que nesse capítulo aparece ao lado da datação dos tipos de cada cidade, nas variedades de cada padrão de representação. Nesse caso, vide por exemplo, n.39 na variedade (b) de "atirando o raio".
} 


\section{II.2.1 O PADRÃO “CABEÇA"}

Dentro do padrão de representação "cabeça" de Zeus, a classificação das imagens monetárias revelou três formas de representação, as quais podemos chamar de sub-padrões: (1) Amon; (2) não-Amon e sem coroa; e (3) não-Amon e com coroa. Conforme se observa no gráfico 40 , dentre essas três variedades, a mais numerosa é a cabeça de Zeus "não-Amon e com coroa". O sub-padrão de representação começou a ser usado no século $\mathrm{V}$

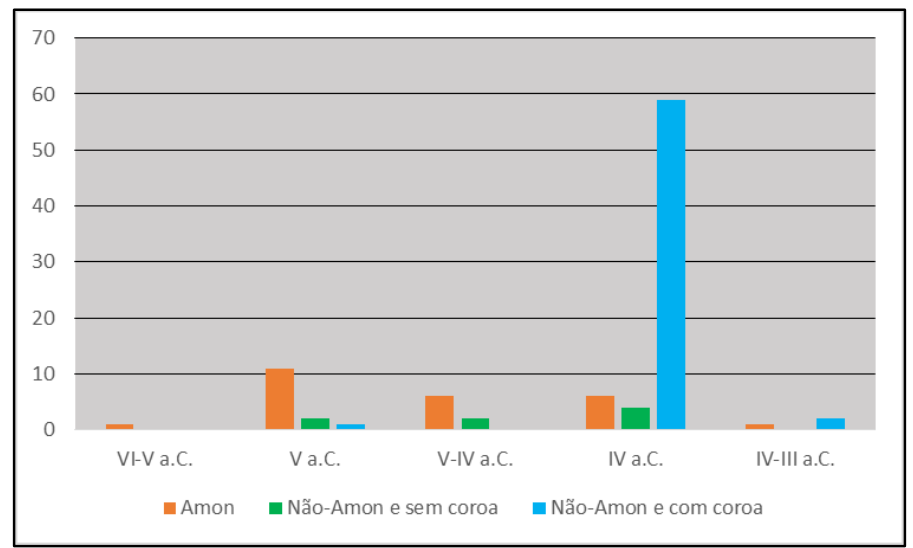

Gráfico 40- Zeus- Quantidade por séculos de tipos monetários de cabeças (sécs. VI-IV/III a.C.).

a.C., embora de maneira inexpressiva (1 tipo monetário no total), ao passo que foi durante o século IV a.C. que essa forma de representar a cabeça de Zeus com a coroa (de folhas de oliveira, louro ou carvalho) ganhou maior expressão e uso entre autoridades emissoras do mundo grego (59 tipos encontrados no total). O segundo sub-padrão de representação de "cabeças" de Zeus foi a variedade "Amon" que, como vemos a partir do gráfico, foi a predominante no século $V$ a.C. (11 tipos no total), apesar de ter sido usada pela primeira vez na segunda metade do século $V$ a.C. (1 tipo). Repara-se que entre os séculos $V$-IV a.C. houve uma diminuição no uso desse sub-padrão (6 tipos), se mantendo no século IV a.C. (6 tipos), quando a variedade não-Amon e com coroa passou a ser a forma preferida de representar Zeus em moedas gregas do período. $O$ padrão cabeça de Zeus Amon passou a deixar de ser usado no período a partir dos séculos IV-III a.C. (1 tipo). 0 terceiro padrão de cabeças de Zeus (não-Amon e sem a coroa), foi o menos usado em moedas gregas ao longo de todos esses períodos (séculos VI-IV/III a.C.). Trata-se da representação da cabeça de Zeus não-Amon apenas com uma fita ou sem qualquer adereço sobre a cabeça (fita ou coroas). O sub-padrão foi usado pela primeira vez no século V a.C. (2 tipos no total), tendo o seu uso sido mantido entre os séculos V-IV a.C. (2 tipos). O sub-padrão deixou de ser utilizado entre os séculos IV-III a.C. em detrimento do uso de cabeças de Zeus não-Amon e com coroa. Abaixo, segue a descrição e discussão acerca dos tipos monetários dentro de cada sub-padrão e suas respectivas variedades de representação. É preciso ressaltar, que os números de cada tipo monetário obedecem a ordem do catálogo numismático (anexo à tese), elaborado a partir de uma sequência cronológica e não tipológica. É por essa razão, assim, que no capítulo 3 e no capítulo 4 os tipos monetários não seguem uma ordenação numérica contínua. 


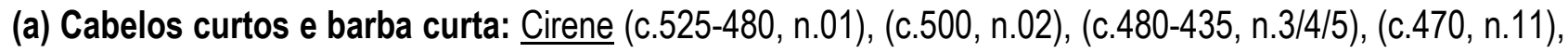
(c.465, n.12); Barce (c.480-435, n.7); Euresperides (c.480-435, n.6); Kheriga (c.450-435, n.30 crespos?);

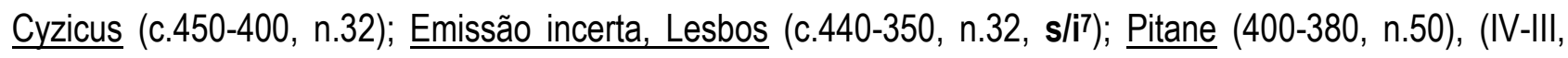
n.100); Nisyros (2a . met.IV, n.96); Metaponto (c.425-350 a.C., n.44).
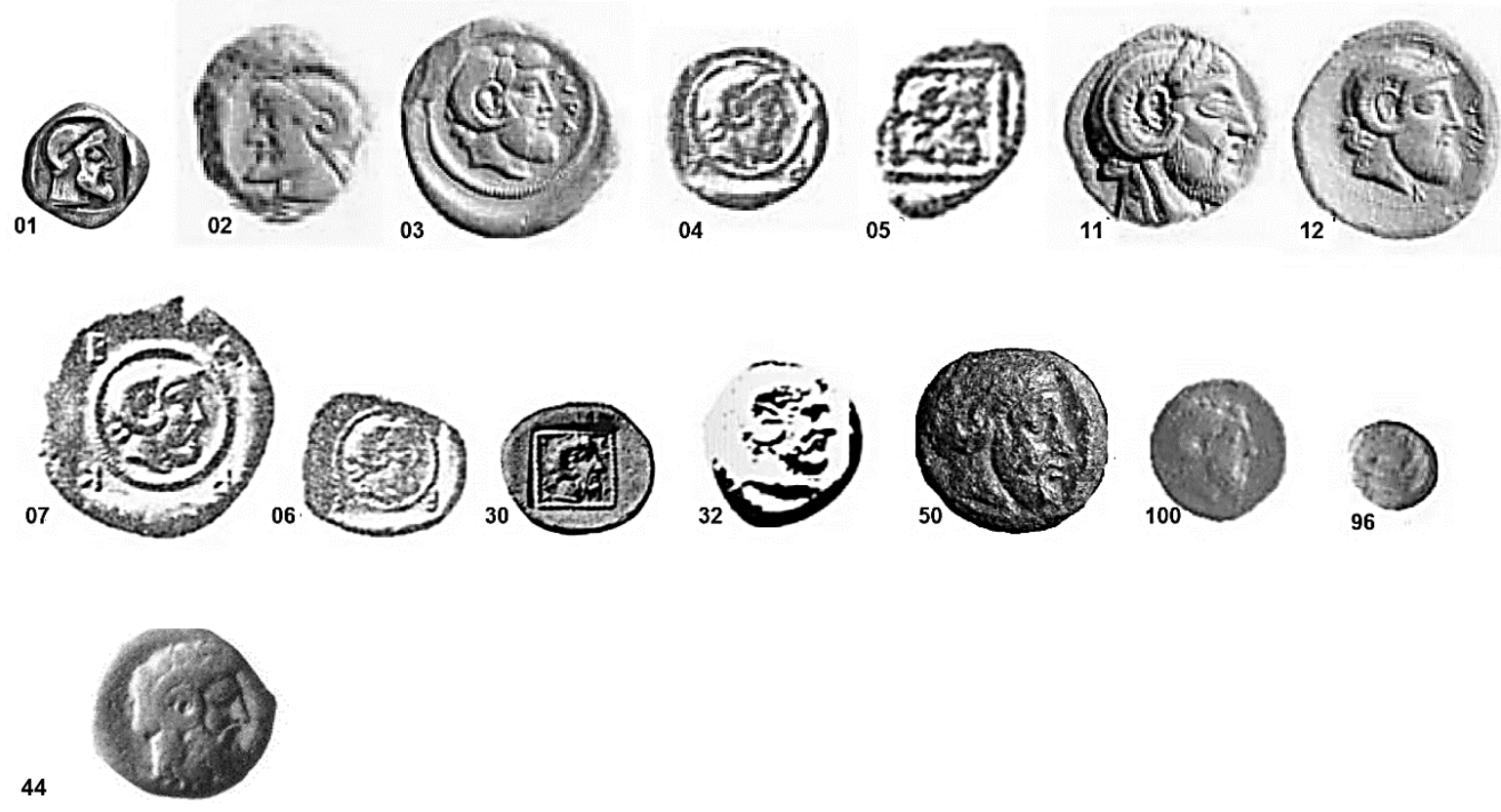

(b) Cabelos crespos e barba crespa: $\underline{\text { Cirene (c.435, n.34, curtos); (c.435-308, n.36/37); (c.400, n.49); Barce }}$ (c.435, n.35, curtos), (c.435-308, n.38).
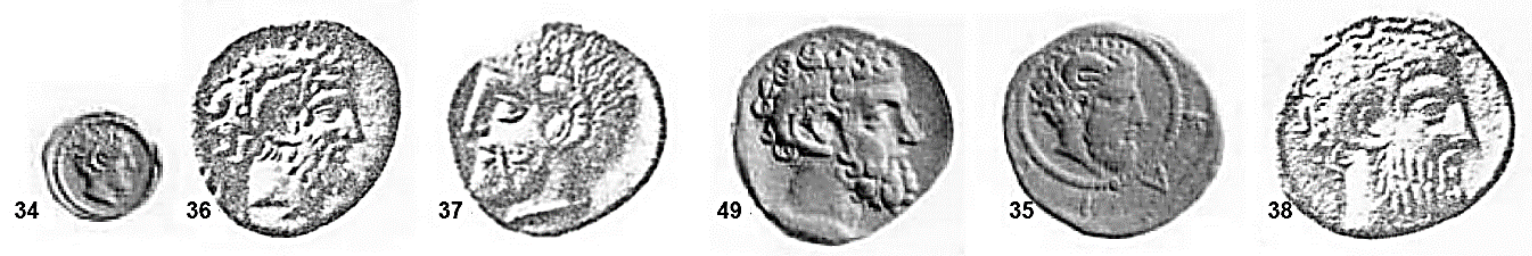

${ }^{7} \mathrm{~A}$ abreviatura s/i se referem aos tipos monetários sem imagem no catálogo numismático. 


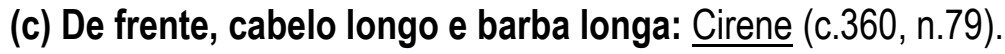

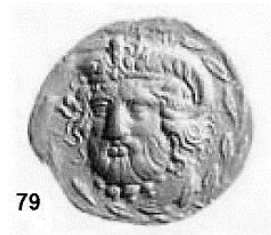

(d) De frente, cabelo longo e barba curta: Barce (c.360, n.80, crespos).

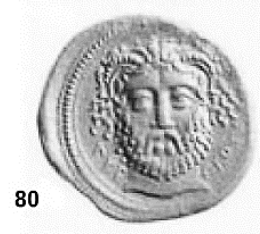

Conforme mostra o gráfico 41 acerca da quantidade por regiões de tipos monetários de cabeça de Zeus "Amon", foram 6 regiões do mundo grego que usaram a representação em moedas gregas entre os séculos VI-IV/III a.C. (Libia, Mysia, Lycia, Lesbos, Itália do Sul e Cária). Com exceção da Líbia, situada no norte da África, todas as demais são áreas localizadas na Ásia Menor, portanto, no lado Oriental do mundo grego, onde o culto de Zeus

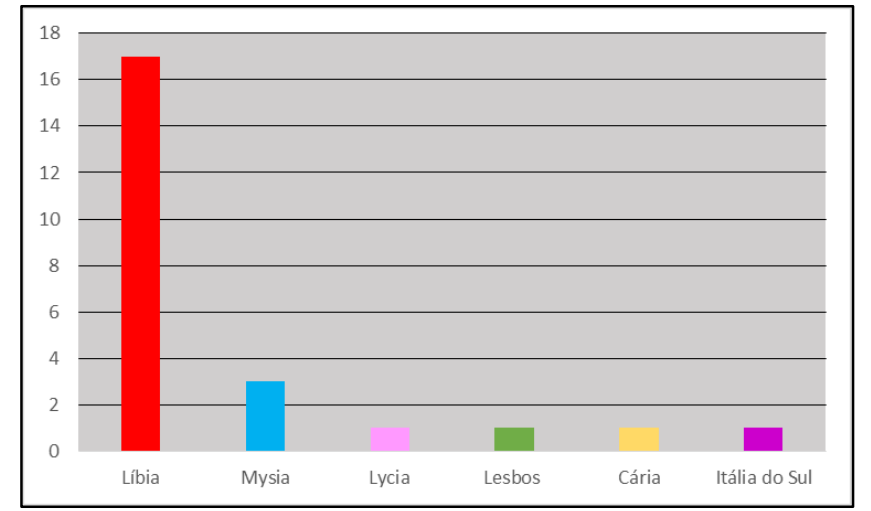

Gráfico 41- Quantidade por regiões de tipos monetários de cabeça de Zeus “Amon” (sécs. VI-IV/III a.C.). Amon alcançou certa proeminência. A Líbia é a região onde foi emitida a maior quantidade de tipos monetários com a cabeça de Zeus "Amon" (17 tipos no total), justamente a área responsável pela criação da representação da divindade em moedas gregas e na arte em geral, como vimos anteriormente. A Mysia é a segunda região com a maior quantidade de tipos (3 tipos no total), que é bem menor em relação ao uso do padrão de representação pela Líbia. A Itália do Sul, a Lycia, Lesbos e a Cária são as regiões que menos usaram essa imagem monetária da divindade (cada qual com 1 tipo).

Na classificação dos tipos monetários da cabeça de Zeus "Amon" encontramos 4 variedades de representação, as quais estão relacionadas com o desenho do cabelo e da barba, são elas: (a) cabelos curtos e barba curta; (b) cabelos crespos e barba crespa; (c) de frente com cabelo longo e barba longa; e (d) de frente com cabelo longo e barba curta.

\begin{tabular}{|l|r|r|r|r|r|r|}
\hline Tipo monetário "Cabeça - Amon" & VI-V a.C. V a.C. & V-IV a.C. & IV a.C. & IV-III a.C. & Total \\
\hline (a) Cabelos curtos e barba curta & 1 & 9 & 3 & 2 & 1 & 16 \\
\hline (b) Cabelos curtos crespos e barba curta cres/ & 0 & 2 & 3 & 1 & 0 & 6 \\
\hline (c) De frente, cabelos longos e barba longa & 0 & 0 & 0 & 1 & 0 & 1 \\
\hline (d) De frente, cabelos longos e barba curta & 0 & 0 & 0 & 1 & 0 & 1 \\
\hline
\end{tabular}

Tabela 7- Variedades de tipos monetários da cabeça de Zeus "Amon" (sécs. VI-IV/III a.C.) 
Como resume a tabela 7, os tipos monetários de cabeça de Zeus "Amon" mais numerosos em quantidade, e em variedades regionais de autoridades emissoras, são aqueles em que o deus é retratado com cabelos curtos e barba curta (16 tipos no total). Trata-se da variedade do tipo monetário mais antigo de Zeus, o único emitido nos séculos VI-V a.C. Foi Cirene que criou o padrão e a variedade em 525-480 a.C. Das quatro variedades, foi a mais usada durante o século V a.C. (9 tipos) - por 3 cidades líbias (Cirene, Barce, Euesperides) e 1 autoridade emissora na Lycia (o rei Kheriga). E o mais utilizado nos séculos IV e entre o IV-III a.C., apesar da pouca diferença em número com e entre os demais. Todas as demais variedades foram criações líbias e emitidas somente por póleis da região. O segundo mais utilizado (6 tipos no total), o tipo de cabeça de Zeus "Amon" com cabelos crespos e barba crespa foi usado pela primeira vez concomitantemente por Cirene e Barce no século $V$ a.C. (c.435 a.C.) as quais podem ter compartilhado a imagem monetária em suas emissões. $O$ tipo foi mais usado entre os séculos V-IV a.C. (3 no total) - 2 tipos foram emitidos por Cirene e 1 por Barce no período. O uso da representação caiu no século IV a.C. (1 tipo), entrando em desuso entre os séculos IV-III a.C. A representação da cabeça de Zeus "Amon" de frente foi a menos utilizada com cabelo longo e barba longa ou com barba curta. O sub-padrão e as variedades foram criações do século IV a.C. compartilhadas novamente por Cirene e Barce em moedas de 360 a.C. e que não tiveram continuidade no período seguinte, entre os séculos IV-III a.C. Cirene emitiu o tipo de frente (mais três-quartos se comparado com a de Barce) com cabelo longo e barba longa, ao passo que o tipo da cabeça de Zeus Amon de Barce é totalmente frontal com cabeleira e barbas crespas.

\section{NÃO-AMON E SEM COROA}

(a) Cabelos curtos e barba curta: Liga Arcádia (c.420, n.45).

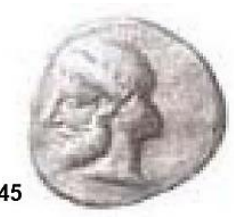

(b) Cabelos longos e barba longa: Liga Arcádia (c.430-420, n.43), Parrhasia (c.431-370, n.40), (final V-início IV, n.48).

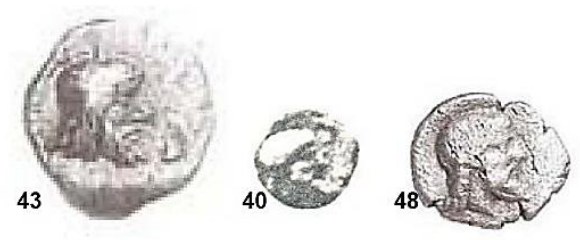


c) Cabelos curtos com fita e barba curta: Kierion (400-360, n.51); Élis (360, n.78).
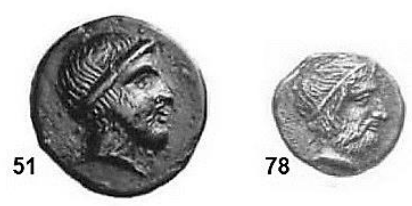

O gráfico 42 traz as informações acerca da quantidade por regiões de tipos monetários de cabeça de Zeus "não-Amon e sem coroa". Observa-se que foram 3 as regiões que emitiram os tipos monetários no período: Arcádia, Élis e Tessália. Autoridades emissoras da Arcádia foram as que criaram e mais usaram o padrão de representação no mundo grego (4 tipos no total) em contraste ao número menor usado pelas

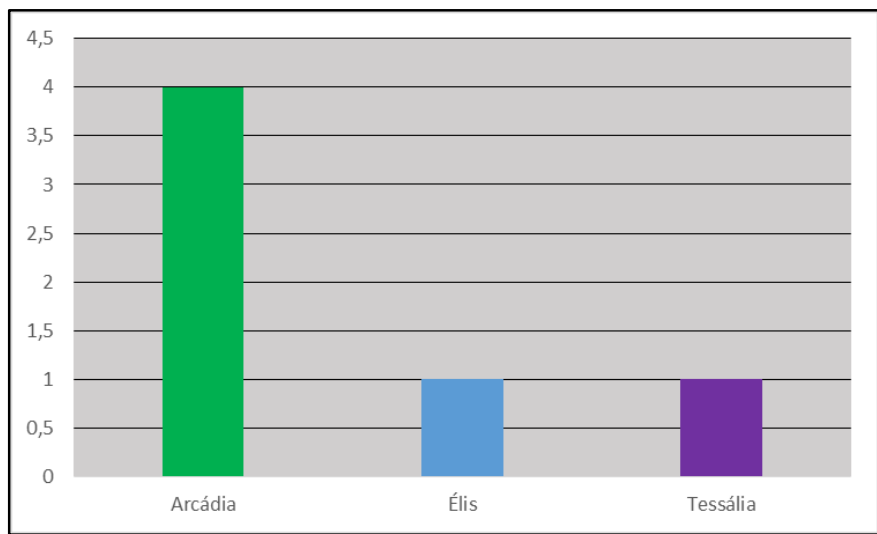

Gráfico 42- Quantidade por regiões de tipos monetários de cabeça de Zeus "não-Amon e sem coroa" (sécs. VI-IV/III a.C.). demais regiões (cada qual 1 tipo monetário).

\begin{tabular}{|l|r|r|r|r|r|r|}
\hline Tipo monetário "Cabeça não-Amon e sem coroa" & VI-V a.C. & V a.C. & V-IV a.C. IV a.C. & IV-III a.C. Total \\
\hline (a) Cabelos curtos e barba curta & 0 & 1 & 0 & 0 & 0 \\
\hline (b) Cabelos longos e barba longa & 0 & 1 & 2 & 0 & 0 \\
\hline (c) Cabelos curtos com fita e barba curta & 0 & 0 & 0 & 2 & 0 \\
\hline
\end{tabular}

Tabela 8- Variedades de tipos monetários de cabeça de Zeus "não-Amon e sem coroa" (sécs. VI-IV/III a.C.)

A tabela 8 mostra as variedades de representações que acompanham a imagem monetária da cabeça de Zeus não-Amon sem a coroa de folhas. Trata-se de três variedades também relacionadas à cabeleira, barba e a um tipo de ornamento na cabeça. São elas: (a) cabelos curtos e barba curta; (b) cabelos longos e barba longa; e (c) cabelos curtos com fita e barba curta. De acordo com a datação dos tipos monetários, a Liga Arcádia (alguma autoridade emissora sobre a qual ainda não se conhece) foi a responsável pela elaboração da imagem da cabeça de Zeus "não-Amon e sem coroa" em moedas gregas. Se pensarmos o culto de Zeus sem estar associado ao culto líbio-egípcio de Amon, então, os exemplares monetários atribuídos à Liga Arcádia, datados entre 430-420 a.C. (n.43/45), possuem a representação mais antiga da cabeça de Zeus em moedas gregas. Nessa perspectiva, tanto os tipos monetários com cabelos curtos e barba curta, e com cabelos longos e barba longa, desse padrão de representação de cabeça, seriam, concomitantemente, os mais antigos da divindade. No entanto, não se pode ignorar que nesse período (segunda metade do século V a.C.) cabelos curtos e barba curta já eram utilizados para a figura de Zeus (embora Amon) desde o segundo quartel do século VI a.C. em Cirene. Também não se pode ignorar uma rede preexistente de contato entre os arcádios e a pólis de Cirene, efetivada após a metade do século VI a.C., com a vinda e reforma de Demonax de Mantinéia em Cirene, que distribuiu novos lotes de terra e assentou os novos colonos peloponésios na cidade líbia (Bonacasa, 2007: 236). 
Pode ser que os arcádios tenham se baseado nos famosos tipos de cabeça de Zeus Amon para bater seu tipo monetário de cabeça de Zeus sem coroa com cabelos curtos e barba curta, já que no período não havia outra imagem da cabeça da divindade em moedas a não ser naquelas moedas de Cirene, Barce e Euesperides, na Líbia.

Isto posto, os tipos monetários de cabeça de Zeus "não-Amon e sem coroa" com cabelos longos e barba longa foram os mais usados (3 tipos monetários), sendo 1 tipo do século $V$ a.C., batido por Mantinéia entre 430-420 a.C. (o mais antigo desse sub-padrão), e 2 tipos monetários batidos no nome do sub-éthnos arcádio, a Parrhasia, entre 431-370 a.C. (n.40) e entre o final do século V e o início do século IV a.C. (n.48). Os tipos monetários com cabelos curtos com fita e barba curta são a segunda variedade mais numerosa (2 tipos no total), próprios do século IV a.C. e não foram emitidos em área arcádia. De acordo com as datações, a pólis de Kierion, na Tessália, pode ter criado o tipo da cabeça de Zeus usando uma fita entre 400-360 a.C. (n.51). De 360 a.C. data um tipo muito semelhante (pelo desenho estriado do cabelo e a posição da fita) emitido por Élis para o santuário de Olímpia (n.78). E em menor número de tipos (2 tipos no total), os tipos com cabelos curtos e barba curta, sem nenhum ornamento, cuja imagem foi usada no século $V$ a.C. nas moedas atribuídas à Liga Arcádia de c.420 a.C. (n.45). Se somarmos os tipos monetários com cabelos curtos e barba curta sem fita e com fita, a variedade terá o mesmo número daquela de cabelos e barba longos (4 tipos no total). 
(a) Cabelos curtos e barba curta: Phalanna (400-344, n.57); Kierion (400-360, n.356), (início IV, 58/359); Krannon (1 ${ }^{\text {a }}$ met.IV, n.59); Melitaia (1a. met.IV, n.60/363); Mytilene (377-326, n.67); Liga Tessália (361-360, n.76); Élis (416, n.355), (360, n.77/345/346), (356, n.347), (344, n.354); Abakainon (c.450 a.C., n.28); Halus (c.400-344, n.357); Pisa (c.365, n.361); Dia (met. IV, n.365); Lampsacos (362, n.75); Alontion (c.344 a.C., n.370); Aetna (c.344 a.C., n.369).
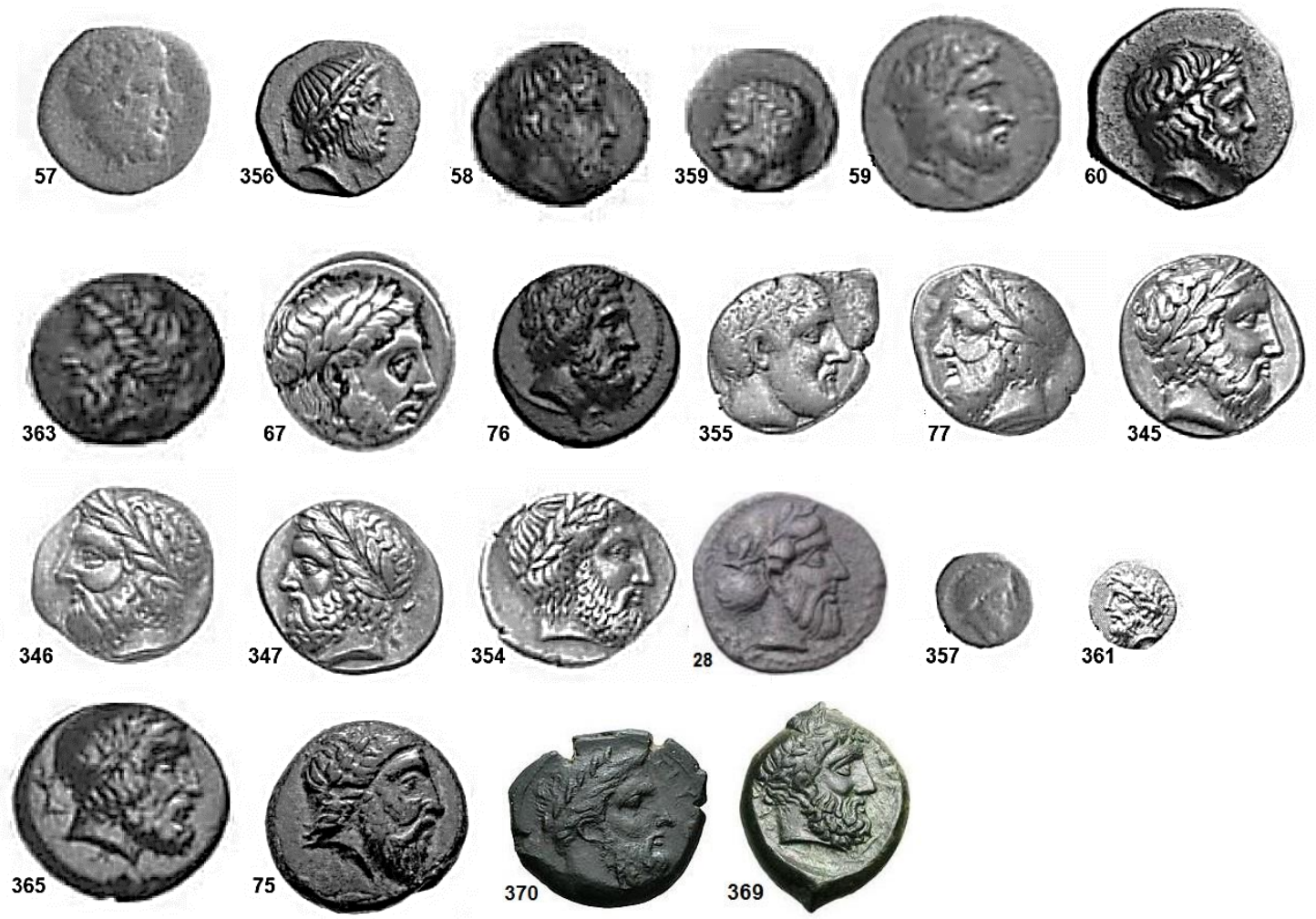
(b) Cabelos longos e barba longa: Kierion (400-360, n.52); (c.350, n.85); Aenianes (c.400-344, n.53/54), (IVIII, n.99); Felipe II (359-336, n.81), (348-336, n.364); Iolla (Met. IV, n.82); Melitaia (1 ${ }^{\text {a }}$.met.IV, n.360/366), (met.IV, n.83); Ekkara (c.350-300, n.94); Élis (352, n.387), (c.352-348, n.349/350/351/353), (348, n.371/372/373); Gonnos (350s, n.84); Gyrton (400-344, n.56); yypata (c.400-380, n.358); Lampsacos (c.350, n.87 c/ cetro atrás?).

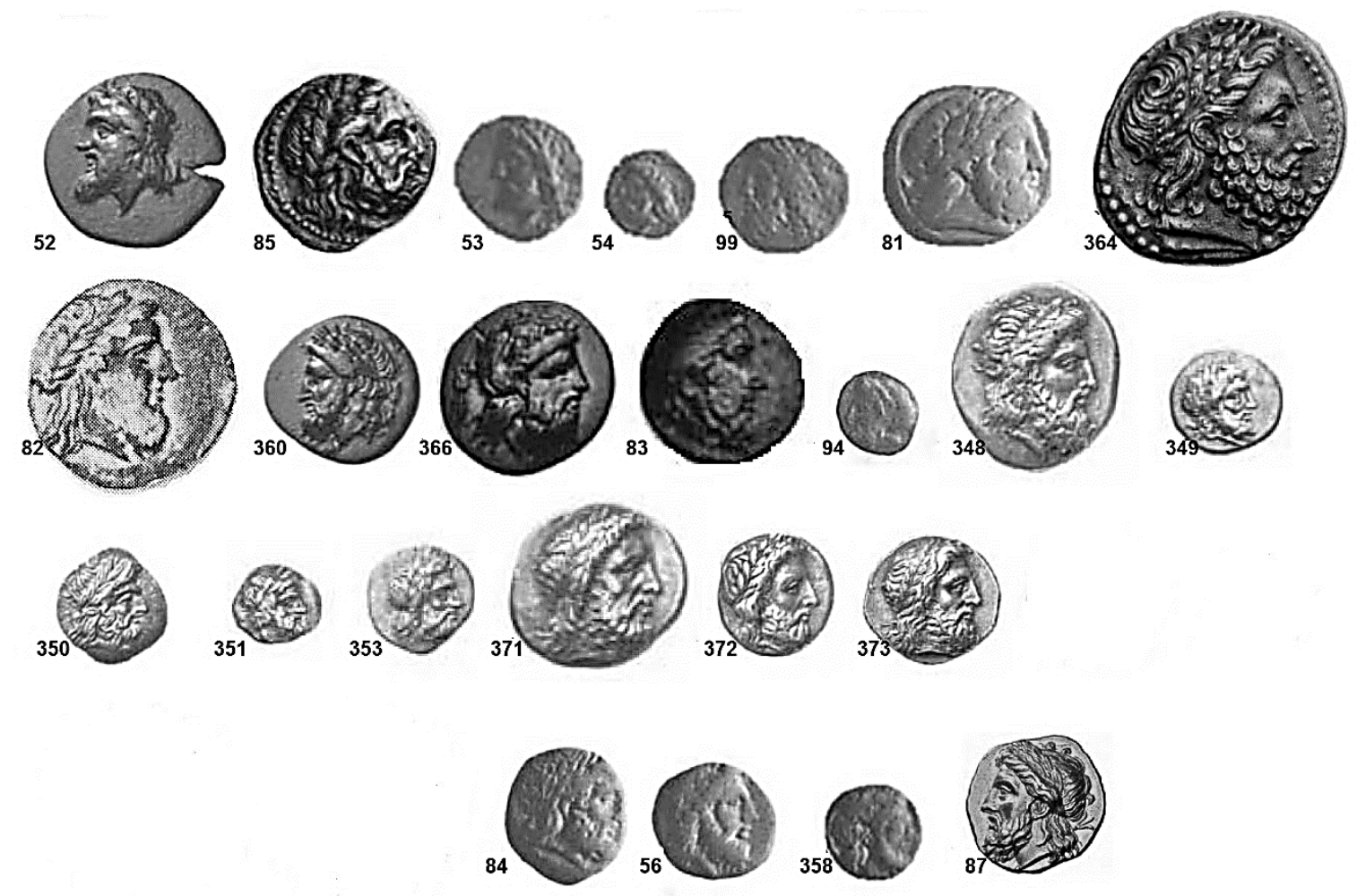

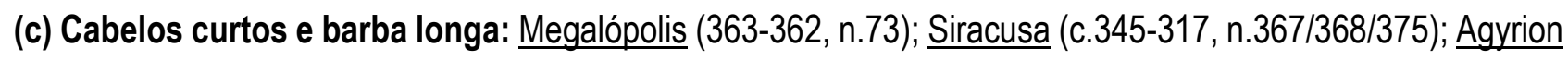
(c.345, n.374); Sesamus (última met. IV, n.97).
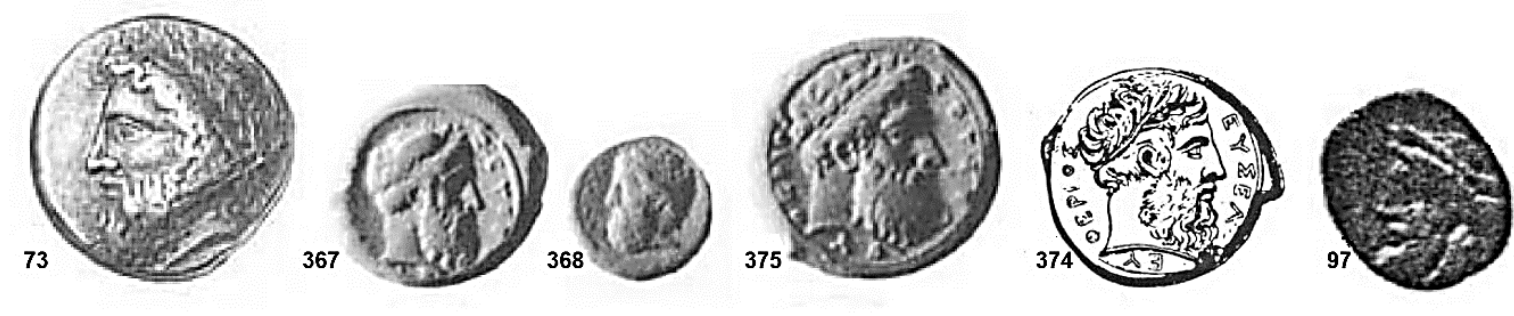
(d) Cabelos longos e barba curta: Megalópolis (363-350, n.74); Pharos (1 ${ }^{\text {a } . m e t . ~ I V, ~ n .61 / 62 / 63) ; ~ K i e r i o n ? ~}$ (c.400-344, n.55); Melitaia (c.350, n.86); Felipe II (365-355, n.362); Cromna (última met. IV, n.98); Élis (c.352348, n.352).

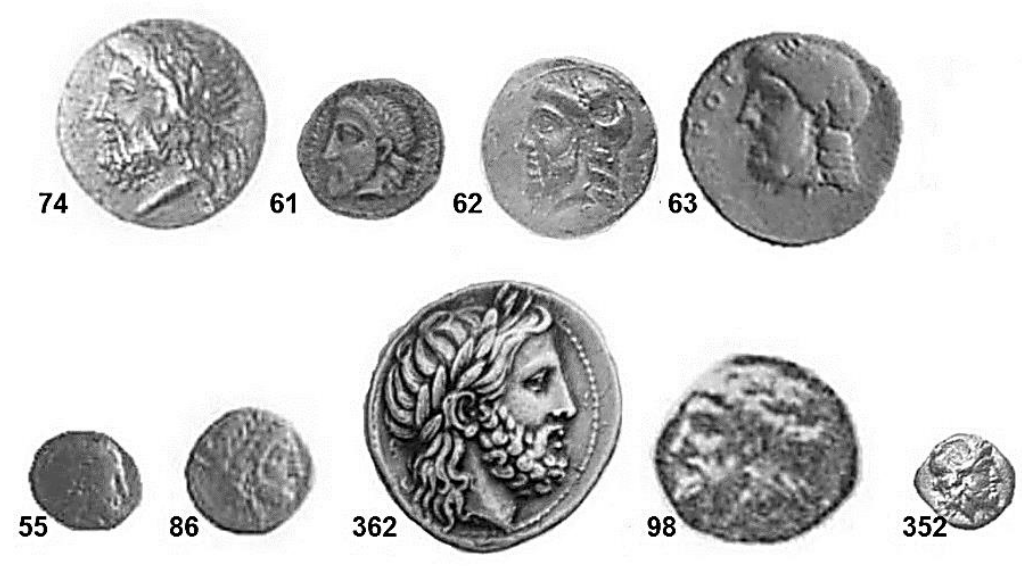

De acordo com 0 gráfico 43, acerca da quantidade por regiões de tipos monetários de cabeça de Zeus "não-Amon e com coroa", autoridades emissoras de 12 regiões do mundo grego emitiram moedas com a representação Tessália, Élis, Sicília, Itália do Sul, llíria, Mysia, Arcádia, Mar Negro, Trácia, Macedônia, Lesbos, Pisatis - um número e variedade quase três vezes maior em relação aos demais subpadrões de tipos monetários de cabeça de Zeus.

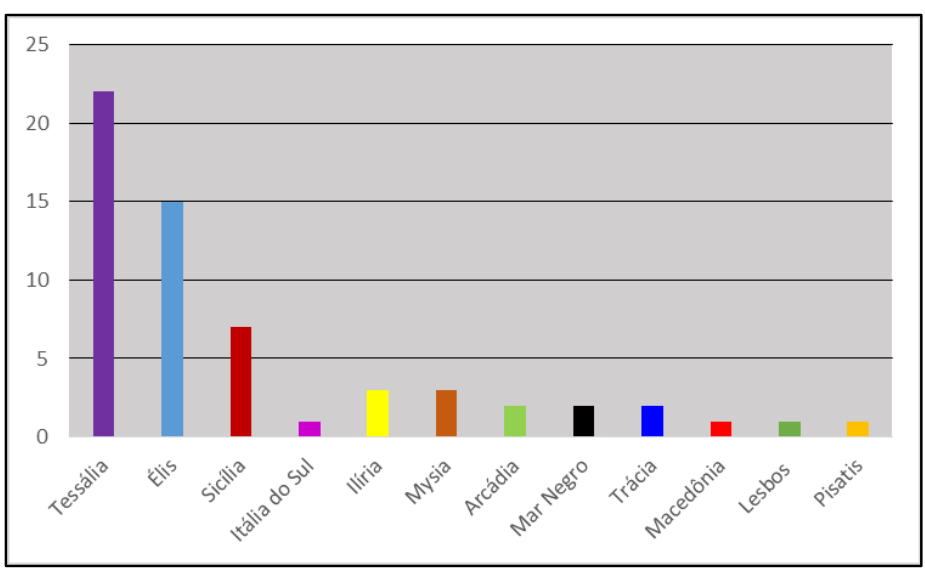

Gráfico 43- Quantidade por regiões de tipos monetários de cabeça de Zeus "não-Amon e com coroa" (sécs. VI-IV/III a.C.).

O tipo monetário de cabeça de Zeus com coroa de folhas foi usado por toda a parte do mundo grego, do Ocidente ao Oriente, mas predominantemente por autoridades emissoras da região norte da Grécia Balcânica (Tessália, Macedônia, Trácia e llíria), do Peloponeso (Élis, Pisatis e Arcádia) e Ocidente grego (Sicília e Itália do Sul). Dentre todas as regiões, foram encontrados mais tipos monetários de cabeças de Zeus com coroa de folhas emitidos na Tessália (22 tipos no total), seguido por Élis responsável pela emissão de 15 imagens monetárias. A Sicília é a terceira região com maior concentração de imagens monetárias dessa variedade 7 tipos). 0 levantamento encontrou a mesma quantidade de tipos monetários provenientes da llíria e da Mysia (cada qual 3 tipos) e na Arcádia, Mar Negro e Trácia (cada qual 2 tipos). Interessante perceber que a Arcádia, mesmo tendo criado o padrão de representação da cabeça de Zeus em moedas gregas (fora do culto de Amon), as autoridades emissoras da região usaram pouco o padrão cabeça, optando pela representação de Zeus sentado, como veremos. A Macedônia, Lesbos, a Itália do Sul e a região de Pisatis foram aquelas em que menos encontramos a imagem monetária (cada qual 1 tipo monetário). 


\begin{tabular}{|l|r|r|r|r|r|}
\hline Tipo monetário "Cabeça não-Amon e com coroa" VI-V a.C. & V a.C. & V-IV a.C. & IV a.C. & IV-III a.C. & Total \\
\hline (a) Cabelos curtos e barba curta & 0 & 2 & 0 & 20 & 0 \\
\hline (b) Cabelos longos e barba longa & 0 & 0 & 0 & 21 & 22 \\
\hline (c)Cabelos curtos e barba longa & 0 & 0 & 0 & 6 & 0 \\
\hline (d) Cabelos longos e barba curta & 0 & 0 & 0 & 10 & 0 \\
\hline
\end{tabular}

Tabela 9- Variedades de tipos monetários de cabeça de Zeus "não-Amon e com coroa (séculos VI-IV/III a.C.).

No caso desse padrão de tipos monetários de cabeça de Zeus, há 4 variedades de representação também relacionadas ao modo de representar a cabeleira e a barba e, nesse caso, a coroa de folhas, sobre a qual, em muitos casos, é difícil identificar o tipo de planta da qual provém a folhagem (se de oliveiras, de louro ou de carvalho). São elas as variedades: (a) cabelos curtos e barba curta; (b) cabelos longos e barba longa; (c) cabelos curtos e barba longa; e (d) cabelos longos e barba curta.

De acordo com a tabela 9 , a variedade cabelos longos e barba longa é um pouco mais numerosa (23 tipos monetários no total) do que a variedade de cabelos e barba curtos (22 tipos no total). Como se vê, essa variedade não existe antes do século IV a.C., quando o tipo foi utilizado em grande número (21 tipos), em contraste ao período seguinte, entre os séculos IV-III a.C. (2 tipos no total). A segunda variedade mais numerosa corresponde aos tipos com cabelos curtos e barba curta que, com coroa de folhas, foram emitidos apenas 2 tipos monetários pela primeira vez no século V a.C. Trata-se do tipo de Abaikanon, na Sicília, de c.450 a.C. (n.28) e de Élis de c.416 a.C. (n.355). O padrão de cabeça de Zeus com coroa de folhas, cabelos curtos e barba curta, que de Zeus Amon predominou no século V a.C., foi mais utilizado durante o século IV a.C. (20 tipos), da mesma forma que a variedade com cabelos longos e barba longa. Interessante notar que a imagem de Zeus com cabelos curtos e barba curta aparece nos vasos áticos a partir de 460 a.C., quando Zeus já vinha sendo assim representado nas moedas das póleis líbias e naquelas atribuídas à Liga Arcádia. E foi no final do século V a.C. que esse padrão de representação de Zeus com cabelos e barba curtos começou a ser usado efetivamente na cerâmica ática (e a tendência no século IV a.C.), correspondendo também ao que acontece na documentação numismática - 0 aumento do uso desse tipo monetário no século IV a.C. Cabelos longos e barba curta foi a terceira variedade mais encontrada pelo levantamento e foi própria do século IV a.C. (10 tipos), não existindo imagens monetárias anteriores a este período. 0 mesmo ocorre para a variedade em menor número. A variedade com cabelos curtos e barba longa (6 tipos) foi igualmente utilizada somente no século IV a.C. Devese também chamar a atenção para o detalhe estilístico da moeda de Abakainon - o uso do króbylos ou coque - o único exemplar, dentre as representações de cabelos e barba curtos, no qual a divindade usa tal amarração de cabelo. Esse detalhe iconográfico é visto também e tão somente no tipo monetário atribuído à Liga Arcádia (sem coroa) de c.420 a.C. (n.45).

Acerca da segunda variedade mais numerosa, com cabelos curtos e barba curta, o tipo monetário siceliota de Abakainon pode ser o exemplar mais antigo dessa forma de representação, caso de fato este aluda ao Zeus grego e não a uma divindade do panteão sículo, como veremos em detalhe no capítulo seguinte. 
Embora consideremos a moeda de Abakainon no repertório numismático sobre Zeus, o tipo monetário de Élis permanece como a evidência mais segura e antiga do padrão de representação de Zeus com cabelos e barba curtos em moedas gregas. Mesmo assim, não podemos excluir a hipótese de que foi numa pequena pólis grego-sícula, em meados do século V a.C., que essa representação foi usada pela primeira vez. Depois de Élis, provêm da Tessália as imagens monetárias mais antigas de cabeças de Zeus com coroa de folhas e cabelos curtos e barba curta, cunhadas por Kierion (400-360, n.356), Phalanna (400-344, n.57) e Halus (400-344 a.C., n.357). Por meio da datação dos tipos, podemos inferir que, muito provavelmente, as cidades da Tessália foram as primeiras a utilizarem a ideia criada por Élis, ou na pequena oficina monetária de Abakainon, para emitir suas primeiras imagens monetárias da divindade. Além desse padrão de representação de Zeus, a coroa de folhas de oliveira aparece no tipo monetário de Abakainon, o que nos força a rever a nossa conclusão de uma pesquisa anterior de que se trataria de uma criação específica do santuário de Olímpia (Laky, 2008: 234). No momento não podemos afirmar com convicção que tal esquema iconográfico ocorreu primeiro na Sicília e depois em Olímpia. Devemos aguardar novas pesquisas acerca da religião e das séries monetárias de Abakainon, assim como o estudo completo e revisado da cronologia das moedas de Élis do século V a.C.

O uso da representação de Zeus com uma coroa de folhas, no caso de oliveira, nesse período, não era uma novidade. De acordo com o levantamento de imagens de Zeus na cerâmica pintada, é possível que a coroa tenha sido utilizada pela primeira vez, na imagem da cabeça de Zeus, no início do século $\mathrm{VI}$ a.C. na cerâmica ática (570-560 a.C.) (Fig.126), embora em menor uso. No entanto, com segurança, pode-se afirmar que a coroa de folhas de oliveira começou a ser usada na representação de Zeus em pinturas de vasos áticos, com mais frequência, no século V a.C. (entre 500-450 a.C.). Em Olímpia, contudo, a coroa de folhas de oliveira, associada à imagem de Zeus, ganhou um outro significado. Em primeiro lugar porque era o prêmio concedido aos atletas pela vitória nos jogos de Olímpia, e em segundo lugar por mais um significado que assumiu ao ornar à cabeça da estátua de Zeus de Fídias. No final do século V a.C. Olímpia já era o grande centro de referência a todos aqueles artistas interessados na iconografia de Zeus, dada a presença da legendária estátua de culto de Zeus Olímpio de Fídias, já instalada em seu templo na época da emissão do tipo, e a variedade de estátuas votivas da divindade dedicadas pelas póleis, que ornavam o Altis nessa época (Tiverios, 1997: 337). Assim, pode-se imaginar o impacto e influência da primeira imagem monetária da cabeça de Zeus cunhada por Élis, que circulava à ocasião dos jogos. Foi sugerido por C.M. Kraay que a representação da cabeça de Zeus nessa moeda (n.355) poderia conter os traços da estátua de Zeus Olímpio de Fídias (Kraay, 1976: 105). Mas essa tese foi refutada por vários autores, dentre eles L. Lacroix o qual afirma, baseado na marca de assinatura e no estilo do desenho, que, nesse caso, "o artista gravador do cunho interpretou o tema de acordo com sua própria concepção e não a partir de um modelo imposto por uma obra da grande arte"8 (Lacroix, 1949: 262).

\footnotetext{
8 De acordo com L. Lacroix, houve uma influência da estátua de Zeus de Fídias somente em época imperial romana, em moedas de bronze de Élis, emitidas por Adriano (Lacroix, 1949: 262).
} 
A representação (com cabelos curtos ou longos, barba curta ou longa) tornou-se a principal, a mais numerosa no século posterior, utilizada pelas autoridades emissoras interessadas em usar a imagem de Zeus em suas moedas. Além de Élis, o tipo monetário da cabeça de Zeus, com coroa de folhas de oliveira e com cabelos e barba curtos, foi emitido no século IV a.C. por 7 autoridades emissoras da Tessália (Phalanna, Kierion, Krannon, Melitaia, Liga Tessália, Halus e Dia), por 1 de Lesbos (Mytilene), por 1 da Mysia (Lampsacos) e por Pisa, cujo tipo monetário foi emitido à ocasião da administração do santuário de Olímpia por Pisa em 365 a.C. (n.361). Ressalta-se que, após o tipo de 416 a.C., Élis voltou a bater moedas com a cabeça de Zeus apenas em 360 a.C. quando retoma o controle do santuário de Olímpia. Percebe-se nos novos tipos monetários de Élis uma melhora na elaboração da coroa de folhas de oliveira, no tamanho e desenho das folhas (mais realísticas). Nesse grupo de moedas com a imagem de Zeus com coroa, cabelos curtos e barba curta, pode-se reconhecer esse provável "padrão de Olímpia" principalmente nas moedas de Melitaia (n.60) e Kierion (n.359), na Tessália. Nota-se também a semelhança na representação da cabeça de Zeus entre os tipos monetários de Dia, na Tessália (n.365) e Lampsacos, na Mysia (n.75), regiões tão distantes umas das outras.

No grupo dos tipos monetários de cabelos longos e barba longa, além de Élis, há novamente a predominância de autoridades emissoras da Tessália (7 no total: Kierion, Aenianes, Melitaia, Ekkara, Gonnos, Gyrton e Hypata), da Mysia (Lampsacos e lolla), da Macedônia e da Trácia (emissões de Pella e de Philippi, de Felipe II). Conforme a datação dos exemplares, novamente aqui, cidades da Tessália parecem terem sido as primeiras a cunhar tipos monetários da cabeça de Zeus com coroa, cabelos longos e barba longa a partir de 400 a.C. (Kierion n.52; Hypata n.358; e Gyrton, n.56; Aenianes, n.53/54, respectivamente). Kierion e Hypata podem ter sido as primeiras autoridades emissoras tessálias a usar a imagem de Zeus em moedas da região. A escolha em representar a cabeça de Zeus com esse tamanho de cabeleira e barba foram seguidos, provavelmente, pelas autoridades emissoras de Philippi, na Trácia, na emissão do tipo monetário de Felipe II de 359-336 a.C. (n.81). Nesse caso, assim, parece que Élis passou a usar esse padrão de representação, ao redor de 352 a.C., após ele ter se tornado uma tendência em moedas gregas do norte da Grécia Balcânica. Ainda com relação a representação da cabeça de Zeus com cabelos longos e barba longa, observa-se que nos tipos monetários anteriores a primeira metade do século IV a.C. Zeus ainda é representado de maneira mais jovem em comparação a maioria dos tipos datados de 350/348 a.C. em diante em que a divindade é retratada com aspecto de mais velho, com exceção do tipo de Lampsacos (n.87). Trata-se de um tipo monetário em que Zeus tem ainda um aspecto mais jovem, embora possua disposição / desenho de coroa, cabelos e barba muito semelhantes ao das moedas de Élis de 348 a.C. (principalmente n.371 e 373). Como vimos acerca das esculturas e relevos de Zeus no século IV a.C., esse aspecto de Zeus como um homem mais velho, e não mais jovem, que aparece somente nos tipos monetários de cabeça de Zeus com cabelos longos, está relacionado à ideia de Zeus como um deus-pai que emergiu ao longo do período. Se nas moedas essa ideia aparece antes, nos vasos áticos, a representação de Zeus com cabelos longos e barba longa aparecem associados a um deus ainda jovem até 350-340 a.C. (Fig.165). 
A terceira variedade de cabeça de Zeus com coroa, cabelos curtos e barba longa foi usada por autoridades emissoras da Arcádia, Sicilia e Mar Negro. De acordo com a datação dos exemplares, a pólis de Megalópolis foi a primeira a bater uma moeda com o tipo entre 363-362 a.C. (n.73) para a Liga Arcádia. Na Sicília, o tipo monetário foi usado por Siracusa e Agyrion no período de Timoleonte em c.344 a.C. Sesamus, no Mar Negro, usou o tipo monetário na última metade do século IV a.C. Se nas moedas se trata de um padrão de representação do século IV a.C., na cerâmica ática, vemos o tipo de representação de Zeus com cabelos curtos e barba longa em um período bem preciso no século V a.C., em cenas de dois vasos datados de 460 a.C. (Figs.155 e 156). Na estatuária, o padrão também aparece na estátua de bronze de Artemísio também datada de 460 a.C. (Fig.144). A última variedade de representação refere-se aos tipos de cabeça com coroa, cabelos longos e barba curta, usados, além de Élis, por autoridades emissoras da Arcádia (Megalópolis), llíria (Pharos), Mar Negro (Cromna), Trácia (Anfípolis para Felipe II) e Tessália (Kierion e Melitaia). O tipo mais antigo provém de Kierion de 400-344 a.C. (n.55). Os tipos de Megalópolis, Pharos, de Anfípolis para Felipe II são datados da primeira metade do século IV a.C., ao passo que os de Melitaia, Élis e Cromna foram batidos na segunda metade do século IV a.C. Com relação à iconografia, todos os tipos monetários apresentam a mesma disposição / desenho do cabelo solto atrás da nuca de Zeus, exceto os tipos de Pharos, onde o cabelo aparece encaracolado ou preso por uma trança (n.60/62/63). De acordo com o nosso levantamento, o uso da imagem de Zeus com cabelos longos e barba curta não aparece em cenas de vasos pintados, mas em estatuetas de bronze de Zeus Keraunios datadas do início do século V a.C. (Figs.136 e 139).

Da nossa análise das imagens monetárias de cabeças de Zeus com coroa pode-se concluir que ao menos a maioria delas (que possuem o desenho bem visível graças à qualidade da fotografia disponível no catálogo numismático) refere-se às folhagens de oliveira (de folhas finas, com ponta levemente abaulada) e não de louro

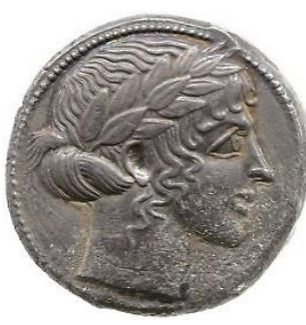

(mais grossas, volumosas e com pontas finas), como tem repetidamente usado a literatura a respeito na descrição nos catálogos, ao definirem a cabeça de Zeus com coroa com 0 termo "laureado" (Laky, 2008: 222). Abaixo, vê-se a diferença entre a coroa de louros na cabeça de Apolo em uma moeda de Leontino, na Fig.173- Cabeça laureada de Apolo à direita, anverso de tetradracma de prata, Leontino, c.455-430 a.C. (SNG ANS: 222).
Sicília, datada de 455-430 a.C. (Fig.173) e a de folhas de oliveira, usada no tipo monetário de Zeus de Olímpia de 360 a.C. (Fig.174) - duas representações bem realísticas de ambas as plantas como coroa em moedas gregas. 


\section{II.2.2 O PADRÃO “EM PÉ”}

A representação de Zeus em pé em moedas gregas possui dois sub-padrões: (1) atirando o raio; e (2) segurando o cetro. De acordo com o gráfico 44, acerca da quantidade por séculos de tipos monetários de Zeus "em pé", os dois sub-padrões de representação foram usados quase na mesma proporção pelas autoridades emissoras no mundo grego: atirando o raio (9 tipos no total) e segurando o cetro (8 tipos). No século V a.C. - quando o padrão

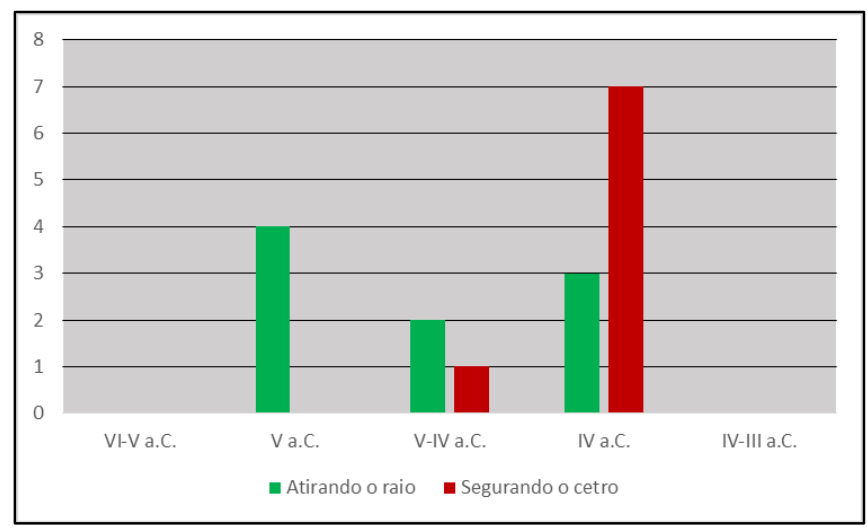

Gráfico 44- Quantidade por séculos de tipos monetários de Zeus "em pé" (sécs. VI-IV/III a.C.). Zeus "em pé" é representado pela primeira vez em moedas gregas -, o sub-padrão Zeus em pé "atirando o raio" foi o único a ser usado no período (4 tipos monetários). Entre o século V-IV a.C., o uso desse sub-padrão diminuiu em relação ao século V a.C. (2 tipos no total) e a imagem de Zeus em pé "segurando o cetro" começou a ser usada em moedas gregas (1 tipo no total). No século IV a.C., vemos um aumento em emissões de tipos monetários de Zeus em pé "atirando o raio" (3 tipos no total), mas foi o sub-padrão em pé "segurando o cetro" que prevaleceu no período (7 tipos no total). Entre os séculos IV-III a.C. não foram encontrados imagens monetárias de Zeus com o padrão de representação "em pé". Na sequência, segue a descrição e os comentários da iconografia acerca dos sub-padrões de Zeus "em pé" e de suas variedades de representação.

\section{ATIRANDO O RAIO}

(a) Nu, atirando o raio com a mão direita e clâmide sobre os braços: Zancle (c.460, n.18).

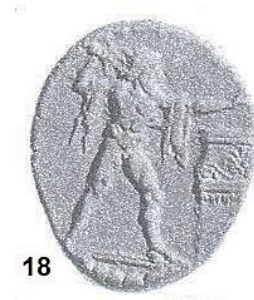

(b) $\mathrm{Nu}$, atirando o raio com a mão direita e braço esquerdo estendido: Ambrácia (c.432-342, n.39).

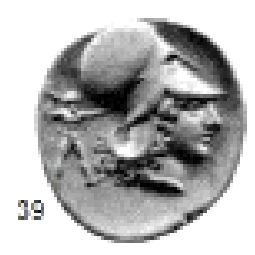


(c) $\mathrm{Nu}$, atirando o raio com a mão direita e águia voando ou em pé sobre braço esquerdo estendido: Élis (c.452-432, n.340/341), (final 450s, n.342); Messênia (c.370/69-330, n.72); Gomphi (c.350, n.89); Kierion (2a . met.IV, n.95); Posidônia (c.420-390 a.C., n.47).
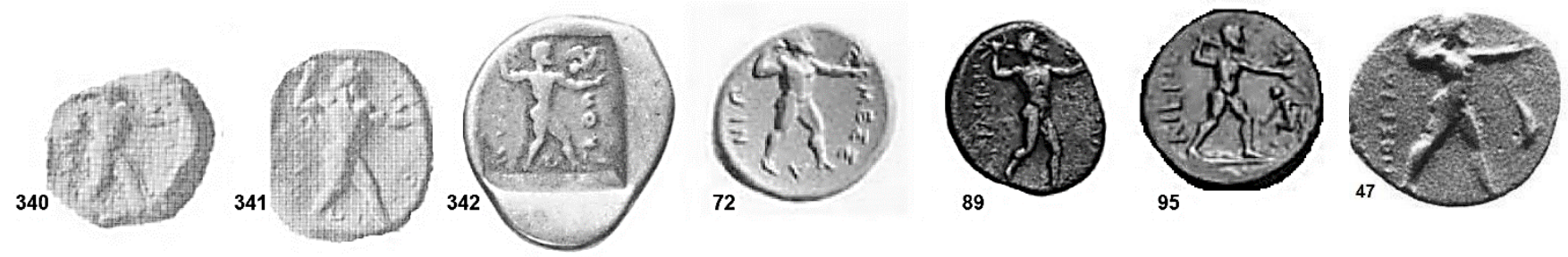

Conforme mostra o gráfico 45 , sobre a quantidade por regiões de tipos de Zeus em pé "atirando o raio", o padrão foi utilizado em 5 regiões do mundo grego: Élis, Tessália, Sicília, Messênia e Ambrácia. Com exceção da Tessália, nota-se que se trata de um tipo monetário próprio de áreas à Ocidente no mundo grego: Élis e a Messênia são regiões limítrofes entre elas e estão localizadas no oeste do Peloponeso, no mar Jônio,

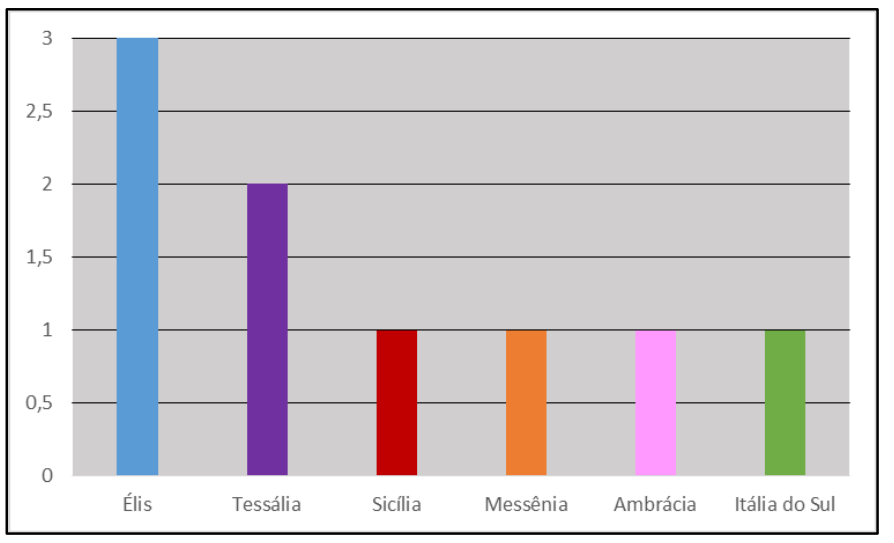

Gráfico 45- Quantidade por regiões de tipos monetários de Zeus em pé "atirando o raio" (sécs. VI-IV/III a.C.). como a Sicília que é a área mais a Ocidente de todas as cinco. E a Ambrácia, mesmo no norte, no Épiro, também está a oeste, na costa do mar Jônio. Observa-se no gráfico que Élis foi responsável por emitir a maior quantidade de tipos monetários (3 tipos monetários no total), seguida pela região da Tessália (2 tipos no total). A Sicília, Messênia, Ambrácia e Itália do Sul são as quatro regiões que usaram menos o padrão de representação de Zeus "em pé" (cada qual 1 tipo monetário).

Dentro do sub-padrão de representação de Zeus em pé "atirando o raio" foi possível definir 3 tipos de variedades de tipos monetários: (a) nu, atirando o raio com a mão direita e clâmide sobre os braços; (b) nu, atirando o raio com a mão direita e braço esquerdo estendido; e (c) nu, atirando o raio com a mão direita e águia voando ou em pé sobre braço esquerdo estendido.

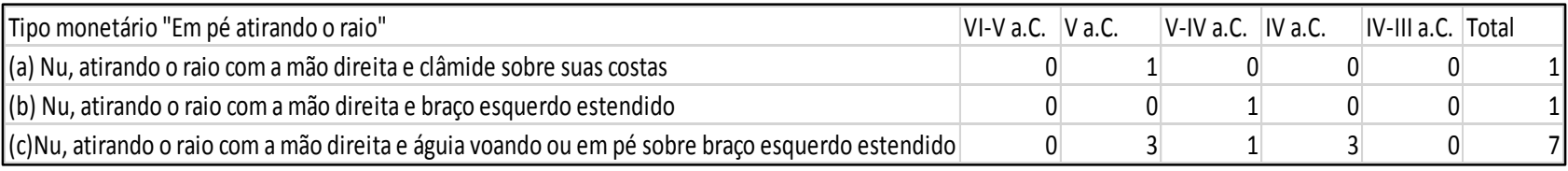

Tabela 10- Variedades de tipos monetários de Zeus em pé "atirando o raio" (sécs. VI-IV/III a.C.)

De acordo com a tabela 10, dentre as três variedades encontradas para o tipo de Zeus em pé "atirando o raio", a mais numerosa é aquela em que Zeus é representado nu, atirando o raio com a mão direita e águia voando ou em pé sobre braço esquerdo estendido (7 tipos monetários no total), que foi usada na mesma proporção no século V e IV a.C. (cada qual 3 tipos). As demais variedades foram usadas em uma igual 
quantidade e em bem menor número (cada qual 1 tipo). O tipo monetário de Zeus em pé, atirando o raio com a mão direita, braço esquerdo estendido e clâmide sobre os braços foi próprio do século $V$ a.C., ao passo que a variedade de Zeus em pé nu, atirando o raio com a mão direita e braço esquerdo estendido foi usado em uma moeda grega entre os séculos V-IV a.C.

A variedade mais antiga do padrão de representação de Zeus em pé "atirando o raio" em moedas gregas, é a que o deus aparece nu, atirando o raio com a mão direita, braço esquerdo estendido e com clâmide sobre os braços (a). Datado de c.460 a.C., o único tipo monetário (n.18) provém da Sicília, da pólis de Zancle, situada na costa oriental, no mar Jônio. Esse padrão e variedade de representação pode já ser visto na segunda metade do século VI a.C. em uma hídria calcídica de 540 a.C., embora a clâmide apareça cobrindo toda a parte da frente do abdómen de Zeus (Fig.118). Uma diferença na posição da clâmide também pode ser vista nas cerâmicas áticas, datadas exatamente do período de emissão da moeda. Em duas ânforas nolanas, uma de 470-460 a.C. (Fig.149) e a outra de 460 a.C. (Fig.150), a clâmide aparece cobrindo somente o ombro e parte do braço esquerdo de Zeus, que também segura um cetro com a mão esquerda. A imagem gravada no tipo monetário de Zancle, encontra correspondência apenas na estatueta de bronze de Zeus Keraunios, sem águia, proveniente de Olímpia, datada do início do século V a.C. (Fig.142). Acreditamos que a imagem monetária de Zeus de Zancle traga aspectos tanto da estatuária (pela representação da clâmide) como também das cerâmicas pintadas, pois o cabelo e a barba do deus, na moeda, é muito semelhante à forma como aparece retratado na cerâmica calcídica e ática.

Somente a ausência da clâmide e a presença da águia diferem da variedade anteriormente descrita daquela mais numerosa de Zeus em pé "atirando o raio" (c). Em primeiro lugar, trata-se de uma representação que em moedas foi usada somente por autoridades emissoras da Tessália, da Itália do Sul e do Peloponeso ocidental (Élis e Messênia). De acordo com as datações das moedas, Élis foi a primeira a usar a representação em moedas na metade do século V a.C. (a partir de 450 a.C., n.340/341/342) e Posidônia a segunda, entre c.420-390 a.C. A Messênia e as póleis da Tessália (Kierion e Gomphi) fizeram o uso da imagem em moedas no século IV a.C. Dentre as três póleis, foi a Messênia que emitiu o primeiro tipo monetário no século IV a.C. à ocasião da fundação da pólis em 370/69-330 a.C. (n.72). Esse padrão de representação de Zeus em pé nu, atirando o raio com a mão direita e com águia voando ou em pé sobre braço esquerdo estendido, encontra correspondência somente nas estatuetas de Zeus Keraunios, com águias - criações dos séculos VII-VI a.C. as quais se tornaram típicas do início do século V a.C. (490-480 a.C.) - que, como vimos anteriormente, são características do Monte Lykaion (Fig.124), de Olímpia (Fig.141) e da Ambrácia (estatueta foi produzida em Corinto) (Fig.139). De fato, L. Lacroix, no exame acerca das representações de estátuas em moedas gregas, já na década de 1940 concluiu que os artistas gravadores de cunho, dessas moedas, se inspiraram nesses tipos de estatuetas de Zeus (Lacroix, 1949: 73). É preciso dizer que a imagem de Zeus que aparece na moeda de Messênia representa a escultura de Zeus Ithomates feita por Ageladas em 455 a.C. e que foi transferida de Naupaktos para Messênia durante a fundação da cidade, conforme sugerem vários estudiosos. É possível 
também que os gravadores da moeda messênia "tenham sido influenciados pelos tipos monetários de Élis do século V a.C., mais antigos" (Lacroix, 1949: 230). Encontramos uma única representação de Zeus Keraunios, com a águia, gravada no estrigilo da Sicília, datado de 430 a.C. (Fig.143), diferente da forma como a ave aparece nas moedas. No estrigilo, a águia está em pé à direita sobre o braço de Zeus com a cabeça virada à esquerda para Zeus. De fato, a única diferença entre a representação nas moedas e nas estatuetas é a posição da águia. Nas estatuetas, a ave aparece na mão de Zeus com as asas abertas, ao passo que nas moedas, os artistas representaram a águia em uma nova maneira: voando sobre o braço (Élis, n.340/341/342) ou em pé com asas erguidas ou abertas sobre o braço esquerdo estendido (Messênia, n.72; Kierion, n.95; e talvez Gomphi, n.89).

Sobre a variedade (b) retratada na moeda de Ambrácia (n.39) - Zeus em pé nu, atirando o raio com a mão direita e braço esquerdo estendido -, não há a representação da águia e nem da clâmide sobre os braços do deus. A imagem de Zeus na moeda de Ambrácia (V-IV a.C.) é a própria representação de Zeus Keraunios, sem águia, das estatuetas do início do século $V$ a.C. Interessante notar que o artista responsável pela gravação do desenho da moeda, representou Zeus sem a águia, que aparece na estatueta encontrada nessa pólis, discutida por G. Mylonas.

\section{SEGURANDO O CETRO}

(a) Segurando o raio e cetro: Corinto (c.430-330, n.41/42).

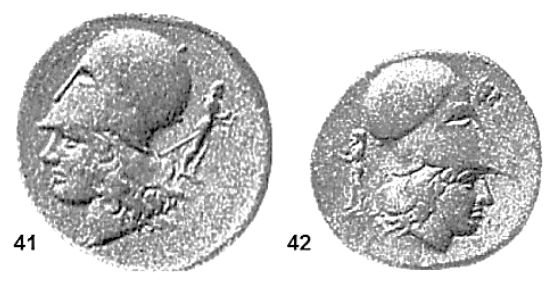

(b) Segurando cetro e parte do himátion com a mão esquerda e lábrys com a mão direita: Mylasa (380,

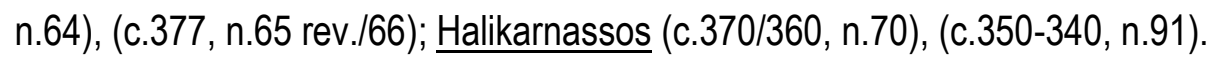
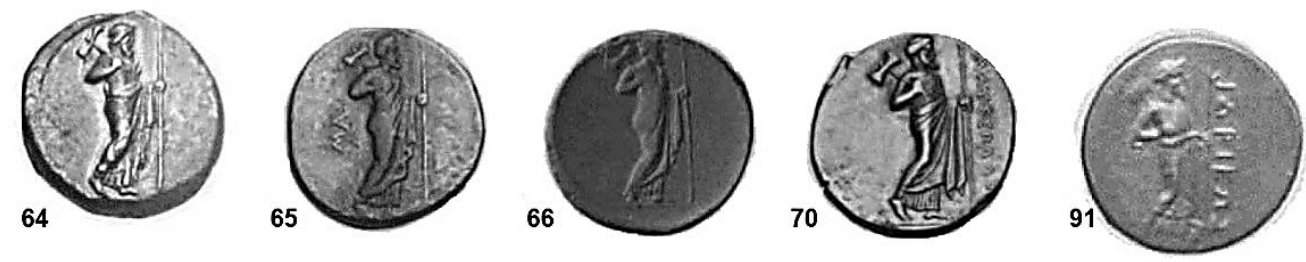
(c) Vestindo himátion, segurando tridente com a mão direita e uma águia com a esquerda (?): Mylasa (c.377, n.65 anv.).

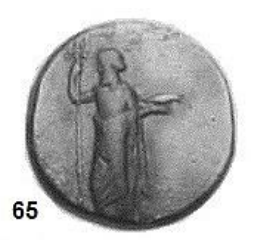

(d) De frente, com a cabeça virada à direita, vestindo himátion na cintura e segurando longo cetro com a mão direita: Cirene $(375-308$, n.68).

68

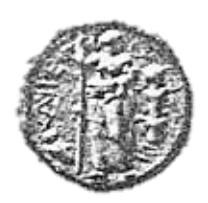

Conforme as informações no gráfico 46, a respeito da quantidade por regiões de tipos monetários de Zeus em pé "segurando o cetro", apenas em 3 regiões ocorreu o uso dessa representação: Cária, Corinto e Líbia, áreas bem distintas das observadas no sub-padrão "atirando o raio". A Cária foi a região que mais usou a imagem em moedas ( 6 tipos monetários no total), em contraste com Corinto (2 tipos no total) e com

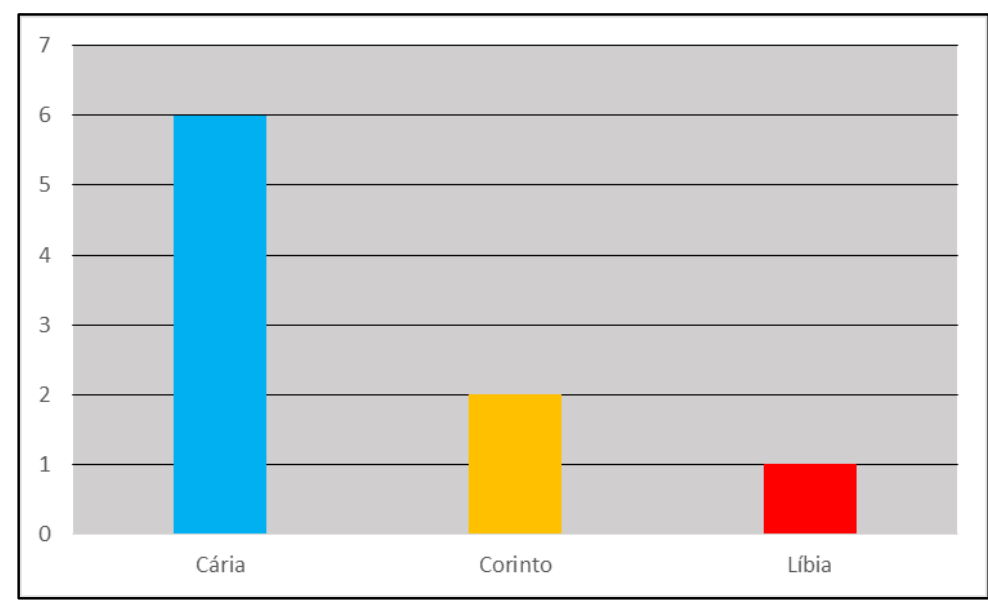

Gráfico 46- Quantidade por regiões de tipos monetários de Zeus em pé "segurando cetro" (sécs. VI-IV/III a.C.). a Líbia (1 tipo no total).

Nesse sub-padrão de representação de Zeus em pé "segurando o cetro", foram definidas 4 variedades de tipos monetários: (a) segurando o raio e o cetro; (b) segurando cetro e parte do himátion com a mão esquerda e lábrys com a mão direita; (c) vestindo himátion, segurando tridente com a mão direita e uma águia com a esquerda; e (d) de frente, com a cabeça virada à direita, vestindo himátion na cintura e segurando longo cetro com a mão direita.

\begin{tabular}{|c|c|c|c|c|c|c|c|}
\hline Tipo monetário "Em pé segurando o cetro" & VIIV a.C. Va.C. & \multicolumn{3}{|c|}{ V-IV a.C. IV a.C. } & \multicolumn{3}{|c|}{ IV-III a.C. Total } \\
\hline (a) Segurando o raio e cetro & 0 & 0 & 2 & C & & 0 & 2 \\
\hline (b) Segurando cetro e parte do himátion com a mão esquerda e lábrys com a mão direita & 0 & 0 & 0 & 5 & & 0 & 5 \\
\hline (c)Vestindo himátion, segurando tridente com a mão direita e águia com a esquerda & 0 & 0 & 0 & 1 & & 0 & 1 \\
\hline (d) De frente, com a cabeça virada à direita, vestindo himátion na cintura e segurando longo cetro com a mão direita & 0 & 0 & 0 & 1 & & 0 & 1 \\
\hline
\end{tabular}

Tabela 11- Variedades de tipos monetários de Zeus em pé “segurando o cetro" (sécs. VI-IV/III a.C.). 
Observa-se na tabela 11 que a variedade (b) do sub-padrão "segurando o cetro" é a mais numerosa (5 tipos monetários no total), usada somente no século IV a.C. Da segunda variedade mais numerosa (a), há 2 tipos monetários emitidos entre o século V-IV a.C., ao passo que foram encontrados apenas 1 tipo monetário para cada uma das demais variedades. Repara-se que todos as imagens monetárias pertencem ao século IV a.C.

Sobre a variedade de Zeus em pé "segurando o raio e cetro" (a), trata-se de uma representação única do deus em moedas gregas cunhada em Corinto. 0 deus, que aparece representado parado à esquerda (n.42) ou à direita (n.41), parece estar nu e, como se trata de uma imagem usada como tipo secundário, é difícil saber com qual das mãos segura o cetro e o raio. Esse tipo de representação encontra correspondência apenas na cerâmica ática. Na ânfora ática, datada de c.480 a.C., Zeus aparece em pé, parado, segurando um cetro com a mão direita e o raio com a esquerda (Fig.147). A diferença entre a representação das duas moedas e a do vaso, é que no vaso Zeus não está nu e aparece vestindo um longo himátion e quíton. No tipo monetário de Cirene da variedade (d), datado de 375-308 a.C. (n.67), em contrapartida, Zeus aparece frontalmente com a cabeça virada para à d., vestindo um himátion na cintura e segurando um longo cetro com a mão direita. $\mathrm{Na}$ pintura em vasos, Zeus aparece assim representado (vestindo himátion na cintura e segurando o cetro) apenas no padrão sentado no trono (Figs.162 e 163), no banco (Fig.165) ou reclinado (Fig.161) em cerâmicas áticas e ápulas datadas entre os séculos V-IV a.C. e o século IV a.C.

A variedade mais numerosa é formada por tipos monetários provenientes apenas da Cária. Trata-se de imagens monetárias de Zeus Labraundos, em cujo culto o deus é representado segurando o machado duplo (a lábrys) e não o raio, como nas representações gregas do deus (Lacroix, 1949: 93). Zeus Labraundos era a principal divindade dos cários, que administravam o santuário do deus em Labraunda, próxima à Mylasa. Uma lenda contada por Plutarco diz que, essa arma, a lábrys, tomada por Héracles de Hipólito, depois transmitida por Omphale aos reis da Lídia, teria sido removida por Arselis de Mylasa, que a dá a Zeus Labraudos (Lacroix, 1949: 93). Nas imagens monetárias batidas por Mylasa em 380 a.C. (n.64) e em c.377 (n.65 reverso e n.66) e por Halikarnassos em 370/360 a.C. (n.70) e 350-340 a.C. (n.91), a imagem do deus é repetitiva: Zeus segura o cetro e parte do himátion com a mão esquerda e a lábrys com a mão direita, apoiando-a sobre o ombro. $\mathrm{A}$ imagem não encontra paralelo em outras representações de Zeus nas moedas e em outros tipos de suportes imagéticos. Zeus Labraundos de Mylasa carrega não só o machado duplo, mas uma lança e foi cultuado assim pelos guerreiros cários como Strátios ("Senhor dos exércitos") (Cook, II: 848). Mas a lança é interpretada também como um cetro (Lacroix, 1949: 94). Zeus em pé segurando cetro ou lança e vestindo himátion é um tipo comum em cerâmicas áticas de 460 e 450 a.C. (Fig.155 e 146), mas é a lábrys que torna diferente essa representação de Zeus. E na última variedade (c), Zeus é representado em pé segurando com a mão direita um tridente ao invés do cetro, tipo monetário emitido por Mylasa em c.377 a.C. (n.65 anverso). Trata-se da representação de Zeus Osogollis que era cultuado em um importante santuário em Mylasa. 


\section{II.2.3 O PADRÃO “SENTADO”}

Nas imagens monetárias de Zeus "sentado" encontramos 3 padrões de representação: (1) sentado "no trono"; (2) sentado "sobre rocha"; e (3) sentado "de cócoras ou ajoelhado". Conforme o gráfico 47 acerca da quantidade por séculos de tipos monetários de Zeus "sentado", o padrão de Zeus sentado "no trono" é o mais numeroso e foi típico do século $V$ a.C. (19 tipos monetários no total). O padrão também foi utilizado no século IV a.C., mas

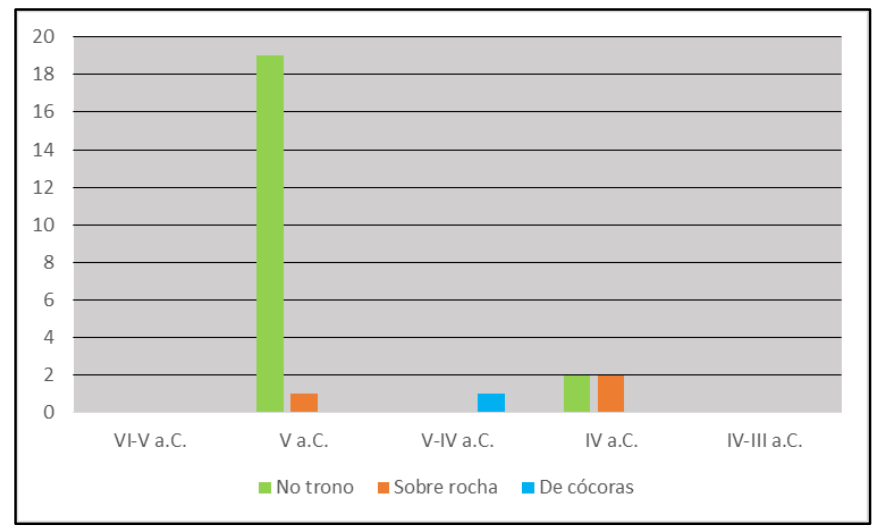

Gráfico 47- Quantidade por séculos de tipos monetários de Zeus "sentado" (sécs. VI-IV/III a.C.).

em uma quantidade bem menor (2 tipos monetários). Mas mesmo assim, continuou sendo o padrão mais utilizado para os tipos monetários de Zeus "sentado". O segundo padrão mais usado de Zeus "sentado" foi aquele em que o deus aparece sentado "sobre uma rocha", cujo uso se iniciou no século V a.C., embora em menor número (1 tipo no total) em contraste à quantidade de Zeus sentado "no trono". No século IV a.C. o padrão de representação sofreu um ligeiro aumento no uso em moedas (2 tipos no total). No caso do padrão de representação de Zeus sentado "de cócoras ou ajoelhado", houve um uso isolado entre os séculos V-IV a.C. (1 tipo monetário no total). Não foram encontradas imagens monetárias de Zeus "sentado" entre os séculos IVIII a.C. Abaixo, seguem os tipos monetários de Zeus sentado e suas variedades de representação.

\section{NO TRONO}

(a) Nu ou vestindo himátion na cintura, segurando cetro com a mão esquerda e águia voando ou pousada sobre mão direita: Liga Arcádia (c.470, n.10 águia voando com asas abertas), (c.465-460, n.13 águia pousada com asas erguidas), (início 460, n.17 águia pousada com asas erguidas), (c.460-450, n.20 águia voando com asas abertas?); Liga Arcádia (c.465-460, n.14 águia pousada com asas erguidas), (c.460-450, n.23 águia pousada com asas erguidas?); Liga Arcádia (c.450-440/30, n.29 águia voando com asas abertas), (c.420, n.46 águia voando com asas erguidas); Élis (c.452-432, n.26).
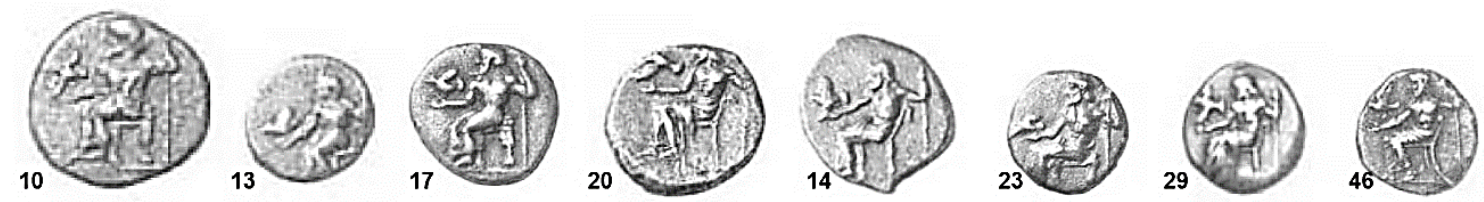
(b) Nu ou vestindo himátion na cintura (?), segurando o cetro com a mão esquerda (à frente de Zeus) e raio com a mão direita; águia voando na frente: Liga Arcádia (c.465-460, n.15), (c.460-450, n.24).

15

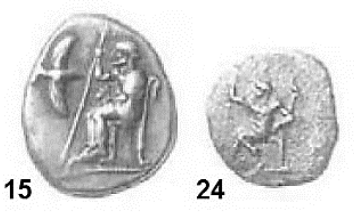

(c) Segurando o cetro com a mão esquerda e águia sobre cetro à esquerda: Galária (c.450, n.27).

27

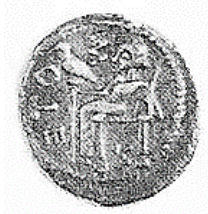

(d) Vestindo um himátion, segurando um raio ou cetro com a mão direita e com a esquerda um raio alado; águia pousada sobre planta à direita e trono coberto por pele de pantera: Aetna-Inessa (c.465-460 a.C., n.16).

16

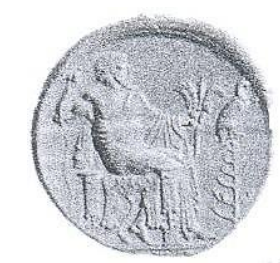

(e) De frente, vestindo himátion na cintura com cabeça virada à esquerda, segurando cetro com a mão esquerda e águia voando sobre a mão direita: Liga Arcádia (c.460-450, n.19).

19

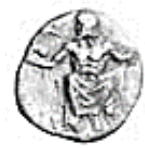

(f) Parcialmente de lado, vestindo himátion na cintura, segurando cetro longo com a mão esquerda e águia em pé à direita com asas abertas: Liga Arcádia (c.460-450, n.21/22).

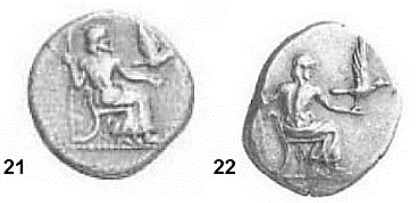

(g) Parcialmente de lado (?), vestindo quíton e himation, segurando raio com a mão direita e braço abaixado, e águia sobre braço esquerdo levantado: Liga Arcádia (c.460-450, n.25). 
(h) Segurando raio com a mão direita e cetro com a mão esquerda; sobre cetro, águia pousada à direita:

Aetna-Catânia (c.475-470 a.C., n.08/09).

08
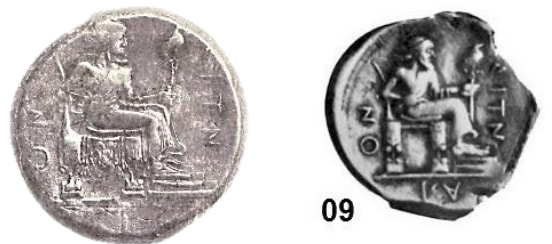

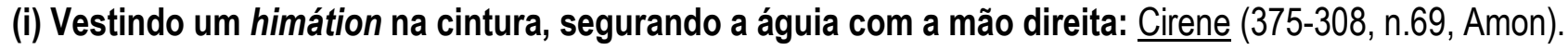

68

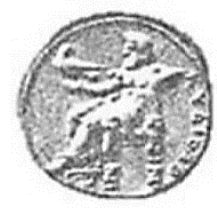

(j) Vestindo himátion na cintura, segurando cetro com a mão esquerda e águia sobre mão direita estendida: Liga Acaia (c.370-360, n.71 quíton sobre braço esquerdo?).

71

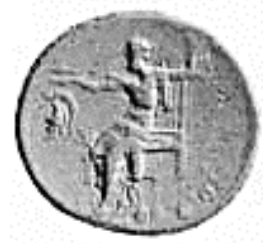

Conforme nos mostra o gráfico 48 , com relação à quantidade por regiões de tipos monetários de Zeus sentado "no trono", foram encontrados tipos monetários desse padrão em 5 regiões do mundo grego: Arcádia, Sicília, Élis, Líbia e Acaia. Observa-se que a Arcádia é a região com a maior quantidade de imagens monetárias emitidas de Zeus sentado "no trono" (13 tipos no total), seguida pela região da Sicília, onde

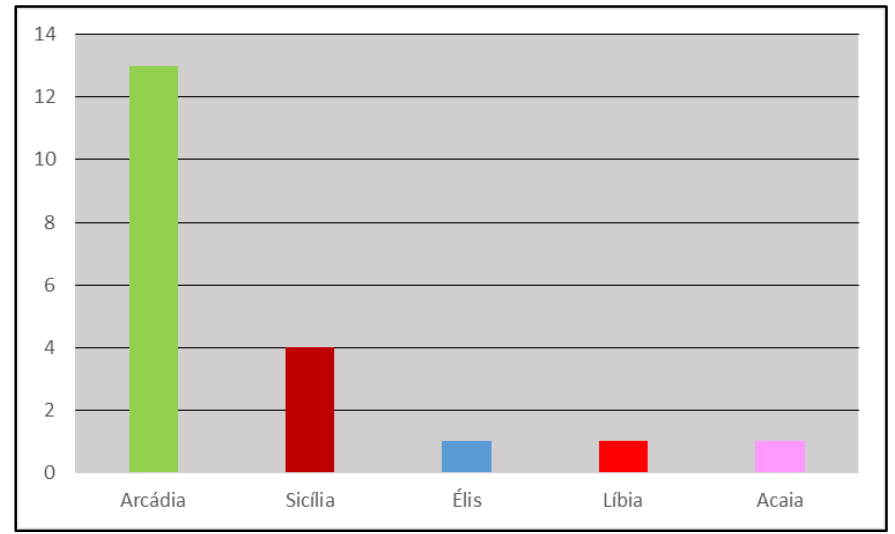

Gráfico 48- Quantidade por regiões de tipos monetários de Zeus sentado "no trono" (séculos VI-IV/III a.C.). encontramos o padrão de representação em um menor número (4 tipos no total). Nas demais regiões, o tipo monetário foi usado em menor quantidade (cada qual apenas 1 tipo monetário). Dentro do padrão de representação de Zeus sentado "no trono" foram definidas 10 variações na forma como o deus aparece nas moedas, a maior já encontrada para tipos monetários de Zeus. São elas: (a) nu ou vestindo himátion na cintura, segurando cetro com a mão esquerda e águia voando ou pousada sobre mão direita; (b) nu ou vestindo himátion na cintura (?), segurando cetro com a mão esquerda (à frente de Zeus) e raio com a mão direita; águia voando na frente; (c) segurando cetro com a mão esquerda e águia sobre cetro à esquerda; (d) vestindo um himátion, segurando um raio ou cetro com a mão direita e com a esquerda um raio alado; águia pousada sobre planta à 


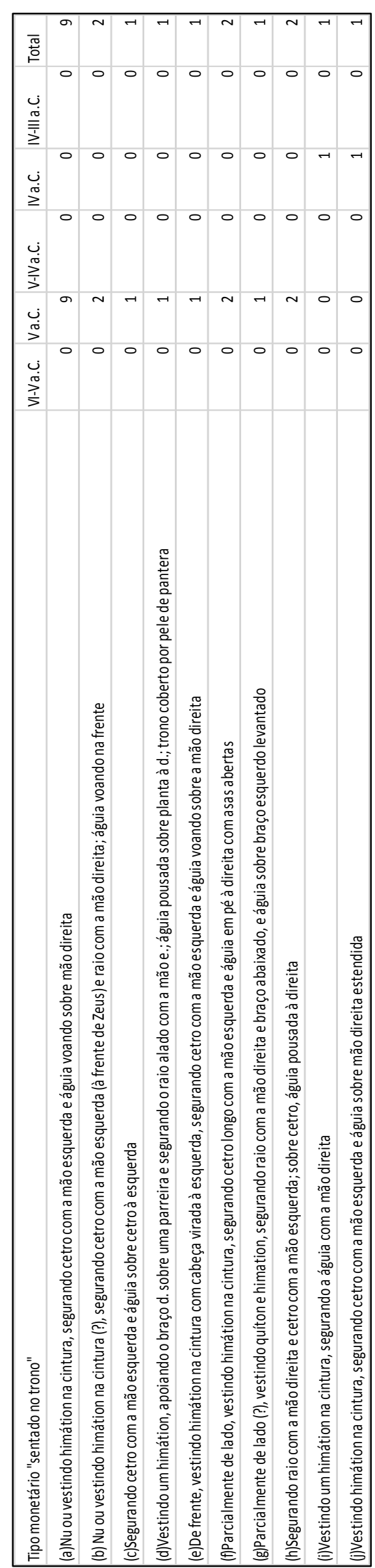

Tabela 12- Variedades de tipos monetários de Zeus sentado "no trono" (sécs. VI-IV/III a.C.).

direita e trono coberto por pele de pantera; (e) de frente, vestindo himátion na cintura com cabeça virada à esquerda, segurando cetro com a mão esquerda e águia voando sobre a mão direita; (f) parcialmente de lado, vestindo himátion na cintura, segurando cetro longo com a mão esquerda e águia em pé à direita com asas abertas; (g) parcialmente de lado (?), vestindo quíton e himation, segurando raio com a mão direita e braço abaixado, e águia sobre braço esquerdo levantado; (h) segurando raio com a mão direita e cetro com a mão esquerda; sobre cetro, águia pousada à direita; (i) vestindo um himátion na cintura, segurando um cetro com a mão esquerda e a águia com a mão direita; e (j) vestindo himátion na cintura, segurando cetro com a mão esquerda e águia sobre mão direita estendida.

Na tabela 12, vemos reunidas todas as variedades encontradas de tipos monetários de Zeus sentado "no trono". Observa-se que a variedade (a), a mais utilizada pelas autoridades emissoras (9 tipos monetários no total), foi própria do século $V$ a.C., não tendo sido usada nos períodos subsequentes. As segundas variedades mais usadas do padrão de Zeus sentado "no trono" foram: (b), (f) e (h) (cada qual 2 tipos monetários no total). As variedades de representação (b) e (f) foram usadas somente no século $V$ a.C., ao passo que a (i) apenas no século IV a.C. As demais variedades foram as menos utilizadas no padrão de representação: (c), (d), (e), (g), (i), (j) (cada qual 1 tipo no total). Dessas variedades, todas foram usadas em moedas no século $V$ a.C., com exceção das (i) e (j) que aparecem somente no século IV a.C.

Já a variedade mais numerosa (a) do padrão de Zeus sentado "no trono" refere-se às imagens monetárias, todas no anverso, de Zeus nu ou vestindo um himátion na cintura, segurando cetro com a mão esquerda e águia voando sobre a mão direita. Os tipos monetários desse grupo, datados desde 470 a.C. (Liga Arcádia, n.10) até 420 a.C. (Liga Arcádia, n.46), referem-se à Liga Arcádia e à Élis e o santuário de Olímpia. Nas nove imagens monetárias é possível perceber algumas diferenças principais, como no desenho dos tronos e na disposição das águias (se de asas abertas ou erguidas e sua posição em relação ao braço de Zeus). O tipo monetário mais antigo foi emitido pela Liga Arcádia ao redor de 470 a.C. (n.10), o qual pode ser um dos mais antigos do 
padrão de representação de Zeus sentado "no trono", ao lado dos dois tipos de Aetna-Catânia. Nessa moeda da Liga Arcádia, assim, Zeus é retratado nu, sentado em um trono baixo sem encosto, e a águia voa, à esquerda, com as duas asas abertas sobre a mão de Zeus. Em outro tipo monetário dessa pólis de c.465-460 a.C. (n.13), Zeus ainda é retratado nu, mas a águia aparece pousada sobre a mão do deus com as asas erguidas. 0 mesmo parece ocorrer na moeda do início de 460 a.C. (n.17). Na última moeda da Liga Arcádia, desse grupo, datada de c.460-450 a.C., a iconografia muda: o deus é retratado usando um himátion na cintura, o seu trono agora alto possui cabeça de cisne no topo do encosto e a águia aparece voando, à esquerda, com as duas asas abertas sobre a mão de Zeus. O mesmo tipo de representação se observa na moeda da Liga Arcádia de c.465-460 a.C. (n.14), exceto a imagem da águia que aparece pousada sobre a mão de Zeus com as duas asas erguidas. Na moeda de c.460-450 a.C., também da Liga Arcádia (n.23), o deus aparece representado sentando em um trono baixo, vestindo um himátion na cintura e a águia parece voar à esquerda com as duas asas abertas. No tipo monetário da Liga Arcádia de c.450-440/30 a.C. (n.29), Zeus é retratado com himátion na cintura e sentado no trono com topo de encosto com cabeça de cisne. No tipo, a águia aparece, à esquerda, em pleno vôo com as duas as abertas. Em outro tipo monetário, também dessa liga, datado de c.420 a.C. (n.46), a águia aparece voando, também à esquerda, com as duas asas erguidas. A imagem monetária de Élis de c.452-432 a.C. (n.26), cujo braço direito estendido de Zeus assemelha-se com as moedas de 465-460 a.C. (n.13) e de 450/440-430 a.C. Trata-se de uma "clara influência das imagens monetárias da Liga Arcádia na representação da moeda de Élis, como já atentou Lacroix na década de 1940" (Lacroix, 1949: 261).

Esse esquema iconográfico de Zeus sentado no trono, e segurando o cetro, que vemos nas moedas da Liga Arcádia, já aparece em vasos áticos de figuras negras datados da primeira metade do século VI a.C. $\mathrm{Na}$ taça ática de figuras negras de 560 a.C. (Fig.129), Zeus aparece sentado no trono segurando cetro com a mão direita e vestindo um himátion longo e um quíton, não sendo, portanto, retratado nu ou com himátion na cintura, como nas moedas. Nas cerâmicas áticas, a águia somente foi acrescentada a esse padrão de representação em ânforas de figuras vermelhas de 500 a.C., aparecendo em pé sobre o cetro de Zeus, diferentemente do modo como é retratada nos tipos monetários. Uma observação deve ser feita também ao cabelo e barba de Zeus. Nessas moedas da Liga Arcádia, o cabelo e a barba da divindade foi desenhada de uma maneira muito semelhante à forma como aparece na ânfora ática de figuras vermelhas de c.470-460 a.C.

(Fig.149). Contudo, esse tipo de representação usado repetidamente pela Liga Arcádia - de Zeus sentado no trono, segurando cetro e águia voando ou em pé sobre braço - foi utilizado somente em moedas, podendo ter sido uma criação dos arcádios sobre a iconografia de Zeus.

Os tipos monetários da variedade (b) também pertencem às emissões da Liga Arcádia e por isso mantêm as mesmas características das demais imagens monetárias, ou seja, o tipo de trono, de cetro e desenho de cabelo e barba. Nessa variedade, então, Zeus é retratado nu ou vestindo himátion na cintura, segurando cetro com a mão esquerda (agora à frente do deus) e raio com a mão direita. Na moeda de Mantinéia 
de c.465-460 a.C. (n.15), Zeus parece vestir somente um quíton ou clâmide e o trono, com topo de encosto com cabeça de cisne, tem um apoio para os pés. A novidade na imagem, é que Zeus segura um raio com a mão esquerda. Esse esquema iconográfico no qual Zeus é retratado sentado no trono, segurando raio e cetro aparece somente no século VI a.C., em um trípode kóthon ático de figuras negras datado de c.570-565 a.C. (Fig.125). Na segunda moeda da Liga Arcádia, de 460-450 a.C. (n.24), o deus parece retratado nu, segurando o cetro à sua frente com a mão direita. Com o braço esquerdo fletido, parece segurar um raio, embora não seja possível identifica-lo da forma como é descrito no catálogo. A posição da perna esquerda de Zeus (para trás) também é uma novidade entre as imagens monetárias descritas. No topo do encosto do trono de Zeus parece haver algo a mais desenhado, que não é a cabeça de cisne que costuma ser representada no encosto. Com relação à águia, ela aparece retratada apenas na primeira moeda (n.15) e de uma maneira diferente como vinha sendo representada nesse padrão de representação: ela aparece em um tamanho maior, de asas abertas à direita, e de frente à figura de Zeus. A ave, em relação a Zeus na imagem, foi retratada de uma maneira muito semelhante à forma como aparece na famosa taça lacônia de 560-550 a.C. (Fig.130), onde voa de frente para Zeus, grandiosa. Trata-se de uma representação única e que encontramos paralelo apenas nesse tipo monetário da Liga Arcádia (n.15). Assim como o raio na mão do deus, esse modo de representar a águia, em tipos monetários de Zeus sentado no trono e segurando o cetro, é próprio das moedas da liga. Nas moedas da Liga Arcádia da variedade (a), a águia parece partir de Zeus, como indica a sua posição à esquerda, sempre pousada com a asa erguida como que pronta para voar ou em pleno vôo. Já na moeda da variedade (b), a ave retorna para Zeus.

Na variedade (c), o tipo monetário traz a representação de Zeus sentado no trono e segurando o cetro com a mão esquerda e águia sobre cetro. Trata-se de uma variedade única que aparece em um tipo monetário de Galária, na Sicília, datado de 450 a.C. (n.27). Na imagem monetária, Zeus é retratado vestindo um himátion longo e o cetro aparece na frente de Zeus, segurado pela mão direita da divindade. Sobre o cetro está a águia à esquerda, em pé e de asas fechadas. Esse mesmo tipo de representação pode ser visto nas duas moedas de Aetna-Catânia de c.475-470 a.C. (n.08/09) da variedade (h) na qual Zeus segura um raio com a mão direita, a única diferença iconográfica com o tipo de Galária. Esse padrão de representação encontra correspondência em uma cena de uma ânfora ática de figuras vermelhas datada de c.500 a.C., embora a águia apareça retratada de asas abertas e de frente para Zeus (Fig.158). Já na cratera ática de figuras vermelhas, a águia aparece em pé sobre cetro e de frente para Zeus, que está sentado no trono segurando uma taça com a mão direita (Fig.159). A datação dos dois exemplares de Aetna-Catânia coloca-os entre aqueles mais antigos do padrão de representação de Zeus sentado no trono em moedas gregas. Pode-se afirmar, assim, que a Sicília e a Arcádia, mais uma vez, se caracterizam pelas primeiras criações e inovações iconográficas na imagética dessa divindade em moedas gregas. Na variedade (d), cujo desenho também é proveniente de um tipo monetário da Sicilia, Zeus é representado vestindo um himátion longo, apoiando o braço direito em uma parreira e segurando um raio alado com a mão esquerda. A águia aparece em pé, à direita, de asas fechadas sobre uma planta local. 
Trata-se de uma moeda da pólis de Aetna-Inessa, datada também de 465-460 a.C. (n.16), que traz uma série de inovações em desenhos ao padrão iconográfico de Zeus sentado no trono, como a pele de pantera sobre 0 trono, o raio alado na mão de Zeus, e a águia que aparece sobre uma planta e não sobre um cetro, o que não encontra nenhum paralelo em pinturas de vasos áticos ou esculturas e relevos da divindade.

As variedades (e), (f) e (g) referem-se a tipos monetários da Liga Arcádia. A variedade (e) traz a imagem monetária de Zeus de frente, vestindo himátion na cintura com a cabeça virada à esquerda e a águia voando sobre a mão direita. Trata-se de um tipo monetário da Liga Arcádia de c.460-450 a.C., que traz um desenho completamente novo: a representação de Zeus sentado no trono de frente. A representação frontal de Zeus em imagens monetárias não é nova: a cabeça do deus já foi representada de frente em moedas de Cirene do século IV a.C. Em contraste, a novidade no desenho da variedade (f), é a representação de Zeus parcialmente de lado, quase de costas. 0 deus veste um himátion na cintura, segura o cetro longo com a mão esquerda e a águia aparece em pé sobre o braço direito estendido do deus. Ambos os tipos monetários da Liga Arcádia de c.460-450 a.C. (n.21/22) são bem semelhantes no tipo de trono (com cabeça de cisne no topo do encosto). Destacamos o desenho da águia do segundo tipo monetário (n.22), cujas asas erguidas esticadas, parecem indicar que a águia está pronta para voar. Já na variedade (g), o deus é retratado, ao que parece, parcialmente de lado, vestindo himátion longo e quíton, segurando o raio com a mão direita e braço abaixado. De acordo com o catálogo, a águia aparece sobre braço esquerdo levantado. Trata-se de um tipo monetário da Liga Arcádia de c.460-450 a.C. (n.25) com uma representação completamente nova: o raio é segurado pelo braço abaixado e a águia é retratada sobre o braço levantado.

Diferentemente do que vimos até o momento do esquema iconográfico "Zeus sentado no trono, segurando cetro e águia", a variedade (i) refere-se a um tipo monetário de Cirene, datado de 375-308 a.C. (n.69), em que Zeus, sentado no trono, segura apenas a águia. O cetro não aparece na imagem monetária. Trata-se de uma representação nova tanto na imagética de Zeus em moedas, quanto em outros suportes. Na representação, Zeus é retratado vestindo um himátion na cintura e seu trono possui um encosto para os pés tal como na moeda da Liga Arcádia de c.465-460 a.C. (n.15). O braço da divindade parece estar apoiado no encosto do trono.

No tipo monetário da última variedade (j), Zeus aparece sentado na beirada do trono, vestindo um himátion na cintura e uma clâmide sobre o ombro esquerdo, segurando o cetro com a mão esquerda e a águia parece voar sobre braço direito estendido. Nessa moeda, batida pela Liga Acaia em c.370-360 a.C. (n.71), a águia aparece retratada, com as duas asas erguidas, sobre a palma da mão direita de Zeus. Tratar-se-ia de um tipo monetário com o padrão de representação das moedas do século V a.C. da Liga Arcádia, mas o desenho da clâmide, o elmo embaixo do braço direito de Zeus diferenciam este tipo. 
(a) Vestindo um himátion na cintura, descansando mão esquerda sobre rocha, águia sobre ou fora de sua mão direita estendida; cetro atrás, inclinado: Élis (c.430s, n.343).

343

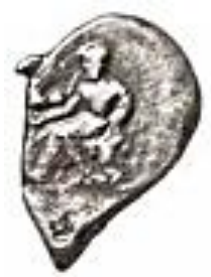

(b) Vestindo himátion na cintura, segurando cetro e apoiando mão esquerda sobre rocha: Gomphi (c.350, n.88); (c.350-306, n.92).

88

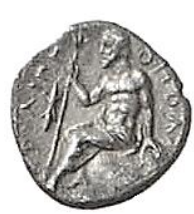

92

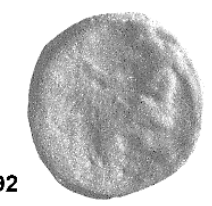

De acordo com 0 gráfico 49, acerca da quantidade por regiões de tipos monetários de Zeus sentado "sobre rocha", o padrão de representação foi próprio de apenas 2 regiões: Élis e Tessália. Foram encontrados pelo levantamento 2 tipos monetários emitidos por autoridades emissoras da Tessália, ao passo que apenas 1 exemplar monetário em Élis, colocando a Tessália como a região de maior quantidade de imagens

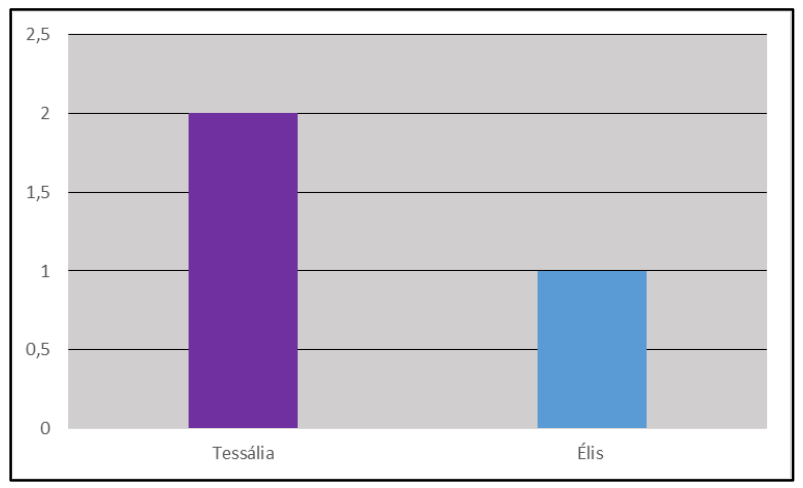

Gráfico 49- Quantidade por regiões de tipos monetários de Zeus "sentado sobre rocha" (sécs. VI-IV/III a.C.). monetárias desse padrão de representação.

Durante a classificação dos tipos monetários de Zeus sentado "sobre rocha", definimos 2 variedades de representações: (a) vestindo um himátion na cintura, descansando mão esquerda sobre rocha, águia sobre ou fora de sua mão direita estendida; cetro atrás, inclinado; (b) vestindo himátion na cintura, segurando cetro e apoiando mão esquerda sobre rocha.

\begin{tabular}{|l|r|r|r|r|}
\hline Tipo monetário "sentado sobre rocha" & VI-Va.C. & Va.C. & V-IV a.C. IVa.C. IV-III a.C. & Total \\
\hline (a)Vestindo um himátion na cintura, descansando mão esquerda sobre rocha, águia sobre ou fora de sua mão direita estendida; cetro atrás, inclinado & 0 & 1 & 0 & 0 \\
\hline (b)Vestindo himátion na cintura, segurando cetro e apoiando mão esquerda sobre rocha & 0 & 1 \\
\hline
\end{tabular}

Tabela 13- Variedades de tipos monetários de Zeus "sentado sobre rocha" (sécs. VI-IV/III a.C.). 
A partir da tabela 13, observa-se que foi encontrado apenas 1 tipo monetário da variedade (a), sendo o único datado do século $V$ a.C., ao passo que foram encontrados 2 tipos monetários da variedade (b), própria do século IV a.C. Dentre as variedades, o tipo monetário mais antigo é proveniente de Élis, sendo datado da década de 430 a.C. (n.343). Na moeda, Zeus é retratado vestindo um himátion na cintura, descansando a mão esquerda sobre a rocha, a águia é retratada sobre o braço direito estendido e o cetro aparece encostado atrás do braço direito do deus. A representação de Zeus "sentado sobre uma rocha" encontra correspondência em uma cena

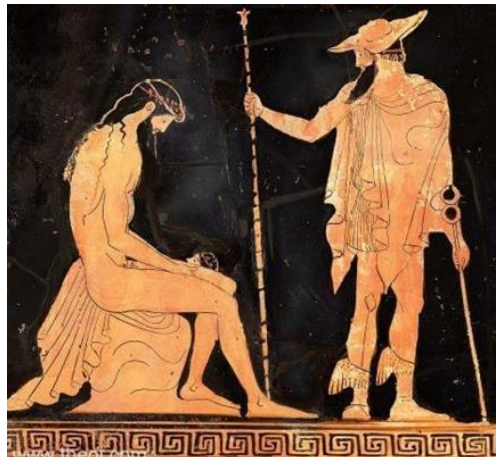
Fig.175- Nascimento de Dioniso, lécito ático de figuras vermelhas, c.470-460 a.C., Boston, Museum of Fine Arts. de um lécito ático de figuras vermelhas, datado de 470-460 a.C., que retrata o nascimento de Dioniso, da coxa de Zeus. No momento do nascimento, Zeus está nu, seu sentado sobre suas vestes (um himátion ou clâmide) que cobre a rocha e seu cetro é segurado por Hermes (Fig.175). Embora Zeus apareça retratado sentado sobre a rocha, o esquema iconográfico apresentado pela moeda de Élis é completamente novo em moedas gregas. A variedade iconográfica foi provavelmente seguida pela pólis de Gomphi, na Tessália, que emitiu uma moeda em c.350 a.C. (n.88) e a outra em c.350-306 a.C. (n.92). As únicas diferenças entre as imagens de Gomphi e a de Élis é a ausência da águia nas moedas tessálias e a presença do raio no campo e o cetro sendo segurado pela mão direita de Zeus.

\section{DE CÓCORAS OU AJOELHADO}

(a) Vestindo um himátion na cintura, apoiado sobre cetro que segura com a mão direita e águia voando com asas erguidas ou em pé sobre mão esquerda: Cyzicus (c.450-400, n.31).

31

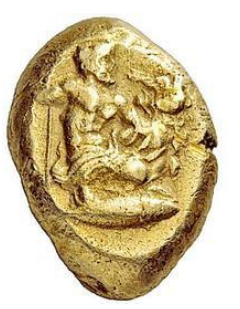

O último padrão de representação de Zeus "sentado" é aquele em que o deus é retratado "de cócoras ou ajoelhado". Trata-se de uma representação nada usual relacionada ao deus. Nossa pesquisa encontrou somente um tipo monetário que foi cunhado pela pólis de Cyzicus, na Mysia, entre aproximadamente 450-400 a.C. (n.31). A imagem não encontra paralelo, no período, em outras representações monetárias e em outros suportes, como na cerâmica pintada, em relevos e em esculturas. O tipo monetário possui a imagem de Zeus sentado "de cócoras ou ajoelhado" à direita, vestindo um himátion na cintura, segurando o cetro com a mão direita e a águia parece estar sobre sua mão direita. Nessa representação de Cyzicus, embora não-usual, Zeus carrega os mesmos elementos presentes que são próprios das moedas da Liga Arcádia, principalmente da 
variedade (b): o himátion na cintura, a águia de asas erguidas sobre a mão de Zeus, como se estivesse pronta para voar, e o cetro segurado pela mão direita do deus. De acordo com S. Kremydi-Sicilianou, esse tipo monetário "deve ser analisado no contexto de outras cunhagens de Cyzicus onde figuras ajoelhadas são recorrentes" (Kremydi-Sicilianou, 1997: 370).

\section{II.3 A REPRESENTAÇÃO DO RAIO NA ARTE GREGA ATÉ A ÉPOCA CLÁSSICA}

Diferentemente da águia, como veremos mais adiante, o estudo da iconografia dos raios na arte grega é indissociável da representação de Zeus. Somente em moedas gregas é possível analisar a imagem dos raios, sem necessariamente estar vinculada à figura de Zeus, naqueles tipos onde o raio é a figura principal. $\mathrm{Na}$ iconografia das águias veremos como o desenho da ave teve um percurso independente ao da imagem da divindade. Ela aparece predominantemente em vasos, sempre associada às certas narrativas mitológicas ou como a figura principal na cerâmica pintada. Assim, na análise iconográfica dos raios nos reportaremos às representações que aparecem junto a Zeus na cerâmica pintada e nas esculturas já descritas aqui em relação à divindade.

Os primeiros estudos sobre o raio na religião e na arte grega foram publicados no início do século XX. P. Jacobsthal, em Der Blitz in der orientalischen und griechischen Kunst (1906), é responsável pela primeira análise sistemática da representação do raio na arte grega. Nesse livro, o autor estuda a origem da imagem do raio na arte grega a partir da religião assíria e o percurso de desenvolvimento de sua forma na Grécia, examinando, por exemplo, a relação da flor de lótus na sua representação. Foi Jacobsthal que influenciou posteriormente o trabalho de A.B. Cook em Zeus: a study in ancient religion (volume II). Veremos um pouco de suas ideias através das referências que citaremos de Cook ao longo de nossa análise iconográfica. Alguns anos mais tarde, C. Blinkenberg, em The thunderweapon in religion and folklore - a study in comparative archaeology (1911), estuda o raio e o trovão na cultura material de povos dos cinco continentes de sorte a traçar relações de seu papel entre as religiões. Seu ponto de partida para a comparação com as religiões é a Grécia, sobre a qual um capítulo é dedicado, onde examina as evidências materiais ao lado dos textos. De lá para cá, os raios foram estudados em relação à iconografia e ao culto de Zeus, como fez G.W. Elderkin, em seu artigo Bronze Statuettes of Zeus Keraunios (1940).

Representações do raio na mão de Zeus são conhecidas do início do século VII a.C., como evidencia a imagem no pithos de Cnossos, datado de c.700 a.C. (Fig.113) (em uma forma menos parecida com a que se definiu no século VI a.C.) e no aríbalo proto-coríntio de 680 a.C. (Fig.176), onde o desenho do raio é facilmente reconhecido. No caso do pithos de Cnossos, sabemos que os três feixes, na mão da figura masculina (Fig.177), representam, irrefutavelmente, a figura de um raio com

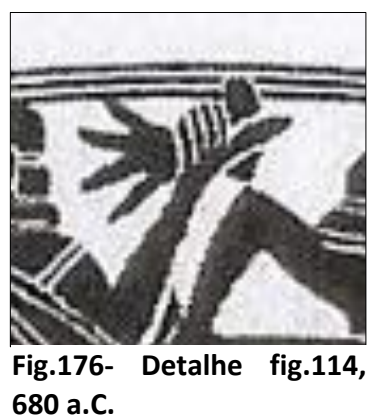
base na estela hitita com a representação de Tessub em pé, segurando o machado não mão direita e o "garfo- 


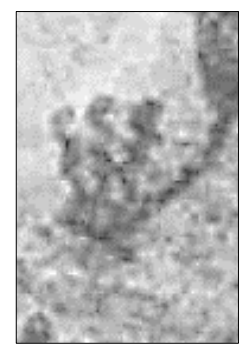

Fig.177- Detalhe da Fig. 113, 700 a.C.

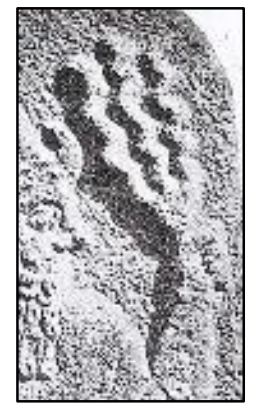

Fig.178- Detalhe da fig.116, séc. $X$ a.c.

raio" com a mão esquerda (Fig.178). A. B. Cook é quem explica a origem da representação do raio de Zeus, e sua associação com a divindade, na Mesopotâmia. A partir de uma série de representações de vários raios, associados às divindades mesopotâmias e gravadas em selos ou estelas, Cook, influenciado por Jacobsthal, conseguiu traçar o desenvolvimento das formas que o raio assumiu na arte mesopotâmia. Assim, de acordo com o estudioso, nos períodos mais antigos quando vem associado ao deus Ramman, o raio tem um formato bipartido ou tripartido (Cook, II: 764). 0 formato bipartido, o mais comum e provavelmente 0 mais antigo, aparece como um garfo composto de zigue-zagues ou linhas curvas. $O$ formato tripartido, que é encontrado primeiramente sob a dinastia Kassita, é formado de curvas ou linhas estreitas e aparece representado junto ao deus Tessub, em estelas hititas (Fig.116) (Cook, II: 764-766). A partir do século IX a.C. e em diante, houve uma tendência em duplicar esses garfos, como se vê na estela hitita com a representação de Marduk, principal deus da cidade de Babilônia (Fig.115) (Cook, II: 767-769). É interessante notar, assim, como a representação do raio tal como aparece na estela hitita de período Kassita, encontrada na Babilônia, datada do final da Idade do Bronze e início da Idade do Ferro, pôde influenciar as representações mais antigas do raio associadas a Zeus no mundo grego séculos depois. E justamente em uma representação do raio produzida em Creta, que há milênios possuía contatos em vários níveis com o Oriente próximo.

Ainda com base nas representações mesopotâmias, Cook nos mostra como o Oriente próximo pôde influenciar todas as representações gregas subsequentes dos raios, sobretudo a partir de época arcaica. Durante a dinastia Sargônida (c.700 a.C.) houve uma mudança na representação do raio. O garfo (de ponta dupla ou única) passou a ser representado no formato semelhante ao da flor de lótus, como se vê no relevo em pedra de c.700 a.C. de uma divindade, não identificada, segurando o raio com a mão direita, encontrado próximo a Mosul (Fig.179) (Cook, II: 767-769). Com base nessa informação, também é interessante perceber que já na época da produção do pithos de Cnossos, na época do império neo-assírio, o raio já era representado da forma como viria a ser usado durante muito tempo pelos gregos. Talvez nessa época ainda a nova imagem não havia sido conhecida em Creta, onde os artistas utilizavam a antiga maneira oriental, uma reminiscência de tempos mais antigos.

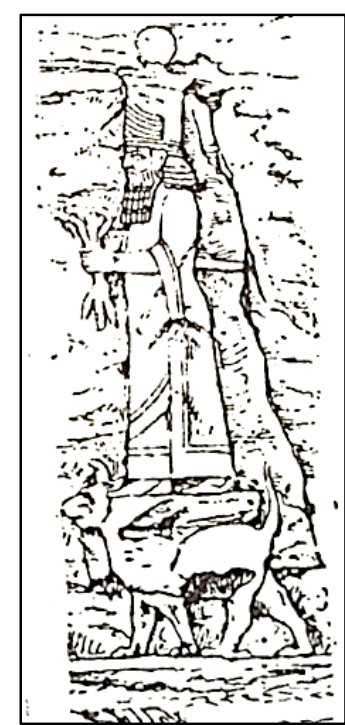

Fig.179- Relevo em pedra da Dinastia Sargônida (c.700 a.C.), (Cook, II: fig. 733)

De acordo com a teoria de Cook, os formatos dos raios - como garfos ou lotiformes -, formulados no Oriente próximo, entraram no mundo grego através da Ásia Menor e depois pela Jônia, um processo ocorrido durante a Idade do Ferro e que se estendeu à época arcaica, quando todo o Mediterrâneo sofreu influência oriental (Cook, II: 769-770). Variados temas orientais, como de esfinges, grifos, leões, panteras, palmetas e a própria flor de lótus passaram a figurar na arte grega, seja ela cerâmica ou produzida pela metalurgia. Para 0 
estudioso, o formato de lótus do "garfo-raio", da arte assíria tardia, apareceu pela primeira vez como o raio grego em vasos da Jônia. Cook usa como evidência uma taça de estilo calcídico, encontrado na ilha de Rodes, que traz o tema da apresentação de Héracles ao Olimpo (Fig.180). Na cena, Zeus é retratado sentado no trono segurando em sua mão esquerda um raio muito semelhante a um maço de folhas ou pétalas, enquanto do braço direito de seu trono nasce um botão de lótus de enorme dimensão. A nosso ver, contudo, a representação do raio que aparece nessa taça calcídica está mais associada com a de um vaso muito mais antigo descrito anteriormente, o aríbalo proto-coríntio de 680 a.C., cuja cena retrata a luta do deus contra um centauro. Nos dois vasos, a imagem do raio assemelha-se ainda, em algum aspecto, ao antigo formato oriental de garfo. A datação do vaso proto-coríntio pode indicar que esse tipo de representação já circulava no mundo grego muito antes de ter entrado pela Jônia. A confirmação da tese de Cook dependeria, contudo, de mais evidências antigas provenientes das cidades gregas nas costas da Ásia Menor. De todo modo, é interessante notar, que 0 formato de garfo - ou melhor, as reminiscências desse tipo de representação - aparece na arte grega até ao menos o início do século VI a.C., como evidencia o raio na mão de Zeus no relevo do pedimento oeste do templo de Ártemis, em Corfu, datado de c.580 a.C. (Fig.181). Já na cerâmica pintada, vemos tanto a mistura do formato de garfo com o tipo lotiforme a partir de 570-565 a.C. (Fig.182), no trípode kóthon ático de figuras negras, como a permanência da predominância do formato de garfo em uma ânfora ática de 570-560 a.C. (Fig.183). A análise comparativa das representações nas cerâmicas pintadas, de figuras negras, indica que 0 formato lotiforme começou a predominar na arte grega a partir de meados do século VI a.C., como mostram a taça ática de 560 a.C. e a ânfora ática de 540 a.C. (Figs.184 e 185). A nossa análise e levantamento confirmam a conclusão de Cook acerca da hídria calcídica de 540 a.C. De acordo com o estudioso, o raio na mão de Zeus, que luta contra Tifeu, pode ser considerada uma das primeiras representações do formato lotiforme na arte grega (Fig.186) (Cook, II: 731 e 771). É preciso salientar, no entanto, que apesar de nesse período o formato lotiforme ter começado a se consolidar com o único tipo de representação do raio para os gregos, ainda é possível ver alguma reminiscência do tipo garfo em outros suportes imagéticos, como na placa em relevo de prata de Zeus lutando contra Tifeu de 540-530 a.C. (Fig.187).

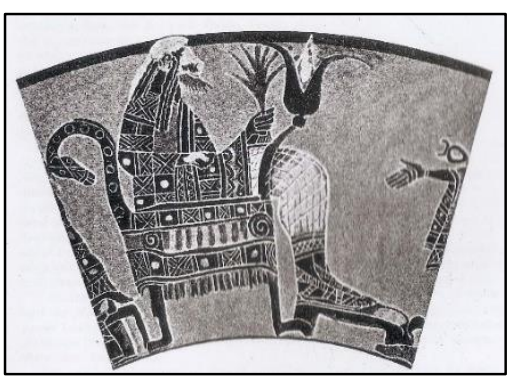

Fig. 180- Apresentação de Héracles ao Olimpo, taça de estilo calcídico, período arcaico (Cook, II: fig.334).

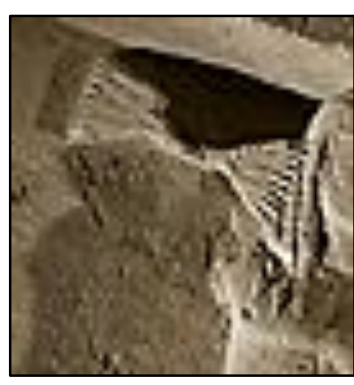

Fig.181- Detalhe fig.117, 580 a.C.

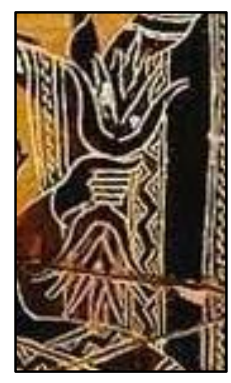

Fig.182-

Detalhe da

Fig.125, de Zeus sentado, c.570565 a.C.

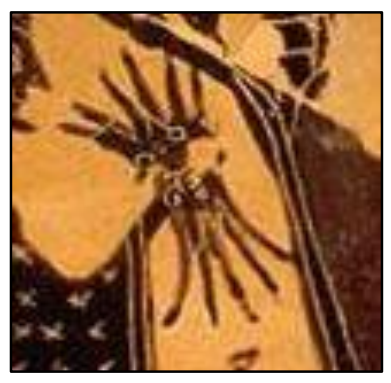

Fig.183- Detalhe da Fig.126, de Zeus sentado, c.570-560 a.c. 


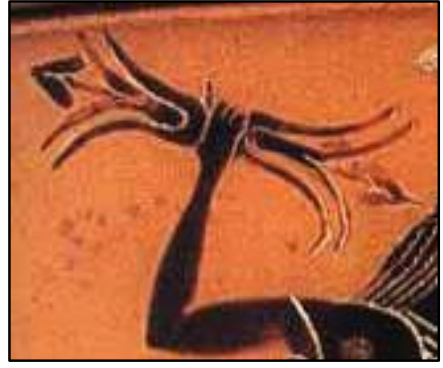

Fig.184- Detalhe da Fig.127, de Zeus sentado no trono com o braço erguido, c.560 a.C.

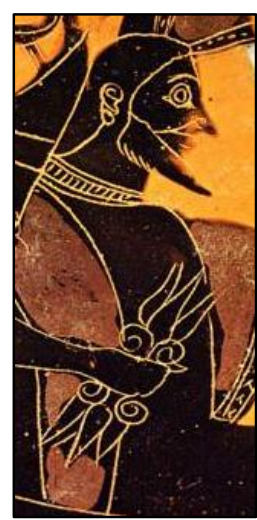

Fig.185- Detalhe da Fig.128, de Zeus sentado no trono, c.540 a.C.

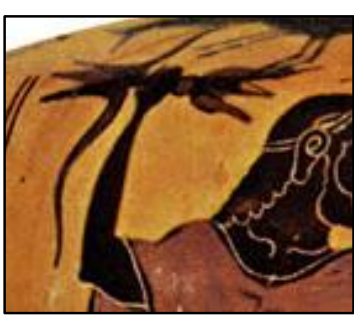

Fig.186- Detalhe da Fig.118, de Zeus atirando o raio, c.540 a.C.

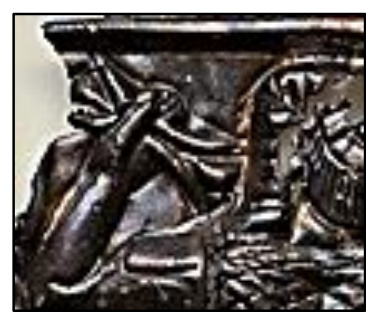

Fig.187- Detalhe da Fig.122, de Zeus atirando o raio, c.530 a.C.

Ainda de acordo com Cook, a popularidade da flor de lótus, em conexão com o raio, foi devida, em parte, as suas qualidades ornamentais, mas principalmente pelo significado acumulado desde muito antes. Em geral, "o fogo foi algumas vezes associado pelos antigos como uma flor, e o sol, em particular, foi associado com o lótus na religião egípcia e também na indiana" (Cook, II: 771-772 e 774). Nesse contexto, portanto, "os gregos que entenderam o raio como sendo feito da mesma substância ardente do sol, podem bem ter aderido, por essa razão, a forma lotiforme do raio" (Cook, II: 774). Assim, na primeira metade do século VI a.C., a representação do raio em flor de lótus começou a se consolidar entre os gregos, como vimos na cerâmica pintada do período. A partir da segunda metade do século VI a. C. já é possível identificar, com clareza, o desenho da flor em imagens de raios em uma das mãos de Zeus. Em 540 a.C. a flor de lótus no raio, passou a vir acompanhada pelo desenho de volutas na cerâmica ática, continuando em uso até ao menos 500 a.C. (Figs.188 e 189). Foi a partir desse período, então, que o raio começou a ser representado muito ornamentado, recebendo, por exemplo, o desenho de volutas. Como o lótus já era um elemento ornamental na cerâmica grega, algumas formas decorativas nos vasos podem até ser confundidos com o próprio desenho do raio, como ocorre no fragmento de taça ática, encontrado em Leontino, na Sicília, e datado da segunda metade do século VI a.C. (Fig.190).

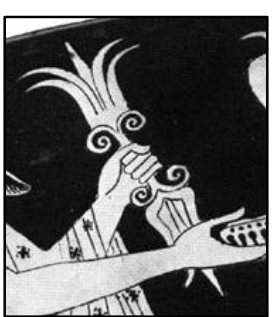

Fig.188- Detalhe da fig. 157, Zeus sentado, c.520 a.C.

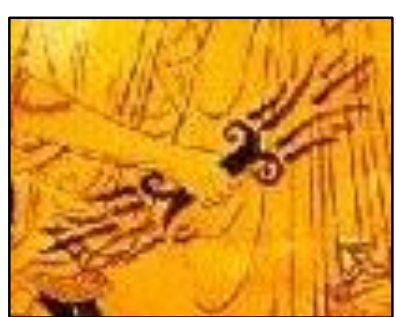

Fig.189- Detalhe da fig.158, de Zeus sentado no trono, c.500 a.C.

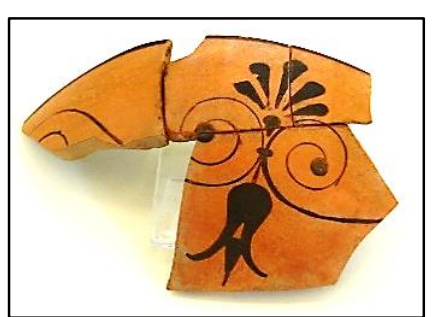

Fig.190- Fragmento de taça ática de figuras negras, decoração com espirais e flor de lótus e palmeta contraposta, fossa votiva, colina de Metapiccola, 2a. metade do século VI a.C., Lentini, Sicília (Fonte: Archeologia dei Nebrodi) 
Durante os séculos VI e V a.C., os gregos preferiram acrescentar, nos desenhos, flores às flores ou botões aos botões, tendo sido o primeiro esquema o favorito dos pintores de vasos e o segundo, o mais conveniente para os escultores (Fig.192) (Cook, II: 776). De fato, esse esquema de sobreposição de flores pode ser visto claramente já na cerâmica ática da segunda metade do século VI a.C. (Figs.185 e 189), tendo sido usado principalmente ao longo do século $V$ a.C., sobretudo em cenas de vasos do início desse período, de 480 a 475 a.C. (Figs.193, 194 e 195). Também

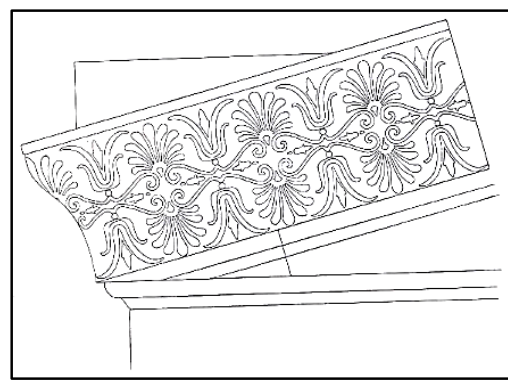

Fig.191- Padrão de desenho inciso em cornija inclinada, templo de Poseidon, Súnion, meados do séc. $\mathrm{V}$ a.C. (Lawrence, 1996: fig.102). aqui, esse tipo de representação encontra paralelo na arte decorativa, nesse caso não na cerâmica, mas na arquitetura templária grega. Um desenho inciso na cornija inclinada do tempo de Poseidon em Súnion, de meados do século $V$ a.C., mostra flores de lótus, uma de cada lado, em sobreposição, intercaladas por palmetas, um tipo de representação muito semelhante ao que definimos como raio na cerâmica ática do período ou em evidências numismáticas (Fig.191).

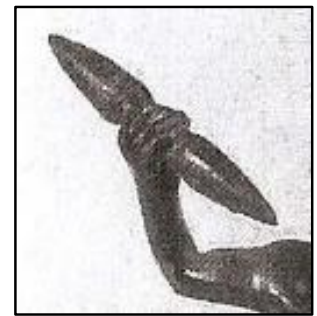

Fig.192- Detalhe da Fig.135, estatueta de Zeus Keraunios, c.480470 a.C.

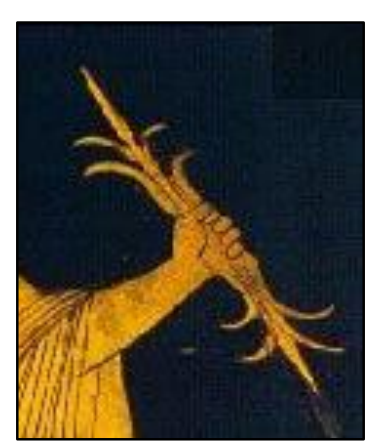

Fig.193- Detalhe da Fig.194Fig.147, de Zeus em pé, capturando c. 480 a.C.

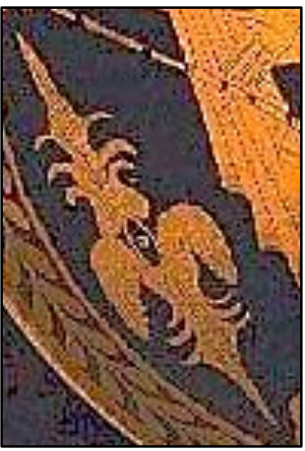

Ganimedes, cálice ático de figuras vermelhas, c.475-425 a.C., Ferrara, Museo Archeologico

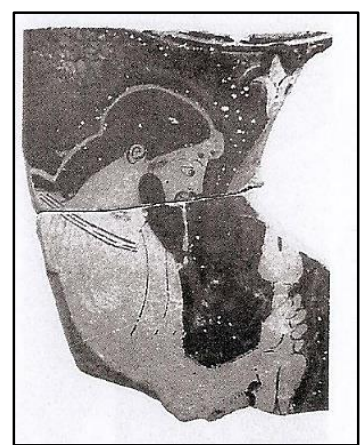

Fig.195- Zeus segurando raio, fragmento de ânfora ática, c.470 a.C. (LIMC) VIII: fig.118).

Apesar de os dois traços laterais que aparecem no raio da hídria calcídica de 540 a.C. parecerem indicar asas (Fig.186), com segurança, foi em um período bem específico no século V a.C., entre 475 e 460 a.C., que pela primeira vez os raios passaram a ser representados com asas na cerâmica ática (Figs.194, 196 e 197). Notavelmente, foi no mesmo período que esse tipo de representação aparece em moedas gregas e justamente nos tipos monetários mais antigos de raios, como veremos mais adiante. Para Cook, esse é o segundo tipo de modificação que a representação do raio assumiu em terras gregas (Cook, II: 777). A imagem de um raio alado apareceu pela primeira vez na poesia ática do século V a.C. como em Aristófanes (Aves, 1714). Provavelmente, de algum modo, a representação nos vasos deu forma a uma ideia que já circulava no período. De acordo com Cook, não há dúvidas de que o raio alado foi originalmente modelado na águia, o reconhecido pássaro-raio dos gregos. 0 estudioso usa como base para a premissa um fragmento de Niobe de 
Ésquilo em que Zeus declara: "sim, casa de Amphion, eu queimarei com águias carregando fogo" (Cook, II: 777). Na visão de Cook, assim, aqueles que viam a águia como a portadora natural do raio, compreenderiam as asas dos raios como as penas das águias (Cook, II: 779).

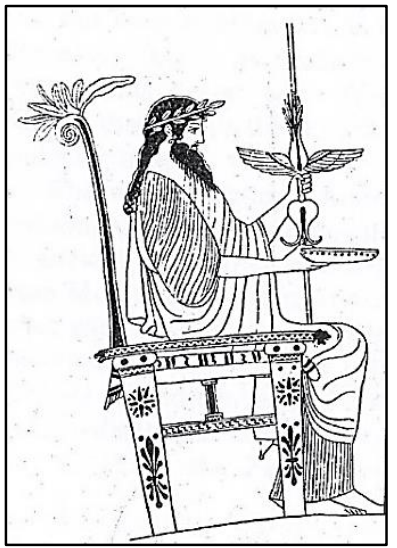

Fig.196- Zeus, Atenas e Héracles (detalhe), cratera ática de figuras vermelhas, c.475-425 a.C. (Cook, II:

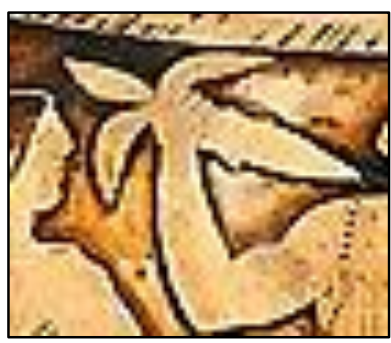

Fig.197- Detalhe da Fig.154, de Zeus em pé atirando o raio, c.460 a.C.

Interessante notar que na primeira metade do século V a.C., na cerâmica ática, a sobreposição de flor de lótus deu lugar a uma representação mais simples, onde somente foi retratado o cálice da flor com um botão, ao centro, fechado. Esse tipo de representação foi predominante entre 470-450 a.C. (Figs.198-204), podendo ser também visto em uma lâmina de prata de Zeus Keraunios, datada de 450 a.C., de Dodona, no Épiro (Fig.138). Esse tipo de representação do raio, foi utilizado ao menos até a metade do século IV a.C. e não somente na cerâmica pintada ática, mas também na ápula, por exemplo. É o caso do cântaro-rython de figuras vermelhas de c.360-350 a.C. (Fig.209).

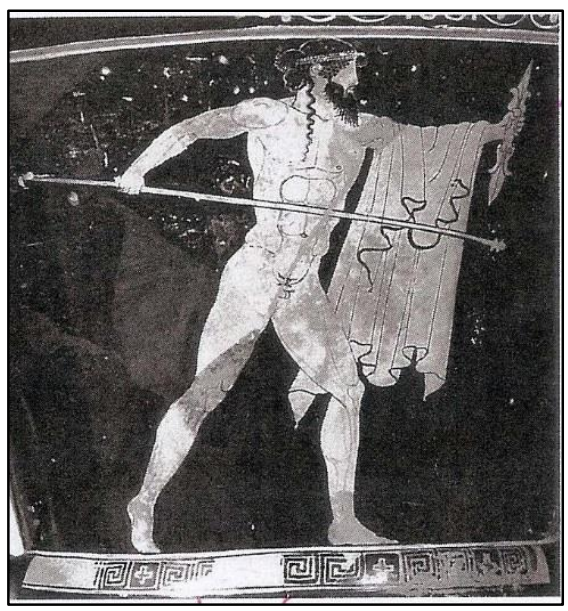

Fig.198- Zeus em pé, segurando raio e cetro, cálice cratera ática de figuras vermelhas, c.470 a.C (LIMC, VIII: fig.105).

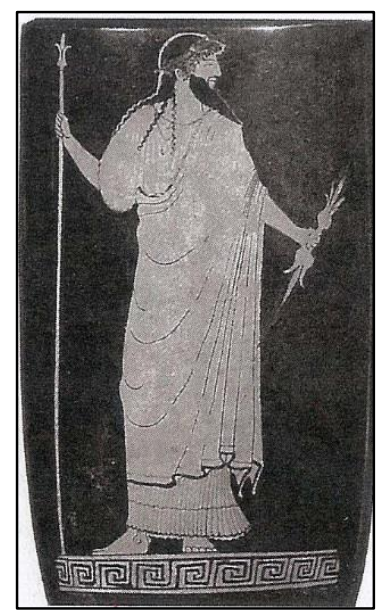

Fig.199- Zeus em pé segurando cetro e raio, lécito ático, c.470 a.C. (LIMC, VIII: fig.84).

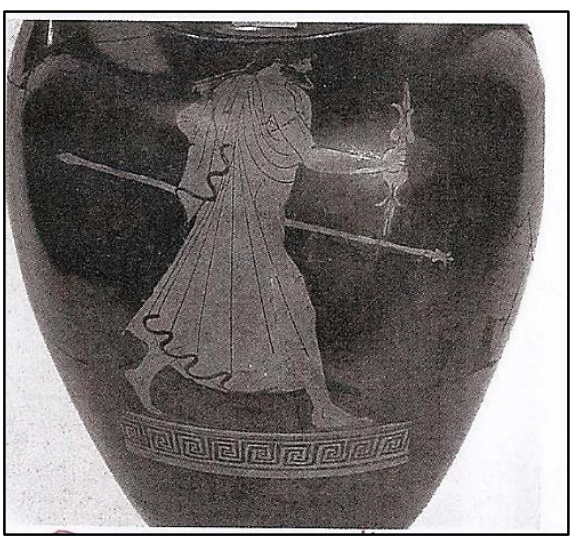

Fig.200-Zeus em pé segurando raio e cetro, ânfora ática de figuras vermelhas, c.460450 a.C. (LIMC, VIII: fig.111). 


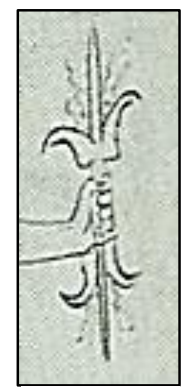

Fig.201Detalhe da Fig.156,

Zeus em pé, a.C. c.470 a.C.

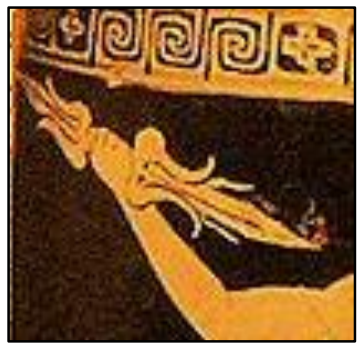

Fig.202- Detalhe da Fig.203- Detalhe da Fig.153, Zeus atirando o raio, c.470-460 a.C.
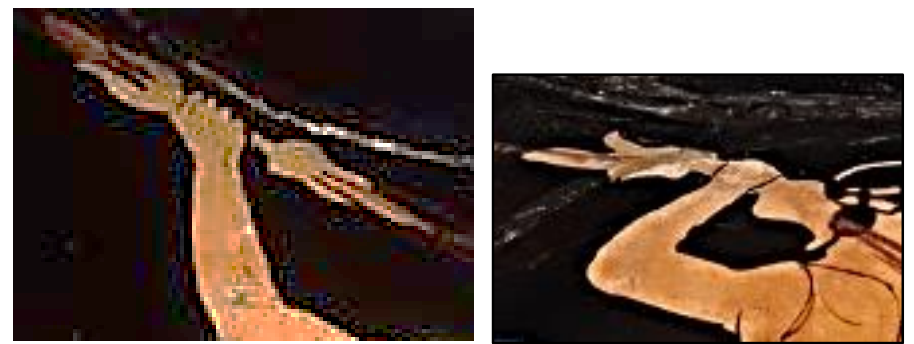

Zeus em pé atirando o raio, c.460 a.c.

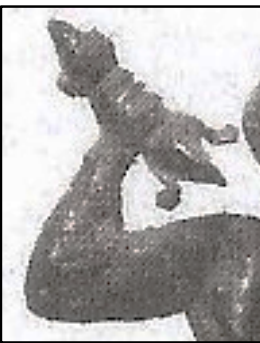

Fig.205- Detalhe da Fig.138, de Zeus atirando $o$ raio, c. 450 a.C.

Conforme Cook, o raio em forma de lótus foi submetido a três modificações em solo grego. A primeira mudança diz respeito a transformação de suas pétalas em chamas, podendo serem vistas desde o início do século V a.C. até o início do século IV a.C., aparecendo em alternância com os tipos de representação na cerâmica ática de figuras vermelhas desse período. É o caso da ânfora ática de figuras vermelhas de 500 a.C. (Fig.189), da cratera ática de figuras vermelhas de c.460 a.C. (Fig.206), da taça de 410-400 a.C. (Fig.207) e da ânfora de c.400-390 a.C. (Fig.208). A terceira modificação, descrita por Cook, é a representação do raio como espiral, a mais utilizada em esculturas e nas artes menores, como as moedas. Trata-se da imagem do espigão ou botão do lótus, desenhado de forma retorcida, em espiral (Cook, II: 779). Esse tipo de representação também tem base nos textos antigos de vários períodos, como indicam o epíteto homérico de Zeus, terpikéraunos ("que retorceu o raio") e o trecho de Ésquilo, que diz: "relampejo de luz, espirais ardentes do raio". Veremos que no século V a.C., essa imagem do raio foi utilizada pontualmente em moedas gregas (Cook, II: 779).

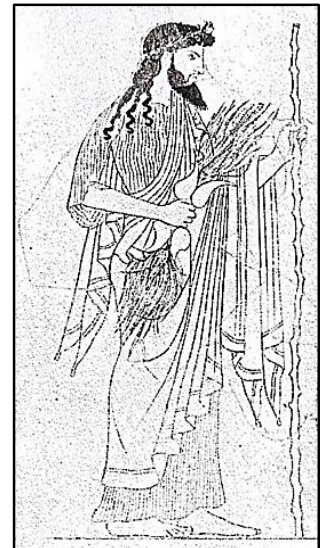

Fig.206- Héracles pesando as almas de Aquiles e Memnon (detalhe), cratera ática de figuras vermelhas, c.460 a.C. (Cook, II: fig.665).

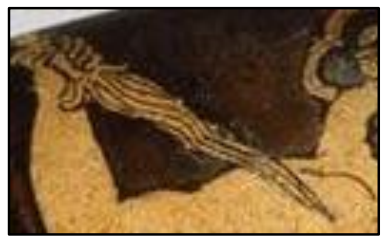

Fig.207- Detalhe da fig.151, de Zeus atirando o raio, c. $410-400$ a.C.

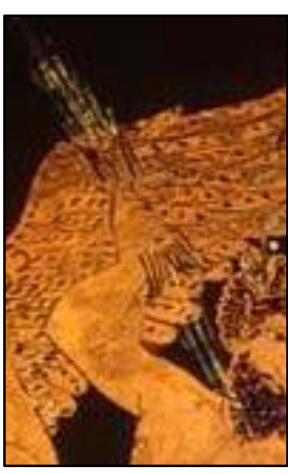

Fig.208- Detalhe da fig.152, de Zeus em pé atirando o raio, c.400-390 a.C.

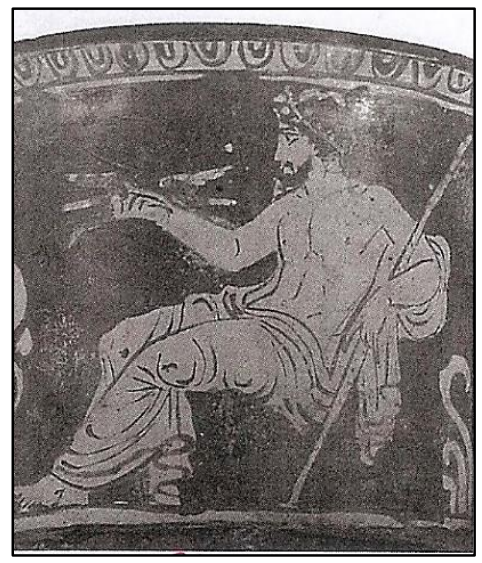

Fig.209- Zeus sentado segurando cetro e raio, kantharos-rhyton ápulo de figuras vermelhas, c.360350 a.C. (LIMC, VIII: fig.198). 
Assim, quisemos mostrar nesse breve estudo, o desenvolvimento da iconografia do raio, evidenciando como a flor de lótus teve uma longa duração na representação dos raios de vários tipos. Com a evidência numismática, veremos como essa flor continuou em uso e predominou no século IV a.C.

\section{II.4 A ICONOGRAFIA DOS RAIOS EM MOEDAS GREGAS}

Como no caso da iconografia de Zeus e de águias em moedas gregas, no caso dos raios, há também três padrões de representação do raio como imagem monetária: (1) "alado"; (2) "chamejante"; e (3) "flor de lótus", ainda que os dois primeiros padrões também derivem do desenho dessa flor. Para os raios, não foram definidas variedades dentro de cada sub-padrão de representação, como ocorre com os tipos monetários de Zeus e águias. De acordo com 0

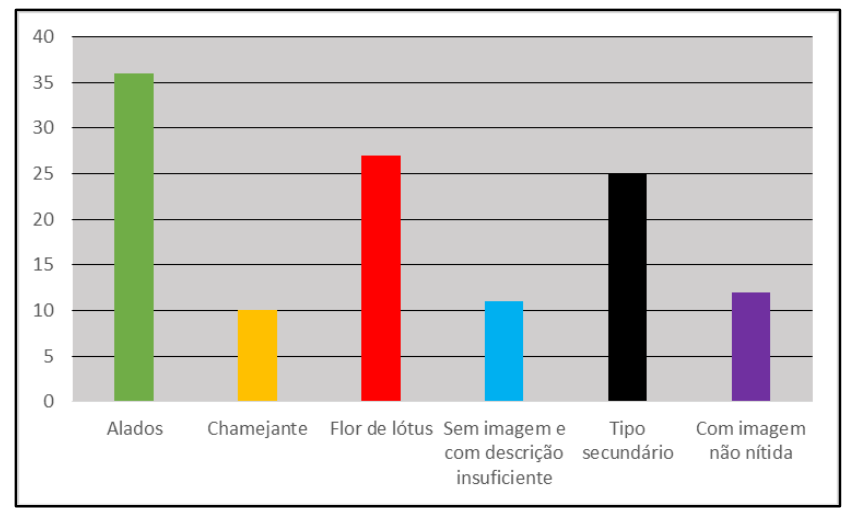

Gráfico 50- Quantidade total de tipos monetários de raio (sécs. V-IV/III a.C.)

gráfico 50, o padrão "alado" foi o mais usado (36/87 tipos monetários), seguido pelo padrão "flor de lótus" (27/87 tipos). O padrão de representação "chamejante" foi o menos recorrente como imagem monetária (10/87 tipos), ainda que em um número próximo ao do tipo "flor de lótus". Dentre as imagens de Zeus e das águias, a do raio é a mais utilizada como tipo secundário em moedas gregas (25/87 tipos monetários). Desse número, apenas 9 puderam ser classificados dentro de variedades, pois estes eram os únicos visíveis. É importante dizer que, dos 87 tipos monetários do raio encontrados no levantamento, 23 tipos não puderam ser incluídos na classificação tipológica dos sub-padrões de representação, em virtude da ausência de imagens e descrições insuficientes nos catálogos numismáticos (11/87 tipos) ou da falta de nitidez das fotografias de certos

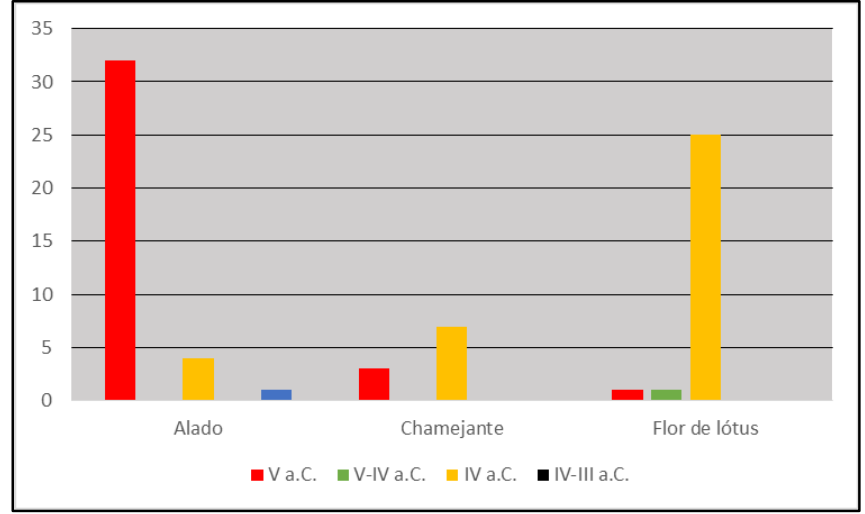

Gráfico 51- Quantidade por séculos de tipos monetários "alado", "chamejante" e "flor de lótus" (sécs. V-IV/III a.C.). exemplares (12/87 tipos monetários). Já o gráfico 51 mostra que o padrão "alado" foi o preponderante no século $V$ a.C. (36 tipos monetários no total). 0 padrão "chamejante" aparece também pela primeira no período e foi utilizado paralelamente no século $\mathrm{V}$ a.C. em moedas gregas, embora em menor grau (4 tipos no total). No século IV a.C., por outro lado, o uso do padrão "alado" foi substancialmente reduzido (4 tipos no total) e o "chamejante" passou a ser mais utilizado (7 tipos no total). Em contraste, o padrão de raio "flor de lótus" foi usado pela primeira vez em moedas entre os séculos V a.C. (1 tipo monetário). No século IV a.C., quando atingiu o maior número de tipos (25 no total), o padrão tornou-se o mais utilizado no período. 
Com relação ao uso da imagem do raio como tipo secundário em moedas, 0 gráfico 52 mostra que o padrão "flor de lótus" foi o único utilizado como tipo secundário e somente a partir do século IV a.C. (7 tipos monetários no total). Não há imagens monetárias de raios usados dessa maneira anteriores a esse período. Acerca da quantidade por regiões de tipos monetários de raios usados como tipo secundário, o gráfico 53 demonstra a ocorrência de tipos em 9 regiões do

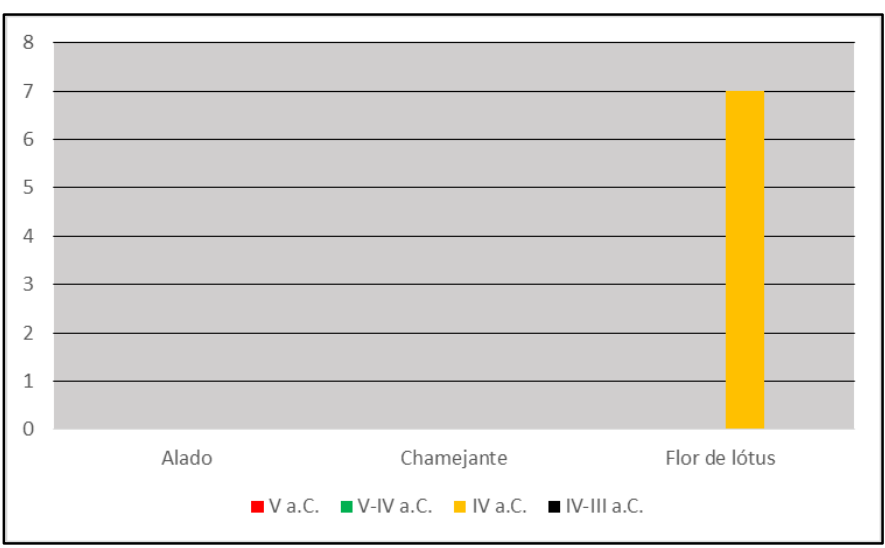

Gráfico 52- Quantidade por séculos de tipos monetários "alado", "chamejante" e "flor de lótus" usados como tipos secundários (sécs. V-IV/III a.C.). mundo grego, desde a porção ocidental a oriental, de norte a sul, a saber: Tessália, Itália do Sul, Élis, Lesbos, Trôade, Macedônia, Trácia, Eubéia e Argos. Nesse gráfico, foram considerados os tipos monetários com imagens não nítidas e aqueles sem imagens com descrição insuficiente. A Tessália e a Itália do Sul foram as regiões que mais utilizaram a imagem do raio como tipos secundários (8 e 6 tipos no total respectivamente). Foram as duas regiões também que usaram, pela primeira vez, a imagem do raio como tipo secundário. A pólis de Crotona, na Itália do Sul, cujo exemplar é datado de c.425-375 a.C. (n.318), e Kierion, na Tessália, cujo tipo é de 400-360 a.C. (n.356). Na moeda de Crotona, como tipo secundário, o raio acompanha a imagem principal do trípode no reverso, já na de Kierion, o raio acompanha a imagem da cabeça de Zeus com cabelos curtos e barba curta no anverso. De acordo com a datação do tipo monetário, muito provavelmente, trata-se do exemplar mais antigo, onde o raio aparece como tipo secundário junto a figura de Zeus, sendo então uma criação da pólis tessália. Esse esquema iconográfico criado, então, na Tessália, foi usado somente por póleis da região entre 400-344 a.C. (Halus, n.357 e Hypata, n.385), no início do século IV a.C. também por Kierion em outra

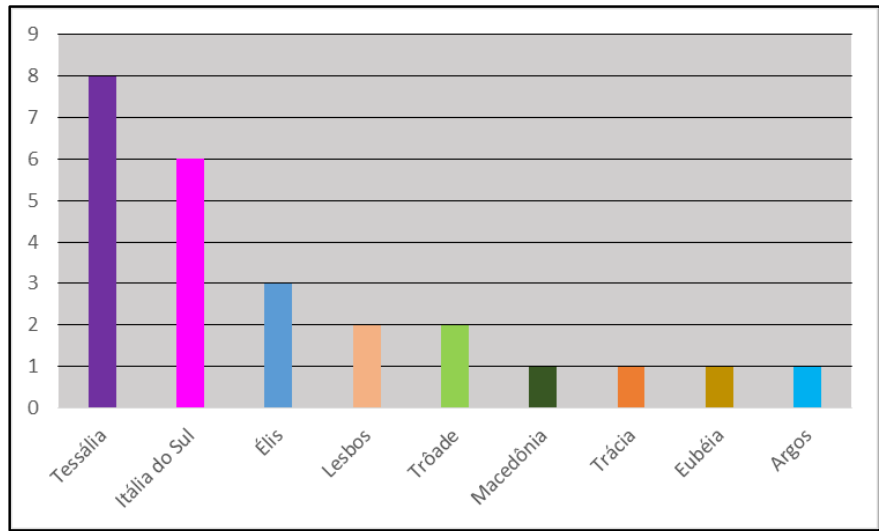

Gráfico 53- Quantidade por regiões de tipos monetários de raio usados como imagem secundária (sécs. V-IV/III a.C.) emissão (n.359), na primeira metade do século IV a.C. (Melitaia, n.360) e na metade do século IV a.C. (Melitaia, n.363 e 366; Dia, n.365). Élis aparece como área e pólis responsável pela terceira maior quantidade de tipos emitidos (3 tipos no total), Lesbos e a Trôade com 2 tipos monetários cada uma. A Macedônia, a Trácia, Creta, Eubéia e Argos foram as regiões que menos usaram o raio como imagem monetária (cada qual 1 tipo monetário no total). As datações indicam que Mytilene, em Lesbos, esteve entre os primeiros locais a usar o raio como tipo secundário em imagens monetárias, como indica a moeda de 400-350 a.C. (n.285). 
O tipo do raio como imagem secundária esteve mais associado a certos tipos de figuras. Ele aparece associado a atributos de Apolo em Crotona (425-375 a.C, n.318) com o trípode e em Mytilene com a lira (350250 a.C., n.294). O pequeno raio foi muito associado ao tema do "cavaleiro sobre cavalo galopando" na Trácia, no reverso de moedas de Felipe II cunhadas em Anfípolis (356-355 a.C., n.362), na Macedônia em Pella (348336 a.C., n.364) e em Dardanus na Trôade (IV a.C., n.298). Já o tipo do "cavalo galopando" foi usado também na Trôade, em Gargara (400-284 a.C., n.286). Há casos únicos onde o raio foi associado a determinadas figuras sem repetição. Em Argos, o raio aparece abaixo de um grande "A" no reverso de um exemplar do século IV a.C. (n.297). Além de Zeus, o raio apareceu no campo junto à cabeça de duas outras divindades: Afrodite em uma moeda de Mytilene (400-350 a.C., n.285). Contudo, o levantamento mostrou, sem surpresa, que o pequeno raio foi mais utilizado em moedas gregas do período juntamente aos tipos da cabeça de Zeus (7 tipos) e àqueles da águia (6 tipos). Já em relação aos raios com os tipos principais de águias, os raios ocorrem de forma marcante em três moedas de Élis de 348 a.C. (n.371, 372 e 373), onde a águia aparece em pé, e em uma de Cálcis de 369-313 a.C. (n.337) com a águia voando carregando serpente no bico. Esse parece ser o tipo monetário mais antigo em que o raio é representado como imagem secundária junto à águia como tipo principal.

\section{II.4.1 O PADRÃO “ALADO”}

Para o padrão de representação "alado", foi estabelecido 9 sub-padrões: (1) com asas embaixo e sem volutas; (2) com asas em cima e com volutas; (3) com asas em cima e volutas embaixo; (4) com asas embaixo e volutas em cima; (5) com asas e palmetas com volutas em cima; (6) com asas no meio, com lótus com duas pétalas abertas e volutas em cima; (7) com asas no meio, volutas embaixo e lótus com duas pétalas abertas em cima; (8) com

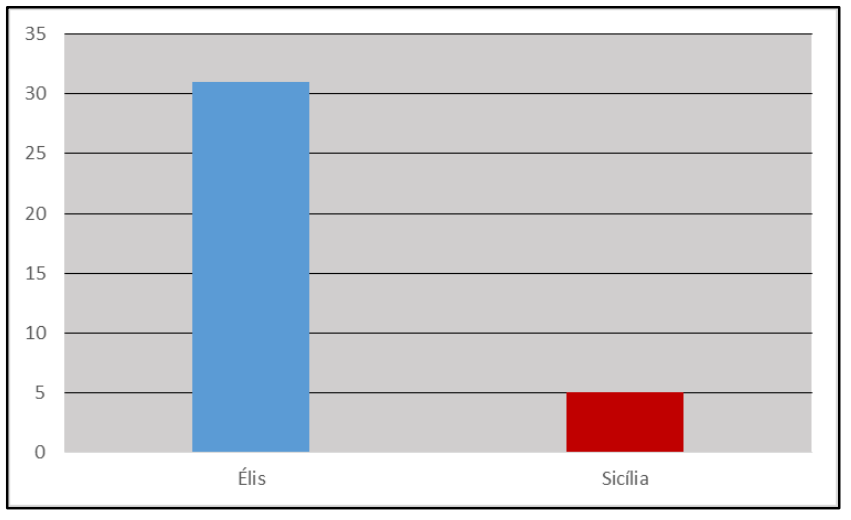

Gráfico 54- Quantidade por regiões de tipos monetários de raios "alados" (sécs. V-IV/III a.C.). asas no meio, volutas em cima e lótus com duas pétalas abertas embaixo; e (9) com asas no meio e volutas em cima e embaixo. Conforme o gráfico 54 , acerca da quantidade por regiões de tipos monetários de raios "alados", o sub-padrão é próprio de apenas 2 regiões do mundo grego: Élis e Sicília, sendo Élis a região/autoridade emissora responsável pela emissão da maior quantidade de tipos monetários (31 tipos no total), seguida pela Sicília (5 tipos no total). 
1. Com asas embaixo e sem volutas: Aetna-Inessa (c.475-460, n.274).

274

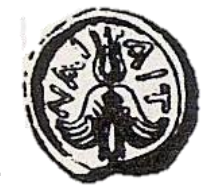

2. Com asas em cima e com volutas: Catânia (c.461, n.275), (c.460-450, n.276), (c.461-413, n.277).

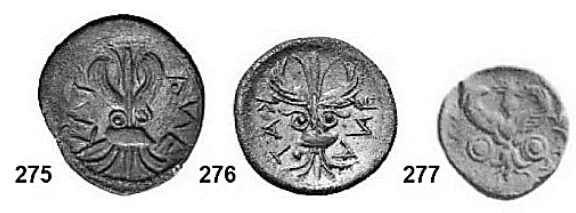

3. Com asas em cima e volutas embaixo: Élis (c.468, n.299/301), (c.460s, n.302), (c.460s-450s, n.303/304), (final 450s, n.306), (c.440-430s, n.308/310), (c.432, n.312), (final 420s, n.320), (c.420, n.322), (c.416-404, n.323), (c.408, n.324), (c.404, n.325), (c.388, n.335 asas fechadas).
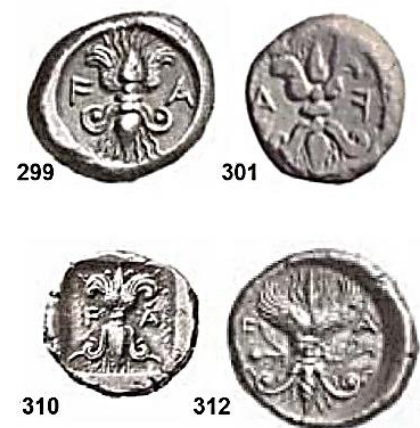

320
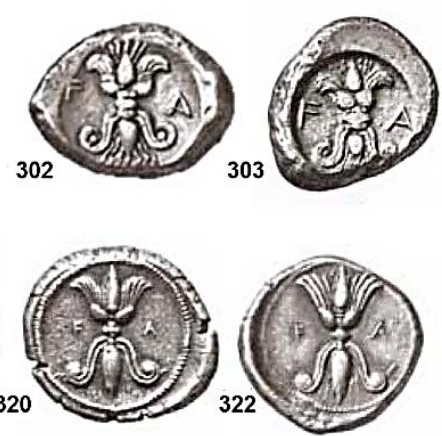
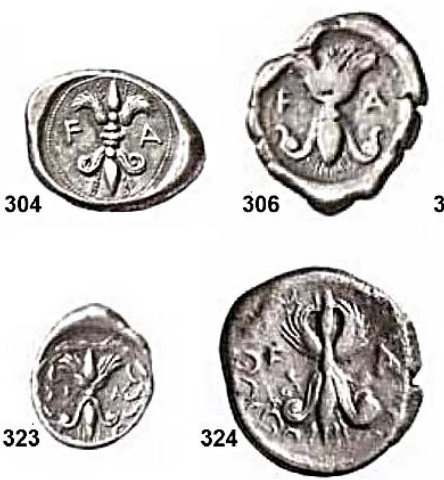
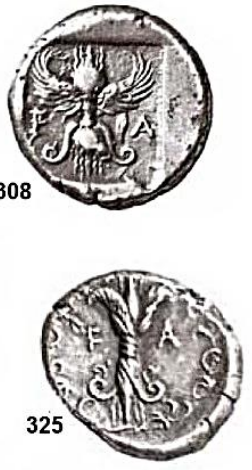
4. Com asas embaixo e volutas em cima: Élis (c.416, n.355), (c.412, n.281), (c.468, n.300), (c.460s-450s, n.305), (c.440s, n.307), (c.440s-430s, n.309), (c.432-420s, n.316/317), (c.420, n.321), (final c.390s-380, n.331/333), (c.360, n.292 de ave).
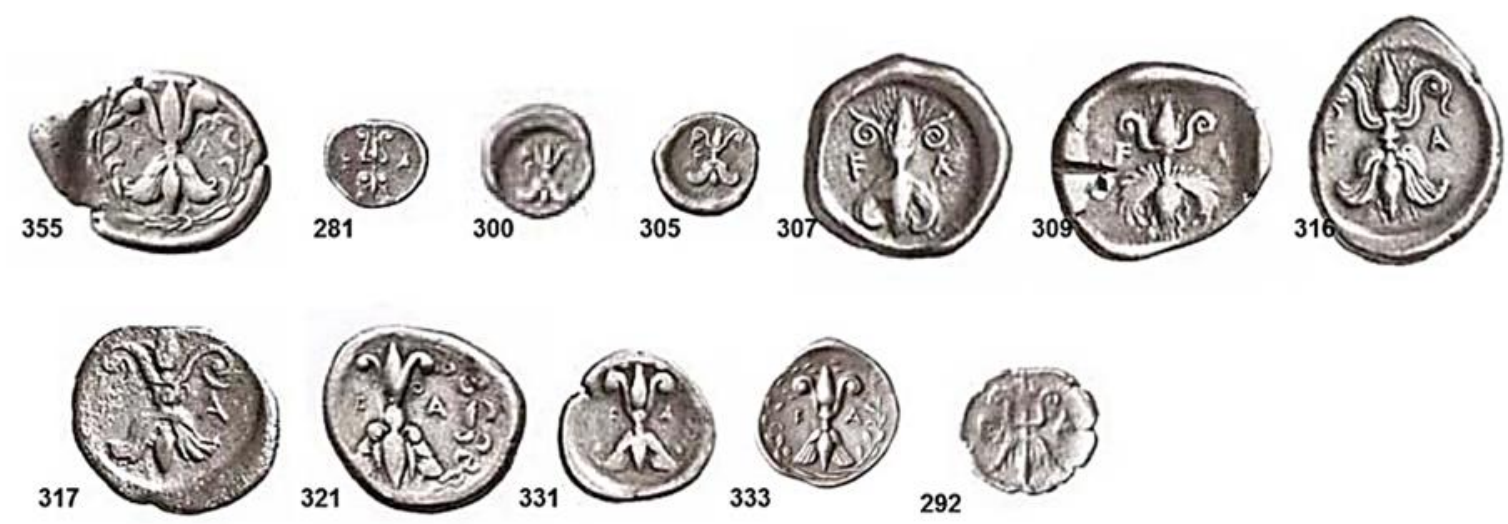

292

5. Com asas embaixo e palmeta com volutas em cima: Élis (c.432-420s, n.315).

315

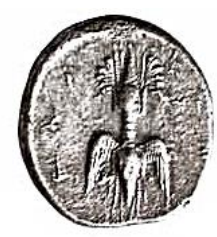

6. Com asas no meio, com lótus com duas pétalas abertas e volutas em cima: Élis (c.440s-430s, n.311).

311

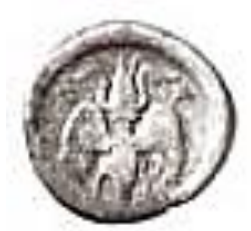

7. Com asas no meio, volutas embaixo e lótus com duas pétalas abertas em cima: Élis (c.432, n.313).

313

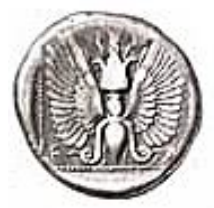

8. Com asas no meio, volutas em cima e lótus com duas pétalas abertas embaixo: Catânia (410-402, n.283).

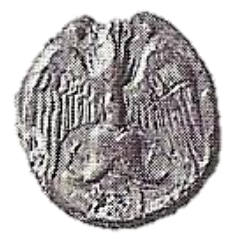


9. Com asas no meio e volutas em cima e embaixo: Élis (c.432, n.314).

314

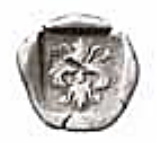

De acordo com a tabela 14, dos nove sub-padrões, o mais usado em moedas foi o (3) "com asas em cima e volutas embaixo" (15 tipos monetários no total), majoritariamente usado no século V a.C. (14 tipos no total), em contraste ao século IV a.C. (1 tipo no total). O sub-padrão (4) "com asas embaixo e volutas em cima é o segundo mais recorrente (12 tipos no total), sendo a maior parte do século $V$ a.C. (9 tipos no total) e uma minoria do século IV a.C. (3 tipos). E o terceiro mais utilizado foi o sub-padrão (2) com asas em cima e volutas (3 tipos no total), embora em bem menor número, aparece em moedas somente do século $V$ a.C. Os subpadrões (1), (5), (6), (7), (8) e (9) foram os menos recorrentes em moedas gregas e foram usados apenas no século $V$ a.C. (cada qual 1 tipo monetário no total).

\begin{tabular}{|c|c|c|c|c|c|}
\hline Tipo monetário "alado" & V a.C. & V-IV a.C. & IV a.C. & IV-III a.C. & Total \\
\hline (1)Com asas embaixo e sem volutas & 1 & 0 & 0 & 0 & 1 \\
\hline (2)Com asas em cima e com volutas & 3 & 0 & 0 & 0 & 3 \\
\hline (3)Com asas em cima e volutas embaixo & 14 & 0 & 1 & 0 & 15 \\
\hline (4)Com asas embaixo e volutas em cima & 9 & 0 & 3 & 0 & 12 \\
\hline (5)Com asas embaixo e palmeta com volutas em cima & 1 & 0 & 0 & 0 & 1 \\
\hline (6)Com asas no meio, com lótus com duas pétalas abertas e volutas em cima & 1 & 0 & 0 & 0 & 1 \\
\hline (7)Com asas no meio, volutas embaixo e lótus com duas pétalas abertas em cima & 1 & 0 & 0 & 0 & 1 \\
\hline (8)Com asas no meio, volutas em cima e lótus com duas pétalas abertas embaixo & 1 & 0 & 0 & 0 & 1 \\
\hline (9)Com asas no meio e volutas em cima e embaixo & 1 & 0 & 0 & 0 & 1 \\
\hline
\end{tabular}

Tabela 14- Sub-padrões de representação de raios alados em moedas (sécs. V-IV-III a.C.).

Antes da descrição da iconografia das imagens monetárias de cada sub-padrão, é preciso salientar que os desenhos dos raios de todos os padrões, tem como base o lótus. Assim, do sub-padrão (1) "com asas embaixo e sem volutas" há apenas um exemplar, que é também o tipo monetário de raio mais antigo, conforme a cronologia de todas as 87 imagens monetárias. Trata-se de uma moeda batida em Aetna-Inessa, na costa oriental da Sicília, entre 475-460 a.C. (n.274). A imagem do raio aparece pela primeira vez em moedas gregas sob o padrão "alado". Caso os tipos monetários de raio alado de Élis-Olímpia não sejam datados do século VI a.C., como afirmam alguns estudiosos, Aetna-Inessa pode ter sido a autoridade emissora precursora desse tipo de representação em moedas, antecipando uma tendência que, como veremos, ficou famosa a partir das moedas batidas em Élis com esse padrão de representação. Aetna (tanto Aetna-Catânia, quanto Aetna-Inessa) foi, também, a única autoridade emissora a usar o raio alado na mão de Zeus nos tipos monetários do padrão "sentado no trono" (n.08/09/16). Também da costa oriental da Sicilia, provêm os únicos três tipos monetários do sub-padrão (2) "com asas em cima e volutas". Todas as moedas foram emitidas em Catânia primeiramente em c.461 a.C. (n.275) e depois em 460-450 a.C. (n.276) e 461-413 a.C. (n.277). Como veremos, as volutas, que já eram usadas nas representações de raios na cerâmica ática da segunda metade do século VI a.C, aparecem nas imagens dos raios alados nas moedas de Élis, apesar de ser difícil de saber qual lugar teria 
influenciado o outro já que a datação dos primeiros tipos de Élis é de 468 a.C. (n.299/ 300/301) e daquele mais antigo de Catânia é de 461 a.C., datas relativamente próximas. No entanto, percebe-se que, as volutas nas imagens das moedas de Catânia, são diferentes das de Élis, aparecendo totalmente enroladas entre as asas em cima e um tipo de desenho de uma pequena base retangular embaixo, o qual não existe no terceiro tipo monetário (n.277). A flor de lótus, em cima, é estreita e possui apenas um botão estreito com uma pétala de cada lado. Vê-se nesse caso, mais uma vez, a Sicília e Élis como centros de inovação na imagética relativa a Zeus em moedas gregas. A nosso ver, em razão das datações controvertidas, e da proximidade cronológica entre eles, devemos olhar esses tipos monetários siceliotas e os de Élis como as evidências mais antigas sobre esse tipo de representação em moedas e das trocas de traços culturais entre essas áreas.

O sub-padrão (3) "com asas em cima e volutas embaixo" tem exemplares provenientes somente de Élis. Trata-se das imagens monetárias de raios alados mais variadas já emitidas no mundo grego, cuja variação dependeu de cada período de emissão. Os tipos mais antigos são datados de 468 a.C. (n.299 e 301). Reparase como o desenho das asas variou ao longo do tempo, podendo serem definidos grupos para cada tipo de imagem de asas. E repara-se como predominaram, nas moedas, pequenas linhas que saem da parte de cima e de baixo do raio, definidas como chamas, uma inovação de Élis na representação dos raios em moedas gregas (tipos monetários datados entre 468 e 432 a.C. e 416 e 388 a.C.). As chamas estão ausentes nos tipos monetários da década de 420 a.C. (n.320 e 322). O formato em espiral - definido por Cook com uma das três características gregas da representação do raio na arte - aparecem em moedas gregas somente em dois tipos monetários de Élis desse sub-padrão. Trata-se dos tipos monetários de c.432 a.C. (n.312) e de 404 a.C. (n.325), em ambos exemplares, o espiral pode ser observado no botão ou espigão inferior do raio.

Apesar de serem representações com as mesmas características daquelas do sub-padrão (3), apenas tendo invertidas as posições das asas e das volutas, o sub-padrão (4) "com asas embaixo e volutas em cima", possuem algumas novidades na iconografia, que não apareceram antes. Em primeiro lugar, não são todos os tipos monetários que possuem as pequenas linhas de chamas, possíveis de se ver apenas nos exemplares da década de 440 a.C. (n.307), entre as décadas de 440 e 430 a.C. (n.309) e de 432-420 a.C. (n.316). As volutas são representadas de formas diferenciadas nos tipos de 412 a.C. (n.281), da década de 390-380 a.C. (n.331 e 333) e de 360 a.C. (n.292). No tipo de 432-420 a.C. (n.316 e 317) é possível ver duas pequenas folhas de oliveira, uma abaixo e de cada lado do caracol das volutas do tipo monetário. Gavinhas podem ser vistas também no tipo das décadas de 440-430 a.C. (n.309), saindo do desenho das volutas. E, com relação as asas, observa-se que nos exemplares de 420 a.C. (n.321), de 412 a.C. (n.281) e do final de 390-380 a.C. (n.331 e 333), as asas da ave são na verdade asas de moscas. Segundo a teoria de Seltman sobre esses tipos monetários, a representação de asas de moscas em moedas de Élis, algo completamente novo na iconografia do raio na arte grega, esteve relacionada ao culto de Zeus Apomyios ("afastador de moscas") no santuário de Olímpia, que era evocado localmente nas ocasiões de dias quentes quando as moscas, em grande quantidade tomavam conta dos animais sacrificados no santuário (Cook, II: 781). 
No sub-padrão (5) "com asas embaixo e palmeta com volutas em cima", há apenas um tipo monetário de Élis, datado entre o ano de 432 e a década de 420 a.C. (n.315). A palmeta, que aparece unicamente nesse exemplar, foi um elemento decorativo muito associado a flor de lótus na cerâmica pintada, como evidencia o fragmento cerâmico encontrado em Lentini, na Sicilia, um esquema iconográfico muito semelhante ao do raio. Parece que o espigão ou botão do lótus também é retratado em espiral nesse tipo monetário e as chamas saem de cima e de baixo do raio.

Nos sub-padrões (6), (7), (8) e (9), as asas são representadas saindo do meio do raio. 0 tipo mais antigo é o do sub-padrão (6) "com lótus com duas pétalas abertas e volutas em cima", cujo exemplar foi emitido por Élis entre as décadas de 440-430 a.C. (n.311). Os segundos tipos mais antigos são do sub-padrão (7) e (9), ambos de Élis e datados de c.432 a.C. (313 e 314). Naquele do sub-padrão (7) "com volutas embaixo e lótus com duas pétalas abertas em cima", as asas tomam conta praticamente de todo o campo da moeda, como ocorre no sub-padrão (8) "com volutas em cima e lótus com duas pétalas abertas embaixo", um tipo monetário de Catânia, na Sicília, de 410-402 a.C. (n.283), cujo desenho deve ter sido inspirado de algum modo no tipo de Élis. Repara-se também o tamanho pronunciado dos cálices das flores de lótus de ambos os exemplares. Já no tipo monetário do sub-padrão (9), "com volutas em cima e embaixo", o tamanho das asas é bem reduzido. A representação das asas, entre os dois espigões ou botões dos raios é a única que aparece para raios alados na cerâmica pintada ática de c.475-425 e 460 a.C. (Figs.194, 196 e 197).

\section{II.4.2 O PADRÃO “CHAMEJANTE”}

O padrão de representação "chamejante" possui 3 sub-padrões iconográficos, a saber: (1) "com chamas em cima e embaixo (e sem volutas)"; (2) "com chamas embaixo e volutas em cima"; e (3) "com chamas em cima e volutas embaixo". Todos os sub-padrões de representação de raios "chamejante" foram criados e usados exclusivamente por Élis para o santuário de Olímpia ao redor de 420 a.C. (n.274). 0 padrão foi usado em reversos de moedas até 388 a.C. (n.288), fazendo conjunto com a imagem de Hera ou da águia no anverso. Foi o padrão menos usado e menos variado.

1. Com chamas em cima e embaixo (e sem volutas): Élis (c.420, n.279), (c.416, n.280), (c.400, n.284), (c.392, n.287), (c.388, n.288).
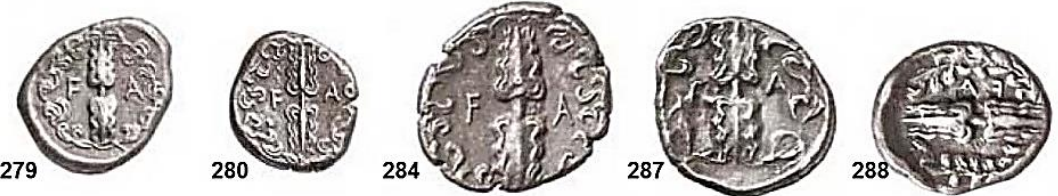
2. Com chamas embaixo e volutas em cima: Élis (c.412, n.326), (c.400, n.327/330 com folhas de oliveiras nas volutas), (c.412 a.C., n.282).
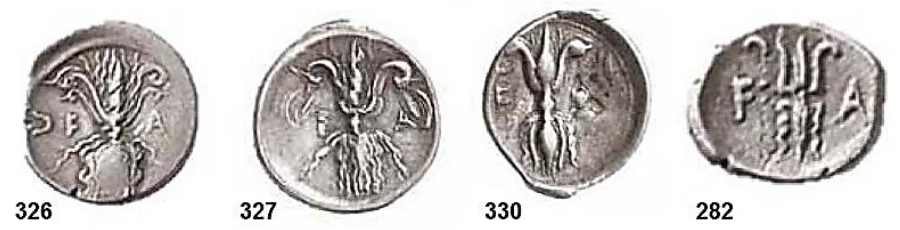

282

3. Com chamas em cima e volutas embaixo: Élis (c.400, n.328).

328

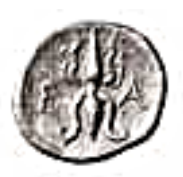

Conforme mostra a tabela 15, o sub-padrão (1) "com chamas em cima e embaixo foi o mais numeroso (5 tipos monetários no total), emitidos no século V a.C. (2 tipos no total) e no século IV a.C. ligeiramente em maior número (3 tipos no total). O sub-padrão (2) "com chamas embaixo e volutas em cima" foi o segundo mais utilizado (4 tipos monetários no total), sendo apenas 2 tipos datado do século $\mathrm{V}$ a.C. e 2 outros datados do século IV a.C. E por último, o sub-padrão (3) "com chamas em cima e volutas em baixo" foi usado apenas uma única vez no século IV a.C. (1 tipo monetário).

\begin{tabular}{|l|r|r|r|r|r|}
\hline Tipo monetário "chamejante" & V a.C. & \multicolumn{1}{|c|}{ V-IV a.C. IV a.C. } & IV-III a.C. Total \\
\hline (1)Com chamas em cima e embaixo (e sem volutas) & 2 & 0 & 3 & 0 & 5 \\
\hline (2)Com chamas embaixo e volutas em cima & 2 & 0 & 2 & 0 & 4 \\
\hline (3)Com chamas em cima e volutas embaixo & 0 & 0 & 1 & 0 & 1 \\
\hline
\end{tabular}

Tabela 15- Sub-padrões de representação de imagens monetárias de raios “chamejantes" (sécs. V-IV/II a.C.).

As imagens monetárias do sub-padrão (1) "com chamas em cima e embaixo (sem volutas" são bem parecidas. $O$ desenho das chamas sai diretamente dos dois espigões ou botões de lótus, sendo todos os tipos ornados por uma coroa de folhas de oliveira que circunda o campo da moeda. O tipo monetário mais antigo é aquele emitido por Élis em 420 a.C. (n.279) e o mais recente o de 388 a.C. (n.288). No caso do sub-padrão (2) "com chamas embaixo e volutas em cima", as imagens monetárias são mais variadas e possuem alguns elementos que acompanham as imagens de Élis dos raios alados, como as linhas de chamas que saem da parte de cima do raio com as volutas. Os exemplares mais antigos datam de c.412 a.C. (n.326/282). Com relação aos detalhes iconográficos desse sub-padrão, observa-se o desenho de duas pequenas folhas de oliveira embaixo de cada uma das volutas dos tipos monetários de 400 a.C. (n.327 e 330), muito semelhantes àqueles dos raios alados do sub-padrão (4) (n.281 e 292). No caso do sub-padrão (3) "com chamas em cima e volutas embaixo" há apenas um tipo monetário de 400 a.C. (n.328), semelhante ao exemplar n.329. A imagem 
do raio chamejante em moedas gregas não encontra correspondência no desenho com aquela produzida para a cerâmica pintada, onde as chamas saem de dentro do cálice da flor e não paralelamente e do lado de fora como nas moedas de Élis.

\section{II.4.3 O PADRÃO “FLOR DE LÓTUS”}

Definimos de padrão "flor de lótus" todos os tipos monetários de raios nos quais a imagem do raio é derivada diretamente da flor, aparecendo somente o espigão ou botão, o cálice e as pétalas da flor, e não elementos adicionais como volutas, asas, chamas, etc. Estabelecemos 5 sub-padrões de representação "flor de lótus": (1) "com duas pétalas abertas e um botão fechado (em cima e embaixo)"; (2) "com quatro pétalas abertas e um

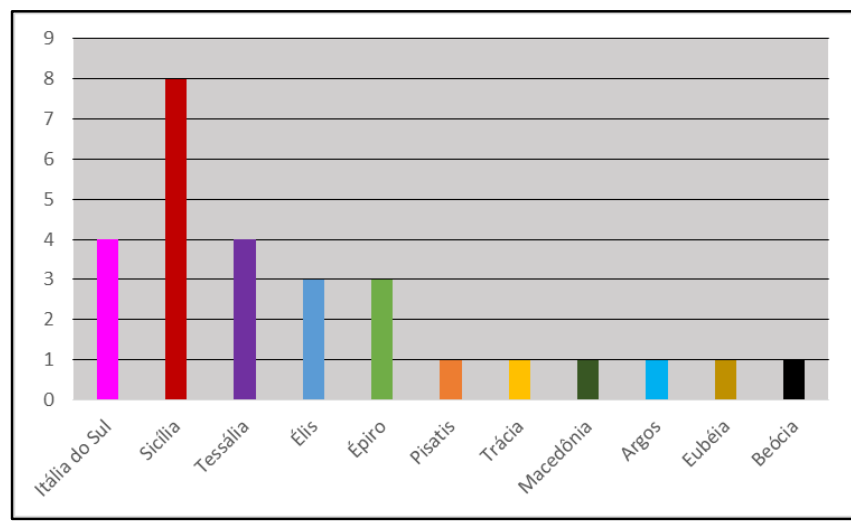

Gráfico 55- Quantidade por regiões de tipos monetários de raios "flor de lótus" (sécs. V-IV/II a.C.). botão fechado (em cima e embaixo)"; (3) "com duas pétalas quase fechadas e um botão fechado (em cima e embaixo) "; (4) "com duas pétalas quase fechadas, um botão fechado e volutas (em cima e embaixo)"; e (5) "com duas pétalas quase fechadas e um botão fechado (em cima e embaixo e volutas fechadas".

De acordo com 0 gráfico 55 , as imagens monetárias foram recorrentes em 11 regiões diferentes do mundo grego: Itália do Sul, Sicília, Tessália, Élis, Épiro, Pisatis, Trácia, Macedônia, Argos, Eubéia e Beócia, uma variedade bem maior do que a dos demais padrões de representação. A Sicília, a ltália do Sul e a Tessália foram, nessa ordem, as três regiões com maior recorrência de tipos monetários (cada qual 8, 4, 4 tipos no total respectivamente). Élis e o Épiro tiveram o mesmo número de tipos monetários (cada qual 3 tipos no total). Pisatis, Trácia, Macedônia, Argos, Eubéia e Beócia foram as regiões como menos ocorrência de tipos monetários (cada qual 1 tipo monetário). 
1. Com duas pétalas abertas e um botão fechado (em cima e embaixo): Pisa (c.365, n.361); Molossi (c.375, n.290) (360-330, n.291 anv.); Larissa (c.370-360, n.336); Crotona (1 ${ }^{\text {a }}$.met.IV, n.338) (antes de 425 a.C., n.278); Felipe II (Anfípolis) (356-355, n.362), (Pella) (348-336, n.364); Dia (met.IV, n.365); Argos (IV, n.297).
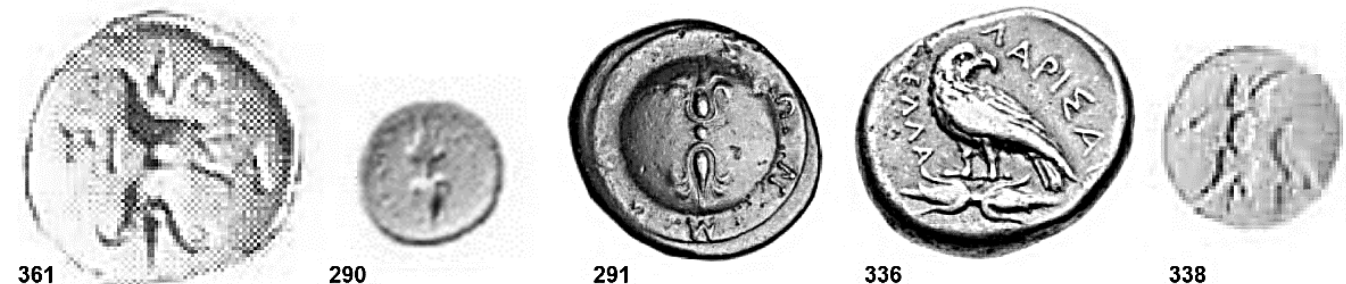

290

291

336

338
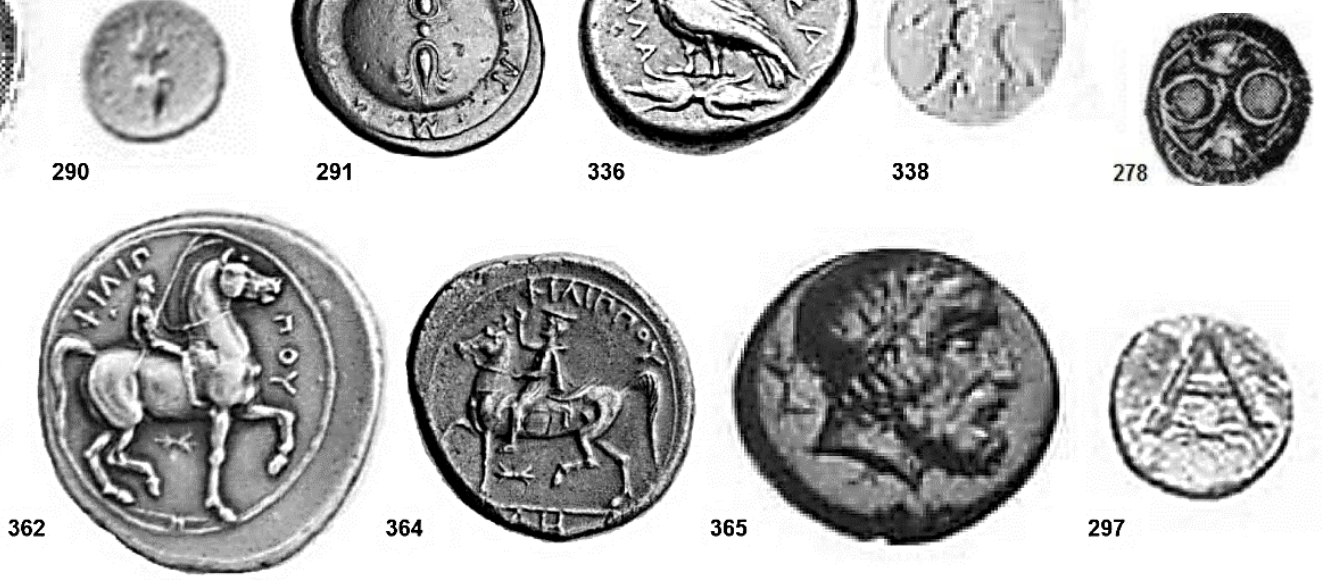

2. Com quatro pétalas abertas e um botão fechado (em cima e embaixo): Siracusa (c.344, n.367/368/375); Agyrion (c.344, n.374); Alaisa (344 a.C., n.296); Crotona (c.400-350, n.329); Alontion (c.344 a.C., n.370); Aetna (c.344 a.C., n.369).
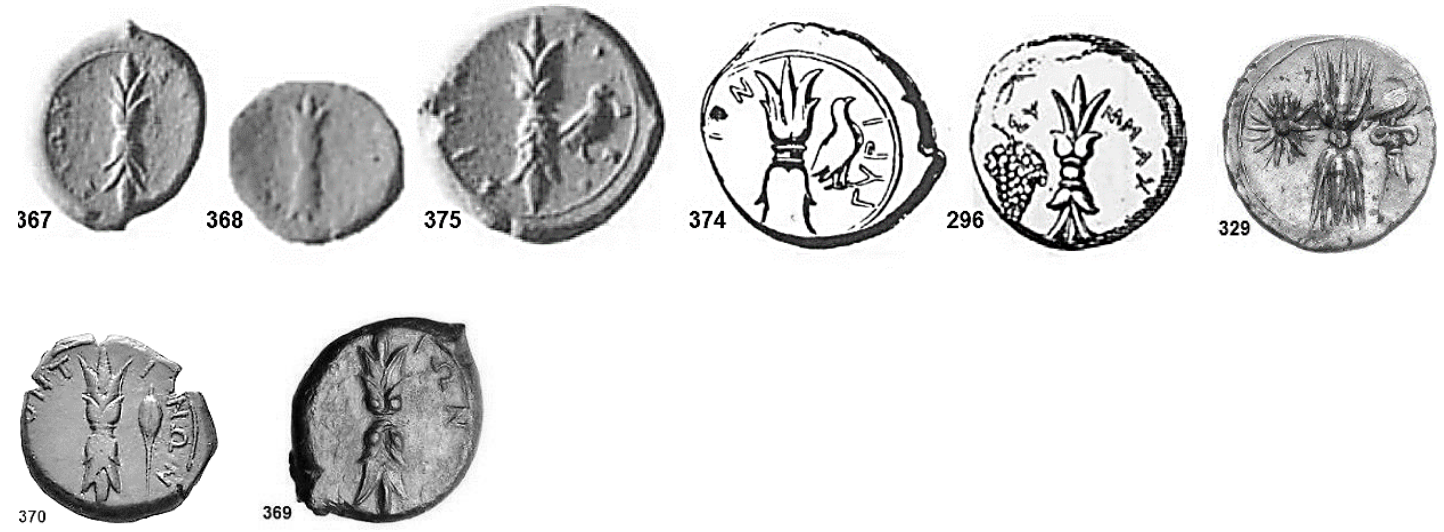
3. Com duas pétalas quase fechadas e um botão fechado (em cima e embaixo): Molossi (360-330, n.291), (c.350, n.339); Crotona (c.425-375, n.319); Cálcis (369-313, n.337); Kierion (c.400-360, n.356); Élis (final c.390s-c.380, n.332 com voluta?); Melitaia (met.IV, n.366).
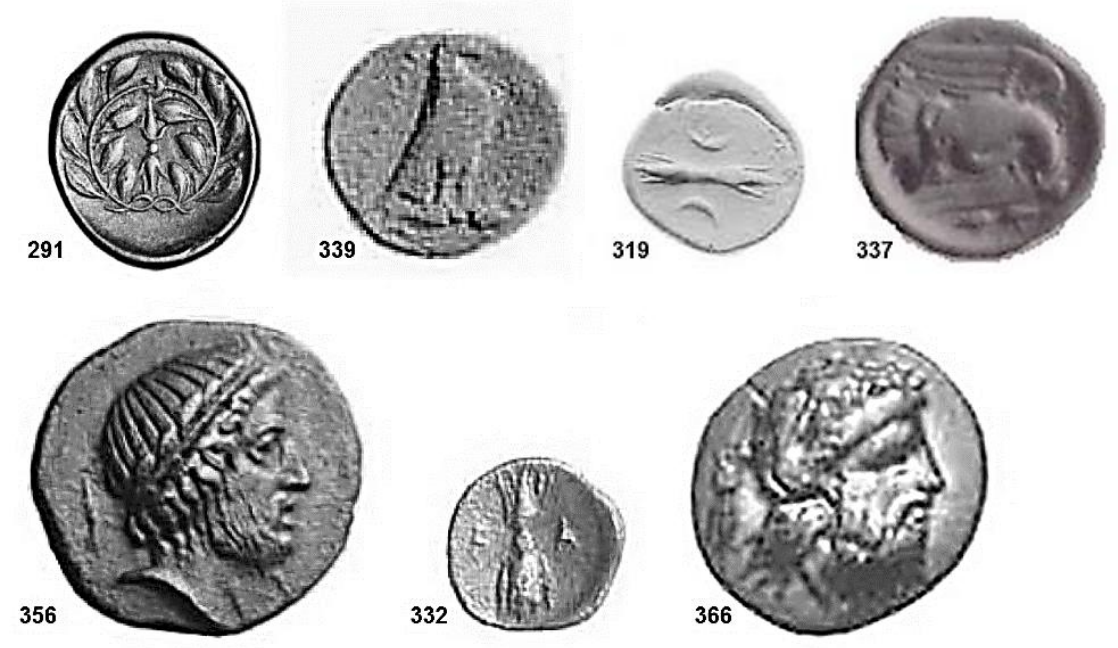

4. Com duas pétalas quase fechadas e um botão fechado (em cima e embaixo) e volutas em cima e embaixo: Mycalessos (c.387-374, n.289 com volutas em cima e embaixo).

298

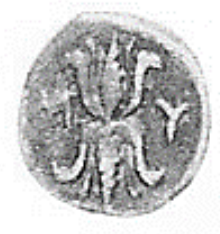

5. Com duas pétalas quase fechadas e um botão fechado (em cima e embaixo) e volutas embaixo: Élis (final c.390s-c.380, n.334).

334

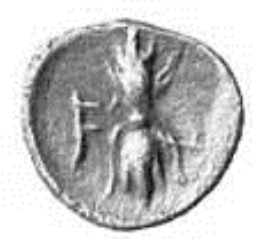

Sobre a distribuição dos sub-padrões de representação de raios de "flor de lótus", a tabela 16 mostra que o sub-padrão (1) foi o mais abundante (10 tipos monetários no total), tendo sido usado em maior número no século IV a.C. (9 tipos no total) e em menor quantidade entre os séculos $V$ a.C. (1 tipo no total). $O$ segundo sub-padrão de representação mais recorrente (2) tem no total 8 tipos monetários referentes apenas ao século IV a.C. O sub-padrão (3) foi o terceiro mais usado (7 tipos no total), principalmente no século IV a.C. (6 tipos). O sub-padrão (4) e (5) foram usados em menor número no século IV a.C. (cada qual 1 tipo monetário). 


\begin{tabular}{|c|c|c|c|c|c|}
\hline Tipo monetário "flor de lótus" & Va.C. & V-IV a.C. & IV a.C. & IV-III a.C. & Total \\
\hline (1)Com duas pétalas abertas e um botão fechado (em cima e embaixo) & 1 & 0 & 9 & 0 & 10 \\
\hline (2)Com quatro pétalas abertas e um botão fechado (em cima e embaixo) & 0 & 0 & 8 & 0 & 8 \\
\hline (3)Com duas pétalas quase fechadas e um botão fechado (em cima e embaixo) & 0 & 1 & 6 & 0 & 7 \\
\hline (4)Com duas pétalas quase fechadas e um botão fechado (em cima e embaixo) e volutas em cima e embaixo & 0 & 0 & 1 & 0 & 1 \\
\hline (5)Com duas pétalas quase fechadas e um botão fechado (em cima e embaixo) e volutas embaixo & 0 & 0 & 1 & 0 & 1 \\
\hline
\end{tabular}

Tabela 16- Sub-padrões de representação por séculos de imagens monetárias de raios de "flor de lótus" (sécs. V-IV/II a.C.).

O sub-padrão (1) "com duas pétalas abertas e um botão fechado (em cima e embaixo)", o mais numeroso, tem como tipo mais antigo a moeda batida por Crotona antes de 425 a.C. (n.278), seguido pelos Molossi, no Épiro, em c.375 a.C. (n.290) e pela imagem monetária de Larissa, na Tessália, de c.370-360 a.C. (n.336), na qual a águia aparece em pé sobre o raio. Todas as imagens dos raios, nesse sub-padrão, possuem alguma variação no desenho. Da primeira metade do século IV a.C., datam os tipos de Pisa de c.365 a.C. (n.361), dos Molossi de 360-330 a.C. (n.291), de Crotona (n.338) e de Felipe em Anfípolis de 356-355 a.C. (n.362). Da metade do século IV a.C. datam as imagens monetárias de de Pella de 348-336 a.C. (n.364) e de Dia, na Tessália (n.365). De alguma data do século IV a.C., data o tipo monetário de Argos (n.297). Dessas, destacamos a imagem do raio retratado em um escudo na moeda dos Molossi de 360-330 a.C. (n.291, anverso), uma representação única no caso do raio em moedas gregas. Observa-se que o cálice da flor de lótus no tipo de Crotona (n.338) assemelha-se muito ao do tipo de Pisa, ao passo que o desenho do raio na moeda de Larissa (n.336) é semelhante àquela dos Molossi (n.298). As imagens do raio, desse sub-padrão, são semelhantes àquelas que aparecem em um momento bem preciso na cerâmica ática, entre 470-460 a.C. e que também vemos na lâmina de prata encontrada em Dodona de 450 a.C. (Figs. 198-205).

No sub-padrão (2) "com quatro pétalas abertas e um botão fechado (em cima e embaixo), predominam imagens monetárias de póleis da Sicilia e da Itália do Sul e possuem datações próximas. As imagens monetárias mais semelhantes entre si são aquelas emissões diferentes cunhadas pela mesma pólis, como é 0 caso das moedas de Siracusa de c.344 a.C. (n.367, 368 e 375). Repara-se a semelhança entre a iconografia dos tipos de Siracusa com os de Agyrion (n.374), de Alontion (n.270), de Aetna (n.269) e de certa forma o de Alaisa (n.296), todos datados do mesmo ano, c.344 a.C., e relacionados ao período de Timoleonte. 0 único exemplar não relacionado a esse período é o mais antigo dessa variedade - trata-se de uma imagem monetária batida por Crotona entre c.400-350 a.C. Esse sub-padrão de representação na verdade retrata a sobreposição de flores de lótus, também observada na cerâmica pintada ática do início do século V a.C., entre 480-470 a.C.

(Figs. 193, 194 e 195).

Sobre o sub-padrão (3) "com duas pétalas quase fechadas e um botão fechado (em cima e embaixo), o tipo monetário mais antigo provém de Crotona, datado de c.425-375 a.C. (n.319). Trata-se do tipo monetário mais antigo de raio em "flor de lótus". As outras imagens monetárias mais antigas provêm de Kierion de c.400360 a.C. (n.356) e de Élis datadas do final da década de 390 até 380 a.C. (n.332). Da primeira metade do século IV a.C. são os tipos monetários de Cálcis de 369-313 a.C. (n.349) e dos Molossi de 360-330 a.C. (n.296) e da 
metade do século IV a.C. é datado o tipo dos Molossi de 350 a.C. (n.339). De uma data genérica no século IV a.C. é uma moeda de Melitaia (n.390). Todos as imagens dos raios são bem semelhantes entre si.

Os demais sub-padrões (4) e (5) possuem apenas, cada qual, um único tipo monetário. No sub-padrão (4) "com duas pétalas quase fechadas e um botão fechado (em cima e embaixo) e volutas em cima e embaixo" o exemplar é proveniente de Mycalessos, na Beócia, e é datado de c.387-374 a.C. (n.298). As volutas do tipo são muito semelhantes a que aparecem nas moedas de Élis do tipo de raio "chamejante" (n.328 e 329) de 400 e 396 a.C., respectivamente. No sub-padrão (5) "com duas pétalas quase fechadas e um botão fechado (em cima e embaixo) e volutas embaixo" o tipo monetário é de Élis, do final dos anos 390 até c.380 a.C. (n.334). Trata-se de um exemplar semelhante ao de Élis do sub-padrão (3), o qual pode ter o desenho de chamas. 


\section{II.5 A REPRESENTAÇÃO DA ÁGUIA NA ARTE GREGA ATÉ A ÉPOCA CLÁSSICA}

A representação da águia na arte grega da época arcaica e clássica (ao menos até o início do século V a.C.) ocorre de duas maneiras (em esculturas e predominantemente na cerâmica pintada): 1-) vinculada a temas mitológicos, sem nenhuma relação direta com Zeus, e 2-) a temas onde a ave aparece associada à figura da divindade nas imagens ou ainda à proveniência de esculturas de alguns de seus santuários.

Não existem muitos estudos acerca de sua iconografia em termos de mundo grego e a maior parte deles é dedicada ao significado simbólico da imagem da águia quando ela aparece associada à cobra. Destes, o primeiro parece ter sido o extenso artigo escrito por R. Wittkower, Eagle and serpent - a study in the migration of symbols (1939), onde analisa a trajetória do esquema iconográfico "águia carregando cobra" na longa duração com enfoque na arte europeia. Wittkower examina esse tipo de representação e seu significado simbólico, com origem na Mesopotâmia, passando pela Índia, Grécia e Roma até atingir o período cristão e terminar em época renascentista e barroca. Examinando também o significado simbólico desse tipo de representação da águia, mais recentemente, D. Rodríguez Pérez no artigo Contextualizing symbols: the eagle and the snake in the ancient Greek world (2010) se atém ao estudo de determinadas imagens vasculares nas quais ocorrem a associação da figura da águia com a cobra. Pérez se utiliza da abordagem funcionalista para tentar compreender em que medida a presença da figura da águia com ou sem a cobra em determinadas cenas de vasos do século $\mathrm{VI}$ a.C. podem ter significado, para os artistas, querer introduzir uma ideia de futuro nas narrativas. E assim, ao que parece, G. Mylonas, em The eagle of Zeus (1946), parece ter sido o primeiro e 0 único até o momento a dedicar um ensaio inteiro acerca da origem da associação da águia ao culto de Zeus, tendo como base principalmente como evidências as estatuetas de Zeus Keraunios, representações em vasos e informações das fontes literárias.

De acordo com Wittkower, as representações mais antigas de águias são conhecidas das cerâmicas da Babilônia, em Elam, e também do Vale do Indo. A imagem da águia com a cobra, que vemos repetidamente em relatos escritos e em vasos, tem alguma origem antiga no Oriente. Em uma cerâmica elamita do $4^{0}$. milênio a.C., a ave com as asas abertas aparece em três diferentes maneiras muito semelhantes a que vemos na arte grega de época arcaica e clássica: sozinha, com uma cobra próxima a ela, e segurando uma cobra em seu bico e em suas garras (Wittkower, 1939: 294). Na Idade do Bronze grega, a águia aparece retratada no esquema iconográfico "águia e cobra" em gemas gravadas

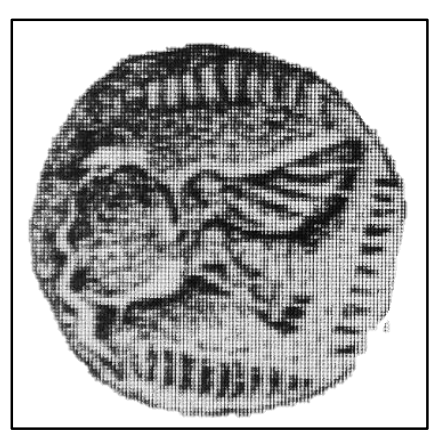

Fig. 210- Águia voando carregando cobra, selo minoico, Museu Britânico (Wittkower, 1939: Pr. 49, e) minóicas com função de talismã (Fig.210). No $2^{\circ}$. milênio a.C. a representação ocorre ocasionalmente em cilindros e gemas, segundo Wittkower, sob influência hitita (Wittkower, 1939: 309).

Para a análise iconográfica da águia realizamos um breve levantamento sobre sua imagem na arte grega - em esculturas, mas especialmente na cerâmica pintada, onde sua representação é mais recorrente. 
Vasos áticos e lacônios, datados do segundo quartel do século VII até o segundo quartel do século VI a.C., possuem as imagens mais antigas com a águia não associada às cenas com Zeus. As representações mais antigas de águias nas cerâmicas gregas, referem-se aos seguintes temas, usados paralelamente: (1) o mito de Prometeu; (2) a águia representada como tema único voando e carregando uma cobra; (3) a ave retratada em escudos; (4) a ave voando de frente a Zeus ou em pé próxima a ele; e (5) a águia acompanhado cavaleiros.

Sobre as representações não associadas à figura de Zeus, a imagem mais antiga que dispomos pertence a um aríbalo proto-coríntio de figuras negras do século VII a.C. em que a águia aparece voando atrás de dois guerreiros lutando (Fig.211). A segunda imagem mais antiga refere-se a um skyphos ático de figuras negras, datado de c.625-575 a.C. (Fig. 212). Trata-se de uma cena em que Héracles vai salvar Prometeu, que se encontra amarrado pelos pés e pelas mãos. Héracles, colocado à esquerda na cena, atira flechas na águia que morde o coração e o fígado de Prometeu, colocado no centro da cena. A ave, representada voando (em um tamanho quase maior que o de Héracles e do Titã), é atingida pelas flechas, que penetram seu corpo. No segundo vaso mais antigo, um lekanis ático de figuras negras de c.600-550 a.C., a águia é representada voando à direita com as duas asas abertas, carregando a cobra pelo bico (Fig.213). A cobra aparece retratada de frente para a águia, com a boca aberta em sinal de bote, não estando enrolada no corpo da ave. De 560-540 a.C., na ânfora ática de figuras negras, Héracles aparece representado lutando contra o gigante Geryon, que na cena é retratado pelos três soldados (Fig.214). Um deles carrega um escudo com o desenho de uma águia (pintada de branco, como o desenho do trípode no outro escudo) voando com as duas asas abertas e sem a cobra. De 540 a.C. data outra ânfora ática de figuras negras com o mesmo tema e a mesma representação da águia no escudo, agora com destaque principal na cena (Fig.215). De 550-500 a.C., data uma série de cenas em vasos áticos (crateras, ânforas e taças), de figuras negras, em que a águia aparece voando sempre atrás de cavaleiros nus ou vestidos e segurando longas lanças (Figs. 216 e 217), vestidos sem lança (Fig.218) ou com lança (Fig.219), ou de dois cavaleiros vestidos, sendo um em pé com escudo e o outro montado no cavalo (Fig.220). Já em uma taça lacônia de figuras vermelhas, datado de c.530 a.C., o desenho da águia ocupa todo o fundo do vaso (Fig.221). A águia aparece voando à esquerda com as duas asas abertas, segurando uma serpente pelo bico e pelas garras, que está enrolada no corpo da ave. Como veremos, trata-se de uma imagem muito semelhante às usadas em moedas. Também de c.530 a.C., um amphoriskos lacônio de figuras negras, traz a cena de Atlas com Prometeu sendo mordido no peito pela águia (Fig.223). A ave aparece em pé de asas erguidas sobre as pernas do Titã e bicando o seu coração. Uma cobra aparece no canto esquerdo da cena, atrás de Atlas. Datada entre os séculos VI-V a.C. (c.525-475 a.C.), a taça ática de figuras negras, traz a imagem da águia voando à direita, carregando a cobra (enrolada em seu corpo) pelos bicos e garras (Fig.222). 0 tema é igual ao da Fig.221, apenas o desenho da ave é diferente. Em c.500 a.C., a águia aparece ainda representada no tema de Héracles libertando Prometeu (Fig.224). Na cena, a ave aparece voando à esquerda, de frente a Prometeu, que aparece sendo desamarrado por Héracles. Da ave, parece pingar o sangue do Titã, como indicam os pingos pintados abaixo da águia, na direção de seu bico. 


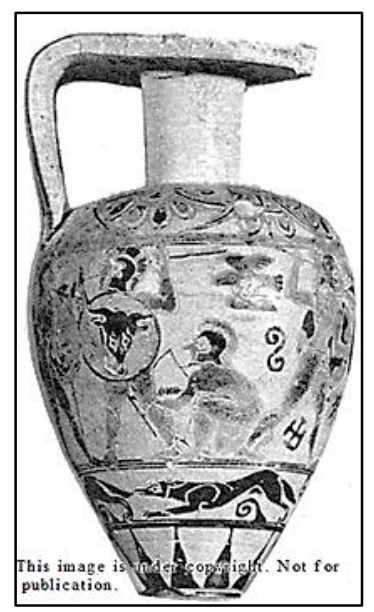

Fig.211- Guerreiros lutando, aríbalo protocoríntio de figuras negras, Paris, Museu do Louvre (Beazley Archive: no. 1007182)

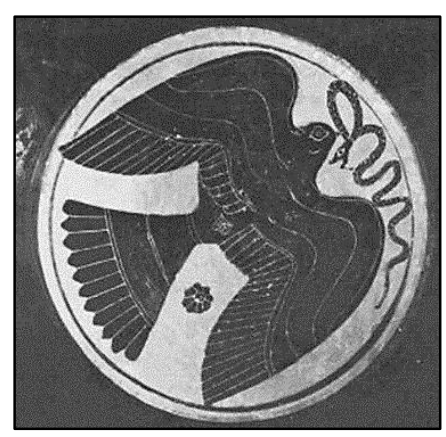

Fig.213- Águia voando carregando cobra, lekanis ático de figuras vermelhas, c.600-550 a.C. Basel, Market, Munzen und Medaillen (Beazley Archive: no306498)

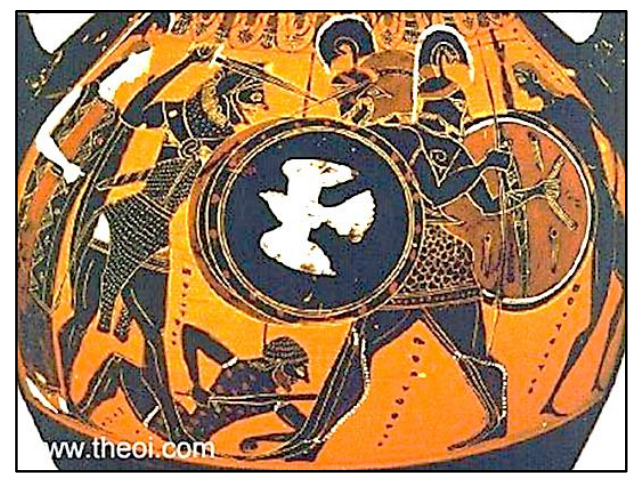

Fig.215- Héracles lutando contra Geryon, ânfora ática de figuras negras, c. 540 a.C., Munique, Antiken-sammlungen.

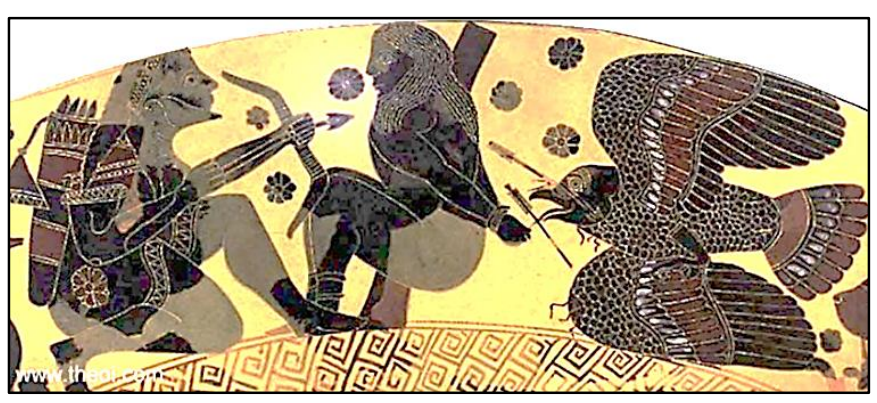

Fig.212- Héracles libertando Prometeu, skyphos ático de figuras negras, c.625-575 a.C., Museu Arqueológico Nacional de Atenas.

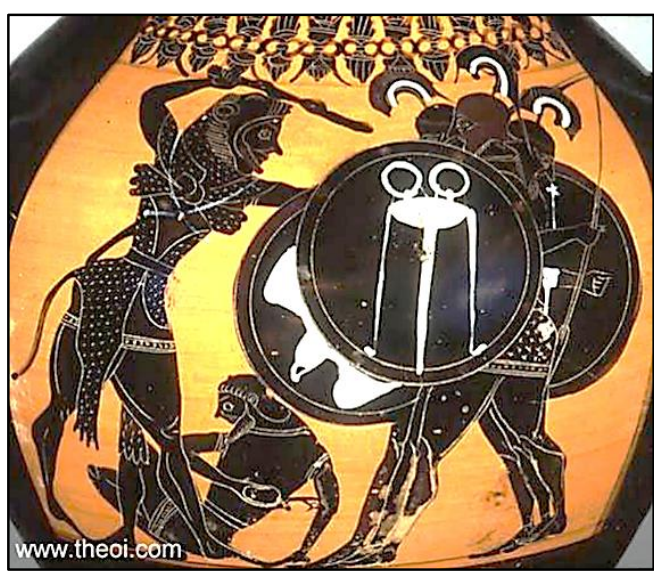

Fig. 214- Héracles lutando contra Geryon, ânfora ática de figuras negras, c.560-540 a.C., Paris, Museu do Louvre.

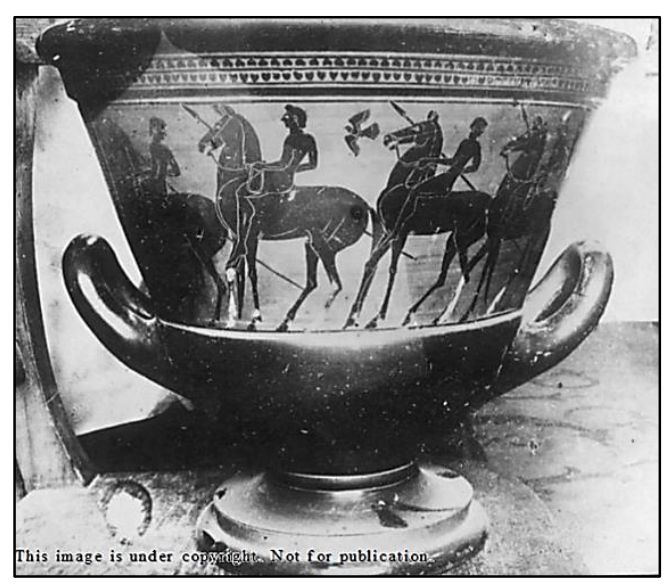

Fig.216- Cavaleiros, cratera-taça ática de figuras negras, c.550-500 a.C., São Petersburgo, Museu Hermitage (Beazley Archive: no. 320269) 


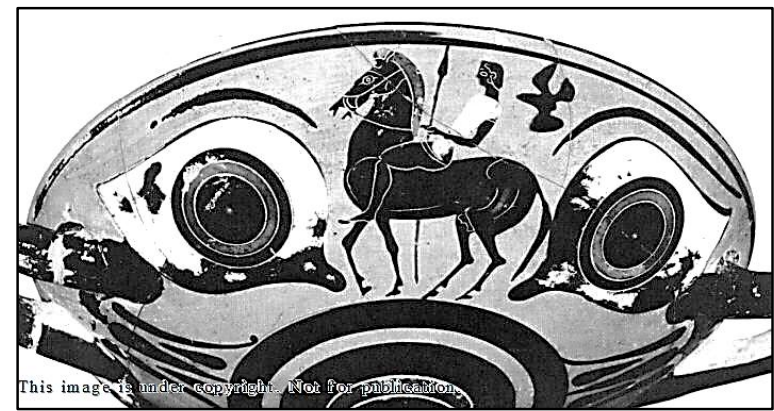

Fig.217- Cavaleiro, taça ática de figuras negras, c.550-500 a.C., Hamburgo, Museum fur Kunst und Gewerbe. (Beazley Archive: no.350818)

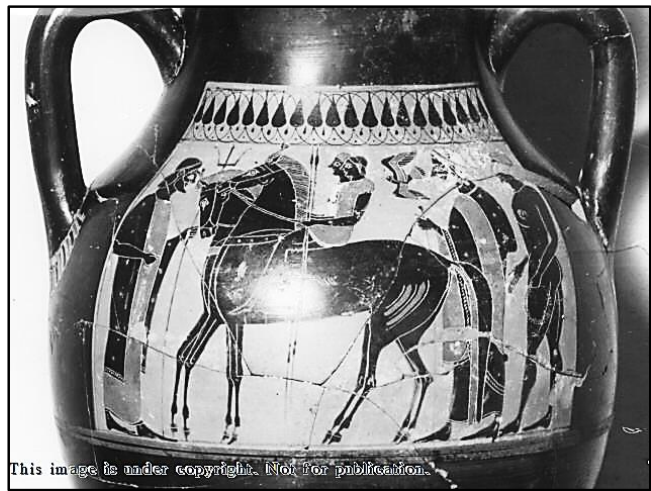

Fig.219- Cavaleiros ou Dióscuros partindo, ânfora $B$ ática de figuras negras, c.550-500 a.C., Boston, Museum of Fine Arts (Beazley Archive: no.340413)

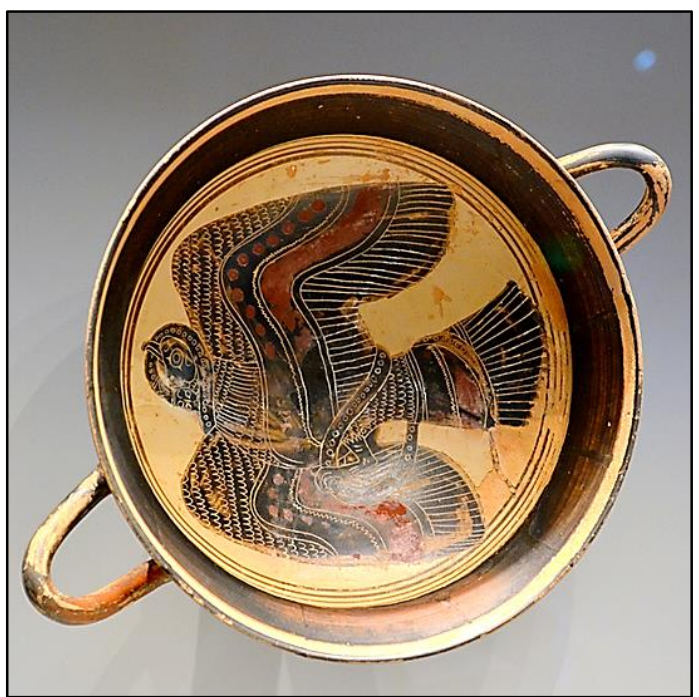

Fig.221- Águia voando com a serpente, cálice lacônio de figuras negras, c.530 a.C., Los Angeles, Paul Getty Museum.

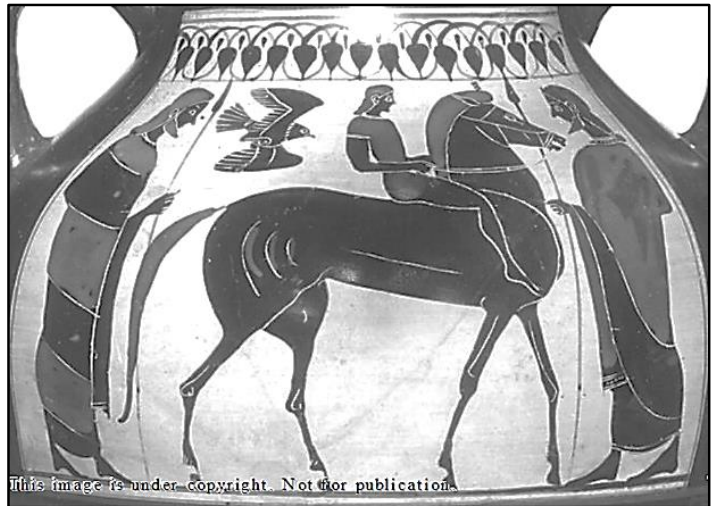

Fig.218- Cavaleiros ou Dióscuros partindo, ânfora B ática de figuras negras, c.550-500 a.C. (Beazley Archive: no.340544)

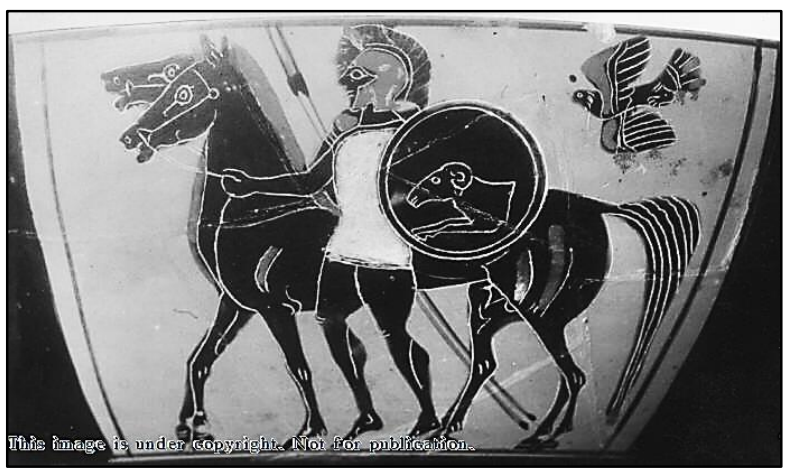

Fig.220-Dois guerreiros, taça ática de figuras negras, c.550500 a.C., Vaticano, Museu Gregoriano Etrusco (Beazley Archive: no. 340396)

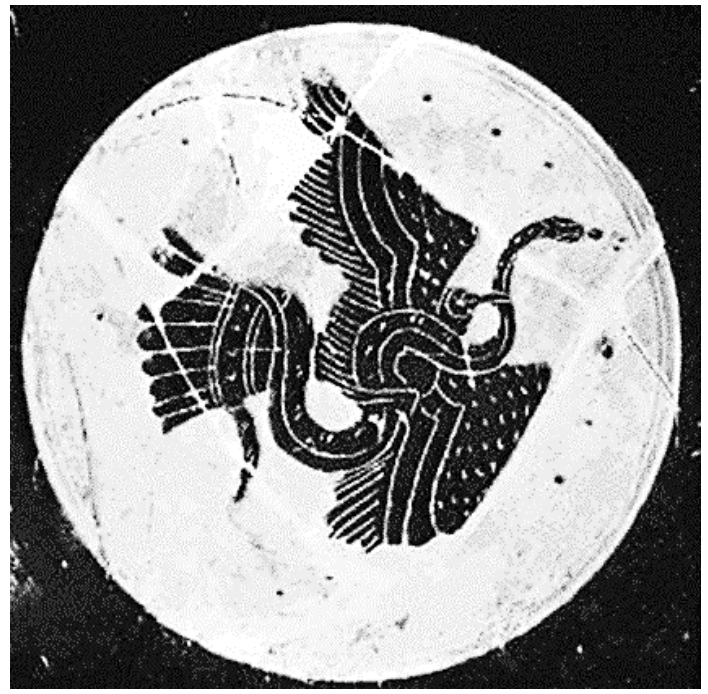

Fig.222- Águia voando com a cobra, cálice ático de figuras negras, c.525-475 a.C., Heidelberg, RuprechtKarls-Universitat. (Beazley Archive: no.331612) 


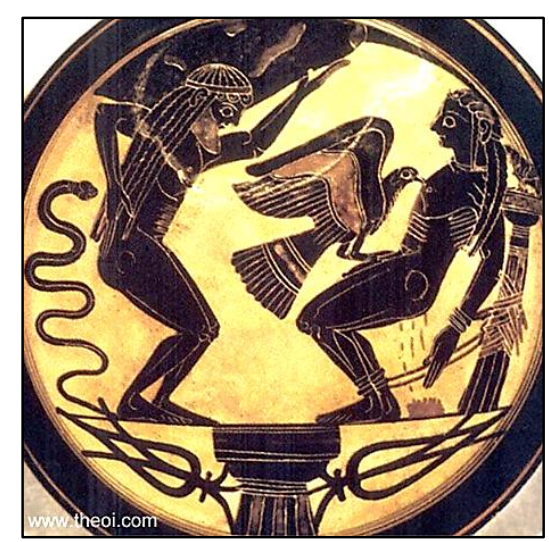

Fig.223- Atlas e Prometeu, amphoriskos lacônio de figuras negras, c.530 a.C., Museu do Vaticano.

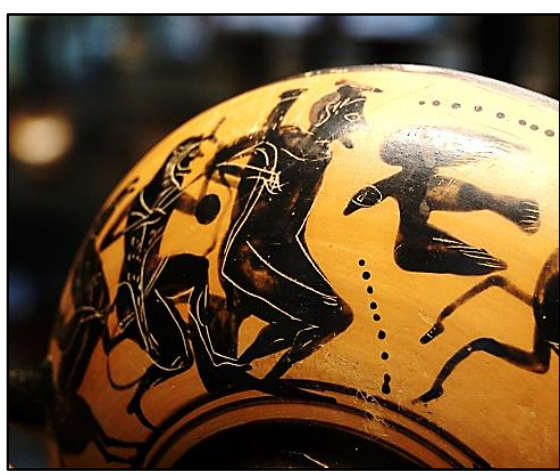

Fig.224- Héracles libertando Prometeu, cálice ático de figuras negras, c.500 a.C.

Esses tipos de representação da águia, não associadas a representação de Zeus nos vasos, na cerâmica pintada ática ou lacônia, são na maior parte datados do século VI a.C., com exceção de um vaso, cuja datação se inicia no século VII a.C. As cenas de Prometeu sendo libertado por Héracles têm uma longa duração na cerâmica ática, ocorrem entre 625 e 500 a.C., assim como a águia carregando a serpente enrolada em seu corpo, as quais são datadas entre 600 e 475 a.C. A imagem da ave no escudo, em cenas da luta de Héracles com Geryon, já são predominantes entre a metade e a segunda metade do século VI a.C.

Com relação às representações da ave associadas à figura de Zeus, é difícil identifica-la, com segurança, junto ao deus em cenas de vasos anteriores ao século $\mathrm{VI}$ a.C. No pithos cretense de c.700 a.C. a ave na mão esquerda de Zeus não pode ser considerada uma águia (Fig.113). No aríbalo proto-coríntio de 680 a.C. vê-se três pequenas águias, retratadas voando de frente com a cabeça virada à direita. Elas podem estar tanto associadas a Zeus, como serem parte do estilo orientalizante, que usou desenho de animais e monstros para decorar as cerâmicas. A cerâmica lacônia traz, ao que parece, as imagens mais antigas de Zeus com a águia conhecidas acerca dos vasos. Na taça lacônia de figuras negras, datada de c.560-550 a.C. (comentada na análise iconográfica sobre Zeus), uma imagem de uma grande águia está voando de frente a Zeus, que veste um longo himátion com seus braços para dentro da roupa (Fig.225). Esse tipo de representação ocorre somente em taças lacônias do período, não sendo vista na cerâmica ática. Nessa taça, a águia é retratada no mesmo desenho e cores em que aparece representada nas taças lacônias em que carrega a serpente, sendo, portanto, um estilo local. É possível encontrar uma imagem semelhante de uma águia grande, voando de frente para Zeus sentado, apenas em uma moeda atribuída à Liga Arcádia, de 465-460 a.C. (sub-padrão sentado no trono, n.15, variedade C). Datada entre 530-525 a.C., outra taça lacônia de figuras negras contém uma imagem da águia, que, nesse caso, volta a aparecer retratada em pé de asas fechadas atrás de Zeus sentado no trono (Fig.226). Nesse período, na cerâmica ática, Zeus é representado apenas portando o raio, a águia aparece pela primeira vez em 500 a.C., retratada no topo do cetro do deus. Essa seria, provavelmente, uma inovação da Lacônia na representação de Zeus, criada pelos artistas locais no século VI a.C. 
Na estatuária dos séculos VII e VI a.C., a imagem mais antiga da águia com Zeus é, segundo G. Mylonas, a estatueta de Zeus Keraunios proveniente do santuário do Monte Lykaion, na Arcádia, datada do século VII a.C., na qual o deus é retratado segurando a águia em sua mão esquerda. De acordo com Mylonas, essa estatueta comprovaria a sua tese de que a associação da águia ao culto de Zeus teria ocorrido primeiramente no santuário do Monte Lykaion, em um período bem mais antigo, e em nenhum outro local de culto à divindade no mundo grego anterior a esse período. Esse tipo de representação, próprio do culto no local no século VII-VI a.C., seria resultado de um processo concluído no final do século VIII a.C. Em seu estudo sobre o altar de Zeus nesse santuário, Mylonas tenta mostrar os processos históricos que levaram a águia a ganhar um novo significado e lugar no culto do deus. 0 estudioso lembra que 0 altar de Zeus era flanqueado por duas colunas, no topo das quais podiam ser vistas, no tempo de Pausânias (VIII, XXXVIII. 7), duas águias voltadas para leste. Em seu estudo, Mylonas postula que o altar deve ter sido um lugar de culto pré-histórico, que foi retomado para o culto de Zeus quando as tribos gregas do período histórico completaram sua posse da terra. Naquele altar pré-histórico, e em acordo com a prática bem estabelecida dos tempos remotos pré-históricos, teriam sido exibidas duas águias da mesma espécie. As aves e os outros elementos do altar foram mantidos pelos novos grupos que se estabeleceram na região, pelos arianos que cultuavam Zeus. Em tempos préhistóricos, as aves indicavam a epifania da divindade. Provavelmente, no início dos tempos históricos, as aves continuaram a indicar a epifania de Zeus, mas, gradualmente, foram concebidas como companheiras e atributos da divindade (Mylonas, 1946: 206).

Entretanto, já nessa época, ao menos a partir da metade do século VI a.C., a águia já aparecia, de algum modo, associada ao culto de Zeus não na Grécia balcânica, mas na ilha de Creta. Datada desse período, uma estátua de uma águia, em pé com as asas fechadas, esculpida em calcário, ao lado de uma estatueta de gavião de mesma proporção, era exposta sobre um pilar na área sagrada do santuário de Zeus Thenatas em Amnisos (Fig.227). Essa estátua, que não é citada por Mylonas em seu estudo, pode indicar a relação da ave com a divindade em algum nível cultual em Creta já nesse período.

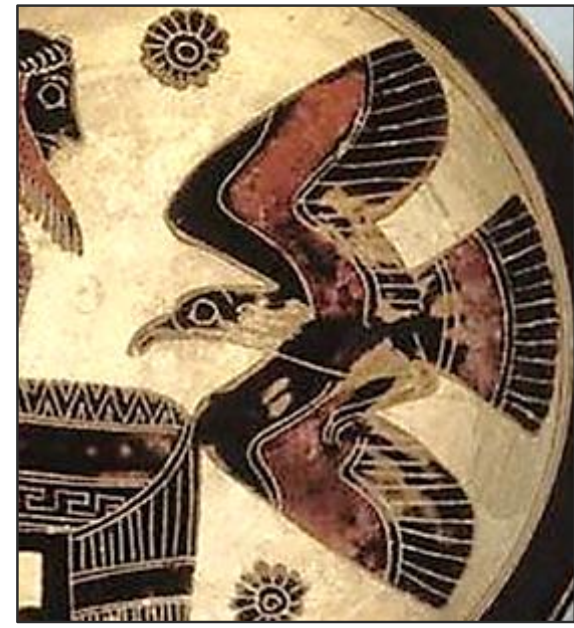

Fig.225- Detalhe da fig.130 da águia voando diante de Zeus, taça lacônia, 560 550 a.C.

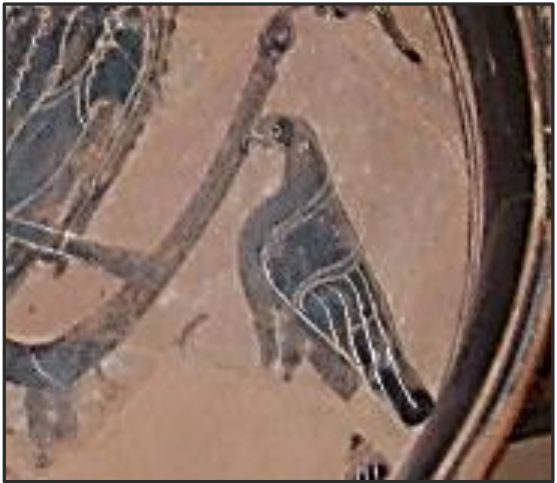

Fig.226- Detalhe da fig.21 de águia em pé de asas fechadas atrás do trono de Zeus, taça lacônia, 530-525 a.C.

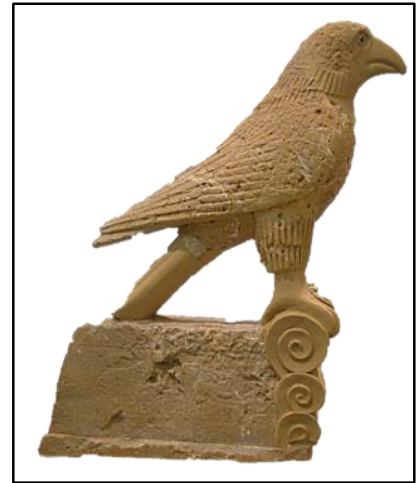

Fig.227- Águia em pé de asas fechadas, calcário, metade do século VI a.C., santuário de Zeus Thenatas, Amnisos, Creta, Museu Arqueológico Nacional de Heráklion (Foto: arquivo pessoal/2014) 
Ainda na estatuária, uma imagem em bronze de uma águia em pé de asas fechadas, a qual provavelmente ornava a ponta de um cetro, é proveniente da área sagrada de Afrodite dentro do santuário de Dodona, no Épiro, e foi datada do final do século VI e início do século $V$ a.C. (Fig.228). É provável que a imagem tenha ornado o topo do cetro de alguma estátua de Zeus, que se perdeu. Essa escultura em bronze de Dodona pode ser tomada como um indicativo da presença da águia no culto de Zeus, nesse período, em santuários de outras partes do mundo grego, nesse caso em sua porção mais norte.

Esse tipo de representação da águia, em pé sobre o cetro de Zeus, começou a aparecer na cerâmica ática somente no início do século V a.C., como vimos anteriormente no estudo iconográfico acerca da divindade. A ideia de colocar a águia, sobre o cetro do deus, em cenas associadas a ele, parece ter sido concebida tanto entre os artistas visuais quanto pelos artistas literários entre o final do século VI e início do século

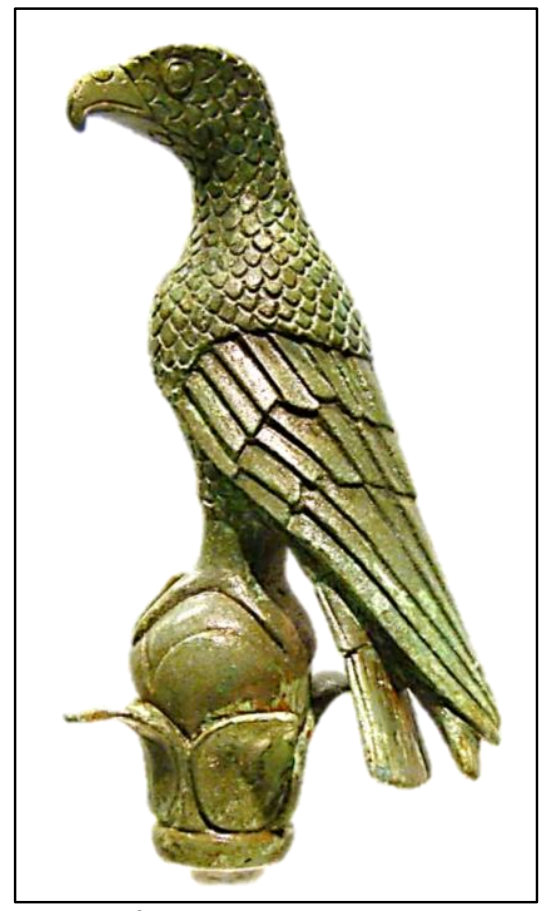

Fig.228- Águia em pé de asas fechadas, bronze, VI-V a.C., Dodona, Museu Arqueológico de loánnina (Foto: arquivo pessoal/2014) V a.C., como demonstra a escultura encontrada em Dodona, datada nesse período. Píndaro (Pítica I, 5) é o primeiro a descrever tal imagem em um de seus epinícios justamente nessa época. Na cerâmica ática, em uma ânfora de figuras vermelhas de 500 a.C., a águia aparece retratada à esquerda no topo do cetro de Zeus com asas abertas e cabeça virada à direita. $O$ deus segura o raio com a mão (Fig.229). Na cratera ática de figuras vermelhas de 490-480 a.C. a águia também aparece no topo do cetro de Zeus, com suas asas fechadas e virada para o deus. Zeus aparece sendo servido de vinho por Ganimedes (Fig.230). Fora do cetro de Zeus, mas agora na posição de combate de ao atirar o raio - típica do período arcaico - a águia aparece sobre a mão do deus, em uma ânfora de figuras vermelhas de 480-470 a.C., tal como ocorre nas estatuetas de Zeus Keraunios (Fig.231). Os pintores áticos recuperaram a representação de Zeus guerreiro para retratar as cenas da Gigantomaquia, típicas em vasos áticos do período. E assim, nessas representações da cerâmica ática do início do século V a.C., águias e raios, os dois atributos de Zeus, foram representados juntos, nesse tipo de suporte, pela primeira vez.

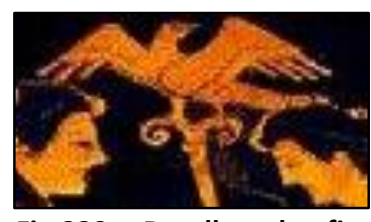

Fig.229- Detalhe da fig. 158, águia em pé de asas abertas sobre cetro de Zeus, ânfora ática, 500 a.C.

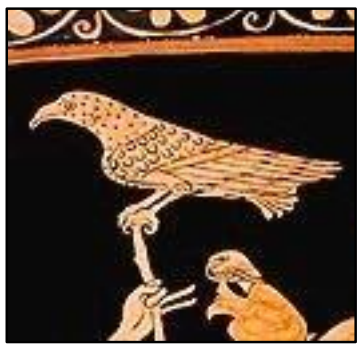

Fig.230- Detalhe da fig.159, águia em pé de asas fechadas sobre cetro de Zeus, cratera ática, 490-480 a.C.

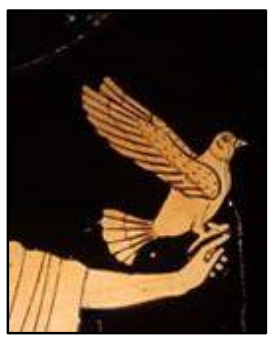

Fig.231- Detalhe da fig.153, águia em pé de asas erguidas sobre mão de Zeus, ânfora ática, 480470 a.c. 


\section{II.6 A ICONOGRAFIA DA ÁGUIA EM MOEDAS GREGAS}

Assim como na iconografia monetária de Zeus, há três padrões de representação da águia em moedas gregas: (1) cabeça; (2) voando; e (3) em pé. Conforme o gráfico 56 , acerca da quantidade total de cada tipo monetário de águia, o padrão mais numeroso de representação é aquele das águias "em pé" (118/234 tipos monetários no total), seguido pelo da águia "voando" (75/234 tipos no total).

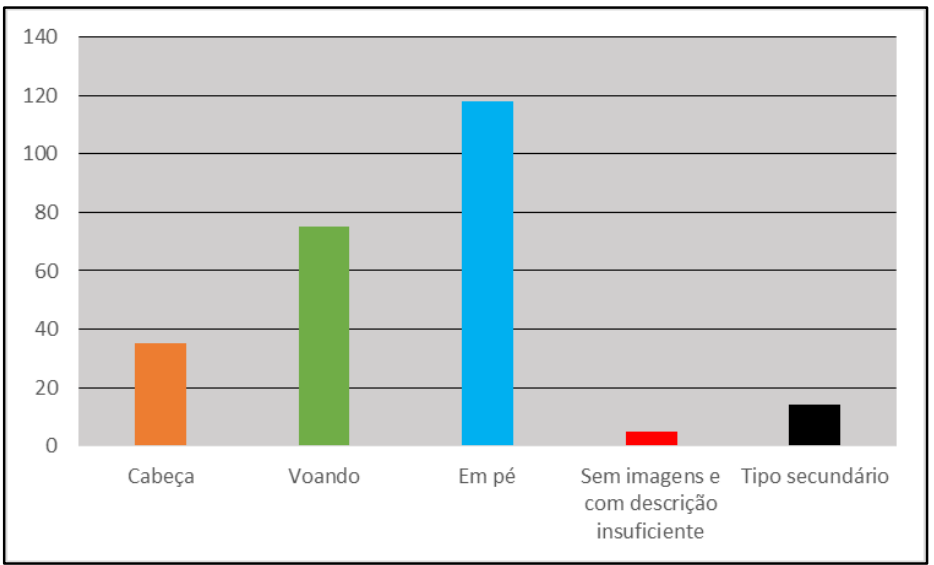

Gráfico 56- Quantidade total de tipos monetários de águias (sécs. VIIIV/III a.C.).

O padrão de representação da "cabeça" foi 0

menos usado por autoridades emissoras no mundo grego (apenas 35/234 tipos no total). Apesar desse grande volume de documentação monetária em relação à imagem da águia, de ser os tipos monetários mais numerosos dentre as três figuras examinadas nesse estudo, somente 5/234 tipos monetários não foram incluídos na análise iconográfica, pois o catálogo pesquisado não trazia a fotografia do tipo e a descrição oferecida era insuficiente para classifica-la dentro dos sub-padrões e variedades de representação da ave. Como tipo secundário, a imagem da águia foi mais usada (14/234) do que a de Zeus.

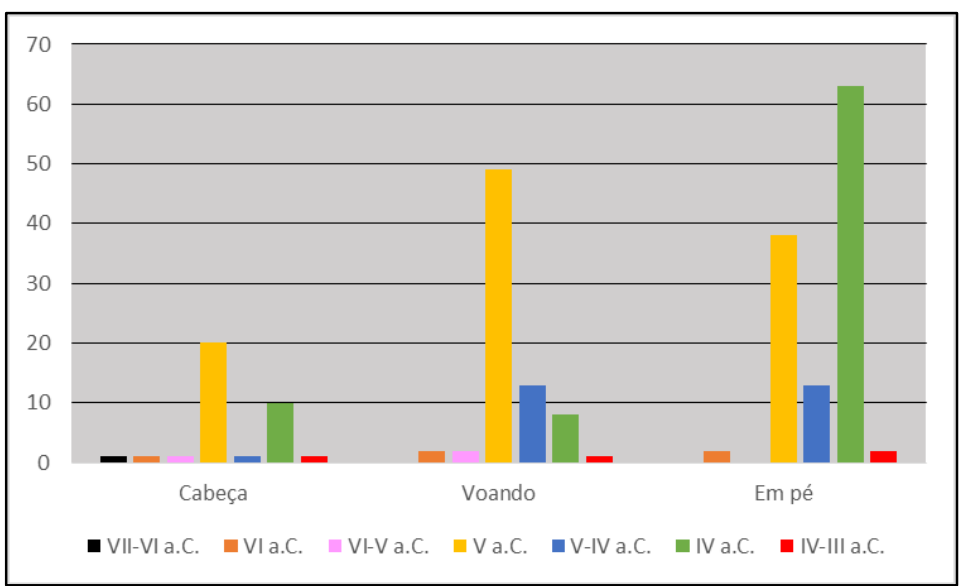

Gráfico 57- Quantidade por séculos de tipos monetários de "cabeça", "voando" e "em pé" (sécs. VII-IV/III a.C.).
De acordo com o gráfico 57,0 padrão de representação mais numeroso, 0 da águia "em pé", teve o seu pico de uso pelas autoridades emissoras durante 0 século IV a.C. (63 tipos monetários no total), que também foi o período de maior uso das imagens de águias em moedas gregas. Como todos os padrões de representação da águia, o tipo "em pé" foi usado no século VI a.C. em pequena quantidade (2 tipos no total). Não há imagens monetárias datadas dentre os séculos VI-V a.C., tendo ocorrido um aumento significativo na utilização da imagem no século V a.C. (38 tipos monetários no total). Após o aumento no século IV a.C, 0 padrão da águia "em pé" diminuiu consideravelmente em relação ao século IV-III a.C. (2 tipos monetários). Em contraste, o segundo padrão mais usado, o da águia "voando", teve o ápice de uso no século V a.C. (49 tipos no total). O padrão é um dos mais antigos da ave em moedas gregas, começando a aparecer em moedas gregas entre os séculos VII-VI a.C. (1 tipo no total). Nos séculos VI e entre os séculos VI-V a.C. houve um pequeno aumento no uso da imagem (2 tipos monetários), que aumentou significantemente no século $V$ a.C. $A$ 
partir dos séculos V-IV a.C. e depois do século IV a.C. (13 e 8 tipos no total, respectivamente), contudo, o uso da imagem decresceu drasticamente, entrando quase em desuso no século IV-III a.C. (apenas 1 tipo monetário). No século IV a.C., pode-se dizer, que o padrão foi preterido pelo da águia "em pé". Já o padrão menos utilizado, o da "cabeça" da águia também foi típico do século V a.C. (20 tipos no total). Assim como 0 padrão "voando", a imagem monetária da cabeça da águia surgiu entre os séculos VII-VI a.C. (1 tipo monetário). O padrão foi pouco usado no século VI e entre o VI-IV a.C. (cada qual 1 tipo monetário), aumentando consideravelmente no século $\mathrm{V}$ a.C. Entre os séculos V-IV a.C. foram encontrados poucos tipos monetários (1 tipo no total), em contraste ao século IV a.C. (10 tipos no total). A representação voltou a ser menos utilizada entre os séculos IV-III a.C. (1 tipos no total). Observa-se que os três padrões de representação diminuíram significantemente entre os séculos IV-III a.C.

Com relação aos tipos monetários de águias usados como tipos secundários, o gráfico 58 mostra que as águias foram usadas dessa maneira somente a partir do século $V$ a.C. $O$ padrão "em pé" foi o mais utilizado (8 tipos no total), a partir do século $V$ a.C. (2 tipos no total), tendo seu uso aumentado no século IV a.C. 6 tipos). O segundo mais numeroso, de águias "voando", foi, em contraste, mais usado no século

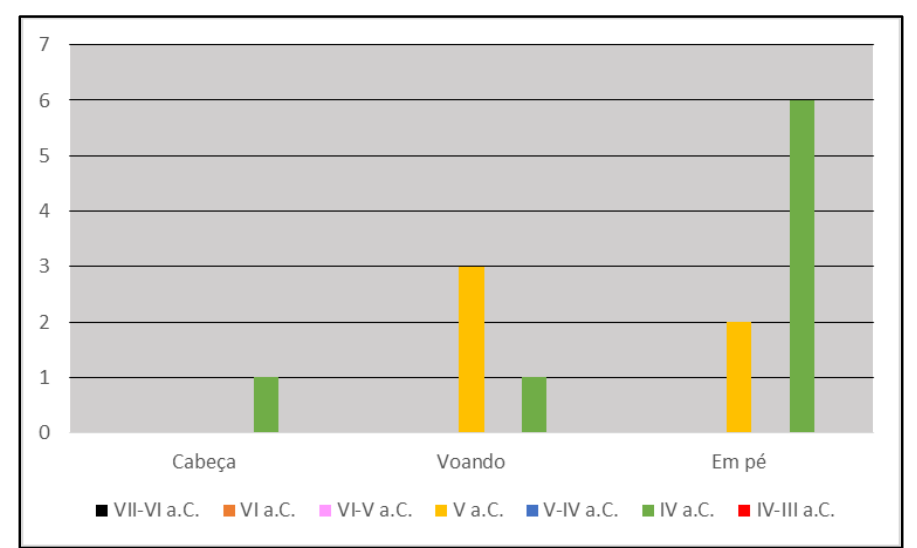

Fig.58- Quantidade por séculos de tipos monetários usados como tipos secundários (sécs. VII-IV/III a.C.). V a.C. (3 tipos), diminuído no século IV a.C. (1 tipo), em detrimento do uso da "cabeça" e do padrão "em pé" nos séculos IV a.C. O padrão "cabeça" foi usado como tipo secundário somente no século IV a.C. (1 tipos no total). Conforme o gráfico 59, a Sicília se destaca como a região de maior ocorrência de imagens monetárias

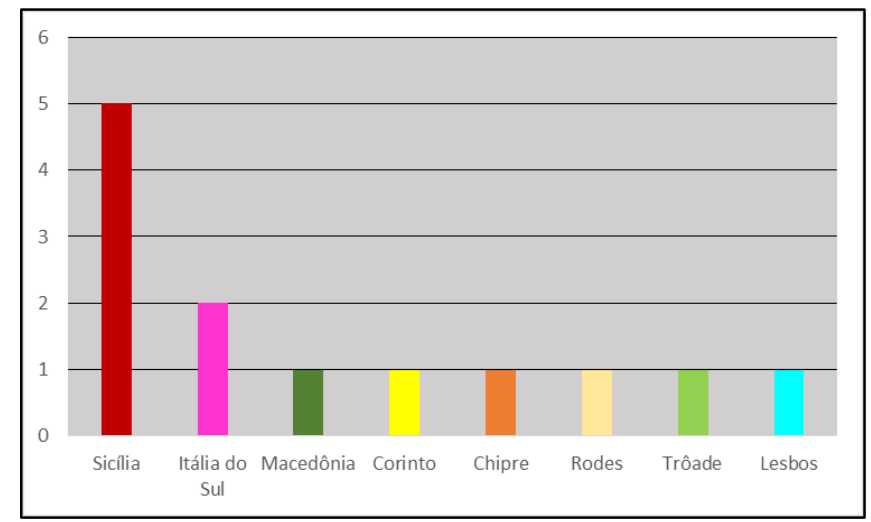

Gráfico 59- Quantidade por regiões de tipos monetários de águias usados como tipos secundários (sécs. VII-IV/III a.C.). de águias usadas como tipos secundários. $\mathrm{Na}$ região, o padrão da águia "em pé" foi o mais usado (4 tipos no total), seguido pelo padrão "voando" (1 tipo). Também no Ocidente grego, a Itália do Sul é a segunda região que mais utilizou a águia como uma imagem secundária no campo da moeda no padrão "em pé" (2 tipos monetários). As demais regiões usaram a imagem da águia em menor proporção (cada qual apenas 1 tipo monetário). Na Macedônia e em Chipre, as autoridades emissoras usaram o padrão "voando", enquanto Rodes e a Trôade, usaram 0 padrão "em pé". Corinto utilizou a imagem da "cabeça". 


\section{II.6.1 O PADRÃO “CABEÇA”}

Para o padrão de representação de cabeças de águia, estabeleceu-se 4 sub-padrões de representação: (1) cabeça "para frente sem presa"; (2) "para frente e carregando presa no bico"; (3) "para frente e carregando cobra no bico"; e (4) para trás e sem presa. De acordo com 0 gráfico 60 e com a tabela 17, com relação à quantidade por séculos de tipos monetários de "cabeças" de águias, a representação da cabeça de águia "para frente e carregando presa no bico" (um atum) é o mais antigo de todos, tendo sido

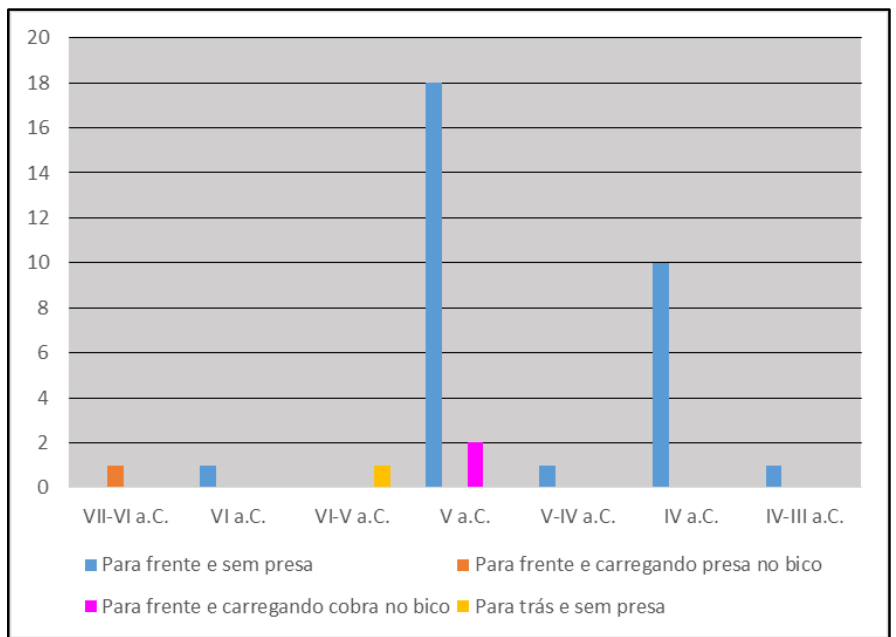

Gráfico 60- Quantidade por séculos de tipos monetários de "cabeças" de águias (sécs. VII-IV/III a.C.) encontrado apenas 1 tipo monetário entre os séculos VII-VI a.C. O sub-padrão mais numeroso, e que ocorre entre os séculos VI-IV/III a.C., é o da cabeça de águia "para frente e sem presa". O sub-padrão começou a ser utilizado no século $\mathrm{VI}$ a.C. em pequeno número (1 tipo monetário), aumentando significantemente no século $\mathrm{V}$ a.C. (18 tipos no total), tornando-se no período a principal representação de cabeça de águias em moedas gregas. Foram encontrados apenas 1 tipo monetário no século V-IV a.C. e no século IV a.C. o número voltou a aumentar (10 tipos no total), embora em menor quantidade do que no século V a.C. Entre os séculos IV-III a.C. houve novamente uma diminuição no uso desse sub-padrão de representação. $O$ sub-padrão "para trás e sem presa" foi utilizado somente entre os séculos VI-V a.C. (1 tipo monetário), ao passo que aquele "para frente e carregando presa no bico" foi utilizado somente no século V a.C. (2 tipos monetários). Não há, para esse padrão, variedades de representação, como ocorre para os demais tipos monetários de águias (voando e em pé), apenas sub-padrões.

\begin{tabular}{|l|r|r|r|r|r|r|r|r|}
\hline Tipo monetário "cabeça" & VII-VI a.C. VI a.C. & VI-V a.C. V a.C. & V-IV a.C. IV a.C. & IV-III a.C. Total \\
\hline (1)Para frente e sem presa & 0 & 1 & 0 & 18 & 1 & 10 & 1 \\
\hline (2)Para frente e carregando presa no bico & 1 & 0 & 0 & 0 & 0 & 0 & 0 \\
\hline (3)Para frente e carregando cobra no bico & 0 & 0 & 0 & 2 & 0 & 0 & 0 \\
\hline (4)Para trás e sem presa & 0 & 0 & 1 & 0 & 0 & 0 & 0 & 1 \\
\hline
\end{tabular}

Tabela 17 - Quantidade por séculos de sub-padrões de "cabeça" de águias em moedas gregas (sécs. VII-IV/III a.C.). 
1. Para frente e sem presa Éfeso (500-420, n.121/122), (480-450, n.135), (415-394, n.198 s/i); Sinope (VI, n.110), (480-450, n.130/129), (425-410, n.168); lalysos (500, n.119); Paphos (490, n.124); Cyme (c.480450, n.132/133/134); Agrigento (antes 406, n.210); Crotona (c.400 a.C., n.219); Élis (c.416-404, n.194/195/323), (408, n.324), (404, n.325), (400, n.326 escudo/327 cabeça lagarto campo/328), (c.390s380, n.331/332/333/334), (380, n.235); emissão incerta, Jônia (V, n.213); Corinto (400-350, n.225); Mytilene (c.350-250, n.266 s/i).
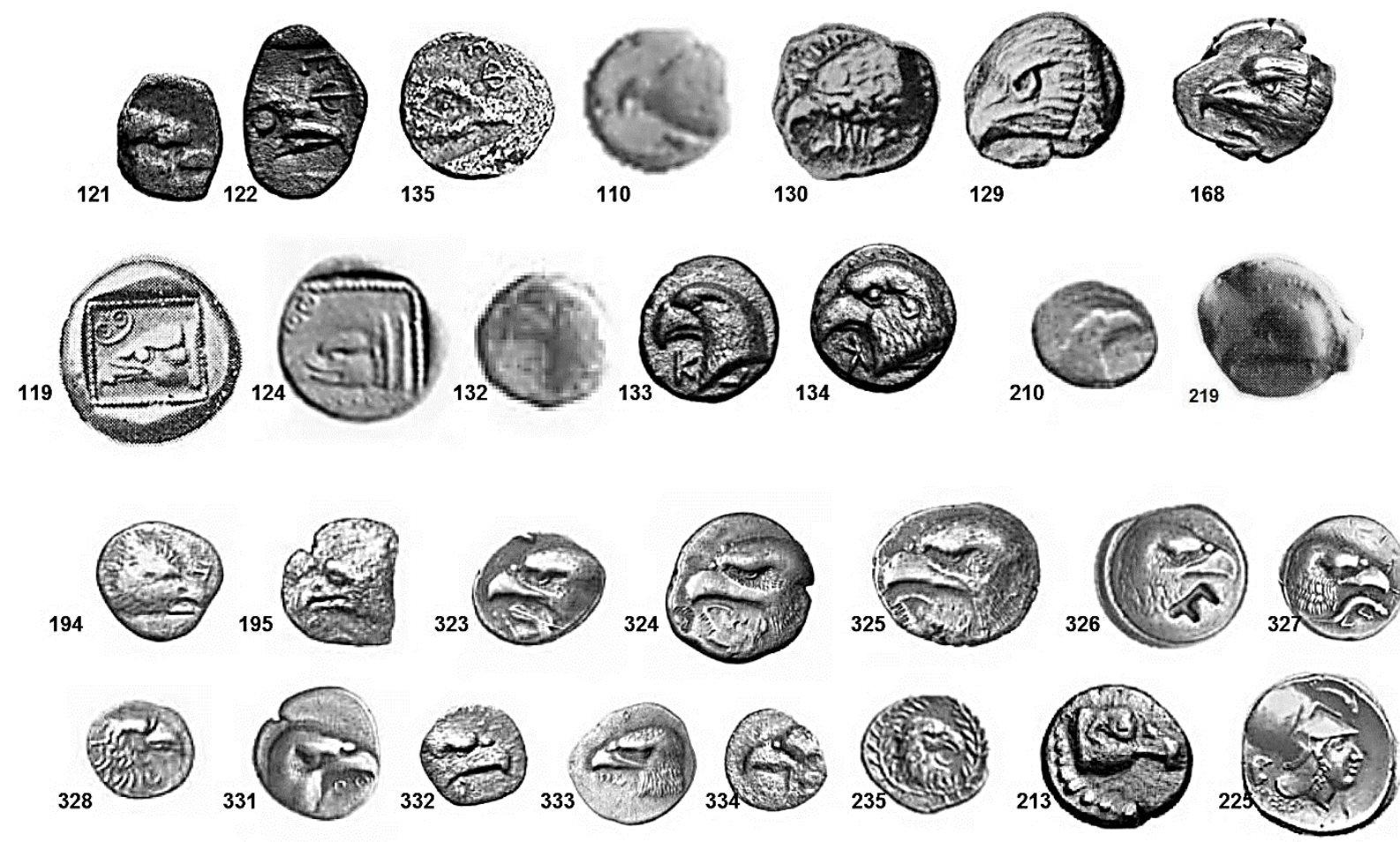

De acordo com o gráfico 61 , os tipos monetários foram encontrados em 10 regiões do mundo grego: Élis, Jônia, Mar Negro, Aeolis, Itália do Sul, Rodes, Chipre, Sicília, Corinto e Lesbos. Em Élis foi encontrada a maior quantidade de tipos monetários desse sub-padrão (13 tipos no total). Na Jônia e no Mar Negro foi a encontrada a mesma quantidade de imagens monetárias (cada qual 4 tipos no total). Em

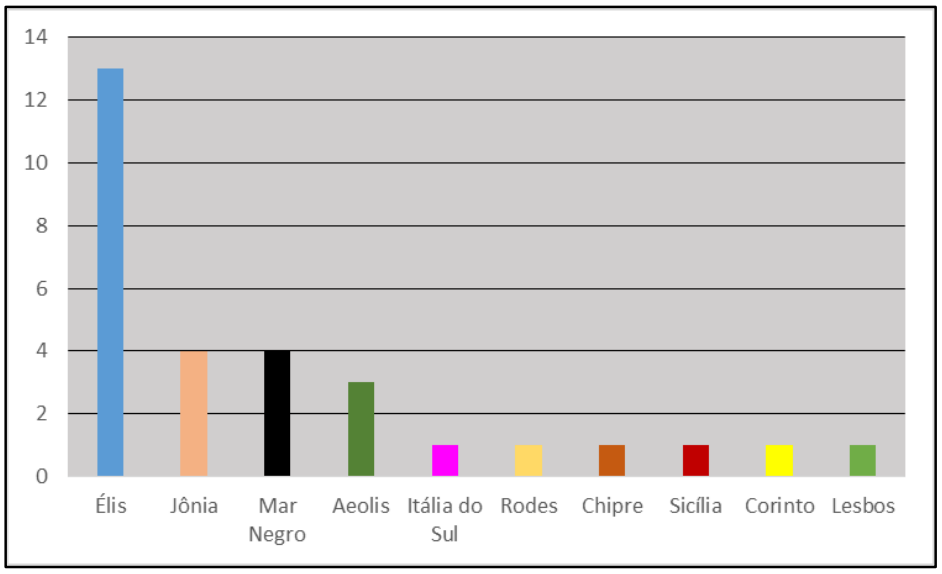

Gráfico 61- Quantidade por regiões de tipos monetários de cabeça de águias "para frente e sem presa" (séculos VII-IV/III a.C.).

Aeolis o levantamento recuperou 3 tipos monetários no total e na Itália do Sul, somente 2 tipos. Rodes, Chipre, Sicília, Corinto, Itália do Sul e Lesbos são as regiões que menos utilizaram o sub-padrão (cada qual 1 tipo monetário). 
O tipo monetário mais antigo de cabeça de águia "para frente e sem presa" foi emitido por Sinope, no Mar Negro, no século VI a.C. (n.110). Os primeiros tipos monetários emitidos no século $V$ a.C. foram cunhados por Éfeso entre 500-420 a.C. (n.121 e 122) e por lalysos em 500 a.C. (n.119). Éfeso, na Jônia, Sinope, no Mar Negro, Paphos, em Chipre, e Cyme, em Aeolis, são as cidades que emitiram tipos monetários entre 490-480 a.C. Apesar de a maior quantidade de imagens monetárias ter se concentrado em Élis, no Peloponeso ocidental, esse sub-padrão de representação foi uma criação de regiões situadas no lado oriental do mundo grego, como o Mar Negro, a Jônia e as ilhas de Rodes e Chipre. De todos os tipos monetários, repara-se a semelhança entre a imagem batida por lalysos, em Rodes, em 500 a.C. (n.119) e a de Paphos, em Chipre, de 490 a.C. (n.124). A certa proximidade entre as ilhas e a proximidade cronológica entre os exemplares, sugere uma influência de um desenho sobre o outro. Repara-se também que Élis foi usar o tipo da cabeça de águia, somente sem presa, entre 416 e 380 a.C., dentre os quais ressalta-se o tipo monetário de 400 a.C. (n.326) - a primeira representação de uma águia retratada sobre um escudo em moedas gregas. Esse sub-padrão de representação foi usado em menor escala no Ocidente grego, como evidencia o tipo monetário único de Agrigento, na Sicília, de antes de 406 a.C. (n.210), a segunda autoridade emissora responsável pela maior quantidade de tipos monetários de águia, e de Crotona de c.400 a.C. (n.219).

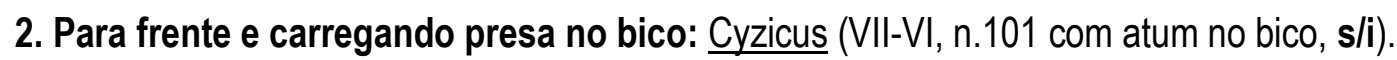

3. Para frente e carregando cobra no bico: Cirene (500, n.115); lalysos (500, n.118).

115

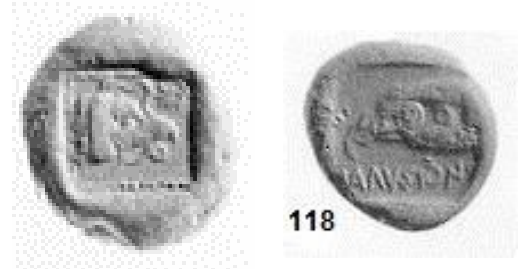

4. Para trás e sem presa: Abydus (final VI-início V, n.111).

111

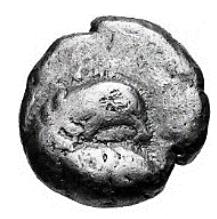

Com relação ao sub-padrão de representação de cabeça de águias "para frente e carregando presa no bico", trata-se de um exemplar único de Cyzicus, na Mysia, datado entre o século VII-VI a.C. (n.101), considerado um dos mais antigos com a ave. A presa, neste caso, é um atum que a ave carrega no bico, peixe muito comum nas imagens monetárias dessa pólis. $O$ terceiro sub-padrão de representação de cabeça de 
águias "para frente e carregando cobra no bico", possui apenas dois tipos monetários, um de Cirene, na Líbia (n.115), e o outro de lalysos (n.118), em Rodes. Ambos são datados de 500 a.C. Observa-se a semelhança entre o tipo monetário de Cirene e aqueles da cabeça de águia "sem presa" de lalysos e Paphos, datados do mesmo período. E por fim, há apenas um tipo monetário do sub-padrão de cabeça de águias "para trás e sem presa". O tipo provém de Abydus, na Trôade, e é datado entre o final do século VI e início do V a.C. (n.111). Trata-se de um tipo muito específico em que aparece parte do ombro da asa direita da águia.

\section{II.6.2 O PADRÃO “VOANDO”}

Para o padrão de representação de águias "voando" em moedas gregas, estabelecemos 2 tipos de sub-padrões: (1) com asas abertas (uma em cima e a outra embaixo); e (2) com as duas asas erguidas. Conforme 0 gráfico 62, acerca da quantidade de tipos monetários de águias "voando", o sub-padrão de águias voando "com as asas abertas" é o mais numeroso (56 tipos monetários no total), tendo sido usado pela primeira vez no século VI

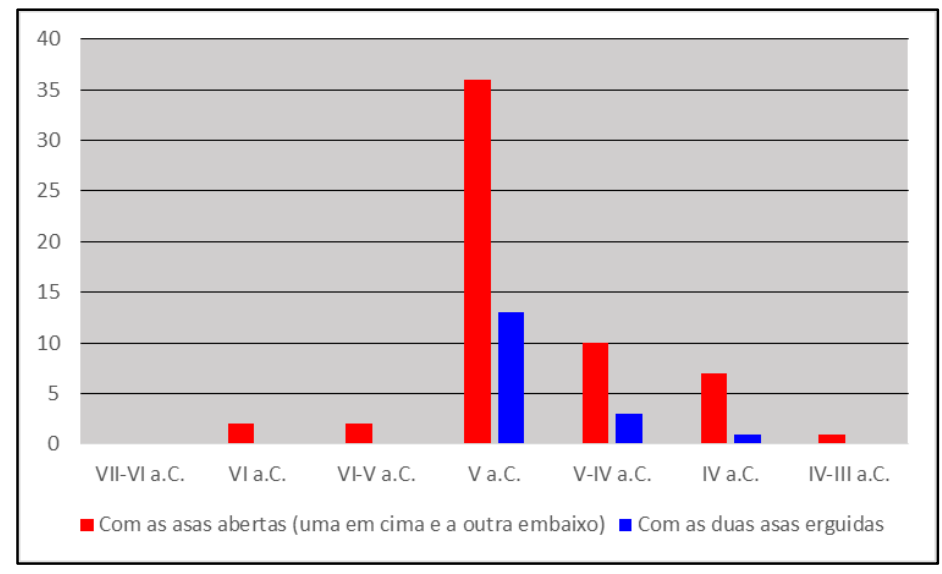

Gráfico 62- Quantidade de tipos monetários de águias "voando" (sécs. VII-IV/III a.C.).

a.C., mantendo o mesmo número entre os séculos VI-V a.C. (cada período 2 tipos no total). Foi no século $\mathrm{V}$ a.C. que o sub-padrão atingiu o ápice de uso em moedas gregas (36 tipos no total), diminuindo gradativamente entre os séculos V-IV a.C. (10 tipos no total), no século IV a.C. (7 tipos) até quase cair em desuso entre os séculos IV-III a.C. (1 tipo monetário). Em contraste, o sub-padrão de águias voando "com as duas asas erguidas" figurou em moedas gregas a partir do século V a.C. (13 tipos monetários no total), também diminuindo gradativamente de uso entre os séculos V-IV a.C. (3 tipos no total), no século IV a.C. (1 tipo), não sendo mais usado entre os séculos IV-III a.C. 


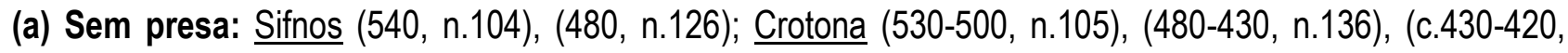
n.163); Cálcis (515, n.106), (500, n.113); emissão incerta Macedônia (início V, n.112); Alexandre I (480/74477/76, n.127); 銆to (V, n.212); Lyttos (c.425-320, n.179/181/182/184/183/186/187/188), (c.400, n.217); Paphos (c.425, n. 167), (2a.met. V-final V, n.211); Gela (410-405 sobre quadriga, n.206), Amanthus (c.350 sobre

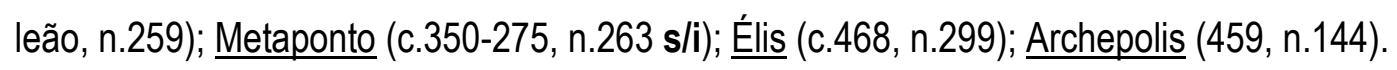
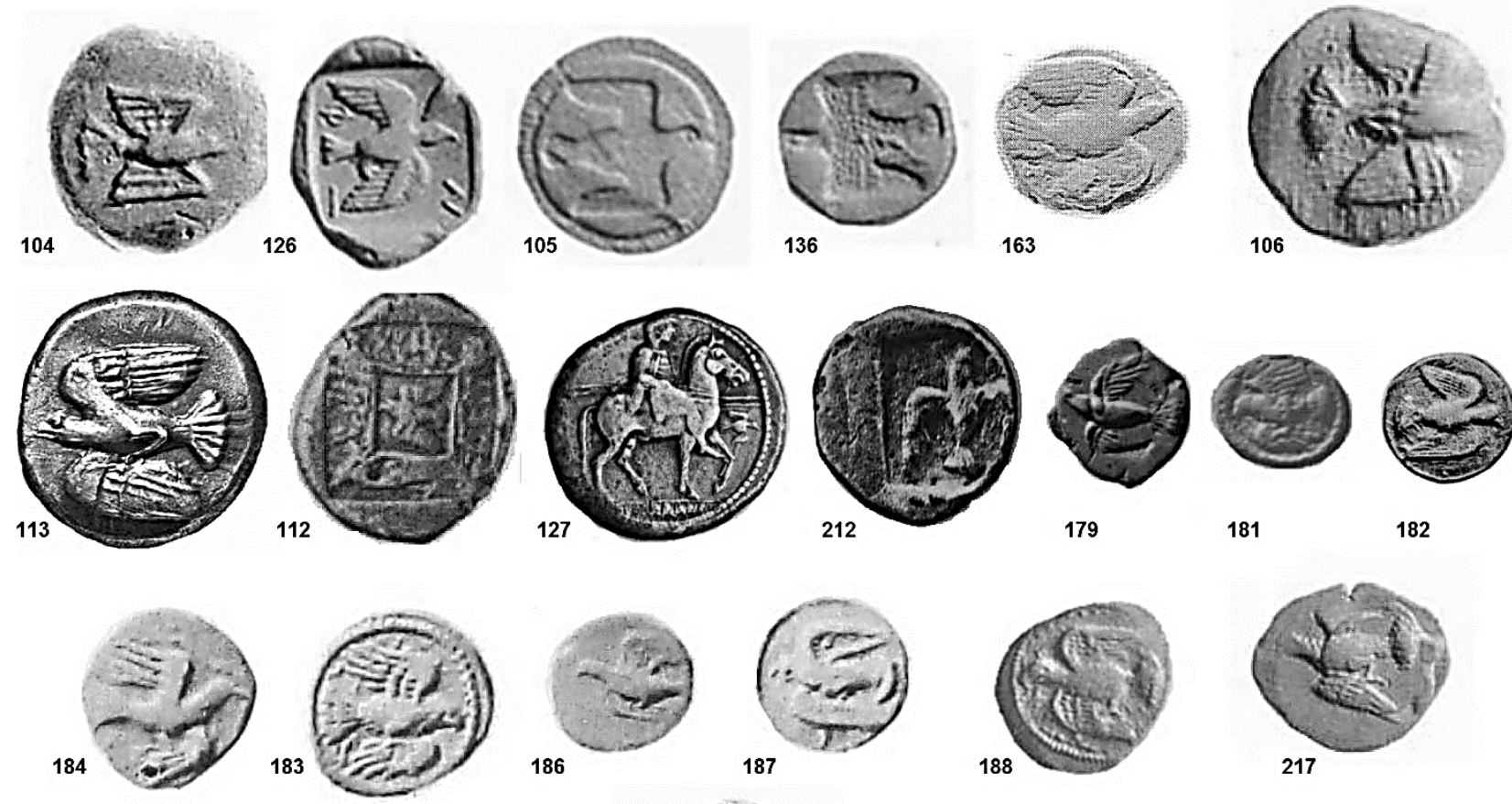

181

182
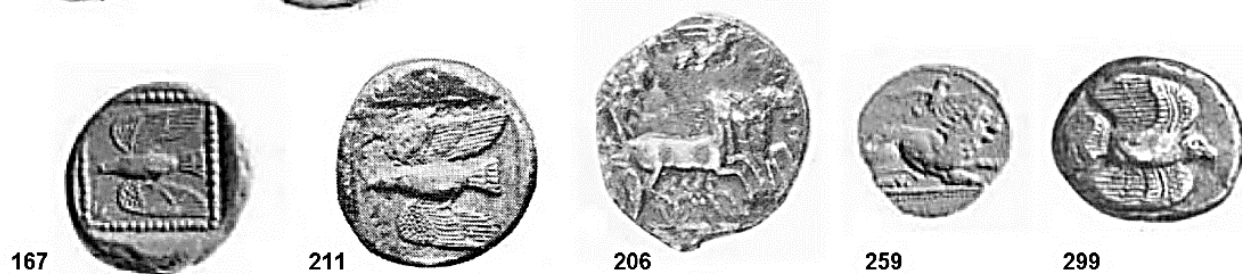

299
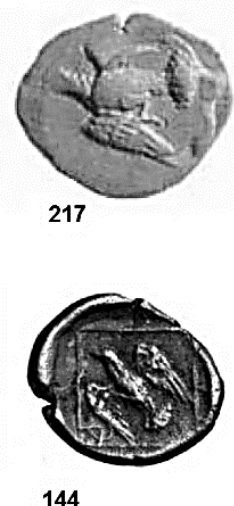

(b) Carregando cobra pelas garras e cabeça erguida: Agrigento (c.411 sobre quadriga, n.203).

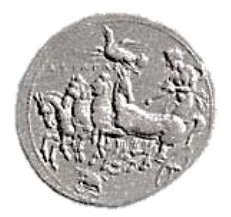


(c) Com cobra no bico, enrolada no corpo e presa nas garras: Cálcis ( 515 ou 465, n.167), (500, n.114); Élis (468, n.139), (c.468, n.300), (c.460s, n.302), (c.452-432, n.340), (final 450s, n.306), (final 450s, n.342).
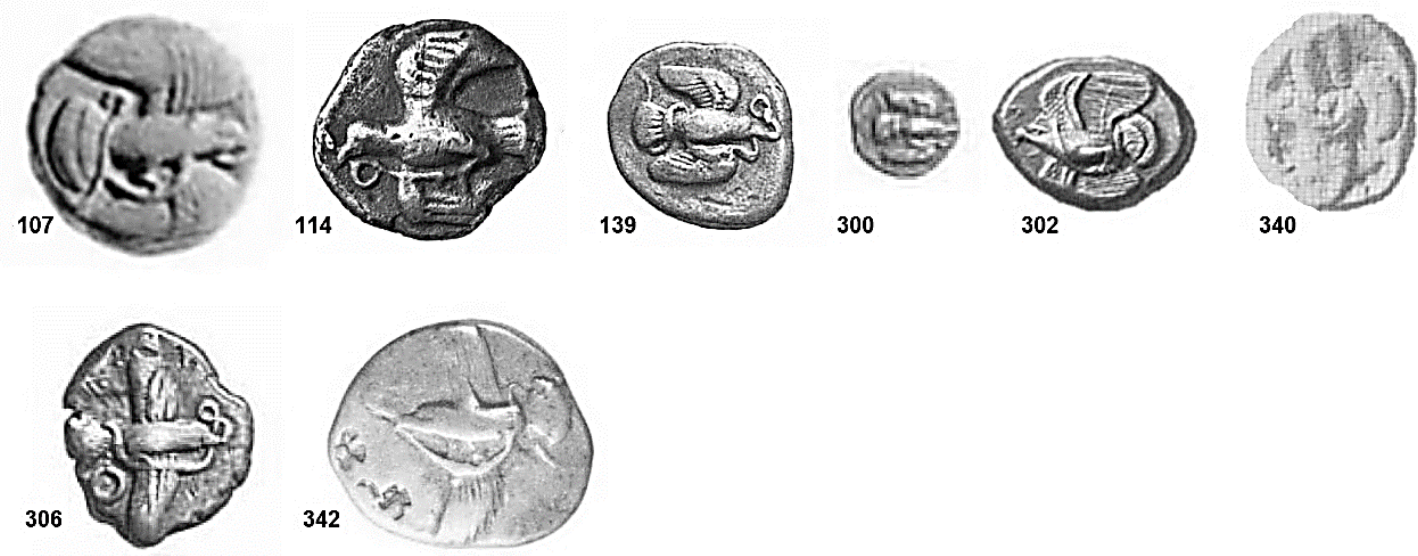

(d) Carregando cobra no bico, nas garras e não enrolada no corpo: Élis (final 450s, n.152), (c.440s-430s, n.155), (c.430s, n.343), Sparadocus (antes 424, n.166); Cálcis (369-336, n.242/243), (369-313, n.246/337).
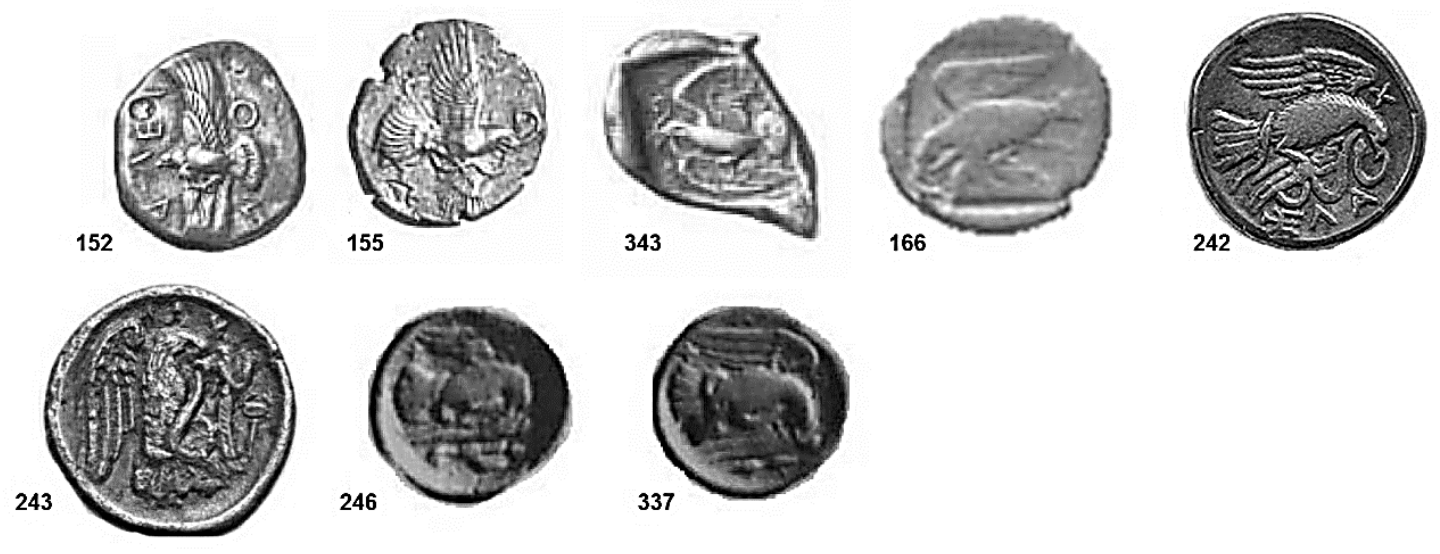

(e) Carregando lebre e devorando-a: Élis (c.468, n.301), (c.450-440, n.149 barriga), (c.432, n.158 costas).
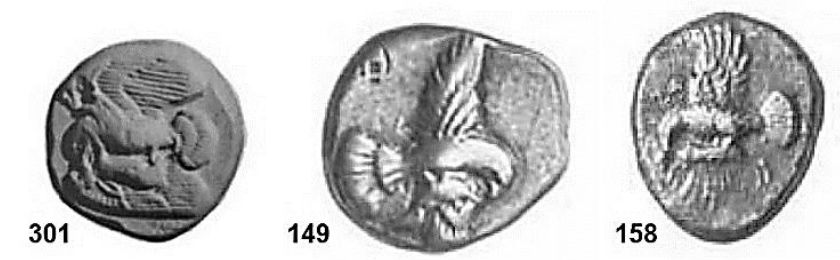
(f) Carregando veado, devorando-o: Élis (c.432, n.312).

312

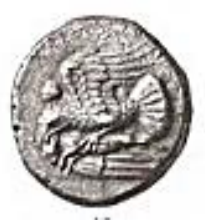

(g) Carregando tartaruga: Élis (c.470, n.138).

138

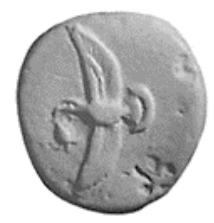

(h) Carregando banda (taenia) no bico: Lyttos (c.425-320, n.185).

185

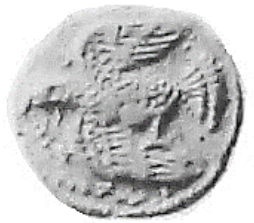

(i) Carregando golfinho: Ólbia (437-410, n.157), (430-400/n.165).

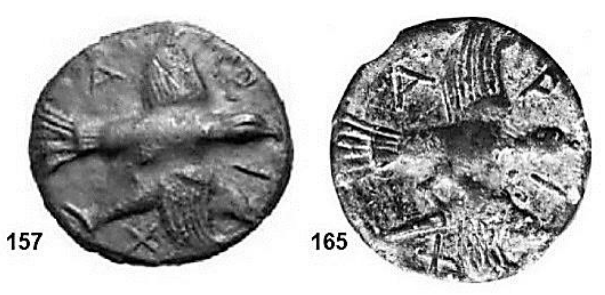

(j) De frente, sem presa, com a cabeça virada: Magnésia (c.465, n.140); Élis (final 450, n.151).

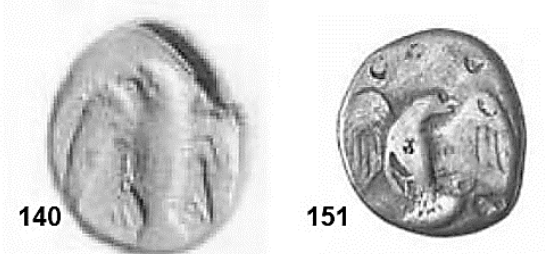


(k) De frente, carregando cobra no bico: Olinto (440?, n.154), (432-420, n.161); Sparadocus (445-435, n.153);

Sifnos $(400-350$, n.226).
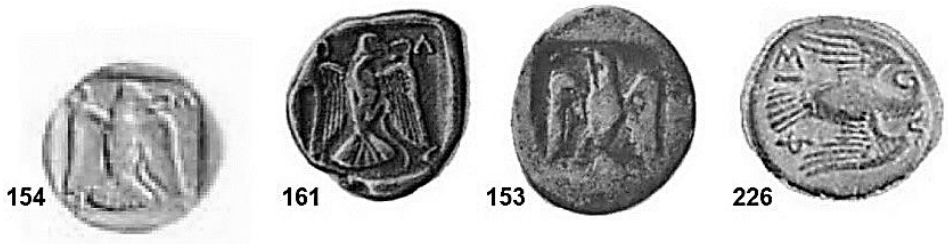

(I) De frente, carregando tartaruga: Élis (452-432, n.341).

341

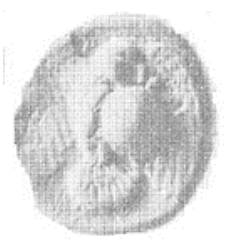

De acordo com o gráfico 63, o subpadrão foi recorrente em 11 regiões do mundo grego: Élis, Creta, Eubéia, Trácia, Itália do Sul, Egeu, Chipre, Macedônia, Sicília, Jônia e Mar Negro. Observa-se que se trata de um sub-padrão que foi usado por autoridades emissoras de toda a parte do mundo grego - do Ocidente ao Oriente, de norte a sul. A maior quantidade de tipos monetários de águias voando "com asas

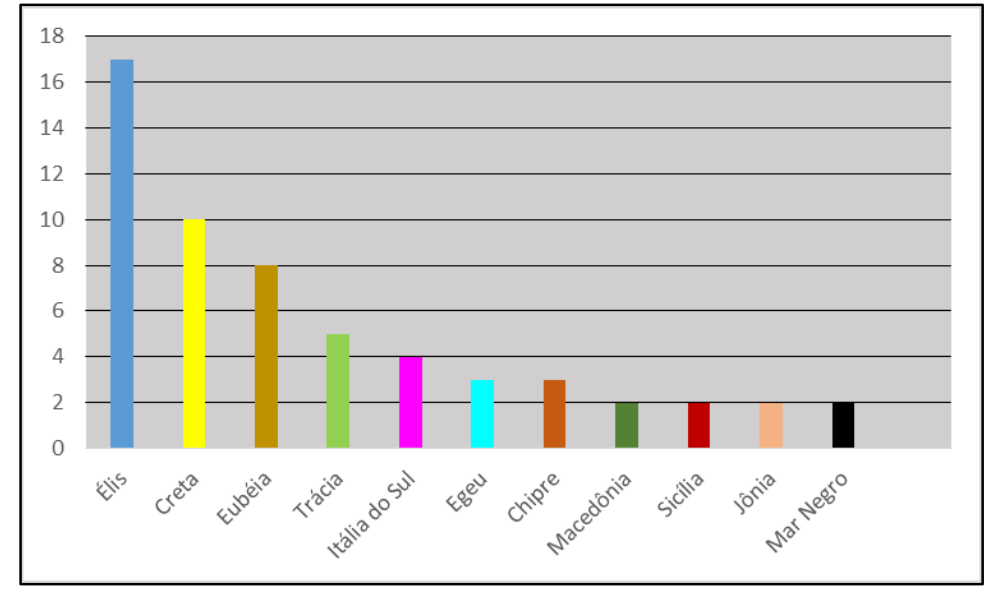

Gráfico 63- Quantidade por regiões de tipos monetários de águias voando "com asas abertas" (sécs. VII-IV/III a.C.). abertas" foram emitidos por Élis para o santuário de Olímpia (17 no total). Creta é a segunda região com maior concentração de tipos monetários (10 tipos no total), seguida pela Eubéia (com 8 tipos monetários no total). A Trácia e a Itália do Sul emitiram tipos monetários quase na mesma quantidade (5 e 4 tipos respectivamente), ao passo que na área egéia e no Chipre foi possível encontrar o mesmo número de imagens monetárias (cada qual 3 tipos no total). A Macedônia, a Sicilia, a Jônia e o Mar Negro são as regiões com menos ocorrência da representação em moedas (cada qual 2 tipos monetários no total). É possível ver esse sub-padrão de representação em tipos monetários de Zeus sentado no trono das variedades (b), (c) e (i).

Dentro do sub-padrão de representação da águia voando "com asas abertas" foi possível definir 12 variedades de tipos monetários, a saber: (a) sem presa; (b) carregando cobra pelas garras e cabeça erguida; (c) com serpente no bico, enrolada no corpo e presa nas garras; (d) carregando serpente no bico, nas garras e não enrolada no corpo; (e) carregando lebre e devorando-a; (f) carregando veado e devorando-o; (g) 
carregando tartaruga; (h) carregando banda (taenia) no bico; (i) carregando golfinho; (j) de frente, sem presa e com a cabeça virada; (k) de frente e carregando cobra no bico; e (I) de frente e carregando tartaruga.

\begin{tabular}{|c|c|c|c|c|c|c|c|c|c|}
\hline Tipo monetário "voando / com asas abertas" & VII-VI a.C. & & VI-V a.C. & V a.c. & V-IV a.C. & IV a.C. & IV-III a.C. & Total & \\
\hline (a)Sem presa & 0 & 2 & 1 & 12 & 8 & 2 & 1 & & 26 \\
\hline (b) Carregando cobra pelas garras e cabeça erguida & 0 & 0 & 0 & 1 & 0 & 0 & 0 & & 1 \\
\hline (c)Com cobra no bico, enrolada no corpo e presa nas garras & 0 & 0 & 1 & 7 & 0 & 0 & 0 & & 8 \\
\hline (d)Carregando cobra no bico, nas garras e não enrolada no corpo & 0 & 0 & 0 & 4 & 0 & 4 & 0 & & 8 \\
\hline (e)Carregando lebre e devorando-a & 0 & 0 & 0 & 3 & 0 & 0 & 0 & & 3 \\
\hline (f)Carregando veado, devorando-o & 0 & 0 & 0 & 1 & 0 & 0 & 0 & & 1 \\
\hline (g)Carregando tartaruga & 0 & 0 & 0 & 1 & 0 & 0 & 0 & & 1 \\
\hline (h)Carregando banda (taenia) no bico & 0 & 0 & 0 & 0 & 1 & 0 & 0 & & 1 \\
\hline (i)Carregando golfinho & 0 & 0 & 0 & 1 & 1 & 0 & 0 & & 2 \\
\hline (j)De frente, sem presa, com a cabeça virada & 0 & 0 & 0 & 2 & 0 & 0 & 0 & & 2 \\
\hline (k)De frente, carregando cobra no bico & 0 & 0 & 0 & 3 & 0 & 1 & 0 & & 4 \\
\hline (I)De frente, carregando tartaruga & 0 & 0 & 0 & 1 & 0 & 0 & 0 & & 1 \\
\hline
\end{tabular}

Tabela 18- Variedades de tipos monetários de águias voando “com asas abertas" (sécs. VII-IV/III a.C.).

Observa-se a partir da tabela 18 que a variedade (a) com asas abertas e "sem presa" é a mais numerosa (26 tipos monetários no total). Essa variedade foi a única a ter sido usada pela primeira vez no século VI a.C. (1 tipo monetário), tendo atingido o ápice de uso no século $V$ a.C. (12 tipos no total). A partir do período entre os séculos V-IV a.C., o uso da variedade passou a diminuir (8 tipos no total), uma tendência nos períodos seguintes, como ocorreu no século IV a.C. (2 tipos no total) e entre os séculos IV-III a.C. (1 tipo no total), quando entrou praticamente em desuso. As variedades (c) e (d) foram usadas na mesma quantidade (cada qual 8 tipos monetários no total). A variedade (c) começou a aparecer em moedas gregas entre os séculos VI-V a.C. (1 tipo monetário), permanecendo a ser utilizada até o século $V$ a.C., o período de maior uso (7 tipos no total). Em contraste, a variedade (d) foi usada somente no século V e IV a.C. e na mesma quantidade (4 tipos em cada período). A variedade ( $k$ ) foi a terceira variedade com maior uso (4 tipos no total), tendo sido usada somente no século V a.C. (3 tipos no total) e no século IV a.C. (1 tipo no total). E a variedade (e) é a quarta em maior quantidade, tendo sido usada somente no século V a.C. (3 tipos no total). As variedades (i) e (j), por sua vez, foram usadas em igual número (cada qual 2 tipos monetários no total). Foi encontrada a mesma quantidade de tipos monetários da variedade (i) provenientes do século V a.C. e entre os séculos V-IV a.C. (1 tipo em cada período). Da variedade (j) foram encontrados tipos monetários apenas do século V a.C. (2 tipos no total). As variedades (b), (f), (g), (h) e (l) foram as menos utilizadas em moedas gregas, tendo sido utilizadas apenas uma vez em imagens monetárias do século $V$ a.C., com exceção da variedade (h), que aparece em 1 tipo monetário do período entre os séculos V-IV a.C.

Com relação aos tipos monetários de águias voando "sem presa" da variedade (a), a mais numerosa, provém da ilha de Sifnos, no mar Egeu, a imagem monetária mais antiga, datada de 540 a.C. (n.104). 0 segundo tipo monetário do século VI a.C. é proveniente de Cálcis, na Eubéia, datado de 515 a.C. (n.106). E entre os séculos VI-V a.C. encontramos a imagem monetária de Crotona, na Itália do Sul, datada entre 530500 a.C. (n.105). Essas três póleis continuaram a usar essa variedade de imagem em outros tipos monetários até o início do século V a.C. Sifnos (n. 126) e Cálcis (n.113) emitiram tipos dessa variedade em 500 e 480 a.C., já Crotona continuou a bater imagens monetárias até 420 a.C. E cada uma das cidades possui um desenho 
característico para a representação das águias, sobretudo com relação às asas. No século $V$ a.C., a emissão mais numerosa foi a de Lyttos, que cunhou tipos monetários dessa variedade entre 425-320 a.C., com alguma variação entre os desenhos das águias. Em uma emissão incerta da Macedônia, a águia aparece dentro de um pequeno quadrado no centro de um quadrado incuso em um tipo do início do século V a.C. De Olinto, na Trácia, e da Magnésia, na Jônia (emissão de Archepolis), provêm dois tipos monetários muito semelhantes, ambos datados do século V a.C. (n.212 e n.144 respectivamente). Com relação à iconografia da águia retratada na moeda de Élis de 468 a.C. (n.299), que bateu uma única moeda de águia sem presas, observa-se, no estilo do desenho, uma semelhança com as representações da ave na cerâmica ática e lacônia do século VI a.C., especialmente com o skyphos ático de figuras negras de c.625-575 a.C. (Fig.212) e com a taça lacônia de figuras negras de 530 a.C. (Fig.221). Parece que o artista que gravou o cunho da moeda de Élis pautou-se em representações específicas arcaicas das águias em vasos. O mesmo se observa com moedas de Cálcis e de Élis da variedade (c), como veremos. O pontilhado que aparece nos "ombros" das asas das águias, pintadas em ambos os vasos e também na taça ática de figuras negras de c.525-475 a.C. (Fig.222), foi utilizado também nos desenhos das águias das moedas de Paphos, em Chipre, de 425 a.C. (n.167) e da segunda metade ao final do século V a.C. (n.211), na de Lyttos de 425-320 a.C. (n.188) e na de Crotona de 480-430 a.C. (n.136). Também encontra paralelo na cerâmica ática pintada do século VI a.C., a representação da águia voando junto ao cavaleiro montado no cavalo na moeda de Alexandre I da Macedônia de 480/74-477/76 a.C. (n.127). De entre 550-500 a.C. data uma série de cenas (muito semelhantes ao do tipo monetário) de cavaleiros, montados em cavalos, vestidos ou nus, carregando ou não lanças, usando ou não escudos, mas com a águia voando atrás do cavaleiro, como que a acompanha-lo, e não na frente do cavalo e embaixo no campo, como aparece na moeda (Figs.216 a 220). A moeda de Gela de 410-405 a.C. (n.206) também possui uma representação que ressoa no esquema iconográfico dos cavaleiros montados acompanhados pela águia voando. No tipo monetário, Nike dirige uma quadriga. Na cerâmica ática, contudo, é possível ver o esquema "cavaleiro, quadriga e águia" em uma cena com a deusa Atena dirigindo uma quadriga, sendo seguida por uma águia que vem logo atrás, em uma ânfora de figuras negras de 550-500 a.C. Há uma única emissão do século IV a.C. de Amanthus, em Chipre, de c.350 a.C. (n.259) em que a águia é retratada voando sobre um leão à direita, e uma única de c.350-275 a.C. de Metaponto (n.263). Essa variedade de representação da águia também pode ser vista em tipos monetários de Zeus sentado no trono cunhados pela Liga Arcádia (n.10, 15, 20, 23, 29) e por Élis (n.26) no século $V$ a.C.

$\mathrm{Na}$ variedade (b) dos tipos monetários da águia voando "carregando cobra pelas garras e cabeça erguida", há um exemplar único de Agrigento, na Sicília de c.411 a.C. (n.203) em que aparece o deus Hélio dirigindo uma quadriga e a águia voando sobre a quadriga, carregando uma cobra pelas garras e com a cabeça erguida, como que a gritar. Nas moedas, então, a representação da águia sobrevoando uma quadriga é típica de emissões siceliotas do século V a.C., não aparecendo em moedas de outras áreas do mundo grego. 
$\mathrm{Na}$ variedade (c) e (d), as segundas mais numerosas, a águia é representada carregando uma cobra, tal como é descrita na llíada, sendo a diferença entre ambas a forma como a serpente aparece carregada pela ave. Na variedade (c), a águia é retratada voando com a serpente no bico, enrolada no corpo da ave e presa pelas suas garras. Apenas as pólis de Élis e de Cálcis usaram essa variedade em moedas entre o final do século VI e a primeira metade do século V a.C. De acordo com a cronologia dos exemplares, Cálcis parece ter sido a primeira a bater moedas com a imagem da águia carregando a cobra, sendo o tipo monetário mais antigo datado de 515-465 a.C. (n.107). A pólis emitiu um novo tipo monetário em 500 a.C. (n.114), antes ainda de Élis iniciar suas emissões para o santuário de Olímpia ao redor de 468 a.C. (n.139 e 302). A pólis bateu novas imagens monetárias da águia carregando a cobra a partir de 452 a.C., onde a ave é retratada com um desenho novo, local, com as asas desenhadas em uma nova maneira, assim como a cobra que aparece pendente embaixo do abdómen da ave (n.340, 306, 342). À maneira antiga, pode-se classificar os tipos de Cálcis (n.107) e de Élis (n.139, 300, 302), nos quais a águia é retratada à semelhança da ave na taça lacônia de 530 a.C. (Fig.221). Dentre esses tipos monetários, destacamos o de Élis, cunhado na década de 460 a.C. (n.302), o qual é idêntico a imagem da ave na taça lacônia. Nesse caso, é bem provável que o artista responsável pelo desenho na moeda de Élis tenha sido influenciado pelas representações das águias das taças lacônias do século VI a.C. e não diretamente nas moedas de Cálcis, como tem sido sustentado. Na variedade (d), em contraste, a águia carrega a cobra pelo bico e pelas garras, não aparecendo enrolada no corpo da ave, como na variedade (c). Esse tipo aparece nas moedas de Élis pela primeira vez na década de 450 a.C. (n.152), permanecendo em uso nas décadas de 440 e 430 a.C. (n.155 e 343) em tipos monetários de desenhos muito diferente entre eles. 0 tipo monetário da década de 450 a.C. (n.152) ainda tem o estilo do desenho dos tipos dessa época da variedade (c) (n.340, 206, 342). Na Trácia, a variedade foi usada na emissão do rei Sparadocus antes de 424 a.C. (n.166), um tipo muito semelhante ao de Olinto da variedade (a) (n.212). Cálcis bateu novas imagens monetárias, e em uma nova maneira, no século IV a.C. entre 369-336 a.C. (n.242 e 243) e entre 369313 a.C. (n.246 e 337) em que a águia parece retratada não apenas carregando a serpente, mas como que brigando com a cobra em pleno vôo, em pleno ar.

Nas variedades (e), (f), (g) e (l) a águia deixou de ser retratada carregando a águia para carregar novos animais. Na variedade (e), a águia é retratada voando, carregando a lebre e devorando-a. Trata-se de uma inovação de Élis na imagética de águias em moedas gregas ou quiçá na dos vasos também, já que representação não aparece na cerâmica pintada ao menos do período arcaico. Apenas nas moedas de Élis, datadas a partir do período mais antigo de 468 até 432 a.C., a águia passou a ser representada carregando uma lebre pela barriga (n.301 e 144) ou pelas costas (n.158). Já na variedade (f), também de Élis de c.432 a.C. (n.312), a águia aparece voando, carregando um veado pelas costas e devorando-o. Na variedade (g) e (I), a ave carrega uma tartaruga. Na variedade (g), um tipo monetário de c.470 a.C. (n.341) a ave voa de lado e carrega o animal pela ponta de seu casco, já na variedade (I), ela voa de frente, mostrando bem a parte de cima do casco do animal. Assim, Élis é a primeira e única autoridade emissora a usar a lebre, o veado e a 
tartaruga como presas de águias no sub-padrão voando "com as asas abertas". Como veremos mais adiante, a lebre e o veado aparecem como presas nas representações das águias "em pé", assim como novos animais também foram utilizados nesse padrão de representação.

Na variedade (i), a águia é retratada pela primeira vez voando e carregando um golfinho. Trata-se de uma criação da pólis de Ólbia, no Mar Negro, durante o século V a.C. Nos tipos monetários de 437-410 a.C. (n.157) e de 430-400 a.C. (n.165), a águia carrega um golfinho que, na realidade, deveria ser muito maior do que a ave.

Já as variedades (j), (k) e (l) trazem a representação da águia voando "de frente", com o abdómen e a parte de dentro das asas bem à mostra e a cabeça virada para um dos lados. Na variedade (j), a águia é representada sem a presa em moedas da Magnésia de c.465 a.C. (n.140), emitida durante o governo de Temístocles, e na de Élis do final de 450 a.C. (n.151). Na variedade (k), as águias são retratadas dentro de um quadrado incuso, carregando a cobra pelo bico em tipos muito semelhantes entre si, em moedas de Sparadocus de 445-435 a.C. (n.153), de Olinto de 440 a.C. (n.154) e de 432-420 a.C. (n.161), ambas na Trácia, e de Sifnos, no mar Egeu, de 400-350 a.C. (n.226) sem o quadrado incuso.

\section{COM AS DUAS ASAS ERGUIDAS}

(a) Sem presa: Lyttos (c.425-320, n.177/178?). 
(b) Carregando lebre e devorando-a: Élis (460s-450s, n.303/304/305 barriga), (450-440, n.150 barriga), (440s-430s, n.156 costas), (c.440s, n.307 costas), (c.440s-430s, n.308/309/310 barriga/311 costas), (432, n.160

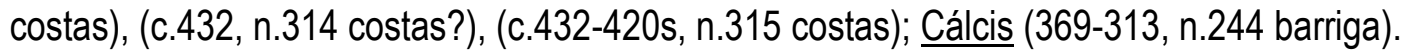

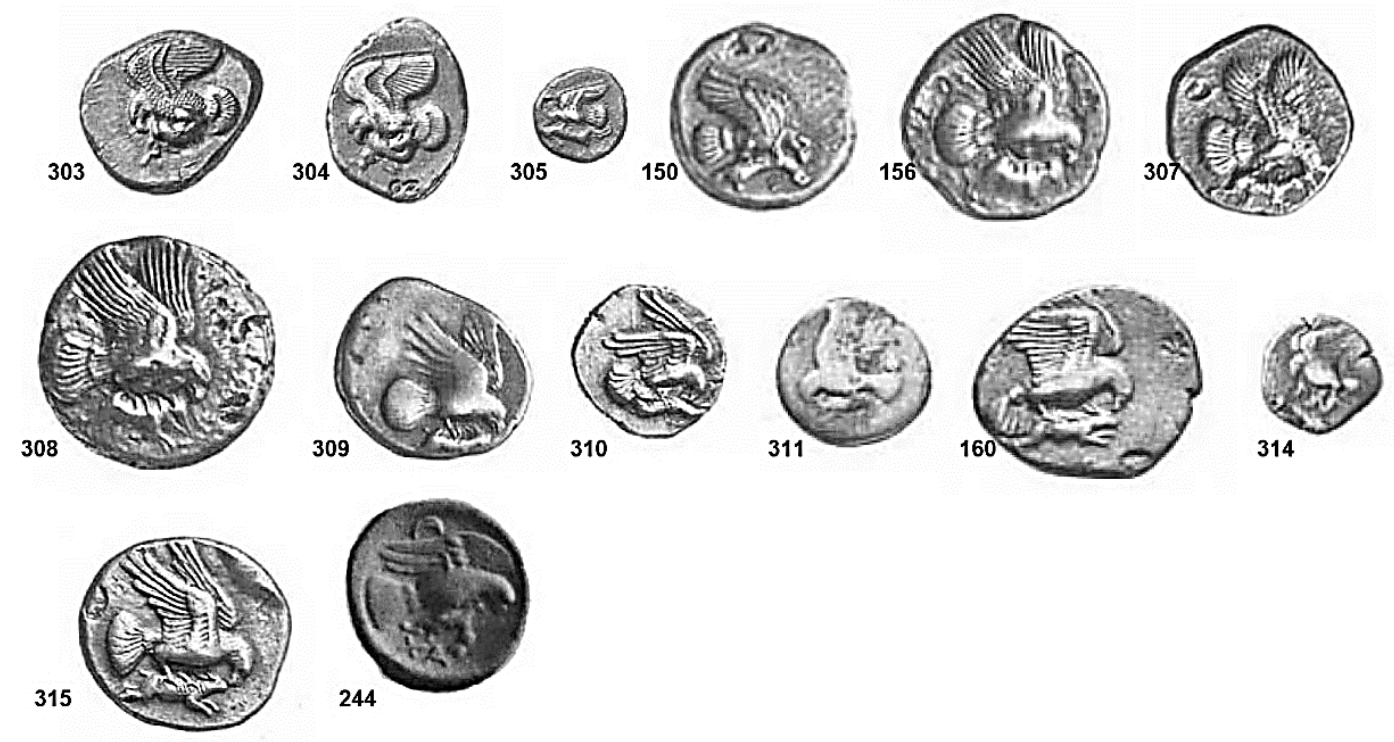

(c) Carregando presa indefinida: Lyttos (c.425-320, n.180)

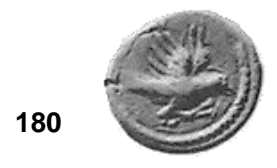

De acordo com o gráfico 64, o uso desse sub-padrão foi mais restrito regionalmente, em contraste ao das águias voando "com as asas abertas". Apenas em 3 regiões - Élis, Creta e Eubéia - foram encontrados tipos monetários desse sub-padrão. A maior quantidade de tipos monetários foi emitida por Élis (13 tipos no total), Creta é a segunda região com a maior quantidade de imagens monetárias ( 3 tipos no total) e a

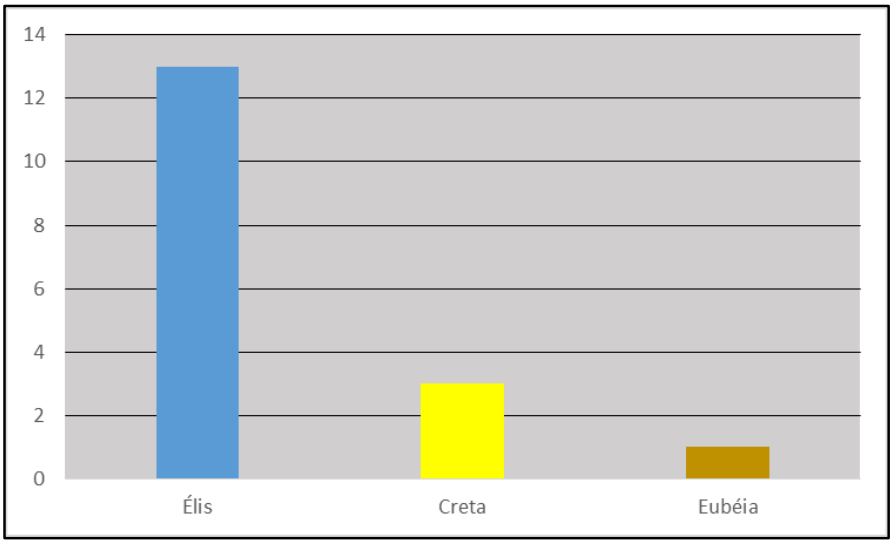

Gráfico 64- Quantidade por regiões de tipos monetários de águias voando "com as duas asas erguidas" (sécs. VII-IV/III a.C.).

Eubéia com a menor quantidade (1 tipo monetário). É possível ver esse sub-padrão em tipos monetários de Zeus sentado no trono das variedades (b) e (g) e de Zeus de cócoras ou ajoelhado da variedade (a). 
Foi possível estabelecer 3 variedades dentro desse sub-padrão de representação, a saber: (a) sem presa; (b) carregando lebre e devorando-a; e (c) carregando presa indefinida.

\begin{tabular}{|c|c|c|c|c|c|c|c|c|}
\hline Tipo monetário "voando / com as duas asas erguidas" & VII-VI a.C. VI a.C. & & VI-V a.C. & V a.C. & V-IV a.C. & IV a.C. & IV-III a.C. & Total \\
\hline (a)Sem presa & 0 & 0 & 0 & 0 & 2 & 0 & 0 & 2 \\
\hline (b)Carregando lebre e devorando-a & 0 & 0 & 0 & 13 & 0 & 1 & 0 & 14 \\
\hline (c)Carregando presa indefinida & 0 & 0 & 0 & 0 & 1 & 0 & 0 & 1 \\
\hline
\end{tabular}

Tabela 19- Variedades de tipos monetários de águias voando "com as duas asas erguidas" (sécs. VII-IV/III a.C.).

Observa-se na tabela 19 que a variedade (b) é a mais numerosa (14 tipos monetários no total), tendo sido usada na maior parte durante o século V a.C. (13 tipos no total), caindo quase em desuso no século IV a.C. (1 tipo no total). A variedade (a) é a segunda que foi mais utilizada desse sub-padrão, tendo sido usada entre os séculos V-IV a.C. (2 tipos no total). A variedade (c) aparece apenas entre os séculos V-IV a.C. (1 tipo monetário no total).

Os tipos monetários mais antigos do sub-padrão de representação da águia voando "com as duas asas erguidas" pertencem à variedade (b), a mais numerosa, nos quais a águia aparece carregando uma lebre pela barriga ou pelas costas. Trata-se dos tipos monetários de Élis datados entre as décadas de 460 e 450 a.C. (n.303, 304, 305), cuja cronologia coloca Élis como a autoridade emissora que criou esse sub-padrão de representação. Trata-se de imagens de águias após o bote ou em pleno bote da lebre. Nas moedas em que a lebre aparece de costas, como em fuga (especialmente n. 160 e 315), podemos supor que o artista quis retratar a águia no momento em que ela desce do vôo e tenta se apoderar da presa. Já nos tipos em que a lebre aparece sendo carregada pela barriga, é retratado o momento em que a ave conseguiu capturar a sua presa. As representações das águias nas moedas de Élis mostram um realismo nunca alcançado anteriormente na representação da ave, seja como aparece no sub-padrão de "asas abertas" ou no sub-padrão "com as duas asas erguidas". Esse realismo na imagem da águia foi alcançado para representações em moedas gregas e não em outro tipo de suporte imagético. Sobre o estilo do desenho, repara-se que a águia desenhada no tipo monetário das décadas entre 460 e 450 a.C. traz ainda elementos da imagem das águias arcaicas da cerâmica ática (Figs.212) e lacônia (Fig.221), como evidencia o pontilhado usado para preencher o desenho do "ombro" da asa da ave. Além de Élis, Cálcis foi a única autoridade emissora a usar essa variedade de representação em um tipo monetário de 369-313 a.C. (n.244) no qual a ave carrega a lebre pela barriga. Essa é, então, uma clara influência dos tipos monetários de Élis nas emissões de Cálcis do período9 ${ }^{9}$.

Na variedade (a), a águia é retratada voando com as duas asas erguidas "sem presa" em emissões de duas cidades cretenses. Nos tipos monetários de Lyttos de c.425-320 a.C. (n.177 e 178), a águia é retratada de um modo quase a dar a impressão de estar em pé, mas aqui seguimos a classificação dos catálogos numismáticos. Na variedade (c), onde a águia é retratada "carregando uma presa indefinida", o exemplar 
provém de Lyttos de c.425-320 a.C. (n.180), no qual a águia possui um desenho diferente das asas em relação aos tipos de Lyttos da variedade (a).

\section{II.6.3 O PADRÃO “EM PÉ”}

Do padrão de representação da águia "em pé", estabelecemos 4 subpadrões que aparecem em tipos monetários: (1) de "asas fechadas"; (2) de "asas abertas (cada uma ao lado do corpo)"; (3) de "asas erguidas (as duas juntas para cima)"; e (4) de "duas águias". Conforme nos mostra 0 gráfico 65, acerca da quantidade por séculos de tipos monetários de águias "em pé", o sub-padrão de representação mais

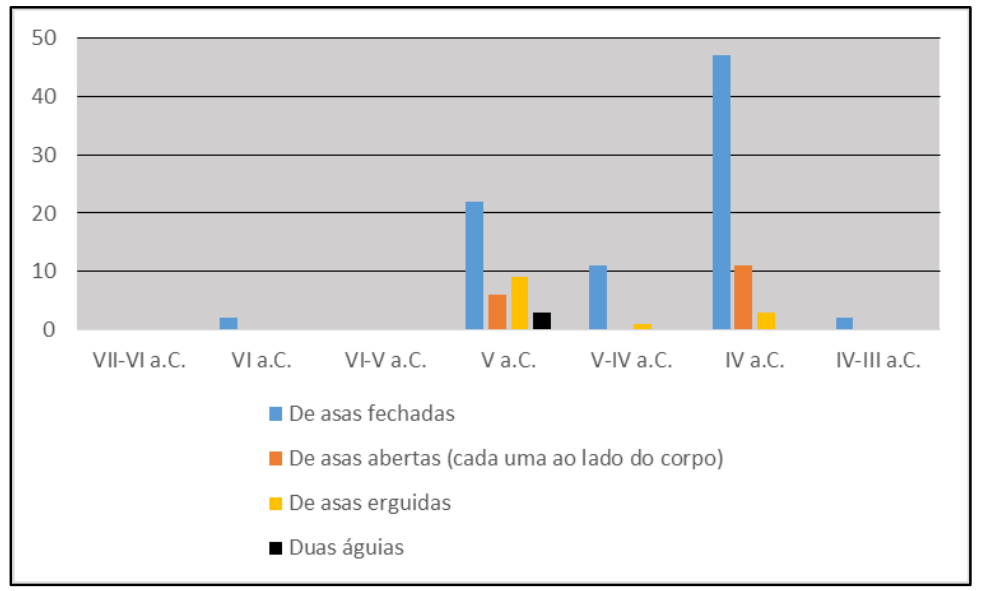

Gráfico 65- Quantidade por séculos de tipos monetários de águias "em pé" (sécs. VII-IV/III a.C.).

comum e numeroso é o das águias em pé "de asas fechadas" (84 tipos monetários no total). O sub-padrão começou a ser utilizado em moedas gregas a partir do século VI a.C. (2 tipos no total), tendo ocorrido um primeiro aumento na escolha pelo uso da imagem no século $V$ a.C. (22 tipos no total). De entre os séculos VIV a.C. foram encontrados menos tipos monetários (11 tipos no total), ao passo que no século IV a.C. o subpadrão foi usado como nunca antes (47 tipos no total). Entre os séculos IV-III a.C., o sub-padrão, que foi o único a figurar em moedas no período, diminuiu significantemente (2 tipos no total). 0 segundo sub-padrão mais numeroso, refere-se às imagens da águia em pé "de asas abertas" (17 tipos monetários no total). A representação começou a ser utilizada em moedas no século V a.C. (6 tipos no total), voltando a aparecer em moedas no século IV a.C. quando foi usado (11 tipos monetários no total). O sub-padrão de representação de águias em pé "de asas erguidas" foi o terceiro mais numeroso (13 tipos no total). Este foi utilizado a partir do século V a.C. já em maior quantidade (9 tipos no total), tendo diminuído entre os séculos V-IV a.C. (1 tipo no total) e aumentado novamente no século IV a.C. (3 tipos no total). E o sub-padrão que menos aparece é o das "duas águias" em pé, típico do século V a.C. (3 tipos monetários no total). É possível ver esse sub-padrão de representação em tipos monetários de Zeus sentado no trono das variedades (d), (e), (j) (com a cabeça para frente) e (k) (com a cabeça para trás). 
(a) Parada com a cabeça para frente: Emissão incerta, Jônia (c.600-550, n.103); Agrigento (510, n.108), (480, n.128), (após 464, n.141 anv./rev.), (460, n.142); Abydus (500-480, n.120), (antes 480, n.125), (480-450, n.131), (411-387, n. 204 sobre aplustre), (final V-início IV, n.214), (início IV-335, n.228), (380, n.233); (IV, n.273); Eryx (480-400, n.137); Paphos (450 c/ folhinhas oliveira, n.147/146 s/ folhinhas), (c.425, n.344 s/i), (420 c/ folhinhas n.190); Kherei (c.420, n.189); Agyrion (420-353 c/ folhinhas oliveira, n.193), (c.345, n.374); Motya (c.400, n.216);

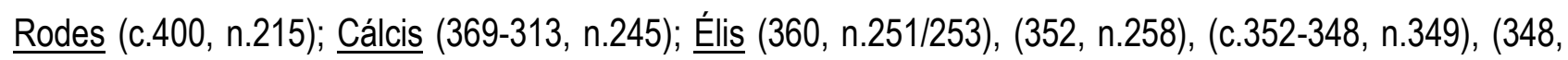

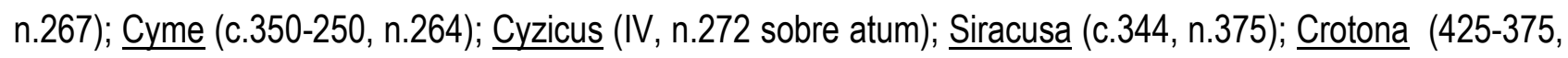
n.319 sobre cabeça carneiro); Cebren (400-310, n.227).
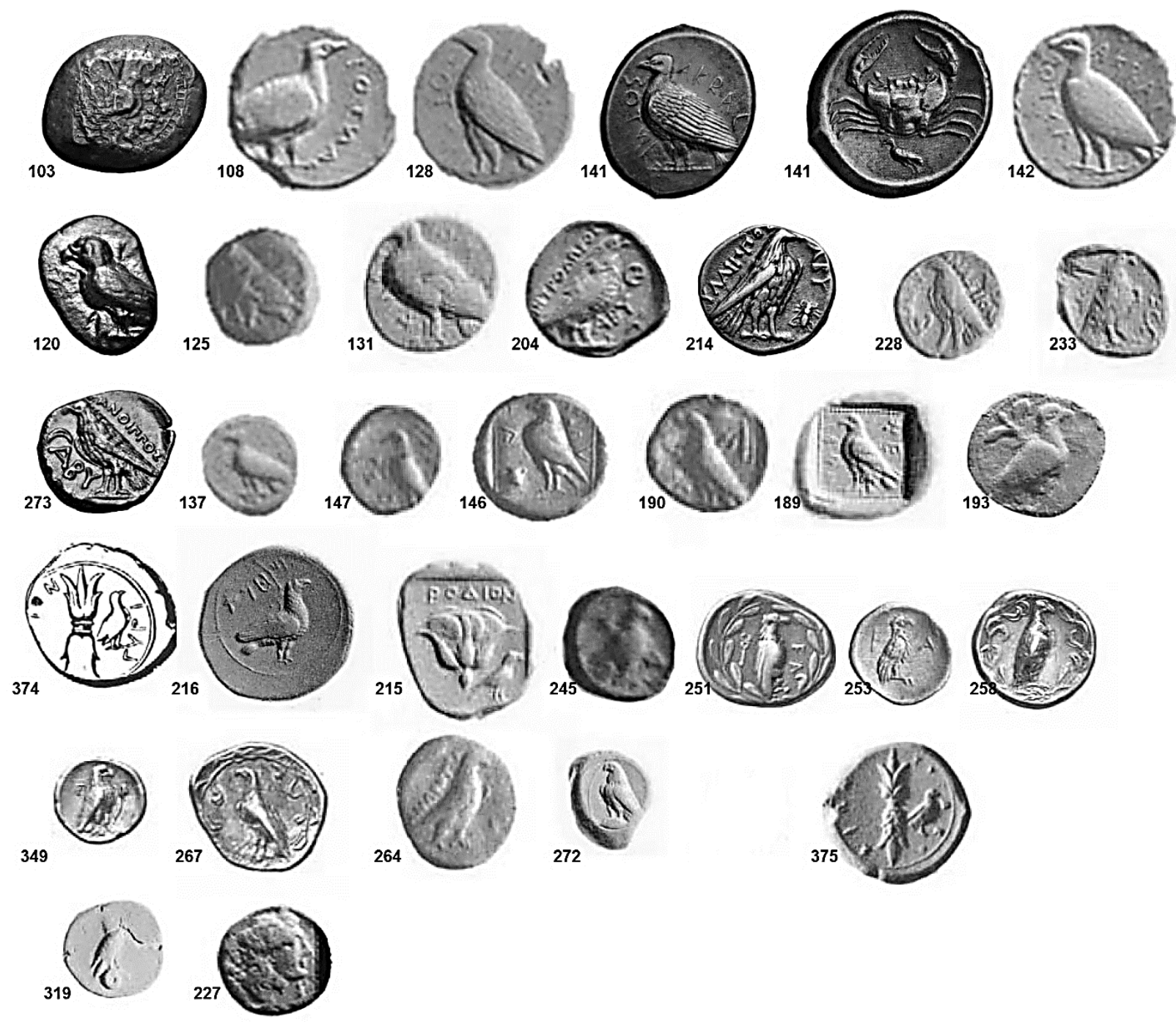
(b) Parada com a cabeça para trás: $\underline{\text { Abydus }}$ (500, n.116 sobre uma lebre/117); Mileto (499-494, n.123); Agrigento (425-406 sobre atum, n.169); Crotona (c.425-350 perto crânio cabra, n.172), (425-375, n.318 sobre cabeça carneiro), (425-350 sobre cabeça carneiro, n.171), (425-350, n.192 sobre cabeça de veado), (420-400, n.176), (2 ${ }^{\text {a }}$ met. IV, n.271); Élis (368, no.247), (360, n.250/252), (356, n.256), (c.352-348, n.350/351/352); Perdicas (364-359, n.249); yme (c.350-320, n.262 s/i); (c.350-250, n.265); Amyntas III (381-369, n.232); Mytilene (c.377-326, n.238).

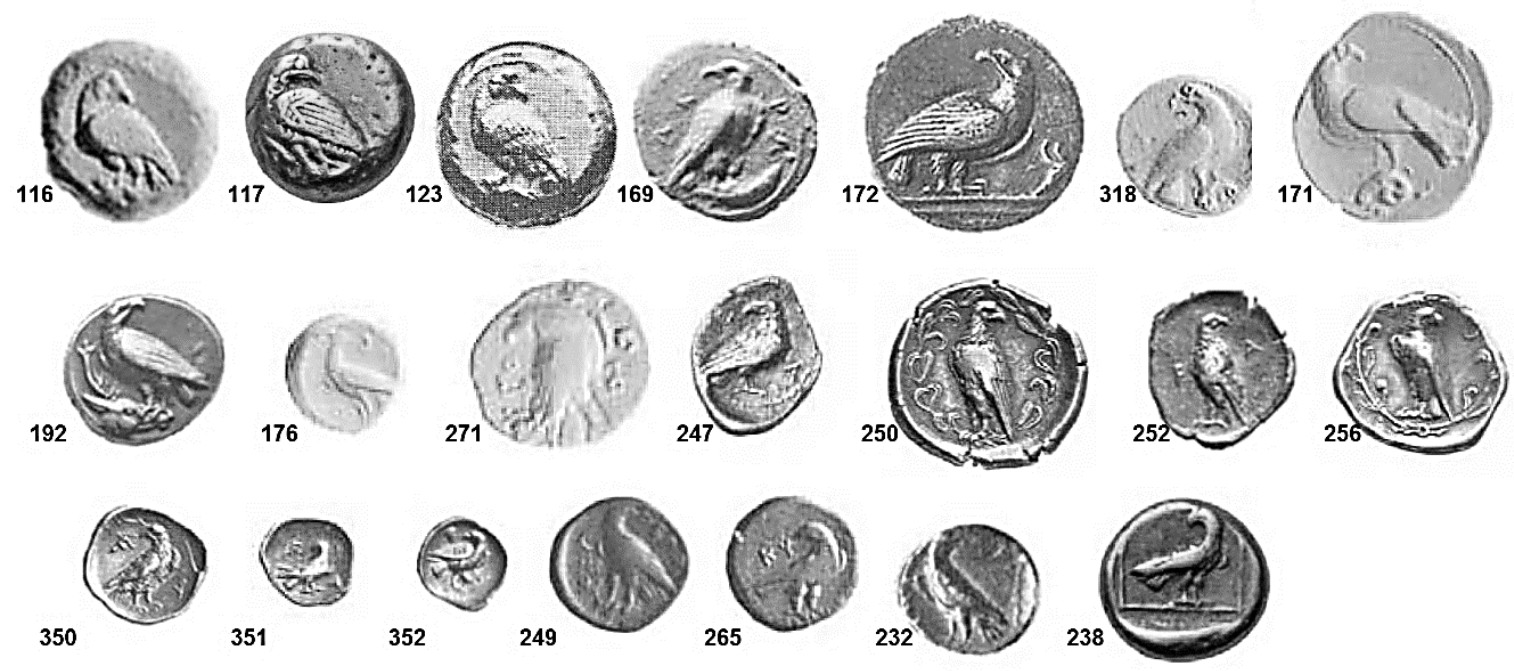

(c) Cabeça para frente e parada sobre a coluna de um capitel jônico: Motya (Antes 415, n.196); Agrigento (460-450, n.143), (450, n.145), (400-380, n.220); hipana (450, n.148); Crotona (c.425-350, n.170), (1 ${ }^{\text {a }}$.met.IV, n.338 c/ cabeça p/ trás); Élis (360, n.345/346), (356, n.347), (352, n.348?), (348, n.353), (348, n.371/372/373), (344, n.354).

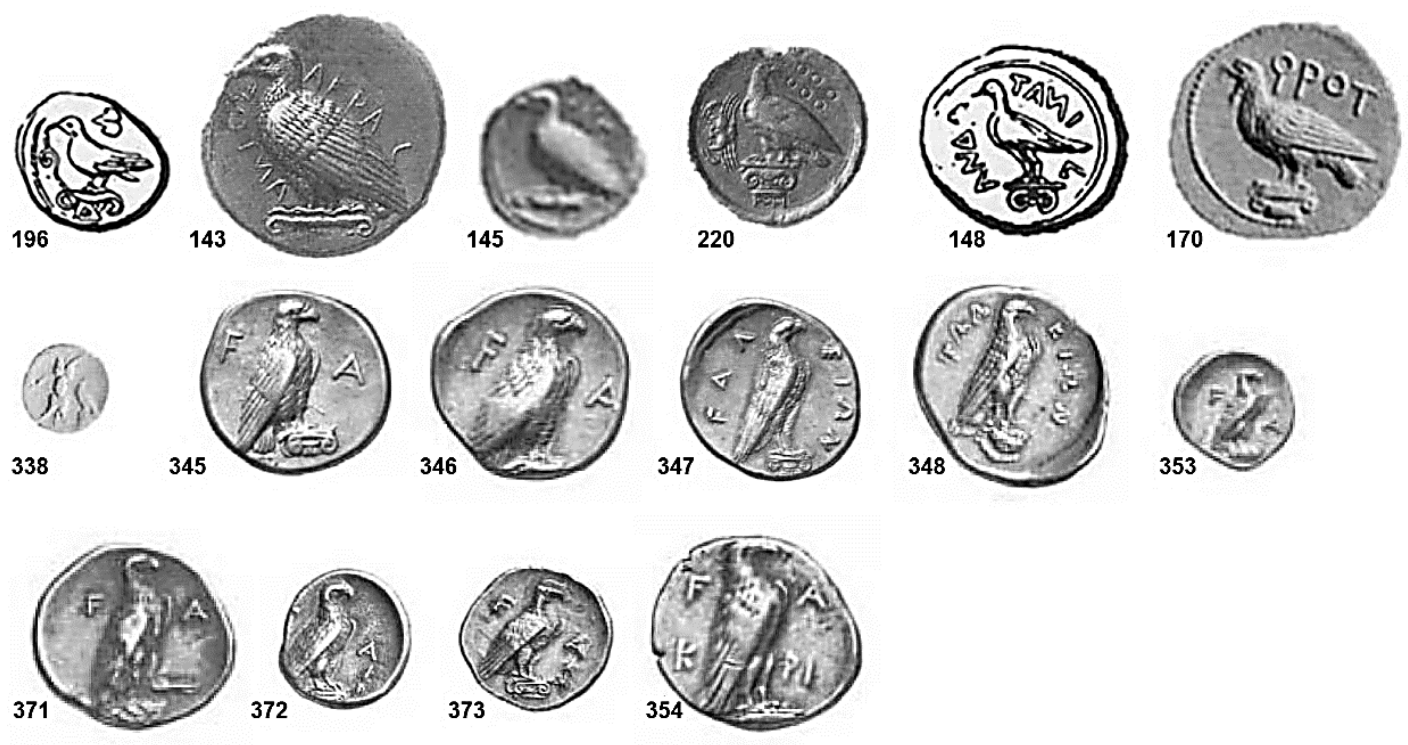


(d) Cabeça para trás e parada sobre a coluna de um capitel jônico: Crotona (c.400-350; n.329).

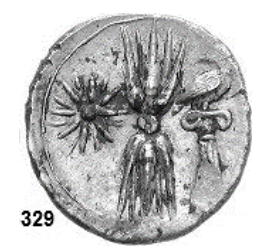

(e) Cabeça para frente e parada sobre um raio: Molossi (c.350, n.339).

339

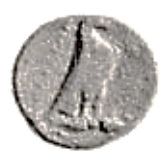

(f) Cabeça para trás e parada sobre um raio: Larissa (c.370-360, n.336).

336

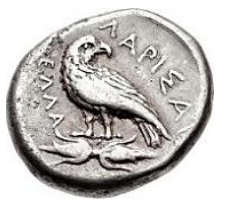

(g) Curvada sobre cobra, bicando-a ou devorando-a: Messana (c.412-408, n.202); Agrigento (c.413-406, n.199); Pydna (c.389-379, n.229); Amyntas III (381-369, n.231); Élis (396, n.330 escudo); Abdera (385-375, n.230).
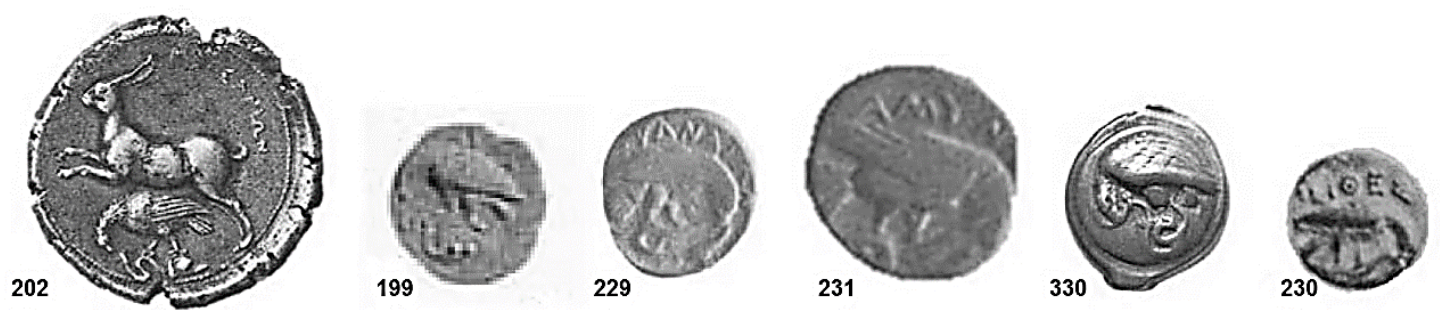

(h) Curvada sobre golfinho, bicando-o ou devorando-o: Istros (c.400, n.218); Ólbia (380-360, no.236).
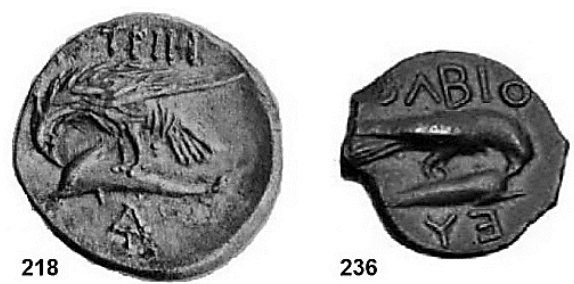
(i) Curvada sobre lebre, bicando-a ou devorando-a: Élis (420, n.321/322).

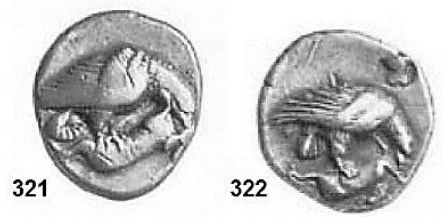

(j) Curvada sobre carneiro, bicando-o ou devorando-o: Élis (388, n.335 escudo).

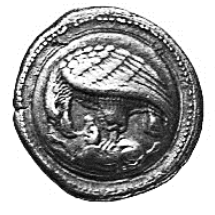

Segundo nos mostra o gráfico 66, 0 sub-padrão foi recorrente em 17 regiões do mundo grego, a saber: Élis, Sicília, Itália do Sul, Trôade, Chipre, Macedônia, Aeolis, Jônia, Mar Negro, Lycia, Rodes, Eubéia, Mysia, Lesbos, Épiro, Tessália e Trácia. Observa-se uma predominância de regiões da porção oriental do mundo grego, na Ásia Menor ou próximas à essa área (Trôade, Chipre, Aeolis, Jônia, Mar Negro, Lycia, Rodes, Mysia e

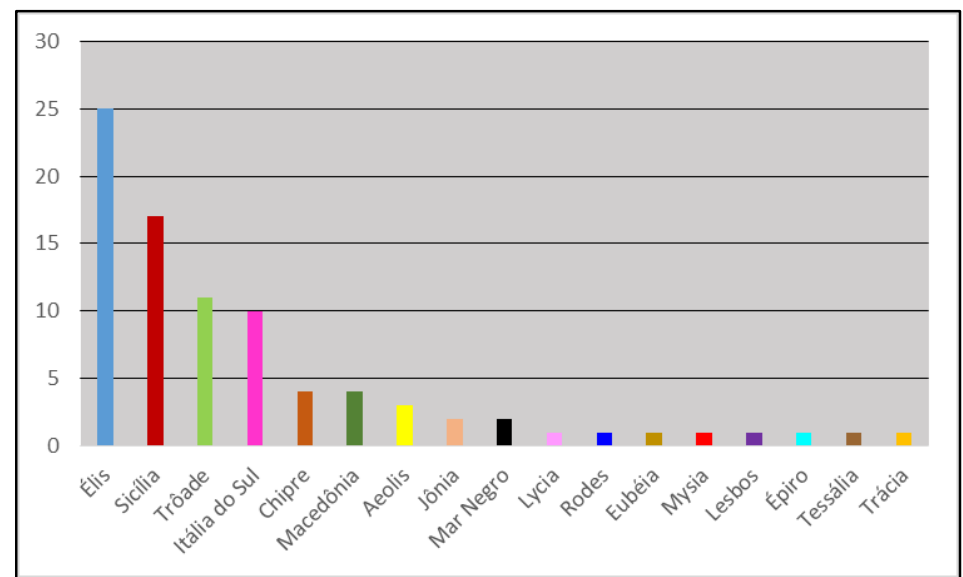

Gráfico 66- Quantidade por regiões de tipos monetários de águias em pé "de asas fechadas" (sécs. VII-IV/III a.C.). Lesbos) e do norte da Grécia Balcânica (Macedônia, Épiro, Tessália e Trácia). Mesmo assim, a maior quantidade de tipos monetários foi encontrada em Élis e no Ocidente grego (Sicília e Itália do Sul). O maior número de tipos monetários da águia em pé "de asas fechadas" foi emitido por Élis (25 tipos no total). A Sicília é a segunda região com a maior concentração de imagens monetárias (17 tipos no total), seguida pela Trôade (11 tipos) e Itália do Sul (10 tipos). Da ilha de Chipre e a Macedônia pertencem cada qual 4 tipos monetários e de Aeolis apenas 3 tipos monetários. Da Jônia e do Mar Negro provêm, cada qual, 2 tipos monetários. As regiões da Lycia, de Rodes, Eubéia, Mysia, Lesbos, Épiro, Tessália e Trácia foram as que menos usaram 0 sub-padrão de representação em relação às demais áreas (cada qual apenas 1 tipo no total).

Foi possível definir 11 variedades dentro do sub-padrão de representação da águia em pé "de asas fechadas", são elas: (a) parada com a cabeça para frente; (b) parada com a cabeça para trás; (c) cabeça para frente e parada sobre a coluna de um capitel jônico; (d) cabeça para trás e parada sobre a coluna de um capitel jônico; (e) cabeça para frente e parada sobre um raio; (f) cabeça para trás e parada sobre um raio; (g) curvada 
sobre cobra, bicando-a ou devorando-a; (h) curvada sobre golfinho, bicando-o ou devorando-o; (i) curvada sobre lebre, bicando-a ou devorando-a; e (j) curvada sobre carneiro, bicando-o ou devorando-o.

\begin{tabular}{|c|c|c|c|c|c|c|c|c|}
\hline Tipo monetário "em pé / de asas fechadas" & VII-VI a.C. VI a.C. & & VI-V a.C. & Va.C. & V-IV a.C. & IV a.C. & IV-III a.C. & Total \\
\hline (a)Parada com a cabeça para frente & 0 & 2 & 0 & 11 & 5 & 14 & 1 & 33 \\
\hline (b)Parada com a cabeça para trás & 0 & 0 & 0 & 3 & 5 & 12 & 1 & 21 \\
\hline (c)Cabeça para frente e parada sobre a coluna de um capitel jônico & 0 & 0 & 0 & 4 & 1 & 11 & 0 & 15 \\
\hline (d)Cabeça para trás e parada sobre a coluna de um capitel jônico & 0 & 0 & 0 & 0 & 0 & 1 & 0 & 1 \\
\hline (e)Cabeça para frente e parada sobre um raio & 0 & 0 & 0 & 0 & 0 & 1 & 0 & 1 \\
\hline (f)Cabeça para trás e parada sobre um raio & 0 & 0 & 0 & 0 & 0 & 1 & 0 & 1 \\
\hline (g)Curvada sobre cobra, bicando-a ou devorando-a & 0 & 0 & 0 & 2 & 0 & 4 & 0 & 6 \\
\hline (h)Curvada sobre golfinho, bicando-o ou devorando-o & 0 & 0 & 0 & 0 & 0 & 2 & 0 & 2 \\
\hline (i)Curvada sobre lebre, bicando-a ou devorando-a & 0 & 0 & 0 & 2 & 0 & 0 & 0 & 2 \\
\hline (j)Curvada sobre carneiro, bicando-o ou devorando-o & 0 & 0 & 0 & 0 & 0 & 1 & 0 & 1 \\
\hline
\end{tabular}

Tabela 20- Variedades dos tipos monetários de águias em pé “de asas fechadas” (sécs. VII-IV/III a.C.).

Como mostra a tabela 20 , a variedade (a) foi aquela utilizada em maior quantidade (33 tipos monetários no total), tendo sido a única usada pela primeira vez no século $\mathrm{VI}$ a.C. (2 tipos no total). No século $\mathrm{V}$ a.C., a variedade (a) passou a ser mais utilizada (11 tipos no total). Entre os séculos V-IV a.C. foram encontrados menos tipos monetários (5 no total), ao passo que no século IV a.C., a variedade atingiu o ápice de seu uso por autoridades emissoras (14 tipos no total), tendo quase entrado em desuso entre os séculos IV-III a.C. (1 tipo no total). A segunda variedade mais utilizada foi a (b) (21 tipos monetários no total), tendo sido usada pela primeira vez no século V a.C. (3 tipos monetários). Entre os séculos V-IV a.C., a quantidade de tipos monetários aumentou (5 tipos no total), atingindo o maior número no século IV a.C. (12 tipos no total). Foi encontrado apenas 1 tipo monetário datado entre os séculos IV-III a.C. A variedade (c), a terceira em quantidade (15 tipos no total), aparece em moedas a partir do século V a.C. (4 tipos no total). Encontrou-se apenas 1 imagem monetária datada dos séculos V-IV a.C. e a maior quantidade concentra-se também no século IV a.C. (11 tipos no total). Não há tipos com essa variedade entre os séculos IV-III a.C. A variedade (g), a quarta mais recorrente, foi usada no século V a.C. (2 tipos no total) e no século IV a.C. (4 tipos). As variedades (h) e (i) aparecem em mesmo número (cada qual 2 tipos monetários). A variedade (e) foi usada somente no século IV (1 tipo monetário), ao passo que a variedade (h) foi usada somente no século IV a.C. (2 tipos no total) e a (i) apenas no século V a.C. (2 tipos no total). As variedades (f) e (j) são as menos recorrentes (cada qual 1 tipo monetário). As variedades (d), (f) e (j) foram usadas somente no século IV a.C.

A variedade (a), a mais numerosa, com a representação da águia em pé de asas fechadas, "parada com a cabeça para frente", teve o tipo monetário mais antigo batido por uma autoridade emissora desconhecida na Jônia entre c.600-550 a.C. (n.103). O segundo e último tipo monetário do século VI a.C. provêm de Agrigento, na Sicília, e é datado de 510 a.C. (n.120). Abydus, na Trôade, parece ter sido a primeira autoridade emissora a emitir tipos monetários dessa variedade no século V a.C., em 500-480 a.C. (n.120 e 125) e depois entre 480450 a.C. (131). Nesse período, entre 480 e 460 a.C. (n.128, 141, 142), Agrigento também emitiu tipos monetários dando continuidade à emissão que iniciou no século VI a.C. Eryx, também na Sicília, emitiu um tipo 
monetário da variedade entre 480-400 a.C. (n.137), muito semelhante ao estilo das águias nas moedas de Agrigento dessa variedade. Paphos, em Chipre, que também possui emissões numerosas dessa variedade, passou a emitir tipos monetários a partir de 450 a.C. (n.147 e 146) até o segundo quartel do século V a.C., em c.425 a.C. (n.344) e 420 a.C. (n.190). Nesse período, em c.420 a.C. (n.189), o rei Kherei, na Lycia, emitiu um tipo monetário dessa variedade em seu nome, Agyrion, na Sicília, bateu uma imagem monetária entre 420-353 a.C. (n.193) e Crotona, na Itália do Sul, bateu um tipo datado entre 425-375 a.C. (n.319). Entre o final do século V e início do século IV a.C., Abydus emitiu três tipos monetários (n.214, n.204 entre 411-387 a.C. e n.228 entre 0 início do século IV-335 a.C.). Motya, na Sicília, e Rodes, na ilha de Rodes, emitiram cada qual dois tipos monetários em 400 a.C. (n.216 e 215 respectivamente) e Cebren, na Trôade, emitiu entre 400-310 a.C. um tipo em que a variedade aparece como tipos secundários. Na primeira metade do século IV a.C. ocorreram uma série de emissões com a variedade. Em 380 a.C., Abydus emitiu um tipo monetário (n.233), entre 369-313 a.C., Cálcis, na Eubéia, bateu uma imagem monetária (n.245), em 360 a.C. Élis emitiu dois tipos (n.251 e 253), dando continuidade nas emissões em 352 a.C. (n.258) e entre 352-348 a.C. (n.349). Na metade do século IV a.C., Cyme usou a variedade em um tipo monetário (n.264). Na segunda metade do século IV a.C., Élis emitiu o seu último tipo monetário dessa variedade, em 348 a.C. (n.267), Siracusa e Agyrion, ambas na Sicília, usaram a variedade como tipo secundário junto ao raio como figura principal, nas emissões de 344 a.C. (n.375 e 374 respectivamente) do período de Timoleonte. De data não definida no século IV a.C. são os tipos monetários de Abydus (n.227) e de Cyzicus (n.272).

Com relação à iconografia das águias em pé e de asas fechadas da variedade (a), trata-se de imagens muito realísticas, tornando possível a identificação das espécies. As diferenças nos desenhos, então, são fruto das variedades de espécies de águias existentes nas 17 regiões onde foram emitidos os tipos monetários. Repara-se que o galhinho com folhas de oliveiras é recorrente no campo das moedas de Paphos (n.147 e 190) e no tipo de Agyrion (n.192), datados quase do mesmo período, embora representados de diferentes maneiras. A coroa de folhas de oliveira, que circunda a imagem da águia em pé, foi usada apenas por Élis em alguns tipos monetários (n.251, 258 e 267). Algumas das águias aparecem em pé sobre um animal ou algum tipo de objeto. Na moeda de Abydus (n.204), a águia é representada sobre um aplustre, na de Cyzicus (n.272) sobre um atum, e na de Crotona (n.319) sobre a cabeça de um carneiro. Esse tipo de imagem da águia em pé de asas fechadas e cabeça para frente aparece na metade do século VI a.C. na estatuária em calcário em Creta (Fig.227) e na cerâmica lacônia entre 530-525 a.C. (Fig.131). Nas moedas, a representação parece ter sido utilizada antes do que em outros tipos de suportes, como os vasos. Esse tipo de representação foi utilizado para figurar sobre o cetro de Zeus na escultura em bronze de Dodona, datada do final do século VI e início do século V a.C. (Fig.228), e na cerâmica ática de 490-480 a.C. (Fig.159). Essa variedade de representação da águia também aparece no início do século $\mathrm{V}$ a.C. em tipos monetários de Zeus sentado no trono de póleis na Sicília, Galária (n.27) e Aetna (n.16/08/09). 
Na variedade (b), a águia é representada em pé, de asas fechadas e parada com a cabeça virada para trás. Os tipos monetários mais antigos provêm de Abydus, na Trôade, de 500 a.C. (n.116 e 117) e de Mileto, na Jônia, de 499-494 a.C. (n.123). Iconograficamente, é preciso dizer, que se trata de tipos monetários muitos semelhantes entre eles, dando a impressão de que pertencem a mesma emissão monetária. No século $V$ a.C., os tipos são datados na maior parte a partir do segundo quartel do século $V$ a.C. Agrigento bateu uma imagem monetária entre 425-406 a.C. (n.169) e Crotona, entre 425-350 a.C. (n.172, 318, 171 e 192) e entre 420-400 a.C. (n.176). Todos os demais tipos monetários são datados a partir da primeira metade do século IV a.C., como os do rei Amyntas III, da Macedônia, de 381-369 a.C. (n.232), de Mytilene em Lesbos de 377-326 a.C. (n.238), de Élis de 368 a.C. (n.247), de 360 a.C. (n.250 e 252), de 356 a.C. (n.256), de 352-348 a.C. (n.350, 351, 352), do rei Perdicas, na Macedônia, de 364-359 a.C. (n.249) e de Cyme em Aeolis de 350-250 a.C. (n.262 e 265). Como na variedade (a), algumas águias aparecem em pé cada um sobre um animal diferente. Na moeda de Abydus (n.116), a águia está sobre uma lebre, na de Agrigento sobre um atum (n.123) e na de Crotona sobre a cabeça de um carneiro (n.318 e 171) e sobre a de um veado (n.192). Em algumas das moedas de Élis da variedade (b) a águia também é circundada por uma coroa de folhas de oliveira (n.250 e 256). Essa representação da águia também aparece em um tipo monetário de Zeus sentado no trono em uma moeda de Cirene (n.69) do século IV a.C.

Na variedade (c), em que a águia é representada com a cabeça para frente e parada sobre a coluna de um capitel jônico, o tipo mais antigo é proveniente de Agrigento, datado entre 460-450 a.C. (n.143). De 450 a.C. também é um segundo tipo de Agrigento (n.145) e de Hipana, também na Sicília (n.148). Do segundo quartel do século V a.C., entre c.425-350 a.C., é datado um tipo monetário de Crotona, na Itália do Sul (n.170) e de antes de 415 a.C. uma imagem monetária de Motya, na Sicília (n.196). No século IV a.C., a variedade foi usada em moedas de Élis a partir de 360 a.C. (n.345 e 346), em 356 a.C. (n.347), em 352 a.C. (n.348), em 348 a.C. $(353,371,372,373)$ e em 344 a.C. (n.354). A variedade também ocorre em Crotona, em um tipo monetário da primeira metade do século IV a.C. (n.338). Observa-se, assim, que essa variedade parece ter origem na Sicília, em Agrigento, circulou entre algumas póleis siceliotas e da Itália do Sul, e foi difundida para Élis, que no século IV a.C. usou a criação em suas moedas. O tema é sempre o mesmo, havendo apenas diferenciações no estilo do desenho das águias e dos capitéis jônicos, parecendo também ser próprio da documentação numismática. Já a variedade (d) refere-se ao mesmo esquema iconográfico da (c), com exceção da posição da cabeça da águia, desenhada virada para trás, como se vê no tipo de Crotona de c.400-350 a.C. (n.329).

Na variedade (e) e (f) a águia é representada pela primeira vez em pé sobre um raio, ocorrendo em emissões a partir do século IV a.C. A variedade (e), com a cabeça para frente e para sobre um raio, foi usada pelos Molossi, no Épiro, em c.350 a.C. (n.339). A variedade (f), com cabeça para trás e parada sobre um raio, possui o tipo monetário mais antigo, de Larissa, na Tessália, datado de c.370-360 a.C. (n.336).

Nas variedades (g), (h), (i) e (j), as águias aparecem retratadas em uma nova maneira: curvada, posição sempre associada a uma presa, uma representação própria do sub-padrão de águias "em pé". Na variedade 
(g), a águia é retratada curvada sobre cobra, bicando-a ou devorando-a. O tipo monetário mais antigo dessa variedade foi emitido por Messana, na Sicília, entre c.430-420 a.C. (n.202), no qual a ave foi usada como tipo secundário ao tipo principal da moeda, uma lebre que dá um salto largo sobre a águia. Do século V a.C., também, data o segundo tipo monetário mais antigo, proveniente da Sicília. Trata-se da moeda de Agrigento de c.413-406 a.C. (n.199). A maior parte dos tipos provêm do século IV a.C., de Élis de 396 a.C. (n.330), de Pydna, na Macedônia, de c.389-379 a.C. (n.229); de Abdera, na Trácia, de 385-375 a.C. (n.236) e de Amyntas III, da Macedônia, de 381-369 a.C. (n.231). Trata-se, assim, de uma variedade própria do norte da Grécia Balcânica, Sicilia e Élis. Dentre estes, destaca-se o tipo monetário de Élis em que a águia é retratada na face de um escudo como o tipo monetário de cabeça de águia para frente e sem presa de 400 a.C. (n.326). Nota-se também a semelhança iconográfica entre os tipos monetários de Pydna, Abdera e Amyntas III, que pode evidenciar uma influência de um desenho sobre o outro, como indica a proximidade geográfica e cronológica dos exemplares. A variedade (i), que tem a águia curvada sobre lebre, bicando-a ou devorando-a, tem apenas dois tipos monetários de Élis, ambos datados de 420 a.C. (n.321 e 322), os mais antigos com a águia curvada, depois da imagem monetária de Messana da variedade $(\mathrm{g})$. Nessas imagens monetárias de Élis, 0 artista quis mostrar o momento em que a ave já dominou a sua presa, a lebre. Nas moedas de Élis desde 468 até 420 a.C., em que a águia tem a lebre como presa, é possível ver, no tempo, quase uma sequência de imagens do momento em que a águia voa com a presa, nas moedas mais antigas - voando com as asas abertas e com asas erguidas nas variedades (f) e (b) de cada sub-padrão - e quando ela já pousou e matou o animal, nas moedas mais recentes. Na variedade (j), a ave aparece representada na face de um escudo, curvada sobre um carneiro, bicando-o ou devorando-o, em um tipo monetário de Élis de 388 a.C. (n.335).

Própria de póleis do Mar Negro, na variedade (h), a ave é retratada curvada sobre um golfinho, bicandoo ou devorando-o, em tipos monetários de Istros de c.400 a.C. (n.218) e de Ólbia de 380-360 a.C. (n.236), que usou o animal marinho pela primeira vez em tipos monetários da águia voando com as duas asas abertas.

\section{DE ASAS ABERTAS (CADA UMA AO LADO DO CORPO)}

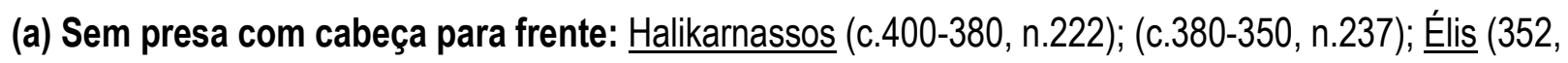
n.257).
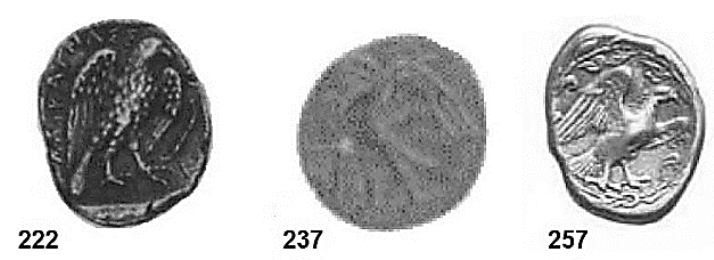
(b) Sem presa com cabeça para trás: Élis (c.432-420, n.317), (380, n.234), (376, n.239), (368, n.248), (344, n.268).
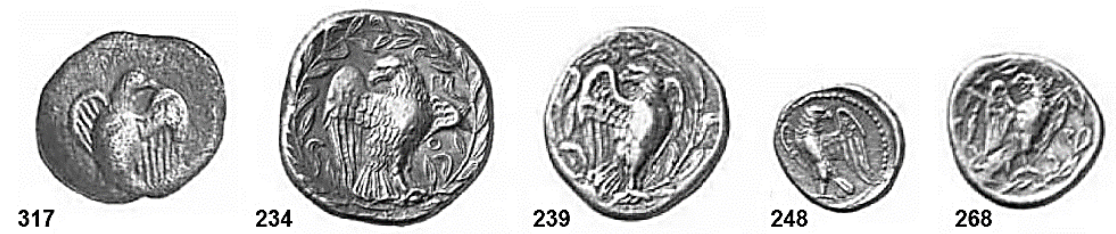

(c) Com presa e com cabeça para trás: Élis (c.432-420s, n.316).

316

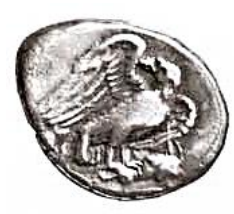

(d) Cabeça para baixo e sobre peixe (?): Agrigento (antes 406, n.209).

209

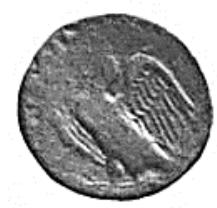

(e) Cabeça para trás sobre cabeça de veado: Élis (344, n.269).

269

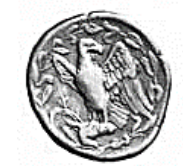

(f) Cabeça para trás e sobre golfinho: Ólbia (350-330, n.260/270); (2ª .met IV, n.261).
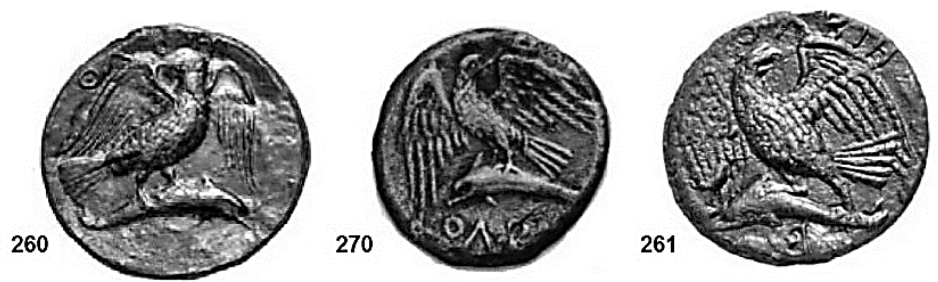
(g) Cabeça erguida e sobre peixe: Agrigento (c.415, n.197).

197

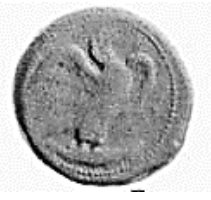

(h) Cabeça erguida e sobre lebre: Agrigento (antes 406, n.208).

208

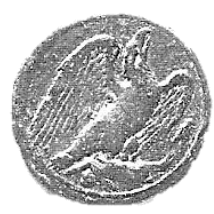

(i) Cabeça para frente com cobra enrolada: Élis (final 420s, n.320).

320

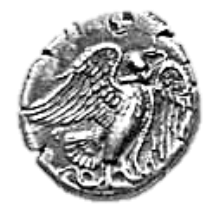

De acordo com o gráfico 67,0 subpadrão de representação foi usado por autoridades emissoras de 4 regiões do mundo grego: Élis, Sicília, Mar Negro e Cária. Predominaram tipos monetários batidos por Élis (9 tipos monetários no total), sendo a Sicília e o Mar Negro as segundas regiões com maior quantidade de imagens monetárias (3 tipos no total). A Cária e a Itália do Sul são as regiões em que menos foi utilizado esse sub-

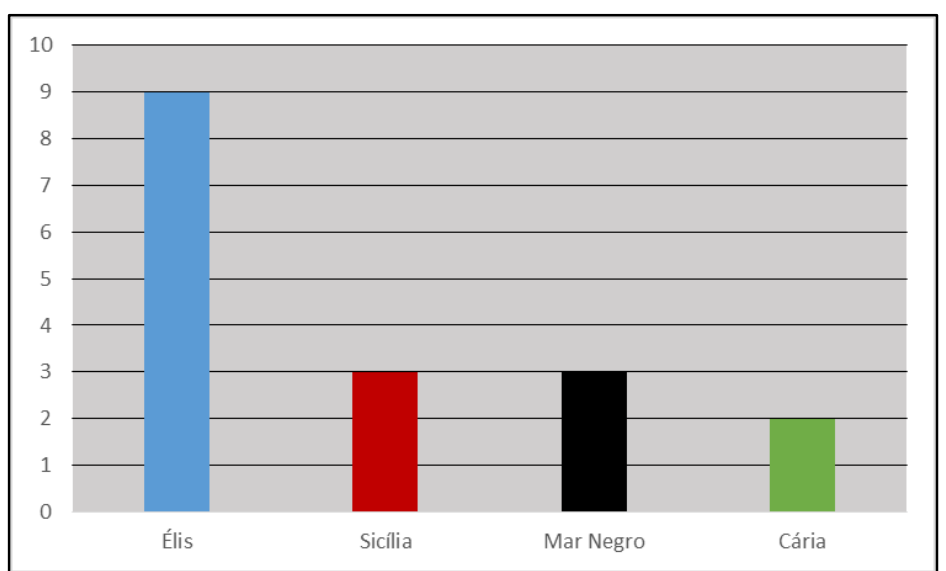

Gráfico 67- Quantidade por regiões de tipos monetários de águias em pé "de asas abertas" (sécs. VII-IV/III a.C.). padrão (cada qual 2 tipos no total). Trata-se de uma quantidade e variedade menor de regiões em relação ao sub-padrão "em pé".

A partir da classificação dos tipos monetários desse sub-padrão, foi possível definir 9 variedades de representação, são elas: (a) sem presa e com cabeça para frente; (b) sem presa com cabeça para trás; (c) com presa e com cabeça para trás; (d) cabeça para baixo e sobre peixe (?);(e) cabeça para trás sobre cabeça de veado; (f) cabeça para trás e sobre golfinho; $(\mathrm{g})$ cabeça erguida e sobre peixe; (h) cabeça erguida e sobre lebre; e (i) cabeça para frente com cobra enrolada. 
A partir da classificação dos tipos monetários desse sub-padrão, foi possível definir 9 variedades de representação, são elas: (a) sem presa e com cabeça para frente; (b) sem presa com cabeça para trás; (c) com presa e com cabeça para trás; (d) cabeça para baixo e sobre peixe (?);(e) cabeça para trás sobre cabeça de veado; (f) cabeça para trás e sobre golfinho; $(g)$ cabeça erguida e sobre peixe; (h) cabeça erguida e sobre lebre; e (i) cabeça para frente com cobra enrolada.

\begin{tabular}{|c|c|c|c|c|c|c|c|c|c|}
\hline Tipo monetário "em pé / de asas abertas" & VII-VI a.C. VI a.C. & & VI-V a.C. & V a.c. & V-IV a.C. & IV a.C. & IV-III a.C. & Total & \\
\hline (a)Sem presa com cabeça para frente & 0 & 0 & 0 & 0 & 0 & & 0 & & 3 \\
\hline (b)Sem presa com cabeça para trás & 0 & 0 & 0 & 1 & 0 & & 0 & & 5 \\
\hline (c)Com presa e com cabeça para trás & 0 & 0 & 0 & 1 & 0 & & 0 & & 1 \\
\hline (d)Cabeça para baixo e sobre peixe (?) & 0 & 0 & 0 & 1 & 0 & & 0 & & 1 \\
\hline (e)Cabeça para trás sobre cabeça de veado & 0 & 0 & 0 & 0 & 0 & & 0 & & 1 \\
\hline (f)Cabeça para trás e sobre golfinho & 0 & 0 & 0 & 0 & 0 & & 0 & & 3 \\
\hline (g)Cabeça erguida e sobre peixe & 0 & 0 & 0 & 1 & 0 & & 0 & & 1 \\
\hline (h)Cabeça erguida e sobre lebre & 0 & 0 & 0 & 1 & 0 & & 0 & & 1 \\
\hline (i)Cabeça para frente com cobra enrolada & 0 & 0 & 0 & 1 & 0 & & 0 & & 1 \\
\hline
\end{tabular}

Tabela 21- Variedades de tipos monetários de águias em pé e “de asas abertas” (sécs. VII-IV/III a.C.).

Conforme mostra a tabela 21 , a variedade (b) é a mais comum (5 tipos monetários no total), tendo sido utilizada a partir do século V a.C. (1 tipo no total) e em maior quantidade no século IV a.C. (4 tipos no total). A variedade (a) foram as segundas mais recorrentes desse sub-padrão de representação, ocorrendo apenas no século IV a.C. (3 tipos no total). A variedade (f) foi a terceira mais usada e somente no século IV a.C. (3 tipos no total). As demais variedades (c), (d), (e), (g), (h), (i) foram as menos utilizadas em moedas gregas (cada qual 1 tipo monetário no total). As variedades (c), (d), (g), (h) e (i) foram usadas somente no século V a.C. e somente a (e) foi usada no século IV a.C.

Da variedade (a), a águia representada em pé, de asas abertas, sem presa e com a cabeça para frente, os tipos monetários mais antigos provêm de Halikarnassos, na Cária, cujos exemplares datam de c.400-380 a.C. (n.222) e 380-350 a.C. (n.237). Os demais, são provenientes de Élis de 352 a.C. (n.257). Repara-se novamente, aqui, com exceção da Cária, uma predominância do Ocidente grego e de Élis no uso das imagens monetárias.

O que distingue a variedade (b) da (a) é a posição da cabeça da águia nas imagens. Na variedade (b), a mais numerosa, a ave é representada em pé com as abertas, sem presa e com a cabeça para trás, tendo sido usada por Élis (em maior número). De acordo com a datação de todos os exemplares do sub-padrão em pé "de asas abertas", um dos tipos monetários mais antigos pertencem a essa variedade, foi batido por Élis entre c.432-420 a.C. (n.317). No século V a.C., esse tipo de representação é visto na cerâmica ática de 500 a.C., onde a águia aparece sobre o cetro de Zeus (Fig.158). Élis continuou a emitir tipos monetárias dessa variedade ao longo do século IV a.C., em 380 a.C. (n.234), em 376 a.C. (n.239), em 368 a.C. (n.248) e em 344 a.C. (n.268). 
A variedade (c), da águia com presa (indefinida) e cabeça para trás, aparece uma única vez nas moedas de Élis de c.432-420 a.C. (n.316). Na imagem da moeda, uma das mais antigas desse sub-padrão, a ave aparece ligeiramente mais reclinada em relação aos demais tipos monetários do sub-padrão de águias em pé com asas abertas. Na variedade (d) a águia é representada com a cabeça para baixo e aparentemente sobre um peixe, apenas em um tipo monetário de Agrigento de antes de 406 a.C. (n.209). Na variedade (e), a águia é retratada em um tipo monetário de Élis de 344 a.C. (n.269) com a cabeça para trás sobre a cabeça de um veado, empoleirada bem na ponta de seu focinho. A imagem da águia é rodeada por uma coroa de folhas de oliveira, como em moedas da variedade (b).

A variedade (f) é própria da área do Mar Negro. A águia é retratada em pé, com as asas abertas, com a cabeça para trás e sobre um golfinho, em três moedas de Ólbia, duas de 350-330 a.C. (n.260 e 270) e uma da segunda metade do século IV a.C. (n.261).

As variedades $(\mathrm{g})$ e (h) dizem respeito a representação da águia com a cabeça erguida em moedas de Agrigento. Na variedade (g), a águia está em pé sobre um peixe em um tipo de Agrigento de c.415 a.C. (n.197), na variedade (h), a ave está sobre uma lebre em um tipo de antes de 406 a.C. (n.208). Na variedade (i), a águia aparece com a cabeça para frente, em pé sobre uma cobra, que puxa pelo bico em um tipo específico de Élis, datado do final da década de 420 a.C. (n.320).

As imagens nas moedas das variedades (d), (f), (g), (h) e (i) passam a ideia de movimento das águias proporcionado pelo desenho das asas, da posição das cabeças, ao contrário do que se observa nas demais variedades desse sub-padrão.

\section{DE ASAS ERGUIDAS (AS DUAS JUNTAS PARA CIMA)}

(a) Sem presa e cabeça para trás: Arquelaos I (413-399, n.201).

201

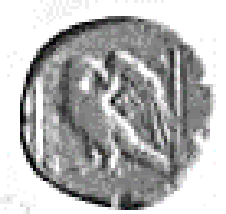

(b) Sem presa e cabeça para frente: Élis (c.432, n.159 garça morta no campo).

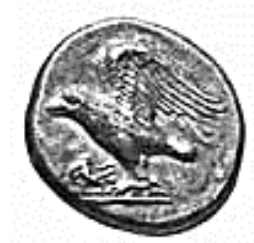


(c) Cabeça para frente e sobre barriga de jumento: Agrigento (c.413-406, n.200).

200

(d) Curvada sobre barriga de uma lebre, bicando-a ou devorando-a: Agrigento (c.420, n.191); (antes 406, n.207).

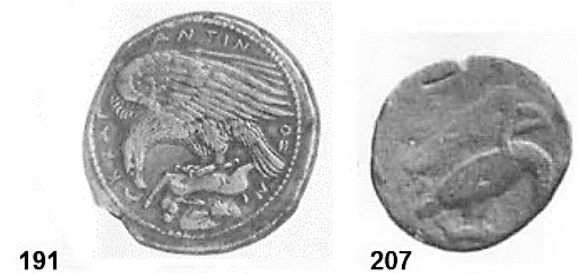

(e) Curvada sobre golfinho, bicando-o ou devorando-o: Ólbia (400-380, n.221), (400-350, n.224).
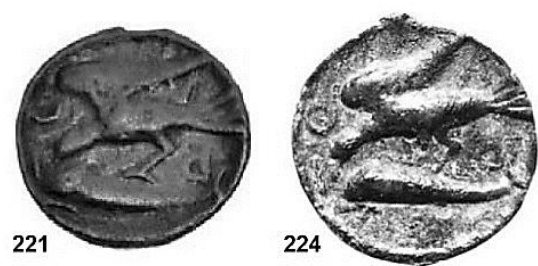

(f) Curvada sobre cobra, bicando-a ou devorando-a: Sparadocus (c.430, n.162).

162

(g) Cabeça erguida e sobre ramo de oliveira: Crotona (c.425-350, n.173); (360-340, n.254 cabeça não tão erguida).
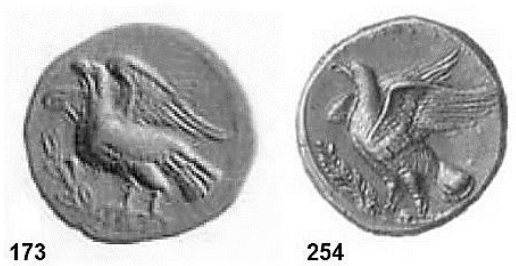
(h) Cabeça para frente e sobre cobra: Élis (c.432, n.313).

313

Conforme 0 gráfico 68 , 0 subpadrão ocorreu em 6 regiões do mundo grego: Itália do Sul, Sicília, Élis, Mar Negro, Macedônia e Trácia. Os tipos monetários foram mais recorrentes na Itália do Sul 6 tipos no total) e na Sicilia (3 tipos no total). Em Élis, no Mar Negro e na Itália do Sul foram encontrados 2 tipos monetários para cada região, ao passo que para a Macedônia e para a Trácia apenas 1 tipo para cada área.

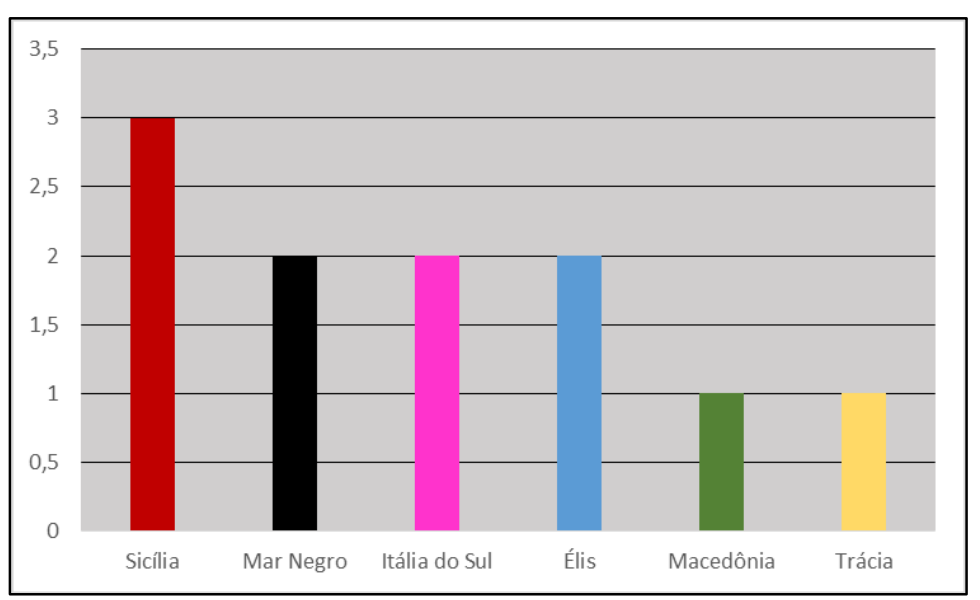

Gráfico 68- Quantidade por regiões de tipos monetários de águias em pé "com asas erguidas" (sécs. VII-IV/III a.C.).

Há 9 variedades de representação do sub-padrão em pé "de asas erguidas", são elas: (a) sem presa e cabeça para trás; (b) sem presa e cabeça para frente; (c) cabeça para frente e sobre barriga de jumento; (d) curvada sobre barriga de uma lebre, bicando-a ou devorando-a; (e) curvada sobre golfinho, bicando-o ou devorando-o; (f) curvada sobre cobra, bicando-a ou devorando-a; (g) cabeça erguida e sobre ramo de oliveira; (h) sobre rocha; e (i) cabeça para frente e sobre cobra. Na tabela 22 é possivel ver quantidade das variedades em relação aos períodos.

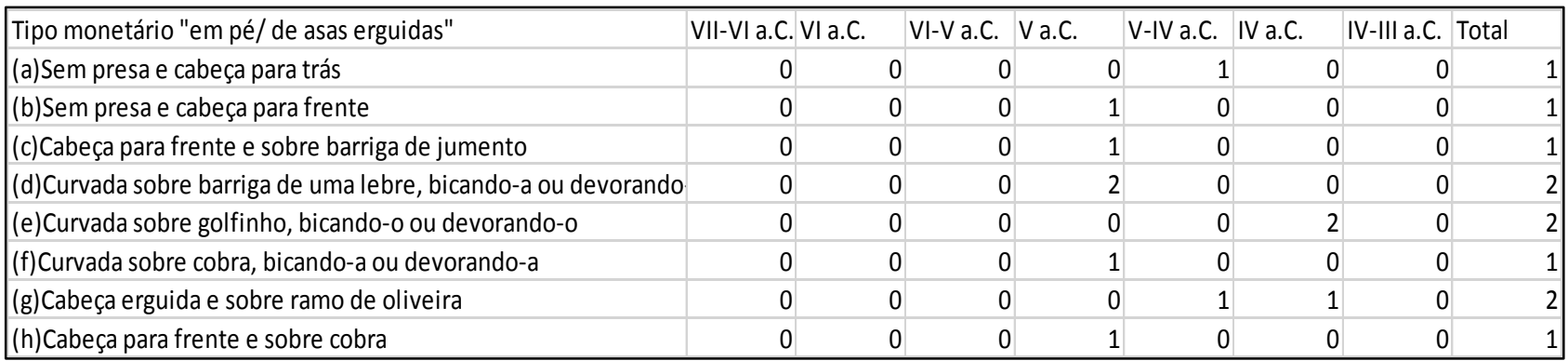

Tabela 22- Variedades de tipos monetários de águias em pé “de asas erguidas" (sécs. VII-IV/III a.C.).

De acordo com a tabela, as variedades (d), (e) e (g) são as mais numerosas (5 tipos monetários no total), tendo sido a (a) usada apenas no século V a.C., a (e) apenas no século IV a.C. e a (g) entre os séculos V e IV a.C. e no século IV a.C. As variedades (a), (e) e (g) possuem cada qual 2 tipos monetários no total. Da variedade (g) há cada qual 1 tipo datado entre os séculos V-IV a.C. e outro datado do século IV a.C. E da variedade (e), há apenas 2 tipos do século IV a.C. As variedades (b), (c), (f), (h) e (i) são as menos numerosas. 
Da variedade (a) há apenas um tipo datado entre os séculos VI-IV a.C. Das variedades (b), (c), (f) e (i) há cada qual 1 tipo monetário datado do século $V$ a.C.

A variedade (a), sem presa e cabeça para trás, aparece em um tipo monetário emitido pelo rei Arquelaos I, na Macedônia, entre 413-399 a.C. (n.201). Da variedade (b), sem presa e cabeça para frente, há apenas 1 tipo monetário de Élis de c.432 a.C. (n.159). Trata-se de um dos tipos mais antigos desse sub-padrão de representação. Esse tipo de representação aparece primeiramente na cerâmica ática de 480-470 a.C., onde a ave é retratada sobre a mão de Zeus no ato de atirar o raio (Fig.153). Essa variedade de representação da águia também pode ser vista em tipos monetários de Zeus em pé atirando o raio cunhados por Élis no século V a.C. (n.342) e por Messênia (n.72), Gomphi (n.89) e Kierion (n.95) no século IV a.C. A variedade também ocorre em imagens monetárias de Zeus sentado no trono, cunhadas pela Liga Arcádia no século V a.C. (n.13, 14, 17, 21, 22, 46) e pela Liga Acaia no século IV a.C. (n.71), e de Zeus ajoelhado ou de cócoras, cunhada por Cyzicus (n.31) entre os séculos V-IV a.C.

Da variedade (c), com cabeça para frente e sobre barriga de jumento, há somente uma imagem monetária de Agrigento de c.413-406 a.C. (n.200). A representação do jumento, como presa, é única nos tipos monetários de águias.

As variedades (d), (e) e (f) retratam a águia de modo curvado sobre diferentes tipos de presas. $\mathrm{Na}$ variedade (d), a águia aparece curvada sobre a barriga de uma lebre, bicando-a ou devorando-a em um tipo monetário de Agrigento, de antes de 420 a.C. (n.191), e de outro de antes de 406 a.C. (n.207). Na variedade (e), a ave é retratada curvada sobre um golfinho, bicando-o ou devorando-o em duas moedas de Ólbia, uma de 400-380 a.C. (n.221) e a outra de 400-350 a.C. (n.224). E na variedade (f), a águia aparece curvada sobre uma cobra, bicando-a ou devorando-a em um tipo de Sparadocus, um rei da Trácia, em 430 a.C. (n.162), um dos tipos mais antigos desse sub-padrão.

Na variedade (g), a águia é retratada de um modo novo: com a cabeça erguida e sobre um ramo de oliveira. Trata-se de uma criação de Crotona, como indica a existência de apenas seus tipos monetários nessa variedade, um tipo de c.425-350 a.C. (n.173) e o outro de 360-340 a.C. (n.254). E na variedade (h), em um tipo de Élis de c.432 a.C. (n.313), a águia aparece com a cabeça para frente e sobre uma cobra, um tipo tão antigo quanto 0 da variedade (b). 
(a) Sobre barriga de lebre, uma com cabeça erguida e asas fechadas e outra curvada com asas erguidas, bicando ou devorando lebre: $\underline{\text { Agrigento }}$ (c.411, n.203).

203

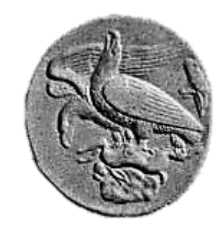

(b) Sobre ônfalo, uma de frente para a outra: Cyzicus (430-415, n.164), (c.410, n.205).

164
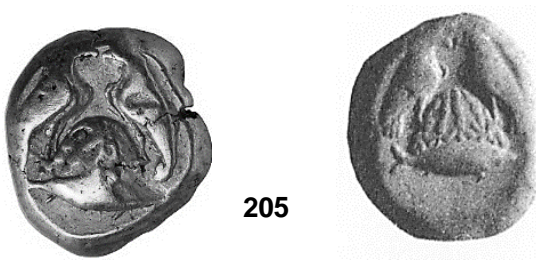

De acordo com o gráfico 69, acerca da quantidade por regiões de tipos monetários de "duas águias" em pé, o sub-padrão foi utilizado apenas na Mysia, em maior quantidade (2 tipos monetários), e na Sicília (1 tipo monetário). Trata-se de uma representação muito restrita regionalmente, comum da segunda metade do século $V$ a.C., pouco usada e quase rara para águias em moedas gregas. Dentro desse sub-padrão, foi estabelecida apenas 2

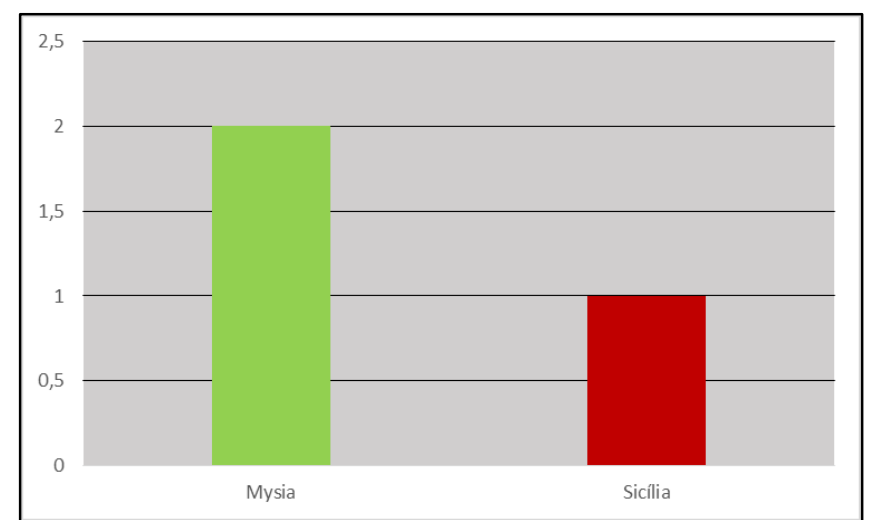

Gráfico 69- Quantidade por regiões de tipos monetários de "duas águias" em pé (sécs. VII-IV/III a.C.).

variedades de representação: (a) sobre barriga de lebre, uma com cabeça erguida e asas fechadas e outra curvada com asas erguidas, bicando ou devorando lebre; e (b) sobre ônfalo, uma de frente para a outra, cuja distribuição com relação aos períodos pode ser vista na tabela 23.

\begin{tabular}{|c|c|c|c|c|c|c|c|c|c|}
\hline Tipo monetário "duas águias" & VII-VIa.C. VIa.C. & & C.C. Va.C. & & .C. & \multicolumn{4}{|c|}{ IV-III a.C. Total } \\
\hline (a)Sobre barriga de lebre, uma com cabeça erguida e asas fechadas e outra curvada com asas erguidas, bicando ou devorando lebre & 0 & 0 & 0 & 1 & 0 & & 0 & 0 & 1 \\
\hline (b)Sobre ônfalo, uma de frente para a outra & 0 & 0 & 0 & 2 & 0 & & 0 & 0 & 2 \\
\hline
\end{tabular}

Tabela 23- Variedades de tipos monetários de "duas águias" em pé (sécs. VII-IV/III a.C.). 
A variedade (b), de duas águias sobre um ônfalo, uma de frente para a outra, foi a mais usada (2 tipos monetários), ambos emitidos por Cyzicus, na Mysia, um entre 430-415 a.C. (n.164) e 0 outro de c.410 a.C. (n.205), as moedas mais antigas desse sub-padrão. 0 atum, embaixo do ônfalo, é próprio das emissões monetárias de Cyzicus. A representação de duas águias, uma de frente a outra, sobre o ônfalo, pode ser uma referência ao mito que conta sobre as duas águias enviadas por Zeus, as quais se encontraram no lugar que se tornaria o santuário de Apolo em Delfos. Na variedade (a), há apenas 1 tipo monetário datado do século $\mathrm{V}$ a.C., de c.411 a.C. (n.203). A imagem monetária traz duas águias sobre a barriga de uma lebre, uma com a cabeça erguida (como a gritar) e asas fechadas, e a outra curvada com asas erguidas, bicando ou devorando o animal. Representar duas águias juntas pode ter indicado um desejo em transmitir algum significado mais forte, já que a representação não era comum em moedas gregas. Vê-se que são inovações de póleis que desde muito cedo, e em emissões numerosas, emitiram tipos monetários da ave. 


\section{ANÁLISE CONTEXTUAL DO SIGNIFICADO SIMBÓLICO DAS IMAGENS DE ZEUS, ÁGUIAS E RAIOS}

Nessa terceira parte do capítulo, discutiremos os significados simbólicos por trás das imagens de Zeus, águias e raios, adquiridos ao longo do período estudado, por meio das descrições nas fontes literárias e das representações tal como aparecem na arte grega, principalmente em vasos. Através dos tipos de narrativas nas fontes literárias, nas cerâmicas pintadas, e da proveniência dos achados em bronze, é nossa intenção, estabelecer um contexto simbólico para os tipos de representações do deus e de seus atributos usados nas moedas gregas entre os séculos VII-IV/III a.C. Conforme a metodologia do LIN (Lexicon Iconographicum Numismaticae), "o significado das imagens se explica com o exame de todos os tipos monetários cunhados por uma cidade colocados em confronto com imagens análogas, presentes em outras moedas ou documentos arqueológicos, estudadas nos diversos contextos em que aparecem" (Caccamo Caltabiano, 1999-2000: 1). Como coloca I. Hodder, "analisar os dados arqueológicos contextuais, nos seus próprios termos, é aproximarse à especificidade dos significados do passado" (Hodder, 1994). De acordo com a análise contextual, "para se chegar ao conteúdo de um significado no passado, deve-se primeiro identificar vários tipos de diferenças e semelhanças relevantes que, por sua vez, formam vários tipos de associações contextuais". "Logo, é possível partir do contexto para, então, se chegar ao significado em termos de função e conteúdo" (Hodder, 1994: 140). Assim, reconstruir o contexto do significado das imagens do deus e de seus atributos, tal como aparecem nas moedas, nos permite acessar a que universo simbólico estavam vinculadas para os antigos gregos. Tal análise é fundamental para nós, já que nas moedas em geral, não dispomos de uma narrativa imagética da forma como ocorre nos vasos. Normalmente, possuímos somente uma imagem principal, associada ou não à imagens secundárias no mesmo campo da moeda. Então, para saber o que significavam devemos reconstruir o contexto a que pertenciam nas artes visuais e nos autores antigos.

$\mathrm{Na}$ associação entre as descrições nas fontes literárias e as representações nas artes figurativas, levaremos em consideração que a correspondência temporal existente entre algumas descrições nos textos e certos padrões de representação em vasos, esculturas, moedas pode indicar uma ideia coletiva presente em um determinado período - nesse caso uma ideia religiosa acerca da concepção de Zeus -a qual pode ter sido apropriada simultaneamente tanto pelos artistas visuais (tanto das ditas artes maiores e quanto das ditas menores) como pelos literários. Ou ainda que certas descrições nos textos antigos, a respeito da divindade, emergiram depois nas artes visuais. Também levaremos em consideração a independência criativa, dos artistas visuais, em relação às descrições literárias acerca de deuses e heróis na composição de temas narrativos em vasos, principalmente (Snodgrass, 2004: 108; 219). 


\section{III.1 ZEUS}

Como vimos na análise iconográfica dos tipos monetários de Zeus, há três padrões principais de representação da divindade em moedas gregas - cabeça, em pé e sentado - os quais encontram correspondência em outros tipos de suportes imagéticos. Os padrões de representação mais comuns tanto no documento monetário como na documentação de vasos e esculturas são aqueles de Zeus em pé e Zeus sentado. A representação da cabeça do deus, que não aparece na cerâmica pintada, é própria da documentação monetária, apesar de ser encontrada, em certa quantidade, em esculturas, inclusive por motivo de fragmentação. Já que buscamos compreender o significado simbólico contido nos tipos de representações usados nas moedas, nos ateremos à análise contextual dos tipos de imagens monetárias que encontram correspondência em vasos, esculturas e em descrições nas fontes literárias, portanto as de Zeus em pé atirando o raio e a de Zeus sentado no trono.

Zeus em pé atirando ou segurando o raio. Em moedas gregas, datadas entre os séculos V-IV/III a.C., o padrão mais comum de representação de Zeus em pé é aquele em que o deus aparece em posição de movimento para atirar o raio (com as pernas abertas, com braço esquerdo estendido e braço direito erguido). Embora seja um padrão também comum às esculturas em bronze do século $\mathrm{V}$ a. C. (estatuetas de Zeus Keraunios), na cerâmica pintada, Zeus em pé é retratado atirando o raio (da mesma maneira como nas moedas) ou segurando o raio, posições sugeridas pelo modo em que a divindade porta o raio em mãos. Para visualizarmos e assim compreendermos melhor a associação entre o padrão de representação e o contexto a que se refere (tema e/ou proveniência), construímos a tabela abaixo: 
Tabela 24- Representações de Zeus em pé atirando ou segurando o raio em vasos e estatuetas (sécs. VII-IV a.C.)

\begin{tabular}{|c|c|c|c|c|c|}
\hline $\begin{array}{c}\text { TIPO DE } \\
\text { REPRESENTAÇÃO }\end{array}$ & DATA & PROVENIÊNCIA & OBJETO & DESCRIÇÃO & $\begin{array}{l}\text { CONTEXTO / } \\
\text { TEMA }\end{array}$ \\
\hline Atirando o raio em pé & c.680 a.C. & Corinto? & $\begin{array}{l}\text { Aríbalo } \\
\text { proto- } \\
\text { coríntio }\end{array}$ & $\begin{array}{l}\text { Zeus segura raio com braço e. } \\
\text { erguido e cetro com a mão d. (luta } \\
\text { contra centauro?) (Fig.114) }\end{array}$ & Centauromaquia? \\
\hline Atirando o raio em pé & c.580 a.C. & $\begin{array}{l}\text { Templo de } \\
\text { Ártemis, Corfu }\end{array}$ & $\begin{array}{l}\text { Relevo do } \\
\text { pedimento } \\
\text { oeste }\end{array}$ & $\begin{array}{l}\text { Zeus segura raio com braço d. } \\
\text { erguido (contra figura ajoelhada) } \\
\text { (Fig.117) }\end{array}$ & $\begin{array}{l}\text { Gigantomaquia } \\
\text { ou Titanomaquia }\end{array}$ \\
\hline Atirando o raio em pé & c.550 a.C. & $\begin{array}{l}\text { Olímpia (de } \\
\text { fabricação } \\
\text { coríntia }\end{array}$ & $\begin{array}{l}\text { Placa de } \\
\text { relevo em } \\
\text { bronze,bra } \\
\text { çadeira de } \\
\text { escudo }\end{array}$ & $\begin{array}{l}\text { Zeus segura raio com braço d. } \\
\text { erguido (luta contra Tifeu) } \\
\text { (Fig.119) }\end{array}$ & Luta contra Tifeu \\
\hline Atirando o raio em pé & c.550 a.C. & $\begin{array}{l}\text { Olímpia (de } \\
\text { fabricação } \\
\text { coríntia) }\end{array}$ & $\begin{array}{l}\text { Placa de } \\
\text { relevo em } \\
\text { bronze,bra } \\
\text { çadeira de } \\
\text { escudo }\end{array}$ & $\begin{array}{l}\text { Zeus segura raio com braço d. } \\
\text { erguido (luta contra Tifeu) } \\
\text { (Fig.120) }\end{array}$ & Luta contra Tifeu \\
\hline Atirando o raio em pé & c.550 a.C. & $\begin{array}{l}\text { Olímpia (de } \\
\text { fabricação } \\
\text { coríntia) }\end{array}$ & $\begin{array}{l}\text { Placa de } \\
\text { relevo em } \\
\text { bronze,bra } \\
\text { çadeira de } \\
\text { escudo }\end{array}$ & $\begin{array}{l}\text { Zeus segura raio com braço d. } \\
\text { erguido (luta contra Tifeu) } \\
\text { (Fig.121) }\end{array}$ & Luta contra Tifeu \\
\hline Atirando o raio em pé & c.540 a.C. & $?$ & $\begin{array}{l}\text { Hídria } \\
\text { calcídica } \\
\text { de figuras } \\
\text { negras }\end{array}$ & $\begin{array}{l}\text { Zeus semi-ajoelhado segura raio } \\
\text { com braço d. erguido (Fig.118) }\end{array}$ & Luta contra Tifeu \\
\hline Atirando o raio em pé & $\begin{array}{l}\text { c. } 540-530 \\
\text { a.c. }\end{array}$ & Itália do Sul & $\begin{array}{l}\text { Placa de } \\
\text { relevo em } \\
\text { prata }\end{array}$ & $\begin{array}{l}\text { Zeus segura raio com braço d. } \\
\text { erguido (Fig.122) }\end{array}$ & Luta contra Tifeu \\
\hline Atirando o raio em pé & $\begin{array}{l}510-500 \\
\text { a.c. }\end{array}$ & $\begin{array}{l}\text { Ugento, Itália } \\
\text { do Sul }\end{array}$ & $\begin{array}{l}\text { Estatueta } \\
\text { de bronze } \\
\text { sobre } \\
\text { coluna }\end{array}$ & $\begin{array}{l}\text { Zeus segura raio com braço d. } \\
\text { erguido (Fig.123) }\end{array}$ & - \\
\hline Atirando o raio em pé & $\begin{array}{l}\text { Início do } \\
\text { séc. V a.C. }\end{array}$ & $\begin{array}{l}\text { Olímpia, } \\
\text { Peloponeso }\end{array}$ & $\begin{array}{l}\text { Estatueta } \\
\text { de bronze }\end{array}$ & $\begin{array}{l}\text { Zeus segura raio com braço d. } \\
\text { erguido (s/águia) (Fig.142) }\end{array}$ & - \\
\hline Atirando o raio em pé & c.490 a.C. & Dodona, Épiro & $\begin{array}{l}\text { Estatueta } \\
\text { de bronze }\end{array}$ & $\begin{array}{l}\text { Zeus segura raio com braço d. } \\
\text { erguido (s/águia) (Fig.134) }\end{array}$ & - \\
\hline Atirando o raio em pé & $\begin{array}{l}\text { c. } 490-480 \\
\text { a.C. }\end{array}$ & Ambrácia, Épiro & $\begin{array}{l}\text { Estatueta } \\
\text { de bronze }\end{array}$ & $\begin{array}{l}\text { Zeus segura raio com braço d. } \\
\text { erguido (c/águia) (Fig.139) }\end{array}$ & - \\
\hline Atirando o raio em pé & c.480 a.C. & $\begin{array}{l}\text { Olímpia, } \\
\text { Peloponeso }\end{array}$ & $\begin{array}{l}\text { Estatueta } \\
\text { de bronze }\end{array}$ & $\begin{array}{l}\text { Zeus segura raio com braço d. } \\
\text { erguido (c/águia) (Fig.141) }\end{array}$ & - \\
\hline Atirando o raio em pé & $\begin{array}{l}\text { c. } 480-470 \\
\text { a.C. }\end{array}$ & Dodona, Épiro & $\begin{array}{l}\text { Estatueta } \\
\text { de bronze }\end{array}$ & $\begin{array}{l}\text { Zeus segura raio com braço d. } \\
\text { erguido (s/águia) (Fig.135) }\end{array}$ & - \\
\hline Atirando o raio em pé & $\begin{array}{l}\text { c. } 470-460 \\
\text { a.C. }\end{array}$ & Dodona, Épiro & $\begin{array}{l}\text { Estatueta } \\
\text { de bronze }\end{array}$ & $\begin{array}{l}\text { Zeus segura raio com braço d. } \\
\text { erguido (s/águia) (Fig.136) }\end{array}$ & - \\
\hline Atirando o raio em pé & $\begin{array}{l}\text { c. } 480-470 \\
\text { a.C. }\end{array}$ & $?$ & $\begin{array}{l}\text { Ânfora } \\
\text { nolana } \\
\text { ática de } \\
\text { figura } \\
\text { vermelha }\end{array}$ & $\begin{array}{l}\text { Zeus segura raio com braço d. } \\
\text { erguido e águia com braço e. } \\
\text { estendido (Fig.153) }\end{array}$ & Gigantomaquia \\
\hline Atirando o raio em pé & $\begin{array}{l}\text { c. } 470-460 \\
\text { a.c. }\end{array}$ & $?$ & $\begin{array}{l}\text { Ânfora } \\
\text { ática de } \\
\text { figuras } \\
\text { vermelhas }\end{array}$ & $\begin{array}{l}\text { Zeus segura raio com braço d. } \\
\text { erguido e cetro com braço e } \\
\text { estendido (Fig.149) }\end{array}$ & Gigantomaquia \\
\hline Atirando o raio em pé & c.460 a.C. & $?$ & $\begin{array}{l}\text { Ânfora } \\
\text { nolana } \\
\text { ática de } \\
\text { figura } \\
\text { vermelha }\end{array}$ & $\begin{array}{l}\text { Zeus segura raio com braço d. } \\
\text { erguido e cetro com braço e } \\
\text { estendido (Fig.150) }\end{array}$ & $?$ \\
\hline
\end{tabular}




\begin{tabular}{|c|c|c|c|c|c|}
\hline Atirando o raio em pé & c.460 a.C. & $?$ & $\begin{array}{l}\text { Cratera } \\
\text { ática de } \\
\text { figuras } \\
\text { vermelhas }\end{array}$ & $\begin{array}{l}\text { Zeus segura raio (alado) com braço } \\
\text { d. erguido (luta contra Egina) } \\
\text { (Fig.154) }\end{array}$ & Captura de Egina \\
\hline Atirando o raio em pé & $\begin{array}{l}\text { 1à. met. } \\
\text { séc. V a.C. }\end{array}$ & $\begin{array}{l}\text { Mt. Lykaion, } \\
\text { Arcádia, } \\
\text { Peloponeso }\end{array}$ & $\begin{array}{l}\text { Estatueta } \\
\text { de bronze }\end{array}$ & $\begin{array}{l}\text { Zeus segura raio com braço d. } \\
\text { erguido (s/águia) (Fig.140) }\end{array}$ & - \\
\hline Atirando o raio em pé & c.430 a.C. & $\begin{array}{l}\text { Entre Leontino } \\
\text { e Siracusa, } \\
\text { Sicília }\end{array}$ & $\begin{array}{l}\text { Relevo em } \\
\text { estrigilo de } \\
\text { bronze }\end{array}$ & $\begin{array}{l}\text { Zeus segura raio com braço d. } \\
\text { erguido (c/águia) (Fig.143) }\end{array}$ & - \\
\hline Atirando o raio em pé & c. $410-400$ & $?$ & $\begin{array}{l}\text { Cálice ático } \\
\text { de figuras } \\
\text { vermelhas }\end{array}$ & $\begin{array}{l}\text { Zeus segura raio com braço d. } \\
\text { erguido e cetro com braço e } \\
\text { estendido (luta contra Porphyrion) } \\
\text { (Fig.151) }\end{array}$ & Gigantomaquia? \\
\hline Atirando o raio em pé & $\begin{array}{l}\text { c. } 400-390 \\
\text { a.C. }\end{array}$ & $?$ & $\begin{array}{l}\text { Ânfora } \\
\text { ática de } \\
\text { figuras } \\
\text { vermelhas }\end{array}$ & $\begin{array}{l}\text { Zeus segura raio com braço d. } \\
\text { erguido e cetro com braço e. } \\
\text { (Fig.152) }\end{array}$ & $?$ \\
\hline $\begin{array}{l}\text { Segurando o raio em } \\
\text { pé }\end{array}$ & 700 a.C. & $\begin{array}{l}\text { Cemitério de } \\
\text { Fortetsa, } \\
\text { Cnossos, Creta }\end{array}$ & Pithos & $\begin{array}{l}\text { Zeus segura raio com mão d., } \\
\text { braço abaixado ao longo do corpo } \\
\text { (Fig.113) }\end{array}$ & $\begin{array}{l}\text { A presença de um } \\
\text { trípode, e de uma } \\
\text { figura feminina } \\
\text { (Gê?) que sai da } \\
\text { terra embaixo } \\
\text { dele, indica } \\
\text { relação de Zeus } \\
\text { com oráculos. }\end{array}$ \\
\hline $\begin{array}{l}\text { Segurando o raio em } \\
\text { pé }\end{array}$ & VII a.C. & $\begin{array}{l}\text { Mt. Lykaion, } \\
\text { Arcádia, } \\
\text { Peloponeso }\end{array}$ & $\begin{array}{l}\text { Estatueta } \\
\text { de bronze }\end{array}$ & $\begin{array}{l}\text { Zeus Keraunios (c/ águia), pernas } \\
\text { fechadas, com braço erguido e } \\
\text { estendido (Fig.124) }\end{array}$ & - \\
\hline $\begin{array}{l}\text { Segurando o raio em } \\
\text { pé }\end{array}$ & c.480 a.C. & $?$ & $\begin{array}{l}\text { Ânfora } \\
\text { panatenaica } \\
\text { de figuras } \\
\text { vermelhas }\end{array}$ & $\begin{array}{l}\text { Zeus segura raio com braço e. } \\
\text { erguido e cetro com braço d. } \\
\text { erguido (Fig.147) }\end{array}$ & $?$ \\
\hline $\begin{array}{l}\text { Segurando o raio em } \\
\text { pé }\end{array}$ & c.470 a.C. & $?$ & $\begin{array}{l}\text { Lécito } \\
\text { ático de } \\
\text { fundo } \\
\text { branco }\end{array}$ & $\begin{array}{l}\text { Zeus com as pernas abertas, } \\
\text { segura raio com o braço e. } \\
\text { estendido e tridente com o braço } \\
\text { d. (Fig.156) }\end{array}$ & $?$ \\
\hline $\begin{array}{l}\text { Segurando o raio em } \\
\text { pé }\end{array}$ & c.470 a.C. & ? & $\begin{array}{l}\text { Cálice- } \\
\text { cratera } \\
\text { ática de } \\
\text { figuras } \\
\text { vermelhas }\end{array}$ & $\begin{array}{l}\text { Zeus com pernas abertas segura } \\
\text { raio com a mão e. e cetro com o } \\
\text { braço d. (Fig.198) }\end{array}$ & $?$ \\
\hline $\begin{array}{l}\text { Segurando o raio em } \\
\text { pé }\end{array}$ & c.470 a.C. & $?$ & $\begin{array}{l}\text { Lécito } \\
\text { ático de } \\
\text { figuras } \\
\text { vermelhas }\end{array}$ & $\begin{array}{l}\text { Zeus com pernas fechadas segura } \\
\text { raio com braço e. e cetro com o d. } \\
\text { (Fig.199) }\end{array}$ & $?$ \\
\hline $\begin{array}{l}\text { Segurando o raio em } \\
\text { pé }\end{array}$ & $\begin{array}{l}\text { c. } 460-450 \\
\text { a.c. }\end{array}$ & $?$ & $\begin{array}{l}\text { Ânfora } \\
\text { ática de } \\
\text { figuras } \\
\text { vermelhas }\end{array}$ & $\begin{array}{l}\text { Zeus com pernas abertas segura } \\
\text { raio com braço e. e cetro com o d. } \\
\text { (Fig.200) }\end{array}$ & $?$ \\
\hline
\end{tabular}

Como se percebe a partir da exposição dos dados na tabela 24, para a análise contextual das representações não dispomos das proveniências dos vasos (o contexto de seu achado) e, na maior parte dos casos, do tema da cena em que Zeus se insere. Esse é o problema das representações em que o deus é representado sem estar envolvido numa cena complexa, numa narrativa, como ocorre nas ânforas nolanas, por exemplo. Infelizmente, as descrições dos vasos no LIMC não fornecem nem a proveniência e nem o restante das imagens que aparecem no vaso. As descrições são restritas àquelas cenas em que Zeus participa, ou seja, às que podem ser descritas pelas fotografias que constam no verbete a respeito da divindade. 
Entre os séculos VII-VI a.C., a representação de Zeus em pé atirando o raio esteve vinculada, na arte figurativa, aos temas da Titanomaquia, da Gigantomaquia, da luta contra o monstro Tifeu e da Centauromaquia na cerâmica pintada (proto-coríntia e calcídica), na arquitetura templária (relevo do pedimento do templo de Ártemis em Corfu), em objetos votivos provenientes da Itália do Sul (relevo em placa de prata) e de Olímpia (placas de relevo em bronze de braçadeiras de escudos). Nota-se que a vinculação desse tipo de representação com esses episódios míticos circulava em diversas partes do mundo grego, parecendo não ser restrita a uma área específica ou a um suporte imagético específico. $O$ tema da Gigantomaquia apareceu novamente no final do século $V$ e início do século IV a.C. na cerâmica ática. A representação de Zeus em pé atirando o raio, embora tenha sido preponderante nos vasos do período arcaico, reapareceu na cerâmica ática vinculada a outro tema de narrativa. Perto da primeira metade do século $V$ a.C., a representação é usada dentro do tema da Captura de Egina, narrativa circunscrita aos vasos áticos desse período. De acordo com K. Arafat e C. Morgan, "nos vasos áticos podem ser encontradas alusões às realizações atenienses, como é o caso da vitória de Atenas sobre Egina em 458 a.C., refletida em cenas de Zeus capturando a ninfa epônima da ilha" (Arafat; Morgan, 1995: 109).

Para entendermos o sentido da Titanomaquia e da luta de Zeus contra Tifeu, devemos nos voltar à leitura da Teogonia de Hesíodo, onde estes mitos estão descritos. De acordo com a descrição de Hesíodo, a Titanomaquia (vv.617-719) foi a batalha final entre os deuses olímpios, liderados por Zeus, e os Titãs (também imortais filhos de Urano e Gaia) que, após dez anos de lutas, decidiria qual geração de deuses teria o domínio sobre o universo. Ao final, os deuses olímpios consolidam o seu domínio e poder e os Titãs são presos no Tártaro. Na narrativa da batalha, desenha-se a figura de Zeus como o atirador de raios:

Do céu e do Olimpo relampejando [Zeus] avançava sempre, os raios com trovões e relâmpagos juntos voavam do grosso braço (vv.689-692) / apesar de fortes, cegava-os nos olhos o brilhar fulgurante do raio e do relâmpago (vv.698-699) / o trovão, o relâmpago e o raio flamante, dardos de Zeus grande, levavam alarido e voz ao meio das frentes, estrondo imenso erguia-se da discórdia atroz. Mostrava-se o poder dos braços. A batalha decai (vv.707-711).

Já na batalha contra Tifeu (vv.820-880), Zeus enfrenta o monstro sem a ajuda dos demais imortais, como Cotos, Briareu e Giges, fundamentais na derrota dos Titãs. Conforme a narrativa de Hesíodo, Tifeu foi um monstro concebido por Gaia após o fim da batalha contra os Titãs e o último adversário de Zeus à época do início do mundo e do poder dos olímpios. Era um ser demoníaco representante das forças primordiais dos ventos maléficos e do fogo destruidor (Touchefeu-Meynier, 1997: 147). Na narrativa da luta, a figura de Zeus como atirador de raios se consolida ao vencer o monstro e enviá-lo ao Tártaro:

Zeus encrista seu furor, agarra as armas, o trovão, o relâmpago e o raio flamante, e fere-o saltando do Olimpo. Fulmina em torno todas as cabeças divinas do terrivel prodígio. E ao dominá-lo açoitando-o com os golpes mutila e abate-o, e geme a terra prodigiosa (vv.853-858).

Conforme a leitura de J. Torrano da Teogonia, os inimigos vencidos de Zeus são excluídos do lúcido e bem ordenado tempo do deus, porque a própria natureza deles pertence a uma temporalidade de outra natureza 
que a de Zeus. "Esses inimigos, forças que são da violência e da desordem, não são compatíveis com o tempo regular, organizado e cíclico que, sob o nome de Horas, Zeus gerou unido a Têmis" (Torrano, 1986: 68).

Ao contrário da Titanomaquia e da luta contra Tifeu, a Gigantomaquia não é narrada por Hesíodo na Teogonia. O autor antigo menciona somente a origem dos Gigantes ("rútilos nas armas e com lanças nas mãos") no sangue salpicado de Urano, no episódio quando é castrado por Cronos (Teogonia, 185-186). Conforme W. Burkert, o mito da Gigantomaquia não pode ser atribuído com segurança a nenhuma fonte literária antiga conhecida, provavelmente foi um poema épico perdido que descrevia a guerra entre os Gigantes e os deuses olímpios pela supremacia do cosmos (Burkert, 1993: 258). Há apenas menções esparsas aos Gigantes em Homero (Odisséia 7,58-60) e à Gigantomaquia em Xenófanes (21, B1). Apolodoro (1, 34-38) é a principal fonte literária a respeito. No século VI a.C., principalmente, a luta entre os deuses e os Gigantes foi um tema preponderante na cerâmica ática, onde é retratada por duelos individuais entre deuses olímpios sempre triunfantes, utilizando cada qual a sua arma (Burkert, 1993: 258). No duelo é salientado o papel de Héracles que, combatendo contra os Gigantes pela constituição do cosmos de Zeus, cumpre uma grande ação entre os imortais (Valenza-Mele, 1979: 24). "Os episódios da Gigantomaquia foram mais requisitados em Atenas durante o tempo de Pisístrato" (Valenza-Mele, 1979: 26). Para Valenza-Mele, "a política de Pisístrato, que pretendia pôr em ordem o desordenado mundo político ateniense, bem se aproxima a uma cosmogonia e a uma vitória de Zeus sobre os Gigantes, última etapa antes de instaurar a ordem no mundo" (Valenza-Mele, 1979: 27).

Dos quatro temas, aquele a que a representação de Zeus em pé atirando o raio aparece vinculado na cerâmica pintada, a Centauromaquia, parece ter sido o menos utilizado ou até mesmo não associado à divindade. De acordo com Tiverios, a cena contendo a imagem de Zeus no aríbalo proto-coríntio de 680 a.C., em confronto com uma figura metade homem e metade cavalo, parece indicar um Centauro, embora não haja um episódio preservado na tradição literária envolvendo Zeus na Centauromaquia tessália. A sua conclusão é a de que Zeus, na imagem desse vaso, intervém em uma disputa entre um único Centauro e um herói, que podia ser um dos favoritos do deus - novamente "um episódio não mencionado nos textos antigos" (Tiverios, 1997: 317). De todo modo, os Centauros eram monstros e o seu enfrentamento por Zeus possui também o significado de ordenação do cosmo ante o caos, da luta entre monstros e a humanidade, entre a civilização e o mundo bárbaro. Os mitos da Titanomaquia, do enfretamento de Zeus contra Tifeu, da Gigantomaquia e ainda da Centauromaquia expressam a luta dos deuses olímpios contra os inimigos da ordem divina. Para os gregos, "o desenvolvimento do cosmos fora do caos, da forma de confusão, foi percebido como uma das características elementares da vida, o princípio organizador da sociedade humana" (Schefold, 1992: 50).

É nesse contexto, portanto, que devemos analisar o significado das imagens de Zeus em pé atirando o raio que foram usadas por determinadas cidades gregas em suas moedas nos séculos $V$ e IV a.C. A inserção desse tipo de representação dentro da narrativa de tais episódios míticos, descritos nas fontes literárias e nas artes visuais, revelada principalmente na pintura vascular, propicia um contexto preciso que nos permite acessar o seu significado perante os gregos. Assim, podemos dizer que a imagem de Zeus em pé atirando o 
raio expressa um deus guerreiro em ação de luta pela imposição da ordem sobre o caos, portanto de liberação da violência e da desordem no cosmos. De acordo com J.-P. Vernant e W. Burkert, Zeus era o fundador da ordem, onde havia uma ordem protetora, o deus estava presente (Vernant, 2006: 34-36; Burkert, 1993: 261).

A esse significado principal e maior subjacente a esse tipo de representação de Zeus - a imposição da ordem sobre o caos -, estão associadas também as ideias de guerra, vitória e competição, que, por sua vez, estão profundamente inter-relacionadas na cultura grega antiga ${ }^{10}$. A esse respeito, então, a proveniência das estatuetas de Zeus Keraunios datadas a partir de 480 a.C., bem como dos relevos em placas de bronze, contendo tais representações, nos confirmam essas associações. Algumas das estatuetas e dos relevos em bronze são provenientes de Olímpia, santuário interestadual que tinha uma função destacada na esfera agonística e também militar11 desde ao menos o século VIII a.C. com o oráculo de Zeus Olímpio, o qual exercia um papel nas soluções para problemas prementes de guerra a partir desse período (Valavanis, 2004: 47). Em Olímpia, a memorialização de conflitos militares através da dedicação de despojos de guerra (tropaia), próximo ao estádio, era uma característica regular do santuário até o século VI a.C. (Scott, 2010: 169). É desse contexto de tropaia, portanto, que provêm as imagens gravadas de Zeus em pé atirando o raio, em luta contra Tifeu, em relevos pertencentes às braçadeiras de escudos de bronze dedicado ao deus. A representação que simboliza guerra, vitória e luta foi usada para ornar um equipamento defensivo, bélico. É nesse contexto, também, que estátuas de Zeus eram dedicadas por todo o santuário principalmente para representar vitórias militares, mas também nos jogos, e as estatuetas de Zeus Keraunios tornaram-se um padrão de dedicação no século V a.C. (Himmelmann, 2001: 158; Scott, 2010: 172). A proveniência dessas outras classes de objetos arqueológicos confirma, assim, o significado simbólico da imagem de Zeus em pé atirando o raio com a esfera militar, de disputa bélica ou atlética, de busca pela vitória, um sucesso na guerra ou em algum nível em competição.

Se a representação de Zeus em pé atirando o raio expressa ação dentro de episódios míticos específicos e são encontradas tanto na arte grega em geral quanto nas moedas, aquela do deus em pé segurando o raio é encontrada em bem menor grau na documentação numismática (com uso restrito apenas como tipo secundário em moedas de Corinto), sendo predominante nas cerâmicas pintadas. Nesse tipo de representação, a figura de Zeus pode até manifestar algum tipo de ação, sinalizada pela posição das pernas abertas e posição dos braços, embora o ato de atirar não exista, já que a divindade apenas porta o raio. Em

\footnotetext{
10 Os textos antigos nos fornecem uma série de evidências a esse respeito. Nos poemas homéricos, disputas atléticas e batalhas encontram-se freqüentemente combinadas; óbvios exemplos incluem os jogos fúnebres para Pátroclo, na llíada, e a competição do arco, que resulta em um combate mortal na Odisséia. Píndaro (Ist. 1.51-53) declara que vitoriosos em guerra e atletas recebem os mesmos prêmios e elogia atletas vitoriosos usando uma linguagem homérica e elegíaca, geralmente reservada para a aclamação de guerreiros (Barringer, 2005: 228-229). Finalmente e ainda mais reveladora, é a notícia de Pausânias (V, 20.2) de que as coroas de folhas de oliveira concedidas aos campeões olímpicos eram mantidas no templo de Hera em uma mesa juntamente com imagens, dentre as quais uma que personificava o Ágon e outra Ares, o deus da guerra e pai de Enomau (Barringer, 2005: 229).

${ }^{11}$ A tradição mítica sobre a origem dos jogos olímpicos nos informa sobre como a função militar de Olímpia esteve presente nas origens míticas dos jogos conservadas em duas odes de Píndaro. Na segunda Ode Olímpica (2.1-5) o poeta diz que Héracles estabeleceu os jogos como primícias de guerra e na décima Olímpica (10. 24) proclama que o herói fundou os jogos com os espólios da derrota de Áugias.
} 
contraste às representações de Zeus em pé atirando o raio, essas em que aparece segurando-o não há a informação do contexto / tema das representações para podermos situar a que tipo de episódios míticos estariam relacionadas. Apenas a imagem na cerâmica mais antiga, o pithos de Cnossos, pode ser inserida dentro de uma narrativa, uma cena maior. Os demais vasos possuem a representação de Zeus sem estar associada a uma cena. No pithos, a presença de um trípode e da figura que emerge da terra debaixo dele, interpretada como Gaia, denotam algum oráculo. Nesse sentido, a presença de Zeus na cena lhe associa a algum episódio ou evento oracular (Tiverios, 1997: 316-317). Sabemos como desde ao menos o final da Idade do Ferro, Zeus exercia uma função oracular nos santuários interestaduais de Olímpia e Dodona.

Mesmo na ausência de um contexto preciso das imagens vasculares, acreditamos que nesse tipo de representação, a posição de Zeus segurar, e de não atirar, indique o raio como um atributo do deus, sinalize a figura da divindade em diferenciação às das demais, podendo ter sido também um recurso dos pintores para apenas caracterizar Zeus. Obviamente, subjacente à representação de Zeus em pé segurando o raio esteve os mesmos significados da representação discutidos anteriormente. A imagem de Zeus como sua arma primordial, para os gregos antigos, evocava imagens de narrativas míticas antigas, de luta com monstros e imortais pela ordem no caos.

Zeus sentado no trono. Em moedas gregas, datadas entre os séculos V-IV/III a.C., o padrão de representação mais comum de Zeus sentado é aquele em que o deus é retratado sentado no trono. Esse padrão também é comum às cerâmicas pintadas e à estatuária, embora em menor grau. Como na documentação numismática, nos vasos o deus é retratado sentado em seu trono segurando o seu cetro e/ou 0 raio ou ainda atirando o raio. A tabela na sequência traz esses tipos de representação em vasos e esculturas, quando possível relacionadas ao seu contexto / tema: 
Tabela 25- Representações de Zeus sentado no trono em vasos e estatuetas (sécs. VI-IV a.C.)

\begin{tabular}{|c|c|c|c|c|c|}
\hline $\begin{array}{c}\text { TIPO DE } \\
\text { REPRESENTAÇÃO }\end{array}$ & DATA & PROVENIÊNCIA & OBJETO & DESCRIÇÃO & CONTEXTO / TEMA \\
\hline $\begin{array}{l}\text { Atirando o raio } \\
\text { sentado }\end{array}$ & c.560 a.C. & $?$ & $\begin{array}{l}\text { Cálice ático de figuras } \\
\text { negras }\end{array}$ & $\begin{array}{l}\text { Zeus segura raio com o } \\
\text { braço d. erguido (contra } \\
\text { Hefesto) (Fig.127) }\end{array}$ & $\begin{array}{l}\text { Nascimento de } \\
\text { Atena }\end{array}$ \\
\hline $\begin{array}{l}\text { Atirando o raio } \\
\text { sentado }\end{array}$ & VI a.C. & Desconhecida & Estatueta de bronze & $\begin{array}{l}\text { Zeus segura raio com } \\
\text { braço d. erguido } \\
\text { (s/águia) (Fig.131) }\end{array}$ & - \\
\hline $\begin{array}{l}\text { Segurando o raio } \\
\text { sentado }\end{array}$ & $\begin{array}{l}\text { c.570-565 } \\
\text { a.C. }\end{array}$ & $?$ & $\begin{array}{l}\text { Trípode kothon ático de } \\
\text { figuras negras }\end{array}$ & $\begin{array}{l}\text { Zeus segura raio com a } \\
\text { mão e. e cetro com a d. } \\
\text { (Fig.125) }\end{array}$ & $\begin{array}{l}\text { Nascimento de } \\
\text { Atena }\end{array}$ \\
\hline $\begin{array}{l}\text { Segurando o raio } \\
\text { sentado }\end{array}$ & $\begin{array}{l}\text { c. } 570-560 \\
\text { a.C. }\end{array}$ & $?$ & $\begin{array}{l}\text { Ânfora ática de figuras } \\
\text { negras }\end{array}$ & $\begin{array}{l}\text { Zeus segura raio com a } \\
\text { mão e. (Fig.126) }\end{array}$ & $\begin{array}{l}\text { Nascimento de } \\
\text { Atena }\end{array}$ \\
\hline $\begin{array}{l}\text { Segurando o raio } \\
\text { sentado }\end{array}$ & c.540 a.C. & $?$ & $\begin{array}{l}\text { Ânfora ática de figuras } \\
\text { negras }\end{array}$ & $\begin{array}{l}\text { Zeus segura raio com } \\
\text { mão d. (Fig.125) }\end{array}$ & $\begin{array}{l}\text { Nascimento de } \\
\text { Atena }\end{array}$ \\
\hline $\begin{array}{l}\text { Segurando o raio } \\
\text { sentado }\end{array}$ & $\begin{array}{l}\text { c. } 530-520 \\
\text { a.C. }\end{array}$ & $\begin{array}{l}\text { Mt. Lykaion, } \\
\text { Arcádia, } \\
\text { Peloponeso }\end{array}$ & Estatueta de bronze & $\begin{array}{l}\text { Zeus segura dois raios, } \\
\text { um com cada mão } \\
\text { (Fig.128) }\end{array}$ & - \\
\hline $\begin{array}{l}\text { Segurando o raio } \\
\text { sentado }\end{array}$ & c.520 a.C. & $?$ & $\begin{array}{l}\text { Cálice ático de figuras } \\
\text { vermelhas }\end{array}$ & $\begin{array}{l}\text { Zeus segura raio com } \\
\text { mão e. e taça com a } \\
\text { mão d. (Fig.157) }\end{array}$ & $\begin{array}{l}\text { Ganimedes } \\
\text { servindo vinho a } \\
\text { Zeus }\end{array}$ \\
\hline $\begin{array}{l}\text { Segurando o raio } \\
\text { sentado }\end{array}$ & c.500 a.C. & $?$ & $\begin{array}{l}\text { Ânfora ática de figuras } \\
\text { vermelhas }\end{array}$ & $\begin{array}{l}\text { Zeus segura raio com } \\
\text { mão d. e braço abaixado } \\
\text { e cetro com mão e. com } \\
\text { águia sobre (Fig.158) }\end{array}$ & $\begin{array}{l}\text { Reunião dos } \\
\text { deuses no } \\
\text { Olimpo }\end{array}$ \\
\hline $\begin{array}{l}\text { Segurando o raio } \\
\text { sentado }\end{array}$ & $\begin{array}{l}\text { c. } 475-425 \\
\text { a.C. }\end{array}$ & $?$ & $\begin{array}{l}\text { Cratera ática de figuras } \\
\text { vermelhas }\end{array}$ & $\begin{array}{l}\text { Zeus segura raio e cetro } \\
\text { com braço e. e taça com } \\
\text { braço d. (Fig.196) }\end{array}$ & $?$ \\
\hline $\begin{array}{l}\text { Segurando o raio } \\
\text { sentado }\end{array}$ & $\begin{array}{l}\text { c. } 360-350 \\
\text { a.C. }\end{array}$ & $?$ & $\begin{array}{l}\text { Cântaro-rhyton ápulo de } \\
\text { figuras vermelhas }\end{array}$ & $\begin{array}{l}\text { Zeus segura raio com } \\
\text { braço d. estendido e } \\
\text { cetro com o braço e. } \\
\text { (Fig.209) }\end{array}$ & Iliopersis \\
\hline $\begin{array}{l}\text { Com o cetro } \\
\text { sentado }\end{array}$ & c.560 a.C. & ? & $\begin{array}{l}\text { Cálice ático de figuras } \\
\text { negras }\end{array}$ & $\begin{array}{l}\text { Zeus segura cetro com a } \\
\text { mão d. (Fig.129) }\end{array}$ & $\begin{array}{l}\text { Apresentação de } \\
\text { Héracles ao } \\
\text { Olimpo }\end{array}$ \\
\hline $\begin{array}{l}\text { Com o cetro } \\
\text { sentado }\end{array}$ & $\begin{array}{l}\text { c. } 490-480 \\
\text { a.C. }\end{array}$ & $?$ & $\begin{array}{l}\text { Cratera ática de figuras } \\
\text { vermelhas }\end{array}$ & $\begin{array}{l}\text { Zeus segura taça com a } \\
\text { mão d. e cetro com } \\
\text { águia com a e. (Fig.159) }\end{array}$ & $\begin{array}{l}\text { Ganimedes } \\
\text { servindo vinho a } \\
\text { Zeus }\end{array}$ \\
\hline $\begin{array}{l}\text { Com o cetro } \\
\text { sentado }\end{array}$ & c.480 a.C. & $?$ & $\begin{array}{l}\text { Cálice ático de figuras } \\
\text { vermelhas }\end{array}$ & $\begin{array}{l}\text { Zeus segura taça com a } \\
\text { mão d. e cetro com a e. } \\
\text { (Fig.160) }\end{array}$ & $\begin{array}{l}\text { Ganimedes } \\
\text { servindo vinho a } \\
\text { Zeus }\end{array}$ \\
\hline $\begin{array}{l}\text { Com o cetro } \\
\text { sentado }\end{array}$ & $\begin{array}{l}\text { c. } 450-400 \\
\text { a.C. }\end{array}$ & $?$ & $\begin{array}{l}\text { Pyxis ático de figuras } \\
\text { vermelhas }\end{array}$ & $\begin{array}{l}\text { Zeus segura cetro com } \\
\text { mão d. (Fig.162) }\end{array}$ & Zeus e Hera \\
\hline $\begin{array}{l}\text { Com o cetro } \\
\text { sentado }\end{array}$ & $\begin{array}{l}\text { c. } 405-385 \\
\text { a.C. }\end{array}$ & $?$ & $\begin{array}{l}\text { Cratera ápula de figuras } \\
\text { vermelhas }\end{array}$ & $\begin{array}{l}\text { Zeus segura cetro com } \\
\text { mão e. (Fig.161) }\end{array}$ & $\begin{array}{l}\text { Nascimento de } \\
\text { Dioniso }\end{array}$ \\
\hline $\begin{array}{l}\text { Com o cetro } \\
\text { sentado }\end{array}$ & c.400 a.C. & $?$ & $\begin{array}{l}\text { Cratera ática de figuras } \\
\text { vermelhas }\end{array}$ & $\begin{array}{l}\text { Zeus segura cetro com a } \\
\text { mão e. (Fig.163) }\end{array}$ & $\begin{array}{l}\text { Zeus, Hera e } \\
\text { Atena }\end{array}$ \\
\hline $\begin{array}{l}\text { Com o cetro } \\
\text { sentado }\end{array}$ & $\begin{array}{l}\text { c. } 400-380 \\
\text { a.C. }\end{array}$ & $?$ & $\begin{array}{l}\text { Cratera ápula de figuras } \\
\text { vermelhas }\end{array}$ & $\begin{array}{l}\text { Zeus segura cetro com } \\
\text { Nike com a mão d. } \\
\text { (Fig.164) }\end{array}$ & $\begin{array}{l}\text { Europa } \\
\text { suplicando pela } \\
\text { vida de Sarpedon }\end{array}$ \\
\hline $\begin{array}{l}\text { Com o cetro } \\
\text { sentado }\end{array}$ & $\begin{array}{l}\text { c. } 350-340 \\
\text { a.C. }\end{array}$ & $?$ & $\begin{array}{l}\text { Loutróphoros ápulo de } \\
\text { figuras vermelhas }\end{array}$ & $\begin{array}{l}\text { Zeus segura cetro com } \\
\text { mão d. (Fig.165) }\end{array}$ & Zeus e Afrodite \\
\hline
\end{tabular}

Como se observa na tabela 25 , dispomos de mais informações sobre o contexto / tema de representação de Zeus sentado no trono nas cerâmicas pintadas. Nota-se também a maior variedade de temas narrativos relacionados a essa representação. Repara-se que esses temas são próprios de certos períodos. Típico do século VI a.C., o tema do Nascimento de Atena em vasos áticos esteve mais relacionado às representações de Zeus sentado no trono atirando ou segurando o raio em comparação aos demais temas. A 
presença do raio na mão de Zeus sentado no trono não é tão comum para os temas de Ganimedes servindo vinho a Zeus, Reunião dos deuses do Olimpo e da lliupersis. O uso do raio está completamente ausente das representações dos demais temas em que Zeus sentado no trono aparece segurando somente o cetro, predominantemente do século V a.C., tais como a Apresentação de Héracles ao Olimpo, Zeus e Hera, Nascimento de Dioniso, Zeus, Hera e Atena, Europa suplicando pela vida de Sarpedon e Zeus e Afrodite.

De acordo com K. Schefold, o tema do Nascimento de Atena, tão popular na cerâmica ática do século VI a.C., não expressou somente a ligação entre Atena, patrona da cidade de Atenas, com seu pai (Schefold, 1992: 7-8). A representação do nascimento da cabeça de Zeus enfatiza os poderes criativos da mente em oposição aos poderes da natureza (Schefold, 1992: 9). Para o estudo comparativo com a documentação numismática, levantamos apenas representações em que Atena está nascendo da cabeça de Zeus, mas há outras em vasos do período em que a deusa já nasceu e está de pé próxima ao pai12. Interessante notar que nas imagens vasculares, nas quais Atena está nascendo de Zeus, o deus segura o raio, já naquela em que Atena já nasceu, o deus não porta o raio na representação. É possível que a presença do raio na mão do deus, nessa narrativa específica, sinalize o momento do nascimento de Atena, deusa de característica guerreira. Nesse aspecto, em algumas dessas representações, a deusa sai da cabeça de Zeus com o escudo em mãos. Lembremos que, de acordo com o mito, Zeus teria sentido dores de cabeça e Atena nascido após o deus ter sido golpeado por um machado de Hefesto. Nesse sentido, Zeus sentado no trono atirando ou segurando 0 raio conserva o significado de arma do deus, cujo sentido veremos mais adiante na análise contextual e simbólica do raio.

Na cerâmica ática, o segundo tema mais recorrente, no qual se insere a representação de Zeus sentado no trono, é aquele de Ganimedes servindo vinho a Zeus, próprio do final do século VI e início do século V a.C. Conforme explica J. Barringer, Zeus e Ganimedes era "um protótipo para o relacionamento pederasta verdadeiro, por isso vemos tal tema, na maior parte das vezes, figurar em taças do final do período arcaico e início do período clássico relacionadas ao contexto do simpósio, onde a pederastia foi parte integrante" (Barringer, 2001: s/página).

Da variedade de temas relacionados à representação de Zeus sentado no trono, percebe-se que todos trazem cenas vinculadas ao ambiente do Olimpo, onde o deus residia em seu trono, na companhia do demais deuses, e comandava a vida de mortais e imortais. A esse respeito, são as fontes literárias que melhor descrevem a atuação de Zeus quando sentado em seu trono.

Na Teogonia de Hesíodo não há nenhuma menção ao trono e Zeus. Em Homero, na llíada, possuímos as referências mais antigas a respeito do tipo de poder que o deus exercia sentado em seu trono. De seu trono, Zeus exercia o poder sobre o Olimpo (Ilíada VIII, 443-444) e comandava o destino dos imortais e mortais, como diz a passagem sobre Ájax: Então Zeus pai de seu alto trono incutiu medo no coração de Ájax (Ilíada XI, 544).

\footnotetext{
12 Ver nesse caso Schefold, 1992, p.15, fig.7, no capitulo The birth of Athena.
} 
Se possuímos as primeiras referências a esse respeito na poesia de Homero, é a partir dos autores do teatro trágico ateniense do século $V$ a.C. que podemos acessar as descrições mais importantes que caracterizam a atuação de Zeus sentado no trono no alto do Olimpo. Nas Suplicantes de Ésquilo também encontramos trechos a esse respeito:

De suas esperanças muito elevadas, ele lança a humanidade para a destruição; no entanto, ele não ordena qualquer violência armada - tudo que é feito pelo poder divino está livre de labuta. Sentado em seu trono sagrado, imóvel de forma misteriosa ele realiza a sua vontade (Suplicantes, 96-100).

Ele não senta em seu trono por mandato de outro e sustém seu domínio embaixo de um mais poderoso. Ninguém se senta acima dele, cujo poder ele mantém em temor. Ele fala e é feito - ele se apressa para executar o que quer que sua mente aconselhadora conceba (Suplicantes, 595).

De acordo com Ésquilo, o destino dos homens depende da vontade de Zeus. Também vemos em Eurípides tal característica de poder além do apelo dos mortais que era esperado chegar até o deus no Olimpo:

Mas Zeus, que vê claramente de seu trono no céu, trouxe outro destino (...) (Helena, 1315).

Oh terra, oh lua que fica no alto a noite toda, oh raios brilhantes do deus que traz a luz aos mortais, carregue a mensagem, eu peço! Eleve sua mensagem para o céu, ao trono de Zeus (...) (Héracles, 748750).

Já Sófocles nos fornece um trecho em que associa o poder da Justiça ao poder de Zeus, colocando-a ao lado do trono do deus:

(...) a Justiça senta-se ao lado de Zeus para compartilhar seu trono através da sanção de leis primordiais (Édipo em Colono, 1380).

Com outra natureza de texto literário, Demóstenes, orador ateniense do século IV a.C., também nos deixou uma comparação muito semelhante à de Sófocles, mas agora em relação à Deusa da Ordem:

[Deusa da Ordem] senta ao lado do trono de Zeus e oriente todos os trabalhos dos homens (Contra Aristogiton 1, 25, 11).

Diferente do caso das representações de Zeus em pé atirando o raio, cujas representações são inseridas em narrativas míticas específicas nos vasos ou na arte em geral, e que associadas aos textos nos fornecem o contexto do significado desse tipo de imagem de Zeus, as representações de Zeus sentado no trono nos vasos são mais variadas, abertas a episódios míticos variados. Por essa razão, nessa análise do significado simbólico da imagem de Zeus sentado no trono, consideraremos principalmente as descrições apresentadas nas fontes literárias.

Portanto, a nosso ver, enquanto o tipo de Zeus em pé atirando o raio associa-se à luta, à guerra, à vitória sobre inimigos difíceis e, sobretudo, à ordem sobre o caos, a representação de Zeus sentado no trono significou para os antigos gregos, soberania, governo, controle, vigilância e decisão de Zeus sobre a vida dos homens. Sentado no trono, Zeus podia observar e receber as súplicas humanas e determinar o destino humano. Do alto do trono podia enviar seus desígnios aos mortais. Assim como Zeus poderia dirigir a vida dos homens, 
também poderia determinar as decisões da cidade, dos cidadãos. Lembremos que Zeus era tido como 0 supervisor da ordem e dos sistemas políticos e legais da pólis (Larson, 2007: 19).

Nesse contexto, a representação de Zeus sentado no trono em moedas gregas pode ter significado um pedido de controle de Zeus sobre a pólis, que pode ter sido mais importante em algum momento político específico. A sua representação na moeda sentado sobre o trono pode ter funcionado como uma fixação de energia em relação à manutenção da ordem, ou sobre a desordem e sua ameaça - 0 enfrentamento de algum tipo de inimigo, uma situação de instabilidade política, etc. Zeus tem o poder de instaurar a vitória sobre o caos, apaziguá-lo, instaurar a ordem que seja mais importante para a cidade. Embora com significados a princípio diferentes, percebe-se que, ao final, o significado dos dois tipos de representação se cruzam, são interrelacionáveis, associáveis.

Se pensarmos no significado simbólico contido na cena da Captura de Egina por Zeus na cerâmica ática, veremos que os atenienses quiseram se colocar, se representar na figura de Zeus, um deus sempre vencedor e também instaurador da ordem. Os atenienses usaram da figura do deus para mostrar vitória sobre um inimigo ou uma situação desfavorável. Assim também podemos pensar as representações de Zeus nas moedas cunhadas pelas cidades gregas em geral, como veremos no próximo capítulo.

É preciso lembrar que os significados contidos nessas imagens, aqui examinados e contextualizados, requeridos pela cidade grega por motivos específicos, muito provavelmente, podem ter se somado a outros por influência de uma história regional, da existência de um culto local a Zeus em uma dada região, cidade e ainda por situações históricas de um dado período. Todos esses significados específicos serão considerados na interpretação das imagens monetárias dentro do contexto da respectiva autoridade emissora.

\section{III.2 O RAIO}

Da análise iconográfica das moedas, vimos que o raio foi representado em moedas gregas de duas maneiras: em composição com a figura de Zeus (em sua mão ou ao lado do deus) e como figura principal, ocupando todo o campo da moeda. Ele passou a ser representado dessa última maneira, em moedas gregas, somente a partir do início do século V a.C. O contexto de representação do raio na arte grega e nas fontes literárias é dado pelas descrições dos textos e pelas representações de Zeus na arte, as quais examinamos nas páginas anteriores. Aqui nos ateremos à análise do raio como arma de Zeus e ao seu significado simbólico tal como podemos apreender dos textos antigos - consideraremos até aqueles datados do século $\mathrm{V}$ a.C., contemporâneos as primeiras representações monetárias.

Nas narrativas míticas de luta de Zeus contra forças cósmicas, o raio é protagonista. É de conhecimento comum que Zeus usou o raio sempre quando tinha que lutar contra adversários cósmicos ou quando procurava punir a arrogância humana (Bremer, 2006-2007: 22). É Hesíodo, na Teogonia, que primeiro relata como o raio teria se tornado a arma de Zeus: 
[Zeus] livrou das terriveis prisões os tios paternos Brontes, Esteropes e Arges de violento ânimo, filhos de Urano a quem o pai em desvario prendeu; e eles lembrados da graça benéfica deram-lhe o trovão, o raio flamante e o relâmpago que antes Gaia prodigiosa cobria (vv.505-509).

Segundo uma leitura de J. Torrano acerca desse trecho, a tradução dos nomes dos Ciclopes - Brontes, Esteropes e Arges - os revela como sendo não só os fabricantes e forjadores das armas de soberania de Zeus, mas as próprias armas, trovão, relâmpago e raio. Eles são os artífices da vitória de Zeus, já que é com esses instrumentos de triunfo que Zeus assegura a sua vitória sobre os Titãs e o monstro Tifeu (Torrano, 1986: 92).

Em Homero, as cenas de batalhas cósmicas com Zeus atirando raios, tal como conhecemos de Hesíodo, são completamente ausentes: quer mostrar dramas humanos na narrativa épica, não havendo espaço para lutas entre deuses, Titãs e monstros. Seu foco poético está no efeito do raio sobre o homem comum: seu impacto brutal e repentino (Bremer, 2006-2007: 25). Assim, na llíada (XIV, 414-419), Ájax atinge o peito de Heitor com uma enorme rocha e Heitor cai ao chão (Bremer, 2006-2007: 25-26). No trecho, Homero compara o golpe sofrido por Heitor com o efeito do raio de Zeus:

Tal como, sob a violência do raio de Zeus, veio abaixo carvalho gigante, espalhando ao redor cheiro forte de enxofre - dificilmente a coragem manter conseguiria quem perto dele, nessa hora, se achasse, que o raio de Zeus é terrível - o robustíssimo Heitor, desse modo rolou na poeira.

Já na Odisséia (XII, 417-421), o efeito do raio é descrito no episódio após os homens de Odisseu terem feito um banquete com a carne das vacas sagradas ao deus Hélio depois da passagem do estreito de Silas e Caribide. Hélio reclama a Zeus e o deus pune a tripulação do herói com uma tempestade no mar. Narra Odisseu:

Então em um momento, Zeus trovejou e atingiu o barco com um raio. Todo o barco cambaleou pelo golpe, alastrando-se vapores de enxofre. Meus homens foram arremessados para fora do barco, lançados ao redor do casco preto como gaivotas nas ondas. Os céus negaram-lhe o sonhado regresso.

O sentido do raio como arma de Zeus, tal como descrito na poesia épica de Hesíodo e Homero, se conservou nos textos dos autores teatro ateniense do século $V$ a.C. Em Ésquilo, por exemplo, vemos sua imaginação trabalhar nas linhas desenhas por Hesíodo: Zeus usa sua arma cósmica para punir e aniquilar seus adversários (Bremer, 2006-2007: 25). Em Ésquilo, vemos particularmente ressaltado o poder de destruição do raio. Abaixo, seguem os trechos mais significativos de algumas de suas peças a esse respeito:

Um ardente raio viria de Zeus, que destruiria completamente toda a raça (Prometeu Acorrentado, v.665).

Eu confio que o raio portador do fogo virá justamente a ele e, quando vier, não haverá nada mais do que o calor do sol do meio dia (Sete contra Tebas, vv.440-445).

Possa Zeus atingi-los com seu raio fora dos muros e destruí-los (Sete contra Tebas, v.630).

$O$ caráter de arma infalível, cuja destruição leva à morte, aparece em um trecho de Sófocles:

O raio alado de Zeus me levará logo para o Hades (Édipo em Colono, v.1460). 
O sentido de arma de Zeus também aparece em outros autores, que comparam o raio a tipos de armas. Aristófanes, em As Aves, compara o raio a uma seta: raio, seta alada de Zeus (v.1714). A mesma associação aparece antes na épica de Baquílides $(8,25)$, no seguinte trecho: Zeus, cuja lança é o raio.

Dos trechos encontrados acerca da descrição do raio nos autores antigos, nota-se a associação do raio com o fogo, com seu aspecto ardente e chamejante, o qual vemos retratado nas artes visuais (em vasos e moedas). Píndaro na Ode Pítica $(I, 5)$ chama o raio de guerreiro de fogo eterno. Como vimos, Ésquilo o nomeia de portador do fogo em Sete contra Tebas (vv.440-445). Homero, na llíada (VIII, 94) já descrevia o raio como ardente, sendo seguido na descrição séculos mais tarde por Ésquilo em Prometeu Acorrentado (v.665). E por fim, Aristófanes, em As Aves (1745), define o raio como chamejante de Zeus. Essa associação do raio com o fogo vai ao encontro da teoria de Cook acerca dos traços da flor de lótus na representação do raio na arte grega em geral (Cook, II: 771-772 e 774). A associação da flor de lótus à criação da imagem do raio na arte, não teria sido por uma mera questão de estilo, de decoração, tal como aparece em ornamentos na arquitetura, por exemplo. Na representação do raio de Zeus, o lótus remeteria aos gregos a um significado e associação antigos, aquele do fogo com essa flor ${ }^{13}$.

Assim, nas palavras de J. Bremer, para os gregos, o raio de Zeus era uma arma letal que produzia destruição radical. Isso se alinha com a experiência universal humana. Onde e quando um raio cai, o resultado é sempre catastrófico: homens são mortos no local, edifícios são destruídos, árvores são escurecidas e, o que sobram delas, caem ao chão (tal como Homero descreve na llíada sobre o carvalho). Mesmo uma floresta inteira pode queimar e cair ao chão após ser atingida por um raio (Bremer, 2006-2007: 28). Nesse sentido, a partir do que revelam os trechos retirados da literatura antiga, como também o contexto de representação do raio junto a Zeus nas artes visuais, podemos dizer que o significado simbólico da representação do raio em moedas relaciona-se primariamente à guerra e ao universo a ela vinculado. É com esse primeiro significado que devemos procurar os outros significados contidos em sua representação em moedas, os quais se revelarão mais adiante na contextualização dos tipos monetários dentro de seu histórico de emissão.

\section{III.3 A ÁGUIA}

Como vimos na análise iconográfica das moedas, há três padrões principais de representações de águias em moedas gregas emitidas entre os séculos VII-IV/III a.C.: cabeça, voando e em pé. Assim como no caso das imagens de Zeus, o padrão cabeça é próprio do documento monetário, não encontrando paralelo na

\footnotetext{
${ }^{13}$ Essa teoria de Cook se baseia no estudo comparativo com religiões antigas, e parece não ter nenhuma confirmação nos textos gregos. Na literatura antiga grega, "o lótus é descrito somente como tendo duas funções: o de planta forrageira, para a pastagem de cavalos (Ilíada II, 776; Odisséia IV, 603), e de comida". "Hérodoto descreve o costume dos egípcios de se alimentarem do lótus que crescia no rio Nilo (Histórias II, 92)" (Assunção, 2013: 2-3). Mas é da Odisséia (IX, 82-104) o relato mais famoso do lótus como comida. Homero fala sobre a terra dos lotófagos, onde os homens que se alimentam dessa flor experimentam um efeito semelhante ao do ópio. Um estudo completo a esse respeito foi apresentado por Teodoro Renó Assunção no XIX Congresso da SBEC em Brasília no ano de 2013. $O$ texto, ainda não publicado, foi gentilmente cedido pelo autor.
} 
cerâmica pintada, por exemplo, onde a ave é representada sempre com o corpo inteiro (voando e em pé). Por essa razão, concentraremos a análise do contexto do significado das representações da águia nos padrões voando e em pé.

Antes de iniciarmos a análise contextual das imagens da águia (voando e em pé), devemos dizer sobre a problemática própria da representação da ave na arte grega em geral, vista nas artes visuais e literária, a qual traz implicações diretas na análise e interpretação de seu significado. Diferente do raio, cujas representações na cerâmica pintada e descrições nas fontes literárias confirmam a sua estrita vinculação a Zeus, veremos que a representação da águia nas artes visuais (tanto nos vasos como nas moedas) e na descrição nos textos antigos nem sempre são diretamente ou claramente relacionáveis à divindade. Na cerâmica pintada, por exemplo, a águia aparece em narrativas míticas sem nenhuma relação com Zeus, mas em outras acompanha a figura do deus. Embora predominem descrições da águia com ações de Zeus nos textos antigos, nesse tipo de documentação encontramos também a mesma situação vista nos vasos. Diante desse problema, a partir da documentação levantada de vasos e estatuária, e da tradição literária, tentaremos definir quais os contextos aos quais a águia aparece vinculada e os significados da ave que deles advém ao longo dos séculos VII-V a.C. Em última análise, tentaremos mostrar quais os significados da representação da águia na arte grega ao longo desse período e em que medida a ave pode ser relacionada a Zeus. Trata-se esta de uma pesquisa fundamental, pois se na cerâmica pintada ou nos textos dispomos de um contexto preciso para a representação ou descrição da águia, na grande maioria das moedas possuímos a figura da ave sozinha sem nenhuma cena narrativa que nos permita contextualizar o seu significado. São as narrativas dos textos antigos e daquelas da cerâmica que ajudam a elucidar o contexto do significado da águia, ainda que de forma primária e geral, para as imagens monetárias da ave.

Voando sem presa ou com presa. Em moedas gregas, o padrão voando para a representação de águias é o segundo mais comum, ficando em número somente atrás do padrão em pé, sendo datado entre os séculos VI-IV/III a.C. Dos sub-padrões de representação da águia voando em moedas, apenas um encontra correspondência na cerâmica pintada - aquele no qual a águia é retratada voando com uma asa em cima e a outra embaixo do corpo, não com as asas erguidas sobre o corpo, por exemplo. Nas artes visuais, a representação ocorre entre os séculos VII-V a.C., ao que parece, somente na cerâmica pintada. Na cerâmica pintada, a ave é retratada portando uma cobra como presa, como aparece nas moedas, embora nestas encontremos uma variedade maior de animais como presas, o que não ocorre nos vasos, onde a única presa da águia é a cobra. A tabela, na sequência, reúne os dados dos vasos com a representação e o tipo de contexto a que se referem: 
Tabela 16- Representações de águias voando sem ou com presa em vasos e relevos (sécs. VII-V a.C.)

\begin{tabular}{|c|c|c|c|c|c|}
\hline $\begin{array}{c}\text { TIPO DE } \\
\text { REPRESENTAÇÃO }\end{array}$ & DATA & PROVENIÊNCIA & OBJETO & DESCRIÇÃO & CONTEXTO / TEMA \\
\hline Voando sem presa & VII a.C.? & $?$ & $\begin{array}{l}\text { Aríbalo proto-coríntio } \\
\text { de figuras negras }\end{array}$ & $\begin{array}{l}\text { Voando à e. em cima e atrás } \\
\text { de guerreiros (Fig.211) }\end{array}$ & $\begin{array}{l}\text { Guerreiros } \\
\text { lutando }\end{array}$ \\
\hline Voando sem presa & $\begin{array}{l}\text { c. } 625-575 \\
\text { a.C. }\end{array}$ & $?$ & $\begin{array}{l}\text { Skyphos ático de } \\
\text { figuras negras }\end{array}$ & $\begin{array}{l}\text { Voando à e. atrás de } \\
\text { Prometeu; atingida por } \\
\text { flechas de Héracles (Fig.212) }\end{array}$ & $\begin{array}{l}\text { Héracles } \\
\text { libertando } \\
\text { Prometeu }\end{array}$ \\
\hline Voando sem presa & $\begin{array}{l}\text { c. } 560-550 \\
\text { a.C. }\end{array}$ & $?$ & $\begin{array}{l}\text { Taça lacônia de figuras } \\
\text { negras }\end{array}$ & $\begin{array}{l}\text { Voando à d. de frente a Zeus } \\
\text { sentado (Fig.130) }\end{array}$ & $?$ \\
\hline Voando sem presa & $\begin{array}{l}\text { c. } 560-540 \\
\text { a.C. }\end{array}$ & $?$ & $\begin{array}{l}\text { Ânfora ática de figuras } \\
\text { negras }\end{array}$ & $\begin{array}{l}\text { Voando à e. (em escudo) } \\
\text { (Fig.214) }\end{array}$ & $\begin{array}{l}\text { Héracles lutando } \\
\text { contra Geryon }\end{array}$ \\
\hline Voando sem presa & $\begin{array}{l}\text { c. } 550-500 \\
\text { a.C. }\end{array}$ & $?$ & $\begin{array}{l}\text { Cratera-taça ática de } \\
\text { figuras negras }\end{array}$ & $\begin{array}{l}\text { Águia voando à e. entre } \\
\text { cavaleiros (Fig.216) }\end{array}$ & Cavaleiros \\
\hline Voando sem presa & $\begin{array}{l}\text { c. } 550-500 \\
\text { a.C. }\end{array}$ & $?$ & $\begin{array}{l}\text { Taça ática de figuras } \\
\text { negras }\end{array}$ & $\begin{array}{l}\text { Águia voando à e. atrás de } \\
\text { cavaleiro (Fig.217) }\end{array}$ & Cavaleiros \\
\hline Voando sem presa & $\begin{array}{l}\text { c. } 550-500 \\
\text { a.C. }\end{array}$ & $?$ & $\begin{array}{l}\text { Ânfora } B \text { ática de } \\
\text { figuras negras }\end{array}$ & $\begin{array}{l}\text { Águia voando à d. atrás de } \\
\text { cavaleiro (Fig.218) }\end{array}$ & Cavaleiros \\
\hline Voando sem presa & $\begin{array}{l}\text { c. } 550-500 \\
\text { a.C. }\end{array}$ & $?$ & $\begin{array}{l}\text { Ânfora } B \text { ática de } \\
\text { figuras negras }\end{array}$ & $\begin{array}{l}\text { Águia voando à e. atrás de } \\
\text { cavaleiro (Fig.219) }\end{array}$ & Cavaleiros \\
\hline Voando sem presa & $\begin{array}{l}\text { c. } 550-500 \\
\text { a.C. }\end{array}$ & $?$ & $\begin{array}{l}\text { Taça ática de figuras } \\
\text { negras }\end{array}$ & $\begin{array}{l}\text { Águia voando à e. atrás de } \\
\text { cavaleiros (Fig.220) }\end{array}$ & Cavaleiros \\
\hline Voando sem presa & c.540 a.C. & $?$ & $\begin{array}{l}\text { Ânfora ática de figuras } \\
\text { negras }\end{array}$ & $\begin{array}{l}\text { Voando à e. (em escudo) } \\
\text { (Fig.215) }\end{array}$ & $\begin{array}{l}\text { Héracles lutando } \\
\text { contra Geryon }\end{array}$ \\
\hline Voando sem presa & c.500 a.C. & $?$ & $\begin{array}{l}\text { Taça ática de figuras } \\
\text { negras }\end{array}$ & $\begin{array}{l}\text { Voando à e. de frente a } \\
\text { Prometeu (Fig.224) }\end{array}$ & $\begin{array}{l}\text { Héracles } \\
\text { libertando } \\
\text { Prometeu }\end{array}$ \\
\hline $\begin{array}{l}\text { Voando com presa } \\
\text { (cobra) }\end{array}$ & $\begin{array}{l}\text { c. } 600-550 \\
\text { a.C. }\end{array}$ & $?$ & $\begin{array}{l}\text { Lekanis ático de } \\
\text { figuras vermelhas }\end{array}$ & $\begin{array}{l}\text { Voando à d. com cobra no } \\
\text { bico (cabeça da cobra virada } \\
\text { para ela, tentando-lhe picar) } \\
\text { (Fig.213) }\end{array}$ & $?$ \\
\hline $\begin{array}{l}\text { Voando com presa } \\
\text { (cobra) }\end{array}$ & c.530 a.C. & $?$ & $\begin{array}{l}\text { Taça lacônia de figuras } \\
\text { negras }\end{array}$ & $\begin{array}{l}\text { Voando à e. com cobra presa } \\
\text { no bico e enrolada no corpo } \\
\text { (ocupa todo o fundo da taça) } \\
\text { (Fig.221) }\end{array}$ & $?$ \\
\hline $\begin{array}{l}\text { Voando com presa } \\
\text { (cobra) }\end{array}$ & $\begin{array}{l}\text { c. } 525-475 \\
\text { a.C. }\end{array}$ & $?$ & $\begin{array}{l}\text { Taça ática de figuras } \\
\text { negras }\end{array}$ & $\begin{array}{l}\text { Voando à d. com cobra presa } \\
\text { no bico e enrolada no corpo } \\
\text { (ocupa todo o fundo da taça) } \\
\text { (Fig.222) }\end{array}$ & $?$ \\
\hline $\begin{array}{l}\text { Voando com presa } \\
\text { (cobra) }\end{array}$ & $\begin{array}{l}480-470 \\
\text { a.C. }\end{array}$ & Vulci, Itália & $\begin{array}{l}\text { Ânfora nolana ática de } \\
\text { figuras vermelhas }\end{array}$ & $\begin{array}{l}\text { Voando à e. com cobra presa } \\
\text { no bico e nas garras (em } \\
\text { escudo de Gigante) (Fig.232) }\end{array}$ & Gigantomaquia \\
\hline
\end{tabular}

Como é possível observar na tabela 26 , a representação da águia voando aparece vinculada a temas ${ }^{14}$ bem específicos predominantemente na cerâmica pintada (coríntia, ática e lacônia) datada entre os séculos VII e V a.C., tais como os de Guerreiros lutando (proto-coríntia), Héracles libertando Prometeu (ática), Zeus sentado diante de águia (lacônia), Cavaleiros (ática), Gigantomaquia (ática) e Héracles lutando contra Geryon (ática), que também aparece na decoração de um escudo de bronze em Olímpia ${ }^{15}$. A águia voando sem presa ou com presa (cobra) aparece vinculada aos temas dos Cavaleiros, embora aqui apenas apareçam

\footnotetext{
14 Os temas levantados e descritos são os mais recorrentes. Mas a representação da águia voando sem presa pode ser vista vinculada a outros tipos de temas na cerâmica lacônia do século VI a.C. Em Schefold, foram encontradas duas taças lacônias, onde essa imagem aparece na cena da Captura de Cerbero (c.560 a.C.) e da Captura de Cronos (c.530 a.C.), ver Schefold, 1992, p.129, fig.149 e p.53, fig.55, respectivamente.

${ }^{15}$ Héracles lutando contra Geryon, relevo em bronze de braçadeira de escudo, 550 a.C., Olympia B 1975, ver em Schefold, 1992, p.122, fig. 141.
} 
selecionados vasos em que a águia é retratada sem a presa. Na imagem de escudos na cerâmica pintada, a águia pode aparecer retratada tanto sem a cobra, como vemos no tema de Héracles lutando contra Geryon, como com a cobra, como no caso da Gigantomaquia. Já a águia voando carregando a cobra nunca aparece vinculada aos temas referentes a Prometeu, como o de Héracles o libertando, por exemplo.

De todos esses temas retratados nos vasos, o tema dos Cavaleiros é o que melhor nos auxilia a introduzir a discussão acerca do significado simbólico da águia voando com ou sem presa. 0 tema dos Cavaleiros começou a aparecer na Ática na segunda metade do século VI a.C., possui relação com a classe dos Hippeis e provavelmente refere-se à partida para guerra (Pérez, 2010: 4). De acordo com D. Rodríguez Pérez, em um estudo sobre o significado simbólico da águia com a cobra na arte grega, a águia voando próximo aos cavaleiros, retratados nos vasos, indica algum tipo de sinal profético, um presságio (bom ou ruim), para esses homens que na cena partem ou chegam da guerra (Pérez, 2010: 3-4).

Nesse aspecto, as mais antigas e importantes fontes de informação acerca da associação da águia a presságios, na cultura grega, são a llíada e a Odisséia de Homero. Em ambos os textos vê-se que os gregos entendiam o surgimento repentino de uma águia em vôo no céu, com uma presa ou não, como algum sinal profético de decisão em algum evento. Na llíada a águia aparece seis vezes na narrativa, sendo em quatro delas descrita como a ave que traz algum tipo de presságio que interpretado como tal, mudava o rumo dos acontecimentos na guerra. $\mathrm{O}$ vôo da águia na llíada muda o rumo, define acontecimentos nas batalhas. No primeiro trecho (llíada VII, 245-252), a águia é descrita como um sinal favorável enviado por Zeus aos aqueus:

Zeus potente abalado se mostra, e consentiu, com um sinal, que seu povo não fosse destruído. Uma águia, logo, mandou, dentre as aves a mais auspiciosa, que um gamozinho de corça veloz carregava nas garras, o qual soltou, ao passar pelo altar, onde ofertas opimas ao deus que tudo responde (...). Estes, então, compreendendo o sinal que Zeus grande mandara, com novo ardor belicoso atiramse contra os troianos.

O segundo trecho (Ilíada XII, 199-209) refere-se ao episódio mais comentado na bibliografia a respeito da águia portadora de presságios, mas agora relacionada à cobra. No momento em que os troianos iam transpor o fosso das muralhas, uma águia sobrevoa o seu exército, carregando em suas garras uma serpente, que a fere durante 0 vôo. Na sequência da narrativa, a águia parte largando a serpente contorcida que cai no meio do campo. Polydamas explicou o ocorrido como um presságio que proibia o ataque contra os navios gregos, e aconselhava os troianos a abandonar o seu projeto, a estarem satisfeitos com sua vitória e, assim, a se retirarem dos muros troianos. Heitor, aguardando por uma vitória final, se recusa a querer obedecer aves que voam solitárias no céu:

(...) Ao chegarem à beira do fosso, indecisos, pararam / é que, quando iam transpô-lo, por eles uma ave perpassa / a águia de altíssimo vôo, que / à esquerda fechou todo o exército / a qual nas garras, a imano dragão cor de sangue estringia/ vivo, a mexer-se, que não se esquecera de cruentos combates / pois, para trás encurvando-se, junto do colo, no peito / a ave feriu. Trespassada de dor excruciante, esta, logo / violentamente o jogou para longe, no meio do povo / Grito estridente solta 
a águia, partindo com o sopro do vento / Estremeceram os Teucros, ao verem no meio do campo / Como portento de Zeus, a serpente de cores cambiantes / Polydamas de Heitor se aproxima e the diz o seguinte: / "(...) Ora pretendo dizer-te o que julgo ser mais proveitoso: / Não prossigamos, a fim de lutar junto às naves, com os Dânaos. / Posso prever o futuro, se, foi um sinal, como penso, I a ave que aos Teucros baixou no momento de o fosso transpormos, / a águia de altíssimo vôo, que à esquerda fechou todo o exército, / a qual na garra a imano dragão cor de sangue estringia, / vivo, soltando-o muito antes de alçar-se até o ninho querido, / sem que lhe fosse possível / aos filhos, por cibo, levá-lo. / Do mesmo modo há de dar-se conosco: se as portas e o muro / À viva força rompermos e os Dânaos, dali, repelirmos / retornaremos, depois, pelo mesmo caminho, sem ordem, / e deixaremos inúmeros Teucros, que os fortes Aquivos / hão de fazer perecer, defendendo os navios escuros.

Nos dois últimos trechos, que relacionam a águia a presságios, a ave é descrita sem carregar qualquer tipo de presa. No primeiro (Ilíada XIII, 81-83), a águia novamente é interpretada como sinal de bom agouro para os aqueus:

Nesse entrementes, uma águia de altíssimo vôo passou-Ihes pela direita. Os aqueus levantaram um grito de júbilo encorajados.

Já no segundo trecho (llíada XXIV, 310-321), a águia é enviada por Zeus a pedido do rei Príamo, como sinal positivo à empreitada contra os aqueus:

“(...) Manda-me, como sinal, de tua parte, a mais forte das aves, a que tu próprio prefiras, de vôo mais rápido. Venha pela direita, que, tendo-a, de fato, ante os olhos, reflita, para confiante, empreender a viagem à nau dos aqueus". Isso disse ele, na súplica; Zeus o atendeu poderoso, e, logo, uma águia lhe manda, perfeita entre todas as aves, fosca de nome, por causa das penas, veloz caçadora. Quanta é a largura de um grande portão de ferrolhos, que homem de muitos haveres no tálamo construísse, tanto ela as asas escuras estende, equilibrando-se altiva. Alça-se pela direita, por sobre a cidade; alegram-se quantos a viram, de júbilo o peito de todos enchendo-se (...).

Se na llíada o vôo da águia traz bons presságios para um dos lados (troianos ou aqueus), na Odisséia, o vôo da águia é sempre descrito como um sinal de mau agouro, trazendo preocupação aos envolvidos nos episódios. No primeiro trecho (Odisséia II, 145-155), o povo de Ítaca havia sido convocado para uma assembleia geral para escutar as palavras de Telêmaco que havia atingido a idade viril. Para eles e para Telêmaco, Zeus envia duas águias de cima do Olimpo que voam uma ao lado da outra e que ao chegarem ao centro da assembléia agitam-se e começam a se atacar, expressando olhares de morte. Quando Halitherses tentava explicar o presságio como um sinal certo de destruição dos pretendentes de Penélope, e tentou usá-lo como um meio de incitar o povo contra eles, exclama com fúria: "Vários pássaros de fato voam sob os raios do sol, mas nem todos trazem um presságio". A afirmação é resultado de um temor sobre o sinal enviado pela ave.

No segundo trecho (Odisséia XV, 155-176), Helena interpreta o vôo da ave como o sinal de que Odisseu voltará para punir: 
Enquanto ele falava, uma ave alçou vôo à direita. Era uma águia com um ganso, manso como os de pátio. Perseguiram-na homens e mulheres. Aproximou-se da carruagem e ganhou as alturas na frente dos cavalos.

O terceiro trecho (Odisséia XIX, 535-540) refere-se a um sonho premonitório de Penélope:

Posso contar um sonho que tive? Queres interpretá-lo? Crio aqui no palácio vinte gansos, alimentamse de trigo e água. Observo-os, sinto calores. Desce da montanha uma águia imensa, de bico adunco. Parte-lhes o pescoço, acaba com eles. Deixa-os amontoados. As asas a erguem à imensidão divina. Gemo e choro no sonho.

E por fim, o último trecho (Odisséia XX, 242-245) a esse respeito:

Veio-lhes, entretanto, o vôo de uma ave pela esquerda. Uma pomba se debatia nas garras de uma águia. Falou-lhes Anfínomo: "Amigos, os auspícios não são bons. Deixemos a morte para depois. Pensemos em comida".

Esse caráter mântico da águia -visto nesses dois poemas do início do período arcaico - é descrito de igual maneira na literatura grega do século $V$ a.C. Entre os autores do teatro grego do período, Aristófanes em as Vespas (v.15), diz nas palavras de Xanthias sobre o vôo de uma águia sobre a ágora, que não porta uma presa, mas leva um escudo:

Eu vi uma águia, um pássaro gigante, descendo sobre o mercado; ela apreendeu um pequeno escudo de bronze com suas garras e levou-o para o mais alto dos céus.

Já Xenofonte, em Ciropedia $(2.4,20)$, narra um episódio muito semelhante àqueles que vimos na llíada sobre presságios favoráveis:

(...) uma lebre começou a subir. E uma águia voando a partir de leste a avistou e, como ela corria, agarrou-a e levou-a para cima e, em seguida, para uma colina não longe onde deixou a presa a seu prazer. Então Ciro, observando o presságio, ficou encantado, prestou homenagem ao soberano Zeus e disse aos que estavam presentes: "A nossa caça, companheiros, será bem sucedida".

Como vimos até aqui, nos trechos extraídos da literatura antiga, o vôo da águia é diretamente relacionado aos presságios, tem um valor mântico, de anunciar algum acontecimento futuro, seja ele bom ou ruim para o receptor do sinal trazido pela ave. Ressaltado também em alguns dos trechos, o vôo da águia às grandes alturas, onde poderia alcançar uma visão ampla, era relacionado pelos antigos gregos ao poder mântico da ave (Wittkower, 1939: 309). Os trechos descritos também nos levam a um segundo tipo de significado da águia também comum às artes visuais. Além do significado mântico da águia, a análise contextual dos episódios mostra a sua relação com guerras (na llíada) e disputas (na Odisséia). Mesmo no trecho de Aristófanes fica evidente tal relação quando descreve que a águia carrega justamente um escudo para o céu, objeto de evidente caráter bélico, ou o trecho de Xenofonte em relação à caça, uma prática que envolve um tipo de disputa entre homens pelos animais. Em última análise, além ainda dos significados de guerra e disputa estão aqueles de competição e vitória. Ora, vimos no caso de Zeus como guerra e competição continham significados completamente imbricados um no outro dentro da cultura grega antiga. $\mathrm{E}$ que vitória é sempre 0 
fim último de uma disputa, competição ou de uma guerra. Na llíada, a trama da guerra mostra a disputa entre gregos e troiamos pela busca da vitória de um sobre o outro. Na Odisséia, os presságios não favoráveis são vistos por aqueles que disputam o trono de Odisseu. E em Ciropedia, a caça bem sucedida pode ser entendida como um sinal de vitória.

Assim, após a leitura dos trechos da literatura pertencente à época dos vasos analisados, ao nos voltarmos novamente às cenas contidas na cerâmica pintada, onde as águias são representadas em pleno vôo, carregando ou não uma presa, contextualiza-se melhor os tipos de significados a elas ali atribuídos. Percebese, de antemão, que todas as cenas se referem às disputas ou à guerra, seja no tema dos guerreiros lutando no aríbalo proto-coríntio, no de Héracles lutando contra Geryon, de Héracles libertando Prometeu, no da Gigantomaquia e no tema dos Cavaleiros. Em todos esses temas, com exceção daquele de Prometeu, no qual a ave tinha um papel bem determinado na narração mítica, a águia que na cena surge voando pode ser interpretada como um indicativo de futuro. De acordo com D. Rodríguez Pérez, que se atém à análise das representações apenas com a cobra, "a presença da águia voando com ou sem a cobra (como no caso dos vasos com o tema dos Cavaleiros) funcionava como sinal de aviso e advertência, um marco de exclamação que introduz um futuro incerto na cena, que avisa ao espectador da narrativa contada no objeto, que alguma coisa boa ou ruim está por vir" (Pérez, 2010: 16). E ainda, "a presença da cobra com a águia não pode ser tomada como um aspecto negativo de futuro em todos os casos" (Pérez, 2010: 3). Na visão de Pérez, as representações nos escudos ${ }^{16}$, como aparecem naqueles do Gigante e de Geryon, "significam, em primeira instância, o desejo do guerreiro (representados nessas duas figuras míticas) em derrotar o inimigo e predizer um retorno feliz, um bom agouro na batalha contra o inimigo" (Pérez, 2010: 6). A nosso ver, o guerreiro que carrega consigo um escudo com a figura de uma águia sem a presa pode ter tido a intenção de requerer para si tanto um bom agouro na luta quanto repelir/afastar qualquer resultado desfavorável, pois são esses dois tipos de presságios que uma águia poderia trazer. Ao mesmo tempo que ele quer para si esse tipo de proteção ao portar o escudo com a representação, quem vê a imagem é o inimigo, é a ele também que a mensagem da imagem é endereçada. Em um escudo com a representação da águia com a cobra, a representação pode ter tido o significado de derrota eminente do inimigo: "como a águia destrói a cobra, assim o guerreiro destruirá o inimigo" (Wittkower, 1939: 310). Ou que com ele estavam os bons presságios, aqueles favoráveis à vitória na guerra. A águia também era considerada a mais forte ${ }^{17}$ das aves, que voa mais alto ${ }^{18}$ e a mais rápida ${ }^{19}$,

\footnotetext{
${ }^{16}$ De acordo com P. Pontin, os motivos nos escudos, além de um destino decorativo, tinham a função de inspirar medo, petrificar simbolicamente os adversários (Pontin, 2006: 82). Em seu estudo O escudo grego: simbologia de um equipamento defensivo, Pontin faz o levantamento sistemático dos tipos de imagens que ornavam a frente dos escudos, concluindo que a águia aparece em $2,76 \%$ das imagens vasculares (Pontin, 2006: 255).

17 Homero, lliada XXIV, 310-321.

18 Homero, Ilíada XIII, 81-83.

19 Píndaro, Nemeanas 3, 80.
} 
características requeridas e almejadas por guerreiros ${ }^{20}$. Além, é claro, de ser a ave mensageira de Zeus, divindade, como vimos, ligada à esfera da guerra em vários níveis.

Algumas considerações devem ser ditas acerca das presas que acompanham as águias em alguns presságios nas narrativas, presentes nas fontes textuais e em cenas de vasos, as quais são abundantemente representadas junto à ave na documentação numismática. Nas moedas, encontramos a águia carregando, atacando ou sobre cobras, veados, tartarugas, lebres, carneiros, peixes, cabras, jumentos e até golfinhos. De acordo com o nosso levantamento, nas cenas pintadas nos vasos a cobra é o único animal que acompanha a representação da águia nesse tipo de suporte imagético. Já nos textos literários apresentados, vimos o envolvimento de outros animais no vôo mântico da ave, como o veado, a lebre e o ganso, indicando que outros animais, além da cobra, também eram considerados como parte da mensagem de presságio. Na narrativa dos textos, cada um desses animais parece não trazer implicações evidentes na leitura, favorável ou não, dos presságios, apesar de serem animais muito diferentes entre si, podendo ter significados bem diferentes para os gregos durante a observação do ataque de uma águia. Veados, lebres e gansos são animais com temperamento manso e não arredio em comparação com a cobra, o único destes que pode entrar em confronto com a águia e até a matar, como quase ocorre na llíada (XII, 199-209). Na literatura antiga, encontramos alguns testemunhos sobre a diferenciação entre esses dois animais, que possuíam um significado especial para os gregos. Aristóteles, em Historia Animalium (IX, 1-2; 32,6), descreve a águia e a cobra como inimigas naturais. Um pouco antes no tempo, Sófocles, em Antígona (v.110) emprega a luta da águia com a cobra como um símile para os exércitos de luta (Wittkower, 1939: 310). Os antigos gregos, assim como outros povos antigos, perceberam que existia uma diferença profunda e definitiva entre ambos os animais - a antiga ideia de uma luta antagônica de opostos com grande significado na cultura grega (nesse caso, altura/profundidade, céu/terra, luz/sombra) (Pérez, 2010: 1-2). Levando em consideração as características naturais dos dois animais, "a águia e a cobra foram usadas, pelos antigos, para caracterizar o comportamento humano: o confronto entre os homens são metaforicamente expressos em termos de luta entre esses dois animais" (Pérez, 2010: 16).

Em pé sem presa. Dos três padrões de representação da águia em moedas gregas, o padrão em pé é o mais abundante entre os tipos monetários encontrados datados entre os séculos VII-IV/III a.C. Todos os subpadrões de representação da águia em pé em moedas - de asas fechadas, de asas abertas e asas erguidas encontram correspondência na cerâmica pintada e na estatuária, com o detalhe de que nas artes visuais, aqui comentadas, a ave é retratada sem presa. Na cerâmica pintada, esse tipo de representação pode ter começado a ocorrer a partir da segunda metade do século VI a.C. na cerâmica ática e lacônia, tendo perdurado ao menos até o século V a.C. Na estatuária, a representação ocorre a partir do século VI a.C. e início do século V a.C. Em relevos, a representação também aparece ao longo do século $V$ a.C., como mostra a imagem no estrigilo.

\footnotetext{
20 Tanto é assim que na llíada (XVII, 673-680; XXII, 308-311), em dois trechos diferentes, as astúcias de Menelau e de Heitor na guerra são comparadas às características das águias.
} 
Na sequência, a tabela traz o resumo dos dados acerca desses tipos de objetos, assim como o contexto / tema a que se inserem as representações das águias em pé:

Tabela 27- Representações de águias em pé sem presa em vasos, estatuetas e relevos (sécs. VI-V a.C.)

\begin{tabular}{|c|c|c|c|c|c|}
\hline $\begin{array}{c}\text { TIPO DE } \\
\text { REPRESENTAÇÃO } \\
\end{array}$ & DATA & PROVENIÊNCIA & OBJETO & DESCRIÇÃO & $\begin{array}{l}\text { CONTEXTO / } \\
\text { TEMA }\end{array}$ \\
\hline Em pé sem presa & VII a.C. & $\begin{array}{l}\text { Mt. Lykaion, } \\
\text { Arcádia, } \\
\text { Peloponeso }\end{array}$ & $\begin{array}{l}\text { Estatueta de Zeus } \\
\text { Keraunios }\end{array}$ & $\begin{array}{l}\text { De asas abertas (sobre a } \\
\text { mão de Zeus) (Fig.124) }\end{array}$ & - \\
\hline Em pé sem presa & $\begin{array}{l}\text { Met. séc. } \\
\text { VI a.C. }\end{array}$ & $\begin{array}{l}\text { Amnisos, santuário } \\
\text { de Zeus Thenatas, } \\
\text { Creta }\end{array}$ & Estátua de cálcario & $\begin{array}{l}\text { Águia de asas fechadas } \\
\text { que ficava sobre um pilar } \\
\text { na área do santuário } \\
\text { (Fig.227) }\end{array}$ & - \\
\hline Em pé sem presa & c.530 a.C. & $?$ & $\begin{array}{l}\text { Amphoriskos ático de } \\
\text { figuras negras }\end{array}$ & $\begin{array}{l}\text { À d., sobre perna de } \\
\text { Prometeu, mordendo-o } \\
\text { (Fig.223) }\end{array}$ & $\begin{array}{l}\text { Atlas e } \\
\text { Prometeu }\end{array}$ \\
\hline Em pé sem presa & $\begin{array}{l}\text { c.530- } \\
525 \text { a.c. }\end{array}$ & $\begin{array}{l}\text { Olímpia (aterro } \\
\text { norte do estádio) }\end{array}$ & $\begin{array}{l}\text { Taça lacônia de } \\
\text { figuras negras }\end{array}$ & $\begin{array}{l}\text { À e., de asas fechadas } \\
\text { (atrás de Zeus sentado no } \\
\text { trono) (Fig.131) }\end{array}$ & Zeus e Hera \\
\hline Em pé sem presa & VI a.C. & $\begin{array}{l}\text { Mt. Lykaion, } \\
\text { Arcádia, } \\
\text { Peloponeso }\end{array}$ & $\begin{array}{l}\text { Estatueta de Zeus } \\
\text { Keraunios }\end{array}$ & $\begin{array}{l}\text { De asas abertas (sobre a } \\
\text { mão de Zeus) (Fig.124) }\end{array}$ & - \\
\hline Em pé sem presa & VI-V a.C. & $\begin{array}{l}\text { Dodona, Épiro } \\
\text { (área do santuário } \\
\text { de Afrodite) }\end{array}$ & $\begin{array}{l}\text { Estatueta em bronze, } \\
\text { possivelmente parte } \\
\text { do topo de um cetro }\end{array}$ & $\begin{array}{l}\text { De asas fechadas (sobre } \\
\text { um cetro?) (Fig.228) }\end{array}$ & - \\
\hline Em pé sem presa & c.500 a.C. & $?$ & $\begin{array}{l}\text { Ânfora ática de } \\
\text { figuras vermelhas }\end{array}$ & $\begin{array}{l}\text { De asas abertas em pé } \\
\text { sobre cetro de Zeus } \\
\text { (sentado no trono) } \\
\text { (Fig.158) }\end{array}$ & $\begin{array}{l}\text { Reunião dos } \\
\text { deuses no } \\
\text { Olimpo }\end{array}$ \\
\hline Em pé sem presa & $\begin{array}{l}\text { c. } 490- \\
480 \text { a.C. }\end{array}$ & $?$ & $\begin{array}{l}\text { Cratera ática de } \\
\text { figuras vermelhas }\end{array}$ & $\begin{array}{l}\text { De asas fechadas sobre } \\
\text { cetro de Zeus (sentado no } \\
\text { trono) (Fig.159) }\end{array}$ & $\begin{array}{l}\text { Ganimedes } \\
\text { servindo vinho a } \\
\text { Zeus }\end{array}$ \\
\hline Em pé sem presa & $\begin{array}{l}\text { c. } 490- \\
480 \text { a.C. }\end{array}$ & Ambrácia, Épiro & $\begin{array}{l}\text { Estatueta de Zeus } \\
\text { Keraunios }\end{array}$ & $\begin{array}{l}\text { De asas abertas (sobre a } \\
\text { mão de Zeus) (Fig.139) }\end{array}$ & - \\
\hline Em pé sem presa & c. 480 a.C. & Olímpia & $\begin{array}{l}\text { Estatueta de Zeus } \\
\text { Keraunios }\end{array}$ & $\begin{array}{l}\text { De asas abertas (sobre a } \\
\text { mão de Zeus) (Fig.141) }\end{array}$ & - \\
\hline Em pé sem presa & $\begin{array}{l}\text { c. } 480- \\
470 \text { a.c. }\end{array}$ & Vulci, Itália & $\begin{array}{l}\text { Ânfora nolana ática } \\
\text { de figuras vermelhas }\end{array}$ & $\begin{array}{l}\text { De asas abertas (sobre a } \\
\text { mão de Zeus) (Fig.153) }\end{array}$ & Gigantomaquia \\
\hline Em pé sem presa & c. 430 a.C. & $\begin{array}{l}\text { Siracusa-Leontino, } \\
\text { Sicília }\end{array}$ & Relevo em estrigilo & $\begin{array}{l}\text { De asas fechadas (sobre o } \\
\text { braço de Zeus) (Fig.143) }\end{array}$ & - \\
\hline
\end{tabular}

Conforme vemos na tabela 27 , a representação da águia em pé sem presa não aparece vinculada a temas específicos (repetidos) na cerâmica pintada, tal como ocorre para a representação da águia voando com ou sem presa. Na cerâmica ática, a representação ocorre no tema de Atlas e Prometeu, da Reunião dos Deuses, de Ganimedes servindo vinho a Zeus e no da Gigantomaquia. Na cerâmica lacônia, a águia é retratada em pé de asas fechadas no tema de Zeus e Hera. Na estatuária, a águia é retratada em pé, com as asas abertas sempre nas mãos das estatuetas de Zeus Keraunios provenientes do Monte Lykaion, de Olímpia e de Ambrácia. A representação da águia sem Zeus na escultura calcária de Creta é proveniente do santuário de Zeus Thenatas em Amnisos, Creta. A ave aparece retratada em pé de asas fechadas sobre o braço de Zeus, que também atira o raio, em um estrigilo encontrado na Sicília.

Repara-se que a representação da águia em pé sem presa nesses tipos de suportes está predominantemente associada a figura de Zeus. Nos objetos encontrados com a representação da águia em 
pé sem presa, a ave ocupa espaços específicos em relação a Zeus. A ave aparece atrás de Zeus sentado no trono (cerâmica lacônia), sobre o cetro de Zeus sentado no trono (cerâmica ática), sobre uma das mãos de Zeus atirando o raio (cerâmica ática e estatuária) e sobre o braço de Zeus atirando o raio (relevo em bronze). A única exceção parece ser 0 amphoriskos ático de c.530 a.C., cujo tema é Atlas e Prometeu, onde a águia é retratada com as asas erguidas sobre a perna do Titã. Na estatuária, a representação da águia em pé sem presa também pode ser vista na escultura em calcário de Amnisos, em Creta, e na escultura em bronze do topo de um cetro encontrada em Dodona, em dois santuários de Zeus. O tema de Prometeu também aparece na representação da águia voando sem presa, no qual Héracles liberta Prometeu - expressão de um mito ático, uma versão local da narrativa mítica de Prometeu (Schefold, 1992: 53). A presença da águia voando ou em pé sem presa nos temas de Prometeu explica-se no mito narrado por Hesíodo na Teogonia (vv.521-525), onde Zeus envia a ave para comer o fígado do Titã:

E prendeu com infrágeis peias Prometeu astuciador, cadeias dolorosas passadas ao meio de uma coluna, e sobre ele [Zeus] incitou uma águia de longas asas, ela comia o fígado imortal, ele crescia à noite, todo igual o comera de dia a ave de longas asas.

Mas mesmo na narrativa hesiódica, a águia, em algum nível, é associada a Zeus: é o deus que envia a ave para comer o fígado de Prometeu. Essa associação da representação da águia em pé, e sempre sem presa, associada à representação de Zeus a partir do século VI a.C. nas artes visuais, nos coloca o debate acerca da relação entre a ave e o deus - de quando a representação / presença da águia pode ser considerada como um atributo de Zeus.

Como vimos, as descrições mais antigas que associam a águia a Zeus remontam aos textos homéricos do século VIII a.C., onde ela é definida como a ave que envia presságios de Zeus. Nas cerâmicas pintadas, essa associação, parece ter tomado forma, emergido, entre 550 e 530 a.C., em meio aos pintores lacônios. Mais inovadora nesse sentido é a taça lacônia, proveniente de Olímpia, onde a águia aparece, pela primeira vez, representada em pé atrás de Zeus sentado no trono. Com relação às esculturas arquitetônicas, de Creta, desse mesmo período, data a estátua monumental de calcário de uma águia que, sobre um pilar, ficava na área do santuário de Zeus Thenatas em Amnisos. Com relação à estatuária, do Peloponeso e do século VII a.C. (infelizmente sem uma data precisa nesse período), provém a estatueta de Zeus Keraunios do Monte Lykaion, santuário que, segundo a teoria de G. Mylonas, teria sido o local onde a águia primeiro teria sido concebida como um atributo direto de Zeus, mas nesse caso, sua epifania - concepção que não aparece nos textos homéricos, mas teria sido formulada no mesmo período dos poemas no culto de Zeus na montanha arcádia. As estatuetas com o mesmo padrão de representação de Zeus com a águia provenientes de Olímpia e da Ambrácia (com origem em Corinto), posteriores àquela do Lykaion, são consideradas evidências da influência do santuário arcádio na associação da águia ao culto de Zeus no Peloponeso (Mylonas). A nosso ver, ainda que o Monte Lykaion tenha sido o local onde no culto primeiro a águia foi considerada como epifania de Zeus, 
acreditamos que tais representações da ave junto ao deus na cerâmica lacônia ou na estatuária peloponésia, estariam associadas à concepção homérica da águia portadora de sinais, presságios, enviados por Zeus.

Nos textos do século VIII a.C., como a llíada e a Odisséia, em alguns dos trechos referentes às águias, vimos que a ave é descrita como enviada por Zeus como um sinal de presságio solicitado ou não ao deus para a decisão de uma batalha. No texto da llíada é possível compreender que o vôo da águia (com ou sem a presa) era um sinal enviado por Zeus, que podia ser interpretado pelos receptores tanto como a vontade do deus no desenrolar de certo acontecimento (como no canto VII, 245-252), quanto um sinal em aberto, de livre-arbítrio, cuja decisão dependia somente da leitura e compreensão de quem o recebia (como no canto XXIV, 310-321). Essa concepção da águia em relação a Zeus não muda na tradição literária até ao menos entre os séculos VI e V a.C. Na poesia lírica de Píndaro (Ístmica 6, 45-50), por exemplo, a ave é descrita ainda como aquela que envia um sinal profético de Zeus. Na lírica de Baquílides (Epinícios 5, 15-20) essa concepção é conservada, apesar do poeta agora nomear a ave de mensageira do deus:

Bem acima, cortando o ar profundamente (com suas asas douradas rápidas, a águia, mensageira do alto trovão, todo poderoso Zeus) confia corajosamente em sua força poderosa (...).

Mas parece ter sido Píndaro (Pítica I, 5) o primeiro a descrever a águia sobre o cetro de Zeus, analogia antes inexistente nos textos gregos:

(...) a águia dorme sobre o cetro de Zeus, relaxando suas asas velozes em cada lado, o rei dos pássaros.

Ainda ao longo do século $V$ a.C., esse caráter da águia como portadora de um sinal vindo do céu permanece sendo descrito em textos do teatro ateniense, como em As Vespas de Aristófanes (datado de 422 a.C.), cujo trecho foi visto anteriormente. Nas fontes literárias, uma concepção da águia mais próxima à figura de Zeus, definida como seu animal divino, e relacionada às características divinas do deus, parece ter sido caracterizada pela primeira vez no próprio teatro ateniense. Ésquilo, em As Suplicantes (v.212), texto datado de c.463 a.C., descreve a águia como o pássaro de Zeus. E é em Aristófanes (Aves, v.515), datado de 414 a.C., que a águia é descrita, pela primeira vez, como um símbolo da realeza de Zeus:

Pisthetaerus: Mas a prova mais forte de tudo isso é que Zeus, que agora reina, é representado como em pé, com uma águia sobre a sua cabeça como um símbolo de sua realeza (...).

Talvez seguindo Píndaro, Sófocles, autor do teatro trágico ateniense, que nasce no início do século V a.C., também descreve a águia sentada no cetro de Zeus. Mas na mesma frase, recuperada de um fragmento 21 , o autor trágico chama a águia de cão de Zeus, provavelmente definindo pela primeira vez a ave como companheira de Zeus. Essas concepções, que chegaram a nós através desses textos, muito provavelmente refletem ideias que vinham sendo formuladas na religião grega, naquele período, a respeito de Zeus.

\footnotetext{
21 Incertarum Fabularum, F884 (799), em: Radt, S. Tragicorum Graecorum Fragmenta, vol.4, Sophocles. Göttingen: Vandenhoeck \& Ruprecht, 1999, p. 571.
} 
Interessante notar certa correspondência temporal entre as novas descrições em relação à águia de Píndaro e dos autores trágicos, Ésquilo e Sófocles, com as primeiras imagens vasculares áticas de Zeus com a águia. Em contraste com a cerâmica lacônia, a representação de Zeus com a águia ocorreu na cerâmica ática somente entre 500 e 470 a.C., quando a ave passou a figurar sobre o cetro de Zeus e sobre a mão do deus. De acordo com Tiverios, acerca dessas imagens na cerâmica ática, a águia não deve ser vista apenas como meramente enfatizando a majestade de Zeus, mas um atributo vital, cujo poder ajudará o deus quando a necessidade ocorresse (Tiverios, 1997: 333). Até então na cerâmica ática, a águia era representada voando sem associação ao deus, vinculada a outros temas mitológicos onde possui um significado mântico. Será essa correspondência temporal entre as primeiras representações da águia com Zeus e as descrições dos textos expressão de uma nova concepção da águia como atributo de Zeus que começou a circular na Ática a partir do início do século $V$ a.C.? Ou ainda, no mundo grego?

Assim, se compararmos as descrições da águia na tradição literária do período arcaico com as dos textos do século $V$ a.C. veremos uma nítida mudança em sua concepção em relação a Zeus. Nos textos atenienses do século $V$ a.C. a águia não é mais somente associada a Zeus nos momentos em que o deus envia um sinal de presságio, como ocorria anteriormente - ela passou a figurar nesses textos como a ave companheira de Zeus que repousa sobre o seu cetro. A nosso ver, trata-se de uma nova concepção que se soma à mais antiga, se pensarmos na permanência de descrições do papel mântico da águia em Aristófanes (As Vespas), por exemplo.

Assim, a partir do exame minucioso da associação da documentação literária com a arte figurativa, podemos dizer que a águia sempre foi considerada pelos gregos como um atributo de Zeus, cujo significado mudou (somando-se ao mais antigo) entre a época arcaica e início da clássica. A vinculação da águia em algum nível com Zeus, seja pelos sinais enviados pelo deus, ou seja como símbolo de sua realeza, expressam, em algum nível, características que definem a divindade, podendo por isso qualificar a ave como um atributo, ao nosso ver, já na poesia homérica, ainda que nas artes visuais essa associação tenha aparecido mais tarde.

Nessa perspectiva, quando nos voltamos às centenas de tipos de representações de águias em moedas gregas de época arcaica e clássica, devemos assumir que a águia tinha um significado duplo na compreensão dos antigos gregos. Ao mesmo tempo em que a águia era por eles reconhecida como ave de Zeus, ela também era compreendida como a ave dos presságios, que traz uma mensagem a respeito do futuro. Em certos momentos, um significado poderia prevalecer em relação ao outro, ora a representação da águia em uma moeda, poderia indicar a associação direta com Zeus, ora poderia significar o desejo de um bom agouro ou repelir situações futuras ruins em determinada conjuntura histórica e política dentro da pólis, quando os significados de guerra, competição e vitória foram importantes. Ou ainda, tais significados poderiam ser requeridos ao mesmo tempo ao se escolher representar a águia em uma moeda. Tais significados, por detrás da representação da águia, estavam imbricados nesse período. 
Evidência da existência desse significado duplo da águia para os gregos antigos, é a ânfora ática de figuras vermelhas, datada de 480-470 a.C., cuja cena mostra Zeus em pé atirando o raio com a mão direita, e a águia sobre a esquerda, no confronto contra um Gigante armado com uma lança, um elmo e um escudo com a representação de uma águia carregando uma serpente (Fig.232).

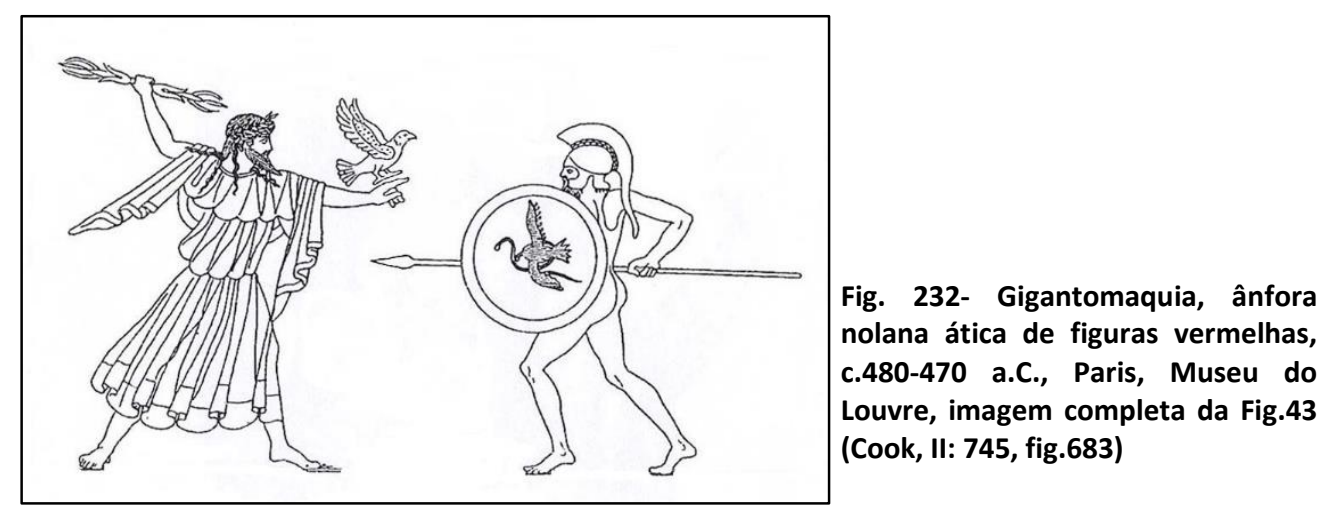

\section{III.4 ZEUS, O RAIO E A ÁGUIA}

A análise contextual do significado simbólico das imagens de Zeus, raios e águias, empreendida até aqui, revelou várias associações entre os significados referentes ao deus e a seus dois atributos, as quais merecem ser comentadas conjuntamente. Queremos dizer que vários dos significados vinculados às imagens dos raios e das águias mostraram-se ser consonantes com as características da personalidade e da figura do próprio Zeus (como aparece descrito na tradição literária) e com a sua esfera de atuação e culto.

Guerra, competição, disputa e vitória - os significados simbólicos comuns contidos nas imagens de raios e águias - são também aspectos importantes do culto de Zeus no mundo grego e também observáveis na representação da própria divindade. Vimos anteriormente como esses significados na cultura grega eram imbricados entre si e estavam presentes, por exemplo, no culto de Zeus em Olímpia, principal espaço de competição entre as cidades, local de seu oráculo, na dedicação dos tropaia a Zeus Olímpio ao longo do estádio. A atuação de Zeus no sucesso de batalhas está associada ainda a outra característica importante de Zeus, o seu aspecto guerreiro. De acordo com W. Burkert, o poder do mais forte dos deuses manifesta-se na luta (Burkert, 1993: 259). E o texto antigo que melhor caracteriza essa faceta de Zeus é a llíada, onde o deus exerce poder de decisão sobre os rumos da guerra.

A águia é o atributo que melhor caracteriza Zeus. Na tradição literária, a águia é descrita como o rei dos pássaros ${ }^{22}$, a mais forte das aves ${ }^{23}$, a perfeita ${ }^{24}$, a de penetrante visão $0^{25}$, de altíssimo vôo ${ }^{26}$ e de amplidão

\footnotetext{
22 Píndaro, Píticas I, 5; Ístmicas, VI, 45-50.

23 Homero, llíada XXIV, 310-321.

24 Idem.

25 Homero, llíada XVII, 673-680.

26 Idem, XIII, 81-83.
} 
divina ${ }^{27}$ - características que também qualificam Zeus como o rei dos deuses e dos homens, a sua onipotência, o seu poder mântico e sua associação com o céu. Sobre o significado que a relaciona com o futuro, como a águia que tem penetrante visão, Zeus é descrito nos textos como multiocular ${ }^{28}$ e de larga visão ${ }^{29}$, definições que descrevem o poder de Zeus em determinar o destino dos homens, a sua atuação oracular bem conhecida nos santuários de Dodona e Olímpia. Assim como a águia voa em grandes alturas para ter uma visão ampla, característica da ave que provavelmente determinou sua concepção como animal mântico, Zeus também do alto de seu trono no Olimpo tem uma visão completa que lhe permite decidir os rumos de uma batalha, os rumos da vida dos homens. Essas características da águia também a associaram à luz ${ }^{30}$ e ao céu, o que nos leva a outra associação com o deus. Uma das características mais antigas de Zeus é a que o qualifica como 0 deus celeste e dos fenômenos atmosféricos. O próprio vocábulo Zeus provém de uma raiz indo-européia que significa brilhar e o seu epíteto Aitherios ("céu claro") o relaciona como o deus do céu luminoso (Lévêque; Sechan, 1990: 81). De acordo com a teoria de Cook, em época pré-helênica, antes de se tornar uma figura antropomórfica de deus do céu dos gregos, Zeus foi o próprio céu "animado" (Cook, II: 1). A águia, assim, encontrou seu lugar ao lado do deus celeste (Wittkower, 1939: 307).

Nesse ponto, da associação das características da águia com Zeus, podemos dizer que a ave veio a ser considerada como epifania da divindade, uma manifestação na natureza de sua energia divina. 0 mesmo ocorre com o raio, que nos textos vemos nomear Zeus, como em Baquílides (Epinícios 5, 15-20), trecho já comentado nessa parte do capítulo, e em tantos autores antigos de época arcaica e clássica.

Da mesma maneira que vemos relações simbólicas entre a águia, o raio e Zeus, havia também uma associação simbólica específica entre ambos os atributos. Na literatura antiga, tanto a águia como o raio são relacionadas ao fogo. Em um fragmento encontrado de Niobe, Ésquilo fala de águias carregando fogo ${ }^{31}$, já Píndaro, em Píticas (I, 5), chama o raio de guerreiro de fogo eterno. Essas associações antigas refletem-se na imagética quando vemos o raio ser representado com as asas, que, segundo Cook, são asas de águias.

Essas energias divinas, do raio e da águia, encontravam-se reunidas, conforme nos mostra a documentação literária e numismática, em que vemos as imagens dos atributos juntas em uma mesma moeda ou representados combinados no mesmo campo monetário. Descrições nos textos nos fornecem as imagens dessa combinação de energias que vemos nas moedas. Baquílides descreve a águia como mensageira do alto trovão e Aristófanes (Aves, v.1247) de pássaro porta-raios.

\footnotetext{
27 Odisséia XIX, 535-540.

28 Sófocles, Édipo em Colono v.1085.

${ }^{29}$ Odisséia IV, 172.

${ }^{30}$ A respeito da associação da águia à luz do sol ou ao próprio sol, ver Cook, I, p.341 e Wittkower, 1939, pp.294-308. A águia teve um significado relacionado ao sol na religião babilônia. Sobre a Grécia antiga, nem Cook e nem Wittkower oferecem explicações contundentes sobre essa associação, embora ela não seja improvável e tenha origem em algum substrato antigo na religião grega. Em Baquílides (Ep. 5, 15-20) e Xenofonte (Cirop. 7.1, 3-4), as asas da águia são descritas como douradas. Wittkower lembra que as duas colunas com figuras de águias no témeno de Zeus, no santuário do Mt. Lykaion, eram viradas para o nascer do sol (Wittkower, 1939: 308). Em um trecho de Ésquilo (Suplicantes v.212), o sol é invocado como o pássaro de Zeus. Mas o trecho é descartado como evidência da associação com a ave porque nessa parte a peça faz referência a um mito greco-líbio (Cook, II: 341-342).

31 Citado por Cook, II: 777.
} 
E assim, após essa análise dos vários contextos dos significados de Zeus, do raio e da águia, e do caráter simbólico revelado em cada tipo de representação, temos elementos para pensar as razões pelas quais a pólis requereu para si tais significados ao escolher usar as imagens do deus e de seus atributos em moedas. Uma maior compreensão do uso dessas imagens e de seus significados para a cidade grega se mostrará à medida que descobrirmos as motivações político-sociais vigentes por trás de cada emissão. 


\section{CAPÍTULO IV - ANÁLISE REGIONAL INTERPRETATIVA DAS IMAGENS MONETÁRIAS DE ZEUS, ÁGUIAS E RAIOS}

\section{INTRODUÇÃO}

Após a análise quantitativa, iconográfica e contextual do significado simbólico dos tipos monetários de Zeus, águias e raios, vista anteriormente, realizaremos, nesse capítulo, uma análise interpretativa das imagens monetárias no contexto de sua emissão pelas diversas autoridades a partir de uma perspectiva regional. Examinaremos cada situação histórica relacionada ao uso das representações de Zeus e de seus atributos em moedas gregas - as motivações político-sociais vigentes relacionadas à cada emissão em época arcaica e clássica - para compreender os significados simbólicos assumidos por essas imagens quando apropriadas pela cidade grega. Para tanto, partiremos dos significados simbólicos primários de cada representação, revelados na análise contextual das artes visuais e literária, para ver em que medida esses se somaram a novos significados que podem ter emergido por influência ou não, por exemplo, de uma história regional única em relação ao culto de Zeus. Em última análise, objetivamos compreender em que medida esses novos significados estiveram relacionados à política e à identidade da pólis. Nesse caso, analisaremos as emissões monetárias do Peloponeso, da Sicilia, da Itália do Sul e de Creta - as regiões do mundo grego onde os tipos monetários do deus e de seus atributos mais se propagaram entre as autoridades emissoras (com exceção de Creta), que, por sua vez, foram responsáveis pela criação de certos padrões iconográficos e trocaram, entre elas, variedades de representações nas moedas.

Já que nosso enfoque é regional, organizaremos e discutiremos a documentação numismática, primeiramente, de acordo com cada região, e sub-regiões, a partir de uma ordenação cronológica dos tipos monetários. Nesse capitulo, consideraremos as imagens presentes nos anversos e reversos dos tipos monetários ainda que em um deles o tipo não se refira às representações de Zeus, águias e raios. Trata-se de uma escolha determinada pela abordagem metodológica contextual que seguiremos - àquela da Escola de Messina, do Lexicon Iconographicum Numismaticae (LIM), a qual julgamos mais adequada para o tipo de análise dos significados das imagens que iremos empreender. De acordo com a análise do LIN, "a moeda é um instrumento eminentemente comunicador de aspectos jurídicos e sociais ligados à comunidade e exprime a identidade da autoridade que a produziu" (Caccamo Caltabiano, 1998: 57; 2004: 14). As diversas mensagens, nelas gravadas, "são expressas através de códigos icônicos de formação antiga, consolidados no tempo, mas cuja compreensão não é sempre imediata, se não conhecemos suas regras, se não estamos culturalmente habilitados para decifrá-la" (Caccamo Caltabiano, 1998: 57). No caso dos gregos, e dos homens antigos, havia "uma forte tendência em revestir os conceitos abstratos de formas visíveis, criando um sistema de sinais feito para a comunicação de tudo o que era percebido como misterioso e incompreensível" (Caccamo Caltabiano, 
1998: 58). Assim, "esse sistema de comunicação somente pode ser compreendido na reconstrução do milieu cultural dentro do qual o documento monetário ganhou vida" (Caccamo Caltabiano, 2004: 12).

No estudo da iconografia antiga, "o caráter limitado do campo da moeda determinou a adoção de uma linguagem estritamente sintética e imediata, na qual, pode-se dizer, que as imagens, analogamente aos ideogramas, correspondem diretamente às palavras, ou seja a elementos únicos que exprimem um conceito ou constituem um discurso" (Caccamo Caltabiano, 1998: 58). Na acepção do LIN, "assim como na língua falada existem nomes dotados de sentido completo (substantivos), há outros sem autonomia, mas com função qualitativa os quais acompanham os substantivos (adjetivos)". "No campo icônico estes são definidos como imagens secundárias - se associam àquelas principais (o tipo, com função análoga a dos substantivos nas linguagens verbais) para exprimir qualidade ou função no tema representado" (Caccamo Caltabiano, 1998: 58 e 63). Nesse caso, "as imagens secundárias têm a finalidade de qualificar e especificar a mensagem expressa pelo tipo" (Caccamo Caltabiano, 1998: 63). Da mesma forma como cada palavra é dotada de um significado específico (ou significado de base), também a imagem monetária deve ter tido um significado conhecido a todos, caso contrário não teria sido possível a comunicação entre o emitente e o destinatário da mensagem. No estudo da iconografia, distingue-se o significante do significado, os quais são comuns também à palavra. Nesse sentido, significante seria a imagem que vemos, a que se costuma definir como forma, enquanto 0 significado seria o conteúdo da imagem. O significado pode ser denotativo (de base ou primário), conotativo (suplementar, acrescentado pelas imagens secundárias) ou simbólico (inferido na correlação semântica entre o tipo principal e o símbolo, a imagem secundária (Caccamo Caltabiano, 2004: 17). Assim, nessa perspectiva de análise, todas as representações que compõem a imagem monetária, no anverso e reverso das moedas, devem ser lidas em conjunto, interpretadas como peças de um quebra-cabeça que, completo, revela a mensagem que a autoridade emissora quis transmitir.

Para se chegar ao significado da imagem monetária, a metodologia do LIN propõe, em primeiro lugar, "categorizar o tipo a um reagrupamento mais amplo de temas, caracterizados por elementos objetivos que consentem a sua identificação (divindades, animais, heróis fundadores, etc.), considerando as diversas modalidades de representação (cabeça, prótomo, figura inteira) ou as diferentes posições (em pé, sentado, voando, correndo, etc.), as quais modificam ou enriquecem a sua semântica" (Caccamo Caltabiano, 2004: 21). Em segundo lugar, "é necessário se voltar à linguagem iconográfica utilizada pela oficina monetária nas suas escolhas tipológicas, ou, na ausência de exemplos provenientes de uma mesma cidade, estudar imagens análogas utilizadas na mesma área geográfica e datáveis do mesmo período" (Caccamo Caltabiano, 1998: 69). E ainda, para se obter uma visão mais ampla e completa sobre o significado de uma imagem monetária devese evitar concentrar o estudo a apenas uma área geográfica dentre as muitas outras onde os tipos apareçam. É necessário "recuperar todos os contextos de uso e caracterizar todos os falantes daquela determinada linguagem, pois apenas no confronto, na comparação e caracterização das similaridades e diferenças, podemos 
encontrar os significados comuns a todos os falantes, aquilo que se define significado de base" (Caccamo Caltabiano, 2004: 21).

$\mathrm{Na}$ interpretação que propomos realizar nesse capítulo, consideraremos também a perspectiva de que as imagens de Zeus, águias e raios, em moedas gregas, eram representações de energias divinas. Trata-se de uma perspectiva preconizada por J. Bayet (1959), que primeiro a aplicou no estudo de moedas gregas. "Havia uma crença comum entre os povos pré-industriais - e os gregos não eram uma exceção - de que certos objetos, como as pedras, as plantas, os animais, ou mesmo qualquer objeto fabricado pelo homem, poderia ter - devido a circunstâncias particulares - um poder, uma energia interna denominada de maná. De acordo com a mesma crença, uma imagem poderia substituir, em alguma medida, a energia de um objeto" (Florenzano, 1995: 226). "A imagem tinha o poder de fixar determinadas energias, de colocá-las sob controle e ao mesmo tempo de propiciá-las" (Florenzano, 1995: 226). Nessa perspectiva, "a representação de uma lança, de um raio, de uma espiga de trigo, de um animal e, por que não, de uma divindade, estariam impregnadas de energia" (Florenzano, 1995: 226). Ao representar um objeto (uma arma, um escudo, uma espiga) ou uma divindade, a "sensação deve ter sido de controle sobre aquelas energias representadas, de ordenação destas energias e de eventualmente uso em favor próprio" (Florenzano, 1995: 227). No caso das representações monetárias, acreditamos que os antigos gregos, ao escolher os tipos que queriam figurar em suas moedas, agiam segundo esse princípio básico de eficácia da imagem. Na moeda, "emblema da comunidade ou do poder constituído, a imagem adquiria uma dupla função: não apenas identificava o poder emissor a uma força divina ou extraordinária, como também invocava essa força para a proteção deste" (Florenzano, 1995: 227). No caso das divindades gregas, "esse era um meio de propiciar o deus, reconhecendo os seus poderes e invocando a sua proteção" (Florenzano, 1995: 227). Nesse sentido, "com relação aos atributos de Zeus, para J. Bayet, a águia e o raio são as energias, forças ou carismas, divinas do deus" (Bayet, 1959: 88). "A águia, o animal mensageiro de Zeus, é portadora da vontade e da realidade psíquica do deus" (Bayet, 1959: 77).

Nesse contexto de fixação e controle de energias, propiciados pelas imagens, está também o caráter apotropaico das imagens monetárias (Florenzano, 1995: 226-227). "Trata-se de um raciocínio - característico da religião antiga - de que alguém pode combater uma energia indesejada com uma energia igual a ela (Florenzano, 1995: 227). O termo apotropaion tem sua raiz no verbo grego apotrepein ("afastar" ou "evitar")" (Faraone, 1992: 4). "Se as imagens usadas como talismãs protegiam pela sua mera presença, uma imagem apotropaica tinha o objetivo de afastar e intimidar forças humanas e sobre-humanas ruins" (Faraone, 1992: 4). As representações monetárias não escapavam desse caráter mágico próprio da religião grega, o qual deve ser também considerado quando nos perguntamos sobre que tipos de motivações levaram as autoridades emissoras a usar imagens de divindades gregas em suas moedas. De acordo com M.B.B. Florenzano, "as divindades olímpicas por mais generosas e benfazejas que fossem, sempre tinham um lado aterrorizador. Quando enfurecidas podiam trazer à pólis grandes desgraças, como a fome, as epidemias, as pragas. Zeus, Apolo, Atena, Ártemis, Deméter, enfim, praticamente todas as divindades do panteão grego tinham poderes 
que podiam ser dirigidos para um lado e para o outro. Todas eram divindades que deviam ser invocadas, propiciadas; todas precisavam ter seus poderes e energias controladas, colocadas "a favor" (Florenzano, 1995: 227).

Essa perspectiva de Bayet sobre as energias divinas contidas nas representações monetárias de divindades em moedas gregas, principalmente seu valor apotropaico, alinha-se à ideia de agência dos objetos. De acordo com Hodder, "os objetos têm agência não porque simbolizam simplesmente, mas porque incorporam uma força que trazem à mente associações significativas para a pessoa ou para o grupo afetado pelo objeto. Assim, nós damos poderes aos objetos de tal modo que eles podem agir em nós" (Hodder, 2003: 101-102). "Trata-se, então, não apenas de ver essas imagens monetárias como arte e expressões de valores sociais, mas como agentes na interação social" (Hölscher, 2014: 674).

É sob essa perspectiva que devemos interpretar as imagens monetárias de Zeus e de seus atributos que, como vimos, muito provavelmente estiveram associadas, em algum momento político específico, à necessidade de manutenção da ordem sobre a desordem e sua ameaça.

\section{TENDÊNCIAS REGIONAIS NA REPRESENTAÇÃO DE ZEUS, ÁGUIAS E RAIOS EM MOEDAS GREGAS EM ÉPOCA ARCAICA E CLÁSSICA}

Diante do mapa exposto no capítulo 3, das áreas do mundo grego mais relevantes para o estudo dessas representações em moedas, e das trocas culturais entre elas, analisaremos, como estudo de caso, as emissões monetárias do Peloponeso, da Sicília, da Itália do Sul e também da ilha de Creta, que será considerada por representar, ao lado do Peloponeso, uma das áreas mais antigas na qual o culto de Zeus se manifestou em santuários interestaduais e políades. A Tessália não será investigada, como estudo de caso, em razão de não haver um estudo sistemático e completo sobre as emissões monetárias relacionadas a Zeus no período estudado. A Líbia, que aguarda uma revisão completa das datações das séries monetárias, será analisada como comparadum no último capítulo da tese.

Dessa maneira, justifica-se a escolha do Peloponeso, Sicília, Itália do Sul e Creta na análise regional para o estudo interpretativo dos tipos monetários de Zeus e de seus atributos em moedas gregas, no período proposto, com a finalidade de entender, à luz do contexto histórico das emissões, as razões político-sociais que levaram a pólis a escolher usar tais imagens em suas moedas. Trata-se de tentar perceber em que medida essas imagens foram usadas em momentos específicos, onde política e identidade foram mais importantes expressões visíveis de identidade e poder político de determinado grupo.

Nessa perspectiva, e levando em consideração a metodologia do LIN, tentar-se-á compreender, ao final, se existiu ou não uma correspondência semântica entre essas áreas as quais trocaram traços culturais, ou seja, se o significado adquirido pelas imagens de Zeus, raios e águias assemelha-se ou variou entre essas regiões com relação à apropriação desses tipos pelas comunidades políticas em época arcaica e clássica. 


\section{I.1 PELOPONESO}

O Peloponeso foi uma região do mundo grego dividida em sub-áreas que podem ser consideradas grandes regiões, como Élis, a Arcádia, a Acaia e a Messênia, por serem caracterizadas, se diferenciarem, por definições étnicas precisas e grandes centros urbanos que exerciam domínio sobre outras comunidades políticas, articulando, assim, o quadro político regional (Fig.234) (Purcell, 2012: 1101). No maior centro regional de culto a Zeus no mundo grego, as imagens de Zeus, da águia e do raio foram usadas em moedas gregas, como tipos principais, predominantemente na porção ocidental do Peloponeso, nas sub-áreas mencionadas acima. As imagens da águia e do raio parecem ter sido as primeiras a aparecerem como tipo monetário já no início do século $V$ a.C. nas cunhagens de Élis-Olímpia, a única autoridade emissora a usá-las como tipos principais em moedas na região. Zeus como imagem monetária principal ocorreu nos três padrões conhecidos (cabeça, sentado e em pé) e parece ter sido usada pela primeira vez, em moedas no Peloponeso, na subregião da Arcádia após o final das guerras pérsicas, no final do primeiro quartel do século $V$ a.C. Nas cunhagens de Élis-Olímpia, a imagem da divindade ocorreu um pouco depois, na metade do século $V$ a.C. Na Messênia e na Acaia, imagens monetárias de Zeus emergiram, pontualmente, somente a partir do final do primeiro quartel do século IV a.C. Apenas em Élis-Olímpia e na Arcádia tipos monetários do deus se mantiveram em cunhagens nos séculos V e IV a.C. A associação entre as imagens de Zeus e seus atributos, como tipos principais em moedas, foi restrita à Elis-Olímpia, sendo usadas em combinação, pela primeira vez, no século $V$ a.C.

\section{I.1.1 Élis}

Pólis administradora do santuário de Olímpia desde ao menos o século VI a.C., Élis foi a autoridade emissora que mais emitiu - em seu nome, mas para o uso em Olímpia -, tipos monetários de Zeus, raios e águias no mundo grego no período estudado, considerando a quantidade de todos os tipos do deus e de seus atributos cunhados entre os séculos VII-IV/III a.C. Foi a autoridade emissora a primeiro combinar a representação de Zeus, águias e raios (águias + raios; Zeus + águias; Zeus + raios; Zeus + águias + raios) no primeiro quartel do século $V$ a.C. (no caso de águias e raios), associações que foram seguidas, principalmente, como veremos, por autoridades emissoras da Sicília e da Itália do Sul. Além dessas associações, a oficina monetária de Élis foi responsável por algumas inovações na imagética de Zeus em moedas. A representação da cabeça de Zeus não-Amon e com coroa de folhas de oliveira, em uma moeda, parece ter sido usada pela primeira vez por Élis, sendo quase contemporânea ao que parecem ser os tipos monetários mais antigos da cabeça de Zeus não-Amon, mas sem a coroa de folhas, emitidos talvez pela liga arcádia entre c.430-420 a.C. Nas moedas de Élis aparecem, também pela primeira vez, a imagem de Zeus nu em pé, atirando o raio, com a águia sobre ou voando próximo ao braço esquerdo do deus. Também foi a sua oficina monetária que criou uma nova forma de representar o deus sentado - além de ter usado a tradicional imagem de Zeus sentado no trono 
em uma emissão, também criou a imagem monetária de Zeus sentado sobre uma rocha, alterando também a posição do cetro e da águia na representação. Inovações também são vistas nas representações do raio e da águia. Imagens do raio alado também parecem ter sido usadas primeiramente por Élis, assim como o raio chamejante deve ter sido uma criação de sua oficina monetária, pois não encontra paralelo em nenhuma outra emissão monetária no mundo grego. Sobre a águia, sob a autoridade de Élis foram criadas formas novas de representar a ave voando ou em pé e abordando as suas presas.

Essa mesma documentação, a mais rica acerca da pesquisa numismática sobre Zeus e seus atributos, impõe, infelizmente, uma série de limitações de ordem cronológica que ainda aguarda um novo e completo estudo sobre as séries monetárias, revisto com base na discussão mais recente acerca da história da pólis de Élis. Sobre a historicidade das fontes escritas referentes aos episódios históricos que envolveram Élis e Olímpia, os quais foram usados para nortear muitas das datações das emissões monetárias, como foi o caso, por exemplo, da Lista dos Vencedores Olímpicos, de Hípias de Élis, cuja informação da cronologia dos jogos parece ser equivocada (Roy, 2013: 107). Responsável pelo primeiro estudo, e ainda o mais completo a respeito das cunhagens de Élis, C.T. Seltman, na década de 1920, organizou as emissões monetárias em espaços de quatro anos, de acordo com os anos dos jogos olímpicos realizados, conhecidos da Lista de Hípias. C. Kraay também seguiu a proposição de Seltman, de que as cunhagens teriam sido realizadas a cada festival (Kraay, 1976: 103). Esse critério cronológico foi recentemente criticado por $\mathrm{H}$. Nicolet-Pierre que chega a afirmar ser difícil de ser provado (Nicolet-Pierre, 2002: 179). Desde o estudo de Seltman, alguns estudos foram publicados, sugerindo novas datações, mas estes não realizaram uma análise completa das emissões de época clássica, somente de determinadas séries monetárias, como é o caso, por exemplo, do artigo de Nicolet-Pierre dos anos de 1970. F. Wojan, mais recentemente, se devotou à análise das emissões de Élis dos séculos IV a.C. ao III d.C., mas seu estudo aguarda a publicação. Assim, na ausência de uma nova e completa proposição para a cronologia de toda a cunhagem das moedas de Élis para Olímpia de época clássica, seguiremos aquela disponível no catálogo da BCD Collection, organizado por A. Walker, o qual se baseou, em parte, em C.T. Seltman e C. Kraay, e que situa o início das emissões no primeiro quartel do século $V$ a.C. em relação à construção do templo de Zeus no santuário.

A cunhagem mais antiga de Élis foi composta por estateres (ou didracmas), dracmas, hemidracmas e óbolos, batidos em padrão eginético (estateres de $12 \mathrm{~g}$ como os de Egina), o predominante no Peloponeso desde o início das emissões na área no final do século VI a.C. (Kraay, 1976: 95; Nicolet-Pierre, 2002: 179; Psoma, 2012: 167; Walker, 2004: s/p). Durante o século IV a.C., novas pequenas denominações foram introduzidas, como o tritetartemorion e o trihemitertatermorion, e houve até uma cunhagem em ouro de óbolo no nome de Pisa, quando esta, por um curto período, controlou Olímpia. De acordo com H. Nicolet-Pierre, "antes de baterem suas moedas no padrão eginético, a circulação monetária na região era suprida, essencialmente, pelos estateres de Egina" (Nicolet-Pierre, 1975: 16). Os tipos monetários, das emissões mais antigas às mais recentes, foram batidos no nome dos eleios (dependendo da série monetária, no genitivo plural 
na forma cheia, $F A \wedge E I O N, F A \wedge E I \Omega N$, ou de forma abreviada $F / A)$, com exceção do período de interrupção da administração de Élis entre 365-362 a.C., quando o Estado de Pisa, recém-formado, ganhou o controle do santuário e produziu uma emissão em seu nome (no nominativo singular, ПIIA) (Kraay, 1976: 103; NicoletPierre, 2002: 179; Psoma, 2012: 167; Roy, 2013: 108; Walker, 2004: s/p).

Há três debates principais sobre a documentação numismática de Élis-Olímpia: um acerca do início e os outros com relação à função das emissões monetárias e à localização da oficina monetária. Sobre o início da cunhagem de Élis, há uma controvérsia entre os estudiosos. Dos primeiros autores a estudarem essas moedas, B.V. Head parece ter sido o primeiro a assumir que os eleios emitiram suas moedas somente após 0 sinecismo de Élis em c.471 a.C. Dentre esses antigos estudiosos, E. Babelon (Traité II, 1) localizou as mais antigas emissões no final do século VI a.C., sendo seguido por C.T. Seltman, que, baseando-se em paralelos estilísticos com a cunhagem de tipos monetários de águias de Cálcis, na Eubéia, do final do período arcaico, datou as primeiras emissões de Olímpia em c.510 a.C. ou antes (apud Walker, 2004: s/p). Mais recentemente, essa datação foi seguida por H. Nicolet-Pierre e C. Kraay (Nicolet-Pierre, 1975: 16). Contudo, em seu manual, Kraay retornou para a data de 471 a.C., proposta por Head, convencido por uma pesquisa mais atual sobre novas datações das moedas de Cálcis (Kraay, 1976: 104). A. Walker, em sua detalhada introdução acerca das moedas de Olímpia para o catálogo da $B C D$ Collection, prefere seguir a proposição de que as primeiras emissões de Élis-Olímpia não teriam sido anteriores a 470 a.C. (Walker, 2004: s/p). Para esse estudioso, essa constatação é baseada na ausência de moedas de Élis nos maiores tesouros monetários de moedas gregas de prata datados do final do século VI a.C. ou do primeiro quartel do século $\mathrm{V}$ a.C. - o tesouro mais antigo contendo moedas de Élis foi enterrado em c.460 a.C. em Naupactos (IGCH 19) (Kraay, 1976: 104; Walker, 2004: s/p).

Já uma outra linha interpretativa, influenciada pelo estudo crítico de J. Roy sobre o sinecismo de Élis, prefere desvincular, o início das cunhagens, desse evento, descrito principalmente por Diodoro e Estrabão (Nicolet-Pierre, 2002: 179; Psoma, 2012: 167; Roy, 2002: 261). Segundo J. Roy, o fato de que antes do sinecismo, datado arbitrariamente em 471/70 a.C., já havia um assentamento urbano significativo em Élis, e que essa pólis, nesse momento, já era bem organizada politicamente, significa que ela teria sido perfeitamente capaz de bater moedas antes do sinecismo - não haveria razões para supor que a cunhagem mais antiga deveria ser posterior a tal acontecimento, como foi proposto inicialmente (Roy, 2002: 261). Nicolet-Pierre, e mais recentemente S. Psoma, em manuais numismáticos, reiteram a datação dos primeiros tipos monetários de Élis a um período muito anterior a 471/70 a.C., sem mencionar o seu início no século VI a.C. (Nicolet-Pierre, 2002: 179; Psoma, 2012: 167). A nosso ver, a informação advinda dos entesouramentos é importante e deve ser considerada. Apesar de os desenhos das águias em vôo, com ou sem a cobra, das séries mais antigas de Élis, se alinharem com o estilo do desenho da ave que aparece retratada em cálices lacônios de c.530 a.C. (Fig.221) e em skyphoi áticos ainda mais antigos (de c.625-575 a.C.) (Fig.212), consideramos as imagens monetárias mais antigas datadas do primeiro quartel do século $V$ a.C. Até a asa de Nike, que acompanha no 
reverso o tipo da águia voando no anverso, contém traços estilísticos muito semelhantes ao da ave, que aparece nessa cerâmica pintada do período citado. A nosso ver, os artistas gravadores das ditas séries monetárias mais antigas de Élis, com o tipo da águia, devem de algum modo, no início do século V a.C., terem sido influenciados por um estilo vigente de desenho da águia próprio da arte arcaica do século VI a.C., provavelmente, por proximidade regional, de oficinas cerâmicas lacônias, as quais parecem ter difundido mais esse modelo. A julgar pela data de ambos os vasos, essa imagem da águia em vôo parece ter circulado entre os artistas, ao menos, por todo o século VI a.C. Outra evidência disso é um relevo de loutherion, proveniente de Agrigento, na Sicília, o qual será analisado mais adiante (Fig.233). Datado do final do século VI a.C., o vaso traz representações de Nike muito semelhantes às primeiras vistas nas moedas eléias (correndo com a coroa na mão).

Outro tema polêmico, e de muita controvérsia entre os estudiosos, refere-se à localização da oficina monetária, se ela se encontrava estabelecida em Élis ou no próprio santuário de Olímpia, já que as moedas foram batidas no nome dos eleios, mas teriam sido utilizadas durante o funcionamento do santuário (Walker, 2004: s/p). De acordo com Walker, P. Gardner, responsável pelo primeiro estudo sério sobre as moedas (NC, 1879), situou as emissões na cidade de Élis (apud Walker, 2004: s/p). Seltman, seguido, posteriormente, por Babelon (Traité III), Kraay e outros, propôs, pela primeira vez, que as moedas foram batidas no próprio santuário de Olímpia, em um recinto anexo ao templo de Zeus, já que as moedas carregavam a imagem da divindade. Esse estudioso encontrou a mesma explicação para as imagens monetárias de Hera, as quais teriam sido produzidas, como uma segunda emissão, em um recinto no seu templo. Duas oficinas monetárias independentes (a de Zeus e a de Hera), assim, foram propostas, como base na ausência de cunhos compartilhados entre as duas emissões (Psoma, 2012: 167; apud Walker, 2004: s/p). A explicação de Seltman leva ao tema da função e do uso dessas moedas - o santuário de Olímpia teve uma necessidade real por moedas devido ao grande número de visitantes que vinham para os jogos, como também aos milhares de peregrinos e viajantes que visitavam o local ao longo do ano (Walker, 2004: s/p). "Por essa razão, é mais plausível considerar que as emissões monetárias eram realizadas em Olímpia para facilitar a rápida troca de moedas de fora pelas locais, de Élis, já que essa pólis situava-se c.60 km a noroeste do santuário, distante ao menos um dia de jornada" (Walker, 2004: s/p). Enquanto a maior parte dos estudiosos segue essa teoria, outros ainda preferem acreditar que a produção das moedas ocorria em Élis, com base na premissa de que atividades industriais teriam sido inapropriadas dentro de um santuário (Walker, 2004: s/p). De fato, as escavações alemãs até o momento "não identificaram traços de uma oficina monetária em nenhuma área. Para A. Walker, embora haja provas de que a oficina de Fídias tenha sido permitida dentro da área dos principais edifícios do santuário, deve-se considerar a possibilidade de que a oficina monetária tenha estado situada nos seus arredores, em uma área não escavada" (Walker, 2004: s/p).

Como dissemos, a localização da oficina monetária coloca o problema da função e do uso, o terceiro e último tema de discussão sobre as moedas de Élis-Olímpia. Seltman propôs que as as moedas emitidas por Élis para Olímpia "teriam sido o dinheiro sagrado de Zeus, como base na premissa de que usaram as imagens 
referentes à divindade e foram batidas em seu santuário e para o seu funcionamento" (Seltman, 1921: 69). Além da simples ideia de que as moedas foram necessárias em Olímpia para atender a demanda de visitantes participantes no culto e nos jogos, sabe-se que no santuário, durante os festivais, ocorria um grande mercado, o qual atraía uma grande audiência de vendedores e compradores de várias partes do mundo grego (Walker, 2004: s/p). De acordo com J. Taita, "o mercado ocorria em ocasião da panegyris quadrienal, ao menos desde a segunda metade do século V a.C., devido à presença de milhares de pessoas" (Taita, 2007: 86). Pesos de bronze com o nome de Zeus, inscrito no genitivo, "indicam a presença de uma suposta ágora no setor sul do Altis" (Taita, 2007: 86, nota 15). Para tal demanda, segundo Walker, "o Estado de Élis precisava assegurar que os pesos e medidas oficiais de Élis fossem os únicos permitidos a serem usados pelos mercadores em Olímpia" (Walker, 2004: s/p). Embora os eleios tenham permitido a entrada irrestrita de moedas de outras proveniências do mundo grego, "todas as transações deveriam ser realizadas com a cunhagem local de Élis" (Walker, 2004: $\mathrm{s} / \mathrm{p})$. De fato, "a maior parte do metal usado para bater as moedas locais deve ter vindo da troca com as moedas de fora do santuário - ao chegarem em Olímpia, mercadores e indivíduos devem ter sido obrigados a entregar as moedas de prata de fora as quais pretendiam usar no local. Após a dedução de uma pequena taxa, assim, estes receberiam o equivalente na cunhagem local de Élis" (Walker, 2004: s/p). Tal taxa deve ter propiciado um considerável lucro para as autoridades de Élis, que provavelmente o usaram para ajudar a manter o santuário (Walker, 2004: s/p). Além disso, "a cunhagem de Élis tinha um peso abaixo em comparação a outras em padrão eginético, mostrando que foi projetada para circulação local durante os jogos, e atividades relacionadas, assim como para a visitação anual entre os festivais" (Psoma, 2012: 167). A cunhagem de Élis, durante o século V a.C. e até as primeiras décadas do século IV a.C., recebeu, extensivamente, contramarcas com uma ampla variedade de punções (desenhos geométricos, florais e figurativos) (Psoma, 2012: 167; Walker, 2004: s/p). C. Kraay sugeriu que, "como as autoridades de Élis teriam produzido uma nova cunhagem para cada festival, emissões anteriores eram, então, desmonetizadas, declaradas não usáveis, ao menos que fossem revalidadas pelo uso das contramarcas para as quais uma pequena taxa deve ter sido cobrada" (Kraay, 1976: 16).

Essa circulação mais restrita localmente à Olímpia parece ter sofrido uma ampliação no início do século IV a.C., quando as autoridades de Élis permitiram o uso externo dessas moedas, ainda que elas não tenham sido encontradas muito além do Peloponeso (Walker, 2004: s/p). Como veremos, a partir desse período, também, houve uma mudança na escolha tipológica, tipos antigos foram abandonados e novos incluídos, denominações menores que óbolos passaram a ser utilizadas, assim como o bronze foi requisitado como metal para as cunhagens a partir da segunda metade do século IV a.C. (Walker, 2004: s/p).

Antes de empreendermos a descrição e discussão dos tipos monetários, deve ser ressaltado que estes foram, sem dúvidas, o produto o trabalho dos maiores artistas gravadores do mundo grego naquele período, dada a excepcional característica das imagens. Segundo Walker, "tal beleza e inovações nas imagens de Zeus, raios e águias, Hera e Olímpia indicam que os eleios importaram tais artistas para acrescentar mais prestígio ao santuário e advertir sua importância a todos aqueles que usassem as moedas" (Walker, 2004: s/p). Assim, 
após apresentarmos o estado da arte a respeito do início, localização, uso e função das emissões monetárias de Élis, é que podemos oferecer um resumo descritivo das imagens monetárias e suas respectivas datações e denominações. Para tanto, partiremos do padrão de cada tipo de imagem de Zeus, raios e águias (considerando os tipos de Hera, Nike e Olímpia dentro da descrição daqueles do deus e de seus atributos) para mostrarmos, objetivamente, o desenvolvimento destas no tempo, portanto, quando surgiram, se mantiveram e caíram em desuso nas emissões. Reiteramos que se trata apenas de um resumo, elaborado de sorte a oferecer subsídios, mais adiante, à interpretação dos significados dos tipos monetários.

Zeus em pé. Trata-se de um dos primeiros tipos de representação do deus que foi usado nas moedas de Élis-Olímpia a partir da metade do século V a.C. Nesse caso, sempre como imagem do reverso, Zeus é retratado nu, atirando o raio com o braço direito erguido e, próximo ao braço esquerdo estendido, encontra-se a águia voando. A representação foi usada em três séries monetárias de estateres: duas delas batidas entre C.452-432 a.C. (Fig.235 - n.340/341) e uma outra do final da década de 450 a.C. (Fig.235 - n.342). A águia voando, carregando a cobra ou a tartaruga, é o tipo que acompanha esse padrão de representação de Zeus nas moedas de Élis, pois era o padrão típico da ave naquele período. Outro detalhe interessante dessas emissões, é a legenda do étnico no neutro plural O^YMПIKON ("dos olímpicos"), que ocorre sempre junto à imagem de Zeus, nesse caso, substituindo a legenda padrão FA^EION ("dos eleios"). Outro ponto interessante também, é a presença da águia, voando próxima ao braço de Zeus, um elemento completamente novo, naquele período, nesse padrão de representação da divindade em moedas. Vimos no capítulo anterior como a águia está ausente no tipo monetário de Zeus em pé, atirando o raio, um pouco mais antigo que os de Élis, cunhado em Zancle em c.460 a.C. As cronologias de todos os tipos monetários de Zeus desse padrão, parecem indicar que a águia foi utilizada, dessa maneira, pela primeira vez nas moedas de Élis, tornando-se um esquema iconográfico seguido posteriormente por autoridades emissoras de outras regiões (Posidônia, Itália do Sul; Messênia, Peloponeso; Gomphi e Kierion, Tessália). Concordamos com L. Lacroix, que diz que esse padrão de representação foi inspirado nas estatuetas votivas de Zeus Keraunios, muitas das quais encontradas em Olímpia (Lacroix, 1949: 73). Discordamos de Kraay e Walker que preferem ver nas imagens a representação de uma suposta estátua de culto arcaica de Zeus presente em seu templo até c.430 a.C. quando foi então substituída pela obra-prima de Fídias (Kraay, 1976: 104-105; Walker, 2004: 30). As diversas estatuetas votivas de Zeus atirando o raio, encontradas em Olímpia, indicariam que haveria uma estátua de culto principal e mais antiga nesse formato (Kraay, 1976: 105). Esses estudiosos seguem a premissa de Scwabacher, que diz que 0 "neutro singular da legenda deve ser compreendido em associação com a palavra agalma ("estátua")" (apud Kraay, 1976: 105; apud Walker, 2004: 30). As referências literárias, principalmente em Pausânias, nos informam sobre uma série de estátuas votivas, não miniaturísticas, de Zeus Keraunios dedicados por indivíduos e cidades e expostas ao longo do Altis. É razoável afirmar, a nosso ver, que a imagem monetária reflete, ao menos, uma tendência de representação de Zeus, que começou no século VI e continuou ao menos até a metade do século V a.C. Se dependentes ou não da arte da estatuária, os artistas gravadores de cunhos devem ter sido 
influenciados, nesse período ainda, por uma concepção iconográfica de Zeus típica das primeiras décadas do século V a.C. É preciso ainda chamar atenção para o fato de que, nesses tipos monetários de Zeus em pé e atirando o raio com a águia, próprios de Olímpia, foi seguida uma tendência tipicamente peloponésia de usar a ave, como também vimos na análise do capítulo anterior. Uma interpretação completamente diferente, de S. Psoma, prefere ver a legenda como um adjetivo possessivo do cunho, que se refere aos estateres de peso eginético, por analogia com outras legendas (Dalfikon, Fokikon e sobretudo Arkadikon) (Psoma, 1999: 90). Para a estudiosa, "a questão permanece em aberto, já que não se sabe o que a legenda definia, se uma estátua ou a própria moeda" (Psoma, 1999: 90). Se recuperarmos a premissa de Seltman sobre o caráter sagrado dessa cunhagem a Zeus Olímpio, essa legenda pode ser a única evidência concreta que comprove a teoria desse estudioso.

Zeus sentado. Foi a outra imagem monetária mais antiga de Zeus a ser utilizada nas moedas de ÉlisOlímpia também a partir da metade do século $V$ a.C. No caso desse padrão de representação de Zeus, Élis usou duas formas, ou sub-padrões, diferentes, nesse caso, como imagens de anverso: sentado sobre o trono e sentado sobre rocha. $O$ tipo de Zeus sentado sobre o trono foi o primeiro a ser utilizado em uma série de estater datada de c.452-432 a.C., na qual Nike sentada é a imagem do reverso (Fig.235 - n.26). Na representação, Zeus é representado de uma maneira tipicamente arcádia - vestindo uma himátion na cintura, segurando o cetro com a mão direita e a águia voando próximo ao braço esquerdo estendido. Como vimos no capítulo anterior, e veremos mais adiante na discussão sobre a Arcádia, esse tipo monetário, cunhado por Élis, é quase uma cópia do modelo de representação de Zeus sentado no trono usado nos hemidracmas cunhados no nome dos arcádios entre o início e o segundo quartel do século $V$ a.C. Esse tipo monetário de Élis tratar-seia de mais uma evidência dos traços culturais trocados entre essas duas regiões (Élis e Arcádia), nesse caso, em nível religioso em relação a Zeus. Em oposição a essa imagem mais antiga, cujo padrão Élis parece ter seguido de uma cunhagem conhecida regionalmente naquela época, o tipo de Zeus sentado sobre a rocha parece ter sido uma criação da oficina monetária dos eleios. No estater da década de 430 a.C., com a imagem da águia voando com a cobra, no reverso, o deus é retratado sentado sobre uma rocha, vestindo um himátion na cintura, e a posição do cetro e da águia aparece modificada - o braço esquerdo de Zeus aparece repousando sobre a rocha, a águia parece estar voando ou sobre a mão direita e o cetro está inclinado atrás, também do lado direito (Fig.235 - n.343). Ao que parece não há legenda nem nesse tipo e nem no outro. Em moedas gregas, esse padrão de Zeus sentado sobre rocha foi pouco utilizado, sendo recorrente, no período estudado, na Tessália (em Gomphi) a partir da metade do século IV a.C.

Cabeça de Zeus. Nesse histórico do uso da imagem de Zeus em moedas de Élis, o tipo da cabeça de Zeus aparece mais tarde em relação aos demais descritos, somente na penúltima década do século $\mathrm{V}$ a.C. Esse padrão de representação do deus ocorreu sempre no anverso, do início ao fim das emissões. Na primeira série monetária com esse tipo de representação (de estater de c.416 a.C. com o raio lado no reverso), a cabeça de Zeus foi retratada com cabelos e barba curtos e com um elemento iconográfico que parece ter sido mais 
uma inovação da oficina de Élis para as moedas do santuário de Olímpia: a coroa de folhas de oliveira sobre a cabeça da divindade (Fig.236 - n.355), caso o tipo monetário de Abakainon, na Sicília, não tenha sido uma imagem da divindade. Até anteriormente a c.416 a.C., as imagens monetárias atestadas de Zeus eram aquelas de Zeus Amon, com chifres de carneiro na Líbia, e aquelas sem ou com uma fita na cabeça, batidas muito provavelmente na Arcádia. Do padrão iconográfico não-Amon e com coroa, esse tipo monetário batido por Élis pode ter sido o primeiro, ou ter estado entre os primeiros, a ser criado no mundo grego para as moedas, já que no tipo monetário de Abakainon, datado da metade do século $V$ a.C., há também o desenho da coroa. A coroa de folhas de oliveira é um símbolo totalmente local, entre outras coisas, prêmio dos atletas vitoriosos, sendo por isso fácil compreender porque justamente ela teria aparecido pela primeira vez, associada a Zeus, nas moedas locais, se assim tiver sido. Numa linha de tendência da representação da cabeça de Zeus não-Amon em moedas gregas, é interessante ver como o tipo pode ter ocorrido primeiro na Sicília, em Abakainon, depois na Arcádia entre c.430-420 a.C., e como a imagem aparece posteriormente em moedas de Élis-Olímpia. De alguma forma, mais uma vez, se percebe traços culturais compartilhados sobre Zeus entre Élis, a Arcádia e a Sicília. A bibliografia a respeito tende a associar a imagem monetária de Élis com a estátua de Zeus de Fídias, já que o tipo rompeu com o modelo iconográfico das moedas anteriores locais (Kraay, 1976: 105; Walker, 2004: 41). Mas nesse caso, também, preferimos seguir $L$. Lacroix, o qual afirma, baseado na marca de assinatura no reverso $(\Delta \mathrm{A})$ e no estilo do desenho que, nesse caso, "o artista gravador do cunho interpretou o tema de acordo com sua própria concepção e não a partir de um modelo imposto por uma grande obra" (Lacroix, 1949: 262).

No histórico das emissões monetárias de Élis, o tipo da cabeça de Zeus voltou a ocorrer no século IV a.C., no período de controle pisate sobre o santuário, em c.365 a.C. (Fig. 237 - n.361). No óbolo de ouro, com a imagem do raio no reverso, Zeus também é retratado com cabelos e barba curtos e com a coroa de folhas de oliveira, que aparece de forma mais clara no desenho. De todo o repertório iconográfico, os pisates, escolheram utilizar o esquema cabeça de Zeus no anverso / raio no reverso para sua curta emissão, uma tendência de uso preconizada pelos eleios no século V a.C. Após o domínio de Pisa em Olímpia, com a retomada da administração de Élis, a imagem da cabeça de Zeus voltou a figurar nas moedas locais a partir de c.360 a.C., ainda representada com cabelos e barba curtos e com a coroa de folhas de oliveira desenhada de forma bem evidente desta vez. Trata-se de duas séries de estateres, sendo que uma delas possui no reverso o tipo da águia em pé, com asas fechadas, sobre o capitel jônico (Fig.237 - n.345/346). Com essa série, a oficina monetária de Élis inaugurou a tradição de uso do tipo da cabeça de Zeus, no anverso, e o da águia em pé (normalmente sobre um capitel jônico), no reverso, a qual se estendeu por todo o século IV a.C. e depois (Fig.237 - n.356/348-350-353/371-373/354). A outra série traz outra novidade: o tipo da cabeça da ninfa Olímpia (identificada pela inscrição), usada pela primeira vez nas moedas de Élis (Fig.237 - n.77). A associação das legendas "dos eleios", no anverso, e "Olímpia", no reverso, tem sido interpretada como uma afirmação dos eleios na administração do santuário (Kraay, 1976: 106; Walker, 2004: 53). Sobre a imagem da cabeça de Olímpia, esta foi requisitada, pelos eleios, especificamente para as cunhagens de c.360 a.C., não tendo 
sequência em emissões posteriores - a única imagem feminina, como tipo, preponderante, e que se firmou nas moedas eléias, foi a da deusa Hera. Nas séries dessa data, a cabeça de Olímpia é retratada, no reverso de estateres, como tipo que acompanha o de Zeus no anverso, conforme descrevemos. Como imagem de anverso, o tipo de Olímpia ocorre em estateres e óbolos, nos quais a águia em pé - de asas fechadas cabeça para trás ou não, dentro ou não de uma coroa de folhas de oliveira - é a imagem de reverso (Fig.237 - n.251/252/253). Em hemióbolos, ainda, o raio alado ocorre como imagem de reverso, acompanhando a imagem da cabeça de Olímpia no anverso (Fig.237 - n.292). Nessa época ainda, em c.360 a.C., foi emitido um tritetartemorion com uma representação única de Zeus nas moedas de Élis - a cabeça de Zeus, de cabelos e barba curtos, possui uma fita no lugar da coroa de folhas de oliveira, e o reverso possui a legenda T/T/T no lugar de uma imagem (Fig.237, n.78). Essa imagem de Zeus é muito semelhante a um tipo monetário de Kierion, na Tessália, datado entre c.400-360 a.C.

Imagens monetárias de Zeus com cabelos e barba curtos foram utilizadas, como único padrão de representação de Zeus, na série de estateres de c.356 a.C. (Fig.237 - n.356). A partir das séries monetárias de c.352 a.C., Zeus passou a ser retratado, sempre com a coroa de folhas de oliveira, com cabelos e barba longos, padrão de representação que predominou ao menos até as emissões, também de estateres, de c.348 a.C. (Fig.237 - n.348-353/371-373). Apesar de esse ter sido o padrão predominante nas emissões monetárias de Élis no século IV a.C. e em diante, e também em outras áreas do mundo grego nesse período, a imagem de Zeus com cabelos e barba curtos voltou a ser utilizada, pontualmente, como tipo em estateres de c.344 a.C. até ter sido substituído, novamente, pelo tipo de Zeus com cabelos e barba longos (Fig.237 - n.354). Entre c.352-348 a.C., o tipo da cabeça do deus com cabelos e barba longos foi utilizado em pequenas denominações (hemidracmas e óbolos) - nos hemidracmas, a águia aparece representada em pé e de asas fechadas sobre 0 capitel jônico (Fig.237 - n.353), ao passo que nos óbolos a ave é retratada em pé, de asas fechadas, sem estar sobre o capitel e, ainda, acompanhada ou não por uma folha de oliveira no campo (Fig.237 - n.349/350/351). É importante lembrar que o padrão de representação da cabeça de Zeus com cabelos e barba longos não foi uma invenção de Élis, mas uma tendência iniciada no norte da Grécia Balcânica, entre autoridades emissoras da Tessália, como vimos de modo aprofundado no capítulo anterior. É importante também chamar a atenção para o fato de que o raio, como símbolo, aparece pela primeira vez em c.352 a.C., no estater, junto à imagem de Zeus no anverso, voltando a aparecer nas séries monetárias de estateres de c.348 a.C., mas junto à imagem da águia no reverso (Fig.237 - n.371/372/373). Essas podem ser as associações mais antigas, em moedas gregas, das imagens de Zeus, águias e raios.

Raio alado. Como os tipos da águia voando e de Nike, o raio alado esteve entre as mais antigas imagens escolhidas para figurar nas emissões de Élis-Olímpia desde o primeiro quartel do século $\mathrm{V}$ a.C. (Fig.235- n.299-302) até 388 a.C. (Fig.237 - n.335). O tipo do raio alado aparece apenas no reverso - 0 anverso é ocupado pelos tipos da águia voando (c.470-420 a.C.) (Fig.235- n.299/300-312/315), da cabeça de águia (c.416-380 a.C.) (Fig.236-n.323/324/325/331/333), dela em pé (até c.388 a.C.) (Fig.236- 
n.313/314/316/317/320/321/322/335), da cabeça de Zeus (c.416-344 a.C.) (Fig.236 - n.355), cabeça de Hera (c.412 a.C.) (Fig.236 - n.281) e cabeça de Olímpia (c.360 a.C.) (Fig.237 - n.292). Como se vê pelo arco cronológico dos tipos usados no anverso, o raio alado foi mais usado com aqueles da águia voando, da cabeça de Zeus e da cabeça de águia, em menor grau. Não houve outra autoridade emissora no mundo grego, além de Élis, que tenha mais usado esse padrão de representação do raio em moedas - o tipo aparece somente na Sicília oriental, mas não foi requisitado na mesma profusão (variedade de tipos e número de emissões). Nas moedas de Élis, o raio alado ganhou várias formas de representação, tais como: (1) com asas embaixo e volutas em cima (estateres e pequenas denominações, c.468-360 a.C.), (2) com asas em cima e volutas embaixo (estateres, c.468-388 a.C.), (3) com asas embaixo e palmeta com volutas em cima (estateres, c.432-década de 420 a.C.), (4) com asas no meio, com lótus com duas pétalas em cima e volutas em cima (estateres, década de 440-década de 430 a.C.), (5) com asas no meio, volutas embaixo e lótus com duas pétalas em cima (estater de c.432 a.C.), e (6) com asas no meio e volutas em cima e embaixo (hemidracma, c.432 a.C.). À parte às variações dos tipos de asas usadas (desde asas de águias desenhadas de inúmeros modos até asas de moscas), a partir de uma série monetária de c.420 a.C., o raio alado passou a figurar dentro de uma coroa de folhas de oliveira, usada em emissões cujo raio alado acompanha as imagens da águia em pé, sobre lebre (estater de c.420 a.C.) (Fig.236 - n.321), da cabeça de Zeus (estater, c.416 a.C.) (Fig.236 - n.355) e da cabeça da águia (hemidracma, c.416-404 a.C.) (Fig.236 - n.323), (estater, c.408 a.C.) (Fig.236 - n.324), (hemidracma, final 390-380 a.C.) (Fig.236 - n.333). O uso da coroa de folhas de oliveira no anverso, parece ter sido um traço específico das cunhagens de a partir de 420 a.C., pois esta aparece também nos reversos com o raio chamejante ou a águia em pé (nas emissões dos tipos de Hera).

Raio chamejante. Esse padrão de representação do raio ocorreu, quase exclusivamente, para acompanhar o tipo da cabeça de Hera no anverso das séries monetárias datadas a partir de c.420 a.C. até 388 a.C., quando parece ter sido substituído pela imagem da águia em pé (Fig.236 - n.279/280/284/287/288). A imagem do raio chamejante foi, sem dúvidas, usada somente nas moedas de Élis, sendo essa, seguramente, uma criação para as cunhagens locais. Houve três variedades de representações: (1) com chamas em cima e embaixo e sem volutas (estateres, c.420-388 a.C.), (2) com chamas em baixo e volutas em cima (estateres, dracmas, óbolos, c.412-396 a.C.), (3) com chamas em cima e volutas embaixo (hemióbolos com o tipo da águia em pé no anverso, c.400 a.C.). O uso do raio chamejante nas séries monetárias foi concomitante ao da cabeça da deusa Hera. Esta apareceu como imagem de anverso a partir de c.420 a.C. (Fig.236 - n.279) e foi usada para além das emissões de c.344 a.C. (Figs.236 e 237, todas as cabeças femininas exceto os n.253/292/251/77). A inscrição de um " $\Lambda$ ", no anverso, sugere que havia dois gravadores ativos nesse período (" $\wedge$ " e " $\Delta A$ "), indicando, portanto, a existência de duas emissões independentes, a de Hera e a de Zeus (Walker, 2004: 40). A deusa é identificada pela legenda H/P/A inscrita em cima ou em seu próprio diadema nas emissões mais antigas. 
Águia voando. Sem ou com uma presa, foi o primeiro padrão de representação da ave a ser usado nas moedas de Élis, talvez já no século VI a.C., perdurando nas emissões até a década de 420 a.C. Foi sempre usada como imagem do anverso dos tipos monetários, assim com o raio alado e Nike sempre são os tipos de reverso. A representação da águia voando somente aparece no reverso em um tipo monetário de Zeus atirando o raio, no anverso, cunhado na década de c.430 a.C. (Fig.235 - n.343). A imagem da águia voando, no anverso, foi utilizada, portanto, predominantemente em séries com o raio alado ou Nike no reverso. Por figurarem nas primeiras séries monetárias de Élis, junto a esse padrão da águia, as imagens do raio alado e de Nike estão entre as primeiras a serem utilizadas por essa autoridade emissora.

De acordo com a cronologia inicial de Walker, de c.468 a.C. são datados o tipo da águia voando (retratada com uma asa em cima e outra embaixo) sem a cobra (no estater) e com a cobra (no hemidracma) e o raio alado (Fig.235 - n.299/139/300/301). Mais requisitada do que a imagem da águia sem a cobra, o tipo da águia voando com a cobra / raio alado perdura nas cunhagens de estateres de Élis na década de c.460 até 0 final da década de 450 a.C. (Fig.235 - n.306). A lebre também aparece como presa nos tipos da águia voando I raio alado a partir de c.468 a.C. (Fig.235 - n.301). No entanto, ela aparece associada mais ao sub-padrão de representação no qual a águia é retratada voando com as duas asas para cima (estateres e hemidracmas a partir das décadas de $460-450$ a.C.) (Fig.235 - n.303/304/305), (estateres da década de 440 a.C.) (Fig.235 n.307) e (estateres e dracmas entre as décadas de c.440-430 a.C.) (Fig.235 - 309/310/311). Nestes tipos monetários, a águia aparece voando, carregando a lebre pela barriga ou pelas costas, já no estater datado de c.432-década de 420, a ave é retratada no momento de vôo em que vai dar o bote na lebre correndo (Fig.236 - n.315). Essas são as imagens monetárias batidas com o raio alado no reverso.

Como mencionamos, paralela a essa emissão, havia aquela de Nike no reverso, a qual durou, segundo a cronologia dos exemplares, até o final da década de c.430 a.C. Carregando uma tartaruga pelo bico, a águia aparece voando (com uma asa em cima e a outra embaixo) e Nike é retratada correndo, segurando uma coroa da vitória, em um dos estateres mais antigos, datados de c.470 a.C. (Fig.235 - n.138). Nos tipos com reversos de Nike, a águia também aparece voando (com uma asa em cima e a outra embaixo) carregando a cobra em hemidracmas de c.468 a.C., nos quais Nike é retratada correndo e segurando uma coroa da vitória, padrão próprio das emissões mais antigas de Élis (Fig.235 - n.139). No final da década de c.450 a.C., a águia é retratada da mesma maneira, com a cobra, em estateres, nos quais Nike aparece em pé portando uma fita (Fig.235 - n.152). Já entre as décadas de c.440-430 a.C., a águia voando é retratada em estateres com as duas asas para cima e a Nike aparece sentada (Fig.235 - n.155; Fig.235 - n.160). Com a lebre, novamente 0 padrão predominante, da águia voando, é aquele com as duas asas erguidas, com exceção do estater datado de c.450-440 a.C., no qual a Nike é retratada correndo (Fig.235 - n.150). Esse é o padrão representado da águia no dracma de mesma data, no qual Nike aparece correndo e segurando sua veste, como também ocorre no estater da década de c.440-430 a.C. (Fig.235 - 156). De c.432 a.C. são datados dois estateres, nos quais Nike aparece sentada e a águia voando (com as asas erguidas), sendo que em um dos exemplares a ave é 
retratada no momento do bote, como demonstra a lebre correndo (Fig.235 - n.160). É preciso ressaltar que os tipos da águia voando, de Nike e do raio alado são típicos do século $V$ a.C. e estiveram já em desuso nas emissões monetárias do século IV a.C. A variedade de tipos principais, assim, se tornou menor no século IV a.C. e mais determinada para as imagens de Zeus e Hera no anverso.

Além de ter sido usada para figurar em moedas com o raio alado e Nike, o tipo da águia voando pode ser visto em algumas séries monetárias com imagens de Zeus a partir da metade do século $V$ a.C. Como imagem de anverso, acompanhando a de Zeus atirando o raio no reverso, a águia voando (com uma asa em cima e a outra embaixo) aparece retratada carregando a cobra (estateres, c.452-432 a.C. e final da década de 450 a.C.) (Fig.235 - n.340/342) e voando de frente e carregando uma tartaruga (estater, c.452-432 a.C.) (Fig.235 - n.341). Como imagem de reverso, acompanhando o tipo de Zeus sentado sobre rocha, no anverso, a ave é retratada voando, carregando a cobra (estater, década de 430 a.C.) (Fig.235 - n.343). As datações dos exemplares indicam que essa associação, entre a imagem de Zeus e da águia, em uma mesma moeda, deve ter sido uma outra criação e inovação da oficina monetária de Élis. Além dessa associação ser, ao que parece, uma novidade das moedas de Élis, devemos destacar alguns dos tipos monetários, descritos, que trazem novas formas de mostrar a águia voando com certas presas: (1) com uma asa em cima e a outra embaixo - com a cobra no bico, mas não enrolada no corpo (em estateres com Nike e Zeus datados entre o final da década de 450 a.C. até a de 430 a.C.), e carregando uma tartaruga de frente (no estater com Zeus de c.452432 a.C.); (2) com as duas asas erguidas - carregando a lebre morta pela barriga (estateres e hemidracma com o raio das décadas de 460-450 a.C., dracma com Nike de c.450 e 440, estater, dracma e hemidracma com o raio das décadas de 440-430 a.C.), e dando o bote pelas costas da lebre correndo no chão (estater com Nike das décadas de 440-430 a.C., estater com Nike de c.432 a.C., estater com o raio de c.432-década de 420 a.C.).

Águia em pé. Já durante o período das últimas emissões de tipos monetários de águias voando (432década de 420 a.C.), a oficina monetária escolheu usar um novo padrão de representação, o da águia em pé, que teve uma longa duração nas cunhagens de Élis, tornando-se, já no século IV a.C., o único tipo de imagem usado da ave. Esse padrão de representação da águia com alguma presa (cobra ou lebre), foi usado como imagem de anverso em moedas, cujos tipos no reverso ainda eram o do raio alado e de Nike entre 432 e a década de 420 a.C. (Fig.236 - 313/314/316/320). Já como imagem de reverso, a águia em pé aparece em moedas, cujo anverso são as imagens de Hera e da ninfa epônima Olímpia entre c.420-344 a.C. (no caso de Hera) e em c.360 a.C. (no caso de Olímpia) já descritas nas sessões descritivas anteriores sobre os tipos monetários de Zeus e raios. Também como imagem de reverso, a águia em pé aparece acompanhando tipos monetários de Zeus a partir de 360 a.C., quando é retratada sobre o capitel de uma coluna jônica. Essa forma de representar a águia (sobre o capitel jônico) é própria dos tipos monetários de Zeus, assim como a águia em pé, rodeada por uma coroa de folhas de oliveira foi usada apenas para os tipos de Hera e, em menor grau, para os de Olímpia. A partir do século IV a.C., pode-se dizer que o padrão de representação da águia em pé tornouse o tipo próprio de reverso e também o único usado no período. 
Assim, nas primeiras séries com a representação da águia em pé e o raio alado, a ave é retratada com algumas variações no desenho. Sobre a cobra, a ave aparece com as duas asas erguidas em um estater e em um hemidracma de c.432 a.C. (Fig.236 - n.313/314). Com o raio alado no anverso, a águia em pé voltou a ocorrer em um estater de c.388 a.C., no qual a ave é retratada curvada, de asas fechadas, sobre um carneiro dentro de um escudo (Fig.237 - n.335). Já em um estater de c.396 a.C., o raio no reverso é do padrão chamejante. Neste tipo monetário, a águia aparece curvada, de asas fechadas, sobre uma cobra também dentro de um escudo (Fig.236 - n.330). Essas representações da águia dentro do escudo não são vistas em outros tipos monetários da ave no mundo grego: trata-se, pois, de uma evidente inovação da oficina monetária de Élis. Com o tipo de Nike sentada com o cetro, no reverso, a águia é retratada, no anverso, com as duas asas erguidas, aparentemente sem estar sobre presa alguma (apenas há uma garça morta próxima às garras da ave), em um estater de c.432 a.C. (Fig.235 - 159).

Já como imagem de reverso, o tipo da águia em pé aparece de forma variada, acompanhando as representações da cabeça de Hera ou da ninfa Olímpia, sempre em anversos. Com os tipos de Hera, a ave é retratada com as asas abertas (sempre uma de cada lado do corpo), cabeça para frente e dentro de uma coroa de folhas de oliveira (estater, c.380 a.C. e estater, c.352 a.C.) (Fig.237 - n.257) ou com a cabeça para trás com coroa (estater, c.376 a.C. e estater, c.344 a.C.) (Fig.237 - n.239/269) ou sem a coroa (hemidracma, c.368 a.C.) (Fig.237 - n.248). A ave também aparece representada de asas fechadas com a cabeça para trás e dentro de uma coroa de folhas de oliveira (estater, c.356 a.C.) (Fig.237 - n.256) ou sem a coroa (hemidracma, c.368 a.C.) (Fig.127 - n.247) e ainda com a cabeça para frente e dentro da coroa (estater, c.348 a.C.) (Fig.237 n.258/267). Com os tipos de Olímpia, todos datados de c.360 a.C., a águia ocorre apenas com as asas fechadas, com a cabeça para trás ou para frente, dentro da coroa de folhas de oliveira (em duas séries de estateres) (Fig.237 - n.251) ou sem esta (duas séries de óbolos) (Fig.237 - n.253/252). A descrição dos tipos da águia sobre o capitel jônico encontra-se no comentário sobre a representação de Zeus com cabelos e barba longos. Dentre todos os modos de representar a águia em pé com as presas, Élis teria também inovado nos seguintes tipos de representações: de asas fechada e curvada sobre a barriga de uma lebre e devorando-a (hemidracma com raio alado de c.420 a.C.) (Fig.236 - n.321/322), ou da mesma forma sobre carneiro (estater com raio alado de c.388 a.C.) (Fig.237 - n.335), de asas abertas, com cabeça para trás e sobre cabeça de veado (estater com Hera de c.344 a.C.) (Fig.237 - n.269), ou com a cabeça para frente, sobre parte do corpo da cobra, a qual a ave segura a cabeça com o bico (estater com raio alado do final da década de 420 a.C.) (Fig.236- n.330).

Cabeça de águia. Foi outro tipo monetário usado por um período específico e menor, a partir de c.416 a.C. até 380 a.C. Esse padrão de representação da cabeça da águia, sempre sem presas no bico, foi usado pela primeira vez nas moedas de Élis concomitantemente ao da cabeça de Zeus nas séries monetárias. Embora não seja assinada, o tipo monetário de c.416 a.C. também é associado ao artista das iniciais " $\Delta \mathrm{A}$ " (Fig.236 n.323) (Walker, 2004: 43). Deve-se dizer, que esse padrão de representação já existia em moedas de Sinope, 
no século VI a.C., e de Éfeso do início do século V a.C. A oficina monetária de Élis, portanto, não foi a responsável pela criação e uso dessa imagem em moedas, apesar de sua oficina ter inovado nos traços e no estilo do desenho. Embora tenha sido um tipo predominantemente de anverso, foi também utilizado como imagem de reverso em uma série de óbolos de c.380 a.C., acompanhando a imagem da cabeça de Hera no anverso (Fig.236 - n.235). Os tipos mais antigos (hemióbolo e trihemitertatemorion, c.416-404 a.C.) acompanham um reverso sem imagem, mas apenas com a legenda A e F (retrogrado) (Fig.236 - n.194/195), respectivamente, ou também a imagem do raio alado - (hemidracma, c.416-404 a.C.) (Fig.236 - n.323), (estater, 408 a.C.) (Fig.236 - n.324), (estater, c.404 a.C.) (Fig.236 - n.325) e (hemidracma e hemióbolo, final 390-380 a.C.) (Fig.236 - n.331/332). Com o raio chamejante, a cabeça da águia foi usada como tipo em c.400 a.C. (estateres e hemióbolos) (Fig.236 - n.328) e no final de 390-380 a.C. No estater de c.400 a.C. um lagarto aparece como símbolo junto a à imagem da cabeça da ave (Fig.236 - n.327).

O que chama a atenção na tipologia iconográfica das moedas de Élis-Olímpia são as inúmeras referências às folhas de oliveira. Estas foram usadas, nas moedas, em alguns tipos de raios alados (como elemento decorativo junto às volutas ou ao lótus), em tipos da águia em pé (como elemento símbolo no campo), e como coroa, ornando desde a cabeça de Zeus e os tipos de raios alados e águias em pé, até aparecendo na mão de Nike nos tipos mais antigos. O uso intensivo das folhas de oliveira, no repertório iconográfico da oficina monetária de Élis, é incomum no restante do mundo grego - todos essas maneiras de representa-las nas imagens, associando às imagens de Zeus, raios, águia e Nike, como muita probabilidade devem ter sido criações também locais, assim como também foram certas representações da águia, da cabeça de Zeus, do raio alado e chamejante, e as associações das imagens de Zeus e de seus dois atributos, em moedas gregas, como mostramos ao longo do resumo descritivo dos tipos monetários.

Para interpretarmos o significado simbólico dessas imagens monetárias, é necessário retomarmos alguns dos pontos mais importantes sobre Élis na prostasia ("presidência") do santuário de Olímpia desde o século VI a.C., e seu papel hegemônico entre as comunidades da região, para, dessa maneira, precisarmos as razões políticas subjacentes à essa emissão monetária que, batida no nome dos eleios, foi destinada ao uso no santuário interestadual.

Contrariamente ao que colocam as fontes literárias a respeito do sinecismo no século $V$ a.C., as evidências arqueológicas indicam que Élis, em época arcaica, já se constituía como o principal centro urbano da região. De acordo com J. Taita, "a comunidade dos eleios aparece caracterizada pela continuidade de assentamento desde a segunda metade do século IX a.C. (Taita, 2007: 74). Entre o fim do século X a.C. e 0 início do século VIII a.C., núcleos de populações adensaram-se no que se tornaria o território cívico de Élis" (Taita, 2007: 69-70). "Somente a partir do século VI a.C. as evidências se tornaram mais conspícuas, demonstrando a escolha de uma zona precisa da área políade como sede central para o desenvolvimento de atividades de interesse comum, como indica o achado de uma lâmina de bronze com uma inscrição de natureza judiciária" (Taita, 2007: 70). O local do achado dessa inscrição, a ágora arcaica, parece indicar a presença, em 
época bem anterior ao sinecismo, "de uma autoridade capaz de concentrar a execução de atos de interesse coletivo referentes às populações esparsas que habitavam a região" (Taita, 2007: 70). A pólis de Élis, então, "teria se formado por esses grupos que residiam na área do vale do rio Peneus, os quais escolheram em tempos anteriores, presumivelmente de comum acordo, um lugar central destinado ao desenvolvimento de atividades de decisões, como as de âmbito judiciário, que favoreciam a convivência pacífica entre eles" (Taita, 2007: 70). "O momento de guinada, para os sítios no vale, foi o início do século VI a.C. se não o final do século VII a.C., com a escolha de um lugar destinado a ser o pivô sagrado e administrativo para a inteira comunidade da área" (Taita, 2007: 74). Parece que a organização de um espaço público constituiu o êxito de uma "crise política atestada por Aristóteles, que envolveu os eleios justamente nesse período, no qual a instauração de um regime aristocrático pôde favorecer a instituição de um ponto de referência central para todos os membros da comunidade, incentivando os registros escritos referentes à estrutura governativa e administração da justiça, como testemunha a inscrição de natureza judiciária" (Taita, 2007: 74). Taita conclui que, "para a definição da identidade do Estado de Élis, o primeiro terço do século VI a.C. foi o momento principal, com a ruptura dos equilíbrios pré-existentes e a consolidação da consciência política de uma camada alargada dos cidadãos" (Taita, 2007: 74). Por essa razão, segundo a autora, "não pode ser coincidência que tal guinada se alinhe cronologicamente aos eventos que, entre 580-570 a.C., assinalaram a prevalência de Élis nas formas administrativas do santuário de Olímpia" (Taita, 2007: 74). Como coloca J. Roy, "no século VI a.C., Élis já era uma pólis no sentido político, existindo como centro urbano - o sinecismo não criou um novo centro urbano do zero, como ocorreu no caso de Megalópolis no século IV a.C." (Roy, 2002: 262).

Essa função de Élis, desde suas origens, como ponto de convergência das comunidades da região, caracterizaram o seu poder "em se expandir sobre tais comunidades a partir do início do século VI a.C." (Taita, 2007: 74-75). Trata-se do processo de "periocização" de toda a área a norte do rio Alfeu, concluído no início do século V a.C., o qual reduziu às comunidades à condição de periecas, sujeitas ao controle político e cultural de Élis (Taita, 2007: 76). "Os perioikoi eram estados com seus próprios direitos, separados de Élis, mas subordinados a essa pólis" (Roy, 2002: 252). A pólis transformou todas essas comunidades em aliadas subordinadas ao seu controle (Roy, 2013: 107). Conforme explica J. Roy, mais recentemente, "ao redor de 550 a.C., Élis já tinha elaborado uma política de incorporar algum território e fazer de seus habitantes cidadãos eleios, além de transformar, outras comunidades da Élide, ao status de aliados subordinados" (Roy, 2013: 107). Tal expansão, segundo este autor, foi em parte militar - "Élis deve ter se aliado a essas comunidades devido a dificuldades com alguma outra na bacia do Alfeu" (Roy, 2002: 260; 2013: 108). "A expansão de Élis continuou no século $V$ a.C., embora a sul do Alfeu nenhum território tenha sido incorporado - todas as comunidades da área tornaram-se apenas aliadas" (Roy, 2013: 108). "Após a guerra eleio-espartana entre c.402-400 a.C., Esparta privou Élis de todos seus aliados subordinados e esta, por sua vez, tentou recuperar o controle sobre eles" (Roy, 2013: 108). 
Nessa grande área sob a influência crescente da pólis de Élis, havia o chamado distrito de Pisa, formado por oito comunidades no vale do Enipeus e Harpina (Taita, 2007: 59). "Em origem, Pisa indicaria a pequena área de planície onde surgia o santuário de Olímpia, desde o início do século VIII a.C. atribuída como local de pouso dos peregrinos" (Taita, 2007: 59). A essa imagem do distrito olímpico, continua Taita, se "sobrepõe aquela de uma faixa territorial mais ampla, estendida a oeste e a noroeste do santuário, ao longo do vale do Enipeus, a leste, até o confim com a Arcádia, a norte" (Taita, 2007: 59). Com a conquista de Élis sobre Olímpia, e do corredor territorial no eixo do Enipeus, "o distrito de Pisa sofreu uma sensível contração com relação a sua extensão originária - estritamente pisate permaneceu apenas o segmento a leste de Olímpia e 0 setor ocidental tornou-se parte constituinte da khóra cívica de Élis, permanecendo como tal até c.365 a.C." (Taita, 2007: 59-60). Somente a partir dessa data, "ajudados pelos arcádios, os habitantes da khóra pisate deram vida ao Estado pisate que, formado por diversas komai, agiu em modo unitário, batendo moeda, estipulando tratados de aliança e decretando honras a estrangeiros" (Taita, 2007: 59). Durante essa guerra, as "forças arcádias confederadas capturaram Olímpia e instalaram uma guarnição de soldados na colina de Cronos (Xenofonte, Helênicas 7.4.14)" (Nielsen, 2007: 36). Olímpia permaneceu, assim, por um certo período, fora do controle de Élis, que também perdeu uma parte significativa de seu território a sul (Nielsen, 2007: 36). O santuário esteve, na verdade, controlado pelos arcádios que usaram o dinheiro local para financiar o exército federal (Xenofonte, Helênicas 7.4.33). Mas os arcádios não possuíam uma reivindicação com base histórica para sustentar a sua administração de Olímpia, ao contrário dos pisates, que naquele momento se colocaram como os originais prostatai ("líderes") do santuário, insinuando, dessa forma, a justa retomada de seu controle sobre o local (Nielsen, 2007: 36). Essa reivindicação tem base em mitos locais e certos registros históricos. As fontes literárias posteriores aos eventos (Xenofonte, Pausânias e Diodoro) registram a presença dos pisates em Olímpia em três anos isolados - na $8^{a}$ Olimpíada (748 a.C.), na $34^{a}$ Olimpíada (644 a.C.) e na $104^{a}$ Olimpíada (364 a.C.) com a ajuda dos arcádios e alguma tensão foi registrada na $48^{a}$ Olimpíada (588 a.C.) (Taita, 2007: 34-35). Como coloca J. Taita, "apesar de ser possível aceitar a identidade étnica dos pisates já durante o tardo-arcaísmo - baseada em critérios territoriais e míticos - o toponímio "Pisa" e o étnico "pisates" voltaram a ocorrer nas fontes literárias justamente no momento da formação do Estado de Pisa, antes da metade do século IV a.C." (Taita, 2007: 55 e 132-133). "Ao redor de 362 a.C., Élis recuperou o controle de Olímpia e da área pisates" (Roy, 2013: 108).

De acordo com J. Taita, que realizou um estudo crítico sobre as fontes literárias à luz da documentação epigráfica disponível para os séculos VI e V a.C., "é irrefutável que a cidade de Élis, desde c.570 a.C., tenha substituído o distrito de Pisa no controle da prostasia de Olímpia, dirigindo a organização das atividades sagradas e agonísticas - a documentação existente não permite afirmar se os eleios estavam de algum modo no controle de Olímpia nos séculos anteriores, apesar disso não ser improvável" (Roy, 2013: 107; Taita, 2007 : 141). Já J. Roy situa o início da administração de Élis duas décadas depois, em c.550 a.C. (Roy, 2013: 107). Conforme Taita, "com certa coerência sabe-se da derrota dos pisates entre 588-572 a.C., a qual teria assinalado 
a passagem definitiva da prostasia para os eleios. Estes, do segundo quartel do século VI a.C. até ao redor do final do século IV d.C. - com uma única interrupção da não-Olimpíada pisate-arcádia em c.364 a.C. - detiveram a administração do santuário" (Taita, 2007: 36). A prostasia de Élis sobre Olímpia tornou-se possível, a partir do primeiro quartel do século $\mathrm{VI}$ a.C., graças ao controle conquistado do corredor territorial no qual gravitavam as comunidades pisates (Taita, 2007: 57 e 79). Para Taita, é pouco provável que "apenas os eleios tenham organizado cotidianamente as cerimônias a partir do segundo quartel do século VI a.C." (Taita, 2007: 114). "A dedicação de votivos feitas pelas comunidades da região leva a pensar que o Estado eleio pudesse ter recorrido ao auxílio de funcionários provenientes dos assentamentos subordinados" (Taita, 2007: 114). A participação dessas comunidades teria cessado no último quartel do século V a.C. (Taita, 2007: 142). Para Roy, contudo, as inscrições, nos objetos votivos, testemunham a participação das comunidades da região no culto em Olímpia, mas não são evidências de que essas tinham parte na administração do santuário (Roy, 2013: 111).

Desde ao menos a metade do século VI a.C., quando provavelmente iniciou seu controle sobre Olímpia, Élis parece ter localizado sua administração parcialmente na cidade e parcialmente no santuário, como indica o buleutério de Olímpia, datado inicialmente dessa época (Nielsen, 2007: 47-48 e 50). Como bem coloca Roy, "Olímpia foi de longe o maior e mais importante santuário no território eleio, e estes, por sua vez, celebraram constantemente por lá ritos de vários cultos" (Roy, 2013: 108). Os eleios utilizaram Olímpia para a administração não apenas do santuário, mas também de sua própria pólis (Roy, 2013: 108). Nesse sentido, "o uso de Olímpia para propósitos políticos dos eleios caracterizam Élis como uma pólis bicêntrica" (Roy, 2002: 262; 2004: 497). Élis expunha documentos públicos em Olímpia e, para isso, escolheu uma forma de língua que diferenciava os textos eleios de outros escritos em dialetos gregos ocidentais (Roy, 2013: 108-109). De acordo com T.H. Nielsen, não apenas inscrições públicas foram exibidas em Olímpia com também na própria cidade de Élis, mas edifícios públicos foram construídos em ambos os lugares (Nielsen, 2007: 48). Os hellanodíkes (árbitros dos jogos) tinham seus alojamentos na cidade de Élis e no santuário de Olímpia, assim como existia um buleutério em cada local (Roy, 2013: 108). "Não se sabe, ao certo, se o mesmo conselho eleio se reunia em ambos os edifícios, mas, de todo modo, mesmo que tenha havido um conselho olímpico à parte, seus membros eram de Élis" (Roy, 2013: 108). Para Nielsen, "devemos assumir que os dois conselhos (o eleio e o olímpico) foram de fato o mesmo - quando este se reunia em Élis era uma bulé comum de uma pólis e quando era transferido para Olímpia, durante as celebrações dos jogos, era denominado de conselho olímpico, onde se podia apelar, por exemplo, contra as decisões dos hellanodíkes” (Nielsen, 2007: 52). Já o pritaneu, na sua fase inicial datado do início do século $V$ a.C., oferece um caso à parte, pois "parece que este edifício não existiu na pólis de Élis, mas somente em Olímpia" (Roy, 2013: 108). Como explica Nielsen, o edifício de Olímpia deve ter funcionado como o pritaneu de Élis e o significado de sua localização no santuário é clara - em seu centro religioso, "os eleios escolheram construir o edifício que significava a vida de uma pólis (Nielsen, 2007: 53). E mesmo se tenha existido um pritaneu em Élis, seu significado simbólico tornar-se-ia maior e teria servido para ligar, intimamente, cidade e santuário" (Nielsen, 2007: 53). 
A localização desses edifícios políades em Olímpia, bem como a exposição de decretos, foram demonstrações visíveis de afirmação do poder de Élis sobre Olímpia para uma audiência maior. O complexo de edifícios e o posicionamento de magistrados dessa pólis no santuário teriam servido como "uma advertência, a todos os visitantes, das relações especiais de Élis com Olímpia" (Nielsen, 2007: 52). A procissão que ligava Élis e o santuário, um dos prelúdios do festival, também tem sido interpretada dessa maneira (Nielsen, 2007: 46). Para Nielsen, "essa procissão extremamente longa teria servido como uma demonstração periódica conveniente do domínio de Élis sobre Olímpia, servindo como um sinal de supremacia, particularmente em tempos de ameaça da perda do controle dessa pólis sobre o santuário" (Nielsen, 2007: 47). Como bem concluiu esse autor, Olímpia foi um componente vital da identidade local da pólis de Élis e os eleios demonstraram isso de várias maneiras: tornando-a o segundo centro da administração de sua pólis, na longa e incomum procissão da cidade ao santuário, no uso da força militar no Altis em 364 a.C. contra os arcádios e, finalmente, na escolha dos temas para os tipos monetários de sua cunhagem (Nielsen, 2007: 53). "Os eleios, assim, fizeram Olímpia muito eléia" (Roy, 2013: 108). "O santuário foi parte central dessa pólis e seu caráter eleio era muito claro - 0 controle de Olímpia foi crucial para a identidade na qual Élis se apresentou ao mundo grego" (Roy, 2013: 109).

É no contexto desse processo, no qual Élis começou a materializar seu domínio sobre Olímpia, entre a metade do século VI a.C. e as décadas iniciais do século V a.C., que devemos analisar a cunhagem de moedas e o significado de suas imagens, evidências adicionais de tal processo. Apesar de poder ser considerada uma emissão monetária cívica, realizada no nome dos eleios, os tipos usados são alusões explícitas a Olímpia, assim sendo uma demonstração das relações muito próximas entre Élis e o santuário (Nicolet-Pierre, 2002: 179; Nielsen, 2007: 43, 44 e 45). Élis escolheu, como tipos monetários, aqueles que afirmavam melhor sua identidade - imagens de deuses, e atributos, venerados em seu território (Nicolet-Pierre, 2002: 179). As cunhagens de Élis, portanto, devem ser vistas como outro tipo de evidência do bicentrismo dessa pólis, já que foram batidas nos nomes dos eleios e carregaram imagens referentes aos jogos e aos cultos próprios do santuário. Como afirmaram reiteradamente J. Roy e T. H. Nielsen, o santuário de Olímpia foi parte da identidade eléia (Nielsen, 2007: 53; Roy, 2013: 108). Ao mesmo tempo que os tipos remetem a Olímpia, remetem também a Élis, já que Olímpia foi um local que compôs parte importante de sua identidade. Por meio das moedas, usadas nas transações locais, a comunidade política de Élis podia afirmar a sua hegemonia sobre Olímpia. Ao associar a legenda do étnico no plural, referente à comunidade como um todo, às imagens locais, Élis procurou afirmar, repetidamente, a sua autoridade e domínio, sobre o santuário de Zeus e os jogos, para uma audiência local e pan-helênica, que manuseava as moedas - mercadores, peregrinos e participantes no culto e nos jogos. Nesse sentido, a nosso ver, tipos e legenda expressam Olímpia como parte da identidade política de Élis.

Os tipos monetários de Élis têm sido categorizados como de divindades olímpicas (Zeus e seus atributos, Hera e a ninfa Olímpia) e exclusivamente agonísticos (Nike). Interessante notar que outras figuras míticas importantes para a comunidade dos eleios, as quais aparecem nos relatos sobre as fundações dos jogos, como os heróis Pélope e Héracles, não foram escolhidos para figurar nas moedas, como poderia ter 
ocorrido. A oficina monetária eléia escolheu concentrar os tipos nas divindades principais do santuário, bem como nas imagens de suas energias divinas, como foram, para Zeus, o raio, a águia e também Nike, de certa forma, como veremos. A nosso ver, devemos olhar essas imagens não apenas a partir dessa simples categorização, ou seja, como referências explícitas à Olímpia (ao culto e aos jogos), como explicamos acima, mas como símbolos requeridos e cheios de significado para a comunidade dos eleios em momentos importantes de afirmação de seu poder e domínio diante de disputas em relação a Esparta, principalmente nos séculos VI e V a.C., e depois aos arcádios, por um pequeno período no século IV a.C. A prostasia de Élis em Olímpia, bem como sua prevalência como pólis dominante sobre as demais comunidades da região, devia ser continuamente afirmada e mantida. Zeus, o raio, a águia, Nike, Hera e Olímpia são imagens que, obviamente, falam do santuário, e de sua divindade maior, a qual as cunhagens devem Ihe ter sido sagradas, mas que foram igualmente caras à Élis pelo significado talismânico e apotropaico, enquanto comunidade política frente à prostasia de Olímpia. Além de serem referências explícitas ao culto de Zeus, o raio, a águia voando ou em pé (na maior parte das vezes com uma presa), o próprio Zeus em pé atirando o raio ou sentado no trono, foram símbolos conhecidos para os antigos gregos, cujos significados, dentro do universo da ordem frente a desordem, da guerra, vitória e competição, circulavam nas narrativas antigas e eram evocados, como tais, de diversas maneiras por indivíduos e/ou suas comunidades em momentos específicos de sua história, como vimos no capítulo anterior.

Diante dessa perspectiva, então, por que as imagens da águia voando, do raio alado e de Nike foram usadas pela oficina monetária de Élis em suas emissões mais antigas? Não seria de se esperar ver a representação do próprio Zeus nas primeiras cunhagens? A nosso ver, houve uma série de razões específicas que levaram os atributos de Zeus e Nike a terem sido as primeiras escolhas iconográficas para a comunidade dos eleios.

$\mathrm{Na}$ literatura existente, acerca das moedas de Élis, a representação de Nike tem sido interpretada, primariamente, como a Vitória nos jogos, aquela que preside as competições (Kraay, 1976: 104; Lacroix, 1974 : 13; Nicolet-Pierre, 2002: 179). A coroa de folhas de oliveira, a fita, o galho de oliveira e de palma, todos aparecem retratados como símbolos, em uma ou outra série monetária, nas mãos de Nike, sendo referências explícitas aos jogos (Moustaka, 1992: 42). Muitas teorias, sobre seu significado simbólico, foram propostas com base nas várias maneiras nas quais foi retratada. Nas emissões mais antigas, nas quais aparece correndo com a coroa de folhas de oliveira na mão direita, sobre o qual foi proposto se tratar de uma referência à coroação do vencedor ou ainda de uma cena fúnebre - a divindade estaria correndo com a coroa para depositá-la na tumba de Pélope (Fig.235 - n.139) (Kraay, 1976: 104; Lacroix, 1974: 17). O mesmo significado seria atribuído à imagem na qual Nike aparece em pé segurando uma fita, um símbolo conhecido de premiação nos jogos olímpicos (Fig.235 - n.152). Nas emissões mais recentes, em contraste, Nike é representada sentada sobre uma lastra, segurando um cetro com a cabeça para frente ou ainda segurando uma palma (ou ramos de oliveira) com a cabeça abaixada, apoiada pela mão esquerda (Fig.236 - n.160). A essa representação, na qual Nike é 
retratada pensativa ou aflita, foi atribuído um caráter fúnebre e também político. Na primeira interpretação, proposta por E. Gabrici, Nike dessa maneira representada, aludiria ao rito fúnebre em honra a Pélope - a divindade estaria sentada sobre a tumba do herói (apud Lacroix, 1974: 17). Na segunda proposição, A.R. Bellinger e M.A. Berlincourt explicam que o artista procurou retratar o sentimento geral no início da Guerra do Peloponeso, já que essa imagem monetária data de c.432 a.C. (apud Lacroix, 1974: 18). Para L. Lacroix, no entanto, "tais interpretações não procedem, pois as imagens monetárias, em geral, celebram as glórias das cidades e não seus fracassos políticos, além de que não combinariam com o caráter comemorativo do festival olímpico" (Lacroix, 1974: 20). Esse autor conclui que os artistas responsáveis pelas imagens mais antigas procuraram mostrar a deusa em plena ação, já aqueles posteriores, ao invés de indicarem claramente a ação, procuraram apenas sugeri-la (Lacroix, 1974: 21). "Nike estaria meditando à espera do vencedor que seria revelado ao final da competição" (Lacroix, 1974: 21).

Uma interpretação totalmente diferente foi proposta por A. Moustaka, que prefere relacionar Nike ao aspecto local de Zeus Olímpio. Conforme a estudiosa, "as fontes arqueológicas e textuais indicam que 0 simbolismo de Nike em Olímpia foi especialmente relacionado à guerra, como evidenciam as representações da deusa disponíveis no próprio santuário, dentre elas a dedicação da escultura monumental da Vitória de Peônios" (Moustaka, 1992: 43). A seu ver, em Olímpia, "Nike teria sido uma epifania de Zeus guerreiro, 0 aspecto predominante do culto Olímpio do deus" (Moustaka, 1992: 40). De fato, Nike virou um atributo de Zeus na concepção de Fídias, quando este a colocou sobre a mão da estátua do deus. Concordamos com $A$. Moustaka sobre o aspecto guerreiro de Nike e sua relação com Zeus, como sua manifestação, sua epifania, já que nos poemas homéricos, como a llíada, o deus é descrito como aquele que define o destino de uma guerra e a qual dos lados pertence a vitória. Nesse sentido, o aspecto guerreiro de Nike se complementa com aquele da vitória nos jogos, de quem preside as competições. Esses mesmos significados de Nike (de guerra, vitória e competição), se alinham perfeitamente com os da águia e do raio, como vimos no capítulo anterior. Esse é especialmente o caso das emissões monetárias eléias com as imagens da águia voando e de Nike, principalmente aquelas em que é retratada correndo com a coroa. Um fragmento de relevo de um loutherion de Agrigento, datado do final do século VI a.C., citado por I. Jenkins em sua obra sobre a cunhagem de Gela, comprova tal proposição. Datado do final do século VI a.C., o relevo mostra uma cena narrativa na qual duas Nikes correm carregando ao que parece uma ave, com a mão esquerda, e a coroa da vitória com a mão direita. Ambas aparecem atrás e à frente de um auriga que dirige uma quadriga, sobrevoada por uma águia. Veremos que esse esquema iconográfico, da águia sobrevoando a quadriga, apareceu, pela primeira vez, nas moedas, em tetradracmas de cidades siceliotas do final do século V a.C. (Gela e Agrigento). A semelhança estilística e semântica entre relevo e moedas é mais uma prova das inúmeras trocas de traços culturais entre Élis e as póleis do Ocidente grego. 


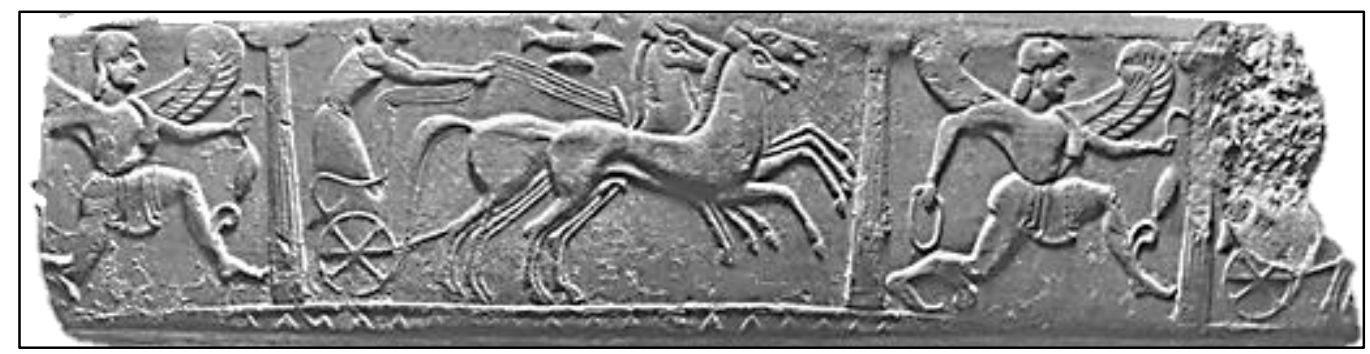

Fig.233 - Fragmento de relevo de loutherion, final do século VI a.C., Agrigento (Jenkins, 1970: pr.41, 1; Lo Monaco, 2008-2009: pr.II, 5)

Mas aqui queremos mostrar, através desse relevo, como no final do século VI a.C., Nike correndo com a coroa e a águia voando (nesse caso sem presa) eram associadas para falar do tema da vitória em uma competição bélica ou agonística. Nesse sentido, a partir da correspondência temporal e imagética entre os dois tipos de evidências (moedas e relevo), podemos interpretar as séries monetárias de Élis, com a águia voando e Nike correndo, como uma única narrativa, tal como aparece no loutherion - a presença da águia em vôo sobre o auriga é um auspício de vitória para o competidor, o que é confirmado pela presença de Nike, que lhe acompanha na frente e atrás. Vimos na análise contextual do significado simbólico da águia voando, nas fontes literárias e iconográficas, que esta esteve vinculada a um bom agouro na luta, sua presença para o guerreiro ou competidor lhe era um agouro propício para repelir um resultado desfavorável - carregando a cobra, a águia era ainda um sinal de derrota eminente do inimigo. A águia foi um símbolo de vitória para quem a usava, como vimos no caso da representação em escudos. Todos esses significados de vitória, guerra e competição foram parte do culto de Zeus em Olímpia, como vimos nos capítulos anteriores. Por essa razão e por aquela explicada por A. Moustaka, podemos considerar Nike nas séries monetárias, nesse contexto de Olímpia, como outro atributo de Zeus representado, assim como foram o raio e a águia. A ave voando (com ou sem presa) e Nike eram ao mesmo tempo símbolos do culto Olímpio de Zeus e símbolos dos ideais dos jogos, almejados pelos participantes em tantas modalidades e provenientes de tantas origens do mundo grego. Esse significado simbólico da águia com Nike, nas moedas de Élis, foi já apontado por R. Wittkower no final da década de 1930. A águia voando com a cobra foi usada em moedas gregas, segundo esse autor, para trazer vitórias política e atlética - tal significado é confirmado pela presença de Nike, associada à ave, nas moedas de Élis (Wittkower, 1939: 310). Como bem colocou Pérez, a águia e a cobra foram usadas, pelos antigos, para caracterizar o comportamento humano: o confronto entre os homens são metaforicamente expressos em termos de luta entre esses dois animais - interpretação que dá mais ainda força a essa associação entre esse tipo e as competições (Pérez, 2010: 16). O aspecto simbólico mântico da ave em vôo não pode ser ignorado e nas moedas de Élis, para Olímpia, parece ter adquirido um significado maior. Em alguma medida, a representação da ave voando, nessas moedas, pode ter sido uma alusão figurativa à função oracular de Zeus Olímpio no santuário que, como vimos, tinha tido um papel importante em mediar conflitos desde o século VIII a.C.

Nessas séries monetárias mais antigas de Élis, a águia voando foi representada junto ao raio alado em emissões que tiveram uma longa duração (até a década de 420 a.C.). Trata-se da primeira associação dos dois 
atributos de Zeus em um mesmo documento monetário, nesse caso, cada um ocupando um lado da moeda. Da nossa análise da documentação iconográfica e literária sobre a águia, disponível para a época arcaica e clássica, foi possível perceber uma correspondência temporal entre essa mais antiga associação nos estateres de Élis e uma provável mudança da concepção da ave como atributo de Zeus, que teria se firmado no início do século $V$ a.C., como indicam as referências no teatro ateniense e na cerâmica ática. A nosso ver, essa associação inédita da águia com o raio nas moedas de Élis não teria ocorrido por acaso por volta dessa mesma época. Ao contrário da águia, o raio parece ter sido reconhecido muito antes como um atributo ou epifania de Zeus. Por isso, ao colocar a ave na mesma moeda com o raio, conhecido atributo do deus, justamente em Olímpia, santuário de tantas inovações no culto de Zeus, seria uma prova de que a ave, nesse período, teria sido reconhecida, se firmado entre os gregos como um atributo e epifania da divindade assim como era o raio desde muito antes. Vimos na descrição dos tipos, como sob a autoridade de Élis ocorreram inovações na imagética principalmente com relação aos atributos de Zeus em suas emissões e como a associação entre ambos também foi uma dessas novidades. Nesse contexto, a oficina monetária de Élis, ao usar os dois atributos de Zeus reunidos em uma mesma moeda, muito provavelmente foi a primeira a invocar, por meio das representações das duas imagens, a força divina do deus para mobilizá-la duplamente a seu favor. Assim, essa perspectiva amplia a compreensão da razão pela qual as imagens monetárias da águia voando e do raio alado estiveram entre as mais antigas usadas por Élis, o porquê terem figurado antes mesmo que a do próprio Zeus nas moedas que circulavam em seu santuário por excelência - pode ter se tratado de um resultado de um fenômeno maior. Esse tipo de análise contextual - que consegue encontrar processos que levaram a escolha de determinadas imagens para figurarem em moedas gregas em determinados períodos - nos faz compreender a documentação para muito além do que ela simplesmente aparenta ser, no nosso caso, o que seria apenas uma óbvia reunião das imagens dos dois atributos mais conhecidos de Zeus em moedas de seu santuário mais importante.

Assim como a águia voando, o raio também tinha seu significado simbólico vinculado ao universo da guerra e da vitória. Vimos no capítulo anterior que ele foi a arma cósmica usada por Zeus para punir e aniquilar seus adversários de forma letal e repentina. Trata-se da arma que assegurou a vitória de Zeus sobre o caos, representados pelos Titãs e Tifeu na narrativa hesiódica da Teogonia. O raio foi a arma usada por Zeus para assegurar sua soberania e realeza dentre os mortais e imortais. Vimos também que vários dos significados vinculados às imagens dos raios e das águias mostraram-se consonantes com as características da personalidade e da figura do próprio Zeus (tal como aparece descrito nas fontes literárias) e com a sua esfera de atuação e culto. Tal constatação deve ser levada em consideração na análise interpretativa das imagens monetárias de águias e raios associados. Essa associação mostra a intenção deliberada em se mobilizar as energias divinas da divindade manifestadas na natureza, a águia e o raio, a favor da comunidade política dos eleios, as quais naquele momento, por algum motivo, foram mais importantes do que a própria imagem de Zeus. De fato, apesar dessa consonância, havia uma diferença simbólica entre retratar o próprio deus em 
moedas e/ou seus atributos. Representar a imagem de Zeus seria uma forma de propiciar diretamente a divindade, pedir pela sua proteção, ao passo que a de seus atributos seriam apenas uma forma de colocar a favor suas energias divinas? Como veremos, os diferentes tipos de imagens de Zeus possuíam significados convergentes aos de seus atributos, embora cada tipo de imagem, incluída a do deus tenha tido alguma atuação específica. Como emblemas monetários, a águia voando e o raio alado, associados, identificavam Élis às forças divinas de Zeus - na busca, dessa comunidade, pela auto-afirmação de sua soberania e manutenção de seu poder no período.

Estas imagens (águia voando, raio alado e Nike) foram cuidadosamente escolhidas pela autoridade emissora de Élis por serem símbolos fortes auspiciosos para aquela audiência de participantes no culto e/ou nas competições. Mas além disso, essas imagens, que figuraram junto ao nome dos eleios, exerceram, muito provavelmente, um significado talismânico e apotropaico também para a própria comunidade. Essas imagens foram escolhidas para figurar nas séries monetárias por todo o século $V$ a.C., marcado pelo auge e afirmação do domínio dessa pólis frente à prostasia de Olímpia e às comunidades da região e do mundo grego. Esse período abarcou o expansionismo de Élis, o dito sinecismo, que provavelmente foi a organização de uma nova população na cidade, a construção do templo de Zeus, considerado pelos especialistas com um monumento à memória do poder de Élis sobre Olímpia (Roy, 2002: 260). Nesse período, Élis ainda mantinha relações de aliança com Esparta, com a qual entrou em disputa entre o final do século $\mathrm{V}$ e o início do IV a.C. $\mathrm{O}$ final das emissões dessas séries monetárias também correspondem ao período da primeira década da Guerra do Peloponeso, quando os eleios ainda eram aliados dos espartanos e baniram os atenienses da participação no santuário até a Paz de Nícias em c.421 a.C. (Kraay, 1976: 105). Diante desse contexto, acreditamos que as imagens da águia voando e também em pé, Nike (nos seus vários tipos) e o raio alado foram símbolos importantes para comunidade dos eleios nesse momento de afirmação de seu domínio no santuário e em escala regional. Ao mesmo tempo em que refletiram o momento favorável aos eleios na manutenção de seu poder, foram requisitados como emblemas monetários de Élis, por portarem significados almejados pela comunidade naquele período - no sucesso e na vitória, sempre estaria também a ameaça, o perigo de perde-los, por isso 0 uso desses tipos de símbolos era importante na concepção religiosa e filosófica dos antigos gregos. Da mesma forma como eram usados nos escudos dos guerreiros gregos, para atrair a sorte ou repelir um mal, nas moedas esses tipos de imagens também eram requisitados da mesma maneira por comunidades políticas, por portarem algum tipo de proteção para a existência delas enquanto tais.

Como vimos no resumo descritivo sobre os tipos monetários, a imagem de Zeus foi requisitada pela primeira vez para figurar nas moedas de Élis a partir de c.452 a.C. (Fig.235 - n.26/340/341), aparecendo, como tipo, junto a dois daqueles mais antigos (águia voando e Nike), que já vinham sendo usados, com o raio alado, desde 0 início das emissões, as quais, provavelmente, começaram no primeiro quartel do século $\mathrm{V}$ a.C. $\mathrm{A}$ imagem de Zeus foi utilizada em associação àquela do raio alado apenas mais tarde, no segundo decênio do século V a.C. com o primeiro tipo da cabeça do deus. Foi nesse mesmo período, em meados do século V a.C., 
que o tipo da águia em pé também apareceu pela primeira vez como imagem monetária, mas a sua associação com a imagem de Zeus somente ocorreu mais tarde, no século IV a.C., após a dominação arcádia e pisate. A partir da metade do século $V$ a.C., o tipo da águia em pé com a presa foi somente associado com os tipos de Nike e do raio alado. Nessas primeiras emissões com a imagem de Zeus, o deus foi representado, como vimos, em pé atirando o raio (sempre acompanhado pelo tipo da águia voando com a cobra no anverso) e sentado sobre o trono ou rocha (com o tipo de Nike e da águia voando com a cobra, respectivamente ambas no reverso), padrões de representação do deus que perduraram nas cunhagens de Élis até a década de 430 a.C.

Como dissemos, as imagens dos atributos de Zeus (a águia e o raio) foram usadas antes mesmo que a do próprio deus nas emissões monetárias de Élis. Vimos que o motivo para essa escolha, da oficina monetária eléia, pode ter sido influenciado, em algum grau, por um fenômeno maior de quando a águia se firmou como um atributo da divindade. Mas além disso, a causa, para a emergência da imagem de Zeus nas moedas de seu santuário mais importante, pode ter estado em uma tendência em termos de mundo grego. Vimos no capítulo anterior, e veremos mais adiante também, que a representação de Zeus em moedas gregas foi usada pela primeira vez por autoridades emissoras, na Sicília e na Arcádia, duas décadas antes e por volta desse mesmo período (à parte das moedas líbias com o tipo de Zeus Amon). A interação entre Olímpia e essas duas regiões mostraram uma profusão de trocas de traços culturais e, nesse sentido, o uso da imagem de Zeus no santuário nesse período pode ter estado implicado, de alguma maneira, nessas relações. Nessa interação destacamos a região vizinha de Élis, a Arcádia, como área que difundiu muitas ideias, em termos de culto de Zeus, para Olímpia. Trata-se das duas regiões com os dois mais importantes centros de culto da divindade no Peloponeso e também no mundo grego. Veremos mais adiante na análise interpretativa sobre a Sicília, que foi sugerida pelo pesquisador italiano G. Manganaro uma influência dos imigrantes arcádios no uso das imagens monetárias de Zeus pelas póleis da Sicília oriental por volta da metade do século V a.C., em razão de que estes já tinham a tradição no uso da imagem de Zeus nas cunhagens batidas em seu nome, as quais examinaremos em detalhe mais adiante. Nessa perspectiva, baseada em um contexto maior, pode ser que as primeiras imagens de Zeus, nas moedas de Élis, tenham sido usadas somente nesse período por influência de alguma nova situação no culto de Zeus em termos peloponésios, ou até mesmo por uma influência direta arcádia, como parece ter sido o caso na Sicília. Prova de que essa troca direta ocorria nesse período entre Élis e a Arcádia são os próprios tipos monetários do deus cunhados em Olímpia. Uma clara e reconhecida alusão às cunhagens arcádias é 0 estater com tipo de Zeus sentado no trono, vestindo um himátion na cintura e segurando o cetro com a mão esquerda e a águia voando próxima ao braço direito, emitido por Élis entre c.452-432 a.C. Mesmos os tipos de Zeus em pé, atirando o raio com o braço direito e a águia voando próxima ou pousada sobre o braço esquerdo estendido, de Élis desse mesmo período, trazem, mesmo que de forma indireta, uma influência arcádia na representação, dado o uso da águia nesse padrão, uma criação do santuário no Monte Lykaion do século VI a.C., a qual foi adotada em Olímpia na estatuária do deus a partir do início do século V a.C. 
Essas imagens de Zeus em pé atirando o raio e sentado no trono possuíam também significados bem precisos, como vimos na análise contextual realizada no capítulo anterior. As descrições literárias e a documentação iconográfica mostram que a representação de Zeus em pé e atirando o raio expressou, aos antigos gregos, um deus guerreiro em ação de luta pela imposição da ordem sobre o caos, portanto da liberação da violência e da desordem no cosmos. A representação na moeda de Élis pode ter até sido uma referência às estátuas votivas de Zeus Keraunios, mas a nosso ver o significado contido na imagem foi mais importante. 0 tipo invocava imagens de narrativas míticas antigas, de luta contra monstros e imortais pela ordem no cosmos. Seu significado simbólico alinha-se com a esfera militar de disputa, de sucesso na guerra ou na competição. Já a imagem de Zeus sentado no trono expressou significados de soberania, governo, controle, vigilância e decisão de Zeus sobre a vida dos homens - sentado no trono, do alto do Olimpo, o deus podia observar e receber as súplicas humanas e determinar o destino humano, decidir uma guerra. Esse mesmo significado pode ser aplicado à imagem de Zeus sentado na rocha, já que ele porta o cetro e a ave. $O$ uso dessas imagens em moedas, pela pólis, pode ter funcionado tanto como uma invocação pela proteção de Zeus para a manutenção da ordem sobre a desordem e sua ameaça (no enfrentamento com algum inimigo, uma situação de instabilidade política, etc.), como uma forma de controlar e colocar esses poderes do deus a seu favor em algum momento político específico. Assim, nota-se que ambos os tipos de imagens possuem significados que se associam, se complementam com relação à ordenação do mundo e à guerra. Esses significados simbólicos também se alinham à esfera de atuação de Zeus Olímpio como divindade guerreira - 0 aspecto principal de seu culto em Olímpia, predominante desde ao menos o início da época arcaica, como indicam a sua função oracular e as oferendas votivas a ele dedicadas no santuário. Além dos despojos de guerra dedicadas a Zeus Olímpio em Olímpia, lembremos das estatuetas de Zeus Keraunios e das braçadeiras de escudos com a cena de luta de Zeus atirando o raio contra Tifeu, provenientes desse santuário. Lembremos também do papel de Zeus Olímpio na sanção da instauração de relações pacíficas intercomunitárias e na regulação de eventuais controvérsias a nível local (Taita, 2007: 141-142). Além dessa necessidade de proteção, requisitada pela autoridade emissora por meio da representação da divindade ou de suas energias nas moedas, é preciso dizer que essas mesmas imagens podem também ter sido uma alusão à identificação do poder emissor, no caso Élis, aos poderes divinos de Zeus Olímpio a quem a cunhagem também Ihe era sagrada.

Mas antes de associarmos esses significados simbólicos de Zeus com aqueles de Nike e da águia voando, com as quais o deus foi primeiro representado nas moedas de Élis, devemos destacar a presença da pequena águia desenhada com os dois tipos do deus, a qual reforça mais ainda o significado dessas imagens. Em ambas as representações, Zeus é retratado portando a águia que, como vimos, foi uma característica peloponésia. Nos dois casos a águia é enviada por Zeus, retratada partindo dele, tal como é descrita nos textos antigos - o deus envia a ave como mensageira e portadora de sua vontade. Nessas imagens de Zeus, a águia (sem presa) pode ter acrescentado um significado mântico, pelo seu caráter de portadora de presságios. Com todos os elementos que compõem as duas imagens de Zeus, retratado com o raio naquela do deus em pé e 
com o cetro naquela de Zeus sentado no trono ou rocha, a águia voando é um elemento que completa, assim, todos os poderes do deus - aqueles de soberania, de prever e determinar o destino humano, de escolher a quem dar a vitória, de impor a ordem na desordem. Isto posto, diante de todos os significados simbólicos, vistos até agora, é possível afirmar que aqueles de Nike e da águia voando, com presa, são afins aos revelados nos tipos de Zeus. Os significados dos dois atributos de Zeus, a águia e Nike, portanto, se inter-relacionam, se complementam e potencializam aqueles expressos nas duas imagens do deus.

Com esses significados revelados para todos esses tipos monetários, resta a pergunta: por que essas imagens que falam de guerra, luta, vitória e ordem sobre o caos foram utilizadas pela oficina de Élis em uma época caracterizada por relativa paz em Olímpia e no mundo grego, o intervalo entre as guerras médicas e a guerra do Peloponeso? Em primeiro lugar, não podemos deixar de considerar que esses tipos se referem, basicamente, aos jogos olímpicos e ao culto de Zeus, foram idealizados para esse universo e para essa audiência. Em segundo lugar, conforme defendemos, essas imagens também foram concebidas e consideradas no repertório iconográfico das moedas por possuírem um valor para a autoridade emissora, Élis. Não somente porque os tipos se referem a símbolos importantes de Olímpia e, como o santuário formava parte importante da identidade de Élis, esta os usou em seu repertório de imagens. Entre a década de 450 a.C. e 430 a.C., a pólis de Élis passou pelo período de apogeu de sua hegemonia na prostasia de Olímpia - a pólis já havia vivido seu período de expansão e sinecismo e no santuário a prova disso foi a construção do templo de Zeus, considerado por especialistas como um monumento do poder local dos eleios. A partir de c.431 a.C., houve o início da guerra do Peloponeso, Élis aliou-se à Esparta e os atenienses e seus aliados foram excluídos do Altis. A nosso ver, essas imagens monetárias de Zeus com Nike e a águia voando, que aludem a vitória, bons presságios, manutenção da ordem, mas também à luta e guerra, foram requistados pela autoridade emissora por sua função talismânica para a comunidade enquanto possuidora de sua soberania em Olímpia e na região. Se as imagens monetárias identificavam o poder emissor a uma força divina, como também invocava essa força para a proteção dele, então, usar as imagens de Zeus nesse período teria a ver com a necessidade, dessa comunidade política, na manutenção de sua soberania, no afastamento de uma instabilidade política e da ameaça de perda de poder, especialmente no caso de Élis, dado seu histórico de hegemonia na região. Através dessas representações do deus, a comunidade dos eleios garantia a proteção de Zeus Olímpio na manutenção de seu poder, associando às imagens dele às de seus atributos, energias que precisavam ser propiciadas e controladas, como bem explicou M.B.B. Florenzano sobre a representação de divindades em moedas gregas.

A águia voando, das séries mais antigas, foi substituída pelo tipo da águia em pé nas séries monetárias de a partir de c.432 a.C. Trata-se de um período no qual se iniciaram várias inovações no repertório iconográfico das moedas de Élis e que se estendeu até o final do século V a.C. Como vimos no resumo descritivo dos tipos, a imagem da águia voando, durante as emissões do século $V$ a.C., foi retratada acompanhando o tipo de Nike sentada (pontualmente em c.432 a.C.) e os tipos do raio alado (séries do século $V$ a.C.) e do chamejante (séries 
do século IV a.C.) em séries entre c.432-388 a.C. Essa nova representação da águia, passou a ser usada pela oficina monetária eléia em correspondência aos eventos que prepararam ou iniciaram (considerando que são datas aproximadas) a guerra do Peloponeso (c.431 a.C.) quando Élis aliou-se à Esparta e os atenienses e aliados foram proibidos de frequentar Olímpia. As formas de representação da águia em pé mostram a ave em várias posições devorando ou atacando sua vítima, lebres na maior parte dos casos e até mesmo cobras e veados. Em nossa análise contextual do significado simbólico da águia voando e em pé, concluímos que essa forma de representação da ave foi associada sempre a Zeus e alinha-se mais a um símbolo de realeza e soberania, embora os significados mânticos com relação à vitória, guerra e competição também fazem parte de seu universo simbólico. Nesse caso também, os significados de Nike e do raio alado se inter-relacionam, complementam e potencializam aqueles presentes nas imagens da águia em pé com a presa. Veremos mais adiante nesse capítulo, na parte referente à Sicília e à Itália do Sul, que o padrão de representação da águia em pé sobre a presa foi usado por Agrigento e Crotona a partir do segundo quartel do século $\mathrm{V}$ a.C. em momentos específicos de ameaça urgente a sua autonomia e soberania enquanto comunidades políticas. Esses momentos, nessas regiões, se referem à guerra contra um tipo de inimigo externo à comunidade. Nos três casos, de Élis, de Agrigento e de Crotona, o significado simbólico da águia em pé e com a presa, evocou, muito provavelmente, a necessidade de derrota sobre um inimigo e uma sorte favorável na guerra. Como também se vê nos tipos monetários de Agrigento e Crotona, as formas como a ave aborda a presa, expressam luta com o animal ou total controle sobre sua vítima, que na maior parte dos casos é mansa e não tem o poder de caça da águia. Estas, a nosso ver, devem ter sido imagens ideais para comunidades desejosas em mostrar superioridade na derrota do inimigo pela manutenção de poder e autonomia. Em síntese, as ideias de vitória militar, soberania territorial e de afirmação de liderança, que provavelmente estiveram contidas nesse tipo de representação da águia, devem ter sido de alguma forma importantes para Élis em um momento delicado, enquanto administradora de um centro pan-helênico, de guerra entre diversos centros do mundo grego, em aliança com Esparta, o poder político regional mais forte naquele período.

O período de início da guerra do Peloponeso também é aquele de término do uso dos tipos monetários mais antigos descritos até o momento - águia voando e Nike, águia voando e Zeus em pé atirando o raio, Zeus sentado no trono e Nike e Zeus sentado sobre rocha e águia voando. Os tipos monetários com a águia voando e o raio alado permaneceram em uso até a década de 420 a.C. Após c.421 a.C., quando ocorreu a Paz de Nícias, Élis abandonou a aliança com Esparta, e se uniu, em um tratado de symmachia, à Atenas, Argos e Mantinéia. O motivo para a deserção dos eleios, na liga peloponésia, foi a tentativa de Élis em tentar recuperar a pólis de Lepreonte, subordinada anteriormente e libertada com a ajuda espartana (Nielsen, 2007: 32). Em c.420 a.C., os espartanos foram expulsos dos jogos. A partir desses acontecimentos, Élis foi se encaminhando para uma guerra com Esparta, a qual ocorreu entre o final do século $V$ a.C. e início do IV a.C., como veremos mais adiante. Este foi o período de fim das relações pacíficas mantidas entre Élis e Esparta desde o século VI a.C. (Taita, 2007: 118). Nessa nova fase política para Élis e a região, inovações iconográficas significativas 
foram introduzidas pela oficina monetária, tais como o tipo da cabeça de Hera e do raio chamejante, da cabeça de Zeus e da cabeça da águia. É interessante notar que em correspondência a esses eventos - após a Paz de Nícias e a quebra da aliança com Esparta -, o desenho de uma coroa de folhas de oliveira passou a ornar, em algumas séries monetárias, as imagens do raio alado e do chamejante a partir de c.420 a.C. A partir desse período, essa coroa passou a ser utilizada como um elemento iconográfico a mais no reverso de moedas também com a águia em pé durante o século IV a.C. Uma interpretação objetiva das imagens revela 0 significado de guerra e de ordenação subjacentes à imagem do raio e a coroa lhe acrescenta o significado de vitória - ideias presentes nos tipos monetários locais desde o início de suas emissões. Além de ter sido uma escolha do artista em compor novas imagens mantendo significados locais importantes, acreditamos que 0 prêmio mais esperado para os atletas vencedores nas competições, a coroa de folhas de oliveira, passou a ser retratado nas moedas de Élis, nesse contexto, por ter contido algum significado importante para a autoridade emissora, enquanto comunidade política, nessa fase de trégua entre Atenas e Esparta e de nova conformação de alianças na retomada da guerra, quando os eleios abandonaram a liga peloponésia, liderada pelos espartanos.

Nesse mesmo período, quando se acirraram os embates de Élis com Esparta em c.420 a.C., a oficina monetária de Élis usou pela primeira vez a imagem da deusa Hera em suas emissões. Como dissemos anteriormente, tem se acreditado que a imagem da deusa foi usada por uma nova oficina instalada em Olímpia em detrimento dos cunhos dessas novas séries com a divindade não terem similaridades aos das emissões anteriores. Até hoje não há um consenso entre os pesquisadores sobre a existência do culto de Hera em Olímpia. De acordo com A. Moustaka, "é improvável que o culto de Hera tenha sido importante no santuário como foi o de Zeus desde os períodos mais antigos" (Moustaka, 2002: 205). A seu ver, "o primeiro templo dórico de Olímpia, datado do início do século VI a.C., atribuído à deusa, na verdade, deve ter sido o primeiro edifício sagrado dedicado a Zeus, transformado, posteriormente em um tipo de monumento sagrado e uma espécie de tesouro já à época da construção do templo de Zeus no século V a.C." (Moustaka, 2002: 204-205). "Na época de Pausânias, que descreveu o antigo templo dórico como um Heraion, a memória desses desenvolvimentos deve ter sido esquecida e o periegeta acabou se convencendo da antiguidade do culto à deusa" (Moustaka, 2002: 205). Ao contrário das evidências encontradas sobre o culto das divindades femininas nos tempos mais antigos de Olímpia, daquelas inúmeras sobre Zeus, as representações monetárias de Hera são as únicas evidências conhecidas sobre a divindade no santuário. Para se ter uma idéia, a inscrição Hera sobre o diadema da deusa, nas moedas, é a única menção ao seu nome em Olímpia encontrada até o momento (Moustaka, 2002: 204). Como observou essa autora, "no momento em que a imagem de Nike, desapareceu das emissões de Élis, o tipo de Hera foi introduzido" (Moustaka, 1992: 42). Interessante também observar que Hera passou a figurar como tipo monetário acompanhando os atributos de Zeus - a águia e o raio não foram substituídos por atributos da deusa. E a sua cabeça, passou a ser retratada por volta do mesmo período no qual o tipo cabeça passou a ser um padrão para as representações monetárias de Zeus e também da águia, embora essa última 
tenha sido usada por um curto período. A introdução do tipo cabeça pode ser explicada como uma tendência artística vigente nesse período para a representação de divindades gregas em moedas. Sobre a presença do tipo de Hera nas emissões monetárias de Élis, por alguma razão, nesse momento, o culto foi institucionalizado ou assumiu alguma importância ao lado do de Zeus (sempre o preponderante). Mesmo a aliança com Argos, importante inimiga de Esparta, detentora de um renomado santuário regional à Hera, foi excluída como causa para o uso da imagem da divindade nas emissões eléias (Seltman, 1921: 86). A deusa, esposa do principal deus do santuário, deve ter sido propiciada, através das imagens monetárias, por alguma razão específica que hoje ainda desconhecemos.

Do período após a Batalha de Mantinéia, ocorrida em c.418 a.C., com a vitória decisiva de Esparta sobre a coalização de Argos, Mantinéia e Élis, data a introdução da imagem da cabeça de Zeus nas moedas de Élis (c.416 a.C.), a qual acompanha a do raio alado com a coroa de folhas de oliveira (Fig.235 - n.355). Trata-se do tipo monetário mais antigo, no mundo grego, no qual se encontram associadas a imagem do deus e de seu atributo, o raio. Essa seria outra inovação da oficina de Élis na imagética de Zeus e de seus atributos em moedas gregas, ou seja, juntar na mesma moeda atributo e divindade. Até então, as imagens de Zeus, dentre as quais as de sua cabeça, figuraram em moedas, cujo tipo, normalmente de reverso, não traz uma imagem referente ao deus, e sim a de outro aspecto importante à autoridade emissora. Esse é o caso dos tipos monetários mais antigos de cabeça de Zeus (nesse caso não-Amon) emitidos na Arcádia entre c.430-420 a.C. A nosso ver, a ocorrência do uso da cabeça de Zeus somente nesse período nas moedas de Élis tenha sido motivada, ao que parece, por uma tendência regional (de Élis e Arcádia). O padrão cabeça de Zeus em moedas gregas foi um tipo preponderante entre autoridades emissoras durante o século IV a.C., embora o uso tenha se iniciado, em bem menor escala, no século V a.C. Nesse caso também, vemos uma troca entre Élis e a Arcádia, talvez uma influência dessa última, em algum grau e de alguma maneira, na forma de representar Zeus em moedas. A associação da imagem da face do próprio Zeus Olímpio, com a de seu raio alado, revela um significado totalmente relacionado à guerra e também a necessidade da ordenação do que era o mundo, 0 cosmos, para a comunidade dos eleios. Nesse contexto, propiciar a divindade através de sua própria representação, no caso a sua face, era uma forma eficiente de assegurar àquela comunidade, os seus poderes a favor, no caso, para os eleios as energias divinas de vitória sobre a guerra e de ordenação proporcionadas por Zeus para a normalização da vida, das instituições políticas, do poder, sempre ameçadas por um inimigo em tempos de guerra.

Nesse mesmo período do primeiro tipo monetário da cabeça de Zeus, a cabeça da águia, sem a presa, também foi usada como imagem pela primeira vez nas moedas de Élis. 0 tipo monetário da águia faz parte daqueles, cujas séries monetárias tiveram início no século $V$ a.C. e terminaram no século IV a.C., ao menos esse é o caso das composições com o raio alado, as quais terminaram no final dos anos de 380 a.C. - foram ativas, portanto, em meio à guerra do Peloponeso, à guerra eleio-espartana (de c.402-404 a.C.) e o período que lhe sucedeu. Já com o raio chamejante, o tipo da cabeça da ave foi usado em séries monetárias datadas 
a partir do ano final do conflito com Esparta (c.400 a.C.) e subsequentemente (anos de 380 a.C.). Os tipos monetários com a inscrição $A / F$, exclusivos de pequenas denominações, remontam somente à época da guerra do Peloponeso. Do repertório iconográfico dessas séries monetárias, devemos destacar o tipo monetário da cabeça de águia com o raio chamejante, datado de c.400 a.C., retratada dentro de um escudo, evidenciado pela curvatura das bordas no campo monetário do anverso. A representação da águia em um escudo foi usada também no tipo monetário da águia em pé, curvada sobre um carneiro, com o raio alado de c.388 a.C. - tratase, então, de uma tipologia pontual própria do início século IV a.C. nas emissões de Élis.

Essa escolha do uso do escudo com a águia (cabeça ou em pé sobre presa), em 400 e 388 a.C., certamente esteve associada ao momento bélico de Élis com Esparta, que não se limitou à guerra terminada em c.400 a.C. De acordo com Nielsen, Xenofonte recorda que no início do século IV a.C. (c.400 a.C.), os espartanos derrotaram os eleios em uma guerra para conter o poder político de Élis, procurando privá-la de seu controle de Olímpia (Nielsen, 2007: 31). A expulsão de Esparta de Olímpia, o açoitamento de um atleta espartano, que se fizera passar por tebano nos jogos e a expulsão do rei Agis do santuário, foram os motivos, ocorridos por volta de 420 a.C., que irritaram os espartanos a tal modo a ponto de tentarem tirar a administração de Élis (Nielsen, 32 e 35). Mas a razão oficial para a guerra entre c.402-400 a.C. "foi o fato de Élis ter se recusado de dar autonomia as suas comunidades perioikoicas" (Nielsen, 2007: 31; Taita, 2007: 75). Já no início dos anos de 380 a.C., o rei espartano Agesipolis não teria repeitado a regra olímpica sobre a proibição em consultar o oráculo de Zeus Olímpio para o enfrentamento contra outro Estado grego. Segundo Xenofonte (Helênicas 4.7.2), o rei realizou a consulta sobre uma questão envolvendo uma agressão armada contra Argos (Nielsen, 2007: 35). Nessa época, portanto, cerca de duas décadas após a guerra contra Esparta, os eleios, segundo Nielsen, "tiveram de se curvar ao poder dos espartanos" (Nielsen, 2007: 35). Equipamento defensivo de guerra, vimos, no capítulo anterior, como na representação da águia no escudo, o guerreiro requeria para si um bom agouro na luta e o afastamento de qualquer resultado desfavorável em guerra. Ao mesmo tempo que procurava esse tipo de proteção para ele, ao portar o escudo com a imagem, quem vê a imagem da águia é 0 inimigo, é a ele que a mensagem é endereçada. No caso da imagem da águia dominando a presa, como no tipo monetário de c.388 a.C., o significado, assim, é de derrota eminente do inimigo. A intenção da oficina monetária dos eleios foi transmitir esse significado aplicado ao escudo para a moeda. É nessa perspectiva, e no contexto político com Esparta, que as imagens monetárias da águia no escudo assumiram, ao lado do raio alado no reverso dos dois tipos, um significado protetor e favorável à autoridade dos eleios em Olímpia e na região naquele período.

Outras emissões foram atribuídas a esse conturbado período de c.380 a.C., tais como o tipo monetário da cabeça de Hera acompanhado pelo tipo da cabeça da águia no reverso ou da cabeça de Hera e do tipo da águia em pé, representada ou não dentro de uma coroa de folhas de oliveira - padrão que perdurou nas cunhagens além de c.344 a.C. 
Ao redor de 365 a.C., a prostasia dos eleios em Olímpia voltou a ser ameaçada, mas dessa vez pelos arcádios, e por consequência a cunhagem foi interrompida. Como comentamos anteriormente, nesse ano, 0 exército arcádio capturou Olímpia e instalou uma guarnição na colina de Cronos.

Após algum confronto com Esparta, no sul da Arcádia, os arcádios dirigiram sua atenção para Olímpia. Nesse ano, a guerra ocorreu entre Élis e aliados e a confederação arcádia (incluindo os pisates). Foi durante essa guerra que os arcádios capturaram Olímpia. 0 ano seguinte à ocupação, 364 a.C., era um ano olímpico, assim os arcádios, juntos aos pisates - os quais alegavam ter sido os primeiros a comandar o santuário -, preparam as celebrações dos jogos naquele ano (Nielsen, 1999: 55). Foram os arcádios que de fato controlaram o santuário, usaram o dinheiro sagrado para pagar as tropas federais e aparentemente ajudaram os pisates a criar uma mitologia cívica, ligada às tradições arcádias (Nielsen, 1999: 55 e 56; Roy, 2013: 111). Assim, Olímpia não esteve mais sob o controle de Élis e perdeu uma parte importante de seu território a sul (Nielsen, 2007: 36). Como os arcádios não possuíam uma base histórica, que justificasse sua reivindicação pelo controle de Olímpia, não poderiam permanecer à frente do santuário. Foi por essa razão que estes ajudaram os pisates a constituir um estado "marionete" e a colocar-se na prostasia do santuário (Nielsen, 2007: 36 e 38). De acordo com Nielsen, não há dúvidas de que Pisa tornou-se um Estado nesse período, porque bateu moedas e estabeleceu decretos garantindo proxenia e theodorokia a estrangeiros (Nielsen, 1999: 56). "Foi nesse contexto que os pisates emitiram uma única série monetária de óbolos de ouro com a imagem da cabeça de Zeus, no anverso, com cabelos e barba curtos, e o raio (não alado e não chamejante) no reverso, acompanhando pela legenda do étnico de toponímio no singular (ПI/LA)" (Kraay, 1976: 106; Nielsen, 1999: 56; 2007: 43; Roy, 2013: 109; Taita, 2007: 56). Interessante notar, que estes não romperaram totalmente com o repertório iconográfico anterior, da oficina eléia, e mantiveram os tipos associados pela primeira vez por Élis em c.416 a.C. - a cabeça de Zeus e o raio. Como coloca Nielsen, tratou-se de uma maneira de afirmar a ligação entre o santuário e 0 Estado pisate (Nielsen, 1999: 56). Pode ter se tratado de uma forma de continuar a usar símbolos marcados como tradicionais de uma cunhagem conhecida no mundo grego, reconhecida como de Olímpia. De fato, esse autor está certo, mas, se observarmos bem, o raio no reverso é uma simples representação do tipo lótus, não sendo nem alado e nem chamejante, o que evidencia certa ruptura com o modelo anterior da oficina eléia (de seu ou seus mestres gravadores), cujos tipos do raio representaram uma tradição cultural local própria dessa comunidade. Manter os tipos da cabeça de Zeus e do raio, pelo Estado de Pisa na prostasia, pode ter significado também o desejo dessa comunidade em ser identificada e protegida pela principal divindade de Olímpia, e guerreira, em um momento de necessidade de afirmação e muita instabilidade em se manter na administração do santuário, como tradicionalmente Élis vinha fazendo.

Como coloca Nielsen, não se sabe o que aconteceu ao pequeno estado de Pisa, quando a confederação arcádia e Élis concluíram a paz, mas, presumivelmente, a área foi reabsorvida pelo Estado eleio (Nielsen, 2007: 43). Roy explica que "os eleios renegaram o Estado pisate abolindo as quatro phylai as quais pertenciam os pisates transformados cidadãos eleios" (Roy, 2013: 111). Então, completa o autor, a guerra 
acabou em c.362 a.C. e Élis recuperou a área pisate e Olímpia (Roy, 2013: 111). Como resultado da retomada da prostasia, Élis declarou os jogos de 364 a.C. como inválidos e apagou-os dos registros oficiais, segundo Diodoro (15.78.3) e Pausânias (6.22.3) (Nielsen, 2007: 43). As emissões monetárias eléias foram retomadas ao redor de 360 a.C. com certas inovações iconográficas. Houve duas séries monetárias com a cabeça de Zeus, no anverso, com cabelos e barba curtas e a coroa de folhas de oliveira. Em uma delas o reverso é ocupado pela águia em pé, de asas fechadas e cabeças para frente sobre um capitel jônico e na outra, a cabeça da ninfa Olímpia é retrada pela primeira vez, como indica a inscrição com seu nome no campo monetário junto à imagem. Em outra série monetária, a ninfa também aparece, mas como imagem de anverso, no lugar da de Zeus, com o raio alado no reverso. E por fim, em uma outra série monetária, a cabeça de Zeus com cabelos e barba curtos é retratada pela primeira vez, nas moedas de Élis, com uma fita na cabeça no lugar da coroa de folhas de oliveira. O reverso é ocupado pelas três letras "T", indicando a pequena denominação. Desses tipos monetários, destacamos as emissões com a cabeça de Zeus / cabeça de Olímpia e cabeça de Zeus / águia em pé sobre capitel. A bibliografia consultada é unânime em aceitar que o tipo monetário de Zeus com Olímpia teria sido uma referência direta à retomada da prostasia por Élis. "A inscrição do étnico "dos eleios", no anverso com Zeus, e a inscrição "Olímpia", no reverso com a ninfa, significaria que Olímpia mais uma vez pertencia à Élis" (Kraay, 1976: 106; Nielsen, 2007: 45; Roy, 2013: 109). A presença da ninfa Olímpia, como tipo, levou Seltman a propor que essa seria uma moeda comemorativa do retorno do controle dos eleios (Seltman, 1921: 62). Para Hill, nessa moeda, o étnico dos eleios aparece completo pela primeira vez e associado com a cabeça do principal deus do santuário. E a cabeça da ninfa Olímpia, legivelmente identificada, expressa a afirmação dos eleios no domínio do santuário, no qual ela é a personificação (apud Nielsen, 2007: 45, nota 158).

A nosso ver, tal interpretação deve estar correta. Dentre essas séries de c.360 a.C. gostaríamos de chamar a atenção para o desenho da águia em pé sobre o capitel jônico. Trata-se de um esquema iconográfico, ao que parece, criado pela oficina monetária de Agrigento na Sicília na primeira metade do século V a.C., o qual foi muito copiado nas emissões de centros não-gregos na ilha ainda durante o século $\mathrm{V}$ a.C. $\mathrm{O}$ tipo foi usado, ainda antes de Olímpia, pela pólis de Crotona na Itália do Sul no segundo quartel do século V a.C. O contexto histórico do uso dessa imagem em ambas cidades gregas ocidentais revelou um significado relacionado à afirmação de soberania dessas comunidades em termos regionais, como veremos com profundidade mais adiante nesse capítulo. Esse mesmo significado pode ser interpretado no tipo de Élis - a águia em pé sobre o capitel jônico teria sido um símbolo, conhecido no Ocidente grego, requisitado pela oficina monetária eléia para figurar nesse momento de retomada da hegemonia de Élis em Olímpia e diante das comunidades da região.

O tipo de Zeus com cabelos e barba curtos com a águia sobre o capitel jônico voltou a aparecer, de forma pontual, numa série monetária de c.344 a.C. Após as séries monetárias de c.360 a.C., marcadas por um novo repertório iconográfico, somente a partir de c.352 a.C. vemos novas formas de representações, principalmente com relação a Zeus nas moedas - desde as séries desse ano, o deus passou a figurar com 
cabelos e barba longos e como sempre no anverso das moedas. A águia em pé, de asas fechadas e sobre 0 capitel jônico permaneceu como o tipo de reverso mesmo após essa mudança na representação da cabeça de Zeus. A diferença é que em algumas emissões entre 352-348 a.C., a folha de oliveira aparece no campo da moeda junto à representação da águia, de uma forma como nunca foi usada anteriormente. 0 tipo da cabeça de Hera voltou a substituir o de Olímpia, no anverso, e permaneceu em uso até o fechamento de suas emissões em c.324 a.C. (Walker, 2004: 54). A novidade maior desse período no repertório iconográfico das emissões de Élis foi a inserção da imagem do raio, pequeno no campo, em associação à imagem de Zeus, em uma série de c.352 a.C., e em associação, dessa mesma maneira à imagem da águia em pé sobre o capitel, em séries de c.348 a.C. De acordo com a opinião de A. Walker, a representação do raio atrás da cabeça de Zeus não seria uma símbolo de um magistrado, como suporam alguns estudiosos, mas simplesmente uma referência ao próprio Zeus (Walker, 2004: 57). Essa associação entre o deus e seus dois atributos em uma mesma moeda parece ter ocorrido pela primeira vez nas moedas de Élis, como sugere a datação do tipo em contraste com os tipos monetários de Siracusa e Agyrion, na Sicília, datados de um pouco posteriormente no período de Timoleonte. Vimos no capítulo 3 que a associação entre estas três imagens em moedas gregas foi própria de Élis e da Sicilia, ao menos até c.344 a.C., o limite cronológico de nossa pesquisa. Essa associação iconográfica também apareceu em moedas de Lócris e Hipponion, na Itália do Sul, após essa data de 344 a.C. Em termos gerais, esse pequeno período (entre c.352-344 a.C.) foi de continuidade nos tipos de representações monetárias, apesar da mudança iconográfica de Zeus, própria do período clássico tardio, e da associação dos atributos com a divindade.

A partir do final do período clássico, portanto, a imagem de Zeus, do raio e da águia foram reunidas em moedas gregas, mas por qual razão essa associação não ocorreu antes? A oficina monetária de Élis iniciou essa forma de usar os atributos associados ou um deles associados ao deus como imagens monetárias - um ou outro e não todos juntos em moedas. Anteriormente, teria sido uma redundância usar os dois atributos com Zeus, já que águia e raio expressavam juntos as características do deus? A razão pode estar numa mudança na concepção religiosa sobre Zeus em decurso a partir do século IV a.C., como mencionamos na análise da documentação iconográfica sobre Zeus. De todo modo, o uso das três imagens associadas, como emblema monetário, foi a forma mais completa possível de tanto evocar sua proteção e propiciar todas as energias e forças da divindade a favor da comunidade, como de se auto-identicar com elas. Vimos na análise contextual, empreendida no final do capítulo anterior, os vários significados vinculados às imagens dos raios e das águias mostram-se consonantes com as características do próprio Zeus e com a sua esfera de atuação e culto. Guerra, competição, disputa e vitória - os significados comuns por detrás das imagens de raios e águias - são também aspectos importantes do culto de Zeus no mundo grego e também observáveis na representação da própria divindade.

A bibliografia consultada nessa discussão sobre Élis, pouco informa sobre a situação política dessa pólis no período após a retomada de sua prostasia em Olímpia, principalmente entre 352 e 344 a.C. No entanto, 
sabemos que algumas mudanças em termos de mundo grego influenciaram o desenvolvimento dos jogos e provavelmente, de algum modo, a administração eléia no santuário nessa época. O século IV a.C. ficou conhecido como o período do atletismo profissional. Já a partir de c.356 a.C., a intervenção dos macedônios nas questões políticas no sul da Grécia Balcânica, o Peloponeso, encontrou expressão no interesse pessoal de Felipe II com a participação dele em duas modalidades nos jogos desse ano (Valavanis, 2004: 118). A expressão arquitetônica desse interesse foi o Phillipeion (Valavanis, 2004: 118). Sabemos que, ao menos para um período um pouco posterior, as relações entre Élis e os macedônios foram sempre difíceis, complicadas pela tensão em Élis entre apoiadores e oponentes à Macedônia (Roy, 2013: 117). Nesse período, novas coalizações foram formadas entre as póleis gregas, contra ou não ao império macedônio. Esparta já não era mais o poder com que Élis se confrontava, desde ao menos a Batalha de Leuctra em c.371 a.C. Nesse contexto, as imagens de Zeus, águias e raios, e as suas formas já tradicionais de representação e de significado, permaneceram requisitadas pelos eleios mobilizadas provavelmente de outra forma, em um período diferente daquele do século $\mathrm{V}$ e início do IV a.C. quando espartanos e arcádios confederados eram as ameaças a um lado importante de identidade da comunidade, o de administradora de Olímpia. Já em um outro tempo, portanto, acreditamos que os significados básicos das imagens monetárias de Zeus e de seus atributos foram preservados pela e para a comunidade dos eleios e a audiência dos jogos, ainda que de certa forma tenham sido rearranjados, se associado, e transmitido uma mensagem mais forte, por alguma razão, sobre a necessidade, dessa comunidade política, de identificação, proteção e sanção de Zeus Olímpio, a divindade maior do santuário a qual administrava.

\subsubsection{Arcádia}

Em contraste ao que ocorreu com Élis-Olímpia, responsável por uma longa emissão de tipos monetários referentes a todas as formas de aludir a Zeus em moedas gregas (não apenas imagens do deus, mas de águias e raios como imagens principais), na Arcádia somente a imagem do deus foi usada com tipo principal em moedas de duas categorias de autoridades emissoras durante o século V e IV a.C. - ligas e subéthnos. A Arcádia foi a segunda sub-região do Peloponeso prolífica em representações monetárias de Zeus. Como atributos do deus, a águia e o raio aparecem como tipos secundários compondo a imagem de Zeus como tipo monetário principal. $O$ padrão de Zeus sentado no trono foi usado como tipo principal em uma cunhagem no nome dos arcádios durante uma parte específica do século V a.C. (Fig.237 - n.10-46). A cabeça de Zeus aparece pela primeira vez em séries monetárias anepígrafas, atribuídas à liga arcádia, a partir de um pouco antes do segundo quartel do século V a.C. (Fig.238 - n.43/45). Entre o final do século V a.C. e o início do IV a.C., o mesmo padrão de representação da cabeça de Zeus em moedas (sem coroa de folhas), é atribuído aos parrhasios, sub-éthnos arcádio (Fig.238 - n.40/48). Um pouco antes e durante a metade do século IV a.C., a cabeça de Zeus (agora com coroa de folhas) voltou a aparecer em moedas, batidas no nome dos arcádios 
confederados (Fig.238 - n.73/74). O tipo de Zeus sentado no trono foi exclusivo das cunhagens arcádias do século V a.C., sendo substituído pelo padrão da cabeça de Zeus que, como vimos no capítulo anterior, se transformou na tendência principal em representar o deus em moedas gregas a partir do segundo quartel do século V a.C.

Assim, as primeiras emissões sobre Zeus na região são aquelas com a legenda ARKA $\triangle I K O N$ ("dos arcádios"), a qual aparece inscrita de forma abreviada ou não nas séries monetárias, com a imagem de Zeus sentado no trono, no anverso, o qual é consenso se tratar de Zeus Lykaios, e a representação de uma cabeça feminina no reverso, interpretada pelos especialistas com sendo de divindades de apreço regional (Ártemis, Despoina ou Calisto). No histórico do uso da representação de Zeus em moedas gregas, estas emissões no nome dos arcádios estão entre as mais antigas com a imagem do deus, junto àquelas de Élis e de Cirene.

Trata-se majoritariamente de emissões de frações sempre em prata (hemidracmas, óbolos, trióbolos e hemióbolos) no padrão eginético (Kraay, 1976: 97; Psoma, 1999: 81). Há um acirrado debate com relação à cronologia das séries e a função dessas emissões monetárias batidas no nome dos arcádios. Autor do estudo até hoje mais completo sobre essas moedas, R.T. Williams datou o primeiro período entre c.490-477 a.C. com base na semelhança estilística da cabeça feminina, nos reversos, com a forma de representação da cabeça de Atena em vasos áticos de figuras negras de c.490-480 a.C. e, nas moedas, com aquela de Aretusa, no demareteion de Siracusa, e de Atena, no tetradracma ateniense datado por volta dessa data (Williams, 1965: 1-2). Williams relacionou o início da cunhagem à época de uma coalização arcádia contra o rei espartano Cleomenes (Williams, 1965: 3). Cerca de uma década depois de Williams, C. Kraay sugeriu uma nova datação para o início das emissões arcádias com base nas datas revisadas para o demareteion siracusano (em c.470/60 a.C.) e o tetradracma ateniense (de após 480 a.C.) (Kraay, 1976: 97). Para esse autor, "os cunhos arcádios não teriam sido inspirados pelas emissões atenienses com coroa, mas por aquelas emitidas antes de 470/69 a.C." (Kraay, 1976: 97). A seu ver, "o início do primeiro período deveria remontar logo após o fim das guerras pérsicas, ao invés de c.490 a.C., e o do segundo período de Williams (c.477-468 a.C.) deveria ser abaixado para meados dos anos 460 a.C., correspondendo, portanto, à época da batalha de Dipaea (c.479-465 a.C.), quando os arcádios, exceto os mantineus, se uniram militarmente para expulsar os espartanos dessa pequena cidade arcádia" (Kraay, 1976: 97-98; Nielsen, 1999: 57; Psoma, 1999: 82). C. Kraay e S. Psoma proporam novas datas apenas para os dois períodos iniciais, organizados por Williams, e para o final das cunhagens não há uma nova proposição para os três demais períodos. Kraay, seguindo o próprio Williams, situou o fim das emissões no nome dos arcádios após a batalha de Mantinéia (c.418 a.C.), se baseando na premissa de que teriam terminado quando as emissões autônomas das cidades arcádias se iniciaram no final do século $\mathrm{V}$ a.C. (Kraay, 1976: 98). Já Psoma, a qual concorda com Kraay acerca da data do início dessas emissões, diverge com esse autor sobre o término das cunhagens relacionados à batalha de Mantinéia. Para ela, "as emissões teriam se encerrado no final do terceiro quartel do século $V$ a.C. e estariam associadas, portanto, a um período um pouco anterior a essa batalha" (Psoma, 1999: 84 e 87-88). 
A constatação de três diferentes séries não correlatas entre si, deduzidas por variações importantes no desenho dos tipos de Zeus e da cabeça feminina (embora correlações dentro das séries sejam frequentes), levou Williams a propor que se tratava de três oficinas monetárias diferentes sediadas nas póleis de Kleitor, Mantinéia e Tegea (Kraay, 1976: 98; Psoma, 1999: 82). Contudo, como afirmaram Kraay e Psoma, "não há qualquer evidência para a atribuição dessas emissões a essas três cidades" (Kraay, 1976: 98; Psoma, 1999: 82). A. Walker mais recentemente, ao organizar o catálogo The BCD collection, Coins of Peloponnesos, considerou a cronologia inicial dos tipos monetários dos arcádios, proposta por Kraay, e a final, proposta por Psoma, mas manteve a atribuição de Kleitor, Mantinéia e Tegea como as autoridades emissoras responsáveis em emitir tais moedas. Na construção de nosso catálogo, consideramos os tipos do catálogo organizado por Walker com as novas datações, mas evitamos a atribuição a essas póleis arcádias, considerando a discussão mais recente a respeito da Arcádia.

Se hoje os especialistas conseguiram estabelecer uma cronologia mais acertada para essas moedas, batidas no nome dos arcádios, a falta de evidências sobre as oficinas monetárias, as autoridades emissoras responsáveis por essas emissões, Ihe confere, ainda até hoje, um certo caráter enigmático quanto ao uso desses tipos monetários (Jost, 1985: 183-184; Kraay, 1976: 98; Nielsen, 1999: 22; Psoma, 1999: 87; Roy, 2009: 59; Williams, 1965: viii). O padrão repetitivo das imagens nelas gravadas (de Zeus sentado no trono e da divindade feminina), em associação à legenda ARKA $\triangle \mathrm{IKON}$, o padrão monetário e as denominações usadas nessas emissões, são, ao lado dos dados advindos dos entesouramentos, as únicas informações que dispomos para saber sobre seu uso e função. Atualmente, os especialistas se dividem entre duas proposições - uma que vê uma função estritamente religiosa nessas cunhagens, e as relaciona ao santuário de Zeus no Monte Lykaion, e a outra que as define como emissões realizadas por uma aliança ou liga para pagamento militar. Mais recentemente, em ambas as interpretações, os estudiosos têm considerado essas moedas como evidências únicas de um período especial de saliência da identidade étnica dos arcádios, com base na legenda e nas imagens de Zeus Lykaios, divindade de forte apelo regional (Jost, 1985: 184; Nielsen, 1999: 27 e 44; Psoma, 1999: 81; Roy, 2009: 59).

Os primeiros a proporem um caráter religioso e agonístico, às cunhagens dos arcádios, foram E. Curtius e W.M. Leake - o primeiro estudioso a associou ao santuário de Zeus no Monte Lykaion e o segundo aos jogos lykaios, supondo que o estado emissor foi Lykossoura (apud Williams, 1965: vii). Babelon aceitou a teoria de Imhoof-Blumer sobre a qual Heraia teria sido a responsável pelas emissões, acrescentando que esta pólis teria sido a presidente dos jogos lykaios (apud Williams, 1965: viii). Essa teoria de Babelon e Imhoof-Blumer foi seguida por muitos estudiosos, inclusive por B.V. Head (Head, 1963: 444; Jost, 1985: 183-184; apud Williams, 1965: viii). T. H. Nielsen afirmou que a organização das festas e dos jogos em honra a Zeus Lykaios (as Lykaia) foram a ocasião ideal para a cunhagem dessas moedas (apud Psoma, 1999: 87). Para esse autor, que segue a teoria de G. Fougères, essas moedas foram batidas por uma anfictionia pan-arcádia, um tipo de associação religiosa, responsável pela administração do santuário de Zeus no Monte Lykaion (apud Nielsen, 1999: 44 e 
57). Mas mais recentemente Nielsen parece ter admitido que o santuário "não foi controlado por nenhuma das grandes póleis da região e nem por uma anfictionia" (Nielsen, 2013: 236). Na perspectiva de Fougères, o Monte Lykaion teria tido um estatuto de santuário federal (apud Jost, 1985: 184). Mas essa teoria foi recentemente descartada, de forma bem fundamentada, por Nielsen, o qual mostra que "o santuário não foi, entre outras coisas, um local de publicação federal nem no século V a.C. e nem no IV a.C." (Nielsen, 2013: 239-241).

Na contra-mão dessa teoria, S. Psoma defende que os tipos monetários, que aludem a cultos arcádios, "não são evidências suficientes para atribuir essas cunhagens ao santuário de Zeus no Monte Lykaion" (Psoma, 1999: 89). A autora lembra ainda que as Lykaia continuaram a ocorrer regularmente também após a batalha de Mantinéia, quando, um pouco antes, essas emissões teriam cessado. Esse seria um bom motivo para não as relacionar à organização das festas e dos jogos no Monte Lykaion (Psoma, 1999: 87-88). Acrescentando ao debate as informações dos entesouramentos, Psoma coloca que as moedas dos arcádios "tiveram uma circulação ampla dentro da Arcádia, onde, por um longo tempo, foram as únicas moedas de troca, de modo que não se limitaram à zona onde se localizava o santuário de Zeus no Monte Lykaion, que é muito isolada" (Psoma, 1999: 90). Além disso, Psoma também lembra que não há, até o momento, evidências de um culto a alguma divindade feminina associada a Zeus no Monte Lykaion, o que coloca por terra a tese da cunhagem no santuário (Psoma, 1999: 89). Para essa estudiosa, "a união dos arcádios, evidenciada apenas pela legenda nessas moedas, não foi de natureza religiosa, pode ter se tratado de uma liga de caráter militar" (Psoma, 1999: 90).

0 primeiro a suspeitar do caráter estritamente religioso dessas cunhagens, no nome dos arcádios durante o século V a.C., foi R. Weil ainda no início do século XX. O caráter político, subjacente à essas moedas, foi reconhecido por G. Richter e W.P. Wallace (apud Williams, 1965: viii). Williams parece ter sido o primeiro a afirmar que essas moedas foram batidas por uma confederação ou liga durante o século $V$ a.C., norteando todo o seu estudo das séries monetárias arcádias desse período, com base nessa premissa, e estabelecendo, como dissemos, três oficinas monetárias responsáveis pelas emissões da liga arcádia. Sua proposição acerca da liga foi aceita por C. Kraay, A. Walker e descartada por Nielsen em seu estudo sobre a etnicidade arcádia (Kraay, 1976: 97-98; Nielsen, 1999: 57; Psoma, 1999: 87). De acordo com Psoma, seguindo C. Kraay, "a emissão de de um grande número de trióbolos talvez se ligue ao pagamento de soldados mercenários arcádios" (Kraay, 1976: 98; Psoma, 1999: 94). Nesse sentido, como coloca a autora, "um argumento a favor da hipótese da liga, como organismo emissor, poderia ser a referência em Tucídides sobre o uso de três óbolos eginéticos como pagamento diário a um hoplita peloponésio em 421 a.C." (Psoma, 1999: 93). Psoma conclui em seu estudo que "as moedas com legenda ARKA $\triangle I K O N$ foram batidas a partir de um grande número de cunhos, indicando que as exigências foram de grande duração. A seu ver, certos eventos militares envolvendo os arcádios, no século V a.C., foram financiados com esse dinheiro - as iniciativas do rei Leotychidas de Esparta exilado em Tegea, 0 confronto militar entre espartanos e tegeatas em Tegea, as operações conduzidas em comum entre tegeatas e argivos contra Micenas, a enigmática batalha de Dipaea, depois da qual os arcádios (incluindo os tegeatas) se uniram em aliança aos espartanos" (Psoma, 1999: 92). É interessante notar, como coloca Psoma, que não 
houve uma interrupção dessas emissões após o ingresso dos arcádios na liga espartana, levando a propor que Esparta, provavelmente, deve ter pago os soldados mercenários com esse dinheiro durante a quarta guerra messênica e também posteriormente, durante o confronto com Argos e com Atenas (Psoma, 1999: 94). Sabese que algumas póleis, as quais por algum motivo não possuíam cunhagens, como foi o caso de Esparta nessa época, utilizavam moedas de outras cidades (Psoma, 1999: 94). "As emissões monetárias individuais, no nome das cidades arcádias, que se iniciaram depois na região, devem ter provido, de um lado, a dissolução da liga e, do outro, continuado a satisfazer as mesmas ou diferentes exigências econômicas" (Psoma, 1999: 92-93). É essa proposição de Psoma que consideraremos em nossa interpretação sobre o significado simbólico das imagens monetárias de Zeus nessas emissões.

Sem organizar as moedas em grupos e fazer atribuições, como fez Williams, Psoma chegou a propor Tegea, Orcômenos, Heraia, Kleitor e talvez Mantineia como as cidades emissoras dessas cunhagens da liga (Psoma, 1999: 90). Em contraste, Nielsen, seguindo S. Psoma e D. Tsangari chegou a admitir, muito recentemente, "que essas moedas podem ter sido batidas por uma symmachia liderada por Tegea ou sido parte de uma cunhagem cívica dessa própria cidade, sinalizando suas aspirações à hegemonia arcádia" (Nielsen, 2013: 237; Psoma; Tsangari, 2003: 112). Para ele ainda, Tegea e Mantinéia teriam explorado os mitos e símbolos do santuário no Monte Lykaion para seus próprios objetivos políticos locais durante o século V a.C. (Nielsen, 2013: 237). Mas trata-se apenas de uma hipótese já que não há qualquer evidência a respeito, a não ser a posição de liderança de Tegea entre os arcádios nessa época.

Com relação aos tipos monetários, E. Curtius parece ter sido o primeiro estudioso a identificar o tipo de Zeus sentado no trono, no anverso de todas as séries monetárias dos arcádios, como sendo a imagem de Zeus Lykaios, mas, ao que parece, ele se baseou na importância regional do santuário do Monte Lykaion como principal centro regional de culto à divindade no período das emissões (apud Williams, 1965: 33). Somente mais tarde, no século XX, G. Mylonas estabeleceu um critério iconográfico que permitiu confirmar tal atribuição - a presença da águia na iconografia de Zeus é própria do santuário do Monte Lykaion, como vimos no capítulo anterior (apud Jost, 1985: 183). Se por um lado existe uma grande discussão sobre a verdadeira função dessas moedas, por outro, a bibliografia a respeito é unânime em aceitar que se trata de Zeus Lykaios nessas cunhagens (Kraay, 1976: 97; Nielsen, 1999: 36 e 59; Psoma, 1999: 88). A controvérsia maior, com relação aos tipos monetários dessas moedas, está na imagem de reverso, que é a figura de uma cabeça feminina. Para Williams, a identificação da deusa parece oscilar entre Despoina e Ártemis, embora esse estudioso tenda a atribuí-la à Artemis (Williams, 1965: 33). Segundo Williams, "a atribuição à Despoina se baseia na afirmação de Pausânias (VIII, 37, 9), o qual recorda que os arcádios cultuaram a deusa mais do que qualquer outra divindade" (Williams, 1965: 33). Esse autor parece ter sido o primeiro a chamar a atenção para o fato de que Despoina não era cultuada em toda a Arcádia, mas apenas na sua porção ocidental, o que impediria de ser considerada uma divindade representante de todos os arcádios a ponto de figurar nas moedas com tal legenda (Williams, 1965: 33). Contra a atribuição a essa deusa, Psoma ainda lembra que não há evidências de qualquer 
tipo sobre um culto comum a Zeus Lykaios e Despoina no Monte Lykaion ou em outra área da Arcádia (Psoma, 1999: 88, nota 29). A maior parte dos estudiosos se coloca a favor da identificação da imagem com Ártemis. Head parece ter sido o primeiro a associar a imagem das moedas dos arcádios com a da deusa em Lykossoura (apud Psoma, 1999: 89). Além disso o culto da deusa foi mais comum na região (Psoma, 1999: 89; Williams, 1965: 33). Para Williams, a evidência de que se tratou de imagens monetárias de Ártemis seriam as letras iniciais AR, do étnico dos arcádios, inscritas justamente junta à cabeça da divindade feminina (Williams, 1965: 33).

Uma terceira linha interpretativa, vê na imagem feminina a cabeça da ninfa Calisto - que após ter sido seduzida por Zeus deu à luz a Arkas, o epônimo ancestral dos arcádios (Nielsen, 1999: 33; Walker, 2006: 334). Além de ter sido mãe de Arkas, Calisto teria sido irmã de Lykaon, o responsável por estabelecer o culto a Zeus Lykaios e os jogos lykaios (Nielsen, 1999: 32). Walker, citando um estudo de K.P. Erhart, conclui que "a cabeça feminina, nas emissões dos arcádios, representou Calisto, em razão de que Ártemis e Despoina foram cultuadas em partes específicas da Arcádia, enquanto Calisto não foi específica a uma área, sendo muito mais apropriada para representar todos os arcádios diante de todo o seu valor e papel no mito arcádio" (apud Walker, 2006: 334). Acreditamos que a proposição de Erhart sobre Calisto é a mais correta para a identificação da divindade feminina nas moedas dos arcádios ainda mais por sua associação no mito a Lykaon, relacionado ao culto de Zeus Lykaios e ao seu santuário no monte. Portanto, como se vê, houve sim um aspecto religioso (relacionado à identidade étnica regional) contido nessas cunhagens no nome dos arcádios, conforme indicam as imagens nelas representadas, o que é diferente de afirmar que essas moedas foram cunhadas por uma motivação estritamente religiosa.

Vimos na discussão do capítulo sobre os santuários como a análise do culto de Zeus Lykaios revelou aspectos muito diferentes de atuação - originalmente de um deus celeste a um deus-lobo, depois de panarcádio a pan-helênico (Jost, 1985: 268). Para Jost, "o prestígio de Zeus Lykaios foi um fenômeno único e a complexidade de sua personalidade tenha sido, talvez, a causa de seu renome: deus dos camponeses, a quem interessa o tempo, deus dos praticantes dos concursos atléticos e deus regional" (Jost, 1985: 269). Além de deus dos fenômenos naturais e do pan-arcadismo, na Arcádia, "Zeus assumiu o papel de árbitro dos destinos políticos, como veremos melhor no caso da confederação arcádia no século IV a.C." (Jost, 1985: 271).

Vimos também como a bibliografia é unânine em aceitar a relação do culto de Zeus Lykaios no Monte Lykaion com a consciência étnica arcádia. De acordo com M. Jost, "antes de adquirir um caráter pan-arcádio, o Monte Lykaion foi um santuário mais restrito aos parrhasios, devido principalmente a sua localização dentro da área desse sub-éthnos arcádio, a Parrhasia" (Jost, 1985: 183; Nielsen, 1999: 52). Essa é uma teoria que foi proposta por $\mathrm{G}$. Fougères no início do século $\mathrm{XX}$ a qual aguarda uma revisão à luz das novas descobertas arqueológicas proporcionadas pelas escavações americanas na montanha, sobretudo com base na proveniência das oferendas votivas depositadas no santuário e na área agonística. Recentemente, Nielsen chegou a afirmar que "o santuário pode ter servido como um centro simbólico para o Estado parrhasio, ou até 
mesmo ter sido controlado por ele, mas não há evidências que suportem essa ideia, além do fato de que esteve situado na Parrhasia" (Nielsen, 2013: 234, nota 45 e 235-236). Conforme Jost, foi durante o século V a.C. que a audiência do santuário cresceu, atraindo indivíduos de dentro e fora da Arcádia, mas principalmente de arcádios (Jost, 1985: 183). Tal processo parece ter se iniciado nesse período, atingindo o ápice no século IV a.C. quando o Monte Lykaion se consolidou como um centro religioso e agonístico pan-arcádio e pan-helênico (Jost, 1985: 184). Prova de que Zeus Lykaios teria adquirido uma importância pan-arcádia já no início do século V a.C. são essas cunhagens de moedas, com a imagem do deus associada à de Calisto, batidas no nome dos arcádios nessa época (Nielsen, 1999: 27). Nielsen sugere que "a conexão entre a identidade étnica arcádia e o culto de Zeus Lykaios foi enfatizada pela participação de indivíduos de outros grupos étnicos gregos nos jogos lykaios" (Nielsen, 1999: 31-32). Duas estelas encontradas no complexo agonístico de Kato Kambos, no Monte Lykaion, possuem inscrições com nomes de atletas vitoriosos nos Lykaia mostrando que o étnico regional arcádio Arkas foi usado junto ao nome dos atletas da região para diferenciá-los daqueles de outras partes do mundo grego (Nielsen, 1999: 28; 2013: 236). "Enquanto o uso do étnico arcádio é recorrente fora da Arcádia, principalmente em Olímpia e Delfos, foi somente no santuário de Zeus no Monte Lykaion, no contexto dos Lykaia, que o étnico arcádio foi usado dentro da própria arcádia" (Nielsen, 1999: 28). Esse uso interno do étnico arcádio é atestado no monte somente no século IV a.C., não havendo, por enquanto, evidências para o século V a.C. (Nielsen, 1999: 28). Mais uma vez, as evidências monetárias são as principais indicações da relação do culto com a identidade arcádia no século $V$ a.C.

Nielsen considera que somente no século IV a.C. houve de fato uma unidade política construída sob a etnicidade arcádia - "uma organização política verdadeira unindo todos os arcádios não é atestada antes de 370 a.C." (Nielsen, 1999: 56-57). No entanto, esse autor admite, com base em um trecho de Heródoto (9.35.2), que "durante o século $\mathrm{V}$ a.C. os arcádios (exceto os mantineus nesse período aliados à Esparta) uniram-se militarmente entre c.479-465 a.C. para expulsar os espartanos de Dipaea, uma pequena cidade da região - a seu ver, uma quase unificação pan-arcádia ocorreu nesse período" (Nielsen, 1999: 57). Nessa perspectiva, a "identidade étnica arcádia teria emergido, tido saliência nesse período em oposição à Esparta, considerada por Nielsen um fator vital da identidade arcádia" (Nielsen, 1999: 44). As moedas com a legenda ARKA $\triangle I K O N$, portanto, foram batidas nesse contexto de emergência da identidade étnica arcádia no século $V$ a.C. e é sob esse aspecto que o significado das imagens nelas gravadas deve ser analisado.

Toda a bibliografia crítica a respeito da Arcádia no período clássico - desde a específica à numismática até a restrita ao estudo histórico e arqueológico da região - explica essas representações monetárias de Zeus sentado no trono apenas pelo viés do culto local e da identidade regional. Até o momento, não há estudos que se propuseram interpretar essas imagens monetárias do deus relacionando o contexto de seu significado na arte e na literatura gregas com o contexto de seu uso, como pagamento militar no período de saliência da identidade étnica arcádia, de união dos arcádios contra Esparta. À primera vista, a tipologia monetária de Zeus nessas cunhagens arcádias do século $V$ a.C. pode parecer um pouco monótona tendo o deus sempre sentado 
no trono segurando o cetro e com a águia a ele sempre associado. No entanto, se observarmos bem, os artistas responsáveis por cada fase dessas cunhagens foram capazes de não somente mudar um pouco a maneira de representar Zeus (colocando-o quase de costas ou totalmente de frente, acrescentando um chiton), mas também de criar novas maneiras de posicionar a águia na representação e acrescentar o raio em certas emissões. $O$ tipo de Zeus sentado no trono, com himátion na cintura, segurando o cetro com a mão esquerda e a águia voando sobre a mão direita partindo do deus (com as asas abertas, uma em cima e a outra embaixo) é o mais antigo, aparecendo na primeira série arcádia de c.470 a.C. (Fig.237 - n.10) e nas demais de c.460450 a.C. (Fig.237 - n.20/23) (com Zeus sentado de frente) (Fig.237 - n.19), e de c.450-440/30 a.C. (Fig.237 n.29) e de c.420 a.C. (segurando também o raio) (Fig.237 - n. 46). O mesmo esquema iconográfico foi mantido em séries de c.465-460 e de 460-450 a.C., exceto pela posição da águia que é retratada em pé na mão direita de Zeus (com as duas asas erguidas, como pronta a voar, a partir do deus) (Fig.237 - n.13/14/17/21/22). Esses dois padrões de representação de Zeus sentado no trono são os mais comuns nas cunhagens dos arcádios. As demais imagens foram utilizadas em menor grau, em séries monetárias pontuais. Em uma série datada entre c.460-450 a.C., o cetro aparece na mão esquerda de Zeus (com chiton) assim como a águia em pé e 0 raio estão na sua mão direita (Fig.237 - n.24). Em outra série desse período, Zeus é retratado com o cetro em sua mão direita, o raio na esquerda e a águia parece voar à direita (a imagem é ruim e o catálogo coloca em dúvida a presença da águia) (Fig.237 - n.25). E finalmente, datado de c.465-460 a.C., o tipo de Zeus com a mão esquerda e o raio com a direita - a águia aparece grande voando no campo de frente e em direção ao deus (Fig.237 - n.15). Trata-se de um desenho inovador das séries arcádias.

Isto posto, o significado das imagens monetárias de Zeus sentado no trono nessas emissões deve ser avaliado considerando-se a presença da águia e do raio e as formas como aparecem no esquema iconográfico com o deus. Diferente das representações monetárias de Zeus sentado no trono das póleis siceliotas de Aetna e Galária, onde a águia aparece sentada sobre o cetro, nas emissões dos arcádios a ave é retratada voando sobre a mão ou em pé sobre esta como que partindo ou, como ocorre em menor grau, retornando voando para a divindade. Essa forma de representar a águia em relação a Zeus sentado no trono refere-se, em primeiro lugar, ao papel da ave como mensageira do deus, portadora, na maior parte dos casos, da vontade do deus sobre o destino humano, sobre o resultado de uma batalha, de uma guerra. Em segundo lugar, a águia que parte de Zeus, além de sua mensageira, quando vista em vôo pelos gregos era considerada como um sinal de um presságio, um bom agouro na luta, tinha um significado talismânico e apotropaico de afastar um resultado desfavorável na guerra. Já o raio, que aparece na mão de Zeus em algumas das séries arcádias (a ênfase nas cunhagens é dada à águia como atributo do deus), visto dessa maneira somente nos tipos monetários de Aetna, sabe-se ter sido reconhecido pelos antigos gregos como a arma infalível com a qual Zeus assegurou sua vitória sobre seus piores inimigos e conseguiu restaurar a ordem sobre o caos. Vimos reiteradamente como a águia e o raio, além do próprio Zeus, eram símbolos relacionados ao universo da guerra e da vitória. Todos esses significados simbólicos dos atributos devem ser somados aquele contido na representação de Zeus sentado no 
trono segurando o seu cetro - de soberania, governo, controle, vigilância e decisão do deus sobre a vida dos homens. Na concepção religiosa dos gregos, Zeus tinha o poder de instaurar a vitória sobre o caos, de apaziguá-lo, de instaurar a ordem, competências que eram exercidas do seu trono do alto do Olimpo. Assim, associando esses significados ao contexto das imagens monetárias nessas emissões dos arcádios, é possível se chegar a algumas conclusões sobre o seu uso, que extrapolam as explicações dadas sobre elas até 0 momento.

Se Zeus do alto do Olimpo controla e define o destino humano, do alto do Lykaion, também seu domínio, poderia exercer o mesmo tipo de poder, e ser propício aos arcádios. A nosso ver, nessas cunhagens usadas para pagamento militar durante os eventos bélicos na área durante o século $V$ a.C., os arcádios requisitaram, nas imagens monetárias, a proteção de sua divindade maior, Zeus Lykaios, junto ao papel universal de Zeus como propiciador no sucesso militar, para ordenar e garantir a manutenção de sua identidade e soberania regional, portanto, de sua autonomia enquanto arcádios e também de cada comunidade política que compôs a região no momento no qual todos esses valores fundamentais para sua sobrevivência enquanto um grupo maior, étnico, se encontravam ameaçados pelos espartanos e sua política de hegemonia no Peloponeso, de expansão e submissão das áreas conquistadas. A ameaça era comum, então se uniram como arcádios evocando Zeus Lykaios e divindades importantes em termos de identidade (como Calisto) para identificarem esse grupo enquanto poder emissor responsável por essas emissões utilizadas, muito provavelmente, para pagamento dos mercenários. Se essas moedas foram usadas em determinado momento também por Esparta, como afirma Psoma, essas imagens de Zeus e de Calisto teriam também servido para afirmar a identidade étnica dos arcádios para os espartanos e mostrar que estes estavam sobre a proteção da mais importante divindade regional, Zeus Lykaios. Esse momento de disputa com Esparta durante o século V a.C. foi o mais importante para os arcádios invocarem, propiciarem e colocarem a seu favor as energias e poderes divinos da divindade que exerceu proteção sobre todos os aspectos que lhes identificavam enquanto um grupo. Uma prova interessante dessa propiciação foi o amplo uso dessas moedas dos arcádios como oferendas votivas dedicadas ao próprio deus, em agradecimento ou na expectativa de algum favor, no santuário do Monte Lykaion.

Além da imagem de Zeus nas moedas se referir ao culto no Monte Lykaion, a única relação religiosa que de fato pode ser atribuída entre essa cunhagem e o santuário está no uso dessas moedas como oferendas dedicadas na área do témeno e no próprio altar da divindade no pico do monte. Kourouniotis, quem primeiro realizou escavações sistemáticas no local, encontrou duas moedas de prata, datadas do século $V$ a.C. próximo ao témeno de Zeus Lykaios - uma da Liga Arcádia e a outra da pólis de Argos (Romano; Voyatzis, 2014: 577). Na mesma área, próximo à base das duas colunas, o arqueólogo grego encontrou também mais duas moedas - uma da Liga Arcádia e a outra de Egina - junto a outros tipos de achados em metal: uma cobra com duas cabeças de bronze, um protetor de caneleira de bronze com inscrição do século $\mathrm{V}$ a.C., e mais dez anéis gravados (Romano; Voyatizis, 2014: 578). Durante as escavações americanas, realizadas mais recentemente, os achados monetários se concentraram na área do altar. Foram recuperadas trinta e três moedas no total, 
sendo trinta e duas, na trincheira Z, e uma na trincheira ZZ (Romano; Voyatzis, 2014: 622). As moedas foram encontradas em camadas misturadas por todo o altar e datam entre os séculos VI e IV a.C. (Romano; Voyatzis, 2014: 622). Três das moedas da Liga Arcádia foram recuperadas no reaterro da trincheira de Kourouniotis (Romano; Voyatzis, 2014: 622). Provenientes do altar, portanto, são doze moedas da Liga Arcádia, seis de Egina, duas de Élis, quatro de Mantinéia, três de Sicione e uma moeda para cada uma dessas cidades: Corinto, Fócis, Delfos, Phokaia, Tebas e Argos (Romano; Voyatzis, 2014: 622). Romano e Voyatzis chamam a atenção para o fato de mais onze moedas terem sido encontradas no santuário debaixo, aquela área destinada às práticas agonísticas, cujos resultados aguardam publicação (Romano; Voyatzis, 2014: 622, nota 33). Percebese que, embora haja moedas de áreas externas à Arcádia, a maior parte encontrada, na área sagrada principal, é justamente de moedas da Liga Arcádia do século V a.C. (total de 12 moedas somente na área do altar). Novas escavações ainda podem revelar novos achados monetários no témeno futuramente, área, cujos escavadores, tanto Kourouniotis quanto os americanos, relataram uma curiosa ausência de evidências arqueológicas de caráter cultual (Romano; Voyatzis, 2014: 577 e 626).

$\mathrm{O}$ achado das moedas da Liga Arcádia em maior número, dedicadas ao lado de moedas de outras proveniências, principalmente no altar, mostra que estas foram usadas como oferendas votivas a Zeus Lykaios. Não se trata de terem sido concebidas para tal fim, como prova o número de moedas de outras localidades usadas para fins econômicos também dedicadas, mas que foram depositadas como dedicações por fiéis e peregrinos, à divindade em seu altar. De acordo com I. Morris, "oferendas votivas são definidas como dedicações voluntárias aos deuses, resultantes não de rituais prescritos ou calendários, mas de votos de indivíduos ou comunidades em circunstâncias geralmente de ansiedade, transição e realização" (Morris, 2012: 1564). "Dedicações consistiram em renúncia e em investimento simbólico de longa-duração no divino, na espera da vinda de boas coisas. Diferente do sacrifício, que implica em destruição, pelo depósito de um objeto perceptível em um santuário este é perdido e tornado eterno" (Morris, 2012: 1564). Em um nível pessoal, assim como as orações, oferendas votivas enfatizavam as relações "if-then" com os deuses (Morris, 2012: 1564). A variedade de objetos votivos era enorme e dependia da ocasião e da função da divindade (Morris, 2012: 1565; Murgan, 2014: 66). Moedas, como dedicações, "estavam entre aqueles objetos que originalmente serviram a outros propósitos - jóias, espólios de guerra, trípodes -, possuiam valor intrínseco e podem ter sido de uso pessoal antes de serem depositados" (Kindt, 2012: 64; Murgan, 2014: 66). A deposição de moedas, como outros tipos de objetos valiosos em metal, pode nos informar sobre a devoção do peregrino ou do fiel em confronto à divindade e ao seu santuário. Kourouniotis, um dos primeiros escavadores do Monte Lykaion, nos faz pensar sobre a relação entre devoção e tipos de oferendas em um santuário de localidade remota como foi 0 do Monte Lykaion. Para ele, as pessoas, em sua prática de culto, poderiam, frequentemente, ter oferecido aqueles objetos mais baratos como um sinal de devoção e sem um motivo particular, à parte aquele de mostrar devoção e prece usuais. Contudo, "aqueles que visitavam o santuário no Monte Lykaion muito raramente, tinham uma importante razão para fazê-lo e tinham de oferecer algo mais precioso do que figurinhas de argila 
comuns - estatuetas de bronze e outros objetos de metal, como moedas, eram certamente mais preciosos do que as oferendas mais comuns do santuário" (Kouroniotis, 1904: 179).

A dedicação de moedas, ou objetos de troca e valor, em santuários foi uma prática de alguma forma disseminada em santuários no mundo grego, os casos mais famosos são aqueles do achado de espetos de bronze no Heraion de Argos e o de elétrons nas fundações do Artemísion de Éfeso (Florenzano, 2001: 202203). I. Pafford lembra que moedas também eram usadas, na forma de dedicações, como pagamento de taxas em santuários (Pafford, 2013: 56-57). Inscrições sobre a administração financeira de santuários na ilha de Kós, em época helenística, detalham o uso das moedas como oferenda para a manutenção do santuário, as quais iam para o tesouro do deus, e para uma dedicação tangível e permanente no local (Pafford, 2013: 56-57). Mas diferente do caso das dedicações encontradas na área sagrada ou nas fundações dos templos, onde objetos de metal e moedas eram armazenados geralmente em depósitos votivos, tornando-se parte do tesouro da divindade, a dedicação de moedas em um altar, como foi o caso do santuário do Monte Lykaion, parece ter tido uma outra característica já que permenaceram ali por séculos, como objetos de valor imobilizado junto a outros tipos de votivos. Conforme explica A.M Murgan, "os objetos dados aos deuses entram numa esfera de longaduração, às vezes de conversão performada ritualmente" (Murgan, 2014: 73). Uma vez "sacrificados", tinham de permanecer em seu novo contexto e não poderiam ser removidos a não ser que tal restrição fosse superada por uma decisão pública ou sacrifícios adicionais (Murgan, 2014: 73). Nesse sentido, essas moedas depositadas no altar de Zeus Lykaios estavam desmonetizadas - a partir da dedicação, de dinheiro ganho passaram a ser um pedido de longa-duração à divindade. Esse ato de desmonetização é explicado por Kurke acerca da dedicação de espetos de ferro no santuário de Apolo em Delfos, conforme conta uma narrativa de Heródoto (Kurke, 1999: 223-224). Em contraste à sua entrada na esfera consagrada por meio do sacrifício, objetos valiosos como moedas, podem ter readquirido suas funções monetárias uma vez que saíssem dessa esfera, voltassem à esfera das transações, da curta duração, por exemplo para pagar reparos no santuário (Murgan, 2014: 74). Esse processo não ocorreu com as moedas dedicadas no témeno e principalmente no altar de Zeus no Monte Lykaion, pois permaneceram ali até serem recuperadas pelos arqueólogos - não foram recolhidas pela organização do santuário, durante a antiguidade, para serem armazenadas em um suposto tesouro de Zeus, do qual não possuímos nenhuma notícia.

Isto posto, quais teriam sido as razões para as moedas dos arcádios terem sido dedicadas como votivos e qual teria sido o significado de dedicar moedas, com imagens de Zeus Lykaios, no altar e no témeno do santuário dessa mesma divindade?

Em primeiro lugar, como dissemos, as moedas dos arcádios representam o maior grupo de achados monetários no santuário. Acreditamos que isso seja reflexo da participação dos arcádios como o maior grupo que frequentou o santuário do Monte Lykaion e do fato de que estas moedas eram parte das únicas emissões ativas na região durante o século $V$ a.C. Também não podemos descartar a hipótese de que as moedas de 
outras ${ }^{1}$ proveniências também tenham sido dedicações de indivíduos arcádios e que as moedas arcádias possam ter sido dedicadas por peregrinos de outras origens, apesar da maior participação arcádia seja bem atestada arqueologicamente, epigraficamente, textualmente e nesse sentido numismaticamente. Em segundo lugar, a dedicação dessas moedas dos arcádios são provas de que estes relacionavam a imagem monetária da divindade ao seu santuário - foram dedicadas pela afinidade da imagem de Zeus Lykaios com o seu culto e o seu significado. A correspondência entre imagem monetária dedicada e a divindade cultuada no altar não é tão comumente encontrada no mundo grego, devendo ter tido um significado a mais para o ofertante, já que estava oferencendo um objeto com a representação da divindade titular do santuário. Nesse aspecto, a nosso ver, ofertar um objeto com a representação da divindade cultuada, mesmo que este tenha sido uma moeda, teria equivalido, em certo grau, à dedicação de uma estatueta votiva da divindade, como aquelas encontradas no próprio Monte Lykaion, em Olímpia ou em Dodona. Essa ideia é reforçada por Murgan o qual afirma que "as moedas, e suas imagens, podiam carregar uma relevância particular (além daquela de ofertar um objeto que Ihe foi valioso), ligar o doador a uma divindade alvo, como no caso das figurinhas de terracota ou de bronze feitas de modelos produzidos em grande quantidade" (Murgan, 2014: 66).

Diferente das estatuetas votivas do deus que também possuíam um valor intrínseco pelo bronze, no qual eram feitas, e foram confeccionadas exclusivamente para serem votivos, as moedas, como suportes imagéticos, tinham, além do valor de seu metal, no caso a prata, um valor de uso, pessoal, para o ofertante. Antes de entrarem na esfera ritual, de consagração, essas moedas tiveram outras funções na esfera da curtaduração, tendo sido usadas em trocas e no pagamento por serviços prestados, como no caso dos soldados mercenários, atestado para essas emissões. Isso coloca o problema sobre a identificação dos tipos de fiéis e peregrinos responsáveis pela dedicação dessas moedas, que é muito difícil acessar. No entanto, algumas categorias específicas de objetos votivos, associados aos achados dessas moedas, podem trazer alguma indicação. Uma oferenda, em especial, encontrada por Kourouniotis no témeno, contemporânea e associada à moedas da Liga Arcádia, indica a presença de soldados como dedicantes no santuário. Trata-se da caneleira de bronze, parte de uma armadura de soldado, dedicada no témeno com uma inscrição do dedicante "Eutelídas dedica a Zeus Lykaios e Atena" (IG V 2, linha 551) (Kourouniotis, 1904: 210-211). Como vimos, na interpretação de Psoma e Kraay, as moedas dos arcádios, que supriram a circulação monetária na região durante o século $\mathrm{V}$ a.C., parecem ter sido concebidas e usadas, a princípio, como pagamento militar, o que nos faz pensar se essas moedas não foram dedicações de soldados no santuário, como pode indicar 0 achado da caneleira. É difícil afirmar com certeza se apenas soldados foram os únicos ou os principais ofertantes dessas moedas a Zeus Lykaios até porque, no presente estado das investigações, despojos de guerra não parecem estar entre os principais objetos votivos depositados ao deus no local - os objetos datados de época arcaica e clássica são muito heterogêneos. Ao lado dos restos cerâmicos de vários períodos, dos trípodes muito

\footnotetext{
${ }^{1}$ Moedas de Egina, Sicione, Argos e Corinto foram muito difundidas na circulação monetária do Peloponeso principalmente numa fase na qual não havia cunhagem de moedas em determinadas sub-áreas.
} 
recorrentes na Idade do Ferro, as moedas (incluindo aí as arcádias e de outras proveniências) representam um dos grupos mais homogêneos e numerosos de oferendas depositadas no altar.

Se não é possível determinar o perfil do peregrino responsável, e nem as intenções individuais por subjacentes à essas dedicações, os aspectos predominantes do culto no século $V$ a.C. podem nos fornecer, ao menos, a pista final sobre o sentido dessas dedicações. Se bem antes da época clássica, e de determinada parte da época arcaica, o aspecto atmosférico e celeste do culto de Zeus Lykaios deve ter predominado, atraindo a população pastoril da área, como ocorreu em Olímpia na Idade do Ferro, durante o século $\mathrm{V}$ a.C. a atuação do deus se ampliou regionalmente e passou a ter significado na esfera identitária arcádia, como mostra a maior ocorrência de peregrinos e participantes nos Lykaia provenientes da região. Nesse poder da divindade em atuar no nível da identidade étnica local, não pode ser ignorado e deve ser acrescentado o aspecto militar, muito presente no culto de Zeus no mundo grego, e que no Monte Lykaion também é testemunhado pelos objetos votivos, tanto a caneleira, adagas, como pela estatueta de Zeus Keraunios, também recorrente em Olímpia, santuário de forte apelo militar. Diante desse aspecto do culto de Zeus Lykaios, já predominante no século V a.C., essas moedas dos arcádios, que representam para o nosso tema um caso muito especial, foram usadas como oferenda, a nosso ver, como reconhecimento da proteção desse deus na esfera identitária de grupo (onde o seu aspecto militar também foi importante) particularmente requisitada durante o século $\mathrm{V}$ a.C., conforme vimos.

Como símbolos tangíveis dessa relação da identidade arcádia e do culto de Zeus Lykaios, as moedas com as imagens do deus foram usadas para expressar e afirmar internamente e externamente a identidade do grupo - ao mesmo tempo que foram criadas para esse fim pelos arcádios tiveram agência sobre eles, a ponto de terem sido entregues como dedicações ao protetor dos arcádios, Zeus Lykaios, em seu témeno e altar no alto da montanha. Por terem tido um valor pan-arcádio é difícil dizer se essas moedas foram dedicadas apenas por soldados mercenários arcádios dedicando parte de seu salário ao deus, o que não pode também se descartar. Contudo, é mais provável que essas moedas tenham sido objetos de amplo significado a todos os habitantes da região e por isso terem sido depositadas por qualquer indivíduo arcádio e até por gente de fora, devota de uma divindade que no século $V$ a.C. começara a alcançar prestígio pan-helênico.

À parte dessa cunhagem dos arcádios, com tipos monetários de Zeus sentado no trono, de a partir do início do segundo quartel do século $V$ a.C. são datados algumas moedas com imagens da cabeça de Zeus atribuídos às oficinas monetárias da região. Dois desses tipos monetários foram atribuídos por Williams ao período final das emissões no nome dos arcádios. Trata-se de dois hemióbolos de prata, anepígrafos, com a imagem da cabeça de Zeus sem coroa de folhas de oliveira, no anverso, e com a cabeça de Hermes no reverso. Naquele datado de c.430-420 a.C., Zeus é retratado com cabelo e barba longos, Hermes está usando um petasos e aparece retratado dentro de um quadrado incuso (Fig.238 - n.43). Já no tipo monetário de c.420 a.C., Zeus aparece de cabelos e barba curtos e króbylos, e Hermes usa um barrete (Fig.238 - n.45). A descrição do catálodo de Walker diz que a representação de Hermes também está dentro de um quadrado 
incuso, embora a nosso ver este não seja aparente. Williams situou os dois hemióbolos no período $\mathrm{V}$ das moedas da liga arcádia, atribuindo-os às emissões de Mantinéia (Williams, 1965: 33 e 121). Devido à ausência de inscrições, esses tipos chegaram a serem vistos como emissões de Stratos, na Acarnânia, por ImhoofBlummer, e de Heraia, na Arcádia, por Babelon (Williams, 1965: 121). O estilo dos desenhos, a denominação e o tipo de Hermes - divindade popular da Arcádia - levaram Williams atribuir esses tipos monetários às emissões dos arcádios, embora ele mesmo reconheça que se trata de moedas de identificação incerta (Williams, 1965: 33 e 121). Estes são tipos classificados como raros no catálogo de Walker, são oriundos de coleções privadas de museus europeus, provavelmente são destituídos de seus contextos de achado e, ao que parece, não são comuns em entesouramentos e escavações arqueológicas. Nessa pesquisa, consideraremos estes como tipos monetários arcádios, mas não oriundos de Mantinéia, já que não há inscrições que lhes atestem a procedência e porque essas oficinas monetárias (Kleitor, Tegea, Mantiniéia) não são atestadas arqueologicamente.

Se cunhados ou não pelos arcádios no contexto de sua liga no século V a.C., essas imagens monetárias de Zeus, assim como a de Hermes, se referem a divindades de forte devoção local. 0 uso da imagem de Zeus em moedas já havia se estabelecido na região desde o começo do século $V$ a.C. e a partir desse momento ganhou uma nova forma de representação (cabeça). Assim como Zeus na Arcádia teve um papel definidor na identidade local, Hermes parece também ter assumido um tipo de significado na esfera identitária arcádia. De acordo com M. Jost, Hermes teve como função essencial ser o deus dos pastores arcádios - santuários a ele dedicados são encontrados em várias partes da Arcádia, além também do fato de pequenas estatuetas votivas com a sua representação serem recorrentes em áreas sagradas pertencentes a outras divindades na região (Jost, 1985: 439, nota 2, 440). Mas, como lembra essa autora, as lendas gregas sobre Hermes fazem dele um deus autóctone na Arcádia e os arcádios o veneraram como seu ancestral (Jost, 1985: 441). Todos os gregos viram Hermes como um deus arcádio (Jost, 1985: 441). Percebe-se no culto arcádio a Hermes, portanto, um valor étnico importante que se associa ao de Zeus Lykaios. Nessa perspectiva, as imagens de Zeus e Hermes nessas moedas compartilham do mesmo significado de identidade de grupo pensado e requerido nas imagens monetárias de Zeus Lykaios sentado no trono e Calisto. É provável, então, que esses tipos monetários sejam, de fato, relacionados ao mesmo fenômeno de saliência da identidade étnica dos arcádios do século $V$ a.C. e aos eventos ligados à Esparta nesse período.

\section{Parrhasia}

Além desses hemióbolos, sem inscrição, com o tipo da cabeça de Zeus, as demais emissões com imagens da cabeça do deus são atualmente atribuídas aos parrhasios. Trata-se de dois óbolos de prata novamente pequenas denominações - datados entre os séculos V-IV a.C. O mais antigo parece ser o datado por Walker em c.431-370 a.C., o qual possui a cabeça de Zeus com cabelos e barba longos, no anverso, e uma 
grande letra П ocupando todo o campo do reverso, acompanhado pelas letras A e R (retrogrado) (Fig.238 n.48). Já o tipo do catálogo do Museu Britânico fornece uma data genérica entre os séculos V-IV a.C. e parece carregar os mesmos tipos de imagem e legenda (Fig.238 - n.40). A Parrhasia foi um distrito ou sub-área arcádia, com fronteira com a Lacônia, cujos habitantes ligavam-se por uma identidade étnica comum, compartilhavam, por exemplo, cultos comuns, como foi o caso de Zeus Lykaios em época arcaica e de Apolo Parrhasios (Nielsen, 1999: 52). "Os arcádios, como um todo, constituíram um éthnos com uma conformação distinta: internamente, o éthnos foi sub-dividido em um número de sub-grupos menores, tribos e póleis, cada qual com sua própria identidade" (Nielsen, 1999: 54). No período clássico, "haviam cinco tribos sub-regionais na Arcádia: os eutrésios, os kynourios, os mainalios, os trifílios e os parrhasios" (Nielsen, 1999: 54). Trata-se, segundo Nielsen, de identidades sub-regionais politizadas (unidades políticas) (Nielsen, 1999: 54). "A identidade parrhasia propiciou a base para a organização política, unindo comunidades parrhasias diferentes em um Estado" (Nielsen, 1999: 52). "Os parrhasios e os demais sub-grupos étnicos arcádios, com exceção dos trifilios, desapareceram após a fundação de Megalópolis" (Roy, 2012: 134).

A cunhagem dos parrhasios é pouco mencionada nos manuais ou catálogos numismáticos sobre 0 Peloponeso. De acordo com A. Walker, os parrhasios produziram uma pequena cunhagem de óbolos com tipos de Zeus, hoje considerada extremamente rara, que podem ter sido batidos em Lykossoura (Walker, 2006: 378). Esse autor lembra que as moedas chegaram a ser atribuídas ao vilarejo de Paroréia, do qual pouco se conhece (Walker, 2006: 378). Assim, o uso da imagem da cabeça de Zeus nessas poucas emissões parrhasias explicase pela proximidade e afinidade desse sub-éthnos com o culto de Zeus Lykaios no Monte Lykaion, atestado ao menos desde a época arcaica, conforme Jost. C. Kraay diz que essas emissões parrhasias teriam feito parte das cunhagens locais autônomas retomadas após o fim da liga dos arcádios do século $V$ a.C., situando os tipos monetários dos parrhasios após a Batalha de Mantinéia em c.418 a.C. É difícil saber a função dessas cunhagens na Parrhasia, se também foram concebidas como pagamento militar, como indicaria a pequena denominação no qual foram feitas. No mínimo, é possível dizer, a combinação da cabeça de Zeus Lykaios e as iniciais do sub-éthnos, nessas moedas, aludiram e transmitiram significados de identidade parrhasia entre esse sub-grupo e sobre eles para os demais arcádios.

\section{Megalópolis}

O uso da representação da cabeça de Zeus voltou a ocorrer na região muito antes da metade do século IV a.C. no contexto da confederação arcádia nesse período. Conforme explica Nielsen, após derrotar 0 movimento arcádio no século V a.C., e vencer a Guerra do Peloponeso, Esparta se manteve em posição hegemônica e militar dominantes até ser derrotada definitivamente pela confederação beócia e a confederação arcádia, formada em reação à hostilidade espartana, na batalha de Leuctra em c.370 a.C. (Nielsen, 1999: 5859). A Arcádia, e outras sub-áreas do Peloponeso, nunca mais seriam marionetes dos espartanos novamente 
(Nielsen, 1999: 59). "A confederação arcádia foi uma organização, uma unidade política verdadeira, não atestada na união dos arcádios ocorrida no século V a.C., construída sob critérios de etnicidade, sendo um dos quais a oposição à Esparta" (Nielsen, 1999: 31, 56-57). "Essa organização política étnica arcádia foi parte de um fenômeno maior ocorrido no Peloponeso nas primeiras décadas do século IV a.C. - um número de mudanças, que não apenas afetaram o equilíbrio de poder e o mapa político da região, mas incluiu também a redefinição de fronteiras étnicas e a emergência de novas entidades étnicas, como os trifilios, o Estado pisate e o messênio" (Luraghi, 2008: 212-213). De acordo com N. Luraghi, "a unificação política da Arcádia, imediatamente após a batalha de Leuctra, foi o ponto culminante no aumento da saliência da etnicidade arcádia, a qual remontou às primeiras décadas do século IV a.C." (Luraghi, 2008: 212). Foi nesse contexto que um movimento democrático anti-espartano na Arcádia levou, inicialmente, Mantinéia e Tegea a constituir um Estado federal em c.369 a.C., na base de uma coerência étnica, formado pela maior parte dos Estados arcádios (Nielsen, 1999: 36-37; Roy, 2012: 135). Cinco póleis arcádias propiciaram fundadores, mas uma forte influência é creditada, nas fontes literárias, ao tebano Epaminondas (Roy, 2012: 924). Conforme U.W. Gans e U. Kreilinger, "o propósito da nova cidade fortificada foi proteger a Arcádia contra a expansão espartana" (Gans; Kreilinger, 2002: 187). A confederação, contudo, não uniu os arcádios por muito tempo, quebrando em partes em c.363 a.C. e dissolvendo-se totalmente ao redor de c.324/23 a.C. (Nielsen, 1999: 29 e 56-57). "O que é interessante desse período, segundo Nielsen, é a constatação de que a oposição à Esparta teve um efeito politizante sobre a identidade arcádia - quando Esparta era derrotada, esse fator politizante desaparecia e, junto dele, a necessidade e o desejo de uma organização política pan-arcádia”2 (Nielsen, 1999: 59).

Megalópolis, o novo Estado arcádio, foi a sede da oficina monetária responsável pelas emissões de tipos da cabeça de Zeus no nome dos arcádios confederados. De acordo com A. Walker, "a cunhagem em Megalópolis começou logo após a fundação da cidade com séries de estateres de prata batidos no final da década de 360 a.C." (Walker, 2006: 361). No anverso é retratada a cabeça de Zeus com cabelos e barba longos usando uma coroa de folhas (talvez de louros) e no reverso está a figura de Pã jovem, sentado sobre rocha coberta por seu manto, segurando lagobolon com a mão direita e descançando braço esquerdo sobre a rocha, embaixo na rocha há um syrinx (flauta de Pã, um atributo da divindade) (Fig.238 - n.73). O étnico arcádio aparece abreviado (AR) à esquerda no campo e a inscrição O $\mathrm{YYM}$ (que provavelmente se refere ao nome do gravador) está à direita embaixo no campo. Já nas emissões datadas entre c.363 e a década de 350 a.C., a cabeça de Zeus com cabelos e barba longos, usando a coroa de folhas, manteve-se como imagem de anverso nos trichalkoi de bronze, e o syrinx e a letra A aparecem, no reverso, retratados dentro de uma coroa de folhas, provavelmente de oliveira (Fig.238 - n.72). Essa combinação de imagens também foi usada em chalkoi datados da mesma época, embora as iniciais AR tenham sido usadas no reverso.

2 Embora a identidade arcádia nunca cessou de existir após o colapso de Esparta, conforme deixa claro Políbio (Nielsen, 1999: 59). 
Os arcádios confederados durante o século IV a.C. escolheram manter a imagem de Zeus Lykaios, considerada por Nielsen ${ }^{3}$ sua divindade patrona, como divindade protetora dos arcádios nessa época. Queremos dizer que no século IV a.C. houve uma continuidade de significado contido na representação de Zeus Lykaios nas moedas arcádias. Nessa época, o culto de Zeus Lykaios havia se consolidado como o panarcádio por excelência, como demonstra o fato de que este foi o período mais próspero do santuário no Monte Lykaion (Jost, 1985: 184). Nessa época, portanto, o culto assumiu importância na pólis, como indica a instituição do culto em Megalópolis e em Tegea, que parece ter ocorrido nessa época. Ao lado de Hermes, Pã foi outra divindade especialmente conectada com a Arcádia. "Panía ("terra de Pã) foi o outro nome da Arcádia em alguns textos antigos" (Nielsen, 1999: 39). Diferente dos outros gregos, os arcádios investiram mais recursos em santuários de Pã, sendo essa, segundo Nielsen, uma evidência de que os arcádios usaram o culto do deus para marcar a sua etnicidade (Nielsen, 1999: 40). No século IV a.C., Pã tinha se tornado, ao lado de Zeus Lykaios, um símbolo da Arcádia (Nielsen, 1999: 39). Nesse sentido, no momento em que os arcádios pela primeira vez se organizaram, politicamente, escolheram como símbolos de seu estado étnico as divindades afirmadoras e protetoras de sua identidade étnica - cujas energias precisavam ser propiciadas e colocadas a favor no momento de manutenção de sua autonomia e afirmação política frente à Esparta e aos demais poderes da região.

\section{I.1.3 Acaia}

A imagem de Zeus em moedas também ocorreu no século IV a.C. na região da Acaia, onde comunidades aqueias bateram um tipo monetário da divindade com o étnico regional no plural, no nome de todos os aqueus, muito provavelmente no contexto da confederação ou liga aqueia em existência nesse período. Como explicaremos adiante, "Zeus Homarios na Acaia teve um papel destacado na identidade étnica dos aqueus, mas, diferente do caso do culto de Zeus Lykaios na Arcádia, o deus desempenhou uma função efetiva em nível federativo" (Nielsen, 2013: 241). Na Arcádia, como vimos, o santuário no Monte Lykaion não desenvolveu uma função federativa como ocorreu no caso do santuário de Zeus Homarios na Acaia, local de reuniões religiosas e assembleias políticas (Nielsen, 2013: 241; Rizakis, 2013: 14). A moeda em questão, um estater em prata de peso eginético, possui, no anverso, a imagem da cabeça de uma divindade feminina com cabelos presos, brinco e colar e, no reverso, a imagem de Zeus sentado no trono, vestindo um himátion na cintura, um chiton sobre o ombro esquerdo, segurando um cetro com o braço esquerdo e a águia (com as duas asas erguidas) aparece sobre a mão direita do deus, cujo braço está estendido (Fig.238 - n.71). No reverso, à esquerda no campo, aparece, como símbolo de emissão, um elmo com crista, e à direita, a legenda $A X A \mid \Omega N$ ("dos acaios") (Head, 1963: 416; Kraay, 1976: 101; Rizakis, 2013: 26). De acordo com Walker, "a cunhagem da 
liga aqueia foi produzida durante cinco períodos diferentes, sendo o primeiro deles dedicado às emissões muito limitadas de estateres, dracmas e hemidracmas" (Walker, 2006: 107). Como destaca Kraay, "à parte das poucas cunhagens locais autônomas de Aegae e Pellene, esta se tratou de uma notável emissão federal da qual se destaca o único estater sobrevivente, com os tipos da cabeça feminina e de Zeus sentado no trono" (Kraay, 1976: 101).

Com relação à cronologia, Head foi um dos primeiros estudiosos a propor que essa cunhagem mais antiga da liga aqueia, a qual pertence o estater em questão, remonta ao período após a batalha de Leuctra (c.371 a.C.), entre c.370-360 a.C. (Head, 1963: 416). Essa datação foi seguida por Kraay e mais recentemente por Walker (Kraay, 1976: 101; Walker, 2006: 107). Kraay admite que a ocasião para essa emissão é incerta, mas mesmo assim situa o estater da liga aqueia nesse período em associação aos estateres da liga arcádia e de Messênia - resultantes dos acontecimentos políticos no Peloponeso após Leuctra (Kraay, 1976: 100-101). Com base na raridade desses estateres, e também das demais denominações do período mais antigo das cunhagens no nome dos aqueus, Walker chegou a afirmar que estes foram cunhados apenas por prestígio, mas não fundamenta sua opinião (Walker, 2006: 107). Já Psoma e Tsangari preferem datar o estater ao redor de 352/51 a.C. à época da terceira guerra sagrada (Psoma; Tsangari, 2003: 116-117). Uma datação com uma explicação totalmente diferente vê a cunhagem desse estater como uma comemoração da mudança do lugar de reunião da liga aqueia no santuário de Poseidon Helikonios destruído em Helike ao santuário de Zeus Homarios em Aigion (Walker, 2006: 107). Trata-se de uma proposição defendida por C. Morgan e J. Hall: essa emissão seria datada de c.373 a.C., do período subsequente à destruição de Helike e a promoção consecutiva de Aigion, provável local da cunhagem (apud Rizakis, 2013: 26-27). Como explica Rizakis, "essa datação levou esses dois autores a considerar que essa emissão teria celebrado a adoção de um novo culto federal - para eles, a moeda confirmaria a ideia de que Zeus Homarios assumiu um papel político no seio do koinon aqueu, a partir dessa data, que até então havia sido assegurada por Poseidon Helikonios" (apud Rizakis, 2013: 26-27). Em seu artigo mais recente sobre a liga aqueia, Rizakis, baseando-se em dois autores (Ghiraki e Mackil), traz o foco da discussão para os elementos iconográficos de Zeus - as características iconográficas dessa emissão de Aigion dificultam a sua datação no século V a.C., mas não excluem uma datação no início do século IV a.C., antes da catástrofe de Helike em c.373 a.C. (apud Rizakis, 2013: 27). Nessa perspectiva, "a moeda, portanto, seria contemporânea às emissões cívicas das cidades aqueias, entre elas a de Helike" (Rizakis, 2013: 27).

A representação de Zeus sentado no trono alcançou grande uso e expressão nas moedas da Arcádia durante o século $V$ a.C., sendo, à época da cunhagem desse estater no nome dos aqueus, um padrão de imagem do deus conhecido na região do Peloponeso e associado aos arcádios. Como as moedas dos arcádios teriam sido os únicos modelos ou parâmetros regionais para a imagem de Zeus sentado no trono, Head chegou a sugerir uma influência destas na representação e no uso da imagem na moeda aqueia (Head, 1963: 416). 0 esquema iconográfico mais próximo seria, então, o das moedas arcádias. De fato, a oficina monetária de Aigion, e o gravador responsável pelo cunho, escolheram usar os mesmos elementos iconográficos presentes na maior 
parte dos tipos monetários arcádios - o himátion apenas na cintura, o braço esquerdo apoiado no longo cetro e a águia (de asas erguidas) sobre a mão direita de Zeus, cujo braço aparece estendido. 0 chiton sobre 0 ombro no estater aqueu ocorre somente em tipos monetários pontuais arcádios. As séries monetárias arcádias possuem uma grande variedade e alternância de elementos menores nas imagens de Zeus (como a presença ou não do raio na mão de Zeus ou o posicionamento do próprio deus no trono e da águia), mas em nenhuma delas o trono representado é do tipo alto, tal como ocorre no estater dos aqueus.

Interessante notar, que essa variedade de representação do trono não é própria das imagens monetárias de Zeus sentado no trono datadas do século V a.C. e do século IV a.C. (aquelas até c.344 a.C.). Tanto no Peloponeso, entre os arcádios, quanto nos tipos monetários de Zeus sentado no trono provenientes da Sicília (Aetna e Galária) e da Líbia (Cirene), o trono é aquele do tipo baixo. Esse trono de pernas e encosto alongados é típico das representações do deus em moedas de póleis cretenses, como de Olonte ${ }^{4}$ e principalmente do caso do tipo de Praisos ${ }^{5}$, datadas perto do segundo quartel do século IV a.C. ou do início do século III a.C. Esse tipo de trono parece ter se consolidado como o mais utilizado nas imagens monetárias de Zeus sentado a partir do final do século IV a.C., como também mostram algumas emissões, referentes à Alexandre, o Grande, dos tipos monetários da cabeça de Hércules / Zeus sentado. Diante dessas evidências, portanto, o tipo de Zeus do estater dos aqueus, ao mesmo tempo que seguiu um padrão consolidado já em sua época, de Zeus sentado no trono em moedas, parece também ter sido inovador, como demonstra o desenho do trono. Não parece ser o caso que esse estater seja, na verdade, mais recente ao contrário do que supõem os especialistas até o momento. Preferimos ver a moeda como suporte de uma forma nova de representar 0 deus sentado em seu trono. Prova de que foi possível a concepção da representação de Zeus sentado sobre um trono alto, nessa época do estater, são as cerâmicas pintadas, nas quais, durante o século IV a.C. esse tipo de trono já fazia parte do repertório iconográfico relacionado ao deus desde ao menos o início do século $\mathrm{V}$ a.C. ${ }^{6}$

Assim, é difícil, portanto, como afirmou Rizakis, situar o estater aqueu entre as emissões monetárias do século V a.C. A imagem da cabeça de uma divindade feminina, no anverso da moeda, parece corroborar tal afirmação. Baseando-se em elementos iconográficos peloponésios, Head sugere uma associação entre a imagem do estater dos aqueus com aquela dos estateres de Stymphalos, na Arcádia, datado de c.362 a.C., no qual Ártemis é retratada com o mesmo penteado e tipo de brincos, sendo a única exceção a presença de uma coroa de folhas sobre sua cabeça (Head, 1963: 416). Nessa perspectiva, portanto, parece ser possível atribuir o tipo monetário aqueu ao período sugerido por Head e Kraay - logo após a batalha de Leuctra, entre 370-360 a.C.

Sobre a proposta em datar o estater aqueu em c.373 a.C., em relação à destruição de Helike, Rizakis, em seu artigo mais recente sobre o tema da liga aqueia, tenta desvincular a cunhagem desse estater com a

\footnotetext{
4 Sear, vol.l: 3340 , estater de prata, c.330-270 a.C.

5 Sear, vol.I: 3363, estater de prata, c.325-275 a.C.

6 Vide repertório iconográfico vascular referente a Zeus no cap.3.
} 
tese de Morgan e Hall, chegando a considerar uma data bem no início do século IV a.C. para a emissão. A seu ver, "Zeus Homarios teria sido, desde muito antes, o deus de todos os aqueus e seu santuário em Aigion, 0 principal local de reuniões religiosas e políticas da região antes mesmo da destruição de Helike pelo terremoto" (Rizakis, 2013: 14). Como vimos no capítulo 2, esse estudioso acha pouco provável que o santuário de Poseidon Helikonios tenha sido o centro cultual da liga aqueia, já que, bem antes de sua destruição, havia sido o deus tutelar incontestável de Helike e mais vinculado aos jônios aqueus (Rizakis, 2013: 14 e 18). Rizakis justifica sua teoria tentando mostrar que essa preponderância de Zeus teve origem já em época micênica na região, quando os Átridas, que controlavam a Acaia oriental, acreditavam que seu poder provinha do deus (Rizakis, 2013: 21). Mapeando o culto de Zeus na região, em períodos posteriores, Rizakis também procura mostrar a afinidade do culto da divindade na esfera política da pólis e na identidade étnica aqueia (Rizakis, 2013: 21). "Teria sido através de um longo processo de oposições de identidade na região (entre Aigialeus e jônios, aqueus e eólios), que Zeus teria se tornado depositário da identidade aqueia e de um lugar de culto comum - na qualidade de um deus que protege, que reúne, Zeus Homarios teria reunido genos pela primeira vez na região" (Rizakis, 2013: 22). "Rizakis reconhece que Zeus Homarios e Poseidon Helikonios foram divindades cultuadas paralelamente por um longo período, mas com atribuições diferentes" (Rizakis, 2013: 23). A promoção de Zeus Homarios em nível regional teria limitado o impacto do culto de Poseidon Helikonios (Rizakis, 2013: 23). Em resumo, Rizakis defende que "a identidade aqueia começou a tomar forma mais concreta, e contornos políticos, a partir do momento em que Zeus se tornou a divindade patrona dos aqueus" (Rizakis, 2013: 37). Pela sua íntima ligação com o passado aqueu, "Zeus assegurou, melhor que todas as outras divindades, essa função integradora próxima às comunidades do noroeste do Peloponeso" (Rizakis, 2013: 37-38).

Essa proposição de Rizakis baseia-se no trecho de Políbio referente às fundações aqueias na Itália do Sul e a formação de uma liga na região sob a tutela de Zeus Homarios - baseada no modelo aqueu do Peloponeso e na formação da identidade étnica aqueia nos séculos VI e V a.C. Para esse autor, e outros como M. Osanna, o relato indicaria que a liga aqueia e o santuário de Zeus Homarios existiram anteriormente à c.430 a.C., data da fundação da liga das cidades aqueias ocidentais (Osanna, 1996: 205). No entanto, Morgan e Hall colocam em dúvida a validade do relato polibiano, dizendo que este não teve a intenção de "documentar a história da liga per se, mas de estabelecer uma credencial histórica para a existência da liga em seu tempo" (Morgan; Hall, 2004: 474). Assim, se não considerarmos o trecho de Políbio como evidência da existência da liga e do culto federal de Zeus Homarios já no século V a.C., como fazem Rizakis, Osanna e outros, 0 testemunho mais antigo disponível e tangível sobre ambos (liga e santuário federativo de Zeus Homarios) permanece sendo o estater com a imagem da cabeça feminina, no anverso, e de Zeus sentado no trono, no reverso, batido no nome de todos os aqueus após o início do século IV a.C. Além da moeda, a outra evidência tangível é uma inscrição datada apenas do final do século IV a.C., a mais antiga referente a um documento federal encontrada junto a outras a noroeste de Aigion (Rizakis, 2013: 30). 0 estater, portanto, parece ser a 
evidência material mais antiga, até o momento, acerca do papel de Zeus Homarios como divindade tutelar da liga aqueia (Morgan; Hall, 2004: 475).

Mesmo diante da problemática exposta acerca da documentação material e literária disponível para a época clássica, assim como da interpretação sobre o tema realizada até o momento pelos estudiosos, concordamos com A. Rizakis e M. Osanna sobre a existência do culto federal a Zeus Homarios já no século V a.C., e o reconhecimento do deus, nessa época, como o patrono dos aqueus. No século $V$ a.C. a identidade étnica dos aqueus havia se firmado, havendo, portanto, um contexto propício para o desenvolvimento do culto federativo de Zeus e a formação de uma liga que reunisse todos os aqueus. Nessa perspectiva, a imagem monetária de Zeus sentado no trono pode bem ter sido sinal de um processo de consolidação do culto e do papel do santuário federal, em decurso no século V a.C., mas que se materializou, por algum motivo específico, apenas após o início do século IV a.C. no estater batido no nome de todos os aqueus. A nosso ver, o fato da primeira emissão da liga aqueia com a imagem de Zeus remontar a esse período não significa, necessariamente, que o culto federal tenha existido somente após a destruição de Helike em c.373 a.C. e não anteriormente a essa data. Em atividade desde ao menos a metade do século V a.C., como afirma Osanna, acreditamos que a liga de todas as comunidades aqueias teria emitido o estater no contexto pós batalha de Leuctra entre c.370-360 a.C. escolhendo como uma das imagens aquela da divindade que melhor representava a sua união comum. Aceitamos, portanto, a opinião tradicional sobre a cronologia do tipo monetário e, apesar das datas quase coincidirem (aquela de Morgan e Hall de após 373 a.C. e a de Head e Kraay pós Leuctra), desvinculamos a sua emissão de uma suposta efetivação do culto federativo a Zeus Homarios após a destruição de Helike e da consequente perda de importância do culto de Poseidon Helikonios em termos federativos.

Conforme observa D. Giacometti, "a história da Acaia em época arcaica e clássica é praticamente desconhecida, com exceção dos fatos bem documentados, tanto arqueologicamente como textualmente, sobre a participação dos aqueus na fundação de cidades na Itália do Sul" (Giacometti, 2001: 7). As fontes literárias, como Heródoto e Tucídides, "permitem reconstruir parte do quadro político territorial da Acaia em relação à Sicione, Esparta e Argos nos séculos VI e V a.C." (Giacometti, 2001: 8). De acordo com Rizakis, "a ameaça de Sicione contra as cidades aqueias orientais e aquelas de Esparta na metade do século VI a.C. favoreceram uma união política regional, que alcançou expressão política no decurso da primeira metade do século $\mathrm{V}$ a.C. com a constituição da liga aqueia" (Rizakis, 2013: 22-23). Giacometti acrescenta que essa "necessidade de uma confederação, apta a determinar escolhas comunitárias no campo da política externa, deveu-se, principalmente, aos projetos hegemônicos de Esparta sobre a Acaia e o resto do Peloponeso durante os séculos VI e V a.C." (Giacometti, 2001: 27-28). Essa autora ressalta que, durante o século V a.C., os aqueus viam Esparta com pouca simpatia, ao menos ate a época da eclosão da guerra do Peloponeso (Giacometti, 2001: 31). Durante a guerra do Peloponeso, os aqueus permaneceram neutros, mas Pellene, de forma independente, juntou-se aos peloponésios e Esparta interviu, estabelecendo ali oligarquias em c.417 a.C. (Walker, 2006: 106). 
A neutralidade provou-se impossível e a Acaia caiu sobre a esfera de influência de Esparta (Errington, 2012: 4). A região, assim como as demais do Peloponeso tais como a Arcádia e a Messênia, permaneceram sob a hegemonia de Esparta até a derrota em Leuctra em c.371 a.C. Conforme bem coloca C. Grandjean sobre esse período, "as cunhagens peloponésias de estateres datadas após a batalha, como a da Arcádia, da Messênia e da Acaia, visaram celebrar a soberania dos jovens estados de espírito anti-espartano" (Grandjean, 2003: 59; Kraay, 1976: 100). É nesse contexto, portanto, nesse momento político de quebra da preponderância espartana que devemos considerar o motivo da cunhagem aqueia e interpretar o significado simbólico do uso das imagens de Zeus Homarios e da cabeça feminina no estater datado a partir dessa época.

$\mathrm{Na}$ análise do significado requerido pelos aqueus através dessas duas imagens, no que parece ter sido a primeira cunhagem no nome desse grupo étnico, é necessário tentar esclarecer, na medida do possível, a identidade da divindade representada pela cabeça feminina no anverso. Os estudiosos propuseram algumas atribuições mesmo diante da ausência de atributos, que impede a sua correta identificação (Kraay, 1976: 101; Rizakis, 2013: 26). Ritter, segundo Rizakis, reconhece na figura Deméter Panachaia, fundamentando-se no penteado e no fato de que o epíteto Hamaria foi usado em associação à deusa na região (apud Rizakis, 2013: 26, nota 70). Essa opinião é compartilhada por Walker, que atribui a imagem a Deméter Panachaia, cultuada em Aigion, provável local da cunhagem desse estater (Walker, 2006: 107). Outros autores preferiram ver no anverso da moeda a representação de Atena Homaria ou Ártemis Laphria, como foi o caso de Head (Head, 1963: 416; Rizakis, 2013: 26, nota 70). Considerando a antiguidade e a popularidade de Ártemis em toda a Acaia, Rizakis prefere identificar a imagem da cabeça feminina, na moeda, com essa divindade (Rizakis, 2013: 26, nota 70). A ausência de atributos de Deméter e Atena, e o aspecto jovem da representação, permitem identificá-la mais provavelmente com Ártemis, do que com essas deusas ou com uma ninfa desconhecida na região (Rizakis, 2013: 26, nota 70).

Diferente de Deméter Panachaia e Atena Homaria, divindades que tiveram uma atuação associável e complementar a de Zeus Homarios na liga aqueia, Ártemis teve suas competências relacionadas tanto às atividades cívicas e sociais, quanto ao domínio da natureza e dos ciclos de vegetação, como demonstra a variedade de áreas sagradas a ela dedicadas na região - nos espaços urbanos (acrópole, ágora ou em suas proximidades) e onde domina o agros (Lafond, 1991: 431; Osanna, 1996: 306). As fontes literárias documentam a presença constante da deusa na Acaia em várias formas de assentamento e experiências políticas (Osanna, 1996: 306). Na Acaia, conforme resume Y. Lafond, "Ártemis desempenhou funções variadas - como protetora da pureza e da castidade da vida feminina, na natureza e na fertilidade do solo e, nos confins do território da região com Élis e Sicione, assumiu o papel de uma forte divindade guerreira" (Lafond, 1991: 431). Mas Lafond e Osanna concordam que foi na esfera cívica que a atuação da deusa foi preponderante (Lafond, 1991: 431; Osanna, 1996: 306). Embora seja considerada uma divindade pan-aqueia, por ter sido cultuada com diferentes epítetos por toda a região, conforme o descrito pelos dois autores, Ártemis parece não ter exercido um papel federativo e na identidade étnica aqueia, tal como tiveram Deméter e Atena, em certo grau, ao lado de Zeus 
Homarios. Por essa razão, seria mais fácil aceitarmos a tese de que a divindade feminina representada com Zeus no estater, independente ou não da presença de atributos, seria Deméter Panachaia ou talvez Atena Homaria, como sugeriram alguns autores.

Em sua conclusão sobre os cultos da Acaia, M. Osanna dá destaque a Ártemis em relação às demais divindades cultuadas na região - diferente de outros contextos, onde raramente áreas urbanas foram escolhidas para o culto da deusa, a Acaia se diferenciou, desde a época arcaica, pela sua presença em todos os espaços e atividades da pólis (Osanna, 1996: 311). Se de fato Ártemis é a deusa representada no anverso do estater, podemos inferir que a escolha de sua imagem, para uma moeda batida no nome de todos os aqueus, tenha significado, naquele contexto, a necessidade de propiciar, e controlar seus poderes e energias como divindade guerreira e cívica a favor dos aqueus confederados, unidos pela sua identidade étnica já consolidada desde 0 final do século V a.C. No contexto da época da emissão do estater, após a quebra da hegemonia espartana e a busca pela manutenção das autonomias regionais no Peloponeso, as competências de Ártemis como guerreira, na proteção das fronteiras, e de divindade cívica, protetora de aspectos da pólis, devem ter sido muito valorizadas. Embora reunidos em uma liga e unidos por uma identidade étnica comum, os aqueus antes de tudo se reconheciam como pertencentes às suas comunidades políticas, suas póleis, por essa razão faz sentido, de certo modo, escolher como símbolo regional, para figurar na moeda, uma divindade que zelava pelos aspectos políticos da cidade tão variados e ao mesmo complementares. Além disso, também, confederações ou ligas eram formadas com base em uma identidade étnica regional, que unia o grupo entorno de um objetivo comum, para enfrentar um inimigo que ameaçava a autonomia e soberania das cidades de uma dada região. Nesse sentido é possível aceitar a identificação com Ártemis e a necessidade de proteção da deusa sobre o que era ser aqueu naquele período - opor-se à Esparta deve ter sido um dos componentes importantes da identidade aqueia. De acordo com Giacometti, tanto no contexto peloponésio quanto no magnogrego, a distância respeito à doricidade espartana e tarentina faziam parte da "acaicidade" (Giacometti, 2001: 31).

Também presente em muitas cidades aqueias com diferentes epítetos, Deméter, em contraste a Ártemis, foi cultuada como Panachaia em um santuário nas proximidades daquele de Zeus Homarios em Aigion (Osanna, 1996: 209). De acordo com Rizakis, esse título de Deméter em Aigion sugere uma ambição panaqueia e política de seu culto ao lado do de Zeus. As duas divindades atuaram nas assembleias, foram, portanto, "garantidoras das reuniões que debateram questões políticas" (Rizakis, 2013: 34). Com essa atribuição ao lado de Zeus faria sentido vê-la como imagem monetária escolhida para o estater, que foi provavelmente emitido em Aigion, local dos santuários das duas divindades. Nessa perspectiva, o significado da imagem de Deméter Panachaia e a de Zeus Homarios seriam complementares em associação à legenda que se refere ao étnico regional no plural. No período da emissão do estater, portanto, ambas as divindades já eram reconhecidas na região por representar, etnicamente e politicamente, todos os aqueus. 
Se Ártemis ou Deméter, cada qual teria exercido um tipo de competência relevante às comunidades políticas aqueias naquele período ao lado de Zeus Homarios, representado, no estater, sentado em seu trono. Vimos ao longo da discussão sobre o Peloponeso, acerca de Élis e da Arcádia, o significado simbólico relacionado a esse padrão de representação da divindade. 0 esquema iconográfico composto pelo trono, 0 cetro e a águia, pronta para voar, basicamente retrata e expressa as competências do deus na soberania, governo, vigilância e no poder de decisão sobre o destino dos homens. Além do seu papel político, de protetor das decisões políticas, a imagem de Zeus sentado no trono, em associação à águia, exerceu um significado na esfera militar. Tal significado encontra comprovação no papel do santuário federal, na origem do culto de Zeus Homagyrios ("Convocador"), outro nome para Zeus Homarios, conforme uma notícia de Pausânias (VII, XXIV.14). Segundo o periegeta, tal epíteto foi dado ao deus porque teria sido em seu santuário que Agamemnon reuniu os homens mais eminentes da Grécia para que eles pudessem juntos se consultar em como fazer guerra no império de Príamo. Mesmo sendo de época bem posterior ao século IV a.C., o trecho demonstra a vocação militar do santuário de Zeus Homarios. Essa proteção militar de Zeus Homarios, presente em outros cultos de Zeus no mundo grego, foi importante enquanto os aqueus estiveram reunidos em confederação para enfrentar inimigos externos, como, por exemplo, os espartanos em determinado momento em época clássica. Além desse poder militar, a competência de Zeus Homarios como patrono dos aqueus referiu-se, também, ao papel da divindade "em apaziguar as diferenças ou manter a coerência entre grupos de gregos de diversas origens" (Laky, 2013: 315). No caso da Acaia e do santuário federativo, essa coerência pode ser relacionada à diversidade dos indivíduos de diferentes póleis que compuseram o éthnos aqueu e frequentaram o seu santuário federal em busca da sanção da divindade na tomada de decisões comuns em assembleia no santuário federativo de Zeus Homarios. Trata-se de forças, energias divinas, que precisavam ser colocadas a favor e uma forma de propiciá-las era usá-las como imagens nas moedas. Foi esse também o caso aqueu no uso da imagem de Zeus.

A nosso ver, essa forma de representar Zeus em moedas (sentado no trono) expressou o poder consolidado do deus como o protetor da identidade étnica aqueia e das decisões políticas da liga. Ao lado de Ártemis ou de Deméter, qualquer que seja a divindade, como deus patrono, Zeus foi escolhido como emblema (da liga) dos aqueus para mostrar, interna e externamente, que estes estavam sob a sua proteção. Em última análise, ao usarem o étnico regional juntamente à imagem do deus no reverso do estater, os aqueus, enquanto grupo étnico, se identificaram na figura de Zeus, buscando se afirmar, politicamente e etnicamente, por meio da imagem monetária da divindade, em um momento livre da hegemonia espartana, cuja autonomia regional, de cada comunidade política, precisava ser mantida e protegida sob a égide e os desígnios do deus. 


\section{I.1.4 Messênia}

A imagem de Zeus em pé, atirando o raio, padrão recorrente apenas em Élis no século $V$ a.C., voltou a ser utilizada, no Peloponeso, nas moedas de Messênia, logo após a libertação da região e da fundação da pólis homônima em c.370/69 a.C. (Psoma, 2012: 168). As primeiras moedas batidas por Messênia, assim como aquelas das cunhagens da Arcádia e da Acaia dessa época, são tradicionalmente associadas à derrota dos espartanos em Leuctra em 371 a.C. (Grandjean, 2003: 28; Kraay, 1976: 100; Psoma, 2012: 168). De acordo com C. Grandjean, essas cunhagens peloponésias visaram celebrar a soberania dos jovens estados de espírito anti-espartano (Grandjean, 2003: 59).

Como ocorreu para a maior parte das cidades do Peloponeso, Messênia bateu suas denominações em prata em padrão eginético (Kraay, 1076: 95). As emissões monetárias de Messênia foram sistematicamente estudadas por C. Grandjean, que propôs três séries para as denominações em prata, datadas entre 370/69330 a.C., e quatro para aquelas em bronze, datadas até a segunda metade do século III a.C. (Grandjean, 2003: 21-23, 33-39). Seguindo o critério cronológico dessa pesquisa, interessa-nos as séries I, II e III, das denominações em prata, e a série IV, das denominações em bronze. As séries I e II (de estateres e trióbolos, respectivamente) trazem no anverso, a imagem da cabeça de Deméter à esquerda com coroa de trigo, e, no reverso, a imagem de Zeus nu em pé à direita, atirando o raio com o braço direito erguido e, sobre o braço esquerdo estendido, há a representação de uma águia em pé, com as asas abertas e cabeça para trás, voltada para o deus (Fig.238 - n.72). A legenda do étnico no plural aparece junto à representação de Zeus no reverso em ambas as séries. A série III (de óbolos) também é datada de 370/69-330 a.C., possui o tipo de Deméter no anverso, mas não traz o tipo de Zeus em pé no reverso, e sim a imagem do trípode com três alças. $A$ inscrição do étnico aparece abreviada no reverso. Na série IV, em bronze de chalkoi, datada também de 370/69-330 a.C., o tipo de Deméter foi mantido no anverso e a legenda do étnico abreviado (ME) ocupa todo o reverso. Nas séries monetárias em bronze, o tipo de Zeus em pé foi utilizado somente na segunda metade do século III a.C., aparecendo, assim, somente nas emissões em prata entre 370/69-330 a.C. A cabeça de Deméter, Zeus em pé e o trípode são os únicos tipos principais usados pela oficina monetária de Messênia ao menos até a segunda metade do século III a.C. As semelhanças técnicas e estilísticas levaram a pensar que se trata de emissões concomitantes (Grandjean, 2003: 23). Já a datação inicial dos tipos monetários, de logo após a fundação da pólis de Messênia, tem sido proposta com base na correspondência tipológica do desenho de Deméter, nas moedas messênias, com o de Aretusa, criado por Evainetos para as moedas siracusanas datadas de c.390 a.C., o qual influenciou um número de tipos monetários dessa época ao redor do mundo grego (Grandjean, 2003: 24; Kraay, 1976: 102; Psoma, 2012: 168).

Como mencionado anteriormente, essas séries monetárias mais antigas de Messênia estiveram fortemente relacionadas à necessidade de afirmação da soberania dessa nova comunidade política diante dos espartanos, das outras comunidades da região e do mundo grego. Até o período pós-Leuctra, a Messênia, bem 
como a Lacônia, áreas sob controle espartano, não tiveram cunhagens (Psoma, 2012: 166). Até antes de 370/69 a.C. não houve condições político-sociais que pudessem ter ocasionado emissões monetárias na região da Messênia. Foi somente a partir do segundo momento do processo de etnogênese dos messênios no século IV a.C. que houve fatores determinantes para a criação de um estado na região e a subsequente cunhagem de moedas em seu nome. Como vimos no capítulo 2, acerca dos santuários, toda a região da Messênia esteve sob influência e domínio espartano desde ao menos a segunda metade do século VIII a.C., como indicam as fontes literárias, posteriores, e, principalmente, as similaridades culturais presentes nos santuários da região com aqueles da Lacônia. De acordo com N. Luraghi, "as evidências arqueológicas mostram que a Messênia arcaica foi uma extensão significativa da Lacônia, habitada por um povo que aparentemente falava a mesma língua dos lacedemônios, a leste do Mt. Taygetos, empregaram o mesmo alfabeto e produziram o mesmo tipo de cerâmica e de bronze" (Luraghi, 2008: 142-143). Para esse autor, as comunidades de perioikoi, e não os hilotas, como a tradição historiográfica tem continuamente afirmado, foram as responsáveis pela produção de tais evidências. De todo modo, é aceito pela historiografia que o "domínio de Esparta sobre essas populações a oeste do Taygetos forneceu a base econômica espartana a partir da conquista do vasto território fértil messênio, cuja extensão nenhuma outra pólis do período possuía" (Bettali, 2013: 116; Kraay, 1976: 102). A historiografia também é unânime em aceitar que teriam ocorrido três revoltas das populações messênias contra o domínio espartano desde o século VIII a.C. A terceira revolta ocorreu na primeira metade do século $\mathrm{V}$ a.C., após um forte terremoto que devastou as duas áreas, a leste e a oeste do Taygetos. Nesse momento, os messênios tinham ocupado e fortificado o Mt. Ithome, local, como vimos, que foi o centro da resistência aos espartanos (Dumbabin; Hooper; Spawforth, 2012: 752). Mas mesmo assim, estes foram rendidos pelos espartanos após um longo cerco e os sobreviventes foram assentados pelos atenienses em Naupactos (Woodward; Hooper; Spawforth, 2012: 938).

Conforme N. Luraghi, "Naupactos permaneceu como um reduto messênio por mais da metade de um século até após o final da guerra do Peloponeso" (Luraghi, 2008: 188). Para esse autor, o exílio em Naupactos corresponde ao primeiro momento de etnogênese dos messênios - o segundo ocorreu na libertação da Messênia por Epaminondas (Luraghi, 2008: 145-146). Na sua leitura, "os messênios em Naupactos não se viram como uma colônia, mas como uma comunidade exilada, temporariamente vivendo longe de seu próprio território. Suas dedicações em Olímpia e em Delfos documentam a tentativa da comunidade em se se auto conceituar como uma entidade política e em chamar a atenção da audiência pan-helênica" (Luraghi, 2008: 191 e 200). Assim, "no século V a.C., se por um lado tornar-se messênio significou, essencialmente, rebelar-se contra Esparta, por outro, Luraghi conclui que esse primeiro momento de etnogênese foi baseado em um conceito de etnicidade flexível o suficiente para acomodar o padrão cultural essencialmente lacônio, o qual encontramos na área da Messênia no final do período arcaico e início do clássico" (Luraghi, 2008: 246 e 248). Esse não foi um processo repentino, mas gradual - as populações a oeste do Taygetos (perioikoi e hilotas) teriam de tempos em tempos se engajado, por exemplo, em um comportamento cultual diferente daquele da 
população da Lacônia, e tradições locais não estiveram completamente ausentes no período arcaico na região (Luraghi, 2008: 145). Essa etnicidade messênia, como coloca Luraghi, "forjada no século V a.C., ofereceu um modelo estrutural para o segundo momento de etnogênese no século IV a.C." (Luraghi, 2008: 248). Assim como para os messênios do século V a.C., paradoxalmente, o elemento lacônio permaneceu como parte formadora de sua etnicidade no século IV a.C., mesmo após a fundação da pólis de Messênia (Luraghi, 2008: 248). Traços espartanos fizeram parte da identidade messênia desde a sua mais antiga manifestação, ultrapassando, inclusive, o momento da criação e consolidação de uma entidade política na região, a pólis de Messênia, a qual se originou da reação à preponderância de Esparta no Peloponeso. Em seu estudo sobre a elaboração da identidade messênia, Luraghi "conclui que o nascimento da Messênia livre de Esparta foi possível graças a uma convergência de extraordinárias condições favoráveis - não poderia ter ocorrido sem a vitória tebana em Leuctra e a subsequente invasão da Lacônia, onde o envolvimento arcádio e argivo foram claramente importantes" (Luraghi, 2008: 248). Além disso, "o Peloponeso nas primeiras décadas do século IV a.C. passou por mudanças que não apenas afetaram o equilíbrio de poder e o mapa político da região, mas incluíram também a redefinição de fronteiras étnicas e emergência de novas entidades étnicas" (Luraghi, 2008: 212). "Essa dinâmica caracterizada por uma maior fluidez étnica, peculiar ao Peloponeso no período, deve ter facilitado a aceitação de uma nova entidade étnica na região, como foi o estado de Messênia" (Luraghi, 2008: 213 e 248).

Como bem colocou C. Grandjean, "a cunhagem de moedas, especialmente em Messênia, foi parte de um programa de defesa e ilustração da nova pólis, no qual a comunidade procurou exaltar um sentimento regional messênio e evocar um passado glorioso - bater moedas, pela primeira vez, significou romper com a velha ordem e proclamar a existência de uma nova" (Grandjean, 2003: 63-64). Esse momento propício de fundação da cidade no século IV a.C., quando a comunidade política passou a existir em autonomia, como pólis, explica porque os messênios, exilados em Naupactos, jamais bateram moedas em seu nome naquela época, apesar de naquele momento terem já se percebido como um grupo étnico e uma entidade política (Grandjean, 2003: 29). É nesse contexto de formação e afirmação da pólis de Messênia, e de consolidação de uma identidade regional e política, que a imagem de Zeus em pé atirando o raio deve ser analisada e o seu significado simbólico interpretado.

Com relação ao estado atual da discussão, que procura explicar o uso da imagem de Zeus em pé, atirando o raio, nas moedas de Messênia, há dois caminhos interpretativos propostos pelos especialistas. A maior parte dos estudiosos vê no tipo monetário de Zeus uma alusão ou a própria representação da estátua de culto do santuário de Zeus Ithomatas, obra de Ageladas, executada pelos messênios enquanto exilavam-se em Naupactos (Kraay, 1976: 102; Luraghi, 2008: 233; Psoma, 2012: 168). Outra linha interpretativa prefere ver 0 tipo monetário do deus tanto como o desenho da estátua de Ageladas como uma influência, nos gravadores de cunho, de outros modelos inspirados em outras obras de arte, em particular, imagens monetárias de outras cidades (Lacroix, 1949: 229-230). Nessa linha, C. Grandjean acredita que o tipo de Zeus atirando o raio das 
moedas de Élis-Olímpia, de meados do século V a.C., teriam sido os verdadeiros modelos inspiradores usados para as moedas messênias (Grandjean, 2003: 27). Essa autora considera apenas os tipos monetários de Zeus atirando o raio, cunhados durante a segunda metade do século III a.C. (série VI, em bronze), como possíveis representações da estátua de Zeus Ithomatas, como sugere, a seu ver, uma linha abaixo dos pés do deus, vista por muitos como a base da estátua, a qual somente aparece na emissão desse período (Grandjean, 2003: 41 e 63).

O que é consenso entre os especialistas é a forte conotação étnica messênia contida no uso da imagem de Zeus nas moedas da cidade, como demonstra o histórico relacionado ao antigo culto de Zeus no Mt. Ithome (Grandjean, 2003: 62-63; Luraghi, 2008: 205, 209-210; Zunino, 1997: 101). 0 culto a Zeus Ithomatas, como vimos no capítulo 2, esteve entre os poucos cultos locais, estritamente messênios, a parte daquela grande variedade de santuários de traços lacônios distribuídos por toda a região a oeste do Taygetos (Luraghi, 2008: 134, 206, 235 e 247). O Mt. Ithome e o santuário de Zeus são reputados por terem tido uma função importante nas guerras messênicas: ficaram conhecidos, na chamada pseudo-história local, como o centro de resistência aos espartanos (Grandjean, 2003: 62; Luraghi, 2008: 209-210; Zunino, 1997: 101). Luraghi explica que 0 Ithome, "além de ter sido, pelas qualidades estratégicas na região, a área ideal para a fundação da pólis de Messênia, o monte tinha conotações simbólicas também importantes" (Luraghi, 2008: 209). Mesmo assumindo que a maior parte da história da resistência messênia no período arcaico ter se originado mais tarde, principalmente em época helenística, Luraghi admite que "o Ithome foi um monumento à resistência desse grupo - foi lá, por exemplo, que os messênios se mantiveram por vários anos contra os espartanos durante a revolta do século V a.C." (Luraghi, 2008: 209).

Além dessa referência sobre a revolta, que antecedeu o exílio em Naupactos, C. Grandjean e M. Zunino lembram de outras referências em Pausânias que atestam, de algum modo, o papel simbólico do Ithome e do santuário de Zeus Ithomatas na elaboração da identidade messênia. De acordo com Grandjean, Zeus Ithomatas já era considerado a divindade tutelar dos messênios ao menos após a primeira guerra messênica, como indica uma famosa referência em Pausânias (IV, 12, 7-10) sobre uma consulta dos messênios no oráculo de Delfos (Grandjean, 2003: 62). Conforme o trecho, o oráculo teria prometido a vitória a quem (messênios ou espartanos) oferecesse a Zeus Ithomatas, em seu santuário, uma centena de trípodes (Grandjean, 2003: 62). Grandjean e Zunino citam outra referência mais sintomática ainda, do culto para os messênios, fornecida pelo periegeta. Segundo Pausânias (IV, 20, 4), os messênios possuíam um talismã que, se fosse perdido, a Messênia estaria para sempre submersa pela água, mas se fosse conservado, com o tempo os messênios recuperariam a sua terra. Na sequência da narrativa, Aristomenes teria guardado esse talismã no Ithome, pedindo a Zeus para guardar o objeto e não ceder aos espartanos a única esperança de retorno dos messênios. Na leitura de Grandjean e de Zunino, a narrativa expressa um significado político e religioso relacionado a Zeus Ithomatas, representado, assim, como o símbolo da promessa de renascimento e independência do estado messênio (Grandjean, 2003: 52; Zunino, 1997: 101). Ainda sobre esse papel político de Zeus Ithomatas, Zunino, se 
baseando em outra indicação de Pausânias (IV, 27, 6), recorda que foi dedicado ao deus o primeiro sacrifício pan-messênio no ato da fundação da nova capital livre (Zunino, 1997: 105). Assim, pode-se afirmar, por essas e outras informações, que "Zeus Ithomatas foi evocado, desde o início da fundação da cidade, como um ponto chave da identidade dos novos messênios que pode ter tido origem em períodos mais antigos" (Luraghi, 2008: 209).

Esse é o estado atual da discussão acerca do papel do culto de Zeus Ithomatas para a identidade messênia e do significado simbólico mais aceito subjacente ao uso da imagem da divindade já nas primeiras emissões monetárias da cidade recém fundada. Com relação a escolha do tipo de Zeus em pé atirando o raio para as moedas messênias, possuímos algumas observações acerca do contexto de uso desse padrão de representação que pode ajudar a iluminar as razões por de trás da escolha desse padrão pela oficina monetária de Messênia. Em primeiro lugar, o padrão de representação de Zeus em pé e atirando o raio em moedas gregas foi mais utilizado por autoridades emissoras no século V a.C., embora no século IV a.C. apareça numa quantidade não muito distante daquela do século anterior. Mesmo na arte grega em geral, o padrão de Zeus em pé e atirando o raio não foi comum no século IV a.C., mas sim típico da estatuária em bronze e da cerâmica pintada do século V a.C. Em segundo lugar, com respeito ao que ocorreu no Peloponeso para as imagens monetárias de Zeus, no período investigado, o padrão em pé e o sub-padrão nu, atirando raio e sustentando a águia com o braço esquerdo estendido, ocorreu, de fato, nas moedas de Élis da metade do século $\mathrm{V}$ a.C. No Peloponeso, durante o século IV a.C., a liga arcádia e a liga acaia (junto a Messênia as outras duas autoridades a usarem imagens de Zeus em moedas) não utilizaram o tipo de Zeus em pé atirando o raio - a liga arcádia cunhou tipos monetários da cabeça de Zeus e a liga acaia optou pelo tipo de Zeus sentado no trono. Nessa região e nesse período, o tipo de Zeus em pé, atirando o raio, foi usado exclusivamente por Messênia. Esse tipo monetário foi usado no século IV a.C., além de Messênia, somente fora do Peloponeso, por póleis na Tessália (Gomphi e Kierion) na metade e na segunda metade desse século. Em Posidônia, na Itália do Sul, o tipo de Zeus em pé e atirando o raio aparece nas moedas datadas entre o século V-IV a.C. Assim, mesmo durante o período (o século IV a.C.) no qual o uso do tipo da cabeça de Zeus foi preponderante entre as autoridades emissoras que escolheram usar a imagem da divindade em suas moedas, Messênia, recém estabelecida como comunidade política, escolheu como tipo de Zeus aquele em pé e atirando o raio.

Por essas constatações, acreditamos que essa escolha tipológica tenha estado diretamente relacionada à tradicional representação da estátua de Zeus Ithomatas, criada no primeiro momento de etnogênese dos messênios no século V a.C. A nosso ver, a escolha pelo padrão de representação não teria sido norteada por uma mera convenção artística, pautada na arte grega em geral ou em moedas de outras cidades. Embora Pausânias, responsável por indicar a existência da estátua de Ageladas, não ofereça uma descrição (se se tratou de uma imagem de Zeus sentado no trono ou em pé atirando o raio), a julgar pelo período de sua elaboração (primeira metade do século $V$ a.C.), é bem provável que tenha se tratado de uma representação de Zeus em pé atirando o raio. Essa correspondência temporal, com o padrão de representação, 
chegou a ser levantada por Grandjean, apesar dessa estudiosa não seguir essa proposição (Grandjean, 2003: 26). Como bem colocou Luraghi, as primeiras moedas batidas pelos messênios mostram a imagem de Zeus Ithomatas, em uma maneira antiga, em um estilo antigo, provavelmente significando algum pedigree tradicional para a nova comunidade política (Luraghi, 2008: 233). Tendemos, nesse sentido, a acreditar que a escolha tipológica esteve mais alinhada com a representação de Zeus que era tradicional para aquele grupo e por isso escolhida para figurar como tipo monetário. Até onde sabemos, a única estátua de culto de Zeus Ithomatas foi essa descrita por Pausânias.

Na discussão sobre a escolha tipológica de Zeus para as moedas de Messênia, devemos também considerar até que ponto o significado simbólico dessa representação também teria influído nessa escolha. Como vimos na análise contextual do significado simbólico das imagens de Zeus, cada padrão de representação do deus possuiu algum significado específico para os gregos antigos. No caso de Zeus em pé, atirando o raio e portando a águia, vimos como expressou um deus guerreiro, em luta pela imposição da ordem sobre o caos, portanto, da liberação da violência e da desordem. Vimos também como o padrão interrelacionou-se com ideias de guerra, vitória e competição. Se associarmos esses significados ao contexto histórico do uso da imagem na moeda ou supostamente da estátua de Ageladas, encontraremos as razões dessa escolha. Considerando que o relato de Pausânias tenha certa historicidade, a escultura de Ageladas foi providenciada no momento em que os messênios viviam como uma comunidade exilada em Naupactos no século V a.C. A representação de Zeus voltou a ser apropriada pelos messênios em suas primeiras moedas, batidas no momento em que haviam se estabelecido em definitivo como comunidade política no século IV a.C.

Embora o primeiro momento tenha sido de exílio e o segundo de consolidação de uma entidade política, ambos se referem à necessidade de libertação de um poder opressor, que impede o grupo de se auto-afirmar como tal e de desenvolver sua autonomia enquanto uma comunidade política estabelecida. Evidente alusão ao culto de Zeus Ithomatas, a nosso ver, a escolha da representação de Zeus em pé, atirando o raio e portando a águia, se foi ou não o tipo da estátua de Ageladas, teve um significado simbólico bem preciso para os messênios ao usarem-na em suas moedas no século IV a.C. - assegurar a libertação do jugo de Esparta, assegurar o novo governo e sua autonomia, o novo domínio recém instaurado, que precisava ser mantido tanto em relação à Esparta como em relação a preponderância do poder de Messênia em relação às demais comunidades da região. Essa imagem de Zeus teve um valor talismânico e apotropaico, o qual foi cuidadosamente escolhido pela autoridade emissora, por evocar significados de ordenação fundamentais para a comunidade política recentemente estabelecida. Como veremos mais adiante nesse capítulo, esses mesmos significados estiveram presentes no uso da imagem de Zeus atirando o raio, portando ou não a águia, em moedas batidas por comunidades gregas na Sicília e na Itália do Sul. Em Zancle, o tipo monetário representou, claramente, 0 momento de libertação da tirania e de restabelecimento da comunidade dos zancliotas. Em Posidônia, os lucanos bateram moedas com esse tipo de Zeus na época que necessitavam assegurar o seu governo recém instaurado. Repara-se que a imagem emergiu, nessas comunidades, após um momento de luta, guerra e 
conquista de autonomia desses grupos com outros grupos ou tipos de poder. A imagem assumiu significado para essas comunidades quando ainda precisavam firmar seu governo, sua autonomia e sua identidade enquanto grupo étnico e comunidade política.

Esse significado simbólico revelado no uso da imagem de Zeus nas moedas de Messênia foi reforçado pela associação às demais representações escolhidas pela oficina monetária, como a imagem da cabeça feminina (interpretada como Deméter) e a do trípode presentes no anverso ou no reverso dos tipos monetários. O trípode é unanimemente interpretado como uma referência a Zeus Ithomates, um objeto votivo tipicamente dedicado à divindade no monte, como indicam as evidências materiais encontradas na área e o episódio contado por Pausânias sobre o oráculo de Delfos (Grandjean, 2003: 62). No trecho, o trípode aparece claramente associado à restauração da Messênia (Grandjean, 2003: 63). Alguns autores interpretam a cabeça feminina nos anversos das moedas como a heroína local Messênia, outros, como Grandjean, preferem vê-la como a imagem de Deméter. Esse problema de identificação é presente, também, no famoso culto de mistérios em Andania, cujo santuário é atribuído seguramente a Deméter somente no século I a.C. 0 santuário foi edificado sobre as ruínas de um mais antigo, do século VII a.C., que P. Themelis prefere identificar como pertencente a heroína Messênia (Zunino, 1997: 128-129). Aqui acataremos a interpretação de C. Grandjean. Para ela, como o deus do Ithome, Deméter também foi associada ao passado messênio (Grandjean, 2003: 62). A deusa teve um papel importante, na pseudo-história messênia, como registra uma das passagens em Pausânias, que diz sobre a libertação de Aristomenes por uma sacerdotisa de Deméter, após ter sido preso pelos espartanos (Grandjean, 2003: 61). Grandjean ressalta a competência de Deméter na esfera política, interpretando a imagem da divindade como a representação da perenidade da Messênia como estado (Grandjean, 2003: 61). Em suma, a pólis de Messênia escolheu, deliberadamente, para suas moedas, os símbolos, cujos significados se completam e se referem ao desejo de construção, afirmação e manutenção da comunidade política.

\section{I.1.5 Considerações gerais sobre as imagens monetárias de Zeus e de seus atributos no Peloponeso}

Em resumo, sobre o uso das representações de Zeus, da águia e do raio em moedas em época arcaica e clássica (até 344 a.C.), o Peloponeso se confirmou como o centro de inovações na imagética do deus e de seus atributos. Trata-se de inovações, cujos traços foram compartilhados internamente entre Élis e a Arcádia durante períodos específicos no século $\mathrm{V}$ a.C., principalmente no se que se refere à representação de Zeus. Como veremos, na sequência sobre a Sicília e a Itália do Sul, essas inovações foram difundidas para fora do Peloponeso durante os séculos V e IV a.C. devido, provavelmente, a fatores migratórios e à influência de Olímpia e às trocas culturais entre esse santuário e essas duas áreas ocidentais do mundo grego.

No caso do Peloponeso, as imagens monetárias de Zeus, e de seus atributos, estiveram relacionadas, a priori, ao culto local da divindade. Em Élis, na Arcádia, na Acaia e na Messênia o culto a Zeus é bem atestado 
e exerceu um papel de destaque para as comunidades dessas regiões. Os significados das imagens monetárias de Zeus, da águia e do raio, remeteram ao papel político e da identidade étnica do santuário eleio e pan-helênico de Olímpia em Élis, pan-arcádio e pan-helênico do Monte Lykaion na Arcádia, federal de Zeus Homarios na Acaia e pan-messênio de Zeus Ithomates na Messênia. Em todos esses casos, as imagens monetárias expressaram a consolidação de identidades regionais e políticas. As póleis de Élis e de Messênia foram as únicas a bater tipos monetários do deus, e de seus atributos (no caso de Élis), no étnico no plural, no nome do povo que formou a comunidade política. Já nos casos da Arcádia e da Acaia, as imagens monetárias de Zeus foram batidas no nome do étnico regional no plural, referindo-se, portanto, à identidade étnica do grupo que habita a região.

Nesse contexto do uso dessas imagens, Élis parece ter sido um caso à parte. A apropriação das imagens de Zeus, de águias e raios por essa pólis para figurar em moedas emitidas em seu nome, teve a ver com Olímpia ter sido parte da identidade política eléia, enquanto comunidade política hegemone na região e na admistração do santuário mais importante na região de Élis, no Peloponeso e em termos de mundo grego. Mas, mesmo assim, como ocorreu na Arcádia, na Acaia e na Messênia, essas imagens da divindade e de seus atributos podem ter ganho um significado a mais no contexto da afirmação da autonomia e soberania de Élis, na região e em Olímpia, frente à política expansionista de Esparta nos séculos V e IV a.C. No entanto, no caso de Élis, não se tratou de uma afirmação de forte caráter étnico, como ocorreu na Arcádia, Acaia e Messênia. A todas as quatro sub-regiões peloponésias, a ameaça de Esparta, como principal potência regional, foi um fator marcante no uso das imagens de Zeus e, em menor escala, de seus atributos em moedas, principalmente no século IV a.C., ainda que durante o século V a.C. o fator espartano tenha sido um catalisador importante no uso de imagens monetárias do deus em Élis e principalmente na Arcádia. Durante o século IV a.C., imagens monetárias de Zeus emergiram no contexto da redefinição de fronteiras e no surgimento de novas entidades étnicas no Peloponeso ocorrida após a derrota espartana na batalha de Leuctra, na Messênia e na formação de confederações na Arcádia e na Acaia. Imagens monetárias de Zeus foram requisitadas, ganharam um novo significado nesse período, também em oposição à Esparta, no momento da busca da manutenção da autonomia e soberania políticas e regionais após sua derrota como potência hegemone no Peloponeso. A Messênia foi um caso especial, pois Esparta foi um poder dominante na região desde ao menos a Idade do Ferro, o qual impediu a auto-afirmação étnica messênia até o início do século IV a.C.

No Peloponeso, portanto, Zeus, através de seus cultos, teve um papel em agregar, promover e afirmar identidades regionais e políticas, se pensarmos no caso de Élis e da Acaia. O uso de sua imagem, a que foi preponderante na região, mais do que a de seus atributos, nasceu da necessidade de se requisitar a proteção de Zeus como o protetor de identidades étnicas e políticas, quando soberania e autonomia regionais e de suas comunidades políticas foram importantes frente a um inimigo maior, externo. 


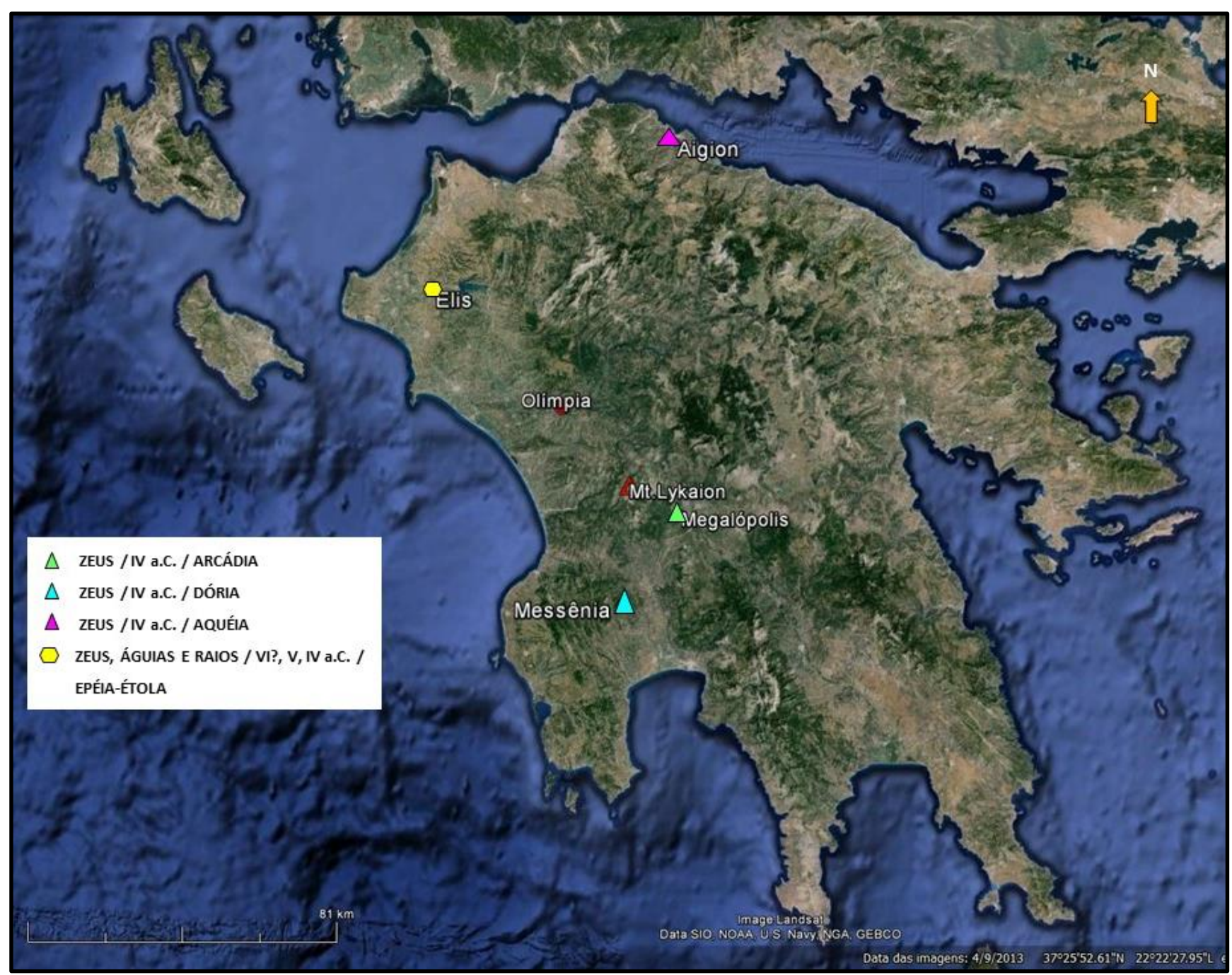

Fig.234 - Mapa do Peloponeso: autoridades emissoras que emitiram tipos monetários de Zeus, águias e raios (sécs. VI-IV a.C.) e santuários inter-regionais de Olímpia e Mt. Lykaion. Não constam a Parrhasia e nem a Liga Arcádia por não se conhecer seus centros emissores. 

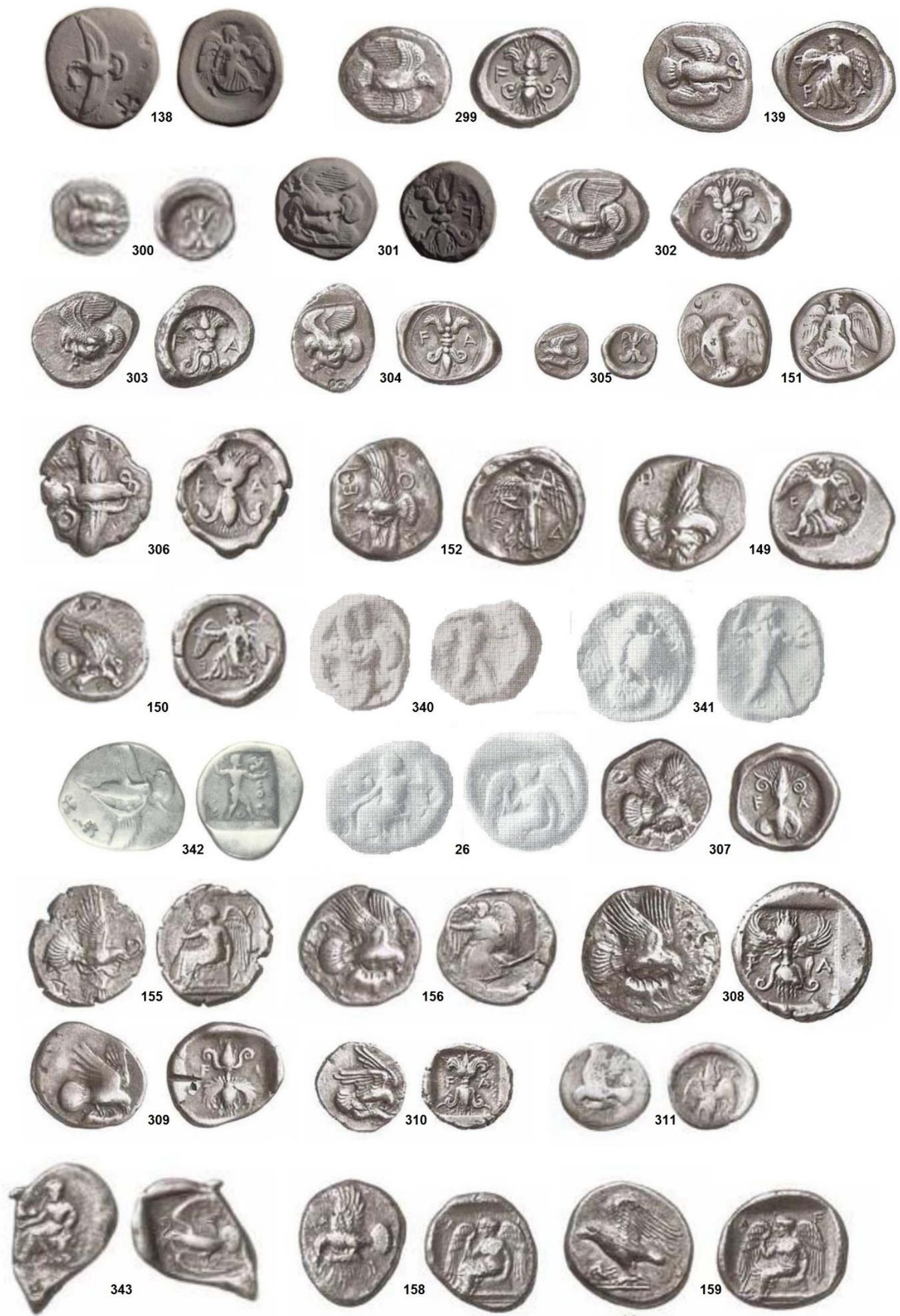

Fig.235 - Peloponeso: tipos monetários de Élis-Olímpia 


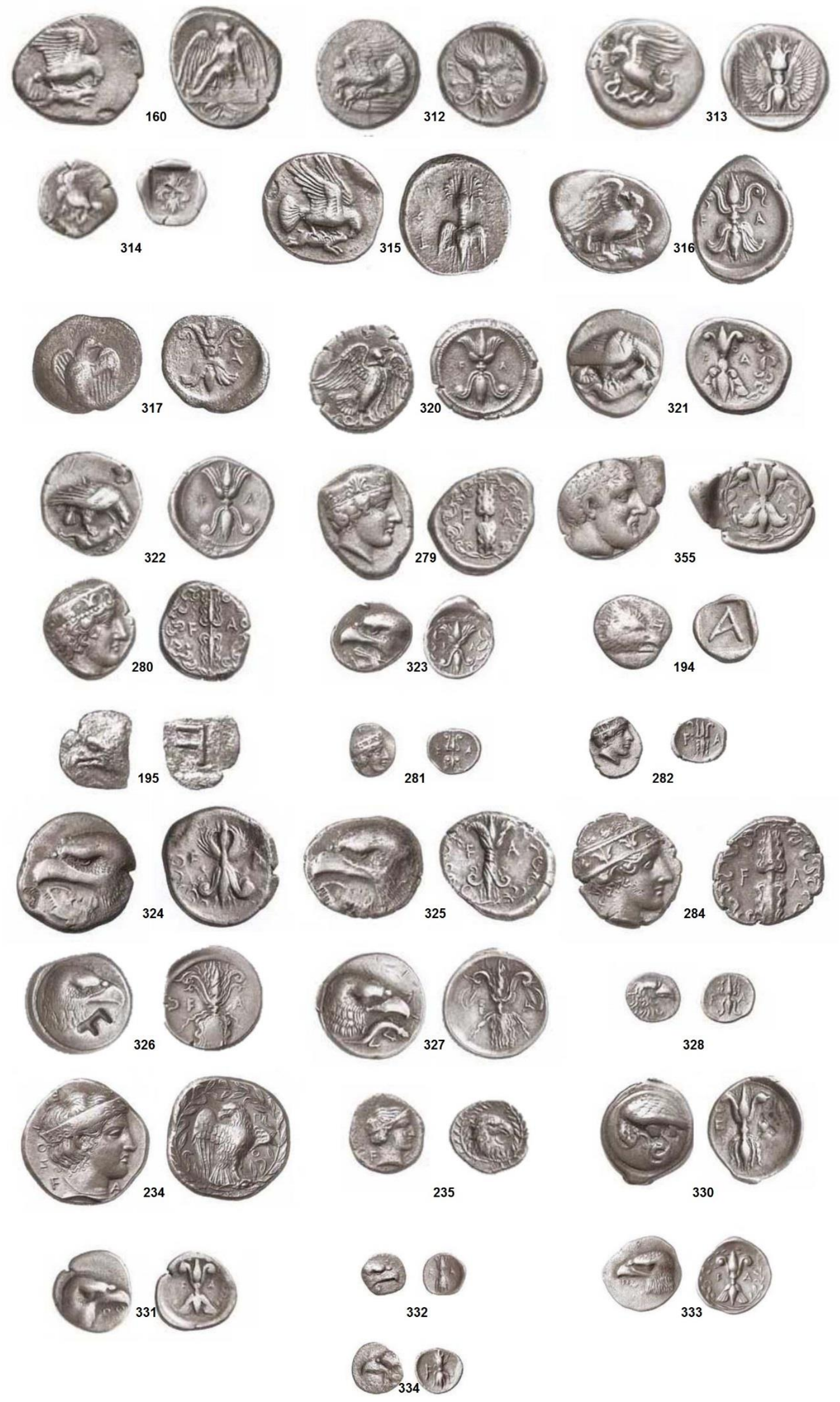

Fig.236 - Peloponeso: tipos monetários de Élis-Olímpia 


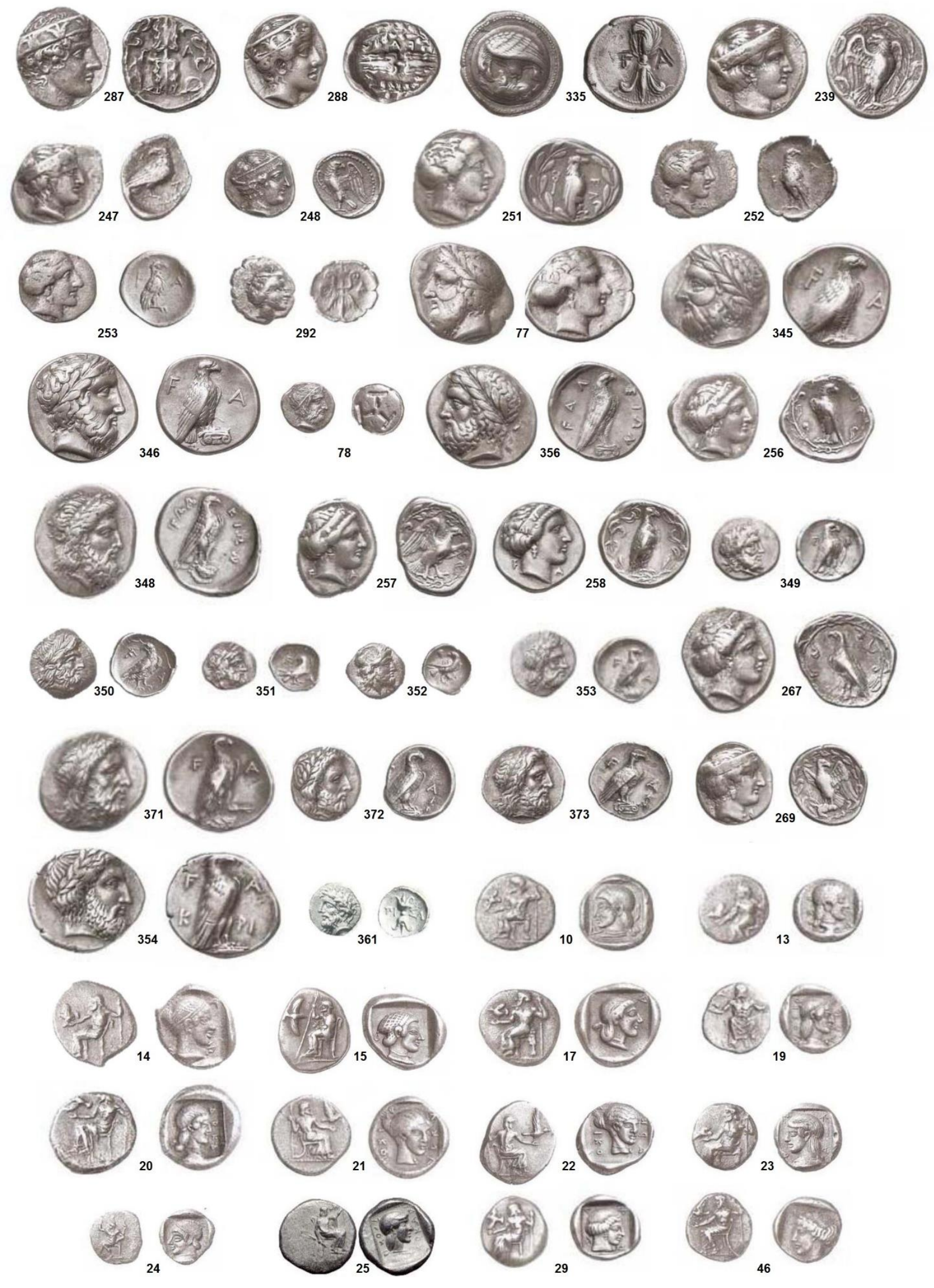

Fig.237 - Peloponeso: tipos monetários de Élis (n.287-354), Pisa (n.361), Liga Arcádia (n.10-46) 


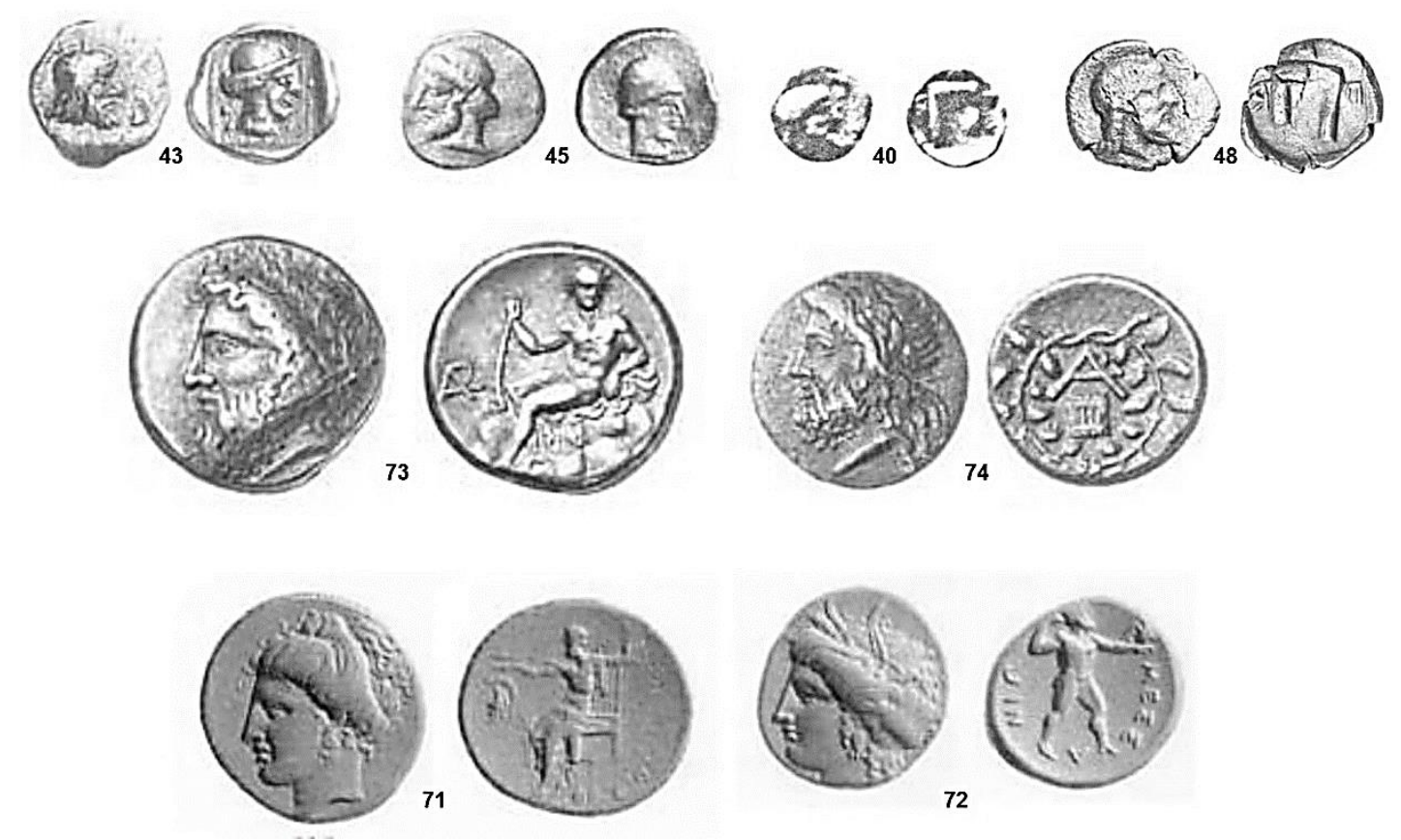

Fig.238 - Peloponeso - tipos monetários da Liga Arcádia (n.43/45), Parrhasia (n.40/48), Megalópolis (n.73/74), Messênia (n.71) e Liga Acaia (n.72)

\section{I.2 SICÍLIA}

O uso da imagem de Zeus e do raio em moedas gregas emergiu pela primeira vez, na Sicília, na área da costa leste no primeiro quartel do século V a.C. (Fig.239). A imagem do deus ocorreu também na metade do século V a.C. na área mais a norte, na parte nordeste - predominando inicialmente, portanto, na porção oriental da ilha. Das três imagens principais, que investigamos, a da águia foi a que primeiro apareceu na Sicilia, no final do século VI a.C., sendo restrita, inicialmente, à costa sul da ilha. Veremos que a imagem da águia em moedas se difundiu a outras partes da ilha ao longo do século $V$ a.C. Veremos também que as três imagens associadas foram usadas em moedas no norte e nordeste da Sicília somente após a segunda metade do século IV a.C. Para realizarmos a análise regional dos tipos monetários na Sicília, será necessário, primeiramente, contextualizá-los nas emissões de suas autoridades emissoras.

\subsubsection{Agrigento}

Responsável pela cunhagem mais profícua no sudoeste da Sicília e da segunda maior quantidade de emissões de tipos monetários de águias no mundo grego em época arcaica e clássica, Agrigento começou a bater suas moedas em c.510 a.C., ou talvez um pouco antes, já usando as imagens da águia em pé, no anverso, e do caranguejo, no reverso, as quais se mantiveram até o fim de suas emissões (Fig.240 - n.108-220) (Jenkins, 1990: 43; Kraay, 1976: 208-209 e 226; Stazio, 1992: 220). Até a primeira (510-480 a.C.) e a segunda 
fase de suas cunhagens (480-472/71 a.C.), Agrigento esteve inserida na chamada área do didracma, predominante no sudoeste da Sicília, em contraposição à dita área do tetradracma, denominação difundida por Siracusa no início desse período (Kraay, 1976: 208-209; Stazio, 1992: 220-221). É difícil precisar sob qual forma de governo Agrigento começou a emitir suas moedas e a ter escolhido a imagem da águia e do caranguejo como tipos. A tirania de Téron se iniciou ao redor de 488 a.C. ou talvez anteriormente a esse período. É provável que tenha havido um período de democracia antes de Téron ter se instaurado como tirano (Fischer-Hansen, Nielsen, Ampolo, 2004: 187). De toda forma, foi sob a tirania de Téron que a cunhagem dos tipos monetários da águia e do caranguejo se mantiveram como símbolos da cidade. Ao longo da primeira e da segunda fase das cunhagens de Agrigento, ocorreu a conquista e dominação da pólis de Himera (483-472 a.C.), localizada na costa norte da ilha, um velho sonho do tirano Faláris (572-554 a.C.) que Téron realizou, expandindo 0 território agrigentino em direção ao mar Tirreno (Stazio, 1992: 221). O botim da batalha permitiu a Agrigento a realização de obras públicas no século V a.C. e o contato direto com as regiões da Campânia, Etrúria e lbéria, possibilitado pelo acesso à costa setentrional da Sicília (Stazio, 1992: 221-222). Durante o período de dominação de Himera a cunhagem de Agrigento cessou e aquela de Himera sofreu uma modificação substancial e significativa, adotando o sistema ponderal de Agrigento e a imagem do caranguejo como tipo (Stazio, 1992: 222). O volume das emissões de Himera, e a adoção da imagem do caranguejo das moedas de Agrigento, levaram Stazio a propor que, provavelmente, nesse período, a moeda de Himera tenha sido usada também por Agrigento diante das exigências de mercado na área tirrênica, novo para a pólis, mas familiar para Himera (Stazio, 1992: 222).

Após a morte de Téron em 472 a.C., Trasideu assumiu como tirano de Agrigento por um breve período, até a sua derrocada. A última fase da tirania dos Eumênidas em Agrigento foi marcada pelo conflito com Siracusa e a consequente derrota de Trasideu por Hieron na batalha do rio Salso em 471 a.C. A derrota trouxe a expulsão desse tirano, a instauração da democracia na cidade e o fim do domínio sobre Himera. Então, uma nova fase na cunhagem de Agrigento se iniciou com o período democrático, permanecendo os mesmos tipos tradicionais da águia em pé e do caranguejo com algumas pequenas modificações. 0 sistema ponderal, no entanto, passou a ser o tetradracma, segundo o modelo de Siracusa, talvez um sinal de inserção da cidade na área siracusana em consequência da vitória militar dessa última sobre Agrigento no rio Salso em 446 a.C. (Kraay, 1976: 226; Stazio, 1992: 223-224). Litras de prata também foram emitidas nessa nova fase. O período democrático foi de grande desenvolvimento econômico, principalmente na agricultura e no comércio com Cartago. Mesmo assim, observa Stazio, apesar do aumento de atividade econômica, as emissões monetárias foram escassas, embora a qualidade artística tenha sido alta, testemunhando o bom nível cultural e o desejo de cuidar adequadamente da imagem da cidade (Stazio, 1992: 224). A explicação da escassez de emissões estaria no fato de esse ter sido um período de eudaimonia - o período de maior volume de produção monetária corresponderia a momentos de crise ou de necessidades militares (Stazio, 1992: 224). Dos didracmas da fase tirânica, aos tetradracmas do período democrático, ocorreram poucas modificações no tocante aos tipos 
monetários da águia em pé. Até os tipos de c.450 a.C., manteve-se a imagem das primeiras emissões - aquela da águia em pé, parada com as asas fechadas, e cabeça para frente sem nenhuma presa, e acompanhada pela legenda com o étnico da cidade (Fig.240 - n.108/128/141). Somente a partir dos tipos de c.460-450 a.C. esse padrão de representação passou a ser usado com a ave sobre a coluna de um capitel jônico (Fig.240 n.143/145).

A partir do último quartel do século $V$ a.C. muitos acontecimentos militares ocorreram na Sicília e causaram uma nova configuração política entre as póleis da ilha nessa época. Um deles foi a primeira expedição ateniense (427-424 a.C.), o qual levou a polaridade entre Siracusa, e as cidades dórias, e Leontino, e as cidades calcídias (jônias) com o apoio de Atenas (Dreher, 2008: 37). Embora dória, Agrigento parece ter se aliado a Atenas em 422 a.C., contra Siracusa, conforme diz Tucídides (V, 4. 6) (Fischer-Hansen, Nielsen, Ampolo, 2004: 187). O fim do primeiro conflito terminou com o chamado congresso de Gela (c.424 a.C.), quando as póleis siceliotas selaram a paz ao perceberem a intenção expansionista de Atenas sobre a Sicília (Dreher, 2008: 37 38). É nesse contexto, em aproximadamente 425 a.C., que se atribui a primeira emissão de moedas de bronze em Agrigento (Stazio, 1992: 228; Westermark, 1979: 13). Agrigento bateu litras e hemilitras nesse metal, emissões que duraram até o período de destruição da cidade em c.406 a.C. e de sua retomada no início do século IV a.C. É justamente no início dessa fase da cunhagem de moedas em bronze que a águia em pé, pela primeira vez nas emissões de Agrigento, passou a ser representada sobre algum tipo de presa (peixe, lebre e cobra) com as asas abertas, cabeça erguida ou curvada devorando o animal tanto em emissões de bronze quanto de prata (Fig.240 - n.169/191/197/200/207/208/209). Como observa Stazio, "desde o congresso de paz em Gela, ocorreu, para a cunhagem de Agrigento, uma série de mudanças tipológicas e ponderais significativas e também um aumento de emissões, em conexão, evidentemente, com os eventos bélicos que envolveram a sua queda em 406 a.C." (Stazio, 1992: 224).

Mas a mudança ponderal e tipológica mais significativa nesse período mostra-se na emissão dos decadracmas de prata datados entre 413-411 a.C. A datação indica que foram emitidos após o final da segunda expedição ateniense à Sicília (415-413 a.C.) causada por novas disputas entre póleis siceliotas e Siracusa e 0 retorno dos atenienses ainda interessados em controlar a Sicília. Nessa segunda fase do conflito, Agrigento também esteve ao lado dos atenienses, chegando a bloquear a passagem de seu território às tropas aliadas aos siracusanos em 415 a.C. (Tucídides VII, 32.1) (Fischer-Hansen, Nielsen, Ampolo, 2004: 187). A guerra levou à derrota ateniense e hegemonia inconteste de Siracusa sobre a ilha (Dreher, 2008: 38-39). 0 final da expedição ateniense confirmou a proeminência de Siracusa, mas o conflito entre os gregos e os elímios - de Segesta e Siracusa, que levou a segunda guerra contra Atenas - trouxe Cartago à cena (Fischer-Bossert, 2012: 150). Apesar de serem datados logo após o fim da expedição ateniense à Sicília, o que os ligaria a esse evento, os decadracmas de Agrigento são relacionados ao ataque cartaginês que levou à destruição da cidade em 406 a.C. (Stazio, 1992: 226). Essa seria a datação mais recente: os decadracmas teriam sido emitidos logo após a destruição da cidade em 406 a.C. (Fischer-Bossert, 2012: 148). De acordo com a opinião tradicional, os 
decadracmas teriam tido um caráter celebrativo, atualmente, contudo, aceita-se que teriam sido emissões com função financiária (Stazio, 1992: 226). Novos tipos de imagens foram escolhidos especialmente para figurar nessa nova denominação. No anverso de ambos os decadracmas há a representação de duas águias em pé sobre a barriga de uma lebre, uma com as asas fechadas e a cabeça para cima e a outra com as asas abertas e cabeça para baixo. 0 reverso possui dois tipos de imagens - em um deles o tradicional caranguejo com a figura de um peixe ou de Sila embaixo no campo, e no outro exemplar a imagem de uma quadriga galopante (Fig.240 - n.203). Se o tipo de denominação escolhida (o decadracma) já não é usual, a imagem de duas águias em pé representa também uma nova concepção na representação dessa ave em moedas. A imagem da quadriga em moedas da Sicília foi uma criação de Siracusa para suas primeiras emissões de moedas no final do século VI a.C. e que se difundiu, juntamente à denominação do tetradracma, a outras póleis da ilha, tornando-se, dessa maneira, com certas variações na imagem, uma representação típica das moedas gregas da Sicília, principalmente aquelas do século V a.C. (Fischer-Bossert, 2012: 146; Kraay, 1976: 209). Mas foi somente no final do século $\mathrm{V}$ a.C. que Agrigento adotou o tipo em suas moedas - talvez sinal de uma maior abertura em relação à Siracusa nesse período (Stazio, 1992: 225).

Relacionada ao período de emissão dos decadradracmas, está a emissão de dióbolos de ouro de evidente exigência militar, que portam a imagem da águia em pé, que devora agora uma cobra, e do caranguejo (Fig.240 - n.199) (Stazio, 1992: 226-227). Para C. Kraay, essa pequena denominação em ouro, provavelmente, foi cunhada durante o final do cerco cartaginês a Agrigento (Kraay, 1976: 226). Já para Jenkins, essas moedas em ouro foram emitidas após a destruição da cidade para o pagamento de soldados mercenários (Jenkins, 1990: 104). Logo após a destruição da cidade em 406 a.C., Agrigento emitiu moedas com desenho sofisticado, algumas delas assinadas pelos artistas gravadores de cunhos (Fischer-Hansen, Nielsen, Ampolo, 2004: 189). São pequenas denominações em bronze, datadas em 406 a.C. e 400-380 a.C., estas últimas assinaladas à retomada da cidade no início do século IV a.C. Em uma emissão de antes de 406 a.C., o caranguejo figura no anverso e no reverso aparece pela primeira vez, na história da cunhagem de moedas em Agrigento, a cabeça da águia, sem uma presa (Fig.240 - n.210). Na emissão de 400-380 a.C., a imagem do caranguejo foi trocada por aquela da cabeça de um jovem, o deus rio Ácragas, e a águia volta a aparecer representada em pé, sem presa, sobre a coluna de um capitel jônico (Fig.240 - n.220). O caranguejo aparece no campo como símbolo (Westermark, 1979: 14).

Após essa introdução acerca do contexto histórico, das motivações político-sociais relacionadas às emissões dos tipos monetários em Agrigento, é possível discorrer sobre quais seriam os significados das imagens da águia requeridos por essa pólis ao usá-las em suas moedas durante um longo período.

Como vimos, as imagens da águia em pé e do caranguejo foram os tipos principais das emissões monetárias de Agrigento. Diversos autores ofereceram as mais diversas explicações a respeito do significado simbólico desses dois tipos para essa cidade. U. Westermark diz que o caranguejo é um tipo pouco comum em moedas gregas, ocorrendo apenas nas moedas de Terina, Consentia e dos Brettii na Itália do Sul. Mas o sema 
do caranguejo pode ser relacionado a ambientes de cultura ródia - ou em geral, micro-asiática - onde esteve presente, como notou Manganaro (1988) sobre algumas moedas da ilha de Kós a partir da época arcaica (Lo Monaco, 2008-2009: 9). Já na época de Westermark, a interpretação a respeito do significado do caranguejo estava em aberto - o crustáceo poderia ser um emblema de Poseidon ou, como propôs primeiro B.V. Head, um símbolo do rio epônimo Ácragas, já que se tratava de um caranguejo de espécie de água doce (Westermark, 1979: 8). N. K. Rutter, seguindo Head, propõe que o tipo do caranguejo seria "um símbolo de identidade da pólis, pois sinalizaria uma característica topográfica da cidade, o rio, em cujas margens Agrigento foi estabelecida. Para demonstrar a importância do rio para essa pólis, o estudioso chama a atenção para trechos das odes Píticas (VI. 6; XII, 2-3), de Píndaro, em que o poeta destaca, recorrentemente, a importância do rio para essa cidade, chamando-a de "rio", por exemplo" (Rutter, 2000: 74-75). "A prova de que o caranguejo remeteria ao rio epônimo da cidade seria o fato de que, nos poucos casos em que o caranguejo não aparece como tipo, ele é substituído pela cabeça do jovem deus rio Ácragas" (Rutter, 2000: 74). Outra interpretação totalmente diferente, que parece não ter encontrado seguidores, propõe que o caranguejo seria, na verdade, um tipo "falante" da cidade (Cazzaniga, 1972: 31). Cazzaniga vê, na característica do caranguejo como "aquele que caminha na ponta dos pés" (akrobatos), uma semelhança com a palavra akra-bás a qual teria gerado 0 nome akra-gás - no dialeto dórico da Sicília usava-se a letra gamma no lugar da letra beta (Cazzaniga, 1972: 28). Portanto, para esse autor, o emblema do caranguejo pode ser entendido, por ainigma, como akrois-gás "aquele que caminha na ponta dos pés", ou seja, o nome da própria cidade (Cazzaniga, 1972: 28). Cazzaniga lembra que naquele período, existia em Agrigento, a famosa escola de Empédocles, responsável por formular metáforas altamente imaginativas e misticamente simbólicas a partir da técnica de dizer por meio de ainigma (Cazzaniga, 1972: 29). Para Jenkins, seguindo a explicação mais aceita, "o caranguejo expressaria o elemento aquoso do rio ou do litoral e que, junto à imagem da águia, um símbolo celeste, comporia o significado de domínio da pólis em uma amplitude tão grande entre o céu e o mar" (Jenkins, 1990: 43 e 103).

Entre os autores, a imagem da águia nas moedas da cidade é unanimemente relacionada a Zeus (Florenzano, 1995: 227; Jenkins, 1990: 43; Stazio, 1992: 220). Além de relacioná-la como pássaro de Zeus, Jenkins ressalta na imagem da águia seu valor simbólico celeste, como senhora do ar (Jenkins, 1990: 43). Stazio já prefere associar a presença da imagem da águia, nas moedas de Agrigento, aos cultos locais de Zeus, no caso o de Zeus Atabyrios e o de Zeus Olímpio (Stazio, 1992: 220). De fato, já à época da primeira emissão de Agrigento na última década do século VI a.C., existia na cidade um culto antigo a Zeus Atabyrios, relatado por Políbio (IX.27.6), proveniente da metrópole Rodes e provavelmente relacionado ao período mais antigo da cidade. Embora o templo a Zeus Olímpio tenha começado a ser erigido poucas décadas depois da primeira emissão monetária (ao redor de 480 a.C.), é provável que a culto à divindade já ocorria anteriormente na cidade (Laky, 2013: 171). Vê-se, portanto, uma tradição em dedicar santuários a Zeus em Agrigento, que pode remontar ao século VI a.C., quando a pólis foi fundada - uma ligação especial dessa pólis com a divindade e que pode justificar o uso da águia em suas moedas, embora nem sempre a imagem da águia tenha sido usada 
em moedas de pólis que tenham dedicado o culto a Zeus em algum nível. Devemos destacar que a águia (o tipo da cabeça) começou a ser usada em moedas pela pólis de lalysos na ilha de Rodes na mesma época do início das emissões de Agrigento, o que pode indicar uma tradição rodésia, compartilhada entre metrópole e colônia, a esse respeito.

Todas as análises descritas acima são complementares e, de alguma forma, corretas. Analisemos, então, o uso da imagem da águia dentro de dois momentos específicos: um primeiro, quando foi adotada como tipo em pé sem presa e um segundo, quando passou a figurar acompanhada por tipos de presas. A águia em pé, de asas fechadas, cabeça para frente e sem presa foi o primeiro tipo da ave adotado por Agrigento já em sua primeira emissão na última década do século VI a.C. É dessa maneira que ela costuma aparecer sobre o cetro de Zeus em representações monetárias e vasculares. Por algum motivo, Agrigento começou a bater suas moedas somente no final do século VI e não em um período anterior como outras póleis da Sicília, Himera, Zancle e Naxos. Nessa época, Agrigento expandia-se territorialmente, conquistando ou reconquistando Heraclea Minoa e um pouco mais tarde Himera, adquirindo, então, o controle sobre a costa setentrional (La Torre, 2010: 84). Mesmo que não saibamos que forma de governo escolheu a imagem da águia para as moedas, acreditamos que deva ser sob essa perspectiva que devemos interpretar o significado dessa necessidade do uso da ave nas moedas da cidade e especificamente desse padrão de representação. Ora, vimos no capítulo anterior como a imagem da águia esteve relacionada para os antigos gregos à guerra (disputas) e à vitória e, como energia divina de Zeus, foi expressão de sua realeza, onipotência e soberania. Concluímos que a imagem da águia pode ter significado a intenção em repelir situações futuras ruins, em momentos incertos, em determinada conjuntura da pólis, quando vitória, guerra e competição foram importantes. Assim, nesse contexto histórico, acreditamos que a imagem da águia foi escolhida por expressar tais idéias, mas sobretudo a de querer impor, através da figura da ave, essa onipotência e soberania de Agrigento sobre as demais póleis de sua região na época que ganhava o aumento de seu território, adquiria 0 controle de uma vasta área após disputas com Selinonte e Himera nos séculos VI e V a.C. Lembremos que Agrigento, ao longo da história da Sicília arcaica e clássica, sempre foi uma força no sudoeste da ilha que buscou impor sua presença e seu domínio sobre as póleis de sua região, como se vê também na sua rivalidade com a outra grande força existente na costa oriental, Siracusa. Independente da forma de governo que a idealizou para as moedas da cidade, se em período democrático ou na época de Téron, observa-se que esse tirano não a substituiu por outro tipo de imagem ao longo de seu governo. Lembremos também da associação de Zeus a governos tirânicos em época arcaica e clássica (Laky, 2013).

Diferente da águia estática e portentosa, que caracterizou as emissões até 450 a.C., as representações em que a ave aparece com tipos de presas a partir de 425 a.C., se também em posição parada, curvada ou de cabeça erguida, são marcadas, em sua maioria, pela agressividade com que dominam a sua presa. Essas são emissões relacionáveis a um período em que Agrigento já havia perdido sua hegemonia para Siracusa (446 a.C.), passava pela invasão ateniense à Sicília e enfrentava a destruição cartaginesa de sua cidade - 
acontecimentos militares que levaram a uma mudança na paisagem política da Sicília no final do século V a.C. (Fischer-Bossert, 2012: 150). Percebe-se, assim, que o significado simbólico da águia com a presa, que evocava a necessidade de derrota sobre um inimigo e requeria uma sorte favorável na guerra, foi usada pela pólis justamente nessa conjuntura política - a mais ameaçadora de sua história. É interessante notar que é justamente nas emissões relacionadas à invasão cartaginesa que Agrigento usou as imagens mais agressivas das águias diante de suas presas - na representação de duas águias devorando uma lebre, nos decadracmas, e na da águia devorando a cobra, que aparece pela primeira vez nas pequenas denominações em bronze. Dessas imagens, a representação das duas águias é a que expressa maior agressividade perante a presa, a lebre. $O$ desenho é inovador, tem um alto nível de elaboração artística, foi criado para figurar em uma denominação importante, valiosa, não usual. Querer representar a força de duas águias, que dominam a sua presa, certamente deve ter tido a intenção de querer duplicar a energia, o significado conhecido da imagem de apenas uma águia com seu festim. Acreditamos que a representação evoque o momento militar conturbado e ao mesmo tempo indique o tipo de proteção requerido pela pólis naquele momento que, de acordo com as interpretações mais recentes, tenha sido a destruição da cidade em 406 a.C. É interessante notar que a águia voltou a ser representada em pé, sem qualquer presa, sobre a coluna de um capitel jônico, nas emissões que datam do início do século IV a.C., da subsequente retomada da cidade, de um outro momento político.

No anverso de um dos decadracmas, Agrigento usou pela primeira vez o tipo da quadriga galopante, cujos modelos siracusanos permitiram datar a emissão em 413 a.C. ${ }^{7}$ (Stazio, 1992: 225). A imagem da quadriga nas moedas é um símbolo aristocrático, que teve origem nos proprietários de terra e foi apropriado pelos tiranos. De antemão ela evoca as predileções culturais aristocráticas, dentre elas a corrida de carros em festivais panhelênicos. Trata-se, assim, da auto-representação desse grupo no poder da cidade (Fischer-Bossert, 2012: 146). Outra perspectiva, vê a representação das quadrigas, em moedas, como a necessidade de determinada pólis de evocar a sua ligação com o mundo agonístico de Olímpia (Manganaro, 2001: 8). No decadracma de Agrigento, a quadriga galopante é dirigida pelo deus Hélios, sobre ele há uma águia voando carregando uma cobra e, embaixo, no campo da moeda, há um caranguejo. Várias interpretações foram propostas para esse esquema iconográfico. Dentro da perspectiva de moeda comemorativa, para C. Kraay e I. Jenkins, essa imagem retrata e celebra a vitória olímpica do atleta agrigentino Exainetos um ano antes da emissão - evento celebrado em grande estilo em seu retorno à cidade, em uma procissão com quinhentos cavalos brancos. E para ambos os autores, a composição da águia, sobre a quadriga, e o caranguejo embaixo dela, simbolizariam o céu e 0 mar (Jenkins, 1990: 103-104; Kraay, 1976: 226). Para Stazio, que relaciona a emissão dos decadracmas às exigências de caráter bélico, a quadriga de Hélios parece ser uma alusão à divindade protetora de Rodes, metrópole de Agrigento. Acreditamos que a imagem da quadriga no decadracma pode tanto ter significado vitória política como atlética, como indicou R. Wittkower sobre esse tipo monetário em seu estudo sobre 0

\footnotetext{
${ }^{7}$ No catálogo numismático referente aos tipos monetários de águias mantivemos a data de C. Kraay (c.411 a.C.).
} 
simbolismo da águia com a serpente (Wittkower, 1939: 31). Nessa representação da quadriga, a águia não aparece como emblema, como no anverso das moedas de Agrigento, mas como elemento que compõe uma cena. Ao nosso ver, essa composição da águia com a quadriga, ressoa naqueles esquemas iconográficos dos cavaleiros dos vasos áticos do século VI a.C. A águia com a serpente, voando sobre o carro de cavalos e seu cavaleiro, no caso Hélios, não significaria meramente um aspecto celeste como vem sendo afirmado, mas um presságio favorável, de vitória, àquele que disputa na competição ou na guerra - tendo como parâmetro interpretativo o significado desse tipo de representação na llíada e na cerâmica pintada. Nesse sentido, ao associarmos o tipo de imagem do anverso e do reverso do decadracma podemos descobrir um significado simbólico e uma mensagem totalmente relacionados à guerra e à sua necessidade de vitória. Mas como guerra e competição eram imbricados na cultura grega, não se pode também descartar o significado de vitória e disputa atléticas.

O caranguejo, representado embaixo no campo, sob a quadriga, não seria um símbolo do mar, mas um elemento sinalizador da identidade da pólis de Agrigento ou do cavaleiro, naquela composição da quadriga. Ao analisarmos o significado simbólico da águia e do caranguejo nas emissões monetárias de Agrigento vê-se que ambos possuem significados complementares. O caranguejo significou, de fato, a identidade da pólis, em todas as suas interpretações. Tanto é assim que foi o caranguejo o tipo escolhido para figurar nas moedas de Himera durante o período de dominação de Agrigento sobre essa pólis. 0 caranguejo era um símbolo específico, pouco recorrente em cunhagens e fortemente identificado com as moedas de Agrigento e a sua identidade, seja ela relacionada ao seu nome ou ao seu rio. Já a representação da águia esteve vinculada ao universo simbólico do poder, no caso de Agrigento, de uma soberania territorial e da vitória militar. Nesse caso, a representação da águia com a presa pode não ter tido apenas uma função talismânica - de atrair o melhor mas também uma função apotropaica. Apesar de a águia, no contexto de Agrigento, poder ser considerada a auto-representação da cidade, quando a ave é mostrada dominando a sua presa também poderia ter tido qualquer função apotropaica - querer repelir, afastar, aquele tipo de situação da pólis, naquele contexto bélico. Contudo, não podemos desvincular de Zeus o significado simbólico da águia. Essa soberania territorial e 0 sucesso na guerra, na concepção religiosa dos antigos gregos, vinham de Zeus, como vimos, uma divindade diretamente relacionada à guerra e ao poder. A representação da águia nas moedas, nesse contexto, requeria a energia divina dessa divindade sobre a pólis, a sua proteção e mediação sobre esses aspectos, os quais foram os mais importantes dentro das características e demandas específicas de Agrigento como comunidade política nos séculos VI e V a.C.

\section{I.2.2 Aetna}

Em Aetna, no outro lado da Sicília, na costa oriental, a imagem de Zeus veio a ser usada pela primeira vez em moedas da ilha. Em c. 485 a.C., Siracusa, a cidade mais poderosa da Sicília naquela época, caiu nas 
mãos de Gélon, o tirano de Gela, e dentro de poucos anos seu poder se estendeu sobre a maior parte da ilha. Gélon, cujo reino ficou conhecido como uma "idade do ouro", foi sucedido após sua morte em 478 a.C. pelo seu irmão Hieron, que continuou a manter a hegemonia da família sobre Siracusa e a maior parte da Sicília (Callatäy; Gliter, 2004: 9). Hieron, notório por seus modos suspeitos e despóticos, não gozou da mesma popularidade de seu irmão. Poucos anos após a sua ascensão ao poder, em 476/75 a.C., Hieron decidiu transferir a capital de Siracusa para Catânia, possivelmente temendo a população siracusana hostil ao seu governo. Primeiramente, ele removeu a população de Catânia e Naxos para Leontino e, somente após expulsar a população de Catânia, Hieron reassentou na cidade um contigente formado pela combinação de 5.000 siracusanos leais ao seu governo e 5.000 do Peloponeso, nomeando a nova capital de Aetna (Callatäy; Gliter, 2004: 9; Fischer-Hansen, Nielsen, Ampolo, 2004: 184; Kraay, 1976: 212). A fundação de Aetna foi resultado de um processo de remoção de populações locais (metoikismos) para o estabelecimento de uma nova fundação, reforçar uma já existente ou ainda fazer um posto de mercenários em um lugar estratégico - característica do governo dos tiranos na Sicilia (Kraay, 1976: 212). Embora Hieron tenha sido o oikistes de Aetna, seu filho Deinomenes foi o basileus da cidade. Enquanto Deinomenes esperava atingir a idade madura, a cidade teve um epitropos na pessoa de Chromios, cunhado de Hieron e tio de Deinomenes, que desempenhava o papel de seu tutor (Caccamo Caltabiano, 2009: 101; Fischer-Hansen, Nielsen, Ampolo, 2004: 184).

Dessa nova fundação, chamada na literatura numismática de Aetna-Catânia, resultaram a emissão de um tetradracma e outra de um dracma, ambos atribuídos a c.475-470 a.C. (Kraay, 1976: 212; Callatäy, Gliter, 2004: 28). O tetradracma traz no anverso a imagem de Atena com um elmo arcaizante, dirigindo uma quadriga e sendo coroada por uma Nike alada. Paralelos a essa cena são encontrados em tetradracmas de Siracusa e Leontino datados da década de 480 a.C., embora o tipo de Aetna difira dos demais por ser Atena quem dirige a quadriga e não uma figura masculina. O reverso do tetradracma, então, retrata Zeus sentado no trono, coberto por uma pele de leão, segurando um raio com a mão direita e o cetro com uma águia no topo e o pé do deus repousa sobre um descanso (Fig.240 - n.08) (Callatäy, Gliter, 2004: 28-29). Essa moeda foi batida sobre uma emissão mais antiga, mas o tipo por baixo é irreconhecível (Callatäy, Gliter, 2004: 28). 0 dracma, por outro lado, traz no anverso a figura de um cavaleiro nu dentro de um círculo de pérolas. Esse motivo tem paralelo nas moedas de Siracusa e Leontino datadas do primeiro quartel do século $V$ a.C. O reverso também retrata Zeus sentado no trono, sem a pele de leão, mas o esquema iconográfico, com o cetro e o raio, é o mesmo (Fig.240 - n.09) (Callatäy, Gliter, 2004: 29). Esses dois tipos monetários estão entre os mais antigos, ao lado das moedas da Liga Arcádia, do padrão de representação de Zeus sentado no trono em moedas gregas.

Cinco anos após a morte de Hieron, em 461 a.C., a população de siracusanos e peloponésios, realocada pelo tirano, foi expulsa de Aetna-Catânia após um longo período de luta contra Siracusa e os sículos liderados por Ducézio. A população originária de Catânia retornou para sua cidade, seguindo-se uma nova conformação geopolítica (Fischer-Hansen, Nielsen, Ampolo, 2004: 184). O povo de Aetna, por sua vez, retirouse para Inessa, um sítio sículo no interior, nas proximidades do Monte Etna, refundando ali a sua comunidade, 
proclamando Hieron o oikistes e preservando o nome de Aetna (Fischer-Hansen, Nielsen, Ampolo, 2004: 185). Na causa da expulsão do povo de Aetna de Catânia esteve também um problema de disputa territorial. No ato da fundação como pólis em 476 a.C., Aetna recebeu um território muito vasto, o qual tocava a khóra de Leontino e a da sícula Inessa (Manganaro, 1974-1975: 10). Ao redor de 461 a.C., então, vinha ascendendo ao poder 0 líder sículo Ducézio que, apoiado pelos leontinos interessados na retomada de suas terras, conseguiu uma vitória sobre Aetna e a subsequente expulsão de seu povo (Manganaro, 1974-1975: 28). Certamente, o povo de Aetna, nos anos sucessivos ao metoikismos de Inessa, lutaram contra a oposição das póleis calcídias reconstituídas (Catânia, Naxos, Leotino) e especialmente Ducézio (Manganaro, 1974-1975: 34). Uma década depois, ao redor de 452/451 a.C., Ducézio, no progressivo alargamento de sua esfera de influência, ocupou Aetna-Inessa, eliminando o seu tirano (Fischer-Hansen, Nielsen, Ampolo, 2004: 185; Manganaro, 1974-1975: 16-18, 34). Ducézio havia conseguido por uma década realizar uma coalização dos grupos de sículos, já helenizados, do seu território, dentro daquele de Leontino, organizando um domínio de tipo tirânico. Em c.450 a.C., Siracusa conseguiu neutralizá-lo e enviá-lo para o exílio em Corinto. Finalmente, a partir dessa época período de eudaimonia das cidades gregas na Sicília -, Aetna-Inessa pôde realizar um tipo de comunidade econômico-política com Naxos e com Catânia, em relação ao porto dessas últimas, para conduzir/escoar a sua produção (Manganaro, 1996: 306).

Do período de ocupação de Inessa data outro tetradracma atribuído ao povo de Aetna, conforme indica a legenda nele inscrita. As características mais inovadoras do estilo do início do período clássico nesse tetradracma (dito de Bruxelas), as quais diferem do estilo das moedas anteriormente mencionadas, o dataram ao redor de 465-460 a.C., sendo por essa razão que os especialistas o atribuíram ao período de Aetna-Inessa (Callatäy, Gliter, 2004: 29-30; Fischer-Hansen, Nielsen, Ampolo, 2004: 185; Kraay, 1976: 213; Manganaro, 1974-1975:19). Outro fator para datá-lo no segundo estágio de existência da cidade é a similaridade estilística com os tipos gravados no tetradracma de Naxos datado de 461 a.C. A similaridade é tão marcante que ambas as moedas têm sido atribuídas ao mesmo artista, conhecido como o "mestre de Aetna" (Callatäy; Gliter, 2004: 33). No anverso do tetradracma de Aetna-Inessa, dentro de um círculo de pérolas, está retratada a cabeça de Sileno usando uma coroa de folhas de hera e abaixo, no campo, o desenho de um besouro. A inscrição do étnico acompanha a representação. Já no reverso, aparece a imagem de Zeus sentado no trono, sobre uma pele de pantera, segurando um raio alado com a mão esquerda e, a direita, um galho de parreira. A águia é retratada repousando sobre uma conífera (Fig.240 - n.16) (Callatäy; Gliter, 2004: 15-18).

Cronologicamente e iconograficamente relacionado ao tetradracma, é um grupo de litras de prata, cujo anverso traz a cabeça de Sileno e, o reverso, o raio alado (Fig.240 - n.274). A similaridade estilística entre a cabeça de Sileno, no tetradracma e nas litras, sugere que o tipo foi produzido pelo mesmo artista. Uma ligação adicional entre as duas denominações está no uso do raio alado, que também aparece no reverso do tetradracma, na mão de Zeus (Callatäy; Gliter, 2004: 30; Kraay, 1976: 213; Manganaro, 1996: 308). Inteiramente diferente dessas emissões mencionadas de Aetna, é um tipo de fração de prata, de óbolos ou litras, também 
batido no nome do povo de Aetna. $O$ anverso traz a imagem de uma espécie de camarão dentro de um círculo de pérolas, já o reverso mostra uma roda com quatro compartimentos, tendo, em cada qual, uma letra da legenda do étnico. Como não há paralelos para o tipo monetário, a emissão foi datada entre 475-460 a.C. (Callatäy; Gliter, 2004: 31).

Assim, para resumir a tipologia presente nas moedas de Aetna, o padrão de Zeus sentado no trono foi o tipo principal para o reverso do tetradracma e do dracma na primeira e do tetradracma na segunda fase de emissões monetárias (Aetna-Catânia e Aetna-Inessa). O tipo é substituído pelo raio alado no reverso dos óbolos batidos na segunda fase (Aetna-Inessa). As imagens do anverso são mais variadas: na primeira fase foram usados o tema da quadriga e do cavaleiro e, na segunda, os temas mudam completamente, são trocados pela cabeça de Sileno presente tanto nos tetradracmas como nos óbolos. O tipo da quadriga, usado no primeiro tetradracma de Aetna, costuma ser estilisticamente associado aos tipos criados para as moedas de Siracusa, havendo algumas similaridades entre os desenhos que ajudaram a datar a moeda de Aetna (Rutter, 1997: 128129). No entanto, o tipo da quadriga, que nos tetradracmas de Siracusa aparece dirigida por uma figura masculina, no de Aetna é substituída pela figura de Atena (Caccamo Caltabiano, 2009: 101). A presença de Atena, nessa composição, tem sido interpretada de maneiras muito diferentes. G. Manganaro relaciona o uso da imagem de Atena, no tetradracma de Aetna, ao mundo religioso da Arcádia e da Messênia, de onde teriam vindo parte do contingente de população peloponésia que se assentou, juntamente aos siracusanos, em AetnaCatânia (Manganaro, 1974-1975: 39). Para M. C. Caccamo Caltabiano, "a imagem de Atena, protetora dos heróis e representada em seu aspecto guerreiro, como sugere o elmo, teria sido usada para substituir a figura masculina, do modelo de quadriga siracusano, porque Deinomenes não poderia ser representado na figura do auriga, como ocorre, em sua acepção, nos tetradracmas de Siracusa". Nestes, para Caccamo Caltabiano, a figura masculina representaria Hieron e, como em Aetna, Deinomenes não podia governar, em razão da idade, não haveria razão para representa-lo como líder que "segura as rédeas do Estado" (Caccamo Caltabiano, 2009: 101). De todo modo, vimos anteriormente como o tipo da quadriga expressou um valor aristocrático, relacionado também à esfera agonística, cuja figura do auriga pôde tanto ter simbolizado aquela do governante, ou do governo da cidade já que foi usada em períodos democráticos, ou ainda do atleta vencedor, na modalidade, em algum dos prestigiosos jogos realizados na Grécia Balcânica. Essa interpretação de Caccamo Caltabiano nos leva também ao tipo do anverso do dracma de Aetna, datado igualmente do período de Aetna-Catânia. Trata-se da imagem de um jovem cavaleiro nu montado sobre seu cavalo, segurando as rédeas, cuja autora 0 relacionou à figura do jovem Deinomenes, caracterizável pelo desenho dos membros pequenos, cabelos compridos caídos em cada lado da face do cavaleiro (Caccamo Caltabiano, 2009: 101). Se imagem do próprio Deinomenes ou não, como a quadriga, a figura do cavaleiro também possui conhecidas conotações aristocráticas.

Esses seriam os significados prováveis dos dois tipos que acompanham aquele de Zeus sentado no trono nos reversos do tetradracma e do dracma de Aetna-Catânia. Como descrito anteriormente, o deus é 
retratado sentado em seu trono, segurando o raio com a mão direita e o cetro com a esquerda, onde a águia está representada pousada sobre ele. A única diferença, entre o tipo do tetradracma e do dracma, é a pele de leão sobre o trono, ausente no dracma. Muitas interpretações tentaram explicar o uso da imagem de Zeus e 0 seu esquema iconográfico nas moedas de Aetna. Uma delas procura ver uma influência de xenoi arcádios entre os peloponésios assentados por Hieron em Aetna. Para Manganaro, "o modelo iconográfico de Zeus sentado no trono em moedas era típico das emissões da Liga Arcádia naquela época" (Manganaro, 1974-1975: 37; 1975: 54). Outras interpretações preferem aceitar a existência de um culto a Zeus no Monte Etna e em Aetna. Para Callatäy e Gliter, concordando com a tese de Adolf Holm do final do século XIX, "a representação de Zeus, em ambas as moedas, seria uma alusão a Zeus Aetnaios, deus patrono da montanha e da cidade, e a uma estátua de culto existente em alguma área sagrada da divindade no alto do monte" (Calltäy; Gliter, 2004: 21; Morgan, 2015: 67). Tal estátua estaria de algum modo indicada pela descrição de Píndaro (Pit. I) sobre a águia que repousa sobre o cetro de Zeus, tal como aparece na imagem do tetradracma e do dracma de Aetna (Morgan, 2015: 67; Rutter, 1997: 128). Mas mesmo assim essa não pode ser considerada uma evidência claramente relacionável à suposta estátua de culto. Ao que parece, não há indicações diretas sobre essa estátua nos testemunhos literários. K.A. Morgan, citando Boehringer, diz que a estátua seria sugerida por bases de blocos, sob os dois pés do trono, e pelo encosto para os pés do deus, não usuais em representações monetárias (Morgan, 2015: 67, nota 133). Já outra linha, prefere associar o tipo de Zeus com a pintura produzida em vasos (Morgan, 2015: 67, nota 133).

Se por um lado não dispomos de informações sobre a tal estátua, ou a sua suposta área sagrada, por outro, Píndaro nos fornece algumas indicações sobre a existência de um culto a Zeus dito Aetnaios. Um escólio de Píndaro (OI.VI,162a) diz que havia, em Aetna, um festival a Zeus Aetnaios chamado Aetnaia, no qual se realizavam jogos provavelmente em homenagem ao seu fundador, Hieron (Morgan, 2015: 58). Zeus do Etna é assim nomeado por Píndaro (Ol. VI, 97) e, como essa ode homenageia Hagésias de Siracusa pela vitória em Olímpia em 468 a.C., foi proposto que o culto a Zeus Aetnaios teria sido acolhido também por essa pólis (Manganaro, 1974-1975: 20). A mesma denominação de Zeus aparece em outra ode (Nem. I, 7), agora dedicada a Chromios, tutor de Deinomenes, pela vitória na corrida de cavalos nos jogos nemeanos. Essas pequenas informações dos textos nos dão ao menos a indicação de que o monte Etna foi associado a Zeus naquele momento. De acordo com N. Luraghi, "trata-se de um culto não atestado antes do início do século $\mathrm{V}$ a.C. e que aparece com insistência nas odes dedicadas a Hieron e sua família - a sua instituição é, de algum modo, relacionada a esse tirano" (Luraghi, 1994: 339). O estudioso precisa que Zeus Aetnaios não havia ganho esse nome da cidade de Aetna, mas do monte. Para Luraghi, "o culto teria se originado da grande erupção do Etna ao redor de 476/75 a.C., a qual trouxe muita destruição ao território de Catânia - o culto, com evidentes implicações apotropaicas, pode ter sido instituído logo após a erupção e antes da fundação de Aetna naquela área" (Luraghi, 1994: 340). 
Nessa direção, K.A. Morgan nos mostra como a chave para entender a relação de Zeus com o Etna está na ode Pítica I de Píndaro, composta em 470 a.C., que celebra a vitória de Hieron, vencedor na corrida de carros em Delfos. A ode é também considerada um hino de coroação para a cerimônia na qual o filho de Hieron, Deinomenes, foi empossado como o basileus de Aetna (Rutter, 1997: 128). De acordo com a autora, "Píndaro transformou os elementos confusos, presentes na batalha de Zeus contra Tifeu, do texto hesiódico, em sua própria visão da batalha dos elementos da natureza durante a erupção do Etna - rios de fumaça ardente, rochas incandescentes rolando até o mar -, cujo acontecimento ocorreu durante o reino de Hieron, antes da fundação de Aetna em Catânia" (Morgan, 2015: 320). Através da erupção, "Píndaro reencenou a derrota do monstro Tifeu por Zeus, fazendo lembrar da vitória do deus e que o monstro continuava vivo, ainda lutando" (Morgan, 2015: 320). É nessa perspectiva que Morgan vê a mensagem que Píndaro, ao longo da Pítica I, tentou transmitir, ao associar as tormentas de Tifeu, no Tártaro, com a paisagem de Hieron. "As forças de Tifeu teriam afetado 0 reino de Hieron de duas maneiras - a erupção do vulcão ameaçou o assentamento e afetou a paisagem da cidade que iria fundar, e os bárbaros de leste que atacaram as forças de Hieron, que desejava vencer em Cumas" (Morgan, 2015: 320). Assim, Tifeu, os fenícios, os etruscos estavam todos alinhados como inimigos opostos a Zeus e a seu regente terreno Hieron (Morgan, 2015: 314).

Presumivelmente, continua Morgan, dada a sua vitória contra Tifeu, Zeus governa o Monte Etna, que é descrito como o canto de frutífera terra (Pit.l, 30). A partir desse trecho, ao invés da justaposição da neve e da assustadora erupção, a ênfase passa ser a fertilidade da terra, passando-se, então, do cume em direção à terra habitável. Essa, é resultado de sua natureza vulcânica e, mais uma vez, se vê como a derrota do monstro funcionou para o maior dos deuses: se alguém agrada a Zeus, o resultado é fertilidade e fecundação da cidade. Zeus não apenas preside sobre a montanha, mas Zeus Aetnaios foi o deus patrono da nova cidade de Aetna (Morgan, 2015: 321). Assim, na interpretação contextualizada de Morgan, da ode Pítica de Píndaro, "o triunfo de Zeus sobre Tifeu é um triunfo sobre o caos e marca o estabelecimento da ordem de Zeus - sendo assim também a fundação de Aetna a instalação de uma nova ordem divina" (Morgan, 2015: 316).

Essa interpretação final de Morgan alinha-se à nossa conclusão sobre o significado simbólico contido na imagem monetária de Zeus sentado no trono usada nos reversos do dracma e do tetradracma de AetnaCatânia. Essas duas emissões foram produzidas como resultado de um deslocamento populacional, da fundação de uma nova cidade e da reunião de gregos - ainda que todos dórios - de várias origens. As emissões devem ainda ser relacionadas ao triunfo de Hieron na fundação de Aetna e à consagração de Deinomenes como basileus da cidade. É nesse contexto que a imagem de Zeus foi usada pela primeira vez em Aetna e também na Sicília. Assim, nesse caso, acreditamos que nesse momento político de Aetna-Catânia, o uso da imagem de Zeus sentado no trono nas moedas não teve apenas a mera finalidade de representar a divindade local, Zeus Aetnaios, nas moedas. Acreditamos que, muito além disso, o uso dessa imagem esteve na necessidade de requisitar para a cidade, e por extensão para o grupo em seu poder, a proteção daquela energia divina contida na representação de Zeus sentado no trono, segurando sua arma, o raio, e o cetro com a águia, 
sua mensageira. $\mathrm{Na}$ análise do contexto do significado simbólico realizada no capítulo anterior, vimos com a representação de Zeus sentado no trono expressou, para os gregos antigos, ideias de realeza, soberania, governo, controle, vigilância e decisão de Zeus sobre a vida dos homens e como a presença do raio e da águia com o deus, afirma e reforça esses poderes do deus. Vimos nas fontes literárias, como sentado no trono do alto do Olimpo, Zeus podia observar e receber as súplicas humanas e determinar o destino humano. Em termos de comunidade política, concluímos que o uso desse tipo de representação do deus, em moedas, teria funcionado como um tipo de pedido de controle de Zeus sobre a pólis, importante em algum momento político específico. Teria funcionado também como um pedido de proteção pela manutenção da ordem ou sobre a desordem e sua ameaça - no enfrentamento de algum tipo de inimigo, uma situação de instabilidade política, etc. Nesse sentido, a imagem de Zeus sentado no trono, batida no nome do povo de Aetna, teria significado, para essa comunidade política, a necessidade do estabelecimento da ordem de Zeus, como propôs Morgan, e, a nosso ver, a necessidade da manutenção da ordem sobre o caos - a desordem necessária para a fundação dessa cidade na área antes devastada pela erupção do vulcão, o deslocamento populacional e a reunião de gente de diversas origens que precisava coexistir como comunidade, como pólis. Nesse sentido, se aplica a interpretação de Luraghi sobre a função apotropaica do culto: Zeus do Aetna teria sido evocado para apaziguar esse momento de instabilidade e porque não para proteger a nova comunidade de outras novas erupções destruidoras do vulcão, já que o deus exercia o domínio sobre o monte. Se Zeus sentado no trono do alto do Olimpo controla e define o destino humano, do alto do Etna, também seu domínio, ele poderia exercer o mesmo tipo de poder, propício a Aetna e ao mesmo tempo aos Deinomênidas.

Ao juntarmos esse significado simbólico da imagem de Zeus Aetnaios, nas duas denominações, com a imagem da quadriga dirigida por Atena, no anverso do tetradracma, e do cavaleiro, no dracma, encontrar-seá uma mensagem de afirmação política do grupo no poder da cidade e da cidade como comunidade. Lembremos das implicações políticas e territoriais da fundação de Aetna. De acordo com Luraghi, "a fundação teria garantido um controle mais seguro das margens setentrionais dos domínios dos Deinomênidas na Sicília e, ao mesmo tempo, ter sido um posto permanente de um grupo seguro de fiéis apoiadores de Hieron e sua família"'” (Luraghi, 1994: 337). Além da função apotropaica vista na representação do deus mais importante, especificamente para aquela área da Sicília ao menos até a primeira metade do século $V$ a.C., devemos lembrar da afinidade dos tiranos com o poder de Zeus, requisitado por esse grupo político, quando no poder em vários períodos e regiões do mundo grego. Por essa razão, Zeus Aetnaios deve ter sido requisitado como um tipo de divindade protetora dos Deinomênidas nesse contexto de expansão territorial a partir da fundação de Aetna. Nesse sentido, diante das interpretações já propostas e vistas anteriormente sobre as imagens da quadriga e do cavaleiro, acreditamos que a proposição de K.A. Morgan esteja correta, acerca da associação desses dois tipos de representações com a de Zeus Aetnaios sentado no trono. Para essa autora, moeda e poema (nesse caso, a ode Pítica I) funcionaram juntos em um programa único de celebração com uma imagética determinada - a quadriga de Siracusa, a vitória de Hieron nessa modalidade, a proteção divina de Atena e Zeus em favor 
do tirano (Morgan, 2015: 67). Essa autora, assim, entende as moedas de Aetna, ao lado da ode de Píndaro, como símbolos permanentes de vitória dos Deinomênidas (Morgan, 2015: 67-68). Assim, devemos ver 0 significado simbólico dessas imagens monetárias de Zeus em seus vários níveis - não apenas como significativa a comunidade política de Aetna, mas, em termos mais amplos, aos seus governantes.

O tipo monetário de Zeus sentado no trono continuou a ser usado nas moedas de Aetna em um segundo momento político dessa cidade. Como vimos, entre 465-460 a.C., já na fase de Aetna-Inessa, foram emitidos o tetradracma, cujo anverso traz a cabeça de Sileno e o reverso a imagem de Zeus sentado no trono, e as litras com a representação do mesmo tipo da cabeça de Sileno, no anverso, e o raio alado, no reverso. Com relação ao uso da imagem de Sileno, este era conhecido como o mais antigo dos sátiros, filho de Hermes ou Pã e companheiro ou tutor de Dioniso (Callatäy; Gliter, 2004: 18). Considerando os vinhedos que cercam 0 Etna, não é uma surpresa encontrar a imagem de uma figura associada a Dioniso em uma moeda da região (Callatäy; Gliter, 2004: 18-19). Há uma tradição que associa Sileno com o mais velho servo do ciclope Polifemo, que vivia em uma grande caverna no Etna (Eurípides, Os Ciclopes, v.408), explicando o uso de sua imagem no anverso do tetradracma. Deve ser também notado que os Ciclopes são algumas vezes descritos como os forjadores das armas e do raio de Zeus, talvez estabelecendo aí uma ligação adicional entre o anverso e 0 reverso da moeda (Callatäy; Gliter, 2004: 19). A relação simbólica da imagem de Sileno com Dioniso é reconhecida por todos os autores que estudaram o tetradracma de Bruxelas (Callatäy; Gliter, 2004: 18-19; Caccamo Caltabiano, 2009: 104). Caccamo Caltabiano é a única autora que propõe uma interpretação da imagem monetária de Sileno em relação a Deinomenes e Chromios. Na sua leitura do tipo, ela associa o papel de Chromios, como tutor de Deinomenes, com aquele de Sileno e o jovem Dioniso (Caccamo Caltabiano, 2009: 104). O besouro ou escaravelho, que aparece embaixo no campo - uma espécie da Sicília e do norte da África aparentemente usada como símbolo de contra-marca da emissão -, comprovaria a sua tese (Callatäy; Gliter, 2004: 19-20; Caccamo Caltabiano, 2009: 109). O besouro estaria associado à várias simbologias relacionadas a Dioniso em moedas do século V a.C. de Abdera, na Trácia, e seria sinal de uma função iniciatória (Caccamo Caltabiano, 2009: 104). Caccamo Caltabiano explica o uso do escaravelho como símbolo no tetradracma a partir do contato da Sicília com o Egito naquela época (Caccamo Caltabiano, 2009: 105). Já na perspectiva de J. Bayet, em contraste, "a imagem de Sileno no tetradracma de Aetna teria representado todas as forças brutas do Etna" (Bayet, 1959: 94).

Assim, para a denominação maior, o tetradracma, o padrão de representação de Zeus sentado no trono, no reverso, foi mantido, embora a imagem tenha sofrido algumas modificações substanciais - 0 deus segura o raio (alado) com a mão esquerda, com o braço direito ele se apoia numa parreira, a pele sobre o trono passa a ser a de uma pantera, e a águia é retratada não mais sobre o cetro segurado por Zeus, mas sobre uma conífera. A inscrição do étnico passa a figurar no anverso, junto à imagem de Sileno. Trata-se de uma nova simbologia escolhida pela autoridade emissora, acrescentada ao significado visto a respeito da imagem de Zeus sentado no trono, a qual alude às características do território de Aetna na área do vulcão. Tanto a pele de 
pantera, quanto o ramo de videira remetem a Dioniso, sendo por isso interpretadas como alusões aos vinhedos ricos dos arredores do Etna (Callatäy; Gliter, 2004: 22). A área do Etna já era conhecida na antiguidade pela produção do bom vinho, devido à fertilidade de sua terra vulcânica (Callatäy; Gliter, 2004: 19). Esse significado relacionado à produção de vinho e a Dioniso liga-se, então, aquele da imagem de Sileno no anverso (Callatäy; Gliter, 2004: 22). Já a árvore conífera, sobre a qual a águia está repousando, foi interpretada como a espécie Abies nebrodensis, único abeto próprio da Sicília e que encobria as encostas do Monte Etna. A colocação da águia sobre 0 abeto, uma composição totalmente nova na imagética da águia e de Zeus nas moedas e na arte em geral, foi interpretada como tendo a seguinte mensagem: "Zeus está nesse lugar" (Callatäy; Gliter, 2004: 24). Para F. de Callatäy e H. Gliter, "a águia, retratada na posição de um pássaro de rapina, parece significar a olhar do deus, que ela própria representa, sobre o mundo existente abaixo do cume da montanha" (Callatäy; Gliter, 2004: 23-24).

A continuidade do uso da imagem de Zeus no reverso - divindade tradicional para essa comunidade mostra a necessidade em requerer a proteção do deus sobre tudo o que era importante à existência daquela comunidade enquanto tal, as quais lhe identificavam, sua economia e sua paisagem, por exemplo. $A$ área de Aetna caracterizava-se pela instabilidade do Etna, cuja nova erupção, sempre aguardada, poderia arriscar a produção agrícola (a viticultura) e também impor, pela destruição, uma nova paisagem àquela população. Tratase, assim, de uma região onde a vida era instável, poderia mudar de acordo com a manifestação, a intensidade da erupção do vulcão. Como vimos, Zeus exercia domínio sobre o Etna e era o propiciador da fertilidade das planícies, onde os gregos cultivavam suas uvas. Nesse sentido, a representação de Zeus sentado no trono na moeda, associado a tantos elementos simbólicos que remetem às características locais, como a viticultura, muito provavelmente, pode ter tido a função de equilibrar as energias desfavoráveis à Aetna e à sua sobrevivência, as quais estavam fora do controle dos homens, sobre as quais apenas Zeus tinha o poder de apaziguá-las, de manter ou restaurar a ordem sobre o caos - seja ele a erupção incerta do Etna ou uma situação política específica como o novo metoikismos de Aetna em Inessa, provocado pela expulsão de sua população de Catânia.

A interpretação que associa o uso da imagem de Sileno em Aetna são válidas. Contudo, se considerarmos a interpretação de Bayet, a imagem de Sileno, no anverso, completaria o significado simbólico do tipo de Zeus no reverso do tetradracma dito de Bruxelas. A imagem de Sileno pode ter funcionado como um tipo apotropaico. Como representação das energias brutas do Etna, a imagem desse sátiro pode ter tido, ao mesmo tempo, a função de repeli-las, de neutralizá-las, de modo que as forças desgovernáveis do vulcão não recaíssem sobre a comunidade que retratou Sileno em suas moedas. A imagem de Sileno também foi usada no anverso das litras de prata nas quais o raio alado de Zeus aparece no reverso. Utilizado pela primeira vez na Sicília nas moedas da fase de Aetna-Inessa, a representação do raio possui um significado simbólico que se alinha com o momento político de Aetna e com as energias divinas representadas na figura de Sileno no anverso das litras. $O$ raio, como arma de Zeus, nos textos antigos, é inúmeras vezes comparado ao fogo, uma 
característica que poderia relacioná-lo às forças naturais destrutivas do próprio Etna. Na narrativa hesiódica, 0 raio teria sido forjado pelos Ciclopes, os quais, como vimos em uma tradição conservada em Eurípides, teriam vivido em uma caverna no Etna, onde Sileno seria servo de Polifemo. Nesse sentido, o uso da imagem do raio complementaria o significado daquela de Sileno, no anverso, que remete diretamente às energias do vulcão.

Mas o significado do raio, cuja presença nessas litras costuma ser meramente interpretada como um símbolo de Zeus Aetnaios, relacionava-se também à guerra e ao universo simbólico a ela vinculado. Como vimos na análise contextual realizada no capítulo 3, nos textos antigos, o raio era a arma de soberania de Zeus, letal e de destruição radical, usada por ele para punir e aniquilar seus adversários cósmicos - foi o raio que assegurou a vitória de Zeus sobre o caos, representado pelos Titãs e Tifeu. Assim, explica-se o uso do raio como imagem monetária nessa nova situação de instabilidade política de Aetna, de ameaça e de subsequente perda de seu território e de sua cidade em Catânia. Escolher representar o raio nas moedas naquele momento, significou, para Aetna, requerer essa energia divina de Zeus, de vitória sobre o caos, de uma nova ordenação, que pode ser entendida como a continuidade dessa pólis como comunidade política, embora em outro lugar. Essa nossa interpretação é complementária àquela do reverso do tetradracma de prata. Os novos elementos presentes no padrão iconográfico de Zeus sentado no trono, cujo modelo foi usado pela primeira vez na fase de Aetna-Catânia, foram acrescentados, a nosso ver, para reforçar os aspectos identitários importantes para a comunidade de Aetna-Inessa naquele momento de expulsão de sua cidade por Ducézio e os leontinos e, consequentemente, de um novo deslocamento populacional e de sua nova fundação na sícula Inessa. Ao bater esse tipo monetário no nome do povo de Aetna, a comunidade procurou, assim, auto afirmar sua identidade após se assentar em uma nova cidade, e auto afirmar-se diante das demais comunidades políticas da costa oriental da Sicília, principalmente as póleis calcídias, fortalecidas após o retorno de suas populações. Como bem colocou G. Manganaro, "essas emissões representaram um modo legítimo de afirmar, diante de outras comunidades gregas na Sicília, a sobrevivência política após o metoikismos" (Manganaro, 2001: 14).

Essa é a interpretação que propomos para os tipos do tetradracma de Bruxelas e das litras, emitidos nessa segunda fase da pólis de Aetna. Nessa nova fase da cidade (Aetna-Inessa), a nosso ver, os tipos monetários estariam mais alinhados com significados simbólicos importantes para Aetna enquanto comunidade política, embora não possamos descartar a permanência de uma simbologia relacionada aos Deinomênidas, como por exemplo mostra a manutenção do uso da imagem de Zeus Aetnaios sentado no trono - divindade ao menos inicialmente diretamente relacionada a esse grupo no poder. Como lembra Caccamo Caltabiano, "0 tetradracma com o Sileno refletiria o momento histórico particular ligado a crise da poderosa dinastia dos Deinomênidas e a tentativa dos senhores de Aetna em salvar e consolidar seu poder" (Caccamo Caltabiano, 2009: 104). Os tipos do tetradracma e do dracma da primeira fase (Aetna-Catânia), além de expressarem significados relevantes para a cidade em termos de comunidade, teriam também refletido, em maior grau, a ideologia dos Deinomênidas, como demonstram os tipos da quadriga e do cavaleiro abandonados na segunda fase. 


\section{I.2.3 Catânia}

Após o retorno das populações à Naxos e Catânia, ao redor de 461 a.C. - provocado, entre outros fatores, pela expulsão do povo de Aetna após a queda da tirania e de lutas contra Ducézio e os leontinos -, as emissões monetárias dessas cidades calcídias foram retomadas ou se iniciaram pela primeira vez, como foi 0 caso de Catânia, localizada na costa oriental da Sicília, entre Naxos a norte e Mégara Hiblea e Siracusa a sul (Fischer-Hansen, Nielsen, Ampolo, 2004: 207; Jenkins, 1990: 87; Kraay, 1976: 217; Manganaro, 2001: 14; Rutter, 1997: 136). Foi a reconstituição das póleis e suas fronteiras, com uma nova distribuição de terra em lotes aos cidadãos retornados, que permitiu a inauguração de oficinas monetárias autônomas, como em Catânia e nas demais cidades da área (Manganaro, 1996: 306). Essas novas cunhagens foram expressão da recuperação da independência cívica dessas cidades (Kraay, 1976: 215).

Catânia parece ter sido a primeira dessas cidades a bater moeda nesse período, a partir de c.461 a.C., no padrão ático e com denominações baseadas, inicialmente, no tetradracma (Fischer-Hansen, Nielsen, Ampolo, 2004: 207; Manganaro, 1996: 306-307). Essas primeiras emissões de tetradracma ocorreram entre 461-450 a.C. ou, na opinião de Manganaro, até 440 a.C., ano da morte de Ducézio (Kraay, 1976: 217; Manganaro, 1996: 308). Os tetradracmas carregam, no anverso, a imagem do rio local Amenanos (representado na forma de um touro), sendo coroado por Nike ou pulado por Sileno, e, no reverso, a legenda do étnico da cidade é acompanhada pela figura de Nike em pé correndo, segurando uma coroa de folhas com uma mão e/ou uma ou duas fitas (Jenkins, 1990: 88; Kraay, 1976: 217; Manganaro, 1996: 306-307; Rutter, 1997: 137). Uma emissão de litras de prata iniciou-se no período desses primeiros tetradracmas (c.461-450 a.C.). Trata-se de tipos monetários com a cabeça de Sileno, no anverso, ora com uma coroa de hera, ora com a orelha caprina, e com a imagem do raio alado e a inscrição do étnico no reverso (Fig.240 - n.275/276/277). Por carregarem os mesmos tipos das litras de prata de Aetna, datadas entre 475-460 a.C., alguns autores preferem situa-las ao redor de 461 a.C., ano que coincide com o final das emissões de Aetna e o início daquela de Catânia, ocorrida após o retorno de seus habitantes (Callatäy; Gliter, 2004: 32-33). Já outros situam a emissão de litras a partir de 450 a.C. (Fischer-Hansen, Nielsen, Ampolo, 2004: 207).

A cunhagem de tetradracmas, com os tipos de Amenanos, na forma de touro, e de Nike, foi substituída em 450 a.C. por novos tipos com uma clara influência de Siracusa e Leontino, como a quadriga, inicialmente sem a Nike, no anverso, e a cabeça de Apolo no reverso (Fischer-Hansen, Nielsen, Ampolo, 2004: 207; Jenkins, 1990: 87; Kraay, 1997: 217; Manganaro, 1996: 311). As imagens da quadriga e de Apolo, a partir desse período, perduraram na cunhagem de Catânia - sofreram apenas algumas modificações no desenho, dentre os quais, alguns deles, foram obras de artistas gravadores de cunho (Manganaro, 1996: 309-310). Relacionadas às emissões desses tetradracmas, são as séries de dracmas, hemidracmas, trihemióbolos e litras com os tipos, no anverso, da cabeça de Sileno (agora frontal), de Apolo, ou da ninfa, e, no reverso, da cabeça de Amenanos, de Sileno ou do touro "cornipeta" (Manganaro, 1996: 310-311). Dentre esses, está um hemidracma com a 
cabeça de Apolo, no anverso, e o touro, no reverso, batido em c.405 a.C., em sympoliteia, no nome de Catânia e Leontino (Manganaro, 1996: 311).

Emitidos contemporaneamente a outras denominações, os tipos da cabeça de Sileno e do raio alado, usados nas litras, tiveram uma longa duração na cunhagem de Catânia no século V a.C., tendo sido usados, apenas nessas pequenas frações, até o final desse século (ao redor de 402 a.C.), sofrendo algumas modificações nos desenhos dos tipos e na inscrição do étnico ao longo desse período. À essa série de litras de Catânia, estão relacionadas outras séries de pequenas frações, como aquelas de hemilitras e hexantes (dionkia) com o tipo da cabeça de Sileno, no anverso, o raio alado ou a cítara no reverso; de tetrantes (trionkia) com a cabeça de Apolo ou de Amenanos com chifre, no anverso, e a cítara, no reverso; e hexantes com a cabeça de Apolo ou de Amenanos, no anverso, e o raio alado, no reverso (Manganaro, 1996: 308). Ao redor de 405/403 a.C. foram emitidas as primeiras e as últimas emissões de bronze, tetrantes e onkiai com os tipos da cabeça de Amenanos com ou sem os chifres, com a inscrição de frente ao deus frente ao rosto do deus fluvial e o raio estilizado (Fig.240 - n.283) (Manganaro, 1996: 311). Todas essas pequenas frações foram emitidas entre 450-402 a.C. (Fischer-Hansen, Nielsen, Ampolo, 2004: 207).

Diferentemente de Leontino, politicamente em crise por problemas internos até 422 a.C., ocasionados, entre outras razões, pelo apoio à Atenas na primeira expedição ateniense à Sicília, Catânia conseguiu manter a sua autonomia política em 415-413 a.C., durante a segunda expedição de Atenas, tornando-se a base da frota ateniense e o centro de refúgio para os sobreviventes depois da batalha de Assinaro (Manganaro, 1996: 311). Em 406 a.C., começou uma década de luta entre os cartagineses e seus aliados, do oeste da Sicília, contra Siracusa, onde Dionisio I emergiu como tirano (Fischer-Bossert, 2012: 150). Lembremos que o final da segunda expedição ateniense confirmou a supremacia de Siracusa na ilha (Fischer-Bossert, 2012: 150). A partir de 403 a.C., o tirano Dionisio I cancelou a autonomia de Catânia, Aetna e Naxos, colocando uma cidade contra a outra, cessando, assim, a cunhagem de moedas nessas e outras cidades gregas da Sicília (Fischer-Bossert, 2012: 150; Manganaro, 1996: 312). A oficina monetária da cidade permaneceu ativa ao menos até 403/402 a.C., alguns anos após a paz entre Siracusa e Cartago em 405 a.C., ano em que emitiu o hemidracma em sympoliteia com Leontino (Manganaro, 1996: 311).

Com relação às escolhas tipológicas da oficina monetária de Catânia, vê-se certa repetição dos tipos nas emissões realizadas ao longo do século $V$ a.C. O repertório iconográfico das primeiras emissões, de 461 a.C., tem claras conotações de afirmação de identidade e de vitória, como indica o uso da imagem do rio Amenanos, na forma de touro, sendo coroado por Nike, ou pulado por Sileno, associado àquela de Nike, representada de corpo inteiro, portando uma coroa ou fitas. Amenanos era o rio local de Catânia e a sua representação intencionou exaltar uma característica local, assim como a proteção dessa que era uma divindade própria dali. A coroação de Amenanos por Nike, no anverso, e a representação da própria deusa, no reverso, inédita até então nas moedas das póleis da Sicília, são referências evidentes à celebração da retomada da cidade, após a expulsão da população de Aetna por volta desse ano. É nesse contexto, de afirmação de 
identidade e também de vitória que foi usado, pela primeira vez, o tipo do raio alado em pequenas frações da cidade.

Na bibliografia a respeito, mesmo no estudo de Manganaro de 1996 dedicado às cunhagens de Catânia, não encontramos explicações sobre a semelhança entre os tipos de Sileno e do raio das litras de Aetna e de Catânia, com exceção do que diz Callatäy e Gliter com base em Boehringer. Para eles, não haveria razões para os exilados de Catânia baterem moedas em seu nome em imitação aos tipos usados pelos apoiadores de Hieron em Aetna - talvez tenham decidido empregar os desenhos já aceitos e que enfatizavam as características específicas do lugar (Callatäy; Gliter, 2004: 32-33). Nessa perspectiva, poderia haver uma razão religiosa para esse fenômeno: vimos como a figura de Sileno possuía significados diretamente relacionados ao Etna e como o raio era a representação das energias divinas de Zeus, nesse caso de Zeus Aetnaios, o qual exercia o domínio sobre o Etna e possuía um culto restrito, naquele período, ao lado oriental da Sicília. Como também poderia haver uma razão política: o povo de Catânia pode ter procurado afirmar a retomada de sua cidade, sobre o povo de Aetna, ao emitir os mesmos tipos dessa cidade em seu nome. Lembremos também que, essas emissões, especificamente, representaram um modo de afirmar, diante de outras comunidades, a sobrevivência política após os deslocamentos populacionais (Manganaro, 2001: 14). É difícil precisar as razões que levaram essas cidades a escolherem os mesmos motivos. Essas eram também imagens de figuras pertencentes ao universo religioso local - de Naxos e suas fundações, Leontino e Catânia, localizadas na área do Etna - e que circulavam entre essas cidades. Os estudiosos têm apontado certas influências de uma cidade sobre a outra no lado leste da Sicília no século V a.C.- nas cunhagens e escolhas dos tipos entre Naxos, Catânia, Leontino e também Aetna, pólis dória que, pela sua localização geográfica, de certo modo esteve sob a influência cultural dessas cidades calcídias. As razões para a repetição dos tipos de Sileno e do raio alado, nas litras de Aetna e Catânia, podem estar, em algum grau, na relação entre as oficinas monetárias dessas cidades. Ou na influência de Naxos sobre as cunhagens de Catânia. Por exemplo, a cabeça de Sileno nas pequenas denominações das moedas de Catânia, segundo L. Donnellan, "seria uma influência das imagens desse sátiro representadas nas moedas de Naxos, nas quais motivos relacionados a Dioniso prevaleceram nesse período" (Donnellan, 2012: 176).

Já na fase dos tetradracmas, emitidos a partir de 450 a.C., os tipos predominantes são a quadriga, no anverso, e a cabeça laureada de Apolo, no reverso. A imagem da quadriga remete a alguma influência de Siracusa, já aquela de Apolo refere-se a aspectos identitários das três póleis calcídias. De acordo com L. Donnellan, que muito recentemente propôs uma nova interpretação sobre a função do culto de Apolo Arquegueta na Sicília, "Apolo não esteve presente em cunhagens de outras cidades da ilha, a não ser em Catânia, Leontino e Naxos, que usaram a imagem" (Donnellan, 2012: 177). Para essa pesquisadora, "foi em conexão à queda da tirania em 461 a.C. e o retorno dos habitantes à Naxos e Catânia, que Leontino e Catânia começaram a emitir moedas com a imagem da cabeça da divindade" (Donnellan, 2012: 177). A importância de Apolo em Naxos, Leontino e Catânia, serviu para enfatizar a idéia de um laço, existente através da fundação 
comunal, centrado ao redor de Naxos (Donnellan, 2012: 177). Nesse período, então, a imagem de Apolo, nesse caso Arquegueta, na cunhagem em Naxos, Leontino e Catânia, as três póleis que clamaram terem sido fundadas pelo oikista Theokles, expressou, portanto, idéias de origem, de fundação comum (Donnellan, 2012: 178). Ao enfatizar suas origens comuns, essas cidades procuraram se distinguir de Siracusa (Donnellan, 2012 : 177).

De todo o modo, o padrão iconográfico do raio alado permanece no repertório dos tipos do reverso das moedas de Catânia até o final do século V a.C., acompanhando a imagem da cabeça de Sileno, de Amenanos e, menos frequentemente, de Apolo. Acompanharia esses tipos, majoritariamente, calcídios nas moedas porque o raio foi uma imagem importante, de proteção, no contexto bélico das expedições atenienses e depois da guerra contra Cartago e a supremacia de Siracusa no final do século V a.C. O raio, que foi usado pela primeira vez na Sicilia por Aetna, em Catânia, entrou no repertório de tipos compartilhados pelas cidades calcídias, ao longo do século $\mathrm{V}$ a.C. Nesse sentido, é interessante ver como Aetna, apesar de ter sido dória e inimiga de Naxos, Leontino e Catânia, compartilhou, em algum nível, tipos monetários com essas cidades, demonstrando sua inserção numa área cultural restrita à região do Etna.

Assim, o repertório iconográfico das moedas de Catânia no século $V$ a.C., possui tipos relacionados estritamente à cidade, como o do deus rio Amenanos, o touro e a ninfa, e outros com importância local em termos regionais ligadas às cidades calcídias do leste da Sicília, como o Sileno e Apolo. O tipo do raio alado, apesar de ter se difundido de forma restrita, cronologicamente e localmente na Sicília, junto à imagem de Nike, representada em pé de corpo inteiro, remetem aos tipos emitidos, no mesmo período, por Élis para o santuário de Olímpia. O padrão de representação do raio alado e de Nike, correndo com a coroa de folhas, foi utilizada por Élis, em suas moedas, desde ao menos c.468 a.C. (sem considerar a cronologia proposta do século VI a.C.) e foram tipos que figuraram em uma mesma emissão monetária (no anverso e no reverso). Apesar de possuírem diferenças no desenho - a Nike dos tetradracmas de Catânia tem as asas para trás enquanto aquelas dos estateres de Élis possuem as asas abertas, uma em cada lado do corpo -, podemos dizer que Aetna, e Catânia em um grau maior, compartilharam traços culturais importantes com Olímpia nessa época. Desse modo, vemos como a iconografia do raio nesse ambiente ao redor do Etna deve ter expressado um significado múltiplo (até pan-helênico) tanto para dórios como para os calcídios, que de algum modo ali se identificavam culturalmente.

\subsubsection{Zancle}

No mesmo período em que Catânia emitiu suas emissões de litras com a imagem do raio alado, em c.460 a.C., Zancle, uma fundação calcídia localizada no extremo nordeste da Sicília, às margens do estreito, bateu tetradracmas de prata no nome de sua comunidade política com o tipo de Zeus em pé, atirando o raio, no anverso, padrão de representação de Zeus utilizado pela primeira vez nas moedas da ilha nesse período. 
Juntamente a Naxos e Himera, Zancle foi uma das póleis a produzir as emissões monetárias mais antigas da Sicília - duas ou uma década antes das primeiras cunhagens das cidades gregas de Egina, Atenas e Corinto na Grécia Balcânica (Fischer-Bossert, 2012: 143; Kraay, 1976: 206).

As primeiras cunhagens de moedas batidas no nome de Zancle ocorreram ao redor de 540/530 a.C., inicialmente em padrão calcídio e com a denominação baseada principalmente no dracma (Fischert-Bossert, 2012: 149; Kraay, 197: 206). Os tipos usados nessas emissões mais antigas foram o desenho do golfinho dentro do porto em formato de foice, no anverso, e da concha representada dentro de um quadrado incuso ou da imagem repetida do golfinho, no reverso. A inscrição nesse período figura no anverso e o étnico refere-se ao toponímio da cidade (Fischert-Bossert, 2012: 149). A data final para essa cunhagem pode ser fixada ao redor de 494/93 a.C. quando imigrantes de Samos, vindos da Revolta Jônia, capturaram a cidade instigados por Anaxilas, tirano de Régio (Fischert-Bossert, 2012: 149; Kraay, 1976: 207 e 213). Interessado no controle do Estreito, essa foi a primeira tentativa de Anaxilas em capturar Zancle - persuadir os sâmios que, contudo, enganaram o tirano fazendo uma aliança com Hipócrates de Gela, permanecendo, assim, na cidade por cinco anos (Fischer-Bossert, 2012: 149; Fischer-Hansen; Nielsen; Ampolo, 2004: 235; Kraay, 1976: 213). Nesse período (494/93-489/88 a.C.), os sâmios emitiram tetradracmas em padrão ático-eubóico com tipos derivados de Samos, como a pele de leão, no anverso, e a proa de uma galé sâmia, no reverso (Fischer-Bossert, 2012: 149; Fischer-Hansen; Nielsen; Ampolo, 2004: 235; Kraay, 1976: 213). As inscrições nesses tipos monetários não se referem a Zancle e nem a Samos, mas a cada ano da cunhagem (Fischer-Hansen; Nielsen; Ampolo, 2004: 235). Ao redor de 489/88 a.C., Anaxilas expulsou os sâmios de Zancle, assentando messênios do Peloponeso e renomeando a cidade de Messana (Fischer-Bossert, 2012: 149; Kraay, 1976: 213). As primeiras emissões realizadas durante o regime de Anaxilas ocorreram entre 488-480 a.C., foram baseadas em tetradracmas e usaram tipos emprestados de Régio - a cabeça de leão de frente, no anverso, e a cabeça de novilho, no reverso (Fischer-Bossert, 2012: 149; Fischer-Hansen; Nielsen; Ampolo, 2004: 235; Kraay, 1976 : 214). A inscrição do étnico, geralmente no reverso das moedas, agora se refere ao povo de Messana (FischerHansen; Nielsen; Ampolo, 2004: 236). Após 480 a.C. os tipos monetários mudaram novamente: um carro de mulas, o qual evoca a vitória de Anaxilas em Olímpia, aparece no anverso e uma lebre saltitante, no reverso (Fischer-Bossert, 2012: 149; Fischer-Hansen; Nielsen; Ampolo, 2004: 236; Kraay, 1976: 214). Com a morte de Anaxilas em c. 476 a.C., seus filhos assumiram o governo de Régio e Zancle, até serem expulsos pela população dessas duas cidades em c.461 a.C. (Fischer-Hansen; Nielsen; Ampolo, 2004: 234; Kraay, 1976: 214). Enquanto Régio mudou os tipos de suas moedas após a queda da tirania, em Messana, os tipos das moedas do período de Anaxilas se mantiveram nas cunhagens até o final do século V a.C. (Fischer-Bossert, 2012: 149-150; Fischer-Hansen; Nielsen; Ampolo, 2004: 236; Kraay, 1976: 215).

A queda da tirania em c.461 a.C. permitiu, por um curto período, o restabelecimento de uma facção zancliota (Fischer-Hansen; Nielsen; Ampolo, 2004: 236). Alguns autores supõem que durante o retorno das populações, após a queda das tiranias, os exilados zancliotas e seus descendentes (da captura sâmia ou do 
repovoamento posterior de Anaxilas) teriam brevemente retomado o controle de Messana e restaurado seu nome antigo. Não há, contudo, registros literários sobre esse suposto acontecimento (Kraay, 1976: 216). Essas têm sido as explicações que os estudiosos tentaram dar para a emissão do tetradracma com a imagem de Zeus em pé atirando o raio, cunhado no nome do povo de Zancle nessa data (Fig.240 - n.18). É possível que essa emissão isolada possa ser evidência de que os exilados zancliotas, tal como os sibaritas na Itália do Sul, sobreviveram como comunidade e emitiram suas moedas em algum lugar onde encontraram refúgio (Kraay, 1976: 216; Manganaro, 2001: 13). Esse lugar, para Manganaro, deve ter sido Mylai, um posto avançado de Zancle, fundada no final do século VIII a.C. na área da atual Milazzo (Fischer-Hansen; Nielsen; Ampolo, 2004: 234; Manganaro, 2001: 14). Essa emissão, então, indica uma retomada do papel político dos antigos cidadãos de Zancle (Manganaro, 2001: 16). Evidências provenientes de Olímpia confirmam tais colocações. Conforme Manganaro, "os zancliotas devem ter preservado sua identidade política ainda depois de 461 a.C., pois dois campeões olímpicos - Leontiskos de 456 a.C. e Symmachos de 424 a.C. - foram declarados zanklaioi" (Manganaro, 2001: 16-17). Um despojo dos zancliotas em Olímpia contém uma inscrição referente à sua nomeação de mylaioi pelos messânios (Manganaro, 2001: 14). Considerado uma emissão isolada, esse tetradracma de Zancle foi datado ao redor de 461 a.C. com base no estilo do desenho dos tipos, posteriores à mudança do nome de Zancle para Messana por Anaxilas (Kraay, 1976: 216).

Essa interpretação, que vê o tetradracma com o tipo de Zeus como uma cunhagem que atesta a sobrevivência política pós-tirania, da comunidade de Zancle em Mylai, é a mais aceita entre os estudiosos. Mas durante 0 século $X X$ várias outras teorias foram propostas. $O$ tipo de Zeus atirando o raio, na moeda, foi interpretado como uma referência à estátua de culto Zeus Ithomatas dos Messênios, obra de Ageladas - uma influência de um suposto contingente messênio misturado à população de Zancle (Mertens, 1947: 21 -22 e 30 31). J. Mertens, seguindo A.B. Cook, chegou a propor que a divindade atirando o raio, no anverso do tetradracma, não seria Zeus, mas Poseidon - a clâmide, desenhada sobre o ombro esquerdo do deus, teria substituído a águia para se adequar a um tipo de Poseidon (Mertens, 1947: 23 e 32). 0 autor usa como base as moedas de Posidônia, na Itália do Sul, do final do século V a.C., que tradicionalmente é classificada como um tipo de Poseidon usando a clâmide e atirando o raio (Mertens, 1947: 33). Já C.M. Lehmann ofereceu uma interpretação, a qual não encontrou seguidores, que retrocede a datação do tetradracma de 461 a.C. para 490 a.C., relacionando-a com a expansão de Hipócrates de Gela na Sicília (Lehmann, 1981: 30). Esse autor se baseia no estilo do desenho de Zeus, o qual remontaria às duas primeiras décadas do século $V$ a.C., de acordo com as representações na cerâmica ática (Lehmann, 1981: 28). Mas em nosso estudo das representações de Zeus, no capítulo anterior, vimos como a imagem de Zeus em pé atirando o raio, com a clâmide sobre os ombros, da mesma forma como ocorre no tetradracma de Zancle, foi usada na cerâmica ática entre 470-460 a.C., portanto no mesmo período da moeda (vide a esse respeito, figs.149 e 150). O levantamento de Lehmann, das representações vasculares, não é exaustivo a ponto de poder afirmar com veemência tal interpretação. $E$ mais, tais representações, datadas entre 470-460 a.C., não são citadas pelo autor em seu estudo. 
No tetradracma de Zancle, Zeus é retratado no anverso em pé, segurando o raio com a mão direita e uma clâmide aparece sobre os ombros do deus, não havendo uma águia sobre o seu braço esquerdo estendido como em outros tipos monetários. De frente a Zeus, há um altar quadrangular. Manganaro compara essa composição de Zeus e o altar com a imagem da ninfa Himera que liba sobre um altar no reverso dos tetradracmas dessa cidade (Manganaro, 2001: 16). No reverso, o golfinho e a concha, das emissões mais antigas de Zancle, são retratados juntos à inscrição do étnico no genitivo plural, que se refere à comunidade. Como lembra C.M. Kraay, "a omissão da imagem do porto de Zancle, no anverso, e sua substituição pelo tipo de Zeus, é significativa nessa nova cunhagem" (Kraay, 1976: 216). A nosso ver, a ausência da imagem do porto - tradicional nas primeiras emissões da cidade ainda no século VI a.C. e um símbolo topográfico de identidade local - significaria que os zancliotas já não tinham mais a posse daquela área da cidade, que naquele momento havia se tornado Messana. Esse, então, pode ser um sinal de que os zancliotas teriam se refeito como comunidade política em outro lugar.

A imagem de Zeus, usada por Zancle em um momento especial de sua história, tem sido interpretada como "um símbolo de libertação da tirania" (Caccamo Caltabiano, 1999-2000: 19; Fischer-Hansen; Nielsen; Ampolo, 2004: 235; Manganaro, 2001: 15). Caccamo Caltabiano e Manganaro acreditam que "a imagem no tetradracma seria aquela de Zeus Eleutherios, da estátua que os siracusanos após a queda da tirania na cidade, conforme nos conta Diodoro (XI, 72. 2)" (Caccamo Caltabiano, 1999-2000: 19; Manganaro, 2001: 15). Para Manganaro, que vai além nessa interpretação, "os zancliotas, inimigos dos messênios assentados em Messana, teriam sido solidários aos siracusanos, os quais também lutaram para expulsar os xenoi de sua cidade, e assim compartilhado a mensagem política expressa através do culto a Zeus Eleutherios, associado a libertação de todos os feitos dos tiranos" (Manganaro, 2001: 15). "Os xenoi eram uma população peloponésia, que havia se assentado e se espalhado por algumas cidades, como Aetna e Messana, por exemplo, durante o período tirânico. Como haviam recebido cidadania durante a tirania, com o fim desse regime nas várias cidades, foram expulsos por terem tentando manter a sua participação política e na distribuição de terra" (Manganaro, 19741975: 10 e 15).

O relato de Diodoro não descreve a estátua de Zeus Eleutherios dos siracusanos, assim, não podemos saber se esta era, de fato, um tipo de Zeus em pé atirando o raio, como defendem Caccamo Caltabiano e Manganaro. De todo modo, o tipo de Zeus em pé, atirando o raio, pode sim ser associado ao significado de libertação. Vimos, na análise contextual no capítulo 3, como a imagem de Zeus em pé, atirando o raio, expressou a ideia de um deus guerreiro, em ação de luta, pela instauração da ordem sobre o caos, portanto da liberação da violência e da desordem no cosmos. Esse tipo de representação do deus evocava, aos antigos gregos, imagens de narrativas míticas antigas, de luta com monstros e imortais pela ordem. Concluímos que 0 significado simbólico da imagem se relaciona com a esfera militar, de disputa bélica ou atlética, de sucesso/vitória na guerra ou na competição. Embora não se possa excluir a influência do culto a Zeus Eleutherios na imagem do tetradracma de Zancle, pela sua função e pelo momento político em que foi fundado, 
acreditamos que a escolha em usar esse tipo de Zeus nas moedas pelos zancliotas possa ter sido motivada pelo seu valor simbólico, pelo significado mítico atribuído à essa imagem pelos gregos. Devemos também considerar o contexto do uso da imagem de Zeus e de seu culto, que já nesse período, havia ganhado grande expressão no lado oriental da Sicília, desde sua parte setentrional até a meridional. Vimos até aqui, como a imagem de Zeus foi requisitada pelas póleis, dessa área, em algum momento de mudança e instabilidade da sobrevivência enquanto comunidade, durante ou no fim do período tirânico. Em Aetna, o tipo de Zeus sentado no trono foi usado no momento em que essa pólis procurou afirmar a sua fundação e, mais tarde, sua sobrevivência como comunidade política em outro lugar, como foi o caso de Zancle. Nesse sentido, a colocação de C. Kraay deve estar certa, quando esse autor sugere "uma analogia de significado entre a cunhagem de Aetna-Inessa e Zancle - a adoção da imagem de Zeus aludiria a uma nova casa, portanto, ao restabelecimento dessas póleis em um novo lugar" (Kraay, 1976: 216).

O repertório iconográfico das moedas de Zancle e Messana refere-se aos grupos que dominaram a cidade. A imagem do porto de Zancle, nas primeiras emissões, "alude a uma característica topográfica e um aspecto identitário da cidade, já o golfinho e a concha podem ter simbolizado o aspecto Delphinios de Apolo, segundo Caccamo Caltabiano" (Caccamo Caltabiano, 1999-2000: 19). No período de ocupação sâmia, o tipo da pele de leão e da proa eram referências às imagens monetárias da cunhagem de Samos. No período em que Zancle passou a se chamar Messana, o tipo da lebre, segundo a maior parte das interpretações, estaria associado a Pã, uma divindade peloponésia, podendo remeter a um culto trazido pelos messênios, já a cabeça de novilho aludiria a origem comum Eubéia ("rica em gado") de Régio e Zancle (Kraay, 1976: 214). Zeus em pé, em contraste, não pode ser considerado um tipo desses que evoca a identidade de um grupo específico ou uma característica local - a imagem pertence a outro universo simbólico. Ao usarem a representação de Zeus em pé atirando o raio, no anverso do tetradracma após a retomada de Zancle como comunidade política, em outro lugar, os zancliotas procuraram a proteção desse deus que tem o poder de equilibrar e acabar com situações de instabilidade, nesse caso, o momento de mudança ocasionado pelo restabelecimento e afirmação dos zancliotas como comunidade política diante de si próprios e das póleis da Sicília naquela época. A imagem do golfinho, no reverso, associada àquela de Zeus, no anverso, pode até ter tido um significado relacionado ao papel de salvador de Apolo Delphinios como propõe Caccamo Caltabiano (Caccamo Caltabiano, 1999-2000: 19). Mas, a nosso ver, a escolha em usar o tipo junto ao de Zeus, na mesma moeda, estaria mais relacionada à manutenção do golfinho e da concha, das primeiras emissões de Zancle, como imagens já tradicionais que procuraram ser repetidas como referências identitárias da comunidade. A concha também tinha um significado identitário, pois representava um tipo muito difundido nas praias do promontório Peloritano, além de ser 0 símbolo da deusa local Pelorias (Caccamo Caltabiano, 1999-2000: 27). Nesse sentido, o tipo do golfinho e da concha eram tão importantes para os zancliotas que estes emitiram litras com essas imagens também a partir de c.461 a.C. (Manganaro, 2001: 16). 
Isto posto, Zeus em pé na posição de atirar o raio - tipo de representação associado à luta de Zeus contra Tifeu e os Gigantes - pode ser entendido como uma imagem monetária talismânica, já que esta pode ter sido usada para repelir, afastar daquela comunidade, que buscava se fortalecer e se afirmar, todos os infortúnios e restrições trazidos pelo regime tirânico: a anulação da identidade cívica e política da pólis de Zancle, quebrada no momento em que é obrigada a mudar de nome e a misturar/coexistir sua população calcícia com a dória dos messênios. A esse respeito, conforme Manganaro, "a legenda no tetradracma indicaria uma superioridade de Zancle sobre o elemento messênio" (Manganaro, 2001: 16).

Em meados do século $V$ a.C., ao redor de 450 a.C., imagens monetárias de Zeus apareceram, em pequenas denominações, em centros sículos na porção centro-leste e nordeste da Sicília. As cunhagens nesses centros, muito provavelmente, devem ter sido restritas ao uso local, dificilmente devem ter tido um papel na circulação monetária na Sicília como tiveram grandes centros gregos da ilha (Jenkins, 1975: 78). De acordo com I. Jenkins, a adoção da cunhagem, por vários centros sículos no século V a.C., representou uma verdadeira assimilação da cultura grega, principalmente àquelas realizadas em prata, um típico padrão grego (Jenkins, 1975: 78). Tais cunhagens são extremamente esporádicas, representam um número de emissões muito limitadas a poucos centros isolados (Jenkins, 1975: 78). Sikeloi foi o nome usado pelos gregos para indicar as populações, da Sicília centro-oriental, com quem entraram em contato ao longo do processo de fundação das cidades gregas e depois com a penetração grega no interior (Cusumano, 2006: 121). Infelizmente, sobre os sículos, a documentação escrita fornece poucas informações, sempre do ponto de vista grego (Cusumano, 2006: 121). Até que os sículos sejam percebidos como alteridade étnica aos gregos, "são tratados pela historiografia grega antiga como coletividade anônima e, quando esta começou a mostrar protagonistas sículos (a partir de Ducézio), já está em curso o processo que tornou a sua identidade irrelevante - o processo de reurbanização dos centros sículos no formato grego" (Cusumano, 2006: 121-122).

\section{I.2.5 Galária}

Na porção centro-leste, a pólis greco-sícula de Galária emitiu uma série de litras de prata, nesse período, com o tipo de Zeus sentado no trono, no anverso, e o de Dioniso em pé, no reverso (Fig.240 - n.27). De acordo com a tradição, Galária - também conhecida como Galarina ou Galeria - foi uma cidade fundada pelo sículo Morges, líder epônimo da tribo itálica dos Morgeti, que teria imigrado da Itália para a Sicília (FischerHansen; Nielsen; Ampolo, 2004: 192; Jenkins, 1975: 83). Até hoje a localização de Galária permanece incerta. Os relatos históricos não trazem nenhuma indicação, embora a bibliografia situe o assentamento em Gagliano, próxima à Aetna e Agyrion, ou no Monte S. Mauro, nas proximidades de Caltagirone (Jenkins, 1975: 83). No século V a.C., Galária realizou duas emissões monetárias de litras de prata. Na primeira, datada de c.450 a.C., Zeus é retratado sentado no trono, no anverso, segurando um cetro, com a mão direita, com uma águia em pé repousando sobre este, já no reverso, Dioniso é retratado em pé, de frente, segurando um cântaro com a mão 
direita e um galho com um cacho de uvas com a mão esquerda. A legenda com as iniciais do nome da cidade aparece no reverso, enquanto que uma inscrição com o epíteto Sóter de Zeus ocorre junto a representação da divindade no anverso (Jenkins, 1975: 84-85). Na próxima e última emissão, de 430-420 a.C., os tipos referemse somente a Dioniso - o deus aparece no anverso em pé, segurando o cântaro, com a mão direita, e o thyrso, com a esquerda, já no reverso está o desenho de um cacho de uvas, acompanhado pela inscrição do étnico da cidade no genitivo plural (Jenkins, 1975: 85). Essa segunda emissão de Galária é tida como evidência de que o centro sículo existia após a queda de Ducézio e a repressão dos sículos por Siracusa em 440 a.C. (Jenkins, 1974: 86-87).

Embora a bibliografia não costume associar nenhum contexto histórico à primeira emissão de Galária, com o tipo de Zeus sentado, pela datação do exemplar, acreditamos que esta possa estar relacionada com 0 fim do período do movimento sículo de Ducézio. Em seu estudo sobre as pequenas frações de prata de c.450 a.C. de Abakainon, outra pólis greco-sícula, L. Rizzo concluiu que estas foram emitidas para o pagamento de liturgias militares (tropas e defesa do território) no contexto dos eventos que envolveram todos os centros grecoindígenas nas dinâmicas de independência ocorrida na metade do século V a.C. (Rizzo, 2011: 5). Acreditamos que a emissão da mesma fração por Galária, com o tipo de Zeus, deva pertencer a esse mesmo contexto e uso. Assim, é nesse contexto que devemos analisar as razões por detrás do uso da imagem de Zeus por essa cidade.

O uso da imagem de Zeus nas litras de Galária costuma ser explicado, pelos especialistas, como a assimilação de uma divindade grega ao panteão sículo (Jenkins, 1975: 84; Vonderstein, 2006: 184). Já o padrão do tipo monetário de Zeus, sentado no trono, costuma ser associado aquele do tetradracma e do dracma de Aetna-Catânia, datados entre 475-470 a.C. A disposição geral da figura de Zeus, e especialmente da águia sobre o cetro, indicam que o tipo de Aetna-Catânia possa ter sido o modelo para aquele tipo, décadas posterior, da litra de Galária (Jenkins, 1975: 84). Defensor da influência dos xenoi peloponésios na origem e difusão de certos tipos iconográficos e cultos na Sicília oriental no século V a.C., Manganaro acredita que a explicação para a semelhança entre os tipos monetários de Aetna e Galária estaria na origem comum, peloponésia, da população assentada nessas duas cidades (Manganaro, 1974-1975: 37). Embora pareça não haver provas de que gente do Peloponeso tenha se assentado em Galária, Manganaro postula que "o surgimento de certas imagens monetárias nessa área da Sicília tenha sido possível como resultado da dispersão dos xenoi peloponésios após o fim da tirania e durante o movimento de Ducézio" (Manganaro, 194-1975: 35). Assim, na interpretação desse autor, "a representação de Zeus Sóter nas litras de Galária recorda, por certos detalhes como a estrutura rígida do desenho, aquela de Zeus Lykaios dos hemidracmas da Liga Arcádia e dos didracmas de Élis" (Manganaro, 1974-1975: 37). Poder-se-ia afirmar com veemência que tanto o tipo de Galária, quanto 0 de Aetna, teriam sido inspirados nas emissões da Liga Arcádia e de Élis, se não fosse pelo detalhe iconográfico da águia pousada sobre o cetro de Zeus, vista somente nas emissões dessas duas cidades siceliotas (Manganaro, 1974-1975: 37). Mesmo assim, Manganaro conclui que "a população peloponésia, confluída em 
Aetna e Galária, devia ser constituída por grupos originários da Messênia misturados aos arcádios - duas subregiões por muitos aspectos afins culturalmente e nas quais circulavam as moedas com os tipos de Zeus dos arcádios e também de Olímpia" (Manganaro, 1974-1975: 37).

Manganaro lista uma série de nomes de indivíduos arcádios presentes na Sicília entre o final do século VI e início do século V a.C., que vale a pena aqui citar: "Arkadion, pai do selinontino Aristogeitos morto sob o muro de Motya em c.500 a.C.; Praxiteles, filho de Krinis, oriundo de Mantinéia, tornado siracusano e depois camarinense em c.461 a.C.; Phormes de Menalo, que, sob os Deinomênidas tornou-se cidadão siracusano e rico o suficiente para realizar dedicações em Olímpia e Delfos; Agesia de Estínfalos, feito siracusano por Hieron; Kyniathos e Epochos de uma inscrição arcaica de Gela, Mikythos o tutor dos filhos de Anaxilas, que se retirou para Tegea" (Manganaro, 1974-1975: 38). Para esse autor, "alguns desses personagens, representantes da aristocracia arcádia, devem ter chegado à Sicília como chefes dos grupos de peloponésios, nos quais os messênios devem ter constituído o componente mais forte" (Manganaro, 1974-1975: 38). Em sua conclusão, o tipo de Zeus sentado no trono de Galária e Aetna "remete ao mundo religioso da Arcádia e da Messênia, onde o culto de Zeus Lykaios, dos tipos monetários da Liga Arcádia, exerceu um papel importante" (Manganaro, 1974-1975: 39). Uma prova disso é o achado de um lingote de prata de $730 \mathrm{~g}$, encontrado na área de Himera, na costa norte da Sicília, com a inscrição de uma consagração a Zeus Lykaios por uma mulher no início do século V a.C. (Bergese, 1995: 111-112). Trata-se de uma evidência de que "o culto de Zeus Lykaios chegou na Sicilia com o contigente de arcádios nesse período" (Bergese, 1995: 111).

O epíteto Sóter que aparece inscrito junto à imagem de Zeus, no anverso, também é relacionado, por Manganaro, a uma origem arcádia e messênia. Como esse título de Zeus não é atestado na Sicília antes da época helenística, o estudioso acredita que o culto teria sido trazido do Peloponeso (Manganaro, 2003: 5). Entretanto, o culto de Zeus Sóter, atestado em Mantinéia e Megalópolis, na Arcádia, e na pólis de Messênia, foi introduzido nesses centros, ao que parece, somente no século IV a.C., como indicam as evidências literárias e materiais referentes a esses santuários (Lo Monaco, 2009: 357 e 388). Assim, como coloca M. Vonderstein "é difícil traçar a origem do culto em Galária, já que o epíteto Sóter foi muito difundido pelo mundo grego" (Vonderstein, 2006: 184). A nosso ver, a inscrição no tipo monetário de Galária, que se refere ao aspecto "Salvador" de Zeus, não foi, necessariamente, a indicação de um culto local a Zeus Sóter, como acreditam os autores (Fischer-Hansen; Nielsen; Ampolo, 2004: 192; Vonderstein, 2006: 184). A legenda "Sóter" pode ter sido acrescentada à imagem de Zeus na moeda para qualificar aquela representação e por uma mera necessidade de proteção referente a um momento político específico, quando o aspecto "Salvador" de Zeus foi importante para aquela comunidade. De acordo com Vonderstein, "Zeus Sóter é a divindade à qual se voltavam tanto indivíduos quanto cidades inteiras com pedidos de proteção e para ações de graça pelo livramento diante dos perigos" (Vonderstein, 2006: 25). M. Jost explica que "durante o século IV a.C. na Arcádia Zeus Sóter foi adorado como símbolo do renascimento regional no contexto da derrota dos espartanos em Leuctra, podendo ser considerado um deus protetor da nação" (Jost, 1985: 272). A presença da imagem de uma divindade em 
uma moeda nem sempre significou a presença do culto no local. A comunidade de Galária deve ter usado a imagem de Zeus por uma razão desvinculada da existência de uma área sagrada organizada ou não em seu território.

Acreditamos que a hipótese de Manganaro acerca do elemento arcádio, como fator que influenciou 0 uso dos tipos monetários de Zeus sentado no trono na Sicília oriental, pode estar certa. De fato, as evidências da migração arcádia e messênia nesse período, na Sicília, são significativas e os tipos de Zeus sentado no trono da Liga Arcádia já eram bem conhecidos, tinham uma tradição de emissão desde o início do século $\mathrm{V}$ a.C. Contudo, esse padrão de representação de Zeus em moedas, na Sicília, sofreu uma modificação influenciada por uma concepção de Zeus que apareceu na épica de Píndaro (Pítica I, coincidentemente composta a Hieron de Siracusa) e na cerâmica ática do início do século V a.C., na qual o deus segura um cetro com a águia, de asas fechadas, repousando sobre ele. A nosso ver, o tipo peloponésio de Zeus sentado no trono, das moedas arcádias, adquiriu formato e significado locais na área de influência de Zeus Aetnaios. Tanto é assim que vemos no reverso do tipo de Galária com Zeus, de c.450 a.C. e na segunda emissão de 430-420 a.C., a imagem de Dioniso relacionada aos vinhedos do Etna - os mesmos temas que aparecem relacionados aos tipos das moedas de Aetna, Naxos e Catânia - tida, pelos autores, como uma referência à zona fértil dos vinhedos da região (Fischer-Hansen; Nielsen; Ampolo, 2004: 192; Manganaro, 1974-1975: 36 e 39 ). O tipo monetário de Zeus de Galária deve ser estudado como resultante de uma área cultural única na Sicília, na qual centros sículos compartilharam traços culturais, em vários níveis, com as fundações gregas.

Acreditamos também que a imagem monetária de Zeus de Galária deva ser inserida em um contexto mais amplo que é aquele das cidades gregas, da porção leste da Sicília, que já haviam usado a representação da divindade ou de seu atributo, o raio, em suas moedas, como Aetna, Catânia e Zancle. Assim, o significado grego da imagem monetária de Zeus - construído naquela área desde ao menos o primeiro quartel do século $V$ a.C. - deve ter se inserido e se mantido também em contexto sículo. A imagem de Zeus sentado no trono das litras de Galária - segurando apenas o cetro com a águia, sem o raio, o que a difere de algum modo das moedas de Aetna-Catânia - deve ter conservado o significado que encontramos nos primeiros tipos de Aetna. Como indica a datação do tipo monetário, a função ordenadora de Zeus, e também salvadora como indica a inscrição, foi requisitada por essa pólis greco-sícula em um momento de instabilidade política - a época na qual Ducézio, de líder sículo a favor dessa população, passou a governar nos moldes tirânicos até ser exilado em Corinto ao redor de 450 a.C. Trata-se do momento do fim do movimento de independência dos centros sículos, quando o uso das litras de prata foram usadas como pagamento para tropas e defesa do território da cidade. $\mathrm{O}$ uso do tipo de Zeus sentado no trono, nesse contexto, mostra mais uma vez como essa imagem da divindade foi requisitada, nas moedas da Sicília oriental, em uma fase de desordem para a cidade. Nessa perspectiva, a invocação do aspecto "Sóter" de Zeus fez sentido para a comunidade no momento de libertação e renovação de Galária enquanto comunidade política autônoma. Retratar a imagem do deus nas moedas pode ter refletido, 
para Galária, o desejo pela proteção da energia ordenadora de Zeus, que também exercia um poder na esfera militar, a favor da comunidade naquele período.

\section{I.2.6 Abakainon}

No mesmo período da emissão do tipo monetário de Galária, ou um pouco depois, a partir da segunda metade do século V a.C., no nordeste da Sicília, a imagem da cabeça de Zeus parece ter sido usada pela primeira vez, na ilha, em moedas de outra pólis greco-sícula. Localizada a sudeste de Tyndaris, na moderna Tripi, Abakainon foi estabelecida no interior, numa área pouco distante das vias marítimas em posição dominante na costa setentrional da Sicília - a relação direta com a costa tirrênica e jônia proporcionou o contato com o mundo calcídio e com a área do Estreito (Fischer-Hansen; Nielsen; Ampolo, 2004: 182; Rizzo, 2011: 4 e 103). Propriamente nada é conhecido sobre os anos mais antigos de Abakainon: não se sabe ao certo 0 ano exato de sua fundação e os restos da antiga cidade foram encobertos pela construção de Tripi (Fischer-Hansen; Nielsen; Ampolo, 2004: 182; Rizzo, 2011: 3). A documentação numismática é aquela que fornece mais informações a respeito da cidade a partir da metade do século V a.C. e até a época romana (Rizzo, 2011: 3).

Abakainon emitiu séries monetárias em ouro e prata - sendo a emissão em prata a mais antiga -, que foram usados em pequenas frações de litras, e em alguns casos de óbolos, os quais se referem à unidade de peso da dracma calcídia e do sistema indígena da litra (Rizzo, 2011: 3). As frações de prata estiveram em relação com as de outras emissões de moeda divisionária, circularam simultaneamente àquelas das cidades calcídias, como Naxos, Messana e Régio, mas também de outros centros sículos como Morgantina (Rizzo, 2011: 112). O papel econômico do centro de Abakainon, assim, seguramente não foi marginal e se interseccionou com a economia dos centros calcídios e dórios e com outros centros sículos (Rizzo, 2011: 26). De acordo com L. Rizzo, "a cunhagem de Abakainon parece ter sido inserida em um sistema mais amplo, no qual tenha contribuído com suas frações, destinadas à transações externas, mais do que internas à comunidade" (Rizzo, 2011: 122). Após um estudo profundo das séries fracionárias dos séculos V e IV a.C., Rizzo concluiu que "a cunhagem de Abakainon provavelmente integrou um sistema federal de emissões, representando a contribuição dessa cidade para o pagamento de defesas militares" (Rizzo, 2011: 113). Essa autora também concluiu que "a pequena oficina monetária da cidade teve uma forte e significativa ligação com a oficina de Naxos, não somente com relação ao padrão adotado, mas também nos aspectos técnico e estilístico" (Rizzo, 2011: 130). Como lembra Manganaro, nesse período, "as póleis de Catânia, Naxos e Aetna, as quais se ligaram à Abakainon e Piakos, constituíram uma área econômica única, na qual todas as realidades se integraram e se condicionaram reciprocamente" (Manganaro, 1974-1975: 35). Nesse sentido, o estudo de Rizzo sobre as emissões de Abakainon mostra como as cunhagens desses centros sículos puderam ter um papel dinâmico no contexto de outras emissões locais, não foram limitadas apenas a poucos centros isolados, como afirmou Jenkins na década de 1990. 
As primeiras emissões de Abakainon, de acordo com Rizzo, estiveram diretamente relacionadas aos eventos no século V a.C. que acenderam, nos sículos, o entusiasmo de independência para depois aderir à aliança nas fases preparatórias do conflito com Siracusa, como todos os centros sículos (Rizzo, 2011: 107). As fontes informam como todos esses centros, quando caíram sob a hegemonia siracusana em 450 a.C., entraram sob o seu controle lhe fornecendo apoio militar, como foi o caso de Abakainon, enquanto outros obtiveram independência política (Rizzo, 2011: 113). A cidade teve um papel político estratégico importante na Sicília setentrional e oriental a partir da metade do século $\mathrm{V}$ a.C., o que corresponderia à série que data entre a constituição da Liga de Ducézio até a hegemonia de Siracusa (Rizzo, 2011: 124). É nesse contexto que Abakainon emitiu os tipos monetários que, no anverso, trazem a imagem de uma cabeça masculina, barbada, com cabelos curtos e coroa de folhas de oliveira, e no reverso a figura de um javali, acompanhado de diversos símbolos (porquinho, grão de cevada, fruto do carvalho) e da inscrição do étnico da cidade abreviado ou não (Fig.241 - n.28). As séries com o tipo da cabeça masculina, com coroa, duraram até o último decênio do século $V$ a.C., quando séries monetárias começaram a usar, no anverso, a imagem de uma cabeça masculina, mas sem a coroa de folhas de oliveira (Bertino, 1975: 119). A partir de c.440/430 a.C., o influxo da arte monetária de Siracusa alcançou a oficina de Abakainon, influenciando o uso, por esta cidade, do tipo da cabeça de ninfa, representada de lado ou de frente, no anverso das moedas (Bertino, 1975: 117). As últimas emissões de Abakainon, com a imagem da ninfa, no anverso, podem ter sido realizadas no período das expedições atenienses e durante a expansão siracusana (Rizzo, 2011: 124).

Para nossa discussão, nos interessa os tipos monetários com a cabeça masculina com coroa de folhas de oliveira. Os autores costumam atribuir essa imagem à representação da cabeça de Zeus ou a de um deus sículo a ele assimilado (Bertino, 1975: 111; Fischer-Hansen; Nielsen; Ampolo, 2004: 183; Manganaro, 19741975: 34; Rizzo, 2011: 118; Vonderstein, 2006: 183). Manganaro é o único autor que, com veemência, afirma se tratar de uma imagem monetária de Zeus. Para ele "tratar-se-ia da representação da cabeça de Zeus Aetnaios e a coroa de folhas de oliveira aludiria à Olímpia - imagem monetária também trazida pelos xenoi messênios que teriam se estabelecido em Abakainon nessa época" (Bertino, 1975: 127; Manganaro, 19741975: 34). A coroa de oliveiras de fato é um símbolo de vitória e prêmio concedido aos atletas vitoriosos somente em Olímpia. Vimos no capítulo anterior, como a coroa de folhas de oliveira é típica dos tipos monetários de cabeça de Zeus emitidos nesse santuário. No entanto, na época dessa emissão de Abakainon, os tipos monetários de Olímpia, com esse padrão de representação, não haviam sido ainda emitidos por Élis, ocorrendo somente a partir de 416 a.C. e depois em c. 363 a.C. Nessa época, a coroa de folhas aparece somente nas mãos de Nike ou ornando os tipos monetários de raios alados. Assim, diante da datação dos exemplares, é difícil afirmar que tenha havido uma influência iconográfica de Olímpia sobre o tipo de Abakainon, da forma como afirmou Manganaro na década de 1970.

Isto posto, a nosso ver, a cabeça masculina, com coroa de folhas de oliveira, nas moedas de Abakainon pode ser considerada uma representação de Zeus e talvez de Zeus Aetnaios, como acredita Manganaro. Ora, 
se nos voltarmos ao contexto de uso da imagem de Zeus entre póleis gregas (calcídias e dórias) e centros sículos no lado leste e nordeste da Sicília, há um histórico no qual haveria sentido outro centro sículo, helenizado, ter se apropriado da imagem da divindade para suas moedas - batidas, lembremos, no mesmo contexto de Galária, por exemplo. Trata-se de uma cidade na área de uso da imagem de Zeus em moedas na Sicília. Se olharmos friamente para os elementos que compõe a cabeça masculina, nas moedas de Abakainon - a barba curta, o cabelo curto em króbylos e a coroa de folhas de oliveira - veremos que o desenho contempla todos os elementos presentes na representação da cabeça de Zeus em moedas, no período, de outras regiões e autoridades emissoras. Vimos, no capítulo anterior, como as imagens monetárias das primeiras cabeças de Zeus possuem tais características. 0 króbylos, por exemplo, está presente nas representações mais antigas da cabeça de Zeus, cunhadas nas moedas de Cirene, de época arcaica, e da Arcádia de c.420 a.C. e em imagens vasculares áticas do deus, datadas entre 480-460 a.C. Mas o elemento que confere a atribuição da representação monetária à Zeus é a coroa de folhas, neste caso, de oliveira, a qual não é comumente retratada, em moedas, na cabeça de figuras masculinas a não ser na de Zeus, mesmo que isso tenha ocorrido um pouco depois em Olímpia, no Peloponeso. Se assim for, esse pequeno centro sículo, no nordeste da Sicília, teria inovado, antes mesmo de Olímpia, na representação do deus em moedas gregas ao usar a coroa de folhas de oliveira, quando ela não havia sido utilizada nos tipos monetários desse padrão nas cunhagens mais antigas de Cirene, na Líbia, e da Arcádia. Pode ser que o artista, responsável pela gravação do cunho, tenha, de algum modo, se apropriado de uma ideia, a respeito da representação da divindade, que já circulava naquela época, influenciada pelo culto de Olímpia - com que cidades da região já trocavam traços culturais desde ao menos o século VI a.C. Lembremos do culto de Zeus Olímpio em Siracusa, do início do século VI a.C., e das imagens monetárias do raio de Aetna e Catânia da primeira metade do século $V$ a.C. e tantas outras referências atléticas de tiranos e de membros da aristocracia nos jogos olímpicos.

Com a imagem monetária da cabeça de Zeus de Abakainon, a Sicília, então, teria batido, junto à Líbia e à Arcádia, um dos tipos monetários mais antigos desse padrão no mundo grego. Embora desenhos da cabeça de Zeus, sem a coroa de folhas de oliveira, com ou sem fita, tenham sido atribuídas como imagens monetárias da divindade, na Arcádia, na Tessália e em Olímpia, é difícil afirmar se as imagens monetárias de Abakainon, desse tipo, cunhadas no último decênio do século $V$ a.C. sejam de fato da divindade. Por essa razão, consideraremos tipos monetários de Zeus somente aqueles ornados pela coroa de folhas.

A imagem monetária da cabeça masculina no anverso, que pensamos se tratar de Zeus, é acompanhada, no reverso pelo tipo do javali em pé - representação presente na maior parte dos reversos das moedas de Abakainon de época grega. 0 javali, e os símbolos que acompanham a sua representação, tais como um porquinho, o grão de cevada e o fruto do carvalho, são tradicionalmente interpretados como tipos inspirados na economia (Bertino, 1975: 108). O grão de cevada testemunharia, no território de Abakainon, 0 cultivo para uso alimentar, muito difundido na Sicília (Bertino, 1975: 111). Já o javali, para Manganaro, deve corresponder à realidade de uma pequena pólis, situada entre florestas de carvalho, e indicar a criação 
difundida do animal para exportação (Bertino, 1975: 127). Essa tipologia teria expressado, também, a natureza local selvagem e de bosque do território montanhoso dos Nebrodes (Bertino, 1975: 111). De fato, essas imagens podem ter estado associadas à economia, mas também não podemos ignorar seus significados religiosos. 0 javali é relacionado ao culto de Ártemis em Samos, onde era o animal sacrificado à deusa, conhecida localmente como Kaprophagos, e em Kalydon, na Etólia, onde nas lendas locais, Ártemis teria enviado um imenso javali para assolar os campos da região (Larson, 2007: 102). Alguns animais selvagens eram sagrados à deusa, cuja função era proteger e regular as caças (Larson, 2007: 101-102). Pode ser que a representação do javali, nas moedas de Abakainon, pode ter aludido, não diretamente à economia local, mas ao aspecto selvagem da região, em algum nível relacionado à Artemis, protetora dessa força da natureza. 0 fruto do carvalho, em época clássica, era um alimento consumido somente em tempos de fome e usado para a alimentação na criação de animais, também de javalis (Brown, 1841: 47; Hansen, 1998: 261). Desconhecemos qualquer aspecto simbólico a respeito do fruto. 0 grão de cevada, por outro lado, foi muito utilizado como símbolo em outras emissões monetárias da Sicília do século $V$ a.C., como em Gela, Leontino, Himera e Segesta. É sabido que seu significado simbólico esteve vinculado, como atributo de Deméter e Perséfone e, assim, à fertilidade da terra, à agricultura e ao mesmo tempo ao mundo ínfero (Florenzano, 2005: 14 e 17). Nesse sentido, acreditamos que a figura do javali e a do fruto do carvalho tenham significado um aspecto local, selvagem, da região dos Montes Nebrodes, mas ao mesmo tempo, sua representação pode ter tido um fundo apotropaico, no qual o uso de sua representação pode ter servido para equilibrar essa energia, da natureza, propiciá-la e controla-la em favor da comunidade. 0 javali era um animal de caça, mas que também tinha um poder destruidor de plantações, lavouras, sobretudo durante épocas em que esse animal atingia um grande número em uma dada região.

A imagem da cabeça de Zeus, nas moedas de Abakainon, assim, aparece vinculada a um significado local, relacionado à esfera selvagem e provavelmente à sua domesticação. 0 contexto histórico dessas emissões é que revela o significado final para o uso do tipo monetário do deus. De acordo com Rizzo, as emissões das pequenas frações de prata foram batidas em momentos importantes para a afirmação dessa pólis, sejam eles à época das lutas de independência dos centros sículos ou a sua queda sob a hegemonia siracusana em c.450 a.C., o que parece ter sido o caso de Abakainon. De alguma maneira, nesse contexto, na escolha da imagem de Zeus para as litras e os óbolos, por essa comunidade nesse período, pode ter sido importante 0 aspecto ordenador do deus, conhecido e evocado na área do Etna, mas também o de protetor na esfera militar e de vitória, dado o contexto e o uso da coroa de folhas de oliveira sobre a sua cabeça, um conhecido símbolo grego de vitória. Se divindade sícula assimilada a Zeus ou não, vemos no tipo monetário de Abakainon os elementos iconográficos e significados do deus grego compartilhados por outras cidades gregas na Sicilia e no mundo grego. Por alguma razão, que provavelmente esteja na nova conformação política ocorrida após a queda das tiranias nos centros gregos, a independência dos sículos e a hegemonia de Siracusa, 
a imagem de Zeus, em meados do século V a.C., ganhou também significado entre alguns centros sículos helenizados.

\section{I.2.7 Motya, Eryx, Hipana, Nakona, Agyrion}

Somente após a metade do século IV a.C. a imagem monetária de Zeus voltou a ser usada pelas póleis gregas na Sicília - associada às imagens da águia e do raio. Do início do século $V$ a.C. a esse período, tipos monetários da águia foram usados esporadicamente por centros não gregos e cidades gregas da Sicília. $\mathrm{A}$ bibliografia informa que, alguns desses centros de origem não grega, como Motya (cidade púnica), Eryx (elímia), Hipana (sicana), Nakona (elímia?) e Agyrion (sícula), bateram moedas com imagens da águia por influência da hegemonia de Agrigento (Cutroni, 1967: 100; Fischer-Hansen; Nielsen; Ampolo, 2004: 201; Holloway, 1975: 141; Kraay, 1976: 228). Por essa razão, tais imagens da águia estariam desvinculadas de qualquer culto e significado simbólico, em relação a Zeus, requerido por essas comunidades (Vonderstein, 2006: 185, 188 e 189). No caso de Motya, a partir de 480 a.C., momento da afirmação política do elemento grego na Sicília e do processo de penetração econômico-cultural nas comunidades púnico-elímias, deu-se o início da gradual introdução e difusão do sistema monetário agrigentino-siracusano (Cutroni, 1967: 98). Motya emitiu dois tipos monetários com a águia: no primeiro, a ave aparece no anverso em pé, de asas fechadas, sobre a coluna de um capitel jônico, em uma litra ou óbolo datada até 415 a.C., cujo reverso traz as imagens do golfinho e da concha como nas moedas de Zancle (Fig.241 - n.196); e no segundo tipo, um tetradracma de prata de c.400 a.C. a ave aparece em pé, sem estar sobre o capitel e a figura do reverso é o caranguejo (Fig.241 - n.216). Esse segundo tipo assemelha-se àquele de Eryx datado entre 480-400 a.C. (Fig.241 - n.137). 0 primeiro tipo monetário de Motya tem uma clara semelhança com a litra de Hipana de c.450 a.C. e de Nakona8 (Cutroni, 1967: 100-101; Fischer-Hansen; Nielsen; Ampolo, 2004: 201; Holloway, 1975: 143-144). Esse tipo monetário da águia em pé, com asas fechadas, sobre a coluna de um capitel jônico teria sido copiado das emissões de tetradracma de prata de Agrigento de 460-450 a.C., pólis que parece ter criado o padrão de representação para as moedas gregas. Já a imagem monetária de Agyrion, cidade sícula na área da Sicília oriental, fora da esfera de influência púnica-elímia, também esteve envolvida no sistema monetário agrigentino-siracusano, como mostra o tipo, datado de c.420-353 a.C., do anverso da águia em pé, de asas fechadas, e aquele da roda no reverso, uma referência às numerosas frações siracusanas (Fig.241 - n.193) (Holloway, 1975: 141). Nota-se nesse tipo monetário, provavelmente o mais antigo de Agyrion, a presença, no campo, de um galinho com folhas de oliveira, junto à águia, que é visto desse modo, somente fora da Sicília, em moedas desse período de Paphos, em Chipre.

\footnotetext{
8 Não dispomos da imagem desse tipo monetário de Nakona em nosso catálogo, pois este não foi localizado na bibliografia numismática a respeito.
} 


\section{I.2.8 Messana}

Entre 412-408 a.C., Messana, no Estreito, bateu um tetradracma de prata, cujo reverso possui a imagem da águia em pé, de asas fechadas, curvada sobre uma cobra (Fig.241 - n.202). O desenho, que aparece em composição com a tradicional imagem da lebre, pode ter sido, também, uma influência dos tipos de águias criados por Agrigento. Trata-se do período no qual Messana passou a acrescentar símbolos no reverso, embaixo no campo, junto à lebre, e a ninfa Messana passou a figurar, no anverso, no lugar do cocheiro que dirigia a quadriga (Kraay, 1976: 219). De acordo com Kraay, "a imagem da águia, devorando a cobra, reproduz 0 anverso das moedas de ouro de Agrigento, cunhadas, provavelmente, durante 0 final do cerco cartaginês" (Kraay, 1976: 226). Muito provavelmente, o mesmo significado simbólico, contido nessa imagem, foi requisitado por Messana no contexto entre a segunda expedição ateniense, a qual permaneceu em posição de neutralidade, e o período de luta contra Cartago (Caccamo Caltabiano, 1999-2000: 5). A imagem da águia com a cobra, associada ao tipo tradicional da lebre, um símbolo já consolidado de identidade de Messana, vem acrescentar outro significado ao tipo monetário. No contexto de dois momentos militares importantes para todas as póleis siceliotas, a imagem da águia, que devora a cobra, assume um significado apotropaico, como nas moedas de ouro de Agrigento, que era o de repelir o domínio do inimigo e uma situação desfavorável para a pólis no momento de guerra e de conflitos, e também um sentido talismânico, de requerer vitória, já que a representação da ave também recaía nesse domínio. O significado do reverso, assim, combina com aquele da imagem do anverso, no qual a deusa Nike é retratada coroando a ninfa Messana. É interessante ver como a imagem da águia, devorando a cobra, nas moedas da Sicília, são usadas nesse período conturbado, militar, do último decênio do século $V$ a.C.

\section{I.2.9 Gela}

Em um tetradracma de Gela, datado entre 410-405 a.C., a águia é retratada, no anverso, voando sobre uma quadriga dirigida por Nike (Fig.241 - n.206). O tipo monetário, relacionado ao mesmo período de instabilidade na Sicília, encontra paralelo no tipo do anverso do decadracma de Agrigento, batido provavelmente no mesmo período, um pouco antes ou depois, com a diferença que no tipo de Gela a águia não carrega a serpente com as presas (Jenkins, 1990: 104). Entretanto, de acordo com Jenkins (1970), o primeiro tetradracma de Gela, com esse esquema iconográfico, foi batido em 415 a.C. Por essa razão, esse autor acredita na influência de Gela na adoção desse tipo monetário por Agrigento e não o contrário (apud Lo Monaco, 20082009: 14). De fato, o tipo monetário de Gela mais antigo, em questão, possui um estilo de desenho aparentemente mais antigo que os das emissões posteriores com essa imagem, as quais se assemelham mais ao tipo do decadrama de Agrigento. Mas mesmo assim, ainda é difícil saber com precisão qual cidade teria influenciado a outra, já que essas cronologias permanecem sempre mudando, além também do tipo monetário 
apontado como mais antigo por Jenkins estar desgastado e não mostrar a imagem nítida da águia. De todo modo, "tratar-se-ia de um esquema iconográfico próprio e/ou compartilhado por metrópole (Gela) e colônia (Agrigento) e que ganhou visibilidade nas moedas nessa porção do século V a.C. em ambas as cidades" (Lo Monaco, 2008-2009: 15).

Com relação ao significado simbólico, assim como dissemos anteriormente sobre o decadracma de Agrigento, a composição da águia com a quadriga, ressoa nos esquemas iconográficos dos cavaleiros nos vasos áticos do século VI a.C., significando, nesse caso também, um presságio favorável de vitória àquele que disputa na competição ou na guerra. Gela escolheu retratar esse tipo monetário entre o momento do ataque cartaginês e a destruição da cidade pelo general Himilcon em 405 a.C., tendo sido, então, importante para a cidade retratar nas moedas um símbolo favorável, relacionado à guerra e à sua necessidade de vitória. Também aqui, o significado do tipo do anverso ganha sentido complementar com aquele do reverso, o tipo do prótomo do rio Gelas - imagem tradicional de identidade da comunidade desde o início do século V a.C. Interessante ver como a composição da águia voando sobre a quadriga, nesse caso sem a cobra, foi usada por póleis gregas somente nos eventos militares que levaram a uma nova conformação política na Sicília no final do século $\mathrm{V}$ a.C. Também é interessante ver como Agrigento pôde participar, nesse contexto, da difusão dos tipos monetários da águia, mesmo se nesse último caso não tenha sido a cidade responsável pelo primeiro uso da imagem da quadriga com a águia em moedas gregas.

\subsubsection{Siracusa, Agyrion, Alaisa, Alontion, Aetna}

Aproximadamente um século transcorreu para que imagens monetárias de Zeus voltassem a figurar em moedas na Sicilia. As próximas imagens monetárias de Zeus foram batidas, associadas ou não a tipos de águias e raios, ao redor de 344 a.C. no contexto da symmachia, entre cidades do nordeste e leste da Sicília, criada à época de Timoleonte. Apesar de a cronologia desses tipos monetários ser até hoje muito debatida, seguiremos àquela proposta por G. Manganaro e mais recentemente seguida e atualizada por L. Karlsson, a respeito da datação da chamada série $\mathrm{A}$ (tipos monetários de Zeus com cabelos curtos e barbas longas) em ou logo após 344 a.C. (Garrafo, 1976-1977: 19; Karlsson, 1995: 164).

Timoleonte foi um general de Corinto que ficou conhecido na história da Sicília grega como o reconstrutor das póleis e de suas instituições democráticas, comprometidas após anos dos efeitos da tirania de Dionisio I de Siracusa (406-387/86 a.C.) - que com sua política expansionista subjugou cidades e transformou suas populações em escravas - e de sua continuidade no governo de Dionisio II (367-357 a.C.). Esse último teve seu governo ameaçado e posteriormente destituído por Dion, seu tio, que procurou torna-lo um monarca "humanista" por influência das ideias de Platão (Dreher, 2008: 50). Acusado pelos seus adversários de procurar ameaçar o poder de Dionisio II, Dion foi expulso de Siracusa e exilado em Atenas, de onde voltou alguns anos depois com um exército de mercenários do Peloponeso, obtendo o apoio de cidades gregas importantes e dos 
sículos e sicanos, os quais não se aliaram, naquele momento a Dionisio II. Dessa maneira, Dion conseguiu entrar em Siracusa e o tirano refugiou-se em Ortígia (Dreher, 2008: 51). Após uma fuga para Lócris, na Itália do Sul, Dionísio retornou com uma grande frota, a qual não foi suficiente para obter a vitória sobre Dion, naquele momento com o controle de Siracusa, propiciado pelos siracusanos (Dreher, 2008: 52). Foi dessa maneira que Dion conseguiu pôr fim à tirania dos Dionísios que já durava cerca de meio século (Dreher, 2008: 52). A intenção de Dion era dar à pólis siracusana uma nova constituição que combinasse elementos monárquicos, aristocráticos e democráticos, como propunha Platão. Contudo, no decorrer dos fatos, o seu governo tornou-se sempre mais despótico e similar àquele de um tirano, revelando-se incapaz de conquistar o consenso da cidadania sobre os objetivos constitucionais e exercendo seu poder sem envolver a assembleia do povo (Dreher, 2008: 52). Dion foi assassinado em 354 a.C. e Siracusa foi governada por uma sucessão de indivíduos até Dionísio II retornar ao governo brevemente em 346 a.C. (até 344 a.C.) (Rutter, 1997: 165). Nessa época, 0 interior e as cidades da Sicília oriental encontravam-se devastados, a população havia se empobrecido e as fontes de riqueza estavam esgotadas (Rutter, 1997: 165).

Foi nesse contexto que Corinto, metrópole de Siracusa, enviou o general coríntio Timoleonte a pedido de Hicetas, um antigo membro do círculo de Dion e exilado em Leontino (Rutter, 1997: 165). Em Siracusa, Timoleonte devia expulsar Dionísio II de Ortígia, onde se encontrava barricado, e normalizar a situação interna da cidade (Dreher, 2008: 55). Mas o general coríntio devia também defender a Sicília dos cartagineses, os quais aproveitaram a fragmentação das forças gregas na ilha, após a expulsão de Dionísio II, para reforçar a própria posição (Dreher, 2008: 55). No momento em que Timoleonte chegou à Régio, Hicetas havia se instaurado no poder de Siracusa, apesar da presença de Dionísio ainda em Ortígia. Nesse momento obteve apoio dos cartagineses e tentou fazer o general coríntio desistir de sua viagem à Sicília (Dreher, 2008: 55-56). Timoleonte desembarcou em Tauromenion em 344 a.C., onde foi recebido pelo tirano Andromaco de quem obteve um importante apoio para a batalha pelo controle da cidade de Hadranon, a oeste do Etna, onde venceu Hicetas em 344 a.C. (Dreher, 2008: 56; Karlsson, 1995: 154; Rutter, 1997: 165). Antes mesmo de chegar à Siracusa, Timoleonte havia obtido sua primeira vitória (Dreher, 2008: 56). Essa ocasião fez Hadranon, Tyndaris, Catânia, e outros vários centros, a fecharem tratados de aliança (symmachia) com Timoleonte. Foram justamente as cidades a oeste do Etna, nos vales do rio Chrysas e do Symaithos, as primeiras a se juntarem ao general coríntio (Karlsson, 1995: 154). Em 342 a.C. (ou 339 a.C.), Timoleonte tomou Leontino, onde Hicetas, o último "tirano" de Siracusa, tinha resistido com suas forças mercenárias, tornando-se, nesse momento senhor da pólis siracusana (Dreher, 2008: 56; Karlsson, 1995: 154). Então, o general coríntio continuou até Engyon e Apolonia, provavelmente marchando até o vale do Chrysas, terminando em Entella, na parte centro-oeste da ilha, que foi capturada (Karlsson, 1995: 154). Naquele tempo, Timoleonte deve ter organizado a sua symmachia, a qual concentrou-se nas partes central e nordeste da ilha - centro da cunhagem relacionada com o tipo de Zeus Eleutherios com cabelos curtos (Karlsson, 1995: 154). Nesse mesmo ano, Timoleonte retomou a luta 
contra os cartagineses até o tratado de paz de 339 a.C., o qual proclamou todas as cidades gregas livres (Dreher, 2008: 56; Karlsson, 1995: 154).

A intenção de Timoleonte foi a de expulsar todos os tiranos das cidades da Sicília. Ele depôs Hicetas em Leontino, Leptines em Engyon, Nikodamos de Centuripe, Appoloniadas de Agyrion, Mamerkos de Catânia e Hippon de Messana. Apenas seu amigo Andromacos, de Tauromenion, foi poupado (Karlsson, 1995: 154). Conforme nos diz Diodoro (XVI, 73.2), as cidades da ilha juntaram-se a Timolente devido à política de restauração de sua autonomia (Karlsson, 1995: 155). A política de Timoleonte não se baseava na extensão de sua soberania a partir de Siracusa, como fez Dionísio I, mas sobre a autonomia das comunidades (Dreher, 2008: 57). Na sua política, os tradicionais ideais de autonomia e liberdade não eram apenas slogans, mas princípios efetivamente respeitados nas estruturas políades (Dreher, 2008: 57). Os tiranos foram expulsos, os cartagineses vencidos, e um novo período de reavivamento econômico e cultural começou na Sicília (Karlsson, 1995: 155). Nessa nova fase, ocorreu a reconstrução das cidades, chamada de uma segunda fase de colonização. Muitos siceliotas retornaram à ilha e novos cidadãos, provenientes da Itália do Sul e da Grécia Balcânica, foram naturalizados. Essa foi a nova colonização ou refundação das cidades - destruídas anteriormente pelos cartagineses e submetidas por Dionísio I - de Agyrion, Camarina, Gela, Agrigento, Megara Hibleia e talvez também de Naxos e Heraclea Minoa. Timoleonte promoveu não apenas a refundação de Siracusa, onde foi venerado como um oikista, mas também de outras póleis gregas, renovando profundamente a Sicília grega. As suas medidas econômicas, sociais e urbanísticas tiveram, para o desenvolvimento da Sicília, consequências muito mais profundas do que suas regulamentações políticas em senso estrito (Dreher, 2008: 60). Segundo M. Dreher, "Timoleonte foi o último expoente, na Sicília, do mundo grego da pólis" (Dreher, 2008 : 61). É sob esse contexto que as evidências numismáticas do período devem ser estudadas, ao invés daquele da carreira e dos feitos de Timoleonte (Kraay, 1976: 236).

Quando Timoleonte chegou à Sicília, a situação monetária que ele encontrou era desesperadora. Com exceção de Siracusa, as cidades gregas não emitiam moedas há mais de 50 anos e os dias das cunhagens prolíficas de Dionísio I já haviam terminado (Kraay, 1976: 236; Rutter, 1997: 165). Não havia, assim, cunhagem local para pagar soldados mercenários e a sua falta foi largamente sanada com o uso das moedas de Corinto (chamadas de pegasi em alusão à representação do cavalo alado nelas gravadas) (Kraay, 1976: 236; Rutter, 1997: 165). Os estateres de Corinto serviram como um modelo a outras cidades, que logo retomaram as suas cunhagens (Fischert-Bossert, 2012: 151). Além dos pegasi de Corinto, logo uma cunhagem de litras de bronze iniciou-se em Siracusa, a qual foi produzida em grande quantidade (Kraay, 1976: 237). Entre essas também foram emitidas séries de estateres de prata com o tipo da cabeça de Atena, no anverso, e o golfinho e uma estrela, no reverso, além das meias-litras com a imagem da cabeça de Atena, no anverso, e do Pégaso, no reverso (Kraay, 1976: 237).

De acordo com os especialistas, as imagens monetárias de Zeus, assinaladas tradicionalmente ao período de Timoleonte, devem ser classificadas em duas séries monetárias, com cronologias diferentes, 
baseadas no estilo dos tipos (Garrafo, 1976-1977: 19; Karlsson, 1995: 149 e 157). A série mais antiga (1a ou A) é aquela com o tipo monetário de Zeus com cabelos curtos e barba longa, no anverso, e com o raio (com ou sem a águia), no reverso. Essa série teria sido emitida, conforme Manganaro e Karlsson, ao redor de 344 a.C. (nessa data ou logo após) (Karlsson, 1995: 157 e 163). Várias cidades da Sicília (centros gregos e gregossículos), tais como Siracusa, Agyrion, Alaisa, Alontion e Aetna bateram moedas de bronze com esses dois tipos associados (Zeus e raio com ou sem a águia) (Karlsson, 1995: 157). Como dissemos inicialmente, essas primeiras imagens monetárias de Zeus foram emitidas no contexto dos tratados de symmachia, possuem a inscrição referente ao nome de Zeus Eleutherios, no anverso junto ao desenho da cabeça do deus, e o étnico no genitivo plural que se refere a comunidade como um todo. A imagem da águia em pé, de asas fechadas, associada à do raio, no reverso, pode ser vista nas moedas de Siracusa (Fig.241 - n.375) e de Agyrion (Fig.241 - n.374), embora Siracusa também tenha cunhado o reverso do raio sem a águia (Fig.241 - n.367/368). Esse mesmo esquema iconográfico de Siracusa, sem a presença da águia junto ao raio no reverso, pode ser visto nas moedas de Aetna (Fig.241 - n.369) e Alontion (Fig.241 - n.370). Nas moedas de Alaisa ${ }^{9}$, foram usados 0 tipo do anverso da cabeça de Zeus de cabelo curto e barba longa, com a inscrição referente a Zeus Eleutherios, e no reverso a inscrição $\Sigma$ IMMAXIKON, que não acompanha o raio, mas imagens de divindades (ninfa Sikelia, Apolo Arquegueta e Kore) ou seus símbolos (tocha e grão de trigo de Deméter e Kore) (Karlsson, 1995: 150). De Alaisa, também, há uma emissão em que o raio aparece no reverso com a inscrição alusiva à symmachia, e a imagem do anverso não é a de Zeus Eleutherios, mas a cabeça de Apolo Arquegueta (Fig.241 - n.296). As moedas da symmachia são exclusivamente relacionadas às emissões siracusanas com o tipo da cabeça de Zeus com cabelos curtos, no anverso, e uma águia e um raio no reverso (Karlsson, 1995: 158). O uso do mesmo cunho deve ter ocorrido em Siracusa e no interior da Sicília (Karlsson, 1995: 158). Essas moedas da symmachia pertencem, estilisticamente e metrologicamente, a um grande grupo de moedas de bronze siceliotas interrelacionadas, nas quais a imagem de Zeus foi substituída pelas das divindades locais citadas acima (Karlsson, 1995: 158).

A segunda série monetária (1b ou B), a mais recente, é datada de 337/36 a.C., época de uma provável reforma monetária, ocorrida em algum momento entre a batalha de Crimissos em 339 a.C. e a abdicação de Timoleonte (Karlsson, 1995: 159). A datação dessa série foi especialmente muito debatida entre os estudiosos e aqui seguiremos a proposição de Karlsson. Nessas novas emissões, a cabeça de Zeus, no anverso, é representada com cabelos longos e barba longa, e o reverso é ocupado pela figura do Pégaso (em Siracusa) ou pela da águia em pé (em Agrigento, por exemplo) (Karlsson, 1995: 159). Alguns desses tipos monetários de Zeus, cunhados em Siracusa, foram comparados àqueles de Élis e Megalópolis do período, os quais, se acredita, teriam influenciado os tipos siracusanos (Karlsson, 1995: 159). Em razão da datação ultrapassar 0 período proposto nessa pesquisa (de até 345/44 a.C.), essa segunda série não será analisada.

\footnotetext{
${ }^{9}$ Não dispomos da imagem desse tipo monetário de Alaisa em nosso catálogo, pois este não foi localizado na bibliografia numismática a respeito.
} 
Isto posto, nos interessa a primeira série monetária de c.344 a.C., momento em que a imagem de Zeus Eleutherios ("Libertador") foi escolhida, pela primeira vez na ilha, para figurar nas moedas do período da symmachia de Timoleonte. Na Sicília, o culto a Zeus Eleutherios teve origem em Siracusa, no século V a.C., na época da expulsão de Trasíbulo da cidade em c.466 a.C., o último dos Deinomênidas. De acordo com Diodoro (XI, 72.2), para comemorar a liberação da tirania, os siracusanos erigiram uma estátua do deus e instituíram um festival anual - as Eleutheria - em sua honra. Como coloca Karlsson, provavelmente, esse festival foi interrompido na retomada da tirania, no período dos Dionísios, e reavivado posteriormente pelo general coríntio (Karlsson, 1995: 151). Segundo esse autor, "pode-se assumir que os siracusanos viram Zeus Eleutherios como um símbolo de democracia e de liberdade da tirania, ao invés do símbolo de vitória sobre os cartagineses, como chegou a ser afirmado" (Karlsson, 1995: 152). Karlsson acrescenta ainda outro dado, fornecido por Diodoro (XVI, 70.6), que mostra a importância de Zeus para Timoleonte: o sacerdote de Zeus Olímpio em Siracusa tornou-se epônimo para o ano siracusano nas suas novas reformas constitucionais (Karlsson, 1995: 152). Em seu artigo sobre o significado simbólico de Zeus Eleutherios e do Pégaso, nas séries 1a e 1b, Karlsson concluiu que a imagem do deus foi um símbolo de democracia, familiar aos siceliotas e à Timoleonte, que a usou à sua maneira nas moedas (Karlsson, 1995: 164).

De fato, a interpretação de Karlsson sobre o significado de liberação e democracia, relacionado aos tipos monetários, está correta. Para os gregos, ao menos a partir da primeira metade do século V a.C., havia uma tradição em evocar Zeus Eleutherios após a libertação de um poder ou inimigo opressor. A função de Zeus Eleutherios estava mais ligada à ideia de libertação de uma cidade diante de um perigo interno ou externo (Vonderstein, 2006: 25). Em contraste a Zeus Eleutherios, Zeus Sóter parece ser uma divindade salvadora mais abrangente, que era cultuada tanto em âmbito político quanto no privado (Vonderstein, 2006: 25). De acordo com Tucídides (II, LXXI.2-3), em Platéia, na Beócia, os gregos ofereceram sacrifícios a Zeus Eleutherios, na ágora da cidade, após a batalha de Platéia em 479 a.C. contra os persas. Pausânias (IX, II.4-7) diz que, em razão da comemoração da vitória na batalha, foram erigidos uma estátua e um altar ao deus, onde todos os anos eram celebrados jogos em um festival chamado também de Eleutheria. Um culto de Zeus Eleutherios também foi estabelecido em Samos em c.479 a.C., quando essa pólis foi libertada dos poderes persa e tirânico - a história a qual diz de uma origem mais antiga, uma invenção daquele ano (Raaflaub, 2000: 255). A propósito do culto de Zeus Eleutherios, nesse contexto, K. Raaflaub concluiu que "a liberdade teve um valor político à época das guerras pérsicas. Esse valor foi aplicado à pólis tanto na luta contra a sujeição e a escravidão sob os persas, quanto sob o domínio tirânico, tendo sido esse valor quase imediatamente transferido à esfera religiosa, onde encontrou expressão no culto de Zeus Eleutherios, o deus da liberdade" (Raaflaub, 2000: 254).

Bem nessas emissões, relacionadas à symmachia de Timoleonte, os dois atributos de Zeus são representados junto a Zeus em uma mesma moeda, ou apenas um deles - 0 raio - aparece associado pela primeira vez ao deus em tipos monetários da Sicília. Mas essas associações não foram criações siceliotas, ao que parece. 0 uso da imagem de Zeus, junto ao da águia e do raio, em uma mesma moeda, ocorreu pela 
primeira vez nas moedas de Élis-Olímpia, cunhadas ao redor de 348 a.C., quase que na mesma época dos tipos monetários de Zeus com cabelos curtos do período de Timoleonte. Concluímos no capítulo anterior, que, embora tenha sido, provavelmente, uma criação de Élis, essa associação predominou no Ocidente grego (na Sicilia e na Itália do Sul) e foi típica do século IV a.C. Já no caso dos tipos monetários de Zeus e raios, a associação ocorreu, primeiramente, no século V a.C., em c.416 a.C., novamente em Élis-Olímpia, predominando, depois, no século IV a.C. na Tessália. A nosso ver, a escolha das comunidades em usar a reunião das imagens de Zeus, do raio e ou não da águia, em uma mesma moeda, mostra a intenção deliberada em referenciar essas emissões somente ao deus e a determinado culto dele, como evidencia a inscrição do título Eleutherios de Zeus. Mas, também, essa reunião da imagem de Zeus e de seus atributos mostra a intenção em querer reforçar, ou super dimensionar, todos os significados e energias divinas contidos em cada representação, os quais, ao final, são complementares e convergentes. Vimos no final do capítulo anterior que os significados do raio e da águia - de guerra, competição, disputa e vitória - são todos consonantes com as características da personalidade e figura de Zeus, com sua esfera de atuação e culto. Desses significados, aquele de vitória é particularmente ressaltado pelo uso da coroa de folhas de oliveira na cabeça do deus nesses tipos monetários. Vimos, também, como esses significados mostram que o raio e a águia eram epifanias da divindade, na concepção dos gregos, manifestações na natureza de suas energias divinas. Nesse sentido, nesses tipos monetários mostra-se bem quais foram os aspectos mais importantes de Zeus, requeridos pelas comunidades, para se chegar à normalização da pólis e de suas instituições, nesse caso, democráticas, defendidas por Timoleonte. Nesse caso, não se requisitou em favor da comunidade as energias de Zeus, que sempre se referem, genericamente, à guerra e a sua vitória, a ordenação sobre o caos, mas, além disso, um aspecto preciso de Zeus, o de liberação de algo que ameaça a estabilidade da comunidade política. Assim, os primeiros tipos monetários de Zeus Eleutherios, com cabelos curtos e barba longa, associado às imagens do raio com ou se a águia, mostram que o deus teve um papel político destacado - o de protetor e propiciador da ordenação, das comunidades siceliotas, que naquele momento correspondia à restruturação da pólis, a instauração e manutenção da democracia e de sua autonomia.

De acordo com L. Donnellan, "Timoleonte empreendeu um programa bem definido de propaganda contra seus adversários, usando símbolos claros nas cunhagens" (Donnellan, 2012: 178). Além de Zeus Eleutherios, esses símbolos foram, principalmente, as imagens de Apolo Arquegueta e da ninfa Sikelia - todas com uma mensagem patriótica siceliota (Donnellan, 2012: 178; Karlsson, 1995: 158). Como defende Donnellan, "foi nesse período que a identidade étnica siceliota foi firmemente estabelecida, após ser despertada à época das expedições atenienses no século V a.C. Foi justamente nesse contexto que a ninfa epônima Sikelia passou a ser representada em moedas e que Apolo Arquegueta, um símbolo monopolizado por Naxos, Catânia e Leontino, ganhou uma dimensão pan-siceliota" (Donnellan, 2012: 181). Em contraste ao significado de identidade relacionado às divindades representadas contemporaneamente a Zeus Eleutherios nas moedas, a 
imagem do deus, portanto, não reforça nenhum aspecto de identidade local, pan-siceliota, o que confirma 0 papel e a mensagem estritamente políticos a ele vinculados naquele momento.

As emissões de Timoleonte são as últimas dos tipos monetários de Zeus, raios e águias que podemos atribuir ao período clássico na Sicília. Ao longo da contextualização dos tipos monetários dentro de suas respectivas emissões pelas autoridades emissoras, vimos que as imagens de Zeus em moedas foram usadas em dois momentos diferentes. No primeiro, estas foram circunscritas às póleis gregas do lado oriental da ilha, na sua parte leste e nordeste a partir 475 até 460 a.C. A partir de 450 a.C., imagens monetárias da divindade passaram a ser usadas por centros gregos-sículos nessa mesma região. Da análise contextual, conclui-se que as imagens de Zeus em moedas foram requisitadas tanto em período tirânico (em menor grau) quanto em período pós-tirania (em maior grau), predominantemente em momentos de instabilidade política - a sobrevivência política, afirmação da comunidade e restabelecimento da pólis em outro lugar. O contexto de uso nas póleis gregas foram desde os primeiros deslocamentos populacionais, provocados pelos tiranos, até 0 retorno (possível ou não) das populações às suas cidades originárias após a queda da tirania. Nas póleis sículas, o contexto de uso foi o restabelecimento desses centros entre o fim do movimento nacional sículo de Ducézio e a perda de autonomia para Siracusa. Foram nesses contextos que a imagem de Zeus ganhou significado na Sicília. O caráter ordenador do deus foi o significado mais importante para as póleis da região no século $V$ a.C. Ao usarem os tipos de Zeus em suas moedas, as póleis procuraram requerer a proteção, a energia divina, da divindade com maior competência nesse aspecto, para o estabelecimento, manutenção e afirmação da identidade política e cívica delas enquanto comunidades.

\subsubsection{Considerações gerais sobre as imagens monetárias de Zeus e de seus atributos na Sicília}

Conclui-se que as imagens de Zeus, na Sicília durante o século V a.C., foram resultantes de uma área cultural única, ao redor do Etna, na qual centros sículos helenizados também compartilharam traços culturais. A imagem do raio também foi usada nesse mesmo contexto no século $V$ a.C. (a partir de 465 a.C.) e também em área etnea (somente Aetna e Catânia). 0 tipo do raio (alado) foi requisitado, em bem menor grau, somente por comunidades gregas no contexto dos deslocamentos populacionais e restabelecimento da pólis em período pós-tirania. Imagens monetárias de Zeus e do raio, nesse período, não foram restritas a um grupo étnico específico - estas foram compartilhadas por póleis dórias e calcídias (jônias) e por centros sículos no lado oriental da Sicília. Se por um lado o tipo de Zeus não foi restrito a dórios ou a calcídios, por outro, devemos destacar que a imagem de Zeus em moedas emergiu na Sicília no momento da chamada dorização da área calcídia, ocorrida inicialmente com a migração de peloponésios durante a fundação de Aetna e depois de Messana (Grasso, 2008). Nesse sentido, é possível que o elemento peloponésio tenha sido o catalisador, entre dórios e calcídios, do uso da imagem de Zeus e também do raio, nessa grande área cultural do lado leste da 
ilha, pois, como vimos, no Peloponeso havia uma importante e pioneira tradição no uso desses tipos em moedas.

No segundo momento do uso do tipo monetário de Zeus, a imagem da águia e do raio, Ihe são associadas pela primeira vez na Sicília, nas emissões de Timoleonte da segunda metade do século IV a.C., que provavelmente também seguiu uma tendência, de uso dos tipos associados, originária do Peloponeso (ÉlisOlímpia). Nessa época, as três imagens, especialmente a de Zeus, foram requisitadas na quebra do regime tirânico, em época pós-tirania a favor da instituição da pólis democrática. Nos outros casos do século V a.C., em que a imagem de Zeus em moedas emergiu em período pós-tirania, não temos dados suficientes para saber a que tipo de governo (se oligárquico ou democrático) as póleis estavam submetidas. De acordo com a bibliografia, contudo, após a queda da tirania, as póleis siceliotas viveram um período de democracia até a ascensão de Dionísio I em 406 a.C., embora G. Vallet fale de uma tendência oligárquica das póleis calcídias e do retorno desse poder em algumas dessas cidades, como em Messana nessa nova fase (apud Dreher, 2008 : 34).

Na Sicilia, portanto, o estudo da contextualização dos tipos mostra que Zeus, quando apropriado pela pólis para figurar nas moedas, não teve um significado pan-siceliota como teve Apolo, Deméter/Kore ou a ninfa Sikelia. Zeus não atuou na esfera de pertença de identidade de um grande grupo (étnico), ao contrário, teve agência somente sobre outro nível de identidade, a identidade políade.

Primeiro tipo a ser utilizado em moedas da ilha ainda no final do século VI a.C., a águia foi usada, como imagem principal, majoritariamente no sudoeste da Sicília, pela pólis de Agrigento. Imagens monetárias da águia parecem ter sido usadas pela primeira vez em época tirânica, embora não tenham caído em desuso em época democrática, ao longo do século $V$ a.C. Concluímos que a águia foi considerada a auto-representação da cidade, pois ela significou onipotência e soberania, nesse caso, territorial e de hegemonia sobre as demais póleis de sua região, numa época de consolidação de sua expansão. O tipo da águia em pé, de asas fechadas, e sem presa, foi concebido e usado como tipo monetário de Agrigento nesse contexto. Já os tipos da águia em pé, com as asas agitadas, com presas, pertence e expressa o período dos acontecimentos militares, que envolveram toda a Sicilia a partir de 425 a.C. - a hegemonia de Siracusa, a invasão ateniense e cartaginesa até a destruição da cidade. $O$ uso dessa representação condiz com o momento conturbado enfrentado por Agrigento. Acreditamos que por essa razão, a comunidade tenha escolhido representar nas moedas a águia com a presa, requerendo para si o significado que a imagem expressa: derrota e vitória sobre o inimigo. Portando esse mesmo significado, a águia com a presa, no caso a cobra, foi representada, pela primeira vez em uma moeda de Agrigento, compondo a imagem da tradicional quadriga. E assim, como dissemos, essa soberania territorial e o sucesso na guerra, na concepção religiosa dos antigos gregos, vinham de Zeus, como vimos, uma divindade diretamente relacionada à guerra e ao poder. A representação da águia nas moedas, nesse contexto, requeria a energia divina dessa divindade sobre a pólis, a sua proteção e mediação sobre esses aspectos. Agrigento teve também um papel na difusão de tipos monetários da águia para centros da ilha. 
Entre centros de origem não-grega (púnico, elímios, sicanos e sículos) o tipo da águia em pé, sem presa, sobre a coluna de um capitel jônico foi o mais difundido durante o século $V$ a.C. Já entre centros gregos, tipos monetários da águia com presa e/ou voando sobre a quadriga, usados por Agrigento à época dos eventos militares da segunda metade do século $V$ a.C., também ganharam significado entre outras póleis gregas, também de fora as Sicília, que os utilizaram em suas moedas, no mesmo momento militar e político.

Em suma, embora o uso não tenha sido restrito a nenhum grupo específico, foram póleis dórias as responsáveis por introduzir os tipos monetários de Zeus, raios e águias na Sicília. 


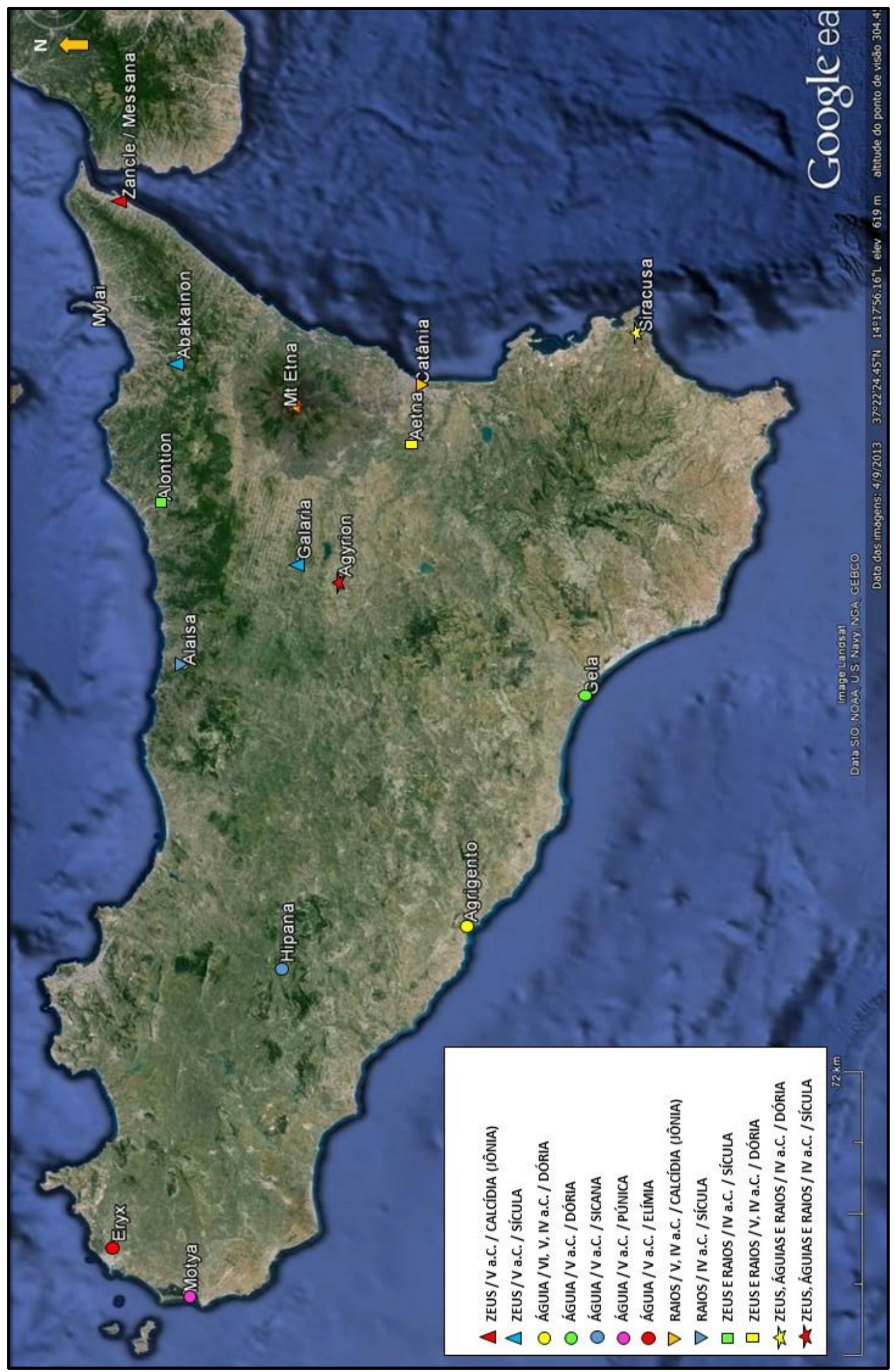

Fig.239 - Mapa da Sicília: autoridades emissoras que emitiram tipos monetários de Zeus, águias e raios (séculos VI-IV a.C.) 

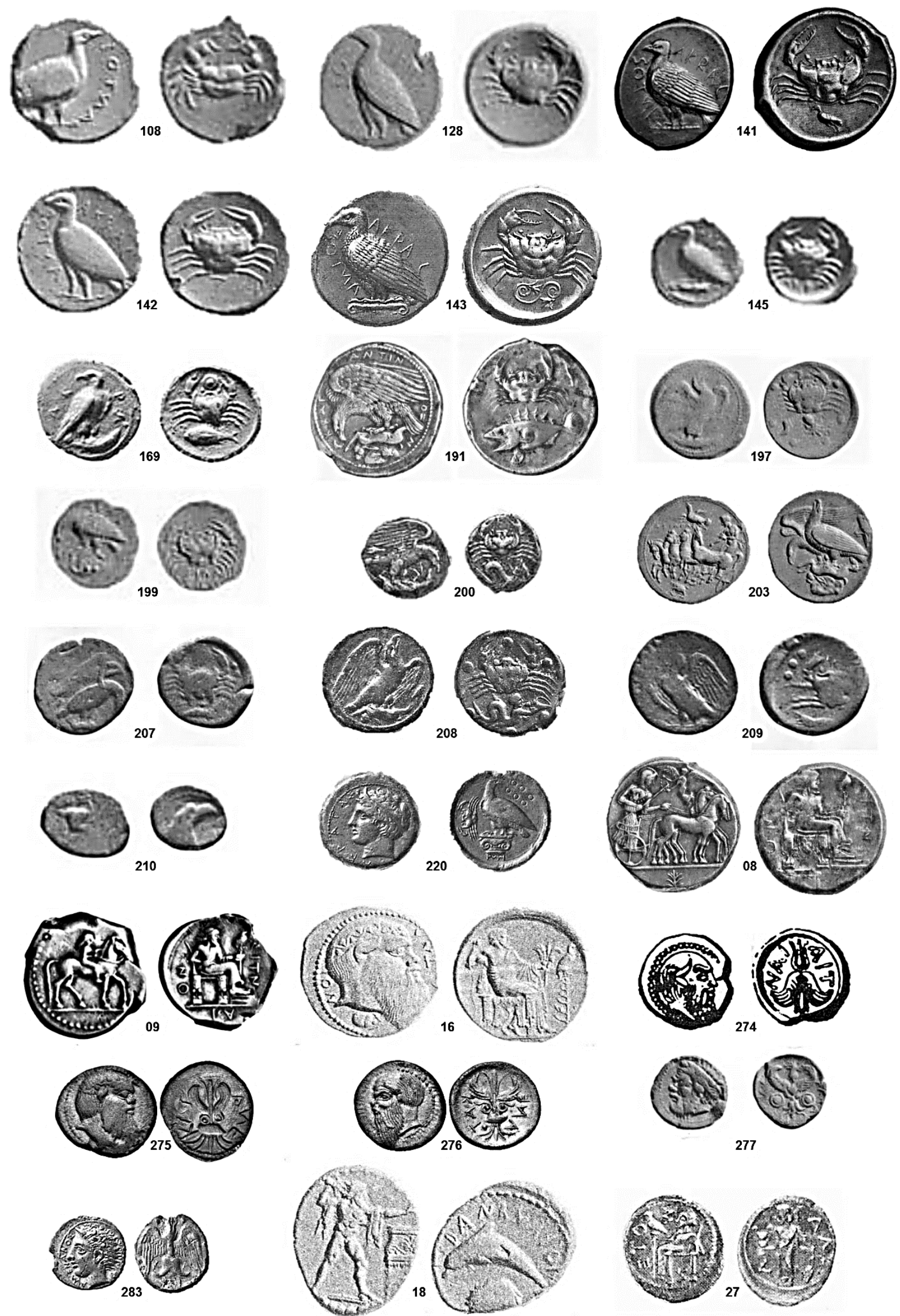

Fig.240 - Sicília: tipos monetários de Agrigento (n.108-220), Aetna (n.08-274), Catânia (n.275-283), Zancle (n.18) e Galária (n.27) 

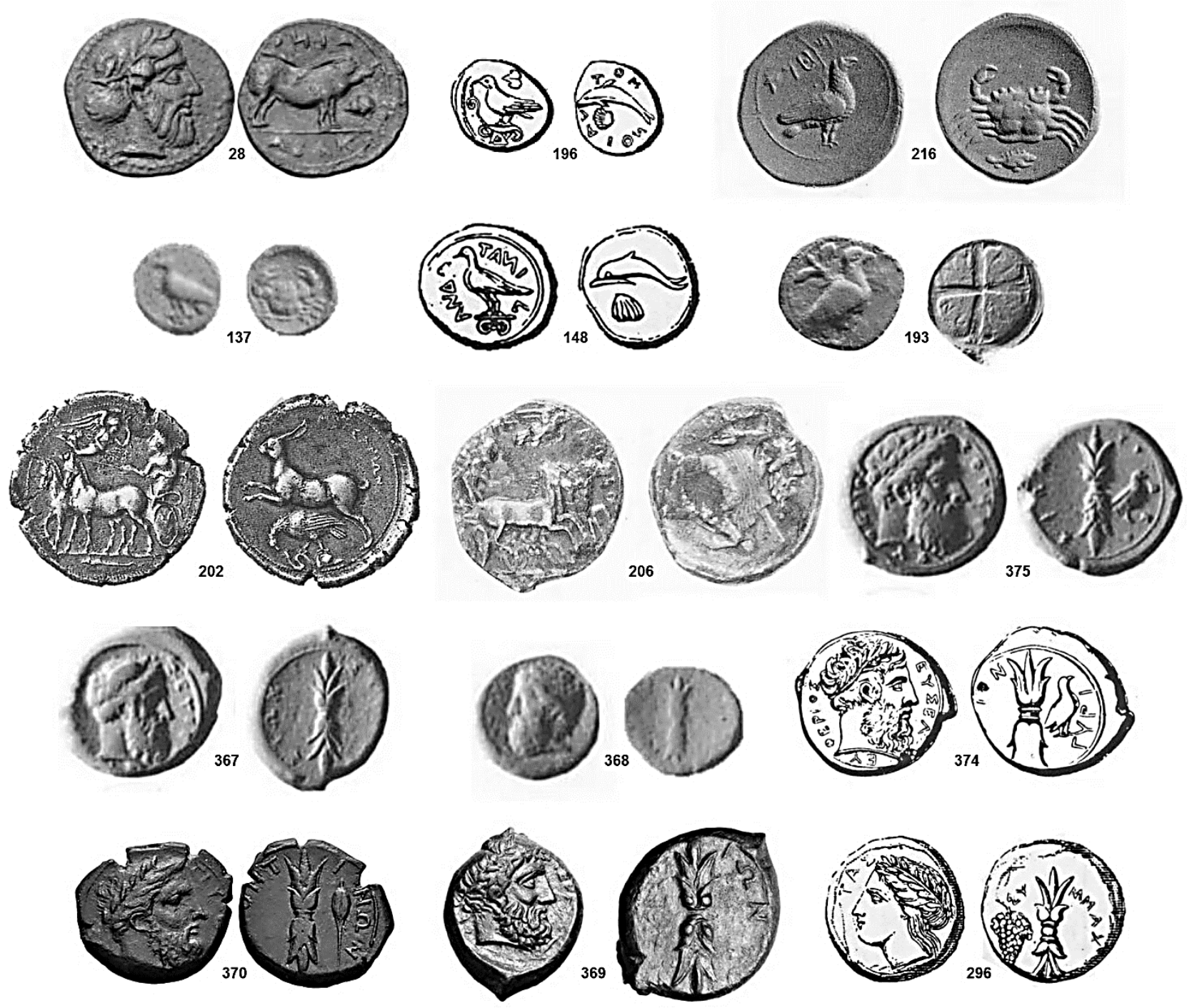

Fig.241 - Sicília: tipos monetários de Abakainon (n.28), Motya (n.196/216), Eryx (n.137), Hipana (n.148), Agyrion (n.193/374), Messana (n.202), Gela (n.206), Siracusa (n.375-368), Alontion (n.370), Aetna (n.369) e Alaisa (n.296)

\section{I.3 ITÁLIA DO SUL}

Até o limite cronológico proposto para essa pesquisa (345/44 a.C.), o uso da imagem de Zeus, águias e raios, na Itália do Sul, esteve restrito, inicialmente, às comunidades gregas de origem aquéia (Fig.243). Imagens de Zeus ocorreram pela primeira vez a partir do segundo quartel do século $V$ a.C. nas áreas da costa jônica e da costa tirrênica. Das três imagens, a da águia foi a que primeiro passou a figurar em moedas da região já no segundo quartel do século VI a.C. O raio foi usado como tipo monetário na costa jônica, de acordo com uma cronologia entre o segundo quartel do século $V$ a.C. e o primeiro quartel do século IV a.C., e com outra proposição, no início do século IV a.C. Já a associação entre a imagem do raio e da águia, em uma mesma moeda, ocorreu nesse mesmo período e área. Veremos, ao final, que as imagens de Zeus, águias e raios, após terem figurado inicialmente somente entre as póleis aquéias, passaram a ser usadas, em grande profusão, por Lócris e sua sub-colônia Hipônio apenas, contudo, após o período que cobre essa pesquisa. 


\subsubsection{Crotona}

Crotona foi a terceira autoridade emissora, ao lado de Lyttos em Creta, a mais bater moedas com 0 tipo da águia no mundo grego no período levantado (séculos VII-IV/III a.C.), ficando, em quantidade de tipos monetários, atrás apenas de Élis e Agrigento. Também foi a segunda cidade a combinar tipos de águias e raios em uma mesma moeda entre os séculos V e IV a.C. Uma das fundações aqueias estabelecidas na Itália do Sul ao redor de 709/08 a.C., Crotona foi uma das três póleis desse grupo, juntamente a Síbaris e Metaponto, a primeiro iniciar a cunhagem de moedas na região (Jenkins, 1990: 38; Kraay, 1976: 167; Rutter, 1997: 17; 2001: 3; 2012: 128). Metaponto e Síbaris iniciaram suas emissões ao redor de 550 a.C., enquanto que Crotona começou a bater suas moedas em c.530 a.C., conforme indica uma moeda crotoniata recunhada sobre um dos tipos monetários mais antigos de Corinto (Kraay, 1976: 163; Parise, 1990: 300; Stazio, 1984: 373). Crotona e as demais fundações aqueias não apenas empregaram um padrão comum de peso - aqueu-coríntio baseado em um estater de $8 \mathrm{~g}$, dividido em 3 dracmas - como também a técnica incusa para a cunhagem das moedas, característica dessas cidades da Itália do Sul (Kraay, 1976: 163; Parise, 1990: 299; Rutter, 1997: 17; 2001: 3; 2012: 128; Stazio, 1984: 369).

As primeiras emissões monetárias de Crotona, então, caracterizam-se pelo reverso incuso, no caso com a imagem do trípode que, devido à técnica, aparece tanto no anverso quanto no reverso das moedas (Rutter, 2001: 3; Stazio, 1984: 369). De acordo com C. Kraay, o qual estabeleceu três fases para a técnica incusa, "os primeiros tipos monetários incusos com o trípode foram batidos, predominantemente, na fase em que se empregava o disco largo (de diâmetro superior a $25 \mathrm{~mm}$ e datados antes de 500 a.C.) e, em menor grau, na fase de disco médio (de 22 a $25 \mathrm{~mm}$ de diâmetro e datados de 500-480 a.C.). Esses tipos monetários incusos, com o trípode, aparecem com símbolos (caranguejo ou garça-real) nos exemplares posteriores ou sem a presença destes nos exemplares mais antigos" (apud Parise, 1990: 299-300; Stazio, 1984: 370). A cunhagem em Crotona foi introduzida duas décadas antes da batalha no rio Sagra, em c.550 a.C., quando Lócris derrotou a cidade em sua tentativa de ampliar a sua área costeira (La Torre, 2011: 91). O confronto é tido como 0 segundo episódio decisivo para o ajustamento duradouro nas relações de força e de equilíbrio territorial entre as póleis na Magna Grécia ao longo do século VI a.C. (o primeiro parece ter sido a destruição de Siris pelas póleis aqueias em c.570 a.C.) (Braccesi; Raviola, 2008: 85). Um equilíbrio estável territorial entre Crotona e Lócris, cujos territórios faziam fronteira, manteve-se como resultado dessa guerra - apesar de um novo conflito entre as duas póleis, que também envolveu as fundações lócrias de Medma e Hipônio, ter ocorrido no final do século VI a.C., como indica uma inscrição proveniente de Olímpia (Braccesi; Raviola, 2008: 86). Introduzida em c.530 a.C., a cunhagem em Crotona iniciou-se, assim, no período da chegada de Pitágoras à cidade o qual, segundo os estudiosos, interviu na fase de depressão civil que se seguiu à derrota em Sagra (Braccesi; Raviola, 2008: 101; La Torre, 2008: 92; Parise, 1990: 301; Stazio, 1984: 374). Fugido da tirania de Polícrates em Samos, Pitágoras fundou a Escola Pitagórica em Crotona, reformando os costumes da oligarquia, em uma campanha 
contra a cultura de luxúria e lassidão, atraindo membros de uma nova classe dominante, formada por membros selecionados da restrita aristocracia da cidade (Braccesi; Raviola, 2008: 102; Cerchiai, 2004: 106). É lugar comum na historiografia sobre a Magna Grécia, que Pitágoras teria inaugurado um período de renascimento da cidade (Braccesi; Raviola, 2008: 101). Assim, é nesse contexto que emissões monetárias foram inauguradas em Crotona.

Os autores costumam associar o crescimento da produção monetária de Crotona, desde o seu início, com a preparação, as exigências da guerra e, subsequentemente, a vitória sobre Síbaris em c.510 a.C. (Parise, 1990: 301; Stazio, 1984: 375). As causas dessa guerra estiveram nas intenções de Síbaris, já configurada como um "império", em estender seu território em direção ao de Crotona e também nas orientações políticoinstitucionais opostas entre as duas cidades (Braccesi; Raviola, 2008: 103; La Torre, 2011: 90). Na raiz do conflito esteve o pedido negado, a Télis de Síbaris, do retorno de exilados da aristocracia sibarita, fugidos após a ascensão desse tirano de governo fortemente anti-aristocrático (La Torre, 2011: 89-90). Crotona, na qual Pitágoras já exercia o seu magistério, contribuindo ativamente na tomada de decisões políticas da cidade, ao negar o pedido do tirano sibarita em repatriar os exilados, aceita o risco de um confronto militar (La Torre, 2011: 90). Como resultado da derrota e destruição de Síbaris, a Sibaritide e todo o seu domínio, passou a ser terra dos e para os crotoniatas (Braccesi; Raviola, 2008: 103). Nesse período iniciou-se a chamada crise pitagórica em Crotona, que se estendeu pelo menos até meados do século $V$ a.C., culminando com o exílio de Pitágoras em Metaponto, como veremos mais adiante (Braccesi; Raviola, 2008: 125). Nas origens dessa crise estiveram o desacordo entre a facção pitagórica aristocrática, que pressionava para ser reintegrada na nobreza sibarita, a qual tinha lutado contra Telis, e a facção democrática, liderada por um nobre chamado Kylon, o qual queria a aristocracia sibarita diluída entre os cidadãos de Crotona (Cerchiai, 2004: 106). Em resumo, havia a facção que desejava a restituição de Síbaris aos seus sobreviventes e a outra que defendia uma Sibaritide subjugada por Crotona (Braccesi; Raviola, 2008: 103). Até o final do século VI a.C. a democracia foi introduzida na cidade e um interlúdio de governo tirânico deve ter ocorrido no início do século V a.C. (Cerchiai, 2004: 106; Luraghi, 1994: 74; Fischer-Hansen; Nielsen; Ampolo, 2004: 268). As fontes literárias não informam ao certo como a tirania de Clinias ${ }^{10}$ teria substituído a democracia no início do século V a.C. Sabe-se apenas que ele teria sustentado o seu poder com o apoio dos exilados sibaritas na cidade (Fischer-Hansen; Nielsen; Ampolo, 2004: 268). Com a tirania de Clinias, Crotona estendeu o seu controle por toda a Sibaritide (Taliercio Mensitieri, 1987: 158). De todo modo, após o período tirânico, a democracia foi retomada na cidade ao menos até a metade do século V a.C., quando ocorreu o retorno da oligarquia (Fischer-Hansen; Nielsen; Ampolo, 2004: 268).

É nesse contexto que se assinalam as emissões de estater de prata com o tipo da águia incusa no reverso e o trípode, que se manteve como imagem no anverso (Fig.244 - n.105 e 136). Apesar dessas moedas serem classificadas por C. Kraay, A. Stazio e N. Parise pertencentes à fase do disco médio (500-480 a.C.) e do

\footnotetext{
10 Alguns estudiosos situam a tirania de Clinias após a expulsão de Pitágoras da cidade na metade do século V a.C., como La Torre, 2011, p.92.
} 
disco estreito (depois de 480 a.C.), no Historia Numorum (2001) há um único tipo monetário com a águia incusa catalogado dentro da fase do disco largo (530-500 a.C.), o qual seria, assim, o exemplar mais antigo da representação da águia nas moedas de Crotona (Fig.244 - n.105) (Parise, 1990: 399-300; Stazio, 1984: 372; Rutter, 2001: 166). Stazio propôs que as cunhagens de estateres com a águia incusa situam-se no período sucessivo à destruição de Síbaris por Crotona (Stazio, 1984: 375). Mas a datação do único exemplar batido em disco largo, datado a partir de 530 a.C., coloca o uso da imagem da águia em moedas da cidade no período da chegada de Pitágoras, anterior à guerra com Síbaris. Foi a partir desse período que a imagem da águia passou a ser, ao lado do trípode, um tipo principal nas moedas da cidade. Na técnica incusa, a águia aparece representada, nos estateres, voando à direita ou à esquerda, com as asas abertas (uma em cima e outra embaixo) e sem carregar alguma presa. Na análise tipológica do capítulo anterior, vimos como esse primeiro tipo monetário da águia de Crotona pode ser o segundo mais antigo desse padrão de representação (voando) da ave em moedas, precedido apenas pela imagem monetária da ilha de Sifnos, no Egeu, datada de um pouco antes, de 540 a.C.

Esses tipos monetários com a águia incusa são definidos e denominados, por grande parte dos estudiosos, como emissões estranhas, separadas e subsidiárias ds cunhagens de Crotona (Caccamo Caccamo Caltabiano, 2009: 119-210; Kraay, 1976: 168 e 174; Parise, 1990: 302). Para C. Kraay, "a presença de um tipo diferente (a águia) daquele do trípode no reverso das cunhagens incusas, incomum às cunhagens nessa técnica de outras autoridades emissoras da região, teria indicado a participação de outra cidade na emissão das séries - tratar-se-ia de uma emissão de aliança" (Kraay, 1976: 168; Parise, 1990: 302; Rutter, 1997: 29-30; Stazio, 1984: 375). Em posse de toda a área do antigo império de Síbaris, Crotona seguiu a estratégia sibarita de fazer das emissões monetárias um eficaz instrumento de controle de seus novos domínios - essas são chamadas, pelos estudiosos, de moedas de império, de aliança ou subsidiárias (Kraay, 1976: 168; Parise; 1990: 301-302; Rutter, 1997: 29-30; Stazio, 1983: 967). Entre o fim do século VI e até a metade do século V a.C, Crotona bateu moedas conjuntamente com Síbaris, Pandosia, Temesa - estateres com dupla tipologia (o trípode crotoniata e o emblema da outra cidade) e duplo étnico (com o nome de Crotona e das comunidades sob a sua esfera hegemônica) (Kraay, 1976: 168; Luraghi, 1994: 74; Parise, 1990: 301-302; Stazio, 1984: 375). Nesse sentido, essas moedas de aliança teriam sido batidas nas oficinas dessas cidades (Stazio, 1984: 375). No caso dos estateres com as águias incusas, Kraay propôs que estas teriam sido batidos em uma oficina subsidiária em Hipônio com base no uso de tipos da águia em emissões mais tardias dessa cidade (Gargano, 2012: 882; Kraay, 1976: 168; Parise, 1982: 115-116; 1990: 302; Rutter, 1997: 30; Stazio, 1984: 375). Essa proposição de Kraay é seguida e repetida por vários autores em artigos ou manuais de numismática da região, na ausência de outras teorias que expliquem o uso repentino da águia nas cunhagens incusas de Crotona. Stazio, em seu estudo das cunhagens crotoniatas, é o único a explicar as séries com a águia como uma nova expressão da oficina crotoniata (Stazio, 1984: 375). De fato, nessas séries não há a legenda abreviada do nome de Hipônio acompanhando o étnico de Crotona, como ocorre para os outros casos de moedas de aliança, apenas a 
inscrição referente à pólis crotoniata aparece nas moedas. A nosso ver, representações muito posteriores de águia, nas moedas de Hipônio, datadas entre o século IV e III a.C., não podem ser usadas como confirmação para o funcionamento de uma oficina subsidiária de Crotona naquela cidade.

Entre a última fase da técnica incusa de disco estreito (após 480 a.C.) até o emprego do relevo duplo na oficina monetária de Crotona (no último quartel do século $V$ a.C.), o tipo da águia voando, sem carregar qualquer presa, continuou a figurar nas cunhagens da cidade, sendo trocado, na fase do relevo duplo, por outro padrão de representação da ave (em pé), usado ao lado de novos tipos de representações (Fig.244 - n.170192/254-271/318-338). Antes do emprego do relevo duplo nas emissões de Crotona - durante as últimas emissões incusas em discos médios e estreitos - a produção da oficina monetária da cidade aumentou: ao lado do estater, foi emitido um número maior de dracmas e pela primeira vez ocorreu a cunhagem de óbolos (Parise, 1990: 303). Entre esse período, que vai do início ao segundo quartel do século V a.C., Crotona viveu o apogeu, obtido pela conquista do território de Síbaris, e também a desintegração de seu poder territorial e político. A vitória sobre os sibaritas assinalou um período de expansão massiva de Crotona por toda a primeira metade do século V a.C. No entanto, Crotona, ao longo do tempo, não foi capaz de administrar a grande extensão do império sibarita com seu enorme potencial produtivo, o que levou à desestabilização do equilíbrio interno da cidade (Cerchiai, 2004: 106). Além disso, entre 476 e 445/44 a.C. houve cinco tentativas em refundar Síbaris, empreendidas por exilados sibaritas dispersos pelas cidades de seus antigos domínios. Todas as tentativas de refundação foram fracassadas por Crotona, com exceção de Síbaris V, fundada na área do rio Traente. Ainda por volta desse período, Crotona tentou manter seu domínio na costa do mar Tirreno, fundando Terina (Cerchiai, 2004: 106). A fundação da quinta Síbaris é considerada pelos historiadores como um sinal da impotência da comunidade crotoniata naquele momento. E com a fundação de Túrio em 444 a.C., com o apoio de Atenas no local da primeira Síbaris, Crotona perdeu a Sibaritide para sempre (Braccesi; Raviola, 2008: 127). Como vimos anteriormente, a cidade passava, também, pela crise do pitagorismo, agravada ao redor de 450 a.C. Os pitagóricos, em poder em Crotona, não foram capazes de gerir o imenso poder herdado de Síbaris tanto que, ao longo desse período, surgiram na cidade revoltas que levaram à expulsão de Pitágoras e dos seus seguidores que se opunham, em defesa dos princípios de austeridade e moderação dos costumes, ao desejo e necessidade dos cidadãos de dividir as terras férteis subtraídas de Síbaris, as quais não haviam sido divididas até a metade do século V a.C. (La Torre, 2011: 92). Após a expulsão dos pitagóricos, Crotona viveu um estado de guerra endêmica praticada pelos opositores ao governo democrático, os oligarcas, os quais conseguiram voltar ao poder nesse período (Braccesi; Raviola, 2008: 142; Fischer-Hansen; Nielsen; Ampolo, 2004: 268). Todos esses fatores, segundo os estudiosos, contribuíram para o declínio de Crotona como autoridade emissora na última parte do século $V$ a.C., como evidenciam a queda do peso do estater e a diminuição ou até mesmo alguma interrupção da produção de sua oficina monetária (Rutter, 2001: 4; Stazio, 1984: 384).

A segunda metade do século $V$ a.C. foi uma época de conflitos internos nas fundações gregas da ltália do Sul, caracterizados por levantes e reformas, democracia incipiente, luta civil entre democratas que emergem 
e oligarcas que resistem (Braccesi; Raviola, 2008: 127). À essa crise do equilíbrio político na Magna Grécia, somou-se a vinda e interferência das populações não-gregas, principalmente lucanas, no caso das cidades gregas de origem aquéia na costa jônica. Após a destruição de Síbaris em 510 a.C., as populações não-gregas, ligadas por vínculos políticos e econômicos a essa pólis, entraram quase todas em crise, como mostra 0 esgotamento e o redimensionamento de muitos dos centros principais, e de suas necrópolis, e o fim das cunhagens de aliança, que os sibaritas haviam realizado juntamente a alguns desses centros (La Torre, 2011: 90). Esse processo levou essas sociedades não-gregas a se reorganizarem para então reaparecerem no cenário político entre a segunda metade do século $\mathrm{V}$ a.C. e o início do século IV a.C. com uma fisionomia sociocultural diferente, ciente de sua força, derivada do prolongado contato com os gregos e pela completa assimilação de seus modelos culturais, organizacionais e militares. Trata-se do período de etno-gênese dessas populações (La Torre, 2011: 116).

Como resultado da crise na região, e principalmente relacionada às póleis aqueias na costa jônica, organizou-se, pela primeira vez uma liga entre algumas dessas cidades. Políbio é a principal fonte de informação a respeito da primeira fase da liga, denominada, em seu segundo momento no século IV a.C., de liga italiota. De acordo com Políbio (2, 39,1; 2, 39, 7), após o incêndio dos sinédrios pitagóricos em Crotona, com a consequente desordem interna, fez-se necessária uma mediação vinda de fora - foi com os aqueus da metrópole, no Peloponeso, que as cidades aqueias da Itália do Sul solicitaram intervenção (De Sensi Sestito, 1994: 198; Fronda, 2013: 124). Essa que pode ser considerada a primeira intervenção não-militar da metrópole nos acontecimentos do Ocidente colonial, foi chamada, em primeiro lugar naquele momento, a recompor as divisões internas em Crotona, as turbulências que acometiam também toda a área aquéia, e em segundo lugar, à defesa contra os povos nativos do interior, nesse caso os lucanos (Braccesi; Raviola, 2008: 142). Os aqueus da Itália do Sul não apenas aceitaram a orientação dos aqueus da metrópole como também, após algum tempo, tornaram-se imitadores de sua constituição, organizando uma liga ao redor de 430 a.C. com a liderança de Crotona e a participação de Caulônia e de Síbaris, a quinta cidade fundada no rio Traente. À mesma maneira dos aqueus do Peloponeso, crotoniatas, sibaritas e cauloniatas escolheram o templo de Zeus Homarios como lugar de reunião comum e conselho (Braccesi; Raviola, 2008: 142; De Sensi Sestito, 1994: 199). A adoção da politeia dos aqueus da metrópole teve uma finalidade política bem determinada - a busca por um governo moderado e estável em Crotona e nas fundações aquéias (Braccesi; Raviola, 2008: 142; De Sensi Sestito, 1994: 204). Segundo G. De Sensi Sestito, trata-se da primeira experiência de federalismo em âmbito colonial (De Sensi Sestito, 1994: 201-202).

No século IV a.C. a liga abandonou o modelo aqueu de estado federal e configurou-se de outra maneira - diante de novos perigos (Dionísio I e os lucanos) a federação teve necessidade de abrir-se a uma forma de agregação de tipo militar e defensivo maior, acolhendo cidades com outras origens e organizações políticas (De Sensi Sestito, 1994: 204). É Diodoro (XIV, 91, 1) que nos fornece as informações sobre essa segunda fase da liga, situando a sua nova conformação após a paz de Dionísio I com Cartago em 392 a.C., quando o tirano 
pôde reforçar a sua presença na Itália do Sul (Braccesi; Raviola, 2008: 152). Enquanto a forma mais antiga da liga reuniu-se no santuário de Zeus Homarios, refletindo e promovendo a identidade aquéia dos membros originários, quando a liga se tornou mais inclusiva, e pan-italiota, o local para reunião, provavelmente, foi 0 santuário de Hera Lacínia em Crotona, que naquele tempo já havia se tornado, ao menos desde o final do século V a.C., em um local frequentado pelas cidades gregas da Itália do Sul (Fronda, 2013: 133 e 136). Após o estabelecimento de um acordo de Dionísio I com os lucanos, o tirano e a liga italiota entraram em confronto, após a destruição de Caulônia, ocorrendo a vitória do tirano siracusano sobre a liga na batalha de Helesporo em 389/88 a.C., a partir daí estendendo seu controle sobre a maior parte da Itália do Sul (Braccesi; Raviola, 2008: 153; Fronda, 2013: 134; La Torre, 2011: 123). Uma década depois, em c. 379/78 a.C., ocorreu uma batalha decisiva entre Crotona e Dionísio I com a derrota e ocupação dessa cidade pelo tirano, que durou aproximadamente vinte anos (Braccesi; Raviola, 2008: 155; Cerchai, 2004: 106; Fischer-Hansen; Nielsen; Ampolo, 2004: 268; Fronda, 2013: 134). Durante todo o século IV a.C. - da época de Dionísio I até a queda de Pirro, mais tarde - o volume de emissões da oficina de Crotona permaneceu escasso (Stazio, 1984: 388). Mas durante o período de ocupação do tirano na cidade, muito provavelmente a produção monetária sofreu uma súbita diminuição ou até mesmo interrupção (Stazio, 1984: 393).

Após a morte de Dionísio I em c.367 a.C., assumiu seu lugar Dionísio II, que empreendeu uma política externa na Magna Grécia diferente da de seu pai, neutralizando o elemento não-grego em defesa da grecidade na região - foi um aliado natural da liga italiota, a qual continuou ativa após a sua derrota na batalha de Ellesporo (Braccesi; Raviola, 2008: 156 e 158; Fronda, 2013: 134). Já nesse período (entre 367-361 a.C.), Tarento havia se consolidado como o centro de poder na Itália do Sul, tendo se sobreposto gradativamente à hegemonia de Siracusa desde antes da queda de Dionísio II em 357 a.C. (Braccesi; Raviola, 2008: 159). Antes de deixar o poder, em 362 a.C., Dionísio II estabeleceu um acordo de paz com os lucanos, mas alguns anos após a sua queda os lucanos e os brettii se fortaleceram, unindo-se em uma confederação em c.356/55 a.C. e tornandose uma ameaça à sobrevivência das cidades gregas na costa jônica. A partir dessa época, algumas das cidades gregas caíram sob a dominação desses povos não-gregos, outras abdicaram de sua soberania para não desaparecer e outras, ainda, mantiveram sua própria autonomia, como foi o caso de Crotona e Túrio (Braccesi; Raviola, 2008: 159). O declínio de Crotona, que havia começado com a conquista da cidade por Dionísio I, se mostrou na perda da liderança da liga italiota para Tarento (Cerchiai, 2004: 106; La Torre, 2011: 127). Foi em algum momento do final do século IV a.C. que a liderança da liga passou de Crotona para Tarento e o lugar de reunião comum foi transferido para Heraclea, provavelmente para o santuário de Deméter na cidade o qual havia adquirido importância pan-italiota ao longo do século IV a.C. (Fronda, 2013: 134-135). Nesse período, Crotona foi alvo de contínuos ataques dos bretti, com os quais, provavelmente, alcançou formas de colaboração e integração antes da intervenção romana (Cerchiai, 2004: 106; La Torre, 2011: 127; Lomas, 2012: 395).

Após apresentarmos o contexto histórico da época da produção monetária de Crotona nos séculos $\mathrm{V}$ a.C. e IV a.C. (até o seu segundo quartel), podemos discorrer sobre os tipos monetários datados entre 0 
segundo quartel do século $V$ a.C. e a segunda metade do século IV a.C. - todos relacionados a eventos militares envolvendo Crotona, e toda a Magna Grécia com destaque para a área aquéia, e que levaram ao declínio político final dessa cidade. Como mencionamos, a partir do último quartel do século $V$ a.C., quando a técnica do relevo duplo se firmou em Crotona, houve uma certa continuidade no uso dos tipos tradicionais do trípode, no anverso, e da águia voando, no reverso, embora por um curto espaço de tempo (Fig.244 - n.163) (Stazio, 1984: 384). Foi nesse período, no entanto, que a tipologia monetária das moedas se reavivou: o trípode foi relegado a imagem secundária, no reverso, e a águia se afirmou como o tipo do anverso, não aparecendo mais em vôo, mas em pé, geralmente sobre um capitel jônico ou sobre alguma presa, com as asas fechadas ou erguidas, cabeça para frente, para trás ou curvada (em estateres) ou apenas com as asas fechadas e cabeça para trás (em pequenas denominações em prata e bronze) (Kraay, 1976: 181; Rutter, 1997: 82; 2001: 170; Stazio, 1984: 384 e 395). Antes de descrevermos os tipos da águia, cunhados nesse período, é preciso destacar que, nessa fase do duplo relevo no século V a.C., a imagem do raio (ladeada por dois grandes anéis) foi usada pela primeira vez em moedas de Crotona, no reverso, acompanhando, no anverso, o trípode do tipo tradicional do período incuso. Foram sugeridas várias datações para esse dióbolo de prata, que não possui inscrição. Aqui consideraremos aquela datação do século V a.C. que termina em 425 a.C. (Fig.244 - n.278) (Rutter, 2001: 170).

Relacionados ao período pós-formação da primeira fase da liga italiota, e da ocupação de Crotona por Dionísio I após a batalha de Helesporo, estão os tipos datados entre c.425-375 a.C., nos quais a águia é retratada com as asas fechadas, cabeça para trás sobre a cabeça de um carneiro, enquanto o raio aparece no reverso no lugar do trípode, acompanhado ou não por dois crescentes em pequenas denominações de bronze (Fig.244 - n.318/319). Do período subsequente à primeira fase da liga italiota, sob a liderança de Crotona, até o período em que Tarento tomou a liderança, entre c.425-350 a.C., datam os estateres, nos quais a ave aparece de asas fechadas e cabeça para frente, sobre capitel jônico, ou com a cabeça para trás, ou ainda sobre cabeça de carneiro ou arquitrave (com crânio de cabra ao lado) (Fig.244 - n.170/171/172); em pequenas denominações de prata (dióbolo), é retratada de asas fechadas e cabeça para trás sem estar sobre presa ou algum suporte (Fig.244 - n.176). Desse mesmo período, data um estater no qual a águia é retratada com as asas erguidas e cabeça para frente, sobre ramo de oliveira ou de louro ou ainda sem nenhuma presa (Fig.244 -n.254), e um outro em que a ave aparece com a cabeça curvada (não se sabe se a posição das asas) sobre cobra (n.175) ${ }^{11}$. Da época ainda anterior à derrota em Helesporo e ao domínio de Dionísio em Crotona é o estater datado de c.420-400 a.C., no qual a águia aparece de asas fechadas, cabeça para trás, sobre nariz de veado (Fig.244 - n.192). Os tipos monetários, descritos na sequência, repetem as fases já descritas de eventos relacionados à cidade. Da primeira metade do século IV a.C., data uma pequena denominação em prata (trióbolo) com a imagem do trípode, no anverso como nos tipos mais antigos, e da águia de asas fechadas e

\footnotetext{
${ }^{11}$ Tipo monetário não incluído entre as moedas da Fig.224 por ausência de imagem, vide informações a partir do número dessa moeda no catálogo numismático.
} 
cabeça para trás sobre capitel jônico, no reverso. É desse período também, entre 400-350 a.C., outro trióbolo de prata com a figura do trípode, também no anverso, com a imagem do raio no reverso como tipo principal, acompanhado pelo desenho de uma águia de asas fechadas e cabeça para trás sobre uma coluna jônica (no lado direito do campo) e pelo de desenho de um crescente (no lado esquerdo) (Fig.244 - n.329). É justamente nesse trióbolo que o raio e a águia aparecem pela primeira vez representados no mesmo campo de uma moeda de Crotona. Em c.400 a.C., quando o bronze ${ }^{12}$ foi introduzido nas cunhagens de Crotona, a representação da cabeça da águia foi usada, exclusivamente e pela primeira vez, no reverso de uma fração batida nesse metal, na qual o trípode foi usado, também nesse caso, como a imagem do anverso (Fig.244 - n.219). Um estater de c.360-340 a.C. possui a imagem da águia de asas erguidas e cabeça para frente sobre um ramo de oliveira ou louro (Fig.244 - n.254). Da segunda metade do século IV a.C., uma pequena denominação de bronze traz a imagem da ave de asas fechadas e cabeça para trás, aparentemente sem estar sobre presa, ramo ou capitel (Fig.244 - n.271).

Contemporâneas a essas emissões com o tipo da águia em pé, representada majoritariamente no reverso, são aquelas com as imagens, no anverso, de Hera, Héracles e Apolo, divindades relacionadas à história lendária de Crotona (Kraay, 1976: 181). No último quartel do século V a.C., em estateres, Herácles foi representado, no anverso, sentado sobre uma rocha diante de um altar aceso, em ato de sacrifício, segurando a clava com a mão esquerda e ramo de louro com a direita. O reverso possui a imagem do trípode sem ou com a figura de Apolo abrigado, sob esse objeto, ao lado esquerdo, atirando flechas na serpente que aparece no lado direito do campo da moeda. Trata-se da serpente Python, vencida pelo deus para obter o controle de Delfos (Kraay, 1976: 181; Rutter, 2012: 132; Stazio, 1984: 386). A legenda, que faz referência a Héracles como oikista da cidade, evidencia que o herói é retratado como o lendário fundador de Crotona (Jenkins, 1990: 114; Kraay, 1976: 181; Rutter, 2012: 132; Stazio, 1984: 385-386). Nesse tipo monetário, portanto, duas tradições da fundação de Crotona aparecem misturadas - fundação lendária atribuída a Héracles e aquela no século VIII a.C. empreendida pela ordem do oráculo de Apolo (Kraay, 1976: 181; Lacroix, 1965: 158). Dos primeiros anos do século IV a.C., data a emissão monetária com a imagem da cabeça de Hera, no anverso, representada de frente, usando um polos, e de Héracles sentado, no reverso, sobre pele de leão, segurando clava com a mão esquerda e taça com a mão direita (Kraay, 1976: 196; Stazio, 1984: 389). A imagem de Hera, segundo os estudiosos, é uma referência ao santuário da deusa no cabo Lacínio, na área de Crotona, e uma alusão à liga italiota, cujo local de reunião já havia sido transferido a esse santuário nessa época (Fronda, 2013: 133; Kraay, 1976: 196; Stazio, 1984: 390). Também do início do século IV a.C., é datada a emissão com a imagem da cabeça laureada de Apolo, no anverso, e com a de Héracles criança, estrangulando serpentes, no reverso (Stazio, 1984: 391). Mais uma vez, Apolo e Héracles aparecem associados em uma mesma série monetária, ainda que em esquemas iconográficos completamente diferentes (Stazio, 1984: 391). Além disso, pela primeira

\footnotetext{
12 Stazio, 1984: 395.
} 
vez a cabeça de Apolo foi usada na cunhagem de Crotona - tipo que caracterizou, a partir desse momento, uma longa série de emissões (Stazio, 1984: 391). Também pode ser relacionado a esses tipos monetários de divindades, a fração em bronze, datada de 375-325 a.C., na qual a cabeça de Atena é retratada, no anverso, usando um elmo ático com crista, acompanhada, no reverso, pela imagem da águia em pé com asas fechadas sobre a cabeça de um veado (n.240) ${ }^{13}$. Essas emissões, atribuídas aos primeiros anos do século IV a.C. por Stazio, são relacionadas, por esse autor, à época da expansão de Dionísio I na região, assim como à pressão dos lucanos (Stazio, 1984: 390). Pode ser também atribuída à invasão dos lucanos na segunda metade do século IV a.C. o tipo monetário com a imagem da cabeça de Héracles, no anverso, e a da águia em pé, no reverso (Fig.244 - 271). Por essa razão, Stazio interpretou as imagens de Héracles, nessas emissões, primeiro como "um defensor dos inimigos externos à cidade (quando está lutando com a serpente) e segundo como expressão de um conceito de defesa vitoriosa contra os inimigos da helenidade italiota (quando é retratado sentado sobre a pele de leão)" (Stazio, 1984: 393).

Esse panorama acerca dos tipos monetários emitidos por Crotona, desde 0 início de suas emissões até ao menos o segundo quartel do século IV a.C., nos permite visualizar como, quando e por que as imagens de águias e de raios foram utilizadas pela oficina monetária da comunidade. Vale destacar que a cidade não usou imagens de Zeus em suas moedas, mas escolheu apenas a de seus dois atributos. A águia desde as emissões incusas, no século VI a.C., figurou como tipo principal nas moedas, após o trípode ter se firmado como primeiro tipo monetário da cidade. A imagem da ave nas moedas manteve-se em uso nas fases subsequentes, assumindo outro padrão de representação. $O$ raio, por outro lado, passou a ser usado pela oficina monetária da cidade muito provavelmente antes do segundo quartel do século $V$ a.C., firmando-se como tipo das moedas de Crotona a partir de c.425 a.C. e tornando-se uma imagem recorrente nas emissões monetárias do século IV a.C. O uso associado de águias e raios, um no anverso e outro no reverso, ocorreu pela primeira vez nesse período, ao passo que a ideia em usar os dois atributos juntos, em um mesmo lado da moeda, é visto pela primeira vez em Crotona na primeira metade do século IV a.C.

Sobre o significado da águia nas moedas de Crotona, todas as interpretações propostas procuraram relacioná-la ao culto de Zeus no local e ao santuário de Olímpia. De acordo com Stazio, o significado da águia como tipo monetário teria sido uma alusão a Zeus e ao seu culto, não documentado em Crotona (Stazio, 1984: 370-371 e 376). Esse mesmo autor, baseando-se em uma hipótese de A. Mele, propõe que a introdução do tipo da águia nas emissões crotoniatas teria se devido a Callias, um membro da famosa família de adivinhos de Élis, os lamides, responsáveis durante séculos pelo oráculo de Zeus Olímpio em Olímpia. Segundo uma informação de Heródoto ( $V$, 44-45), na época da guerra contra Síbaris, Callias teria passado a apoiar os crotoniatas após realizar um sacrifício com um presságio não propício aos sibaritas, prevendo a derrota destes. Os crotoniatas, por sua vez, doaram terras a Callias de Élis e seus descendentes ainda residiam ali no tempo

\footnotetext{
13 Tipo monetário não incluído entre as moedas da Fig.244 por ausência de imagem, vide informações a partir do número dessa moeda no catálogo numismático.
} 
de Heródoto (Stazio, 1984: 376). Stazio prefere ver na existência dos lamides em Crotona a explicação para a presença da ave na moeda, evitando aquela, presente repetidamente na bibliografia, de que o uso da ave teria sido devido à participação dos atletas crotoniatas nos jogos olímpicos (Stazio, 1984: 376 e 385). A introdução do tipo da águia, na cunhagem crotoniata, conclui, indicou um momento de ligação com o santuário de Olímpia (Stazio, 1984: 376). Acerca da relação atletismo, Olímpia e Crotona, citando uma informação de Ateneu, Parise acredita ser mais verossímil a hipótese que relaciona a introdução do tipo da águia com a tentativa da cidade em organizar Olimpíadas locais (Parise, 1990: 303). Essa proposição é rebatida por Vonderstein, o qual lembra que Crotona, no século VI a.C., tinha interesse em manter boas relações com o santuário de Olímpia, sendo pouco provável, por essa razão, que a cidade tivesse tentado realizar jogos locais (Vonderstein, 2006: 28). A seu ver, teria havido, ao invés disso, versões locais dos jogos de Olímpia com os quais não se desejava entrar em rivalidade com o santuário pan-helênico, mas, sim, estabelecer um local de culto e de disputa esportiva, nos moldes de Olímpia, na região sul da península itálica (Vonderstein, 2006: 28). C. Kraay, seguido por N.K. Rutter, vê a explicação para o uso de tipos monetários da águia em pé sobre capitel jônico e presas, datados entre o século V-IV a.C., semelhantes aos de Olímpia, na reputação dos atletas crotoniatas nesse santuário (Kraay, 1976: 181; Rutter, 1997: 82; 2001: 170). Dentre todos os tipos da águia em pé desse período, aquele 0 qual a ave é representada sobre o capitel de uma coluna jônica seria a principal evidência dessa relação, já que o tipo é recorrente nas moedas de Élis. No entanto, como colocou primeiro Stazio e depois Vonderstein, no século IV a.C. a proeminência atlética de Crotona havia diminuído consideravelmente em relação aos séculos anteriores (Stazio, 1984: 385; Vonderstein, 2006: 26).

Para Vonderstein, "a águia, como real indicativo de um culto a Zeus na cidade, permanece sendo a explicação mais sensata' (Vonderstein, 2006: 26). Nesse caso, esse autor conclui que se trataria de Zeus Olímpio - o qual teria permanecido como divindade central do panteão de Crotona até a tomada da cidade pelos romanos (Vonderstein, 2006: 28). Para tal afirmação, Vonderstein se baseia na premissa de que a águia, representada em pleno vôo nas primeiras emissões da cidade, seria um emblema de Zeus Olímpio nas moedas crotoniatas, pois o tipo já era recorrente em moedas de Cálcis, na Eubéia, e nas de Élis, datadas do mesmo período das de Crotona, isto se aceitarmos que as emissões de Élis em Olímpia tenham se iniciado em 530 a.C. (Vonderstein, 2006: 26). Em Cálcis, o culto a Zeus Olímpio é atestado na cidade no início da época clássica, por essa razão a águia, presente nas primeiras emissões, seria também uma alusão a Zeus Olímpio, como ocorre no caso de Olímpia (Vonderstein, 2006: 26). O autor vale-se também das semelhanças tipológicas das moedas de Élis do fim do século V a.C. e do século IV a.C., que possuem motivos comuns àquelas de Crotona, emitidas quase contemporaneamente - a águia em pé sobre a coluna e sobre as presas (Vonderstein, 2006: 26). E por fim, outra teoria não relaciona a Olímpia a presença da águia em pé dos tipos de Crotona, datados entre os séculos V-IV a.C., mas à formação da liga das cidades aqueias em c.430 a.C. (Rutter, 2001: 170). Entretanto, essa proposição foi refutada recentemente por M. Fronda em seu artigo sobre a liga italiota (Fronda, 2013: 129). 
De fato, como já bem apontaram Stazio e Vonderstein, houve uma clara relação entre Crotona e Olímpia, evidenciada pelas fontes literárias em relação à afinidade dessa pólis, com o atletismo no santuário e visualizável, de certa forma, na tipologia monetária dessa cidade. Sobre a proposição de A. Mele, seguida por Stazio, com relação aos lamides, vimos em um estudo anterior como a presença de membros dessa família de Élis na fundação de Siracusa, na Sicília, pôde ter influenciado a introdução do culto de Zeus Olímpio naquela pólis (Ciaceri, 1894: 5; Laky, 2013: 71). Os lamides, no Ocidente grego, teriam sido responsáveis pela difusão, nessa área, de traços culturais de sua região originária, Élis. A nosso ver, a chegada dos lamides em Crotona quase ou contemporaneamente ao início do uso da águia nas moedas da cidade pode tanto ter ocorrido por influência, em algum grau, dessa família como ser somente mais um testemunho das ligações entre Crotona, a região de Élis e o santuário de Olímpia durante o final da época arcaica.

Com relação a correlação entre os tipos monetários crotoniatas e os de Élis, uma análise mais cuidadosa e precisa baseada nos critérios estabelecidos por nós dos padrões de representação, indica que não houve uma influência tão direta assim da tipologia da águia de Élis nas moedas de Crotona tal como defendem os estudiosos até o momento. O tipo monetário da águia voando, emitido em Crotona, não possui a cobra como naqueles de Élis e de Cálcis, como comparou Vonderstein. $O$ tipo da águia voando sem carregar a cobra, nas moedas de Élis, veio a ocorrer em emissões de c.468 a.C., portanto, muito posteriormente aos primeiros estateres incusos de Crotona. A imagem da águia voando, sem presa, era um tipo muito recorrente em moedas de outras regiões do mundo grego entre a segunda metade do século VI a.C. e o início do século V a.C., como em Sifnos, no Egeu, Cálcis, na Eubéia, e Olinto, na Trácia. No caso dos tipos da águia em pé com alguma presa, Élis realmente usou presas (no caso a lebre e uma garça morta no campo da moeda), antes de Crotona, em seus tipos nos quais a ave aparece de asas erguidas datados a partir de 432 a.C. Contudo, nos tipos crotoniatas da águia em pé com presas, cunhados a partir de c.425 a.C., a ave, não retratada de asas erguidas, mas com asas fechadas e cabeça para trás ou para frente, está sobre a cabeça de um carneiro, de um veado, de um crânio de uma cabra ou sobre uma cobra - presas diferentes presentes nos tipos monetários de Élis anteriores aos crotoniatas. 0 uso da lebre como presa, muito recorrente nos tipos de Élis, não foi usado por Crotona até o período aqui estudado e o veado dos tipos monetários crotoniatas, só foi usado nas moedas de Élis ao redor de 344 a.C. A águia retratada com as asas erguidas sobre um ramo de oliveira e de louro de moedas de c.425-350 e 360-340 a.C. não é vista dessa maneira nas moedas de Élis. Nas moedas de Élis o ramo de oliveira aparece como guirlanda, rodeando o campo, em tipos datados a partir de 432 a.C. Repetidamente citado na bibliografia, a imagem da águia em pé, de asas fechadas, sobre o capitel de uma coluna jônica foi usada antes por Crotona a partir de 425 a.C. e não por Élis, cujo tipo monetário é datado de 360 a.C. O único caso que pode ser citado como uma influência de Élis nas escolhas tipológicas de Crotona, é o tipo da cabeça de águia usado pela primeira vez por Élis em 416 a.C. e depois por Crotona em c.400 a.C., embora devamos lembrar que esse padrão de representação apareceu antes em elétrons cunhados em Éfeso, na Jônia, no início do século $V$ a.C. 
Acrescentamos a essa interpretação que vê a ligação com Olímpia, a correspondência cronológica e simbólica dos tipos monetários de Crotona com aqueles tipos da águia em pé emitidos por Agrigento na metade e no segundo quartel do século $V$ a.C. Nesse sentido, seguimos o que propõe a Escola de Messina: na ausência de tipos monetários semelhantes e contemporâneos em uma mesma região, no caso a Itália do Sul, devemos observar as emissões mais próximas, nesse caso Agrigento, pólis do Ocidente grego que mais emitiu tipos monetários de águias no período. Assim como Crotona, Agrigento emitiu os tipos de águia, usando-os como imagem principal de suas moedas, no século $\mathrm{VI}$ a.C., ainda que poucos anos depois da pólis crotoniata. Nas primeiras emissões de ambas as cidades, a águia é retratada sem portar qualquer presa, somente em pé, no caso de Agrigento, e voando, no caso de Crotona. As imagens associáveis entre as duas autoridades emissoras correspondem àquelas posteriores da ave em pé sobre o capitel jônico e as presas. 0 tipo da águia em pé, de asas fechadas e sobre o capitel de uma coluna jônica foi cunhado por Agrigento entre 460-450 a.C., antes de Crotona (de c.425-350 a.C.) e quase um século antes de Élis (de c.360 a.C.), o que coloca por terra a idéia de que Élis teria criado essa composição e, por sua vez, influenciado Crotona. Esse caso mostra que existia, em termos de iconografia monetária, não apenas uma influência de Élis e Olímpia sobre o Ocidente grego, de mão única, mas uma influência do Ocidente grego na difusão de traços culturais a Olímpia e sua região. 0 padrão de representação da cabeça da águia também foi usado em moedas de Agrigento anteriormente a Crotona, antes de 406 a.C.

Assim como Crotona, a partir do segundo quartel do século V a.C., a oficina monetária de Agrigento mudou completamente o tipo antigo da representação da águia, nesse caso em pé sem presas, para aquele no qual a ave é retratada com uma grande variedade de posições e de presas. Vale lembrar que o padrão de representação da águia em pé foi uma tendência do século IV a.C., que se iniciou no século $V$ a.C., diferente daquele da ave voando, típico do século $V$ a.C. e que diminui consideravelmente no século IV a.C. em emissões monetárias. Acreditamos que essa correspondência temporal, no uso do tipo da águia em pé com presas, não esteve meramente associada a um simples processo de difusão de tipos de imagens de um local a outro, de Olímpia para Crotona, como foi proposto, ou de Agrigento para Crotona, ou ainda ao culto de Zeus Olímpio na cidade, mas tenha sido expressão de momentos comuns de ameaça à comunidade política, ainda que os eventos tenham sido diferentes para essas duas cidades, uma localizada na Sicília e a outra no sul da península itálica. Esses tipos de Agrigento, pertencem ao período que abarca desde a hegemonia de Siracusa, a invasão ateniense e cartaginesa até a destruição da cidade. Em Crotona, esses tipos começaram a ser produzidos no período de crise e de declínio da cidade, após a formação da liga das cidades aqueias, lideradas por Crotona, em razão da crise política interna à cidade e à região, da hegemonia de Dionísio I e invasão dos lucanos, do domínio desse tirano na cidade, da perda da direção da liga para Tarento e à chegada dos brettii. Portanto, os tipos da águia em pé com a presa passaram a ser usados pela oficina monetária quando Crotona perdeu 0 controle do império que havia conquistado de Síbaris. Nesse sentido, o significado proposto para os tipos monetários de Agrigento também se aplicaria àqueles de Crotona - o de vitória e derrota sobre o inimigo. Vimos 
como esse padrão de representação da águia esteve relacionado à necessidade em repelir situações eminentes ruins em determinada conjuntura da pólis, quando guerra, competição e vitória foram importantes. Interessante notar que esse fenômeno da adoção simultânea do tipo da águia em pé com presas por Agrigento e Crotona, póleis no Ocidente grego, justamente em momentos militares importantes e definidores do futuro da comunidade política também ocorreu para Olímpia, onde o padrão em pé com presa (no caso a lebre) passou a ser usado em c.432 a.C., um pouco antes do início da guerra do Peloponeso. Presas (a lebre ou a cobra) são representadas com a águia nas moedas de Élis-Olímpia desde as primeiras emissões no início do século $\mathrm{V}$ a.C., embora nesse período a ave seja representada voando. Foi justamente em c.432 a.C., um período não muito distante das cunhagens referidas de Crotona e Agrigento, que Élis passou a usar a águia em pé sobre uma presa (a lebre). Diante das relações de Agrigento e Crotona com o santuário de Olímpia em época arcaica e clássica, podemos afirmar que, nesse período, havia uma rede entre esses três locais no tocante as escolhas tipológicas da águia e aos seus significados. Se considerarmos as relações estabelecidas entre Olímpia e essas duas cidades, é provável que o significado dessas imagens, usados por Élis, à época da guerra do Peloponeso, tenha sido requisitado da mesma maneira pelas póleis no Ocidente, a exemplo das moedas de Olímpia, nos momentos militares e políticos decisivos para a região, assim como foi o conflito no Peloponeso. Assim, as cidades aproveitaram para afirmar, através da representação dos tipos conhecidos de Olímpia, a sua ligação com o santuário, apesar de os tipos não serem estritamente iguais.

Mas, a nosso ver, os tipos monetários da águia em pé, cunhados em Crotona, não foram alusivos apenas à relação local com Olímpia e ao culto de Zeus Olímpio, como propôs Vonderstein. Os crotoniatas, provavelmente, devem ter tido uma afinidade com o culto de Zeus Olímpio, apesar de o culto, até onde se sabe, não ter se materializado na cidade até a época clássica. Na interpretação desse autor, a águia voando das primeiras emissões, deve ser considerada como um símbolo de Zeus Olímpio (Vonderstein, 2006: 26). De fato, vimos nos textos de Homero, principalmente na llíada, que a águia voando (com ou sem a presa) era um presságio enviado por Zeus do alto do Olimpo, por essa razão, Vonderstein não deixa de estar certo. Mas o tipo da águia voando não pode ser tomado como evidência contundente do culto do deus na cidade da maneira como coloca 0 autor. Os gregos associavam a águia a Zeus, mas nem sempre o uso da ave em moedas de uma cidade atesta o culto no local. Muitas vezes a ave como tipo monetário era usada apenas como símbolo das energias divinas da divindade, requisitadas como emblemas para a proteção da comunidade em algum momento específico. Nesses casos, podemos dizer, a águia nas moedas era uma alusão indireta a Zeus. Em outros casos, quando o culto é um dos principais da cidade, realizado em santuários, o uso da imagem de um atributo como é a águia, pode ser dito uma alusão direta ao deus. Acreditamos que no caso de Crotona tenha ocorrido uma alusão indireta à divindade. Em suma, em Crotona, como em Agrigento, apesar de lá o culto ser atestado em santuários, a escolha pelo tipo da águia em pé, nos períodos assinalados, deve ter expressado em primeiro lugar o significado "universal" aos gregos desse tipo de representação - vitória e derrota sobre os inimigos - como vimos na análise contextual do capítulo anterior. O significado de vitória, requisitado nessas 
moedas, pode ser confirmado pela presença de tipos secundários (ou talvez símbolos) presentes no campo monetário junto ao trípode no reverso. Trata-se, entre outros, de folhas de oliveira e louro, claros símbolos agonísticos de vitória. Os tipos monetários da águia em pé sobre ramo de oliveira e louro aludem também a esse significado. As datações dos tipos (c.425-350 e 360-340 a.C.) podem indicar que foram escolhidos para afirmar a posição de liderança da cidade na primeira fase da liga e a estabilidade alcançada após a intervenção aqueia, como a reconquista de sua autonomia após o domínio de Dionísio I. As cidades podem até ter escolhido os tipos para aludir à Olímpia, seguir um conceito de representação usado pelo santuário (no caso da representação com as presas), mas o significado requisitado pela pólis no uso da imagem deve ser por nós procurado no significado simbólico geral desse tipo de representação e na sua correspondência temporal ou não com as situações históricas vigentes as quais envolveram determinada autoridade emissora.

É dessa maneira que também devemos buscar o significado simbólico da águia voando usada como imagem principal em uma das primeiras emissões monetárias de Crotona. Vimos anteriormente, a partir da datação dos exemplares, que a águia nas emissões incusas, pode ter sido emitida tanto na época da chegada de Pitágoras à cidade em 530 a.C. quanto após a vitória sobre Síbaris em 510 a.C. Vimos também como o tipo continuou a ser usado pela oficina monetária de Crotona durante a fase do relevo duplo entre 430-420 a.C. Percebe-se, assim, que a imagem da águia voando foi usada pela primeira vez no momento pós-batalha de Sagra, quando mesmo vinte anos depois a cidade atravessava uma crise em decorrência de sua derrota, provavelmente ainda em época de governo oligárquico, antes do período democrático no final do século VI a.C. Novamente nesse caso, se vê como o tipo da águia voando também aparece relacionado à guerra - à batalha de Sagra e aquela contra Síbaris mais tarde. $\mathrm{Na}$ análise contextual do significado desse padrão de representação, vimos como a imagem da águia voando foi compreendida e usada como um sinal de bom agouro na luta, de presságios favoráveis à vitória e também, ao mesmo tempo, para afastar um resultado desfavorável na guerra. A esse respeito, como prova adicional, de que esse significado era compreendido e compartilhado na região naquele momento, dispomos de um trecho de Justino (XX 2, 9-3, 8) que testemunha o surgimento de uma águia no campo de batalha de Sagra, que se manteve ali até que Lócris vencesse o confronto. Na sequência no trecho, Justino dá a entender que o surgimento da águia no campo marca ou anuncia, de algum modo, a aparição dos Dióscuros os quais foram vistos combater no conflito até que desaparecessem. Assim, 0 uso da águia em pleno vôo nas moedas de Crotona, e seus valores talismânicos e apotropaicos, remontam ao período da crise pós batalha de Sagra. Mas seus valores talismânicos e apotropaicos, requisitados inicialmente nesse período, se mantiveram durante a época de apogeu do império herdado de Síbaris, como no seu declínio com a crise pitagórica e a formação da liga das cidades aqueias. Por essa razão não podemos relacionar o uso do tipo da águia nas moedas da cidade com a formação da liga italiota em 430 a.C., simplesmente pelo fato das cidades aqueias terem escolhido um santuário dedicado a Zeus Homarios para suas reuniões, como reitera M. Fronda (Fronda, 2013: 129). A introdução da imagem da águia como tipo nas moedas é muito anterior à liga e sua longa duração na cunhagem perpassa e se relaciona a outros períodos da história da cidade. Nem mesmo 
os tipos monetários da águia em pé com presa ou com o capitel podem ser considerados evidências da formação da liga e da instituição do culto a Zeus Homarios no período. Como vimos, o uso dessas imagens por Crotona deve ser entendido como resultado de várias conjunturas históricas, as quais levaram à busca em usar a águia, em seus vários tipos de representações, como símbolo, cujo significado específico funcionasse para a comunidade política em momentos bem determinados.

Não considerado pelos estudiosos no debate acerca da presença da águia nas moedas de Crotona, 0 raio também foi um atributo de Zeus tão importante como a águia, embora não tenha sido usado como tipo principal, tal como a ave e o trípode, nas emissões da cidade. Vimos, anteriormente, que o raio foi representado sozinho (no anverso) com o trípode (no anverso) no século V a.C., antes de 425 a.C.; junto à águia em uma mesma moeda (um atributo no anverso e o outro no reverso) a partir de c.425 a.C.; e em um mesmo lado da moeda com a águia (ambos no reverso) entre 400-350 a.C. Conforme vimos no capítulo anterior, o uso das imagens do raio e da águia, em uma mesma moeda (cada qual em um lado) foi uma criação de Élis para as moedas do santuário de Olímpia ao redor de 468 a.C. Essa combinação dos dois atributos foi usada pela primeira vez fora de Olímpia, por Crotona a partir de c.425 a.C. Trata-se de mais uma evidência que corrobora a existência de uma rede de difusão de traços entre essa cidade e o santuário pan-helênico, nesse caso sendo Olímpia a responsável por propagar uma ideia ao Ocidente grego e não o contrário, como vimos com relação à imagem da águia sobre o capitel. Já o uso combinado dos dois atributos, em um mesmo lado de uma moeda, pode ter sido uma inovação de Crotona, pois essa forma em usar as imagens do raio e da águia aparecem em moedas de Larissa, na Tessália, de c.370-360 a.C., e dos Molossos, no Épiro, em c.350 a.C. - assinalados quase ao mesmo período (primeira metade do século $V$ a.C.). Mas em Larissa e entre os Molossos, o raio é representado sob os pés da águia, sendo um esquema diferente daquele usado em Crotona. 0 esquema iconográfico no qual o raio aparece como tipo principal, vertical, e a águia ao seu lado no campo parece de fato ser uma criação ocidental de Crotona, vista somente em tipos monetários do período de Timoleonte em Siracusa.

O raio passou a ser utilizado pela oficina monetária de Crotona em suas emissões no período da crise pitagórica, ou de seus desdobramentos até após a formação da liga em em c.430 a.C. com a liderança dessa cidade - 0 atributo entrou no repertório tipológico no momento em que a cidade e as outras da região buscavam por seu equilíbrio político. 0 raio se afirmou no repertório iconográfico das moedas da cidade no mesmo momento político e militar em que a águia passou a ser representada em pé sobre as presas ou sobre o capitel a partir de c.425 a.C. até 375 e/ou 350 a.C. Arma de soberania de Zeus, usada pela divindade para punir e aniquilar seus adversários cósmicos, o raio assumiu um significado preciso como emblema de Crotona em suas moedas desse período - associar a sua representação à Crotona deve ter sido expressão de afirmação da vitória da ordem requerida sobre o caos - as crises que ameaçavam a estabilidade política e a sua existência como pólis, a sua autonomia, a qual vimos ter sido repetidamente posta em prova sobretudo ao longo do século IV a.C. O raio, usado como emblema da cidade, também pode ter expressado, como símbolo do poder 
inexorável de Zeus, uma auto-afirmação da soberania de Crotona, no período em que se manteve líder da liga italiota. Nesse sentido, de forma mais clara e direta do que a águia, o uso do raio nas moedas crotoniatas prova a afinidade dessa cidade com a esfera de atuação de Zeus. Diferente da águia, o raio é sempre uma alusão direta ao deus. A associação da águia e do raio em uma mesma moeda, pela oficina monetária da cidade, evidencia o desejo, da comunidade, em reforçar e super dimensionar as energias divinas do deus a seu favor em um momento de crise, de enfrentamento com o outro, seja ele um tirano siceliota, os lucanos e os brettii, ou a sua própria perda de poder.

Ao contextualizarmos os tipos monetários da águia voando / em pé e do raio dentro do repertório iconográfico usado nas moedas de Crotona até a segunda metade do século IV a.C., passa-se a entender melhor as mensagens transmitidas pela comunidade por meio dos emblemas escolhidos para as moedas. Assim, no momento mais antigo da cunhagem, Crotona escolheu usar o trípode de Apolo, como emblema único da cidade, sendo, naquele momento, o símbolo mais importante para a comunidade, por aludir à sua fundação e por conectá-la ao santuário de Delfos. Em um segundo momento, quando passou a utilizar o tipo da águia voando, a pólis buscou usar, a seu favor, um símbolo muito conhecido de agouro na guerra para, provavelmente também, aludir a Zeus (ainda que de forma indireta) e a Olímpia em algum nível. Esse pode ter sido o caso do raio. $\mathrm{O}$ trípode é uma referência à identidade da cidade, à sua história, à sua origem determinada por Delfos, a como a cidade veio a existir como comunidade. Já a águia relaciona-se também à identidade da cidade, mas em um outro nível, provavelmente o político, por demonstrar soberania e poder, e pan-helênico, por remeter à Olímpia. O trípode manteve-se nas emissões do século IV a.C. ${ }^{14}$, embora com outro desenho, mostrando uma necessidade permanente da pólis em referenciar a sua origem. Nesse período, o trípode já havia se consolidado com um emblema de Crotona, que o identificava perante as demais cidades. Esse também foi o caso da águia, que foi mantida como tipo principal durante o século IV a.C. ${ }^{15}$ Vimos como a partir do segundo quartel do século V a.C. o repertório iconográfico das moedas foi ampliado com o uso da imagem de Héracles e de Apolo e depois no início do século IV a.C. com as de Hera e de Atena e com outras formas de representações dos dois deuses citados. Vimos também que as imagens da águia em pé e do trípode, em uma mesma moeda, continuaram a ser emitidas junto a esses novos tipos e, que algumas vezes, esses emblemas foram representados nas moedas com essas divindades e com o raio também. Diante dos significados, levantados, relacionados a todos esses tipos de representações e do contexto das emissões, é possível dizer que águias e raios nas emissões datadas entre os séculos V-IV e IV a.C. tiveram um valor simbólico comum, convergente, aos de Héracles, Hera e Apolo no período. Trata-se dos significados mais importantes para a pólis naquela época - defesa e vitória sobre o inimigo, de afirmação de poder e soberania de sua autonomia enquanto comunidade política, portanto, a afirmação da identidade políade, política e italiota.

\footnotetext{
14 Segundo L. Lacroix, citando J. Bérard, o trípode manteve-se como imagem principal nas emissões monetárias de Crotona até a época romana (Lacroix, 1965: 159).

${ }^{15}$ A águia foi um tipo utilizado nas moedas até o fechamento da oficina em 277 a.C. (Vonderstein, 2006: 24).
} 


\section{I.3.2 Posidônia}

Imagens monetárias de Zeus, nas cidades gregas da Itália do Sul, foram usadas pela primeira vez por duas póleis de origem aqueia, Metaponto e Posidônia, a partir do segundo quartel do século V a.C. Fundada em c.600 a.C. por aqueus de Síbaris, e por um certo contingente dório de Trezena no Peloponeso, Posidônia, no mar Tirreno, foi responsável por um número de emissões de tipos monetários de Zeus em pé atirando o raio a partir de c.420 a.C., logo no início do domínio lucano na cidade (Cerchiai, 2004: 62; Cipriani et alii, 1996: 5; Fischer-Hansen; Nielsen; Ampolo, 2004: 287; Rutter, 1997: 66-67). Durante a fase grega de Posidônia, desde suas primeiras emissões em c.530-525 a.C., a pólis sempre priorizou o uso da imagem de Poseidon em suas moedas, seja inicialmente tanto no anverso e no reverso (na fase incusa), como depois apenas no anverso (fase do duplo relevo) (Taliercio Mensitieri, 1987: 140). A cunhagem de Posidônia, que começou um pouco depois daquela de Crotona, caracterizou-se também pelo uso da técnica incusa, embora o padrão adotado tenha sido o local, o fenício-foceu com o peso do estater em c. 7,5g, diferente, portanto, daquele das póleis aqueias na costa jônica (Fischer-Hansen; Nielsen; Ampolo, 2004: 289; Rutter, 2001: 108; 2012: 129-130). A fabricação de estateres na técnica incusa durou até c.500 a.C., talvez como resultado da destruição de Síbaris em 510 a.C. e, até c.470 a.C., a cidade emitiu apenas pequenas denominações (Fischer-Hansen; Nielsen; Ampolo, 2004: 289; Kraay, 1976: 169; Rutter, 2001: 108; 2012: 133-134). A partir de c.470 a.C. a fabricação de estateres voltou a ocorrer, mas na técnica de duplo relevo no padrão aqueu-coríntio das fundações aqueias da costa jônica (Kraay, 1976: 176; Rutter, 2001: 108; 2012: 134; Taliercio Mensitieri, 1987: 146). Nessa nova fase, o tipo do anverso de Poseidon usando uma clâmide e atirando o tridente foi mantido e um novo tipo aparece, 0 touro, uma imagem usada por Síbaris em suas emissões e por isso considerado uma influência dos sibaritas assentados em Posidônia após a destruição por Crotona de sua segunda fundação em c.476 a.C. (FischerHansen; Nielsen; Ampolo, 2004: 289; Kraay, 1976: 173; Taliercio Mensitieri, 1987: 156). Segundo Taliercio Mensitieri, "a retomada da cunhagem em Posidônia, com o uso do tipo do touro de Síbaris, ao mesmo tempo que remete à origem da cidade, representa uma ligação a qual indica continuidade, de hereditariedade, com a sua metrópole" (Cerchiai, 2004: 62; Taliercio Mensitieri, 1987: 161). Em pequenas denominações, desse período, o reverso é ocasionalmente ocupado pelas imagens do tridente ou da roda (Rutter, 2012: 134).

Desde a sua fundação, ao período do império de Síbaris e até depois da destruição por Crotona, Posidônia "foi o último baluarte da helenidade aqueia em meio aos florescentes centros etruscos, a norte do rio Sele, e mediadora privilegiada das comunidades enótrias na costa tirrênica, papel que perde com a fundação de Vélia" (La Torre, 2011: 89). Se dispomos de algumas informações sobre Posidônia no século VI a.C., em razão do seu contato com Síbaris, praticamente nada se sabe da história da cidade no século V a.C. (Cipriani et alii, 1996: 8). A única evidência sobre a vida política da cidade no período é o eclesiastério datado da metade do século V a.C. que indica a existência de uma assembleia na época (Fischer-Hansen; Nielsen; Ampolo, 2004: 288). O que mais se sabe sobre o século $V$ a.C. é que Posidônia foi conquistada pelos lucanos no último 
quartel, perdendo toda a sua autonomia (Cerchiai, 2004: 62; Fischer-Hansen; Nielsen; Ampolo, 2004: 288; Kraay, 1976: 186; La Torre, 2011: 119). A esse respeito a principal fonte de informação é Estrabão (VI, I, 1.252), que não informa em qual ano ocorreu a batalha entre os posidoniatas, e aliados, e os lucanos (Cipriani et alii, 1996: 5). Graças às descobertas arqueológicas, contudo, sabemos que Posidônia foi ocupada pelos lucanos ao redor de 420 a.C. As mesmas descobertas arqueológicas - na cidade, na área do Heraion na foz do Sele e nas necrópoles - nos autorizam a precisar que, já ao menos três decênios antes, havia começado na cidade 0 processo de infiltração de grupos itálicos, facilmente reconhecível, principalmente, pelos seus usos funerários (Cerchai, 2004: 62; Cipriani et alii, 1996: 5; Kraay, 1976: 186). Isso permite situar a "lucanização" da cidade em um contexto precedido pelo assentamento na khóra de grupos militarizados, provavelmente utilizados como mercenários (em um confronto com Vélia (La Torre, 2011: 119). Segundo La Torre, isso explicaria o motivo pelo qual o processo de "lucanização" não alterou minimamente a planta urbana nem o sistema dos cultos da fase grega até o primeiro quartel do século IV a.C. (La Torre, 2011: 119). Tudo dentro da cidade - os monumentos e os espaços públicos e religiosos e as instituições políticas estabelecidas pelos gregos - continuou como antes durante o tempo dos lucanos (Cerchiai, 2004: 65).

A conquista de Posidônia pelos lucanos não assinalou o fim da produção monetária no nome da cidade (Kraay, 1976: 187; Rutter, 2001: 108; Taliercio Mensitieri, 1987: 165). Como vimos, a ocupação lucana, mesmo traumática, não pareceu ter provocado o colapso, nem a mudança das estruturas econômico-sociais precedentes (Taliercio Mensitieri, 1987: 170). A continuidade monetária, marcada pela permanência do étnico grego e dos tipos tradicionais dos estateres, é sinal da adesão ao modelo grego, do elevado grau de helenização alcançado pelas populações não-gregas não só ali, mas em outras partes da Magna Grécia (Taliercio Mensitieri, 1987: 170-171). De acordo com Taliercio Mensitieri, "as séries de estateres de prata dessa época (420-410) se caracterizam pelos étnicos inscritos sem ou com letras do alfabeto jônico, pela retomada dos tipos tradicionais de Poseidon, imberbe ou com barba, atirando o tridente, no anverso, e pelo touro, no reverso, e pela presença de um símbolo marinho (geralmente um golfinho)" (Taliercio Mensitieri, 1987: 165 e 170). É nesse período que formas de étnico em letras jônicas começaram a predominar (Rutter, 2012: 134). Os tipos do Poseidon no anverso, dos estateres de prata, são semelhantes àqueles de Zeus atirando o raio das emissões em bronze (Fig.244 - n.47) (Taliercio Mensitieri, 1987: 167-168). Somente em época lucana o bronze começou a ser utilizado nas cunhagens da cidade, após a mudança da forma das letras nas legendas (Kraay, 1976: 187; Rutter, 2012: 136). A cunhagem em bronze articula-se em vinte quatro grupos que cobrem um arco de tempo entre 420-290 a.C. Desses grupos, os primeiros seis são datados entre 420-390 a.C. e os restantes são datados a partir da metade do século IV a.C. (Taliercio Mensitieri, 1987: 168). São os grupos três a seis que se distinguem pelas inovações tipológicas - 0 uso da imagem de Zeus, da cabeça de Atena e do tridente -, apresentam elementos de ligação, no plano figurativo e epigráfico, com os estateres de prata por correspondência de seus símbolos - golfinho e lula - e pela afinidade iconográfica e estilística (Rutter, 1997: 67 e 76; Taliercio Mensitieri, 1987: 169). Em pequenas frações de bronze, Zeus aparece representado em pé, 
no anverso, com as pernas abertas, atirando o raio com a mão direita e sobre o braço esquerdo estendido está a águia; o golfinho sempre aparece no lado direito do campo. No reverso, desses tipos monetários do deus, aparece retratado o touro e sob ele, no campo, uma lula como símbolo (Rutter, 1997: 67).

A imagem de Zeus atirando o raio nessas frações foi interpretada por R. Guarrucci, no final do século XIX, como evidência do culto de Júpiter entre os lucanos (Taliercio Mensitieri, 1987: 169, nota 183). Mas como colocou M. Vonderstein bem mais recentemente, Guarrucci propôs tal interpretação baseado em moedas muito mais recentes, as quais se relacionam com as cunhagens posteriores na Brécia e na cidade de Pentélia, que por sua vez, não apresentam qualquer tradição relacionada às moedas de Zeus emitidas em Posidônia (Vonderstein, 2006: 59). Outro estudioso, P. Erbner, na década de 1970, propôs que a imagem de Zeus aludiria a Zeus Dodonaios, pressupondo ter se tratado de uma influência causada pela presença de Alexandre, 0 Molosso, na Itália do Sul (Taliercio Mensitieri, 1987: 169, nota 183). Novamente, Vonderstein rebate tal tese pela simples constatação de que os tipos são muito anteriores ao período do rei epirota (Vonderstein, 2006: 59). Além disso, o tipo de Zeus em pé atirando o raio não está entre o repertório iconográfico daqueles do deus usado nas moedas batidas por Alexandre, o Molosso (Vonderstein, 2006: 59-60).

É interessante notar que mesmo em época lucana o tipo tradicional de Poseidon foi mantido e preponderante nas cunhagens contemporâneas ao uso do tipo de Zeus. O culto de Poseidon deve ter sido importante no primeiro assentamento de Posidônia (talvez em Agropolis), mas não é atestado naquele principal, onde se fez a cidade, exceto nas moedas (Fischer-Hansen; Nielsen; Ampolo, 2004: 289). Apesar disso, a oficina monetária da cidade em época grega e lucana manteve o uso da imagem por ser tradicional, remeter a um culto antigo que nas primeiras fases da fundação deve ter tido uma função importante, e também identificar a cidade, por ser um emblema já conhecido sobre Posidônia entre as demais fundações e também pelo nome da divindade aludir ao nome da cidade, muito provavelmente por derivação deste. Assim, é importante reiterar que nas cunhagens da Posidônia lucana, a oficina monetária não se desfez do tipo de Poseidon, no anverso, para passar a usar o tipo de Zeus no mesmo lado da moeda. Para M. Taliercio Mensitieri, "a introdução de Zeus, da cabeça de Atena, nas moedas subsidiárias, e somente marginalmente de Hera, nos estateres, todas divindades pertencentes ao panteão local, indica uma clara vontade de marcar uma continuidade cultual com o período grego, o que corresponde à continuidade do uso dos monumentos religiosos, sem que tivessem ocorrido mudanças significativas nesse aspecto" (Taliercio Mensitieri, 1987: 171-172). Nesse caso, o culto a Zeus em Posidônia é atestado em época grega - uma inscrição arcaica a Zeus Ksenios da área do dito templo de Poseidon pode indicar que o edifício foi a ele dedicado, assim como uma estátua em terracota policroma do deus sentado encontrada nessa mesma área e datada da mesma época (Cerchiai, 2004: 70; Fischer-Hansen; Nielsen; Ampolo, 2004: 288-289).

Mas o que teria levado os lucanos a usar, pela primeira vez, a imagem de Zeus nas moedas da cidade? De alguma maneira, devemos pensar, que o culto do deus deve ter sido importante para figurar nas moedas, assim como foi o caso de Poseidon, Hera e Atena, essas últimas com importantes santuários na cidade. É 
notável que justamente essas três divindades - Zeus, Hera e Atena -, cujos cultos tinham especial veneração no período grego foram usadas como imagens monetárias pela primeira vez na cidade, de modo significativo, em época lucana. No período grego "parece ter havido uma espécie de conservadorismo, nesse caso, em manter o tipo de Poseidon como o principal da oficina monetária da cidade, apesar de o tipo da cabeça de Atena ter aparecido pela primeira vez em hemióbolos de prata datados entre c.445-420 a.C." (Rutter, 2001: 110). É notável também que os lucanos usaram um esquema iconográfico, para retratar Zeus, já usado no Peloponeso ocidental no período em que passou a ser adotado em Posidônia. O tipo de Zeus em pé, atirando o raio com a mão direita e o braço esquerdo estendido, com uma águia sobre ele ou sobre a mão do deus, foi usado por Élis, pela primeira vez, entre c.452-432 a.C. O padrão de representação voltou a ser utilizado na região no século IV a.C. por Messênia em c.369 a.C. e na Tessália, em Gomphi, em c.350 a.C., e em Kierion, na segunda metade desse mesmo século. Vimos, no capítulo anterior, se tratar de um tipo típico do século $\mathrm{V}$ a.C. e também do período entre os séculos V-IV a.C., o mais recorrente do padrão "em pé". Os lucanos, então, não escolheram usar outros padrões de representação, como o da "cabeça" ou o de "Zeus sentado", mas o mesmo daquele antigo, de Poseidon atirando o tridente, o que muitas vezes confundiu os especialistas no momento da classificação dos tipos monetários, já que em alguns não há a presença dos atributos acompanhando a figura masculina que possa diferenciá-los. Acreditamos que a explicação possa estar na relação entre as duas divindades na religião grega, cujas representações, até o início do século $\mathrm{V}$ a.C. encontravam-se misturadas. Os lucanos podem ter procurado retratar Zeus à semelhança da forma como tradicionalmente era retratado Poseidon, pela relação dos dois na tradição religiosa antiga, ou ainda por uma simples convenção artística.

Se considerarmos o significado simbólico da imagem de Zeus, encontrar-se-á, contudo, um outro caminho interpretativo. Os lucanos, muito provavelmente, conheciam o significado grego do uso da imagem de Zeus em pé atirando o raio e segurando a águia - 0 aspecto guerreiro do deus, o significado na esfera militar, a imposição da ordem sobre o caos, a idéia de que Zeus exercia o poder no campo da guerra e determinava os acontecimentos, o destino. Por alguma razão, a imagem de Zeus, nesse sentido, ganhou alguma importância para os lucanos, passando a ser um emblema da cidade nas moedas. Essa importância pode ser encontrada na nova ordem estabelecida, no novo governo, no primeiro domínio lucano do assentamento grego. $O$ uso da imagem logo no início da conquista da cidade pode ter sido requisitado como afirmação ou proteção, após o momento da guerra com os posidoniatas, mas também num momento de transição, de início, quando as bases do novo domínio precisavam ser asseguradas, afirmadas. Nesse sentido, a proteção de Zeus precisava ser garantida, chamada, suas energias, a favor da cidade, deveriam ser equilibradas, apaziguadas, controladas. Prova de que o culto de Zeus tinha assumido alguma importância para os lucanos é o santuário dedicado a Zeus, provavelmente, por eles na ágora, localizado a algumas centenas de metros a oeste do eclesiastério, datado entre o final do século V a.C. e início do século IV a.C. (Greco, 2008: 40). Há também uma inscrição em 
uma estela do final do séc. IV a.C., exposta no museu, em alfabeto grego e língua osca com dedicação a Zeus feita por um magistrado lucano de nome Stazio (Greco, 2008: 39).

\section{I.3.3 Metaponto}

Em Metaponto, localizada na costa jônica, a imagem de Zeus foi usada também pela primeira vez no período inicial da cunhagem em bronze, mais ou menos no mesmo período que Posidônia. Entre c.425-350 a.C. a oficina monetária da cidade emitiu uma pequena denominação com o tipo, no anverso, da cabeça de Zeus Amon com cabelos curtos e barba curta. A imagem da águia voando também aparece entre os tipos usados, no anverso, pela oficina monetária da cidade em uma pequena denominação em bronze, mas datada entre c.350-275 a.C. Fundada ao redor de 630 a.C. por um grupo de aqueus enviado por Síbaris, com o intuito de ocupar uma área fronteiriça com Tarento, e assim bloquear sua expansão, Metaponto iniciou sua cunhagem de moedas ao redor de ou logo após 550 a.C., batendo estateres de prata na técnica aqueia incusa e no padrão aqueu-coríntio (Cerchiai, 2004: 130; Fischer-Hansen; Nielsen; Ampolo, 2004: 279; Kraay, 1976: 163; La Torre, 2011: 52 e 92; Rutter, 1997: 27; 2001: 3; 2012: 128-129). A espiga de trigo foi o primeiro tipo adotado pela cidade, usado, durante a fase incusa, como imagem única de anverso e reverso, se consolidando como emblema da cidade nos períodos posteriores, ocupando o anverso ou o reverso das moedas até o final do século III a.C., quando a cunhagem cessou em Metaponto (Rutter, 1997: 28; 2012: 129). A representação tem sido interpretada como um símbolo de riqueza relacionado ao cultivo agrícola nas planícies dos baixos rios Bradano e Basento e a Deméter que presidia a produção dos grãos (Rutter, 1997: 28). O uso do tipo da espiga de trigo como emblema de Metaponto mostra a finalidade primária da fundação - o aproveitamento sistemático das terras muito férteis da khóra (La Torre, 2011: 92).

Na metade do século $V$ a.C. a cunhagem em duplo relevo foi introduzida na cidade e a partir daí a oficina monetária aumentou o repertório iconográfico das moedas, passando a usar imagens de divindades (Fischer-Hansen; Nielsen; Ampolo, 2004: 282; Rutter, 2001:132). Em estateres de prata, datados entre c.440430 a.C., o tipo da espiga de trigo foi mantido no anverso, enquanto no reverso a imagem de uma estrela formada por cinco grãos de trigo aparece, em uma emissão, e a do deus-rio Aqueloos em pé, com cabeça de touro e segurando uma patera, aparece em outra. A representação de Héracles em pé, usando uma pele de leão, segurando uma clava e realizando uma libação sobre um altar, e a de Apolo também em pé, segurando um arco e uma pequena árvore de louro também foram usadas como tipos no reverso de estateres no período (Rutter, 2001: 132-133). Em pequenas denominações de prata, a cabeça de Aqueloos (em dióbolos), cinco crescentes, a cabeça de um boi e uma roda (óbolos) foram usados como tipos pela primeira vez. Já em emissões datadas a partir de c.430-400 a.C., as divindades passaram a ser retratadas no anverso, em denominações também em prata, e a espiga de trigo passou a figurar como tipo do reverso (Rutter, 2001: 133). Embora haja a figura de Apolo em pé, tocando lira, a maior parte das divindades são retratadas pelo tipo da 
cabeça, como é o caso Héracles, Deméter e Dioniso que aparecem tanto em estateres como em frações. Nesse período, as inscrições dos nomes Hygieia, Homonoia, Soteria e Nika, junto às imagens de cabeças femininas, identificam as divindades (Fischer-Hansen; Nielsen; Ampolo, 2004: 282; Rutter, 2001: 133; Stazio, 1974: 85). A representação da cabeça de divindades no anverso se tornou uma característica das cunhagens de Metaponto (Rutter, 2001: 132).

A partir do último quartel do século V a.C., como Crotona e Posidônia, Metaponto passou a emitir moedas também em bronze, usando-o em maior quantidade do que a maior parte das cidades gregas da região (Rutter, 2001: 138; 2012: 136). Nessas emissões, houve uma maior variedade de divindades representadas além daquelas retratadas nas emissões de prata. Assim, entre c.425-350 a.C., foram usadas, no anverso, em pequenas denominações, além da cabeça de Deméter, as imagens de Hermes em pé, segurando uma patera, da cabeça de Atena, usando um elmo coríntio, da cabeça de Ártemis, de Nike, de Apolo, de Pã e de Zeus Amon (Rutter, 2001: 138-139; Stazio, 1974: 85). A imagem da cabeça de Leucippos - lendário rei de Messênia que teria conduzido colonos aqueus para fundar Metaponto - foi usada pela primeira vez nesse período (Rutter, 1997: 93; 2001: 139). O trípode também aparece como tipo no anverso dessas denominações em bronze (Rutter, 2001: 138). Todas essas emissões com os tipos das divindades, incluindo parte daquelas das emissões em prata, datam do período de declínio de Metaponto ocasionado pela fundação de Heraclea por Túrio e Tarento entre 434-433 a.C. - que proporcionou um enfraquecimento do poder territorial e político e a absorção progressiva da cidade à órbita tarantina - e pela luta contra os lucanos (Cerchiai, 2004: 130 e 132; La Torre, 2011: 114 e 116). O período abrange o acirramento da presença e invasão dos lucanos e dos brettii na região da costa jônica com a união confederativa criada ao redor de 356/55 a.C. (Braccesi; Raviola, 2008: 362). De um pouco depois desse período, entre c.350-275 a.C., datam pequenas denominações em bronze com os mesmos tipos de imagens de divindades no anverso e da espiga de trigo no reverso, além dos tipos monetários da cabeça de Leucippos ou Ares e da de Sileno. É nesse período que a imagem da águia voando apareceu nas moedas de Metaponto pela primeira vez (Rutter, 2001: 139).

As imagens da cabeça de Zeus Amon e da águia voando foram usadas muito eventualmente nas emissões monetárias de Metaponto durante os séculos V e IV a.C. (Vonderstein, 2006: 37). A cabeça de Zeus Amon com cabelos curtos, e aparentemente com barba longa, foi o primeiro tipo de Zeus a ser usado pela oficina monetária da cidade, começando a figurar nas moedas no contexto do uso das divindades como emblemas da cidade (Fig.244 - n.44). A imagem de Zeus voltou a ser utilizada, em estateres de prata, associada ao título Eleutherios, entre 340-330 a.C. Trata-se de um tipo monetário derivado da cunhagem siracusana de Timoleonte (Rutter, 2001: 135). O tipo de Zeus Amon voltou a ocorrer cinco vezes nas cunhagens de dióbolos de prata de 325-275 a.C. A cabeça laureada de Zeus foi usada duas vezes em cunhagens de pequenas denominações em bronze entre c.275-250 a.C. Conforme coloca K. Rutter, "as diversas origens da população de Metaponto pode ser inferida pela diversidade de cultos, os quais, por sua vez, refletem-se na variedade dos tipos monetários de divindades" (Rutter, 2001: 130). Este, provavelmente, é o caso de Zeus 
Amon, cujo uso da imagem em moedas parece ser um caso único no Ocidente grego. A presença cultual de Zeus em Metaponto remonta pelo menos à metade do século VI a.C., quando foram instituídos os cultos a Zeus Agoraios, no ângulo noroeste do eclesistério e a Zeus Aglaos, em San Biaggio alla Venella. Com relação a Zeus Amon, contudo, infelizmente não dispomos de evidências sobre o seu culto na cidade. Para $M$. Vonderstein, "as imagens monetárias de Zeus Amon apenas nos possibilitam pensar que o deus pertencia ao grupo de divindades cultuadas oficialmente na cidade" (Vonderstein, 2006: 38). Esse autor ainda questiona se o culto a Zeus Amon em Metaponto também pode ser explicado a partir das relações comerciais. Questiona também a suposição de que os metapontinos mantivessem estreitas relações com Cirene e o oráculo do deus, que ainda estão para ser demonstradas (Vonderstein, 2006: 38). Cada divindade, representada nas moedas de Metaponto, possuiu um significado específico para a cidade. Algumas dessas têm significado mais evidente, como é o caso de Deméter, cuja imagem monetária pode ser vinculada, em algum grau, ao caráter agrário da cidade, e de Apolo, divindade cultuada em um dos principais santuários urbanos e que liga a cidade a Delfos por alguns relatos míticos, como aquele contado por Estrabão (VI, 264) acerca de uma colheita de ouro consagrada ali pelos colonizadores de Pylos, na Messênia, também participantes da fundação da cidade (Lacroix, 1965: 154). Mas Zeus Amon pertence àquele grupo de divindades, cujo significado para cidade é difícil de se precisar, diferente dos casos de imagens monetárias do deus vistos até agora, os quais são relacionáveis com mais precisão a eventos específicos referentes às cidades e suas regiões.

Com relação à águia, esta foi muito menos usada nas emissões monetárias da cidade (n.263) ${ }^{16}$. Além do tipo monetário datado entre c.350-275 a.C., a ave aparece retratada em pé, com asas abertas, no anverso de uma pequena denominação em bronze de c.275-250 a.C. A águia, que na Magna Grécia, foi usada extensivamente e quase que exclusivamente por Crotona nos séculos VI, V e parte do IV a.C., em Metaponto ela aparece pela primeira vez sendo representada voando, como nas emissões de estateres de prata em relevo duplo de Crotona de c.430-420 a.C. A amplitude cronológica da datação desse exemplar (séculos IV-III a.C.) permite associá-lo ao período de Pirro, assim como podem ser associadas a ele algumas das imagens mais posteriores de Zeus (Vonderstein, 2006: 37). A nosso ver, de alguma maneira, a imagem da águia voando deve ter sido requisitada nesse momento, por algum motivo específico que nos escapa, pelo seu significado auspicioso em relação à vitória na guerra.

\section{I.3.4 Lócris Epizefiri}

Outro grande centro de produção de tipos monetários de Zeus, águias e raios, na Itália do Sul, foi a pólis de Lócris Epizefiri, fundação de gregos da Lócrida do final do século VIII a.C. na costa do mar Jônico, a sul da área aqueia (Cerchiai, 2004: 90; La Torre, 2011: 55-56). Lócris iniciou suas cunhagens muito tardiamente

\footnotetext{
16 Tipo monetário não incluído entre as moedas da Fig.134 por ausência de imagem, vide informações a partir do número dessa moeda no catálogo numismático.
} 


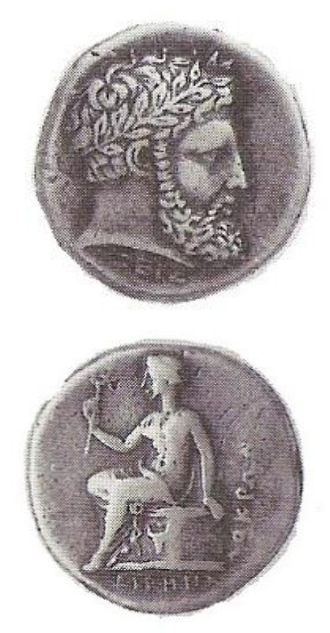

Fig.242- Estater de prata, Lócris Epizefiri, c.339/38 a.C. (Cahn et alii, GMGS: 208).

tipos de Zeus das moedas de Olímpia, enquanto Holm datou o tipo na época de Alexandre o Molosso, opinião compartilhada por Pozzi Paolini e mais recentemente por Rutter. C. Kraay propôs uma datação mais alta, em c.380 a.C., relacionada aos anos sucessivos à vitória de Dionísio I na batalha de Helesporo em 388 a.C. contra a liga italiota (Filocamo, 2009-2012: 115; Rutter, 2012: 137). Mais recentemente, A. Filocamo, em seu estudo acerca da relação entre a cunhagem de Lócris e o arquivo do santuário de Zeus Olímpio, propôs que o tipo monetário Zeus/Eirene seja datado antes de 339/338 a.C. em analogia aos tipos monetários de Zeus Eleutherios batidos por Siracusa (Filocamo, 2009-2012: 115-116 e 119). Além dessa analogia estilística com os tipos monetários siracusanos, Filocamo se baseia no fato de que, após a expulsão de Dionísio II de Lócris, a pólis não saiu da órbita política de Siracusa, de quem se torna quase uma oficina monetária subsidiária (Filocamo, 2009-2012: 116). Como sintetiza Vonderstein, "a datação desse tipo monetário foi proposta, muitas vezes, em dependência da interpretação histórica da imagem de Eirene no reverso, a qual aludiria a um momento comemorativo de paz "(Pozzi Paolini, 1976: 243-244; Vonderstein, 2006: 90). A cabeça de Zeus com cabelos e barba curtos é bastante característica e permite "uma comparação com moedas de bronze, que foram cunhadas depois do ano de 344 a.C. em Siracusa sob o domínio de Timoleonte e, por sua vez, remetem iconograficamente às moedas de Olímpia" (Vonderstein, 2006: 90).

Apesar de que as pesquisas mais recentes tendam a situar o estater em uma data posterior, portanto fora do nosso limite cronológico (345/44 a.C.), algumas considerações em relação a esse tipo monetário podem ser feitas aqui por nós. Diante de todas essas proposições, acreditamos que a de A. Filocamo seja a mais correta, embora, a nosso ver, o tipo monetário de Zeus/Eirene deva ser correlacionado diretamente às imagens monetárias provenientes de Olímpia, indo ao encontro do que também pensa Vonderstein (Vonderstein, 2006: 91). Para esse autor, "essa correlação entre as moedas de Lócris e de Olímpia traria maiores conclusões sobre a origem do culto de Zeus nessa cidade" (Vonderstein, 2006: 91). Como preferimos seguir a proposição mais recente sobre a datação desse tipo monetário de Lócris, o que o coloca fora do repertório numismático dessa pesquisa, não iremos realizar nenhuma interpretação do significado simbólico subjacente ao uso da imagem 
para a cidade. No entanto, gostaríamos apenas de chamar atenção para o fato de que esse tipo monetário mais antigo de Zeus, cunhado por Lócris, encontra paralelo no padrão iconográfico dos tipos monetários de Zeus de Élis-Olímpia de uma data anterior, de c.360 a.C. Como vimos, a coroa de folhas de oliveira, o uso de cabelos curtos e barba curtas parecem ter sido criações de Élis. A influência de Siracusa sobre Lócris não deve ser descartada, mas será que, nesse caso, não deveríamos também considerar uma influência direta dos tipos monetários de Élis-Olímpia sobre as imagens monetárias usadas em Lócris?

Lócris, como sua sub-fundação Hipônio, na costa tirrênica, se tornaram, nos períodos subsequentes, ao longo dos séculos IV-III a.C., importantes emissoras de tipos monetários que associam as imagens de Zeus, águias e raios em uma mesma moeda. $\mathrm{O}$ uso da imagem do deus e de seus atributos, em combinação, se tornou a partir do final do século IV a.C. uma tendência própria da Itália do Sul, uma influência de Olímpia, catalisada por esses dois centros emissores. A difusão dessas imagens entre as duas cidades concentrou-se, segundo os especialistas, nos períodos de Alexandre, o Molosso, Agátocles e Pirro (Filocamo, 2009-2012: 117; Gargano, 2012: 884; Vonderstein, 2006: 90).

\section{I.3.5 Considerações gerais sobre as imagens monetárias de Zeus e de seus atributos na Itália do Sul}

Até 344 a.C. 0 uso dos tipos monetários de Zeus, águias e raios pelas póleis na Itália do Sul foi este descrito. Até o limite cronológico proposto para essa pesquisa, o uso da imagem do deus e de seus atributos, na região, esteve restrito, inicialmente, nos séculos VI e V e até meados do IV a.C., à algumas das comunidades aqueias (Crotona, Posidônia, Metaponto), tendo ocorrido uma mudança nessa tendência justamente após 344 a.C. com a disseminação dos tipos entre Lócris e uma de suas fundações. Mas, contrariamente ao que parece indicar, Zeus não exerceu um papel numa dimensão pan-aqueia, na Itália do Sul, como teve o culto à Hera entre os aqueus italiotas, apesar de em c.430 a.C. 0 culto de Zeus Homarios ter sido escolhido para presidir a liga das cidades aqueias na região a exemplo da Acaia no Peloponeso. Diferente de Zeus, Hera, segundo vários especialistas, teve um papel destacado na construção da identidade aqueia ${ }^{17}$ na Magna Grécia (apud Diniz, 2011: 163). Em termos de identidade dos grupos de gregos na região, os tipos de Zeus, águias e raios não ganharam visibilidade pela formação ou existência de uma identidade comum, regional. Cada pólis, que se apropriou dessas representações, apesar de certa correspondência étnica, teve uma razão específica para usar tais imagens - para algumas foi a rede com Olímpia, como foi o caso de Crotona e mais tarde de Lócris, para outras a mera presença do culto no local ou quem sabe alguma espécie de rede com Cirene, como foi o caso de Metaponto em relação à imagem monetária de Zeus Amon, e para outras, simplesmente, o que a imagem

\footnotetext{
17 Segundo S. Diniz, os santuários de Hera delimitavam as duas fronteiras da koiné aqueia: o de Tavole Palatine demarcava o limite de Metaponto com Tarento e o da foz do Sele, demarcava a fronteira de Posidônia com a região além do rio Sele (Diniz, 2011: 166). A função dos Heraia na organização do espaço das póleis aqueias são um dos elementos culturais formadores da koiné aqueia (Diniz, 2011: 166).
} 
significava simbolicamente, como parece ter sido para Metaponto em relação à águia e para Posidônia em relação ao uso do tipo de Zeus atirando o raio entre os lucanos.

O momento político, mais do que a identidade de grupo, foi o fator responsável pelo uso dessas imagens. Vimos que, apesar da imagem da águia em moedas ter emergido no século $\mathrm{VI}$ a.C., o tipo da ave predominou a partir do segundo quartel do século $\mathrm{V}$ a.C., momento que se iniciou também o uso do tipo monetário de Zeus na região. Em Crotona, o período após o segundo quartel do século $V$ a.C. compreendeu 0 período de crise e declínio político da cidade, a formação da primeira liga, o confronto e hegemonia de Dionísio I e a invasão dos lucanos. Nesse contexto, para Crotona, a imagem da águia, assim como a do raio, embora em menor grau, exerceu significado para a pólis no campo de sua soberania e poder, de sua identidade em um nível político, em momentos de ameaça de sua soberania. Além disso, de certa forma, o uso dos tipos da águia nas emissões pode ter remetido a uma identidade mais ampla, pan-helênica em relação à ligação com Olímpia. Em Posidônia, o último quartel do século $V$ a.C. refere-se à perda do poder dos gregos de sua cidade e ao domínio dos lucanos. Nesse sentido, a imagem de Zeus atirando o raio, nas moedas desse período, esteve também relacionada à identidade política da cidade para esse novo grupo - o deus teria sido requerido para assegurar o novo governo, o novo domínio, recém instaurado, que precisava ser mantido. Em Metaponto, o segundo quartel do século V a.C., quando foi adotado o tipo de Zeus Amon nas cunhagens de moedas, correspondeu ao declínio da cidade, ocasionado pela hegemonia de Tarento e enfraquecimento de seu poder e autonomia após a fundação de Heraclea, além também da presença dos lucanos que se intensificou nas décadas seguintes. $\mathrm{O}$ uso da águia nas moedas da cidade, a partir da metade do século IV a.C., ocorreu justamente no acirramento da crise proporcionada pela união entre lucanos e brettii. Percebe-se, assim, que, de modo predominante, os tipos monetários de Zeus, águias e raios, e seus significados simbólicos, foram requisitados por algumas póleis, ganharam importância na região, no momento de crise e de ameaça de sua soberania, seja para os gregos, na maior parte dos casos, como para os lucanos, mostrando que Zeus foi requisitado a exercer suas mesmas competências entre populações não gregas, mas helenizadas, como ocorreu de forma marcante entre centros sículos na Sicilia. Em todo caso, Zeus, se pela própria representação ou pela imagem de suas energias divinas, o raio e a águia, exerceu um papel importante e específico no tocante a identidade política nas póleis italiotas a partir dos séculos $\mathrm{VI}$ e $\mathrm{V}$ a.C., nos momentos que assinalaram tanto 0 auge como o declínio (de forma mais marcada) dos centros gregos na Magna Grécia.

Os tipos monetários de Zeus, águias e raios parecem não ter sido usados por grupos políticos específicos no poder das cidades gregas na Itália do Sul durante o período estudado. Mesmo tendo sido adotados a princípio por determinado grupo, como provavelmente pela oligarquia em Crotona, os tipos continuaram a fazer parte do repertório iconográfico das oficinas monetárias durante a vigência de outras formas de governo, apesar de não possuirmos informações detalhadas sobre a organização política das cidades gregas da Itália do Sul no período. 
Como as póleis dórias na Sicília, foram as póleis aqueias as responsáveis pela introdução das imagens de Zeus, águias e raios nas emissões monetárias da Itália do Sul.

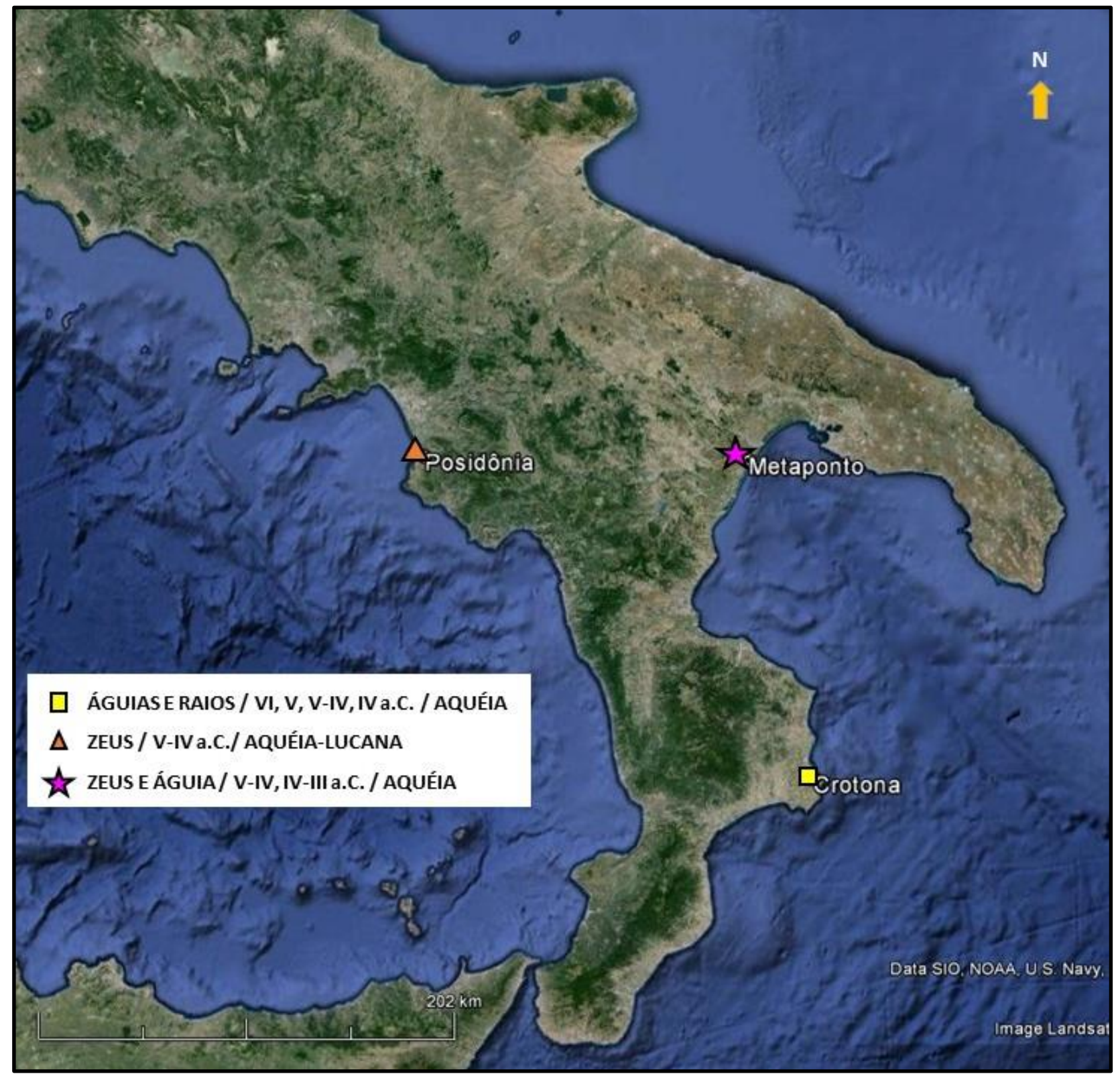

Fig.243 - Mapa da Itália do Sul: autoridades emissoras que emitiram tipos monetários de Zeus, águias e raios (sécs. VI-IV/III a.C., até 345/44 a.C.) 

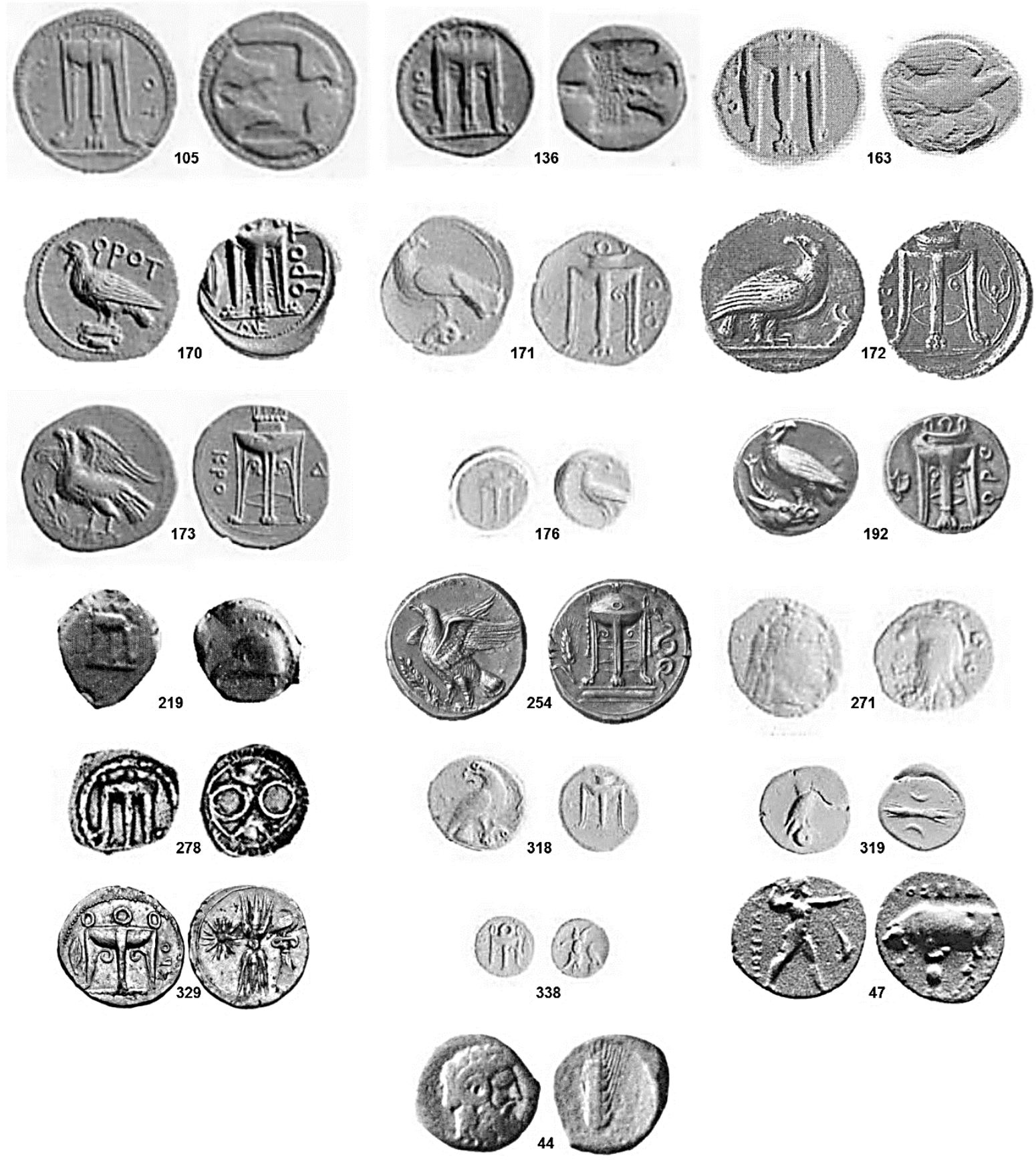

Fig.244 - Itália do Sul: tipos monetários de Crotona (n.105-338), Posidônia (n.47) e Metaponto (n.44)

\section{I.4 CRETA}

Dentre as imagens de Zeus e de seus atributos, a do deus e a da águia foram as mais usadas nas moedas cretenses em época clássica e helenística (Fig.245). A imagem do raio figurou raramente em moedas de cunhagens da ilha nesses dois períodos, aparecendo como símbolo, ao que parece, apenas em alguns poucos tipos monetários de Cnossos do final do século IV a.C. Das três imagens referentes à divindade, a da águia foi a primeira a ser utilizada como tipo principal em moedas em Creta, pela pólis de Lyttos, localizada no 
lado centro-oriental da ilha, a partir do último quartel do século $\mathrm{V}$ a.C. Responsável pela maior e mais duradoura emissão de tipos monetários de águia em Creta, Lyttos manteve o uso da imagem da ave por todo o século IV a.C. Em Gortina, localizada no lado centro sul da ilha, ao redor de 430 a.C., a ave também aparece em algumas moedas, mas em composição com a imagem de Europa, não ocorrendo, portanto, como um tipo principal como em Lyttos. De acordo com a cronologia revista por G. Le Rider, autoridades emissoras cretenses não utilizaram a imagem de Zeus em moedas até ao menos as quatro décadas finais do século IV a.C. Foi a partir dessa época que houve um aumento de tipos monetários da divindade que durou por toda a época helenística. Aproximadamente 15 póleis ${ }^{18}$ usaram os três padrões principais de represesentação da divindade, com destaque para o tipo da cabeça. Nas cunhagens de Creta, a associação entre a imagem de Zeus, da águia e do raio, ou entre seus dois atributos, foi muito rara. Os únicos casos encontrados referem-se ao tipo monetário de Malla ${ }^{19}$, do século III a.C., que possui a cabeça de Zeus, no anverso, e o raio e a águia, no reverso, e o de Lyttos $^{20}$, de época helenística, que traz a cabeça de Zeus no anverso e a águia em pé junto ao javali, no reverso. Entre as autoridades emissoras de Creta que fizeram uso da imagem de Zeus e de seus atributos, portanto, esse traço cultural, típico do oeste do Peloponeso (Élis) e do Ocidente grego (Sicília e Itália do Sul), não foi tão comum como nessas outras áreas do mundo grego.

Na pesquisa dos tipos monetários cretenses de Zeus e seus atributos procuramos seguir o estudo de G. Le Rider que propõe novas datações para aquelas estabelecidas pela bibliografia mais tradicional, a saber as obras de Svoronos, Wroth e Head sobre as cunhagens de Creta. Como bem coloca K. Sheedy, estudos sobre as principais emissões cretenses, bem como as dos centros menores, ainda estão para serem feitos (Sheedy, 2012: 119). A maior parte dos tipos monetários possuem, portanto, uma cronologia estabelecida ainda no final do século XIX, por Svoronos e Wroth, com datas muitos amplas e pouco específicas para determinado período. Além desse problema cronológico, há também a falta de um histórico completo e específico sobre a maior parte das emissões monetárias cretenses. Esses foram os dois principais problemas encontrados durante a elaboração do estudo dos tipos monetários de águias de Lyttos, os únicos referentes ao período pertinente à nossa investigação.

\footnotetext{
18 Um pouco antes do início do último quartel do século IV a.C., destacam-se as cunhagens de Eleutherna de c.330-270 a.C., com o tipo da cabeça laureada de Zeus (Sear, vol.I: 3296), de Arcades de c.330-270 a.C. com o tipo da cabeça de Zeus Amon (Sear, vol.I: 3274), de Olous de c.330-200 a.C., com o tipo de Zeus sentado no trono segurando águia e cetro (Head, 1963: 472), de Hierapytna de c.330 a.C. com o tipo da cabeça laureada de Zeus (BMC Crete: Pr.XII,1), de Polyrhenion de c.330 a.C. com o tipo da cabeça laureada (BMC Crete: Pr.XVI,13), e de Moda de c.330 a.C., também com o tipo da cabeça laureada do deus (Sear, vol.I: 3339 ). Baseando-se no manual de Head, R.F. Willets apresenta uma relação dos tipos monetários de Zeus de época helenística, dos séculos III-I a.C.: Axos de c.300-67 a.C. com o tipo da cabeça de Zeus e o raio, de Aptera de c.250-67 a.C. com o tipo da cabeça laureada de Zeus, de Chersonesos de c.300-200 a.C. com o tipo da cabeça de Zeus, de Kydonia de c.200 a.C. com o tipo de Zeus em pé atirando o raio usado como símbolo, de Arcades de c.200 a.C. com os tipos da cabeça ou de Zeus atirando o raio, de Gortina de c.200-67 a.C. com o tipo da cabeça laureada de Zeus, de Cnossos da mesma data com o tipo da cabeça de Zeus, e de Malla do século III a.C. com o tipo da cabeça de Zeus acompanhado a águia e o raio (Willets, 1962: 231-232, 246 e 249). Todas as datações desses exemplares se baseiam na cronologia tradicional e devem se revistas com base no estudo de G. Le Rider (1966).

${ }^{19}$ Ver Willets, 1962: 246.

20 Svoronos, no.75, pr.XXII, 10.
} 
Durante muito tempo a adoção da cunhagem de moedas em Creta foi considerado um fenômeno tardio, como afirmou G. Le Rider nos anos de 1960, premissa seguida por C. Kraay uma década depois. A interpretação tradicional, a partir desses autores, coloca que as primeiras emissões locais teriam se iniciado somente a partir da metade do século V a.C. (apud Stefanakis, 1999: 247, nota1). A ausência de fontes nativas de prata é considerada um fator que teria inibido a produção de cunhagem local (apud Sheedy, 2012: 117). Antes dessa data foram os estateres de Egina que supriram a demanda por metal nas transações comerciais em Creta (Kraay, 1976: 49; Price, 1981: 463; Sheedy, 2012: 118). O tesouro de Matala, datado entre c.500-490 a.C. e formado inteiramente pelas moedas de Egina, atesta, entre os cretenses, a prática de importar moedas estrangeiras muito antes das comunidades políticas locais baterem suas próprias moedas (Price, 1981: 463). De acordo com M. Stefanakis, "a cunhagem de Egina foi importada por Creta, na segunda metade do século VI a.C., como resultado da combinação da grande atividade de comércio de Egina e da localização de Creta na rota do Oriente Próximo" (Stefanakis, 1999: 256). Conforme esse autor, "foi por meio da pólis de Kydonia que o grande influxo de moedas de Egina entrou em Creta" (Stefanakis, 1999: 257). A introdução da cunhagem a partir dessa cidade cretense e sua relação com Egina é explicada pelo histórico das relações comerciais e culturais entre ambas. Evidências materiais e literárias atestam a fundação de Kydonia por Egina no contexto das redes comerciais no Egeu durante o período arcaico (Stefanakis, 1999: 254). De Kydonia, localizada na costa noroeste de Creta, o uso de moedas eginetas deve ter se espalhado por todo o oeste, alcançando também, um pouco depois, as grandes cidades das partes centrais e leste da ilha (Stefanakis, 1999: 257).

Essa adoção do uso das moedas em Creta, denominada tardia, foi explicada de várias maneiras pelos pesquisadores. A falta de prata e a necessidade de importar o metal, e uma suposta proibição em leis, por influência de uma lei espartana, são apontadas como as principais causas. Mas outra perspectiva, mais atual, afirma ser errônea essa interpretação mais tradicional de Le Rider e Kraay sobre a introdução tardia da cunhagem em Creta (Stefanakis, 1999: 247). Na realidade, a cunhagem foi familiar a Creta desde a segunda metade do século VI a.C., a partir das relações de Egina e Kydonia (Stefanakis, 1999: 247). É dessa época também que data a evidência epigráfica mais antiga sobre o uso de moedas na ilha: trata-se de uma referência a 200 estateres em uma inscrição de Phaistos (Stefanakis, 1999: 249). Datadas entre a metade do século VI a.C. e início do século $V$ a.C., são uma série de inscrições provenientes de póleis cretenses referentes à unidades monetárias (Stefanakis, 1999: 250). A princípio os pesquisadores as consideraram como meras indicações metrológicas, mas, como bem coloca Stefanakis, como essas medidas não aparecem especificadas (por exemplo, aparece somente estater e não estater de grão) devem ter se referido a valores monetários (Stefanakis, 1999: 250). Nesse caso, esses valores monetários não se referem a uma cunhagem local cretense, mas a cunhagem estrangeira que circulava na ilha, composta, na maior parte, por moedas de Egina (Stefanakis, 1999: 250).

Como mencionamos, 0 início das cunhagens locais cretenses foi situado entre c.450-425 a.C., mas mais recentemente, Stefanakis, seguindo Price, sugeriu uma data ao redor de 470 a.C. (apud Stefanakis, 1999: 
247, nota 1). Como no caso da introdução do uso da moeda, algumas causas foram sugeridas para o início das emissões locais. A redução das emissões de moedas em Egina, reflexo do declínio dessa ilha quando Atenas ganhou o domínio do Egeu em c.479 a.C., e as implicações políticas que emergiriam do uso dessa cunhagem no tempo da rivalidade entre Egina e Atenas são apontadas como fatores que teriam levado às póleis cretenses a começar a bater suas próprias moedas (Stefanakis, 1999: 257-258). No entanto, nenhuma dessas duas explicações podem ser provadas. A explicação mais plausível até o momento, então, relaciona-se a dois fatos inter-ligados - "as póleis cretenses iniciaram suas próprias emissões monetárias em razão do declínio da cunhagem de Egina e também do fato de que os cretenses já estavam, nessa época, acostumados ao uso da cunhagem para transações e por isso abriram suas próprias emissões, recunhando sobre moedas estrangeiras até então reservadas em tesouros" (Stefanakis, 1999:258). As primeiras póleis a bater moedas foram Gortina e Phaistos ao redor de 470 a.C., seguidas por Cnossos e Lyttos no segundo quartel do século V a.C. ou um pouco antes (Kraay, 1976: 50; Price, 1981: 463; Nicolet-Pierre, 2002: 182; Stefanakis, 1999: 258). As séries monetárias mais antigas batidas por essas quatro cidades foram re-cunhadas em moedas de Egina, as quais nenhuma pós-data a metade do século V a.C., o que situaria em novas datas as emissões de Cnossos e Lyttos (Nicolet-Pierre, 2002: 184; Stefanakis, 1999: 251). As emissões monetárias de Creta são caracterizadas por terem sido batidas sobre os discos de moedas de fora da ilha - prática que durou até o final do século IV a.C. (Kraay, 1976: 49; Sheedy, 2012: 118). Os discos metálicos de emissões cretenses foram reutilizados para novas cunhagens locais, quando não as antigas moedas de Egina (Kraay, 1976: 49). Essas primeiras emissões monetárias cretenses também foram caracterizadas por um estilo (tipos e legendas) e execução de aparência arcaica, que ocultam sua data verdadeira (Kraay, 1976: 49; Sheedy, 2012: 119).

Se por um lado as cunhagens de Gortina e Phaistos são consideradas propriamente as primeiras realizadas por autoridades emissoras de Creta, com tipos e legendas criados e referentes a elas, K. Sheedy lembra que as cunhagens mais antigas também podem ser consideradas aquelas de Kydonia, caracterizadas por serem imitações de moedas de Egina (Sheedy, 2012: 118). Essa cidade introduziu moedas emitidas em seu próprio nome e tipos somente no século IV a.C., ao redor de 330/20 a.C. (Sheedy, 2012: 118-119). Outra característica importante atribuída a essa cunhagem mais antiga de Kydonia foi a criação de um peso chamado de pseudo-eginético (Sheedy, 2012: 118). Trata-se de uma diminuição do peso do estater eginético aplicado durante a recunhagem das moedas de Egina, que teria facilitado pagamentos com uma denominação menor, equivalente a hemidracmas (Sheedy, 2012: 118-119). Na perspectiva de Stefanakis "o denominado padrão pseudo-eginético, ou eginético reduzido, tratou-se, na realidade, do padrão de peso cretense, o qual foi logo adotado por outras autoridades emissoras da ilha" (Stefanakis, 1999: 260-261). Para Stefanakis, "é bem provável que as autoridades emissoras cretenses tenham concordado em padronizar as próprias cunhagens a partir de um peso mais baixo, do que aquele eginético, em reação à escassez de prata da ilha" (Stefanakis, 1999: 261). Como uma ilha naturalmente isolada do resto do mundo grego, Creta e suas várias cidades foram 
interdependentes por necessidade - a necessidade por cunhagem facilmente trocável na ilha deve ter sido uma razão importante para as cidades adotarem um padrão comum (Stefanakis, 1999: 263).

Os autores parecem estar de comum acordo sobre a disseminação da atividade emissora em Creta durante o século IV a.C., que parece ter sido lenta até as últimas décadas desse período (Sheedy, 2012: 120). Três emissões menores apareceram antes da metade do século IV a.C., como as de Sybrita e Axos, no lado centro-oeste, e a de Itanos, a primeira emissão no lado leste de Creta²1 (Sheedy, 2012: 120). Nas emissões já ativas desde o século $V$ a.C., e operantes no início do século IV a.C., algumas mudanças ocorreram entre c.380-340 a.C., como o aumento no tamanho dos discos dos estateres e o significativo aprimoramento no estilo (Sheedy, 2012: 120). Até perto do final do século IV a.C., a cunhagem em Creta foi restrita à emissões ocasionais requisitadas para satisfazer as necessidades de poucas cidades principais (Kraay, 1976: 54). Tem se assumido que a maior parte das cidades cretenses começaram a bater suas próprias moedas a partir do final do século IV a.C., a partir de c.330/20 a.C., causando um grande aumento na produção de moedas na ilha, principalmente em prata (Sheedy, 2012: 120; Stefanakis, 1999: 247 e 259). De acordo com Le Rider, nos anos entre c.330 a.C. e 280/70 a.C., um número estimado de 28 emissões cretenses estiveram ativas, várias das quais emitiram moedas pela primeira vez (apud Sheedy, 2012: 120-121).

Essa explosão de cunhagens em Creta no final do século IV a.C. tem sido explicada como resultado do retorno de soldados mercenários, do comércio ou dos distúrbios militares no Egeu, como as atividades de Mausolos da Cária, durante a guerra na qual aliados da segunda liga ateniense revoltaram-se contra Atenas entre c.357-355 a.C., as de Phalaicos e seus mercenários em c.344 a.C. e aquelas de Agis de Esparta em c.333 a.C. (Stefanakis, 1999: 259). Stefanakis propõe que "esse aumento das cunhagens locais se explica por dois motivos. 0 primeiro deles refere-se a uma mudança de mentalidade econômica de seus habitantes - é possível que os soldados mercenários cretenses e mercadores, acostumados com transações em dinheiro enquanto fora da ilha, contribuíram para a adoção de cunhagens em suas cidades natais" (Stefanakis, 1999: 260). O segundo motivo parece ter sido "o influxo repentino de prata estrangeira nos tesouros de várias cidades cretenses sem emissões no final do século IV a.C., que deve ter oferecido a elas a oportunidade de participar ativamente na economia monetária da ilha" (Stefanakis, 1999: 260). As cidades podem ter tido a necessidade de re-emitir a prata em sua possessão, desenvolver suas próprias cunhagens com seus próprios tipos e legendas, numa época em que o padrão de peso local já existia em Creta por um século e meio (Stefanakis, 1999: 260). No século III a.C., em c.270 a.C., houve um declínio na emissão de moedas em prata, tendo uma década depois iniciado as cunhagens locais em bronze (Sheedy, 2012: 121).

\footnotetext{
${ }^{21}$ Le Rider afirma que as oficinas de Itanos, Sybrita e Axos abriram nos primeiros decênios do século IV a.C. e as póleis de Eleutherna, Praisos, Rhaucos, Chersonesos, Priansos, Tylisos, Hierapytna, Aptera, Polyhernion e Phalasarna começaram a bater moedas antes de 350 a.C. (Le Rider, 1966: 174).
} 


\subsubsection{Lyttos}

Foi no contexto das primeiras emissões monetárias cretenses que a imagem da águia apareceu como tipo monetário em Creta, na pólis de Lyttos. É preciso destacar que Lyttos foi uma das autoridades emissoras que mais emitiu moedas com o tipo da águia no período estudado por essa pesquisa - ao lado de Crotona foi a terceira autoridade emissora a bater moedas com a imagem da ave, ficando atrás em número apenas de Élis e Agrigento. A antiga Lyttos localiza-se no lado centro-leste da ilha, a noroeste do platô do Lassithi e da gruta do Dicta, no interior a norte de Chersonisos, situada na costa. A pólis foi construída em uma zona colinar, que domina atualmente a cidade moderna de Kastelli, de onde é possível avistar o mar a norte e os platôs que bordeiam a Mesara a sul (Le Rider, 1966: 235). Chersonisos foi a saída natural de Lyttos para o mar Egeu, Ihe servindo de porto durante momentos na antiguidade (Le Rider, 1966: 235). Unidades monetárias já eram mencionadas em documentos de Lyttos, como cita Stefanakis a respeito de uma inscrição datada entre o final do século VI a.C. e início do século V a.C. (Stefanakis, 1999: 250). Mas a cidade de Lyttos bateu moedas em prata (estateres, dracmas e hemidracmas) no padrão eginético somente a partir do terceiro quartel do século $\mathrm{V}$ a.C. ou um pouco antes dessa época (Pearlman, 2004: 1177). Durante toda a época grega, e em todas as denominações, a águia em pé ou voando, no anverso, e a cabeça de javali dentro de um quadrado incuso, no reverso, foram os tipos monetários predominantes (Kraay, 1976: 53; Pearlman, 2004: 1177). A única exceção parece ter sido uma denominação em bronze, de época helenística, com a imagem da cabeça de Zeus à direita com coroa, no anverso, e com as imagens de uma águia em pé e da cabeça de javali, no reverso (Wroth, 1884: 41, nota 6). As legendas referem-se ao étnico no nominativo singular e no genitivo plural e foram inscritas em alfabeto epicórico até o final do século IV a.C., quando formas de letras locais deixaram de ser empregadas (Kraay, 1976: 53; Pealman, 2004: 1177). Moedas de Lyttos foram re-cunhadas em moedas de Egina e a moeda mais antiga, cunhada sobre um disco mais espesso, na opinião de Le Rider, foi provavelmente mais antiga do que as primeiras emissões de Cnossos (Kraay, 1976: 53; apud Price, 1981: 464-465).

Nas emissões monetárias de Lyttos houve certa variação na representação da águia, embora tenha sido muito menor e mais restrita do que vimos em relação às cunhagens de Élis, Agrigento e Crotona. Também é preciso dizer que apesar de serem conhecidos como tipos monetários repetitivos, o estilo do desenho da águia e do javali sempre mudou ao longo das séries monetárias ${ }^{22}$. Assim, dos 13 tipos monetários selecionados por nossa pesquisa, nas primeiras séries de dracmas e estateres, a águia aparece retratada em pé, de asas erguidas, sem carregar qualquer tipo de presa, e a cabeça do javali aparece dentro de um quadrado incuso, cujas lados possuem ou não o desenho de linhas (Fig.246 - n.177 e 178). Nas demais séries, predominou 0 tipo da águia voando com as asas abertas (uma em cima e a outra embaixo do corpo da ave) (Fig.246 - n.179,

\footnotetext{
22 Le Rider chegou a sugerir a influência das águias representadas nas moedas de Élis em dois exemplares específicos de Lyttos datados entre os séculos IV-III a.C. - pr. VII, 24 e pr. VIII, 1 (Le Rider, 1966: 183 e 196). Em nosso levantamento e estudo iconográfico empreendido no capítulo 3 não encontramos uma influência direta de Élis, mas das representações dos vasos áticos e lacônios datados do século VI a.C. com relação ao pontilhado que aparece nos "ombros" das asas das águias.
} 
181-217), carregando eventualmente presa (Fig.246 - n.180) ou um objeto como uma banda (taenia) no bico (Fig.246 - n.183), a única exceção parece ter sido um tipo monetário no qual a ave é retratada voando com as asas erguidas e carregando uma presa não identificada (Fig.246 - n.180). Vimos no capítulo anterior que Lyttos foi a responsável pela emissão mais numerosa do padrão de representação da águia voando sem presa (com uma asa em cima e a outra embaixo) durante o século $V$ a.C. Já a cabeça do javali continuou sendo representada dentro do quadrado incuso, mas na maior parte dos casos os lados desse quadrado são desenhados por um pontilhado. Basicamente, são esses os padrões e variações nas formas de representação da águia, e também do javali, nas cunhagens de Lyttos assinaladas à época clássica.

Os autores têm relacionado a imagem da águia, e também a do javali, nessas emissões monetárias de Lyttos, com referências míticas sobre o nascimento de Zeus na região, identificando a ave ao culto da divindade. Wroth parece ter sido o primeiro a associar um testemunho de Hesíodo (Teogonia, 481-484) no qual diz que teria sido na gruta do Monte Aegaeon, perto de Lyttos, que Rhea deu à luz a Zeus e o escondeu de Cronos (Prent, 2005: 169-170; Wroth, 1884: 42). Essa interpretação foi seguida mais tarde por Head e Willets, o qual definiu a presença da águia nessas emissões como um aparente símbolo de Zeus (Head, 1963: 471; Willets, 1962: 232). Até hoje, a identificação da águia como um atributo de Zeus é a única proposta pelos estudiosos, não tendo havido controvérsias sobre tal atribuição. Mais recentemente, Sheedy, influenciado por esses mesmos autores, também interpretou a águia como um símbolo de Zeus Cretagenes, e identificou o javali com o porco que, segundo uma versão local do século III a.C., teria amamentado o deus no Monte Dicta (Sheedy, 2012: 119; Stefanakis, 2014: 608-609). Em nossa opinião, contudo, javali e porco são animais caracteristicamente diferentes e por isso essa associação provavelmente está equivocada. Vimos no caso de Abakainon na Sicília que a imagem monetária do javali, nas moedas dessa pólis, pode ter aludido, não diretamente à economia local, mas ao aspecto selvagem da região, em algum nível relacionado à Artemis, protetora dessa força da natureza, com a qual esse animal é relacionado na religião grega. Esse pode também ter sido o caso dos tipos monetários de Lyttos, situada numa zona montanhosa e boscosa no interior de Creta.

Já a identificação da ave como de fato um atributo ou símbolo de Zeus pode encontrar comprovação em um tipo monetário de Zeus, no anverso, e a águia e o javali, no reverso, já mencionado e datado na época helenística, posteriormente aos tipos em questão. A nosso ver, trata-se de uma evidência que indica a relação de Lyttos em algum nível com o culto de Zeus, cuja imagem, como tipo principal, apareceu somente posteriormente àquelas da águia nas moedas da cidade. Embora as pesquisas arqueológicas não tenham até agora encontrado evidências sobre um santuário ou culto de Zeus como divindade políade de Lyttos, assim como parece ter sido o caso de Atena Polias, compreendemos o testemunho de Hesíodo como mais uma indicação da relação de Lyttos com o culto de Zeus na região do Lassithi. Vimos no capítulo 2, que muito provavelmente já durante a Idade do Ferro, o platô do Lassithi foi parte do território de Lyttos (Pearlman, 2004: 1177; Watrous, 1996: 104). O santuário na gruta de Dicta teria sido frequentado pela população de Lyttos e influenciado de algum modo pelo controle dessa pólis na região (Watrous, 1996: 104). M. Prent, recentemente, 
chegou a propor que o testemunho de Hesíodo sobre o Monte Aegaeon pode se referir, na verdade, à gruta de Psychro, considerada a gruta de Dicta descrita nos textos antigos (Prent, 2005: 169-170). Essas são todas as evidências que dispomos para justificar o uso da imagem da águia, como um atributo de Zeus, nas moedas de Lyttos datadas entre os séculos V-IV a.C. Nesse sentido, é possível considerar essas imagens monetárias das águias como as únicas evidências materiais da relação de Lyttos com o culto de Zeus, seja na esfera do mito local, que a conecta com o nascimento de Zeus, ou em uma participação efetiva no santuário de Psychro.

Vimos ao longo desse capítulo que o significado simbólico da ave, voando e em pé, em moedas esteve relacionado às ideias de soberania política e territorial de suas autoridades emissoras no período no qual fizeram uso de tais imagens, como foi o caso de Élis, Agrigento e Crotona. Mas no caso de Lyttos, o que a escolha pela imagem da águia em pleno vôo, ou em pé de asas erguidas, na maior parte das vezes sem presa, durante tanto tempo, e desde o início de suas emissões, pode ter significado para essa autoridade emissora?

Infelizmente as informações literárias e arqueológicas / epigráficas sobre a pólis de Lyttos nos séculos V e IV a.C. são muito escassas, em contraste à profusão de informações sobre a época helenística. 0 que sabemos basicamente sobre esse período das cunhagens é que entre o final do período arcaico e o início do século IV a.C. Lyttos esteve envolvida em um processo de expansão territorial em sua região e que na metade do século IV a.C. a pólis sofreu a primeira conquista e destruição por Cnossos (Pearlman, 2004: 1176). Esse processo de expansão territorial, que a caracterizou como um centro de certo domínio na porção centro-leste de Creta, foi atribuído, por Watrous e D. Viviers, aos séculos VI e V a.C. (apud Viviers, 1994: 252). Conforme Viviers, "Lyttos se expandiu territorialmente, em primeiro lugar, na direção do Lassithi já em época arcaica, depois na direção sul o acesso à costa do mar líbio parece ter ocorrido a partir do século $V$ a.C. com o controle sobre Dattalla e Biennos, comunidades periecas com certa autonomia política" (Viviers, 1994: 255-256 e 258). A conquista do acesso ao mar na costa norte egéia parece ter se concluído na metade do século IV a.C., embora uma inscrição de Lyttos identifique Chersonisos como a parte costeira de Lyttos já em meados do século VI a.C. (Viviers, 1994: 253; Pearlman, 2004: 1176). Com relação à conquista de Cnossos na metade do século IV a.C., dispomos apenas de uma informação de Diodoro (16.62.3-4) que diz que o general Phalaicos colaborou na expulsão da população de Lyttos (Pearlman, 2004: 1176). De acordo com um outro trecho de Diodoro (16.62.4), o rei Archidamos de Esparta, antes de partir para Tarento, teria libertado a cidade e ajudado a população a se restabelecer (Malkin, 1994: 80). Esse e outros trechos em autores antigos têm sido considerados evidências de que Lyttos foi uma fundação espartana (Pearlman, 2004: 1176; Svoronos, 1890 : 225-226). Mas, como bem chamou a atenção I. Malkin, não há evidências arqueológicas que sustentem tal proposição (Malkin, 1994: 80). A seu ver, é possível que a origem espartana de Lyttos tenha sido inventada em um período posterior - a ocasião descrita por Diodoro pode ter sido usada para aumentar a crença existente nas origens coloniais de Lyttos (Malkin, 1994: 80; Pearlman, 2004: 1176). Assim, é difícil atestar a origem dória de Lyttos, conforme testemunham os textos antigos. 
Mesmo diante dessas poucas informações históricas sobre Lyttos nos séculos VI, V e IV a.C., pode-se assumir que 0 aspecto expansionista sobre sua região foi um traço importante enquanto comunidade política cretense nesse período. Portanto, nessa perspectiva, é possível relacionar esse caráter expansionista de Lyttos à escolha da águia como emblema monetário da cidade, inalterável nas cunhagens dessa cidade por tanto tempo. Lyttos foi umas das quatro primeiras póleis cretenses a cunhar suas próprias moedas (com tipos que Ihe caracterizavam e legendas que a identificavam), correspondendo, em importância, aos principais centros urbanos da ilha no período. Embora não saibamos precisamente as razões da adoção da cunhagem em Lyttos, os motivos devem ser os mesmos que levaram a adoção da cunhagem em Gortina, Phaistos e Cnossos e, também, e estar nas relações entre elas. Assim, acreditamos que a imagem monetária da águia em Lyttos, nesse contexto histórico e no contexto do significado local do culto de Zeus, deve ser interpretada como um símbolo que, em algum grau, foi requisitado para expressar e identificar a autoridade emissora à energia divina do deus, de sua realeza, onipotência e de seu poder mântico. Essas forças de Zeus, associadas aos significados da águia com relação à guerra, vitória e competição foram importantes em momentos de hegemonia e expansão territorial, como vimos marcadamente no caso de Élis e vemos no caso de Lyttos. A nosso ver, portanto, Lyttos se tratou de mais um caso de uma pólis que procurou ser identificada no poder de Zeus e ao mesmo tempo mostrar, às demais comunidades políticas da região, que esta e sua população estavam sob a proteção da divindade suprema que se acreditava por ali ter nascido. Águia e javali, animais usados como emblemas monetários, expressaram e afirmaram aspectos importantes para Lyttos, que lhe identificaram enquanto comunidade política, como o da força selvagem da natureza, onde estava imersa, e da soberania de Zeus, miticamente relacionado a sua localidade desde ao menos o início da época arcaica, como testemunha Hesíodo.

\subsubsection{Considerações gerais sobre as imagens monetárias de Zeus e de seus atributos em Creta}

A cronologia tradicional indica uma série de imagens monetárias de Zeus datadas entre o início e a metade do século IV a.C., pertencentes às póleis de Cnossos, Phaistos, Praesos, Eleutherna e Sybrita, as quais na ausência de uma nova proposição para as datações poderiam ser incluídas nessa pesquisa. Trata-se de exemplares com datas muito amplas e que ainda hoje mereceriam um estudo novo e específico de suas emissões à luz dos dados arqueológicos mais recentes sobre esses sítios. Mesmo diante dessa limitação, contudo, foi possível questionar a cronologia desses tipos monetários de Zeus com base no estudo de G. Le Rider, da década de 1960, que faz uma revisão acurada das datações das emissões monetárias cretenses entre os séculos V e III a.C. 
Assim, sobre Eleutherna, Head data um tipo monetário da cabeça de Zeus entre c.450-300 a.C.23, sendo que hoje se aceita, com base em Le Rider, que as emissões monetárias dessa pólis começaram um pouco depois de 350 a.C. (Le Rider, 1966: 174). Esse estudioso francês data essa imagem monetária entre 0 final do século IV a.C. e c.280-270 a.C. (Le Rider, 1966: 197). Sobre Cnossos, uma pequena denominação em bronze com o tipo da cabeça de Zeus é datada por Wroth em c. 400-350 a.C. ${ }^{24}$ no catálogo do Museu Britânico, mas Le Rider situou as primeiras emissões de bronze nessa pólis entre c.320-300 a.C., antes da data que situa o uso desse metal nas cunhagens cretenses (Le Rider, 1966: 244). Também de Cnossos, o catálogo do Museu Britânico data entre c.400-350 a.C. ${ }^{25}$ um tipo monetário de Zeus sentando no trono segurando cetro e uma patera ou fiala, cuja cronologia foi revisada por Le Rider, que o situa entre c.340-330 a.C. (Le Rider, 1966: 176). Dessa mesma pólis pode ser citado um último caso de problema de cronologia - trata-se de um tipo monetário de Zeus sentado no no trono segurando Nike, com uma data entre c.350-220 a.C.26 também do catálogo do Museu Britânico, que parece ter sido situada por Le Rider entre c.320-270 a.C. (Le Rider, 1966: 178-179). Sobre Praesos, Wroth e Head datam entre c.400-350 a.C. ${ }^{27}$, um tipo monetário que possui o desenho de Zeus sentado no trono, segurando águia e cetro. Este foi datado por Le Rider entre o final do século IV a.C. e início do século III a.C. (Le Rider, 1966: 197). Esse autor viu nessa imagem monetária de Praesos, atribuída a Zeus Dictaios, uma influência dos tipos da divindade nos tetradracmas de Alexandre (Le Rider, 1966: 186). Sobre Sybrita, Head também situa um tipo monetário da cabeça de Zeus entre c.400-300 a.C. ${ }^{28}$, mas Le Rider, posteriormente, reviu essa cronologia datando todas as imagens monetárias dessa pólis (com exceção dos tipos com influência de Gortina) entre c.320-270 a.C. (Le Rider, 1966: 196). E finalmente sobre Phaistos, Wroth identificou, por meio da legenda junto ao desenho, a imagem de (Zeus) Velchanos numa figura masculina nua, encostada numa árvore. No manual do Museu Britânico o tipo é datado em c.350 a.C. ${ }^{29}$ e no manual de Head entre c.430-300 a.C. Le Rider, contudo, mais recentemente, situou os exemplares com essa imagem entre c.322-300 a.C. (Le Rider, 1966: 195).

Isto posto, as datações revistas por G. Le Rider nos permitem afirmar que as autoridades emissoras de Creta parecem não ter usado imagens de Zeus em moedas até pelo menos c.340 a.C., como indica o tipo monetário de Zeus sentado no trono, segurando fiala, emitido em Cnossos a partir dessa época. Confirma-se, portanto, a premissa de que a representação do deus foi apropriada pelas comunidades políticas cretenses a partir do final da época clássica.

A mesma situação parece ocorrer com a imagem do raio, que foi usada como símbolo em tipos monetários de Cnossos. Um exemplar encontrado na SNGCop traz a imagem de um pequeno raio junto ao

\footnotetext{
${ }^{23}$ Head, 1963: 465.

24 BMC, Crete and the Aegean islands: pr.V, 5 e 6.

25 Head, 1963: 461.

${ }^{26}$ BMC, Crete and the Aegean islands: pr.V, 14.

27 SNGCop Thessaly to Aegean Islands: Pr.11, 540.

28 Head, 1963: 478.

${ }^{29} \mathrm{BMC}$, Crete and the Aegean islands: pr.XV, 10.
} 
desenho do labirinto no reverso, com a imagem da cabeça de Hera no anverso. De acordo com Le Rider, tratase de um tipo monetário datado entre c.320-270 a.C. (Le Rider, 1966: 178-179). Nesse sentido, o raio que não aparece como tipo principal em nenhuma das emissões cretenses, ao menos em época clássica, foi usado apenas como símbolo somente nas décadas finais do século IV a.C.

A águia, portanto, permanece como o único tipo de imagem, vinculada a Zeus, nas moedas cretenses entre os séculos V e IV a.C. (até 345/44 a.C.). Além das emissões monetárias de Lyttos, a bibliografia classifica um tipo monetário de Praesos, das primeiras séries monetárias dessa cidade, como tendo a imagem da ave. Trata-se de moedas com a imagem de um guerreiro nu, ajoelhado e disparando uma flecha com um arco, no anverso, e com a de uma ave voando com as duas asas erguidas ${ }^{30}$. De acordo com Wroth, Imhoof-Blummer parece ter sido o primeiro a identificar essa figura masculina com Héracles e a ave com o pássaro do Stymphalos (apud Wroth, 1884: 55). Wroth parece concordar com a atribuição da imagem à Héracles, mas, a seu ver, a ave, na verdade, seria a representação da águia, a qual pode ser relacionada ao culto de Zeus Dictaios, mencionado pelos textos em Praesos (Wroth, 1884: 55). Vimos no capítulo 2 que há uma controvérsia sobre a localização do templo de Zeus Dictaios, relacionado à Praesos, se, na realidade, se tratava do santuário situado em Palaikastro (Pearlman, 2004: 1184). Sobre a identificação da ave representada, uma análise comparativa interna entre os desenhos da ave nas séries monetárias de Praesos com uma interna sobre os padrões de representação da águia em moedas gregas leva-nos a perceber uma aproximação maior dos traços com o de uma pomba, como propôs Kinner, autor citado por Wroth (apud Wroth, 1884: 55). Apesar da suposta presença do culto a Zeus nessa pólis, a nosso ver, ou se trata de fato da imagem de uma pomba ou o artista responsável pela gravação do cunho não destacou as características que definem a águia, como a cabeça e o bico, por exemplo. Além do desenho levar-nos a exclusão dessa imagem monetária no repertório numismático sobre as águias, a datação mais recente do tipo o situa no último quartel do século IV a.C., posterior às datações de Wroth e de Head (Head, 1963: 475; Le Rider, 1966: 197).

Nesse sentido, em Creta, que se destaca pela antiguidade do culto a Zeus, as imagens a ele relacionadas apareceram tardiamente em relação ao início das emissões locais, com exceção da águia que foi usada pela primeira vez em moedas da ilha ainda durante o século V a.C. No período estudado, portanto, a imagem monetária da águia, assim como sua alusão a Zeus, foi um fenômeno muito restrito e circunscrito a uma área específica de Creta nesse período. Uma pesquisa futura que considere a situação política de Creta e o contexto de culto a Zeus em época helenística pode elucidar as razões que levaram a proliferação de imagens monetárias da divindade nesse período entre as póleis cretenses.

$\mathrm{Na}$ ausência de mais dados sobre o grupo ou grupos étnicos participantes na fundação da pólis de Lyttos, e especialmente sobre a veracidade da participação espartana, não é possível afirmar com certeza se

\footnotetext{
30 Svoronos: XXVII, 4.
} 
foram os dórios os responsáveis pela introdução do uso da imagem da águia, relacionada a Zeus, em moedas cretenses tampouco o grupo ou regime político vigente nessa pólis durante as primeiras emissões monetárias.

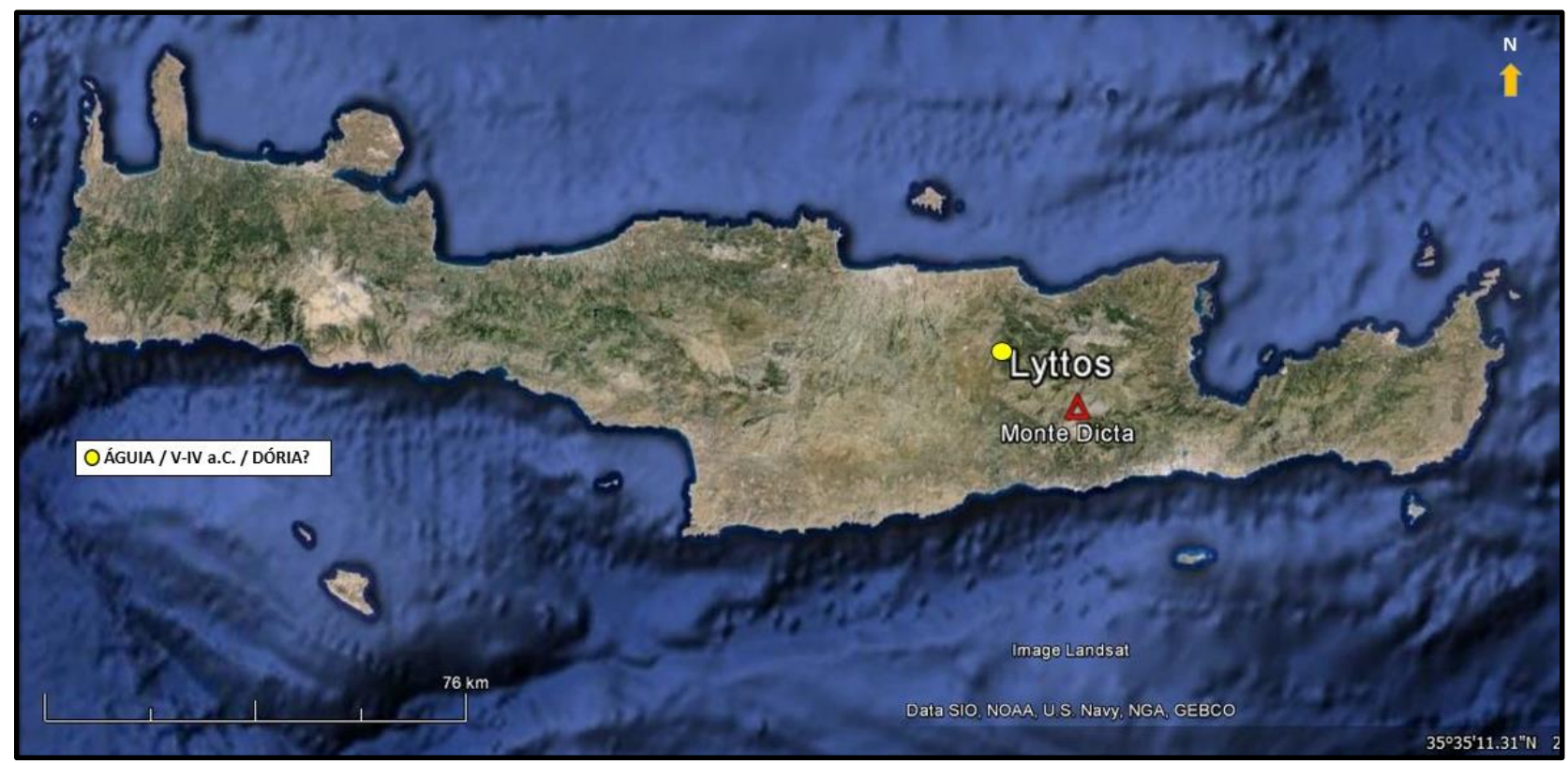

Fig.245 - Mapa de Creta: autoridade emissora de tipos monetários de águia (séculos V-IV a.C.) e santuário do Mt.Dicta
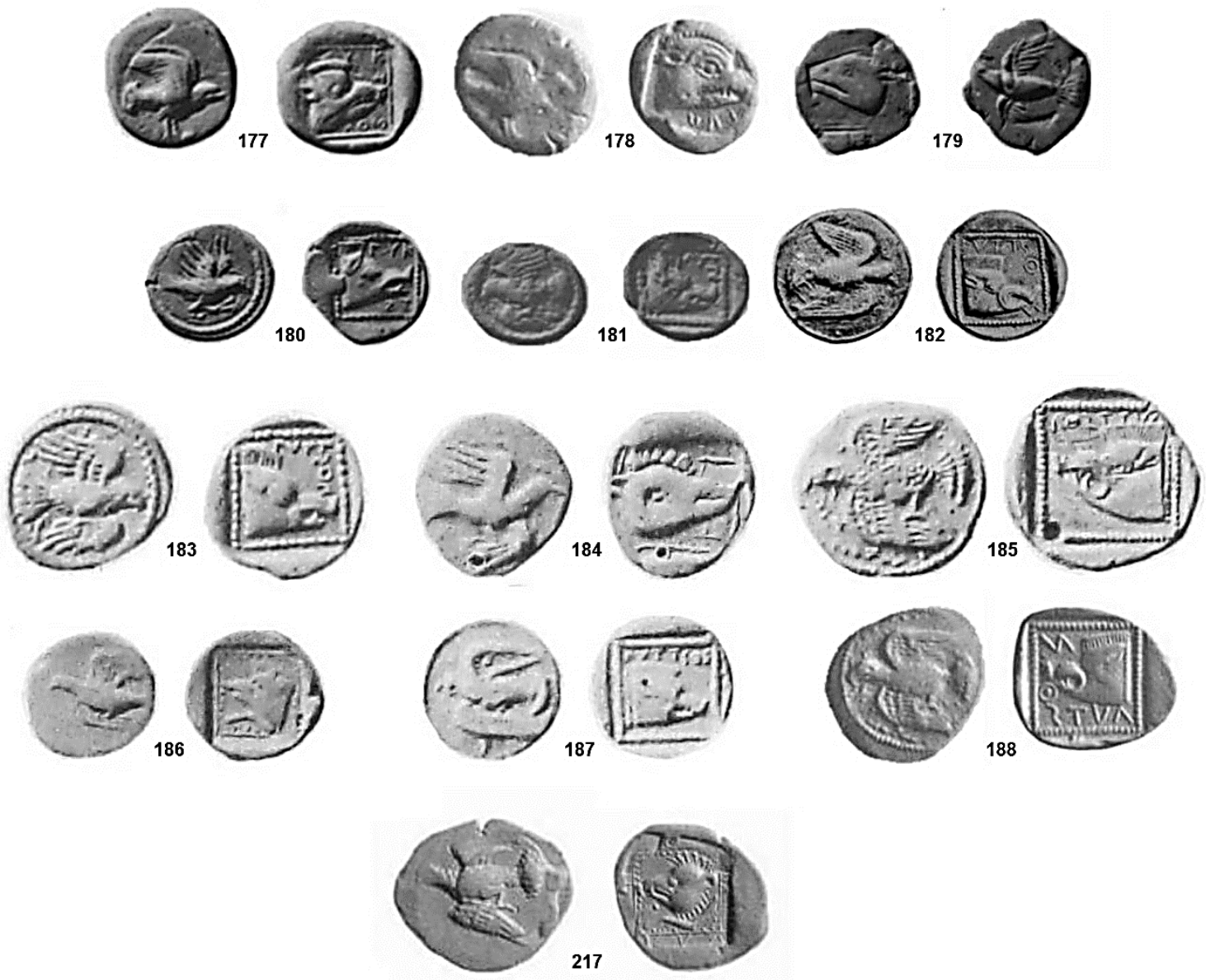

Fig.246 - Creta: tipos monetários de Lyttos 


\section{CONSIDERAÇÕES FINAIS: CORRELAÇÕES DO CONTEXTO DE USO E DO SIGNIFICADO SIMBÓLICO DAS IMAGENS MONETÁRIAS DE ZEUS, ÁGUIAS E RAIOS ENTRE PELOPONESO, SICÍLIA, ITÁLIA DO SUL E CRETA}

A análise regional e interpretativa empreendida até aqui revelou, predominantemente, uma série de correspondências semânticas, ou seja, dos significados simbólicos assumidos pelas imagens monetárias de Zeus, águias e raios no Peloponeso, na Sicília, na Itália do Sul e em Creta. Relacionadas à essas correspondências de significado, estão situações históricas semelhantes que motivaram o uso dessas imagens, pelas autoridades emissoras, nessas quatro regiões do mundo grego entre o final da época arcaica e o final da época clássica (até 345/44 a.C.). Essa correlação final entre os significados assumidos pelas imagens do deus e de seus atributos em moedas nessas áreas é importante, pois, conforme a metodologia do LIN, apenas no confronto, na comparação e caracterização das similaridades e diferenças, podemos encontrar os significados comuns - aquele de base - a todos os falantes ${ }^{31}$, nesse caso, as autoridades emissoras responsáveis pelo uso das imagens relacionadas a Zeus em moedas, cujos significados foram compartilhados no Ocidente grego e nas duas áreas mais antigas do culto ao deus no mundo grego, o Peloponeso e a ilha de Creta. Aqui, tentaremos mostrar em que medida os significados variaram ou não regionalmente e no tempo, portanto, se houve mais similaridades ou diferenças no significado buscado pelas autoridades emissoras dessas áreas ao longo dos séculos VI, V e IV a.C.

\section{II.1 AFIRMAÇÃO DE SOBERANIA E DE IDENTIDADE DAS COMUNIDADES POLÍTICAS}

As ideias de soberania e de identidade das comunidades políticas foram aquelas principais relacionadas ao uso das imagens monetárias de Zeus, águias e raios entre as autoridades emissoras de Élis, Arcádia, Acaia, Messênia, Sicília, Itália do Sul e Creta. De uma forma geral, esses tipos monetários encontramse vinculados, em momentos específicos, às necessidades de 1-) auto-afirmação e de manutenção do poder, de comunidades dessas regiões, em escala regional; 2-) afastamento de uma instabilidade política de ameaça de poder e de perda de autonomia; 3-) afirmação da identidade política dessas comunidades e também, em alguns casos, da identidade regional, quando o culto de Zeus assumiu importância fora das comunidades individuais e adquiriu um papel em congregar e fortalecer laços regionais e étnicos. Tais motivações aparecem predominantemente relacionadas ao significado simbólico principal de Zeus relacionado à todas as suas representações ou de seus atributos: o aspecto ordenador requisitado pelas comunidades políticas em todos esses contextos.

\footnotetext{
31 Caccamo Caltabiano, 2004: 21.
} 
Raio. Em Élis, em associação ou não à águia, o raio foi usado antes da metade do século $V$ a.C. ou ainda no século VI a.C. no contexto do expansionismo dessa pólis sobre as comunidades periecas da região e durante o momento de sua afirmação e auto-afirmação da soberania em escala regional, como detentora da prostasia de Olímpia. Nesse contexto, o raio, além de ser uma evidente alusão da força divina de Zeus Olímpio, principal divindade do santuário, foi usado pelo seu significado no campo político, de disputa bélica, e de manutenção de poder. Em Aetna-Inessa, a partir do primeiro quartel do século $\mathrm{V}$ a.C., o raio figurou como um dos emblemas monetários da cidade justamente no momento de instabilidade política, portanto, da ameaça e subsequente perda de seu território para a população de Catânia. A invocação dessa energia divina de Zeus, por meio do raio, evocou as ideias de vitória sobre o caos, de uma nova ordenação a qual pode ser entendida como a continuidade dessa pólis como comunidade política, embora em outro lugar. Além disso, o uso do raio como imagem monetária em Aetna-Inessa pode ter significado a auto-afirmação de sua identidade política, após se restabelecer em uma nova cidade (Inessa) e afirmar-se, diante das demais comunidades políticas da costa oriental da Sicília, principalmente os centros calcídios, fortalecidos após o retorno de suas populações. Em Catânia, um pouco depois, o raio também fez parte do repertório iconográfico das moedas, provavelmente por duas razões - por essa cidade fazer parte da área cultural etnea e do culto de Zeus Aetnaios (o raio fazia parte do universo religioso local), e por uma razão política, a de afirmação da retomada da cidade após a expulsão do povo de Aetna. Também para a comunidade de Catânia, o uso da imagem do raio como emblema monetário, nesse contexto, significou a afirmação de sua sobrevivência política após o deslocamento populacional e o retorno da população para sua cidade de origem, Catânia. O raio perdurou como imagem monetária da cidade durante o período da expedição ateniense e depois da guerra contra Cartago e a supremacia de Siracusa na Sicília no final do século V a.C. Tratou-se de um símbolo importante nessa área da Sicília em contextos de disputas territoriais bélicas. Em Crotona, na Itália do Sul, o atributo entrou no repertório de tipos monetários da cidade no momento no qual a cidade, e demais da região, buscavam por equilíbrio político após os desdobramentos da crise pitagórica e a formação da liga aqueia em c.430 a.C. com a liderança de Crotona. Nesse caso também o raio representou a afirmação da vitória da ordem sobre o caos - as crises que ameaçavam a estabilidade política e sua existência como pólis, a sua autonomia (invasão lucana e hegemonia de Dionisio I). Em Alaisa, na Sicília, o raio foi usado, sem também estar associado à imagem de Zeus, no período da symmachia de Timoleonte.

Percebe-se, assim, que crise e instabilidade política, um novo recomeço para as comunidades políticas, enquanto tais, levaram ao uso da imagem do raio no Peloponeso e no Ocidente grego ao longo dos séculos $V$ e IV a.C. Com exceção de Élis, o culto a Zeus não é atestado arqueologicamente e textualmente em Aetna, Catânia, Crotona e Alaisa. Em Aetna e Catânia muito provavelmente houve uma influência de um culto a Zeus no Etna, mas só isso. No caso do raio, sem estar associado a Zeus ou à águia, essas comunidades políticas mostraram, por outras razões que não aquela diretamente vinculada ao culto, afinidade com as energias divinas da divindade, no caso o raio. 
Águia voando carregando presa ou não. Já um pouco antes do segundo quartel do século VI a.C., a oficina monetária de Crotona fez uso da imagem da águia voando, sem portar uma presa, no momento pósbatalha de Sagra, quando atravessava uma crise econômica em decorrência de sua derrota. O uso da imagem da ave em suas moedas manteve-se na época que herdou o império de Síbaris, como também em um novo período de crise, a pitagórica, e durante e depois da formação da liga aquéia, que teve a liderança de Crotona. Concluímos em nossa análise, que a imagem da águia nesse tipo de representação, significou, para a pólis, um sinal de bom agouro na luta, na guerra, na crise, de afastar presságios desfavoráveis nesse contexto. Em Élis, a águia voando é retratada carregando ou não uma presa (normalmente uma cobra ou uma lebre) e é, às vezes, associada ao raio. Trata-se de uma alusão direta a Zeus, a seu significado como energia divina da divindade e sua manifestação, ao mesmo tempo que esse significado também recaía sobre o desejo de proteção da divindade na manutenção da soberania de Élis, de sua expansão na região em tempos de aliança com Esparta, se ainda no século VI a.C. ou a partir do século V a.C. Em Agrigento, na Sicilia, a ave é retratada, voando sobre uma quadriga e carregando uma cobra, no decadracma datado de c.413-411 a.C. que se refere à época da segunda expedição ateniense à Sicília. A nosso ver, a composição da águia sobre a quadriga pode ser interpretada como um presságio favorável à vitória na guerra ou na competição requerido pela comunidade política ao usá-la como emblema monetário. O mesmo esquema iconográfico (mas sem a presa) e significado podem ser encontrados em um tetradracma de Gela de c.410-405 a.C., o qual remonta ao período de destruição da cidade pelo general cartaginês Himilcon. Em Lyttos, na ilha de Creta, esse tipo de representação da águia parece ter sido requisitado por essa pólis, entre os séculos V-IV a.C. para expressar a sua identificação com a energia divina do deus, de sua realeza, onipotência e de seu poder mântico. Como força divina de Zeus, no campo da guerra, da vitória e da competição, foram importantes em momentos de hegemonia territorial de Lyttos sobre a região centro-leste da ilha nesse período. Sobre Metaponto, que cunhou moedas com o padrão de representação sem a presa, falta-nos dados, mas a datação indica que a imagem foi requisitada no momento da invasão lucana e dos brettii, do declínio da cidade após a fundação de Heraclea e a hegemonia de Tarento entre os séculos IV-III a.C. Um significado auspicioso na guerra, na disputa, pode ser inferido para o uso da imagem da ave nesse período em Metaponto.

Parece, assim, que a imagem monetária da águia voando, com ou sem uma presa, predominou entre essas autoridades emissoras do Peloponeso, da Itália do Sul e de Creta que viviam algum tipo de crise, ocasionada pela perda de autonomia e de soberania (Crotona e Metaponto), ou interessadas em manter seu poder territorial sobre a região na qual faziam parte (Crotona, Élis e Lyttos). Esse padrão de representação da ave como emblema monetário, nesse contexto, assumiu um significado talismânico em favorecer, se na crise ou na manutenção do poder, com os auspícios de Zeus, a comunidade política que os portasse.

Águia em pé sobre presa. Em Élis, a imagem da águia em pé sobre presa (principalmente a lebre), sempre em associação ao raio, foi usada a partir de c.432 a.C. no contexto da guerra do Peloponeso, antes de romper com Esparta, e permaneceu nas séries monetárias até o início do século IV a.C., já em outro momento, 
quando a pólis rompeu com o poder espartano. A nosso ver, o uso dessa representação nesse período teve a ver com a situação militar, quando precisou afirmar sua soberania territorial e liderança regional, importantes para Élis enquanto administradora do centro pan-helênico. Em Agrigento, esse padrão de representação figurou nas moedas a partir do último quartel do século $V$ a.C., um pouco depois de Élis, na época dos principais acontecimentos militares os quais mudaram a paisagem política da Sicília, tais como a perda de hegemonia de Agrigento para Siracusa, a invasão ateniense à Sicília e a destruição cartaginesa da cidade. A esse respeito concluímos que o significado simbólico desse esquema iconográfico da águia com a presa (na maior parte das vezes a lebre ou a cobra) teve relação com a derrota eminente do inimigo e o desejo de vitória sobre ele. Em Messana, a águia aparece curvada sobre uma cobra em um tipo monetário do último decênio do século $\mathrm{V}$ a.C., tal como aparece em uma denominação em ouro de Agrigento. O contexto de uso foi a segunda expedição ateniense à Sicília e o período de luta contra Cartago. O significado simbólico da imagem refere-se à ideia de dominar o inimigo ou situações desfavoráveis à pólis em momentos de guerra e à sua necessidade de vitória. O mesmo significado foi encontrado para as representações nas moedas de Crotona, datadas a partir do mesmo período daquelas de Agrigento. Lá, a águia em pé sobre a presa foi usada como emblema monetário no período a partir da formação da liga das cidades aqueias e da crise política da região, ocasionada pela hegemonia de Dionisio I, e sua conquista de Crotona, a invasão dos lucanos, a perda da liderança da liga para Tarento e a invasão dos brettii às póleis da região. No caso de Crotona, também, a águia passou a aparecer em pé sobre a presa nas moedas da cidade em um momento importante de enfrentamento com o outro, de liderança e subsequente ameaça e declínio de poder. Concluímos também que o significado simbólico desse tipo de representação foi requisitado por essas duas póleis do Ocidente grego no mesmo tipo de situação, muito provavelmente a exemplo das moedas de Élis-Olímpia, em momentos militares e políticos decisivos nessas três regiões (Peloponeso, Sicília e Itália do Sul). Repara-se também que foram cidades hegemônicas em suas regiões que fizeram uso dessa representação e praticamente no mesmo período, ao redor do último quartel do século V a.C.

Águia em pé sem presa. Dentre as autoridades emissoras das quatro regiões analisadas, Agrigento provavelmente foi a pioneira nesse tipo de representação a partir do final do século $\mathrm{VI}$ a.C. De acordo com o contexto de uso da imagem pela oficina monetária da cidade, época que esta ganhou o aumento de seu território e adquiriu o controle de uma vasta área após disputas com Selinonte e Himera, o significado simbólico contido na representação relaciona-se à onipotência e soberania de Agrigento em sua área. O uso da águia em pé sem a presa se tratou, a nosso ver, da identificação dessa pólis às forças divinas de Zeus no campo do poder. Em Lyttos, embora em menor grau, a águia é retratada nesse padrão de representação e seu significado simbólico também se alinha com o de Agrigento, dada a expansão territorial em sua área, uma característica dessa pólis entre os séculos V-IV a.C. A representação foi particularmente muito utilizada por Élis em suas moedas ao longo do século IV a.C., dentro de uma coroa de folhas de oliveira, símbolo de vitória. $\mathrm{O}$ tipo monetário foi associado, inicialmente, ao período que Élis retoma a presidência dos jogos, após a sua interrupção durante 0 
domínio arcádio e pisate. Vê-se, portanto, que do século VI ao IV a.C. a águia em pé nas moedas das autoridades emissoras da Sicília, de Creta e de Élis aludiu à ideias de domínio territorial, de liderança regional, diferente do que ocorreu com o tipo associado às presas, que remontam aos períodos de crise e declínio das comunidades que o utilizaram. Esse mesmo contexto e esse mesmo significado simbólico pode ser relacionado ao padrão de representação da cabeça da águia, retratada sem a presa nas moedas de Élis, Agrigento e Crotona entre os séculos V e IV a.C.

Águia em pé sobre capitel jônico. O padrão de representação, que aparece primeiro em Agrigento, remonta à metade do século $V$ a.C., ao período de eudaimonia da cidade em época democrática, e depois voltou a ser reutilizado no início do século IV a.C. na época da retomada da cidade após a destruição cartaginesa. O esquema iconográfico foi muito difundido entre centros não gregos da Sicília ao longo do século V a.C. por influência de Agrigento. Em Crotona, o tipo monetário é relacionado à fase de liderança dessa cidade na liga aquéia como também aos momentos de crise enfrentados a partir dessa época e em diante. Em Élis, a oficina monetária escolheu a representação para figurar nas moedas, junto ao tipo da cabeça de Zeus, nas primeiras emissões monetárias da retomada da presidência do santuário de Olímpia uma década antes da metade do século IV a.C. Percebe-se que o esquema iconográfico da águia em pé sobre o capitel jônico expressou significados de afirmação de soberania, se em momentos de eudaimonia ou de crise entre os séculos V e IV a.C. no Ocidente grego e no Peloponeso (Élis-Olímpia).

Zeus em pé atirando o raio. A imagem foi usada pela primeira vez por Zancle, na Sicília, um pouco antes de meados do século $V$ a.C. no contexto da libertação da tirania local e do restabelecimento dessa pólis em outro lugar - a imagem monetária provavelmente aludiu à sobrevivência política pós-tirania, da comunidade de Zancle em Mylai e à afirmação de sua identidade política em outro lugar. Logo depois, em meados do século V a.C., esse tipo monetário de Zeus foi usado por Élis, em associação ao tipo da águia como imagem principal, no momento no qual essa pólis procurava manter sua soberania na prostasia de Olímpia e em relação às demais comunidades da região, principalmente aquelas que Ihes eram dependentes. Em Posidônia, o tipo monetário foi usado pela oficina monetária entre o segundo quartel do século $V$ a.C. e o primeiro decênio do século IV a.C., tornando-se um dos emblemas da cunhagem lucana, quando estes tentavam se manter e se afirmar no domínio da cidade aqueia. Em Messênia, a imagem foi usada nas primeiras moedas batidas na cidade recém fundada em c.370/69 a.C., no momento em que os messênios se estabeleceram em definitivo como comunidade política no século IV a.C. e quando foi necessário manter o novo governo e sua autonomia e afirma-lo perante Esparta e as demais comunidades da região. Nessa pólis, a representação pode ainda ter sido uma alusão ao culto de Zeus Ithomates totalmente relacionado à afirmação da identidade messênia e por essa razão ter sido requisitada como tipo para as primeiras emissões da pólis recém fundada.

Percebe-se que, embora a imagem tenha sido usada em períodos variados durante dois séculos, no Peloponeso ocidental, na Sicília e na Itália do Sul, as necessidades por detrás do uso da imagem em moedas parecem ter sido as mesmas entre elas. Em Messênia e Zancle, a imagem monetária emergiu no contexto da 
libertação de um poder opressor, no primeiro caso Esparta e no segundo caso os tiranos filhos de Anaxilas de Régio, e de afirmação da identidade enquanto comunidades políticas. Em Messênia, a afirmação da identidade étnica também foi expressa pela imagem monetária. Em Élis e Posidônia, o tipo monetário foi invocado, ao que parece, quando o poder ou domínio local já estava estabelecido, mas precisava ser mantido. Para essas quatro autoridades emissoras, a imagem de Zeus atirando o raio, portando ou não a águia, evocou significados fundamentais de ordenação. O padrão foi usado, predominantemente, por comunidades que possuíam algum tipo de culto local à divindade, com exceção de Zancle.

Zeus sentado no trono. A imagem parece ter aparecido em moedas gregas quase concomitantemente em Aetna, na Sicília, e na Arcádia a partir do primeiro quartel do século V a.C. Em Aetna-Catânia, nessa época, o tipo foi usado em um contexto bem preciso - na fundação da cidade após o deslocamento populacional empreendido por Hieron e na reunião de gregos, ainda que dórios, de várias origens na nova cidade. 0 tipo parece ter sido parte de uma propaganda do triunfo de Hieron na fundação de Aetna e na consagração de Deinomenes como basileus da cidade, como indicam a imagem associada principalmente no anverso do tetradracma e referências textuais. 0 tipo do período subsequente remonta ao metoikismos de Aetna em Inessa, ocasionado pela expulsão dos aetneus pela população de Catânia, e traz elementos simbólicos relativos às características do território na área do vulcão Etna. Concluímos que as imagens de Zeus sentado no trono, no contexto de Aetna, além de aludir à afinidade dos Deinomênidas ao culto de Zeus Aetnaios, podem ter remetido à necessidade do estabelecimento e da manutenção da ordem de Zeus sobre a desordem na fundação da cidade em Catânia, devastada pelo vulcão, ou mais tarde na expulsão da população de Aetna para Inessa. Tratou-se de invocar, no uso da imagem da divindade, como emblema da cidade, o aspecto ordenador de Zeus - provavelmente no uso da imagem, a comunidade de Aetna, nos dois períodos (de Catânia e de Inessa) requisitaram a proteção da divindade que tinha o poder de apaziguar as instabilidades políticas enfrentadas pela comunidade e aquelas da natureza, representadas pelo Etna, sobre o qual Zeus exercia domínio pleno.

Mais ou menos a partir desse mesmo período, os arcádios, reunidos em uma liga, usaram a imagem da principal divindade pan-arcádia no momento em que os valores fundamentais para a sobrevivência política de suas comunidades, e enquanto grupo étnico, encontravam-se ameaçadas pelos espartanos e seu expansionismo no Peloponeso. Nesse contexto, os arcádios usaram a imagem de Zeus Lykaios, sentado no trono, para afirmar, internamente e externamente, para si e para os demais, sua identidade étnica por meio da proteção de sua divindade mais importante - Zeus Lykaios exerceu proteção sobre todos os aspectos que lhes identificavam como grupo. Élis e Galária, essa última na Sicília, usaram o tipo de Zeus sentado no trono praticamente no mesmo período, em meados do século V a.C. A oficina monetária de Élis utilizou a imagem, ao que parece, no período no qual a pólis era possuidora, inconteste, de sua soberania política em Olímpia e na região. Já em Galária, a função ordenadora de Zeus, e também salvadora, como indica a inscrição junto ao desenho da divindade, foi requisitada pela comunidade em um momento de instabilidade política, no fim do 
movimento de independência dos centros sículos - tratou-se do período de libertação e renovação de Galária enquanto comunidade política autônoma. $O$ tipo de Zeus sentado no trono voltou a ser empregado em moedas após o primeiro quartel do século IV a.C. entre os aqueus no norte do Peloponeso, no contexto de sua confederação nesse período. No caso aqueu, foi possível concluir, também, que a interferência espartana na região, de algum modo, levou os aqueus escolher a imagem de Zeus Homarios (divindade protetora da reunião política dos aqueus) como emblema de sua liga para mostrar, interna e externamente, que estes estavam sob a sua proteção e sanção. Deus protetor da identidade étnica aquéia e das decisões políticas da liga, os aqueus se identificavam na figura de Zeus, e buscaram por meio de sua imagem afirmar, politicamente e etnicamente, em um momento livre da hegemonia de Esparta, que cada comunidade política da região estava protegida sob a égide e os desígnios do deus.

Vê-se, assim, que esse padrão de representação de Zeus, que predominou no Peloponeso e na Sicília foi apropriado, de forma geral, por comunidades possuidoras ou vinculadas a um culto local importante ao deus, com exceção de Galária. Do mesmo modo que o tipo de Zeus em pé atirando o raio, o de Zeus sentado no trono foi usado com o significado de ordenação das instâncias políticas das comunidades, que lhes fizeram uso, tanto no contexto de ameaça da estabilidade como nos momentos nos quais sua soberania já afirmada, precisava ser mantida, garantida. Destacamos que a característica única do padrão de representação de Zeus sentado é a sua emergência, no Peloponeso, em períodos de saliência étnica e união em ligas frente a um inimigo comum, como foi o caso dos arcádios e aqueus contra os espartanos, tanto no século $V$ a.C. como no século IV a.C., cujo culto local de Zeus tinha um papel preciso em congregar e afirmar identidades étnicas. A imagem também foi apropriada por um grupo político no poder durante o século $V$ a.C., como foi o caso dos Deinomênidas em Aetna-Catânia, que muito provavelmente se identificou na realeza e poder de Zeus Aetnaios. Tanto no caso de Aetna quanto no caso dos arcádios, a imagem monetária de Zeus sentado no trono esteve vinculada a um culto de montanha (Monte Etna e Monte Lykaion) e o uso desse padrão de representação pelas autoridades emissoras pode ter aludido à realeza da divindade no Olimpo de onde exercia, sentando no trono, seu poder sobre o destino dos mortais e imortais.

Cabeça de Zeus. A representação foi usada em moedas gregas associada ou não aos seus dois atributos durante os séculos V e IV a.C. Esta foi usada em contextos semelhantes aos dos demais tipos, carregando, assim, os mesmos significados observados nos outros dois padrões de imagem de Zeus em moedas. Abakainon na Sicília, talvez a primeira autoridade emissora a fazer uso da imagem da cabeça da divindade como emblema monetário, usou o tipo em meados do século $V$ a.C. no contexto da nova conformação política, de independência dos centros sículos, e da hegemonia de Siracusa, portanto, no momento de afirmação política da pólis, tal como vimos no caso de Galária, outro centro sículo e grego. $O$ aspecto ordenador de Zeus, conhecido na área do Etna, mas também o de protetor na esfera militar e de vitória (como indica a coroa de folhas de oliveira) foram provavelmente requisitados por Abakainon nessa época. Na Arcádia, a partir de aproximadamente duas décadas depois, a cabeça de Zeus apareceu como emblema monetário, mas sem 
o desenho da coroa de folhas de oliveira. O tipo expressou, para os arcádios nessa época, os mesmos significados encontrados na imagem de Zeus sentado no trono - de identidade étnica arcádia e de sua afirmação étnica e política nos eventos ligados à Esparta. Durante a confederação arcádia no século IV a.C., a oficina monetária em Megalópolis, bateu no nome da liga, um tipo monetário da cabeça de Zeus com a coroa, o qual foi o símbolo do estado étnico arcádio, organizado politicamente, pela primeira vez, na fundação de Megalópolis. Tratou-se de usar a imagem da principal divindade da liga e dos arcádios para proteção de sua autonomia e afirmação política e étnica frente à Esparta, recentemente derrotada em Leuctra, e aos demais poderes da região. Ainda relacionado à Arcádia, o tipo da cabeça sem coroa foi usado em moedas do subéthnos da Parrhasia e, segundo nossa análise, aludiu a significados de identidade local entre os próprios parrhasios, que detinham a localização do santuário do Monte Lykaion, e os arcádios.

Em associação à arma do deus, o raio, como emblema monetário, a cabeça de Zeus figurou, durante o século V a.C., em moedas de Élis, datada após o último quartel do século V a.C., no contexto posterior à Paz de Nícias e à quebra de aliança regional de Élis com Esparta. Nesse caso, vimos que a associação de Zeus ao raio expressou significados totalmente relacionados à guerra, mas também de necessidade de normalização das instituições políticas e da comunidade dos eleios frente à prostasia de Olímpia, ameaçada por Esparta, e às comunidades da região. No ambiente de Olímpia, a mesma combinação de tipos voltou a aparecer como emblema monetário de Pisa uma década antes da metade do século IV a.C., expressando o desejo dessa comunidade em ser identificada e protegida pela principal divindade do santuário, e guerreira, no momento que precisava se manter na presidência de Olímpia. Fora do Peloponeso, na Sicília, a associação da imagem da cabeça de Zeus e a imagem do raio voltou a ocorrer, sem ou com a imagem da águia, somente ao redor de 344 a.C., no contexto da symmachia das cidades do nordeste e leste da ilha à época de Timoleonte, em moedas de Siracusa, Agyrion, Alontion e Aetna. Como vimos em detalhe nesse capítulo, Zeus Eleutherios (título que qualifica a representação monetária da divindade) já era, nesse período, um símbolo conhecido de democracia e de libertação da tirania. Vimos também que o significado da imagem monetária da cabeça de Zeus, associada ao raio e/ou à águia, esteve na necessidade de normalização da pólis e de suas instituições políticas, no caso democráticas, defendidas por Timoleonte. Além dos significados requisitados ao deus em favor na guerra e na vitória, de ordenação sobre o caos, o aspecto preciso de Zeus, o de libertação de algo que ameaça a estabilidade política das comunidades - as tiranias locais. Nesse período, Zeus teve o papel destacado de protetor e propiciador da ordenação das comunidades políticas siceliotas naquele momento, que correspondia à restruturação da pólis, a instauração, manutenção da democracia. Na década de 340 a.C., a associação da águia e do raio no mesmo tipo monetário com a cabeça de Zeus ocorreu em Élis no contexto do período macedônio, quando Esparta já não era mais o poder político regional. A associação da figura de Zeus com a de seus dois atributos teve intenção de expressar uma mensagem mais forte por alguma razão específica a esse período da segunda metade do século IV a.C. 
Em associação à águia em pé sobre o capitel jônico, a cabeça de Zeus apareceu somente em moedas de Élis a partir da retomada do controle de Olímpia pelos eleios ao redor de 360 a.C., ao lado também, em menor grau, do uso da cabeça da ninfa Olímpia. Concluímos que essa combinação com a águia, como emblema monetário, se tratou de uma afirmação dos eleios no domínio do santuário e na região, como evidencia esse tipo da ave que, como vimos, já era, nessa época, um conhecido símbolo de soberania no Ocidente grego.

Ao que parece, não houve diferenças importantes no significado simbólico e no contexto de uso das imagens monetárias da cabeça de Zeus entre Peloponeso e Sicília durante os séculos V e IV a.C. Novamente a Arcádia se destaca como a região onde a imagem assumiu uma importância a mais na esfera da identidade étnica nos dois períodos, apesar desta não estar desvinculada do significado político comuns às imagens monetárias de Zeus. A tirania e a hegemonia espartana aparecem como fatores propulsores do uso das imagens da cabeça de Zeus na Sicília e no Peloponeso, respectivamente em ambos os períodos, como vimos também no caso dos outros padrões de representação da divindade em moedas. A associação ao raio parece reforçar o significado militar/bélico da imagem de Zeus, ao passo que o da águia, também com significado referente à guerra, parece enaltecer o significado de soberania subjacente à imagem do deus.

Em síntese, a correlação, referente a toda a documentação analisada, revelou que há mais correspondências com relação ao contexto de uso e ao significado simbólico dos tipos monetários de Zeus, águias e raios entre as autoridades emissoras do Peloponeso, Sicília, Itália do Sul e Creta (entre os séculos VIIV/III a.C.) do que contrastes. Houve, portanto, um compartilhamento de significado de base para essas imagens do deus e de seus atributos em moedas gregas entre essas quatro áreas culturais, o qual pode ser explicado pelas redes existentes, nesses três séculos, entre Peloponeso e Ocidente grego e entre o Peloponeso e Creta, onde traços culturais, referentes nesse caso ao culto de Zeus, circularam em mão-dupla de um lugar a outro, como foi o caso de Élis e o Ocidente grego e vice-versa e a Arcádia e a Sicília. Sobre a afirmação de soberania e de identidade das comunidades, repetidamente citadas como as motivações principais para o uso dessas imagens relacionadas a Zeus em moedas, de fato, no estudo aprofundado da história grega antiga, sabe-se que tais ideias permearam a existência política de todo tipo de comunidade grega, seja ela a pólis ou o éthnos, levando a pensar que estas não foram motivações exclusivas das comunidades e regiões aqui estudadas ou da relação com apenas uma divindade. Mas, no caso de Zeus, deus com uma atuação particular nas instâncias políticas da pólis e da identidade grega, em vários níveis, a apropriação de sua imagem em um contexto político específico ou de saliência étnica é totalmente possível, verossímel, como acabou sendo caracterizado, revelado, na análise contextual nesse capítulo.

Com relação aos grupos políticos relacionados àa escolha tipológica, foi difícil vincular o uso de determinados tipos monetários de Zeus, águias e raios a determinado grupo ou regime político no poder devido, principalmente, à ausência de dados. Quando foi possível identifica-los e associá-los às imagens monetárias, concluiu-se que as imagens podem ter sido adotadas como emblemas monetários por determinado grupo, inicialmente, mas permanecendo no repertório iconográfico das moedas da cidade em períodos posteriores 
quando outros regimes eram vigentes. Este foi o caso de Crotona e de Agrigento, cujos tipos monetários das águias foram adotados em período tirânico e continuaram em uso em períodos democráticos ou oligárquicos. Outras vezes, a imagem emergiu em um período específico, como foram os casos do tipo da cabeça de Zeus Eleutherios no século IV a.C., apropriado em época democrática, na liberação da tirania, e de Zeus Sóter, sentado no trono, em Galária, usado no século V a.C. na época de libertação da tirania de Ducézio. Esses dois casos se referem a mobilização de imagens de dois cultos específicos de Zeus, com o título Eleutherios e Sóter.

Várias das autoridades emissoras que fizeram uso das imagens do deus e de seus atributos não eram possuidoras de áreas sagradas dedicadas à Zeus em seu centro urbano e/ou território, indicando que as razões para o uso não foram meramente cultuais. Das 22 autoridades emissoras discutidas nesse capítulo, 8 possuiram um santuário dedicado a Zeus (Élis, Arcádia, Messênia, Acaia, Agrigento, Siracusa, Posidônia e Metaponto), 5 tiveram influência de uma área cultural onde o culto teve papel importante, como foi o caso do Etna e do Monte Dicta (Aetna, Catânia, Galária, Abakainon e Lyttos) e 9 não possuem qualquer evidência de um culto local a Zeus no período (Crotona, Zancle, Messana, Gela, Alaisa, Motya, Eryx, Hipana e Agyrion). Tal conclusão nos faz rever a premissa, muitas vezes repetidas entre os estudiosos de divindades gregas, de que a existência da evidência numismática sobre certa divindade, em uma dada localidade, é prova cabal da existência de um culto local. Houve múltiplas razões para as autoridades emissoras, no caso a pólis, escolher usar a imagem de uma divindade ou de suas energias divinas, seus atributos, em suas moedas. Algumas delas podem ter estado relacionadas a determinada situação histórica que, em associação a alguma rede local influenciada ou pelo culto (como foi o caso de Crotona, Agrigento e Élis em relação ao tipo da águia em pé com a presa) ou não (como em Motya, Eryx, Hipana, Agyrion com respeito ao tipo da águia em pé sobre o capitel) podem ter levado a emergência das imagens de divindades e de seus atributos em moedas gregas. Foi isso que quisemos mostrar nessa longa análise interpretativa. 


\section{CONCLUSÃO - A APROPRIAÇÃO E CONSOLIDAÇÃO DO CULTO DE ZEUS PELA CIDADE GREGA EM ÉPOCA ARCAICA E CLÁSSICA}

\section{O CULTO DE ZEUS NO DESENVOLVIMENTO DA CIDADE GREGA: POLÍTICA E IDENTIDADE}

Na nossa análise e interpretação da documentação numismática e dos santuários de Zeus foi possível identificar, entre os quatro séculos da época arcaica e clássica, momentos de transformação do culto do deus em relação à pólis grega, que correspondem às várias fases do desenvolvimento das cidades nesses dois períodos da história grega antiga. Também foi possível caracterizar o culto de Zeus durante o período de formação da pólis na Idade do Ferro. A nossa análise confirmou a premissa de que nessa época a divindade "não era relacionada ainda ao Estado e à vida urbana (a pólis) em geral" (Zolotnikova, 2011: 239). De fato, na Idade do Ferro, o deus não tinha sido incluído entre as divindades cultuadas pela pólis emergente, como foram Apolo, Atena e Ártemis, por exemplo (Laky, 2013: 321). Como bem coloca C. Morgan, "a hierarquia olímpica não foi seguida automaticamente no estabelecimento de cultos cívicos no século VIII a.C. - Zeus como uma divindade rústica no período pode não ter sido particularmente apropriada como um símbolo do antigo Estado" (Morgan, 1994: 26-28). Embora as cidades gregas emergentes tenham procurado o culto a Zeus em seus vários santuários extra-urbanos, com funções regionais, desde a Idade do Ferro, o culto a Zeus, praticado pelas cidades, em suas áreas urbanas ou não-urbanas, ocorreu mais tarde. Em nossa conclusão a respeito desse período, vimos que embora o culto de Zeus, tanto na esfera regional como na cívica, tenha sido relacionado ainda ao agrário e ao pastoril, este exerceu influência entre as elites das comunidades da Idade do Ferro, principalmente na esfera militar, um traço do culto que se conservou na maior parte das áreas sagradas da divindade em época arcaica e clássica. Há poucos santuários de Zeus, conhecidos, relacionados à formação da pólis durante a Idade do Ferro, mas os casos analisados em detalhe acerca de Creta e do Peloponeso (em Argos, em Messênia-Ithome e Praisos), demonstram que estes, no período, desempenharam, ao menos, um papel importante na integração social das elites desses assentamentos.

Foi somente a partir da época arcaica que Zeus passou a desempenhar papéis reguladores no funcionamento das comunidades políticas. A vinculação do deus às funções políticas e jurídicas é atestada a partir do final do século VII a.C. nas cidades gregas, conforme indica a evidência mais antiga (epigráfica) do culto de Zeus Agoraios nessa época na ilha de Creta, em Dreros - até hoje, esse epíteto do deus não é encontrado em outros contextos regionais anteriormente a esse período. Assim, é possível considerar o final do século VII a.C. o terminus post quem da função do culto de Zeus na pólis. No que diz respeito às imagens monetárias de Zeus e seus atributos, entre os séculos VII-VI a.C., a águia foi usada pela primeira vez como imagem em moedas por cidades na porção oriental do mundo grego, na Mysia e na Jônia, antes mesmo da representação do próprio Zeus ter sido usada em moedas. Apesar dessas duas regiões não terem sido alvo de 
nossa análise interpretativa, consideramos tais imagens de águias símbolos da epifania ou um atributo de Zeus, e não um mero animal com significado apotropaico, já que nessa época a ave já era relacionada ao deus na poesia homérica e na iconografia do culto em outras partes do mundo grego (no Peloponeso, no Mt. Lykaion). A imagem da águia passou a ser difundida em moedas gregas em concomitância com o processo do estabelecimento do significado político que começou a ser atribuído a divindade no século VI a.C. Nessa perspectiva, é possível atribuir ao período, a partir do final do século VII a.C., o início de um fenômeno que se tornou mais visível e difundido no século VI a.C.: a apropriação do culto de Zeus pela cidade. Uma evidência desse fenômeno, do envolvimento do culto com a cidade grega nesse período, são também as oferendas votivas de Olímpia, que passaram a portar o nome do ofertante e também de sua cidade de origem a partir dessa mesma época.

Consideramos o século VI a.C. como o período no qual a cidade grega se apropriou do culto de Zeus, como demonstra um número significativo de áreas sagradas que passaram a ser estabelecidas, pela primeira vez, no centro urbano e no território da cidade, além também dos epítetos Olímpio e Agoraios de Zeus, que apareceram e se difundiram em áreas sagradas nesse período. É preciso destacar a respeito desses dois cultos de Zeus, que seus santuários mais antigos, conforme indica a documentação arqueológica disponível, foram estabelecidos primeiro nas apoikiai no Ocidente grego, onde, como vimos, o culto de Zeus emergiu diretamente no contexto da cidade grega, diferente do que ocorreu na Grécia Balcânica e na ilha de Creta, onde o culto alcançou expressão primeiramente em áreas sagradas regionais. É nesse contexto, portanto, do desenvolvimento da pólis no século $\mathrm{VI}$ a.C. que ocorreu a construção de templos em santuários arcaicos de Zeus e uma primeira fase edilícia de monumentalização em santuários mais antigos da divindade, datados da Idade do Bronze e da Idade do Ferro. Destaca-se, a esse respeito, os santuários dedicados a Zeus Olímpio a partir do início do século VI a.C., que possuem os maiores templos em dimensão já dedicados à divindade templos perípteros cujas dimensões estiveram entre 20 x 60 m até 55 x 110 m (Laky, 2013: 17). Com relação às imagens monetárias, houve um aumento no número de autoridades emissoras e regiões a usar o tipo da águia em suas moedas, dentre as quais se destacam as ilhas de Sifnos, da Eubéia, ambas no Egeu, e a Sicília. Esse atributo de Zeus permaneceu em época arcaica sendo usado como um símbolo do deus até o período entre os séculos VI-V a.C., quando a imagem de Zeus foi usada pela primeira vez em moedas gregas, na região da Líbia, em Cirene, caso a cronologia proposta pelo catálogo do Museu Britânico se mantiver nas pesquisas numismáticas futuras. Isto posto, paradoxalmente, a divindade que inicialmente não havia sido adotada na origem da cidade, em razão de suas características relacionadas à natureza, como colocou Morgan, passou a ter significado na cidade grega justamente no momento quando esta passou a alcançar seu primeiro grande desenvolvimento urbano no último século da época arcaica.

Concluímos que a época clássica foi o grande período de vinculação do culto de Zeus à pólis grega, como mostram as evidências referentes à monumentalização dos santuários de Zeus e o aumento significativo de áreas sagradas urbanas, associado também à predominância de epítetos do deus relacionados à esfera 
política da cidade grega nesse período. A apropriação do culto do deus pelas comunidades políticas, iniciada no século VI a.C., se intensificou no século V a.C., atingindo o ápice no século IV a.C. Uma prova da ocorrência desse fenômeno é o início do uso e a proliferação das imagens de Zeus e de raios em moedas das cidades gregas nos séculos V e IV a.C. Há uma linha interpretativa ${ }^{1}$ que assinala os tipos monetários de Zeus Amon em Cirene entre o primeiro quartel e a metade do século $V$ a.C., ao mesmo período, portanto, das primeiras imagens monetárias de Zeus, não-Amon, conhecidas, cunhadas pela Liga Arcádia e Élis-Olímpia, na Grécia Balcânica, e por cidades na Sicília. As imagens de raios em moedas são também datadas do mesmo período das primeiras imagens de Zeus, a partir do primeiro quartel do século $\mathrm{V}$ a.C., quando foram emitidas por comunidades políticas na Sicília, Itália do Sul e por Élis-Olímpia. A cronologia dos tipos monetários indica que também foi justamente nesse período (a partir do primeiro quartel do século $V$ a.C.) que os atributos de Zeus, a águia e o raio, foram usados associados pela primeira vez em moedas gregas por Élis-Olímpia. No século $\mathrm{V}$ a.C., Zeus e águias figuraram em um mesmo tipo monetário a partir da metade do século V a.C. em Élis-Olímpia e no Chipre, e Zeus e raios no último decênio desse século em Élis-Olímpia e na Tessália. Com relação ao século IV a.C., houve um aumento no uso das imagens de Zeus e do raio em moedas, assim como uma maior diversificação de autoridades emissoras e de regiões do mundo grego, que se apropriaram dos tipos. O século IV a.C. também representa o período no qual Zeus passou a figurar em moedas gregas associado a seus dois atributos em Élis-Olímpia e na Sicília. Nesse sentido, é possível considerar o século IV a.C. como o período de consolidação do culto de Zeus na cidade grega, como indicam as evidências numismáticas e o número significativo de santuários do deus instalados principalmente na ágora, e em menor grau na acrópole, e os epítetos Agoraios, Sóter e Polieus pela primeira vez muito recorrentes. Evidência de tal processo, no século IV a.C., é o uso recorrente dos santuários de Zeus como arquivos cívicos das cidades exatamente nesse período, quando foram também usados para a exposição de decretos públicos (Mégara, Mylasa, Dion, Lócris, Mantinéia, Megalópolis, Cabo Kenaion). Os principais períodos dos ápices das atividades cultuais dos santuários de Zeus, datados da Idade do Bronze até a época clássica, comprovam tal constatação - a época arcaica (século VI a.C.) e a época clássica representam também os períodos de auge do culto de Zeus tanto em seus santuários regionais quanto naqueles cívicos.

Como se vê, houve mudanças no culto de Zeus, em relação à cidade grega, que se revelaram somente no estudo associativo entre santuários e imagens monetárias da divindade, conforme demonstra a correspondência visível entre a emergência e a proliferação de imagens monetárias e santuários principalmente em época clássica. Trata-se da abordagem do contexto único de produção que defendemos nessa tese, no estudo do culto de divindades gregas e de sua função nas comunidades políticas em época arcaica e clássica. Como vimos, reiteradamente, moedas e santuários têm em comum o caráter de oficialidade e de identidade da

\footnotetext{
1 Essa é a opinião do Prof. Giovanni Gorini, obtida em uma conversa por mensagens de e-mail durante 0 ano de 2015. Segundo 0 estudioso, que se baseia em novos estudos sobre as cronologias das primeiras séries monetárias de Cirene, as primeiras imagens monetárias de Zeus Amon devem remontar ao período do rei Arcesilaos IV (475-450 a.C.) e não à transição dos séculos VI-V a.C. tal como estabeleceu Robson no catálogo numismático do Museu Britânico sobre a Cirenaica.
} 
cidade grega, partem de uma mesma entidade política, a pólis. Também ambos provêm de um único contexto histórico: santuários e moedas são produções formais da pólis e mesmo tendo públicos e razões diferentes, se articulam a um mesmo contexto histórico, obedecendo, assim, a tradições culturais únicas, a contextos de produção únicos (Andrén, 1998: 153 e ss.). Até aqui, apresentamos os momentos de mudança do culto, em relação à cidade grega, expressos tanto na documentação numismática como na dos santuários. Contudo, no interior dessas transformações estiveram fatores políticos e sociais que promoveram a apropriação e consolidação do culto do deus nas comunidades políticas no período assinalado, visíveis concomitantemente em ambos os tipos de documentação. A partir da análise interpretativa regional dos tipos monetários e santuários do Peloponeso, Creta, Sicília e Itália do Sul, foi possível estabelecer que o fenômeno de apropriação do culto de Zeus, pela cidade grega, ocorreu relacionado predominantemente 1-) à expressão de determinados grupos políticos no poder nas cidades gregas; 2-) à expressão de poder e soberania das comunidades; 3-) à ordenação do funcionamento das instâncias políticas da cidade; 4-) e à formação e articulação de redes de identidade grega (em seus vários níveis) em contexto políade.

Com relação à expressão de determinados grupos políticos no poder nas cidades gregas, a documentação dos santuários revelou de forma mais precisa o papel destacado do culto de Zeus na integração social das elites das cidades gregas desde a Idade do Ferro, tanto em contextos regionais como nos cívicos nas quatro regiões analisadas. No caso do Peloponeso e do Ocidente grego, as áreas sagradas oferecem exemplos de como o culto foi apropriado e instituído por tiranos e membros da aristocracia, por expressão de poder do grupo político no controle das cidades. Este também foi o caso do uso das imagens de águias e Zeus em moedas por tiranos no Ocidente grego. Não foi possível inferir da documentação numismática a apropriação das imagens de Zeus e seus atributos pela aristocracia das cidades tal como se vê nos casos dos santuários. A documentação numismática revelou na Sicília e da Itália do Sul o uso de tipos monetários por tiranos em Agrigento e provavelmente em Crotona entre os séculos VI-V a.C., que utilizaram a imagem da ave, e também em Aetna-Catânia, onde a imagem do deus sentado no trono foi requisitada por esse grupo no poder no primeiro quartel do século $V$ a.C. É possível afirmar que, nesses três casos, os tiranos procuraram expressar seu poder na figura de Zeus ou de seu atributo, a águia, que, como vimos, expressou significados nesse mesmo âmbito. Resta dizer, que o estudo dos santuários demonstrou que 0 aspecto militar de Zeus foi um elemento comum ao culto de Zeus em Creta, no Peloponeso, na Sicília e na Itália do Sul, tanto em áreas sagradas com função regional quanto naquelas cívicas. A guerra também esteve presente no contexto do uso das imagens de Zeus e águias relacionadas, inicialmente, ao período tirânico na Sicília e Itália do Sul.

No segundo aspecto, acerca da expressão de poder e soberania das comunidades, vimos no caso dos santuários que, através do uso do espaço e da monumentalização da área sagrada, principalmente do templo, determinadas comunidades políticas gregas apropriaram-se do culto e o usaram como expressões de poder e soberania em seu território e também na área urbana. Na Sicília e no Peloponeso tal característica do culto relaciona-se também ao período de governo tirânico, responsável pela iniciativa da instituição e apropriação do 
culto dessa maneira pela cidade. No Ocidente grego, principalmente na Sicília, com relação aos santuários, floresceu uma associação intencional da comunidade ao poder de soberania e onipotência exercido por Zeus Olímpio. As evidências numismáticas analisadas nas quatro regiões nos levaram a conclusões nessa mesma direção: o significado de soberania foi um dos principais relacionados ao uso das imagens monetárias de Zeus, águias e raios entre as autoridades emissoras de Élis, Arcádia, Acaia, Messênia, Sicília, Itália do Sul e Creta em época arcaica e clássica. Dentro do significado de soberania, concluímos que certas imagens de Zeus, águias e raios estiveram relacionadas à auto-afirmação e manutenção do poder das comunidades políticas que as usaram. Entre os séculos VI-IV a.C., a águia em pé nas moedas das autoridades emissoras da Sicília, de Creta e de Élis aludiu às ideias de domínio territorial, de liderança regional, diferente do que ocorreu com o tipo associado às presas, que remontam aos períodos de crise e declínio das comunidades. 0 esquema iconográfico da águia em pé sobre o capitel jônico expressou significados de afirmação de soberania, se em momentos de eudaimonia ou de crise entre os séculos V e IV a.C. no Ocidente grego e no Peloponeso (ÉlisOlímpia). O tipo do raio foi usado nas moedas de Élis para Olímpia no contexto do expansionismo dessa pólis sobre as comunidades periecas da região e durante o momento de sua afirmação e auto-afirmação da soberania em escala regional, como detentora da prostasia de Olímpia. O tipo de Zeus em pé atirando o raio, em Élis e Posidônia, foi usado quando o poder ou domínio local dessas comunidades já estava estabelecido, mas precisava ser mantido durante o século V a.C. e entre os séculos V-IV a.C. A imagem de Zeus sentado no trono também foi usada, pelas comunidades políticas, nos momentos nos quais sua soberania já afirmada, precisava ser mantida, garantida.

Agrigento é o melhor exemplo acerca do contexto único na apropriação do culto como expressão de poder e soberania das comunidades, pois tal fenômeno materializou-se, concomitantemente, tanto no uso de imagens monetárias quanto nos santuários. A comunidade política de Agrigento procurou expressar, em vários níveis, o seu poder político por meio da monumentalidade do templo de Zeus Olímpio. A nosso ver, o templo do santuário agrigentino de Zeus Olímpio deve ter sido um importante símbolo da realização política da comunidade de Agrigento no início da época clássica, seja ele o triunfo da cidade após a batalha de Himera e a sua posição soberana no lado sudoeste da Sićlia, no contexto de soberania territorial alcançada pela cidade durante a época arcaica após a conquista de Heraclea Minoa e o controle da costa setentrional, incluindo Himera (La Torre, 2011: 84). Esse valor simbólico político e de poder do Olimpieion, nesse contexto do início do século $V$ a.C., correlaciona-se ao uso da águia nas moedas da cidade, cuja emissão é quase contemporânea à construção do templo de Zeus Olímpio. Templo e moedas são atribuídos ao período de tirania de Téron na cidade. Assim, houve uma intenção em associar à cidade à soberania e à onipotência da divindade, como mostra o uso do atributo do deus como emblema da cidade no mesmo período da concepção do templo.

No que diz respeito à ordenação do funcionamento das instâncias políticas da cidade, observa-se, tanto em áreas sagradas inter-regionais como naquelas cívicas, o papel do culto de Zeus na organização política das comunidades em época arcaica e clássica, tanto no seu funcionamento interno como, na mediação política com 
outra comunidade, conforme mostrou o conteúdo de determinados arquivos cívicos, os cultos de Zeus Agoraios e de Zeus Sóter, no Peloponeso e no Ocidente grego, além daquele em Olímpia. O papel de Zeus na regulação e ordenação do funcionamento das instâncias políticas da cidade também foi observado nas evidências numismáticas. A análise contextual do significado simbólico de certas imagens monetárias de Zeus, raios e águias revelou o seu uso vinculado a momentos de crise da comunidade política: na necessidade do afastamento de uma instabilidade política, de ameaça de poder e de perda de autonomia. Nesse sentido, as imagens foram requisitadas pelas comunidades políticas pelo papel de Zeus na restauração da ordem sobre 0 caos, de um novo equilíbrio político. A imagem monetária da águia voando, com ou sem uma presa, predominou entre autoridades emissoras do Peloponeso, da Itália do Sul e de Creta que viviam algum tipo de crise, ocasionada pela perda de autonomia e de soberania (Crotona e Metaponto), ou interessadas em manter seu poder territorial sobre a região na qual faziam parte (Crotona, Élis e Lyttos). Esse padrão de representação da ave como emblema monetário, nesse contexto, assumiu um significado talismânico em favorecer, se na crise ou na manutenção do poder, com os auspícios de Zeus, a comunidade política que os portasse. Crise e instabilidade política, um novo recomeço para as comunidades políticas, enquanto tais, levaram o uso da imagem do raio em moedas no Peloponeso e no Ocidente grego ao longo dos séculos V e IV a.C. O tipo de Zeus sentado no trono foi usado com o significado de ordenação das instâncias políticas das comunidades no Peloponeso e na Sićlia, que Ihes fizeram uso, tanto no contexto de ameaça da estabilidade como nos momentos nos quais sua soberania já afirmada, precisava ser mantida, garantida. Já o tipo de Zeus em pé atirando o raio embora tenha sido usado em períodos variados durante dois séculos, no Peloponeso ocidental, na Sicília e na Itália do Sul, os significados subjacentes à imagem em moedas parecem ter sido os mesmos entre elas. Em Messênia e Zancle, a imagem monetária emergiu no contexto da libertação de um poder opressor, no primeiro caso Esparta e no segundo caso os tiranos filhos de Anaxilas de Régio, e de afirmação da identidade enquanto comunidades políticas. Para essas autoridades emissoras, a imagem de Zeus atirando o raio, portando ou não a águia, evocou significados fundamentais de ordenação.

O papel do culto de Zeus na formação e articulação de redes de identidade grega (em seus vários níveis) em contexto políade pode ser considerado o mais expressivo em relação à divindade, dentre os demais, principalmente no Peloponeso em época arcaica e clássica. Nessa região, vemos melhor o papel do culto na elaboração/articulação de identidades regionais no nível político, como vimos nos casos da Arcádia, da Messênia e da Acaia sobretudo em época clássica. Também são casos que demonstram tal fenômeno, concomitantemente, na documentação numismática e dos santuários, representam, portanto, os melhores exemplos sobre o contexto único de produção. Na Messênia, o culto de Zeus Ithomatas foi um elemento importante na elaboração da identidade étnica messênia desde a época arcaica até a época clássica, quando no século V e IV a.C. se consolidou como um símbolo da resistência contra os espartanos, conforme vimos em relação ao santuário da divindade, e sua imagem foi usada como símbolo, nas moedas, do Estado messênio recém fundado. Na Acaia, onde a imagem de Zeus foi usada em moedas da liga aqueia no século IV a.C., Zeus 
Homarios foi considerado o deus de todos os aqueus já no século V a.C. e seu santuário em Aigion, o principal local de reuniões religiosas e políticas da região nessa época (Rizakis, 2013: 14). O funcionamento de um santuário como espaço de reuniões e deliberações comuns para todas as comunidades aqueias demonstra, claramente, o papel político regional de Zeus Homarios na Acaia. Nesse processo, "a ameaça de Sicione, contra as cidades aqueias orientais, e de Esparta, na metade do século VI a.C. favoreceram a união política regional, que alcançou expressão política no século V a.C. com a constituição da liga aqueia" (Rizakis, 2013: 22-23). Em Olímpia, todas essas participações de grupos étnicos gregos se deram no nível político: participantes dórios, jônios, eólios e aqueus eram representados no santuário por meio de suas comunidades políticas de origem. Assim também, devemos lembrar, que o santuário de Olímpia se tornou parte da identidade política da pólis de Élis desde a época arcaica. Na Arcádia, no Mt.Lykaion, o culto de Zeus Lykaios, se consolidou como divindade pan-arcádia, por excelência, no século V a.C. no primeiro momento de afirmação da identidade étnica arcádia, como indicam, principalmente, as moedas cunhadas com a imagem do deus no nome dos arcádios. O culto de Zeus Lykaios foi importante na coalização das comunidades políticas arcádias no século $V$ a.C., quando bateram conjuntamente moedas com a imagem do deus, e no século IV a.C., durante a fase da confederação arcádia, liderada por Megalópolis.

Concluímos, ao longo de nossa análise, que o caso de Megalópolis oferece o melhor exemplo sobre 0 papel do culto de Zeus na formação de redes de identidade grega (no caso étnica e regional) em contexto cívico ou políade - quando este assumiu importância étnica / regional na esfera política da cidade. O culto regional de Zeus Lykaios foi apropriado pela pólis, lá instituído na ágora como um santuário cívico muito provavelmente no século IV a.C. Uma evidência desse fenômeno é o uso da imagem da cabeça de Zeus Lykaios nas primeiras emissões monetárias de Megalópolis, recém fundada. Ainda que Pausânias não ofereça referenciais para a datação do santuário, e este não tenha sido localizado, muito provavelmente o santuário de Zeus Lykaios em Megalópolis foi fundado no século IV a.C. no momento em que o deus assumiu um papel político na confederação arcádia, que também corresponde a participação dessa cidade na organização da área sagrada no Mt.Lykaion. Em períodos posteriores, em época helenística o culto entrou em declínio, devido, entre outros fatores ao fim da confederação, o que justifica a não introdução do culto após o período clássico (Kreutz, 2007: 266).

Um caso diferente é o de Argos, onde o culto de Zeus Nemeios e os jogos foram apropriados pela cidade não por uma questão étnica, como nas demais regiões, mas por algum motivo, que deve estar na esfera do poder das cidades, quando a prática agonística nos santuários pan-helênicos havia alcançado grande prestígio entre as comunidades políticas. Isso pode explicar, em parte, a apropriação dos jogos e do culto em Neméia pela comunidade argiva, tornando-se parte da identidade política dessa comunidade já a partir da época arcaica.

Sobre as demais regiões, o papel do culto na articulação de identidades se vê apenas acerca dos santuários. Na Itália do Sul, Zeus Homarios articulou a identidade aqueia, na reunião política das cidades com 
essa origem, a partir do último quartel do século V a.C. É importante destacar que nos casos do Peloponeso e da Itália do Sul, a divindade assumiu tal papel, em agregar as cidades de mesma origem étnica, no contexto da ameaça da perda de soberania das comunidades políticas perante os espartanos (Peloponeso) e as ameaças dos povos itálicos e de Dioniso I (Itália do Sul). Na Sicília, o culto de Zeus Olímpio tornou-se parte da identidade política de algumas cidades dórias, por meio de uma relação política e social construída com o santuário de Olímpia. Nesse aspecto, Agrigento é a única comunidade política da Sicília na qual se vê a apropriação do culto de Zeus Olímpio tanto nas evidências numismáticas (imagens monetárias da águia) quanto em seu santuário políade. Em Creta, o papel do culto na articulação de identidades é observado de forma marcada no caso do santuário em Palaikastro, onde o culto ajudou a criar e a reforçar uma identidade regional típica do lado leste de Creta, aquela dita eteo-cretense desde a Idade do Ferro. Já o santuário no Mt.Ida oferece um exemplo da articulação do culto, muito provavelmente, na identidade regional das comunidades políticas (não étnica como se vê nos casos peloponésios) da porção central de Creta, com segurança, a partir da época clássica.

Isto posto, foi possível discernir, no Peloponeso e no Ocidente grego, fatores políticos e sociais que promoveram a apropriação do culto de Zeus pela cidade grega. No Peloponeso, conclui-se que o fator espartano foi o catalisador, nos séculos VI, V e IV a.C., de certos processos de afirmação de identidades regionais que levaram à apropriação do culto do deus (pela instituição ou consolidação de santuários e uso de imagens de Zeus e seus atributos em moedas) na Messênia, na Arcádia, na Acaia e de certa forma em Élis, como vimos na análise interpretativa dos tipos monetários emitidos para o santuário de Olímpia. Na Sicília, 0 fenômeno da tirania no início do século V a.C., de várias formas, desde a afirmação do poder dos tiranos na figura ou epifania de Zeus até o livramento de um período tirânico, como evidencia nos primeiros tipos monetários de Zeus em área etnea no início do século $V$ a.C. e no final do século IV a.C. no período de Timoleonte.

Na Sicília, também se destaca, nesse fenômeno, o que se pode chamar de fator arcádio na emergência da iconografia de Zeus em moedas na região, confirmando, assim, a premissa de G. Manganaro na década de 1970. Manganaro postula que o surgimento de certas imagens monetárias de Zeus de Aetna e Galária (como a de Zeus sentado no trono) tenha sido possível como resultado da dispersão dos xenoi peloponésios pelos centros da ilha após o fim da tirania e durante o movimento de Ducézio (Manganaro, 194-1975: 35). O estudioso conclui que a população peloponésia, confluída em Aetna e Galária, devia ser constituída por grupos originários da Messênia misturados aos arcádios - duas sub-regiões por muitos aspectos afins culturalmente e nas quais circulavam as moedas com os tipos de Zeus dos arcádios e também de Olímpia datadas da mesma época, ou talvez mais antigas que os tipos monetários siceliotas (Manganaro, 1974-1975: 37). De fato, as evidências da migração arcádia e messênia nesse período, na Sicília, são significativas e os tipos de Zeus sentado no trono da Liga Arcádia já eram bem conhecidos, tinham uma tradição de emissão desde o início do século V a.C., conforme, nesse caso, a cronologia de Williams. Nessa perspectiva, as primeiras imagens de Zeus nas moedas da Sicília podem ter surgido do processo de mobilidade arcádia, e peloponésia, à ilha no início do século V a.C. 
Entendemos aqui mobilidade, no caso a migração, "como a conectividade, um mecanismo que serviu para estabelecer, motivar e modificar identidades diaspóricas, trans-regionais e locais", que interferiram, por sua vez, na dimensão material (Van Dommelen; Knapp, 2010: 8). Além da mobilidade arcádia, uma rede de cidades siceliotas com Olímpia pode ter motivado o uso de certas imagens monetárias, como veremos no próximo tópico.

Na Itália do Sul, o quadro é diferente. Crises políticas próprias internas à região entre o final da época arcaica e todo o período clássico (o declínio de soberania regional de determinadas póleis, invasões dos povos itálicos às cidades, e de poderes hegemônicos regionais, como o de Dionisio I) levaram ao uso de imagens monetárias relacionadas a Zeus por determinadas póleis - 0 momento político, mais do que a identidade regional ou um grupo político no poder, foi o fator responsável pelo uso de imagens de Zeus e seus atributos em moedas na região e na formação da liga aqueia. Também no caso da Itália do Sul, existiu uma rede com Olímpia, no caso de Crotona e Lócris, que extrapolou a origem étnica das cidades.

Com relação ao contexto único de produção, e o estudo do culto de divindades em cidades gregas a partir da associação de moedas e santuários, é preciso dizer que muitos processos e fenômenos são apreensíveis apenas em uma ou na outra documentação. Na Sicília, por exemplo, o que se observa sobre a apropriação das imagens de Zeus e dos raios em moedas de comunidades políticas, além de dórias, nas jônias também (de origem calcídia), não se vê em relação aos santuários. Na ilha, o culto de Zeus Olímpio, como vimos, ganhou significado, conforme as evidências arqueológicas disponíveis, entre algumas cidades dórias, como Agrigento, Selinonte e Siracusa. Além dessa observação, é preciso lembrar que nem sempre onde a imagem de uma divindade foi usada como emblema monetário houve o culto cívico a ela dedicado na comunidade política. Como vimos no capítulo 4, das 22 autoridades emissoras distribuídas entre o Peloponeso, Creta, Sicília e Itália do Sul, 9 delas não possuíram qualquer evidência de culto a Zeus no local. Apesar de 0 número ser menor em relação às cidades emissoras de tipos monetários do deus e de seus atributos com santuários ou influenciadas em algum nível por centros de culto à divindade, deve-se considerar que houve outras razões, como vimos acima, além da presença do culto local, no uso de imagens de divindades em moedas gregas.

Ao resumirmos o papel de Zeus no desenvolvimento da pólis grega em época arcaica e clássica, é preciso chamar a atenção para a discussão sobre o caráter urbano ou não do culto da divindade. É um lugar comum na bibliografia a respeito especificamente de Zeus, ou sobre as divindades gregas em geral, que o deus foi raramente ou pouco associado às cidades gregas, assumindo uma função destacada apenas como divindade principal de santuários inter-regionais, como os de Olímpia, Neméia e Dodona (De Polignac, 1995: 25, Kreutz, 2007: 265 e 268; Larson, 2007: 15; Morgan, 1994: 26-28; Zolotnikova, 2011: 239). Responsável pelo primeiro estudo sistemático sobre os santuários de Zeus e a pólis grega, N. Kreutz defende que a "maior divindade do panteão grego raramente ocupou um lugar proeminente no panteão urbano das cidades", exercendo "raramente a função de divindade protetora" (Kreutz, 2007: 265). Para essa conclusão, a estudiosa 
se baseou, principalmente, na limitada ocorrência de santuários de Zeus em acrópoles - que na sua acepção é o lugar mais importante de culto em uma pólis - e na monumentalidade destacada de seus santuários políades extra-urbanos (Kreutz, 2007: 265-266). A seu ver, as ágoras, onde Zeus exerceu uma função importante cívica, não podem ser consideradas espaços religiosos de importância como as acrópoles, ou outras partes de uma cidade grega, dado o seu caráter secular, de espaço das instituições políticas e administrativas (Kreutz, 2007: 265). Por essa razão, diz Kreutz, "em nenhum lugar o estabelecimento do culto de Zeus na ágora levou a pólis, como um todo, a ser colocada sob a proteção do maior dos deuses" (Kreutz, 2007: 265). A nosso ver, contudo, os estudiosos, como Kreutz, têm excessivamente tentado definir Zeus a partir do que é urbano, por isso, chegando sempre a mesma conclusão a respeito do papel da divindade em relação à cidade. Acreditamos que os santuários e o culto de Zeus na cidade grega não devem ser interpretados sob o conceito de urbano, mas sob o conceito do que é cívico, tal como descreve Vernant. Na definição de Vernant, a religião cívica uniu, num todo único, o conjunto do espaço cívico, com seu centro urbano e sua khóra (Vernant, 2006: 41-42). Conforme L. Thromas, "o espaço cívico compreendeu todo o conjunto dos polos de uma cidade: o centro urbano e 0 território, não somente o centro da vila onde estavam as atividades políticas e administrativas" (Thromas, 2009: 65). Assim, acreditamos que interpretar Zeus a partir do que é cívico amplia a nossa concepção sobre a divindade e a coloca como uma importante divindade da pólis em época arcaica e clássica, tal como mostram não somente seus santuários situados no centro urbano, mas também nas aforas da cidade.

\section{CENTROS REGIONAIS DE INOVAÇÃO DO CULTO DE ZEUS}

Além das conclusões acerca do desenvolvimento do culto de Zeus na cidade grega, ao longo de nossa pesquisa, foi possível concluir sobre a importância de certas regiões e santuários de Zeus no mundo grego que tiveram um papel importante na criação e difusão de traços do culto a outras áreas, sobretudo com relação à iconografia do culto. Esse foi o caso do santuário de Olímpia e do Mt. Lykaion, ambos no Peloponeso. Essas duas áreas sagradas com função inter-regional difundiram para comunidades políticas, e também entre si, padrões iconográficos tanto em moedas gregas como na iconografia do culto do santuário, vistos nos tipos de votivos e na escultura arquitetônica. Trata-se de uma rede estabelecida entre os santuários de Olímpia e o Mt. Lykaion, entre o Mt. Lykaion e Creta, e entre Olímpia e o Ocidente grego (Sicília e Itália do Sul).

No caso da rede entre Olímpia e o Mt. Lykaion, a cronologia de estatuetas votivas e de tipos monetários indicam a influência do santuário arcádio sobre o de Olímpia. Vimos como G. Mylonas, muito provavelmente, esteve certo em afirmar que o Mt. Lykaion foi responsável em difundir o tipo da representação de Zeus Keraunios com a águia na estatuária, como demonstra as estatuetas votivas de bronze de Zeus, desse tipo, próprias do santuário arcádio desde o século VII a.C., que passaram a ser usadas no culto em Olímpia no início do século V a.C. Outra prova dessa rede entre os dois santuários são os próprios tipos monetários do deus cunhados em Olímpia. Uma clara e reconhecida alusão às cunhagens arcádias é o estater com tipo de Zeus 
sentado no trono, vestindo um himátion na cintura e segurando o cetro com a mão esquerda e a águia voando próxima ao braço direito, emitido por Élis entre c.452-432 a.C. Mesmos os tipos de Zeus em pé, atirando o raio com o braço direito e a águia voando próxima ou pousada sobre o braço esquerdo estendido, de Élis desse mesmo período, trazem, mesmo que de forma indireta, uma influência arcádia na representação, dado o uso da águia nesse padrão, uma criação do santuário no Monte Lykaion, como vimos. Nesse sentido, a Arcádia se destaca como área peloponésia que difundiu muitas ideias, em termos de culto de Zeus, para Olímpia. Tratase das duas regiões, como vimos, com os dois mais importantes centros de culto da divindade no Peloponeso e também no mundo grego. Nessa perspectiva, explica-se a possível influência dos arcádios no uso de determinadas imagens de Zeus em moedas de comunidades políticas na Sicília durante o início do século $\mathrm{V}$ a.C.

Com relação ao Mt.Lykaion e Creta, é provável que houve uma rede entre o culto arcádio de Zeus Lykaios e o Zeus cretense em época arcaica, que levou a introdução de aspectos próprios do culto heládico de Zeus, como pai celeste, conforme se vê no santuário em Amnisos. Ora, como vimos na discussão sobre Creta, o único paralelo no mundo grego para as duas colunas com as duas águias douradas no topo, descritas por Pausânias no altar de Zeus Lykaios, são as esculturas de calcário de duas aves (uma águia e um falcão, segundo o museu de Heráclion, e duas águias, segundo Marinatos) que ornavam o santuário de Zeus Thenatas em Amnisos. Ambas datam da metade do século VI a.C., portanto, da época em que a águia já fazia parte da iconografia do culto de Zeus no Mt. Lykaion, a mesma época que a ave passou a ser associada, pela primeira vez, na cerâmica lacônia à imagem de Zeus - outro fenômeno regional (peloponésio) importante sobre a consolidação da águia como um atributo de Zeus em época arcaica. Nesse sentido, se a associação da águia como um atributo de Zeus (em santuários e nas artes visuais), foi um fenômeno peloponésio - primeiramente arcádio a partir ao menos do século VII a.C. e lacônio a partir do século VI a.C., como demonstram as cerâmicas pintadas -, então, o uso da águia na arquitetura do santuário cretense em Amnisos justamente a partir do século VI a.C. deve ter ocorrido por alguma influência peloponésia mais direta, motivada por um rede específica entre Creta e o Peloponeso em relação ao culto de Zeus no final da época arcaica, ou indireta, motivada, também, por uma tendência peloponésia vigente no culto de Zeus em termos de mundo grego no período.

E por fim, uma importante rede entre Olímpia e o Ocidente grego ocorreu entre o último século da época arcaica e o período clássico. Vimos como o santuário em Élis foi responsável pela difusão do culto de Zeus Olímpio entre póleis de várias regiões do mundo grego, mas especialmente entre aquelas de origem dória na Sicília. Na Itália do Sul, há evidências arqueológicas do culto do deus apenas na pólis de Lócris. Se os santuários de Zeus Olímpio são evidências suficientes da existência da rede entre o santuário inter-regional e as duas regiões, a profusão entre traços compartilhados entre Olímpia, Sicília e Itália do Sul no âmbito da iconografia monetária enriquecem a nossa compreensão sobre as relações entre o Peloponeso ocidental e 0 dito Ocidente grego em época clássica. A correspondência temporal entre o uso do raio alado como imagem monetária na Sicília (Aetna e Catânia) e de Élis-Olímpia, nunca antes usadas em moedas gregas, pode indicar 
uma influência dos famosos tipos de Olímpia ou até mesmo uma influência siceliota sobre a oficina monetária de Olímpia. Nesse aspecto, vimos como o padrão de representação da águia em pé, de asas fechadas, sobre a coluna de um capitel jônico foi uma criação compartilhada entre Agrigento, Crotona e Olímpia, que, muito provavelmente, de acordo com as datações dos exemplares, foi uma criação do Ocidente grego difundida ao santuário pan-helênico. Em Lócris, também é possível afirmar um compartilhamento de traços entre Olímpia e essa pólis no uso da imagem da cabeça de Zeus com cabelos curtos e coroa de folhas de oliveira, na sua primeira emissão de moedas no século IV a.C. Além dos detalhes iconográficos, vimos como a associação dos atributos de Zeus, a águia e o raio, e de Zeus com seus dois atributos, foi uma criação da oficina monetária de Olímpia, entre os séculos V e IV a.C., que foi difundida, de forma marcante e notória, entre autoridades emissoras da Sicília e Itália do Sul.

Assim, essas são as redes, encontradas em nossa pesquisa, estabelecidas, em época arcaica e clássica, entre as quatro regiões analisadas nessa tese. Se por um lado a análise geral da documentação disponível sobre santuários de Zeus e as imagens nas moedas, com a iconografia do deus e de seus atributos, proporcionou uma percepção geral sobre o desenvolvimento do culto na longa duração, por outro, as conclusões da análise interpretativa regional sobre o Peloponeso, Creta, Sicília e Itália do Sul fornecem parâmetros de estudo suficientes para as demais regiões do mundo grego onde o culto de Zeus também alcançou expressão.

Outono de 2016 


\section{ANEXO I \\ CATÁLOGO dos SANTUÁRIOS DE ZEUS}

ANEXO II

CATÁLOGO das IMAGENS MONETÁRIAS DE ZEUS, ÁGUIAS E RAIOS 


\section{REFERÊNCIAS BIBLIOGRÁFICAS}

\section{ABREVIATURAS}

AA

Aegaeum

AEMTh

AEphem

AllN

AIONArch

AJA

Alt-Olympia I-V Olympia

AM

AnnPisa

AntK

Arch.Anz

ArchEph

ASAtene

Atti Taranto

BABesh

$\mathrm{BCH}$

BSA

BSR

Bull. Ép

CGT

DHA

Hesperia

GAL-S

GAL-MG

GAM-G

GCMGS
Archäologischer Anzeiger

Annales d'Archéologie Égéenne de l'Université de Liège

To Archalologiko Ergo sten Makedonia kai Thrake

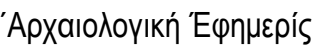

Annali dell' Istituto Italiano di Numismatica

Annali dell'Istituto Universitario Orientale di Napoli. Dipartimento di Studi del Mondo Classico e del Mediterraneo Antico. Sezione di Archeologia e Storia Antica

American Journal of Archaeology

Die Ergebnisse der von dem Deutschen Reich veranstalteten Ausgrabung I (1897); II (1892-96); III (1894-97); IV (1890); V (1896)

Mitteilungen des Deutschen Archäologischen Instituts, Athenische Abteilung

Annali della Scuola Normale Superiore di Pisa

Antike Kunst

Archaeologie Anzeiger

Archeologia Ephemerides

Annuario della Scuola Archeologica di Atene e delle Missioni Italiane in Oriente

Atti del Convegno di Studio sulla Magna Grecia. Taranto: Istituto per la Storia e l'Archeologia della Magna Grecia (ISAMG)

Bulletin Antieke Beschaving. Annual Papers on Classical Archaeology

Bulletin de Correspondance Hellénique

The Annual of the British School at Athens

Papers of the British School at Rome

Bulletin Épigraphique

SPAWFORTH, T. The Complete Greek Temples. Londres: Thames and Hudson, 2006

Dialogues d'Histoire Ancienne

Hesperia. The Journal of the American School of Classical Studies at Athens

COARELLI, F; TORELLI, M. Sicilia. Bari: Laterza \& Figli, 1984 (Guide Archeologiche Laterza)

GRECO, E. Magna Grecia. Bari: Laterza \& Figli, 1982 (Guide Archeologiche Laterza)

TORELLI, M.; MAVROJANNIS, T. Grecia. Milão: Mondadori, 2002 (Guide Archeologiche)

CERCHIAI, L. et al. The Greek Cities of Magna Graecia end Sicily. L. Angeles: Paul Getty Museum, 2004. 
GRBM

GrRomByzSt

HFM

IACP

IGO

IstMitt

JdI

JHS

Kernos

LIMC

$\operatorname{MDAl}(\mathrm{A})$

MonAnt

NSc

OIForsch

OlBer

OpAth

PK (I a V)

PP

Praktiká

REA

RA

REG

RM

RNum

SicArch

SIMA

ZPE
Greek, Roman and Bizantine Monuments

Greek, Roman and Bizantine Studies

Historik-filosofiske Meddeleser

HANSEN, H.H.; NIELSEN, T. An Inventory of Archaic and Classical Greek Poleis. Oxford: Oxford University Press, 2005 (Københavns Universitet; Polis Centret; Danish National Research Foundation)

PUGLIESE-CARRATELLI, G.P. I Greci in Occidente. Veneza: Bompiani, 1996.

Istanbuler Mitteilungen

Jahrbuch des Deutschen Archäologischen Instituts

Journal of Hellenic Studies

Kernos. Revue International et Pluridisciplinaire de Religion Grecque Antique

Lexicon Iconographicum Mythologiae Classicae. Düsseldorf, Zürich: Artemis, 1997

Vol. I. Thespiades - Zodiacus et Supplementum Abila - Thersites

Vol. VIII (1 e 2). Thespiades-Zodiacus et Supplementum Abila-Thersites

Mitteilungen des Deutschen Archäologischen Instituts. Athenische Abteilung

Monumenti Antichi

Notizie degli Scavi di Antichità

Olympische Forschungen

Bericht über die Ausgrabungen in Olympia

Opuscula Atheniensia

Palaikastros

La Parola del Passato

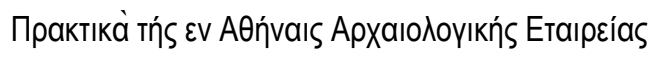

Revue des Études Anciennes

Revue Archéologique

Revue des Études Grecques

Mitteilungen des Deutschen Archäologischen Instituts, Römische Abteilung

Revue Numismatique

Sicilia Archeologica

Studies in Mediterranean Archaeology

Zeitschrift für Papyrologie und Epigraphik 


\section{FONTES TEXTUAIS}

APOLLODORUS (1976). Gods and heroes of the Greeks: the library of Appolodorus. Trad. de Michael Simpson e Leonard Baskin. Amherst: University of Massachusetts Pres.

APOLLONIUS RHODIUS (2015). Argonautica. Trad. de William H. Race. Cambridge: Harvard University Press, 2015 (Loeb Classical Library).

ARISTOPHANES (2000). Birds, Lysistrata, Women at the Thesmophoria. Trad. de J. Henderson. Cambridge; Harvard: Harvard University Press.

ARISTOPHANES (1998). Clouds, Wasps, Peace. Trad. de J. Henderson. Cambridge; Harvard: Harvard University Press.

ARISTOTLE (1959). Politics. Trad. de H. Rackham. Harvard: Harvard University Press (Loeb Classical Library).

ARISTOTLE (2011). Historia animalium. Trad. Allan Gotthelf. Cambridge: Cambridge University Press.

ARRIAN (1980). Storia di Alessandro. Trad. de Luigi Belloni. Milão: Rusconi (I Classici di stpria, Sezione Greco-romana, 3).

BACCHYLIDES (1993). Dithyrambes, epinicies, fragments. Trad. de J. Irigoin, J. Duchemin e L. Bardollet. Paris: Les Belles Lettres.

CALLIMAQUE (2002). Origines; Réponse aux Telchines; Élégies; Épigrammes; lambes et pièces lyriques; Hécate; Hymnes. 3.ed. ver. e corr. Trad. de Emille Cahen. Paris: Les Belles Lettres (Collection des universités de France).

CLEMENS ALEXANDRINUS (2004), Protrettico ai greci. Trad. de Franzo Migliore. Roma: Città Nuova (Collana di testi patristici, 179).

DEMOSTHENES (1935). Orations. Trad. J.H. Vince. Cambridge; Harvard: Harvard University Press.

DIODORUS SICULUS (1963). Library. Trad. de C.H. Oldfather. Cambridge: Harvard University Press (The Loeb Classical Library).

AESCHYLUS (2008). Fragments. Trad. A.H. Sommerstein. Cambridge; Harvard: Harvard University Press.

AESCHYLUS (2009). Persians, Seven against Thebes, Suppliants, Prometheus bound. Trad. A.H. Sommerstein. Cambridge; Harvard: Harvard University Press.

STEPHANOS BYZANTIOS (1992). Ethnikon: a geographical lexicon on ancient cities, peoples, tribes and toponyms. Trad. de August Meineke. Chigaco: Ares Publishers.

STRABO (1960). The Geography. Trad. de Horace Leonard Jones. Cambridge, Mass; Londres: Harvard University Press (The Loeb Classical Library).

ARISTOTLE (1998). The Nicomachean Ethics. Trad. de W.D. Ross, J.A. Ackrill e J.O. Urmson. Oxford; New York: Oxford University Press (Oxford world's classics).

EURIPIDES (2002). Helen, Phoenician Women, Orestes. Trad. D. Kovacs. Cambridge; Harvard: Harvard University Press.

EURIPIDES (1998). Suppliant Women, Electra, Heracles. Trad. D. Kovacs. Cambridge; Harvard: Harvard University Press.

HERODOTUS (1960). The Histories. Books 1-2. Trad. de A. D. Godley. Londres: William Heinemann; Cambridge Harvard University Press (Loeb Classical Library).

HERODOTUS (1960). The Histories. Books 3-4. Trad. de A. D. Godley. Londres: William Heinemann; Cambridge Harvard University Press (Loeb Classical Library).

HERODOTUS (1960). The Histories. Books 5-7. Trad. de A. D. Godley. Londres: William Heinemann; Cambridge Harvard University Press (Loeb Classical Library).

HERODOTUS (1960). The Histories. Books 8-9. Trad. de A. D. Godley. Londres: William Heinemann; Cambridge Harvard University Press (Loeb Classical Library).

HESíODO (1986). A Teogonia. Trad. de J.A.R. Torrano. São Paulo: R. Kempf. 
HOMERO (2004). llíada. Trad. de Carlos Alberto Nunes Rio de Janeiro: Ediouro.

ISOCRATES (2006). Isocrates. Reimpr. Trad. de Larue Van Hook. Cambridge: Harvard University Press (The Loeb classical library).

LIVY (1976). Rome and the Mediterranean: books XXXI-XLV of The history of Rome from its foundation. Trad. de Henry Bettenson. Harmondsworth: Penguin (Penguin classics).

LUCIAN OF SAMOSATA (2009). Icaromenippo, o, L'uomo sopra le nuvole. Trad. de Alberto Camerotto. Alessandria: Edizione dell'Orso (Hellenica: Alessandria, Italy; 29).

PAUSANIAS (1954). Description of Greece. Trad. de W. H. S. Jones e H. A. Ormerod. Londres: William Heinemann; Cambridge: Harvard University Press.

PINDARUS (1997). Nemean Odes. Isthmian Odes. Fragments. Trad. de William H. Race. Londres: William Heinemann; Cambridge: Harvard University Press (Loeb Classical Library).

PINDARUS (1997). Olympian Odes. Pythian Odes. Trad. de William H. Race. Londres: William Heinemann; Cambridge: Harvard University Press (Loeb Classical Library).

PLUTARCH (1914). Lives. Theseus and Romulus. Lycurgus and Numa. Solon and Publicola. Trad. de Bernadotte Perrin. Londres: William Heinemann; Cambridge: Harvard University Press (Loeb Classical Library).

PLUTARCH (1914). Themistocles and Camillus. Aristides and Cato Major. Cimon and Lucullus. Trad. de Bernadotte Perrin. Londres: William Heinemann; Cambridge: Harvard University Press (Loeb Classical Library).

PLUTARCH (1916). Pericles and Fabius Maximus. Nicias and Crassus. Trad. de Bernadotte Perrin. Londres: William Heinemann; Cambridge: Harvard University Press (Loeb Classical Library).

PLUTARCH (1919). Sertorius and Eumenes. Phocion and Cato the Younger. Trad. de Bernadotte Perrin. Londres: William Heinemann; Cambridge: Harvard University Press (Loeb Classical Library).

PLUTARCH (1927). Moralia. Trad. de Frank Cole Babbitt. Londres, W. Heinemann; New York, G.P. Putnam (The Loeb classical library).

PLUTARCH (1960). The rise and fall of Athens; nine Greek lives: Theseus, Solon, Themistocles, Aristides, Cimon, Pericles, Nicias, Alcibiades, Lysander. Trad. de lan Scott-Kilvert. Harmondsworth: Penguin Books (Penguin classics).

PLUTARCH (2013). The rise of Rome: twelve lives. Trad. de lan Scott-Kilvert, W. Jeffrey Tatum e C.B.R. Pelling. Londres: Penguin Books (Penguin classics).

POLYBIUS (2010). The Histories. Books 3-4. Trad. de W.R. Paton. Londres: William Heinemann; Cambridge: Harvard University Press (Loeb Classical Library).

POLYBIUS (2012). The Histories. Books 9-10. Trad. de W.R. Paton. Londres: William Heinemann; Cambridge: Harvard University Press (Loeb Classical Library).

SOPHOCLES (1982). Trachiniae. Trad. de P.E. Easterling. Cambridge; New York: Cambridge University Press (Cambridge Greek and Latin classics).

SOPHOCLES (1994). Antigone, The Women of Trachis, Philoctetes, Oedipus at Colonus. Trad. H. Lloyd-Jones. Cambridge; Harvard: Harvard University Press.

THEOPHRASTUS (1990). Enquiry into plants and minor works on odours and weather signs: in two volumes, 1. Reimpr. Trad. de Arthur F. Hort. Londres: Heinemann (The Loeb classical library).

THEOPHRASTUS (1990). De Causis Plantarum, Volume II: Books 3-4. Trad. de Benedict Einarson e George K.K. Link. Cambridge: Harvard University Press (Loeb classical library).

TUCÍDIDES (1982). História da Guerra do Peloponeso. Trad. de Mário da Gama Kury. Brasília: Editora da Universidade de Brasilia.

VITRÚVIO POLIÃO, Marco (2002). Da Arquitetura. Trad. e notas Marco Aurélio Lagonegro. 2. ed. São Paulo: Hucitec, Annablume [1999]. 
VITRUVIUS (1983). On Architecture. Vol. I (livros I a V). Editado a partir do manuscrito 2767 e traduzido para o inglês por Frank Granger. 5. reimpr. [1. ed. 1931] Cambridge: Harvard University Press; Londres: William Heinemann. (The Loeb Classical Library)

XENÓFANES (2006). Fragmentos. In: VIEIRA, T. Xenofanias. Trad. de Trajano Vieira. Campinas, Ed. Unicamp; São Paulo, Imprensa Oficial.

XENOFONTE (1918). Hellenica. Books 1-4. Trad. de Carleton L. Brownson. Londres: William Heinemann; Cambridge: Harvard University Press (Loeb Classical Library).

XENOFONTE (1922). Anabasis. Trad. de C. Brownson. Londres: William Heinemann; Cambridge: Harvard University Press (Loeb Classical Library).

XENOFONTE (1914). Cyropaedia. Books 1-8. Trad. W. Miller. Cambridge; Harvard: Harvard University Press.

\section{BIBLIOGRAFIA GERAL E ESPECÍFICA (NUMISMÁTICA E ARQUEOLÓGICA)}

AA. VV. (1924). Chronique des fouilles et dècouvertes archéologiques dans l'Orient Hellénique. BCH, 48: 446-515.

ADAMESTEANU, D. (1973). Metaponto. Nápoles: La Buona Stampa.

ADAMESTEANU, D. (1978). Metaponto. Atti Taranto, 18, Gli Eubei d'Occidente: 350-352.

AKERSTROM, A. (1966). Die architektonischen Terrakotten kleinasiens. Lund: C.W.K. Gleerup (Acta Instituti Athenienns Regni Sueciae, Series in $\left.4^{\circ}, 11\right)$.

ALONGE, M. (2005). The Palaikastro Hymn and the modern myth of the Cretan Zeus. Princeton and Stanford working papers in Classics. Stanford University, Dezember 2005. Disponivel em: < http://www.princeton.edu/ pswpc/papers/authorAL/alonge/alonge.html>; acesso em: 5 abr. 2016.

AMANDRY, P. (1987). Trépieds de Delphes et du Péloponnèse. BCH, 111: 79-131.

AMOURETTI, M.; RUZÉ, F. (1993). O Mundo Grego Antigo: dos palácios de Creta à conquista romana. Lisboa: Publicações Dom Quixote.

ANDRÉN, A. (1998). Between Artifacts and Texts: Historical Archaeology in Global Perspective. N. York; Londres: Plenum Press.

ANNELLO, P; MARTORANA, G.; SAMMARTANO, R. (2006). Ethne e religione nella Sicilia antica. Atti del Convegno Internazionale (Palermo, 6-7 dicembre). Roma: G. Bretschneider (Supplementi a "Kókalos", 18).

ANTONACCIO, C. (2001). Ethnicity and Colonization. In: MALKIN, I. (Ed.). Ancient Perceptions of Geek Ethnicity. Cambridge, MA; Londres, Harvard University Press: 113-157.

ANTONACCIO, C. (2007). Colonization: Greece on the Move, 900-480. In: SHAPIRO, H.A. (Ed.). The Cambridge Companion to Archaic Greece. Cambridge, Cambridge University Press: 201-224.

ANTONACCIO, C. (2009). The Western Mediterranean. In: RAAFLAUB, K.A.; WEES, H. (Eds.). A Companion to Archaic Greece. Massachusets; Oxford, Willey-Blackwell: 314-329.

ANTONETTI, C.; DE VIDO, S. (2009). Temi Selinuntini. Pisa: Edizioni ETS.

ARAFAT, K. W. (1990). Classical Zeus: a Study in Art and Literature. Oxford: The Clarendon Press; New York: Oxford University Press.

ARAPOJANNI, X. (1998). Praktiká.

ARAPOJANNI, X. (1996). Ergon, 43: 41-47.

ARAPOJANNI, X. (1996). Praktiká.

ARAPOJANNI, X. (1997). Ergon, 44: 43-49.

ARAPOJANNI, X. (1998). Ergon, 45: 51-53.

ARJONA PÉREZ, M. (2007). Tres santuarios liminales de Eubea. Saldvie, 7: 49-69. 
ASSUNÇÃO, T.R. (2013). Lotófagos (Odisseia IX, 82-104): comida floral fácil e risco de desistência. Comunicação apresentada no XIX Congresso da Sociedade Brasileira de Estudos Clássicos (SBEC), Brasília (texto não publicado, mas cedido pelo autor).

BACCHIELLI, L. (1998). II Tempio di Zeus Olimpio a Cirene: Storia e Programma degli Scavi e Restauri. In: CATANI, E.; MARENGO, S.M. (Org.). La Cirenaica in età antica. Atti del convegno Internazionale di Studi (Macerata 18-20 Maggio 1995). Pisa-Roma, Istituti Editoriali e Poligrafici Internazionali: 23-40.

BAKALAKIS, G. (1977). "Avaбkạǹ Líou 1964-1971. Achaia Macedonia / Ancient Macedonia II: Papers Read at the Second International Symposium held in Thessaloniki 19-24 August 1973. Thessalonica, Institute for Balkan Studies: 255 (Hidryma Meletōn Chersonēsou tou Haimou, 155).

BARRINGER, J. (2001). The hunt in ancient Greece. Baltimore: John Hopkins University Press.

BARRINGER, J. (2009). The Olympic Altis before the Temple of Zeus. Jdl, 124: 223-250.

BARRINGER, J. (2010). 'Zeus in Olympia'. In: ERSKINE, A.; BREMMER, J.N. (Eds.). The Gods of Ancient Greece: Identities and Transformations. Edimburgo, Edinburgh University Press: 155-177 (Edinburgh Leventis Studies).

BARRINGER, J. (2015). The Changing Image of Zeus at Olympia. AA, 1: 19-37.

BARRINGER, J. M. (2005). The Temple of Zeus at Olympia, Heroes, and Athletes. Hesperia, 74: 211-241.

BAYET J. (1959). Idéologie et Plastique. I: l'expression des énergies divines dans le monnayage des Grecs. Mélanges d'Archéologie et d'Histoire, tomo 71, 1: 65-106.

BEECHEY, F.W.; BEECHEY, H.W. (1828). Proceedings of the expedition to explore the northern coast of Africa, from Tripoli eastward. Londres: J. Murray.

BEJOR, G. (1977). Problemi di Localizzazione di Culti a Selinunte. Annali della Scuola normale superiore di Pisa, ser. III, 7 (1): $439-457$.

BENZI, M. (1984). Evidence for a middle Minoan settlement on the acropolis at lalyssos, Mount Philerimos. In: HÄGG, R.; MARINATOS, N. (Eds.). The Minoan Thalassocracy. Myth and Reality. Proceedings of the third International Symposium at the Swedish Institute at Athens, 31 May-5 June, 1982. Estocolmo; Skrifter utgivna av Svenska Institutet i Athen, Ser. 4, Vol. 32: 93-104.

BÉQUIGNON, Y. (1937). Recherches archéologiques à Phéres de Thessalie. Paris: Bourriot $F$.

BÉRARD, C.; DURAND, J.-L. (1984). Entrer en imagerie. In: VERNANT, J.-P (Ed.). La Cité des Images, Religion et Societé en Grèce Antique. Lausanne, Fernand Nathan LEP: 19-34.

BERGESE, L.B. (1995). Tra Ethne e Poleis: pagine di storia arcade. Relazioni interstatali nel mondo antico. Pisa: Scuola Normale Superiore (Fonti e studi, 6).

BERNARDINI, C. (2006). I Bronzi della Stipe di Camiros. Monographie della Scuola Archeologica Italiana di Atene e della Missione Italiane in Oriente, 18. Atenas.

BERRANGER, D. (1992). Recherches sur l' Histoire et la Prosopographie de Paros à l'Époque Archaïque. ClermontFerrand: Association des Publications de l'UFR Lettres de Clermont.

BERTINO, A. (1975). Le emisione monetali di Abaceno. Le emissioni dei centri siculi fino all'epoca di Timoleonte e i loro rapporti con la monetazione delle colonie greche di Sicilia. Atti del $4^{\circ}$ Convegno del Centro Internazionale di Studi Numismatici, Napoli 9-14 aprile 1973. AlIN, 20: 77-103.

BERVE, H.; GRUBEN, G. (1963). Greek Temples, Theatres and Shrines. Londres: Thames and Hudson.

BETANCOURT, P.; CHANIOTIS, A. (1992). Die Geschichte von Amnissos von Homer bis zur Eroberung Kretas durch der Türken. In: SCHÄFER, J. (Ed.). Amnissos Nach den archälogischen, historischen und epigraphischen Zeugnissen des Altertums und der Neuzeit. Berlim, Forschungen des Archäologischen Instituts der Universität Heidelberg; Deutsches Archäologisches Institut (Berlin) Abteilung: 73-128.

BETTALI, M.; D’AGATA; MAGNETTO, A. (2013). Storia Greca. Nuova Edizione. Roma: Carocci Editore.

BIANCO, L.; SAMARTANO, A. (2004). Sèlinonte. Marsala: La Medusa Editrice.

BINTLIFF, J. (2012). The Complete Archaeology of Greece. From hunter-gatherers to the $20^{\text {th }}$ century A.D. Massachusets; Oxford: Willey-Blackwell. 
BLINKENBERG, C. (1911). The Thunderweapon in Religion and Folklore: a study in comparative archaeology. Cambridge: Cambridge University Press (Cambridge Archaeological and Ethnological series).

BLOEDOW, E. (1991). Evidence for an Early Date for the cult of Cretan Zeus. Kernos, 4: 139-177.

BOKERN, A.; ROWAN, C. (Eds.) (2014). Embodying Value? The Transformation of Objects in and from the Ancient World. Oxford: Archeopress (BAR international series, 2592).

BONACASA, N. (2000). Topografia e Urbanistica. In: BONACASA, N.; ENSOLI, S. (Org.). Cirene. Milão, Electa: 37-49.

BONACASA, N. (2007). I Culti della Colina di Zeus a Cirene. Karthago, 27: 233-243.

BONACASA, N.; ENSOLI, S. (Orgs.) (2000). Cirene. Milão: Electa.

BOOKIDIS, N. (2003). The Sanctuaries of Corinth. In: WILLIAMS II, C.K.; BOOKIDIS, N. (Eds.). Corinth. The Centennary 1896-1996. Atenas, The American School of Classical Studies at Athens: 247-259 (Results of Excavations Conducted by the American School of Classical Studies at Athens, Vol. XX).

BOSANQUET, R.C. (1901-1902). Excavations at Palaikastro, I. BSA, 8: 286-316.

BOSANQUET, R.C. (1901-1902). Excavations at Praesos, I. BSA, 8: 231-270.

BOSANQUET, R.C. (1939-1940). Dicte and the temples of Dictaean Zeus. In: HUTCHINSON, R.W.; ECLES, E.; BENTON, S. (Eds.). Unpublished Objects from Palaikastro and Praisos, II. BSA, 40: 38-59.

BOSANQUET, R.C.; DAWKINS, R.M.; TOD, M.N.; DUCKWORTH, W.L.H.; MYRES, J.L. (1902-1903). Excavations at Palaikastro, II. BSA, 9: 274-387.

BOTTINI, A. (1989). La Basilicata. Atti Taranto, 29, La Magna Grecia e il Lontano Occidente: 565-566.

BRACCESI, L.; RAVIOLA, F. (2008). La Magna Grecia. Bolonha: II Mulino.

BRELICH, A. (1964/65). La Religione Greca in Sicilia. Kokalos, X-XI: 35-62.

BREMER, J. (2006-2009). Zeus' lightining in early Greek myth and in Kleanthes' hymn. Roczniki Humanistyczne, 54-55 (3): 21-36.

BRIZE, Ph. (1992). Die Adler des Zeus Thenatas. In: SCHÄFER, J. Amnisos. 2 vols. Textband, tafelband. Berlim, Gebn. Mann: 254-273.

BROCK, R.; HODKINSON, S. (Eds.) (2002). Alternatives to Athens. Varieties of political organization and community in Ancient Greece. Oxford: Oxford University Press.

BROUCKE, P.B.F.J. (1996). The Temple of Olympian Zeus at Agrigento. Dissertação. Yale University. Ann Arbor, Michigan.

BRUNEAU, P.; DUCAT, J. (1966). Guide de Délos. École Française d’ Athènes. Paris: De Boccard.

BRUNO, G. (2005). Aristocrazia, tirannide e democrazia. In: MINÀ, P. (Org.). Urbanistica e Architettura nella Sicilia Greca. Palermo; Regione Siciliana, Assessorato dei Beni Culturali Ambientali e della Pubblica Istruzione: 15-20.

BURASELIS; K.; ZOUMBOULAKIS, K. (Eds.) (2003). The idea of European community in history. Conference proceedings, vol.II. Aspects of connecting poleis and ethne in ancient Greece. Atenas: National and Capodistrian University of Athens.

BURKERT, W. (1983). Homo Necans: The Anthropology of Ancient Greek Sacrificial Ritual and Myth. Berkeley: University of California Press.

BURKERT, W. (1993). Religião Grega na Época Clássica e Arcaica. Lisboa: Fundação Calouste Gulbekian.

BURKERT, W. (1995). Greek Poleis and Civic Cults: some further thoughts. In: HANSEN, M.; RAAFLAUB, K. (Eds.). Studies in the Ancient Greek Polis. Stuttgart, Franz Steiner: 201-210.

CABANES, P. (1988). Les concours des Naia de Dodone. Nikephoros, 1: 5-14.

CABANES, P. (1989). L'organization de l'espace en Épire et Illyrie méridionale à l'époque classique et hellénistique. DHA, $15(1): 49-62$. 
CABANES, P. (1996). La Grèce du Nord (Épire, Macédoine) en plein développement au IVe siècle avant J.-C. In: CARLIER, P. (Ed.). Le IVe siècle avant J.-C. Approches historiographiques. Nancy, A.D.R.A.: 195-204.

CACCAMO CALTABIANO, M. (1998). Immagini-parola, grammatica e sintassi di un lessico iconográfico monetale. In: ARSLAN, A.E. (a cura di). La "parola" delle immagini e delle forme di scrittura: modi e tecniche di comunicazione nel mondo antico. Messina, Dipartimento di Scienze dell' Antichità dell' Università degli Studi di Messina: $57-74$.

CACCAMO CALTABIANO, M. (1999-2000). Incontri di Popoli e Culture nel Mediterraneo. Miti e culti dello Stretto nelle monete antiche (fine VI-inizi III sec. a.C.). The Dracma Project. Messina: Università degli Studi di Messina.

CACCAMO CALTABIANO, M. (2004). Comunicare per immagini: grammatica e sintassi di un lessico iconografico monetale. In: TRAVAINI, L.; BOLIS, A. (a cura di). L'Immaginario e il Potere nell'Iconografia Monetale. Dossier di lavoro del seminario di studio, Milano, 11 marzo 2004. Milão, Società Numismatica Italiana: 11-40.

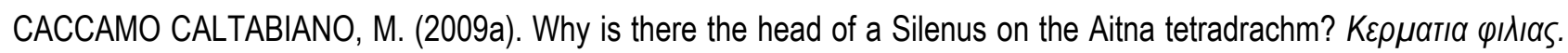

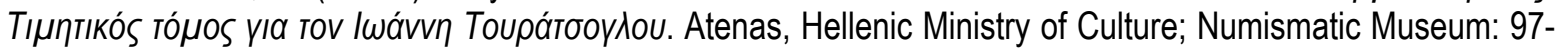
107.

CACCAMO CALTABIANO, M. (2009b). La moneta di Temesa tra storia e mito. In: LA TORRE, G.F. (Ed.). Dall'Oliva al Savuto. Studi e ricerche sul territorio dell'antica Temesa. Atti del convegno, Campora San Giovanni (Amantea, CS), 15-16 settembre 2007. Pisa; Roma, Fabrizio Serra Editore: 119-137.

CACCAMO CALTABIANO, M.; RACCUIA, C; SANTAGATI, E. (2010). Tyrannis, Basileia, Imperium: forme, prassi e simboli del potere politico nel mondo greco e romano. Atti delle Giornate seminariali in onore di S. Nerina Consolo Langher (Messina 17-19 Dicembre 2007). Messina: Dipartimento di Scienze dell'Antichità dell'Università degli Studi di Messina (Di.Sc.A.M.).

CALLATÄY, F.; GITLER, H. (2004). The Coin of Coins. Jerusalém: The Israel Museum.

CALLIÒ, L.M. (2001). II santuario di Camiro. Analisi delle struture e ipotesi di ricostruzione della grande stoà dórica. Orizzonti, II: 85-107.

CAMP, J. (2001). The Archaeology of Athens. New Haven: Yale University Press.

CAPDETREY, L.; LAFOND, Y. (Orgs.) (2010). La Cité et ses Élites. Pratiques et représentation des formes de domination et de contrôle social dans les cités grecques. Textes réunis par L. Capdetrey et $\mathrm{Y}$. Lafond. Bordeaux: Ausonius.

CARAPANOS, C. (1978). Dodone et ses ruines. Paris: Librarie Hachette.

CARDOSA, M.; BARELLO, F. (1996). Santuari a Locri Epizefiri. L'area sacra di Zeus Olympios. In: LATTANZI, E. (Ed.). I Greci in Occidente. Santuari della Magna Grecia in Calabria. Nápoles, Electa: 69-73.

CARINCI, F. (1958). s.v. Elide, n.1. In: Enciclopedia dell'Arte Antica Classica e Orientale. Roma: Istituto della Enciclopedia Italiana.

CARROCCIO, B. (2005). I Bronzi Zeus Hellanios/Aquila e l'organizzazione dell'attività monetaria siracusana tra officine parallele e concentrazioni cronologiche. In: ALFARO, C.; MARCOS, C.; OTERO, P. (Eds.). XIII Congreso Internacional de Numismática, Madrid, 2003: actas/proceedings/actes, I. Madri; Ministerio de Cultura, Subdirección General de Publicaciones, Información y Documentación: 331-337.

CARROCCIO, B. (2007). Tra Iconografia e Storia: aquile epirote o aquile tolemaiche nelle monetazioni magnogreche? Miscellanea di Studi Storici Università della Calabria, 14: 83-105.

CATLING, H.W. (1990). A sanctuary of Zeus Messapeus: excavation at Aphyssou, Tsakona, 1989. Londres: British School at Athens.

CATLING, H.W. (1990). Zeus Messapeus near Sparta: an interim report. Atenas: Etaireía Lakonikón Spoudón.

CATLING, H.W. (2002). Zeus Messapeus at Tsakona, Lakonia. Atenas: Etaireía Lakonikón Spoudón.

CATLING, H.W.; SHIPLEY, D.G. (1989). Messapian Zeus: An early Sixth-century inscribed cup from Lakonia. BSA, 84: 187-200.

CAZZANIGA, I. (1972). Un'ipotesi sul significato dell'emblema del granchio nella monetazione di Akragas sicula. Numismatica e antichità classiche. Quaderni Ticinesi, I: 27-31. 
CERCHIAI, L. (2004). Kroton. In: CERCHIAI, L. et alii (Eds.).The Greek Cities of Magna Graecia end Sicily. Los Angeles, Paul Getty Museum: 104-113.

CERCHIAI, L. (2004). Metapontion. In: CERCHIAI, L. et alii (Eds.). The Greek Cities of Magna Graecia end Sicily. Los Angeles, Paul Getty Museum: 130-143.

CERCHIAI, L. (2004). Poseidonia/Paestum. In: CERCHIAI, L. et alii (Eds.).The Greek Cities of Magna Graecia end Sicily. Los Angeles, Paul Getty Museum: 62-81.

CERCHIAl, L. et alii. (Eds.) (2004). The Greek Cities of Magna Graecia end Sicily. Los Angeles: Paul Getty Museum.

CHAMOUX, F. (1963). Cyrène sous la Monarquie des Battiades. Paris: De Boccard (Bibliothèque des Écoles Françaises D’Athènes et de Rome).

CHANIOTIS, A. (1988). Habgierige Götter, habgierige Städe Heiligtumsbesitz und Gebietsanspruch in den kretischen Staatsvertragen. Ktema, 13: 29-32.

CHANIOTIS, A. (2009). Extra-urban Sanctuaries in Classical and Hellenistic Crete. In: DELIGIANNAKIS, G.; GALANAKIS, Y. (Eds.). The Aegean and its Cultures. Proceedings of the first Oxford-Athens graduate student workshop organized by the Greek Society and the University of Oxford Taylor Institution, 22-23 April 2005. Oxford: Archaeopress: 59-67.

CHANIOTIS, A. (Ed.) (1999). From Minoan farmers to Roman traders. Sidelights on the economy of ancient Crete. Stuttgart: Franz Steiner.

CHRISTENSEN, L. (2009). 'Cult' in the study of religion and archaeology. In: SCHULTZ, P.; WICKKISER, B.; HINGE, G. (Eds.). Aspects of Greek Cult: Context, Ritual, Iconography. Santa Barbara, Aarhus University Press: 13-27.

CIACERI, E. (1894). Contributo alla Storia dei Culti dell' Antica Sicilia. Annali della Scuola Superiore di Pisa: i-v, 1-97 (Serie filologia e storia, $\mathrm{X}$ ).

CIPRIANI, M.; GRECO, E.; LONGO, F.; PONTRANDOLFO, A. (1996). I Lucani a Paestum. Paestum; Salerno: Fondazione Paestum.

CLEMMENSEN, P.; VALLOIS, R. (1925). Le temple de Zeus à Némée. BCH, 49: 1-20.

COARELLI, F; TORELLI, M. (1984). Sicilia. Bari: Laterza \& Figli (Guide Archeologiche Laterza).

COLE, S.G. (1995). Civic cults and civic identity. In: HANSEN, M.H. (Ed.). Sources for the Study of the Ancient Greek City-State. Acts of the Copenhagen Polis Center, vol.2. Symposium August, 24-27, 1994. Historik-filosofiske Meddelelser, 72: 292-324.

COOK, A.B. (1914). Zeus: A study in Ancient Religion, vol.1. Cambridge: Cambridge University Press.

COOK, A.B. (1914-1940). Zeus: A study in Ancient Religion I-III. Cambridge: Cambridge University Press.

COOK, A.B. (1990). Crise et transformation des sociétés archaïques de I'ttalie antique au Ve siècle av. JC. Actes de la table ronde de Rome (19-21 novembre 1987). Roma: École Française de Rome.

COOPER, F.A. et alii. (1983). The temple of Zeus at Nemea: Perspectives and prospects. A Guide to the Exhibition, Benaki Museum April 1983. Atenas: Benaki Museum.

CORDIANO, G. (1998). Lo Zeus dell'Alece: una proposta di localizzazione. Gerión, 16: 161-175.

CORNELLI, G. (org.) (2010). Representações da Cidade Antiga: categorias históricas e discursos filosóficos. Coimbra: Imprensa Universidade de Coimbra.

CORSO, A. (2002). The triad of Zeus Soter, Artemis Soteira and Megalopolis. In: ØSTBY, E. (Ed.). Ancient Arcadia. Papers from the third international seminar on Ancient Arcadia held at the Norwegian Institute at Athens, 7-10 May 2002. Atenas, Norwegian Institute at Athens: 225-234.

COSTABILE, F. (Org.). (1992). Polis ed Olympieion a Locri Epizefiri. Costituzione, Economia e Finanze di una città della Magna Grecia. Catanzaro: Rubbetino.

COSTAMAgNA, L.; SABBIONE, C. (1990). Una Città in Magna Grecia. Locri Epizefiri. Guida Archeologica. Reggio Calabria: Laruffa Editore.

COULSON, W.; KYRIELEIS, H. (Eds.) (1992). Proceedings of an International Symposium on the Olympic Games, 5-9 september, 1998. Atenas: Deutsches Archäologisches Institut Athen. 
COULTON, J.J. (1977). Greek Architects at Work. Londres: Paul Elek.

COURBIN, P. (1954). Chronique des Fouilles en 1953. BCH, 78: 95-229.

CUNNINGHAM, T.; SACKETT, L.H. (2009). Does the widespread cult activity at Palaikastro call for a special explanation? In: D'AGATA, A.L.; VAN DE MOORTEL, A. (Eds.). Archaeologies of Cult: Essays on Ritual and Cult in Crete. Hesperia, Suppl., 42. Princeton, American School of Classical Studies: 79-97.

CUSUMANO, N. (2006). I siculi. In: ANNELLO, P.; MARTORANA, G.; SAMMARTANO, R. (Eds.). Ethne e Religione nella Sicilia Antica. Atti del convegno Internazionale (Palermo, 6-7 dicembre). Roma, G. Bretschneider: 121-145 (Supplementi a "Kókalos", 18).

DAKARIS, S. (2003). Dodona. Atenas: Cassa Fondi Archeologici ed Espropri.

DAUX, G. (1960). Chroniques de fouilles er découvertes archéologiques en Grèce en 1959. BCH, 84 (2): 617-874.

DAWKINS, R.M. (1905-1906). Excavations at Palaikastro, V. BSA, 12: 1-8.

DAWKINS, R.M.; CURRENLLY, C.T. (1903-1904). Excavations at Palaikastro, III. BSA, 10: 192-231.

DAWKINS, R.M.; HAWES, C.H.; BOSANQUET, R.C. (1904-1905). Excavations at Palaikastro, IV. BSA, 11: 258-308.

DE ANGELIS, F. (2003). Megara Hyblaia and Selinous. The Development of Two Greek City-States in Archaic Sicily. Oxford: Oxford University School of Archaeology (Oxford University School of Archaeology Monograph, 57).

DE JULIIS, E.M. (2001). Metaponto. Città della Magna Grecia. Bari: Edipuglia.

DE POLIGNAC, F. (1994). Mediation, competition, and sovereignty: the evolution of rural sanctuaries in Geometric Greece. In: ALCOCK, S.E.; OSBORNE, R. (Eds.). Placing the Gods: sanctuaries and sacred space in ancient Greece. Oxford, The Clarendon Press: 3-18.

DE POLIGNAC, F. (1995). Cults, Territory and the Origins of the Greek City-State. Chicago; Londres: The University of Chicago Press.

DE POLIGNAC, F. (1999). L'instalation des dieux el la genèse des cités en Grèce d'Occident, une question resolute? In:: AA.VV. La Colonization Grecque en Mediterranée Occidentale. Roma, École Française de Rome: 202-229.

DE POLIGNAC, F. (2005). Forms and process: some thoughts on the meaning of urbanization in early Archaic Greece. In: OSBORNE, R.; CUNLIFFE (Eds.). Mediterranean Urbanization 800-600 BC. Oxford, Oxford University Press: 45-69 (Proceedings of the Bristish Academy, 126).

DE POLIGNAC, F. (2006). Analyse de l'espace et urbanisations en Grèce archaïque: quelques pistes de recherche recentes. REA,108 (1): 203-223.

DE SENSI SESTITO, G. (1994). II federalismo in Magna Grecia: la lega italiota. In: FORESTI, L.A. (Ed.). Federazioni e Federalismo nell' Europa Antica. Milão, Vita e Pensiero: 195-216.

DE SIENA, A. (1978). Scavo del teatro-ekklesiasterion di Metaponto. In: Atti Taranto, 18, Gli Eubei d'Occidente: 357366.

DE SIENA, A. (1998). Metaponto: problemi urbanistici e scoperte recenti. In: GRECO, E. (Ed.). Siritide e Metapontino. Storie di due territori coloniali. Atti dell'Incontro di Studio; Policoro, 31 ottobre-2 novembre 1991. NapolesPaestum, Centro Jean Bérard; Fondazione Paestum: 141-170 (Cahiers du Centre Jean Bérard, 20).

DELIGIANNAKIS, G.; GALANAKIS, Y. (Eds.) (2009). The Aegean and its Cultures. Proceedings of the first OxfordAthens graduate student workshop organized by the Greek Society and the University of Oxford Taylor Institution, 22-23 April 2005. Oxford: Archaeopress.

DENGATE, C. (1988). The sanctuaries of Apollo in the Peloponnese. Tese. Chicago: University of Chicago.

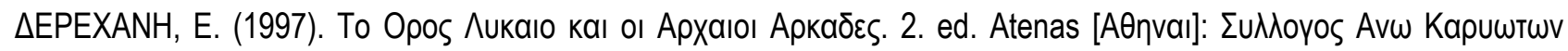
Аркабіаб.

DEUBNER, L. (1932). Attische Feste. Berlim: Wissenschaftliche Buchgesellschaft.

DI GIOVANNI, G. (1991). Selinunte. Itinerario Archeologico. Agrigento: Studio Media; Palermo: Priulla.

DINIZ, S. (2011). Os santuários de Hera enquanto elementos do espaço políade. Dissertação. Mestrado em Arqueologia. São Paulo: Museu de Arqueologia e Etnologia, Universidade de São Paulo. 
DINSMOOR, W.B. (1949). The Largest Temple in the Peloponnesos. Hesperia Supplements. Comemorative Studies in Honor of Theodore Leslie Shear, 8: 104-115.

DINSMOOR, W.B. (1950). The Architecture of Ancient Greece. An Account of its Historic Development. Londres; N. York; Toront; Sidney: B.T. Batsford.

DONNELLAN, L. (2012). Apollo mediating identities in ancient Greek Sicily. BABESCH Annual Papers on Mediterranean Archaeology, 87: 173-186.

DREHER, M. (2008). La Sicilia antica. Bolonha: II Mulino.

DRIESSEN, J.M.; MacGILLIVRAY; SACKETT, L.H. (2002). Ancient Palaikastro: an exhibition to mark 100 years of archaeological work 1902-2002. Atenas: The British School at Athens.

DRIESSEN-GAIGNEROT, F. (2011). The frieze from the temple of Dictaean Zeus at Palaikastro. In: AN $\triangle P E A \triangle A K H-$

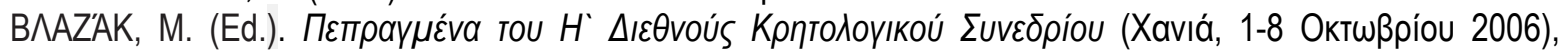
Touos A5, Xaniá: 425-436.

DUARTE, C.W.G. (2010). Geometria e Aritmética na Concepção dos Templos Dóricos Gregos. Dissertação. Mestrado em Arqueologia. São Paulo: Museu de Arqueologia e Etnologia, Universidade de São Paulo.

DUEV, R. (2008). Zeus and Dionysus in the light of linear B records. In: SACCONI, A.; DEL FREO, M.; GODART, L.; NEGRI, M. (Eds.). Atti del XII Colloquio internazionale di Micenologia. Roma, 20-25 frebbraio 2006. Pasiphae, I. Pisa; Roma, Fabrizio Serra Editore: 223-230.

DUMBABIN, T.J.; HOOPER, R.J; SPAWTHORTH, A. (2012). Ithome (s.v.). In: HORNBLOWER, S.; SPAWTHORTH, A.; EIDINOW, E. (Eds.). The Oxford Classical Dictionary. 4. ed. Oxford, Oxford University Press: 752.

DUPLOUY, A. (2012). Culti e cultura nella Grecia di etá geométrica (1000-750 a.C.). Atti del Cinquantesimo convegno di studi sulla Magna Grecia (Taranto 1-4 Ottobre 2010). Tarento: Istituto per la storia e l'archeologia dela Magna Grecia: 103-132.

EHREMBERG, V; RHODES, P.J. (2012). Tyranny (s.v.). In: HORNBLOWER, S.; SPAWFORTH, A.; EIDINOW, E. (Eds.). The Oxford Classical Dictionary. 4. ed. Oxford, Oxford University Press: 1523.

EIDINOW, E. (2011). Networks and narratives: a model for ancient Greek religion. Kernos, 24: 9-38.

ERRINGTON, R.M. (2012). Achaean confederacy (s.v). In: HORNBLOWER, S.; SPAWTHORTH, A.; EIDINOW, E. (Eds.). The Oxford Classical Dictionary. 4. ed. Oxford, Oxford University Press: 4-5.

ETIENNE, R. (2004). Athènes, espaces urbains et histoire. Des origines à la fin du Ille siècle ap. J.-C. Paris: Hachette.

EVGENIDOU, D. et alii (2007). Coins in the ancient Greek world. Atenas: Ministry of Culture; Numismatic Museum.

FABBRICOTTI, E. (2000). Ain Hofra, Cirene. In: BONACASA, N.; ENSOLI, S. (Eds.). Cirene. Milão: Electa.

FABBRICOTTI, E. (2000). La Chora. In: BONACASA, N.; ENSOLI, S. (Eds.). Cirene. Milão, Electa: 181-182.

FALEZZA, G. (2009). I Luoghi di Culto della Grecia Settentrionale in Età Romana. Tese. Pádua: Università degli Studi di Padova.

FARAONE, C.A. (1992). Talismans and Trojan Horses: Guardian Statues in Ancient Greek Myth and Ritual. Oxford: Oxford University Press.

FERRI, S. (1923). Contributi di Cirene alla Storia della Religione Greca. Roma: Libr. di Cultura (Collezione "Graphé", 2).

FILOCAMO, A. (2009-2012). Locri Epizefiri. L'archivio di Zeus e la monetazione. Minima Epigraphica et Papyrologica, XII-XV, 14-17: 115-155.

FISCHER-BOSSERT, W. (2012). The coinage of Sicily. In: METCALF, W.E. (Ed.). The Oxford Handbook of Greek and Roman coinage. Oxford, Oxford University Press: 142-156.

FISCHER-HANSEN, T.; NIELSEN, T.H.; AMPOLO, C. (2004). Italia and Kampania. In: IACP: 249-320.

FISCHER-HANSEN, T.; NIELSEN, T.H.; AMPOLO, C. (2004). Sikelia. In: IACP: 173-248.

FISHER, N.; VAN WEES, H. (Eds.) (1998). Archaic Greece: new approaches and new evidences. Londres; Swansea: Duckworth and The Classical Press of Wales. 
FLORENZANO, M.B.B. (1995). Anotações sobre as representações de monstros nas moedas da Grécia antiga. Revista do Museu de Arqueologia e Etnologia, São Paulo, 5: 223-234.

FLORENZANO, M.B.B. (2001). Fontes sobre a invenção da moeda: apresentação crítica. Revista do Museu de Arqueologia e Etnologia, São Paulo, 11: 201-211.

FLORENZANO, M.B.B. (2005). Coins and religion: representations of Demeter and Kore-Persephone on Sicilian Greek Coins. Revue Belge de Numismatique et de Sigillographie, 41: 1-29.

FLORENZANO, M.B.B. (2010). A origem da Pólis: os caminhos da Arqueologia. In: CORNELLI, G. (Org.). Representações da Cidade Antiga: categorias históricas e discursos filosóficos. Coimbra, Imprensa Universidade de Coimbra: 39-49.

FORESTI, L.A. (Ed.) (1994). Federazioni e Federalismo nell' Europa Antica. Milão: Vita e Pensiero.

FOUGĖRES, G. (1898). Mantinée et l' Arcadie Orientale. Tese. Faculté des Lettres de Paris. Paris: A. Fontemoing (Bibliothèque des Écoles Françaises d'Athènes et de Roma, 78).

FRONDA, M. (2013). Southern Italy: sanctuary, panegyris, and Italiote identity. In: FUNKE, P.; HAAKE, M. (Eds.). Greek Federal States and their Sanctuaries. Identity and integration. Stuttgart, Franz Steiner: 123-138.

FUNKE, P.; HAAKE, M. (Eds.) (2013). Greek Federal States and their Sanctuaries. Identity and integration. Stuttgart: Franz Steiner.

FÜRTWÄNGLER, A.; FIECHTER, E.R.; THIERSCH, H. (1906). Aegina: das Heilgtum der Aphaia I. Munique, Akademie der Wissenschaften.

GABRICI, E. (1927). II santuario della Malophoros a Selinunte. MonAnt, 32: 91-105.

GALVAGNO, E. (2000). Politica ed Economia nella Sicilia greca. Roma: Carocci Editore.

GANS, U.W.; KREILINGER, U. (2002). The sanctuary of Zeus Soter at Megalopolis. In: HÄGG, R. (Ed.). Peloponnesian Sanctuaries and Cults. Proceedings of the Ninth International Symposium at the Sweedish Institute at Athens, 11-13 June 1994. Estocolmo, Instituti Atheniensis Regni Sueciae: 187-191 (Acta Instituti Atheniensis Regni Sueciae, Series 4a, 58).

GARDINER, N. (1925). Olympia, its History and Remains. Oxford: The Clarendon Press.

GARGANO, G. (2012). Vibo Valentia, fonti numismatiche. In: GULLETTA, M.I.; CASSANELLI, C. (Eds.). Siti Torre Castelluccia - Zambrone. Pisa, Scuola Normale Superiore; Roma, École Française de Rome; Napoli, Centre J. Bérard: 882-889 (Bibliografia topografica della colonizzazione greca in Italia e nelle isole tirreniche, 21).

GARRAFO, S. (1976-77). Zeus Eleutherios - Zeus Olympios: note di numismatica siracusa. AIIN, 23-24: 9-50.

GEORGIADIS, M.; GALLOU, C. (2009). The Past in the Past: the significance of memory and tradition in the transmission of culture. Oxford: Archaeopress (BAR International Series, 1925).

GIACOMELLI, R. (1988). Achaea Magno-Graeca. Le iscrizioni archaiche in alfabeto acheo di Magna Grecia. Brescia: Paideia.

GIACOMETTI, D. (2001). L'Acaia fra VI e V secolo a.C. Rivista Storica dell'Antichità, 31: 7-41.

GIACOMETTI, D. (2005). Metaponto. Gli dei e gli eroi nella storia di una polis di Magna Grecia. Cosenza: Edizioni Lionello Giordano.

GIANGIULIO, M. (1993). Le Città di Magna Grecia e Olimpia in Età Arcaica. Aspetti della Documentazione e della Problematica Storica. In: MASTROCINQUE, A. (Ed.). I Grandi Santuari della Grecia e I'Occidente. Labirinti, vol. 3. Trento, Università degli Studi di Trento: 93-118.

GIARDINO, L.; DE SIENA, A. (1999). Metaponto. In: GRECO, E. (a cura di). La Città Greca Antica. Istituzioni, società e forme urbane. Roma, Donzelli editore: 329-363.

GOETTE, H.R. (2008). Athens, Attica and Megarid. An archaeological guide. Londres; N. York: Routledge.

GRANDJEAN, C. (2003). Les messéniens de 370/369 au 1er siècle de notre ère. Monnayages et histoire. BCH, Supplément 44, Paris-Atenas.

GRANDJEAN, Y.; SALVIAT, F. (2000). Guide de Thasos. Atenas: École Française d"Athènes. 
GRECO, E. (1990). Spazi pubblici e impianti urbani. In: PUGLIESI CARRATELLI, G. (Ed.). Magna Grecia. Arte e Artigianato. Milão, Electa: 9-48.

GRECO, E. (2006). Agora e Zeus Agoraios. In: MORANDI BONACOSSI, D. et alii (Eds.). Tra Oriente e Occidente. Studi in onore di Elenea di Filippo Balestrazzi. Padua, Sargone Editrice e Libreria: 327-335.

GRECO, E. (2008). Magna Grecia. Roma-Bari: Laterza (Guide Archeologiche Laterza).

GRECO, E. (2011). Topografia di Atene. Sviluppo Urbano e Monumenti dalle origini al III secolo d.C. Tomo 2. Colline sud-occidentali-valle dell'llisso. Atenas/Paestum: Scuola Archeologica Italiana di Atene; Pandemos (Studi di Archeologia e di Topogarfia di Atene e dell'Attica, 1).

GRECO, E.; D'AMBROSIO, I.; THEODORESCU, D. (1995). Guida Archeologica e Storica agli Scavi, al Museo ed alle Antichità di Poseidonia-Paestum. Tarento: La Colomba-Scorpione Editrice (Capire l'Antico).

GRECO, E.; GRECO, G.; PONTRANDOLFO, A. (2008). Magna Grecia. Bari: Editori Laterza (Guide Archeologiche Laterza).

GRECO, E.; GRECO, G.; PONTRANDOLFO, A. (c. 2000). Da Poseidonia a Paestum. Paestum: Museo Archeologico Nazionale di Paestum; Ingegneria per la Cultura.

GRECO, E.; LONGO, F. (2000). Tekmeria. Paestum: Pandemos; Fondazione Paestum.

GRECO, E.; LONGO, L. [2000]. Poseidonia-Paestum. La visita della città. Roma: Ingegneria per la Cultura.

GRECO, E.; THEODORESCU, D. (1983). Poseidonia-Paestum II. L'Agora. Roma: École Française de Rome.

GRECO, E.; TORELLI, M. (1983). Storia dell'Urbanistica. II Mondo Greco. Bari: Laterza.

GRIFFO, P.I. (2005). Akragas - Agrigento. La storia, topografia, i monumenti, gli scavi. Agrigento: Legambiente.

GROTTA, C. (2010). Zeus Meilichios a Selinunte. Roma: Giorgio Bretschneider Editore (Historica, 9).

GRUPICO, T.M. (2008). The Influence of Urban Planning on Temple Design in West Greece. Tese. N. Brunswick; N. Jersey: The State University of N. Jersey.

GULLETTA, M.I.; CASSANELLI, C. (Eds.). (2012). Siti Torre Castelluccia - Zambrone. Pisa, Scuola Normale Superiore; Roma, École Française de Rome; Napoli, Centre J. Bérard (Bibliografia topografica della colonizzazione greca in Italia e nelle isole tirreniche, 21).

GULLINI, G. (1989). L'Architettura. In: PUGLIESE-CARRATELLI, G.P. (Org.). Sikanie. Storia e Civiltà della Sicilia Greca. Milão, Garzanti: 460-472.

HÄGG, R. (Ed.) (2002). Peloponnesian Sanctuaries and Cults. Proceedings of the Ninth International Symposium at the Sweedish Institute at Athens, 11-13 June 1994. Estocolmo: Instituti Atheniensis Regni Sueciae (Acta Instituti Atheniensis Regni Sueciae, Series 4a., 48).

HALL, J.M. (1998). Ethnic Identity in Greek Antiquity. Cambridge: Cambridge University Press.

HALL, J.M. (2001). Quem eram os gregos. Revista do Museu de Arqueologia e Etnologia, São Paulo, 11: 213-225.

HALL, J.M. (2002). Hellenicity: Between Ethnicity and Culture. Chicago: Chicago University Press.

HALL, J.M. (2006). Dorians. In: WILSON, N. (Ed.). Encyclopedia of Ancient Greece. N. York, Routledge: 240.

HALL, J.M. (2007a). A History of Archaic Greek World ca. 1200-479 B.C.E. Malden: Blackwell.

HALL, J.M. (2007b). Polis, Community and Ethnic Identity. In: SHAPIRO, H.A. (Ed.). The Cambridge Companion to Archaic Greece. Cambridge, Cambridge University Press: 40-60.

HANSEN, M.H. (2006). Polis. An introduction to the ancient Greek-city-state. Oxford: Oxford University Press.

HANSEN, M.H.; NIELSEN, T.H. (Eds.). (2004). An Inventory of Archaic and Classical Poleis. Oxford; Nova York: Oxford Univiversity Press (Københavns Universitet; Polis Centret; Danish National Research Foundation).

HANSEN, M.H.; RAAFLAUB, K. (Eds.) (1996). More Studies in the Ancient Greek Polis. Stuttgart: Franz Steiner.

HATZOPOULOS, M.B. (2005). Dion (s.v.). In: IACP: 800-801.

HEAD, B. (1963). Historia Numorum, a manual of Greek numismatics. London: Spink \& Son. 
HEBERDEY, R. (1919). Altattische Poroskulptur. Ein Beitrag zur Geschichte der archaischen griechischen Kunst. Viena: Deutsches Archäologisches Institut; Osterreichisches Archäologisches Institut: A. Hölder.

HEILMEYER, W.D.; KALTSAS, N.; GHERKE, H.J.; HATZI, G.E.; BOCHER, S. (2012). Mythos Olympia. Kult und Spiele. Munique; Londres; N. York: Prestel.

HELLMANN, M.C. (1998). L'Arquitecture Grecque. Paris: Librairie Generale Française.

HELLMANN, M.C. (2002). L'Arquitecture Grecque, 1. Les Principes de la construction. Paris: Picard.

HELLMANN, M.C. (2006). L'Arquitecture Grecque, 2. Architecture religieuse et funéraire. Paris: Picard.

HELLSTRÖM, P. (2007). Labraunda. A guide to the Karian sanctuary of Zeus Labraundos. Istambul: Ege Yayinlari.

HELLSTRÖM, P.; THIEME, T. (1982). The Temple of Zeus. Estocolmo: Paul Aström Publishers (Labraunda Swedish Excavations and Researches, Vol.I, Parte 3).

HILL, B.H. (1966). The Temple of Zeus at Nemea. Princeton: American School of Classical Studies at Athens.

HIMMELMANN, N. (2001). La vie religieuse à Olympie: fonction et typologie des offrandes. In: PASQUIER, A. (Ed.). Olympie. Paris, Musée du Louvre: 153-179 (Louvre Conférences et Colloques).

HODDER, I. (1994). Interpretación en Arqueología: corrientes actuales. Barcelona: Critica; Grupo Grijalbo-Mondadori.

HODDER, I. (2003). Reading the Past. Current approaches to interpretation in archaeology. Cambridge: Cambridge University Press.

HOLLOWAY, R. (1975). Le monetazione di Agyrion, Aluntion, Entella, Hipana, Nakone, Stiela. In: Le Emissioni dei Centri Siculi fino all'Epoca di Timoleonte e i loro Rapporti con la Monetazione delle Colonie Greche di Sicilia. Atti del 4. Convegno del Centro Internazionale di Studi Numismatici, Napoli 9-14 aprile 1973. AIIN, 20: 133-145.

HÖLSCHER, T. (2014). Semiotics to Agency. In: MARCONI, C. (Ed.). The Oxford Handbook of Greek and Roman Art and Architecture. Oxford, Oxford University Press: 662-686.

HORNBLOWER, S.; SPAWFORTH, A.; EIDINOW, E. (Eds.) (2012). The Oxford Classical Dictionary. 4. ed. Oxford: Oxford University Press.

HORSTER, M.; KLÖCKNER, A. (2013). Cities and Priests. Cult personnel in Asia Minor and the Aegean islands from the Hellenistic to the Imperial period. Berlin; Boston: De Gruyter.

HUMPHREYS, S.C. (2004). The Strangeness of Gods: Historical Perspectives on the Interpretacion of Athenian Religion. Oxford; N. York: Oxford University Press.

JACOBSTHAL, P. (1906). Der Blitz in der orientalischen und griechischen Kunst (bis zum Einsetzen des rotfigurigen Stiles): ein formgeschichtlicher Versuch. Berlin, Weidmannsche Buchhandlung.

JACQUEMIN, A. (2001). Pausanias, témoin de la religion grecque dans le sanctuaire d'Olympie. In: PASQUIER, A. (Ed.). Olympie. Paris, Musée du Louvre: 181-213 (Louvre Conférences et Colloques).

JAMESON, M.H. (1965). Notes on the Sacrificial Calendar from Erchia. BCH, 89 (1): 154-172.

JAMESON, M.H.; JORDAN, D.R.; KOTANSKY, R.D. (1993). A lex sacra from Selinous. GRBM, 11: 81-102.

JANNELLI, L. (2004). Selinunte. In: CERCHIAI, L. et alii (Eds.). The Greek Cities of Magna Graecia end Sicily. Los Angeles, Paul Getty Museum: 256-267.

JENKINS, I. (1975). The coinages of Enna, Galaria, Piakos, Imachara, Kephaloidion and Longane. In: Le emissioni dei centri siculi fino all'epoca di Timoleonte e i loro rapporti con la monetazione delle colonie greche di Sicilia. Atti del $4^{\circ}$ Convegno del Centro Internazionale di Studi Numismatici, Napoli 9-14 aprile 1973. AIIN, 20: 77-103.

JENKINS, I. (1990). Ancient Greek Coins. Londres: Seaby.

JOST, M. (1985). Sanctuaries et Cults d'Arcadie. Paris: École Française d'Athènes (Études Péloponnésiennes, 9).

JOST, M. (1994). The Distribution of Sanctuaries in Civic Space in Arkadia. In: ALCOCK, S.E.; OSBORNE, E. (Eds.). Placing the Gods. Oxford, Oxford University Press: 217-230.

JOST, M. (1996). Les cultes dans une ville nouvelle d'Arcadie au IVe siècle: Mégalopolis. In: CARLIER, P. (Ed.). Le IVe siècle av. J.-C. Approches historiographiques. Nancy; Paris, De Boccard: 103-109. 
JOST, M. (1999). Les schémas de peuplement de l'Arcadie aux époques archaïque et classique. In: NIELSEN, T.H.; ROY, J. (Eds.). Defining Ancient Arkadia. Symposium, April, 1-4 1998. Copenhague [Munksgaad]: 192-247 (Historisk-Filosofiske Meddelelder, 78; Acts of the Copenhagen Polis Center, vol. 6).

JOST, M. (2005). Bêtes, hommes et dieux dans la religion arcadienne. In: ØSTBY, E. (Ed.). Ancient Arcadia. Papers from the third International Seminar on Ancient Arcadia held at the Norwegian Institute at Athens (7-10 May 2002). Atenas, Norwegian Institute at Athens: 93-104.

KARLSSON, L. (1995). The symbols of freedom and democracy on the bronze coinage of Timoleon. Acta Hyperborea. Danish Studies in Classical Archaeology, 6: 149-169.

KINDT, J. (2009). Polis Religion: a critical appreciation. Kernos, 22: 9-34.

KINDT, J. (2012). Rethinking Greek Religion. Cambridge: Cambridge University Press.

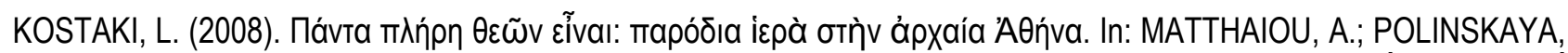

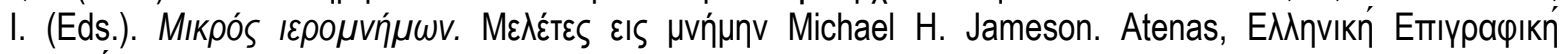
Eтаıргі́: $145-177$.

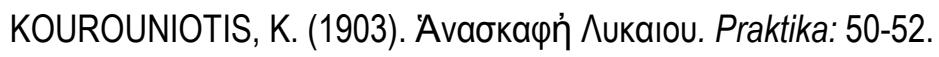

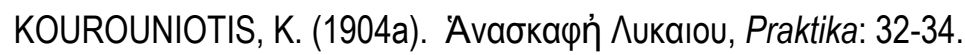

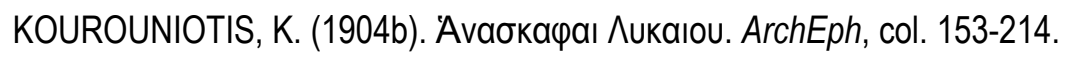

KOUROUNIOTIS, K. (1905). Comptes Rendus du Congrès International d'Arche'ologie I, Athènes. Atenas, Imprimerie Héstia: 255-256.

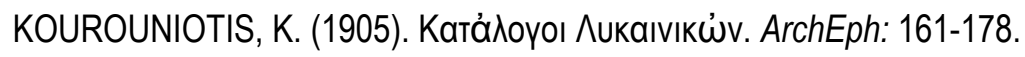

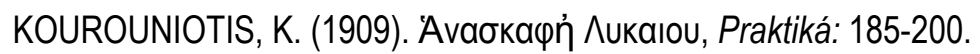

KOUTSOUMBA, D. (2004). Olympia. Archaeological Guides. Atenas: Explorer.

KRAAY, C.M. (1976). Archaic and Classical Greek Coins. Londres, Methuen.

KREMYDI-SICILIANOU, S. (1997). Coins. LIMC, vol. VIII (1 e 2). Thespiades - Zodiacus et Supplementum Abila Thersites. Düsseldorf, Zürich: Artemis.

KREMYDI-SICILIANOU, S. (2004). Multiple Concealments from the Sanctuary of Zeus Olympios at Dion. Three Roman Provincial Coin Hoards. Atenas; Paris: Diffusion de Boccard (ME/ETHMATA, 35).

KREUTZ, N. (2007). Zeus und die griechischen Poleis: topographische und religionsgeschichtliche. Untersuchungen von archaischer bis in hellenistische Zeit. Rahden/ Westf.: Marie Leidorf (Tübinger archäologische Forschungen, 3).

KURKE, L. (1999). Coins, Bodies, Games, and Golds: the politics of meaning in Archaic Greece. Princeton: Princeton University Press.

KYRIELEIS, H. (2001). Les fouilles allemandes à Olympie. In: PASQUIER, A. (Ed.). Olympie. Paris, Musée du Louvre: 45-74 (Louvre Conférences et Colloques).

KYRIELEIS, H. (2006). Anfänge und Frühzeit des Heiligtums von Olympia. Die Ausgrabungen am Pelopion 1987-1996. OIForsch, 31, Berlim.

KYRIELEIS, H. (2007). Olympia. Excavations and Discoveries at the Great Sanctuary. In: VALAVANIS, P. (Coord.). Great Moments in Greek Archaeology. Los Angeles, The J. Paul Getty Museum: 100-117.

LA TORRE, G.F. (2010). La tiranide dei Falaride e la politica territoriale di Agrigento. In: CACCAMO CALTABIANO, M.; RACCUIA, C; SANTAGATI, E. (Eds.). Tyrannis, Basileia, Imperium: forme, prassi e simboli del potere politico nel mondo greco e romano. Atti delle Giornate seminariali in onore di S. Nerina Consolo Langher (Messina 1719 Dicembre 2007). Messina, Dipartimento di Scienze dell'Antichità dell'Università degli Studi di Messina (Di.Sc.A.M.): $73-88$.

LA TORRE, G.F. (2011). Sicilia e Magna Grecia. Archeologia dela colonizzazione greca d'Occidente. Roma-Bari: Laterza.

LaBUFF, J. (2010). Karian sympoliteiai: causes and implications of political merger at the periphery of the Greek world. Dissertação. Pensylvannia: University of Pennsylvania. 
LACROIX, L. (1949). Les Reproductions de Statues sur les Monnaies Grecques. Liège: Faculté de Philosophie et Lettres.

LACROIX, L. (1965). Monnaies et Colonisation dans I'Occident Grec. Bruxelas: Académie Royale de Belgique.

LACROIX, L. (1974). Études d'Archéologie Numismatique, Vol.3. Paris: de Boccard.

LAFOND, Y. (1991). Artémis en Achaïe. REG, 104: 410-433.

LAKY, L.A. (2007). As moedas de Olímpia e a consolidação da imagética de Zeus na Grécia Clássica. Relatório final de iniciação científica da FAPESP. São Paulo: Universidade de São Paulo; Museu de Arqueologia e Etnologia.

LAKY, L.A. (2008). As moedas de Olímpia e a consolidação da imagética de Zeus na Grécia Clássica. Revista do Museu de Arqueologia e Etnologia, São Paulo, 18: 211-237.

LAKY, L.A. (2011). Olímpia e os Olimpieia: a origem e difusão do culto de Zeus Olímpio na Grécia dos séculos VI e V a.C. Dissertação. Mestrado em Arqueologia. São Paulo: Museu de Arqueologia e Etnologia, Universidade de S. Paulo.

LAKY, L.A. (2013). Olímpia e os Olimpiéia: a origem e difusão do culto de Zeus Olímpio na Grécia dos séculos VI e V a.C. Revista do Museu de Arqueologia e Etnologia, São Paulo, Suplemento 16.

LALONDE, G.V. (2006). Horos Dios: an Athenian shrine and cult of Zeus. Leiden; Boston: Brill (Monumenta Graeca et Romana, 11).

LAMBERT, S.D. (2000). Two notes on Attic Leges Sacrae. ZPE, 130: 71-80.

LANDOLFI, M. (1985). La stipe votiva del santuario di Zeus. Studi su lasos di Caria. Bollettino d'Arte, Suppl. AL, 31-32: 59-66.

LANG, F. (1992). Die Keramik von Babes in der Landschaft Elis. MDAI(A), 107: 43-105.

LANGDON, M.K. (1976). Sanctuary of Zeus on Mount Hymettos. Princeton, N. Jersey: American School of Classical Studies at Athens (Hesperia Supplement, XVI).

LARSON, J. (2007). Ancient Greek Cults. A Guide. N. York; Londres: Routledge.

LAVIOSA, C. (1985). II santuario do Zeus Megistos e il suo kouros arcaico. Studi su lasos di Caria. Bollettino d'Arte, Suppl. AL, 31-32: 47-54.

LAWRENCE, A.W. (1998). Arquitetura Grega. São Paulo: Cosac \& Naify.

LAZZARINI, M.L. (1998). Zeus Meilichios e le Eumenidi: alcune considerazione. In: CATANI, E.; MARENGO, S.M. (Orgs.). La Cirenaica in età antica. Atti del Convegno Internazionale di Studi (Macerata 18-20 Maggio 1995). Pisa-Roma, Istituti Editoriali e Poligrafici Internazionali: 311-318.

LE RIDER, G. (1966). Monnaies crétoises du Ve au ler siècle av. J.-C. Paris: Librairie Orientaliste P. Geuthner.

LECLANT, J; CLERC, G. (1997). Ammon. LIMC, vol.I. Düsseldorf; Zürich, Artemis.

LEHMANN, C. (1981). The striding god of Zancle-Messana. Revue Belge de Numismatique, 127: 19-32.

LEVENTI, I. (1997). Classical Period II: 4th Centh. B.C. LIMC, vol. VIII (1 e 2). Thespiades - Zodiacus et Supplementum Abila - Thersites. Düsseldorf; Zürich, Artemis.

LÉVÊQUE, P.; SECHAN, L. (1990). Les Grandes Divinités de la Grèce. Paris: Armand Colin Éditeur.

LHÔTE, E. (2006). Les lamelles oraculaires de Dodone. Genebra: Librairie Droz (Hautes Études du Monde GrécoRomaine, 36).

LINKE, B. (2006). Zeus als Gott der Ordnung. In: FREITAG, K.; FUNKE, P.; HAAKE, M. (Eds.). Kult-Politik-Ethnos: überregionale Heiligtümer im Spannungsfeld von Kult und Politik. Kolloquium, Münster, 23.-24. November 2001. Stuttgart, Franz Steiner: $89-120$ (Historia, Einzelschriften, 198).

LIPPOLIS, E. (1988-89). II santuario di Athena a Lindo. ASAtene, 66-67: 97-157.

LIPPOLIS, E.; LIVADIOTTI, M.; ROCCO, G. (2007). Architettura Greca: storia e monumenti del mondo della polis, dalle origini al V secolo. Milão: Mondadori.

LISSI, E. (1958). Siracusa: Scavo presso L'Olympieion (anno 1953). NSc, 12: 197-223.

LO MONACO, A. (2009). II crepusculo degli dei d'Achaia. Religione e culti in Arcadia, Elide, Laconia e Messenia dalla Conquista Romana ad Età Flavia. Roma: "L'Erma" di Bretschneider. 
LO MONACO, V. (2008-2009). Le emissioni d'argento di Akragas della fine del V sec. a.C. Tesi di laurea. Università degli Studi di Catania; Scuola di Specializzazione in Archeologia.

LO PORTO, F.G. (1988). Testimonianze di culti metapontini. Xenia, 16: 5-28.

LOMAS, K. (2012). Croton (s.v.). In: HORNBLOWER, S.; SPAWTHORTH, A.; EIDINOW, E. (Eds.). The Oxford Classical Dictionary. 4. ed. Oxford, Oxford University Press: 395.

LURAGHI, N. (1994). Tirannidi Archaiche in Sicilia e Magna Grecia. Da Panezio di Leontini alla caduta dei Deinomenidi. Firenze: Leo S. Olschki.

LURAGHI, N. (2008). The Ancient Messenians. Constructions of Ethnicity and Memory. Cambridge: Cambridge Univiversity Press.

MacGILLIVRAY, J.A.; SACKETT, L.H. (2010). Palaikastro. In: CLINE, E.H. (Ed.). The Bronze Age Aegean. Cap. 43. Oxford, Oxford University Press: 570-581 (The Oxford Handbook).

MADDOLI, G. (Ed.) (1982). Temesa e il suo Territorio. Atti del colloquio di Perugia e Trevi (30-31 maggio 1981). Taranto: Instituto per la Storia e I'Archeologia della Magna Grecia.

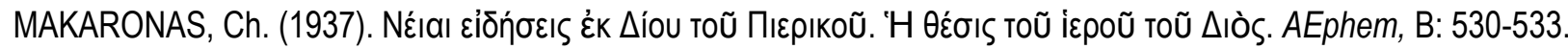

MALKIN, I. (1994). Myth and Territory in the Spartan Mediterranean. Cambridge: Cambridge University Press.

MALKIN, I. (2005). Mediterranean Paradigms and Classical Antiquity. Londres: Routledge.

MALKIN, I. (2006). Networks and the Rise of Greek Civilization in the Archaic Period. Nellie Wallace Lectures in Oxford (no prelo).

MALKIN, I. (2011). A Small Greek World. Oxford: Oxford University Press.

MALKIN, I. (Ed.) (2003). Networks and the emergence of Greek Identity. Mediterranean Paradigms and Classical Antiquity. Mediterranean Historical Review, 18: 56-74.

MALKIN, I.; CONSTANTAKOPOULOU, C.; PANAGOPOULOU, K. (Eds.) (2009). Greek and Roman Networks in the Mediterranean. Londres; N. York: Routledge.

MANGANARO, G. (1974-1975). La caduta dei Deinomenidi e il 'politikon nomisma' in Sicilia nella prima metà del V sec. a.C. AIIN, 21-22: 9-40.

MANGANARO, G. (1975). II 'politikon nomisma' nella Sicilia fino a Timoleonte: caratteri unitari e grecità integrale di esso. In: Le emissioni dei centri siculi fino all'epoca di Timoleonte e i loro rapporti con la monetazione delle colonie greche di Sicilia. Atti del 4. Convegno del Centro Internazionale di Studi Numismatici, Napoli 9-14 aprile 1973. AIIN, 20: 53-65.

MANGANARO, G. (1996). Appendice: La monetazione di Katane dal V al I sec. a.C. In: GENTILI, B. (Ed.). Catania antica: atti del Convegno della S.I.S.A.C. (Catania 23-24 maggio 1992). Quaderni Urbinati di Cultura Classica. Atti di convegni, 6: 303-321.

MANGANARO, G. (2001). Metoikismos dei Danklaioi a Mylai. Revue Suisse de Numismatique, 80: 7-18.

MANGANARO, G. (2003). Ancora sui culti della Sicilia greca: Zeus Sóter e il fiume Sichas. Rivista Svizzera di Numismatica, 82: 5-15.

MARCHETTI, P. (1994). Mythes et topographie d'Argos II-III. BCH, 118: 131-160.

MARCHETTI, P.; KOLOKOTSAS, K.; ABADIE-REYNAL, C. (1995). Le nymphée de l' agora d'Argos: fouille, étude architecturale et historique. Paris: De Boccard; École Française (Études Péloponnésiennes, 11).

MARCONI, C. (1994). Selinunte. Le Metope dell'Heraion. Modena: Panini Franco Cosimo Editore.

MARCONI, C. (1997). I Titani e Zeus Olimpio. Sugli Atlanti dell'Olympieion di Agrigento. Prospettiva, 87/88: 2-13.

MARCONI, C. (2007). Temple Decoration and Cultural Identity in the Archaic Greek World: the Metopes of Selinus. Cambridge: Cambridge University Press.

MARI, M. (2002). Al di là dell'Olimpo: Macedoni e Grandi Santuari della Grecia dall'età Arcaica al Primo Ellenismo. Paris; Atenas: Diffusion; De Boccard (ME/ETHMATA, 34).

MARINATOS, N. (1994). Investigations at the Amnissos Cave (abstract). AJA, 98: 306. 
MARINATOS, N.; HÄGG, R. (1993). Greek Sanctuaries. New Approaches. Londres; N. York: Routledge.

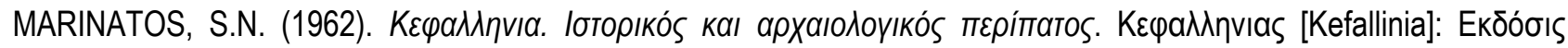
T.E.Г.

MARKETOU, T. (1988). New evidence on the topography and site history of prehistoric lalysos. In: DIETZ, S.; PAPACHRISTODOULOU, I. (Eds.). Archaeology in Dodecanese. Copenhague, National Museum of Denmark, Dept. of Near Eastern and Classical Antiquities: 27-33.

MARTELLI, M. (1988). La stipe votiva dell'Athenaion di lalysos, un primo bilancio. In: DIETZ, S.; PAPACHRISTODOULOU, I. (Eds.). Archaeology in Dodecanese. Copenhague, National Museum of Denmark, Dept. of Near Eastern and Classical Antiquities: 104-120.

MARTELLI, M. (1996). laliso: la stipe votiva dell'Athenaion di laliso. In: LIVADIOTTI, M.; ROCCO, G. (Eds.). La presenza italiana nel Dodecaneso tra II 1912 e il 1948. La ricerca archeologica, la conservazione, le scelte progettuali. Catânia, Edizioni del Prisma: 46-50.

MARTIN, R. (1951). Recherches sur L'Agora Grecque. Paris: Boccard.

MARTIN, R. (1956). L'Urbanisme dans la Gréce Antique. Paris: Picard.

MARTIN, T.R. (1985). Sovereignty and Coinage in Classical Greece. N. Jersey: Princeton University Press.

MARTIN, T.R. (1995). Coins, Mints, and the Polis. HfM, 72: 257-291.

MARTORANO, F. (1992). L'Olympieion ed il suo Temenos. In: COSTABILE, F. (Org.). Polis ed Olympieion a Locri Epizefiri. Costituzione, Economia e Finanze di una città della Magna Grecia. Catanzaro, Rubbetino: 37-39.

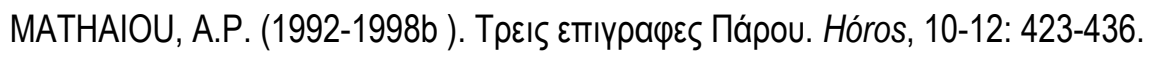

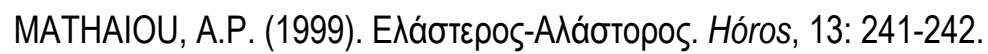

MERTENS, D. (1982). Das Theater-Ekklesiasterion auf der Agora von Metapont. Architectura, 12: 93-124.

MERTENS, D. (2006). Città e Monumenti dei Greci d'Occidente. Roma: L'"Erma" di Bretschneider.

MERTENS, J. (1947). Le tétradrachme à la légende $\triangle A N K \wedge A I O N$. Revue Belge de Numismatique, 93: 19-33.

MERTENS-HORN, M. (1992). Die archaischen Baufriese aus Metapont. RM, 99: 1-122.

METCALF, W.E. (2012). The Oxford Handbook of Greek and Roman Coinage. Oxford: Oxford University Press.

MEYER, E. (1939). Peloponnesische Wanderungen. Reisen und Forschungen zur antiken und mittelalterlichen Topographie von Arkadien und Achaia. Zurique e Leipzig: M. Niehans.

MEYER, E. (1957). Neue Peloponnesische Wanderungen. Berna: Aedibus A. Francke.

MICHAUD, J.- P. (1970). "Dion”. BCH, 94 (2), Chronique des Fouilles en 1968 et 1969: 1060.

MILI, M. (2015). Religion and Society in Ancient Thessaly. Oxford: Oxford University Press.

MILLER, S.G. (1975). Excavations at Nemea. Hesperia, 44: 143-172.

MILLER, S.G. (1976). Excavations at Nemea. Hesperia, 45: 174-202.

MILLER, S.G. (1977). Excavations at Nemea. Hesperia, 46: 1-26.

MILLER, S.G. (1978). Excavations at Nemea. Hesperia, 47: 58-88.

MILLER, S.G. (1979). Excavations at Nemea. Hesperia, 48: 73-103.

MILLER, S.G. (1980). Excavations at Nemea. Hesperia, 49: 178-205.

MILLER, S.G. (1981). Excavations at Nemea. Hesperia, 50: 45-67.

MILLER, S.G. (1982). Excavations at Nemea. Hesperia, 51: 19-40.

MILLER, S.G. (1983). Excavations at Nemea. Hesperia, 52: 70-95.

MILLER, S.G. (1988). Excavations at Nemea. Hesperia, 57: 1-20. 
MILLER, S.G. (1988). Excavations at the Panhellenic site of Nemea: cults, politics and games. In: RASCHKE, W.J. (Ed.). The Archaeology of the Olympics. The Olympics and other festivals in antiquity. Madison, Wis, University of Wisconsin Press: 141-151 (Wisconsin Studies in Classics).

MILLER, S.G. (2004). Nemea. A Guide to the Site and Museum. Atenas: Ministry of Culture; Archaeological Receipts Fund.

MORENO, P. (1995). Lisippo. L'arte e la fortuna. Roma: Palazzo delle Esposizioni; Milão: Fabbri.

MORGAN, C. (1993). The Origins of Pan-hellenism. In: MARINATOS, N.; HÄGG, R. (Eds.). Greek Sanctuaries. New Approaches. Londres; N. York, Routledge: 18-44.

MORGAN, C. (1994). Athletes and Oracles. The transformation of Olympia and Delphi in the eighth century B.C. Cambridge: Cambridge University Press.

MORGAN, C. (1997). The Archaeology of Sanctuaries in Early Iron Age and Archaic Ethne: A Preliminary View. In: MITCHELL, L.G.; RHODES, P.J. (Eds.). The Development of the Polis in Archaic Greece. Londres; N. York, Routledge: 168-198.

MORGAN, C. (2005). Early Greek States beyond the Polis. N. York: Routledge.

MORGAN, C.; HALL, J.M. (2004). Achaia. In: IACP: 473-488.

MORGAN, K.A. (2015). Pindar and the construction of Syracusan monarchy in the fifth century B.C. Oxford: Oxford University Press.

MORRIS, I. (2012). Votive offerings (s.v.). In: HORNBLOWER, S.; SPAWTHORTH, A.; EIDINOW, E. (Eds.). The Oxford Classical Dictionary. 4. ed. Oxford, Oxford University Press: 1564-1565.

MORRIS, I. (Ed.) (1995). Classical Greece: ancient histories and modern archaeologies. Cambridge: Cambridge University Press.

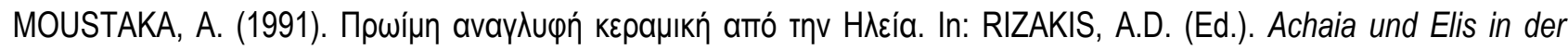
Antike. Akten des I. Internationalen Simposiums (Athen, 19-21 Mai, 1989). Atenas, Research Center for Greek and Roman Antiquity; National Hellenic Research Foundation: 341-350.

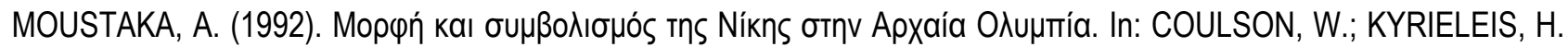
(Eds.). Proceedings of an International Symposium on the Olympic Games, 5-9 September, 1998. Atenas, Deutsches Archäologisches Institut Athen: 39-44.

MOUSTAKA, A. (2002a). On The Cult of Hera at Olympia. In: HÄGG, R. (Ed.). Peloponnesian Sanctuaries and Cults. Proceedings of the Ninth International Symposium at the Sweedish Institute at Athens, 11-13 June 1994. Estocolmo, Acta Instituti Atheniensis Regni Sueciae: 199-205 (Acta Instituti Atheniensis Regni Sueciae, Series 4a, 48).

MOUSTAKA, A. (2002b). Zeus und Hera im Heiligtum von Olympia und die Kulttopographie von Elis und Triphylien. In: KYRIELIS, H. (Ed.). Olympia 1875-2000: 125 Jahre deutsche Ausgrabungen; Internationales Symposium, Berlin 9-11. November 2000. Mainz, Deutsches Archäologisches Institut: 301-315.

MURGAN, A.M. (2014). Heavy metal in hallowed contexts. Continuity and change in aes deposits in Central Italy and Sicily. In: BOKERN, A.; ROWAN, C. (Eds.). Embodying Value? The Transformation of Objects in and from the Ancient World. Oxford, Archeopress: 65-75 (BAR international series, 2592).

MURRAY, O. (2012). Polis (s.v.). In: HORNBLOWER, S.; SPAWFORTH, A.; EIDINOW, E. (Eds.). The Oxford Classical Dictionary. 4. ed. Oxford, Oxford University Press: 1170-1171.

MUSTI, D. (2005). Magna Grecia. Il quadro storico. Bari: Laterza.

MUSTI, D. et alii (Eds.) (1991). La Transizione dal Miceneo all'Alto Arcaismo. Roma: Consiglio Nazionale delle Ricerche.

MYERS, J.W.; MYERS, E.E. (1992). The Aerial Atlas of Ancient Crete. Berkeley: University of California Press.

MYLONAS, G. (1943). The Lykaian Altar of Zeus. In: OLDFATHER, W.A. (Ed.). Classical Studies in Honour of William Abbott Oldfather. Urbana, Illinois; The University of Illinois Press: 122-133.

MYLONAS, G. (1944). The bronze statue from Artemision. Hesperia, 48 (2):143-160.

MYLONAS, G. (1946). The eagle of Zeus. The Classical Journal, 41 (5): 203-207. 
MYLONOPOULOS, J. (2006). Das Heiligtum des Zeus in Dodona. Zwischen Orakel und venatio. In: MYLONOPOULOS, J.; ROEDER, H. (Eds.). Archäologie und Ritual. Auf der Suche nach des rituellen Handlung in den antiken Kulturen Ägyptens und Griechenlands. Viena, Phoibos: 185-214.

NEER, R.T. (2007). Delphi, Olympia, and the Art of Politics. In: SHAPIRO, H.A. (Ed.). The Cambridge Companion to Archaic Greece. Cambridge, Cambridge University Press: 225-264.

NICOLET-PIERRE, H. (1975). Remarques sur la chronologie relative des plus anciennes séries de stateres éléens. RN, $6(17): 6-18$.

NICOLET-PIERRE, H. (2002). Numismatique Grecque. Paris: Armand Colin.

NIELSEN, T.H. (1996). Was there an Arkadian confederacy in the fifth century B.C.? In: HANSEN, M.H.; RAAFLAUB, K. (Eds.). More Studies in the Ancient Greek Polis. Stuttgart: Franz Steiner: 39-62.

NIELSEN, T.H. (1999). The concept of Arkadia. The people, their land, and their organization. In: NIELSEN, T.H.; ROY, J. (Eds.). Defining Ancient Arkadia. Symposium, April, 1-4, 1998. Copenhagen, Franz Steiner: 16-79 (Det Kongelige Danske Videnskabernes Selskab; Acts of the Copenhagen Polis Centre; 6).

NIELSEN, T.H. (2002). Even more Studies in the Ancient Greek Polis. Stuttgart: Franz Steiner (Papers from the Copenhagen Polis Centre; 6).

NIELSEN, T.H. (2004). Triphylia. In: IACP: 540-546.

NIELSEN, T.H. (2007). Olympia and the Classical Hellenic City-State Culture. HfM, 96: 1-139.

NIELSEN, T.H.; ROY, J. (2009). The Peloponnese. In: RAAFLAUB, K.A.; WEES, H. (Eds.). A Companion to Archaic Greece. Massachusets; Oxford, Willey-Blackwell: 255-272.

NIELSEN, T.H.; ROY, J. (2013). Can 'Federal sanctuaries' be identified in Triphylia and Arkadia? In: FUNKE, P.; HAAKE, M. (Eds.). Greek Federal States and their Sanctuaries. Identity and integration. Stuttgart, Franz Steiner: 227-241.

NIELSEN, T.H.; ROY, J. (Eds.) (1999). Defining Ancient Arkadia.Symposium, April, 1-4, 1998. Copenhagen: Franz Steiner (Det Kongelige Danske Videnskabernes Selskab; Acts of the Copenhagen Polis Centre; 6).

OLBRICH, G. (1976). Ein Heiligtum der Artemis Metapontina? Zur ikonographie der Terrakotta-Figuren von S. Biaggio bei Metapont. PP, 31: 376-408.

ORSI, P. (1903). L'Olympieion di Siracusa. MonAnt, 13: 369-392.

OSANNA, M. (1996). Santuari e Culti dell'Acaia Antica. Nápoles: Edizione Scientifiche Italiane.

OSBORNE, R.; CUNLIFFE (Eds.) (2005). Mediterranean Urbanization 800-600 BC. Oxford: Oxford University Press (Proceedings of the Bristish Academy, 126).

ØSTBY, E. (1978). The Temple of Casa Marafioti at Locri and some related buildings. Acta ad Archaeologiam et Artium Hisoriam Pertinentia; Institutum Romanum Novegiae, I (8): 25-47.

ØSTBY, E. (1992). Der dorische Tempel von Pherai. OpAth, 19: 85-113.

ØSTBY, E. (1994). A reconstruction of the Classical temple at Pherai. In: MISDRACHI-KAPON, R. (Ed.). La Thessalie. Quinze années de recherches archéologiques, 1975-1990. Billans et perspectives. Actes du Colloque International (Lyon 17-22 avril 1990). Atenas, Ministério da Cultura, Kapon: 139-142.

PAFFORD, P. (2013). Priestly Portion vs. Cult Fee. The Finances of Greek Sanctuaries. In: HORSTER, M.; KLÖCKNER, A. (Eds.). Cities and Priests. Cult personnel in Asia Minor and the Aegean islands from the Hellenistic to the Imperial period. Berlin; Boston, De Gruyter: 49-64.

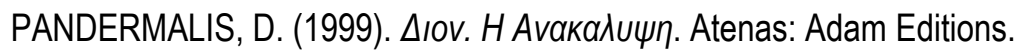

PARISE PRESICCE, C. (1984). Nuovo santuario periferico di Selinunte. Archeologia Classica, 36: 19-132.

PARISE PRESICCE, C. (2000). II Quartiere dell'Olympieion. In: BONACASA, N.; ENSOLI, S. (Orgs.). Cirene. Milão, Electa: $137-147$. 
PARISE, N.F. (1982). Crotone e Temesa. Testemonianze di uma monetazione d'Impero. In: MADDOLI, G. (Ed.). Temesa e il suo territorio. Atti del colloquio di Perugia e Trevi (30-31 maggio 1981). Taranto, Instituto per la Storia e l'Archeologia della Magna Grecia: 103-118.

PARISE, N.F. (1990). Moneta e società in Magna Grecia. L'esempio di Crotone. In: Crise et transformation des sociétés archaïques de l'ttalie antique au Ve siècle av. JC. Actes de la table ronde de Rome (19-21 novembre 1987). Roma, École Française de Rome: 299-306.

PARKE, H.W. (1967). The Oracles of Zeus: Dodona, Olympia, Ammon. Oxford: Blackwell.

PARKE, H.W. (1977). Festivals of the Athenians. Ithaka; N.Y: Cornell University Press.

PARKER, R. (2005). Polytheism and Society at Athens. Oxford: Oxford University Press.

PASQUIER, A. (2001). Olympie. Paris: Musée du Louvre (Louvre Conférences et Colloques).

PEARLMAN, P. (1995). Invocatio and Imprecatio: The Hymn to the Greatest Kouros from Palaikastro and the Oath in ancient Crete. JHS, 115: 161-167.

PEARLMAN, P. (2004). Crete. In: IACP: 1144-1195.

PEATFIELD, A. (1990). Minoan peak sanctuaries: History and Society. OpAth, 18: 117-131.

PEDLEY, J. (2005). Sanctuaries and the Sacred in the Greek World. Cambridge: Cambridge University Press.

PENDLEBURY, J. (1939). The Archaeology of Crete. Londres: University Paperbacks.

PÉREZ, D.R. (2010). Contextualizing symbols: the eagle and the snake in the ancient Greek world. Boreas, 33: 1-18.

PESCE, G. (1947-1948). II Grande Tempio in Cirene. Campagna di Scavi 1939-1942. BCH, 71-72: 307-358.

PFAFF, C.A. (2003). Archaic Corinthian Architecture. In: WILLIAMS II, C.K.; BOOKIDIS, N. (Eds.). Corinth.The Centennary 1896-1996. Atenas, The American School of Classical Studies at Athens: 95-140 (Results of Excavations Conducted by the American School of Classical Studies at Athens, Vol. XX).

PHILLIPP, H. (1992). Le caratteristiche delle relazione fra il santuario di Olimpia e la Magna Grecia. Atti Taranto, 21, Megale Hellas, nome e immagine: 29-51.

PICARD, O. (1979). Chalcis et la Confédération Eubéene: étude de numismatique et d'histoire, IVe-le. Atenas: École Française d'Athènes; Paris: Diffusion de Boccard.

PIÉRART, M.; THALMANN, J.P. (1978). Rapport sur les travaux de l'École Française en Grèce en 1977. Argos II: zone du portique. $B C H, 102:$ 777-790.

PILZ, O. (2011). The Uses of Small Things and the Semiotics of Greek Miniature Objects. In: SMITH, A.C.; BERGERON, M.E. (Eds.). The Gods of Small Things. Toulouse, Presses Universitaires du Mirail: 13-28 (Pallas, 86).

PLASSART, A. (1928). Les Sanctuaires et les Cultes du Mont Cynthe. Exploration Archéologique de Delos. Paris: De Boccard.

POLINSKAYA, I. (2006). Lack of Boundaries, Absence of Oppositions: the City-Countryside Continuum of a Greek Pantheon. In: ROSEN, R.M.; SLUITER, I. (Eds.). City, Countryside, and the Spatial Organization in Classical Antiquity. Leiden, Boston; Brill: 61-92.

POLINSKAYA, I. (2013). A Local History of Greek Polytheism. Gods, people and the land of Aigina, 800-400 BCE. Leiden; Boston: Brill.

PONTIN, P.B.V. (2006). O Escudo Grego: a simbologia de um equipamento defensivo. Tese. Doutorado em Arqueologia. São Paulo: Museu de Arqueologia e Etnologia, Universidade de São Paulo.

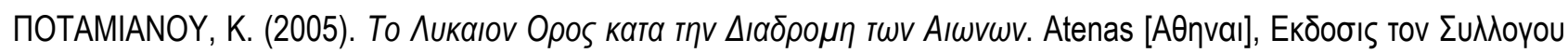
twv Amavtaxou Kotuגiwv.

POZZI PAOLINI, E. (1977). La monetazione. In: Locri Epizefiri. Atti del sedicesimo convegno di studi sulla Magna Grecia, 3-8 Ottobre 1976. Nápoles, Arte tipografica: 217-340.

PRENT, M. (2005). Cretan Sanctuaries and Cults. Continuity and change from Late Minoan IIIC to the Archaic Period. Leiden, Boston: Brill. 
PRENT, M. (2008). Glories of the Past: Ritual Activities at Palatial Ruins in Early Iron Age Crete. In: VAN DYKE, R.M.; ALCOCK, S. (Eds.). Archaeologies of Memory. Oxford, Blackwell: 81-103.

PRENT, M.; THORNE, S.M.V. (2000). The sanctuary of Diktaean Zeus at Palaikastro: a re-examination of the

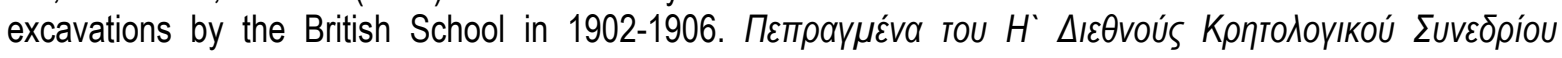

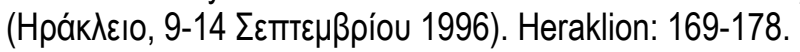

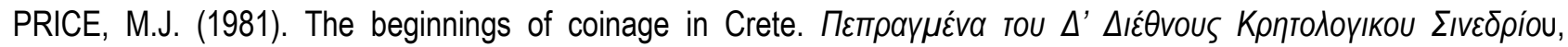
Heráklion, 29 agosto - 3 setembro 1976, Tomo A' (2). Atenas: 461-466

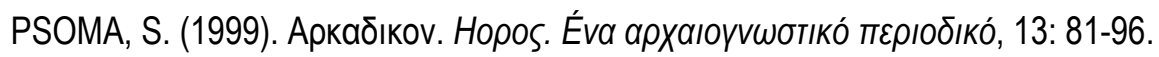

PSOMA, S. (2012). Greece and the Balkans to 360 B.C. In: METCALF, W.E. (Ed.). The Oxford Handbook of Greek and Roman Coinage. Oxford: Oxford University Press: 157-174.

PSOMA, S.; TSANGARI, D. (2003). Monnaie commune et états fédéraux. La circulation des monnayages frappes par les états fédéraux du mond grec. In: BURASELIS; K.; ZOUMBOULAKIS, K. (Eds.). The idea of European community in history. Conference proceedings, vol.ll. Aspects of connecting poleis and ethne in ancient Greece. Atenas, National and Capodistrian University of Athens: 112-141.

PURCELL, N. (2012). Peloponnesus (s.v.). In: HORNBLOWER, S.; SPAWFORTH, A.; EIDINOW, E. (Eds.). The Oxford Classical Dictionary. 4. ed. Oxford: Oxford University Press: 1101.

QUANTIN, Fr. (1997). La Vie Religieuse en Épire Antique. Tese. Lyon: Université Lyon 2.

QUANTIN, Fr. (1999). Aspects épirotes de la vie religieuse antique. REG, 112 (1): 61-98.

QUANTIN, Fr. (2008). Recherches sur l'histoire e l' archéologie du sanctuaire de Dodone: Les oikoi, Zeus Naios et les Naia. Kernos, 21: 9-48.

QUEYREL, A. (2003). Athènes. La Cité Archaïque et Classique du VIIle siècle à la fin du Ve siècle. Paris: Picard.

RAAFLAUB, K. (2000). Zeus Eleutherios, Dionysos the Liberator, and the Athenian Tyrannicides. Anachronistic Uses of Fifth-Century Political Concepts. In: FLENSTED-JENSEN, P.; NIELSEN, T.H.; RUBENSTEIN, L. (Eds.). Polis \& Politics. Studies in Ancient Greek History Presented to Mogens Herman Hansen and His Sixtieth Birthday, August 20, 2000. Copenhagen; Museum Tusculanum Press, University of Copenhagen Press: 249-275.

RAAFLAUB, K. (2004). The Discovery of Freedom in Ancient Greece. Chicago: The University of Chicago Press.

RAAFLAUB, K.A.; WEES, H. (2009). A Companion to Archaic Greece. Massachusets; Oxford: Willey-Blackwell.

RADT, S. (1999). Sophocles. Tragicorum Graecorum Fragmenta, 4. Göttingen: Vandenhoeck \& Ruprecht.

RAMBACH, J. (2002). Dörpfelds Bau VII in der Altis von Olympia. Ein früheisenzeitliches Apsidenhaus und 'Haus des Oinomaos'? AA, 2002/1: 119-134.

RANDSBORG, K. (Ed.). (2002). Kephallénia-Archaeology and History. The Ancient Greek Cities. Acta Archaeologica, 73 (1 e 2); Supplementa, vol. IV: 1 e 2.

RIOTTO, M. (1985). II santuario della Malophoros a Selinunte: spunti per una discussion storico-religiosa. SicArch, 18 : 25-51.

RIZAKIS, A.D. (2013). États fédéraux et sanctuaries: Zeus Homarios et la construction de l'identité achéene. In: FUNKE, P.; HAAKE, M. (Eds.). Greek Federal States and their Sanctuaries. Identity and integration. Stuttgart: Franz Steiner: $13-48$.

RIZZO, L. (2011). La Monetazione di Abaikanon. Studio sulla serie delle frazioni del V-IV sec. a.C. Tesi di laurea. Università degli Studi di Padova.

ROCCO, G. (1996). L'isola di Coo: le mura di cinta. In: LIVADIOTTI, M.; ROCCO, G. (a cura di). La Presenza Italiana nel Dodecaneso tra II 1912 e il 1948. La ricerca archeologica, la conservazione, le scelte progettuali. Catânia, Edizioni del Prisma: 96-102.

ROCCO, G.; LIVADIOTTI, M. (1999). II tempio di Athena Polias a laliso: un contributo alla conoscenza dell'architettura

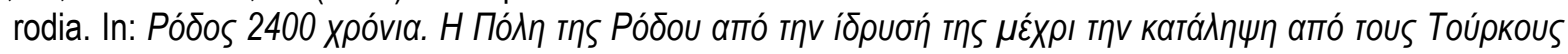
(1523). Convegno Internazionale di Studi (Rodi, 24-29 Ottobre, 1993). Atenas: 109-118. 
ROMANO, D.G. (1997). Topographical and Architectural Survey of the Sanctuary of Zeus on Mt. Lykaion, Arcadia. AJA, 101 (2): 374.

ROMANO, D.G. (2005). A New Topographical and Architectural Survey of the Sanctuary of Zeus at Mt. Lykaion. In: $\varnothing$ STBY, E. (Ed.). Ancient Arcadia. Papers from the third International Seminar on Ancient Arcadia held at the Norwegian Institute at Athens (7-10 May 2002). Atenas: Norwegian Institute at Athens: 381-396.

ROMANO, D.G.; VOYATZIS, M.; PANAGIOTOPOULOU, A. (2007). "Excavations at the Sanctuary of Zeus on Mt. Lykaion". Poster Session. Archaeological Institute of America Annual Meeting, San Diego, January 5.

ROMANO, D.G.; VOYATZIS, M.; PANAGIOTOPOULOU, A. (2014). Mt. Lykaion excavation and survey project, part 1: the upper sanctuary. Hesperia, 83: 569-652.

ROMANO, D.G.; VOYATZIS, M.; PANAGIOTOPOULOU, A. (2015). Mt. Lykaion excavation and survey project, part 2: the lower sanctuary. Hesperia, 84: 207-276.

ROMANO, D.G.; VOYATZIS, M.E. (2010). Excavating at the Birthplace of Zeus. Expedition, 52: 9-21.

ROUX, G.; LÉVÊQUE, P. (1950). Chronique des Fouilles et Découvertes Archéologiques en Grèce en 1949. BCH, 74 (1): 336-341.

ROY, J. (2002). The synoikism of Elis. In: NIELSEN, T.H. (Ed.). Even more Studies in the Ancient Greek Polis. Stuttgart, Franz Steiner: 249-264 (Papers from the Copenhagen Polis Centre, 6).

ROY, J. (2004). Elis. In: IACP: 489-504.

ROY, J. (2009). Living in the mountains: Arkadian identity in the classical period. In: GEORGIADIS, M., GALLOU, C. (Eds.). The Past in the Past: the significance of memory and tradition in the transmission of culture. Oxford, Archaeopress: 57-66.

ROY, J. (2012). Megalopolis (s.v.). In: HORNBLOWER, S.; SPAWTHORTH, A.; EIDINOW, E. (Eds.). The Oxford Classical Dictionary. 4. ed. Oxford, Oxford University Press: 924.

ROY, J. (2013). Olympia, identity and integration: Elis, Eleia, and Hellas. In: FUNKE, P.; HAAKE, M. (Eds.). Greek Federal States and their Sanctuaries. Identity and integration. Stuttgart: Franz Steiner: 107-122.

RUTKOWSKI, B. (1972). Cult Places in the Aegean World. Polish Academy of Sciences, Institute of the History of Material Culture.

RUTKOWSKI, B. (1986). The Cult Places of the Aegean. New Haven: Yale University Press.

RUTKOWSKI, B.; NOWICKI, K. (1996). The Psychro Cave and other Sacred Grottoes in Crete. Varsóvia: Art and Archaeology.

RUTTER, N.K. (1997). The Greek Coinages of Southern Italy and Sicily. Londres: Spink.

RUTTER, N.K. (2000). Coin Types and Identity: Greek cities in Sicily. In: SMITH, C.J.; and SERRATI, J. (Eds.). Sicily from Aeneas to Augustus. New Approaches in Archaeology and History. Edimburgo, Edinburgh University Press: 73-83.

RUTTER, N.K. (2001). Historia Numorum Italy. Londres: The British Museum.

RUTTER, N.K. (2012). The coinage of Italy. In: METCALF, W.E. (Ed.). The Oxford Handbook of Greek and Roman Coinage. Oxford, Oxford University Press: 128-141.

SACCONI, A.; DEL FREO, M.; GODART, L.; NEGRI, M. (Eds.). Atti del XII Colloquio internazionale di Micenologia. Roma, 20-25 frebbraio 2006. Pasiphae, I. Pisa; Roma: Fabrizio Serra.

SAINT NON, J.Cl.R. de (1783). Voyage Pittoresque ou Description des Royaumes de Naples et de Sicile. Troisième Volume contenant le Voyage ou circuit de la partie Méridionale de l'Italie, anciennement appellée GrandeGrèce. Paris: Paris Clousier.

SAKELLARAKI, E.S. (1995). Chalkis. History, Topography and Museum. Atenas: Archaeological Receipts Fund.

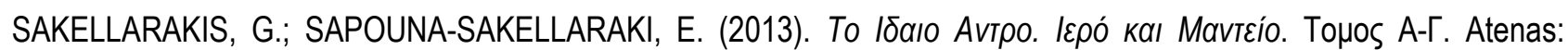
Sociedade Arqueológica Grega.

SAKELLARAKIS, J.A. (1985). L’Antro Ideo. Cento Anni di Attività Archeologica. In: Atti di Convegni Lincei (74). Cento Anni di Attività Archeologica Italiana in Creta. Roma, Accademia Nazionale dei Lincei: 19-48. 


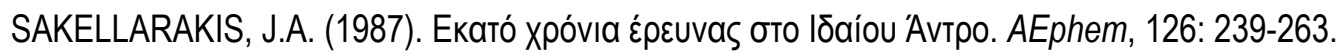

SAKELLARAKIS, J.A. (1988a). The Idaean cave. Minoan and Greek worship. Kernos, 1: 207-214.

SAKELLARAKIS, J.A. (1988b). Some Geometric and Archaic votives from the Idaean Cave. In: HÄGG, R; MARINATOS, N.; NORDQUIST, C.G. (Eds.). Early Greek Cult Practices. Proceedings of the $5^{\text {th }}$ International Symposium at the Swedish Institute al Athens, 26-29 June 1986. Estocolmo, Swedish Institute al Athens: 173-193.

SAPORITI, M. (2006). Recensione a Lalonde. ASAtene, 84: 780-791.

SCHÄFER, J. (1991). Amnissos, 1984-1988: Das Problem der Kultkontinuität im Falle des Heiligtums des Zeus Thenatas. In: MUSTI, D. et alii (Eds.). La Transizione dal Miceneo all'Alto Arcaismo: dal palazzo alla cità. Roma, Consiglio Nazionale delle Ricerche: 349-358.

SCHÄFER, J. (Ed.). (1992). Amnissos Nach den archälogischen, historischen und epigraphischen Zeugnissen des Altertums und der Neuzeit. Berlim: Forschungen des Archäologischen Instituts der Universitat Heidelberg; Deutsches Archäologisches Institut (Berlin) Abteilung.

SCHAWBL, H. (1978). Zeus. Munique: Alfred Druckenmüller.

SCHEFOLD, K. (1992). Gods and Heroes in Late Archaic Greek Art. Cambridge; N. York: Cambridge University Press.

SCHULTZ, P.; WICKKISER, B.; HINGE, G. (Eds.). Aspects of Greek Cult: Context, Ritual, Iconography. Santa Barbara, Aarhus University Press.

SCOTT, M. (2010). Delphi and Olympia. The Spatial Politics of Panhellenism in the Archaic and Classical Periods. Cambridge: Cambridge University Press.

SELTMAN, C.T. (1921). The Temple Coins of Olympia. Cambridge: Cambridge University Press.

SERVI, K. (2011). L'Acropoli, il Museo dell' Acropoli. Atenas: Ekdotike Athenon.

SHEEDY, K. (2012). Aegina, the Cyclades, and Crete. In: METCALF, W.E. (Ed.). The Oxford Handbook of Greek and Roman Coinage. Oxford: Oxford University Press: 105-127.

SHIPLEY, G. (2004). Messenia. In: IACP: 547-568.

SIMON, E. (1983). Festivals of Attica. An Archaeological Commentary. Madison (Wis.): University of Wisconsin Press.

SINN, U. (2000). Greek Sanctuaries as Places of Refuge. In: BUXTON, R. (Ed.). Oxford Readings in Greek Religion. Oxford, Oxford University Press: 70-87.

SJÖGREN, L. (2008). Fragments of Archaic Crete. Archaeological studies on time and space. Upsala: Acta Universitatis Upsaliensis.

SMITH, C.J.; SERRATI, J. (2000). Sicily from Aeneas to Augustus. Edimburgo: Edinburgh University Press (New Approaches in Archaeology and History).

SMITH, R.M.; PORCHER, E.A. (1864). History of the Recent Discoveries at Cyrene, made during an expedition to the Cyrenaica in 1860-61, under the auspices of Her Majesty's Government. Londres: Day and Son.

SNODGRASS, A.M. (1974). Cretans in Arcadia? In: LEVI, D.; RIZZA, G. (a cura di). Antichità Cretesi: studi in onore di Doro Levi, Vol. II. Catania; Università di Catania, Istituto di Archeologia: 196-201 (Cronache di Archeologia, 13).

SNODGRASS, A.M. (2004). Homero e os Artistas. Texto e pintura na arte grega antiga. São Paulo: Odysseus.

SOURVINOU-INWOOD, C. (2000). What is Polis Religion? In: BUXTON, R. (Ed.). Oxford Readings in Greek Religion. Oxford, Oxford University Press: 13-37.

SPORN, K. (2002). Heiligtümer und Kulte Kretas in klassischer und hellenisticher Zeit. Heidelberg: Archäologie und Geschichte (Studien zu antiken Heiligtümern, 3).

STAZIO, A. (1974). Osservazione sulla monetazione di Metaponto. In: Metaponto. Atti del Tredicesimo Convegno di Studi sulla Magna Grecia, 14-19 Ottobre 1973. Nápoles, Arte Tipográfica: 67-106.

STAZIO, A. (1983). Monetazione greca e indigena nella Magna Grecia. In: Modes de Contacts et Processus de Transformation dans les Sociétés Anciennes. Actes du Colloque de Cortone (24-30 mai 1981). Scuola Normale Superiore; l'École Française de Rome (org.); Centre de Recherches d'Histoire Ancienne de l'Université de Besançon (colab.). Pisa; Roma, Scuola Normale Superiore: 963-978. 
STAZIO, A. (1992). Moneta, economia e società. In: BRACCESI, L.; DE MIRO, E. (Eds.). Agrigento e la Sicilia Sreca. Atti della settimana di studio, Agrigento, 2-8 maggio 1988. Roma, "L'Erma" di Bretschneider: 219-20.

STEFANAKIS, M.I. (1999). The introduction of coinage in Crete and the beginning of local minting. In: CHANIOTIS, A. (Ed.). From Minoan Farmers to Roman Traders. Sidelights on the economy of ancient Crete. Stuttgart: Franz Steiner: 247-268.

STEVENS, G.P. (1940). The setting of the Periclean Parthenon. Hesperia, Suppl. 3: 79-86.

STEVENS, G.P. (1946). The northeast corner of the Parthenon. AJA, 15: 12-15.

STUCCHI, S. (1966-1967). La Ripresa dei Lavori nel Temenos di Zeus a Cirene. Lybia Antiqua, III-IV: 199-201.

STUCCHI, S. (1968). I lavori nel temenos di Zeus a Cirene. Libya Antiqua, V: 105-107.

STUCCHI, S. (1975). Architettura Cirenaica. Roma: "L’Erma" di Bretschneider.

SVORONOS, J. (1890). Numismatique de la Crète Ancienne. 2 vols. Paris: Macon.

TAITA, J. (2007). Olimpia e il suo Vicinato in Epoca Arcaica. Milão: Edizioni Universitarie di Lettere Economia Diritto.

TALIERCIO MENSITIERI, M. (1987). Aspetti e problemi della monetazione di Poseidonia. Atti Taranto, 27: 133-188 (1988).

THEMELIS, P. (2004). Antica Messene. Atenas: Casa Fondi Archeologici e Espropri.

THEMELIS, P. (2004). Cults on Mont Ithome. Kernos, 17: 143-154.

THEODORESCU, D,; GRECO, E.; LONGO, F. (2000). Paestum: Scavi, Studi, Ricerche. Bilancio di un decenio (19881998). Paestum: Pandemos; Fondazione Paestum.

THIEME, T. (1993). The Architectural remains of Archaic Labraunda. In: Les Grands Ateliers d'Architecture dans le Monde Égéen du Vle siècle av.J.-C. Istambul: Varia Anatolica, 3 (1): 47-55.

THORNE, S.; PRENT, M. (2002). 'The sanctuary of Dikataian Zeus'. In: DRIESSEN, J.M.; MacGILLIVRAY, J.A.; SACKETT, L.H. Ancient Palaikastro: an exhibition to mark 100 years of archaeological work 1902-2002. Atenas, The British School at Athens: s./p.

THROMAS, L. (2009). Espace politique et identité civique des cités péloponnésiennes aux époques archaïque et classique: les savoirs d'Athéna. Geographia Antiqua, 18: 63-74.

TIVERIOS. P. (1997). Early times to 5th centh. B.C. LIMC, vol. VIII (1 e 2). Thespiades - Zodiacus et Supplementum Abila - Thersites. Düsseldorf, Zürich: Artemis.

TÖLLE-KASTENBEIN, R. (1994b). Zur Genesis und Entwicklung des Dipteros. Jdl, 109: 41-76.

TOMLISON, R.A. (1995). Greek Architecture. Londres: Bristol Classical Press.

TOMLISON, R.A. (2012). Temple (s.v.). In: HORNBLOWER, S.; SPAWFORTH, A.; EIDINOW, E. (Eds.). The Oxford Classical Dictionary. 4. ed. Oxford, Oxford University Press: 1438-1439.

TORELLI, M.; MAVROJANNIS, T. (2002). Grecia. Milão: Mondadori (Guide Archeologiche).

TORRANO, J.A.R. (1986). Comentários. In: HESÍODO. A Teogonia. Trad. de J.A.R. Torrano. São Paulo: R. Kempf.

TOUCHEFEU-MEYNIER, O. (1997). Typhon. LIMC, vol. VIII (1 e 2). Thespiades - Zodiacus et Supplementum Abila Thersites. Düsseldorf, Zürich; Artemis: 147-152.

TOUTAIN, J. (1911). L'antre de Psychro et le $\triangle I K T A I O N$ ANTחON. Revue de l'Histoires des Religions, 64: 277-291. Disponivel em: < http://www.jstor.org/stable/23662637>; acesso em 14 abr. 2016.

TRAVLOS, J. (1971). Pictorial Dictionary of Ancient Athens. Londres: Thames and Hudson.

TSIGARIDA, E.B. (2011). The sanctuary of Zeus Amon at Kallithea (Chalcidice). Kernos, 24: 165-181.

TSIOLIS KARANTASI, V. (2002). Mantinea-Antigonea. Aspectos históricos de una ciudad arcadia. Toledo: [Bremen].

TUSA, V. (1967). Le Divinità ed I Templi di Selinunte. Kokalos, 13: 186-193.

TUSA, V. (1977). Nuovi rinvenimenti nell'area del santuario della Malophoros a Selinunte. Cronache di Archeologia e di Storia dell'Arte, Università di Catania, 16: 115-118. 
TUSA-CUTRONI, A. (1967). Mozia, monetazione e circolazione. In: BRANCOLI, I. et alii (Eds.). Mozia III: rapporto preliminare della Missione archeologica della Soprintendenza alle Antichità della Sicilia Occidentale e dell'Università di Roma. Studi Semitici, 24: 97-119.

TYREE, E.L. (1974). Cretan sacred caves: Archaeological evidence. Tese. Columbia: University of Missouri.

TZOUVÁRA-SOÚLI, Ch. (2004). "The cult of Zeus in Ancient Epirus". In: CABANES, P.; LAMBOLEY, J.-L. (Eds.). L'lllyrie Méridionale et Épire dans l'Antiquité. Actes du IVe colloque international de Girenoble, 10-12 octobre 2002. Paris, De Boccard: 515-547.

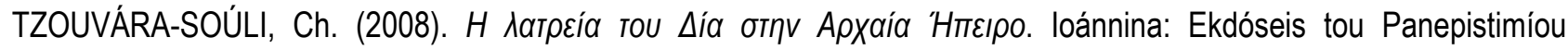
loanínnon.

VACCARELLO, P. (1986). Rilievo del tempietto di Zeus Meilichios a Selinunte. SicArch, 19: 60-61.

VALAVANIS, P. (2004). Games and Sanctuaries in Ancient Greece. Olympia, Delphi, Isthmia, Nemea, Athens. Atenas: Kapon Editions.

VALDÉS-GUIA, M. (2003-5). Hectémoros, Campesinos y culto a Zeus en Atenas Arcaica. Arys, 6: 63-76.

VALDÉS-GUÍA, M. (2008). La revalorización de la tierra y de la autoctonía en la Atenas de los Pisistrátidas: el nacimento de Erictonio y de Dioniso órfico. Gerión, 26 (1): 235-254.

VALDÉS-GUIA, M. (2009). Riflessioni su Zeus Agoraios a Selinunte. In: ANTONETTI, C.; DE VIDO, S. (Eds.). Temi Selinuntini. Pisa, Edizioni ETS: 29-51.

VALENZA-MELE, N. (1979). Eracle euboico a Cuma, la gigantomachia e la via Heraclea. In: LEPORE, E.; MARTIN, R.; VALENZA-MELE, N. et alii. (Eds.). Recherches sur les Cultes Grecs et l'Occident. Vol. I. Nápoles, Institut Français de Naples: 19-51.

VALLET, G. (1967). La cité et son territoire dans les colonies grecques d'Occident. Atti Taranto, 7: 67-112 (1968).

VAN BUREN, E.D. (1926). Greek Fictile Revetment in the Archaic Period. Londres: J. Murray.

VAN DOMMELEN, P.; KNAPP, A. B. (Eds.) (2010). Material Connections in the Ancient Mediterranean: mobility, materiality and identity. Nova York: Routledge.

VANDERPOOL, E. (1954). News Letter from Greece. AJA, 58 (3): 231-241.

VANDERPOOL, E. (1960). News Letter from Greece. AJA, 64 (3): 265-271.

VERBRUGGEN, H. (1981). Le Zeus Crétois. Paris: Les Belles Lettres.

VERNANT, J.-P (Ed.) (1984). La Cité des Images, Religion et Societé en Grèce Antique. Lausanne: Fernand Nathan LEP.

VERNANT, J.-P. (2006). Mito e Religião na Grécia Antiga. São Paulo: Martins Fontes.

VEROIA, D.B. (2009). Studien zum System des Vokabulars der Architektur dorischer Ordnung am Beispel des Ringhallentempels archaischer und klassischer Zeit. Tese. Darmstadt: Universität Darmstadt.

VERONESE, F. (2006). Lo Spazio e la Dimensione del Sacro. Santuari greci e territorio nella Sicilia arcaica. Pádua: Esedra.

VINK, M.C.V. (1997). Urbanization in late and sub-geometric Greece: abstract considerations and concrete case studies of Eretria and Zagora c.700 BC. In: ANDERSEN, H. D. (Ed.) Urbanization in the Mediterranean in the 9th to 6th Centuries BC. Acta Hyperborea, 7: 111-137.

VIVIERS, D. (1994). La cité de Dattalla et l'expansion territoriale de Lyktos en Crète centrale. BCH, 118 (1): 229-259.

VLASSOPOULOS, K. (2007). The regional identity of the Peloponnese. Proceedings of the Centre for Spartan and Peloponnesian Studies conference, 'Being Peloponnesian', 31 March - 1 April, 2007: 1-17.

VLASSOPOULOS, K. (2011). Regional perspectives and the study of Greek history. Incidenza dell'Antico, 9: 9-31.

VLASSOPOULOS, K. (2015). Ethnicity and Greek history: re-examining our assumptions. Bulletin of the Institute of Classical Studies, 58: 1-13.

VONDERSTEIN, M. (2006). Der Zeuskult bei den Westgriechen. Weisbaden: Reichert. 
VOUTIRAS, E. (2006). Le Culte de Zeus em Macédoine avant la Conquête romaine. In: GUIMIER-SORBETS, A.-M.; HATZOPOULOS, M.; MORIZOT, Y. (Eds.). Rois, Cités, Necropoles. Institutions, Rites et Monuments em Macedonie. Actes des Colloques de Nanterre (Decembre 2002) et D’Athène (Janvier 2004). Atenas; Paris, Diffusion de Boccard: 333-346 (MEAETHMATA, 45).

VOYATZIS, M.E. (1999). The Role of Temple Building in Consolidating Arkadian Communities. In: NIELSEN, T.H.; ROY, J. (Eds.). Defining Ancient Arkadia. Copenhague, Copenhagen Polis Center: 130-168 (Acts of the Copenhagen Polis Center, vol. 6).

WALKER, A. (2004). Coins of Olympia: The BCD Collection. Auction LEU 90. Zürich: Leu Numismatics LTD.

WALKER, A. (2006). Coins of Peloponnesos: The BCD Collection. Auction LHS 96. Zürich: Leu Numismatics LTD.

WALLACE, S. (2010). Ancient Crete. From successful collapse to democracy's alternatives, twelf to fifth centuries BC. Cambridge: Cambridge University Press.

WATROUS, L.V. (1996). The Cave Sanctuary of Zeus at Psychro. A study of extra-urban sanctuaries in Minoan and Early Iron Age Crete. Liège: Université de Liège (Aegeum, 15).

WAUGH, N. (2009). Visualising fertility at Artemis Orthia's site. In: CAVANAGH, W.G.; GALLOU, C.; GEORGIADIS, M. (Eds.). Sparta and Laconia: from Prehistory to Pre-modern. Londres, British School at Athens: 159-167.

WESTERMARK, U. (1979). The fifth century bronze coinage of Akragas. Le origini della monetazione di bronzo in Sicilia e in Magna Grecia. Atti del $6^{\circ}$ Convegno del Centro Internazionale di Studi Numismatici, Napoli 17-22 aprile 1977. AllN, Supplemento 25, Roma: 3-17.

WHITLEY, J. (2009). Crete. In: RAAFLAUB, K.A.; WEES, H. (Eds.). A companion to Archaic Greece. Massachusets; Oxford, Willey-Blackwell: 273-293.

WHYCHERLEY, R.E. (1964). The Olympieion at Athens. GrRomByzSt, 5: 161-179.

WILLETTS, R.F. (1955). Aristocratic Society in Ancient Crete. Londres: Routledge and Paul.

WILLETTS, R.F. (1962). Cretan Cults and Festivals. Londres: Routledge and Kegan Paul.

WILLIAMS II, C.K. (1964). Excavations at Nemea, 1962. AJA, 68 (2): 201-202.

WILLIAMS, R.T. (1965). The Confederate Coinage of the Arcadians in the Fifth Century B.C. N. York: The American Numismatic Society.

WILLIAMSON, C. (2012). City and sanctuary in Hellenistic Minor. Civic identity in the sacred landscapes of Mylasa and Stratonikeia in Karia. Dissertação. Groningen: University of Groningen.

WILLIAMSON, C.G. (2013). Public space beyond the city. The sanctuaries of Labraunda and Sinuri in the chora of Mylasa. In: DICKENSON, C.P.; VAN NIJF, O.M. (Eds.). Public Space in the Post-Classical Greek City. Leuven, Peeters: 1-36 (Caeculus. Papers on Mediterranean Archaeology and Greek and Roman Studies, 7).

WISEMAN, J. (1967a). Excavations at Corinth: the Gymnasium Area, 1965. Hesperia, 36 (1): 13-41.

WISEMAN, J. (1967b). Excavations at Corinth: the Gymnasium Area, 1966. Hesperia, 36 (4): 402-428.

WISEMAN, J. (1969). Excavations at Corinth: the Gymnasium Area, 1967-1968. Hesperia, 38 (1): 64-106.

WISEMAN, J. (1972).The Gymnasium Area at Corinth, 1969-1970. Hesperia, 41 (1): 1-42.

WISEMAN, J. (1978). The Land of the Ancient Corinthians. Gotemburgo: P. Aström (Studies in Mediterranean Archaeology, 50).

WITTKOWER, R. (1939). Eagle and serpent, a study in the migration of symbols. Journal of Warburg Institute, 2 (4): 293-325.

WOODWARD, A.M.; HOOPER, R.J.; SPAWFORTH, A. (2012). Messenia (s.v.). In: HORNBLOWER, S.; SPAWTHORTH, A.; EIDINOW, E. (Eds.). The Oxford Classical Dictionary. 4. ed. Oxford, Oxford University Press: 937-938.

WREDE, W. (1934). Attika: Vortrag in der deutschen Arbeitsgemeinschaft zu Athen. Atenas: Deutdches Archaologisches Institut: Athenische.

WROTH, W. (1884). Cretan coins. Numismatic Chronicle, 4: 1-58. 
WROTH, W. (1963). The British Museum Catalogue. A Catalogue of Greek Coins. Crete to Aegean Islands. Bolonha: Arnaldo Forni Editore [edição original do início do século XX].

WYCHERLEY, R.E. (1964). The Olympieion at Athens. GrRomByzSt, 5: 161-179.

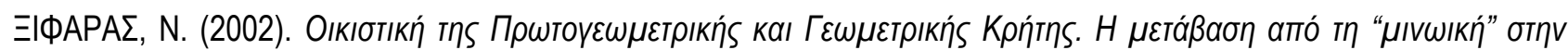

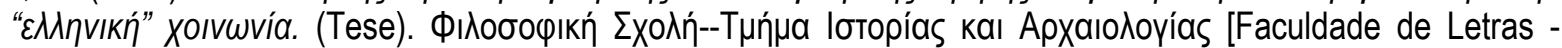

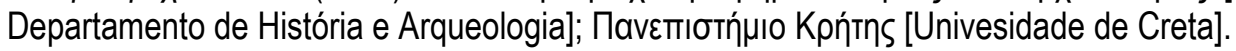

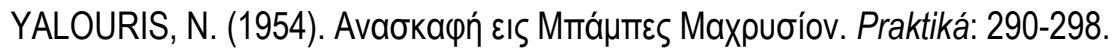

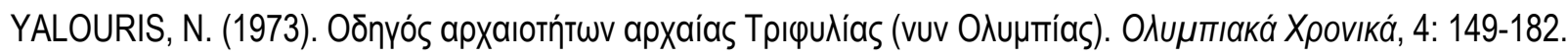

YALOURIS, N. (1981). Olympie et la Grande Grèce. Atti Taranto, 20: 9-22.

YALOURIS, N. (1996). Ancient Elis, Cradle of the Olympic Games. Atenas: Adam Editions.

YALOURIS, N. (Org.) (2004). Os Jogos Olímpicos na Grécia Antiga. São Paulo: Odysseus.

YAVIS, G.C. (1949). Greek altars: origins and typology. Missouri: Saint Louis University Press.

YOUNGER, J.G.; REHAK, P. (2009). Technical Observations on the Sculptures from the Temple of Zeus at Olympia. Hesperia, 78 (1) (Jan.-Mar.): 41-105.

ZOLOTNIKOVA, O. (2013b). The cult places of Zeus in the northeastern Peloponnese in the Geometric - Late Archaic periods. In: KISSAS, K.; NIEMEIER, W.D. (Eds.). The Corinthia and the Northeast Peloponnese. Topography and History from Prehistoric Times until the End of Antiquity. Proceedings of the International Conference organized by the Directorate of Prehistoric and Classical Antiquities, the LZ' Ephorate of Prehistoric and Classical Antiquities and the German Archaeological Institute, Athens, held at Loutraki, March 26-29, 2009. Athenaia, 4: 111-123.

ZOLOTNIKOVA, O. A. (2005). The Cult of Zeus Lykaios. In: ØSTBY, E. (Ed.). Ancient Arcadia. Papers from the third International Seminar on Ancient Arcadia held at the Norwegian Institute at Athens (7-10 May 2002). Atenas, Norwegian Institute at Athens: 105-119.

ZOLOTNIKOVA, O. A. (2011). Evidence for the worship of Zeus during the late prehistoric-early historic periods. In: MAZARAKIS-AINIAN, A. (Ed.). The "dark ages" revisited. Acts of an International Symposium in memory of William D.E. Coulson. University of Thessaly, Volos, 14-17 June 2007. Volos, University of Thessaly Press: 233-246.

ZOLOTNIKOVA, O. A. (2013a). Zeus in the Early Greek Mythology and Religion: from prehistoric times to early archaic period. Oxford: Archeopress (BAR international series, 2492).

ZUNINO, M.L. (1997). Hierá Messeniaka. Udini: Forum.

\section{SITES}

ROMANO, D.G.; VOYATZIS, M.E. (2010). Excavating at the Birthplace of Zeus. Expedition, 52: 9-21 (lykaionexcavation.org). Disponível em: <http://c84362.r62.cf2.rackcdn.com/assets/lykaion/files/Expedition_Magazine_Spring2010.pdf>. Acesso em 27 fev. 2016.

UNIVERSITY OF PENNSYLVANIA (2008). New discoveries at the Ash Altar of Zeus - Mount Lykaion. PhysOrg.com, Thursday, January 24. Disponivel em: < http://phys.org/news/2008-01-discoveries-ash-altar-zeus-.html>. Acesso em 27 fev. 2016.

BEAZLEY ARCHIVE. Classical Art Research Center; University of Oxford. Disponivel em: http://www.beazley.ox.ac.uk/index.htm. Acesso em 01 mar. 2015. 
Tese - A apropriação e consolidação do culto de Zeus pela cidade grega: moedas e santuários, política e identidade em época arcaica e clássica

Lilian de Angelo Laky

CATÁLOGO I

Santuários de Zeus atestados pelas fontes arqueológicas

e literárias da Idade do Bronze ao século IV a.C. (345/44 a.C.) 


\section{ÍNDICE}

\section{Catálogo}

1.Mt.Ida (Creta) - (1)

2.Mt.Dicta (Creta) - (8)

3. Mt.Lykaion (Peloponeso) - (14)

4.Olímpia (Peloponeso) - (30)

5.Agia Triada (Creta) - (41)

6. Amnisos (Creta) - (44)

7.Palaikastro (Creta) - (55)

8.Atenas-Mt. Himeto (Ática) - (64)

9.Dodona (Épiro) - (69)

10.Argos-acrópole Larisa (Peloponeso) - (73)

11.Messênia-Mt.Ithome (Peloponeso) - (75)

12.Atenas-Mt.Parnes (Ática) - (79)

13.Mt.Apesas (Peloponeso) - (81)

14.Tsakona (Peloponeso) - (84)

15.Mt.Arachnaion (Peloponeso) - (89)

16.Atenas-Mt.Tourkouvouni (Ática) - (91)

17.Mt.Atavvyros (Rodes) - (93)

18.Praisos (Creta) - (95)

19.Egina-Mt.Oros (Golfo Sarônico) - (97) 
20.Mt.Helikon (Beócia) - (101)

21.Neméia (Peloponeso) - (102)

22.Sta Marmara (Megárida) - (106)

23.Pherai (Tessália) - (108)

24.Labraunda (Cária) - (110)

25.Delos-Mt.Cynthos (Cíclades) - (114)

26.Naxos-Mt.Zas (Cíclades) - (117)

27.Selinonte-Gaggera (Sicília) - (118)

28.Atenas-Agrai (Ática) - (121)

29.Siracusa (Sicília) - (123)

30.lalysos (Rodes) - (128)

31.Atenas-Ilissos (Ática) - (130)

32.Kefalonia-Mt.Enos (Jônio) - (134)

33.Metaponto-ágora (Itália do Sul) - (136)

34.Metaponto-S.Biaggio (Itália do Sul) - (140)

35.Lócris Epizefiri (Itália do Sul) - (142)

36.Selinonte-Marinella (Sicília) - (146)

37. Corinto (Peloponeso) - (150)

39.Bambes (Peloponeso) - (154)

39.lasos (Cária) - (157)

40.Cabo Kenaion (Eubéia) - (161)

41.Figaléia (Peloponeso) - (164)

42.Kamiros (Rodes) - (168) 
43.Mégara (Megárida) - (169)

44.Atenas-colina das Ninfas (Ática) - (171)

45.Cirene-setentrional-oriental (Líbia) - (178)

46.Atenas-acrópole (Ática) - (183)

47.Agrigento (Sicília) - (185)

48.Cálcis (Eubéia) - (189)

49.Cirene-Ain Hofra (Líbia) - (191)

50.Paros-Mt.Kounados (Cíclades) - (193)

51.Mylasa (Cária) - (194)

52.Mantinéia (Peloponeso) - (195)

53.Posidônia (Itália do Sul) - (197)

54.Díon (Macedônia) - (199)

55.Thasos (Trácia) - (203)

56. Lindos (Rodes) - (206)

57.Megalópolis (Peloponeso) - (207)

58.Aphytis (Macedônia) - (210)

59.Aegiae (Macedônia) - (213)

60.Argos-ágora (Peloponeso) - (215)

Santuários de Zeus atestados pelas fontes textuais (216) 
Datação: Minóico Médio IA (2000-1900 a.C.) - período romano (séc. V d.C.).

Localização: Região central de Creta, em uma gruta situada na denominada montanha do Ida ou Psiloritis, a uma altitude de $1500 \mathrm{~m}$ e a $100 \mathrm{~m}$ acima da planície alta de Nida (Prent, 2005: 158; Watrous, 1996: 58).

Tipo de santuário: Gruta em pico / inter-regional, inter-estadual e sub-regional (a partir da Idade do Ferro).

Referências textuais: (Mito) Píndaro, Nem 10.70; Diodoro IV.17.3 / IV.80.1-2 / V.64.3 / V.70.1-2/2-6; (Culto) Estrabão 10.3.7 / 10.3.19; (Rito/culto) Estrabão 10.3.11; (Rito) Estrabão 10.3.13; (Gruta) Estrabão 10.4.12; (Oferendas) Teofrasto, Hist. das Plantas III, 3,4.

Inscrições: Inscrições de Gortina sobre controle do santuário de Zeus na gruta do Mt. Ida (IACP, p.1163): I.Cret. IV 80, início séc.V a.C.; I.Cret. IV 146, séc.IV a.C.

Histórico dos achados: Localmente conhecida como a gruta de Voskopoulos, foi identificada pela primeira vez em 1591 pelo botânico italiano Casabona como a famosa caverna de Zeus Kretagenes. As primeiras investigações arqueológicas foram empreendidas em 1885 por Halbherr e Aerakis, após algumas antiguidades terem sido mostradas a eles por alguns pastores. A descoberta de inscrições votivas romanas confirmou que, ao menos nesse período, a caverna foi dedicada a Zeus Idaios. Mais escavações foram realizadas por Faure em 1955 e por Marinatos em 1956, as quais propiciaram informação sobre o período mais antigo, o minoico. Escavações sistemáticas em larga escala foram iniciadas em 1982 por Sakellarakis (Prent, 2005: 158).

\section{Documentação arqueológica}

I. Altar: Em frente à entrada da gruta há uma área aberta com um grande altar feito na rocha (c.4,9 x 2,1 x 0,90 m) de data desconhecida (Prent, 2005: 159). Watrous diz que o altar é datado de época romana (Watrous, 1996: 59).

II. Altar de cinzas: A camada misturada de terra na caverna é descrita como queimada e oleosa, contendo carvão e ossos, alguns deles queimados (Prent, 2005: 160).

I. Objetos votivos: Idade do Bronze - A caverna foi primeiro ocupada no final do período neolítico-minóico antigo I. A atividade cultual na caverna, provavelmente, começou no período minóico médio IA (c.2000 a.C.), como indicam a grande quantidade de cerâmica (taças e jarros com decoração barbotina), argamassa nas 
pedras do chão e lâminas de obsidiana, datadas do período, encontradas na parte traseira da caverna. Algumas dessas cerâmicas são provenientes de Mesara. Achados proto-palaciais são relativamente poucos; relatórios mencionam louça de Kamares e um selo de cristal de rocha (Watrous, 1996: 58). Os achados aumentaram no período neo-palacial: oferendas consistiam em cerâmicas (vasos decorados com relevo, rhyton e pithoi com decoração incisa), dois selos, um amuleto, colar de contas de cristal, algumas agulhas de ossos, figurinhas em bronze de humanos e animais, um machado duplo em bronze, uma pinça de bronze, mesas de pedra para libação e kernoi, e um muro de témeno (?) dentro da caverna. Massas de ossos de animais, cinzas e carvão, encontrados em contextos misturados, são evidências de sacrifício animal e refeições rituais. Uma miniatura de espada é seguramente datada do período neo-palacial ou adaga da caverna indica que alguns dos quarenta exemplos similares encontrados na caverna também datam desse período. Grandes ferramentas estão ausentes. Entre a caverna e o vilarejo de Anogeia, uma estrutura grande minóica, construída no minóico tardio IA em Zominthos, pode estar relacionada ao culto da caverna (Watrous, 1996: 58). Quantidades de material de culto do minóico tardio III recuperadas: figurinhas de roda, de animais e seres humanos, várias taças finas, vasos para culto de diferentes tipos, grelha em terracota, selos, brincos de bronze, espada em cristal, etc. De acordo com Sakellarakis, achados sem estratigrafia, atribuíveis aos períodos subminóico e proto-geométrico, indicam que o culto continuou sem interrupção do minóico tardio Ill ao período geométrio (Watrous, 1996: 58).

Época grega - $\mathrm{O}$ grande período de oferendas na gruta de Ida é entre o séc.VIII e VI a.C. Particularmente impressionante é o número de objetos de bronze (escudos, trípodes, etc.), de ouro e marfim, alguns dos quais são produções locais e outros provenientes do Oriente próximo. A caverna produziu terra preta e cinzas misturada com ossos queimados de animais (de boi, ovelha, cabra e lebre). Achados incluíram figurinhas de argila geométricas de bovinos, alguns trípodes de bronze, datados do séc.VIII a.C., um aplique de ouro de dois guerreiros, lamparinas, figurinhas de humanos e animais, muitas lanças de ferro e setas, as famosas séries de escudos de bronze, tigelas fenícias de bronze, uma phiala de bronze do séc.VII a.C., taças, rodas votivas de terracota, figurinhas de marfim, broches de ouro, uma pyxis síria, sete selos de marfim, contas, um colar de espirais em ouro, botões, fíbulas e outros ornamentos do séc.VIII a.C. Fragmentos de pyxides de marfim datam, provavelmente, do mesmo período (Watrous, 1996: 59). Muito material do período clássico é relatado, tal como dois vasos encontrados com cinzas e ossos de animais, desenhados por Sakellarakis. Dedicações helenísticas incluíram anéis, vaso de terra sigilata, placas, figurinhas, moedas (de Itanos, Chersonesos, Cnossos, Gortina, Tylissos, Eleutherna e Polyrrhenion) e lamparinas.

Época romana - Oferendas do período romano são especialmente numerosas. Vasos (muita terra sigillata), placas (representação de bucrânios, folhas de cântaros, Pluto e Cérbero), milhares de lamparinas, anéis (de homens e mulheres) e outros objetos de joalheria. Uma placa de argila com inscrição da caverna nomeia Zeus Idaios. Um grande altar feito de rocha no terraço natural, fora da entrada da caverna, é dito datar do período romano. Achados da caverna continuaram até o séc. V d.C. (Watrous, 1996: 59).

Tipo de culto: Na gruta de Ida o foco do culto foi Zeus Kretagenes: o Zeus nascido em Creta, uma divindade que parece ter tido uma formação histórica longa. A identificação de seu culto em Ida é confirmada por uma inscrição romana, que parece encontrar comprovação na característica dos objetos votivos do início da Idade do Ferro (Prent, 2005: 591). Enquanto Themelis acredita que o culto de Zeus na gruta de Ida teria se iniciado no século VIII a.C., Sakellarakis defende a continuidade de culto entre a Idade do Bronze e a Idade do Ferro, postulando uma mudança decisiva no culto da divindade durante o período minoico tardio III, quando a antiga divindade minoica da vegetação, que anualmente nasce e renasce, sincretizou-se com o Zeus héladico, o pai celeste (Prent, 2005: 597; 
Sakellarakis, 1988a: 212; Themelis, 2004: 144). De acordo com Prent, que concorda com a posição de Sakellarakis, a fusão de um deus indígena e o Zeus heládico teve lugar vários séculos antes da dedicação do tympanon e de escudos no final do século IX a.C., provavelmente, portanto, no final da Idade do Bronze. Evidências desse processo são os objetos votivos do início da Idade do Ferro, encontrados na gruta, que retratam uma mistura de elementos das tradições minoicas e micênicas, tal como um dos escudos que contém, com muita probabilidade, a imagem de um raio, talvez uma referência às qualidades de Zeus como pai celeste (Prent, 2005: 603). Mas, como colocou Prent, essa mudança não significou que o culto ao Zeus cretense alcançou nessa fase sua forma final (Prent, 2005: 597). Sobre o início da Idade do Ferro, os autores aceitam que ritos de iniciação aristocráticos ocorreram no santuário da gruta do Ida (Prent, 2005: 598). Para esse estudioso, esses ritos devem ter sido praticados por homens adultos, guerreiros já estabelecidos, como indicam as dedicações (Prent, 2005: 598). 0 caráter místico do culto em Ida, de ritos de mistérios, é atestado a partir do período clássico tardio e em diante por meio de testemunhos da época (Prent, 2005: 599). A ênfase maior no culto na gruta de Ida foi a grande ênfase em aspectos de mistérios de Zeus Idaios (Prent, 2005: 604).

Pelas suas configurações espaciais e seu posicionamento na paisagem, o santuário da gruta de lda revela fortes paralelos com aqueles santuários inter-regionais do início da Idade do Ferro em outras áreas do mundo grego, como Olímpia e Delfos, por exemplo (Prent, 2005: 565-566; Watrous, 1996: 103-104). A sua função chave foi a de propiciar um local de encontro neutro para indivíduos de diferentes comunidades. Significante a esse respeito é o posicionamento da gruta de Ida em uma área marginal que formou a transição entre as regiões noroeste e sudeste de Creta (Prent, 2005: 566). Assim como Syme, a gruta de Ida não se localiza proximamente às principais rotas antigas - a jornada a esses santuários foi, portanto, uma verdadeira peregrinação, que passava pelo 'campo selvagem' normalmente não percorrido (Prent, 2005: 567). Essa configuração do santuário da gruta de Ida durante o início da Idade do Ferro, a certa distância de um grande número de assentamentos da ilha desse período, destacou o seu potencial de neutralidade (Prent, 2005: 568). Durante 0 início da Idade do Ferro, são escassas as evidências sobre a participação ou organização de comunidades individuais no culto na gruta de Ida (Prent, 2005: 569). De acordo com M. Prent, somente a análise estilística dos objetos votivos e a reconstrução das oficinas pode indicar a origem das comunidades participantes no culto (Prent, 2005: 569). 0 que a princípio é muito claro a partir da quantidade numerosa de bronzes e orientalia, é a presença dominante de fiéis da aristocracia a partir do século IX a.C. (Prent, 2005: 569). O estudo das oficinas dos escudos de bronze, por exemplo, revelou a presença de indivíduos de assentamentos do setor central e centro-oeste de Creta nessa época (Prent, 2005: 570). Tais assentamentos, segundo Watrous, teriam sido Axos, Eleutherna, Cnossos, Tylissos, Phaistos e Gortina (Watrous, 1996: 103-104). Sobre a natureza do culto no início da Idade do Ferro, a raridade de objetos de terracota indica que uma participação limitada de membros não pertencentes à elite das comunidades da região e indivíduos tais como pastores locais (Prent, 2005: 571). No entanto, figurinhas de animais em bronze foram encontradas em certa quantidade, podendo representar uma continuidade funcional com a grande quantidade de oferendas de animais em argila e Chifres de Consagração no período minoico tardio IIIC-sub-minoico (Prent, 2005: 571). A preocupação expressa por figuras e figurinhas de animais tem uma base agrícola e pastoril, diferindo das conotações mais militares-aristocráticas relacionadas aos escudos e armamentos de bronze (Prent, 2005: 571). Prent conclui que a gruta de Ida, além de ter servido como um local de encontro inter-regional para a elite aristocrática de diferentes comunidades do início da Idade do Ferro, manteve suas mais antigas funções em nível (sub-)regional - funções locais para pastores que frequentavam as montanhas ao redor e talvez, em menor escala, para grupos não de elite de comunidades vizinhas (Prent, 2005: 571). Ainda sobre as oferendas desse período, Prent lembra ainda que 0 culto na gruta de Ida teve um componente feminino importante, como indicam a grande quantidade de jóias em ouro, o tipo de objeto votivo feminino mais precioso, não visto em outros 
santuários cretenses do período, como Psychro, por exemplo (Prent, 2005: 570-571). Com relação aos períodos mais posteriores do santuário, é difícil saber em que época, exatamente, a gruta de Ida passou a atrair comunidades para além daquelas mais próximas do setor central e centro-oeste da ilha (Prent, 2005: 568). É certo que para os períodos entre os períodos clássico tardio e helenístico tardio há várias indicações que a gruta de Ida adquiriu uma função pan-cretense e atrair até mesmo peregrinos de fora da ilha de Creta (Prent, 2005: 568 e 593). Há várias inscrições e referências literárias que comprovam essa função ampliada do santuário nesses períodos. Tratados entre as cidades, como foi o caso de Kydonia e Apolonia no oeste de Creta, eram expostos na gruta, e juramentos/acordos entre as cidades eram evocados no nome de Zeus Idaios, como ocorreu com Eleutherna, Gortina, Lyttos e Priansos e comunidades do leste da ilha, Olous e Hierapytna (Prent, 2005: 568). Há uma inscrição do século V a.C. que diz sobre a imposição por Gortina de uma taxa fixa para o sacrifício de animais, após essa pólis ter conquistado Rhizenia (Prent, 2005: 568). Isso, a princípio, indicaria um papel dominante de Gortina no controle do santuário, mas é mais provável, como afirmou Chaniotis (1988), que a organização do culto no final do período helenístico estivesse nas mãos de uma anfictionia, na qual Gortina teria sido um membro importante (apud Prent, 2005: 569; Watrous, 1996: 103-104).

Comentário: Parafernália de culto são similares entre a caverna de Ida e de Dicta, assim como as oferendas votivas (Watrous, 1996: 59).

Referências bibliográficas: Bloedow, E. Evidence for an Early Date for the cult of Cretan Zeus, Kernos (4), 1991, pp.139-177; Hansen, M.H.; Nielsen, T.H. The Inventory of Archaic and Classical poleis (IACP). Oxford Univ. Press, 2005, p. 1163; Peatfield, A. Minoan peak sanctuaries: History and Society, OpAth (18), 1990, pp. 117-131; Praktiká 1983-1986; Prent, M. Cretan sanctuaries and cults. Continuity and change from Late Minoan IIIC to the Archaic Period. Leiden-Boston, 2005, pp. 332-336; Rutkowski, B. The Cult Places of the Aegean. New Haven and London, 1986; Sakellarakis, J.A. L'Antro Ideo. Cento Anni di Attività Archeologica,

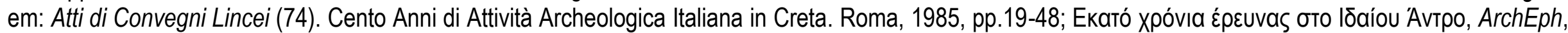
1987, pp.239-263; The Idaean cave. Minoan and Greek worship, Kernos (1), 1988a, pp.207-214; Some Geometric and Archaic votives from the Idaean Cave, em: Hägg, R; N. Marinatos, N.,Nordquist, C.G. (eds.), Early Greek Cult Practices, Proceedings of the $5^{\text {th }}$ International Symposium at the Swedish Institute al Athens, 26-29 June 1986, Stockholm, 1988b,pp. 173-193; Themelis, P. Cults on Mount Ithome, Kernos (17), 2004, pp.143-154; Toutain, J. L'antre de Psychro et l'Idaion antron, RHR (64), 1911, pp.277-291; Tyree, L. Cretan sacred caves: Archaeological evidence (PhD dissertation). Missouri, 1974; Verbruggen, H. Le Zeus Crétois.

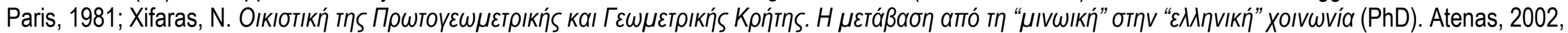
p.72; Watrous, L.V. The cave sanctuary of Zeus at Psychro. A study of extra-urban sanctuaries in Minoan and Early Iron Age Crete. Aegeum 15. Universite de Liège, 1996; Willetts, R. Aristocratic society in Ancient Crete. Londres, 1955; Cretan cults and festivals. N. York, 1962. 


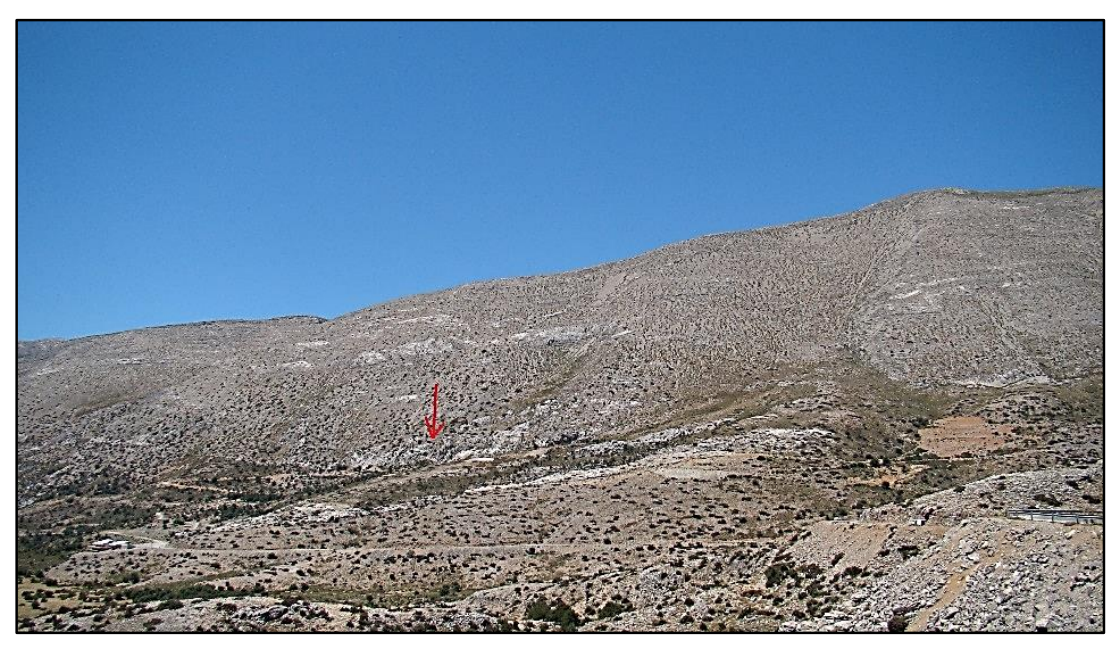

Fig.1- Monte Psiloritis ou Ida, a flecha vermelha indica a localização do santuário da gruta de Ida (Foto: arquivo pessoal/2014)

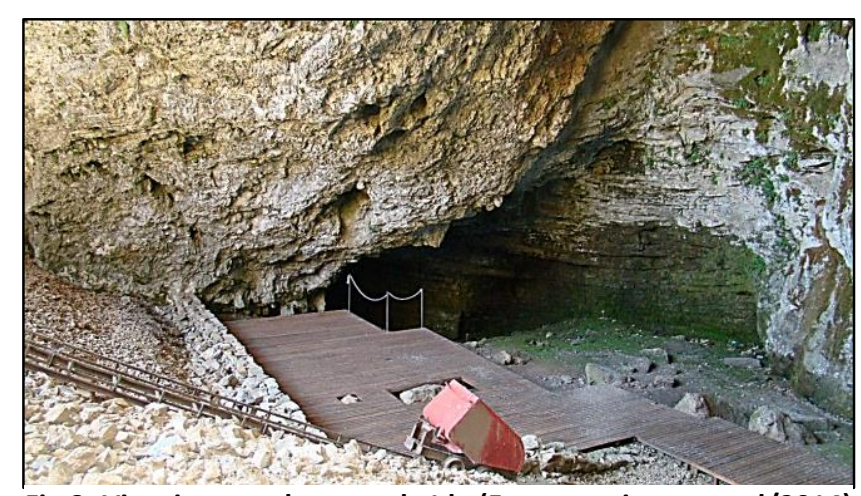

Fig.3- Vista interna da gruta de Ida (Foto: arquivo pessoal/2014)

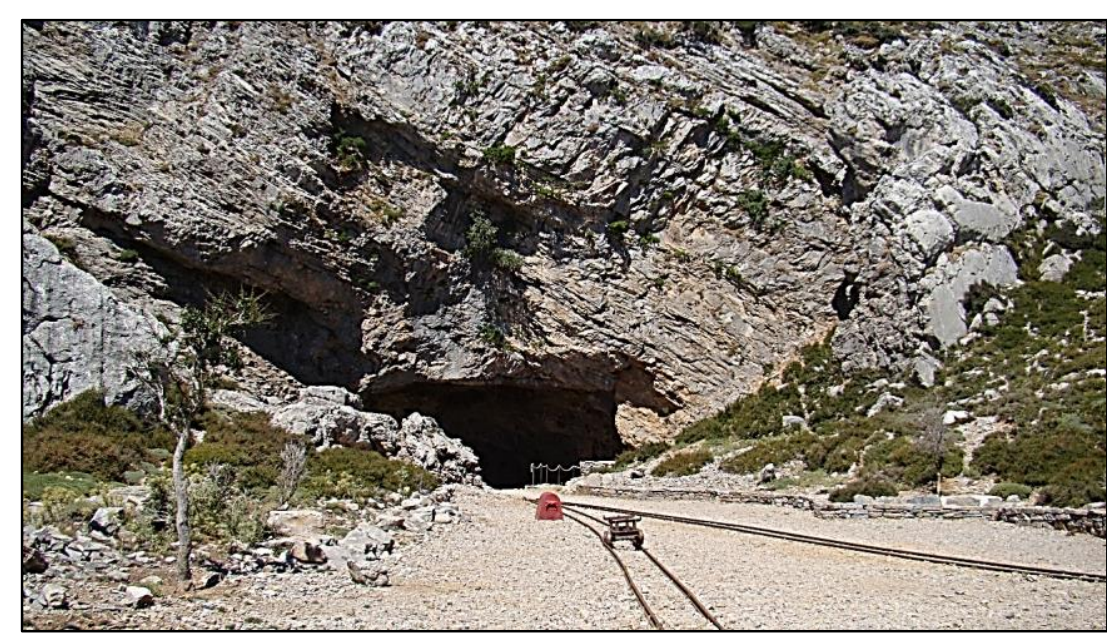

Fig.2- Entrada da gruta de Ida a partir de norte? (Foto: arquivo pessoal/2014)

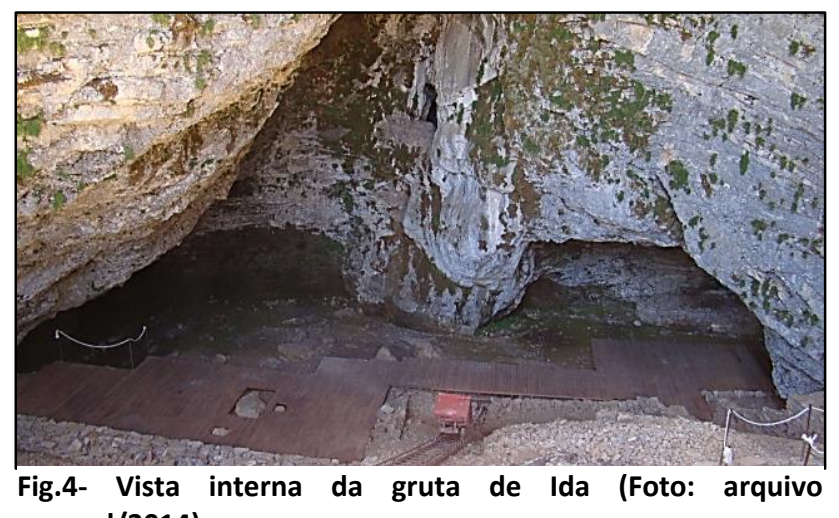
pessoal/2014) 


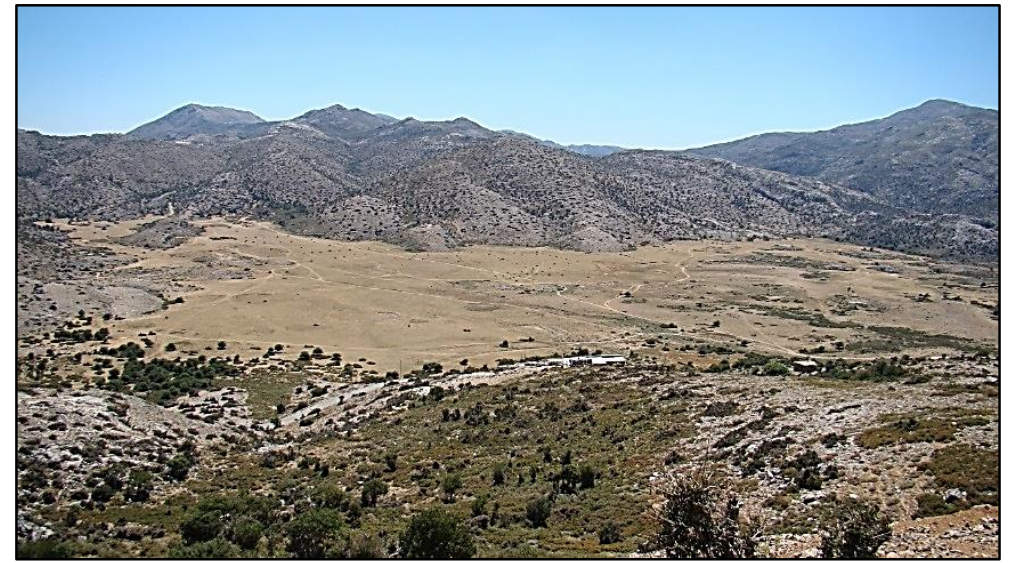

Fig.5- Planície de Nida vista da área da entrada da gruta de Ida (Foto: arquivo pessoal/2014)

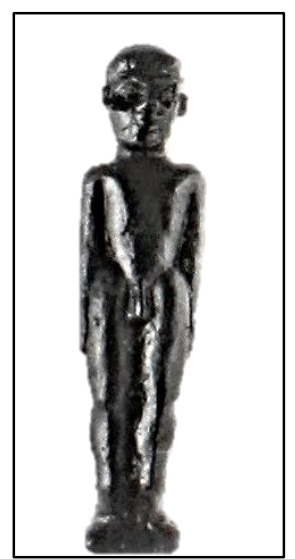

Fig.7- $\quad$ Figurinha masculina em bronze, período geométrico (Sakellarakis; SapounaSakellaraki, 2013: vol. , fig.3, pr.64)

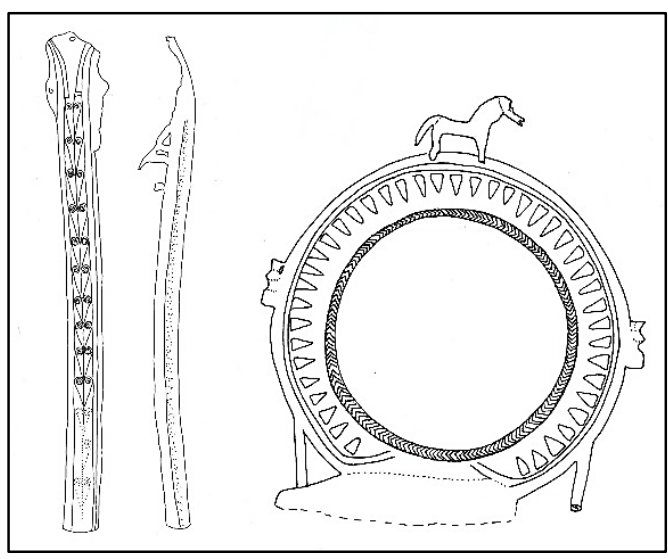

Fig.8- Fragmentos de trípode de bronze, período geométrico (Prent, 2005: fig.61)

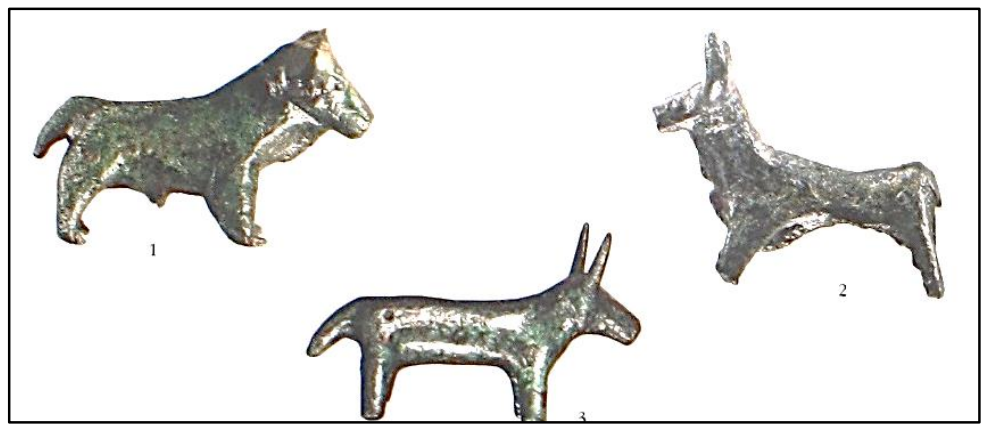

Fig.6- Figurinhas de touro em bronze do período minoico (Sakellarakis; Sapouna-Sakellaraki, 2013: vol.., figs.1,2,3, pr.70)

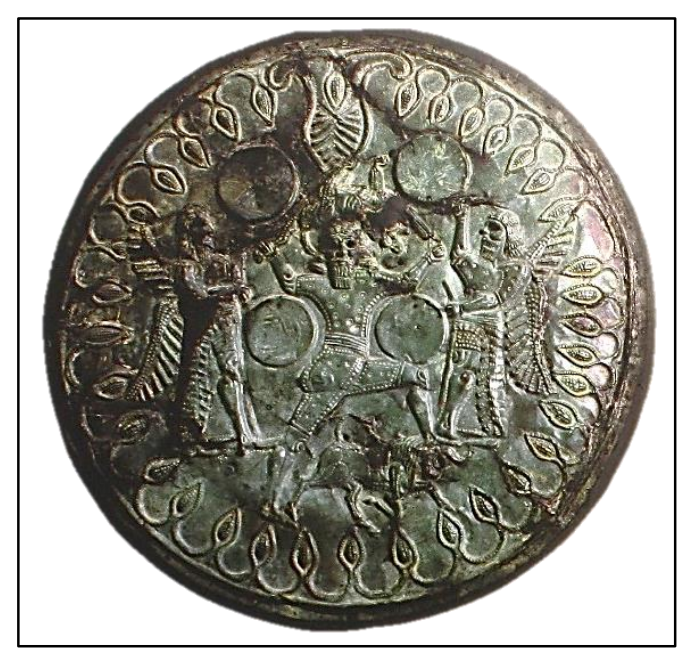

Fig.9- Tympanon de bronze, período geométrico (Sakellarakis; Sapouna-Sakellaraki, 2013: vol.H, 166) 


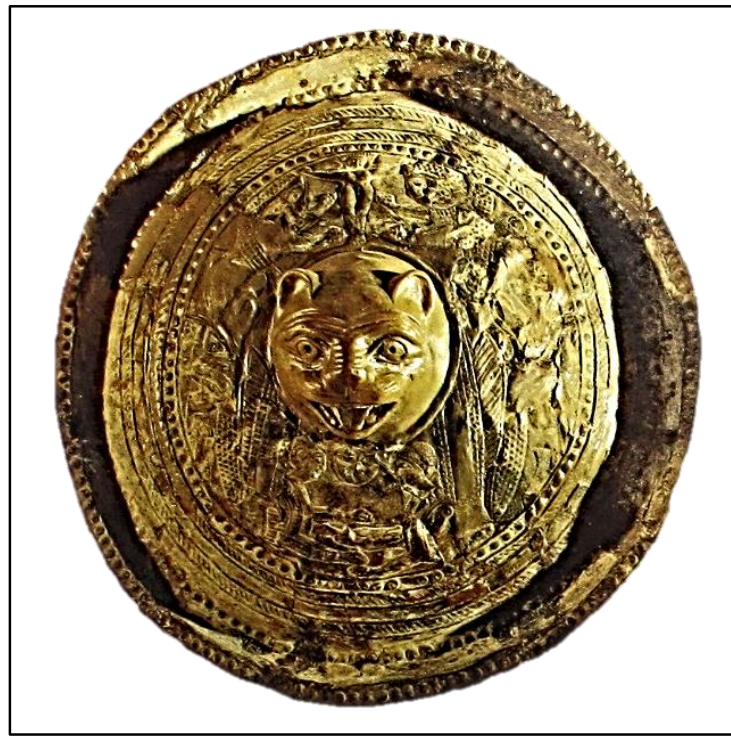

Fig.10- Escudo em bronze com prótomo de leão, período geométrico (Sakellarakis; Sapouna-Sakellaraki, 2013: vol.Г, pr.28)

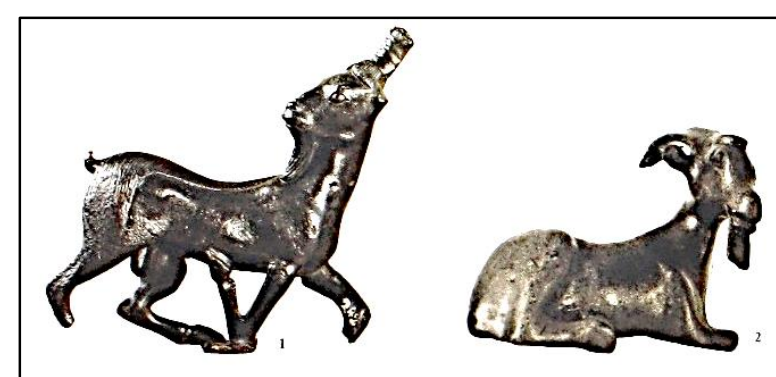

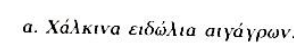
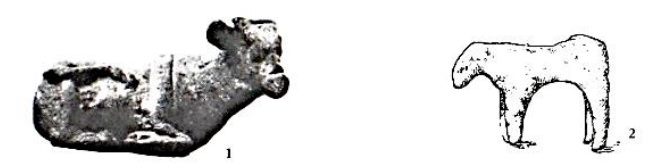

Fig.11- Figurinhas de bode e bezerro em bronze, período geométrico ou arcaico (Sakellarakis; Sapouna-Sakellaraki, 2013: vol. r, figs.1, 2, 3, pr.72)

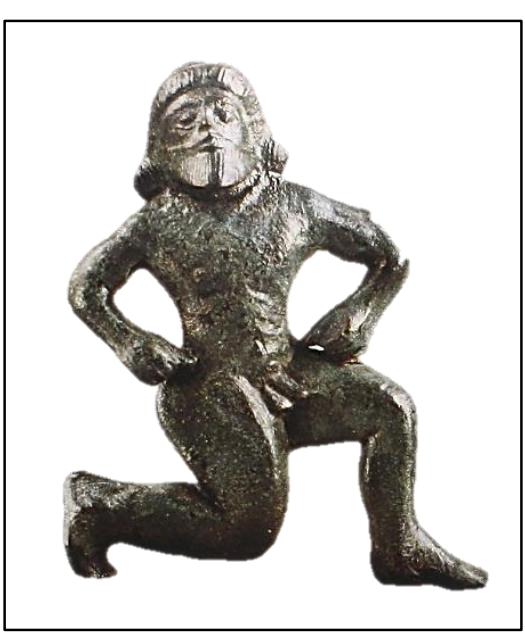

Fig.12- Figurinha masculina em bronze, período arcaico (Sakellarakis; SapounaSakellaraki, 2013: vol. r, fig.3, pr.66) 
Datação: Minóico Médio IB-II (1950-1800 a.C.) - época romana tardia.

Localização: Região centro-leste de Creta, na gruta de Psychro no lado sudoeste do platô de Lassithi, a uma altitude de 1025 m em relação ao nível do mar, e a uma altura de $130 \mathrm{~m}$ acima do nível do platô (Prent, 2005: 167). A entrada da caverna, voltada para norte no Lasithi, dá para Karphi e, o lado oeste, está próximo à pólis de Lyttos (Watrous, 1996: 17).

Tipo de santuário: Gruta em pico / Watrous: interestadual e inter-regional (a partir do séc. VIII a.C.); Prent: extraurbano (Idade do Bronze) / suburbano e subregional (a partir da Idade do Ferro e do início da época arcaica).

Referências textuais: (Mito sobre o nascimento de Zeus na gruta de Dicta) Diodoro IV.80.1-2 / V.70.1-2,2-6 / V.64.3.

Inscrições: Sem referências na bibliografia consultada.

Histórico dos achados: Após as descobertas de antiguidades por habitantes locais em 1883, as primeiras escavações na caverna foram empreendidas por Chatzidakis e Halbherr, que trabalharam na entrada da caverna em 1886. Arthur Evans escavou a parte posterior da câmara superior em 1896, seguido por P. Demargne em 1897. David Hogarth foi o primeiro a explorar sistematicamente a caverna. Hogarth e Evans foram os primeiros a identificar Psychro com a caverna de Dicta, famosa na Antiguidade como o local de nascimento de Zeus (Prent, 2005: 167; Watrous, 1996: 17-18). J. Boardman na década de 1960 realizou uma síntese da história da gruta, se baseando nas evidências estratigráficas nos relatórios mais antigos das escavações e na análise estilística dos artefatos (Prent, 2005: 167-168).

\section{Documentação arqueológica}

I. 0 santuário (o espaço da gruta): É fisicamente organizada em três áreas: um terraço amplo fora da entrada da caverna, uma câmara superior (Upper Grot de Hogarth) e a caverna inferior (Lower Grot). 0 terraço exterior estende-se norte-sul por um comprimento de mais de $40 \mathrm{~m}$ e tem $4 \times 5 \mathrm{~m}$ de largura. 0 terraço, construído em alvenaria ciclópica visível em sua face exterior leste, é uma construção minóica. Aproximando-se da caverna pode-se ver à direita (norte) a câmara superior, cuja sala principal tem cerca de $25 \mathrm{~m}$ largura e $20 \mathrm{~m}$ de profundidade. A desordem de rochas hoje (da escavação de Hogarth) cobre o chão original. No período neo-palacial um altar e uma "dispensa" (storeroom) adjacente (o témeno de Hogarth) ficam no canto norte da câmara superior. A entrada da câmara inferior está localizada na extremidade sul da câmara superior e leva para baixo, $(35 \mathrm{~m})$ nas profundidades da caverna. No fundo da caverna está uma piscina 
profunda de água e uma matriz de estalagmites e estalactites, nas fendas das quais Hogarth encontrou centenas de facas de bronze, adagas, pontas de lança, navalhas, pinças e machados duplos (Watrous, 1996: 17). A caverna de Psychro foi usada como local de habitação durante o final do período neolítico. Não há evidências de qualquer visitação humana após o neolítico tardio até o minóico médio I. O uso do local como santuário começou no minóico médio IA (ou no início do IB) quando se situa a sequência de oferendas do MM I-II. Pertencente ao período neo-palacial é o altar suspenso por três pés, feito de pedras esquadrinhadas e provavelmente coberto por estuque colorido o qual ficava na parte posterior da câmara superior. Este era cercado por um pavimento de pedras de mármore (a leste do altar), muitas cinzas, mesas votivas, taças cônicas e outros objetos que permitiram datá-lo no período (Watrous, 1996: 48). Conforme a descrição de Hogarth da estratigrafia do témeno (storeroom), a área da câmara superior cessou sua função como "storeroom" após o minóico tardio I (Watrous, 1996: 52-53). A câmara inferior continuou em uso no período geométrico e arcaico e o terraço foi usado para refeições de culto e dedicações (Watrous, 1996: 54). Há dois monumentos de pedra do período romano-medieval (Watrous, 1996: 55).

II. Altar e témeno: Uma pequena estrutura retangular no primeiro nicho da caverna pode ter sido 0 altar, que foi cercado por quatro diferentes estratos com objetos votivos do minoico médio, minoico médio III-minóico tardio I, minoico tardio III, geométrico e períodos posteriores (Prent, 2005: 168). O nicho nordeste foi chamado de témeno devido à presença de pavimento de pedras, o qual foi parcialmente cercado por um grande muro de pedra (Prent, 2005: 168). Fora da caverna foram encontrados achados, mas não restos arquitetônicos (Prent, 2005: 168).

II. Objetos votivos: Minóico Médio IB-II - As oferendas mais antigas foram encontradas na câmara superior, nos níveis mais baixos do estrato de terra preta (ossos de animais, potes "kamares", mesas de pedra e cacos esmaltados pintados. Poucos objetos provêm da câmara inferior. Oferendas em argila do período Proto-palacial incluem: taças decoradas, tigelas, jarros, vasos miniaturísticos, figurinhas humanas femininas e masculinas. As primeiras oferendas de bronze datam do Minóico Médio I-II (Watrous, 1996: 47). Minóico Médio III-Minóico Tardio I - mesas votivas, taças cônicas, armas ornamentos pessoais, ferramentas e outros objetos (Watrous, 1996: 48). Minóico Tardio II- IIIB1 - oferendas de argila, de bronze (armas, figurinhas), objetos de joalheria (Watrous, 1996: 52-53). Minóico Tardio IIIB2-Protogeométrico - as oferendas continuaram a diminuir em ambas as câmaras; oferendas do minóico (vasos de argila, fíbulas, mesmo padrão do período anterior), do período protogeométrico (várias contas de argila) (Watrous, 1996: 53). Geométrico-Arcaico - a maior parte dos achados vem de uma camada uniforme de terra preta misturada com pedras e um pouco de figurinhas de argila, bronzes, ferro e um pouco de cerâmica. Armas continuaram a ser ofertadas, como ornamentos, figurinhas animais e humanas de bronze e cerâmica. Placas encontradas no terraço indicam que foram penduradas em árvores na entrada da caverna. Novos objetos em bronze: a figurinha de um coche, carroça puxado por um boi ou cabra, uma miniatura de phiale, figurinhas femininas e masculinas. As figurinhas masculinas são mostradas nuas ou com elmo ou são representadas como guerreiros armados. Uma placa de um caçador retrata o fiel trazendo uma cabra selvagem para o sacrifício no santuário, uma figurinha feminina retrata a pose de Vênus pudica, e uma estatueta de Amon-Ra do Egito (Watrous, 1996: 55). Clássico-Helenístico - Pouquíssimos achados são datados do período, mesmo as duas moedas helenísticas podem ter sido trazidas à caverna em um período posterior (Watrous, 1996: 55). Romano-Medieval - o culto prosseguiu no período romano de forma muito reduzida; achados: um jarro, três lamparinas, anéis, fibulas, cinco contas de vidro, floral em bronze, etc.; achados posteriores incluem uma placa em "estilo animal", um gancho para lamparina, 
uma moeda veneziana, duas fivelas e uma cruz cristã de prata; Evans menciona um bloco de mármore com uma cobra esculpida na face, que pode ser uma referência a Zeus Meilichios (Watrous, 1996: 55).

Tipo de culto: Muitos estudiosos duvidaram que Psychro havia sido a gruta de Dicta e assumiram que ela estivera situada em algum lugar no lado leste de Creta, conforme algumas referências helenísticas. Esta posição se complicou pelo deciframento do tablete de Linear B (Fp1) de Cnossos o qual registra uma oferenda de óleo a Zeus Dicteu (Watrous, 1996: 18). Estudos sobre nomes de lugares nos tabletes de Cnossos mostraram, contudo, que não se referem ao extremo leste da ilha. $O$ santuário a que se refere o tablete Fp1 deve, provavelmente, ser localizado no centro de Creta. Além disso a exploração de Faure de 120 cavernas no leste de Creta indicou que cavernas não foram usadas ali como santuários no período pré-histórico. No fim, não há evidência real que conecte Psychro diretamente com oferendas de Cnossos a Zeus Dicteu, embora não seja impossível, já que vários vasos cnossos foram ofertados em Psychro no Minóico Tardio III (Watrous, 1996: 19). O santuário maior de caverna conhecido na região de Lytthos durante a Idade do Ferro era a gruta de Psychro, que foi suficientemente importante para atrair oferendas de Cnossos, de Corinto e do Egito. Entretanto, esta identificação apenas sugere que o local nos séculos VIII e VII a.C. foi amplamente conhecido como o local do nascimento de Zeus. E isso não nos diz se Zeus em Psychro tinha o epíteto de Dicteu, nem se havia outro. Parece que um "Zeus de Dicta" já existia no Minóico Tardio III e que a tradição grega posterior, relativa ao jovem Zeus Dicteu, focalizou o nascimento e infância de Zeus em uma caverna. Escritores helenísticos (Schiliast to Aratos, Phenomena 33, Calímaco, Hino a Zeus, 4-7) identificaram a caverna do Ida como o local do nascimento de Zeus Dicteu. Nesse sentido, parece improvável que no período minóico uma divindade tão importante tivesse sido unicamente cultuada em um único local da ilha (Watrous, 1996: 19). A evidência epigráfica da Idade do Bronze não nos informa se o santuário de Zeus Dicteu era em uma caverna ou no cume de uma montanha em um único lugar em Creta. De fato, dada a evidência arqueológica, parece mais provável que durante o período Minóico e o início da Idade do Ferro, o nascimento e juventude de Zeus foram celebrados em vários tipos de santuários por toda Creta (como no período clássico e períodos posteriores) e que a busca pelo culto minóico de Zeus Dicteu é anacrônico. O santuário de Psychro, portanto, foi provavelmente um dos vários santuários dedicados ao jovem Zeus cretense (Watrous, 1996: 19). Conforme Watrous, os grandes santuários de montanha da era minóica - Ida, Syme e provavelmente Psychro - tornaram-se santuários interestaduais no séc. VIII a.C. Ao menos há certeza para Ida já que a divindade patrona da caverna, Zeus Bidatas, foi cultuada por várias cidades cretenses em seus tratados e leis (ver Chaniotis, 1988). No final do séc. VIII a.C., Psychro foi também um santuário popular, que atraiu numerosos bronzes votivos e importações de outras partes de Creta e do mundo grego. Essa mudança corresponde ao surgimento do poder da pólis de Lyttos. Em algum momento da Idade do Ferro, a área do Lasithi provavelmente tornou-se parte do território de Lyttos. No período arcaico, a cidade foi uma das mais poderosas de Creta. Psychro atraiu preregrinos da parte central e leste de Creta, provavelmente incluindo a área entre Lyttos e Lato (Watrous, 1996: 102-103). Também compara Ida com Psychro em termos rituais e objetos votivos, comparando-os, nesse último aspecto, aos santuários do Peloponeso de Olímpia e Bassai (Watrous, 1996: 104).

Quase uma década depois, M. Prent oferece uma explicação totalmente contrária a essa de L.V. Watrous - a seu ver, a identificação do santuário de Psychro com a gruta de Dicta não é certa, tampouco a classificação de Psychro como um santuário interestadual na Idade do Ferro (Prent, 2005: 169). Para Prent, os escritores antigos, bem posteriores a Hesíodo, teriam confundido Dicta (localizada mais a leste de Creta) com Aigaion, a montanha descrita pelo poeta tebano como o local de nascimento de Zeus. A proximidade de Aigaion, nas vizinhanças de Lyttos, com Psychro, no platô do Lassithi, teria levado a tal confusão (Prent, 
2005: 169). Com relação às características do santuário, Prent defende que Psychro foi um lugar de culto extraurbano durante a Idade do Bronze, transformandose em suburbano no início da Idade do Ferro por interferência do desenvolvimento da pólis de Papoura, o maior assentamento da região do Lassithi nesse período (Prent, 2005: 609). Com base no tamanho do assentamento de Papoura, sua posição estratégica nas principais rotas de acesso e sua proximidade à gruta de Psychro, é muito provável, segundo Prent, que a organização do culto em Psychro no início da Idade do Ferro pertenceu aos habitantes desse assentamento (Prent, 2005: 609). A relação entre Psychro e Papoura seria, talvez, o paralelo mais próximo, em Creta, do modelo bipolar de De Polignac (Prent, 2005: 609). Uma mudança no tipo de objetos votivos - de figurinhas de bronze para figurinhas e objetos de terracota - durante o século VII a.C. pode indicar que foi justamente nessa época que Psychro se tornou o santuário suburbano de Papoura (Prent, 2005: 610). Ao mesmo tempo, o santuário da gruta de Psychro teria funcionado como um centro de culto sub-regional, portanto, para os diferentes assentamentos presentes naquela época no plato do Lassithi, 0 que teria inibido 0 desenvolvimento de Psychro em um grande santuário inter-regional (Prent, 2005: 610).

Referências bibliográficas: Chaniotis, A. Habgierige Götter, habgierige Städe Heiligtumsbesitz und Gebietsanspruch in den kretischen Staatsvertragen, Ktema (13), 1988, pp.29-32; Dengate, C. The sanctuaries of Apollo in the Peloponnese (PhD dissertation). Univ. of Chicago, 1988; Pendlebury, J. The Archaeology of Crete. Londres, 1939; Myers, E. e W. The aerial atlas of Ancient Crete. Berkeley, 1992; Prent, M. Cretan sanctuaries and cults. Continuity and change from Late Minoan IIIC to the Archaic Period. Leiden-Boston, 2005; Rutkowski, B.; Nowicki, K. The Psychro cave and other Sacred grottoes in Crete, Varsóvia, 1996; Toutain, J. L'antre de Psychro et l'Idaion antron, RHR (64), 1911, pp.277-291; Tyree, L. Cretan sacred caves: Archaeological evidence (PhD dissertation). Missouri, 1974;

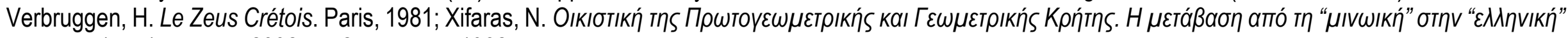
Xolvwvía (PhD). Atenas, 2002, p.72; Watrous, 1982. 


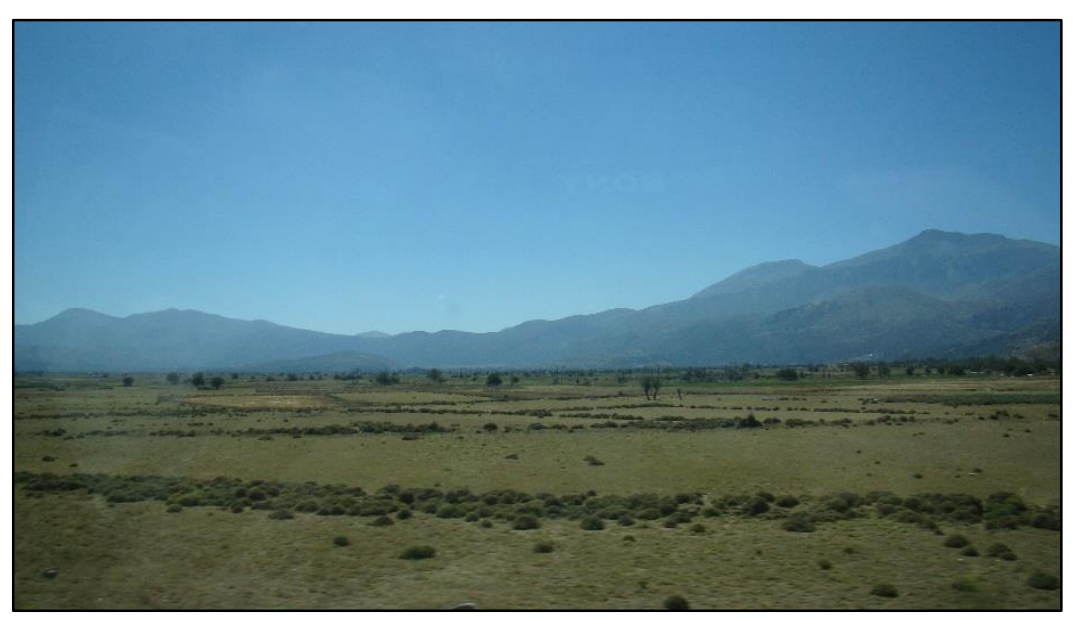

Fig.1- Platô do Lassithi e Monte Dicta (mais alto) visto a partir da área do mosteiro de Vidiani (Foto: arquivo pessoal/2014)

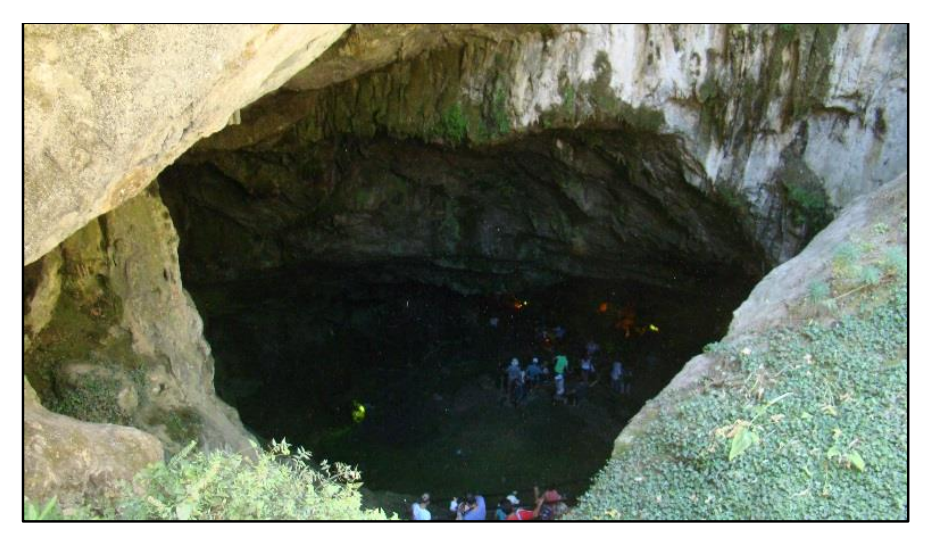

Fig.3- Entrada da gruta de Psychro (Foto: arquivo pessoal/2014)

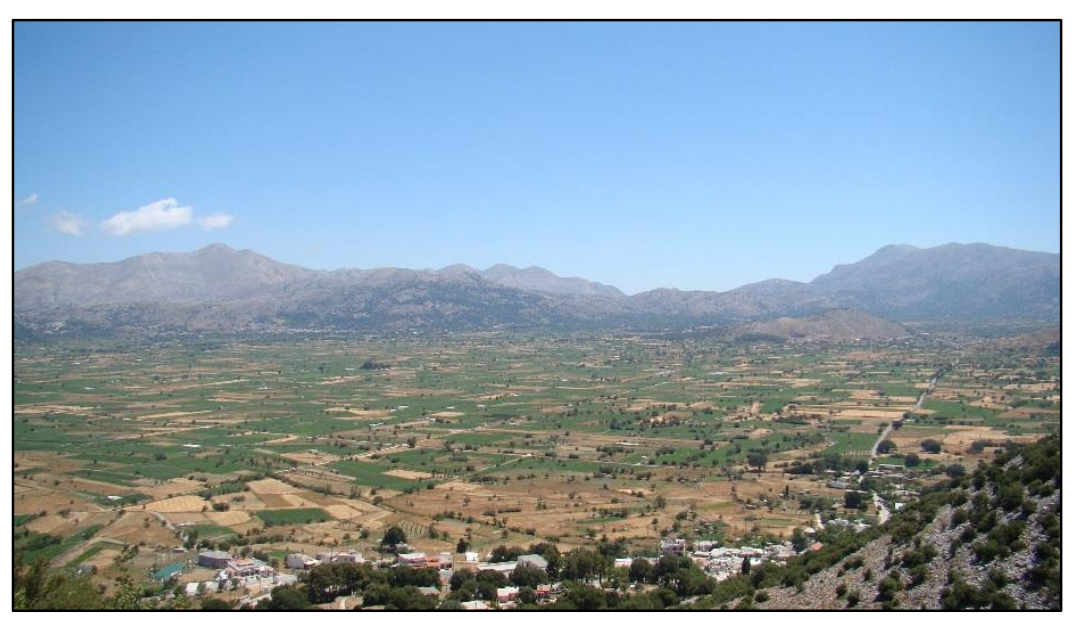

Fig.2- Platô do Lassithi visto a partir da área da entrada da gruta de Psychro (Foto: arquivo pessoal/2014)

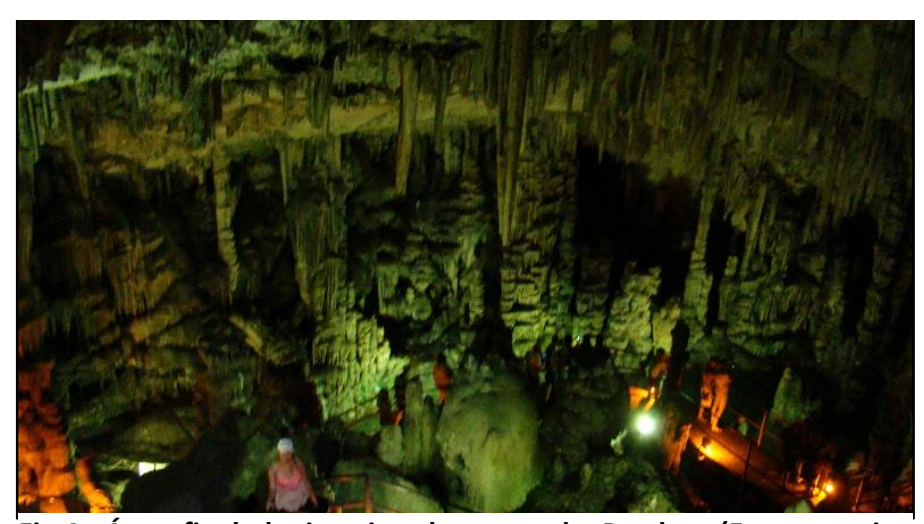

Fig.4- Área final do interior da gruta de Psychro (Foto: arquivo pessoal/2014) 


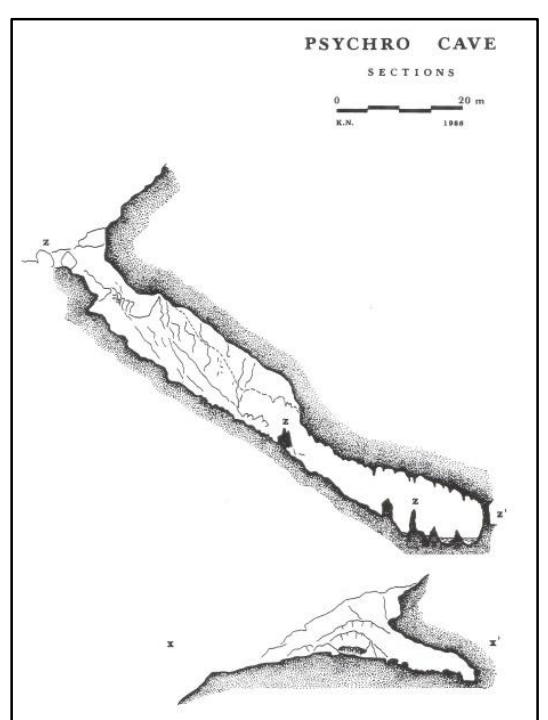

Fig.5- Perfil da parte interna da caverna de Psychro (Watrous, 1996: pr.III)

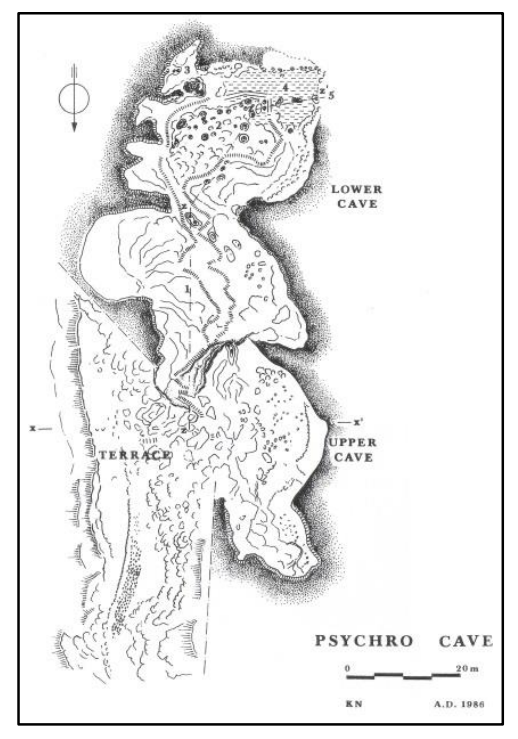

Fig.6- Desenho da parte interna da caverna de Psychro (Watrous, 1996: pr.II)

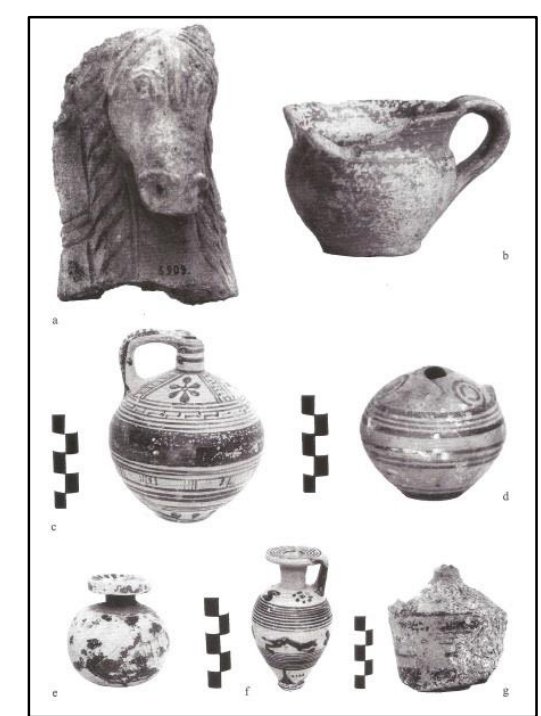

Fig.7- Cerâmica geométrica de Psychro (Watrous, 1996: pr.XXVIII)

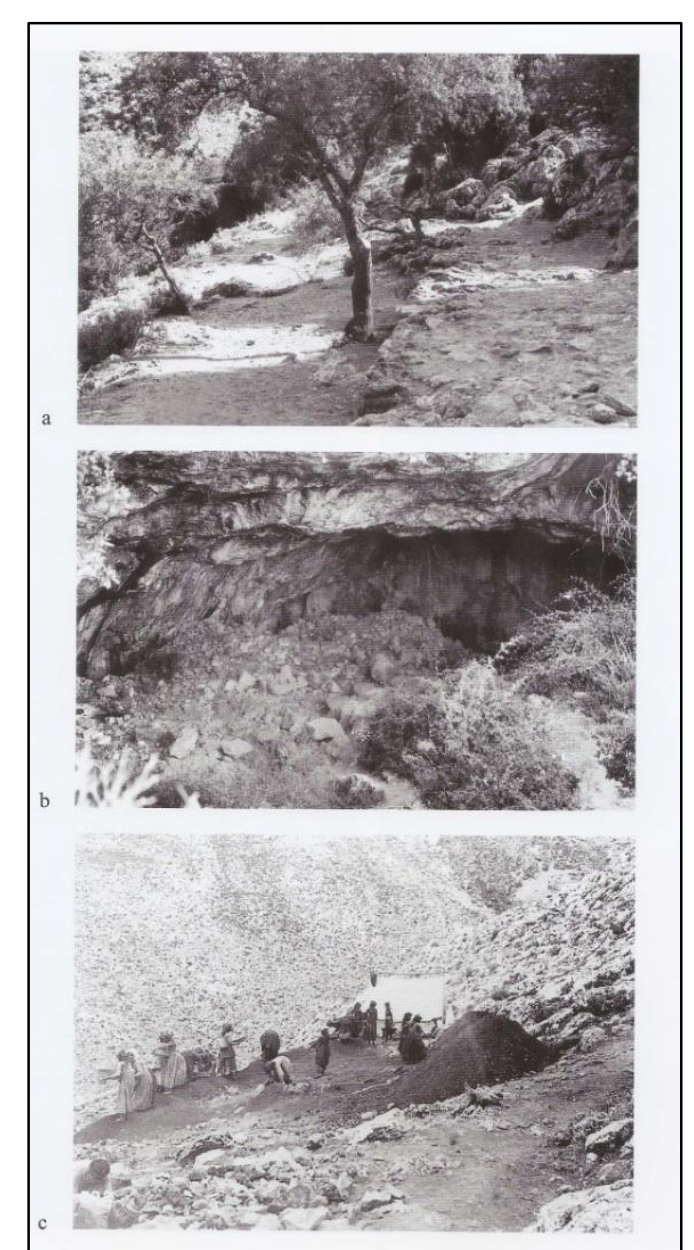

Fig.8- Parte externa da caverna de Psychro (Watrous, 1996: pr.V) 
Datação: Heládico tardio IIB (1510-1390 a.C.) / IIIC (1200-1070 a.C.) - final da época helenística.

Localização: Atual Monte Ágios Elias, localiza-se no sudoeste da Arcádia, a oeste de Megalópolis, nas proximidades do vilarejo moderno de Ano Karyés (lykaionexcavation.org).

Tipo de santuário: Pico / sub-regional (a partir da Idade do Ferro até o século VI a.C.) / sub-regional, inter-regional e interestadual (a partir do século V a.C.) com função agonística (desde?).

Referências textuais: (Santuário) Tucídides V.XVI.3; (Templo) Estrabão 8.8.2; (Témeno) Pausânias IV, XXII.4-7 / VIII, XXXVIII.6-9; (Altar) Pausânias VIII, XXXVIII.6-9; Píndaro Ol 13. 105-110; Políbio IV.33.2-9; (Altar e jogos) Pausânias VIII, II.4; (Jogos e festival) Píndaro, Nem 10. 45; Xenofonte, Anab I.II.9-11; Píndaro Ol 9.90-96; (Mito e sacrifício) Pausânias VI, II.VIII.2; (Mito) Pausânias VIII, XXXVIII.2; (Sacrifícios) Pausânias VIII, II.4-7 / VIII, XLIV.5; Tucídides V.LIV.12; (Sacerdote, ritual e sacrifício) Pausânias VIII, XXXVIII.3-6.

Inscrições: (Sobre organização do festival religioso e atlético / lista dos vencedores nos jogos - séc. IV a.C.) IG V ii 549-550; (perneira de bronze com uma inscrição votiva dedicada a Zeus Lykaios e Atena - séc. V a.C.) IG V, 2, linha 551.

Histórico dos achados: O santuário de Zeus no Monte Lykaion foi escavado pela primeira vez por Kontopoulos em 1897 e mais tarde por Kourouniotis em 1902 , ambos da Sociedade Arqueológica de Atenas. Estas investigações iniciais identificaram e descobriram várias características do santuário, incluindo o monte de cinzas (o altar no pico sul da montanha a $1382 \mathrm{~m}$ ), e um temenos a $24 \mathrm{~m}$ abaixo do altar. Na parte inferior do santuário, Kourouniotis também encontrou 0 hipódromo, o estádio, a casa de banhos, duas fontes, uma stoá, os assentos (de frente em uma área aberta), e um edifício que ele identificou como xenon, ou hospedaria, identificado atualmente como um prédio administrativo. No final dos anos de 1990 Spyropoulos, então superintendente das regiões da Lacônia e Arcádia, escavou trincheiras no altar, no temenos e no santuário debaixo (Romano; Voyatzis, 2014: 575). 0 santuário permaneceu quase 100 anos sem ser escavado até 1996, quando a Universidade da Pennsylvania, sob a direção de D. G. Romano e M. Voyatzis, conduziu um importante survey na topografia e arquitetura do Monte Lýkaion. A primeira escavação americana (Univ. Pennsylvania e Arizona) se iniciou em 2004 e durou até 2010 . A partir de 2011 até 0 momento atual, o time iniciou os trabalhos de análise da documentação na apoteca em Tripolis. Novas escavações e outras pesquisas estão previstas para os próximos anos (lykaionexcavation.org). Os achados da escavação de Kourouniotis encontram-se no Museu Arqueológico de Atenas e os achados das escavações americanas estão em Lykossoura e na apoteca de Trípolis. 


\section{Documentação arqueológica}

\section{Santuário de cima}

I. Témeno e objetos votivos: Escavado por Kourouniotis, o témeno está situado a $20 \mathrm{~m}$ abaixo do cume na altura da capela de Ágios Elias e ocupou uma área de 55 x 120 m no pequeno platô denominado de "Taverna". Apenas uns alinhamentos de pedra marcavam os limites e, no interior do cercado, Kourouniotis escavou várias trincheiras sem encontrar algum traço de construção. No setor oriental, a camada de terra foi mais espessa e mais preta. Kourouniotis pensou que a terra tinha essa coloração devido ao derramamento de sangue dos animais: para ele ali teria sido um tipo de prothysis, onde as vítimas eram abatidas antes de serem queimadas no cume do Lykaion. Com relação às bases de duas colunas, trata-se de duas bases quadradas de pedra, distantes $7 \mathrm{~m}$ uma da outra, próximas das quais foram encontradas outras bases de pedras (Jost, 1985: 181). Na escavação na área dessas duas bases das colunas, de frente ao témeno, Kourouniotis encontrou estatuetas na área da base norte, e duas moedas perto da base sul. 0 arqueólogo grego abriu trincheiras dentro da área do témeno, mas nada foi encontrado, exceto alguns objetos de ferro na área sul. Essa ausência de achados vai de encontro à descrição de Pausânias (8.38.6) do témeno como um ábaton, onde nenhum homem poderia caminhar por medo da morte dentro de um ano (Romano; Voyatzis, 2014: 577). A maior concentração de achados foi ao redor da área das duas bases de colunas. De frente ao témeno, Kourouniotis encontrou 9 estatuetas de bronze completas e parte de uma décima, assim também como as bases de outras estatuetas similares, e uma águia de bronze, que datou do início do século $V$ a.C. Várias dessas figurinhas foram encontradas na área $10 \mathrm{~m}$ a oeste das bases das colunas. As estatuetas de bronze são de dois Hermes do século $V$ a.C. Também foram encontrados jóias em bronze, uma placa em bronze, várias telhas e nenhuma cerâmica. Próximo a essa área foram recuperados uma cobra de bronze com duas cabeças, um askos em bronze, duas moedas de prata, 10 anéis gravados ( 9 de bronze e 1 de ferro) uma perneira de bronze do século $\mathrm{V}$ a.C. com uma inscrição votiva dedicada a Zeus Lykaios e Atena (IG V, 2, linha 551). Já na área da base de coluna norte, Kourouniotis encontrou uma figura em bronze de Zeus nu segurando o raio com sua mão direita e uma águia pousada sobre a esquerda - o objeto mais antigo encontrado que data do final do século VII a.C. - que deve ter sido parte de um trípode. Outras estatuetas de Zeus, todas de bronze, incluem uma imagem de Zeus Ithomatas do início do século VI a.C., um Zeus sentado arcaico (540-530 a.C.), uma estatueta de Zeus com um himátion, uma mão de Zeus segurando uma forma de raio (haste) do século V a.C.; um pé, provavelmente de Zeus, do século V a.C., e uma miniatura de águia do século V a.C. (Romano; Voyatzis, 2014: 577-578). Embora Kourouniotis tenha, com convicção, identificado a localização e determinado o perímetro do témeno, sua área precisa permanece incerta. A área aproximada do témeno descrito por Kourouniotis é de $6.438 \mathrm{~m}^{2}$ e tem um perímetro de $363 \mathrm{~m}$. De acordo com Romano e Voyatzis, é provável que a região ao redor das duas bases de colunas, como também aquela imediatamente a oeste, identificada por Kourouniotis como pré-sacrificial, não foram parte do témeno, mas a área fora dele (Romano; Voyatzis, 2014: 629). A maior parte da área considerada anteriormente como o témeno é plana e segue até a base do pico sul da montanha. Uma linha parcial de pedras baixas, encontrada por Kourouniotis na base do pico sul, podem ter sido os restos do muro de témeno (Romano; Voyatzis, 2014: 629). Ao contrário de Kourouniotis, que recuperou estatuetas de Zeus e Hermes, as escavações americanas não encontraram sequer um objeto no témeno e na área ao redor. Acredita-se que isso se 
deva ao uso moderno da área, principalmente aquele relacionado às festividades anuais do Profeta Elias, cuja capela foi construída na área, 0 que deve ter provocado o desaparecimento dos achados (Romano; Voyatzis, 2014: 626 e 628). Sobre um caminho que deveria ligar o santuário de cima ao debaixo, Kourouniotis sugeriu que as bases de pedra das colunas teriam originalmente suportado duas colunas com duas águias, as quais teriam marcado a entrada leste do témeno. Os pesquisadores americanos sugerem que esse caminho teria ligado o lado norte ao leste do pico sul da montanha, passando pela fonte Hagno ou casa da fonte (Romano; Voyatzis, 2014: 626).

II. Altar e objetos votivos: Situado no pico sul a $1382 \mathrm{~m}$ acima do nível do mar, o altar de Zeus Lykaios estava no ponto mais elevado. A área inteira do pico sul da montanha, de aproximadamente $700 \mathrm{~m}^{2}$, foi coberta por cinzas e ossos queimados de animais dos sacrifícios (Romano; Voyatzis, 2014: 579). 0 altar, então, não era uma construção de pedras e nem um amontoado de cinzas, mas um monte artificial de $30 \mathrm{~m}$ de diâmetro e 1,5 m de altura, feito de terra enegrecida pelo fogo das cinzas, e dos ossos de animais queimados, e pontilhado por grandes pedras, que na época Kourouniotis acreditou se tratar de um túmulo na montanha (Jost, 1985: 180). Kourouniotis recuperou pequenas phialai e skyphoi, com verniz sólido preto, típicas dos séculos V e IV a.C., fragmentos de lamparinhas de terracota e muitas telhas, algumas com inscrições estampadas datadas, provavelmente, do século IV a.C. (Romano; Voyatzis, 2014: 575-576). Também foram recuperados uma faca de ferro de época arcaica, alguns anéis de bronze, uma chave de ferro, uma figurinha de pássaro de terracota do século IV a.C., uma moeda arcaica de Egina, uma moeda da Liga Arcádia e duas miniaturas de trípodes de bronze do século VII a.C. (Romano; Voyatzis, 2014: 576). De acordo com as escavações americanas, realizadas no altar entre 2007 e 2010, a área que corresponde a parte de intensa queima (Z3) foi datada entre o século X a.C. e os períodos arcaico e clássico de acordo com os achados encontrados (fragmentos cerâmicos do período héladico, geométrico e arcaico e uma miniatura completa de um trípode de bronze) (Romano; Voyatzis, 2014: 581). A grande concentração de material dos períodos mais antigos de uso do altar foi encontrada na base de pedra, que corresponde ao nível mais baixo da trincheira Z, tendo sido datada entre o heládico tardio IIB e IIIC até a Idade do Ferro. Embora a maior parte do material seja micênico, foram também recuperados material cerâmico do final de neolítico, heládico antigo e heládico médio (Romano; Voyatzis, 2014: 581). Figurinhas do héladico tardio de animais e de humanos foram também recuperadas na área (Romano; Voyatzis, 2014: 582). Da análise do material cerâmico recuperado na trincheira Z, concluiu-se que este foi usado entre o final do neolítico e período clássico tardio (Romano; Voyatzis, 2014: 584). Essa descoberta muda o que Kourouniotis havia encontrado - apenas material cerâmico dos séculos V e IV a.C. (Romano; Voyatzis, 2014: 584). A descoberta significativa de uma grande quantidade de cerâmica micênica no altar de cinzas pode ajudar não só a identificar um culto micênico no local, mas a demonstrar a continuidade de culto desde o final da Idade do Bronze até a Idade do Ferro (Romano; Voyatzis, 2014: 591). Sobre os demais tipos de achados votivos na área do altar, foram recuperados, da Idade do Bronze tardia, figurinhas de terracota e um selo de cristal; de períodos posteriores, 40 miniaturas de trípodes de bronze, uma pequena mão de uma estatueta de bronze segurando um raio em prata; objetos de ferro (machados duplos; dois espetos, uma faca, anéis e fragmentos de miniaturas de trípodes). Foram também encontrados, lamparinas, fragmentos de vasos de vidro, ferramentas de pedra e moedas (total de 33), de época clássica. As miniaturas de trípodes e os machados duplos indicam atividade de culto na Idade do Ferro. As coroas de chumbo são provavelmente do século VII a.C. e a miniatura de 
kouros é de data arcaica. A mão de bronze de Zeus é provavelmente do final da época arcaica e início da clássica, encontrando paralelo a uma encontrada por Kourouniotis no século XIX (Romano; Voyatzis, 2014: 615). Dos achados das 33 miniaturas de trípodes de bronze, concluiu-se que a prática de dedicar tal objeto no altar começou no início do século X a.C. e durou até o século VII a.C. Miniaturas de trípodes de bronze foram encontradas em poucos santuários, como em Olímpia, onde também foram encontrados trípodes de tamanho grande, os dois tipos recuperados, principalmente, na camada de terra preta entre 0 setor sul do Heraion e o Pelopion (Romano; Voyatzis, 2014: 618).

III. Edifício antigo: Foram encontradas, no altar de cinza e no témeno restos de telhas de tipos coríntio e lacônio, sugerindo que estas teriam pertencido ao telhado de um ou mais antigos edifícios no pico sul ou a apenas a um, provavelmente um naískos (Romano; Voyatzis, 2014: 624).

IV. Proto-estádio: Teria se localizado na área a sul do altar e témeno, a aproximadamente $130 \mathrm{~m}$ a sudoeste do pico sul do altar, a uma elevação de $48 \mathrm{~m}$ abaixo deste, em um terraço plano e limitado a leste e oeste pelas encostas da montanha. A área tem c. $150 \times 12 \mathrm{~m}$, corre em um sentido de norte a sul, pode ter servido como o caminho sul ao pico sul da montanha durante a antiguidade, um possível caminho de procissão e usado para as competições dos jogos lykaios, como um tipo de proto-estádio antes da construção dos edifícios no santuário debaixo (Romano; Voyatzis, 2014: 629). 0 achado de uma estatueta de bronze de um corredor por Kourouniotis na área do témeno ajuda a reforçar tal tese (Romano; Voyatzis, 2014: 626 e 628).

\section{Santuário debaixo}

V. Casa da fonte e fonte Hagno: Hagno: Situada a aproximadamente meio caminho entre o santuário de cima e o debaixo, por isso deve ter sido um ponto de parada importante na antiga rota entre os dois setores. Em 1996, D. Romano localizou a fonte $145 \mathrm{~m}$ abaixo do altar de cinzas (Romano; Voyatzis, 2014: 630). Kourouniotis a identificou com a fonte Korités, situada a dez minutos a norte do altar (no lugar chamado de Anémorrachi ou Phatoureïko), entre o setor de baixo e o de cima (Jost, 1985: 181-182). Casa da fonte: De acordo com as últimas pesquisas na estrutura, a casa da fonte localiza-se a c.20 m a sudoeste do prédio administrativo, se trata de uma estrutura de c.6,97 x 3,83 m de várias fases de construção (Romano; Voyatzis, 2015: 229). 0 material de sua construção permitiu data-la no século IV a.C. A casa da fonte foi mantida por uma fonte natural no lado da montanha, serviu como a principal fonte de água no santuário debaixo, primariamente para as estruturas a sul do hipódromo e estádio, o prédio administrativo, a stoá e os assentos (Romano; Voyatzis, 2015: 230).

VI. Assentos ou degraus, terraços e área de monumentos: A aproximadamente $21 \mathrm{~m}$ a norte da stoá, medindo 39,09 m de comprimento (Romano; Voyatzis, 2015: 238). A data para sua construção parece ter ocorrido no século IV a.C. (Romano; Voyatzis, 2015: 245). Concluiu-se que estes estiveram relacionados aos eventos agonísticos, possivelmente usados para ver as procissões ou para a avaliação de cavalos ou atletas (Romano; Voyatzis, 2015: 241). 
VII. Edifício semi-circular: As dimensões totais são de 6,8 x 5,8 m, há cinco colunas jônicas prostilas, sem função conhecida (Romano; Voyatzis, 2015: 237 238).

VIII. Stoá: Foi construída provavelmente no período clássico tardio, embora possa ter havido uma fase mais antiga, baseada na aparência do que pode ter sido as suas fundações mais baixas (Romano; Voyatzis, 2015: 231). As dimensões totais são de 67,08 x 13,70 m (Romano; Voyatzis, 2015: 231).

IX. Corredor: Feito de paredes de pedras poligonais mediu entre suas extremidades 2,60 x 2,38 m e o comprimento total de $25 \mathrm{~m}$ (Romano; Voyatzis, 2015 : 217). O uso do corredor mudou drasticamente durante a história do santuário - foi aparentemente convertido em área de descarte em algum momento no século III a.C. Os pesquisadores americanos sugerem que o material descartado provavelmente veio do edifício administrativo e talvez da stoá nas proximidades (Romano; Voyatzis, 2015: 228). Originalmente serviu como corredor que trazia os atletas da área do edifício administrativo à área atlética a norte, assim como pode Ihe ser atribuída uma função religiosa/cerimonial (Romano; Voyatzis, 2015: 228).

X. Edifício administrativo: Os pesquisadores americanos identificaram a estrutura, anteriormente classificada por Kourouniotis como um xenon ou hospedaria, em um edifício administrativo para o santuário e seu festival religioso. Sabe-se que esse edifício tinha várias salas e pátios, características comuns aos pritaneia, por exemplo. $O$ achado de uma grande quantidade de cerâmica assinalou uma função de refeição a esse edifício ou a uma área próxima. Duas estelas, encontradas em uma das salas do lado oeste do edifício, contêm a inscrição IG V ii 449-550, que menciona os damiourgoi, um grupo aparentemente relacionado à organização do festival do Lykaion, e propiciam, além disso, informações importantes relacionadas ao festival religioso, o nome dos sacerdotes dos deuses e informações sobre os atletas (os eventos nos quais foram vitoriosos e suas origens). Pode ter havido uma ligação física entre o lado leste do edifício administrativo, o corredor adjacente e o local das competições, como o hipódromo e o estádio a norte (Romano; Voyatzis, 2015: 216).

XI. Santuário de Pã: As escavações americanas não encontraram qualquer evidência, levando-os a pensar que teria se tratado de um culto modesto sem templo (Romano; Voyatzis, 2015: 245).

XII. Hipódromo e estádio: O hipódromo é o único exemplo, no mundo grego, que pode ser visto e medido (Romano; Voyatzis, 2015: 245). Situa-se c.217 m abaixo da elevação do altar de cinzas e mede c. 260 x 102 m (Romano; Voyatzis, 2015: 245). Com base em investigações de Kourouniotis, bem como o trabalho arqueológico mais recente no local, parece que o hipódromo e o estádio foram construídos como duas partes de um todo, com os dromos do estádio sendo encontrado dentro dos limites do hipódromo. Este é um projeto arquitetônico único, não só na Grécia continental, mas também em todo o mundo grego. Kourouniotis encontrou características arquitetônicas específicas do hipódromo e do estádio, muitos das quais foram redescobertas e documentadas nas escavações americanas (Romano; Voyatzis, 2015: 246). No que diz respeito aos elementos arquitetônicos do hipódromo, Kourouniotis encontrou evidências para dois marcos (colunas de pedra) na superfície do campo do hipódromo, bem como duas bases circulares de pedra em seus prováveis lugares orinais. As recentes 
escavações redescobriram os componentes de ambos os postes e foi possível, assim, reconstruir como os marcos pareciam (Romano; Voyatzis, 2015: 248). Os resultados das escavações americanas revelaram uma pequena porção do nível do pavimento do hipódromo que data entre os séculos III-II a.C., como evidenciou uma taça helenística encontrada associada. Concluiu-se que a extremidade sul do hipódromo era ao menos $80 \mathrm{~m}$ a norte do ângulo nordeste da stoá. Fragmentos de cerâmicas de figuras negras indicaram atividades próximas ao hipódromo durante os séculos V e IV a.C. Também foram encontradas na área evidências do pavimento do dromos do estádio. Embora não se conheça ainda a data mais antiga para o uso do estádio e do hipódromo, os americanos tendem a sugerir que a atividade atlética mais antiga no santuário pode ter ocorrido no chamado proto-estádio, adjacente ao pico sul da montanha, no local do altar de cinzas (Romano; Voyatzis, 2015: 258).

XIII. Banhos: Parcialmente visíveis, estão localizados imediatamente adjacentes ao hipódromo em sua extensão nordeste. É possível ver um reservatório grande e retangular no lado final do que teria sido o edifício, que mede na parte exterior c.17 x $10 \mathrm{~m}$ e na exterior $15,2 \times 8,7 \mathrm{~m}$. O total do comprimento, leste-oeste, é de 49 m (Romano; Voyatzis, 2015: 259).

Tipo de culto: Com base nos resultados obtidos durante as campanhas americanas entre 2006 e 2010, concluiu-se que o pico sul do Monte Lykaion foi claramente um lugar importante de culto no período micênico (do Heládico tardio IIB até o IIIC), indo de encontro ao que G. Mylonas afirmou, quase intuitivamente, na década de 1940, sobre a origem antiga do culto de Zeus no local, sem mesmo ter tido o conhecimento dos achados micênicos somente revelados muitas décadas depois pelas escavações americanas. Para esse estudioso, o altar de cinzas e as colunas embaixo, representaram um culto primitivo e pré-micênico que sobreviveu até o período histórico (Mylonas, 1943; Romano; Voyatzis, 2014: 628). A cerâmica do período proto-geométrico e a dedicação de miniatura de trípodes de bronze e outros objetos assinalam a continuidade do culto na Idade do Ferro e à época arcaica em diante. A partir da metade do século VII a.C. em diante, parece ter ocorrido uma reorganização do altar, a julgar pela evidência do sistema de contenção a oeste da estrutura, junto a alta concentração de rocha partida pelo fogo com cerâmica arcaica e oferendas. As dedicações do século V ao IV a.C. são consideráveis, mas durante o século III a.C. há poucas evidências de atividade (Romano; Voyatzis, 2014: 628). A evidência para a continuidade do culto da época micênica à Idade do Ferro e ao século IV a.C., que é muito forte no caso do Lykaion, é um fenômeno atestado apenas em poucos sítios no mundo grego (Romano; Voyatzis, 2014: 629). As evidências também sugerem que a atividade ritual ocorreu no altar de cinzas do Monte Lykaion séculos antes de Olímpia, distante 22 milhas (Romano; Voyatzis, 2014: 631). Há uma atividade contínua no altar durante os períodos proto-geométricos e geométricos, mas foi durante o século VII a.C. que parece ter ocorrido uma expansão significativa no sítio tanto no santuário de cima quanto no de baixo (Romano; Voyatzis, 2014: 632). No altar de cinzas, pode ter ocorrido uma organização maior no século VII a.C., evidenciam a construção de um sistema de contenção e 0 aumento de atividades em ternos de oferendas e dedicações queimadas. Essa atividade no santuário de cima continua forte até o período clássico tardio (Romano; Voyatzis, 2014: 632).

Sobre as investigações no santuário debaixo, foram encontrados traços significativos de atividade que remontam ao século VII a.C., os quais serão melhor investigados em futuras pesquisas na área (Romano; Voyatzis, 2015: 263). Concluiu-se que durante os períodos arcaico, clássico e helenístico que o santuário 
debaixo foi o local dos festivais atléticos em honra a Zeus Lykaios e Pã (Romano; Voyatzis, 2015: 262). As datações das cerâmicas e moedas encontradas na área dos assentos, na área do corredor e a cerâmica encontrada no terraço a oeste do hipódromo indicam que a área sofreu uma fase maior e única de construção no segundo quartel do século IV a.C., que provavelmente correspondeu à fundação de Megalópolis (Romano; Voyatzis, 2015: 262- 263). Foi durante esse período que a maior parte dos edifícios foi construída no terraço da montanha. Não está claro ainda quanto tempo durou essa fase de atividade, já que os jogos (e talvez o próprio culto de Zeus) podem ter sido deslocados à Megalópolis no século III a.C., como informa o texto da inscrição IG II2 993 (Romano; Voyatzis, 2015: 263). Já que Megalópolis teria adquirido o santuário de Zeus Lykaios como parte de seu sinecismo em 368/67 a.C., não seria surpreendente se o santuário arcádio mais famoso tivesse sofrido uma revitalização e reorganização nessa época (Romano; Voyatzis, 2015: 263). O período entre 368-362 a.C. seria o mais provável para a campanha de maior construção no santuário de Zeus no Monte Lykaion, com a intenção de monumentalizar o famoso santuário arcádio, de onde se avista Megalópolis e o Monte Ithome na Messênia (Romano; Voyatzis, 2015: 263). Pausânias (8.30.2) menciona que havia um santuário de Zeus Lykaios na ágora de Megalópolis, mas não se sabe a data desse culto (Romano; Voyatzis, 2015: 258, nota 96). Em todo caso, houve uma continuidade de extensiva atividade de refeições ao menos numa parte do santuário, como evidencia a abundância de cerâmica no santuário debaixo datadas entre os séculos III-I a.C. (Romano; Voyatzis, 2015: 263). Embora se saiba de inscrições sobre vitoriosos encontradas por Kourouniotis no edifício administrativo (IG V ii 549-550) que competições atléticas dos jogos lykaios ocorriam na montanha até o final do século IV a.C., os jogos refundados podem ter ocorrido na cidade de Megalópolis. A data da inscrição IG II 993 pode refletir o início do festival renovado ocorrido nessa cidade, ou seja, em 215 a.C. É provável que Megalópolis tenha controlado os jogos lykaios desde a época da fundação da cidade em 370/69 a.C. É claro das evidências do corredor que continuou a ocorrer uma atividade significativa no santuário debaixo durante o século I a.C. (Romano; Voyatzis, 2015: 258).

Os americanos assumem que a atividade cultual no Lykaion ocorreu de forma muito semelhante ao caso de Creta, usando como justificativa o fato que Zeus é atestado em documentos em Linear B de Creta e da Grécia continental entre 1400-1200 a.C. (Romano; Voyatzis, 2010: 13). Em uma publicação de 2008, os americanos reconhecem que a atividade do altar pré-data o culto de Zeus e pode ter sido usado nos períodos mais antigos em conexão com fenômenos atmosféricos ou terremotos, associados a uma divindade, como em Creta na Idade do Bronze os santuários atribuídos a Zeus foram dedicados a divindade ligada à vegetação, que nasce e renasce todo ano (Romano; Voyatzis, 2010: 13).

Acerca da estruturação do santuário no pico, Langdon vê similaridades entre o Monte Lýkaion e o Óros em Egina. Ambos tinham um recinto mais baixo e um altar em uma plataforma plana no cume. Assim como o altar de Zeus no Monte Himetos, os dois casos se encaixam bem no primeiro estágio de Cook sobre 0 culto de Zeus no topo de montanhas: a dedicação de um simples altar sem templo e uma estátua do deus. Os altares no Himetos e no Óros mostram que este estágio foi predominante ao menos do período protogeométrico ao arcaico, enquanto o de Zeus Lykaios é um exemplo posterior (Langdon, 1976: 82). É preciso dizer que a afirmação de Langdon precisa ser revista com base nas novas descobertas dos americanos no monte.

Sobre a função do culto, Zeus Lykaios era evocado como o propiciador de chuva, mas sua esfera de atuação era muito mais variada e ampla (Langdon, 1976: 82). A tradição literária registra a partir de Platão que sacrifícios humanos eram realizados no monte (Burkert, 1983: 84). De acordo com M. Jost, os aspectos 
topográficos de seu santuário (com seu altar no topo da montanha), arquitetônicos escultóricos (as águias sobre as colunas descritas por Pausânias) e a iconografia do culto (expressa pelas estatuetas votivas do deus) indicam que no Monte Lykaion foi cultuado sob suas características celestes e atmosféricas as quais se contrapõem ao do deus lobo, como pode indicar o epíteto Lykaios, com certo significado ambíguo, não muito claro - a raíz pode derivar de $\lambda$ úkn ("luz") ou de Aúkos ("lobo") (Jost, 1985: 268; Lo Monaco, 2009: 413). Com relação ao aspecto celeste de Zeus, G. Mylonas defende que a águia como epifania do deus remontou à época pré-histórica do culto no monte, tendo sido essa uma associação local (apud Jost, 1985: 254). Além desses dois aspectos, que podem remontar à fase mais antiga de seu culto no Monte Lykaion, Zeus Lykaios exerceu suas competências na esfera agonística tal como Zeus Olímpio em Olímpia. A nosso ver isso pode indicar também o aspecto guerreiro de Zeus Lykaios, não muito explorado. Zeus Lykaios exerceu seu papel em nível regional, na afirmação da identidade étnica, entre os parrhasios em época arcaica e entre os arcádios a partir, seguramente, do século V a.C. (Jost, 1985: 268; Lo Monaco, 2009: 413). No século IV a.C. a divindade e os jogos lykaios adquiriram fortes conotações políticas na época da confederação arcádia, tanto é assim que sua importância diminuiu com o colapso da liga posteriormente (Kreutz, 2007: 266).

Referências bibliográficas: Burkert, W. Homo Necans: The Anthropology of Ancient Greek Sacrificial Ritual and Myth. Berkeley, 1983, pp. 84-93; Cook,

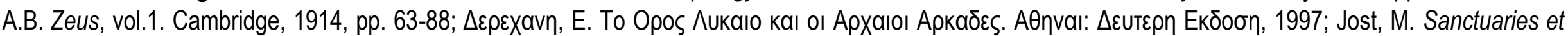
cults d'Arcadie. Études Péloponnésiennes IX. Paris: École Française d'Athènes, 1985, pp.179-185; Jost, M. The Distribution of Sanctuaries in Civic Space in Arkadia. Em: S.E. Alcock, S.E.; Osborne, E. (eds.). Placing the Gods. Oxford, 1994, pp. 217-30; Jost, M. Arcadian cults and myths. Em: Hornblower, S.; Spawforth, A. (eds.). The Oxford Classical Dictionary. Oxford, 1996, p. 139; Jost, M. Les schémas de peuplement de l'Arcadie aux époques archaïque et classique. Em: Nielsen, T.H.; Roy, J. (eds.). Defining Ancient Arkadia. Acts of the Copenhagen Polis Center, vol. 6., Copenhagen, 1999, pp. 192-247; Jost, M. À propos des sacrifices humains dans le sanctuaire de Zeus du mont Lycée. Em: Hägg, R. (ed.). Peloponnesian Sanctuaries and Cults. Proceedings of the Ninth International Symposium at the Swedish Institute at Athens, 11-13 June 1994, 2002, pp. 183-6; Jost, M. Bêtes, hommes et dieux dans la religion arcadienne. Em: Østby, E. (ed.). Ancient Arcadia. Papers from the third International Seminar on Ancient Arcadia held at the Norwegian Institute at Athens (7-10 May 2002). Atenas, 2005,

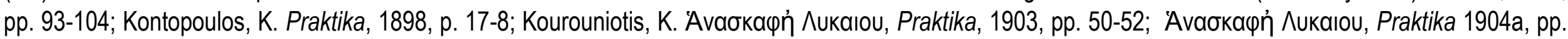

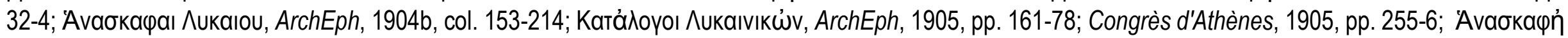
^ukaıou, Praktika, 1909, pp. 185-200; Kreutz, N. Zeus und die griechischen Poleis: topographische und religionsgeschichtliche Untersuchungen von archaischer bis in hellenistische Zeit. Tübinger archäologische Forschungen; Bd. 3. Rahden/ Westf.: Verlag Marie Leidorf, 2007. Lo Monaco, A. II crepusculo degli dei d' Achaia. Religione e culti in Arcadia, Elide, Laconia e Messenia dalla conquista romana ad età flavia. Roma: L'Erma, 2009; Mylonas, G. E. The Lykaian Altar of

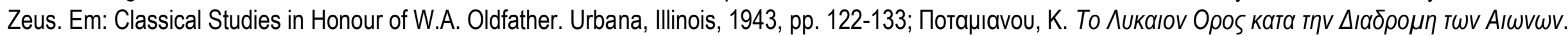

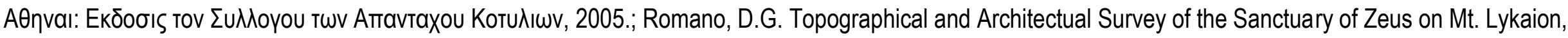


Arcadia, AJA 101, 1997, p. 374; A New Topographical and Architectural Survey of the Sanctuary of Zeus at Mt. Lykaion. EM: Østby, E. (ed.). Ancient Arcadia. Papers from the third International Seminar on Ancient Arcadia held at the Norwegian Institute at Athens (7-10 May 2002). Atenas, 2005, pp. 381-396; Romano, D.G.; M.E. Voyatzis, Excavating at the Birthplace of Zeus, Expedition, vol. 52, 2010, pp. 9-21; Romano, D.G.; Voyatzis, M.; Panagiotopoulou, A. Excavations at the Sanctuary of Zeus on Mt. Lykaion, Poster Session, Archaeological Institute of America Annual Meeting, San Diego, January 5, 2007; Mt. Lykaion excavation and survey project, part 1, the upper sanctuary. Hesperia, 83: 569-652, 2014; Mt. Lykaion excavation and survey project, part 2, the lower sanctuary. Hesperia, 84: 207-276, 2015; Voyatzis, M.E. The Role of Temple Building in Consolidating Arkadian Communities. Em: Nielsen, T.H.; Roy, J. (eds.). Defining Ancient Arkadia. Acts of the Copenhagen Polis Center, vol. 6., Copenhagen, 1999, pp. 130-168; Zolotnikova, O. The Cult of Zeus Lykaios. Em: Østby, E. (ed.). Ancient Arcadia. Papers from the third International Seminar on Ancient Arcadia held at the Norwegian Institute at Athens (7-10 May 2002) Atenas, 2005, pp. 105-119; "New discoveries at the Ash Altar of Zeus - Mount Lykaion," PhysOrg.com, Thursday, January 24, 2008. 


\section{Imagens}

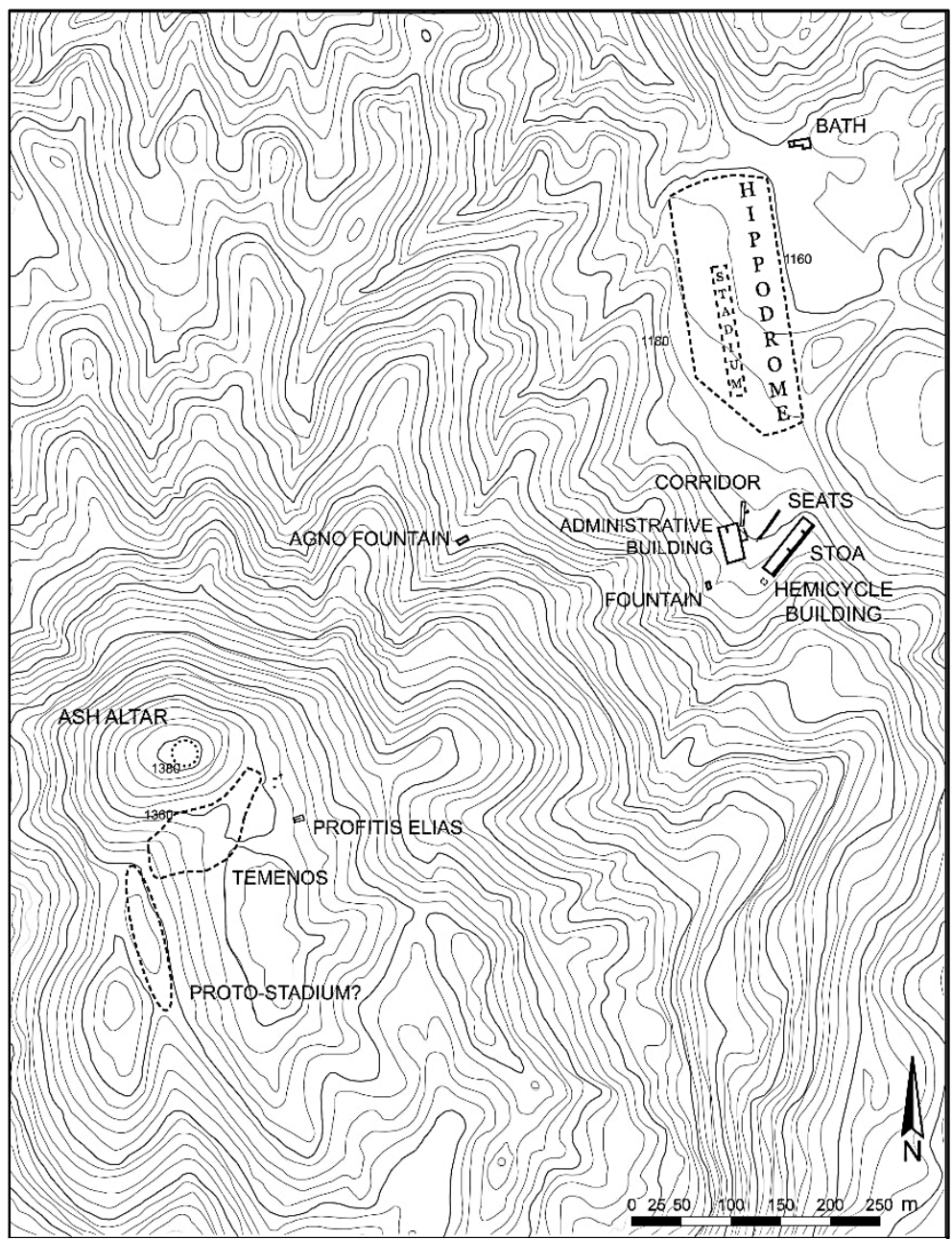

Fig.1- Planimetria santuário do Monte Lykaion (de cima e debaixo) (Romano; Voyatzis, 2014: fig.2)

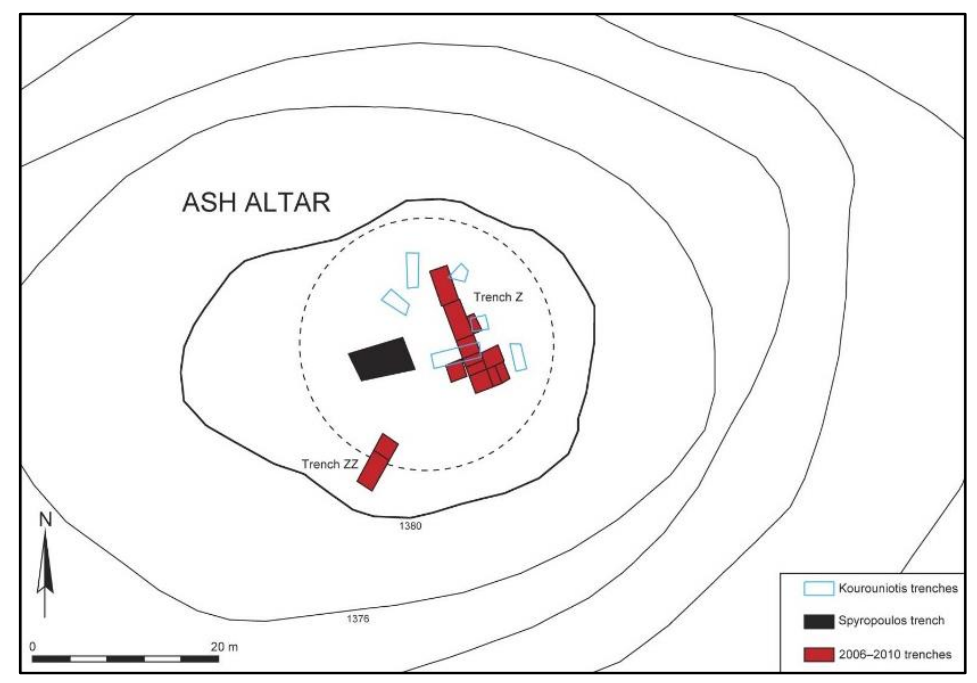

Fig.2- Planimetria da área do altar (Romano; Voyztzis, 2014: fig.3) 


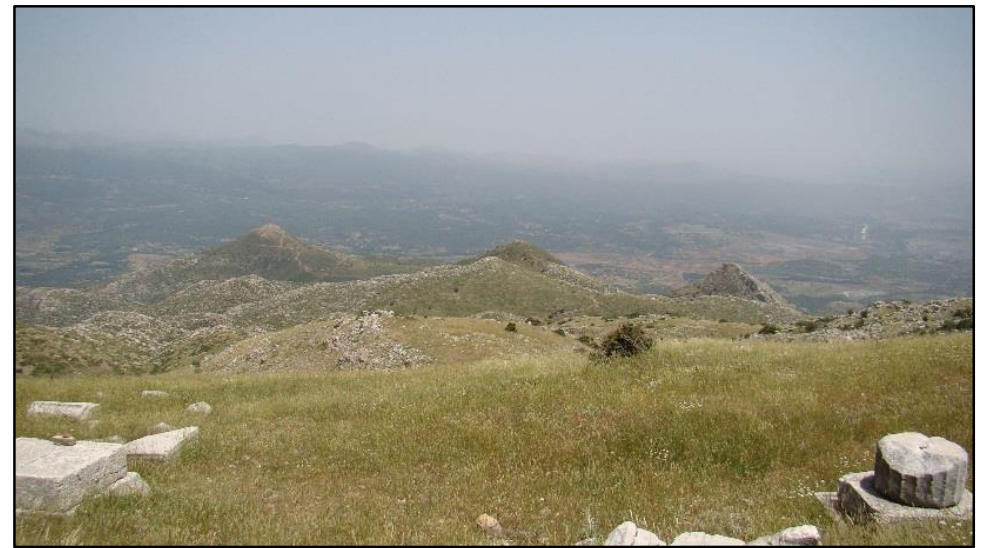

Fig.3- Vista a partir de oeste das bases da colunas no santuário de cima; embaixo no vale, Megalópolis (Foto: arquivo pessoal/2014)

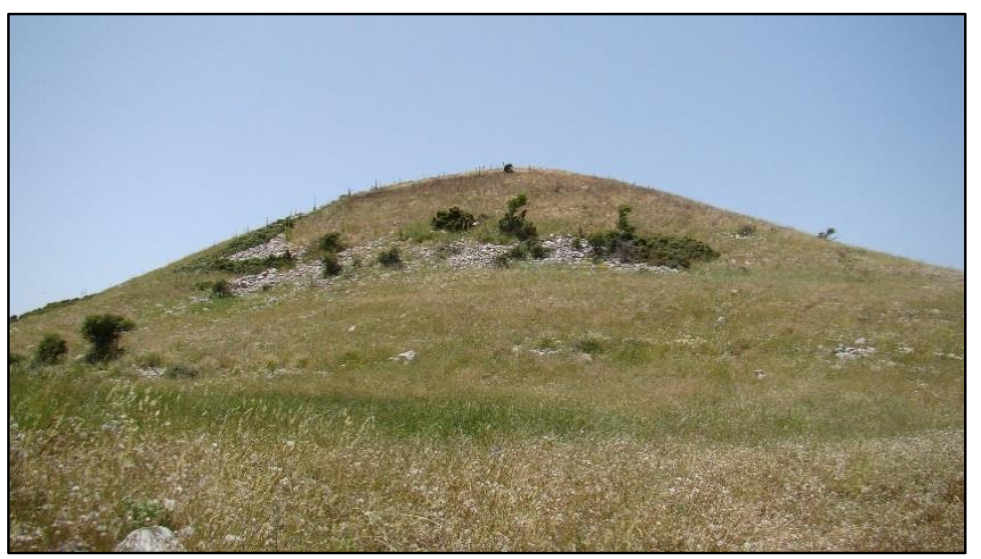

Fig.5- Vista a partir de leste da área do altar no pico sul (Foto: arquivo pessoal / 2014)

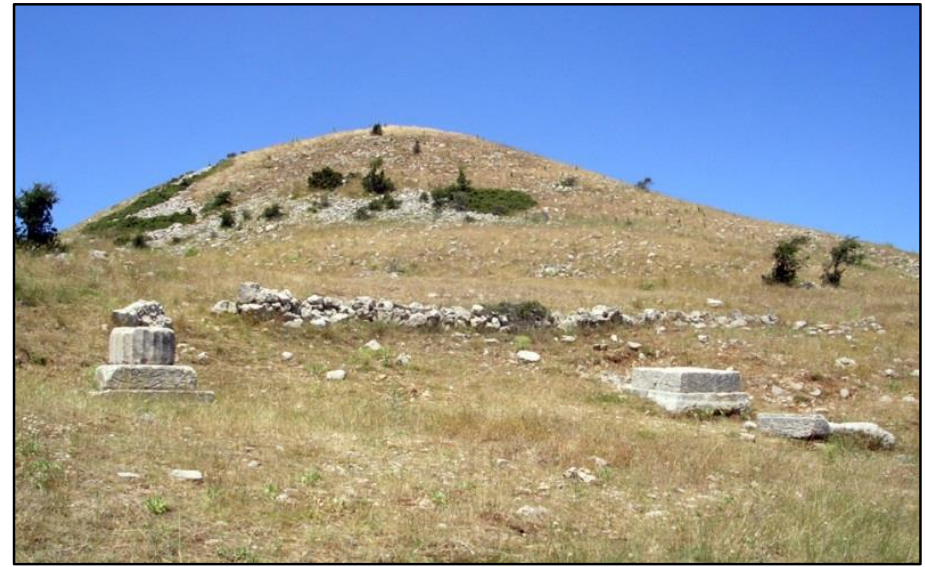

Fig.4- Vista a partir do leste do témeno, bases de colunas e altar no pico sul (Romano; Voyatzis, 2014: fig.4)

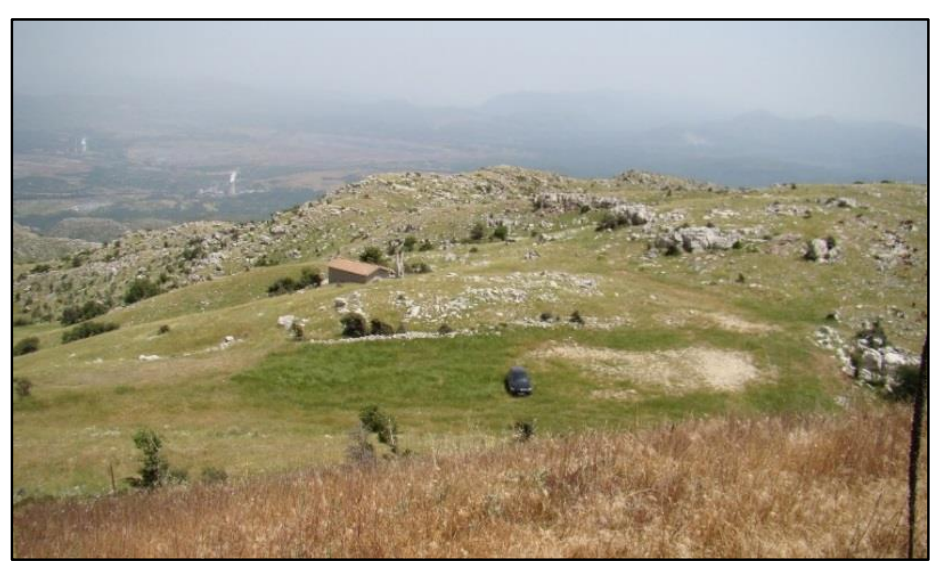

Fig.6- Vista de leste do témeno, capela de Ágios Elias e Megalópolis a partir do altar de Zeus Lykaios (Foto: arquivo pessoal / 2014) 


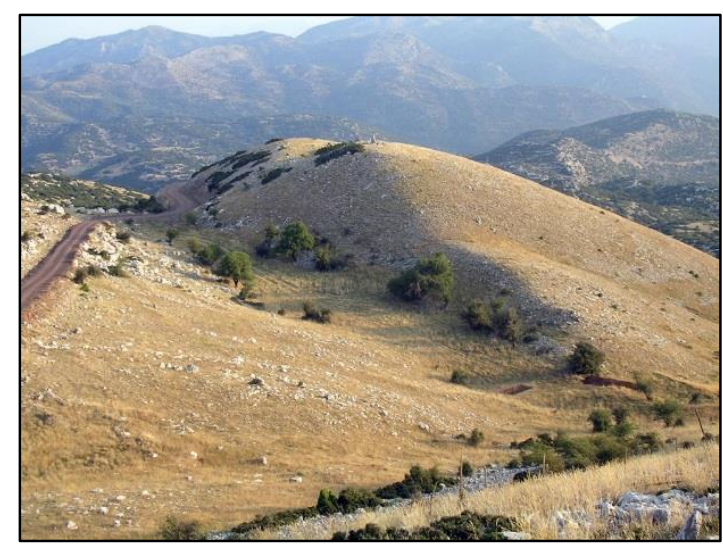

Fig.7- Proto-estádio visto a partir de norte e da área do altar (Romano; Voyatzis, 2014: fig.34)

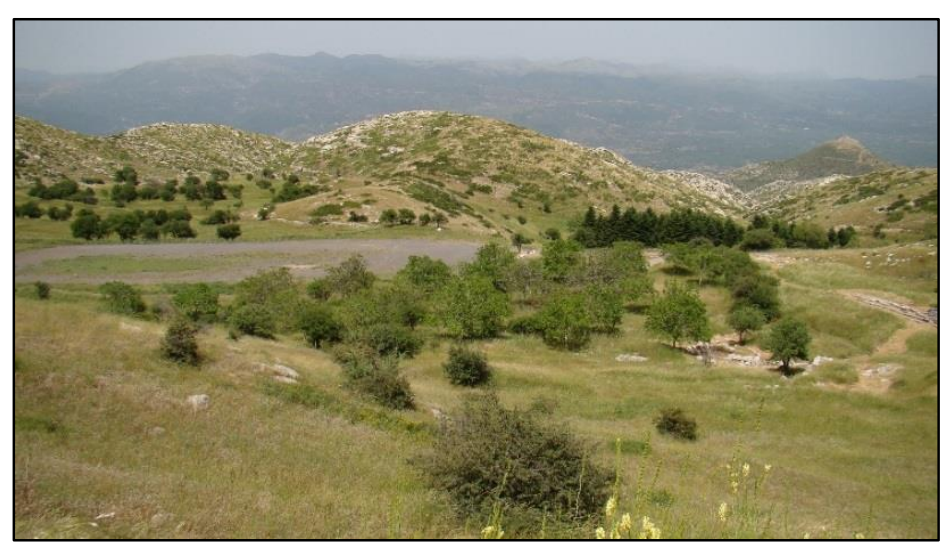

Fig.9- Hipódromo e santuário debaixo visto a partir de seu lado oeste (Foto: arquivo pessoal / 2014)

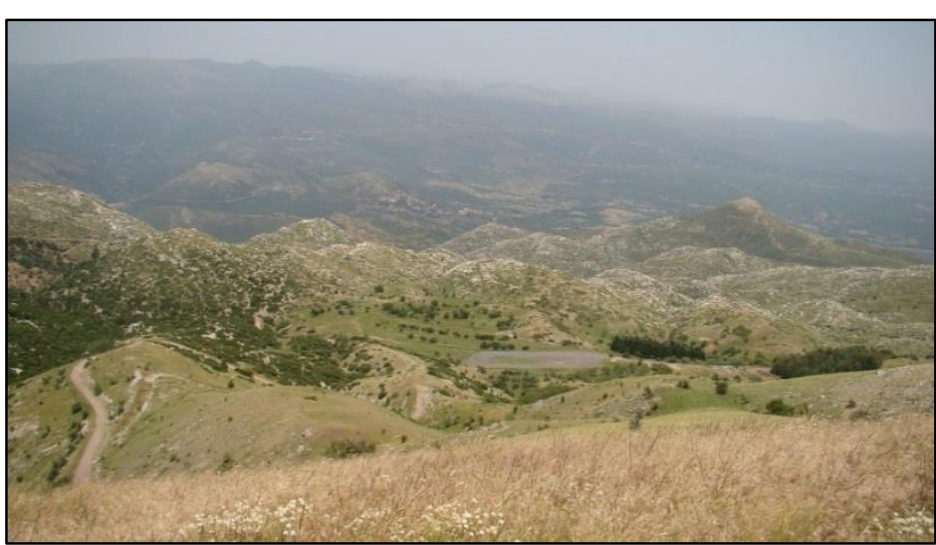

Fig.8- Vista da área do santuário de baixo visto a parir de oeste do altar de Zeus Lykaios (Foto: arquivo pessoal / 2014)

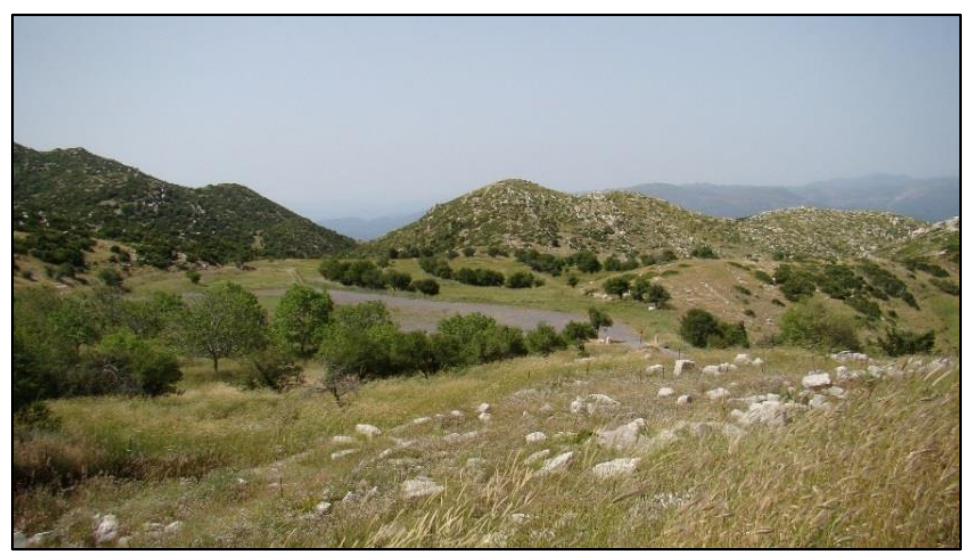

Fig.10- Hipódromo e santuário debaixo vistos a partir de sudoeste (foto: arquivo pessoal / 2014) 


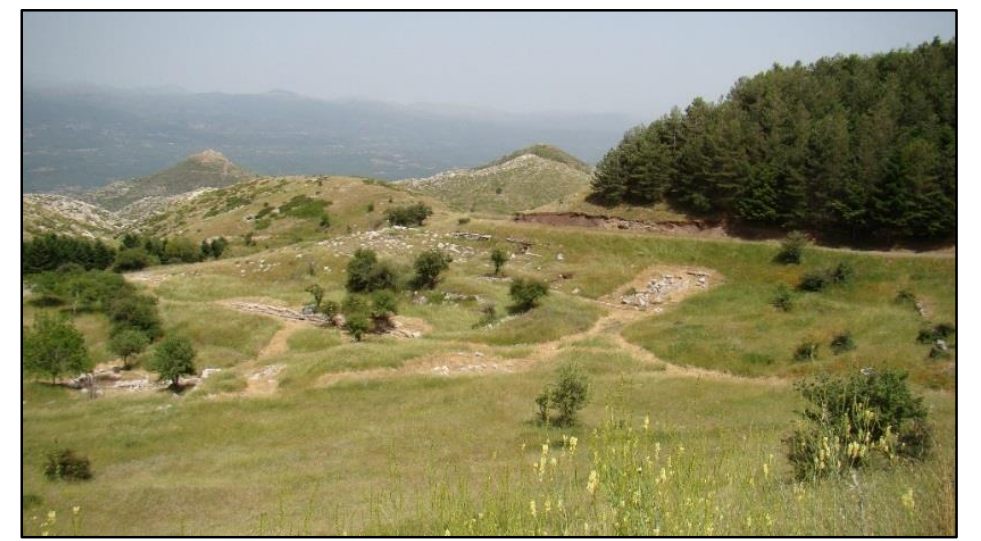

Fig.11- Santuário debaixo, área dos edifícios vistos a partir de oeste (Foto: arquivo pessoal / 2014)

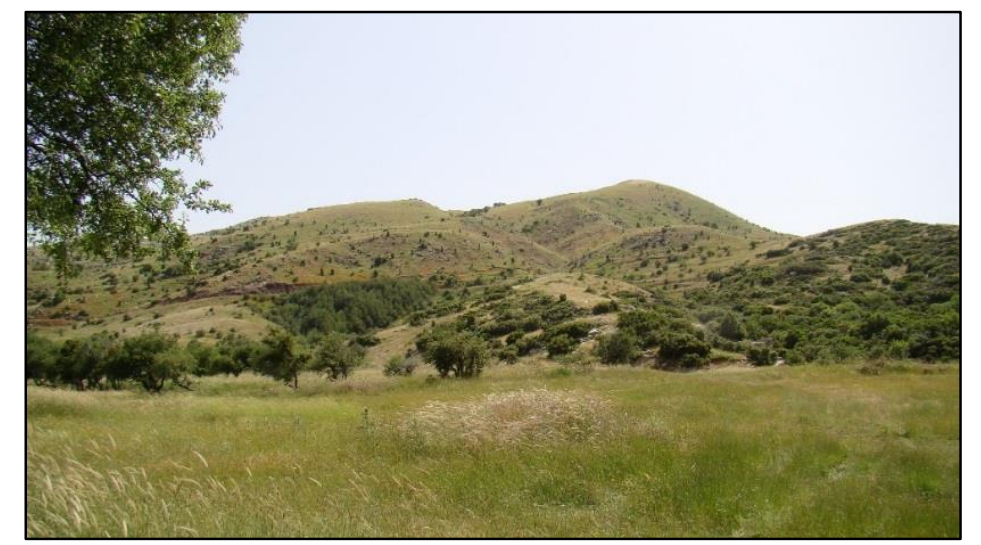

Fig.13- Vista da área do pico sul (témeno e altar) a partir de nordeste do hipódromo (Foto: arquivo pessoal / 2014)

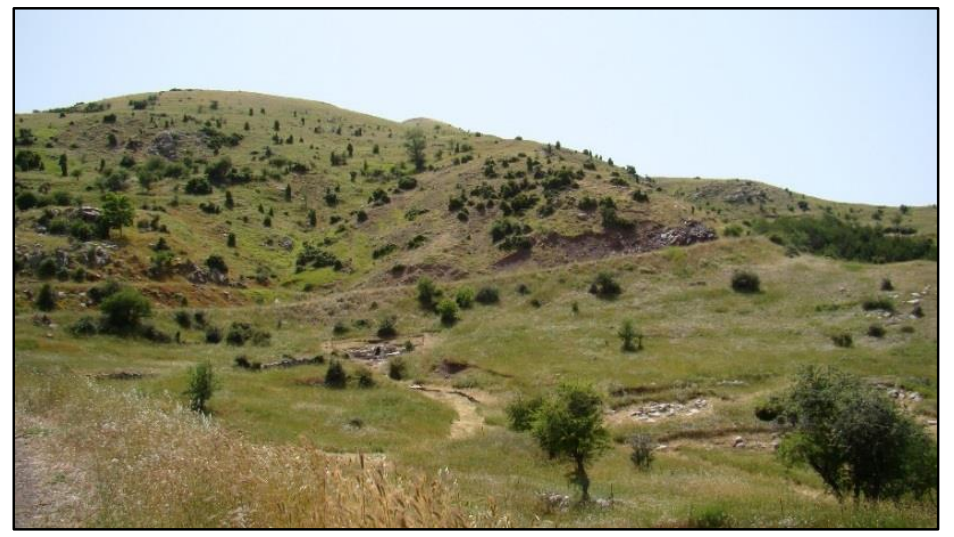

Fig.12- Pico sul, casa da fonte vistos a partir de leste do santuário debaixo (Foto: arquivo pessoal / 2014)

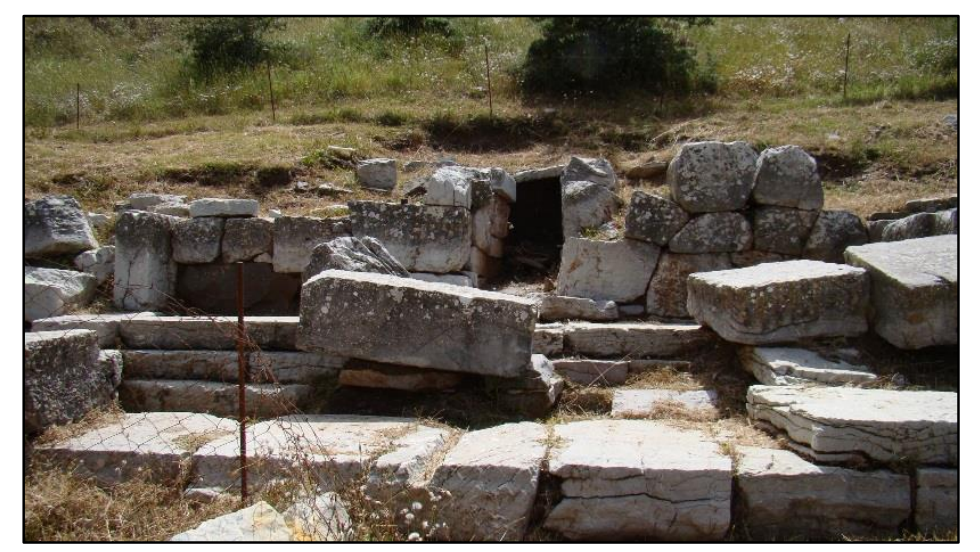

Fig.14- Casa da fonte vista a partir de seu lado leste (Foto: arquivo pessoal / 2014) 


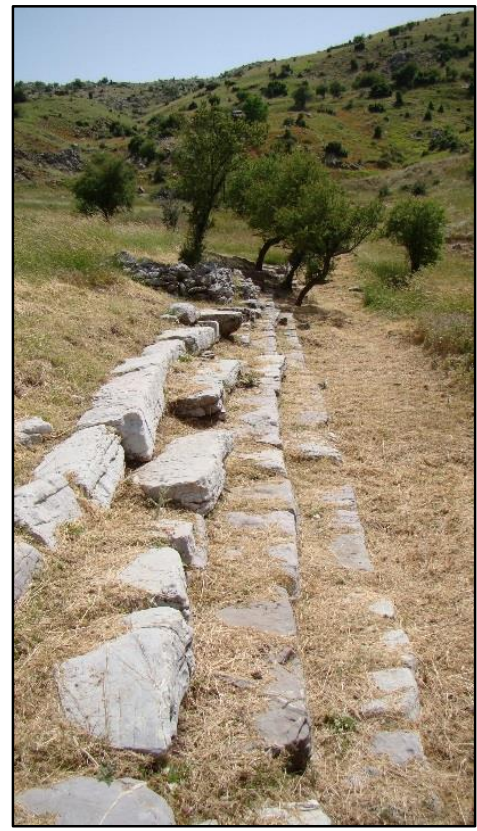

Fig.15- Assentos vistos a partir de leste (Foto: arquivo pessoal / 2014)

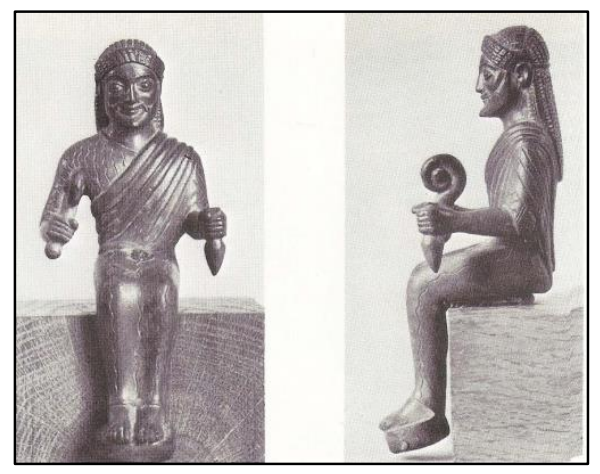

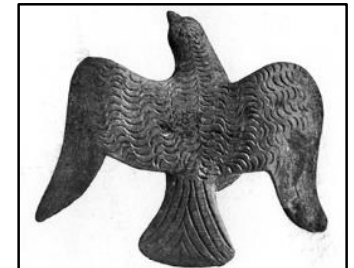

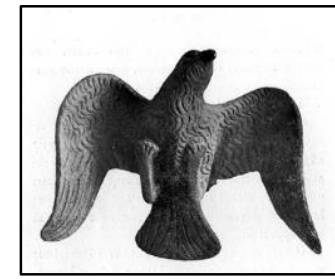

Fig.16- Águia de bronze encontrada no témeno por Kourouniotis, do início do século $\mathrm{V}$ a.C. (Korouniotis, 1904: figs.18 e 19)

Fig.19- Estatueta em bronze de Zeus, segunda metade séc. VI a.C. (Kourouniotis,

fig.12)

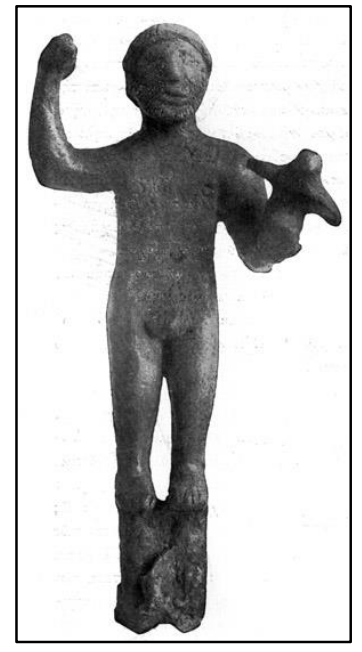

Fig.17- Estatueta em

bronze de Zeus, séc. VII a.C., Kourouniotis, 1904: fig.8)

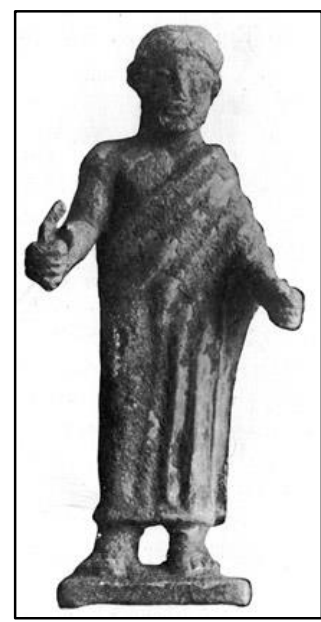

Fig.20- Estatueta em bronze de Zeus fig.15) (Kourouniotis, 1904:

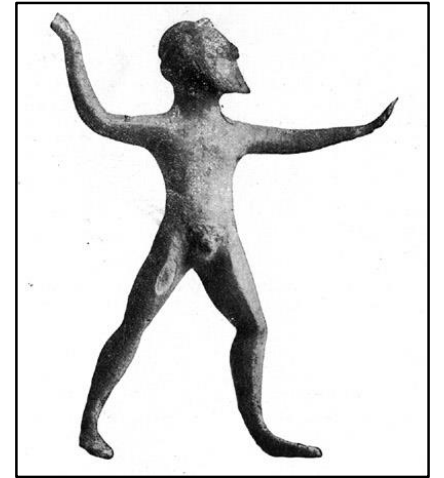

Fig.18- Estatueta em bronze de Zeus, VI a.C.? (Kourouniotis, 1904: fig.11)

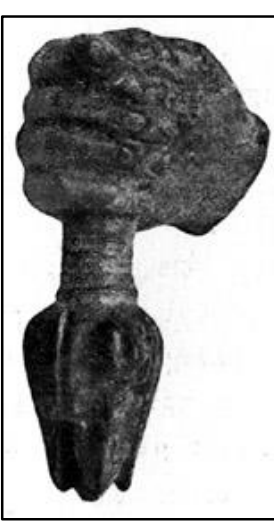

Fig.21- Parte de uma mão e raio de uma estátua em bronze de

Zeus, VI-V a.C. (Kourouniotis, 1904: fig.16) 

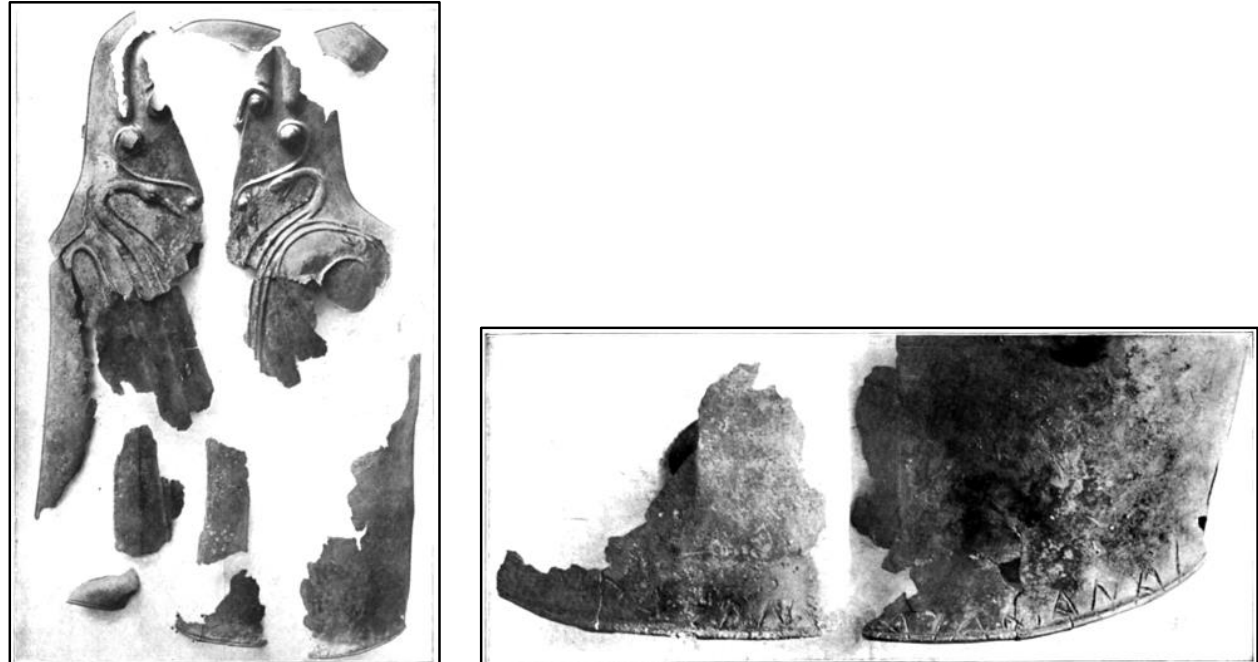

Fig.22- caneleira de bronze de armadura com detalhe de inscrição a Atena e Zeus Lykaios, início séc. $V$ a.C. (Kourouniotis, 1904: figs. 25 e 26 )

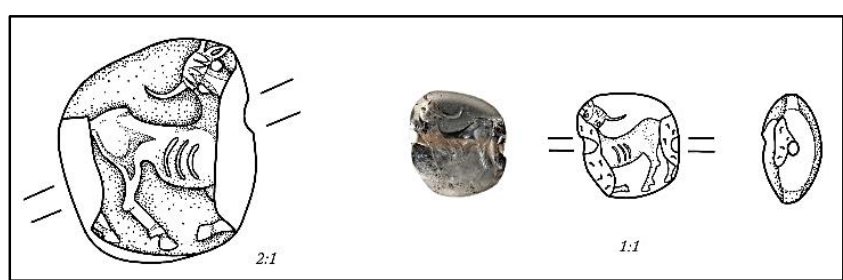

Fig.25- Selo de cristal, minoico tardio IB-II (Romano; Voyatzis, 2014: no.104)

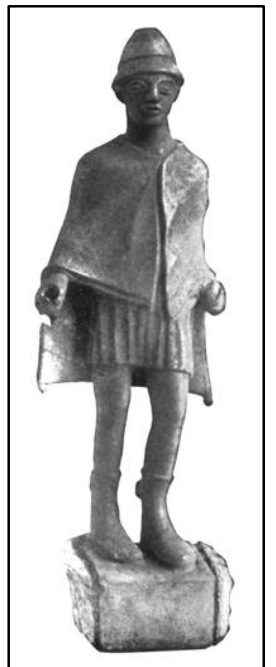

Fig.23- Estatueta em bronze de Hermes, último quartel do século $V$ a.C. (Kourouniotis, 1904: fig.9)

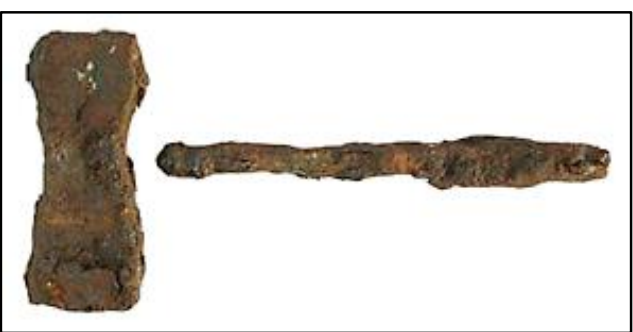

Fig.26- Machado duplo em ferro, Idade do Ferro (lykaionexcavation.org)

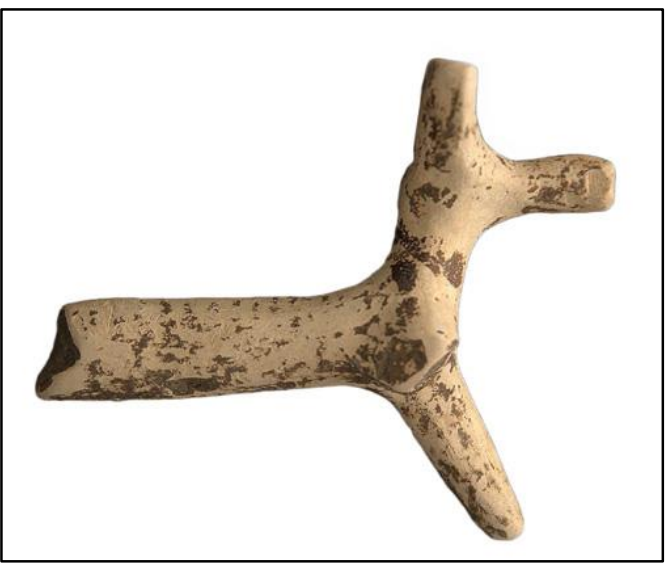

Fig.24- Figurinha de terracota de anima recuperada no altar, héladico tardio IIIB (Romano; Voyatzis, 2014: no.100)

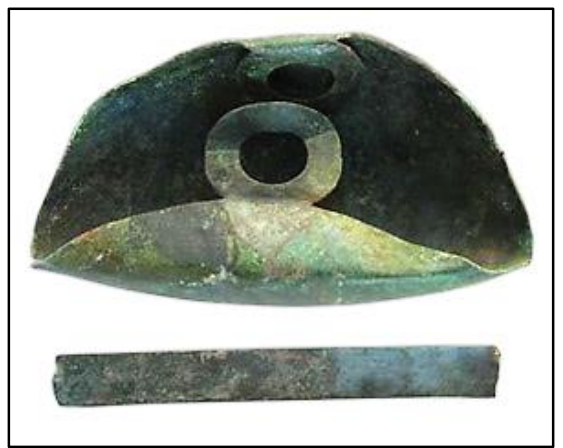

Fig.27- Fragmentos de trípode, Idade do Ferro (lykaionexcavation.org) 


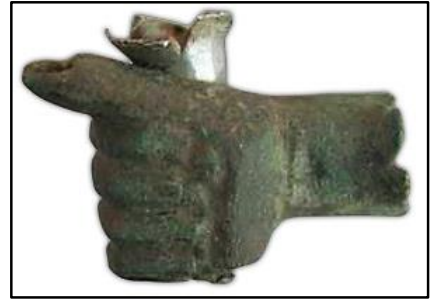

Fig.28- Fragmento de mão em bronze com raio em prata

recuperado lykaionexcavation.org)

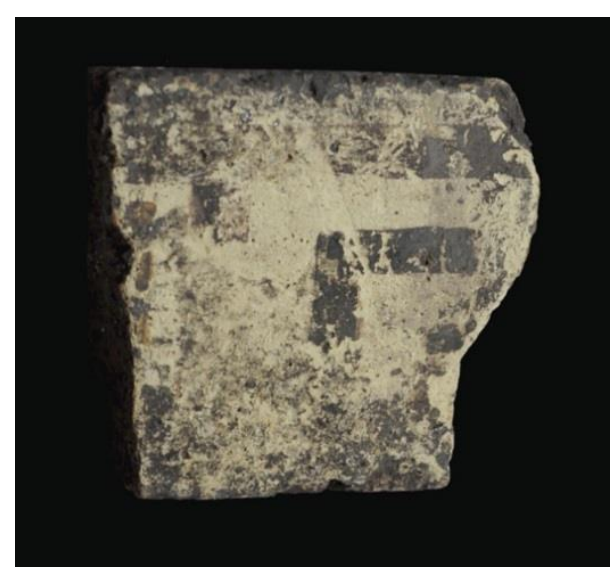

Fig.29- Telha em terracota de tipo coríntio, segundo quartel do séc. $V$ a.C. (Romano; Voyatzis, 2014: no.119)

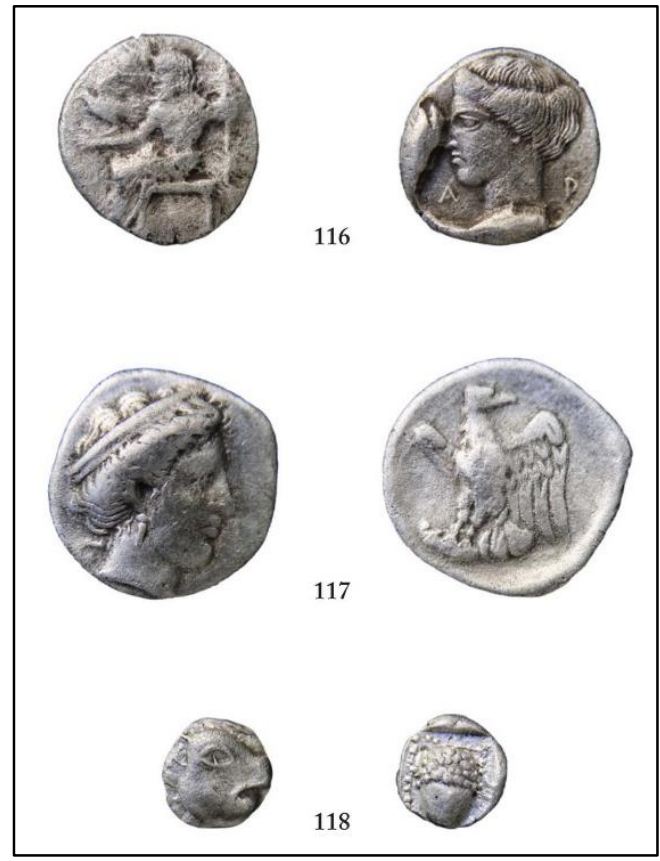

Fig.30- Moedas de prata recuperadas no altar (Liga Arcádia, Élis e Mantinéia), séculos V e IV a.C. (Romano; Voyatzis, 2014: nos.116, 117, 118) 
Datação: Heládico tardio IIIC (1200-1070 a.C.) / submicênico (1070-1000 a.C.) - época romana (séc. IV d.C.).

Localização: No vale dos rios Alfeu e Cladeus, na porção ocidental do Peloponeso, na antiga área de Pisatis e atual região de Élis - cercada pela Trifilia e Messênia a sul, pela Acaia a norte e pelas montanhas áridas da Arcádia a oeste.

Tipo de santuário: Planície e vale / sub-regional, inter-regional e inter-estadual (a partir dos sécs. IX-VIII a.C.) com função oracular (a partir séc. VIII a.C.) e agonística (a partir do séc. VII a.C.).

Referências textuais: Relacionadas a Zeus Olímpio - (Santuário) Píndaro, Ist 2.20-25; Píndaro, OI 8.1-5; Pausânias V, I.IV.2-5; (Témeno) Pausânias VI, II.Il.1215; Píndaro, Ol 3.15-20; Píndaro, Nem 6.60; Xenófanes, Fragm. II, 2; (Oráculo) Estrabão 8.3.30; Xenofonte, Hell. 4.7.2; (Altar) Pausânias V, I.XIII.7-10; PausâniasV, I.XII.10-XIV.1; Pausânias V, I.XIV.1-4; Pausânias V, I.XIV.7-10; Pausânias V,I.XV.7-11; Tucídides V.50.1-2; Píndaro OI 10.95-100; Píndaro OI 6.510; Píndaro OI 6.65-70; (Templo) Pausânias V, I.X.1-4/4-7/7-9; Estrabão 8.3.30; Heródoto II.7; Tucídides III.XIV.1-2; Pausânias V, I.XXIV.1-4; Políbio? Fragm. XXX.10.6; (Templo/oferenda) Pausânias V, I.XII.2-5; (Estátua) Pausânias V, I.XI.8.10; Pausânias V, I.XI.2-5; Pausânias V, I.XIV.4-7; Pausânias IV, XXXI.4.7; Estrabão 8.3.30; Políbio? Fragm. XXX.10.6; (Tributo) Tucídides V.XXXI.1-6; (Mito) Pausânias V, I.VIII.1-5; Pausânias V, I.XIII.3; Diodoro IV.14.1; Diodoro IV.53.45; Heródoto IV.73.3.4; (Território/sagração) Estrabão 8.1.2; Estrabão 8.3.30; Píndaro, Ol 2.1-5; Píndaro, Ol 13.20-25; Plutarco, Péricles II.1; Píndaro, OI 9.5-10; Pausânias V, I.X.1; (Festival) Píndaro, Pit 7.10; Tucídides I.CXXVI.1-5-10; (Jogos) Pausânias VI, II.X.6-9; Plutarco, Teseu XXV.3-5; (Sacrifícios) Xenofonte, Hell III.II.23-27; (Inscrição/oferenda/multa) Pausânias V, I.XXI.7-10; (Inscrição/oferenda/estátua) Pausânias V,I.XXIV.1-4; Pausânias VIII, XLII.7-10; (Inscrição/oferenda) Pausânias VI, II.XIX.4-7; relacionadas aos demais cultos de Zeus, consultar Apêndice I mestrado.

Inscrições: IVO 1 (VII-VI a.C.); IVO 2 (580 a.C.); SEG 11:1208 (c.550-500 a.C.); SEG 24:296 (c.550-500 a.C.); SEG 24:297 (c.550-500 a.C.); SEG 24:298 (c.550500 a.C.); SEG 31:344 (c.550-500 a.C.); SEG 31:364 (c.500 a.C.); SEG 39:400 (c.500 a.C.); IvO 252 (VI a.C.); SEG 11:1204 (VI a.C.); SEG 24:299 (final VI a.C.); SEG 41:396F/G (final VI a.C.); IVO 244 (VI-V a.C.); IVO 5 (c.500-450 a.C.); IVO 6 (c.500-450 a.C.); IVO 12 (c.500-450 a.C.); SEG 24:318/319 (c.500-450 a.C.); SEG 24:320 (c.500-450 a.C.); IVO 16 (c.500-450 a.C.); SEG 24:309 (início V a.C.); SEG 24:311 (c. 487-481 a.C.?); SEG 11:1212 (c. $475-450$ a.C.?); SEG 17:205 (c. 447-446 a.C.); IGASMG V 13,a (c. 443-433 a.C.); IVO 259 (c.421 a.C.); SEG 11:1235a, Add (V a.C.); IVO 294 (c. 350-300 a.C.); IVO 651/651a (c. 350-300 a.C.).

Histórico dos achados: As primeiras escavações arqueológicas foram conduzidas em 1829 pela Expédition Scientifique de Morée, considerada a pioneira da exploração moderna de Olímpia e cujo trabalho se concentrou principalmente sobre as ruínas do templo de Zeus (Kyrieleis, 2001: 47-48; 2007: 102-103). 0 
primeiro e decisivo período de escavações em Olímpia ocorreu entre os anos de 1875 e 1881. No decurso de seis temporadas de escavações empreendidas graças ao trabalho de Gustav Hirschfeld, Adolf Bötticher, Georg Treu, Wilhelm Dörpfeld e Adolf Furtwängler sob a direção geral de Ernst Curtius e Friedrich Adler, a maior parte das ruínas de Olímpia vieram à luz junto a uma imensa coleção de inscrições, esculturas e dedicações de todos os tipos. Nos primeiros dois anos (1875-1877) foram removidas as camadas de sedimentos sobre o templo de Zeus. Durante essas explorações sistemáticas ao redor do edifício revelaram-se as esculturas dos pedimentos e as métopas, as quais foram consideradas a descoberta mais importante das escavações de Olímpia (Kyrieleis, 2001: 50). Entre 1954 e 1958 a Oficina de Fídias foi descoberta sob a igreja bizantina a oeste do templo de Zeus (Kyrieleis, 2001: 53-54; 57; 2007: 106; 110). As campanhas entre 1937-1967 recuperaram inúmeros achados de objetos de bronze durante as escavações do estádio, na maior parte, despojos de guerra (escudos, elmos e cnémides). Atualmente, além das escavações, os projetos em Olímpia têm se ocupado da conservação dos monumentos e da sua reconstituição visual, através da restauração de sua arquitetura original, na paisagem do santuário, como, por exemplo, a realização da anastilose de uma das enormes colunas do templo de Zeus - sob os cuidados de W. Koenig - por ocasião dos jogos olímpicos modernos de 2004 em Atenas e em Olímpia (Kyrieleis, 2007: 116).

\section{Documentação arqueológica}

I. Altar e oferendas votivas (Idade do Ferro): $O$ achado de taças de época sub-micênica de caráter eminentemente cultual atesta que a seleção do local do santuário de Olímpia ocorreu provavelmente antes de 1.000 a.C. (Valavanis, 2004: 34). Já as figurinhas votivas de terracota e bronze datadas do final do século XI e início do século X a.C. assinalam a instituição da atividade religiosa em Olímpia nesse período (Morgan, 1994: 57). As taças e as figurinhas foram encontradas na camada de terra preta formada por uma mistura de restos sacrificiais (cinzas e ossos de animais) e por objetos datados a partir da época geométrica até 0 início da arcaica (século VII a.C.). A camada se estende desde a área do Pelópion até o Heraion, onde atinge o setor mais oriental do Altis (Himmelmann, 2001: 156; Kyrieleis, 2001: 60-61; Morgan, 1994: 34). Segundo a opinião dominante, trata-se de um aterramento dos resíduos de atos rituais realizados durante os trabalhos de desenvolvimento e aplainamento da área do Altis no período geométrico (900-750 a.C.) (Kyrieleis, 2001: 60). Alguns autores atribuem às cinzas e os materiais encontrados na terra preta ao grande altar de Zeus (Himmelmann, 2001: 155; Morgan, 1994: 33-34). A inexistência de alguma continuidade estratigráfica da camada com as construções do início da Idade do Bronze testemunha um hiato entre o fim da primeira fase do bronze e do início da Idade do Ferro. Entretanto, uma parte intacta da terra preta se conservou sob os blocos do ângulo nordeste do muro do Pelópion clássico, revelando elementos preciosos sobre a sua composição e o início da história do santuário. Nessa área foram recuperadas quantidades impressionantes de terracotas geométricas - mais de cem peças por $3 \mathrm{~m}^{3}$ de terra em ótimo estado de conservação - e importantes fragmentos de taças do período micênico recente ou do sub-micênico, cujos aspectos e decoração são comparáveis às taças do bronze recente (XII-XI a.C.) descobertas no oeste e sul do Peloponeso. Assim, apesar de esses achados não terem possibilitado o estabelecimento de uma cronologia relativa, revelaram pela primeira vez a continuidade cultual que existiu em Olímpia a partir do fim da Idade do Bronze (Kyrieleis, 2001: 61; Morgan, 1994: 33-34). Em meio às figurinhas geométricas recuperadas da terra preta, foram encontradas pequenas representações masculinas de terracota, sendo a mais antiga datada do início século X a.C. Embora haja poucos elementos que possibilitem uma classificação precisa, alguns especialistas as têm considerado como as imagens mais antigas de Zeus encontradas em Olímpia e as únicas evidências que asseguram a 
identificação de seu culto no santuário a partir do século X a.C. (Morgan, 1994: 26; Valavanis, 2004: 35). Essas figurinhas são associadas exclusivamente com Olímpia, pois tipos similares não foram encontrados em nenhuma outra parte da Grécia. Por outro lado, como sugere Kyrieleis, não se pode excluir totalmente a possibilidade que um culto micênico (modesto) de Zeus tenha existido no topo da colina de Cronos em Olímpia (apud Polignac, 1995: 29). De qualquer modo, supõe-se que ao menos desde a época geométrica a predominância do culto de Zeus em Olímpia foi completa, podendo ter sobreposto 0 culto às divindades femininas anteriormente cultuadas no local (Koutsoumba, 2004: 18; Moustaka, 2002a: 204). Algumas figurinhas de terracota e bronze dedicadas no Altis, ao longo da Idade do Ferro, têm claras conotações agriculturais e por essa razão sugerem que algum tipo de celebração rústica foi realizado no santuário nesse período. A principal evidência sobre a realização de cultos agrários no Altis é a presença de altares de divindades ligadas à fertilidade, como Gê, Themis e Deméter Chamyne (Morgan, 1994: 43; Valavanis, 2004: 42-43).

II. Oferendas votivas (época arcaica e início da clássica): Com relação às dedicações realizadas em Olímpia, desde a época da construção do primeiro estádio na metade do século VI a.C., a exposição de tropaia parece ter sido uma prática entre os espectadores e participantes dos jogos. De acordo com M. Scott, a memorialização de conflitos militares através da dedicação de despojos de guerra (tropaia) era uma característica regular do santuário desde ao menos o século VIII a.C. (Scott, 2010: 169). Em contraste, ao mesmo tempo em que a dedicação de tropaia havia se tornado mais popular, as estátuas de Zeus - outro tipo de comemoração militar - também aumentaram em popularidade. Dedicadas desde ao menos a época do tirano coríntio Cípselo, as estátuas do deus tinham uma durabilidade muito maior no tempo de exposição e ainda no início do século V a.C. eram usadas especialmente para representar vitórias militares (Scott, 2010: 172). Pequenas estatuetas de Zeus na posição em pé e lançando o raio também apareceram no final do século VI a.C. e tornaram-se um padrão de dedicação no século V a.C. (Himmelmann, 2001: 158).

III. Templo: Datado de 470-456 a.C., orientado leste-oeste, o templo de Zeus Olímpio era períptero hexastilo regular com 6x 13 colunas e suas dimensões de 27,68 x 64,12 metros no estilóbato, e a altura total de 20 metros, fizeram dele um dos maiores templos dóricos construídos na Grécia balcânica (Berve; Gruben, 1963: 319; Grupico, 2008: 208; Hellmann, 1998: 113; Hirmer, 2001: 56; Tomlison, 1995: 34; Valavanis, 2004: 72; Veroia, 2009: 9; Younger; Rehak, 2009: 53). A cela media internamente 13,06 × 28,74 metros, atingiu a altura de 14,3 metros e era dividida em pronaos, naós e opistódomo (Gardiner, 1925: 239). 0 pronaos era profundo, tinha duas colunas na entrada e um vão de porta de 5 metros de altura que era fechado por uma grade de ferro (Dinsmoor, 1950: 152; Gardiner, 1925: 239; Younger; Rehak, 2009: 53). O naós tinha uma ala central com uma fileira de sete colunas dóricas de cada lado que ao final era formado por meiascolunas sobre as quais se elevava uma fileira de colunas mais leves (Dinsmoor, 1950: 152; Gardiner, 1925: 239). Esta ala central media 6,50 metros de largura e era dividida em quatro seções. Na primeira havia uma antecâmara de 7,50 metros de comprimento que se estendia até a segunda coluna. A segunda era a mais importante, media 9,50 metros e prolongava-se até a base da estátua na altura da quinta coluna. Imediatamente na frente da base havia um quadrado de 6,50 metros pavimentado com calcário negro de Elêusis cercado por uma borda elevada de mármore pentélico. Nesta seção foram encontrados no piso traços de numerosos monumentos e altares. A terceira seção era completamente ocupada pela base da estátua que media 6,65 x 9,93 metros e 1,09 metros de altura. A quarta e última compreendia a parte de trás da estátua, tinha apenas 1,74 metros de profundidade e funcionava como passagem para as duas alas laterais do 
naós (Gardiner, 1925: 239-240). Já o opistódomo era raso e distilo in antis (Gardiner, 1925: 238; Younger; Rehak, 2009: 53 ). 0 edifício foi construído com um calcário conchífero local extraído de colinas localizadas a leste do santuário nas proximidades do vilarejo moderno de Louvro. Provavelmente, o material foi transportado à Olímpia por balsas através do rio Alfeu. Quando o edifício estava pronto, a superfície irregular do calcário foi revestida com estuque branco com policromia para dar a impressão de que era feito de mármore. O mármore pário foi usado somente para as esculturas dos pedimentos e das métopas do friso do pronaos e do opistódomo, para as telhas e sima (Dinsmoor, 1950: 151; Hellmann, 1998: 113; Valavanis, 2004: 72 e 76). O crepidoma - assentado na metade superior do nível do solo recoberto por terra - atingiu a altura total de 1,52 metros e era formado por três degraus (Gardiner, 1925: 235). A perístasis do templo era composta por 32 colunas, as quais eram cobertas por estuque e mediam 10,43 m de altura ou duas vezes a distância entre os eixos centrais das colunas que varia de 2 a $3 \mathrm{~cm}$. As colunas das partes frontais medem na base 2,25 metros de diâmetro, já aquelas das partes laterais do edifício medem 2,21 metros. 0 diâmetro superior das colunas de ambos os lados é de 1,78 metros e o das colunas in antis do pronaos e do opistódomo é de 1,685 metros. Cada coluna tinha vinte caneluras, três anéis incisos na gola e quatro nos capitéis. Do entablamento (arquitrave e friso) foram recuperadas partes dos blocos da arquitrave, blocos da cornija e fragmentos do mútulo. A arquitrave atingiu 2 metros de espessura e os tríglifos 1,06 metros de largura. Traços de vermelho permaneceram em algumas partes da superfície da arquitrave e de azul nos mútulos e tríglifos (Coulton, 1977: tab.1; Gardiner, 1925: 236). A altura frontal total do entablamento era de 4,080 metros, enquanto que a total lateral era de 4,155 metros (Dinsmoor, 1950: 340-341). Os achados mais importantes desta parte do edifício foram as métopas com a representação dos Doze Trabalhos de Héracles as quais ornavam os frisos do pronaos e do opistódomo (Dinsmoor, 1950: 152; Berve; Gruben, 1963: 323). A sua descrição e interpretação serão apresentadas mais adiante. o pedimento leste - que ornava a fachada da entrada do templo - retrata um dos mitos associados ao santuário: a corrida de carros entre Pélope e Enomau. A cena escolhida não foi a própria corrida, mas o momento de sua preparação (Valavanis, 2004: 77). Assim, a partir da esquerda, vêem-se as seguintes figuras: o deus rio Alfeu (A); o vidente sul (L); o serviçal ajoelhado (C); os cavalos (D); o serviçal ajoelhado (B); Estérope (F); Enomau (J); Zeus $(\mathrm{H})$; Pélope $(\mathrm{G})$; Hipodâmia (K); o serviçal ajoelhado (O); os cavalos (M); o vidente norte (N); o serviçal sentado (E); o deus rio Cladeus (P) (Younger; Rehak, 2009: 42, fig1). O pedimento oeste é caracterizado pelo movimento intenso decorrente do próprio tema: a batalha entre Lápitas e Centauros. De acordo com o mito, a batalha foi provocada quando os Centauros enbebedaram-se no casamento de Perithoos - o rei dos Lapitas por quem eles tinham sido convidados - e atacaram uma mulher. O rei teve ajuda de seu amigo Teseu, quem o ajudou a expulsá-los (Valavanis, 2004: 82). No grupo estão representadas as seguintes figuras, a partir da esquerda: a mulher jovem reclinada (A); a mulher idosa reclinada (B); 0 jovem lapita (C); 0 centauro (D); a mulher lapita (E); o garoto (F); o centauro (G); Deidameia (H); o centauro Eurytion (J); Peirithoos (K); Apolo (L); Teseu (M); o centauro (N); a mulher lapita (O); o centauro 'vigarista' (P); o jovem 'crespo' (Q); a mulher lapita (R); o centauro (S); a jovem lapita (T); a mulher idosa reclinada (U); a mulher a jovem reclinada (V) (Younger; Rehak, 2009: 42, fig.1). Sob a mesma interpretação dos pedimentos foram analisadas as esculturas das métopas, posicionadas no friso do pronaos e do opistódomo, as quais retratam os Doze Trabalhos de Héracles - 0 outro fundador dos jogos, o herói popular de todos os gregos e 0 modelo ideal de um atleta.

IV. Estátua de Zeus Olímpio: Os achados de moldes de terracota encontrados na oficina de Fídias - usados para fazer os componentes ornamentais da roupa da estátua - são as únicas evidências materiais provenientes da própria estátua. Eram utilizados para fazer as dobras em vidro ou em outro tipo de material e 
muitos deles foram usados pelos artesãos apenas como teste, como demonstram as marcas incididas na superfície de algumas peças (Berve; Gruben, 1963: 323).

Tipo de culto: A datação das figurinhas levou os estudiosos a associarem a instalação do culto de Zeus nessa época (séc. X a.C.) ao grupo dos etólios-dórios que se assentaram na área do Altis ao redor desse período. Atualmente se aceita, com base em uma notícia de Estrabão (8.3.30) e de Pausânias (V, I. 3 - IV. 7), que, após o colapso do mundo micênico, tribos de etólios-dórios se estabeleceram no oeste do Peloponeso entre o século XI e X a.C., sobretudo na área de Élis aonde deslocaram os antigos habitantes de Olímpia (Kyrieleis, 2001: 63; Valavanis, 2004: 34; Yalouris, 1996: 22; 2004: 87-88). Todavia, a teoria que relaciona a origem do culto de Zeus Olímpio em Olímpia com a Tessália não teve seqüência, não sendo seguida pelos pesquisadores do santuário atualmente. Por essa razão, é difícil traçar a origem do próprio nome Olímpia com o Olimpo, conforme sugeriram Berve e Gruben os quais postularam que os tessálios teriam utilizado o nome do monte (sagrado) para nomear Olímpia devido ao caráter sagrado pré-existente no local (Berve; Gruben, 1963: 14). Sobre a origem do nome do santuário, deve-se considerar a possibilidade, embora não mencionada pelos estudiosos, de o nome Olímpia ser derivado do próprio título Olímpio de Zeus. Além das imagens de terracota, algumas figurinhas masculinas de bronze da primeira metade do século IX a.C. são tidas como prováveis representações de Zeus "epifânico" em razão dos braços estendidos das imagens. De acordo com Estrabão (8.3.30), Olímpia alcançou sua primeira e proeminente ascensão muito antes dos jogos à existência de um oráculo relacionado ao antigo culto de Gê (Parke, 1967: 180; Valavanis, 2004: 46). Muito antes dos jogos o aspecto militar de Zeus Olímpio foi o elemento primário no culto em Olímpia, e que a função oracular associada com a guerra foi a razão para o prestígio desfrutado pelo santuário em todo o mundo grego desde o final do século VIII a.C. (Valavanis, 2004: 47). Como resultado do caráter militar do antigo culto de Zeus, o oráculo em Olímpia passou a se especializar em questões relacionadas à guerra. Também sabemos de Heródoto (IX. 33-35), que muitas gerações antes de seu tempo, profetas de Olímpia serviram em póleis beligerantes, freqüentemente acompanharam exércitos em campanhas distantes com o intuito de realizar sacrifícios antes das batalhas e aconselhamentos sobre estratégias militares, invocando a proteção de Zeus Olímpio. Ao redor da mesma época de Heródoto, Píndaro na oitava Ode Olímpica refere-se a Olímpia como a mãe dos jogos e preceptora da verdade: Oh preceptora da coroa dourada e da verdade. Portanto, percebe-se a partir do poeta que jogos e profecias tinham a mesma importância no santuário (Jacquemin, 2001: 187; Valavanis, 2004: 46). O relato soma-se à existência de tantas dedicações militares feitas pelas cidades gregas, umas realizadas na forma de troféus em agradecimento a Zeus por suas vitórias e outras na forma de estátuas de Vitórias aladas, nesse caso, não associadas ao sucesso atlético, mas às vitórias militares (Jacquemin, 2001: 188; Valavanis, 2004: 46). Um testemunho de Xenofonte a respeito de um episódio do início do século IV a.C. mostra como os representantes das póleis procuravam o santuário para obter do oráculo conselhos sobre circunstâncias favoráveis antes de dar início a uma campanha (Jacquemin, 2001: 188). Mais recentemente, contudo, a professora Aliki Moustaka sugeriu que o culto de Hera em Olímpia foi instituído somente no século V a.C. e esteve vinculado a mudanças políticas na área como o sinecismo de Élis ao redor de 471 a.C. (Moustaka, 2002a: 205). Em sua perspectiva, o Heraion, na verdade, teria sido inicialmente o mais antigo templo de Zeus em Olímpia, substituído mais tarde pelo edifício projetado pelo arquiteto Libon de Élis no século V a.C. (Moustaka, 2002a: 204). Para tal inferência, a arqueóloga se baseia principalmente nos tipos de dedicações realizadas em Olímpia desde a época geométrica. Através da análise das oferendas votivas argumenta que há indícios quase nulos da presença de Hera no santuário no período geométrico e arcaico (Moustaka, 2002b: 302). Em primeiro lugar, porque não foi descoberta em Olímpia qualquer tipo 
de oferenda que seja semelhante àquelas encontradas em outros santuários de Hera: miniaturas de modelo de casas - um denominador comum aos principais santuários da deusa como em Argos, Perachora e Samos - não foram encontradas no Altis (Moustaka, 2002a: 200; 2002b: 302). Em todos os três santuários de Hera são registrados diferentes tipos de dedicações com inscrições referentes à deusa, ao contrário de Olímpia onde não há evidências na epigrafia até a época clássica. As inúmeras inscrições nos objetos votivos se referem a Zeus, que, indubitavelmente, reinou fortemente no santuário como um deus guerreiro desde ao menos o início do período geométrico. Diretamente associado a esse aspecto é a pletora de armas e elementos de panóplias de todo o tipo que forma grande parte dos achados de Olímpia. Em contraste, nos santuários de Hera citados, a presença de armamentos é praticamente inexistente (Moustaka, 2002a: 200). Em segundo lugar, as figurinhas de terracota predominantes no santuário em época geométrica são representações masculinas classificadas como Zeus. 0 número de estatuetas femininas é mínimo e os tipos nus referem-se muito mais às deusas da fertilidade tais como Gê, Rhea e Eileithyia cultuadas no sopé da colina de Cronos desde os tempos mais antigos (Moustaka, 2002a: 204; 2002b: 302). Em terceiro lugar, a topografia cultual em Élis e na Trifilia mostrou que não há evidências de culto a Hera nas regiões.

Uma interpretação complementar, e ao mesmo tempo nova, foi proposta por J. Taita que coloca uma ênfase no aspecto agrícola e pastoril do culto Zeus nos tempos mais antigos de Olímpia. De acordo com essa autora, a partir da segunda metade do século XI a.C. o culto praticado em Olímpia funcionou como fator veiculante à unidade dos diversos grupos que gravitavam na bacia do Alfeu (Taita, 2007: 86). A tipologia das oferendas recuperadas em Olímpia pertencentes aos séculos X e IX a.C. demonstram o caráter eminente pastoril do culto no local nesse período (Taita, 2007: 89). 0 quadro histórico, social e econômico do culto em Olímpia induz a admitir que a divindade venerada desde a segunda metade do século IX a.C. teve uma conotação eminentemente atmosférica e foi procurada para garantir a fertilidade da terra e a fecundidade dos rebanhos (Taita, 2007: 95). A seu ver, é pouco provável a qualidade guerreira que costuma ser atribuída ao deus já na fase inicial de seu culto, com base nas mais antigas figurinhas antropomórficas de terracota encontradas em Olímpia (Taita, 2007: 95, nota 42). 0 caráter fragmentário de tais objetos votivos não oferece elementos precisos para atribui-los a tipologia de um Zeus guerreiro, mas apenas como imagens dos próprios devotos em vestes armadas (Taita, 2007: 95, nota 42). Nessa perspectiva, o aspecto oracular do culto de Zeus teria se configurado como um componente coerente com o quadro da economia local, em origem, prevalentemente pastoril (Taita, 2007: 95). A possibilidade de que no início consultas oraculares ocorressem relativas aos interesses das populações para as quais a criação de animais representava a principal fonte econômica e de prestígio social (Taita, 2007: 91). 0 culto a Zeus Olímpio nessa época ofereceu a ocasião de encontro, ao menos anual, a todos os grupos de populações gravitantes na área, como a celebração de uma festa coletiva fundada na comensalidade e capaz de coagular o sentido de pertencimento a uma comunidade vasta, mas etnicamente homogênea (Taita, 2007: 97). As oferendas não epicóricas evidenciam que, entre os séculos IX e o VIII a.C., a festa a Zeus Olímpio alcançou uma certa notoriedade além do vale do Alfeu, constituindo, também, uma ocasião de importância econômica para os artesãos especializados em bronze (Taita, 2007: 102). Em época alto arcaica, artesãos e peregrinos das regiões externas ao vale do Alfeu foram atraídos à Olímpia devido ao oráculo de Zeus (Taita, 2007: 102). Devido a presença do oráculo, e sobretudo pela instituição dos jogos, o santuário perdeu o caráter originário de culto pastoril no início da época arcaica, como evidencia a progressiva diminuição na oferenda de miniaturas do século VII a.C. (Taita, 2007: 97). O prestígio do oráculo de Zeus pediu a celebração de um ritual mais solene com a realização de uma grande festa que previa competições esportivas (Taita, 2007: 106). Os jogos foram introduzidos como parte do cerimonial em honra a Zeus e a instituição das competições representou uma forma de devoção nova em relação àquela praticada anteriormente - a comensalidade sagrada e a oferta de miniaturas em 
declínio entre o fim do século VIII a.C. e início do século VII a.C. (Taita, 2007: 106). Entre os séculos VIII-VII a.C. ocorreu uma reestruturação no culto e no santuário: o deslocamento do altar e a instalação da pista de corrida no primeiro quartel do século VII a.C., foram mudanças significativas para a ampliação do espaço no setor oriental (Taita, 2007: 107-108).

Além dessa leitura de Taita, novas interpretações foram propostas, mais recentemente, para o início do culto de Zeus em Olímpia - sobre o que teria sido o altar e o templo mais antigo da divindade no santuário - graças aos resultados das escavações chefiadas por H. Kyrieleis nos anos 1980 e 1990 apenas publicadas nos anos 2000. De acordo com A. Duplouy, que resume os novos resultados publicados a esse respeito, contrariamente à ideia muito difundida na bibliografia, 0 estrato de terra preta não é relacionado a um antigo altar de cinzas, o predecessor daquele visto por Pausânias a nordeste do Pelópion (Duplouy, 2012: 106). A terra preta, na realidade, liga-se a uma estrutura em pedra da Idade do Bronze (Edifício I) situada a noroeste do Pelópion - ao redor desse edifício que foi encontrada a maior concentração de oferendas votivas de época geométrica (Duplouy, 2012: 106-107). Estrutura originalmente absidal datada do heládico antigo III, e que no final da Idade do Bronze foi transformada em um edifício retangular, o Edifício I pode ter sido utilizado como o altar mais antigo do santuário (Duplouy, 2012: 107). Ao longo dos séculos, esse edifício sofreu uma série de outras transformações, tal como o seu uso como área de enterramento no heládico médio I e cerca de um milênio depois, quando a sepultura deve ter aflorado do solo, começaram-se ali a ocorrer sacrifícios e, por consequência, a acumular restos de oferendas e banquetes (Duplouy, 2007: 107). Foi somente bem mais tarde, portanto, ao redor de 600 a.C., em ocasião de uma reestruturação completa do santuário, como mencionado por Taita, à ocasião da construção do denominado tradicionalmente Heraion (na realidade provavelmente consagrado a Zeus), que o altar de Zeus foi deslocado a leste, provavelmente no lugar no qual viu Pausânias (Duplouy, 2012: 107). Essa operação de mudança foi realizada contemporaneamente ao nivelamento do terreno e à dispersão dos restos de culto do estrato de terra preta (Duplouy, 2012: 107). Um túmulo de pedras e pilastras de calcário, identificado por Dorpfeld e datado do heládico antigo II, se trata de outra construção relacionável à origem do culto de Zeus em Olímpia - pela sua visibilidade na paisagem no início da Idade do Ferro, o culto a Zeus pode ter se desenvolvido em relação a esse túmulo que, na opinião de $\mathrm{H}$. Kyrieleis, deve ser desvinculado do culto a Pélope, introduzido na reestruturação, somente no início da época arcaica (c.600 a.C.) (Duplouy, 2012: 107). A terceira e última construção atualmente relacionada pelos especialistas ao início do culto de Zeus em Olímpia é o denominado Edifício VII, situado entre o templo de Zeus e o Metroon (Duplouy, 2012: 108). Descoberto na escavação de 1880, e interpretado como um resto de um grande altar de Zeus, o edifício foi considerado por Dorpfeld uma estrutura pré-histórica em $\mathrm{U}$ de $4 \mathrm{~m}$ de largura e da metade do segundo milênio a.C. Contudo, mais recentemente um re-exame permitiu datar a construção da Idade do Ferro, e revelou medidas diferentes $(7,5-8 \mathrm{~m})$, que a colocou como o maior edifício da Idade do Bronze do santuário de Olímpia (Duplouy, 2012: 108). O Edifício VII tem sido relacionado às numerosas oferendas votivas dedicadas em Olímpia no início do primeiro milênio a.C. Assim, devido também às suas dimensões monumentais é muito possível que tenha se tratado do primeiro templo de Zeus construído no santuário (Duplouy, 2012: 109). Tem sido aceito, assim, que se trataria, desde o início, de um culto a Zeus Olímpio e não a um herói mítico local como Pélope (Duplouy, 2012: 107). Não é impossível que as ruínas do primeiro templo de Zeus - se esta identificação é correta - foram associadas a uma época indeterminada, a uma figura local de tempos heroicos, enquanto as funções do edifício foram retomadas em c.600 a.C. pelo chamado Heraion, primeiro templo de pedra do santuário, e depois no segundo quartel do 
século V a.C. pelo grande templo de Zeus (Duplouy, 2012: 109). Em síntese, a atividade de culto em Olímpia remonta ao heládico tardio IIIC/submicênico, enquanto que atividades micênicas identificadas no e ao redor da colina de Cronos assinalam a existência de um assentamento da Idade do Bronze tardia na própria colina e no Altis (Zolotnikova, 2011: 235).

Referências bibliográficas: Berve, H.; Gruben, G. Greek Temples, Theatres and Shrines. Londres: Thames and Hudson, 1963; Coulton, J.J. Greek Architects at Work. Londres: Paul Elek, 1977; Dinsmoor, W.B. The Architecture of Ancient Greece. An Account of its Historic Development. Londres; N. York; Toront; Sidney: B.T. Batsford LTD., 1950; Duplouy, A. Culti e cultura nella Grecia di etá geométrica (1000-750 a.C.), in: Atti del Cinquantesimo convegno di studi sulla Magna Grecia (Taranto 1-4 Ottobre 2010). Tarento: Istituto per la storia e l'archeologia dela Magna Grecia, 2012, pp. 103-132; Gardiner, N. Olympia, its History and Remais. Oxford: The Clarendon Press, 1925; Grupico, T.M. The Influence of Urban Planning on Temple Design in West Greece (Tese). N. Brunswick; N. Jersey: The State University of N. Jersey, 2008; Heilmeyer, W. et alii. Mythos Olympia. Kult und Spiele. Munique: Prestel, 2012; Hellmann, M.C. L'Arquitecture Grecque. Paris: Librairie Generale Française, 1998; Himmelmann, N. La vie religieuse à Olympie: fonction et typologie des offrandes. Em: Pasquier, A. Olympie. Louvre Conférences et Colloques. Paris: Musée du Louvre, 2001, pp. 153-179; Jacquemin, A. Pausanias, témoin de la religion grecque dans le sanctuaire d'Olympie. Em: Pasquier, A. Olympie. Louvre Conférences et Colloques. Paris: Musée du Louvre, 2001, pp. 181-213; Koutsoumba, D. Olympia. Archaeological Guides. Atenas: Explorer, 2004; Kyrieleis, H. Les fouilles allemandes à Olympie. Em: Pasquier, A. Olympie. Louvre Conférences et Colloques. Paris: Musée du Louvre, 2001, pp. 45-74; Anfange und Fruhzeit des Heiligtums von Olympia. Die Ausgrabungen am Pelopion 1987-1996, OIF 31, Berlin, 2006; Olympia. Excavations and Discoveries at the Great Sanctuary. Em: Valavanis, P. (Coord.). Great Moments in Greek Archaeology. Los Angeles: The J. Paul Getty Museum, 2007, pp. 100117; Morgan, C. Athletes and Oracles - The transformation of Olympia and Delphi in the eighth century B.C.. Cambridge: Cambridge University Press, 1994; Moustaka, A. On The Cult of Hera at Olympia. Em: Hägg, R. (ed.) Peloponnesian Sanctuaries and Cults. Proceedings of the Ninth International Symposium at the Sweedish Institute at Athens, $11-13$ June 1994. Acta Instituti Atheniensis Regni Sueciae, Series 4a., XLVIII. Estocolmo, 2002 a; Zeus und Hera im Heiligtum Von Olympia. Em: Kyrielis, H. (ed.). Olympia 1875-2000: 125 Jahre Deutsche Ausgrabungen; Internationales Symposium Berlin 9-11. November 2000 / Deutsches Archäologisches Institut, 2002 b, pp. 301-316; Parke, H.W. The Oracles of Zeus: Dodona, Olympia, Ammon. Oxford: Blackwell, 1967; Rambach, J., 2002. Dorpfelds Bau VII in der Altis von Olympia. Ein fruheisenzeitliches Apsidenhaus und 'Haus des Oinomaos'?, AA: 119-134, 2002; Scott, M. Delphi and Olympia. The Spatial Politics of Panhellenism in the Archaic and Classical Periods. Cambridge: Cambridge University Press, 2010; Taita, J. Olimpia e il suo vicinato in epoca arcaica. Milão: Edizioni Universitarie di Lettere Economia Diritto, 2007; Tomlison, R.A. Greek Architecture. Londres: Bristol Classical Press, 1995; Valavanis, P. Games and Sanctuaries in Ancient Greece. Olympia, Delphi, Isthmia, Nemea, Athens. Atenas: Kapon Editions, 2004; Veroia, D.B. Studien zum System des Vokabulars der Architektur dorischer Ordnung am Beispel des Ringhallentempels archaischer und klassischer Zeit (Tese). Darmstadt: Universität Darmstadt, 2009; Yalouris, N. Ancient Elis, Cradle of the Olympic Games. Atenas: Adam Editions, 1996; Younger, J.G.; Rehak, P. Technical Observations on the Sculptures from the Temple of Zeus at Olympia. Hesperia, vol. 78, no. 1 (Jan.-Mar.): 41-105, 2009; Zolotnikova, O. Evidence for the worship of Zeus during the ElA, in: Mazarakis-Ainian, A. (ed.) The "dark ages" revisited. Volos, 2011, pp. 233-246. 

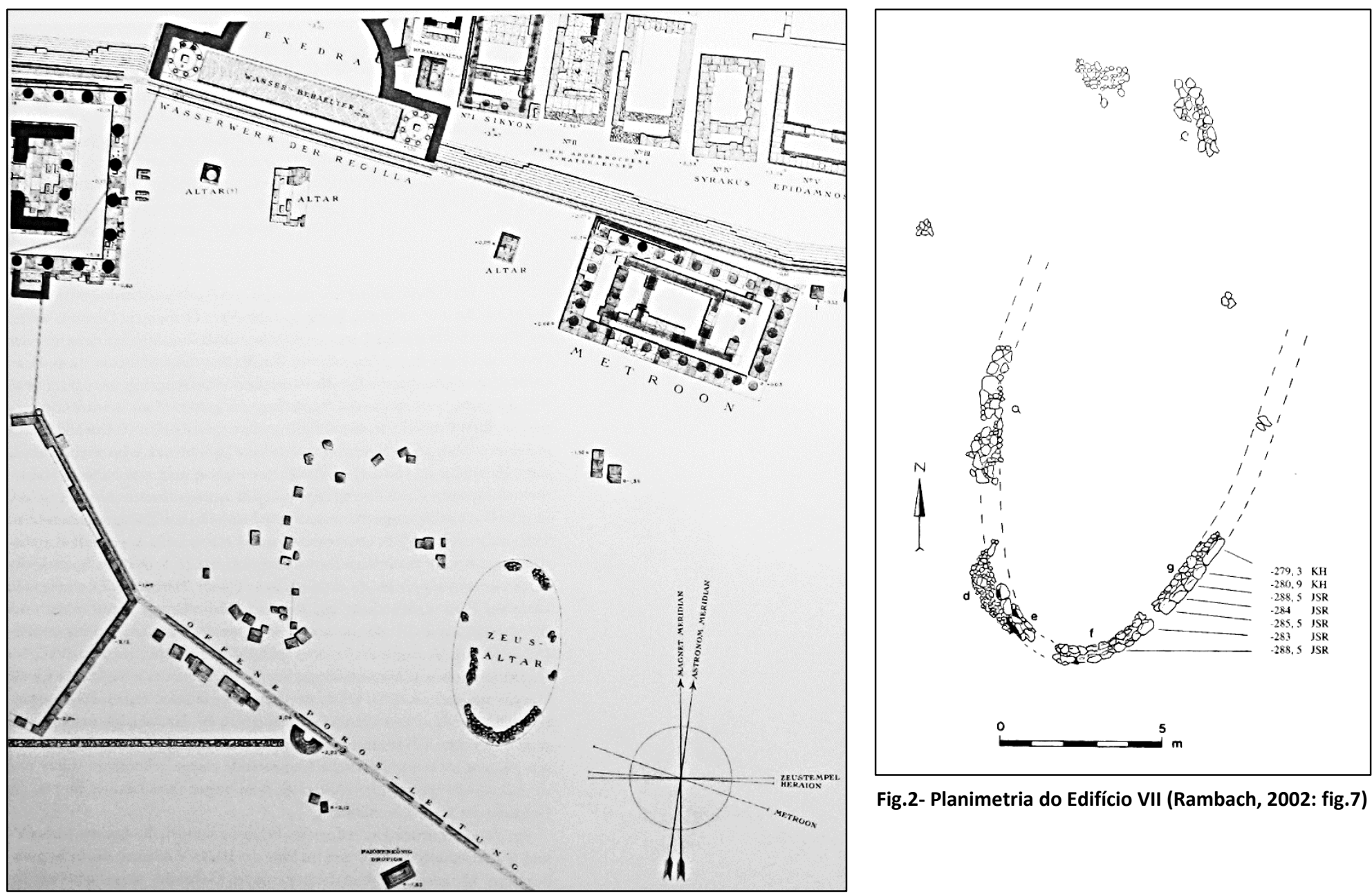

Fig.2- Planimetria do Edifício VII (Rambach, 2002: fig.7)

Fig.1- Planimetria da área nordeste do santuário de Olímpia mostrando o Edifício VII (altar de Zeus) (Rambach, 2002: fig.1) 


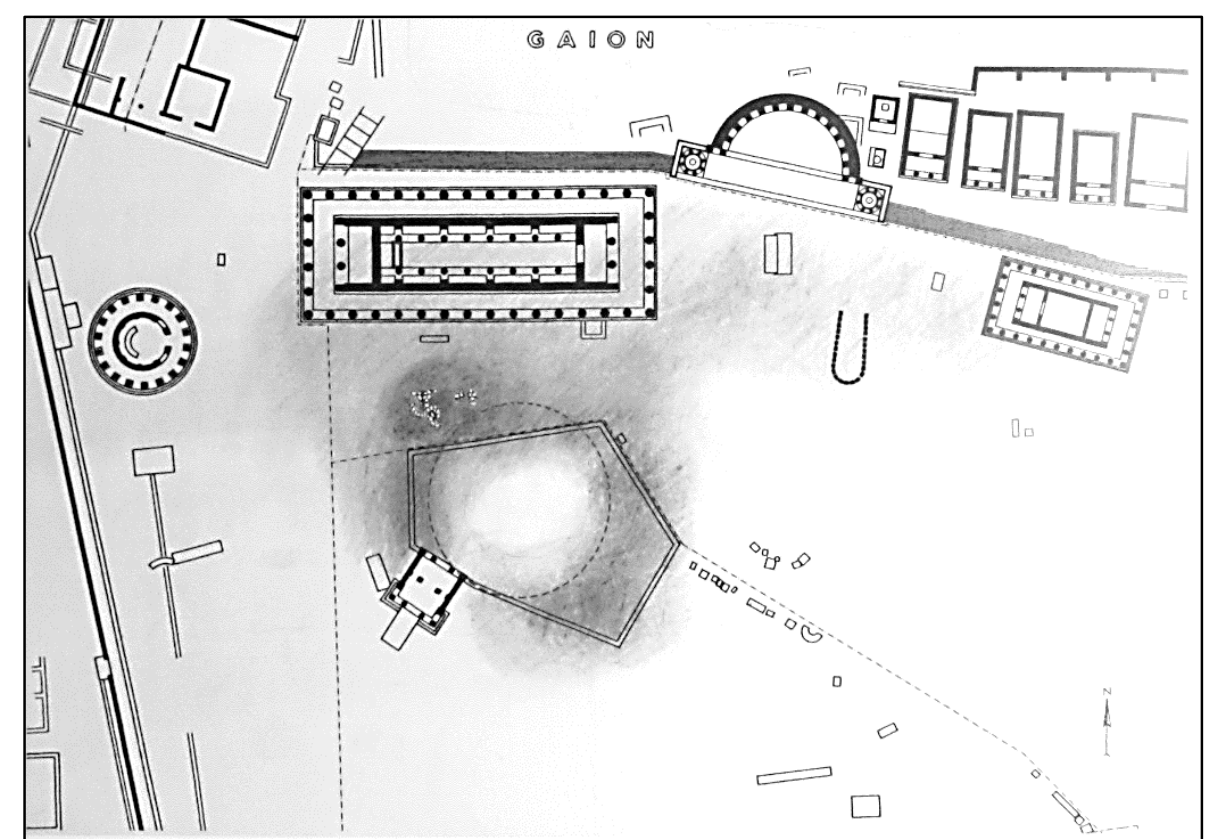

Fig.3- Planimetria da área da chamada "camada preta" no santuário de Zeus em Olímpia (Kyrieleis, 2006: Pr. 12) 

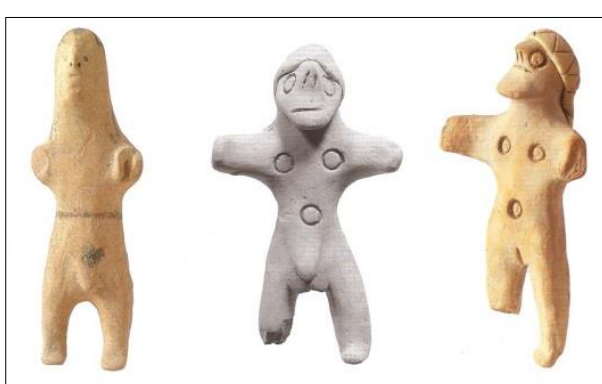

Fig.4Terracotas de figurinhas protogeométricas masculinas atribuídas por alguns autores como Zeus (séc. $X$ a.C.) (Heilmeyer et alii, 2012: p.115, fig.3)

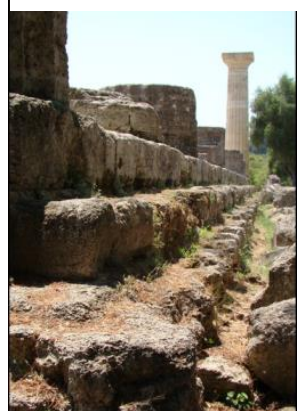

Fig.10- Crepidoma do ângulo nordeste $e$ coluna reerguida em 2004 no ângulo noroeste (Foto: arquivo

pessoal/2009)
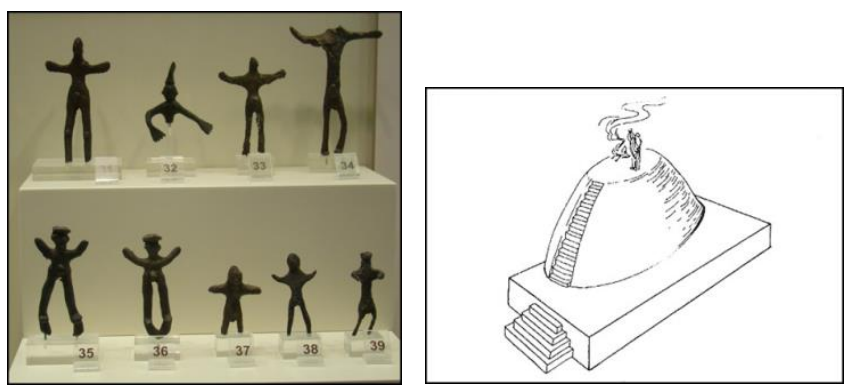

Fig.5- Figurinhas masculinas Fig.6- Fig.214 - Desenho de Fig.7- Estatueta de de bronze classificadas como reconstituição do altar de cinzas bronze de Zeus atirando Zeus "epifânico" (1… metade de Zeus Olímpio (Swaddling, do séc. IX a.C.) - Novo Museu 1980: 15) de Olímpia (Foto: arquivo pessoal/2009)

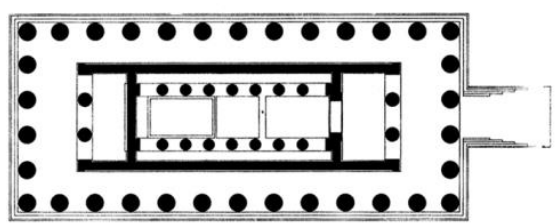

Fig.11- Planta do templo de Zeus (por Grundriss) (Mallwitz, 1972: fig.2)

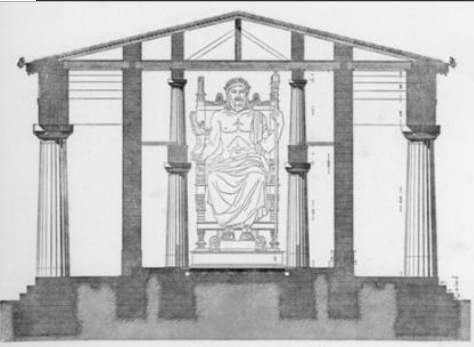

Fig.12- Seção da cela com estátua de Zeus Olímpio (por Curtius e Adler, Olympia II, 1892) (apud Berve; Gruben, 1963: 320, fig. 9)

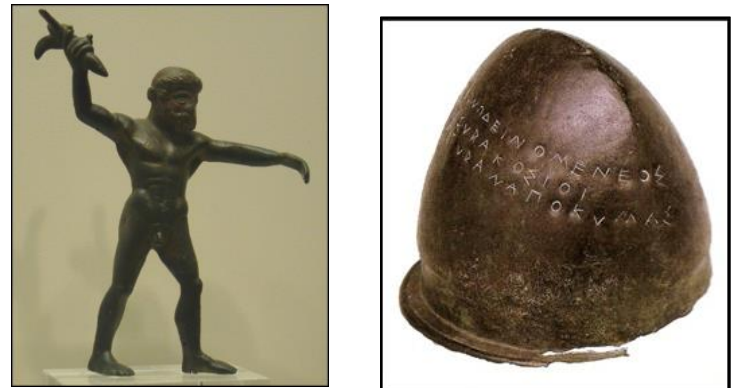

Fig.8- Elmo etrusco (c.474 a.C.) dedicado por Hieron em Olímpia. Museu Britânico e Novo Museu

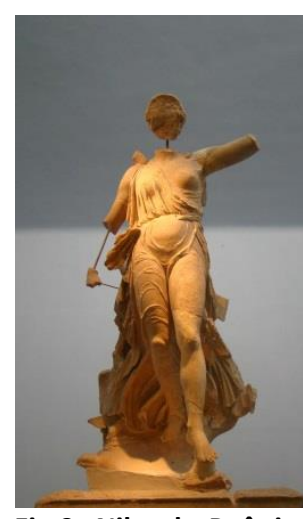

Fig.9- Nike de Peônios (421 a.C.), Novo Museu de Olímpia (Foto: arquivo pessoal 2009) de Olímpia (Bruno, 2005 15)

Novo Museu de

Foto:

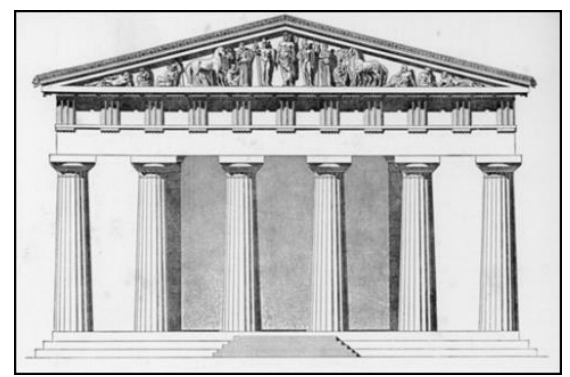

Fig.13- Fachada leste (por Curtius e Adler, Olympia II, 1892) (apud Berve; Gruben 1963: 321, fig. 12) 
Datação: Minóico tardio IIIC (1200-1100 a.C.) / subminóico (1100-1000/975 a.C.) - período helenístico tardio.

Localização: No lado centro-sul de Creta, na denominada Piazza dei Sacelli, o pátio pavimentado a sul do da stoá da Idade do Bronze (Prent, 2005: 162-163).

Tipo de santuário: Planície / extraurbano (a partir da Idade do Ferro).

Referências textuais: Inexistentes.

Inscrições: Evidências epigráficas do período helenístico tardio que mencionam o culto de Zeus Velchanos em Agia Triada.

Histórico dos achados: As primeiras escavações foram realizadas por Halbherr e Paribeni entre 1902-1914 e retomada nos anos 1970 pela Escola Italiana, por Levi e Laviosa e então por La Rosa (Prent, 2005: 162).

\section{Documentação arqueológica}

I. Objetos votivos: O grande depósito votivo, que assinalou a identificação de um santuário na área, é composto por objetos datados do minoico tardio III ao período helenístico, que tinham se espalhado pela erosão. D'Agata, que re-estudou o material da antiga escavação, distinguiu três fases de uso interrupto: 1-) minoico tardio IIIC-Subminóico; 2-) proto-geométrico B-antigo orientalizante; e 3-) helenístico tardio (Prent, 2005: 163). Os achados mais antigos formam um grupo homogêneo que data do minoico tardio IIIC ao subminoico - à época após o abandono do assentamento (ocorrido no minoico tardio IIIB) (Prent, 2005: 163). Os votivos foram encontrados espalhados por uma grande área, cobrindo a Piazzale e parte da encosta mais baixa a norte da área. A área a sul da Piazzale não forneceu restos nem do minoico médio e nem do minoico tardio, sugerindo que talvez tenha sido o local de um bosque sagrado (Prent, 2005: 163). 0 pátio deve ter sido, em grande medida, rodeado por ruínas de edifícios desertos no tempo do culto. Um total de 141 objetos de terracota (touros "wheelmade", animais fantásticos metade touro, metade homem, figurinhas vestindo túnicas, sandálias e caneleiras, chifres de consagração, outros animais como cavalos, machado duplo, rhyta) foram associadas à fase do minoico tardio IIIC-subminoico e apenas 3 de bronze (figurinhas de bovinos) (Prent, 2005: 163-164).

II. Construção: Uma construção fragmentária a sul, possivelmente do minoico tardio IIIC, deve ter servido para demarcar o pátio ou como uma área com degraus para os celebrantes sentarem (Prent, 2005: 163). Alguns restos arquitetônicos do período geométrico foram descobertos a norte da Piazzale, a leste da stoá e podem indicar certas atividades de construção no espaço do santuário nessa época (Zolotnikova, 2013: 114). 
Tipo de culto: Tratou-se de um santuário ao ar livre, cuja atividade cultual pode ter mudado em caráter e local (Prent, 2005: 321). Houve uma interrupção nas atividades de culto após o minoico tardio IIIC-sub-minoico, com uma retomada no período proto-geométrico B. Entre o proto-geométrico B e 0 início do orientalizante foi a fase mais importante da vida do santuário (Prent, 2005: 321). Enquanto o culto mais antigo ocorreu na Piazzale ou a sul dessa área, aquela do início da Idade do Ferro parece ter sido concentrada na Piazzale e na área entre a estrada pavimentada da Idade do Bronze e a Stoá FG. A leste da stoá foi encontrada uma fossa com ossos de animais e fragmentos de kernoi assinalados ao proto-geométrico B e o início do orientalizante (Prent, 2005: 321). Entre as dedicações da Idade do Ferro, predominaram figurinhas em bronze de animais e humanas de terracota (Zolotnikova, 2013: 113). Os objetos votivos dessa fase possuem o mesmo tipo de representações de bovinos, cavalos, carneiros e humanos de ambos os gêneros vistos na fase da Idade do Bronze (Zolotnikova, 2013: 113). Há pouquíssimas evidências para a reconstrução do ritual - os relatórios mais antigos afirmam explicitamente que nenhum dos votivos mostravam traços de queima e que não há indicações de traços de um altar de cinzas ou depósitos sacrificiais contendo ossos (Prent, 2005: 164). Com base nos tipos dos votivos, o culto em Piazzale é considerado relacionado à fertilidade e à proteção das colheitas e dos animais (Prent, 2005; 164). Evidências epigráficas do período helenístico tardio testemunham um culto de Zeus Velchanos em Agia Triada, associada a um altar dessa época na Piazzale e a um pequeno edifício de culto a nordeste. $O$ epíteto pode referir-se a um tipo de árvore ou vegetação em geral (Prent, 2005: 164, 323). Como coloca Zolotnikova, há algumas dúvidas sobre a identidade da divindade masculina cultuada em Agia Triada durante o período pré-histórico tardio e o início do período histórico, se se tratou de Zeus. Considerando-se o culto a testado a Zeus em fase posterior em outros centros cretenses de culto ao deus no início da Idade do Ferro, no aspecto de um deus jovem, é possível associar o deus Velchanos a Zeus em Agia Triada já no período histórico mais antigo (Zolotnikova, 2013: 114). Ritos iniciatórios podem ocorrido em Agia Triada, conforme uma similaridade entre o objeto votivo de uma figurinha tocando flauta encontrado em Syme em Agia Triada (Prent, 2005: 323). Talvez um consumo coletivo de comida, preparada deliberadamente fora da área sagrada, fez parte das atividades religiosas no início da Idade do Ferro (Zolotnikova, 2013: 113-114). Contudo, sacrifício animal com queima parece ter sido excluído do ritual (Zolotnikova, 2013: 114). Parte da razão para a escolha do sítio de Agia Triada para o local de um culto após seu abandono pode ter estado na sua proximidade ao vale fértil a norte (Prent, 2005: 521).

Referências bibliográficas: Prent, 2005, p. 162-164; Zolotnikova, 2013, p.108-109. 


\section{Imagens}

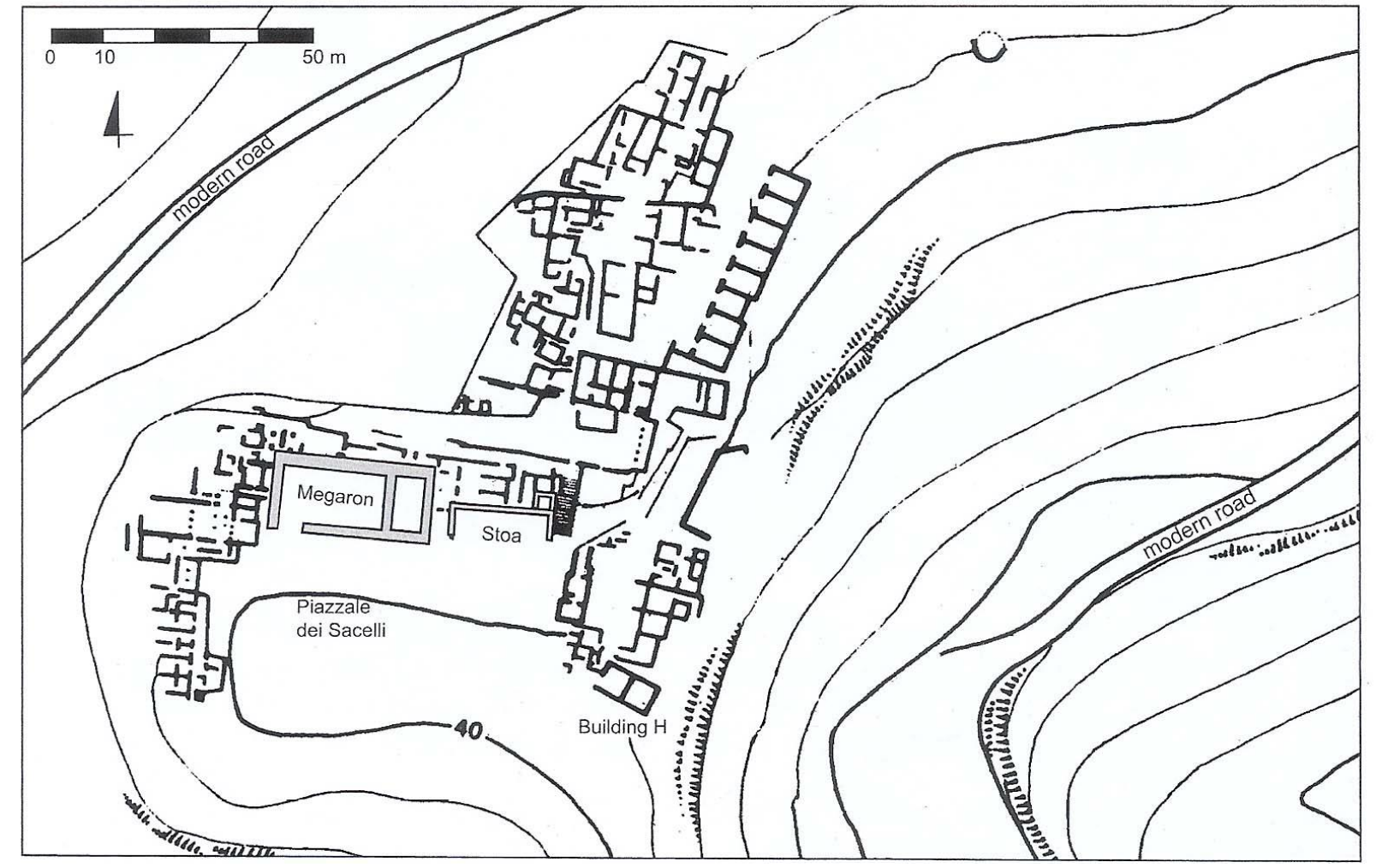

Fig.1- Planimetria de Agia Triada (Prent, 2005: fig.15) 
Datação: Minóico médio III (1700-1600 a.C.) / minoico tardio I (1600-1425 a.C.) - época romana.

Localização: Na base ocidental da colina de Palaiochora, na planície costeira de Karteros, no lado norte-central da ilha de Creta (Prent, 2005: 332-333).

Tipo de santuário: Extraurbano (a partir da Idade do Ferro) com função marítima.

Referências textuais: (Sobre Omphalion pedon e Thenai) Calímaco, Jov. 42-45; Diodoro 5.70.4; Stephanos de Bizâncio, s.v. Ozvaí.

Inscrições: Numerosas inscrições dedicatórias (THNI OENATAI) datadas do período helenístico tardio (110-69 a.C.) (Schäfer, 1991: 351).

Histórico dos achados: As primeiras escavações, na vila minoica e no santuário, foram realizadas por Sp. Marinatos entre 1932-1938. Entre 1963-1967, as escavações de salvamento de Alexiou revelaram mais restos da Idade do Bronze em diferentes pontos ao redor e sobre a colina Palaiochora. Achados do período minoico tardio, recuperados das escavações de Marinatos, foram re-examinados por Kanta em 1980, enquanto o trabalho topográfico e um estudo completo das antigas escavações foram realizados pelo Instituto Alemão sob a direção de Schäfer entre 1983-1985.

\section{Documentação arqueológica}

I. Muro, escadas e pódios: Na área $\mathrm{D}$, Marinatos encontrou uma estrutura de mais de $44 \mathrm{~m}$ de comprimento, um muro de alvenaria de contenção $\mathrm{A}-\mathrm{F}$ (do minoico médio IIIB) e dois pequenos pódios norte e sul (do período neopalacial). A continuação do muro, e de outros remanescentes, estão, provavelmente, ainda enterrados debaixo da área (Prent, 2005: 33-34; Schäfer, 1991: 351). Marinatos sugeriu que os muros foram preservados de tal maneira que podem ter sido reutilizados em períodos posteriores à Idade do Bronze, como indica também as duas escadas de época helenística, anexadas na parte central e sul dessa construção e as pedras de calcário acrescentadas nesse período facilmente distinguíveis daquelas de época minoica de outro material (Prent, 2005: 333-334, Schäfer, 1991: 349 e 351). De acordo com M. Prent, por ter sido parcialmente escavado, a função original do muro da Idade do Bronze não pôde ser estabelecida. Devido à proximidade à escarpa oeste da colina, foi sugerido que a estrutura, e os dois pódios menores de frente a ela, foi parte de uma plataforma ao invés de um complexo de edifício (Prent, 2005: 528). Talvez devido ao caráter incompleto da escavação, não há construções atribuídas ao início da Idade do Ferro (Prent, 2005: 33-34). A presença de uma fossa ou depósito votivo pode indicar que o muro serviu para propósitos cultuais na Idade do Bronze e foi relembrada como tal, ou representa a descoberta da fase do início da Idade do Ferro, dando origem a suposição de que se trataria do edifício mais antigo do santuário (Prent, 2005 : 528). Contudo, o muro não fornece qualquer evidência de uso ritual durante a ldade do Bronze e novas escavações serão necessárias para esclarecer a função 
dessa estrutura, que estava longe da linha da praia no momento de sua criação (Schäfer, 1991: 355). Em nossa visita ao sítio em julho de 2014, encontramos partes dos remanescentes de uma estrutura (blocos de pedra muito semelhantes aos do muro minoico), para além da cerca do sítio, que terminava próxima à beira da praia. A estrutura, que estava em péssimas condições de conservação, seguia a mesma direção norte-sul do muro minoico.

II. Outros remanescentes arquitetônicos e escultóricos: De acordo com Schäfer, além dos remanescentes das construções minoicas e helenísticas tardias, também deve ter existido uma construção do período arcaico tardio, pois uma grande parte dos blocos de calcário, distinguíveis pelo formato irregular, pode ter pertencido a uma parte de estilóbato caracterizado como arcaico. Apenas novas escavações poderão mostrar a localização original desse edifício. Da época dessa construção arcaica datam duas esculturas de águia (em pé e de asas fechadas) em calcário, maior do que o tamanho natural, recuperadas em meio aos restos do santuário, que ficavam expostas sobre um pilar na área sagrada (Schäfer, 1991: 353). Na exibição das duas esculturas, no Museu Arqueológico Nacional de Heráclion, a placa informativa diz que se trata de uma águia e de um falcão, o símbolo de Zeus e de Hera, respectivamente, datados da metade do século VI a.C., os quais ficavam sobre duas colunas retangulares, na área do santuário, para serem visíveis a partir de certa distância.

III. Fossa votiva: Uma pequena fossa ou depósito, encontrada nas proximidades do muro minoico, continha cerâmica do minoico médio (figurinhas de touro e parte de um kernos de terracota) e foi assinalada por Marinatos a um ritual de purificação, de limpeza do santuário, realizada pelos fundadores do culto posterior (Prent, 2005: 528).

IV. Altar de cinzas: Na área de frente ao muro, em um grande espaço aberto, uma camada de solo preto e oleoso, de c.0,70 m de espessura, contendo ossos de animais e objetos queimados pelo fogo, foi encontrada por cima dos dois pódios até o muro. Nenhuma estratigrafia pôde ser determinada dentro da camada de cinza, perturbada durante a antiguidade, permanecendo problemática a sua datação (Prent, 2005: 334; Schäfer, 1991: 349). Todos os objetos votivos da Idade do Ferro provêm desse altar de cinzas e ossos, que se acumulou ao longo dos mais de $44 \mathrm{~m}$ do muro de contenção no sopé da colina. Os achados desses objetos proporcionaram um estágio não menos monumental, que em Cnossos, Phaistos e Kommos, para as atividades cultuais no san tuário no início da Idade do Ferro (Prent, 2005: 528).

V. Objetos votivos: Minóico médio III / minoico tardio I e geométrico tardio: duas miniaturas de lâminas de machado duplo provenientes do altar de cinzas não é certa. Idade do Bronze: adaga com rebites dourados proveniente das camadas da Idade do Bronze e posteriores na parte inferior da camada de cinzas. Protogeométrico - início do geométrico: uma figurinha masculina de bronze de joelhos dobrados, outra figurinha e dois fragmentos de trípodes, também de bronze. Início do geométrico - início do orientalizante: aro de bronze (Prent, 2005: 334). Geométrico médio - orientalizante: figurinhas de touro e uma de cavalo, pequena roda de um modelo de coche, e escudo votivo com figura de prótomo de leão (?), todas de terracota. Geométrico tardio ou orientalizante: figurinha de touro, alça de uma vasilha, pequena roda, pequeno disco, fragmento de trípode e chapa de um pingente, todos em bronze, e cabeça humana em calcário com polos e olhos com incrustação de ossos de oficina norte síria. Orientalizante: número de objetos de faiança, recuperados no altar de cinzas, datados da segunda metade do 
século VII a.C., tais como vasilhas e figurinhas (Bes e uma de Astarte) várias das quais podem ser de produção egípcia e outras levantinas e do leste do mundo grego. Arcaico: figurinha feminina parcialmente preservada sentada sobre um bovino ou equídeo (c.600 a.C.). Arcaico-clássico (VI-V a.C.): Figurinhas de touro de bronze. Nenhum vaso completo foi recuperado do altar de cinzas, mas apenas fragmentos (skyphoi, ânforas e crateras) de todos os períodos até o início do orientalizante. As cerâmicas de outros pontos do santuário possuem o mesmo alcance de formas e têm sido assinaladas ao período geométrico e posteriores (Prent, 2005: 335). Inscrições de 69 a.C. e posteriores não foram encontradas no altar (Schäfer, 1991: 353).

Tipo de culto: 0 santuário tem sido atribuído ao culto de Zeus Thenatas com base no achado de várias inscrições posteriores, do final do período helenístico. Conforme Prent, o culto de Zeus durante o início da Idade do Ferro, defendido pelos pesquisadores alemães, não está claramente refletido na escolha dos votivos (Prent, 2005: 335-336 e 529). Tendo em vista o uso contínuo do altar, é muito provável que Zeus, atestado apenas no período helenístico a partir das inscrições, tenha sido cultuado desde o período geométrico (Schäfer, 1991: 355). A partir de outra perspectiva, contudo, Chaniotis argumenta a favor de uma origem aqueia do final da Idade do Bronze do culto de Zeus Thenatas, considerando ser muito provável que o culto em Amnisos tenha sido dedicado à divindade desde o início da Idade do Ferro e em diante (apud Prent, 2005: 335-336). Esse autor ainda defende que Thenai pode ter sido um toponímio em Creta vinculado a Zeus no período de sincretismo minoico-micênico. Embora não haja evidências para a continuidade de culto ininterrupta da Idade do Bronze (nem no minoico tardio IIIC nem no subminóico) ao início da Idade do Ferro, o tipo do culto mostra claras ligações com o final da Idade do Bronze tardia (Prent, 2005: 529). A continuidade cultual é atestada apenas entre a Idade do Ferro e a época helenística (Schäfer, 1991: 355). Nessa perspectiva também, Schäfer, embora coloque em dúvida a continuidade do culto com a Idade do Bronze, não descarta a ligação histórico-religiosa com o período minoico, de um deus que nasce e morre, ligado ao ritmo das estações do ano, descrito no hino de Palaikastro (Schäfer, 1991: 355 e 357). Para Schäfer, as ruínas minoicas podem ter atraído para o estabelecimento de um altar de cinzas a Zeus durante os anos de 1000-700 a.C. (Schäfer, 1991: 357). Zeus Thenatas era o deus de Thenai, onde, de acordo com a tradição helenística (especialmente em Calímaco e Diodoro) teria sido o lugar no qual teria caído o cordão umbilical do deus quando as ninfas o trouxeram de Dicta para Ida. Nessa época (helenística?), a planície ao redor de Thenai era chamada de Omphalion Pedon (Schäfer, 1991: 355). Não pode ser provado que a colina de Palaiochora foi designada como Thenaion ou a área próxima ao rio Amnisos foi designada de Thenai, ou seja, que a fundação do culto estivesse diretamente ligada com a região de Amnisos. O local de culto mais antigo, talvez até da Idade do Bronze, pode ter sido em outro lugar (Schäfer, 1991: 355). De acordo com M. Prent, considerando o uso tradicional de Amnisos como porto, pode ser afirmado que o começo do culto no início da Idade do Ferro aconteceu por razões similares que em Kommos - restabelecer uma presença em uma área de limite que adquiriu nova importância com o aumento das comunicações além-mar a partir do período proto-geométrico em diante (Prent, 2005: 527).

Referências bibliográficas: Betancourt, P.; Chaniotis, A. Die Geschichte von Amnissos von Homer bis zur Eroberung Kretas durch der Türken, em: Schäfer, J.(ed.). Amnissos Nach den archälogischen, historischen und epigraphischen Zeugnissen des Altertums und der Neuzeit. Berlin, 1992, pp.73-128; Marinatos, N. Investigations at the Amnissos Cave, (abstract), AJA (98), 1994, p.306; Lippolis, E.; Livadiotti, M.; Rocco, G. Architettura Greca: storia e monumenti del mondo della polis, dalle origini al V secolo. Milão: Mondadori, 2007, p.756; Prent, M. Cretan sanctuaries and cults. Continuity and change from Late Minoan IIIC to the 
Archaic Period. Leiden-Boston, 2005, pp. 332-336; Schäfer, J. Amnissos, 1984-1988: Das Problem der Kultkontinuität im Falle des Heiligtums des Zeus Thenatas, em: Musti, D. et alii (eds.). La transizione dal miceneo all'alto arcaismo. Roma, 1991, pp.349-358; Schäfer, J.(ed.). Amnissos Nach den archälogischen, historischen und epigraphischen Zeugnissen des Altertums und der Neuzeit. Berlin, 1992; Sjögren, L. Fragments of Archaic Crete. Archaeological Studies on Time and Space.

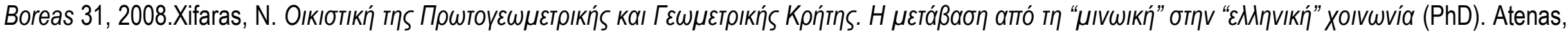
2002, p.72. 


\section{Imagens}

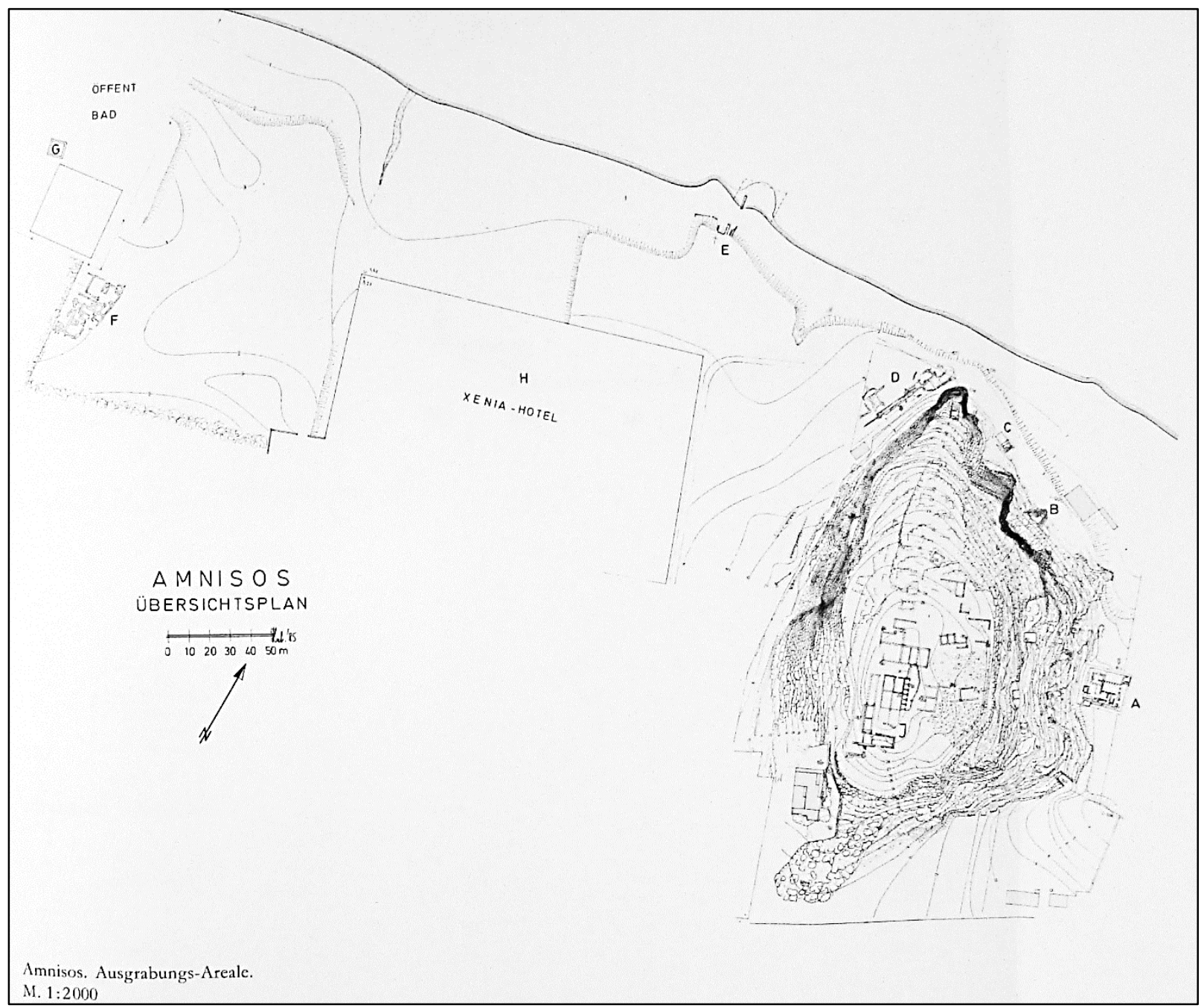

Fig.1- Planimetria geral de Amnisos (Schäfer, 1992: ?). 


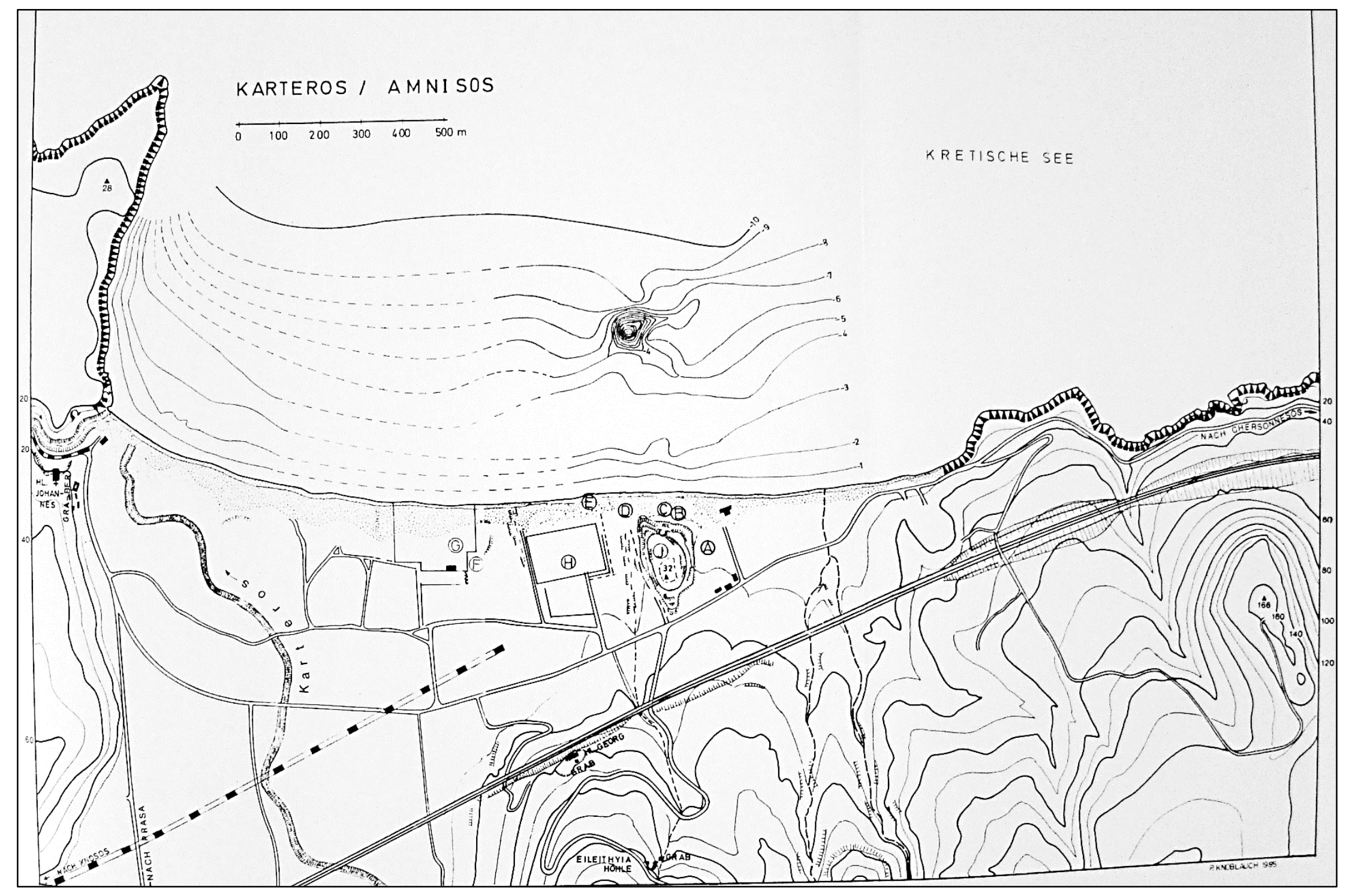

Fig.2- Planimetria geral de Amnisos (Schäfer, 1992) 


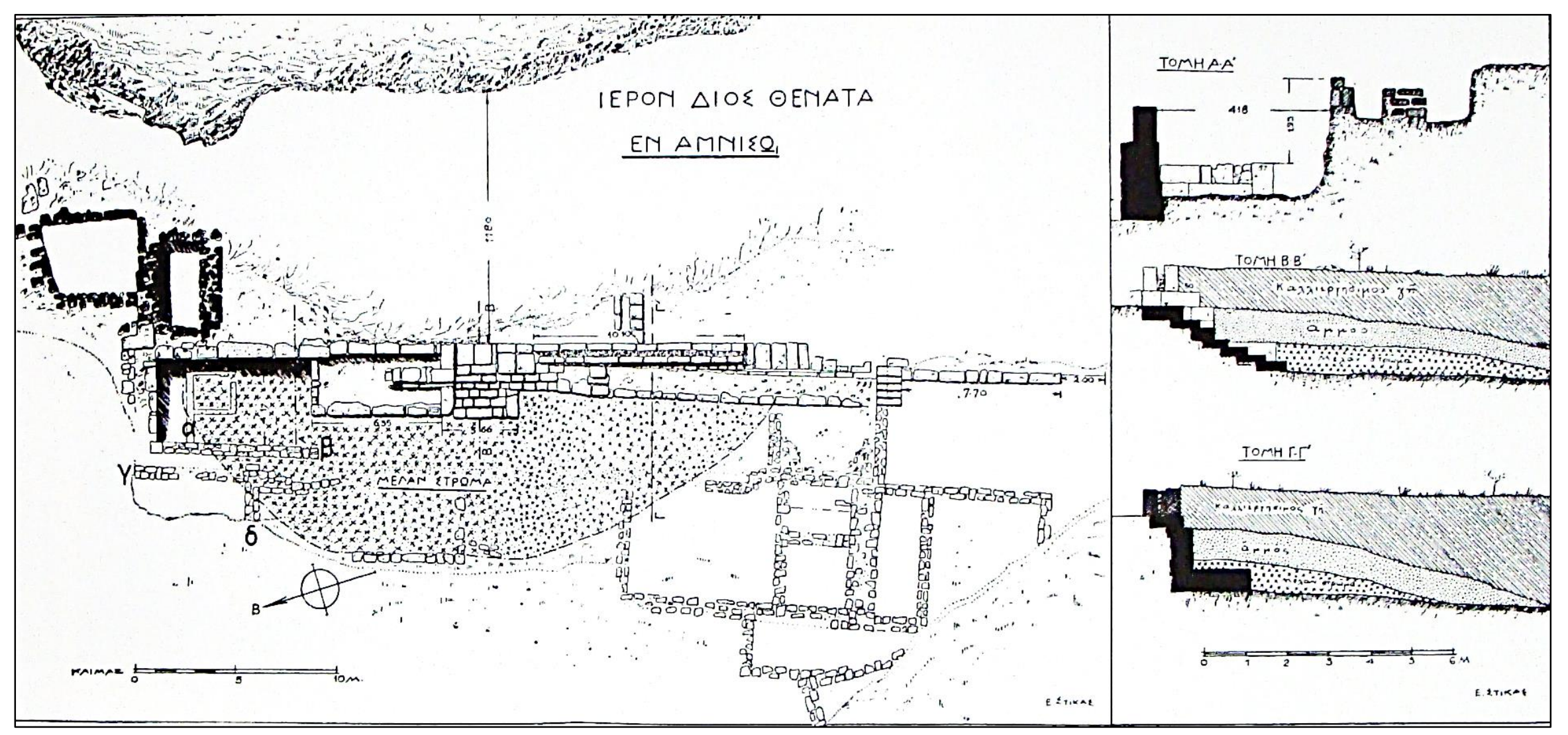

Fig.3 - Planimetria do santuário de Zeus Thenatas (área D) $\alpha-\delta$ (por E. Stikas, 1938) (Schäfer, 1992) 


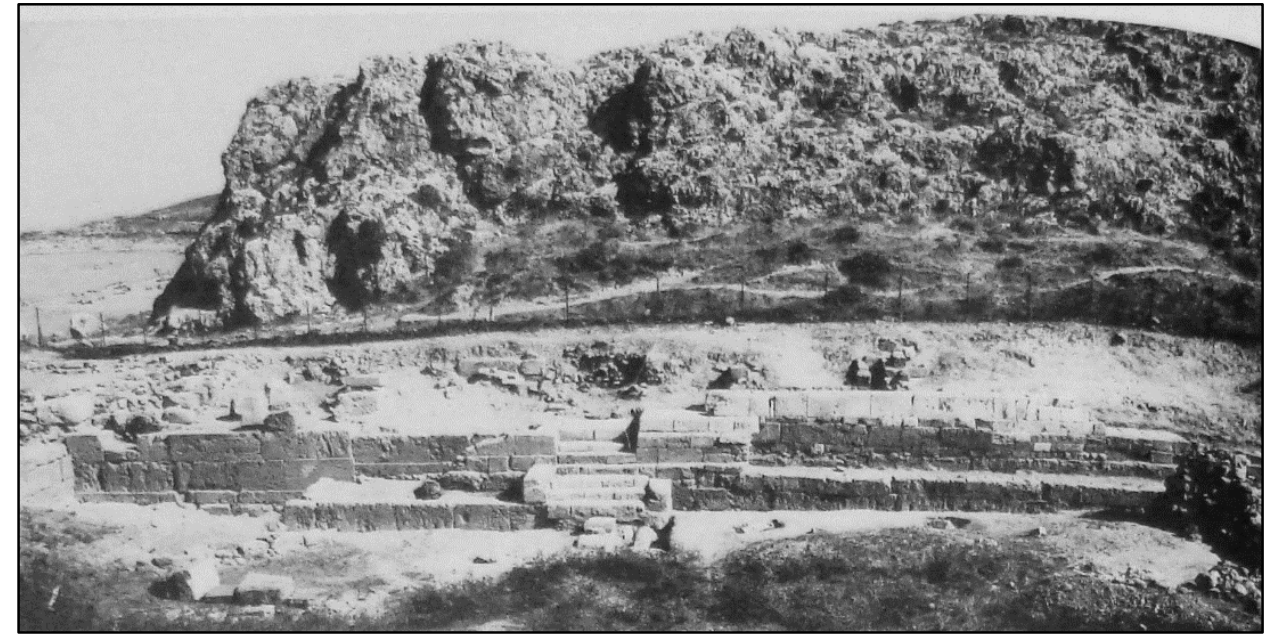

Fig.4- Área D, muro minoico visto de oeste na época das antigas escavações (Schäfer, 1992: pr.30 vol.2)

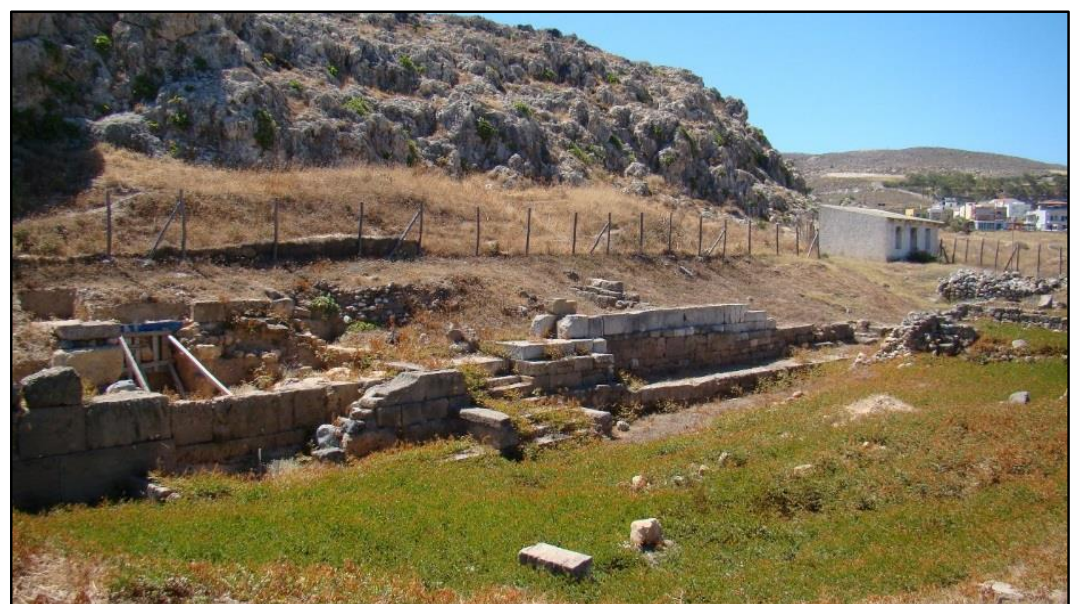

Fig.6- Área D, muro minoico atualmente visto de oeste (Foto: arquivo pessoal/2014)

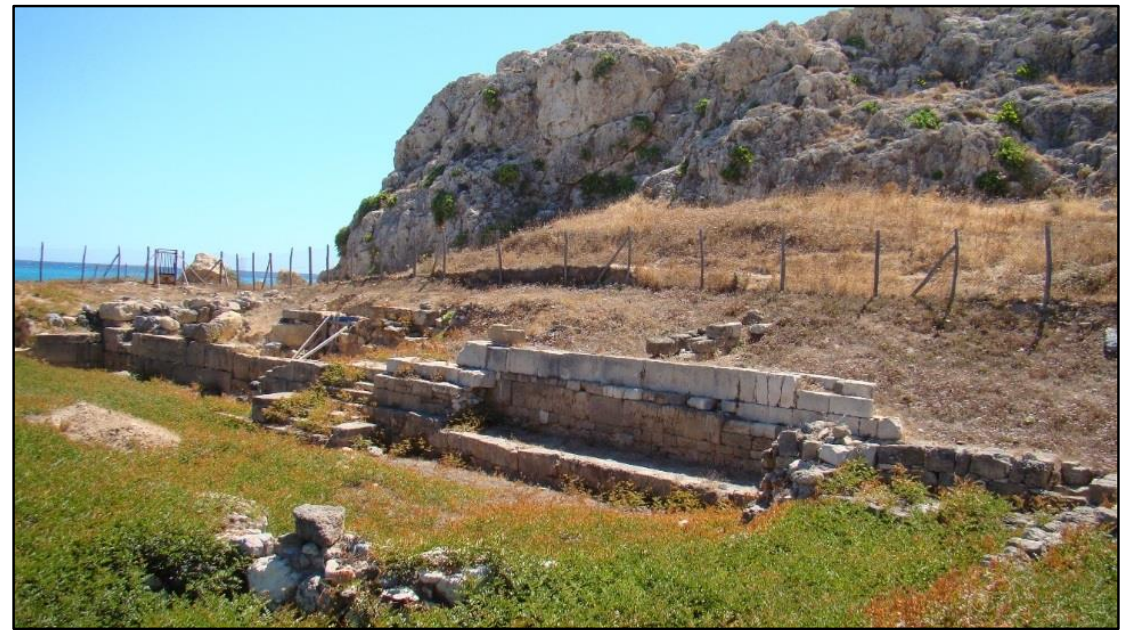

Fig.5- Área D, muro minoico atualmente visto de oeste (Foto: arquivo pessoal/2014)

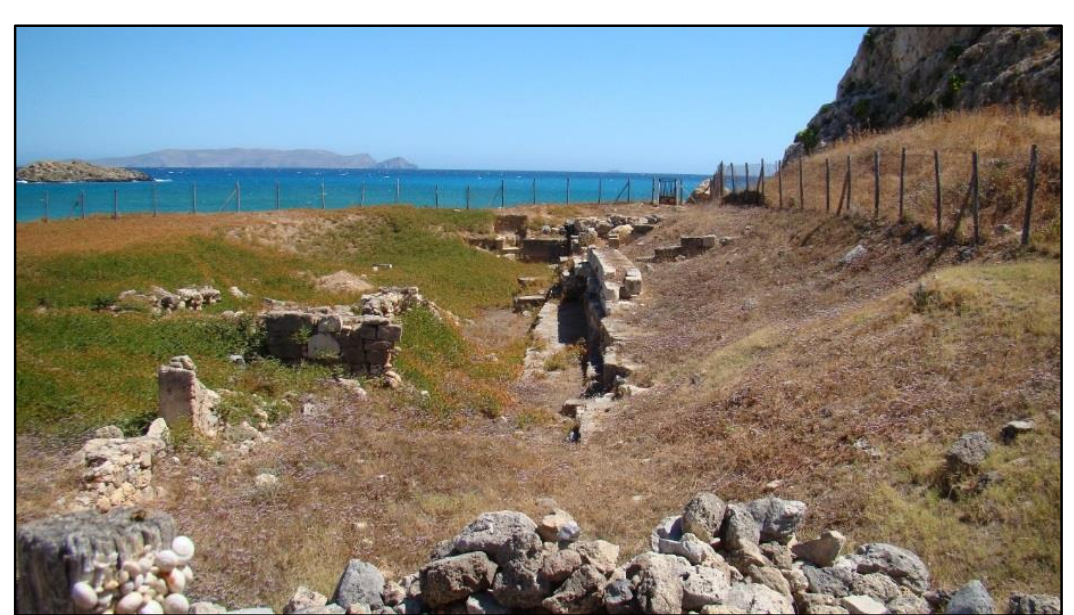

Fig.7- Área D, muro minoico atualmente visto de sul (Foto: arquivo pessoal/2014) 


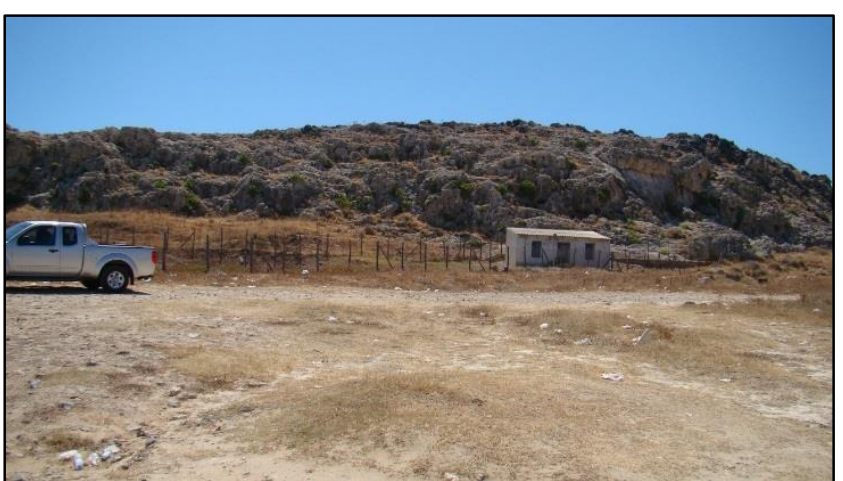

Fig.8- Vista total de oeste da área D e da colina de Palaiochora atrás (Foto: arquivo pessoal/2014)

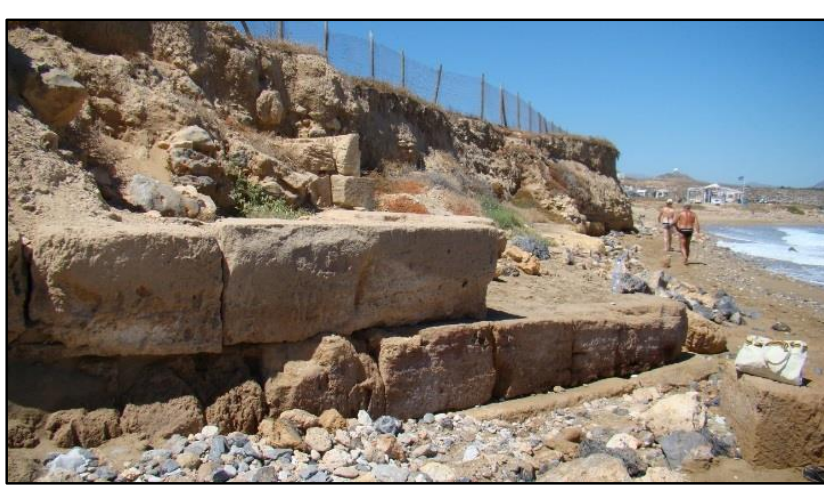

Fig.11- Vista de leste da área $\mathrm{D}$ a norte, continuação do muro minoico? (Foto: arquivo pessoal/2014)

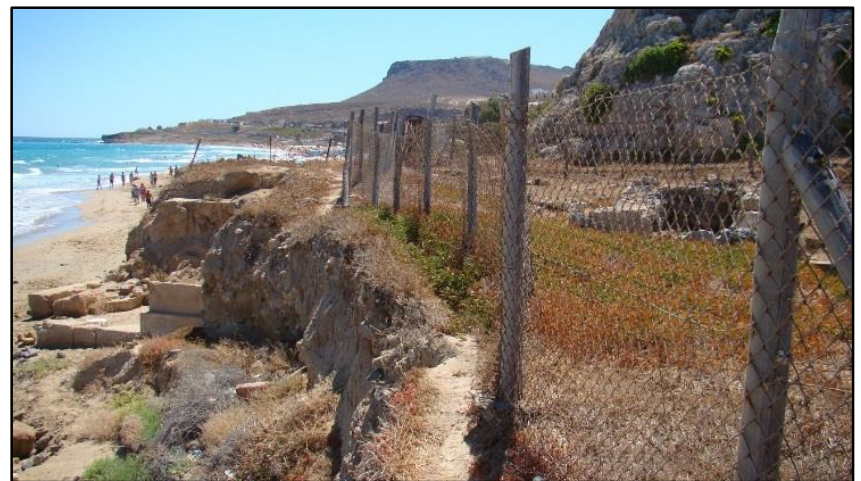

Fig.9- Vista de oeste da área $D$ a norte, restos da continuação do muro minoico? (Foto: arquivo pessoal/214)

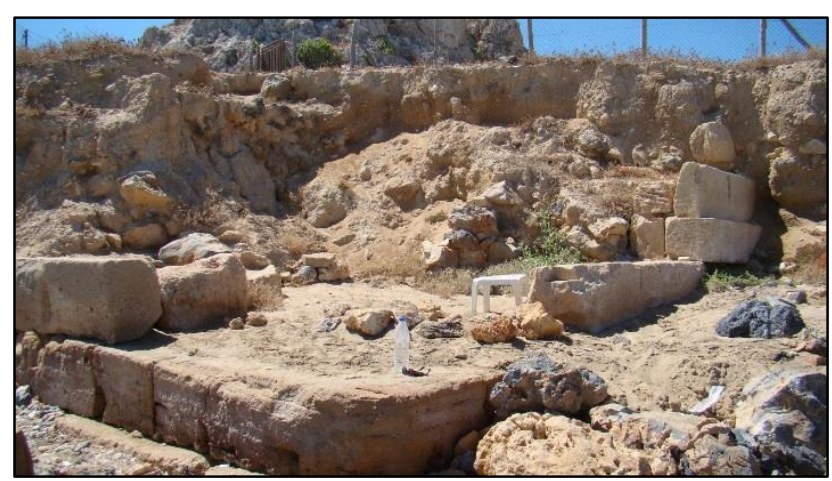

Fig.12- Vista de norte dos prováveis restos do muro minoico (Foto: arquivo pessoal/2014)

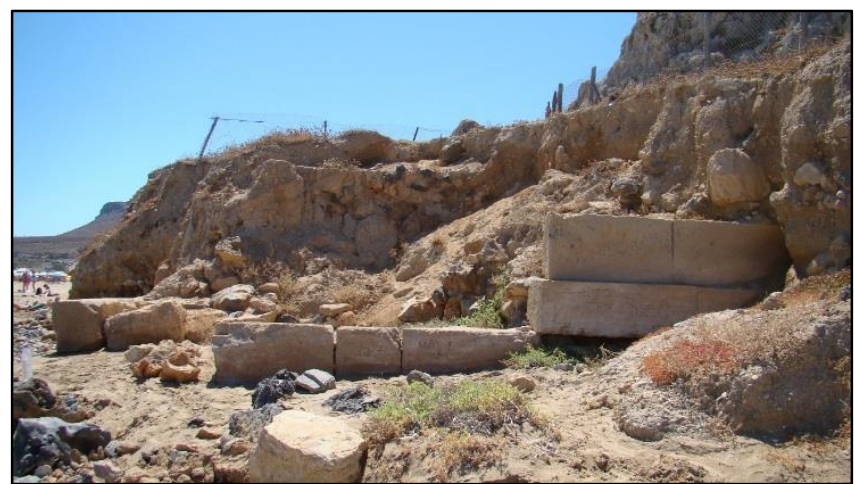

Fig.10- Vista de oeste da Área D a norte, restos da continuação do muro minoico? (Foto: arquivo pessoal/2014)

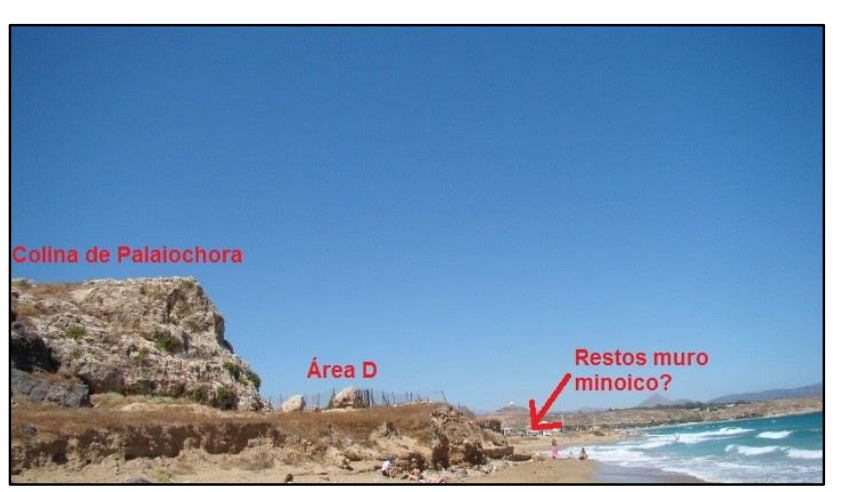

Fig.13- Vista de leste da colina de Palaiochora, área $D$ e dos prováveis restos do muro minoico (Foto: arquivo pessoal/2014) 


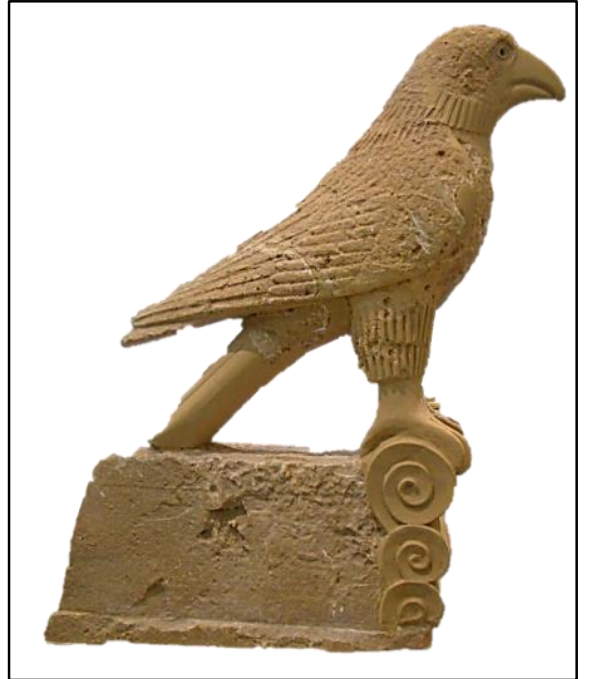

Fig.14- Escultura de águia de calcário, 0,99 $\mathrm{m}$, metade do séc.VI a.C., Museu Arqueológico Nacional de Heráclion (Foto: arquivo pessoal/2014

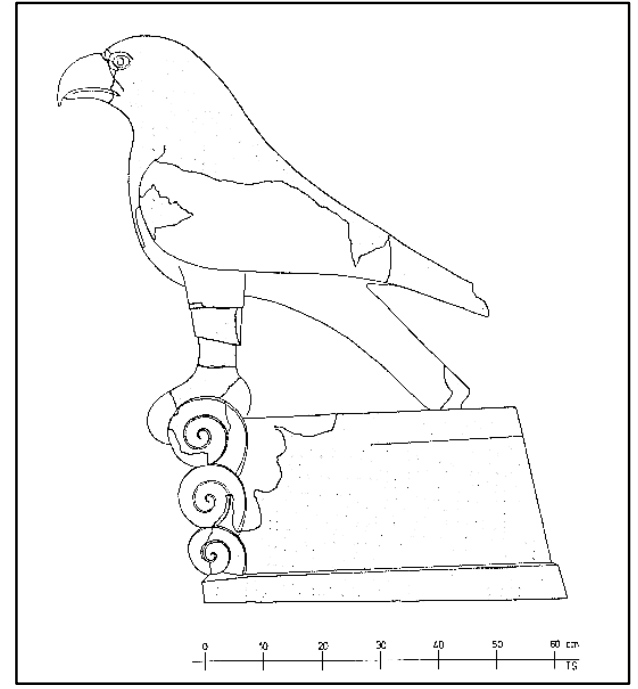

Fig.15- Desenho da escultura da águia (Schäfer, 1992: D,1.d2, pr.107)

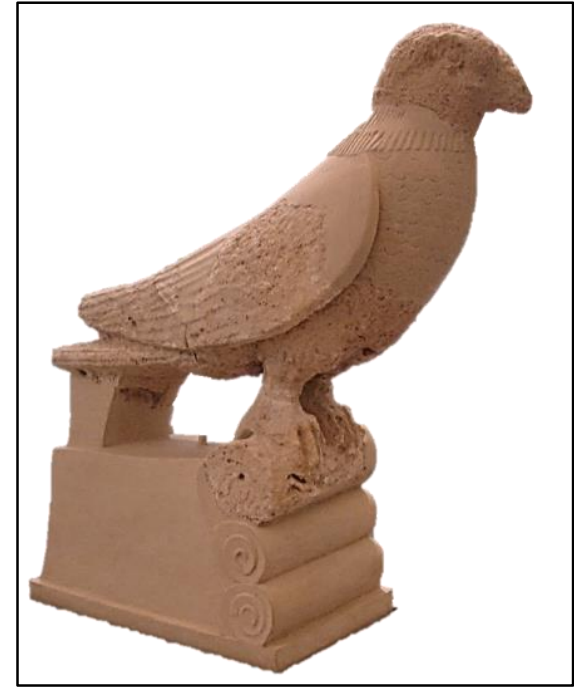

Fig.16- Escultura de falcão de calcário, $1 \mathrm{~m}$ metade do séc. VI a.C., Museu Arqueológico Nacional de Heráclion (Foto: arquivo pessoal/2014)

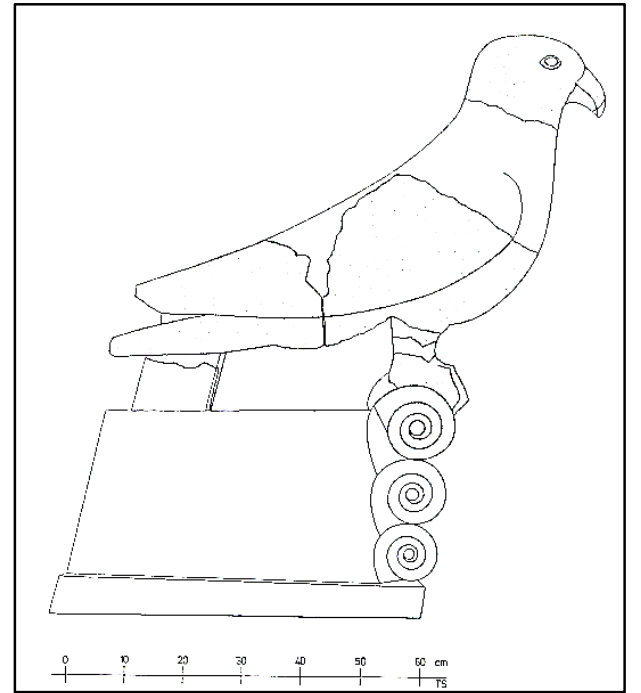

Fig.17- Desenho da escultura de falcão (Schäfer, 1992: D,1.d3, pr.108) 


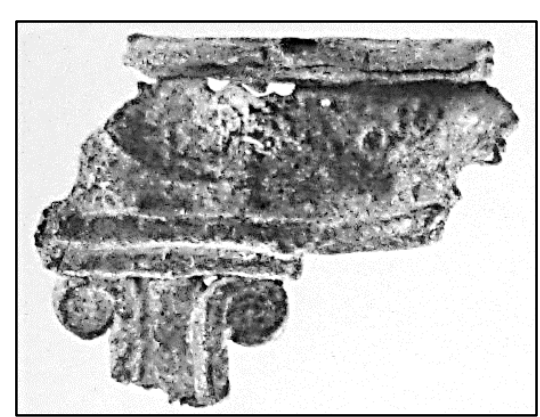

Fig.18- Fragmento de trípode de bronze, séc. IX a.C. (Schäfer, 1992: D,1.b10, pr.75)

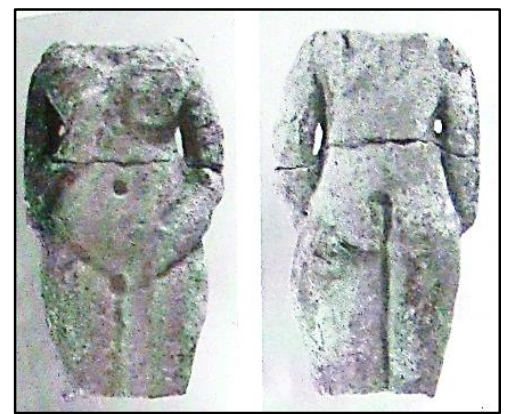

Fig.22- Estatueta de faiança de Astarte, orientalizante (Schäfer, 1992: D,1.c8, pr.79)

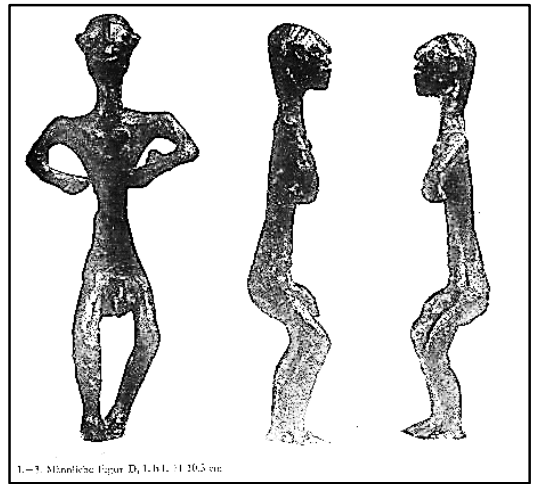

Fig.19- Figurinha em bronze masculina, proto-geométrico-início geométrico (Schäfer, 1992: D,1.b1, pr.73)

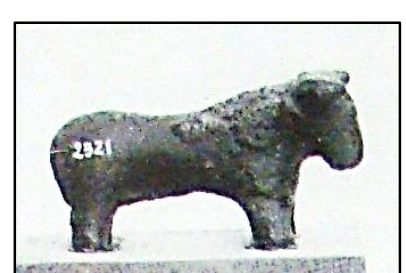

Fig.20- Figurinha de touro em bronze, séc. VII a.C. (Schäfer 1992: D,1.b4, pr.74)

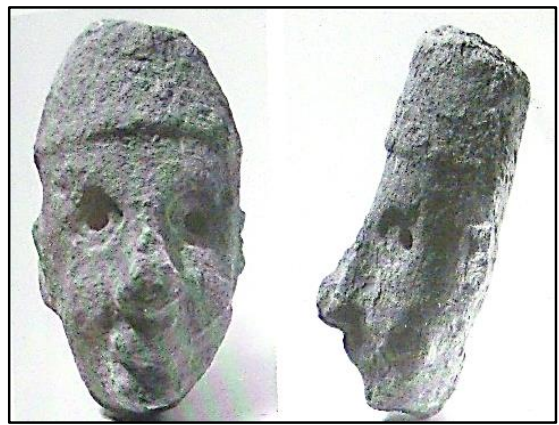

Fig.21- Márcara em calcário com polos, geométrico tardio ou orientalizante (Schäfer, 1992: D,1.b1, pr.81)

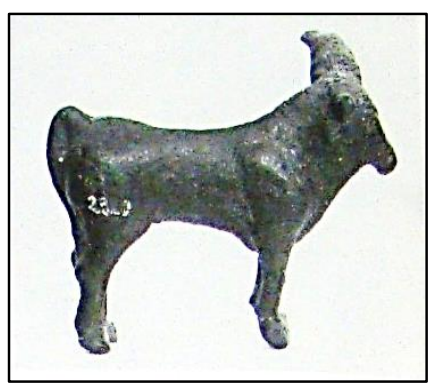

Fig.23- Figurinha de touro em bronze, final do VI a.C. - metade do século V a.C. (Schäfer, 1992: D,1.b6, pr.74)

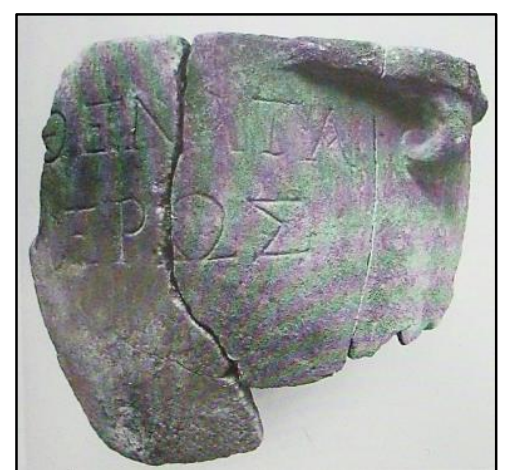

Fig.24- Fragmento de cratera em mármore com inscrição [---] OENATA

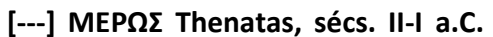
(Schäfer, 1992: D,1.d5, pr.109) 
Datação: Proto-geométrico (1000-900 a.C.) - época romana (séc. IV d.C.).

Localização: Na área das quadras minóicas Chi e Pi, do assentamento da Idade do Bronze de Palaikastro, no vale fértil costeiro de Roussolakos, no extremo leste de Creta (Prent, 2005: 350).

Tipo de santuário: Planície / extraurbano, inter-regional e interestadual (a partir da Idade do Ferro).

Referências textuais: (Templo e Praesos) Estrabão (10.4.6; 10.4.12); (sobre a localização de Dicta) Diodoro (5.70.6), Apolônio Ródio (Argonautika 4.1635-1693).

Inscrições: Fragmentos do "Hino a Zeus Dicteu", uma inscrição do século III d.C. encontrada em uma fossa próxima à quadra Chi (Bosanquet, 1909), provavelmente composto nos séculos IV ou III a.C. No hino, o jovem Zeus é convocado a retornar à Dikte, onde estava seu altar sagrado (MacGillivray; Sackett, 2010: 574). Inscrições indicam que o santuário continuou a funcionar como um importante lugar de culto para os habitantes das cidades a leste de Creta nos períodos helenístico e romano (MacGillivray; Sackett, 2010: 575). A localização do santuário foi indicada pela descoberta de fragmentos da inscrição que registra o "Hino a Zeus Dicteu". Inscrição de Toplou, do século Il a.C., sobre a longa disputa territorial entre várias cidades do leste de Creta pelo santuário de Zeus Dicteu no período (Prent, 2005: 534).

Histórico dos achados: 0 santuário arcaico, clássico e romano de Zeus Dicteu (o Diktaion de Estrabão) foi escavado na primeira campanha realizada em Palaikastro, entre 1902 e 1906, pela Escola Britânica com direção de Robert Carr Bosanquet e Richard MacGillivray Dawkins (MacGillivray; Sackett, 2010: 572). Na campanha de 1904 foram encontrados os fragmentos do hino a Zeus Dicteu em fossos próximos ao bloco Chi (Crowther; MacGillivray, 2002: s/p). Em 1905, foram recuperadas partes das simae no sítio. Outras partes ainda foram adquiridas pelo predecessor do Museu de Heráclion na década de 1880, após terem sido vistas em um estábulo na área de Palaikastro (Driessen-Gaignerot, 2011: 425-426). Durante as campanhas de 1987-1988 e 1990 foram recuperados os cem fragmentos da estatueta de marfim, argila e ouro denominada de Kouros de Palaikastro encontrados ao longo do edifício 5 (Sackett, 2002 : s/p).

\section{Documentação arqueológica}

I. Altar de cinzas: $\mathrm{O}$ altar de cinzas demonstra que, antes de o culto ser abrigado pelo templo no século $\mathrm{VI}$ a.C., este era realizado à céu aberto desde quando foi estabelecido em meio às ruínas da cidade minoica em Roussoulakkos (Thorne e Prent, 2002: s/p). Uma concentração de cinzas, de 0,25 m de espessura e 3 
m de comprimento, foi encontrada ao longo das quadras Chi 25-26 e Pi 38-40, na área dentro do témeno tardio (Prent, 2005: 351). Ali foram achados vários objetos (vasilhas de bronze e esculturas miniaturísticas) (Prent, 2005: 351 e 538).

II. Templo e muro de témeno: A construção do muro de témeno (provavelmente de $36 \mathrm{~m}$ de comprimento) pode ser datado do mesmo período do templo (século VI a.C.) (Prent, 2005: 350-351). Os autores costumam situar a primeira fase de construção do templo durante o século VI a.C., como também as simae de terracota com cenas de guerreiros e cavaleiros (Thorne e Prent, 2002: s/p.; Prent, 2005: 351). No entanto, mais recentemente, o estudo iconográfico e estilístico comparativo, empreendido por Driessen-Gaignerot, datou as simae no final do século VII a.C., em concordância ao que havia afirmado Bosanquet anteriormente (Driessen-Gaignerot, 2011: 430). O templo foi reconstruído várias vezes, em períodos posteriores, como testemunham uma sequência de telhas de cobertura e elementos escultóricos, como uma série de antefixas de cabeças de górgonas, datadas entre os séculos VI-V a.C., e um friso de flores de lótus e palmetas (Prent, 2005: 538; Thorne e Prent, 2000 apud MacGillivray; Sackett, 2010: 575).

III. Objetos votivos: Durante o período mais antigo de culto em Roussolakkos, Zeus Dicteu recebeu oferendas votivas de bronze de trípodes, de figurinhas de touro, de escudos decorados, elaboradamente, e de tipos de armadura (couraças, elmos, miniatura de escudos) e taças e tigelas de argila, lamparinas e suportes de tochas (MacGillivray; Sackett, 2010: 575). No depósito de cinzas ao redor do altar foram encontradas taças de bronze, miniaturas de escudos e selos (Prent, 2005: 351; Watrous, 1996: 104). Dentre os inúmeros achados, pode-se citar, possivelmente do proto-geométrico (haste de um trípode de bronze); do século VIII a.C. (fragmentos de uma perna e alça de trípodes de bronze, escudos de bronze decorados (?) com animais, um deles com uma figura feminina e prótomos de leões); século VII a.C. (um elmo em tamanho natural e um em miniatura, uma figurinha de leão em metal, figurinhas de touro?) (Prent, 2005: 351-352). Nenhuma figurinha e placas de terracotas foram encontradas no santuário. Sobre as cerâmicas encontradas na área sagrada, estas consistiram de taças, pyxides e fragmentos cerâmicos do período geométrico e pithoi do orientalizante (Prent, 2005: 352).

Tipo de culto: $O$ achado do Hino a Zeus Dicteu é tomado por MacGillivray e Sackett como prova de que o sítio em Roussolakkos era Dikte, famosa na Antiguidade como o local do nascimento de Zeus. Os autores citam Diodoro que diz que após Zeus subverter Cronos, o deus voltou ao seu local de nascimento para fundar a cidade (MacGillivray; Sackett, 2010: 574). No hino a divindade é invocada como o "maior kouros" e chamada a vir à Dicta. A discussão sobre a sua localização exata, frequentemente considerado um toponímio de uma caverna sagrada ou montanha em algum lugar no leste de Creta, tem uma tradição que remonta à época helenística (Prent, 2005: 353). Crowther identificou Dicta ao Mt. Petsofas (de $215 \mathrm{~m}$ ), a sul do santuário, e ao assentamento minoico (apud Prent, 2005 : 353). Esse autor se vale da informação de Diodoro (5.70.6) e da inscrição JA-DI-KI-TE-TE em linear A em mesas de libação encontradas no próprio Mt. Petsofas, um santuário de pico da Idade do Bronze (Prent, 2005: 353). Já a estatueta do Kouros, de marfim, ouro e argila, tem sido considerada a representação de uma divindade masculina e mais uma evidência de ligações de culto próximas entre Palaikastro e Petsofas ainda na Idade do Bronze (período neo-palacial) (Prent, 2005: 543). O fato de o hino ser dedicado ao deus como "kouros" e este ser chamado a ir à Dicta, tem levado aos modernos escavadores em relacionar o culto da Idade do Bronze e aquele do poderoso kouros celebrado no santuário do início da Idade do Ferro (Prent, 2005: 544).Enquanto esta não é uma prova direta 
da continuidade do culto - há um intervalo de 300 anos entre o abandono final do edifício 5 e a dedicação do primeiro trípode de bronze no período protogeométrico - isso sugere a preservação de uma associação (geral) da área de Palaikastro com o culto do deus de Dicta (Prent, 2005: 544). As oferendas votivas sugerem que o santuário de Palaikastro serviu acima de tudo como um local neutro de encontro para indivíduos de diferentes comunidades ao redor na Idade do Ferro. A presença desses tipos de objetos (preponderância de trípodes, escudos, armas e miniaturas dos mesmos) e a ausência de oferendas em terracota, e a localização extraurbana do sítio, fazem de Palaikastro um modelo de santuário (inter)regional, cuja função primária foi a de local neutro para os membros das elites de diferentes comunidades reforçarem os laços entre os membros de diferentes comunidades no lado extremo leste de Creta (Prent, 2005: 537 e 550). Por quais razões Palaikastro teria sido escolhida como lugar de encontro para aristocratas da região no início da Idade do Ferro, razões territoriais e outras considerações práticas, como o acesso a um bom porto, parecem ter sido menos relevantes do que em Kommos ou Amnisos - não há importados entre 0 conjunto de objetos votivos no santuário de Palaikastro que poderia indicar contatos além-mar (Prent, 2005: 538). Também não encontra justificativa na documentação identificar a área sagrada como de fronteira, a qual marcava fronteiras agrícolas de uma das comunidades do leste de Creta, pois há escassez de pequenos assentamentos de agricultores no período nas áreas costeiras. Para Prent, portanto, parte da razão da localização do santuário nas ruínas da cidade minoica se deve à natureza remota da área no período (Prent, 2005: 539). A seu ver, tal localização remota em uma área que deve ter sido dedicada primeiramente ao pastoreio concorre com a função de 'local neutro de encontro' e coloca Palaikastro no mesmo patamar dos santuários extraurbanos de Ida e Syme (Prent, 2005: 539). Outra razão para a escolha do local estaria no aspecto significativo da área, na memória respeitável da grandeza de outrora da cidade. Os resultados das mais recentes pesquisas arqueológicas sugerem que há mais razões específicas de culto para a escolha do local. Além disso, embora não haja provas diretas de atividades de culto ininterruptas no local do santuário (tal como defendeu Bosanquet), desde a Idade do Bronze ao início da Idade do Ferro, há várias indicações sobre uma continuidade na associação da área de Palaikastro com o culto de um importante deus local, como explicado anteriormente (Prent, 2005: 540). Os especialistas têm aceito ver Zeus Dicteu como uma divindade indígena, local e, mais especificamente, como uma manifestação de Zeus Kretagenes (Prent, 2005: 540). Prent conclui que mais do que atrair visitantes de além-mar, o santuário de Palaikastro, ao contrário, serviu na manutenção de contatos entre indivíduos de outras regiões e, sobretudo, pode ter ajudado a criar e a reforçar uma identidade típica comum e regional no lado leste de Creta. Esse autor assume que essa identidade regional tomou a forma de uma consciência autóctone ou eteo-cretense do início da Idade do Ferro e em diante (Prent, 2005: 545). 0 culto em Palaikastro teve como foco uma divindade da Idade do Bronze que preservou muitas características antigas (Prent, 2005: 545). Em períodos posteriores, entre 0 clássico tardio e o helenístico tardio, os objetos votivos (cerâmicas, lamparinas e o hino) indicam que o culto de mais agrícola e pastoril para mercantil e cívico se tornou menos um negócio de elite e perdeu, ao final, sua ênfase militar-aristocrática (Prent, 2005: 550).

De acordo com Watrous, Praesos fundou o santuário em Palaikastro, bem na costa, para servir como o limite oriental de seu território (em face de Itanos a norte). Os ritos militares celebrados no santuário suportam essa afirmação. Inscrições indicam que em época helenística, este santuário extraurbano funcionou como um santuário interestadual para as cidades do leste de Creta (Watrous, 1996: 104-105). Para Prent, contudo, é difícil afirmar se Praisos teria tido parte na fundação do santuário na Idade do Ferro, diante das evidências de similaridades entre o santuário de Palaikastro e aquele do "Altar Hill" em Praisos, tal como defendeu Bosanquet (Prent, 2005: 537). A participação de Praesos no controle do santuário pode ser atestada para períodos mais posteriores, como indica a similaridade 
entre os antefixos de górgona, datados entre os séculos VI-V a.C., encontrados em Palaikastro e muito semelhantes aos do santuário em Praesos (Prent, 2005: 538).

Referências bibliográficas: Alonge, M. The Palaikastro Hymn and the modern myth of the Cretan Zeus, Princeton/Stanford working papers in Classics, 2005, pp.1-23; Bosanquet, R.C. Excavations at Praesos. I, BSA (8), 1901/2, pp. 231-270; Bosanquet, R.C. Dicte and the temples of Dictaean Zeus. Em: Hutchinson, R.W.; Ecles, E.; Benton, S. Unpublished objects from Palaikastro and Praisos. II, BSA (40), 1939-1940, 1940, pp.38-59; Cunningham, T.; Sackett, H. Does the widespread cult activity at Palaikastro call for a special explanation? Em: D'Agata, A.L.; Van de Moortel, A. Archaeologies of Cult: Essays on Ritual and Cult in Crete, Hesperia Suppl. 42, Princeton: American School of Classical Studies, 2009, pp.79-97; Driessen, J.M.; MacGillivray; Sackett, L.H. Ancient Palaikastro, An exhibition to mark 100 years of archaeological work 1902-2002. Athens: The British School at Athens, 2002; Driessen-Gaignerot, $F$. The frieze from the temple of

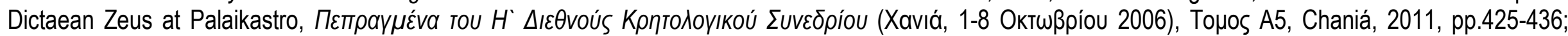
MacGillivray, J.A.; Sackett, L.H. Palaikastro (Cap. 43). Em: Cline, E.H.(ed.). The Oxford Handbook - The Bronze Age Aegean. Oxford Univ. Press, 2010, pp.570581;PKI: Bosanquet, R.C. Excavations at Palaikastro. I, BSA (8), 1901-1902, pp.286-316; PKII: Bosanquet, R.C.; Dawkins, R.M.; Tod, M.N.; Duckworth, W.L.H.; Myres, J.L. Excavations at Palaikastro. II, BSA (9), 1902-1903, pp.274-387; PKIII: Dawkins, R.M.; Currenlly, C.T. Excavations at Palaikastro. III, BSA (10), 19031904, pp. 192-231; PKIV: Dawkins, R.M.; Hawes, C.H.; Bosanquet, R.C. Excavations at Palaikastro. IV, BSA (11), 1904-1905, pp.258-308; PKV: Dawkins, R.M. Excavations at Palaikastro. V, BSA (12), 1905-1906, pp.1-8; Prent, M.; Thorne, S.M.V. The sanctuary of Diktaean Zeus at Palaikastro: a re-examination of the

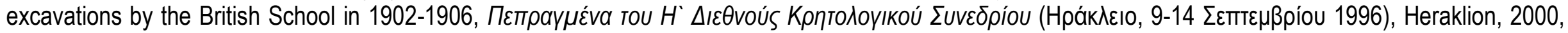
pp.169-178; Prent, M. Glories of the Past: Ritual Activities at Palatial Ruins in Early Iron Age Crete. Em: Van Dyke, R.M.; Alcock, S.(eds.). Archaeologies of Memory. Oxford: Blackwell, pp.81-103; Prent, M. Cretan sanctuaries and cults. Continuity and change from Late Minoan IIIC to the Archaic Period. Leiden-Boston, 2005, pp. 332-336; Thorne, S.; Prent, M. 'The sanctuary of Dikataian Zeus', in: Driessen, J.M.; MacGillivray; Sackett, L.H. Ancient Palaikastro, An exhibition to

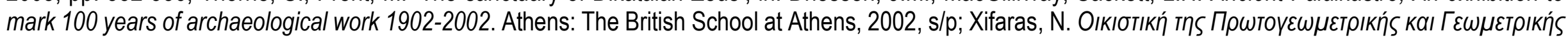

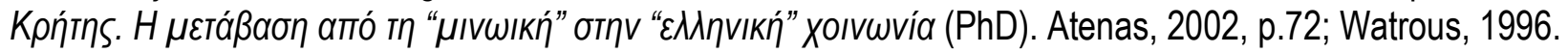




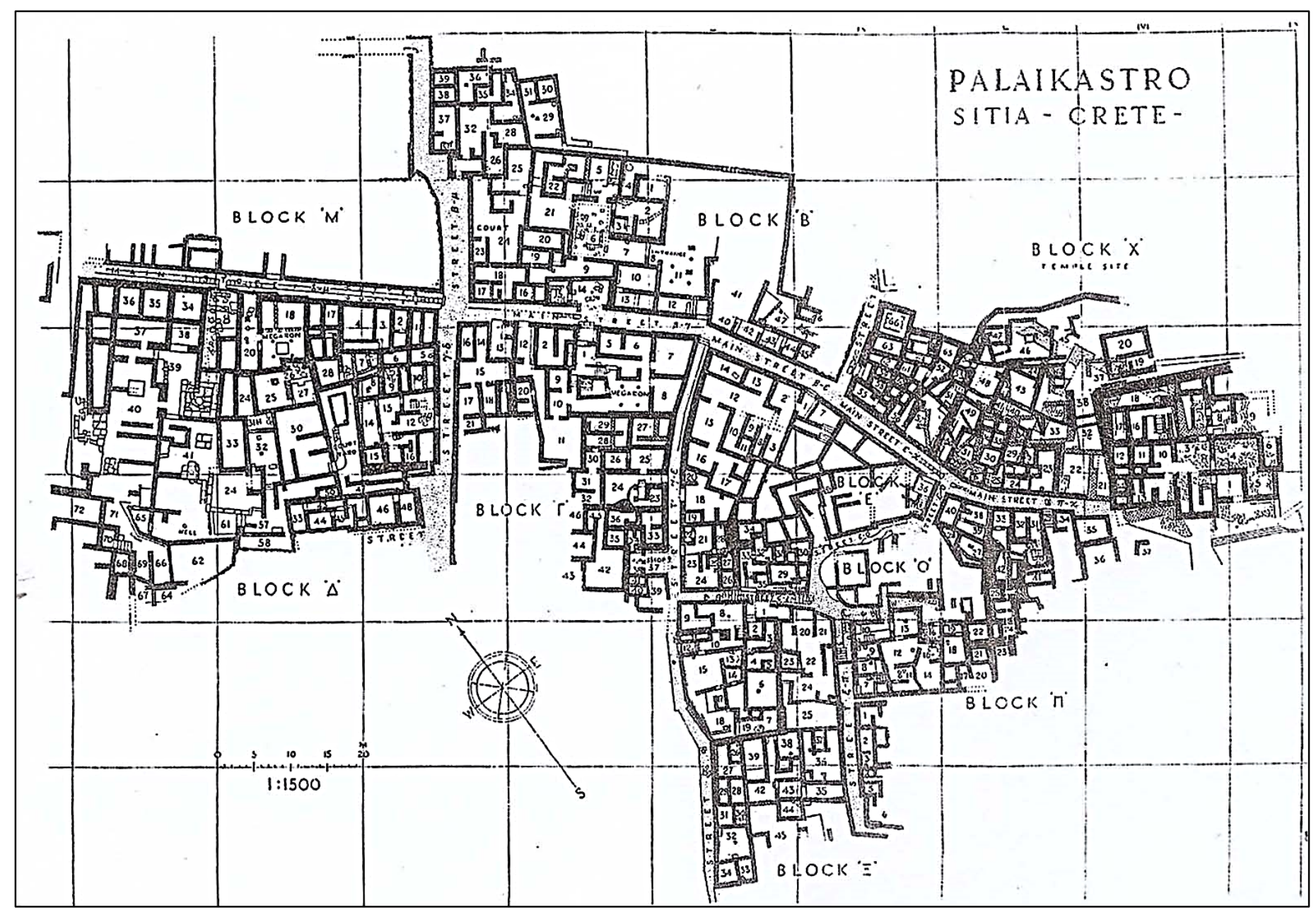

Fig.1- Planimetria geral de Palaikastro (Thorne; Prent, 2000: fig.1) 


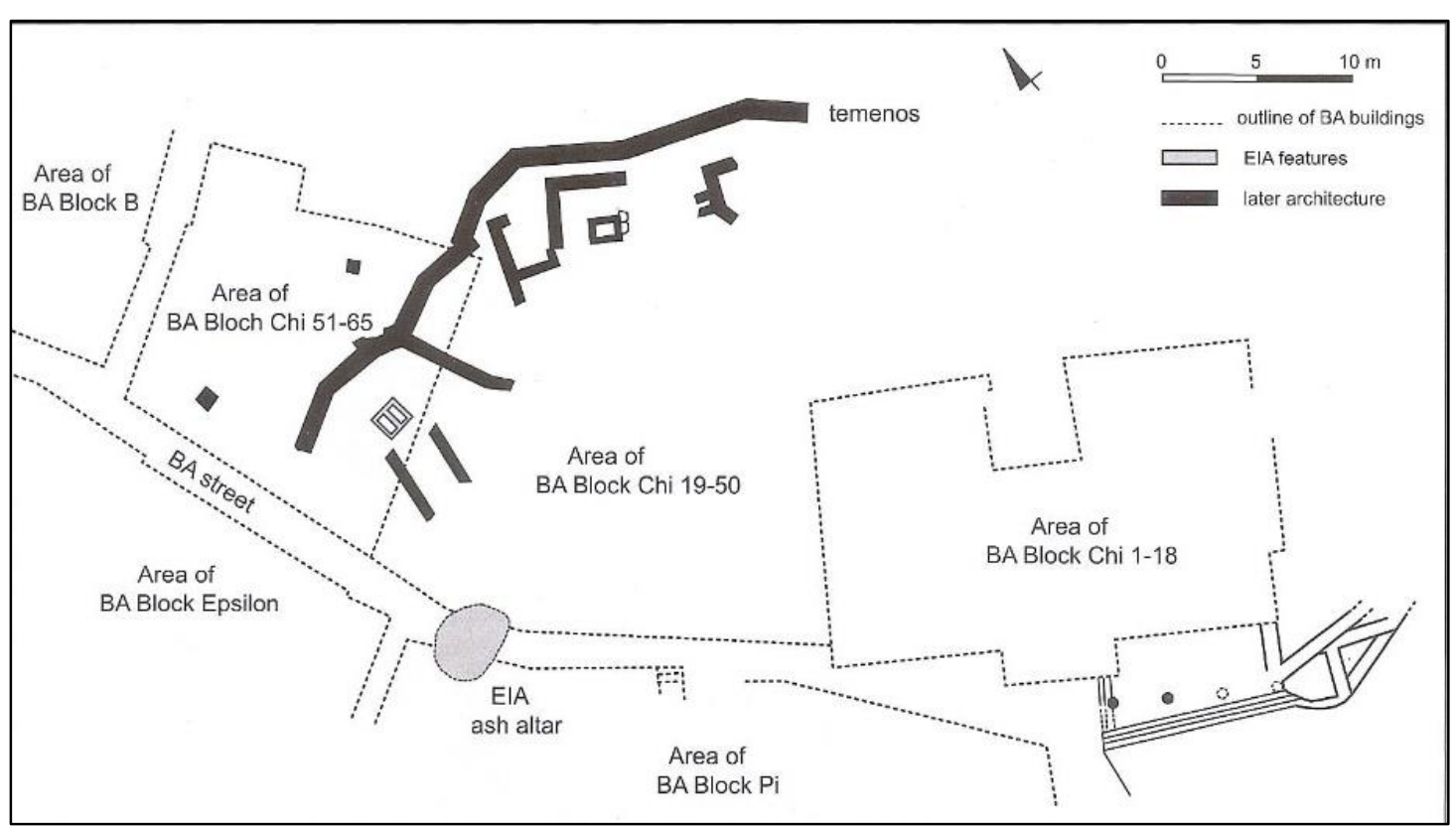

Fig.2- Planimetria do santuário de Zeus Dicteu em Palaikastro (Prent, 2005: fig.73)

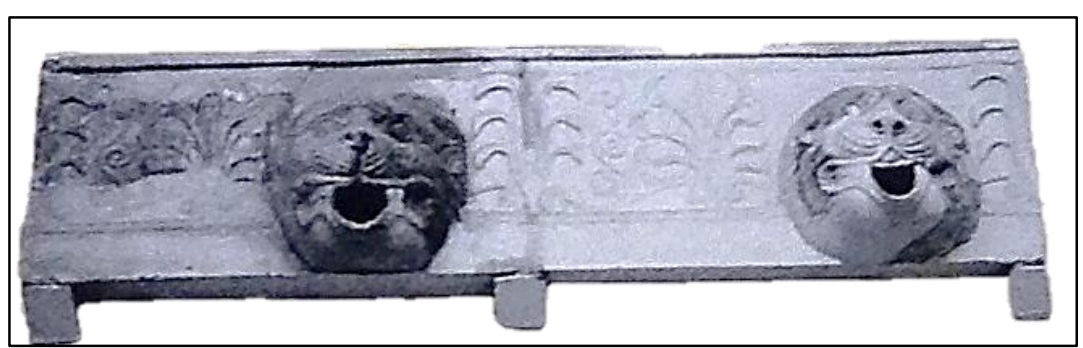

Fig.4- Sima com cabeças de leão e flores de lótus, quarto templo de Zeus Dicteu, Palaikastro (Thorne; Prent, 2002: fig.8)

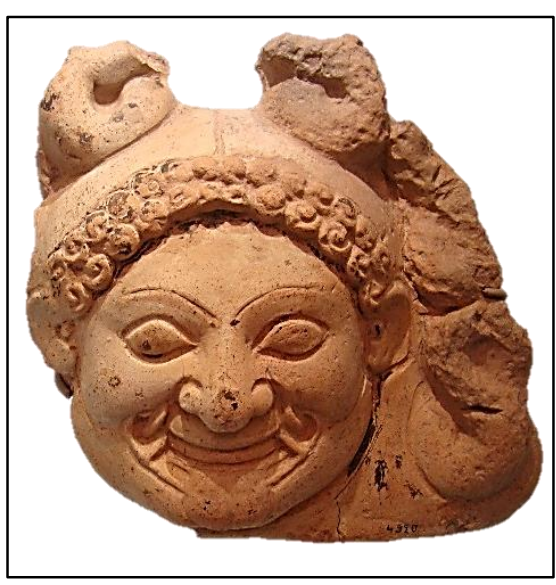

Fig.3- Sima de terracota de Górgona, segundo templo de Zeus Dicteu, Palaikastro, VI-V a.C., Museu Arqueológico Nacional de Heráclion (Foto: arquivo pessoal/2014) 


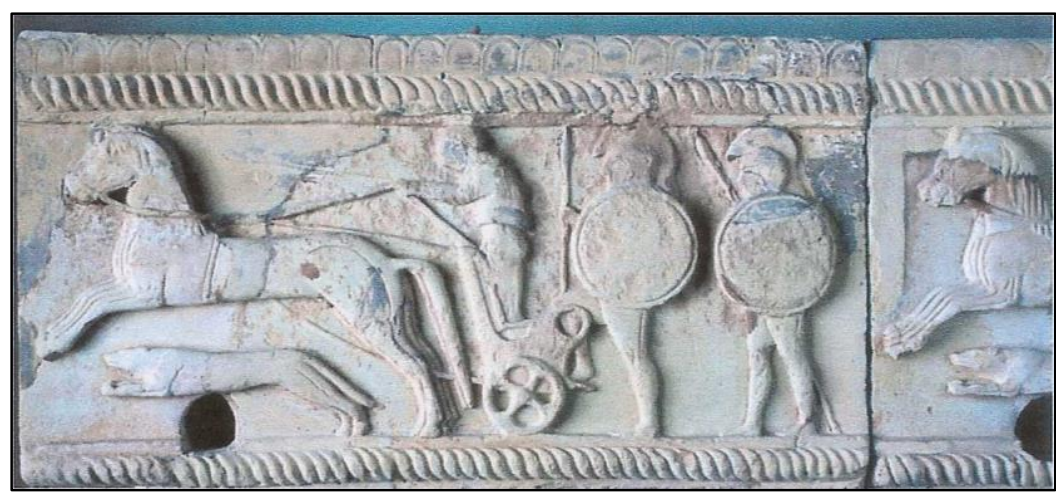

Fig.5- Friso (sima) do templo de Zeus Dicteu em Palaikastro (Driessen-Gaignerot 2011: 430, fig.2)

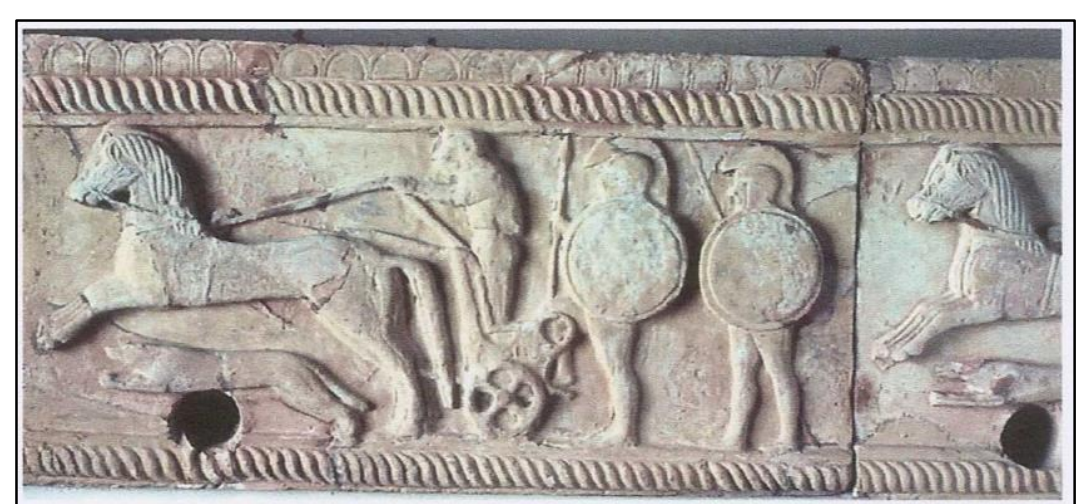

Fig.7- Friso (sima) do templo de Zeus Dicteu em Palaikastro (Driessen-Gaignerot, 2011: 431, fig.4)

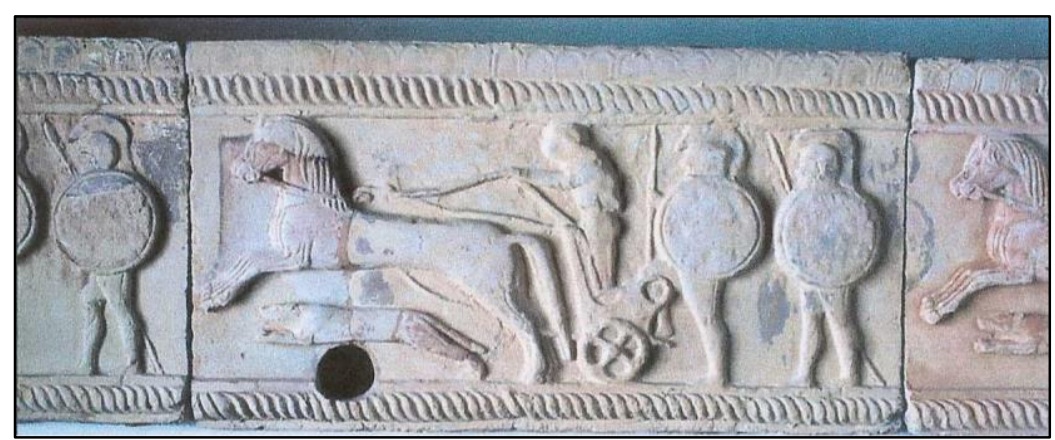

Fig.6- Friso (sima) do templo de Zeus Dicteu em Palaikastro (Driessen-Gaignerot, 2011: 430, fig.3)

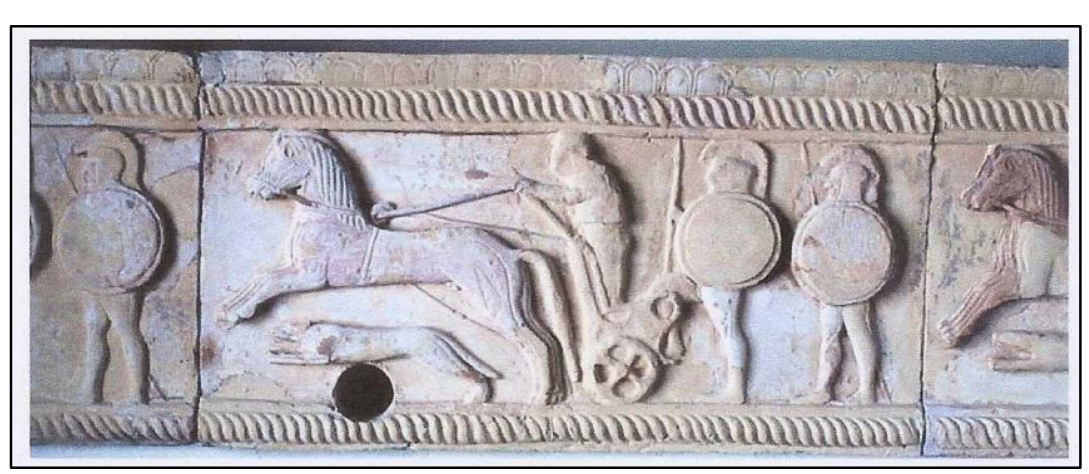

Fig.8- Friso (sima) do templo de Zeus Dicteu em Palaikastro (Driessen-Gaignerot, 2011: 431, fig.5) 


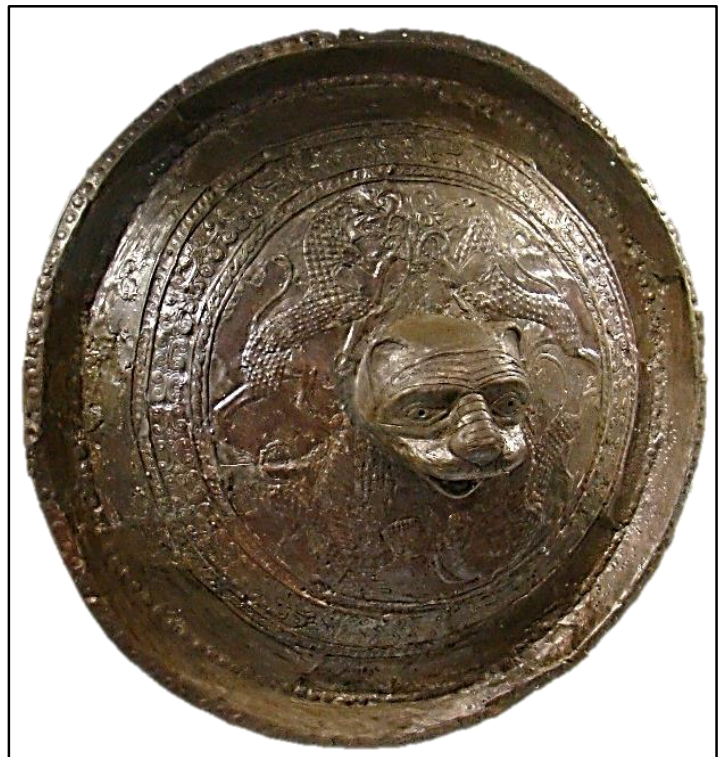

Fig.9- Escudo de bronze com prótomo de leão, período geométrico, Museu Arqueológico Nacional de Heráclion (Foto: arquivo pessoal/2014)

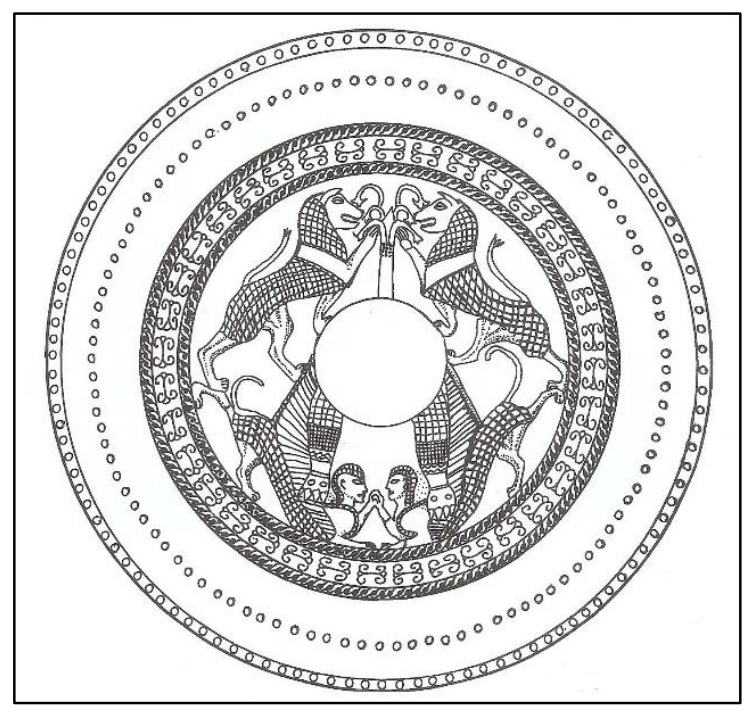

Fig.10- Desenho de escudo de bronze, período geométrico (Dawkins, Hawes e Bosanquet, 1904-1905) (Prent, 2005: fig.74).

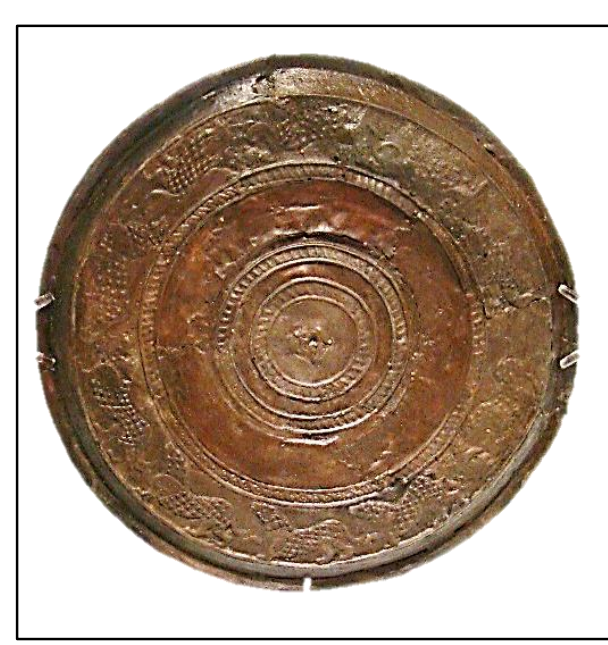

Fig.11- Miniatura de disco de bronze, período geométrico, Museu Arqoeológico Nacional de Heráclion (Foto: arquivo pessoal/2014) 


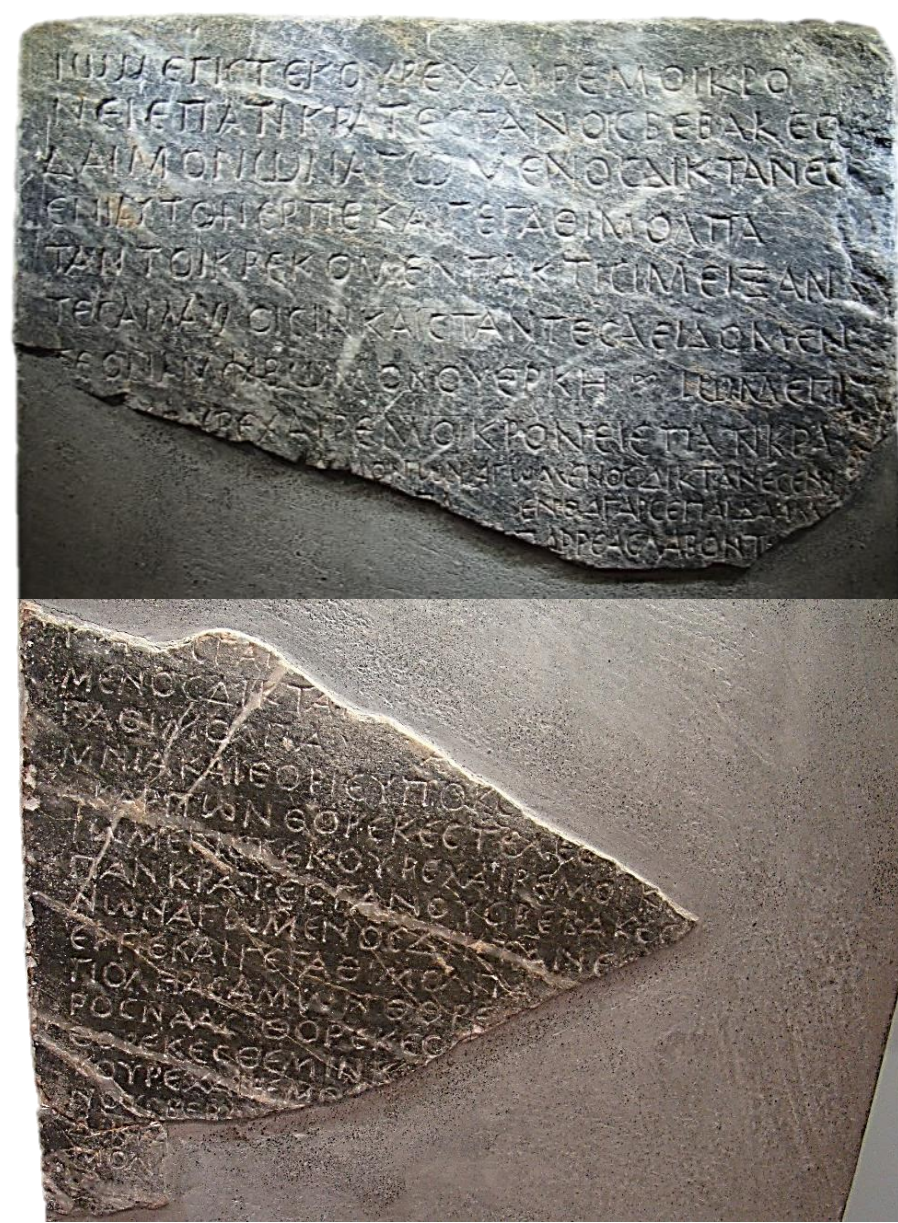

Fig.12- Inscrição do hino a Zeus, séc. III d.C., Museu Arqueológico Nacional de Heráclion (Foto: arquivo pessoal/2014)

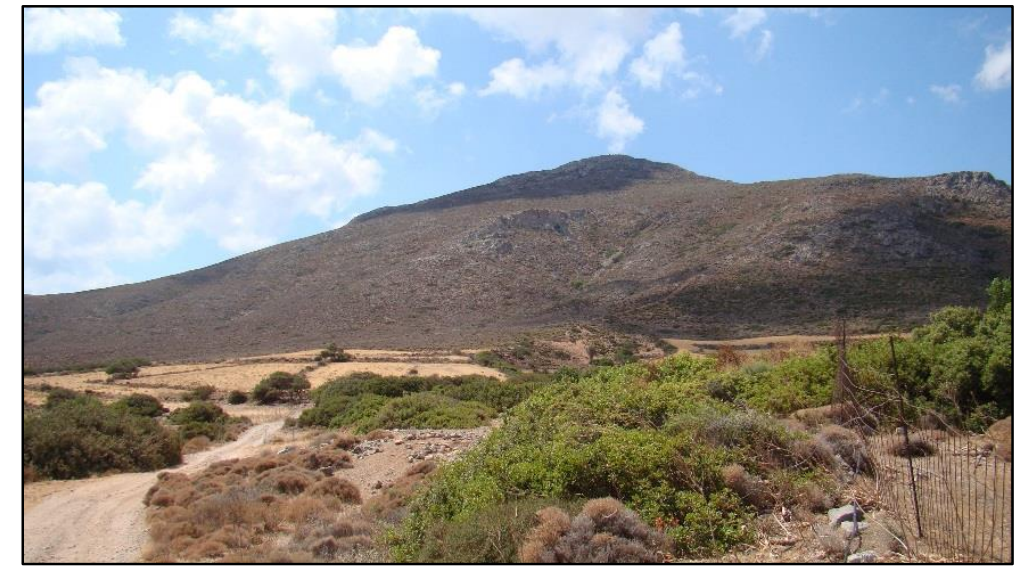

Fig.13- Monte Petsofas visto de oeste, da área arqueológica da cidade minoica de Palaikastro (Foto: arquivo pessoal/2014)

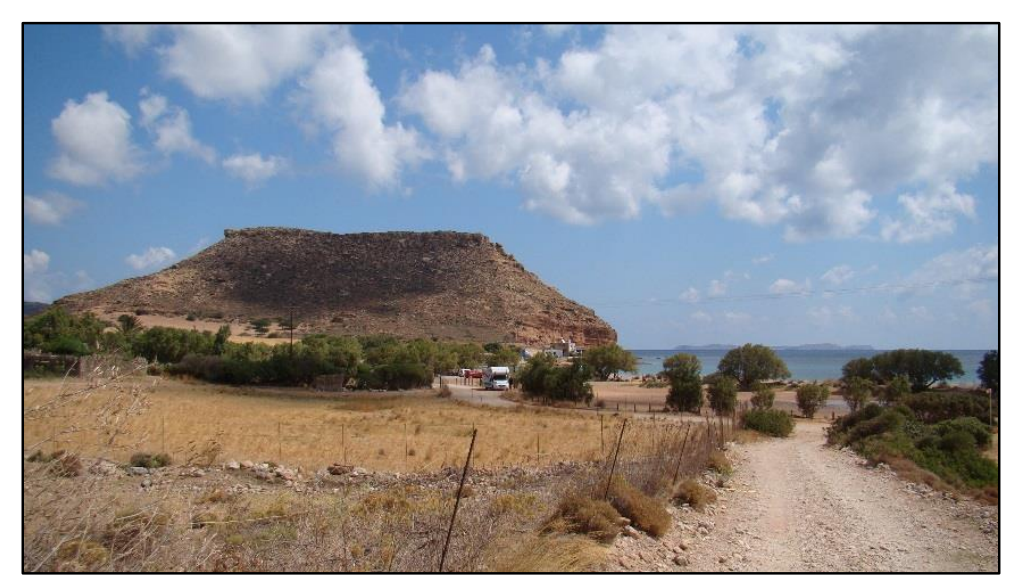

Fig.14- Promontório de Kastri visto de sul, da área arqueológica da cidade minoica de Palaikastro (Foto: arquivo pessoal/2014) 
Datação: Protogeométrico (última metade do séc. X a.C.) - período romano (sécs. IV-V d.C.).

Localização: No Monte Himetos, ao redor de uma depressão natural, profunda e bem protegida, localizada a menos de meia milha a norte do ponto mais alto. Dela não se tem uma visão aberta, podendo ser visto apenas seus lados rochosos e o céu. De cima da depressão, entretanto, desfruta-se de uma visão desobstruída de toda a planície ateniense. A Ática oriental está completamente fora de visão do cume, o qual se eleva ainda mais a leste da depressão (Langdon, 1976: 1).

Tipo de santuário: Pico / extraurbano e sub-regional (a partir da Idade do Ferro).

Referências textuais: (Altar e estátua) Pausânias I, XXXII.3; (Monte) Teofrasto, de Signis Tempestatum 1, 20, 24; 343.

Inscrições: Trata-se de inscrições do séc. VII a.C., sobre vários tipos de vasos, com referência direta a Zeus que foram selecionadas do Catálogo de Langdon: (no.1 e 2, p.13), (no. 3, 4, 5, 6, 7, 8, p.15).

Histórico dos achados: Investigações foram conduzidas por Carl Blegen em 1923 e 1924 e por ele e S. Young em 1939 e 1940 (Langdon, $1976: 1)$. M.K. Langdon é quem oferece pela primeira vez um estudo interpretativo completo do santuário e do material cerâmico e inscrições. Na década de 1970, todo o cume já era uma área militar restrita e a depressão tinha se tornado moradia de refugiados albaneses (Langdon, 1976: 1).

\section{Documentação arqueológica}

I. Recinto: Duas fundações encontradas fora da depressão podem ter sido um muro de recinto contendo dentro um simples altar ao relento. A fundação maior mede aproximadamente $5,80 \mathrm{~m}$ em um lado e assenta-se acima e exatamente a oeste da depressão. Foi construída com pedras grosseiras livremente colocadas em um leito rochoso, sem nenhum material de ligação entre elas. Os muros sul e oeste eram relativamente estreitos (c.0,80 m de espessura) comparados aos muros norte e leste ( $2 \mathrm{~m}$ de espessura cada). Dentro deste recinto algumas lajes de pavimento planas foram preservadas no ângulo sudoeste e defronte ao muro leste estava uma pilha de pedras que pode ter sido os restos de um simples altar. A fundação menor, $31 \mathrm{~m}$ a oeste desta, pode ter sido um recinto similar, embora quando encontrada preservava apenas dois lados paralelos, nenhum dos quais tinha um canto nas extremidades. Uma fundação curva dentro da depressão (2,80 m de diâmetro) era talvez uma fossa feita com pedras alinhadas para o armazenamento das oferendas votivas (Langdon, 1976: 1). Os escavadores estavam 
incertos se algumas pedras imediantamente a sul desta fossa pertenciam a uma outra fossa ou câmara. A figura 4 mostra a localização destas fundações em relação à depressão (Langdon, 1976: 3).

II. Objetos votivos: Nenhuma estratificação significativa pôde ser detectada pelos escavadores na depressão no cume do Himetos. Uma grande massa de cerâmica, incluindo vários cacos completos, foi recuperada e verificou-se uma ampla variação em data. Os cacos e vasos mais completos estavam misturados de modo que mesmo nos níveis mais profundos da escavação cacos do período clássico e fragmentos de lamparinas romanas foram encontrados lado a lado do material do período geométrico e subgeométrico. As cerâmicas estavam concentradas principalmente na extremidade norte da depressão, oposta à fundação retangular acima e a oeste, que se conjecturou ter sido o altar de Zeus. A proximidade da massa da cerâmica com esta fundação sugere que a depressão serviu como um depósito para dedicações descartadas do altar acima, podendo explicar a ausência de estratificação (Langdon, 1976: 51). Idade do Bronze: Material datável do Heládico antigo, médio e tardio foi encontrado, mas a quantidade total para cada uma dessas fases é tão pequena que coloca em dúvida se estes têm relação com o santuário posterior. Período protogeométrico: Após a cerâmica da Idade do Bronze mais recente, uma taça submicênica é a única peça até o protogeométrico tardio. Nenhuma cerâmica do protogeométrico antigo ou médio foi encontrada. Mas um número de vasos pertencentes à última fase do protogeométrico indica que o santuário foi estabelecido neste período, na última metade do século $X$ a.C. Período geométrico: Exceto para o Geométrico antigo I, toda fase do período geométrico é representada por alguma cerâmica do Geométrico médio II e geométrico tardio I-II. A pequena quantidade do geométrico antigo e médio indica uma declínio na atividade do protogeométrico, ou pode refletir uma tendência na classificação do material (Langdon, 1976: 74-76). Se por exemplo os vasos mais comumente dedicados nas fases antigas do Geométrico eram taças simples esmaltadas com uma alça, estas podem não ter atraído a atenção dos escavadores e números de fragmentos podem ter sido discartados. Reciprocamente, todos os cacos identificáveis do protogeométrico foram sem dúvidas guardados. Devemos, portanto, evitar concluir que o culto no santuário declinou abruptamente após o protogeométrico (Langdon, 1976: 76). Século VII a.C.: A atividade do santuário era agora maior do que durante qualquer outro período, durando por todo o século. Século VI a.C.: $\mathrm{O}$ número de achados diminuiu consideravelmente em relação ao século anterior. As últimas dedicações inscritas e oferendas regulares foram feitas neste período. Séculos $\mathrm{V}$ ao I a.C.: $\mathrm{O}$ punhado de cacos e outros objetos desses séculos não constituem muita evidência para o culto no santuário, mas representam oferendas esporádicas. Período romano: Algum material foi depositado no sítio principalmente no período romano tardio. Fragmentos de cerca de 120 lamparinas indicam algum tipo de atividade nos séculos IV e V d.C. (Langdon, 1976: 76). Vários ossos queimados de animais e uma quantidade considerável de cinzas foram encontrados ao longo da massa de cerâmica na depressão. Mas não se sabe se era uma prática normal aos fiéis realizarem sacrifícios de animais. Talvez um sacrifício era feito apenas em determinados períodos, tal como em um período de estiagem ou em um dia especial do festival. Qualquer que seja o caso, pouquíssima cerâmica mostra sinais de combustão, indicando, provavelmente, que os sacrifícios eram realizados em outro lugar que não o altar do recinto, onde a cerâmica com dedicatória se acumulou (Langdon, 1976: 77).

Tipo de culto: 0 sítio é identificado como um santuário de Zeus a partir da descoberta de vários cacos cerâmicos com dedicações inscritas mencionando a divindade pelo nome. Apenas um deles preserva o título, uma dedicação a Zeus Semios, mas a exata natureza do culto de Zeus pode ser esclarecida por uma 
consideração de outros tipos de dados relacionados à montanha. Durante a maior parte da Antiguidade, e mesmo em tempos modernos, o Himetos foi visto como um indicador climático natural, especialmente para a aproximação de chuva (Teofrasto, de Signis Tempestatum 1, 20, 24; 3 43) (Langdon, 1976: 3). Uma espessa concentração de nuvens aglomeradas ao longo de seu cume foi, e ainda é hoje, considerada quase portento de impedimento de inundações (Langdon, 1976: 3 e 5). Esta propriedade da montanha foi conhecida em tempos antigos pela posição, em algum lugar do cume, de um altar de Zeus Ombrios ("Chuvoso") (Pausânias I, XXXII.2). Não é afirmado exatamente onde o altar situava-se, mas podemos razoavelmente conjecturar que estava colocado no topo onde as qualidades proféticas de chuva da montanha e o próprio deus da chuva formaria uma associação mais apropriada. De fato, Langdon não tem dúvidas que 0 altar de Zeus Ombrios, mencionado por Pausânias, estava no cume do Himetos, e já que nenhum dos outros remanescentes de natureza religiosa foram encontrados por lá, acredita que o sítio escavado por Blegen e Young é o local sagrado. O sítio do altar de Zeus Ombrios foi por muito tempo localizado em outros lugares. Milchhöfer, seguido por Kolbe, localizou-o na encosta leste do Himetos, no cume do Profeta Elias, acima de Koropi. Lá, sobre um pequeno platô inclinado que propicia uma boa visão da planície de Mesogeia, há uma capela de Profeta Elias construída sobre uma fundação antiga. Milchhöfer notou que a população local recorria a esta capela durante períodos de estiagem para oferecer orações por chuva. Ele concluiu que na Antiguidade o lugar tinha uma função similar e que a fundação sob a capela era o altar de Zeus Ombrios. A área foi investigada mais tarde pelo arqueólogo grego N. Kotzias, que mostrou que a fundação sob a capela, na verdade, pertenceu a um templo do séc. VI a.C. Em seu primeiro relatório preliminar, Kotzias seguiu a linha de pensamento de Milchhöfer e concluiu que o templo pertenceu a Zeus Ombrios. Mas após a descoberta de um outro templo menor, e uma curta distância a oeste durante escavações subsequentes, ele mudou de opinião e assinalou a Zeus Ombrios o edifício menor. Kotzias foi induzido a esta interpretação pela abundância de cacos cerâmicos pertencentes à ânforas e hídrias, as quais pensou serem oferendas adequadas para o deus da chuva. Argumentou que já que o templo saiu de uso antes do tempo de Pausânias, o periegeta mencionou apenas o altar (Langdon, 1976: 5). Mas, conforme Langdon, nada do raciocínio de Kotzias é coerente e suas conclusões não podem ser levadas a sério. A mera presença de uma capela de Profeta Elias construída sobre a fundação de um templo não é uma boa evidência para concluir que na Antiguidade Zeus Ombrios foi cultuado ali. Nenhuma evidência foi encontrada por Kotzias que indicasse as divindades cultuadas nos dois templos (Langdon, 1976: 7).

O sítio próximo ao cume do Monte Himetos é identificado definitivamente como sendo um santuário de Zeus. Os argumentos apresentados acima permitem a conclusão de que se trata de um santuário de Zeus Ombrios. Trata-se de uma hipótese, mas que pode ser sustentada com maior certeza do que a de Kotzias. 0 material cerâmico revela que o altar no cume esteve em uso principalmente dos séculos XII ao VI a.C. Por outro lado, Pausânias nos dá a referência mais antiga sobre 0 altar de Zeus Ombrios séculos mais tarde. Se de fato os dois altares são apenas um e o mesmo, é muito provável que o título Ombrios tenha sido conferido à divindade séculos mais tarde e que muito antes tenha sido cultuado com qualquer epíteto que os devotos quisessem lhe chamar, é o que material epigráfico parece sugerir. Grande parte das oferendas de todos os períodos de uso do altar foram trazidas a Zeus como oferendas por chuva. Segundo a tese de Langdon, o santuário de Zeus parece ter servido como um lugar que a população agrícola poderia procurar o favor do deus pela chuva. 0 local foi predominantemente usado pelos residentes de toda a planície ateniense e por isso não deve ser visto como uma área sagrada exclusivamente ateniense, apesar de o Himetos e Atenas estarem estreitamente conectados e a montanha ser uma característica familiar na paisagem da cidade. Prova disso é que o santuário floresceu nos períodos geométricos e arcaico quando Atenas era relativamente um vilarejo pequeno, não muito maior que outros assentamentos vizinhos 
(Langdon, 1976: 7). A diferença é que o santuário foi usado principalmente pela população vivente no lado oeste do Himetos e não tanto por aqueles residentes a leste (Langdon, 1976: 7-8). A topografia ditou, em grande parte, esta conclusão: a partir de oeste, o cume é muito facilmente alcançado por um número de acessos, talvez tendo sido a rota mais fácil a longa e ampla espinha dorsal de rocha que segue continuamente e diretamente ao topo a partir do monastério de Kaisariani. A encosta leste, ao contrário, é muito íngreme e não oferece uma rota fácil e direta ao cume. Não há uma boa trilha de Paiania até o cume, de lá é necessário percorrer um caminho até Atenas que não leva às proximidades do santuário. Alguns habitantes de Mesogeia, especialmente aqueles residentes perto do Himetos, sem dúvida fizeram grande esforço para ir até o santuário para deixar oferendas, embora não devem ter feito isso em grande número. A maior parte deles, contudo, visitaram santuários localizados em várias montanhas na Ática oriental, assim deixando o santuário do Himetos aos residentes da planície ateniense (Langdon, 1976: 8). Por ter funcionado em períodos específicos (protogeométrico, geométrico, arcaico e romano tardio), pode-se pensar que a atividade do santuário tenha sido um reflexo da história agrícola da Ática. A chuva foi de suprema importância em épocas quando a cidadania ateniense foi dependente da comida baseada no próprio solo ático. Em poutros períodos, quando a maior parte da comida foi importada, a principal preocupação era com a manutenção de rotas de comércio abertas para navios de carga (Langdon, 1976: 87). A autora desenvolve essa tese entre as páginas 87 e 95.

Referências bibliográficas: Langdon, M.K. Sanctuary of Zeus on Mount Hymettos. Hesperia Supplement XVI. Princeton; N. Jersey: American School of Classical Studies at Athens, 1976.

\section{Imagens:}

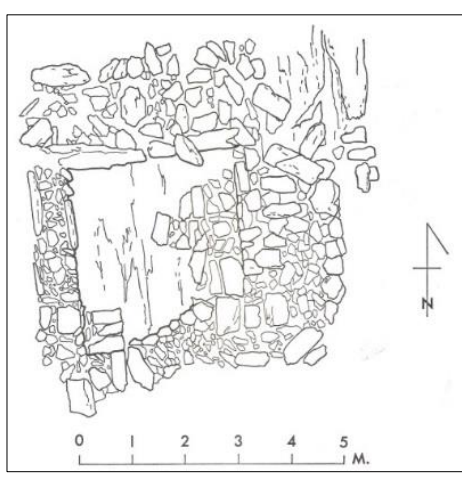

Fig.1- Planimetria do altar de Zeus (Langdon, 1976: 2, fig.1)

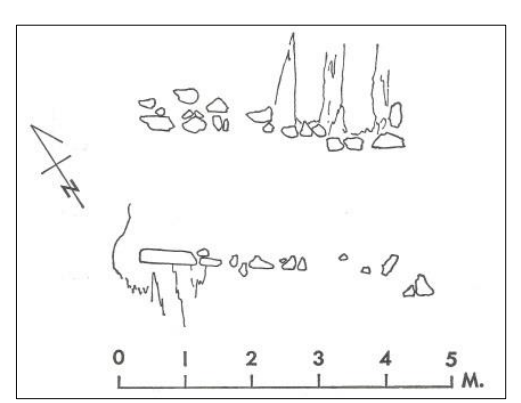

Fig.2- Planimetria da fundação menor (Langdon, 1976: 3, fig.2)

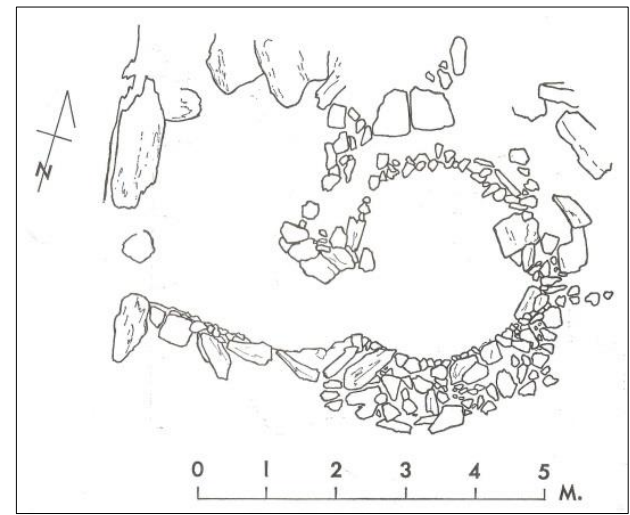

Fig.3- Planimetria da fossa votiva (Langdon 1976: 4, fig.3)

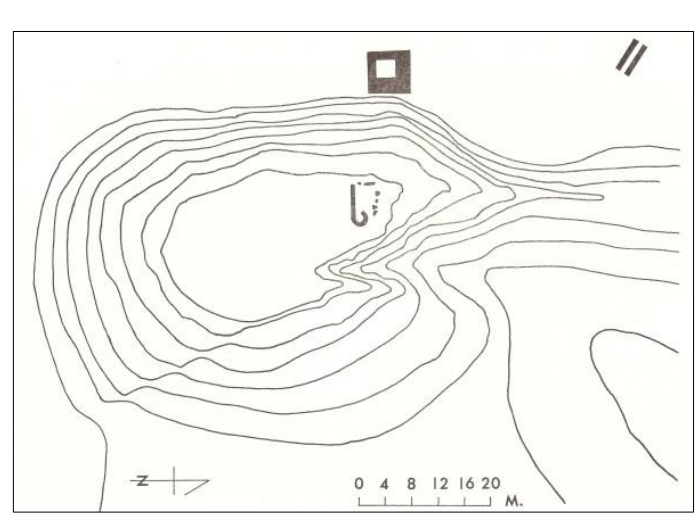

Fig.4- Planimetria da área da depressão remanescentes (Langdon, 1976: 6, fig.4) 


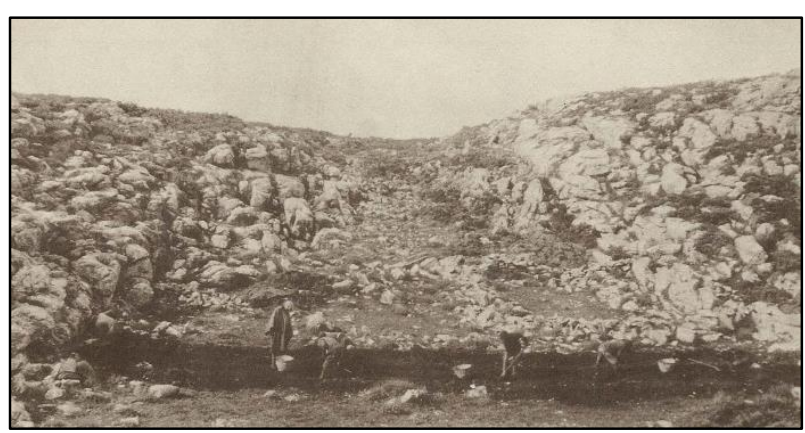

Fig.5- Fotografia de 1923 da depressão a partir de norte (Langdon, 1976:pr.2)

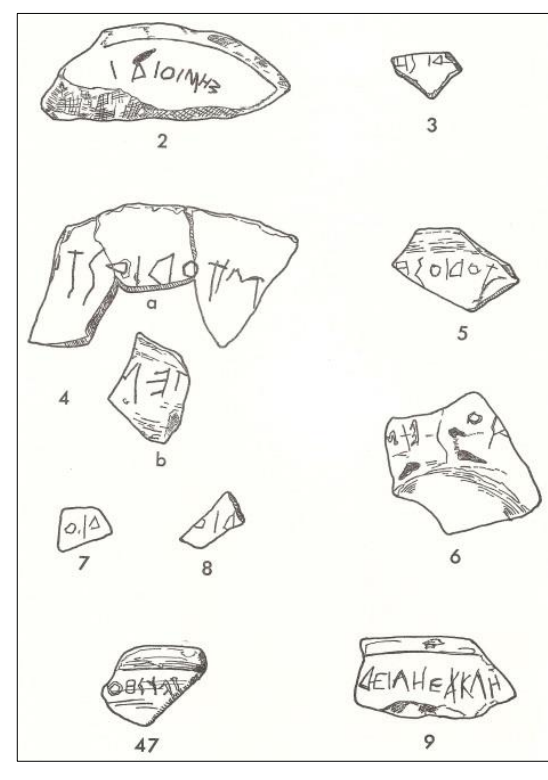

Fig.6- Prancha com cacos cerâmicos com

inscrições a Zeus (Langdon, 1976: 14,

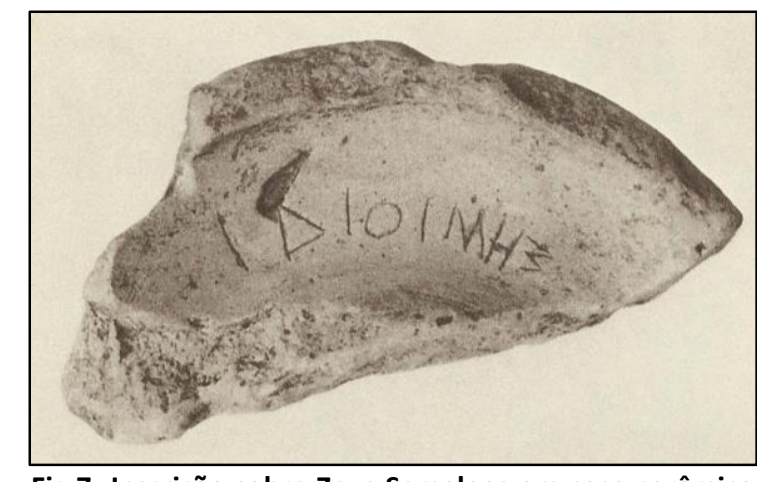

Fig.7- Inscrição sobre Zeus Semaleos em caco cerâmico do séc. VII a.C. (Langdon, 1976: pr.2, fig.2) 
Datação: Proto-geométrico (1000-900 a.C.) - época romana.

Localização: Situada no centro de um vale dominado a sudoeste pelo Monte Tomaros, o atual Olytzika, de cumes gêmeos (1972m e 1816m), e das denominadas "cem fontes".

Tipo de santuário: Planície e vale / extraurbano e sub-regional (a partir da Idade do Ferro) e inter-regional e interestadual (a partir da época arcaica?) com função oracular (a partir da Idade do Ferro).

Referências textuais: (Evocação) Pausânias X,XII.8; Estrabão 5.2.3-4; (Oráculo/mito) Estrabão 7.9.10; (Oráculo) Estrabão Fr 1, Livro VII, Fr 1b, Livro VII; Heródoto II.55; Plutarco Temístocles, XXVIII.3; (Santuário) Pausânias I, XVII.4-6; (Templo) Estrabão 7.7.12; Políbio IV.67.3.

Inscrições: Nas lâminas de bronze e nas dedicações.

Histórico dos achados: C. Carapanos iniciou as primeiras escavações em Dodona ainda durante o período turco, em 1875, trazendo à luz os principais edifícios. Meio século mais tarde, com a aquisição do Épiro pela Grécia, a Sociedade Arqueológica de Atenas retomou os trabalhos sob a direção de G. Sotiriades em 1920 e de D. Evangelidis de 1926 a 1936 e 1950 a 1959 e depois de S.J. Dakaris de 1965 a 1997. Atualmente os trabalhos são coordenados por Ch. TzouvaraSouli, A. Vlachopoulou e K. Gravani (Quantin, 2008: 10-11).

\section{Documentação arqueológica}

I. Oferendas votivas: Fragmentos de trípodes de ferro e bronze dos séculos IX e VIII a.C. foram encontrados na área do antigo recinto a céu aberto, que precede a construção do primeiro templo de Zeus. Os achados confirmam a tradição que diz que lebetes e trípodes cercavam o grande carvalho sagrado, cujo farfalhar das folhas e o som ecoado dos lebetes e trípodes, ocasionados pelo vento, eram interpretados o oráculo de Zeus (Dakaris, 2003: 14). Tal recinto funcionou assim até o início do séc. IV a.C.

II. Templo (quatro fases): $1^{\circ}$.oîkos: Pequeno edifício, datado da primeira metade do séc.lV a.C., de 4 x 6,50m com pronaos aberto por uma porta en façade e elementos decorativos em terracota. $2^{\circ}$.oîkos: Construção de um períbolo isodomo e aberto a sudeste $(11,80 \times 13 \mathrm{~m})$, cuja parede, que cercava o oîkos não era alta e não isolava visualmente o oîkos, é datado da segunda metade do séc.IV a.C. e contemporâneo a oferenda dos corcireus (Quantin, 2008: 15-16). Trata-se 
de uma estátua de bronze de um menino sobre uma coluna que tinha um chicote de bronze com três correntes de astrágalos, a qual substituiu o uso dos lebetes e trípodes (Dakaris, 2003: 14). Início séc.lll a.C.- sob o reinado de Pirro (297-272 a.C.), o recinto isodômico foi substituído por um mais espaçoso, com três pórticos jônicos sobre três lados do pátio e com entrada sobre a fachada. No lado oriental, onde se encontrava 0 carvalho, não foi construído um pórtico. Característica é a articulação do espaço interno com o pátio e os pórticos em forma de $\Pi$ que circundava o carvalho (Dakaris, 2003: 14). Final do séc.lll a.C. com o butim de Thermos, os epirotas reconstruíram a casa sagrada, demolida pelos etólios na invasão de 219 a.C. No lugar do pequeno templo, foi construído um edifício maior com prostase jônica tetrastila, cela mais ampla e ádito com três pórticos jônicos na parte interna e propileu com quatro colunas jônicas na fachada. No lugar do carvalho foi encontrada uma fossa profunda e pequenas pedras trabalhadas, as quais talvez circundavam a árvore sagrada (Dakaris, 2003: 15-16).

Tipo de culto: Conforme resume Quantin, Zeus tornou-se uma divindade oracular em Dodona depois dos poemas homéricos. Zeus com o epíteto Naios não aparece para Dodona na literatura grega do séc.V a.C. Píndaro, proxenos dos molossos, parece ignorar Zeus Naios, que conhece bem o manteion epirota, onde as lâminas oraculares mais antigas datam de c.525-500 a.C. Zeus não é Naios nas consultações oraculares no séc.V a.C., e as dedicações pouco nos permitem remontar a difusão da epíclese além do fim do séc.V a.C. Nesta época, o deus é Dodonaios, Pater e Thesprôtos. A presença de sua parêdra, Dione, não é atestada antes de sua menção em 408/407 a.C. no Arquelaos de Eurípides (Quantin, 2008: 43). Apesar de o casal composto por Dione e Zeus ser seguramente mais antigo, a chegada do culto da parêdra em Dodona é concomitante com a difusão da epíclese Naios de Zeus e as festas, as Naia (Quantin, 2008: 41). As Naia são atestadas a partir do séc.lll a.C. (Quantin, 2008: 33). A difusão da epíclese Naios é, grosso modo, contemporânea à construção do primeiro oîkos de Zeus no santuário, na primeira metade do séc.IV a.C. Zeus "Residente" é, portanto, um deus alojado em uma arquitetura de pedra (Quantin, 2008: 38). Esse deus "residente", é verdadeiramente um deus que acompanha um movimento de reagrupamento das populações, de urbanização (Quantin, 2008: 39).

Dodona é epirota e pertence a uma vasta região onde a cultura e o imaginário são gregos. É a escala regional que nos obriga primeiro tentar compreender as mudanças que afetam o santuário. Thesprôta desde a sua origem, o santuário de Dodona foi anexado pelos molossos antes do fim do séc.V a.C., ou entre os séc.V e IV a.C., tornando-se sede da reunião do koinon molosso (Quantin, 2008: 43-44). É sob os molossos que Dodona experimentou uma mudança em sua paisagem e geografia política (Quanti, 2008: 45). Bem na época da monumentalização do culto de Zeus no santuário.

Referências bibliográficas: Cabanes, P. Les concours des Naia de Dodone, Nikephoros (1), 1988, pp.5-14; La Grèce du Nord (Épire, Macédoine) en plein développement au IVe siècle avant J.-C., Em: Carlier, P. (ed.). Le IVe siècle avant J.-C. Approches historiographiques. Nancy, pp.195-204; L'organization de l'espace en Épire et Illyrie méridionale à l'époque classique et hellénistique, DHA (15), 1989, pp.49-62; Carapanos, C. Dodone et ses ruines. Paris, 1878; Dakaris,

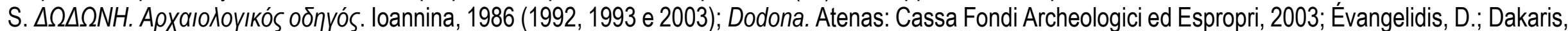

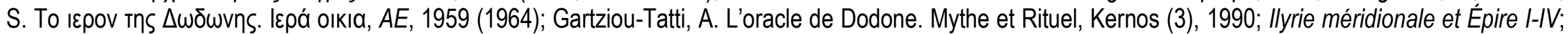
Lhôte, E. Les lamelles oraculaires de Dodone (Hautes Études du monde gréco-romaine, 36). Genebra, 2006; Mylonopoulos, J. Das Heiligtum des Zeus in Dodona. Zwischen Orakel und venatio, Em: Mylonopoulos, J.; Roeder, H. (eds.). Archäologie und Ritual. Auf der Suche nach des rituellen Handlung in den antiken Kulturen 
Ägyptens und Griechenlands. Viena, 2006, pp.185-214; Parke, H.W. The Oracles of Zeus. Dodona-Olympia-Ammon. Oxford, 1967; Quantin, Fr. La vie religieuse en Épire antique, thèse de l'Université Lyon 2, 1997; Aspects épirotes de la vie religieuse antique, REG (112-1), 1999, pp.61-98; Recherches sur l'histoire e l' archéologie du sanctuaire de Dodone, Les oikoi, Zeus Naios et les Naia, Kernos (21), 2008, pp.9-48; Reinach, Th. Une monnaie de bronze au type de Zeus Naos,

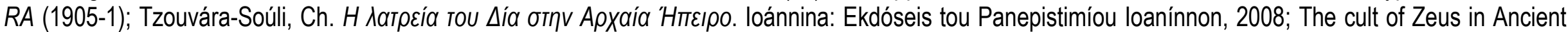
Epirus, em: Illyrie méridionale et Épire IV, pp.515-547.

\section{Imagens:}
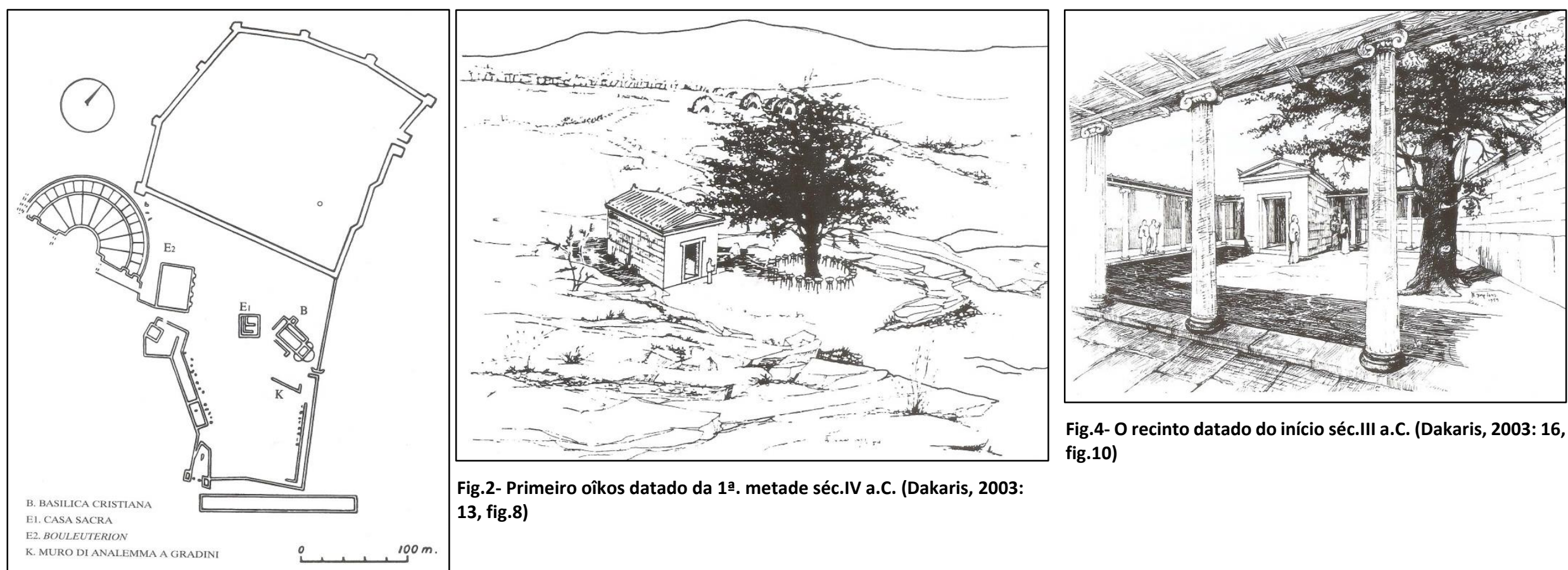

Fig.2- Primeiro oîkos datado da 1a. metade séc.IV a.C. (Dakaris, 2003

Fig.4- 0 recinto datado do início séc.III a.C. (Dakaris, 2003: 16, 13, fig.8)

Fig.1-Planta de Dodona (Dakaris, 2003: 12, fig.7) 


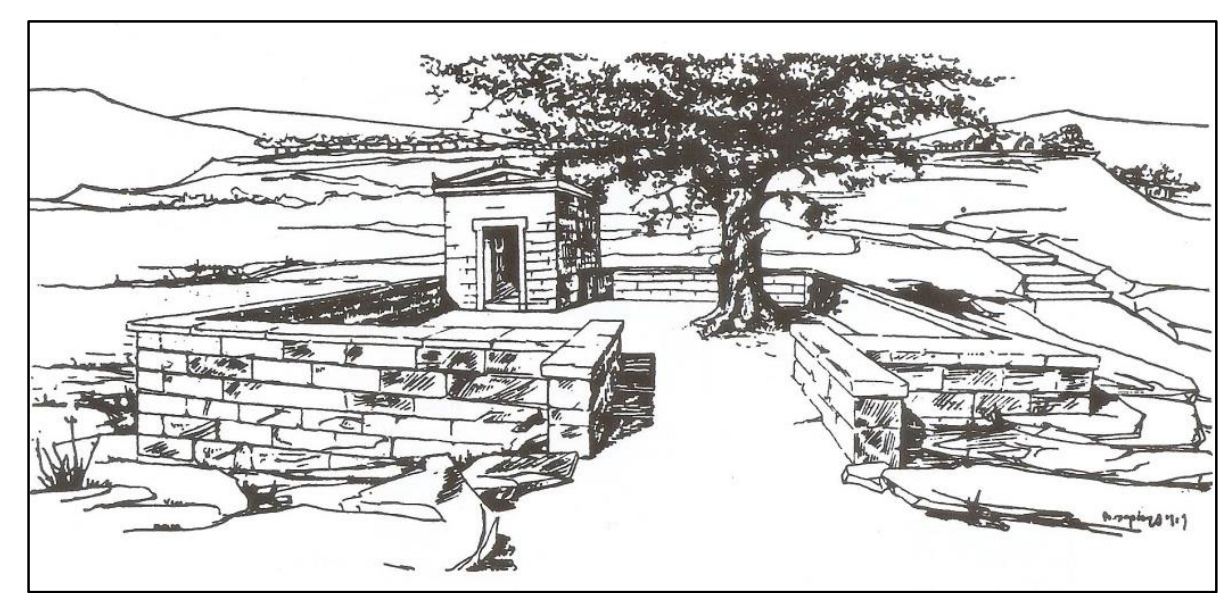

Fig.3- Segundo oîkos datado da 2a metade séc.IV a.C. (Dakaris, 2003: 15, fig.9)

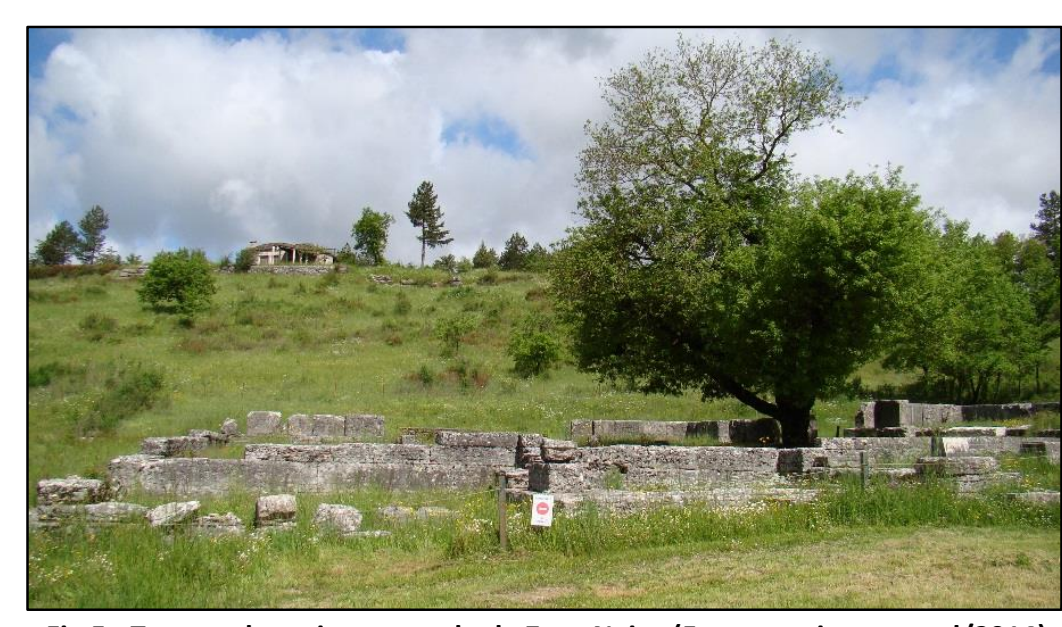

Fig.5- Terraço do recinto sagrado de Zeus Naios (Foto: arquivo pessoal/2014)

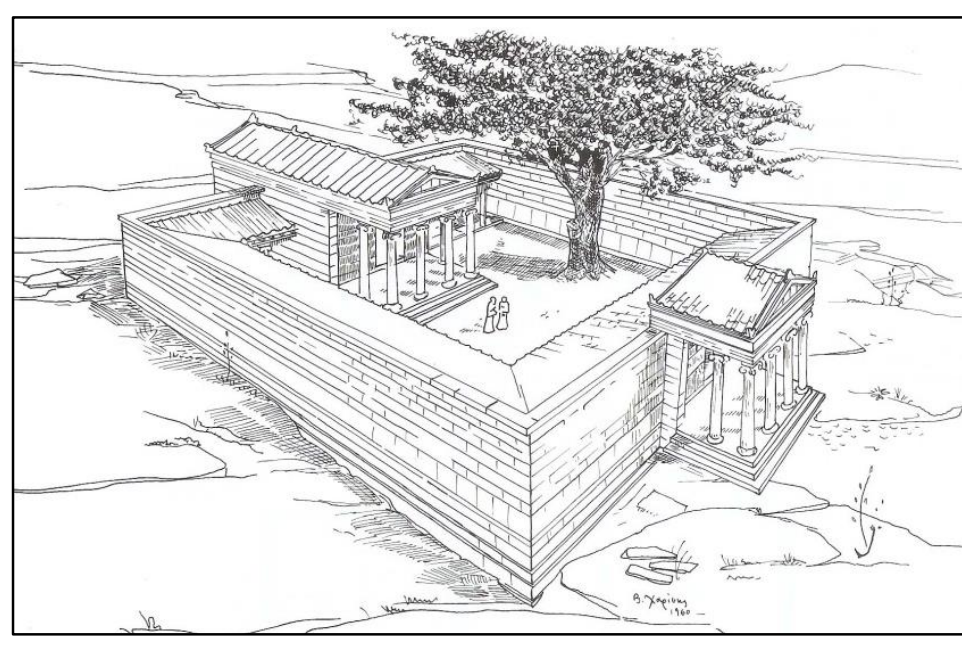

Fig.4- O recinto datado do final do séc.III a.C. (Dakaris, 2003: 18, fig.12)

Fig.6- Lâmica de chumbo com inscrição incisa em alfabeto coríntio e em

boustrophédon pergunta de pelegrino a Zeus,

Arqueológico de
loannina (Dakaris, 2003: Museu 47, fig.30)

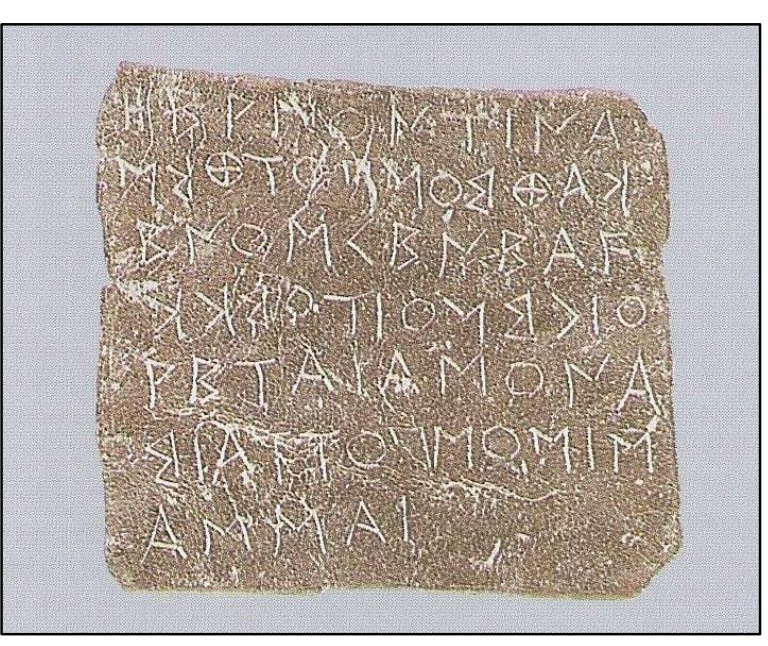


Datação: Geométrico (900-700 a.C.) / início do arcaico (VII a.C.) - época romana?

Localização: Na área nordeste do topo da colina de Larissa, a acrópole da pólis de Argos (Zolotnikova, 2013: 86).

Tipo de santuário: Urbano (a partir da Idade do Ferro)?

Referências textuais: (Templo/estátua) Pausânias II, 24.3.

Inscrições: Inexistentes.

\section{Histórico dos achados:?}

\section{Documentação arqueológica}

I. Objetos votivos: A principal evidência arqueológica sobre o santuário é o significante depósito votivo descoberto na área do santuário - um pequeno número de fragmentos cerâmicos foi datado entre os períodos proto-geométrico e início do geométrico, indicando atividades religiosas na colina já nessa época (Zolotnikova, 2013: 86). Contudo, o volume do depósito, constituído por mais de 300 pequenos potes, foi datado pelos escavadores entre a metade do século VIII a.C. e a metade do século VII a.C. com motivos e cenas específicas de carros, cavalos, grupos de dança de mulheres com homens também; foi notada especialmente a abundância de símbolos solares (Zolotnikova, 2013: 87). No mesmo depósito também foram encontradas miniaturas de machados duplos, um de osso e o outro de bronze, romãs de terracota, centenas de anéis, armas de ferro e alguns outros objetos (Zolotnikova, 2013: 87). Não foram relatados qualquer traço de um altar (Zolotnikova, 2013: 87).

Tipo de culto: As evidências disponíveis sugerem que o culto praticado na colina de Larisa, no início do período histórico, compreendeu cerimônias coletivas e individuais envolvendo o consumo de bebida, refeições rituais e danças. 0 culto do início da Idade do Ferro para ter sido especialmente relacionado à natureza solar, a energia primaveril (como as representações de danças com ramos pode indicar) e a fertilidade em geral, assim como habilidades militares (Zolotnikova, 2013: 87). De acordo com a opinião dominante, o santuário na Larisa foi inicialmente somente dedicado à Atena. Contudo, como defende Zolotnikova, Zeus foi cultuado em Argos desde o início do período histórico, se não desde o final da Idade do Bronze, como sugere a associação do santuário na Larissa com Zeus na época da guerra de Tróia, no nome do rei mítico argivo Diomedes (llíada 2.559-568), derivado do genitivo Diós, que implica certa ligação direta da família 
governante local micênica com o deus (Zolotnikova, 2013: 87). A aparência primitiva da estátua com três olhos de Zeus, descrita por Pausânias também é considerada pela estudiosa como evidência da antiguidade do culto da divindade na colina (Zolotnikova, 2013: 87).

Referências bibliográficas: Zolotnikova, 2013, pp.86-87.

\section{Imagens}

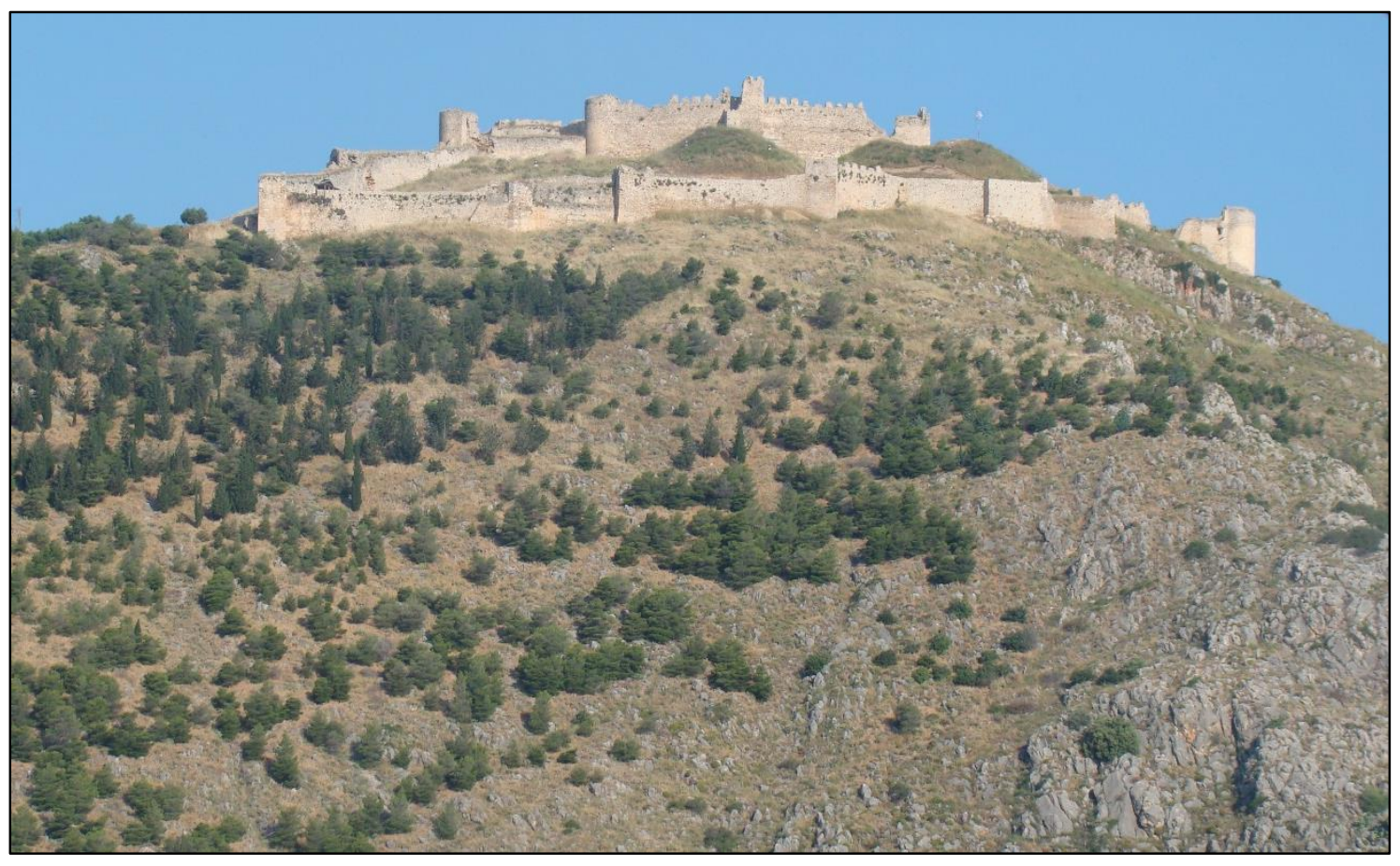

Fig.1- Acrópole Larisa vista da cidade moderna de Argos (Foto: arquivo pessoal/2011) 


\section{Messênia}

Datação: Proto-geométrico/ Geométrico (1 $1^{\text {a }}$.metade do séc.VIII a.C.) - época romana.

Localização: No cume do Monte Ithome (802 m), a leste do antigo monastério de Voulkano.

Tipo de santuário: Pico / extraurbano e sub-regional (a partir da Idade do Ferro) / urbano (a partir do séc. IV a.C. ou depois).

Referências textuais: (Témeno e trípode) Pausânias IV,III.7-10; (Santuário) Pausânias IV, XII.8 / IV, XXXIII, 1-2; Plutarco, Arat. 50,3-5; (Altar e trípode) Pausânias III, XXV.1 / IV, XII.5-7 / IV, XIII.1-4; (Estátua) Pausânias III, XXVI.3-6-10 / IV, XXXIII, 1-2; (Evocação) Tucídides I.CIII.2-3; (Sacrifício) Pausânias IV, XIX.1-4 / IV,

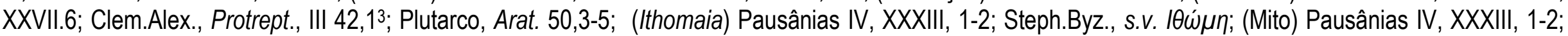
(Profecia e súplice) Pausânias IV, XXIV.7.

Inscrições: Inscrições de época romana sobre sacerdotes de Zeus Ithomates (SEG XLI 334-339 e 374 B-D; IG V 1,1468-1469; BCH (94), 1970, p.984).

\section{Histórico dos achados: ?}

\section{Documentação arqueológica}

I. Santuário: De acordo com P. Themelis, no cume do Monte Ithome, a leste do antigo monastério de Voulkano, conservam-se as fundações do santuário de Zeus Ithomates (Themelis, 2004: 117-118).

II. Oferendas votivas: Themelis e Luraghi dizem sobre o pé de um trípode de bronze encontrado perto do mosteiro o qual prova que o culto remonta ao menos ao período geométrico (Themelis, 2004: 117-118; Luraghi, 2008: 115). Já Amandry nos informa sobre a base em pedra de um tripé que foi encontrada reutilizada na construção do monastério de Voulkano (ou Vourkano). Ela foi afixada no ângulo sudeste da igreja, sobre uma face lateral e apresenta sua face superior a sul. Cortada de uma base de calcário muito rachada, o bloco tem um formato quadrado de 1,25m em média de lado. Tem uma altura de c. 0,50m, mas na face lateral, que é visível, mede 0,42m; a parte inferior permaneceu em estado bruto. Na face superior há uma cavidade circular talhada no centro, no interior de um quadrado de profundidade rebaixada e mais três cavidades dispostas em triângulo (Amandry, 1987: 127). 
Tipo de culto: $O$ culto parece remontar ao final do séc.IX a.C. e esteve em relação direta com uma cidadezinha chamada lthome, habitada continuamente do séc.VIII ao IV a.C. De acordo com as fontes textuais e materiais, o santuário já nesta época hospedava uma competição de música, conforme o testemunho de Pausânia sobre Eumelo. Em período posterior (quando?), nas Ithomaia ocorriam jogos, realizados no estádio de Messênia (Themelis, 2004: 119). Desde esta época ao menos até o séc.IV a.C. o culto de Zeus Ithomates esteve associado aos trípodes. De acordo com Themelis, segundo a tradição, o culto foi fundado pelos primeiros soberanos da região, Policaon e Messene, e, durante o reino de Glauco, o culto foi adotado também pelos habitantes de origem dória (Themelis, 2004: 117-118). Nas moedas de Messênia do séc.IV a.C. há a representação de uma estátua de aspecto arcaico de Zeus em pé atirando o raio e um trípode ao lado da divindade. Zolotnikova lembra de uma rocha grande com furos para a colocação de estátuas, localizada no ângulo nordeste do monastério, no platô ocidental, que pode ter sido usada como altar no culto arcaico e clássico como nos períodos mais antigos, como na Idade do Ferro. A autora compara esse altar com aquele externo na gruta de Ida em Creta (Zolotnikova, 2013: 106).

Comentário: Trata-se de um santuário de uma cidade (Ithome) que existia muito antes da fundação da pólis de Messênia por Epaminondas em 369 a.C. A datação do santuário de Zeus Ithomates no séc.VIII a.C. é feita (Themelis e Luraghi) com base no achado do pé de trípode e em Pausânias que cita Eumelo, poeta coríntio do séc.VIII a.C. Há raríssimas informações sobre evidências materiais do santuário. Também não se entende se as fundações estão embaixo ou a leste do monastério. Pela bibliografia não se pode saber sequer se o santuário foi escavado.

Referências bibliográficas: Amandry, P. Trépieds de Delphes et du Péloponnèse, BCH (111), 1987, p.79-131; Luraghi, N. The Ancient Messenians. Constructions of Ethnicity and Memory. Cambridge Univ.Press, 2008; Themelis, P. Antica Messene. Atenas: Casa Fondi Archeologici e Espropri, 2004; Cults on Mount Ithome, Kernos (17), 2004, pp.143-154; Zolotnikova, O. Zeus in the early Greek mythology and religion - from prehistoric times to early archaic period. BAR series, 2013, p.105-107; Zunino, M.L. Hierá Messeniaka.Udini: Forum, 1997. 


\section{Imagens:}

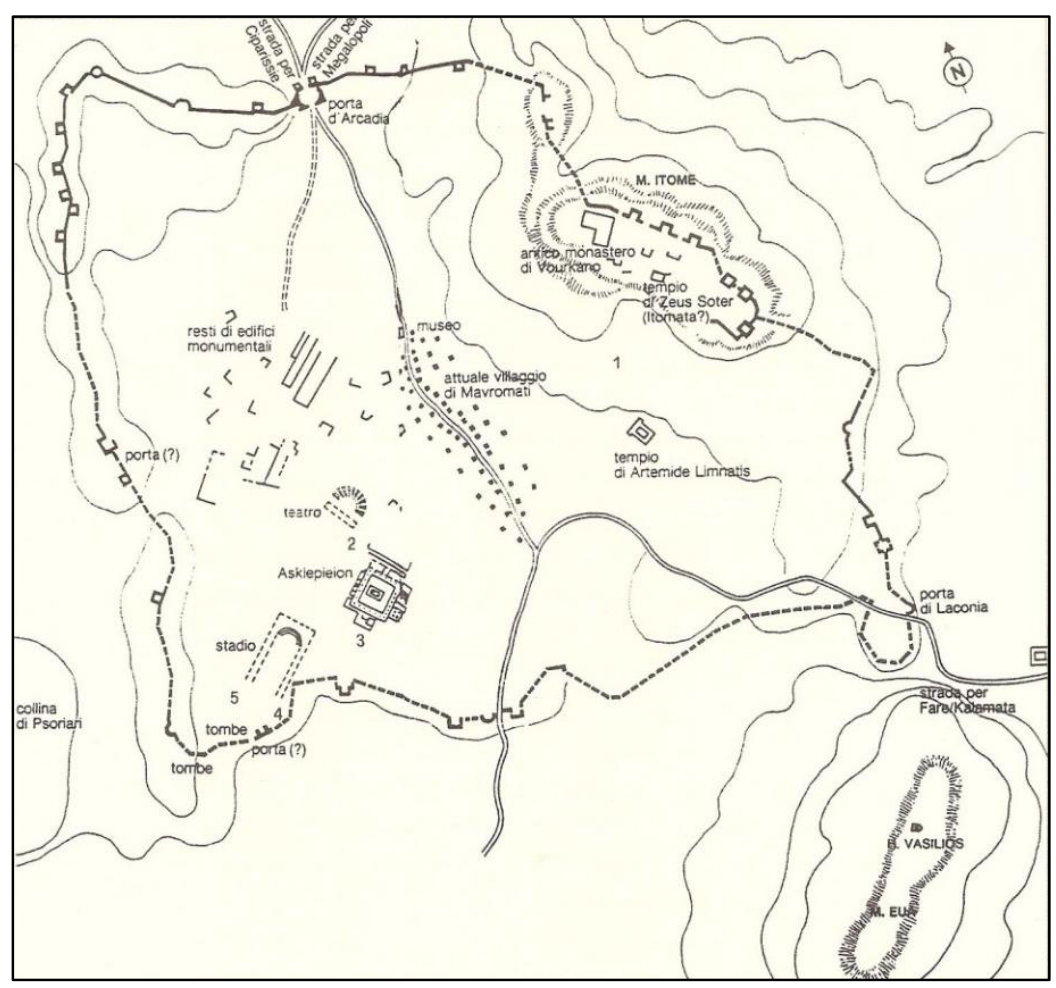

Fig.1- Planta de Messênia (Zunino, 1997: pr.III)

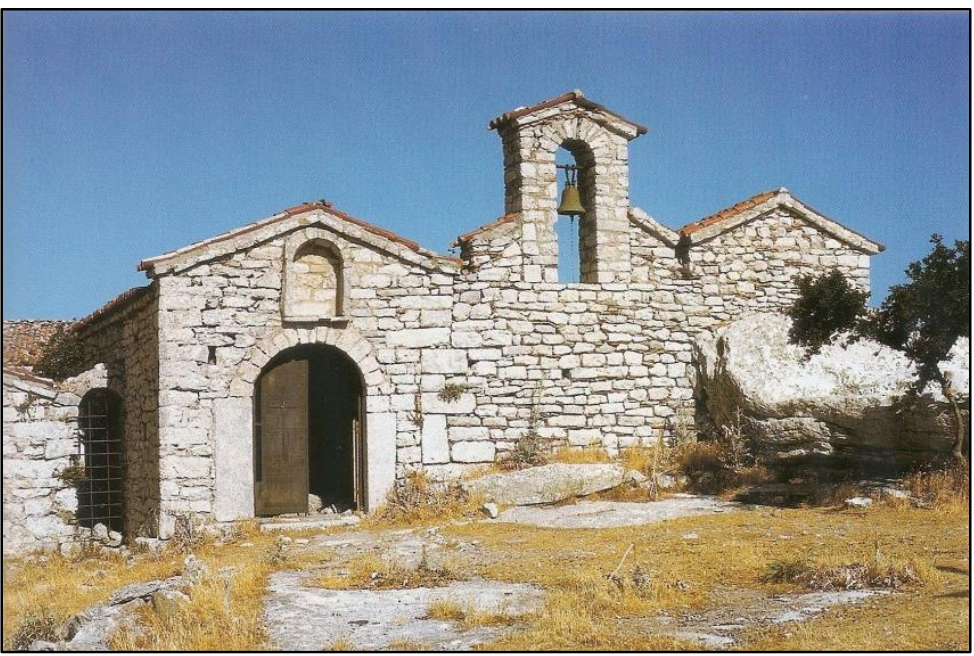

Fig.2- Monastério de Voulkanos no cume do Monte Ithome (Themelis, 2004: fig.120)

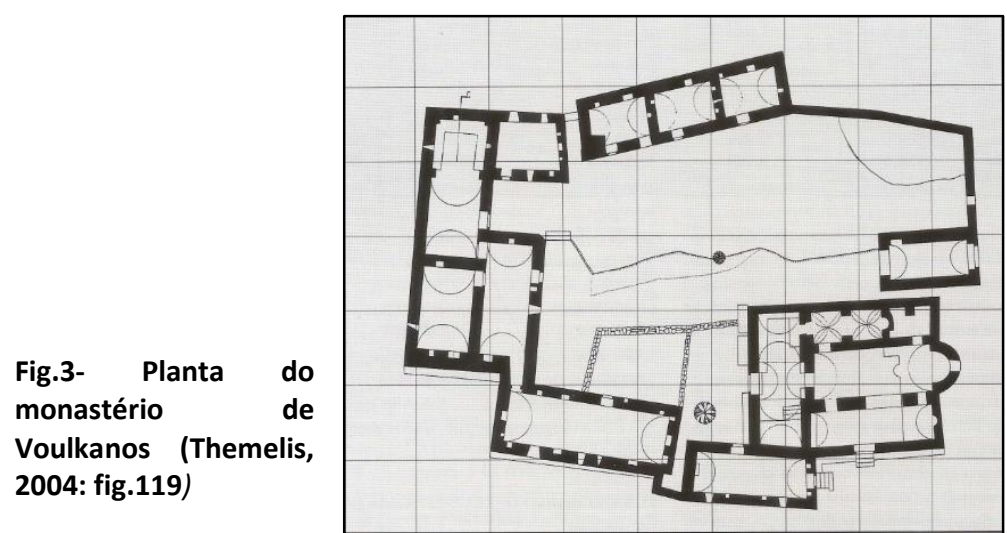




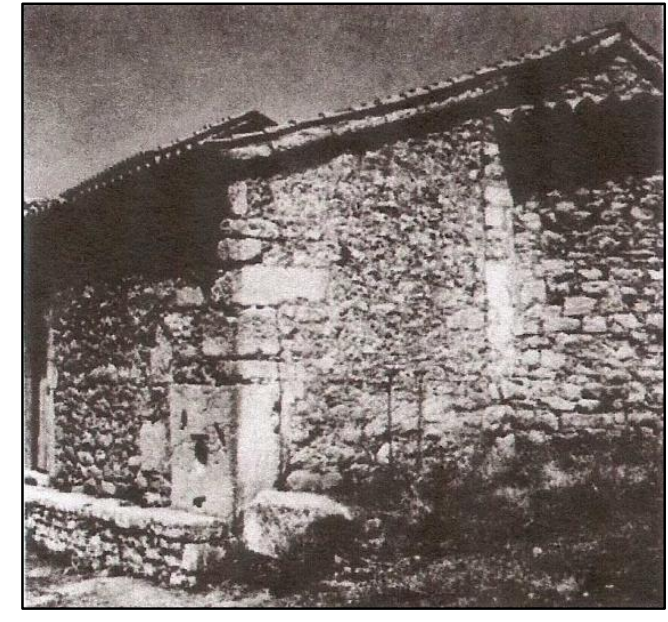

Fig.5- Base na parede do monastério de Voulkanos (Amandry, 1987: 128, fig.29)

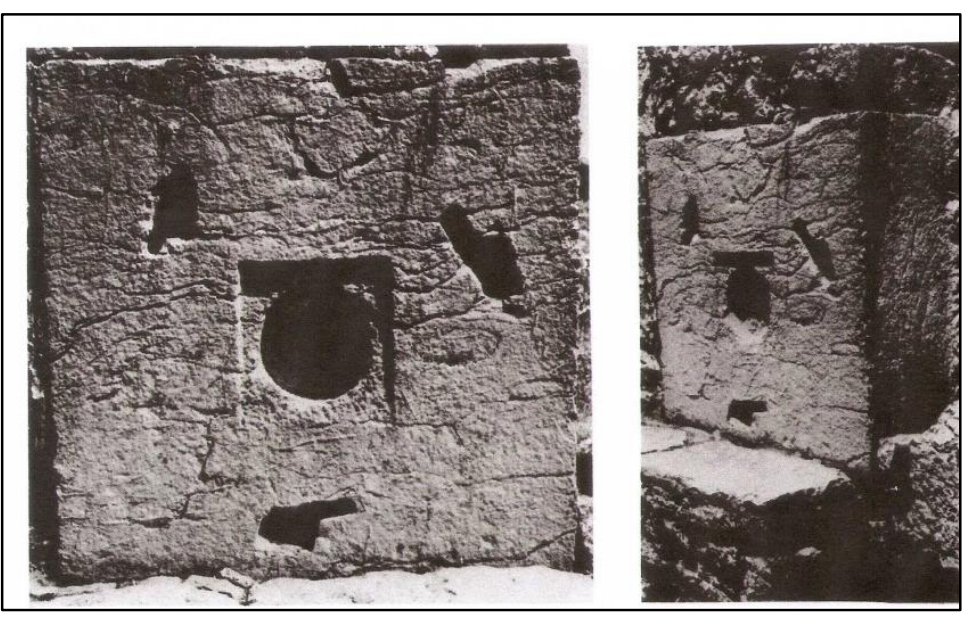

Fig.6- Base de tripé encaixada na parede do monastério de Voulkanos (Amandry, 1987: 129, fig.30) 
Datação: Geométrico inicial (séc. IX a.C.) - período arcaico (séc. VII-VI a.C.).

Localização: No Monte Parnes, em Ozea, o pico mais alto (1412m).

Tipo de santuário: Pico / extraurbano e sub-regional (a partir da Idade do Ferro).

Referências textuais: (Estátua de Zeus Parníthios, altares de Zeus Semaleos e Ombrios) Pausânias I, XXXII.3.

Inscrições: Inexistente.

Histórico dos achados: 0 depósito de cinzas, o provável altar de Zeus Ombrios e Apemios, foi descoberto em 1959 durante a construção de uma instalação militar no Ozea. Nenhum relatório oficial da escavação foi publicado, apenas um breve relato em um jornal local que descreveu a camada de cinzas.

\section{Documentação arqueológica}

I. Depósito votivo no pico Ozea: Trata-se de um grande depósito votivo de cinzas preenchido com ossos de animais queimados, cerâmica do início do período geométrico ao período arcaico (aríbalos coríntios, fragmentos de facas de bronze, alfinetes, escudos, cerca de 3000 punhais de ferro e algumas lamparinas romanas). Nenhuma inscrição foi relatada a qual pode identificar o culto, permanecendo apenas uma possibilidade que se trate do depósito do altar de Zeus Ombrios e Apemios mencionado por Pausânias. Segundo Langdon, há algumas similaridades cronológicas com o sítio no Monte Himetos, embora nada comparável ao grande número de aribalos coríntios e adagas de ferro recuperados por lá.

Tipo de culto: $O$ depósito votivo no Ozea é identificado, por Langdon, com o altar a Zeus Ombrios e Apemios com base em Pausânias. Langdon diz que os objetos do depósito votivo podem ser explicados como oferendas votivas a Zeus Apemios, cujo culto é desconhecio em outros lugares.

Em Harma $(867 \mathrm{~m})$, a certa distância de Phyle, a sudoeste do Ozea, é sugerida a localização do altar de Zeus Semaleos com base no testemunho de Teofrasto (de Signis Tempestatum 3,47) e Estrabão (IX,2,11) sobre sinais climáticos que vinham daquela parte do monte e interpretados como manifestações do deus. De acordo com Langdon, a conexão entre Zeus Semaleos e Harma foi por muito tempo reconhecida, embora a área, com pouca terra e muitas rochas grosseiras, tenha uma superfície muito irregular para um altar ou para a base da estátua de Zeus Parnésios. A ausência de cortes na rocha e cerâmica levaram a localização do altar de Zeus Semaleos perto daquele de Zeus Ombrios. 
Referências bibliográficas: Langdon, 1976, pp.100-101; Daux, G. BCH 84, 1960, p.658; Hood, M.S.F. Arch. Reports for 1959-60, p.8, Arch. Reports for 196061, p.5; Vanderpool, E. AJA 64, 1960, p. 26.

Imagens: ? 
Datação: Geométrico médio (séc. IX a.C.) / tardio (sec. VIII a.C.) - época romana.

Localização: No Monte Apesas (873 m), atual Monte Fokás, no sudoeste da região de Corinto, a norte de Neméia, no cume em formato de mesa, uma área espaçosa inclinada de leste a oeste (Langdon, 1976: 107; Zolotnikova, 2005: 111).

Tipo de santuário: Pico / extraurbano e sub-regional (a partir da Idade do Ferro).

Referências textuais: (Mito) Pausânias II, XV.3; Hesíodo, Teogonia 327-331; Píndaro, Ol. 9, 43-45.

Inscrições: Inexistentes.

Histórico dos achados: Ernst Meyer descreveu o sítio em uma publicação de 1939, seguido por M.K. Langdon que na década de 1970 desenvolveu a hipótese dos achados serem os restos do altar de Zeus Apesantios. A dispersão da cerâmica e das cinzas ocorreu com a instalação de marcos topográficos para uma pesquisa do exército grego na área em 1953 (Zolotnikova, 2013: 113). A maior pesquisa no topo do Monte Fokás foi empreendida pelo Nemea Valley Archaeological Project dirigido por J.C. Wright entre 1984-1989, que recolheu e datou a maior parte das cerâmicas (Zolotnikova, 2013: 113).

\section{Documentação arqueológica}

I. Altar e objetos votivos: Na extremidade leste do cume do monte, ao redor de um marcador moderno de vistoria, está evidente um caminho de terra queimada com cacos de cerâmica e fragmentos de ossos. Os cacos são na maior parte de fábrica coríntia reconhecível do período geométrico tardio e séc.VII a.C. com um pouco de partes em verniz preto (Langdon, 1976: 107). O Nemea Valley Archaeological Project datou a maior parte da cerâmica coletada ao final do geométrico tardio ao século VII a.C. e postulou que ao menos uma parte de uma jarra pode ser do geométrico médio. Fragmentos de cerâmica dos períodos clássico, helenístico e romano foram recuperados (Zolotnikova, 2013: 113). A cronologia da área sagrada, no entanto, não é ainda clara sem a escavação sistemática e o estabelecimento de uma estratigrafia (Zolotnikova, 2013: 113). Nenhum objeto votivo de terracota e bronze foi encontrado no topo do monte (Zolotnikova, 2013: 114). Nenhuma construção é discernível, mas cascalhos soltos são especialmente numerosos na área, podendo ser resultado do tombamento de um altar de seixos. Embora não haja uma referência antiga explícita sobre um altar de Zeus Apesantios no cume, Langdon acredita que esse conjunto de achados indiquem a presença de um (Langdon, 1976: 107). A área plana do cume do monte mede mais do que $400 \mathrm{~m}$ de leste-oeste e c.200 m de norte-sul. Há três platôs no cume: 
o de cima que mede c.100 m noroeste-sudeste e 70 m nordeste-sudoeste; o platô do meio, localizado c. $10 \mathrm{~m}$ abaixo e mede c.90-100 m nordeste-sudoeste e 60-70 m noroeste-sudeste; e o terceiro e mais baixo platô a leste do platô do meio e cai levemente a sudeste (Zolotnikova, 2013: 112-113).

Tipo de culto: 0 santuário no topo do Monte Apesas parece ter sido um lugar de culto destacado entre o geométrico médio/tardio e o início do arcaico, que, apesar de seu difícil acesso, teria sido propício para cerimônias envolvendo grandes grupos de pessoas. Seu ponto focal teria sido o altar de cinzas, que deve ter sido de um enorme tamanho (Zolotnikova, 2013: 114). Do final do século VIII a.C. e por todo o século VII a.C., o santuário pode ter sido o principal daqueles de Zeus na região da Coríntia e no norte da Argólida. Contudo, a partir do século VI a.C., houve um declínio abrupto nas atividades do santuário, que foi usado em muito menor grau durante os períodos clássico, helenístico e romano (Zolotnikova, 2013: 115). A autora explica esse declínio com o prestígio do santuário de Zeus em Neméia a partir do século VI a.C. Tipologicamente, o altar do santuário no Monte Apesas pertence a um grupo de altares de cinza de Zeus da Idade do Ferro em topos de montanha que os ultrapassa em tamanho (Zolotnikova, 2013: 115). Zolotnikova reconstrói o ritual no topo da montanha, tendo o fogo sido 0 elemento principal, assim como a destruição de vasos diretamente nas chamas, dentre outros atos, envolvendo a participação de famílias (Zolotnikova, 2013: 114). As antigas tradições não associam o culto local de Zeus à tempestades e à chuva. O epíteto "Apesantios" ("que manda embora", "que afasta") tem conotação apotropaica e indica o caráter purificatório do culto (Zolotnikova, 2013: 115). A julgar pelo tamanho do altar, e pela proximidade da montanha a importantes centros urbanos do início da Idade do Ferro como Corinto, Kleonai e Phlious, pode ser pensado que o santuário teve um significado regional e na verdade teria sido muito mais do que um santuário local e rural para habitantes locais (Zolotnikova, 2013: 114-115).

Referências bibliográficas: Langdon, 1976, p.107; Meyer, E. Peloponnesische Wanderungen. Zurich and Leipzig, 1939, pp.16-18; Zolotnikova, 2013, pp.111116. 
Imagens

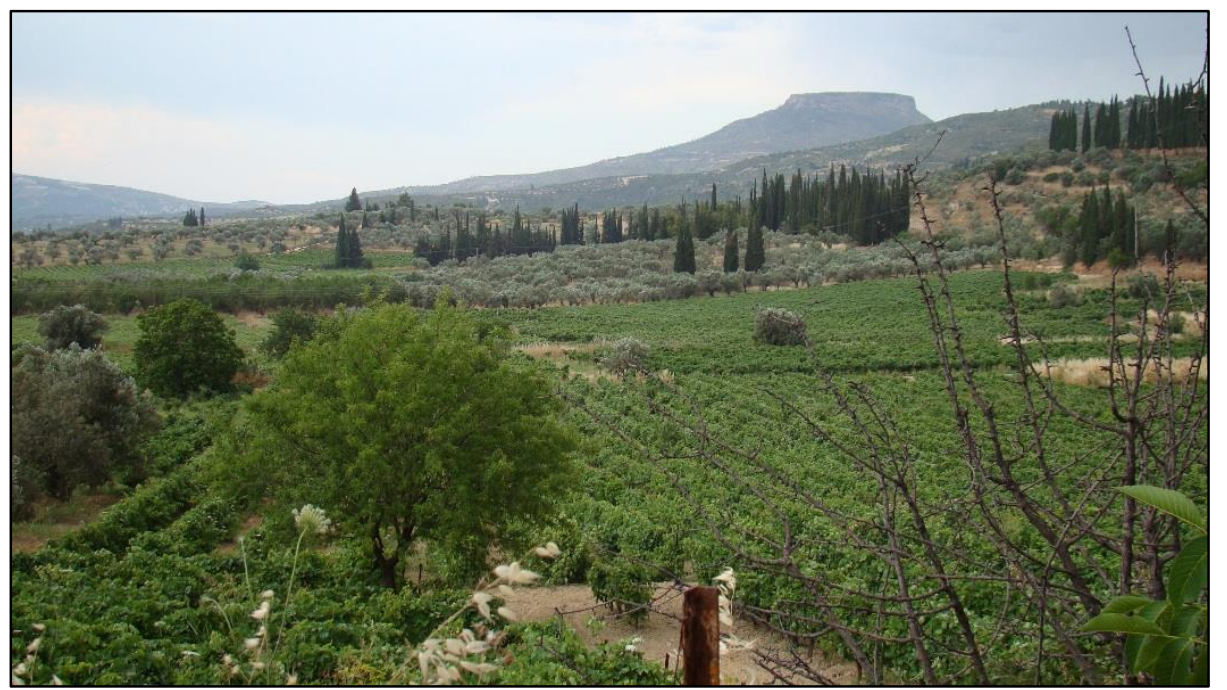

Fig.1- Monte Apesas ao fundo visto de Neméia (Foto: arquivo pessoal/2009) 
Datação: Geométrico tardio (séc. VIII a.C.) - época romana (sécs.III ou IV d.C.).

Localização: Na colina mais alta da serra de Tsakona, localizada no vilarejo de Aphyssou próximo ao Menelaion, a 2,25 km a leste-sudeste de Esparta (Catling, 1990: 15 e 18).

Tipo de santuário: Colinar? / extraurbano e sub-regional ? (a partir da Idade do Ferro).

Referências textuais: (Témeno em Pháris) Pausânias III, XX.2-5.

Inscrições: (1) no kýlix do séc. VI a.C., encontrado próximo do santuário de Tsakona; (2) na estampa de uma telha de Anthochori; (3) na estampa de telhas encontradas em Tsakona (vide "Tipo de culto").

Histórico dos achados: 0 sítio em Tsakona foi identificado em 1984 durante o survey na Lacônia realizado pela Escola Britânica de Atenas, mas a escavação propriamente dita ocorreu em duas campanhas entre maio e agosto de 1989 (Catling, 1990: 16). O sítio sofreu muita destruição pela erosão, cultivo da terra e incêndios. Também até 1988 a área era usada como depósito de entulho doméstico pelas autoridades municipais de Esparta (Catling, 1990: 16 e 18).

\section{Documentação arqueológica}

A dispersão do achados, durante o survey, determinou a extensão do santuário em um espaço de $45 \mathrm{~m}$ leste-oeste e $10 \mathrm{~m}$ norte-sul e a dispensão dos objetos votivos abaixo das encostas norte e sul estendeu-se em uma linha de ao menos $75 \mathrm{~m}$ (Catling, 1990: 18). Nenhum sinal de muro de témeno foi encontrado (Catling, 1990: 21).

O santuário possui uma questão sobre a cronologia e continuidade de seu uso. Há longos estágios dentro do período de 1000 anos para os quais não há nenhuma evidência (Catling, 1990: 33). Os objetos representam cada qual um período do santuário, mas não podem ser associados aos contextos arquitetônicos e estratigráficos. Cacos cerâmicos recuperados na encosta norte da colina e um alfinete de bronze fragmentário do edifício I situam o início do culto no séc. VIII a.C. Mas cerâmicas provenientes de ambos os edifícios sugerem que foram abandonados simultaneamente no final do séc. V a.C. (os terremotos de Esparta noticiados por Tucídides?). As telhas situam uma reconstrução do edifício I no séc. I a.C. Enquanto não há material datado para os séculos I e II d.C. (o culto não 
foi atrativo para Roma como também no caso de Menelau e Helena?), as lamparinas de molde e estatuetas indistinguíveis das arcaicas e clássicas mostram que o santuário esteve ativo no séc. IV e V d.C.(reavivamento antiquário do culto de Zeus Messapeus?) (Catling, 1990: 34-35).

I. Edifício 1: 0 principal do santuário, localiza-se sobre o morro, seu longo eixo orientava-se na direção nordeste-sudoeste, seguindo o longo eixo da colina (Catling, 1990: 21). Era uma estrutura retangular de pedra construída no centro da colina e media $5 \times 22 \mathrm{~m}$ (Catling, 1990: 23). Nas partes mais preservadas, os muros mediam 0,60 m de largura e embora em muitas partes apenas um único curso da alvenaria tenha permanecido, parte do muro sudeste tinha ainda 5 cursos. $O$ edifício teve uma entrada a leste de aproximadamente $1,50 \mathrm{~m}$ de lagura. Também é provável que os muros norte e sul tinham antas, embora não tenha sido encontrada nenhuma base de coluna para o fuste necessária para suportar o lintel de um pórtico com antas. Do muro norte apenas restaram as pedras mais baixas do curso do muro da porção oeste, ao contrário da porção leste do muro do lado sul, relativamente preservada. 0 delianeamento do muro oeste poderia não ser registrado dada a sua conservação. Os blocos no local indicam que o edifício era construído com poros e xisto azulado da região, mas não se sabe se era todo feito neste material ou se os cursos mais altos dos muros eram de tijolos de barro (Catling, 1990: 24-25). Nenhum pavimento foi encontrado. Certamente era coberto com telhas lacônias esmaltadas com antefixas e acrotério em disco, como indicam os achados no local (Catling, 1990: 25). Dentro do edifício foi encontrada uma fossa oval ( 1 × 1,40 m e 0,50 m de prfundidade) contendo uma ponta de lança de bronze com encaixe curto. A leste desta, estava um compelxo de quatro fossas que abrangia uma área de 1,80 m (norte-sul) e $1 \mathrm{~m}$ (leste-oeste), que podem ter sido usados como "post-settings" (Catling, 1990: 26). Dentro da entrada leste, uma fossa ( $1,80 \times 2 \mathrm{~m}$ e 0,20-30 m de profundidade) também foi encontrada e era preenchida com um solo bastante escuro de cinzas, contendo lamparinas de terracota, pequenos fragmentos de vidro, estatuetas de terracota, miniaturas de aríbalos, fragmentos de lamparinas romanas feitas em moldes (Catling, 1990: 26). Fora do edifício, $2 \mathrm{~m}$ a leste e a $1 \mathrm{~m}$ do muro sul, uma fossa $(1,10 \times 1,20 \mathrm{~m} \mathrm{e} \mathrm{0,50} \mathrm{m}$ de profundidade) continha lajes de calcário cuidadosamente depositas ali. Estudos revelaram se tratar de estelas não decoradas que possivelmente foram usadas e, danificadas, enterradas dentro do témeno (Catling, 1990: 26). Uma sepultura de época romana tardia (III e IV d.C.) foi encontrada atravessada no canto sul do edifício (Catling, 1990: 26).

II. Edifício 2: Edifício auxiliar de função desconhecida, foi eregido em cima de uma erosão natural na borda oeste da colina, tendo sido aproveitado a característica natural do terreno para a sua construção. Os remanescentes indicam que ele começava $14 \mathrm{~m}$ a sudoeste da extremidade oeste do edifício 1 e era orientado norte-leste e sul-oeste (Catling, 1990: 21). Media $5 \mathrm{~m}$ (leste-oeste) e apenas $3 \mathrm{~m}$ (norte-sul), apenas a parte sul do edifício restou, tendo sido protegida por uma escarpa rasa da encosta, $1,40 \mathrm{~m}$ do muro oeste e $3,10 \mathrm{~m}$ do muro leste e nenhum trato do muro norte. Não há vestígios de uma entrada. Os muros têm espessura de 0,45 e $0,75 \mathrm{~m}$ de altura. Este edifício é aparentemente posterior ao I, como indicou um amontoado de lajes e blocos de xisto, na extremidade leste da forma erosiva, que se assentava sobre um nível de solo escuro contendo duas estatuetas de terracota. Confirmação adicional da sequência relativa da construção foi propiciada por fragmentos de aríbalos de verniz preto e duas ou três terracotas encontradas na composição dos muros do edifício (Catling, 1990: 27).

III. Objetos votivos: Poucas oferendas de bronze e acima de 100 objetos de ferro foram registrados (soquetes-encaixes de pontas de lanças, pregos ou ganchos), dessas apenas seis peças foram recuperadas no edifício II. Normalmente encontrados aos milhares nos santuários da Lacônia, apenas 20 figurinhas votivas de 
chumbo ("lead votives") foram encontradas em Tsakona (16 coroas, 2 fragmentos de guerreiros, uma grande e um possível diadema e mais 5 objetos desse tipo não-votivos). Mais de 2600 estatuetas de terracota feitas à mão foram registradas, cujo número representa um tipo de figura masculina agachada, sentada ou ajoelhada com grande falo, às vezes encurvado no braço esquerdo, às vezes apoiado por ambos os braços, ocasionalmente não apoiado, com uma mão elevada à cabeça. Figuras itifálicas em pé são raras. Figuras de sexo indeterminado (com veste aparentemente drapeada), figuras em pé de mulheres nuas, mulheres grávidas, mulheres de cócoras, com as pernas abertas (em posição de parto?), um quadrúpide (equino, presumivelmente) com cestos, um quadrúpide não diferenciado. A técnica é homogênia e a alturas das figuras não ultrapassa os $2 \mathrm{~cm}$. Fragmentos de terracotas de moldes incluem uma figura dedálica imperfeita de uma mulher (provavelmente um apêndice de vaso), uma cabeça fina de um kouros arcaico tardio e a cabeça arcaica tardia de um homem com barba (a raridade desse tipo de material é notável) (Catling, 1990: 30). Pouco material cerâmico de vasos: de 450 potes, 347 são miniaturas, 46 aríbalos de tamanho normal, 6 taças sem alças e dois oinochoi. No edifício II foram encontrados 18 aríbalos de tamanho normal e apenas 11 miniaturas, enquanto 302 miniaturas foram encontradas dentro e ao redor do edifício I, 32 aríbalos de tamanho normal, taças sem alças e oinochoi. Nenhuma cerâmica é decorada ou contém figuras, a maioria possui verniz preto. Da fase romana pertencem 388 lamparinas de moldes, encontradas na metade do edifício I, e fragmentos de vasos de vidro (Catling, 1990: 31). Um selo de tipo grego-persa datável do século IV a.C. (Catling, 1990: 32). Armas, armaduras e equipamentos de atletas também compõem o repertório de objetos votivos (Catling, 1990: 34).

Tipo de culto: $O$ fragmento de um kylix lacônio (séc. VI a.C.) descoberto na superfície do solo, a 250-300 m do santuário (ponto x), contendo a inscrição incompleta ---] EMELAПEY, foi reconhecido como uma dedicação a Zeus Messapeus, cujo título é atestado apenas em Pausânias e Theopompos (citado por

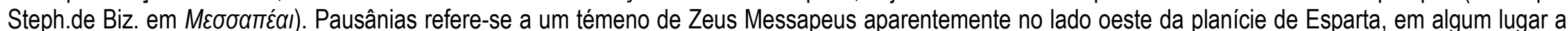
norte do moderno vilarejo de Xerokambos. Uma estampa de telha, encontrada nas escavações de Christou em Anthochori, a 2 km de Xerokambos, contém a

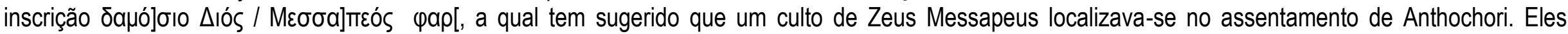
reconhecem a possibilidade de mais do que um santuário do deus no vale de Esparta e recomendam cautela em identificar Tsakona como um segundo santuário do deus com base em um único achado que pode ter sido extraviado e a uma considerável distância do santuário de Tsakona. Conforme Catling, contudo, a escavação de 1989 mostrou que com quase certeza houve um culto de Zeus Messapeus em Tsakona (Catling, 1990: 22). No edifício I, quatro ou cinco estampas fragmentárias de telhas recuperadas, parecem confirmar o culto. A mais preservada: $\triangle$ AMOCIO / MECC[---(Catling, 1990: 32). 0 tipo de representação das estatuetas de terracota de homens (a maioria) e mulheres (a minoria) sugere um culto preocupado com a reprodução humana e provavelmente de uma divindade masculina (Catling, 1990: 21). Catling supõe que o culto masculino por pedido de fertilidade/virilidade masculina pode ser indicativo do problema da oligantropia em Esparta (Catling, 1990: 34).

Referências bibliográficas: Catling, H.W.; Shipley, D.G. Messapian Zeus: An early Sixth-century inscribed cup from Lakonia. The Annual of British School at Athens, vol. 84, 1989: 187-200; Catling, H.W. A sanctuary of Zeus Messapeus: excavation at Aphyssou, Tsakona, 1989. Londres: British School at Athens, 1990; 
Zeus Messapeus near Sparta: an interim report. Atenas: Etaireía Lakonikón Spoudón, 1990; Zeus Messapeus at Tsakona, Lakonia. Atenas: Etaireía Lakonikón Spoudón, 2002.

\section{Imagens:}

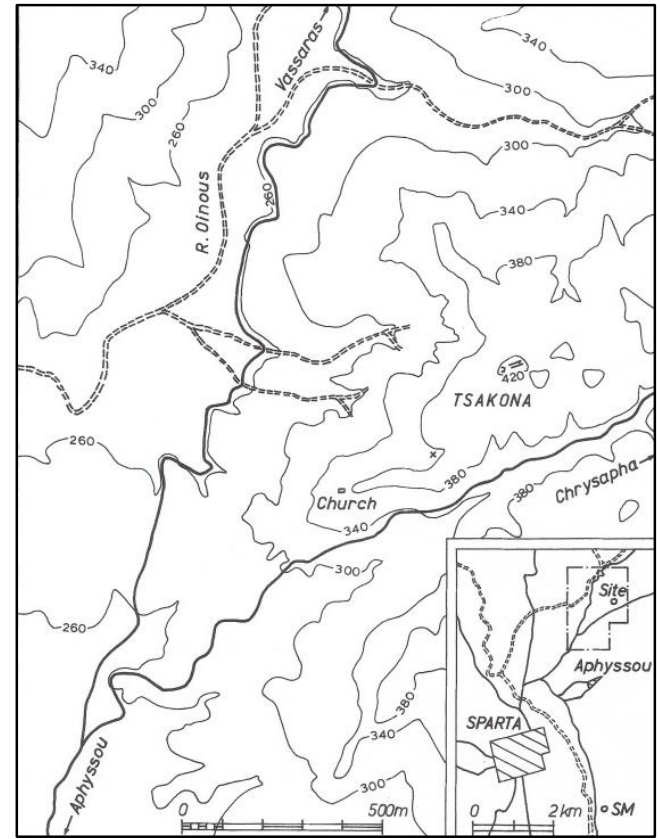

Fig.1- Planimetria de Tsakona (Catling, 1990 fig.1)

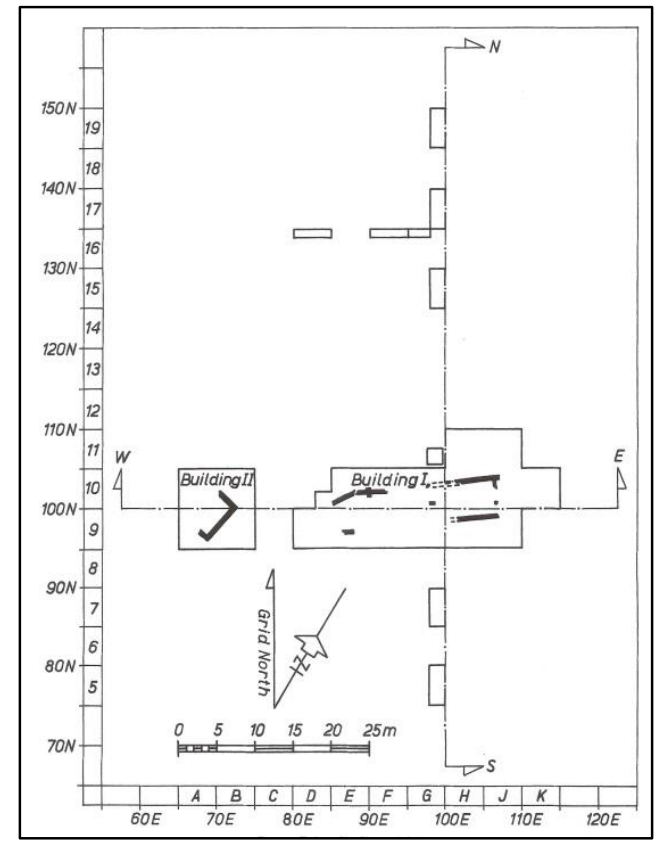

Fig.2- Planimetria do sítio de Tsakona (Catling, 1990: fig.2)

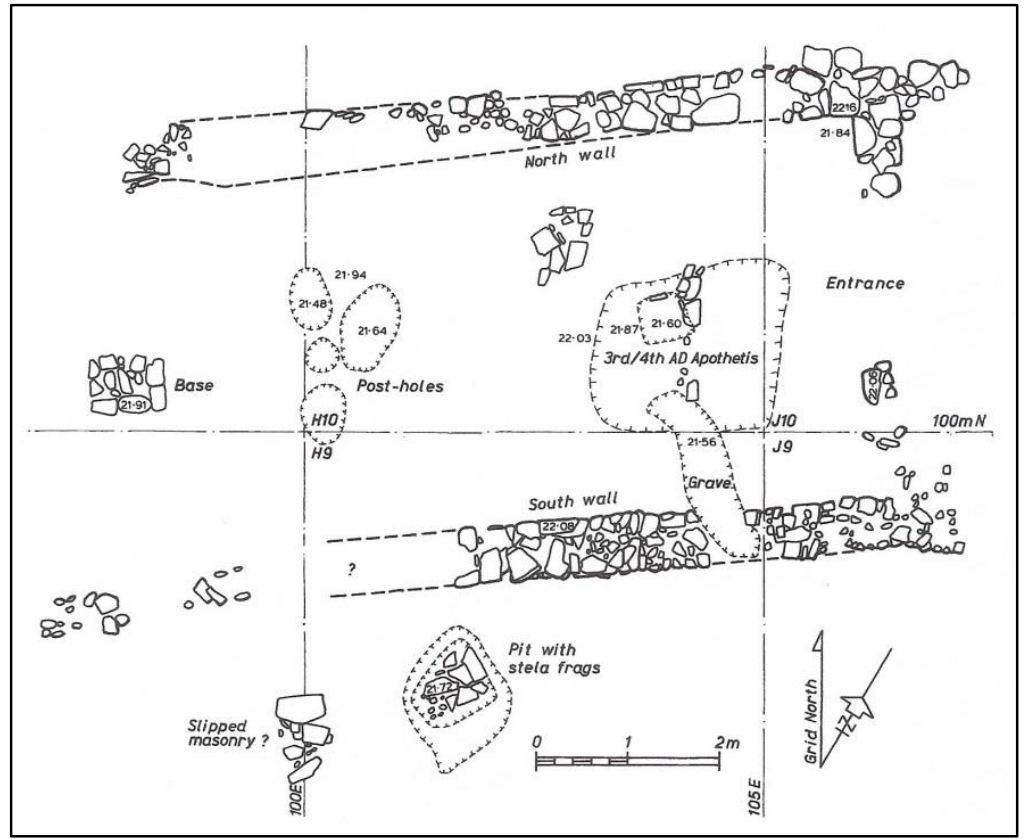

Fig.3- Planimetria do edifício 1 (Catling, 1990: 25) 


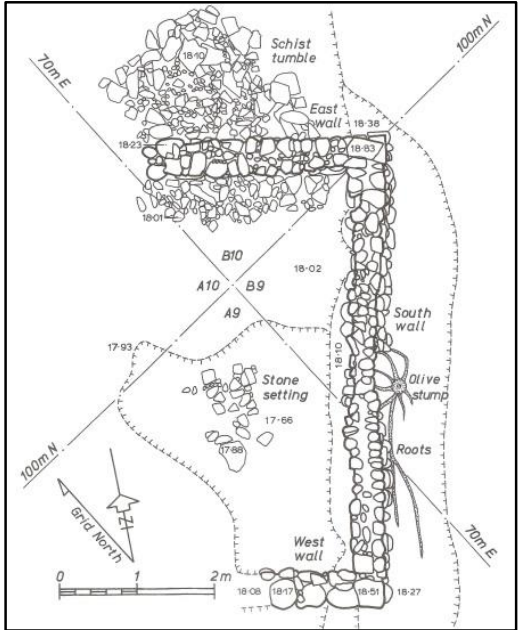

Fig.4- Planimetria do edifício 2 (Catling, 1990: 28, fig.5)

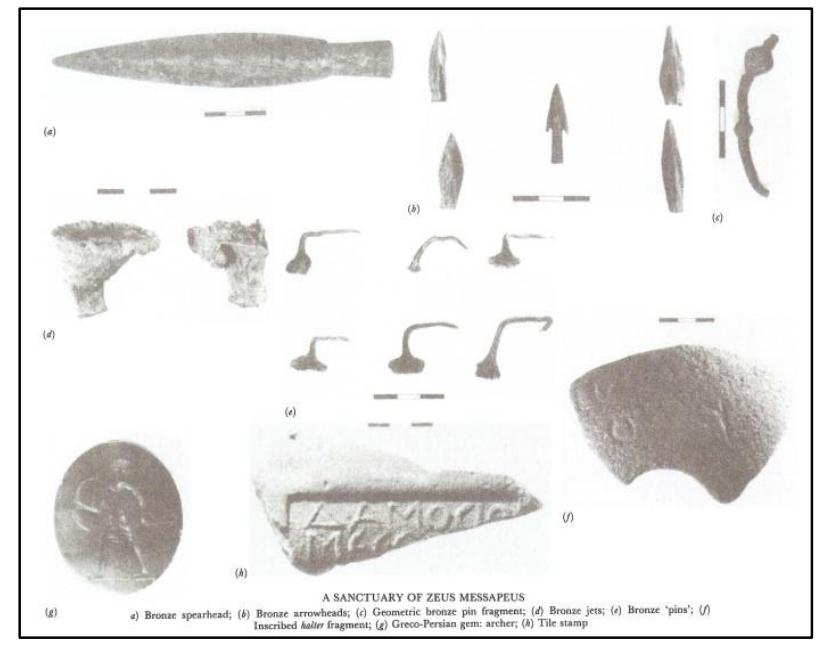

Fig.6- Pontas de lança de bronze, selo greco-persa e telha com estampa inscrita $\triangle A M O C I O$ / MECC (Catling, 1990: prancha 5)

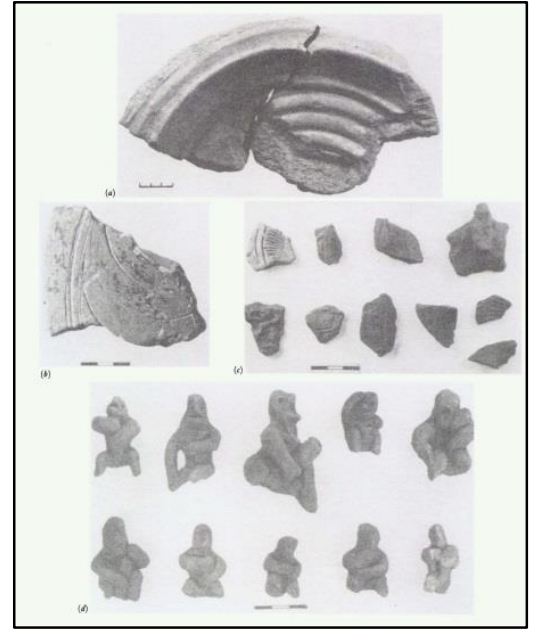

Fig.5- Acrotérion, antefixa e figurinhas masculinas (Catling, 1990: prancha 6) 
Datação: Geométrico tardio (séc.VIII a.C.) - época clássica (sécs. V-IV a.C.)

Localização: No pico de Profeta Elias (1199 m), o mais alto do Monte Arachnaion (localizado a noroeste do santuário de Asclépio em Epidauro), uma área do cume que oferece uma visão de toda a Argólida (Langdon, 1976: 108).

Tipo de santuário: Pico / extraurbano e sub-regional (a partir da Idade do Ferro)?

Referências textuais: (Altar) Pausânias II, XXV.10.

Inscrições: Inexistentes.

Histórico dos achados: Langdon diz que Boblaye parece ter sido o único explorador a visitar o sítio e a dar em primeira mão a descrição dos remanescentes. Subsequentemente outros viajantes o copiaram (Langdon, 1976: 107, nota 24).

\section{Documentação arqueológica}

I. Altar e objetos votivos: As fundações de duas estruturas antigas situam-se no cume e estão (na época de Langdon) completamente enterradas na terra enegrecida que cobre o topo. Contudo, o suficiente está visível para a determinação de seu tamanho e formato. Ambas são construções retangulares bastante grandes, uma com $6 \times 13 \mathrm{~m}$ e a outra com $5 \times 12 \mathrm{~m}$. 0 interior de ambas foi cavado e estão preenchidos com quantidades de cascalho. Os muros têm a espessura de 0,50 e 0,75 m e são construídos com blocos de calcário de tamanho médio com as faces exteriores grosseiramente regulares. Cacos cerâmicos abundam por todo o topo, mas são especialmente numerosos aqueles do período geométrico tardio e do séc. VII a.C. (fragmentos cerâmicos argivos de c.750-690 a.C., protocoríntio de c.700-640 a.C. e do início do arcaico de c.690-650 a.C.). Foram encontradas três concentrações de objetos votivos que podem ser os candidatos ao altar de cinzas (Zolotnikova, 2013: 86). Fragmentos de ossos também ocorrem em quantidades. Para Langdon, este sítio é o candidato mais adequado para os altares de Zeus e Hera mencionados por Pausânias (Langdon, 1976: 108). Recentemente, segundo Zolotnikova, restos micênicos foram encontrados foram de contexto estratificado na parte leste do platô do pico leste - fragmentos de figurinhas de argila femininas e de animais, fragmentos cerâmicos do heládico tardio III (taças e potes para cozimento) (Zolotnikova, 2013: 86). As evidências encontradas nos depósitos não são consideradas como prova da continuidade do culto entre a Idade do Bronze e a Idade do Ferro - o cume parece ter sido usado continuamente da segunda metade do século VIII a.C. e por todo o século VII a.C. 
até o século VI a.C. e possivelmente o V a.C. O local parece ter sido usado exporadicamente em época romana (Zolotnikova, 2013: 86). Estruturas arquitetônicas foram encontradas no platô do pico, mas sua data não pode ser estabelecida (Zolotnikova, 2013: 86).

Tipo de culto: Pausânias afirma que Zeus e Hera tinham um altar no monte e a população da área lhes oferecia sacrifícios por chuva (Langdon, 1976: 107). De acordo com Zolotnikova, a natureza do culto praticado no pico, durante o período pré-histórico, parece ter sido relacionada, ao menos parcialmente, a uma divindade feminina, mas até o momento não é possível ter um quadro mais claro de seu caráter e funções diante do estado das evidências, nem pode ser confirmado que se tratou do culto de Hera nessa época. A associação de Zeus com o cume do monte pode ser datada ao redor do período histórico, contudo, a natureza de seu culto, tal como foi praticada na Idade do Ferro não é indicada pelos achados recuperados na área (Zolotnikova, 2013: 86).

Referências bibliográficas: Langdon, 1976, pp. 107-108; Zolotnikova, 2013, p.86.

Imagens: ? 
Datação: Geométrico tardio (séc. VIII) - época clássica (IV a.C.).

Localização: No pico setentrional do Monte Tourkovouni(a) (o antigo Anchesmos), a cerca de 330m acima do nível do mar, no setor nordeste de Atenas.

Tipo de santuário: Colinar? / extraurbano e sub-regional (a partir da Idade do Ferro)?.

Referências textuais: (Estátua) Pausânias I, XXXII.3.

Inscrições: Inexistente?

Histórico dos achados: Conforme Langdon o santuário foi descrito por Wrede, que identificou o altar cercado por um circuito de muros e uma boa quantidade de cacos cerâmicos, especialmente do período geométrico. 0 santuário foi escavado, mas nenhum relatório foi publicado.

\section{Documentação arqueológica}

I. Santuário: Um altar antigo foi encontrado no pico setentrional. De acordo com o material cerâmico (cacos cerâmicos do período geométrico e taças e skyphoi do subgeométrico), havia um lugar de culto já no século VIII a.C. Após um declínio temporário de atividade cultual no século VI a.C., o culto foi renovado e o sítio arquitetonicamente realçado com um muro de cercado oval dentro do qual um pequeno altar de estrutura retangular e pedras rústicas, que ficava sobre um platô levemente elevado, poderia ter tido, próximo a ele, uma estátua. De acordo com Langdon, não há evidência clara entre os remanescentes que uma estátua tenha estado presente ali. Esta instalação simples e rústica, datada do final do século IV a.C., cobriu o lugar de culto mais antigo dentro do muro.

Tipo de culto: A atribuição do culto a Zeus tem como base em Pausânias, a única fonte antiga que menciona o Mt. Anchesmos como uma montanha pequena na vizinhança de Atenas com uma estátua de Zeus (Langdon, 1976). Mas há a possibilidade de que o culto no local tenha pertencido a um herói desconhecido (Goette, 2008).

Referências bibliográficas: Goette, H.R. Athens, Attica and Megarid. An archaeological guide. Londres; N. York: Routledge, 2008, pp. 137-138; Langdon, 1976, pp.101-102; Wrede, W. Attika: vortrag in der deutschen Arbeitsgemein-shaft zu Athen, DAl Abteilung Athen, 1934, pp.13, 29 , pl.9. 


\section{Imagens:}

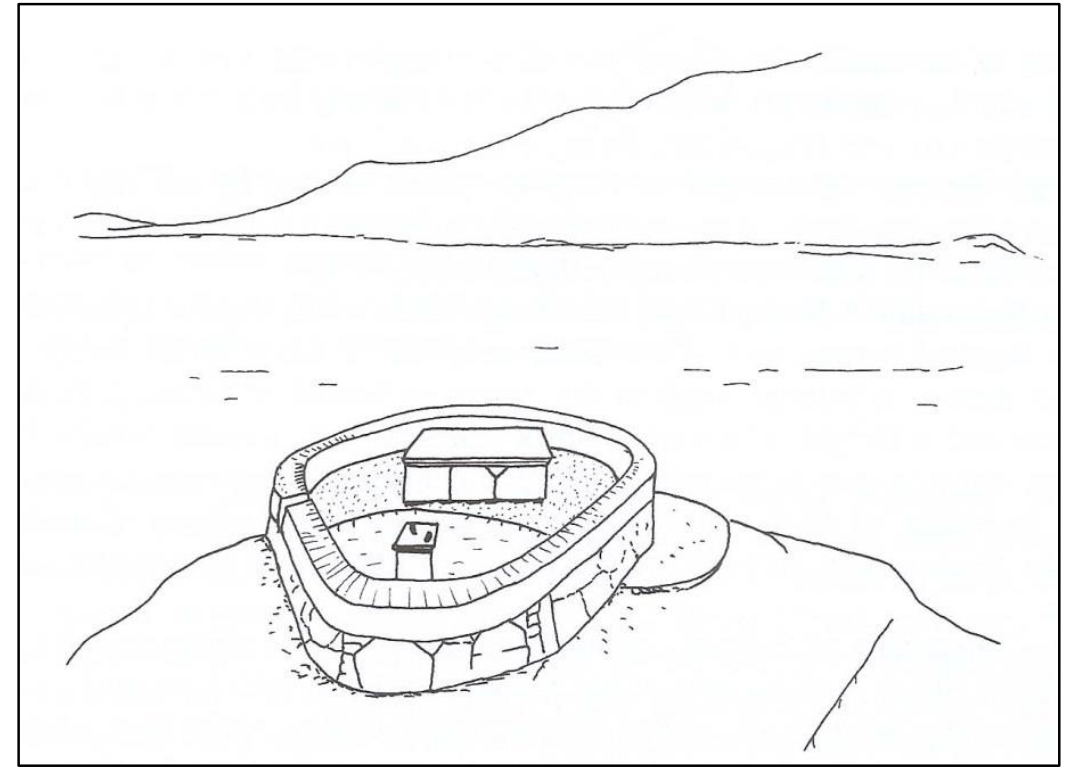

Fig.1- Reconstituição do santuário no Monte Tourkovouni (Anchesmos) (Goette, 2008: 138, fig.40) 
Datação: Geométrico tardio (séc. VIII a.C.) - época romana.

Localização: No pico mais alto do Monte Attavyros (1215 m).

Tipo de santuário: Pico / extraurbano, sub-regional (a partir da Idade do Ferro)?

Referências textuais: Templo (Diodoro V, 59.2; Políbio, fragm. XXVIII.14.1); templo e montanha (Píndaro Ol.7, 85-90); (Estrabão 14.2.12); santuário/altar (Apolodoro 3.2.1; Diodoro V, 59.1-2).

Inscrições: Em potes que atestam atividade de culto no início do arcaico.

Histórico dos achados: A prospecção de superfície e uma escavação limitada, conduzidas no topo do monte em 1927, identificaram os restos do antigo santuário (Zolotnikova, 2013: 109).

\section{Documentação arqueológica}

I. Muro de períbolo e propileu: As fundações do muro de períbolo e partes de um edifício, que pode ser um propileu, indicam que muito provavelmente se tratou de um santuário monumental, destruído, infelizmente durante o período bizantino quando o sítio foi usado para a construção da igreja de Ágios Prodromos (Zolotnikova, 2013: 109).

II. Objetos votivos: Numerosas figurinhas votivas em bronze de touros foram encontradas no topo e nas encostas fora de contextos estratificados - algumas podem ser datadas do século VIII a.C., indicando atividade cultual no final do geométrico (Zolotnikova, 2013: 109). Dessa mesma época datam dedicações de potes com inscrições e outros objetos que atestam a atividade de culto no início do período arcaico (Zolotnikova, 2013: 110).

Tipo de culto: As formas iniciais do culto não puderam ser estabelecidas e nem a identificação do altar original, estabelecido pelos colonos cretenses (Zolotnikova, 2013: 109-110). No início do período arcaico, é provável que o local sagrado no topo da montanha tenha se tornado oficialmente um santuário de Zeus. A fama pan-helênica do local é conhecida a partir da primeira metade do século V a.C., quando Píndaro apelou a Zeus Atabyrios. A etimologia do epíteto é obscura: este pode derivar da língua fenícia, hitita, cária, semita ou ter origens religiosas cretenses (Zolotnikova, 2013: 110). O estabelecimento de um local de culto a Zeus no 
Monte Attavyros pode ser atribuído às atividades religiosas de habitantes ao redor da montanha, possivelmente os antigos camirenses (Zolotnikova, 2013: 110). A associação de algum conceito originalmente solar e masculino com o pico pode remontar ao período pré-histórico (Zolotnikova, 2013: 110).

Referências bibliográficas: Zolotnikova, 2013, p.109-110.

\section{Imagens}

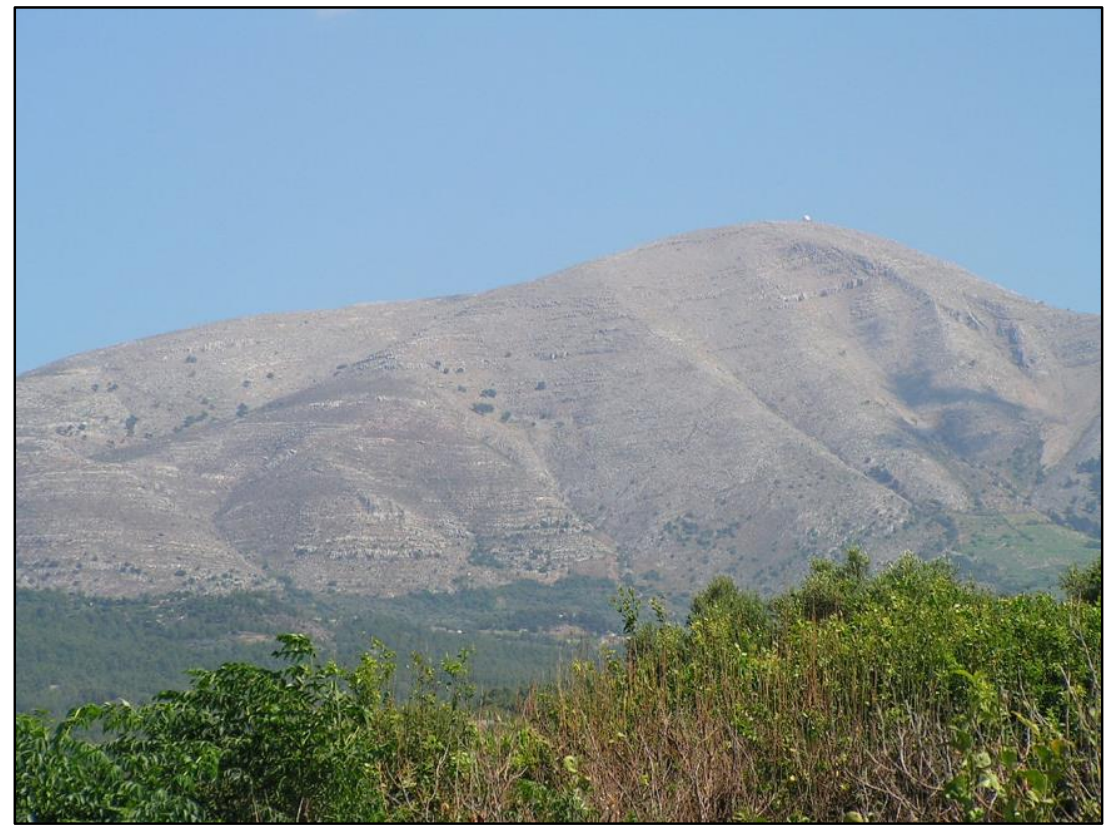

Fig.1- Monte Attavyros, Rodes (Fonte: Wikipedia “Attavyros"/2015)

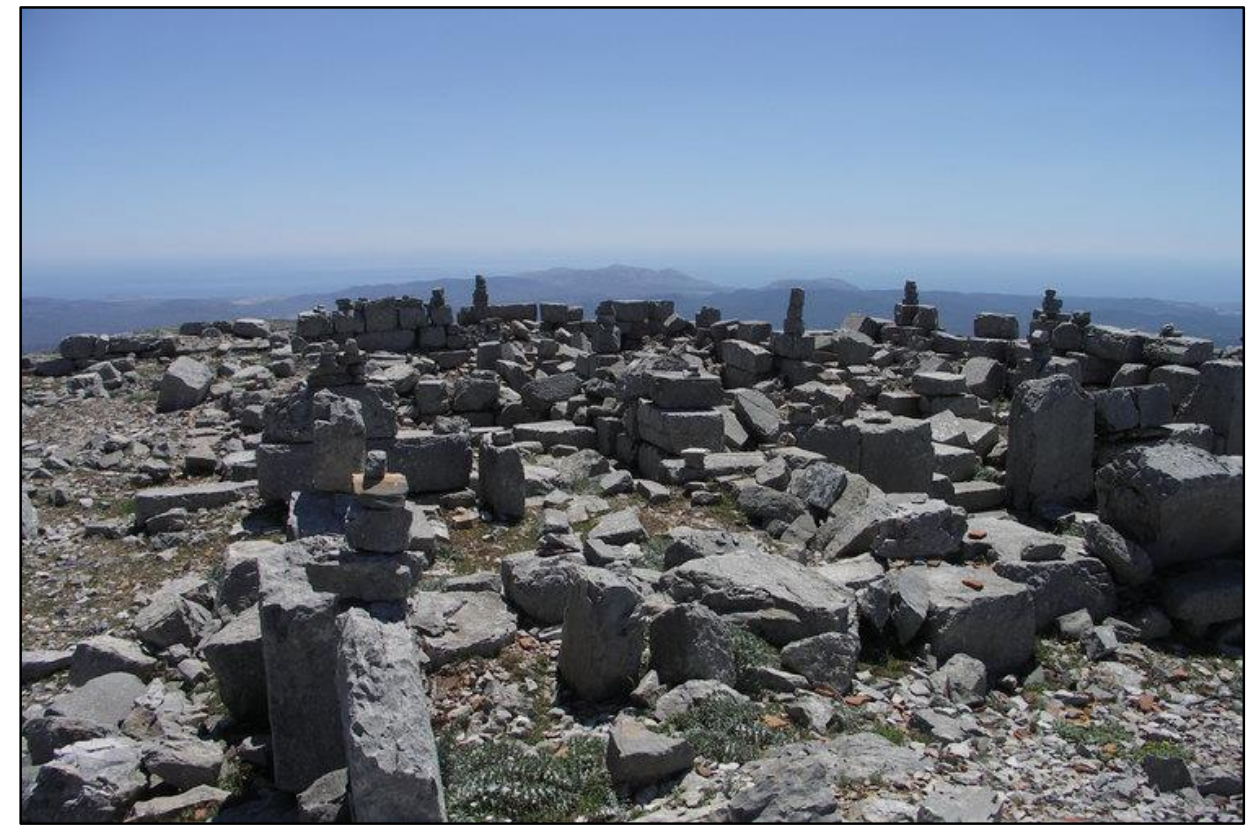

Fig.2- Remanescentes do santuário de Zeus Atabyrios, Monte Attavyros, Rodes (Fonte: Wikipedia “Attavyros"/2015) 
Datação: Geométrico tardio (final do séc. VIII a.C.) - período helenístico (III-I a.C.).

Localização: Na terceira acrópole da cidade, denominada "Altar Hill" (325 m), que se situa a sudoeste das demais colinas do assentamento, na rota de acesso sul para Praisos (Prent, 2005: 304).

Tipo de santuário: Colinar / suburbano (a partir da Idade do Ferro).

Referências textuais: (Templo) Estrabão 10.4.6; 10.4.6.12.

Inscrições: Inexistentes.

Histórico dos achados: A escavação de Halbherr de 1894 revelou um provável altar no meio do topo da colina (Prent, 2005: 304).

\section{Documentação arqueológica}

I. Altar e objetos votivos: Aproximadamente no meio do topo da terceira acrópole, é provável ter havido um altar para sacrifícios, como indica a presença de ossos queimados de bois e carneiros (Zolotnikova, 2013: 114). As dedicações datadas da Idade do Ferro incluem trípodes ou caldeirões de bronze, pequenos discos de bronze, duas terracotas de imitações de escudos, seis miniaturas de elmos de bronze, um elmo coríntio, uma lança, pontas de lança, uma fíbula de bronze, uma cabeça de machado de bronze; fragmentos de ao menos duas estátuas sphyrelaton de bronze, menores em tamanho do que o Kouros de Dreros (Zolotnikova, 2013: 114).

Tipo de culto: Bosanquet assinalou o lugar de culto na "Altar Hill" a Zeus Dicteu, já que um dos santuários da divindade era, de acordo com Estrabão, situado na ou próximo a cidade de Praisos. Ele confirmou a identificação pelos votivos de armas e em particular pelos discos pequenos de bronze, interpretados como címbalos usados no ritual de dança em êxtase dos Kouretes - as terracotas de leão (de uma data tardia) talvez indiquem que Rhea foi cultuada ao lado do filho (Prent, 2005: 306).Como coloca Zolotnikova, a identidade real da divindade cultuada na área, durante o início do período histórico não é documentada e sua identificação atual com Zeus não pode ser datada com certeza (Zolotnikova, 2013: 114).

Referências bibliográficas: Prent, 2005, pp.304-306; Zolotnikova, 2013, p.113. 
Imagens
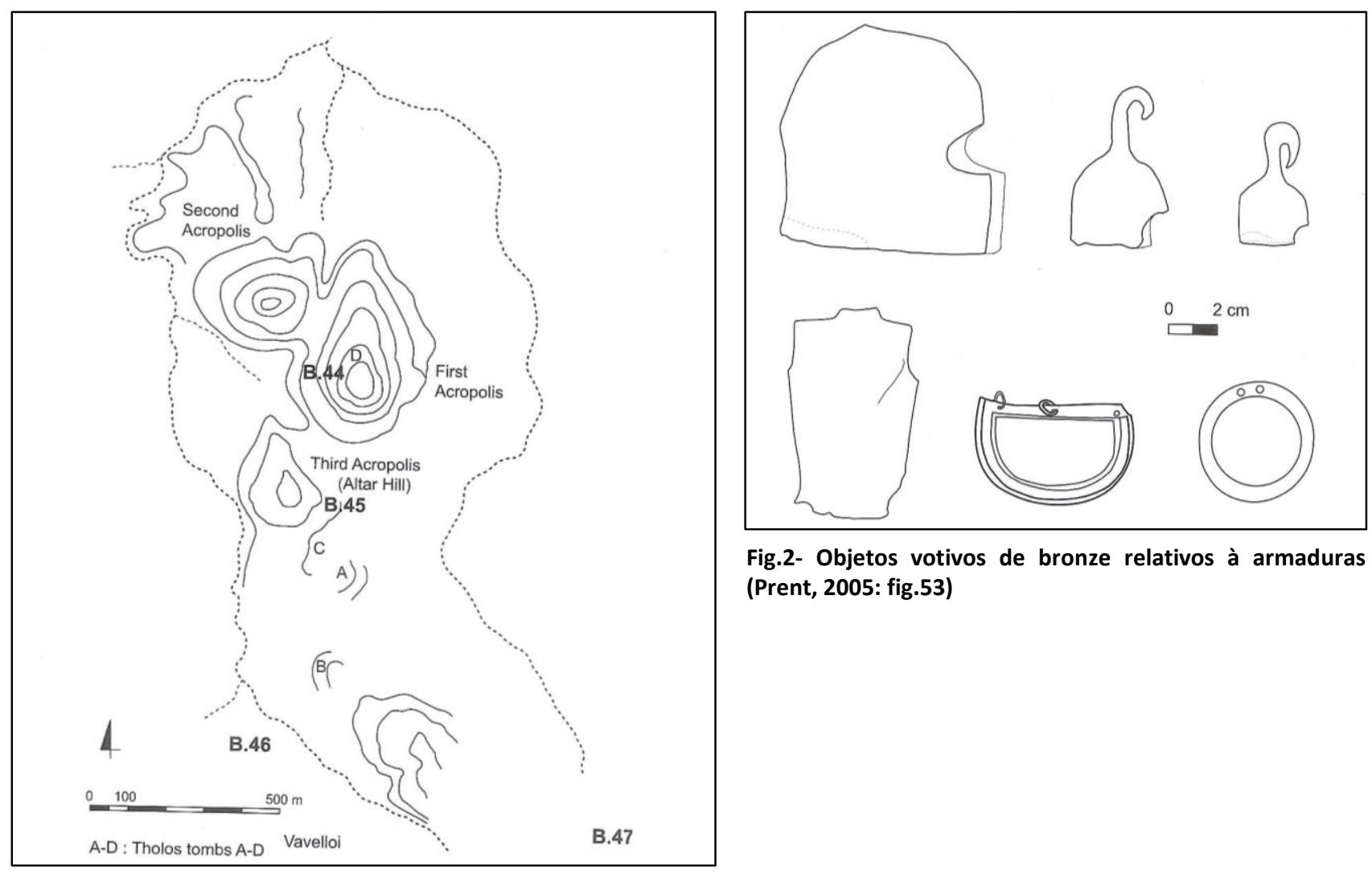

Fig.2- Objetos votivos de bronze relativos à armaduras (Prent, 2005: fig.53)

Fig.1- Planimetria de Praisos, B.45 identifica a área do santuário de Zeus Dicteu (Prent, 2005: fig.52)

96 
Datação: Geométrico tardio (séc. VIII a.C.) - época helenística (séc. III a.C.).

Localização: Na encosta norte, logo abaixo do ponto mais alto do Monte Oros (c.531 m).

Tipo de santuário: Pico / extraurbano, sub-regional (a partir da Idade do Ferro) e inter-regional (a partir da época arcaica) com função agonística?

Referências textuais: (Mito) Pausânias II, XXIX.2; Diodoro IV.72.4-5; Isócrates IX,14-15, (Sacrifício) Pausânias II, XXIX.5-8; Pausânias I, XLIV.8-10; (Sagração de território) Pausânias II, XXX.3; (Santuário) Pausânias II, XXX.3-6; (Témeno) Heródoto II.178; (Altar) Píndaro Nem 5.10; (Culto) Píndaro Peã 6.120-125.

Inscrições: Uma inscrição na oferenda arcaica, um suporte em forma de coluna, exibida no topo da subida com degraus; uma segunda inscrição no prato sacrificial datado do séc.VI a.C.; e uma terceira inscrição na hídria de bronze datada de 480-460 a.C., que foi dedicada por dois irmãos a Zeus Hellanios (IG IV2 1056). Estas duas últimas oferendas encontram-se no Museu de Egina (Goette, 2008: 346; Polinskaya, 2013: 336).

Histórico dos achados: Langdon nos informa que o relatório de escavação do santuário nunca foi publicado (Langdon, 1976: 81, nota 12). Breves relatos são fornecidos por Fürtwangler e Welter. Já Goette diz que recentes escavações dataram os remanescentes arquitetônicos do santuário (Goette, 2008: 346 ).

\section{Documentação arqueológica}

Goette nos informa que restos de um assentamento pré-histórico foram encontrados nas antigas encostas terraceadas que cercam o topo da colina (Goette, 2008: 346). Langdon comenta que material cerâmico do período geométrico ao período romano tardio foi encontrado no santuário, mas não foi estudado (Langdon, 1976: 81).

I. Terraço: Consiste em um muro alto no lado norte, sendo o terceiro muro mais a oeste feito de blocos trabalhados os quais, em grande parte, foram retirados para serem reutilizados em prédios mais tardios. As outras partes do muro do terraço são de construção irregular. No centro do muro do lado norte há uma rampa com degraus que leva para cima do platô. Os lados da rampa são feitos de blocos retangulares cuidadosamente trabalhados. A área sudeste do santuário é delimitada por um impressionante afloramento rochoso do qual veio o material de construção dos muros e fundações. Recentes escavações conseguiram datar os muros de terraceamento e o largo caminho da subida (a rampa?) em c.500 a.C. Trata-se de uma arquitetura de tipo popular no período arcaico tardio nas Cíclades e usada no período helenístico em Kós (Asclepiéion) e em Rodes (templo de Atena em Lindos) (Goette, 2008: 348).

II. Edifício: Trata-se de um edifício dórico, que não é o templo da divindade, feito de poros egineta trazido da costa. O monastério bizantino dos Taxiarchas - a capela do Profeta Elias - foi construído em cima do centro da instalação a partir de restos de antigos espólios do santuário. Restos dos muros das celas podem ser vistos. A igreja com domo em forma de cruz tem um longo nártex que é posterior à sua construção e foi edificado no ponto da antiga base de uma estátua de 
bronze incorporada dentro da alvenaria. Goette diz que a instalação foi interpretada como espaço dedicado ao festival, para os ritos da comunidade, festas dos peregrinos que vinham participar dos atos sacrificiais. Vários restos de ossos de animais, alguns com marcas de ruptura e combustão, suportam a idéia (Goette, 2008: 348).

III. Altar: De acordo com Langdon e Goette, situa-se no cume do Monte Oros (Goette, 2008: 348; Langdon, 1976: 81).

IV. Templo: Trata-se de um edifício de dimensões pequenas também situado no cume do Monte Oros (Goette, 2008: 348).

V. Stoá: Datada dos anos do domínio de Pérgamo em Egina (211-133 a.C.), a stoá helenística é um anexo de três colunatas e situa-se no lado norte dos muros do monastério bizantino (Goette, 2008: 348).

VI. Quartos/salas: Goette comenta que pequenos grupos de quartos/salas (não diz quantos), construidos com cascalhos na sua parte interna, podem ser vistos na subida ao santuário (a partir da rampa?) (Goette, 2008: 3468).

VII. Cisterna: A sul do pátio do monastério bizantino há uma cisterna pequena talhada na rocha, e cerca de $100 \mathrm{~m}$ mais acima uma outra cisterna também talhada na rocha. A hídria de bronze com dedicação a Zeus Hellanios foi encontrada ali. As cisternas, cobertas com telhas finas, guardavam água para os peregrinos e hoje são os pastores que obtêm água para seus rebanhos (Goette, 2008: 348).

Tipo de culto: Goette diz que inicialmente o epíteto de Zeus era Hellanios e que somente mais tarde Zeus Hellanios passou a ser evocado como Panhellanios ("de todos os gregos"), sendo o seu festival muito semelhante ao de Olímpia, pois todas as cidades mandavam participantes para os dias do festival e a elas era permitida a passagem livre em tempos de guerra. Uma idéia da importância do santuário pode ser obtida das odes de Píndaro, que viveu na ilha por um tempo como amigo do governante egineta, compondo odes em honra aos vitoriosos nos jogos dos grandes festivais gregos. Uma indicação adicional que o culto de Zeus era o mais importante de Egina é que os marinheiros eginetas fundaram um santuário de Zeus Hellanios em sua colônia mercantil em Naucratis no Delta do Nilo (Goette, 2008: 345). Mas na origem do culto, em tempos mais antigos, o culto de Zeus no Oros estaria relacionado à chuva. Um mito que data do período mais antigo da ilha diz que os agricultores teriam vindo ao rei Aiakos suplicando por ajuda e ele, então, implorou a Zeus pela vinda da chuva do pico do Monte Oros. Quando o seu pedido foi atendido, os eginetas, então, teriam erigido um altar no Oros, que se tornou a origem do santuário, cultuando Zeus como 0 "reunidor" de nuvens. Ainda hoje as nuvens reunidas acima do Oros são interpretadas pela população local como um sinal eminente de tempestade e rezam por chuva na capela do Profeta Elias, construída na área do santuário de Zeus (Goette, 2008: 346; Langdon, 1976: 81). Polinskaya, que realizou um estudo completo acerca dos cultos em Egina, explica que o achado de material mais antigo no topo do Monte Oros (do geométrico) do que 0 encontrado na área onde ocorria 0 festival (datado de época arcaica) sugere dois estágios no desenvolvimento do complexo de culto no monte - um mais antigo com o foco inicial no topo da montanha e o outro posterior, relacionado ao festival, na encosta norte (Polinskaya, 2013: 325-326). Segundo essa autora, o culto de Zeus Hellanios no monte Oros em Egina ocorreu de forma diferenciada a outros santuários de pico do deus com a função de propiciador de chuva - embora estes tenham sido realizados em grandes altares de cinza com depósitos votivos significativos, nenhum é comparável à estrutura construída no Oros com um terraço, amplas escadas e 0 
hestiatório, localizados na encosta norte. A seu ver, essa disposição do santuário egineta testemunha o papel cívico do culto de Zeus em Egina, a seu status de Zeus-pai e não apenas o de propiciador de chuva (Polinskaya, 2013: 328). Além disso, a localização do santuário em uma área remota da ilha, considerando-se a localização da pólis egineta na extremidade noroeste da ilha, e a dedicação de estátuas votivas a Zeus no Monte Oros (como indicam as bases encontradas no local), revela que este e o seu festival atraiu um número significativo da parcela da população local, lembrando que exibição/exposição pública é mais efetiva em lugares de importância cívica, onde o ato de dedicar acrescenta mais honra ao dedicante (Polinskaya, 2013: 329). Polinskaya defende o papel cívico de ZeusPai, o patrono dos eginetas, e não o de propiciador de chuva, com base na premissa de que votivos a esse culto do deus costumam ser pequenos objetos, ao contrário do que se encontrou no Oros (Polinskaya, 2013: 329-330). A presença de estátuas deve ser atrubuida, a seu ver, ao papel social de Zeus como o deus patrono dos eginetas (Polinskaya, 2013: 331). A autora conclui que o culto de Zeus Hellanios no Monte Oros foi associado com o controle da precipitação pluvial e como o patrono de Egina, servindo como marcador da identidade egineta na arena internacional (Polinskaya, 2013: 336 e 343 ). A seu ver, não há evidências que suportem a ideia de que Zeus Hellanios tenha desempenhado um papel pan-helênico, ao contextualizar as referências de Heródoto e Aristófanes a respeito (Polinskaya, 2013: 341). Em outra interpretação de Polinskaya, sobre a origem e o papel pan-helênico ou regional de Zeus Hellanios, a posição topográfica do Monte Oros - visível praticamente de todo ponto da costa do golfo Sarônico, de todas as áreas da Ática e de Atenas, principalmente de suas principais colinas teria sido familiar à toda a área. O Oros teria funcionado como um barômetro de chuva a todos os gregos no raio de visão do monte (Polinskaya, 2013: 337-338). O epíteto de Zeus egineta em época arcaica e clássica foi Hellanios; em época romana (tempo de Adriano) deve ter passado a ser Panhellanios (Polynskaya, 2013: 337). Vários relatos dizem que Zeus é chamado Hellanios porque (todos) os gregos (Hellenes) vieram pleitear com Aiakos, enquanto outros (Isócrates $370-$ 365 a.C.) dizem que é porque eles estabeleceram um culto comum dos gregos (Polinskaya, 2013: 337). Não há indicações de um estádio para a prática agonística.

Referências bibliográficas: Goette, 2008; Langdon, 1976, p.81; Fürtwängler, A. Aegina, Das Heilgtum der Aphaia I, pp.473-474; Polinskaya, I. A local history of Greek polytheism. Gods, people and the land of Aigina, 800-400 BCE. Leiden; Boston, Brill, 2013, pp.319-343; Werter, G. Arch.Anz.33, 1938, cols. 8-16. 


\section{Imagens:}

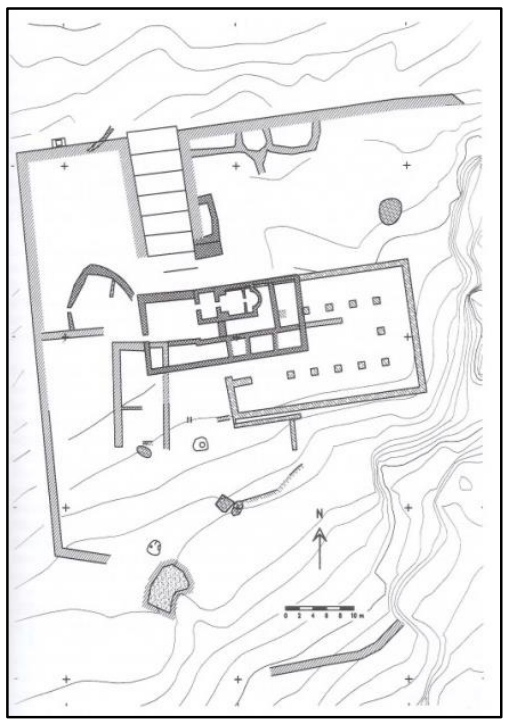

Fig.1- Planta do santuário de Zeus Hellanios (Goette, 2008: 347, fig.105)

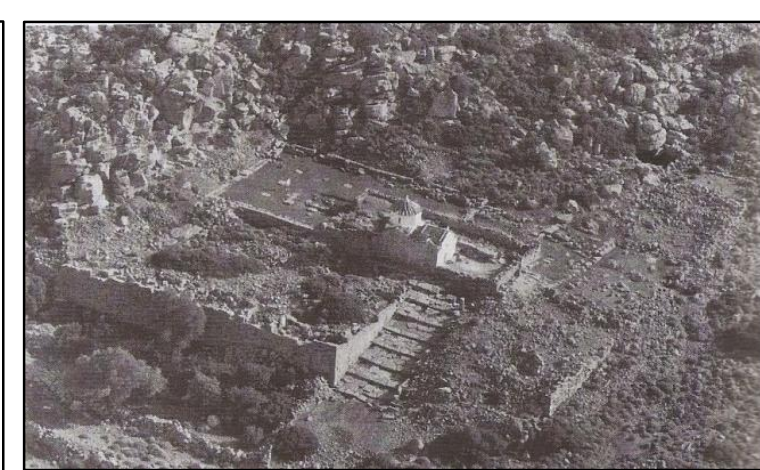

fig 2-Vista aérea do santuário de Zeus Hellanios a partir de noroeste (Goette, 2008: pr.91)

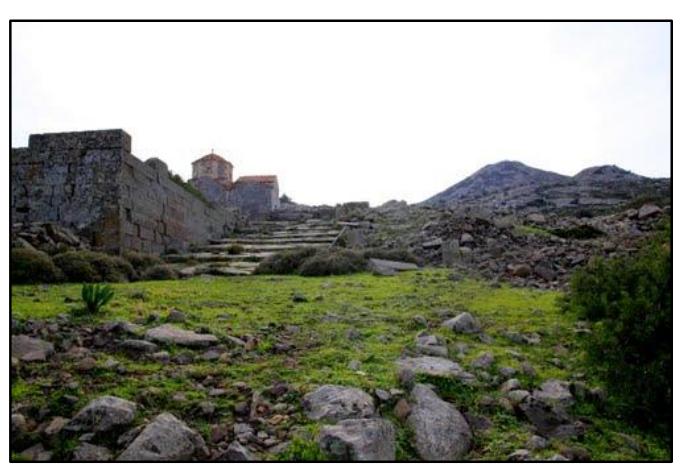

Fig.3- Vista da rampa e do muro de terraceamento a partir de norte (Foto:Diojan/Panoramio.com)

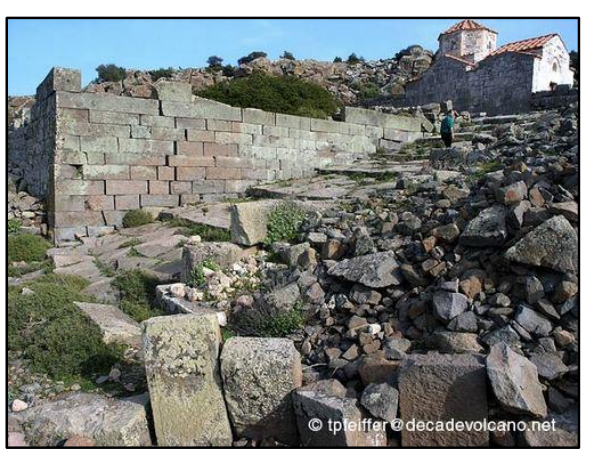

Fig.4- Muro de terraceamento e rampa vista de

noroeste Methana/Panoramio.com)

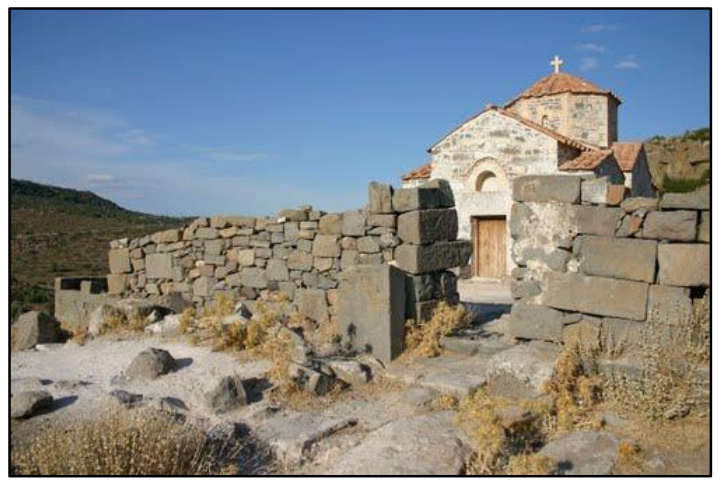

Fig.5- Muros do edifício e capela do Profeta Elias (Foto: Nikon/Panoramio.com)

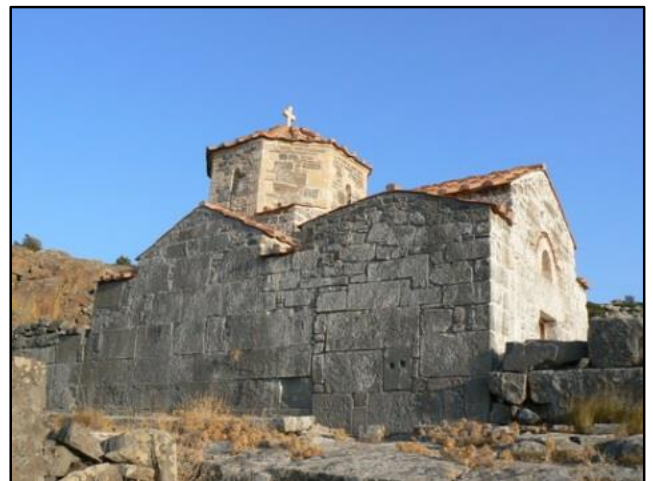

Fig.6- Capela do Profeta Elias vista a partir de noroeste Castelli/Panoramio.com) 
Datação: Geométrico tardio (séc. VIII a.C.) - época clássica (sécs. V-IV a.C.).

Localização: No pico mais oriental do Monte Zagaras (1748 m), localizado no sudoeste da Beócia (Zolotnikova, 2013: 76).

Tipo de santuário: Pico / extraurbano e sub-regional (a partir da Idade do Ferro)?

Referências textuais: (Altar) Hesíodo, Teogonia 4.

Inscrições: Inscrição fragmentária dedicatória na borda de um caldeirão de bronze ---]EI TO ENIKN[IO datada do período arcaico (Zolotnikova, 2013: 76).

\section{Histórico dos achados:?}

\section{Documentação arqueológica}

I. Altar e objetos votivos: 0 altar é formado por uma construção retangular que tinha muros espessos (c.1,35 m cada) e mediam $5 \times 10 \mathrm{~m}$. A cerâmica coletada no local é datada do século $\mathrm{VI}$ a.C. e consiste, principalmente, de telhas e fragmentos de taças com verniz. Também foi encontrado o fragmento de um caldeirão de bronze de época arcaica (Zolotnikova, 2013: 76).

Tipo de culto: M. Langdon acredita, embora reconheça a fragilidade da evidência, que a inscrição no caldeirão de bronze se referira a Zeus Helikonios, citado por Hesíodo na Teogonia (Zolotnikova, 2013: 76).

Referências bibliográficas: Langdon, 1976, p.109; Zolotnikova, 2013, p.76.

Imagens:? 
Datação: Geométrico tardio/início do período arcaico (entre o final do séc. VIII a.C. e início do séc. VII a.C.) - época helenística (séc.III a.C.).

Localização: Situada entre a Coríntia, a nordeste, a Argólida, a sul, e a Arcádia, a leste, em um vale de terras altas, nos sopés orientais das montanhas arcádias, cercado a sudeste pelo monte Evangelistria, a sudoeste pelo Monte Daouli, a oeste pelo pico de Profeta Elias (o antigo Trikaranon) e a leste pelo Monte Phokás (o antigo Apesas) (Miller, 2004: 19-20).

Tipo de santuário: Planície e vale / extraurbano e sub-regional (Idade do Ferro) / inter-regional e inter-estadual (a partir da época arcaica e clássica) com função agonística (a partir do séc. VI a.C.)?

Referências textuais: (Santuário) Tucídides III.XCVI.I; Píndaro, Nem. 2.1-5; (Templo) Pausânias II, XV.2-4; (Sacrifícios) Pausânias II, XIX.3-5; (Jogos) Pausânias II, XXIV.2-4; Píndaro, Nem 2.20; Píndaro, Nem 4.5.

Inscrições: Sobre dedicações, como por exemplo na caneca com inscrição incisa Tou Liós (P778) (Miller, 2004: 42 e 94).

Histórico dos achados: 0 templo de Zeus foi escavado pela primeira vez em 1766 pela Society of the Diletanti de Londres, que abriu uma trincheira na frente do templo. Em 1884, arqueólogos franceses escavaram o templo, retornando em 1912. Em 1924 a Escola Francesa cedeu os direitos de escavação em Neméia para a Escola Americana sob os auspícios da Univ. de Cincinnati e direção de B.H. Hill e C.W. Blegen. As escavações americanas ocorreram até 1926 e voltaram a ocorrem em 1964. Em 1973 as campanhas voltaram a ocorrer por meio da Univ da Califórnia e direção de S.G. Miller e perduram até hoje (Miller, 2004: 23-25).

\section{Documentação arqueológica}

I. Templo: Situado no lado norte do santuário, o templo de Zeus do séc.IV a.C. (c.330 a.C.) foi construído sobre o templo mais antigo, datado da primeira metade do séc.VI a.C. (provavelmente da época do festival de 573 a.C.) e destruído no final do séc.V a.C. A violência dessa destruição é mostrada claramente no depósito de cinzas e carbono em meio a detritos e objetos queimados, como setas de lanças e elementos arquitetônicos do edifício. Os construtores do templo do séc.IV a.C. desmantelaram e reutilizaram os blocos do antigo templo quando montaram as fundações do edifício posterior (Miller, 2004: 50 e 153-154). Embora a planta seja de difícil reconstrução, sondagens efetuadas dentro das extremidades leste e oeste das fundações do templo do séc. IV a.C. indicaram que o primeiro templo tinha a mesma orientação, leste-oeste, mas uma axis longa c.0,60 m a sul de seu sucessor. 0 antigo templo também era menor e mais longo em proporção e largura; as suas dimensões gerais eram de c.10,10 x 36,30 m. Este tamanho e ausência de evidências para as colunas sugerem que 0 antigo edifício não tinha 
perístasis, sendo provavelmente uma estrutura simples com uma fachado distila in antis, um telhado caído (hipped) na sua fachada oeste e um pedimento pintado na fachada leste. Parece que tinha um pavimento cimentado, ao menos no lado norte (Miller, 2004: 155-156). No lado esquerdo da prateleira debaixo da vitrine (case) 11, do Museu de Neméia, estão vários fragmentos de telhas do período inicial do primeiro templo, incluindo fragmentos de telhas (pan tiles) com estampas das oficinas oleiras (AT245, 205, 224). Na prateleira de cima, há uma telha de canto de tipo coríntio (AT434) e antefixas com decoração na parte da frente proveniente dos beirais do telhado (AT82,91). Esses elementos têm sido associados para reconstruir o telhado na fachada oeste. 0 templo arcaico de Zeus Nemeios, como alguns do mesmo período de Ístmia e Corinto, não tinham frontões ou pedimentos nas duas fachadas, sendo o lado oeste fechado por um telhado caído (Miller, 2004: 50). Já a fachada leste, desses antigos templos muitas vezes eram decoradas por esculturas. No caso de Neméia, não foram encontrados adornos escultóricos, mas vários fragmentos de pedra com decoração pintada do lado oeste. Três desses estão na vitrine 11 e são de difícil interpretação (o bico de um pássaro? [A458], listras de penas de uma sa?[A469], um olho humano em perfil? [A475]). No meio da prateleira 11 há um fragmento de argamassa com revestimento em estuque sobre um lado (A173). Vários fragmentos foram encontrados em associação ao templo antigo e está claro que foram usados como pavimento para muros externos do edifício e para juntar as telhas no telhado (Miller, 2004: 51). As prateleiras superior e inferior, à direita da vitrine 11, possuem fragmentos de acrotéria $(\mathrm{AT} 117,119,224)$, cuja base consistiu em uma telha de tipo coríntio dobrada em ambas as extremidades para seguir os lados inclinados do telhado. $O$ final restante sobre essa base foi pintado nos dois lados com uma voluta dupla, acima da qual estava uma palmeta com folhas em vermelho e preto profundos (Miller, 2004: 51). O coração dessa palmeta era talhado, vasado, de modo que o céu azul podesse se visto através da palmeta no alto do telhado. Essa peça é importante, pois seu estilo do final do período arcaico (c.500 a.C.), indica que pertence a uma reparação ou renovação do antigo templo realizada nessa época (Miller, 2004: 52). Dúzias de blocos de calcário (0,31-032 $\mathrm{m}$ x 0,88 $\mathrm{m}$ x 0,92-0,93 $\mathrm{m}$ ) são provenientes da parte de cima do muro (Miller, 2004: 52 ). Dois deles preservam traços de incêndio e buracos usados para o seu içamento durante a construção do templo (A163) (Miller, 2004: 52). Na prateleira de cima da vitrine 11 estão duas telhas retorcidas e vitrificadas pela ação do fogo (AT93,115). As camadas de restos do templo arcaico também produziram várias setas de bronze (BR77,113,162, etc) e lanças e cabos de ferro (IL116, 174, etc). Esses objetos mostram com igual clareza que a causa da destruição do templo foi uma batalha campal, cuja data, com base nas cerâmicas e nos restos, pode ser assinalada ao final do séc.V a.C. (415-410). Tucídides registra uma manobra militar em Neméia e região em 419/18 A.c. (Tuc.5.58-60) e em 415/14 a.C. (Tuc.6.95). Uma consequência dessa batalha foi certamente a remoção dos jogos nemeanos até 330 a.C. (Miller, 2004: 52 e nota 48).

II. Altar: $\mathrm{O}$ grande altar, datado do séc. VI a.C., posiciona-se a leste do templo arcaico de Zeus Nemeios e conserva, da fase arcaica, somente uma breve parte, em blocos de calcário a norte, relativa às fundações (Lippolis, 2007: 647).

Tipo de culto: Apesar das evidências mais significativas (templo e altar) indicarem, com segurança, a fase mais antiga do culto de Zeus em Neméia no século VI a.C., Zolotnikova defende que o culto pode remontar entre o final do século VIII a.C. e o início do século VII a.C. (Zolotnikova, 2013: 118). Essa autora se baseia nos restos de atividade ritual (sacrifícios) desse período encontrados nas trincheiras escavadas no lado leste e oeste do altar de Zeus e próximos ao templo (fragmentos de cratera e de skyphoi datados do final do período geométrico (Zolotnikova, 2013: 117). Zolotnikova chega a pensar na possibilidade de que 
a atividade cultual do final da época geométrica relacione-se aos estratos micênicos que, a princípio, não estão relacionados a algum culto, questionando-se se em Neméia houve a tradição de re-uso de sítios da Idade do Bronze (Zolotnikova, 2013: 116-117). Outra indicação da existência do culto de Zeus em Neméia já entre o final do século VIII a.C. e o início do século VII a.C. pode ser a lenda referente ao santuário no período de vida de Hesíodo (Zolotnikova, 2013: 118). A seu ver, ainda, o culto de Neméia teria espelhado, propositalmente, aquele realizado no Monte Apesas nessa época (Zolotnikova, 2013: 117). Diante da diminuição das evidências materiais do culto no Monte Apesas no século VI a.C. e do aumento de frequência em Neméia, nesse período, Zolotnikova defende que o santuário de Neméia pode ter passado a ser o principal local de culto a Zeus na área (papel do Monte Apesas entre o final do geométrico e início do arcaico) a partir desse século devido às suas condições mais favoráveis para maiores grupos de fiéis, como para o atletismo inter-regional praticado em época arcaica (Zolotnikova,

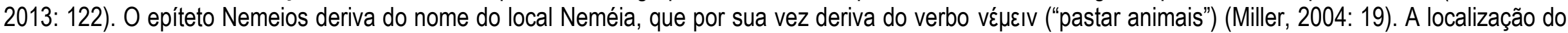
santuário no campo pode ser tomada como um indicativo do conceito inicial de Zeus Nemeios como o de um deus rústico, responsável pelas colheitas, rebanhos e da prosperidade em geral da comunidade agrícola que confiava nele (Zolotnikova, 2013: 118).

Comentário: Ao contrário de Olímpia, nas publicações mais gerais não encontramos muita informação sobre oferendas votivas a Zeus, estatuetas que representem a divindade, etc. Há, ao que parece, uma única indicação em Miller sobre uma estatueta em terracota de Zeus (Miller, 2004: 41).

Referências bibliográficas: Clemmensen, P.; Vallois, R. Le temple de Zeus à Némée, BCH (49), 1925, pp.1-20; Cooper, F.A. et alii. The temple of Zeus at Nemea: Perspectives and prospects. Atenas, 1983; Hill, B.H. The temple of Zeus at Nemea. Princeton, 1966, p.29; Lippolis et alii, 2007,p. 647; Miller, S.G. Excavations at Nemea, Hesperia (44), 1975, pp.143-172; Hesperia (45), 1976, pp.174-202; Hesperia (46), 1977, pp.1-26; Hesperia (47), 1978, pp.58-88; Hesperia (48), 1979, pp.73-103; Hesperia (49), 1980, pp.178-205; Hesperia (50), 1981, pp.45-67; Hesperia (51), 1982, pp.19-40; Hesperia (52), 1983, pp.70-95; Hesperia 1984-1996; Hesperia (57), 1988, pp.1-20; Nemea. A guide to the site and Museum. Atenas: Ministry of Culture. Archaeological Receipts Fund, 2004, pp.50-52, 153-156 (templo), 178-182 (altar); Miller, S.G. Excavations at the Panhellenic site of Nemea: cults, politics and games, em: The Archaeology of the Olympics. Madison, 1988, pp.141-151; Williams II, C.K. Excavations at Nemea, AJA (68), 1964, pp.201-202; Zolotnikova, 2013, pp. 111-123. 


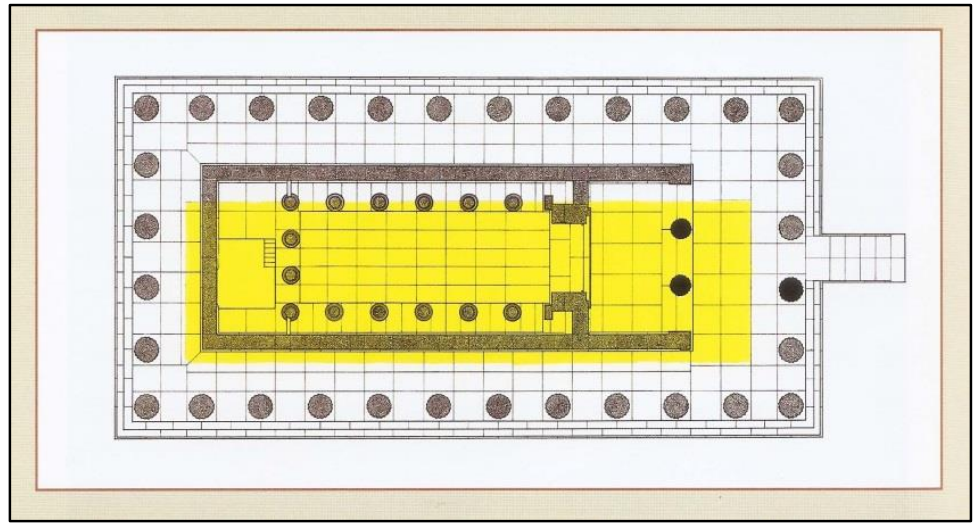

Fig.1- Planta do templo clássico de Zeus com templo arcaico (em amarelo) (em Hill 1966, no.116, pr.IV) (apud Miller, 2004: fig.110)

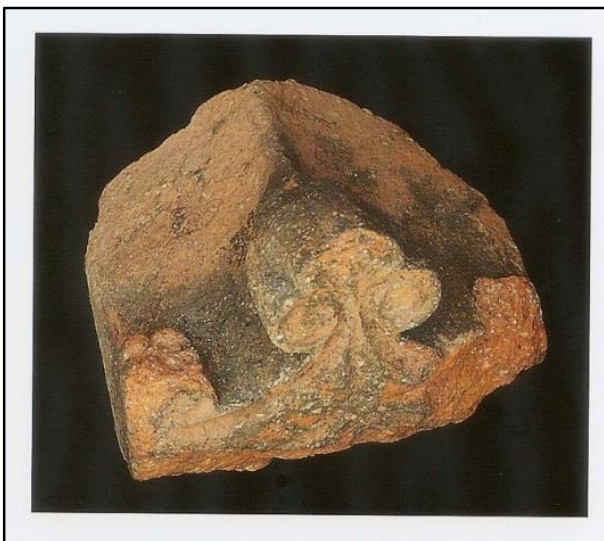

Fig.3- Antefixa de terracota do templo arcaico de Zeus (Miller, 2004: fig.28)

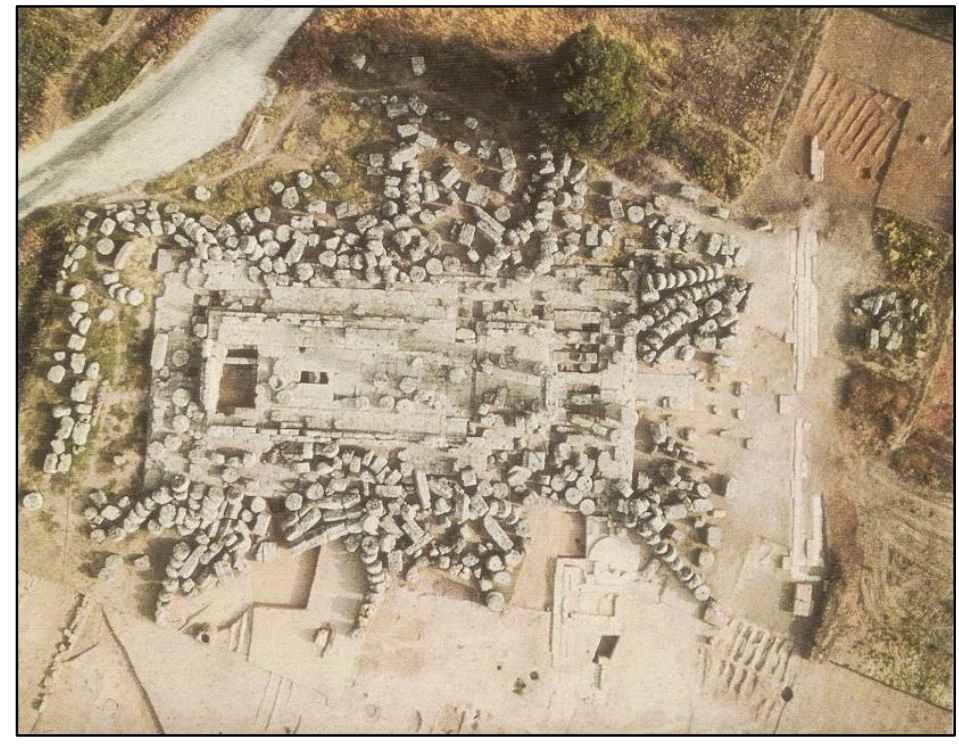

Fig.2- Vista aérea das ruínas do templo clássico de Zeus em 1977 (Miller, 2004: fig.10)

Fig.4- Bloco da parte de cima de um muro do templo arcaico de Zeus (Miller, 2004: fig.30)

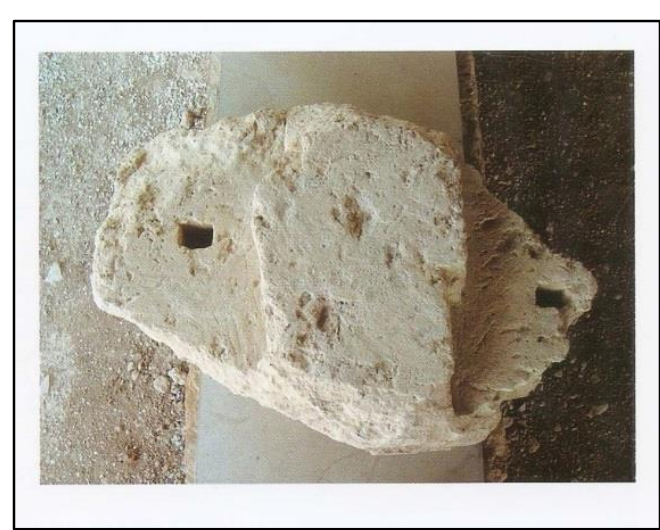




\section{Sta Marmara}

Datação: Geométrico (900-700 a.C.) - época romana?

Localização: Em uma área logo abaixo do topo do Monte Geraneia (503 m), localizado a sudoeste da pólis de Mégara (Langdon, 1976: 82; Zolotnikova, 2013: 82).

Tipo de santuário: Pico / extraurbano e sub-regional? (a partir da Idade do Ferro)?

Referências textuais: (Santuário / mito): Pausânias I, 44.9.

Inscrições: Inexistentes.

Histórico dos achados: O santuário foi escavado pela primeira vez e tão somente no final do século XIX por D. Philios, que publicou os resultados no ano de 1890 (Langdon, 1976: 82). Atualmente os restos das construções são pouco visíveis (Langdon, 1976: 82, nota 19).

\section{Documentação arqueológica}

I. Templo, altar e outros edifícios: Escavações no sítio descobriram as fundações de um templo, um altar e um complexo de outros edifícios, cujos achados receberam várias interpretações (Langdon, 1976: 82; Zolotnikova, 2013: 82). A estrutura grande próxima ao templo foi interpretada como a residência do sacerdote e uma residência particular (Langdon, 1976: 82, nota 18).

II. Objetos votivos: Os votivos mais antigos e os mais antigos fragmentos datados com segurança, encontrados no local do santuário, são datados do período arcaico, mas um dos fragmentos coletados, pintado com círculos concêntricos, pode ser de época proto-geométrica ou geométrica (Zolotnikova, 2013: 82). Tal evidência leva a propor que a atividade de culto no Sta Marmara pode ser datada do período geométrico, embora as formas iniciais do culto não sejam traçáveis (Zolotnikova, 2013: 82).

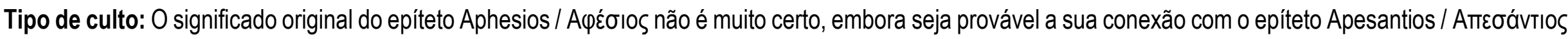

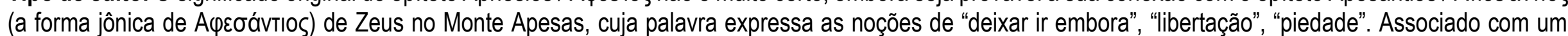
deus, tais noções parecem indicar a percepção dele como o que afasta o mal ou purifica de toda a impureza e culpa. As tradições mitológicas e etiológicas consideraram Zeus Aphesios como o "libertador de chuva" (Pausãnias, I, 44.9) ou um "salvador (de inundação)" (Zolotnikova, 2013: 83). Para Langdon, o santuário 
teria funcionado mais do que um local de culto ao deus da chuva (Langdon, 1976: 82). A vista do santuário dá para o distrito fértil agrícola de Mégara e para a maior parte do golfo Sarônico (Langdon, 1976: 82, nota 19).

Referências bibliográficas: Langdon, 1976, pp. 82; Zolotnikova, 2013, pp.82-83.

\section{Imagens}

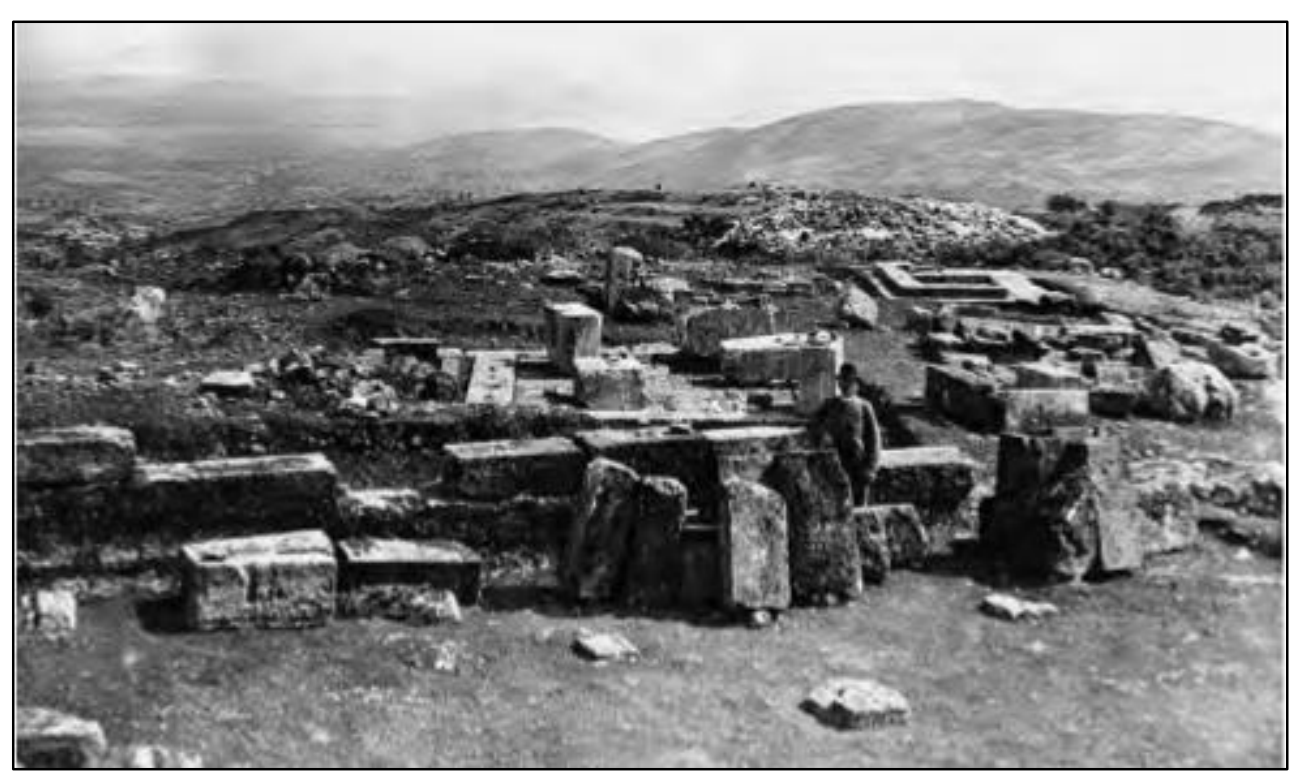

Fig.1- Santuário de Zeus Aphesios, Sta Marmara, em c.1890 (Goette, 2008: fig.77) 
Datação: Geométrico (900-700 a.C.) - época clássica (fim do séc.IV a.C.).

Localização: No declive nordeste da acrópole, em direção à estrada (moderna ou antiga?) para Larissa.

Tipo de santuário: Suburbano (a partir de?).

Referências textuais: Inexistentes?

Inscrições: ?

Histórico dos achados: 0 templo foi escavado por Arvanitopoulos na década de 1920, que pela primeira vez sugeriu a presença do templo arcaico.

\section{Documentação arqueológica}

I. Templo (séc. VI a.C.): A existência do templo arcaico foi deduzida da presença de alguns blocos em poros nas fundações do edifício do séc. IV a.C. e do achado de outros elementos arquitetônicos pertencentes ao edifício mais antigo, em parte, também reutilizados nas fundações. As dimensões e a tipologia do templo são de difícil reconstrução, mas algumas características da ordem são apreensíveis dos diversos fragmentos de colunas (com 20 escalanaturas), alguns traços de estuque, reutilizados nas fundações do lado oriental do templo mais recente, e dos outros elementos recuperados nas vizinhanças, como um fragmento de capitel dórico com uma pequena porção do equino e parte dos três anuli, cujo perfil é datado entre a segunda metade e o final do século VI a.C., e restos de antefixas e de uma cornija de terracota pintada em roxo e preto com palmetas e meandros.

O templo arcaico foi construído sobre um santuário já existente desde a época tardo-arcaica, em uma área já ocupada por uma vasta necrópole do período geométrico. Talvez por essa razão Arvanitopulos propôs a existência de mais fases arcaicas para o templo, a primeira das quais datada de 750 a.C. (Chronique, 1924).

II. Templo (séc.IV a.C.): Conserva-se parte do crepidoma do templo dórico períptero de 6x12 colunas em poros com estuque e decoração arquitetônica da primeira metade do século IV a.C. (Torelli, Mavrojannis, 2002). Lippolis diz que o edíficio é do fim do séc.IV a.C. Remanescentes estão no Museu de Atenas e de Volos. 
Tipo de culto: Costuma-se associar o culto de Zeus Thaulios no templo com o de Ennodia, divindade ínfera particularmente venerada em Pherai. Contudo, essa associação é realizada apenas com base na importância da divindade na cidade e na monumentalidade do templo no quadro das outras estruturas sagradas da pólis.

Referências bibliográficas: Béquignon, Y. Recherches archéologiques à Phéres de Thessalie, Paris, 1937, pp.44-47; Chronique des fouilles et dècouvertes archéologiques dans l'Orient Hellénique, BCH 48, 1924, pp.446-515; Lippolis, E.; Livadiotti, M.; Rocco, G. Architettura Greca: storia e monumenti del mondo della polis, dalle origini al V secolo. Milão: Mondadori, 2007, p.511-512; Østby, E. Der dorische Tempel von Pherai, OpAth 19, 1992, pp.91-120; Østby, E. A reconstruction of the Classical temple at Pherai, Em: La Thessalie. Quinze Années de recherches archéologiques - 1975-1990. Billans e perspectives. Actes du Colloque International (Lyon 17-22 avril 1990), Atenas, 1994, pp.139-142; Torelli; Mavrojannis, 2002, p.260; Van Buren, E.D. Greek Fictile Revetment in the Archaic Period. Londres, 1926, pp. 57-58.

Imagens: ? 


\section{Labraunda}

Datação: Época arcaica (sécs.VII a.C.) - época romana (sécs.IVN d.C.).

Localização: Situada na porção ocidental da Cária, na Ásia Menor, cujo território, a c.700 m acima do nívelo do mar, é limitado a norte pelo rio Meandro (Büyük Menderes Çayi) e a leste pelo rio Indos (Dalaman Cayi).

Tipo de santuário: Colinar? / extraurbano / sub-regional e inter-estadual (séc. IV a.C. ou antes?) / extra-urbano de Mylasa com função sub-regional? (a partir séc. III a.C.) com função agonística (a partir do séc. IV a.C.)?

Referências textuais: (Estátua) Estrabão; Plutarco; (Témeno) Heródoto V.119; (Culto) Heródoto I.171; (Sacrifício) V.66

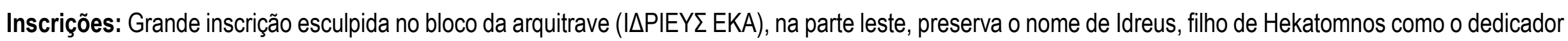
do templo de Zeus do séc. IV a.C.

Histórico dos achados: 0 templo de Zeus em Labraunda foi descoberto na campanha de escavação de 1948, durante a primeira campanha da Escola Sueca coordenada por Axel W. Persson. Nos anos de 1949 e 1950 a escavação do templo havia sido concluída (Hellström, 2007: 49).

\section{Documentação arqueológica}

I. Témeno: Está situado a noroeste em uma encosta bastante íngreme, que necessitou da construção de uma série de terraços onde os edifícios foram erigidos. Há cinco terraços, mas o antigo témeno do período arcaico e início do clássico (VI-V a.C.), consistiu em um único terraço superior, limitado a sul por um muro baixo de alvenaria poligonal a leste do templo (no.15). Na parte ocidental do terraço do primeiro templo, um pequeno templo com duas colunas in antis foi construído provavelmente em c.500 a.C. (no.16). Quando o templo do séc. IV a.C. foi erigido, o terraço do templo foi estendido c. $10 \mathrm{~m}$ a sul e 0 antigo muro do terraço (no.15) foi coberto por terra e escondido da visão (Hellström, 2007: 57).

II. Templo: Edifício 1 (final séc.VI a.C., c.500 a.C.): Era distilo in antis na fachada leste, tinha uma cela quadrada que media na parte interna 6,6 x 6,6 m, na parte externa era idêntico à cela e ao pronaos do templo posterior períptero, medindo 8,04 x 11,28 m. Um capitel jônico, grandes dentículos e alguns blocos com óvulos jônicos foram identificados como pertencentes ao antigo templo (Hellström, 2007: 111). Edifício 2 ( $2^{\mathrm{a}}$.metade séc.IV a.C., c.344 a.C.): Era orientado a leste, tinha 6 × 8 colunas jônicas e media 13,87 x 18,71 m entre os ângulos do estilóbato (Hellström, 2007: 111). A cela consistia em um pronaos de 6,57 m de largura e 3,18 m de profundidade, tinha uma cela quadrada de $6,57 \mathrm{~m}^{2}$ com uma entrada de c.2,44 m e um opistódomo muito raso de 1,60 m de profundidade. 
Houve provavelmente duas colunas entre as antas orientais e é também provável que o opistódomo tivesse duas colunas para conter a arquitrave entre as antas, embora elas bloqueassem o opistódomo quase inteiramente (Hellström; Thieme, 1982: 40). A altura das colunas foi calculada em c.6,4 m incluindo o capitel. Um capitel jônico de canto está ainda localizado no ângulo noroeste. Na parte de trás do templo, alguns blocos de mármore. No topo do muro posterior da cela. mostra a disposição da superestrutura: acima do bloco de arquitrave segue um bloco com dentículos e um geison. Na frente leste, uma grande inscrição esculpida

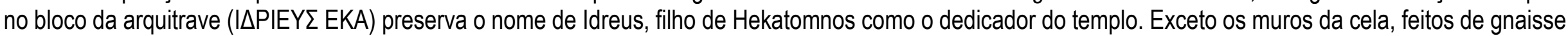
local, o templo era todo de mármore. Partes do pavimento e degraus de mármore ainda estão preservados in situ. 0 interior do templo, onde a estátua de culto de Zeus esteve originalmente colocada, está completamente destruído (Hellström, 2007: 113 e 115). Preservaram-se o eutintério, partes do crepidoma (no ângulo noroeste, na parte norte da fachada oeste e na metade do lado norte), doo estilóbato (no pteroma norte e no pronaos), e blocos da arquitrave (Hellström; Thieme, 1982: 39). A datação do templo foi bem estabelecida graças à inscrição de dedicatória na fachada superior da arquitrave da frente leste, que preserva o nome de Idreus que morreu em 344 a.C. Não há indicações sobre se qualquer detalhe do templo tivesse sido deixado inacabado ou se alguma parte do edifício foi terminada em alguma data após o séc.IV a.C. Acredita-se que a dedicação foi realizada no ano de 344 e que ao menos a cela e a parte leste da perístasis estivesse acabada (Hellström; Thieme, 1982: 47).

III. Altar: A pequena estrutura quadrada $(\mathrm{H})$, que está confinada na frente leste da fundação do templo, foi um altar da época do primeiro templo. Se sim, o caráter sagrado e inviolável da área do altar pode ter impedido estender o novo templo mais para leste (Hellström, 2007: 111).

Tipo de culto: Labraunda foi um santuário interestadual sagrado para os antigos cários que, uma vez por ano, vinham ao local para sacrificar no altar, competir em corridas no estádio ou assistir aos jogos e festejar durante cinco dias em honra a Zeus. A cidade antiga mais próxima de Labraunda é Mylasa, a c.14 km de distância. Era o santuário mais importante para os antigos cários e parece ter sido um santuário independente, sem ter pertencido a nenhuma cidade, local de peregrinação controlado por sacerdotes e pertencente ao povo dos vilarejos ao redor (Hellström, 2007: 15). O santuário passou a pertencer Mylasa no séc.llI a.C. (Hellström, 2007: 41). É concebíbel que Labraunda foi vista primeiro como um local sagrado devido a uma rocha notável logo acima do santuário, que tem a aparência de ter sido dividida em duas partes por um raio. É muito provável que esta rocha junto as tempestades de trovão naquele tempo tenham sido interpretadas pelo povo local como um sinal do deus do céu (Hellström, 2007: 17).

Comentário: É bem provável que o culto e témeno de Zeus em Labraunda seja muito mais antigo que o primeiro templo do final do séc.VI a.C. As escavações no témeno de Zeus encontraram cacos cerâmicos da metade do séc.VII a.C. a leste do templo do deus (Hellström, 2007: 40). Os testemunhos literários também propiciam indicações da anterioridade da área sagrada. Estrabão diz que a estátua de Zeus do templo era um xoánon que, em relevos e moedas, é mostrado com uma lança na mão esquerda e um machado duplo na direita. Plutarco relata que esse machado duplo tinha sido uma vez conquistado por Héracles da rainha das Amazonas e dado aos reis lídios; subsequentemente, na metade do séc.VII a.C. o rei Arselis de Mylasa deu o machado para a estátua de Zeus em Labraunda, 
após tê-lo recebido como presente do rei Gyges de Sardes como retribuição pela sua ajuda na luta pelo poder na Lídia (Hellström, 2007: 113). É preciso dizer que a Cária no séc.VI a.C. formava parte do império persa e que no séc.IV a.C. foi controlado por sátrapas de uma dinastia local (Hellström, 2007: 15).

Referências bibliográficas: Hellström, P. Labraunda. A guide to the Karian sanctuary of Zeus Labraundos. Istambul: Ege Yayinlari, 2007; Hellström, P.; Thieme, T. The temple of Zeus. Labraunda Swedish Excavations and Researches, vol.I Part 3. Estocolmo: Paul Aström Publishers, 1982; LaBuff, J. Karian sympoliteiai: causes and implications of political merger at the periphery of the Greek world (Dissertation). University of Pennsylvania, 2010; Thieme, T. The Architectural remains of Archaic Labraunda, em: Les grands ateliers d'architecture dans le monde égéen du Vle siècle av.J.-C. Varia Anatolica 3. Istambul, 1993, pp.47-55; Williamson, C. City and sanctuary in Hellenistic Minor. Civic identity in the sacred landscapes of Mylasa and Stratonikeia in Karia (Dissertation). University of Groningen, 2012.

\section{Imagens:}
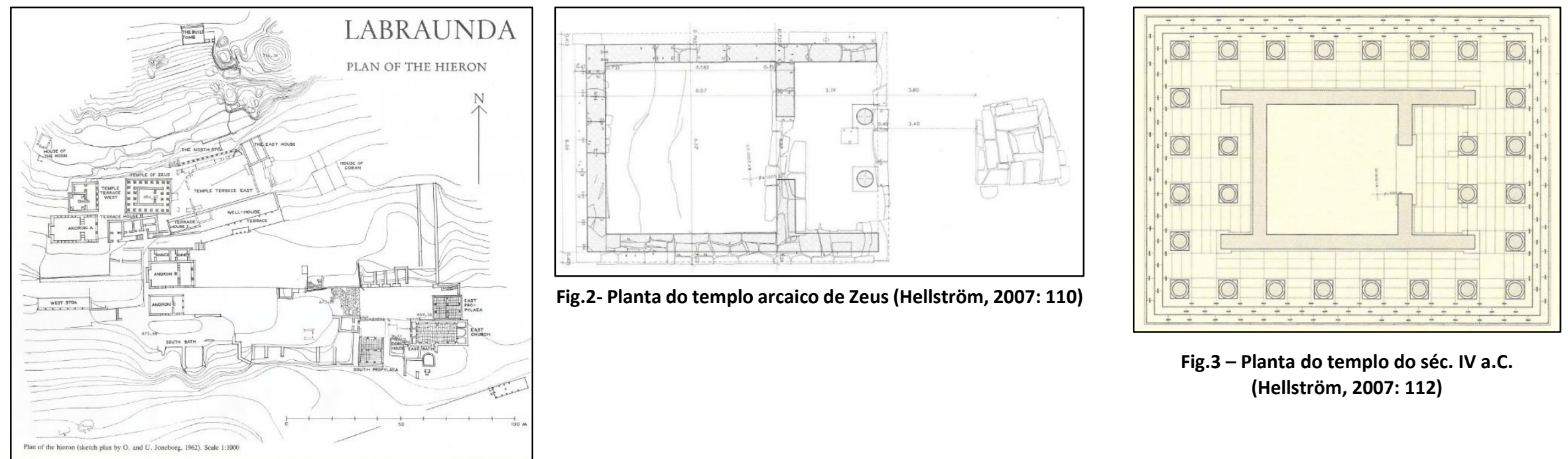

Fig.2- Planta do templo arcaico de Zeus (Hellström, 2007: 110)

Fig.3 - Planta do templo do séc. IV a.C. (Hellström, 2007: 112)

Fig.1- Planta de Labraunda (Hellström; Thieme, 1982: pr.26) 


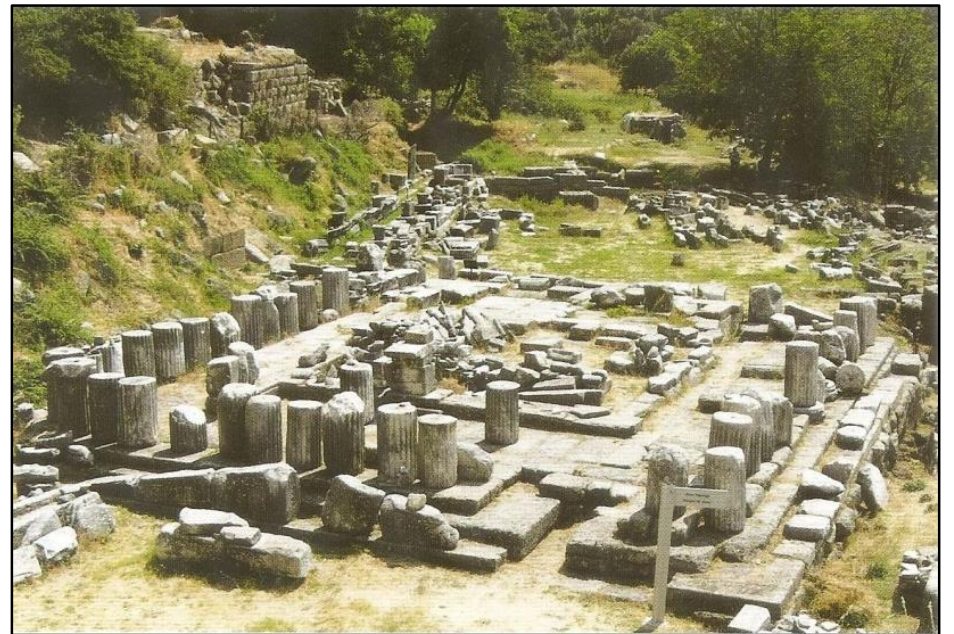

Fig.4- Vista do templo de Zeus a partir de sudoeste (Hellström, 2007: 110)

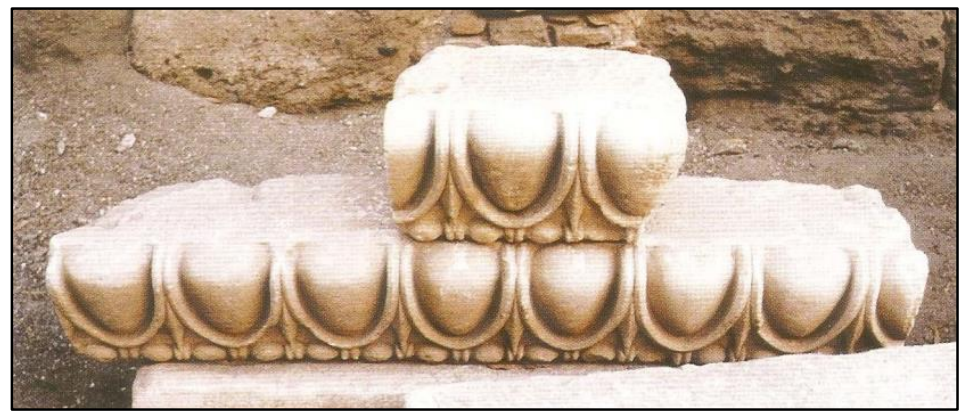

Fig.6- Blocos com óvulo jônico do templo arcaico de Zeus, Museu de Bodrum (Hellström, 2007: 111)

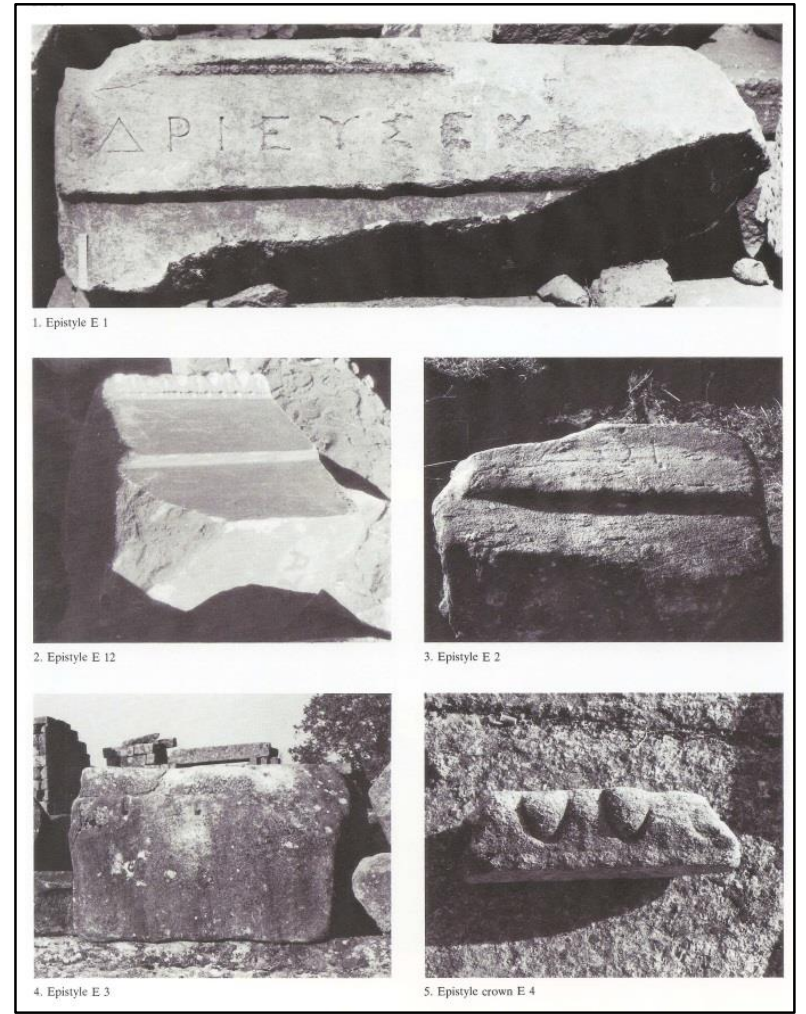

Fig.5- Blocos do epistilo; acima bloco E1 com inscrição Idrieus (Hellström; Thieme, 1982: pr.16) 
Datação: Início da época arcaica (séc. VII a.C.) - início da época helenística (séc. III a.C.).

Localização: No cume do Monte Cynthos (112,60 m), que está localizado a $2 \mathrm{~km}$ da extremidade norte da ilha e 2,6 km da extremidade sul, onde o limite do monte é marcado pelo vale de Inopos (Plassart, 1928: 1).

Tipo de santuário: Colinar / dentro de um santuário interestadual de Apolo.

Referências textuais: (Território/sagração) Píndaro, Peã 12.5-10.

Inscrições: Inscrições referentes a Zeus incisas nos cacos cerâmicos do séc. VII a.C. e inscrições do séc. II a.C. (aquelas recuperadas por Lebègue?) sobre prescrições sobre o uso do santuário de Zeus

Histórico dos achados: As escavações no Monte Cynthos foram as primeiras pesquisas arqueológicas realizadas pela Escola Francesa em Delos no final do século XIX. Durante sete semanas em 1873, A. Lebègue escavou a terraça do santuário helenístico de Zeus e descobriu vinte inscrições que asseguravam a existência do santuário entre as ruínas. Em 1881, A. Hauvette desenterrou a área do terraço do santuário, tendo sido o trabalho concluído por M.P. Roussel nas campanhas de 1909 a 1911. Novas escavações foram realizadas por Roussel em 1913 e depois em 1920 por M.R Demangel (Plassart, 1928: 8).

\section{Documentação arqueológica}

As escavações francesas no Monte Cynthos encontraram uma série de habitações, chamadas de "pré-helênicas" por Plassart. É difícil prever a sucessão dos tempos a partir das descobertas feitas nos aterros do terraço do santuário, contudo, sabe-se que depois de um longo abandono, o cume do Cynthos foi frequentado de novo nos tempos da cerâmica de estilo micênico. Após este período, vasos de decoração geométrica foram introduzidos no cume do monte. Os cacos, pouco numerosos, parecem ser provenientes de cerâmicas das Cíclades (geométrico insular e geométrico argivo-cicládico), dos quais os mais interessantes são datados do séc. VII a.C. (Plassart, 1928: 52).

I. Santuário e objetos votivos: De acordo com A. Plassart, a construção do santuário de Zeus e Atena no séc. III a.C. destruiu os restos das construções anteriores que poderiam estar no nível mais alto do que o novo terraço (o helenístico). No cume do Cynthos nenhum resto de arquitetura pode ser relacionado a alguma construção anterior ao séc. III a.C. No entanto, o estudioso diz sobre uma linha de fundação no interior do terraço helenístico: um muro oeste-leste de 8 
$\mathrm{m}$ de comprimento, paralelo à seção mediana do recinto norte, a uma distância de 1,85 m (Plassart, 1928: 51). Esta fundação, que alcança mais de $1 \mathrm{~m}$ de profundidade da rocha e está inclinada na direção sul, traz algumas lajes de época helenística. Plassart supõe que o pequeno naós, anterior às construções do tempo da independência deliana (314-116 a.C.), poderia estar sobre esta linha de fundação e o rochedo norte (Plassart, 1928: 52). Também afirma isso com base no achado de cacos cerâmicos arcaicos e um pequeno escaravelho de faiança encontrados entre as pedras desta fundação (Plassart, 1928: 52). Entre a localização da fundação e o ponto onde se deveria ter acesso ao cume a partir de oeste, foi recolhido um grande número de cacos cerâmicos e uma ânfora também arcaica. Numerosos restos de ossos de animais, cacos sem decoração de grandes vasos, que deveriam conter ossos, cacos mais finos de vasos decorados arcaicos, uma plaqueta de bronze em forma de folha, figurinhas de terracota do mesmo período, foram todos recuperados em uma localização aos pés da parede sul do rochedo central, correspondente às pequenas construções que Plassart chama de "pré-helênicas" (a e $\beta$ ) e aos espaço intermediário (Plassart, 1928: 52). Segundo o estudioso, estes foram enterrados à direita dos restos de oferendas e sacrifícios no mais tardar na época do estabelecimento do terraço no séc. III a.C. e não trazem indicações sobre os edifícios construídos nos tempos das antigas habitações e a época helenística (Plassart, 1928: 52).

II. Objetos votivos: Os cacos cerâmicos geométricos recuperados na área do santuário de Zeus pertencem aos estilos orientalizante e ático, dos quais fragmentos são numerosos (Plassart, 1928: 57). Alguns portam inscrições incisas que nos asseguram que foram trazidos para o cume do Cynthos para serem depositados no santuário de Zeus. Tais cacos evidenciam que o culto de Zeus foi fixado no cume no séc. VII a.C.(Plassart, 1928: 57-58). Plassart destaca seis

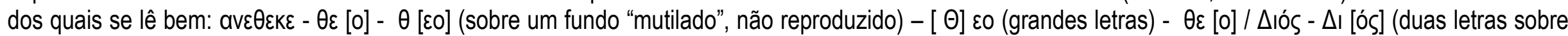
cada "anse") (Plassart, 1928: 58). Os objetos mais antigos encontrados entre as oferendas trazidas ao Cynthos são os vasos decorados do estilo geométrico que datam do séc. VII a.C. (Plassart, 1928: 64). Foram encontrados também fragmentos cerâmicos do estilo insular geométrico (séc. XI a.C.), outros do estilo argivocicládico (IX a.C.), sendo a maior parte dos fragmentos desse grupo mais antigo datados do século VIII a.C. (Zolotnikova, 2013: 108).

Tipo de culto: De acordo com Zolotnikova, os fragmentos cerâmicos com inscrições referentes a Zeus indicam com segurança a prática de culto a Zeus no topo do monte em Delos a partir do século VII a.C., embora possa ser te iniciado de modo moderado muito antes, no século VIII a.C. ou ainda entre os séculos XI-IX a.C., conforme indicam achados cerâmicos desses períodos (Zolotnikova, 2013: 108). Trata-se de um culto de Zeus dentro de um santuário interestadual dedicado a Apolo. Segundo Plassart, Zeus Kynthios é o deus da montanha de Delos (Plassart, 1928: 66). O culto de Atena foi introduzido posteriormente ao de Zeus, somente no séc. VI a.C., como indicam as oferendas de estatuetas femininas, imagens da deusa, encontradas no local (Plassart, 1928: 62-63 e 68). A veneração da deusa na ilha teria aumentado/consolidado no momento da influência ateniense na ilha (Plassart, 1928: 69). Ao tentar compreender a razão de ser do culto de Zeus no monte deliano, Plassart tenta traçar associações entre o culto de Zeus Kynthios com o Zeus cretense. Correlacionando as prescrições ao uso do santuário de Zeus em Delos (registradas nas inscrições do séc. II a.C. e que diz poder remontarem a costumes de tempos mais antigos da área sagrada) com o texto de Eurípides (Cretense, frag. 472), ele encontrou similaridades no rito entre Delos e o Monte Ida: 0 uso de vestimentas brancas, castidade, abstinência de carne (Plassart, 1928: 66-67). Para Zolotnikova, é tentador derivar a prática de culto no local das tradições minoicas religiosas, contudo, a natureza original de Zeus Kynthios é muito desconhecida. Sua presença independente na ilha, dedicada a um deus jovem como Apolo (o filho mais querido de Zeus de acordo com 
as tradições) pode sugerir que o deus foi sempre visto em Delos como um deus-pai. Cerimônias para beber vinho parece terem sido praticadas em honra a Zeus, como sugerem os achados cerâmicos. Nada mais preciso é conhecido nesse ponto. Além disso, Zolotnikova não relaciona o culto de Zeus ao de Hera, fundado no início da Idade do Ferro (Zolotnikova, 2013: 108).

Referências bibliográficas: Bruneau, P.; Ducat, J. Guide de Délos. École Française D’ Athènes. Paris: Bocard, 1966; Plassart, A. Les sanctuaires et les cultes du Mont Cynthe. Exploration archéologique de Delos. Paris: Boccard, 1928; Torelli, M.; Mavrojannis,T. Grecia. Guide Archeologiche. Milão: Mondadori, 2002, p.382; Zolotnikova, 2013, p.108.

\section{Imagens:}

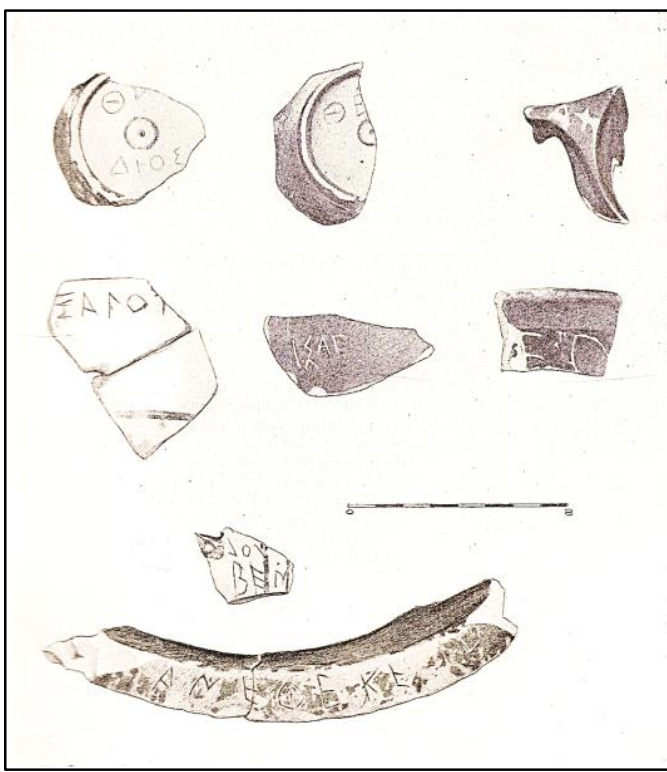

Fig.1- Cacos cerâmicos do séc. VII a.C. com inscrições referentes a Zeus (Plassart, 1928: 57, fig.48)

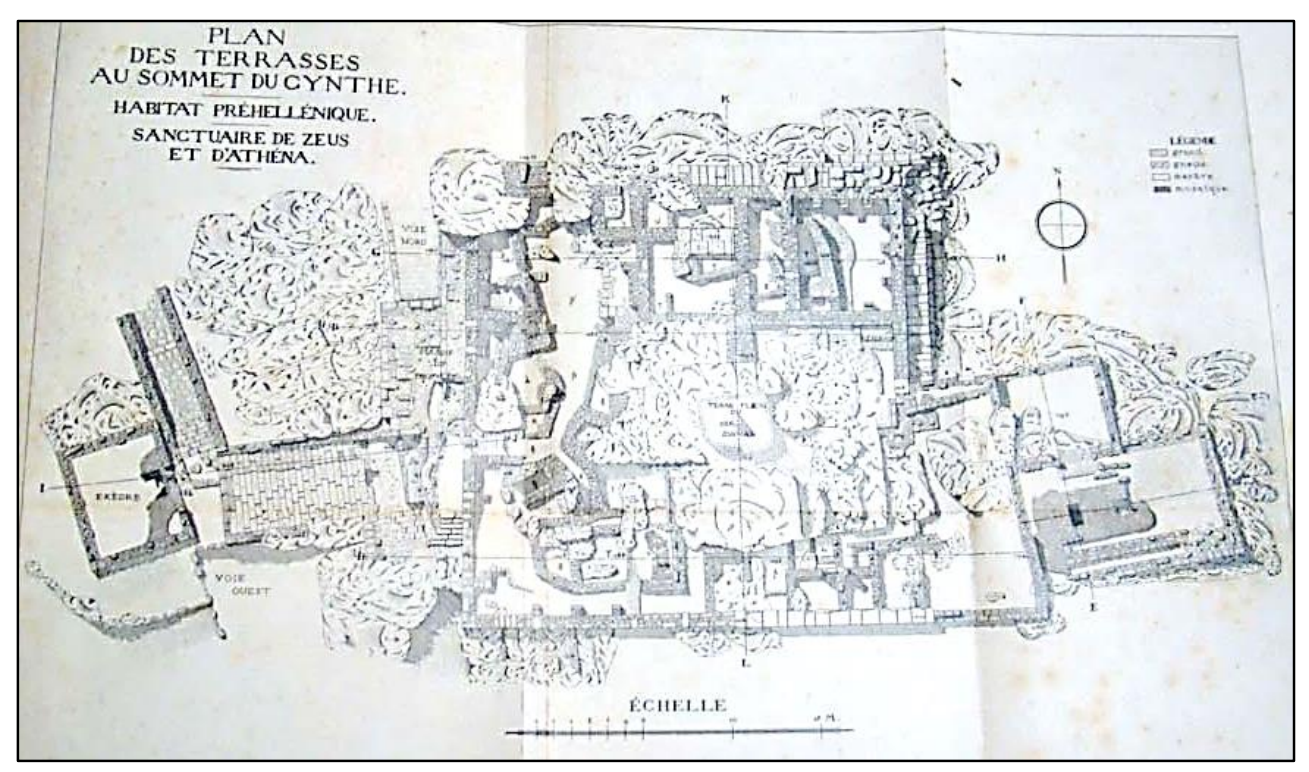

Fig.2- Planimetria do terraço do santuário de Zeus no Monte Cynthos (Plassart, 1928, pr.III) 
Datação: Início da época arcaica (séc. VII a.C.) - época clássica (séc. IV a.C.).

Localização: No Monte Zas (1003 m), na parte meridional da ilha, a 35 m a norte do marco moderno, perto do cume (Langdon, 1976: 111).

Tipo de santuário: Pico / extraurbano e sub-regional (a partir do séc. VII a.C.).

Referências textuais: Localização (Diodoro 5.51.4).

Inscrições: Inscrição em rocha (hóros?) na encosta norte da montanha, em Levgasa, no caminho que leva ao topo: "montanha de Zeus Melósios" (IG XII, 5, 48 - séc.IV a.C.) e outra inscrição rupestre "Zevs" (Langdon, 1976: 111).

\section{Histórico dos achados: ?}

\section{Documentação arqueológica}

Em uma área plana, a $35 \mathrm{~m}$ a norte do topo, há a presença de um depósito de solo enegrecido contendo uma grande quantidade de ossos de animais queimados e cacos de potes, cuja maior parte não é diagnosticável. Eles são revestidos com um verniz amorfo, listrado marrom ou preto e pertencem a simples formas abertas assinaláveis aos séculos VII e VI a.C. Não há evidências de uma estrutura, mas é bem possível que a cerâmica e os fragmentos de ossos representem oferendas feitas em um altar pequeno e rústico perto do cume (Langdon, 1976: 111). A única peça seguramente datável deste depósito é o fragmento de uma base de um kotyle corínto do séc.VII a.C.(Langdon, 1976: 111, nota 37).

Tipo de culto: Conforme o IACP (p.762) e Langdon (p.111, nota 36) Diodoro (5.51.4) localiza o santuário de Zeus Melósios no lado leste do Monte Drios (moderno Ozia) perto de Philoti. O Monte Drios, conforme Langdon, é o Monte Zas. Conforme Zolotnikova, nenhum santuário organizado do deus foi relatado. $O$ epíteto "Melósios" tem um significado relacionado à pele de carneiro (Zolotnikova, 2013: 109). Para essa autora, as ideias religiosas de base egéia, habitantes de uma caverna no monte, com uma longa e contínua habitação (do neolítico I até o início do arcaico) podem tem propiciado a base para o culto no Monte Zas - 0 conceito de criança nascida da deusa terra, já que ali se diz Zeus ter sido amamentado (Zolotnikova, 2013: 109).

Referências bibliográficas: IACP, p. 762; Langdon, 1976, p.111; Zolotnikova, 2013, p.108-109. Imagens: ? 
Datação: Época arcaica (final do séc. VII a.C.) - época clássica (metade do séc.IV a.C.).

Localização: No setor central da colina de Gaggera (a oeste da acrópole), a noroeste do santuário de Malophóros, não distante da necrópole de Manicalunga.

Tipo de santuário: Colinar? / extraurbano.

Referências textuais: Inexistentes.

Inscrições: Inscrições nas estelas referem-se a Meilichios (Veronese, 2006: 527).

Histórico dos achados: Escavado por E. Gabrici na década de 1920.

\section{Documentação arqueológica}

I. Témeno: De forma quase quadrada, abriga altar e naískos (Lippolis, 2007: 838; Veronese, 2006: 527-528).

II. Naíkos e altar: Datado do primeiro quartel do séc.VI a.C, está localizado no setor oriental do témeno, mede 2,97 x 5,30 m era articulado em pronaos e naós distilo in antis, tinha um crepidoma similar, do ponto de vista planimétrico, ao do mégaron de Malophóros, colunas monolíticas dóricas e entablamento com elementos da ordem jônica. Tinha uma "rastrematura" evidente debaixo ao alto do edifício e o acesso ao naíkos provavelmente se dava na parte leste. Conservaram-se do edifício um único bloco em correspondência com a base na qual foi obtido/deduzido o crepidoma, outros blocos estão inseridos nos ângulos da base segundo a técnica de "armação horizontal", talvez de finalidade anti-sísmica. A elevação é constituída por muros com espessura de 0,37m que se afinam na parte de cima, blocos do entablamento obtidos dos elementos escultóricos unidos, e provável cobertura de madeira. 0 edifício era precedido por um altar (Veronese, 2006: 527-528).

III. Campo de estelas e altar com "betili": Datado entre o final do séc. VII-V a.C. (altar) e VI-III a.C. (estelas), localizam-se na área a oeste do témeno. O campo de estelas e "cippi" anicônicos, de várias formas e datações, é uma área com deposições votivas caracterizada pela presença de um altar de tipo oriental com três "betili" sobre alta base (1,05m) situado no centro da área sagrada (Grotta, 2010: 41, 47, 49, 53 e 57; Lippolis, 2007: 838; Veronese, 2006: 527-528).

IV. Material votivo: Estelas, cerâmicas e estatuetas misturadas a material com combustão (Veronese, 2006: 527). 
Conforme Veronese, para a época arcaica os dados são muito lacunosos. Uma fase intensa de monumentalização da área sagrada é atestada a partir do séc. $V$ a.C. e a destruição de toda a área ao redor da metade do século IV a.C. (Veronese, 2006: 527). A datação das estruturas é controversa, sobretudo a do edifício sagrado de época arcaica, de acordo com os últimos estudos (Veronese, 2006: 527-528).

Tipo de culto: Divindade titular identificada com Zeus Meilichios que talvez tenha sido cultuado ao lado de uma divindade feminina. Zeus Meilichios, cujo culto apresenta implicações escatológicas, é uma divindade estritamente ligada ao mundo dos mortos (Veronese, 2006: 527). As particularidades que caracterizam o témeno denotam, do ponto de vista cultual e arquitetônico, a constante interação entre o mundo grego, o fenício-púnico e o elímio. Não está excluída a frequentação pré-grega da área, contudo, no estado atual das pesquisas permanecem abertas muitas questões sobre a relação entre gregos e indígenas (Veronese, 2006: 527-528). Segundo Grotta, se tratou de um culto que exprimiu uma forte relação com o ambiente familiar e nobiliário, predominando a característica privada da experiência religiosa (Grotta, 2010: 226). O culto praticado no campo de estelas não demonstra nenhum aspecto público (Grotta, 2010: 226).

Comentário: Não está claro pela bibliografia consultada (Lippolis e Veronese) se há dois altares na área sagrada.

Referências bibliográficas: Famà, Tusa, V. Le stele del Meilichios a Selinunte. Padova, 2000; Gabrici, E. II santuario della Malophoros a Selinunte, MonAnt (32), 1927, col.5-414 (91-105); Grotta, C. Zeus Meilichios a Selinunte. Historica 9. Roma: L’Erma, 2010; Lippolis, 2007, p.838; Tusa, V. Nuovi rinvenimenti nell'area del santuario della Malophoros a Selinunte. II tempietto in Sicilia, 1977, pp. 115-118; Tusa, V. Nuovi rinvenimenti nell'area del santuario della Malophoros a Selinunte, SicArch (XVII), 54-55, pp.11-15; Vaccarello, P. Rilievo del tempietto di Zeus Meilichios a Selinunte, SicArch (XIX), 60-61, 1986, pp. 89-96; Veronese, F. Lo spazio e la dimensione del sacro. Santuari greci e territorio nella Sicilia arcaica. Pádua: Esedra, 2006, pp.527-528. 


\section{Imagens:}

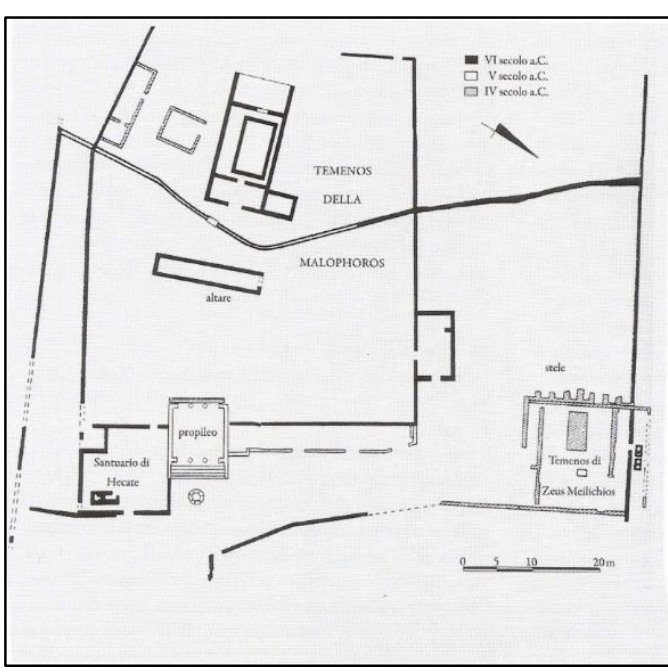

Fig.1-Planimetria santuário de Malophóros e Zeus Meilichios (por Hellmann, 2006) (apud Lippolis, 2007: 837, fig.34.9.4b)

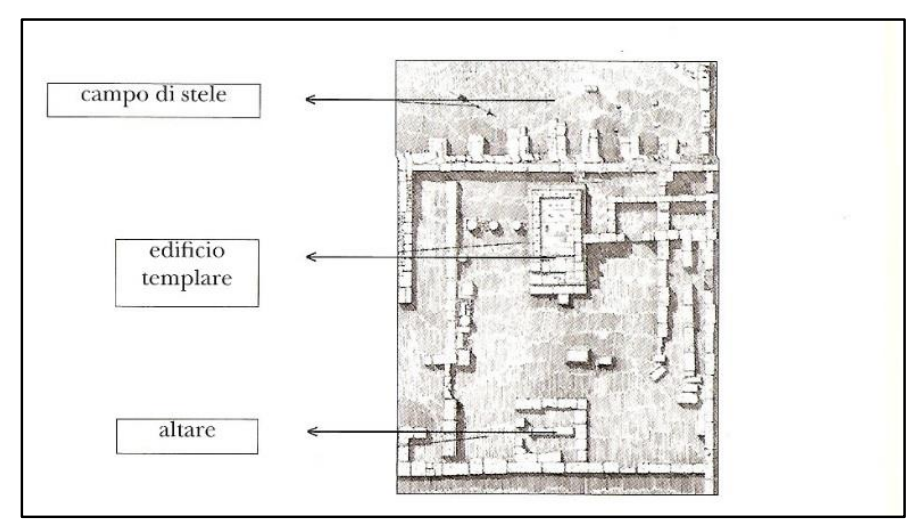

Fig.2- Planimetria do santuário de Zeus Meilichios (Veronese, 2007:fig.11.17)

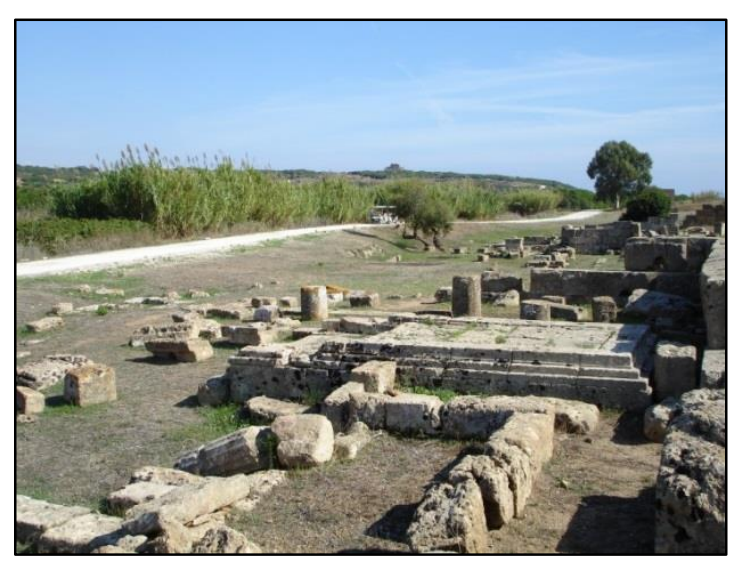

Fig.3- Vista do santuário de Zeus Meilichios (acervo Labeca/2005) 
Datação: Época arcaica (final do séc.VII a.C.) - época helenística (séc. III a.C.?).

Localização: No setor sudeste, na área do rio llissos em Agrai, entre o Olimpiéion, a denominada "ilha das rãs" e o templo jônico (Greco, 2011: 489).

Tipo de santuário: Planície e vale / extraurbano.

Referências textuais: (Diasia) Sch.Ar.Nu. 408c; Lucianus Icar. 24; Tucídides 1.26.6; Ar.Nu. 408-411 e 863-864; Plutarco Moralia 477d; Xenofonte Anabasis 7.8.4-5; Sch.Th.1.126.6); (Altar) Pausânias I, XXXVII.2-5.

Inscrições: Sobre a festa Diasia e o deus em dois calendários sacrificiais (IG I3 234.3-5, 480-460 a.C.); sacrifício dos demotai de Erchia e outros demos áticos no santuário de Zeus Meilichios durante as Diasia (SEG 21.541A.37-43, SEG 33.147.34-35, metade do séc.IV a.C.).

\section{Histórico dos achados: ?}

\section{Documentação arqueológica}

I. Objetos votivos: A presença de Zeus Meilichios na área do llissos parece ser confirmada pelo achado de uma série de relevos votivos datados entre os séculos IV e III a.C., alguns dos quais com dedicação ao deus, outros, simplesmente, atribuídos com base na iconografia (Greco, 2011: 489).

Tipo de culto: As Diasia, festas dedicadas a Zeus Meilichios no dia 23 de Antestérion (fevereiro-março), tinham fama de serem antigas. De acordo com Tucídides a festa já ocorria no final do séc.VII a.C., no tempo em que Cílon conjurou. A festa era muito popular na época clássica, cada indivíduo participava conforme suas possibilidades, oferecendo vítimas ou bolos rústicos em formatos de animais em substituição. A importância do culto na vida comunitária é atestada da presença do deus em dois calendários sacrificiais datados, respectivamente, de 480-460 a.C., e da presença de gente proveniente de outros demos áticos, como o de Erchia,que cumpriam sacrifícios no santuário urbano de Zeus Meilichios, como indica a inscrição da metade do séc.IV a.C. Sobre a localização do santuário, Tucídides coloca a sede da festa fora da cidade (ekso tes poleos), mas o calendário de Erchia permite localizá-la em Agrai. Controvérsias permanecem sobre a existência de um local de culto. Pensa-se no envolvimento de Zeus nos ditos Pequenos Mistérios e, em ligação às suas valências purificadoras, diversos estudiosos, a partir de Mölibus (1935/16), propuseram ambientar as Diasia no Metroon de Agrai. Todavia, não se pode excluir que o culto fosse realizado sobre um simples altar, como no caso de um santuário de Zeus assinalado por Pausânias ao longo da via sagrada às margens do Cefiso. Em todo caso, a presença 
de Zeus na área do llissos, em particular entre o templo jônico, a ilha das rãs e o Olimpiéion, parece confirmada pelo achado de uma série de relevos votivos dos séculos IV e III a.C. (Greco, 2011: 489).

Referências bibliográficas: Deubner, Attische Feste. Berlin, 1932, pp.155-157; Greco, E. Topografia di Atene. Sviluppo Urbano e Monumenti dalle origini al III secolo d.C. Tomo 2. Colline sud-occidentali-valle dell'llisso. Scuola Archeologica Italiana di Atene, SAIAA 1. Atenas; Paestum: Pandemos, 2011, p.489; Jameson,

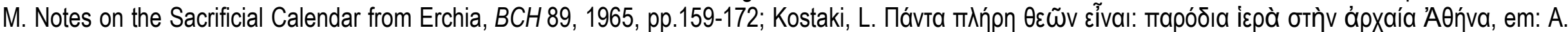

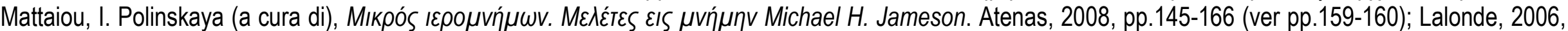
pp.70, 107-112; Parke, H.W. Festivals of the Athenians, Londres, 1977, pp.120-122, 176; Parker, R. Polytheism and Society at Athens. Oxford, 2005, p.466; Saporiti, M. Recensione a Lalonde 2006a, ASAtene 84, pp. 780-791, 2006; Simon, E. Festivals of Attica. An Archaeological Commentary, Madison (Wisc.), 1983, pp.12-15.

Imagens: ? 


\section{Siracusa}

Datação: Época arcaica (final do séc. VII a.C.) - época romana.

Localização: Situado a sul de Lisimeleia e da foz dos rios Anapos e Ciane, respectivamente, no subúrbio de Polichne, após a necrópole de Fusco, e a oeste da estrada Helorina.

Tipo de santuário: Planície / extraurbano.

Referências textuais: (Santuário) Plutarco, Nícias XIV.?; Pausânias X, XXVIII.3-6; (Templo e estátua) Diodoro X.28.1-2; (Templo) Diodoro XIII.6.4 / XIII.7.5 / XIV.62.3-4 / XIV.63.3 / XIV.74.5 / XIV.76.2 / XVI.68.1-2 / XX.29.2-3; Tucídides VI.LXIV.1-2 / VI.LXV.3 / VI.LXX.3-4 / VI.LXXV.1-2 / VII.IV.6-7 / VII.XXXVII.3 / VII.XLII.6; Plutarco, Nícias XVI.?; (Olimpiéion romano na ágora) Diodoro XVI.83.2; (Anfipolia de Zeus Olímpio) Diodoro XVI.70.3-6.

Inscrições: Inexistente?

Histórico dos achados: A primeira escavação foi realizada em 1839 pelo engenheiro Franc. Sav. Cavallari cujos achados e proposições sobre a posição e altimetria do templo de Zeus Olímpio, foram publicados na obra de Serradifalco, Le antichità della Sicilia. A primeira escavação sistemática do Olimpiéion ocorreu em 1893 sob supervisão de Paolo Orsi e foi promovida pelo Serviço Arqueológico do Reino. Nesta primeira campanha, Orsi descobriu as partes do templo que foram recobertas por Cavallari após suas pesquisas na área, e centrou seu objetivo em evidenciar no terreno os traços da arquitetura do templo e recolher evidências arquitetônicas e decorativas (Orsi, 1903: 369-370). Em 1902, P. Orsi realizou a segunda escavação na área. As duas campanhas revelaram as partes principais do estilóbato oriental, e o ângulo sudeste que sustenta uma das colunas sobreviventes; três traços do estereóbato meridional; dois blocos do ângulo sudoeste, os quais permitiram o conhecimento do comprimento do edifício; e parte do estereóbato setentrional (Lissi, 1958: 197-198). Em 1953, E. Lissi coordenou uma nova campanha que durou três meses e trouxe à luz todo o encaixe na rocha para a colocação dos blocos da perístasis; fragmentos de colunas e de um capitel; muitos fragmentos de terracota arquitetônica que permitiram a reconstrução da decoração do lado lateral do templo, dos quais o principal achado é o friso decorativo da sima; e alguns fragmentos decorativos, dos quais é destaque o achado de partes de um gorgoneion. De acordo com informações obtidas em Siracusa, a Soprintendenza Archeologica reiniciou em 2009 escavações na área ao redor do santuário.

\section{Documentação arqueológica}

I. Templo: A arquitetura do Olimpiéion o data do início do século VI a.C. Já a evidência de ocupação sícula e a informação de Diodoro sobre a estátua de Zeus são, para Orsi, indicações da existência de um templo em madeira contendo um xóanon do deus no final do século VIl a.C. construção templária em madeira, 
então, foi substituída pela de pedra no início do século VI, permanecendo da época anterior a antiga imagem de madeira do deus. Na bibliografia sobre o edifício não há uma datação precisa seguida por todos os autores. A cronologia que o situa no fim do século VII e início do VI a.C. foi afirmada por Orsi, Koldewey e Puchstein, Dumbabim, Pace, Dinsmoor e Coarelli-Torelli. Datas precisas no século VI a.C. foram colocadas por Marconi (580-570 a.C.), Robertson (575 a.C.) e por Berve-Gruben (560-550 a.C.) (Lissi, 1958: 199, nota 2). Em nossa análise, então, aceitamos e seguimos a datação mais anterior do templo proposta por Marconi. Orientado leste-oeste, o templo de Zeus Olímpio é dórico e hexastilo com uma segunda fileira de colunas no lado oriental. A característica alongada e estreita da planta foi definida pelas 6 × 17 colunas e pelas dimensões de 20,50 × 60 metros. Devido ao estado de conservação da área do edifício no nível do estilóbato, não é clara a articulação dos espaços internos. Contudo, a hipótese é de que o templo tinha uma cela alongada com pronaos distilo in antis e um ádito sem opistódomo (Coarelli; Torelli, 1984: 281; Gullini, 1989: 471; Lissi, 1958: 199, nota 2; Marconi, 2007: 50; Mertens, 2006: 111; Veronese, 2006: 326). As fundações do templo eram largas e não profundas devido ao tipo de solo em que foi erigido o edifício. 0 exame da crosta rochosa feito em diversos pontos do estilóbato levou Orsi a concluir que os construtores removeram o estrato superior do solo de origem vulcânica e escolheram o leito de areia amarela (macia, compacta e elástica) para fazerem a incisão e estabeleceram as fundações, que não ultrapassam 1 metro de profundidade. Desse dado, concluiu-se que toda a estrutura da arquitrave pode ter sido feita de madeira e de terracota (Orsi, 1903: 375). Já a largura das fundações atingiu 5 metros no lado ocidental e setentrional e 3,70 metros no lado oriental (Orsi, 1903: 375). A fundação é composta por blocos menores ao contrário daqueles esquadrinhados e regulares que formam as várias divisões onde se assentam o estilóbato. Estes são feitos de calcário vulcânico, trazido de jazidas próximas à cidade, e medem 2,00 x 0,90 x 0,60 metros (Orsi, 1903: 376; Veronese, 2006: 327). Com relação ao estilóbato, foram encontrados cinco trechos de diferentes dimensões. No lado leste, o trecho com uma das duas colunas em pé mede 10,40 m de comprimento, tendo o bloco mais inferior a medida de 3,64 m. 0 estilóbato sul possui três trechos: o primeiro deles no ângulo sudeste possui duas divisões de blocos à mostra com 2,73 $\mathrm{m}$ de largura a parte inferior e com 7,48 $\mathrm{m}$ de comprimento total; 0 segundo trecho - 0 menor - é composto por uma fileira de seis pedaços de blocos de rocha, tendo a parte inferior 5,84 m de comprimento; 0 último trecho é o mais longo, tem 3,74 $\mathrm{m}$ de largura máxima, possui a segunda coluna em pé e tem quatro divisões de blocos de rocha do ponto onde está a coluna até embaixo. Do estilóbato do lado oeste restou um trecho de 1,84 m de comprimento, o qual foi determinante para o conhecimento do comprimento do templo. E por fim, no lado norte está o maior trecho conservado de todo o edifício. Este é formado por quarenta e cinco rochas paralelepípedas da parte mais baixa da divisão, que medem $24,80 \mathrm{~m}$ de comprimento e 3,10 m de largura máxima (Orsi, 1903: 373-374; Veronese, 2006: 326). O Olimpiéion possuía um crepidoma de três degraus ao contrário do Apolonion que possuía quatro (Marconi, 2007: 50). As duas colunas que se conservaram são monolíticas e feitas de calcário. Conforme a medição de Orsi, elas medem 6,50 m de altura, mas podem ter alcançado 8 metros como ocorreu no templo de Apolo. Apresentam 16 caneluras com um tipo de colarinho na parte inferior e posterior, não possuem êntasis e são terminadas por um equino muito expandido. A coluna do lado leste tem 1,87 m de diâmetro na parte inferior e 1,42 $\mathrm{m}$ de diâmetro na parte superior. Já a coluna do lado meridional mede 1,85 m de diâmetro na parte inferior (Coarelli; Torelli, 1984: 281; Lissi, 1958: 199, nota 2; Orsi, 1903: 376377). 0 único fragmento de capitel do templo foi encontrado durante as escavações de 1953, mas o estado do material impossibilitou a reconstituição de seu aspecto. De todo modo, devia apresentar uma aparência muito arcaica, muito expandida, semelhante aquela dos capitéis do Apolonion, do antigo Athenaion de Siracusa e de Gela. Não foi encontrado nenhum fragmento do ábaco (Lissi, 1958: 203-204). De acordo com os cálculos de Orsi e de Koldewey e Puchstein, o intercolúnio frontal era mais largo, media 4,10 metros, em relação ao lateral que media 3,75 metros (Coarelli; Torelli, 1984: 281; Lissi, 1958: 199 nota 2; Marconi, 
2007: 50; Orsi, 1903: 378; Veronese, 2006: 326). Nenhum elemento arquitetônico escultórico do entablamento (friso e arquitrave) foi encontrado. Contudo, essa lacuna é parcialmente compensada pelo bom estado de preservação de várias terracotas arquitetônicas do revestimento (sima, cornija e telha) encontradas na escavação de 1953 (Marconi, 2007: 50). A sima foi encontrada quase inteira entre a área do templo e as fossas A e B. Pertence a uma das laterais do templo e é formada por uma faixa superior limitada no alto por um bastão oblíquo vermelho e preto e decorada na parte debaixo por um meandro preto sobre um fundo branco. 0 cano para a saída da água é decorado por grandes folhas vermelhas e pretas circundadas por uma fita preta; os triân gulos formados entre eles são pretos. A goteira é um tubo cilíndrico ornado por um disco amplo com rosetas de oito pétalas vermelhas e pretas e por um círculo branco, que é delimitado na parte interna e externa por uma faixa preta. A altura total do ornamento é de 1,17 metros (Lissi, 1958: 204 e 207). Da fachada do templo provém uma outra parte bem conservada. Trata-se de um cano decorado com folhas pretas e vermelhas circundadas também por uma faixa preta (na parte interna se desdobram) com um motivo que não há na sima da lateral do edifício. O bastão inferior é decorado por pontas de flechas pretas e vermelhas. A faixa inferior é quadriculada, vermelha, preta e branca. $O$ exemplar da cornija, pertencente à lateral do templo, é composto por um bastão com pontas de flecha pretas e vermelhas alternadas por um fundo branco-creme. A frente é decorada com o motivo da trança dupla, com rosetas de quatro pétalas e entre os espaços há o desenho de palmetas com três folhas (Lissi, 1958: 205). No húmus e na terra da fossa A, aberta em 1953, foram encontrados três fragmentos com forma de voluta (com traços de branco e preto) e dois fragmentos diversos (com cor vermelha bem preservada) pertencentes à cabeleira de uma Górgona. Outros três fragmentos encontrados pertencem à pelaria e a crina de um cavalo. Estas partes sugerem que a parte frontal era decorada por uma gorgoneion (cabeça de Górgona) e um cavalo (Lissi, 1953: 212). As três escavações empreendidas no Olimpiéion não localizaram indícios do altar e nem de outro tipo de edifício relacionado ao santuário. Contudo, ao longo dos trabalhos de 1953 dois cortes irregulares nas fossas A e B foram relacionados a alguma obra de defesa, portanto, eram mais que uma simples realização para a colocação de blocos. 0 achado de cerâmica negra de tipo italiota no estrato relacionou os dois cortes ao episódio do assédio a Siracusa pelo general cartaginês Himilcon, que estabeleceu um acampamento próximo ao templo em 396/5 a.C. (Lissi, 1958: 219-220).

Tipo de culto: A origem do culto de Zeus Olímpio em Siracusa é atribuída a um grupo de indivíduos provenientes da região de Élis que se juntaram aos coríntios na fundação da cidade. Veronese (2006: 281) lembra Estrabão (VI,2,4) quem diz que Árquias fundou a pólis juntamente a outros dórios. Apesar de ainda restarem dúvidas sobre a origem destes dórios, acredita-se que entre eles estiveram arcádios e eleios, como mostra Píndaro na ode Olímpica VI, 45,75,95 em que enaltece a figura de Hagésias - descendente de lamos o fundador dos lamides, a família de sacerdotes responsáveis pelo antigo oráculo de Zeus Olímpio em Olímpia (Ciaceri, 1894: 5; Philipp, 1991: 40; Yalouris, 1980: 11). Ciaceri (1894: 5) acrescenta que o culto a Zeus Olímpio pode ter sido "importado" da metrópole Corinto, pois lá havia um templo consagrado à divindade (Pausânias II,V.2-5-8; II,VII.2-4; III,VIII.9-IX.2), que foi venerada desde tempos antigos devido as relações entre os coríntios com a Élida. $O$ autor também considera que na fundação de Siracusa participaram indivíduos da região de Olímpia, explicando, assim, como do Peloponeso o culto de Zeus Olímpio passou à Siracusa (Brelich, 1964-65: 53; Coarelli; Torelli, 1984: 210; Parise Presicce, 1984: 67-68; Polignac, 1995: 123). A relação do culto de Zeus Olímpio em Siracusa com Olímpia foi recentemente estudado por nós, que vimos a instituição do culto do deus nas póleis como um fenômeno resultante da participação das elites em Olímpia e da emergência da identidade grega nos séculos VI e V a.C. (Laky, 2013). 
Referências bibliográficas: Brelich, A. La Religione Greca in Sicilia. Kokalos, X-XI: 35-62, 1964-1965; Ciaceri, E. Contributo alla Storia dei Culti dell'antica Sicilia. AnnPisa, 1894; Coarelli, F; Torelli, M. Guide Archeologiche Laterza. Sicilia. Bari: Laterza \& Figli, 1984; Gullini, G. L'Architettura. Em: Pugliese-Carratelli, G.P. (org.) Sikanie. Storia e Civiltà della Sicilia Greca. Milão: Garzanti, 1989, pp. 460-472; Laky, L..A. Olímpia e os Olimpiéia: a origem e difusão do culto de Zeus Olímpio na Grécia dos séculos VI e V a.C. Revista do MAE, Supplemento 16, 2013; Lissi, E. Siracusa: Scavo presso L'Olympieion (anno 1953). NSc, vol. 12: 197-223, 1958; Marconi, C.Temple Decoration and Cultural Identity in the Archaic Greek World: the Metopes of Selinus. Cambridge: Cambridge University Press, 2007; Mertens, D. Città e Monumenti dei Greci d'Occidente. Roma: L'Erma di Bretschneider, 2006; ORSI, P. L'Olympieion di Siracusa. MonAnt, vol. 13: 369-392, 1903; Parise Presicce, C. Nuovo santuario periferico di Selinunte. Archeologia Classica, XXXVI: 19-132, 1984; Phillipp, H. Le caratteristiche delle relazione fra il santuario di Olimpia e la Magna Grecia. Atti Taranto, 21: 29-51, 1992; Polignac, F.. Cults, Territory and the Origins of the Greek city-state. Chicago; Londres: The University of Chicago Press, 1995; Veronese, F. Lo spazio e la dimensione del sacro. Santuari greci e territorio nella Sicilia arcaica. Pádua: Esedra, 2006.

Imagens:

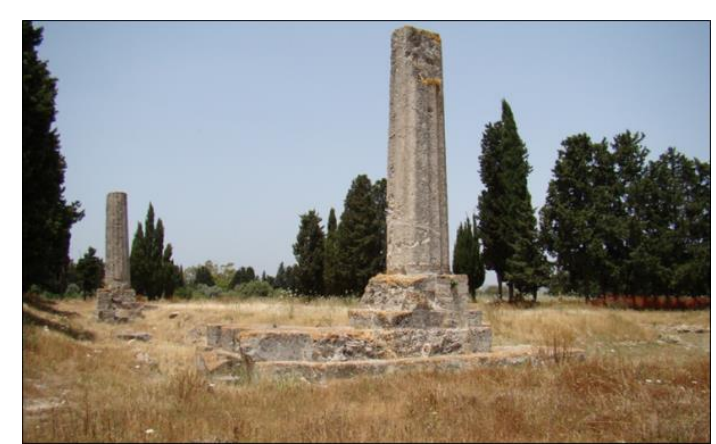

Fig.1- Vista do estilóbato com coluna do ângulo sudeste (mais à frente) e do estilóbato sul com coluna (mais atrás) (Foto: arquivo pessoal/2009)

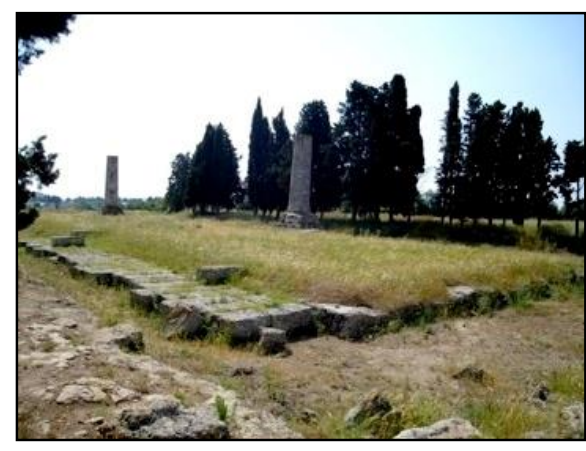

Fig.2- Blocos do estilóbato do ângulo sudoeste(Foto: arquivo pessoal/2009)

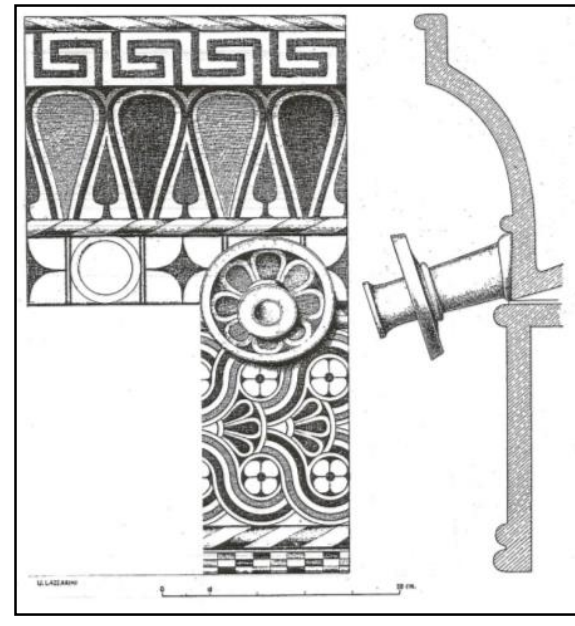

Fig.3- Sima encontrada nas fossas A e B (Lissi, 1958: fig.10) 


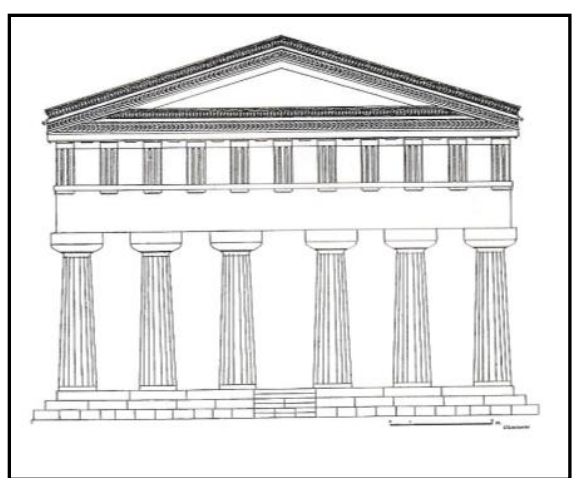

Fig.4- Fachada oriental do Olimpiéion (por Lazzarini) (apud Lissi, 1958: 208, fig.14)

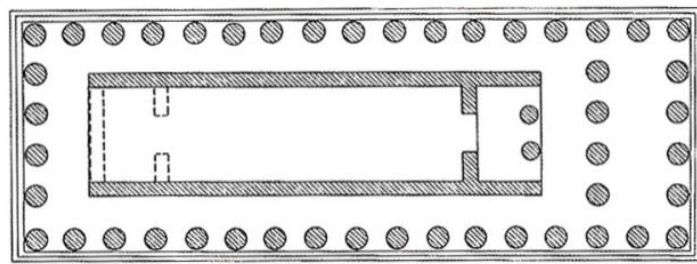

Fig.5- Planta do Olimpiéion (por Gullini 1985) (apud Veronese, 2006: 328, fig.8.22)

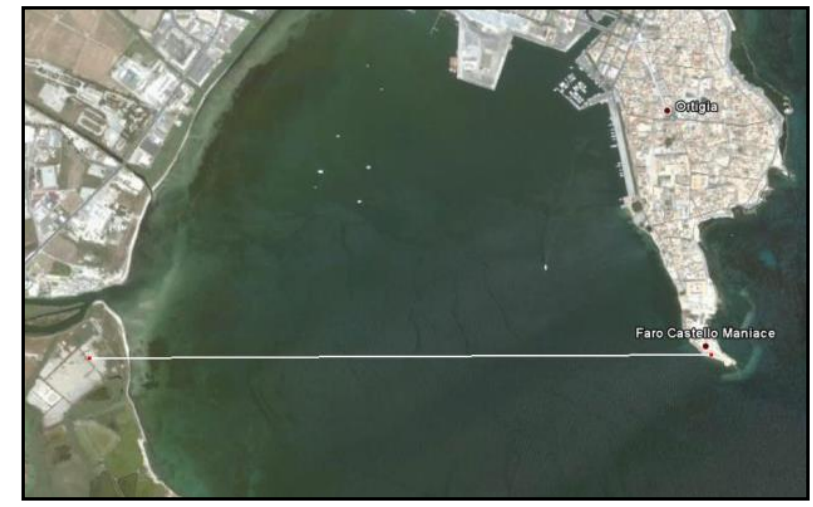

Fig.30 - Vista de satélite da posição correspondente entre o Olimpiéion e a ponta de Ortígia (GoogleEarth/2008) 


\section{Ialysos}

Datação: Época arcaica (c.VII-VI a.C. (fase I)) - época clássica (fim do séc.IV a.C. (fase II)) (Livadiotti; Rocco, 1999 apud Lippolis, 2007: 723).

Localização: Na acrópole, no cume do Monte Phileremos (267 m).

Tipo de santuário: Colinar / urbano.

Referências textuais: Inexistentes?

Inscrições: Rh.I no.54

\section{Histórico dos achados: ?}

\section{Documentação arqueológica}

O sítio da acrópole de lalysos foi sede de ocupações já em época minóica (Benzi, 1984; Marketou, 1988). O local de culto da acrópole, atestado epigraficamente, era frequentado ao menos a partir do séc. VIII a.C., como demostram os materiais do depósito votivo recuperados na escavação (Martelli, 1988; Martelli, 1996).

I. Plataforma: Antes do templo, o local do culto tinha apenas uma plataforma lajeada de planta quadrangular (fase I) (a 2,90m, I conservado 2,75m), conservada no centro da cela do edifício mais tardio, a 1,30m acima da quota do estilóbato. A estrutura, que deveria estar na maior parte no sentido norte-sul (o seu lado norte, contudo, aparece interrompido pela fundação da estátua de culto do templo posterior), foi realizada com lajões em poros prevalentemente quadrangulares, dispostos sobre duas fileiras apoiadas sobre a rocha, propositalmente aplainada; um desses (lajões?) apresenta um trabalho de anathyroses e outro uma "fasciavista" decorada "a bugna" circundada pela periteneia lisa. Isso por um lado atesta a presença de materiais reutilizados (talvez uma reparação da mesma plataforma ocorrida no decurso do séc.VI a.C.), por outro, fornece ao menos um terminus ante quem baseado na introdução destas técnicas de trabalho na Grécia a partir do início do séc.VI a.C.(Lippolis, 2007: 723).

II. Templo: Encontram-se preservados no local os restos do templo dórico prostilo tetrastilo $(12,61 \times 23,38 \mathrm{~m})$ do final do século IV a.C. (fase II), mas um número limitado de membros arquitetônicos e telhas de cobertura atestam a existência de um predecessor do séc.VI a.C. (IACP: p.1199). 
III. Depósito votivo: Abaixo da plataforma, as pesquisas de 1925 recuperaram materiais datáveis que, nos diários da escavação, foram definidos como "de transição entre o micênico e o proto-arcaico" (diário de 7 de abril de 1925). Entre os materiais recuperados no depósito estão gorgoniea de época tardo-arcaica pertencentes a uma cobertura de terracota que poderia ser atribuída a uma estrutura de proteção da própria plataforma, um tipo de edifício "a baldacchino" (Lippolis, 2007: 723). O IACP diz que o depósito, que estava a sul do templo, continha oferendas datadas do séc.IX ao V a.C.(IACP: p.1199).

Tipo de culto: O IACP atribui o santuário ao culto compartilhado de Zeus Polieus e Atena Polias, já Lippolis atribui somente à Atena Polias.

Referências bibliográficas: Akestrom, A. Die architektonischen Terrakotten kleinasiens. Acta Instituti Athenienns Regni Sueciae, 11. Lund, 1966, pp. 117-118; Benzi, M. Evidence for a middle Minoan settlement on the acropolis at lalysos, Mount Philerimos. Em: The Minoan Thalassocracy. Myth and reality. Proceedings of the third International Symposium at the Swedish Institute at Athens (Athens, 31 may-June 1982). Stockholm, 1984, pp.93-104; IACP, p. 1199; Lippolis, 2007, p.723; Marketou, T. New evidence on the topography and site history of prehistoric lalysos. Em: Dietz, S.; Papachristodoulou, I. Archaeology in Dodecanese. Copenhagen, 1988, pp.27-33; Martelli, M. La stipe votiva dell'Athenaion di lalysos, un primo bilancio. Em: Dietz, S.; Papachristodoulou, I. Archaeology in Dodecanese. Copenhagen, 1988, pp.46-50; Martelli, M. La stipe votiva dell'Athenaion di laliso. Em Livadiotti, M.; Rocco, G. La presenza italiana nel Dodecaneso (1911-1948), La ricerca archeologica, la conservazione, le scelte progettuali. Catania, 1996, pp.46-50; Rocco, G. Le mura di cinta. Em: Livadiotti, M.; Rocco, G. La presenza italiana nel Dodecaneso (1911-1948), La ricerca archeologica, la conservazione, le scelte progettuali. Catania, 1996, pp.46-50; Rocco, G.; Livadiotti,

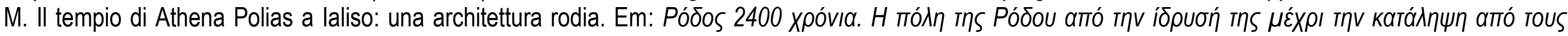
Toúpкous (1523). Convegno Internazionale di Studi (Rodi, 24-29 Ottobre, 1993). Atenas, 1999, pp. 109-118.

Imagens: ? 
Datação: Época arcaica (início do séc. VI a.C.) - época romana (séc. II d.C.?).

Localização: Localiza-se no setor sudeste e ocupa a área norte do complexo dos santuários e edifícios do vale do llissos, entre o antigo distrito urbano de Limnai, a oeste, e o suburbano de Agrai, a sudeste.

Tipo de santuário: Planíce e vale / urbano.

Referências textuais: (Santuário) Tucídides II.15; Pausânias XVIII.6-9; (Templo) Aristóteles, Política V.11.4; Vitrúvio VII.15; (Festas) Plutarco, Phocion 37.1.

Inscrições: Um hóros com a inscrição Limite do recinto de Zeus Olímpio - encontrado, curiosamente, na ágora -, de uma lista de tesouro e de uma inscrição que menciona sacrifícios (Wycherley, 1964: 168); e inscrições relativas às Olympiéia: IG I²310.26, 70, 160; II² 333c15, 1257B 5F; Marmor Parium FgrHist 239 A4 (fundação mítica do culto por Deucalião).

Histórico dos achados: A primeira campanha de escavação foi realizada sob os auspícios da Escola Britânica de Atenas entre os anos de 1883 e 1886 com coordenação de F. Penrose, o responsável pelo achado dos remanescentes do Olimpiéion Pisistrátida e de um templo mais antigo. A área ao redor do templo foi escavada continuamente de 1886 até 1907 pela Sociedade Arqueológica grega (Travlos, 1971: 402-403; Wycherley, 1964: 161-162). A primeira escavação no século XX foi chefiada pelo arqueólogo alemão G. Welter em 1922, o qual investigou os restos do edifício anterior ao Pisistrátida, acrescentando novas interpretações às estruturas descobertas por Penrose. 0 templo voltou a ser escavado sistematicamente na década de 1960 por John Travlos, enquanto era membro da Escola Americana de Atenas (Travlos, 1971: 402-403; Wycherley, 1964: 161-162).

\section{Documentação arqueológica}

I. Templo: O Olimpiéion de Atenas compreendeu cinco fases de construções que ocorreram no espaço de sete séculos entre a época grega e romana: o edifício (I) do início do século VI a.C.; edifício (II) dos Pisistrátidas de 515 a.C.; o edifício III da época de Licurgo no final do período clássico; 0 edifício (IV) do século II a.C. coríntio de Antioco Epifanes; e o edifício (V) do século II d.C. também coríntio do imperador Adriano. A primeira fase, arqueologicamente e textualmente conhecida, é o alvo de nossa investigação e diz respeito ao projeto empreendido durante o governo tirânico dos Pisistrátidas na segunda metade do século VI a.C. O Olimpiéion dos tiranos atenienses foi projetado para rivalizar em dimensão ( 40 x 105 metros) e planta com os contemporâneos templos jônicos de Samos, Éfeso e Dídima (Berve; Gruben, 1963: 108; Camp, 2001: 36; Etienne, 2004: 50; Queyrel, 2003: 51; Wycherley, 1964: 163). Ao longo das escavações no final do século XIX Penrose encontrou os restos de um templo mais antigo dentro do edifício Pisistrátida. Trata-se de uma antiga fundação orientada norte-sul em meio 
a cela do templo posterior, com seu extremo sul subjacente a uma coluna da colunata sul interior. Welter investigou a antiga fundação, estabeleceu seus ângulos noroeste e sudoeste e os associou ao que Penrose tinha pensado ser um estrato contínuo para as subestruturas individuais das colunas internas do lado norte. Interpretou esses restos como o curso mais baixo da fundação de uma perístasis, que media 30,50 metros por provavelmente c. 60 metros e tinha $8 \times 16$ colunas. As fundações tinham 2,50 metros de largura, são feitas de calcário da Acrópole e parecem ter sido projetadas para a colunata de um grande templo períptero. Todo o resto deste antigo edifício foi removido quando o Olimpiéion Pisistrátida foi construído e sua datação não é clara (Travlos, 1971: 402; Wycherley, 1964: 162). $O$ templo é nomeado na bibliografia como pré-Pisistrátida, mas será que este não pertenceu também ao período tirânico do século VI a.C.? De acordo com Greco, que se baseia em Tölle-Kastenbein, na ausência de informações literárias e de outras evidências de escavação, o terminus post quem é, desde recentemente, a reforma de Sólon, a quem se atribui a introdução do pé ático, utilizado na modulação do templo (Greco, 2011: 459). Já a cronologia do Olimpiéion Pisistrátida foi definida com base nas informações arqueológicas e textuais. Baseado nos remanescentes arquitetônicos, Welter foi o primeiro a sugerir que as obras do templo iniciaram-se em 515 a.C. ao longo do arcontado do jovem Pisístrato (522/1 a.C.) - filho de Hípias e neto do tirano Pisístrato (600-527 a.C.). Para 0 arqueólogo alemão, os achados materiais estão em acordo com Aristóteles (Pol.V.11.4). Todavia, a bibliografia geral sobre a arquitetura e 0 urbanismo em Atenas considera o Olimpiéion obra do tirano Pisístrato e de seus filhos Hípias e Hiparco, os Pisistrátidas (Berve; Gruben, 1963: 108; Camp, 2001: 36; Etienne, 2004: 50; Martin, 1956: 88-89; Queyrel, 2003: 51). Nesta perspectiva, Pisístrato teria concebido o projeto nos anos finais de seu governo e teria visto o local ser preparado e as primeiras pedras serem colocadas. 0 templo não foi finalizado por ele e parece que a obra foi retomada pelos seus filhos, que também não a terminaram possivelmente devido ao fim do período tirânico em Atenas em 510 a.C. (Camp, 2001: 36; Martin, 1956: 88; Torelli; Mavrojannis, 2002: 107; Wycherley, 1964: 166). Somente os estudos do templo especificam e salientam que o edifício foi de fato empreendido pelo neto e não pelo avô (Travlos, 1971: 402; Wycherley, 1964: 163). Uma releitura de Aristóteles e Vitrúvio em associação à datação dos fragmentos cerâmicos de 530 a.C. podem na verdade indicar que o Olimpiéion foi construído em um período anterior, correspondente à época da terceira tirania de Pisístrato, que findou com sua morte em 527 a.C. Welter, o responsável pela cronologia de 515 a.C. postergou a construção, considerando que houve um intervalo entre o preenchimento das fundações com os cacos cerâmicos de 530 a.C. e a continuação das obras (Wycherley, 1964: 163). E ainda, é importante lembrar que o santuário de Zeus Olímpio no vale do llissos é considerado muito mais antigo, como indicam os testemunhos literários e o achado de estruturas de um templo anterior. Pausânias (l. 18.8), em um relato posterior acerca do templo de Adriano, atribuiu a construção do santuário de Zeus Olímpio à época do rei lendário Deucalião, cujo túmulo os atenienses acreditavam não estar distante do templo de época romana. Também Tucídides (II.15) - na cronologia dos autores antigos o testemunho mais antigo acerca do santuário - diz que o culto de Zeus Olímpio era de idade antiga.

O Olimpiéion Pisistrátida era orientado leste-oeste, díptero e dórico de dimensão de 41,10 x 107,75 metros. Esta era a mesma medida de largura e comprimento do templo de Antioco Epifanes, considerado uma continuação do templo de Pisístrato ao menos na planta (Berve; Gruben, 1963: 394; Travlos, 1971: 402; Wycherley, 1964: 170). Infelizmente nada conhecemos da divisão interna da cela e da quantidade de colunas da perístasis. As fundações da colunata mediram 4,70 metros de largura, eram feitas de calcário proveniente da Acrópole e de Kara e foram estabelecidas em alvenaria poligonal de encaixe perfeito. A profundidade das fundações dependeu dos contornos do morro, mas foi encontrado um caminho de fundação no lado leste, enquanto que há vinte caminhos abaixo do eutintério no ângulo sudoeste. A colunata da parte de fora estava sobre fundações contínuas, ao passo que a colunata interna estava sobre sua própria 
fundação feita de grandes blocos de calcário (Camp, 2001: 36; Travlos, 1971: 402). Os únicos elementos estruturais que restaram acima das fundações foram o eutintério e os degraus construídos com calcário duro e compacto e unidos por grampos duplos na forma de T. Os tambores de colunas são os únicos elementos arquitetônicos escultóricos remanescentes. Vários deles foram encontrados reutilizados como materiais de construção nas fundações do templo helenístico ou em outras estruturas próximas ao propileu do Olimpiéion romano. Em 1886 uma fundação construída com tambores de colunas do templo Pisistrátida encontrada próxima ao propileu foi caracterizada como "uma estrutura curiosa". Mais tambores vieram a luz nas escavações de Travlos, o qual demonstrou que a estrutura ímpar notada no século XIX era na verdade o grande portão IX, um tipo de dipylon no muro de Temístocles. Os tambores de coluna, assim, foram usados extensivamente nesta parte da fortificação (Travlos, 1971: 402; Wycherley, 1964: 165). As partes das colunas foram medidas e estudadas, constatando-se que o menor diâmetro é de 2,42 metros e a altura total foi estimada em 10 metros (Travlos, 1971: 402). De acordo com Greco, a terceira fase de época clássica foi caracterizada graças a recentes pesquisas baseadas na análise de algumas características técnicas e formais da arquitetura do templo. Observaram-se similaridas na execução entre os conci de mármore da elevação do templo e os edifícios de época clássica da acrópole (Pártenon, Propileu, Erectéion) e também com o monumento de Lisícrates, tal fase situa-se no período de Licurgo, quando deve remontar o projeto do Olimpiéion em mármore (Greco, 2011: 460-461). Greco ainda lembra que ainda não foi resolvida a interpretação de algumas fundações de época geométrica (VIII a.C.) encontradas a sul do témeno do Olimpiéion, em uma área de necrópoles micênicas e geométricas, atribuídas ou ao culto de Apolo Delphinios (Travlos) ou ao de Zeus (Valdés-Guia 2008, que segue Robertson, 1992, o qual liga o culto de Zeus Olímpio ao do Palladion) (Greco, 2011: 459).

II. Altar: Acerca do altar do templo, Welter atribuiu o fragmento de um grande astrágalo em mármore pentélico encontrado por Penrose, e outro no Museu Nacional, ao altar arcaico (Wycherley, 1964: 167).

Tipo de culto: De acordo com as evidências arqueológicas e textuais, o segundo culto mais antigo ou contemporâneo ao de Zeus Polieus foi o praticado a Zeus Olímpio. Tucídides (II. 15) situa a área sagrada do deus entre as mais antigas de Atenas no setor sul, uma das primeiras regiões ocupadas na cidade juntamente à Acrópole. Pausânias (XVIII.6-9) também se refere à antiguidade de Zeus Olímpio quando diz que o santuário foi construído por Deucalion, que teria vivido em Atenas e sido enterrado nas proximidades do local. No século IV a.C., também, esteve ativa uma festa em honra a Zeus Olímpio - as Olympiéia, que ocorriam no décimo nono dia do mês de Munichion. Conhecemos a festa através de inscrições (IG $I^{2} 310.26,70,160$; $I^{2} 333 c 15$, 1257B 5F) e de um trecho de Plutarco (Phocion 37.1), que a descreve na ocasião da execução por cicuta de Phocion, um político do século IV. O relato diz como a cavalaria ateniense, a qual participava da procissão, passava perto da prisão onde acontecia a execução e que as pessoas removiam as guirlandas usadas para celebrar a ocasião, enquanto outros com lágrimas nos olhos contemplavam as portas da prisão. Conforme a passagem, a população estava indignada porque a sentença ocorria durante o festival público consagrado a Zeus (Parke, 1977: 144). De acordo com H.W. Parke (1977: 144) e S. Humphreys (2004: 65), as Olympiéia, uma grande ocasião para a cavalaria ateniense, tinham sido instituídas no século VI a.C. por Pisístrato quando ele lançou as fundações do Olimpiéion e sempre se realizavam na data do aniversário do templo. Xenofonte também descreve no século IV a.C. que o festival incluía exercícios de cavalaria no Hipódromo que eram acompanhados por sacrifícios em larga escala. Em 334/3 a.C. sabemos que o registro oficial marcou 671 dracmas ganhas da venda dos couros das vítimas (Parke, 1977: 145). Além 
dos registros sobre as Olympiéia, sabemos da continuidade do culto de Zeus Olímpio no século IV a.C. através de um hóros com a inscrição Limite do recinto de Zeus Olímpio - encontrado, curiosamente, na ágora -, de uma lista de tesouro e de uma inscrição que menciona sacrifícios (Wycherley, 1964: 168). Na encosta noroeste da Acrópole, foram encontradas evidências do culto de Zeus Olímpio na caverna C localizada entre os cultos de Apolo Hypoakraios e de Pan. Infelizmente, as informações a respeito do culto são escassas e a datação é indeterminada (Travlos, 1971: 29 e 417). O culto de Zeus Olímpio em Atenas pode ser muito anterior ao templo Pisistrátida. No entanto, acreditamos que as duas vitórias de Pisístrato no téthrippon em Olímpia, na $62^{\text {a }}$ Olimpíada (532 a.C.), tenham motivado a monumentalização do santuário com a construção do Olimpiéion (Laky, 2013: 127).

Referências bibliográficas: Berve, H.; Gruben, G. Greek Temples, Theatres and Shrines. Londres: Thames and Hudson, 1963; Camp, J. The Archaeology of Athens. New Haven: Yale University Press, 2001; Etienne, R. Athènes, espaces urbains et histoire. Des origins à la fin du IIle siècle ap. J.-C. Paris: Hachette, 2004; Greco, 2011; Humphreys, S.C. The Strangeness of Gods: Historical Perspectives on the Interpretacion of Athenian Religion. Oxford; N. York: Oxford University Press, 2004; Laky, 2013; Martin, R. L'Urbanisme dans la Gréce Antique. Paris: Picard, 1956; Parke, H.W. Festivals of the Athenians. Ithaka; N. York: Cornell University Press, 1977; Queyrel, A. Athènes. La Citè Archaïque et Classique du VIlle siècle à la fin du Ve siècle. Paris: Picard, 2003; Travlos, J. Pictorial Dictionary of Ancient Athens. Londres: Thames and Hudson, 1971; Tölle-Kastenbein, R. Zur Genesis und Entwicklung des Dipteros. Jdl, 109: 41-76, 1994b; Valdés-Guia, M. La revalorización de la tierra y de la autoctonía en la Atenas de los Pisistrátidas: el nacimento de Erictonio y de Dioniso órfico, Gerión, vol.26, no.1, 2008, pp. 235-254; Whycherley, R.E. The Olympieion at Athens. GrRomByzSt, 5: 161-179, 1964.

\section{Imagens:}

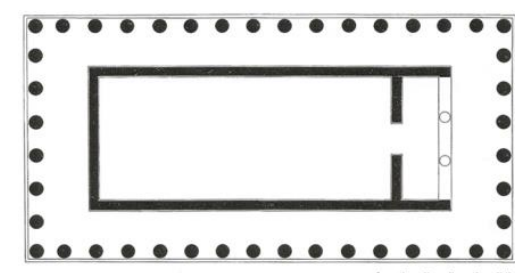

Fig.1 - Planta do Olimpiéion Pisistrátida (por Grundriss) (Tölle-Kastenbein, 1994b: 55, fig. 7)

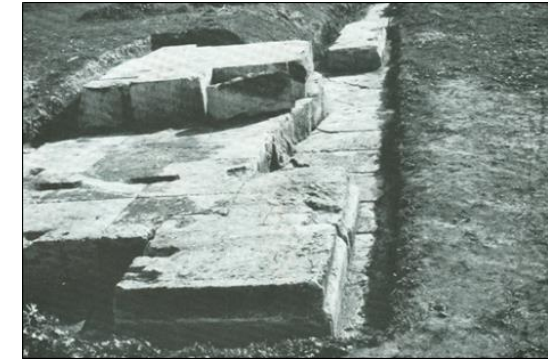

Fig.2 - Ângulo noroeste do eutintério (Travlos, 1971: fig.522)

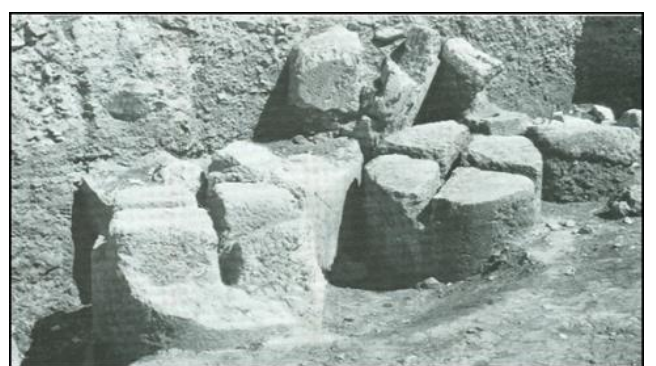

Fig.3 - Tambores de colunas próximos ao muro de Temístocles e propileu romano (Travlos, 1971: fig.521)

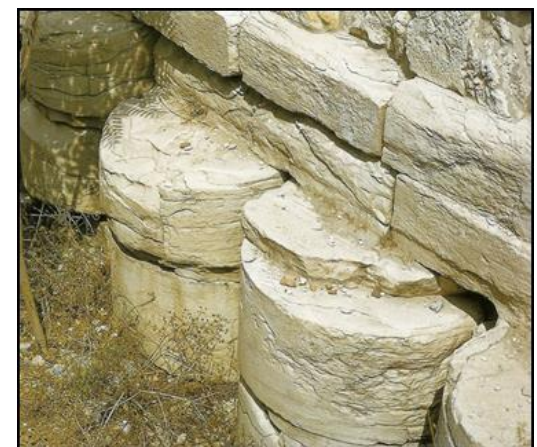

Fig.4 - Colunas do Olimpiéion Pisistrátida no muro de Temístocles (Spawforth, 2007: 30) 


\section{Kefaloniá}

Datação: Época arcaica (início do séc. VI a.C.) - ?

Localização: No Monte Enos (Ainos), no pico mais baixo e oriental (1628 m).

Tipo de santuário: Pico / extraurbano e sub-regional (a partir da época arcaica?).

Referências textuais: Hesíodo fr.57 Rz³ fr.156M.-W.; (Templo) Estrabão X.II.10.2.15; Apoll. Rhod. II.296/297b; Timosthenes, 0. Bd. VI A S.1317, 15ff; S 1319, 5.59; Periplus de Kleon, o.Bd. XI s. 718, 61ff; Eth. Magn., 153, 41; 156,8.

Inscrições: Inexistente?

\section{Histórico dos achados: ?}

\section{Documentação arqueológica}

Templo e santuário: Torelli e Mavrojannis dizem que o templo de Zeus Ainésios foi edificado no Monte Enos contemporaneamente ao templo de Miniés, no início do século VI a.C. (Torelli; Mavrojannis, 2002: 329). Conforme Marinatos, os vestígios do santuário ainda existem e ossos de animais sacrificados estão evidentes no local (Marinatos, 1962: 69).

\section{Tipo de culto: ?}

Comentário: São quase raras as informações bibliográficas sobre o santuário no Monte Enos, nem mesmo a publicação do survey sueco traz informações. Na internet alguns sites sobre Kefaloniá informam que de frente à praia de Avithos há uma ilha rochosa chamada Dias, que foi nomeada assim a partir de um antigo altar de Zeus. Tal altar teria estado em constante contato com o santuário de Zeus Ainésios. A tradição diz (oral ou dos textos antigos?) que sacerdotes faziam sacrifícios no Enos quando viam fumaças do altar do templo de Zeus na ilha de Dias (Marinatos, 1962: 70). Dizem também que sob a pequena capela de Panagiá Vlahernon está 0 antigo templo de Zeus, do qual apenas os degraus podem ser vistos na rocha. A minúscula ilha foi repetidamente destruída por terremotos e 0 de 1953 teria acabado com os vestígios do edifício. Uma grande quantidade de ossos de animas e cerâmica foi encontrada na área. Todo ano, em 2 de julho, há uma peregrinação religiosa de barcos de Pessada até a ilha em honra a Santa Diotissa. 


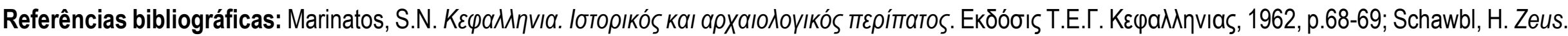
Munique: Alfred Druckenmüller, 1978, p.203; Randsborg, K. (ed.). Kephallénia-Archaeology and History. The Ancient Greek Cities. Acta Archaeologica, vol.73:1 e 2 Supplementa, vol.IV: 1 e 2, 2002; Torelli; Mavrojannis, 2002, p.329; www.ionian-sland.co.uk/worldpress/kefalonia-beaches/avithos-beach (consultado em 19/03/13 às 16h38); www.hiddenkefalonia.com/page.cfm?lang=en\&content=whykefalonia (consultado em 19/03/13 às 16h53).

\section{Imagens:}

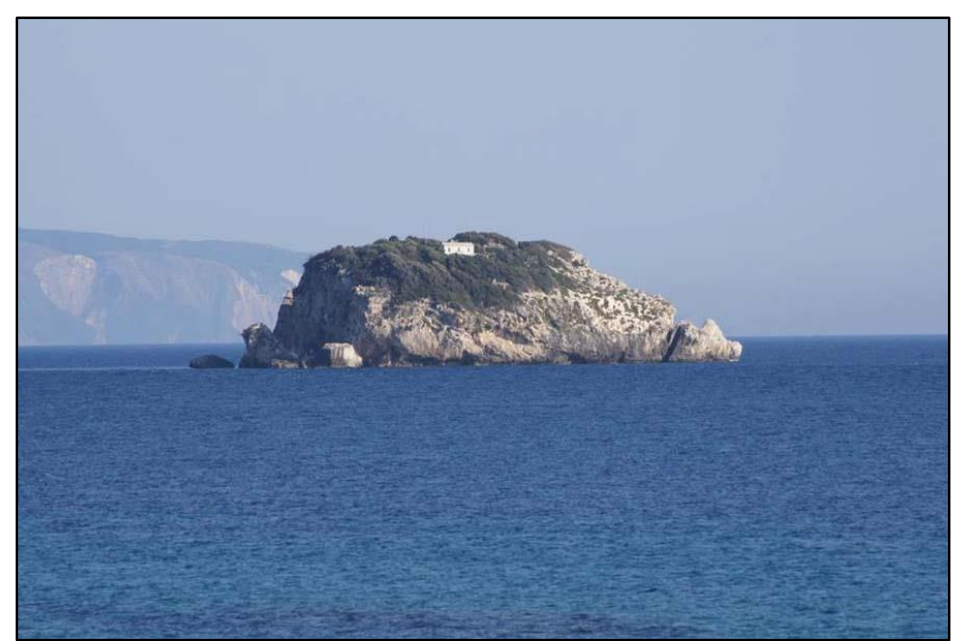

Fig.1- A ilha de Dias (Facebook: Dias Rock, Kefalonia, 2012) 
Datação: Época arcaica (1 ${ }^{\text {a }}$. metade do séc.VI a.C.) - época helenística (séc. III a.C.?).

Localização: Na ágora, no ângulo noroeste do eclesiatério.

Tipo de santuário: Planície / urbano.

\section{Referências textuais: Inexistente?}

Inscrições: (1) Inscrição $\triangle \mathrm{IO \Sigma} \mathrm{/} \mathrm{AГOPA} \mathrm{("ágora} \mathrm{de} \mathrm{Zeus"),} \mathrm{em} \mathrm{aqueu} \mathrm{arcaico,} \mathrm{sobre} \mathrm{pequeno} \mathrm{"cippo"} \mathrm{de} \mathrm{rocha} \mathrm{vulcânica} \mathrm{(1,11} \mathrm{x} \mathrm{0,35} \mathrm{x} \mathrm{0,60m)} \mathrm{com} \mathrm{superfície}$ irregular, foi datada, com base estratigráfica e epigráfica, da primeira metade do séc.VI a.C. (Greco, 2008: 236-237); (2) inscrição $\triangle I O \Sigma$ / AГ AAO ("esplêndido", "luminoso") em alfabeto aqueu sobre "cippo", encontrado em 1989 em posição quase simétrica ao primeiro "cippo" (inscrição 1) em relação ao altar, datável da primeira metade do séc.V a.C. (De Juliis, 2001: 169).

Histórico dos achados: O cippo de Zeus Agoraios (e o témeno?) foi descoberto por Adamesteanu. A segunda inscrição de Zeus Aglaos foi encontrada em 1989.

\section{Documentação arqueológica}

I. Témeno - (Fase 1): Do mesmo período da primeira inscrição (1 ${ }^{\mathrm{a}}$. metade do séc.VI a.C.) podem pertencer os dois muros paralelos que circundam o cippo, constituindo um verdadeiro témeno de Zeus (Greco, 2008: 236-237). Entorno a metade do séc.VI a.C. foi construído o eclesiastério e o lugar de culto dedicado a Zeus recebeu uma sistematização monumental, consistindo em um altar em pedra ladeado pelo cippo com inscrição a Zeus Agoraios. Adamesteanu (1978), que o descobriu e o publicou, foi quem primeiro a traduziu como "ágora de Zeus", dando-a um valor topográfico (De Juliis, 2001: 167). Diferentemente, Lo Porto

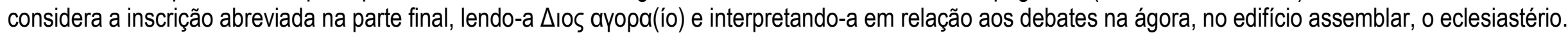
(Fase 2): Entre o primeiro e segundo quartel do séc. V a.C., ocorreu em correspondência com a transformação monumental do contíguo eclesiastério (II) (De Juliis, 2001: 168-169). Nesta ocasião foi colocado um segundo cippo com inscrição (2) acima do velho muro do témeno arcaico demolido nas fileiras superiores e em correspondência com o altar, provavelmente refeito nesta ocasião. Neste mesmo tempo foi construído um amplo recinto com blocos regulares os qual abarca o témeno de Zeus e outros monumentos sagrados, que devia ser limitado a oeste por uma "transenna lignea" de que se segue o encaixe por um trecho de 3,68m (De Juliis, 2001:169). (Fase 3): A terceira e última intervenção edilícia ocorreu na segunda metade do séc.IV a.C. com a transformação do eclesiastério em um grande teatro, cujo perímetro externo se aproximava do témeno de Zeus. Devido a instabilidade do terreno, construiu-se um reforço no analemma do 
eclesiastério, em correspondência ao cippo de Zeus Agoraios, que apesar da extrema proximidade foi respeitado. Isso indica que o altar e os dois cippi eram ainda visíveis e o recinto sagrado era utilizado no período. Somente na metade do séc.lll a.C. foi necessário reforçar, naquele ponto do analemma do eclesiastério, com uma terraplenagem, o qual recobriu todas as estruturas presentes entre o muro do teatro e a parede ocidental do témeno. Na fase intermediária (entre o fim do séc.IV e a metade do III a.C.), coloca-se a construção de uma grande base de blocos reutilizados, a qual parece ter pego o lugar do altar e dos dois cippi já enterrados do santuário de Zeus. A imponência da base (unida ao emprego de uma grande quantidade de material lítico precioso na área metapontina), induziu os estudiosos a atribuí-la a uma base para uma estátua de grandes dimensões de bronze ou de pedra, dedicada provavelmente a Zeus (De Juliis, 2001: 170).

II. Pínakes: Numerosos fragmentos de pínakes da segunda metade do séc.IV a.C., representando Zeus com o raio e a águia, foram recuperados dentro do témeno e em outros pontos vizinhos (De Siena, 1978; Lo Porto, 1988; Moreno, 1995 apud De Juliis, 2001: 170).

Tipo de culto: Segundo De Juliis, a expansão do culto de Zeus em Metaponto nos primeiros decênios do séc.V a.C. encontra uma comparação interessante na notícia de Pausânias, segundo o qual os metapontinos dedicaram em Olímpia uma estátua do deus, obra do escultor egineta Aristonoos (De Juliis, 2001: 169).

Referências bibliográficas: Adamesteanu, D. Metaponto. Atti del 18. Convegno di Taranto (8-12 ottobre 1978), Gli Eubei d'Occidente, 1978, pp.350-352; Bottini, A. La Basilicata. Atti del 29. Convegno di Taranto (6-11 ottobre 1989), La Magna Grecia e il lontano Occidente, 1989, pp.565-566; De Juliis, E.M. Metaponto. Città della Magna Grecia. Bari: Edipuglia, 2001, pp.167-170; De Siena, A. Scavo del teatro-ekklesiasterion di Metaponto. Atti del 18. Convegno di Taranto, 1978, pp.357-366; Giacomelli, R. Achea Magno-Graeca. Le iscrizioni archaiche in alfabeto acheo di Magna Grecia. Brescia, 1988; Giardino, L.; De Siena, A. Metaponto, Em: Greco, E. (a cura di), La città greca antica. Istituzioni, società e forme urbane. Roma, 1999, pp. 329-363 (ver 353-363); Greco, E. Magna Grecia. Guide Archeologiche. Roma-Bari: Laterza, 2008, pp.236-237; Mertens, D. Das Theater-Ekklesiasterion auf der Agora von Metapont, Architectura (12), 1982, pp.93-124; Moreno, P. Lisippo. L'arte e la fortuna. Roma, 1995, pp.278 sq, figs.4.40.2 e 3, Olbrich, G. Ein Heiligtum der Artemis Metapontina? Zur ikonographie der TerrakottaFiguren von S. Biaggio bei Metapont, PP (XXXI), 1976, pp.376-408. 


\section{Imagens:}
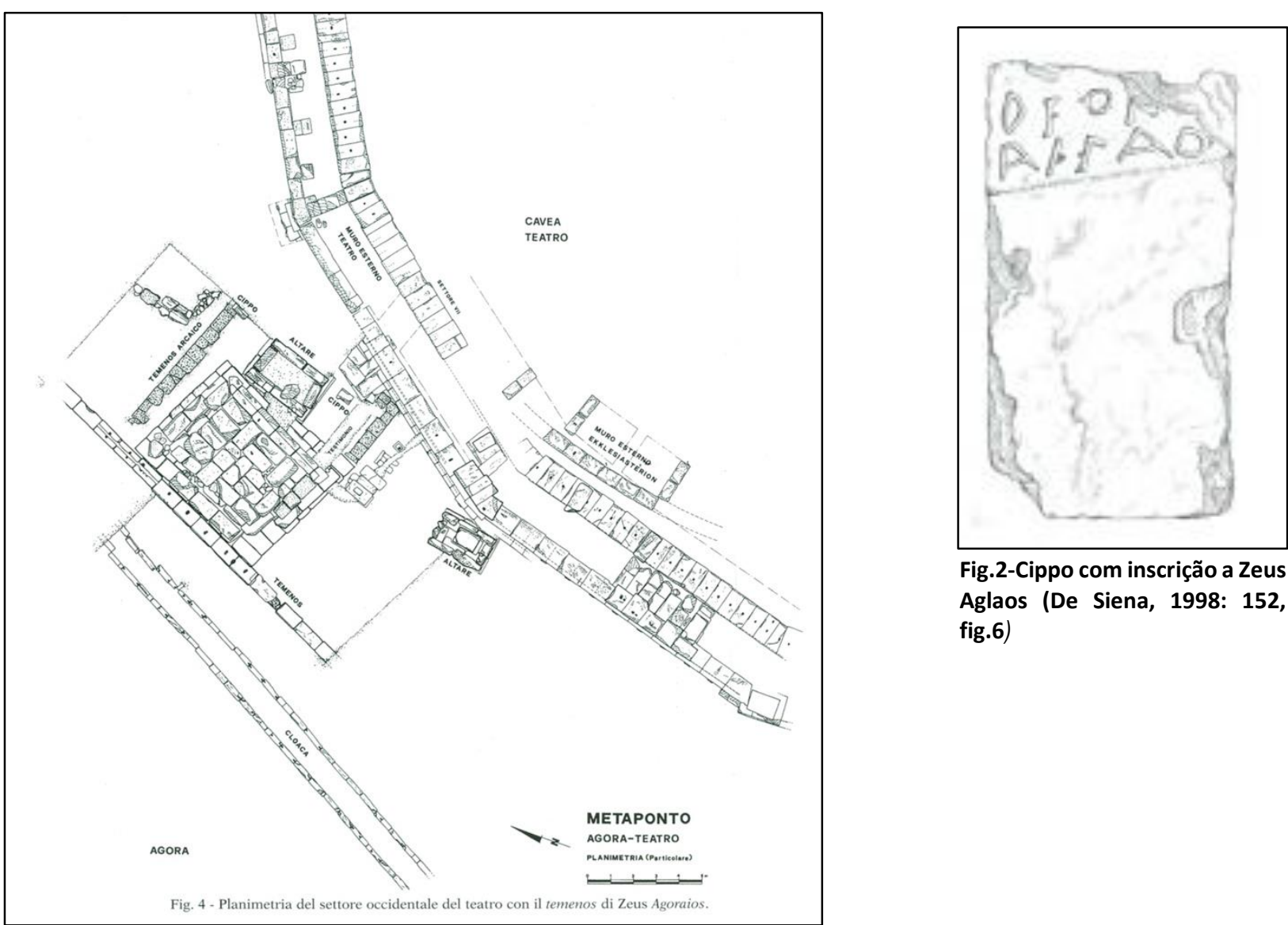

Fig.2-Cippo com inscrição a Zeus

Aglaos (De Siena, 1998: 152 fig.6)

Fig.1- Planimetria do setor ocidental do teatro com o témeno de Zeus Agoraio (De Siena, 1998: 150, fig.4) 


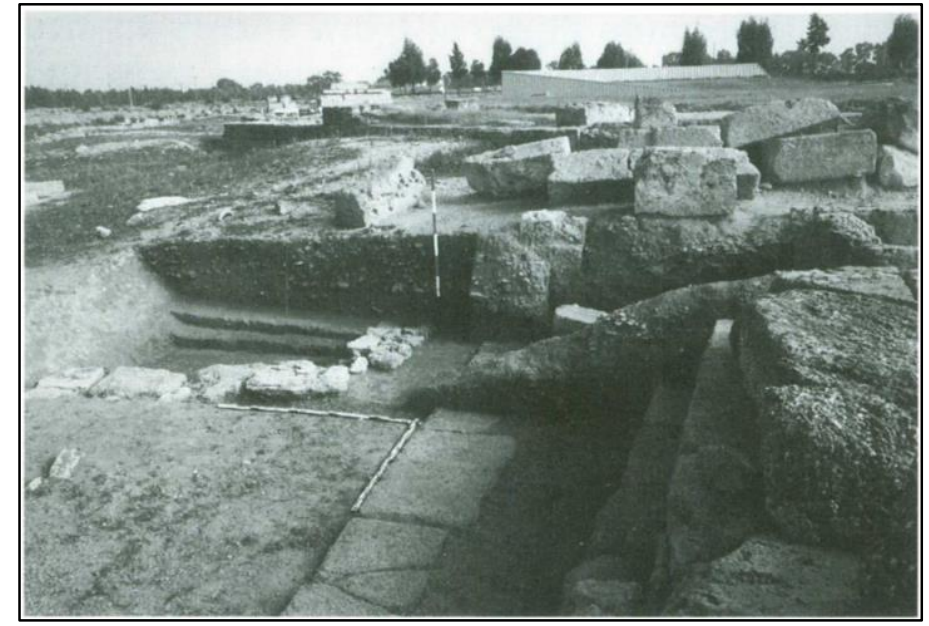

Fig.3- Estruturas de fundação dos témenos mais antigos e cippo de Zeus em fase de escavação (De Siena, 1998: 152, fig.5)

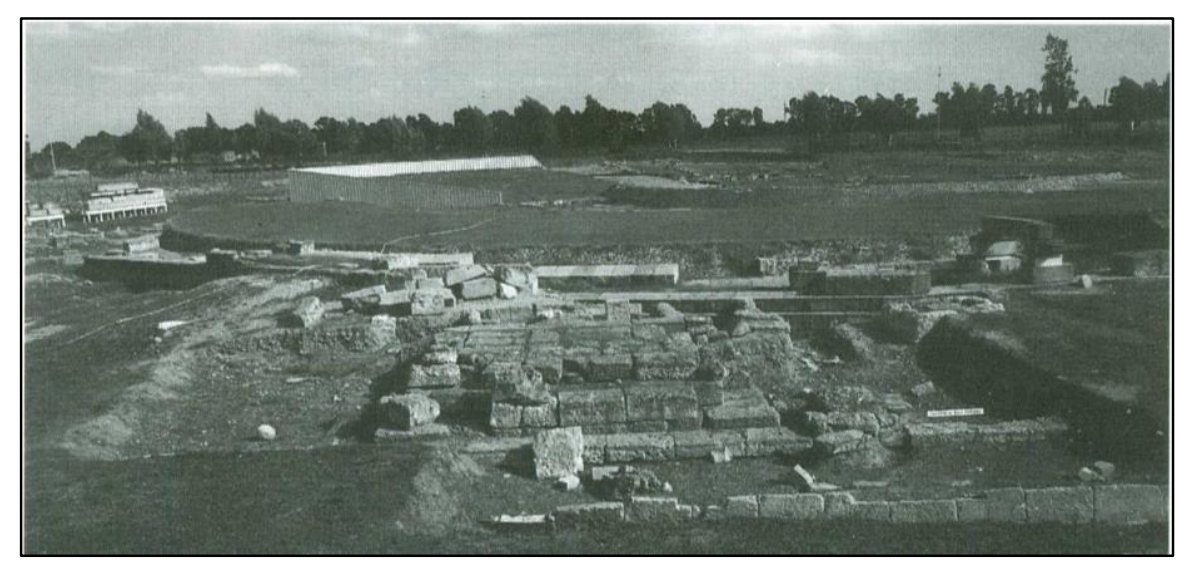

Fig.5- Panorâmica a partir de oeste do témeno de Zeus e ao centro a grande base (De Siena, 1998: 153, fig.8)

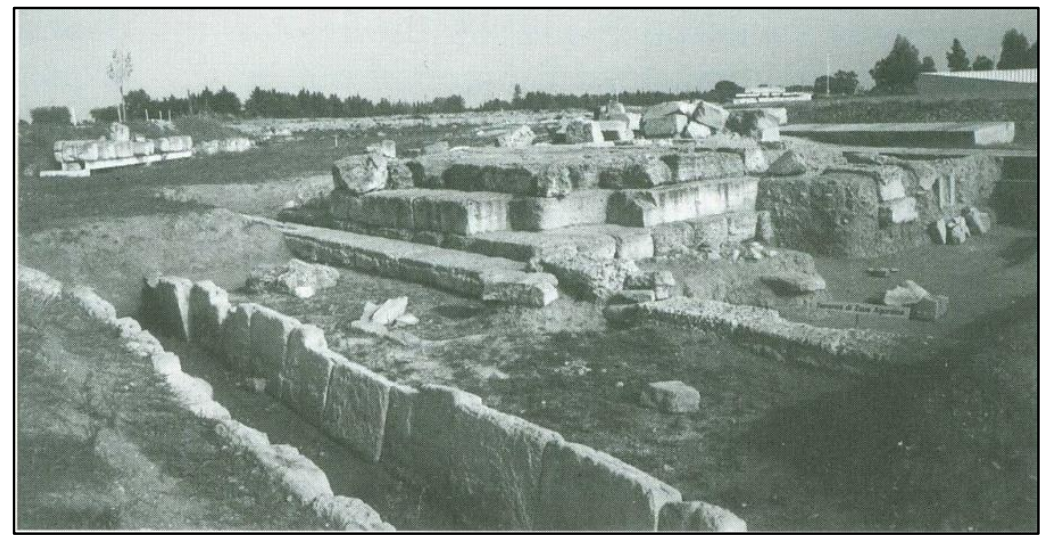

Fig.4- Panorâmica a partir de sul do témeno e da entrada (De Siena, 1998: 153, fig.7) 
Datação: Época arcaica (metade do séc.VI a.C.) - ?

Localização: Em San Biaggio alla Venella, próximo ao santuário de Ártemis.

Tipo de santuário: Planície / extraurbano.

Referências textuais: Inexistentes.

Inscrições: Inscrição $\triangle \mathrm{IO \Sigma} \mathrm{/} \mathrm{AГ \Lambda AIO} \mathrm{em} \mathrm{"cippo"} \mathrm{de} \mathrm{calcarenito}(0,60 \times 0,50$ × 0,30m) datada da metade do séc.VI a.C.

\section{Histórico dos achados: ?}

\section{Documentação arqueológica}

I. Cippo com inscrição: Foi descoberto na área do santuário de Ártemis em S. Biaggio reutilizado como cobertura de uma tumba romana tardia.

A maior parte dos estudiosos considera o cippo pertencente às ruínas do santuário, reconhecendo a presença do culto de Zeus ao lado daquele principal de Ártemis. Sobre uma posição contrária a esta tese, coloca-se Lo Porto (1988) o qual suspeita que o cippo tenha sido recolhido em época imperial entre as ruínas da área sagrada de Metaponto e transportado para o local juntamente a outros materiais recuperados. Uma confirmação a esta hipótese parece ter ocorrido após a descoberta do cippo com a inscrição Zeus Aglaos na área da ágora. Bottini (1989), então se referindo ao cippo conhecido em S. Biaggio, concluiu que o culto de Zeus Aglaos seria urbano, que não haveria um santuário em San Biaggio. De Siena (1998) defende a impossibilidade de se transportar o cippo pesado de Metaponto para San Biaggio, pensa, ao invés, na transferência do culto de Zeus Aglaos do santuário extraurbano para a ágora. Seria, portanto, uma duplicação do culto após a gradual dissolução do poder econômico e político dos ghene (De Juliis, 2001: 100-101).

II. Estatueta: A favor da localização do culto de Zeus em San Biaggio foi assinalada uma estatueta de terracota proveniente de tal santuário e identificada como o deus por Mertens-Horn (1992).

\section{Tipo de culto: ?}


Comentário: Não há nenhuma evidência de partes do santuário de Zeus Aglaos, somente a inscrição e a estatueta sustentam a tese de sua existência, que costuma ser associada ao santuário de Ártemis, cujos remanescentes são bem documentados.

Referências bibliográficas: Adamesteanu, D. Metaponto. Nápoles: La Buona Stampa, s/ano; Bottini, A. La Basilicata. Atti del 29. Convegno di Taranto (6-11 ottobre 1989), La Magna Grecia e il Iontano occidente, 1989, pp.565-566; De Juliis, E.M. Metaponto. Città della Magna Grecia. Bari: Edipuglia, 2001, pp.100-101; De Siena, A. Metaponto: problemi urbanistici e scoperte recenti, in "Siritide e Metapontino. Storie di due territori coloniali", Atti dell'incontro di studio (Policoro 1991), Naples-Paestum 1998, Cahiers CJB, XX), pp. 141-170.1998; Lo Porto, F.G. Testimonianze di culti metapontini, Xenia (16), 1988, pp.14sq; Mertens-Horn, M. Die archaischen Baufriese aus Metapont, RM (99), 1992, pp.1-122.

\section{Imagens:}
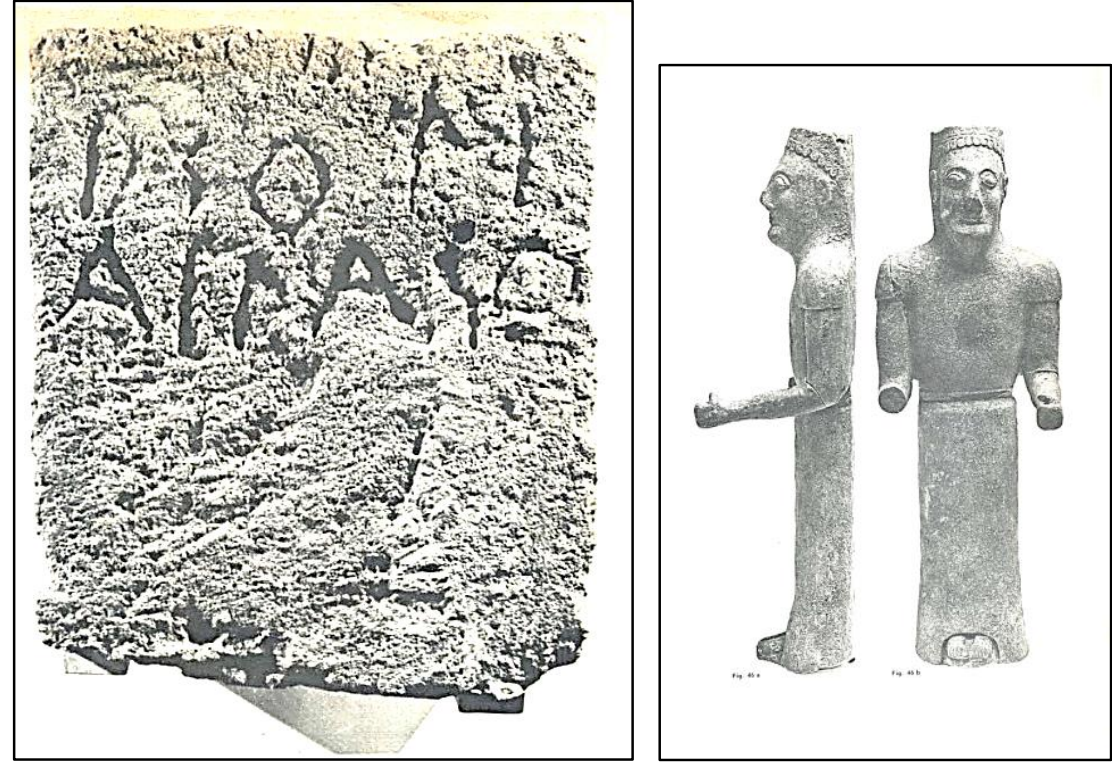

Fig.2-Estatuetas de terracota de Zeus Aglaos

Fig.1- Cippo com inscrição a Zeus Aglaios (Adamesteanu, s/ano: figs.46a e 46b)

(Adamesteanu, s/ano: 87, fig.48) 


\section{Lócris Epizefiri}

\section{Santuário de Zeus Olímpio}

Itália do Sul

Datação: Época arcaica (2a .metade do séc. VI a.C. [540/30 a.C.]) - época helenística (séc.III a.C.?).

Localização: No setor leste, próximo aos muros e em posição elevada e dominante, localiza-se sobre o altoplano de Contrada Cusemi, que se estende até a planície. A 100 metros noroeste do teatro e a cerca de 90 metros ao norte da teca do arquivo de Zeus Olímpio, estando todo este complexo de estruturas entre os vales de Milligri (a oeste) e de Saitta (a leste).

Tipo de santuário: Colinar? / Urbano.

Referências textuais: Inexistentes.

Inscrições: As 39 tábuas de bronze datam do período democrático de Lócris, portanto ao redor da segunda metade do século IV a.C. e da primeira metade do século III a.C. Os textos, estudados pelo arqueólogo italiano Alfonso De Franciscis, estão escritos em dialeto dórico local que tem influência ateniense. As tábuas constituem uma documentação única em todo o mundo grego e representam uma excepcional fonte de informação sobre a vida e a organização política da cidade no período: a articulação dos cargos públicos, a subdivisão da população, a função econômica do santuário, que concedeu à pólis contribuições em dinheiro, muitos destinados à restauração e ao reforço da cinta murária. Em uma das tábuas são citadas contribuições a um basileus, que segundo alguns estudiosos seria um magistrado da cidade e segundo outros, seria Pirro, o rei do Épiro (Costamagna; Sabbione, 1990: 164 e 261). Sabemos que as informações nas tábuas se referem a um santuário dedicado a Zeus Olímpio porque o seu nome aparece duas vezes na tábua de bronze de número 9 e o nome Olimpiéion na de número 21. Além também da ocorrência do nome Zeus nas tábuas 5, 12, 15, 22, 25, 28, 34, 35.

Histórico dos achados: Jean Claude Richard De Saint Nôn e François Bielinski, respectivamente, em suas obras Voyage Pittoresque ou Description des Royaumes de Naples et de Sicile (1783) e Troisième Centaine que commence avec l'année 1791 (1791) descreveram a área do templo e, principalmente, registraram que ainda naquela época (décadas finais do século XVIII) duas colunas do templo ainda estavam em pé. O primeiro a escavar o santuário e o templo foi o Duc de Luynes em 1830 o qual relatou que a última, das duas colunas restantes, tinha sido demolida dois anos antes por um viticultor para servir como cerca ao seu jardim (Costabile, 1992: 54-55). Mas o santuário de Zeus Olímpio, sob a Casa Marafioti, foi escavado sistematicamente pela primeira vez por P. Orsi em um campanha em 1910, quando foram identificados os restos do templo e o muro de contenção entre a teca e o santuário. Em 1959 foi descoberta, a $90 \mathrm{~m}$ a sul do santuário, a teca do arquivo de Zeus Olímpio, um fosso de pedra contendo 37 tábuas de bronze com inscrições sobre registros financeiros da cidade. Duas outras tábuas foram encontradas dias depois por Ugo Serafino escondidas em um estábulo (Costamagna; Sabbione, 1990: 261). 


\section{Documentação arqueológica}

I. Muro de contenção: Construído no declive da colina, o muro de Contrada Pirettina era feito de blocos isodômicos de arenito de 2,5 metros de largura, orientado leste-oeste e se ligava a leste provavelmente ao vale Saitta. É possível que esta estrutura murária fosse o períbolo (muro do témeno) do santuário de Casa Marafioti, ou o analemma de sustentação da colina, ou ainda, como pensou P. Orsi, tenha tido a função militar além da de sustentação (Costamagna; Sabbione, 1990: 63-64; Costabile, 1992: 37 e 39).

II. Teca: Foi feita em um único bloco de calcário, internamente oco e de forma cilíndrica, que mede 1,57 metros de diâmetro, 1,26 metros de altura e as paredes $31 \mathrm{~cm}$ de largura são fechadas por uma sólida tampa. Na parte externa da tampa há quatro anéis grossos de bronze maciço diferentes entre eles pela dimensão e sistema de fixação, quando eram usados para deslocar lateralmente a tampa.

III. Templo: Dórico períptero de $8 \times 17$ colunas, com uma fileira interna de colunas em cada fachada, e dimensão de $20 \times 36-40 \mathrm{~m}$. Na extremidade sudeste foi encontrada uma fileira de seis rochas de $45 \mathrm{~cm}$ de altura e 1,50 metros de comprimento, que pertence ao estilóbato. Nesta extremidade, também, foi encontrada a maior parte dos elementos arquitetônicos escultóricos importantes, tais como o fragmento de métopa, o pentaglifo angular, o fragmento calcário de cornija com influência jônica, uma parte da sima (calha) decorada com palmeta, flor de lótus e a extremidade com prótomos leoninos (apud Costabile, 1992: 57-59). Os capitéis de colunas mais preservados provêm desta parte - ambos arcaicos e de calcário, um sem ábaco e anéis e o outro liso -, um fragmento de tambor de coluna de calcário com vinte caneluras e fragmentos da arquitrave (apud Costabile, 1992: 59-61). No lado oeste do templo, foram recuperados abundantes elementos de terracota, provavelmente provenientes da decoração do frontão ocidental do templo. Destes achados, destacam-se uma sima frontal decorada com relevo de palmeta e flores de lótus; e uma placa decorada com meandro com uma parte da cornija. Mas o achado em terracota mais importante nesta porção do templo foi um grupo, pertencente ao acrotério, de um cavaleiro e seu cavalo sobre uma esfinge com influência jônica, que está assentada sobre uma telha larga (apud Costabile, 1992: 66-70). No lado norte foram localizados seis fragmentos (comprimento 3 metros) das rochas que compunham o estilóbato central e uma parte mínima pertencente ao muro interno do opistódomo ou da cela. Dos elementos arquitetônicos escultóricos, todos de calcário, os mais importantes são a anatirose arcaica, partes da cornija em calcário e dois fragmentos de colunas, fustes e restos do equino. De terracota, foi encontrada uma sima lateral com prótomos leoninos composta por uma telha grande vertical com cornija em cima e embaixo. Foram encontrados também onze exemplares de prótomos leoninos que deviam decorar a cornija (apud Costabile, 1992: 74-79). As escavações não localizaram o altar e nem depósitos votivos por causa das alterações e dos desníveis do terreno (apud Costabile, 1992: 72).

Tipo de culto: Alguns autores conjecturam que o santuário de Zeus Olímpio pode estar na planície, nas proximidades do teatro; não excluem a possibilidade de haver outros edifícios religiosos na zona, embora não terem proposto nenhuma nova hipótese de localização (Costabile, 1992: 39). Entretanto, uma proposta diferente localiza o santuário de Zeus Olímpio não em meio aos principais edifícios de Lócris, mas nos confins da pólis, próximo à fronteira com Régio (Cordiano, 
1998). De toda maneira, é fato que existiu um santuário de Zeus Olímpio em Lócris Epizefiri. A atribuição do templo Marafioti ao deus é tardia, pois as tábuas datam do século IV e III a.C. Não há evidências textuais, epigráficas e numismáticas, sobre o templo e a divindade, contemporâneas ao templo (século VI-V a.C.). A ausência de evidências do período do edifício, porém, não impedem que o santuário tenha ganhado a teca um ou dois séculos depois (Laky, 2013: 104). A origem do culto de Zeus Olímpio em Lócris, a nosso ver, está na relação da pólis com Olímpia, na instituição do culto do deus nas póleis como um fenômeno resultante da participação das elites em Olímpia e da emergência da identidade grega nos séculos VI e V a.C. (Laky, 2013).

Referências bibliográficas: Cordiano, G. Lo Zeus dell'Alece: uma proposta di localizzazione. Gerión, 16: 161-175, 1998; Costabile, F. (org.). Polis ed Olympieion a Locri Epizefiri. Costituzione, Economia e Finanze di una città della Magna Grecia. Catanzaro: Rubbetino Editore, 1992; Costamagna, L. Sabbione, C. Una Città in Magna Grecia. Locri Epizefiri. Guida Archeologica. Reggio Calábria: Laruffa Editore, 1990; Laky, 2013.

Imagens:

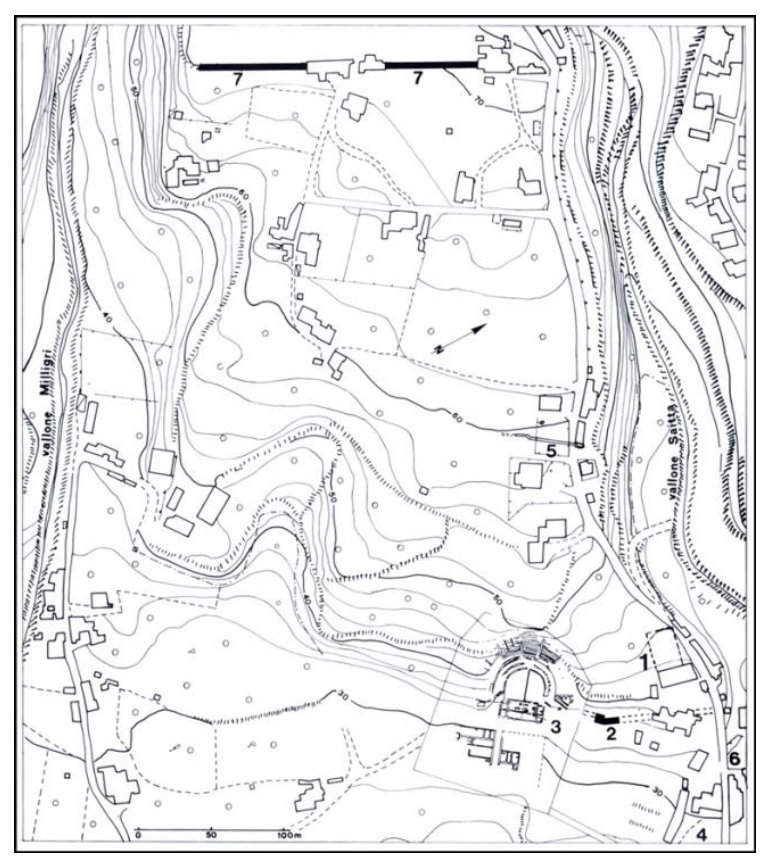

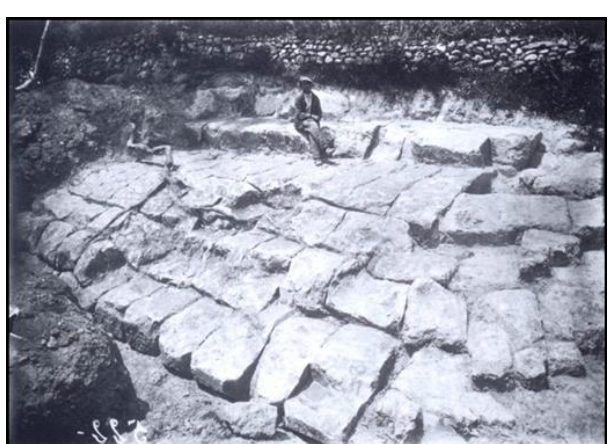

Fig.2 - Muro de Contrada Pirettina, foto tirad no momento da escavação de 1911 (Costabile, 1992: 88)

Fig.1 - Planimetria do setor leste - 1. Sítio do santuário de Zeus Olímpio de Casa Marafioti; 2. Muro de Contrada Pirettina; 3. Teatro e casas helenísticas; 4. Teca do arquivo de Zeus Olímpio; 5. Ninfeu helenístico; 6. Muro de Contrada Callipari; 7. Muro de Contrada Cusemi (Costabile, 1992: 38)

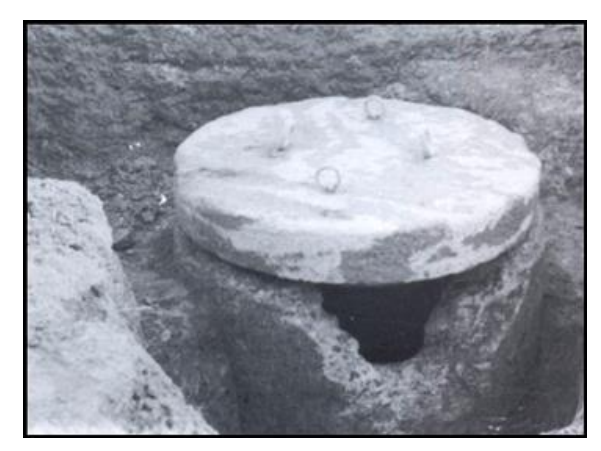

Fig.3- Teca lítica do arquivo de Zeus Olímpio no momento da escavação em 1959 (Costamagna; Sabbione, 1990: 164)

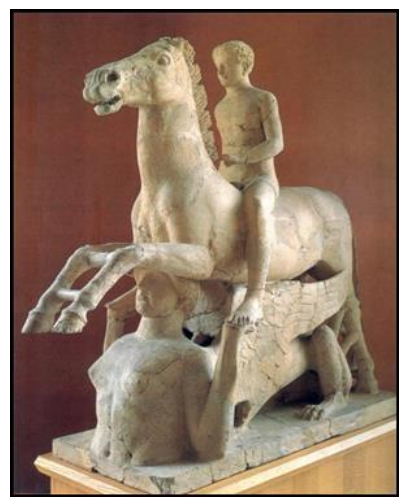

Fig.4- Acrotério de terracota, grupo esfinge, cavalo e cavaleiro encontrados no lado ocidental (Serafino, 1991: 35) 


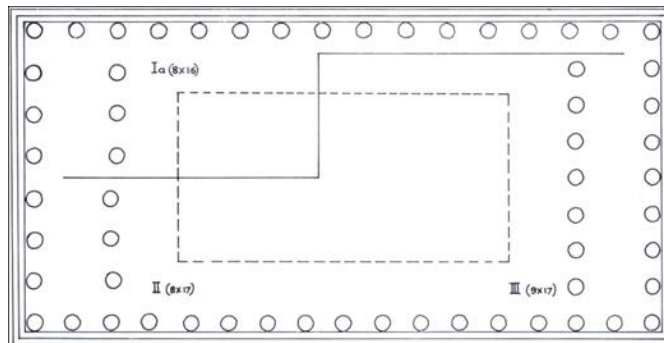

Fig.5 - Planta do Olimpiéion de Casa Marafioti (por Østby 1978) (apud Costabile, 1992: 41)

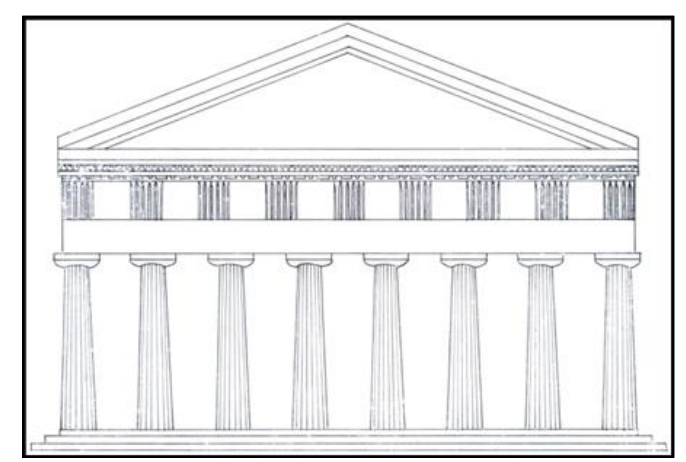

Fig.6- Reconstrução da fachada leste do Olimpiéion de Casa Marafioti (por Østby 1978) (apud Costabile, 1992: 41) 
Datação: Época arcaica (séc. VI a.C. [c.530 a.C.]) - época clássica (409 a.C.?).

Localização: Situa-se no setor oriental da pólis, sobre a colina de Marinella, a oeste do rio Cottone (hoje seco) e a norte dos templos F e E, respectivamente.

Tipo de santuário: Colinar? / extraurbano.

Referências textuais: Inexistente.

Inscrições: Tábua de Selinote (IG XIV, 268) datada da metade do séc. V a.C.

Histórico dos achados: A primeira escavação no Olimpiéion ou templo G ocorreu em 1831 e 1832, cujos trabalhos foram dirigidos pelos comissários Domenico Lo Faso Pietrasanta Duca di Serradifalco e Valerio Villareale com supervisão arquitetônica de Domenico Cavallari. A escavação da Comissione di Antichità e Belle Arti della Sicilia foi a primeira tentativa de investigação das ruínas dos templos da colina oriental (Marconi, 1994: 23-24 e 27). Na temporada de 1832 as operações estenderam-se ao templo F e G (Marconi, 1994: 30). Foi durante os trabalhos de 1832 que Valerio Villareale restaurou a coluna do lado sudeste do templo, a denominada pelos camponeses de "fuso da velha". Em 1871 Domenico Cavallari descobriu a Tábua de Selinonte na anta direita da entrada do ádito do edifício (Bianco; Sammartano, 2004: 94; Di Giovanni, 1991: 56).

\section{Documentação arqueológica}

I. Templo: Apesar do deplorável estado das ruínas, o templo G tem uma planta suficientemente conhecida. Orientado leste-oeste, era pseudodíptero, portanto, um edifício cuja perístasis é separada da cela pela largura não apenas de um intercolúnio, como é norma para os templos perípteros, mas por dois para simular a presença de uma dupla perístasis como nos templos jônicos dípteros em voga na Grécia de leste, em Éfeso, Dídima e em Samos a partir da metade do século $\mathrm{VI}$ a.C. (Coarelli; Torelli, 1984: 86). Mertens acrescenta que a prova de que se trata de um pseudodíptero é a ausência das fundações indispensáveis para sustentar o segundo anel de colunas internas da perístasis (Mertens, 2006: 232). A planta retangular alongada mede, segundo este autor, 49,97 x 109,12 metros $+-5 \mathrm{~cm}$ respectivamente e segundo Veronese, Coarelli e Torelli, mede 54,05 x 113,34 metros no estilóbato. A perístasis era composta por $8 \times 17$ colunas (Coarelli; Torelli, 1984: 85; Mertens, 2006: 232; Veronese, 2006: 514). A cela possuía um pronaos profundo prostilo e tetrastilo, portanto, com $4 \times 2$ colunas e tinha a dimensão de c. $17 \times 20$ metros de largura interna. O naós era dividido em três naves de duas fileiras de 10 colunas terminantes em um naískos interno - 0 ádito - destinado à conservação da estátua de culto e considerado um elemento típico da arquitetura sagrada da Sicília e de Selinonte em particular. 0 tamanho das colunas, pequenas para sustentar um teto, e o achado de um canal para escoamento de água, acuradamente trabalhado no pavimento da cela, induziram a 
reconstrução do naós na forma de sêkós (não coberto pelo teto). Esta é uma das características principais do templo de Apolo Didimeus em Dídima, concebido em forma de sêkós e com um naískos semelhante ao templo G, o qual novamente encontra paralelos de relevo nos grandes templos dípteros do Oriente (Coarelli; Torelli, 1984: 86; Mertens, 2006: 233-234; Veronese, 2006: 514). $O$ opistódomo distilo in antis não se comunicava com a cela e provavelmente funcionava para a conservação do tesouro do templo. Na área interna da cela foram encontradas escadinhas laterais, que provavelmente davam acesso ao telhado e ao subtelhado (Coarelli; Torelli, 1984: 86; Veronese, 2006: 514). Sobre as fundações, o crepidoma e o estilóbato nenhuma informação está disponível na bibliografia consultada. Percebe-se a presença dos blocos do estilóbato, mas, como salienta Veronese, está soterrado pelo grande acúmulo de ruínas, formado, sobretudo, pelos restos das colunas (Veronese, 2006: 514). A perístasis do templo $G$ era larga e espaçosa - uma das características basilares do templo arcaico no Ocidente -, as galerias mediam 12 metros de largura (Mertens, 2006: 232). As colunas constituem a maior parte dos achados arquitetônicos do templo. Como todos os elementos arquitetônicos escultóricos encontrados, as colunas eram feitas de calcário. Aquelas da perístasis atingiram 16,27 metros de altura, tinham uma circunferência de 10,70 metros. O diâmetro na base do fuste mede 3,41 metros, na parte mais alta media 1,41 metros e o capitel possui um ábaco de $16 \mathrm{~m}^{2}$ (Bianco; Sammartano, 2004: 89; Coarelli; Torelli, 1984: 85; Di Giovanni, 1991: 56; Veronese, 2006: 514). O intercolúnio totalizou homogeneamente 6,52 metros, enquanto os intercolúnios normais da frente ocidental atingiram 6,62 metros e aqueles de ângulo 6,28 metros (Mertens, 2006: 233; Veronese, 2006: 514). São as colunas também que propiciaram os elementos de datação do edifício. O longo período de construção do templo se refletiu, sobretudo, na diferença estilística. A transformação da forma e nas proporções dos membros arquitetônicos, e de um modo mais claro nas colunas e nos capitéis, demonstram fases distintas da construção do edifício (Mertens, 2006: 233). Sabemos, assim, que a frente oriental, o lado setentrional e meridional se caracterizaram por colunas do último quartel do século VI a.C., são, portanto, os lados mais antigos, onde predominaram colunas relativamente mais finas com ábacos bem expandidos. Já na frente ocidental as colunas, de proporções mais robustas com equino mais proporcional e sem a cavidade entre este e o fuste, indicam que este lado foi realizado no século $\mathrm{V}$ a.C. no estilo severo. A ausência de caneluras em várias colunas e os restos de estuques em outras indicam que o templo não foi finalizado (Coarelli; Torelli, 1984: 85 e 87; Mertens, 2006: 232 e 233; Veronese, 2006: 514). Ainda acerca dos elementos de datação, algumas considerações advêm da planta do templo. As modificações transcorridas durante as fases de construção mostram que o opistódomo foi realizado na fase de estilo severo e o pronaos e naós, a julgar pela forma dos membros, foram concebidos na época tardo-arcaica. A decoração do capitel de anta do pronaos - de grande formato e fortemente plástico com um motivo de brotos e palmetas - é posterior a 520 a.C. (Mertens, 2006: 233). Dos membros arquitetônicos da parte superior do templo, conhecemos somente um elemento do entablamento: a arquitrave. Realizados também em calcário, os blocos da arquitrave medem $6,50 \times 2,30$ metros e pesam, cada um, dezenas de toneladas. Neles foram encontrados traços dos encaixes para o transporte da Cave de Cusa ao local do templo (Veronese, 2006: 514). 0 entablamento media quase 14 metros de altura e a associação das dimensões das colunas com as dimensões da arquitrave indica que o templo teria alcançado 30 metros de altura (Coarelli; Torelli, 1984: 85; De Angelis, 2003: 138; Veronese, 2006: 514). Nenhum traço do altar foi encontrado e pouco sabemos da cobertura e do aparato decorativo do edifício (Coarelli; Torelli, 1984: 86; Veronese, 2006: 514). Os únicos achados escultóricos na área interna do edifício foram a Tábua de Selinonte e um torso de gigante de época tardo-arcaica recuperado na área do ádito (Coarelli; Torelli, 1984: 86). 
Tipo de culto: Consideramos que o templo G era dedicado a Zeus e para isto nos baseamos na interpretação da Tábua de Selinonte e no padrão de dimensões dos templos da divindade do século VI e V a.C. Consideramos, igualmente, que era dedicado a Zeus Olímpio com base no posterior Olimpiéion de Agrigento (Laky, 2013: 250).

Referências bibliográficas: Bejor, G. Problemi di Localizzazione di Culti a Selinunte. AnnPisa, ser. III, vol. VII, 1: 439-457, 1977; Bianco, L.; Samartano, A. Sèlinonte. Marsala: La Medusa Editrice, 2004; Coarelli; Torelli, 1984; Di Giovanni, G. Selinunte. Itinerario Archeologico. Agrigento: Studio Media; Palermo: Priulla, 1991; Marconi, C. Selinunte. Le Metope dell'Heraion. Modena: Panini Franco Cosimo Editore, 1994; Mertens, D. Città e Monumenti dei Greci d'Occidente. Roma: L’Erma di Bretschneider, 2006; Laky, 2013; Tusa, V. Le Divinità ed I Templi di Selinunte. Kokalos, XIII: 186-193, 1967.

\section{Imagens:}

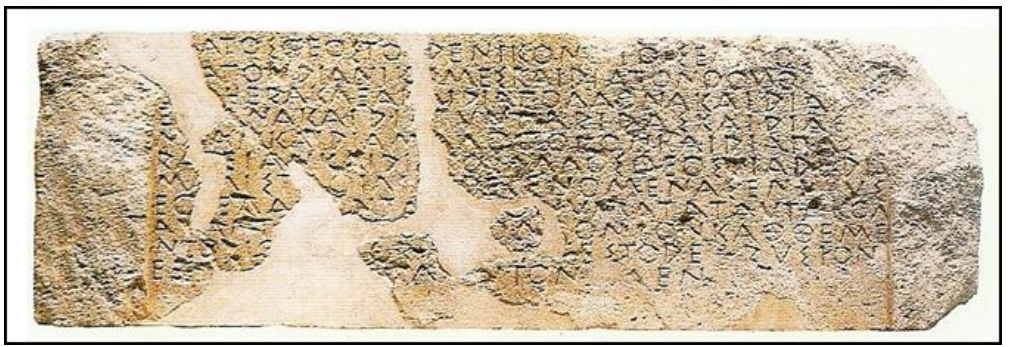

Fig.1 - A Tábua de Selinonte (metade séc. V a.C.). Museu Arqueológico Regional A. Salinas - Palermo (Di Giovanni, 1991: 54)

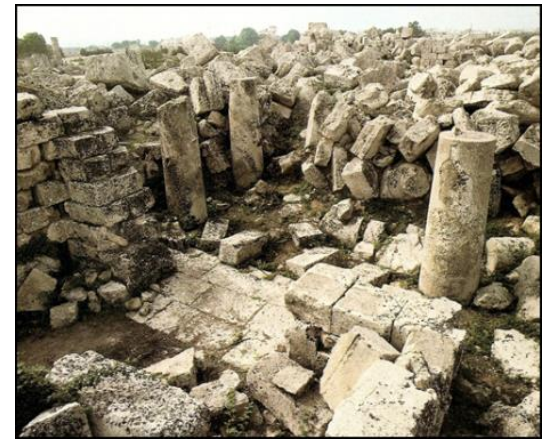

Fig.2 - Vista do naískos dentro da cela com o início de duas fileiras de colunas que dividiam a cela em três naves (Gullini, 1989: fig.510)

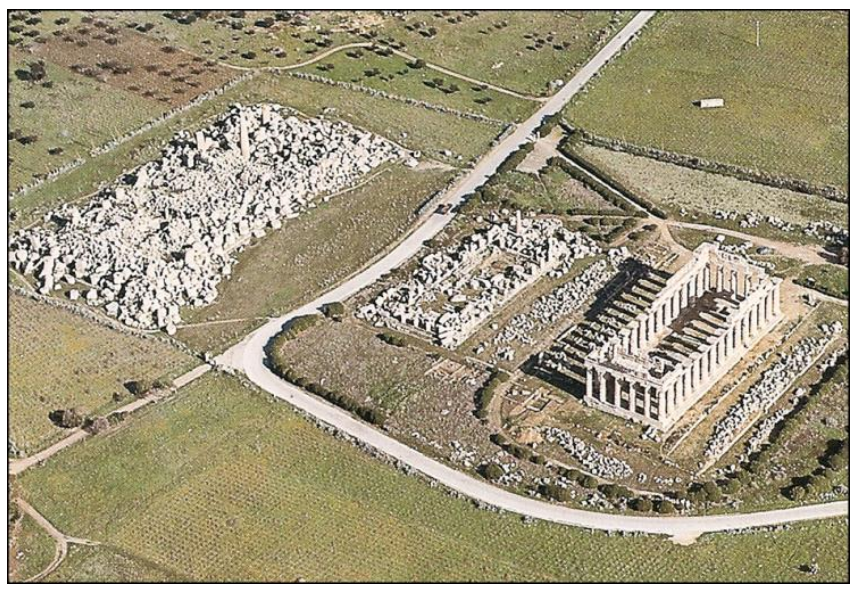

Fig.3 - Vista a partir do lado oeste dos templos G, F, E na colina oriental (Di Giovanni, 1991: 17) 


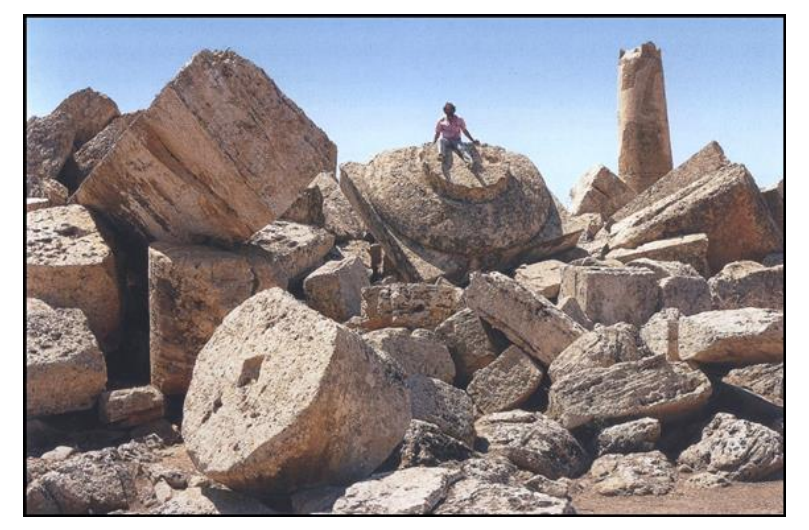

Fig.4- Vista de capitel com ábaco, tambores, colunas e blocos de arquitrave do lado leste (Mertens, 2006: 231, fig. 399)

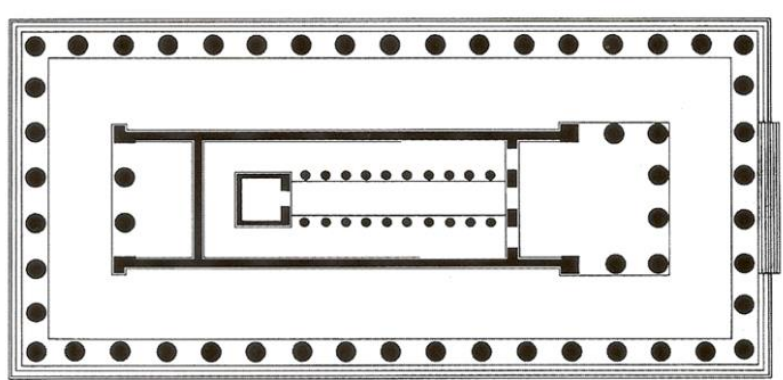

$0.20 m$

Fig.5 - Planta do templo G (Mertens, 2006: 232) 
Datação: Época arcaica (final do século VI a.C.) - época clássica (início do século IV a.C.?).

Localização: A noroeste da cidade, na estrada para Sicione, nas cercanias do rio Asopus.

Tipo de santuário: Planície / suburbano ou extraurbano.

Referências textuais: (Templo) Pausânias,II,V.2-5 / III, VIII.9-IX.2 / II, VII.2-4.

Inscrições: Inexistentes?

Histórico dos achados: Em 1806 o viajante inglês Leake observou que na estrutura do denominado "muro epsitilo" havia também vários fragmentos arquitetônicos de um templo grego e foi o primeiro a descrevê-los e a medí-los. A primeira escavação sistemática na estrutura foi realizada por Richardson em 1896, quando abriu uma trincheira encontrando vários tambores de colunas (Dinsmoor, 1949: 104-105). O material foi estudado por Dinsmoor o qual propôs em 1949 que os achados pertenciam ao maior templo do Peloponeso (Dinsmoor, 1949: 104; Pfaff, 2003: 116; Wiseman, 1978: 84). Escavações na área do ginásio empreendidas por Wiseman em 1966 revelaram outros achados que proporcionaram novas interpretações, sendo a mais recente a de Pfaff de 2003 (Wiseman, 1967b: 412-413; Pfaff, 2003: 116-118).

\section{Documentação arqueológica}

I. Templo: Por enquanto as escavações no setor norte da antiga Corinto não revelaram traços do templo, possivelmente porque não foram realizadas mais a oeste, ao longo da estrada para Sicione após os muros, onde Pausânias viu as ruínas do edifício. Não há ainda evidências materiais disponíveis acerca da localização do templo, que permanece um mistério (Wiseman, 1978: 84). Todavia, há a possibilidade de que algumas partes do Olimpiéion tenham sido descobertas no denominado Muro Epistilo - situado próximo ao ginásio no setor norte da cidade. A estrutura, construída no século IV d.C., para conter as invasões dos Godos de 395 d.C., foi formada a partir de materiais reutilizados, (depois unidos com cimento) das ruínas do ginásio, do edifício com domo e do sistema hidráulico do setor oeste, destruídos no terremoto de 375 d.C (Bookidis, 2003: 253; Pfaff, 2003: 115; Wiseman, 1967b: 411-412; 1972: 7; 1978: 84). 0 material estudado por Dinsmoor encontrado no final do século XIX compôs-se de partes de um grande tambor de coluna e de um bloco de arquitrave (epistilo). De acordo com o pesquisador, o tambor pertenceu a uma coluna monolítica semelhante às do templo de Apolo em Corinto e, esta parte encontrada no muro, tinha 1,15 metros de altura preservada. Das vinte caneluras, apenas treze se conservaram, e o diâmetro da coluna encontrada foi estimado em 1,817 metros (Dinsmoor, 1949: 106). O bloco da arquitrave, por sua vez, foi transformado em uma circunferência para facilitar o seu deslocamento até a área do muro, e conservou a altura 
original de 1,751 metros, o comprimento máximo de 1,71 metros e a largura de 0,965 metros (Dinsmoor, 1949: 107). Na face sul conservada estão ainda visíveis os contornos da tênia e da meia régula, que mede 0,587 metros de comprimento. A medida levou Dinsmoor a estabelecer a largura do tríglifo em 1,174 metros (Dinsmoor, 1949: 107). Aparentemente desconhecidas a Dinsmoor, as escavações empreendidas por De Waele de 1929 a 1934 nas áreas próximas ao Asclepiéion trouxeram à luz outros pequenos fragmentos que podem ser assinalados ao mesmo grande templo, tais como duas pequenas partes de um fuste de coluna dórico, sete gotas do mútulo e fragmentos de telhas de mármore (Pfaff, 2003: 116). Na primeira campanha de escavações na área do ginásio em 1965, Wiseman descobriu uma série de materiais reutilizados, de outras construções, na fundação de um muro apoiado no lado sul do edifício com domo. Dentre os remanescentes foi identificado um bloco de cornija dórica em calcário muito maior do que qualquer outro encontrado em Corinto (Wiseman, 1967a: 29). Nele preservou-se o mútulo no ponto exato da quinta fileira de gotas. Embora tenham sido removidas, as suas marcas permitiram estabelecer a medida das gotas em 0,064 metros na raiz. Ao longo das pesquisas, algumas gotas encontradas soltas devem ter pertencido ao bloco, pois medem 0,0626 metros de altura e tem um diâmetro de 0,064 metros na raiz e 0,0695 metros na base (Wiseman, 1967a: 29-30). O bloco da cornija deve ter tido dois mútulos completos e duas vias na parte inferior e atingido 2,37 metros de comprimento; o espaçamento axial indicado é de 4,74 metros (Wiseman, 1967a: 31; 1978: 84). Durante as escavações de 1966, foram encontradas várias gotas, todas de grande tamanho, que, juntamente com aquelas encontradas na primeira campanha, provavelmente pertenceram ao mesmo edifício, como o fragmento de bloco de cornija recuperada perto do edifício com domo. Várias partes de colunas dóricas de calcário foram também encontradas, incluindo um fragmento que tem uma canelura de 0,253 metros de largura. Mas o remanescente arquitetônico mais interessante encontrado em 1966 foi a parte de uma base de acrotério central, cuja altura máxima preservada é de 1,455 metros. Os cortes na face vertical indicam que o edifício era coberto com telhas de Corinto; as telhas de baixo eram 0,731 metros larga e as de cobertura 0,279 metros (Wiseman, 1967b: 412-413). Em 1968, na área do ginásio, foi recuperado o ábaco de um capitel, que mediu 2,89-2,93 metros de largura (Wiseman, 1978: 84). Dinsmoor (1949) propôs as principais dimensões do templo com base no bloco maior do epistilo, onde encontrou partes preservadas da tênia e, no final direito, da régula. Acreditando que tivesse sido preservado, também, 0 lado final esquerdo original, concluiu que a distância entre ambos os lados finais da régula era equivalente à metade do total de seu comprimento. Assumindo ser a régula restaurada equivalente a largura dos tríglifos do friso - como é normalmente o caso da ordem dórica - estimou as dimensões dos tríglifos e das métopas. Dessas dimensões estimou o espaçamento interaxial das colunas $(5,438 / 5,773$ metros) e então a altura e o diâmetro da parte mais baixa das colunas (Pfaff, 2003: 115-116). Estas dimensões restauradas por Dinsmoor provaram ser maiores do que aquelas do templo de Zeus em Olímpia e por isso levaram o pesquisador a nomear o edifício como o maior templo do Peloponeso (Pfaff, 2003: 116; Wiseman, 1967a: 31; 1978: 84). Wiseman (1967 e 1969) baseado no bloco da cornija, que preservou uma parte suficiente do mútulo e o comprimento de uma parte inteira, realizou uma aproximação do comprimento da unidade do friso e do espaçamento inter-axial das colunas, menores $0.80 \mathrm{~m}$ que o proposto por Dinsmoor (Pfaff, 2003: 116-117). Pfaff (2003) constatou que o final do bloco do epistilo não tinha anatirose porque era oblíquo. Tinha uma superfície ondulada causada, possivelmente, pelo corte de uma serra, o que indica um segundo uso do material. Portanto, o lado final esquerdo do bloco não era original, o comprimento da régula e todas as outras dimensões derivadas dela, medidas por Dinsmoor, eram inválidas. Já as poucas dimensões confiáveis do bloco do epistilo, sua altura e sua profundidade, são perfeitamente adequadas à escala do bloco de cornija e a outros elementos encontrados por Wiseman (Pfaff, 2003: 117). Devido à aparente disparidade nas escalas e nas datações entre o templo de Dinsmoor e os elementos descobertos a partir de 1965, Wiseman foi levado a concluir que se tratavam, na verdade, de dois edifícios colossais representados 
pelos membros arquitetônicos na área do Muro Epistilo (Pfaff, 2003: 117; Wiseman, 1978: 84). A investigação de Pfaff, contudo, indicou que havia realmente apenas um templo colossal não tão grande como Dinsmoor estimou. A reconstrução das elevações demonstrou que a escala era um pouco menor que a do templo de Zeus em Olímpia: a altura do epistilo era menor 0,02 metros, e os intercolúnios eram, aproximadamente, 0,48 metros menores. No entanto, a escala é $25 \%$ maior que a do templo de Apolo em Corinto, demonstrando que este templo tinha um significado extraordinário para os antigos coríntios (Pfaff, 2003: 117). O prestígio do templo também ficou evidente no uso das caras telhas de mármore branco ao invés das usuais telhas de terracota (Pfaff, 2003: 118). Embora as dimensões totais do templo não possam ainda ser determinadas, e a despeito do edifício ser menor do que o templo de Zeus em Olímpia, Pfaff defende que é prudente evitar chamá-lo como o maior templo do Peloponeso, da forma como aparece no artigo de Dinsmoor. Assim, o pesquisador sugere que o título Grande Templo seja empregado como uma designação conveniente e apropriada para o maior edifício de Corinto (Pfaff, 2003: 117). Até o momento nenhuma fundação do templo foi localizada e, por esse motivo, a planta e as dimensões totais não podem ser determinadas. Entretanto, é certo que um edifício desta escala era períptero e é igualmente provável que tivesse uma fachada de tipo hexastilo (Pfaff, 2003: 117). A pesquisa de Pfaff indicou que o templo não fora construído no início do século VI a.C. ou no final do século V a.C., como propuseram Wiseman e Dinsmoor, mas no final do século VI a.C. O pesquisador defendeu a data com base nos anéis do capitel encontrado, pois são típicos do final da época arcaica e do início do período clássico. As gotas do epistilo foram esculpidas livremente na face da estrutura como no templo de Apolo em Corinto, datando ainda o templo no século VI a.C. O edifício não pode ser datado antes do final do século VI a.C. devido aos detalhes da cornija, especificamente o perfil curvo para o gotejamento e pela combinação das viae estreitas e pelos mútulos largos com três fileiras de seis gotas, que se tornou um padrão para as cornijas dóricas do último quartel do século VI a.C. A data do final do século VI a.C. é também indicada pelo aspecto de lewis holes no epistilo, que não é atestado antes de c.540-530 a.C. (Pfaff, 2003: 118-119; Wiseman, 1978: 84). O primeiro a assinalar que os remanescentes pertenceram ao templo de Zeus Olímpio visto por Pausânias parece ter sido Wiseman no seu relatório das escavações na área do ginásio em 1965 (Wiseman, 1967a: 31). Ao longo das pesquisas acerca do edifício, os pesquisadores cogitaram que os membros arquitetônicos poderiam pertencer ao templo de Zeus Kapetolios/Koriphaios localizado pelo viajante grego nas proximidades do teatro, na direção do ginásio. Mas, como lembra Wiseman, este templo de Zeus deveria ainda existir na época da visita de Pausânias (Pfaff, 2003: 119; Wiseman, 1978: 84). Pfaff chama atenção para o fato de que alguns dos elementos do Grande Templo carregam traços de estuque romano, indicando que o edifício, como o templo de Apolo, foi reparado no período romano. Por esta razão, seria difícil atribuir os remanescentes ao Olimpiéion, que aparentemente estava queimado quando o viajante o viu no século II d.C. Pfaff termina sua discussão sobre a atribuição do templo considerando a afirmação de Wiseman de que é bem possível que as porções do Grande Templo tenham sido desmanteladas e reutilizadas antes da chegada de Pausânias em Corinto. Por isso, seria difícil, mas não impossível associar o edifício ao templo de Zeus Olímpio (Pfaff, 2003: 119).

Tipo de culto: Por outro lado, é possível sim atribuir a instituição do culto de Zeus Olímpio a um período mais antigo, à época da tirania Cipsélida. De acordo com Estrabão (8.3.30) e Platão (Fedro, 236B), Cípselo dedicou uma estátua de Zeus em ouro ao templo do deus em Olímpia. A origem do culto em Corinto, assim, tem origem na relação da pólis com o santuário, que é bem antiga: Corinto foi uma das primeiras cidades a participar dos jogos (Laky, 2013: 237). 
Referências bibliográficas: Bookidis, N. The Sanctuaries of Corinth. Em: Williams II, C.K.; Bookidis, N. (eds.). Corinth. The Centennary 1896-1996. Results of Excavations Conducted by the American School of Classical Studies at Athens. Volume XX. Atenas: The American School of Classical Studies at Athens, 2003, pp. 247-259; Dinsmoor, W.B. The Largest Temple in the Peloponnesos. Hesperia Supplments. Comemorative Studies in Honor of Theodore Leslie Shear, vol. 8: 104-115, 1949; Laky, 2013, pp. 232-237; Wiseman, J. Excavations at Corinth: the Gymnasium Area, 1965. Hesperia, 36: 13-41, 1967a; Excavations at Corinth: the Gymnasium Area, 1965. Hesperia, 36: 402-428, 1967b; The Land of the Ancient Corinthians (SIMA 50), Gotemburgo, 1978.

\section{Imagens:}
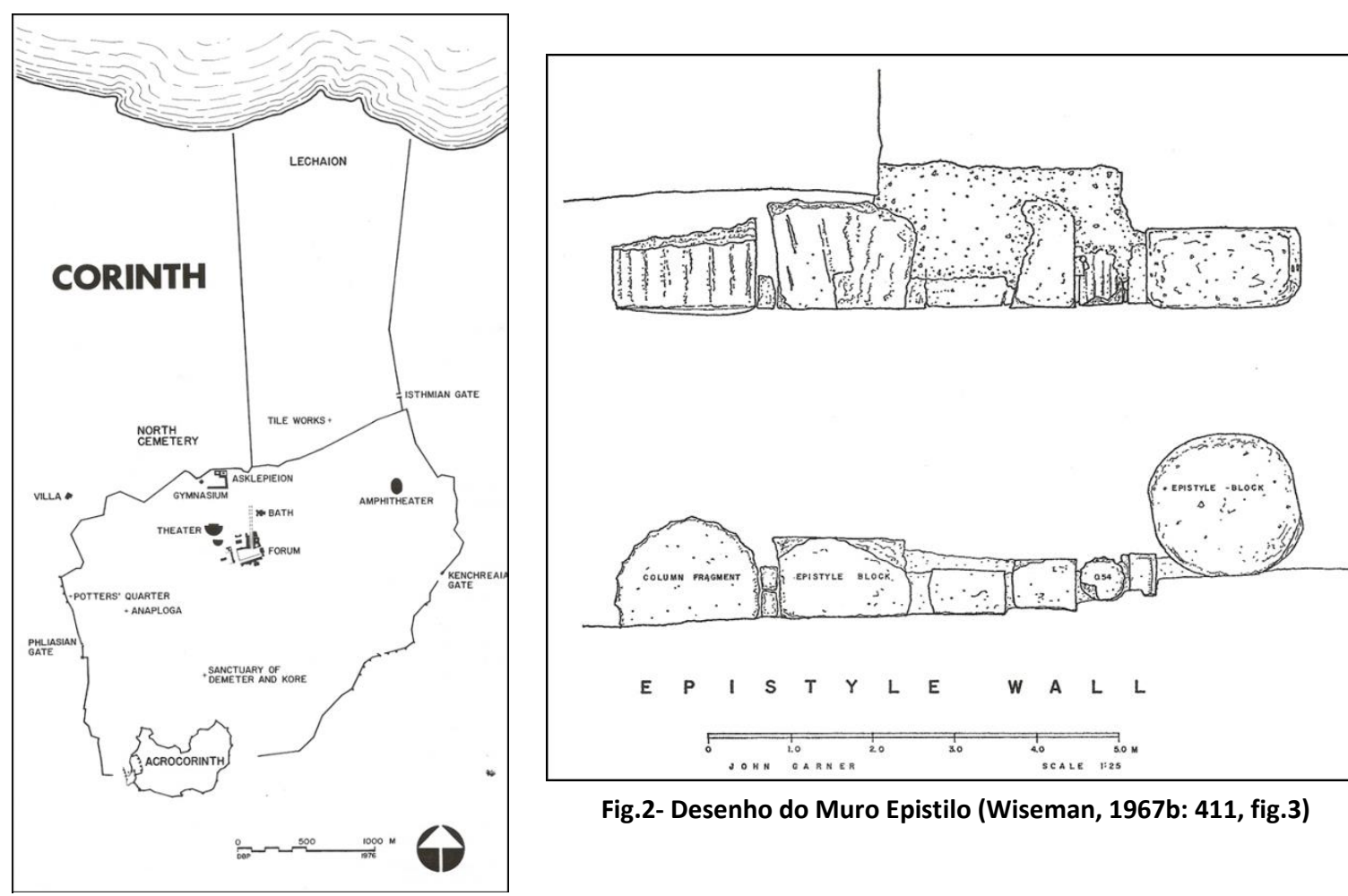

Fig.2- Desenho do Muro Epistilo (Wiseman, 1967b: 411, fig.3)

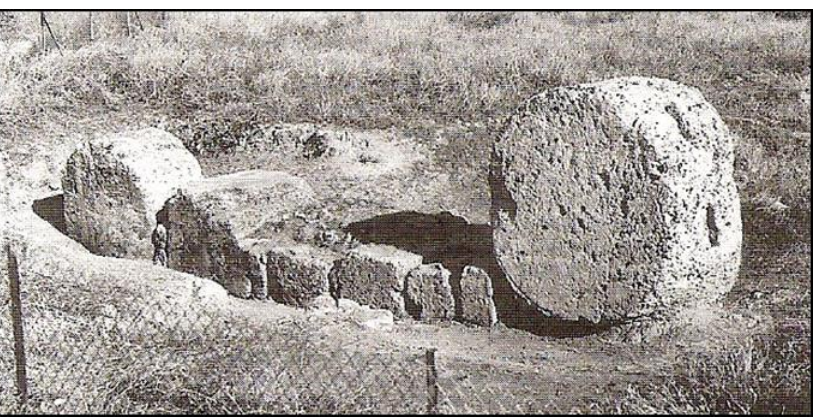

Fig.3- O Muro Epistilo (Pfaff, 2003: 115, fig.7.27)

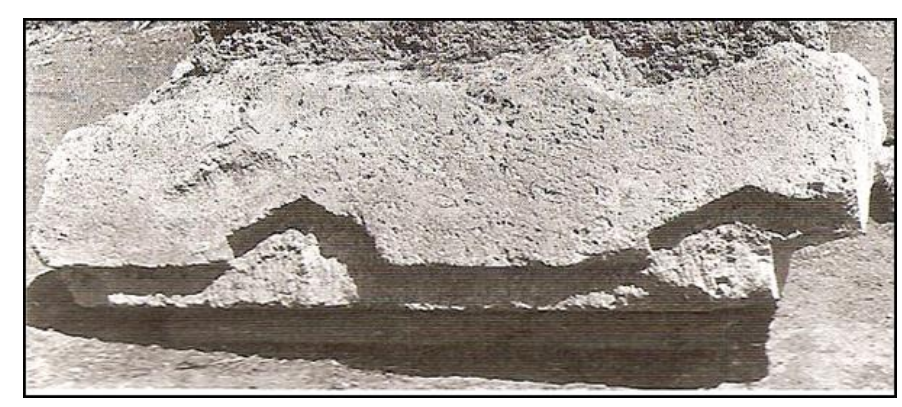

Fig.4 - A base do acrotério central (Pfaff, 2003: 116, fig.7.30)

Fig.1 - Planimetria geral de Corinto (Williams II; Bookidis, 2003: XXVIII) 
Datação: Final da época arcaica ou início da clássica (séc.VI-V a.C.) - ?

Localização: Na Trifilia setentrional, em uma colina perto de Skillounte, na área do atual vilarejo de Bambes (Bábes-Makrisíon, provável antiga pólis de Pyrgos), a 3-4 km a sudeste de Olímpia (Lippolis, 2007: 650; Taita, 2007: 43).

Tipo de santuário: Colinar / Urbano de Pyrgos? / extraurbano entre Pyrgos e Skillounte?

\section{Referências textuais: Inexistente.}

Inscrições: Um bloco fragmentário encontrado na cela, no nível do solo, porta a inscrição TO $\Delta \mathrm{IO}$, que permitiu a atribuição do templo a Zeus (Lippolis, 2007: 650; Taita, 2007: 43). Mas Taita, citando Moustaka (2002, pp.309-310, no.11), diz que a atribuição do templo a Zeus foi confirmada pelo achado de um peso com a epígrafe $\Delta$ Ios ka入 (Taita, 2007: 43, nota 9).

Histórico dos achados: $O$ templo foi escavado em 1953 por N. Yalouris e o resultado da pesquisa foi publicado por ele em Praktiká (1954). Breves relatos da pesquisa foram divulgados no mesmo ano no BCH 78 (1954) e AJA 58 (1954).

\section{Documentação arqueológica}

I. Templo: Trata-se de um edifício dórico prostilo, articulado em pronaos e cela de dimensões de $4,55 \times 8,40 \mathrm{~m}$. Tinha um crepidoma de 2 degraus, sua altura conservada atinge $0,90 \mathrm{~m}$ e era todo construído em calcário conchífero. Foram encontrados fragmentos de tríglifos e telhas de tipo coríntio e lacônio de época clássica. O frontão não hospedava algum grupo escultóreo (Lippolis, 2007: 650).

II. Aparato de culto: Apesar de o templo remontar ao final do arcaísmo, a tipologia de algum aparato cerimonial em cerâmica sugere que a comunidade praticava atividades sagradas há mais tempo (Taita, 2007: 43). Trata-se, em particular, de duas perirrhanteria, uma do último quartel do séc. VII a.C., e a outra da primeira metade do séc. VI a.C. (Taita, 2007: 43, nota 10).

Tipo de culto: A singularidade de tal santuário leva-se a questionar as razões que levaram a dedicar, nesta comunidade, de um templo a Zeus não apenas alguns decênios antes da construção do templo de Zeus em Olímpia, mas também a brevíssima distância do grande santuário, valorizando a relação com o culto central em termos de eventual filialidade ou concorrência (Taita, 2007: 16).

Comentário: Além do templo na área, ao longo do declive da colina mais elevada, na parte nordeste, foi encontrado um complexo de ao menos quatro habitações, dentre as quais uma pertencente ao final do séc. VII a.C. A existência de estruturas permanentes foi confirmada pelos elementos arquitetônicos do início do 
arcaísmo. Os achados mais antigos de vasilhames encontrados nos edifícios são do final do séc. VII, mas a maior parte pertence ao início do séc. VI a.C. Não foi definitivamente resolvida a função destes vasilhames: podem se tratar de recipientes para o uso cotidiano ou instrumentos de uso ritual (Taita, 2007: 43). Segundo Taita, o cume da colina, que domina o vale do Alfeu, devia ter sido reservado ao desenvolvimento de cerimônias, reforçando a interpretação das habitações a pouca distância do templo como estruturas para os funcionários sacros. A documentação arqueológica permite situar a existência deste assentamento ao menos no fim do séc. VII a.C., o achado de votivos do período geométrico tardio com figuração de animais denuncia, no entanto, uma ocupação mais antiga do território, quanto menos para a prática do culto. A cronologia da produção cerâmica coloca 0 ápice do sítio entre 0 séc. VI e V a.C. $O$ material encontrado, em grande parte ainda inédito, contribuirá para a definição das fases de formação e evolução da comunidade e a natureza da relação instaurada com o culto vizinho de Zeus Olímpio (Taita, 2007: 44).

Referências bibliográficas: Carinci, F. s.v. Elide, n.1, em: Enciclopedia dell'arte antica classica e orientale. Roma, 1958-; Courbin, P. Chronique des Fouilles en 1953, BCH, 78 (1954), pp.95-229; IACP, p.545; Lang, F. Die Keramik von Babes in der Landschaft Elis, MDAI(A), 107 (1992), pp.43-105 (ver p.46); Lippolis, 2007,

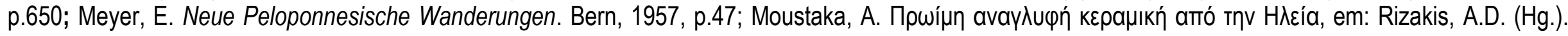
Achaia und Elis in der Antike, Akten des I. Internationalen Simposiums (Athen, 19-21 Mai, 1989), Athen, 1991, pp.341-350; Moustaka, 2002, pp.303, 304-307,

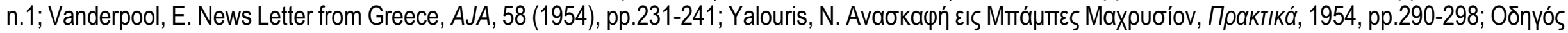
apхаıоти́т 


\section{Imagens:}

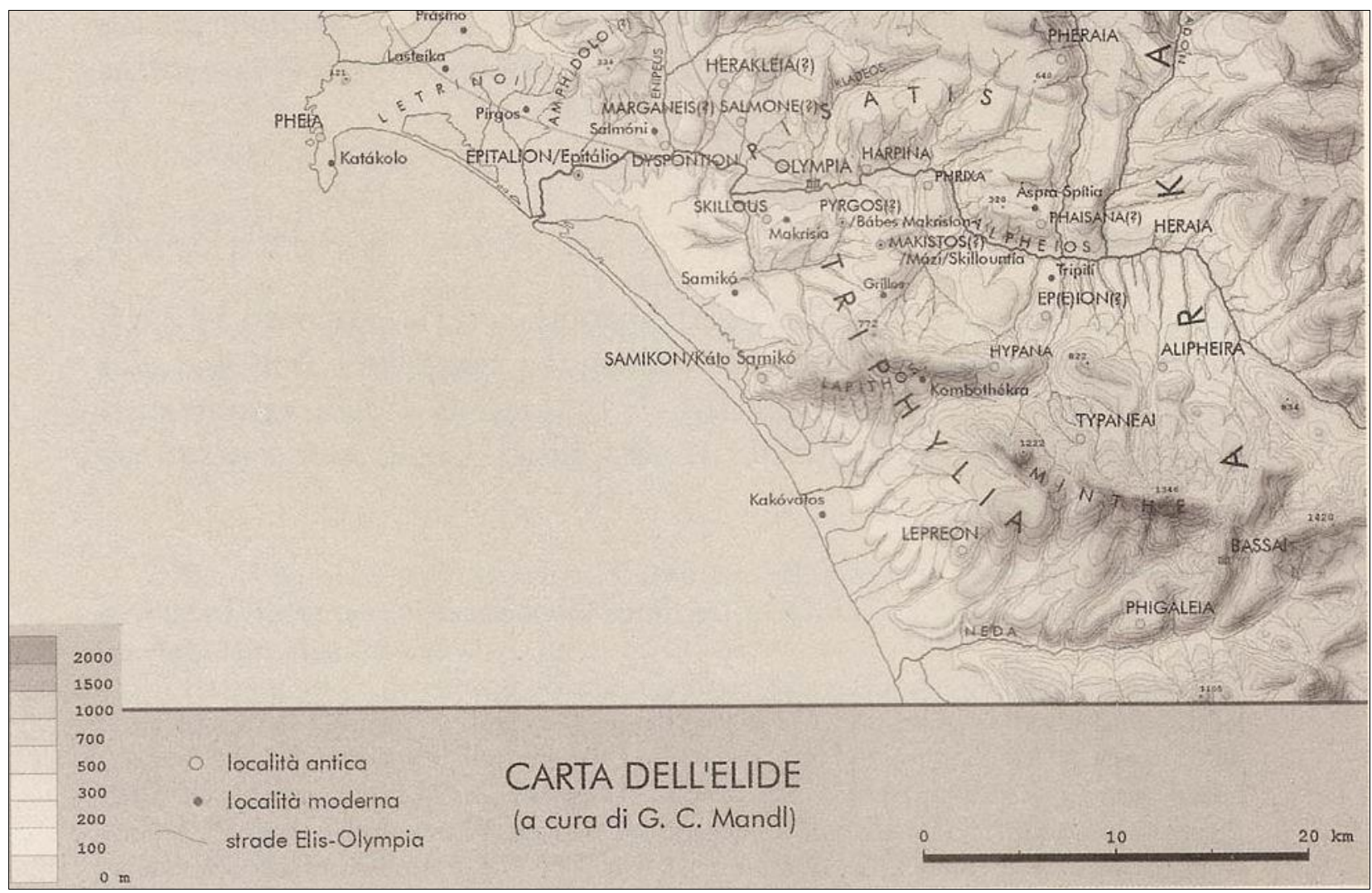

Fig.1- Mapa da área de Élis (Taita, 2007: 18) 
Datação: Época arcaica (séc. VI a.C.) - período helenístico (I a.C.).

Localização: No lado leste da cidade, nas proximidades do porto grande e à muralha nessa área (Laviosa, 1985: 47-48).

Tipo de santuário: Urbano.

\section{Referências textuais: Inexistente?}

Inscrições: Sobre o culto e os seus sacerdotes entre os séculos V-I a.C.; uma inscrição da metade do século IV a.C. faz referência a um colégio de onze sacerdotes; epígrafe fragmentária, do último quartel do século IV a.C., que menciona Zeus e uma segunda divindade, a qual se aceita se tratar de Hera; exposição de tratados no santuário, tal como o de Ptolomeu I entre três chefes mercenários, a cidade de lasos, que foi encontrado no muro bizantino; a oeste do muro do fundo do tesouro foram encontrados inscritos numerosos decretos (Laviosa, 1985: 47-48, 51; Landolfi, 1985: 59).

Histórico dos achados: O início das escavações no santuário de Zeus Megistos ocorreu em 1962, quando foi encontrada a epígrafe sobre o tratado de Ptolomeu I sobre um dos blocos do muro dentro da porta leste (Laviosa, 1985: 48). Nas escavações de 1973, foram recuperadas as bases votivas para estelas e dedicações votivas e atrás da base oriental foi encontrado o kouros arcaico (Laviosa, 1985: 50). Nas campanhas nos anos seguintes vieram à luz o naikos ou tesouro (Laviosa, 1985: 50). Na campanha de 1982, logo a oeste do muro de fundo do tesouro, foi encontrada uma porta na qual foram inscritos numerosos decretos, que fazem referência ao santuário de Zeus e Hera (Laviosa, 1985: 51).

\section{Documentação arqueológica}

I. Témeno: Em direção oeste, depois de poucos metros, o muro do períbolo formava um ângulo reto e prosseguia em direção norte, o que levou a concluir que a área escavada correspondia ao ângulo sudoeste do témeno (Laviosa, 1985: 50).

II. Naikos ou tesouro: A bibliografia deixa em dúvida se se tratava de um edifício de culto ou apenas um tesouro para abrigar os objetos votivos mais valiosos do santuário. Este aparece datado da época clássica, no artigo de Laviosa, e do início da época helenística, no artigo de Landolfi (Landolfi, 1985: 59; Laviosa, 1985: 50). Há indícios que o edifício foi ampliado a leste talvez depois do século IV a.C. (Laviosa, 1985: 51). A oeste do muro do naiskos ou tesouro foi encontrada uma porta, na qual foram inscritos vários decretos (Laviosa, 1985: 51). 
III. Bases votivas: Foram encontradas várias bases votivas na área do santuário. Na quota de 1,20-1,30 m da parte de cima conservada do muro bizantino veio à luz um pavimento formado por grandes lajes de pedra, sobre o qual se apoiavam uma série de bases típicas para estelas e dedicações votivas, próprias dos séculos IV e III a.C. Atrás da base mais oriental foi encontrado o kouros arcaico, datado de c.520 a.C. (Laviosa, 1985: 50 e 52). No ângulo sudoeste do témeno também foram encontradas outras bases votivas (Laviosa, 1985: 50). No fundo do naiskos ou tesouro, ao longo do lado oposto da entrada, estava outra dessas bases (Laviosa, 1985: 51). No lado oeste do tesouro foram encontradas outras bases para estelas votivas, algumas das quais da época da destruição do santuário (Laviosa, 1985: 51).

IV. Depósito votivo e objetos votivos: Foi encontrado sob o naiskos ou tesouro e indica, claramente que o culto clássico e helenístico foi precedido por um longo culto de época arcaica (Laviosa, 1985: 51). 0 depósito possuía dois estratos diferentes - os objetos votivos do estrato superior são posteriores à construção do naiskos, enquanto aqueles do inferior são anteriores. A maior parte dos objetos votivos se trata de figurinhas de terracota datadas entre a segunda metade do século VI a.C. e os séculos III-II a.C. e uma grande quantidade de fragmentos de cerâmica local datadas entre a segunda metade do século VI a.C. e o primeiro quartel do século V a.C. (Landolfi, 1985: 59). Do ponto de vista quantitativo, dominam prótomos femininos de tipo ródio, datados entre os séculos VI-V a.C, ligados ao culto de divindades ctonias; estatuetas femininas com chiton e himátion com os braços abaixados ao lado do corpo, típicos da estatuária de Samos e da costa anatólica; estatueta que representa um casal divino sentado interpretado como a hierogamia de Zeus e Hera, elaborado em ambiente sâmio e conhecido em Rodes. De época arcaica prevalece a figura feminina sentada ou em pé proveniente da Jônia meridional (Landolfi, 1985: 59 e 61). De material cerâmico, são poucas as importações de Corinto e muito abundantes as de cerâmica do leste grego (da Jônia e de Samos), sendo a predominante aquela proveniente da Ática (séculos VI-V a.C.).

Tipo de culto: Atribui-se o estrato inferior do depósito votivo a uma divindade feminina indígena, cujos atributos, em época helenística, podem ter sido assimilados por Hera (Landolfi, 1985: 65). Novas escavações permitirão estabelecer se tal santuário ocupou só uma parte do témeno de Zeus Megistos ou se desde o início do culto de Zeus este esteve associado ao de Hera (Laviosa, 1985: 51). O epíteto Megistos de Zeus ocorre na área da Ásia Menor em período muito antigo, ao menos desde o século V a.C. (Laviosa, 1985: 47). Inscrições do século V a.C. asseguram o culto de Zeus Megistos já nesse período (Laviosa, 1985: 47).

Referências bibliográficas: Landolfi, M. La stipe votiva del santuario di Zeus, in: Studi su lasos di Caria. Bollettino D’Arte, Suppl. AL, no.31-32: 59-66, 1985; Laviosa, C. Il santuario do Zeus Megistos e il suo kouros arcaico, in: Studi su lasos di Caria. Bollettino D'Arte, Suppl. AL, no.31-32: 47-54, 1985. 


\section{Imagens}

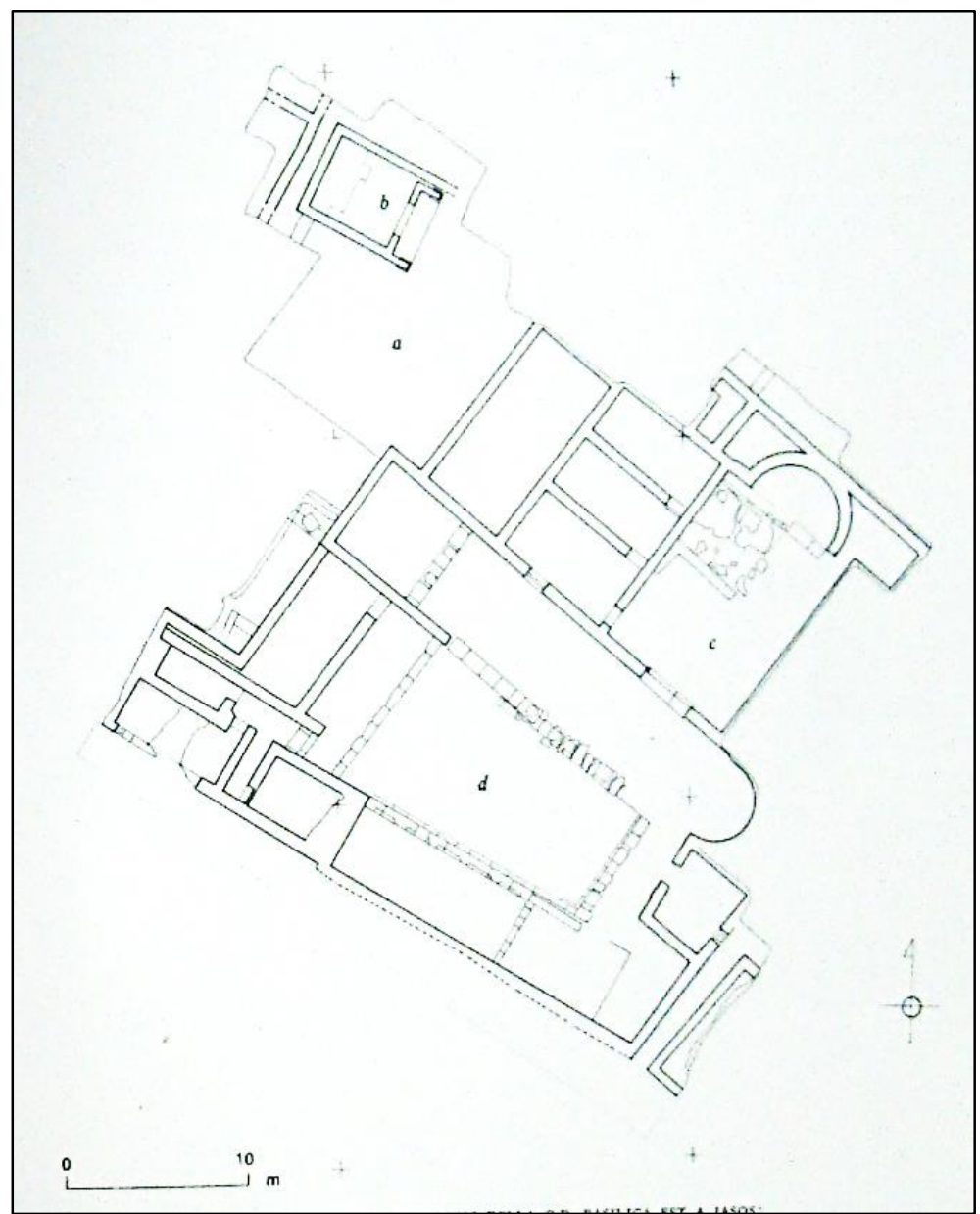

Fig.1- Planimetria do complexo da basílica bizantina: a-) área do santuário de Zeus Megistos; b-) tesouro (Laviosa, 1985: 49, fig.2)

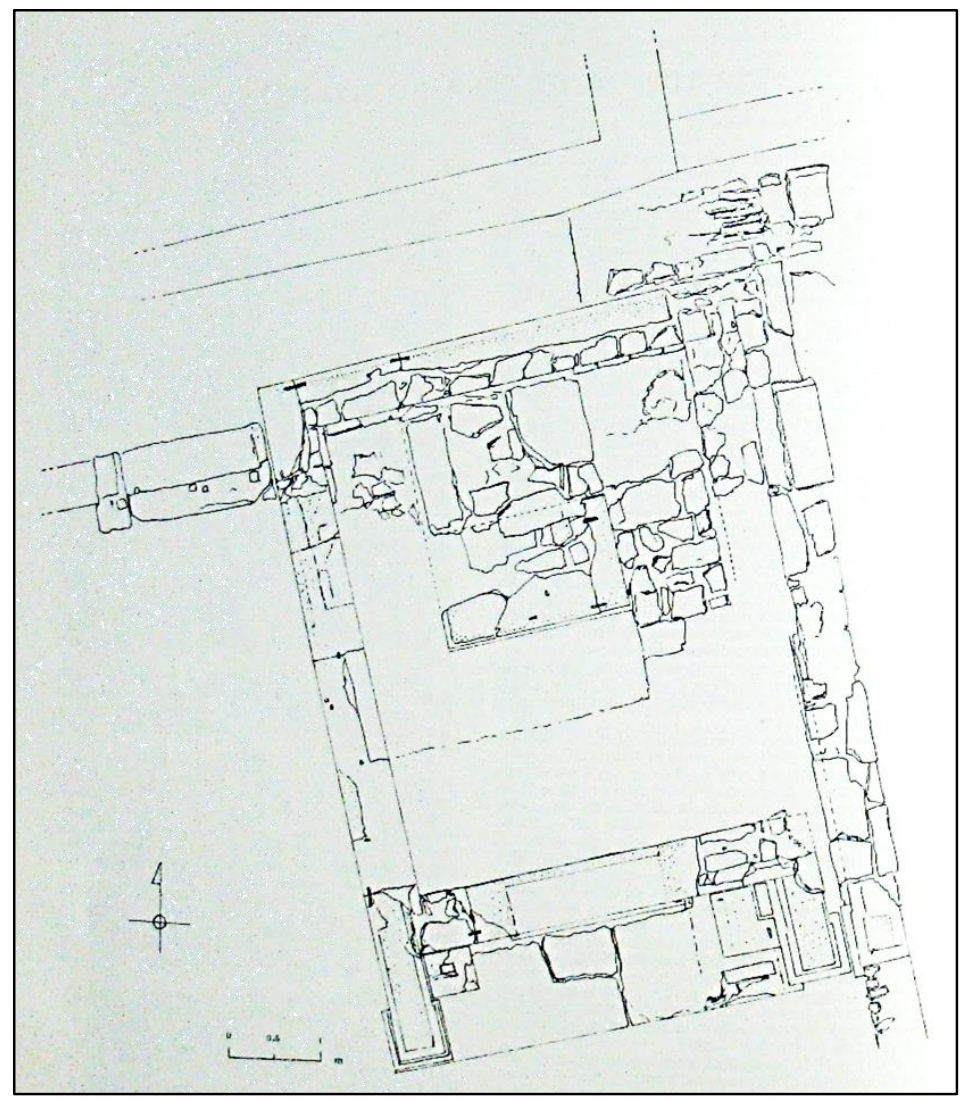

Fig.2- Planimetria do naiskos ou tesouro (Landolfi, 1985: 60, fig.1) 


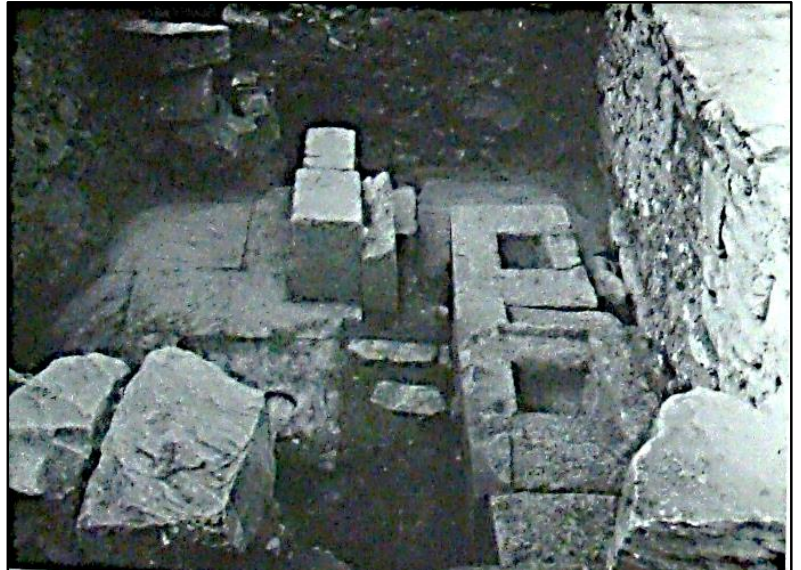

Fig.3- Bases votivas do lado sul do períbolo do santuário de Zeus Megistos (Laviosa, 1985: 50, fig.3)
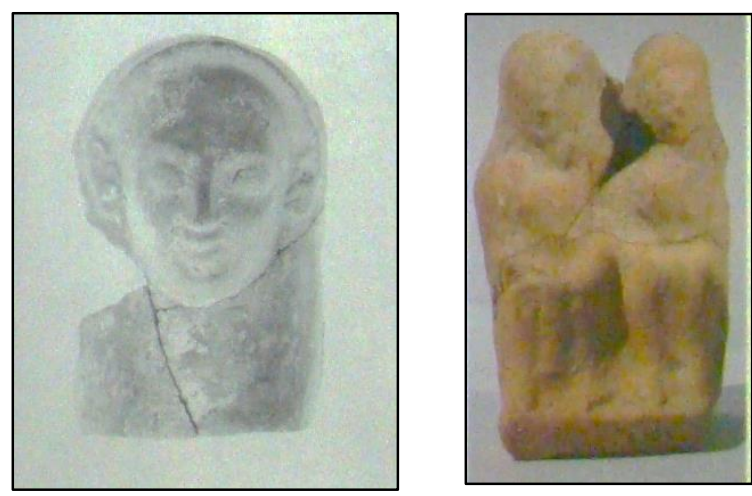

Fig.7- Estatueta de

hierogamia

encontrada no

depósito votivo do

santuário de Zeus

Megistos (Landolfi,

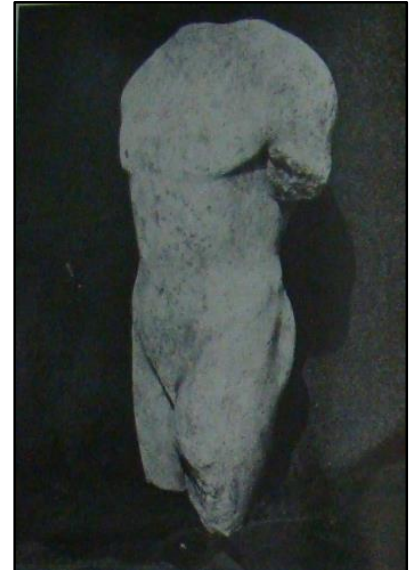

Fig.5- Kouros arcaico

encontrado próximo às bases votivas próximo ao muro bizantino (Laviosa, 1985: 52, fig.6)
Fig.6- Prótomo feminino arcaico do depósito votivo do santuário de Zeus Megistos (Landolfi, 1985: 61, fig.2) 
Datação: Época arcaica (século VI a.C.?) - época romana.

Localização: Na extremidade noroeste da Eubéia, no cabo Kenaion, na área da pólis de Dion.

Tipo de santuário: Planície? / extraurbano, sub-regional e interestadual com função marítima (a partir da época arcaica ou antes?).

Referências textuais: Sacrifícios (Baquílides, Ditirambos 16, linhas 13 e sq.); fundação, descrição, sacrifícios e rituais (Sófocles, As Traquínias 237 e $752 ; 238$ e 754; 760-762; 783-784; 792 sq.); menção? (Estrabão 10.1.9).

Inscrições: Tratado de C.410-390 a.C. entre Erétria e Histiaea faz referência ao santuário, mas sem explicitar a divindade (IG XII, 9, 188, linhas 18-19).

Histórico dos achados: Em 1912, G. Papabasileiou encontrou os restos do que teria sido um templo antigo, identificando a estrutura de um altar e do muro de períbolo, advertindo a atividade de expoliação e transporte dos blocos de pedra do edifício para o litoral da Lócrida (Arjona Pérez, 2007: 54). Uma década depois, N. Pappadakis retomou as investigações, não encontrou as estruturas do tempo, concentrando-se na área do períbolo, onde encontrou uma construção do tipo arcaica destinada ao uso dos peregrinos e três torres, além de material cerâmico (Arjona Pérez, 2007: 55). Atualmente nos arredores da área da igreja de Ágios Konstantinos não se vê as estruturas do períbolo investigado por Pappadakis (Arjona Pérez, 2007: 55).

\section{Documentação arqueológica}

I. Muro de períbolo: Restos do santuário foram descobertos no local da igreja de Ágios Konstantinos em Lithada, como as fundações do muro de períbolo e uma quantidade de cerâmica, principalmente de época clássica, helenística e romana; alguns cacos encontrados podem ser de época arcaica e anterior (Arjona Pérez, 2007: 54-55; Zolotnikova, 2013: 107). O períbolo tinha uma planta pentagonal e foi construído sobre fundações de calcário de $2,5 \mathrm{~m}$ de largura e dos cincos lados se conservaram apenas em bom estado o sudoeste, o noroeste e o nordeste (Arjona Pérez, 2007: 55).

II. Altar: A poucos metros do muro de períbolo, de planta circular e com três filas de pedras (Arjona Pérez, 2007: 54).

III. Torres: Foram encontradas as estruturas de três torres situadas nos ângulos do pentágono, edificadas com blocos de calcário pro-isodomos e de largura de c.3 m (Arjona Pérez, 2007: 55). 
Tipo de culto: 0 material cerâmico encontrado por Pappadakis sugere que em algum momento no período helenístico o santuário sofreu um programa edilício, provavelmente custeado pela pólis de Histiaea, que controlava a península do Kenaios (Arjona Pérez, 2007: 55). Para M. Arjona Pérez, não se pode descartar a possibilidade de que Zeus Kenaios havia tido alguma função na vida política das póleis que controlaram a área sagrada. A seu ver, deve-se também relacionar 0 culto à cidade de Dion, vinculada etimologicamente ao deus. A inscrição permite pensar que Histiaea escolheu o local, talvez posteriormente, para expor determinadas decisões votadas pelo corpo cívico da cidade (Arjona Pérez, 2007: 55). Sobre Dion, para Zolotnikova, o toponímio pode indicar que a extremidade noroeste da Eubéia foi dedicada a Zeus em períodos mais antigos, como na Idade do Ferro - o deus, a seu ver, pode ter sido cultuado em algum tipo de santuário na cidade de Dion (Zolotnikova, 2013: 108). Por memória de tempos mais antigos, talvez durante a época arcaica, a veneração de Zeus na área adquiriu grande importância e um novo santuário foi estabelecido em um porto mais importante, o cabo Kenaion, provavelmente para servir a propósitos regionais (Zolotnikova, 2013: 108). Nada se sabe da natureza mais antiga, do caráter original do culto de Zeus Kenaios (Zolotnikova, 2013: 108). Em seu estudo sobre a área sagrada, Arjona Pérez conclui que o santuário pode ter desempenhado uma função política para as póleis locais - onde as populações podiam consultar disposições de governo -, mas também uma função marítima, como ponto de contato entre viajantes e navegantes que por ali passavam (Arjona Pérez, 2007: 55). Teria sido um espaço sagrado, onde tanto os membros de um corpo cívico de uma pólis como os estrangeiros poderiam depositar oferendas originárias de distintas regiões (Arjona Pérez, 2007: 56).

Referências bibliográficas: Arjona Pérez, M. Tres santuarios liminales de Eubea. Saldvie, no.7: 49-69, 2007; Zolotnikova, 0. Zeus in the early Greek mythology and religion - from prehistoric times to early archaic period. BAR series, 2013. 


\section{Imagens}

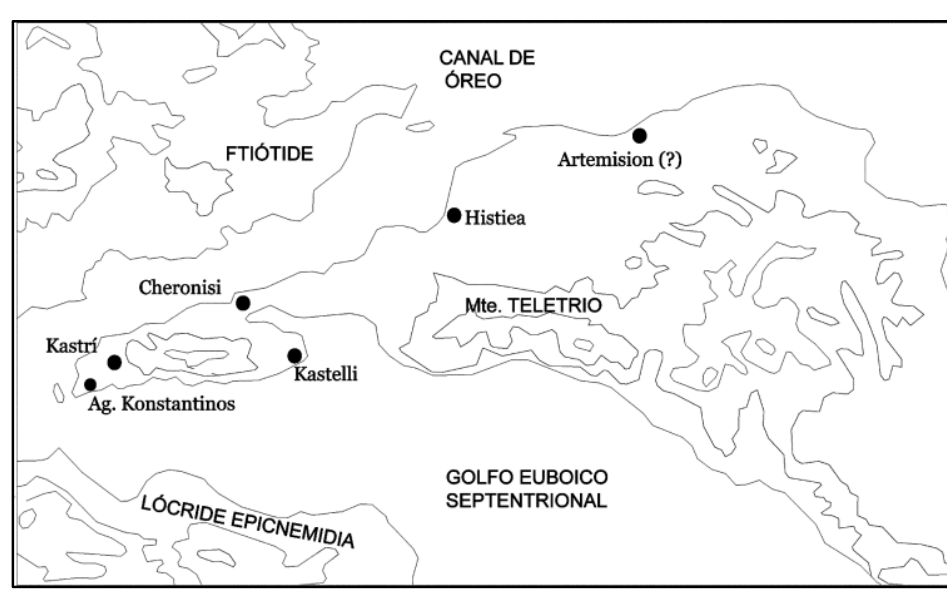

Fig.1- Mapa do golfo

setentrional da Eubéia,

localizando Ágios

Konstantinos no cabo

Kenaion (Arjona Pérez, 2007: 52, fig.2)

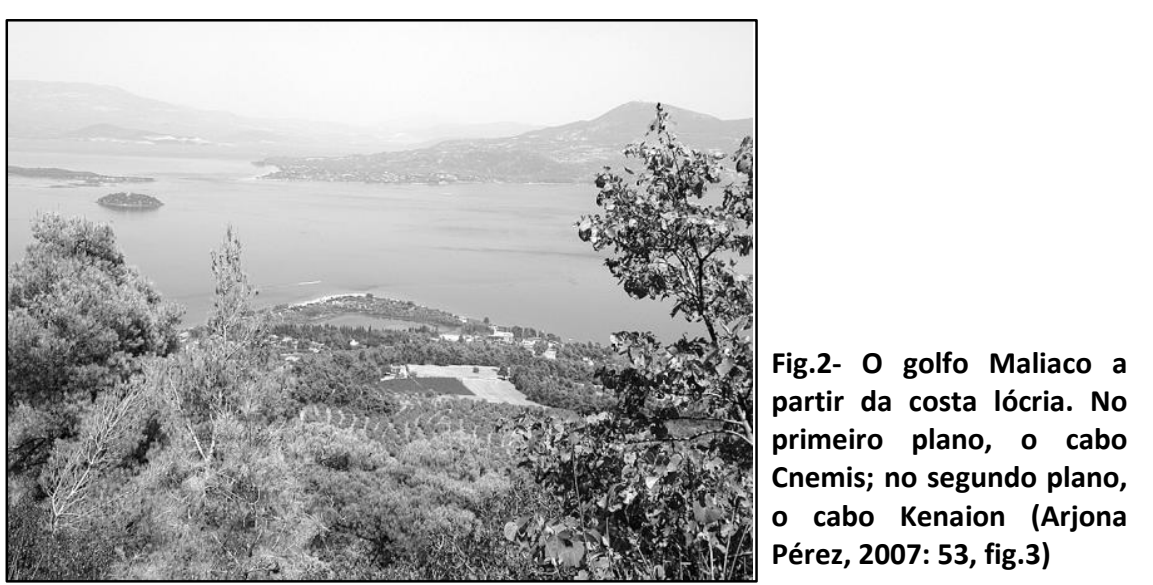


Datação: Época arcaica (sécs. VII-VI a.C.?) - época romana (séc. I a.C.?).

Localização: No setor sudoeste da cidade, sobre a colina de Kourdoubouli, que se situava ao lado sudoeste da ágora.

Tipo de santuário: Colinar / urbano.

Referências textuais: Inexistente.

Inscrições: Inscrição do século IV a.C. em base de estátua com dedicação à Atena e Zeus Sóter (SEG LI 511); inscrição do século I a.C. que se refere a uma restauração do templo de Atena (Lo Monaco, 2009: 434). Inscrição "Atena" no pino/alfinete de bronze (Lo Monaco, 2009: 435). Decretos de proxenia de cidades vizinhas de Lepreonte, Alipheira, Megalópolis, Alea, Bizâncio, Kefalonia, Aegion e Éfeso (datados entre os séculos IV-I a.C.), sendo que em um deles há uma referência à Atena como Polias (Lo Monaco, 2009: 434). Outras inscrições à Atena desse período.

Histórico dos achados: Escavações da Ephoria dirigidas por X. Arapojanni nos anos de 1996, 1997 e 1998 (Lo Monaco, 2009: 433).

\section{Documentação arqueológica}

I. Templo e base de estátua de culto: Do século IV a.C.: edifício de ordem dórico, orientado a leste, mede 7,70 x $15,70 \mathrm{~m}$ e é dividido em um estreito pronaos de 2,85 ×5,80 m e em uma cela profunda de 5,80 × 8,80 m. Dentro da cela foi encontrada in situ a base da estátua de culto, composta por uma base de dois degraus e por um corpo quadrangular de $1,70 \times 1,64 \times 0,60 \mathrm{~m}$. Foram também encontrados, diante da base da estátua de culto, traços de cerâmica queimada muito provavelmente de sacrifícios. A norte da estátua de culto, foram encontradas três bases de estátuas, sendo uma delas para uma de bronze, a qual conserva a inscrição que recorda uma dedicação realizada por Evagoras de uma estátua em honra de um Kallikrates à Atena e Zeus Sóter (SEG LI 511). Misturada à terra de preenchimento dentro do templo foram recuperados numerosos fragmentos de bases destinadas a colocação de estelas (Lo Monaco, 2009: 433). De época arcaica: A existência de um tempo precedente, de época arcaica, é assegurada pelo achado de dois septos de muros em pedra dentro da cela (0,50 $\times 3 \mathrm{~m})$ e por um pavimento, talvez arcaico, encontrado no ângulo nordeste. Tais dados se associam bem ao achado de fragmentos arquitetônicos de ordem dórica (capitéis, fragmentos de coluna e da arquitrave) (Lo Monaco, 2009: 434). Diante da estátua de culto deveria existir um tipo de mesa, como indicam certos remanescentes estruturais na área (Lo Monaco, 2009: 434). Segundo Arapojanni, sobre a base da estátua, encontrada na cela, deveria estar uma estátua de Atena e outra de Zeus Soter, sobre as quais, todavia, não foram encontrados nenhum elemento (Lo Monaco, 2009: 434). $O$ edifício permaneceu em uso até a época bizantina. 
II. Objetos votivos: Foi recuperada uma grande quantidade de placas e fios de bronze, alfinetes de bronze para cabelos, anéis, brincos, escudos miniaturísticos, pontas de flecha e muitos attachés em ferro de vasos e outros utensílios. São numerosos pesos de tear, figurinhas de terracota de animais, bustos femininos e três figuras no ato de sacrificar. Dentro do templo foram encontrados muitos votivos em bronze, ferro e chumbo, prótomos femininos com alto polos e véu, anéis de chumbo e um pino/alfinete em bronze com dedicação à Atena. Atestados em grande quantidade são pequenas naves que Arapojanni interpretou como pequenas lamparinas (Lo Monaco, 2009: 434-435).

Tipo de culto: Trata-se de um culto feminino com referência particular ao mundo da tecelagem. É possível que o culto de Zeus Sóter tenha se iniciado talvez no século IV a.C. ao lado daquele arcaico de Atena (Lo Monaco, 2009: 435).

Referências bibliográficas: Arapojanni, Ergon 43, 1996, pp.41-47; Praktiká, 19996, pp.129-137; Ergon, 44: 43-49, 1997; Praktiká, pp.115-120; Ergon, 45: 5153; Praktiká, 1998, pp.127-128; BCH 122, 2: 779, 1998; Jost, 1985, pp. 85; Lo Monaco, 2009, pp.433-435. 


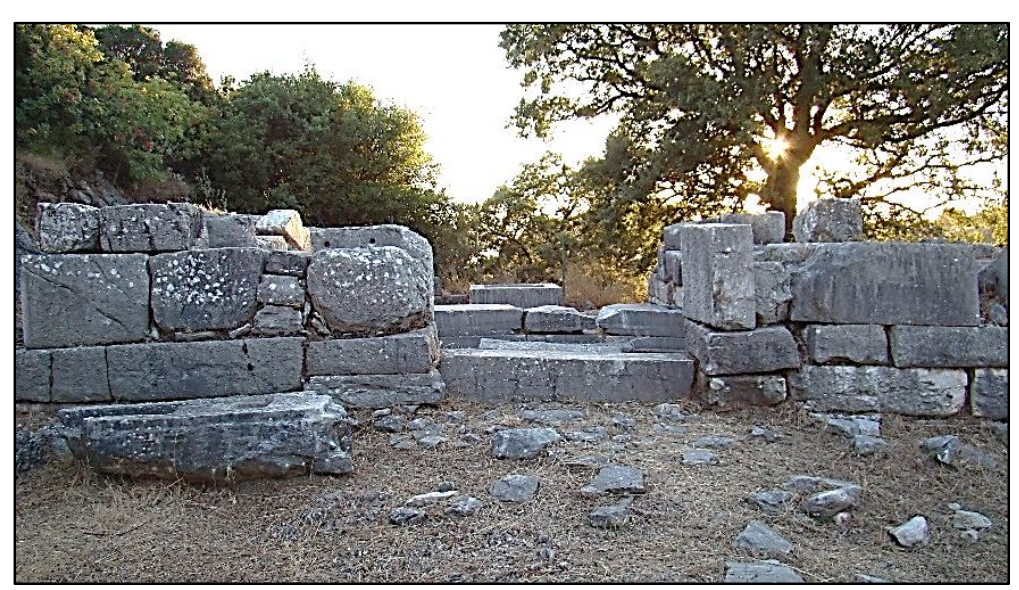

Fig.1- Vista a partir de leste do templo de Atena e Zeus Sóter, Figaleia (Foto: arquivo pessoal/2014)

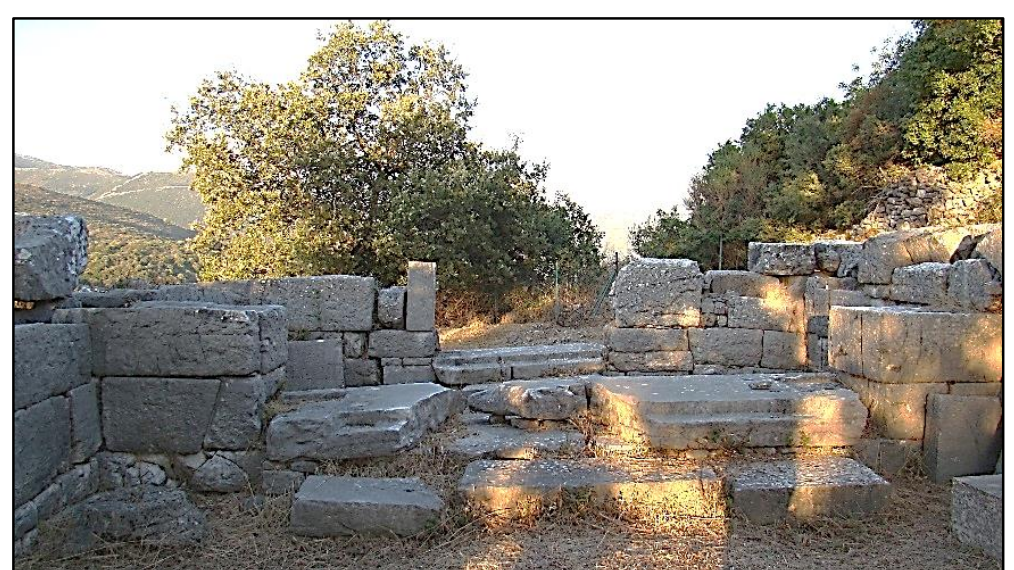

Fig.3- Vista a partir de oeste da parte interna do templo de Atena e Zeus Sóter, Figaleia (Foto: arquivo pessoal/2014)

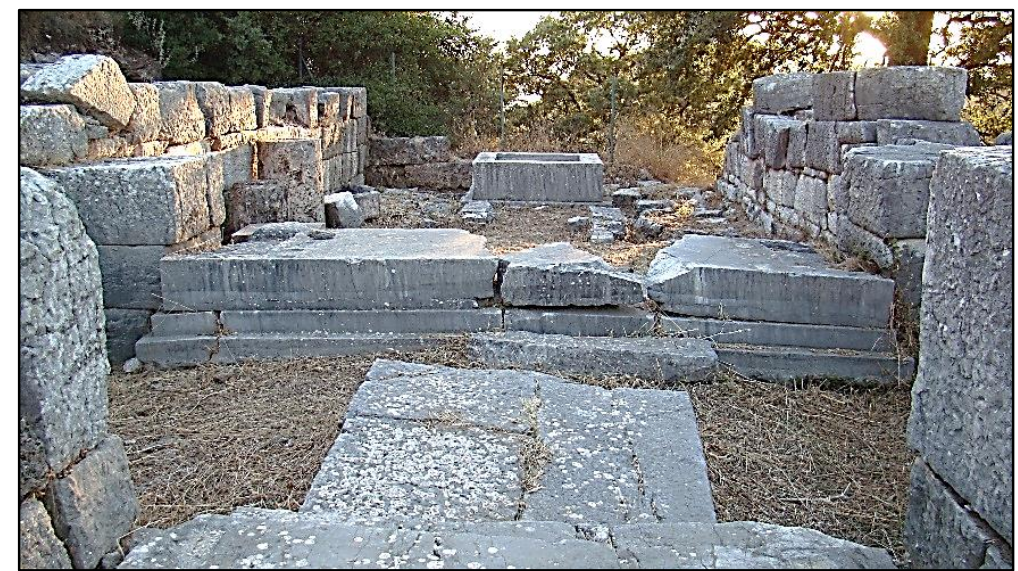

Fig.2- Vista a partir de leste do pronaos e da cela com base de estátua de culto ao fundo do templo de Atena e Zeus Sóter, Figaleia (Foto: arquivo pessoal/2014)

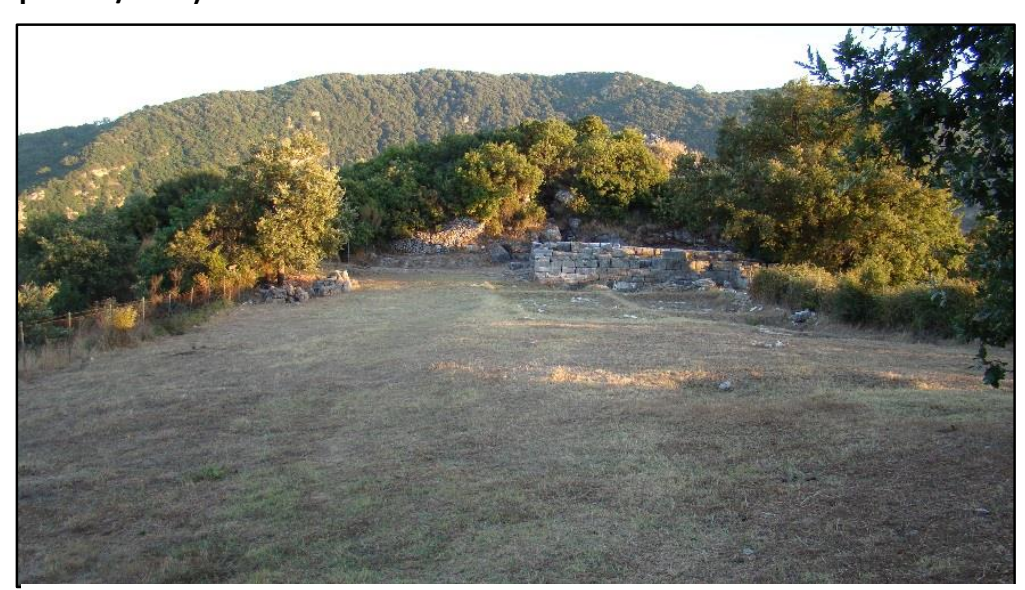

Fig.4- Vista a partir de norte do lado norte do templo de Atena e Zeus Sóter, Figaleia (Foto: arquivo pessoal/2014) 


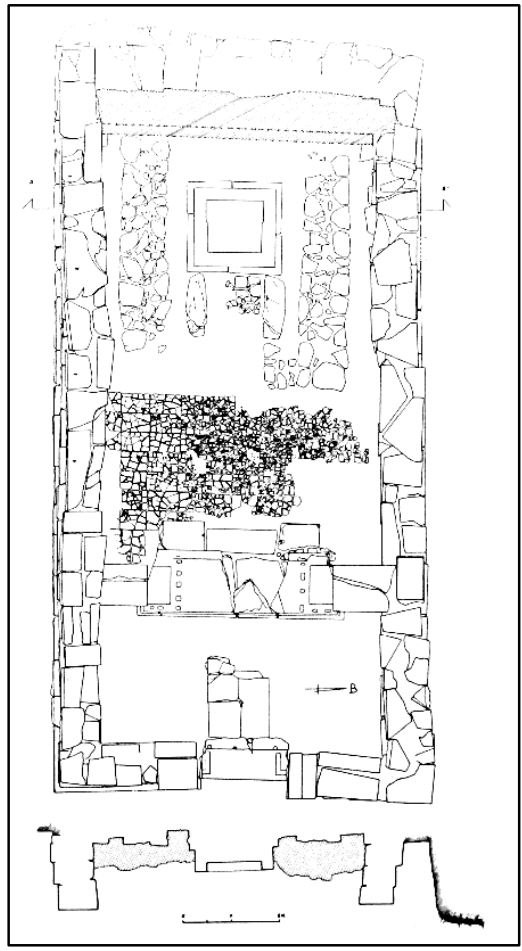

Fig.5- Planimetria do templo de Atena e Zeus Sóter, Figaleia (Arapojannis, 1996: fig.1-2 Praktiká)

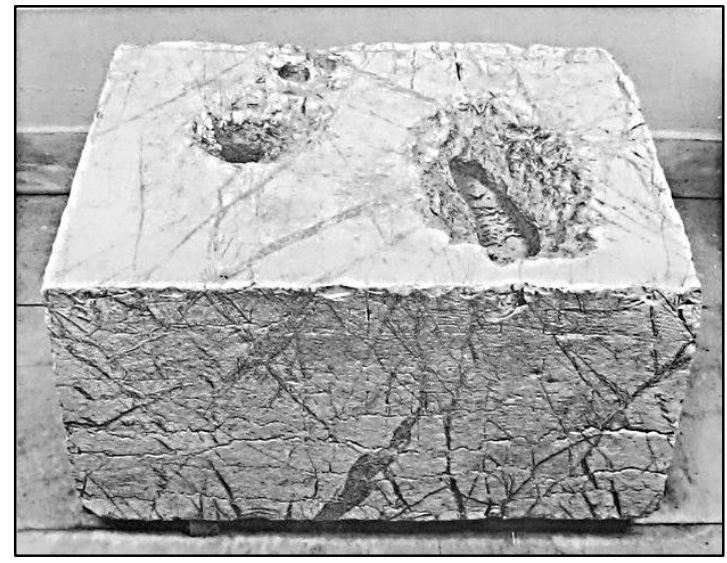

Fig.6- Base de estátua de bronze com a inscrição votiva a Atena e Zeus Sóter, Figaleia (Arapojannis,1996: pr.48, fig. $\alpha$, Praktiká)

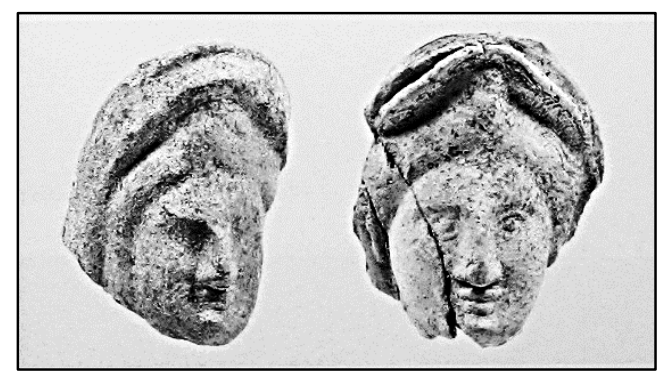

Fig.8- Cabeças de terracotas femininas com polos do santuário de Atena e Zeus Sóter, Figaleia (Arapojanni, 1997: pr.67, fig. $\beta$ )

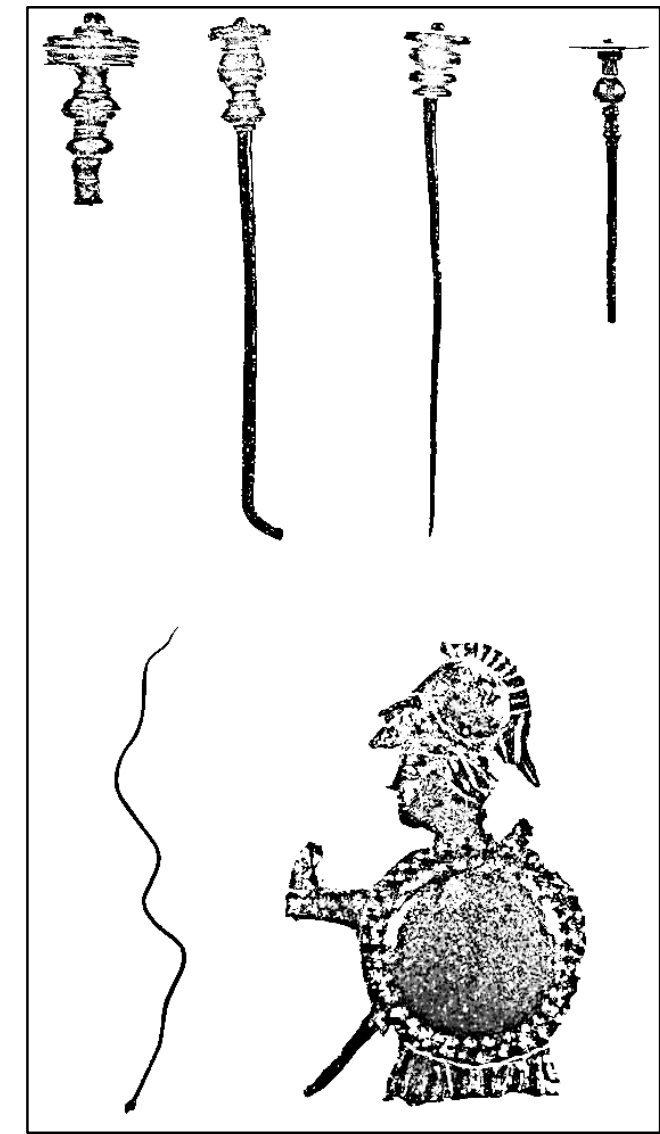

Fig.7- Objetos votivos encontrados no santuário de Atena e Zeus Sóter, Figaleia: alfinetes de bronze e lâmina de bronze com a representação de Palas Atenas (Arapojanni, 1996: pr.50, figs. $\alpha_{\text {, }}$ $\beta, \gamma$, Praktiká) 


\section{Kamiros}

Datação: Época arcaica - época helenística?.

Localização: Na acrópole de Kamiros, logo acima da área residencial.

Tipo de santuário: Colinar / Urbano.

\section{Referências textuais: Inexistentes?}

Inscrições: (Zeus Polieus) Tit.Cam.15.8, final do séc.lll a.C.; (Atena Polias) Tit.Cam.14.8, séc. III a.C.

\section{Histórico dos achados: ?}

\section{Documentação arqueológica}

I. Templo: A existência de um templo da época arcaica e clássica é indicada pelos vários remanescentes encontrados. No entanto, a estrutura conservada pertence ao templo do período helenístico, um dórico tetrastilo com orientação leste-oeste (IACP: 1201). Uma antefixa em palemta, encontrada na vizinhança, e uma cisterna no terraço inferior pode pertencer ao santuário (mas a qual período?) (Lippolis, 2007: 721).

Tipo de culto: Conforme Lippolis, o santuário deixou testemunhos de frequentação cultual ao menos desde o séc. IX a.C. Os achados de materiais do depósito votivo de época arcaica confirma o caráter internacional que o santuário parece ter tido no período (Lippolis, 2007: 721).

Referências bibliográficas: Bernardini, C. I bronzi della stipe di Camiros. Monographie della Scuola Archeologica Italiana di Atene e della Missione Italiane in Oriente, 18. Atenas, 2006; Calliò, L.M. II santuario di Camiro. Analisi delle struture e ipotesi di ricostruzione della grande stoà dorica, Orizzonti, II, 2001, pp. 85107 (86-89); IACP: p.1201; Lippolis, 2007, p.721.

Imagens: ? 
Datação: Época arcaica (após metade do séc. VI a.C. ou final do VI/início do V a.C.?) - época clássica (IV a.C.?).

Localização: No setor norte, a noroeste da acrópole Cária e a nordeste da fonte erigida pelo tirano Theagenes, fora das acrópoles e a nordeste da ágora.

Tipo de santuário: Colinar? I Urbano.

Referências textuais: (Santuário, templo e estátua) Pausânias, XL.2-4; (Santuário) Pausânias XL.4; (Templo) Pausânias XLI.1.

Inscrições: São provenientes e referentes ao arquivo cívico do santuário de Zeus Olímpio (SGDI 3003-3005; 3007-3011; 3024; IG VII, 1-14; 31).

Histórico dos achados: De acordo com informações obtidas no Museu Arqueológico de Mégara em 2009, o santuário foi localizado e as fundações do templo, embaixo de uma casa moderna, vêm sendo pesquisado por uma pesquisadora da Univ. de Thessaloniki.

\section{Documentação arqueológica}

I. Templo: Durante nossa visita à Mégara em junho de 2009 foi-nos informado que as fundações do Olimpiéion já haviam sido localizadas abaixo de uma residência moderna. Estes escassos remanescentes estão sendo estudados por uma pesquisadora grega e ainda serão publicados. A única informação do templo que pudemos obter e levar do Museu Arqueológico de Mégara foi a planta da cidade antiga a qual já possui o posicionamento do edifício no espaço da cidade.

Tipo de culto: Acreditamos que o culto de Zeus Olímpio foi introduzido em Mégara a partir, possivelmente, de sua relação muito antiga com o santuário de Olímpia. Embora a relação com Olímpia tenha sido mais forte e direta, não excluímos a hipótese de que o culto possa ter sido instituído por influência de Atenas, de quem Mégara estava próxima e com que manteve relações bélicas ou não ao longo de sua história. Além disso, nota-se que o templo de Zeus projeta-se nas saídas em direção à pólis ateniense (Laky, 2013: 224).

Referências bibliográficas: Laky, 2013, pp.222-225. 


\section{Imagens:}
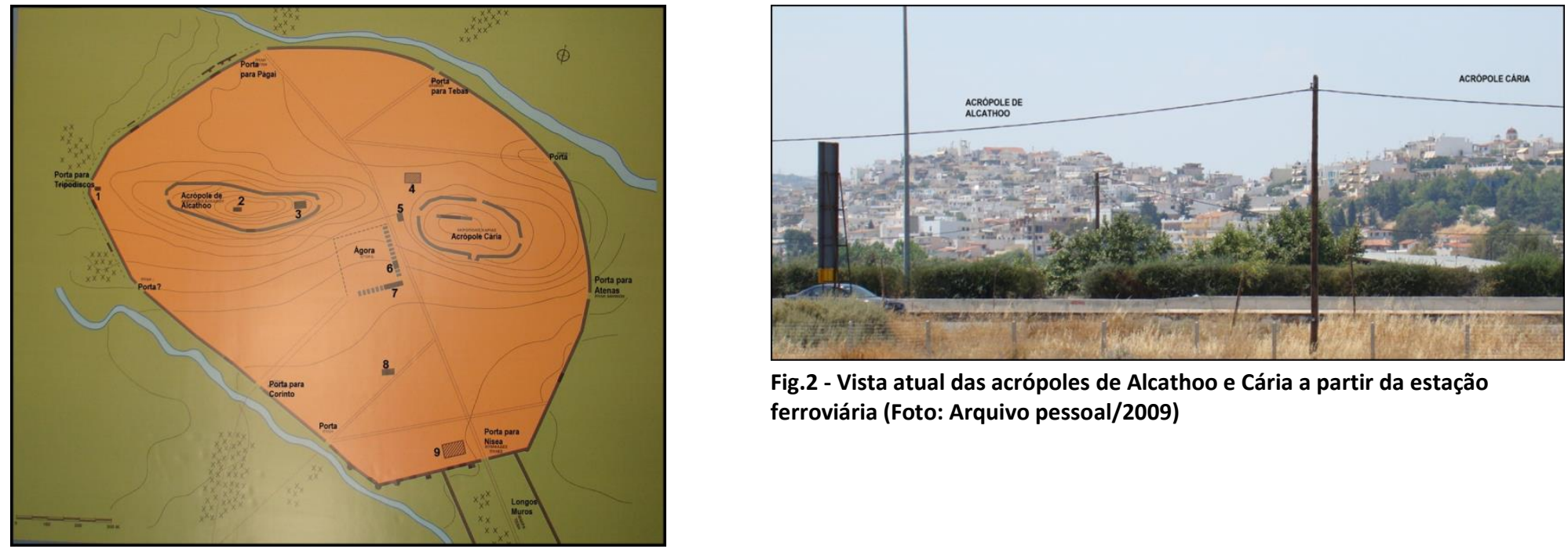

Fig.2 - Vista atual das acrópoles de Alcathoo e Cária a partir da estação ferroviária (Foto: Arquivo pessoal/2009)

Fig.1 - Planimetria de Mégara com modificações: 1 . Fonte; 2 Templo de Atena; 3. Templo de Apolo (?); 4. Olimpiéion; 5. Fonte de Teagenes; 6-7. Stoai da ágora; 8. Recinto de Apolo Prostatírios; 9. Ginásio. Museu Arqueológico de Mégara (Foto: arquivo pessoal/2009) 


\section{Atenas}

Datação: Final da época arcaica ou início da clássica (anterior ao final do séc. VI ou início do V a.C.) - época clássica (séc.IV a.C.).

Localização: No lado oriental da colina das Ninfas, na área entre a igreja de Ágia Marina e Apostolou Pavlou, no setor oeste de Atenas, a norte da Pnix, entre a porta de Demian a norte e a de Melitides a sul, a sudoeste da ágora e a noroeste do areópago.

Tipo de santuário: Colinar / Urbano.

Referências textuais: Inexistentes.

Inscrições: Horos A: IG $1055 \mathrm{~A}$ (horos Dios) e Horos B: IG³ 1055B (horos), ambas datadas do final do séc. VI ou início do V a.C., Ag. Inscr. 5983 e SEG 23.95 (horos hierou Dios Exopsiou) do séc. IV a.C. (Greco, 2011: 333).

Histórico dos achados: Pittakis foi o primeiro a notar a presença do altar de Zeus acima do Horos A, onde a rocha parecia nivelada. Em 1885, A. Milchhöfer mencionou um altar de Zeus que dizia não ser distante da margem do platô de Ágia Marina. Cinco anos depois, C. Wachsmuth escreveu brevemente, embora de forma informativa, que os Horoi $\mathrm{A}$ e $\mathrm{B}$ foram entalhados na rocha próxima a um lugar de culto quadrangular reservado na superfície da rocha. Judeich foi quem observou que os Horoi A e B indicavam um culto de Zeus na encosta leste da colina das Ninfas. Wicherley acrescentou que as marcas nas rochas eram traços do témeno, altar e um pequeno edifício de culto. G.V. Lalonde é quem pela primeira vez realizou um estudo topográfico completo do santuário e remanescentes do culto de Zeus (Lalonde, 2006: 13-14).

\section{Documentação arqueológica}

I. Témeno: A superfície rochosa inclinada da colina das Ninfas é marcada pela presença de uma série de cortes destinados a conter o témeno e uma série de habitações da época clássica. Na porção mais elevada, colocada logo abaixo da igreja, estão diversas terraças (acessíveis através de uma escada) caracterizadas pela presença de um altar e de uma bacia lustral, onde foram encontradas duas inscrições, do final do séc. Vl ou do início do V a.C., As indicações horos Dios e simplesmente horos são marcadores de confins, esculpidos na superfície rochosa e colocados a pouca distância um do outro, que definiram, o primeiro, o espaço de um grande témeno dedicado a Zeus, e o segundo, o caminho que conduzia ao santuário (Greco, 2011: 333). De acordo com Lalonde, dentro de um raio de c.15 m do hóros $A$, está um grande agrupamento de cortes na rocha que, pela sua forma, localização e coerência, podem ser interpretados como os remanescentes centrais e mais antigos do culto de Zeus (áreas A-J) (Lalonde, 2006: 14). Apesar de ser possível reportar os elementos do culto ao redor do hóros A como pertencentes à fase arcaica, isso não implica que todos esses elementos vieram a existir ao mesmo tempo. No início, o culto de Zeus pode ter sido 
simplesmente um altar essencial que gradualmente foi cercado por estruturas acessórias: portanto, os primeiros elementos do culto podem ter precedido o corte da inscrição do hóros no final do séc. Vl e no início do séc. V a.C. (Lalonde, 2006: 14). Embora não possam ser datados com alguma certeza, as adições ao culto no lado leste do declive, são consideradas uma replicação grosseira dos elementos originais e, assim, partes de um esquema de evolução topográfica não unificada do culto (Lalonde, 2006: 15). Em algum ponto nesta evolução, o final leste e oeste do culto foram provavelmente determinados e marcados com suas estelas de hóros incorporadas na rocha natural. Nesse sentido, o culto de Zeus tinha uma marcação específica pelo hóros A no final do séc. VI ou bem no início do V a.C. e, provavelmente, uma outra delimitação mais posterior de data indeterminada (Lalonde, 2006: 15).

II. Escada arcaica (C): Na rota direta de acesso a área do hóros A, na antiga estrada leste-oeste (Ninfas/rua Pnix) que margeava o espigão íngreme ao longo da atual rua Otryneon. A $12 \mathrm{~m}$ a leste do hóros A, onde o espigão é mais baixo, uma escada primitiva de cerca de 8 degraus, cortados na rocha, percorre cerca de $5 \mathrm{~m}$ na borda do espigão (C; 127-129E, 31-37.5N, Fig.8). Os degraus são altamente irregulares em forma e dimensões (60-90 cm de largura e $50-70 \mathrm{~cm}$ de profundidade). Já que os degraus propiciaram o acesso mais direto aos elementos centrais do culto, a escada deve ser tão antiga quanto o hóros A e por isso foi chamada de escada arcaica (Lalonde, 2006: 15).

III. Caminho sul (D): Localizado no final da escada arcaica, se estende a oeste por $24 \mathrm{~m}$ acima da extremidade sul do espigão, dando acesso ao hóros $\mathrm{A}$ e às estruturas centrais do culto (fig.9). A Os antigos construtores fizeram sulcos ao longo desta "via sagrada" para dar aderência aos pés dos visitantes, onde a chuva e o uso contínuo tornariam o local escorregadio. Um canal irregular corre ao longo do lado norte do caminho sul e provavelmente drenou o lado central sul do espigão rochoso, guardando água para uso dos quartos (K) de frente à estrada (Lalonde, 2006: 15).

IV. Espaço (E): Trata-se de uma área aberta, localizada a oeste do hóros A, de c. $25 \mathrm{~m}^{2}$ (E; 110-115E, 30-37N) que se eleva a norte-noroeste em direção a um grupo de rochas cortadas identificadas por Lalonde como a área sacrificial e seu altar. Se o Espaço $E$ foi de fato aberto, ele pode ter sido uma área onde pequenos grupos de devotos reuniam-se antes de proceder imediatamente à área sacrificial a norte ou ter sido também um espaço extra para se ver os ritos do culto de Zeus e para a refeição sacrificial (Lalonde, 2006: 16).

V. Área sacrificial (F) e altar (F1): Um visitante de frente ao hóros A, a partir do caminho sul, pode ver em c. $5 \mathrm{~m}$ além da inscrição (no outro lado da extremidade leste do Espaço E) um complexo de rochas cortadas (Fig.10) que consiste em um espaço retangular de rocha nivelada limitado nos lados sul, leste e norte por canais cortados na rocha. E imediatamente a oeste deste, uma escarpa vertical cortada na rocha, acima da qual um afloramento rochoso foi lavrado na forma de uma prateleira circular parcialmente cercada por um núcleo irregular (F; 106-116E, 39-47N; Figs.11,12,13: F1-F5). Esses cortes provavelmente são aqueles identificados com o que Pittakis se referiu ser o espaço nivelado e altar acima do hóros de Zeus, portanto, a área sacrificial, o ponto central do culto (Lalonde, 2006: 16). O núcleo irregular do altar está totalmente preservado em seu $1,75 \mathrm{~m}$ de diâmetro e a plateleira horizontal (F2), cortada na rocha, está c.60 cm mais abaixo. A prateleira circundante parece ter sido uma prothysis, o degrau mais baixo ou a base que dá acesso ao centro do altar ou ainda, o que é mais provável, 
a base para o encaixe de uma pedra circular lavrada ou de argila (Fig.14), elementos que teriam formado um altar de cerca de 2/4 ou 3/4 m de diâmetro (Lalonde, 2006: 16). De menor importância ritual do que o altar, o espaço retangular nivelado (F3) (fig.11 e 13) e os canais cortados na rocha bem abaixo e a leste do altar, são os que primeiro chamam a atenção do espectador na área sacrificial. 0 espaço mede $c .15 \mathrm{~m}^{2}$ e os canais que 0 cercam nos três lados $(0,30 \mathrm{~m}$ de largura e 0,20-30 m de profundidade) teriam servido para prevenir o fluxo de água da chuva e inundação do pavimento de rocha do cercado da estrutura (V) e para propósitos rituais práticos, como o escoamento dos resíduos sacrificiais da área sagrada (Lalonde, 2006: 17-18). A localização do espaço retangular dentro desses canais, abaixo e imediatamente a leste do altar sugere um local para os devotos ou participantes do sacrifício permanecerem (Lalonde, 2006: 18). No piso do lado sul, dois conjuntos de cortes na rocha (F4) parecem ter sido bases para duas mesas de culto que serviram para propósitos sacrificiais (deposição do sacrifício, preparação da carne dos animais sacrificados ou uma superfície para a colocação de utensílios e vasos de sacrifício) (Lalonde, 2006: 18). Bem dentro da extensão oeste do canal sul (onde se encosta o lado oeste do altar) está outra base cortada na rocha, que deve ter mantido um mobiliário similar da área sacrificial (Lalonde, 2006: 19). Um lugar de 2m2 (F5) (fig.13) no lado oeste do altar é compatível com um espaço reservado para a prática do sacerdote ou de um oficial do culto que poderia vigiar o altar defronte a leste, e para acomodar um número pequeno de devotos. Essa interpretação é apoiada pela sua congruência com um espaço para um edifício $(G)$ relativamente grande a 2 ou $3 \mathrm{~m}$ a oeste acima da encosta, que foi a única edificação coberta no santuário de Zeus (Lalonde, 2006: 19)

VI. Edifício de culto (G): Acima da encosta do leito rochoso, a c. 3 a $10 \mathrm{~m}$ a oeste e sudoeste do altar (F1, F2) estão os restos, cortados na rocha, do edifício de culto (G) (G; 99-108E, 28-44N; Fig.15:G), assim chamado devido a sua localização, orientação e forma (Lalonde, 2006: 19-20). Os plintos das paredes dos dois quartos existentes, que foram escavadas na rocha, forneceram a dimensão da construção. Assim, a parede de fundo da escarpa norte-sul tem uma altura máxima de 1,40 m e um comprimento de 11,90 m e a dimensão leste-oeste foi determinada em $4 \mathrm{~m}$ com base na extremidade norte do muro (Lalonde, 2006: 20). As dimensões do quarto menor são de $4 \mathrm{~m}^{2} \mathrm{e}$ foram determinadas do plinto interior e da parede de fundo da escarpa, já o quarto maior tem uma dimensão na parte interior norte-sul de $7 \mathrm{~m}$ entre o plinto e o muro norte e uma profundidade leste-oeste de $4 \mathrm{~m}$ (Lalonde, 2006: 20). 0 topo do plinto do muro que divide os dois quartos era cortado em degraus aparentemente para receber uma superestrutura de tijolos de barro ou das pedras lavradas na escavação extensiva dos quartos (Lalonde, 2006: 20). 0 edifício foi um pequeno templo ou, mais provavelmente, um facilitador auxiliar na área sacrificial. "Templo" implica em uma estátua de culto que provavelmente não existiu neste santuário. Como única estrutura coberta defrente à área sacrificial, o edifício $\mathrm{G}$, possivelmente, serviu como um lugar de administração, um refúgio de chuva e frio do inverno, do calor do verão, um armazém para a parafernália de rituais e ainda um quarto de refeições para pequenos grupos que ofereceram sacrifícios (Lalonde, 2006: 21).

VII. Bacia lustral $(\mathbf{H})$ : Trata-se de um dique cortado na rocha localizado a norte do caminho sul em um ponto a apenas $8 \mathrm{~m}$ a sudoeste do hóros $\mathrm{A}$, a $12 \mathrm{~m}$ do altar e bem abaixo do quarto sul do edifício $\mathrm{G}(\mathrm{H} ; 109 \mathrm{E}, 30 \mathrm{~N}$; Fig.16). A beira do dique é contornada por uma moldura talhada, seu interior mede $0,93 \mathrm{~m}$ (eixo longo) e 0,48 m (eixo curto) e tem uma profundidade de 0,17 m (Lalonde, 2006: 21). O dique, ou bacia lustral, está orientado de nordeste para sudoeste em seu longo eixo e tem um canal de transbordamento no ângulo sudeste, do qual o excesso de água teria saído pelo dreno ao lado do caminho sul, imediatamente 
abaixo. A forma, tamanho e localização deste dique indicam que foi uma fonte de água imediata para o culto, um perirrhanterion (uma bacia para aspersão ritual), um chernibon para lavar as mãos, ou uma fonte para encher vasos lustrais portáteis a serem usados nos rituais da área sacrificial e em outros lugares de culto (Lalonde, 2006: 21). A posição da bacia de forma adjacente ao caminho sul, indica que estava ali situada para as necessidades dos devotos e participantes do culto na purificação pessoal simbólica, na aspersão com um aspersor antes de cruzar a norte e entrar no terreno sagrado indicado pelo hóros A (Lalonde, 2006 : 21).

VIII. Plataformas votivas na rocha (I): Na parte sul-central do esporão nordeste da colina das Ninfas, estão várias superfícies horizontais cortadas na rocha que apenas fazem sentido como plataformas para objetos votivos dedicados após o cumprimento ou agradecimento que acompanharam os sacrifícios a Zeus. Praticamente todas estão dentro de um raio de $25 \mathrm{~m}$ do hóros A. Trata-se de mais de 40 plataformas de tamanho variado, mas a maior parte tem grande dimensão (Lalonde, 2006: 22). As várias localizações foram intencionalmente escolhidas, em parte, devido à visibilidade na antiga estrada Ninfas/Pnix e ao longo da rua moderna Ostryneon, e em relação aos elementos centrais e originais do culto ao redor do hóros A e da área sacrificial (I; 100-110E, 25-31N; Fig.17) (Lalonde, 2006: 24).

IX. Estrutura (J): Antes de partir da parte central-sul do esporão, nota-se um outro conjunto de cortes na rocha que parecem, a partir de sua localização e formato, as fundações de outra estrutura sagrada. Imediatamente a norte do caminho sul e a c.5,5 m morro abaixo, a leste do hóros A, estão dois nítidos "wall beddings" cortados na rocha unidos em um ângulo reto que se salienta em direção nordeste (J; 122.5-125E, 37-39.5N) (Lalonde, 2006: 24-25). Estes assemelham-se a um tipo de recinto ao redor de rochas sagradas, ou altares de rocha, encontrados em certas localidades da ágora e da Pnix (Lalonde, 2006: 25).

Tipo de culto: $O$ culto é anterior ao final do séc. VI a.C. (Lalonde, 2006: 19). De acordo com Lalonde, o estudo do levantamento dos lugares dos achados e a dispersão provável dos artefatos com inscrições e esculpidos de Zeus na região da ágora e oeste de Atenas, sugerem que a divindade principal do culto, ao menos até o séc. IV a.C., foi Zeus Meilichios. Quando o autor testou a hipótese com base no amplo alcance de evidências comparativas de Zeus Meilichios provenientes de outros sítios arqueológicos, artefatos, inscrições e testemunhos da literatura antiga, notou que o caráter, rituais e santuários desse culto de Zeus são compatíveis em um grau significativo com a topografia do culto de Zeus na colina das Ninfas (Lalonde, 2006: 40). Ainda acrescenta que as formas arquitetônicas peculiares da seção superior do esporão, sem sequer um sinal de um hóros intervindo, pode indicar devoção a mais do que uma divindade no esporão nordeste da colina das Ninfas. Nesse aspecto, Lalonde lembra que Zeus Meilichios era frequentemente cultuado ao lado de outros deuses e heróis (Lalonde, 2006: 39).

Comentário: Na "documentação arqueológica" escolhemos descrever apenas as estruturas pertencentes à área sagrada mais antiga definida por Lalonde como os cortes na rocha de $\mathrm{A}$ até $\mathrm{J}$, sendo que toda a descrição da área da colina alcança a letra Z! A presença de apenas cortes nas rochas torna este santuário um dos mais complexos do ponto de vista interpretativo, quase uma abstração, o que aumenta o mérito do autor do estudo. 
Referências bibliográficas: Greco, 2011; Jameson, M.H. Jordan, D.R.; Kotansky, R.D. A lex sacra from Selinous, GRBM, 11 (1993), ver pp.58-60; Lalonde, G.V. Horos Dios: an Athenian shrine and cult of Zeus. Monumenta Graeca et Romana, vol. XI. Leiden; Boston: Brill, 2006; Lambert, S.D. Two notes on Attic Leges Sacrae, ZPE, 130 (2000), pp.71-80 (ver p.77, nota 46); Riotto, M. II santuario della Malophoros a Selinunte, Spunti per una discussion storico-religiosa, SicArch, 18 (1985), pp. $25-51$ (ver p.44).

Imagens:

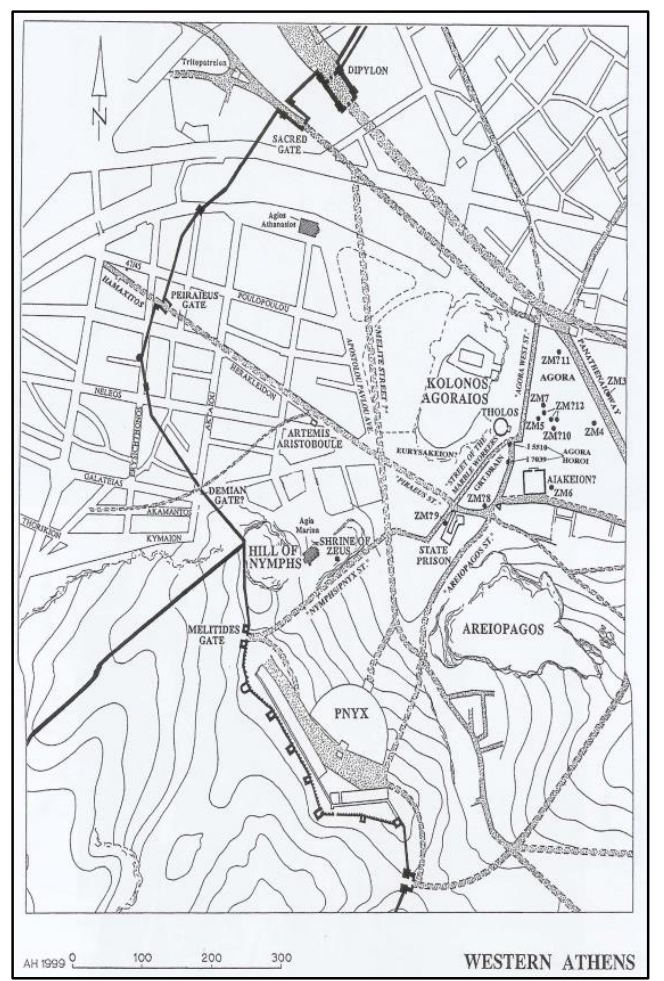

Fig.1- Planimetria do setor oeste de Atenas com colina das Ninfas (Lalonde, 2006: Fig.1)

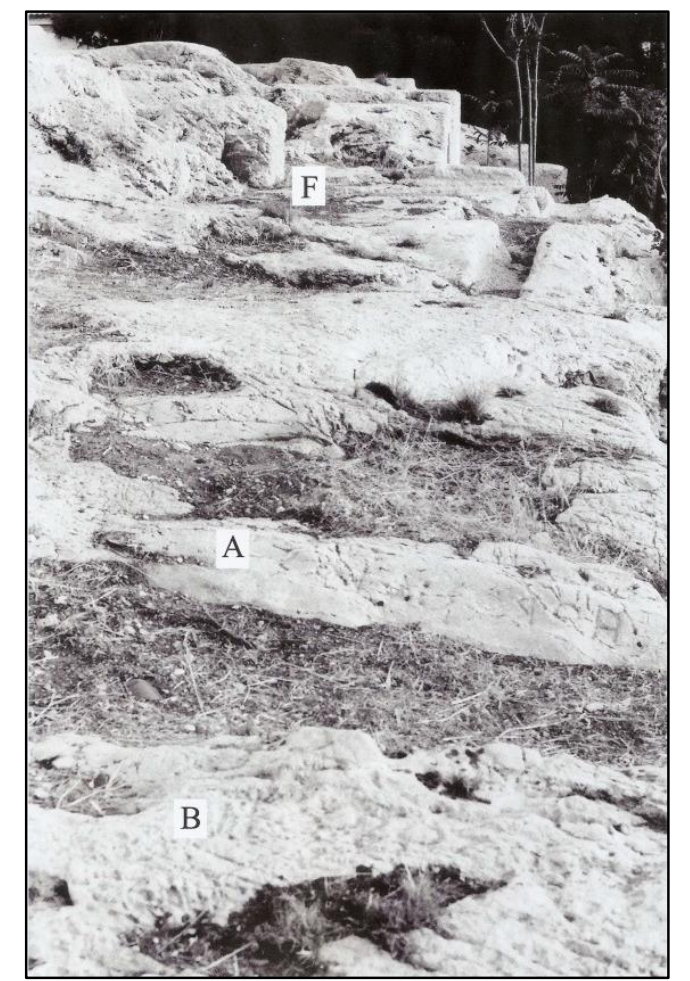

Fig.2- Hóroi A e B e área sacrificial F vistos a partir de sul-sudeste (Lalonde, 2006: Fig.10)

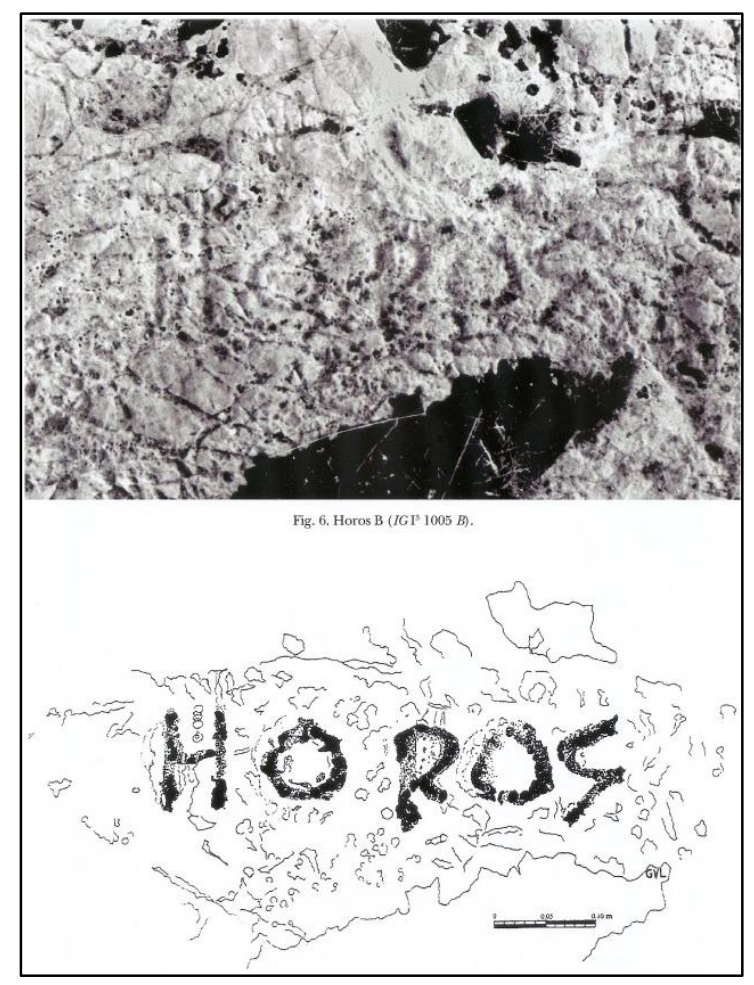

Fig.3- Hóros B (Lalonde, 2006: figs. 6 e 7)

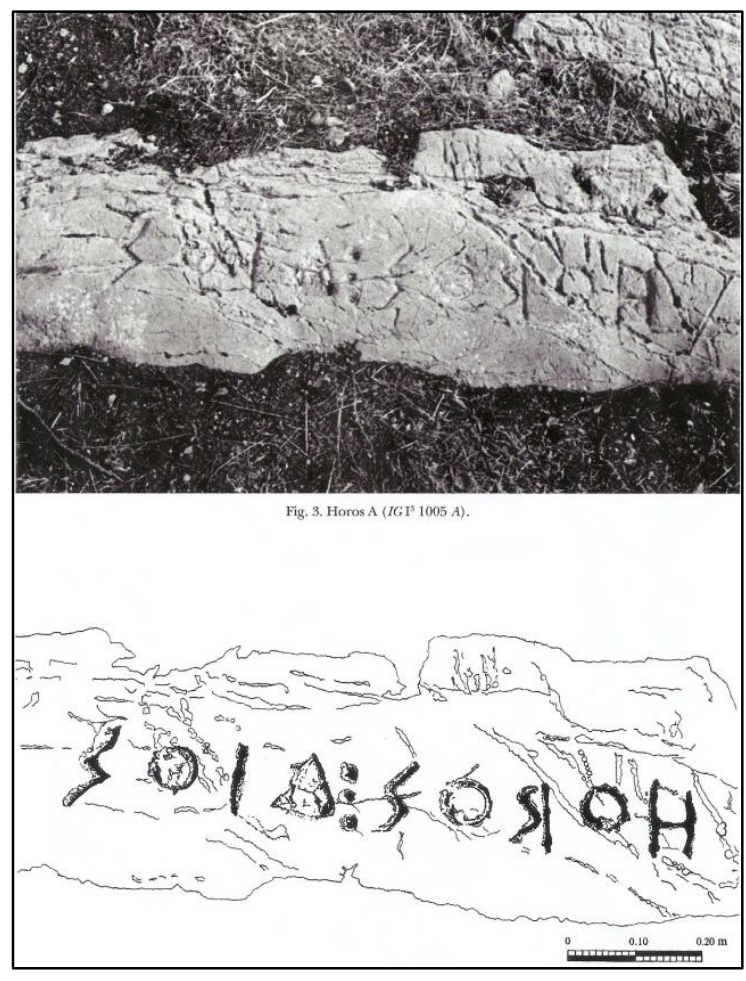

Fig.4- Hóros A (Lalonde, 2006: figs. 3 e 4) 


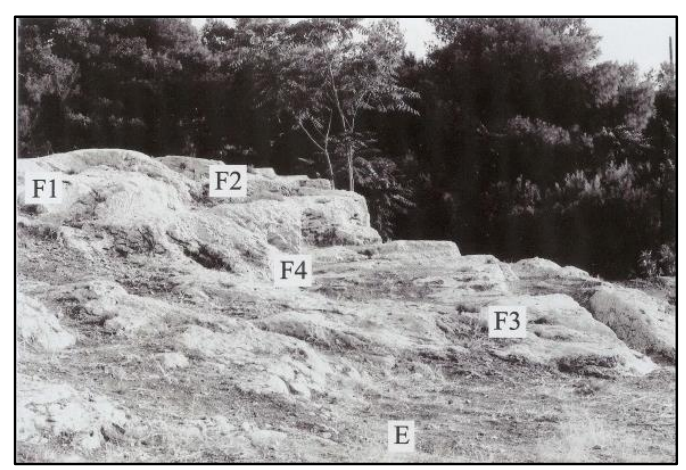

Fig.5- Área sacrificial F vista a partir de sul-sudeste (Lalonde, 2006: Fig. 11)

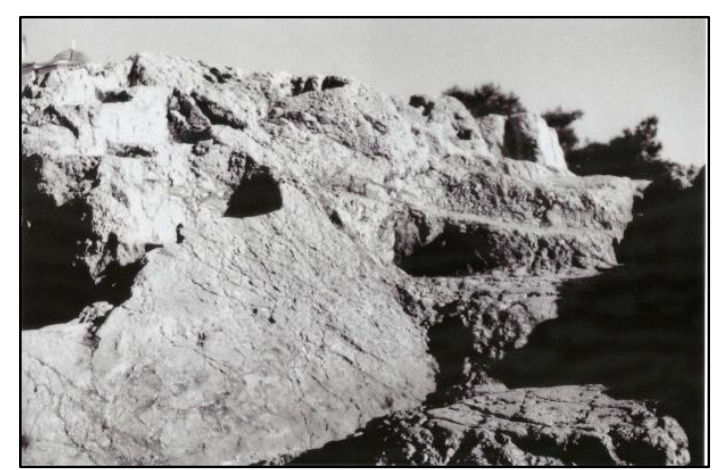

Fig.6- Escada arcaica $\mathrm{C}$ com nichos votivos a partir de sul-sudeste (Lalonde, 2006: Fig.8)

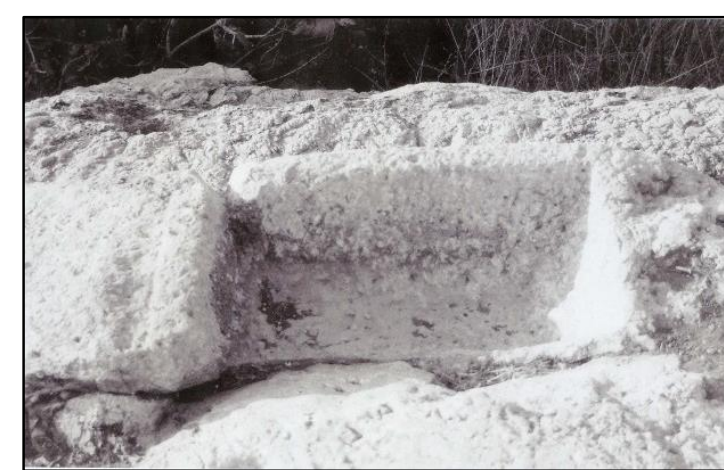

Fig.7- Bacia lustral vista de cima e a partir de noroest (Lalonde, 2006: Fig.16)

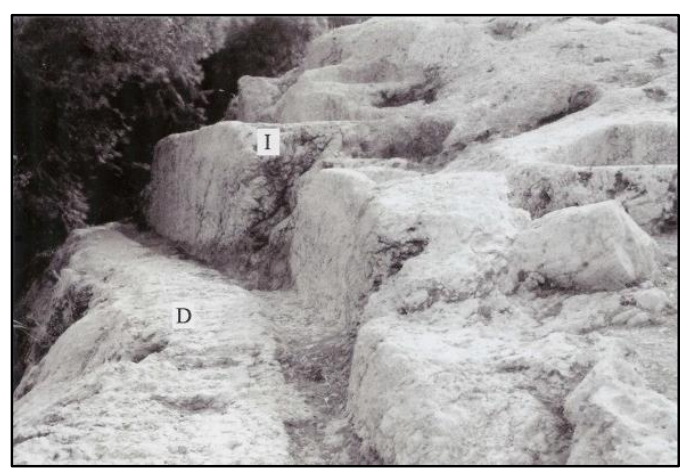

Fig.8- Plataformas votivas I acima do caminho sul D vistas a partir de leste-nordeste (Lalonde, Fig. 17) 


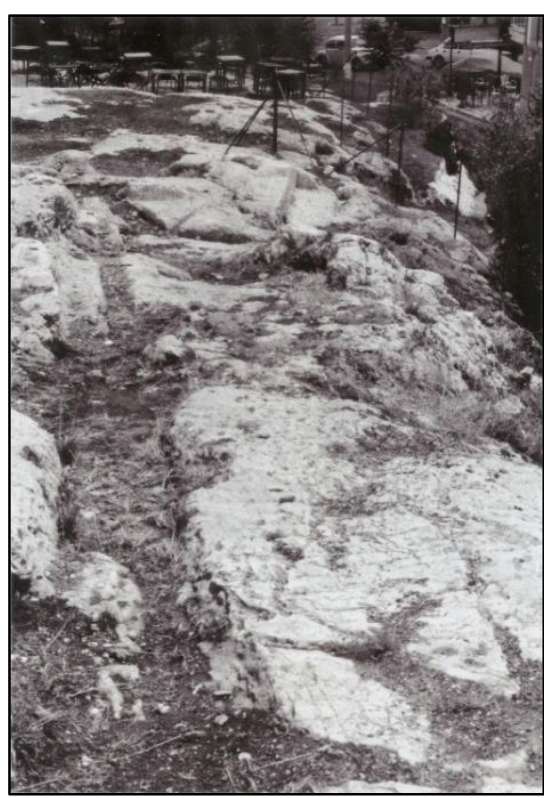

Fig.9-Caminho sul $D$ e canal de drenagem Fig.10- Planta e reconstrução da área à esq. (Lalonde, 2006: Fig.9)

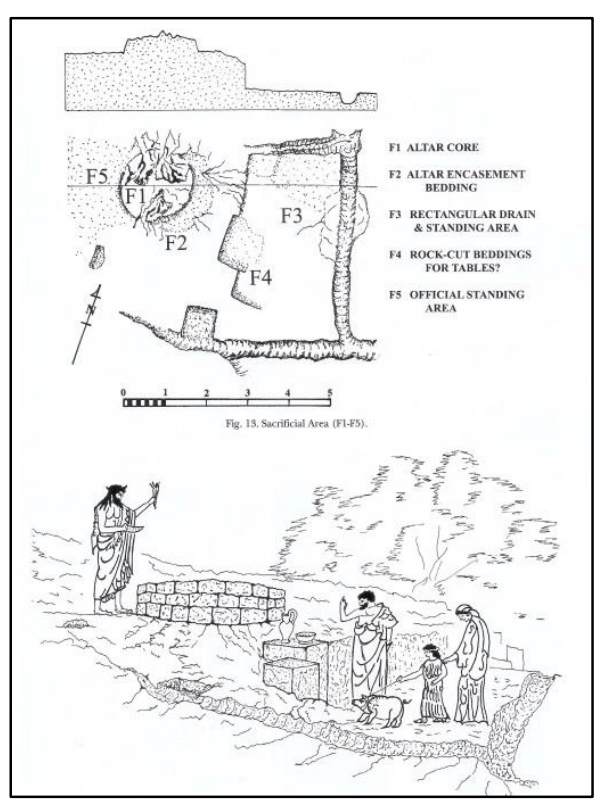

sacrificial (Lalonde, 2006: Figs. 13 e 14)
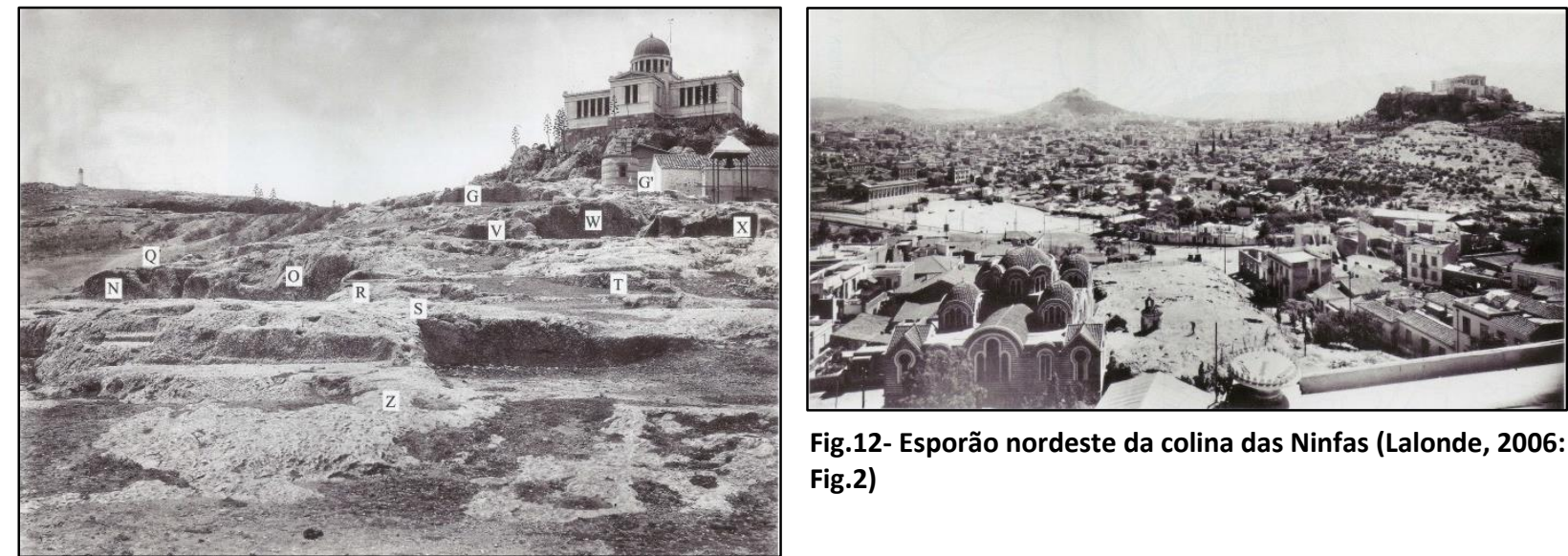

Fig.12- Esporão nordeste da colina das Ninfas (Lalonde, 2006: Fig.2)

\section{Fig.11- Esporão nordeste da colina das Ninfas vista a partir de}

nordeste (Lalonde, 2006: Fig.15) 
Datação: Início da época clássica (500/480 a.C.) - época romana (séc.ll d.C.?).

Localização: Localiza-se no setor da colina setentrional-oriental de Cirene, chamada por Heródoto (IV, 203) de a colina de Zeus Lykaios, e está a oeste do hipódromo.

Tipo de santuário: Colinar / suburbano até o séc. III a.C.

Referências textuais: (Colina) Heródoto IV.203.

Inscrições: Uma inscrição (SEG XVII, 769) do século III-II a.C. menciona trabalhos realizados no templo e no santuário. De acordo com outra inscrição (SEG XVII, 800-801), entre 172 e 175 d.C., época do pro-cônsul Cláudio Átalo, a cela foi reconstruída, as paredes recobertas por mármore e as colunas substituídas. De época helenística (século III-II a.C.), a estela com edícula com a representação talvez de Zeus e Hera contém a referência mais antiga a Zeus Olímpio em

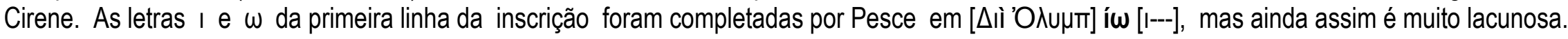

Histórico dos achados: Entre 1821 e 1822, os irmãos Beechey foram os primeiros a registrarem a existência do edifício e os responsáveis pela denominação tradicional de Grande Templo, que Ihe conferiu o primeiro lugar na hierarquia dos monumentos conhecidos da cidade (Beechey e Beechey, 1828: 111). Em junho de 1861 dois oficiais da marinha inglesa, Smith e Porcher, por sete semanas executaram dentro da cela as primeiras escavações (Smith e Porcher, 1864: 71; 105; 110-112). A primeira escavação sistemática foi realizada por G. Guidi em 1926, no momento em que substituía temporariamente G. Oliverio na direção da Soprintendenza alle Antichità della Cirenaica. Guidi liberou inteiramente a cela do templo, peneirando a terra já perturbada pelos escavadores ingleses. A sua transferência para Tripoli em 1928 e a sua morte prematura em 1936 não lhe permitiram completar o ambicioso programa de trabalhos, que previa a reunificação da área com as outras zonas de escavação. Foi durante a sua intervenção que foi descoberta a cabeça de Zeus em mármore e uma inscrição com dedicação a Zeus Olímpio, as quais consentiram a identificação definitiva da divindade titular do edifício (Bacchielli, 1998: 24; Bonacasa, 2007: 233; Parise Presicce, 2000: 137; Stucchi, 1966-1967: 199). As escavações foram retomadas por G. Pesce alguns anos depois em 1939 e prosseguiram até 1942 quando foram interrompidas pela ocupação britânica na Cirenaica. Os trabalhos revelaram, então, a grande plataforma retangular sobre a qual se erguia o edifício e as colunas que circundavam a cela. De toda maneira, as pesquisas de Pesce, prontamente publicadas, tornaram-se a primeira tentativa de restituição gráfica da fachada do templo (Bacchielli, 1998: 24-25; Bonacasa, 2007: 233; Parise Presicce, 2000: 138; Pesce, 197-1948: 307-358; Stucchi, 1966-1967: 199). A partir da década de 1960 iniciaram-se os trabalhos de anastilose do templo de Zeus. A partir de 2001 foram escavados e parcialmente recompostos os três blocos da cornija superior do entablamento enfiados no terreno a norte do local de queda da arquitrave N8-N9. Desde a morte de L. Bacchielli em 1996, C. Parise Presicce é o responsável científico do projeto do templo de Zeus (Bonacasa, 2007: 233). 


\section{Documentação arqueológica}

I. Templo: Orientado leste-oeste, o templo de Zeus é um períptero dórico de $8 \times 17$ colunas e de $32 \times 70$ metros de dimensão. A cela, cujas fundações não possuem qualquer ligação com as da perístasis, mede 18,32 x 53,19 metros, é longa três vezes a largura de sua frente e ocupa dois terços do comprimento do templo. 0 pronaos era distilo in antis com as antas voltadas para dentro, e tinha as duas colunas alinhadas com as duas colunas centrais da fachada. 0 naós mede 14.10 x 31,85 metros, era dividido em três naves por duas fileiras de colunas sobrepostas e apoiadas sobre um estilóbato de espessura reduzida. E o opistódomo, com 5,70 x 14,10 metros de dimensão, aberto na parte externa, era tristilo in antis (Bacchielli, 1998: 27 e 30; Chamoux, 1963: 320 e 322; Parise Presicce, 2000: 139-140; Stucchi, 1975: 20 e 23). A estrutura das paredes da cela era composta por grandiosos ortostates appaiates de 1,94 metros de altura e 4,25 - 4,70 metros de comprimento na base, sobre os quais se apoiavam numerosas fileiras de blocos coroadas por um friso dórico, que corre ao longo de todo o perímetro (Chamoux, 1963: 321; Parise Presicce, 2000: 140; Stucchi, 1975: 20). O crepidoma e o estilóbato do pteroma são formados, externamente, por quatro fileiras sobrepostas de blocos de calcário conchífero. As duas fileiras inferiores têm a face externa no mesmo plano vertical. Ao todo há três degraus com duas pisadas e três elevações. A altura total do crepidoma, desde a linha do eutintério até o plano do estilóbato, é de 1,50 metros. A estrutura se conserva integramente, com exceção do estilóbato do lado oriental, que foi reforçado na parte por blocos de parâmetro em um período sucessivo (Pesce, 1947-1948-1948: 311 e 316). Os principais elementos escultóricos disponíveis pertencem à perístasis - formada por 46 colunas -, que circundava um espaço amplo entre esta e as paredes da cela (6 metros na fachada e 4 metros nas laterais). As colunas, formadas por nove tambores, mediram no fuste 7,59 metros e atingiram 8,94 metros no total (o fuste com o capitel). $O$ diâmetro na base é de 1,94 metros e 0 da parte superior da coluna é de 1,45 metros e cada uma repousava sobre um grande pavimento do estilóbato, onde se encaixavam sobre um disco em relevo de 1,90 metros de diâmetro. O fuste foi talhado com 20 caneluras e os capitéis, enormes, alcançaram 1,35 metros de altura - imitaram aqueles do pronaos e do opistódomo - e o ábaco 2,70 metros de lado. 0 intercolúnio variou de 3,65 metros a 4,25 metros (Chamoux, 1963: 321; Stucchi, 1975: 23-24). Da parte superior do templo, é bem conhecido apenas o entablamento. A arquitrave atingiu 1,85 metros de altura e era ornada por uma tênia e uma régula de mesma altura, 0,16 metros, com seis gotas. 0 friso dórico mede no total 1,48 metros de altura e é composto por métopas quadradas de 1,48 metros de lado, sem ornamentos, e por triglifos de 0,87 metros. A cornija era composta por seis blocos (inferior e posterior), estando o inferior apoiado sobre o plano superior do friso e tinha um mútulo com três fileiras de cinco gotas acima dos triglifos e de mútulos mais próximos, de três fileiras e três gotas, acima das métopas. Cada bloco tinha um mútulo inteiro e em alguns deles, no lado oriental, foram encontrados traços da cor azul (Chamoux, 1963: 321; Pesce, 1947-1948-1948: 329). Nada foi encontrado dos frontões do edifício, mas já que não podemos supor que o Grande Templo não teve frontões, devemos imaginar que, caídos os tímpanos com toda a perístasis, os blocos frontais tenham sido levados em um tempo sucessivo para serem reutilizados como material de construção (Chamoux, 1963: 322; Pesce, 1947-1948: 330-331). Um torso de mármore, recuperado na área antes do início das escavações de Guidi, apresenta nas costas um típico encaixe para ser ancorado em uma parede de fundo e o é mármore típico das esculturas expostas ao aberto no triângulo do tímpano. Estas características induziram a atribuir à estátua à decoração frontal do templo. A imagem - identificada com Boreas que rapta llícia - e o estilo revelaram a dependência a um modelo ático e sugeriram uma datação pouco sucessiva àquela proposta para construção do templo (Parise Presicce, 2000: 140). Numa visão total das partes descritas do edifício, a fachada leste, em seu conjunto, é a mais danificada e foi quase inteiramente perdida, enquanto na oeste 
conservaram-se completamente todos os elementos, incluídos aqueles do muro de fundo do frontão (Stucchi, 1975: 24). Todo o edifício foi construído com calcário conchífero, cujas análises petrográficas mostraram ser idêntico aquele do plano rochoso circundante. Há a hipótese, também, de que alguns dos blocos da construção sejam provenientes do hipódromo localizado a leste do templo (Parise Presicce, 2000: 140).

II. Altar: Chamoux em 1963 escreveu que não foram encontrados, até então, o altar nem os limites do témeno. Mas Stucchi, após as escavações empreendidas entre 1967-1968, relatou que um exame praticado ao longo de uma linha paralela no lado leste do templo demonstrou a existência de um imenso acúmulo de cinzas, que recorda muito o altar de Zeus Olímpio do santuário de Olímpia, formado também por um símile agrupamento (Stucchi, 1968: 105-106).

Tipo de culto: Estudar Zeus Olímpio em Cirene é buscar compreender a instalação do deus de Olímpia na área sob influência de Zeus Amon, cultuado no famoso oráculo do oásis de Siwa situado no Deserto Líbio, na área noroeste do atual Egito. A data da instalação do culto de Amon em Siwa permanece desconhecida. Parece que o culto de Amon-Ra foi identificado com um deus-carneiro líbio venerado em Siwa na época que um grupo de sacerdotes egípcios instalou-se por lá, no momento em que os residentes e o seu chefe eram líbios (Heródoto, II.32;33). Mesmo incerta, a data para o estabelecimento dos sacerdotes é sugerida na vigésima quinta dinastia (716-664 a.C.) ou ainda mais tarde (Malkin, 1994: 159; Parke, 1967: 196). O conhecimento grego e os contatos pessoais com o oráculo de Amon parecem ter iniciado no século VII a.C. com a chegada de mercenários, mercadores e colonos gregos no Egito, que se assentaram em Naucrátis em 630 a.C. Outras comunidades gregas também se assentaram na cadeia de oásis iniciada em Kargeh, o provável local de um povoado estabelecido por Samos ao redor de 525 a.C. (Malkin, 1994: 159-160). Siwa nunca foi considerado um oráculo grego, mas, mesmo assim, os gregos identificaram Amon com Zeus porque ambos eram clamados como divindades supremas (Malkin, 1994: 160; Parke, 1967: 203). O relato mais antigo, sobre o conhecimento do oásis de Amon no mundo grego, é a famosa passagem em Heródoto (l.46) que descreve a consulta do rei lídio Creso ao oráculo. Não há referências a Zeus Amon em Homero e nem em Hesíodo, cujos textos guardam os registros mais antigos sobre as divindades gregas (Parke, 1967: 200-201). Enquanto colonizadores reais ou virtuais, os gregos interessados na Líbia, viram Zeus Amon como sua divindade tutelar (Malkin, 1994: 158). A visão da Líbia colonial como terra de Zeus Amon foi comum aos habitantes da Cirenaica. O principal testemunho sobre isso é a ode Pítica IV de Píndaro, que contém a referência mais explícita da Líbia como 0 recinto do deus (Malkin, 1994: 162-163). Para os cireneus, "Amon" era outro título de Zeus Olímpio como recorda Píndaro (Fr.36, Schol. Pít. IX.90e) ao denominálo senhor do Olimpo. Mas, ao ser apropriado por Cirene, Zeus, com o aspecto de Amon, passou a ser representado com os chifres de carneiro (Bonacasa, 2007: 243; Chamoux, 1963: 335; Malkin, 1994: 160). De fato, a pólis parece ter sido a responsável pela criação da imagem do deus na arte grega, por cunhar o seu perfil com os chifres do carneiro (Bonacasa, 2000: 46; Malkin, 1994: 160; Parke, 1967: 203). À tese de que os colonos peloponésios teriam trazido o culto de Zeus Lykaios para Cirene, acrescentamos a de que teriam trazido, também, o de Zeus Olímpio. 0 santuário do Monte Lykaion, na Arcádia, e o de Olímpia, em Élis, eram geograficamente próximos e por isso freqüentados pela população da Arcádia, Trifilia, Messênia e da própria Élis desde a Idade do Ferro (Morgan, 1994: 79-85). Os dois santuários pan-helênicos compartilharam traços culturais desde muito cedo, como demonstrou o estudo de C. Morgan e o nosso estudo sobre as moedas de Olímpia para a época clássica. A instalação do culto de Zeus Lykaios e de Zeus Olímpio em Cirene, se de fato forem concomitantes, correspondeu quase à mesma época em que Olímpia e as cidades da Liga Arcádia cunharam tipos monetários de Zeus muito semelhantes e que pela primeira 
vez apareceram no mundo grego (Laky, 2008: 218 e 231). Diante desse contexto, ambos os cultos de Zeus (Lykaios e Olímpio) podem sim terem compartilhado a mesma paisagem, o mesmo espaço na colina. A segunda explicação para a origem do culto de Zeus Olímpio em Cirene está na relação direta entre a pólis e o santuário de Olímpia. A soma das evidências - a correspondência temporal entre o momento da primeira vitória em Olímpia e a construção do tesouro - indica que Cirene efetivou sua presença no santuário entre o final do século VI e início do século V a.C. Assim, acreditamos que, ao mesmo tempo em que quis marcar sua presença em Olímpia com a edificação do tesouro, escolheu efetivar-materializar na própria cidade a relação com o santuário ao erigir um templo a Zeus Olímpio. Amon é o culto mais antigo de Zeus na Cirenaica e esteve relacionado com o ambiente religioso encontrado pelos gregos na Líbia (Bonacasa, 2007: 242). Zeus Lykaios e Zeus Olímpio relacionam-se a outra fase da colonização de Cirene, quando a pólis já havia se estabelecido e se organizado espacialmente.

Referências bibliográficas: Bacchielli, L. II Tempio di Zeus Olimpio a Cirene: Storia e Programma degli Scavi e Restauri. Em: Catani, E.; Marengo, S.M. (org.). La Cirenaica in età antica. Atti del convegno Internazionale di studi (Macerata 18-20 Maggio 1995). Pisa-Roma: Istituti Editoriali e Poligrafici Internazionali, 1998, 23-40; Beechey, F.W.; Beechey, H.W. Proceedings of the expedition to explore the northern coast of Africa from Tripoli eastward. Londres, 1828; Bonacasa, N. I Culti della Colina di Zeus a Cirene. Karthago, vol. 27: 233-243, 2007; Chamoux, F. Cyrène sous la monarquie des Battiades. Bibliothèque des Écoles Françaises D’Athènes et de Rome. Paris: De Boccard, 1963; Laky, 2008; Malkin, I. Myth and Territory in the Spartan Mediterranean. Cambridge University Press, 1994; Morgan, 1994; Parise Presicce, C. II Quartiere dell'Olympieion. Em: Bonacasa, N.; Ensoli, S. (org.). Cirene. Milão: Electa, 2000, pp. 137-147; Parke, H.W. The Oracles of Zeus: Dodona, Olympia, Ammon. Oxford: Blackwell, 1967; Pesce, G. II Grande Tempio in Cirene. Campagna di Scavi 1939-1942. BCH, LXXI-LXXII: 307-358, 1947-1948; Smith, R.M.; Porcher, E.A. History of the recent discoveries at Cyrene, made during an expedition to the Cyrenaica in 1860-61, under the auspices of Her Majesty's Government. Londres,1864; Stucchi, S. La Ripresa dei Lavori nel Temenos di Zeus a Cirene. Lybia Antiqua, vol. III-IV: 199-201, 19661967; I lavori nel temenos di Zeus a Cirene. Libya Antiqua, vol. V: 105-107, 1968; Architettura Cirenaica. Roma: L'Erma di Bretschneider, 1975. 
Imagens:

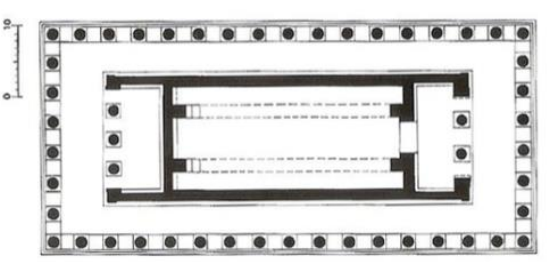

Fig.1 - Planta do templo de Zeus de 500-480 a.C. (Parise Presicce, 2000: 143)

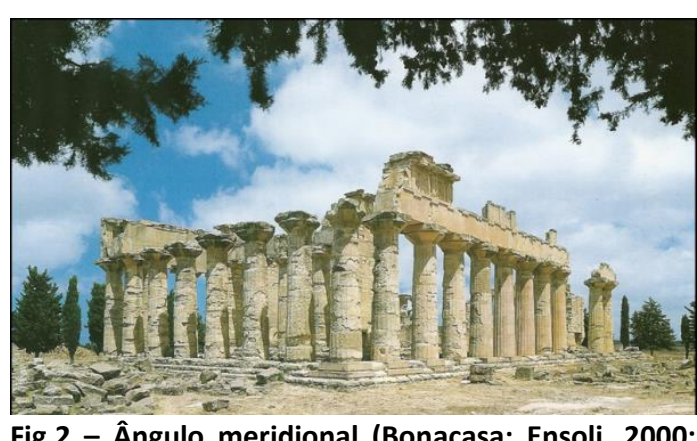

Fig.2 - Ângulo meridional (Bonacasa; Ensoli, 2000

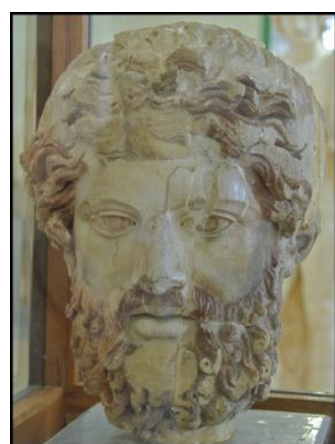

Fig. 3 - A cabeça de Zeus em mármore pentélico (II

d.C.) (Foto: Sebastià Giralt - Flickr.com)

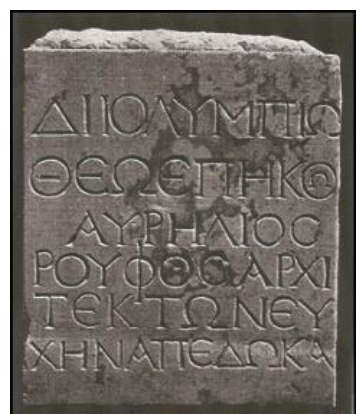

Fig.4 - Inscrição em laje de mármore dedicada por Aurélio Rufo (II d.C.)

(Guidi, 1927: 40, fig.11) 


\section{Atenas}

Datação: Início época clássica (500 a.C., fase I) - época clássica ( $2^{a}$. metade do séc. V a.C., fase II).

Localização: Na acrópole, a pequena distância do ângulo nordeste (ou noroeste?) do Pártenon (Lippolis, 2007: 556).

Tipo de santuário: Colinar / Urbano.

Referências textuais: Pausânias I, XXIV.3-5; I,XXVIII.10.

\section{Inscrições: ?}

\section{Histórico dos achados: ?}

\section{Documentação arqueológica}

Trata-se de um santuário com duplo recinto (Lippolis, 2007: 556).

I. Recinto 1: Constituído por um témeno a céu aberto fechado por um muro de témeno; 0 acesso era pelo lado sul e norte e coincidia com a zona mais alta da acrópole (156,63 m) (Lippolis, 2007: 556).

II. Recinto 2 e edifício: Comunicável com o lado leste, o segundo recinto tinha em sua parte interna um pequeno edifício, orientado a norte, de 4,62 x 6,66m, do qual restaram somente as trincheiras das fundações talhadas na rocha e uma série de outras cavidades, que levaram Stevens (1940) a reconstruir o local para os touros destinados ao sacrifício. O pequeno edifício, reconstruído como distilo in antis (Heberdey, 1919) ou como prostilo distilo (Stevens, 1940), devia estar diretamente conectado com o rito do sacrifício. Segundo Stevens (1946) a construção teria sido de pedra somente na parte inferior e a superior de madeira. No centro da cela há uma cavidade retangular interpretada como uma banheira para água ou um receptáculo para as cinzas do sacrifício, enquanto a uma distância de $2 m$ da frente alguns cortes na rocha atestariam a presença de um altar ou de uma trapeza (mesa) sagrada (Lippolis, 2007: 556-557) .

A porção correspondente ao recinto oeste $(\mathrm{a} 16, \mathrm{I26})$ (1 ou 2?) foi poupada do aplainamento da superfície rochosa da acrópole a leste e a norte do Pártenon, conectada à sistematização da área entorno do templo. Isso é visivel, sobretudo, a partir do lado sul, onde a rocha apresenta uma quota maior com relação à superfície de época clássica. O santuário, portanto, devia já estar implantado nesta zona no período arcaico. No âmbito da fase II, datada da época de Péricles, 
o lado sul e o ângulo sudoeste do períbolo foram modificados "recuando" para consentir uma adequada passagem em correspondência da dedicação de um importante monumento que Stevens identifica como a quadriga de Pronates, comandante da cavalaria ateniense provavelmente em 446 a.C. (Lippolis, 2007 : $557)$.

Tipo de culto: No âmbito da festa ateniense da Diipolia, era realizada todos os anos no $14^{\circ}$.mês, o Skiroforiónos (fim de junho), o sacrifício de um boi, descrito por Pausânias. Sobre o altar do deus era colocada a cevada misturada a grãos. Quando o boi destinado ao sacrifício se aproximava e comia os grãos, ele era morto por um sacerdote chamado bouphonos ("matador de boi"), que depois de matá-lo se apressava em fugir. Em seguida, os atenienses submetiam o boi ao instrumento de incisão, o machado (Servi, 2011: 61-62).

Referências bibliográficas: Heberdey, R. Altattische Poroskulptur. Wien, 1919, pp. 172-174; Lippolis, 2007, pp.556-557; Servi, K. L'Acropoli, il museo dell' Acropoli. Atenas, Ekdotike Athenon, 2011, pp. 61-62; Stevens, G.P. The setting of the Periclean Parthenon, Hesperia, Suppl.(3), 1940, pp. 79-86; Stevens, G.P. The northeast corner of the Parthenon, AJA (15), 1946, pp. 12-15.

\section{Imagens: ?}


Datação: Época clássica (séc. V a.C. [490/80 a.C.]) - época clássica (406 a.C.).

Localização: No setor sudoeste, a oeste da porta IV e do templo de Héracles e da ágora inferior, e a leste de partes da grade urbana (estenopes e quarteirões), do santuário das Divindades Ctônias, do Novo Santuário Arcaico, a Colimbetra e o templo de Hefesto.

Tipo de santuário: Planície? / urbano.

Referências textuais: (Templo) Diodoro XIII. 82.1-5; Políbio IX.27.6; (Santuário) Diodoro XIII, 82,1-5; XXIII, 18,2.

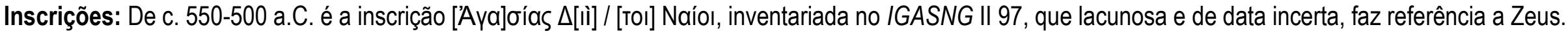

Histórico dos achados: As primeiras escavações no Olimpiéion foram realizadas entre 1802 e 1804 sob a supervisão de G. Lo Presti, superintendente de antiguidades de Agrigento, e tiveram o patrocínio dos reis Carlos de Nápoles e Carlos III de Espanha. As escavações de Bourbon, como ficaram conhecidas, embora tenham revelado partes da planta do templo, poucos documentaram os achados. As escavações de Boubon pela primeira vez tornaram possível o estudo da planta do templo como um todo, permitindo aos escavadores estabelecer os aspectos básicos da planta e finalmente abriram o caminho para os estudos sistemáticos das ruínas (Broucke, 1996: 85-87). Novas escavações foram realizadas na área das ruínas da colunata sul entre 1925 e 1927 por Pirro Marconi e supervisão de P. Orsi. Em 1940 G. Ricci, superintendente de antiguidades, conduziu escavações na parte nordeste da cela, descobrindo os muros do pronaos e duas plataformas que contém cisternas. As pesquisas continuaram sob a direção de P. Griffo, que assumiu a Superintendência. E. De Miro, novo superintendente, realizou novas escavações em 1969, descobrindo os blocos do entablamento. O altar foi noticiado pela primeira vez pelo pintor francês de topografias Jean Pierre Laurent Hoüel (1735-1813) e Koldewey e Puchstein (1890) foram os primeiros pesquisadores a publicarem uma discussão e descrição sobre a construção.

\section{Documentação arqueológica}

I. Templo: Conforme D. Mertens (2006: 261), o templo estava orientado leste-oeste, era pseudodíptero e foi construído sobre fundações altas. Tinha a dimensão de 56,30 x 112,60-70 metros no estilóbato e uma pseudo-perístasis de 7 × 14 semi-colunas dóricas (meia-circunferência). A colunata, portanto, não era aberta, e entre as colunas foram construídos muros com pilastras quadradas. A planta se divide em três naves e o pronaos, naós e opistódomo eram divididos por três pilastras internas e paredes transversais. O pronaos e o opistódomo são abertos e a parte interna da cela, o naós, foi concebida em forma de sêkós. A cela era constituída por um muro ligado a uma série de doze pilastras para cada lado longo, cujas angulares delimitavam os espaços do pronaos e do opistódomo. As naves laterais eram amplas 12 metros e a entrada do templo era mediante duas portas localizadas nos ângulos da parte leste (Coarelli; Torelli, 1984: 143; Griffo, 
2005: 117; Mertens, 2006: 265). As fundações do Olimpiéion medem de 6 a 7 metros de altura e junto com o crepidoma do edifício constituem a maior parte dos remanescentes no local como ocorre com os templos pobremente preservados (Broucke, 1996: 222; Mertens, 2006: 261). As escavações de Pirro Marconi nos anos 1920 e as escavações de Ferri na época da guerra revelaram as fundações do muro do pronaos e os paredões nos flancos $\{11 / 3\}$ e $\{11 / 5\}$, a parte da cela norte, partes do interior do estilóbato sul e algumas seções da parte externa do estilóbato norte. Mas infelizmente os resultados destas campanhas não foram publicados (Broucke, 1996: 222). No lado norte, leste e sul, grandes partes da subestrutura da perístasis estão preservados. Partes da subestrutura da cela estão bem preservadas nos quatro paredões da extremidade do edifício, ou seja, nos $\{2 / 3\},\{2 / 5\},\{12 / 3\}$ e $\{12 / 5\}$ (Broucke, 1996: 223). No lado sul, a profundidade das fundações da perístasis é desconhecida. A parte exposta da face dentro das fundações visíveis na trincheira de escavação dentro da perístasis, contudo, indica que as fundações seguem até o curso -11. Sendo este o caso, as fundações alcançam um nível de ao menos 6,6 metros abaixo do nível do estilóbato. No lado oeste nada do estilóbato ou do crepidoma está preservado acima do nível do terreno. Trincheiras profundas realizadas por P. Marconi nesta área revelaram apenas a parte mais baixa de três cursos das fundações do lado oeste. No lado sul, a profundidade das fundações da perístasis é desconhecida. A parte exposta da face dentro das fundações visíveis na trincheira de escavação dentro da perístasis, contudo, indica que as fundações seguem até o curso -11. Sendo este 0 caso, as fundações alcançam um nível de ao menos 6,6 metros abaixo do nível do estilóbato. No lado oeste nada do estilóbato ou do crepidoma está preservado acima do nível do terreno. Trincheiras profundas realizadas por $P$. Marconi nesta área revelaram apenas a parte mais baixa de três cursos das fundações do lado oeste. Assim como no lado sul, a profundidade exata das fundações do lado norte não é conhecida. Na parte exterior da perístasis, o curso -13 é o mais baixo visível. As fundações, então, estendem-se até o curso -14 alcançariam, consequentemente, uma profundidade de ao menos 7,35 metros abaixo do nível do estilóbato (Broucke, 1996: 227-228). O crepidoma é composto por cinco degraus, sendo que o superior possui o dobro de altura dos inferiores, formando assim o conjunto uma espécie de pódio que separava notadamente a elevação do templo do ambiente circunstante (Broucke, 1996: 233; Mertens, 2006: 261). Assim como as fundações, o crepidoma não está preservado em todos os lados do edifício, somente a parte leste foi recuperada e possivelmente a única finalizada. A parte do lado oeste foi inteiramente perdida e no flanco sul do templo, uma pequena parte está preservada em \{8/1\} (Broucke, 1996: 233-234). Embora a altura das colunas permaneça incerta, foram propostas as medidas entre 19,20 metros e 21,57 metros de altura e entre as pilastras terminadas em forma de capitel de anta dórico teriam ainda cerca de 1,90 metros a mais de altura (Mertens, 2006: 262). Os capitéis tinham eqüinos constituídos por dois grossos blocos justapostos e ornados com uma gola de quatro aneletes e ábaco composto por três grandes lajotas. 0 diâmetro das colunas mede 4,05 metros na base e é considerado 0 maior já realizado. As meias-colunas da pseudo-perístasis do Olimpiéion foram construídas como muros e não montadas com tambores, como era a maneira tradicional (Broucke, 1996: 250-254; Dinsmoor, 1950: 101; Griffo, 2005: 116). Também em relação aa pseudo-perístasis, foram identificadas entre as ruínas bases de colunas. Ao todo foram encontrados dois Atlantes completos e por isso sabemos que mediam 7,65 metros de altura. Três cabeças preservaram-se e evidenciam que não eram iguais entre eles, sendo documentados dois tipos: um maduro com barba, bigodes e cabelos longos, o outro jovem, imberbe e com cabelos curtos encaracolados (Marconi, 1997: 2) 
II. Altar: Está a 50 metros de distância da frente oriental do templo, em posição paralela, mede 54,50 x 17,50 metros. Dele restaram uma série de pilastras sobre as quais se apoiava uma laje da plataforma para os sacrifícios e os blocos da escada de acesso. Este foi o maior altar do Ocidente grego até a construção do altar de Hieron II em Siracusa (Mertens, 2006; 265).

Tipo de culto: No caso de Agrigento, a documentação arqueológica para o culto de Zeus no século VI a.C. não é segura. Dois tipos de evidências sugerem que o culto teria se iniciado próximo à data da fundação da cidade, no início do século VI a.C. Um naískos dentro da área do santuário de Zeus Olímpio, datado de 580-550 a.C., a sudeste do grande templo, é interpretado por alguns pesquisadores como o primeiro edifício dedicado ao deus (Broucke, 1996: 325-327). Mas como veremos mais adiante - 0 achado de estátuas votivas femininas sugere outro uso para o edifício. De todo modo, dentre os cultos de Zeus, 0 de Zeus Olímpio é o que melhor conhecemos em Agrigento. A sua origem - como escreveu E. Ciaceri em seu precioso Contributo alla Storia dei Culti dell'Antica Sicilia (1894) - não era de Rodes, mas de Élis se considerarmos como eram renomados os acragantinos nos jogos olímpicos já desde a época de Píndaro (Ol. II; III). É natural pensar que deveriam existir antigas relações entre os dois lugares (Ciaceri, 1894: 9). Foi à época da maior proeminência de Agrigento nos jogos olímpicos - na transição do VI para o V a.C e ao longo deste século - que a pólis erigiu o Olimpiéion, justamente próximo ao ano da vitória de Téron, o responsável pela obra do templo (Laky, 2013: 172).

Referências bibliográficas: Broucke, P. B. F. J. The Temple of Olympian Zeus at Agrigento (Tese). Ann Arbor: University of Michigan, 1998; Ciaceri, E. Contributo alla Storia dei Culti dell'antica Sicilia. AnnPisa, 1894; Coarelli; Torelli, 1984; Dinsmoor, W.B. The Architecture of Ancient Greece. An Account of its Historic Development. Londres; N. York; Toront; Sidney: B.T. Batsford LTD., 1950; Grifo, P. Akragas - Agrigento. La storia, topografia, I monumenti, gli scavi. Agrigento: Legambiente, 2005; Marconi, C. I Titani e Zeus Olimpio. Sugli Atlanti dell'Olympieion di Agrigento. Prospettiva, 87/88: 2-13, 1997; Mertens, 2006 ; Laky, 2013. 
Imagens:

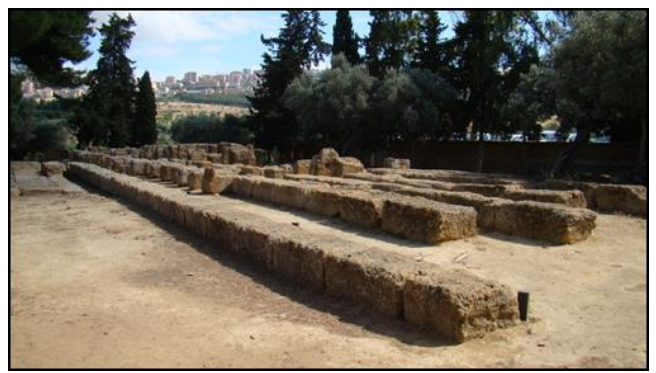

Fig.1 - Ângulo sudeste do altar (Foto: arquivo pessoal/2009)

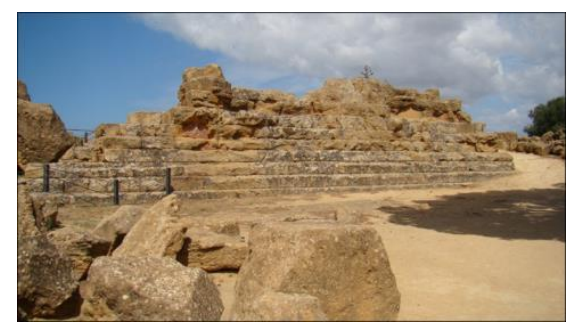

Fig.5 - Crepidoma do lado leste (Foto: arquivo pessoal/2009)

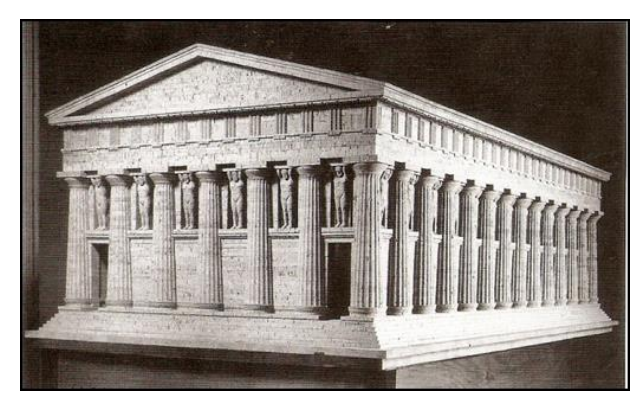

Fig.2 - Reconstituição plástica do Olimpiéion (por Prado 1954) Museu Arqueológico Regional de Agrigento (Marconi, 1997: 8, fig. 7; Mertens, 2006: 262, fig.468)

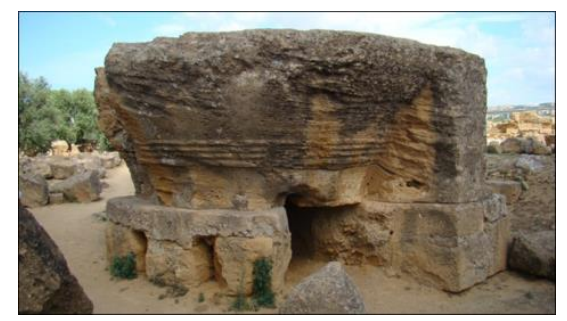

Fig.6 - Capitel de coluna em que se pode perceber (à direita) parte do muro que ligavam as colunas (Foto: arquivo pessoal/2009)

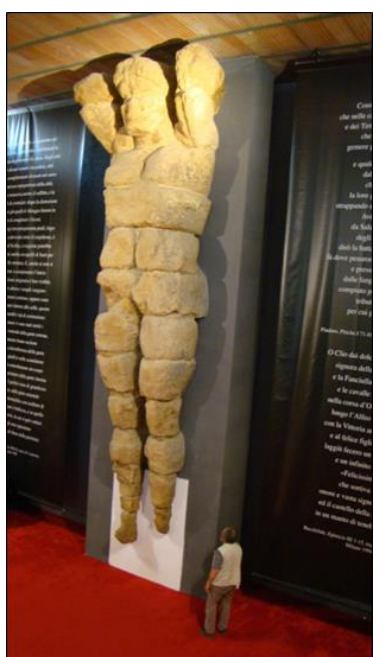

Fig.3- Atlante original exposto no Museu Arqueológico Regional de Agrigento (Foto: arquivo pessoal/2009)

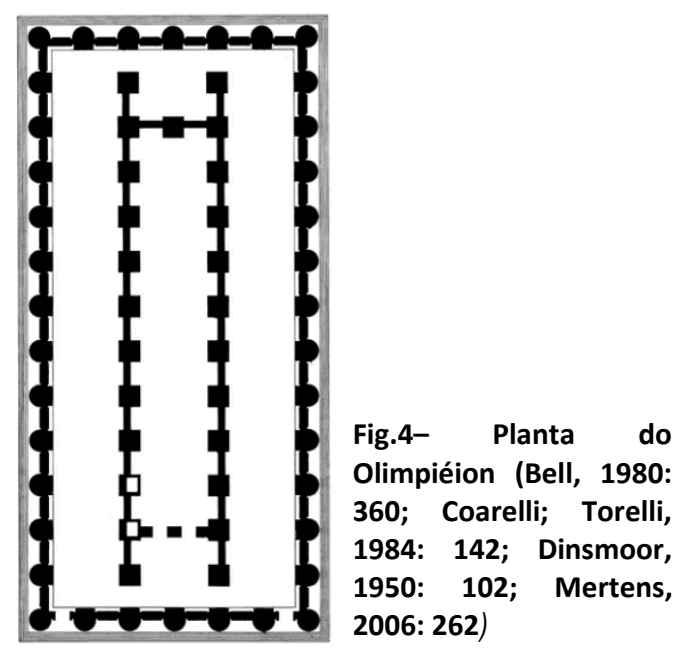

$4+\ldots+2, \ldots$ 
Datação: Época clássica (480 a.C.?) - época romana.

Localização: Na direção do canal de Euripos, distante do centro da cidade antiga (Sakellaraki, 1995: 32; 40). O templo e o santuário teriam ocupado a área onde foi erigida a basílica de Ágia Paraskevi no atual distrito de Kamares-Ágios loánnis (Sakellaraki, 1995: 40).

Tipo de santuário: Planície? / extraurbano?

Referências textuais: (Culto?) Plutarco, Titus, 16, 378; Diodoro XVI, 70.

Inscrições: Decreto (IG $\left.\left.\right|^{3} 40,21-36\right)$ encontrado na acrópole de Atenas datado de 446/5 a.C., texto escrito na época em que a pólis juntou-se à primeira liga ateniense (Sakellaraki, 1995: 26; 40); uma inscrição do século IV e outra do séc.ll a.C., ambas referentes ao culto; e outra (IG XII,9 900 A.1) datada entre os

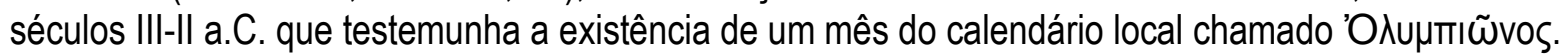

\section{Histórico dos achados: ?}

\section{Documentação arqueológica}

I. Templo: Do templo são atribuídos apenas cinco capitéis dóricos de calcário recuperados nos distritos modernos de Kastro e Vourkos, datados de 480/70 a.C., os quais os estudiosos de Cálcis acreditam terem pertencido ao templo de Zeus Olímpio (Sakellaraki, 1995: 27; 32). Lembramos que a reconstrução urbana de Cálcis é problemática, porque a maior parte dos remanescentes arquitetônicos foi reaproveitada na edificação dos muros venezianos da cidade, nas igrejas e nas fundações de edifícios e, por isso, não estão relacionados com qualquer outro membro arquitetônico e não possuem indicações de sua proveniência original (Sakellaraki, 1995: 51).

Tipo de culto: Apesar de as evidências da influência de Olímpia na instituição do culto de Zeus Olímpio em Siracusa serem indiscutíveis, a sua relação com Corinto - sua pólis fundadora - e com a Eubéia - cuja população da região é atestada na cidade antes de sua fundação oficial - são consideráveis. É possível que tanto os coríntios quanto os eubeus possam ter transmitido alguma tradição do culto de Zeus Olímpio já presente entre eles. No caso de Mégara e Cálcis a instituição do culto da divindade em ambas as cidades pode ter sido motivada pela disputa bélica constante com Atenas no século VI e V a.C., pólis que tinha tradição do culto ao deus e que nessa época já ostentava um grandioso Olimpiéion. Em todos esses casos, a interação e competição entre as cidades tanto em Olímpia como entre elas mesmas, se por vias bélicas ou não, promoveram os meios, os canais para a instituição do culto políade de Zeus Olímpio ao redor do mundo grego (Laky, 2013: 27).

Referências bibliográficas: Laky, 2013, pp. 229-232; Sakellaraki, E.S. Chalkis. History, Topography and Museum. Atenas: Archaeological Receipts Fund, 1995. 


\section{Imagens:}

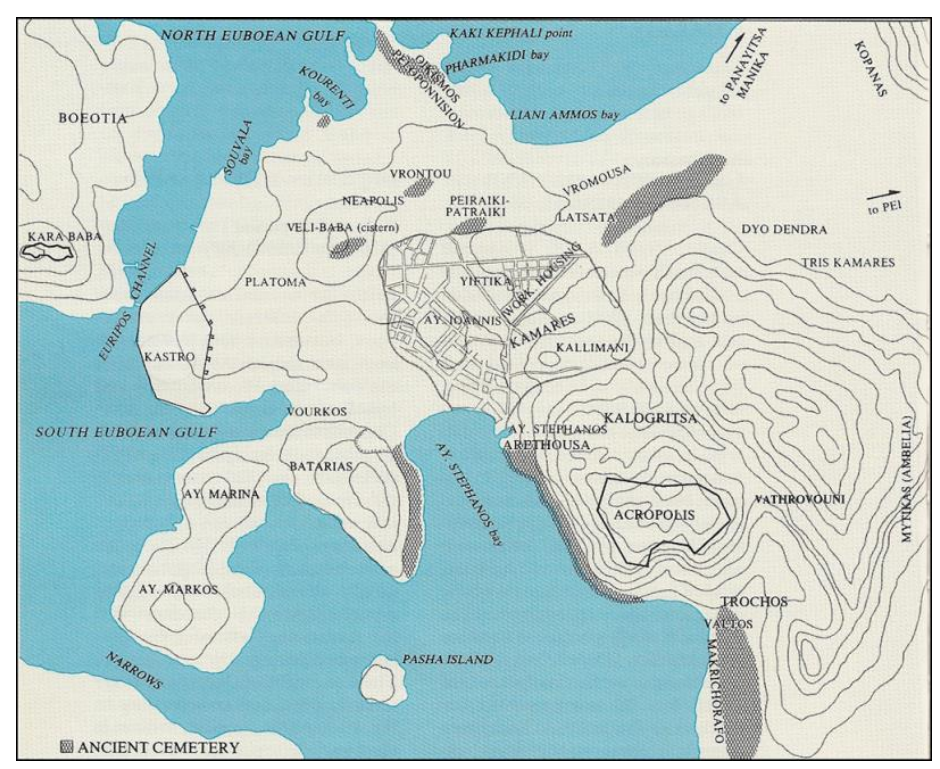

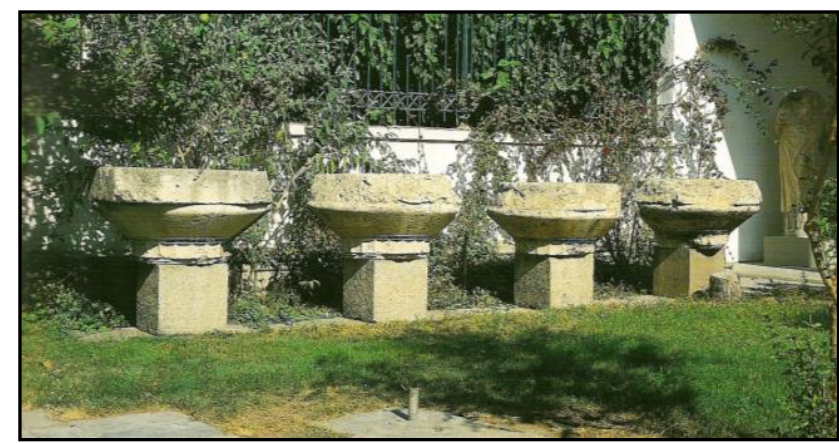

Fig.2- Quatro dos cinco capitéis dóricos encontrados em Kastro e Vourkos (Sakellaraki, 1995: 27, fig.8)

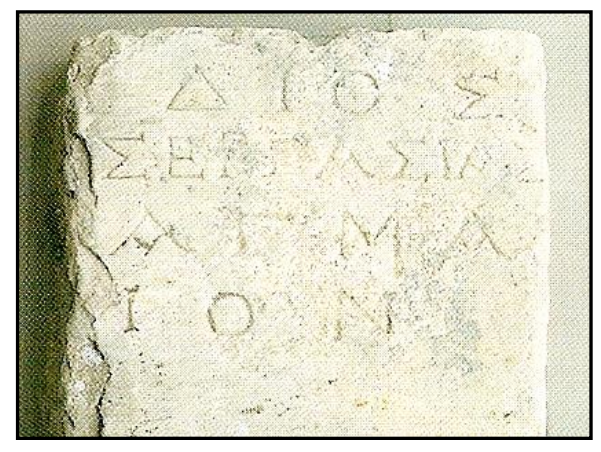

Fig.3 - Inscrição em mármore (IV a.C. (Sakellaraki, 1995: 33, fig.12)

Fig.1- Topografia geral de Cálcis e região (Sakellaraki, 1995: 18, fig. 5) 


\section{Cirene}

Datação: Época clássica (séc. V a.C.) - ?

Localização: Situado na entrada do uadi de Ain Hofra, em posição ligeiramente elevada, em cima de uma nascente de água, a cerca de $2 \mathrm{~km}$ de Cirene.

Tipo de santuário: Colinar? / suburbano? extraurbano?

Referências textuais: Inexistente?

Inscrições: A partir das inscrições (SEG IX, 325-346) recuperadas no local foi possível datar e atribuir o culto.

\section{Histórico dos achados: ?}

\section{Documentação arqueológica}

I. Santuário: É um imenso ninfeu re-escavado sobre e entorno a uma nascente de água, ao lado da qual se abrem várias exedras com banquinhos. Da nascente partem dois aquedutos com canais em pedra. Sobre a parede ocidental há centenas de nichos simples ou duplos escavados na rocha, vários dos quais possuem inscrições gregas a Zeus Meilichios, aos Eumênidas e aos heróis. Um pequeno plano de deposição embaixo dos nichos servia, provavelmente, para a deposição dos objetos votivos.

II. Tumbas: Altas escadas e estradinhas trabalhadas na rocha conduzem em direção à fonte, passando enfrente a uma fachada rupestre com um pórtico com duas pilastras retangulares com capitéis eólicos e sobre bases ligeiramente indicadas. Trata-se de uma câmara funerária do século VI a.C., considerada não acabada, ou um lugar de culto. No lado setentrional há uma necrópole e, no oriental, uma tumba do século IV a.C. construída com blocos isodômicos e com teto de pedra (similar a um templinho) e eleva-se sobre uma plataforma de cinco degraus.

Tipo de culto: Trata-se de um culto às águas dedicado a Zeus Meilichios, aos Eumênidas e aos heróis, cujas presenças indicam um rito propiciatório no qual a água era um elemento purificador. A ligação entre os santuário e as tumbas faz pensar em um culto ctônio dedicado a Zeus Meilichios - divindade ínfera - e aos Eumênidas pelos cuidados dos mortos. A associação das tumbas com o santuário da divindade e dos heróis levou os especialistas a pensar que se tratasse de um culto que heroicizou os mortos enterrados no local, os quais, com toda a probabilidade, pertenciam às famílias aristocráticas de Cirene, os descendentes dos colonos de Thera.

Referências bibliográficas: Fabbricotti, E. Ain Hofra, Cirene. Em: Bonacasa, N.; Ensoli, S. Cirene. Milão: Electra, 2000, p.182; Ferri, S. Contributi di Cirene alla storia della religione greca. Roma, 1923, p.12sq; Lazzarini, M.L. Zeus Meilichios e le Eumenidi: alcune considerazione. Em: Catani, E.; Marengo, S.M. (org.). La 
Cirenaica in età antica. Atti del convegno Internazionale di studi (Macerata 18-20 Maggio 1995). Pisa-Roma: Istituti Editoriali e Poligrafici Internazionali, 1998, pp. 311-318; Stucchi, S. Architettura Cirenaica. Roma: L'Erma di Bretschneider, 1975.

\section{Imagens:}

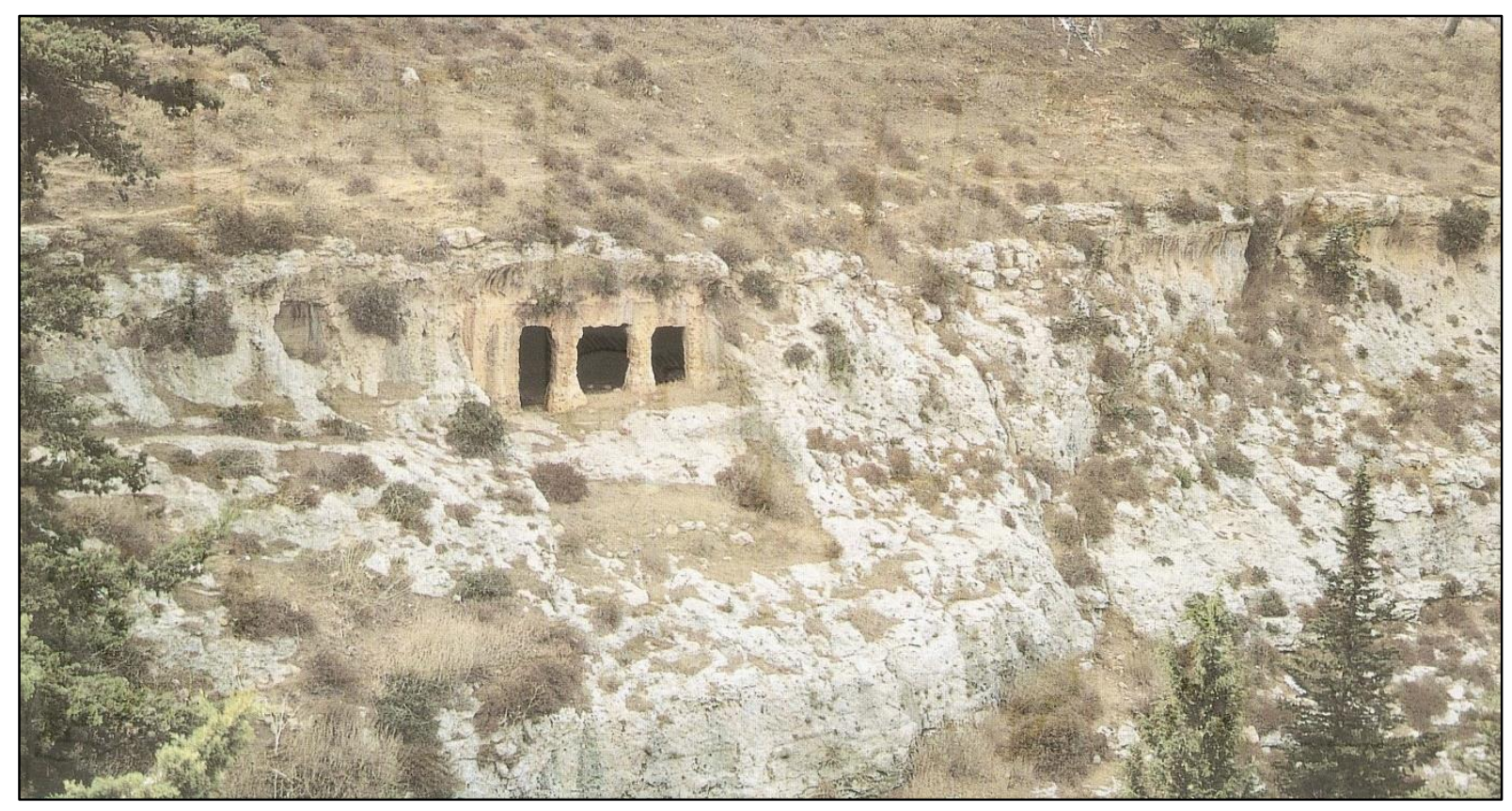

Fig.1- Entrada do santuário de Ain Hofra (Bonacasa; Ensoli, 2000: 182) 
Datação: Época clássica (séc. V a.C.) - ?

Localização: No cume do Monte Kounádos.

Tipo de santuário: Pico? / extraurbano e sub-regional?

Referências textuais: Inexistentes?

Inscrições: Inscrição (IG.XII.5.183) em hóros do séc. V a.C. sobre (Zeus) Hypatos (IACP, p.766).

\section{Histórico dos achados: ?}

\section{Documentação arqueológica}

A inscrição no hóros com o epíteto Hypatos de Zeus provém do Monte Kounádos, onde Zeus possuía um santuário que pode ser muito mais antigo (IACP, p.766). A capela do Profeta Elias no cume do monte, segundo Torelli e Mavrojannis, foi construída sobre o templo de Zeus Hypatos (Torelli; Mavrojannis, 2002: 388).

Tipo de culto: De acordo com o IACP, outras inscrições atestam em Paros o culto de Zeus sob múltiplos epítetos: Aigioichos (IG XII.5 215.6, séc.V a.C.); Elasteros (IG XII.5 1027, c.500 a.C. e outras inscrições, ver IACP, p.766); Eleutherios (SEG 26 978, séc. V a.C.); Patroios (IG XII suppl.208, séc.IV a.C.).

Referências bibliográficas: Berranger, D. Recherches sur l' histoire et la prosographie de Paros à l'époque archaïque. Clermont-Ferrand, 1992; IACP, p.766;

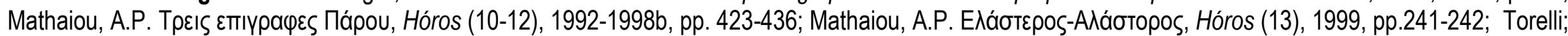
Mavrojannis, 2002, p.388.

Imagens: ? 
Datação: Época clássica (séc. V a.C.) - época helenística (séc. I a.C.?).

Localização: Na moderna cidade de Milas, na extremidade sul da antiga Mylasa.

Tipo de santuário: Planície? / Urbano.

Referências textuais: (Santuário) Estrabão 14.2.23.

Inscrições: De época helenística sobre o envolvimento do santuário no arrendamento de terras.

\section{Histórico dos achados: ?}

\section{Documentação arqueológica}

I. Muro de períbolo: Os restos de um muro que cercavam o témeno do templo de Zeus são provavelmente do séc. V a.C. (IACP: 1128). Trata-se de um muro poligonal que pode ter sido parte de seu terraço, de acordo com outra interpretação (Williamson, 2012: 92, nota 3).

Tipo de culto: Em época helenística, Zeus Osogollis foi a principal divindade da cidade de Mylasa, em contraste a Zeus Labraundos relacionado à identidade cária (Williamson, 2012: 134). O santuário nessa época exibiu vários decretos (Williamson, 2013: 15).

Referências bibliográficas: IACP, p.1128; Williamson, C. Public space beyond the city. The sanctuaries of Labraunda and Sinuri in the chora of Mylasa. in C.P. Dickenson \& O.M. van Nijf, eds, Public Space in the Post-Classical Greek City. Caeculus 7: 1-36, 2013; City and sanctuary in Hellenistic Asia Minor.

Constructing civic identity in the sacred landscapes of Mylasa and Stratonikeia in Karia, PhD diss. University of Groningen, 2012.

Imagens: ? 
Datação: Época clássica (séc.IV a.C. [371/70 a.C.]) -?

Localização: Situado na margem ocidental da ágora, de frente ao analemma sudeste do teatro.

Tipo de santuário: Planície / urbano.

Referências textuais: (Templo) Tucídides (V,47,11); Pausânias VIII, 9.2.

Inscrições: Inscrição em um hóros do século V a.C. citado por Lo Monaco.

Histórico dos achados: Os remanescentes do santuário foram escavados por Fougères no final do século XIX.

\section{Documentação arqueológica}

I. Templo: Fougères (1898: 187-190) reconheceu o templo no edifício retangular $(6,75 \times 12,10 \mathrm{~m})$, orientado norte-sul, situado na margem ocidental da ágora, perto do analemma sudeste do teatro e da entrada sudoeste. Sobre uma fundação em fileira de lajes de calcário, coloca-se, levemente recuada, uma segunda fileira de lajes retangulares, acima da qual está o muro feito em grossos blocos calcários. Provavelmente, a parte superior do muro foi construída com material mais leve, talvez em tijolos de barro cru ou de pedra. 0 edifício parece não ter tido colunata. Buracos de uma soleira encontrados sobre a fileira superior do lado norte parecem pertencer a um remanejamento sucessivo, do qual não foi fornecido nenhum dado complementar. A entrada principal devia ser no lado meridional como indica a falta de espaço no lado setentrional entre este edifício e o templo sucessivo. Na parte interna estão traços de um calçamento com lajes delineadas (apud Lo Monaco, 2009: 356-357).

Tipo de culto: A identificação do templo com o culto de Zeus foi proposta por Fougères na base de vários testemunhos que recordam a função de um arquivo da cidade a partir de um trecho de Tucídides $(\mathrm{V}, 47,11)$ que cita um templo de Zeus na ágora, no qual era exposto o tratado de 421 a.C. e de um hóros do século $\checkmark$ a.C. com a dedicação de um templo onde os mantineus tinham o seu arquivo. Fougères pensou, portanto, se tratar do templo de Zeus Sóter, adorado como deus protetor da cidade. Com efeito, tal culto, atestado em outros centros do Peloponeso de nova definição como Megalópolis e Messênia, adquiri o caráter de divindade propiciadora do renascimento citadino: contudo, se este tipo de introdução refere-se ao século IV a.C. no âmbito da (re)fundação dos núcleos urbanos, não se pode tratar do mesmo templo recordado por Tucídides; a introdução em Mantinéia poderia, então, remontar à refundação da pólis unitária e centralizada 
em 371/70 a.C. (Osanna, 2003: 333). Nenhum dos dois cultos de Zeus recordados por Pausânias parecem corresponder com aquele de Zeus na ágora. Osanna diz que não é possível deduzir da passagem de Pausânias se a associação deste culto com aquele de Zeus Epidotes, citado logo depois, seja devido a uma relação de continuidade física dos dois santuários, ou derive unicamente da dedicação de ambos a Zeus (apud Lo Monaco, 2009: 357).

Referências bibliográficas: Fougères, G. Mantinée et l' Arcadie orientale (BEFAR 78). Paris, 1898, pp.187-190; Jost, 1985, pp.125-126,130-131; Lo Monaco, A. II crepusculo degli dei d' Achaia. Religione e culti in Arcadia, Elide, Laconia e Messenia dalla conquista romana ad età flavia. Roma: L'Erma, 2009, pp. 356-357; Osanna, 2003, p.333; Tsiolis, V. Mantinea-Antigonea. Aspectos históricos de una ciudad arcadia. Toledo, 2002, p.159.

\section{Imagens: ?}




\section{Poseidônia}

Datação: Época clássica, período lucano (final do V a.C. - início do séc. IV a.C.) - época helenística (III a.C., 273 a.C.)?

Localização: Na ágora, a algumas centenas de metros a oeste do eclesiastério (Greco, 2008: 40).

Tipo de santuário: Planície / Urbano.

Referências textuais: Inexistente.

Inscrições: Uma inscrição em uma estela do final do séc. IV a.C., exposta no museu, em alfabeto grego e língua osca com dedicação a Zeus feita por uma magistrado lucano de nome Stazio (Greco, 2008: 39).

\section{Histórico dos achados: ?}

\section{Documentação arqueológica}

I. Templo: 0 denominado templinho (T) foi construído com blocos reutilizados de um edifício de época arcaica. Da estrutura, que mede 3,60 x 4,75 m, resta somente parte da cela com uma pavimentação com lajes de pedras retiradas de uma tumba de época medieval (Greco, 2008: 40). Foi reestruturado em época lucana e funcionou após este período também. Com a chegada dos romanos em 273 a.C. o edifício foi desmontado e preenchido com pedras, terra e ossos de boi (restos sacrificiais). Acima do preenchimento foi edificado um santuário a que pertencem os blocos escuros mais altos (Greco, 2008: 40).

Tipo de culto: Conforme Greco e Longo, ao traçar a linha medinha do templinho constata-se que está perfeitamente em eixo com o pequeno altar (?) e estela com dedicação a Zeus encontrada dentro do eclesiastério. Por esta razão, os estudiosos identificaram o edifício ao culto de Zeus e, a Agoraios, em analogia à situação do témeno da divindade em Metaponto (Greco; Longo, s/ano: 34; Greco, 2008: 40).

Comentário: Não há nenhuma evidência arqueologica ou textual que se permita atribuir ao culto Agoraios de Zeus.

Referências bibliográficas: Greco, E.; D’Ambrosio, I.; Theodorescu, D. Poseidonia-Paestum. Guida Archeologica e Storia agli scavi al museo ed alle antichità. Tarento: La Colomba-Scorpione Editrice, 1995; Greco, E. Magna Grecia. Guide Archeologiche. Roma-Bari: Laterza, 2008, pp.39-40; Greco, E.; Fausto, L. 
Poseidonia-Paestum. La visita della città. Ingegneria per la cultura, s/ano, pp. 34; Greco, E.; Theodorescu, D. Poseidonia-Paestum II. L'Agora. Roma, 1983; Greco, E.; Longo, F. Paestum, Scavi, Studi, Ricerche. Bilancio di un decenio (1988-1998). Paestum, 2000.

\section{Imagens:}

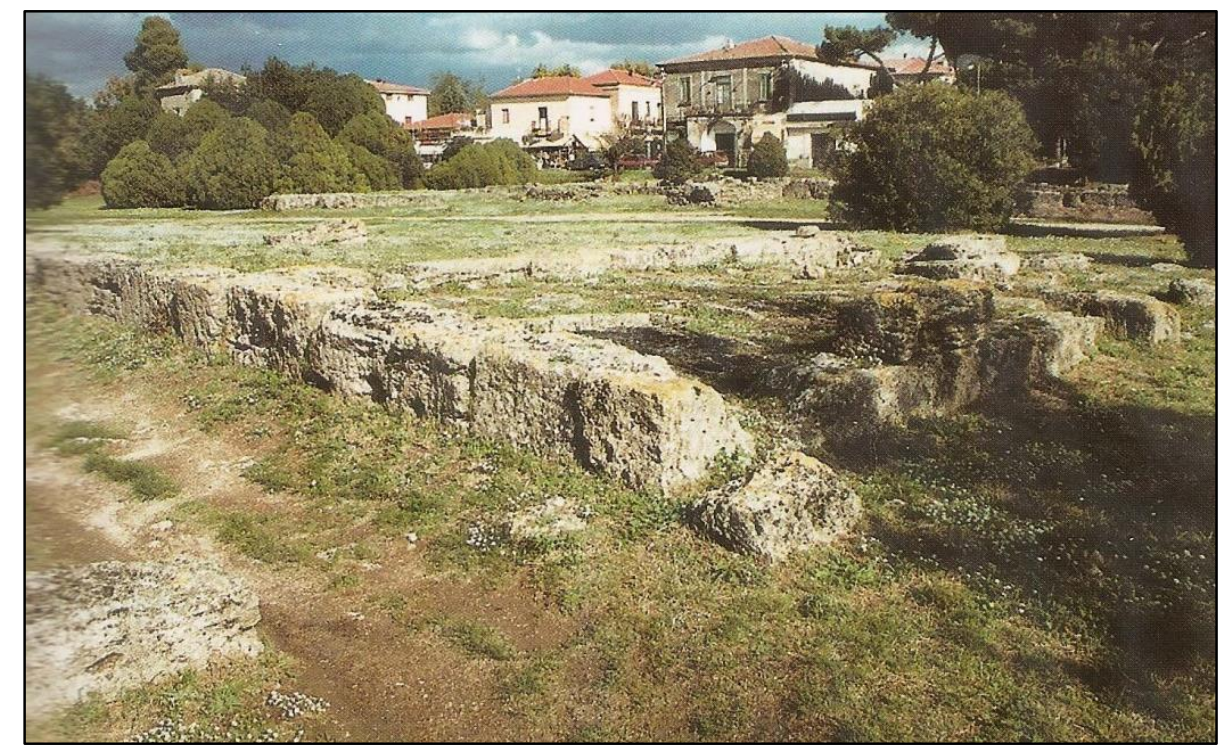

Fig.1- Vista a partir de sudoeste do templinho de Zeus Agoraios (Greco; D’Ambrosio; Theodorescu, 1995: 43) 
Datação: Época clássica (final do século V a.C.) - época romana.

Localização: Localiza-se em uma área mais meridional e distante dos demais santuários, o recinto posiciona-se na região do teatro romano e helenístico (Hatzopoulos, 2005: 801; Kremydi, 2004: 19-20; Pandermalis, 1999: 44; Voutiras, 2006: 334).

Tipo de santuário: Planície / extraurbano, sub-regional.

Referências textuais: (Templo) Diodoro XVIII.4,5; Lívio, 44.7.2-3; (Santuário) Políbio, 4.62.2-3; (Festival) Diodoro XVII.16.3-4; Arriano 1.11.1; Demóstenes XIX, 192; Stefano de Bizâncio (s.v. $\Delta$ Ĩov).

Inscrições: Inscrições recuperadas na região foram definitivas na localização do santuário. Em 1964, por exemplo, durante os trabalhos agrícolas os habitantes encontraram, entre o teatro romano e helenístico, duas inscrições incompletas que se referem diretamente ao santuário: tò ícpòv tòũ $\Delta$ Iòs 'O $\lambda u \mu$ míou (Michaud, 1970: 1060). Um texto de um decreto honorário do século IV a.C. menciona que a inscrição deveria ser estabelecida enfrente ao templo, enquanto que uma estátua deveria ser colocada dentro do témeno (SEG 46 (1996) 739, nota 6). o texto epigráfico (Hatzopoulos, Bull. ép, no.453, 2000), que assinala o santuário na parte externa dos muros de Díon, indica a existência de um verdadeiro naós dentro do témeno (apud Mari, 2002: 53, nota 1).

Histórico dos achados: A descoberta do témeno ocorreu na década de 1930, quando a cidade antiga foi escavada pela primeira vez sob a supervisão do Professor G. Soteriadis (Kremydi, 2004: 19-20, nota 5). Nesta época, a sua localização foi deduzida pela combinação de evidências literárias e achados arqueológicos esporádicos, mas somente foi confirmada por escavações sistemáticas na área após 1995 (Kremydi, 2004: 20). Soteriades (1931 e 1932), o seu primeiro escavador, acreditava que o santuário situava-se dentro dos muros da cidade, mas sua hipótese foi corrigida mais tarde por Ch. Makaronas (1937) e seguida por G. Bakalakis (1977), o próximo escavador do sítio e D. Pandermalis nos anos 1990 e 2000 (Kremydi, 2004: 20).

\section{Documentação arqueológica}

I. Témeno e altares: Embora a pesquisa esteja longe de estar completa, uma imagem geral do santuário emergiu: as escavações revelaram o muro do témeno, bases para estátuas honorárias, outros edifícios pequenos e dois altares com várias peças de ornamentação (Kremydi, 2004: 20; Mari, 2002: 53, nota 1). Conforme Pandermalis, o altar maior mede 22 metros de comprimento, foi construído com grandes pedras angulares e o seu interior preenchido com tijolos semi-cozidos; o altar menor posiciona-se na lateral e a norte deste primeiro (Pandermalis, 1999: 46). Associadas aos altares foram encontradas uma fileira de onze bases de 
pedra, fincadas no terreno enfrente do grande altar de Zeus, com anéis de bronze. Estas eram usadas para amarrar os animais à espera do sacrifício (Pandermalis, 1999: 48). Uma colunata com um pórtico central separava a área onde estava o altar do grande pátio a oeste.

II. Templo: De acordo com Kremydi, os poucos fragmentos arquitetônicos de um grande edifício dórico, encontrados nas escavações, talvez tenham pertencido a um templo. Como nenhuma fundação do edifício foi localizada, considera-se atualmente a hipótese de que o templo de Zeus não estava situado dentro do témeno, mas em algum lugar próximo. Um texto de um decreto honorário do século IV a.C. menciona que a inscrição deveria ser estabelecida enfrente ao templo, enquanto que uma estátua deveria ser colocada dentro do témeno (SEG 46 (1996) 739, nota 6). Portanto, devido à inscrição e a ausência das fundações, os pesquisadores acreditam que havia duas áreas sagradas distintas, das quais o témeno original protegia os ex-votos mais valiosos (Kremydi, 2004: 20). Por outro lado, o texto epigráfico (Hatzopoulos, Bull. ép, no.453, 2000), que assinala o santuário na parte externa dos muros de Díon, indica a existência de um verdadeiro naós dentro do témeno (apud Mari, 2002: 53, nota 1).

Tipo de culto: Acredita-se que em épocas mais antigas, o culto de Zeus Olímpio era realizado em um bosque, dada a ausência de achados materiais que atestem um santuário estruturado em época arcaica e clássica (Voutiras, 2006: 335). Já a origem do culto do deus na cidade é muito mais que uma hipótese, pois foi atestada por um fragmento de compilação mitográfica conservada no papiro de Oxyrrhynchos publicado em 1995 (POxy 4306 fr.l, col.i, I.19-29) (Voutiras, 2006: 335). $O$ texto diz que o altar de Zeus Olímpio em Díon foi fundado por Deucalião e era uma dos mais antigos do deus. Sem dúvidas, a atribuição ao herói tessálio é uma maneira de sublinhar, pelo viés do mito, a antiguidade do culto. Ora, lembremos que Deucalião e sua mulher Pyrrha, sobreviventes do dilúvio provocado por Zeus, foram os ancestrais comuns a todos os gregos. Lembremos também que Deucalião foi o primeiro a construir templos para os deuses e a tornar-se rei entre os homens (Voutiras, 2006: 336 e nota 25). O primeiro testemunho histórico acerca do santuário de Zeus Olímpio, de Diodoro, é relativo a uma importante reorganização do culto: a instalação de uma festa suntuosa de vários dias (uma panegyris) instituída pelo rei Arquelaos no fim do século V a.C. (Voutiras, 2006: 337). A instituição de concursos dramáticos e atléticos em honra a Zeus e às Musas foi noticiada por Diodoro (XVII.16.3-4), por Arriano (1.11.1), por um escólio de Demóstenes (XIX, 192) e por Stefano de Bizâncio (s.v. Aĩov) no final da Antiguidade. As fontes literárias dizem que as festas duravam nove dias, cada qual dedicado a uma Musa, compreendiam uma série de eventos distintos entre os quais a hecatombe a Zeus Olímpio, jogos teatrais, musicais e atléticos. É provável que as Olímpias de Díon ocorressem no outono, no mês inicial do calendário macedônio, consagrado a Zeus e que hospedassem os encontros oficiais do soberano com o synédrion e com os mesmos delegados das diversas póleis macedônias (Mari, 2002: 52; Voutiras, 2006: 339). A fundação das Olímpias potencializou a função sagrada da cidade e a importância dos seus santuários. O témeno de Zeus, em particular, estava destinado a se tornar, se já não o era, 0 mais importante dos locais de culto macedônios, lugares privilegiados para a colocação de textos oficiais, dedicações ofertadas pela dinastia e monumentos celebrativos (Mari, 2002: 55). O sucesso da iniciativa de Arquelaos, sem dúvidas, se explica pela popularidade do culto de Zeus na região, na ausência e pela ausência de outros santuários importantes desse deus. Neste contexto, portanto, facilmente o culto poderia ser aceito como "nacional" e ao mesmo tempo panhelênico (Voutiras, 2006: 338). No caso de Díon não podemos traçar a origem do culto em Olímpia. No sopé do Olimpo, a cidade pode ter sido o único caso em que o santuário de Zeus Olímpio tenha origem na montanha sagrada dos gregos. No entanto, sabemos com segurança que no final do século $\mathrm{V}$ a.C. 0 culto de 
Díon sofreu influência daquele realizado ao deus de Olímpia: Arquelaos, ao instituir os jogos olímpicos na região em honra a Zeus e ás Musas, tornando a cidade a Olímpia na Macedônia, acrescentou um novo sentido ao culto. A partir dali, não era somente o deus do Olimpo reverenciado, mas também o deus de Olímpia (Laky, 2013: 229).

Referências bibliográficas: Hatzopoulos, M.B. Dion (s.v.). Em: Hansen, H. H.; Nielsen, T.H. (org.) An Inventory of Archaic and Classical Poleis. Oxford University Press, 2005, 800-801; Kremydi-Sicilianou, S. Multiple Concealments from the Sanctuary of Zeus Olympios at Dion. Three Roman Provincial Coin Hoards. MENETHMATA, 35. Atenas; Paris: Diffusion de Boccard, 2004; Laky, 2013, pp. 225-229; Mari, M. Al di Là dell'Olimpo: Macedoni e Grandi Santuari della Grecia

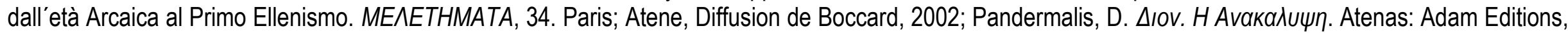
1999; Voutiras, E. Le Culte de Zeus em Macédoine avant la Conquête romaine. Em: Guimier-Sorbets, A.-M.; Hatzopoulos, M.; Morizot, Y. (Ed.). Rois, Cités, Necropoles. Institutions, Rites et Monuments em Macedonie. Actes des Colloques de Nanterre (Decembre 2002) et D’Athène (Janvier 2004). MEAETHMATA, 45. Atenas; Paris: Diffusion de Boccard, 2006, pp. 333-346. 


\section{Imagens:}
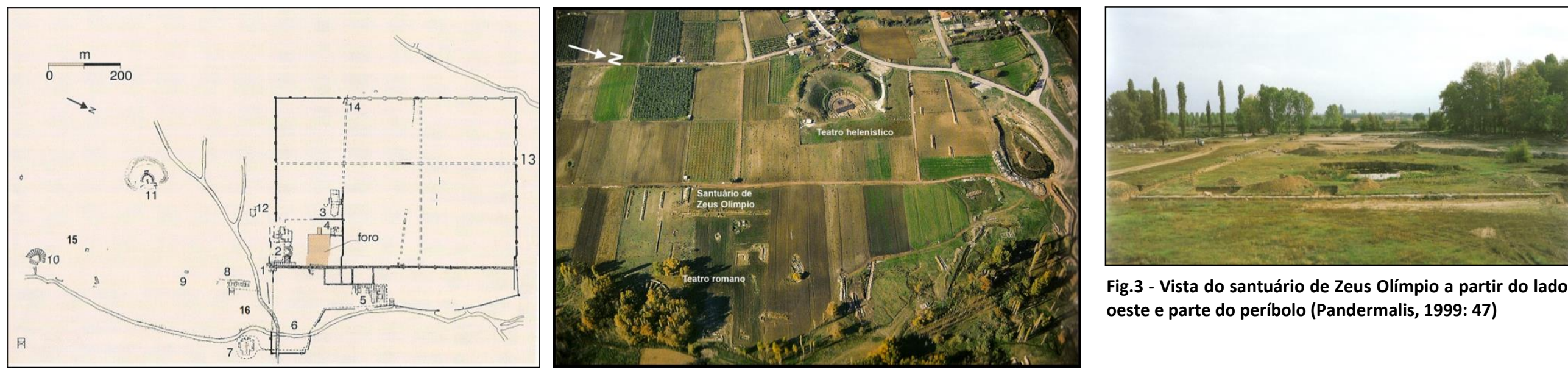

Fig.3 - Vista do santuário de Zeus Olímpio a partir do lado oeste e parte do peribolo (Pandermalis, 1999: 47)

Fig.1 - Planimetria de Díon: 1. Entrada para o sítio; 2. Termas romanas; 3. Fig.2- Vista a partir de leste do setor do santuário de Zeus Olímpio Basílica paleo-cristã; 4. Habitações helenísticas; 5. Vila de Dioniso; 6. Rio (Pandermalis, 1999: 44)

Vaphyras; 7. Santuário de Ísis; 8. Santuário de Deméter; 9. Santuário de

Asclépio; 10. Teatro romano; 11. Teatro helenístico; 12. Basílica do

cemitério; 13. Porta da muralha helenística (B II); 14. Tumba macedônia; 15.

Santuário de Zeus Olímpio; 16. Santuário de Zeus Hypsistos (Torelli e

Mavrojannis, 2002: 137)
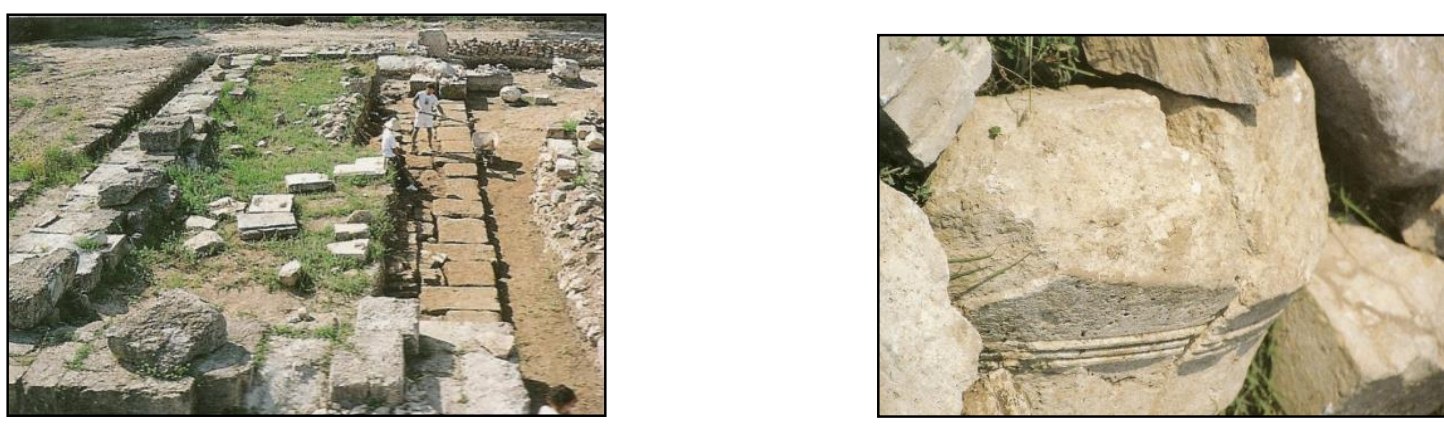

Fig.5- Capitel dórico encontrado no santuário de Zeus Olímpio (Pandermalis,

Fig.4 - Escavação

do grande altar 1999: 48)

(Pandermalis, 1999: 46) 


\section{Thasos}

Datação: Época clássica (início séc. IV a.C.) -?

Localização: Na ágora, no ângulo norte.

Tipo de santuário: Planície / Urbano.

Referências textuais: Inexistentes.

Inscrições: Pilar encontrado na área com inscrição "(domínio de) Zeus Agoraios Thasios" (IG XII 8,361), que assegura a identificação do santuário, a gravura da inscrição a situa no fim do séc. V ou no início do IV a.C.; base com inscrição a Zeus Kataibatés (IG XII, Sup.406), perto do primeiro edifício confirma a identificação (Grandjean; Salviat, 2000: 76; Roux; Lévêque, 1950: 336).

Histórico dos achados: O santuário (peribolo, naós e altar) foi descoberto durantes as campanhas de escavação empreendidas em 1948 pela Escola Francesa de Atenas (Roux; Lévêque, 1950: 333). Foi Fr. Chamoux que assinalou a atribuição do santuário a Zeus Agoraios com base na inscrição (Roux; Lévêque, 1950: 336).

\section{Documentação arqueológica}

I. Témeno e períbolo: $O$ ângulo norte da ágora foi quase inteiramente ocupado pelo santuário de Zeus Agoraios Thasios, cujo recinto (no.34) é limitado por uma barreira de apoio. As bases subsistentes suportaram uma vez os pilares de mármore do balaústre. Essa barreira era à clarabóia, exceto sobre o pequeno lado sudeste, onde o intervalo entre os pilares foi ocupado por duas placas verticais. Um dos pilares tem a inscrição que assegura a identificação do local ao culto de Zeus Agoraios Duas portas, uma no ângulo oeste e outra no lado norte, davam acesso ao interior do recinto (Grandjean; Salviat, 2000: 76; Roux; Lévêque, 1950: 333 e 335).

II. Templo: As fundações do pequeno templo medem 6,10 x 11,65m. Orientado a leste, a parede divisória do edifício permite distinguir um pronaos profundo de $4,65 \mathrm{~m}$ e uma cela de $7 \mathrm{~m}$. A fileira (assise) de pedra das fundações é constituída por grandes lajes de gnaisse, enquanto que a parede divisória sobre as três pedras estão no lugar (ou acima?) de dois blocos de mármore. A oeste e a leste, uma fileira (assise) de mármore permanece acima das fundações de gnaisse. Apenas na parte da frente permanecem in situ três pedras colocadas e seladas para formar com o lado leste do templo um pequeno retângulo (Roux; Lévêque, 1950: 336). 
III. Altar: Estrutura retangular, cujas fundações delimitam um maciço de 2,37 x 3,53m. No longo lado noroeste, uma placa de mármore adjacente $(1,10 \times 2,50 \mathrm{~m})$ representa, sem dúvidas, a protysis. Dois encaixes quadrados são os traços dos anéis onde as vítimas sacrificiais eram amarradas. Ao redor do altar a terra é mais negra do que em outros lugares devido às cinzas dos animais misturadas ao solo. Não distante do lado direito do altar há uma base retangular (0,84 x 0,98 x 0,30m), com um grande encaixe na parte superior que provavelmente suportou uma estátua de mármore (Chamoux, 1949: 544).

Segundo Roux e Lévêque, os dados estratigráficos e arquitetônicos são de difícil datação. 0 santuário foi datado, sobretudo, com base na inscrição de Zeus Agoraios e em um caco cerâmico de verniz negro com escrita semelhante a do séc. IV a.C. (Roux; Lévêque, 1950: 336-337).

\section{Tipo de culto: ?}

Referências bibliográficas: Chamoux, Fr. BCH (73), 1949, pp.543-544; Grandjean, Y.; Salviat, F. Guide de Thasos. Atenas: École Française d"Athènes, 2000, pp.30 e 76; Roux, G.; Lévêque, P. BCH (74), 1950, pp.336-341; Torelli; Mavrojannis, 2002, pp.296-297. 


\section{Imagens:}

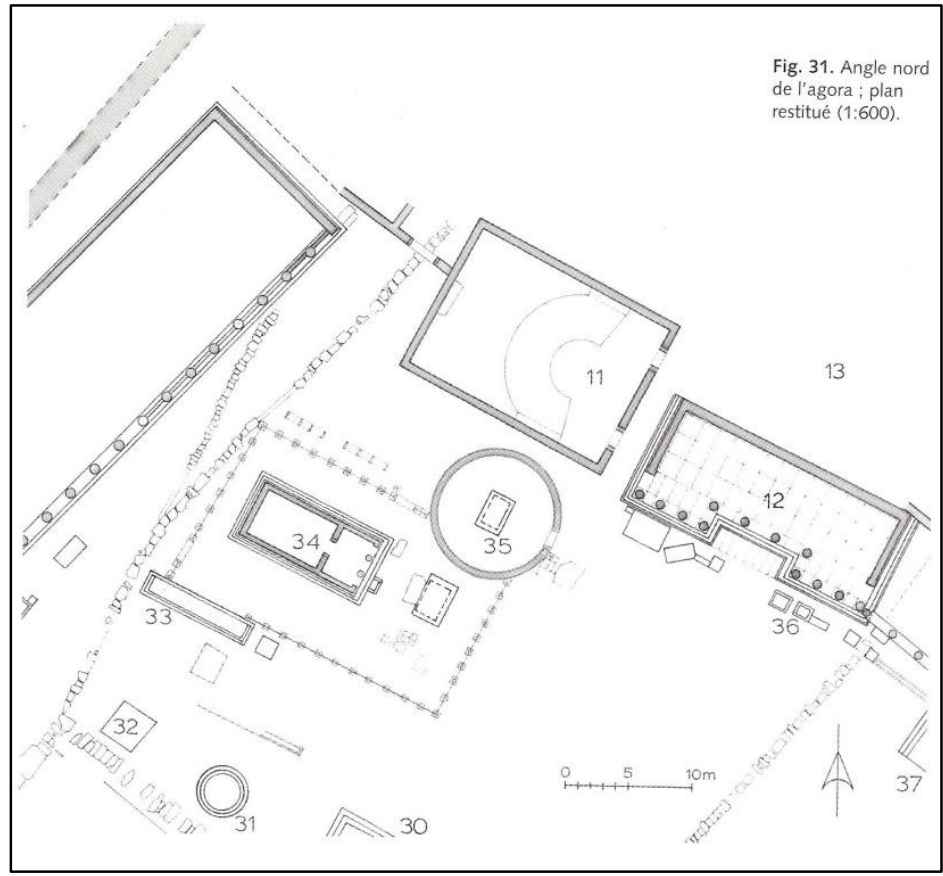

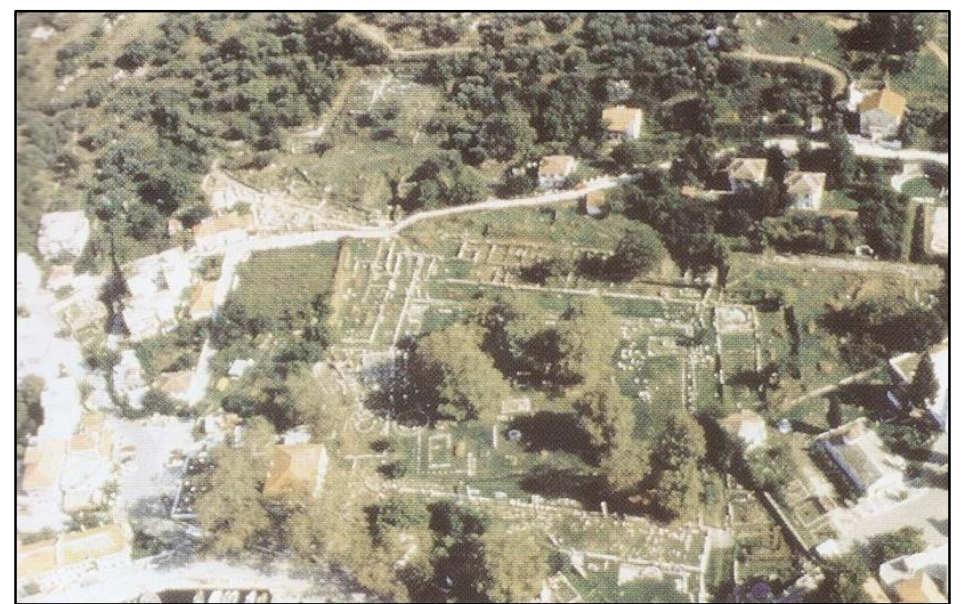

Fig.2- Vista aérea da agora Grandjean; Salviat, 2000: fig.22)

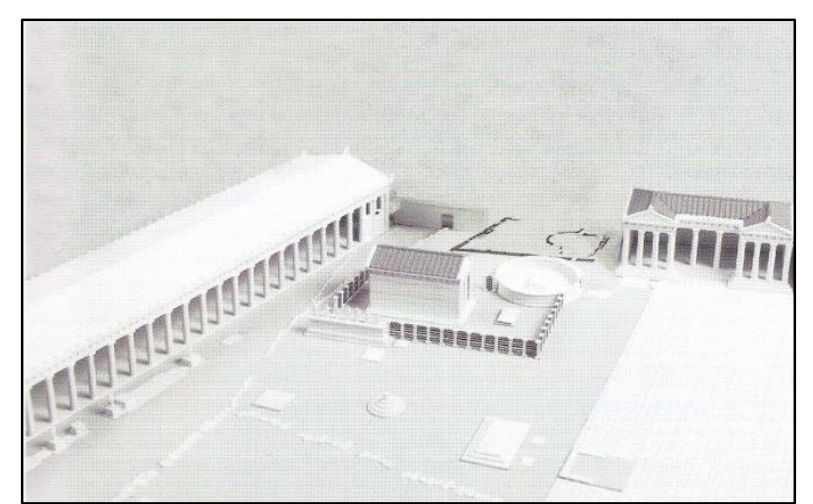

Fig.3-Maquete do ângulo norte da ágora com santuário de Zeus (Grandjean; Salviat, 2000: fig.32)

Fig.1- Ângulo norte da ágora e santuário de Zeus Agoraios (no.34) (Grandjean; Salviat, 2000: fig.31) 


\section{Lindos}

Datação: Época clássica (séc. IV a.C. [400-313 a.C.]) - ?

Localização: Na acrópole, na área a norte (Torelli; Mavrojannis, 2002: 363).

Tipo de santuário: Colinar / urbano.

Referências textuais: Inexistentes?

Inscrições: (Zeus Polieus) I. Lindos 56.13 (313-275 a.C.); (Zeus) I. Lindos 26.2 (c.400 a.C.); (Zeus Polieus) I. Lindos 56 (c.313 a.C.).

\section{Histórico dos achados: ?}

\section{Documentação arqueológica}

I. Templo: Sobre um nível superior ao de Atena se encontrava um pequeno templo in antis atribuível a Zeus Polieus e hoje invisível (Torelli; Mavrojannis, 2002: 363).

Tipo de culto: Parece que o culto de Zeus Polieus foi introduzido posteriormente ao de Atena Polias, somente no século IV a.C. O culto de Atena Polias remonta ao período geométrico e teve uma primeira organização arquitetônica no séc. VI a.C. talvez ligada à atividade do tirano Cleobelo (Lippolis, 2007: 723). Deste tempo remonta o sistema defensivo da área, com entrada a norte, uma escada levava ao cume da colina onde se encontrava o templo arcaico de cela alongada, prostilo tetrastilo (Lippolis, 2007: 723).

Referências bibliográficas: IACP, p.1204; Torelli; Mavrojannis, 2002, p.361; Lippolis, 2007, p.723; Lippolis, E. II santuario di Athena a Lindo. Em ASAtene (6667), 1988-89, pp.97-157.

Imagens: ? 
Datação: Época clássica (c.371 a.C.) - época romana (II d.C.).

Localização: Na ágora da cidade, na extremidade oriental do lado meridional.

Tipo de santuário: Planície / Urbano.

Referências textuais: (Santuário) Pausânias VIII. 30, 10.

Inscrições: Festas Soterias e sacrifício em honra de Zeus Sóter (Lo Monaco, 2009: cat Arc. Meg 3); sobre dedicação de estela no témeno de Zeus Sóter por cidadão local (IG V 2 436); menção ao santuário no período romano, na época de Augusto (Lo Monaco, 2009: cat Arc. Meg 5).

Histórico dos achados: Escavações inglesas nos anos 1890 (E. Gardner e W. Loring), retomadas por Knoblauch nos anos 1940. Novas pesquisas foram realizadas por H. Lauter em colaboração com a V Ephoria (dirigida por Spyropoulos) e o Instituto Arqueológico Alemão de Atenas (Lo Monaco, 2009: 385).

\section{Documentação arqueológica}

O santuário foi explorado apenas parcialmente devido à inundação do rio Helisson, que perturbou o setor meridional da área sagrada (Lo Monaco, 2009: 385). Sabe-se, no entanto, que a porção meridional do santuário teve uma obra de contenção, já na porção setentrional as fundações foram realizadas diretamente no terreno natural; todas as estruturas foram conservadas apenas no nível da fundação (Lo Monaco, 2009: 386).

I. Témeno: Trata-se de uma área quadrada $(47 \times 54 \mathrm{~m})$ articulada entorno de um pátio rodeado por pórticos em três dos quatro lados; os blocos da fundação do períbolo são isodômicos (Lo Monaco, 2009: 386).

II. Propileu: Apenas as fundações do lado oriental estão conservadas $(5,85 \times 10,05 \mathrm{~m})$.

III. Stoá: Em colunata dupla, uma de ordem jônica e a outra dórica, como indicam o achado de uma semi-coluna com base jônica e um capitel dórico. Foi sugerido por Gans e Krelinger que o edifício, na verdade, se tratava de um hestiatório (apud Lo Monaco, 2009: 386). 
IV. Templo: Localiza-se de frente ao propileu, no lado ocidental, mede $11,64 \times 21,2 \mathrm{~m}$, tinha um pronaos muito estreito de $3,71 \times 11,64 \mathrm{~m}$, era talvez tetrastilo com cela ampla (Lo Monaco, 2009: 387).

V. Altar: Alinhado com o templo, no centro da área central encontrava-se as fundações de um grande altar longo (5,39 x 11,36 m). Foi suposto se tratar, na verdade, de uma estrutura funcional para suportar talvez um grupo escultórico (Lo Monaco, 2009: 387).

VI. Monumentos honorários: Foram encontradas três bases para a sustentação de estátuas a norte e de frente à fachada do pórtico do templo (Lo Monaco, 2009: 387).

Tipo de culto: Há ainda muita controvérsia com relação à fundação do santuário de Zeus Sóter em Megalópolis. A ausência de material cerâmico embaixo das fundações na área sagrada fez os especialistas pensarem que o santuário foi fundado logo depois da fundação da cidade em c.370 a.C. (Lo Monaco, $2009: 388$ ). Mas a análise arquitetônica, associada a um material cerâmico, indicou definitivamente uma datação mais baixa em c.340 a.C., com base principalmente na semelhança entre os elementos arquitetônicos da stoá de Felipe e o templo de Zeus Sóter (Gans; Kreilinger, 2002: 187). Aqui consideramos que o estabelecimento do culto e do altar à divindade remonta à fundação da cidade, ainda que a monumentalização do santuário tenha ocorrido em c.340 a.C. (Corso, 2005: 225). Assim, toda a documentação arqueológica descrita é datada a partir de c.340 a.C. em diante. De acordo com M. Jost, assim como no caso de Mantinéia, onde 0 culto de Zeus Sóter também foi instalado na ágora, o deus foi cultuado em Megalópolis com símbolo de renascimento nacional, após a derrota da hegemonia espartana por Epaminondas em Leuctra em c.371 a.C. (Jost, 1985: 272).

Referências bibliográficas: Corso, A. The triad of Zeus Soter, Artemis Soteira and Megalopolis. In: Ostby, E. (ed.). Ancient Arcadia. Papers from the third international seminar on Ancient Arcadia held at the Norwegian Institute at Athens, 7-10 May 2002. Athens, pp. 225-234; Gans, U.W.; Kreilinger, U. The sanctuary of Zeus Soter at Megalopolis. Em: Hägg, R. (ed.) Peloponnesian Sanctuaries and Cults. Proceedings of the Ninth International Symposium at the Sweedish Institute at Athens, 11-13 June 1994. Acta Instituti Atheniensis Regni Sueciae, Series 4a., XLVIII. Estocolmo, 2002, pp. 187-191; Lo Monaco, A. II crepusculo degli dei D'Achaia. Roma: L'Erma, 2009, pp.385-396; Jost, M. Sanctuaires et cultes d'Arcadie. Paris: Librairie Philosophique J. Vrin, 1985, pp. 271-272. 


\section{Imagens}

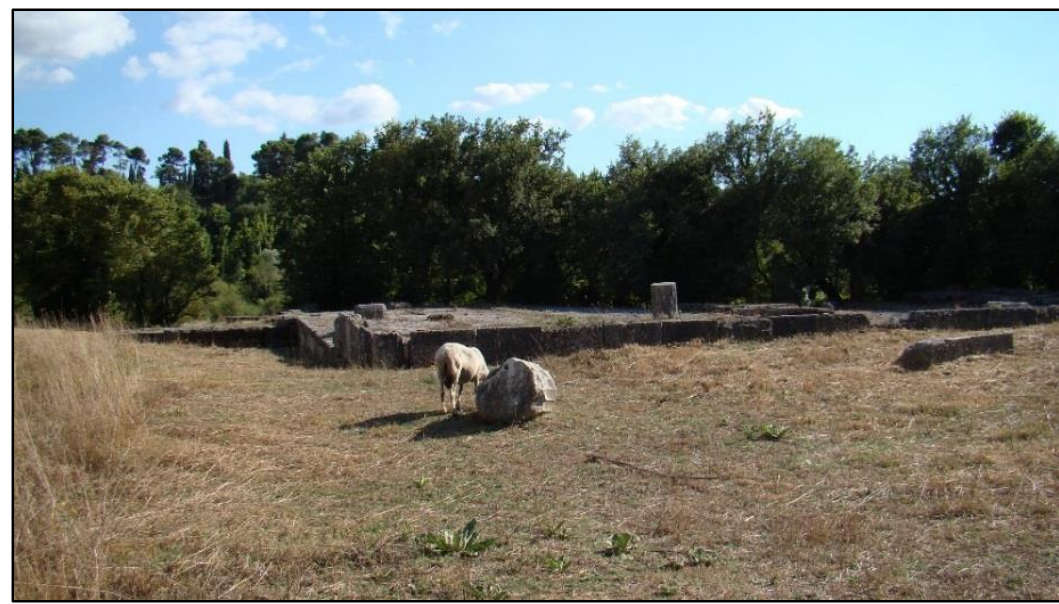

Fig.1- Templo de Zeus Sóter em Megalópolis a partir de nordeste (Foto: arquivo pessoal/2014)

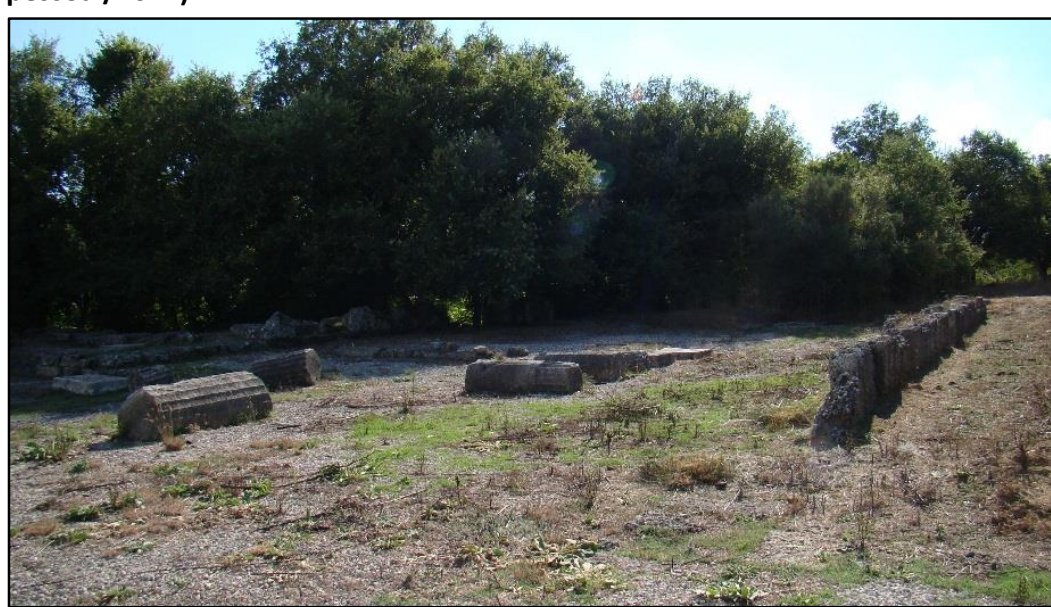

Fig.3- Templo de Zeus Sóter em Megalópolis a partir de leste (Foto: arquivo pessoal/2014)

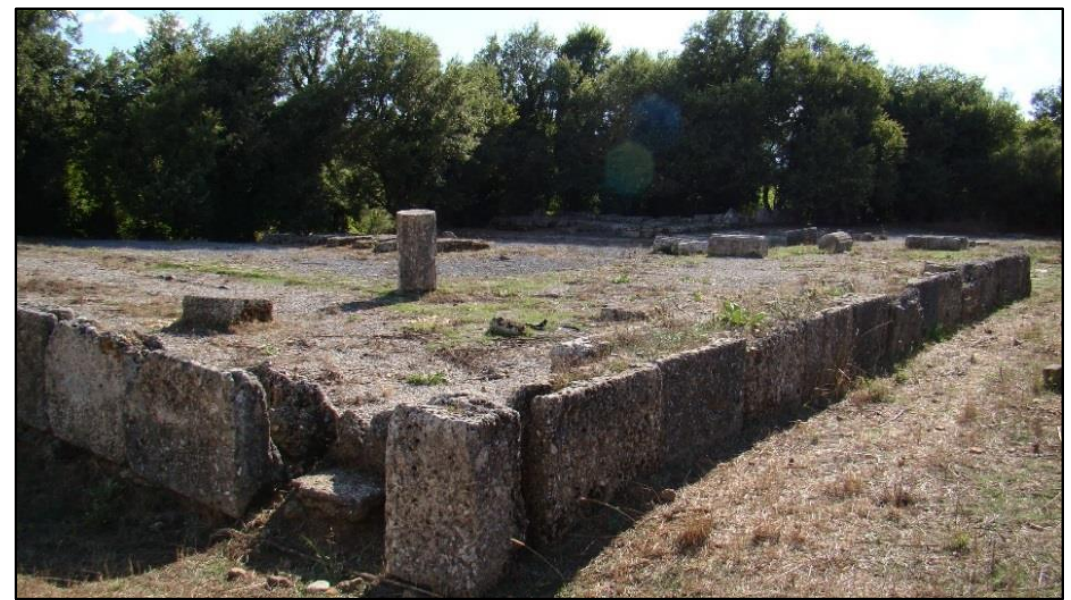

Fig.2- Templo de Zeus Soter em Megalópolis a partir de nordeste (vista mais próxima) (Foto: arquivo pessoal/2014)

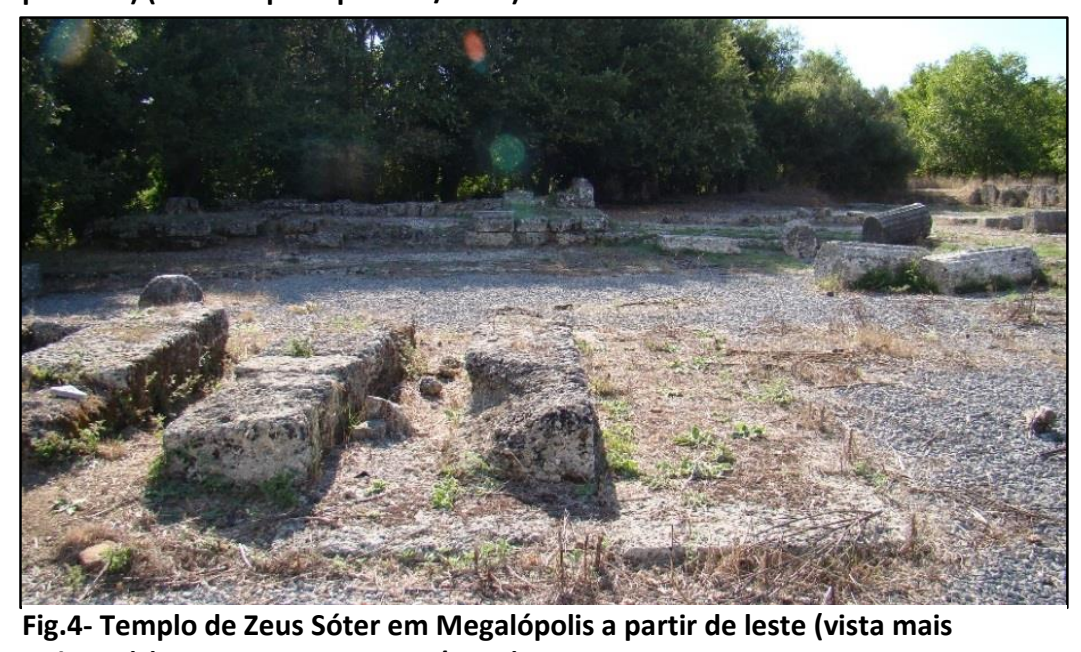
próxima) (Foto: arquivo pessoal/2014) 
Datação: Época clássica (2a .metade do séc. IV a.C.) - época romana.

Localização: No território da colônia erétria de Aphytis, no declive de uma colina arborizada com fontes e quedas d' água que desaguam no mar (Tsigarida, 2011: 166).

Tipo de santuário: Colinar? / extraurbano?

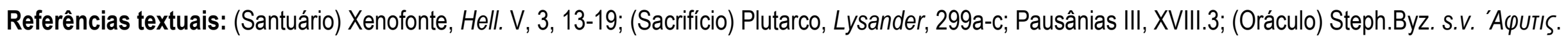

Inscrições: Uma inscrição votiva em um fragmento de lekane com o nome de Zeus Amon foi encontrada durante a escavação de resgate e permitiu atribuir o culto à divindade no santuário (Tsigarida, 2011: 170 nota 1 e 13).

Histórico dos achados: O sítio foi descoberto em 1968 quando atividades edilícias ilegais destruíram parte das fundações do crepidoma do templo. A escavação de resgaste ocorreu entre 1969 e 1970 e trouxe à luz o templo atribuído a Zeus Amon. O santuário (e áreas adjacentes) foi escavado novamente entre 2005 e 2008 como parte do projeto "Santuário de Zeus Amon de Calcídia, aprimoramento e apresentação para o público", financiado pela UE e pelo governo grego (Tsigarida, 2011: 165-166).

\section{Documentação arqueológica}

I. Templo: Século IV a.C. - Orientado norte-sul, o templo é um períptero de 6 x 11 colunas, de dimensão de 10,51 x 21,43 m (medida semelhante ao do Asclepiéion de Epidauro) e é dividido em pronaos e cela. Atualmente, apenas seis fileiras das pedras da alvenaria (fundação, eutintério e crepidoma) e uma pequena parte do estilóbato estão preservados, enquanto poucos tambores de colunas dóricas e capitéis são os únicos remanescentes do pteron (Tsigarida, 2011: 170). A datação do templo é baseada nos detalhes arquitetônicos e não em dados estratigráficos. Os escavadores do templo o dataram na segunda metade do séc.IV a.C. na base da analogia de seus capitéis com aqueles do templo de Atena Alea em Tegéia. As proporções de seu entablamento, e suas telhas, são similares àquelas da Stoá sul de Corinto. A escavação da década de 1960 forneceu uma variedade de antefixas e simas com relevo decorativo e policromia e se assumiu que provinham do templo. Contudo, a descoberta de achados similares em toda a área da escavação do santuário durante a investigação recente sugeriu que sua atribuição deve ser reconsiderada. $O$ templo foi destruído no final do séc.IV a.C., provavelmente pelo terremoto que também destruiu Aphytis, ou mais tarde, durante a invasão dos gauleses. Época helenística - Foi imediatamente reparado; o entablamento foi substituído por um de mármore e as telhas originais do telhado trocadas pelas de tipo coríntio helenístico de argila marrom. Época romana - De acordo com os dados da escavação dos anos 1960, outro reparo ocorreu 
no período romano imperial (provavelmente no séc.ll d.C.). As telhas foram novamente substituídas pelas de tipo lacônio e a parte externa sofreu as maiores mudanças. Dois edifícios retangulares paralelos foram construídos enfrente ao templo para acomodar os espectadores que assistiam aos rituais. Membros arquitetônicos dóricos e jônicos foram incorporados nos muros desses edifícios, sugerindo que vários edifícios clássicos ou do início do helenístico já tinham sido destruídos quando estes foram incorporados. A incorporação de capitéis de pedra dóricos do templo sugere que o pteron provavelmente não mais existia neste período, o que significa que houve maiores alterações na planta do templo (Tsigarida, 2011: 171).

Tsigarida diz que a identidade do rei que ordenou a construção do novo templo, e de bases monumentais a leste do edifício, não é conhecida, pois a datação não pode ser precisada. Três reis reinaram na $2^{\mathrm{a}}$.metade do séc.IV a.C.: Felipe II, que recebeu um oráculo para sacrificar a Zeus Amon; Alexandre, o Grande, que foi considerado filho do deus; e Cassandro, que fundou Cassandreia. Os últimos dois são os mais prováveis. Plutarco relata que o rei espartano Lisandro parou o cerco à Aphytis e libertou a cidade em 403 a.C. quando o deus lhe apareceu à noite, Ihe pedindo isto. Lisandro ordenou aos habitantes que sacrificassem a Zeus Amon. É muito provável que o culto do deus tenha sido introduzido no local após este evento (Tsigarida, 2011: 1975).

A investigação recente forneceu um grande número de achados, incluindo cerâmicas, membros arquitetônicos, fragmentos de estátuas e achados pequenos, a maior parte dos quais não tem estratigrafia, já que foram encontrados nas trincheiras da escavação mais antiga (Tsigarida, 2011: 173).

Tipo de culto: $O$ culto esteve associado ao de Dioniso, cujo santuário também existiu na área, e à existência de um oráculo a Zeus Amon (Tsigarida, 2011: 175176). O IACP (p.825) cita moedas de prata do séc.V a.C. cujo anverso possui a cabeça de Zeus Amon ou a de Ares com o elmo e o reverso um cântaro ou águia (inscrição AФY ou AФYTAION). E moedas de bronze do séc.IV a.C. com as imagens de Zeus Amon ou de Apolo Karneios no anverso.

Referências bibliográficas: Tsigarida, E.B. The sanctuary of Zeus Amon at Kallithea (Chalcidice), Kernos (24), 2011, pp.165-181. 


\section{Imagens:}

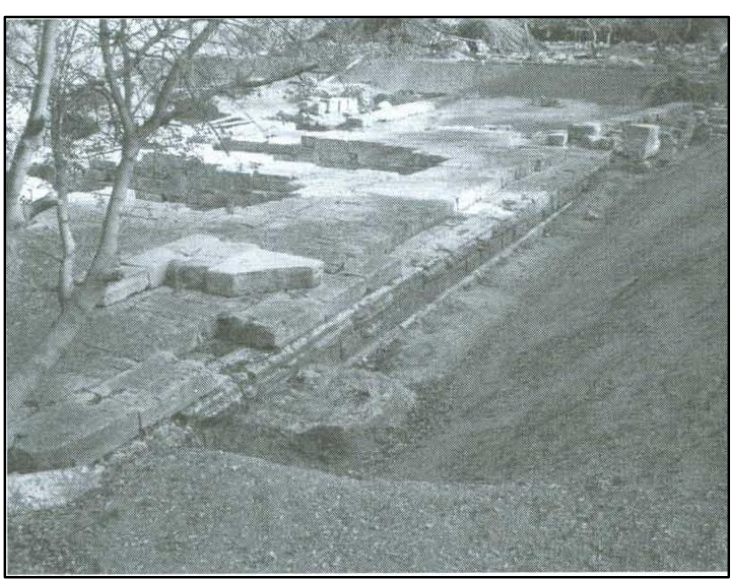

Fig.1-O templo de Zeus Amon (Tsigarida, 2011: 170 fir $a l$
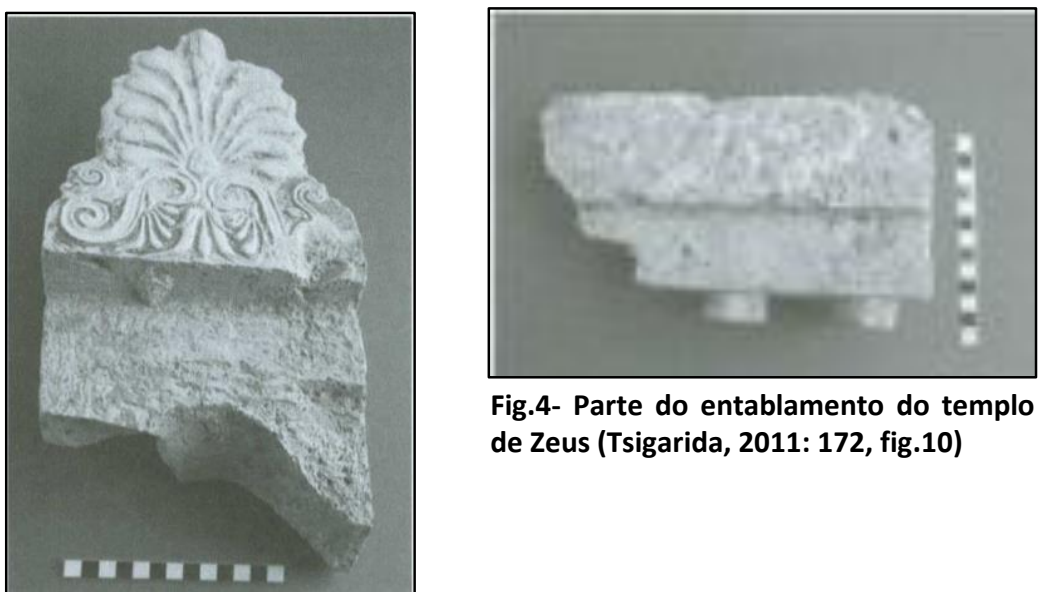

Fig.4- Parte do entablamento do templo de Zeus (Tsigarida, 2011: 172, fig.10)

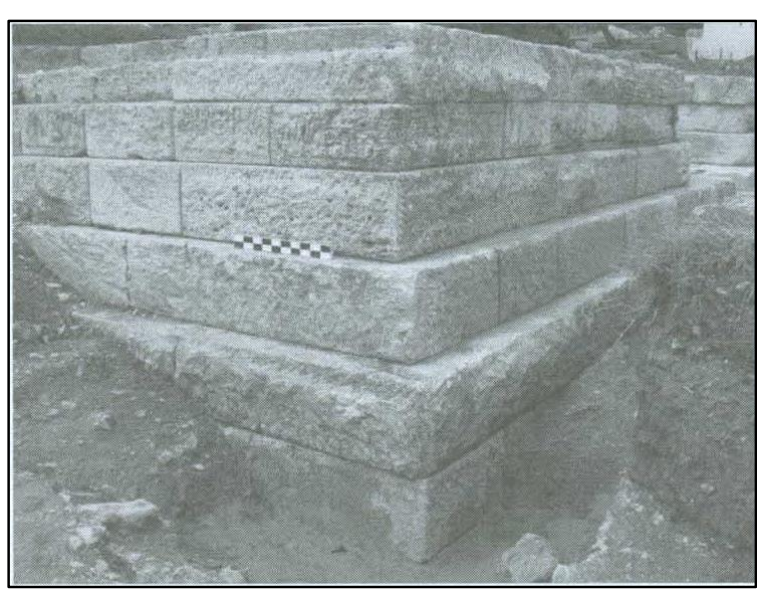

Fig.2- Fundação, eutintério e crepidoma do templo de Zeus Amon (Tsigarida, 2011: 171, fig.7)

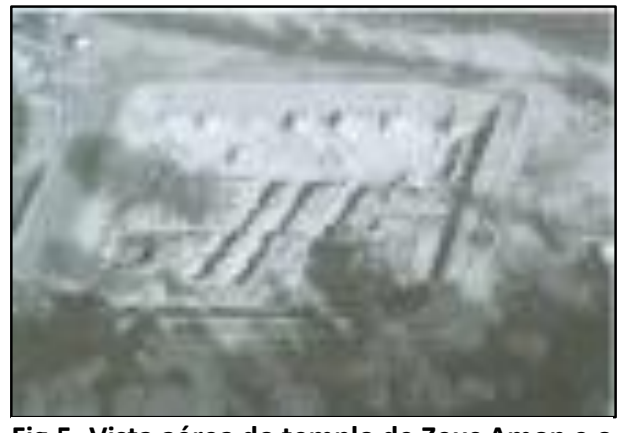

Fig.5- Vista aérea do templo de Zeus Amon e o corredor a céu aberto ladeado pelas bases monumentais (Tsigarida, 2011: 173, fig.14)

Fig.3- Antefixa de palmeta da escavação do templo de Zeus Amon (Tsigarida, 2011: 172, 


\section{Aegiae (Vergina)}

Datação: Época clássica (2a .metade do séc. IV a.C.) - época romana.

Localização: A norte na planície, na área onde se acredita ter sido a ágora (ainda não encontrada) e a pouca distância do teatro (Falessa, 2009: 12).

Tipo de santuário: Planície / urbano.

Referências textuais: Inexistentes.

Inscrições: Inexistentes.

Histórico dos achados: 0 complexo do santuário de Eukleia, onde se encontra o templo de Zeus Meilichios, foi objeto de escavações anuais e regulares da Sociedade Arqueológica Grega desde 1982. O templo maior, dedicado a Zeus, foi escavado em 1985 e entre 1990 e 1991 foram encontrados os três depósitos de escultura na área do templo grande (Falezza, 2009: 13).

\section{Documentação arqueológica}

I. Templo: O templo de Zeus Meilichios faz parte do complexo do santuário de Eukleias e esteve localizado no setor leste. Trata-se de um dos dois edifícios na área sagrada, ambos datados da segunda metade do século IV a.C. O templo de Zeus Meilichios é o mais setentrional, dórico in antis e maior em relação ao outro $(9,30 \times 12,80 \mathrm{~m})$, apresenta no centro da cela uma eschára, a que se relaciona uma serpente colossal (do séc. II a.C.) encontrada no pronaos, atribuída ao culto de Zeus Meilichios (Falezza, 2009: 13).

II. Altar: $O$ templo é precedido por um altar de 4,5 × 6,5 m, feito em blocos de poros e alinhado em eixo norte-sul à três bases de estátuas, dispostas em uma fila paralela ao muro oeste do templo de Eukleia (Falezza, 2009: 14).

III. Objetos votivos: No ângulo nordeste do templo de Zeus Meilichios foi encontrado um grande depósito com numerosos fragmentos de estátuas do século IV a.C. Mas em um depósito descoberto no pronaos (do séc. Il a.C.) provém uma serpente de dimensões colossais em mármore, de significado ctônio, provavelmente uma imagem anicônica de Zeus Meilichios, cujo templo a ele era provavelmente dedicado (Falezza, 2009: 14). De um grande depósito votivo no templo de Zeus Meilichios, provêm alguns elementosarquitetônicos, tal como uma terracota ornamental e uma sima leonina (Falezza, 2009: 14). 
Tipo de culto: A bibliografia não faz considerações sobre as razões do culto de Zeus Meilichios estar relacionado ao de Eukleias, como indica o edifício do deus no mesmo santuário dessa divindade feminina, ligada ao culto de Ártemis e difundida em algumas áreas do mundo grego. 0 culto de Zeus é atestado com base somente na estela com a imagem da cobra.

Referências bibliográficas: Falezza, G. I luoghi di culto della Grecia settentrionale in età romana (tese de doutorado). Padova: Università degli Studi di Padova, 2009, pp. 12-16; Torelli; Mavrojannis, 2002, p.326.

\section{Imagens}

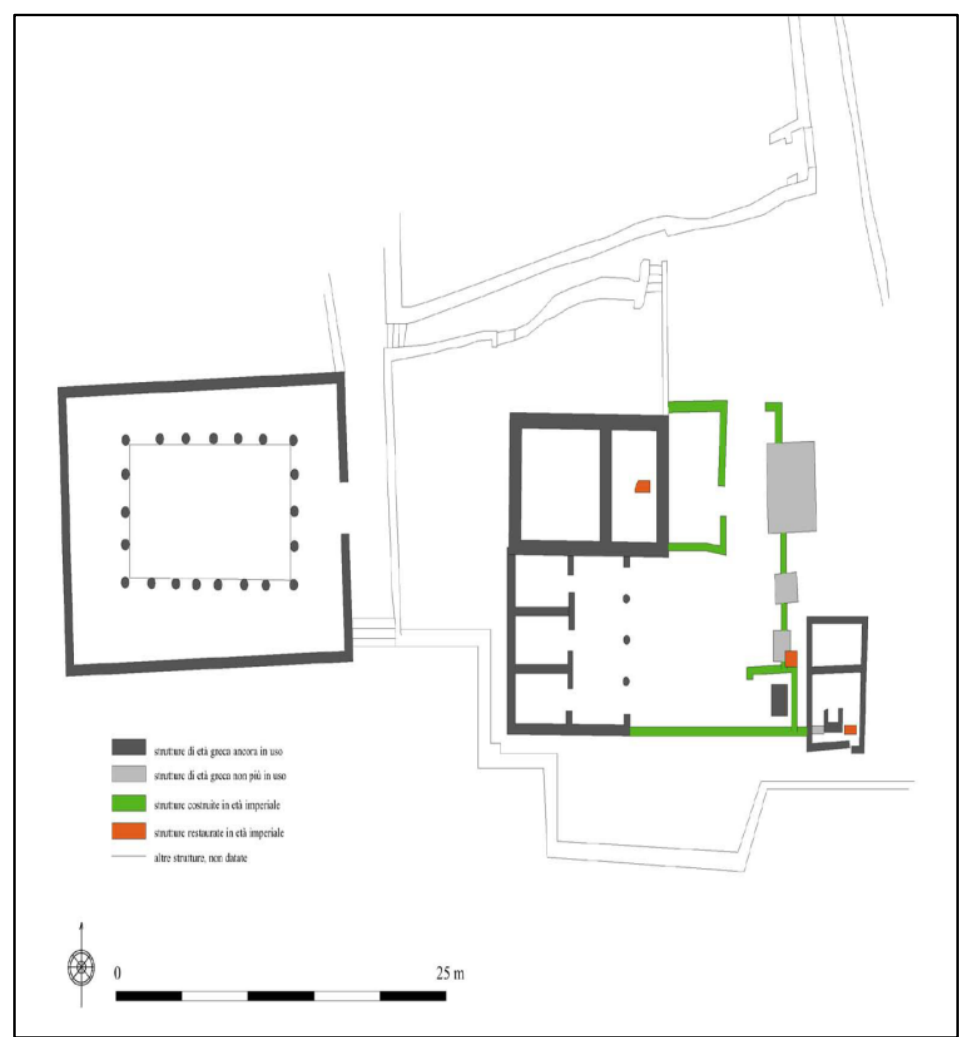

Fig.1- Planimetria do santuário de Eukleias, Aegiae, à

d. no alto, templo de Zeus Meilichios (Falezza, 2009.

19, fig.2) 
Datação: Época clássica - ?

Localização: Na zona noroeste da ágora, entre a sala hipostila e a estrutura semi-circular ao abrigo do terraço de Apolo.

Tipo de santuário: Planície / urbano.

\section{Referências textuais: ?}

Inscrições: ?

\section{Histórico dos achados: ?}

\section{Documentação arqueológica}

I. Témeno: Se trata de um espaço triangular no qual devia ocorrer o culto de Zeus (Lippolis, 2007: 633).

Tipo de culto: Sabemos de Pausânias (II, 20,1-7) que o deus era celebrado na ágora como Hyettios, Meilichios, Sóter, Mechaeus e Nemeios, cujo último epíteto pode ser o titular do santuário (Piérart, 1978). De opinião diversa é Marchetti, quem sugere a localização deste témeno imediatamente a sul da área dedicada ao culto de Apolo Lykeios (Marchetti, 1994) (apud Lippolis, 2007: 633).

Referências bibliográficas: Lippolis, 2007, p.633; Marchetti, P. Mythes et topographie d'Argos II-III, BCH (118), 1994, pp.131-160; Marchetti, P.; Kolokotsas. Le nymphée de l' agora d'Argos: fouille, étude architecturale et historique, Études Péloponnésiennes 11. Paris: Bocárd, 1995; Piérart, M.; Thalmann, J.P. Rapport sur les travaux de l'École Française en Grèce en 1977. Argos II: zone du portique, BCH (102), 1978, pp. 777-790.

Imagens: ? 


\section{Entre Lébedos e Colófon, Jônia \\ Templo de Zeus}

Tucídides VIII.XIX.1-2

Tal foi a aliança. E imediatamente após ela, os chianos tripularam mais dez navios e velejaram para Anaea, desejando se informar sobre a situação em Mileto e ao mesmo tempo induzir as cidades à revolta. Mas a mensagem veio dos calcideus os ordenando que navegassem de volta novamente, já que Amorges chegaria logo por terra com uma armada e, então, eles velejaram para o templo de Zeus; lá, eles avistaram dezesseis navios aproximando-se com que Diomedon tinha deixado Atenas mesmo depois da partida de Trasycles.

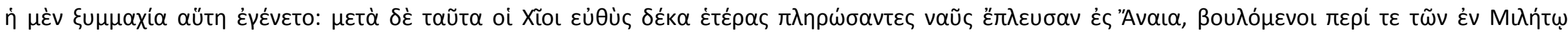

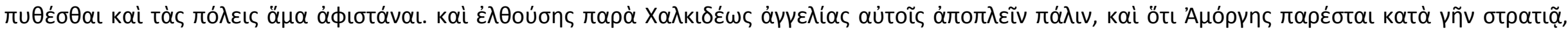

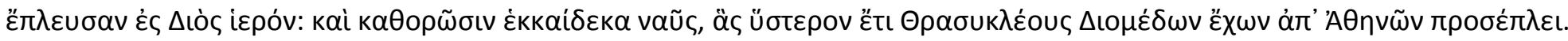

\section{Crotona, Síbaris e Caulônia, Itália do Sul Templo, témeno e liga de Zeus Hamarios \\ Políbio II. 39.4-6}

E não foi apenas neste período que mostraram sua aprovação dos princípios políticos aqueus; mas pouco tempo depois, resolveram modelar sua própria constituição exatamente como aquela da liga (acaia). Os crotoniatas, os sibaritas e os cauloniatas, tendo convocado uma conferência e formado uma liga, primeiramente estabeleceram um templo comum e um local sagrado de Zeus Hamarios para seus encontros e debates, e depois, adotando os costumes e leis dos aqueus, decidiram conduzir seu governo de acordo com eles.

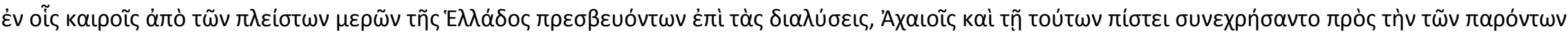

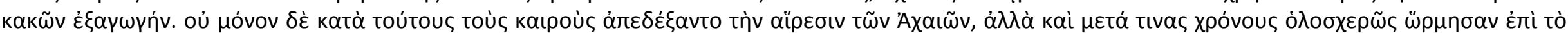

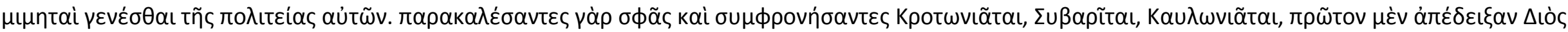

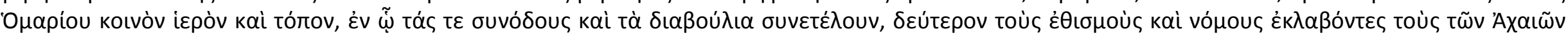

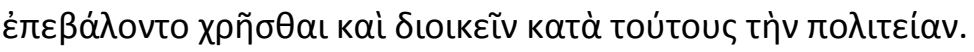




\section{Aigion, Acaia \\ Conselho e témeno de Zeus Hamarios \\ Estrabão 8.7.3}

Agora por vinte anos, os aqueus continuaram a ter uma secretaria geral e duas gerais, elegidas anualmente; e com elas, um conselho comum era convocado e um lugar (este era chamado de Amarion).

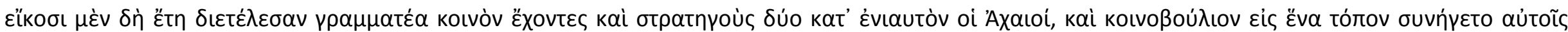

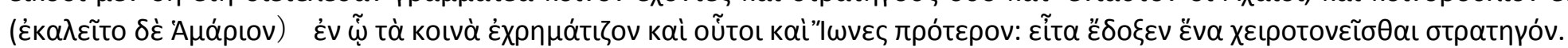

\section{Aigion, Acaia}

\section{Témeno e conselho de Zeus Homários}

\section{Estrabão 8.7.5}

Aigeira está situada em um morro. Boura, que foi engolida por um terremoto, está situada acimada do mar, a cerca de quarenta estádios; e dizem que era da fonte Síbaris em Bura que o rio na Itália ganhou seu nome. Aega (também chamada Aegae) é agora habitada e a cidade está em possessão do povo de Aigion. Mas Aigion tem uma população considerável. Há uma história contada por lá que Zeus foi cuidado por uma cabra, bode por lá, como Aratus diz: "Bode sagrado, que, na história, fizeste segurar teu peito o' er Zeus"; e ele segue e diz que os intérpretes chama-na de cabra, bode "oleniana" de Zeus, assim claramente indicando que o lugar é próximo a Olenê. Aqui também está Ceraunia, a qual está situada sobre uma rocha alta. Esses lugares pertencem a Aigion e faz Helike e Amarion recintos de Zeus, onde os aqueus se encontram para deliberar assuntos de interesse comum.

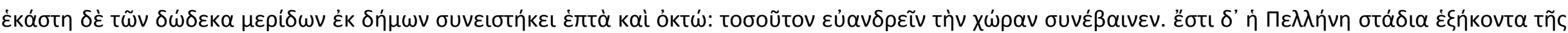

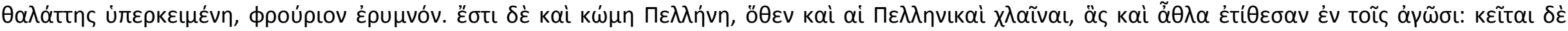

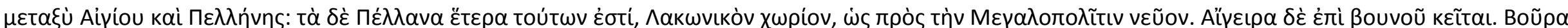

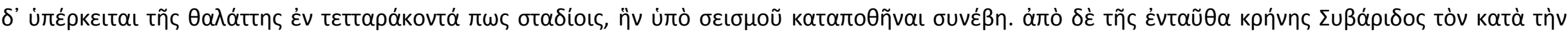

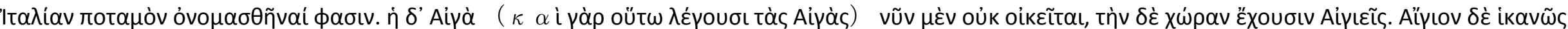

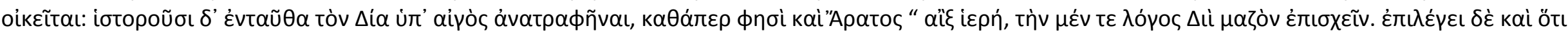

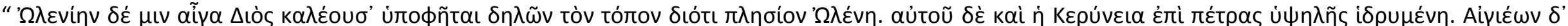

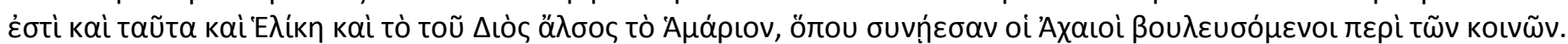




\section{Aigion, Acaia \\ Santuário de Zeus Homagyrios \\ Pausânias VII, XXIV.1-4}

Pelo mar em Aigion está um santuário de Afrodite e depois um de Poseidon; há também um de Koré, filha de Deméter, e um de Zeus Homagyrios (Convocador). Aqui estão imagens de Zeus, Afrodite e de Atena. O nome Convocador foi dado a Zeus porque neste local Agamemnon reuniu os homens mais eminentes da Grécia para que eles pudessem juntos se consultar como fazer guerra no império de Príamo (...).

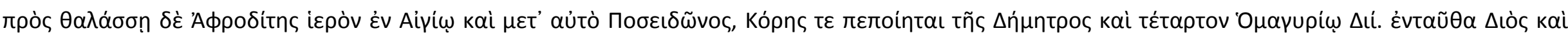

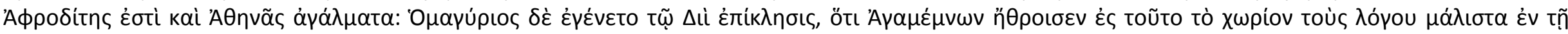

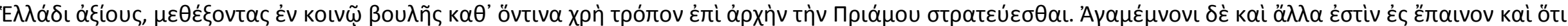

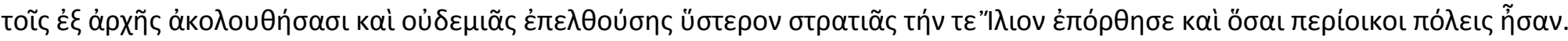

\section{Aigion, Acaia}

\section{Témeno de Zeus Sóter}

Pausânias VII, XXIII.9

Há também na ágora um recinto de Zeus chamado Salvador, com duas imagens ambas de bronze; uma que não tem barba parece ser a mais antiga (...).

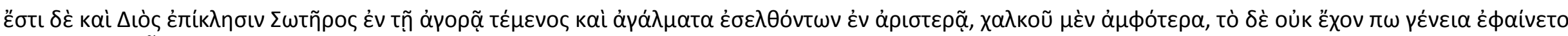

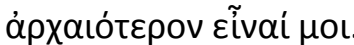




\section{Aigeira, Acaia \\ Santuário de Zeus}

Pausânias VII, XXVI.2-6

Das vistas de Aigeira, a mais digna de nota inclui um santuário de Zeus com uma imagem sentada de mármore pentélico, obra de Eucleides, o ateniense.

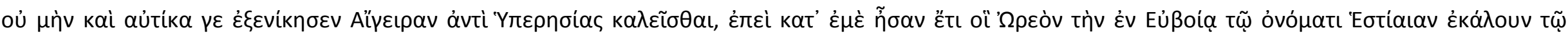

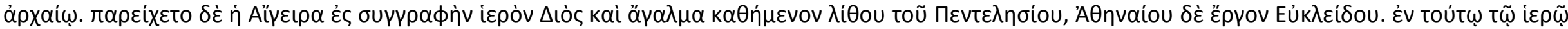

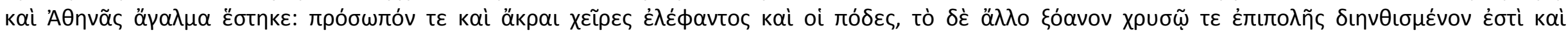
фарна́коเৎ.

\section{Aigeira, Acaia}

Santuário de Zeus

Pausânias VII, XXVI.9-13

Há uma estrada estreita do santuário de Zeus em Aigeira, passando pelas montanhas e escarpas.

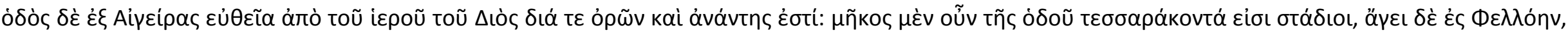

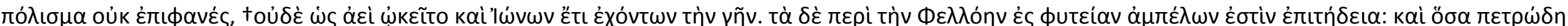

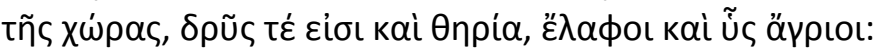




\section{Patras, Acaia}

\section{Templo de Zeus Olímpio}

Pausânias VII, XX.3-6

Na ágora está um templo de Zeus Olímpio; o próprio deus está em um trono com Atena em pé por ele.

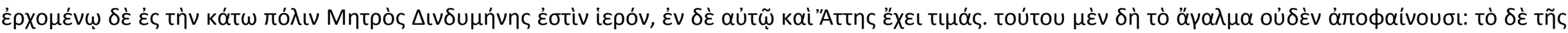

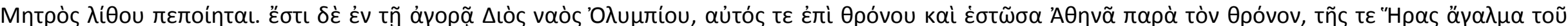

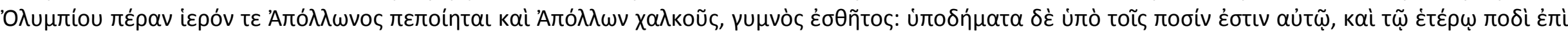

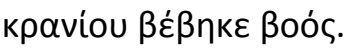

\section{Agrigento, Sicília}

\section{Templo de Zeus Atabírios em Agrigento e sobre o seu culto em Rodes}

Políbio Fragm. IX.27.6-8

No seu cume encontram-se os templos de Atena e de Zeus Atabírios como em Rodes; já que Agrigento foi fundada pelos ródios este deus naturalmente carrega o mesmo título como em Rodes.

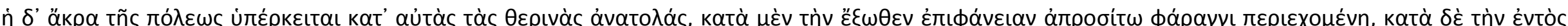

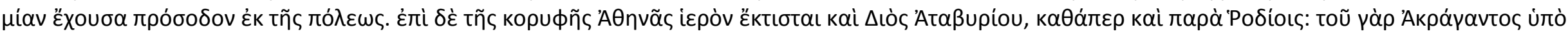

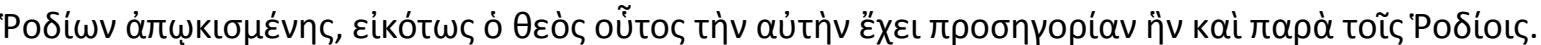




\section{Kamiros, Rodes \\ Templo de Zeus Atabírios no Monte Atabírios \\ Diodoro V.59.2}

Althamenes (o filho de Catreus, rei de Creta), então, desembarcou em Rodes em Kamiros, e no Monte Atabírios, ele fundou um templo de Zeus que chamou de Zeus Atabírios; e por esta razão, o templo mantém uma honra especial até este dia, situado como está sobre a parte elevada do pico do qual se pode avistar Creta.

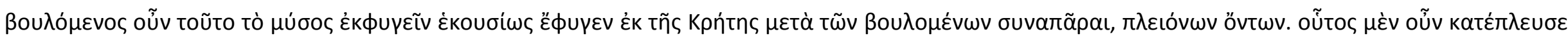

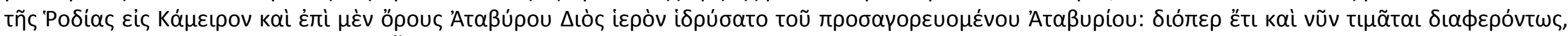

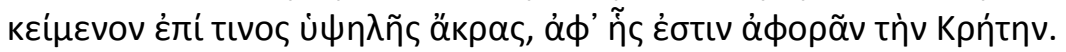

\section{Cydonia ou Apollonia?, Creta \\ Templo de Zeus Idaios}

Políbio fragm. XXVIII.14.1-4

Por enquanto, eles (os cydoniatas) foram não apenas amigos dos apoloniatas, mas unidos com eles em uma comunidade, e compartilharam com eles em geral todos os direitos observados pelos homens, lá estando o tratado jurado para este efeito depositado no templo de Zeus Idaios.

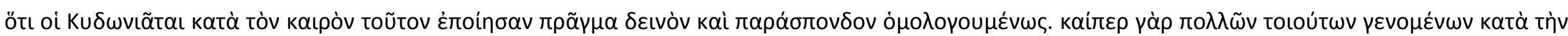

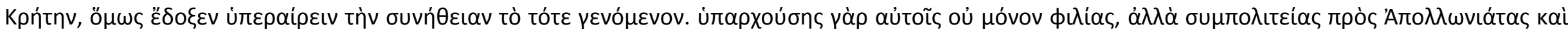

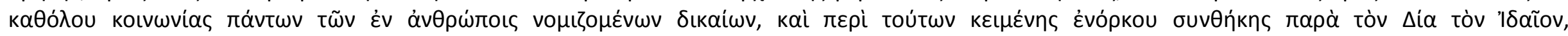

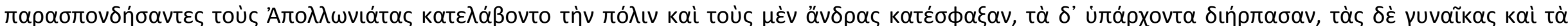

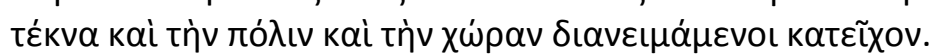




\section{Troezen, Argólida \\ Santuário de Zeus Sóter \\ Pausânias II, XXXI.8-10}

Há um santuário de Zeus denominado Salvador, que, eles dizem, foi feito por Aetius, o filho de Anthas, quando ele era rei.

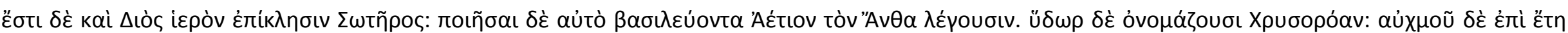

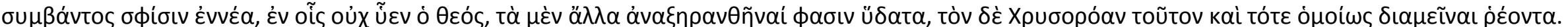

\section{Oeste de Herminone, Argólida}

\section{Santuário de Zeus Kokkygios}

\section{Pausânias II, XXXVI.2}

(...) Outra montanha, chamada em tempos antigos de Thornax; mas eles dizem que o nome mudou porque, de acordo com a lenda, foi aqui que ocorreu a transformação de Zeus em um cuco. Mesmo no presente dia há santuários nos topos das montanhas, no monte Kokkygion um é de Zeus (...).

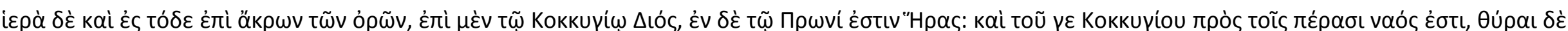

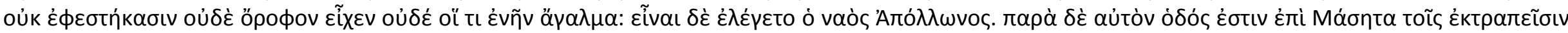

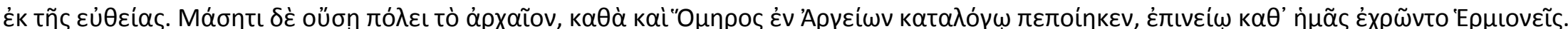

\section{Acrópole Lárissa, Argos}

\section{Templo de Zeus Lariseus}

\section{Pausânias II, XXIV.3}

No topo da Lárissa está um templo de Zeus chamado Lariseus, que não tem telhado; a imagem de madeira eu já não mais encontrei sobre seu pedestal.

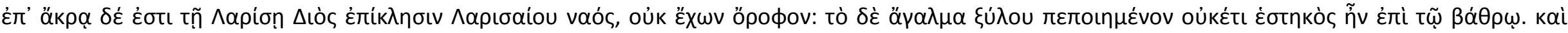

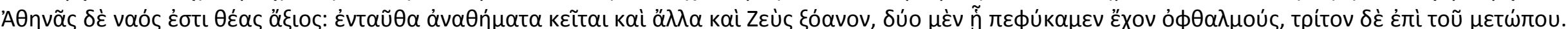

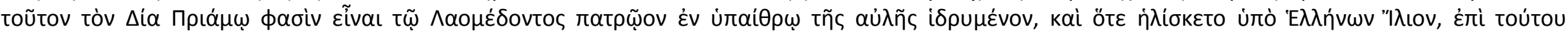

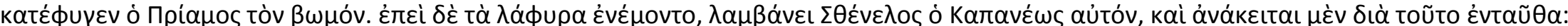




\section{Território de Argos \\ Santuário de Zeus Sóter}

Pausânias II, XX.6

Aqui há também um santuário de Zeus o Salvador.

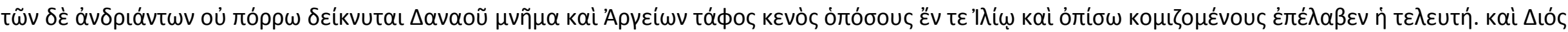

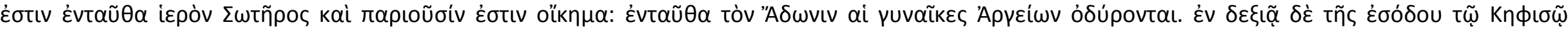

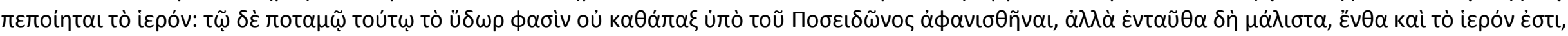

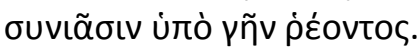

\section{Argos}

\section{Santuário de Zeus Nemeios}

Pausânias II, XX.3-5

Em frente dele (santuário de Hera) está um santuário de Zeus Nemeios e uma estátua de pé de bronze do deus feita por Lysippos.

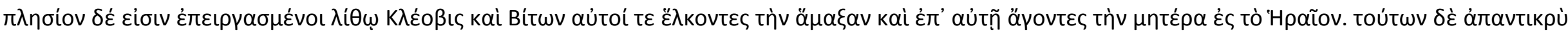

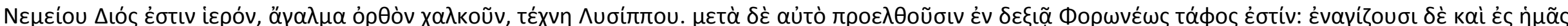

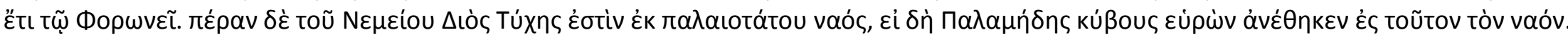




\section{Muníquia, Ática \\ Templo de Zeus \\ Pausânias I, I.3-7}

Aqui há também um templo de Atena Sciras e um de Zeus a alguma distância.

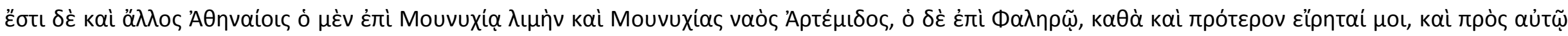

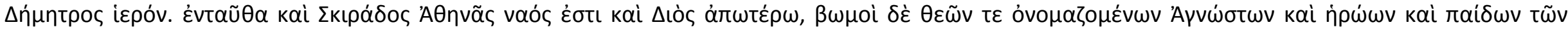

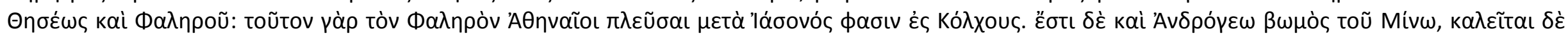

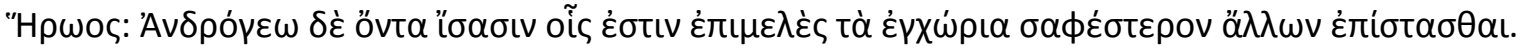

\section{Pireu, Ática}

\section{Témeno de Atena e Zeus}

\section{Pausânias I, I.3}

O local mais notável no Pireus é um recinto de Atena e Zeus. Ambas suas imagens são de bronze; Zeus segura um cetro e uma Vitória, Atena uma lança.

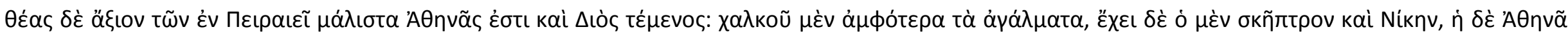

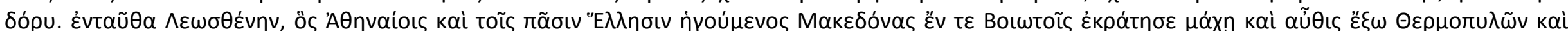

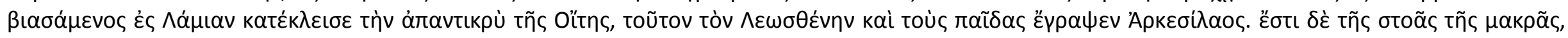

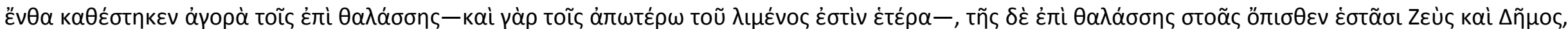

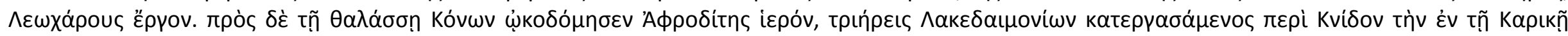

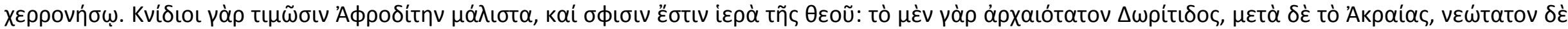

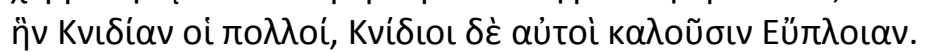




\section{Pireu, Ática \\ Templo de Zeus Sóter \\ Estrabão 9.1.15}

(...) E transformou o Pireu em um pequeno assentamento, em torno dos portos e do templo de Zeus Sóter.

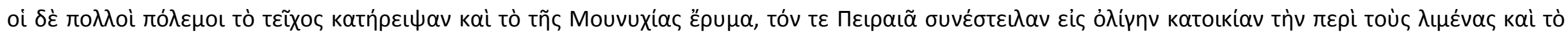

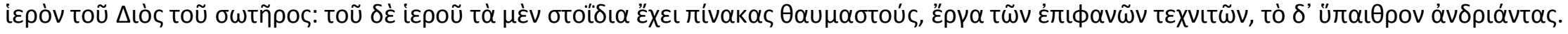

\section{Eleutherae, Beócia}

Templo de Zeus Eleuthérios

\section{Estrabão 9.2.31}

Foi aqui que as forças dos gregos aniquilaram Mardônio e seus trezentos mil persas; e eles construiram um templo de Zeus Eleuthérios e instituiram os jogos atléticos, nos quais o vencedor recebia uma coroa, chamados de Eleutheria.

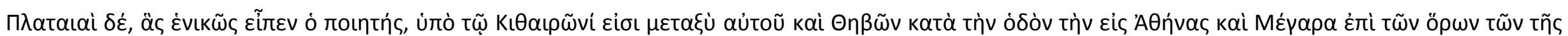

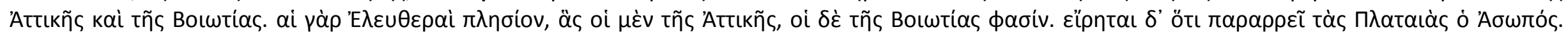

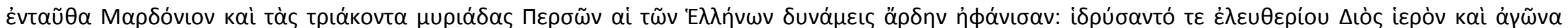

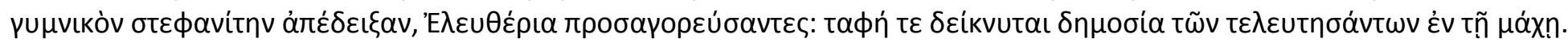

\section{Tebas, Beócia}

\section{Santuário de Zeus Hypsistos}

Pausânias IX, VIII.5

O portão Creneu e Hypsistos levam estes nomes pela seguinte razão (...) e pelo Hypsistos está um santuário de Zeus chamado Hypsistos.

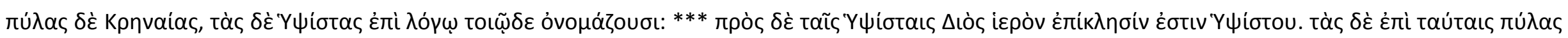

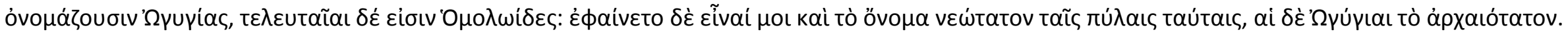




\section{Tebas, Beócia}

\section{Santuário de Zeus Agoraios}

Pausânias IX, XXV.4

Ao longo da estrada do portão Neistan estão três santuários. Há um santuário de Themis, com uma imagem de mármore; contíguo está um santuário dos Destinos enquanto o terceiro é de Zeus Agoraios. Zeus é feito de pedra (...).

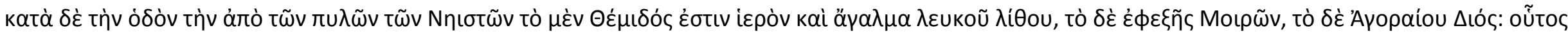

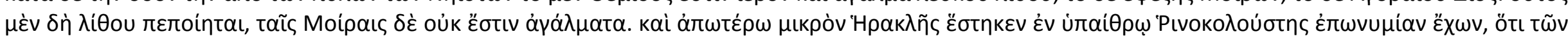

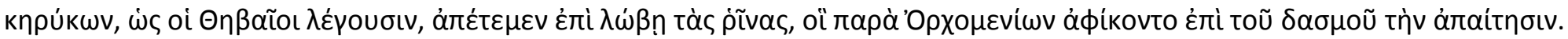

\section{Lebadéia, Beócia}

\section{Santuários de Zeus Hyettios e de Zeus Basileus}

Pausânias IX, XXXIX.4

O mais famoso no bosque são o templo e imagem de (Zeus) Trophonios; a imagem feita por Praxiteles (...). Há também um santuário de Deméter chamada Europa e um de Zeus Chuvoso no aberto. Se você sobe ao oráculo e dali em diante sobre a montanha, você chega ao que é chamado de Donzela Caçadora e um templo de Zeus Basileus. Este templo eles deixaram inacabado, devido ao seu tamanho ou as longas sucessões de guerras.

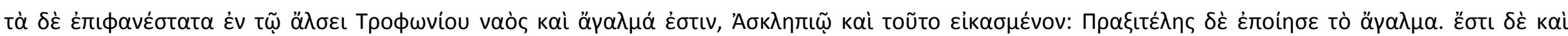

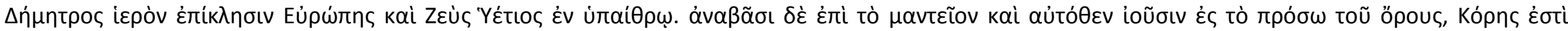

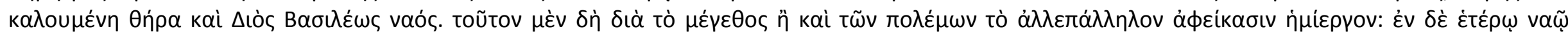

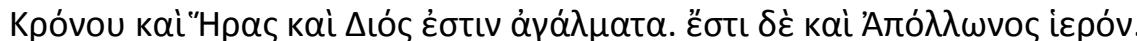




\section{Monte Laphystios, Beócia}

\section{Témeno de Zeus Laphystios}

Pausânias IX, XXXIV.5

A distância de Coronéia ao Monte Laphystios e o recinto de Zeus Laphystios é de cerca de vinte estádios. A imagem é de pedra. Eles dizem que quando Athamas estava para sacrificar aqui Phrixius e Helle, um cordeiro com seu velo de ouro foi enviado por Zeus para a criança, e que na parte de trás deste cordeiro eles fizeram boa a sua fuga.

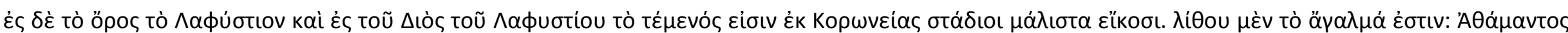

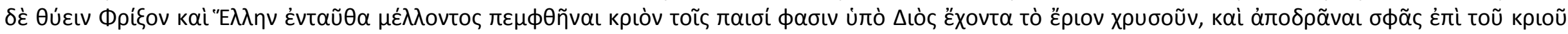

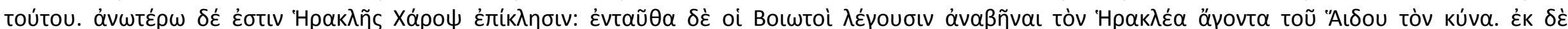

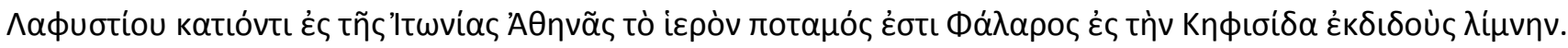

\section{Esparta, Lacônia}

Santuário de Zeus Olímpio

Pausânias III, XIV.5

Os espartanos têm também um santuário de Serápis, o mais novo da cidade, e um de Zeus chamado Olímpio.

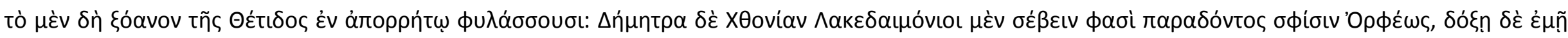

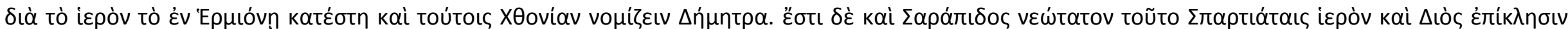
'Oגuнríou. 


\section{Esparta, Lacônia}

Santuário de Zeus Agoraios

Pausânias III, XI.9

Não longe dali (da ágora e do choros de Esparta) está o santuário de Gê e de Zeus Agoraios (...).

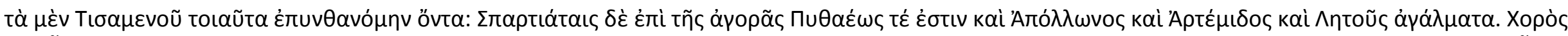

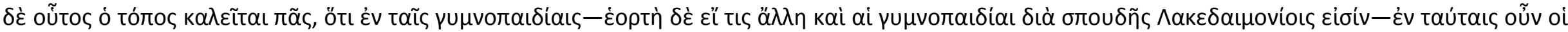

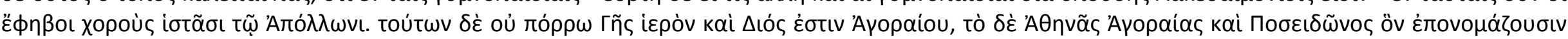

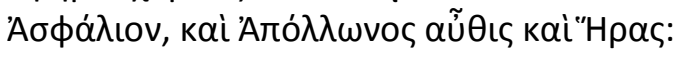

\section{Esparta, Lacônia}

Santuário de Zeus Ksênios

Pausânias III, XI.11

Existe também um (santuário) de Zeus Ksênios e de Atena Ksênia.

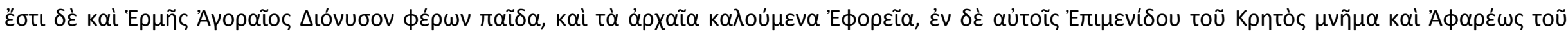

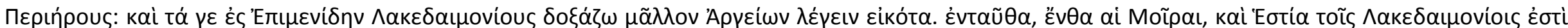

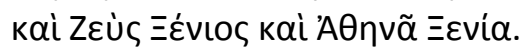




\section{Esparta, Lacônia}

\section{Santuário de Zeus Tropáios}

Pausânias III, XII.8-9

No lugar chamado Fortes está o templo de Ártemis, e um pouco mais adiante, foi construída uma tumba para os adivinhos de Élis, chamados lamidae. Existe também um santuário de Maron e de Alfeu.

(...) o santuário de Zeus Tropáios foi feito pelos dórios quando eles conquistaram na guerra os amycleios, tal como os outros aqueus, que naquele tempo ocuparam a Lacônia.

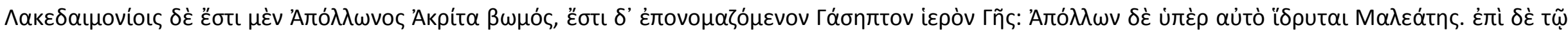

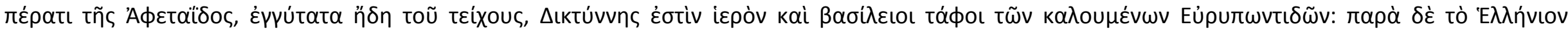

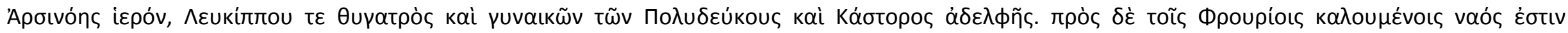

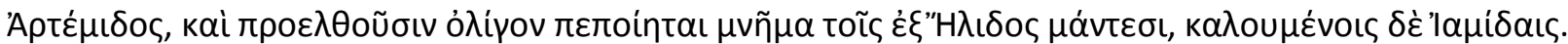

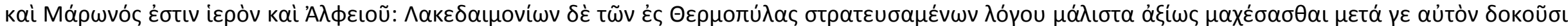

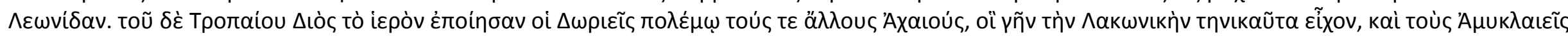

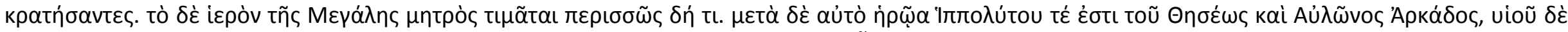

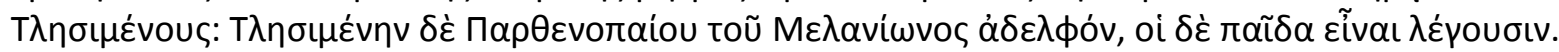

\section{Esparta, Lacônia}

\section{Santuário de Zeus Euanémon}

Pausânias III, XIII.5-9

Não longe do (santuário de) Dioniso está o santuário de Zeus de Vento Bom (...).

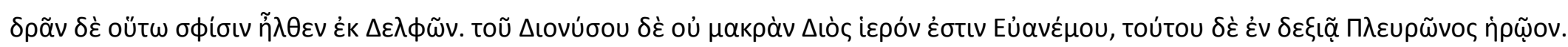




\section{Esparta, Lacônia}

\section{Templo de Zeus Cosmetas}

Pausânias III, XVII.4

Quando se vai do pórtico sul há um templo de Zeus chamado Cosmetas (Ordenador) (...)

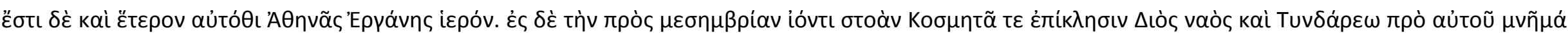

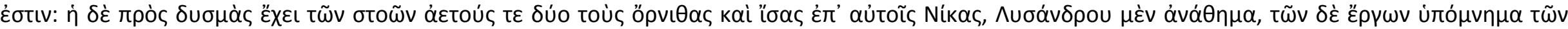

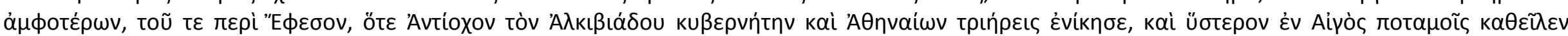
AӨnvaíwv tò vautikóv.

\section{Esparta, Lacônia}

Templo de Zeus Syllanios

Plutarco, Lycurgos VI.1

Tão impaciente era Licurgo para o estabelecimento desta forma de governo, que ele obteve um oráculo de Delfos sobre isso, que eles chamam de um rhetra. E esta é a forma como ele é executado:

"Quando tu construíste um templo para Zeus Syllanios e Atena Syllania, dividiste o povo em phylai e em obai, e estabeleceste um senado de trinta membros, incluindo os archagetai (...).

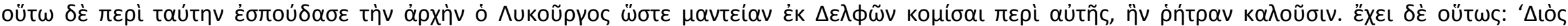

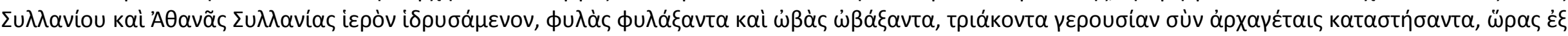

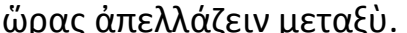




\section{Epidauro Limera, Lacônia}

Templo de Zeus Sóter

Pausânias III, XXIII.10

(...) um templo de Atena na acrópole e o de Zeus com o título de Salvador em frente ao porto.

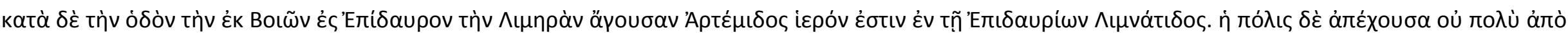

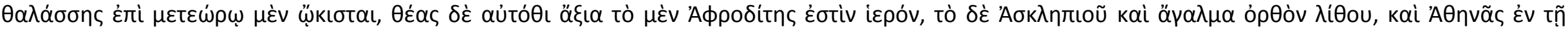

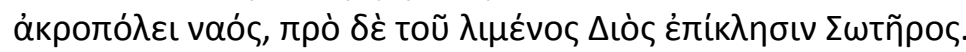

\section{Amyclai, Lacônia}

\section{Santuário de Zeus Ploúsios}

Pausânias III, XIX.7

Antes de cruzar o Eurotas, um pouco acima do banco, está um santuário de Zeus Rico.

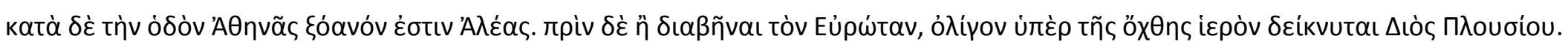

\section{Lepreonte, Trifília}

Templo de Zeus Leucaeus

Pausânias V, V.5

Os lepreatas me disseram que em sua cidade uma vez existiu um templo de Zeus Leucaeus (do Álamo Branco) (...).

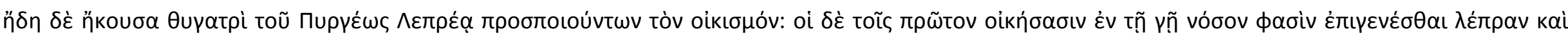

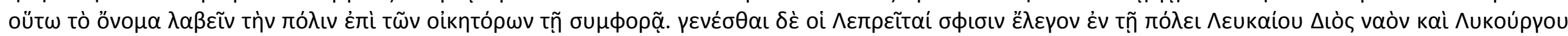

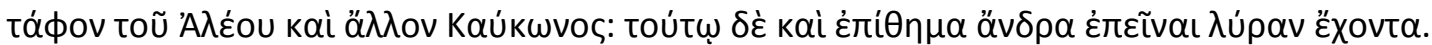




\section{Mantinéia, Arcádia}

\section{Santuários de Zeus Sóter e de Zeus Epidótou}

Pausânias VIII, IX.4

Os mantineus têm outros santuários também, um de Zeus Salvador e outro de Zeus Doador de Presentes.

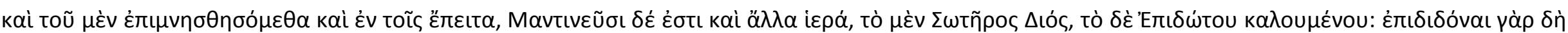

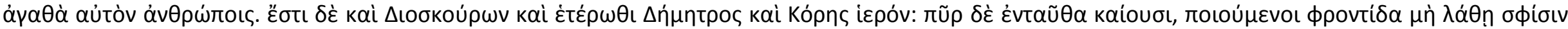

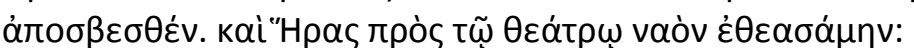

\section{Mantinéia, Arcádia \\ Templo de Zeus Sóter? \\ Tucídides V.XLVII.1-11}

“Para a renovação do juramento, os atenienses irão para Élis, para Mantinéia e para Argos, trinta dias antes dos jogos olímpicos; e os argivos, eleios e mantineus irão para Atenas dez dias antes das grandes Panatenaias. A condição, a respeito do tratado, dos juramentos, e da aliança deverá ser inscrita em uma coluna de pedra, pelos atenienses na acrópole, pelos argivos na ágora no templo de Apolo, pelos mantineus na ágora no templo de Zeus; e um pilar de bronze deverá ser erguido por eles juntamente nas jogos olímpicos deste ano".

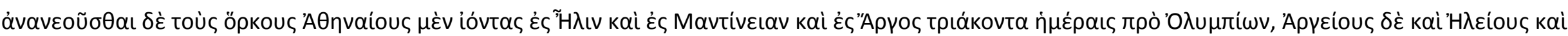

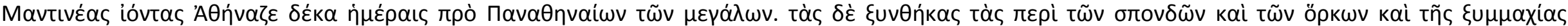

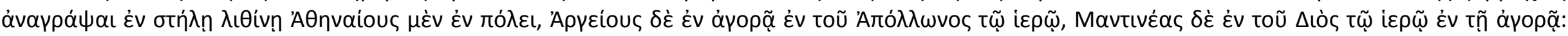

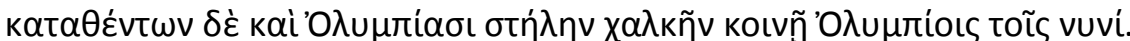




\section{Mantinéia, Arcádia}

\section{Santuário de Zeus Chármonos}

Pausânias VIII, XII.1

Apenas cerca de um estádio da tumba de Epaminondas está um santuário de Zeus chamdo Chármonos (...).

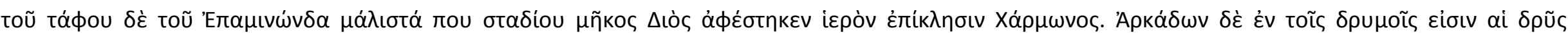

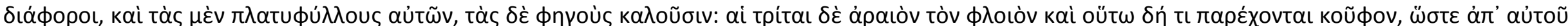

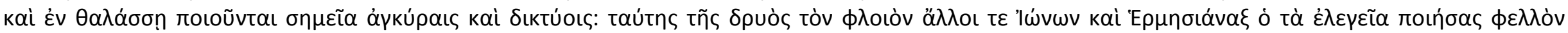
óvouáłouolv.

\section{Megalópolis, Arcádia}

\section{Santuário de Zeus Lykaios}

Pausânias VIII, XXX.1-4

O rio Helisson divide Megalópolis assim como Cnidos e Mitilene são divididas em duas pelo seu estreito, e na seção norte, à direita como alguém que desprezza o rio, os habitantes fizeram sua ágora. Nela, está um cercado de pedras e um santuário de Zeus Lýkaios com uma entrada para ele.

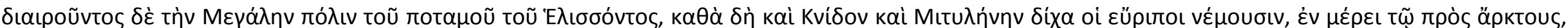

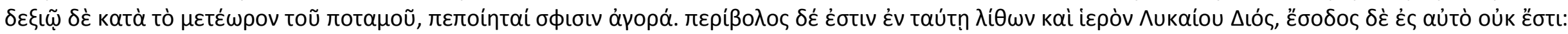

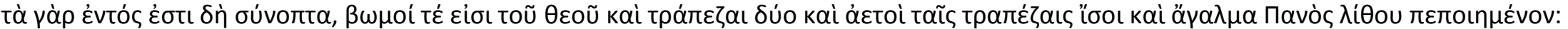




\section{Megalópolis, Arcádia \\ Santuário de Zeus Sóter \\ Pausânias VIII, XXX.10}

Muito próximo a este pórtico, a leste, está um santuário de Zeus chamado Salvador. Este é adornado com pilares ao redor. Zeus está sentado em um trono e ao seu lado está Megalópolis à direita e uma imagem de Ártemis Salvadora à esquerda. Estas são de mármore pentélico e foram feitas pelos atenienses Cephisodotus e Xenophon.

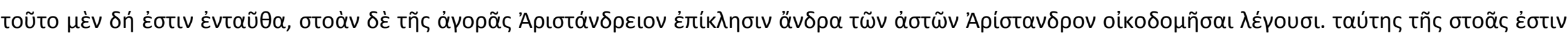

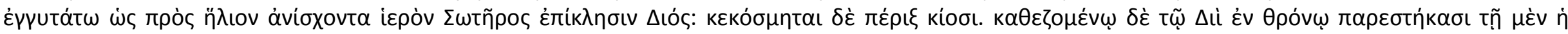

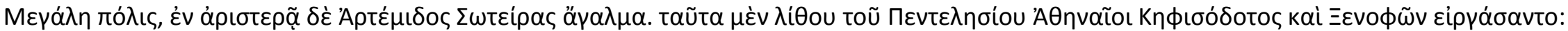

\section{Megalópolis, Arcádia \\ Templo de Zeus Philios \\ Pausânias VIII, XXXI.1-4}

Dentro do recinto está um templo de Zeus Amigável. Policleitos de Argos fez a imagem.

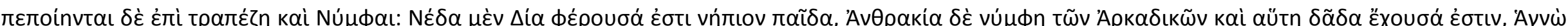

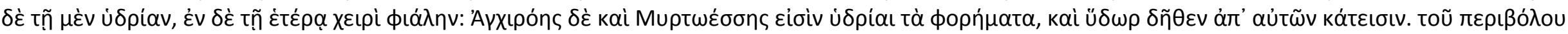

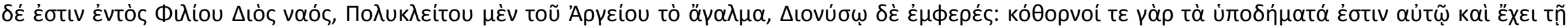

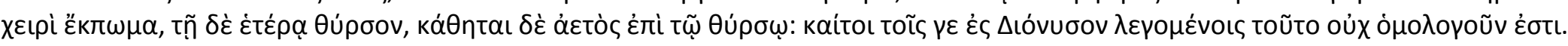




\section{Megalópolis, Arcádia \\ Templo de Zeus Agáthos \\ Pausânias VIII, XXXVI.4-7}

Passando pelo portão em Megalópolis chamado do portão do pântano, e prosseguindo pelo lado do rio Helisson em direção de Menelau, lá está à esquerda da estrada um templo do bom deus. Se os deuses são propiciadores de boas coisas aos homens e se Zeus é o supremo entre os deuses, seria consistente inferir que se trata de (um templo) de Zeus.

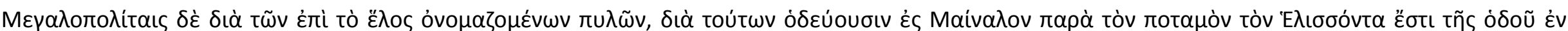

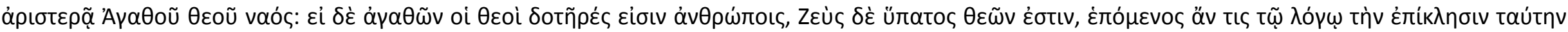

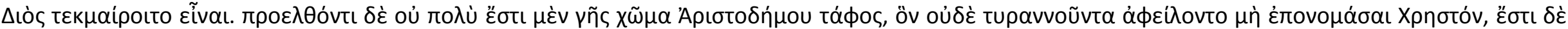

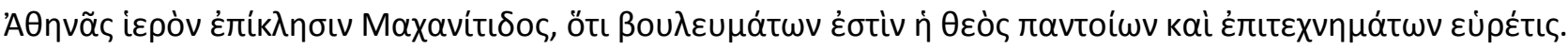


Tese de doutorado - A apropriação e consolidação do culto de Zeus pela cidade grega: moedas e santuários, política e identidade em época arcaica e clássica

Lilian de Angelo Laky

CATÁLOGO II

Tipos monetários de Zeus , raios e águias emitidos no mundo grego nos séculos VII-IV a.C. (até 345/44 a.C.) 
ÍNDICE

Catálogo

Zeus (1)

Séc. VI-V a.C. (1)

Sé. V a.C. (1)

Séc. IV a.C. (22)

\section{Águias (43)}

Séc. VII-VI a.C. (43)

Séc. V a.C. (44)

Séc. V a.C. (48)

Séc. IV a.C. (89)

\section{Raios (116)}

Séc. V a.C. (116)

Séc. IV a.C. (120)

Águias e raios (125)

Séc. V a.C. (125)

Séc. IV a.C. (138) 


\section{Zeus e águias (144)}

Séc. V a.C. (144)

Séc. IV a.C. (146)

Zeus e raios (151)

Sé. V a.C. (151)

Séc. IV a.C. (151)

Zeus, raios e águias (158)

Séc. IV a.C. (158) 


\section{ZEUS}

\section{SÉCULOS VI-V a.C.}

\section{Cirene, Líbia}

Data: c.525-480 a.C.

Anverso: Fruta de silphium.

Reverso: Cabeça de Zeus Amon à d. com cabelos curtos, tudo dentro de quadrado incuso.

Metal / denominação: AR / hemidracma ático.

Referências: BMC Cyrenaica: 26, p.7, pr.IV, 22.

Exemplares similares: BMC Cyrenaica: 27-29, p.7, pr.IV, 23-25.

\section{SÉCULO V a.C.}

02. Cirene, Líbia

Data: c.500 a.C.

Anverso: Silphium com frutas dentro de um círculo de pontos.

Reverso: Cabeça de Zeus Amon à e. com cabelos e barba curtos.

Metal / denominação: AR / tetradracma.

Referências: Kraay, ACGC: Pr.62, 1067. 


\section{Cirene, Líbia}

Data: c.480-435 a.C.

Anverso: Silphium de tipo Ic.

Reverso: Cabeça de Zeus Amon à d. com cabelo e barba curtos; à d., KYPA.

Metal / denominação: AR / tetradracma ático.

Referências: BMC Cyrenaica: 42, p.10, pr.V, 16; Kraay, ACGC*: Pr.62, 1072 (440 a.C.).

Exemplares similares: BMC Cyrenaica: 44-45, p.11, pr. VI, 1-2.

\section{Cirene, Líbia}

Data: c.480-435 a.C.

Anverso: Silphium de tipo IC.

Reverso: Cabeça de Zeus Amon à d. cabelos e barba curtos; círculo pontilhado dentro de quadrado incuso; KYPA.

Metal / denominação: AR / dracma asiático.

Referências: BMC Cyrenaica: 50, p.12, pr.VI, 14.

Exemplares similares: BMC Cyrenaica: 49, 51, 52, p.12, pr.VI, 13, 17, 19 .

\section{Cirene, Líbia}

Data: c.480-435 a.C.

Anverso: Cabeça feminina à d. com cabelo curto e moldurada por coroa de folhas de oliveira.

Reverso: Cabeça de Zeus Amon à d. com cabelos e barba curtos, tudo dentro de um quadrado incuso pontilhado.

Metal / denominação: AR / trihemióbolo asiático.

Referências: BMC Cyrenaica: 59, p. 14, pr. VII, 14. 


\section{Euesperides, Líbia}

Data: c.480-435 a.C.

Anverso: Silphium de tipo Ic.

Reverso: Cabeça de Zeus Amon à d. com cabelos e barba curtos; círculo pontilhado dentro de quadrado incuso nos cantos e fora do círculo, E $\Sigma$ Y E.

Metal / denominação: AR / dracma asiático.

Referências: BMC Cyrenaica: 2, p.110, pr.XXXVIII, 8.

\section{Barce, Líbia}

Data: c.480-435 a.C.

Anverso: Silphium.

Reverso: Cabeça de Zeus Amon à d. com cabelos e barba curtos; círculo pontilhado dentro de quadrado incuso nos cantos e fora do círculo, E K/ A P.

Metal / denominação: AR / tetradracma asiático?

Referências: BMC Cyrenaica: pr.XXXIV, 1. 


\section{Aetna-Catânia, Sicília}

Data: c. $475-470$ a.C

Anverso: Atena correndo em uma quadriga à d. e Nike voando à e.

Reverso: Zeus sentado no trono à d. segurando raio (?) com a mão d. e com a mão e. segura o

cetro e sobre ele está a águia parada.

Metal / denominação: AR / tetradracma.

Referências: Kraay, ACGC: pr.49, 837.

\section{Aetna-Catânia, Sicília}

Data: c. $475-470$ a.C

Anverso: cavaleiro nu dentro de um círculo de pérolas.

Reverso: Zeus sentado no trono à d., vestindo himátion, segurando raio com a mão d. e cetro com a e.; águia sobre cetro; AITN/AI/ON.

Metal / denominação: AR / dracma.

Referências: Caccamo Caltabiano, 2009: pr.l, 2. 


\section{Liga Arcádia}

Data: c.470 a.C. (mestre de Copenhagen)

Anverso: Zeus Lykaios sentado à e. em trono baixo, segurando cetro longo com sua mão esquerda e águia voando sobre sua mão direita.

Reverso: Cabeça de Kallisto à e., usando taenia, colar e uma trança no cabelo;

tudo dentro de um quadrado incuso;

Metal / denominação: AR / hemidracma.

Referências: $B C D$, Peloponnesos*: 1393; Williams I, 1, $6^{\text {a }}$ (cunhagem de Kleitor).

Exemplares similares: $B C D$, Peloponnesos: 1394; Williams I, 2, 16d.; 1395; Williams I, 2, 20; 1396

(no anverso inscrição e no reverso [ ] ] Williams I, 3, 30e); 1397 (óbolo, com inscrição no reverso

[ ], Williams I, 3, 31a)

\section{Cirene, Líbia}

Data: c.470 a.C.

Anverso: Cabeça de Zeus Amon à d. com cabelo e barba curtos.

Reverso: À d. do campo, cabeça de cavalo; à d, silphium; no centro embaixo, fruta; Y P.

Metal / denominação: AR / tetradracma.

Referências: Kraay, ACGC: Pr.62, 1070. 


\section{Cirene, Líbia}

Data: c.465 a.C.

Anverso: Silphium de tipo IC.

Reverso: Cabeça de Zeus Amon à d. com cabelos e barba curtos; K VPA.

Metal / denominação: AR / tetradracma.

Referências: Kraay, ACGC*: Pr.62, 1071; BMC Cyrenaica: 45, p. 11, pr. VI, 1.

\section{Liga Arcádia}

Data: c. $465-460$ a.C.

Anverso: Zeus Lykaios sentado à e. em trono baixo com cabeça de cisne no topo do

encosto, segurando cetro longo com sua mão esquerda e águia voando sobre sua mão direita.

Reverso: Cabeça de Kallisto à d., usando taenia e colar; tudo dentro de um quadrado incuso; AR /

Metal / denominação: AR / hemidracma.

Referências: BCD, Peloponnesos*: 1401; Williams II, 2, 62e (cunhagem de Kleitor).

Exemplares similares: $B C D$, Peloponnesos: 1402 (Reverso com inscrição

e cabeça de Kallisto á e., Williams II, 2, 66a);

1403 (óbolo, Williams II, 2, 70); 1404 (óbolo, reverso com inscrição

Williams II, 2, 72c), 1405 (c. $460-450$ a.C., reverso com inscrição

, Williams III, 1, 132); 1406 (c.460-450 a.C., Williams III, 1, 138e). 


\section{Liga Arcádia}

Data: c.465-460 a.C.

Anverso: Zeus Lykaios sentado à e. em trono baixo com cabeça de cisne no topo do encosto, segurando cetro longo com sua mão direita e águia voando à e. sobre sua mão direita.

Reverso: Cabeça de Kallisto à d., seu cabelo preso por uma taenia e amarrado em um coque atrás; tudo dentro de um quadrado incuso; RK[ ].

Metal / denominação: AR / hemidracma.

Referências: $B C D$, Peloponnesos*: 1709; Williams II, 1, 73 (0.54); II, 2, 85 (cunhagem de Tegea).

Exemplares similares: $B C D$, Peloponnesos: 1710 (reverso com cabeça de Kallisto à e. e vestindo um colar no pescoço);

1711 (koppa master); 1712 (reverso com inscrição A A, Williams III, 1, 183); Williams II, 1, 79; SNGCop Suppl.274.

\section{Liga Arcádia}

Data: c.465-460 a.C.

Anverso: Zeus Lykaios sentado à e. em trono baixo com apoio para os pés e cabeça de cisne no topo do encosto, segurando cetro longo com sua mão direita e raio com a e., águia voando à d.

Reverso: Cabeça de Kallisto à d., seu cabelo preso por uma sakkos e usando um colar simples com um único pingente; tudo dentro de um quadrado incuso.

Metal / denominação: AR / hemidracma.

Referências: $B C D$, Peloponnesos*: 1451; Williams II, 1, 104d (cunhagem de Mantinéia).

Exemplares similares: $B C D$, Peloponnesos: 1452 (reverso com inscrição A-R-K-A nos quatro cantos do quadrado incuso); 1453 (óbolo, Williams II, 1, 108); 1454 (no reverso Kallisto está usando um colar de pérolas, Williams II, 2, 112); 1555

(no reverso Kallisto usa uma taenia sobre o sakkos e um colar plano com um pendente). 


\section{Aetna-Inessa, Sicília}

Data: c.465-460 a.C.

Anverso: Cabeça de Silenus à d. círculo de pérolas; NOI TN $\Omega$.

Reverso: Zeus sentado no trono, sobre uma pele de pantera, segurando um raio alado com a mão esquerda e, a direita, um galho de parreira e, a águia repousa sobre uma conífera.

\section{Metal / denominação: AR / tetradracma.}

Referências: Kraay, ACGC: pr.49, 838.

\section{Liga Arcádia}

Data: Início de 460 a.C.

Anverso: Zeus Lykaios sentado à e. em trono baixo, segurando cetro longo com sua mão esquerda e águia voando sobre sua mão direita.

Reverso: Cabeça de Kallisto à d., usando taenia, colar e uma trança no cabelo; tudo dentro de um quadrado incuso;

\section{Metal / denominação: AR / hemidracma.}

Referências: $B C D$, Peloponnesos*: 1398; Williams I, 3, 40c (cunhagem de Kleitor).

Exemplares similares: $B C D$, Peloponnesos: 1399 (Williams I, 43-44); 1400 (óbolo de c. 465-460 a.C.

reverso com inscrição ， Kallisto usa uma coroa de folhas de oliveira e um colar, Williams II, 1). 


\section{Zancle, Sicília}

Data: c. 460 a.C.

Anverso: Zeus atirando um raio à d. com a mão d.; sobre suas costas aparece um manto (égide?).

Reverso: Golfinho à e., círculo de pérolas; $\triangle \mathrm{ANK} \wedge[\mathrm{Al}] \mathrm{O}[\mathrm{N}]$.

Metal / denominação: AR / tetradracma

Referências: Kraay, ACGC: pr.45, 774.

\section{Liga Arcádia}

Data: c. $460-450$ a.C

Anverso: Zeus Lykaios sentado de frente com sua cabeça virada à e., em trono baixo, segurando cetro longo com sua mão esquerda e águia voando sobre sua mão direita.

Reverso: Cabeça de Kallisto à d., usando taenia e colar; tudo dentro de um quadrado incuso; ARKA $\triangle I K O$ Metal / denominação: AR / hemidracma.

Referências: $B C D$, Peloponnesos*: 1407; Williams III, 1, 150 (cunhagem de Kleitor).

Exemplares similares: $B C D$, Peloponnesos: 1408 (Williams III, 2, 153). 


\section{Liga Arcádia}

Data: c. 460-450 a.C.

Anverso: Zeus Lykaios sentado à e., em trono baixo com cabeça de cisne no topo do encosto, segurando cetro longo com sua mão esquerda e águia voando sobre sua mão direita.

Reverso: Cabeça de Kallisto à d., usando taenia, colar e cabelo preso por trança; tudo dentro de um quadrado incuso; ARKA.

Metal / denominação: AR / hemidracma.

Referências: $B C D$, Peloponnesos*: 1409; Williams III, 3, 155b (cunhagem de Kleitor).

Exemplares similares: $B C D$, Peloponnesos: 1410 (reverso com inscrição ARKADIKO , Williams III, 3, 159);

1411 (Reverso com inscrição ARKA e cabeça de Kallisto com coque, Williams III, 4, 168d).

\section{Liga Arcádia}

Data: c.460-450 a.C. (mestre de Paris)

Anverso: Zeus Lykaios visto parcialmente de lado, sentado à $\mathrm{d}$. em trono baixo com cabeça de cisne no topo do encosto, segurando cetro longo com sua mão esquerda e águia em pé à d.com asas abertas sobre sua direita.

Reverso: Cabeça de Kallisto três quartos de frente à d., usando colar com pingente e com seu cabelo preso por uma taenia e amarrado em um coque atrás; tudo dentro de um quadrado incuso; ARKADIKON retrogrado.

Metal / denominação: AR / hemidracma.

Referências: BCD, Peloponnesos*: 1713; Williams III, 2, 185 (cunhagem de Tegea).

Exemplares similares: $B C D$, Peloponnesos: 1714 (reverso com cabeça de Kallisto quase que de frente); Williams III, 2, 186a. 


\section{Liga Arcádia}

Data: c.460-450 a.C.

Anverso: Zeus Lykaios laureado visto parcialmente de lado, sentado à $\mathrm{d}$. em trono baixo com cabeça de cisne no topo do encosto, segurando cetro longo com sua mão esquerda e águia em pé à d.com asas abertas sobre sua direita.

Reverso: Cabeça de Kallisto três quartos de frente à d., usando colar com pingente e com seu cabelo preso por uma taenia e amarrado em um coque atrás; tudo dentro de um quadrado incuso; ARKADIKON retrogrado.

Metal / denominação: AR / hemidracma.

Referências: BCD, Peloponnesos*: 1715; Williams III, 3, 196 (cunhagem de Tegea).

\section{Liga Arcádia}

Data: c.460-450 a.C.

Anverso: Zeus Lykaios sentado à e. em trono baixo, segurando cetro com sua mão esquerda e águia sobre sua mão direita.

Reverso: Cabeça de Kallisto à e., usando colar e com seu cabelo preso por uma taenia e pendurado por uma trança atrás; $K$

Metal / denominação: AR / hemidracma.

Referências: BCD, Peloponnesos*: 1716; Williams 218b (cunhada em Tegea). 


\section{Liga Arcádia}

Data: c.460-450 a.C.

Anverso: Zeus Lykaios sentado à e. em trono baixo com apoio para os pés e cabeça de cisne

no topo do encosto, segurando cetro longo com sua mão direita e raio com a e., águia voando à d.

Reverso: Cabeça de Kallisto à e., usando sakkos com taenia; tudo dentro de um quadrado incuso.

Metal / denominação: AR / óbolo.

Referências: $B C D$, Peloponnesos*: 1456; Williams III, 1, 229 (cunhagem de Mantinéia).

Exemplares similares: $B C D$, Peloponnesos: 1457 (hemidracma, reverso com inscrição A-R-K-A e Kallisto usando

taenia, um colar com um único pingente e seu cabelo preso por uma trança, Williams III, 2, 238); 1458 (hemidracma, Williams III, 2, 240).

\section{Liga Arcádia}

Data: c. $460-450$ a.C.

Anverso: Zeus Lykaios sentado no trono à d., vestindo himátion e chiton, segurando raio com a mão direita e braço abaixado, e águia sobre mão e.

Reverso: Cabeça de Kallisto à d., usando taenia; tudo dentro de um quadrado incuso; ARKAL-IKON.

Metal / denominação: AR / hemidracma.

Referências: William: Período III, 163 (cunhagem de Kleitor); Roma Numismatic Auction 8, lote 252. 


\section{6. Élis-Olímpia, Peloponeso}

Data: c. 452 a.C. a c. 432 a.C.

Anverso: Zeus sentado no trono à e. segurando um cetro com a mão e. e a águia voando próximo ao braço $\mathrm{d}$.

Reverso: Nike sentada à e. com suas asas abertas e segurando um cetro com a mão d.; A / F.

Metal / Denominação: AR / estater.

Referências: Seltman: $99(A Z / \beta \sigma)$.

\section{Galária, Sicília}

Data: c. 450 a.C.

Anverso: Zeus Sóter sentado no trono à e., segurando cetro com a mão e. e sobre o cetro encontra-se a águia parada, círculo de pérolas ; ¿O TEP.

Reverso: Dioniso jovem vestindo um longo chíton, segurando um cântaro com a mão d. e com a mão e. um cacho de uvas; $C A$ / $\Lambda$ A.

Metal / denominação: AR / .45 litra.

Referências: BMC Sicily: 1, p.64; Mildenberg e Hurter, ASDCGC*: Pr.28, 591. 


\section{Abakainon, Sicília}

Data: c. 450 a.C.

Anverso: Cabeça de Zeus (?) à d. com coroa de folhas de oliveira, cabelos e barba curtos; círculo de pontos.

Reverso: Javali à d.; grão de orzo à d. no campo; AINI (retrogrado) / ABAK.

Metal / Peso: AR / 1,08g.

Referências: Rizzo, 2011: pr.Vl, 1.

Exemplares similares: Rizzo, 2011: pr.VI, 2-8; VII, 9-14

\section{Liga Arcádia}

Data: c.450-440/30 a.C.

Anverso: Zeus Lykaios sentado à e. em trono baixo com apoio para os pés e cabeça de cisne no topo do encosto, segurando cetro longo com sua mão direita e raio com a e., águia voando à e.

Reverso: Cabeça de Kallisto à d., com seu cabelo enrolando ao redor de sua taenia e vestindo um colar simples com um pingente e um brinco de cacho de uva; tudo dentro de um quadrado incuso.

Metal / denominação: AR / hemidracma.

Referências: BCD, Peloponnesos*: 1459; Williams IV, 1, 244 (cunhagem de Mantinéia).

Exemplares similares: $B C D$, Peloponnesos: 1460 (reverso com inscrição A-R-K-A e Kallisto usando taenia, um colar com um único pingente e um brinco com um pingente e seu cabelo com uma trança atrás, Williams IV, 1, 250); 1461 (óbolo, Williams IV, 1, 273); 1462 (reverso com inscrição A-R-K-A, Williams IV, 5, Ob.188 [251 e 283]); 1463 (reverso com inscrição [AR]KA $\Delta I K O[N]$,

Kallisto com cabelo preso por coque, usando taenia, um colar de pingentes, Williams IV, 5, 292c; 1464 (cabeça de Kallisto à e.,

usando uma coroa e um colar de pérolas, com cabelo apertado embaixo da coroa). 


\section{Kheriga, Lycia}

Data: c.450-435 a.C.

Anverso: Cabeça de Atena à d. com elmo ático.

Reverso: Cabeça de Zeus Amon à d. com cabelos e barba curtos; tudo dentro de

um quadrado incuso de pérolas; Kheriga.

Metal / peso: AR? / 2,05g.

Referências: CLD, 1976: Pr.II, 25.

\section{Cyzicus, Mysia}

Data: c.450-400 a.C.

Anverso: Zeus sentado à d. sobre os joelhos, vestindo um himátion, segurando um cetro

Com a mão direita e a águia com a mão esquerda.; embaixo, atum à d.

Reverso: Quadrado incuso.

Metal / denominação: El / estater.

Referências: Greenwell, Nr. 2, Taf. I 2; von Fritze, Nomisma VII 145 Taf. IV 32; SNG France 296;

Auction 154: $\underline{\text { http://www.acsearch.info/search.html?term=Cyzicus+stater\&category=1\&images=1\&currency=usd\&order=0 }}$ 


\section{Cyzicus, Mysia}

Data: c.450-400 a.C.

Anverso: Cabeça de Zeus Amon à d. com cabelos curtos e barba curta.

Reverso: Quadrado incuso "mil-sail pattern".

Metal / peso: El / 247.1.

Referências: BMC Mysia: Pr. VI, 1 (período III).

\section{Emissão incerta?, Lesbos (sem imagem?)}

Data: c.440-350 a.C.

Anverso: Cabeça de Zeus Amon à d. com cabelos curtos e barba curta?

Reverso: Cabeça feminina à d. usando um stephano; tudo dentro de um quadrado incuso.

Metal / peso: El / ?

Referências: BMC Troas, Aeolis and Lesbos: Pr. XXXII, 26.

\section{Cirene, Líbia}

Data: c.435 a.C.

Anverso: Silphium.

Reverso: Cabeça de Zeus Amon à d. com cabelos e barba curtos, tudo dentro de cículo de pérolas.

Metal / denominação: AR / hemidracma.

Referências: Kraay, ACGC: Pr.62, 1077.

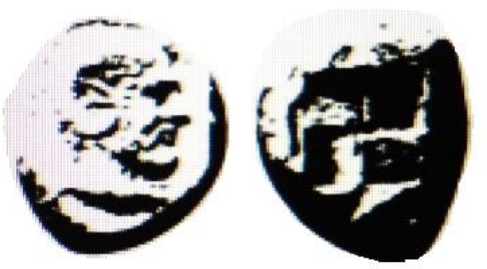




\section{Barce, Líbia}

Data: c. 435 a.C.

Anverso: Silphium.

Reverso: Cabeça de Zeus Amon à d. com cabelos e barba curtos dentro de um cículo de pérolas; fora, BAP]KAIO[N.

Metal / denominação: AR / tetradracma.

Referências: Kraay, ACGC*: Pr.62, 1073; BMC Cyrenaica: 9, p.94, pr.XXXIV, 4.

\section{Cirene, Líbia}

Data: c.435-308 a.C

Anverso: Silphium de tipo IIB; K P N] / V A A.

Reverso: Cabeça de Zeus Amon à d. com cabelos e barba curtos e desgrenhados.

Metal / denominação: AR / tetradracma asiático.

Referências: BMC Cyrenaica: 69, p. 17, pr. VIII, 1.

\section{Cirene, Líbia}

Data: c.435-308 a.C.

Anverso: Silphium de tipo IC; V A] / K P (retrogrado).

Reverso: Cabeça de Zeus Amon à e. com cabelos e barba curtos.

Metal / denominação: AR / tetradracma asiático.

Referências: BMC Cyrenaica: 71, p. 17, pr. VIII, 9. 


\section{Barce, Líbia}

Data: c.435-308 a.C.

Anverso: Silphium de tipo IC; B P A / A K [I.

Reverso: Cabeça de Zeus Amon à d. com cabelos encaracolados e barba curtos e desgrenhados, dentro de um círculo incuso.

Metal / denominação: AR / tetradracma asiático.

Referências: BMC Cyrenaica: 24, p. 99, pr. XXXV, 8.

\section{Ambrácia, Épiro}

Data: c. 432-342 a.C.

Anverso: Pégaso voando à e.

Reverso: Cabeça de Atena à d. com elmo coríntio; à e., Zeus em pé à d. atirando o raio com a mão direita. Metal / denominação: AR / 130.5grns

Referências: BMC Corinth and Colonies: Pr. XXVIII, 12.

\section{Parrhasia, Arcádia}

Data: c. 431-370 a.C.

Anverso: Cabeça laureada de Zeus à d. com cabelos longos e barba pontuda.

Reverso: RАГГ.

Metal / denominação: AR / óbolo.

Referências: BMC Peloponnesus: PI. XXXV, 22. 


\section{Corinto, Peloponeso}

Data: c.430-330 a.C.

Anverso: Pégaso voando à e.; koppa.

Reverso: Cabeça de Atena à e. usando elmo; à d., estátua de Zeus em pé à d. segurando raio e bastão, dentro de um círculo incuso raso.

Metal / denominação: AR / estater.

Referências: SNG Lockett Collection Vol. III: 2060.

Exemplares similares: BMC Corinth and Colonies: Pr. IV, 14 (400-338 a.C.).

\section{Corinto, Peloponeso}

Data: c.430-330 a.C.

Anverso: Pégaso voando à e.

Reverso: Cabeça de Atena à d. usando elmo; à e., estátua de Zeus em pé à e. segurando raio e bastão; acima, cabeça de leão à d.

dentro de um círculo incuso raso.

Metal / denominação: AR / estater.

Referências: SNG Lockett Collection Vol. III: 2061.

Exemplares similares: BMC Corinth and Colonies: Pr. IV, 15 (400-338 a.C.). 


\section{Liga Arcádia}

Data: c.430-420 a.C.

Anverso: Cabeça de Zeus à d. com cabelos e barba longos.

Reverso: Cabeça de Hermes à d. usando um petasos; tudo dentro de um quadrado incuso.

Metal / denominação: AR / hemióbolo.

Referências: BCD, Peloponnesos: 1468 (cunhagem de Mantinéia).

\section{Metaponto, Itália do Sul}

Data: c.425-350 a.C.

Anverso: Cabeça de Zeus Amon à d. com cabelos e barba curtos.

Reverso: Grão-de-trigo.

Metal: $A E$

Peso: $4,34 \mathrm{~g}$

Referências: SNGCop*: 1248; Rutter, HN: 1603.

\section{Liga Arcádia}

Data: c.420 a.C.

Anverso: Cabeça de Zeus à e. com cabelos e barba curtos.

Reverso: Cabeça de Hermes à d. usando um barrete; tudo dentro de um quadrado incuso.

Metal / denominação: AR / hemióbolo.

Referências: $B C D$, Peloponnesos: 1469 (cunhagem de Mantinéia). 


\section{Liga Arcádia}

Data: c.420 a.C.

Anverso: Zeus Lykaios sentado à e. em trono baixo com apoio para os pés e cabeça de

cisne no topo do encosto, segurando cetro longo com sua mão direita e raio com a e., águia voando à d.

Reverso: Cabeça de Kallisto à e., com cabelo enrolado ao redor de sua fronte e um coque atrás;

tudo dentro de um quadrado incuso; A- - - $[A]$.

Metal / denominação: AR / hemidracma.

Referências: $B C D$, Peloponnesos: 1465 (cunhagem de Mantinéia).

Exemplares similares: BCD, Peloponnesos: 1466 (cabeça de Kallisto à d., com seu cabelo em um sakkos e usando um brinco simples e um colar de pérolas, Williams V, 306a); 1467 (reverso com inscrição A-P-[K-A], Kallisto com cabelo delimitado por uma taenia dupla, Williams V, 308).

\section{Posidônia, Itália do Sul}

Data: c.420-390 a.C.

Anverso: Zeus em pé, com as pernas abertas, atirando o raio com a mão d. e sobre o braço e. estendido,

a águia; o golfinho no lado d. do campo; $\Pi \mathrm{EEI} \Delta \mathrm{A}$.

Reverso: Touro; embaixo, uma lula; ПО乏EI $\Delta$.

Metal / peso: AE / 2,46g.

Referências: SNG John Morcom Collection: vol.X, 299 (SNGuk_1000_0299) (c.430-400 a.C.).

Exemplares similares: Rutter, HN: Pr.22, 1154; Granauer: 6 e 7, IV (c.410-405 a.C.); SNG München: 1079 (c.410-405 a.C.). 


\section{Parrhasia, Arcádia}

Data: Final do séc. V - início IV a.C.

Anverso: Cabeça laureada de Zeus à d., com barba pontuda e cabelo comprido.

Reverso: ПА o redor de um grande $\Pi$ com grande e pequeno pi retrogrado.

Metal / denominação: AR / óbolo.

Referências: BCD, Peloponnesos: 1594.

\section{SÉCULO IV a.C.}

\section{Cirene, Líbia}

Data: c.400 a.C

Anverso: Silphium tipo IIC; K P N / V A A

Reverso: Cabeça de Zeus Amon à d. com cabelos e barba curtos.

Metal / denominação: AR / tetradracma.

Referências: Kraay, ACGC*: Pr.62, 1074; BMC Cyrenaica: 74, p.18, pr.IX, 4. 


\section{Pitane, Mysia}

Data: 400-380 a.C.

Anverso: Cabeça de Zeus Amon com barba.

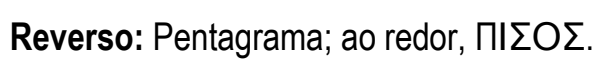

Metal / peso: AE/ 0,65 g.

Referências: BMC 4; Imhoof ZfN I, p. 138

(http://www.wildwinds.com/coins/greece/mysia/pitane/BMC_04.txt).

\section{Kierion, Tessália}

Data: $400-360$ a.C.

Anverso: Cabeça masculina à d. (provavelmente Zeus) com cabelos e barba curtos, presos por uma fita ou coroa com folhas bem pequenas.

Reverso: Ninfa Arne ajoelhada sobre joelho direito e jogando astrágalos; KIEPIE[ISN].

Metal / denominação: $A E$ / dichalkon.

Referências: BCD Thessaly (Nomos): 1068, p.49.

\section{Kierion, Tessália}

Data: 400-360 a.C.

Anverso: Cabeça de Zeus à e. com cabelos e barba compridos (pontuda).

Reverso: Ninfa Arne ajoelhada sobre joelho direito e jogando astrágalos; KIEP/ IEI/ $\Omega$ N.

Metal / denominação: AE / dichalkon.

Referências: BCD Thessaly (Nomos): 1070, p.49. 


\section{Aenianes (Aeniania), Tessália}

Data: c.400-344 a.C.

Anverso: Cabeça laureada de Zeus à e.

Reverso: Guerreiro atirando no javali e segurando chlamys e petasos; Aıvıav wV.

Metal / denominação: AR/ hemidracma.

Referências: SNGCop Thessaly to Aegean Islands: Pr.1, 1; BCD Thessaly: 23, p.22.

\section{Aenianes (Aeniania), Tessália}

Data: c.400-344 a.C.

Anverso: Cabeça laureada de Zeus à e.

Reverso: Espada na bainha e javali; à e., Aıvıav.

Metal / denominação: AR / óbolo.

Referências: SNGCop Thessaly to Aegean Islands: Pr.1, 3; BCD Thessaly: 28, p.24.

\section{Kierion (Thessaliotis), Tessália}

Data: c.400-344 a.C.

Anverso: Cabeça laureada de Zeus à $\mathrm{d}$.

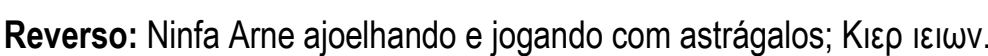

Metal / denominação: AR/ trihemióbolo

Referências: SNGCop Thessaly to Aegean Islands: Pr.1, 32; BCD Thessaly: 104.1, p.65.

Exemplares similares: $B C D$ Thessaly: 100, p.64; $B C D$ Thessaly (Nomos): 1073, p.50 


\section{Gyrton (Pelasgiotis), Tessália}

Data: 400-344 a.C.

Anverso: Cabeça laureada de Zeus à $\mathrm{d}$.

Reverso: Cavalo arreado; Гupt $\omega$ viwv

Metal / peso: AE/ 6,62 g.

Referências: SNGCop Thessaly to Aegean Islands: Pr.2, 59; BMC Thessaly: Pr. III, 5 e 6.

\section{Phalanna (Perrhaebia), Tessália}

Data: c.400-344 a.C.

Anverso: Cabeça laureada de Zeus (?) à d.; abaixo, $\Lambda$ o.

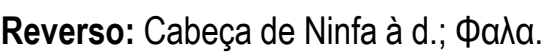

Metal / peso: AE/ 4,80 g.

Referências: SNGCop Thessaly to Aegean Islands: Pr.4, 208.

Exemplares similares: SNGCop Thessaly to Aegean Islands: Pr.4, 173.

\section{Kierion, Tessália}

Data: Início do século IV a.C.

Anverso: Cabeça laureada de Zeus à d. com cabelos e barba curtos.

Reverso: Cabeça da ninfa Arne à d. com cabelo preso com uma banda ou diadema; [K] / / E (retrogrado).

Metal / denominação: AR / hemióbolo.

Referências: BCD Thessaly: 98, p.63.
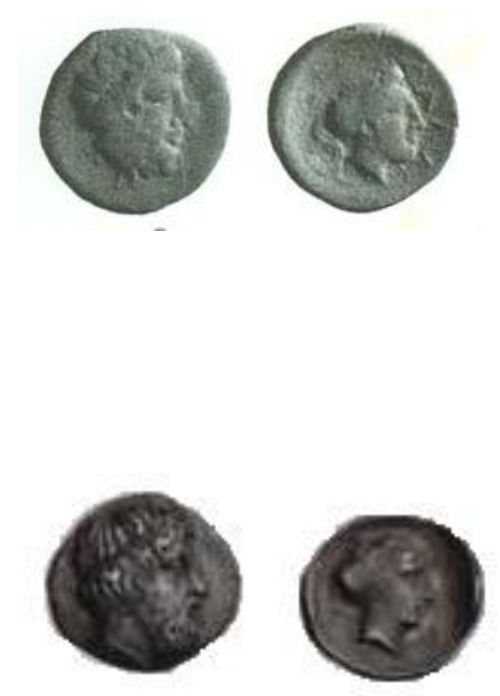


\section{Krannon, Tessália}

Data: $1^{\text {a }}$. metade do século IV a.C.

Anverso: Cabeça laureada de Zeus à d. com cabelos e barba curtos.

Reverso: Cavaleiro à d. usando petasos; embaixo, tridente; KPA.

Metal / denominação: AE / dichalkon.

Referências: BCD Thessaly (Nomos): 1081.1, p.52.

Exemplares similares: BCD Thessaly (Nomos): 1081.2, p.52.

\section{Melitaia, Tessália}

Data: $1^{\text {a }}$. metade do século IV a.C.

Anverso: Cabeça laureada de Zeus à d. com cabelos e barba curtos. Reverso: Prótomo de touro à $\mathrm{d}$. com cabeça levemente para a frente, tudo dentro de uma coroa de folhas de carvalho; M / E / $\Lambda$ / I.

Metal / denominação: AR / hemidracma.

Referências: BCD Thessaly (Nomos): 1198, p.84.

\section{Pharos, llíria}

Data: $1^{\text {a }}$. metade do séc. IV a.C.

Anverso: Cabeça laureada de Zeus à e. com cabelos e barba curtos.

Reverso: Cabra em pé à e.; embaixo; ФAPI.

Metal / denominação: AR / tetróbolo.

Referências: Mandinic, GN: $87^{*}$ e 88 . 


\section{Pharos, llíria}

Data: $1^{\text {a }}$. metade do século IV a.C.

Anverso: Cabeça laureada de Zeus à e. com cabelos e barba curtos.

Reverso: Cabra em pé à e.; à e., cobra; embaixo; $\Phi A P I \Omega N$.

Metal / denominação: AE / hemilitra.

Referências: Mandinic, GN: 89.

Exemplares similares: Mandinic, GN: 90; 91; 92; 93.

\section{Pharos, llíria}

Data: $1^{\text {a }}$. metade do séc. IV a.C.

Anverso: Cabeça de Zeus à e.

Reverso: Cabra

Metal / peso: AE/ 17,24 g.

Referências: SNGCop Thessaly to Aegean Islands: Pr.11, 545.

Exemplares similares: SNGCop Thessaly to Aegean Islands: Pr.11, 546.

\section{Hekatomnos (Mylasa), Cária}

Data: c.380 a.C.

Anverso: Zeus Labraundos em pé à d., vestindo himation, segurando labrys com a mão $\mathrm{d}$.

e lança (?) com a e.

Reverso: Leão em posição de ataque à d.; em cima no campo, EKATOMNO?

Metal / denominação: AR / tetradracma.

Referências: Konuk, CIUH: PI.2, 15. 


\section{Maussollos (Mylasa), Cária}

Data: c.377 a.C.

Anverso: Zeus Osogollis em pé à e., vestindo himation, segurando um tridente com a mão d. e uma águia (??) com a e.

Reverso: Zeus Labraundos em pé à d., vestindo himation, segurando labrys com a mão d.

e lança (?) com a e.; MA.

Metal / denominação: AR / tetradracma.

Referências: Konuk, CIUH: PI.2, 19.

\section{Maussollos (Mylasa), Cária}

Data: c.377 a.C.

Anverso: Rei Maussollos em pé à d. com um kindaris, atirando com um arco.

Reverso: Zeus Labraundos em pé à d., vestindo himation, segurando labrys com a mão d.

e lança (?) com a e.

Metal / denominação: AR / tetradracma.

Referências: Konuk, CIUH: PI.2, 20. 


\section{Mytilene, Lesbos}

Data: 377-326 a.C.

Anverso: Cabeça laureada de Zeus à d. com cabelos e barba curtos (?).

Reverso: Prótomo de serpente à d. dentro de um quadrado.

Metal / denominação: El / hekte.

Peso: 2,54g.

Referências: SNG Ashmolean Museum (SNGuk_0509_1540).

\section{Cirene, Líbia}

Data: $375-308$ a.C.

Anverso: Quadriga em três-quartos à d. em rápido movimento, dirigida por um cocheiro homem.

Reverso: Zeus Amon em pé de frente com cabeça virada para a d., vestindo um himation

e segurando longo cetro com a mão direita; silphium no campo à d.

Metal / denominação: AV / estater.

Referências: BMC Cyrenaica: 105, p. 25, pr. XIII, 2. 


\section{Cirene, Líbia}

Data: $375-308$ a.C

Anverso: Quadriga em três-quartos à d. no ato de retornar, dirigida por um cocheiro homem.

Reverso: Zeus Lycaeus sentando no trono à e., segurando uma águia com a mão direita estendida, tem o cabelo longo laureado e veste um himation; no campo o nome do magistrado, KY $\triangle \mid O \Sigma \Theta . . . ?$

Metal / denominação: AV / estater.

Referências: BMC Cyrenaica: 114, p. 28, pr. XIII, 21.

\section{Maussollos (Halikarnassos), Cária}

Data: c.370/360 a.C.

Anverso: Cabeça de Apolo de frente.

Reverso: Zeus Labraundos em pé à d., vestindo himation, segurando labrys com a mão $\mathrm{d}$.

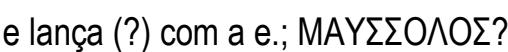

Metal / denominação: AR / tetradracma.

Referências: Konuk, CIUH: PI.2, 21. 


\section{Liga Acaia}

Data: c.370-360 a.C.

Anverso: Cabeça de Ártemis à e.

Reverso: Zeus sentado no trono à e. com cetro na mão d. (?) e sobre a mão e. a águia e sob a mesma mão, um elmo.

Metal / denominação: AR / didracma.

Referências: Kraay, ACGC: Pr.17, 318.

\section{Messênia, Peloponeso}

Data: c. 370/69-330 a.C.

Anverso: Cabeça de Deméter à e.

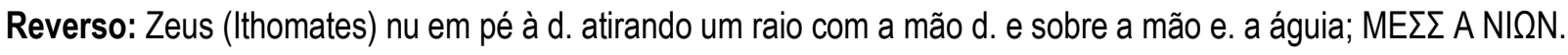

Metal / denominação: AR / didracma.

Referências: Kraay, ACGC*: pr.17, 322; BMC Peloponnesus: PI. XXII, 1; SNGCop Thessaly to Aegean Islands: pr.10, 501.

Exemplares similares: Grandjean, BCH, Suppl. 44: Pr.l, 3-4 (trióbolos). 


\section{Megalópolis, Liga Arcádia}

Data: 363-362 a.C.

Anverso: Cabeça laureada de Zeus Lykaios à e.

Reverso: Pã jovem à e., nu, sua cabeça está de frente, sentado em uma rocha coberta por seu manto, segurando lagobolon em sua mão direita e descansando seu braço esquerdo na rocha, syrinx; em pequenas letras, O^YM; no campo à e., AR.

Metal / denominação: AR / estater.

Referências: $B C D$, Peloponnesos: 1511.

Exemplares similares: BCD, Peloponnesos: 1512; 1513; Kraay, ACGC: Pr.17, 319.

\section{Megalópolis, Liga Arcádia}

Data: $363-350$ a.C.

Anverso: Cabeça laureada de Zeus à e.

Reverso: AR sobre syrinx; tudo dentro de uma coroa de folhas de carvalho, tries acima.

Metal / denominação: AE / trichalkon.

Referências: $B C D$, Peloponnesos: 1514.

Exemplares similares: $B C D$, Peloponnesos: 1515; 1516.1; 1516.2 


\section{Lampsacos, Mysia}

Data: 362 a.C.

Anverso: Cabeça laureada de Zeus à d. com cabelos curtos e barba curta?

Reverso: Prótomo de Pégaso à d.; inscrição?

Metal / peso: AE / 1,90g.

Referências: SNGCop: 199.

\section{Liga Tessália}

Data: $361-360$ a.C

Anverso: Cabeça laureada de Zeus à $\mathrm{d}$. com cabelos e barba curtos.

Reverso: Prótomo de cavalo à d. emergindo de uma rocha; $\Pi E T / \Theta A / \wedge \Omega N$.

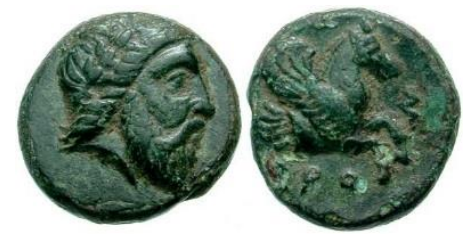

Metal / denominação: AE / chalkous.

Referências: $B C D$, Thessaly: 23, p.22.

\section{7. Élis-Olímpia, Peloponeso}

Data: 360 a.C.

Anverso: Cabeça laureada de Zeus à e. com cabelos e barba curtos; $F A \wedge E I O N$.

Reverso: Cabeça da ninfa epônima Olímpia à d., usando brinco com pendente e com seu cabelo em um sphendone; OЛYMПIA.

Metal / denominação: AR / estater.

Referências: BCD, Olympia*: 118; Seltman: 175 (CA/סג); Kraay, ACGC: 334 


\section{8. Élis-Olímpia, Peloponeso}

Data: 360 a.C.

Anverso: Cabeça de Zeus à d., usando taenia, com cabelos e barba curtos.

Reverso: FA $\wedge$ nos intervalos entre TTT.

Metal / denominação: AR / tritetartemorion.

Referências: BCD, Olympia*: 120; Seltman: pr.VIII, 25.

\section{Cirene, Líbia}

Data: c.360 a.C.

Anverso: Cabeça de Zeus Amon de frente e à e., usando um diadema laureado.

Reverso: Silphium tipo IIA; V P A / K A N (retrogrado).

Metal / denominação: AR / tetradracma.

Referências: Kraay, ACGC*: Pr.62, 1075; BMC Cyrenaica: 77, p.19, pr.IX, 9.

\section{Barce, Líbia}

Data: c.360 a.C.

Anverso: Triplo silphium, coruja, camelo e jerboa; B A P K A I O N (retrogrado).

Reverso: Cabeça de Zeus Amon de frente.

Metal / denominação: AR / tetradracma.

Referências: Kraay, ACGC*: Pr.62, 1076; BMC Cyrenaica: 33, p.101, pr.XXXVI, 9. 


\section{Felipe II, Macedônia}

Data: 359-336 a.C. (emitida em Philippi)

Anverso: Cabeça laureada de Zeus à d. com cabelos longos e barba, círculo de pérolas?

Reverso: O rei montado à e. sobre um cavalo; ФINIП ПOY.

Metal / denominação: AR / tetradracma.

Referências: SNGCop Thrace and Macedonia: Pr.13, 543.

Exemplares similares: Kraay, ACGC: pr.28, 512; SNGCop Thrace and Macedonia: Pr.13, $544-547$ (emitidas em Philippi),

548-549 (emitidas em Pella), 550-559 (emitidas em Amphipolis), 560-563 (emitidas em Uranopolis), 564-565 (emissões de oficinas incertas).

\section{Iolla, Mysia}

Data: Metade do século IV a.C.

Anverso: Cabeça laureada de Zeus à d. com cabelos e barba compridos.

Reverso: Prótomo de cavalo alado à d.; embaixo, grão de trigo; IO $M$ A.

Metal / denominação: AE / 17.

Referências: Sear, GCTV, vol. 2: 3875.

\section{Melitaia (Phthiotis), Tessália}

Data: Metade do século IV a.C.

Anverso: Cabeça laureada de Zeus à e. com cabelos e barba curtos (?).

Reverso: Abelha; M / E / $/$ I.

Metal / denominação: $A E$ / chalkous.

Referências: BCD Thessaly: 458.2, p. 202. 


\section{Gonnos (Pelasgiotis), Tessália}

Data: 350 s a.C.

Anverso: Cabeça laureda de Zeus à $\mathrm{d}$.

Reverso: Carneiro; abaixo monograma; Гov vewv.

Metal / peso: AE/ 5,84 g.

Referências: SNGCop Thessaly to Aegean Islands: Pr.2, 53;

BCD Thessaly: 75, p.52.

Exemplares similares: $B C D$ Thessaly: 75 e 76.1 (350s a.C.).

\section{Kierion, Tessália}

Data: c. 350 a.C.

Anverso: Cabeça de Zeus à e. com cabelos e barba compridos.

Reverso: Jovem Asclépio sentado à e. sobre rochas, segurando longo cetro com sua mão e.

E descansando seu braço d. sobre joelho d.; [KIEPIEI $\Omega$ N].

Metal / denominação: AR / estater.

Referências: BCD Thessaly (Nomos): 1071, p.50. 


\section{Melitaia (Phthiotis), Tessália}

Data: c. 350 a.C.

Anverso: Cabeça laureada de Zeus à e. com cabelos longos e barba.

Reverso: Abelha; MENI.

Metal / denominação: AE / dracma.

Referências: SNGCop Thessaly to Aegean Islands: pr.4, 172.

Exemplares similares: SNGCop Thessaly to Aegean Islands: pr.4, 173.

\section{Lampsacos, Mysia}

Data: c. 350 a.C

Anverso: Cabeça laureada de Zeus à e. com cabelos longos e barba longa; atrás, cetro com ponta de lótus.

Reverso: Prótomo de Pégaso dentro de um quadrado incuso parcial.

Metal / denominação: AV / estater.

Referências: Kraay-Hirmer: Pr.202, 729; SNG France: 1138; Traité II: Pr. CLXXI, 3;

BMC Mysia: Pr.XIX, 6 (ao invés de cetro, raio?). 


\section{Gomphi-Philippopolis, Tessália}

Data: c. 350 a.C.

Anverso: Cabeça de Hera de frente, usando stephanos, brincos de pendentes e um colar tipo torque.

Reverso: Zeus sentado à e. sobre rocha, segurando cetro com a mão direita

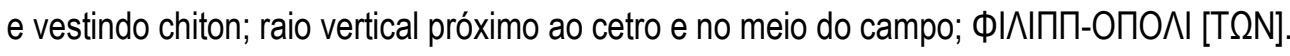

Metal / denominação: AR / hemidracma.

Referências: BCD Thessaly (Nomos): 1041, p.40.

\section{Gomphi-Philippopolis, Tessália}

Data: c. 350 a.C.

Anverso: Cabeça de Hera à d., usando stephanos.

Reverso: Zeus nu em pé atirando raio com a sua mão direita e uma águia voando sobre sua esquerda; ФІ ІІПП-[OПONITSN].

Metal / denominação: AR / óbolo.

Referências: BCD Thessaly (Nomos): 1042, p.40.

\section{Thymbra, Troas}

Data: c.350 a.C.

Anverso: Cabeça de Zeus Amon à e.

Reverso: Estrela; $\Theta Y$.

Metal / peso: AE / ?

Referências: BMC Troas, Aeolis and Lesbos: Pr. XVI, 12. 


\section{Idreus (Halikarnassos), Cária}

Data: c.350-340 a.C.

Anverso: Cabeça de Apolo de frente.

Reverso: Zeus Labraundos em pé à d., vestindo himation, segurando labrys com a mão d.

e com a mão e., cetro com ponta floral tripartida.

Metal / denominação: AR / didracma.

Referências: Konuk, CIUH: PI.3, 27.

Exemplares similares: Konuk, CIUH: PI.3, 28 (tetradracma).

\section{Gomphi-Philippopolis (Histiaeotis), Tessália}

Data: c.350-306 a.C.

Anverso: Hera de frente, usando um stephanos.

Reverso: Zeus Palamnaeus sentado em rochas.

Metal / peso: AE/ 5,97 g.

Referências: SNGCop Thessaly to Aegean Islands: Pr.2, 50.

\section{Leuce, Jônia (sem imagem)}

Data: c.350-300 a.C.

Anverso: Cabeça de javali à d.

Reverso: Cabeça laureada de Zeus à d.; $\Lambda$ EY[K?].

Metal / peso: AR / 7.4.

Referências: BMC lonia: Pr. XVII, 13. 


\section{Ekkara (Phthiotis?), Tessália}

Data: c.350-300 a.C.

Anverso: Cabeça laureada de Zeus à e.

Reverso: Ártemis em pé; Eкkapєwv.

Metal / peso: AE/ 1,44 g.

Referências: SNGCop Thessaly to Aegean Islands: Pr.1, 47;

$B C D$, Thessaly: 65.1 e 65.2, p.45 (datadas de 325-320 a.C.).

Exemplares similares: SNGCop Thessaly to Aegean Islands: Pr.1, 48.

\section{Kierion, Tessália}

Data: 2a. metade séc. IV a.C.

Anverso: Cabeça laureada de Apolo à d.

Reverso: Zeus nu em pé à d., atirando raio com sua mão d. e águia voando próxima ao seu braço e. estendido; no campo à d., Arne ajoelhada jogando astrágalos; KIEPIE [ISN].

Metal / peso: AE / trichalkon.

Referências: $B C D$ Thessaly: 101, p.64. 


\section{Nisyros, Cária}

Data: $2^{\mathrm{a}}$.metade do séc. IV a.C.

Anverso: Cabeça de Zeus Amon à d.

Reverso: Golfinho; abaixo, Nı.

Metal / peso: AE / 0,99 g.

Referências: SNGCop Jonia, Caria and Lydia: Pr.17, 708.

Exemplares similares: Sear, GCTV, vol.II: 5028

\section{Sesamus, Paphlagonia (sem imagem?)}

Data: Última metade do séc. IV a.C.

Anverso: Cabeça laureada de Zeus à e. com cabelo curto (?) e barba longa.

Reverso: Cabeça feminina (Ártemis?) à e.; $\Sigma \mathrm{H} / \Sigma \mathrm{A}$.

Metal / peso: AE / ?

Referências: BMC Pontus, Paphlagonia, Bithynia and the King of Bosphorus: Pr. XXI, 9.

\section{Cromna, Paphlagonia}

Data: Última metade do séc. IV a.C.

Anverso: Cabeça laureada de Zeus à e. com cabelos longos e barba curta?

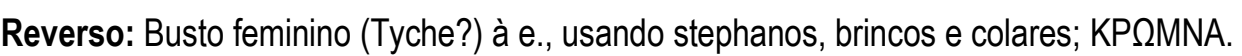
Metal / peso: AR / 52:4.

Referências: BMC Pontus, Paphlagonia, Bithynia and the King of Bosphorus: Pr.XXI, 1. 


\section{Aenianes, Tessália}

Data: Séc. IV-III a.C.

Anverso: Cabeça de Zeus à e.

Reverso: Lançador ajustando sua lança; embaixo dele, dois javalis; Aıvıa vwv.

Metal / peso: AE/ 4,13 g.

Referências: SNGCop Thessaly to Aegean Islands: Pr.1, 4.

Exemplares similares: SNGCop Thessaly to Aegean Islands: Pr.1, 5; BCD Thessaly: 31.1 (IV-III a.C.).

\section{Pitane, Mysia}

Data: Séc. IV-III a.C.

Anverso: Cabeça de Zeus Amon com barba.

Reverso: Pentagrama; Пıта.

Metal / peso: AR / 4,23 g.

Referências: SNGCop Bosphorus-Bithynia: Pr.14, 530; Sear, GCTV, vol.Il: 3879 e 3970.

Exemplares similares: SNGCop Bosphorus-Bithynia: Pr.14, 531-535 


\section{ÁGUIAS}

\section{SÉCULO VII-VI a.C.}

101. Cyzicus, Mysia (sem imagem)

Data: VII e VI a.C.

Anverso: Cabeça de águia à d. com atum no bico.

Reverso: Quadrado incuso.

Metal / peso: El / 20.6.

Referências: BMC, Mysia: Pr.III, 12.

102. Emissão incerta, Jônia (sem imagem)

Data: VII e VI a.C. (padrão eubóico)

Anverso: Águia voando à d.

Reverso: Quadrado incuso.

Metal / peso: El / 22.15.

Referências: BMC, Ionia: Pr.ll, 21. 


\section{SÉCULO VI a.C.}

\section{Emissão incerta, Jônia}

Data: c.600-550 a.C.

Anverso: Águia em pé à d. com asas fechadas; tudo dentro de um círculo ornamental.

Reverso: Quadrado incuso com superfície irregular.

Metal / denominação: El / estater.

Peso: 14,10g.

Referências: Ex Fortuna Fine Arts \& Vilmar Collecti bles Coins FPL 2008, lote, 34.

Gemini, LLC, Auction 12 (lote 150).

\section{Sifnos, Egeu}

Data: c.540 a.C.

Anverso: Águia voando à d.

Reverso: Quadrado incuso dividido em compartimentos triangulares.

Metal / denominação: AR / estater.

Peso: $12,38 \mathrm{~g}$

Referências: SNGCop Bosphorus-Bithynia: Pr.16, 744; Kraay, ACGC*: Pr.6, 119 (c.540 a.C.). 


\section{Crotona, Itália do Sul}

Data: c.530-500 a.C.

Anverso: Trípode; POTO ou POTON

Reverso: Águia voando à d.; incusa.

Metal / denominação: AR / estater.

Referências: Rutter, HN: 2084; Kraay, ACGC*: Pr.35, 620.

\section{Cálcis, Eubéia}

Data: c.515 a.C.

Anverso: Águia voando à d.

Reverso: Roda.

Metal / denominação: AR / tetradracma.

Referências: Kraay, ACGC: Pr.15, 264.

\section{Cálcis, Eubéia}

Data: c.515 a.C. (datado também de 465 a.C.)

Anverso: Águia voando com cobra.

Reverso: Roda.

Metal / denominação: AR / tetradracma.

Referências: Kraay, ACGC: Pr.15, 265.

Exemplares similares: Há um tetróbolo de 465 a.C., cujo anverso é idêntico e o reverso é uma roda dentro de um triângulo incuso? Numismatik Lanz München, Auktion 111, Münzen von Euboia, 2002, no.117

(http://www.numislanz.de/auktion111/a111.htm). 


\section{Agrigento, Sicília}

Data: c.510 a.C.

Anverso: Águia à e. com asas fechadas; ao redor, Akpa yavtos.

Reverso: Caranguejo.

Metal / denominação: AR / didracma.

Referências: Kraay, ACGC: Pr.46, 790; SNGCop Italy-Sicily*: Pr.1, 20-23

(com variações na posição e. ou d. das águias e nas inscrições); Cahn et alii, GMGS: 252.

109. Cálcis, Eubéia (sem imagem)

Data: Antes de 507 a.C.

Anverso: Águia devorando lebre.

Reverso: Quadrado incuso irregular.

Metal / peso: El / 44,4grs.

Referências: BMC, Central Greece: PI.XX, 12; HN: s/no., p.358. 


\section{Sinope, Paphlagonia}

Data: VI a.C.

Anverso: Cabeça de águia à d.; abaixo, golfinho.

Reverso: Quadrado incuso quadripartido; os compartimentos granulados mais profundos, cada um contendo uma bolinha.

Metal / denominação: AR / dracma.

Peso: $6,14 \mathrm{~g}$.

Referências: SNGCop Bosphorus-Bithynia: Pr.8, 272.

Exemplares similares: SNGCop Bosphorus-Bithynia: Pr.8, 273; Kraay, ACGC: Pr.53, 907 (460 a.C.).

\section{Abydus, Troas}

Data: Final do séc. VI - início do séc. V a.C.

Anverso: Cabeça de águia à d., com corpo virado à e.

Reverso: Quadrado incuso.

Metal / peso: El. / 1,10g.

Referências: Classical Numismatic Group, Auction 34, lote 181.
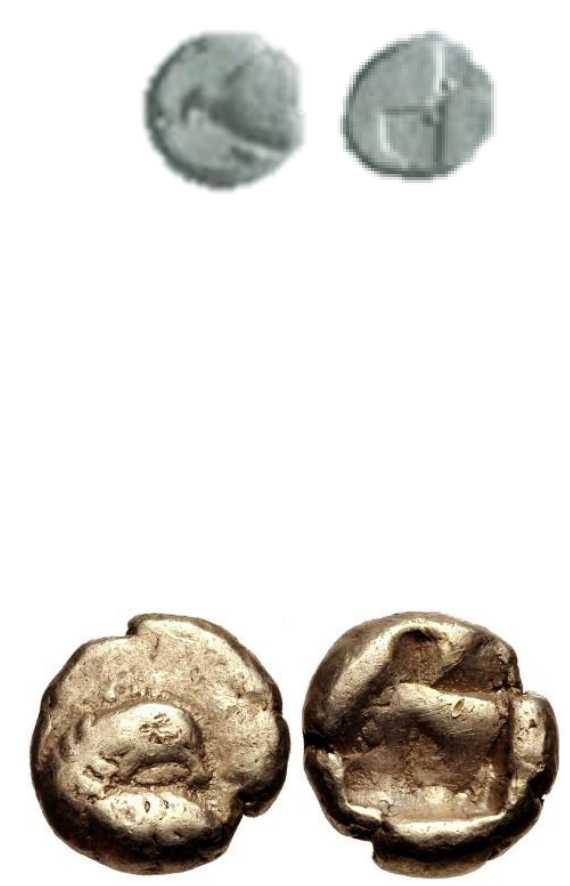


\section{SÉCULO V a.C.}

\section{Emissão incerta, Macedônia}

Data: Início século V a.C.

Anverso: Quadriga com cocheiro; abaixo, símbolo de fertilidade (?).

Reverso: Águia voando à e. dentro de quadrado incuso; tudo dentro de um quadrado incuso.

Metal / denominação: AR / tetradracma.

Referências: Price, CM: Pr.IV, 21.

\section{Cálcis, Eubéia}

Data: c.500 a.C.

Anverso: Águia voando à e.

Reverso: Roda dentro de quadrado incuso.

Metal / denominação: AR / tetradracma.

Referências: Ex Bank Leu 15 (4 May 1976), 220, Numismatik Lanz München, Auktion 111,

Münzen von Euboia, 2002 (http://www.numislanz.de/auktion111/a111.htm). 


\section{Cálcis, Eubéia}

Data: c.500 a.C.

Anverso: Águia voando à e. carregando cobra com o bico e garras?

Reverso: Roda dentro de quadrado incuso irregular.

Metal / denominação: AR / tetróbolo.

Referências: Lote 115, Numismatik Lanz München, Auktion 111, Münzen von Euboia, 2002

(http://www.numislanz.de/auktion111/a111.htm).

\section{Cirene, Líbia}

Data: c.500 a.C.

Anverso: Silphium, fruta e cabeça de leão.

Reverso: Cabeça de águia à d. carregando cobra, tudo dentro de um quadrado incuso pontilhado. Metal / denominação: AR / tetradracma.

Referências: Kraay, ACGC*: Pr.62, 1068; BMC Cyrenaica: 13, p.4, pr.II,4 (525-480 a.C.).

\section{Abydus, Troas}

Data: c.500 a.C.

Anverso: Águia em pé à e., com asas fechadas e cabeça virada à d. e sobre uma lebre

Reverso: Quadrado incuso

Metal / denominação: El. / estater.

Referências: Kraay, ACGC: Pr.4, 75.

Exemplares similares: BMC Ionia: Pr.l, 23 (padrão fenício de 500 a.C. ou antes; no anv., águia dentro de círculo de pérolas). 


\section{Abydus, Troas}

Data: .500 a.C.

Anverso: Águia em pé à e., com asas fechadas e cabeça virada à d.

Reverso: Quadrado incuso

Metal / denominação: El. / estater.

Peso: 4,66 g.

Referências: Aufhauser Sale 20, 2007, 73.

\section{8. lalysos, Rodes}

Data: c.500 a.C.

Anverso: Prótomo de javali alado à d.

Reverso: Cabeça de águia à d. com cobra no bico?

Metal / denominação: AR / tetradracma.

Referências: Kraay, ACGC: Pr.4, 94.

Exemplares similares: The Aegean of the coins, p.99; Sear, GCTV, vol.2: 3559 (cabeça de águia à d. e sem cobra).

\section{Ialysos, Rodes}

Data: c.500 a.C.

Anverso: Prótomo de javali alado à e.

Reverso: Cabeça de águia à e.

Metal / denominação: AR / estater.

Referências: Sear, GCTV, vol.2: 3560. 


\section{Abydus, Troas}

Data: c.500-480 a.C.

Anverso: Águia em pé à e.

Reverso: Quadrado incuso quadripartido.

Metal / denominação: AR / dióbolo.

Referências: SNG von Aulock 1, lote 217 (NumisBids).

\section{1. Éfeso, Jônia}

Data: c.500-420 a.C.

Anverso: Abelha; dentro de um círculo de pérolas.

Reverso: Cabeça de águia à d.; tudo dentro de um quadrado incuso; $E \Phi$.

Metal / denominação: AR / tetartemorion.

Referências: SNG Kayhan: 126 (Forum Ancient Coins).

\section{2. Éfeso, Jônia}

Data: c.500-420 a.C.

Anverso: Abelha; dentro de um círculo de pérolas.

Reverso: Cabeça de águia à d.; tudo dentro de um quadrado incuso; $E \Phi$.

Metal / denominação: AR / tetartemorion.

Referências: https://www.cointalk.com/threads/ancients-the-stag-of-artemis.249728/
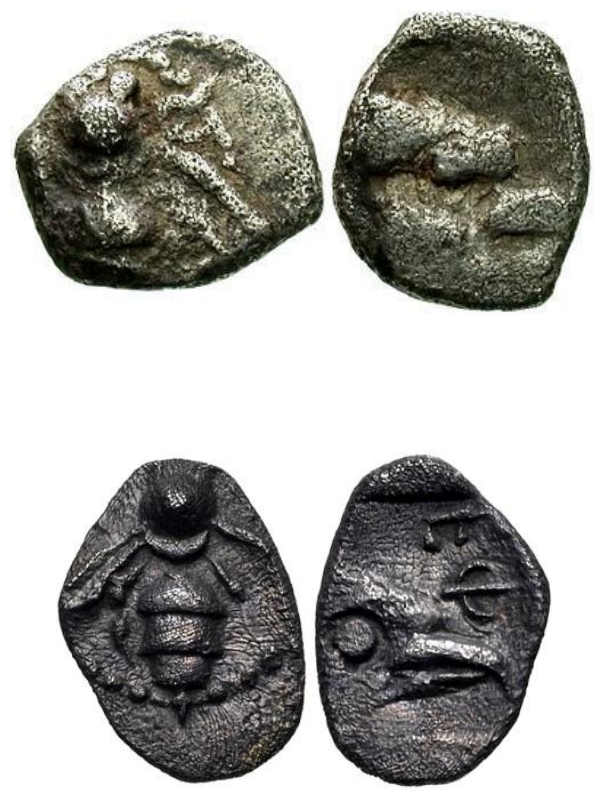


\section{Mileto, Jônia}

Data: $499-494$ a.C.

Anverso: Águia em pé à e. com a cabeça virada à d.

Reverso: Quadrado incuso quadripartido.

Metal / denominação: El / estater.

Referências: Sear, GCTV, vol.2: 3567.

\section{Paphos, Chipre}

Data: c.490 a.C. (governo de Pny(tos) I)

Anverso: Touro à e., acima, traços de inscrição.

Reverso: Cabeça de águia à e., acima à e., palmeta dentro de espirais juntas; abaixo, padrão revestido; tudo dentro de um quadrado incuso pontilhado.

\section{Metal / denominação: AR / estater}

Peso: $10,98 \mathrm{~g}$

Referências: SNGCop Cyprus-Cappadocia: Pr.I, 25; Kraay, ACGC*: Pr.63, 1088. 


\section{Abydus, Troas}

Data: Antes de 480 a.C.

Anverso: Águia em pé.

Reverso: quadrado incuso quadripartido.

Metal / peso: AR / 1,42.

Referências: SNGCop Bosphorus-Bithynia: Pr.1, 1.

Exemplares similares: SNGCop Bosphorus-Bithynia: Pr.1, 2.

\section{Sifnos, Egeu}

Data: Séc. V a.C. (480 a.C.)

Anverso: Cabeça de Apolo à d.

Reverso: Águia voando à d.; acima de sua cabeça, folha de louro; $\Sigma ı \varphi$ retrogrado; tudo dentro de um quadrado incuso.

Metal / denominação: AR / dracma.

Peso: 3,89g.

Referências: SNGCop Bosphorus-Bithynia: Pr.16, 745; Kraay, ACGC*: Pr.6, 125 (c.480 a.C., Kraay diz que anverso é Ártemis).

Exemplares similares: SNGCop Bosphorus-Bithynia: Pr.16, 747 (séc. IV a.C.); The Aegean of the coins, pp.76-77 


\section{Alexandre I, Macedônia}

Data: 480/79-477/76 a.C.

Anverso: Cavaleiro à d., carregando duas lanças; em frente ao cavalo, águia voando à $\mathrm{d}$.

Reverso: Quadrado incuso; ao redor, A^E [EAN $\triangle \mathrm{PO}]$.

Metal / denominação: AR / octadracma.

Referências: Coins of Macedonia, no.11, p.33.

\section{Agrigento, Sicília}

Data: c.480 a.C.

Anverso: Águia em pé à e. com asas fechadas; Aкpa.

Reverso: Caranguejo; embaixo, elmo coríntio.

Metal / denominação: AR / didracma.

Referências: Kraay, ACGC*: Pr.46, 791; SNGCop Italy-Sicily: Pr.1, 38.

\section{Sinope, Paphlagonia}

Data: $480-450$ a.C.

Anverso: Cabeça de águia à d.; abaixo, golfinho.

Reverso: Quadrado incuso com superfície granulada.

Metal / denominação: AR / dracma.

Referências: Sear, GCTV, vol.2 : 3687.
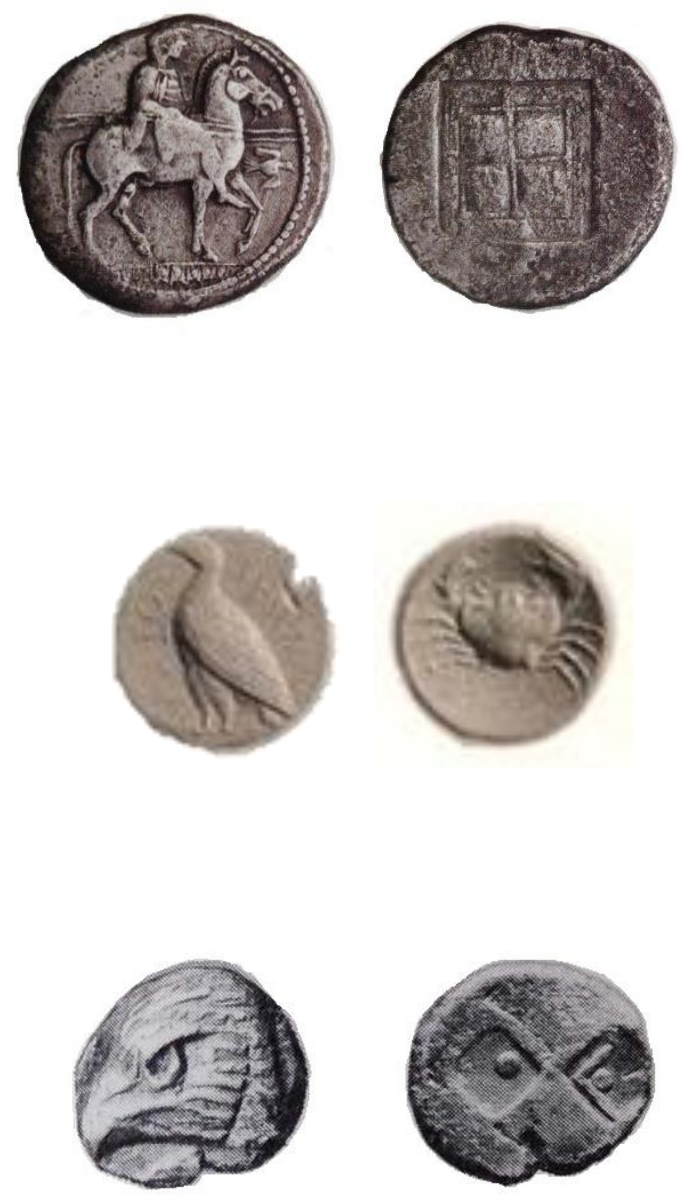


\section{Sinope, Paphlagonia}

Data: $480-450$ a.C.

Anverso: Cabeça de águia à d.; abaixo, golfinho.

Reverso: Quadrado incuso sem superfície granulada.

Metal / denominação: AR / dracma.

Referências: Sear, GCTV, vol.2: 3689.

\section{Abydus, Troas}

Data: $480-450$ a.C.

Anverso: Águia em pé; Aßuס̄nvov.

Reverso: Gorgoneion dentro de um quadrado incuso.

Metal / denominação: AR / dracma.

Peso: $5,03 \mathrm{~g}$.

Referências: SNGCop Bosphorus-Bithynia: Pr.1, 3; Kraay, ACGC*: Pr.53, 909.

Exemplares similares: SNGCop Bosphorus-Bithynia: Pr.1, 4-5. 


\section{Cyme, Aeolis}

Data: c.480-450 a.C.

Anverso: Cabeça de águia à e.

Reverso: Quadrado incuso, padrão mill-sail.

Metal / denominação: AR / hemióbolo.

Peso: 0,36 g.

Referências: SNGCop Bosphorus-Bithynia: Pr.1, 31.

Exemplares similares: SNGCop Bosphorus-Bithynia: Pr.1, 32-33.

\section{Cyme, Aeolis}

Data: c.480-450 a.C.

Anverso: Cabeça de águia à e.; KY .

Reverso: Quadrado incuso, padrão mill-sail.

Metal / denominação: AR / hemióbolo.

Referências: SNGCop: Pr.I, 31; Numisbids lote 226.

\section{Cyme, Aeolis}

Data: c.480-450 a.C.

Anverso: Cabeça de águia à e.; $\mathrm{K}$ (retrogado).

Reverso: Quadrado incuso, padrão mill-sail.

Metal / denominação: AR / hemióbolo.

Referências: SNG von Aulock: 1623; Numisbids lote 227. 


\section{5. Éfeso, Jônia}

Data: c.480-450 a.C.

Anverso: Abelha; dentro de um círculo de pérolas.

Reverso: Cabeça de águia à d.; tudo dentro de um quadrado incuso; EФ.

Metal / denominação: AR / tetartemorion.

Referências: Karwiese 25, série IV, 1 (www.vcoins.com).

\section{Crotona, Itália do Sul}

Data: c.480-430 a.C.

Anverso: Trípode; $\mathrm{PO}$, às vezes retrogrado.

Reverso: Águia voando à e. ou à d.; incusa.

Metal / denominação: AR / estater.

Referências: Rutter, HN: 2108; Kraay, ACGC*: Pr.35, 623 (c. 450 a.C.).

Exemplares similares: Rutter, HN: 2109 (dracma), 2110 (óbolo).

\section{Eryx, Sicília}

Data: c.480-400 a.C.

Anverso: Águia em pé à e.; ao redor, Epukı(vov).

Reverso: Caranguejo.

Metal / denominação: AR / óbolo.

Referências: SNGCop Italy-Sicily: Pr.6, 241; BMC Sicily: 2-3, p.61.

Exemplares similares: BMC Sicily: 1 (no anverso águia à d.), p.61. 


\section{8. Élis-Olímpia, Peloponeso}

Data: c.470 a.C.

Anverso: Águia voando à e., com asas abertas acima e abaixo de seu corpo, carregando tartaruga no bico. .

Reverso: Nike com asas abertas andando à d., segurando coroa em sua mão direita

estendida e levantando a bainha de seu chiton com a mão esquerda; A / F (retrogrado).

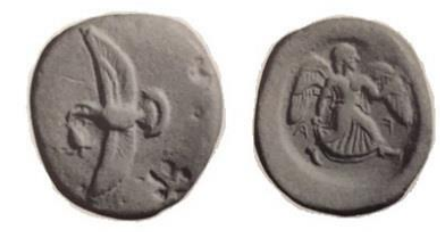

Metal / denominação: AR / didracma.

Referências: CCCCRL: Pr.IX, 1925.

\section{9. Élis-Olímpia, Peloponeso}

Data: c.468 a.C.

Anverso: Águia voando à d., com asas abertas acima e abaixo de seu corpo, carregando cobra com bico e garras.

Reverso: Nike com asas abertas andando à e., segurando coroa em sua mão direita estendida e levantando a bainha de seu chiton com a mão esquerda; $F$ A.

Metal / denominação: AR / hemidracma.

Referências: $B C D$, Olympia: 3; Seltman: ?

\section{Temístocles (Magnésia), Jônia}

Data: c.465 a.C.

Anverso: Apolo em pé à $\mathrm{d}$..

Reverso: Águia voando de frente? Com cabeça virada para a e.; M A?

Metal / denominação: AR / didracma.

Referências: Kraay, ACGC: Pr.53, 906. 


\section{Agrigento, Sicília}

Data: Após 464 a.C.

Anverso: Águia em pé à e. com asas fechadas; ao redor, Akpac avtos.

Reverso: Caranguejo; embaixo, águia em pé à e. com asas fechadas.

Metal / denominação: AR / tetradracma.

Referências: Europe of Greece, no.33, p.150.

\section{Agrigento, Sicília}

Data: c.460 a.C.

Anverso: Águia em pé à e. com asas fechadas; ao redor, Aкpa yavtos.

Reverso: Caranguejo.

Metal / denominação: AR / tetradracma.

Referências: Kraay, ACGC: Pr.46, 792; SNGCop Italy-Sicily*: Pr.1, 41-42.

\section{Agrigento, Sicília}

Data: $460-450$ a.C.

Anverso: Águia em pé à e. com asas fechadas sobre capitel jônico; AKPAC

Reverso: Caranguejo; embaixo, duplo espiral.

Metal / denominação: AR / tetradracma.

Referências: Cahn et alii, GMGS: 254.
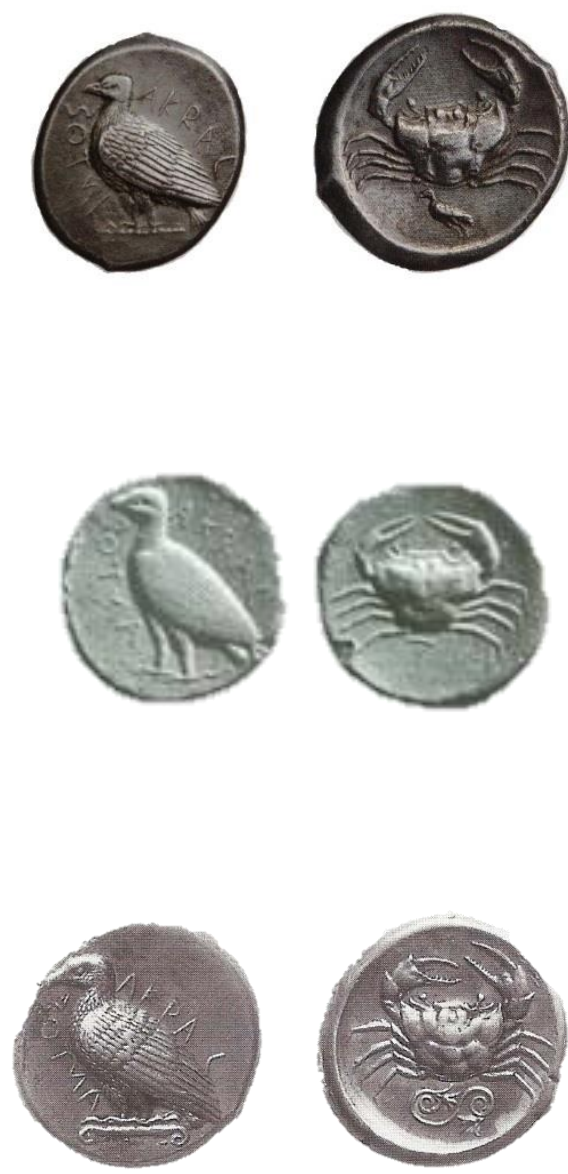
144. Archepolis (Magnésia), Jônia

Data: 459 a.C.

Anverso: Cabeça de figura masculina à d. com barba e diadema.

Reverso: Águia voando à e.; tudo dentro de quadrado incuso; embaixo, A?

Metal / denominação: AR / tetartemorion.

Referências: CNG Auction 334, lote 84.

Exemplares similares: CNG Auction 334, lote 85 (águia voa à d.).

\section{Agrigento, Sicília}

Data: c.450 a.C.

Anverso: Águia em pé à e. com asas fechadas sobre capitel jônico; Пદv.

Reverso: Caranguejo; embaixo, Aкpa.

Metal / denominação: AR / litrae.

Referências: Kraay, ACGC: Pr.46, 795; SNGCop Italy-Sicily*: Pr.1, 46

(47-51 possuem variações nas inscrições Akpa no anverso e $\Lambda$ ı no reverso). 


\section{Paphos, Chipre}

Data: c.450 a.C. (governo de Stasandros)

Anverso: Touro à e., acima, solar disco alado; na frente, ankh; no exergo, palmeta com dois espirais.

Reverso: Águia em pé à e., na frente, vaso com uma alça; Pa.si.sa.ta.sa; tudo dentro de um quadrado incuso pontilhado.

Metal / denominação: AR / estater

Peso: $10,98 \mathrm{~g}$

Referências: SNGCop Cyprus-Cappadocia: Pr.I, 26.

Exemplares similares: SNGCop Cyprus-Cappadocia: Pr.I 27/28; Kraay, ACGC: Pr.63, 1089.

\section{Paphos, Chipre}

Data: c.450 a.C. (governo de Stasandros)

Anverso: Touro à e., acima, solar disco alado; na frente, ankh; no exergo, palmeta com dois espirais (sem bolinha em cima do touro).

Reverso: Águia em pé à e., acima à d., enchimento de oliva; à e, sa.pa. em cipriota e ankh.

Metal / denominação: AR / hemióbolo.

Peso: $0,51 \mathrm{~g}$

Referências: SNGCop Cyprus-Cappadocia: Pr.I, 29. 


\section{Hipana, Sicília}

Data: c.450 a.C.

Anverso: Águia em pé à e. com asas fechadas sobre capitel jônico, segurando no bico objeto incerto; acima, folha de hera; borda plana; ANA TA I.

Reverso: Golfinho à e.; embaixo., concha.

Metal / denominação: AR / litra.

Peso: 11,3 g.

Referências: BMC Sicily*: 1, p.239; Sear, GCTV, vol.I: 822.

\section{9. Élis-Olímpia, Peloponeso}

Data: c.450-440 a.C.

Anverso: Águia voando à d., com as asas acima e abaixo de seu corpo, carregando uma lebre pela barriga com suas garras e dilacerando-a com seu bico.

Reverso: Nike caminhando à e., segurando coroa com sua mão direita estendida e com seu braço esquerdo pendendo ao lado do corpo; $F$ A.

Metal / denominação: AR / estater.

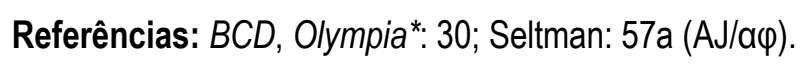

Exemplares similares: $B C D$, Olympia: 31 (no reverso, raio com asas embaixo e volutas em cima, Seltman: 59 AK/a $\psi$ ). 


\section{0. Élis-Olímpia, Peloponeso}

Data: c.450-440 a.C.

Anverso: Águia voando à d., com ambas as asas juntas acima de seu corpo, carregando uma lebre pela barriga com suas garras e dilacerando-a com seu bico.

Reverso: Nike caminhando à e., segurando coroa com sua mão direita estendida e a bainha de seu chiton com a esquerda; F A (a primeira letra em retrogrado).

Metal / denominação: AR / dracma.

Referências: $B C D$, Olympia*: 32; Seltman: p.20, pr.VIII,4.

Exemplares similares: $B C D$, Olympia: 33 (no reverso, raio com asas em cima e volutas embaixo, Seltman: pr.VIII, 4);

34 (óbolo, no anverso, águia à e. e, no reverso, raio com asas em cima e volutas embaixo).

\section{1. Élis-Olímpia, Peloponeso}

Data: Final c.450s a.C.

Anverso: Águia voando para cima com cabeça à d., asas abertas, carregando uma cobra com suas garras e bico.

Reverso: Nike andando à d., segurando a bainha de seu chiton com ambas as mãos; $F$ A.

Metal / denominação: AR / estater.

Referências: $B C D$, Olympia*: 24; Seltman: AR (anverso similar). 


\section{2. Élis-Olímpia, Peloponeso}

Data: Final c.450s a.C.

Anverso: Águia voando à e., com as asas acima e abaixo de seu corpo, carregando uma cobra com suas garras e bico; F]A^EION.

Reverso: Nike andando à d., seu dorso está de frente para o observador, segurando uma taenia comprida de uma lado a outro de seu corpo, entre sua mão esquerda levantada e sua direita abaixada; $\mathrm{F} \mathrm{A}$.

Metal / denominação: AR / estater.

Referências: $B C D$, Olympia*: 26; Seltman: $71(A O / \beta \beta)$;

Exemplares similares: $B C D$, Olympia: 27 (no reverso, Nike corre à d. com coroa na mão esquerda e mão direita segurando a bainha do chiton, Seltman: p.33 e pr. VIII,6).

\section{Sparadocus, Trácia}

Data: $445-435$ a.C.

Anverso: Prótomo de cavalo trotando à e.; círculo de pontos; $\Sigma \Pi$ / A.

Reverso: Águia voando de frente com cabeça virada à e. carregando cobra no bico.

Metal / denominação: AR /dióbolo.

Referências: Youroukova, CAT: Pr. IV, 20.

Exemplares similares: Youroukova, CAT: Pr. IV, 21, 22, 23. 


\section{Olinto, Trácia}

Data: c.440 a.C.

Anverso: Cavalo à d.

Reverso: Águia voando de frente com cabeça virada à d. carregando cobra no bico?; $0 \wedge$ ?; quadrado incuso.

Metal / denominação: AR / 4 obeloi.

Referências: Kraay, ACGC: Pr.26, 476.

\section{5. Élis-Olímpia, Peloponeso}

Data: c.440s-430s a.C.

Anverso: Águia voando à d., com as asas acima e abaixo de seu corpo, carregando uma cobra com suas garras e bico.

Reverso: Nike sentada à e. sobre uma base quadrada, coroando a fonte de bicas de leão com uma coroa em sua mão direita estendida e descansando a sua mão esquerda na base; nos quatro cantos, $\mathrm{FA} \wedge$.

Metal / denominação: AR / estater.

Referências: $B C D$, Olympia*: 38; Seltman: 80 (AS//K). 


\section{6. Élis-Olímpia, Peloponeso}

Data: c.440s-430s a.C.

Anverso: Águia voando à d., com ambas as asas acima de seu corpo, carregando uma lebre pelas costas com suas garras e dilacerando-a com seu bico.

Reverso: Nike correndo à e., segurando coroa com a sua mão direita estendida e sua chlamys na cintura com sua mão esquerda; nos quatro cantos, $\mathrm{FA} \wedge$.

Metal / denominação: AR / estater.

Referências: $B C D$, Olympia*: 39; Seltman: $92 b(A N / \beta \eta)$.

\section{7. Ólbia, Mar Negro}

Data: $437-410$ a.C.

Anverso: Gorgoneion.

Reverso: Águia voando à d. com asas abertas, segurando golfinho com suas garras; ao redor, A-P-I-X.

Metal / peso: AE (cast) / 137,81g.

Referências: Triton XVI, Lot: 27 (http://www.cngcoins.com/Coin.aspx?CoinlD=222165);

SNG BM Black Sea: 383; SNG Pushkin: 38-42; SNG Stancomb: 343.

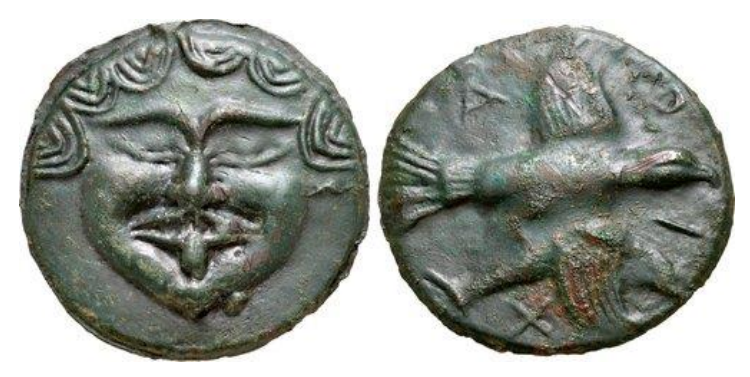




\section{8. Élis-Olímpia, Peloponeso}

Data: c.432 a.C.

Anverso: Águia voando à e., com ambas as asas acima de seu corpo, carregando uma lebre pelas costas com suas garras e dilacerando-a com seu bico.

Reverso: Nike sentada à e. sobre uma base baixa, como um degrau de um pedestal, vestindo um longo chiton e peplos, segurando um cetro longo com sua mão direita e descansando a sua mão esquerda sobre o pedestal; A F.

Metal / denominação: AR / estater.

Referências: $B C D$, Olympia*: 45; Seltman: 106/99 (BC/ $/ \sigma)$.

\section{9. Élis-Olímpia, Peloponeso}

Data: c.432 a.C.

Anverso: Águia em pé à e. sobre uma linha de chão, suas asas estão erguidas acima de suas costas e à e. garça morta.

Reverso: Nike sentada à e. sobre uma base baixa, como um degrau de um pedestal, vestindo um longo chiton e peplos, segurando um cetro longo com sua mão direita e descansando a sua mão esquerda sobre o pedestal; A F.

Metal / denominação: AR / estater.

Referências: $B C D$, Olympia*: 46; Seltman: 118b.

Exemplares similares: $B C D$, Olympia: 47 (no reverso, Nike está sentada à d. sobre uma base quadrada, apoiando sua cabeça em sua mão esquerda, com seu cotovelo esquerdo apoiado no seu joelho esquerdo, cruzado sobre sua perna esquerda, e com dois ramos de oliveira caídos em sua mão direita, caídos sobre a base quadrada em inscrição A^EION, Seltman: $120 \mathrm{BF} / \mathrm{Y} \beta)$. 


\section{0. Élis-Olímpia, Peloponeso}

Data: c.432 a.C.

Anverso: Águia voando à d., com ambas as asas acima de seu corpo, carregando uma lebre pelas costas com suas garras e dilacerando-a com seu bico.

Reverso: Nike sentada à e., vestindo peplos e chiton, no segundo degrau mais alto, com seu pé direito atrás do degrau mais baixo e o esquerdo na frente, segurando com sua mão direita um galho longo de palmeira, encostado sobre seu joelho direito, com

a fronda atrás de sua cabeça, e descansando sua mão esquerda atrás do degrau; abaixo,

no degrau de baixo, galho de oliveira; $F$ A.

Metal / denominação: AR / estater.

Referências: $B C D$, Olympia*: 52; Seltman: 133b (BK/үع).

\section{Olinto, Trácia}

Data: $432-420$ a.C.

Anverso: Cavalo andando à d. em frente a uma coluna jônica.

Reverso: Águia voando de frente com cabeça virada à d. carregando cobra no bico, dentro de quadrado incuso; $\mathrm{O} \wedge \mathrm{Y}[\mathrm{N}]$.

Metal / denominação: AR / tetróbolo.

Referências: Coins of Macedonia, no.83, p.92.

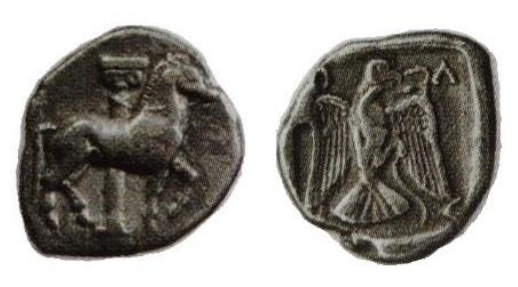




\section{Sparadocus, Trácia}

Data: c.430 a.C.

Anverso: Cavaleiro sobre cavalo à e.

Reverso: Águia à e. atacando uma cobra, tudo dentro de um quadrado incuso; A ?

Metal / denominação: AR / tetradracma.

Referências: Kraay, ACGC*: Pr.29, 526.

\section{Crotona, Itália do Sul}

Data: c.430-420 a.C.

Anverso: Trípode; PO.

Reverso: Águia voando à d.

Metal / denominação: AR / estater.

Referências: Rutter, $H N$ : 2120.

Exemplares similares: Rutter, HN: 2121 (óbolo); Kraay, ACGC: Pr.35, 625 (c.440 a.C.).

\section{Cyzicus, Mysia}

Data: c.430-415 a.C.

Anverso: Duas águias em pé com asas fechadas, de frente uma a outra sobre um ônfalo coberto por uma rede de fitas?; abaixo, atum.

Reverso: Quadrado incuso quadripartido.

Metal / denominação: El / estater.

Referências: SNG Paris: 348; Boston: 1535; The N. York Sale, Auction XXV, lote 73. 


\section{5. Ólbia, Mar Negro}

Data: $430-400$ a.C.

Anverso: Gorgoneion.

Reverso: Águia voando à e. carregando golfinho?; APIX.

Metal / peso: AE / 104,37g.

Referências: SNG British Museum: vol.IX, 383 (SNGuk_0901_0383).

\section{Sparadocus, Trácia}

Data: Antes de 424 a.C.

Anverso: Cavalo andando à e.; ao redor, $\Sigma$ пар аס око.

Reverso: Águia voando à e. com serpente, tudo dentro de quadrado incuso.

Metal / denominação: AR / dracma.

Referências: SNGCop Thrace and Macedonia: pr.21, 1064.

Exemplares similares: SNGCop Thrace and Macedonia: pr.21, 1065-1067 (dióbolo).

\section{Paphos, Chipre}

Data: c.425 a.C. (governo de Moagetas).

Anverso: Touro;

Reverso: Águia voando à e.; tudo dentro de um quadrado de pérolas.

Metal / denominação: AR / estater.

Referências: Kraay, ACGC*: Pr.63, 1090 (em Sear, GCTV, vol.II, a moeda é atribuída à Moagetas, no.5775);

BMC, Cyprus: PI. VIII, 5 (2ª metade do século V a.C.).

Exemplares similares: Sear, GCTV, vol.Il: 5776 (third stater).
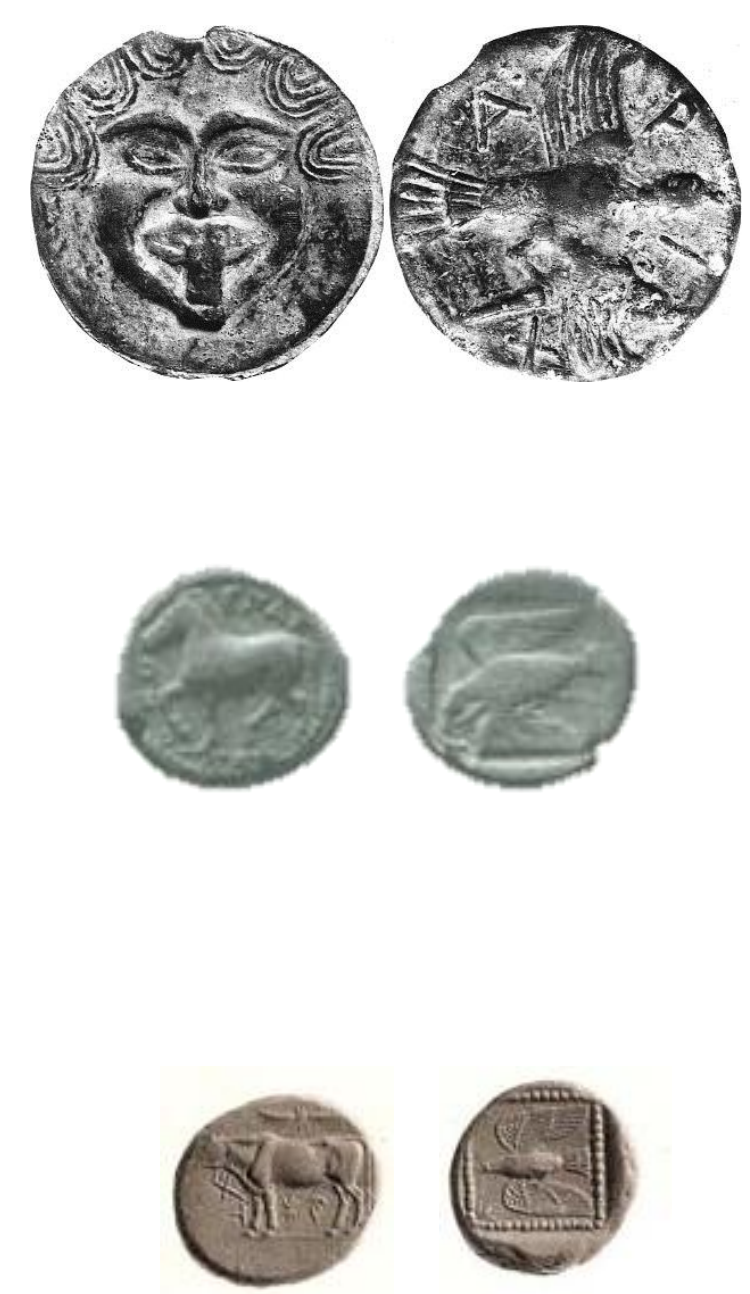


\section{Sinope, Paphlagonia}

Data: $425-410$ a.C.

Anverso: Cabeça de águia à e.; embaixo, golfinho à e.

Reverso: Quadrado incuso quadrpartido; bolinha dentro do primeiro quadrado e bolinha e B dentro do segundo.

Metal / denominação: AR / dracma.

Referências: SNG von Aulock 6839; The N. York Sale XXXIV, lote 139.

\section{Agrigento, Sicília}

Data: $425-406$ a.C.

Anverso: Águia em pé à d. com cabeça virada para trás à e.; AK PA.

Reverso: Caranguejo; embaixo, peixe; em cima, pontinho em círculo.

Metal / peso: AE / 3,45

Referências: SNG John Morcom Collection: Pr.XX, 527.

\section{Crotona, Itália do Sul}

Data: c.425-350 a.C.

Anverso: Águia em pé à e. ou à d. com asas dobradas, sobre um capitel jônico; POT.

Reverso: Trípode; no campo, grão de trigo; no exergo, E; POT.

Metal / denominação: AR / estater.

Referências: Rutter, HN: 2140; Kraay, ACGC*: Pr.36, 630 (c.420 a.C.).

Exemplares similares: Rutter, $H N$ : 2141; 2142; 2143 e 2144 (águia no anverso com ramo de oliveira). 


\section{Crotona, Itália do Sul}

Data: c.425-350 a.C.

Anverso: Águia em pé à e. com asas dobradas e cabeça virada para trás, sobre uma cabeça de carneiro.

Reverso: Trípode com pescoço alto; raminho de oliveira; $\mathrm{PO}$.

Metal / denominação: AR / estater.

Referências: Rutter, $H N$ : 2145.

Exemplares similares: Rutter, $H N$ : 2146 (a águia está sobre a cabeça de um veado e o trípode acompanha um ramo com folha de hera); Kraay, ACGC: Pr.35, 634 (anverso, águia sobre cabeça de veado, c.380 a.C.)

\section{Crotona, Itália do Sul}

Data: c.425-350 a.C.

Anverso: Águia em pé à d. com asas dobradas, sobre uma arquitrave; no campo, crânio de cabra?

Reverso: Trípode com pescoço alto; raminho de oliveira ou de folhas de louro; PO.

Metal / denominação: AR / estater.

Referências: Rutter, HN: 2147; Cahn et alii, GMGS*: 201 (36-340 a.C.). 


\section{Crotona, Itália do Sul}

Data: c.425-350 a.C.

Anverso: Águia em pé à d. com asas dobradas, cabeça erguida, sobre ramo de oliveira; sem presa.

Reverso: Trípode com pescoço alto; folha de hera ou grão de trigo/cevada; PO.

Metal / denominação: AR / estater.

Referências: Rutter, HN: 2149; Kraay, ACGC*: Pr.36, 635 (c.350 a.C.).

Exemplares similares: Rutter, HN: 2148 (águia não está sobre ramo de oliveira e trípode é acompanhado por folha de louro).

\section{Crotona, Itália do Sul (sem imagem)}

Data: c.425-350 a.C.

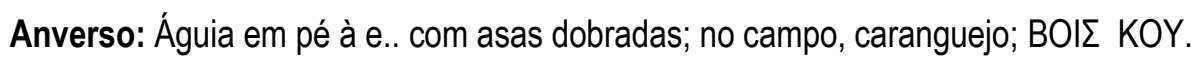

Reverso: Trípode com pescoço alto; filleted; PO.

Metal / denominação: AR / estater.

Referências: Rutter, $H N$ : 2150.

Exemplares similares: Rutter, $H N$ : 2151 (águia está à d. e trípode é acompanhado por ramo de loureiro e POTSN).

\section{Crotona, Itália do Sul (sem imagem)}

Data: c.425-350 a.C.

Anverso: Águia em pé à e. com cabeça baixa, sobre cobra.

Reverso: Trípode com pescoço alto; folha de louro; PO; folha de videira ou grão de trigo.

Metal / denominação: AR / estater.

Referências: Rutter, $H N$ : 2152.

Exemplares similares: Rutter, HN: 2149 (águia está sobre ramo de oliveira e trípode é acompanhado por folha de hera ou grão de trigo/cevada). 


\section{Crotona, Itália do Sul}

Data: c.425-350 a.C.

Anverso: Trípode com pescoço alto; no campo, KP ou sem inscrição.

Reverso: Águia em pé à e. ou à d. com asas fechadas e cabeça para trás; 00 e crescente.

Metal / denominação: AR / dióbolo.

Referências: Rutter, $H N$ : 2156.

\section{Lyttos, Creta}

Data: c.425-320 a.C.

Anverso: Águia em pé à d.

Reverso: Cabeça de javali à direita; em cima, ГVK, à direita, TS, embaixo, ON (retrogrado).

Metal / denominação: AR / dracma?

Peso: 5,95 g.

Referências: Le Rider: Pr.XXV, 11.

Exemplares similares: Le Rider: Pr.XXV,12. 


\section{Lyttos, Creta}

Data: c.425-320 a.C.

Anverso: Águia voando à d.

Reverso: Cabeça de javali; ^ut(бov) reversed; tudo dentro de um quadrado incuso.

Metal / denominação: AR / estater.

Peso: $12,30 \mathrm{~g}$.

Referências: SNGCop Bosphorus-Bithynia: Pr.10, 489;

Exemplares similares: Svoronos: Pr.XXI, 1,2,3.

\section{Lyttos, Creta}

Data: c.425-320 a.C.

Anverso: Cabeça de javali à e.; tudo dentro de um quadrado.

Reverso: Águia voando à e.

Metal / denominação: AR / estater?

Peso: $11,42 \mathrm{~g}$.

Referências: Le Rider: Pr.XXV,14. 


\section{Lyttos, Creta}

Data: c.425-320 a.C.

Anverso: Águia voando à d. carregando presa com suas garras; círculo de pérolas.

Reverso: Cabeça de javali à d.; em cima, $\Lambda$ YK, em baixo, $\mathrm{S}$ (retrogrado)T.

Metal / peso: AR / 2,81g.

Referências: Le Rider: Pr.XXV,17.

Exemplares similares: Le Rider: Pr.XXV, 18 e 19.

\section{Lyttos, Creta}

Data: c.425-320 a.C.

Anverso: Águia voando à e.; círculo de pérolas.

Reverso: Cabeça de javali à d.;AYT/T?; quadrado em forma de pontos.

Metal / peso: AR / ?.

Referências: Le Rider: Pr.XXV,20.

Exemplares similares: Svoronos: Pr. XXI, 9 e 10.

\section{Lyttos, Creta}

Data: c.425-320 a.C.

Anverso: Águia voando à d.; círculo de pérolas?

Reverso: Cabeça de javali à d.; quadrado em forma de pontos; $\Lambda$ YTTS/O/N (retrogrado).

Metal / peso: AR / ?.

Referências: Sear, GCTV, vol.I: 3236 (380-320 a.C.); Svoronos: Pr.XXI, 14 e 16.

Exemplares similares: Le Rider: Pr. XXV, 15 e 16; Svoronos: Pr.XXI, 13. 


\section{Lyttos, Creta}

Data: c.425-320 a.C.

Anverso: Águia voando à e. carregando com seu bico uma banda de pontos (ténie);

círculo de pérolas.

Reverso: Cabeça de javali à e.; tudo dentro de quadrado de pontos; $\Lambda$ YTTSON (retrogrado).

Metal / peso: AR / ?.

Referências: Svoronos: Pr. XXI, 11.

\section{Lyttos, Creta}

Data: c.425-320 a.C.

Anverso: Águia voando à d.

Reverso: Cabeça de javali à d.; tudo dentro de quadrado incuso.

Metal / peso: AR / ?

Referências: Svoronos: Pr. XXI,15.

\section{Lyttos, Creta}

Data: c.425-320 a.C.

Anverso: Águia voando à d.; tudo dentro de um círculo de pérolas.

Reverso: Cabeça de javali à d.; tudo dentro de quadrado incuso de pérolas; $\Lambda$ YTT/ SON (retrogrado).

Metal / peso: AR / ?

Referências: Svoronos: Pr. XXI, 20.

Exemplares similares: Svoronos: Pr.XXI, 19. 
186. Lyttos, Creta

Data: c.425-320 a.C.

Anverso: Águia voando à e.

Reverso: Cabeça de javali à e.; tudo dentro de quadrado incuso de pérolas.

Metal / peso: AR / ?

Referências: Svoronos: Pr. XXI, 4.

Exemplares similares: Svoronos: Pr.XXI, 5

\section{Lyttos, Creta}

Data: c.425-320 a.C.

Anverso: Águia voando à e.

Reverso: Cabeça de javali à d.; tudo dentro de quadrado incuso; $\Lambda$ YTTSOS.

Metal / peso: AR / c.6,15g.

Referências: Svoronos: Pr. XXI, 17.

Exemplares similares: Svoronos: Pr.XXI, 18 (peso: c.2,80g). 


\section{Lyttos, Creta}

Data: c.425-320 a.C.

Anverso: Águia voando à e.

Reverso: Cabeça de javali; ^utбov dentro de um quadrado pontilhado; tudo dentro de um quadrado incuso.

Metal / denominação: AR / estater.

Peso: $11,79 \mathrm{~g}$

Referências: SNGCop Bosphorus-Bithynia: Pr.10, 490; Svoronos: Pr. XXI, 7 e 8.

Exemplares similares: SNGCop Bosphorus-Bithynia: Pr.10, 491-497; Le Rider: Pr.XXV, 15 e 16 (no rev., estilo do javali e inscrições diferem deste exemplar.

\section{Kherei (emissão incerta), Lycia}

Data: c.420 a.C.

Anverso: Galo em escudo.

Reverso: Águia em pé à e. com asas fechadas, dentro de um quadrado incuso e pontilhado;

Kherei em alfabeto lício.

Metal / denominação: AR / estater.

Referências: Kraay, ACGC: Pr.57, 986.

Exemplares similares: $C L D, 1976$ : Pr.ll, 20 e 21 


\section{Paphos, Chipre}

Data: c.420 a.C. (governo de Pny(tos) II)

Anverso: Touro à e., acima, solar disco alado; na frente, ankh; no exergo, palmeta com dois espirais.

Reverso: Águia em pé à e., acima à d., enchimento de oliva; à e, Pu.pa. em cipriota e ankh.

Metal / denominação: AR / trihemióbolo.

Peso: $1,30 \mathrm{~g}$

Referências: SNGCop Cyprus-Cappadocia: Pr.1, 30.

Exemplares similares: Sear, GCTV, vol.II: 5772 (sixth estater, c.425 a.C.).

\section{Agrigento, Sicília}

Data: c.420 a.C.

Anverso: Águia em pé à e. com asas abertas sobre barriga de lebre deitada sobre uma rocha; ao redor, AKPAГ ANTIN O N.

Reverso: Caranguejo; embaixo, badejo (Polyprium cernium) à e.; à e., concha; à d., grão de trigo?

Metal / denominação: AR / tetradracma.

Referências: Kraay, ACGC: Pr.46, 793; Cahn et alii, GMGS*: 257.

\section{Crotona, Itália do Sul}

Data: $420-400$ a.C.

Anverso: Águia em pé à e. olhando à d. sobre nariz de veado.

Reverso: Trípode; PO.

Metal / denominação: AR / estater.

Referências: Sear, GCTV, vol.I: 470. 


\section{Agyrion, Sicília}

Data: c.420-353 a.C.

Anverso: Águia em pé à d. com asas fechadas; atrás, galho de duas folhas de oliveira e fruto.

Reverso: Roda, dentro da qual letras de inscrição; Ayupıva.

Metal / peso: AE / 17,71 g

Referências: SNGCop Italy-Sicily: Pr.3, 126; SNG John Morcom Collection*: Pr.XX, 513.

\section{4. Élis-Olímpia, Peloponeso}

Data: c.416-404 a.C.

Anverso: Cabeça de águia à d.; $F$, retrogrado.

Reverso: A em um quadrado incuso.

Metal / denominação: AR / hemióbolo.

Referências: $B C D$, Olympia*: 80; Seltman: pr. VIII, 17.

\section{5. Élis-Olímpia, Peloponeso}

\section{Data: c.416-404 a.C.}

Anverso: Cabeça de águia à e.

Reverso: $F$ (retrogrado) em um quadrado incuso.

Metal / denominação: AR / trihemitetartemorion.

Referências: $B C D$, Olympia*: 81; Seltman: pr. VIII, 17. 


\section{Motya, Sicilia}

Data: Antes de 415 a.C.

Anverso: Águia em pé à e. com asas fechadas sobre capitel jônico, segurando no bico uma cobra; acima, folha de hera; círculo de pontinhos.

Reverso: Golfinho à e.; à e., concha; MOT NAION (retrogrado).

Metal / denominação: AR / litra.

Referências: BMC Sicily: 1, p.115 (480-413 a.C.); Sear, GCTV, vo.I: 864.

\section{Agrigento, Sicília}

\section{Data: c.415 a.C}

Anverso: Águia em pé à d. com asas abertas e cabeça levantada para cima, sobre peixe?

Tudo dentro de um cículo de pontinhos; ao redor, Akpayavtivov?

Reverso: Caranguejo; embaixo, polvo; seis bolinhas ao redor e outro símbolo embaixo não identificado.

Metal / denominação: $A E$ / hemilitron.

Referências: Kraay, ACGC*: Pr.46, 798; SNGCop Italy-Sicily: Pr.2, 72-73. 


\section{8. Éfeso, Jônia (sem imagem)}

Data: c.415-394 a.C.

Anverso: Abelha; círculo de pérolas.

Reverso: Cabeça de águia ou de grifo à d.; tudo dentro de um quadrado incuso; EФ.

Metal / denominação: AR / tetartemorion.

Referências: BMC Ionia: no.24.

\section{Agrigento, Sicília}

Data: c.413-406 a.C.

Anverso: Águia em pé à e. com asas fechadas e devorando serpente;

embaixo, dois pontinhos indicando que a moeda passou para dois didracmas; Акра errado.

Reverso: Caranguejo; embaixo, $\Sigma ı \lambda a v o \zeta$.

Metal / peso: AV / 1,35 g.

Referências: Kraay, ACGC*: Pr.46, 796; SNGCop Italy-Sicily: Pr.1, 52; Cahn et alii, GMGS: 262.

\section{Agrigento, Sicília}

Data: c.413-406 a.C.

Anverso: Águia em pé à e. com asas abertas e devorando jumento? No campo, grão de trigo.

Reverso: Caranguejo; embaixo, pistrix engolindo um peixe; $A[k \rho] a$.

Metal / denominação: AR / hemidracma.

Referências: : SNG Italy-Sicily: Pr.2, 55; Cahn et alii, GMGS*: 259 (420-410 a.C.)

Exemplares similares: SNGCop Italy-Sicily: Pr.2, 56-60 (no anverso, a águia está sobre a barriga de uma lebre). 


\section{Arquelaos I, Macedônia}

Data: 413-399 a.C.

Anverso: Cavalo trotando à e.

Reverso: Águia em pé à e. com cabeça virada para trás à d., dentro de um quadrado incuso quadrático; Apx乏^a.

Metal / denominação: AR / didracma

Referências: SNGCop Thrace and Macedonia: pr.12, 505.

\section{Messana, Sicília}

Data: c.412-408 a.C.

Anverso: Ninfa Messana à d. coroando o cocheiro de uma biga à e.

Reverso: Lebre saltando á e. sobre uma águia em pé à e. sobre uam rocha, de asas fechadas, devorando uma cobra; ME $\Sigma \Sigma A N I \Omega N$.

Metal / denominação: AR / tetradracma.

Referências: Cahn et alii, GMGS: 368.

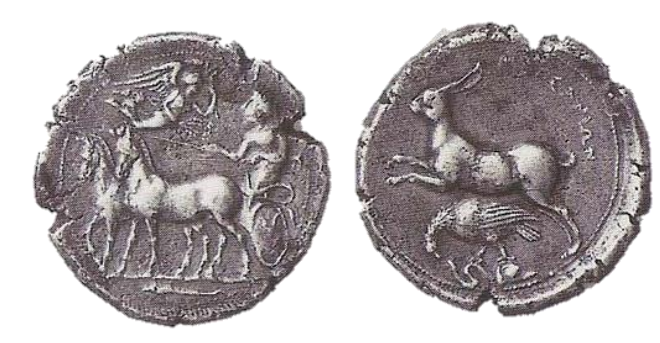




\section{Agrigento, Sicília}

Data: c.411 a.C.

Anverso: Hélio dirigindo quadriga; em cima, águia voando carregando cobra; embaixo, caranguejo? Aкрayas.

Reverso: Duas águias em pé à e. sobre a barriga de duas lebres; a primeira está com a cabeça levantada e asas fechadas a segunda com a cabeça abaixada e as asas abertas; à d., símbolo não identificado.

Metal / denominação: AR / 10 dracma.

Referências: Kraay, ACGC: Pr.46, 797.

Exemplares similares: Kraay, ACGC: Pr.46, 794 (tetradracma, c.410 a.C.).

\section{Abydus, Troas}

Data: 411-387 a.C.

Anverso: Cabeça laureada de Apolo à d.

Reverso: Águia em pé à d. sobre aplustre; no campo à d., triskeles dentro de círculo;

Tudo dentro de um círculo incuso; ABY / YTPO $\triangle \Omega P O \Sigma$.

Metal / peso: AR / ?

Referências: BMC Troas, Aeolis and Lesbos: Pr. I, 8. 


\section{Cyzicus, Mysia}

Data: c.410 a.C.

Anverso: Ônfalo; em cada lado, uma águia; abaixo, atum.

Reverso: Quadrado incuso quadripartido.

Metal / denominação: AR / estater.

Peso: 16,02 g.

Referências: SNGCop Bosphorus-Bithynia: Pr.2, 44.

\section{Gela, Sicília}

Data: $410-405$ a.C.

Anverso: Quadriga dirigida por Nike; acima, águia voando à d.; no exergo, pontinho; $\Gamma E \wedge \Omega \mid \Omega N$.

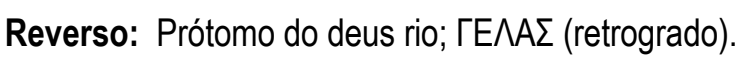

Metal / denominação: AR / tetradracma.

Referências: Mildenberg e Hurter, ASDCGC: Pr.29, 607.

Exemplares similares: BMC Sicily: 57-59, p.72 (no reverso, a águia voa sobre a quadriga).

\section{Agrigento, Sicília}

Data: Antes de 406 a.C.

Anverso: Águia em pé à d. com asas abertas sobre a barriga de uma lebre.

Reverso: Caranguejo; embaixo, lagostim.

Metal / denominação: AE / hemilitron.

Referências: SNGCop Italy-Sicily: Pr.2, 65.

Exemplares similares: SNGCop Italy-Sicily: Pr.2, 66-70. 


\section{Agrigento, Sicília}

Data: Antes de 406 a.C.

Anverso: Águia em pé à d. com asas abertas, cabeça para cima e sobre uma lebre.

Reverso: Caranguejo; embaixo, Cila segurando um murex; ao redor seis pontinhos (cinco são visíveis).

Metal / denominação: AE / hemilitron.

Referências: SNGCop Italy-Sicily: Pr.2, 71; Cahn et alii, GMGS*: 268 (420-406 a.C.).

\section{Agrigento, Sicília}

Data: Antes de 406 a.C.

Anverso: Águia em pé à e. com asas abertas, cabeça para baixo, barriga de frente e sobre um peixe?

Reverso: Caranguejo; embaixo, lagostim, seis pontinhos (três à e. estão visíveis).

Metal / denominação: $A E$ / hemilitron.

Referências: SNGCop Italy-Sicily: Pr.2, 74.

\section{Agrigento, Sicília}

Data: Antes de 406 a.C.

Anverso: Caranguejo; embaixo, monograma.

Reverso: Cabeça de águia à $\mathrm{d}$.

Metal / peso: AE / 2,54 g

Referências: SNGCop Italy-Sicily: Pr.2, 86.

Exemplares similares: SNGCop Italy-Sicily: Pr.2, 87. 


\section{Paphos, Chipre}

Data: $2^{\mathrm{a}}$. metade do século V a.C. - final do século V a.C. (governo de Aristo...).

Anverso: Touro em pé à e., disco solar alado acima; ankh antes; embaixo, letras cipriotas a.ri.

Reverso: Águia voando à e.; tudo dentro de um quadrado incuso.

Metal / denominação: AR / estater.

Referências: Sear, GCTV, vol.Il: 5774 (final do séc. V a.C.); BMC, Cyprus: PI. VIII, 1 (2ª metade do século V a.C.).

\section{Olinto, Trácia}

Data: V a.C.

Anverso: Figura masculina guiando cavalo de frente com cabeça à d.

Reverso: Águia voando de frente dentro de quadrado incuso.

Metal / denominação: AR / tetróbolo.

Referências: Coins of Macedonia, no.84, p.93.

\section{Emissão incerta, Jônia}

Data: V a.C.

Anverso: Cabeça de águia à d.; círculo de pérolas à e.

Reverso: Coroa dentro de quadrado incuso.

Metal / denominação: AR / tetartemorion.

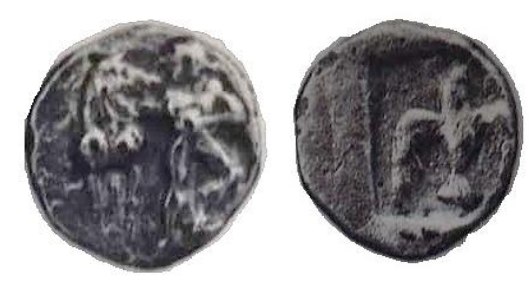

Referências: Classical Numismatic Group, Auction 335, lote 194. 


\section{Abydus, Troas}

Data: Final do séc. V a.C. - início IV a.C.

Anverso: Cabeça laureada de Apolo à d.

Reverso: Águia em pé à d. com asas fechadas; abelha à d. no campo; ABY / YMМIחПOL.

Metal / denominação: AR / hemidracma.

Referências: SNG München: 13; Numisbids: lote 214.

Exemplares similares: Numisbids: Iote 214 (no rev. águia e abelha à e., IV a.C.); BMC (320-280 a.C.).

\section{SÉCULO IV a.C.}

\section{Rodes}

Data: c.400 a.C.

Anverso: Cabeça de Hélios de frente.

Reverso: Rosa e águia?; em cima, POAION.

Metal / denominação: AR / tetradracma.

Referências: Kraay, ACGC: Pr.55, 941. 


\section{Motya, Sicília}

Data: c.400 a.C.

Anverso: Águia em pé à d.

Reverso: Caranguejo; embaixo, peixe?

Metal / denominação: AR / tetradracma.

Referências: Kraay, ACGC: Pr.50, 861.

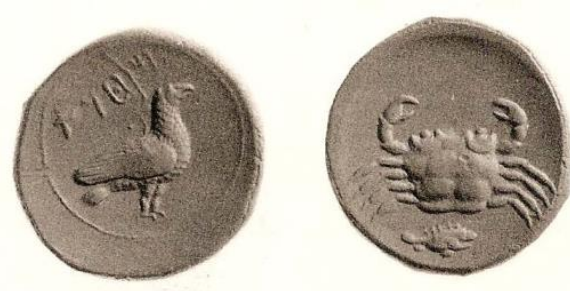

\section{Lyttos, Creta}

Data: c.400 a.C.?

Anverso: Águia voando à e.

Reverso: Cabeça de javali à e.

Metal / denominação: AR / didracma.

Referências: Kraay, ACGC: Pr.8, 153; Le Rider: Pr.XXV, 13.

\section{Istros, Mar Negro}

Data: c.400 a.C.

Anverso: Cabeças dos Dióscuros.

Reverso: Águia marinha sobre golfinho à d.; ILTPIH.

Metal / denominação: AR / dracma.

Referências: Europe of Greece, no.82, p.258. 


\section{Crotona, Itália do Sul}

Data: c.400 a.C.

Anverso: Trípode.

Reverso: Cabeça de águia à e. dentro de círculo de pérolas.

Metal / peso: AE / ?

Referências: Rutter, HN: 2203.

\section{Agrigento, Sicília}

Data: $400-380$ a.C.

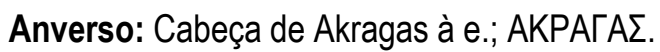

Reverso: Águia em pé à e. com cabeça para trás à d., asas fechadas e sobre coluna de capitel jônico; à e., caranguejo; à d. seis pontinhos.

Metal / denominação: $A E$ / hemilitron.

Referências: Cahn et alii, GMGS*: 269; SNG John Morcom Collection: Pr.XXI, 534. 


\section{1. Ólbia, Mar Negro}

Data: $400-380$ a.C

Anverso: Gorgoneion.

Reverso: Águia voando à e. com asas levantadas, segurando golfinho com suas garras;

ao redor, O- $\Lambda$-B-I.

Metal / peso: AE (cast) / 19,83g.

Referências: Triton XVI, Lot: 33 (http://www.cngcoins.com/Coin.aspx?CoinlD=222171);

SNG BM Black Sea: 396-8; SNG Pushkin: 55-6 and 59-63; SNG Stancomb: 347.

\section{Halikarnassos, Cária}

Data: c.400-380 a.C.

Anverso: Cabeça de Apolo de frente.

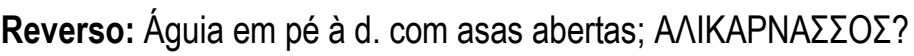

Metal / denominação: AR / tetradracma.

Referências: Konuk, CIUH: PI.2, 22. 


\section{Sinope, Paphlagonia}

Data: c.400-370 a.C.

Anverso: Sinope; sem brincos ou colar.

Reverso: Águia marinha sobre golfinho; abaixo, $\Sigma ı v \omega$.

Metal / denominação: AR / dracma.

Peso: $5,70 \mathrm{~g}$.

Referências: SNGCop Bosphorus-Bithynia: Pr.8, 274.

Exemplares similares: SNGCop Bosphorus-Bithynia: Pr.8, 275.

\section{4. Ólbia, Mar Negro}

Data: 400-350 a.C.

Anverso: Gorgoneion.

Reverso: Águia marinha sobre golfinho; abaixo,

Metal / peso: AR / 19,14 g.

Referências: SNG British Museum: Vol.IX, 398 (SNGuk_0901_0398).

\section{Corinto, Peloponeso}

Data: $400-350$ a.C.

Anverso: Pégaso em pé à e.; embaixo, koppa.

Reverso: Cabeça de Atena à d. com elmo coríntio; em cima, golfinho; atrás, cabeça de águia.

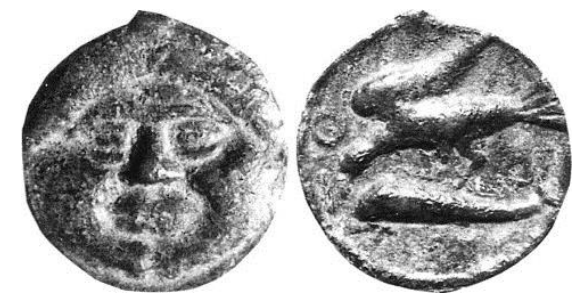

Metal / denominação: AR / estater.

Referências: Sear, GCTV, vol.l: 2628. 


\section{Sifnos, Egeu}

Data: $400-350$ a.C

Anverso: Cabeça de Ártemis à d.

Reverso: Águia voando de frente com à cabeça à e., carregando cobra no bico;

embaixo, $\Sigma 1 / \Phi$

Metal / peso: AE / ?

Referências: Sear, GCTV, vol.I: 3149.

\section{Cebren, Troas}

Data: $400-310$ a.C.

Anverso: Cabeça laureada de Apolo à d.; embaixo, águia em pé à d. de asas fechadas.

Reverso: Cabeça de carneiro; $\mathrm{E}($ retrogrado)K.

Metal / peso: AE / 8

Referências: BMC Troas, Aeolis and Lesbos: Pr. VIII, 18.
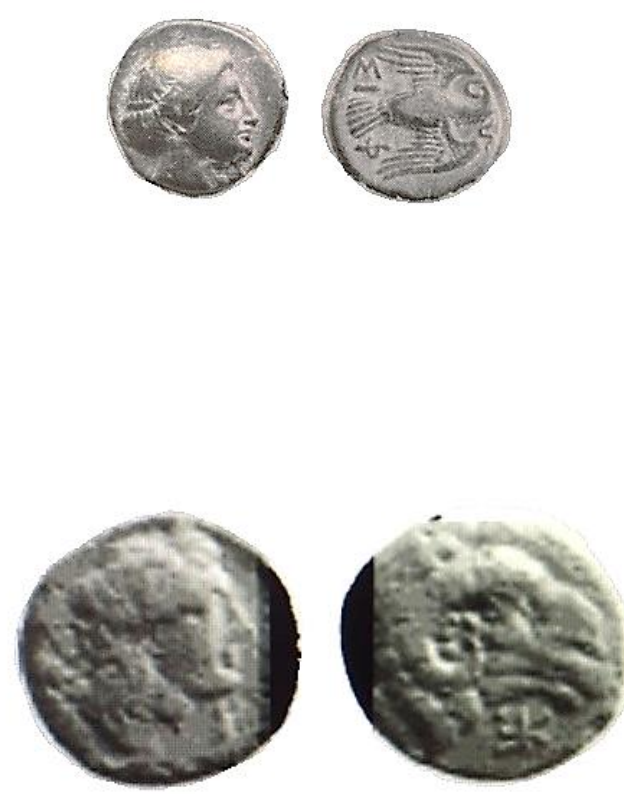


\section{Abydus, Troas}

Data: Início do séc. IV a.C. - 335 a.C.

Anverso: Cabeça laureada de Apolo à d.

Reverso: Águia em pé à e.

Metal / denominação: AR / dracma.

Peso: 2,56 g.

Referências: SNGCop Bosphorus-Bithynia: Pr.1, 6.

Exemplares similares: SNGCop Bosphorus-Bithynia: Pr.1, 6-16; 17-21-23.

\section{Pydna, Macedônia}

Data: c.389-379 a.C.

Anverso: Cabeça de Héracles à d. com pele e leão.

Reverso: Águia em pé, curvada à d. segurando serpente; Пuঠ̃vaıwv.

Metal / denominação: $\mathrm{AE}$ / ?

Peso: $4 \mathrm{~g}$

Referências: SNGCop Thrace and Macedonia: Pr.8, 317; Sear, GCTV, vol.I: 1453A. 


\section{Abdera, Trácia}

Data: 385-375 a.C.

Anverso: Grifo saltando à e.

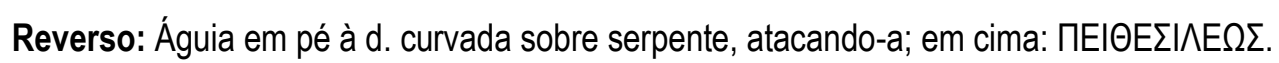

Metal / denominação: AE / ?

Peso: ?

Referências: Sear, GCTV, vol.I: 1557.

\section{Amyntas III, Macedônia}

Data: 381-369 a.C. (período II)

Anverso: Cabeça de Héracles à d. com pele de leão.

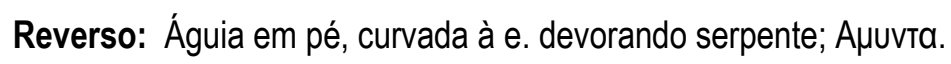

Metal / peso: AE / 4,75 g.

Referências: SNGCop Thrace and Macedonia: Pr.12, 517.

Exemplares similares: SNGCop Thrace and Macedonia: Pr.12, 518.

\section{Amyntas III, Macedônia}

Data: 381-369 a.C.

Anverso: Cabeça de Héracles à d. com pele de leão.

Reverso: Águia em pé à e. com cabeça virada à d.; Auuvta.

Metal / denominação: AR / trióbolo.

Referências: Sear, GCTV, vol.l: 1510. 


\section{Abydus, Troas}

Data: c.380 a.C.

Anverso: Nike sacrificando um carneiro à e.

Reverso: Águia em pé à d.

Metal / denominação: Al / estater.

Referências: Kraay, ACGC: Pr.53, 910.

\section{4. Élis-Olímpia, Peloponeso}

Data: 380 a.C.

Anverso: Cabeça de Hera à d. usando um stephanos ornamentado com cinco palmetas conectadas por gavinhas; $\mathrm{F} A \bigwedge E I O N$.

Reverso: Águia em pé à d., com sua cabeça virada para trás à e., e suas asas abertas, tudo dentro de uma coroa de folhas de oliveira; abaixo e acima da asa esquerda da águia, $\Pi 0$; abaixo da coroa, $[\Lambda]$ YKA.

Metal / denominação: AR / estater.

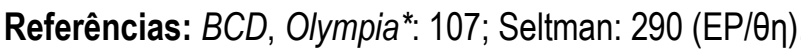

Exemplares similares: $B C D$, Olympia: 108 (Seltman: 292d EQ/ $\theta \theta$ ). 


\section{5. Élis-Olímpia, Peloponeso}

Data: 380 a.C.

Anverso: Cabeça de Hera à d. usando um stephanos estreito; $\mathrm{F} \mathrm{A}$.

Reverso: Cabeça de águia à d. dentro de uma coroa de folhas de oliveira.

Metal / denominação: AR / óbolo.

Referências: BCD, Olympia*: 109; Seltman: pr.XII, 10.

\section{6. Ólbia, Mar Negro}

Data: 380-360 a.C.

Anverso: Cabeça de Deméter à d.

Reverso: Águia sobre gofinho à d., dilacerando sua cabeça; em cima, O^BIO;

embaixo, EY (retrogrado).

Metal / peso: AE / 4,23 g.

Referências: Triton XVI, Lot: 36 (http://www.cngcoins.com/Coin.aspx?CoinlD=222174\#);

SNG BM Black Sea: 413 var. (retrograde EYФ on rev.); SNG Pushkin: 55-6 e 59-63;

cf. SNG Stancomb: 350. 


\section{Halikarnassos, Cária}

Data: c.380-350 a.C.

Anverso: Cabeça laureada de Apolo jovem à e.

Reverso: Águia em pé à d. com asas abertas; ANI.

Metal / denominação: AE / Chalkous.

Referências: Konuk, CIUH: PI.2, 24.

\section{Mytilene, Lesbos}

Data: c.377-326 a.C.

Anverso: Cabeça de Apolo Karneios à d.

Reverso: Águia em pé à d. com cabeça virada à e.; tudo dentro de uma linha quadrada. Metal / denominação: El / hekte.

Referências: Bondenstedt 104. 


\section{9. Élis-Olímpia, Peloponeso}

Data: 376 a.C.

Anverso: Cabeça de Hera à $\mathrm{d}$. usando um stephanos ornamentado com seis palmetas conectadas por gavinhas; $\mathrm{F} \mathrm{A}$.

Reverso: Águia em pé à d., com sua cabeça virada para trás à e., e suas asas abertas, tudo dentro de uma coroa de folhas de oliveira.

Metal / denominação: AR / estater.

Referências: $B C D$, Olympia*: 110; Seltman: $249 f(E R / \theta 1)$.

Exemplares similares: $B C D$, Olympia: 112 (368 a.C., no anverso, o stephanos de Hera é ornamentado por cinco palmetas e tem a inscrição H P A, Seltman: $303 \mathrm{EU} / \theta \pi$ ).

\section{Crotona, Itália do Sul (sem imagem)}

Data: c.375-325 a.C.

Anverso: Cabeça de Atena com elmo ático com crista; KPO.

Reverso: Águia em pé de asas fechadas à e. sobre cabeça de veado; TPI.

Metal / peso: AE / 25,86g.

Referências: Rutter, $H N$ : 2211. 


\section{Sinope, Paphlagonia}

Data: c.370-362 a.C.

Anverso: Sinope; brincos com pendente, mas sem colar.

Reverso: Águia marinha sobre golfinho; abaixo, $\Delta$ ata $\mu$ as.

Metal / denominação: AR / dracma.

Peso: $5,72 \mathrm{~g}$.

Referências: SNGCop Bosphorus-Bithynia: Pr.8, 276.

Exemplares similares: SNGCop Bosphorus-Bithynia: Pr.8, 275.

\section{Cálcis, Eubéia}

Data: $369-336$ a.C

Anverso: Cabeça de Hera à $\mathrm{d}$.

Reverso: Águia voando à d. verticalmente, carregando cobra com suas garras e bicos; embaixo, tridente; ao redor, $\mathrm{X} / \mathrm{A} \wedge$.

Metal / denominação: AR / dracma

Referências: BMC, Central Greece: 110, 46 


\section{Cálcis, Eubéia}

Data: 369-336 a.C.

Anverso: Cabeça de Aretusa à $\mathrm{d}$.

Reverso: Águia voando à d. verticalmente, carregando cobra com suas garras e bicos; embaixo, caduceu; ao redor, $\mathrm{X} / \mathrm{A} \wedge$ ?

Metal / denominação: AR / dracma.

Referências: BMC, Central Greece: 53.

\section{Cálcis, Eubéia}

Data: 369-313 a.C.

Anverso: Cabeça feminina $d$.

Reverso: Águia voando à d., devorando lebre;

embaixo, crescente e XA.

Metal / denominação: AR / hemidracma.

Referências: SNG Cop Thessaly to Aegean?: PI.?, 440.

Exemplares similares: SNG Cop Thessaly to Aegean?: PI.?, 441. 


\section{Cálcis, Eubéia}

Data: 369-313 a.C.

Anverso: Cabeça feminina d.

Reverso: Águia em pé; XA.

Metal / denominação: AR / tetartemorion.

Referências: SNG Cop Thessaly to Aegean?: PI.?, 442.

\section{Cálcis, Eubéia}

Data: 369-313 a.C.

Anverso: Cabeça de Hera de frente.

Reverso: Águia segurando serpente; embaixo, troféu; XA .

Metal / peso: AE / 1,76g.

Referências: SNG Cop Thessaly to Aegean?: PI.?, 443.

Exemplares similares: SNG Cop Thessaly to Aegean?: PI.?, 444 (rev.embaixo, Ártemis correndo?); 445 (rev. e em cima, crescente); 446 (no rev. embaixo, trípode). 


\section{7. Élis-Olímpia, Peloponeso}

Data: 368 a.C.

Anverso: Cabeça de Hera à d. usando um stephanos ornamentado com quatro palmetas.

Reverso: Águia em pé à d. com cabeça virada para trás à e., com asas fechadas tudo dentro de um círculo pontilhado; $F$ A.

Metal / denominação: AR / hemidracma.

Referências: $B C D$, Olympia: 111.

\section{8. Élis-Olímpia, Peloponeso}

Data: 368 a.C.

Anverso: Cabeça de Hera à d. usando um stephanos ornamentado com duas palmetas; entre elas H P A.

Reverso: Águia em pé à e. com cabeça virada para trás à d., com as asas abertas; tudo dentro de um círculo pontilhado; $F$ A.

Metal / denominação: AR / hemidracma.

Referências: $B C D$, Olympia: 113.

Exemplares similares: $B C D$, Olympia: 114 (c.360s a.C., dracma) ; 115; 116; 117. 


\section{Perdicas, Macedônia}

Data: $364-359$ a.C.

Anverso: Cabeça de Héracles à d. com pele de leão.

Reverso: Águia em pé à e. com cabeça virada para trás à d.; Пદрס̄ıкa.

Metal / peso: AE / 4,58 g.

Referências: SNGCop Thrace and Macedonia: Pr.12, 522.

\section{0. Élis-Olímpia, Peloponeso}

Data: 360 a.C.

Anverso: Cabeça da ninfa epônima Olímpia à d., usando brinco com pendente, colar, e com seu cabelo em um sphendone; $F$ A.

Reverso: Águia em pé à e. com cabeça virada para trás à d. com asas fechadas, tudo dentro de uma coroa de folhas de oliveiras.

Metal / denominação: AR / estater.

Referências: $B C D$, Olympia*: 122; Seltman: $376 \mathrm{~g}(E \mathrm{~W} / \delta \sigma)$.

Exemplares similares: $B C D$, Olympia: 124 (hemidracma, Seltman: XII, 11); 129 (356 a.C., reverso similar, águia em pé à d. com cabeça virada à e., Seltman: $310 \mathrm{a}$ EX/日X). 


\section{1. Élis-Olímpia, Peloponeso}

Data: 360 a.C.

Anverso: Cabeça da ninfa epônima Olímpia à d., usando brinco com pendente, colar, e com seu cabelo em um sphendone; $F$ A.

Reverso: Águia em pé à d. com cabeça virada para frente com asas fechadas, sobre capitel de coluna jônica, à e., kerykeion, tudo dentro de coroa de folhas de oliveiras; F A. Metal / denominação: AR / estater.

Referências: $B C D$, Olympia: 123; Seltman: 307 (EW/ $\theta \mathrm{T})$.

\section{2. Élis-Olímpia, Peloponeso}

Data: 360 a.C.

Anverso: Cabeça da ninfa epônima Olímpia à d., usando brinco com pendente, colar, e com seu cabelo em um sphendone; $F$ A.

Reverso: Águia em pé à e. com cabeça virada para trás à d. com asas fechadas; $F$ A.

Metal / denominação: AR / óbolo.

Referências: $B C D$, Olympia: 125. 


\section{3. Élis-Olímpia, Peloponeso}

Data: 360 a.C.

Anverso: Cabeça da ninfa epônima Olímpia à d., usando brinco com pendente, colar,

e com seu cabelo em um sphendone; $\mathrm{FA}$.

Reverso: Águia em pé à d. com cabeça virada para frente com asas fechadas; F A.

Metal / denominação: AR / óbolo.

Referências: $B C D$, Olympia: 126.

\section{Crotona, Itália do Sul}

Data: 360-340 a.C.

Anverso: Águia em pé à e. com asas abertas e garra direita segura um ramo; KPO[TSNIATAN.

Reverso: Trípode; à e., grão de trigo; à d. cobra.

Metal / denominação: AR / estater.

Peso: $7,88 \mathrm{~g}$.

Referências: Cahn et alii, GMGS: 202. 


\section{Sinope, Paphlagonia}

Data: c.360-320 a.C.

Anverso: Sinope; brinco com pendente triplo e colar; de frente, aplustre.

Reverso: Águia marinha sobre golfinho; abaixo, $\Sigma \mathrm{iv} \omega$.

Metal / denominação: AR / dracma.

Peso: $5,72 \mathrm{~g}$.

Referências: SNGCop Bosphorus-Bithynia: Pr.8, 277.

Exemplares similares: SNGCop Bosphorus-Bithynia: Pr.8, 278-283; 284-285; 286; 287-289.

\section{6. Élis-Olímpia, Peloponeso}

Data: 356 a.C.

Anverso: Cabeça de Hera à d.

Reverso: Águia em pé à e. com cabeça virada para trás à d. com asas fechadas, tudo dentro de uma coroa de folhas de oliveiras.

Metal / denominação: AR / estater.

Referências: $B C D$, Olympia*: 130; Seltman: 313 (EX/Ia). 


\section{7. Élis-Olímpia, Peloponeso}

Data: 352 a.C.

Anverso: Cabeça de Hera à d., usando um stephanos estreito ornamentado com uma palmeta e um lírio; $F$ A.

Reverso: Águia em pé à d. com asas abertas tudo dentro de uma coroa de folhas de oliveira.

Metal / denominação: AR / estater.

Referências: $B C D$, Olympia*: 134; Seltman: 314 (EX2//B).

\section{8. Élis-Olímpia, Peloponeso}

Data: 352 a.C.

Anverso: Cabeça de Hera à d., usando um stephanos estreito ornamentado com duas palmetas e um lírio e um brinco com pendente; $\mathrm{F} \mathrm{A}$.

Reverso: Águia em pé à d. com cabeça virada para frente com asas fechadas; tudo dentro de uma coroa de folhas de oliveira.

Metal / denominação: AR / estater.

Referências: $B C D$, Olympia*: 135; Seltman: 321b (EY/OW).

\section{Amanthus, Chipre}

Data: c.350 a.C.

Anverso: Leão à d., sobre ele, águia voando de frente.

Reverso: Prótomo de leão à d.

Metal / denominação: AR / didracma.

Referências: Kraay, ACGC: Pr.64, 1107. 


\section{0. Ólbia, Mar Negro}

Data: 350-330 a.C.

Anverso: Cabeça de Deméter de frente.

Reverso: Águia em pé sobre gofinho à d., asas abertas e cabeça voltada para a e.;

em cima, $\mathrm{O} \wedge \mathrm{BIH}$.

Metal / peso: AE (cast) / 105,90 g.

Referências: Triton XVI, Lot: 40 (http://www.cngcoins.com/Coin.aspx?CoinlD=222178);

SNG BM Black Sea: 393; SNG Pushkin: 96-7.

\section{1. Ólbia, Mar Negro}

Data: $350-330$ a.C.

Anverso: Cabeça de Deméter de frente.

Reverso: Águia em pé à e. sobre gofinho, asas abertas e cabeça voltada para a d.;

em cima, $\mathrm{O} \wedge \mathrm{BIH}$.

Metal / peso: AE (cast) / 106,50 g.

Referências: Triton XVI, Lote: 39 (http://www.cngcoins.com/Coin.aspx?CoinID=222177);

SNG BM Black Sea: 390-2 var.; SNG Pushkin: 91-3 var. (mesmo); SNG Stancomb: 348 var. 
262. Cyme, Aeolis (sem imagem)

Data: c.350-320 a.C.

Anverso: Águia em pé à d. com asas fechadas com cabeça virada à e.

Reverso: Prótomo de cavalo à d.; $\Theta / E Y \Gamma / E / H \Sigma$.

Metal / peso: AR / 94.1

Referências: BMC Troas, Aeolis and Lesbos: Pr. XIX, 10.

263. Metaponto, Itália do Sul (sem imagem)

Data: c.350-275 a.C.

Anverso: Águia voando à e. ou d.

Reverso: Grão de trigo; M-E.

Metal / peso: $\mathrm{AE} / 1,8 \mathrm{~g}$.

Referências: Rutter, HN: 1672. 


\section{Cyme, Aeolis}

Data: c.350-250 a.C.

Anverso: Águia em pé à e.; nome de magistrado.

Reverso: Vaso com uma alça; Ku.

Metal / peso: AE / 3,47 g

Referências: SNGCop Bosphorus-Bithynia: Pr.2, 46.

Exemplares similares: SNGCop Bosphorus-Bithynia: Pr.1, 47-68.

\section{Cyme, Aeolis}

Data: c.350-250 a.C.

Anverso: Águia em pé, olhando para trás; acima, Ku.

Reverso: Prótomo de cavalo.

Metal / denominação: AR / hemidracma.

Referências: SNGCop Bosphorus-Bithynia: Pr.1, 35.

Exemplares similares: SNGCop Bosphorus-Bithynia: Pr.1, 36-45.

\section{Mytilene, Lesbos (sem imagem)}

Data: c.350-250 a.C.

Anverso: Cabeça feminina à d. (Afrodite?).

Reverso: Lira; à d., cabeça de águia; M/Y/T/l.

Metal / peso: AE/ 55 .

Referências: BMC Troas, Aeolis and Lesbos: no.64. 


\section{7. Élis-Olímpia, Peloponeso}

Data: 348 a.C.

Anverso: Cabeça de Hera à d., usando um stephanos estreito ornamentado com uma palmeta e um lírio; F A.

Reverso: Águia em pé à e. com cabeça virada para frente, tudo dentro de uma coroa de folhas de oliveira.

Metal / denominação: AR / estater.

Referências: $B C D$, Olympia*: 148; Seltman: 324 (EZ/ın).

Exemplares similares: $B C D$, Olympia: 149 (Seltman: 327 a FB/ın).

\section{8. Élis-Olímpia, Peloponeso}

Data: 344 a.C.

Anverso: Cabeça de Hera à d., usando um stephanos estreito ornamentado com quatro palmetas,

um brinco de pendente e um colar.

Reverso: Águia em pé à d. com cabeça virada para trás à e., com asas abertas, tudo dentro de uma coroa de folhas de oliveira.

Metal / denominação: AR / estater.

Referências: $B C D$, Olympia*: 151; Seltman: $329(\mathrm{FC} / \mu)$. 


\section{9. Élis-Olímpia, Peloponeso}

Data: 344 a.C.

Anverso: Cabeça de Hera à d., usando um stephanos estreito ornamentado com quatro palmetas, um brinco de pendente e um colar.

Reverso: Águia em pé à e. com cabeça virada para trás à d., com asas abertas e sobre cabeça de um veado, tudo dentro de uma coroa de folhas de oliveira.

Metal / denominação: AR / estater.

Referências: $B C D$, Olympia*: 152; Seltman: 332 (FC/10).

\section{0. Ólbia, Mar Negro}

Data: $2^{\text {a }}$. metade séc. IV a.C.

Anverso: Cabeça de Deméter à e.

Reverso: Águia sobre gofinho à e., com asas abertas e cabeça à d.; $\mathrm{O} \wedge \mathrm{BIO}$.

Metal / denominação: AR / estater

Referências: Europe of Greece, no.89, p.274.

\section{Crotona, Itália do Sul}

Data: $2^{a}$. metade séc. IV a.C.

Anverso: Cabeça à de Héracles e.; à e., KPO.

Reverso: Águia em pé à d.; asas fechadas e cabeça para trás; KPOT.

Metal / peso: AE / 2,3 g.

Referências: Rutter, $H N$ : 2224. 


\section{Cyzicus, Mysia}

Data: Séc. IV a.C.

Anverso: Águia em pé à e. com asas fechadas sobre atum.

Reverso: Quadrado incuso.

Metal / denominação: El. / estater.

Referências: Kraay, ACGC: Pr.56, 963.

\section{Abydus, Troas}

Data: Séc. IV a.C.

Anverso: Cabeça laureada de Apolo à d.

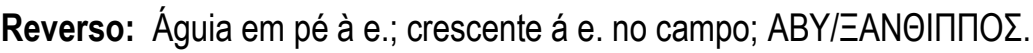

Metal / denominação: AR / hemidracma.

Referências: SNG Ashmolean: 959; Numisbids, lote 216. 


\section{RAIOS}

\section{SÉCULO V a.C.}

\section{Aetna-Inessa, Sicília}

Data: $475-460$ a.C.

Anverso: Cabeça de Sileno à d.; círculo de pontos.

Reverso: Raio alado; AIT NAI.

Metal / peso: AR / 0,648g.

Referências: $B M C$ Sicily: 12, p.43.

Exemplares similares: BMC Sicily: 8 (tipo arcaico), p.42; 13-16, p.43.

275. Catânia, Sicília

Data: 461 a.C.

Anverso: Cabeça de Sileno à d. sem diadema; tudo dentro de um círculo e pérolas.

Reverso: Raio com duas asas; KAT/ANE.

Metal / peso: AR / litra.

Referências: SNG ANS: 1237 (https://www.numisbids.com/n.php?p=lot\&sid=559\&lot=40). 


\section{Catânia, Sicília}

Data: $461-450$ a.C.

Anverso: Cabeça de Sileno à e. sem diadema; tudo dentro de um círculo e pérolas.

Reverso: Raio com duas asas; KAT/ANE.

Metal / peso: AR / litra.

Referências: SNG Tübingen: 590 (https://www.numisbids.com/n.php?p=lot\&sid=559\&lot=39).

\section{Catânia, Sicília}

Data: $461-413$ a.C.

Anverso: Cabeça de Sileno à e. coroada com diadema.

Reverso: Raio com duas asas, à e. e d., escudo; Katavaııv.

Metal / peso: AR / litra.

Referências: SNGCop Italy-Sicily: Pr.4, 183.

Exemplares similares: SNGCop Sicily: Pr.4, 182 (no anverso, Sileno usa coroa de folhas de hera)

\section{Crotona, Itália do Sul}

Data: Antes de 425 a.C.

Anverso: Trípode dentro de um círculo.

Reverso: Raio dentro de um círculo; de cada lado, pequenos círculos.

Metal / denominação: AR / dióbolo.

Referências: Rutter, $H N$ : 2134. 


\section{9. Élis-Olímpia, Peloponeso}

Data: 420 a.C.

Anverso: Cabeça de Hera à d. com stephanos ornamentado com três palmetas ligadas

por gavinhas; acima HPA; abaixo do queicho, $\Lambda$.

Reverso: Raio chamejante, tudo dentro de uma coroa de folhas de oliveira; F A.

Metal / denominação: AR / estater.

Referências: $B C D$, Olympia*: 62; Seltman: 242 (EA/na).

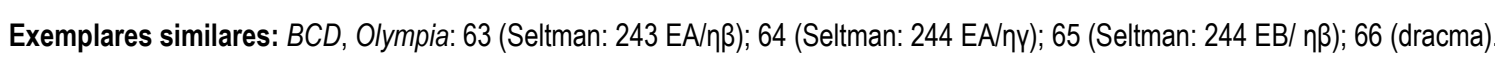

\section{0. Élis-Olímpia, Peloponeso}

Data: 416 a.C.

Anverso: Cabeça de Hera à d. com stephanos ornamentado com duas palmetas e

dois lírios e com as letras HPA entre eles.

Reverso: Raio chamejante, tudo dentro de uma coroa de folhas de oliveira; F A.

Metal / denominação: AR / estater.

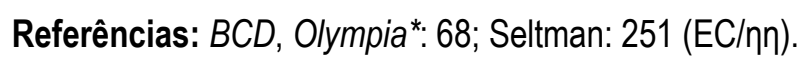

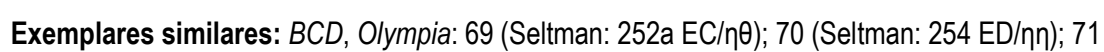

(412 a.C., Seltman: 257 EE/Kk); 72 (412 a.C., Seltman: $258 \mathrm{~b}$ EF/nk); 73 (412 a.C., hemidracma, Seltman: pr.XII, 5);

74 (412 a.C., hemidracma). 


\section{1. Élis-Olímpia, Peloponeso}

Data: 412 a.C.

Anverso: Cabeça de Hera à d. com stephanos ornamentado com duas palmetas e com as letras $\mathrm{H} P$ entre elas.

Reverso: Raio com asas embaixo e volutas em cima; $F$ A.

Metal / denominação: AR / óbolo.

Referências: $B C D$, Olympia*: 75; Seltman: pr.XII, 4.

\section{2. Élis-Olímpia, Peloponeso}

Data: 412 a.C.

Anverso: Cabeça de Hera à d. com stephanos ornamentado com duas palmetas e

com as letras H P A entre elas.

Reverso: Raio chamejante; FA.

Metal / denominação: AR / óbolo.

Referências: $B C D$, Olympia*: 76; Seltman: pr.XII, 6.

\section{Catânia, Sicília}

Data: $410-402$ a.C.

Anverso: Cabeça de Amenanos à e. com pequeno chifre; AMENANO乏.

Reverso: Raio com duas asas; $\mathrm{KA}$.

Metal / denominação: AR / tetras.

Peso: 1,36 g.

Referências: Cahn et alii, GMGS: 342. 


\section{SÉCULO IV a.C.}

\section{4. Élis-Olímpia, Peloponeso}

Data: 400 a.C.

Anverso: Cabeça de Hera à d., usando stephanos ornamentado com duas palmetas e dois lírios.

Reverso: Raio chamejante, tudo dentro de uma coroa de folhas de oliveira; $F$ A.

Metal / denominação: AR / estater.

Referências: $B C D$, Olympia*: 88; Seltman: 274 (EJ/nX).

\section{Mytilene, Lesbos (sem imagem)}

Data: $400-350$ a.C.

Anverso: Cabeça laureada de Apolo à d.

Reverso: Cabeça feminina à d. (Afrodite?) usando brincos; raio.

Metal / denominação: AR / 20.2.

Referências: BMC Troas, Aeolis and Lesbos: Pr. XXXVII,15.

\section{Gargara, Troas (sem imagem)}

Data: 400-284 a.C.

Anverso: Cabeça laureada de Apolo à d.

Reverso: Cavalo galopando à d.; embaixo, raio; ГAP.

Metal / denominação: AR / 20.2.

Referências: BMC Troas, Aeolis and Lesbos: Pr. X, 6. 


\section{7. Élis-Olímpia, Peloponeso}

Data: 392 a.C.

Anverso: Cabeça de Hera à d., usando stephanos ornamentado com duas palmetas e dois lírios.

Reverso: Raio chamejante, tudo dentro de uma coroa de folhas de oliveira ; F A.

Metal / denominação: AR / estater.

Referências: $B C D$, Olympia*: 91; Seltman: 279 (EL/ $\eta \omega)$.

\section{8. Élis-Olímpia, Peloponeso}

Data: 388 a.C.

Anverso: Cabeça de Hera à d. com stephanos ornamentado com duas palmetas e dois lírios ligados por gavinhas.

Reverso: Raio chamejante, tudo dentro de uma coroa de folhas de oliveira ; F A (retrogrado).

Metal / denominação: AR / estater.

Referências: $B C D$, Olympia*: 93; Seltman: 283 (EM/ $\theta \beta)$.

Exemplares similares: $B C D$, Olympia: 94 (Seltman: $284 \mathrm{EM} / \theta \mathrm{\theta}$ ).

\section{Mycalessos, Liga Beócia}

Data: c.387-374 a.C.

Anverso: Escudo beócio.

Reverso: Raio; M Y.

Metal / denominação: AR / óbolo

Referências: Mildenberg e Hurter, ADCGC: Pr. 80, 1489. 


\section{Molossi, Épiro}

Data: c.375 a.C.

Anverso: Cão de caça à e.

Reverso: Raio na horizontal; ao redor, MO $\triangle \mathrm{\Sigma \Sigma} \Omega \mathrm{N}$.

Metal / denominação: AR / hemidracma.

Referências: Kraay, ACGC: Pr.24, 444.

\section{Molossi, Épiro}

Data: c.360-330 a.C.

Anverso: Raio em escudo; ao redor, $\mathrm{MO} \Lambda[\mathrm{O} \Sigma[\Sigma \Omega \mathrm{N}$.

Reverso: Raio dentro de coroa de folhas de louro.

Metal / peso: AE / 6,03g.

Referências: ANS 1941.131.514 (Franke, p.104.40).

\section{2. Élis-Olímpia, Peloponeso}

Data: 360 a.C.

Anverso: Cabeça da ninfa epônima Olímpia à d., usando brinco com pendente (?)

e com seu cabelo em um sphendone; $F$ A.

Reverso: Raio com volutas em cima e asas embaixo; $F$ A.

Metal / denominação: AR / hemióbolo.

Referências: $B C D$, Olympia: 127. 


\section{Felipe II (Pella), Macedônia}

Data: $359-336$ a.C.

Anverso: Cabeça laureada de Apolo à d.

Reverso: Raio; abaixo, Фı।ıाтाто e máscara de leão.

Metal / denominação: AV / estater.

Referências: SNGCop Thrace and Macedonia: Pr.13, 542.

Exemplares similares: SNGCop Thrace and Macedonia: Pr.14, 621.

\section{Mytilene, Lesbos (sem imagem)}

Data: c.350-250 a.C.

Anverso: Cabeça laureada de Apolo à $\mathrm{d}$.

Reverso: Lira com fita anexada; tudo dentro de um compartimento; à e., raio; MY/T/I.

Metal / denominação: AR / 176 .

Referências: BMC Troas, Aeolis and Lesbos: Pr.XXXVII, 20.

Exemplares similares: BMC Troas, Aeolis and Lesbos: no. 80 (sem imagem).

\section{Kierion, Tessália}

Data: $2^{a}$. metade do século IV a.C.

Anverso: Cabeça de jovem à d. (de Apolo?) usando taenia.

Reverso: Raio dentro de uma coroa de louros; em cima, KIEPI e embaixo, EISN.

Metal / denominação: AE / chalkous.

Referências: BCD Thessaly (Nomos): 1076, p.51. 


\section{Alaisa, Sicília}

Data: 344 a.C.

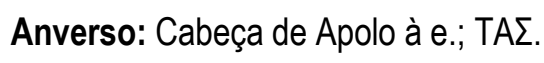

Reverso: Raio e ao lado esquerdo, cacho de uvas; $\Sigma$ Y MMAX.

Metal / peso: AE / ?

Referências: BMC Sicily: no.4, p.29.

\section{Argos}

Data: Séc. IV a.C.

Anverso: Cabeça de lobo à e.

Reverso: A; abaixo, raio.

Metal / denominação: AE / chalkos.

Peso: 1,24 g.

Referências: BCD Peloponnesos: 1056.2.

\section{Dardanus, Troas (sem imagem)}

Data: Séc. IV a.C.

Anverso: Cavaleiro à $\mathrm{d}$. vestindo chiton, chlamys e petasos sobre cavalo galopando; abaixo, raio; Tudo dentro de círculo de pérolas.

Reverso: Galo em atitude de luta à d.; embaixo, grão de trigo.

Metal / peso: AE / 6

Referências: BMC Troas, Aeolis and Lesbos: Pr. IX, 11. 


\section{ÁGUIAS E RAIOS}

\section{SÉCULO V a.C.}

\section{9. Élis-Olímpia, Peloponeso}

Data: c.468 a.C.

Anverso: Águia voando à d., com asas abertas acima e abaixo de seu corpo, segurando nada em seu bico e garras.

Reverso: Raio com asas em cima e volutas embaixo; $F$ A.

Metal / denominação: AR / estater.

Referências: BCD, Olympia*: 1; Seltman: 1 (A/a).

\section{0. Élis-Olímpia, Peloponeso}

Data: c.468 a.C.

Anverso: Águia voando à d., com asas abertas acima e abaixo de seu corpo, carregando cobra com bico e garras.

Reverso: Raio com asas embaixo e volutas em cima; F A.

Metal / denominação: AR / hemidracma.

Referências: $B C D$, Olympia*: 2; Seltman: ?

Exemplares similares: $B C D$, Olympia: 4 (no reverso, F A é retrogrado). 


\section{1. Élis-Olímpia, Peloponeso}

Data: c.468 a.C.

Anverso: Águia voando à d., com asas abertas acima e abaixo de seu corpo, carregando lebre pela barriga e atacando-a com seu bico.

Reverso: Raio com asas embaixo e volutas em cima; A F (retrogrado).

Metal / denominação: AR / didracma.

Referências: CCCCRL: Pr.IX, 1922.

\section{2. Élis-Olímpia, Peloponeso}

Data: c.460s a.C.

Anverso: Águia voando à e., com asas abertas acima e abaixo de seu corpo, carregando cobra com bico e garras.

Reverso: Raio com asas em cima e volutas embaixo; F A.

Metal / denominação: AR / estater.

Referências: $B C D$, Olympia*: 5; Seltman: 5/28 (E/w).

Exemplares similares: $B C D$, Olympia: 6 (Seltman: 16 var.); 7 ( no reverso está Nike à e. tem diadema na cabeça, Seltman: 20 N/p); 8-10 (dracma, Seltman: p.12, a, pr.VIII, 3); 11-12 (hemidracma, Seltman: p. 12); 13-15

(óbolos, a 13 foi recunhada em cima de moeda de Tegea, da Liga Arcádia); 16 (óbolo, no reverso a inscrição F A é retrograda). 


\section{3. Élis-Olímpia, Peloponeso}

Data: c.460s-450s a.C.

Anverso: Águia voando à e., com ambas as asas acima de seu corpo, carregando uma lebre pela sua barriga com suas garras e a dilacerando-a com seu bico.

Reverso: Raio com asas em cima e volutas embaixo; $F$ A.

Metal / denominação: AR / estater.

Referências: $B C D$, Olympia*: 17; Seltman: 26 (S/ $\eta$ ).

Exemplares similares: $B C D$, Olympia: 18 (no reverso está Nike à d. segurando coroa em sua mão esquerda levantada e

segurando a bainha de seu chiton com a mão direita; F A, Seltman: $30 \mathrm{U}$ aß); 19 (Seltman: 31 var.); 21 (Seltman: 31 var. anv. W e rev. $\beta \delta$ );

22 (hemidracma, no reverso a inscrição é em retrogrado, Seltman: p.20 e pr.VIII,5).

\section{4. Élis-Olímpia, Peloponeso}

Data: c.460s-450s a.C.

Anverso: Águia voando à e., com ambas as asas acima de seu corpo, carregando uma lebre pela sua barriga com suas garras e dilacerando-a com seu bico.

Reverso: Raio com asas em cima e volutas embaixo, tudo dentro de um círculo de pontos; F A.

Metal / denominação: AR / estater.

Referências: $B C D$, Olympia*: 20; Seltman: 32 (W/aס). 


\section{5. Élis-Olímpia, Peloponeso}

Data: c.460s-450s a.C.

Anverso: Águia voando à e., com ambas as asas acima de seu corpo, carregando uma lebre pela sua barriga com suas garras e dilacerando-a com seu bico.

Reverso: Raio com asas embaixo e volutas em cima; $F$ A.

Metal / denominação: AR / hemidracma.

Referências: $B C D$, Olympia: 23.

\section{6. Élis-Olímpia, Peloponeso}

Data: Final c.450s a.C.

Anverso: Águia voando à d., com as asas acima e abaixo de seu corpo, carregando uma cobra com suas garras e bico.

Reverso: Raio com asas em cima e volutas embaixo; F A.

Metal / denominação: AR / estater.

Referências: $B C D$, Olympia*: 28; Seltman: 43b (AF/a६).

Exemplares similares: $B C D$, Olympia: 29 (no reverso, Nike caminhando à e., segurando coroa com sua mão direita estendida e com seu braço esquerdo pendendo ao lado do corpo, Seltman: $45 \mathrm{AF} / \mathrm{ar}$ ). 


\section{7. Élis-Olímpia, Peloponeso}

Data: c.440s a.C.

Anverso: Águia voando à d., com ambas as asas acima de seu corpo, carregando uma lebre pelas costas com suas garras e dilacerando-a com seu bico.

Reverso: Raio com volutas em cima e asas embaixo; F A.

\section{Metal / denominação: AR / dracma.}

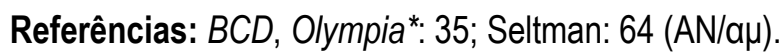

Exemplares similares: $B C D$, Olympia: 36 (no reverso, raio com asas em cima e volutas embaixo, Seltman: 67 AN/aw).

\section{8. Élis-Olímpia, Peloponeso}

Data: c.440s-430s a.C.

Anverso: Águia voando à d., com ambas as asas acima de seu corpo, carregando uma lebre pelas costas com suas garras e dilacerando-a com seu bico.

Reverso: Raio com asas em cima e volutas embaixo; $F$ A.

Metal / denominação: AR / estater.

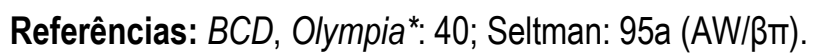




\section{9. Élis-Olímpia, Peloponeso}

Data: c.440s-430s a.C.

Anverso: Águia voando à d., com ambas as asas acima de seu corpo, carregando uma lebre pelas costas com suas garras e dilacerando-a com seu bico.

Reverso: Raio com volutas em cima e asas embaixo; FA.

Metal / denominação: AR / dracma.

Referências: $B C D$, Olympia*: 41; Seltman: pr.VIII,7.

\section{0. Élis-Olímpia, Peloponeso}

Data: c.440s-430s a.C.

Anverso: Águia voando à d., com ambas as asas acima de seu corpo, carregando uma lebre pela barriga com suas garras e dilacerando-a com seu bico.

Reverso: Raio com asas em cima e volutas embaixo; $F$ A.

Metal / denominação: AR / hemidracma.

Referências: $B C D$, Olympia: 43. 


\section{1. Élis-Olímpia, Peloponeso}

Data: c.440s-430s a.C.

Anverso: Águia voando à e., com ambas as asas acima de seu corpo, carregando uma lebre pelas costas com suas garras e dilacerando-a com seu bico.

Reverso: Raio com lírio em cima, com asas embaixo e volutas em cima; $F$ A.

Metal / denominação: AR / dracma.

Referências: $B C D$, Olympia*: 51; Seltman: pr.VIII, 12.

\section{2. Élis-Olímpia, Peloponeso}

Data: c.432 a.C.

Anverso: Águia voando à e. com asas em cima e embaixo de seu corpo, carregando um veado pelas costas com suas garras e dilacerando-o com seu bico; acima à e., concha.

Reverso: Raio com asas em cima e volutas embaixo; à e., galhinho com duas folhas de oliveira e fruto; à d., folha de videira com gavinha; $\mathrm{F}$ A.

Metal / denominação: AR / estater.

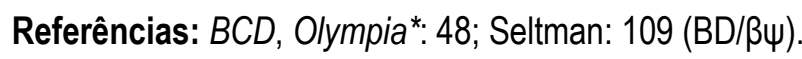




\section{3. Élis-Olímpia, Peloponeso}

Data: c.432 a.C.

Anverso: Águia em pé à e., com asas agitadas acima, carregando com suas garras uma cobra enrolada que está tocando o bico aberto da ave; F A.

Reverso: Raio grande com lírio em cima, volutas embaixo e duas asas muito grandes em cada lado, tudo dentro de um quadrado pontilhado; $F$ A.

Metal / denominação: AR / estater.

Referências: $B C D$, Olympia*: 49; Seltman: $124(B H / \beta X)$.

\section{4. Élis-Olímpia, Peloponeso}

Data: c.432 a.C.

Anverso: Águia voando à e., com ambas as asas acima de seu corpo, carregando uma lebre pelas costas com suas garras e dilacerando-a com seu bico.

Reverso: Raio com volutas em cima e embaixo e com asas no meio; F A.

Metal / denominação: AR / hemidracma.

Referências: $B C D$, Olympia: 50. 


\section{5. Élis-Olímpia, Peloponeso}

Data: c.432-420s a.C.

Anverso: Águia voando à d., com ambas as asas acima de seu corpo, carregando uma lebre pelas costas com suas garras e dilacerando-a com seu bico.

Reverso: Raio com asas embaixo e palmeta com volutas em cima; F A^EION.

Metal / denominação: AR / estater.

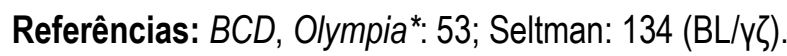

\section{6. Élis-Olímpia, Peloponeso}

Data: c.432-420s a.C.

Anverso: Águia em pé à d. com asas abertas e olhando para trás à e., sobre o corpo de uma presa.

Reverso: Raio com asas embaixo e volutas em cima; $F$ A.

Metal / denominação: AR / estater.

Referências: $B C D$, Olympia*: 54; Seltman: $136 f$.

Exemplares similares: $B C D$, Olympia: 55 (hemidracma, Seltman: pr.VIII, 14); 56 (hemidracma, Seltman: pr.VIII, 14).

\section{7. Élis-Olímpia, Peloponeso}

Data: c.432-420s a.C.

Anverso: Águia em pé à e. com asas abertas e olhando para trás à d.

Reverso: Raio com asas embaixo e volutas em cima; F A.

Metal / denominação: AR / óbolo.

Referências: $B C D$, Olympia: 57. 


\section{Crotona, Itália do Sul}

Data: c.425-375 a.C.

Anverso: Águia à d. sobre cabeça de carneiro; no campo, proa? arco?

Reverso: Trípode; ? POT ou raio.

Metal / peso: AE / 5-7 g.

Referências: Rutter, $H N$ : 2207.

\section{Crotona, Itália do Sul}

Data: c.425-375 a.C.

Anverso: Águia à d. sobre cabeça de carneiro; no campo, proa? arco?

Reverso: Raio na horizontal entre dois crescentes.

\section{Metal / peso: AE / 4-5 g.}

Referências: Rutter, $H N$ : 2208. 


\section{0. Élis-Olímpia, Peloponeso}

Data: Final 420s a.C.

Anverso: Águia em pé à d. com asas abertas, segurando com seu bico o pescoço de uma cobra, cuja cabeça sobe para atacar à e. a cabeça da águia; o restante do corpo da cobra circunda o pescoço da águia e cai ao chão onde é agarrado pelas garras da águia e forma um caracol embaixo do rabo da águia; em letras pequenas $\Delta \mathrm{A}$.

Reverso: Raio com asas em cima e volutas embaixo, tudo dentro de um círculo de bolinhas; F A.

Metal / denominação: AR / estater.

Referências: $B C D$, Olympia*: 58; Seltman: 140a (BN//k).

\section{1. Élis-Olímpia, Peloponeso}

Data: 420 a.C.

Anverso: Águia com asas fechadas à d., sobre a barriga de uma lebre morta, esticando seu pescoço para dilacerar a lebre com o bico.

Reverso: Raio com asas embaixo e volutas em cima, tudo dentro de uma coroa de folhas de oliveira;

FA.

Metal / denominação: AR / estater.

Referências: $B C D$, Olympia*: 59; Seltman: 143 (BP/Yv). 


\section{2. Élis-Olímpia, Peloponeso}

Data: 420 a.C.

Anverso: Águia com asas fechadas à d., sobre a barriga de uma lebre morta, esticando seu pescoço para dilacerar a lebre com o bico.

Reverso: Raio com asas em cima e volutas embaixo, tudo dentro de um círculo de bolinhas;

FA.

Metal / denominação: AR / hemidracma.

Referências: $B C D$, Olympia*: 60; Seltman: VIII, 15.

Exemplares similares: $B C D$, Olympia: 61 (óbolo, Seltman: VIII, 16).

\section{3. Élis-Olímpia, Peloponeso}

Data: c.416-404 a.C.

Anverso: Cabeça de águia à d.; abaixo, grande folha de oliveira à d.

Reverso: Raio com asas em cima e volutas embaixo; tudo dentro de uma coroa de folhas de oliveira; F A.

Metal / denominação: AR / hemidracma.

Referências: $B C D$, Olympia: 79. 


\section{4. Élis-Olímpia, Peloponeso}

Data: 408 a.C.

Anverso: Cabeça de águia à d.; abaixo, grande folha de álamo à e.

Reverso: Raio com asas em cima e volutas embaixo; tudo dentro de uma coroa de folhas de oliveira; F A.

Metal / denominação: AR / estater.

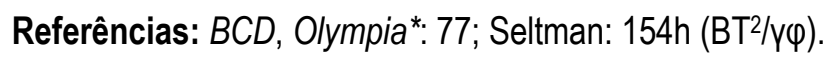

\section{5. Élis-Olímpia, Peloponeso}

Data: 404 a.C.

Anverso: Cabeça de águia à d.; abaixo, grande folha de álamo à e.

Reverso: Raio com asas em cima e volutas embaixo; tudo dentro de uma coroa de folhas de oliveira; F A.

Metal / denominação: AR / estater.

Referências: $B C D$, Olympia*: 78; Seltman: $157\left(\mathrm{BT}^{3} / \mathrm{Y} \omega\right)$. 


\section{SÉCULO IV a.C.}

\section{6. Élis-Olímpia, Peloponeso}

Data: 400 a.C.

Anverso: Cabeça de águia à d. sobre um escudo redondo com uma borda em relevo;

abaixo, grande $\mathrm{F}$ incuso.

Reverso: Raio com volutas em cima e chamas embaixo, na parte de dentro de um escudo

com uma borda estreita e alça à esquerda e à direita do raio; $\mathrm{F} \mathrm{A}$

Metal / denominação: AR / estater.

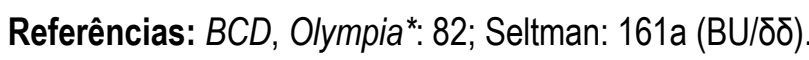

\section{7. Élis-Olímpia, Peloponeso}

Data: 400 a.C.

Anverso: Cabeça de águia à d.; abaixo, lagarto à d. visto de cima.

Reverso: Raio, com volutas em cima, chamas embaixo, e anexados nas volutas, folhas de oliveira à e. e à d.; F A.

Metal / denominação: AR / dracma.

Referências: $B C D$, Olympia*: 83.

Exemplares similares: $B C D$, Olympia: 84 (hemidracma, no reverso, raio com volutas em cima e asas embaixo,

Seltman: pr.VIII, 22); 85 (hemidracma, no reverso, raio com volutas em cima e chamas embaixo, Seltman: VIII, 23). 


\section{8. Élis-Olímpia, Peloponeso}

Data: 400 a.C.

Anverso: Cabeça de águia à d.

Reverso: Raio com chamas em cima e volutas embaixo ; F A.

Metal / denominação: AR / hemióbolo.

Referências: $B C D$, Olympia: 86.

Exemplares similares: $B C D$, Olympia: 87 (tetartemorion, no reverso, T dentro de círculo incuso, Seltman: pr.VIII, 18).

\section{Crotona, Itália do Sul}

Data: 400-350 a.C.

Anverso: Trípode; folha de louro à e.; KPO.

Reverso: Raio vertical; estrela à e.; águia em pé de asas fechadas sobre capitel jônico à d.

Metal / denominação: AR / trióbolo.

Referências: Rutter, HN: 2185. 


\section{0. Élis-Olímpia, Peloponeso}

Data: 396 a.C.

Anverso: Águia em pé à e., agarrando com suas garras uma cobra enrolada e dilacerando o pescoço com seu bico; tudo dentro de um escudo redondo com borda em relevo.

Reverso: Raio com volutas em cima e chamas embaixo; em cada lado das volutas, duas folhas de oliveira; F A (A incuso).

Metal / denominação: AR / estater.

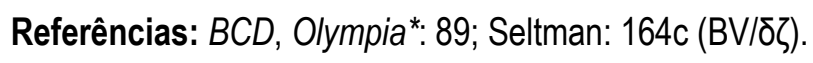

Exemplares similares: $B C D$, Olympia: 90 (392 a.C., no reverso, raio sem folhas de oliveira, Seltman: 168 (BW/סع).

\section{1. Élis-Olímpia, Peloponeso}

Data: Final c.390s-c.380 a.C.

Anverso: Cabeça de águia à d. com pescoço longo; embaixo do bico, $\Pi 0$.

Reverso: Raio com asas embaixo e volutas em cima, tudo dentro de uma coroa de folhas de oliveira; F A.

Metal / denominação: AR / hemidracma.

Referências: $B C D$, Olympia*: 95; Seltman: pr.VIII, 20.

Exemplares similares: $B C D$, Olympia: 96 (óbolo); 98 ( no anverso, a águia tem pescoço curto).

\section{2. Élis-Olímpia, Peloponeso}

Data: Final c.390s-c.380 a.C.

Anverso: Cabeça de águia à $\mathrm{d}$.

Reverso: Raio chamejante; FA.

Metal / denominação: AR / hemióbolo.

Referências: $B C D$, Olympia: 100. 


\section{3. Élis-Olímpia, Peloponeso}

Data: Final c.390s-c.380 a.C.

Anverso: Cabeça de águia à e. com pescoço longo; embaixo do bico, $\Pi$ О.

Reverso: Raio com asas embaixo e volutas em cima, tudo dentro de uma coroa de folhas de oliveira; F A.

Metal / denominação: AR / hemidracma.

Referências: $B C D$, Olympia: 102.

Exemplares similares: $B C D$, Olympia: 103.

\section{4. Élis-Olímpia, Peloponeso}

Data: Final c.390s-c.380 a.C.

Anverso: Cabeça de águia à e. com pescoço longo.

Reverso: Raio com chamas embaixo e em cima; F A.

Metal / denominação: AR / hemióbolo.

Referências: $B C D$, Olympia: 106.

\section{5. Élis-Olímpia, Peloponeso}

Data: 388 a.C.

Anverso: Águia em pé à e., agarrando as costas de um carneiro com suas garras e dilacerando o pescoço com seu bico; tudo dentro de um escudo redondo com borda em relevo.

Reverso: Raio com asas fechadas em cima e volutas embaixo; F A (incuso).

Metal / denominação: AR / estater.

Referências: $B C D$, Olympia*: 92; Seltman: $172(B X / \delta \theta)$ 


\section{Larissa, Tessália}

Data: c.370-360 a.C.

Anverso: Cabeça de Aleuas de frente levemente à e., vestindo elmo cônico; labrys à $\mathrm{d}$.

Reverso: Águia em pé à e. com a cabeça à d. sobre raio;

Metal / denominação: AR / dracma.

Peso: $6,18 \mathrm{~g}$.

Referências: BCD Thessaly II*: 185; Sear, GCTV, vol.l: 2126.

\section{Cálcis, Eubéia}

Data: 369-313 a.C.

Anverso: Cabeça feminina d.

Reverso: Águia voando, carregando serpente; embaixo, raio; XA^.

Metal / denominação: AR / dracma.

Referências: SNG Cop Thessaly to Aegean?: PI.?, 439. 


\section{Crotona, Itália do Sul}

Data: $1^{\text {a }}$. metade séc. IV a.C.

Anverso: Trípode; símbolo: folha, KPOT.

Reverso: Raio entre estrela de oito raios e águia em pé à e. ou à d., asas dobradas e

cabeça virada para trás, sobre coluna jônica.

Metal / denominação: AR / trióbolo.

Referências: Rutter, HN: 2185.

339. Molossi, Épiro

Data: c.350 a.C.

Anverso: Cabeça de Atena.

Reverso: Águia em cima de raio.

Metal / denominação: $A E$ / ?

Peso: ?

Referências: Kraay, ACGC: Pr. 39, 683. 


\section{ZEUS E ÁGUIAS}

\section{SÉCULO V a.C.}

\section{0. Élis-Olímpia, Peloponeso}

Data: c. 452 a.C. a c. 432 a.C.

Anverso: Águia voando à e., com as asas acima e abaixo de seu corpo, carregando uma cobra com suas garras e bico.

Reverso: Zeus nu em pé à d. atirando um raio com a mão d. e segurando no braço e. a águia pronta para voar; O $\triangle Y M \Pi I K O N$ (retrogrado).

Metal / Denominação: AR / estater

Referências: Seltman: 72 (AP/ $\beta$ Y).

\section{1. Élis-Olímpia, Peloponeso}

Data: c. 452 a.C. a c. 432 a.C.

Anverso: Águia de frente com as asas abertas carregando uma tartaruga pelas garras. Reverso: Zeus nu em pé à d. atirando um raio com a mão d. e segurando no braço $\mathrm{e}$. a águia pronta para voar; O YYMПIKON.

Metal / Denominação: AR / estater

Referências: Seltman: $73(A Q / \beta \gamma)$. 


\section{2. Élis-Olímpia, Peloponeso}

Data: Final c.450s a.C.

Anverso: Águia voando à e., com as asas acima e abaixo de seu corpo, carregando uma cobra com suas garras e bico.

Reverso: Zeus em pé à d., atirando o raio com sua mão direita erguida, e em cima de seu braço esquerdo estendido, uma águia com a cabeça virada para trás; O^YMПIKON, retrogrado.

Metal / denominação: AR / estater.

Referências: $B C D$, Olympia: 25; Seltman: 37 (AB/aı); Kraay, ACGC: Pr.18, 325;

Mildenberg e Hurter, ADCGC*: Pr. 95, 1858.

\section{3. Élis-Olímpia, Peloponeso}

Data: c.430s a.C.

Anverso: Zeus nu da cintura para cima, sentado à e. em uma rocha com sua perna direita atrás da sua esquerda, com águia sobre ou fora de sua mão direita estendida, cetro atrás inclinado na direção do ombro direito e sua mão esquerda descansando sobre a rocha.

Reverso: Águia voando à e., com as asas acima e abaixo de seu corpo, carregando uma cobra com suas garras e bico.

Metal / denominação: AR / estater.

Referências: $B C D$, Olympia*: 44; Seltman: 101b (BA/BT). 
344. Paphos, Chipre (sem imagem)

Data: c. 425 a.C. (governo de Pnytos II ou Pnytagoras II).

Anverso: Cabeça laureada de Zeus à $\mathrm{d}$.

Reverso: Águia em pé à e.; antes, ankh e pa.pu; atrás, galho com folhas de louro;

tudo dentro de um quadrado incuso com pérolas.

Metal / Denominação: AR / quarter estater

Referências: Sear, GCTV, vol. I: 5771.

\section{SÉCULO IV a.C.}

\section{5. Élis-Olímpia, Peloponeso}

Data: 360 a.C.

Anverso: Cabeça laureada de Zeus à d. com cabelos e barba curtos.

Reverso: Águia em pé à d. com asas fechadas, sobre o capitel de uma coluna jônica; F A.

Metal / denominação: AR / estater.

Referências: $B C D$, Olympia*: 119; Seltman: 177 var. 


\section{6. Élis-Olímpia, Peloponeso}

Data: 360 a.C.

Anverso: Cabeça laureada de Zeus à e. com cabelos e barba curtos.

Reverso: Águia em pé à d. com asas fechadas, sobre o capitel de uma coluna jônica; F A.

Metal / denominação: AR / estater.

Referências: $B C D$, Olympia*: 121; Seltman: 178 var.

\section{7. Élis-Olímpia, Peloponeso}

Data: 356 a.C.

Anverso: Cabeça laureada de Zeus à e. com cabelos curtos e barba curta.

Reverso: Águia em pé à d. com asas fechadas sobre capitel de coluna jônica; F A $\wedge$ E I $\Omega$ N.

Metal / denominação: AR / estater.

Referências: $B C D$, Olympia*: 128; Seltman: $183(C D / \delta \sigma)$

\section{8. Élis-Olímpia, Peloponeso}

Data: 352 a.C.

Anverso: Cabeça laureada de Zeus à $\mathrm{d}$. com cabelos e barba longos.

Reverso: Águia em pé à d. com cabeça virada para frente com asas fechadas sobre a coluna de um capitel jônico; $F A \wedge E I \Omega N$.

Metal / denominação: AR / estater.

Referências: $B C D$, Olympia*: 131; Seltman: 313 (EX/Ia).

Exemplares similares: $B C D$, Olympia: 132; Seltman: 186-189. 


\section{9. Élis-Olímpia, Peloponeso}

Data: c.352-348 a.C.

Anverso: Cabeça laureada de Zeus à d. com cabelos e barba compridos.

Reverso: Águia em pé à d. com cabeça virada para frente, asas fechadas; à d., folha de oliveira; F A.

Metal / denominação: AR / hemidracma.

Referências: $B C D$, Olympia: 143.

Exemplares similares: $B C D$, Olympia: 144.

\section{0. Élis-Olímpia, Peloponeso}

Data: c.352-348 a.C.

Anverso: Cabeça laureada de Zeus à d. com cabelos e barba compridos.

Reverso: Águia em pé à d. com cabeça virada para trás à e., asas fechadas; F A.

Metal / denominação: AR / óbolo.

Referências: $B C D$, Olympia: 145.

\section{1. Élis-Olímpia, Peloponeso}

Data: c.352-348 a.C.

Anverso: Cabeça laureada de Zeus à d. com cabelos e barba compridos.

Reverso: Águia em pé à d. com cabeça virada para trás à e., asas fechadas; F A. Metal / denominação: AR / óbolo.

Referências: $B C D$, Olympia: 146. 


\section{2. Élis-Olímpia, Peloponeso}

Data: c.352-348 a.C.

Anverso: Cabeça laureada de Zeus à d. com cabelos e barba compridos.

Reverso: Águia em pé à d. com cabeça virada para trás à e., asas fechadas; embaixo, cacho de uvas; F A.

Metal / denominação: AR / óbolo.

Referências: $B C D$, Olympia: 147.

\section{3. Élis-Olímpia, Peloponeso}

Data: $352-348$ a.C.

Anverso: Cabeça laureada de Zeus à d. com cabelos e barba compridos.

Reverso: Águia em pé à d. com cabeça virada para frente, asas fechadas e sobre a coluna de um capitel jônico; $F$ A.

Metal / denominação: AR / hemidracma.

Referências: $B C D$, Olympia: 139.

Exemplares similares: $B C D$, Olympia: 140; 141; 142. 


\section{4. Élis-Olímpia, Peloponeso}

Data: 344 a.C

Anverso: Cabeça laureada de Zeus à d. com cabelos e barba curtos.

Reverso: Águia em pé à d. com cabeça virada para frente, asas fechadas e sobre a coluna de um capitel jônico; F A / K P I.

Metal / denominação: AR / estater.

Referências: $B C D$, Olympia: 150; Seltman: 190 (CF/סW). 


\section{ZEUS E RAIOS}

\section{SÉCULO V a.C.}

\section{5. Élis-Olímpia, Peloponeso}

Data: 416 a.C.

Anverso: Cabeça de Zeus à d. com barba, usando uma coroa de folhas de oliveira selvagem.

Reverso: Raio com asas embaixo e volutas em cima; tudo dentro de uma coroa de folhas de oliveira; el letras pequenas, $\triangle \mathrm{A} ; \mathrm{F}$ A.

Metal / denominação: AR / estater.

Referências: $B C D$, Olympia*: 67; Seltman: 145 (BQ/yo); Kraay, ACGC: 328.

\section{SÉCULO IV a.C.}

\section{Kierion, Tessália}

Data: c.400-360 a.C.

Anverso: Cabeça laureada de Zeus à d. com cabelos e barba curtos; atrás, raio.

Reverso: Ninfa Arne ajoelhada sobre a perna direita com cabeça virada à e.; KI-PIAI-ON / ARNA.

Metal / denominação: AR / hemidracma.

Referências: BCD Thessaly (Nomos): 1067, p.48. 


\section{Halus (Phtiotis), Tessália}

Data: c.400-344 a.C.

Anverso: Cabeça laureada de Zeus Laphystios; em frente, raio.

Reverso: Helle sobre carneiro; ao redor, $A \lambda \varepsilon \omega \mathrm{V}$.

Metal / peso: AE/ 2,79 g.

Referências: SNGCop Thessaly to Aegean Islands: Pr.2, 62; BCD Thessaly: 84, p.58; BCD Thessaly (Nomos): 1056, p.45.

\section{Hypata, Tessália}

Data: c.400-344 a.C.

Anverso: Cabeça laureada de Zeus; atrás, raio.

Reverso: Atena em pé à e.; Yта т a ı

Metal / peso: AE/ 2,08 g.

Referências: SNGCop Thessaly to Aegean Islands: Pr.2, 74; BCD Thessaly: 94, p.62. 


\section{Kierion, Tessália}

Data: Início século IV a.C.

Anverso: Cabeça laureada de Zeus à e. com cabelos e barba curtos; atrás, raio vertical; [K] e I em cada lado do campo.

Reverso: Cabeça da ninfa Arne à d. com cabelo em sakkos; $\mathrm{K}$ e I em cada lado do campo.

Metal / peso: AR / hemióbolo.

Referências: $B C D$ Thessaly: 97, p.63.

Exemplares similares: BCD Thessaly (Nomos): 107, p.51.

\section{Melitaia, Tessália}

Data: $1^{\text {a }}$. metade do século IV a.C.

Anverso: Cabeça laureada de Zeus à e. com cabelos e barba compridos; atrás, raio.

Reverso: Abelha de frente com asas abertas; $M-E / \Lambda-I$.

Metal / denominação: AE / chalkous.

Referências: BCD Thessaly (Nomos): 1199, p.84.

\section{Pisa-Olímpia, Peloponeso}

Data: c. 365 a.C.

Anverso: Cabeça laureada de Zeus à e. com cabelos curtos encaracolados e com barba.

Reverso: Raio com volutas de lótus em cima e embaixo; $\Pi I \Sigma A$.

Metal / Denominação: AV / óbolo.

Referências: Seltman: 174 (BZ/סK); Kraay, ACGC: 333.

Exemplares similares: Seltman: 173 (BY/סI). 


\section{Felipe II, Macedônia (Anfípolis)}

Data: 356-355 a.C.

Anverso: Cabeça laureada de Zeus à d. com cabelos compridos e barba curtos.

Reverso: Cavaleiro à e., saudando com o braço direito levantado; abaixo do cavalo, raio;

em cima no campo, ФI/IחПOY; no exergo, $\Delta \mathrm{H}$.

Metal / Denominação: AR / tetradracma.

Referências: Coins of Macedonia, no.27, p.42.

\section{Melitaia (Phthiotis), Tessália}

Data: Metade do século IV a.C.

Anverso: Cabeça laureada de Zeus à e. com cabelos e barba curtos; raio atrás.

Reverso: Abelha de frente com asas abertas; acima no campo, M / E e abaixo no campo, $\Lambda$ / I.

Metal / denominação: $A E$ / chalkous.

Referências: BCD Thessaly: 458.3, p. 202.

\section{Felipe II, Macedônia (Pella)}

Data: $348-336$ a.C.

Anverso: Cabeça laureada de Zeus à d. com cabelos compridos e barba curtos.

Reverso: Cavaleiro à d., segurando galho de palma com a mão direita; abaixo do cavalo, raio; em cima no campo, ФI/ IП / ПOY.

Metal / Denominação: AR / tetradracma.

Referências: Coins of Macedonia, no.28, p.43.
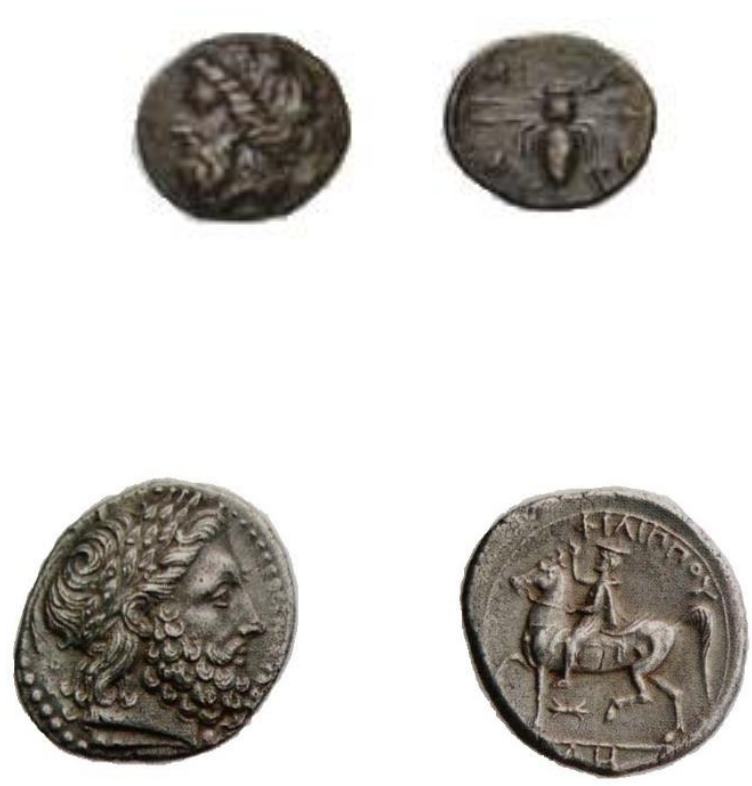


\section{Dia, Tessália}

Data: metade do século IV a.C.

Anverso: Cabeça laureada de Zeus à d. com cabelos e barba curtos, cabelo preso com taenia na forma de coroa; raio atrás.

Reverso: Deméter sentada à e. com chiton longo, segurando phiale com sua mão direita e cetro diagonalmente com a mão esquerda; $[\Delta \mathrm{l}] \mathrm{A} / \Omega \mathrm{N}$ (retrogrado); pequeno $\Delta$.

Metal / denominação: AE / chalkous.

Referências: $B C D$, Thessaly: 64, p.45.

\section{Melitaia, Tessália}

Data: metade do século IV a.C.

Anverso: Cabeça laureada de Zeus à d. com cabelos e barba longos; raio atrás.

Reverso: Abelha de frente com asas abertas; em cima, M-E; embaixo, $\Lambda-$ I.

Metal / denominação: AE / chalkous.

Referências: BCD, Thessaly: 457, p.202. 


\section{Siracusa, Sicília}

Data: c. 344 a.C.

Anverso: Cabeça laureada de Zeus Eleutherios à d. com cabelos e barba curtos;

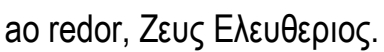

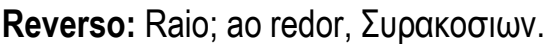

Metal / denominação: AE / ?

Peso: 15,97g.

Referências: SNGCop Italy-Sicily: pr. 16, 726; Cahn et alli, GMGS: 495 (357-354 a.C.).

Exemplares similares: SNGCop Sicily: pr. 16, 729 (no reverso, ao lado d. do raio, grão de trigo)

\section{Siracusa, Sicília}

Data: c. 344 a.C

Anverso: Cabeça lauredada de Zeus Eleutherios à e. com cabelos e barba curtos;

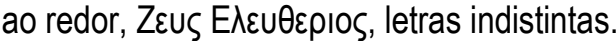

Reverso: Raio; inscrição não visível.

Metal / denominação: $A E$ / ?

Peso: $4,25 \mathrm{~g}$

Referências: SNGCop Italy-Sicily: pr. 16, 730.

Exemplares similares: SNGCop Sicily: pr. 16, 731 (no reverso, polvo, ao redor, traços de inscrição);

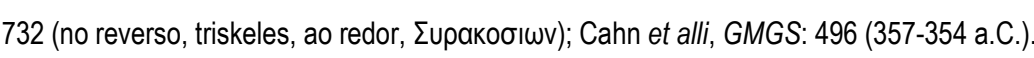




\section{Aetna, Sicília}

Data: c. 344 a.C.

Anverso: Cabeça laureada de Zeus Eleutherios à d. com cabelos e barba curtos;

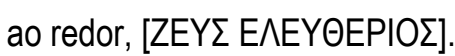

Reverso: Raio; ao redor, [AITNA]ISN.

Metal / Peso: AE / 10,42g.

Referências: Ex NAC 21, 17 de maio de 2001, lote 52 (Gemni LLC)

(http://www.acsearch.info/search.html?id=724432).

\section{Alontion, Sicília}

Data: c. 344 a.C.

Anverso: Cabeça laureada de Zeus Eleutherios à d. com cabelos e barba curtos;

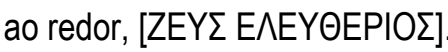

Reverso: Raio; grão-de-trigo no campo à d.; ao redor, A^ONT/IN $\Omega N$.

Metal / Peso: AE / 9,63g

Referências: Naville Numismatics LTD. (http://www.acsearch.info/search.html?id=2410225). 


\section{ZEUS, RAIOS E ÁGUIAS}

\section{SÉCULO IV a.C.}

\section{1. Élis-Olímpia, Peloponeso}

Data: 348 a.C.

Anverso: Cabeça laureada de Zeus à d. com cabelos e barba compridos.

Reverso: Águia em pé à d. com cabeça virada para frente, asas fechadas e sobre a coluna de um capitel jônico; à d., um raio horizontal; $F$ A.

Metal / denominação: AR / estater.

Referências: $B C D$, Olympia*: 136; Seltman: 196-198 var. (CM-novo reverso).

\section{2. Élis-Olímpia, Peloponeso}

Data: 348 a.C.

Anverso: Cabeça laureada de Zeus à d. com cabelos e barba compridos.

Reverso: Águia em pé à d. com cabeça virada para frente, asas fechadas e sobre a coluna de um capitel jônico; à d., um raio vertical; $F$ A.

Metal / denominação: AR / estater.

Referências: $B C D$, Olympia*: 137; Seltman: $200(C N / \varepsilon \theta)$. 


\section{3. Élis-Olímpia, Peloponeso}

Data: 348 a.C.

Anverso: Cabeça laureada de Zeus à d. com cabelos e barba compridos.

Reverso: Águia em pé à d. com cabeça virada para frente, asas fechadas e sobre a coluna de um capitel jônico; à d., um raio vertical; $F$ A.

Metal / denominação: AR / estater.

Referências: $B C D$, Olympia: 138; Seltman: $201(C O / \varepsilon \theta)$.

\section{Agyrion, Sicília}

Data: c. 344 a.C.

Anverso: Cabeça laureada de Zeus Eleutherios à d. com cabelos curtos e barba longa;

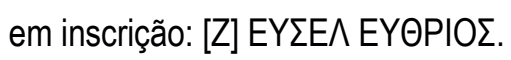

Reverso: Raio e águia ao lado d.; ГYPI NAI.

Metal / peso: AE / ?

Referências: BMC Italy-Sicily, no. 9, p. 26. 


\section{Siracusa, Sicília}

Data: c. 344 a.C.

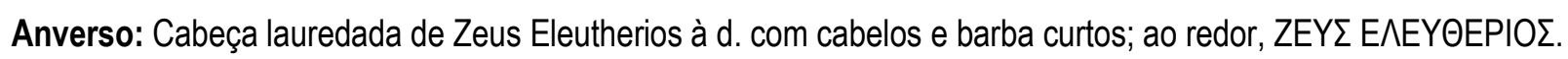

Reverso: Raio, à d., águia em pé à d. com asas fechadas; ao redor, $\Sigma Y P A K O \Sigma I \Omega N$.

Metal / peso: AE / 14,49g.

Referências: SNGCop Italy-Sicily: pr. 16, 727.

Exemplares similares: SNGCop Sicily: pr. 16, 728. 